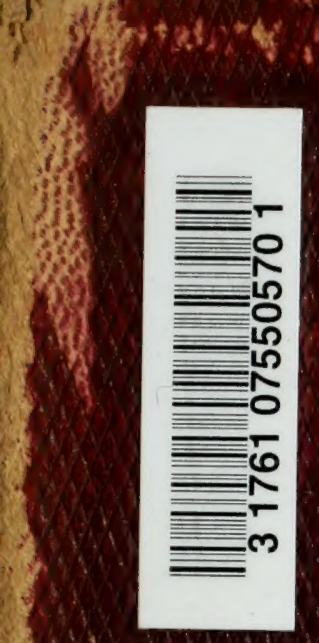




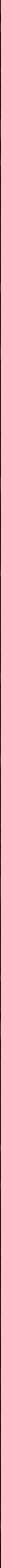




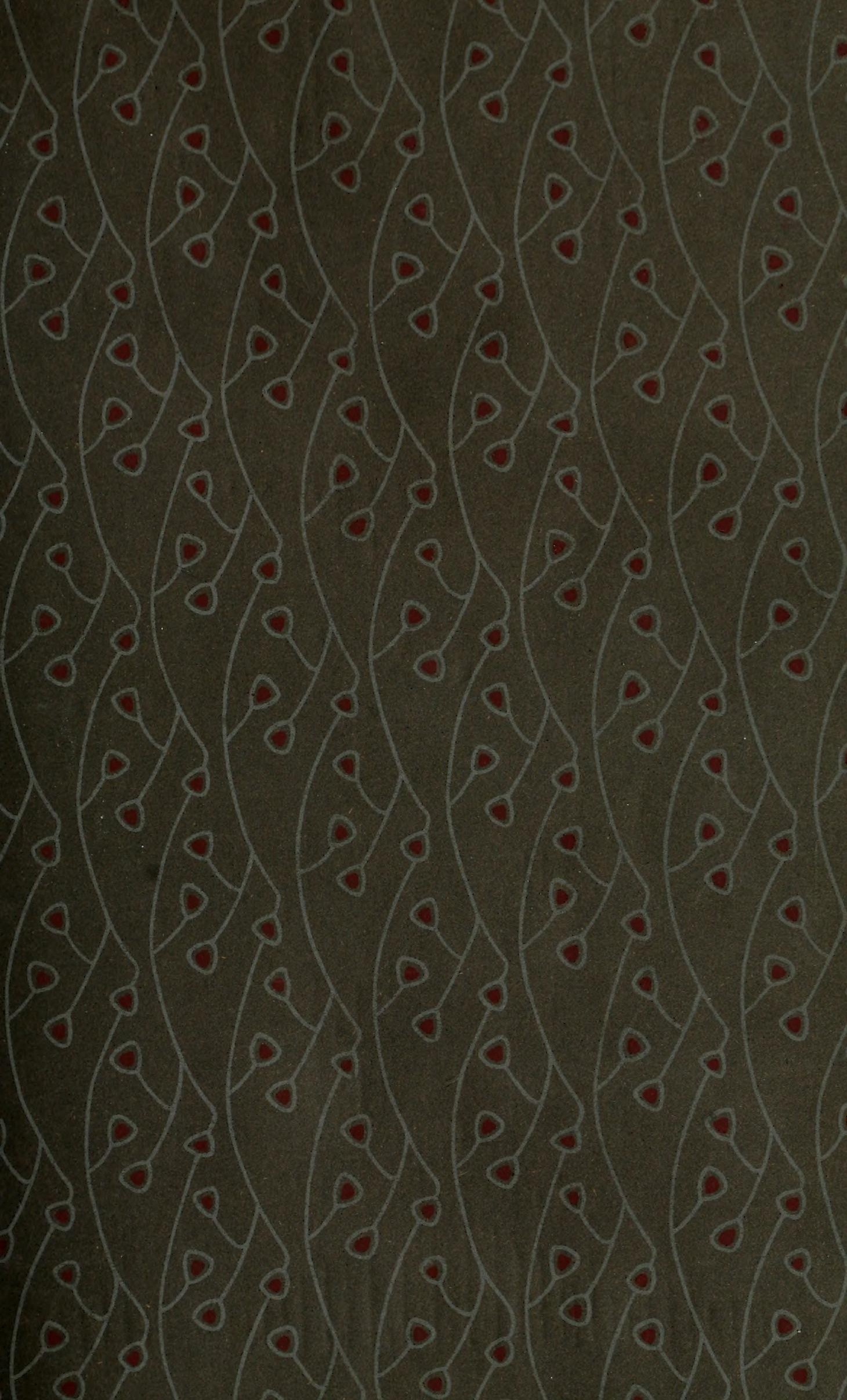









\section{. 1 J $7 \mathrm{AT}$}
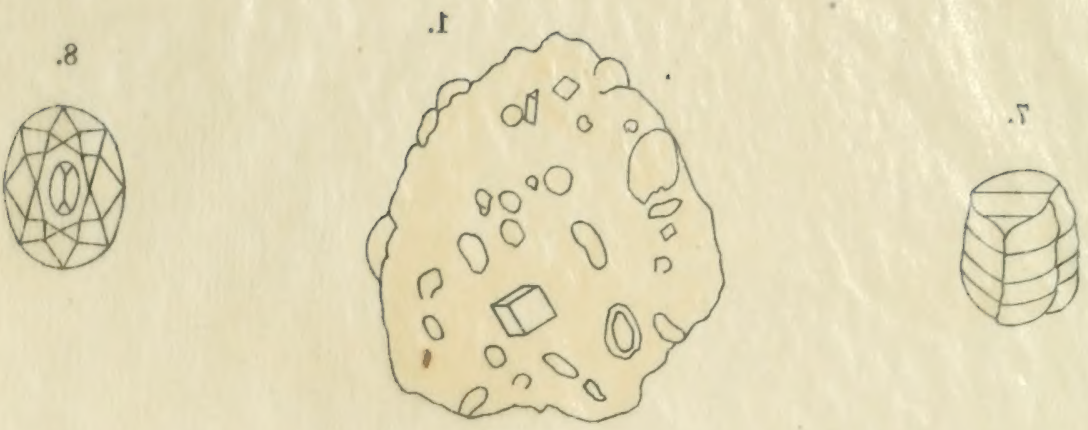

.
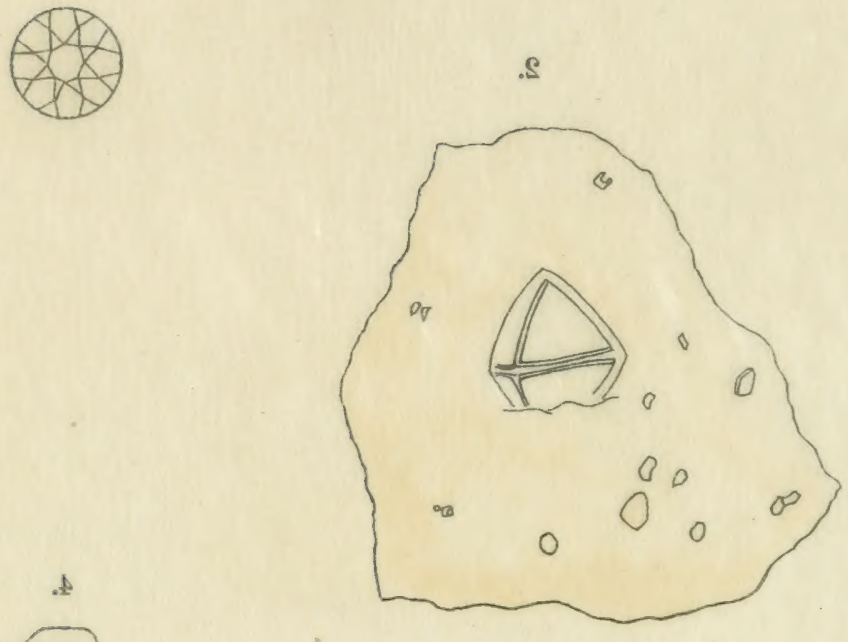

.
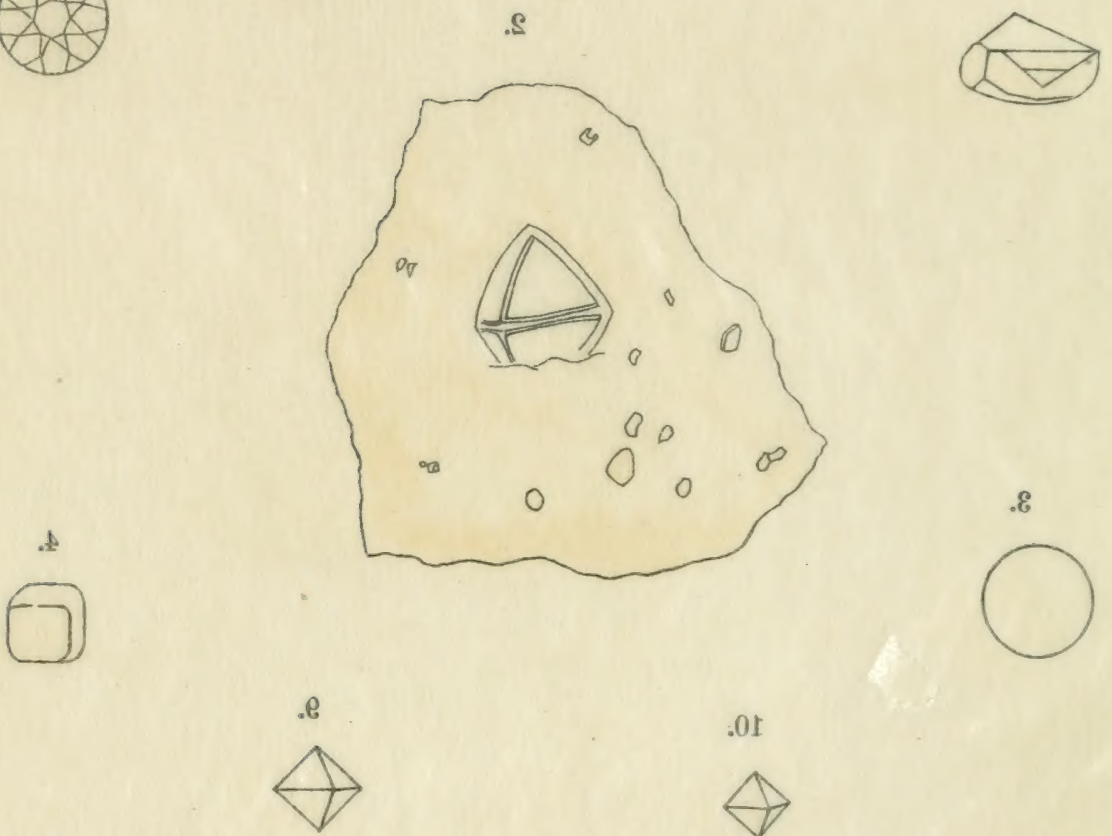

$.0 \mathrm{r}$
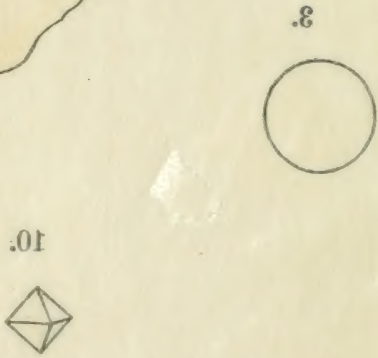

$.8 I$

.II

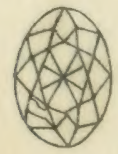

SI
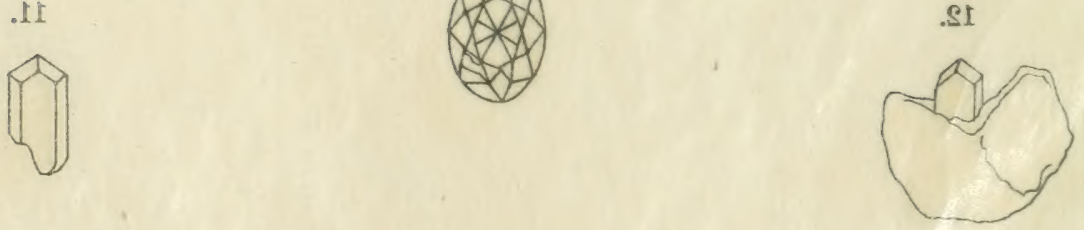

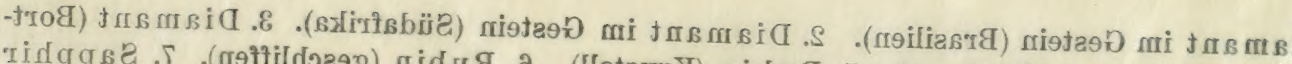

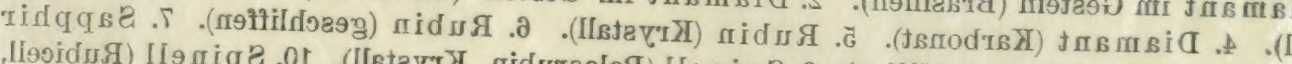

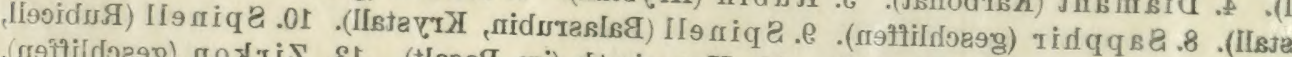

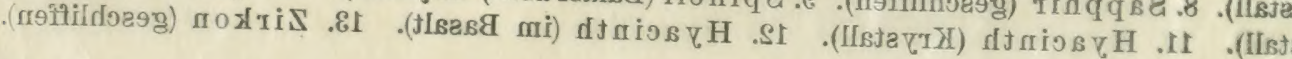


7.
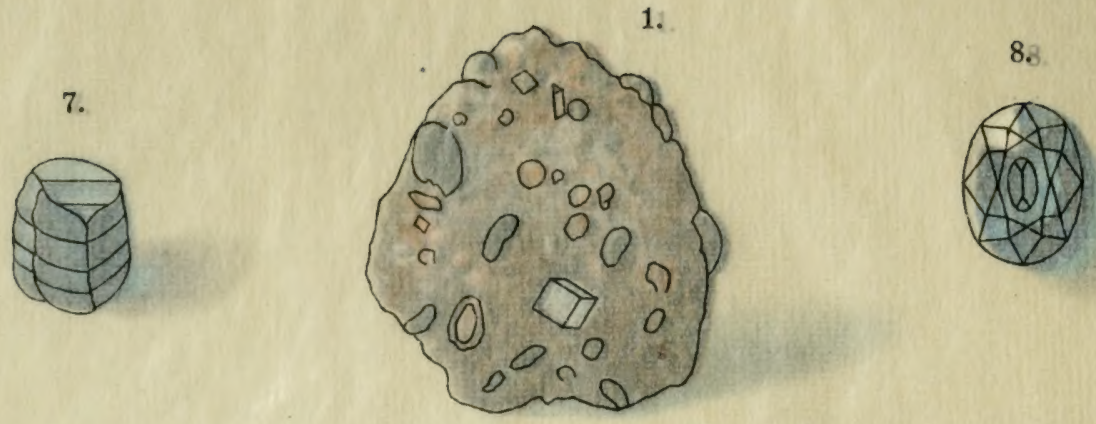

5.

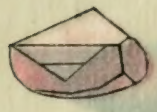

2.

6.
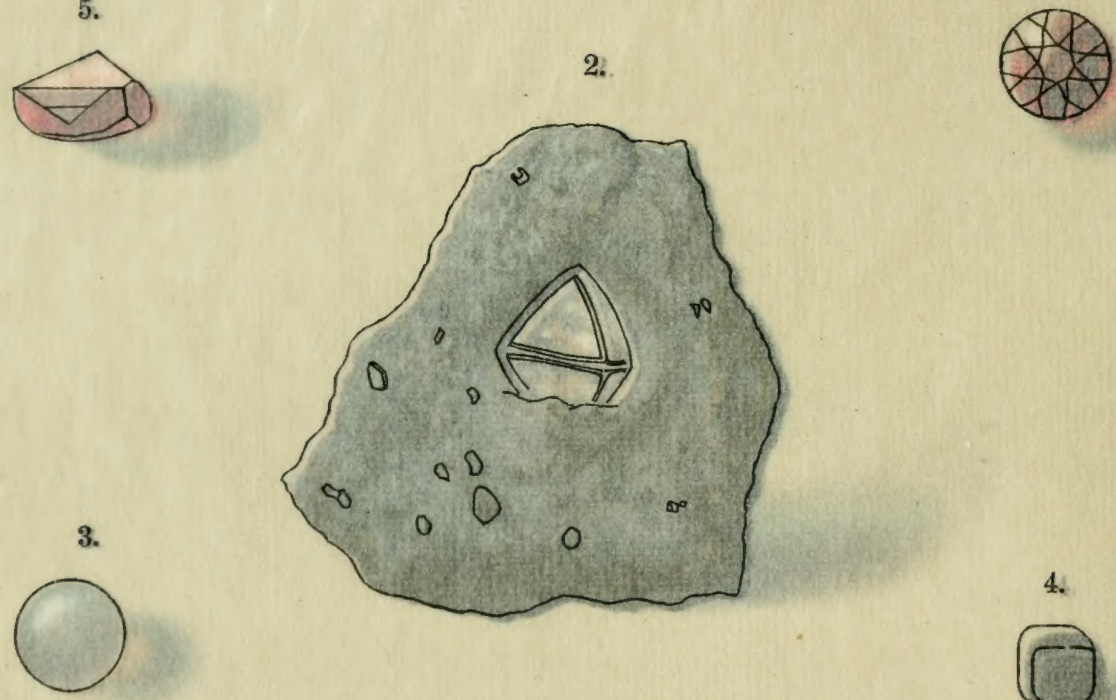

4.

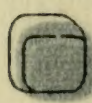

10.

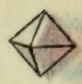

9.

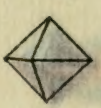

13.

12.

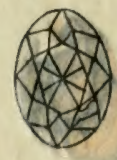

11.

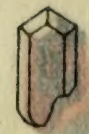

1. Diamant im Gestein (Brasilien). 2. Diamant im Gestein (Südafrika). 3. Diamant (Bortkugel). 4. Diamant (Karbonat). 5. Rubin (Krystall). 6. Rubin (geschliffen). 7. Sapphi (Krystall). 8. Sa pphir (geschliffen). 9. Spinell (Balasrubin, Krystall). 10. Spinell (Rubice Krystall). 11. Hyacinth (Krystall). 12. Hyacinth (im Basalt). 13. Zirkon (geschliff 


\section{EDELSTEINKUNDE}

EINE ALLGEMEIN VERSTÄNDLICHE DARSTELLUNG

DER EIGENSCILAFTEN, DES VORKOMLENS UND DER VERWEALUAG DEI EDELSTEINE, IEBST EINER ANLEITUNG ZUR BEsTIMUCAG DERSELBEN, FÜR MINEIALUGEN, EDELSTEINLIEBIABER, STEI.SCHLEIFER, JUWELIERE

VON

\section{MAX BAUER,}

GEHEIMEM REGIERUNGSRAT

PROEESSOR AN DER UNIVERSITÏT MARBURG.

ZWEITE, TOLLKONMEN DURCHGESEHENE LND TEILWEISE NEUBEARBEITETE AUfLAGE.

MIT 21 TAFELN IN FARBENDRUCK, LITHOGRAPHIE UND AUTOTYPIE, SOWIE 115 ABBILDUNGEN INI TEXT.
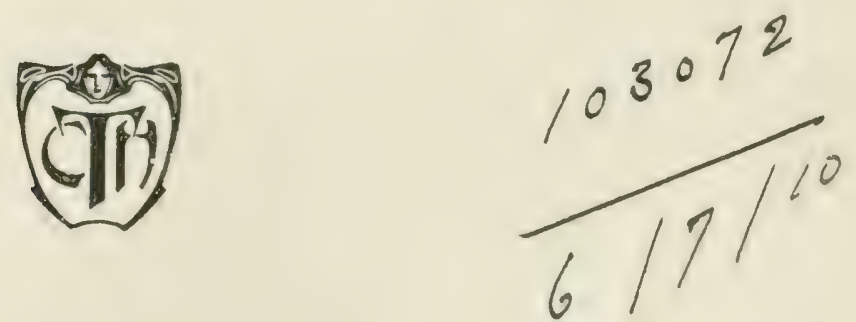

LEIPZIG 1909

CHR. HERM. TAUCHNITZ 
TAFEL I.

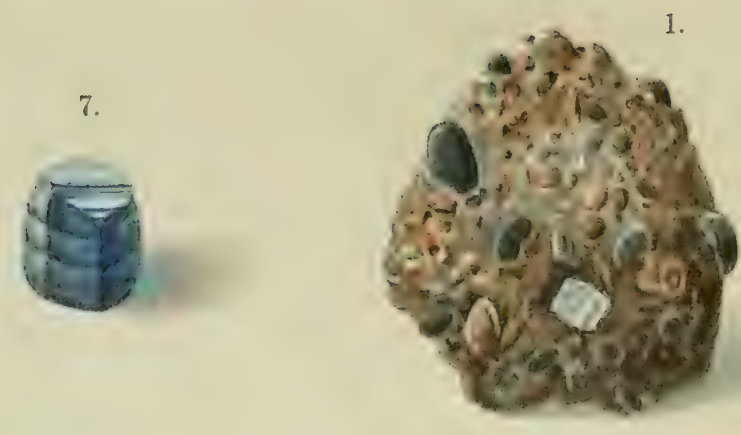

8.

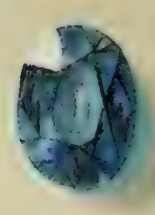

5.

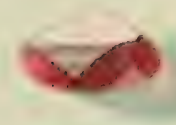

2.

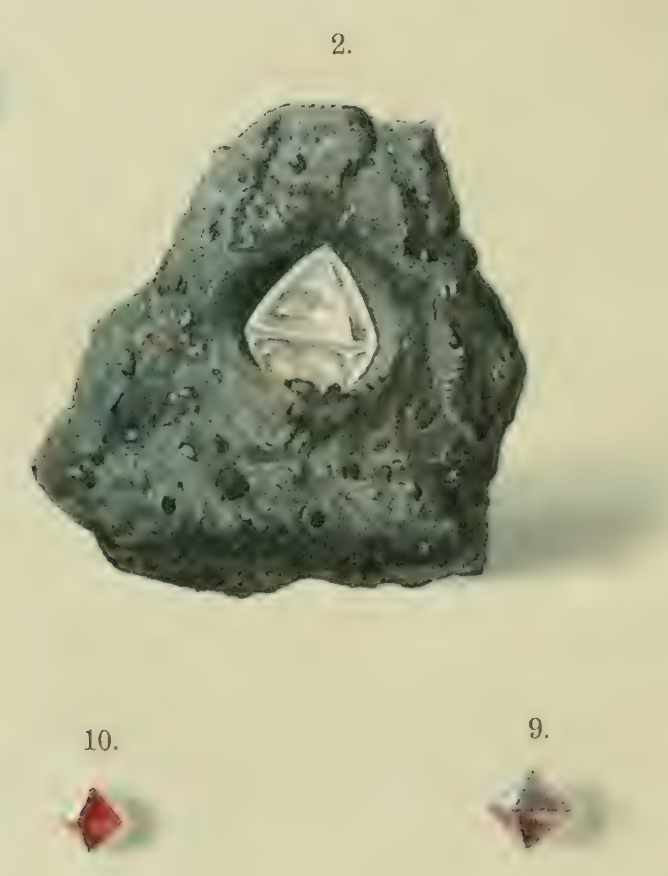

6.

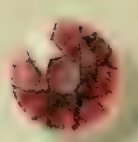

3.
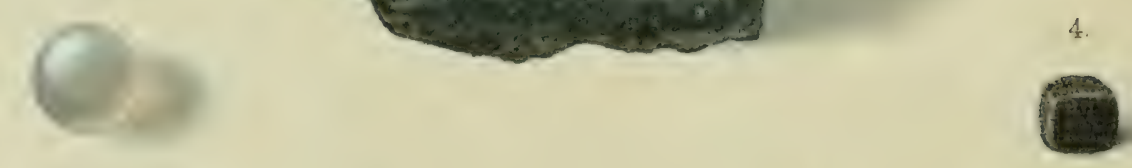

13.
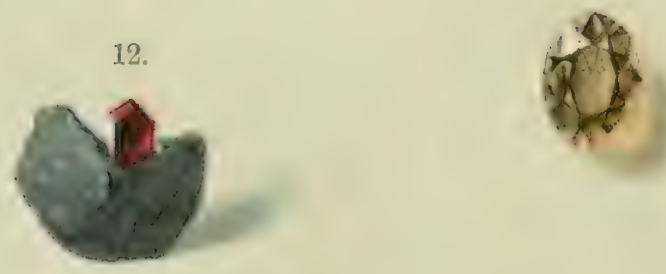

11.

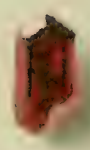




\section{EDELSTEINKUNDE}

EINE ALLGEIEIN VERSTÄNDLICHE DARSTELLUNG

DER EIGENSG'ILAFTEA, DES VORKOMLENS UTD DER VERWENLLAG DER EDELSTENE, NEBST EINER ANLEITUNG ZUR BESTIMUUAG DERSELBEN, FÜR IIINERALOGEA, EDELSTEINLIEBHABER, STEINSCHLEIFER, JUWELIERE

$\operatorname{VON}$

\section{MAX BAUER,}

GEHEIMEM REGIERUNGSR AT

PROFESSOR AN DER UNIVERSIT ÏT MARBUIG.

ZWEITE, TULLKOMIEX DURCHGESEHENE UND TEILWEISE NEUBEARBEITETE ALFLAGE.

MIT 21 TAFELN IN FARBENDRUCK, LITHOGRAPHIE UND AUTOTIPIE, SOWIE 115 ABBILDUNGEN IN TEXT.
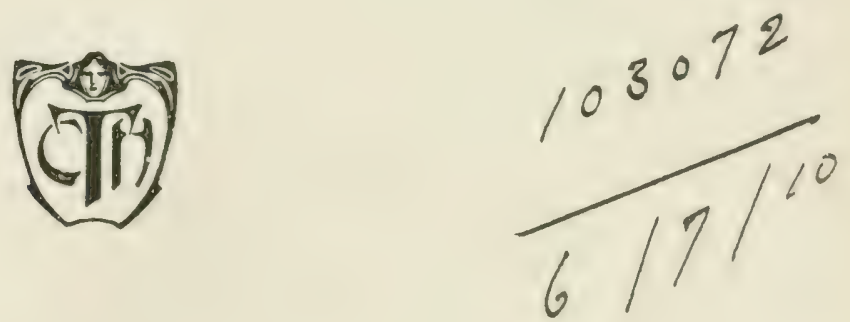

LEIPZIG 1909

CHR. HERM. TAUCHNI'TZ 
Das Recht der Übersetzung in fremde Sprachen ist vorbehalten.

Die Verlagshandlung.

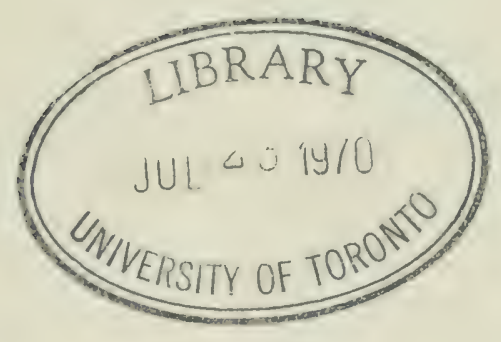

$$
\begin{aligned}
& \text { QE } \\
& 392 \\
& B 34 \\
& 1909
\end{aligned}
$$


SEINER MAJESTÄT

\title{
WILHELM II.
}

KÖNIG VON WÜRT'TEMBERG

\author{
IN TIEFSTER EHRFURCHT
}

UNTERTHÄNIGST GEWIDMET

VOM VERFASSER. 



\section{VORWORT.}

Der Wunsch des Herrn Verlegers, dem deutschen Publikum ein Werk über Edelsteine in ähnlicher Ausstattung darzubieten, wie es die amerikanische Literatur in so ausgezeichneter Weise in: George Frederik Kunz, ..Gems and precious stones of North America" besitzt, gab die Anregung zur Abfassung des vorliegenden Buches. Sellstverständlich mußte aber hier die Gesantheit der Edelsteine dargestellt und sollte auch eine Anleitung zur Bestimmung unbekannter steine mit aufgenommen werden. In letzterer Beziehung konnten die vortrefflichen und umfassenden Anweisungen, die C. Dölter in seiner Edelsteinkunde gibt, zum Muster dienen. Sie sind aber hier etwas modifiziert und vereinfacht. Samentlich wurde auf die Anwendung des konvergenten polarisierten Lichtes rerzichtet, weil Elelsteinhändler und Juweliere, die meistens eingrehende theoretische Studien nicht unternommen hahen, hiervon doch wohl schwerlich einen zweckentsprechenden Gebrauch machen können und für wissenschaftlich gebildete Mineralogen Angraben hierüber überflüssig sind. Jedenfalls war es aber nötig, der Beschreibung der einzeinen Edelsteine eine allgemeine Einleitung rorauszuschicken, in der die einschlïgigen Lehren, namentlich der Physik und der Mineralogie, soweit sie für die Kenntnis der Natur der Edelsteine erforderlich sind, zur Darstellung gelangten.

Ls wurde dabei kein gelehrtes Publikum rorausgesetzt, aber ein solches, das doch nicht ganz ohne naturwissenschaftliche Torkenntnisse ist. Die Darstellung wurke so zu geben versucht, daf ein mit guten Schulkenntnissen ausgestatteter Leser zu folgen rermag. Es ist daher zu hoffen, daß das Buch nicht nur denen genïgen wird, die sich aus allgemeinem naturwissenschaftlichem Interesse mit Edelsteinen beschäftigen wollen, sondern dab es besonders allen, die in dem Kauf und Verkauf, sowie in der Verwendung von Edelsteinen zu Schmuckgerrenstïnden aller Art ihren Lebensberuf haben, also Edelsteinhändlern und Juwelieren, in ausgedehnter Weise nützlich sein wird.

Anfänglich war beabsichtigt grewesen, die Perlen und Korallen, die keine Mineralien, sondern Produkte des Tierreiches sind, hier nicht zu behandeln. Wünsche aus dem Kreise der Leser der einzelnen Lieferungen dieses Buches waren die Teranlassung, dieses Vorhaben aufzugeben, und so sind nachträglich noch diese beiden wichtigen Alsschnitte in einem Anhang bearbeitet worden. Für die Perlen wurden neben anderen hauptsä̈hlich die Werke von Möbius und r. Martens, für die Korallen die von Lacaze Duthiers und von Ca nestrini benutzt.

Der Verfasser hat sich besonders bemïht, die Art des Vorkommens und die Fundorte der einzelnen Steine so eingehend, als es der Lmfang des Bandes erlaubte, mitzuteilen und ihre Verbreitung in den wichtionsten Heimatsländern auf kleinen $̈$ C̈bersichtskärtchen im Text bildlich darzustellen. Auf diesem Gebiete werden auch Fachgenossen des Verfassers manches Neute erfahren, denn auch die neueste mineralogische Literatur zeigt, daf hier vielfach unrichtige Vorstellungeu herrschen. Dies ist auch leicht erklïrlich. denn nur wer sich in diesem Zweige der Vineralogie selbst versucht und die unfassenden, aber weit zerstreuten, vielfach unsicheren und unklaren und nicht selten geradezu 
unrichtigen Literaturangaben über das Vorkommen von Edelsteinen kennen gelernt hat, kann die mit solchen Studien verbundenen Schwierigkeiten ermessen. Namentlich war es vielfach unmöglich, für die Herstellung der Übersichtskärtchen die erforderlichen sicheren Unterlagen zu bekommen; ihre Zahl ist daher beschrïnkter geblieben, als es ursprünglich geplant gewesen war. Zahlreiche Fachgenossen haben durch Mitteilung ihrer persönlichen Erfahrungen und mancher einschlïgigen P'ublikationen ihre Unterstüzung gewährt; ihnen allen aufrichtigen Dank!

Die Art und Weise der Terarbeitung und der Verwendung der Edelsteine gelangt eingehend zur I)arstellung, um so mehr, als auch sie im engsten Zusammenhange mit den natiirlichen Eirrenschaften stehen. Dem allgemeinen Teile sind daher auch Abschnitte iiher die schlifformen, den Schleifprozeß usw. eingefügt, und entsprechende Mitteilungen sind der Beschreibung jedes einzelnen Edelsteins beigefügt.

In der Ausstattung des Werkes hat die Verlagsbuchhandlung den Wiinschen des Vurfassers nach Möglichkeit Rechnung getragen. Die Originalbilder zu den farbigen Tafeln sind ron der kunstfertigen Hand des Herrn E. Ohman $\mathrm{n}$ in Berlin gemalt. Die ab)elildeten vitucke entstammen zum größten Teile den mineralogischen Sammlungen des II useums fïr Naturkunde in Berlin. Dem Direktor derselben, IIerrn Geheimen Bergrat und P'rofessor ('. Klein, sei für die Erlaubnis zur Benutzung der verbindlichste Dank auscesprochen, ehenso dem Kustos, Herrn Professor C. Tenne für das rege Interesse und dice viele Zeit und Mühe, die er der Herstellung der Aquarelle stets gewidmet hat. Ein nicht greringrer Teil des Gelingens dieser farbigen Tafeln ist seiner tätigen Mitwirkung bei ihrer Iferstrllung zuzuschreiben. Dank sei auch Herrn Direktor $\Lambda$. Brezina in Wien, der die Genehmigung zur Reproduktion des bekannten Gemäldes im mineralogischen Ilofmuseum gewährt hat, das die berühmteste und reichste der Diamantgruben am Kap, die Kimberleyrube, darstellt und das hier zum ersten Male zur Teröffentlichung gelangt.

Literaturangaben sind nur in beschrïnkter Zahl gemacht worden. Sie schienen in (inem Werke, das sich in erster Linie an ein größeres Publikum wendet, nicht am Platze zu sein. Dem engere'n Kreise der Mineralogen hoft der Verfasser über manche speziellen J'unkte noch eingehendere wissenschaftliche Mitteilungen machen zu kïnnen. Für die mristen Leser wird es zweckmäßjig sein, daf alle Abschnitte möglichst selbständign und in sich ahgeschlossen gestaltet wurden, so dafs auf Iinweise nach vorn und hinten mïglichst verzichtet werden konnte. Allerdings war damit die Notwendigkeit verbunden, manche Angaben an mehreren Stellen zu wiederholen, was aber hoffentlich nicht in störender Weise geschehen ist.

Das alphabetische Register wurde möglichst vollständig gremacht und darin noch manche Ausdrücke anfgenommen und kurz erklärt, die im Texte keinen Raum gefunden hatten, inmer unter Ilinweis auf die betreffende Stelle, auf die sie sich beziehen.

I) Yerfasser wïrde glauben, das Zicl, das er sich gesetzt, erreicht zu haben, wenn es ihm ecelungen sein sollte, nicht nur Liebhabern und Besitzern von Edelsteinen, sondern anch besonders Edelsteinhä̈ndlem und Juwelieren ein klares Bild von deren natürlicher lieschaffenheit, ihrem Vorkommen sowie ihren versehiedenen Terarbeitungs- und Verwendunesarten gegeben zu haben. Noch mehr würde er aber erfreut sein und seine Niihe belohnt sehen, wenn durch die vorliegende Darstellung einer Anzahl ron zum Teil hesonders merkwürdigen Hineralien regeres Interesse für das Gesamtgebiet der Mineralogie, ron dem die Edelsteinkunde ein Zweig ist, auch in weiteren hreisen geweckt werden wïrde.

Martiotg (mineralogisches Institut der. Universität), Herbst 1896. 


\section{Vorrede zur zweiten Auflage.}

Wie die erste, so beschiiftirnt sich auch die vorliegende nente Auflage vorzugsweist? mit den natiirlichen Verhältnissen der Edelsteine. Namentlich dem Vorkonmen wurde auch jetzt wieller besondere Aufmerksamkeit resebenkt. Überall habe ich eine Darstellung nach dem neuesten stande unserer Kenntnisse angrestrebt und daher die Fortschritte der Wissenschaft his zum Aischlub der Korrektur nach Möglichkeit rerfolgt und beriicksichtignt. Bei der regen Tätigkeit auf manchem dieser Gebiete ist es aber nicht zu verwundern, daß in manchen Punkten der Inhalt des Buches doch von noch neueren Beobachtungen mehr oder weniger iiberholt ist, und daß manche neue Tatsache nicht mehr, oder doch nicht mehr an ilırer eigentlichen, richtigen Stelle, sondern weiter hinten an einem einigremaßen geeigneten Platz aufgeführt wurde. Mehreres konnte sograr nur noch im Register Berücksichtigung finden.

Neu aufgrenommen oder ausführlicher behandelt wurde ror allem die künstliche Darstellung der Edelsteine, namentlich des Riubins, das Terhalten der Edelsteine und namentlich der Edelsteinfarben gegen Röntgen- und gregen Radiumstrahlen und anderes. Daf manche Abschnitte, namentlich die ïber die siidafrikanischen Diamanten, eine vïllige Cmarbeitung erfahren haben, zeigt der Vergleich mit der ersten Auflage ohne weiteres.

Von der einschlïgigen Literatur waren mir besonders nützlich die bekannten jührlichen Übersichten ron George F. Kunz in Tew Tork bis zum .Jahre 1906 und diejenige für 1907 ron seinem Nachfolger, Douglas B. St erret, welche letztere aber nur noch bei der Korrektur benutzt werden konnte. An manchen Punkten ergab auch die englische Übersetzung der ersten Auflage von L. J. Speneer in London (191)4) wichtige Hinweise und Verbesserungen. Leider waren die ron mir benutzten Nachrichten nicht alle gleichwertig. So standen z. B. bei der Abfassung des Abschnitts über die südwestafrikanischen Diamanten nur mehr oder weniger unsichere Zeitungsartikel zur Verfügung, und erst bei der Korrektur konnten die zuverlïssigeren Mitteilungen ron Dernburg, Kaiser und Lotz noch herangezogen werden.

Ich Labe mich aber nicht mit der Verwertung der Literatur begnïgt, sondern mich bestrebt, daneben nach Möglichkeit Nachrichten von Sachverständigen auf dem Gebiet der Edelsteinkunde direkt einzuziehen. IIitteilungen allgemeiner Art verdanke ich rorzugrsweise den Herren G. F. K unz in New Tork. R. Brauns in Bonn. G. Seligmann in Coblenz, C. W. Keßler und Hermann Wild in Idar, A. Dieseldorff in Mamburg. A. Houdelet in Berlin, II ay und Palma in Turnau (Böhmen), A. Miethe in Charlottenburs. Über einzelne spezielle Punlite habe ich wertvolle Aufklärung erhalten von den Herren A. Il a c co, s. Z. in Johannesburgr, über siidafrikanische Diamanten, E. H us sak in Rio de Janeiro über die Diananten und namentlich über die farbigen Edelsteine ron Brasilien, R. L. Codazzi in Bogoti über das Vorkommen des Smaragds in Kolumbien, K. Zimanyi in Pesth iiber das der ungarischen Opale, J. E. Hibsch in Tetschen über die bühmischen Granate, August Leyser in Idar über die Bergkristalle und Citrine ron 
Goyaz (Brasilien), R. Klebs und A. Tormquist in Königsberg über den ostpreußischen Bernstein, IIugo Wild und Julius Caesar in Idar über Perlen und J. M eisenheimer in Marburg über Perlen und Korallen. Ihnen allen sage ich auch hier den besten Dank, ebenso Herm Dr. A. Schwantke, der mir bei der Korrektur wertvolle Hilfe geleistet hat. Den IIauptsitz der deutschen Edelsteinindustrie in Idar und Oberstein luabe ich zu meiner Information mehrere Male besucht und wichtige Nachrichten daselbst geesammelt.

Auch in dem dritten Abschnitt ïber Erkennung und Lnterscheidung der Edelsteine wurden sellsstverstïndlich die neuen Forschungsresultate nach Möglichkeit verwertet. Von großer Bedeutung war hier: Henry A. M i ers, Cantor lectures on precious stones, delivered before the society for the encouragement of arts, manufactures and commerce, 1596. Als neues Hilfsmittel wurden neben der Pyroelektrizität namentlich die Brechungskoeffizienten cingefuihrt und zu deren Bestimmung das kleine Le i ß sche Refraktometer beniitzt, das bei seiner zu dem vorliegenden Zweek bequemen Einrichtung auch von theoretisch minder Kundigen mit genïgender Sicherheit gehandhabt werden kann. Auch dieses Mal hahe ich jedoch die Erscheinungen im konvergenten polarisierten Licht nicht herangezogen. Sie sind ja an sich ron hervorragender Wichtigkeit, aber Erkundigungen bei Juwelieren haben mich zu der Überzeugung gebracht, daß, abgesehen von einzelnen besonders einfachen Fällen, die Methoden für den allgemeinen praktischen Gebrauch doch zu schwierig und zu kompliziert sind. Zudem glaube ich, daß es in fast allen Fällen möglich ist, ohne sie auszukommen.

An alle sachverstïndigen Leser richte ich zum Schluß die Bitte, mich auf etwaige Lücken, Unrichtigkeiten usw. aufmerksam machen zu wollen, damit bei einer vielleicht nötig werdenden weiteren Auflage Abhilfe geschaffen werden kann.

Marburg (Hessen) im Herbst 1909.

Max Bauer. 


\title{
Inhaltsübersicht.
}

\author{
Einleitung,
}

ERSTER TEIL

\section{Allgemeine Verhältnisse der Edelsteine.}

\section{Satioliche Eigensehaften und Vorkommen.}

A. Chemische Zusammensetzung . . . . . 7

B. Kristallformen . . . . . . . . . 9

C. Physikalische Figenschaften . . . . . 12

a) Spezifisches Gewicht . . . . . . 12

b) Spaltbarkeit . . . . . . . 29

c) Härte . . . . . . . . . . 33

d) Optische Eigenschaften . . . . . 38

1. Durchsichtigkeit . . . . . . 38

2. Glanz . . . . . . . . 41

3. Lichtbrechung . . . . . . . 43

4. Doppelbrechung . . . . . . 53

5. Brechungskoeffizienten . . . . 62

6. Farbe . . . . . . 67

7. Dichroismus . . . . . . . . 73

5. Besondere Licht- und Farbenerscheinungen . . . . . . . 77

(') Thermische, elektrische und magnetische

Eigenschaften
1. Thermische Eigenschaften Seite

2. Elektrische Eigenschaften . . $\$ 2$

3. Magnetismus . . . . . . . 84

D. Vorkommen der Edelsteine . . . . . $\$$

II. Verwendung der Edelsteine.

A. Verwendung in der Technik . . . . . Si

B. Verwendung zum Schmuck. . . . . . ST

a) Schliffformen . . . . . . 90

b) SchleifprozeB . . . . . . . 99

c) Bohren . . . . . . . . . . . 104

d) Bearbeitung auf der Drehbank . . . 104

e) Gravieren 104. Ätzen . . . . . . 106

f) Färben. Brennen . . . . . . 106

g) Fassen. Aufbringen . . . . . 108

h) Fehler der Edelsteine . . . . . 110

i) Künstliche Nachbildungen . . . . . 113

k) Verfälschungen, . . . . . . . 114

1) Wert uni Preis der Eilelsteinc. . . 122

Edelsteingewichte . . . . . . 124

Z WEITER TEIL.

\section{Beschreibung der einzelnen Edelsteine.}

Einleitung. Einteilung. . . . . . 131

Diamant . . . . . . . . 137

a) Eigenschaften des Diamants.

1. Chemisches Verhalten . . . 136

2. Kristallformen . . . . . . 143

3. Spezifisches Gewicht . . . . . 151

4. Spaltbarkeit . . . . . . 152

๖. Härte . . . . . . . . 153

6. Optische Eigenschaften . . . . 154

7. Elektrische und thermische Eigenschaften
Seite

b) Vorkommen des Diamants . . . 161

1. Indien . . . . . . . . 166

2. Brasilien . . . . . . 182

3. Guayana . . . . . . . 205

4. Südafrika . . . . . . . 209

๖. Bornen . . . . . . 274

6. Australien . . . . . . 25

7 Nordamerika . . . . . . . 257

8. Ural und Sibirien . . . . . 292

9. Lappland . . . . . . . . 294

10. Meteoriten . . . . . . 295 
Korund

c) Entstehung u. Nachbildungd. Diamants $\begin{array}{r}\text { Seito } \\ 296\end{array}$

d) Verwendung des Diamants . . . . 302

1. Verwendung zu Schmucksteinen . 302

2. Diamantschleiferei . . . . . 306

3. Verwendung in der Teehnik . . 310

4. Große und berïhmte Diamanten 312

5. Wert der Diamanten . . . . 322

6. Nachahmung und Verfïlschung . 328

Sapphir . . . . . . . . . 354

Andere Varietiiten des edlen Korunds . 369

Spinell. . . . . . . . . 372

Chrysoberyll . . . . . . . . 377

Chrysoberyll . . . . . . . . . 379

Alexandrit . . . . . . . . . 382

Beryll . . . . . . . . . . . . 384

Smaragd . . . . . . . . . 387

Edler Beryll (Aquamarin, Aquamarinchrysolith, Goldberyll) . . . . . 401

Euklas . . . . . . . . . 408

Phenakit . . . . . . . . . 410

Topas . . . . . . . . . 411

Zirkon (mit Hyacinth) . . . . . . 426

Granat . . . . . . . . . . 432

Hessonit (Kaneelstein) . . . . . . . 437

Spessartin . . . . . . . . . 439

Almandin . . . . . . . . . . . . 439

Pyrop (böhmischer Granat, Kaprubin usw.) 443

Demantoid mit Grossular, Melanit usw. . 450

Turmalin.... . . . . . . 452

Opal. . . . . . . . . 464

Edler Opal . . . . . . . . 466

Feueropal. . . . . . . . . 480

Andere Opalvarietäten (Gemeiner Opal,

Halbopal usw.) . . . . . . 482

Tiilkis . . . . . . . . . . 486

Zahntürkis . . . . . . . . . . 501

Variscit (Utahlith, Wardit) . . . . . 502

Kallainit (Kallais) . . . . . . . . 503

Lazulith . . . . . . . . . . . . 503

Olivin (Chrysolith, Peridot) . . . . 504

Cordierit . . . . . . . . . 509

Vesuvian (Idokras) . . . . . . . 511

Kalifornit . . . . . . . . 513

Axinit . . . . . . . . . . 513

Cyanit (Disthen, Sapparé) . . . . . . 514

Andalusit (mit Chiastolith) . . . . . . 516

Staturolith . . . . . . . . 517

Epidot (Pistazit) . . . . . . . . 518

Manganepiclot . . . . . . . . 5211

Zoisit......... . . . 520

Dioptas (Kupfersmaragd) . . . . . . 520

Kieselkupfer . . . . . . . . . . 521

Garnierit (Numeait) . . . . . . . . 521

Titanit (Sphen) . . . . . . . 521

Benituit . . . . . . . . . 522

Prehnit (mit Chlorastrolith und Zonochlorit) 523
Thomsonit (mit Lintouit) Seito

Lintonit) . . . . . . . 523

Natrolith . . . . . . . . . . . 524

Kicselzinkerz . . . . . . . . . 524

Zinkspat (Galmei, Smithsonit) . . . . . 524

Gruppe des Feldspats . . . . . . . 525

Amazonenstein . . . . . . . 526

Sonnenstein (Avanturinfeldspat). . . 527

Hondstein . . . . . . . . 530

Labradorisierender Feldspat . . 583

Labradorit . . . . . . . . 533

Eläolith . . . . . . . . . . 5iss

Cancrinit . . . . . . . . . . . 539

Lasurstein (lapis lazuli) . . . . . . . 539

Hauyn . . . . . . . . . . . . 547

Sodalith . . . . . . . . . . . . 547

Obsidian . . . . . . . . . 5 54

Moldawit (Bouteillenstein) . . . . . . 551

Gruppe des Pyroxens und des Amphibols 553

Hypersthen (mit Bronzit, Schillerspat und Diallag). . . . . . . . 553

Diopsid. . . . . . . . . 555

Spodumen. . . . . . . . . 557

Hiddenit (Lithionsmaragd) . . . . 554

Kunzit . . . . . . . . . . 559

Rhodonit 561, Lepidolith . . . . . 56)

Nephrit . . . . . . . . . . 5 tit

Jadeit (mit Chloromelanit) . . . . . 572

Familie des Quarzes. . . . . . . 575

A. Kristallisierter Quarz . . . . . 552

Bergkristall. . . . . . . 552

Rauchtopas. . . . . . . 559

Amethyst . . . . . . . . 591

Citrin. . . . . . . . 597

Rosenquarz . . . . . . . . . . $5 ! 99$

Prasem . . . . . . . 5 5!9

Sapphirquarz . . . . . . . . (it)0

Quarz mit Einschlüssen . . (6)(

Katzenauge . . . . . . . . 603

Tigerauge (mit Falkenauge) . . 6005

B. Dichter Quarz . . . . . . . . 607

Hornstein (m.Chrysopras u.Holzstein) $60 \%$

Jaspis . . . . . . . . . 611

Avanturin . . . . . . . . 615

C. Chalcedon . . . . . . . . 617

Gemeiner Chalcedon . . . . 620

Karneol . . . . . . . . 623

Plasma und Ileliotrop. . . 626

Achat (mit Onyx) . . . . . 62\%

Malachit... . . . . . . 646

Kupferlasur und Azurmalachit. . . . . 649

Faserkalk. Fasergips . . . . . (649)

Flukspat . . . . . . . . . 650

Apatit. . . . . . . . . . 653

Schwefelkies . . . . . . . . 654

Hämatit (mit Iserin) . . . . . . . . 655

Rutil. . . . . . . . . . . 656

Bernstein . . . . . . . . . 657

Gagat (Jet). . . . . . . . . . 683 
DRI'T'T'ER 'I'EIL.

Erkennung und Unterscheidung der Edelsteine.

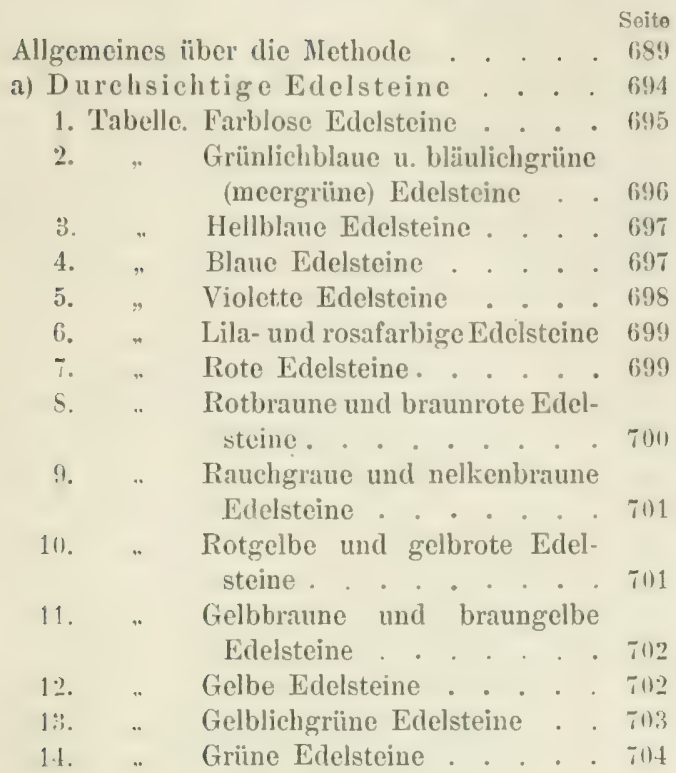

b) Durchscheinende und undurchsichtige Edelsteine...... . . Tll

1. Tabelle. Weiße und lichtgefürbte, sowie graue Edelsteine . . . . Tof;

2. . Blaue Edelsteine . . . . 706;

3. .. Grïne Edelsteine . . . . . 707

4. " Schwarze Edelsteine . . . T118

5. .. Gelbe und braune Edelsteine. Tim

6. .. Rosenrote, rote und lila Edelsteine . . . . . T1!!

ヶ. . Mehrfarbige Edelsteine . . . 70!

8. " Metallglänzende Edelsteine . :11)

c) Steine, die eine besondere Licht-

erscheinung zeigen . . . . . 711

1. Edelsteine mit einem Lichtstern (Sternsteine) . . . . . . . . . 711

2. Edelsteine mit wogendem Lichtschein . 711

3. Edelsteine mit metallischem Schiller . 711

4. Edelsteine mit metallisch schillernden Punkten . . . . . . . 711

5. Edelsteine mit buntem Farbenspiel. . $\$ 11$

\section{An hang.}

Seite

Pcrlen . . . . . . . . . 715

Eigenschaften und Entstehung der Perlen 715

Verwendung der Perlen . . . . . . 724

Perlenfischerei . . . . . . . . . 726

Süßwasserperlen . . . . . . . . . 730

Falsche Perlen. Imitationen . . . . . 732
Koito

allen . . . . . . . . T

Der Korallenstock . . . . . . . 734

Die lebende Koralle . . . . . . . . 754

Vorkommen der Korallen. . . . . . 743

Korallenfischerei. Verwendung der Koral-

len. Handel . . . . . . . . Itti 


\section{Tafelerklärung.}

\section{Tiffel I.}

(Titeltafel.)

Fig. 1. Diamant im Gestein, Brasilien . . 190

. 2. Diamant im Gestein, Südafrika . 225

. 3. Diamant, Bortkugel. . . . . 149

. 4. Diamant, Karbonat . . . . 149. 202

.. 5. Rubin, Kristall . . . . . . . 334

. 6. Rubin, geschliffen . . . . . . 334

7. Sapphir, Kristall . . . . . . 354

S. Sapphir, geschliffen . . . . 355

- 9. Spinell (Balasrubin), Kristall . . 375

. 10. Spinell (Rubinspinell), Kristall . . 374

11. Hyacinth, Kristall . . . . . 427

12. Hyacinth im Basalt. . . . . . 427

. 13. Zirk on, geschliffen . . . . . 427

Tafel II--IV. Schlifformen

Tafel II.

(Zwisehen S. 91 u. 92.)

Fig. 1-8 Brillantformen

. 1. Brillant, zweifaches Gut . . .

2. Engliseher zweifacher Brillant, zweifaehes Gut mit Stern

3. Brillant, dreifaches Gut, ältere Form

4. Brillant, dreifaches Gut, neuere Form, rund .............

5. Brillant, dreifaches Gut, neuere Form, oval

6. Brillant, dreifaches Gut, neuere Form, birnförmig .

7. Brillant, dreifaches Gut, neuere Form, dreiseitig

S. Il albbrillant .

\section{Tatel III.}

(Zwischen S. 96 11. 97.)

Fig. 1. Sternschnitt von Caire

2-4. Treppenschnit. .

2. Treppenschnitt vierseitig . .

3. Treppenschnitt sechsseitig. . .

4. 'Ireppensehnitt achtseitig . . .

5. Gemischter Schnitt . . .

6. Sehritt mit doppelten Facetten

i. Sehnitt mit verlängerten Brillantfacetten

S. Maltheserkren\%.
Tarel IV.

(Zwischen S. 98 u. 99.) Seite

Fig. 1-8. Rosette (Rose) . . . . . 96

1. Rose, rund . . . . . . . 97

2. Rose, birnförmig. . . . . . 97

3. Holländer Rose. . . . . . . 97

4. Brabanter Rose. . . . .

5. Rosen von anderer Form. . . . 97

7. Rose recoupée . . . . . 97

8. Kreuzrosette. . . . . . is

9. Doppelrosette (Pendeloque) . . 95

10. Brillolette . . . . . . 95

11-14. Tafelsteine . . . . . 95

"11. Tafelstein . . . . . 95

$\left.\begin{array}{cc}* & 12 . \\ . & 13 .\end{array}\right\}$ Diinnsteine . . . . . . . . 96

. 14. Tafelstein, oben brillantiert . . If

. $\begin{gathered}15 . \\ \text {." }\end{gathered}$, Dicksteine. . . . . . . 96

" 17-19. Mugeliger Schliff(Cabochon) 95

"17. Einfacher Cabochon (ausgeschlägelt) . . . . . . 9S

"18. Einfacher Cabochon mit Facetten . . . . . 95

"19. Doppelter Cabochon . . . 9s

\section{Tafel V.}

(Zwischen S. 178 u. 179.)

Diamantgrube bei Panna in Indien . . 17s

Tafel Vr.

(Zwischen S. 196 u. 197.)

Diamantwäscherei (Lavra) in Brasilien . 196

Tafiel VII.

(Zwischen S. 238 u. 239.)

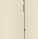

Kimberley-Grube (am Kap), 1572 . . 2037

Tafel VIII.

(Zwischen S. 242 u. 243.)

Oben: Kimberley-Grube, 1574 . . 241

Unten: Kimberley-Grube (Westseite), 18552211

\section{Tafel 1X.}

(Zwisehen S. 306 u. 34t.)

Natïrliche Größe der Brillanten von $1 / 4$ bis 100 Karat . . . . . . : $: 10$ J 
Tafel X, XI und XIa.

Groke Diamanten in natiorlicher Grölie

\section{Tafiel X.}

(Zwischen S. 314 ii. 315.)

rï.. 1. Orlow .

"2. Großmogul . . . . . . 313

. $\therefore$ schah . . . . . . . . . .

" 4. Kohinur, alte Form . . . . . 313

.. 5 Kohinur, nene lorm . . . . . 314

"6. Stewart . . . . . . 319

- 7. Diamant des Herrn E. Dresden 315

\section{Tafel X1.}

(Zwischen S. 318 u. 319.)

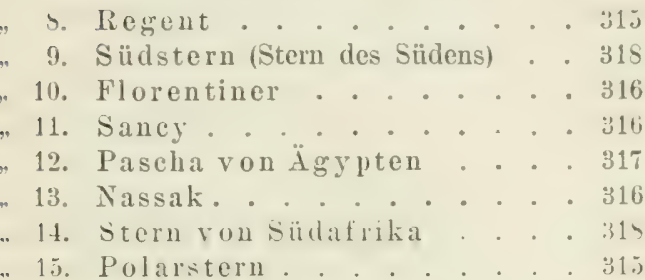

\section{Tafel XIa.}

(Zwischen S. 322 u. 323.)

Cullinan, natürliche Form und Größe 321

\section{Tafel XII.}

(Zwischen S. 402 u. 403.)

Fig. 1. Smaragd, Kristall im Kalkspat, Muzogrube . . . . . 357. 393

2. Smaragd, Kristall im Chloritschiefer, Habachtal . . . 357. 399

3. Smaragd, geschliffen . . 357. 359

4. Beryll (Goldberyll), Kristall . 402. 407

5. A quamarin, Kristall, Adun-Tschilon.

4102. 40:

6. Aquamarin, geschliffen . . . 402

8. Chrys oberyll (Alexandrit), Kristall, Tokowaja . . . . 378. 382

-9a. Alexandrit, geschliffen bei Tageslicht

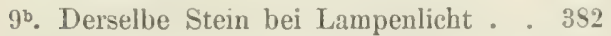

" 10. Chrysoberyll, Kristall, Brasilien 37s

"11. Chrysoberyll(Cymophan od. orient. Katzenauge), geschliffen.

\section{Tifel XIII.}

(Zwischen S. 424 u. 425.)

Fig. 1. Topas; blau, Mursinka 412, 415. 417

"2. Topas, dunkelgelb, Brasilien 412. 413 415. 417. 421. 597 .

3. Topas, hellgelb, Sachsen $412.415 .417 .41 \mathrm{~s}$

4. Rosatopas, Brasilien 412. 416. 417. 421

5 Euklas, Kristall, Brasilien. . . 409

\section{Tafel XIV.}

(Zwischen S. 148 u. 449.)

Fig. 1. Epidot, Kristall, Unter-Sulzbachtal . 519

2. Epidot, geschliffen . . . . 519
Fig. 3. A Imandin, Kristall im Gilimmerschicfer . . . . . . . 4 III

4. Almandin, geschliffen $\left.{ }^{2}\right)$. . 114

5. Pyrop (böhmischer Granat) im Serpentin . . . . . 4 443, 144

6. Pyrop (Kaprubin), geschliffen 443, 11

7. Hessonit (Kaneelstein), Kristalle, Alatal in Piemont . . 404. 435. 554

8. Hessonit (Kancelstein), geschliffen, (civion .

427. $4: 7$

9. Demantoid, roh, Ural . . . . 4.,1)

10. Demantoid, geschliffen . . . . 1:1

11. Chrysolith, Kristall . . . . . 511.)

12. Chrysolith, geschliffen . . . 5nti

Titel XY.

('Wwischen S. 464 u. 465.$)$

Fig. 1. Vesuvian, Kristall, Alatal in Piemont . . . . . . . 512

2. Vesuvian, von dort, geschliffen . 512

3. Vesuvian, vom Vesuv, geschliffen 512

4. Dioptas, Kristalle . . . . 21

5-9. T'urmalin, Kristalle,

ว. Turmalin, rosenrot und grün, Elba 462

6. Turmalin, rot, Sibirien . . . 454

7. Turmalin, grün, Brasilien . . 46?

8. T Turmalin, grünm.rot.Kern, Chester-

9. $\int$ field in Nassachusetts 455. 459. 460.462 10 u. 11. Turmalin, geschliffen.

"10. Turmalin, braun, Ceyion. . . . 4633

11. Turmalin, blau, Brasilien . . 4 (63:

\section{Titfel XVI.}

(Zwischen S. 454 u. 485.)

Fig. 1. Amazonenstein, Kristalle. . . 527

2. Labradorit, angeschliffen . . . 53.5

3. Labradorisierender Feldspat, angeschliffen . . . . . . . .333

4. Adular (Mondstein), roh, Ceylon . $\mathbf{j} 1$

5. Adular (Mondstein), geschliffen . j31

6. Edler Opal, roh, Australien 467. $47 ;$

7. Edler Opal, geschliffen, Australien

S. Edier Opal, roh, Ungarn - 467. 471

y. Edler 0 pal, geschliffen, Ungarn 467. 471

10. Feueropal, roh...... . tsl

11. Feueropal, geschliffen . . . th

\section{Tafel XVII.}

(Zwischen S. 586 u. 587.)

Bergkristalldruse, Dauphiné in Frankreich

\section{Tafel XVIII.}

(Zwischen S. 610 u. 611.)

Fig. 1. Amethyst, Kristall $(a)$ und geschliffen (b) . . . . . 591. 5966

2. Bergkristall mit Einschlïssen (Nadelstein) . . . . . . 553

1) S. die krklärung zu Taf. XVIII, Fig. 7. 


\section{TAFELERTLÄRUNG.}

Fig. 3. Rauchtopas, Kristalle (a), geschliffen $(b$ und $c) \ldots . . . .589$

4. Katzen a uge, braun $(a)$ und griin (b) geschliffen . . . . . . 604

5. Tigerauge, angeschliffen . . . . 605

6. Heliotrop, angeschliffen . . 626

7. Almandin, geschliffen . . . 440

Die Fig. 7 ist dureh ein Versehen auf diese Tafel gekommen; sie war für Tafel XIV. bestimmt.)

Tatel XIX.

(Zwischen S. 630 u. 631.)

Fig. a. Festungsachat, Oberstein . . 628

b. A chat mit horizont. Lagen, Brasilien 629

\section{Tafel XX}

(Zwischen S. 656 u. 657.)

Fig. 1. Lasurstein, angeschliffen . . . 539

.2. Türkis, blau, geschliffen . . . . 459

" 3. Türkis, grün, im Gestein . . . 490

"4. Malachit, $(a)$ roh, (b) angeschliffen 646

"5. 0nyx . . . . . . 641. 645

"6. Karneol mit eingraviertem Buchstaben . . . . 623. 642

„7. Kamee aus Karneolonyx . . 641

" 8. Chrysopras, geschliffen . . . 610

" 9. Bernstein, angeschliffen . . . 660 


\section{Verzeichnis der Textfiguren.}

Iig. 1. Pyknometer . . . . . 13

. 2. Zum Körbchen gebogener Platindraht zur Bestimmung des spezifischen Gewichts .

.. 3. Bänkeben, um eine gewöhnliche Wage als hydrostatische zur Bestimmung d. spezifischen Gewichts zu benutzen

4. Gewöhnliche Wage, mittelst des Bänkchens und des zum Körbchen gebogenen Platindrahts als hydrostatische Wage zur Bestimmung des spezifischen Gewichts eingerichtet

5. Westphalsche Wage zur Bestimmung des spezifischen Gewichts fester Körper .

6. Jollysche Federwage zur Bestimmung des spezifischen Gewichts .

7. Westphalsche Wage zur Bestimmung des spezifischen Gewichts von Fliissigkeiten

8. Spaltbarkeit eines Kalkspatkiistalls

9. Brechung des Lichs beim Eintritt in einen Edelstein

"10. Brechung des Lichts beim Austritt aus einem Edelstein..... 45

,11. Totalreflexion . . . . . . 45

, 12. Totalreflexion im Diamant an Luft

" 13. Totalreflexion im Diamant an Methylenjodid

„ 14. Durchgang des Lichts durch cine von zwei paralellen ebenen Flächen begrenzte Platte . . . . . . .

15. Durchgang des Lichts durch ein Prisma

16. Verschieden starke Ablenkung verschiedentarbiger Lichtstrahlen (Dispersion)

17. Dispersion des Lichts in einer planparallelen Platte

18. Dispersion des Lichts in einem Prisma; Bildung eines Spektrums durch prismatische Zerlegung des weißen Lichts

19. Perspektivische Ansicht des Ganges der Lichtstrahlen durch ein Prisma

20. Gang der Lichtstrahlen in einem Brillant
I'ig. 21. Doppelte Brechung eines Lichtstrahls

. 22. Gang der Lichtstrahlen in einer doppeltbrechenden planparallelen Platte

23. Doppelte Lichtbrechung in einem Spaltungsstück von Kalkspat (Doppelspat)

Srite

$\therefore: i$

24. Gang der Lichtstrahlen iu einem doppeltbrechenden Prisma . . . . .

25. Perspektivische Ansicht des Ganges der Lichtstrahlen durch ein doppeltbrechendes Prisma

26․ Bilder einer Lichtflamme durch einen doppeltbrechenden Edelstein. . .

$26^{b}$. Bilder einer Lichtflamme durch einen einfachbrechenden Edelstein

27. Polarisationsinstrument für paralleles Licht ( $1 / 3$ natürl. Größe)

28 u. 29. Gang der Lichtstrahlen im Refraktometer . . . . . . . . ti:

30. Refraktometer (Ansicht) . . . . ti.t

31. Refraktometer (vert. Durchschnitt) . tit

32. Dichroskop . . . . . . . . it

33. Brillant, (dreifacher, alte Form, Ansichten von oben, von der Seite und von unten)

35. Schliff des 20. Jahrhunderts (Jubiläumsschliff) .

36. Biseauschliff von verschiedener Form

37. Rosette (Ansicht von oben) . . . (1)

35. Rose recoupée von anderer Form . 57 39, $a-s$. Kristallformen des Diamants 144.14 .

40. Natürliche Größe oktaëdrischer Diamantkristalle von 1-1000 Karat . 15n

41. Diamantfelder in Ostinclien. . . 171

42. Diamantfelder in Brasilien . . . . 1s

43. Diamantfelder des Bezirks Diamantina int

44. Diamantfelder der Serra da Cincora in Bahia .

45. Diamantvorkommen in Sïdafrika (westlicher Teil) . . . . . . 니

46. Diamantgruben bei Kimberley . . 213

47. Schematischer Durchschnitt durch die Kimberley-Grube . . . . . . . 22.2

45. Bergbauliche Anlagen in der Kimberley-Grube . 
Fig.49. Bergbauliche Anlagen in der De Beers-Grube . . . . . . 24:

.. al. Diamantgruben d. Oranjefluß-Kolonic 2,2

. 51. Diamantgruben in Transvaal . . . 25.5

. 52. Diamantfelder der Insel Borneo . . 27.

.. 53. Diamantfelder von Australien. . . 24:3

51. Natiuliche Größe der Rosetten aus Diamant von $1-50$ Karat.

.j. Richtungen geringster Härte auf den Facetten eines Brillants

-56. Diamantoktaëder mit Tafel und Kalette als Vorbereitung für den Brillantschliff .

5i. Große Diamantafel von Tavernier

is. Südstern, Gestalt des rohen Steins in natïrl. Größje

. 59. Victoria-Diamant von $4571 / 2$ Karat vom Kap in natürl. Form und Größe

.6 60 De Beers-Diamant von $428 \%$ Karat vom Kap; schematische Form in natïrl. Gröle

.6 61. Tiffany-Brillant von $125^{1 / 2}$ Karat in natiirl. Größe

.. 1i2. Excelsior von $971^{3} / 4$ Karat aus der Jagersfontein-Grube; natürl. Form und Größe

.. 62a. Die drei größten aus dem Cullinan geschliffenen Steine (nat. Größe)

.63, $a-i$. Kristallformen des Korunds (Rubin, Sapphir usw.)

.. (il. Vorkommen des Rubins und Sapphirs in Birma und Siam

.6 65. Rubinfelder in Birma .

.. lif. Rubin- und Sapphirgruben von Mtuang Klung in Siam .

67. Rubingruben in Badakschan am oberen Oxus. . . . . .

. 65. Künstlich dargestellter Rubin nach Frémy . . . . . . . .

. 69. Vorkommen des Sapphirs und anderer Edelsteine auf der Insel Ceylon

$70, a-d$. Kristallformen des Spinells

i1. $a-c$. Kristallformen des Chryso. berylls . . . . . . . .

72, $a-e$. Kristallformen des Berylls (Smaragds, Aquamarins usw.)

7:) Smaragd des Herzogs von Devonshire in natürl. Größe

i. Smaragdgruben im Besitz der Regierung von Colombia . . . . .

7.). Smaragdgruben bei Muzo (Colombia)

7i. 'Teil einer Smaragdgrube bei Muzo (Colombia)
Fig.77. Vorkommen des Berylls bei Mursinka am Ural . . . . . . 405

78. Kristallform des Euklases . . . 409

$79, a-c$. Kristallformen des Phenakits 410

So, $a-d$. Kristallformen des Topases . 4!?

\$1. Vorkommen der gelben Topase in Brasilien . . . . . . . . . 4211

S2, $a-d$. Kristallformen des Zirkons . 126;

S3. $a-d$. Kristallformen des Granats . 431

S4. Karte der Verbreitung des böhmischen Granats

44:

85, $a-e$. Kristallformen des Turmalins tit

S6. Kristallform des Olivins (Chrysoliths) 5114

87. Kristallform des Cordierits . . 50!

88, $a-b$. Kristallformen des Vesuvians 5 il

89. Kristallform des Axinits . . . . .514

90. Kristallform des Cyanits . . . . 514

91. Kristallform des Andalusits . . . 516

92. Chiastolith . . . . . . . . 517

93, a-c. Kristallformen des Epidots . 519

94. Kristallform des Dioptases . . . 521

95, $a-c$. Kristallformen des Feldspats . 525

96. Kristallform des Amazonensteins . 527

. 97. Fundorte des Lasursteins in Badakschan . . . . . . . . . 543

320 "98. Lasursteingruben in der Gegend des Baikalsees

99. Vorkommen des Lasursteins an der Talaja (Baikalsee) .

"100, a-cl. Kristallformen des Quarzes

101. Seepterquarz "

102. Amethystgruben bei MLursinka im Ural $5 ! 5$

„103. Liebespfeile von der Wolfsinsel im Onegasee . . . . . . . (ji)1

. 104. Baumstein (Mokkastein) . . . . . (i22

" 105. Moderner Edelsteinschleifer(Lapidiir), Idar . . . . . . . . . 6336

"106. Innere Ansicht einer modernen Edelsteinschleiferei in Idar . . . . . 6337

"107. Äußere Ansicht einer alten Achatschleife im Idartale . . . . . bi:s

"105. Achatschleiferei in Oberstein (schematisch)

„109. Achatschlciferei von $\mathrm{Aug}$. Wintermantel in Waldkirch (Baden) . (640)

„110. Zerschneiden von Edelsteinen. . . (it)

"111. Edelsteinbohrer . . . . . . 6.42

"112. Edelsteingraveur . . . . . . 61:3

113. Antike Intaglie . . . . . . . . (ifl

114. 115. Antike Kameen . . . . . 644

Die Figuren 113, 114 u. 115 hatten anfäinglich die Nummen 107, 10S u. 109, st 7. B. auf Seite 105 . 


\section{EINLEITUNG.}

Lnter den in der Erdkruste vorkommenden Mineralien gibt es eine gewisse Anzahl, die sich durch besondere Schönheit vor den anderen auszeichnen und die daher seit den ältesten Zeiten zum Sichmuck des menschlichen Körpers und zur Verzierung von Gegenstïnden aller Art benutzt worden sind. Ihr schönes Aussehen beruht auf ihrer Durchsichtigkeit und Klarheit, auf dem Glanz, der Farbe oder einem Farbenspiel, das durch die an der Oherflïche der Steine reflektierten oder in ihrem Innern sich bewegenden Lichtstrahlen hervorgerufen wird. Diese Eigenschaften, die meist erst nach der Bearheitung der Steine durch Schleifen in ihrer ganzen Pracht hervortreten, sind zuweilen alle vereinigt, wie in dem so seltenen schön und lehhaft. z. H. rot oder hlau gefürbten Diamant, oder es fehlt namentlich das Farbenspiel und es wirken nur Durchsichtigkeit, Glanz und Farbe, wie beim Rubin, oder auch diese sind nicht besonders ausgeprägt. und es ist nur ein lehhafter, von der Färbung des Steines unahhängiger Farbenschiller vorhanden, wie heim edlen Opal, oder nur eine schöne Farhe an einer undurchsichtigen und wenig glänzenden Substanz, wie beim Türkis, oder endlich die Farbe tritt giinzlich zurïck und die Schönheit heruht auf Glanz, Durchsichtigkeit und Farbenspiel, wie bei den reinsten farblosen Diamanten.

Es ist aber nicht die Schönheit des Aussehens allein, die für die V'erwendl)arkeit eines Minerals zum Schmuchstein maßgehend ist. Diese darf natïrlich nicht fehlen, sie ist durchaus unerlifflich, aber es mïissen noch andere Eigenschaften hinzutreten, und zwar ror allem ein gewisser, nieht zu geringer Grad ron IIäte und Lnangreifbarkeit durch äufere Einflïsse und Einwirkungen überhaupt. Ein Strin, der iu rollkommen frischen Zustande den schı̈nsten Anblick gewährt, verliert diesen rasch, wenn er nicht die erforderliche Ü̈̈rte besitzt. Die beim Gebrauch unvermeidliche Berührung mit der IIand nimmt ihm in liurzer Zeit Glanz und Durchsichtigkeit und die Farbe wird unansehnlich. Anch wenn er ctwas härter ist. so daß ihm die Beriihrung mit der Hand nicht mehr schadet, greift ihn doch der alles ïberzielıende Staub an, der zu cinem grofen Teil aus kleinen Partikelchen des harten Minerals Quarz besteht. Ein Mineral, das nicht mindestens die Härte des Quarzes hat, wird also im allgemeinen zum Schmuckstein wenig geeignet sein; als das beste erweist sich eine noch gröliere Härte, die darnach so senannte Edelsteinhärte. Indessen ist hier auch die Terwendung des betreffend('in steines ron Einflub. Zu einer Brosehe z. B. wird sich auch ein weicheres Jineral noch eignen, während ein Ringstein, der, namentlich an dex rechten Hand getragen, viel weniger geschont werden kann, eine grü̈liere Hürte beansprucht. Ebensoweniæ darf aber cin solches Mineral in anderer Treise Angriffen von aufen unterliegren, namentlich darf es nicht von der Luft rerïndert werden; auch dadurch schwindet die ursprïngliche Schönheit mancher Mineralsulsstanzen rasch dahin.

Demnach werden zu Schmucksteinen zweckmäfigerweise nur solche Mineralien rerwendet. die mit der Schönheit des Aussehens eine grofe IÏ̈rte rerbinden und die 
ïberhaupt durch äußere Einflüsse keine Veränderung erleiden. Solehe durch Schönheit hervorragende und daher zum Schmuck benützte Mineralsulstanzen, die rermöge der ihnen innewohnenden Eigenschaften der IIärte und Unveränderlichkeit imstande sind, ihr Aussehen auch auf die Dauer zu bewahren, werden Edelsteine (Juwelen) genannt. Nicht allzu oft hat die Natur alle diese auscereichneten Eigensehaften miteinander vereinint; daher ist die Zahl der zu Schmueksteinen verwendbaren Mineralien gering im Verhältnis zu den vielen, die überhaupt bekannt sind, und ebenso finden sich auch im allgemeinen die wenigen hierher gehörigen Mineralspezies in der Erdkruste nur in geringer Menge als Seltenheiten vor, namentlich in etwas gröberen Stiicken und in einer Beschaffenleit, wie es für die Verwendung zum Schmuck erforderlich ist. So kommt es, daß diese Eilelsteine einen sehr hohen Wrert besitzen, daß sie mit zum Kostharsten gehören, das die Erde trä̈nt, und dal) sie daher nur den mit Glïcksgiitern reich Gesegneten in gröherem Lufange zuginglich sind. ITiermit ist aher nicht gesagt, dab nicht auch schr schüne Schmucksteine aus reichlich vorkommenden und daher billigen Mineralien gewonnen werden können. Aber wären diese auch noch so prächtig, sie würden doch höchstens vom großen Haufen zum Schmuck verwendet werden. Der Reiche verlangt zu diesem Zwecke etwas, wodurch er sich vor der Menge auszeichnen kann, etwas Kostbares, nur ihn Zugüngliches, also etwas Seltenes. Für einen Edelstein ist also die Seltenheit bis zu einem gewissen Grade eine wesentlich notwendige Eigensehaft. Die Natur steht aber hierin vollkommen im Einklang mit den Anforderungen der Menschen, denn die nach dem allgemeinen Lrteil schönsten Edelsteine, wie Rubin, Smaragd, Diamant u.s.w., sind auch gleichzeitig die seltensten und kostbarsten.

Nicht alle als Edelsteine benutzten Mineralien haben die hierzu nötiğen Eigenschaften in gleichem Maße. Je höher die Schönheit, die Hërte und die Unveränderlichkeit steigt und je sparsamer das Vorkommen schöner Stiicke ist, desto geschätzter ist der Stein ; solche, bei denen alle diese Eigenschaften den höchsten Grad erreichen - Diamant, Ruhin, Salphir, Smaragd und andere -, gelten ganz allgemein und ausnahmslos als die kostharsten und edelsten. Je mehr sich die anderen Steine hierin von den obengenannten entfernen, namentlich auch bezüglich der IIärte, desto weniger edel sind sie. Nach dieser Beschaffenheit unterscheidet man mehrere Gruppen in der Wertschätzung der verschiedemen Edelsteine, ror allem die beiden Hauptabteilungen der kostbaren ., Eldelsteine.* und die der weniger kostbaren ,IIalbedelsteine“. welehe letztere bei manchmal noch hoher Schönheit namentlich nur verhältnismäbig geringe Härte zeigen und häufiger in der Natur vorkommen.

Bei dieser Einteilung, die übrigens keineswegs ganz fest ist, so daß maneher Stein von dem einen noch zu den echten Edelsteinen, von dem andern schon zu den Halbedelsteinen serechnet wird, handelt es sich aber nicht um eine oder die andere Eigenschaft fiir sich allein, sondern um alle miteinander in ihrer Gesamtheit und in ihrem Zusammenwirken. Clanz, Durchsichtigkeit, Farbe und Farbenspiel, sowie Unveränderlichkeit und IIärte werden bei der Beurteilung des Wertes gegeneinander aboewogen, und daneben wird auch das mehr oder weniger häufige oder sparsame Vorkommen mit in Betracht gezogen. Daher ist der verhältnismäßjig nicht sehr harte Smaragd doch einer der kostbarsten Edelsteine wegen seiner wundervollen griinen Farbe und der grroben Seltenheit tadelloser Stiicke, und die weichen und undurehsichtigen edlen Opale und 'Türkise stehen als echte Edelsteine höher im Werte als der härtere und durchsichtige, aber auch in schönen Stiicken häufige Amethyst, der nur den Rang eines IIalbedelsteines einnimmt.

Wie die Eigenschaften, auf denen die edle Beschaffenheit beruht, in den verschiedenen als Edelsteine benitzten Mineralien nicht überall in gleichem Grade ausgebildet sind, so gilt dies auch von den verschiedenen Stücken jeder einzelnen der hierher zu rechnenden 


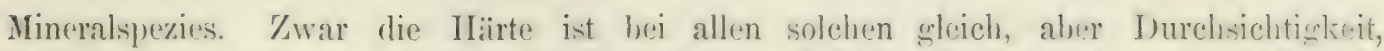
Färbung usw. kïnnen sehr verschieden sein, so daf manche Exemplare eines Minerals die sehönsten Edelsteine: liefern, während andere unscheinhar und triibe und daher zum Sehmuck völlig ungeedignet oder doch weniger schion und daher weniger wertroll sind als jene. So wibt es in der Minaralspezies Beryll aufer dem hierher gehoirigen kestharen Smaragd, von dem eben die liede war, noch den gelben Goldheryll und den blaficrünlichblauen Aquanarin, die in Aussehen hinter dem Smaragd zuriekstrhen, und die zwar ebenfalls noch als Edelstrine verwendet werden, aber doch erheblich geringeren Wert haben als dieser, und endlich den trüben und unschïn gefärbten enemeinem liseryll. der wegen seines unscheinloaren Ausselens keine Verwendung zum Schmuck moln findr.n kann und der daher nicht zu den Edelsteinen und nicht einmal zu den Ilalherdelsteinen zählt. Gamz allgemein pflewt man darnach bei vielen Mineralien die durchsichtigen Abarten als „edle" von den trüben, undurchsichtigen ,gemeinen" zu unterscheiden.

Wir haben soeben die natïrlichen Eigenschaften besprochen, die ein Minrral hahen mub, danit es zu den Edelsteinen erez̈hlit werden kann. Auber der Beschaffenlueit der Steine ist aber hicerbei noch etwas anderes in Betracht zu ziehen, was zu den raben der Natur war keine direkte Beziehung hat, aber doch für die Terwendung als Edelstein von sröfftem Einfluf ist: dies ist die II ode. Oft ohne daf Grïnde erkennbar wïren, wird ein heute kostharer Stein morwen trotz seiner vorziiglichen Eigenschaften auf dem Markte zurückgewiesen und fast ganz ron der Liste der Edelsteine gestrichen. so dal' er auch um billigen Preis keine Küufer mehr findet. Andererseits begïnstigrt der wechselnde Geschmack des Publikums heute ein Tineral, ron dessen Torhandensein gestern die Edelsteinhändler kaum eine Vorstellung hatten, und das daher neu in der Reihe der Edelsteine erscheint. Tamentlich bevorzugt die Mode vielfach abwechselnd, das eine Mal Diamanten, das andere Mal farljige Steine. Es ist nicht gar zu lange her, dalj die Juweliere keine anderen Edelsteine als Diamanten, Rubine, Sapplire, Smaragde, Granaten und gelegentlich vielleicht einen Topas oder Aquamarin in ihren Läden rorrätig hielten. Seitdem ist eine große Anderung eingetreten, und fast alle in diesem Bucbe, beschriebenen (im Inhaltsverzeichnis übersichtlich zusammengestellten), meist farbigen Steine balen größere oder geringere Bedeutung für den Edelsteinhandel erlangt. Man schleift jetzt alle Mineralien, die sich vermöge ihrer natürlichen Beschaffenheit nur einigermaljen zu Schmucksteinen eignen, und namentlich werden in einzelnen Ländern einheimische, anderwärts gar nicht beachtete Steine vielfach bevolzugt und als Produkte des raterländischen Bodens ganz besonders gescbätzt. Wir werden hierfür weiterhin manche Beispiele kennen zu lernen haben.

So ist also die Zahl der zu den Edelsteinen zu rechnenden Mineralien nicht zu allen Zeiten dieselbe gewesen, und es sind auch nicht immer dieselben Mineralien, die dabei in Frage kommen. Aber die wichtigsten, schönsten und kostbarsten, die heute im Edelsteinhandel die größte Bedeutung haben, waren auch schon im Altertum die beliebtesten. Die besonders hervorragenden Eigenschaften, durch die sie ausgezeichnet sind, haben sich doch mächtiger erwiesen als die verïnderlichen Anforderungen des Geschmackes und der Node. Es sind die obengenannten Steine, zu denen nur noch wenige, vor allem der edle Opal und einige Halbedelsteine aus der Reihe der Quarzmineralien (Bergkrystall, Amethyst, Achat mit Onyx usw.) zu zählen sind.

Es gibt noch einige andere Substanzen, die in ganz ähnlicher Weise wie die Edelsteine zum Schmuck rerwendet werden, wie ror allem die Perlen und die Korallen. Sie sind aber keine Edelsteine, sie gehören nicht dem Mineralreich an, sondern sind Produkte des tierischen Lebens und werden daher hier nur anhangsweise betrachtet werden. Dagegen 
wird der Bernste in seine Stelle finden, obwohl auch er als ein Harz vorweltlicher Bäume eigentlich nicht zu den Mineralkörpern gehört. Er wird aber wie diese aus der Erde gegraben und daher einer allgemeinen Gewohnheit entsprechend mit anderen ähnlichen Substanzen zusammen auch mit zu den Edelsteinen gerechnet, und in der Mineralogie abgehandelt.

Da die Edelsteine Nineralien sind, so ist die Elelsteinkunde ein Zweig der Mineralogrie. Es handelt sich bei der Kenntnis der Edelsteine zunächst um die Erforsehung ihrer natürlichen Eigenschaften, der chemischen Zusamnensetzung, der Kristallformen, des physikalischen Verhaltens in Bcziehung auf das spezifische Gewicht, die Härte und Spaltharkeit, die Wirkung der Lichtstrahlen usw., ebenso aber auch um die Ermittelung des Vorkommens in der Erdkruste, der Art und Weise, wie sie in dieser eingelagert sind, und der Orte, wo sie sich finden. Da aber bei den Edelsteinen die praktische Verwendung von wesentlichster Bedentung ist, so hat sich die Edelsteinkunde auch mit dieser zu beschäftigen, mit der Art der Gewinnung und der Bearbeitung der Edelsteine und der Benützung derselben zu Schmuckgegenständen der verschiedensten Art. Dadurch gewinnt die Edelsteinkunde auch die engste Beziehung zur Technologie.

Ein sehr wichtiger Zweig der Edelsteinkunde ist endlich noch die Erkennung der einzelnen Edelsteine und ihre sichere Unterscheidung von anderen ähnlich aussehenden, sowie von betrigerischen Nachbildungen in Glas und anderen wertlosen Materialien.

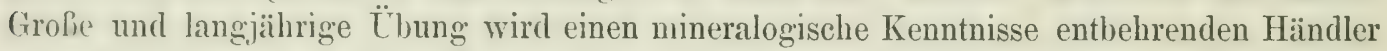
oder Liebhaber in den Stand setzen, einen vorliegenden Stein gewissermaßen dureh ein unbewußtes Gefühl nach den unbestimmten, genauerer Beschreibung und Feststellung unzı mit Sicherheit zu erkennen. Aber in nicht seltenen Fällen werden dabei Zweifel übrig bleiben und sogar Irrtïmer begangen werden, die ein wissenschaftlich gebildeter Mineraloge likcht vermeiden könnte durch die zweckentsprechende Anwendung der strengen auf Maß und Zahl gegrindeten Untersuchungsmethoden seiner Wissenschaft auf die Edelsteine. Es ist claher jeden, der sich mit diesen kostbaren Körpern beschäftigen will, bei deren Bestimmung ein einziger Milggriff die allerunangenehmsten pekuniäien Folgen haben kann, nicht grenug anzuraten, sich wenigstens mit den hier einschlägigen Lehren der Mlineralogie einigermahen vertraut zu machen, um so melır als diese auch wichtige Fingerzeige zu geben imstande ist für die geeignetste und zweckmäßigste Bearbeitung der rohen Steine, wodurch deren Schönheit erst zur vollen Entfaltung kommt.

Daher werden im folgenden in einem ersten Teil die für die Kenntnis der Edelsteine hesomders wichtigen Eigenschaften der Mineralien in allgemeinen auseinandergesetzt und hicran dir allgemeinen Verhältnisse des Vorkommens, der Bearbeitung und der Verwendung angeschlossen. Sodann folgt in einem zweiten T'eil die spezielle Beschreibung der als Edclsteine dienenden Mineralien mit besonderer Berïcksichtigung der hierbei in Betracht kommonden J'unkte. mul endlich wird in einem dritten Teil eine spezielle Anweisung werecten werden, Edlelsteine der Art nach richtig zu bestimmen und von anderen Edelsteinen mol sonstigen Sulstanzen, namentlich von Imitationen durch Glasfliisse etc., zu unterscheiden. 


\section{ERSTER TEIL.}

Allgemeine Verhältnisse der Edelsteine. 



\section{Natürliche Eigenschaften und Vorkommen.}

\section{A. Chemische Zusammensetzung.}

Die Edelsteine unterscheiden sich in Beziehung auf die allgemeinen Verhältnisse ihrer chemischen Zusammensetzung in nichts wesentlichem von den anderen Mineralien. Sie bestehen aus denselhen chemischen Elementen, wie diese, und die Elemente sind auch nach denselben Gesetzen miteinander rerbunden. Man hat wohl frïher (inmal geglaul)t, dalj die durch ihre hesonders hervorragenden Eigenschaften ausgezeichneten edlen Steine auch aus besonders edlen Grundsubstanzen aufgebaut seien und nabm eine sogenannte Edelerde als Hauptbestandteil aller Edelsteine an. Es hat sich aber bei deren genauer chemischer Untersuchung berausgestellt, daß es im Gegenteil die allergemeinsten, an sich in kleinen Uengen ganz wertlosen Stoffe, wie Kohlenstoff, Thonerde und andere sind, ron denen gerade die kostbarsten Steine gebildet werden. Die edlen Metalle, Gold, Ilatin u. s. w., fehlen in der Zusammensetzung der Edelsteine vollkommen und auch die selteneren der nicht zu den edeln zu rechnenden Elemente gehören zu den auljergewöhnlichen Vorkommnissen. Von ilmen sind eigentlich nur zwei ron einer gewissen Bedeutung: das Zirkonium im Hyacinth und das Beryllium im Smaragd und Aquamarin und in einigen anderen seltener angewendeten Edelsteinen.

Im übrigen ist die Zusammensetzung bei den einzelnen hierhergehürigen Steinen sehr verschieden. Bald ist sie sehr einfach, bald kompliziert durch das Zusammentreten sehr zahlreicher Grundbestandteile. Der wichtigste Edelstein, der Diamant, ist zugleich auch der chemisch einfachste. Er ist ein Element, und zwar der allgemein und massenhaft verbreitete Kohlenstoff, allerdings hier in einer durch ganz besondere Eigenschaften ausgezeichneten Ausbildungsform, die sich von clem ebenfalls nur aus Koblenstoff bestehenden Graphit und von der gewöhnlichen Kohle u. s. w. sehr wesentlich durch seine Kristallisation und die anderen damit zusammenhängenden Eigenschaften unterscheidet. Der Diamant ist der einzige Edelstein, zu dessen chemischem Bestande nur ein einziges Element gehört, in allen anderen finden sich deren mindestens zwei, und manche enthalten sogar eine ziemlich große Zahl von diesen chemischen Grundsubstanzen.

Aus zwei Elementen zusammengesetzt und daher ebenfalls noch eine sehr einfache Verbindung darstellend, ist der seltenste und kostbarste aller Edelsteine, der rote Rubin, und ebenso der von diesem chemisch nicht verschiedene blaue Sapphir. Beide, nur in der Farbe voneinander abweichend, bestehen aus dem in neuerer Zeit zu so großer Bedeutung gelangten und so viel verwendeten, den Hauptbestandteil des Thons und vieler anderer der gemeinsten und verbreitesten Mineralien bildenden Metall Aluminium und aus Sauerstoff: sie sind Aluminiumoxyd oder Thonerde, die auch in zahlreichen anderen wertvollen Edelsteinen als wesentlicher Bestandteil neben anderen vorkommt. Ein ähnlich einfaches Oxyd, und zwar des Elements Silicium, stellen alle von der in der Erdliruste so weit verbreiteten Kieselsüure, dem Siliciumdioxyd, gebildeten Edelsteine dar, wie Berg- 
kristall, Amethyst, Achat, Opal und andere, und nicht viel komplizierter ist auch der Zirkon, der Spinell und der Chrysoberyll. Während so die Mineralklasse der Oxyde von größerer Bedentung ist, gibt es in der Abteilung der Schwefelmetalle und in der der Haloidverbindungen, der Verbindungen der Metalle mit Chlor, Brom, Jod und Fluor, kein Glied, das die für einen Edelstein erforderlichen Eigenschaften in hervorragendem Maße besitzt, und dasselbe gilt für die im Mineralreiche sonst so wiehtige Crruppe der Sulfate, der Verbindungen der Schwefelsäure. Zwar werden cinzelne Mineralien aus allen diesen Abteilungen gelegrentlich als Schmucksteine benuitzt, aber keines hat eine nennenswerte Bedeutung. Besonders wichtign ist dageren die Klasse der Silikate, zu der der Smaragd, der Granat, Chrysolith, Topas und manche andere gehëren und ron denen einzelne, vor allem der Turmalin, sich durch sanz besonders lomplizierte Zusammensetzung aus sehr zahlreichen Elementen auszeichnen. Von den anderen Abteilungen des Mineralreiches ist schließlich noch die der Phosphate zu nennem. Diese enthält fast nur einen einzigen, aber einen sehr wichtigen und wertvollen Edelstein, den Tiurkis, in dem die Phosphorsïure mit Thonerde und Wasser verbunden ist. Der' Türkis ist zugleich auch der einzige der kostbaren Edelsteine, zu dessen notwendicren Bestandteilen eine erhebliche Menge Wasser gehört, alle anderen sind wasserfrei. Von den weniger wichtigen ist auch der Malachit wasserhaltig, der zugleich den Irauptreprïsentanten aus der Abteilung der Karbonate, der Verbindungen der Koblensäure, darstellt.

In allewemeine'n ist zur Bestimmung eines vorliegendlen Steines und zur Erkennung seiner Zugehörigkeit zu einer Mineralspezies die chemische $A$ nalyse ein vortreffliches und in manchen Fällen das einzige sichere Mittel. Für die Lntersuchung der Edelsteme ist aber diese Methode nur in sehr beschrïnktem Mabe brauchbar, weil ihre Anwendung die vollkommene Zerstürung der Substanz zur Folge hat, und dies muss natürlich bei solchen Kostharkeiten durehaus vermieden werden. Zwar kamn man zuweilen von rohen Stïcken kleine 'Teile almehmen und chemische Versuche damit anstellen, aber bei greschliffenen Steinen ist dies untunlich, und so ist die Chemie für die bestimmung der Edelsteine von beschränkter Bedeutung.

Am wichtigsten ist in dieser Beziehung noch die Einwirkung von Säuren. Ver-

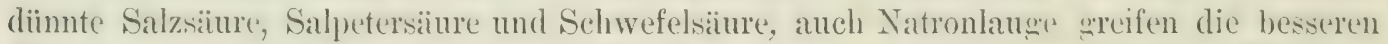
Edelsteme in allgremeinen nicht an, vielleicht nut Ausmahme des Chrysuliths und Türkises. Im konzentrierten Zustand, und namentlich in der Wärme wirken sie viel stärker und es ist s.ut, die Steine dem nicht auszusetzen. Der Dianıant, Korund usw. widerstehen allen derartigen Eingriffen vollkommen. Zur Unterseheidung verschiedener Arten ron Edelsteincm benutzt man gexenwärtio zuweilen mohr oder weniger konzentrierte Flubsäure unter dem Namen (ilasätztinte oder kurz Ätztinte. Diese wirkt lüsend auf alle ans remer Kieselsämre bestelemelen Steine, wie Opal, Berockrystall, Amethyst, ("itrin, Ranehtopas, aber auch anf Mondstein, Chrysolith, T'ïrkis und andere, läbt aber namentlich die kost-

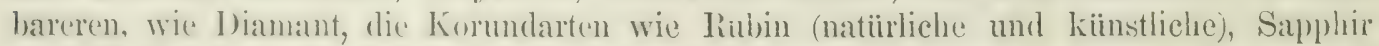
usw., Smaraged und die übrigen Berylle, ferner spinell, Turmalin, Granat, Kunzit und

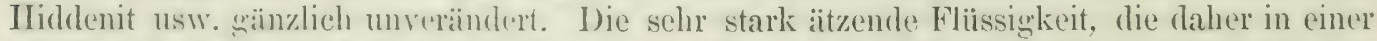
Platin- oder Kantschukflasche anflewahrt werden muls, wird ïber die in einem kleinen Platin-, Blei- odter Celluloidgefäb liegrenden Strine gegossen und diese werden nach etwa einer Minute vorsichtig mit einer Zamge herausgenommen, abgewaschen und getrocknet. Gehören sie zu der ersteren Gruple), damn sind sie oberflächlich angeëitzt und matt, was namentlieh bei geschliffenen Exemplaren deutlich hervortritt. Die Steine der letzteren Gruppe bleiben unveräindert glainzend. Bei der Manipulation mub mit grober sorgafalt darauf gesehen werden, dalb nicht ein 'Tropfen der scharfen Siiure auf die Itaut kommt, wo sie unangenehme Geschwiure hervorbringen wïrde. 


\section{B. Kristallformen.}

Die meisten (hemischen Verbindungen und so anch der eröbte Teil der Mineralien erscheinen in ihrem ursprïnglichen natürlichen Zustande vielfach als Kristalle, d. h. in

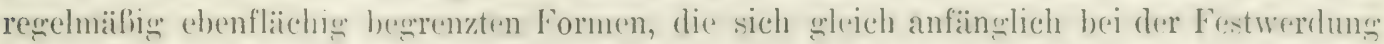
dieser Körper ohne alles äulere Zutum lediglich durch die inneren Kriafte der betreffenden Substanz gebildet haben. Diese regelmäligen Formen nennt man Kristallformen und die Verbindungen, an denen sier vorkommen, kristallisiert. Die Edelsteine sind mit ganz geringen Ausnahmen alle kristallisiert: Diamant, Rubin, Sapphir, Smarawd, Topas usw. finden sich als Kristalle und zeigen Kristallformen in schönster Aushildung. Nur wenigo vor allem der () pal, erseheinen niemals in solcher ehenflïchiger Begrenzunis, sondern

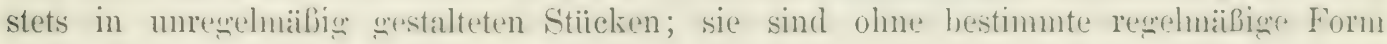
oder, wie man zu sagen pflegt, amorph.

Krystallisierte körper unterscheiden sich also ron den amorphen dadurch, dafi nur sie, nicht aber die letzteren die Fähigkeit haben, bei ihrer Festwerdung dureh die ilmen

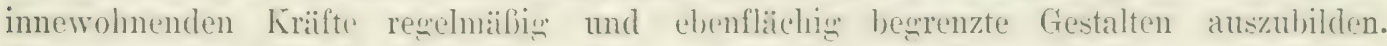
Diese inneren Kräfte bedingen aber in den kristallisierten Körpern auberden noch gewisse Besonderheiten der physikalisehen Beschaffenheit, die hei den amorphen Kürpern sich nicht finden, und aus denen ein wesentlicher innerer Unterschied dieser beiden Gruppen ron Substanzen hervoreht. Man kann sie daran voneinander unterscheiden und

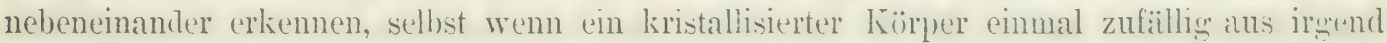
einem Grunde keine regelmäßige Begrenzung besitzen sollte.

Diese kann felslen, wemn die äuferen Umstïnde ihrer Ausbildung hinderlich waren, wenn z. B. ein der Kristallisation fähiger Kärper sich in einem engern Ramme ausbild te. in dem sich die Kristalle nicht frei und unselnindert nach allen Richtungen entwickeln kounten, oder wenn die ursprünglich rorhanden grewesenen dbenen Begrenzmosflächen dureh Abschlagen mit den Itammer odter dureh Abschleifen entfernt worden sind. In beiden Fïllen hat die Substanz zwar lieme rexehuälige urspriungliche Gestalt, aber doeh die inneren Eigenschaften eines kristallisierten Körper's, und diese sind es, auf die es ankommt, die äubere Form ist nur der sichthare Auschuck jener inneren Besehaffenheit, die das ITesen der Fristallisation in fregensatz zur anorphen Beschaffenheit ausmacht. Man bezeichnet eimen kristallisierten Körpex, dem die regelmialiige äulfere Begrenzung fehlt, als kristallinisch oder derb, während ein solcher mit der ibm zuliommenden regelmäßig ebenflïchigen Form ein Kristall genannt wird. Kristallinische oder derbe Massen unterscheiden sich ron amorphen nicht mehr durch die Form, aber immer noch sehr wesentlich dureh ihre physikalischen Eigenschaften, wie wir unten fuir einzelne Fälle noch weiter sehen werden. Kristalle sind dagexen an ihrer ebenflächigen Begrenzung ohne weiteres auf den ersten Blick als kristallisiert zu erkennen.

Die genaue Kemntnis der Kristalle und dor Cretzmïbigkeiten, die in deren äuferer ebenflächiger begrenzung herschen, bilden den Gegenstand einer besonderen Wissenschaft, der Kristallographie. Diese ist eine uncrläbliche Hilfswissenschaft für alle, die sich mit den natürlichen Verhältnissen der Mineralien und speziell der Edelsteine bekannt machen wollen.

Bei der Untersuchung der Formen der einzelnen durch ihre chemische Zusammensetzung charakterisierten und ron anderen unterschiedenen kristallisierten Körpern hat sich herausgestellt, daf jedem ron ihnen und somit auch jedem Edelstein eine ganz besondere, bestimmte Kristallform zukonmt, oder, besser gesagt, eine Reihe von Kristallformen, die in einem gesetzmäfigen Zusammenhang miteinander stele’n und die daher aus einander abgeleitet rerden kïnnen. Anders zusammengesetzte Körper haben im allgemeinen ander 
Kristallformen oder Reiben von Kristallformen, die zwar wieder unter sich, aber nicht mit den Formen jener anderen Verbindungen in gesetzmäßigem Zusammenhange sich befinden und die sich daher zwar auseinander, aber nicht aus den letzteren nach den fiesetzen der Kristallographie ableiten lassen.

Verschieden zusammengesetzte Körper sind also nicht nur durch ihre Zusammensetzung, sondern auch durch die ihnen eigentïmlichen Kristallformen gekennzeichnet. Man kann daher die verschiedenen Förper an ihrer Kristallform erkennen und voneinander unterscheiden und so namentlich auch die verschiedenen Arten von Edelsteinen, wenn sie deutlich auskristallisiert sind. Es leuchtet somit ein, daß die Kenntnis der kristallographischen Terhältnisse der Edelsteine nicht nur theoretisch von Wichtigkeit ist, sondern dass sie auch praktisch für den Kïufer roher Steine die allergrößte Bedeutung haben kann, da der Kundigre die Echtheit oder Unechtheit eines solchen an seiner Form auf den ersten Blick zu erkennen imstande ist. Dies ist um so wichtiger, als bei der Untersuchung der Kristallformen der Stein nicht die mindeste Beschärligung erleidet. Allerdinģs ist dabei rorausgesetzt, dab die regelmäßige Kristallform an den zur Untersuchung vorliegenden Stücken ausgebildet ist. Ist dies nicht der Fall, liegen sie, wie es häufig* vorkommt, nur in Form unregelnäßiger derber Fragmente oder abgerollter Brocken vor, dann ist man ausschließlich auf die unten zu besprechenden physikalischen Eigenschaften angewiesen, um die Natur des betreffenden Stïckes wissenschaftlich zu bestimmen.

Leider ist es nicht möglich, eine kurze allgemein verständliche Darstellung der gesetzmïssigen Beziehungen zu geben, die in der Kristallwelt herrschen. Ebensowenig ist es in Plan dieses Buches gelegen und in Anbetracht seines beschränkten Umfanges gestattet, auf eine ausführliche Auseinandersetzung der Sätze der Kristallographie einzugehen. Sie mul) also hier chensogut, wie manche andere notwendige Hilfswisssenschaft, wenigstens in ihren Elementen als bekannt vorausgesetzt werden, was um so eher tunlich ist, als zahlireiche Spezialwerke über sie vollständige Auskunft geben und auch fast in jedem Lehrbuch der Mineralogie eine genügende Darstellung derselben zu finden ist.

Es sei hier nur in Kürze erwähnt, daß man die allermeisten Kristallformen durch Ehenen in je zwei einander vollkommen gleiche Hälften zerschnitten denken kann, von denen die eine genau das Spiegelbild der anderen ist. Solche Ebenen, Symmetrieebenen, sind in verschiedener Zahl vorhanden. Je mehr Symmetrieebenen an einer Kristallform möglich sind, desto symmetrischer ist diese, desto höher ist der Grad der Symmetrie. Man falit alle Kristallformen, die sich durch gleichviele Ebenen symmetrisch teilen lassen, zusammen und nennt den Inbegegriff aller dieser Formen von gleicher Symmetrie ein Kristallsystem. Solcher giht es im ganzen sechs; einem von ihnen muß jedes Mineral und speziell jeder kristallisierte Edelstein notwendig angehören. Sie sind mit besonderen Namen belegt worden, und zwar sind es die folgenden:

1. das reguläre System mit 9 Symmetrieebenen;

2 das hexagonale System mit 7 Symmetrieebenen;

3. das quadratische System mit 5 Symmetrieebenen;

4. das rhombische System mit 3 Symmetrieebenen;

5. das monokline System mit 1 Symmetrieebene;

6. das trikline System mit 0 Symmetrieebenen.

Zuweilen kommt es vor, dal die von der Symmetrie erforderten Flïehen der Kristallformen nur zur Ilälfte ausgebildet sind. Es entstehen dann neue, abgeleitetete Formen, div man als hemiëdrische oder hallofläichige von den mit allen dureh die symmetrie Exerebenen Flächen versehenen holö̈drischen oder vollflächigen unterscheidet. An den hemiëdrischen Formen ist zuweile'n wieder nur die II:ilfte der Flächen ausgebildet, die 
eigentlich vorhanden sein mübten; dann erhält man tetartö̈rlische oder viertelflächigre Gestalten. Wie alle die vollflächigen Abteilungen der Kristallformen, so kommen auch an den versehiedenen Edelsteinen manche halb- und viertelflächigre (iestalten vor. Stets gehören sämtliche an einer Art von Edelsteinen, z. B. an allen Diamanten, allen Simaragden usw. sich findenden Formen demselben Kristallsystem an, sie haben alle dieselbe Symmetrie oder sie zoigen erentuell dieselhe Art der halb- oder viertelfläichisen Ausbildung. Auch diese Hemiëdrien und Tetartö̈drien sind mit besonderen Namen belegt worden, auf die aber hier nicht weiter eingegangen werden soll.

Nicht selten ist es, dab zwei gleichgebildete Krystalle eines und desselhen Minerals mit einer Fläche so aneinander gewachsen sind, dass sie nach dieser symmetrisch zueinander liegen, dab also gewissermaßen der eine Krystall das Spiegelbild des anderen bildet, wie es z. B. Figur 7), d für den Spinell darstellt. Eine derartige Grupıe zweier Kristalle nennt man einen Zwilling. Ex ist meist daran kenntlich, dab die an der gemeinsamen Fläche liegenden Kristallflächen zum Teil einspringende Winkel bilden, die bei einfachen Kristallindividuen nicht vorkommen. Zuweilen wächst an das zweite Individuum in dersselben Wreise ein drittes an, dann hat man einen Drilling; ähnlich entstehen Vierlinge usw. in allgemeinen Viellinge. Diese Verwachsungen sind oft sehr kompliziert und es ist dann nicht leicht und nur durch genaue Untersuchung zu erkennen, in welcher. Weise eine solche Gruppe aus den verschiedenen Einzelkristallen aufgebaut ist.

Bei der Beschreibung der einzelnen Edelsteine werden auch deren wichtiorste Kristallformen angegeben und abgebildet werden. Sie sind zu wichtig, als dals es erlaubt wäre, sie mit Stilischweigen zu ül)ergehen. Sie werden denen leicht verständlich sein, die sich, wenn auch nur einigermaßen, mit den Gesetzen der Kristallographie und mit den dabei vorkommenden Bezeichnungen bekannt gemacht haben. Solche Leser, bei denen dies nicht der Fall ist, werden in dem Verständnis der einzelnen Formen eines Edelsteines und des zwischen diesen bestehenden Zusammenhangs Schwierigkeiten finden. Da aber alle kristallographischen Angaben auf kleinem Raume beisammenstehen, so können sie leicht iiberschlagen werden. Die Torstellung von dem betreffenden Edelsteine in seinem rohen Zustande wird allerdings dann unvollstïndig sein und nicht vollkommen genügen, doch werden die der Beschreibung beigefügten Abbildungen jedermann wenigstens eine ungeführe Vorstellung von dem Aussehen der ungeschliffenen kristallisierten Edelsteine in ihren Kristallgestalten geben.

Amorphe Substanzen, wie der Opal, die aus eigner Kraft keine regelmäßig ebenflächige Begrenzung bilden können, zeigen zuweilen rundlige, kugelige, traubige, nierenförmige, knollige usw. Oberflächen,-meist ist aber in ihrer Begrenzung lieine irgendwie geartete Regelmäligkeit vorhanden.

Vielfach sind kristallisierte Körper und so auch manche Edelsteine nicht durchweg einheitlich gebaut; sie bestehen nicht aus einem einzigen Kristallindividuum, sondern aus mehreren solchen in unregelmäliger Verwachsung. Eine derartige Vereinigung mehrerer oder vieler kristallisierter Individuen zu einem fest zusammenhaftenden Ganzen wird ein kristallinisches oder derbes Agrregat genannt. Die einzelnen Zusanmensetzungsstiicke dieser Agrgregate sind verschieden gestaltet, bald nach allen Richtungen ziemlich gleichmäßig ausdehnt, bald in einer Richtung stark verlängert oder verkïrzt. Darnach unterscheidet man kürnige, stenglige, faserige, schalige, schuppige usw. Aggregate. Auch die Grölie der Zusammensetzungsstiicke ist verschieden, worauf die Bezeichnung grobkörnig, feinkörnig usw. beruht. Nanchmal sind sie so klein, daß man sie mit blohem Auge oder mit der Lupe gar nicht mehr erkennen kann. Die Masse sieht dann aus, wie wenn sie vollkommen eiuheitlich gebaut wäre, aber die Betrachtung unter dem Mikroskop läßt leicht erkennen, daß sie aus zahlreichen winzigen Körnchen, Fäserchen, 
Schüppehen usw. zusammengesetzt ist, während ein wirklich einheitlicher Körper stets auch unter dem Mikroskop einen vollkommen einheitlichen Bau zeigt. Solche Agregate werden dicht genannt. Sir besitzen zuweilen ebenfalls die rundlichen Oberflichengestalten, die bei amoryhen Körpern rorkommen, rexelmälige Kristallflächen fehlen stets; einzehe Individuen, die an dem Aufhau des Awregrats teilnehmen, können wohl solche haben, nicht aber das Aggregat als solehes.

Bei derartigen mikroskopischen Untersuehungen ist es vielfach notwendig, aus dem in dickeren Stiicken häufium undurchsichtigen Stein eine so diinne Platte herzustellen, daß das Licht ungehindert hindureherehen kamm. Nan schleift zu diesem Zwecke einen Splitter desselben von zwei entgegengesetzten Seiten her an und versieht ilun so mit zwei parallelen Flïchen. Ton diesen wird die eine poliert und mit Kanadabalsam auf eine kleine ebene Glastafel selkeht. Dann wirl die andere Flïche imuer weiter abgeschliffen, das Plättchen wird dadurch immer dünner und endlich so dünn, daß es durchsichtig ist. Man kann, wemn anch diese zweite Fläche poliert ist, durch das Plättehen hindureh lesen, das in diesem Falle oft nur noch einige IIundertstel Millimeter diek ist. Es wird sehlieljlich noch zmm Sehutze mittelst Kanadabalsam mit einem dïnnen Deckelüischen überklebt, und num ist das l'räiparat, dex I) iinnschliff. für die mikroskopische Untersuchung fertig. Diese hat schon viele der wichtigsten und interessantesten Aufschlïsse ïber die Besehaffenheit der Mineralkörper und inshesondere auch mancher Edelsteine sexpeben; speziell hat man in dirser Weise die Natur des Türkis, des Chaleedons und Achats und anderer kennen gelernt, was auf anderem Wege nicht möglich gewesen wäre.

\section{Physikalische Eigenschaften.}

a) Spezifisches Gewicht.

Eine der für die Kenntnis der Edelsteine wichtigsten Eigenschaften ist die Dichte, die Erscheinum, dali ein Stiick ciner Substanz, also z. B. eines Edelsteines, mehr wiegt als ein gleich wrofes Stiick einer anderen Substanz. Man erkennt diese Verschiedenheit u. a. leicht, wenn man sich zwei gleich große Wïrfel zweier verschiedener Substanzen herstellt, z. B. je einen Würfel mit $10 \mathrm{~cm}$ langen Kanten von Schmiedeeisen und von Lindenholz. Der Eisenwuirfel erweist sich schon beim Heben mit der Hand schwerer als der gleich große von Holz, das Eisen ist also, wie man sagt, dichter als Holz. Bestimm man das frewicht der beiden Wrürfel mit der Wage, so findet man, dafs der Eisenwürfel $73 / 4 \mathrm{~kg}$, der Holzwiirfel $1 / 2 \mathrm{~kg}$ wiegt. Der Eisenwiurfel ist also $73 / 4: 1 / 2=151 / 2 \mathrm{mal}$ schwerer als der gleich große Holzwürfel, oder das Eisen ist $151 / 2$ mal dichter oder

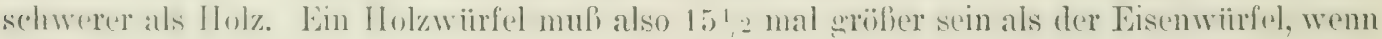
er dasselbe Gewicht haben soll. Auch zwei Edelsteine vom gleichen Gewicht sind daher nicht immer gleich grob. Ein Diamant von 1 Karat ist größer als ein Rubin von dem-

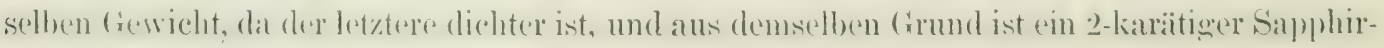
stein kaum gröber als ein Karatstein rles viel leichteren Aquamarin.

Um die Dichte der verschiedenen Körper ïbersichtlich anzugeben, hat man es zweck-

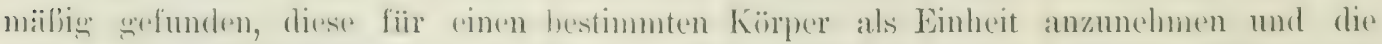

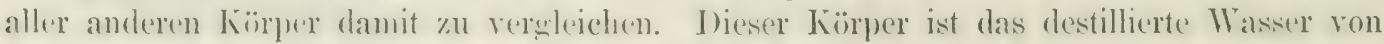
$4^{0} \mathrm{C}$ bei einem Barometerstand ron $760 \mathrm{~mm}$. Man setzt die Dichte solchen Wassers gleich 1 und ermittelt, wievichmal dichter der betreffende Körper ist, d. h. wievielmal schwerer als ein gheichgrofies Volumen dieses solben Wassers. Die Zahl. wolehe angibt,

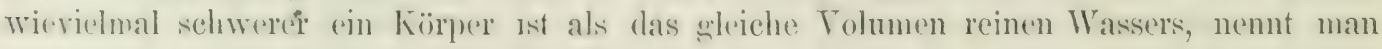
sein spezifisches Gewicht. Für Wasser ist dies demnach $=1$; je böher es bei einem anderen Kïrpere ist, desto dichter ist er. Man crhält das spezifische (rewicht irgend einer 
Sulstanz, wenn man deren wirkliches, mit Wage und Fewichten auf dies gewöhnliche Art zu bestimmendes und in Gramm oder einer anderen Einheit anstredrücktes absolutes Gewicht durch das absolute Gewicht des gleichen Volumens Wasser dividiert. Will man wissen, wievielmal dichter eine Sulstanz ist als eine andere, so hat man ihr spezifisches Gewicht durch das der letzteren zu dividieren.

Die Erfahrung hat gelehrt, daf jede chemische Verbindung, jedes Mineral und also anch jeder Edelstein stets in allen Exemplaren dasselbe spezifische Gewicht hat, das in allememen von dem aller anderen substanzen mehr oder wenicrer abweicht. Das spezifische Gewicht ist a]so oft ein geeignetes Mittel, um ähnlich aussehende Mineralien mit Sicherheit voneinander zu unterscheiden. Für Edelsteine ist dieses Ifilfsmittel um so wertvoller, als bei seiner Bestimmung der Stein nicht verletzt wird, so dab man auch die kostbarsten gesehliffenen Juwelen in dieser Weise ohne jede Gefahr untersuchen kann. Aus dem lutzteren Grunde ist lsaum ein anderes Mittel zur Erkennung und Lnterscheidung von Edelsteinen so wichtig als eben dieses, vielleicht mit Ausnahme der später zu betrachtenden optischen Kennzeichen. Dazu kommt, daß man das spezifische Gewicht ohne grosse Schwierigkeit mit für praktische Zwecke genügender Genauigkeit rasch und sicher ermitteln kann. Daher sollte kein Juwelenhändler versäumen, sich für alle Fälle mit derartigen Untersuchungen vertraut zu machen. Eine einzige Prüfung eines zweifellaften Steines kann die darauf verwendete Mühe und die geringen Kosten für die nötigen Apparate reichlich lohnen. Die empfehlenswertesten Methoden mögen daher hier etwas ausführlicher mitgeteilt werden, nicht nur diejenigen, die sich wegen ihrer besonderen Schärfe zur Ausführung von möglichst exakten Bestimmungen eignen, sondern vor allem auch diejenigen, die bei rascherer und bequemerer Handhabung zwar etwas

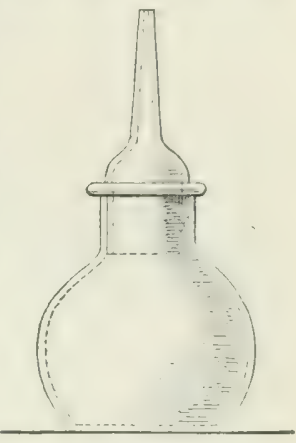

Fig. 1. Pyknometer (natïrl. Größe) weniger genaue, indessen für die Zweeke der Praxis noch genügend sichere Resultate ergeben.

Es muß aber noch darauf aufmerksam gemacht werden, daß die spezifischen Gewichte aller Mineralien nach den vorhandenen Bestimmungen innerhalb gewisser enger Grenzen schwanken, einmal weil jede solche Wägung ohne Ausmahme mit unvermeidlichen kleinen Messungsfehlern behaftet ist, und sodann, weil nicht leicht zwei Stiicke eines und desselhen Minerals einander absolut gleich. sondern fast immer durch wenn auch nur geringe Mengen frender Beimengungen und Beimischungen verunreinigt sind, kleine Hohlräimme einschliefen ete. Solche kleine Schwankungen trifft man also auch bei den Edelsteinen, sie sind aber nur in den seltensten Fällen von Einflub anf die Brauchbarkeit des spezifischen Gewichtes zur Lnterscheidung der einzelnen Arten. Wie weit sie gehen, eroiht sich aus der Zusanmenstellung der spezifischen Gewichte der wichtigsten Edelsteine am Schlusse dieses Abschnittes.

\section{Bestimmungsmethoden.}

1. Methode mit dem Pyknometer. Vielleicht die genaueste aller der vielen Methoden zur Bestimmung des spezifischen Gewichts ist die mit dem Pylinometer. Dies ist ein lileines, möglichst leichtes Glaswefül) mit weitem Halse (Fig. 1), der mittels eines in seiner Mitte durch einen sthr feinen Kanal der Länge nach durchbohrten eingeriebenen Glasstöpsels verschlossen werlen kann. Mit Hilfe eines solchen Fläschchens und einer guten Wage läßt sich das spezifische Gewicht eines Steines auf folgende Weise bestimmen: Man ermittelt durch einfache Wägung zunächst das absolute Gewicht des Steines, es sei im allgemeinen $y$; für einen bestimmten Stein wurde in speziellen $4,38:$ g gefunden. Sodann wird das mit destilliertem Wasser gefüllte Fläschchen gewogen, sein Gewicht sei p, 
was ein für allemal gilt, wenn man mit demselben Flächchen mehrere Bestimmungen ausführt, so daf diese Wägung nicht wiederholt zu werden braucht. Für unseren besonderen Fall ergab sich ein Gewicht von 15,513 g. Es muß hierbei darauf gesehen werden, daß das Wasser die Durchbohrung des Glasstöpsels bis an deren oberen Rand füllt, was meist beim Aufsetzen des Stöpsels auf das gefüllte Fläschchen sich ron selber macht, und daß das Flïsehehen gut abgetrocknet wird. Nun wird der Stein in das Flïschehen ceworfen. Er verdrïngt daraus etwas Wasser, und zwar genau ein dem seinigen grleiches Volumen. Jan setzt den Glasstöpsel wieder auf, wobei sich dessen Durchbohrung wieder von selbst bis oben mit Wasser füllt, und wiegt nun das wie vorhin sorgfältim abgetrocknete Fläschehen mit dem jetzt im Wasser hefindlichen Steme. Das Gewicht sei q oder in vorliegenden speziellen Falle $=15,600$ g. Das Gewicht des Fläschchens mit Wasser und dem außerhalb befindlichen Steine ist $g+p$ oder $4,883+15,543$ $=19,925$, demmach das Gewicht des dureh den Stein vertriebenen Wassers, also einer Menge Wasser wie der Stein, $=g+p-q$ oder $=19,925-18,680=1,215 \mathrm{~g}$. Da nun der Stein selber $g$ oder $4,382 \mathrm{~g}$ wiegt, so ist das spezifische Gewicht des Steines: $d=\frac{g}{g+p-q}=\frac{4,382}{1,245}=3,52$, was dem spezifischen Gewicht des Topases entspricht, und zum Topas gehört auch in der Tat das untersuchte Stück.

Unter der Voranssetzung, daß alle im vorstehenden erwähnten Punkte sorgafältig berïcksichtigt sind, wird die Bestimmung um so genauer, je empfindlicher die Wage ist. Noch ist dabei aber ein wichtiger Punkt zu beachten, dessen Vernachlässigung schwere Irrtïmer veranlassen könnte. Es sind dies die Luftblasen, die in dem bei der Wägung benutzten Wasser aufsteigen und die namentlich, oft mit großer Hartnäekigkeit, an den in das Wasser geworfenenen Steinen hängen. Man löst sie entweder mit einem reinen Platindraht ab oder entfernt sie durch Auskochen des Wassers. Die Methode mit dem Pyknometer hat neben der bei sorgfältiger Arbeit mit guten Instrumenten zu erreichenden Genauigkeit bis zur dritten Dezimalstelle noch den Vorteil, dafs man besonders leicht und bequem auch das spezifische Gewicht mehrerer kleiner Steine zusammen bestimmen kann, wogegen allerdings zu große Stiicke, die nicht durch den Hals der Flasche gehen, answeschlossen sind. Zu klein und leicht darf das der Lntersuchung unterworfene Stiick oder die Gesamtheit der kleineren Stücke nicht sein, sonst ist die Bestimmung auch unter den günstigsten Umständen nicht mehr genau genug.

2. Methode mit der hylrostatischen Wage. Häufiger angewandt und vielleicht bei sorgfältiger IIandhabung ebenso genau wie die Methode mit dem Pyknometer ist die mit der hydrostatischen Wage. Diese Methode beruht darauf, daß ein Körper nach dem Eintauchen in Wasser leichter ist, als in Luft. Er verliert dabei nach dem bekannten Satze des Arehimedes so viel an Gewicht, als das von ihm verdrängte Wasser, d. h. ein dem seinigen gleiches Volumen Wasser wiegt.

Man wiegrt den Körper erst in der Luft und ermittelt so sein absolutes Gewicht $g$; sodann wiegt man ihn, an einem feinen Draht aufgehängt, im Wasser und findet das Gewicht f: Dann ist offenlar der Gewichtsverlust, den der Körper im Wasser erlitten hat, $=y-f$, und dies ist nach jenem Satze das Gewicht des von dem Körper verdrängten, also im Volumen ihm gleichen Wassers. Das spezifische Gewicht $d$ ist somit:

$$
d=\frac{g}{g-t} .
$$

Die zu solchen Zweeken bestimmte hydrostatische Wage unterscheidet sich in keinem wesentlichen Punkte von einer gewöhnlichen Wage. Sie ist aber meistens so eingerichtet, daf die eine Schale an viel kïrzeren Füden aufgrehängt ist, als die andere. Gewöhnlich 
ist die Torrichtuns so, dal) man an einer Wage von der gewöhnlichen Finrichtung dies eine Wagschale entfornen und durch eine andere. kurz aufgehïngte ersetzen kann. Wir nehmen an, die rechte Wagschale sei durch eine von der letzteren beschaffenheit erretzt. An ihrer Unterseite ist in der Mitte ein kleiner Haken angebracht, in den man einen feinen Platindraht hängt, mit Ililfe dessen der Körper, hier der Edelstein. in das Wassor eingetaucht wird. Z/u diesem behufe lïuft der Draht am unteren Ende zwecknälige in ein kleines Zängchen aus, wie bei dem in Fig. 5 abgebildet Instrument. Der Stein

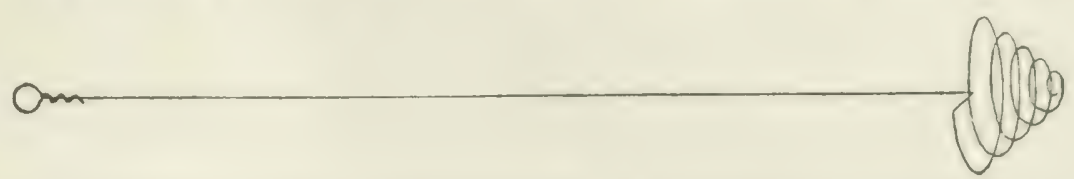

Fig. 2. Zum Körbchen gebogener Platindraht füı die Bestimmung des "spezifischen Gewichts

kann durch Einklemmen in dieses Züngrehen sehr beruem an dem Draht befestigt werden, anderenfalls mul man ihn mit dem Draht muwickeln, oder aus aus diesem durch geedignte Biesung eine Art kleinen Körbehens herstellen (Fim. 2), in das der stein hineingelegt wird. Das Wasser hefindet sich in einem Glasgefail unter der kur\% aufgehängten Wagschale rechts, und der Draht taucht eventuell mit dem Zängehen usw. während dess cranzen Versuches in das Wasser ein, auch schon ehe der Stein daran befestigt ist, um im Wasser stewogen zu werden. Es ist dann nicht nötiz, das Gewicht des Drahtes usw. und seinen Gewichtsverlust beim Eintauchen besonders zu beriicksichtigen, sie heben sich dann bei den verschiedenen Wägungen g'egenseitig von selber auf.

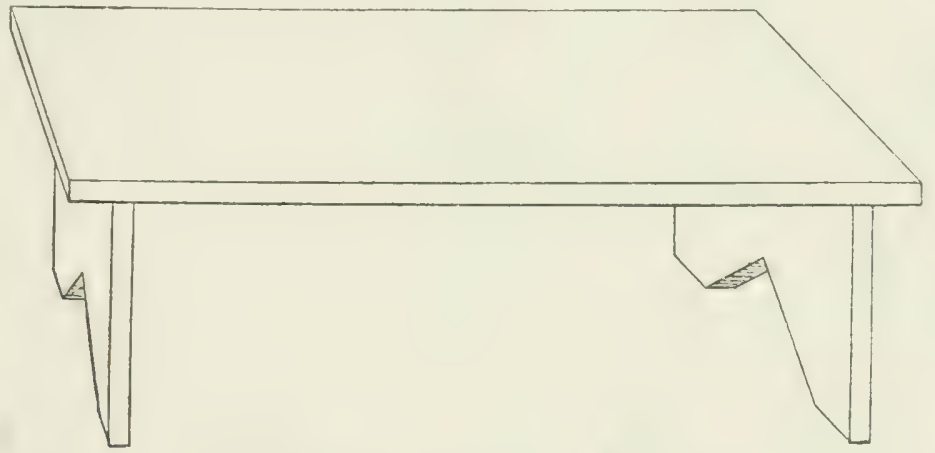

Fig. 3. Bänkchen, um eine gewöhnliche Wage zur Bestimmung des spezifischen Gewichts zu benützen.

Es ist aber nicht durchaus notwendig, eine solche zur Bestimuung des spezifischen Gewichts besonders eingerichtete Wage zu benutzen. Jeder Juwelier hat eine gute Wage von der gewöhnlichen Einrichtung mit zwei gleich lang aufgehängten Schalen, die leicht als hydrostatische Wage benutzt werden kann. Man versieht zu diesem Zwecke den Draht an dem einen Ende mit einer Schleife, bringt diese in den Haken, an dem auch die Schale rechts an dem Waghalken befestigt ist, und läßt das andere Ende mit dem Zängchen oder Körbchen usw. herunterhängen. Das Wassergefäß stellt man auf ein kleines Bänkchen etwa von der in Fig. 3 oder 4 dargestellten oder irgend einer anderen passenden Form, das so über die Wagschale gestellt wird, daß diese darunter zwischen dessen Beinen frei spielen kann. Selbstrerstïndlich mub das Gefäb so schmal sein, daf es die Bewegung der Wage nicht stört, und der Draht muß so lang sein, daß der an seinem unteren Ende befestigte Stein weder auf den Boden des Gefäßes stößt, noch aus dem Wasser auch nur teilweise herausragt, wenn der Wagbalken sich bewegt. Eine derartige Wage ist in Fig. 4 abgebildet. 
Wenn man nun eine Gewichtsbestimmung mit einer solchen Wage ausführen will, verfährt man am besten in folgender Weise: Auf die Schale links wird irgend ein Gegenstand, ein Stiick Mineral oder Metall usw. gelegt, die sogenannte Tara, die bei der ganzen Operation unverïndert liegen bleibt. Sie muß etwas schwerer sein, als der Stein, dessen spezifisches Gewicht bestimmt werden soll. Auf die Wagschale rechts kommen dann so viel Gewichte, daß der Zeiger der Wage gerade einspielt. Die Gewichte werden notiert; es seien $m$ oder für ein bestimmtes Beispiel 10,781 g. Nun werden sie wieder entfernt,

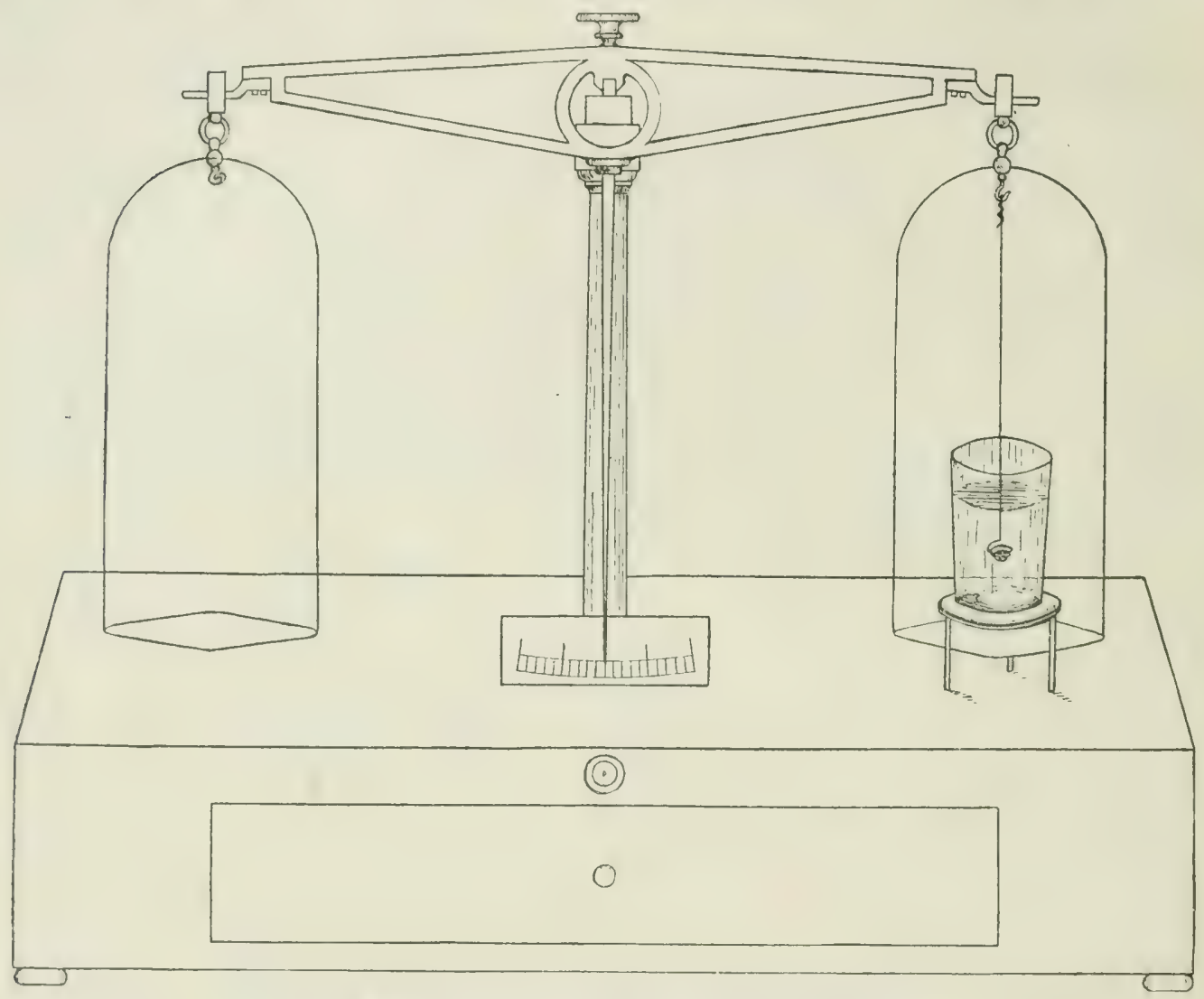

Fig. 4. Gewöhnliche Wage, zur Bestimmmug des spezifischen Gewichts eingerichtet.

der Stein wird auf die rechte Wagsehale gelegt und dazu so viele Gewichte gefiigt, daß der Zeiger der Wage wieder einspielt. Es seien hierzu $l$ oder in dem Beispiel 4,si3 g erforderlich. Dann ist das absolute Gewicht des Steines $g=m-l=10,7+1-1,413=5$, , $1 \times 1 \mathrm{~g}$. Hierauf wird der Stein, mit dem Draht umwickelt oder in das Züngehen eingeklemmt oder in das hörbchen gedegent und so in das Wasser eingetaucht, daf er darin ohne die Wand des Gefäle's zu berühren, zanz frei schwebt; durch Auflegen von Gewichten auf die rechte Schale wird die Wage wiedar zum Einspielen grebracht. Diese Gewichte betragen $t$ oder in dem Beispiel 7 , man g. Der Gewichtsverlust des Steines im Wasser oder, was dasselbe ist, das Gewicht eines dem seinien grenehen Volumens Wasser beträ̈gt dann:

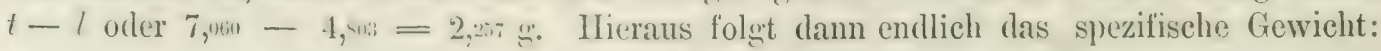

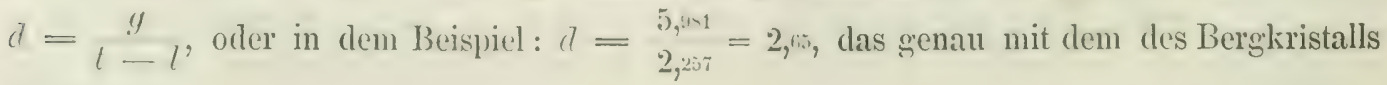
übereinstimmt. 
Je feiner und empfindlicher die Wage ist, desto genauer findet man unter sonst gleichen Verhältnissen das spezifische Gewicht, das im günstigsten Falle und leei sehr sorgfältiger Wägumg noch in der dritten Dezimale richtign bestimmt werden kann, doch darf der Stein nicht erar zu klein sein, da mit abnehmender Grölie die Inessungsfehler wachsen. Es ist aber stets nötige, daß man gewisse Vorsichtsmaliregeln nicht auber acht lälit, namentlich miissen hier ebenfalls alle an dem eingetauchten Stiicke und an dem Drahte hängenden Luftblasen durch Loslüsem mit einem Platindralite sorgfältig entfernt werden. Zur Vermeidumg piner gröbteren Menge von solchen ist es am besten, das angewandte Wasser vorher dureh Auskochen lufterei zu machen. Ebenso muf darauf geschen werden, dab der Stein und die eingretauchten Teile des Apparates vollstiindion vom Wasser benetzt werden, was unter Umständen dureh eine feine Fettschicht infolge häufigen Berihhrens mit den Fingern usw. verhindert wird. Diese muf dann dureh vorheriges Waschen jener Stiicke mit Alkohol oder Äther, oder mit einer Sodalösung. und im letzteren Falle durch nachheriges Abspiilen in reinem Wasser entfernt werden. Auch hier taucht der Draht bei der ganzen Wägung von Anfang an in das Wasser ein.

Hat man der Reihe nach für eine größere Anzahl von Stiicken die spezifischen Gewichte zu bestimmen, dann wählt man eine 'l'ara, die etwas schwerer ist als das schwerste ron ihnen. Diese Tara bleibt für alle Steine unverändert liegen, man braucht dann nur ein einziges Mal das Gewicht $m$ zu ermitteln, das nötig ist, um die Wage mit der Tara allein zum Einspielen zu bringen. Für jeden einzelnen Stein sind hiexauf nur noch zwei Wägungen vorzunehmen, welche die Werte von $l$ und $t$ ergeben, und aus diesen in Verbindung. mit dem ein für allemal festgestellten Wert von $m$ folgen endlich die spezifischen Gewichte in der oben angegebenen Weise.

Soll von mehreren kleineren steinen zusammen das spezifische Gewicht nach dieser Methode ermittelt werden, dann muß der Draht unten die Form des erwähnten Körbchens haben. Auf diesem läßt man alle Steine gemeinsam in das Wasser eintauchen, nachdem man ihr absolutes Gewicht vorher gemeinsam bestimmt hatte, und verfährt sonst wie bei einem einzigen Steine.

Die bisher angewendete Tara hat den Zweck, gewisse Fehler der Wagen auszugleichen. Jan kann sie aber bei einer guten und genauen Wage, wenn es sich nicht um besondere Genauigkeit handelt, auch entbehren. Der Stein wird dann auf die ganz gewöhnliche Weise erst in der Luft gewogen, indem man ibn auf die eine, die entsprechenden Gewichte auf die andere Wagenschale legt; das so ermittelte absolute Gewicht sei $p$. Hierauf wird in derselben Weise das Gewicht des Steines im Wasser bestimmt; es sei q. Dann beträgt der Gewichtsverlust 1 - q, und das spezifische Gewicht ist:

$d=\frac{p}{p-q}$. Hierbei sind unter allen Umständen nur zwei Wägungen erforderlich, das Verfahren ist also etwas einfacher als das mit der 'Tara, wobei im allgemeinen drei gemacht werden müssen, die sich allerdings gleichfalls auf zwei reduzieren lassen, wenn man immer dieselbe Tara benutzt. Dann gehen beide Methoden gleich rasch. Jeclenfalls wird in den meisten Fällen der Praxis die Tara nicht notwendıg sein, der Juwelier wird also, wenn er sich hierzu der hydrostatischen Wage bedienen will, gewöhnlich olıne Tara arbeiten. Beispiel: Ein (iranat (Kaneelstein) wog in der Luft $4,375 \mathrm{~g}(=\mu)$, im Wasser $3,168 \mathrm{~g}(=q)$; der Gewichtsverlust im Wasser ist also: $p-q=4,375-3,168=1,207 \mathrm{~g}$ und das spezifische Gewicht: $d=\frac{4,375}{1,207}=3,63$.

Da die Bestimmung des spezifischen Gewichts selten bei to C. und bei einem Barometerstande von $760 \mathrm{~mm}$ erfolgt, so müibte man eigentlich die unter anderen Umständen erhaltenen Zahlen auf diese Temperatur und diesen Barometerstand durch Rechnung B a u $\theta$, Edelsteinkunde. 2, Aufl. 
zuriickführen. Erst dadurch erhält man das spezifische Gewicht eines Körpers ganz genau, aber einer solchen Genauigkeit bedarf es für unsere praktische Zwecke nicht, und jene Rechnungen sind daher für uns überfliissig.

3. Methode mit der Westphalschen Wage. Die hydrostatische Wage wie das Pyknometer gibt das spezifische Gewicht der Steine mit sehr großer Genanigkeit, die Wägungen sind aber um so umständlicher und zeitraubender, je feiner die Wage und damit je genauer die Resultate. Diese große Genauigkeit ist aber für die praktische Untersuchum der Edelsteine zum Zweeke ihrer sicheren Erkennung und Unterseheidung nur höchst selten nötig. Dagregen ist es wïnschenswert, spezifische Gewichte mit vielleicht etwas geringerer, aber für den praktischen Gebrauch ausreichender Genauigkeit möglichst rasch und bequem bestimmen zu können. Ein Instrument, das sehr leicht und mit geringstem Zeitaufwande die gesuchte Zahl jedenfalls in der ersten, unter einigermaßen grïnstigen Umständen auch noch in der zweiten Dezimalstelle richtig gibt, was für die praktischen Bedürfnisse des Juweliers meist völlig ausreicht, ist die nach dem Verfertiger, Mechanikus Westphal in Celle, benannte Westphalsche Wage. Sie hat auberdem vor der hydrostatischen Wage den Vorzug großer Billigkeit und kann auch zu anderen nuitzlichen Zwecken grebraucht werden, von denen unten noch weiter die Rede sein soll.

Die Westphalsehe Wage ist in der Zusammenstellung, in der sie zur Bestimmung (ler sperifischen Gewichte fester Körper, also auch von Edelsteinen, dienen kann, in Fig. 5 n. S. alygehildet. Bei dieser Einrichtung entspricht sie genau der hydrostatischen Wage mit der Tara, sie ist nur eine Vereinfachung derselben, die darauf beruht, daß auf der linken Seite die fest mit dem Waghalken verbundene Tara a die Wagschale ersetzt. Sie besteht aus einem Wagrbalken alsc, der bei $b$ eine nach unten gekehrte Schneide aus gehärtetem Stahl trägt. Diese ruht auf einem etwas eingekerbten Plättchen, ebenfalls aus hartem Stahl. Um diese Schneide dreht sich der Wagbalken. Die eingekerbte Stahlplatte ist auf einer umgebogenen Messinglatte de befestigt, die ihrerseits auf einem langen zylindrischen vertikalen Messingstabe f' sitzt, der sich in einer hohlen Messingröhre hh nach Bedarf verschieben und mittels der Schraube $g$ in der erforderlichen Höhe festklemmen lälit. Die hohle Messing röhre kann mit einem breiten Fuß $k$ so auf eine dreibeinige Messingscheibe $l$ gestellt werden, daß das eine Ende des Wegbalkens gerade über die Schraube $m$ zu liegren kommt, mittels der sich die Scheibe auf der einen Seite etwas heben und so der Messingstab $i$ vertikal stellen läßt.

I) Wagbalken ist so eingerichtet, daß er auf der linken Seite ein schweres Messinggrewicht " trägt; dieses ist es, das in der erwähnten Weise die linke Wagschale mit der Tara ersetzt. An dessen hinterer Seite befindet sich eine Spitze, welche auf der bei $e$ an dem Messingstiick de befestigten Teilung auf Null zeigt, wenn die Wage einspielt. A uf der rechten Seite des Waghalkens bei $c$ ruht auf einer nach oben gerichteten Schneide ein Iaken, in den mit kurzen Platindrähten die kleine Wagschale n gehängt werden kann, die in einem IIäkchen an der Unterseite cinen feinen Platindraht mit dem Messingzängehen 1) träint. Dieser bei c hängende T'eil entspricht ganz der Schale rechts bei der hydrostatischen Wage mit dem daran häingenden Platindraht usw. Der Waghalken ist zwisehen den Schmeiden bei $b$ und o in 10 gleiche Teile geteilt und mit gleichweit voneinander abstehenden, von $b$ nach $c$ hin mit 1, 2, 3 usw. numerierten Teilstrichen versehen. An allen 'Teilstrichen sind oben kleine Kerben eingeschnitten.

Die zu diesem Apparat besonders konstruierten Gewichte sind zum Teil zum Anhänşen an den Iaken unter $c$ und zum Teil zum Aufsetzen als Reiter auf die Kerben des Wawhalkens bestimmt, wie es die Figur zeigt. Sie folgen nicht dem Gramm- oder einem anderen sonst gebrïuchlichen Gewichtssystem; ihre Größe ist an sich vollständig 
gleichuiltig, sie sind aber fiir winen anderen unten zu besprechenden Zweck des Instruments in besonderer Wrise sewählt. Man hat cin Normalgewicht $X^{T}$, das am Ende dies Wagbalkens in dem Haken hej c aufgehängrt die Gewichtscinheit darstellt, anf droln Wasgbalken aufgesetzt aber bei Teilstrich $1,2,3 \ldots$ den Wert $\frac{1}{10} N, \frac{2}{10} N, \frac{3}{10} N \ldots$. d. h.

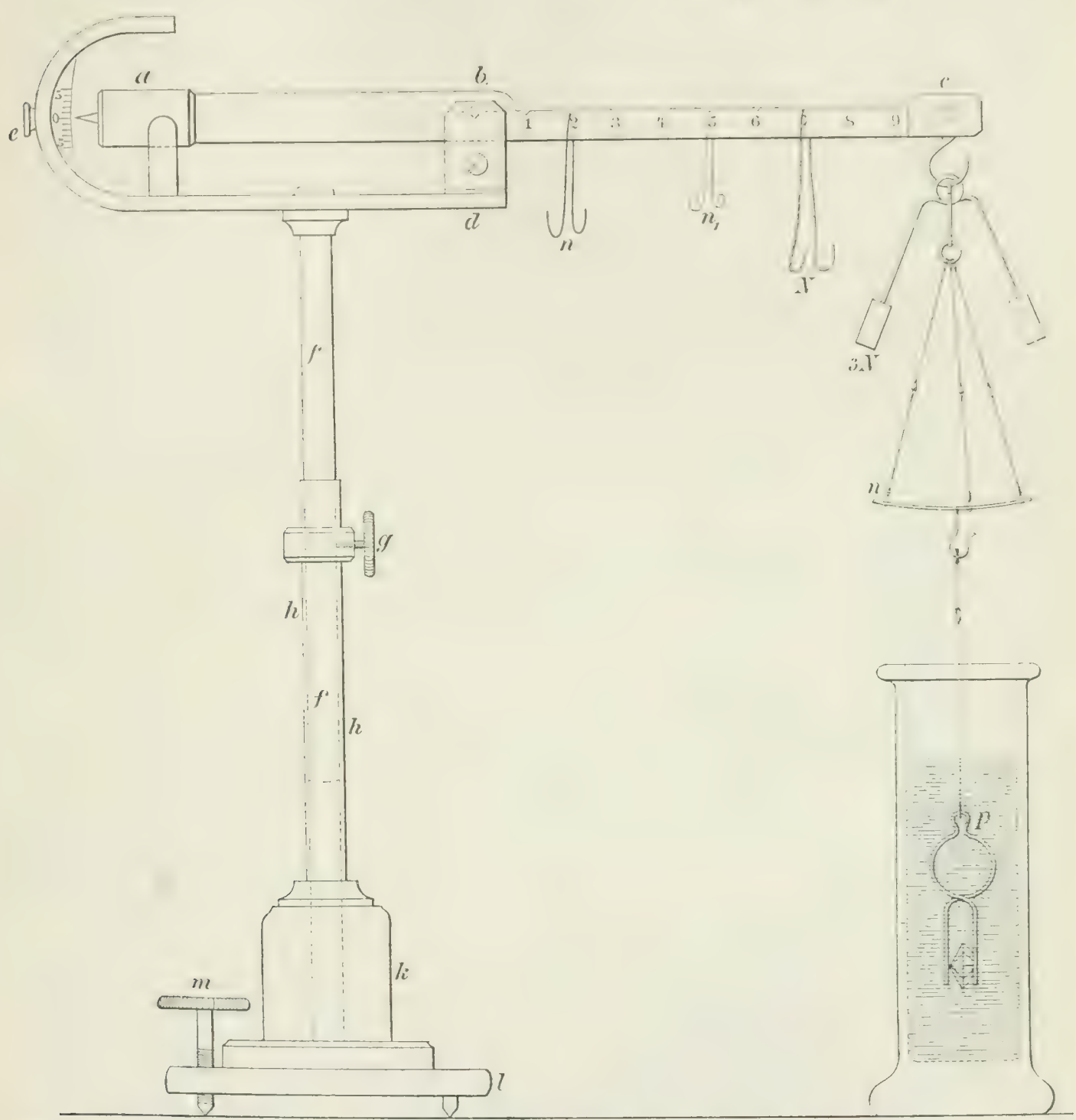

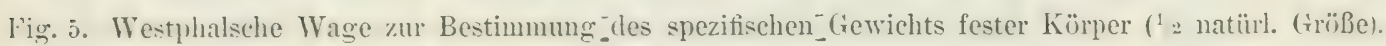
$\frac{1}{10}, \frac{2}{10}, \frac{3}{10} \ldots$ der Gewichtseinheit besitzt. Außerdem ist ein zweites Gewicht $n$ vorbanden, das nur den zelnnten Teil ron $V^{\top}$ beträgt, also $n=\frac{1}{10} N$. Bei $c$ hängend, hat es den Wert von ${ }_{10}^{1} \mathrm{~T}$, beim Teilstrich $1,2,3 \ldots$, auf dem Wagbalken reitend die Werte $\frac{1}{10} n, \frac{2}{10} n, \frac{3}{10} n \ldots$ oder $\frac{1}{100} N, \frac{2}{100} N, \frac{3}{100} N \ldots$ Endlich ist der Wage noch ein 
drittes Gewicht $n_{1}=\frac{1}{10} n=\frac{1}{100} \Lambda^{\top}$ beigegeben. Dieses entspricht, bei $c$ hängend, den eben genannten Werten, bei $1,2,3 \ldots$ reitend den Werten $\frac{1}{10} n_{1}, \frac{2}{10} n_{1}, \frac{3}{10} n_{1} \ldots$ oder $\frac{1}{100} n, \frac{2}{100} n, \frac{3}{100} n$ oder endlich $\frac{1}{1000} N, \frac{2}{1000} N, \frac{3}{1000} N \ldots$ Die Gewichte $n$ und $n_{1}$ sind nur zum Reiten bestimmt, von den Normalgewichten $\lambda^{\top}$ muß mindestens eines zum Reiten, die andern miïssen zum Anhängen bei $c$ eingerichtet sein. Zur Bequemlichkeit sind zuweilen noch wrößere Gewichte im Werte von $2 N^{\top}$ und $3 \mathrm{~N}$, also gleich dem doppelten und dreifachen Normalgewichte, zum Aufbängen bei $c$ zur Verfügung.

Spielt nun die Wage ein, wenn eine Anzahl Normalgewichte $N$ bei $c$ hängen, wenn ein Normalgewicht $N^{\top}$ und gleichzeitig die kleineren Gewichte $n$ und $u$ auf dem Wagbalken in gewissen Kerben reiten, so gibt offenbar die Zahl der bei $c$ hängrenden Gewichte $N$ die Ganzen des zu suchenden Gewichts des betreffenden Körpers, und die Nummern der Kerben, in denen die Gewichte $N, n$ und $n$ reiten, die erste, zweite und dritte Dezimale dieses Gewichtes, ausgedriickt in der Einheit $N$. Weitere Dezimalen können so nicht bestimmt werden, sind aber auch iiberflüssig für die hier vorliegenden praktischen Bedürfnisse. Durch Aufsetzen des kleinsten Gewichtes $n_{1}$ zwischen zwei Kierben kann indessen zuweilen noch eine vierte Dezimale schätzungsweise bestimmt werden. Iängen beispielsweise bei $c 3$ Gewichte $N$ (oder das Gewicht $3 N$ ) und reiten $N, n$ und $n_{1}$ bei Teilstrich 7, 2 und 9, so ist das zu suchende Gewicht gleich 3,729 der Eimheit $N$; ritten die letzteren beiden $n$ und $n 1$ bei 3 und 5 , wäre $\mathrm{N}$ als Reitgewicht überhaupt nicht vorhanden, dann hätte man $3,035 \mathrm{~N}$ usw. Spielt die Wage ein, wenn die Gewichte die in Fig. 5 dargestellte Lage haben, so entspricht das dem Gewicht: 3,725; bei der in Fig. 7 angegebenen Stellung, wo $n$ gar nicht auftritt, wäre es gleich 2,int, jedesmal bezogen auf $N$ als Einheit, also $3, \pi 25 N$ und $2,707 N$.

Die Bestimmung des spezifischen Gewichtes selbst besteht nun aus 3 Teilen:

1) Am Wagbalken werden rechts so viel Gewichte angehängt, daß die Wage mit der Tara einspielt, d. h. die Spitze an ihrem hinteren Ende bei a auf Null steht. Dabei wird zuerst das Gewicht $N$, dann $2 N, 3 N, 4 N$ usw., wenn nötig durch Kombination mehrerer Gewichtsstïcke, bei $c$ aufgehängt. Bei einer bestimmten Wägung war $1 N$ noch zu wenig, $5 N$ zu viel; $4 N$ bleibt also hängen. Hierauf wird ein Reitergewicht $N$ zuerst auf den 9., dann auf den 8., 7. usw. Teilstrich gesetzt; auf dem 3. war es schon zu schwer, auf dem 2. reichte es noch nicht ganz aus; hier bleiht es also sitzen. In derselben Weise erhält das Gewicht $n$ seinen Platz auf dem 5. Teilstrich und $n_{1}$ ebenfalls auf demselben, indem man es an den Haken von $n$ anhängt, wie z. B. in Fig. $7 u_{1}$ an $N$ hängt. Das dem Taragewicht $a$ entsprechende Gewicht wäre dann 4,255, ausgedriickt in der Einheit $N$, oder kurz 4,255 $N$. Wäre das kleinste Gewicht $n_{1}$ bei 5 noch zu leicht, bei 6 schon zu schwer, dann müßte man es zwischen dem 5. und 6. Teilstrich auf den Wagbalken aufsetzen und könnte dann noch eine vierte Dezimalstelle schätzen. Sülo es beim Einspielen der Wage genau in der Mitte zwischen der fünften und sechsten Kerbe, dann hätte man: $4,2555 N$; säße es von 6 noch einmal so weit entfernt als von 5 , dann wäre das Gewicht: $4,2553 N$ usw.

2) Nummehr wird der Stein auf die kleine Wagschale $n$ rechts gelegt und wieder (iewichte in derselben Weise angebracht, his die Wage von neuem einspielt. Es sei hierzu z. B. das in derselben Weise bestimmte Gewicht 3,512 erforderlich. Dann ist das absolute Gewicht des Steines, ausgedriickt in dem Normalgewicht $N$ als Einheit oleich $(1,25-3,512) \Lambda$ $=0,4.4 \mathrm{~N}$. 
3) Endlich wird der Stein in die Zamere greklemmt und in das Wassser geheinger, woher er einen dem Gewicht des verdrängten Wassers gleichen Gewichtsverlust arfeidet, der durch angehängte (iewichtsstiicke wieder essetzt werden mul). Beim Anbringen von Gewichten in dem also nun wioder erröberen Betrage von 3, spielt die Wasre rin. Dann

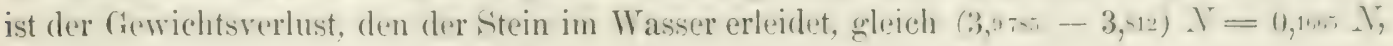
und das spezifische Gewicht $d=\frac{0,4+3}{0,1665}=2,66$. Der Stein hat also wieder das spezifische Gewicht des Bergkristalls, es ist Bergkristall.

Werden wieder alle Luftblasen sorgfältig vermieden in der Weise, wie es schon oben angegeben wurde, verschiebt man das kleinste Gewicht $n$, bis die Wage genau einspielt, werden die eingetauchten Teile vollkommen benetzt, reibt der Stein nicht an der Wand des Wassergefäßes und ist derselbe nicht zu klein, dann kann man den Wert für das spezifische Gewicht auf diese Weise ohne große Miihe in den beiden ersten Dezimalstellen richtig er halten. Dies ist noch der Fall, wenn der Stein nur 1/10 oder $0,100 \mathrm{~g}$ also etwa $1 / 2$ Karat schwer ist. Ist er kleiner und wiegt nur etwa $1 / 4$ bis $1 / 5$ Karat, dann wird die zweite Dezimale unsicher die Bestimmung ist aber für praktische Zwecke fast immer noch brauchbar. Erst bei noch kleineren und leichteren Steinen beginnt die Methode zu versagen, sie gibt dann keine genügend genauen Resultate melır. Für mehrere kleine Steine zusammen kann man auch hier den zu einem Körbchen umgebogenen Platindraht (Fig. 2) oder ein an Platindrähten aufgehängtes Netz aus feinem Platingeflecht anwenden; beide werden in das Zängchen eingeklemmt.

Bei der Wägung taucht auch hier die kleine Zange usw. mit einem Teile des Aufhängedrahtes fortdauernd in das Wasser ein. Der Messingstab $f$ wird in der hohlen Röhre $h h$ so weit aus gezogen, daß bei den Schwingungen des Wagbalkens das Zängchen, eventuell mit dem Stein, weder auf den Boden des Gefäßes stößt noch über die Oberfläche des Wassers hervortaucht, sondern stets mitten im Wasser schwimmt.

Man kann hier ebenfalls die zur Einstellung der 'Tara nötigen Gewichte, also im vorliegenden Fall den obigen Wert 4,255 für allemal bestimmen, später sind dann nur noch zivei Wägungen nötig; zu denen viel weniger Zeit erforderlich ist als bei der Anwendung der hydrostatischen Wage oder des Pyknometers. Selbstverständlich darf der Stein nicht so schwer sein, daß er schon für sich allein die Tara in die Höhe zieht; in diesem Falle könnte man die letztere durch ein aufgelegtes Gewicht noch etwas vermehren, die Wage würde aber dadurch an Empfindlichkeit verlieren. Die Tara reicht aber so, wie sie an dem Instrumente angebracht ist, für die allermeisten Untersuchungen von Edelsteinen, die die Praxis erfordert, aus.

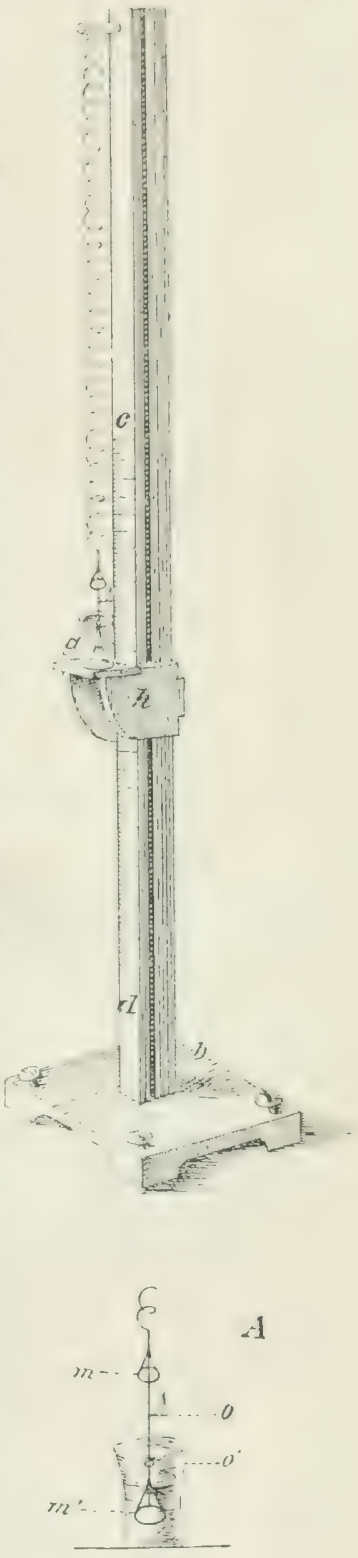

Fig. 6.

Jollysche Federwage.

4. Methode mit der Jollyschen Federwage. Manche Vorteile bietet die von dem früheren Münchener Physiker Jolly erfundene und nach ihm benannte Federwage (Fig. 6), die keine Gewichte erfordert, und die bei sebr einfacher Handhabung noch genügend genaue Werte gibt, wenn nur die Steine nicht zu klein sind. Auf einer horizontalen Platte $b$ steht ein etwa 1 1 2 m langer viereckiger Stab, den man mittels der die 
Fußplatte $b$ durchbohrenden Schrauben und eines Senkels genau vertikal stellen kann. Von $c$ bis $d$ ist an der Vorderseite eine in Millimeter geteilte Skala auf einem schmalen Glasspiegel angebracht. Am oberen Ende ist ein dünner, spiralförmig gedrehter Stahldraht aufgehäingt, der unten an dïnnen Platindrähten bei $m$ und $m^{\prime}$ (Fig. 6, A) zwei kleine Tellerchen aus Glas oder aus feindrahtigem, aber nicht zu engmaschigem Platingeflechte trïgt und ferner zwei Marken bei $o$ und $o^{\prime}$. Der untere Teller taucht in Wasser, das sich in einem bei $g$ (Fig. 6) stehenden Glase befindet und das man mit seinem Stativ $h$ an dem rertikalen Stabe auf- und abwärts schieben und in jeder Stellung festklemmen kann.

Beim Wägen beobachtet man zunächst, ohne daß die Wage belastet ist und für den Fall. dal) der untere Teller bis zur Marke $o^{\prime}$ in das Wasser taucht, den Stand der Marke $o$, eines spitzen Dreieckes, indem man von der Seite her dessen obere Ecke und ihr Spiegrelbild auf der Skala anvisiert. Ecke und Spiegelbild sollen sich, z. B. bei Marke 45, decken. Nun kommt der Stein auf den oberen Teller $m$; die Spirale dehnt sich aus und man folgt dieser Ausdehnung durch Abwärtsschieben des Stativs $h$ mit dem Wasserglase, bis Ruhe eingetreten ist und bis in dieser neuen Gleichgewichtslage die Marke $o^{\prime}$ wieder im Wasserspiegel steht. Die Ecke jenes Dreieckes o habe dann ihre Stellung bei dem 75. Teilstriche. Das Gewicht des Steines entspricht dann 75-45 oder 30 Teilstrichen. Legt man nun den Stein auf den im Wasser befindlichen Teller $m^{\prime}$, dann vermindert sich sein Gewicht wieder um das Gewicht des dem seinigen gleichen Volumens Wasser. Die Spirale verkürzt sich, und man folgt mit dem Stativ $h$ nach oben, wie vorhin nach unten. Die Marke o fällt beim Teilstriche 65 mit ihrem Spiegelbilde zusammen. Der Gewichtsverlust im Wasser entspricht also $75-65=10$ Teilstrichen, und das spezifische Gewicht ist gleich $\frac{30}{10}=3,0$, entsprechend dem des wasserhellen, farblosen Turmalins.

5. Methode mit den schweren Flüssigkeiten. In neuerer Zeit wird eine Methode zur Bestimmung der Dichte sehr häufig benutzt, die darauf beruht, daß ein Stein oben auf einer Flïssigkeit schwimmt, wenn er leichter, daß er darin untersinkt, wenn er schwerer, und daf er endlich in ihr an jedem beliebigen Punkte schwebt, wenn er geracle (henso schwer ist wie sie selber. Ist der Stein nur unbedeutend schwerer als die Fliissigkeit, so sinkt er sehr langsam unter; ist er nur unbedeutend leichter, so steigt er, auf den Grund der Flüssigkeit gebracht, ebenso langsam in die Höhe; je größer die Unterschiede, desto rascher sind die Bewegungen.

Zur Ausführung dieser Methode wird eine möglichst schwer e Flüssigkeit benutzt. Je schwerer diese ist, von um so (spezifisch) schwereren Steinen kann die Dichte bestimmt werden, denn die schwersten Steine, die in einer solchen Flïssigkeit sich noch untersuchen lassen, sind selbstrerständlich solche, die mit ihr gerade gleiches spezifisches Gewicht haben und die daher in ihr an jedem Punkte im Innern schweben können. Alle Steine, die ihres höheren spezifischen Gewichts wegen in der Flüssigkeit zu Boden sinken, sind ausgeschlossen. Diese Flüssigrkeit mul auferdem möglichst farblos, durchsichtig und klar sein, wenigstens ist das sehr zweckmäßjg, damit man die Bewegung der Steine verfolgen kann. Sie mulf eine leicht bewegliche und nicht etwa eine zähe oder dickflïssige Beschaffentreit haben, sonst sind die Bewegungen der Steine in ihr mehr oder weniger sehemmt. Endlich mulj sie sich mit einer anderen leichteren Fliissigkeit in allen Verhältnissen rasch und rollkommen mischen, damit man durch Zusammengießen beider in bequemer Weise Flüssigkeiten ron geringerem fewichte herstellen kann.

Eine Flüssigkeit, die allen diesen Bedlingungen in vorzïglicher Weise ents]rieht, ist das Methylenjodid (Jodmethylen), das aus Kohlenstoff, Wasserstoff und Jod nach der 
chemischen Formel C'II. $\mathrm{J}_{2}$ zusammengesetzt ist. Es ist cine der schworsten Flib-sickeiten, die man kennt; hei mittlerer Zimmerwärme beträgt ihr spezifisches Gewicht ungrefähr :,.: nimmt aber allerdings mit steigender Temperatur nicht unbedeutend ab, bei abnehmender entsprechend zu. In genauen Zahlen ist das spezifische Gewicht dieser Flüsigkeit 3,;s bei $10^{\circ} \mathrm{C}$, 3,3265 bei $15^{\circ} \mathrm{C}$. und 3,3155 bei $20^{\prime \prime} \mathrm{C}$. Man kann also damit Steine untersuchen, deren spezifische Gewichte bis zu diesen Zahlen grehen. Die Farbe ist hellgelblich, die Durchsichtigkeit volikommen und die Beweglichkeit sehr leicht. Mit lienzol läft sich das Methylenjodid in jedem Verhältnisse leicht mischen; man kann dadurch Mischungen erhalten, deren Dichte unter die des Wassers heruntersinkt, da das spezifische (iewicht des Benzols bei gewöhnlicher Temperatur sleich 0, ist, und kann iilerhaupt durch Zusammengieben ron Methylenjodid und Benzol in rerschiedenen Verhältnissen Flüssigkeiten herstellen, deren spezifisches Gewicht von 0, ss bis zu 3,3 ansteigt.

Die Methode der Bestimmung des spezifischen Gewichtes ist nun die, dal) man den zu untersuchenden Stein zunächst in reines Methylenjodid wirft, das sich in einem engen und hohen Standglase befindet, wie es in Fig. 5 u. 7 rechts, in ungefähr halber natïrlicher Gröle dargestellt ist. Sinkt er darin unter, so ist er sehwerer als die Flüssigkeit und kann in dieser nicht untersucht werden. Schwebt er in ihr an jedem Punkte der Höhe oder Tiefe, wenn man ihn mit einem reinen Glasstahe in der Flïssigkeit an verscbiedene Stellen bringt, so hat der Stein genau dasselbe spezifische Gewicht wie diese und wie es für sie oben angregeben ist. Dabei ist nur dafür zu sorgen, dab der Stein nicht an die Glaswand anstöft und daf ihm keine Luftblasen anhängen, die eventuell mit einem Platindrahte entfernt werden müissen. Bleibt der Stein endlich in dem Methylenjodid an der Oberfläche und kommt an diese wieder empor, wenn er mit dem Glasstabe hinuntergestofen wird, so ist er leichter als das Methylenjodid. Nummehr wird allmählich und langsam. Tropfen um Tropfen, Benzol zugesetzt und jedesmal gut umgeribrt, wodurch immer leichtere Wischungen entstehen. Fährt man damit stetig und vorsichtig fort, so werden die Bewegungen des Steines in der Flïssigkeit immer langsamer, und schließlich kommt ein Moment, wo der Stein nicht mehr die Oberfläche und auch nicht melır den Boden der Flïssigkeit sucht, sondern in ihr an jedem Punkte schwebt; dann baben beide dasselbe spezifische Gewicht. Damit ist der erste Teil der Aufgabe erledigt, die Herstellung einer mit dem Steine greich dichten Flüssigkeit. Schon bei geringer Ühung ist es leicht, diese in kurzer Zeit herzustellen.

Sehr einfach und bequem ist es auch, das spezifische Gewicht der Flüssigkeit und damit das des Steines zu bestimmen. Man kann hierzu das Pyknometer verwenden, das man erst mit Wasser, dann mit der Flüssigkeit gefüllt wiegt. Inden man das letztere Gewicht durch das erstere dividiert, heide rermindert um das Gewicht des Pyknometers selbst, erhält man das gesuchte spezifische Gewicht. Vielleicht etwas weniger, aber für die Praxis doch noch geniigend genau und viel bequemer ist aber die Benutzung der oben beschriebenen, jedoch zu dem rorliegenden Zwecke etwas modifizierten Westphalschen Wage, deren neue Einrichtung die Fig. 7, pag. 24 darstellt.

Man ersetzt die kleine Wagschale rechts (Fig. 5 S. 19) durch einen zylindrischen. innen mit einem Thernometer versehenen Schwimmer $q$ aus Glas. Dieser hängt an einem feinen Drahte in dem Haken unter $c$ und ist gerade so schwer, daß die Spitze links auf Null der Teilung bei e einspielt. Ist dies nicht genau der Fall, dann kann es durch eine Drehung der Schraube $m$ leicht bewerkstelligt werden. Taucht jetzt der Schwimmer in destilliertes Wasser ein, das man in einem Gefäße darunterstellt, dann verliert er an Gewicht, und zwar ist der Gewichtsverlust gleich dem Gewichte des ron ihm verdrïngten Wassers. Der Zeiger links bei a sinkt also herab, kann jedoch durch Aufhängen des Tormalgewichts $\mathcal{T}^{\top}$ bei c wieder zum Einspielen auf Null gebracht werden. denn dieses ist genau so grob gemacht, 
daß es den Gewichtsverlust des Schwimmers im Wasse r, also den Gewichtsverlust in einer Flüssigkeit vom spezifischen Gervichte 1, gerade wieder aufhebt.

Umgekehrt erkennt man, daß eine Flïssigkeit das spezifische Gewicht 1 des destillierten Wassers hat, wenn das bei $c$ hängende Normalge wicht $N$ die Spitze bei a genau zum Einspielen auf Null bringt. Ist dazu das doppelte Normalgewicht $2 N$ oder das dreifache $3 \Lambda^{\top}$ usw. nötig, dann hat die Fliissigkeit das spezifische Gewicht 2 oder 3 usw., sie ist zweimal, resp. dreimal usw. so schwer (oder dicht) als Wasser.

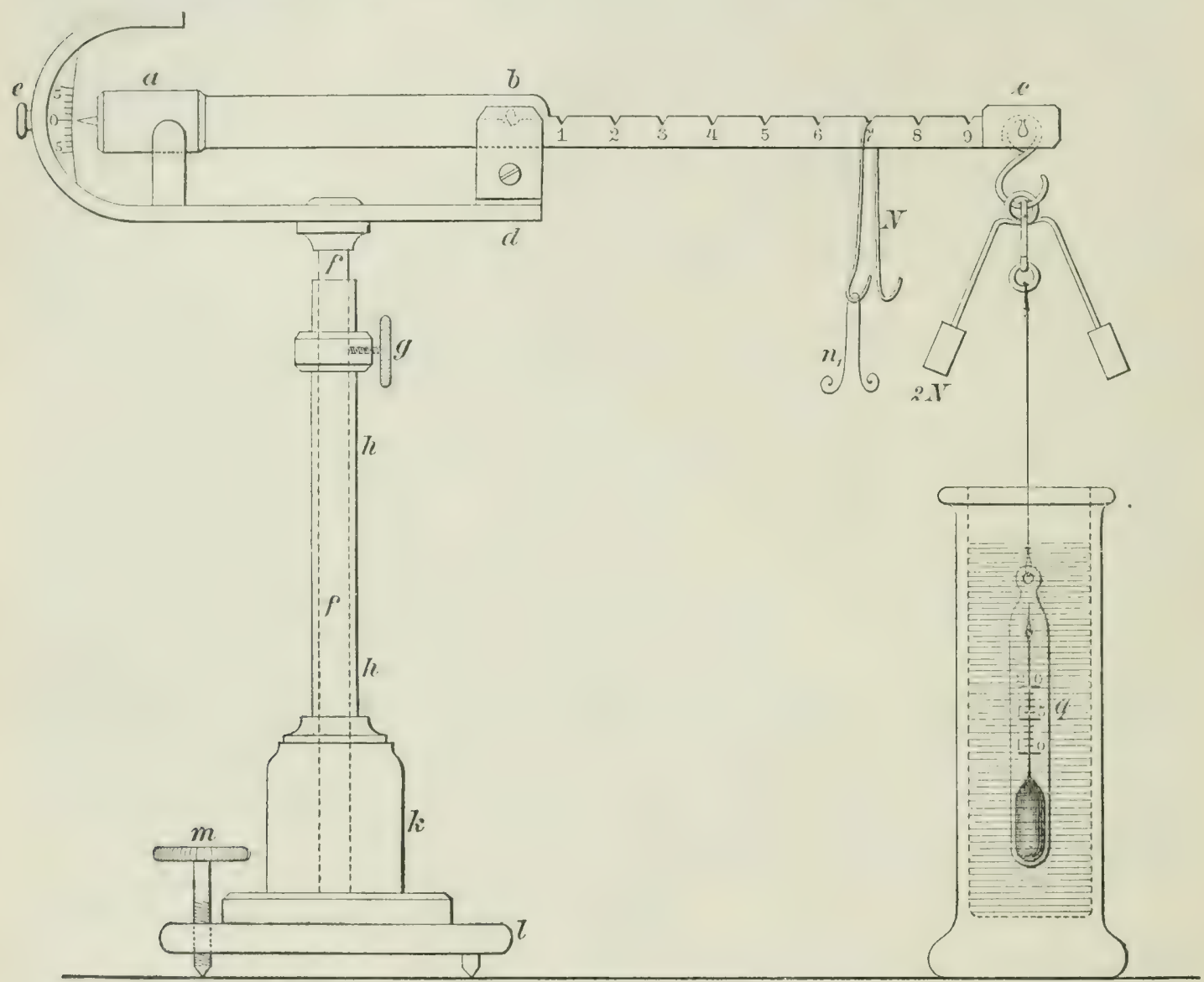

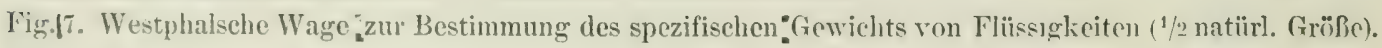

ar. Ist das spezifische Gewicht der Fliissigkeit nicht genau gleich 1, 2 oder 3 usw., so mulb man die Reitergewichte auf den Wagbalken setzen. Spielt die Spitze ein, wenn vorn bei $c$ das dreifache Normalgewicht $3 N$ hängt und wenn das Normalgewicht $N$ bei Teilstrich 2, das Gewicht $n={ }_{10}^{1} N$ bei Teilstrich 5 und das Gewicht $n_{1}=\frac{1}{100} N$ bei Teilstrich 9 aufgesetzt ist, so geben die 3 letzten Zahlen unmittelbar die Dezimalstellen des gesuchten spezifischen Gewichtes der Flïssigkeit, das unter diesen Umständen $=3,259$ ist. Bei der in Fig. 7 abgebildeten Stellung der Gewichte hat die Fliissigkeit das sperifische Gewicht 2,7n\%. Jedenfalls kann man an der Lage der Gewichte die gesuchte Zahl stets auf das bequenste und unter Vermeidung jeglicher Rechnung unmittelbar ablesen. Bei einiger Übung sind stets die beiden ersten Dezimalstellen sicher richtig, und die ganze Operation kann in wenigen Minuten vollendet werden, indem man den Schwimmer in die 
in dem oben erwähnten hohen und engen Standglase befindliche Fliissigkeit, in der der Stein schwebte, so eintaucht, dal) er sich darin frei bewergen kann und dis zum Einspielen der Spitze a nötigen Gewichte rechts anbringt.

Noch rascher kommt man mit den sogenamnten Indikatoren zun Zirle, die aber nicht das genaue spezifisehe fewicht, sondern nur cine allerdinges für pralitische Zwecke meist geniigende Annäherung seben. Indikatoren nennt man kleine, teilweiss: mit (luceksilber gefüllte Glasrïhrehen orl'x kleine Jineralstückehen, deren verschiedene: spezifische Gewichte um ganz geringe Beträge vom leichtesten an aufsteigen und bis zu dem Gewichte der schwersten Fliissigkeit fortschreiten. Eine Reihe soleher Indikatoren enthält u. a. die Mineralien Chalcedon $\left(G_{0}=2,560\right)$, Mikroklin $\left(G_{0}=2,591\right)$, Petalit $\left(G_{0}=2,648\right)$,

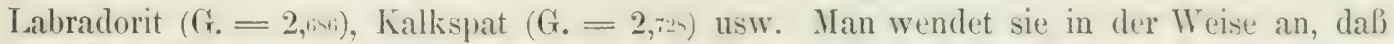
man in die Flïssigkeit, in welcher der zu bestimmende Stein schwebt, zuerst den leichtesten, den Cbalcedon, wirft. Wenn er schwimmt, ist die Flïssigkeit, resp). der Stein, sehwerer als dieses Mineral. Man nimmt es heraus, spült es in Benzol ab und wirft das näehstfolgende der Reihe, den Mikroklin, hinein. Schwimmt auch er, so verfährt man wie oben und geht zum Petalit fort, der gleichfalls oben bleiben soll, während das nächstfolgende, der Labradorit, sinkt. Das spezifische Gewicht des zu untersuchenden Steins liegt dann zwischen 2, und 2,rit, und es ergibt sich daraus die Wahrscheinlichkeit oder doch die Müglichkeit, daß der zu untersuchende Stein Quarz (Bergkristall, Amethyst usw.) ist, bei dem G. $=2$, aber sicherlich kein 'Topas mit dem spezifischen Gewicht $\mathrm{G} .=3$, , -3, w, was nach dem Aussehen möglich wäre. Für den praktischen Gebrauch hält man eine genügende Anzahl solcher Indikatoren von genau bestimmtem spezifischen Gewichte ein für allemal rorrätig und hat sich nur zu hiiten, daß keine Verwechslung derselben eintritt.

Die Methode mit den schweren Fliissigkeiten, speziell mit dem Methylenjodid, hat also die Vorteile, daß man die gesuchte Zahl sehr rasch und leicht mit einer für praktische Zwecke stets genügenden Genaugkeit erhält und außerdem vor allem noch den besonders wichtigen, daß man auch das kleinste Steinchen oder Splitterchen zur Bestimmung benutzen kann, fuir das keine andere Nethode sichere Resultate geben wïrde. Sie hat aber neben anderen geringeren namentlich den einen Mißstand, daß sie für Steine mit einem grïßeren spezifischen Gewichte als 3,3 nicht mehr ganz bequem anwendbar ist. Man kennt wohl schwerere Flïssigkeiten als das Methylenjodid, aber diese haben alle gewisse Nachteile. Sie sind zum Teile erst bei höherer Temperatur flüssig, oder sie sind dickflüssig oder undurchsichtig oder giftig und aus jedem dieser Grïnde weniger brauchbar oder doch weniger angenehm.

Um aber trotzdem noch schwerere Steine nach dieser so bequemen Methode untersuchen zu können, hat man zunächst noch weiter vom Methylenjodid Gebrauch gemacht, das man durch Auflösen von Jod und Jodoform bis zur Sättigung auf die Dichte von 3,6 bringen kann. Steine mit einem spezifischen Gewichte von 3,6 schweben darin, und solche, die schwimmen, können durch Verdiinnen mit reinem Methylenjodid oder Benzol zum Schweben gebracht werden, worauf man wie vorhin das spezifische Gewicht mit der Westphalschen Wage etc. bestimmt. Die auf die angegebene Weise erhaltene Fluissigkeit hat nur den Übelstand, dafs sie sehr dunkel gefürbt, fast undurchsichtig ist, so daß sich die Bewegungen des eingetauchten Steines nicht so bequem verfolgen lassen und dali sein jeweiliger Stand nicht immer auf den ersten Blick erkannt werden kann. Dem ungeachtet ist sie aber in manchen Fällen noch gut zu verwerten, namentlich zu der im folgenden zu erläuternden raschen Bestimmung des annähernden Wertes für das spezifische Gewicht, und man muß um so mehr von ihr Gebrauch machen, als es etwas Besseres zur Zeit kaum gibt. 
Doch hat man ein Mittel gefunden, um nach dieser Methode selbst noch solche Edelsteine in Beziehung auf ihr spezifisches Gewicht zu untersuchen, die schwerer sind als das mit Jorl und Jodoform gesättigte Methylenjodid. Man bedient sich dabei des Thalliumsilbernitrats von der chemischen Zusammensetzung $\mathrm{TlAg}_{2} \mathrm{O}_{6}$, das zwar bei rewöhnlicher Temperatur fest ist, bei $750 \mathrm{C}$. (gleich $60^{\circ} \mathrm{R}$.) aber zu einer leicht wie Wasser beweglichen, vollkommen farblosen und klaren Flüssigkeit schmilzt. Diese Schmelze hat ein spezifisches Gewicht von ungeführ 4,s. Auf ihr schwimmt also noch der schwerste der durchsichtigen Edelsteine, der Zirkon (Hyacinth). Man kann auch hier durch Verdïnnen, und zwar mit kleinen Mengen Wasser, Fliissigkeiten herstellen, in denen die schwereren Edelsteine schweben, und dann deren Gewicht ganz in der oben für das Methylenjodid auseinandergesetzten Weise mittels der Westphalschen Wage oder, was hier vielleicht besonders vorteilhaft ist, mittels hierzu eingerichteter Indikatoren ermitteln. Diese Bestimmung ist nur deshalb etwas weniger bequem als die entsprechende mit IIilfe des Metlylenjodids, weil sie in der Wärme vorgenommen werden muß. Man bringt zu diesem Zwecke das Thalliumsilbernitrat in ein schlankes, hohes, dünnwandiges Becherslas ctwa von der Größe des in Fig. 5 und 7 abgebildeten Gefäßes und erbitzt, am hesten im Wasserbad, bis das Nitrat schmilzt. Der Schmelze wird dann ein wenig Wasser zugesetzt, was die Dichte vermindert und gleichzeitig die Schmelzbarkeit sehr erbeblich hefördert, so daf der Selmelzpunkt dadurch auf $60^{\circ}$ und sogar auf $50^{\circ} \mathrm{C}$. sinkt, ein Umstand, der für die Benutzung des Tballiumsilbernitrats zu dem vorliegenden Zwecke sehr vorteilhaft ist. Man gibt so lange Wasser zu, bis der zu untersuchende Stein eben sehwebt, muf aher dabei mit großer Vorsicht verfahren, damit nicht zu viel Wasser beigefügt wird, denn schon eine sehr kleine Menge erniedrigt das spezifische Gewicht der Schmelze recht erheblich. Man verführt daher zweckmäßig so, daß man absichtlich etwas zu viel Wasser verwendet und den C̈bersehub dureh Verdampfen vertreibt, wobei die Erwärmung so lange fortgescetzt werden muß, bis der anfänglich auf dem Boden des Gefäßes liegende Stein nach dem Unrïhren nicht mehr zu Boden sinkt, auch nicht an die Oberfläche steigt. Es ist dann nur darauf zu sehen, daß die Temperatur bei der Bestimmung des spezifischen Cewichtes mittelst der Westphalsehen Wage oder der Indikatoren dieselbe bleibt wie bei dem Schweben des Steines, da mit ihr sich auch die Dichte nicht unbeträchtlich ändert. Man hat hierdurch ein Mittel, das spezifische Gewicht aller, auch der schwersten Edelsteine mit einzigerer Ausnahme der beiden metallisch glänzenden, des Schwefelkieses und des IÏ̈matits, also vor allen der simtlichen durchsichtigen, die weitaus die wichtigsten sind, auch in den kleinsten Stiickchen mit Leichtigkeit und mit aller wïnschenswerten Genauigkeit festzustellen.

Fïr den praktischen Edelsteinkenner ist die Ermittelung des spezifischen Gewichtes nicht Selbstzweck, sondern lediglich Hilfsnittel zur Erkennung seiner Steine und zu ihrer Unterscheidung von ähnlich aussehenden. Dabei genïgt es oft, festzustellen, ob das Gewicht des zweifelhaften Körpers über einen Betrag, z. B. üher den des Methylenjodids hinausgeht voler hinter ilm zurückbleibt. Hat man z. B. einen farblosen Stein, von dem ('s unsicher ist, ob) er zum Bergkristall (G. $=2$, dann hat man sofort die Entscheidung, wenn man ihn in Methylenjodid $\left(G_{0}=3,3\right)$ wirft. Schwimmt er darin, dann ist "s Berghistall, jedenfalls nicht Topas; sinkt er unter, ist es I'opas und sicher nicht Bergkristall.

Diese Inn̈̈herungsmethode kann man neben anderen Nitteln zur Unterseheidung aller Edelsteine mit grobem Vorteile anwenden, da sie auberordentlich rasch zum Ziele fülırt. Man benutzt aber zweckmäßjigerweise nicht nur eine einzige Flüssigkeit, sondern mehrere von verschiedenem spezifischen Gewichte, in die man den betreffenden Stein erforderlichenfalls der lieihe nach hineinbringt. Es ereibt sich dann durch Schwimmen oder 
Sinken leicht, zwischen welchen beiden Flüssigkeiten der Stein beziiglich des spezifischen Gewichtes liegt oder weleher er auch wohl genau entspricht.

In der Praxis kann man mit vier solchen Flüssigkeiten auskommen:

1. Methylenjodid mit Jod und Jodoform gesättigt $\left(G_{0}=3,6\right)$;

2. reines Iethylenjodid $\left(G_{0}=3,3\right)$;

3. Methylenjodid mit Benzol verdünnt bis $\mathrm{G} .=3,0$ und endlich

4. dieselbe Mischung, aber stärker verdünnt bis $\mathrm{G}_{0}=2,65$, genau wie der Bergkristall. Im folgenden werden diese vier Flüssigkeiten, von der schwersten bis zur leichtesten. als die erste, zweite, dritte und vierte bezeichnet werden. Die dritte Fliissigkeit kann zweckmäßjig durch das symmetrische $\mathrm{A}$ e ety lent e trab r o w id CHBr-Br. $\mathrm{HC}$ ersetzt werden. Das spezifische Gewicht ist hier 2,:3,3,m. Diese Flissigkeit, die sich beim Stehen nicht verändert, wird, wie das Methylenjodid in den chemischen Fabriken für den bier in Rede stehenden Zweck hergestellt, und beide können sehr leicht beschafft werden, ebenso wie alle die anderen hier genannten Sulstanzen. Das Acetylentetrabromid ist sehr viel billiger als das sehr teure Methylenjodid, von dem 10 Gramm ungeführ 1 Mark kosten. Alle diese Vorteile hat auch das Bromoform ('HBr: mit dem spezifischen Gewicht 2, " bei $15^{\prime \prime} \mathrm{C}$.; es könnte, zweckmällig mit Benzol gemischt, statt des verdünnten Methylenjodids als vierte Flïssigkeit dienen und kann auch sonst vielfach statt Methylenjodid zur Beurteilung des spezifischen Gewichts von leichteren Edelsteinen beniitzt werden.

Mit Hilfe dieser 4 Flïssigkeiten läßt sich die fuir praktische Zwecke sehr wertvolle annähernde Bestimmung des spezifischen Gewichtes der Edelsteine mit der allergrößten Leichtigkeit und Raschheit durchführen. Man bringt den Stein zu diesem Zwecke in die erste Fluissigkeit. Sinkt er darin, was man trotz ihrer dunklen Farbe deutlich wahrnehmen kann, dann ist er schwerer als 3, Schwimmt er, so wird er in die zweite Flïssigkeit gebracht, nachdem er mit der Pinzette aus der ersten herausgenommen, in Benzol abgewaschen und getrocknet worden ist. Sinkt er in dieser, dann liegt sein spezifisches Gewicht zwischen 3,3 und :3,i. Schwebt er darin, dann ist es genau gleich 3,3. Schwimmt er dagegen auch in der zweiten Flïssigkeit, dann bringt man ihn mit denselben Vorsichtsmaßregeln in die dritte. Sinkt er in dieser, dann ist sein spezifisches Gewicht größer als 3," und kleiner als 3,: usw., wobei wie vorhin unter Umständen das rasche oder langsame Sinken oder Emporsteigen des Steines vom Boden des Gefäljes noch andeuten kann, ob eine grö̈lere Annäherung an den einen oder den anderen Grenzwert vorhanden ist, denn ein Stein, der nur sehr wenig schwerer ist, als $3, n$, bei dem also etwa $G_{0}=3$, , w wird in der dritten Fliissigkeit sehr langsam sinken und entsprechend in anderen Fällen. In der gleichen Teise wird schließlich auch von der vierten Flïssigkeit Gebrauch gemacht.

Bei solchen Untersuchungen hat man natiurlich die vier Flüssigkeiten fertig zubereitet vorrätig zur Hand. Man stellt sie beim Gebrauche in vier engen, aber weitmündigen Standglïsern, die mit der betreffenden Nummer versehen sind, und in der Reihenfolge dieser Nummern vor sich auf, so dab man die Steine bequem von der einen in die andere bringen kann. Tach dem Gebrauche müssen die Gläser sehr gut verschlossen werden, um Verluste durch Verdunsten zu verhindern.

Es ist natülich von grofer Bedeutung, stets zu wissen, ob eine solche Flïssigkeit auch immer genau das betreffende spezifische Gewicht noch besitzt, oder ob sich dieses nicht vielleicht durch Verunreinigung beim Gebrauche und vor allem durch Verdunstunge des sehr flüchtıgen Benzols veründert hat, was sehr leicht greschehen kann. Dies muß daher stets kontrolliert werden. Man kann dazu u. a. die Westphalsche Wage verwenden. Einfacher und zweckmäliger ist es aber, sich ähnlich wie oben der Indıkatoren zu bedienen, die man aber hier stets in der betretfenden Flïssigkeit belält. Man wählt dazu Mineralien, die den vier Flïssigkeiten entweder im spezifischen Gewichte ge- 
nau entsprechen oder ihnen doch sehr nahe kommen. Zur Kontrolle der vierten Flïssigkeit wirft man einen Berckkristall hinein; dieser mul darin gerade schweben, sonst ist sie nicht richtig. Die dritte Fliissigkeit ist in Ordnung, wenn darin ein Phenakit $\left(G_{.}=2,95\right)$ noch schwimmt, dagegren ein weiler oder rosenroter Turmalin $(\mathrm{G} .=3,12)$ langsam sinkt. In (ler zweiten mulj ein Dioptaskristall $\left(\mathrm{G}_{0}=3,259\right)$ noch schwimmen, ein Olivin (Chrysolith) $(G .=3,33)$ langsam sinken. Endlich $m u$ in der ersten Flïssigkeit ein Topas $(G .=3,55)$ noch schwimmen. Nan korrigiert die Flïssigkeiten durch die nötigen Zusätze von Benzol, Methylenjodid oder auch von Jod und Jodoform, wenn sie nicht mehr ganz den genannten Anforderungen entsprechen. Bei reinem Nethylenjodid und beim Acetylentetrabromid ist, eine solche ständige Kontrolle ïberflüssig. Da sie keine Gemische sind, ändert sich ihr spezifisches Gewicht durch Verdunstung nicht.

Mittelst dieser vier Flïssigkeiten lassen sich die sämtlichen Edelsteine zum Zwecke ihrer Bestimmung nach dem spezifischen Gewichte in fünf Gruppen einteilen:

I. Steine mit $G_{0}=3,60$ oder schwerer;

II. solche, bei denen das spezifische Gewicht zwischen 3,3 und 3,6 ;

III. zwischen 3,0 und 3,3 ;

IV. zwischen 2,65 und 3,3 ; und

V. solche mit $G_{0}=2,65$ und darunter.

Die Steine der I. Gruppe sinken oder schweben in der ersten Flüssigkeit, die der II. schwimmen in der ersten, schwersten, sinken aber in der zweiten zu Boden u. s. f.

Bestimmungen mit Hilfe solcher Flüssigkeiten werden u. a. durch folgende Beispiele klar gemacht. Man hat einen wasserhellen, klaren und farblosen Stein, von dem man nicht weil, ob er Bergkristall $\left(G_{0}=2,65\right)$ oder Phenakit $\left(G_{0}=2,95\right)$ oder weiler Turmalin $\left(G_{0}=3,12\right)$ ist. Wirft man ihn in die vierte Flïssigkeit und er schwebt, so ist er Bergkristall. Sinkt er hier, schwimmt aber in der dritten Flüssigkeit, so ist es Phenakit. Sinkt er auch in dieser, so ist es weißer Turmalin. Oder man hat einen farblosen Stein von dem es nicht sicher ist, ob es Diamant $\left(G_{0}=3,5\right)$ oder farbloser Hyacinth $\left(G_{0}=4\right.$, 65 , ist. Schwimmt er in der ersten Fliissigkeit, so ist es Diamant, sinkt er darin, Iyacinth. Man muß bei allen diesen Versuchen nur zusehen, daß die Temperatur möglichst nahe der gewöhnlichen Zimmertemperatur $(15-200$ C. $)$ ist und daß sie sich während der Versuche möglichst gleich bleibt, weil mit ihr die spezifischen Gewichte aller dieser Flüssigkeiten sich nicht unwesentlich ändern, wie wir oben für das reine Methylenjodid gesehen haben. Die Berïcksichtigung der Temperatur ist namentlich dann nötig, wenn der Stein einer der Flüssigkeiten im spez. Gewichte sehr nahe steht.

In dem der Bestimmung der Edelsteine speziell gewidmeten dritten Abschnitte wird von diesen vier Fliissigkeiten und den auf ilmen beruhenden fünf $\Lambda$ bteilungen ein umfassender Gebrauch gemacht werden. Aber auch bei der Beschreibung der einzelnen Edelsteine soll schon angegeben werden, wie sie sich zu jenen Fliissigkeiten verhalten. Im folgenden sind die wichtimsten Edelsteine nach ihren spezifischen Gewichten, beginnend mit den schwersten und abnehmend bis zu den leichtesten, zusammengestellt und in die durch die vier Normalflïssigkeiten bestimmen fünf Gruppen, wie sie oben erwähnt wurden, eingeteilt. Die Werte für das spezifische Gewicht jedes Edelsteines sind, wie schon oben angegeben, etwas schwankend. Der Betrag dieser Schwankungen ist aber gering. Er folgt aus den in der folgenden Tabelle mitgeteilten Zahlen. 
Tabelle der spezifischen Gerichte:

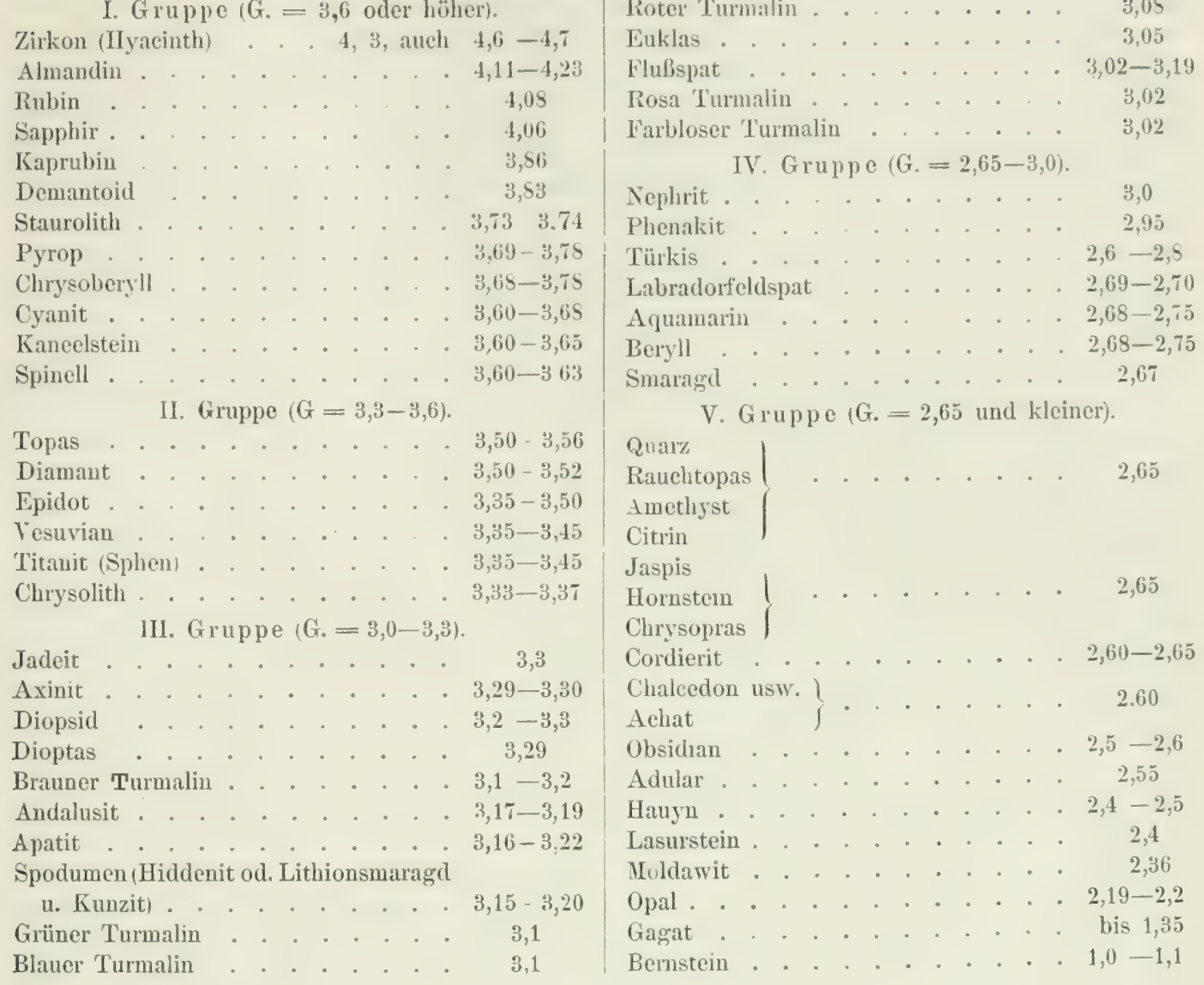

\section{b) Spaltbarkeit.}

Die kristallisierten Mineralien - und zu diesen gehören, wie wir gesehen haben, die allermeisten Edelsteine - haben die Eigenschaft, nach verschiedenen Richtungen einen verschieden festen Zusanmenhang der kleinsten Teilchen zu zeigen, aus denen sie aufgebaut sind. Bel manchen von ihnen ist in gewissen Richtungen dieser Zusammenhalt, die Kohärenz, so schwach, dal sie schon bei einem leichten Schlag nach vollkommen ebenen Flächen auseinanderbrechen, die als Flächen geringster Kohärenz anzusehen sind. In ausgezeichneter Weise zeigt dies unter anderen der Kalkspat, der allerdings nicht zu den Edelsteinen zähit. Schon wenn ein Kalkspatlisistall auf den Boden fällt, zerspringt er nicht selten nach ebenen Flächen, in denen der Zusammenhalt der kleinsten Teilchen sehr schwach und geringer ist als in allen umliegenden Flächenrichtungen.

Am leichtesten und vollkommensten läßt sich diese ebenflächige Trennung in der Weise bewirken, daß man einen scharfen Meißel in der geeigneten Richtung auf den Kristall aufsetzt (Fig. S S. 30) und ihn durch einen IIammerschag in diesen hineintreibt, also durch ein Verfahren, das man als Spalten zu bezeichnen pfleggt. Daher heißen diese Richtungen geringster Kohärenz Spaltungsrichtungen, die cbenen Trennungsflächen Spaltungsflächen, auch Blätterbrüche oder Blätterdurchgänge. Diese sind bei allen Exemplaren eines und desselben Minerals stets in derselben W'eise ausgebildet, entweder nur nach einer Richtung oder nach mehreren, die dann für jede einzelne Nineral- 
spezies eine ganz bestimmte gregenseitige Lage haben. Bei manchen Mineralien fehlen sie allerdings auch ganz oder sind doch sehr wenig deutlich bemerkbar.

Läßt sich auch die Spaltung nicht bei allen Mineralien gleich leicht ausführen, so bewerkstelligt sie sich doch bei allen Exemplaren eines und desselben Minerals nicht nur nach denselben Richtungen, sondern auch stets mit dem nämlichen Grad von Leichtigkeit und Tollkommenheit. Bei vielen, wie z. B. beim Kalkspat, ist die Spaltung stets ohne jede Mühe auszuführen, und die Trennungsfliichen sind vollkommen glatt und eben, ohne Unterbrechung dureh unregelmäßjig krumme Partien. Von den Edelsteinen sind neben anderen besonders leicht spaltbar der Topas und Euklas nach einer Richtung und der Diamant nach vier Richtungen. Bei anderen, wie z. B. beim Smaragd, ist die Spaltung viel schwieriger zu bewerkstelligen, und auf den Spaltungsflächen wechseln ebene und krumme Partien unregelmäßig miteinander ab. Wieder bei anderen Edelsteinen läßt sich Spaltbarkeit überhaupt nicht mehr feststellen, so beim Quarz, Granat, Turmalin. Die Unterschiede der Kohärenz sind bei ihnen so gering, daf sie sich nicht mehr leicht in ebenen Tremmungflächen äußern können. Diese entstehen bei solchen Steinen kaum mehr, wenn man sie absichtlich herzustellen versucht, wohl aber zuweilen unbeabsichtigt durch Zufall.

Bei amorphen Körpern endlich, wie z. B. beim Opal, ist die Kohärenz wie das ganze physikalische Verhalten überhaupt nach allen Richtungen genau dasselbe; bei diesen sind also ebene Spaltungsflächen völlig unmöglich und auch tatsächlich nie vorhanden. Wo man daher auch nur Andeutungen von Spaltbarkeit sicher erkennen kann, weib man bestimmt, dalf ein kristallisierter und nicht ein amorpher Körper vorliegt. Man kann

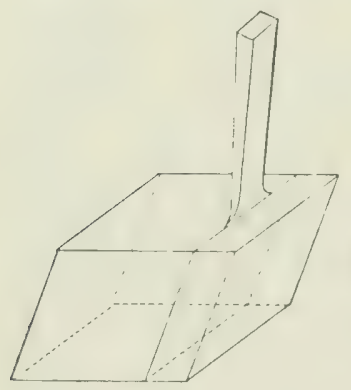

Fig. 8 .

Spaltharkeit eines Kalkspatkristalls. durch dieses Hülfsmittel zuweilen feststellen, daß man es mit einem echten kristallisierten Edelstein zu tun hat und nicht etwa mit einer Nachbildung aus Glas, das stets amorph ist und daher keine Blätterbriiche haben kann.

Sind an einem Kristall melrere, zum mindesten drei Blätterbrïche in geeigneter Richtung vorhanden, so läßt sich aus demselben durch Spalten ein Körper herstellen, der rings von Spaltungsflächen begrenzt ist. Solche Körper nennt man Spaltungsstiicke. So kann man z. B. den oben erwähnten Kalkspat nach drei Flächen spalten, die drei gleiche, aber schiefe Winkel miteinander machen (Fig. 8). Man ist daher imstande, aus einem Kalkspatstïck eine Spaltungsform von der Gestalt eines sog. Rhomboëders herzustellen, also etwa von der Gestalt eines von zwei gegenüberliegenden Ecken aus etwas zusammengedrickten Würfels.

Ebenso erlauben die vier Blätterdurchgänge des Diamants die Herstellung einer Spaltungsform, die ganz einem regulären Oktaeder (Fig. 40) entspricht.

Solehe Spaltungsstiicke sehen gerade aus wie natïliche Kristalle, ihre Begrenzungsflächen sind ebenso regetmälig und eben wie bei diesen, aber sie sind nicht gleich anfangs bei der Entstehung des betreffenden Kristalls durch die inneren Kräfte der Substanz auf rein natiirlichem Wege, sondern später künstlich gebildet worden. Für die Kenntnis, sowie für die Verarbeitung und Benutzung der Edelsteine sind die Blätterbrüiche in mannigfacher Ilinsicht von der gröliten Bedeutung; bei der Beschreibung der einzelnen Steine werden daher die Verhältnisse der Spaltbarkeit stets eingehend dargelegt werden.

Zunächst bietet die Spaltharkeit häufig ein sehr bequenes Mittel, um rohe Steine zu erkennen und von anderen ähnlichen zu unterscheiden. Jeder Art von Edelsteinen kommt, wie wir gesehen hahen, eine ganz besondere Spaltbarkeit zu, die durch die Zabl, die wergenseitige Lage und die Beschaffenheit der Blätterbriche gegeben ist und sich im allseneinen von der Spaltbarkeit der anderen Arten von Edelsteinen unterscheidet. Diese 
sind also durch ihre Spaltharkeit vielfach in bestimmter Weise charakterisiert. So wibt es z. B. zwei bläulichgrüne (meereriune) Steine, den Aquamarin und eine grewisse Varivtiit des Topases, die sich beide durch die Farbe und die aiuberlich erkennhare lieschaffenlerit oft nur schwer voneinander unterscheiden lassen. Der erstere zeint eme nur wenig deutliche Spaltbarkeit in einer Richtung, der zweite ist, obenfalls in einer lichtung, selur vollkommen blätrig. Ist man im Zweifel, weleher von beiden Steinen vorliegrt, so entscheidet eine etwa vorhandene deutliche Spaltungsfläche ohne alles weitere für Topas. Ist keine deutliche Spaltung zu bemerken, dann ist die Sache allerdings zweifelhaft, da selbstrorständlich auch bei sehr leicht spaltharen Mineralien die Blätterhrieche nicht notwendigr immer ausgebildet und äußerlich sichtbar zu sein brauchen.

Zur Erkennung der Spaltbarkeit eines Ninerales ist es abor zuweilen gar nicht nötier, daß diese in Form von Blätterbriichen auch wirklich zum Ausdrucke gelangt. Wenn sie ziemlich vollkommen ist, dann macht sie sich nicht selten durch greradlinige liisse in den betreffenden Richtungen bemerkhar. Auf diesen dringt häufig etwas Luft ein. die dann in der Spalte eine ganz dïnne Schicht bildet, so dab die glänzenden Regrenbogenfarben diinner l'littchen entstehen, das sogenannte Irisieren. Bei farblosen und durchsichtigen Kristallen tritt dies oft als Me rkmal der Spaltharkeit sehr schön hervor. In den Richtungen, denen dentliche Blätterbrïche parallel gethen, bemerkt man auch, wie wir später noch eingehender sehen werden, eine eigentiimliche Art von Glanz, den som. I'erhmutterwlanz, der durchaus auf die Blätterhrïche leicht spaltbarer. Nineralien beschränlit ist und der daher ebenfalls zum Nachweis der in Rede stehenden Beschaffenheit dienen liann. Selbst an geschliffenen Steinen läßt sich zuweilen durch die geradlinigen Risse, das Irisieren und den Perlmutterglanz deutlich die Spaltbarkeit noch feststellen.

So wertvoll aber diese kleinen Spaltungs sis se geschliffener Edelsteine auch für deren Erkennung sein mögen, so sind sie doch an ihnen höchst unerwïnscht. Sie verursachen Unregelmäßigkeiten in der Bewegrung des Lichtes und können dadurch die Schönheit des Steines auf das empfindlichste beeinträchtigen und scinen Wert bedeutend herabmindern. Solche Risse, die sogenannten „Federn“, stellen also einen seh" bedenklichen Fehler, namentlich für die durchsichtigen Edelsteine dar. Sie sind um so unangrenehmer, als anfänglich ganz kleine und kium bemerkbare Spältchen nicht selten im Laufe der Zeit größer werden und deutlicher hervortreten. Zuweilen wird dadurch sogar allmählich ein vollkommenes Zerbrechen des Steines veranlaßt. Rohe Steine, die solehe Risse in einigermaßen bemerkbarer Weise enthalten, lïnnen daher vielfach nicht zu Schmucksteinen verschliffen werden, wenn sie gleich sonst hierzu durchaus greeignet wären; sie würden auch vielfach die Operation des Schleifens nicht aushalten, sondern dabei zerbrechen.

Die leichte Spaltbarkeit bedingt überbaupt, selbst wenn nicht schon kleine Risse vorhanden sind, große Vorsicht beim Schleifen, sie erfordert anch eine besonders sorgfältige Behandlung derartiger Steine beim Tragen in irgendeinem Schmuckstiicke. Das Anstoßen an einen harten Gegenstand, Fallen auf den Boden oder eine ähnliche Erschïtterung; sogar eine unvorsichtige Temperaturerhöhung, z. B durch Eintanchen in warmes Wasser kann leicht die Entstehungr oder Vergrößerung von solchen schädlichen Spaltungsrissen, ja sugar das Zerbrechen veranlassen, wenn der Stein sonst auch noch so hart und fest ist.

Wenn so die Spaltbarkeit unter Umständen von schäidlichem Einflusse sein wirl, so kann man doch in anderen Fällen, namentlich bei der Bearbeitung der Edelsteine durch Schleifen, von ihr mit Vorteil Gebrauch machen. Steine mit deutlichen Blätterbrüchen, z. B. Topas, die für einen einzigen Schmuckstein zu groß sind, lassen sich durch einfaches Spalten mit Leichtigkeit und ohne den geringsten Materialverlust in einzelne Stücke von geeigneter Gröbe zerlegen, während solche ohne Spaltbarkeit mit großem Aufwande von Zeit, Mühe und Kosten zersïgt werden müssen. Wieder in 
anderen Fällen lassen sich rom rohen Steine leicht und rasch einzelne Teile durch Spalten wegnehmen, die sonst weggeschliffen werden müßten, was ebenfalls eine mühsame, zeitraubende und kostspielige Operation ist, und auberdem kann man die abgespaltenen Stücke noch zu kleineren Schmucksteinen herrichten, so daß viel weniger von dem groben Steine verloren geht, als wenn er durchaus vermittelst Schleifen bearbeitet werden müßte.

In dieser IIinsicht ist besonders beim Diamant die leichte Spaltbarkeit mit größtem Nutzen zu verwerten. Der Diamant gibt, wie wir gesehen haben, leicht ein Spaltungsstück von der Form des regulären Oktaëders (Fig. 56), die der Schifform, die man dem Diamant meist zu geben pllegt, der Brillantform, selır nahe steht. Man stellt also beim Schleifen eines Diamants zuerst und mit großer Leichtigkeit und Raschheit ein oktaedrisches Spraltungsstïck dar, und man braucht dann nur noch wenig wegzuschleifen, um die gewïnschte Brillantform zu erhalten. Wäre der Diamant nicht nach den Flächen eines Oktaellers spalthar, so wäre die Herstellung der Brillantform eine Sache von sehr viel größerer Schwierigkeit und sehr viel mühevoller und teurer. Durch die Spaltbarkeit wird aber die Bearbeitung ganz bedeutend vereinfacht und abgekürzt, und die weggespaltenen Stiicke behalten ihren Wert, während sie beim Wegschleifen vollkommen verloren gehen wïrden. Wir werden bei der Betrachtung des Diamants hierauf noch einmal ausführlicher zurückkommen.

Bruch. Wenn an einem Mineral keine deutlichen Blätterbrüche vorhanden sind, so zerspringt es beim Zerschlagen nach unregelmäßigen Flächen, die bei verschiedenen Mineralien verschiedene Gestalt und Beschaffenheit haben. Die Form dieser unregelmäßigen, unehenen Bruchflächen wird kurz als der Bruch dieser Mineralien bezeichnet. Er ist für sie bis zu einem gewissen Grade ebenfalls charakteristisch, und es ist daher bei der Untersuchung roher Steine gut, die vorkommenden Formen der unregelmäßigen Bruchflächen zu kennen.

Häufig haben diese Flächen die rundliche Form der Innenseite glatter Muschelschalen. Ein solcher Bruch heißt daher der m uschlige. Der vertieften Bruchfläche entspricht eine ebensolche, aber erhabene des anderen weggeschlagenen Bruchstïckes. Auf ihr, wie auch auf der vertieften Flïche, laufen $u m$ die Ansatzstelle des Hammers herum zahlreiche, regelmäfig ringförmige Runzeln, die an die sogenannten Anwachsstreifen auf der Aubenfläche glatter Muschelschalen erinnern. Ausgezeichneten muschligen Bruch zeigen u. a. die natürlichen (und kïnstlichen) Gläser, wie z. B. Obsidian. Die Flächen des m uschligen Bruches sind bald flacher, bald tiefer, bald ist der Umfang der Vertiefung größer, bald kleiner und zuweilen sogar schr klein. Man spricht darnach von flach- und tiefmuschligem, großj- und kleinmuschligem Bruch; den letzten nennt man, wenn die Vertiefungen sehr klein sind, den unebenen Bruch. Manchmal nähert sich die Bruchfläche sehr der Ebene, ohne aber irgendwo wirklich vollkommen eben zu sein. Das ist der ebene Bruch, wie er z. B. beim Jaspis vielfach in ausgezeichneter Weise vorkommt; er entwickelt sich durch allmähliche Übergänge aus dem groß- und flachmuschligen und dem unebenen.

Manchmal geschieht die Trennung der Bruchstiicke beim Zerschlagen so, daßs auf den Bruchflächen halb losgerissene dünne Splitter hängen bleiben, die sıch in hellerer Farbe auf dem dunkleren IIintergrunde des Steines sebarf abheben. Ein soleher Bruch heilit der splittrige; er findet sich u. a. beim Chrysopras. Splittrig kann jede der vorhin genannten Bruchflächen sein; wenn dies nicht der Fall ist, heilbt der Bruch glatt.

Auch Sprünge von soleher unregelmäßigen Form dringen oft wie die Blatterbrïche eine Strecke weit in die Edelsteine hinein, ohne daß diese ganz auseinander brechen. Sie vermindern meist die Durchsichtigkeit und Schönheit des betreffenden Stiickes sehr erheblich und 
sind daher ebenso refüchtet wie jene. In manchen Edlelsteinen sind sie nur sparsam vorhanden, in anderen, wie z. B. im smaragrd, erscheinen sie gewöhnlich in srïferer Zahl. Auf ihnen dringt ebenfalls zuweilen Luft ein und bringt in farblosen und durchsichtigen Mineralien auch ohne Spaltbarkeit die Ericheinung des Irisierens hervor. wie z. B. in Bergkristall. Hier sind aber die Spalten und die auf ihnen liegrenden Farhenschichten mehr oder wenger stark gekriimmt, bei vollkommen spaltbaren Steinen dagegen scharf geradlinig und eben. Auch das Farbenspiel des edlen Opals beruht wahrscheinlich auf zahlreichen unrexelmäßimen feinen Sprüngen, die also hier nicht nur nichts schaden, sondern geradezu die Schönheit und den Wert der Steine bedingen.

\section{e) II arte.}

Eine besonders wichtige Eigenschaft der als Edelsteine benutzten Mineralien ist die Härte. Man versteht darunter den Widerstand, den sie dem Ritzen durch ein anderes Nineral oder überhaupt dureh einen anderen Körper entgegensetzen. Je grö̈fer dieser Widerstand ist, desto härter ist der stein. Die Härte ist deshalb so wichtior, weil nur harte Mineralien die auf der Durchsichtigkeit, dem Glanz, der Farbe und dem Farbenspiel heruhende Schönheit dauernd bewahren. Weichere Steine können im vollkommen frischen Zustande, wenn sie eben aus der Hand des Schleifers kommen, gleichfalls einen hohen Grad von Schönheit zeigen, sie werden aber beim Gebrauch aus einem sofort näher zu erörternden Grunde an ihrer Oberfläche bald abgegriffen und sogar zerkratzt und sind dann zum Schmuck nicht mehr verwendbar. Namentlich für durchsichtige Steine ist grobe Härte wichtig, da an ihnen ein kleiner Ritz selbst auf der hinteren, vom Beschauer abgekehrten Seite vielfach gespiegelt in dessen Auge gelangen und so die Schönheit erheblich beeinträchtigen kann. An einem undurchsichtigen Steine schadet eine solche kleine Verletzung weniger, ist aber hier gleichfalls unerwünscht. Die Härte kann auch dazu dienen, Edelsteine von verschiedener Art voneinander zu unterscheiden, und die Edelsteinhändler machen davon einen vielfachen und ausgedehnten Gebrauch. Man sieht hieraus, wie wichtig es ist, diese Eirenschaft der einzelnen Steine grenau festzustellen. Wir werden hier also die allgemeinen Methoden kennen zu lernen haben, mittelst deren die Mineralien nach dieser Richtung hin untersucht werden, und daran die spezielle Anwendung auf die Edelsteine anschließen.

Zunächst kann man leicht ermitteln, welches ron zwei vorliegenden Mineralien das härtere ist. Es ist klar, daß es dasjenige sein mul, mit dem man das andere ritzen kann, wenn man mit einer scharfen Ecke desselben über eine möglichst glatte Fläche des zweiten unter einem gewissen Drucke hinstreicht. Dasjenige, das dabei geritzt wird, ist das weichere, und wenn keines das andere ritzt, sind sie beide gleich hart. Man kann auf diese Weise erkennen, daß alle Exemplare eines jeden Minerals in Beziehung auf die Härte vollkommen miteinander übereinstimmen, daß aber verschiedene Mineralien hierin im allgemeinen mehr oder weniger von einander abweichen und oft sogar sehr bedeutende Unterschiede zeigen. Hierin liegt der Grund für die erwähnte Möglichkeit, verschiedene Edelsteine nach ihrer Härte zu unterscheiden.

Untersucht man in der angegebenen Weise durch gegenseitiges Ritzen die sämtlichen bekannten Mineralkörper, so kann man sie in eine Reihe ordnen, in der die Härte vom weichsten bis zum härtesten stetig zunimmt. Aus dieser Reihe hat der frühere Wiener Mineraloge Mo hs zehn Mineralien herausgegriffen, das weichste, das härteste und acht zwischenliegende, deren Härte in gewissen Zwischenräumen fortschreitet. Diese zehn Mineralien wurden von Mohs als die Härteskala bezeichnet. Ihre Härten wurden gewissermaßen als die Normalhärten angenommen und die der anderen Mineralien damit 
verglichen. Jedes einzelne Glied der Skala reprïsentiert einen Härtegrad, und zwar das weichste den ersten und so weiter bis zum härtesten, dem der zehnte entspricht.

Die Glieder der Härteskala sind die folgenden Mineralien:
1. Talk
6. Feldspat
2. Gips
7. Quarz
3. Kalkspat
8. 'Topas
4. Flulsspat
9. Korund
5. Apatit
10. Diamant.

Man darf sich aber nicht vorstellen, daß diese zehn Mineralien in bezug auf die Härte grleichweit roneinander abstehen. Diamant ist von Korund sehr viel weiter entfernt, als dieser vom Topas, ja sogar weiter als der Korund vom Talk. Die Wahl der Mineralien für die Härteskala ist lediglich nach den praktischen Zwecken der Mineralogie getroffen, die darin bestehen, durch Vergleichung mit den Gliedern der Härteskala die Härte der anderen Mineralien rasch und genügend genau zu bestimmen.

Dies wird in der Weise bewerkstelligt, daß man angibt, welchem Mineral der Härteskala sie entspricht oder zwischen welchen Gliedern derselben sie steht. Dadurch ist dann für jedes Mineral der Härtegrad bestimmt, den man kurz mit seiner Nummer in der Skala $\mathrm{zu}$ schreiben und auch auszusprechen pflegt, also z. B. H. $=8$, d. h. das Mineral hat den achten Härtegrad, mit anderen Worten, es ist ebenso hart wie der Topas, oder $\mathrm{H} .=7-8$, d. h. die Härte des Minerals liegt zwisehen der des Quarzes und des Topases, wobei man zuweilen noch angeben kann, welchem von diesen beiden es näher steht. Ist es näher dem Quarz, so sagt man $I .=71 / 4$; es ritzt dann nicht sehr leicht Quarz, wird aber leicht vom Topas geritzt. Ist es dagegen näher dem Topas, so ist $\mathrm{H}_{0}=7^{3 / 4}$; es ritzt dann leicht Quarz, wird aber schwer von Topas angegriffen. Steht es endlich ziemlich in der Mitte dann sagt man: $\mathrm{H}_{0}=71 / 2$.

Die Ermittelung der Hïrte eines Minerals mit Ililfe der Skala geschieht in der schon ohen angedeuteten W'eise, durch Ritzen. Man hat die Glieder der IIäteskala in passenden Stiicken, mit Kristallflïchen oder glatten Bruchflächen oder, wenn erforderlich mit angeschliffenen und polierten Flächen von genügender Größe, sowie mit scharfen Ecken zum Gebrauch bereit vor sich liegen. Nun nimmt man meist zuerst das weichste Glied der Skala, den Talk und sucht mit diesem das Mineral zu ritzen. Er bringt keinen Eindruck hervor, wenn letzteres härter ist. Man nimmt dann den Gips, der, wie wir annehmen, wieder keinen Eindruck hinterläßt, und so ein Glied der skala nach dem anderen. Dabei entfernt man jedesmal das von dem weicheren ritzenden Nineral auf dem härteren hängen gebliebene Strichpulver durch Abreiben und sieht nach, ob auf der geritzten Fläche wirklich ein Eindruck, ein Ritz, entstanden ist. Je größer die Härte, desto feiner pflegen die Ritze zu sein; daher ist, namentlich bei höheren Härtegraden, wie sie besonders bei den Edelsteinen meist vorkommen, die Betrachtung mit der Lupe sehr zu empfellen, mittels der man auch den feinsten Ritz leicht entdeckt. Lndlich wird das Material seritzt werden. Dies geschehe beispielsweise durch den Topas. Dann hat das zu untersuchende Mineral entweder genau die IIärte 7 , oder es steht zwischen 7 und 8 . Um zu sehen, weleher dieser beiden Fälle vorliegt, sucht man nun umgekehrt mit dem zil untersuchenden Mineral den den 7. Grad der Skala repräisentierenden Quarz zul ritzen. Wird dabei auf dem (Suar\% kein Eindruck hervorgebracht, so dab sich also beide, das Hineral und der Quarz, geegensertig nicht ritzen, dann sind sie beide gleich hart; man hat dann: II. $=7$. Wird dagegen der Quarz geritzt, dann ist das Mineral härter als Quarz; da es aber, wie wir eben gesehen haben, weicher ist als Topas, so ist II. $=7-8$, Ian kamn dabei zuweilen aus dem mehr oder weniger leichten Ritzen des einen durch 


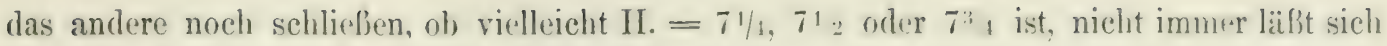
aber eine bestimmte Ansicht bierüber erlangen.

Diesen Gang kann man durch Beohachtung einiger besonderer Merkmale oder durch einige einfache Versuche oft (erheblich abkirzen. Die weichsten Vineralien, die vom ersten Härtegrade, fühlen sich eigentümlich fettig an; dhe vom zweiten Grade werlen leicht mit den Fingernagel geritzt; bei denen vom dritten ist dies nicht mehr müglich, sie lassen sich aber mittels eines Messers sehr leicht ritzen. Dies geht schwieriger bei den Mineralien vom vierten, kaum mehr bei denen des fünften und sechsten, und gar nicht mehr bei denen des siebenten Grades. Die härteren rom siebenten Grade ab geben am Stahl mehr oder weniger starke Funken, was bei denen rom sechsten Grade nur in Spuren, bei den noch weicheren gar nicht mehr der Fall ist. Gröfere Härten als die des Apatits kann man daran erkennen, daß die betreffenden . Mineralien gewöhnliches Fenstergras ritzen, das beinahe genau den fünften IIärtegrad hat; je höher die Härte geht, desto stärker wird das Glas angegriffen.

In der angegebenen Weise geht man bei der Bestimmung der Härte von Mineralien vor, weil dadurch die Härteskala möglichst geschont wird, und so kann man auch bei rohen Edelsteinen verfabren. Geschliffene Steine erfordern jedoch besondere Rüicksicht, da sie durch einen Ritz leicht entstellt und entwertet werden können. Man kehrt daher bei ihnen die Methode um und fährt mit einer Ecke des Steins oder dem Rande über die glatten Flächen der Mineralien der Härteskala. Dabei werden zwar diese stark beansprucht, aber die Steine werden geschont, und man erhält auch so leicht den gesuchten Härtegrad. Indessen ist auch hierbei trotz der beträchtlichen Härte der meisten und kostbarsten Edelsteine die größte Vorsicht geboten. Da das Ritzen mit einem gewissen, nicht zu germgen Druck geschehen muß, so kann die betreffende Ecke, mit der geritzt wird, unter Lmständen leicht ausbrechen, namentlich, wenn, wie z. B. beim Diamant und Topas, leichte Spaltbarkeit vorhanden ist. Härteuntersuchungen sind demnach bei geschliffenen Steinen in ihrer Anwendung zur Erkennung und Unterscheidung immerhin nicht unerheblich beschränkt, und in manchen Fällen mufs man auf die Anwendung dieser an sich so wertvollen Iethode verzichten, während sie bei rohen Steinen stets unbedenklich ist, und daher ein wichtiges Hilfsmittel bildet.

Bei den als Edelsteine rerwendeten Mineralien kommen im allgemeinen nur die höchsten Härtegrade vor. Die kostharsten zeigen den zehnten, neunten oder achten Grad, nur wenige der wertvolleren gehören dem siebenten oder gar einem noch niedrigeren an. Die Härte über der des Quarzes wird daher auch Edelsteinhäıte genannt. Ein Stein, der weicher ist, ist auch wenig zum Schmuckstein geeignet, da er schon rom Staub angegriffen wird. Dieser enthält stets neben anderen Bestandteilen kleine Quarzpartikelchen, die sich selbst beim besten V'erschluf ïberall ablagern. Beim Reinigen durch Abreiben mit einem Tuche werden die Steine von den kleinen Quarzteilchen immer etwas geritzt, wenn sie weicher sind als diese, wenn sie also nicht mindestens den siebenten Härtegrad haben. Sie verlieren dadurch im Laufe der Zeit allmählich ihren Glanz und werden trïbe, matt und unansehnlich, wïhrend die härteren Edelsteine unverletzt bleiben und ihre Schönheit dauernd behalten.

Bei Edelsteinen handelt es sich also, seltene Ausnahmen abgerechnet, immer um hohe Härtegrade. Nur sehr wenige werden von einem Messer angegriffen. Die allermeisten ritzen Glas, das man, eventuell eine Fensterscheibe, stets bequem zur Hand hat. Dies tun natïrlich die so bäufigen Tachahmungen der guten Edelsteine in Glas nicht; sie können an diesem Verhalten oft leicht erkannt werden. Will man behufs sicherer Bestimmung eines Edelsteines dessen Härte nach der Skala genauer ermitteln, dann kann man sich der oben erwähnten Methoden bedienen, wobei es aber nicht nötig ist, die ganze 
Härteskala vor sich zu haben; die niedersten Härtegrade können ganz wegfallen. Es genügt eine kleine Glastafel, die in hinreichender Weise den fünften Härtegrad repräisentıert und die leichter zu beschaffen ist als ein gutes Stïck Apatit; ferner je ein Stück Feldspat, Quarz (am besten in der farblosen und durchsichtigen Abart des Bergkristalls) und Topas, die wie schon hervorgehoben, mit möglichst glatten und glänzenden Flächen versehen sein mïssen, auf denen man auch den kleinsten Ritz eventuell mit der Lupe leicht und sicher erkennt. Auch eine Korund-(Sapphir-1Platte, sowie ein am Ende eines Stiftes befestigter Diamantsplitter, ein sog. Schreibdiamant, sind zuweilen noch von Nutzen. Die ganz wenigen weichen Edelsteine, deren Härte unter der des Apatits liegt, werden daran erkannt, daß sie Glas nicht ritzen, und dies genügt neben den unmittelbar sichtharen Eigenschaften zu ihrer Erkennungr meist vollkommen; wenn ein Stein Glas nicht ritzt, so ist er schwerlich ein wertvoller Edelstein. Steine von größerer Härte als Topas gibt es ebenfalls nur sehr wenige: es ist, wie die unten folgende Tabelle zeigt, der Korund, wohin u. a. der Rubin und Sapphir gehören, und der Chrysoberyll, sowie der bärteste von allen, der allein auch den Korund noch ïbertrifft, der Diamant. Diese ergeben sich daraus, dab sie allein den Topas ritzen, nicht aber, Diamant ausgenommen, den Korund. Sie kömnen, wie übrigens auch die weicheren als Glas, durch das spezifische Gewicht und andere noch zu besprechende Hilfsmittel unterschieden werden. Daher sind auch die beiden höchsten Glieder der Härteskala nicht unbedingt erforderlich.

Die Edelsteinhändler benutzen statt der Härteskala, die in der oben angegebenen Form und Beschränkung für ihre Zwecke am geeignetsten wäre, vielfach lieber einige andere Instrumente, vor allem eine harte Stahlfeile. Diese greift llineralien vom füniten Härtegrad noch stark, solche vom sechsten nur noch schwach an und erzeugt je nach der gröberen oder geringeren Härte mehr oder weniger Pulver. Quarz hat ungefähr dieselbe Härte wie der bestgehärtete Stahl, aus dem die Feile hergestellt ist; Steine vom siebenten Järtegrad werden daher von der letzteren nicht mebr leicht angegriffen, und härtere greifen ihrerseits die Feile an und polieren sie. Dabei hinterbleibt auf dem Stein ein vom abgeriebenen Stah! herrïhrender grauer metallischer Schimmer. Eine ungefähre Schätzung der Härte erlaubt auch der Ton, der beim Streichen des Steines auf der Feile entsteht. Je härter der Stein ist, desto höher ist dieser Ton, wobei aber zur Vergleichung möglichst gleich große Stücke gewählt werden müssen.

Für geschliffene Steine ist aber eine solche Feile nicht melır geeignet. Bei diesen wird in der Praxis vielfach ein möglichst stark gehärteter Stahlstift mit einer scharfen Spitze benutzt. Diese ritzt Feldspat, noch leichter Glas, greift aber Quarz kaum und härtere Steine gar nicht mehr an. Man kann an einem geschliffenen Steine nicht selten cine Stelle finden, wo ein so feiner und kleiner Ritz, wie ihn die Stahlspitze macht, nicht viel schadet, namentlich wenn sie bei der Fassung vom Metall bederkt wird; aus dem eingangs angegebenen Grunde ist aber doch bei durchsichtigen Steinen inmer große Vorsicht geboten, so daß also auch diese schonende Methode nicht unbeschränkt angewendet werden kamm. Der Stahlstift ist besonders wertvoll, um Glasimitationen von echten harten Edelsteinen zu unterscheiden. Nur erstere werden geritzt, über die letzteren gleitet die Spitze weg, ohne einen Eindruck zu hinterlassen.

Von allergrößtem Einfluß ist selbstverständlich die Härte auf das Schleifen der Steine. Nach ihr muss in der Weise, wie es unten bei der näheren Betrachtung des Sichleifprozesses erläutert werden wird, die Schleifscheihe und auch das Schleifpulver aus verschiedenem Materiale gewählt werden. Je härter der Stein, desto schwerer und langsamer schleift er sich, gleiches Schleifmittel vorausgesetzt, aber im allgemeinen wird auch der durch die l'olitur erzeugte Glanz um so schöner und kräftiger und die lianten und Ecken der šchliffform um so schärfer, je grö̈Ber die IIärte. Bei weicheren Steinen sind diese 
Kanten und Ecken ïberhaupt nicht scharf, sondern mehr oder weniger stark gerundrt, und der Stein hat dann ein weniger vorteilhaftes Aussehen. Man sieht daraus, dass die Iärte nicht nur die Dauer der schönheit, sondern einen Teil der śchünheit selbst bedingt.

Aus der zum Ansehleifen einer Fläche nötigen Zeit kann man mit grolier Sicherheit auf die in dieser Flïche herrschende IIäte schlieben. Dabei erkennt man nicht selten, daß sich die Steine in grewissen Richtungen viel leichter und rascher schleifen lassen als in gewissen anderen. Es müssen also in einem und demselben Stück von der Richtung abhängige Härteuntersehiede vorhanden sein. Dab dies in der Tat oft, wenn nicht immer, der Fall ist, daf z. B. nicht alle Flächen eines natïrlichen Kristalls und auch nicht alle Richtungen innerhalb einer und derselben Fläche die gleiche Härte zeigen. dass also die IIärte eines solehen Kristalls sich im allgemenen mit der Richtung ändert, ist auch durch andere Versuche rein wissenschaftlicher Art nachgewiesen und wir werden, namentlich bei der Betrachtung des Diamants noch einmal darauf zurückkommen. MLeist sind diese Unterschiede nur klein, und es bedarf besonderer Instrumente, der Härtemesser oder Sklerometer, um sie zu erkennen; mit Hilfe der verhältnismäßig rohen IL thode des Ritzens in der oben angegebenen Weise lassen sie sich meist nicht konstatieren. Nur bei einem einzigen der als Edelsteine verwendeten Iaterialien, dem Cyanit, ist dies möglich; bei diesem schwankt die Härte in verschiedenen Richtungen zwischen der des Ajatits und des Quarzes, also zwischen dem fünften und siebenten Grade. Jedenfalls zeigren aber diese an einem und demselben Steine auftretenden Härtedifferenzen, daß man aus kleinen Verschiedenheiten an zwei Stiicken nicht ohne weiteres auf deren Zugehörigkeit zu verschiedenen Arten schließen darf; sie können auch daher rühren, daß die Hürte bei beiden nicht in derselben Richtung untersucht worden ist. Übrigens ist dieser Wechsel in der Härte von einer Richtung zur anderen durchaus auf kristallisierte Edelsteine beschränkt, die üherhaupt, wie wir eingangs gesehen haben, sich nach verschiedenen Richtungen physikalisch verschieden verhalten. Amorphe Steine, wie Opal, ebenso alles Glas, sind in der Härte ïberall durchaus gleich, da sie ibrer Natur nach überhaupt nach allen Richtungen hin dieselben physikalischen Eigenschaften besitzen.

Schließlich sei noch bemerkt, daf die IIärte der Mineralien nicht dasselbe ist wie die Zersprengbarkeit, die größere oder geringere Leichtigkeit des Zerschlagens mit dem Hammer. Diese hängt ja mit von der Härte ab, aber nicht von ihr allein. Sie wird u. a. stark erleichtert durch deutliche Blïtterbrïche; daher ist, der Ansicht der Laien entgegen, der Diamant trotz seiner enormen Härte doch verhältnismä̈big leicht zersprengbar, er lïbt sich leicht in Stiicke zerschlagen. Umgekehrt verringern manche Strukturformen der Jineralien die Zersprengbarkeit sehr bedeutend, erhühen also deren Festigkeit in entsprechendem Maße. Besonders solehe Substanzen, die aus kreuz und quer durcheinander geflochtenen feinen, am besten mikroskopisch kleinen Fïserchen aufgebaut sind, zeichnen sich durch außergewöhnliche Festigkeit aus. Hierher gehört vor allem der Nephrit, der kaum die Feldspathärte hat, der aber dem Hammer den allerenergisehsten Widerstand entgegensetzt und von dem selbst kleine Stiicke kaum zerschlagen werden können. Solche schwer zersprengbare Mineralien werden wohl auch zähe, die leicht zersprengharen als spröde bezeichnet. Zu große Sprödigkeit ist für die Benutzung eines Edelsteines nicht güustig; er zerbricht leicht beim Gebrauch, oder wird doch beschädigt, wenn man nicht die größte Vorsicht anwendet.

Im folgenden sind die wichtigsten als Schmucksteine verwendeten Wineralien nach ihrer Härte in aufsteigender Reihe angeordnet. Die jedem einzelnen Namen beigefügte Zahl gibt den Härtegrad an: 


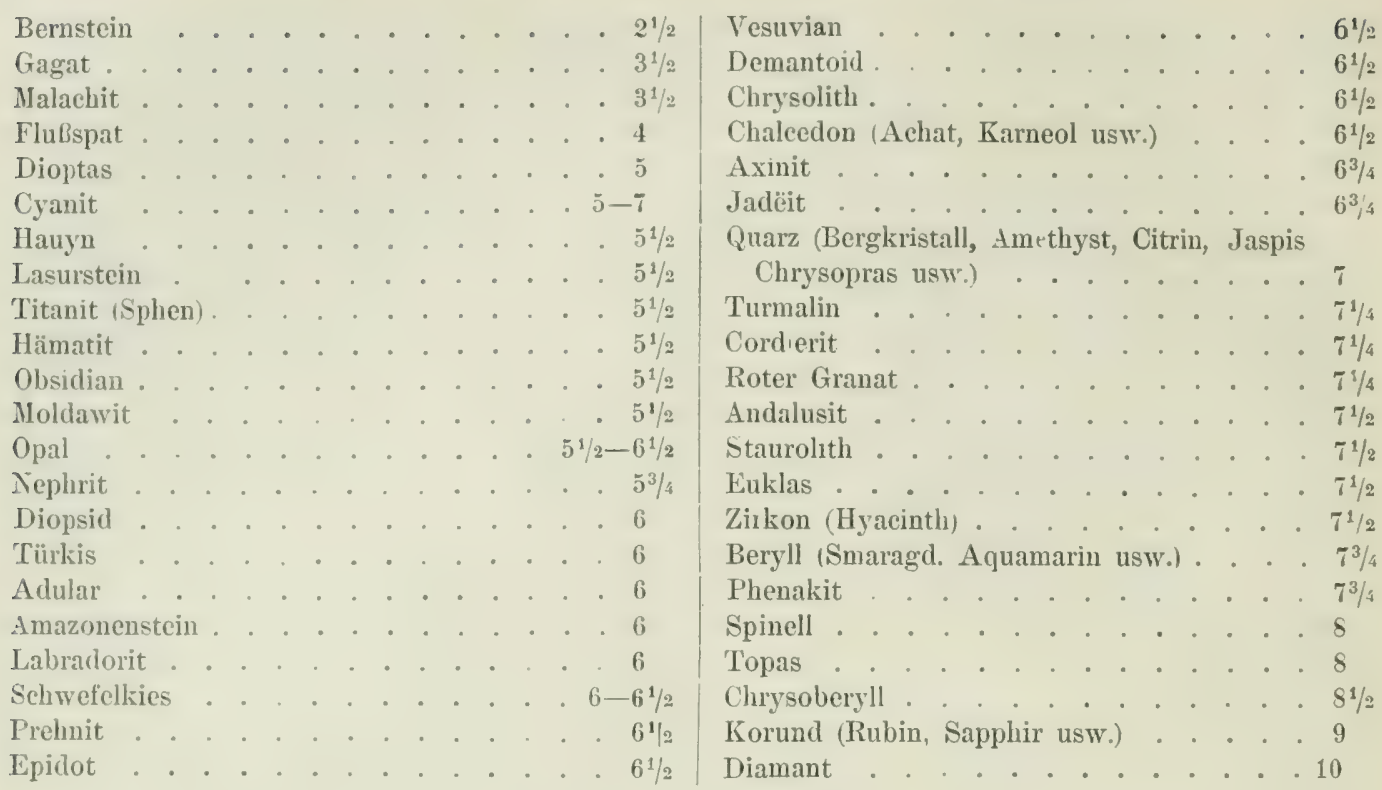

\section{d) Optische Eigenschaften.}

Die optischen Eigenschaften der Edelsteine, ihr Verhalten gegen das Licht, sind aus zwei Grïnden von besonders großer Wichtigkeit und Bedeutung. Einmal beruht auf ihnen, auf der Durchsichtigkeit, dem Glanze, der Farbe, dem Farbenspiele usw. die Schönlıeit des Aussehens; sodann können sie, namentlich die Verhältnisse der Lichtbrechung, rielfach mit besonderem Torteil zur Erkennung und zur Unterscherdung ähnlich aus sehender Steine benutzt werden. Die hierher gehörigen Erscheinungen sind dazu um so wertvoller, als die Steine durch deren Beobachtung in keiner Weise verletzt werden, was, wie wir gesehen haben, bei der Untersuchung der Härte unter Umständen möglich ist. Es ist aber hierbei, wenigstens bis zu einem gewissen Grade, die Kenntnis einiger Gesetze der Optik und einiger Instrumente nötig; die daher, soweit es erforderlich und möglich ist, hier auseinandergesetzt und beschrieben werden sollen.

\section{Durchsichtigkeit.}

I) meisten Edelsteine sind durchsichtig, allerdings vielfach nicht schon im rohen Zustande: da sie in diesem nicht selten einc rauhe Oberfläche haben, die den Durchgang. des lichtes mehr oder weniger hindert. Entfernt man die äufere Sehicht durch $\mathrm{N}$ ). schleifen, dann zeigen viele scheinbar ganz trübe Stiicke die schönste Klarbeit und Durchsichtigkeit. Besonders vollkommen ist diese Eigenschaft namentlich bei all den wertvollsten und kostharsten, beim Diamant, Rubin, Sapphir und anderen, aber auch bei manchen von geringerem Wert, dem Burgkristall, Amethyst usw. Je durehsichtiger die Stiicke jeder einzelnen Art von Edelsteinen sind, desto höher werden sie geschätzt. Nur wenige der Juwelen ersten Tangeses sind nicht rollkommen durchsichtien, so der edle Opal und der Tärkis. Unter den minder kostharen ist dies häufigrer der Fall; nicht durehsichtign ist ron ihnen der Achat, der Chrysopras, Malachit und noch viele sonst. Sie sind Verwachsungen vivler winzinger Kristallteilehen, während die durehsichtigen Edelsteine einheitlich gebaute Kristalle darstellen.

I) ur e h s i cht ig nennt man solche Körper, die dem Licht einen ungestörten Durchwan... westatten, so dal) man durch sie hindureh irgend einen Gegenstand mit ganz scharfen 


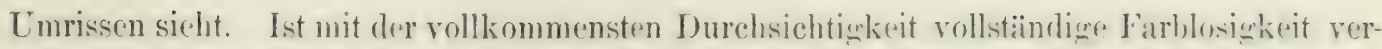
bunden, wie brei vielen Diamanten, dem Bergkristall usw., dann begedelnet man sie als was se rhe ll. Hiranf heruht das, was die Juweliere unter Wasser verstriben. Solche Edelsteine, die vollkommen wasserhell, also im hïehsten firadr durchsichtign und ohne jede Spur einer Fïrbung sind, namentlich Diamanten von dieser Beschaffenlest, worden als Steine vom ersten oder reinsten Wrasser besonders geschätzt. Sind sie, wenn anch nament-

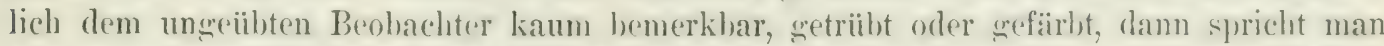
rom zweiten und bei noch stärkerer Abweichung rom Wasserhellen vom dritten Wasser, wie wir bei der Betrachtung des Diamants noch näher sehen werden.

Geht auch durch dickere Stïcke noch viel Licht hindurch, ist aber doch eine merkliche Trübung vorhanden, so daß man z. B. von einer Lichtflanme nicht mehr ein bestimmt umrissenes Bild, sondern ein solches mit verschwommenen Grenzen dureh den Stein hindureh wahrnimmt, dann nennt man diesen ha lb d u rehsich ti k. (tiht dabei die Flamme nur noch einen unbestimmten Lichtschein, dann heift er d u r e h s c he in e n d. IIalbdurchsichtig ist gewöhnlich der eigentliche Chalcedon, durchscheinend der meiste Opal. Ki a teendurebscheinend sind Steine, die nur noch in ganz dïnnen Schichten Iicht hindurchscheinen lassen; dies ist besonders der Fall an den scharfen Kanten der Bruchstïcke mancher sonst ganz undurchsichtigen Mineralien, wie Chrysopras u. a. die daher mit einem schmalen hellen Saum versehen sind, wenn man sie gegen das Licht hält. U n d u r e h s i c h t i g e oder opake Steine endlich lassen auch durch sanz dïnne Lagen kein Licht mehr hindurch, selbst nicht an den schärfsten Rändern, ihnen fehlt also der helle saum der zuletzt genannten. Steine dieser Art, wie z. B. der Iïmatit, können nur noch durch die Stärke ihres Glanzes und die Schönheit ihrer Farbe wirken.

Manche an sich und in den besten Exemplaren rollkommen durchsichtige Edelsteine sind in zahlreichen Stïcken trübe und undurchsichtig. Diese sind dann nur noch bedingt, und wenn die Trübung zu weit geht, gar nicht mehr zum Schmuck zu verwerten. In allen Fällen ist ihr Wert erheblich geringer als der der tadellos klaren Exemplare. Die Ursache dieser Trübungen liegt vielfach in Rissen und sjalten, relehe die Steine durchsetzen, oder in ihrer Struktur. oder in Einschliissen fremder Körper verschiedener Art; der Durehgang des Lichts kann dadurch gestört und sogar unter L'mständen vollstïndig verhindert werden.

Risse sind besonders häufig die Lrsache der Trübung bei leicht spaltbaren Edelsteinen, wie beim Topas usw., kommen aber auch manchmal in grofer Zahl bei solchen ror, die nur undeutliche Blatterbrüche besitzen. Dies ist z. B. bei dem schön griinen Smaragd der Fall, bei dem fast stets mehr oder weniger zahlreiche Risse die Klarheit beeinträchtignen; vollkonmmen tadellos klare Exemplare gehı̈ren zu den grofen Ausnalımen. Ton Eins chl ii ssen fremder Körper findet man nicht selten solche anderer fester Substanzen. So sind in dem Diamant vielfach schwarze und sonstwie gefürbte Körnchen eingewachsen, und der Smaragd beherbergt häufig. Glimmerplättehen in gröferer Zahl. Manchmal sind diese Fremdkörper so klein, dass sie erst unter dem Mikroskop bei starker Vergrößerung einzeln deutlich herrortreten. Diese sind dann gewöhnlich durch den ganzen Stein gleichmässig verteilt und hewirken eine vollständigre Trübung desselben, während einzelne größere Einschlïsse zwischen sich durchsichtige Substanz zu lassen pflegen, so daß triibe Stellen zwischen klaren auftreten. Nanche Edelsteine findet man durchsetzt ron ïußerst zahlreichen, mikroskopisch kleinen hohlen Poren, die, oft scharen- oder streifenweise angeordnet, einen eigentümlichen, läufig seidenartigen, trüben Schimmer verursachen, unter dem die Durchsichtigkeit und Schönheit empfindlich leidet. Trübungen dieser Art bilden einen der unangenehmsten Fehler sonst durchsichtiger Edelsteine, den die Juweliere als "F a h n e n " bezeichnen. 
Von der Struktur ist die Durchsichtigkeit in hohem Grade abhängig. Einheitlich gebaute Kristalle sind, wenigstens soweit Edelsteine in Betracht kommen, meist durchsichtig. Hat man es aber mit einem aus zahllosen Kriställchen desselben Minerals verwachsenen dichten Aggregat zu tun, dann ist dieses höehstens durchscheinend oder auch fast ganz undurchsichtig, weil an der Grenze der vielen Körnchen, Fäserchen usw. stets viel Licht beim Durchgange verloren geht und nicht in das Auge gelangt. Aus diesem Grunde sind der Chalcedon, der Chrysopras usw. nicht durchsichtig, obwohl sie aus an sich durchsichtigen Körnchen des Minerals Quarz besteben, der in seinem reinsten durchsichtigsten Zustande den vollkommen wasserhellen Bergkristall bildet.

Röntgenstrahlen. Von größtem Interesse ist die Durchlässigkeit der Edelsteine für Röntgenstrahlen. Manche lassen diese Strahlen ganz ungehemmt hindurch, manche andere absorbieren sie mehr oder weniger vollständig. Um dies Verhalten festzustellen, muß man das Verfahren mit der photographischen Platte wählen; bei der direkten Beobachtung auf dem Fluoreszensschirm treten die Unterschiede nicht immer deutlich genug hervor. Um diese noch besser bemerkbar zu machen und gewisse Fehlerquellen zu vermeiden, ist es zweckmäßBig, mehrere eventuell mit einander verwechselbare Steine gleichzeitig auf einer Platte zu photographieren. Dabei geben durchlässige Substanzen kein deutlich erkennbares Bild, sondern höchstens einen schwachen Schatten. Je weniger Strahlen hindurchgelassen werden, desto dunkler werden die Bilder und desto schärfer die Umrisse der betr. Steine. Man erkennt so, daß der Diamant vollkommen durchlässig für Röntgenstrahlen ist. Er gibt kein Bild, im Gegensatz zu dem äußerlich ähnlichen Bergkristall, dem farblosen Topas und Iyacinth und namentlich zum Glas (StraB), die sich durch ihre dunklen, scharf umrissenen Bilder auf das bestimmteste vom Diamant unterscheiden. Gerade für die Erkennung des Diamants ist diese Methode besonders wichtig, um so mehr als eine Aufnahme nur 10-15 Minuten in Anspruch nimmt und man gleichzeitig eine große Anzahl von Steinen untersuchen kann, häufig selbst dann, wenn sie gefaßt sind. Aber auch für andere Edelsteine ist dieses Unterscheidungsmittel anwendbar, so für den Korund in seinen verschiedenen Varietäten. Diese sind alle zwar nicht so vollkommen durchlässig wie der Diamant, sie lassen aber noch viele Röntgenstrahlen passieren und geben daher matte Bilder mit nicht sehr scharfen Umrissen, indessen deutlicher als der Diamant. Man unterseheidet sie so leicht von den ganz undurchlässigen ähnlich gefärbten Steinen und Glasflüssen, also Rubin von den roten Spinellen, Granaten, Topasen, Turmalinen usw., Sapphir von Cordierit, Cyanit, blauem Turmalin usw., gelben Sapphir von Goldberyll, Topas, Citrin usw. Die Untersuehung mit Röntgenstrahlen setzt uns danach vielfach in den Stand, kostbare Edelsteine von minderwertigen und von Initationen zu unterscheiden. Außerdem läßt sie auch manchmal Fehler, besonders Einschliisse deutlich erkennen, die bei der gewöhnlichen Beobachtung: mit der Lupe usw. nicht leicht wahrgenommen werden könnten.

Bei der Untersuchung einer großen Zahl von Mineralien beziiglich ihres Verhaltens gegen Röntgenstrahlen hat C. D oelt er, der dieses Verfahren zuerst systematisch verwertete, gefunden, daß sie nach ihrer Durchlässigkeit in versehiedene Klassen geteilt werden können. Die als Edelsteine benützten seien hier angeführt:

1. Vollkommen durchlässige: Diamant, Phenakit, Bernstein, Gagat.

2. Starkdurchlässige: Korund in seinen verschiedenen Abarten.

3. Durchlässige: Opal, Cyanit Chrysoberyll ;

4. Ialbdurchsichtige: Quarz, (Berokristall usw.), Labradorit, Adular (Mondstein) und andere Feldspate, Topas, Diopsid, Spodumen (Kunzit und Hiddenit);

6. Fast undurchlässige: Türkis, Turmalin, Apatit, Olivin, Titanit.

7. Undurchlïssige: Nmandin, Beryll, Epidot, Hyacinth und daneben Straß und alle anderen Glasplasten. (ieringe Unterschiede können natiorlich praktisch nicht verwertet 
werden. Das Terfahren ist aber noch weiterer Ausbildung fähig. Bei der Beschreibung der einzelnen Edelsteinarten soll jedesmal das spezielle Terhalten gergen Röntgenstrablen angegeben werden.

\section{Glanz.}

Fällt auf einen Kö̈rper Licht auf, so wird von diesem stets ein gröberer oder kleinerer Teil an der Oberfläche zurickeneworfen oder reflektiert, während ein anderer Teil in den Körper eindringt und sich in ihm fortpflanzt. Das von der Oherfläche des Körpers ausin das Auge gelangende Licht bedingt den Glanz desselben.

Dieser ist um so stärker, je mehr Licht in das Auge gelangt; danach unterscheidet man verschiedene Grade des Glanzes, die man als stark glïinzend oder spregrelnd, glänzend, wenig glïnzend, schimmernd und matt zu bezeichnen pflegt. Ist eine stark glänzende oder spiegelnde Fläche eines K̈̈rpers eben, wie z. B. eine an einen Edelstein angeschliffene Facette, oder eine regelmäbıge Kristallfläche, so entwirft sie ein vollkommen scharfes Spiegrelbild jedes vor ihm befindlichen Gegenstandes. Auf einer grlänzenden Fläche ist das Spiegelbrld noch deutlich, aber nicht mehr so scharf, und auf einer wenig glänzenden Fliiche entstehen nur noch matte und verschwommene Bilder. Wird auf einer Fläche nur noch ein sehwacher Schein zurückgeworfen, so beilit sie schimmernd, und matt, wenn sie gar kein Licht mehr reflektiert.

Die meisten und namentlich auch die wertvollsten Edelsteine sind selır stark glänzend, zum Teil schon auf ihren natürlich gebildeten Kristalloberfläichen, zum Teil erst nach dem Schliff. Starker Glanz erhöht die Schönheit eines Steines ganz ungemein, man sucht daher beim Schleifen die Oberfläche durch Polieren so grlänzend als nur irgend möghch zu machen. Ein Teil der Aufgabe des Edelsteinschleifers besteht gerade darin, den Glanz eines Steines so hoch zu steigern, als es irgend angeht. Auf dem Glanze beruht das, was man z. T. das Feuer der Edelsteine nennt; man versteht darunter vielfach einen besonders hohen Grad von Glanz; eine andere Bedeutung des Wortes werden wir noch unten bei der Betrachtung der Dispersion kennen lernen. Nur wenige der geschätzteren Edelsteine entbehren im geschliffenen Zustande eines starken und lebhaften Glanzes, so vor allem der Türkis, der auch bei der vollkommensten Politur eine gewisse Mattigkeit auf der Oberfläche behält. Es hängt das wohl, wenigstens zum Teil, mit der greringen IIärte zusammen. Im allgemeinen nehmen härtere Steine, also die wertvollsten Edelsteine, wie Diamant, Rubin und andere, leichter eine sehr gute Politur an als weichere, wie der Türkis, doch sind dabei allerdings auch noch andere Verhältnisse von Einfluß. Jedem Steine kommt ein seiner Beschaffenheit entsprechender höchster Grad von Glanz zu. Der Glanz kann zwar unter Umständen schwächer sein, aber auch dureh die feinste Politur läßt er sich nicht über dieses Maximum hinaus steigern. Dies hängt z.T. mit der Stärke der Lichtbrechung zusammen. Steine mit starker Lichtbrechung können im allgemeinen glänzender werden als solche mit schwacher; so wird z. B. Diamant glänzender als Bergkristall usw.

Jedoch nicht nur der Grad des (tlanzes, seine mehr oder minder bedeutende Stälke, sondern auch die Art desselben ist bei den Steinen verschieden und für sie oft in hohem Grade charakteristisch. Daher kann man nicht selten Steine ron sonst ähnlichem Aussehen leicht an der Art ihres Glanzes ron einander unterscheiden. Niemand, der sein Auge hierin nur ein wenig geibt hat, wird z. B. einen echten Diamant mit einer Imitation aus Bergkristall verwechseln. Beide sehen sich in vielem sehr ähnlich, der Glanz unterscheidet sie auf den ersten Blick.

Es ist nicht möglich, durch Beschreibung diejenigen besonderen Eindrïcke auf die Sehnerven festzustellen und mitzuteilen, die wir als diten des Glanzes oder auch wohl 
schlechtweg als Glanz bezeichnen; man kann aber leicht die Unterschiede erkennen, wenn man verschiedene Gegenstïnde daraufhin aufmerksam betrachtet und miteinander vergrleicht. Ein Stiick blankes Metall, eine Glasfläche, ein geschliffener Diamant, eine Perlmutterschale, eine Schicht fetten Öles odler ein Stiick $\Lambda$ tlas erscheinen alle lebhaft glïnzend, aber doch in sehr verschiedener Weise; die Arten des Glanzes auf diesen versehiedenen Körpern sind ron einander wesentlich abweichend. Der Glanz der Mineralien und so auch der Edelsteine wird angegeben, indem man sagt, mit welchem der genannten typischen Körper sie in dieser IIinsicht ühereinstimmen. Nan erhält durch en einziges Wort eine ziemlich genaue Vorstellung ron dieser Erscheinung, wenn man ausspricht, dals der betreffende Körper Metallglanz, Glasglanz, Diamantglanz (Demantglanz), Perlmutterglanz, Seiden- ofter Atlasslanz orler endlich Fettglanz besitzt. Unter diesen verschiedenen Abteilumgen lassen sich alle an Nineralien beobachteten Hauptarten des Glanzes unterbringen, andere kommen nicht vor. Um aber auch geringere Unterschiede angeben zu können, lat man noch Bezeichnungen für Zwischenstufen, wie z. B. metallischer Demantglanz, feuchter Glasglanz usw. in leicht verständlicher Weise eingeführt.

Diese verschiedenen Arten des Glanzes, die man den Bedürfnissen der Mineralheschreihung entsprechend festgestellt und unterschieden hat, kommen alle in den sämtlichen oben genannten Graden vor; es gibt schwachen und starken Glasglanz, Diamantglanz usw. Sie hängen ab von der Beschaffenheit des betreffenden Minerals, so daß mit gevissen sonstigen Eigenschaften desselben auch stets ein ganz bestimmter Glanz verbunden ist, der das Mineral erkennen und von sonst ähnlichen zu unterscheiden gestattet. Tamentlich sind die Struktur der Mineralien und die z. T. dadurch bedingten, speziellen Verhältnisse der Lichtbrechung hierbei von größtem Einfluß, weil die Art des Glanzes nicht bloß auf den an der Oberfläche reflektierten Strahlen, sondern auch zun Teil auf einer gewissen Lichtmenge beruht, die eine Strecke weit in das Innere des Körpers einsedrungen und ron hier aus wieder nach außen zuriickgeworfen worden ist. Daß die Art und Weise, wie dies geschieht und in welchem Verhälthis auben reflektiertes und von innen kommendes Licht miteinander gemischt sind, also das, wovon eben die Art des Glanzes abhängt, sehr wesentlich durch die Struktur und die ganze innere Beschaffenheit des Körpers bedingt wird, ist selbstverständlich.

Dor If etallglanz, der mit völliger Undurchsichtigkeit selbst der feinsten Schichten dis hetreffenden Minerals verbunden ist, findet sich nur bei wenigen Edelsteinen von geringer Bedeutung; z. B. beim Ilämatit. Ihm gegenüber steht der sehr verbreitete Glasglanz, der hei rollkonmen durchsichtigen Mineralien sich am ausgezeichnetsten findet. I)ie meisten durchsichtigen Edelsteine zeigen ihn mehr oder weniger ausgesprochen und krältign: Bergkristall, Topas, Rubin, Sapphir, Smaragd und andere. Er wird zuweilen durch besondere Eigenschaften des betreffenden Körpers modifiziert. Hat dieser ein sehr starkes Lichtbrechungs- und Farbenzerstreuungsvermögen, so geht der Glasglanz iiber in den D) iamantwlanz, der manchmal wieder eine entschiedene Annäherung an das Metallische zeight. Der eigentliche J)iamantelanz findet sich kaum bei einem anderen Edelsteine, als bei dem, dex ihm den Namen gegeben hat, annähernd auch beim Zirkon, besonders dem farblosen. Ieinfaserire Mineralien, wie z. B. der zuweilen als Sehmuckstein geschliffene Faserkalk (Atlasspat), oder der schön grïne. Malachit, oder das goldig slänzende Tigerauge zeigen Seiden-oder Atlasgy la $z$. Auf Flïchen vollkommener Spaltbarkeit ist dex Perlmuttererlanz vorhanden, aber nur, wenn der Stein nach diesen Richtungen sehon rine gewisse $\Lambda$ ufb]ïtterung erlitten hat. So sieht man ihn z. B. an manehen 'Topasen, Foldspaten (Mondstein) usw., aber nur auf den Flächen, die mit der vollkommenen Spaltbarkeit parallel gehen; auf allen anderen Fliichen ist gewöhnlicher Glasglanz. Fettfrlan\% ist, wie es scheint, stets mit massenhaften mikroskopisch kleinen Einschlïssen ver- 
kniipft, die in manchen Mineralien sanz konstant sich finden und von denen rines oder das andere, \%. 13. der Elïolith, zuweilen als Schmuckstein ereschliffen wird. Dies ist der eigentliche Fettglanz, der auch bei manchen mehr wasglänzenden Mineralien, wie z. I3. beim Olivin, angedentet ist. Gewisse andere Strine gleichen im Glanze mehr einem Stück Wachs, sie haben Wa chsolanz, wie der T'ürkis; oder einen Brocken IIarz, wie manche Granaten, z. B. der Ifessonit, der, namentlich in derben, nicht abgerollten Stücken, damit unter Umständen verwechselt werden könnte (Harzglanz).

\section{Lichtbrechung.}

Von höchster Wichtigkeit für die Kenntnis der Edelsteine ist die Lichthrechung oder Refraktion und die damit verbundenen und davon abhängigen sonstigen Erscheinumgen.

Wrir haben sesehen, daf von dem Lichte, das auf die Oberfläiche eines durchsichtigen Körpers, also auf die eines Edelsteines fällt, ein Teil zuriickgeworfen wird, während ein anderer in den Körper eindringt und sich in diesem fortpflanzt. Diese Fortpflanzung geschieht nur damn in der Richtung; welche die ankommenden Lichtstrahlen haben, wenn diese auf der - im folgenden immer chen vorausgesetzten - Begrenzungsfläche des Körpers senkreeht stehen. Ist dies nicht der Fall, machen die ankommenden Strahlen einen schiefen Winkel mit dieser Fläche, dann werden die in den Körper eintretenden Lichtstrahlen aus ihrer vorherigen Richtung al)gelenkt und pflanzen sich in die-em in einer anderen Richtung fort als die ankommenden; sie werden, wie man sagt, gebrochen.

Ist in Fig. $9 \omega N$ die Grenze des durchsichtigen Körpers (Edelsteines) $S$ gegen die Luft $L$, aus der die Lichtstrahlen unter gewöhnlichen Umständen stets einfallen, dann setzt sich ein an dieser Grenze unter einem schiefen Winkel ankommender Lichtstrahl $A C$ in dem Steine nicht geradlinig nach $C K$ fort, sondern in der abweichenden Richtung $C B$. $C B$ ist in diesem Falle der zu $A C$ gehörige gebrochene Strahl. Die Richtung $C B$ liegt mit $A C$ in einer zu $M N$ senkrechten Ebene, der Einfallsebene, zugleich der Ebene der Zeichnung, in der also auch die in $C$ auf $M N$ errichtete Senkrechte, das Einfallslot $D E$, liegt. Beim Übergange des Lichtes aus Luft in einen

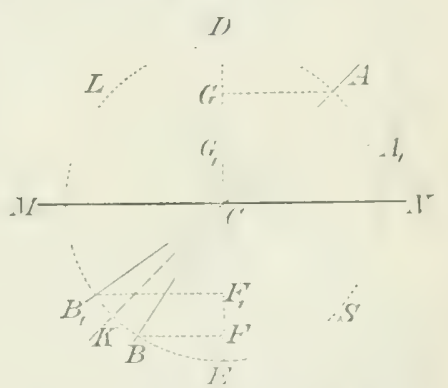

Fig. 4. Lichtbrechung heim Eintritt des Lichts in einen Edelstein. Edelstein liegt der einfallende Lichtstrahl $A C^{\prime}$ stets ron dem Einfallslot weiter ab als der gebrochene Strahl $C B$, der Einfallswinkel $A(D$ ist größer als der Brechungswinkel $B C E$; der gebrochene Strahl nähert sich bei dieser Brechung dem Einfallslot, das Licht wird dem Einfallslot zu gebrochen.

Fällt der ankommende Lichtstrahl in derselben Einfallsebene in einer anderen Richtung, z. B. nach $A_{1} C$ auf die Grenzfläche $M N$ ein, so ist der zu $A_{1} C$ gehörige gebrochene Strahl $C B_{1}$. Ist der neue Einfallswinkel $A_{1} C D$ größer geworden, so ist es auch der Brechungswinkel $B_{1} C E$. Üherhaupt wächst mit zunehmendem Einfallswinkel immer auch der Brechungswinkel, und zwar nach einem ganz bestimmten Gesetz, dem Brechungsgesetz.

Denkt man sich nämlich in der Einfallsebene um $C$ einen Kreis mit einem beliebigen Halbmesser beschrieben, und ron den Schnittpunkten $A, A_{1}, B, B$, dieses Kreises mit den einfallenden und gebrochenen Strahlen die Senkrechten $A G, A_{1} G_{1}, B F, B_{1} F_{1}$, auf das Einfallslot $D E$ gefällt, dann haben die zu einem und demselben Strahl $A C B$, $A_{1} C B_{1}$ usw. gehörigen Senkrechten $A G$ und $B F, A_{1} G_{1}$ und $B_{1} F_{1}$ usw. für jeden einzelnen Körper stets genau dasselbe Verhältnis zu einander, die Einfallswinkel mügen so 
groß oder so klein sein, als sie wollen. Es ist also beim Eintritte von Lichtstrahlen aus der Luft in einen bestimmten Körper stets für jeden beliebigen Strahl:

$$
\frac{A G}{B F^{\prime}}=\frac{A_{1} G_{1}}{B_{1} \mathrm{~F}_{1}}=\ldots=n,
$$

wo $n$ eine für jeden Körper konstante, aber ron einem zum andern wechselnde Zahl ist. Diese Zahl wird das Berechmungserhältuis, oder der Brechungskoeffizient, oder auch der Brechungsindex dieses Körpers genannt. Er ist nach dem Obigren von dem Linfallswinkel ganz unabhängig und hat für jeden Edelstein einen bestimmten Wert, den man an allen Exemplaren desselben wiederfindet, während andere Édelsteine andere Zahlen ergeben.

Da der Einfallswinkel beim Übergange des Lichtes in einen Edelstein aus der Luft, wie wir es im folgenden, wenn nicht etwas anderes besonders bemerkt ist, immer voraus. setzen, stets größer ist als der Brechungswinkel, so müssen auch $A G$ und $A_{1} G_{1}$ stets größer sein als die zugehörigen $B F$ und $B_{1} F_{1}$, woraus folgt, daß die Brechungskoeffizienten gegen Luft für alle Edelsteine größer sind als 1.

Man kann die Brechungsverhältnisse nach verschiedenen Methoden sehr genau und auf mehrere Dezimalstellen richtig bestimmen, worauf aber an dieser Stelle nicht eingegangen zu werden braucht, weil es zunächst für unsere Zwecke keine praktische Bedeutung hat. Wir werden einige solche Methoden, soweit sie für die Unterscheidung der Edelsteine nach ihren Lichtbrechungsverhältnissen wichtig sind, unten (pag. 62) kennen lernen. Es wurden dabei folgende hier beispielsweise und auf nur wenige Dezimalen angegebene Zahlen gefunden, die für einige Edelsteine und für einige zum Vergleich hinzugefügte sonstige Körper gelten:

\begin{tabular}{|c|c|c|c|c|c|c|c|c|}
\hline & & & & & & & & \\
\hline Flul & & & & . & 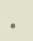 & & & \\
\hline & & & & & & & & $n=$ \\
\hline & & & & & & & & $n=$ \\
\hline ia & & & & & & & & $n=2$, \\
\hline
\end{tabular}

Die Ablenkung eines Lichtstrahles beim Übergange aus der Luft in irgend einen Körper, das Lichtbrechungsvermögen dieses letzteren, ist um so größer, je höher der Brechungskoeffizient, und umgekehrt. Dieser ist für viele Edelsteine sehr hoch, weitaus am höchsten für den Diamant. Die betreffenden Zahlen werden bei der speziellen Beschreibung der Edelsteine stets angregeben werden. Daß der entsprechende Wert für die Luft $=1$ ist, ist nach dem Obigen leicht einzusehen. Man nennt einen Körper, der einen grö̈ßeren Brechungskoeffizienten hat als ein zweiter, „optisch dichter", den anderen „optisch diinner". Danach ist die Luft optisch dünner als alle Edelsteine, diese sind optisch dichter als das Wasser, Diamant optisch dichter als Granat usw.

Nicht immer fällt das Licht aus der Luft auf den Körper ein; manchmal geschieht dies aus einer Flüssigkeit, z. B. wenn man einen Edelstein in einem Gefäß mit einer solchen übergielit. Ein ankommender Lichtstrahl muß dann erst diese passieren, ehe er auf den Edelstein trifft. Auch beim Übergange des Lichtes von der Flïsigkeit in den Stein erloidet der Strahl eine Brechung, und zwar wieder nach dem oben crwähnten Gesetze, aber der Betrag der Ablenkung ist ein anderer, als wenn das Licht direkt aus der Luft auf den Edelstein fiele. Sie ist um so größer, je mehr das Brechungsverhältnis des letzteren sich von dem der Flïssigkeit unterscheidet, und um so geringer, je kleiner dieser Unterschied ist. Sind die Brechungsverhältnisse beider gleich, dann findet beim Eintritt des Lichtes aus der Flüssigkeit in den Edelstein gar keine Ablenkung mehr statt; die ankommenden Lichtstrahlen bewegen sich an der Grenze in der urspriinglichen Einfallsrichtung weiter fort. Da ein Edelstein in seinen Lichtbrechungsverhältnissen einer Flïssigkeit jederzeit viel näher steht als der Luft, so ist die Lichtbrechung stets viel ge- 
ringer, wenn das Licht aus einer Flïssigkeit auf den Stein einfällt, als wenn dies unter demselben Winkel aus der Luft geschieht.

Eine Flïssigkeit, die denselben Brechungskoïffizienten hat, wie z. B. ein Stiick (ilas, kanm man unter anderm erhalten, wenn man das sehr stark lichthrechende Mcthylenjodid, die Flüssigkeit, die wir hei der Bestimmung des speztfischen Gewichts kennen gelernt haben, mit benzol in geepgnefen Verhältnissen mischt. Haben beide gleich brechbare Substanzen auch diesellse Farbe, sind sie wie in diesem Falle beide farblos, so ist es nicht mörlich, den festen Körper, also das (ilas, in der Flüssigkeit deutlich zu sehen, eben weil beide dieselbe Brechharkeit besitzen und daher an ihrer Grenze keine Ablenkung der Lichtstrahlen stattfindet. Wird das Brechungsvermögen der Fliissigkeit greändert, indem man von dem einen oder anderen Bestandteile eine größßere Menge zugilst, dann tritt der feste Körper in seinen Lmrissen hervor, und zwar werden seine Grenzen um so schärfer und bestimmter, je größer der Unterschied der Brechbarkeit zwischen ihm und der Flïssigkeit wird, indem man letztere durch weiteres Zugießen immer mehr in ihrer Mischung ändert. Ian gebraucht dieses Verhalten zuweilen, un versteckte Fehler, Einschlüsse, Risse und Spalten und ähnliches in einem Edelsteine nachzuweisen, indem man ihn in eine stark brechende

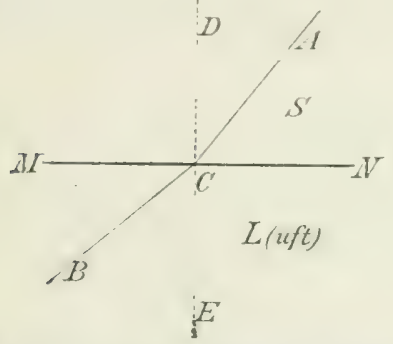

Fig. 10. Lichtbrechung beim Austritt des Lichts aus einem Edelstein.

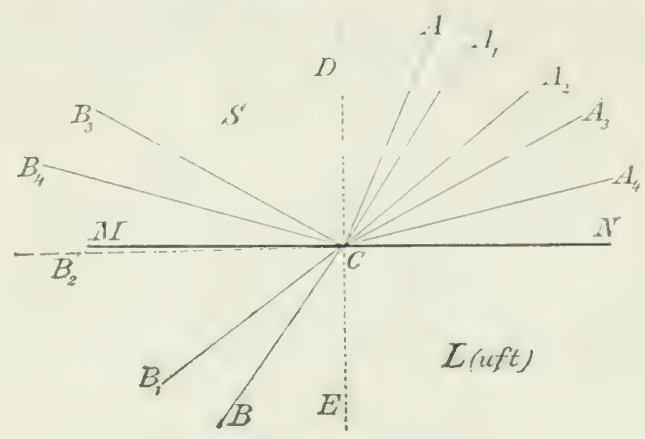

Fig. 11. Totalreflexion.

Flïssigkeit, also z. B. in Methylenjodid, legt. Dadurch werden die Grenzen des Edelsteines der annähernden Gleichheit des Brechungsverhältnisses mit der Flüssigkeit wegen unbestimmt, der Stein rerschwindet gewissermaben, aber seine Fehler bleiben dabei sichtbar und treten viel schärfer hervor. Benützt man verschiedene Flüssigkeiten ron bekannter Lichtbrechung, so kann man nach der Methode von Schroeder van der holk auch die Lichtbrechungsverhältnisse mancher Edelsteine angenähert bestimnen.

Lichtbrechung findet nicht bloß statt, wenn, wie in dem obigen Falle, die Strahlen aus einem optisch dïnneren Medium (z. B. Luft) auf ein dichteres (z. B. einen Edelstein) einfallen. Dasselbe geschieht auch im umgekehrten Falle, wenn z. B. das Licht einen Edelstein durchstrahlt hat und aus ihm wieder in die Luft austritt. Das Gesetz der Brechung ist auch hier wieder dasselbe wie vorhin, aber der im Edelstein an der Grenze ankommende Lichtstrahl macht nun mit dem Einfallslot einen kleineren Winkel als der gebrochene Strahl in der Luft; das Licht entfernt sich in diesem Falle bei der Brechung vom Einfallslot, es wird rom Einfallslot weg gebrochen. Dies zeigt Fig. 10, wo der in dem Edelsteine $S$ sich bewegende Lichtstrahl $A C$ mit dem Einfallslot $U E$ den Einfallswinkel $A C D$ einschliebt, der kleiner ist als der Brechungswinkel $B C E$, den der gebrochene Strahl $C B$ in der Luft $L$ mit jenem Lote macht. Auch in diesem Falle ist die Ablenkung um so bedeutender, je größer der Brechungskoeiffizient des Edelsteines. Sie ist aber dieselbe, ob das Licht von der Luft in den Edelstein übergeht oder umgekebrt. Das eine MIal wäre der Gang des Lichtstrahles $B C A$, das andere Mal $A C B$. 
Auch beim Ühergange des Lichtes in ein dïnneres Mittel, also beim Austritte aus einem Edelsteine in Luft nimmt, der Brechungswinkel gleichzeitig mit dem Einfallswinkel zu wie im umgekehrten Falle. In Fıg. 11 (S. 45), wo wieder $M N$ die ebene Grenzfläche zwischen dem Edelsteine $S$ und der luft $L$ darstellt, wird der ankommende Strahl $A C$ nach $C B, A_{1} C$ nach $C B_{1}$ usw. gebrochen. Wird der Einfallswinkel allmählich immer größer und größer, so geschieht dies auch mit dem Brechungswinkel. Dieser wird endlich gleich einem Rechten, während der Einfallswinkel noch kleiner ist als ein solcher. So wird der einfallende Strahl $A_{2}\left(\right.$ ' nach $C B_{2}$ gebrochen, und dem Einfallswinkel $A_{2} C D$ entspricht der Brechungswinkel $B_{2} C E=9\left(\right.$ )"; der gebrochene Strahl $C B_{2}$ verläuft dann genau in der Grenzfläche $M N$.

Mit $90^{\circ}$ hat offenbar der Brechungswinkel den größten Wert erreicht, den er überhaupt erlangen kann. Noch größer kann er nicht werden, während der Einfallswinkel noch weiter zu wachsen imstande ist. Geschieht dies, nimmt der Einfallswinkel $A_{2} C D$ noch mehr zu, sei es auch um einen noch so kleinen Betrag, dann findet ïberhaupt keine Brechung mehr statt, sondern das einfallende Licht wird an der Grenzfläche $M N$ in den Edelstein, aus dem es kommt, wieder zuriickgeworfen, es kann gar nicht aus dem Steine in die Luft austreten. So ist es z. B. mit dem Strahle $A_{3} C$, der in der Richtung von $C B_{3}$ reflektiert wird, und zwar in der Einfallsebene und nach dem gewöhnlichen Gesetz, wonach die Winkel $A_{3} C J$ ) und $D C B_{3}$ einander gleich sind. In derselben Weise werden auch alle anderen schiefer als $A_{2} C$ auffallenden Lichtstrahlen reflektiert, ohne daß sie in die Luft austreten könnten, so $A_{4} C$ nach $C B_{4}$ usw.

Bei dieser Reflexion, die in einem optisch dichteren Medium, also etwa in einem Edelsteine, an der Grenze gegen ein dünneres, also z. B. Luft, stattfindet, tritt nicht, wie in dem oben erwähnten umgekehrten Falle, wenigstens ein Teil des ankommenden Lichtes an der Grenze durch Brechung aus, sondern dieses wird in seiner Gesamtheit ohne jeden Verlust zuriickgeworfen. Man nennt deshalb diese spezielle $\Lambda$ it von Reflexion die Totalreflexion. Sie kann nur stattfinden an der Grenze einer dichteren Substanz gegen eine dïnnere, wenn das Licht unter einem genïgend schiefen Winkel aus der ersteren auf die Grenze trifft, niemals in dem zuerst betrachteten umgekehrten Falle, wo das Licht aus der optisch diinneren in die dichtere Substanz, also z. B. aus der Luft in einen Edelstein übergeht. Hier ist, auch wenn der Einfallswinkel seinen größten Wert ron $90^{\circ}$ erreicht hat, der Brechungswinkel noch kleiner als ein Rechter, es kann also stets Brechung stattfinden. Aus einer diunneren Substanz in eine dichtere, also aus der Luft in einen Edelstein, kann demnach das Licht jederzeit und bei jedem beliebig schiefen Einfallen und bei jeder denkbaren Größe des Einfallswinkels eindringen. Totalreflexion kann nicht stattfinden, wenn Lichtstrahlen aus der Luft auf einen Edelstein auffallen, sondern nur dann, wenn sie ihn wieder verlassen wollen.

Der Einfallswinkel, der bei der eben betrachteten Art von Lichtbrechung nicht um das allergeringste üherschritten werden darf, wenn nicht statt der Brechung Totalreflexion eintreten soll, also in Fig. 11 der Winkel $A_{2} C D$, heilst der Grenzwinkel der Totalreflexion. Er ist sehr verschieden, je nach der Brechbarkeit der beiden Substanzen, an deren Grenze die Brechung oder Rifflexion statfindet. Je größer der Unterschied ihrer Breelumgrskëffizienten ist, desto früher, d. h. bei um so steilerem Einfallen oder, was dasselhe ist, bei um so kleinerem Grenzwinkel A2CD fängt die Totalreflexion an. Wenn dieser Untersehied sehr klein ist, kömnen sogar sehr schief auffallende Strahlen mit einem sehr großen Einfallswinkel noch austreten, ohne Totalreflexion zu erleiden.

Bewegt sich ein Lichtstrahl z. B. in einem Diamant (Fig. 12 S. 47), dessen Brechungskoïffizient $=2,43$ ist, so kann er aus ihm schon bei einem sehr steilen Einfallen nicht mehr austreten. Dies ist bereits nicht mehr möglich, wenn der Einfallswinkel $A_{1} C^{\prime} D 24^{0} 24^{\prime}$ 
betriigt. Kommt also ein Strahl $A_{1} C$ mit einem nur etwas griöferen Einfallswinkel an der Grenze $M N^{\top}$ zwischen Diamant und Luft in dem ersteren an, dann tritt er nicht in die letztere aus, sondern wird nach $C^{\prime} B_{1}^{\prime}$ reflektiert. Elonso geschieht dies mit den noch weniger steilen, d. h. mit noch größerem Einfallswinkel ankommenden Strahl A.3 ('; dieser wird nach $C B_{3}$ zuriickeworfen. Ein steiler als $A_{1} C^{\prime}$ einfallender Strahl $A_{2}(;$, der also einen kleineren Einfallswinkel hat als $A_{1} C$, erleidet dagegen bei $C$ keine Totalreflexion, sondern er tritt hier, nachdem er eine den Brechungsverhältnissen von Diamant und Luft entsprechende Ablenkung erfahren hat, nach C $B_{2}$ aus dem Edelsteine in die Luft aus.

Ist der optisch dichtere Körper nicht Dianant, sondern Glas mit dem Brechungskoëffizienten 1, sis, dann ist der Crenzwinkel $A_{1} C D$ nieht $2 t^{\prime \prime} 24^{\prime}$, sondern der geringeren Brechbarkeit des Glases, seiner gröberen Annäherung an die der Luft entsprechend, gröber, und zwar gleich $10^{\circ} 30^{\prime}$. Aus solehem Glase können also auch sehr viel wenigrer steil einfallende Lichtstrahlen nach erfolgter Brechung in die Luft austreten, nämlich alle solchen, die mit dem Einfallslot Winkel machen, die kleiner sind als $40^{\prime \prime} 30^{\prime}$; alle anderen werden auch hier durch Totalreflexion in das Glas zurückgeworfen.

Der Grenzwinkel mub sich auch ändern, wenn das Licht nicht in Luft, sondern in eine Flüssigkeit austreten soll, die stets optisch dichter ist als Luft. Legt man den Diamant in ein Gefäß z. B. mit Methylenjodid, das den Brechungskoëffizienten 1, ... hat. damn ist

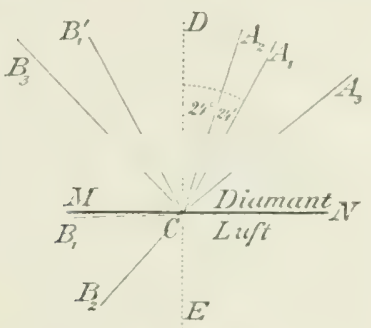

Fig. 12 .

Totalreflexion im Diamant an Luft.

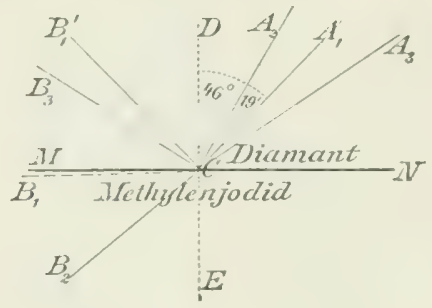

Fig. 13.

Totalreflexion im Diamant an Methylenjodid.

der Grenzwinkel nicht mehr wie für Luft gleich $24^{0} 24^{\prime}$, sondern der geringeren Differenz. in der Brechbarkeit zwischen Diamant und Methylenjodid entsprechend, erheblich srölber. nämlich gleich $46^{\circ} 19^{\prime}$, wie es Fig. 13 darstellt. In diese stark lichtbrechende Flüssigkeit treten also Strahlen unter Einfallswinkeln noch aus, bei welchen sie in Luft nicht mehr austreten könnten, sondern durch Totalreflexion in den Diamant zurückgeworfen werden wïrden. IIan kann also manchen Lichtstrahlen, die zu schief auf die Grenzfiïche von Diamant gegen die Luft auffallen und daher nicht aus jenem austreten können, den Austritt ermöglichen, wenn man den Stein mit Methylenjodid übergießt. Wir werden davon unten noch Gebrauch zu machen haben.

Es wird sich herausstellen, daß die Totalreflexion von größter Bedeutung ist für den Gang der Lichtstrahlen in einem geschliffenen durchsichtigen Edelsteine. Dessen Schünheit beruht zum guten Teile darauf, daf die von vorn auf ihn einfallenden Lichtstrahlen nicht nach hinten aus ihm austreten können, sondern daß sie durch Totalreflexion an der Hinterseite wieder nach vorn zuriickgeworfen werden, um hier erst den Stein zu verlassen und in das Auge des Beschauers zu gelangen. Tïönnte das eintretende Licht den sitein nach hinten verlassen, dann würde dieser einen matten und toten Anblick gewähren. Erst dadurch. daß die Strahlen durch Totalreflexion an der hinteren Seite wieder nach vorn und in das Auge des Beschauers komnen, erfüllt sich der Stein gewissermaßen mit Licht und erhält sein rorteilhaftes Aussehen, das um so schöner wirkt, je weniger Licht durch Austritt nach hinten verloren geht und je mehr infolgedessen seinen Weg wieder nach 
vorn nehmen muß. Ehe wir aber den Gang der Lichtstrahlen in einem Edelsteine genauer verfolgen, haben wir noch einige andere optische Erscheinungen kennen zu lernen, die für die Lichtwirkung der Edelsteine gleichfalls von Wichtigkeit sind.

Bisher haben wir hier nur die Art und Weise betrachtet, wie sich ein Lichtstrahl verbält beim Übergange an der Grenze zweier verschieden brechbarer Körper, wenn er also aus der Luft oder einer Flïssigkeit in einen Edelstein eintritt, oder wenn er umgekehrt sich in einem Edelsteine bewegt und diesen verläßt, um in Luft oder eine Flüssigkeit überzugehen. Aus der Kombination dieser beiden Erscheinungen folgt aber leicht, wie der Gang der Lichtstrahlen sein muß, wenn sie einen Edelstein von einem bis zum anderen Ende durchziehen.

Bildet der durchstrahlte Körper eine von zwei parallelen ebenen Flächen $M N$ und $P Q$ begrenzte sow. planparallele Platte, wie in Fig. 14, so wird der von einer Lichtquelle bei $A$, etwa einer kleinen hellen Flamme kommende und schief auf $M N$ einfallende Strahl $A B$ gebrochen, und zwar gegen das Einfallslot $D E$ hin nach $B C$. Dieser zum erstenmal gebrochene Strahl trifft dann die zweite Grenzfläche $P Q$ in $C$, und zwar kommt er unter einem Einfallswinkel $B C D_{1}$ an, der wegen der Parallelität von $M N$ und $P Q$ gleich dem Brechungswinkel C $B E$ ist. In $C$ wird der Strahl zum zweitenmal gebrochen, und zwar

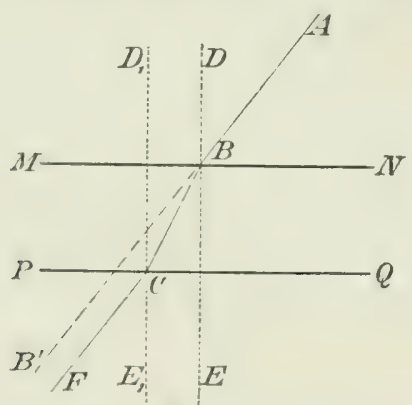

Fig. 14. Durchgang des Lichts durch eine von zwei parallelen ebenen Flächen begrenzte Platte.

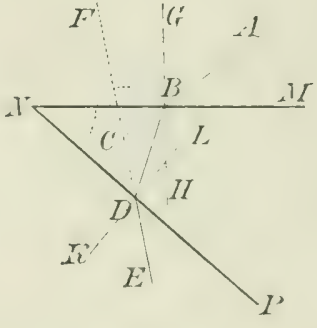

Fig. 15. Durchgang des Lichts durch ein Prisma.

nun beim $\Lambda$ ustritt in Luft vom Einfallslot $D_{1} E_{1}$ weg nach $C F$. Man sieht nun nach früheren Witteilungen leicht, daß der letzte Brechungswinkel $F C E_{1}$ gleich dem ersten Enfallswinkel $A B D$ und daher der austretende Strahl $C F$ dem ankommenden $A B$ parallel sein muli; der erstere ist gegen den letzteren nicht abgelenkt, sondern nur um die kleine Strecke $B^{\prime} F^{\prime}$ zur Seite geschoben. Man erblickt daher durch eine solche planparallele Platte hindurch einen Gegenstand, also die Flamme bei $A$ in der Richtung, in der sie sich wirklich befindet, in der man sie siebt, auch wenn die Platte nicht vorhanden ist, da die austretenden Lichtstrahlen beim Durchgange keine Änderung ihrer ursprünglichen Richtung erfahren haben.

Ist dagesren die eine Begrenzungsfläche $M N$ gegen die andere $N T$ unter einem Winkel $M N T^{\prime}$ genejgt (Fig. 15), dann bildet $M N P$ ein sogenanntes Prisma. Fällt wieder von einer kleinen Lichtflamme $A$ aus ein Lichtstrahl $A B$ auf $M N$, so erleidet er hier eine Brechung nach $B D$ gregen das zur Fläche $M N$ gehörige Einfallslot $G H$ zu und in $D$ beim Anstritte aus dem Prisma cine zweite Brechung nach $D E$ von dem zur Fläche $N P$ grehörigen Einfallslot $K L$ weg. Iier ist nun, da die Flächen $M L N$ und $N P$ nicht parallel sind, auch der austretende Strahl $D E$ nicht mehr parallel mit dem eintretenden $A B$; letzterer hat eine $A b l e n k u n g$ von $A B$ nach $D E$, also um den Winkel $A C F$ erlitten. Man sieht daher das Bild der Flamme $A$ durch das Prisma hindureh nicht mehr in der Richtung von dem bei $E$ befindlichen Auge nach der Flamme $A$, sondern in der ab- 
weichenden Richtung EIJ $F$, die mit der Einfallsrichtung $A B$ den Winkel der $A$ b]enkungr $A C F$ einschliebt. Dirser ist unter verschiedenen Umständen von verschiedener Grïlie. Er wird um so enrüsser, je grösser der brechencle Winkel MNP des Prismas und der Brechungskoëffizient der Substanz ist, aus der das Prisma besteht. Aufjerdem ist er auch von dem Einfallswinkel $A B G$ abhängig; er erhält für eine gewisse Gröbe desselben einen kleinsten Wert, unter den er nicht heruntersinken kann, der Einfallswinkel mag so groß oder so klein sein, als er will.

Beim Durch wange de's Lichtes durch ein P'risma, also durch einen von zwei sich schneidenden ebenen Flächen besrenzten Körper, wird nun eine Erscheinung sichthar, die von höchster Bedleutung für das schöne Aussehen mancher Edelsteine, besonders des Diamants ist, nämlich die Dispersion oder Farbenzerstreumg.

Wir haben bisher nur von einem einzigen Brechungskoëffizienten eines Körpers gresprochen. Dies ist aber nur richtig, wenn man sogenanntes homogenes Licht von einer ganz bestimmten Farbe, rotes, gelbes, grïnes, blaues usw. anwendet, wie man es z. B. durch Dämpfe der Metalle Lithium, Natrium, Thallium und Indium in der Flamme des B unsenschen Gasbrenners oder in einer Weingeistlampe erhält. Bestimmt man die Brechungskoëfficienten eines Körpers für diese verschiedenen Lichtsorten, so erhält man nicht immer dieselben, sondern jedesmal etwas von einander abweichende Werte. Diese sind bei jedem Prisma stets für rotes Licht am kleinsten, sie werden für gelbes, grünes nnd blaues Licht immer größer und sind am größten für violettes. Rote Lichtstrahlen werden also immer am wenigsten, violette am stärksten abgelenkt oder gebrochen, die zwischenliegenden Lichtsorten von rot aus immer mehr, und zwar in der genannten Reihenfolge.

Fällt Licht ein, das gleichzeitig alle diese verschiedenfarbigen und verschieden brechbaren Strahlen enthält, wie es beim Sonnenlicht oder beim Lampenlicht oder überhaupt beim weißen Licht der Fall ist, dann werden diese Strablen bei der Brechung verschieden stark abgelenkt und dadurch voneinander getrennt. Sie gehen, wie es Figur 16 zeigt,

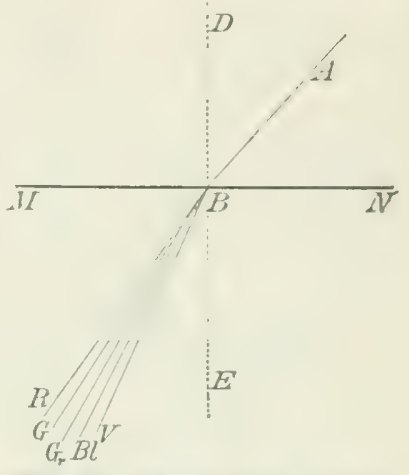

Fig. 16. Terschieden starke Ablenkung verschiedenfarbiger Lichtstrahlen (Dispersion). von dem Punkte $B$ aus, wo der einfallende weilje Strahl $A B$ die Grenzfläche $I N^{\top}$ trifft, in etwas abweichender Richtung auseinander: nach $l i$ geht ein roter; nach $G, G i$, $B l$ ein gelber, grimer und blauer und endlich nach $T^{\top}$ ein violetter Strahl, und dazwischen sind in ununterbrochener Reihe Strahlen ron etwas anderen dazwischenliegenden Farbenniiancen. Diese Erscheinung der Zerlegung rles weifen Lichtes in seine f a r b i g e $\mathrm{n}$ Teilstrahlen bezeichnet man als die Farbenzerstreu u goder D is persion; sie hat für rerschiedene Substanzen abweichende Werte und ist um so bedeutender, je größer der Winkel $R B T$ des äußersten roten mit dem äußersten violetten Strahl.

Nunmehr haben wir zu sehen, wie sich solche farbige Teilstrahlen, die beim Eintritte eines weifen Lichtstrahles in einen Edelstein durch die Brechung aus jenem entstanden sind, verhalten, wenn sie an der entgegengesetzten Seite den Stein wieder verlassen. Wir betrachten zuerst den Fall einer planparallelen Platte, wo die Austrittsflaiche der Eintrittsfläche parallel gegenüber liegt, und dann den, wo diese beiden Flächen einen gewissen Winkel miteinander einschließen, also ein Prisma bilden.

Die erste Möglichkeit ist in Fig. 17 dargestellt. Der Strahl $A B$ fällt schief auf die eine

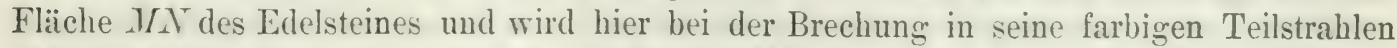
$B R$ bis $B T^{\top}$ zerlegt. Diese treten aus der mit $M \Lambda^{\top}$ parallen zweiten Grenzfläche $P Q$ aus, und zwar, wie wir oben pag. ts gesehen haben, in Richtungen $R R^{\prime}$ bis $T \gamma^{\prime}$, die alle der 
Einfallsrichtung $A B$ und damit auch untereinander parallel sind. (Fig. 14.) Sie kommen also alle gleichzeitig und in gleicher Richtung in das Auge, das sich bei $R^{\prime} V^{\prime}$ befindet; hier vereinigen sie sich wieder und bringen dadurch die Hischfarbe weiß hervor, dieselbe Farbe wie ror der Zerlegung bei $B$. In einer solchen planparallelen Platte ist also zwar Farbenzerstreuung vorhanden, sie tritt aber nicht in die Erscheinung, weil die an der ersten Grenzflïche zerstreuten Farben an der zweiten wieder miteinander vereinigt werden.

Unnittelbar augenfällig wird die Farbenzerstreuung erst im zweiten Falle, wenn das Licht durch eine Prisma hindurehgemangen und dadurch aus seiner urspriinglichen Richtung abgelenkt worden ist. Ein solches Prisma ist in Fig. 18 mit seinen beiden Begrenzungsflächen $M N^{\top}$ und $N^{\prime}$ abgebildet. Fïllt num ein Strahl weißen Lichtes $A B$ anf $M Y$, so wird er gebrochen und zugleich in seine farbigen Teilstrahlen zerlegt. Der äußerste rote geht nach $B R$, der äußerste violette nach $B T$, und dazwischen liegen die gelben, griinen und blauen, sowie alle die anderen. Diese Teilstrahlen werden beim Wiederaustritt in die Luft an der zweiten Grenzfläche $N P$ abermals gebrochen, und zwar dieses Mal von dem Einfallslote weg. Der rote Strahl $B R$ pflanzt sich nach $R$, der violette $B T^{r}$ nach $T$, fort, und alle die andersfarbigen Strahlen, die dazwischen liegen, haben auch

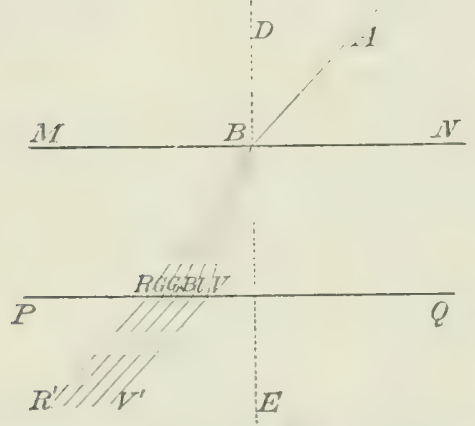

Fig. 17. Dispersion des Lichts in einer planparallelen Platte.

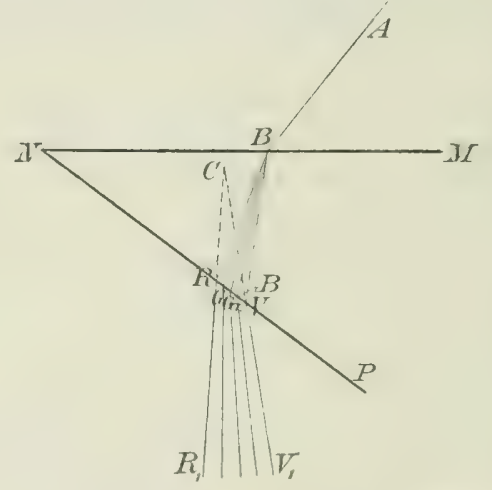

Fig. 15. Dispersion des Lichts in einem Prisma; Bildung eines Spektrums durch prismatische Zerlegung des weißen Lichts.

jetzt ihren Platz zwischen den Grenzen $R$, und $\tau$, Da die Fläichen $M L$ und $N P$ hier nicht parallel sind, so sind es auch nicht die aus dem Prisma austretenden Strahlen $l i$, bis $I^{2}$; sie gehen nun noch weiter auseinander und machen miteinander den Winkel $R,\left({ }^{\prime} T\right.$, Dieser Winkel ist $u$. a. von der Substanz des Edelsteines abhängig; er ist bei dem einen grüljer, bei dem anderen kleiner, und kann um so größer werden, je größßer die Inispersion oder Farbenzerstreumg des Steines ist, er gibt uns ein Maß für dlie Dispersion. Trifft das nun scheinhar von (' ausgehende Strahlenbuischel $R, C V$, das bei $I, V$, befindliche Auge, so sieht dieses alle die verschieden gefürbten Teilstrahlen desselben nebeneinander in verschiedenen Richtungen. Sie treten daher im Auge einzeln deutlich hervor und aus dem einfallenden weißen Strahle entsteht ein in die Länge gezogener Farbenstreifen, ein sogenanntes Fpolitrum. Dieses hat stets ein rotes Ende, das am wenigsten, und ein violettes, das am stärksten von der Richtung des einfallenden Strahles I $B$ abgelenkt ist, und dazwischen folgen sich die Ilauptfarben ohne Unterbrechung in der unabinderlich gleichbleibenden Orinung der Farben des Regenbogens; nach rot kommt orange, gelb, grïn, blau, indigo (dunkelblau), und daran sehließt sich endlich violett. Man kann diese Lichtstrahlen auch auf einen weißen Sehirm fallen lassen, dann entsteht auf diesem ein für viele gleichzeitiw sichthares Bild des Spektrums, dessen rotes Ende $R$, (Fig. 18) der brechenden Kante $N$ des Prismas am nächsten liegt. 
In Fig. 1! ist der fang der von einer Lichtflamme ausugehenden Strahlen durch ein Prisma MNPI' "Y" hindurch perspektivisch darestellt, und zwar speziell der von der Mitte der Flamme $A$ ausgehende Strahl $A B$. Dieser füllt bei $B$ auf die erste,

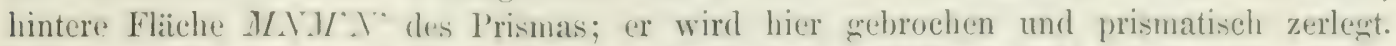
Der rote 'Teilstrahl geht nach lili, der violette nach $B$ F, und dazwischen liegen die iibrigen. Bei li und I verlassen diese beiden Strahlen das l'risma an der zwriten Fläche

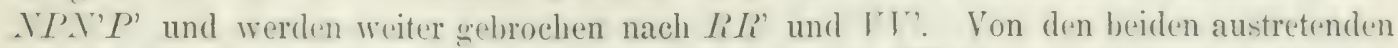
Strahlen ist der rote lili" der am wenigsten, der violette "l" der am stärksten abgelenkte. Aher nicht nur die Mitte der Flamme A, sondern alle Punkte derselben senden Strahlen ans, die für "in bei $l^{\prime \prime} I^{\prime \prime}$ befindliches $A u g e$ ein Bild $L^{\prime}$ der Flamme $A$ entwerten, das

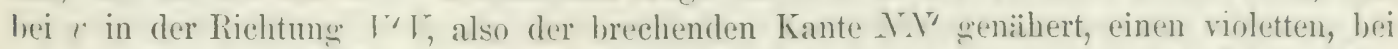
r in der Lichtung $l^{\prime \prime} l_{i}$, also von der brechenden Kante weer, einen roten liand hat. Das

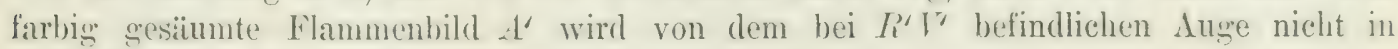
der Richtung nach der Flamme $A$ gesehen, sondern näher der brechenden Kante $N N^{\top}$ des Prismas, bei der in der Zeichnung angenommenen Stellung der Flamme zum Prisma links von der Flamme, so daß diese rechts von der Sehrichtung liegt.

Das Spektrum, das durch ein Prisma gebildet wird, ist bald länger bald kürzer, je nach den Umständen. Seine beiden Enden sind um so weiter von einander entfernt, je größer der Winkel $\left(R^{\prime} V^{\prime}\right)$, und dieser ist außer von dem brechenden Winkel des Prismas in der Kante $N N^{\prime}$ vor allem abhängig von der Substanz des Prismas, von dessen farbenzerstreuender Kraft, denn zrvei Prismen von verschiedenen Substanzen geben unter sonst ganz denselben Verhältnissen Spektren von sehr verschiedener Länge. Die farbenzerstreuende Kraft eines Prismas ist bedingt durch den Unterschied der $\Lambda$ blenkung der roten und violetten Strahlen; sie ist um so grösser, je stärker die letzteren im Vergleiche mit den ersteren abgrelenkt werden, und das ist bei verschiedenen Substanzen sehr verschieden. Sie wird be-

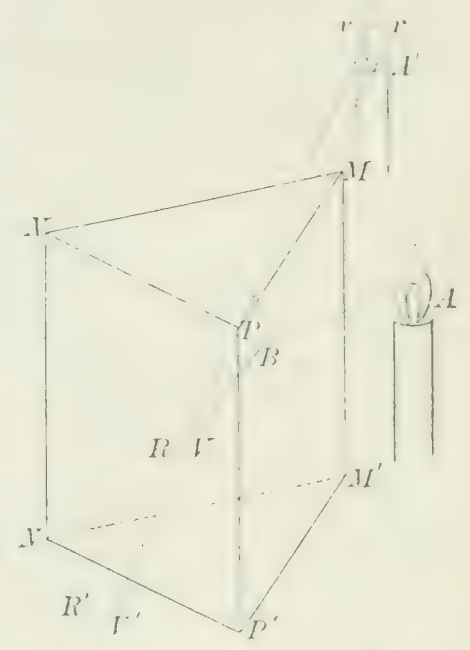

Fig. 19. Perspektivische Ansicht des Ganges der Lichtstrahlen dureh cin Prisma. stimmt durch die Differenz der Brechungskoüffizienten für rotes und violettes Licht, die man auch als das Maß der Dispersion betrachtet und die man speziell die Dispersion des betreffenden Körpers nennt.

Die Dispersion ist unter allen Edelsteinen und beinahe unter allen bekannten Substanzen am grölten beim Diamant. Bei ihm sind die Brechungskoeffizienten für

$$
\begin{aligned}
& \text { rotes Licht }=2,407, \\
& \text { violettes Licht }=2,165, \text { also die } \\
& \text { Dispersion }=2,465,-2,407=0,055 .
\end{aligned}
$$

Dagegen sind beim Fensterglase die Brechungkozffizienten für

rotes Licht $=1,52$,

violettes Licht $=1$, , 45 , also die

Dispersion $\quad=1,545-1,524=0,021$.

Die Dispersion ist also für einen Diamant mehr als noch einmal so groh, als für Fensterglas. Die Folge davon ist, daf bei einem Diamantprisma das Spektrum riel länger, mehr als noch einmal so lang ist, als bei einem Glasprisma mit demselben Winkel, und daß beim ersteren die einzelnen Farbenstrahlen viel größere Winkel miteinander machen als im zweiten Falle. Die verschiedenen Farben treten demnach beim Diamant viel weiter aus- 
einander als beim Glase und ebenso bei den übrigen Edelsteinen, die sich hierin ähnlich wie Glas verhalten. Bein Diamant kommen also die Spektralfarben im Auge mehr getrennt und einzeln zur Geltung und bringen daher eine sehr viel schönere Wirkung hervor als beim Glase usw., wo sie sehr nahe beisammen liegen, so daß sie sich im Auge leicht zu unansehnlichen Mischfarben vereinigen.

Auf der starken Dispersion beruht also das schöne Farbenspiel, das manche Edelsteine und vor allem die Diamanten ganz unabhängig von ihrer eigentlichen Körperfarbe zeigen, wemn sie in zweckmäßiger Form geschliffen und durch günstiges Licht beleuchtet werden. Dieses Farbenspiel ist nichts anderes als die prismatische Zerlegung des einfallenden weißen Lichtes in seine verschiedenen Farben, die um so schöner wirkt, je stärker die Dispersion ist. Daher ist bei dem ganz besonders stark farbenzerstreuenden Diamant dieses Farbenspiel auch schöner als bei irgendeinem anderen Edelsteine. Je zwei nicht miteinander parallele Facetten des geschliffenen Steines bilden in dem oben erwïlunten Sinne ein Prisma, das einen Lichtstrahl farbig zu zerlegen imstande ist, und man geht beim Schleifen absichtlich darauf aus, die Facetten so anzubringen, daß sie an der Yorder- und Hinterseite nicht miteinander parallel laufen, daß also die Zerlegung des Lichtes in die einzelnen farbigen Teilstrahlen möglichst begünstigt und gefördert wird.

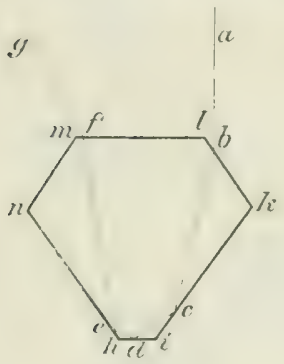

Fig. 20 ,

Gangr der Lichtstrahlen in einem Brillant.

Die hinteren Facetten müssen dabei, wie wir schon gesehen haben, so schief liegen, daß sie das durch den Eintritt in den Stein an dessen Vorderseite farbig zerlegte Licht durch Totalreflexion wieder nach vorn führen und hier austreten lassen. Auch dieses Spiel der prismatischen Farben wird wohl zuweilen als das "Feuer" eines Edelsteins bezeichnet also mit demselben Ausdruck, der wie wir oben gesehen haben, auch für den starken Glanz angewendet wird. Beim Diamant wirkt beides zusammen, um den geschliffenen Steinen ein ausgezeichnetes Feuer zu verleihen.

Je vollständiger eine Schliffform die beiden genannten Anforderungen, die möglichst ausgiebige farbige Zerlegung des einfallenden weißen Lichtes und die Reflexion desselben an den hinteren Facetten, befriedight, desto günstiger wird sie für den betreffenden Stein sein. Für den Diamant hat sich unter allen jetzt lekannten Formen die des Brillants als die vorteilhafteste erwiesen. Sie ist u. a. in Fig. 33 und Taf. II in verschiedenen Ansichten und in Fig. 20 im Durchschnitte abgebildet. Wir werden unten noch wiederholt eingehend auf die Form des Brillants zu sprechen kommen; hier sei nur erwähnt, daf es in der Hauptsache eine durch zahlreiche Facetten etwas abgeänderte vierseitige Doppelpyramide ist, deren eine Spitze sehr stark, die andere gegenüberliegende sehr schwach durch eine angeschliffene Fläche abgestumpft wirl. Ein solcher Brillant wird in den verscliedenen Schmuckstiicken stets so gefaßt, dab die breite Abstumpfungsfläche Im (Fig. 20) nach vorn und dem Beschauer zu-, die entgegengesetzte schmale hi nach hinten und von ihm abgekehrt ist. Auf $7 m$ und die anstoljenden Facetten fällt somit das Licht und auf sie blickt auch der Beschatuer. Das im Steine sich bewegende Licht muß also auf dieser Flïche und den benachbarten wieder austreten, nachdem es den Stein durchlaufen und in ihm seine farbige Zerstreuung erfahren hat, wenn der Stein die vorteilhafteste Wirkung hervorrufen und den schönsten Anblick gewähren soll.

Der Wegr, den der Lichtstrahl in dem Steine unter diesen Umständen zurücklegen mub, ist nun der folgende: Einer der von vorn aus der Luft ankommenden Strahlen ab fällt z. B. auf die schiefe Facette $k$. Fig. 20) und wird hier nach be gebrochen. Der gebrochene Strahl tic fällt sehr schief auf die Facette li und wird daher nach $c d$ total reflektiert, ebenso der Strahl ed an der Facette ih nach de und der Strahl de an der 
Facette $h n$ nach $\%$ Dieser letztere fällt ziemlich steil, fast senkrecht, anf die breite Flïche $l m$ und tritt aus dieser in der Richtungr fig aus, die im allgemeinen eine andere ist als die Einfallsrichtung al). Das in der Richtung al ankommende weilie licht wird also durch die beiden Flïchen $l_{i} l$ und $\mathrm{m}$, allerdings erst nach mehrmaligen zwischenliegrenden Totalreflexionen, aus seiner Richtung durch zweimalige Brechung aberelenkt und dabei prismatisch in die Regrenbogenfarben zerlegt, die nun in dem duge des Beschauers das schöne Farbenspiel hervorbringen. Die anderen neben al) von vorn und der Seite ankommenden Lichtstrahlen nehmen, wenigstens zu einem sehr erheblichen Teile, einen älınlichen Weg; sie werden, ebenfalls prismatisch zerlegt, von linten wieder nach vorn greführt und treten hier aus. Dadurch erseheint der ganz Stein hell, und er erglänzt nach allen Seiten in den lebhaftesten Remenbogenfarben, wenn das Auge auf die Fläche ml blickt, während er, bei unveränderter Stellung der Lichtquelle vor $\mathrm{m}$, von hinten (auf hi) gesehen, einen triiben, glanz- und lichtlosen, toten Eindruck macht.

Daß die beiden genannten Eigenschaften die starke Lichtbrechung und die dadurch bedingte starke 'Totalreflexion, sowie die starke Farbenzerstreuung die Schönheit des Diamants zu einem wesentlichen Teile hervorrufen, sieht man, wenn man einen geschliffenen Diamant mit einem ebenso geschliffenen anderen farblosen Steine, z. B. Bergkristall, vergleicht, der weder starke Lichtbrechung, noch bedeutende Farbenzerstreuung hat. Der Bergkristall sieht neben dem Diamant ganz kalt und tot aus, wïhrend andererseits ein Brillant aus Straß, einer Glassorte mit der starken Lichthrechung und Farbenzerstreuung des Diamants, auch genau dasselbe Aussehen gewährt wie dieser. Nan kann sich aber auch leicht überzeugen, daß die Form die optischen Eigenschaften der Steine unterstiitzen mul, um eine gïnstige Wirkung derselben bervorzurufen. Tergleicht man einen Diamant in einer guten Brillantform mit einem irgendwie anders, z. B. als Rosette (Fig. 37) geschliffenen, so sieht man sofort, dab die Rossete nicht entfernt das schöne Farbenspiel gibt, das den Brillant auszeichnet. Die Form der Rosette und die Anordnung ihrer Facetten hat in dem Steine einen anderen und viel weniger gü̈nstigen Gang der Lichtstrahlen zur Folge, der namentlich das Farbenspiel nur wenig entwickelt.

\section{Doppelbrechung.}

Bisher ist nur von solchen Körpern die Rede gewesen, in denen aus einem ankommenden Lichtstrahle beim Übergange aus der Luft auch nur ein einziger gebrochener Strahl entstelit. Viele Körper und darunter auch die meisten Edelsteine haben aber die Eigenschaft, den einfallenden Lichtstrahl bei der Brechung in zwei gebrochene Strahlen zu spalten, die sich in allerdings nur wenig voneinander verschiedenen Richtungen in dem Körper getrennt fortpflanzen. In Fig. $21 \mathrm{kommt}$ der Strahl $A B$ aus der Luft $L$ an der Grenze $M N$ gegen den Stein $S$ an und tritt in diesen ein. Er zerfällt dabei in die zwei gebrochenen Strahlen $B O$ und $B E$, die miteinander den stets nur kleinen, höchstens einige Grade betragenden Winkel $O B E$ einschließen. Körper, die sich bei der Lichtbrechung in dieser Weise verhalten, heißen d o p p eltbrechend (anisotrop), den bisher betrachteten einfachbrechenden (isotropen) gegenuiber. Die Erscheinung selbst

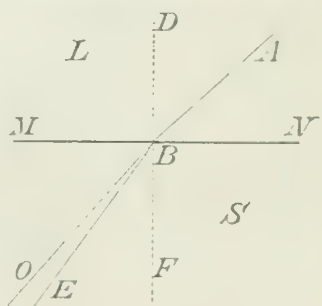

Fig. 21.

Dopruelte Brechung eines Lichtstrahls.

heißt Doppelbrechumg im Gegensatz zur e infache $\mathrm{n} \mathrm{Lich} \mathrm{tbrech} \mathrm{ung.}$

Für das Aussehen, die Durchsichtigkeit, den Glanz, die Farhe, das Farhenspiel usw. eines Edelsteines, also für diejenigen Eigenschaften, die seine Schönheit bedingen, ist es gleichgiiltig, ob er das Licht einfach oder doppelt bricht; die beiden Strahlen, die durch die Doppelbrechung entstehen, laufen so nahe nebeneinander her, daf ihre Anwesenheit dem 
Auge meist nur durch besondere IIilfsmittel bemerkbar gemacht werden kann. Um so wichtiger ist dagegen der Unterschied der einfachen und doppelten Lichtbrechung häufig, wenn es sich um die Unterscheidung und Bestimmung der Edelsteine, namentlich in geschliffenen Zustande, handelt. Die erwähnten IIilfsmittel sind so einfach, dalf es meist leicht ist, einen einfachbrechenden oder doppelthrechenden Körper mit ihrer Hilfe zu erkennen. Jan kann so u. a. sehr leicht feststellen, ob ein vorliegender roter Stein zu dem kostbaren doppeltbrechenden Rubin oder zu dem weniger wertvollen, aber oft sehr ähnlichen cinfachbrechenden Spinell gehört, und ist dadurch unter Umständen in der Lage, sich vor empfindlichem Schaden zu bewahren. Namentlich ist man aber imstande, die stets einfachbrechenden Glasimitationen von den zum sröbten Teil doppeltbrechenden echten Edelsteinen in vielen Fällen mit Sicherheit auf den ersten Blick zu unterscheiden.

Diese Möglichkeit beruht darauf, daß die Art der Lichtbrechung in notwendigem, cesetzmäßjigem Zusammenhange mit der Kristallisation steht. Alle Körper, die gar nicht kristallisiert (amorph) sind, oder die, wenn kristallisiert, dem regulärem Kristallsystem ancehören, brechen das Licht einfach; bei allen anderen Kristallen olne Ausnahme, also bei denen des hexagonalen, quadratischen, rhombischen, monoklinen und triklinen Systems, ist die Lichtbrechung doppelt. Man kann demnach an dem Verhalten eines Steines in Beziehung auf Lichtbrechung, und zwar an jedem noch so kleinen und noch so unregelmäßig begrenzten Bruchstïcke erkennen, ob er einerseits amorph oder regulär kristallisiert ist, oder $o b$ er andererseits einem der fünf übrigen Kristallsysteme angehört. Dieser Unterschied zeigt sich auch in dem obigen Beispiele: der doppeltbrechende Rubin ist hexagonal, der einfachbrechende Spinell regulär kristallisiert. Der Nachweis der Art der Lichtbrechung ist also wenigstens bis zu einem gervissen Grade der Nachweis der Kristallisation, und damit ist schon ein bedeutender, häufig ein entscheidender Schritt in der Erkennumg eines noch zweifelhaften Steines gesebehen. Es ist Fig. 22. Gang iler Lichtstrahlen also vor allem wichtig, die Hittel kennen zu lernen, durch in einerdoppelthrechenden planwelche ein Stein als einfach- oder doppeltbrechend erkannt
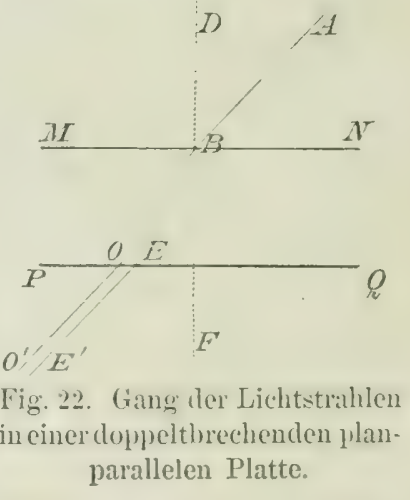
werden kann. In dritten Absehnitte, welcher der Bestimnumg unbekannter Edelsteine speziell gewidmet ist, sowie schon vorher bei der Beschreibung der einzelnen Edelsteine sollen sie dann umfangreiche Anwendung finden.

Bui manchen Substanzen macht sich die Doppelbrechung leicht direkt bemerkbar, indem man durch eine Platte dersell)en hindurch irgendeinen Gegenstand nicht einfach sicht, wie z. J). brim Ilindurchsehen durch eine einfachbrechende Glasplatte, sondern doppelt. Jeder der beiden gebrochenen strahlen $B O$ und $B E$ gibt ein bild des Gegenstandes; die beiden Bilder lexen sich zwar stets sehr nahe, haben aber, wenn schon nicht bei allen, so doch bei verschiedenen Xineralien eine genügende Lutfernung, dab sie nebeneinander deutlich erkennbar werden können.

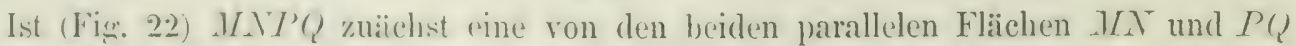
bergrenzte I'latte des dopledthrechenden Körper's und it ein leuchtender P'unlit, z. B. cine likeine Lichtflamme, dam seht von dieser neben anderen der Strahl $A B$ aus. Dieser trifft in $I$ anf dir. Flïche $1 / \mathrm{N}$, tritt in die Platte ein und wird dabei dureh dic Doppel-

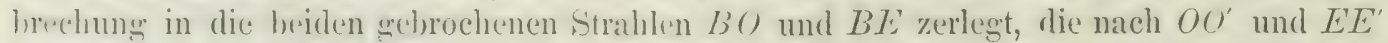
in lichtungen parallel $A B$ wieder in die Luft austreten. Jeder dieser zwei Strahlen or

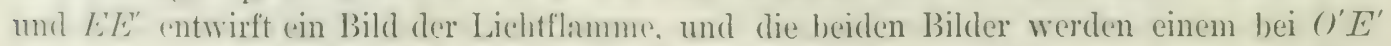
befindlichen Ange lïngs (J) und E'E' neloenemander sichtbar. Unter sonst gleichen Lm- 
ständen sind natülich die beiden durch die Doppellbrechungr exzeugrten Bilder des Gerenstandes $A$ bei einer dicken Platte weiter roneinander entfernt als bei einer diünen.

In ausgrezeichnetster Weise erkennt man so die doppelte Lichthrechung durch einen Kristall oder hesser ein Spaltungsstiick von durchsichtierm lialkspat, den man deshall, auch Doppelspat nennt. I,ext man ein solches auf eine Schrift (Fig. 23), dann erscheint diese überall doppelt, soweit sie von dem Kalkspat bedeckt ist.

Bei dem Doppelspat machen die beiden gebrochenen Strahlen einen verhältnismälbig groben Winkel miteinander, einen viel grö̈feren als bei den meisten anderen Mineralien. Je gröber dieser Winkel (IBE (Fig. 22) bei einem Mineral ist, desto gröber ist seine Doppelbrechung. Die verschicelenen Substanzen lassen in dieser Hinsicht bedeutende Linterschiede erkennen. Bei der gröbten Zahl der Edelsteine, ist die Doppelbrechung nicht sehr stark. Da man es bei ihnen auberdem meist mit dïnnen Stuicken zu tun hat, so liegren die beiden Bilder stets einander sehr nahe und überdecken sich sograr meist teilweise, so daf man oft scheinbar nur ein einziges Bild ror sich liat. Der Stein erscheint dann, auch wenn er tatsächlich doppeltbrechend ist, als einfachbrechend.

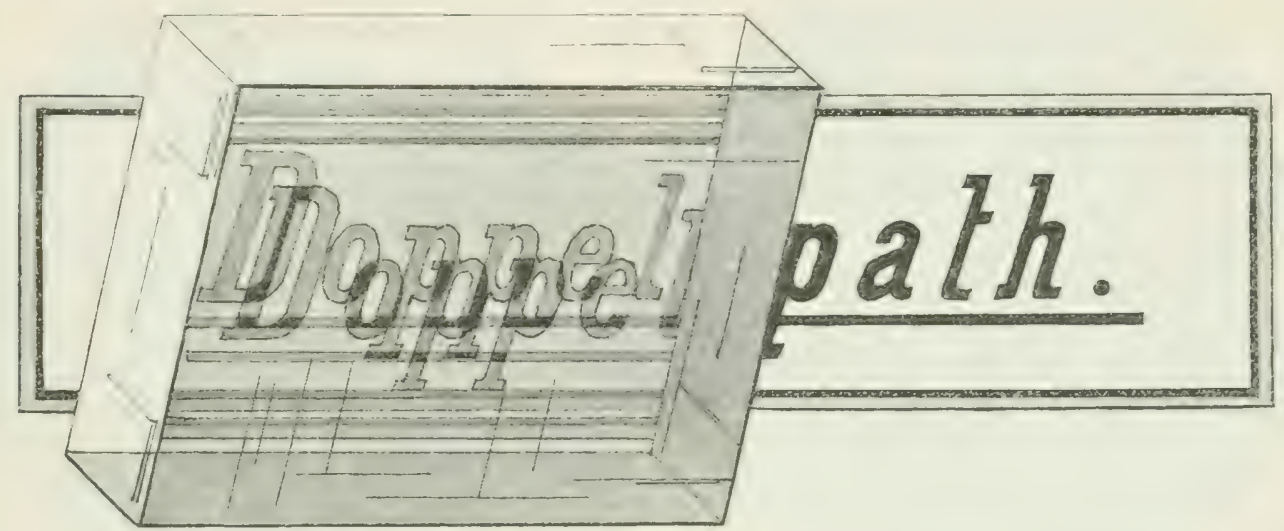

Fig. 23. Doppelte Lichtbrechung in einem Spaltungsstïck ron Kalkspat (Doppelspat).

Man kann aber in einerr solchen Falle die beiden Bilder weiter auseinander treten lassen, wenn man nicht, wie in Fig. 22 und 23, durch zwei parallele Flïchen hindurchsieht, sondern dureh zwei, die sich unter irgendeinem Tinkel schneiden, die also miteinander ein Prisma bilden. In diesem Falle, den Fig. 24 S. 56 darstellt, erhält man aber auch gleichzeitigr wie bei der einfachen Lichtbrechumg (Fig. 15) und wie überhaupt immer in einem Prisma eine farbige Zerlegung des einfallenden weilen Lichtes. Ist z. B. bei A wieder eine kleine, müglichst schmale Lichtflamme, von der der Strahl $A B$ ausgeht, so zerspaltet sich dieser durch die Doppelbrechung in die beitlen grebrochenen Strahlen $B O$ und $B E$, deren jeder aber infolge der Dispersion in seine farbigen Elementarstrablen $B()$. bis $B()$, und $B E_{r}$, bis $B E_{t}$ zerlegt ist. Diese werden an der zweiten Begrenzungsfläche $N P$ des Prismas noch einmal abyelenkt, treten noch weiter auseinander und geben zwei dicht nebeneinander liegende oder sich auch zum Teil überdeckende Bilder $O_{1}^{\prime}()_{\text {, }}^{\prime}$ und $E_{r} E_{i}$ der Flamme. Jedes der beiden Bilder erglänzt in den Spektralfarben wie das eine Bild, das bei der einfachen Lichtbrechung entsteht, und zwar so, daf die roten Enden der beiden hierbei entstehenden Spektren bei $O_{r}^{\prime}$ und $E_{r}^{\prime}$, die violetten bei $O_{v}^{\prime}$ und $E_{v}^{\prime}$ liegen.

In Fig. 25 S. 56 ist die Doplelbrechung in einem prismatisch geschliffenen Kristall per.

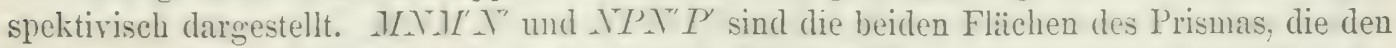

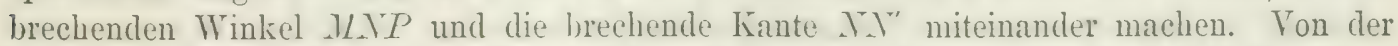

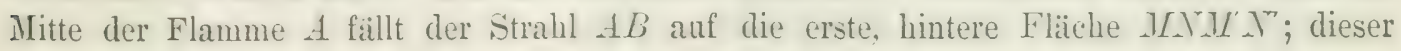


wird hier doppelt gebrochen und in die zwei Strahlen $B O$ und $B E$ gespalten, die prismatisch zerlegt nach $O O^{\prime}$ und $E E^{\prime}$ aus dem Prisma an seiner zweiten Fläche $N P N^{\prime} P^{\prime}$ austreten. Mit allen den anderen von der Lichtflamme und der Kerze ausgehenden Strahlen erhält man dann zwei Bilder jener, die ein bei $O^{\prime} E^{\prime}$ befindliches Auge in lder Richtung $O^{\prime} \mathrm{A}^{\circ}$ und E'EA' sieht. Auch diese beiden Bilder $A^{\circ}$ und $A^{e}$ liegen bei den meisten Edelsteinen dicht nebeneinander und ïberdecken sich oft sogar teilweise, und zwar je nach den Umständen, bald mebr: bald weniger. Jedes einzelne Bild hat einen roten Rand $r$ und einen violetten Rand r; deren lage aus der vorliegenden Figur, sowie aus der Fig. 19 ersichtlich ist, wo in dem einfachbrechenden Prisma jeder der beiden Ränder für sich konstruiert wurde. Dies ist hier nicht geschehen, sondern für jedes Bild nur die Mitte gezeichnet damit nicht durch allzuviele Linien Unklarkeit entsteht.

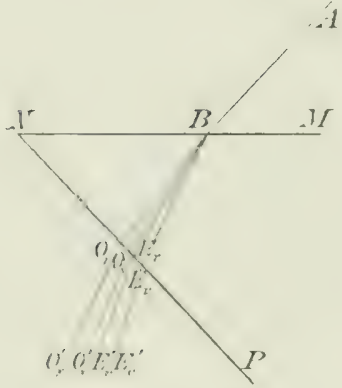

Fig. 24. Gang der Lichtstrahlen in einem doppeltbrechenden Prisma.

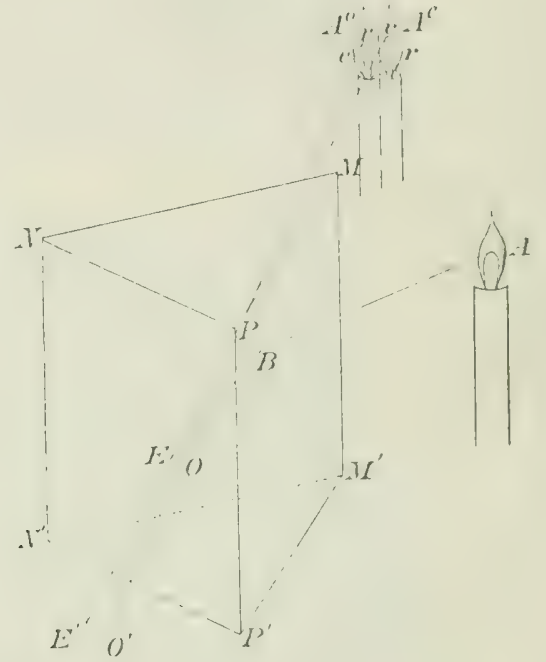

Fig. 25. Perspektivische Ansicht des Gangs der Lichtstrahlen durch ein doppeltbrechendes Prisma.

An einem geschliffenen durchsichtigen Edelsteine bildet nun jede Facette der Vorderseite mit einer ihr nicht parallelen Facette der Hinterseite ein Prisma, und jedes Paar solcher Facetten erzeugt beim geeigneten Anvisieren einer Lichtflamme durch den Stein hindurch ein Bild von dieser. Solche Bilder werden dabei in größerer Zahl entstehen, da einer vorn befindlichen Fläche zahlreiche Facetten hinten gegenuiberliegen, deren jede mit der ersteren ein Flammenbild entstehen läßt. Diese Flammenbilder sind bei einfachbrechenden Steinen einfach, wie in Fig. 19, bei doppeltbrechenden doppelt, zwei Bilder dicht nobeneinander, wie in Fig. 25. Darin liegt ein Nittel, die Art der Lichtbrechung zu erkennen. Am besten bringt man dabei den Stein mit der großen Facette der Vorderseite dicht an das Auge und blickt durch diese hindureh nach einer Flamme. Beim Drehen des Steines wird man bald zahlreiche farbig gresüumte Flammenbilder erblicken, die durch ihre einfache oder doppelte Gestalt die gew ünschte Auskunft geben. Ist der Stein doppeltbrechend, dann entsteht eine Erscheinung, wie die in Fig. 26 a dargestellte, wo jedes der kleinen Flammenbilder, das dureh eine hintenliegende Facette in Verbindung mit der groben vorderen entsteht, doppelt ist: ist der Stein einfachbrechend, dann ist auch jedes dieser Bildchen nur einfach, wie in Fig. $26 \%$. Am besten sieht man diese Erscheinung in einem verdunkelten Zimmer, in das kein anderes Licht eindringen kann als das der kleinen Flamme.

Statt einer Lichtflamme kann man jeden beliebigen Körper durch den Stein hindurch 
beobachten und schen, ob dieser einfache oder doppelte Bilder liefert. IÏ̈ufigr wird hircru eine Nadel benutzt. Man crblickt dann bei einfachbrechenden Edclsteinen vicle einzelne, bei doppeltbrechenden Steinen dagegen Gruppen von je zwei dicht nelseneinander liegrenden rot und blau umsïumten Bildern der Nadel, die bei einer passenden Neigung der letzteren sich einander nälhern und bei einer gewissen Lage derselben übereinander fallen. Selbstrerständlich mïssen diese letzteren Beobachtungen in einem hellen Zimmer vorgenommen werden.

Man kann auf diese. Weise durch direkte Beobachtung nicht selten rasch und sicher feststellen, ob einem vorliewenden Edelsteine die einfache oder die doppelte Lichthrechung zukommt. Nur die Erkennung doppelter Bilder ist aber dabei entscheidend, da scheinbar einfache auch durch sehr grofe Tähe und teilweises Üherdecken der beiden durch schwache Doppelbrechung entstandenen Bilder möglich sind. In vielen Fällen ist die Unterscheidung jedoch nicht so leicht und sicher, wie es auf den ersten Blick erscheinen könnte. Es ist hierzu doch immer eine gewisse Geschicklichkeit erforderlich, die sich nur durch einige Übung erwerben lïft. Daher ist oft die indirekte Beobachtung der

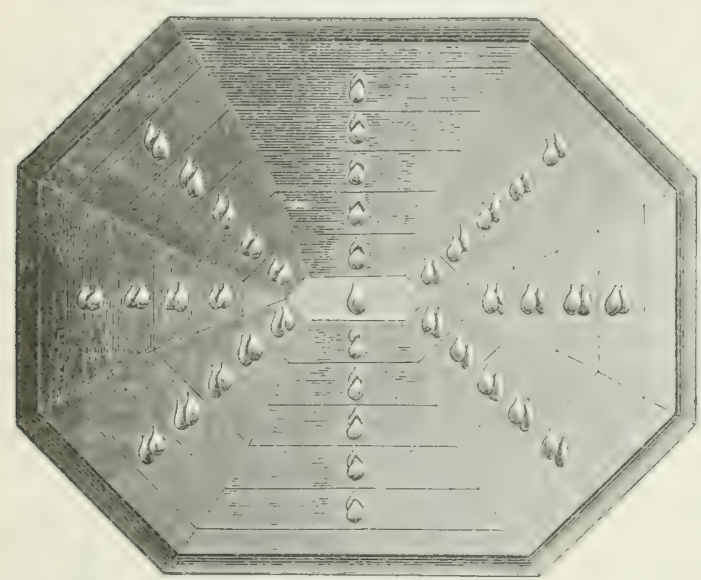

Fig.' 26 a. Bilder einer Lichtflamme durch einen doppelt brechenden Stein.

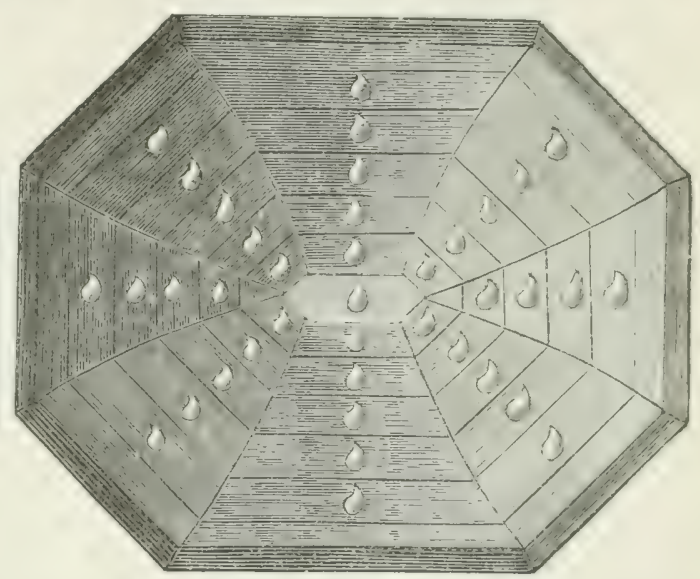

Fig. 26 b. Bilder einer Lichtflamme durch einen einfach brechenden Stein.

Lichtbrechung mittelst gewisser Instrumente vorzuziehen, die noch dazu den Vorteil hat, daß sie auch noch zum Ziele führt an Steinen mit rundlichen Flächen und an ganz unregrelmäßig begrenzten Bruchstïcken, die beim Hindurchsehen nach einer Flamme oder einer Tadel gar keine regelmäbigen Bilder mehr liefern und bei denen demnach die direkte Beobachtung nicht mehr anwendbar ist. Ebenso können auch sehr kleine geschliffene Steine auf dem indirekten Wege noch leicht untersucht werden, bei denen die erwähnte direkte Beobachtung gleichfalls Schwierigkeiten bietet.

Das Instrument, das bei dieser indirekten Methode nötig ist, um einen Stein als einfach- oder doppeltlichtbrechend zu erkennen, ist das Polarisationsinstrument.

Ein solches von sehr einfacher Form, das aber den vorliegenden Zwecken vollständig genügt, ist in etwa ein Drittel der natürlichen Größe in Fig. 27 S. 59 abgebildet. Es besteht aus einem Holzkasten $H$, dessen Deckplatte 1 ' 1 rorn eine runde Durchbohrung hat, in der sich der gleichfalls runde Objektträger o, eine in Messing gefaßte runde Glasplatte, leicht herumdrehen lïbt. Hinten erheht sich die senkrechte Nessingsïule mm, die einen horizontalen Arm $h$ trägt, in dessen runder Durchbohrung, genau senkrecht üher der Mitte ron 0 , sich ein aus Doppelspat gefertigtes Nicolsches Prisma $n$ gleichfalls beliebig drehen lïßt. In dem IIolzkasten $H$ befindet sich ein fester Glassuiegel olne Metallbelag oder 
besser ein sogenannter Glassatz, eine möglichst große Anzahl sehr dünner, übereinandergeschichteter Glastafeln, an die cin gewöhnlicher Spiegel $t$ anstößt, der mittels des Holzkeiles $K$ etwas flacher oder steiler gestellt werden kann. Die vom hellen Himmel kommenden Lichtstrahlen, deren Richtung durch die gestrichelte Linie angegeben ist, fallen zuerst auf den nur zur Beleuchtung dienenden Spiegel $t t$ und von diesem auf den anderen Spiegrel ss, der mit der Vertikalen einen Winkel von nahezu $33^{\circ}$ macht. Auf diesen trefien dann die von $t$ liommenden Lichtstrablen unter einem Einfallswinkel von $57^{\circ}$, werden unter demselben Wrinkel zuriickereworfen und gelangen in senkrechter Richtung durch das Nicolsche Prisma $/$ hindurch, in das unmittelbar über diesem befindliche Auge des Beobachters.

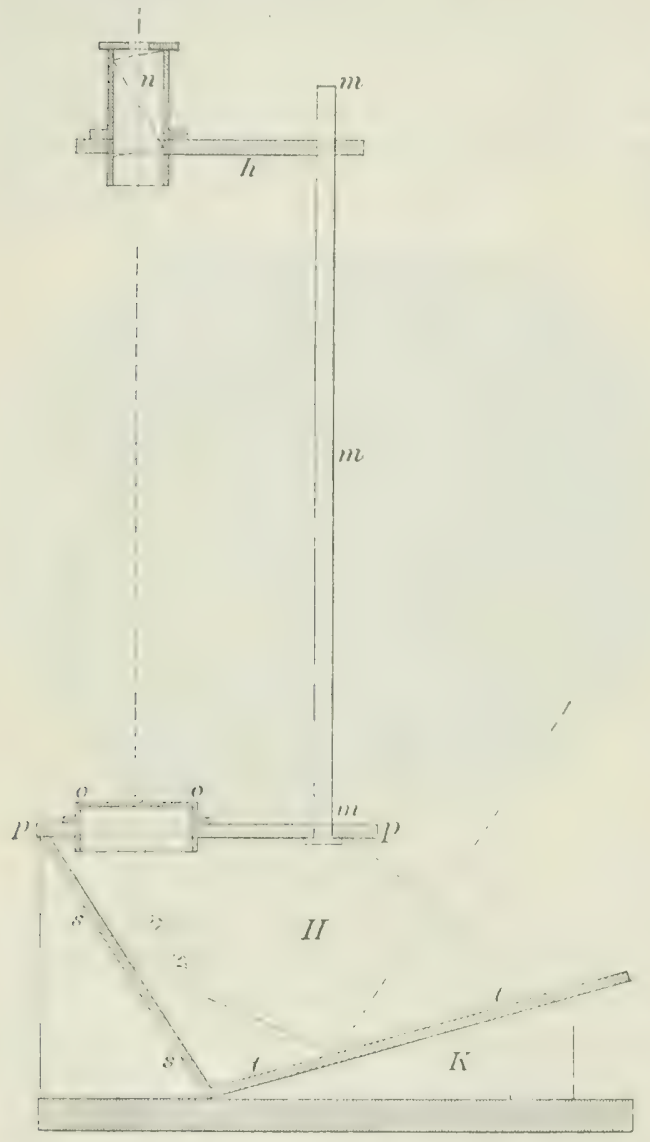

Fig. 27. Polarisationsinstrument für paralleles Licht. 1/3 der natïrlichen Gröle.

Bei der Reflexion an dem Spiegel ss wird das einfallende gewöhnliche Tageslicht in einen besonderen Zustand versetzt, den man als polarisiert bezeichnet; die als gewöhnliche auf $s S$ ankommenden Strahlen gehen dann als polarisierte weiter und gelangen so auf das Nicolsche Prisma $n$. Dreht man dieses, so kann in gewissen Stellungen das von unten, von dem Spiegel ss kommende polarisierte Licht nicht durch dasselbe hindurch, und das Sehfeld erscheint dunkel. In anderen Stellungen durchstrahlt aber das Licht ungehindert das Prisma n, und das Sehfeld ist dann hell. Bei einer vollständigen Drehung des Nicolschen Prismas um $360^{\circ}$ hat man so in regelmäßigen Intervallen von je $90^{\circ}$ einen viermaligen Wechsel von hell und dunkel. Stellt man das Nicolsche Prisma so, daß das Sehfeld vollkommen dunkel ist, dann hat man in dem Polarisationsinstrumente ein vortreffliches Mittel zur leichten und sicheren Unterscheidung einfach- und doppeltbrechender Edelsteine.

Die Erscheinungen, mit deren Hilfe dies möglich ist, sind die folgenden:

Legt man auf den Objekttisch $o$ einen einfachbrechenden Körper, etwa einen Diamant, so bleibt dieser, wie das ganze Sehfeld, andauernd dunkel, während man ihn mit dem Objekttische o um $360^{\circ}$ herumdreht. Es ist dabei wie bei den sämtlichen im folgenden auforeführten Beobachtungen zweckmäibig, durch Vorhalten der Ifand oder besser durch Aufsetzen einer längeren, innen geschwärzten Papierröhre iiber den Objekttiseh alles Seitenlicht mögrichst abzuhalten, damit nicht durch Reflexe an der Oberfläche des Steines der Schein einer Aufhellung durch hindurehgerangenes Licht hervorgebracht wird.

Bringt man nun einen doppeltbrechenden Körper an die Stelle des einfachIrechenden und dreht auch diesen mittels des Objekttisehes o um 360" herum, so wird dieser doppeltbrechende Körper, und zwar in regelmälbign wiederkehrenden Intervallen von 150, viermal aufgehellt und ehenso oft wieder verdunkelt, wïhrend das Sehfeld auber- 
hall, der Umriblinie des Körpers stets unverändert dunkel bleiht, da ja das Yicolsche Prisma seine Stellung auf dunkel unverändert beibehält.

Dies ist also der wesentliche Untersehied, den einfach und doplyellorechende Steine in ihrem Verhalten in Polarisationsinstrumente zeigen, ein Unterschied, der auf der Gesamtheit ihres optischen Verhaltens beruht: die einfachbrechenden bleiben im dunklen Sehfelde des Polarisationsinstrumentes dunkel, die doppelthrechenden wrerden je viermal abweehselnd hell und dunkel, wenn sie auf dem Objekttische jedesmal um 3601" herungedreht werden. Ls ist alser dabei zur Vermeidung" von Irrtïnern noch einiges zu bemerken.

Was zunächst die doppeltbrechenden Steine anbelangt, so ist bei ihnen die Doppelbrechung nicht nach allen Richtungen greich stark. Nach gewissen Richtungen hindurchgesehen, treten die beiden Bilder einer Lichtflamme oder einer Nadel, die durch die Doppelbrechung entstehen, näher zusammen als in anderen, und nach gewissen Richtungen sieht man ïberhaunt blob noch ein einziges Bild; in ihnen findet in dem sonst doppeltbrechenden Körper gar keine doppelte, sondern einfache Lichtbrechung statt.

Solche Richtungen in doppelthrechenden Körpern, in denen trotz der im allgeneinen vorhandenen Doppelbrechung das Licht doch nur einfach gebrochen wird, nennt man optische Ixen. In manchen doppeltbrechenden Steinen ist nur eine einzige solche vorhanden, in manchen anderen sind es deren zwei, und man unterscheidet danach opt is eh einaxige und zweiaxige Körper. Es sei hier im Vorbeigehen erwähnt, daß auch die optischen Axen nach Zahl und Lage mit der Kristallisation auf das engste zusammenhängen: alle hexagonalen und quadratischen Kristalle sind einaxig, und die optische Axe ist ihrer kristallographischen IIauptaxe parallel; alle rhombischen, monoklinen und triklinen Kristalle sind zweiaxig. Für die folgenden Betrachtungen ist dieser I'nterschied aber ron keinem weiteren Interesse.

Die optischen Axen haben nun bei der eben in Rede stehenden Beobachtung im Polarisationsinstrumente eine hervorragende Bedeutung. Legt man nämlich einen doppeltbrechenden Stein so in das Instrument, daß eine optische Axe dessen Sehrichtung parallel ist, daf man also in der Richtung der optischen Axe dureh den Stein hindurchsieht, dann verhält sich dieser ähnlich wie ein einfachbrechender Körper und zeigrt Dunkelheit oder jedenfalls nicht die oben erwähnte abwechselnde Aufhellung und Terdunkelung:

Tieraus folgt, daf ein Stein, der im Polarisationsinstrumente bei ciner gewissen Lage dunkel bleibt, deshalb noch nicht notwendig einfachbrechend sein muf. So wenig wahrscheinlich es im allgemeinen ist, so kann es doch sein, dafs man den Stein zufällig. in einer solchen Stellung in das Instrument gelegt hat, daß das Licht in der Richtung einer optischen Axe hindurchgeht. Man wird also für alle Fälle gut tun, einen Stein, der dunkel bleibt, in einer anderen Lage auf dem Objekttriger, d. h. nachdem er auf eine andere, aber nicht etwa auf die der ersten parallele Facette gelegt ist, nochmals in derselben Weise zu untersuchen. Bleiht er auch dann bei einer Drehung um 360" dunkel, dann ist kaum mehr ein Zweifel möglich, dab er wirklich einfachbrechend ist. Im aber ganz sicher zu sein, muf man den Stein erst noch auf einer dritten Facette liegend beobachten. da das Licht möglicherweise in der zweiten Stellung in der Richtung der zweiten optischen Axe hindurchgegangen sein kïnnte. Dies ist aber so wenig wahrscheinlich, dab man sich mit der Lntersuchung in den beiden ersten Lagen meist zufrieden geben kann. Wenn der Stein in diesen beiden Lagen dunkel bleibt, so ist er mit allerhüchster Wahrscheinlichkeit einfachbrechend. Zeigt der Stein bei irgendeiner Lage abwechselnde Aufhellung und Terdunkeluns, so ist er mit völliger Sicherheit und Bestimmtheit dolnettbrechend; eine weitere Beobachtung ist dann vollkommen überflüissig.

Bleibt ein Stein in drei oder auch nur in zwei Lagen in Polarisationsinstrumente 
bei einer vollen Umdrehung um $360^{\circ}$ dunkel, so ist er, wie wir eben gesehen haben, für einfachbrechend zu halten; es ist dabei aber doch auch hier noch die Möglichkeit einer Täuschung ins Auge zu fassen.

Wenn man irgendeinen geschliffenen Stein auf eine Facette legt, so ist die gegeniiberliegende, nach oben gekehrte Facette der unteren meist nicht parallel, und alle am Rande herumliegenden Facetten sind sogar ziemlich steil gegen jene geneigt. Kommt nun Licht in senkrechter Richtung von unten, so wird es zwar stets in den Stein eintreten, es wird aber auf die nach oben gekehrten Facetten so schief auffallen, daß es in vielen Fällen nicht austreten kann, sondern durch Totalreflexion nach der Seite abgelenkt wird. Es gelangt dann nicht in das Auge, und der Stein bleibt unter diesen Umständen bei einer Drehung um 3600 dunkel, auch wenn er doppeltbrechend ist und das Sehfeld eigentlich aufhellen müßte. Die Ursache der Dunkelheit ist dann aber nicht die einfache Lichtbrechung, sondern die Totalreflexion. Man sieht leicht, daß hierin eine Quelle von Irrtümern liegt, die unter allen Umständen beseitigt werden muß. Dies kann auf verschiedene Weise gesehen.

Die meisten geschliffenen Steine haben, wie die Figuren auf Taf. II--IV zeigen, eine grolie Facette, die sogen. Tafel, der hüufig eine zweite kleine, die Kalette, parallel gegenïberliegt. Die Müglichkeit der Totalreflexion wird beseitigt, wenn man den zu untersuchenden Stein mit der kleinen Fläche, oder doch so auf den Objektträger legt, daß die grobe Fläche gerade nach oben gekehrt ist, was man, wenn nötig, durch geeignetes Festklehen des Steines auf den Objekttisch mit Wachs leicht bewerkstelligen kann. Das von unten kommende Licht tritt dann ungehindert in den Stein ein, fällt genau oder sehr nahe senkrecht auf die grofje Fläche und tritt daher aus dieser anch ebenso ungehindert aus. Im ganzen Gebiet dieser großen Fläche kann man dann sichere und ungestörte Beobachtungen machen. Weniger zweckmäßig ist es, umgekehrt den Stein mit der großen Fläche auf den Objekttrïger zu legen, so daß die kleine nach oben siebt; in diesem Falle kïmnten lä̈ufig nur die Strahlen im Bereiche der kleinen Fläche senkrecht zu dieser austreten, und nur in ihrem oft sehr beschränkten Umkreise wïre die Beobachtung ungestört und sicher; ringsum könnte Totalreflexion stattfinden.

Beobachtet man nun auf der nach oben gekehrten Fläche abwechselnd Aufhellung und Verdunkelung, dann ist der Stein sicher doppeltbrechend. Bleibt er aber dunkel, dann muf er noch in anderen Lagen beobachtet werden. Legt man ihn aber auf eine andere Facette, dann tritt leicht an der dieser gegenüberliegenden Totalreflexion ein. Diese his zu einem gewissen Grade zu beseitigen, gibt es aber ein sehr einfaches Mittel. Man mmibt den Stein mit einer stark lichtbrechenden Fliissigkeit, indem man ihn in ein kleines (ilasschälchen bringt, das mit dieser bis etwas über den Stein hinaus angefuillt ist. Das Brechunosverhältnis des Steines ist dann der Ungebung meist sehr nabe gleich, jedenfalls sehr viel nïher, als wenn dieser von Luft umgeben wäre. Die Folge davon ist, wie wir oben S. 17 gesehen haben, daß sehr schief auf die nach oben gekehrten Facetten auffallende Lichtstrahlen, die in der Luft nicht austreten könnten, von dem Steine in die Fliissigkeit ïbergehen, ohne Totalreflexion zu erleiden. In der Flïssigkeit pflanzt sielı das Licht ziemlich nahe senkrecht nach oben fort, füllt hier auf deren wagerechte Oberflïche und tritt aus dieser in die Iuft aus, ebenfalls ohne daß Totalreflexion eintritt. Die Fliissigkeit beseitigt also die Totalreflexion, wenn nur der Brechungskoeffizient des Strines nicht gar zu grof ist und sich nicht gar zu weit ron dem der Fluissigkeit entfernt, was aber kaum anderswo als beim Diamant der Fall ist.

Flïssigkeiten, die sich hierzu eignen, mïssen durehsichtig und klar, nicht stark grefairht und möglichst stark liehtbrechend sein. Vor allem ist auch zu diesem Zwecke das schom melirfach genannte Methylenjodid zu empfehlen, eine der am stärksten licht- 
brechenden Flïssigkeiten, die man kennt, und ron der wir schon gresehen haben, dafi sie bei Zimmerwärme zwischen 15 und 20 " C. für mittlere Strahlen einen Brechungsindex $=1, \pi$ hat. Diese Zahl ist gröfer als für die meisten Edelsteine, nur wenige derselhen brechen das Licht noch stärker, wie namentlich der Diamant mit dem Brechungsverhä̈ltnisse 2, 13. Während an den oberen Facetten jener schwächer lichtbrechenden Steine üherhaupt keine Totalreflexion mehr stattfinden kann, wenn sie in Methylenjodid liegren, da dann alles eintretende Licht auch stets wieder austreten mulj, wird nach den Auscinandersetzungen auf S. 17 beim Diamant nur an solchen Facetten noch Ablenkung der Lichtstrahlen durch Totalreflexion stattfinden, die mit der Fliiche, auf der der Stein liegt, also mit der horizontalen Fläche des Objekttisches, einen grölieren Winkel als 46; "19' cinschließen, auf die also die von unten kommenden Lichtstrahlen unter einem kleineren Winkel als $43^{\prime \prime} 41^{\prime}$ auffallen. Iier ist also die 'Totalreflexion durch die Flüssigkeit allerdings nicht ıranz aufgehoben, aber doch wesentlich eingeschränkt, da in der Luft schon an Facetten, die nur einen Winkel von $2 f^{\prime \prime} 24^{\prime}$ mit jener Fläche machen, auf die also die Strahlen unter $65^{\prime \prime}$ '36' auffallen, das Licht nicht mehr austreten kann. Beinahe ebenso stark lichtbrechend wie das Methylenjodid ist das viel billigere Monobromnaphtalin, das daher ebenfalls zu dem angegebenen Zwecke Verwendung finden kann, leider nicht auch zur Bestimmung des spezifischen Gerichts, da es sehr viel leichter ist als Methylenjodid.

Fassen wir das bisher über die Verwendung des Polarisationsinstruments zur Lnterscheidung einfach- und doppeltbrechender Edelsteine Gesagte kurz zusammen, so hat man den Stein auf den Objekttisch zu legen und mit diesem herumzudrehen. Bemerkt man bei dieser Gelegenheit, wenn das Seitenlicht gut ausgeschlossen ist, so daf nur die von unten kommenden Lichtstrahlen, die durch den Stein hindurchgegangen sind, Zutritt zum Auge haben, abwechselnde Aufhellung und Verdunkelung, so ist el zweifellos doppeltbrechend. Bleibt er dunkel, dann bringt man ilın in einer anderen Lage auf den Objekttisch und dreht wieder. Zeigt er nunmelır Aufhellung, so ist er mit Sicherheit doppeltbrechend. Der Stein kann aber nun auch bei der zweiten Lage wieder dunkel bleiben, dann ist er einfachbrechend, wenn nicht die Totalreflexion die Dunkelheit verursacht hat. Um dies zu entscheiden, bringt man ihn in eine solche Lage, dab die grofie Fläche gerade nach oben gekehrt ist; dann kann keine Totalreflexion stattfinden, orler man legt ihn in eine der genannten stark lichtbrechenden Flïssigkeiten, die gleichfalls die Totalreflexion vollstïndig oder doch nahezu beseitigen. Bleibt in einer solchen der Stein in mehreren Lagen dunkel, dann kann er als einfachbrechend angesehen werden, namentlich, wenn man dafür sorgt, daß wenigstens eine Facette des Steines dabei in einer nahezu horizontalen Lage sich befindet. Vielleicht ist es zweckmäßig, bei diesen Beobachtungen den Stein zur Beseitigung der Totalreflexion gleich von vornherein in eine solche Flüssigkeit zu legen, namentlich dann, wenn er vollkommen roh und unregelmäßig: begrenzt oder rundlich greschliffen ist. Alle diese Versuche lassen die Steine vollkommen unbeschädigt, auch erfordern sie keine besondere Geschicklichkeit und geben nach kurzer Übung unter Anwendung der nötigen Vorsicht auch dem in physikalischen Beobachtungen sonst nicht Geibten ein sicheres Resultat. Vollständig entscheidend ist dieses namentlich, wenn durch Beobachtung von abwechselnder Aufhellung und Verdunkelung zweifellos Doppebrechung konstatiert werden kann.

Es ist aber doch noch etwas zu erwähnen, was unter Umständen zu Täuschungen Veranlassung geben kann. Manche einfachbrecheude Kürper, wie z. B. der Diamant und andere zeigen zuweilen Erscheinungen der Doppelbrechung, die ihnen nach den Verhältnissen ibrer Kristallisation eigentlich nicht zukommen. Diese sogenannte anomale Doppelbrechmog wird meistens hervorgebracht durch innere Spannungen, die in den 
betreffenden Förpern bei ihrer Festwerdung durch irgendwelche Ursachen entstehen und die so weit gehen künnen, dab manche Ḱristalle, wie z. B. gerade manche Diamanten, oft ohme erkemnlsare äulfere Ursache, ganz von selber in Stiicke zerspringen. Es sind dies die sogenannten ...moky stones", von denen unten noch weiter die Rede sein wird.

Die anomale Doppelbrechung ist meist nur schwach und die durch sie hervorgethrachte Aufhellung im Polarisationsinstrumente ist weit geringer als bei wirklich doppeltbrechenden Kristallen. Die Aufhelluug geht auch häufig nicht wie bei den letzteren Eleichmälig ïher den ganzen Körper weg, sondern sie tritt streifen- oder bänderartig, oder in alwechselnden Fuldern oder rings um Einschliisse fremder Körper auf, wälırend die zwischenliegenden Partieen bei der Drehung dunkel bleilen. Danach ist es bei einiger $\ddot{\text { trbung }}$ selten schwieris, anomale ron wirklicher Doppelbrechung zu unterscheiden. Bei Gläsern, wie sie häufig zur Nachahmung von Edelsteinen verwendet werden, tritt zuweilen noch cine andere hierher gehörige Erscheinung anf. Wenn man eine nicht zu dünne Glasplatte stark erhitzt und dann rasch abkühlt, so sieht man auf ihr oft im Polarisationsinstrumente, trotzdem dali alles (tlas amorph, also eigentlich einfach brechend (isotrop) ist, eine besondere Art von Aufhellung, nämlich z. B. ein mehr oder weniger regelmäifiges schwarzes Kreuz mit zwei aufeinander senkrechten Balken, zuweilen umgeben von hellen farbigen Kreisen. Genau dieselhe Erscheinung oder etwas Ähnliches erblickt man zuweilen in Glasimitationen von Elelsteinen. Man erkennt daraus mit Sicherheit, daß man es mit Glas und nicht mit einem echten Edelsteine zu tun hat.

\section{Brechungshoeffizienten.}

Die Verhältnisse der Liehtbrechung werden für jeden Edelstein gegeben durch die Brechunsionffizienten. Bei einfachbrechenden substanzen ist nur ein einziger Brechungskoeffizient $n$ vorhanden, der für jede Richtung in ihnen in gleicher Weise gilt und der nur mit der Farbe etwas schwankt. Die Lichtbrechung ist hier nach allen Richtungen hin dieselbe. Bei doppeltbrechenden Körpern, wo die Stärke der Doppelbrechung von der Richtung in denselben abhängig ist und sich mit dieser ändert, gilt nicht für alle Richtungen derselbe Brechungskoeffizient; auch er ändert sich mit der Richtung und ist für Lichtschwingungen, die in einem gewissen Sinne vor sich grehen, am criöliten ( $n_{g}$ ) und für andere stets auf den vorigen senkrechte Schwingungen am kleinsten $\left(n_{i}\right)$, beide Werte ebenfalls mit der Farbe etwas schwankend. Je gröber der Untrrschied des gröbten und kleinsten Brechungskoeffizenten eines Edelsteines, desto grö̈ler ist scine Doppelthrechung; diese wird durch die Differenz jener beiden Brechungskoeffizienten ausgedrüickt.

Fiir die Erkennung und Unterscheidung der Edelsteine ist die mehr oder weniger genaus: Kenntnis der (iröbe der Brechungsindices von grober Bedeutung. Die Bestimmung dieser für die einzelnen Mineralien charakteristischen Zahlen in einer für unsere Zwecke am hesten angepaliten Weise haben wir daher jetzt kennen zu lernen. Am bequemsten hierzu ist wohl das Refiaktometer etwa in der Leilosehen Konstruktion, wie sie in der optisch-nechanischen Werkstätte von R. Fuef) in Steglitz-Berlin ausgeführt wird.

Das Instrument beruht auf der Anwendung der Totalreflexion (S. 46). Es besteht in der Hauptsache aus einer IIalbkugel von sehr stark lichtbrechendem Glase mit einem brechungskoeffizienten $n=1,0$ ungrefïhr. Damit kann man Steine mit einem wenn auch nur wenig geringeren Berechnungskoeffizienten untersuchen, ebenso stark oder stärker lichtbrechende dagegen nicht, weil dann unter den nun zu beschreibenden Umständen keine Totalreflexion eintritt. 
Die ebene Grenzflïche I'? (Fig. 25 und 29) der IIalbkugel $/ I$ ist nach oben grekehrt. Auf sie legt man dren schwïcher lichthrechenden Edelstein S und lïlit von drer Scite oder von unten ler Lichtstrahlen von einer passend aufoestellten Flammes in versehiedenen Richtungen durch die Ialbkugel eintreten, die dann an der Lnterfläche des Steins zum Teil Totalreflexion erleiden müssen. Es ist dabei notwendig, dalj der letztere die Halbkuggel mit einer ebenen Fläche, wie sie ja bei Facettenschliff stets vorhanden ist, vollkommen beriihrt, was aber nicht ohne Weiteres leicht zu erreichen ist. Man kann abur diesellue Wirkung erzielen, wenn man zwisehen beirle einen Tropfen einer Flïssigkeit bringt, dis, sich beim Andrïeken des steines an die IIalbkugel zu einer dïnnen, planparallelen Schicht ausbreitet. Diese Flïssigkeit mul) aber die Bedingungen erfüllen, daf ihr Brechungskoeffizient $X$ errölier ist als der des zu untersuchenden steins, auf den genauten Wert ron Ir kommt es aber nicht an: an besten ist er auch eröfer als der des (ilases der Hall)kugel. Eine Flïssigkeit mit einem möglichst hohen Brechnungskoeffizienten ist also besonders vorteilhaft, etwa Methylenjodid $\left(X^{+}=1,-5\right)$, oder Methylenjodid in der Wärme mit Schwefel gesättigt $(N=1,78-1,70)$, oder auch Arsenbromür $\operatorname{AsBr}(N=1,7 s)$, oder eine Lösung von I'hosphor in Schwefelkohlenstoff $(\mathrm{X}=1, \ldots)$ usw. Immer sind von dieser Fliissigkeit nur ganz minimale Mengen erforderlich.

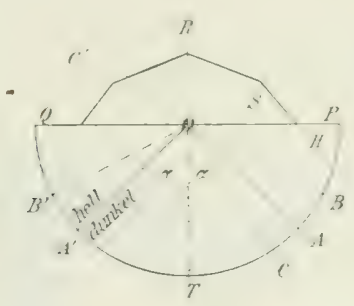

Fig. 28 .

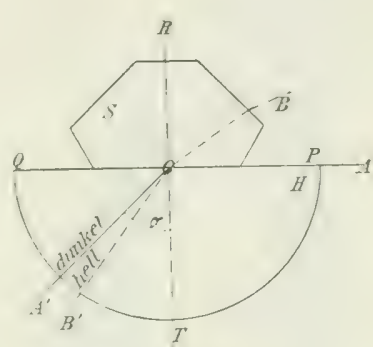

Fig. 29.

Gang der Lichtstrahlen im Refraktometer.

Wir verfolgen nun den Gang der Lichtstrahlen, zunächst in Fig. 28, in der, wie iibrigens auch in Fig. 29, () der Mittelpunkt der Halbkugel $H$, und $R T$ eine Senkrechte in () auf der Grenzfläche $P(\ell$ zwischen dem Stein und der Halbkugel bedentet, indem wir ron der zwischen beiden befindlichen Flïssigkeitsschicht absehen, die ja nur die rollständige Beriilırung beider vamittelt, wegen ihrer planparallelen Form aber den Gang der Strahlen nicht weiter beeinfluft. Der aus einer rechter Hand liegenden Lichtruelle ankommende Strahl to soll der Grenzstrahl seim, bei dem eben Totalreflexion eintritt und der daher vollständig nach () A' zurückgeworfen wird. AO tritt als Radius der Halblugel ohne Brechung in diese ein und ebenso rerläft $\left(\mathcal{A}^{\prime}\right.$ die Halbkugel ohne Brechung, $\triangle \leadsto=A O T=T U A^{\prime}$ ist der Grenzwinkel. Jedu unter einem größeren Winkel, also flacher einfallende Strahl wird an an der Grenzflïche $P($ ebenfalls total reflektiert, z. B. $B O$ nach $\left(1 B^{\prime}\right.$, und so jeder andere, der rechts ron $A(1$ gegen $P$ hin liegt. Dagegen wird jeder steilere Strabl $C($ ) mit einem Einfallswinkel kleiner als c nicht mehr total reflektiert, sondern tritt gel)rochen in der Richtung " C' aus der Halbkugel in den Edelstein über, und ebenso jeder andere links von $A O$. Ein vor $A$ 'befindliches Auge, das nach $O$ blickt, wird also die linke Hälfte des Sehfeldes wegen der dort ankommenden, total reflelitierten Lichtstrablen $O B^{\prime}$ usw. hell sehen, während die rechte Hälfte dunkel erscheint, weil von dort kein Licht in das Auge gelangt. Der Grenze zwischen beiden IIälften entspricht der Grenzstrahl $O A^{\prime}$. Betrachtet man num diese Grenze durch ein ständig auf $O$ gerichtetes, um eine durch $O$ gehende horizontale Achse drehbares Fernrobr, das vorher die Position 
TO hatte, und liest an dem Teilkreis des Instruments diese beiden Stellungen TO und $A^{\prime} O$ $a b$, so erhält man den Grenzwinkel «, und dieser gibt in Verbindung mit dem durch vorhergehende Untersuchung bekannten Brechungskoeffizienten des Glases der Halbkugel vermittelst einer einfachen Rechnung die gesuchte Zahl für den Edelstein. Je kleiner «, desto größer ist der Brechungsindex des Steins, und umgekehrt.

Aler man kann noch auf eine zweite Art mit demselben Instrument verfahren (Fig. 29). Fällt der Lichtstrahl $A^{\prime}()$ unter dem Grenzwinkel $A^{\prime} O T^{\prime}=$ a der totalen Reflexion im Mittelpunkite $O$ auf die Grenzfläche $P Q$, so wird er in der Richtung dieser Grenzflïiche mit einem Brechungswinkel $=90^{\prime \prime}$ nach $O A$ austreten. Tritt umgekehrt von einer reehts von $A$ befindlichen Lichtquelle ein Strahl $A O$ parallel mit der Grenzfläche $P Q$, wie man

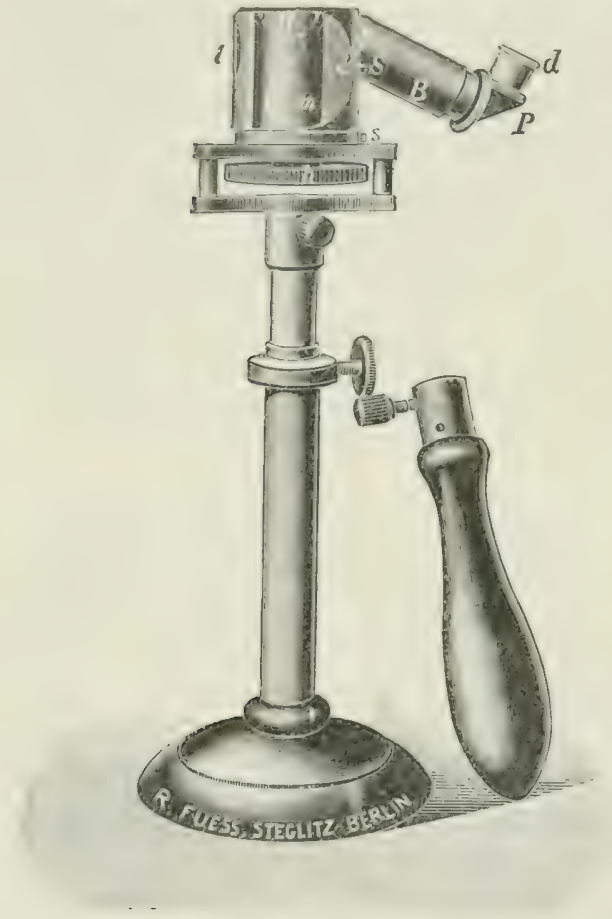

Fig. 30 .

Refraktometer (Ansicht.) sagt streifend, ein, so wird er seinen Weg in der Richtung des Grenzstrahls $O A^{\prime}$ in der Halbkugel fortsetzen. Jeder von oben kommende Strahl $B O$ wird nicht total reflektiert, sondern tritt nach $O B^{\prime}$ in die Halbkugel ein, so daß die Seite rechts von $O A^{\prime}$ hell ist. In dem Instrument ist durch eine Metallhüilse um die Halbkugel dafür gesorgt, daß von unten her keine Strahlen auf diese einfallen können. Der Teil des Sehfeldes links von $O A^{\prime}$ erhält also gar kein Licht und erscheint daher dunkel, und zwar ist die Dunkelheit

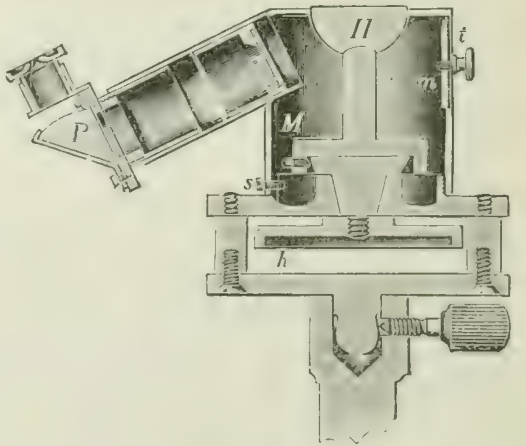

Iig. 31.

Refraktometer (vert. Durchschnitt.)

hier vollstïndiger als in vorigen Fall, wo doch noch etwas Licht in den dunkeln Teil des suffeldes eindringt. Richtet man nun wieder das Fernrohr auf die Grenze OA', nachdem es vorher die Stellung. TO gehabt hatte, so erhält man abermals den Grenzwinkel $u$.

Das Instrument selbst ist nun in Fig. 30 in der äußeren Ansicht, in Fig. 31 im Durchschnitt dargestellt. $H$ ist wieder die gläserne Halbkugel, die von unten gestiitzt und mittelst der Scheibe $h$ in sich drehbar ist. Der Messingmantel.$T$ umgibt sie ringsum und lïlit nur die obere ebene Grenzflaiche frei. Das der bequemeren Beobachtung wegen bei $I^{\prime}$ gehrochene Fermriblirchen $I$ ist auf den Mittelpunkt der Halbkugel gerichtet. Das Instrument kann mittels cines Stativs auf den Tisch gestellt werden, wie in Fig. 30, oder man kann es an dem daneben abgebildeten Handgriff vor das $\Lambda$ uge halten.

Beobachtet kann nun nach den beiden oben angedeuteten Methoden werden, nachdem der Eduktein oben/auf die Halbkuged aufgesetzt ist. Wir betrachten zuerst die durch Fig. 29 erläuterte Methode. 
1. Man stellt die Flamme in die Möhe der (Erenzflichen PQ. Ton ihr grehen Lichtstrahlen nach allen Richtungen aus, also u. a. auch in der Richtung 10 dieser Grenzfläche. Im Fernrohr sicht man dann die Grenze zwischen dem hellen und dunkeln Teil des Selifelds. und man erkennt daran die Riehtung ()A'. Durch Drehen an der Scheihe $h$ kann die (irenze mïglichst deutlich eingestellt werden. Thir haben uns oben das Fernrohr drehbar gedacht. Diese Einrichtung ist hier jedoch durch eine andere berputemere ersctzt. Das Fermrohr steht fest, enthïlt aher bei sirig. 30, 31, eine von oben nach unten gerichtete Skala, die man beim Ilineinblicken in das Fernrohr dentlich sieht. Je nach der Siärie der Lichthrechung des Edelsteins fällt nun die Grenze auf diesen oder jenen Strich der Skala und diese Striche sind mit Zahlen versehen, die den betreffenden Brechungskoffizienten ohne weiteres angeben, so dalo sar keine Rechnung nötig ist. Die Skala greht von 1,i, der kleinsten, etwa rorkommenden Zahl, his 1,in: man kann die zweite Dezimalstelle ummittelbar ahlesen, die dritte noch schäitzen. Fällt z. B. die firenze auf den mit $1, \therefore$ bezeichneten

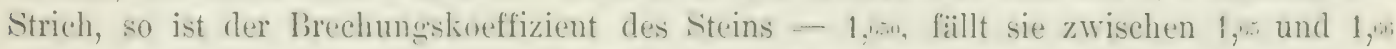
in die Mitte, so ist der gesuchte Wert $=1,055$ usw. Man hat so ein Mittel leicht und olne besonders zu erwerbende (ieschicklichkeit mit minimalem Zeitrerlust die Brechungskotfizienten mit einer für die vorliegrenden Bedürfnisse šenügrenden Genanigkeit zu ermitteln.

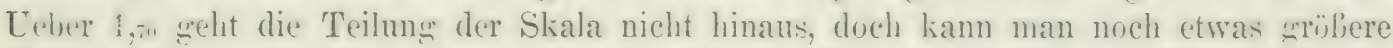
Trerte schätzen. his etwa 1,i... Ist der Brechungskoffizıent noch höher. so fällt die Crenze ïber das Selifeld hinaus oder es tritt überhaupt keine Totalreflexion mehr ein. In desen Fällen ist dann das Instrument nicht mehr ausreichend.

2. Zur Anwendung der zuerst erwïhnten, in Fis. 25 dargestellten Methode ist in dem

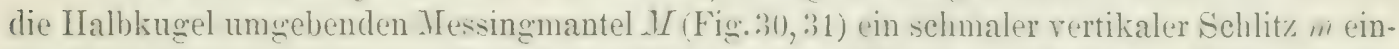
geschnitten, der mittelst eines Knopfes $t$ geöffnet und geschlossen werden kann. Bisher war er geschlossen. nunmehr wird der Terschlnf wesweschoben. Es hann sodann anstatt des streifenden Lichts, indem man die Flamme niedriger stellt. solches ron unten her durch den jetzt offenen Schlitz eintreten, das an der Grenzfliche von Stein und Gias zum Teil Totalreflexion erleidet. Im Fernrohr ist wieder eine Grenze zu sehen, und zwar, wenn man denselhen Stein henutzt an derselben Stelle der Skala wie vorher, nur ist hell und dunkel in beiden Fïllen vertauscht. Die Skala gribt uns wieder den Werth des gesuchten Brechungskoeffizienten, und es gelten dieselhen Beschränkungen wie olen hei der ersten Methode.

In dieser Weise geht man bei einfachbrechenden Edelsteinen vor. Man erhält eine einzige Grenze, die den einzigen Brechungskoeffizienten $n$ liefert. Genau ehenso ist aher auch das Terfahren hei doppeltbrechenden Steinen, nur erblickt man in diesem Fall zwei Grenzen ïhereinander, diese geben dann zwei Brechungskoffizienten, die entweder $=n$, und $n$ sind, oder zwischen ihnen liegen. Von diesen beiden Grenzen wird je die eine durch Drehen eines bei $d$ (Fig. 30, 31) auf das Beobachtungsfernrohr aufgesetzten Nicolschen Prismas zum Terschwinden mehracht. so daf blos die andere sichthar bleibt, was die Bestimmung der beiden Brechungskoeffizienten erleichtert, resp. ermöglicht. Tan kann auf diese Teise nicht nur an den beiden Crenzen erkennen, dals Doppelbrechung vorliegt, sondern auch deren Grofe als Differenz der den beiden Grenzen entsprechenden Brechungskeffizienten bestimmen. Diese Differenz ist bei den schwach doppeltbrechenden Edelsteinen stets klein, bei den stark dopleltbrechenden kann sie ziemlich groß werden; $\quad l=n-n$, geht beim Zirkon bis 0,15, beim Bergkristall hüchstens bis 0,(1), so daß darin ebenfalls ein Merkmal zur Erkennung und Lnterscheidung ron Edelsteinen liegt, das sich zuweilen mit Erfolgr anwenden läßt.

Kann man mit diesem Instrument auch, wie wir gesehen haben, die höchsten Brechungskoeffizienten, die bei Edelsteinen rorkommen, z. B. den des Diamants $(n=2,43)$ nicht mehr zahlenmäßign bestimmen, so ist es doch immerhin ron hohem praktischem Ba uer, Edelsteinkunde. 2. Aufl. 
Wert, festzustellen, daß der betreffende stein ein sehr starkes Lichtbrechungsvermögen besitzt Er kann unter Umstïnden schon daran erkannt werden, denn derartige Brechungsindices kommen doch nicht zu häufig vor. Es handelt sich bei vielen solehen Bestimmungen überhaupt nur darum, ob der Brechungsindex groß oder klein ist, nicht selten geniigt dies für die Bestimmung:

Soll aber in Fällen, wo man von dem Refraktometer im Stich gelassen wird, der Brechungskoeffizient doch noch genau ernittelt werden, so muf man zu der bekannten Prismenmetho de greifen, die in jedem Lehrbuch der Physik auseinandergesetzt wird und daher hier nicht weiter erörtert zu werden braucht. Sie ist fast stets leicht anzuwenden, da man an mit Facetten gresehliffenen Steinen wohl immer zwei passende Flächen findet, die miteinander ein brauchbares Prisma bilden. Allerdings darf dabei der Stein im allgemeinen nicht urefaft sein, wïhrend mit dem Refraktometer auch Steine in der Fassung untersucht werden können, wenn auch nur eine einzige Facette genügend freiliegt.

Es sollen nun hier die Brechungskoeffizienten einiger der wichtigsten Edelsteine zusammengestellt werden, für einfachbrechende der eine $n$, für doppeltbrechende der gröbte $n_{g}$ und der kleinste $n_{k}$, und zwar für Lichtstrahlen, die zwischen dem roten und dem violetten Ende des Spelitrums in der Mitte liegen, also die sogenaunten mittleren Brechungskoeffizienten oder die fiur mittlere Strahlen. Ebenso ist für jeden doppeltbrechenden Stein die Größe d der Doppelbrechung als die Differenz der beiden letztgenannten Zahlen $n_{0}$ und $n_{k}$ fïr den gröbten und kleinsten Brechungskoeffizienten angegeben, also diejenige Zahl, lis zu der dex Unterschied der Brechungskoeffizienten allerhöchstens steigen kann.

a) Einfachbrechende Edelsteine.

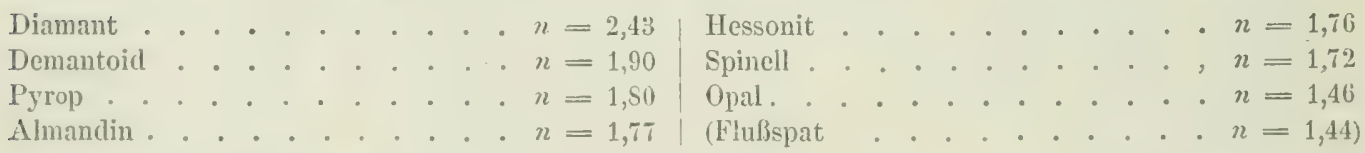

b) Doppeltbrechende Edelsteine.

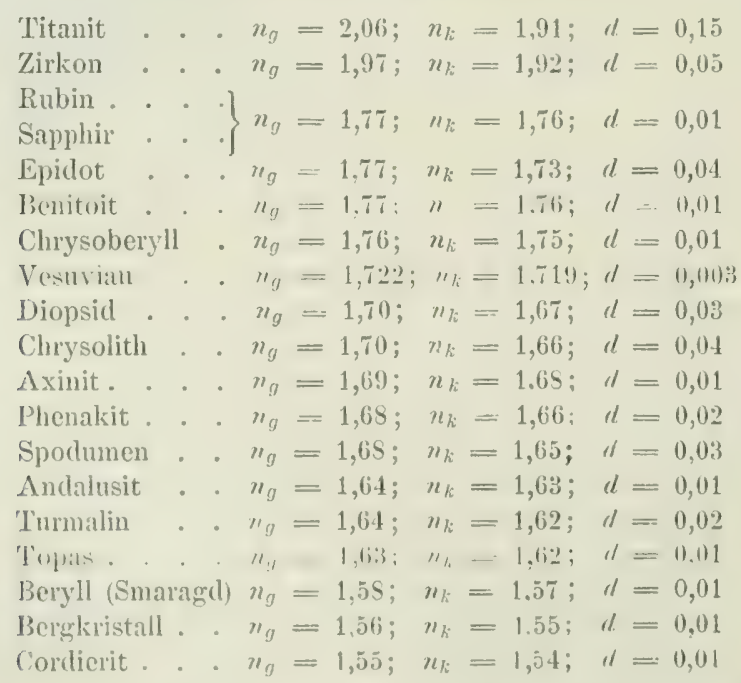

Eine merkwïrdige Beziehung zwischen der Größe der Brechungskoeffizienten und

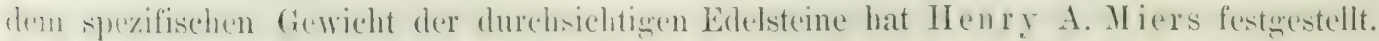

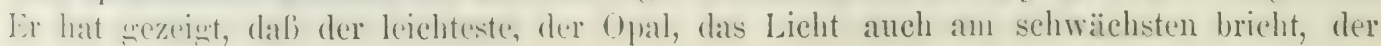




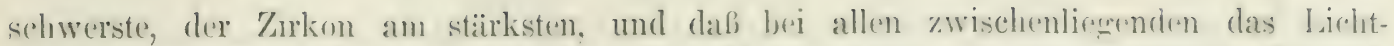
brechungsvermögen fast genau in demselhen Mafe wächst wir das sperificche liewicht

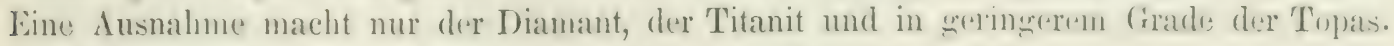
Weniger durchgreifend zeigt auch die Härte ein ähnliches Verhältnis.

$$
\text { 6. Firbe. }
$$

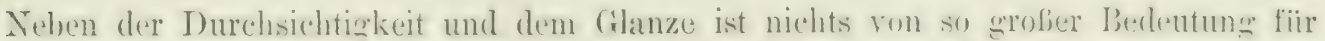
die Schönheit rines Eilelsteines als scine Farbe. Nancher ist nur wenis olinzend unr

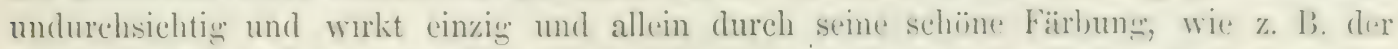
Türkis. Alle möghlichen Farben kommen bei den Mineralien vor, die als Eildsteme zum Sehmuck verwendet werden, abser anch völlige Farblosigkeit verhindert diese Anwendung nicht. Ist diese mit volikommener [)urehsiehtiglicit verbunden, so nennt man den Stein, wie schon erwïhnt, wasserhell voler vom reinsten Wasser. Die farhigen Eilctsteine, linbin, Sipphire, smaragde usw. Werden im Gegensatz zu den fiablosen. besonders zmm Diamant, im Handel kurz "Farbsteine" genannt. Unter "Phantasiesteinen" (fancy stones) rersteht man häufig seltenere Farlemnuancen ron an sich ungefärbten oder anders get:ïrbten Edelsteinen, also \%. 13. egefürbte Diamanten, Korunde von anderen als den gewöhnlichen Farben Rot und Blau des hubins und sapphirs usw. Diese Phantasiesteine gelten vielfach nicht für ganz voll und sind daher billiger als die verbereiteteren Farben, wie dies $\%$. B. beim Korund der Fall ist, doch kommt auch das Umgekehrte ror, wie bei manchen schön gefärbten Diamanten.

In Beziehung anf die Farbe verhalten sich die Edelsteine rerschieden. Manche ron ihnen zeigen unabïnderlich stets in allen Exemplaren dieselbe Färbung, die auch bei dem kleinsten Stïckchen, ja beim feinsten P’ulver noch deutlich hervortritt. Bei solchen Ftrinen ist die Farbe eine wesentliche Eigenschaft der Sulstanz, sie heifen daher farbig. Ein Beispiel hierfür liefert n. a. der Malachit. Jedes Stüch Malachit ist ausnahmos oriin. auch das feine Pulver ist griin, wenngleich etwas blasser als das ganze Stiick.

Andere Edelsteine dagegen, und zwar die weitaus ülerwiegende Menge sind an sich, d. h. in ihrem reinsten Zustande, rollkommen farblos, die eigentliche substanz des Steines hat keine Färbung. Es sind ihr aber hïufig, odler sogar in den meisten Fällen, mehr oder

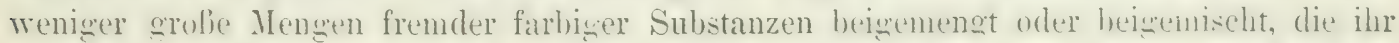
dann die betreffende Färbung verleihen. Hier kann die Fathe von einem zum andern Stein wechsth; sie ist eine unwesentliche. zufällige, schwankende Eigenschaft. Derartige Mineralien nennt man gefäirbt, die fremde Substanz, die die Färbung hervorrufen, das Pigment; von ihrer Beschaffenheit hïngt die Farbe des stiickes ab. Die verschiedenen greförloten Exemplare einer Mineralspezies enthalten nicht immer dasselbe Pigment, daher zetgen sie auch nicht immer diesthe Farbe, ja ein und dassellbe Stiick ist nielit selten an verschiedenen Stellen rerschieden grefïrbt. Bei solchen tefö̈rbten Mineralien tritt die Färbung sewöhnlich nur in dickeren Stiicken deutlich hervor; sehr diinne Plättehen erscheinen sehr blaß oder ganz farblos, und ebenso verbält sich feines Pulver.

Ein Beispiel fuir einen derartigen Edelstein ist der Quarz. Er ist im reinsten Zustand ganz farblos. vollkommen klar und lurchsichtig, wasserhell und heift diann Bereskristall. Ist er braun gefärbt, so bildet er den Rauchtopas, riolett gefärbter Qquarz wird Amethyst, gelber Citrin genannt, erïner und blauer Quarz hat deu Namen Plasma und Sapplirquarz erbalten, und so wibt es noch eine vder die andere sonstige mach der Farbe unterschiedene und besonders benannte Abart dies's Minerals. Ähnlich ist es mit deu Mineral Korund, das nicht selten farblos und zuweilen sogar wasserhell rorkommt, das aber doch meist gefürbt ist. Der rote Kormo ist der kostbare Ribin, der blaue der Sapphir, und so kommen noch zahlreiche andere Farben ror, die bei der Beschreibung des Korunds engehender 
betrachtet werden sollen. Ebenso zeigt der im reinsten Zustande vollkommen wasserhelle Diamant in zahlreichen Exemplaren alle erdenklichen Farben.

Die Gesamtheit aller bei einem gefürbten Mineral vorkonmenden Färbungen heißt dessen Farbenreilhe. Dic Farbenreihe des Quarzes ist also nach dem Obigen außer dem farblosen hraun. violett, gellb, srün. blau; die des Korunds rot, blau, und bei beiden kommen noch einige andere Farbentöne dazu; die des Diamants enthält alle Farben. Nicht jedes gefärbte Mineral zeigrt dieselbe Farbenreihe, bei manchęn kommen nur diese, bei manchen anderen nur jene Farben vor; in der Farbenreihe mancher Mineralien fehlt die eine, in der mancher anderen die andere Farbe.

Dem Bediurfnis der beschreibenden Mineralogie entsprechend unterscheidet man an den nichtmetallischen Nineralien, zu denen, wenige Ausnahmen abgerechnet, alle Edelsteine gehören, acht IIauptfarben: weib, grau, schwarz, blau, griin, grelb, rot, braun. Imnerhalb jeder dieser Hauptabteilungen treten aber wieder Unterabteilungen, Nuancen, hervor, die entweder durch die völlige Reinheit einer Farbe oder durch Mischen von zwei oder mehreren Hauptfarben entstehen. Diese werden teils durch ihre Annüherung: an eine andere Iauptfarbe, z. B. als rötlich-weiß, griinlich-blau, bläulich-schwarz, teils durch Vergleich mit einem allgemein bekannten Gegenstande, z. B. als schwefelgelb, grasgriin, rauchmrau, indigoblau, karminrot usw., in meist leicht verständlicher, unzweideutiger Wrise benannt. Um die Farbe eines Steines richtig zu beurteilen, wird greraten, denselben dicht an das Auge zu bringen; auf diese Weise werden kleine Unterschiede am besten erkannt.

Mehrere Bezeichnungen des Charakters der Farbe durch die Ausdrücke lebhaft, brennend, frisch, matt, zart, sanft, verwaschen, schmutzig, düster usw. ergeben sich aus dem allgemeinen Sprachgebrauch. Dieser Charakter hängt wesentlich mit von dem Glanze und der Durchsichtigkeit des betreffenden Stiickes ab. Auch die Intensität ist bei jeder Farbe an verschiedenen Stiicken eine andere. Nan sprich in dieser Beziehung von tiefen oder dunkeln (d. h. dem Schwarz sich nähernden), hohen oder gesättigten (d. h. reinen und intensiven), lichten oder hellen (d. h. dem WV dif sich nähernden), endlich ron blassen (d. h. stark ins Weil fallenden) Farbentönen. Bei manchen Edelsteinen, z. B. beim Rubin, nannte man frïher Exemplare mit tiefer und gesättigter Fürbung "männlich", solche mit lichteren Farben ,weiblich"; heutzutage ist aber diese Bezeichnung nur noch wenig ge bräuchlich.

Die Intensität der Fürbung hängt ab von der größeren oder geringen Menge der färbenden Substanz; je größer diese ist, desto tiefer ist der Stein gefürbt. Wenn das l'igment durch die Masse des Steines ganz gleichmäbje verteilt ist, dann ist dieser auch ïh) rall gan\% gleich gefürbt. Ist es dagegen nur an einzelnen Stellen vorhanden, an anderen nicht, oder an rerschiedenen Stellen in verschiedener Menge angechäuft, dann hat man an demselhen Stiick abwechselnd farblose und grefürbte oder hellere und dunklere Stellen, die in den meisten Fällen ohne scharfe Grenze allmählich ineinander übergehen. Ist an einer Stelle (ein anderer Farbstoff beigeniseht als an anderen, so können an einem und demselben Stiteke san\% verschiedene Farben auftreten. Blaue Flecken auf farblosem Hintergrunde zeight häufie der Sapplir, violette in der farblosen Hauptmasse der Amethyst usw. Die ungleichmäbige Verteilung der Farbe ist bei diesen Steinen für die Schönheit sehr nachteilig, daher sind sanz einheitlich und namentlich zugleich auch tief scefürbte Exemplare der Edelsteine, also beispielsweise der ebengenannten, Sapphir und Amethyst, besonders wertvoll. Zuweilen ist die $\Lambda \mathrm{rt}$ der Farbenverteilung eine an vielen Stiicken gan\% regelmäbigr wiederkehrende. So findet man die zuweilen als Edelsteine gesehliffenen vierseritigen Sïulen des Diopsids rom Zillertale in Tirol am einen Ende farblos, am anderen Encle schön dunkel houteillengrün, chenso zeigen die sechsseitigen Säiulen des roten und 


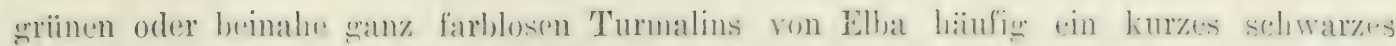
Ende (sogen. Mohrenkijpfor). Beim Turmalin findet man nicht selten noch eine andero

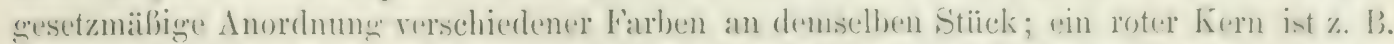

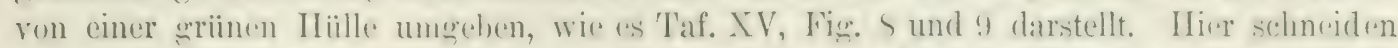
die beiden Farben mit einer scharfen (irenze gerenemander ah. Dassedhe ist anch meist der Fall bei dem buntesten der zu Schnucksteinen verwendeten Minerahen, dem Achat, bei dem die Sehönheit enerale anf dem reichen Farbenwechsel beruht. Dabbi bilden oft nieht blof zwei, sondern mehr versehiedene Farben alle mögliclen Zeichnungen, die mit ähnlich anssehenden fiegenstïnden veroglichen und danach benannt werden. Ausclrücke, wie punktiert, gefleckt, wolkig, geflammt, geadert, marmoriert, gestreift, sebüntert usw. sind danach leicht verständlich.

Hier sind vielleicht auch an besten die bammartigen Zeichmungen von bramer odir schwarzer Farbe zu erwïhnen, die man sehr vielfach auf Gesteinssticken, unter anderem atch in gewissen Chalcedonen nicht selten sielte und die man Dendriten nemnt. Strinr, die solche enthalten, werden in geschickter Weise so greschliffen, dab diese Zeichnungen deutlich hervortreten (Fig. 101). Sie haben den Namen Ba umsteine terhalten. Bei der Betrachtung des Opals, des Chaleedons usw. wird davon nochmals die Rerle sein, ebenso ron dem Moos a chat, bei dem eine eigentimliche Anlä̈ufung grinen Farbstoffs den Inschein erweckt, als hätte man es mit cinem Einschlub von Moos in dem Steine zul tun.

Die Sulstanzen, die die Färbunğ der Edelsteine hervorrufen, die Pigmente. sind ron sehr versehiedener Beschaffenheit, bald, wie man chlaubt, von organischer, bald ron anorganischer Natur. Ihre Menge ist in manchen Steinen nicht unbetrïchtlich, häufig abır auch so gering, daf sehr genaue chemische Analysen dazu gehören, ihre Anwesenlerit festzustellen. In diesem Falle müssen die Pigmente eine ganz besonders intensive fürbende Kraft besitzen; es ist ja aber bekannt, dab es Stoffe gibt, die, wie z. B. der Karmin, schon in den minimalsten Mengen große Quantitäten farbloser Körper merklich zu fürben imstande sind. Wegen der vielfach so geringen Menge der Farbstoffe ist es loei manchen Edelsteinen noch nicht gelungen, deren Natur mit Sicherheit aufzukliiren. Es ist leicht begreiflich, daf derartige Untersuchungen mit großen Schwierigkeiten verknïpft sind. Bei der geringen Menge der färbenden Substanz sind grobe Quantitüten des betreffenden Edelsteins nötig, die sich aber des hohen Preises wegen nicht leicht beschaffen lassen. Trotzdem hat man aber in manchen Fïllen mit Bestimmtheit erkannt, welchen Substanzen sie ihre Färbung verdanken. Bei der Beschreibung ist dies auch für jeden einzelnen Edelstein angegeben. So ist es bei dem smaragd eine kleine Menge einer Verbindung des ICetalls Chrom, bei dem hell apfelgrünen Chrysopras spielt eine Verbindung des Metalls Nickel in geringer Menge dieselbe Rolle; andere Steine werden durch Eisen- oder Kupferverbindungen gzefärbt, bei weiteren, wie z. B. bei dem bramen Quarz, dem Rauchtopas, geschieht dies vielleicht durch eine organische Substanz, die sich als ein dunkelbraunes, brenzlich ricehendes (j) abdestillieren und weiter unterstuchen läßt.

Die Art der Verteilung des Pigments ist in den einzelnen Edelsteinen ebenfalls eine sehr verschiedene. Manchmal ist der Farbstoff durch die ganze Masse so gleichnälig ausgrebreitet, daß man auch bei der stärksten Vergröferung keine einzelnen farbisen Partikelchen eingestreut finclet, die dem Gamzen ihre Farbe mitgeteilt haben. Der Farbstoff

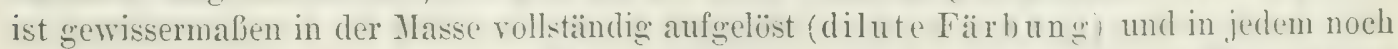
so kleinen Teilchen in derselhen Weise vorhanden wie in jedem anderen. Man erkennt dann nur daran, daf es auch ganz farblose Exemplare desselben Mincrals und solehe von anderer Färbung' gibt, daf man es mit einer gefürbten und nicht mit einer ihrer Tatur 
nach farbigen Sulystanz zu tun hat. So ist es mit dem oben schon erwähnten, schön griinen Smaragrl, mit dem hauen undurehsichtigen, dureh Kupfer und Eisenverbindungen gefärbten 'Türkis, nit dem sleichfalls sehon erwähnten, durch eine Eisenoxydulverbindung grün gefärbten Diopsid und anderen.

In den meisten dieser Fïlle handelt es sich nicht um cine mechanische Beimengung eines Farbstoffes zu der farblosen Crundsubstanz, sondern $u$ die Beimischung einer enefirbten, mit del IIauptmasso des Ellelsteines isomorphen Verbindung zu dieser. Die Mischung ist hier eine chemische und daher eine so innige. So ist es zweifelsohne bei den Diopsid, bei dem dine kleine Menge einer eisenoxydulhaltigen Verbindung von ganz. bestimmter mol hekannter Zusammensetzung einer eisenfreien und daber farblosen isomorphen Verhindung heigemiseht ist, und wahrseheinlich ist es ähnlich beim Smaragal, welcher zu dex zuweilen auch farblos rorkommenden Mineralspezies Beryll gehört; beim 'Türkis und bei manchen anderen beruht die Färbung auf demselben Grunde.

In andiren Fïllen sind es dagegen einzelne bestimmt umgrenzte, farbige Körperehen, die einer farblosen Grundmasse so reichlich mechanisch eingelagert sind, dab das Ganze ilne Farle annimmt. Diese Körperchen sind meist klein, so dab sie selten dem bloßen Augre deutlich erscheinen; dann treten sie nur bei der Betrachtung mit der Lupe oder carr "rst untre dem Miliroskop) bei einer gewissen Vergrößerung als einzelne getrennte Treilchen deutlich hervor. Sie hahen die Formen von Körnchen, Schüppchen, Fäiserchen orler dickeren Tïdlelchen. Kleine blaue Körnchen, die der farblosen Grundmasse des Lastristeines in srofer Zahl heigemengt sind, bedingen die prachtvolle Farbe dieses Edelsteines; srïne Näddelehen und Füscrehen des Minerals Strahlstein färben die farblose Masse de's Quarzes grün und crzengen so die unter dem Namen Prasem als Schmuckstein nicht wan\% unwichtige Abart dessellen; der Feldspat wird zuweilen durch rote Schüppehen des Minerals Eisenglanz sefürbt und bildet dann das, was man ab und zu unter dem Namen Somnenstein als Schmuckstein verwendet, und Chalcedon mit einem ähnlichen roten Pigment gibt den vielbenutzten Karneol.

Fast alle in dieser $W^{r}$ eise rhureh mechanische Beimengung größerer Quantitäten einzelner l'igmentkörperehen exü̈rhte Steine sind mehr oder weniger trübe und manche sogar ganz undurchsichtig. wïhrend diejenigen, die durch chemische Beimischung einer isomoryhen farbigen Substanz oder durch Beimengung äuberst fein rerteilter Substanzen dilut geförbt sind, auch in cröblieren homogenen Tíristallen klar und durchsichtig erseheinen.

bemerkenswert ist eine schoinhare Verönderung, welche die Farbe mancher Edrlsteine bei verschiedener Beleuchtung erleidet. $\Lambda \mathrm{m}$ schönsten ist die Farbe bei fast allen Steinen im hellen 'Tageslieht, in künstliehen Licht wird sie bei manchen unansehnlieh. I) Amrhyst ist bei Tage schön violett, beim Kerzenschein unschön graulich; im Gegensatz dazu behialt der orientalische Anethyst, der violette Korund, seine schöne Farbe auch in kïnstlichen Lichte. Eigentïmlich rerhält sich die als $\Lambda$ lexandrit bekannte $\Lambda$ bart des Chrysuberylls; sie ist, wie wir unten noch eingehender schen werden, bei Tage griun, bei Natht in liunstlicher Beleuchtumg rot. G(dhe Diamanten erscheinen bei Kerzenlicht

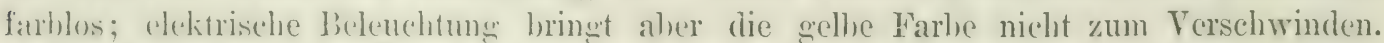
Ähnlehe Indispiele der Anderume, namentlich der Verschlechterune der Farbe im kïnsthehen Jichte, wiht es noch manche; es ist klar, dab die letztere Eigensehaft den Irert und die Brauchbarkeit mancher Steine nicht unerheblich beeinträchtigt.

Von einer scheinharen Verimhlerung der Farbe gelblicher I)iamanten ist in dex letaten

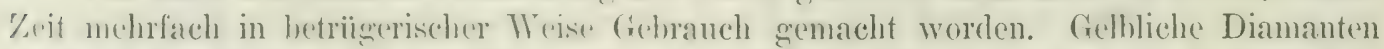
sind seit Entedeckung dex südafrikanischen Lagerstätten sehr häufig und daher rerhältnis-

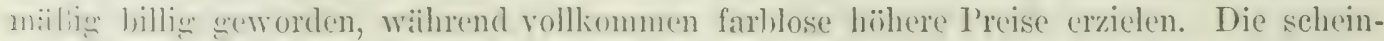

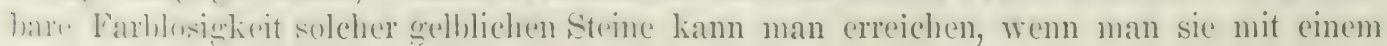


ganz leichten Überzum eines blauen Farbstoffes versieht. I)as Blau und das Gelh wirken da zusanmen und bringren im Auge den Eindruck ron weilf hervor, der so langre anhïlt, bis die diunne blatue Schicht wieder abgerieben wird, worauf der Käufer merkt, dafs er betrogen ist.

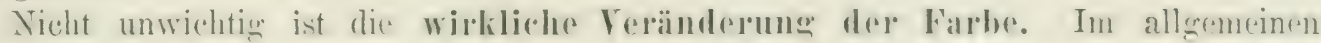
ist die Farbe der Elelstein recht dauerhaft. Sir bleibt bei den meisten unter allen Cmständen bestehen und verschwindet erst. Wenn der Stein sellsst zerstört wird. So ist es mit dor gethen Farbe vieler I) iamanten, mit der Farbe des liubins und andrer. Bei manchen ist ahere die Farbe unter Unständen wenigere konstant und kann sogar; ohne dali die Substanz des Steines eine: Wesentliche Veränderunge erleidet, vollkomment zerstört worden. Dies exeschicht bei gewissen Edelstemen leicht durch starkes Erhitzen, besonders durch Gliihen, weshalb man wohl die betreffenden I'igmente für organische Substanzen hält. Diese werden dabei vernichtet und mit ilonen die durch sie hervorgebrachten Farben. So verhäilt sich u. a. der braune lauchtopas und der rütlichgelbe Ilyacinth, die beide durch Gilihen farblos werden. Bei gewissen steinen gethe in der Hitze die Farbe in eine andre ïber: der violette Amethyst wird dabei wallb, der dunkelgalle Topas rosarot usw. Diese Veränderungen werden zuweilen absichtlich herbeigefïhrt, un sgellsen Quar\% (eceraunten Amethyst) und rosenroten Topas (Rosatopas) herzustellen, die beide als Sehmucksteine geschätzt sind, aber sich in der Natur nicht in senügender Menge finden.

Eigentïmlich ist die voriblergehende Farbenänderung einzelner Edelsteine beim Wechsel der Temperatur. So wird der rote liubin in der Glibhlitze farblos, beim Abkühlen sodann erst grün und endlich wieder ebenso schön rot wie vorher. Er unterscheidet sich dadurch von dem gleichfalls roten Spinell, der, wie der Rubin, beim Glühen farblos, beim Abkühlen dagegen violett und ohne: die criine Zwischenstufe wieder rot wird.

Manchmal bedarf es zur Veränderung der Farbe zar keiner hüheren Temperatur, sie verschwindet bei gewissen Steinen orler blafit schon ab, wenn diese dem Licht und der Iuft auscresetzt sind; sie bleichen aus. Solches Terhalten zeigen zwar nicht alle, aher manche Topase, die schon nach wenigen Monaten merklich heller werden; dasselbe wird beim giünen Chrysopras und beim liosenyuarz beobachtet, sowie bei manchen blaten T'ürkisen, von denen viele auch allmählich grïn werden. Sedhstrerständlich wird der Wert sulcher Steine durch diese üble Ligenschaft stark vermindert; es ist aber oft sehr schwer, sich dabei vor Schaden zu schïtzen, da die Erscheinung. der Verlust der schönen Farbe, erst in einiger Zeit eintritt. Zuweilen wird die Farbe, wenigstens roribbergehend, wieder hergestellt, wenn man den Stein in der Dunkelheit oder in feuchter Erde aufbewahrt oder nit grewiseen C'hemikalien behandelt. Alles dies wird nicht selten zur T'äuschung des I'uhlikums benutzt. Im Gegensatze zum Ausbleichen dieser genannten Steine steht das Terhalten des Bernsteins, dessen gelbe Farbe an der Luft allnählich immer dunkler rothraun wird. und der dabei elsenfalls seine Schönheit einbüilit.

Merkwürdig ist die daucrnde Veränderung der Farbe auffallend vieler Edelsteine durch Bestrahlung mit stark radioaktiren Prïparaten, was wir zuerst dureh 1 . II iethe kennen gelernt haben. Irgendwelche gestumälige Beziehungen und gemeinsame Gesichtspunkte konnten dabei zunächst allerdings noch nicht ermittelt werden, doch geht aus den Beobachtungen soviel hervor, dafi stark gefürbte Mincralien geringen oder gar keinen Trechsel in der Farbe zeigen, wihhrend bei hellen Edelsteinen vielfach leieht eine auffällige Farbenänderung eintritt. I)iese erfolet, fon auben nach innen fortschreitend, mehr oder weniger rasch. und ist oft schon nach wenigen Stunden deutlich zu erkennen. Sie nimmt 
mit der dauernden Einwirkung zu und erreicht nach einer gewissen Zeit ihren höchsten Grad, worauf dann die neue Farbe unverändert stationär bleibt. Durch Erhitzen wird die erworbene Farbe vielfach etwas verändert, aber selten wieder ganz zerstört. Umgekehrt wird die heim Erhitzen verschwundene Farbe mancher Edelsteine durch Radimubstrahlung wieder hergestellt. Üherraschend ist, daß Steine von grewissen Fundorten von den Radiunstrahlen stark becinflubt werlen, wïhrend dies bei Exemplaren derselben Art von einem anderen Fundort nicht, oder nur wenig. oder in anderer Art der Fall ist. Bei der Betrachtung der einzelnen Erlelsteine werden wir diese Verhältnisse berïcksichtigen, hier sollen zunïchst nur einzelne charakteristische Beispiele mitgeteilt werden.

Diamant. Ein farbloser Stein von Borneo wurde zitrongelb; bei $250^{\circ}$ wurde er heller, aber nicht mehr wanz farblos. Ein farbloser brasilianischer Stein blieb unverändert.

Korund. IIellblauer Sapphir aus Ceylon wurde in kurzer Zeit grün, dann hellzuletzt, nach 1 t Tagen, dunkelgelb mit einem Stich ins Kastanienbraun; beim Erhitzen auf die Temperatur, wo der Sapphir seine blaue Farbe verliert, wird der veränderte Stein farblos, sodann beim Abliülen hellblau, endlich hellgelb, und diese Farbe verliert sich auch bei Rotglut nicht. Der gegliihte Stein wird nach Bestrahlung von einigen Stunden wieder dunkelgelb. Auch andere hellblaue und farblose Sapphire von dort nehmen eine schr gleichmïßige schöne gelbe Färbung an, doch brauchen sie dazu sehr verschieden lange Zeit. In einzelnen Fällen bleiben bei den blauen Steinen kleine Flecken von der ursprünglichen Farbe. Im Gegensatz zu denen von Ceylon bleiben die Sapphire von Siam, Australien, Kaschmir und der Iserwiese ganz unverändert. Ebenso zeigen natïrliche und kïnstliche $R$ u b in e keine oder nur sehr schwache Einwirkung, auch ein senön grasgr rï ner Stein von Ceylon nur eine schwache Trübung; dagegen wurde ein heller Violettrubin von dort nach 20) Tagen schmutzig graublau, und diese Farbe blieb beim Erhitzen bestehen.

Beryll. Dunkelgrïner Smaragd von Colombia wird sehr hellgrïn, wobei die Alssorptionsstreifen keine sonstige Veränderung als eine gewisse Schwächung erleiden. Hellgelber Beryll von Mursinka und hellblaner A c uamarin von Brasilien bleibeu unverändert.

Topas. Farbloser von Brasilien wird rasch hellgelb und bleibt so auch nach mehrwöchentlicher Bestrahlung. Bei $150^{\circ}$ tritt dann eine prachtvolle Lumineszenz ein; der Stein leuchtet zuerst grau, dann in raschem Wechsel violett, rubinrot, orangegelb und graublau. Rosatopas von Mursinka (? Sanarka), wird in wenigen Stunden orangegrelb, auch durch Giluihen rot gewordene Topase nehmen eine gelblichrote bis orangebraune Farbe an. Gelber Topas vom Schneckenstein wird schwach rötlichgelb, gelhbrauner T. aus Brasilien wird etwas dunkler, aber blauer T. aus Brasilien behält seine Farbe wie sie war.

Chrysoberyll bleibt in allen seinen Varietäten unverändert.

Turmalin. I)unkel gefärbte Steine lassen keine Einwirkung erkennen, helle zeigen merkwürdige Erscheinungen. Untersucht wurden zwei farblose Stïcke aus Brasilien, eines mit einem hellgrünen, eines mit einem rosa Ende. Der farblose Teil des ersteren wurde präichtig dunkelgrïn, der des zweiten rein rosa, beide sehr langsam.

Quarz. Bergkristall wird sehr allmählich schwarzgrau oder blaturau, Steine verschiedener Fundorte verhalten sich verschieden. Goldgelber Citrin aus Spanien wird langsam rauchgrau, Ancthyst von Oberstein wird langsam rötlichviolett und soleher von Brasilien bleibt unverindert. Dits Ratuchgrau des Rauchtopas yom St. Gotthard verändert sich schwach und langsam in gelblichbraun. Bei allen Ouarzen wird dureh Erwïmen die ursprügliche Farbe wieder hergestellt, doch wird sie beim Citrin nicht mehr so schön leuchtend wie ursprïnglich. 
Durch hohe 'Temperature enthärbte Mineralien nehmen durch Radiumbertrahlunge rine: Farbe an, die ihree fribleren ähnlich ist: Zirkon wird wieder bram Anethyst violett, Ionattopas orangerot und roter 'T'urmalin wieder rot.

Wichtig ist für manche Edelsteine die Möglichkeit der kïnstlichen Färbune und Unfairbung, die zum 'l'eil schon im Altertum bekamnt war und viel auscroiilst wurele. Ileutzutase findet sie hauptsäichlich beim Achat und ähnlichen Steinen statt, hei deren Beschreibung die betreffenden Methoden angegeben werden sollen. Sie heruhen auf der porösen Beschaffenhert der Sulstanz, vermöge deren die Steine färbende Flüssigkeiten in sich aufzunchmen imstancle sind. Die in diesen enthaltenen Farlsstoffe teilen sich dann dem Steine mit und färben ihn oft bis ins Innerste hinein.

Strich. Wir haben oben bei der Betrachtung der farbigen und gefarbten steine Eesehen, dal zuweilen die Farbe des feinen Pulvers eine grewisse bedeutung hesitzt. Auch hei anderen Gelecrenheiten ist dies der Fall. Man hat daher ein Mittel ausgesonnen, das feine l'ulver möglichst rasch und mïhelos darzustellen, um seine Farbe zu untersuchen. Dieses Mittel besteht darin, dals man mit dem betreffenden Nineral über cine rauhe unglasierte P'orzellanplatte, eine sogenannte Biskuitplatte, himstreicht. Auf dieser bleibt etwas ron dem Mineral als feines Pulver hängen, dessen Farbe sich dann auf dem Weili der Platte deutlich abhebt. Danach nennt man die Farbe des Pulvers auch wohl den Strich des Minerals. Er ist manchmal charakteristisch und kann mit zur Erkennung dienen. Selbstverständlich darf das Mineral nicht wesentlich härter sein als die Biskuitplatte. Dies ist bei den meisten Edelsteinen der Fall, aber bei einigen ist der Strich doch zur Lnterscheidung von einer gewissen Wichtigkeit.

\section{\%. Dichroismus.}

Eine wichtige optische Erscheinung an vielen Edelsteinen ist diejenige, die man als Dichroismus oder Pleochroismus bezeichnet. Sie besteht darin, dab die Steine beim Irindurchsehen nach verschiedenen Richtungen verschiedene Farben oder Farbennüancen zeigen, die einander manchmal ziemlich nahe stehen, oft aber auch stark voneinander abweichen. Es gibt ein Mineral, das zuweilen unter dem Namen Luchs-oder Wassersapplhir als Edelstein verschliffen wird, das diese Erscheinung in so austrezeichneter Treise zeigt, dal es danach auch den Tamen Dichroit erhalten hat; sonst nemnen es die Mineralogen meist Cordierit. Dieses Mineral erweist sich beim Hindurchsehen nach drei aufeinander senkrechten Richtungen, die sich kristallographisch in ganz bestimmter Weise bezeichnen lassen -- es sind die drei Axen der dem rhombischen System angehörigen Kristalle -, schün dunkelblau, hellblau und graulichgelb. In den intermediären Richtungen erhïlt man zwischen diesen drei Hauptfarben liegende Nüancen, die der einen oder andern nahe liegen, wenn dies auch mit der Sehrichtung der Fall ist.

Beim Cordierit sind die Farbenunterschiede sehr grob; vielleicht noch größer sind sie bei manchen Turmalinen, wo die Farbe je nach der Richtung zwischen gelblichbraun und spargelgriin, oder bei anderen Kristallen desselben Minerals zwischen dunkel violettbraun und grïnlich-blau, bei wieder anderen zwischen pupurrot und blau usw. wechselt. Dem stehen aber auch sehr geringe Farbendifferenzen bei anderen Edelsteinen gregenüber. So erweist sich z. B. der grelblichgrüne Chrysolith nach allen Seiten hin nahezu grleich in der Farbe und mit ihm die Mehrzahl der sehr hell gefärbten Steine, während starker Dichroismus, also weit auseinanderliegende Farbentöne, nur an dunlileren Mineralien vorkommt. Endlich gibt es weitere Ifineralien, wie Granat, Spinell und andere, die auch bei der allersorafaltigsten Entersuchung keine Spur von Verschiedenheit der Färbung in rerschiedenen Richtungen erkennen lassen, und wie diese verhalten sich auch die zur Nachbildung echter Edelsteine verwendeten farbigen Glasfliisse. 
Wie dic einfache und doppelte Lichtbrechung, so steht auch die Ab-oder Anwesenheit von Dichroismus im engsten Zusammenhange mit der Kristallisation der betreffenden Substanzen, und zwar in genau derselben Weise wie jene. Alle amorphen oder im regulären System kristaltisierten Nineralien zeigen keinen Dichroismus, er ist ausschlieljlich beschränlit auf die farbigen Kristalle der anderen fünf Kristallsysteme, bei denen er allerdingrs zum 'Tril in so schwachem Grade auftritt, daf er kaum bemerkbar ist. Einfachbrechende kiriper sind demmach nie dichroitisch, sondern nur doppeltbrechende, so dalf man also im Dichroismus rin weiteres bequemes Mittel hat, doppeltbrechende Steine zu ('kemne'n und ron cinfachbrechenden zu unterscheiden. Zeigt sich bei einem Kï̈rper auch nur eine Spur dieser Eigensehaft, dann gehört er sicher nicht zu den einfachbrechenden anorphen oder regrulär kristallisierten Substanzen. Ist kein Farbenuntersehied zu bemerken, damn ist die Beohachtung weniger beweisend, da geringe Grade sich unter Umständen der Wahrnehmung auch entziehen können.

Durch die Beobachtung des Dichroismus kann man ebensogut wie durch die der Doppelbredumg die beiden oben schon beispielsweise genamnten roten Steine Rubin und Spincll voncinander unterscheiden. Bemerlit man Dichroismus, so lat man es sicher mit dem hexagomalen und dichroitischen Rubin zu tun, und nicht mit dem regulären und daher nicht dichroitischen Spinell. Der Dichroismus ist auch ein sicheres Mittel, einen echten liubin ron einem roten Gilasflusse zu unterscheiden und so als echt zu erkennen. Der CHasflul) ist amorph und zeigt daher, wie schon erwïhnt, ebenfalls keine Verschiedenheit der Farbe beim Hindurchsehen nach verschiedenen Richtungen.

Bei stark dichroitischen Mineralien erkennt man diese Eigrenschaft meist ohne weiteres. Brei sehr schwach dichroitisehen dagegen geniigt das Hindurchsehen mit bloßem Auge nicht mehr: die Unterschiede der Fürbung sind hier zu gering. Man hat daher Methoden gesucht und auch gefunden, um selhst geringe Spuren des Dichroismus noch nachzuweisen, bei denen nur selrr unbedeutende Farbendifferenzen auftreten.

Solche kïnnen vielfach noch deutlich sichtbar gemacht werden durch Beobachtumg der Edelsteine nittels eines kleinen, von dem früheren Triener Nineralogen II aiding er erfundenen Instrumentchens, das man Dichrolupe oder Dichroskop. oder auch nach dem Erfinder Ha idingersche I.upe nennt. Dieser kleine $A$ lyarat ist äuberst handlich und leicht zu henutzen und vermag sehr gute Dienste zu leisten; er sollte sich daher in d(ب Hand cines jeden befinden, der sich mit dem Kauf und Verkauf von Edelsteinen beschäftight, un so mehr, als sein l'reis sehr gering ist. Ein einziger Blick in das kleine Instrument kann unter Umständen verhängnisvolle Irrtümer beseitigen.

Dasselbe ist Fig. 32 in ungefähr natürlicher Gröfe schematisch im Durchschnitt alocebildert, so dafi man die innere Einrichtung sehen kann. Es besteht in der Haupt-

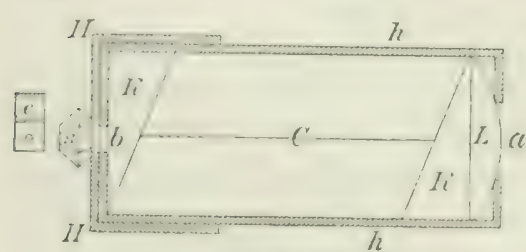

Fig. 32. Dichroskop. sache aus einem rhomboedrischen Spaltungsstiick von Kalkspat $C$, das nach der einen Kante stark in die Länge gezogen ist. Auf dessen beiden schief angesetzten schmalen Seiten sind zwei Glaskeile $k, k$ aufgekittet, deren äußere Flächen auf den' langen Kanten von $C$ senkrecht stehen. Eine runde Messinghülse $h$ umgibt das Ganze. Sie hat links bei $b$ eine kleine quadratische Öffnung und rechts bei $a$ ein rundes Loch, unter welchem

auf der Aulfenfläiche des Keils li eine Linse L, von solcher Irennweite angebracht ist, daß beim Ilindurehsehen in der Kichtung "ll, die quadratische Öfnung l) scharf und deutlich (reschemt. J)a man dabei aher durch den doppeltbrechenden Kalkspat blickt, so erhält

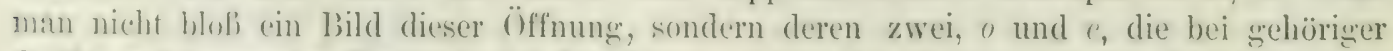

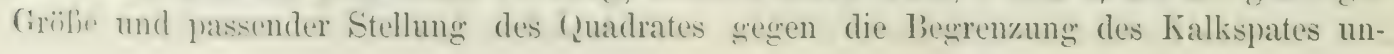


mittellar nebeneinander liegen. I)as fine, ", ist nur wenig alogelenkt und ganz farblos, das andere, stärker abgelenkite, ", hat schmale fatrbige Iiänder, rot nach innen und blau nach aulien, wie die Schraffierung ron e andeutet, und ist im iibrigen ebenfalls farthlos. C.m die Bilder in jene Stellung bringen zu kïmnen, un dere sie sich geenau nach einer fyardrat-

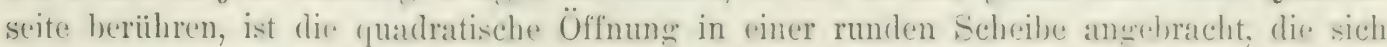
am Ende der runden .Iessinghiilse belinbig in dieser drehen läbt; durch eine kileine Drehung

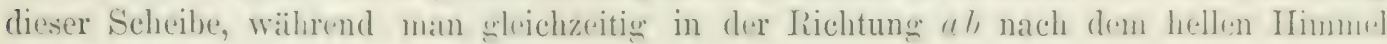
sieht, wird die richtige Stellung leicht erreicht.

Man bringt nun einen Edelstein s so vor die quadratische Öffnung $b$, dals diese ganz oder doch trilweise ron ihm bedeckt wird. Un dies berquem ausführen zu kïnnen, ist das Instrument zuweilen mit einem Objekttrïger in der Form diner zweiten Mr...inghïlse II versehen, die üher die Röhre h lose auferesteckt werden kann, so dalf sie sich

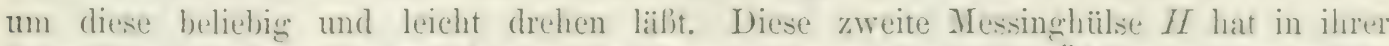
Schlubilatte eine dhen so grofie oder auch vielleicht etwas gröbere öffnung als dir qua-

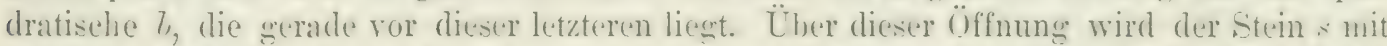

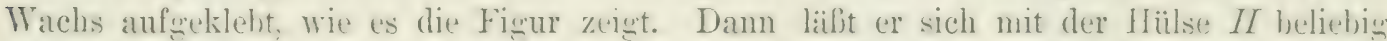
Eesen den Kalkspatkristall des Instrumentes drehen. Fehlt die Hülse $H$, damn wird der

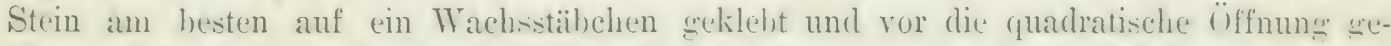
halten, indem man das Instrument gleichzeition langsam zwischen den Finsern dreht. In beiden Fällen teilt der Stein natiirlieh den beiden Bildern " und e seine Farbe nit, wenn man wieder gegen den hellen Himmel sieht.

Ist nun ein Stein nicht dichroitiscb, so haben stets beide Bilder o und $e$ dieselbe Farbe und bebalten diese auch, wenn man ihn vor dem Instrument odre dieses vor jenem um $360^{0}$ herumdreht. Ist der Stein z. B. der nicht dichroitische Granat, si bleiben die Farben von o und " unter diesen Lmständen stets einander gleich und haben bei der ganzen Druhng stets dieselbe rote Farbe, wie sie der Grauat auch hei der gewöhnlichen Betrachtung zeigt.

Ist dagteren der Stein dichroitisch, dann sind zwar die Farben ron " und "ehenfalls noch in vier zueinander senkrechten Stellungen der Hülse $H$ weteleh, beim Drehen werden die beiden Bilder aber versehieden und erlangen bis zu $45^{\prime \prime}$ gegen die Stellung der (ileichheit allmählich ihren grö̈ten Lnterschied. Tou da ab nälıern sich dic Farben ron "und e wieder einander, bis sie nach weiteren 45 "abermals whel geworden sind. Bei einer vollen Drehung um 360" hat man also einen achtmaligen Trehsel zwischen Gileichleit und Verschiedenheit. Da die beiden Bilder o und e unmittelbar nebeneinander liegen, so kann man sehr kleine Furbenunterschede erkennen und hierdurch sehr geringe Grade von Dichroismus konstatieren. Auch bei derartigen Beobachtungen kann Totalreflexion unter Umständen störend sein.

Wie aber in doppeltbrechenden Kristallen eine oder zwei Richtungen einfacher Lichthrechung rorhanden sind, die optischen Axen. so gibt es in jedem pleochroitischen Kristall eine oder zwei Richtungen, in denen lein Pleochroismus statfindet, und diese Richtungren fallen mit denen der optischen Axen zusammen. Es genügt daher nicht, die Abwesenheit ron Dichroismus in einer Richtung festgestellt zu haben, man mulj dassellue auch mindestens noch in einer zweiten und auch, streng genommen, noch in einer dritten je ron der ersten verschiedenten Richtung tun, indem man den stein in immer neuen Lagen auf die Itetallhülse $H$ aufkleht und in jeder neten Lage herumdreht. Erst dann liann man sagen, daß dem Steine der Dichroismus wirklich fehlt, wenn in mindestens drei verschiedenen Laģen keine Farbenunterschiedle aufuetreten sind. Allerdings ist auch hier zu beachten, daf diese unter Lmständen so gering sein liönnen, daß sie auch durch die Dichrolupe nicht bemerklbar werden. Lmmittelhar und direlit 
entscheidend ist dagegren stets das Auftreten von Farbendifferenzen, die jederzeit mit Bestimmtheit auf Dichroismus und damit auf doplyelte Lichthrechung hinweisen, auch wenn sie noch so gering sind.

In sämtlichen Richtungen, außer in denen der optischen Axen, ist, wie wir gesehen haben. Dichrosismus zu beohachten, aber nicht in allen in greichem Grade. Die Stärke des I)ichroismus ist ron der lichtung in dem Kristall abhängrig und ändert sich mit dieser. Die beiden Bilder sind bei allen dichroitischen Steinen einander in der Färbunğ sehr ähnlich, wenn man nahe einer optisehen Axe hindurehsieht; sie zeigen um so gröbere Unterschiede, je weiter sich die Sehrichtung von jenen entfernt. Bei gewissen Richtungen weichen die beiden IBilder so weit voneinander al), als es in dem betreffenden Steine überhaupt möglich ist. I)ie in diesem Falle auftretenden Farben sind die Hauptfarben, von denen schon oben bei der Erwähnung des Dichroits und T'urmalins beispielsweise die Rede war. Durch deren Vischuns in verschiedenen Verhältnissen entstehen dann die beim Ilindurchsehen in anderen Richtungen sich ergebenden weiteren Farbentöne. Solcher Hauptfarben gibt es hei emaxigen liristallen. wie beim Turmalin, zwei, bei zweiaxigen, wie beim Cordierit, drei. sie sind :̈hnlich, aber nicht vollkommen gleich denen, die man beim Findurehswhen durch dichroitische Edelsteine direkt sieht. Bei der Besehreibung der einzelnen Steine werden die IIauptfarben zur Feststellung der Verhältnisse des Dichroismus mitwroteilt werden; aus ihnen folgen dann die anderen noch möglichen Farben als Zwischenfarben.

Der Pleochroismus ist bei farbigen Steinen oft angenehmer und leichter zu beobachten als die Doppelbrechung, daher wird das Dichroskop auch seines geringen Preises wegen mindestens ehenso häufig angewendet als das Polarisatıonsinstrument. Es gibt aber auch rine Methode, dieses letztere zur Beobachtung des Dichroismus in sehr zweckmäßiger Weise zu benutzen. Man hat zu diesem Ende nur das Nicolsche Prisma $n$ (Fig. 2i) zu entfermen und im iibrigen den auf dem Objekttisch o herumgedrehten Kristall ganz wie bei der Beobachtung der Doppelbrechung zu betrachten. Ist der Stein nicht pleochroitisch, z. B. ein Spinell, so bleibt seine Farbe bei einer ganzen Umdrehung wenau dieselbe. Hat er jedoch diese Eigenschaft, wie z. B. ein Rubin, so ändert sich die Farbe und wechselt zwischen zwei Extremen, die bei einer vollen Drehung um $360^{*}$ viermal allmïhlich ineinander ïbergehen. Es sind dieselben Farben, die man mit der dichroskopischen Lupe beobachtet; man erhält sie hier aber nicht reichzeition nebeneinander, sondern nacheinander, so daf sehr geringe Farbenunterschiede auf diese Weise nicht ganz s) leicht erkannt werden. Wie bein Dichroskop mufs man auch hier, wenn in einer Lage des Steines kein Farbenwechsel eintritt, diesen ein- oder zweimal herumdrehen und in der neuen Lage wieder beobachten, ehe man ihn für wirklich nicht pleochroitisch erklären kamn. Wie bei der gewöhnlichen Anwendung des Polarisationssapparates, kann cin Stein auch bei dieser hesonderen durch Totalreflexion dunkel aussehen. Durch Beobachitungr des Strines in gredigneten Lagen oder durch Überwielien mit einer stark lichtbrechenden Fliissigheit wird dieser Ühelstand hier ganz ehenso, wie oben (p. 60) bei Betrachtun der l'olarisation gezeigt wurde, gehoben. Zur Beseitigung störenden seitenlichtes mußs atteh hier bei der beobachtung die Hand vor den Stein sehalten oder eine Papperöhre aufgesetzt werden.

Wir haben in vorherenchenden geteschen, dab die Beobachtung des I)ichroismus zur Erkennmme der Edelsteine und zur Unterscheidung voneinander und von Glastlïssen von

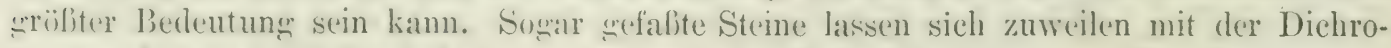
lupe priffen, was oft durch keine andere optische Methode möglich ist. I)ie Erscheinung

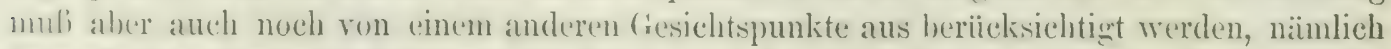
beint sehleifen sulcher Steine, bei denen sie sich sehr stark bemerkbar macht, so dab das 
Auge beim Ifindurehsehen in verschiedenen Richtungen sehr verschiedene Farben whält Ein derartiger stein mulf so gesehliffen werden, dafi die aus ihm in das Auge getangenrlen

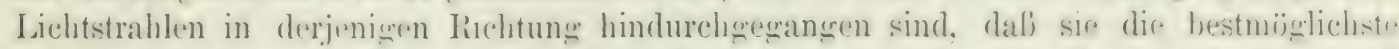
Färbung angenommen haben. Ein Dichroit z. B., wie er oben erwähnt worclen ist, muli so ereschliffen werden, dab die dunkelblaure Farbe erscheint: nur dann ist er schön. während er unansehnlich alussieht, wenn die hindurehgegangenen Lichtstrahlen die liellhlane. oder gellblicheraue Färbung annehmen. Die Schönheit und damit der Wert zwrier solcher Strine derselben Art und rom nämlichen Gewicht und der frleichen liescelaffenheit kamm also je nach der mehr ofler weniger geschickten Anorolnume der Schliffflächen nicht unbeträchtich verschieden sein. Es ist daher auch für den Steinschleifer nicht ohne Nutzen, sich mit den Verhäitnissen des Dichroismus bekannt zu machen.

Zuweilen werden pleochroitische Steine grerade so gesehliffen und gefalit, dafj diese Erscherinung recht deutlich sichtbar wird. Man stellt würfelfürmige Stïcke hrer, deren Flächen senkrecht zu den Richtungen sind, nach welchen beim IIndurchsehen die oröbten Farbenuntersehiede auftreten. Diese Würfel werden meist mit einer Ecke auf Jadeln befestigt: sie geben diann beim Ilerumdrehen jerlesmal eine andlere Farbe. Cordierit. Andat lusit und andere werden in dieser Weise benutzt, wite wir später noch weiter selen werden.

Wie der Pleochorismus, so beruhen auch die charakteristischen Absorptionsivelatra die einige Edelsteine, namentlich der Almandin und der Zirkon zedpen, anf der Absorption des Lichts. Lälitman die Strahlen, die aus diesen beiden Steinen austreten, noch durch ein Sipeltroskop - es weniigt dazu ein kleines sog. Taschenspektroskop mit werader Durehsicht - hindurehechen, so bemerkt man beim Almandin in dem dabei entstehenden spektrum charakteristische schwarze Streifen im Grün, beim Zirkon in Rot. Griin und Blau. Man kann beide mittels dieser sulh bezeichnenden Erscheinungen leicht erkennen und ron anderen ähnlichen Edelsteinen unterscheiden. Dabei ist es nicht einmal nöitig, rlurch den Stein von einem Ende zum andern hindurchzusehen. Ls enüet, mit einem Suektroskop das von dem Stein an der Oberfläche reflektierte Licht zu beobachten, das immer eine gewisse Menge Strahlen enthält, die aus dem Innern kommen. In dem letzteren Fall darf die Lichtouelle nur nicht zu schwach sein. Jedenfalls kann diese Bcoloachtung in genügender Weise auch an gefaßten Steinen gemacht werden.

\section{S. Besondere Licht- und Farbenerscheinungen.}

Die Strulstur und andere Eimensehaften reranlassen bei manchen Mineralien Licht-. sowite von der eigentlichen Körpqerfarhe und oft überbaupt ron färbenden Substanzen unahhängige Farbentrscheinungen besonderer Art, die ihnen zuweilen ein so sehönes tussehen rerleihen, dab sie zu geschätzten Edelsteinen werden. Meistens sind es nur einzelne Stücke der betreffenden Mineralien, die sich in dieser Weise verhalten, wälirend andere Exemplare derselhen Species gar nichts davon erkennen lassen. Diese Erscheinungen herulen auf den Grsetzen der Reflexion und Brechung des Lichtes, die wir oben kennen gelernt haben und die zu ihrer Erklärung nur auf die eigentiimlichen Verhältmisse jener Mineralien antrewerndet zu werden brauchen. was allerdings bisher noch nicht in allen Fillen in nach jeder Ilinsicht genügender Weise möglich grewesen ist. Da diese speziellen Verhältnisse erst hei der Beschreilung der einzelnen Edelsteine dargrelegt werden kïnnen, so lassen sich die zugehörigen Erscheinungen ebenfalls erst dort eingehender besprechen: hier müssen wir uns zunächst nur mit allgemeineren Andeutungen begnügen.

Von dem Farbenspiele des Diamantes ist schon im vorherehenten (S.52) die Rede geresen; es ist eine Erscheinung der Lichtbrechung und Farbenzerstremumg einfachster Art. Das Irisieren ist das Auftreten leuchtender Farben in bunter Abwechslung auf kleinen Rissen durchsichtiger und am besten farbloser Mineralien. Dies geschieht vielfach 
auf unregelmälijigen Sprüngen, besonders häufig zeigen sie sich aber in der Richtung von Blätterdurchgängen, die daran nicht selten erkannt werden können. Auf diesen Rissen, sejen es unregelmälig gestaltete Sprïnge orler ebene Spaltungsflächen, dringt leicht etwas Luft.in den Stein. Diese bildet dann äulierst feine Schichten, welche, wie es bei allen solchen dünnen Lagen durebsichtiger Kürper der Fall ist, in den lebhaftesten Farben, den sog. Farben dïnner Plättchen oder den Newtonianischen Farben, crolänzen. Es sind dieselben Farben, die man u. a. in wrober Schönheit auf Seifenhlasen sieht. Hier liegt diesen Farben ebensowenig wie hei irisierenden Steinen etwas Kïrperliches, also etwa eingemengter Farbstoff zugrunde; sie beruhen auf der Veränderung, die das einfallende weiße Licht erleidet infolge eines Vorwanges, den die I'hysiker als Interferenz der Lichtstrahlen bezeichnen. Zuweilen werden irisierende Steinc', z. B. Berghkristalle, mit dieser Farbenerscheinung so geschliffen, dalf recht lehhaft schillernde Stellen von einigem Umfange möglichst nahe an die Oberfläche kommen, wodurch sie besonders vorteilhaft in die Erscheinung treten; doch ist diese Verwendung nicht gerade häufig. Besonders schöne Farben derselben Art zeigen sich in rinzelnen meist kleinen, aber häufig dicht gedrängten Flecken auf der Oberfläche manchri Stiicke des an sich farblosen, triiben Opals, des danach so genannten edeln Opals, und bedingen dessen prächtigen bunten Farbenglanz (vgl. Taf. XVI, Fig. 6 bis 9). Sicherlich ist die Erscheinung beim Opal nichts anderes als eine Art Irisieren, wenn auch das Zustandeliommen desselben nicht von allen Beobachtern im einzelnen in ganz iibereinstimmender Weise erklärt wird.

Auf gewissen kristallographiseh bestimmbaren Flïchen, nicht aber auf der ganzen Oherfliiche mancher Stiicke des farblosen und stark durchscheinenden bis durehsichtigen Killifeldspates, des Adulars, sieht man einen bläulichen, milchigen Lichtschein, der besonders bei rundlichem Sehliff schön hervortritt und der sich beim Drehen des Steines über drssen Oberlläche hin bewegt. Ein derart beim Drehen eines Steines iiber dessen Oberfläiche hinweg wandernder Lichtschein wird ein wogender genannt. Die Erscheinung speriell beim drular wird als Adularisieren bezeichnet. Man hat sie mit dem milden Lichte des Mondes verenlichen; Stiiele, die sie schön zeigen, werden daher Mondsteine gemamnt und rielfach zu Schmucksteinen verarbeitet. Ein ganz ähnliches Licht entsteht auch auf manchen Stiicken des Chrysoherylls, die grleichfalls als Edelsteine geschätzt sind und die dinn Tamen Cymophan oder anch Katzenauge führen, da der Schimmer diesess meist erimen oder grelblichgriinen bis braunen Steines in der 'Tat an das Aussehen eines Katzmatues erimnert. Wir werden übrigens sehen, dah noch ein anderer stein aus demscllisen Cirunde den letzteren Namen führt; der schillernde Chrysoberyll wird dann als rehtes oflex orientalisches Katzenauge unterschieden. Beim Adular wird die Erscheinung hervorechacht dureh Lichtreflexe auf inneren Blätterdurehgängen oder Absonderungsflïchen in V'rbindung mit nach diesen flächen eingewachsenen mikroskopisch kleinen Kristalltäfelchen (vgl. Taf. XVI, Fig. 4 und 5 und Taf. XII, Fig. 11). Eine ähnliche Erseheinumg zeren auch manche 'Turmaline und Berylle von halifornien, aber nur solche, die wie der Cymophan trüb sind (Turmalin- und Beryllkatzenauge).

In der IIauptsache ebenso und gleichfalls unterstïtot durch kine eingewachsene Kristallplättchen entstehen solu lebhafte Farben auf einigen wanz bestimmten Flächen mancher Stiicke des Labratorfeddepates, sowie eines Kalifeldspates von Frederikssäm im siidlichen Norwegen, der danach als farhenspiclender oder labradorisierender Feldspat bezeichnet wird. Die Erscheinung wird hier Farbenwandlung oder Labradori -

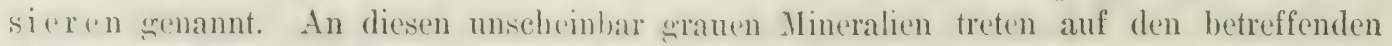
Flïehen, und nur auf diesen, die lehhaftesten sriunen, blauen, violetten, roten, selben usw. Farbenreflexe auf, entweder iiber die wanke Fläche einheitlich orler stellenweise bunt abWechishol, in der Weise, dafi das Farbenspied, wie man unter dem Mikroskope sehen 


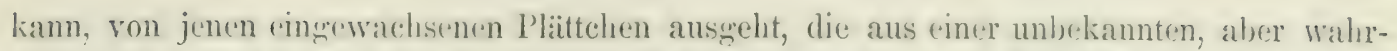
scheinlich sehr schwach lichtlorechenden Substanz bestehen und die vielleicht sogar z. T.

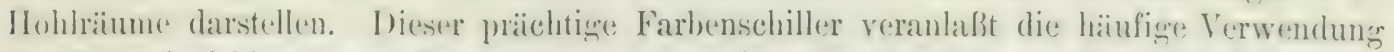
des Labradorfoldspates zu Schmucksteinen, weniger die des labradorisiorenden Foldspates von Frederiksvärn, da bei diesem das Farbenspiel erhehlich matter und schwächer ist (vgl. 'Tafel XVI, Fig. 2 und 3).

Auf gewisen Flichen der Mineralien Hypersthen, Bronzit und Diallag bemerkt man, und zwar wanz einhertlich iiber die sanze Fliche ween, einen metallischen sichiller der diesi nichtmetallisehen Suistanzen, wenigstens in den betrefienden lichtungen rrscheinen läft, als seien sie mit Metallwlanz bexabt. Dieser Śchiller rührt ebenfalls von mikroskopisch likinen metalleglänzenden Plättehen her, die nach jenen Flächen dem Vinerale in profer Zahl eingewachsen sinrl. In dieser lichtung eben oder etwas rundlich geschilffene Stiicke jener Mineralien werden zuweilen als Schmucksteine beniitzt, naurentlich solehe des Iypersthen, desien Schiller durch eine dunkelkupferrote Farbe auscezeichnet

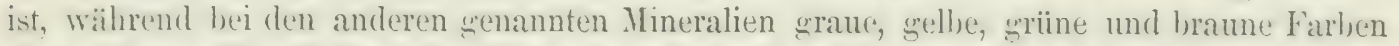
vorkmmen. Wetallischen Schiller von roter Farbe, jedoch nur an einzelnen kleinen, aber zahlreichen Stellen, nicht gleichmäßiщn über die ganze Fläche wegn. zeight auch der Aranturmeuarz durch eingewachsene kleine, aber mit blobem Auge noch deutlich sichthare Gilmmerblïtchen, sowie der Avanturinfeldspat oder Sonnenstein durch kleine Täfelehen von Eisenglanz.

sichöne Lichteffekte heruhen zuweilen auf der mehr oder weniger auswesprochenen fascrigen Beschaffenheit mancher Mineralien. Ein heller, milchiger, wogencler Lichtschein tritt namentlich auf in der Faserrichtung rundich geshliffenen Flïchen sulcher Steine hervor und wandert beim Dreben iiber deren Oberfläche hin. Das Katzenaure, im (regensatze zu dem oben erwähnten orientalischen auch (guarkatzenauge genannt, ist ein Nuarz, der durch zahlreiche, in einer Richtung eingewachsene Fäden des Minerals Ashest oder nach dren Verwitterung durch die zurïckgebliebenen hohlen rianälehen fastrige lieschaffenheit erlangt; es zeigt die genannte Erscheinung, die man nehst der ganz ähnlichen des Adulars und des Cymophans auch wohl als Opalisieren oder Chatoyieren bezeichnet, in ausgezeichneter Weise. Auch hier wird auf den srïnen, braunen und gelben, meist bohnenfürmig geschliffenen Steinen der Eindruck eines wirklichen Katzenauges herrorgehracht. Die Ursachen der Erscheinung sind jedoch beim duarkatzenauge andere als bei den anderen genannten Vineralien. Man hat es hier mit nichts anderem als mit (inem ausgezeichneten, aber durch die Natur des Steines etwas modifizitrten Seidenglanz zu tun, wie er faserigen Substanzen ïberhaujt eigen zu sein pflegt. Einen solehen nit einer starken Annäherung an den Metallshanz bewundert man an dem schïn soldig schimmernden Tigerauge, einem jetzt bei uns massenhaft zu billigen Schmucksachen verwendeten Faserquarz (rol. Taf. XVIII, Fig. $t^{\prime \prime}$ und $t^{*}$ und Fig. 5).

Hier schließt sich wohl auch der Asterismus an, der unter den Edelsteinen namentlich, aber nicht ansschlieblich, beim Sapphir eine sewisse Rolle spielt. Tenn man die sechsflächigen L'yramiden dieses Minerals (Fig. 63 e bis i), das wir unten noch näher kemnen lernen werden, an ihren Endecken eben oder rundlich abschleift, so erblickt man zuweilen beim Hindurchsehen nach ciner Lichtflamme oder beim spiegentn einer solchen auf der Schlifflaiche cinen in dem milchigen Lichte der zuletzt genannten Steine schimmernden sechsstrahligen stern. Steine, an denen er auftritt, heiben darnach Sternsalplinire oder allgencin Sternsteine oder Asterien. Er soll hervorgebracht werlen durch Beugrung des Lichtes an einer L'nzahl langer, äuberst dünner, hohiler Kanälchen, die in drei unter 120 gregencinander geneigten Richtungen parallel jener angeschliffenen Fläche dem Steine 
eingelagert sind und auf denen die Strahlen des Sternes senkrecht stehen, oder auch durch mikroskopisch feine Xäilelchen, die in denselhen Richtungen liegen wie jene Kanälchen. Nach einer anderen Annahme entsteht der Stern durch eine große Zabl von nach drei Richtungen eingewachsenen Zwillingslamellen. Eme ähnliche Erseheinung beobachtet man auch bei Zirkonen und Granaten, die solehe Nïdelchen enthalten, und bei manchen Rosenquarzen ist dergleichen ebenfalls zu sehen.

Endlich folgen dann noch zwei Erscheinungen, die nur kurz erwähnt zu werden brauchen, da sie lïr die Verwendung der Nineralien zu Schmucksteinen von geringer Bedeutung sind. Es sind dies die Lumineszenzerseheinungen die Fluoreszenz und die Phosphoreszenz.

Die Fluoreszenz erscheint in ausgezeichneter Weise bei dem Flußspat aus den Bleierzaingen ron Cumberland. Ton diesem Mineral, dem von den Mineralogen zuweilen so renannten Fluorit, hat sie auch ihren Namen. Eine fluoreszierende Substanz zeigt beim IIndurehsehen eine andere Farbe, als wenn das Licht an der Oberfläche reflektiert wirl. Bei jenem Flufspat z. B. sind diese beiden Farben grin und blau; bei der gewïhnlichen IBetrachtung treten sie beide abwechselnd auf. Der Flußspat hat als Edelstein keine swofie Wiçıtigkeit. T'nter den wirklichen und bäufi@ verwendeten Schmucksteinen ist w wohl blob der Bernstein, bei dem die Fluoreszenz in bemerkbarer Weise erseheint, und auch bei diesem nur an Stiicken von gewissen Fundorten, so namentlich an solchen von Sizilien und ron Birma. Derartige Bernsteinstïcke sind beim Hindurchsehen gelb his braun und reflektieren ein grïnes bis blaues, meist sehr düsteres Licht. Dieses erzeugt auf runtlichen Flïchen einen eigentiumlichen Schiller, der aber nach dem jetzigen Geschmack die Schönheit des Steines und damit seinen Wert wesentlich verringert.

Unter Phosphoreszenz versteht man die Eigenschaft einer Substanz, auf gewisse äubere Einwirkungen hin schon bei niederer 'Temperatur ein weibes oder farbiges mildes Iicht auszustrahlen. das vielfach erst im Dunkeln deutlich erkannt wird. Dieser Lichtschein hält in frexensaty zur Fluoreszenz, die beim Aufhören der äußeren Einwirkung sofort verschwindet, mehr oder weniger lange an; bei manchen Substanzen dauert er stundenlang; bei amderen versehwindet er allerdings schon nach kurzer Zeit, oft nach wenigen Augenblicken. Manche Edelsteine zeigen die Erscheinung und können dann daran unter Uuständen erkannt und von anderen ähnlichen untersehieden werden. Der Bergkristall phosphoresziert, wenn er mit einem anderen Berokristall gerieben wird; der Diamant tut es in ausgezeichneter Weise, wenn dasselbe mit Tuch geschieht, schon beim leichten Überstreichen iiler ein 'Tuchkleid phosphoresziert er im Dunkeln lebhaft. Auch durch Bestrahlen mit direktem Somnenlicht werden cinzelne wenige Diamanten leuchtend; sie schlucken gewissermaßen das Sonnenlicht ein, um es im Dunkeln wieder von sich zu geben. Beim Erwärmen phosphoresziert $u$. a. der Lasurstein von Chile; er leuchtet noch weit unter der Glühhitze, und ebenso verhalten sich weiße Topase (vgl. auch Seite 72) usw. und vielleicht manche Diamanten.

Von grolbem Intresse sind die Phosphoreszenzerseheinungen, die gewisse Edclsteine unter der Eimwirkung von Ra diumstrahlen zeigen. Nit am ausgezeichnetsten verhält sich anch hier der I)iamant. Er leuchtet rasch und elïnzend, und die Erscheinung dauert nach Aufhören der Bestrahlung noch mehrere Stunden an. Allerdings ist dieses Verhalten nicht bei allen Diamanten gleich. Am lebhaftesten ist die Phosphoreszenz bei den sog. „blauweißen" Steinen, die man mit dem besonderen Namen 'T'iffanyit von don iibrigen I iamanten untersehieden hat. In ihnen wird daher eine besondere und zwar rine dem Anthracen ïhnliche, stark phosphoreszierende Substanz vermutet, die das Lenchfen vermittelt. Berokkistall, Topas, (Xlas und andere Substanzen, die ähnlich wie Diamant aussehen kïnnen, werden durch Radiumbestrahlung nicht zum Leuchten gebracht und 
lassen sich auch dadurch von jenem unterseheiden. 'Topas luminesziert präiehtig unter der Einwirkuner von Radlumstrahlen, wenn er vorher gegliiht ist. Riöntgenstrahlen und ultraviolettes Licht bringen beim Diamant denfalls Phosphoreszenzerscheinungen hervor. Isesonder's bemerkinswert und dem des Diamants am nächsten stehend ist bezüglich der L umineszenz das Verhalten des Kunzit. Bei der Betrachtung dieses Edelsteins wird davon noch eingehender die Rede sein.

\section{e) Thermische, elektrisehe und magnetisehe Eigenschaften.}

Das Verhaltem der Elelsteine gesen Wärme, Elektrizitait und Magnetismus ist für ihre Verwendung von nur geringer Wichtigkeit.

\section{Thermische Eigenschaften.}

Yon einer sewissen Bedeutung für die Unterseheidung mancher Kürper ist ihre Wrämeleitungsfähigkeit. Die Mineralien verhalten sich in dieser Bezichung sehr versehieden. Es wibt unter ihnen sute und schlechtr Wärmeleiter; mit zu den besten gehören die meisten Edelsteine. Daher kommt es, daß diese sich bei der Berührung kalt anfïhlen, weil die Wärme der Hand rasch von ihnen abgeleitet und so der letzteren entzogen wird. In Gegensatze dazu sind unechte, in Glas nachgemachte Edelsteine schlechte Wärmeleiter. Das Glas leitet die Wä̈me der IIand nicht rasch fort und die Imitationen fühlen sich daher im Vergleich mit den echten Steinen warm an. Diese Lrschemung des kalten und warmen Anfühlens kann so unter Umständen leicht zur Unterscheidung echter Steine von Glasfliissen führen, nur dürfen die betreffenden Stücke nicht schon längere Zeit mit der Hand beriihrt oder sonst erwärmt und auch nicht zu klein sein. Es wird erzählt, dal es einem Mineralogen mit Leichtigkeit gelungen ist, aus einer größeren Zahl ron in Edelsteinform geschliffenen Glasstiicken einen cchten Diamant herauszufuhlen, der mit jenen in einem Sacke verborgen war.

Einer der schlechtesten Wärmeleiter, ein noch viel schlechterer als Glas, ist der Bernstein, der sich daher durch noch wärmeres Anfühlen selbst von Glase leicht und sicher unterscheiden läßt. Da gewissen Bernsteinsorten zuweilen gelbes Glas untergeschoben wird, so ist dieses Verhalten manchmal von einiger Bedeutung. Ähnlich ist es mit dem Gagat, einer Art Steinkohle, die nicht selten zu Trauerschmuck verarbeitet wirc. Zu demselben Zwecke wird vielfach ein schwarzes undurchsichtiges Glas verwendet. Eine flüchtige Berührung mit der Fingerspitze zeigt dem Kundigen, ob er es mit dem schlechtleitenden, warm sich anfühlenden Gagat oder dem besser leitenden, bei der Berihrung kalt erscheinenden Glas zu tun hat.

Die Juweliere wenden zuweilen zur Lnterscheidung echter Steine von Glasflüssen eine auf dem Wärmeleitungsvermögen beruhende besondere Methode an, indem sie die Stiicke anhauchen. Dabei beschlagen sich echte Steine schwerer mit Feuchtigkeit und verlieren den Beschlag auch leichter und rascher wieder als Gläser, weil sie leichter und rascher sich erwärmen als die letzteren.

Zur Unterscheidung roher Steine kann manchmal die Schmelzbarkeit vor dem Lötrohr benutzt werden. Nur wenige der als Edelsteine viel benutzten Wineralien sind schmelzbar, so z. B. der rote Granat, der sich dadurch leicht von dem gleichfalls roten, aber unschmelzbaren Rubin und dem Spinell unterscheidet. Leicht schmelzbar sind namentlich alle Glasimitationen. Bei geschliffenen Steinen ist diese Methode natïrlich ausgeschlossen, dagegen kann man ron den rohen Stïcken häufig leicht ein Splitterchen abnehmen, das zur Untersuchung genïgt. 
Manche Edelsteine verändern, wie wir gesehen haben, in der Wärme ihre Farbe oder leiden sonst bei starkem Erhitzen, weshalb hierbei unter allen Umständen Vorsicht zu ïben ist. Starke Glut können Rubin, Spinell und Granaten ertragen, im allgemeinen muß diese auch bei Diamanten vermieden werden.

\section{Elektrische Eigenschaften.}

Manche Edelsteine werden durch äußere Einwirkungen mehr, manche andere weniger stark elektrisch erregt. Sie verhalten sich dabei dann auch weiter darin verschieden, daß einige die erworbene Elektrizität lange behalten, während sie bei den übrigen schon nach kurzer Zeit, manchmal nach wenigen Minuten, wieder vollständig verschwunden ist. Diese Unterschiede hat Hä̈y, einer der Begründer der modernen wissenschaftlichen Mineralogie, der um die Wende des 18. und 19. Jahrhunderts in Paris lebte, in ganz hervorragender Weise zur Erkennung und Unterscheidung von Edelsteinen zu benützen gesucht, sehr viel ausgiebiger als die heute hierzu besonders wichtigen optischen Eigenschaften. In seinem 1817 erschienenen Werke: Traité des caractères physiques des pierres précieuses nimmt die Betrachtung des elektrischen Verhaltens 72 von 253 Seiten ein, während den optischen Erscheinungen nur 32 Seiten gewidmet sind. Ein Vergleich mit den entsprechenden Zahlen des vorliegenden Buches wird den Unterschied zwischen einst und jetzt klar machen.

Die Untersuchung des elektrischen Verhaltens hat wie die des optischen den großen Vorzug, daß dabei die Steine nicht die geringste Beschädigung erleiden. Sie hat aber letzterem gegenüber den Nachteil, daß die schwachen Grade von elektrischer Erregung, wie sie die meisten Edelsteine nur entwickeln, schwierig nachzuweisen sind, und daß die Beobachtung eine gewisse Übung und Geschicklichkeit und vor allem ein vollkommen trockenes Lokal erfordert, das nicht immer in genügender Beschaffenheit zur Verfügung steht. Durch die Feuchtigkeit der Luft wird die an der Oberfläche der Steine entwickelte Elektrizität rasch abgeleitet, und ein Stein, der diese in trockenem Raume lange behält, verliert sie in einem feuchten in kurzem. Dadurch wird ein Merkmal, auf das Haüy besonderen Wert legt, nämlich die Lïnge der Zeit, während der ein Stein die an seiner Oberfläche erregte elektrische Spannung zurückbält, mehr oder weniger illusorisch.

Der Grund, warum II ä̈y bei der Bestinmung der Edelsteine die elektrischen Eigenschaften den optischen gegeniiber so stark bevorzugte, liegt, wie schon angedeutet, in dem Stande der Wissenschaft zur Zeit, als er seine Beobachtungen anstellte. Die Methoden der elektrischen Untersuchungen waren wenigstens für die vorliegenden Zwecke damals schon schr entwickelt, und außerdem gelang es Ha ̈̈ y, ein für diese Beobachtungen beruemes IIilfsinstrumentehen zu erfinden, die elektrische Nadel. Dem gegeniuber standen die optischen Methoden weit zurück. Man kannte zwar den Unterschied der einfachen und doppelten Lichtbrechung, aber es gab noch kein Polarisationsinstrument für die berueme und sichere Beobachtung, und der Dichroismus war iberhaupt noch nicht entdeckt. Mit der Erfindung eines bequemen Polarisationsinstrumentes und der dichroskopischen Lupe mußte notwendig die optische Untersuchung in den Vordergrund treten, wie es heutzutage der Fall ist, wo die elektrischen Methoden zur Prüfung von Edelsteinen kaum noch benutzt werden. Daher soll von diesen auch nur kurz die Rede sein.

'Zum Nachweis einer an der Oberfläche eines Steines vorhandenen elektrischen Erregung verwendet man jetzt Elektroskope und Elektrometer von zum 'Teil recht komplizierter Einrichtung, die aber sehr sehwache Spuren von Elektrizitiit noch nachzuweisen erlauben. II a ü y benutzte seine sehon erwähnte elektrische Nadel, ein mit einem Messingkïgrelehen an beiden Enden versehenes Messingstäbchen, das sich wie eine Magnetnadel 
in der Nitte auf einer feinen Stahlspitze leicht herumdrehen kann. Bringt man einen dektrisch erregten Köruer in die Nähe eines der Kïgelehen, so wird dieses angezogen. Noch empfindlicher wird der Apparat, wenn man die Kugrel elektriseh macht; sie wird dann von dem elektrischen Kïrper je nach der Art seiner Ladung angezogen oder alogestoben. Denselben Dienst leistet in ganz entsprechender Weise das elektrische Pendel, ('in an einem feinen Kokonfarlen aufgehängtes Hollundermarkkügelehen.

Mit Ililfe eines dieser Instrumente läßt sich nachweisen, daß an der Oberfläche der Ilineralien, speziell der Edelsteine, auf versehiedene Weise Elektrizität hervorgerufen werden kann, was aber nur bei wenigen von einigem Interesse ist.

Durch Reibung mit Tuch werden alle Edelsteine positiv elektrisch wie Glas, und zwar in grleicher Weise über die ganze Oberflïche hin. Besonders stark werden Topas und Turmalin erregt, weniger stark der Dianant; die meisten werden es nur schwach. Vorzugsweise günstig für die Stärke der Erregung sind glatte Flächen, daher eignen sich weschliffene Steine ausgezeichnet zu solehen Versuchen. Einzelne Edelsteine behalten, wenigstens in ganz trockener Luft, die Elektrizitït lange, am lïngsten wohl der Topas, bei dem man 32 Stunden nach dem Reiben die Erregung noch nachweisen konnte; 5 bis 6 Stunden bleiht der Sapphir, eine halbe stunde lang der Diamant erregt. Man kann mit Hilfe dieses Verhaltens die drei Steine: weißen Topas, farblosen Sapphir und Diamant, voneinander unterseheiden, indem man sie mit Tuch stark reibt und in einem trockenen Raume auf eine Metallplatte legrt. Die meisten anderen Edelsteine verlieren die Elektrizitait sehr rasch wieder, einzelne nach wenigen Augenblicken. Bernstein wird beim Reiben wie andere Harze negativ elektrisch, und zwar so stark, daß er leichte Körper, wie z. B. kleine Stiickchen Papier, kräftig anzieht, um sie nachher wieder abzustoben Bei ihm ist das elektrische Verhalten wertvoll, um ihn von gewissen Substanzen zu unterscheiden, die ihm vielfach untergeschoben werden, wie bei seiner speziellen Beschreibung. eingehender gezeigt werden soll.

Manche Edelsteine werden auch durch Temperaturveränderung, bei dem Erwärmen oder leei der Abkühlung nach dem Erwärmen, elektrisch. Diese Art Elektrizität wird Pyroelektrizität genannt. Dabei wechseln auf der Oberflïche eines und desselben Steines positive und negative stellen miteinander ab, und die bei der Erwärmung positiven Punkte werden bei der Abkühlung negativ und umgekehrt. Besonders stark pyroelektrisch erregrt werden namentlich der Turmalin und der Topas, die sich dadurch von anderen Steinen, die sonst fast alle nur geringe Entwickelung ron Pyroelektrizität zeigen, unterscheiden lassen. Der Tumalin zieht sogar, wenn er erhitzt ist und sich allmählich abkïhlt, infolse der dahei entwickelten Elektrizitït, ähnlich wie der geriebene Bernstein, kleine leichte Körper an. Er und ler Topas wirken auch stark auf die obengenannten Instrumente. Man hann so z. B. roten Turmalin ron Rubin unterscheiden, welcher letztere nicht bemerkbar pyroclektrisch wird, und ebenso den hell grïinlichblauen 'Topas von dem ebenso gefärbten nicht pyroelektrischen Aquamarin.

Der Turmalin hat noch die besondere Eigenschaft, daß3 er polar erregt wird, d. h. so, dals das eine Ende eines Kristalls positiv, das andere negativ ist. Dies kann in ausgezeichneter Weise für das Auge sichtbar gemacht werden durch das Verfahren von Kundt. Bestäubt man einen erhitzten in der Ablïhlung begriffenen Turmalin mit einem durch Schütteln innig. rereinigten Gemenge feinsten Schwefel- und Mennigepulvers, so tritt eine Sonderung ein. Das positive Ende des Steins zieht den elektronegativen Schwefel an und färbt sich dadurch gelb; das negative Ende des Steins wird ebenso durch die elelstropositive Mennige rot. Dadurch liann man einen Turmalin stets leicht und sicher erkennen und unterscheiden, und dieselbe Methode läßt sich natïrlich auch sonst anwenden. An einer solchen elektrisch erregten Oberfläche haftet das Pulver ziemlich fest und ist nicht leicht ron dem 
Stein zu entfernen. War der Stein nicht elektrisch geworden, so findet keine Verteilung der beiden Pulver statt und sie haften nicht an der Oberfläche, von der sie sich leicht wegblasen lassen. Dies ist ein in manchen Fällen charakteristisches Verhalten.

\section{Magnetismus.}

Einige Mineralien sind magnetisch, sie werden vom Magnet angezogen, wie z. B. das Magneteisen. Eine gewisse titanhaltige Abart desselben, der schwarze metallische Iserin nimmt beim Schleifen cinen sehr lehhaften Glanz an und wird daher zuweilen als Schmuckstein verwendet, olne aber iryendwelche Bedeutung zu haben. Der geschliffene Iscrin kann an seinem starken Magnetisnus von anderen schwarzen Steinen unterschierlen werden, die alle nur sehr schwach auf einen Magnet einwirken.

\section{Vorkommen der Edelsteine.}

Zur vollständigen Kenntnis eines Edelsteins gehört auch, zu wissen, an welchen Orten und unter welchen I mständen er vorkommt. Letzteres ist für das Aufsuchen ron Eidelsteinen von grober Bedeutung. Bei der speziellen Beschreibungr der einzelnen Edel. steine wird davon genauer die Rede sein, hier handelt es sich zunäichst nur um einige allgemeine Mitteilungen über die Art und Weise, wie sie sich in der Natur finden.

Wie bei allen anderen Mineralien beobachtet man hierbei eine zweifache Verschiedenheit. Vielfach findet man die Edelsteine noch auf ihrer ursprïnglichen, primären Lagerstïtte, d. h. an der Stelle der Erdkruste und in dem Gestein, wo sie entstanden sind; oder sie sind durch Verwitterung und Zerstörung des ursprünglichen Gesteins aus diesem losgelïst und oft durch das Wasser fortgeschwemmt. Sie finden sich nun, vielfach fern von dem Ursprungsort, auf einer neuen, sekundären Lagerstätte.

Auf ihrer usprönglichen Lagerstïte bilden die Edelsteine häufig Bestandteile der die Erdkruste zusammensetzenden Gesteine. Sic sind in diesen von der Gesteinsmasse, dem sogenannten Muttergestein, ringsum dicht umschlossen und gleichzeitig mit deren übrigen Bestandteilen gebildet worden. Meist sind solche Gesteinsgemengteile unregrelmäißig begrenzt, nicht selten bilden sie aber auch vollkommen regelmäßjig gestaltete Kristalle, die dann ringsum auf ihrer ganzen Außenseite mit Kristallflïehen versehen sind, so daß sie, vorsichtig aus dem Muttergestein herausgenommen, in idealer Vollständigkeit vorliegen. Ein Beispiel cines solchen eingewachsenen Kristalls bietet der Taf. XIV. Fig. 3 abgehildete rote Granat (Almandin), der im Gneis liegt; die Formen solcher aus dem Muttergestein losgelöster Granaten in ihrer ringsum vollständigen Umgrenzung. sind in Fig. 83 dargestellt.

IIäufig sind aber die Mineralien und darunter auch manche Edelsteine nicht gleichzeitig mit den Bestandteilen des umgebenden Gesteins, sondern später als dieses entstanden. Sie sind dann nicht ringsum von der Gesteinsmasse umschlossen, sondern sie haben sich auf den in dieser vielfach vorhandenen Hohlräumen angesiedelt. Dies sind zum Teil ringsum geschlossene IIöhlungen von verschiedener Form und Größe, zum T'eil mehr oder weniger lang sich hinziehende Kliffte und Spalten von betrïchtlicher Weite bis herab zu den feinsten Äderchen. Die später gebildeten Mineralien füllen vielfach diese Hohlräume vollständig aus, häufig bedecken sie aber nur in mehr oder weniger dieken Schichten deren Wände. Wenn sie kristallisiert sind, sitzen die Kristalle mit ihren unteren Fnden auf diesen Wänden auf, meist \%u mehreren oder vielen vereinigt, sogenannte Drusen bildend, und ihre Spitzen ragen frei in den leeren Raum hinein. Derartige a uf gewachsene Kristalle sind selbstverstïndlich an der sogenannten Ansatzstelle, mit der sie auf der Interlage befestigt sind, nicht mit regelmälbigen Flächen versehen, sie sind nicht ringsum 
vollstïndiæ anskristallisiert wie die oben betrachteten dingewachsenen Kristalle, und kïmnen daran, auch wenn sie von dem Gestein wexgebrochen sind, von jenen unterschieden und so nach ihrem ursprünglichen Vorkommen beurteilt werden. Beispiele soleber formen von der Unterlage abgebrochener, ursprïnglich aufgewachsen grewesener Kristalle, und zwar von (Quarz. geden die Fig. 100 b) bis d, während Fig. 100 a im Gerensatz dazu die vollständige Form eines eingewachsen gewesenen Quarzkristalls darstellt. Die unregelmälbigen Ansatzstellen sind bej jenen nach unten grekehrt und ziemlich ausgersdehnt, manchmal sind sie auch klein und zuweilen kaum hemerkbar. Eine Druse solcher (Quarzkrystalle, und zwar der besonderen Abart, die man Bergkristall nennt, wie sie sich vielfach auf Kliiften und Spalten im Gneise der IIochalpen finden, ist auf Taf. XVII abgebildet.

Wichtiger als das primäre Vorkommen in den festen festeinen ist an viclen Orten und für manche Eidelsteine das sekundäre in den lockeren, durch Verwitterung aus diesen entstandenen Massen, den Elelsteinseifen.

Die Gesteine, die die Edelsteme beherbergen, zersetzen sich vielfach an der Erdoberflïche dureh die Terwitterung infolge der Einwirkung der Atmosplä̈rilien, der Luft, des liegrens usw. Dadurch wird der Zusammenhalt der ursprïnglich festen Wasse zerstürt, indem einzelne Bestandteile rom Trasser aus dem Gestein aufgelöst und fortgeführt werden. lis bleibt damn ein mehr oder weniger lockerer, toniger oder sandiger widerstandsfüliger Therrest als Verwitterungsprodukt zuriick. In diesem stecken nun auch alle die in dem ursprü̈glichen Gestein rorhanden gewesenen Edelsteine, denn diese werden durchgängig. von der Verwitterung nicht ergriffen; sie widerstehen ihr hartnäckig, während die meisten anderen (iesteinsbestandteile allmählich zersetzt und aufgelöst werden. Dadurch findet eine nicht unbedeutende Anreicherung der Masse statt. Die Edelsteine bleiben unverändert zurïck, das umgebende Gesteinsmaterial wird zun Teil zerstört und fortgeführt, und der verwitterte Überrest muß infolgedessen verbältnismäßig mehr Edelsteine enthalten, als das urspriingliche feste Gestein.

W:ilhrend also unter Umständen und sogar meistens Edelsteine aus dem festen Gestein nicht mit Nutzen gewonnen werden können, weil es zu arm daran ist, so ist dies aus demselben Gestein im verwitterten Zustande möglich, aber nicht nur der größeren Reichhaltigkeit des Verwitterungsprodukts wegen, sondern auch aus dem Grunde, weil die Siteine in diesem lose liegen, so daß sie ohne erhebliche Mühe gesammelt werden künnen. Aus dem festen Gestein dagegen müften die Edelsteine mïhsam herausgearbeitet werden, was bedeutende Kosten verursachen und wobei, trotz aller Torsicht, manches wertvolle Stiick zerbrechen wïrde.

Ein solcher durch Verwitterung entstandener loser und lockerer Gesteinsschutt, der ein technisch nutzbares Mineral in für die Gewinnung genïgender Henge enthält, wird allgemein eine Seife, wenn er Edelsteine führt, eine Edelsteinseife genannt. Man spricht so speziell von Diamantseifen usw. Solehe Seifen, die überall, wo sie rorkommen, die festen Gesteine bedecken und die äuberste Oberfläche der Erde bilden, liefern uns gerade die wertvollsten und kostbarsten aller Edelsteine, Diamanten, Rubine, Sapphire und andere. Diese werden aus der Schuttmasse meist gewonnen, indem man die feineren und leichteren, meist tonigen oder lehmigen Bestandteile derselben durch Fortschwemmen mit Wasser entfernt und die Steine dann aus den grö̈beren Rückständen ausliest. Man spricht daher auch von Edelsteinwäschereien.

Wenn das verwitterte Gestein noch an der Stelle liegt, wo früher das frische, unverwitterte Gestein gelegen hatte, dann sind die einzelnen, die Schuttmasse zusammensetzenden Mineralkörner und vor allem die darunter befindlichen Edelsteine scharfkantig und eckig und ihre etwaigen Kristallformen sind ebenso wohl erhalten, wie bei den noch im festen Gestein 
steckenden Mineralien. Meist wird die ganze Masse aher rom fließenden Wasser ergriffen. ron den Bächen und Flïssen fortgeführt, weitergeschwemmt und endlich an einer passenden Stelle talabwïrts, oft erst in grober Entfernung, wieder abgelagert. Dies sind die Sande und Kiese usw. die man im allgemeinen als die Fluballuvionen zu bezeichnen pflegt. In Seifen dieser Art sind die Mineralkörner, auch die der Edelsteine, trotz ihrer großen IIärte, durch das gexenseitige Abschleifen und Abwetzen bei der fortgesetzten langandauernden Bewexung nicht mehr cekig, sondern mehr oder weniger abgerollt und abgerichen. rundlich und glatt; sie bilden Gerölle oder Geschiche. Zeigt sich diese Beschaffenheit, so kamn und mulf geschlossen werden, daß die Masse im Wasser geschwemmt worden ist, ganz wie aus den scharfen Kanten und Ecken umgekehrt folgt, daf dies nicht der Fall war. Die härtesten Edelsteine werden auf diese Weise stark abgerundet, mit Ausnalme des Diamants; aber sogar dieser zeigt häufig wenigstens Spuren ron Abrollung, zum Zeichen, daf auch bärtere Steine von weicheren endlich bezwungen werden können, wenn die Einwirkung nur lange genug andauert.

Die algrerollten Stiicke der Seifen sind nicht selten von besserer Beschaffenheit als die nicht abgerollten und die noch in dem Gestein befindlichen Edelsteine. Diese sind vielfach von Rissen durehsetzt, die man oft kaum sieht, nach denen sie aber doch leicht zurlurechen. Anders ist es bei vom Wasser geschwemmiten Stücken in den Seifen. Bei der Bewegung in den Flußalluvionen haben sie so viele Stöße aushalten miissen, daß sie sicher nach allen Richtungen schon zerbrochen sind, nach denen dies mit grö̈lierer Leichtigkeit möglich ist. IIan kann also aus dem Vorkommen in Seifen, aus der abgerollten Form bis zu einem gewissen Grade schließen, dab in solehen Steinen schädliche Risse und leicht brechende Stellen nicht mehr existieren, dab sie, wie man zu sagen pflegt, gesund sind, da sie schon starke Proben ihrer Festigkeit und Dauerhaftigkeit haben bestehen müssell.

Was die geographische Terbreitumg der Edelsteine anbelangt, so kamen die kostbarsten in friiherer Zeit hauptsïchlich aus Indien und anderen heifen Ländern des "Orients" zu uns. Man glaubte daher auch im Mittelalter, daß die glïhende Sonne tropischer Gegenden dazu grehöre, die wertvollen Eigenschaften der kostbaren Edelsteine zur Entwicklung zu bringen, so daf wohl gemeine Exemplare der betreffenden Mineralien sich auch in kälteren Gegenden bilden, nicht aber die prïchtigen Stücke von der edelsten Beschaffenheit. Deswegen wurle von allen guten Steinen, deren Fundorte teilweise frïher nur sehr oberflächlich bekannt waren, angenommen, daß sie aus dem „Orient" stammen. Aus diesem Grunde werden noch heute die kostharsten Edelsteine „orientalische" genannt im Gegensatz zu den weniger wertvollen ,occidentalischen“. Mentzutage weiß man aber, daß die Edelsteine, auch die wertvollsten, nicht auf den „Orient", nicht auf heiße Klimate beschränkt sind, daß sie sich nicht blol in Indien, Ceylon, Birma, Siam, Brasilien, Kolumbien usw. finden, sondern in ebenso vortrefflicher Beschaffenheit in Nordamerika, im Ural und in anderen Gegenden des Nordens. Die Bezeichnung ,orientaliseh" soll demnach heutzutage nicht mehr die Heimat des betreffenden Steines, sondern nur dessen besondere Kostbarkeit angeben; es ist kein geoaraphischer Begriff mehr, sondern ein Qualitätsbegriff, der außer in dem obigen Sinne manchmal auch in der Art angewendet wird, daß die schönsten und besten Exemplare eines Edelsteines als ..orientalisehe" vor den minder vorzïglichen „occidentalischen" ausgezeichnet werden. Wir haben später zahlreiche Beispiele hierfür kennen zu lernen, besonders bei der Betrachtung des Korunds. Im zweiten T'eil sollen für alle Edelsteine die wichtigeren Fundorte, namentlich soweit sie für den IIandel von Interesse sind, ausfiihrlich beschrieben werden. 


\section{Verwendung der Edelsteine.}

Die Ferwendung der Edelsteine beruht entweder auf ihrem schïnen Aussehen und ihrer Ilärte zusammen oder auf ihrer Irärte allein. In ersten Fall dienen sie zum Schmuck. im anderen zu gewissen techni-chen Zwecken, die ein besonders hartes Material erfordern.

\section{A. Verwendung in der Technik.}

Die Verwendung in der Technik ist die weitaus untergeordnctere, wir werden sie daher nur im Vorbeigehen betrachten.

Scit 17nn verwendet man zu Zapfenlagern feiner Uhren harte Edelsteine, weil diese ron den aus Stahl bestehenden Axen der Räider bei deren andauernder Bewegung nicht ancerriffen werten. Man pflegrt diese Steine als ..Rubis" zu bezeichnen. es sind alser keinesweas lauter Rubine, obwohl diese wegen ihrer ganz besonders grrolien Härte vor allem hierzu tauglich wären. sondern ebenso gut und wohl noch häufiger Granat, Chrysoberyll. Topas. Spinell und andere. Es kommt dabei nur darauf an. daf diese Steine eine crö̈liere Ilärte als die des Stahls besitzen, sie künnen aber dabei trüb, undurchsichtig und unrein sein, und in der Tat rerwendet man zu dem angegebenten Zwecke rorzugsweise solehe Exenplare, die ihrer Beschaffenheit wegen nicht zum Schmuck geeignet und daher billiger sind.

In ähnlicher Weise wie bei den Chren werden auch bei anderen feinen Instrumenten, wie Elektrizitätszählern, Wagen usw., Zapfenlager aus harten Steinen, hier namentlich aus Achat, hergestellt, um die Abnutzung auf ein müglichst geringes Maß zurückzuführen. Die feinen Öffnungen zum Ziehen der äußerst dïnnen Gold- und Silberdrähte bringt man in Edelsteinen an, damit sie nicht beim Gebrauch zu bald ausgeweitet und dadurch unbrauchbar werden. Instrumente zum Polieren von Metallen usw. werden gleichfalls aus harten Steinen, und zwar vorzugsweise wieder aus Achat hergestellt, und ebenso manches andere zu ähnlichen Zwecken dienende Gerät.

Die Edelsteine, die in der Technik die größte Bedeutung haben, sind zugleich die hïrtesten, der Diamant und der Korund, letzterer allerding's vorzugsweise in seiner unreinsten Abart, dem sogenannten Schmirgel. Die vielfältige technische Verwendung des ersteren werden wir bei dessen spezieller Beschreibung kennen lernen. Hit dem Korund und allen anderen luarten Steinen hat er aber eine besonders wichtige Verwendung gemein, nämlich die als feines P'ulver zum Schleifen ron Diamanten und anderen Edelsteinen sowie sonstiger harter Gegenstände. Auch hierauf werden wir unten bei der Betrachtung der Edelsteinschleiferei noch einmal eingehender zurückzukommen haben.

\section{B. Verwendung zum Schmuck.}

Viel wichtiger ist die Benutzung der Edelsteine zum Schmuck. Weitaus die meisten und namentlich die schönsten und kostbarsten Edelsteine in ihren wertrollsten Exemplaren werden als Schmucksteine rerwendet. Zu diesem Zseck sind sie aber in ihrem natürlichen, dem sogenannten rohen Zustande, als sogenanntes „brut" des Edelsteinhandels, wenig geeignet, weil sie in diesem meist ein unansehnliches Äußeres haben. Erst nach ihrer Bearbeitung durch das Schleifen und Polieren tritt ihre ganze Schönheit herror, erst im geeschliffenen Zustande sind sie zum Schmuck tauglich. 
Der SchleifprozeB zielt also daranf ab, die Schönheit der Edelsteine möglichst zu heben und ihnen zu diesem Zwecke eine ihren Eigenschaften und ihrer speziellen Benützung entsprechende regelmäßige Form zu geben, die entweder stetig gerundet, mugelig, ist, oder aus einzelnen kleinen Flïchen, den sogenannten Facetten, sich zusammensetzt. Formen dieser letzteren Art werden besonders häufig hergestellt.

Die künstlichen Formen, die man so den Edelsteinen zu geben pflegt, die sogenannten Schlifformen, sind durch die im Laufe der Jahrhunderte gemachten Erfahrungen der Steinschleifer festgestellt. Es hat sich dabei ergeben, daß zur Erlangung der vorteilhaftesten Wirkung Steine verschiedener Beschaffenheit auch im allgemeinen voneinander abweichende Schlifformen erhalten müssen. Durchsichtige Steine werden anders geschliffen als undurchsichtige, tiefgefärbte anders als helle oder ganz farblose. Ein farbloser Stein in der Form der dunkelgefärbten wïrde ebensowenig zur vollen Geltung kommen, als umgrekehrt ein sehr dunkel gefürbter Stein in der Gestalt, die sich für farblose als zweckmäßig und passend herausgestellt hat.

Fïr durchsichtige Steine ist dabei von wesentlicher Bedeutung die Stärke der Lichtbrechung und Farbenzerstreuung, die beide zusammen die Wirkung der Edelsteine, namentlich der Diamanten, beeinflussen. Von ihnnen hängt der Gang der Lichtstrahlen ab, die, wie wir olen (S. 52) gesehen haben, möglichst alle nach vorn aus dem Edelstein austreten mïssen, nachdem sie in ihn eingedrungen und an den hinteren Flächen wieder nach vorn zurïckgeworfen worden sind. Hierzu ist aber vor allem erforderlich, daß die äußere Form den optischen Verhältnissen des Steines so vollkommen wie möglich angepaßt ist, weil ohne diesen Einklang die Wirkung des Steines mehr oder weniger zu wïnschen übrig läßt. Es ist demnach die Aufgabe des Steinschleifers, jedem Stein die Form zu geben, die seine Schönheit am meisten hebt, selbstverständlich unter möglichster Schonung des kostbaren Materials.

Die langjälurige Erfahrung hat den Steinschleifern gewisse allgemeine Regeln gelehrt, die hierbei immer angewendet werden, und die nach der speziellen Beschaffenheit des zu schleifenden Steines wieder gewisse Modifikationen erleiden. Bei allen Steinen muß die Breite und die Dicke ein bestimmtes Verhältnis haben, ebenso die Vorderseite zur Hinterseite. Die farblosen dürfen nicht zu dick, aber auch nicht zu diinn sein, beides beeinträichtigt die Wirkung bedeutend. Zu dicke Steine werden klumpig, zu dïnne gestreckt genannt; klumpig sind meist die z. B. von indischen Schleifereien hergestellten Formen. Von zwei gut geschliffenen Steinen der nämlichen Art von gleicher Form und Gröbe heift der leichtere ebenfalls gestreckt, der schwerere gedrungen. Die crsten werden meist vorgezogen. Die hinteren Facetten müssen eine bestimmte Lage zu den vorderen liaben, weil sie sonst die von diesen kommenden Lichtstrahlen nicht in vollkommener Weise nach vorn zurïckwerfen können. Bei farbigen Steinen gelten dieselben Iiegeln, die Dicke ist hier aber vielleicht von noch größerer Bedeutung. Ein dunkelgefärbter Stein darf nicht zu dick sein, weil sonst die Farbe trübe und matt, fast schwarz erscheint, umgekehrt ein hellgefürbter nicht zu dünn, weil sonst die Farbe nur unvollkommen zur Geltung kommt. Die Dicke kann daher nicht für alle Steine derselben Art die nämliche sein, sondern sie muls sich nach dex Tiefe der Färbung des einzelnen Exemplars richten.

In allgemeinen ist es gleichgïltig, wie die Facetten zu den durch die Kristallisation gegebenen likhtungen in den einzelnen Edelsteinen liegen, wenn sie nur gegeneinander die richtige Anordnung liaben. Doch ist in einzelnen Fällen eine bestimmte Orientierung nach diesen Richtungen vorteilhaft oder sogar notwendig, weil manche Steine, z. B. der Labradorit, der Mondstein und andere, nur in ganz bestimmten Richtungen die Licht- und Farbenerscheinungen zeigen, die sie als Edelsteine verwendbar erscheinen lassen, in anderen 
aber durchaus nicht (S. TS). Auch starker I)ichroismus ist hierbei zu beriicksichtigren (S. 73). Diese Fïlle werden bei der Betrachtung der einzelnen Steine noch besonders hervorgehoben werden.

Wreiter wird man selhstverständlich an einem vorliegenden rohen Steine die Facetten so legen, dab die gewünschte Form mit möglichst geringem Materialverlust erhalten wird und der weschliffene Stein neben der gü̈nstigsten Gestalt noch eine mügrlichst bedeutende Gröle behäilt. Manchmal sind aber bei der Anlage der Facetten noch weitere Rüicksichten zu nehmen, besonders wenn der rohe Stein Fehler besitzt, die dessen Wirkung" im geschliffenen Zustande stören wïrden. Die Facetten werden dann \%weckmäßigg so angeordnet, dab gerade diese fehlerhaften Stellen beim schleifen werfallen, und nach dem Schliff nur der reine Stein zurïckbleibt, oder man richtet es, wenn die vollstïndige Entfernun unmöglich ist. so ein, dab die Fehler im geschliffenen Steine eine die Schünheit möglichst wenig beeinträchtigende Lage erhalten.

Unter Umstïnden kann sich die Frage erheben. ob man einen vorliegenden rohen Stein unter Verzicht auf eine seinen Eigenschaften möglichst vollkonmen angepabte Form so schleifen soll, daf möglichst wenig Material dabei verloren geht, oder ob man nicht lieber eine etwas größjere Gewichtseinbule erleiden will, um eine die Schönheit auf den höchsten Grad erhebende Form zu erhalten. Bei einem solchen Konflikt geht wenigstens in Europa ein geschickter Steinschleifer stets darauf aus, einem Steine die für ihn güustigste Form zu geben und verliert dabei lieber einen etwas größeren Teil desselben, als dah er, um dies zu vermeiden, eine weniger vorteilhafte Form wählt. Etwas lileinere steine von vollkommener Form und daher mit schönster Wirkung sind viel geschätzter und wertvoller als etwas größere derselben Art, die infolge ungünstigen Schliffes ihre volle Schünheit nicht entfalten können. Der gröljere Materialverlust wird also durch die bessere Form reichlich wieder ersetzt. Für jeden einzelnen rohen Stein wird natürlich gresucht, bei der Bearbeitung möglichst wenig wegzuschleifen und das Gewicht möglichst hoch zu erhalten, da der Preis unter sonst ganz gleichen Verhältnissen lediglich vom Gewicht abhängt, aber man tut das nicht auf Kosten der Vollkommenheit der Form. Man verliert oft die Hälfte und noch mehr von dem rohen Steine, um eine gute Form zu erzielen, und der Besitzer desselben macht so ein besseres Geschïft, als wenn er diesen Verlust vernieidet. indem er eine minder gïnstige Form wählt. Der mehr oder weniger große Geschäftsgewinn eines Edelsteinschleifers hängt wesentlich ron der Kunst ab, jedem einzelnen rohen Steine unter mönlichster Erhaltung des Gewichts die vollkommenste Form zu geben.

In frïheren Zeiten herrschten hierüber gerade entgegengesetzte Grundsäitze, und im Orient, in Indien etc. ist es noch jetzt so. Man suchte beim Schleifen die Grülje und das Gewicht möglichst wenig zu vermindern und brachte oft ganz unregelmäßig gegeneinander gelegene Facetten an, die eine möglichst geringe Menge Material wegnahmen, die aber auch die Schönheit des Siteines kaum erhöhten. Daher findet man viele aus alten Zeiten stammende Edelsteine von sehr unvorteilhafter Form, die jetzt häufig nach den modernen Grundsätzen ron neuem geschliffen werden. Sie erhalten dadurch trotz des damit verbundenen Gewichtsverlustes neben dem schöneren Aussehen einen böheren Wert. Dassellue geschieht meistens mit den Steinen, die im angeschliffenen Zustande aus den Fundorten in fernen Weltgegenden zu uns kommen, und die in den unzweckmäßigen Formen, die sie von dort mitzubringen pflegen, in Europa als Schnucksteine iiberbaupt keine Verwendung finden könnten.

Wir werden nunmehr die einzelnen bei der Benutzung der Edelsteine als Schuncksteine in Betracht kommenden Punkte der Reihe nach eingehender betrachten. 


\section{a. Schlifformen}

Die Schlifformen, die nach den jetzigen Erfahrungen in dem oben auseinandergesetzten Sinne als am weeignetsten für die Edelsteine sich erwiesen haben, und die daher gexenwärtig wenigstens für die wertvolleren derselben so gut wie ausschlieblich ansewendet werd(u), künnen nach dem Torhandensein von Facetten im einen und einer runden Form in anderen Falle, und weiter nach der Zahl und Anordnung jener Facetten in fünf Typen eingeteilt werden, die aber durch Übergänge vielfach miteinander verbunderı sind.

Den Formen mit Facetten stehen die runden, die mugeligen Formen gegenüber, welche letztere zusammen den ersten Typus bilden. Sind Facetten rorhanden, so sind sie cntweder rings tum den Stein mehr oder weniger gleichmäßig verteilt, oder sie liegen alle auf (iner Seite desselben, während auf der anderen Seite nur eine einzige grobe Fläche anchracht ist. Wir haben dann die Form einer einfachen Pyramide mit der großen Fläche als Grundfläche. Ist letzteres der Fall, so hat man einen zweiten Typus, den der Rosette oder Rose. Ist der Stein ringsum facettiert, wie z. B. der in Fig. 33 dargestellte, wo a und $c$ die Ansichten von oben und unten und bon der Seite gibt. so kann man ihn als aus zwei Teilen bestehend betrachten. Der eine Teil liegt bei der gewöhnlichen Art und Weise der Fassung in einem Schmuckstiick nach außen oder vorn, dem Beschauer zugekehrt; dies ist der Oberteil (Oberkörper, Krone, Pavillon), Fig. $33^{\text {" und }}$

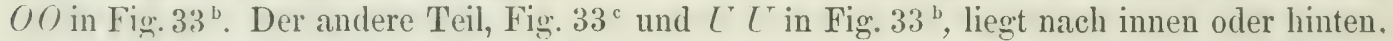
rom Beschauer abgekehrt und in der Fassung verborgen; man nennt ihn Unterteil (Unterkïrper, Külasse, in England und Amerika Pavillon). Die Facetten dieser beiden Teile stoßen in der Mitte in einem Rande $R R$ (Fig. $33^{\mathrm{b}}$ ) zusammen, der die $R$ undiste (Einfassung, Gürtel, auch Rand) heißt, und mit dem die Steine in inrer Fassung befestigt werden. Das Ganze bildet so gewissermaßen eine Doppelpyramide mit neist abgestumpften Spitzen. Die beiden Irïlften haben die Rundiste zur gemeinsamen Grundfläche, so daß in dieser die Facetten und Kanten der einen mit denen der anderen zusammenstoßen. In den drei letzten Typen, dem Brillant und dem Treppenschnitt, sowie dem Tafelstein mit dem Bisenuschliff, sind die drei genannten Teile vorhanden, Oberteil, Unterteil und Rundiste, die Facetten sind in ihnen aber in verschiedener Zahl und in verschiedener Gruppierung: angeorlnet, und darauf beruht die Unterscheidung dieser letzteren drei Formenreihen.

Wir werden nunmehr diese verschiedenen Schlifformen einzeln betrachten. Sie sind auf Tafel II-IT und Fig. 33-35 in Ansichten von verschiedenen Seiten dargestellt. Die zu cinem und demselben Steine gehörigen Bilder sind auf den Tafeln stets mit derselben Nummer, die Ansicht von der Seite ist dabei mit a, die vom Oberteil her mit $\ell$, die von unten mit $c$ bezeichnet. Dieselben Buchstaben sind auch festgehalten, wenn nur eine oder die andere jener drei Ansichten gezeichnet ist. Die Taf. II gibt die Formenreihe de's Brillant; dazu gehïrt noch Fig. 1 von Taf. III. Die übrigen Figuren dieser letzteren Tafel stellen die rerschiedenen Formen des Treppensehnittes dar, und auf Taf. IV sind die Rosetten, die Tafelsteine und die mugeligen Gestalten abgebildet. Aus Fig. 36 ist der zum Typus des 'Tafelsteins gehörige Biseauschliff zu ersehen.

Selbstverständlich ist es nur bei kostbaren und wertvollen Steinen lohnend, komplizierte Schlifformen mit zahlreichen ganz regelmäbig und genau nach den Gesetzen der Erfahrung gerichteten Facetten anzubringen. Die Kosten eines so rollkommenen Schliffes sind sehr beträchtlich und viel zu hoch, als daß sie auch bei billigen Steinen aufgewendet werden könnten. Im allgemeinen findet man allerdings bei ihnen dieselben Formen, aber man reduziert vielfach die Anzahl der Facetten und gibt sich viel weniger Mühe, eine ganz regehnäßjige und gesetzmäßßge Gruppierung derselben zustande zu bringen. Dadurch 
werden die Ausgaben für das Schleifen wesentlich vermindert, aber freilich auch die - ichïnheit des Steines erheblich beeinträchtigt.

1. Brillant. Als Erfinder dieser Form wird der Kardinal Mazarin genannt. Sie jit zum erstenmale, etwa 16.51), heresestellt worden bei frelegenlexit der Anstrengungen, die dieser Minister machte, um die. Diamantschleiferei in Paris wieler zu hehen. Zuerst erschien sie an Diamanten; Mazarin lieli zwiilf dere sü̈liten Steine dieser Art aus dem damaligen französischen Kronsehatz in der genamnten Form schleifen. Das sind die zwölf socenannten "Mazarins", die aber jetzt bis auf einen versehwunden sind, und anch ron diesem ist die Zugehörigkeit zu dieser vielgenannten Zẅ̈lfzahl nicht über jeden Zweifel erhahen. In der Folge hat sich die Überlexenheit des brillantschliffes über alle anderen Formen beim Diamant und anderen farblosen und durchsichtigen, sowie auch bei manchen farbigen Steincen so deutlich herauscestellt, dalj er jetzt für die durchsichtigen Edelsteine die IIauptiorm geworden ist. Tur aus wanz hesonderen Grïnden wird ein Diamant ander's wie als Brillant geschliffen, und die wertvollen durchsichtigen, gefö̈rbten Steine erhalten ebenfalls sehr häufig und am besten diese auch bei ihnen sehr wirkungsvolle Gestalt, wennmleich nicht so ausschließlich wie die Diananten. Wie sehr der Brillant die eigentliche Schlifform gerade des Diamants ist, geht daraus hervor, daf man unter einem Brillant schlechtweg immer einen in dieser Weise geschliffenen Diamant zu verstehen pflegt.
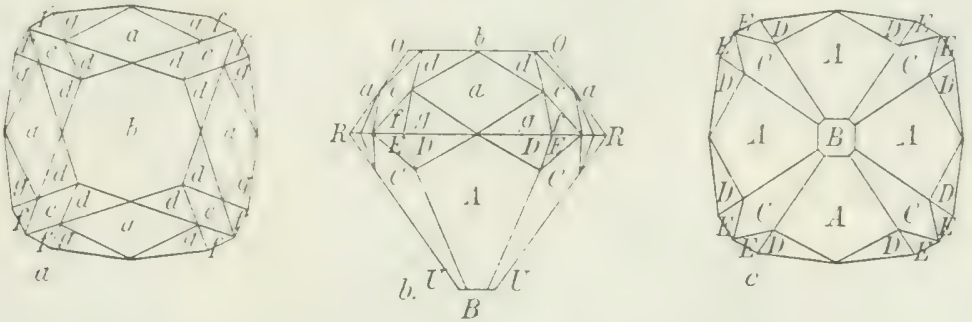

Fig. 33. Brillant (dreifacher, alte Form, $a$ Ansicht von oben, $b$ von der Seite, $c$ von unten).

Jeder Brillant (Fig. 33) hat am Oberteil $O$ (Fig. $3: 3^{3}$ und $33^{\mathrm{b}}$ ) eine breite Facette 7 , die Tafel, der am Unterteil $L^{*}\left(\mathrm{Fig} .33^{\mathrm{b}}\right.$ und $33^{\mathrm{c}}$ ) eine viel kleinere, die Kalette, $B$ gegen-

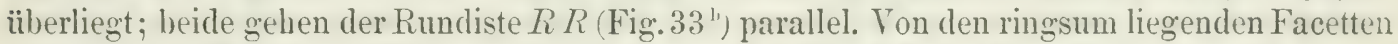
stoben einige mit einer Seite an die Tafel an, die Sternfacetten $d$; sie erscheinen nur am Oberteil. Indere liegen ebenso mit einer Seite an der Rundiste, und zwar oben sowohl als unten; das sind die Querfacetten, $f$ und $g$, sowie $D$ und $E$. Die Stern- und Querfacetten sind dreieckigs; zwischen ihnen liegen noch gröbere vier- und fünfseitige Facetten, $a$ und $c$ am Oberteil, A und $C$ am Unterteil, die aber in einzelnen Fällen zum Teil auch fehlen künnen. Die Rundiste $R$ bildet stets eine Ebene, ihre Form gibt der Umriß der Fig. $33^{\mathrm{a}}$ und $33^{\mathrm{c}}$.

Nach der Zahl der Facetten unterscheidet man eine Anzahl verschiedener spezieller Brillantformen. Der zweifache Brillant (zweifaches Gut) (Taf. II, Fig. 1 a, ". c) hat am Oberteil un die Tafel vier dreiseitige Sternfacetten, an der Rundiste in den Ecken vier gleichschenklig dreieckige und rechts und links von diesen je zwei, also im ganzen acht ungleichschenklig dreieckige Querfacetten. Es sind also am Oberteil außer der Tafeỉ im ganzen sechzehn Facetten rorhanden, die in zwei Reihen übereinander liegen, daher der Name ,zweifacher Brillant... Am Unterteil sind auch (neben der Kalette) sechzehn Facetten: dreiseitige Querfacetten in derselben Zahl und Anordnung wie oben, zwischen ihnen vier fünfseitige Facetten, die an die kleine Kalette mit kurzen Kanten anstoßen.

Eine besondere Art dieser Form ist der englische zweifache Brillant (zweifaches Gut mit Stern) (Taf. II, Fig. $2^{3}$, b, c). Hier liegen acht dreieckige Sternfacetten, 
einen achtstrahligen Stern bildend, um die 'Tafel herum, und zwischen diesen acht gleichfalls dreieckige Querfacetten; der Unterteil ist wie der des gewöhnlichen zweifachen Brillants (Fig. 1 c), doch können die an den Ecken der Rundiste liegrenden gleichsehenklig dreieckigen Querfacetten auch fehlen, so daß die Form Fig. $2^{\circ}$ entsteht.

Diese mit wenigen Facetten versehene Form des zweifachen Brillants trifft man meist nur bei ganz kleinen Diamanten. Sie ist nicht imstande, das Feuer und namentlich das Farbenspiel eines solchen Steines auf das höchste erreichbare Maß zu steigern. Hierzu ist eine größjere Anzahl von Facetten nötig; wie sie der am Ende des 18. Jahrhunderts von Peruzzi erfundene, dreifache Brillant (das dreifache Gut) hat. Drei Reihen von Facetten liegren hier am Oberteil übereinander, im ganzen 32 ohne die Tafel, und zwar acht dreieckige Sternfacetten, sechzehn ebensolche Querfacetten und dazwischen noch weitere acht Facetten von vierseitiger Form. Die Anordnung ergibt sich aus dem obigen, sowie aus Taf. II, Fig. $3^{a}$, b und Fig. $4^{3}$, b. Am Unterteil sind sechzehn Querfacetten wie am Oberteil, darunter acht fünfseitige größere Facetten, die an die kleine Kalette anstoßen. Im ganzen haben wir hier außer der Tafel und der Kalette oben 32, unten 24, also im ganzen 56 Facetten; manchmal erhöht sich diese Zahl, indem die Querfacetten noch
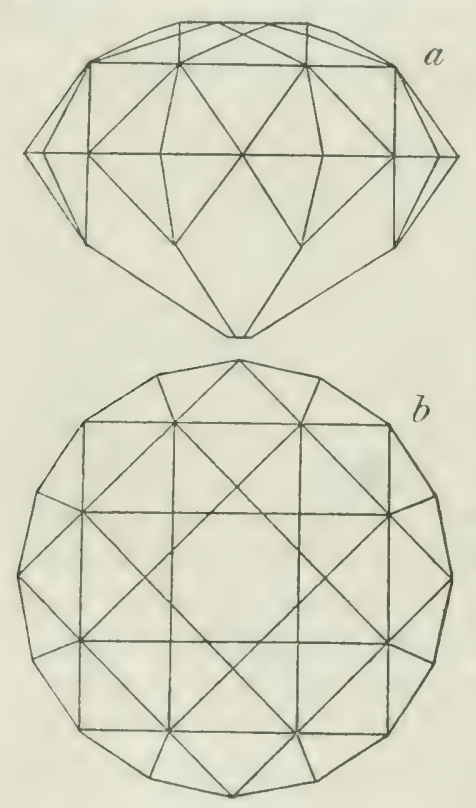

Fig. 31. Amerikanischer Brillantschliff (a von der Seite, b von oben). einmal halbiert werden, oder auf andere Weise. Dies geschieht namentlich bei sehr großen Diamanten, wie dies z. B. der Regent zeigt. (Taf. XI, Fig. $8^{\mathrm{a}}$ und $8^{\mathrm{b}}$ ). Taf. II, Fig. 3 gibt eine ältere Form, bei der die Rundiste einen nahezu quadratischen Umriß hat; es ist dieselbe, wie die in Fig. 33 abgebildete. Sie ist zugunsten der in Taf. II, Fig. 4 abgebildeten verlassen worden. Bei dieser zeigen die Facetten dieselbe Zahl und Anordnung, sie sind aber hier ringsum mehr ins Gleichgewicht getreten, so daß der Umriß der Rundiste sich sehr der Kreisgestalt nähert. Die Form der Rundiste ist überhaupt nicht immer dieselbe, was meist mit der ursprünglichen Form des rohen Steines zusammenhängt. In dem Taf. II, Fig. $5^{\mathrm{b}}$, ${ }^{\mathrm{c}}$ von oben und unten abgebildeten Brillanten ist sie mehr oval (Mar$q u$ is e), in Taf. II, Fig. $6^{\text {b }}{ }^{c}$ birnförmig, endlich in Taf. II, Fig. $7^{\mathrm{b}}$, ${ }^{\mathrm{C}}$ dreiseitig. Im letzteren Falle ist dann auch die Zahl der Facetten eine andere als sonst; sie sind nicht mehr nach der Vierzahl, sondern nach der Dreizahl aneinander gereiht.

Diese Formen können als die Normalformen des Brillants angesehen werden, und genau so werden sie auch sehr häufig, ja wohl in den allermeisten Fällen hergestellt. Doch hindert dies nicht, daf man zuweilen gewisse, aber stets nur kleine Modifikationen anbringt, die sich zum Teil auf die Anordnung der Facetten, zum Teil aber auch auf deren Zahl bezichen, indem manchmal noch einzelne Gruppen kleiner Facetten in regelmäßig' symmetrischer Lage zugefü wert werlen. Eine solche etwas stärkere Modifikation ist auch die Form, die neuerdings in Amerika patentiert worden ist. (Fig. 3.4 "und "von der Seite und von oben). Es ist im wesentlichen die in Taf. II, Fig. 4 dargestellte Form, aber die Tafel ist sehr klein und die grofen vicreckigen Flächen des Oberteils sind in der Mitte horizontal (mebrochen; hieraus ergeben sich dann die anderen kleinen Abänderungen von selbst. Der. Unterteil hat dieselbe Form wie in Fig. :33. Nan hat hier oben 45, unten 21, demmach zusammen 72 Facetten auBer der Tafel und der Kalette, somit 16 mehr als bei dem neuen dreifachen Brillant (Taf. I1, Fig. 4). Die meisten der auf Taf. X u. XI in natïrlicher 

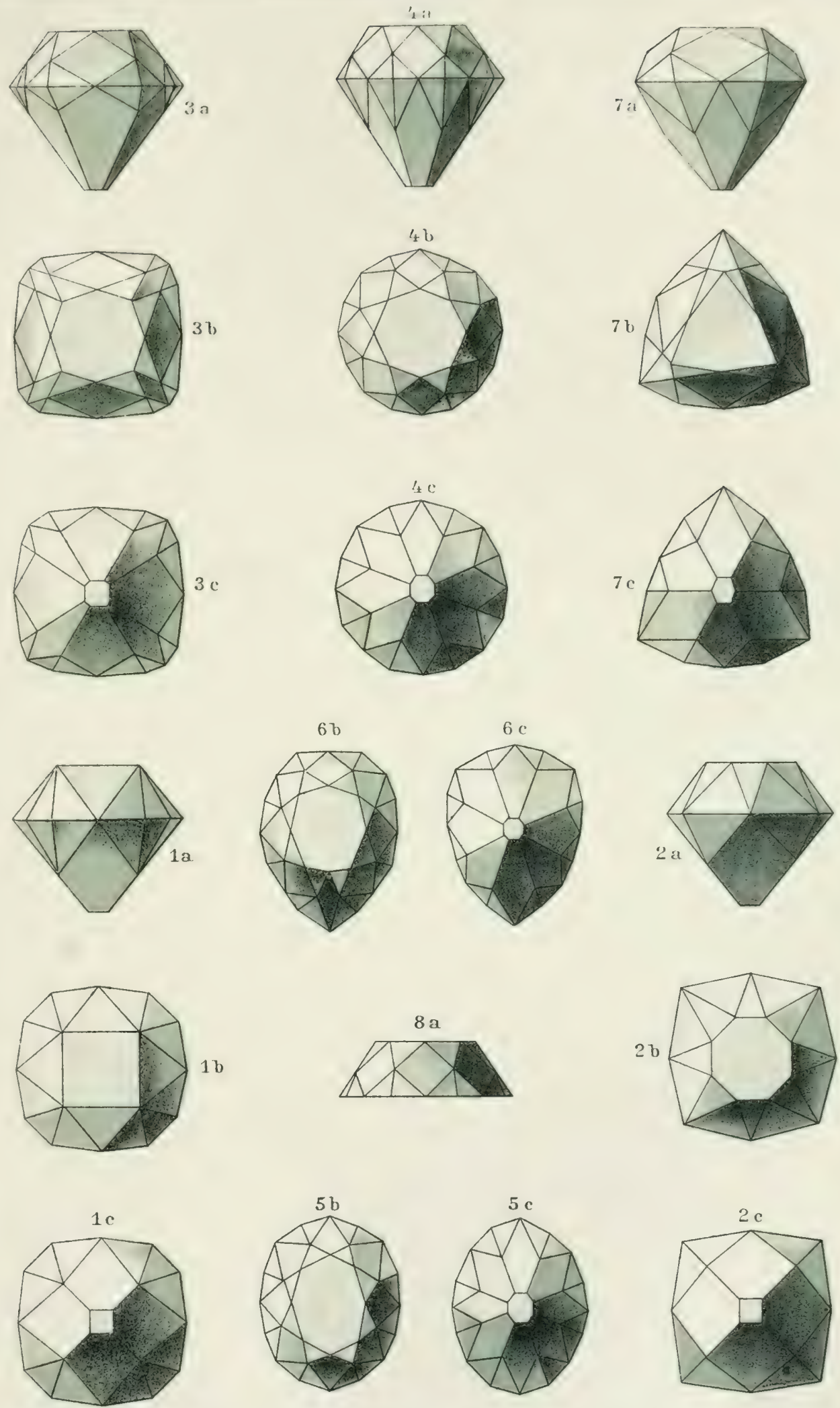

Brillantformen. 1a, b, c. Brillant, zweifaches Gut. 2a, b, c, englischer zweifacher Brillant (zweif. Br. mitStern). 3a, b, c. Brillan t, dreifaches Gut, ältere Form. 4 a, b, c. ditto, neuere Form, rund. $5 \mathrm{~b}$, c. ditto, oval. $6 \mathrm{~b}$, c. ditto, birnförmig. $7 \mathrm{a}, \mathrm{b}$, c. ditto, dreiseitig. $8 \mathrm{a} . \mathrm{Halb}$ brillant. 

Gröbe und Form abgebildeten groben Diamanten sind als Brillanten weschliffen. Ihre Vergleichung mit den Normalformen auf 'Taf. II wird die Übereinstimmung der eneschliffenen Steine mit diesen, aber auch mehrfach kleine Abweichungen erkennen lassen. Ï̈brigens können steine von allen möglichen Formen mit brillantartig angeordneten Facetten versehen werden, so \%. li. Steine mit den sämtlichen in Fig. 36 abgelildeten Umrissen. Nan spricht dann z. B. von Navettebrillantschliff etc.

Es ist durehaus nötig, dali die Facetten eines gnten Brillants sehr regehmäfig und symmetrisch „ruppient sind, und dali die nach ihrer Anordnung grleichartigen und zusammengehörigen auch eldech grols sind. Nur wenn dies der Fall ist, hat der Stein die denkhar vortcilhafteste Wirkumg. Ist jedoch dex Brillant ungenau geschliffen, sind die Facettrn

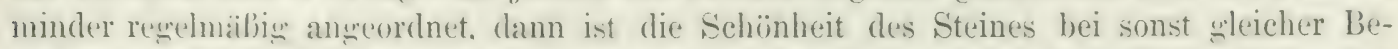
schaffenheit weit weringer. Ehenso sind aber auch die relativen Gröbenverhältnisse der einzehnen T'eile von höchster Bedeutung, weil erfahrungsenemäl nur bei Innehaltung derselhen der Brillant seine höehste Schönheit entfaltet. Es gribt in dieser Irinsicht grewisse allgemeine liegeln, die man stets beobachtet, wenn nicht ganz besondere Grinde kleine Abweichungen erfordurlich machen. Danach ist die Ilöhe des Oberteils über der Pundiste 1:; die des Lnterteils : :; der (iesamthöhe des steines von der Tafel his zur Kalette: der Thurchmesser der Tafel beträigt ig, der der Kalette !: des Durchmessers der Rundiste, also der Kalette $1 / 5$ von dem der Tafel. Kaum ein schöner Brillant zeigt wesentliche Abweichungen von diesen Dimensionen: solche werden nur dann zugelassen, wenn die Gestalt de's rohen steines bei genauter Innchaltumg der richtigen Form allzu grobe Verluste heim sehleifur bedingen würde, oder bei farbigen steinen. um die Dicke der mehr oder weniger tiefen Färbum nach Möglichkeit anzupassen. So weicht aus dem ersteren (rrunde der .Kohinur", der berülmmte grole Brillant der englischen Krone (Taf. X, Fị. j), stark ron der Normalform ab: er ist viel zu niedrig, während der ,.Regent", der größte Brillant des franzïsischen Kronschatzes und einer der vollkommensten und schönsten existierenden Brillanten (Taf. XI, Figg. S), die obigen Verhältnisse in größter Genauigkeit innehält. Der letztere hat daher auch ein ganz anderes Feuer und Farbenspiel als der erstere, bei gleicher Qualitäit der Steine an sich.

E. bleibt noch zu erwähnen übrig, daf die Rundiste der Brillanten zuweilen scharfkantig ist Taf. X, Fig. 5), wie das die englischen Steinschleifer zu machen pfleren. daf sie aher auch vielfach etwas abgeschliffen wird (Taf. XI, Fig. S u. 9), wie in Holland. Die urstere Anordnung bexünstigt die Wirkung des Steines, die Fassung ist aber weniger fest, da die scharfen Kanten leicht ausbrechen.

Es sei hier noch der Halbbrillanten (Brilloneten) gedacht, die manchmal, jedoch als im ganzen seltene Erscheinungen rorkommen. Es sind Brillanten ohne Unterteil (Taf.

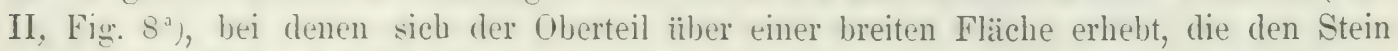
nach unten für sich allein begrenzt, wie bei der Rosette. Die Form wird zuweilen bei sehr flachen rohen Steinen angewendet, ihre ITirkung steht aber weit unter der des vollständigen Brillants.

An die Brillantform schlieft sich der ron dem Pariser Juwelier Caire am Anfang des 19. Jahrhunderts erfundene Sternschnitt an, der 'Taf. III, Fig. 1 a, ", c abgebildet ist. Caire suchte in dieser Form die Vorteile des Brillants mit denen der später zu beschreibenden Rosette zu vereinigen. Die Facetten sind in der aus den Figuren zu ersehenden Weise nach der sechszahl angeordnet. Die Form gewährt namentlich bei Diamanten, für die sie hauptsäichlich ersonnen wurde, einen sehr schönen strablenden Anblick und steht dem eigentlichen Irillant vielfach nicht nach, sie erfordert aber die äuferste Regelmäßigkeit in der Anordnung der Facetten. Fïr manche rohe Steine bedingt sie auch einen erheblich geringeren Materialverlust beim Schleifen, im ganzen ist sie aber doch wenig im Gebrauch. 
Endlich ist noch eine letzte hier sich anschließende Form zu erwähnen, die um den Anfang des 20. Jahrhunderts in Amerika aufgekommen ist und die daher als Schliff des 20. Jahrhunderts, oder nach dem in dieselbe Zeit fallenden Regierungsjubiläum der Königin Vilitoria von England auch als $J u b i l a ̈ u m s s c h l i f f$ bezeichnet wird. Sie ist in
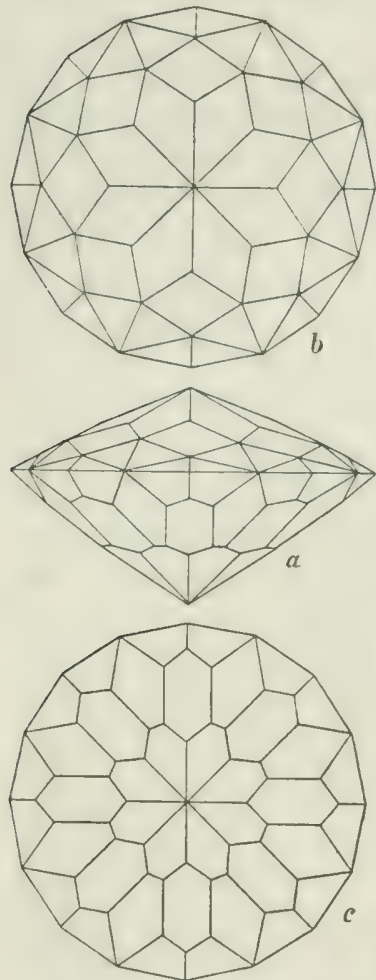

Vig. 95. Schliff des 20 Jahrlıunderts. (Jubilüumsschliff. Fig. $35^{\mathrm{b}}{ }^{\mathrm{b}}$ und ${ }^{\mathrm{c}}$ von der Seite, von oben und von unten dargestellt. Begrenzt ist sie an der Ober- und an der Unterseite von je 40, also im ganzen von 80 Facetten, von denen die vierseitigen Facetten des Oberteils, die mit einer Ecke an die Rundiste anstoßen, zuweilen noch einmal durch eine stumpfe Kante nach der Höhenlinie halbiert werden, wie es die Figur zeigt. Tafel und Kalette fehlen. Dieser Schliff wird für farblose Edelsteine, z. B. Topas, vor allem aber für Diamant, angewendet und ist so namentlich in Amerika beliebt. Er bringt besonders an diesem Stein eine sehr schöne Wirkung hervor, führt aber beträchtlichen Materialverlust herbei und verlangt recht große Sorgfalt in der Herstellung, die daher zeitraubend und folglich teuer ist. Übrigens werden für gewisse Steine und zu besonderen Zwecken vielfach neue Formen ähnlicher Art erfunden, die wir aber hier nicht weiter betrachten können.

2. Treppenschnitt. Die verschiedenen Formen des eigentlichen und modifizierten Treppenschnittes sind in Taf. III, Fig, 2 bis 8 dargestellt. Den eigentlichen Treppenschnitt geben die Figuren 2 bis 4 . Auf einer Rundiste von vierseitigem (Fig. $2^{\mathrm{b}}$ ), sechsseitigem (Fig. $3^{\mathrm{b}}$ ), achtseitigem (Fig. $4^{\mathrm{b}},{ }^{\mathrm{c}}$ ), oder auch wohl zwölfseitigem, zuweilen ringsum gleichmälig ausgedehntem, zuweilen auch in einer Richtung etwas verlängertem, oblongem Umriß erhebt sich ein Oberteil mit einer breiten Tafel von der Form der Rundiste (Fig. $2^{b}, 3^{b} 4^{b}$ ) und ein Unterteil meist mit einer kleinen ebenso grestalteten Kalette (Fig. $2^{3}, 4^{c}$ ), die gelegentlich auch fehlt, so daf der Unterteil ganz spitz ausläuft (Fig. $\left.7^{\mathrm{a}},{ }^{\mathrm{c}}\right)$. An beiden Teilen liegt eine Anzahl von Facetten in der Weise übereinander, daß sie sich in lauter der Rundiste parallelen Kanten schneiden (z. B. Fig. $\left.4^{\text {b }}{ }^{c}\right)$. Die Facetten neigen sich von der Rundiste ab und immer mehr und mehr gegen die Tafel und die Kalette zu, sie liegen also von jener aus immer flacher (Fig. $2^{\text {a }},{ }^{b}$ usw.). Am Oberteil sind zwei, auch wohl drei solcher Facettenreihen, die in ihrer Neigung gegen die 'Tafel nur wenig' voneinander abweichen. Alle sind entweder gleich breit (Fig. 2 ${ }^{b}, 3^{b}$ ), oder die unteren breiter, die oberen an der Tafel liegenden schmäler (Fig. $4^{\circ}$ ). Am Unterteil schwankt die Zahl meist zwischen vier (Fig ( $^{a}{ }^{c}$ ) und fünf in jeder Reihe (Fig. 2a $4^{\mathrm{c}}$ usw.); sie sind hier immer alle gleich breit.

Der Treppenschnitt ist die Form der farbigen Steine, soweit sie nicht als Brillanten geschliffen werden, also namentlich der wenig tief gefärbten. Er hebt Farbe und Glanz bedeutend, mub aber besonders am Lnterteil den speziellen Verhältnissen des Steines angepalit werdem. Zu wenig Facetten lassen das Feuer und die Farbe nicht recht zur Geltung kommen, daher geht man unter vier bis fiunf Reihen kaum herunter, bei schwachęefärbten Steinen wird deren Zahl auch wohl noch vermehrt. Meist hat der Oberteil ein, der Unterteil zwei Drittel der Gesamthöhe. Bei schwachgefäirbten Steinen wird letzterer höher gehalten, bis zu dreiviertel der Gesamthöhe, bei lebhaft gefärbten entsprechend niedriger.

Während der Unterteil als besonders geeeignet für die Entfaltung der Schönheit farbiger 
Steine nur im einzelnen cewissem unbedeutenden Modifikationen unterliegt. wird der Oberteil beim Treppenschnitt vielfach erheblich abgeändert; e's entstehen dadurch Vebenformen, von denen ainige auf Taf. III. Fig. 5 bis 8 abgebildet sind. Bei ihnen allen sind die treppenförmig angeorlneten Facetten des Oberteils durch solche erset»t, die ungreführ ähnlich wie beim Brillant gruppiert sind. Es sind also bis zu einem gewissen Grade Kombinationen von Treppen- und Brillantschnitt, die im allgemeinen für schwachgefürbte Steine besonders greegrnet sind. Eine selır häufig angewandte Form ist der gemischte Schnitt (Fig. 5’, b), wo am Oberteil je tine Reihe dreiechiger Stern- und Querfacetten vorhanden ist, zwischen denen eine Reihe vierseitiger Facetten liegt. Lichtgefürbte Steine erhalten durch diese Form hïheres Feuer und stärkeren Glanz als durch den eigentlichen Treppenschnitt. doch ist diese Form anch für lebhaft gefärbte und schön durchsichtige Steine von genï render Dicke recht vorteilhaft. Der Cmrib der Rundiste ist nicht immer wie in der Figur 5; er kann auch quarlratisch, sechsseitig usw. sein. Dieser Form sehr nahe steht der Schliff mit doppelten Facetten (Fig. $6^{\circ}$, b). Manche Facetten, die an der vorhergehenden Form einfach auftreten. sind hier gewissermalien halbiert, so dab zwei lieiben derselben entstehen, in der Weise, wie es die Figur ohne weiteres zeigt. Diese srofie Zahl der Facetten wird häufig angewendet, um Fehler des Steines zu entfernen oder müglichst unschädlich zu machen, im übrigen wirkt diese Form ähnlich wie der gemischte schnitt. Beim Schnitt mit verlängerten Brillantfacetten ist die Anordnung am (H)erteil wieder sehr ähnlich wie beim vorhergehenden, die Facettenreihen sind aber abweehselnd stark verlängert und rerkürzt $\left(F i g .7^{a},{ }^{b}, c\right)$. Der Lmrib der Rundiste ist entwerler dem quadratischen genähert. wie in der Figur, oder auch in einer Richtung ins oblonge verlängert. Besonders bei solchen länglichen Steinen lsommt dieser sichliff zur Terwendung. der den Glanz stark hebt. Auch wenn der Unterteil keine grolje Dicke hat, wirken die rerlängerten Brillantfacetten günstig. Daher ist diese Form für rohe iteine ron geringer Dicke sehr geeignet. Eine weitere ähnliche Form. das Maltheserkreuz, zeint Fig. S . ' , ', aus der die Anordnung der Facetten im einzelnen zu ersehen ist. Es gibt noch mehrere solche Formen. die sich aber alle den beschriebenen nahe anschließen, so daß ein weiteres Eingehen darauf überflüssig ist.

3. Tafelsteine. Lnter diesem Tamen ist eine Anzahl ron Formen zusammengefaft, die sich alle mehr oder weniger ungezwungen auf eine vierseitige Doppelpyranide, ein sogenanntes regulïres Oktä̈der beziehen und ron diesem ableiten lassen. Diese letztere Form selbst ist an manchen Diamanten alter Schmuckstiicke zu beobachten: es ist die natiuliche Kristallform vieler Diamanten, die man in jenen Zeiten noch nicht durch Schleif’n zu ändern, höchstens auf den rorhandenen natürlichen Flächen etwas zu polieren verstand. Solche durchaus der Vergangenheit angehürige Diamanten werden als Spitzsteine bezeichnet. Der Tafelschnitt und die daran sich anschließenden Formen entstehen aus dem Oktä̈der durch mehr oder weniger starkes Abschleifen zweier gegenüberliegender Ecken (Taf. IV. Fig. 11 bis 16), wobei am Oberteil zuweilen noch einige weitere Facetten angebracht werden (Fig. 11, 13, 14, 16).

Der eigentliche Tafelste in entsteht, wenn zwei gegenüberliegende Ecken eines Oktaïlers gleichweit abgeschliffen werden. Der Oberteil ist dann ebenso grof wie der Unterteil, und die Tafel gleich der Kalette. Der Lmrif der Rundiste ist bald quadratisch, bald oblong. Die Ansicht eines quadratischen Tafelsteines ron oben zeigt Fig. 15 b die eines oblongen der geschliffene Epidot auf Taf. XIV, Fig. 2. Die Mirkung, die der Tafelstein hervorbringt, ist in allgemeinen gering, doch werden manche farbige Steine, wie unter anderen der Smaragd, vorteilhaft in dieser Weise geschliffen. Einige weitere Facetten am Oberteil vermögen den Glanz und das Feuer zu erhöhen. So werden zuweilen die vier Kanten an der Tafel ciurch schmale Facetten ersetzt (Taf. IV, Fig. $11^{a}{ }^{\circ}{ }^{\mathrm{t}}$; oder die vier Kanten, 
in denen die Pyramidenflächen zusammenstolion, werden mehr oder weniger abgestumpft, so daß die Rundiste und die Tafel achtseitig werden (Fig. 16 b); oder der Oberteil wird brillantiert ( $F i g .14^{\mathrm{a}}$, "), wobei aber die Anordnung nieht genau wie bei einem Brillant zu sein braucht. I)ie Abstumpfung der beiden Oktä̈derecken ist mehr oder weniger stark, oft so stark, dal nur cine diumne Tafel tibrig bleibt. Eine solche heißt D ünnstein; sie kann in derselben Weise mit weiteren lacetten versehen sein, wie der Tafelstein (Fig. $12^{a}$ u. $13 \%$. Dickstein ist ein spitzstein, bei dem zwei gegenïberliegende Ecken etwas abgestumpft sind. (Fig. 15\%" "). Dies ist der sogenannte indisehe Schnitt; in soleher Form kommen zahlreiche Edelsteine aus dem Orient, besonders Diamanten aus Indien, die dann in Europa vielfach durch Umschleifen in bessere Formen gebracht werden, denn die Wirkung der Dicksteine ist meist sehr gering. Es ist gewissermaßen die Grundform des Brillants. Alle Modifikationen, die wir am Tafelstein kennen gelernt haben, kommen auch beim Dickstein vor. Steine von der Form $14^{a}$, w und $15^{\text {a }}$ werden zuweilen auch als $\mathrm{Kappgut}$ bezeichnet.

An den Tafelstein schliebt sich der Bis eauschliff an. Nan versteht darunter Formen mit einer breiten Tafel oben, an die sich bis zur Rundiste stets nur eine Reihe schmaler Facetten anschlielit, wie es Tafel IV, Fig. $12^{\circ}$ oder $15^{\text {a }}$ und $15^{\text {b }}$ zeigt. Der Unterteil kann

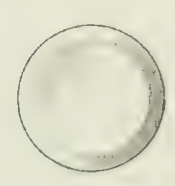

Rund

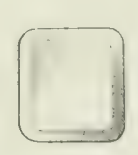

Slunip

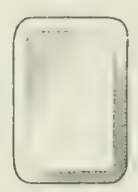

Iang
stumpe

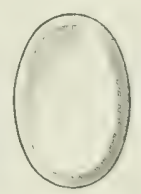

0val

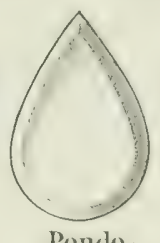

Pende
logue

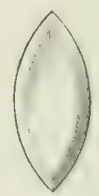

Savolle

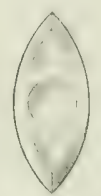

Hall Xirvelle

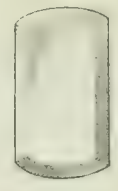

Oblong:

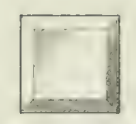

Cauré

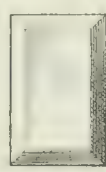

Itang,

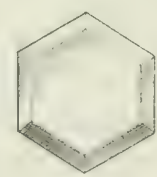

Secliseck

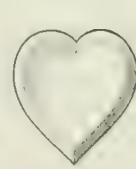

Ire'z

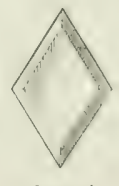

'alré

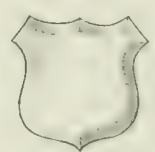

Wappen

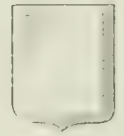

wiupen Fuchisch

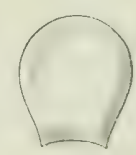

II: :

Fig. 36. Biseauschliff von verschiedener Form, von oben gesehen.

verschieden sein. Er hat entweder dieselbe Ausbildung wie der Unterteil (Fig. 12 a oder $15 \mathrm{~F}$, dann ist es der eigentliche Tafel-, resp). Dünn- oder Dickstein; oder der Unterteil ist mit brillantartig oder treppenartig angeordneten Facetten versehen, letzteres mehrfach so, daf sich eine Reihe schmaler Facetten wie oben an die Rundiste anlegt, auf welche dann eine zweite lieihe von breiteren folgt, die in einer Spitze zusammenlaufen. Auch andere Formen der Unterseite kommen gelegentlich noch vor, namentlich ist sie nicht selten mugelig. Der Umriß in der Rundiste kann sehr verschieden sein, wie Fig. 36 von oben gesehen in den wiehtigsten Beispielen mit beigefügter Bezeichnung darstellt. Es sind in der Ilauptsache Iingsteine aus nicht zu edlen Naterial, Amethyst, Citrin ete. Die randlichen Facetten des Oberteils sind, wie erwähnt, stets schmal, manchmal sehr sehmal. Zuweilen fallen sie ganz. wegr; der Oberteil fehlt dann vollständhe der Stein besteht nur aus dem Unterteil und ist nach oben ausschließlich begrenzt von der grolien Tafel, die bei der Fassung genau mit dem Metall alsehneidet, ohne im geringsten dariber hervorzuragen Dies ist der Spiegelschliff, gewissermaßen eine umgekehrte Rosette.

4. Rosette (Rose, Raute). Der Stein ist nach unten von einer einzigen großen und breiten Fläche, der Girundfläiche. begrenzt, über der er sich pyramidenfürmign 


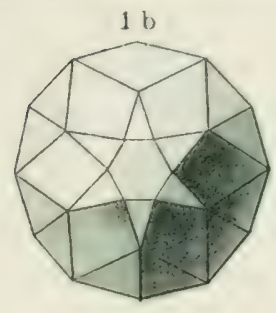

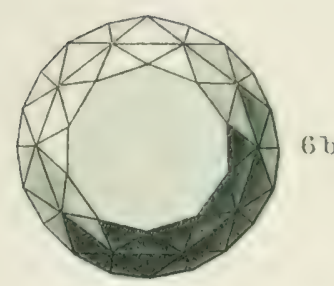

$5 b$
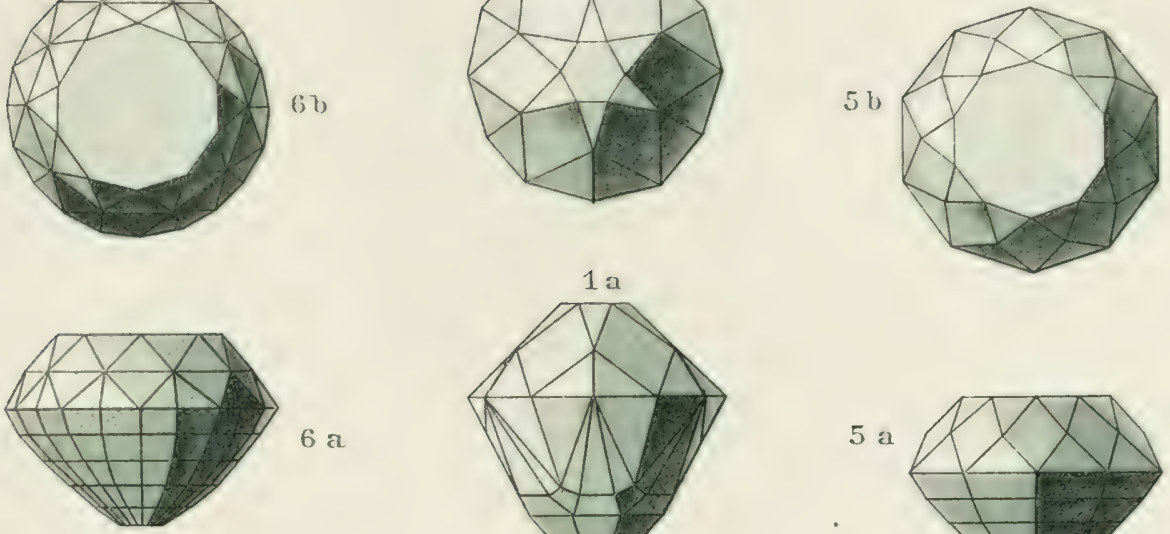

6 a

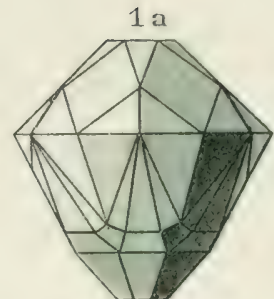

5 a
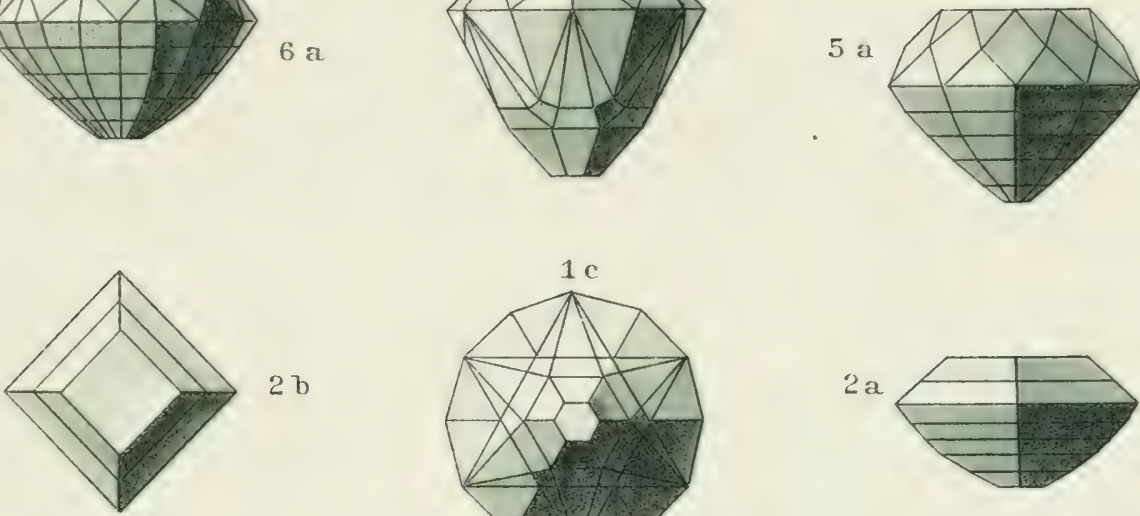

$2 \mathrm{~b}$

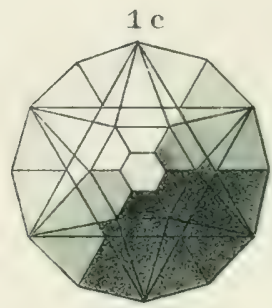

$2 \mathrm{a}$

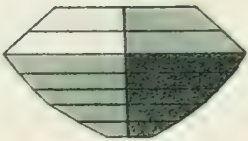

87

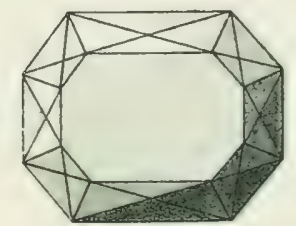

8 a
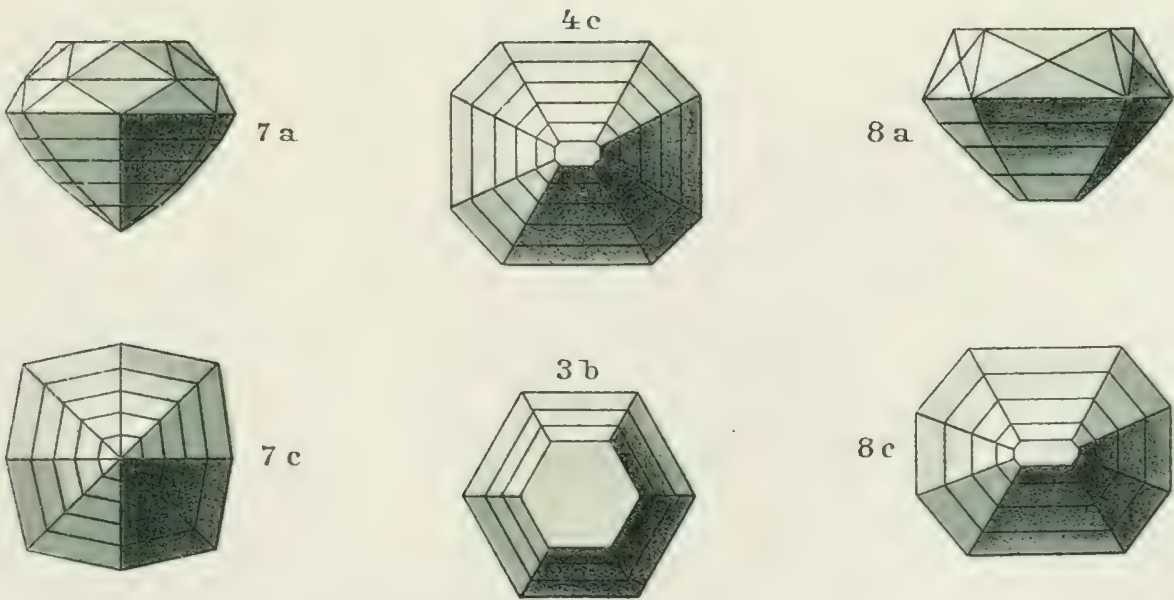

$7 \mathrm{c}$
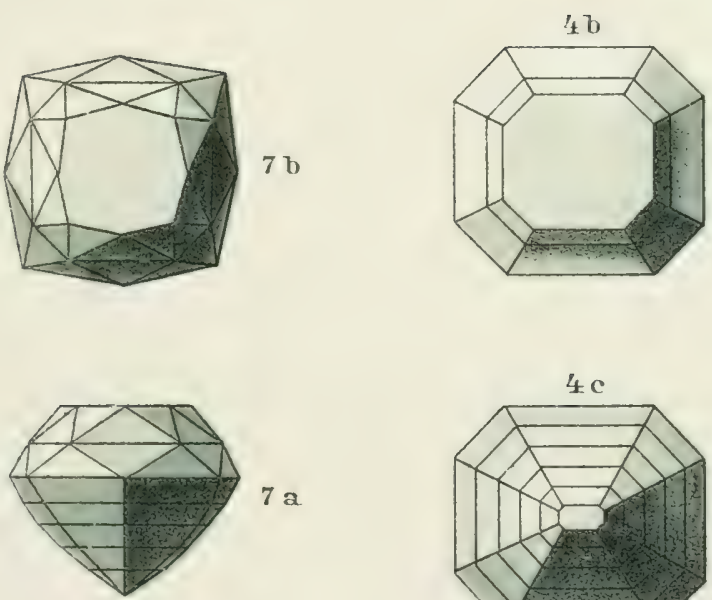

72

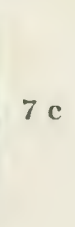

1a, b, c. Sternschnitt von Caire. 2-4. Treppenschnitt. 2a, b. vierseitig. 3 b. sechsseitig. 4 b, c. achtseitig: $5 \mathrm{a}, \mathrm{b}$. Gemischter Schnitt. $6 \mathrm{a}, \mathrm{b}$. Schliff mit doppelten Facetten. $7 \mathrm{a}, \mathrm{b}, \mathrm{c}$. Schliff mit verlängerten Brillantfacetten. $8 \mathrm{a}, \mathrm{b}$, c. Maltheserkreuz. 

erhebt, so dalb die obersten Facetten in einer mehr oder weniger scharfen Ecke zusammenlaufen. Die Form besteht eigentlich nur aus cinem Oherteil, ein Lnterteil fohlt vollständig. In Fig. 37 ist cine Rose der enewöhnlichen Art von when greschen rlargestellt. Die nach der Sechszahl angererdneten lacetten liegen in zwei Reihen ïbereinander, von denen die obere, bestehend aus den Facetten a, die Krone oder der Stern, die untere, gebildet von den Facetten $b$ und $c$, die Spitze (dentelle) genannt wird. Die stets dreiseitigen Facetten $a$ sind die Sternfacetten, die Facetten $b$ und $c$ der unteren Reihe heilen die Querfacetten; sie sind wie in der Figur meist ebenfalls dreiseitig, in einzelnen Fällen (Taf. IV, Fig. 5 ${ }^{\mathrm{a}}$ ) auch vierseitig. Der Stein wurde nach dieser Anordnung der Facetten mit einer aufbrechenden Rosenknospe verglichen und danach benannt. Die Form ist etwa seit $1520 \mathrm{im}$

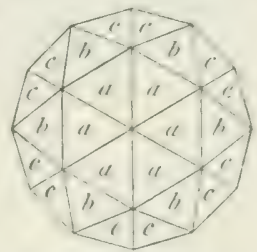

Fig. 37. Rosette (Ansicht von oben). (iebratuch, und zwar hauptsächlich fïr flache, niedrige Diamanten, aus denen sich nur mit sroliem Materialverlust verhältnismäßig kleme Brillanten gewinnen lassen. Es ist die z.weite Ilauptform des Diamants. und man versteht unter Rose oder Rosette kurzweg stets einen in dieser ITeise geschliffenen Diamant. Sir verleiht dem Steine groben filanz, aber nielıt so wollkommen wie der Brillant das schöne Farbenspiel. Farbige Steine erhalten wohl auch zuweilen, aber seltener, diese Form, z. B. der böhmische Granat.

Die Zahl und Anordnung" der Facetten wird bei den Rosen mehrfach modifiziert, und es entstehen dadurch gewisse Lnterformen, die zum Teil mit besonderen Tamen bezeichnet worden sind. Sie sind auf Taf. IT, Fig. 1 bis 7 abgebildet. Die oben beispielsweise erwähnte Rose (Fig. 37) ist die eigentliche oder hollïndische oder Amsterdamer (geklönte) Rose (Taf. IV, Fig. 1" und $3^{a}$ ) mit sechs Stern- und achtzehn Querfacetten. Das Charakteristische bei ibr, den anderen Rosettenformen gegenuiluer. ist die Höhe der Pyramide ïber der Grundfläche: diese soll der Regel nach die Iälfte des Durchmessers der Grundfläiche betragen. ferner soll die Entfernung del Grundflïche der Krone ron der des anzen Steines :5 der Gesamthöhe und der Durchmesser der Grundfläche der Krone $3_{t}$ des Durchmessers des steines ausmachen. Dies ist die gewöhnliche Form der Rose; ihre Grundfläche ist meist rundlich, selten oval oder birnförmig (Taf. IV. Fig. $2^{b}$, aber auch alle in Fig. 36 angegebenen Formen können gelegentlich rorkommen.

Viel weniger im Gebrauch sind andere Arten von Rosen. Unter diesen unterscheidet sich die brabanter (Antwerpener) Rose von der hollåndischen nur dadurch, daf die Sternfacetten viel flacher liegen und eine viel niedrigere Pyramide bilden, während die Querfacetten etwas steiler stehen (Taf. IV. Fig. $4^{3}$ ); die Zahl und Anordnung der Facetten ist aber sonst genau dieselbe wie dort. Einige besondere Abarten der brabanter Rose mit dem niedrigen Stern sind dann ferner in Taf. IV. Fig. $5^{\mathrm{a}}$ und $6^{\mathrm{a}}$ abgebildet, von denen die erstere sechs Stern- und sechs vierseitige Querfacetten hat, während an der zweiten neben den sechs Sternfacetten zwölf Querfacetten vorhanden sind. Eine Form mit einer größeren Anzahl von Facetten ist die Rose recoupée (Taf.IV, Fig. $7^{\mathrm{a}}$, ${ }^{\mathrm{b}}$ ). Sie hat 12 Stern- und 24 dreiseitige Querfacetten, welche letztere ihre Spitzen abwechselnd nach unten und mach oben kehren. Eine andere Form der Rose recoupée ist in Fig. 35 dargestellt.
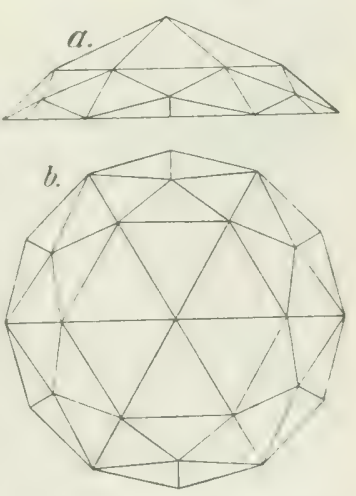

Fig. 35. Rose recompíe (andere Form), a von der Seite, $b$ von oben.

An diese eigentlichen Rosen schliefen sich einige Formen an, die Taf. IT, Fig. $S$ bis 10 abgebildet sind. Fig. $8^{a}$, b stellt die sehr seltene, an einem ror mehr als 100 Jahren geschliffenen Kaneelstein von Schrauf wieder aufgefundene und beschriebene Kreuz- 
rosette (Strahlenrose) dar, an der die Facetten nach der Achtzahl angeordnet sind. Fig. $9^{\text {a }}$ zeigt einen Stein, an welchem gewissermaßen zwei Rosen mit ihren Grundflächen aneinander gewachsen sind, eine Doppelrosette oder Brillantrosette, für die man auch zuweilen den Namen Briolette oder auch Pendeloque angewendet findet, der aber häufiger die sogleich zu erwähnenden birnfürmigen Steine bezeichnet. Die Doppelrosen sind namentlich in früheren Zeiten für Ohren- und Uhrgehänge benutzt worden. Es ist auch die Form, die L. von Berquen, der Grïnder der modernen Diamantschleiferei, den ersten von ihm gesehliffenen Diamanten gab, so unter anderen dem „Florentiner" und dem "Sancy", die beide auf Taf. XI (Fig. 10 u. 11) abgebildet sind. Als eine Modifikation der Doppelrose kann man auch den oben (pag. 94) erwähnten "Schliff des 20. Jahrhunderts" mit 80 Facetten, je 40 oben und unten, auffassen. Hieran schließen sich die Brillolettes, Brioletts oder Pendelo ques, die wie in Taf. IV, Fig. 10, oder auch ringsum bis zur Spitze von lauter kleinen dreieckigen Facetten begrenzt, in einer Richtung mehr oder weniger verlängert und an einem Ende zugespitzt, am anderen abgerundet sind, so daß sie eine birnförmige oder eine mehr flache Gestalt erhalten. In dieser Richtung sind sie vielfach behufs bequemerer Fassung, besonders als Ohrgehänge, oder zum Aufreihen auf eine Schnur durchbohrt. Der Name Briolett und Pendeloque wird übrigens, wie erwähnt, vielfach auch gleichbedeutend mit Doppelrose gebraucht. Die Anwendung dieser Namen auf birn förmig verlängerte Brillanten, Doppelrosen und ähnliche Formen ist außerordentlich schwankend. Kleine, zum Auffassen auf Schnïre in der Mitte durchborte Steine, die ringsum von mehr oder weniger regelmälbig verteilten Facetten versehen, aber nicht nach der einen Seite birnförmig verlänğert sind, werden wohl Perlen genannt. Die birnförmig verlängerten Steine stehen im Gegensatz zu den der Kreisform sich nähernden Rundsteinen.

5. Hugelige Formen. Mit ebenen Facetten werden in der Hauptsache nur durchsichtige Edelsteine versehen, undurchsichtige wie Türkise usw. niemals, durchscheinende wie Chalcedon selten. Sie, aber auch manche durchsichtige tiefgefärbte Steine, wie Granat, ebenso solche, die eine eigentiumliche Lichterscheinung zeimen, wie Katzenauge, Edelopal und andere, erhalten meist eine runde, mugelige Form, einen Schliff en cabochon, wie er auf Taf. IV, Fig. 17 bis 19 dargestellt ist. Auf einer ebenen Grundfläche von kreisförmigem oder elliptischem Umrib erhebt sich eine runde Wölbung (Fig. 17 b), die bei manchen Steinen, z. B. dem Edelopal, ziemlich flach, bei anderen, z. B. den Katzenaugen und den Sterusteinen betrïichtlich höher gzehalten wird. I) urchsichtige Steine, z. B. Granaten von dunkler Farbe werden zur Erhöhung der Durchsichtigkeit und IIelligkeit und zur Entfernumg fehlerhafter Stellen im Innern von der Grundfläche aus liäufig mit einer der Oberflïche entsprechenden Rundung ausgehöhlt, a usgeschlägelt, wie es die punktierte Linie in Fig. $17^{b}$ andeutet. Ein derartiger Stein heilit eine Schale, speziell Granatschale. Vielfach ist statt der ebenen Grundflïche eine zweite. der ersten enteregrengesetzte Wülbung angebracht; die Fig. 19 ${ }^{\text {b }}$ stellt dies ron der Seite gesehen dar. Es ist danr ein Ober- und ein Unterteil vorhanden, die in einer ebenen liundiste ebenfalls von kreisrundem oder elliptischem Umrib zusammenstolien. Wenn dieser Schliff nur die eine der zwei gewölbten Flächen hat, heilst er einfach, wemn beide. doppelt. Auch en cabochon gesehliffene Steine, namentlich "doppelte Cabochons", werden zuwcilen auf eincre Seite spitz zulaufend verlängert, nicht selten sehr stark (pendelorgues en cabochon). Hiex schließen sich runde Formen ohne ausgesprochene Rundiste an, die denfalls l'erlen genamnt werden, entweder kugelig oder eiförmig, spitz an einem, stumpf am andern Ende, oder oval, beiderseits gleich gekrimmt, letztere nach der $\Lambda$ chse teilweise verlängert, teilweise verkärzt und damn anch wohl beiderseits facettiert (Rondell). Steine dieser Art werden nicht selten in der Mitte durehbohrt und auf Schnïre aufgereilit. Vielfach werden bei durchsichtign oder durchscheinenden Steinen am lande noch kleine 

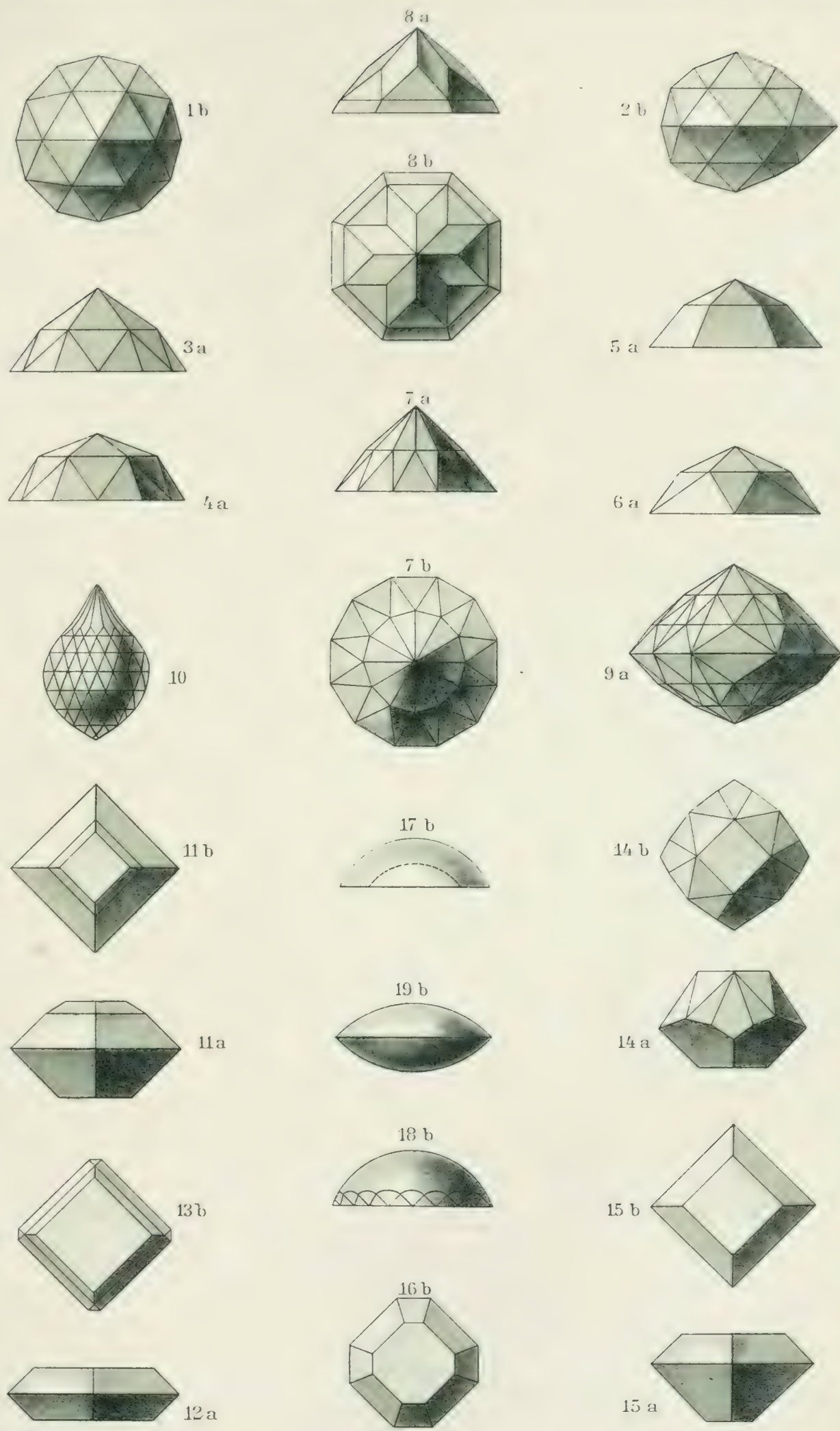

$12 a$

1-8. Rosette (Rose). 1b. Rose, rund. 2b. ditto, birnförmig (von oben). 3a. Holländer Rose. 4a. Brabanter Rose. 5a, 6a. Rosen anderer Form (von oben). 7a, b. Rose recoupée. 8a, b. Kreuzrosette. 9a. Doppelrosette (Pendeloque). 10. Brillolette. 11-14. Tafelstein. 11a, b. Tafelstein. 12a, 13b. Dünnstein. 14a, b. Tafelstein, oben brillantirt. 15a, b, 16b. Dickstein. 17-19. Mugeliger Schliff. 17b. einfach (ausgeschlägelt). 18b. ditto mit Facetten. 19b. doppelt. 



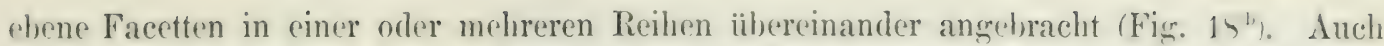
kommt es nieht selten, namentlich bei billigeren Steinen und Glasfliissen, vor, dali die Tafel von Brillanten. Treppen- und Tafelsteinen mugelig geschliffen wird. Eine gerinere Wïlhung heibt goutte de suif. Unregelmälbig rundliche Formen werden barorues genannt.

Damit treten wir in das Gebint der liastardformen ein, die aus einzelnen Teilen der in vorherehenden beschriebenen typischen Schlifformen beliebig kombiniert sind. sir werden nie an wirklich efleln und kostbaren Steinen angebracht, sondern nur an weniger wertvollen, sowie an Glasflissen. Ehenso verhält es sich mit den ganz unregrelmäbigen Formen, die von jenen vollkommen abweichen. Ihre (iestalt unterliegt keinem hestimmten (iesetze, sie entspringt lediglich der Phantasie des Schleifers. Es ist iaher weder möglich noch erforderlich, hierüber besondere Angaben zu machen. Die Facetten sind bei ihnen vielfach immer noch regelnä̈lig symmetrisch angeordnet, vielfach ist dies jedoch nicht der Fall. Auch Steine mit solchen ganz resellos liegrenden Facetten werden vielfach Kappgut genannt.

Von allen den erwähnten Formen wird bei Gelegenlseit der Betrachtung der einzwhen Ellelsteine noch weiter die Rede sein, soweit es sich um ihre Anwendung bei dem finen oder anderen Steine handelt. Sie sind aber keineswegs die einzigen, die bei Edelstrinen vorkommen; es giebt noch viele andere, die sich aber wohl sämtlich an jene mehr oder weniger anschliefien und häufig treten neue auf, wie wir es oben an einigen Beispielen gesehen haben.

\section{b) Schleifprozess.}

Thas Schleifen der Edelsteine berult darauf, dab die Stellen, an denen Facetten ancebracht werden sollen, mit einem härteren stein 1 dem erforderlichen Iaße abfrrieben werden. Der härtere stein reilit dabei von dem weicheren kleine Teile ab; hervoragende stellen des zu bearbeitenden stïckes künnen auf diese Trise allnählich entfernt werden, und an ihrer stelle entstehen bei geepigneter Leitung der Arbeit, des - chleufprozesses, chene Flächen, die sogenannten Facetten. Indem man auf diese Wreise drn Stein ringsum an den passenden Stellen mit Facetten versieht, urbält man die grewimschte sichlifform. Ganz entsprechend rerfïhrt man, wenn diese eine rumbliche Gestalt besitzt.

Fs ist hier nicht der Ort, anf alle technischen Finzelheiten der Edelsteinschle if erei einzugehen. Nur die cirmolzüge dieser Industrie sollen auseinandergesetzt werden, soweit das Verfahren allen Ededsteinen genumschaftlich ist. Besondere Verhältnisse, wie sie bei E'wis:en steinen, namentlich heim Diamant und heim Achat in Betracht kommen, werden bei deren spezieller Beschreibung erwähnt werden.

Der härtere stein, der den zu bearbeitenden Edelstein angreift, das schleifmittel, wird ant stets in Form eines feinen Pulvers angewendet, das man durch sorgfältiges Zerkleinern crïferer stücke erhält. Dieses Pulver, das Schleifpulver, wird nit Olivenül (Diamantpulver) oder Wasser (Schmirgel usw.) zu einem Brei angemacht und so auf die ebene Fläche einer meist metallenen kredsürmigen Scheibe von etwa einem Fub Durchmesser und einem Zoll Dicke, der Schleifscheihe, nahe deren Rand aufgestrichen. Die Scheibe dreht sich an zweckmäßigsten in horizontaler Richtung, also um eine vertikale Achse mit grobur Geschwindigkeit. Auf die Oberfläche, auf der sich das Schleifmittel befindet, wird der Edelstein mit der Stelle, die eine Facette erhalten soll, beim Schleifen angedrïckt; in einer je nach seiner Härte und der des Schleifmittels verschieden langen Zeit wird dann die Facette durch allnähliches Abschleifen sich bilden. Die Scheihe wirkt dabei, indem das barte Pulver in das weichere Metall hineingepreßt wird, ähnlich wie eine Feile 
von der IIärte des Schleifpulvers. Bei der Arbeit hat der schleifer in kurzen Intervallen nachzusehen, oh die Facette schon ihre richtige Gröbe erhalten hat. Wird zuviel wegrgesehliffen und die Facefte dadureh zu grolj, so nennt man sie iiberschliffen. Der stein wird dadurch unregrelmäbig und scin Wert nicht unerheblich verringert. Ebenso ist sorgfältig darauf zu achten, dalo der Stein nicht zu heiß wird, weil er dadurch leicht matte, sogenannte disıge Flecken bekommt, die seine Sehönheit beeinträchtigen. Ist eine Facette fertig, so wirl eine andere Stelle des Steines in derselben Weise der Wirkung der Schleifscheibe auswesetzt, und so nach und nach die ganze Form vollendet. Sellostverständlich mulf diese von vornherein genau bestimms und für die vorteilhafteste Anlage an dem Steine ein fester Plan aufgestellt sein, der sich nach desseu spezieller Beschaffenheit richtet.

Damit der Edelstein beim Schleifen seine richtige Lage unverändert beibehält, wird er in eine Fassung gebracht. Man benutzt dazu die sogenannten Doppen oder Docken, kleine kupferne, halbkugelförmig hohle Hïlsen, die hinten, der öffnung gerade gegenüber, (inen starken kupfernen stiel haben. Die Hülse wird mit Schnellot, einer Legierung von grleich viel Zinn und lilei, gefüllt, dieses geschmolzen und in die sich abkühlende Schmelze der Stein unmittelhar vor dem Erstarren in der richtigen Lage so eingesetzt, dab seine eine IIälite ron dem Lot umgeben ist, während die andere aus diesem heraussieht. Der Stein hat dam in der Doppe eine unveränderlich feste Lage. Vielfach werden die Steine, namentlich weniger kostbare, auf Kittstöcken befestigt, hölzernen und metallenen Griffeln oder Stäbchen, auf deren Ende man sie mittels eines aus Pech, Bernstein oder Schellack und feinstem Ziegrehmehl bestehenden Kittes, sog. Zement, aufklebt. Neuerding's hat man in Amerika namentlich für die Diamantenschleiferei Doppen hergestellt, in denen die Steine mittels Schrauben festgehalten sind und auch herumgedreht werden können.

Die Doppen mit ihren Stielen, resp. die Kittstöcke werden in eine an dem Ende eines Brettchens befindliche Stahlzange eingeklemmt; an anderen Ende des Brettehens sitzen zwei kurze Beine. Mlan kamn dann diesen Apparat so aufstellen, dals die zwei Beine auf einem festen Tisch und der Edelstein in der Doppe oder dem Kittstock auf der $m$ geringer Entfernung ïber der Tischfläche und parallel mit ihr sich drehenden Schleifscheibe ruht, die nun auf den Stein einwirkt. Zur Vermehrung des Druckes wird das Brettchen mit Bleigewichten beschwert, die je nach der Härte des zu schleifenden Steines gröber oder kleiner sind. Damit das Holzgestell von der rotierenden Scheibe nicht mitgerissen wird, stellt man es zwischen zwei fest in die Tischplatte eingelassene eiserne Sififte, und damit die scheibe nicht ungleichmäßig belastet wird, stellt man dem ersten steine gexenüber in derselben Weise einen zweiten auf. Bei stemen von geringerem Wert wird der Kittstock mit der Iland gehalten, bis die Facette fertig gesehliffen ist, was natürlich schlechtere und wenig regelmäßige Formen gibt.

Ist eine Facette vollendet, so wird die Doppe mit dem Stein in der Zange gelockert und damn von neuem, und zwar in der Lage festgeschraubt, dals eine zweite Stelle, wo eine Facette entstehen soll, auf der Schleifscheibe aufruht. Diese wird nun genau in derselben TVeise fertigrestellt wie die erste. Im weiteren Verlauf der Arbeit erhält so allmählich die ganze freiliegende Hailfte des Steines die erforderlichen Facetten, indem man diesen durch fortgesetztes Drehen und Neigen der Doppe resp. des Kittstockes in immer neue Lagen bringt.

Dieses Drehen und Teigen wurde früher nach dem Augenmals bewerkstelligt, weshalb sich die wïnschenswerte Genauigkeit in der gegenseitigen Anordnung der Facetten oft nur unvolliommen erreichen leek. Später hat man besondere Hilfsapparate, sogenamnte (iradhogen oder (Quadranten, angehracht, die cine Neigung. und Drehung des Kittstocks um fanz bestimmte Winkel ermöglichen. Nit ihrer Iilfe künnen die Facetten vollkommen exalkt in der richtigen Lage aneinander gereiht werden. Noch zweckmäßjiger und be- 


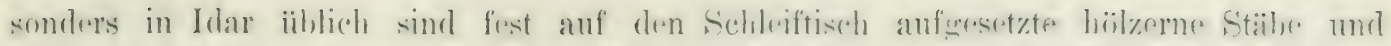

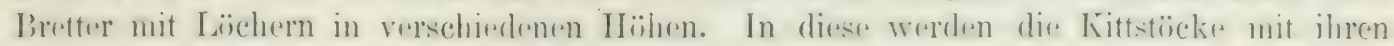
hinteren Enden eingesterekt und erhalten so ohne weiteres rasch die fïr dir verschiredenen Facetten richtige Lage. Diese Vorrichtung" wird "Stock" genannt.

Ist die eine Seite des Steines so weit als möglich gesehliffen, so wird er durch

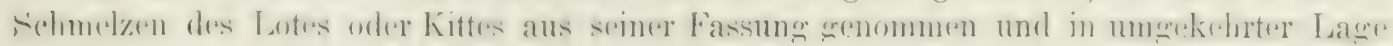
wieder eingesetzt, so daß nun cin anderer Teil der Oberfläche frei liegt; diese erhält

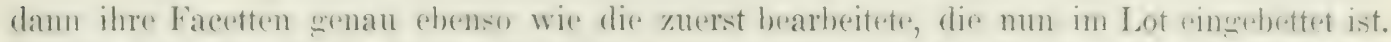

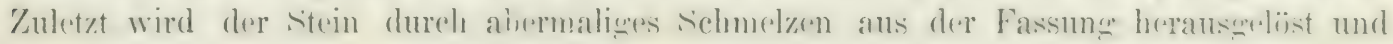
gereinigt.

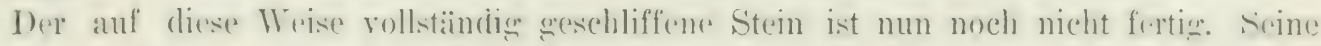

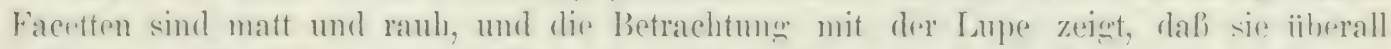
mit kleinen Vertiefungen und listen bedeckt sind, entsprechend den von dem hartren

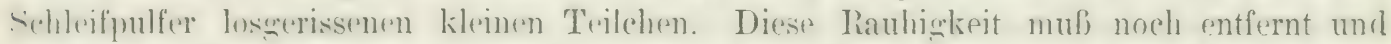
die (Iberfläche des steines slatt und damit anch glänzend enemacht werden. Man brwerk-

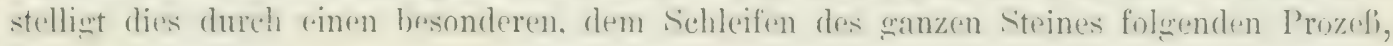
das Polieren.

Das Polieren orechitht in derselben Weise wie das Schleifen. mit denselleen IIaschinen und Aplaraten, nur ist das Sehleifpulver, das jetzt Poliernittel heibt, weicher, so daf es in der Inärte dem zu hearbeitenden Edelstein ziemlich weich steht, es kamn snear u. U. "twas wedeher sein als dieser. Der stein wird selbstrerständlich wieder in fister Fassung mit seinen rauhen, soelien angeschliffenen Facetten auf eine mit rem l'oliermittel rersebene Schleifscheibe, die l'olierscheihe, sesetzt. Fr wird num, anders wie beim sichleifen, sehr wenig angegriffen. die die Tauhigkeit bewirkenden kleinen Vertiefungen und Risie rerschwinden allmälılich, und die Facette wird mmer glänzender. Endlich bemerkt man, dali der (ilanz bei der Fortsetzung der Arbeit nicht weiter zunimmt; dann ist die Facette fertion. sie hat den höchsten Grad der Tollkommenheit erreicht, die sie an dem hetreffenden Strin erlangen kann. Es ist ron der gröbiten Wichtigkeit, die Politur so gut wie irgend mïglich auszufïhren, denn nur dadurch wird die selünheit des Steines rollkmmmen entwickelt.

Würde man gleich von vornherein das weichere Poliermittel schon zum Anschleifen der Facetten henutzen, so würden diese sofort rolliommen slatt in ilrem hüchsten Glanz arscheinen. Lles ist, wie wir sehen werden, beim sichleifen der Diamanten der Fall, für die es kein härteres Schleifmittel gibt als ihr eigenes Pulver. Die Arbeit würde dann aber äuferst langsam vorrïcken und dadurch sehr erhebliche Kosten verursachen. Daher henutzt man zuerst das härtere. also rascher und enereischer wirkende Schleifmittel zur Vorbereitung der Facetten und dann erst das weichere Poliermittel zur schließlichen Vollendung.

Meist geht dem Schleifen und Polieren der einzelnen Facetten eine andere Opleration voraus, die den Zweck hat, die gew inschte Schlifform an dem Stein erst ganz im rohen anzulegen. Man nennt dies das R undieren. Der Arbeiter hält dabei den Kittstock in der IIand und drückt ihn so in der mngefähren Lage der einzelnen Facetten auf die Schleifscheibe. Beim Diamant seschieht die Vorbereitung der Facetten dureh das (ranten, das wir unten näher kennen lernen werden. Beim eigentlichen Schleifen braucht dann die im grohen schon vorhandene Form nur noch weiter in der oben besehriehenen Teise ausgeführt zu werden.

In derselben Weise wie beim Rundieren, durch Festhalten des Kittstockes mit freier Hand und fortwährendes Herumdrehen derselben auf der rotierenden scheibe, werden auch die mugeligen und überhaupt die runden Formen der Steine her- 
gestellt. Selbstverstïndlich wird hier ebenfalls zuerst das rascher wirkende Schleifpulver angewendet und erst zur letzten Tollendung das geeignete Poliermittel benutzt. Zur Herstellung solcher rundlicher Formen ist eine ganz besondere Geschicklichkeit des Arbeiters erforderlich.

Die Schleifscheiben sind fül härtere Steine aus härterem, für weichere aus weicherem Metall. Sie bestehen aus Eisen oder Stahl, oder aus Kupfer, Messing, Zinn und Blei; auch IIolzscheiben werden zuweilen angewendet. Sie müssen an ihrer oberen Fläche, wenigstens in der Nähe des Randes, wo das Schleifen stattfindet, rollkommen eben, aber etwas rauh sein. Die Drehung geschieht meist durch Wasser- oder Dampfkraft oder durch Elektrizitiit. Man gribt den Scheiben eine Geschwindigkeit bis zu 2000 und sogar 3000) Touren in der Minute, und geht in einzelnen Fällen sogar noch höher. Je härter der zu schleifunde Stein, desto geschwinder läßt man die Scheibe laufen, da die rasche BeWetung die Wirkung des Schleifjulvers kräftig unterstützt, so daß sogar Pulver derselben Substanz, wic beim Dianant, zum Schleifen von Edelsteinen verwendet werden kann. Zum Polieren werden Scheiben von denselben Naterialien benutzt, doch nimmt man sie im allemeneinen weicher als zum Schleifen des betreffenden Steines. Hier finden auch mit Leder. Tuch, Filz oder Papier überzogene Holzscheiben vielfach Anwendung.

Zum Schleifen weicher Steine, besonders der zum Quarz gehörigen, dienen zuweilen Simdsteinseheiben ohne besonderes Schleifmittel, so daß also die Substanz des Sandsteines allein wirkt; wir werden bei der Betrachtung der $\Lambda$ chatschleiferei dieses Verfahren näher kennen zu lernen haben.

Das wichtigste Schleifmittel ist der Korund, das härteste Mineral nach dem Diamant, das zweithärteste in der ganzen Reihe, dessen durchsichtige Varietäten deu Rubin, Sapphir und andere kosthare Edelsteine liefern. Dieses Mineral findet sich als undurchsichtiger semeiner Korund sehr reichlich in der Natur, namentlich in einer feinkürnigen allerdings durch fremde, weichere Vineralien stark verunreinigten und dadureh in ihrer Härte nicht unerheblich beeinträchtigten Varietät, die man Schmirgel nennt. Es kommt so in grofen Bläcken von schwarzer Farbe besonders in Kkeinasien und auf der Insel Naxos, auch bei Chester im Staate Massachusetts in Nordamerika und an anderen Orten vor. Namentlich auf Taxos und in Kleinasien wird es in großen Massen gewonnen, je nach Bedarf mehr oder weniger fein gemahlen und so in den Handel gebracht. In derselben Teise benutzt man nicht selten den ebenfalls stellenweise in großen Quantititen vorkommenden kristallisierten gemeinen Korund, der reiner und namentlich nicht nit weicheren Mineralien gremengt ist und daher gröbere Härte besitzt als der Sehmirgel. Auch andere harte .lineralien, wie Topas, - Granat usw., sogar zuweilen der (Quarz, werden gelegentlich zu tichleifpulver verarbeitet. Vielfach angewendet wird jetzt auch das Pulver de's Carbor undum, des durch Zusammensehmelzen von Kohle und Quarz im elektrischen Ofen herosestellten Siliciumkarbids, SiC; dessen IIärte (H. $=91 / 2$ ) übertrifft noch die dess Liorunds und nähert sich der des Diamants. Als Ersatz für s'chmirgel wird wobl auch das Korubin benutzt, die bei dem Thermitverfahren erhaltene korundhaltige Schlacke.

lin hesonders wichtiges. Schleifmittel ist endlich der Diamant. Viele Diamanten sind zu unrein, als dali sie als Schmucksteine verwendet werden können; sie bilden den sogenamnten bort. Dieser und der undurehsichtige schwarze feinkörnige Diamant, der sogenamnte Karbonat, werden sepulvert und so als Schleifmittel benutzt. Wenn diesess auch dinen sehr hohen l'reis hat, so wird doch durch seine enorme Ilärte, welche die aller anderen Edelsteine weit iiberragt, der Schleifprozeb auljerordentlich abgekürzt und dadurch billiger gemacht. Daher hat sich gegenwärtig für viele Edelsteine die Anwendung des teuren Diamantpulvers als Schleifmittel vorteilhafter erwiesen, als die des ungleich wohlfeileren, aber weniger harten Schmirgels usw., namentlich seit durch die Enteleckung 
der südafrikanischen I)iamanten dessen Preis beträchtlich enesunken ist. Für den Diamant sellst gibt es gar kein anderes richleifmittel als sein eigenes Pulver, alles andere ist fuir ihn viel zul weich.

Als Poliermitte I werden meist Tripel, Enclischrot, Bimstein, Zinnasche usw, sämtlich in Form allerfeinsten l'ulvers, benutzt, zuweilen auch Bolus und ähnliches, je: nach der Xatur des zu poliurenden Edidsteines. vie werden. wie die sichleifpulver, ebenfalls mit Wasser, Tripe], zuweilen auch mit śchwefelsäure zu einem brei angeriilurt und wie jene anf die Scheibe anferestrichen. Das Polierunittel kann etwas weicher sein als der zu polierende Stein und in manchen Fäilen ist dies sogar notwendig.

Es wurde schon oben angrodeutet, dafi je nach ihrer Beschafenheit, besonders je nach ihrer Härtı, die Edelsteine nit rerschiedenen sichleifmitteln und auf Scheiben von verschiedenem Material bearheitet werden. Die Answahl der scheiben ihrem Stoffe nach, sowie der schleif- und loliermittel ist dabei zwar innerhalb gewisser (irenzen willizïlich, d. h. für eine gewisse Art von Edlelsteinen wird nicht stets streng nur ein ganz bestimmtes Material angewendet, aber man kann doch die Fesamtheit der Steinarten ziemlich gut nach Alstufungen der IÏ̈rte in einige Crrupjen teilen, deren jede im ganzen auf gleiche Weise behandelt wird. Wir kïnnen aluer hier auf dieste technischen Finzelheiten nicht näher eingehen.

Nicht selten bedarf es einer besonderen Vorbereitung der Steine zum Schleifen. Manche, so vor allem die kostharsten Edelsteine, wie I)iamant, Rubin u. a.. finden sich in der Vatur meist nur in verhältnismäbigr kleinen und vielfach ganz reinen stïcken. In diesem Falle ist eine besondere Vorrichtung der steine vor dem Schleifen nicht nütig. Die gew ẗnschte. Schlifform kann an ihnen sofort und ohne weiteres in der oben angegebenen Treise hergestellt werden. Sind aber, wie es bei anderen Edelsteinen, z. B. hein Ayuamarin, häufig der Fall ist, die in der Natur rorkommenden Stïcke für einen einzigen schmuckstein zu grob, oder sind, wie oft beim edlen Opal usw., nur einzelne stellen eines gröberen Stiickes von geniigender Klarheit und Reinheit und diese von trüben, fehlerhaften und daher unbrauchbaren Partien umgeben, so muf der rohe stein ror dem Schleifen in recigneter Weise zugeriistet werden, indem man ihn in mehrere Teile von passender Gröfe zerlegt, oder indem nan die unhrauchbaren Teile durch eine minder zeitraubende und kostspielige Operation als das Schleifen entfernt.

Dies geschieht meist durch Sägen, durch Zerschneiden mittels einer am besten vertikalen, wie eine Kreissïge um eine horizontale Axe sich rasch drehenden dïnnen Metallscheibe, die man an ihrem scharfen Rande nit Diamantpulver oder einem anderen harten schleifpulver bestreicht, oder in deren Rand man kleine Diamantsplitter fest einprefit. Drïckt man nun den stein an die schneide dieser Scheibe fest an, so wird er allnählich ron dieser durchgeschnitten. Auch durch sägen mittelst eines in einen Bogen eingespannten und mit schleifpulver bestrichenen Drahtes kann eine solche Zerteilung bewerkstelligt werden. Dies geht aber viel langsamer und wird daher in der Praxis jetzt wohl selten mehr auscrefübrt. Bei billigen, in srolien stücken vorkommenden Steinen wird das Überfliissige und Lnhranchbare nicht wegreschnitten, sondern cinfach mit dem Hammer abgeschlagen, eine P'rozedur, die sich begreiflicherweise bei wertrolleren Steinen von selbst verbietet, wenn nicht wie beim Diamant, Topas und anderen nach gewissen Richtungen leichte spaltharkeit vorhanden ist. Solche leicht spaltbare Steine lï̈nnen, wie wir geseben haben, mit dem Meifo! nach den betreffenden Richtungen rasch, sicher und ohne jeden Materialyerlust in Stiicke zerlegt werden, wodurch sich die Bearbeitung sehr wesentlich abkiirzt. Bei der Betrachtung" dieser Steine, besonders des Diamantes, wird davon noch spezieller die Rede sein. Bei kostbarem Material sammelt man die bei diesen Operationen abfallenden Stücke sorefältig, weil sie sich noch zu kleineren Schmucksachen 
verschleifen lassen, oder weil man sie, wenn es sich um harte Steine handelt, als Schleifmittel verwenden kann.

Da die spezielle Behandlung der Edelsteine wesentlich von deren verschiedener Natur abhäingiw ist, die verschiedene Einrichtungen bedingt, so hat sich in der hiermit beschäftigten Industrie eine Arbeitsteilung in der Art herausgebildet, daß in den einzelnen Schleifereien nur bestimmte steine mit Ausschlub der anderen bearbeitet werden. In den Diamantschleifereien werden aubschlieblich Diamanten geschliffen, in den Edelstein-oder Feinschleifereien dagegen, mit einziger Ausnahme des Diamantes, alle anderen Edelsteine und Ualbedelsteine, die zu Schnucksachen (zur Bijouterie) dienen. Die Grolisteinschleiferei stellt auch noch eigentliche Schmucksachen, besonders ron srührem L'mfange und ron glatter Form, oder mit wenig Facetten her, wie Ringsteine, Cadusteine, lireuze, Petschafte und ähnliches. Sie verwendet aber nur weniger kostbare Steinarten, wie Achat, Chalcedon, Jaspis usw. Andererseits verfertigt sie aus diesem Material, aber auch aus Granit, Marmor, Serpentin usw. solche Gegenstände, die nicht mehr unter den Begriff der Schmuckwaren fallen, wie Briefbeschwerer, Schalen, Vasen, Dosen, Etuis, Schreibzeuge, Stockknöpfe, Messerhefte, Plättchen zu eingelegter Arbeit und ähnliches. Die Groß- und Feinschleiferei sind jetzt wohl manchmal wenigstens bis zu einem sewissen Grade in einer Anstalt vereinigt, die Diamantschleiferei dagegen wird stets getrennt und für sich allein betrieben.

\section{c. Bohren.}

Nicht selten werden Edelsteine, z. B. Granaten, auf Schnüre aufgrereiht und so als Schmuck getragen. Sie müssen zu diesem Behufe in der Mitte durchbohrt werden. Auch zu technischen Zwecken werden die Edelsteine zuweilen durchbohrt, namentlich zur Herstellung der Zapfenlager für Uhren, der feinen Öffnungen zum Ziehen von sehr dünnem Golk- und Silherdraht usw. Dieses Durchhohren geschieht mittels einer feinen Diamantspitze, die in ciner cisernen Fassung durch eine in einen Bogen gespannte Schnur eine rasche Umdrehung erhäit, des sogenannten Drillers. Dieser besteht auch vielfach aus einer Stahlspitze, die mit feinem, ölbefeuchtetem Diamantpulver bestrichen wird. Zur Erleichterung des Verfahrens hat man auch eigene Maschinen konstruiert, mittels deren das Durchbohren harter steine besonders berpem und rasch ausgeführt werden kann; auch sie berulien auf der Anwendung des Drillers oder eines ähnlichen Instruments. Namentlich im Orient (Indien usw.) ist das Durchbohren sehr verbreitet.

\section{d. Bearbeitung auf der Drehbank.}

Manche Steine, besonders die in größjeren Stïcken vorkommenden und weicheren, werden auch zur Ilerstellung von Kugeln und anderen runden Formen auf der Drehbank abgedreht. Lis ist dies aber doch mehr eine in der Großsteinschleiferei vorkommende Art der Arhett, die bei eigentlichen Edelsteinen wohl selten zur Anwendung kommt. Allerdings kann man sogar die härteren unter ihnen auf diese Weise formen, wenn man statt der sewöhnlichen Stahlwerkzenge der Dreherei solche mit Diamantspitzen verwendet; es ist jedoch überflïssig; hierauf näher einzugehen.

\section{e. Gravieren.}

Die Eldsteine werden nicht nur in wewissen Formen weschliffen, sondern es werden auch in verschiedener Weise Figuren, Insehriften, Wappen usw. eingraviert. Diese beiden Operationen laben aber versehiedene rwecke. Der Steinschleifer sucht durch die von ilum arzunte Form die natïrlielsen Eizensehaften der steine mö̈lichst zur Geltung zu 
bringen und so deren fichönheit auf die höchste erreichbare IJöhe zu heben; es handrit sich also hienbei wesentlich $10 \mathrm{~m}$ den stein selbst, die Form ist nur das Mittel zum Zweck. Der Gravenr dageenen sueht rin Kunstwerk von selbständigem Wert zu erzengeren, das für sich wirkt. IIier ist das Kunstwerk die IIauptsache; der Stein, das Matrerial fuir Irtzteres, ist von nebensä̈chlicher liedeutung, da der Künstler im allgemeinen zu seiner Arbeit wanz ebensogut irgendeinen anderen Stein hätte verwenden können.

Dee Kunst, Edelsteine zu gravieren oder zu schneiden, ist sehr alt, viel älter als das Schleifen. Die Schrlftsteller berichten hierïher aus den frïhesten historisch bekannten Zeiten, und unsere Museen zeigen uns berriche Kunstwerke dieser Art aus dem Altertum. Auch in der Jetztzeit wird das Gravieren noch getrieben, besonders in Italien, die schleiferei hat aber ihm geceniber eine viel sribbere und allmählich weit ïborwiegrende bedeutumgerewonnen. Man bezeichnet das Gravieren als die Steinschneiderei oder (ilyptik (Lithoglyptik), versteht aher unter dem ersten Wort zuweilen auch die Bearbeitung der Edelsteine nicht nur durch Gravieren. sondern anch die durch sichleifen.

I) ge geschnittenen (gravierten) Schmucksteine werden im allgemeinen Gemmen genamnt. Sie sind in zweierlei rerschiedener Weise gearbeitet. Einmal zeigen sie vertiefte Figuren, dies sind die Intagrlien. Sie werden vielfach zur IIerstellung von Siegrelringen benutzt, zu welchem Zweck man statt der früher mehr ïblichen Figruren jetzt meist Waplen, Buchstaben usw. eingraviert. Steine dieser Art werden daher wohl auch Siegelsteine genannt. Sodann findet man mit erhabenen Figuren versehene Steine, die als Kameen bezeichnet werden; diese dienen nur zum Schmuck. Die Kunst, rertieft zu gravieren, heibt die Skulptur, die Herstellung erhabener Figuren die Tornatur. Die erstere geht der letzteren zeitlich voran, wie alt aber auch diese ist, sieht man unter anderem aus den zahlreichen Kameen in Käferform, die man in den ägyptischen Gräbern findet, den sogenannten Skarabäen.

Zur Herstellung von Intaglien wurden und werden alle möglichen Steine verwendet, durchsichtige und undurchsichtige, harte und weiche. Je srölier die Härte des Steines, desto schärfer die eingravierten Figuren, desto mühevoller aber allerdings auch die Arbeit. Trotz der danit verbundenen Schwierigkeiten ist man sogar vor dem Gravieren in Diamant nicht zurückgeschreckt, auch Ruhin und Sapphir hat man auf diese Weise bearbeitet; doch wurden diese allerhärtesten Edelsteine seltener verwendet als die minder harten und sogar vielfach die ganz weichen. So findet man aus frïheren Zeiten gravierten Smaragd, Aquamarin, 'Topas, Chrysolith, Türkis, Bergkristall, Amethyst, Plasma, Chaleedon, Karneol, Achat, Heliotrop. Opal, Lasurstein, Nephrit, Ohsidian, Iagneteisen, Ilämatit und manche andere. Heutzutage bildet das hauptsïchlichste Material der Quarz und der Chalcedon mit seinen verschiedenen Abarten (Achat, Onyx usw.), der Hämatit oder Blutstein und noch einige wenige der übrigen. Einen vertieft geschnittenen Karneol zeigt Taf. XX, Fig. 6; eine andere Intaglie die Textfigur 107.

Zu Kameen sieht man nur selten durchsichtige Steine rerwendet, meistens undurchsichtige, aber schön gefärbte, namentlich solche, die aus mehreren verschiedenfarbigen dïnnen Lagen bestehen, wie die Abarten des Achats, die man als (Onyx, Sardonyx usw. liezeichnet. Diese werden zur Herstellung ron Figuren, nicht nur von vertieften, sondern auch von erhabenen, z. B. in der Weise benutzt, dab man in einer weißen Lage Gesicht und Hände, in einer schwarzen Haar und Gewandung ausarbeitet. Eine solche aus einer roten und einer weiben Lage geschnittene Kamee, bei der die rote Lage als Hintergrund für die weilie Figur dient, ist Taf. XX, Fig. 7 abgebildet; andere Kameen siehe Fig. $10 S$ u. 109. Indessen werden Kameen auch häufig aus einfarbigen Steinen, wie T'ürkis, Malachit und anderen, geschnitten, das Material der ägyptischen Skarabäen ist sehr häufig der kaum zu den Edelsteinen zu rechnende Serpentin und ähnliches. Statt der genannten Steine 
werden heutzutage in Italien, wo diese Industrie besonders blïht, Kameen auch aus den dicken Schalen gewisser Seeschnecken geschnitten, bei denen wie in manchen Achaten rote und weiße Lagen regelmäßig miteinander abwechseln. Die meisten Kameen, die man z. B. in Neapel feilgeboten sieht, sind aus solchem Material hergestellt, sie lassen sich aber leicht nit dem Messer ritzen und daran von den viel härteren Kameen aus Achat (Onyx usw.) unterscheiden, ebenso dadurch, daß sie mit einem Tropfen Salzsäure lebhaftes Aufbrausen zeigen.

Die Edelsteinschneiderei wird mit Hilfe kleiner eiserner Rädchen ausgeführt, die am Ende einer in einer Drehbank rasch rotierenden Achse befestigt sind. Diese Apparate heißen Zeiger. Die Rïdchen haben oft keine Linie im Durchmesser und vorn eine rerschiedene, konische, kugelige, ebene usw. Fläche. Diese wird mit angefeuchtetem Diamantpulver bestrichen und der zu bearbeitende Stein in einer zweckmäbigen Fassung mit seiner vorher in der gewïnschten Form geschliffenen und gut polierten Oberflïche dagegen gedrïckt. Durch geschickte Bewegung des Steines entsteht die Zeichnung und durch mehr oder weniger lange Einwirkung die größere oder geringere Vertiefung. Eine nachlerige Politur findet meist nicht statt oder muß mit der Hand bewirkt werden; die letzten Feinheiten werden mittels eines Grabstichels angebracht, der mit einer Diamantspitze versehen ist.

İtzen. Das schwierige, zeitraubende und kostspielige Gravieren kann bei manchen Steinen durch das einfachere, rascher fördernde und daher woblfeilere, allerdings auch keine so scharfen und schönen Bilder liefernde Ätzen ersetzt werden. Dies erfordert, daf der Stein von Säuren angegriffen wird, was bei den meisten, namentlich den wertvolleren Edelsteinen, allerdings nicht der Fall ist. Aber eine Gruppe von Schmucksteinen, nämlich die, welche ganz aus Kieselsäure bestehen, wie Bergkristall, Chalcedon, Achat usw., lassen sich ebenso wie Glas leicht in dieser Weise bearbeiten und mit vertieften Figuren versehen. Man ïberzieht die vorher polierte Fläche, die man verzieren will, mit einer dünnen Schicht Wachs, dem Ätzgrund, und graviert in diesen die gewünschten Figuren ein, so daß an ilurer Stelle der Grund vollständig entfernt und die Oberfläche des Steines freigrelegt ist. Dann setzt man diesen der Wirkung wässriger oder gasförmiger Flubsäiure aus, welche den Stein an der Stelle, wo er frei liegt, ist, stark angreift, während der Ätzgrund da, wo er stehen geblieben ist, die Auflösung verhindert. Es entsteht so bald eine vertiefte Zeichnung, und zwar um so tiefer, je länger man die Säure einvirken läßt. Nach vollständiger Entfernung des Ätzgrundes zeigt dann der Stein die entstandene Figur (Buchstaben, Wappen usw.), rauh bei Ätzen mit gasförmiger, glänzend bei Anwendung von flüssiger, in Wasser gelöster Flußsäure.

\section{f. Firben. Brennen.}

Zu der Bearbeitung der Edelsteine gehört auch in manchen Fällen die Veränderums. und Verbesserung ihrer ursprïnglichen Farbe, die, wie wir bei der Betrachtung der allgemeinen Verhältnisse der Färloung schon in Kürze gesehen haben (S. 71), zuweilen rorgenommen werden kann. Nan weilj dies auf verschiedenem Wege zu bewerkstelligen, es ist aber hier nicht von dem oberflächlichen Aufstreichen von Farbstoff die Rede, wie es wohl beim Fassen und Aufhringen der Edelsteine zuweilen angewendet wird, sondern von der Änderung der Körperfarbe des Steines bis möglichst weit in das Innere hinein.

Es gibt einige Edelsteine ron poröser Beschaffenheit, deren ganze Nasse sich durch Einfülarungr eines Farbstoffes kïnstlich lärben läßt, und bei denen dies auch in der l'raxis nicht selten geschieht. Namentlich manche Achate zeichnen sich in dieser IIinsicht aus. Das Verfahren bei der Färbung beruht im wesentlichen darauf, daß man vermittels 
Fliissigkeiten, die cine färbende Sulstanz grelöst enthalten, den porïsen Stein durchtrïnkt, der dann nach dem Trocknen die Farbe jener substanz annimmt. Nicht selten wird auch das Färbemittel erst im Steine selbst erzeugt, indem man diesen mit zwei Flüssinkeiten nacheinander imprägniert, die in seinem Innern einen chemischen Niederschlag von der gewiinschten Farbe hervorbringen. Dieser Niederschlag erfüllt den Stein in ganz gleichmäbiger Verteilung, soweit er poräs ist und sich mit den Flïssigkeiten vollsaugen konnte, und teilt ihm seine Farbe mit.

Bei der Besprechung der Achate sollen diese Manipulationen eingehender erörtert werden. Die Farben, um die es sich dabei vorzugsweise handelt, sind schwarz, rellh, blau, grïn und braun. Nicht ron ihnen allen ist die Art der Ierstellung überall und allgemein

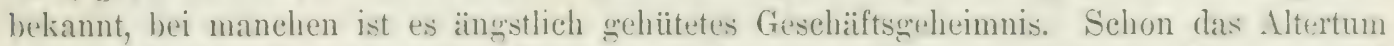
war nach den Berichten des P'linius mit derarticen Kü̈nsten vertraut. Man verstand offenhar sehon damals, Achat in derselben Weise zu fürben wie jetzt. Man war aber auch, wie berichtet wird, imstande, dem Bergkristall gewisse Farben, namentlich die schïn griine des Smaragls, mitzuteilen, was man beutzutage nicht mehr versteht. Man kamn wohl den Bergkristall, der nicht porüs ist und daher keine Fliissigkeit aufsaugt, dadurch fürben, daf man ilın stark erhitzt und dann rasch in eine kalte farbige Flïssigkeit taucht. Dabei erhält er zahllose Sprïnge, in die die Fliissigkeit eindringt, deren Farbe dann der Stein annimmt. Aber infolge der Sprïnge ist ein so behandelter Bergkristall brïchig und oft nicht mehr recht zum Schleifen tauglich; diese Methode ist also praktisch ron keiner Bedeutuug. wälırend die Färbung der Achate grobe Wichtigkeit besitzt. In dieser Weise, stets ziemlich ungleichmäßj心, gefärbte Berghristalle werden Craquelées genannt.

Eine Lmfärlung oder eine Entfürhung mancher Edelsteine kann bewirlit werden durch Verändermon oder Zerstörung ihrer ursprünglichen Farbe in der Ititze, durch das sogenannte Brennen. I)iese Methode wird vielfach angewandt, da sie bei zahlreichen Steinen die natürliche Farbe erhöht und ihr mehr Haltbarkeit gibt, und da man mittels ihrer auch neue Farben hervorzurufen und unschöne Flecken zu beseiticen vermag. Das Erhitzen muf dabei recht langsam und vorsichtig erfolgen, unter sorgfältiger Termeilumg" aller raschen Temperaturänderungen, und in derselben Weise nuf damn nachher auch die Abkühlung geleitet werden, weil sonst die Steine leieht springen und die Ändtrung. der ursprünglichen Farbe of nicht ganz gleichmäßig geschieht. Bei diesen Prozef werden die Stiicke meist in einem Tieşel in irgend einen pulverförmigen Körper, wie Kohlenstaub, feinen Sand, Eisenfeilspäne, auch in Ton, ungelöschten Kalk, Holzasche usw. eingebettet, die wohl den IIauptzweck haben, Erwärmung und Abkïhlung recht gleichmäßıg zu grestalten. Die für die einzelnen Erlelsteine erforderliche Temperatur ist verschieden. Manchmal geniigt schon eine ziemlich unbedeutende Erwärmung, manchmal ist jedoch auch starke Glïhhitze erforderlich, un die Farbe zu zerstören oder umzuändern.

Durch das Brennen wird das in der Hitze nicht haltbare Pigment der Steine, auf dem ilure Farbe beruht, zerstört oder verïndert und in ein anderes umgewandelt, das die nene Farbe bewirkt. Umfärben oder entfürben lassen sich demnach anf diese ITeise nur solche Edelsteine, die einem derartig in der Wärme reränderlichen Stoffe ihre Farbe verdanken. So wird der dunkelgetbe brasilianische Topas beim Erhitzen rosenrot, Amethyst verliert beim gelinden und kurzen Gliihen in einem Gemenge von Sand und Eisenfeilspä̈nen dunkle Flecken, beim starken und andauernden Glïhen wird die violette Farbe in eine gelbe verwandelt (crebrannter Topas und Amethyst). Yancher ron Natur braune Karneol wird beim Glibhen lebhaft rot, inclem dabei das braun färbende Eisenhydroxyd dureh Wasserverlust in das lebhaft rote Eisenoxyd übergeht. Der gelbrote Hyacinth wird farblos und gleichzeitig erhöht sich sein Glanz bedeutend; auch der blaue Sapphir verliert heim Glühen seine Farbe vollständign. Solche und ähnliche Fälle gibt es noch mehr: sie sollen 
bei der Betrachtung der einzelnen Edelsteinarten noch besonders erwähnt werden, da die Farbenänderung durch Brennen zum Teil technisch von Wichtigkeit ist. Die meisten Edelsteine verïndern indessen ihre Farbe auch bei den höchsten Temperaturen nicht.

Wie weit die Farbenänderumg dureh Bestrahlen mit Radium technische Verwendung finden kann, wird die Zukunft lehren (vgl. S. 71).

\section{g. Fassen. Aufbringen.}

Die meisten Edelsteine werden, nachdem sie geschliffen sind, in irgendeiner Weise zur Iler'stellung ron Schmucksachen oder anderen Luxusgegenständen verwendet. Selten und meist nur bei weniger wertvollen Steinen kommt es vor, dali man sie durchbohrt und auf Schnïre aufzieht, hauptsäichlich zur IIerstellung von Arm- und Halsbändern. Ehenso selten ist es, daß sich ganze Schmuckstiicke, z. B. ganze Ringe, aus einem Stiick Edelstein anfertigen lassen, und dies sind dann fast stets solche Steine, die in größeren Massen vorkommen und zugleich die erforderliche Festigkeit besitzen, wie z. B. der Nephrit. IIüufiger geschieht es, daß die Steine in dem Metall, aus dem der mit ihnen zu verzierende Gegenstand in den meisten Fällen besteht, möglichst dauerhaft befestigt oder, wie es die Juweliere nennen, gefaßt werden.

Die Steine bleiben dabei, namentlich wenn sie groß und schün sind, einzeln. oder sie werden von ganz kleinen einer anderen Art umgeben, also z. B. ein grofer Opal von vielen kleinen Diamanten. Die Wirkung des großen trüben Steines wird durch die der rielen durchsichtigen und grlänzenden kleinen wesentlich gehoben; man nennt diese Art der Fassung karmoisieren. Häufig aber werden mehrere Steine derselben oder von rorschiedener Art und Farbe zu geschmackvollen Gruppen, die oft Ornamente, Schmetterlinge, Blumen usw. darstellen, vereinigt, damit sie gegenseitig ihre Schönheit durch die Kontraste in ihrem Aussehen erhöhen. Solche Zusammenstellungen sind selbstverstïndlich im höchsten Grade der Mode unterworfen und ändern sich im Laufe der Zeiten beträchtlich.

Die Befestigung der Steine in Schmucksachen, von denen hier vorzugsweise die Rede sein soll, weil die Terwendung zu solehen am häufigsten ist, geschieht bei kostbaren Arten in Gold oder Silber, bei geringeren sehr häufig in entsprechend billigerem Metall, Messing usw, das manchmal vergoldet wird. Es ist für die Wirkung eines Steines durchaus nicht gleichgiiltig, in welches Metall er gefabt wird. Für Diamanten z. B. ist Silber, fiir Rubine und andere Gold am vorteilhaftesten usw. Stets kommt dabei der Stein an der Rundiste, oder wenn eine solche wie bei Rosetten nicht vorhanden ist, am unteren Pande mit dem Metall in Berïhrung, im übrigen kann aber die Fassung auf verschiedene Weise geschehen.

Die eine Art ist die, daß man den Stein nur an einzelnen Stellen des Randes mit der Mrtallfassumg in Zusammenhang bringt, so dab er hinten und vorn vollkommen frei liegt. Man kann dann vällig ungehindert dureh ihn hindurehsehen. Dies ist die Fassung à jour. Bei der anderen Art wird für den Stein ein seiner Größe entsprechendes Kaistehen in dem Metall der Fassung hergestellt und in diesem der Stein so befestignt, dab er nur von vorn sichthar, nach hinten aber rings von Metall umgeben ist. Dies ist die Fassung im Kasten. Das Hindurchsehen ist in diesem Falle unmöglich, und die Ilinterseite des Steines ist der Betrachtunge entzogen, doch ist zuweilen, um dieses heides zu ermögrichen, die hintere Wand de's Kastens mittels eines Scharniers zum Auf- und Zuklappen eingerichtet.

Bei der Fassung a jour ist der Stein von einem Metallring umgeben, von dem mehrere kleine Metallstibehen, die Krappen oder Krappeln ausegehen. Diese sind vorn etwas gespalten und bilden so eine Art kleiner Zäingelien, die den zu fassenden Stein am 
Rande gewissermaben schwehend festhalten. Diese Art der Befestigung wird wrzurswein. bei durchsichtigen farblosen oder schön gefärbten fehlexlosen Steinen gewählt, die in ihrer natiirlichen Beschaffenheit schon ihre höchste Schönheit entfalten und keinar kïnstlichen Verbesserung bediirfen. Anch die Schlifform ist bei der Wahl der Fassung niche gleichsuiltig. A jour werken namentlich die Stene mit Ober- und Lnterteil, wie Brillanten usw. sefalit, und zwar mit der breiten Tafel nach vorn. Nur fehlerhafte Steine werden zuweilen mit der 'Tafel nach hinten gekehtort dies ist die sogenannte indische Fassung Im Gemensity dazu findet man strine ohne Unterteil selten, Tiosetten niemals a jour gefaßt, sie wirken besser, wenn sie in Kasten gesetzt werden.

Diese Art der Fassung hat den Vorteil, daß die Verbindung des Steines mit dem Intall haltharer und dauerbafter ist. Ein stein fällt aus seinem liasten, in dem crerch Imbiexen des oberen Randes und oft mit einem besonderen kitt befestigt wird, nicht leicht heraus, während er sich bei der Fassung a jour viel ther aus den Krappen lïst und dabei Gefahr läuft, verloren zu gehen.

Gut gefourbte, fehlerlose Steine wroten einfach in den Kasten eingelassen: solchr. bei denen in Färbung orler blanz oder anch in anderer Beziehung zu wünschen übrim bleibt. können aber in dem Kasten besonder's leicht durch gaewisse Hilfsmittel in ihrer Wirkung wesentlich gehohen und Fehler künnen mehr oder weniger vollstïndig verborgen und rerdeckt werden. Operationen beim Fassen, die auf diese Zwecke hinzielen. Werden von den Juwelieren als das Aufloringen der Edelsteine bezeichnet.

Dies kann in verschiedener $1 V^{2}$ eise geschehen. Die am lïngsten geëibte Art des Aufbringens ist die Fassung auf If o or, einer schwarzen Farbe, die aus gebranntem Elfenbein und Mastix gemischt wird. Diese wird hei der Fassung von Edelsteinen mit dunkeln Flecken angewendet, indem man die Stellen im Innern des Kastens, wo die helleren Stellen zu liegen kommen, mit der Farbe bestreicht, während die übricken daron frei bleiben. Der Stein sieht dann auch in seinen helleren Partien dunkler aus, und die Färbung wird gleichmäliger, so dab oft die fleckige Beschaffenheit an dem crefalten Stein gar nicht mehr deutlich wahrgenommen werden kann.

Viel wichtiger und verbreiteter ist jedoch das Aufbringen mit Hilfe von Folien. Dies sind dünne Plättchen von Metall: Gold, siller. Kupfer, Zinn usw, die man in ihrer natürichen Farbe und mit dem ihnen eigentïmlichen starken Glanz dem Steine unterlegt. Statt dieser eigentlichen Folien werden auch zuweilen Stiickchen buntschillernder Seide oder Abschnitte ron Pfauenfedern oder ähnliche Dinge benutzt. Diese natïrlichen Folien schicken ihren Glanz und ihre Körperfarbe durch den darauf liegenden Stein hindurch und lassen ihn glänzender und besser geffürbt erscheinen. Ein helgelber Stein auf tiefgelber Folie (von Gold) wird dann selbst dunkler selb, ein dunkler oder matter auf einem hellen glänzenden Hintergrunde durchsichtiger und grlänzender aussehen. Wenn ein Stein, z. B. ein Diamant, eine ganz lichte Farbe hat, kamn man ihn durch eine Folie von der homplementärfarbe vollkommen farblos erscheinen lassen. Eine eigentiimliche Abänderung der Folie wird zuweilen im Orient mit Rubinen angewendet, deren Hinterseite man ausschlägelt und mit Gold ausfüllt, das die Wirkung des Steines bezüglich des Glanzes und der Farbe ungemein erhöht.

Es ist bei der Foliierung meistens wïnschenswert, dab der Stein und die Folic in der Farbe einander entsprechen. Da nicht alle hierzu nötigen Farben an den ron der Natur dargebotenen Metallen vorhanden sind, so werden die Folien, aber nur solche aus weifem Metall, zuweilen gefürbt, besonclers blau, rot und gelb, auch grün. Hierzu dient Karmin, Safran, Lackmus usw.; durch Mischen können auch Zwischenfarben erzeugrt werden. Die Farbstoffe werden nit reiner Hausenblase in Wasser gelöst und so auf die Metallplättchen aufgestrichen. 
Statt eine Folie einzulegen, kann man den Grund des Kastens oder die Hinterseite des Steines selbst mit der Folienfarbe überziehen; auch dadurch wird dieser in seiner Farbenwirkung sehr gehoben. Ja man kann einen farblosen durchsichtigen Stein durch geeigneten Farbiiberzug auf sciner Ininterseite wie einen farbigen oder, wenn der Überzug bunt ist, wie einen farbenspielenden erscheinen lassen. Letzteres wird gegenwärtig viel angewandt, un Bergkristall oder weißes Glas ähnlich wie Diamant in bunten Farben spielen zu lassen. Steine dieser Art von zum Teil recht hübscher Wirkung sieht man nicht selten unter dem Namen Iris an billigen Schmucksachen aller Art. Namentlich im Orient ist die Verwendung von Farbe außerordentlich entwickelt. Die dortigen Juweliere haben darin eine sehr große Geschicklichkeit, die sie auch nicht selten zum Betrug des Publikums anzuwenden wissen. Durch melr oder weniger tiefe Nuancen der einzelnen Farben kann man verschiedenen helleren und dunkleren Exemplaren derselben Art, z. B. mehreren gelben Topasen usw., eine ganz gleichmäßige Färbung verleihen, was nicht selten wiinschenswert ist bei der Vereinigung zahlreicher Steine, die schwer von der Natur ganz gleich gefärbt zu haben sind, in einem und demselben Scbmuckstiick.

Eine sehr wirksame Methode des Aufbringens ist das Unterlegen eines Steines nit einem zweiten von derselben Art und Schlifform. Sie wird besonder's bei größeren Rosetten angewendet, unter denen man oft eine kleincre mit Folie in dem Kasten anbringt. Der Crlanz und das Feuer der ersteren wird dadurch auf das Wirksamste erhöht. Auf ähnliche Manipulationen werden wir bei der Betrachtung der Verfülschung der Edelsteine noch einmal zurïckkommen.

Die Anwendung aller dieser Hilfsmittel zur Ifebung der Schönheit ist natiurlich am leichtesten bei der Fassung in einem Kasten, wo die ganze Hinterseite verdeckt ist. Schwieriger ist sie bei ì jour gefaßten Steinen, aber auch hier kann man bis zu einem gewissen Grade Gebrauch davon machen. Dies geschieht, indem man die dem Steine zurekehrte Innenseite der Fassung längs der Rundiste mit der hetreffenden Farbe versielit, oder an dieser Stelle einen dïnnen Streifen einer glänzenden Folie anbringrt. Der Stein gewinnt dadurch ebenfalls an Glanz und Farbe. So werlen helle Rubine zuweilen in der Art i jour gefaft, daf man an dem Innemrande der Fassung ein karminrotes Email anbringt, dessen Färbung sich dem Steine in der schönsten Wreise mitteilt, und bei anderen Edelsteinen verfährt man in entsprechender Weise.

\section{h. Fehler der Edelsteine.}

Von höehstem Einflusse für die Schönheit und den Wert der Edelsteine ist die Alwwerenheit aller storenden Fehler. Jeder sute Edelstein muß frei sein von Rissen und Spalten im Innern, der cilanz muß üher die ganze Oberfläche hin gleichmäßien und unmuterbrochen sein. Durehsichtige Edelsteine mïssen vollkommen klar sein, ohne trïlse Stellen, und diirf'n ror allem keine Einschliisse, namentlich keine undurehsichtigen von fremden festen Sulstanzen enthalten; farblose diurfen nirgends wenn auch nur ganz leichte farbige Flecken haben. Bei farbigen Edelsteinen muf die Farbe vollkommen gleichmäßig ïberall diesellhe sein, nirowends dïrfen sich hellere oder dunklere oder gar anders gefïrbte Partien zeigen, rorausgesetzt, daf die Wirkung nicht gerade auf der bunten Abwechslung der Farbe beruht, wie \%. B. beim Achat. Jede Störung in dem angedeuteten Sinne, jeder fremde Einschluß, jeder Ril, jede matte oder trübe oder andersfarbige Stelle usw. ist ein Fehlep des Steines. Ihre Alwesenheit ist namentlich bei durchsichtigen Edelsteinen wichtig: weil sie in diesen klar hervortreten, und weil sie, nach dem Schliff an zahlreichen Facetten gespiegelt, manchmal in scheinbar grofer Zahl sichtbar werden.

Kloine und unbedeutende Fehler lassen, wenn sie wenig zahlreich sind, einen Stein allerdingrs noch nicht als zum Schmuckstein unbrauchbar erseheinen, vermindern aber 
doch seinen Wert, und zwar unter Umstïnden sehr bedeutend. Die Griolis: und die IIiufung derselben beeinträchtigen aber die Schönheit des Aussehens nicht selten derart, dalb ein Stein von solcher Beschaffenheit zum Schmuckstein völlig ungeeignet und daher oft so gut wie wertlos ist, wenn er nicht wegen seiner Ï̈̈rte in der Technik noch irgend eine Verwendung finden kann.

Das Erkennen solcher Fehler, wie z. B. hellerer oder dunlilerer oder anders gefärbter Flecken, ist häufig nicht schwierig und oft schon auf den ersten Blick durch einfaches genaues Betrachten möglich. Iäufig liegen sie aber auch so versteckt im Innern, daf eine scharfe Lupe oder ein Mikroskop oder auch das geibte Auge des Juweliers dazu gehört, sie wahrzunehmen, um so mehr, als ein gewandter Schleifer es versteht, die Facetten so zu legen, dab die Fehler für den unerfahrenen Beobachter wenig oder gar nicht hervortreten. Schon oben bei der Betrachtung der Verhältnisse der Lichthrechung (s. 45) wurle erwähnt, daß die Fehler in durchsichtigen Steinen oft deutlicher sichthar gemacht werlen kïmnen, indem man sie in eine stark lichtbrechende Flüssigkeit, wie Methylenjodid, Monobromnaphthalin, oder auch Öl, Benzol usw. legt. Der englische Physiker Brewster, dem man diese Methode verdankt, hat zu demselben Zwecke zuerst Kanadabalsam, Anisöl oder Sassafrasöl vorgeschlagen.

Sehr leicht lassen sich die Fehler oft verbergen beim Fassen der Steine durch die verschiedenen Arten des Aufbringens, daher gilt die Regel, kostbare und wertvolle Steine von hohem Preise niemals in einer Fassung, sondern nur lose und ungefaßt zu kaufen, damit die Möglichkeit einer allseitigen und ungehinderten Lntersuchung rorhanden jist. Eine solche wird man zwecknäßigerweise bei jedem geschliffenen Steine vornehmen, den man kauft, ebenso aber auch bei jedem rohen. Hier ist die Untersuchung besonders schwierig, da die rauhe Oberfläche die Durchsichtigkeit häufig stark beeinträchtigt und dadurch die Fehler oft fast unbemerkbar macht. Auch in diesem Falle ist es anzuraten, den Stein in einer der genannten Flüssigkeiten liegend zu beobachten, da hierdureh die Wirkung der liauhigkeit bis zu einem gewissen Grade aufgehoben und die Durchsichtigkeit bedentend erhöht wird. Schon im Wasser wird ein solcher Stein viel klarer als in der Luft. Bei rohen Steinen ist es auch wichtig, festzustellen, ob etwaige Fehler ganz im Innern oder nahe der Oberfläche liegen. Im letzteren Falle kanin man sie häufig durch das Schleifen entfernen und auf diese II cise aus einem nicht ganz fehlerfreien Rohprodukte noch einen röllig tadellosen Schmuckstein erhalten.

Die Natur der Fehler, die bei den Edelsteinen am meisten vorkommen, ergibt sich aus dem Vorbergehenden schon von selbst. Einige von ihnen, die häufig und in besonders charakteristischer Weise wiederkehren, sind von den Juwelieren mit besonderen Namen belegt worden. Diese sollen im folgenden etwas spezieller betrachtet werden, während über andere, wie farbige Flecken, größere Einschlïsse fremder Körper usw., weitere allgemeine Bemerkungen nicht erforderlich sind.

Diese häufigeren und wichtigeren Febler der Edelsteine sind nun die folgenden:

1. S a n d. Einzelne kleine Körnchen meist ron weifer, brauner oder rötlicher Farbe, die irgendeiner fremden Substanz angrehören, sind in den Steinen eingeschlossen.

2. Staub. Die Körnchen sind sehr klein und wenigstens an einzelnen Stellen in äußerst feiner Verteilung in Menge zusammengehäuft.

3. Wolken. Verschieden gefärbte, weiße, graue, braune, rötliche, auch grïnliche, wolkenähnliche, trübe Flecken, die, wenn sie beim Schleifen an die Oberfläche kommen, trotz aller Jühe niemals eine glänzende Politur annehmen und daher matte Facetten veranlassen. Sie sind am häufigsten beim Diamant und beim blassen Rubin. 
Diese drei Arten von Fehlern beruhen auf Unreinigkeiten, auf der Anwesenheit kleiner fremder Mineralkörner in den Edelsteinen. Sie künnen, wenn sie nicht gar zu klein sind, zuweilen schon mit bloliem Auge oder doch mit einer guten Lupe erkannt werden, oft ist dazu aber auch die stïrkere Vergrößerung des Mikroskopes nötig. Namentlich bei Anwendung polarisierten Lichtes treten solehe kleine Einschlüsse oft sehr deutlich hervor, indem sie hei der Dunkelstellung des ganzen Steines zwischen gekreuzten Polarisationsehenen hell erscheinen und sogar oft in lebhaften Farben erglänzen.

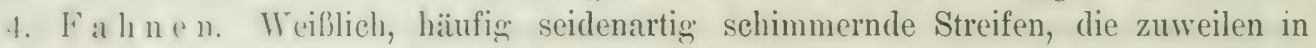
rerschiedenen Richtungen dureh manche Edelsteine hindurchgehen und so die Gleichmäßickeit des Anblicks striren. Sie beruhen ebenfalls auf Einschliissen, aber nicht ron frsten Körpern, sondern von winzigen, eanz leeren oder mit einer Flüssigkeit erfüllten Poren. Derartige IIohlräume finden sich in manchen Edelsteinen in grober Zahl und auch oft ron bedeutender Gröbe, wie z. B. im Topas, Sapphir usw., wo sie manchmal selon mit hlobem Auge oder doch mit der Lupe erkannt werden können. Die Fahnen entstehen aber durch Zusammenhäufung sehr zahlreicher mikroskopisch kleiner Einschlïsse diescer Art, die erst bei starker Vergrößerung einzeln deutlich hervortreten, und die sich oft in hestimmten Schichten oder Streifen anordnen. Durch die Reflexion des hindurchgehenden Lichtes an djesen vielen kleinen Hohlräumen wird der störende, matte Schimmer hervorgebracht, auch haben sie wie die Wolken die Wirkung, daß sie an der Stelle, wo sie an die Oberfläche treten, eine vollkommene Politur verhindern.

5. Fed ern. Risse und Spalten, oft sehr klein, fast mikroskopisch, oft größer, die in allen Arten von Edelsteinen teils cinzeln, teils in größerer Menge nebeneinander vorkommen und den Gang der Lichtstrahlen stören. Sie sind besonders häufig bei steinen, die cine sehr vollkommene Spaltbarkeit besitzen, wie beim Diamant, Topas und anderen; bei diesen verlaufen sie meist den spaltungsflächen entsprechend regrelmäbig ind eben. Aber auch bei nicht spaltharen Steinen, wie bein Bergkristall, Granat usw., fehlen sie nicht, sind aber bei diesen unregelmäligig gekrïmmt und gebogen. Längs solcher Spalten bemerkt man sehr häufig die lebhafte Farbenerscheinung des Irisierens (S. 77), dann treten sie besonder's deutlich hervor. Weniger bemerkbar sind die Federn, wenn auf ilnnen keine Farben erscheinen; dann sind sie auch mit der Lupe oft schwer zu erkennen. Sie sind ganz besonders gefürchtet, mehr als alle anderen Fehler, weil in der Richtung dieser kleinen Spältehen die Steine leicht weitersporingen und so entweder immer unansehnlicher werden oder auch ganz zerbrechen. Dies geschicht besonders leicht beim Schleifen, infolge der damit verbundenen Erschütterungen, oder auch noch nachher bei unvorsichtiger liehandlung und sogar of ohne irgendwelche erkennbare iußere Ursache. E.s ist diher sehr wünschenswert, sich vor dem Schleifen von der Abwesenheit solcher Fehler zu ̈̈berzengen, was auljer durch Einlegen in eine der stark brechenden Flüssigkeiten und Beobachten hei mehr oder weniger starker Vergröberung zuweilen dadurch gerschicht, dal) die Steine erhitzt und rasch im Wasser abgekühlt werden. Sind Risse vorhanden, so (rweitern sich diese und werden deutlicher sichthar; oft springt dabei sogar der gamze Stein mach den vorhandenen Rissen in Stiicke. Die Opreration ist etwas roh und wird daher wohl bei wertyollen Steinen selten oder nie angewendet werden.

6. Eisige Flecken. Das sind Fehler, die nicht von Natur vorhanden sind, sondern dic an manchen Eidelsteinen entstehen, wenn sie beim Schleifen infolge der starken Reibung zu selır erhitzt werden. Es sind Stellen an der Oberfläche, an denen die Steine sich dann nicht mehr grut polieren lassen und keinen schönen Glanz mehr annehmen, sondern matt und trübe bleiben. Sie können vermieden werden. wenn man beim Schleifen zu starke Erlhitzung des Steines vermeidet.

7. M o osig heifen Steine, die kleine moosähnliche Einschlüsse haben, wie sie beim 
Moosachat in Menge vorkommen und bei diesem die Sichönheit hedingen. Aber auch Steine mit Trübung olıne einen bestimmten Fehler der genannten Arten, bei denen also die: Ursache der 'T'ribung nicht deutlich zu erkennen ist, werden ïfters ebenso grenannt.

\section{i. Küinstliehe Yachbildungen.}

Wie viele andere Mineralien, so hat man auch schon die meisten Edrelsteine kimstlich nachzubilden versucht. (l. h. man hat sich bestrebt, Kunstprodukte herzustellen, die in jeder IIinsicht, also namentlich in bezug auf die Kristallisation, die chemische Zusammensetzung und die sämtlichen physikalischen Eigensehaften mit den natürlich vorkommenden Edelsteinen vollstïndig übereinstimmen. Gelingt es auberdem, solche künstliche Wineralien in ehenso klaren und durchsichtigen Stïcken mit dem starken Glanz und Fener und mit der schönen Farbe der natïrlichen zu produzieren, so sind diese künstlichen den entsprechenden natïrlichen vollkommen gleichwertig; sie sind als Schnucksteine ebenso verwendisar wie die letzteren, bringen dieselbe Wirkung hervor und sind wegen der grleichen grolsen Ilärte elenso dauerhaft. Es wäre bei gleicher Qualität ein unbegründetes Vorurteil, das Kunstprodukt für schlechter zu halten als das natürliche, denn die künstlichen Steine wïrden sich eben vor den natürlichen durch keine wesentliche Eigenschaft, sondern nur durch die Entstehung unterscheiden; der künstliche Stein wäre keine Terfïlschung, sondern nur eine Nachbildung des natürlichen.

Solche syuthetischen Nachbildungen sind nun auch in der Tat bei vielen als Edelsteine benïtzten Mineralien schon gegliickt. Aber die erhaltenen Produkte laben, wenn sie gleich hohes wissenschaftliches Interesse besitzen, doch bisher meist noch keine grofe praktische Bedeutung erlangt, da man gewöhnlich entweder nur ganz kleine, sogar mikroskopisch kleine Körnchen, oder Steine von solcher Beschaffenheit erhalten hat, daß sie aus anderen Gründen keine Verwendung als Schmucksteine finden konnten. Ersteres ist z. B. der Fall beim Diamant, letzteres bei sehr vielen anderen. Indessen sind doch auch bei einzelnen Edelsteinen schon ganz befriedigende Resultate erzielt worden, die sogar für den Handel zum Teil nicht ohne Bedeutung sind. So ist es beim Türkis, sodann auch beim Alexandrit und beim roten und blauen Spinell. Von allen diesen lassen sich Steine von Edelsteinqualität und von genügender Größe künstlich berstellen. Ganz besonders wichtig ist aber die Reproduktion des kostbarsten aller Edelsteine, des Rubins und, an diesen sich anschließend, jedoch ron geringerer praktischer Bedeutung, des farblosen, gelben und violetten Edelkorundes.

Die Herstellung des kïnstlichen Rubins war bis vor kurzem vornehmlich in Paris zu Hause, von wo er in prïichtigen Exemplaren in den Handel gebracht wurde. In neuerer Zeit stellt ihn die "Deutsche Edelsteingesellschaft" zu Idar bei Oberstein an der Tahe und deren Direktor Hermann Wild in Verbindung mit dem Professor A. Niethe in Charlottenburg in mindestens ebenso vorzüglicher Qualitït her, daneben alle die anderen genamnten durchsichtigen Edelsteine, deren Reproduktion anderwärts zum Teil noch nicht gelungen sein soll. Die Darstellungsmethoden werden selbstverständlich überall geheim gehalten, doch wird davon bei der Betrachtung des Rubins noch weiter die Rede sein.

Diese künstlichen Steine sind den natïlichen in der chemischen Zusammensetzung rollkommen gleich, die Iürte ist dieselbe, ja zuweilen wegen der Reinheit dex Substanz und des regelmäligen kristallinischen Aufbaus sogar noch etwas hüher als bei dem Naturprodulit, Feuer, Glanz und Klarheit sind wie bei den besten natürlichen Exemplaren, in der Haltharkeit ist kein Lnterschied und in den optischen Eigenschaften, Licht- und Doplpellurechung, Farbe und Dichroismus besteht völlige Übereinstimmung. Kenntlich sind die Kunststeine zuweilen an mikroskopisch kleinen rundlichen Luftblïschen, die indessen

B a u or, Edelsteinkunilo. 2. Aufl. 
der Schönbeit keinen Eintrag tun. Bei guten Stïcken fehlen sie, die Vervollkommnung der Fabrikation hat sie vermeiden gelehrt.

Die Produkte dieser Industrie kommen sorgfältigg geschliffen in verschiedenen Qualitäten in den IIandel, die sich ledighlich durch schönere oder weniger schöne Farbe, vollkommenere oder weniger vollkommene Durchsichtigkeit und durch das Fehlen oder Vorhandensein kleiner sichönheitsfehler unterscheiden und darnach im Preis bewertet werden. In Anbetracht der Schwierigkeiten, die besonders bei absolut fehlerfreien Steinen mit der Grölje schnell wachsen, sind die großen Exemplare verhältnismäßig etwas, aber nicht sehr viel teurer als die kleinen; der Preis pro Karat wächst mit der Größe, aber nicht annïhernd so rasch wie bei den Natursteinen, namentlich bei dem Rubin. Ganz besonders schöne und rollkommene Stücke stehen auch hier höher im Preis, weil bei ihnen wie in der Natur das Zusammentreffen aller zu ihrer Entstehung notwendigen Bedingungen immerhin ungewöhnlich ist und sie daher in dieser erstklassigen Beschaffenheit nur selten vorkommen.

Welche Edelsteine man schon jetzt herzustellen imstande ist, wurde schon oben erwälınt. Die Untersuchungen auf diesem Gebiete werden aber dauernd weitergeführt und der Kreis der synthetisch dargestellten Steine wird sich im Lauf der Zeit mehr und mehr erweitern. Man wird wohl jetzt schon sagen können, daß wir in Zukunft imstande sein werden, die sämtlichen jetzt als Edelsteine benutzten Mineralien in zum Schmuck brauchbaren Exemplaren künstlich zu erzeugen, bei denen sich die immerhin umständliche, äußerst subtile, mïhsame und kostspielige Operation wegren des Preises der Natursteine noch lohnt. Es steht sogar zu elwarten, daß sich der Kreis der als Schmucksteine verwendbaren Mineralien durch diese Bestrebungen noch erweitern wird.

Eine Folge dieser Reproduktion kostbarer Edelsteine auf verhältnismäßig billigem Weg ist die Gefahr, dal die teuern natïrlichen Steine entwertet werden. Die Juwelenhändler haben daher Maßregeln ergriffen, um dies tunlickst zu verhindern, namentlich beim Rubin, der unter den künstlichen Edelsteinen heutzutage weitaus der wichtigste ist und bei dem eine besonders große Preisdifferenz den Natursteinen gegenüber besteht. Wieweit sie dazu auf die Dauer imstande sem werden, muß die Zukunft lehren. Zunächst sind die Gewinnungskosten und somit auch die Preise schöner künstlicher Steine aus dem oben erwähnten Grunde immer noch ziemlich beträchtlich, es ist aber natiirlich nicht ausgeschlossen, daß eine Verbesserung der Fabrikationsmethoden usw. die Ilerstellung guter Exenplare auf weniger kostspieligem Wege ermöglicht. Der betreffende Stein, also z. B. der Rubin, wïrde dann wohl trotz seiner Schönheit aus dem Schmuck der Tieichen ausscheiden und in die billigen Zierate der ärmeren Volksklassen eintreten. Er wäre dann ja jedermann zugänglich und hätte den Hauptreiz verloren, der für den Reichen vielfach nur darin besteht, daß er allein imstande ist, einen solehen Stein zu besitzen.

\section{k. Verfilschumgen.}

Es ist leicht begreiflich, daß bei Gegenständen von so hohem Wert, wie die Edelsteine, häufig der Versuch gemacht wird, statt der kostbaren echten Substanz ähnlich aussehende, minder wertvolle Dinge unterzuschieben und unerfahrene Käufer damit zu betrïgen. Statt hoch im P'reise stehender feiner Steine sucht man diesen andere billigere und gemeinere, oder auch Glasflüsse von derselben Farbe anzuhängen, oder statt fehlerfreier, tadelloser Exemplare solche mit allen möglichen Mängeln, die man tunlichst zu verbergen bestrebt ist. Vielfach werden zwei kleinere Steine aneinander gekittet, sodali der Anschein eines gröferen entsteht, oder es wird sogar ein Oberteil von echtem Material mit einem Unterteil aus unechtem vereinigt, um diese Täuschung hervorzurufen. 
Der erfinderische Geist unredlicher Edrelsteinhändler weil) noch manches andere Mittel zum Betriigen der Abnehmer ausfindig zu machen und diese Mittrel den sperzell vorliegenden Steinen auf das Fesehickteste anzupassen. Drm Kïufrer eines wortrollen und teuren Edelsteines kann daher die äuljerste Vorsicht nicht dringend genug angraten werden, wenn er es nicht mit einem allgemein als absolut zuverlässig bekannten Manne zu tun hat, dessen gesamte fieschäftsverhältnisse die Vornahme solcher betrïgrerischer Manipulationen ausschlieben. Diese Vorsicht ist um so notwendiger, je kostharer die Steine, bei denen im Falle der Gelingens besonders reicher Gewinn in Aussicht strht. Bei ihnen werden die IIerkmale des Betrugs mit gröbter Gewandtheit verboroen, so (lal) zu ihrer Erkemmung oft ein sehr scharfes $A$ uge, grobe Sachkenntnis und langjährige Erfahrung nütig ist, wie sie meist nur ein in solehen Geschäften bewanderter Händler besitzt.

Solche Künste des Betruges sind namentlich im Orient zu hoher Blïte gelangt. Nancher Reisende kauft in Indien, Birma, auf Ceylon usw. von einem eingeborenen Edelsteinsucher einen Vorrat sciner Ware, deren schönes Aussehen jeden Gedanken an Terdacht verscheucht, und rrführt später von einem Sachverständigen, dab er ganz wertlose Dinge, gemeine Steine, geschickt hergerichtete Stiicke von Bouteillenglas und anderes ähnliche's erhandelt hat. Am schlimmsten ist es mit gefabten Steinen, bei denen die Fassung: alle möglichen Betrigrereien verdecken kann. Es sei daher hier die Regel wiederholt, wertvolle und kostbare Steine nicht in gefaßtem Zustande zu kaufen.

Es ist nicht zu leugnen, daß die Operationen, die wir als das Aufbringen (pag. 109) kennen gelernt haben, eigentlich schon anf eine Täuschung hinauslaufen, sofern sie die Steine besser erscheinen lassen als sie in Wirklichkeit sind. Da diese Verbesserung aber offen und unter allgemeiner Kenntnis geschieht, so kann man das Verfahren doch nicht als Betrug auffassen, um so weniger, als im reellen Edelsteinhandel für den durch das Aufbringen verbesserten Stein nicht der hohe Preis des an sich schon guten verlangt wird der keiner künstlichen Verbesserung bedarf.

Allerdings gibt es manche Hilfsmittel zur Verschönerung und Verbesserung von Edelsteinen, die den beim Aufbringen angervendeten sehr ähniich sind und die doch eine ahsichtliche Täuschung bedeuten. Wenn ein farbiger Stein zu seiner Verbesserung mit Folie gefaft oder hinten mit Folienfarbe bestrichen wird, so gehört das zu den erlaubten, hekannten und anerkannten Manipulationen des Aufbringens. Jeder reelle Juwelier verführt in dieser Weise, aber er rerschweigt den Sachverhalt dem Kunden nicht und verlangt auch keinen höheren Preis, als der Qualitït des Steines wirklich entspricht. Wenn dagrexen z. B. ein gelblicher Diamant mit einer dünnen Schicht einer bläulichen Farbe überzogen wird, damit er durch die Kontrastwirkung der beiden Farben weiß aussieht, und wenn er dann als farbloser Diamant zu einem dieser seiner scheinbar besseren Qualität entsprechenden hohen Preise verkauft wird, dann ist das eine betrïgerische Handlung. Man sieht, wie handwerksmäbige Kunstgriffe sich unter Umständen von betriggerischen Kiniffen nur wenig unterscheiden. Ob das eine oder das andere vorliegt, hängt in letzter Linie wesentlich nur davon ab, ob dem Käufer offene ehrliche Xitteilung gemacht und ihm nur der dem wirklichen Wert entsprechende Preis abverlangt wird, oder ob er, ohne den Sachverhalt zu erfahren, eine der scheinbaren Qualität entsprechende Summe zu bezahlen hat, die den wirklichen Wert übersteigt.

Betrug im Edelsteinhandel kann, wie wir gesehen haben, in der verschiedenartigsten Weise begangen werden. Es ist untunlicb, jede einzelne IIöglichkeit zu besprechen, um so mehr, als zu den altbekannten Fällen immer neue von anderer Art hinzutreten. Einige Methoden kehren aber mit besonderer Häufigkeit immer wieder, und diese sollen im folgenden etwas eingehender mitgeteilt werden. 
1. Unterschieben weniger wertvoljer Steine für kostbarere. Man kann das natïrlich mit Aussicht auf Erfolg nur, indem man solche billigere Steine wählt, die den teureren in Farbe, Glanz und überhaupt dem ganzen äußeren Ansehen, ebenso aber auch womöglich in Beziehung auf innere Eigenschaften, wie spezifisches Gewicht, Härte usw. ähnlich sind. Nur dann wird es gelingen auch solche zu hintergehen, die wenigstens einiwe Sachkenntnis besitzen, und nicht selten sogar handwerksmälige .Juweliere. So wird dem Diamant der farblose Topas untergeschoben, der ihm in der Farblosigkeit ganz glejeh ist und im (t)anz sehr nahe steht und der auch dasselbe spezifische Gewicht hat. Dasselbe geschieht mit dem weißen Hyacinth und dem weißen Sapphir. Diese Steine sollen frïher, nach dem Zeugnis von II a we, einem bekannten Londoner Juwclier aus dem Anfange des 19. Jahrhunderts, höhere Preise gehabt haben, als sie eigentlich rerdienten, nur weil sie sehr geeignet sind, betrügerischer Weise als Diamanten noch viel teurer rerkauft zu werden. Dem gelben Topas wird der gelbe Quarz oder Citrin, dem liubin der rote Rubinspinell usw. untergeschoben, und solcher Möglichkeiten gibt es noch viele.

Manche Steine lassen sich nicht in ihrem natürlichen Zustande für andere wertvollere ausgeben. So ist es mit dem schon erwähnten Zirkon, der nicht von Natur weiß, sondern erst durch Erhitzen des gelbroten Hyacinths farblos und damit auch stärker glänzend geworden ist. In ähnlicher Weise läßst sich blauer Sapphir in den ebenfalls schon oben erwähnten farblosen umwandeln. Aber nicht nur Entfärbungen, sondern auch Färbungen kommen vor. So lassen sich manche Chalcedone schön blau färben und gleichen dann bis zu einem gewissen Grade dem gleichfalls blauen Lasursteine, dem sie bei der Herstellung billiger Schmucksachen und anderer kleiner Luxusgegenstände untergeschoben werden.

Ein greschickter Juwelier wird solche und andere ähnliche Betrugsversuche meist leicht und auf den ersten Blick erkennen. Es können aber doch auch Fälle eintreten, wo dies nicht so obne weiteres möglich ist. Dann bleibt nichts übrig, als die Steine, selbstverständlich ohne sie zu zertriimmern oder auch nur an ihrer Oberfläche zu bescbädigen, einer Untersuchung nach den Methoden der wissenschaftlichen Mineralogie zu unterwerfen, die unter allen Umständen zu dem Ziele der Erkennung der vorliegenden Sulstanz führen. Eine Anleitung dazu wird im dritten Abschnitte gegeben und auch bei der Beschreibung jedes einzelnen Edelsteines wird das Verfahren erwähnt werden, das geeignet ist, ihn von ähnlich aussehenden zu unterscheiden.

2. Dubletten. (Dublierte Edelsteine.) Man versteht unter Dubletten Schmucksteine, hei denen zwei Teile, ein Unterteil und ein Oberteil, in den meisten Fällen durch Zusammenkitten mit Mastix, zu einem scheinbar einheitlichen Ganzen vereinigt sind. Sie, gehören nit zu den häufigsten Täuschungen, die im Edelsteinhandel vorkommen.

An wenigsten weit geht die Terfälschung, wenn beide Teile aus echtem Material hestehen, z. 13. aus Diamant, und man nur aus zwei kleineren Stïeken ein grö̈ßeres herstellt, das, wemn es wirklich ein Canzes wäre, wie es nur scheint, einen weit höheren Wort hïtte, als die beiden Stiicke zusammen. Derartige Dubletten künnte man als echte bezeichnen.

Sehr häufig ist jedoch nur der Oberteil ein echter Stein, z. B. Diamant, Rubin, Sapphir usw. Der Unterteil besteht aus irendenem geringeren Stoff, z. B. Bergkistall oder auch Glas von der Farbe des echten Steines. Dirs sind die sog. Mixte. Wen das geschiekt geemacht ist, sieht es aus, als wemn das Ganze aus dem wertrollen Material des Oberteils hestiinde, und auf den ersten lilick zeigt eine solche Dublette die volle Schönheit des rehten Steines, auch wenn von diesem nur eine ganz diume sehicht rorhanden ist. Man -pricht so ron Diamant-, Rubin-, Sapplnir- usw. Dubletten. Aus Antwerpen wird be- 
richtet, dafs vielfach Diamant und weifere Sapphir in der angegebenen Weise mitrinander verbunden werden. Rubin wird nachgremacht, indem man filaspasten mit cinem l'lättchen ron Almandin hedeckt. Manchmal wird auch eine dïnne Zwischenschicht eines sehönfarbigen Steines, z. B. von Smaragd der aus Berorkistall, oder rilas bestehenden wertlosen Initation eingefïgt. Es ist klar, dab der Verfertiger derartiger Fälschumenen srinen Vorteil darin hat, einen scheinhar groben Stein mit riner kleinen Menge des echten Materials herzustellen. Indarige Dublenten heifen halbechte. Wenn der eine Treil Glas ist. wird (re zuweilen an den anderen Teil nicht mit Mastix angekittet, sondern anceschunolzen und auf diese Weise eine innigere und festere Vereinigung erzielt.

In einer Fassung, namentlich in Kasten, sind derartige Falsifikate schwer zu erkemnen; wenn sie nielit gefalit sind, ist es leichter. Auf der Berührungafläche beider 'Teile sirht man zuweilen mit einer scharfen Lupe die Verbindunesnaht, oder man benerkt

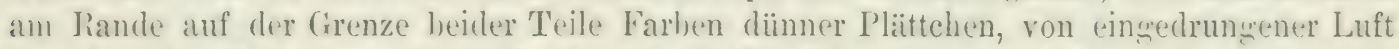
herriblurend. Bringt man eine Duhlette in heiljes Wasser, so zerfällt siv, wenn sie nit Mantix erekittet. selhstverständlich aber nicht, wenn der Oberteil an den Lntertril angershmolzen ist. Wenn (ilas und ein doppelthrechender Stein, wie z. I). Iublum, miteinander verbmden sind, kann man die Zusammensctzung an dem verschiedenen Verbaltun beider Teile im polarisierten Lichte erkemen. Anch die verschiedene Lichthrechung beider kamm benutzt werden, namentlich bei farblosen Steinen, wenn etwa Diamant mit Berrokristall dubliert ist. Man legt die Dublette in eine stark lichthrechende Fliissigkeit, etwa Methylenjolid oder Monohrommaphthalin und rerdünnt diese sn lange, bis man den einen 'Teil, der aus Berghristall besteht, nicht mehr sieht, er also nit der Flissigkeit genan dassthe Lichthrechungsverhältnis hat. Der stärker lichthrechende Diamant ist damn immer noch deutlich mit scharfen Lmrib zu unterscheiden. Auch das spezifische (iewicht kann zur Erkennung dienen.

Alle diese Hilfsmittel sind aber nur nötig, wenn die Dublette sehr reschickt und mit sehr gut zueinander passenden Materialien gemacht ist. Namentlich die indischen Juweliere sind sohr hewandert in der Anfertigung guter Dubletten. Sind solche weniser sorwfältig gemacht, so geniigt vielfach schon der Kontrast des Aussehens der beiden sich dicht brribrenden Teile, um sie mit Sicherheit nebeneinander zu erkennen und roneinander zu unterscheiden.

Bei unechten Dubletten besteht der Oberteil aus Bergkristall oder farblosem (ilase, der Lnterteil aus farbigem Glase. Letzteres teilt damn dem oberteil seine Farbe mit. Dieser Zweck kann auch erreicht werden. wenn man zwischen Ober- und Lnterteil von farblosem Material eine dünne Schicht der Folienfarbe anbringt, oder ein Metallplättchen oder anch ein Stiickehen sefärbtes Gelatinepapier einschicht. sind beicle Teile verschieden gefärbt, so erkennt man die Dublette sofort, wenn man nicht senkrecht zur Tafel des O1,erteils, sondem in deren Richtung seitlich hindurchsieht. Man empfichlt, den Stein zu diesem Zweche auf den Fingernaged zu setzen und gegen das Licht zu halten. Mit der Lupe (rkennt man dann auch eine zwischen zwei farblose Steine gelegte Farlschicht. Ilierbei und ibberhaupt immer bei der Untersuchung der Dubletten ist es aber, wie erwähnt, durchaus erforderlich, daß der Stein nicht gefalit ist.

Eigentiumlich sind die IIohldubletten. In einen Bergkristall oder in farloses (ilas, die als Oberteil greschliffen sind, wird ron hinten eine Ilöhlung getraben und deren Wand fein poliert. Hierauf wird die Höhlung mit einer farbigen Fliissigkeit erfüllt und mit einem Plïtehen aus Berwkristall oder Glas, oder mit einem rollstïndiwen Lnterteil ans diesem Vaterial verschlossen. Die Farbe der Flïssigheit teilt sich ebenfalls dem granzen steine mit, wenn man von der Tafel her auf ihn sieht. Man erkennt aber auch in diesem Falle wie im rorigen dessen Farblosickeit, wenn man ihn von der Sidte her betrachtet. 
3. Glasflüsse. Zu einer hohen Vollkommenheit ist die Kunst gediehen, Glasflüsse mit den wesentlich die Schönheit bedingenden Eigensehaften der echten Edelsteine herzustellen und sie in geschliffenem Zustande diesen unterzuschieben. Solche zur Nachahmung von Edelsteinen geeignete Glasflüsse, aber ebenso die Imitationen selbst werden auch Pasten (Claspasten) grenamnt. Sie dienen zum Ersatz kostbarer Edelsteine in billigen Schmuckstücken, doch werden sie auch vielfach mißbraucht; der mit ihrer Hilfe geübte Betrug ist wohl der hïufigste, der in Edelsteinhandel vorkommt; er ist schon im Altertum gut bekannt sewesen und häufig vorgekommen, so daß die alten Schriftsteller, wie Plinius, bereits ausführlich davon sprechen und eindringlich davor warnen.

Der Fabrikation soleher Gläser liegt also das Bestreben zugrunde, ein Kunstprodukt zu erzeugen, das so vollständig wie möglich die wertvollen und schätzbaren Eigenschaften der echten, natiirlichen Edelsteine besitzt, dessen Preis aber möglichst weit unter dem der letzteren steht. Der einzige $\mathrm{Weg}^{\mathrm{g}}$, den man hierzu kennt, ist die Herstellung einer möglichst klaren und zunächst farblosen Glasmasse; diese wird dann entweder nach Bedarf farblos verwendet, oder es wird ihr, wenn es sich um gefärbte Steine handelt, durch Umschmelzen unter Zusatz geeigneter Metallverbindungen die gewünschte Farbe mitgeteilt. Hauptsächlich in Paris und in Böhmen werden solche Imitationen fabriziert.

Die meisten Edelsteine können auf diese Weise beziiglich ihres Aussehens so tïuschend in Glas nachgeahmt werden, daß oft sehr große Übung dazu gehört, um das Falsifikat vom echten Steine durch Betrachten mit dem bloßen Auge allein und olne eingehende Untersuchung aller Eigenschaften zu unterscheiden. Es gibt solche Gläser, welche nicht nur die Farblosigkeit und Klarheit, sondern auch das durch starke Lichtbrechung und Farbenzerstreuung bedingte Farbenspiel, sowie den eigentiimlichen hohen Glanz der Diamanten vom reinsten Wasser besitzen; chenso gibt es solche mit der prächtigen Farbe der schönsten Rubine, Sapphire, Smaragde, Topase usw. Was man einem solchen Kunstprodukte aber niemals mitteilen kann, das ist die IÏ̈rte. Alle solche "künstlichen Edelsteine" haben nur die IÏ̈rte des Glases $\left(H_{0}=5\right)$, sind sogar meist noch etwas weicher als gewöhnliches Fensterglas. Indessen nehmen sie doch beim Schleifen eine ganz schöne Politur an, aber sie können diese und auch die Schärfe der Kanten und Ecken beim Gebrauch nicht dauernd erhalten. Wenn sie auch ganz neu dem echten Steine täuschend ähnlich sind, so werden sie doch nach kurzem Gebrauche matt und unscheinbar. Könnte man den Glasfliissen auch die grolje Iärte der Edelsteine geben, so wären sie zum Schmucke mindestens ebenso geeignet wie diese; die erwähnten Übelstände würden dann wegfallen. Zur Verdeckung der geringen Härte wird nicht selten ein Plättchen oder ein Oberteil des echten oder doch ('ines harten Steines aufgelegt, wie wir es bei der Betrachtung der halbechten Dubletten gesehen haben.

Die geringe Härte läßt in fast allen Fällen ein solches Glas von dem echten Steine unterseheiden. Das Glas wird von der harten Stahlspitze leicht geritzt, aber nur sehr wenige echte Edelsteine. Neuester Zeit empfiehlt man zur Unterscheidung. von Glasfliissen und echten Edelsteinen einen Aluminiumstift, dessen Spitze beim Streichen auf Glas eine siberigr slïnzende Linie hinterlassen soll, nicht aber auf einem echten Edelstein mit seiner gröljeren Häirte. Es gibt jedoch anch noch andere Merkmale. Das Glas ist wie alle amorphen Substanzen einfach lichtbrechend, im Gegensatz zu den meist doppeltbrechenden Edelsteinen, welchen Untersehied man in der oben beschriebenen Weise mit IIilfe des Polarisationsinstrumentes (p.57) oder unter Unstäinden auch mittelst der dichroskopischen Iupe (p. 74) feststellen kann. Von den Edelsteinen bricht aber der Diamant ebenfalls das Lieht nur einfach, dieser kann also vom Glase mit Hilfe des Polarisationsinstrumentes nicht unterschieden werden. Hier hilft nur die IÏ̈rte, wenn nieht das auf Seite 62 beschriebene schwarze Kreuz für Glas entscheidet. Auch im spezifischen Gewicht 
ist wohl meist eine Differenz zwischen dem Cxlase und dem echten Edratseine. Wenn

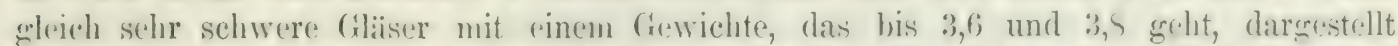
werden kïnnen, so stimmt doch die für das Glas gefundene Zahl im spezirllen Falle sohr selten erenau mit dem Edelsteine, der nachereahmt werden soll. Endlich ist auch der Clasflul sehr schwer wanz frei von kleinen Luftblïschen und anderen Unregelmäligkeiten, sogenannten Schlieren, zu erhalten, die in dieser Weise in den Exlelsteinen nicht vorkommen. Die Betrachtung mit der Lupe, oder wenn nötig auch mit dem Mikroskop, lïbt nicht selten diese Bläischen usw. und damit die Glasimitation erkennen und rhenso den ausgezeichneten muschligen Bruch des Glases, der sogar an den Rändern gresehliffener Stiicke noch häufig in sehr charakteristischer Weise und ganz anders als an echten Edelsteinen auftritt. Ein chemisches Kemnzeichen des Glases dem Diamant und den meisten echten Eddsteinen gergenüber ist die leichte Angreifharkeit durch die Glasätztinte, von der oben S. 8 die Rede war.

Die Masse, vor der man bei der Herstellung aller dieser ,kï̈nstlichen Edelsteine" auseght, ist in den meisten Fällen ein leicht schmelzhares, farbloses, bleihaltiges Glas, das den Namen Strab oder Mainzer Fluf, zuweilen auch Amause (siehe unten) führt. Dieses muli vor allem die höchste Durehsichtigkeit und Klarheit und vollkommene Farblosighkeit zeigen, es ist daher von der grö̈ten Wichtigkeit, daß nur Materialien von möglichster Reinheit rerwendet werden. Im allgemeinen sind es dieselben Stoffe, die auch sonst zur Bereitung des Glases dienen, zu denen aber hier noch einige weitere. besonders die bleihaltige Mennige, hinzutreten.

Es ist vor allem der Quarz, der durchaus eisenfrei sein muf, und den man am besten in der reinen Form des Bergkristals anwendet. Der Kaligehalt des Glases wird meist durch das kohlensaure Kali (Pottasche) geliefert, das möglichst frei von fremden Bestandteilen sein soll. Da der Kalisalpeter leiehter rein erhalten werden kann, so wird er nicht selten statt des kohlensauren Kali zugesetzt, oder auch manchmal aus demselben Grunde weinsaures Kali. Als Ersatz des Kalium dient zuweilen eine gleichwertige Menge Thallium, die in Gestalt irgendeines Thalliumsalzes den anderen Gemengteilen beigegeben wird. Man erhält dann das sogenannte 'Thalliumglas (Thalliumpaste). Die das Blei liefernde Mennige wird aus chemisch reinem Blei dargestellt. Etwas weißer Arsenik wird zuweilen beigefuigt, der aber unwesentlich ist und daher seiner Giftigkeit wegen auch vielfach fortbleibt. Zur Beförderung der Schmelzbarkeit dient eine kleine Menge Borax oder der reineren Borsäure; sie geht nicht in die Substanz des Glases ein, sondern verflïchtigt sich in der Glut des Glasofens.

Diese Stoffe werden möglichst fein pulverisiert, möglichst innig gemengt und in hessischen Tiegeln zusammengeschmolzen bei einer möglichst konstanten Temperatur, die nicht höber sein soll, als gerade zur Schmelzung erforderlich ist. Damit die Masse gleichmälbig und möglichst blasenfrei wird, bleibt sie lange (bis 24 Stunden) im Ofen, und die Erkaltung muß sehr langsam und stetig seschehen. Jegliches Umrühren der Schmelze ist zu rermeiden, weil dadurch Luftblasen erzeugt werden, die sich nicht mehr vertreiben lassen und die das Produkt unbrauchbar machen.

Dabei sind die Mischungsverhältnisse der genannten Bestandteile nicht immer dieselben; namentlich der Zusatz von Mennige ist ein sehr verschiedener, und manchmal fehlt er sogar besser ganz, so daf ein volikommen bleifreies Glas entsteht; dies ist dann kein eigentlicher Straß mehr. Rezepte zur Herstellung von Gläsern, die sich für Edelsteinimitation eignen, sind viele angegeben worden. Einige Mischungen, die gute Sorten liefern, sind die folgenden: 3 'Teile fuiner Quarzsand, 2 Salpeter, 1 Borax, 1 Arsenik; oder 9 Teile Quarz, 3 kohlensaures Kali, 3 gebrannter Borax, 2 reine Mennige, 1.2 Arsenik; oder 8 Teile weißes bleifreies Glas, 3 Bergkristall, 3 Mennige, 3 gebrannter 
Borax, $2 / 3$ Salpeter, 1\% Arsenik; oder 712 Teile Quarz, 10 Mennige, 1 1/2 Salpeter. Eine häufig angewendete Misehung besteht aus 320, Bergkristall, $50 \%$ Mennige, $17 \%$ kohlensaurem Kali, $1 \%$ Borax und 1/3\% Arsenik.

Je nach dem grö̈feren oder reringeren Mennigezusatz wird das beim Schmelzen erhaltene (ilas mehr oder weniger bleihaltig, und auch die anderen Bestandteile wechseln etwas. Der Kieselsaiuregehalt in solchen Gläsern sehwankt zwischen 38 und 59, der Kaligehalt zwischen $\delta$ und 14 und der Bleioxdygehalt zwischen 28 und 53 Prozent. Ein zur Imitation ron Diamant benutztes (Glas (Strab) erab z. B. bei der Analyse: 41,20 ", Kieselsäure, $8,4 \%$ Kali und $50,4 \%$ Bleioxyd.

Mit den Bestandteilen schwanken nun auch die Eigenschaften dieser Gläser sehr bedeutend, namentlich ist hier der Bleigehalt von großem Einfluß. Ist dieser niedrig, dann ist die IÏ̈rte des Glases etwas größer, aber das spezifische Gewicht sowie die Lichtbrechung und Farhenzerstreuung geringer als bei einem bleireichen. Mit dem Bleigehalt steirrern sich namentlich diese letzteren beiden Eigrenschaften erheblich, und ein sehr bleireiches Gilas, also z. B. das, dessen Zusammensetzung oben angegeben wurde, hat die starke Lichtbrechung und Farbenzerstreuung des Diamantes und damit auch dessen schönes Feuer und Farbenspiel. Dies ist der Zweck des Bleizusatzes. Zugleich mit diesem steigt auch das spezifsche Gewicht auf 3,; bis 3,5; also noch über das des Diamantes hinaus. Xoch schöner ist aber das Farbenspiel solcher Gläser, wenn sie 'Thallium statt Kalium enthalten. Der Thalliumgehalt vermehrt die Lichtbrechung und Farbenzerstreuung sehr bedeutend; solche Thalliumbleiglïser stehen daher in dieser Beziebung noch hoch über gewöhnlichem Straß von der angeführten Zusammensetzung, sind aber anch erheblich teurer und daher nur zu feineren Sachen verwendbar. Auch ihr spezifisches Gewicht ist höher und beträgt 4,1 bis 5,4 , steigend mit zunehmendem Thalliumgehalt. Bei einem solchen rom spezifschen Gewicht 4,15, das also nicht sehr viel Thallium enthält, ist die Dispersion = 0,"14, während sie bei gewöhnlichem bleihaltigem Glase (Flintglas von Fraunhofer) nur 0,037 , aber beim Diamant 0,057 beträgt.

Mit den wechselnden Eigenschaften dieser verschieden zusammengesetzten Gläser ist nun anch ihre Verwendung schon angedeutet. Edelsteine mit sehr starker Lichthrechung und Farbenzerstreuung und daher schönem Farbenspiel, wie z. B. Diamant, werden mit sehı bleireichen, eventuell auch Thallium enthaltenden Gläsern nachgeahmt, solehe mit schwacher Licht̂brechung durch bleiarme oder selbst ganz bleifreie. Auch bei der Färbung des Glases ist es zuweilen nicht gleichgültig, ob es Blei enthält oder nicht.

Die oben angegebenen Mischungen liefern nämlich, wenn die Materialien ganz rein waren, cin vollkommen farbloses Glas. Sollen gefürbte Edelsteine nachgeahmt werden, so muli man dem Straß, der stets die Grundlage der gefärbten Edelsteinimitationen bildet, noch einen fürbenden liestandteil beifügen. Dies ist meistens ein Oxyd eines Metalls oder mehrerer, bei denen für die Iferstellung tadelloser Farben vollständige Reinheit ebenso notwendieres Erfordernis ist, wie bei den anderen Bestandteilen. Das vorher vollkommen fertig herestellte farhlose Glas wird möglichst fein gepulvert und so mit gleich foinem l'ulver der Mctalloxyde durch Zusammensieben aufs innigste gremischt. Dieses Gemenge wird dann bei nicht zu boher 'Temperatur geschmolzen, etwa :30 Stunden im Flusse grassen und sehr langsam alogekiihlt. Sehon ganz kleine Quantititen Metalloxyd, wenige Prozente, ïbrigens von den verschiedenen Metallen verschieden srolie Mengen, geniigen, um dem Glase die sewïnschte Farbe zu geben, bei der gröbere oder geringere Intensität dureh Abstufungen in dem (Quantum der färbenden Zusätze erzielt werden kann. Ganz geringe Mengen geben eine wanz lichte Färbung, sehr wrobe können bewirken, daß dickere Schichten ganz undurchsichtig, beinahe sehwar\% aussehen; dazwisehen sind alle

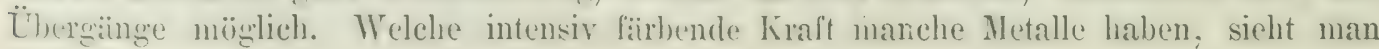


u. a. beispielsweise daraus, dali ein Teil Gold 10000) Teile Strab intensiy rubinrot zu färben imstande ist, und dafi 20 (100) Teile Stralj dadurch immer noch merklich rosa gefärbt erscheinen.

Zur Iferstellung der verschiedencn, bei den Schmucksteinen vorkommenden Farben werden die folgenden Zusiatze eremacht: bla u wird der Strab durch Kobaltoxyd oder

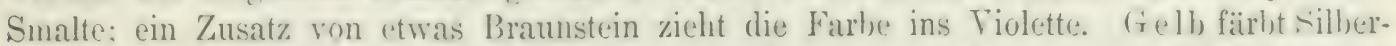
oxyd oder auch Chlorsiller. dienso Antimonoxyd oder statt dessen rotes Spicefglanzeras, in welehem dem Antimonoxyd ctwas Schwefelantimon beigemengt ist. Fell, färbt anch vin geringer Zusatz von Kohle, und zwar je nach der Menge licht honiggerelh bis gethhraum. Ein schönes (ioldgell, gilst eine weiter noch hinzugefügte kleine Beinischung ron liraunstein. Zum Gelbfärben mit Kohle eignen sich aber nur bleifreie Gläser. Grii n liefert ein Zusatz ron Chromoxyd oder Kupferoxyd; durch etwas Kobaltoxyd geht die Fatbe ins Bläuliche, durch etwas Sprefglanzylas ins relbliche. Auch ein remenge von

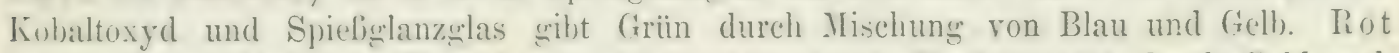
kann auf rerschiedenem Wege hergestellt werden: durch Kupferoxydul, durch Goldoxyd, Foldehlorid oder Goldyurpur (hierdurch entsteht das sogenannte li ubing gas mit einer dem Rubin ähnlichen Farbe, oder durch imöglichst eisenfreien) Braunstein. Die Farbe, die der letztere gibt, ist mehr violett; dureh Zusatz von etwas Kobaltoxyd zum Braunstein wirl sie ausgesprochen violett. Toch gröfiere Beimenæung von Kobaltoxyd macht die Farbe rotbraun. Schwarz, auch in den diinnsten Schichten, wirt unter anderem durch Zusatz einer eröferen Mence ron Zimnoxyd und nachheriges Einschmelzen ciner Mischung von Eisenhammerschlag und Braunstein erzeugt.

Bleiben die letzteren beirlen färbenden Bestandteile wegr, und ist die Menge des Zinnoxydes nicht zu grob, so erhïilt man ein weibes, trühes und undurchsichtiges Glas, ein Ema il (Schmelz, Smalte oder im engeren Sinne Amause), ebenso auch durch Einschmelzen ron phosphorsaurem Kalk oder Knochenasche in das durchsichtige Glas. Solche Massen künnen durch Metalloxyde gleichfalls gefärbt und dadurch undurchsichtige Edelsteine, wie Türkis usw, nachgeahint werden. Die blaue Farbe des letzteren erhält man z. B. durch etwas Kupferoxyd mit einen Zusatz ron wenig Kobaltoxyd. Auch das Aussehen des Opals, des Chalcedons und anderer undurchsichtiger Edelsteine und sogar bis zu einem gewissen Grade die bunte Färbung des Achats, namentlich des Onyx mit seinen verschiedenfarbicen Lagen, lassen sich in ähnlicher Weise in Glas ziemlich tiuschend darstellen.

Bei diesen Cläisern darf man sich aber nicht vorstellen, dab die Kosten ihrer Herstellung gering seien. J)ie frewinnung gruter und wirklich ähulicher Edelsteinimitationen ist im Gegenteil mit ganz crheblichen Ausgaben verknïpft. Die Materialien stehen wegen der erforderlichen Ieinheit hoch im Preise und die Vorrichtungen und die Apparate aller Art, sowie deren richtiger Betrieb, heanspruchen erhehliche Mittel. Man kann daher der hohen Kosten regen nur wertvolle Steine in dieser vollkommenen Weise nachahmen. Rohe Imitationen, die jedermann, manchmal ar der besonders präehtigen Farbe, wie sie bei echten Steinen kaum vorkommt, auf den ersten Blick als Glas erkennt, die aus gemeinem Material ohne besondere Torsicht angefertigt werden, und die nur zum allerbilliwsten Schmuck Verwendung finden, lassen sich allerdings sehr wohlfeil herstellen.

Iit Hilfe der erwähnten Schmelzprozesse erhält man das Rohmaterial fiir die .. kïnstlichen Edelsteine". Dieses wird dann in derselben Weise geschliffen, gefaßt und, wenn crforderlich, anfgebracht wie die echten Steine; es ist nicht nötig, hieriiber noch weiteres hinzuzufügen.

Whie es scheint, sucht man in jüngster Zeit zur Verfälschung der Edelsteine Colister herzustellen, die audier den allwemeinen Bestandteilen noch die charakteristischen bestand- 
teile des betreffenden Steines besitzen, so daß eine oberflächliche chemische Untersuchung den Anschein der Echtheit ergeben kann. So kommen neuestens grïne, offenbar aus Glas hergestellte Strine als Smaragd in den Mandel, die $7-8$ Prozent der für den Smaragd charakteristischen Beryllerde enthalten, welche sonst im Glase fehlt. Alle physikalischen Eigenschaften zeigen aber sofort, daß kein Smaragd, sondern, wie gesagt, ein künstliches Glas rorliegt, über dessen Herstellung jedoch noch niehts näheres bekannt ist.

Wie Glas so rermag man jetzt auch Quarz (Bergkristall) im elektrischen Ofen mit Lcichtigrkeit zu schmelzen. Durch Zusatz derselben Metalle, die wir oben kennen gelernt hahen, nimmt auch das durch Schmelzen erhaltene Quarzglas (oder Kieselglas) eine rote, blaue, griune ete. Farbe an, was benutzt wird, um auch auf diesem Wege Rubin, Sapphir, Smaragd, Aquamarin etc. nachzuahmen. Solche Imitationen unterscheiden sich von den echten Steinen sowie von den eigentlichen künstlichen Rubinen etc. im Polarisationsinstrument durch ihre amorphe Beschaffenheit und einfache Lichtbrechung, durch ilır geringes spezifisches Gewicht $\left(G_{0}=2,2\right)$, ihre geringe IIärte $(H .=6)$ und ihren niederen Brechungskoeffizienten $(\mathrm{n}=1,44)$, auch werden sie im Gegensatz zu jenen von der Ätztinte leicht angegriffen, so daß bei einiger Aufmerksamkeit Verwechselungen ausgeschlossen sind.

\section{Wert und Preis.}

Die Wertschätzung der verschiedenen Arten von Edelsteinen ist außer von den die Schönheit und Dauerhaftigkeit bedingenden inneren Eigenschaften, wie sie oben im allgemeinen geschildert worden sind, noch von vielen anderen Umständen abhängig und wechselt oft sehr stark. Damit ist auch der Preis veründerlich, der sich hier wie bei jeder anderen Ware in der Hauptsache nach Angebot und Nachfrage reguliert. Ist das Angrehot groß und der Bedarf gering, so wird der Preis sinken, im umgekehrten Falle steigen. Ändert sich aber Angebot und Nachfrage in gleichem Sinne, fallen sie beide oder steigen sie beide, dann wird der Preis ebenso unverändert bleiben, wie wenn in jenen beiden Verhältnissen gar kein Wechsel eintritt.

Das Angrebot wird bei jedem Edelstein im wesentlichen bedingt durch die Häufigkeit des Vorkommens und die Größe der Produktion. Sehr reichlich sich findende Edelsteine stehen nie hoch im Wert, auch wenn sie von großer Schönheit sind, so daß oft der Preis cines bearbeiteter Steines den Schleiferlohn kaum übersteigt. Seltene sind inmer mehr oder weniger wertvoll und teuer.

Die in den Handel gebrachte Nenge der einzelnen Arten von Edelsteinen ist nicht jederzeit dieselhe, und damit ändern sich entsprechend die Preise. Das Erschöpfen alter, frïher reich gewesener Fundorte muß die Preise notwendig allmählich in die Höhe treiben; das $\Lambda$ uffinden neuer ergiebiger Quellen sie rasch sinken lassen. Unter anderem gibt hierfür die Geschichte der Diamantenproduktion mehrfache Beispiele. Im siebzehnten Jahrhundert stieg der J'reis dieses Steines wegen der fortdauernden Ersehöpfung der damals allein bekannten indischen Gruben allmählich immer höher, bis im Jahre 1728 die Entdeckung der reichen brasilianischen Gruben einen bedeutenden und raschen Rückgang bewirkte. Allmählich erschüpften sich auch die Lagerstïtten in Brasilien und die Preise stiegen wieder, aber die etwa seit 1870 in immer größerer Zahl in dem IIandel vorkommenden sïdafrikanischen Diamanten hahen ihrer ganz ungeahnten Menge und Größe wergen die Preise wenigstens für die mittlere Marktware auf einen tiefern Stand gebracht wie irgend früher.

Während des Burenkrieges stieg dann der Preis der Kapdiamanten auf das Doppelte, weil während der Belagerung von Kimberley keine Ausfuhr möglich war. Um Preisdriickerei zu verhüten, bringt die dortige De Beers Company jedes Jahr nur soviel 
Diamanten auf den Markt, als nach den vorhandenen Erfahrungern vou Publikum auferenommen werden. Sie hält dadurch künstlich die l'reise auf einer ihrem Interesse entsprechenden Mïhre. Ilier wird also der P'reis durch den Willen des im Besitz des Mronopols befindlichen Produzenten bestimmt.

Ührigens ist die Produktion nicht der einzige Umstand, der das Angebot becinfluft; gröbere angesammelte Vorräte, die gleichzeitig auf den Markt geworfen werlen, kïmnen die Preise ebenfalls bedeutend erniodrigen. Interessant ist in dieser Beziehung die Mitteilungr von Kluge ans dem Jahre 1S(6), dab der Diamantpreis wenige Jahre vorher, während der Leipziger Ostermesse, plötzlich um 50 Prozent gefallen war, weil die brasilianische Regierung die Zinsen ihrer Staatsschuld, statt in barem Gelde, in Diamanten bezahlt hatte.

Von der entgegrengesetzten Wirkung wie das Angebot ist die Tachfrage. Diese hängt vor allem ab von den allgemeinen Erwerbsverhältnissen und dem dadurch bedingten gröberen orler geringeren Wohlstand auch in den breiten Schichten der niederen Volksklassen, ferner von der allgemeinen lage der Weltereignisse und endlich in hohen Grade von der Mode.

In neuerer Zeit hat namentlich durch Käufer aus dem kapitalliräftigen Amerika die Nachfrage nach den bessern Edelsteinen, Diamanten, Rubinen, Sapphiren und Smaragden, aber auch nach Perlen so stark zugenommen, daf die Preise sehr erheblich, zum Teil um früher gestiegen sind.

Als reine Luxusartikel, die nicht irgendein wirkliches Bediurfnis befriedigen und die daher für das Leben vollkommen entbehrlich sind, können die Edelsteine nur in Zeiten des Wohlstandes und des Gedeihens der Völker in ausgredehnterem Maßstabe Verwendung finden. In langen Friedensjahren, wenn sich der Erwerb giinstig gestaltet, werden daher die Preise steigen. Namentlich pflegt dies zu geschehen unter dem Einflusse verschiedener Ereignisse, die die Entfaltung eines besonderen Pompes verlangen, wie Krönungsfestlichkeiten und ähnliches. Sinkt aber die Kaufkraft infolge von Krieg oder von Krisen im IIandel und in der Industrie, dann sinkt auch die Zahl derer, die sich mit Juwelen zu schmïcken in der Lage sind. Der Ankauf namentlich der teueren Arten läßt nach, vielfach wird sogar alter Familienbesitz wieder auf den Markt geworfen; die Preise sinken.

Dies geschah z. B. in ganz erheblichem Maße infolge der großen französischen Revolution und der nachfolgenden langwierigen Kriege, nachdem der bis dahin an allen europäischen IIöfen gretriebene Luxus den Wert der Edelsteine, speziell der Diamanten auf ziemlicher Höhe gehalten hatte. Der große Edelsteinbedarf namentlich des französischen Hofes und vor allem die ruhige Entwicklung in den langen Friedensjahren nach Napoleons Sturz ließen die Preise wieder steigen, bis die Ereignisse des Jahres 1845 einen allerdings nicht lange andauernden plötzlichen Rïckgang um 75 Prozent bewirkten.

Wie stark Handelskrisen wirken können, sieht man u. a. daran, daß nach den Berichten des Reisenden v on Ts ch udi die Diamanten in Brasilien, als 1557 und 1555 Handel und Verkehr in verderblicher Weise stockten, auf die Hälfte ihres Wertes heruntergingen. In solchen Krisen pflegen besonders große und wertvolle Steine im Preise verhältnismäßig stärker zu sinken als kleinere, weil die Nachfrage nach ihnen sich beträchtlicher vermindert. So war es u. A. in der allerjüngsten Tergangenheit besonder's in Tordamerika der Fall, wo auch vielfach Kaufleute, die sich in Zahlungsschwierigkeiten befanden, ihren Besitz an Edelsteinen zu verkaufen gezwungen waren. Im Gegensatz dazu steigen die Edelsteinpreise während eines bedeutenden wirtschaftlichen Aufschwunges. Dies geschah z. B. in bemerkenswertem Maße, als infolge der reichen Ausbeute der siidamerikanischen Silbererzlagerstätten in 16. und 17. Jahrhundert große Schätze nach Europa kamen, und wieder nach der Entdeckung der reichen Goldvorkommen in Kalifornien und Australien im Jahre 1848 und später. 
Von groljen Einfluß ist die If o de, die zeitweise den Verbrauch von Edelsteinen iiberhaupt berrïnstigrt oder beschränkt, die bald den einen, bald den andern Edelstein mehr bevorzugt und solche, die bis dahin hochgeschätzt waren, fast ganz in Vergessenheit geraten, andere stark vernachlässigte dagegen wieder in den Vordergrund treten lïßt. Allerdinęs die sehönsten und kostbarsten, wie Diamant, Rubin, Sapphir, Smaragd und Perlen werden wohl nie ganz außer Gebrauch kommen, wohl aber andere. Ein bezeichnendes Beispiel für den Einflub der Mode gibt das echte Katzenauge, der schillernde ('hrysoberyll. Dieser aus Ceylon stammende Stein fand sich in keinem Juwelierladen vorrittig. da ihn niemand achtete und sein Preis war daher gering, bis der cnglische II rzog ron Connanght seiner Braut, der Prinzessin Margarete von Preußen, einen Terlobmesring nit einem Chrysoberyll schenkte. Nun war der Stein in der Mode, zunïchst in England, dann auch anderwärts. Die Verwendung nahm so stark zu, daß Ceylon kaum wenug Material schaffen konnte, und die Preise stiegen bedeutend. Auf solche Ïnderungen des Geschmacks hin werden auch wohl Spekulationen unternommen. Topas, der friiher sehr viel getragen und daher teuer bezahlt wurde, ist jetzt wenig geschätzt und nit ihm die anderen gelben Steine; sein Preis ist niedrig. In der Hoffnung jedoch, daß im Laufe der Zeit die Gunst des Publikums sich diesen Steinen wieder zuwenden werde, hatte sich eine französische Gesellschaft grebildet, um auf die spanischen sogenannten Topasgruben die Hand zu legen. Diese geben allerdings keinen echten Topas, sondern gelben Quarz von schöner Farbe, der vielfach statt des echten Edelsteins verkauft wird.

Wenn durch die Ungunst der Mode oder anderer Verhältnisse ein Edelstein im Preise sinkt, wird nicht selten das im Handel befindliche Material ganz aus dem Verkehr gezogen $u m$ in besseren Zeiten mit höheren Preisen wieder auf den Markt gebracht zu werden.

Nach dem bisher Gesagten kann es uns nicht wundern, zu erfahren, dab zrvar die kostluarsten Edelsteine ïherall und immer hochgeschätzt wurden und noch werden, dal aber diese Wertschätzung zu versehiedenen Zeiten eine verschiedene und daher auch die Tieihenfolge vom geschütztesten und teuersten ab nicht immer dieselbe war. Nach den Jitteilungen von C. W. King, dem wir sehr viele wichtige historische Nachrichten iiber die Edelsteine rerdanken, war bei den alten Römern, wie bei den alten Indern der 1)iamant dex wertvollste Edelstein, bei den alten Persern stand er dagegen erst an fünfter Stelle hinter Perlen, Rubin, Smaragd und Chrysolith. Benvenuto Cellini berichtet in s.inem Trattato del oreficeria, daf) in der Mitte des 16. Tahrhunderts der Diamant hinter liubin und Smaragnd zuriickstand und dab er achtmal weniger wert war als der erstere, dur als der wertyollste Edelstein galt. Die dritte Stelle des Diamants in der Reihe der dem Werte nach geordneten Eilelsteine bestïtigt aus derselben Zeit (1565) auch der portugiesisehe Schriftsteller (iarcias ab II orto, der aber den Smaragd an die erste Stelle setzt und an die zweite den Ruhin, wenn dieser klar ist. Auch gegenwärtig steht der Diamant nicht als der kostharste an der Spitze der Edelsteine; er wird im Preise auch heute noch rom liubin weit ïbertroffen und ebenso vom Snaragd. Alle diese Vergleiche gelten natïrlich nur bei goleicher (írölie, greicher Beschaffenheit und bei gesehliffenen Steinen für gleiche Vollkommenheit des Schliffes.

In sehr erheblichem Mabe ist Wert und Preis der Edelsteine ron der individuellen Beschaffenheit der einzelnen Stiicke abhängig.

Zunäichst ist ron grober Wichtigkeit deren Gröbe. Diese wird fast stets nach dem firwicht bestimmt. und es ist hierfiir beinahe ïberall eine besondere Einheit in Anwendung:, die das Kalrat heilit. Es soll das Gewieht der Bohne eines afrikanisehen SehotenExwïchsis linara sein, ciner Spezies von Erythrina (E. abyssiniea), deren Früchte sich im 
trockenen Zustande durch "in sehr konstantes Gewicht auszeichnen und die daher in Afrika zum Wiegen des fioldes benutzt worden sein sollen. Von dort hat sich dann die: entsprechende Verwendung fïr Edelsteine zunächst nach Indien aussebredetet. Yach anderen ist es das Gewicht einer bohne der Schoten des Johannishorothaumes (Keratonia). Der Tame. Karat käme dann nicht von Kuara, sondern von der alten grrechischen Bezeichnung Keratia her. Diesem Irsprung entsprechend ist das Gewicht des Karats nicht iiberall dasselbe. Wie dire alten l'funde, Lote usw. schwankt es in der Gröbe nicht unbedeutend ron einem Grt zum andern, ist aber durchweg von dem fünten Teil eines Gramms (200 Milligramm) nicht sehr verschied(n. In Speziellen beträgt es in Miligramm ausgectriickt in:

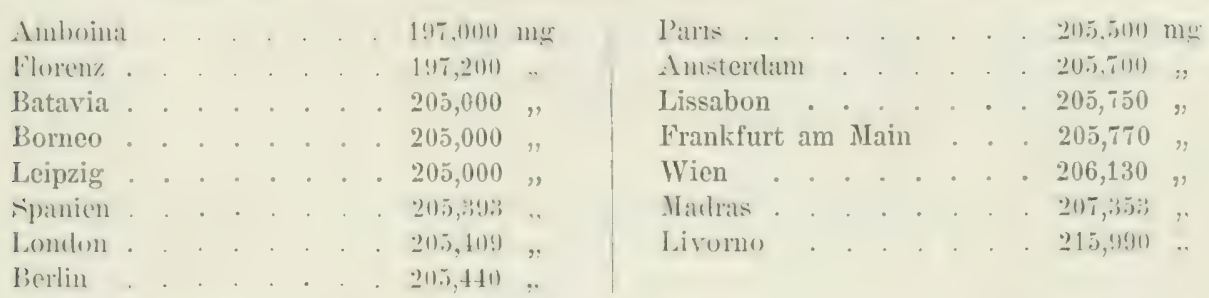

Im Edelsteinhandel wird das Karat in zwei Ilälften geteilt, dieses wieder in zwei gleiche Teile und so weiter durch fortgesetztes Halbieren bis zu Vierundsechziesteln. Diese werden noch beriicksichtigt, kleinere Beträge dagegen oft vernachlïssigt, doch werken zuweilen auch noch Bruchteile von Vierundsechzigsteln (1.2 Vierundsechzigstel ete.) angegehen. Man driickt oft alle Bruchteile eines Karats in Vierundsechzigstel aus; ein solehes wiegt hei (inem Karat von 205,1000 mg deren 3,-n3. Der vierte Teil eines Karats heibt ein Gran oder Grïn; auch dieses Gewicht wird nicht selten angegeben und ist namentlich bei Perlen gebräuchlich. 144 Karat bilden in Frankreich eine Unze.

Trotz der aus obigen Zahlen hervorgehenden unpraktischen Verschiedenheit seiner Werte ist doch keine Aussicht vorhanden, clab das Karat durch das zweckmäbigere Grammgewicht verdrängt wird, das aufer im Edelsteinhandel in fast allen zivilisierten Ländem allgemein im Verkehr angewendet wird. Der Ersatz durch das Grammgewicht ließe sich olıne große Änderung leicht bewerkstelligen, da die IIälfte eines Karats überall sehr nahe $100 \mathrm{mg}$ beträgt. Es ist aber hierzu in den beteiligten Kreisen sehr wenig Neigung vorhanden, trotzdem seit 1872 in Deutschland und seit 1576 in Österreich das Gramm die resetzliche Gewichtseinheit auch für Edelsteine ist, wie seit längerer Zeit schon in Holland. Dagegen hatten die im Jahre 1871 begonnenen und 1577 ernetterten Bestrebungen des Syndikats der Pariser Juweliere auf eine Einigung mehr Erfolg. Diese gingen dahin, das Karat, das in Frankreich gesetzliches Edelsteingewicht ist, überall gleich, und zwar auf $205,000 \mathrm{mg}$ festzustellen, wie es schon immer in Leipzig und in Niederländisch Indien gewesen ist (metrisches Karat). Es ist zu erwarten, daß in nicht zu ferner Zeit das Karat auf der ganzen Erde ohne Ausnahme den obigen Wert haben wird und daß alle anderen Karate aufer Gebrauch kommen. Jedenfalls haben die Juwelenhändler in London und Ansterdam und den anderen Hauptpunkten des Edelsteinlandels in Europa und Amerika sich bereits ihren l'ariser Kollegen angeschlossen. Gleichzeitig ist das Bestreben darauf gerichtet, statt der Einteilung in Vierundsechzigstel die Dezimalteilung des Karats einzuführen, was ebenfalls manche Bequenlichkeiten zur Folge haben würde; einzelne größere Geschäfte sind damit schon vorangegangen.

In England ist beim Edelsteinhandel, besonder's für die billigeren, sog. Ialbedelsteine noch vielfach ein anderes Gewicht im Gebranch, das auch für Edelmetalle, in den Apotheken und bei wissenschaftlichen Untersuchungen angewendet wird. Die Finieit des- 
selben ist das Pfund Troy (Pound troy), das 141/175 eines gewöhnlichen Handelspfundes (Avoirdupois-Pfundes) und $373,212 \mathrm{~g}$ wiegt. Es zerfällt in 12 Unzen (ounces, abgrekürzt: oz.); eine Unze ist gleich 20 Pfenniggewichten (pennyweights, abgekürzt: dwts.), und ein solches ist gleich 24 Gran oder Grän (grains, abgekürzt: grs.), so daß also 5760 Grän Troy ein Pfund Troy geben. Eine Unze oder 480 Grän Troy ist $=31,103 \mathrm{~g}$ oder $=$ 151,722 Karat zu $205 \mathrm{mg}$. Hieraus folgt, daß ein solches Karat $=3,161$ Grän Troy ist und umgekehrt ein Grän Troy $=0,316$ Karat. Ferner ist ein Grän Troy $=1,261$ Grän des Karatgewichts und umgekehrt ein solches $=0,791$ Grän Troy.

Die Anwendung des gleichen Wortes Gran oder Grän für die beiden genannten Gewichte, das Karat- und das Troygewicht, führt selbstverständlich vielfach zu Verwirrung und Irrtiimern, und es bleibt bei vielen Gewichtsangaben von Edelsteinen zweifelhaft, auf welche Einheit sich das Gran bezieht. Dies gilt aber nur für die englischen Verhältnisse; in irgendeinem andern Lande als England kommt das Gran Troy als Edelsteingewicht nicht vor.

Nur lokal und von geringer Bedeutung sind einige Gewichte, die namentlich an gewissen Fundstellen von Edelsteinen für diese manchmal gebraucht werden oder vielmehr wohl besser wurden. Sie sind hier kurz erwähnt, weil sie zuweilen in Reisebeschreibungen und in älteren Schilderungen von Edelsteinen vorkommen, sogar noch in Berichten über die Edelsteinvorkommnisse mancher Länder aus der neueren Zeit, und weil es z. T. schwer ist, nähere Auskunft über sie zu erhalten.

In Brasilien werden das Gold und die Edelsteine nach Oitavas (Oktaven) berechnet. Eine Oitava ist der achte Teil einer Unze und 128 Oitavas geben ein Pfund. Die Oitava zerfällt in 32 Vintems und entspricht 171/2 Karat des gewöhnlichen Edelsteingewichts (zuweilen werden auch 18 angegeben). Manchmal wird auch das Grän des Karatgewichts als Unterabteilung der Oitava benutzt. Da vier davon ein Karat geben, so ist eine Oitava $=70$ (resp. 72) Grän.

Während dieses brasilianische Gewicht ganz auf dem Karatgewicht beruht, sind die in Indien namentlich in früheren Zeiten im Edelsteinhandel verwendeten Gewichte davon vollstïndig unabhängig. Sie sind an verschiedenen Orten verschieden und auch nit der Zeit wechselnd.

Das u. a. hauptsächlich in Sumelpur benutzte Gewicht ist die Mascha; sie zerfällt in S Ratis oder Rutten, die Lauptsächlich zur Gervichtsbestimmung für Diamanten dienen. Ein liati, das Gewicht eines roten Samenkorns mit einem schwarzen Punkt von Abrus precatorius, zerfällt in 4 Dhans. Es wechselt mit Zeit und Ort von 1,56 bis 2,25 Grän Troy. Im Mittel wäre also 1 Rati etwa $=2$ Grän Troy oder $2 \frac{1}{2}$ Grän des Karatgewichts oder etwa $2 / 3$ Karat. 1827 war in Nagpur in der Tat 1 Rati $=2,014$ Grïn Troy; heutzutage wird es grewöhnlich $=1 \%$ s oder 1, s४ Grän T'roy oder $=2,376$ Grän des Karatgewichts gesetzt. Tavernier bemilt 1 Rati auf sieben Achtel Karat.

Das Gewicht von Golconda (Raoleonda, Kollur und Visapur) ist das Mangelin; es ist nach 'Tavernier $=13 / 8$ Karat. ?

Der Mischkâl ist ein persisches Gewicht. Er ist $=40$ Ratis und wird gevöhnlich zu 741/2 Grän Troy, also etwa zu 231/2 Karat angenommen. 2 Mischkâl geben einen Dirhem.

Der Preis der Edelsteine jeder Art wächst natïlich mit der Gröbe, aber in verschiedener Weise je nach der Art ihres Vorkommens. Manche, wie Topas, Aquamarin und andere, finden sich in zahlreichen wrößjeren Stïicken, so daß die Schleifer sich ohne Mühe auch zu grö̈leren Schmucksteinen Material in beliebiger Menge versehaffen können. Bei solchen Steinen wächst der Preis dem Gewicht entsprechend, so daß ein doppelt so grroles Stïck das Doppelte usw. kostet. Bei manchen andern Steinen, wie Diamant, 
Rubin usw. ist dargemen das Vorkommen grölberer Exemplare im Verorleich mit den kleineren beschränkt. Man fördert zwar cine genügende Anzahl kleiner, aber verhältnismäbign wenig eröbere Stiickr, und zwar ist deren Zahl um so geringer, je beträchtlicher die Gröbe ist, so dab solehe von noch nicht einmal sehr hohem Gewicht zu den Seltenheiten grehören. Derartige Steine stehen also dem Käufer nicht jeden Augenblick in belichiger Menge zur Verfügung, sondern dieser mub warten, bis sie gelerentlich einmal vorkommen.

Bei solchen Edelsteinen wïchst daher der Preis in höherem Mabe als das Cewicht, so dab also ein doppelt so schwerer Stein nicht das Doppelte, sondern mehr als das Doppelte usw. kostet.

Für die kostharen Juwelen, besonders für den Diamant, und in erster Linie für den geschliffenen, wurde früher eine Regel zur Bestimmung des Preises grö̈lerer Exemplare aus dem Gewicht aufgestellt, die ursprünglich aus Indien stammt. Man nannte sie darnach die indische orler auch die Taverniersche Regel, weil sie dieser französ iche Reisende, der in den sechziger Jahren des siebzehnten Jahrhunderts den Orient und namentlich auch Indien als Edelsteinhändler bereiste, in seiner 1676 erschienenen Reisebeschreibung nach der allgemeinen Ansicht zuerst in Europa mitgeteilt hatte. Schrauf hat aber gezeigt, daß dies schon beinahe 100 Jahre früher (1595) durch den englischen Reisenden Lincotius geschehen ist, von dem sie in eines der ältesten und beriihmtesten Edelsteinbïcher, die ,Gemmarum historia“ von Anselm B o ëth i us de B o o dt (Hannover 1609), übergegangen war:s

Tach dieser Regel erhält man den Preis eines Steines von hüherem Gewicht als ein Karat, indem man die Zahl der Karate durch Multiplizieren mit sich selbst ins Quadrat erhebt und die so erhaltene Zahl dann mit dem Preis des Steines ron einem Karat multipliziert. Ist also z. B. der Preis eines solchen sog. Karatsteines 200 Mark, so ergiltt sich der Preis eines Steines von 5 Karat zu: $5 \times 5 \times 200=5000$ Mark. Allgemein: ist der Preis des Karatsteines $=p$ Mark und das Gewicht des andern Steines $=m$ Karat; so ist dessen Preis $=m \times m \times p=m^{2} p$ Mark.

Diese Regel hat gewil nie und nirgends unbedingte Geltung gehabt, sie hat wohl blol dazu gedient, allgemeine und ungefähre Anbaltspunkte für die Preisbestimmung namentlich ron größjeren Diamanten zu gewinnen. Sie gab früher die Preise der kleineren Diamanten ziemlich richtig den wirklich bezahlten Marktpreisen entsprechend an, genïgte aber schon bei solchen von wenigen Karaten nicht mehr, indem sie höhere Zahlen als die tatsïchlich bezahlten Preise lieferte. Dieses Mißverhältnis steigerte sich bei schwereren Steinen noch bedeutend. Man hat daher die ursprïngliche Regrel nach dem Vorgange der brasilianischen Diamantenhändler in der Art abgeändert, dab man statt des Wertes eines Karats von derselben Qualitït wie der schwerere Stein den Preis eines Karats von Ausschufdiamanten zugrunde legte, aber auch so entspricht sie den wirklichen Verhältnissen nicht völlig. Schrauf gab daher später (1869) eine andere Anweisung, der zufolge die halbe Zahl der Karate mit der um 2 vermehrten Zahl derselben und mit dem Preise eines Karatsteines multipliziert werden soll. Ist dieser letztere beispielsweise bei einem Diamant wieder 200 Mark, so ist der eines Steines ron 5 Karat $=21 / 2>7<200=3500$ Mark oder allgemein, wenn die Buchstaben die oben angegebenen Werte haben: $\left.=\frac{m}{2} ;(m+2) \because 1\right)=\left(\frac{m^{2}}{2}+m\right)$. Diese Regel gab wohl frïher für Diamanten von höherem Gewicht den Marktpreisen sehr nahe entsprechende Terte, seit aber durch die Entdeckung der siidafrikanischen Diamantfelder große Steine in sehr viel bedeutenderer Menge in den Verkehr kommen als frihher, ist auch sie, wenigstens für die ge- 
wöhnliche Handelsware, nicht mehr zutreffend. Bei der Betrachtung des Diamants und der anderen Edelsteine wird hiervon noch weiter die Rede sein.

Daß ein geschliffener Stein teurer sein muß als ein gleich großer roher ron derselben Qualitït ist selbstverstïndlich. Zu dem Preise des rohen Steines kommen diз namentlich bei harten Steinen und vor allem beim Diamant recht beträchtlichen Kosten des Schleifens hinzu. Außerdem muß ein geschliffener Stein im rohen Zustande mehr gewogen haben, da beim Schleifen ein erheblicher Teil davon verloren geht, unter Unständen die Mälfte und noch mehr. Fin geschliffener Stein hatte also im ursprïnglichen rohen Zustande häufigr etwa das doppelte Gewicht wie später nach der Bearbeitung, und dieses ganze Gewicht multe beim Ankaufe bezahlt werden. Ein geschliffener Stein kostet demnach mindestens das Doppelte, häufig das Melırfache eines rohen von derselben Größe und Beschaffenheit.

Aher nicht allein das Schleifen an sich bedingt einen höheren Preis, anch die Art der Schlifform ist von erheblichem Einfluß, da komplizierte Formen mit zahlreichen Facetten höhere Kosten verursachen als einfachere, facettenärmere. So rechnet man den Preis einer Rosette von Diamant der besten Sorte nur etwa $z u$ t/5 des Preises eines ebenso schweren Brillants von der nämlichen Beschaffenheit.

Sehr betrïchtlich ist natürlicherweise der Einfluf der Qualität auf den Preis. Diese hängt bei den einzelnen Arten der Edelsteine von verschiedenen, ihnen speziell zukommenden, Eigenschaften ab, wie es bei der Beschreibung derselben angegeben werden wird. Kleine dem Laien oft kaum bemerkbare Unterschiede wirken hierbei schon sehr stark ein. So sagt man gewöhnlich, daß ein Karatstein Diamant (Brillant) vom zweiten Wasser nur ²/3 soviel kostet als ein solcher vom ersten. Den Einflub der Qualität auf den Preis des Diamanten ersieht man auch u. a. aus den bei der Beschreibung dieses Edelsteines angegebenen Preistabellen, und ähnlich verhalten sich auch alle anderen Edelsteine, jeder nach seiner speziellen Beschaffenheit. Sehr groß ist namentlich der Einfluß der Fehler, wie sie Seite 106 auseinandergesetzt worden sind; diese können den Wert eines Steines sehr bedeutend herabdrïcken und unter Umständen beinahe auf Null reduzieren. 


\section{ZWEITER TEIL.}

Spezielle Edelsteinkunde. 

$W_{\text {ir }}$ werden in dem hier vorliegenden Abschnitte die rerschiedenen als Edelsteine verwendeten Mineralien der Reihe nach ihrer Wichtigkeit entsprechend mehr oder weniger einechend betrachten: vorher haben wir aber noch die Art und Weise kennen zu lernen, wic sie zu Arten gruppiert, wie sie benannt und eingeteilt werden.

Wenn die Edelsteine auch Mineralien sind und bei der wissenschaftlichen Betrachtung in der Mineralogie ganz in derselben Teise klassifiziert und nit Tamen belegt werden wie alle anderen Mineralien, von denen sie sich rein wissenschaftlich in nichts unterscheiden, so geschicht dies doch nicht ebenso im Edelsteinhandel. Die einzelnen Edelsteine haben hier vielfach ganz besondere, ron den in der Nineralogie gebräuchlichen abseichende Benennungen, auch ist die Einteilung in Arten in der Edelsteinkunde zum Teil eine ganz andere als in der Mineralogie. Man faßt zwar in der Mineralogie wie im Edelsteinhandel alle Steine, die in ihren wesentlichen Merkmalen übereinstimmen, zu einer Art zusammen und belegt sie mit demselhen Namen. Man teilt die in wesentlichen Eigenschaften davon verschiedenen Stiicke einer anderen $A \mathrm{rt}$ zu und gibt ihnen die dieser zukommende Benennung. Aber die Kennzeichen, die für wesentlich gehalten werten mïssen, sind andere in der Mineralogie und in der Edelsteinkunde. In der Mineralogie sind es die chemische Zusammensetzung und die Kristallform in Verbindung mit manchen physikalischen Eigenschaften, die an allen Exemplaren derselben Art konstant und unverändert wiederkehren, während andere Mlerkmale, die ron einem Stïck zum andern wechseln, wie z. B. öfters die Farhe, von keiner Bedeutung sind. Bei den Edelsteinen ist im Gegensatze dazu gerade die Farbe von der allergrö̈ten Wiehtigkeit, da auf ihr die Verwendung des betreffenden Stiickes wesentlich mit beruht. Sie spielt daher hier auch bei der Zusammenfassung zu derselben Art und bei der Trennung in rerschiedene Arten eine sehr erhebliche Rolle, während die chemische Zusammensetzung und die Kíristallform bei einem Schmuckstein für dessen Terwendung gleichgültig sind.

Bei dieser Yerschiedenheit der Grundlagen der Klassifikation ist es leicht begreiflich, daf manche Steine, die in der Alineralogie wegen ibrer gleichen Zusammensetzung, ihrer gleichen Kristallform usw. als Zugehürige derselben Art den gleichen Tamen erhalten haben, als Edelsteine ihrer wechselnden Farbe wegen für etwas Terschiedenes angesehen und daher versehiedenen Arten zugeteilt und mit den rerschiedensten Tamen belegt wurden, da\} dagegen andererseits gleichgefärbte Mineralien, die in der Mineralogie ibrer chemischen und kristallographischen Versehiedenheit wegen mehreren Spezies zugeteilt und abweichend benannt werden müssen, doch bei den Juwelieren für wesentlich gleich 
gehalten werden und daher denselhen Namen führen, höchstens mit Zufügung unterscheidender Beinamen, die auf Härtedifferenzen, kleinen Farbenunterschieden usw. beruhen.

Ein Beispiel fïr den ersten Fall giht das Mineral Forund. Unter diesem Namen faßt man in der Mineralugie alle Steine zusammen, die aus reiner Tonerle besteben und im hexagonalen System liristallisieren. Sie stimmen alle auberdem auch noch in der groben Hairte (H. = 9) und dem hohen spezifischen Gewicht $\left(G_{0}=4\right)$ und in manchen anderen jhlysikalischen Eiģenschaften miteinander überein. Daher bilden sie nach den Grundsätzen der minerulogischen Klassifikation eine Spezies oder Art, die den erwähnten Namen führt. Aher die Exemplare dieser Art weichen beziigheh der Farbe wesentlich vonemander ab. Sie sind farblos, nder rot, blan, gelb, griun, gelblichgrïn, griinlichblau, gelbrot, violett. All. diest Farhenvarietiten spielen als Edelsteine eine allerdings nicht fiir alle gleich wichtige Rolle, aher sic gelten bei den Juwelieren trotz ihrer mineralogischen Gleichheit für sanz verschiedene Dinge und jede wird anders benannt. Die Namen, die sie erhalten haben, sind der Reihe nach: weifer Sapphir (Leukosapphir), Sapplir, Rubin, orientaliseber Topas, orient. smaragd, orient. Chrysolith, orient. Aquamarin, orient. Hyacinth, orient. Amethyst. Ähnlich ist es mit dem Mineral Beryll, von dem eine tiefgrïne, eine bläulichgrine oder grünlichblaue, und eine gelbe Varietät zu Edelsteinen Verwendung findet. Die erstere heift Smaragd, die andere Aquamarin, und nur die letzte hat den Mineralnamen Beryll, der wissenschaftlich alle drei bezeichnet, beibehalten. Sie stimmen sämtlich bezüglich der Zusammensetzung und Kristallformen usw. iiberein und unterscheiden sich nur in der Farbe.

Ein Beispiel für den zweiten Fall ist das, was der Juwelier Chrysolith nennt. Er versteht darunter alle hellgrïnlichgelben bis gelblichgrimen durchsichtigen Steine, grleichguiltig, wie sie zusammengesetzt und kristallisiert sind. So werden Exemplare der Mineralien Olivin, Chrysoberyll, Tesuvian, Korund und auch z. T. solche des eigentümlichen Moldawits oder Bouteillensteines hierher gerechnet, und zur Unterscheidung dienen zuweilen die Bezeichnung Olivin-Chrysolith, opalisierender Chrysolith (z. T.) für den Chrysoheryll, orientalischer Chrysolith fuir den gelblichgrünen Korund usw. Wie dies Wort »orientalisch $\mathrm{zu}$ verstehen ist, wurde schon oben (S. 86) auseinandergesetzt.

Behufs Herstellung einer leichteren Übersicht werden die als Edelsteine verwendeten Nineralien nach den ihre schönheit bedingenden Eigenschaften, weiterhin nach ihrer mineralogischen Beschaffenheit, zum Teil auch nach der mehr oder weniger groben Reichlichkeit des Torkonmmens in ein System gebracht und vielfach hauptsïchlich nach ihrem Wert in eine Anzahl von Gruppen eingeteilt. Iäufig findet man die Einteilung in die eigentlichen Edelsteine oder Juwelen und die IIalbedelsteine. K. E. Kluge gibt in seinem 1860 erschienenen Mandbuch der Edelsteinkunde 5 Gruppen, wobei so gut als mïglich der reelle Wert, den die Edelsteine als Schmucksteine haben, in Verbindung mit der IHirte, den optischen Eigenschaften und der Seltenheit des Vorkommens als Maßstab genommen worden ist. Andere nehmen die Gruppierung in abweichender Weise vor. Jedenfalls ist die Enteilung keine mit scharfen Grenzen; sie ist bis zu einem gewissen Grade willkürlich, und mancher Stein, der von dem einem zu einer höheren Gruppe gestellt wird, steht bei dem andern bei einer niedrigeren. Die Einteilung bei Kluge ist, um eine derselben als Beispiel vorzuführen, die folgende, bei der im allgemeinen der Wert von vorn nach hinten abnimmt:

\section{Juwelen oder eigentliche Edelsteine.}

Ausgezeichnet dureh grofe Härte (die härtesten irdischen Stoffe) und Politurfähigkeit, priehtige Farben und Klarheit, verbunden mit starkem Glanz (Feuer) und Seltenheit des Vorkommens in schleifwürdigen Exemplaren. 


\section{A. Schmucksteine ersten Ramges.}

IÏ̈rte zwischen $\delta$ und 10. Entweder reiner Kohlenstoff oder reine Tonerde: oder doch Tonerde vorherrschend. Selu seltenes Vorkommen in schïnen Exemplaren und höchster Wert.
1. Diamant.
2. Korund.
3. Chrysoberyll.
(Rubin, Sapphir, usw.)
4. Spinell.

IIcutzutage enclten als Edelsteine ersten Ranges: Diamant, Liubin, Sapplir und Smaragd).

\section{B. Sehmucksteine zweiten Ranges.}

Härte zwischen 7 und $b$ (ausg. Edler Opal). Sipez. Gew. meist über 3. Kieselerde vorherrschend. Vorkommen schon häufiger und in gröleren Exemplaren; Wert im allgemeinen geringer als in A., in ausgezeichneten Exemplaren aber immer noch sehr bedeutend und dann geringere Sorten der vorigen übertreffend.
5. Zirkon.
6. Beryll.
(Smaragd usw.)
7. Topas.
8. 'Turmalin.
9. Granat.
10. Edler Opal.

\section{Schmucksteine dritten Ranges}

bilden schon den Ühergang zu den Halbedelsteinen, da sie selten alle spezifischen Merkmale der Edelsteine vereinigt enthalten. II. zwisehen 6 und 7 . G. meist ïber 2,5. Kieselsïure ist vorherrschend, mit Ausnahme des Türkis. Wert im allgemeinen nicht sehr bedeutend; nur sebr schöne Exemplare von einigen (Cordierit, Chrysolitb, Türkis) aus dieser fruppe werden noch ziemlich teuer bezahlt. Vorkommen der meisten ziemlich häufig; jedoch selten in schleifwürdigen Exemplaren.
11. Cordierit.
12. Vesuvian.
13. Chrysolith.
14. Axinit.
15. Cyanit.

16. Staurolith.

17. Andalusit.

18. Chiastolith

19. Pistazit.

20. Türkis.

\section{Sogenannte Halbedelsteine.}

Sie zeigen die bei den Juwelen angeführten ausgezeichneten Eigenschaften in weit geringerem Grade, oder nur einige derselben.

\section{Schmucksteine vierten Ranges.}

II. $=4-7$. G. zwischen 2 und 3 (ausgenommen beidemal der Bernstein). Farbe und Glanz häufig noch lebhaft, dagegen sind nur wenige vollkommen durchsichtig. die meisten nur durchscheinend oder kantendurchscheinend. Fundorte sehr zahlreich. Wert im allgemeinen gering. 
21. Quarz.

A. Kristallisierte Quarze.
a) Bergkristall.
b) Amethyst.
c) Gemeiner Quarz.
a) Prasem.
$\beta$ ) Avanturin.

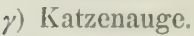

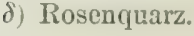

B. Chalcedone.
a) Chalcedon.
b) Achat (mit (0nyx).
c) Karneol.
d) Plasma.
e) Heliotrop.
f) Jaspis.
g) Chrysopras.

C. Opale.
a) Feueropal.
b) Halbopal.
c) Hydrophan.
d) Cacholong.
e) Jaspopal.
f) Gemeiner 0pal.

22. Feldspath.
a) Adular.
b) Amazonenstein.

23. Labrador.

24. Obsidian.

25. Lasurstein.

26. Hauyn.

27. Hypersthen.

28. Diopsid.

29. Flußspat.

30. Bernstein.

\section{E. Schmucksteine fünften Ranges.}

Iärte und spezifisches Gewicht sehr verschieden, Farbe fast immer tribe. Durchsichtigkeit fuhlt ganz. Niedere Grade des Glanzes. Wert hüchst unbedeutend oder war keiner; sie erlangen einen solchen meist erst durch die Bearbeitung. Das Gebiet der Grofsteinsehneiderei füllt hier, wie auch bei einigen aus der vorigen Gruppe, schon mit dem der eigentlichen Steinarbeiten zusammen.
31. Gagat.
32. Nephrit.
33. Serpentin.
34. Bildstein.
35. Speckstein.
36. Topfstein.
37. Diallag.
38. Bronzit.
39. Schillerspat.
40. Faserkalk.
41. Marmor.
42. Fasergips.
43. Alabaster.
44. Malachit.
45. Schwefelkies.
46. Manganspat.
47. Hämatit.
48. Prehnit.
49. Eläolith.
50. Natrolith.
51. Lava.
52. Kieselbreccie.
53. Lepidolith.

Unter den im vorhergehenden aufgezählten Steinen sind einige, wie Marmor, Alabaster usw., die nie zu Schmucksteinen verarbeitet, aus denen aber Gegenstände der Großsteinschleiferei hergestellt werden. Diese sind in dem hier vorliegenden Buche übergangen worden. Dagegen sind in der nachfolgenden Beschreibung einige andere, die von Kluge weggelassen wurden, ilırer wenn auch seltenen Verwendung in der Bijouterie wegen mit aufgenommen. Bei dieser Beschreibung sind die verschiedenen Edelsteine nicht in Klassen eingeteilt, aber in ähnlicher Weise nach dem Wert und nach der Verwandtschaft in mineralogischem Sinne aneinander gereiht. Zu größeren Mineralfamilien gehörige Steine wurden stets zusammengestellt, auch wenn der Edelsteinwert der einzelnen Glieder der Gruppen sich erheblich unterseheidet. Einen Überblick ïber die hier behandelten Edelsteine und ibre Anordnung gibt die folgende Zusammenstellung. 


\section{Übersicht über die im folgenden beschriebenen Edelsteine.}

Diamant.

Korund.

Rubin, Sapphir mit Sternsapphir und weißem Sapphir, orientaliseher Smaragd, orientalischer Aquamarin, orientalischer Chrysolith, orientalischer Topas, orientalischer Hyacinth, orientalischer Amethyst, Demantspat.

Spinell.

Rubinspinell, Balasrubin, Almandinspinell, Rubicell (Essigspinell), blauer Spinell, schwarzer Spinell (Ceylanit).

Chrysoberyll.

Chrysoberyll mit Cymophan torientalisches Katzenauge), Alexandrit.

Beryll.

Smaragd, Aquamarin, Aqua-

Euklas. marin-Chrysolith, Goldberyll.

Phenakit.

Topas.

Zirkon.

Hyacintll, Zirkon.

Granat.

Hessonit (Kaneelstein), Almandin (sirischer Granat), Pyrop (böhmischer Granat) nebst Kaprubin, Demantoid, Grossular, Melanit.

Turmalin.

Opal.

Tiirkis.

Edler Opal, Feueropal, gemeiner Opal u.s.w.

Zahntürkis.

Variscit (Utahlith) mit Wardit.

Lazulith.

Callainit.

O liv in (Chrysolith, Peridot).

Cordierit (Luchssapphir, Wassersapphir).

Vesuvian.

Axinit.

Cyanit.

Staurolith.

Andalusit mit Chiastolith.

Epid ot (Pistazit).

Dioptas (Kupfersmaragd).

Kieselkupfer.

Garnierit.
Titanit (Sphen).

Prehnit.

Chlorastrolith.

Zonochlorit.

Thomsonit.

Lintonit.

Natrolith.

Kieselzinkerz.

Zinkspat.

Feldspat.

Sonnenstein, MIondstein, labradorrsierender Feldspat, Labradorit, Amazonenstein.

Eläolith.

Cancrinit.

Lasurstein.

Hauyn.

Sodalith.

Obsidian.

Moldawit (Bouteillenstein).

Augit und Hornblende.

Hypersthen (mit Bronzit, Schillerspat, Diallag), Diopsid, Hiddenit (Lithionsmaragd) und Kunzit, Rhodonit (mit Lepidolith), Nephrit, Jadëit mit Chloromelanit.

Quarz.

Kristallisierter Quarz: Bergkristall, Rauchtopas, Amethyst, Citrin, Rosenquarz, Prasem, Sapphirquarz, Quarz mit Einschlüssen, Katzenauge, Tigerauge mit Falkenauge.

Dichter Quarz: Hornstein mit Chrysopras und Holzstein, Japsis, Avanturin.

Chalcedon: Gemeiner Chalcedon, Karneol, Plasma, Heliotrop, Achat mit Onyx usw.

Malachit.

Kupferlasur.

Faserkalk.

Fasergips.

FluBspat.

Apatit.

Schwefelkies.

Hä mat it mit= Titaneisen (Iserin).

Rutil.

Bernstein.

Gagat. 


\section{Beschreibung der einzelnen Edelsteine.}

\section{Diamant.}

Unter allen Edelsteinen ist der Diamant, wenngleich nicht der allerwertvollste, so doch ohne Frage der in jeder Hinsicht ausgezeichnetste, wichtigste und interessanteste. Es ist daher gerechtfertigt, ihn an die Spitze der ganzen Reihe zu stellen und etwas ausfübrlicher als die anderen zu behandeln. In vielen wichtigen Eigenschaften übertrifft der Diamant alle anderen Mineralien, er ist das härteste von ihnen, und zeight die schönste Klarheit und Durchsichtigkeit, das höchste Lichtbrechungs- und Farbenzerstrenungsvermögen und daher das früchtigste Farbenspiel und endlich auch den vollkommensten Glanz. So kommt es, daß er als Edelstein ungemein geschätzt ist und einen hohen Wert hat. Da er auch gleichzxitig selbst in tadellosen Exemplaren von einiger Größe nicht ïbermäßig selten ist, so entfällt mehr als neun Zehntel der jälırlich im Edelsteinhandel umgesetzten Summe allein auf den Diamant, der übrigens aufer als Juwel wegen seiner enormen Härte auch in der Technik vielfach Verwendung findet.

\section{a) Eigenschaften des Diamants.}

\section{Chemisehes Verhalten.}

Wie in bezug auf die physikalischen Eigenschaften, auf denen die Brauchbarkeit zum Schmuckstein usw. beruht, steht der Diamant auch hinsichtlich seiner chemischen Beschaffenheit einzig unter allen Edelsteinen da. Auber ilın gibt es keinen, der nur aus einem einzigen Element besteht. Er ist reiner kristallisierter Kohlenstoff, also dasselbe, wie der Craphit und die Kohle, wemn man nur den Stoff ins Auge faßt. Der Unterschied beruht auf der Kristallisation und den damit zusammenhä̈ngenden und zum Teil davon abhängigen physikalischen Eigenschaften.

Dab der Diamant reiner Kohlenstoff ist, war bereits am Ende des achtzehnten Jahrhunderts bekannt und wurde noch frïher vermutet. Schon 1675 liatte Newton aus theoretischen, jetzt allerdingrs nicht mehr zutreffenden Grüunden, nämlich aus der sehr groben lichtbrechenden Kraft, geschlossen, daß der Diamant ein verbrennlicher Körper sein müisse. Versuche hieriiber machte 1694 und 1695 die Aceademia del Cimento in Florenz, deren Mitglieder Iverani und Targioni auf Veranlassung des Großherzogs Cosmos III. von Toskana Diamanten der Wirkung eines sehr heftigen Kohlenfeuers oder auch eines großen Brennsplegels aussetzten. Der Stein verschwand allmählich in der grolien Hitze vollstïndig; 
indem er immer kleiner und kleiner wurde, ohne vorher zu schmelzen und ohne einen bemerkbaren Riickstand zu hinterlassen.

Dadurch war bewiesen, daß der Diamant bei hoher Temperatur flüchtign ist. Auf welche Weise die Verflüchtigung zustande kommt, ob durch einfaches Verdanpfen, wie etwa bei einem Stiick Salmiak, oder dureh einen andern Torgang, war damit aber noch nicht aufgeklärt; dies und die Ermittelung der ehemischen Natur des Diamants iiherhaupt war Lavoisicr und seinen Nachfolgern Teunant, Davy und anderen vorbehalten.

La ro isier, der beriilımte franzïsische Chemiker, der Begrïnder der neueren Chemie, zeigte 1772 und später, dafo die Verflïchtigung des Diamants in der (Aliihhitze nur bei Luftzutritt erfolgt, dali aber ein bei Luftabschluf erhitzter Diamant sein Gewicht auch bei der hëchsten Temperatur völlig unverändert beibehält. Fr konstatierte, daf ein Volumen Luft, in dem ein Diamant sich dureh Erhitzen verfliichtigte, kleiner wurde, dab diese Luft nachher die Eigenschaft hatte, Kalkwasser ebenso zu trüben, wie es Kohlensïure tut, und (laf) Salzsäure in diesem getrïbten Kalkwasser ein Aufbrausen verursacht, gerade wie wenn die Trübung durch Kohlensäure bewirkt worden wäre. Er wiederholte alle Versuche, die er mit Diamant angestellt hatte, mit Kohlenstoff und erhielt genau dieselhen Iiesultate. Aus allen diesen Beobachtungen schlof Lavoisier, daf der Diamant sich nur durch Verbrennung verflïchtige und daß er die größte Ähnlichkeit mit Kohlensinff habe; er wagte jedoch noch nicht, die vollkommene Identität beider auszusprechen.

Diese bewies Tennant 1797, indem er zeigte, daß eine gewisse Gewichtsmenge liamant Kohlensïure, und zwar genau dasselbe Quantum daron liefert, wie eine elsensogrofe Gewichtsmenge reinen Kohleustoffs. Ähnliche Beobachtungen wurden später anch ron anderen Chemikern gemacht, so 1 SI6 ron Humphrey Dary, der gleichzeitig zeigte, daß bei der Verbrennung des Diamants keine Spur Wasser entsteht, daß̉ er also auch keine Spur Wasserstoff enthalten kann, wie $\Lambda$ rago und Biot aus seinem groben Lichtbrechun grsvermögen hatten schließen wollen. Sjäter haben Dumas und Stas, sowie Erdmanu und II archand u. a. alle diese Resultate durch nevere eingehende Untersuchungen bestätigt, und seit langer Zeit schon gehört die Verbrennung eines Diamants im Sauerstoff zu den gewöhnlichen Experimenten chemischer Vorlesungen.

Durch jene Versuche schien aller Zweifel daran ausgeschlossen, daß der Diamant reiner Kohlenstoff ist, bis in jüngster Zeit (1S90) Krause darauf anfmerksam machte, daß diese Frage doch noch nicht ganz endgültig entschieden sei. Er hob hervor, dab die bisherigen Beobachtungen genau genommen nur. festgestellt haben, daf das Atomgewicht des Diamants gleich dem des Kohlenstoffs ist. Es sei aber, wie er meinte, zwischen beiden noch ein Yerhältnis müglich, wie zwischen den beiden Metallen Nickel und Kobalt, die gleiches Atomgewicht und sehr ähnliche chemische Eigenschaften haben. Um die Frage endgültig zu entscheiden, verband Krause die gasförmigen Terbrennungsprodukte des Diamants mit Natron, ebenso auch das Verbrennungsprodukt ron reinem Kohlenstoff. Beidemal erhielt el Kristalle, im letzteren Falle selbstrerständlich ron kohlensaurem Natron, von Soda. Aber mit diesen Sodakristallen stimmten die aus den V'erbrennungsprodukten des Diamants erhaltenen Kristalle in Beziehung auf Kristallform, Wassergehalt, spezifisches Gewicht, Schmelzbarkeit, Lïlichkeit und elektrisches Leitungsvermögen so vollkommen uiberein, daßs sie beide als identisch betrachtet werden müssen: die mit den Verbrennungsprodukten des Diamants erhaltenen Kristalle sind ebenfalls Sodakristalle. Damit ist nun endgiltign bewiesen, daf das Verbrennungsprodukt des Diamants Kohlensüure, also der Diamant selbst Kohlenstoff ist.

Schon 100 Jahre vor Krause hat Guyton de Morveau das Resultat der Untersuchungen von Lavoisier und Tennant auf eine von den gewöhnlicheli Methoden der Chemie abweichende Art und Weise zu prüfen, resp. zu bestätigen gesucht, da es ihm wie 
fast allen seinen Zeitgenossen undenkbar schien, daf der kostbare Diamant nichts anderes als gemeiner Kohlenstoff sein solle. Seine Methode steht an beweisender Kraft weit hinter der von Krause zuriick, an der man nichts irgend Erhebliches bemängeln kann, aber sie besticht uns durch die Originalität des zugrunde liegenden Gedankens. Sie berult darauf, daß weiches Eisen, Schmiede- oder Stabeisen, beim Glühen mit Kohle etwas Kohlenstoff aufnimmt und dadureh in Stahl, sogenannten Zementstahl, uibergeht. Guyton de Morveau machte denselben Versuch mit Diamant statt mit gewöhnlichem Kohlenstoff (Kohle) und crhiclt ganz ebenso wie mit diesem aus dem weichen Eisen Stahl mit allen seinen charakteristischen Eigenschaften, der mit dem in gewöhnlicher Weise dargestellten Zementstahl rollkommen übereinstimmte. Er schlol aus diesem Versuch, daß Diamant in der Tat nichts anderes sein könne als Kohlenstoff.

Tias das spezielle Verhalten des Diamants bei sehr hohen Temperaturen anbelangt, so ist das verschieden, je nachdem man die Erhitzung in der Luft, also bei Gegenwart von Sauerstoff oder bei Luftabschluß vornimmt. In beiden Fällen werden die Steine leicht rissig oder zerspringen in einzelne Stiicke, wenn die Temperatur zu energisch zuoder nach dem Erhitzen wieder abnimmt. Sollen diese Beschädigungen vermieden werden, so clarf die Erwärmung und ebenso die nachfolgende Abkühlung nur sehr langsam und vorsichtig geschehen.

Bringt man einen Diamantkristall in einem Strome reinen Sauerstoffgases zum schwachen Rotgrlühen, so fängt er an zu verbrennen. Er wird immer stärker glühend bis zur hellen Weißglut und brennt ununterbrochen mit einer schwachen blauen Flamme fort, auch wenn die äufere Wärmequelle, etwa eine Gasflamme, entfernt wird. Der Kristall wird immer kleiner und kleiner und verschwindet endlich ganz, indem er im letzten Augenblick noch einmal hell aufleuchtet, etwa wie eine verlöschende Lampe. Er schmilzt dabei nicht, die Verbrennung schreitet von außen nach innen stetig vor, ohne daß sich die Form des Kristalls wesentlich ändert, und die Beschaffenleit der Substanz bleibt ebenfalls während des ganzen Prozesses genau dieselbe.

Erhitzt man den Kristall in gewöhnlicher Luft, so beobachtet man dieselben Erscheinungen mit dem einzigen Untersehied, daß der Diamant sofort erlischt, wenn man die Gasflamme, mittels deren er zum Glïhen erhitzt worden ist, wegnimmt. Er kann in der Luft niclit fortbrennen, wie er es im reinen Sauerstoffgrase tut, da in der Luft der Verbrennungsprozeß ein langsamerer ist. Darum wird in diesem Falle nicht die zum Fortbrennen nötige hohe Temperatur erzeugt wie im Sauerstoff. Der brennende I) iamant muß infolgedessen in der Luft ohne fortdauernde Erwärmung von außen erlöschen.

Die Temperatur, bis zu der ein Diamantkristall in der Luft erhitzt werden mul, damit er verbrennt, ist höher als die Entzündungstemperatur im reinen Sauerstoffgase.

Im Sauerstoff beginnt nach Mo is s a die Verbrennung und die Entwicklung von Kohlensïure schon bei $720^{\circ}$, während erst bei $800^{\circ}$ ein plötzliches Aufglïhen erfolgt, das sich dann sehnell unter starker Besehleunigung der Kohlensïureentwicklung zu blendencler Weiljglut steigert. Oberhalb S00" schreitet die Verbrennung auch ohne Wärmezufuhr fort. Bei anderen Diamanten stieg die Temperatur des Aufglïhens bis auf S20" und $850^{\circ}$, stets ging aber eine langsame Verbrennungr voraus; ein Diamant verlor z. B. dadurch, 4 Stunden auf $7 s^{0}$ grehalten, 41,24 "1/0 seines Gewichts, oline zum Gliihen zu kommen. Bei diesen Verbrennungen ist niemals ein Übergang in eine andere Modifikation des Kohlenstoffs, also etwa in Graphit, daher auch niemals eine Spur von schwarzen Flecken usw. beobachtet worden. Die Verbrennungstemperatur in der Luft ist nach Joly $850^{\circ}$.

Kleinere Kristalle verbrennen leichter als grö̈lere. Nach l’ e t z h o l d t verschwanden einige kleine Diamanten in sehr kurzer Zeit auf einem Platinblech, das von unten her 
durch eine Lötrolirllamme erhitzt wurde; der sanze I'rozels war in wenigen Minuten bre(ndlet. Lesonders leicht verhorennt Diamantpulver, und zwar un so rascher, je feiner es

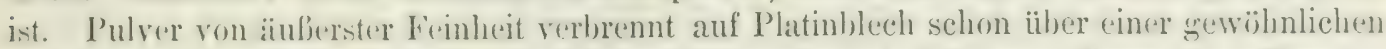
Woingeistlampe beinahe alugenblicklich unter lebhaftem Aufglülen. Unter allen Luständen verbrennt der I) iamant bei gheichen Verhältmissen leichter als die andere kristallisierte Modifikation des Kohlenstoffes, der allbekannte Graphit.

Die verhältnismälige lecichtigkeit der Oxydation, der Verbindung mit Sauerstoff, erkennt man aluch daran, dab) Diamantpulver mit Salpeter zusammengeschmolzen durch den von letzterem dabei abegegebenen siauerstoff rasch verbrennt. Auch beim Schmelzen nit kohlensaurem Natron und Kali verschwindet es rasch unter Entwicklung ron Kohlenoxyd. Eluenso löst es sich bei $150 "$ bis $2300^{\circ} \mathrm{C}$. leicht dureh Oxydation in einem Gemenge von ehromsaurem Kali und Schwefdsäure. Anderen kräftigeren chemischen Reagnentien

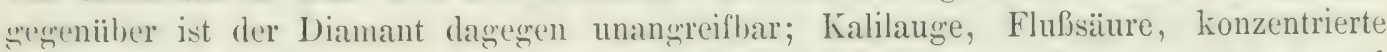
schwef(s)ïure, Salzsiiure und Salpetersiure, ein Gemenge von chlorsaurem Satron und Salpetersïure, wasserfreie Jodsäure und :̈̈hnliche Lösungsmittel, denen wenige andere Substanzen standhalten, haben auf ihn keine Einwirkung, er bleibt in ihnen anch bei den höchsten Temperaturen unverändert.

Unterbricht man den Terbrennungsprozeh, ehe der Diamantliristall ganz rerschwunden ist, so sieht man seine Kanten und Ecken neist mehr oder weniger abgerundet, seine Oberflïche ist triibe und seine glänzenden Fläichen sind matt und narbig geworden. Besondere Erscheinungen bieten die Fliichen oktaëdrisch begrenzter Kristalle von der in Fig. 39, $n$ und 39, o (S. 145) dargestellten Form, die wir unten genauer betrachten werden. Man erkennt auf den Oktaëderflïchen mit der Lupe, deutlicher unter dem Mikroskop, regelmäßige, dreiseitige, pyramidale Vertiefungen, deren gleichseitig dreicekige Grundflächen mit ilren Seiten alle ohne Ausnahme untereinander und den Oktä̈derkanten parallel gehen, wie es Fig. 39, $;$ zeigt, im Gegensatz zu den natürlichen dreiseitigen Eindriicken auf den Oktaëderflächen, die gerade umgekehrt liegen, und die in Fig. 39, q, sowie in Fig. 39, $n$ und 39, o daresestellt sind. Solche Dreiccke sind entweder einzeln, oder dicht gedrängt und in großer Anzahl vorhanden.

Diese Vertiefungen haben ganz den Charakter von sogenannten Ätzfiguren, wie sie auch auf den Flächen anderer Kristalle durch oberflächliches Auflüsen in Wasser, Säuren usw., oder durch Behandeln mit schmelzenden Alkalien usw. hervortreten. Als solche sind sie auch beim Diamant aufzufassen, denn man erhält sie in ganz gleicher Weise, wie beim Erhitzen in der Luft, wenn man den Diamant mit Salpeter schmilzt. Das Ätzmittel ist beide Male der heife Sauerstoff, das eine Mal der der Luft, das andere Mal der ron dem schmelzenden Salpeter abgegrebene. Die Figuren entstehen in beiden Fällen dadurch, daß der Sauerstoff den Diamant nicht über die ganze Oberfläche hin gleichmäßig, sondern im ersten Anfang nur an einzelnen Punkten angreift, von denen aus die Verbrennung daun ganz langsam und stetig gegen das Innere hin fortschreitet.

Geschieht die Erhitzung bei Luftabschluß, etwa indem man den Diamant in Kohlenpulver verpackt in einem geschlossenen Tiegel dem Feuer eines Ofens, sogar der aufjerordentlich starken Mitze eines Porzellanofens oder der hohen Temperatur des elektrischen Flammenbogens aussetzt, dann vermindert sich das Gewicht der angewandten Kristalle nicht, die Hitze mag so energisch und so lange gewirkt haben, wie nur immer möglich. Die Luft und der in ihr enthaltene Sauerstoff konnten eben nicht hinzutreten und daher erfolgte auch keine Verbrennung.

Dagegen finden in diesem Falle andere Veränderungen in dem Diamant statt. Er schwärzt sich an der Oberfläche, indem er in die andere kristallisierte Modifikation des Koblenstoffs, in Graphit übergeht und fürbt infolgedessen beim Reiben auf Papier ab. 
Diese Umwandlung und oberflïchliche Schwärzung erfordert aber, wie es scheint, sehr hohe Temperatur. Wird diese nicht erreicht, dann geht auch die Umwandlung und Schwärzung nicht ror sich. Nach G. Ros e. der dieses Verhalten näher untersucht hat, kann man einen gegen Luftzutritt geschiitzten Diamant sowohl einer Temperatur, bei der Roheisen schmilzt, als auch der heftigsten Hitze des Porzellanofens aussetzen, ohne dlab er auch nur im geringsten verändert wird. Bei einer noch höheren Temperatur aber, etwa der des schmelzenden Stabeisens oder im elektrischen Flammenbogen, füngt er an, sich an der (O)erflïche in Graphit unzuwandeln und schwarz zu werden, und bei grenügend lange andauernder Einwirkung geht der Diamant unter Beibehaltung seiner Form ganz in Graphit ïber. Auch in Crookes'schen Rölren geht eine oberflächliche Umwandlum in Graphit vor sich. In hohem Vacuum bringen kräftige Kathodenstrahlen einen Diamant zur Rot- und Weißght, schlieflich springen Funken aus ihm heraus, er wird schwar\% und nimmt das Aussehen des Coaks an. Die Temperatur war während des Zerspringens bis auf $1890^{\circ} \mathrm{C}$. gestiegen.

Wie sich der Diamant beziiglich der Umwandlung in Graphit beim Glïhen in der I uft verhält, ist noch nicht geniigend festgestellt. Einzelne Versuche, wie z. B. die oben (rwähnten von Mo i ssa n, haben durchaus keine Schwärzung ergeben, auch bei der höchsten Temperatur nicht; bei anderen ist eine solche beobachtet worden, die aber wohl mehrfach nicht auf einer Umwandlung in Graphit, sondern auf einer oberfläichlichen Überrußung durch das brennende Heizmaterial beruht. Nanche Beobachter, z. B. Lavoisier, haben bei der Verbrennung von Diamanten an deren Oberfläche schwarze Flecken entstehen sehen, die sich bei weiter fortschreitendem Prozel mehrere Male hintereinander bildeten und wieder verschwanden. Nach G. Ros e findet keine Umwandlung in Graphit statt beim Erhitzen und Verbrennen in der Muffel und vor dem Lötrohr, vielleicht auch nicht in Knallgasgebliise. Dagegen wurde sie im Brennpunkt von Hohlspiegeln und bei der Verbrennung durch eine elektrische Batterie beobachtet, und in diesen beiden Fällen ist eine Täuschung durch Üherrußung im Qualm des Brennmaterials ausgeschlossen. $J$ a q u e t gibt an, daß ein Diamant in einem von 100 Bunsenelementen gebildeten elektrischen Bogen erweicht und dann in eine coaksähnliche Nasse umgerandelt worden sei. Dabei beobachtete er eine Erniedrigung des spezifischen Gewichts von 3,33 auf 2, , 5 , der urspriinglich die Elektrizität nicht gut leitende Diamant wurde bei der Unwandlung in Coaks resp. Graphit leitend.

Ähnliche Beobachtungen hat auch Gass iot gemacht. Danach wäre der Dianant vor der Umwandlung erweicht, d. h. geschmolzen gewesen. Angaben über Schm elzen des Diamants oder darauf zurïckführende Erscheinungen findet man auch sonst in der Literatur. So berichtet B e r zelius, daß er an einem verbrennenden Diamanten ein Aufwallen auf der Oberfläche beobachtet habe, und Clarke sah beim starken Erhitzen rines Idiamants in der Knallgasflamme dessen Oberfliiche sich mit Blasen bedecken. II o issan nahm im elektrischen Flammenbogen ein Aufblähen, aber ohne Schmelzungwalır, Andere Beobachter haben dagegen unter ganz gleichen Umstäinden derartige Erscheinunen nicht hemerkt, und so ist es doch vielleicht noch zweifelhaft, ob ein Diamant wirklich bei sehr hoher 'Temperatur zum Schmelzen geebracht werden kann oder nicht, da Irrtiimer bei derartigen Berobachtungen nicht ganz ausgeschlossen sind. Seheinhar spricht für Śchmelzung die Abrundung der Kanten und Eeken der Diamantkristalle bei der Erhitzung in der Luft; faktisch beruht aher diese Erscheinung auf der Verbrennung, die an den Kanten und Ecken rascher vor sich geht als auf den Flächen. Durch Zusammenschmelzen wollte Laiser Franz 1. aus mehreren kleinen Diamanten einen größeren herstellen, der Versuch miliang aber vollstïndig, es fand nur eine Verbrennung der kleinen Diamanten statt, ebenso wie bei früheren ähnlichen Versuchen. 
Einer sebr hohen Temperatur hat Despretz den Kohlenstoff und auch speziell den Diamant ausiresetzt, nämlich der von sol) bis bon Bunsenelementen

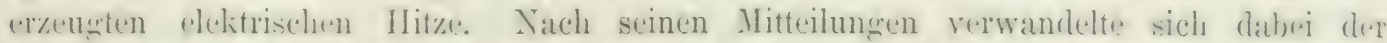

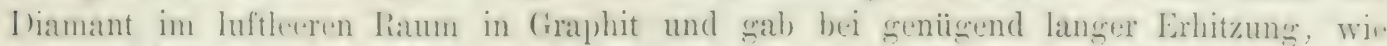
auch vielfach anderer Kohlenstoff geschmolzene Kägelchen, die sonst ebenfalls beobachtet. aber wohl sicher vielfach nichts anderes sind als zu einer harten Masse zusammenere schmolzene Kïgelchen von Aschenhestandteilen, wie sie tatsïchlich manchnal vorkonmen. Der Kohlenstoff schien sich dabei ohne Verbrennung zu verflüchtigen.

Wird ein Diamant vollotïndig verhannt, so dab die Gesamtnenge seines Kohlenstoffs in Kohlensäure übergefïhrt ist, so bleibt nicht der geringste Rïiclstand, wenn er vollkommen farblos und klar gewesen ist. War er aber stärker grefïrbt orler sonst unrein, so hintrbledeibt eine kleine Menge unverbrennlicher Substanz, die sogenannten Aschenlestandteile. Es sind dies unorganische Beimengungen, die der Diamant bei seiner Entstehung in sich aufurenommen hat, Stoffe von verschiedener Natur und Zusammensetzung, dip zum Teil färbend auf die Steine einwirken und diese oft wie mit einem feinen Staube durchtränken und dadurch getrübt erscheinen lassen.

Ihre Menge ist sehr verschieden. Bei sehr reinen Steinen ist sie, wie schon erwähnt, kaum bemerkbar und erkembar, bei weniger reinen steigt sie auf ein Zweitausendstel bis ein Fünfhunderdstel des Cresamterewichts (10,1): bis 10,2 Prozent, selten noch höher. Am meisten von diesen Aschenbestandteilen hat man bisher in dem Karbonat ron Brasilien, einer eigentïmlichen, durch schwarze Farhe und porüse Beschaffenheit ausgezeichneten Abart des Diamants gefunden, nämlich bis 1:2 Prozent. Diese Beimengungen durchzichen die Kristalle oft ziemlich gleichmïfig, zuweilen sind sie auch an einzelnen Stellen mehr angehäuft, die dann getriibt und gefärbt erscheinen, während die Lmgebung farblos und durchsichtig ist. Bei der Verbrennung werden diese Verunreinigungen isoliert und durch die Hitze auch mehr oder weniger stark umgewandelt und, wie wir eben gesehen haben, zuweilen geschmolzen. Die gleichmäßige Verteilung durch die ganzen Kristalle erkennt man daran, dal) sie in einzelnen Fällen nach der Verbrennun als ganz lockere Massen von der Form des verbrannten Diamants zuriickbleiben.

Die hinterbliebene Asche ist entweder brïunlich, oder sie bildet helle, stellenweise gelbe Flocken, manchmal mit einzelnen schwarzen Kürnchen, die vom Magnet angezoren werden. Manchmal ist auch die Beschaffenheit eine noch andere, je nach der Natur der dem Diamant beigemengten Substanzen. Zuweilen sind einige wenige durchsichtigt kristallisierte Körperchen beigemengt, die auf das polarisierte Licht einwirken. Alle diese Eigentïmlichkeiten lassen sich erst unter dem Mikroskop mit Deutlichkeit erkennen. Bei der chemischen Lntersuchung hat sich stets Kieselsäure und Eisenoxyd in der Asche des Diamants gefunden, in gewissen Fällen auch Kalk, Magnesia usw. Eine Analyse der Asche des Karbonats hat ergehen: 33,1 Prozent Kileselsüure, 53,; Eisenoxyd, 13,2 Kalk und eine Spur Magnesia.

Die Aschenbestandteile der Diamanten bestehen also aus Beimengungen ron äußerst minimaler Gröbe, die in sehr feiner Verteilung durch die Masse zerstreut sind, so dab sie auch bei der stärksten Vergröferung vielfach nicht einzeln beobachtet werden können. Nicht immer sind aber diese fremden Kürperchen, die der Diamant als Wirt beherbergt, so klein; häufig sind sie unfangreich genug; dais sie mit der Lupe oder sogar schon mit bloßem Auge deutlich zu sehen sind. Sie bilden dann das, was man als die Einschlüsse des Diamants bezeichnet. Ls sind einzelne scharf umgrenzte Kürner, Splitter, Schuppen, Plättchen, Nädelchen und Fäserchen von verschiedener Farbe und sonstiger Beschaffenheit, nicht selten regelmälig umgrenzt. die entweder einzeln oder zu Gruppen rereinigt in den Diamanten liegen. 
Einige von diesen gröferen Einschliissen sind nach ihrer Natur und Beschaffenheit genau bekannt, bei anderen ist es zweifelhaft, was sie sind. Eigentiimlich sind die sehr seltenen Einlagerungen von kleineren Diamanten in größseren, von denen die ersteren zuweilen cine ganz andere Form und Farhe haben als die letzteren. Der Einschluf und dessen Wirt liaften in einzelnen derartigen Fällen so lose aneinander, daß beim Spalten des letzteren der erstere vollkommen unbeschädigt herausfällt. Sehr selten kommt es vor, daß der ganze Diamantkristall ans einzelnen dïnnen Schichten aufgebaut ist, die in paralleler Lage aufeinander folgen, sodaß er die sog. Zonarstruktur zeigt. Viel häufiger sind vollkommen undurchsichtige, meist unregelmäßig begrenzte Körner von schwarzer Farbe, die in allen Diamantenbezirken in grober Zahl rorkommen; sie bilden die gewöhnlichsten aller Einschliisse des Diamants. Man hatte sie anfänglich für kohlige Substanzen gehalten, dies ist aber keinenfalls immer richtig. In einem Diamant von Sïdafrika hat E. Co b e n einen solehen schwarzen Einschluß von der Kristallform des Eisenglanzes oder Titaneisens beobachtet; er ist daher geneigt, alle solche schwarzen Körner diesen beiden Mineralien zuzuweisen. In der Tat haben sich auch manche von ihnen als unverbrennlich und daher als unorganisch erwiesen, aber andere sind doch nach der Beobachtung von Ch. Fr i e d e 1 gleichzeitig mit dem ganzen Diamanten verbrannt und waren daher jedenfalls kohlige Teilchen von organischer Natur. In einem Diamant rom Kap wurde sogar eine schwarze, klehrige, asphaltartige Masse eingeschlossen gefunden, und dasselbe wird von einigen indischen Kristallen berichtet.

Von sonstigen Mineralien wurden außer den genannten noch manche mit mehr oler weniger großer Sicherheit im Diamant eingeschlossen beobachtet. Genannt werden 11. a.: Quarz, Topas, Rutil, Schwefelkies, teils in Form unregemäßiger Förner, teils als vollkommen ausgebildete Kristalle. Sicher, aber selten, in Brasilien, auch in Siidafrika grefunden, sind Einschlïsse von Goldplättchen. Grüne Täifelchen, zu wurmfürmi gekrümmten Säulchen zusammengeh:̈uft, sind verschieden gedeutet worden. Des Cloizea ux hiclt solche Gebilde für eine Art Chlorit, E. Co h e n grïne Plättchen in Diamanten vom Kap für Kupferverbindungen. In solehen hat man auch rote Einschlüsse ron unbekannter Natur als Seltenheiten angetroffen.

Besondere Erwähnung verdienen Einschlïsse, die durch knäuelförmiges Ineinanderschlingen sehr feiner grüner Näidelehen und Fäserchen entstanden zu sein scheinen. Man hat in diesen und auch in anderen Gebilden ähnlicher Art zuweilen die Struktur von l'flanzenzellen zu crkennen geglaubt, und für Pflanzenreste sind derartige Einschlïsse daher auch schon mit Bestimmtheit wehalten worden, so von dem um die Erforschung der Einschliisse des Diamants sehr verdienten Botaniker Göppert. Es hat sich aber doch später mit Sicherheit beweisen lassen, dab man es mit unorganischen Körperchen zu tun hat. Bisher ist es noch nicht gelungen, anch nur einen einzigen noch so kleinen Pflanzenrest als Einschluf im Diamant unzweideutig nachzuweisen, so sehr die Aufmerksamkeit der Naturforscher gerade auf diesen Punkt gerichtet war.

Alle die genannten Substanzen, die in dem Diamant als wirkliche Einschlïsse vorkommen, müssen schon hei der Eintstehung der Diamantkristalle fertig gebildet gewesen und von diesen eingehiillt worden sein, als letztere allmählich zu ihrer jetzigen Gröbe heranwuchsen. Es gibt aber auch Fremolkïrper im Diamant, die erst nachträglich nach seiner vollständigen Ausbildung hereingekommen sind. So findet man zuweilen Kliftehen und Späiltehen in den Kristallen mit einer braunen Substanz erfïllt, die aus Brauneisenstein besteht und die sich im Laufe der Zcit aus eisenhaltigen Lösungen in jenen abgesetzt hat.

Aber nicht blof fremde Einschliisse fester Substanzen beherbergen die Diamanten; man findet in ihnen auch nicht selten mit einer Fliissigkeit erfüllte oder ganz leere Hohlräume, die allerdings selten über mikroskopische Gröle hinausgehen: 
Die Flissigkeitseinschl üsse erfïllen vielfach die betreffenclen Inohlräume nicht vollständig, man erbliekt dann in der Fliissigneit ein ununterbrochen in Ruhe bleibendes orler auch ein bewergliches Lufthlïschen. eine Libelle, die immer mit Sicherheit auf den fliissigen Inhalt dieser kleinen IḦhlungen hinweist. Durch das ganze Verhalten mancher dieser Fliissigkeitseinschliisse ist man in die Möglichkeit versetzt worden, sie als flüssige Kohlensïure zu erkennen; wir werden hicrauf unten bei der Betrachtung der Entstehung des Diamants noch eimmal zurïckkommen. Andere solche Einschlïsse haben andere Eigenschaften und müssen darnach für Wasser orler wässerige Salzlösungen gehalten werden. Beim Erhitzen verwandelt sich die Flïssigkeit in ('as, durch dessen Spannung manche Steine in Bruchstiicke zersprengt werden.

Auch vollkommen leere, d. h. mit einem Gas (Luft) erfüllte mikroskopisehe II ohlrä ume umsch ließt der Diamant nicht selten, meist, wie auch die Fliissigkeitseinschliusse, zu vielen in einem Steine vereinigt. Sie können zu einem Irrtum Veranlassungr geben. Wenn man sie im Mikroskop) beobachtet, so sind sie sehr häufig ganz oder doch beinahe ganz schwarz, da die von unten kommenden Lichtstrahlen alle, oder doch die den Einschluß in einer breiten Randzone treffenden, nicht in den Hohlraum eintreten können. Sie werden durch Totalreflexion abgelenkt und kommen nicht ins Auge, der IIohlraum bleibt also dunkel. Man darf dann nicht glauben, daf ein fester Einschluf von schwarzer Farbe vorliegre. Der Unterschied beider besteht darin, daß meist der leere Пoblraum rundlich, der feste schwarze Einschlub unregelnäßfig eckig gestaltet ist und daß an viclen der Ilohläume wenigstens die Mitte Licht hindurchgehen lïit. Diese erscheint dann hell, was bei einem festen Einschluß in dieser Weise unmöglich ist. Praktisch künnen solehe Einschliisse in der Art ron Bedeutung sein, dal sie bei zu starker Anhäufung die an sich durchsichtigen Kristalle getrïbt erscheinen lassen. Sie bilden diejenigen Fehler des Diamants, die man, wie wir oben gesehen haben, als . Fahmen" bezeichnet. In theoretischer" Hinsicht kümnen sie vielleicht einmal mit dazu helfen, die Frage nach der Entstehung der Diamanten aufzuklären.

\section{Kristallformen.}

Der Diamant gehört mit zu den bestkristallisierten Nineralien, die es gibt. Fast jexder einzelne Stein ist ron mehr oder weniger regelmäßig ausgebildeten Flächen ungrenzt, derbe Stiicke ohne Kristallflïchen kommen fast niemals vor, wenn es nicht Fragmente größerer Kristalle oder stark abgerollte Geschiebe sind. Die meisten Diamanten sind ringsum und allseitig von Kristallflïchen umgeben, wie es bei den in einem Muttergestein eingewachsenen Kristallen der Fall zu sein pflegt. Nan beobachtet aber auch mit mehr oder weniger großer Deutlichkeit unregelmäßig gestaltete Ansatzstellen, mit denen die Kristalle auf einer Unterlage angewachsen gewesen sein müssen.

Die Flächen der Diamantkristalle unterscheiden sich ron denen der meisten anderen kristallisierten Nineralien dadurch, daß sie meist nicht eben, sondern, und zwar von Anfang an, nicht etwa durch spätere Abrollung, zum größten Teil stark gekriimmt und gewölbt sind. Das hat zur Folge, daß die Formen vielfach nicht besonders leicht erkannt werden können, und daß über manche Fragen der Kristallisation noch Meinungsverschiedenheiten vorbanden sind. Im folgenden sollen die wichtigsten allgemeinen kristallographischen Verhältnisse dargestellt werden; bei der Betrachtung der verschiedenen Fundorte werden die an jedem von ihnen speziell beobachteten Erscheinungen Erwähnung: finden.

Einzelne Beobachtungen iiber die Kristallformen des Diamants gehen bis in den Anfang des 17. Jahrhunderts zurtick. Keppler, Steno, Boyle u. a. haben manche derselben beschrieben, aber erst die Begriinder der wissenschaftlichen Kristallographie, Romé 
de l'Isle und II a ü y haben um die Wende des 19. und 19. Jahrhunderts diese oft recht komplizierten Gebilde unter einheitlichem Gesichtspunkt zusammengefaßt und zuerst die hemiëdrische Ausbildumg der Kristalle konstatiert. Später hat sich namentlich Gustav Rose durch unfassende's Studium der Diamantkristalle grofe Verdienste erworben. Seine Untersuchungen hat nach seinem Tode $\mathrm{A}$. Sadebeck im Jahre 1877 herausgegeben, vermehrt durch zahlreiche eigene Beobachtungen.

Dic Diamantkristalle wehören dem regulïren System an, und zwar nach der Ansicht der ïberwiegenden Zahl der Nineralogen, dessen tetraëdrisch-hemiëdrischer Abteilung:
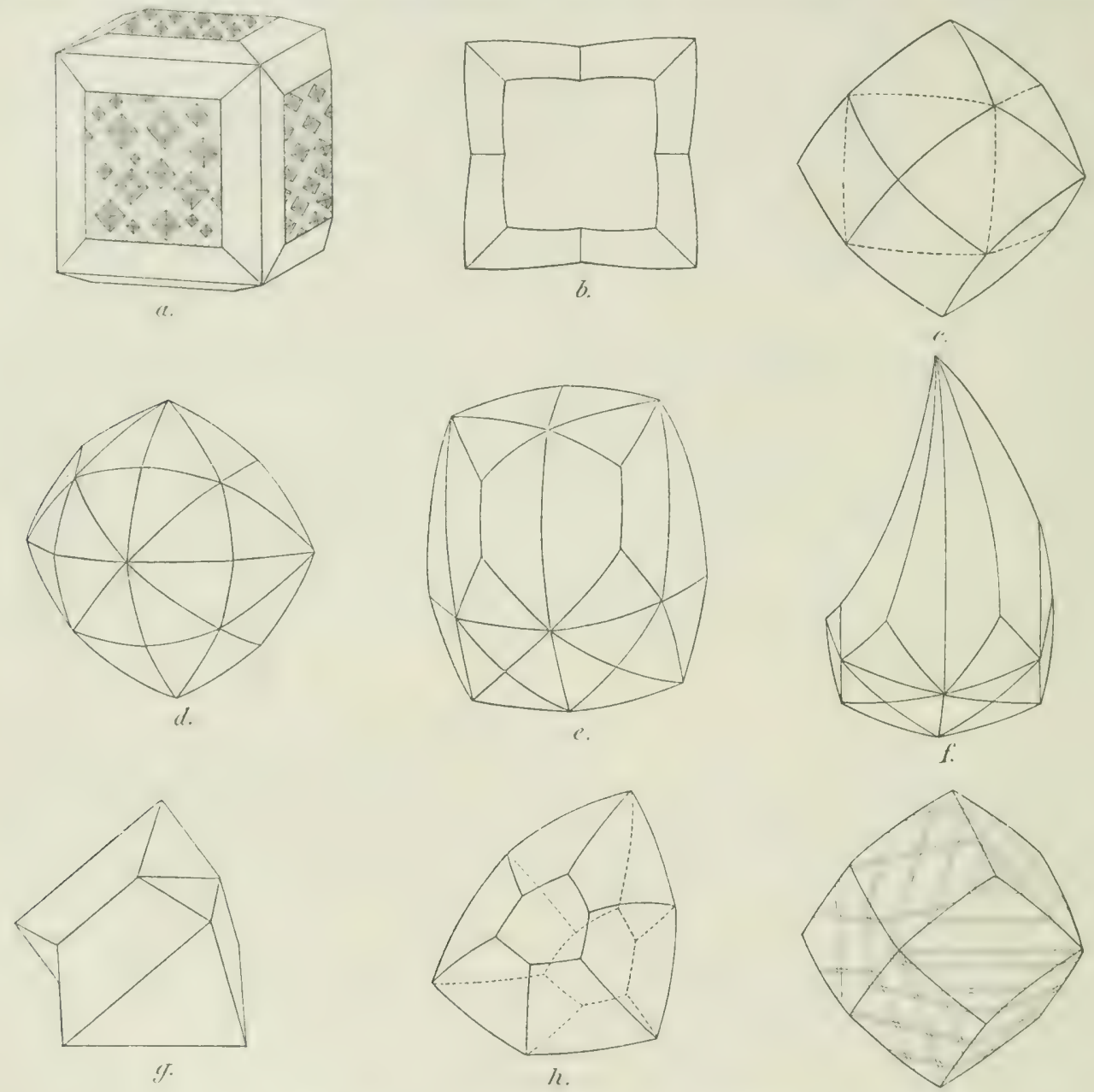

Fig. 39, $a-i$. Krystallformen des Diamants.

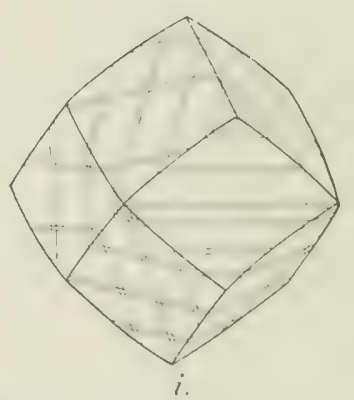

Allerding's liegen heim Diamant einige Besonderheiten vor, so daß in dieser letzteren Beziehung, also hinsichtlich der '/ugehörigkeit zur tetraëdrischen IIeniëdrie, keine völlige Ïbereinstimmung herrseht: manche Mineralogen halten die Kristalle für vollflächig.

Alle einfachen Formen des regulïien Systems sind beim Diamant sehon beobachtet worden, entweder cinzeln für sich, selbständig, oder mit anderen zusammen, in Kombimationen. Einige (iestalten, die in Fig. 39) ( $-l)$ abgebildet sind, kommen besonders häufig. vor, sie werden im folgenden etwas eingehender beschrieben. Es sind teils einfache Kristalle, teils regelmäßige Verwachsungen mehrerer zu Zwillingen. 
Sehr häufig findef man würfelfömige Kristalle, wie in Figr. a. Sie sind meist klein; ilı IIauptraterland ist Brasilien, in anderen Gegenden, besonders am Kap, kommen sie nicht odler nur selten vor. Die Flïchen sind stets matt und rauh und zeigen nach der Mitte hin vielfach eine flache Einsenkung. Die Rauhigkeit wird hervorerebracht durch meist keine, zum Teil aher auch ziemlich grobe, vierseitig pyramidale Verticfungen mit quadratischer Bassis, die mit der Würfelfläche über Eck steht. Diese kleinen eingresenkten Pyramiden sind entweder mehr vereinzelt, oder sie liegen dicht gedrängt, wie es Figs. a
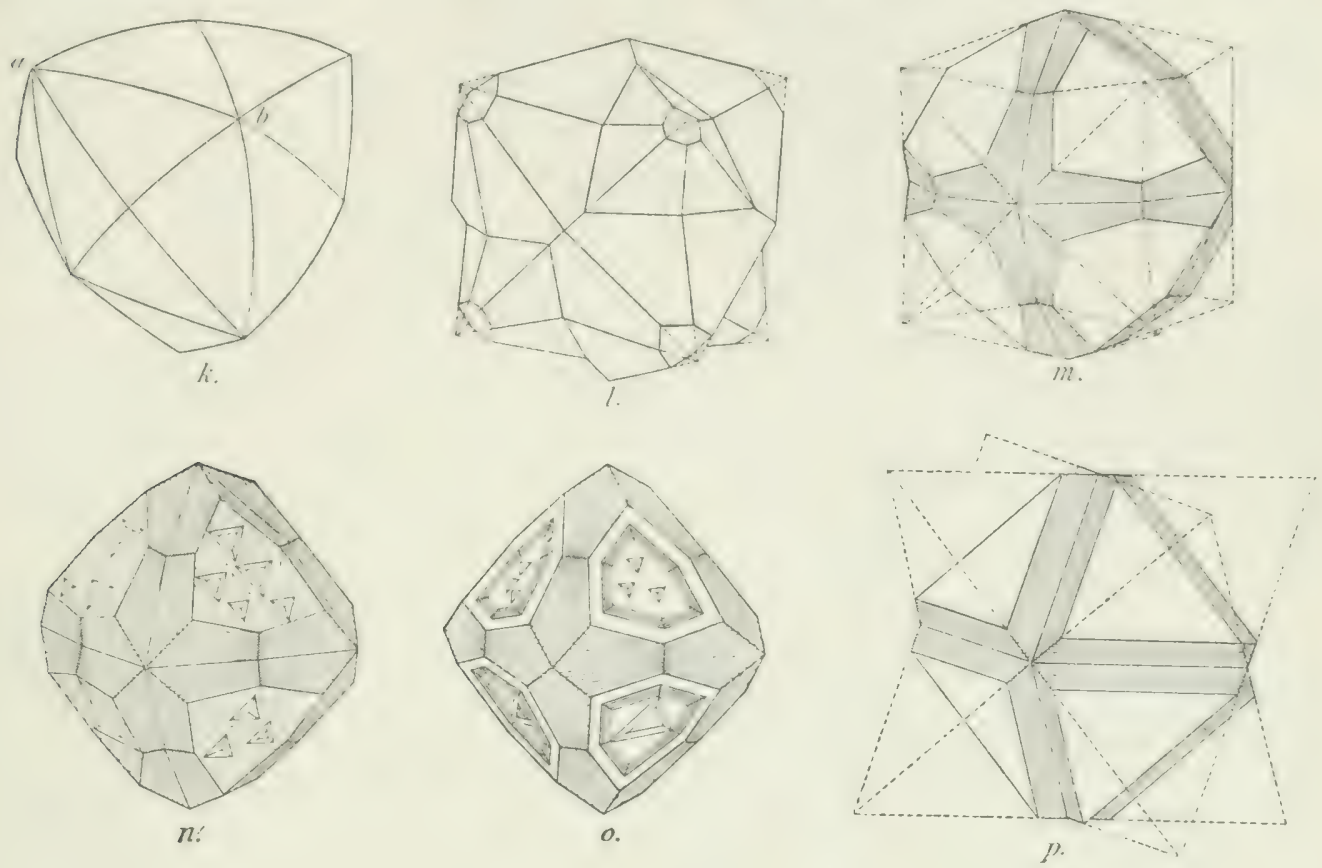

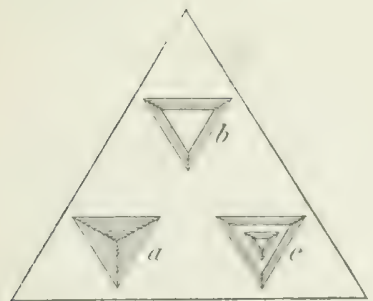

y.

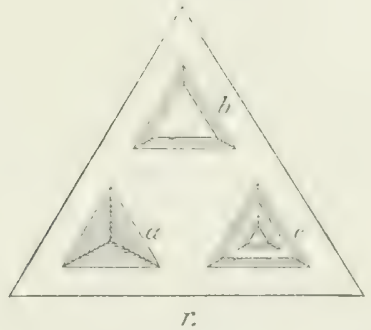

Fig. $39, k-s$. Kristallformen des Diamants.

zeigt. Die Betrachtung mit der Lupe oder besser mit dem Mikroskop läft deutlich die ron den Quadratseiten aus nach innen rerlaufenden Begrenzungsfliichen der Pyramiden erkennen, die vielfach sehr schön eben, häufig aber auch unregelmäßjiger ausgebildet sind. Zwischen den unregehmäßigen und den regrelmäßig pyramidalen Vertiefungen gibt es aber alle müglichen Übergäinge. Ein solcher Diamantwïrfel ist auch Tafel I, Fig. 1 in seinem natïrlichen Vorkommen im Gestein abgebildet.

Bei den meisten wïrfelförmigen Diamantkristallen sind, wie es Fig. a ebenfalls zeigt, sümtliche Kanten durch je zwei Flächen zugeschärft, die zusammen, gehörig erweitert, einen Pyramidenwïrfel bilden wïrden. Sie sind meist schmal, gleichfalls matt und un- 
eben und senkrecht zu den Kanten unregelmäßig gestreift. In der Mitte haben sie vielfach eine flache Rinne, die senkrecht zu den Kanten nach der Mitte der Würfelflächen verläuft, wie es in Fig. b auf einer Würfelfläche nit den vier umliegenden Pyramidenwïrfelflächen dargestellt ist. Pyramidenwürfel ohne Würfelflächen kommen ebenfalls vor, aber seltener als mit dem Würfel zusammen, besonders in Brasilien und Indien. Thro Flächen sind dann zwar glänzend, aber immer gewölbt.

Die Würfel sind auch häufig noch in anderer Weise als durch Zuschärfung der Kanten verändert. So sind z. B. nicht selten die acht Ecken durch acht Flächen abgestumpft, die miteinander ein Oktä̈der bilden. Zugleich sind sehr oft die zwölf Kanten des Würfels durch je eine Fläche abgestumptt; diese zwölf Abstumpfungsflächen begrenzen miteinander, in sehöriger Erweiterung gedacht, ein Rhombendodekaëder (Granatoëder).

Letztere Form ist in selbständiger Ausbildung ebenfalls sehr verbreitet. Die Flächen sind zuweilen eben und nach der langen Diagonale gestreift, viel häufiger jedoch ungestreift, grlatt und glänzend, dann aber stets ziemlich stark gewölbt und schneiden sich infolgedessen in krummen Kanten (Fig c). Die unebenen Flächen haben häufig in der Richtung der kleinen Diagonale einen stumpfen Knick, wie es die punktierten Linien in der zitierten Figur andeuten. Der Körper ist dann eigentlich kein Granatoëder mehr, sondern ein dieser Form nalestehender Pyramidenwiirfel. Ein solches unregelmäßig ausgebildetes Granatoëder begrenzt u. a. einer der größten bis jetzt bekannt gewordenen brasilianischen Diamanten, den "Siidstern", der in Fig. $58 \mathrm{im}$ rohen Zustande abgebildet ist, wie überhaupt diese Form an brasilianischen Kristallen recht häufig auftritt.

Sind die Flächen des Granatoëders auch nach der langen Diagonale geknickt, wie in Fig. d, dann erhält man einen dem Granatoëder in der Form nahestehenden Achtundvierzigflächner. Auch diese Form kommt an Diamantkristallen außerordentlich häufig vor. Die Flïchen sind stets glatt und glänzend, aber ebenfalls stark gewölbt. Es gibt ührigens anch Achtundvierzigflächner von anderer Form, die mehr einem Oktaëder als einem Granatoëder nahe stehen. Diese flächenreichen Körper sind häufig in einer Richtung stark verlängert, so daß eine verzerrte Form wie in Fig. $e$ entsteht, oder sie sind noch stärker verschoben, wie z. B. in Fig. /. Dann scheinen sie auf den ersten Blick etwas ganz anderes zu sein, lassen sich aber bei genauerer Untersuchung doch auf die in Fig. “ abgebildete Form zurïckführen und aus ihr ableiten.

Die Dodekaëder und Achtundvierzigflächner sind wegen der Wölbung der Flächen manchmal nahezu kugelförmig. Diese Ausbildung der Kristalle wird daher auch als die shpäroidische bezeichnet. Sie wurde in früheren Zeiten, als man in der Hauptsache blof indische und brasilianische Diamanten kannte, vorzugsweise von Brasilien erwïhnt. Man nannte sie demnach den brasilianischen 'Typus im Gegensatz zu dem oktaëdrischen oder indischen, den wir im folgenden betrachten werden.

Zuweilen ist an einem Achtundvieryigflächner nur die Hälfte der Flächen, die in den ahwechselnden Oktanten liegren, ausgebildet. Dann erhält man die entsprechende teträ̈drisch-hemiëdrische Form, das in Fig. $k$ daroestellte Mexakistetraëder. 1)ieses ist stets von glatten, glänzenden und cewöllsten Flächen begrenzt, kommt aber im ganzen selten vor. Die vollstïndigen Achtundvierzigflïchner sind bei Annahme der teträ̈drisehen Ieniëdrie als Kombination zweier solcher Hexakisteträ̈ler aufzufassen, sie mïliten daher eigentlieh Flïehen haben, die in den abwechselnden Oktanten verschiedene beschaffenheit. zeigen, diese Verschiedenheit ist aher an den bisher untersuchten Achtundvierzigfläichnern noch nicht beobachtet worden.

IḦ̈ufig sind regrelmälige Verwachsungen zweier soleher einfacher Kristalle zu Zw illingen, die uns zu der oktä̈drischen Ausbildung der Diamantkristalle führen. 
Zwei der in Fig. la dargestellten Hexakisteträider sind an dem in Fig. l dargestellen Kristall, an dem die Kanten aber der Deutlichkeit wegen gerade statt getogen grezeichnet sind, so durcheinander hindurchewachsen, daf sie sich rechtwinklig durchkreuzen. Die scharfen Ecken $a$ des einen Individuums ragen dann über die stumpfen Ecken b des andern nasenartig hervor, und die Flächen beider durcheinander gewachsenen Individuen bilden miteinander rimnenartig einspringende Kanten, die in der Mitte etwas eingeknickt sind. In ihnen verlizuft die Grenze der beiden Indiriduen. Die herausragenden spitzen Ecken sind aher meist nicht vorhanden, sondern sie sind gerade alogestumpft durch je eine Fläche, die an jedtem Individuum der Form eines Tetraëders angehört und die in Gerrensatze zu den Flächen des Granatoëders und des Achtundvierzigflächners niemals Eewölbt, sondern stets rollkommen eben ist. In Fig. $l$ ist diese Abstumpfung nur gering; in Fig. $m$ ist sie dagegen stark. Die sämtlichen acht Abstumpfungsflächen zusammen begrenzen eine vollkommen ebenflächige oktaëdrische Form, statt deren Kanten aher die einsplringenden Rinnen auftreten, die von den meist wie in den Figuren zart lïngsgestreiften Flächen der zwei durcheinander gewachsenen Hexakistetraëder gehildet werlen. Solche Uktaïder mit eingekerbten Kanten sind in Fig. $m$ und $n$ dargestellt. Je stärker die Abstumpfung der Hexakisteträ̈derecken durch die Tetraëderflächen ist, desto schmaler sind diese Rinnen, und wenn die Abstumpfung ihr Maximum erreicht, dann fallen die Rinnen ganz weg; man erhält, allerdings als Seltenheit, ein Oktaëder mit den gewöhnlichen ausspringenden Kanten. Aber diese Form ist kristallographisch gerade, wie dic in Fig. $m$ und $n$ dargestellte, in der oben beschriehenen Weise aufzufassen als ein Grenzfall derselben, in dem die Rinne an den Kanten unendlich klein geworden, d. h. rerschwunden ist.

Am einfachsten ist diese Durchwachsung, wenn nicht zwei Hexakistetraëder, sondern zwei Tetraëder in der angegebenen Weise miteinander vereinigt sind. Dann erhält man Gestalten wie in Fig. p. Diese einfachsten Formen sind allerdings beim Diamant seiten. Bei ibnen verlaufen die Rinnen ganz geradlinig, während sie bei den oben beschriebenen Verwachsungen der Hexakistetraëder in der Vitte einen Knick haben, von dem aus sich die beiden Ir:älften der Rinnen nach den beiden Enden hin etwas erweitern, wie es Fig.m und $n$ zeigt.

In Fị. $n$ ist derselbe Körper wie in Fig. $m$ und wie er an Diamantkristallen selur häufig rorkommt, noch einmal abgebildet und auch die charakteristische Beschaffenheit der Flächen dargestellt. Die schmalen Flächen der Hexakistetraëder, welche die einspringenden Zwillingsrinnen bilden, sind stets etwas gewölbt und in der in der Figur dargestellten Weise mit einer zarten Längsstreifung rersehen. Eine andere Ausbildung eines solchen oktaëdrischen Durehwachsungszwillings, die in Fig. o zur Anschauung gehracht wird, ist elenfalls häufig zu beobachten. Hier ist an den Kanten keine vertiefte Rinne, sondern statt einer solehen ein Paar schmaler Flächen, die in der Mitte der Okitaëderkanten in einer ganz kurzen stumpfen Kante zusammenstolen und ron dieser aus nach beiden Enden lin etwas breiter werden. Auch diese Flïchen sind im Gegensatz zu den acht Oktaëderfläichen gewölbt und haben eine in der gezeichneten Richtung verlaufende feine Streifung. Alle derartigen Formen / bis p stellen den oben erwähnten oktä̈drischen oder indischen Typus der Diamantkristalle dar. Sie werden von den Edelsteinhändlern zumeilen Pint genaunt. Eine solche ist auch auf Tafel I, Fig. 2 im Gestein eingeschlossen abgebildet.

Wir hahen schon oben gesehen, daf, während die Flächen des Dodekä̈der's und die des Achtundvielzigflächners ete. gewülbt und gebogen sind, die des Oktä̈der's allein stets eben erscheinen. Dahei haben aber auch sie oft eine charakteristische Zeichnums und Beschaffenheit, und zwar durch regelmüfige Streifen, die immer in ganz bestimmten Richtungen verlaufen, 
und durch kleine dreieckige Vertiefungen von stets in derselben Weise wiederkehrender Form und Stellung. Die Streifen gehen den symmetrisch sechsseitigen Umrissen der Oktaïderflächen parallel, wie es die Figur o für einen ganzen Kristall und auferden die Fig. s fuir eine einzelne hesonders seezeichnete Fläche angibt. Sie sind bald grüber, bald feiner und stehen entweder mehr einzeln oder auch dichter gedräingt. Nicht selten liegen zwischen gestreiften Flächenteilen sröljere snlatte. Diese Streifung wird dadureh hervorgehracht, dafi die Oktaïderflïchen nach innen hin in sehr niederen Treppen ansteigen, die vom Rande aus nach der Mitte im Umrils immer kleiner werden, aber alle denselben scharf begrenzten Lmril haben wie die Oktä̈derflächen selbst. Es sieht aus, wie wenn den letzteren sehr diume, sleichgeformte, aber nach innen hin immer kleiner werdende Schichten alle mit demselben Mittelpunkte aufgewachsen wären, so daf jede einzelne Schicht eine Treppenstufe und eine Linie der Streifung darstellt.

Die dreicekigen Vertiefungen bilden kleine, vielfach erst unter dem Mikroskop deutlich sichthare regelmälige pyramidale Einsenkungen, deren Basis stets ein grleichseitiges Dreieck bildet, und deren nach innen verlaufende ebene und fein gestreifte Flächen sich in einem Punkte, der Spitze der Pyramide, schneiden (Fig. $q$ bei a). Zuweilen erstrecken sie sich nicht so weit, daf sie sich im Innern treffen; statt der Pyramidenspitze ist dann eine dreieckige Fläiche vorhanden, die der Oktaëderfläche parallel geht (Fig. $q$ bei $b$ ); manchmal ist auch in diese innere Fläiche noch einmal eine Pyramide eingesenkt, wie in Fig. $q$ bei $c$. Diese Yertiefungen sind im großen und ganzen beschaffen wie diejenigen, die bei der Verbrennung auf den Oktaëderflächen entstehen (S. 139); aber während hier die dreiseitige Basis den Oktaëderkanten parallel ist (Fig. r), steht sie bei den natïrlichen Eindriicken mit den Oktaëderflächen über Eck (Fig. q). Sie finden sich, teils nur einzeln, teils in grober Zahl, entweder ohne die oben betrachtete Streifung, wie in Fig. $n$, oder neben dieser, wie in Fig. 0 .

Auker den in Figur 7 bis $\eta$ abgebildeten Zwillingskristallen, deren Gestalt man sich durch kreuzweise Verwachsung zweier hemiëdrischer Formen in der oben angegebenen Weise entstanden denken kann, gibt es aber noch andere, die in Figur $y$ bis $i$ dargestellt, und bei denen zwei olstaëdrisch oder dodekaëdrisch begrenzte Kristalle, wie die im vorhergrehenden beschriebenen, nach einer Oktaëderflïche miteinander verwachsen sind.

In Figur g sind zwei oktaëdrische Kristalle je mit einer ihrer Fliichen so aneinander gewachsen, dalj sie zu dieser gemeinsamen Fläche symmetrisch liegen. Derartige Verwachsungen sind beim Diamant häufig; noch häufiger aber sind sie bei dem Mineral Spinell, woher sie ganz allgemein Spinellzwillinge genannt werden. Sie haben in der Hitte, an der Grenze, wo die beiden Individuen aneinanderstofen, je drei abwechselnd ausund einspringrende Winkel, die eine deutliche Naht bilden. Bei den Händlern heiBen diese Spinellzwillinge des Diamants daher Nahtsteine. In der Richtung senkrecht zu ded gemeinsanen Fläche beider Individuen sind sie häufig stark verkürzt und daher dünn plattenförmig, aber immer haben die Flïchen und Kanten die oben beschriebene Beschaffenheit der Oktaëderflächen und -kanten wie an einfachen Kristallen.

Sehr häufigr sind zwei Cranatoëder oder zwei $\Lambda$ chtundvierzigflächner mit einer Fläche, die der Lage nach einer Olitä̈derfläehe entspricht, aneinandergewachsen, so daß sie beide wieder zu dieser Flïche symmetrisch liegren. Auch diese Zwillingsverwachsungen sind in der Richtung senkrecht zu der heiden Individuen gemeinsamen Oktä̈derfläehe stets stark verkïrzt, und nan hat damn oft Formen wie in Figur h: Kristalle mit gewölbten Flächen von Linsen- oder Iferzgestalt. Ton den beiden in der Figur dargestellten dehtundvierzigflïchnern sind damn nur noch je sechs Flïchen vorhanden, die zwei niedere Pyraniden, zuweilen nit gemeinsamer, der gemeinsehaftlichen Oktaëderfliache entsprechender Basis bilden, und diese Oktaëderfläche ist die Zwillingfläche: 
In Figur $i$ ist noch rine andere derartige Verwachsung darwestellt, wie sir zuweilen

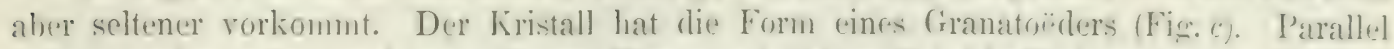

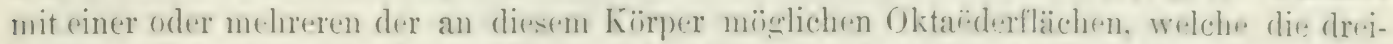
kantigen Eeken alstumplen miiliten, sind sehr diunne Launellen in Zwillingstellung den Kristall eingewachsen, zuweilen in erober Anzahl. Jerle rinzelne dieser Lamellen bildet damn auf den Flïchen des Granatö̈ders oder auch, ganz dieseme rentsprechend, dres Acht-

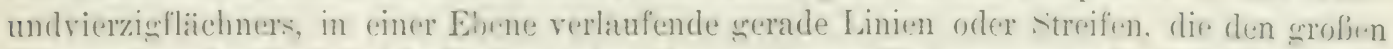

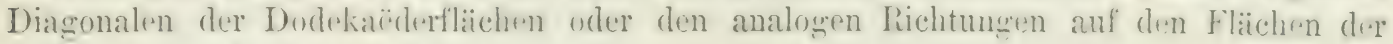
Achtundvierzigflächner parallel gehen.

Alle diese Zwillingshidungen sind ganz rewelmälig und nach kristallographischen Gesetzen genau definirrbar. Es finden sich aber auch unregehnäbige Verwachsungen mehrerer und sogar vieler Dianantkristalle, die sich anf krein allgemeines resetz zuritckführen lassen. Entweder sind einzehe kleine Kristïllehen an einen gröleren angewachsen oder mehrere solehe sind zu einer gröferen firulpe vereinict. Derartige unregelmälige Kristallsupuen sind, wie ïbrigens auch bis zu einem sewissen rirale die ehen hretrachteten Zwillinge, zum schleifen weniger geeignet und werden daher meist nur in der Twelmik benutzt. vie liklen das, was man bort in kristallographischer Hinsicht nennt. Zun Bort in technisch e $\mathrm{m}$ Sinne rechnet man überhaupt alle Diamanten, die aus irgendeinem Gruncle nicht gesehliffen werden kïnnen, auch Einzelkristalle, wenn sie weren schlechter Farhe, oder wegen mangehder Durchsichtigkeit, odter wesen zahlreicher Fehler: oder aus irgendeinem anderen Grunde nicht zu richmucksteinen brauchbar sind.

Eigentimlich sind die sogenannten Bortkugeln, in denen eine grofe Zahl kleiner Krist:̈llehen miteinander zu regelmälig runden, rauhen im Innern radialstrililigen Kugreln rrhbunden sind (Tafel I, Fig. 3), aus deren Oherläche zahllose kleine vijitzen, die Ecken der miteinander verwachsenen Kriställehen, hervorrasen. Derartige Geliilde sind ziemlich rerbreitet. Sie finden sich in allen Diamantenablagerungen und bilden in ihnen 2 his 111 Prozent der Gesamtausheute. Nicht selten hat nur die äufere Schicht die angegehene radialfaserige Beschaffenheit, während man in der Witte einen gröperen rewmäfig und einheitlich gehildeten Kristall findet, der meist nur lose an der kristallinischen Hülle baftet, so daß er, wenn diese zerschlagen wird, herausfällt.

Derber kristallinisch-körniger Diamant ron schwarzer Farbe ist ter Carhonado der Brasilianer, der K a r b o n a t, der nur technisch verwendet werden kann und der daher in diesen sinne ebenfalls zum Bort zählt. Er findet sich fast ausschliefilich in der Provinz Bahia in Brasilien und soll hei der Betrachtung des dortigen Diamantrorkommens im Zusammenhang aller seiner Eigenschaften näher beschrieben werden.

Gröbe der Diamantkristalle. Die Gröfe der Diamantkristalle schwankt zwischen ziemlich weiten Grenzen. Die kleinsten, die im Handel vorkommen, haben noch unter $1 \mathrm{~mm}$ im Durchmesser, doch sind dies nicht die kleinsten, die es iiberhaupt gibt. Beim Durchsieben grü̈ferer Diamantensendungen aus Brasilien durch sehr feinmaschige siebe wurden Steinchen mit einer Kantenlänge roil $1_{1}^{1}$ bis $1:$ mm erhalten, meist Olitä̈der, seltener Dodekaëder und TTürfel von derselben Flächenheschaffenheit, wie die grüßeren Kristalle. Auch an Kap konnten durch sorgfältige Wäsche sehr viel kleinere Steinchen nachgewiesen werden, als sie gewölnnlich im Handel vorkommen, und zwar bis zum Gewicht von $1 / 32$ Karat und noch weiter herab. Diese gingen aber früler hier, wie in Brasilien, bei den üblichen Gewinnungsprozessen verloren, und es lohnte auch nicht die Kosten, sie aufzusammeln; in den rervollkommneten Waschmaschinen der Yeuzeit werden sie dagegen ohne weitere Mühe mit gewonnen.

Steine von mikroskopischer Kleinheit hat man bis vor kurzem nicht gekannt Was als solche angegeben wurde, hat sich als Irrtum erwiesen, so z. B. die ver- 
meintlichen Diamanten im Xanthophlyyllit ron Slatoust im Ural. Neuerding's sind aber solche in dem diamantenführenden Gestein am Kap der guten \#offnung in größerer Menge beobachtet worden, und hüchst wahrscheinlich fehlen sie auch in anderen Diamantlagerstätten nicht.

Während diese kleinen und kleinsten Diamanten in nicht geringer Zahl vorhanden sind, ist die Menge der größeren eine beschräinkte. Je größjer die Steine, desto seltener sind sie, und die gröbten bisher gefundenen sind einzelne äußert sparsame und kostbare Ausnahmen, so dalj die meisten derartigen Fundstiicke besondere Namen erhalten haben. Sie befinden sich zum „r.ößjten Teil unter den Kronjuwelen der verschiedenen Länder.

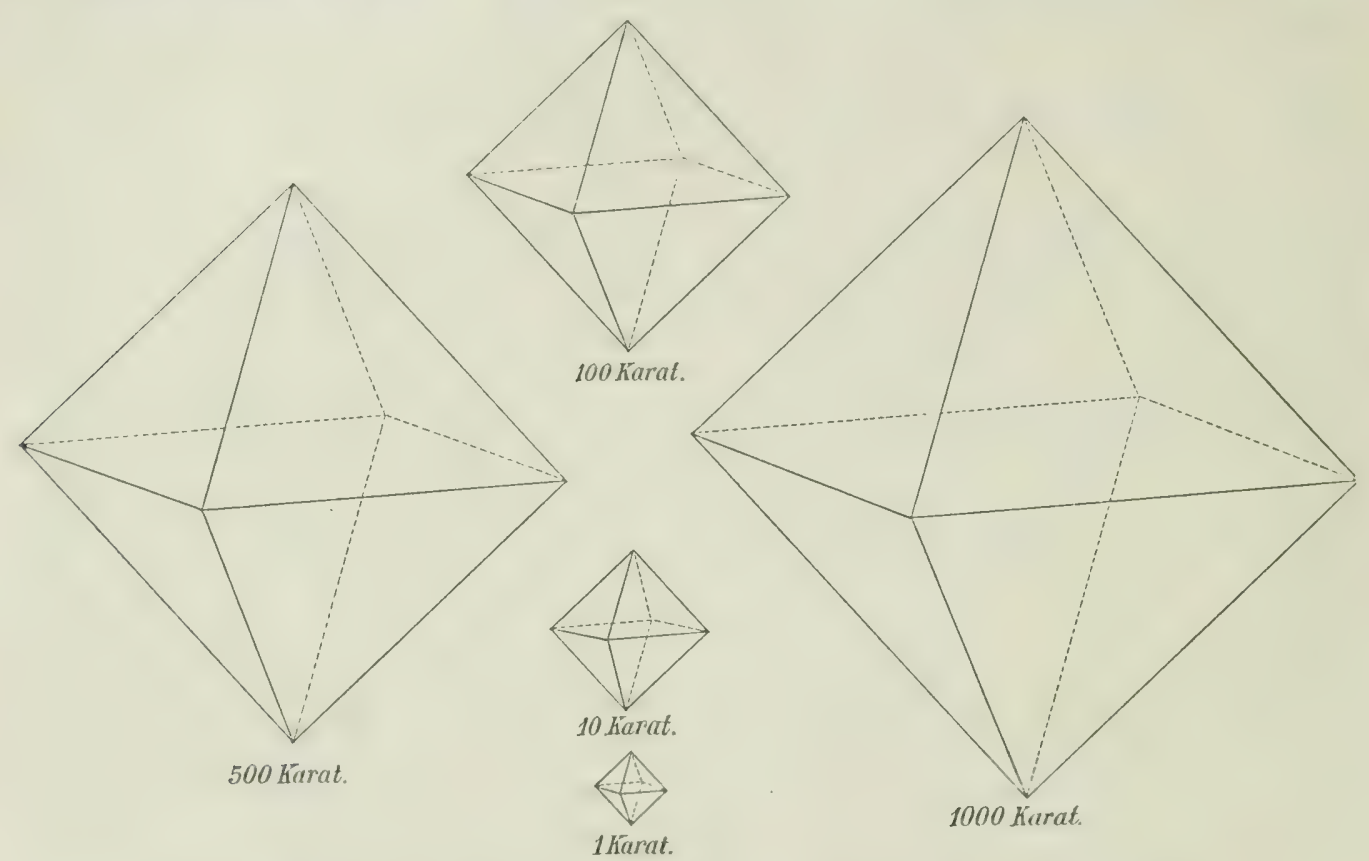

Fig. 40. Natürliche Größe oktaëdrischer Diamantkristalle von 1 bis 1000 Karat.

Inbezug auf die Grölfe der gefundenen Steine verhalten sich die verschiedenen Länder sehr verschieden. Frïher, als nur die Fundorte in Indien und Brasilien bekannt waren, gehörten Steine schon von 20 Karat ab zu den allergrößten Seltenheiten. In Brasilien vergingen in den besten Zeiten der dortigen Produktion zwei bis drei Jahre, bis ein Diamant von dem genannten Gewicht gefunden wurde, und solche von 100 Karat und darüber sind nur einige wenige vorgekommen, die bei der Schilderung der brasilianischen Lagerstätten speziell angeführt werden sollen. Einer der größten von allen, der „Südstern“6 (Fig. 58), Wog 2541/2 Karat. Der "Braganza" der portugiesischen Krone, dessen Gewieht zu 16s0 Karat angegeben wurle, wäre der größte brasilianische Diamant nicht nur, sondern einer der şrößten bekannten iberhaupt; er ist aber mit höchster Wahrseheinlichkeit nur ein schönes Stiick farblosen Topases, kein Diamant.

Etwas giunstiger lagen die Verhältnisse in Indien, wo eine größere Anzalıl von Diamanten ïber 100 Karat gefunden wurde. Die meisten sind nur geschliffen bekannt, ihr Gewicht in ursprünglichen rohen Zustande war wesentlich höher. Von den auch roh sicher bekannten großen indischen Diamanten ist der "Regent" des franzüsischen Kronschatzes der schwerste. Er wogr vor dem Schleifen 110) Karat und gah dabei einen prachtvollen Brillant von 13614,16 Karat. Andere grolje Steine von Indien sind weiter unten 
aufgeführt, ihre Zahlıl ist aller chenfalls noch ziemlich beschränkt. Der grïfite derselben

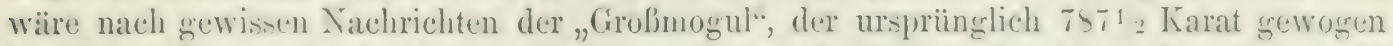
haben soll; e's sind aber keine sicheren berichte darüber vorhanden und es ist nicht bekannt, was aus dem Stein geworden ist. Auch Borneo hat einen oder den anderen gröberen Stein geliefert. Der schwerste von dort, in Gewicht von 367 Karat, ist aber mit ziemlicher Sicherheit kein Diamant, sondern nichts anderes als ein Stück Bcrghristall, also ebensowenig echt wie der sagenhafte „Braganza“.

Diese Verhältnisse änderten sich aber bedeutend, als die Diamanten am Kap entdeckt wurden, wo, wie wir sehen werden, Steine bis zu 150 Karat gar keine Seltenheit sind und wo sogar nicht wenige von mehreren hundert Karat gefunden wurden. Einer der größten ist 1593 entdeckt worden, sein Gewicht beträgt $971^{3 / 4}$ Karat. Figur 61 zeigt seine natiurliche Form und Gröle; er hat den Namen „Excelsior“ erhalten. Noch gröfer ist der im Jahre 1905 sefundene "Cullinan"; er hatte im rohen Zustande den Umfang einer kleinen Faust (Tafel XIa) und wog 3025 Karat oder etwas mehr als 620 Gramm; damit ist er der größte bisher sicher bekannt gewordene Diamant überhaupt.

Die Grölje wird bei den Diamanten wie bei allen anderen Edelsteinen und, wie dies auch im vorhergehenden geschehen ist, meist durch das Gewicht angegeben und in Karat auspredriekt. Es ist aber dem Ungeübten schwer, sich eine Vorstellung von dem Umfange der Steine ron einem bestimmten Gewichte zu machen. Um dies zu ermüglichen, sind in den beifolgenden Abbildungen (Fig: 40 auf voriger Seite) Steine von 1, 10, 100, 500 und 1000 Karat in natürlicher Größe dargestellt unter der Voraussetzung einer regelmäßigren oktaëdrischen Form, die ja bei Diamanten häufig vorkommt. Einige der gröleren Diamanten sind weiter unten bei der speziellen Betrachtung der durch besondere Größe ausgezeichneten Steine in ihren natïrlichen Verhältnissen abgebildet, meist allerdings in der durch Schleifen ihnen verliehenen Gestalt, einige jedoch auch in der ursprünglichen rohen Form. Die natürliche Größe der Brillanten von 1 bis 100 Karat ergibt die Tafel IX und die der Rosetten von 1 bis 50 Karat die Figur 54.

\section{Spezifisches Gewicht.}

Das spezifische Gewicht des Diamants wird von verschiedenen Beobachtern zwischen 3,3 und 3,; angregreben, crute Bestimmungen an reinen, einschlubfreien Steinen haben aber stets Zahlen geliefert, die nicht unter 3,5, und auch nicht viel darïber liegen. Man kann als Mittel wohl 3,52 annehmen. Die Untersuchungen, die ron einigen sorgfältigen Beobachtern an reinem Material angestellt wurden, ergaben folgende spezielle Werte:

Dumas: $3,50-3,53$.

Damour: 3,524 (brasilianischer Diamant).

v. Baumhaner: $3,520-3,524$ (farblose und gelbe Diamanten vom Kap).

J. N. Fuchs: 3,517 (brasilianiseher Diamant).

Halphen: 3,529 (der „Südstern" aus Brasilien).

Schrauf: 3,5213 (der "Florentiner" in der Wiener Schatzkammer).

Liversidge: 3, , (D. von Burandong in Neu-Süd-Wales, Australien).

Grailich: 3,492 (farbloser Diamant von Borneo).

Die letztere Zahl liegt etwas unter 3,5, weil dem Stein bei der Wïgung im Wasser noch einige Luftblasen anhingen.

Die kleinen Unterschiede in diesen Zahlen rïhren wohl nur von fremden Verunreinigungen her, die namentlich in gefürbten Diamanten in geringen Mengen stets rorhanden sind. Daher ist das spezifische Gewicht auch mit der Farbe etwas reränderlich. Bei einer dahingrehenden Untersuchung hat man folgende Resultate erhalten: 


Diamant, farblos: $3,521$.
grün: $3,524$.
" blau: $3,525$.
" rosa: $3,531$.
orange: $3,550$.

Doch findet man auch für farblose die Zahl: 3,519 und für lichtgelb und -griin gefürbte 3,w2 angergeben. Fur weilbe Steine vom Kap wurde $G_{0}=3,521$, für gelbe von dort $\mathrm{G}_{0}=3,521$ sefunden. Etwas schwerer scheinen die harten australischen Steine zu sein; für sie findet man u. a. auch: $G_{0}=3,665$ und 3,578 angegeben.

Zahlen, die sich weiter als die genannten ron dem Mittel: 3,52 entfernen, namentlich die Extreme 3,3 und 3,i und ihnen nahe stehende Werte, beruhen wohl sicher auf falschen Bestimmungen. Wenn ein Stein wirklich ein solches spezifisches Gewicht hat, so ist er kein Diamant.

Die Beanten der De Beers mining company in Kimberley in der Kap-Kolonie haben cinmal folgenden Versuch angestellt: Sie haben ein Gefäß von genau 1 Kubikmeter Inhalt mit Diamanten, wie sie aus den dortigen Gruben und Wäschereien kommen, bis an den Rand vollgefuillt und gewogen. Sie fanden ein Gewicht von nur 11976000 Karat = 24550 (1) Gramm. Nach dem spezifischen Gewicht von 3,52 hätten es 3520000 Gramm sein miissen. Der Untersehied hat seinen Grund in den vielen und verhältnismäßig grolen Zwischenrätmen zwischen den einzelnen Steinen. Beiläufig gesagt war dies die grölite Menge Diamanten, die jemals auf einem Haufen beisammen gewesen sind; ibr Wert wurde auf ca 325 Millionen Mark geschätzt.

Ein niedrigeres spezifisches Gewicht als Diamantkristalle hat der schwarze Carbonado, fiir den 3,141 bis 3,116 gefunden worden ist. Dies beruht auf der porösen Beschaffenheit der Substanz, die selbst in kleinen Stïckchen noch zahlreiche leere Riäume einschließt und dadurch leichter erscheint, als sie wirklich ist.

\section{Spaltbarkeit.}

Wenn man einen Diamantkristall mit dem Hammer auf dem Ambos zersehlägt, oder wenn man ihn rasch erhitzt, oder wenn er erhitzt ist, rasch abkïhlt, zerspringt er in eine Anzahl von Bruchstiicken, die sich meist nach vollkommen ebenen und glänzenden Flïchen voneinander getrennt haben. Sucht man die Richtung, welche diese ebenen Trennungsflächen in den Kristallen haben, so findet man, daf3 sie alle den Flächen des Olitaëclers parallel gehen. Setzt man an einem oktaëdrischen Diamantlisistall einen scharfen Ieibel in der Richtung einer Oktaëderfläche auf und treibt ihn durch einen Hammerschlag in den Kristall hinein, dann zerspringt dieser nach einer vollkommen ebenen Fläche parallel der betreffenden Oktä̈derflïche in zwei Teile, und dasselbe kann in der nämlichen Weise nach jeder der anderen Flächen des Oktaiders bewerkstelligt werden. Will man dagegen einen würfelförmigen Kristall spalten, so ist dies durchaus nicht nach einer Würfelfläche möglich, in dieser Richtung zerbricht er stets nach unebenen Bruchflächen. Nur wenn der Meiled so aufgresetzt wird, dab er die Ecken des Würfels wegnimmt, findet wieder chenflächige Trennung statt, also wieder in der Richtung einer Oktä̈derfläehe, die ja die Ecken des TVürfels gerade abstumplt. In derselhen Weise kamn auch jeder anders gestaltete Diamantkristall nach den Oktä̈derfläehen, aber durchans in keiner anderen Richtung, nach ebenen Flächen gespalten werden. Die Oktaëderflächen und nur sie allein sind also die Spaltungsflächen des Diamants, und zwar ist die Spaltung nach ihmen mit grolier Leichtigheit müglich; der Diamant gehört mit zu den am leichtesten spaltbaren Mineralien. 
I)iese vollkommen whenflächige Sualtung lälst sich aber nur brei einheitlich gebauten Kristallindividuen unerehindert bewerkstelligen; nur bei ihnen gehen die spaltunesflaichen ununterbrochen von einem Ende zum andern durch den Stein hindurch. Jat man dagregen Terwachsungen zweier orler mehrerer Kristalle, entweder wie die in Figur 3!!, y bis $i$

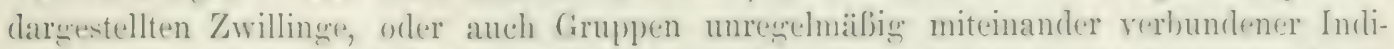
vidurn, damn haben die Spaltungsflïchen in jerlem dieser letzteren eine besondere lage",

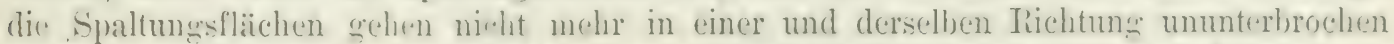
durch den ganzen Stcin hindurch, sondern sie wechscln ron einen Individum zum anderen, und die ebenflächige Trennung ist dadurch unmöglich geworden.

Da man in der when angegerenen Weise jeden einheitlich grebildeten Diamantkristall mach allen seinen Oktaïderfliichen spalten kann, so läfit sich auch aus einem jeden, er maly sonst begrenzt sein, wie er will, ein Spaltungsstiek herstellen, dessen Begrenzungsflächen den Oktä̈derflïchen parallel gehen, das also dic Form eines Oktä̈ders (Fig. 40 oder 56 besitzt. Ton wie grober Wrichtigkeit dies für die Bearbeitung des Diamants durch Schleifen ist, hahen wir schon oben bei der allgemeinen Betrachtunge der Spaltharkeit gesehen und werden es noch weiter bei der Beschreihung der Dianantschleiferei kemnen lernen. Ehenso haben wir schon erfahren, dab die leichte Spaltbarkeit unter Lumstïnden auch schïdlich sein kann, da nach den Spaltungsflächen, hise also nach den Olitaiderflïchen, leicht Risse in den Steinen entstehen, die die Schünheit berinträchtigren und den Wert verringern. Australische Steine sollen weniger leicht spaltbar sein als andere, z. B. die vom Kap.

\section{IIiirte.}

In Beziehung auf die IÏ̈rte steht der Diamant unter allen kïnstlichen und natiirlichen Stoffen einzign da. Er ist der härteste von allen. und wenn ihm anch einige künstlich darestellte Substanzen, wie z. B. das kristallisierte Bor und das oben erwähnte Karborundum nahe kommen, so erreicht ihn doch keine. Er nimmt in der Mohsschen Härteskala den zehnten Grad, den obersten der ganzen Reihe, ein. Ton dem nächst bärtesten natürlichen Kürper, dem Korund, den wir später noch namentlich als Rubin und Sajplin kennen lernen werden, ist der Diamant durch eine weite Kluft getrennt. Er stelit in Beziehung auf die Härte weiter von diesem entfernt, als der Korund von dem weichsten aller Mineralkïrper, dem Talk. Man kann daher den Diamant stets mit vicherheit von sämtlichen anderen Substanzen durch seine Härte unterscheiden: er ritzt sie ohne Ausuahme alle, wird aber umgekehrt von keiner geritzt.

Indessen sind auffallender Weise nicht alle Diamanten gleich hart. Es gibt solche, die etwas härter sind als die Mehrzahl und die daher nicht ron den letzteren geritzt werden künnen, sondern im Gegenteil diese angreifen. So sind die australisehen steine härter als die ïbrigen, und die von Sïdafrika sollen etwas weicher sein als die indischen und brasilianischen. In Borneo findet man schöne schwarze Diamanten, von einer Härte, welche gleichfalls über die der anderen himausgeht. Manche südafrikanischen Diamanten sollen ihre volle eigentümliche Hïrte erst allmählich erhalten, wenn sie einige Zeit an der Luf gelegen haben.

Tie bei allen Kristallen, so ist auch beim Diamant die Härte nicht üherall dieselbe. Man Lat gefunden, daf das Pulver, das durch Abreiben ron der Oberfläche der Diamantkristalle erhalten wird, z. B. bei der Operation des Grauens, von der wir bei der Betrachtung der Diamantschleiferei noch zu reden haben werden, andere Diamanten beim Schleifen erheblich rascher ancreift als solches Pulver, das durch Zerstoßen grö̈berer Stïckchen erhalten wird. Es folgt daraus, dal die Diamantkristalle an der Oberfläche härter sein müssen als im Innern. Aher auch auf der Oberfläche selbst bestehen Lnter- 
schiede; die Kristalle werden auf manchen Flïchen leichter geritzt als auf anderen, z. B. auf denen des Oktä̈ders leichter als als auf denen des Würfels, und auf den einzelnen Flächen in manchen Richtungen leichter als in anderen. Diese Unterschiede bewirken, daf die Steine sich in gewissen Richtungen und an einzelnen Stellen nur schwer schleifen lassen, während dies an anderen Stellen und in anderen Richtungen ohne besondere Schwierigkeit mögheh ist. Wir werden bei der schilderung der Bearbeitung der Diamanten auch hierauf noch einmal zuriickkommen.

A uf der grolien II:irte berulit beim Diamant wie bei anderen Edelsteinen zum Teil die alusgezcichnete Verwendbarkeit zu Schmucksteinen. Sie macht, dab der geschliffene Stein seine scharfen Kanten und Felien nicht verliert und daß der durch die Politur der Flächen erzeugte Glanz auch bei vielfachem Gebrauch erhalten bleibt.

Die IIärte erlaubt auch mehrere wichtige technische Verwendungen des Diamants, von denen unten in einem besonderen Abschnitt die Rede sein wird. Hier soll nur erwälnt werden, daß Diamantpulver vielfach zum Schleifen der harten Edelsteine Verwendung findet und dals die Diamanten selbst von keinem anderen Schleifmittel als ron ihrem eigrenen Pulver angegriffen werden. Die besonders harten Diamanten, wie die australischen, lassen sich sogar nicht einmal mit dem Pulver der anderen weicheren gut schleifen, es ist dazu das von Steinen desselben Vorkommens nötig.

Trotz der großen Härte findet man an den Diamantkristallen in den Seifen, in denen sie gewölnnlich vorkommen, in dem Schutte der Bäche und Flïsse nicht selten die Kanten und Ecken stark abgerollt und die Oberfläche wie mattgeschliffen. Dies beweist, daßs durch die fortgesetzte und ununterbrochen lange Zeitrüume hindurch fortdauernde Reibung der Diamantkristalle an ihren weicheren Begleitern, besonders Quarzkörnern mit spärlichen anderen harten Edelsteinen, auch dieser härteste Körper endlich angegriffen wird.

Nicht selten verwechselt man die Härte des Diamants mit der Zersprengharkeit, mit der Möglichkeit, ihn durch Hammerschläge zu zertriimmern. Viele meinen und namentlich im Altertume und noch im Mittelalter war dies der Fall - daß eher Hammer und Ambos zerspringen, als der Diamant. Plinius, der große Naturforscher des Altertums (gestorben bei der ersten bekannten Eruption des Vesuv, 79 n. Chr.), erzählt dies namentlich von den indischen und arabischen, er teilt aber auch mit, daß man den Diamant zerschlagen kann, wenn man ihn vorber mit frischem, warmem Bocksblut gebeizt hat, aber auch dann noch hält es schwer und Hanmer und Ambos gehen mit in Stiicke. Nach Albertus Magnus (1205-1280) ist das Blut besonders wirksam, wenn der Bock Wein getrunken oder Petersilie gefressen hat. Von dieser Ansicht über die enorme IÏ̈rte und namentlich über die besonders schwierige Zersprengbarkeit stammt der griechische Name für unseren Edelstein, adamas, der auch Stahl bedeutet und worunter etwas Unbezwingliches, Unzerbrechliches verstanden wurde, sie entspricht aber, was die Zersprengloarkeit anbelangt, in keiner W Veise den Tatsachen. Der Diamant zerspringt leicht schon durch einen mäbiggen Hammerschlag, und zwar vorzugsweise infolge der sehr vollkommenen spraltharkeit nach den Fläichen des Oktä̈ders. In dem erwähnten Irrtume befangene Diamantensucher pflegen zweifelhafte Steine mit dem IIammer zu bearbeiten. IIalten diese die Schläge aus, dann sind es ihrer Meinung nach Diamanten, im anderen Falle nicht. Schon mancher gute Stein mag auf diese Weise zerstört und so einem alten Aberglauben zum Opfer gefallen sein.

\section{Optische Eigensehaften.}

Durchsichtiekeit. Der Diamant ist sehr sehön durchsichtig, wenn er rein ist und lieine fremden Einschlïsse beherbergt. Diese stören die Durehsichtigkeit oft sehr, 
und Steine, die viele solehe enthalten, sind beinahe oder sogar vollkommen undurchsichtign. T)asselbe ist häufig auch der Fall bei sehr stark, besonders braun und schwarz zefö̈rbten Diamanten, die nur noch an den Kanten ein wenigg Licht hindurchogehen lassen. Solche mit sehwachen Farbentönen sind nicht viel weniger durchsichtigr als vollkommen farblose. Auberdem hïngt die I)urchsichtigkeit aber auch von der Beschaffenheit der Oberflïche ab. Ist diese rauh, ist z. B. der Stein abgerollt, dann sieht er, selhst wenn er an sich vollkommen klar ist, trïhe und undurchsichtig aus. Er erhält seine Durchsichtigkeit dann erst beim Schleifen. Die Durchsichtigkeit ist das, was man als das Wasser des Diamants zu bezeichnen pflegt. Auf ihr, auf dem Wasser, berulit wesentlich mit die Schönheit der Steine.

Man nennt solche Diamanten, die mit vollkommener Durchsichtigkeit und Fehlerlosingkeit vollständige Farblosigkeit verbinden, Steine rom ersten oder reinsten Wasser. Geringe Trübungen machen den T)iamanten noch nicht zum Schleifen ungeeignet; wenn diese aber einen wewissen Grad überschreiten, ist der Stein nicht mehr als Edelstein verwendbar, er wird dann in der Technik verbraucht.

Für lä̈ntgenstrahlen ist der Diamant vollkommen durchlässig, doch nicht alle Steine in ranz gleichem Maßje. Starkgefärbte, so z. B. ein grïngelber, geben etwas dunklere Bilder als ganz farblose (weile). Auch bei blau, srïn und rot gefürbten scheint ein kleiner Untersehied vorhanden zu sein. Dieses Verhalten ist wohl auf die Beschaffenheit des Pigments zurückzuführen, das demnach eher unorganischer als organischer Art ist, da organische Substanzen die Röntgenstrahlen ungehindert hindurchgehen zu lassen pflegen. Die Unterscheidung des Diamants von ähnlichen Steinen und Imitationen mittels Rüntgenstrahlen haben wir schon oben (S. 40) kennen gelernt.

Glanz. Der Diamant glänzt auf grlatten Flïchen auferordentlich stark und lebhaft. Sein Glanz ist ein ganz eigentiimlicher, zwisehen dem des Glases und dem der Metalle in der Mitte stehender. Es ist der nach ihm so genannte Diamantglanz, der nur noch wenigen anderen Mineralien und kaum noch einem zweiten Edelstein zukommt. Man kann daran den Diamant bei einiger Übung meist mit Leichtigkeit von anderen durchsichtigen Körpern, von gewöhnlichem Glas, Bergkristall usw. unterscheiden. Es gibt aber allerdings, wie wir gesehen haben, eine Glassorte, den Straß, der gleichfalls diamantglänzend ist, und den man daher zuweilen benutzt, um den Diamant nachzumachen.

Auch diese besondere Art von Glanz ist vielfach an der natiirlichen Oberfläche der Kristalle nicht deutlich zu erkennen, besonders wenn diese stark abgerieben ist. In diesen Falle zeigen die Steine ein eigentiinulich bleigraues, metallisches Aussehen, das namentlich in einem Stadium der Bearbeitung, dem darnach so genannten Grauen oder Graumachen ebenfalls herrortritt. In höchster Vollkommenheit zeigt sich der Diamantglanz stets auf den angeschliffenen Facetten, die das Licht ganz regelmäßig reflektieren. Dem Glanze der Netalle nähert sich der ron sehr dunkel gefärbten Diamanten, die durch die starke Färbung einen Teil ihrer Durchsichtigkeit eingebüßt haben. Dasselbe ist aber auch der Fall bei ganz klaren und durchsichtigen Steinen, wenn man das Licht unter einem sehr kleinen Winkel auf eine Fläche auffallen läßt. Diese sieht dann beinahe ans wie eine Fläche von fein poliertem Stahl. Nan kann die Erscheinung beobachten, wenn man einen Stein mit einer ganz glatten Fläche dicht ans Auge bält und ibn, gegen das Licht gekehrt, mehr oder weniger stark gegen die einfallenden Strahlen neigt. Bei gervissen Stellungen zeigt die Fläche die genannte Erscheinung.

Der vollkommene Diamantglanz hängt bei allen Körpern zusammen mit rollkommener Durchsichtigkeit, sehr starker Lichtbrechung und bedentender Farbenzerstreuung. Alle diamantglänzenden Körper, so namentlich der Diamant selber, haben neben der 
erstgenannten die heiden letzteren Eigenschaften, und umgekehrt zeigen alle sehr stark lichtbrechenden und farbenzerstremenden durchsichtignen Körper Diamantglanz. Aber nicht nur die Art des frlanzes hängt mit diesen Lichtbrechungsverhältnissen zusammen, sondern auch die Stärke desselhen, da die schief auf eine Flïche auffallenden Lichtstrahlen um so vollständiger reflektiert werden, je stärker die Lichtbrechung der betreffenden Sulsstanz ist. Der Diamant mit seinem bedeutenden Lichthrechungsvermögen wird also mehr Lichtstrahlen von seiner Oberfläche in tas Auge senden und daher einen stärkeren Glanz zrigen als ein anderer das Licht weniger stark brechender Körper. Der starke Glanz der Elclstrine wird als ihr Feuer bezeichnet; der Diamant hat also ein ganz besonders schoines Fener.

Lichthrechune. Die Lichthrechung des Diamants ist einfach, wie bei allen Körpern, die gleich ihm im regulären System kristallisieren. Wenn ein Lichtstrahl schief auf eine elsene Fläche rines Diamants auffüllt, so wird er beim Eintreten in den Diamant aus sciner Richtung abgelenkt, und es pflanzt sich in demselben ein einziger gebrochener Strahl fort. Die Ablenkung des gebrochenen Strahls von der Richtung des einfallenden ist beim Diamant eine selır starke, stärker als bei den meisten anderen Substanzen, mit anderen Worten: das Lichtbrechungsvermögen ist ein sehr bedeutendes, der BrechungsKoëffizient sehr hoch.

Nit der Lichtbrechung hängt auch die Farbenzerstreume oder die Dispersion zusammen, die beim Diamant gleichfalls außerordentlich stark ist. Die blauen Strahlen werden sehr viel stärker abgelenkt als die roten; das Spektrum, das ein Prisma aus Diamant in weiben Licht macht, ist daher sehr lang, das rote und das blaue Ende sind sehr weit voneinander entfernt. Die einzelnen Farben, in welche die durch einen geschliffenen Diamant hindurchgegangenen weifen Lichtstrahlen zerlegt werden, treten daher einzeln sehr hestimmt hervor, und sie verursachen so das herrliche Farhenspiel des Brillants, auf dessen Pracht die Schönheit des Diamants und seine Verwendung als Schmuckstein zum crö̈liten Teil beruht. Dadurch unterscheidet er sich von weniger stark farbenzerstreuenden Steinen, die man ihm zuweilen unterzuschieben sucht, wie Berckristall, Topas, weiber Sapphir, Zirkon usw., deren Farbenspiel ganz unbedeutend ist. Das Nähere hierüher ist schon oben bei der Betrachtung des Ganges der Lichtstrahlen in einem geschliffenen Edrlstein auseinandergesetzt worden (S. 52). Übrigens sind nicht alle Diamanten in ihrem Licht- und Farbenspiel einander gleich, ohne dab man einen Grund dieser Verschiedenheit anzugehen weif. Wahrseheinlich sind es kleine Untersehiede in der Lichtbrechung und Farbenzerstreumg, die bewirken, daß manche Steine ein schöneres Aussehen haben als andere. Am höchsten stehen hierin die indischen und diesen am näichsten die brasilianischen aus dem Berirk ron Diamantina in der Provinz Minas Geraies und aus den Canavieirasuruben in der Provinz Bahia. Ein verhältnisnü̈Big untergeordnetes, aber doch immer noch sehı schönes Farbenspiel haben die meisten Kapdiamanten. Bemerkenswert ist, dafi manche Steine, so viele rom Kap und von Canavieiras, bei kïnstlicher Beleuchtung das farbenspiel nicht so sehön zeigen wie im Tageslicht; bei den meisten Diamanten ist dies gerade umgekehrt.

Das Lichtbrechungs- und das Farbenzerstreumngsvermögen des Diamants werden beide gremessen durch die Brohumeskofiftizienten. Diese gehen direkt die Stärke der Liehthrechung an, und aus der Differenz dieser Zahlen für das rote und das violette Lieht folgt die Grölje der Farbenzerstremung, der Dispersionskoëffizient. Dal dieser wie die Brechungskö̈lfizienten beim Diamant wrölier ist als bei den meisten bekannten Substanzen, ergeben die folgrenden Zahlen im Verwleich nit den spöter für die anderen Edelsteine anzuführenden, wodurch sich der Diamant auch von diesen unterscheiden läßt. 
Nach Wr a lter gevten fïr die Brechungskoiffizienten bei dem Diamant die folgenden Zahlen:

$$
\begin{aligned}
& \text { rotes Licht: } n=2,40735 \text { (Linie } B \text { des Spektrums) } \\
& \text { gelbes } " \quad=2,41734(n D " \quad, \quad) \\
& \text { griines } "=2,42 \operatorname{col}(" E, \quad E n,
\end{aligned}
$$

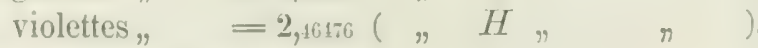

Es ist also der Dispersionskoëffizient

$$
=2,4646-2,40735=0,05741 \text {. }
$$

Zur Vergleichung sind im folgenden die Brechungskoüffizienten für aine grewisse Glassorte angegeben. Man hat gefunden für:

$$
\begin{array}{ll}
\text { rotes Licht: } n & =1,524312 \\
\text { gelbes } " & =1,527952 \\
\text { grïnes } " & =1,531372 \\
\text { violettes" } & =1,544651 .
\end{array}
$$

Der Dispersionskoëffiizent ist also hier

$$
=1,541654-1,524312=0,0203: 2
$$

also nicht gauz halb so grof als beim Diamant, und das Spektrum nur ungefühı hall) so lang, sleiche Verhältnisse in dem Glas und dem Diamantprisma rorausgesetzt.

A nomale Doppelbrechung. Oben wurde erwähnt, daß der Diamant, seinem Kristallsystem semäl, einfach lichtbrechend, isotrop ist. Dies wilt aher in voller Strense nur für solehe steine, die vollkommen farblos oder gelblich, oder sonst nur schwach gefürbt und ganz frei von Einschliissen, Rissen und anderen Störungen sind. Derartige Steine sind im Polarisationsinstrument bei gekreuzten Polarisationsebenen stets dunkel und bleiben es bei einer Drehung um 360 Grad. Zur möglichsten Vermeidung der Totalreflexion werden die Steine bei solchen Lntersuchungen am besten in Methylenjodid oder Monobromnaphthalin gelegt.

Anders rerhalten sich stark gefärbte Steine oder solche mit Rissen oder Einschlïssen, oder anderen Fehlern. Steine dieser Art werden im dunklen Selıfelde des Polarisationsinstrumentes etwas, aber im allgemeinen nur wenig anfgehellt. Sie erscheinen graulich; nur selten sieht man lebhaftere Farben auftreten. Es zeirst sich eine schwache Doppelbrechung, die aber nicht der Substanz eigentïmlich ist, sondern durch äufere Einflüsse in ihr hervorgebracht wird, also eine a nomale Doppelbrechung. Selten wird beim Drehen im Polarisationsinstrumente ein solcher Stein über seine ganze Oberfläche hinweg gleichmäßig bell und dunkel, meist sind einzelne Stellen hell, andere dunkel, und beim Drehen des Steines ändern sie sich. Häufig entstehen einzelne regelmäßig gestaltete Felder von gleichem Verhalten, wïhrend die anstoßenden Felder verschiedenes Aussehen zeigen. Meist sind aber die abwechselnden hellen und dunklen oder verschieden gef:irbten Stellen ganz unregelnäßig gegeneinander abgegrenzt, oder schwach doppeltbrechende Partien sind von vollkommen einfachbrechenden, die stets dunkel bleiben, eingeschlossen.

Gerwöhnlich liegen die doppeltbrechenden Stellen um Einschlïsse oder Risse herum, so dab rings un diese die Doppelbrechung am stärksten und die Färbung in Polarisationsinstrumente am lebhaftesten ist. Ton ihnen aus nimmt die Doppelbrechung gegen außen hin immer mehr ab und verschwindet endich ganz. Manchmal sieht man im Polarisationsinstrumente ein regelmäßjiges schwarzes Kreuz, dessen beide senkrecht aufeinander stehende Balken sich mitten in einem Einschlusse schneiden. Man erkennt daraus deutlich, dals die Erscheinung hervorgebracht wird durch einen ron dem Einschlusse auf den Diamant ausgeübten Druck, der nach auben immer mehr alnimmt, wie die Doppelbrechung auch, und mit dieser allmählich ganz aufhört. 
Während im allgemeinen die anomale Doppelbrechung beim Diamant nur gering ist, gibt es doch einzelne Steine, bei denen sie stïrker auftritt und die daher besonders lebhafte Polarisationsfarben zeigen. Dies sind vor allem die schon mehrfach erwähnten smoky stones ron Südafrika, die wie Glastränen infolge der starken inneren Spannungen zuweilen olne ersichtliche Ursachen in Pulver zerfallen. Wie bei den letzteren, so ist auch bei den doppelbrechenden Diamanten die innere Spannung die Ursache der starken anomalen Doppelbrechung. Farbige Diamanten mit anomaler Doppelbrechung sind zuweilen mehr oder weniger stark pleochroitisch.

Trotz dieses anomalen Verhaltens vieler Diamanten ist es doch in allen Fällen leicht mïglich, einen Stein, der solche Erscheinungen zeigt, von einem wirklich doppelt brechenden Mineral, wie Bergkristall, weißer Topas oder Sapphir usw., zu unterscheiden. Bei diesen ist die Aufhellung in Polarisationsmikroskop weit vollkommener und erfolgt stets gleichmäßig iiber das ganze Stiick hinweg, wie es schon oben bei der allgemeinen Betrachtung der anomalen Doppelbrechung gezeigt wurde (S. 61).

Farbe. Vielfach hält man den Diamant für stets vollkommen farblos, für den Typus der ungefärbten Steine von größter Klarheit und Durchsichtigkeit. Dies ist aber nur zum Teil richtig. Wie es trübe und undurchsichtige Diamanten gibt, und zwar in großer Zahl, so gibt es auch gefürbte und die Fürbung ist sehr mannigfaltig. Zahlreiche Diamanten sind allerdings vollkommen farblos und entsprechen dann ganz der Vorstellung, die man sich von diesem Edelstein zu machen pflegt. Dies ist ungefähr bei einem Viertel sämtlicher Exemplare, die bis jetzt gefunden worden sind, der Fall; ein zweites Viertel zeigt einen ganz leichten Farbenton, und der Rest, mindestens die Hälfte von allen, ist mehr oder weniger lebhaft gefärbt.

Die vollkommen farblosen Steine sind die reinsten. Der reine, als Diamant kristallisierte Kohlenstoff zeigt keine Spur von Färbung. Derartige Steine sind auch im allgemeinen die kostlarsten und wertvollsten. Ist die Farblosigkeit mit vollkommener Durchsichtigkeit verbunden, dann entsteht zuweilen ein eigentümlicher stahlblauer Schein. Solche „h)lauweiße" Diamanten (sog. Tiffanyit S. 80), die in Indien und Brasilien nicht ganz selten sind, die aber auch am Kap, wenngleich nur viel spärlicher vorkommen, sind die geschäitztesten von allen, einige besonders schön gefürbte ausgenommen. Bei Bestrahlung: mit Radium werden farblose Diamanten zum Teil gelb (siehe S. 72), im allgemeinen ändert sich aber dabei die Farbe wenig oder gar nicht.

Wenn dem Diamant irgendeine fremde farbige Substanz beigemengt ist, dann nimmt (r) deren Färbung an, nur ganz leicht, wenn die Substanz in sehr geringer Menge vorhanden ist, bestimmter und intensiver, wenn der Stein mehr von dem färbenden Köruer, dem Pigrment, enthält. Stets ist aber die Menge des letzteren absolut genommen eine äulserst geringe.

Welcher Art diese färbenden Körper sind, ist noch sehr wenig bekannt, da die Untersuchungen hieriib) der Sehwierigkeit und Kostspieligkeit wegen noch wenigr vorgeschritten sind. Es wirl vermutet, daf in vielen Diamanten organische Substanzen, Verbindungen des Kohlenstoffes, vielleicht Kohlenwasserstoffe, die Fäibung hervorrufen; vielfach sind es aher auch unorganische Körper in äußerst feiner Verteilung.

Wir haben schon gesehen, daf) wohl gefärbte Diamanten, nicht aber farblose, kleine Mengen fremder eisenhaltiger Substanzen einschlieben, die beim Verbrennen als Aschenbestandteile zuriickbleiben. lis liegt sehr nahe, zu vermuten, dab in vielen Fällen sie es sind, auf denen die Färbung beruht, un so mehr, als diese beim Glühen des Steines vielfach weder verschwindet noch sich ändert, wie die durch organische Substanzen hervorgebrachten Farben. Fine solche Änderung ist aber doch anch sehon in einzelnen Fïllen zweifellos beobachtet worden, wic unten noch weiter gezeigt werden soll; dann 
könnte die Färbmug wohl auf organische Stoffe zuruickzuführen sein. Dem widerspricht aber wieder das Verhalten farbiger Diamanten gegen Riöntgenstrahlen (S. 155). Darnach sind gefärbte Diamanten, auch wenn die Farbe nur ganz blaf ist, etwas weniger durchliissig als vollkommen farblose. Vermutlich beruht dies darauf, dab die Fïrbung dureh die Anwesenheit irgend eines unoreanischen Pigments, eines Metalloxyds oder derol. herlingt ist, das die Röntgenstrahlen nicht ungehindert hindurchgehen läßt. Wäire der Farbstoff eine organisehe Substanz, ein Kohlenwasserstoff odler etwas ähnliches, so wäre er für diese Strahlen ebenso durehlïssign wie der Diamant selbst, er könnte also die erwähnte Wirkung nicht hervorbringen. Wahrseheinlich ist das Pigment nicht immer das gleiche.

Viele Diamanten sind so schwach gefürbt, daß sie der ungeübte Beobachter für ganz farblos hält. Fïr ilın tritt die Fürbung erst durch den Kontrast hervor, wenn er einen wirklich farblosen stein daneben hält, orler wenn er den schwach gefürbten Diamant aut ein Blatt rein weiben Papiers legt. Das geïhte Auge eines Diamantenhändlers erkennt dagegen eine noch so schwache Färbung auf den ersten Blick ohne alle kïnstlichen Hilfsmittel. Solche ganz schwach gefürbte Steine sind von etwas geringerer Qualität als ganz farblose von gleicher Klarheit und Durchsichtigkeit, der Preisuntersehied ist aber nicht erheblich. Am häufigsten sind ganz lichte gelbe, braune, graue und grïne Farbentïne. Die allermeisten jetzt im Handel rorkommenden, fast ausschlieflich aus Siidafrika stammenden Diamanten zeigen solche ganz belle odlel auch etwas bestimmtere gelbe Töne. Wenn das Gelb nicht zu intensiv ist, dann verschwindet es bei gewöhnlicher kïnstlicher Beleuchtung. In dieser sieht der gelbliche Stein weib, farblos aus, nicht aber bei elektrischer Beleuchtung; diese lïßt die gelbe Farbe deutlich hervortreten. Auch ganz lichte bläuliche Färbungen kommen vor, jedoch weniger häufig.

In derjenigen Hälfte der Diamanten, die eine ausgesprochene bestimnte Färbung haben, kommen fast alle an Mineralien bekannten Farben vor, und zwar meist in zahlreichen Nuancen, so daß die Farbenreihe des Diamants eine sehr große ist. Eine prächtige Sammlung verschieden gefärbter Diamanten, die schönste und reichste, die iuberhaupt existiert, wird in der Schatzkammer der Wiener Hofburg aufbewahrt; sie ist von Helmreichen zusammengebracht, der sich lange Jahre in Brasilien aufhielt, und so imstande war, sie möglichst vollständig zu gestalten.

Am häufigsten ist gelb (zitronen-, wein-, messing־, ocker-, honiggelb, während schwefelgelb noch nicht beobachtet worden ist); gelb in irgendeiner dieser Nuancen sind wie erwähnt, die meisten Kapsteine gefärbt. Nach dem gelb ist wohl grü am rerbreitetsten; es ist die gewöhnlichste Farbe in Brasilien. Ölgrïn oder gelblichgrïn ist besonders hïufig. dann blaß-, lauch-, spargel-, pistazien-, oliven-, zeisig-, smaragd-, bläulich- und graulichgrün. Auch braun ist an allen Fundorten verbreitet (hell-, kaffece, nelken- und rothraun). Nicht selten ist grau (hell-, asch-, rauchgrau), während schwarze wohl ausgebildete Kristalle zu den ungewöhnlichen Torkommnissen gehören. Selten ist auch rot (lila-, rosen-, pfirsichblüt-, kirsch-, hyazinthrot) und am allerseltensten blau (dunkel- und hellsapphirblau).

In allgemeinen ist auch die deutliche Fürloung selten eine intensive; meistens sind es helle Nuancen, die bei den Diamanten vorkommen. Es gibt aber doch auch viele intensir gefürbte Steine und unter diesen solche, die vollkommen klar und durchsichtig sind und die daher zum Schmuck Verwendung finden kïmnen. Die Zahl der letzteren, die also eine ausgeprägte schüne Farbe mit vollkommener Durchsichtigkeit rerbinden, ist aber eine sehr beschränkte, sie bilden daher mit die wertrollsten und kostbarsten Edelsteine, die es überhaunt giht. Ihr kräftiger und schöner Glanz und ihr lebhaftes Farbenspiel, verbunden mit ihrer leuchtenden Kürperfarbe, lassen sie in einer Schönheit strahlen, dab keiner der präichtigsten farbigen Steine, Rubin. Sapphir und andere, sich 
mit ihnen verwleichen läßt; der Glanz ist bei diesen immer geringer und das Farbenspiel fehlt so gut wie ganz.

Verhältnisu'äbig am zahlreichsten sind nach der Auffindung der Kapdiamanten derartige Steine von lebhaft gelber, z. T. ziemlich tiefer Farbe; früher waren auch sie sehr selten. Der grïßte und schïnste gelhe Diamant, den man gegenwärtig kennt, ist der in Figur 62 abgrebildete orangegellye Brillant ron $125 \%$ Karat im Besitz der Juwelierfirma Tiffany in New York. Er stammt rom Kap. Einige gute gelbe Steine aus älterer Zeit bewahrt das grüne Gewölbe in Dresden.

Sehr selten und nur in einzelnen Exemplaren bekannt sind schön grïne, sodann rote und endlich die besonders kostbaren blauen. Ein sehön gr rïner, durchsichtiger Brillant von 151:2 Kilrat befindet sich im grïnen Gewölbe in Dresden, es ist der schönste der bekannten grïnen Diamanten. Bei der Betrachtung der großen Diamanten werden wir noch einmal darauf zurïckkommen. Ein anderer von derselben Beschaffenheit ist in Amerika. Tsclıti erwälnt einen smaragdgrünen und einen meergrünen aus Brasilien, Boutan von ehendort einige Steine genau von der Farbe des Uranglases, die zwischen grün und gelb steht, aber näher dem letzteren.

Yon roten Diamanten wird häufig der für 100000 Rubel angekaufte 10 karätige rubinfarbige Stein des Kaisers Paul I. von Rußland genannt, der sich im russischen Kronschatze befinden soll; nähere Nachrichten sind darïber aber nicht vorhanden. Sicher konstatiert ist der »rote Halphen-Diamant", ein rubinroter Brillant von einem Karat. Gegen Ende des 19. Jahrhunderts soll nach der Mitteilung von Streeter ein schön roter Stein in Borneo gefunden und in Paris verkauft worden sein. Ros en rote, schön durehsichtige Diamanten sind melırere bekannt, so ein soleher des Prinzen della Riceia von 15 Karat und einige kleinere in der Schatzkammer in Dresden, sowie ein Stein von 32 Karat, der schönste rosenrote, den man kennt, in der Schatzkammer in Wien. Ein Rosabrillant, genannt "Fleur de pêcher", befindet sich auch unter den französischen Krondiamanten, und einen pfirsichbliitroten erwähnt Tschudi aus Brasilien vom Rio do Bagagem in Minas Geraës.

Die allerseltenste Farbe ist die blaue. Einen prachtvoll blauen Brillant von $14^{1 / 2}$ Karat besitzt der Bankier Hope in London, die »Perle unter den gefürbten Diamanten«. Er ist wahrscheinlich ein Stiick des 1792 mit den anderen französischen Kronjuwelen gestohlenen blauen Diamanten von Tavernier von 67 \% Karat, der bei den groben Diamanten unten noch besonders besprochen werden soll. Einen kleinen tiefblaten und einen 40 Karat schweren blaßblauen Brillant bewahrt die Mïnchener Schatzkammer. Ein blauer Diamant ist auch im Besitz des Großherzogs von Toskana.

Viclleicht verdienen die schwarzen Diamanten noch eine kure Erwähnung. Es grieht schwarze Diamantkristalle von ganz gleichmäbiger Färbung; besonders scheinen sie in Borneo vorzukommen, als sehr große Seltenheit auch in Südafrika. Diese haben gesehliffen wegen ihrer Undurchsichtigkeit eine eigentïmliche Schönheit, da sie einen besonders hohen, dem metallisehen sich nähernden Glanz annehmen; daher werden sie zuweilen zu kostharem Trauerschmuck verwendet. Nach der Untersuchung von Mo issan sind diese schwarzen Diamanten an sich farblos, aber mit zahlreichen sehwarzen Einschliissen durchsetzt, die die Farbe hervorbringen. Das Pulver ist grau und wird 200" unter der Verbrennumesteniperatur des Diamants farblos und frei von Linsehliissen, die demmach wohl schwarzer Kohlenstoff sincl. Man darf diese schwarzen Diamanten nicht verwechseln mit dem gleichfalls schwarzen Karbonat aus Brasilien, von dem unten noch eingehend die Rede sein wird. Auch einige bra une Steine ron schöner und zarter Kaffefarbe sind bekannt, sie stammen gleichfalls von Brasilien.

Wie bei fast allen Edelsteinen und sonstigen Nineralien, die ihre Fürbung äuferst f'in verteilten, (ingeschlossenen fremden Substanzen verdanken, ist auch beim Diamant 
dic Farbe vielfach nicht vollkommen gleichmälig durch die ganze Nasse hindurch. Nicht selten sind die P'igmente nur an rinzelnen Stellen vorhanden oder doch stärker ancehäuft; nur diese sind dam ïberhaupt oder doch kräftiger geförbt als die anderen. An zahlreichen J)iamanten ist nur eine oberflichliche diinne Schicht gefärbt, der Kern dagegeren farblos oder anders gefärbt. Dies ist in Brasilien eine ganz gew z̈hnliche Erscheinung, namentlich bei den Steinen vom Rio Pardo in Bezirk von I Diamantina. Die äufere Sehicht ist hicer nicht selten hellgriin; durch das Schleifen wird sie entfernt und man erhält daun einen vollkommen farblosen Stein. Tsehudi erwähnt einen herrlichen smaragdgrïnen Brillant aus Brasilien, der vor dem Schleifen sanz rulschwarz gewesen war; ein anderer rulischwarzer behielt diese Farbe beim Schleifen, nur eine einzige Facette wurde weif. Hier war also ein weiber Kern, bei dem zuerst genannten Stein ein smaragdgrïner Kern von einer rußschwarzen Hïlle umgeben.

Nicht selten zeigt sich bei rohen Diamanten die IIauptmasse farblos, und nur die Kanten und Ecken haben einen farbigen Anfluw. So verhalten sich ebenfalls viele brasilianische Steine, aber auch manche von südlafrika, und zwar ein Teil der schon oben erwähnten nach ihrer Färbung sogenannten smoky stones:. Bei rliesen ist die ranchorane Farbe zuweilen nur an den Ecken kräftiger, der Kern ist schwach oder gar nicht wefärbt; sie werden dann "glassy stones with smoky corners" genannt. Bei anderen Diamanten ist aber anch das Umgekehrte der Fall: die Kanten und Eeken sind farblos, der Kern ist gefärbt.

Selten ist es, daß ein Stein aus zwei verschieden gefärbten Teilen besteht. II a we erwähnt einen je zur Hälfte gelben und blauen. Ebenso ist es auch selten, daf vom Mittelpunkt ausstrahlende, verschieden gefürbte Sektoren in regelmäßiger Abgrenzung niteinander abwechseln. So bilden zuweilen rauchgraue und farblose Strahlen regrelmälig sternförmige oder wie das Treff des Kartenspieles gestaltete Figuren auf den Oktäederfläichen.

Interessant ist schließlich noch, daß einzelne Diamanten das Farbenspiel des edlen Opals zeigen. Des Cloizeaux erwähnt einige solche Steine, die sich vom Edelopal in dieser Hinsicht nur dadurch unterscheiden, daß bei ihnen die Farben weniger lebhaft sind als bei diesem. Aveh der von II awe erwähnte hellblau und gelbe zeigt etwas ron dieser Erscheinung.

Die Farbe mancher Diamanten bleibt nicht immer und unter allen Umständen dieselbe, durch manche äußere Einwirkungen kann sie sich :̈ndern. Einzelne Steine bleichen am Sonnenlicht aus; so wird von einem roten Stein berichtet, der an der Sonne allmählich seine Farbe verlor und weif wurde. Sehr eigentiimlich ist die Farbenänderung eines Diamants in Besitze des Pariser Juweliers Halphen. Es ist ein schwach bräunlicher Stein von $4 \mathrm{~g}$ (etwa 20 Karat), der im Feuer eine schön rosenrote Farbe annimmt. Diese bält sich im Dunkeln ungefähr 10 Tage, dann kehrt die urspriingliche bräunliche Nuance allmählich wieder zuriick. Viel rascher geschieht dies aber, wenn der Stein dem Tageslicht oder gar den direkten sonnenstrahlen ausgesetzt wird. Bei abermaligem Erhitzen wiederholt sich dieselbe Änderung und so, wie es scheint, beliebig oft. Wie vorteilhaft es wäre, wenn die rosenrote Farbe zurückgehalten werden künnte, sieht man daran, daf der stein in seiner gewöhnlichen bräunlichen Farbe 60000 Franken, in seiner vorübergehenden rosenroten dagegen 150-200(000 Franken wert ist. Halphen hat auch einen Diamant gesehen, der durch Reiben rosenrot wurde, aber die Farbe fast sogleich wieder verlor.

Manche Steine werden in der Wärme bleibend in ilurer Farbe verändert. Nach Des Cloizeaux wurden blaßgrime Diamanten nach dem Erhitzen im Knallgasgeblïse lichtgelh, und hraune Kristalle wurden dabei graulich. Auch Baumhauer sah einen grrïnen Diamant beim Glïhen gelblich werden, während ein dunkelgrüner eine violette Farbe annahm. Wöhler machte grüune Diamanten durch Glïhen braun, dagexen blieben 
braune unverïndert. Die gelben Diamanten, besonders die vom Kap, behalten ihre Farbe bei den höchsten Temperaturen.

Es ist schon oben erwähnt worden, daß schwach gefärbte Steine weniger hoch im Preise stehen als ganz farblose. Man hat daher schon viele Versuche angestellt, um beliebig die Farbe zu entfernen und so aus grefärbten wertvollere farblose Steine lierzustellen. Das wird mit groljer Leichtigkeit bewirkt bei den schon oben erwähnten brasilianischen, an denen die gefürbte Schicht nur in sehr geringer Dicke einen farblosen Kern umhüllt. Diese Schicht wird einfach verbrannt, indem man die Steine in einem Tiegel mit etwas Salpeter erhitzt. Die Operation geht sehr rasch vor sich; meist schon nach einer oder zwei Sekunden ist die gefärbte Schicht verschwunden und der Stein farblos. Hierbei handelt es sich offenbar nicht um eine Änderung der Farbe, sondern um die Entfernung der gefärbten Aulienschicht, die, wie wir oben gesehen haben, ebensogut durch Wegschleifen erfolgen könnte.

Man hat aber auch schon probiert, die den ganzen Stein durchziehende ungünstige Farbe fortzuschaffen und so einen farblosen Stein herzustellen. Wohl der erste, der sich mit solchen Versuchen beschäftigte, war der Kaiser Rudolph II. Nach der Mitteilung seines juwelenverständigen Gehilfen in solchen Dingen, B ö̈thius de Boodt, besaß er ein Mittel, jeden Diamanten zu entfärben und fehlerlos zu machen. Leider haben die Kundigen das Rezept dazu mit ins Grab genommen, ohne es zu offenbaren. Später hat der Pariser Juwelenhändler Barbot demselben Ziele zugestrebt. Er behauptete gleichfalls, es sei ihm gelungen, durch chemische Nittel und hohe Temperatur grïne, rote und gelbe Steine vollkommen farblos zu machen, während dunkelgelbe, braune und schwarze nur wenig von ibrer Farbe verloren. Auch Barbot gab sein Nittel nicht bekannt, so dal man seine Angaben nicht prïfen kann. Angezeigt ist es, sie vorläufig zu bezweifeln, obwohl er sich auf dem Titel eines seiner Werke stolz: »Inventeur du procédé de décoloration du diamant* nennt. Nach allen unseren Kenntnissen von den färbenden Bestandteilen der Diamanten ist es wenig wahrscheinlich, dal die Farben säinzlich zum Verschwinden gebracht werden können, jedenfalls ist zurzeit kein Mittel be. kannt, dies in allen Fällen zu bewerkstelligen.

Geht es auch nicht an, einen gelben Stein, wie sie jetzt so viel im IIandel rorkommen, wirklich farblos zu machen, so ist es doch leicht möglich, ihn so zu behandeln, daß er aussicht, als wäre er farblos. Dies kann natürlich zu schändlichem Betrug mißbraucht werden, und zwar durch das folgende Verfahren, dem sogar sehr erfahrene Juwelenhändler zum Opfer gefallen sind: Bringt man einen gelben Stein in eine violette Flüssigkeit, ctwa eine verdïnnte Lösung von übermangansaurem Kali, wie es so häufig als Mundwasser verwendet wird, so berleckt er sich nach dem ITerausnehmen und Trocknen mit einer ganz dïnnen s'chicht dieser violetten Substanz. Diese wirkt mit dem Gelb des Diamants so zusammen, daß beide Farben verschwinden und der Stein farblos aussieht, da grelbe und violette Lichtstrahlen gemischt weiß geben. Wenn der Stein nach dem ersten Versuch noch gelh) aussieht, kann er ein zweites, drittes usw. Mal eingetaucht werden; scheint er violett, so kann man von der fürhenden Sulstanz etwas abwaschen. Auch violette Tinte soll zu dem Versuch brauchbar sein. Der Stein ist selbstrerständlich nur so lange weil), als die violette Substanz darauf liegt; reibt sich diese ab, was natürlich sehr leicht geschieht, dann zeight der scheinbar weiße Diamant sofort seine eigentliche gelbe Farbe. Neuerer Zeit ist es leider gelungen, recht dauerhafte farbige Überzüge dieser Art herzustellen. Schon die alten Indier sollen ein Verfahren gekannt haben, gelbliche Diamanten vorübergehend farblos erseheinen zu lassen, und zwar sollen sie sich dabei des Ultramarins bedient haben. 
Die Farbe des Diamantpulvers ist nach den Untersuchungen von Petzoldt, dee in jeder Diamantschleifere bestïtigt werden kïmen, grau bis schwarz, und zwar um so dunkler, je feiner es ist.

Phosphoreszenz. C̈her die Phosphoreszenz des Diamants wird offenhar vied Cnrichtiges mitgeteilt. Man liest, dab der Diamant im Dunkeln leuchte, wemn er vorher von rer come beschienen worlen sei; besonders stark nach der Bestrahlun on mit blauem, weniger nach der mit rotem Licht. Sellbst Steine, von denen durch Zudecken mit Papier usw. und sogar mit rinem brett die direkten Somnenstrahlen abgehalten wurden, so daf nur die Umhüllung diesen ausgesetzt war, sollen im Dunkeln geleuchtet baben. Vorsuche lehren aber, dafs nur wenige Diamanten durch Lichtstrahlen zum Leuchten im Finstern (n+brateht werden können, die meisten weder durch die Sonnenstrahlen, noch durch em intensives künstliches Licht. Streeter berichtet, daf ein 115 -karätiger selber Stein nach dem Bestrahlen mit Kalklicht ein Zimmer erhellte, und Edwards beschreibt einen 92 Karat schweren klaren, wasserhellen Dianant, der nach einstïndiger Insolation 20 Minuten langr ein so starkes Licht ausstrahlte, daf ein in der Tähe liegrender. Bogen weifjen l'apiers im dunkeln Zimmer deutlich gesehen wurde. Dieselbe Virkung wurde durch Bestrahlinng mit elektrischem Licht hervorget)racht. Dagegen fand (:. F. K unz, daf) von 150 Diamanten der verschiedensten Form, Größe und Beschaffenheit nur 3) durch elektrisches Bogrenlicht phosphoreszierend wurden.

Iremn die lielichtung demnach nur greringe Wirkung hat, so werden die Diamanten um so leichter durch lieiben selbstlenchtend. G. F. Kunz beobachtete, dafs alle von ihm unfersuchten Diamanten im Dunkeln Licht ausstrahlten, nachdem sie auf Holz, Leder, wollenem oder sonstigem Zeug usw. gestrichen worden waren. Bei manchen Steinen genïgt ein einziger Strich, besonders auf Wolle, an besten tritt aber die Erscheinung beim Reiben auf IIolz gegen die Fasern auf. Auch Reiben auf Metallen (Eisen, Stahl, Kupfer) soll nach anderen Nachrichten zum Ziel führen.

Ob Diamanten beim Erwärmen (selbstverstïndlich nicht bis zur Glühhitze) eigenes Licht ausstrahlen kïnnen, ist zweifelhaft, dagegen werden manche, die nach dem Bestrahlen mit Sommenlicht ganz dunkel bleiben, leuchtend, wenn elektrische Funken auf sie fallen. Stets und unter allen Lmständen tritt aber die Phosphoreszenz nur dann eim, wenn der Diamant nicht vorher einer starken Hitze ausgesetzt gewesen ist.

Die Intensität des ausgesandten Lichtes ist fast immer nur schwach, viel schwächer als bei vielen anderen phosphoreszierenden Substanzen; am stärksten noch wird durch den elektrischen Funken das eigene Licht erregt. Die Farbe ist meist gelb, unter Lmständen auch blau, griü und rot. Merkwürdigerweise ist das Verhalten des von verschiedenen Flïchen eines und desselben Kiristalls ausgesendeten Lichtes zuweilen verschieden. So berichtet Dessaignes (1S199), dal ein ron der Sonne beschienener Diamant nur von den Würfelfläichen Licht ausgesandt habe, nicht aber von den Oktä̈derflächen, die dunkel blieben. Maskely ne teilt nit, dab ein Diamantkristall auf den Würfelflächen ein schönes aprikosenfarbigres, auf den Dodekaëderflächen ein hellgelbes und auf den Olitä̈derflächen ein anders gelbes Licht ausgesandt habe.

Alle diese Erscheinungen dauern meist nur ganz kurze Zeit, doch wird angegeben, daß ein Diamant eine ganze Stunde nach der Bestrahlung noch Phosphoreszenz grezeigt habe.

Über die Erregung ron Phosphoreszenzerscheinungen durch Radiumstrahlen haben wir schon oben gesprochen (S. 80); es sei hier nur noch erwähnt, daß schwarze Diamanten und Karbonat dabei nicht leuchtend werden.

Der beriilhmte englische Physiker R. B oyle soll der erste gewesen sein, der 1663 die Phosphorescenz des Diamants beobachtete. 


\section{Elektrische und thermische Eigenschaften.}

Der Diamaut wird durch Reiben positiv elektriseh, gleichgültig; ob er roh oder greschliffen ist. Dic erlangte Elektrizität verliert er rasch, spätestens in einer halben Stunde wieder. Er ist ein Nichtle ite r der Elektrizität im Gegensatz zu dem anderen kristallisierten Kohlenstoffe, dem Graphit, der zu den sehr guten Leitern gehört.

Für die IV ärme ist der Diamant ein guter Leiter. Er fühlt sich daher mit der Hand kalt an und kann auf diese Weise von anderen Substanzen untersehieden werden, wie wir oben (S. 81) gesehen haben.

\section{b) Vorkommen und Verbreitung des Diamants.}

Der Diamant ist schon in allen fünf Erdteilen gefunden worden, aber nicht alle sind gleich reich an diesem kostbaren Mineral.

Von srölberer Wichtigkeit für Industrie und Handel sind nur drei Länder, die in der Irauptsache die Bedürfnisse nach diesem Edelstein allein befriedigt haben: zuerst Indien vor unvordenklichen Zeiten bis zum 18. Jahrhundert, dann Brasilien bis 1870, jetzt Südafrika. Alles andere ist dem gegenüber von untergeordneter Bedeutung.

Am längsten bekannt sind die Diamanten von $\mathrm{A}$ s i e $\mathrm{n}$, wo die altberïhmten, jetzt allerdings so gut wie vollständig erschöpften ostindischen Lagerstïtten wahrscheinlich schon in den frïhesten Zeiten ausgebeutet worden sind. An dieses schließt sich das Vorkommen auf der Insel Borneo an. Aber während Ostindien der Welt die reichsten Schätze lieferte, ist die Produktion des letzteren Landes immer eine beschränkte gewesen. Nachrichten von Diamantenfunden auf der Halbinsel Malakka (woher einer Angabe zufolge der berühmte Regent des französischen Kronschatzes stammen soll), in Pegu und Siam, sowie auf den Inseln Java, Sumatra und Celebes sind zum mindesten unsicher, ebenso das Vorkommen in China (Provinz Schantung), in Arabien usw. Dagegen ist das spärliche Auftreten im asiatischen Rußland sicher bestätigt.

In $\Lambda$ merika sind die im Anfang des achtzehnten Jahrbunderts in Brasilien aufgefundenen Diamantfelder berïhmt geworden. Namentlich haben die Provinzen Minas Geraës und Bahia von damals an bis jetzt grobe Ausbeute ergeben. Die brasilianischen Diamanten bildeten den Ersatz für die im Laufe der Zeiten immer spärlicher gefundenen indischen. Sicher konstatiert, aber sehr unbedeutend sind die Funde in der nordamerikanischen Union, wo im Osten die Staaten Georgia, Nord- und Südkarolina und Kentucky, Virminia, Wisconsin, im Westen Kalifornien und Oregon eine geringe Anzahl von Steinen geliefert hahen. Nachrichten aus anderen Teilen des Kontinents (Sierra Madre in Mexiko, Goldgruben von Antioquia in Kolumbien) bedürfen noch durchaus der Bestätigunæ. Ton einiger Bedeutung sind aber vielleicht die neuestens aufgefundenen Lagerstätten in Britisch-Guayana.

Der Weltteil, der gregenwärtig die größte Bedeutung für die Diamantgewinnung hat, ist $\Lambda \mathrm{fr}$ ika, wo der Edelstein seit dem Ende der sechziger Jahre des 19. Jahrhunderts in immer steigendrer, alle anderen Gegenden überflügelnder Menge gesammelt wird. Die Fundstätten liewen im Norden der Kapkolonie, in dem Landesteil, der als Griqualand-West bezeichnet wird, besonders am Vaalflulb und in der Umgebung der Stadt Kimberley, sowie in dem anstoßenden Oranje-Freistaat, in Transvaal, in Rhodlesia und in Deutsch-Siidwestafrika. Gegen die Menge der afrikanischen Funde versehwindet alles, was zurzeit auf der ganzen übrigen Erde gewonnen wird; neunzig l'rozent der gegenwärtig in den IIandel gebrachten steine stammen rom Kap. Ganz unsicher ist das Vorkommen von Diamant in dem Goldsande des Flusses Gumel (nach Lacroix wohl der Oned Rumel) in der Provinz Konstantine in Algier. 1533 sollen hier :3 Exemplare gefunden worden sein, man hat aber seitdem nichts wieder daron gehört. 
Mythisch klinget der liericht eines Afrikareisenden Dr. (' $\mathrm{u} \mathrm{y}$. wonach in den fünfriger Jahren cine ganze Kamelladung I)iamanten aus dem afrikanischen Abendlande nach Darfur gebracht worden sein soll.

In E u ro p a ist es Rulbland, das an seiner östlichen Grenze im Lral und daran sich anschliefend in Sibirien, sowie in Westen, in Lappland, einige wenige Streine geliefert hat; in diesen Gexgenden habeen aber die Funde die Bedeutung mineralogischer sieltenheiten bis jetzt nicht ïbersehritten. Einige Wahrscheinlichkeit hat auch der Bericht iiber das Auffinden viniger Strinchen in Spanien; dagegen ist das Vorkommen in einem Bache in Fermanamh im nördlichen Irland unbestaitigt geblieben. Sicher falsch ist der aus Bïhmen gemeldete Fund. Ein einziges kleines Steinchen fand sich da 1S69 unter den zur Verarbeitung bestimmten Granaten in einer Schleiferei in Dlaschkowitz; ess sollte mit den Granaten aus den in der Nähe befindlichen (iranateruben stammen. Ian kann aleer nach de'l eingehenden Lntersuchungen ron V. r. Z e p h a rovi ch keinen Zweifel hegen, daß der Diamant erst in der Werkstïtte, wo solehe zum Durchbohren der Granaten benutzt werden, durch Zufall unter die Schleifware geraten ist.

Nicht ganz geringe Mengen Diamanten hat in neuerer Zeit auch $A$ ustral i $\mathrm{n}$, besomders Neu-Sür-Wales geliefert, so daf gregenwärtig australische Steine wenigstens eine bescheidene Rolle im Handel spielen.

Endlich ist noch zu erwähnen, dal unser Edelstein nicht nur einen Bestandteil der Erde, sondern auch anderer Irimmelskörper bildet. In mehreren ul e t e o r it e u hat man kleine Diamanten nachgewiesen.

Was die Art und Weise des Vorkommens des Diamants betrifft. so wird er an den meisten Orten auf sekundärer Lagerstätte in Seifeu gefunden. Diese durch Verwitterung des ursprïnglichen Muttergesteins gebildeten Schuttmassen sind meist rollständig lose und locker, manchmal, namentlich in Brasilien und Indien, sind sie aber auch durch ein hinzutretendes Bindemittel zu festen Konglomeraten und Breccien und zu Sandsteinen verkittet. Diese, wie die lockeren Sande der Seifen liegen in Brasilien und auch sonst an den meisten Orten an der Erdoberfläche und sind mit zu den allerjüngsten Bildungen der Erdkruste zu rechnen. In Indien und zum Teil auch in Brasilien und Tordamerika gehören dagregen die diamantführenden Trümmergesteine sehr frühen geologischen Zeiten an, sie sind den allerältesten Gebirgsschichten zwischengelagert und stellen gewissermaßen vorwcltliche, fossile Seifenbildungen dar. Aber diese alten diamantfïhrenden Trümmergesteine sind im Laufe der Zeitun, da, wo sie an die Erdoberfläche treten, wieder verwittert, und es sind aus ihnen vielfach neue sekundïre Seifen ron lockerer Beschaffenheit entstanden. Alus allen solchen werden die Diamanten dann durch den gewöhnlichen Waschprozeß gewonnen. Bei der Beschrtibung der einzelnen Diamantlagerstätten sollen diese Verhältnisse eingehender geschildert werden.

Welches das ursprïngliche Muttergestein gewesen ist, aus dem der Diamant in die Seifen gelangte, hat noch an keinem Orte bis in alle Einzelheiten mit der wïnschenswerten Sicherheit und Klarheit festgestellt werden künnen, wenn auch schon vielfach Anhaltspunkte zur Beurteilung dieser wichtigen Frage gewonnen worden sind. Wir werden im folgrenden die sicher konstatierten Diamantvorkommen etwas genauer betrachten und dabei auch den Crsprung der Edelsteine festzustellen suchen, soweit es die rorliegenden Beobachtungen gestatten. Jedlenfalls steht soviel fest, dab nicht an allen Orten das ursprïngliche Torkommen und das Muttergestein dasselbe gewesen ist, daf dieses in manchen Gegenden zu den älteren kristallinischen sauren Gesteinen, zum Gneis und den anderen kristallinischen Schiefern und den zugehörigen Eruptivgesteinen, wie namentlich Granit, zu rechnen ist, daß der Diamant aber an anderen Orten mit basischen Silikatgesteinen, z. B. mit Diabasen, Peridotiten (Olivingesteinen und den daraus durch L'mwandlung entstandenen 
Serpentinen) usw. zusammenhängt. Höchst wahrscheinlich kommt er auch als Drusenmineral auf Spalten in manchen Gesteinen vor. Woron wir bei der Betrachtung namentlich der brasilianischen Lagerstätten noch weiter sprechen werden.

Ganz eigentiumlich ist das Vorkommen in den siidafrikanischen Diamantenfeldern, woder Edelstein sich vorwiegend nicht in Seifen, sondern in einem grünen serpentinähnlichen Gestein eingewachsen findet. Diese ganz besonderen, wie es scheint von allem anderen sonst bekannten abweichenden Verhältnisse werden wir bei der Schilderung der Kapdiamanten eingehender betrachten.

Wir werden im folgenden die verschiedenen Lagerstätten der Diamanten in nachstehender Reihenfolge kennen lernen.

\begin{tabular}{l|l} 
1. Indien. & 5. Burneo. \\
2. Brasilien. & 6. Australien. \\
3. Guayana. & 7. Nordamerika. \\
4. Südafrika. & 8. Lappland.
\end{tabular}

\section{Indien.}

Das Land, dessen Diamanten am längsten bekannt sind und das die schönsten, beruihmtesten und auch mit die größten Steine geliefert hat, ist Ostindien. Schon die Alten haben von hier ihre Diamanten bezogen, und $\mathrm{Ptol}$ e mä us spricht bereits von einen Diamantfluf in Indien. Daß unser Edelstein in sehr frühen Zeiten in jenen Gegenden hochgeschätzt war, beweisen die ältesten Götterdenkmäler dort, die reich mit Edelsteinen, darunter auch mit Diamanten verziert sind. Aus diesen ist auch zu ersehen, daß die Eingeborenen dort schon lange die Kunst des Schleifens der Diamanten verstanden haben müssen. Bis zur Entdeckung der brasilianischen Lagerstätten im Jahre 1728 war Indien das Land, das die Welt fast allein mit Diamanten versorgte; seit dem 2. bis 3 . Jahrhundert vor Christus kamen solche von hier ins Abendland. Außerdem war damals nur noch die Insel Borneo als Heimat dieses Edelsteines bekannt.

Die zahlreichen Fundorte der Diamanten sind in Indien auf eine weite Landstrecke verteilt. C. Ritter hat sie in seiner Erdkunde von Asien (Band IV, 2. Abt., S. 343) unter Benutzung aller ihm bekannten Nachrichten zum erstenmal ausführlich und sorgfältig zusammengestellt, in neuester Zeit auch V. Ball in dem Manuel of the geology of India (Band III., S. 1-50), wobei auch alle späteren Untersuchungen verwertet worden sind.

Das Vorkommen der Diamanten in Indien ist, soweit man es nach heutigen Funden aus alten Gruben und durch die erwähnten Nachrichten aus früheren Zeiten kennt, beinahe ganz auf die Ostseite des IIochlandes von Dekkan beschränkt. Die am siidlichsten, unter dem 14. Grade nördlicher Breite, grelegenen Fundpunkte gehören dem Flußgebiete des Panar (Penner) an. (Fig. 11, S. 170.) Von hier erstrecken sie sich, dem Ostrande jenes Hochlandes folsend, in einer mehrfach unterbrochenen Linie nach Norden über den Kistnah, den Godavery und Malianady bis zum südlichen Stromgebiete des unteren Ganges in Bengalen unter dem 25. Crade nördlicher Breite. Sie gehen von da westlich über den Sone-Flub im Bandelkhand hinaus his zum Tonse und Sonar und hören am Ken-Fluß östlich von Dschatterpur auf. Was aulerhall) dieses Gebietes etwa noch an Diamanten vorkommt, ist unwichtig, zum Teil sind die dariber vorhandenen Nachrichten auch unsicher. Überhaupt sind manche Diamantenfundorte in Indien zweifelhaft und nicht durch genaue und zuverlässige Mitteilungen oder dureh das Vorhandensein alter Gruben verbürgt.

Vielfach trifft man die Meinung, daß alle indischen Diamantgruben bis in das fernste Altertum hinauf reichen. In der 'Tat weil man von manchen Ablagerungen nicht, wann 
ihre Bearbeitung begann, aber die wichtigsten Gräbereien, von denen man jetzt Kuncle hat, haben diese's hohe Alter nicht, sie sind wohl alle in dem letzen Jahrtausend und zum Teil rest in zimmlich später Zeit in Angriff genommen worden. Von einzelnen C'ruben ist der Beginn der Arbeit genau bekannt, wie wir unten sehen werden.

Der Diamant findet sich in Indien teilweise in anstehenden festen Sandsteinen und Konglomeraten eingerelifossen, trilweise in dem losen und lockeren Verwitterungsprodukte dieser Gesteine, an Stellen, wo sie die Oberfläche des Bodens bilden, teilweise auch als Geschiehe iu Sande und Kiese der Fliisse und Bäche, welche durch die diamantführenden Schichten und deren Vorwitterungsprodukte hindurchflielien und die Steine aus ihren frïheren Lagerstätten fortschwemmten.

Der diamantfïhrende Sandstein ist in Indien sehr weit verbreitet. Er gehört der ältesten . bteilung dex dort bekannten Sedimentärformationen an, die meist unmittelbar auf dem Urgebirece. auf riranit. Gneis, Glimmerschiefer. Hornblendegesteinen, Chlorit- und Talkschiefer und ähnlichen Gesteinen liegen. Tersteinerungen sind in jenen Sandsteinen noch nicht gefunden worden, man kann daher nicht genauer angeben, welchen europäischen Sehichten sie dem Alter nach entsprechen; sie gehören aber sicher dem älteren Übergangsgebirge, etwa dem Silur, an.

Drese älteste Schichtenreihe heißt bei den indischen Geologen die Tindhyaformation. Sie ist in sïdlichen Indien, in der Präsidentschaft Madras, nur mit ihrer unteren Abteilung ausgebildet, die dort den Namen Karnulformation erbalten hat. Im nürdlichen Indien, so im Bandelkhand, sind diese unteren Schichten noch von jüngreren iiberlagert, die die obere Vindhyaformation bilden.

Dieser Vindhyaformation nun gehören die diamantführenden Sandsteine in ganz Indien an. soweit man genauere Nachrichten darüber hat. Während sie aber in den südindischen Diamantenbezirken der unteren Abteilung, den Karnulschichten, zugerechnet werden mïssen und wahrscheinlich ebenso in den geologisch zum Teil noch nicht genauer bekannten Godlavery- und Mahanady-Gegenden, machen sie im nördlichen Indien, im Bandelkhand, einen Teil der oberen Vindhyaformation aus.

Die untere Vindhyaformation (Karnulformation) von S ï dindien besteht in der Hauptsache aus Kalken mit zwischen relagerten Tonschiefern und Sandsteinen, Konglomeraten oder Quarziten. Im südlichen Indien liegt an der Basis dieser Schichtenreihe ein System ron Sandstein- und Konglomeratbänken, die Banaganpillygruppe genannt. Dieser ist hier die diamantführende Schicht eingelagert. Die ganze Masse des Banaganpillysandsteines ist meist zwischen 10 und 20 Fuß mächtig. Die Sandsteine sind gewöhnlich grobkörnig, oft tonig, oft aber auch sehr fest, quarzitisch, stellenweise feldspatführend und eisenschüissig. Thre Farbe ist gewöhnlich dunkel, rot. grau oder braun. Die Geschiebe der zwischengelagerten Konglomeratbänke, aus älteren zerstörten Gesteinen stammend, sind zumeist Quarzite. rerschieden gefürbte Hornsteine, Jaspis, sowie feste Tonschiefer.

Die Diamanten finden sich ausschließlich in einer einzigen ganz bestimmten, erdigen geschiebereichen Schicht, die der untersten Abteilung der Banaganpillygruppe angehört und die sich in anderen Niveaus nicht wiederholt. Die Geschiebe sind in ihr von derselben Art wie die eben genamnten, und zwischen ilhnen zerstrent liegen vereinzelt die Diamanten, die als Geschiebe wie die anderen anzusehen sind, und die auch vielfach Abrollung zeigen wie sie. Diese, die Diamanten wie es scheint ganz ausschließlich enthaltende Schicht, ist von geringer Iächtigkeit; zuweilen milt sie weniger als einen Fuß, selten darüber, nur vereinzelt wird die Dicke zu 21/2 Fuß angegeben.

Im Bandelkhand gehört die Diamantschicht zu der mittleren Abteilung der oberen Vindhyaformation, der Rewahgruppe, und zwar liegt sie an deren Basis in den Pannaschichten. Es ist meist ein rotes, eisenschüssiges Konglomerat, dessen Feschiebe ähnlich 
wie in Südindien aus Quarz, verschieden gefärbtem Jaspis, Kieselschiefer, Brauneisensteinknollen, Sandstein usw. bestehen. Zu gewissen Sandsteingeschieben scheinen die Diamanten dieser Schicht in einer besonderen Beziehung zu stehen.

Nach mehrfachen Beobachtungen, die allerdings vielleicht noch fernerer Bestätigung bedürfen, findet man nämlich im Bandelkhand den Edelstein zuweilen in Stïcken eines eigentïmlichen, festen, grünlichen, hellglasig aussehenden kieseligen Sandsteines in derselben Teise eingewachsen wie die anderen Sandkörner, die das Gestein zusammensetzen. Diese den Konglomeraten der Rewahgruppe beigemengten Sandsteinstiicke stammen hï̈hstwahrscheinlich aus Schichten der unteren Vindhyaformation, die zerstört wurden, und deren 'Trimmer dann mit zu dem Aufbau der jüngeren, der oberen Vindhyaformation angrehörignen Schichten dienten. Die Diamanten, die jetzt in diesen letzteren gefunden werden, wïrden darnach also vielleicht, wie im sïdlichen Indien, ursprünglich der unteren Vindhyaformation angehürt haben; sie hätten dann später eine Umlagerung erfahren, und zwar nicht nur die in jenen Sandsteinstïcken noch vereinzelt eingeschlossenen, sondern auch die isoliert zwischen den Geschieben der Konglomerate liegenden, die durch völlige Zerstïrung des ursprïnglichen Sandsteines ganz aus diesem losgelöst worden wären.

In dieser Weise bedecken die diamanthaltigen Sandsteine und Konglomerate die IÏ̈hen, entweder frei an der Oberfläche liegend oder von jüngeren Schichten überlagert. Iiegen sie frei an der Erdoberfläche, so sind sie der Einwirkung der Atmosphärilien unterworfen, und dasselbe ist der Fall an den Talahlängen, wo die Schichtenköpfe an die Erdolerfliiche treten. Sie verwittern und zerfallen in lockere Sandmassen, in denen die Diamanten lose zwischen den Sandkörnern liegen; es bildet sich mit anderen Worten eine Diamantseife.

Die diamantführenden festen Schichten und die aus ihnen gebildeten Seifen werden überall von Bächen und Flïssen durchbrochen, die das in der Höhe liegende Gesteinsmaterial in Bewergung setzen und in das Tal hinabschwemmen. So gelangt auch der Diamant in mehr oder weniger großer Menge in die Flußalluvionen, in den Sand und Kies der Wasserliufe und wird mit diesen von den Bergen in die vorliegenden Tiefebenen geführt. Diese Alluvionen liegen teils auf dem Grunde der heutigen Flußbetten unter dem jetzigen Wasserspiegel, teils ziehen sie sich, mehr oder weniger hoch ïber diesem, an den Talab. hängen hin als terrassenförmige Ablagerungen, die einer früheren Zeit angebören, und die entstanden, ehe der Fluß sich bis zu seiner gegenwärtigen Tiefe eingenagt hatte. Überall stehen diese diamantführenden Alluvionen mit den anstehenden Diamantschichten in deutlichen Zusammenhange, und überall, wo der Diamant in letzteren sich findet, kommt er auch in den dorther kommenden Bächen und Flüssen vor, wengleich nicht überall in so großer Menge, daß ein systematisches Nachsuchen lohnend wäre.

Die Gewinnung der Diamanten liegt wie früher so auch heutzutage noch fast gänzlich in den Händen der Eingeborenen, meist Angehöriger niedriger Kasten. Versuche, im grolien die Diamantenlager auszubeuten, sind zwar von Europäern schon mehrfach gemacht worden, haben aber noch nie zu einem günstigen Resultate geführt. Die Arbeit ist, den Verhältnissen entsprechend, an verschiedenen Orten mehr oder weniger beschwerlich und mïhsam und danach auch vielfach wenig lohnend. In der Hauptsache werden noch heute dieselben Methoden angewendet wie in den ïltesten bekannten Zeiten, jedenfalls wie während der Anwesenheit des französischen Reisenden und Edelsteinhä̈nders Tarernier 1665. (I.es six voyages de J. B. Tavernier en Turquie, en Perse et aux Indes, 3 Vol. Paris 1676).

In den oberflächlichen Seifenlagern, den lockeren Zersetzungsprodukten der Sandsteinschichten sowohl als in den Fluballuvien, ist die Arbeit leicht. Sie besteht im allgemeinen darin, daß aus der Masse die groben Gesteinstïcke entfernt und die erdigen Bestandteile mit Wasser weggewaschen werden. Aus dem dabei crhaltenen sandigen Rüickstande 
werden dann die Diamanten ausgelesen, vielfach von den Frauten und Kindern der Arbeiter, die das Ausgraben der Erd- und Kiesmassen besorgen.

Schwieriger ist die Bearbeitung der anstehenden Sandsteinschichten. Sie werden nur in Angriff genommen, wenn sie ganz an der Erdoberfläche oder dieser wenigstens sehr nahe liegen. Werden sie von jüngeren Schichten in zu grober Mächtigkeit überlagert, dann können sie nieht mehr von oben her ausgebeutet werden, da die Eingehorenen mit ihren geringen Ililfsmitteln nicht imstande sind, diese mächtigen fiesteinmassen mit Sehäichten zu durchbohren oder sie ganz abzuräumen. Auch würden die Kosten dabei zu grol) werden. Unter solchen Unständen kann die Diamantschicht nur an den Abhänģen der Burge und IIügel, wo sie zu Tage ausgeht, in Angriff genommen werden. Das geschieht auch nicht selten, indem die Arbeiter ron der Seite her auf eine gewisse, aber stets nur geringe Tiefe in den Berg hineingraben.

Liegt die Schicht in geringerer Tiefe unter der Erdoberflïche, dann werden senkrechte Löcher oder Schächte von mehr oder weniger grobem Querschnitte, meist nur ron einigen Quadratfub oder (Quadratmetern und bis zu 20, selten bis zu 30 und in einzelnen Fïllen sogar bis zu 50 Fub Tiefe bis auf die Diamantschicht hergestellt, die man von diesen Schächten aus, wenn es die Festigkeit des ibberlagernden Gesteines crlaubt, unterirdiseh eine Strecke weit verfolgt. Die dabei gewonnene diamantfülırende Gesteinsmasse wird, wenn es nötig ist, vorsiclıtig zerkleinert und in der eben erwälnten Weise durch Waschen und Auslesen weiter verarbeitet.

Das Durchbrechen der harten und festen Sandsteinbänke, die die Diamantschicht sehr häufig bedecken, ist für die Arbeiter bei der Unvollkommenheit ihrer Terkzeuge oft mit den größten Schwierigkeiten verkniipft. Sie wissen sich aber in einigen Gegenden die Mühe durch dasselbe Mittel zu erleichtern, das auch die alten deutschen Bergleute sehr häufig angewendet haben, nämlich durch das Feuersetzen. An der Stelle, wo der Sandstein zum Zwecke der Anlage eines Schachtes durchbrochen werden soll, wird ein großes Feuer angeziindet. Das Gestein wird dadurch stark erhitzt und hierauf durch Übergießen mit kaltem Wasser rasch abgekühlt. Dabei zerspringt dann der feste Sandstein in riele kleinere Stiicke, die mit leichterer Mïhe bewältigt und entfernt werden können.

Tielfach hat sich herausgestellt, daß einmal durchsuchtes diamantfiihrendes Gestein, namentlich aus der anstehenden schicht, bei einer späteren abermaligen Aufbereitung wieder Diamanten lieferte, wenn es einige Zeit an der Luft gelegen hatte, und so zuweilen noch mehrere Male. Daher ist unter den eingeborenen Diamantgrïbern die Sage entstanden, daß sich in dem Gesteinsschutt Diamanten stets wieder von neuem bilden, daß sie gewissermaßen nachwachsen und daf sich kleine Steinchen zu größeren vereinigen. Ähnliche Ansichten trifft man, auf Grund derselben Beobachtungen, auch am Kap. Der wahre Grund, warum rielfach wieder Diamanten gefunden werden, wenn man dieselbe Gesteinsmasse nach einiger Zeit noch einmal durchsucht, ist aber der, daß diese Massen in der Zwischenzeit an der Luft weiter verwittern. Größere Brocken zerfallen dabei in immer kleinere Stiicke, und die darin versteckten Diamanten kommen so allmählich an die Oberfläche, werden isoliert und künnen gefunden werden. Natïrlich wird die ganze Masse dadurch immer ärmer und die Ausbeute bezüglich der Menge und Größe der gefundenen Steine bei jeder neuen Durchsuchung geringer. Trotzdem beruht aber an manclien Stellen der jetzige Betrieb darauf, daß die alten Felder der früheren Diamantgruben immer von neuem durchwühlt werden, und stets werden wieder Steine gefunden, aber jedesmal weniger, bis zur definitiven Erschöpfung.

C. Ritter teilt die ihm bekannt gewordenen Diamantgruben Indiens nach ihrer geographischen Lage und Verbreitung in fünf Gruppen, die er von Süden nach Norden der Reihe nach beschreibt. Im folgrenden sind diese fünf Gruppen von Ritter zwar beibe- 
halten, es sind aber die von ihm nicht angeführten kleineren Grubenfelder an geeigneter Stelle beigefiigt und die Beschreibungen durch neuere Nachrichten, besonders von V. B all, ergänzt. Dieser gibt eine etwas andere Einteilung. Vielleicht wäre es am zweckmäßigsten,

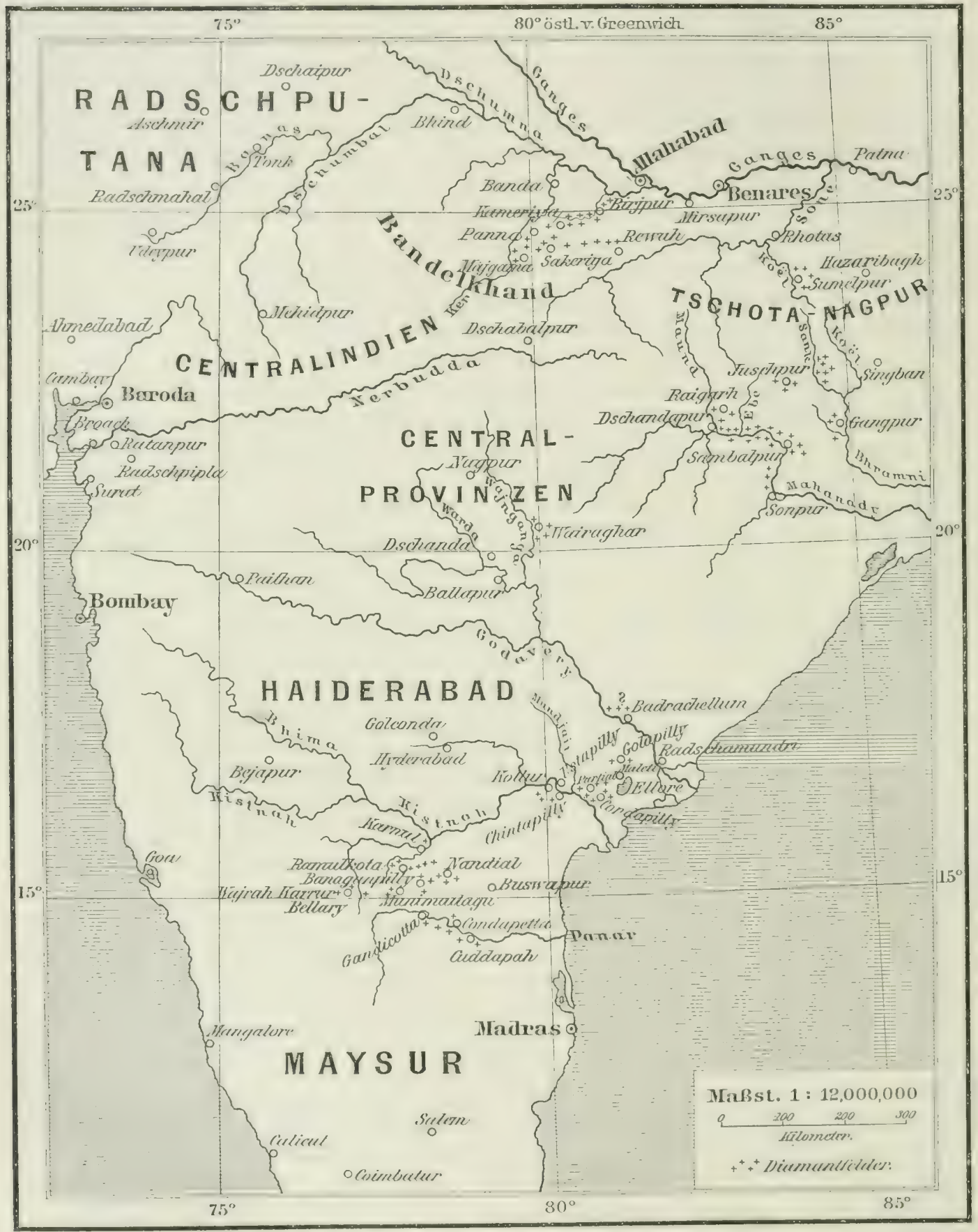

Fig. 41. Diamantfelder in Ostindien.

die drei südlichen Grupuen bis in das Gebiet des Kistnah zu einer einzigen zusammenzufassen, da die Verhältnisse hier überall im wesentlichen dieselben sind. Die Verbreitung. der indischen Diamanten ist auf der Karte Fig. 41 dargestellt. 
1) Die Cuddapah-Gruppe der Diamantlager am Panarflusse. Diese siddlichste Gruppe beginnt mit der Umgebung von Cuddapah am Panar, wo zalilreiche Cruben seit mehreren Jahrhunderten mit wadselndem Erfolge brarbeitet worden sind. Jetzt sind wohl die allermeistrn, zeitweise vielleicht alle anfier Betrich gescotzt, ohwohl nicht anzunchmen ist, daß die Diamantvorräte vïllig erschöpft scien. Die speziellen Fundstell.n sind Dschennur (oder Dschinon) bei ('uddapah am rechten siidlichen Ufer des Panarflusses, sodann etwas weiter flubaufwïts, westlich von Dschennur, Obalumpally (Woblapally) und gecrenüber, auf der anderen Seite des Flusses, das Condapetta der Reisfenden, die frïher diese Gexenden besuchten und beschrieben, wahrscheinlich dem heutigen Cunnapurty entsprechend. Testlich von Dschennur liegen ferner Lamdur und I'imdschetgapadu und einige andere Fundorte, von denen besonders Hussanapur oder Dupand am Anfange dieses Jahrhunderts ertragreich gewesen ist. Noch weiter aufwärts, im Panartale, ist auch bei Gandicotta früher nach Diamanten gesucht worden, aber olne nennenswertes Frgebnis.

Alle diese Gruben werden auch wohl als die Dschenum gruben zusammengefalit. Bei Dschennur selhst stehen die rerlassenen Gruben auf dem Banaganpillysandstein oder auf dem durch dessen Zerstörung gebildeten Sande und Kiese, der früher viele und zum Teil sehr schöne Steine geliefert hat. Namentlich wird ron zwei sehr wertvollen Diamanten aus diesen Gruben berichtet, die für 5000 und 3000 Pfund Sterling rerkauft worden sind. 1569 wurde die Arbeit nach längerer Unterbrechung ron neuem begonnen, aber olne Erfolg. Zu oberst unter der Humusdecke liegt 1 1.2 Fuf Sand und Crus mit Lehm, dann folgt ein zäher blauer oder schwarzer schlammiger Boden, ohne alle Gesteine, 4 Fuf mächtig, und darunter das eigentliche Diamantlager, das sich von der vorhergehenden Schicht wesentlich nur durch die Anwesenheit vieler großer abgrerollter Gesteinsstiicke unterscheidet. Es ist 2-2 21:2 Fuf mächtig und besteht aus Kieseln und Grus, die durch Lehm miteinander verbunden sind. Die Mineralien, die man hier mit dem Diamant zwischen den Geschiebestiicken findet, sind gelblicher durchsichtiger Quarz, Pistazit, rote, blaue und braune Jaspiskiesel, runde haselnußgroße Eisensteinknollen, Korund und andere. Die Gesteinsgeschiebe haben zumeist bis Kopforöße und bestehen aus Sandstein, Basalt usir. und besonders Mornstein, sowie den Trümmern der Felsarten, welche die his 100n Fub über Cuddapah aufragenden Berge zusammensetzen.

Bei Condapetta sind die Gruben 4-12 Ful tief. Man hat hier 3-10 Fuf erdigen Sand, der auf einem Lager aus Rollsteinen ron Nulggröbe bis zum Umfange eines Pflastersteines ruht. In diesem findet man die Diamanten, meist lose, vielfach auch mit den Rollsteinen verkittet. Diese bestehen meist aus eisenschiussigem Sandstein oder sandsteinschiefer und Konglomerat, dazwischen liegen solche ron Quarz, Feuerstein und Jaspis, zum Teil blan mit roten Adern, sowie aus Tonporphyr init Feldspatkristallen. Die meisten Geschiebe stammen aus den umgebenden Bergen, einzelne, so die Tonporphyre, sind rom Wasser weiter hergebracht. Die Gruben wurden hier, wie bei Dschennur, nur zur trocknen Jahreszeit betrieben, weil sie in der Regenzeit voll Wasser laufen, dessen andauernde Beseitigung zu viel Mühe machen würde.

Die Gruben von $\mathrm{Obalumpally}$ wurden um 1750 eröffnet. Die hier gefundenen Diamanten sind flach oder rund, ohne deutliche Kristallform, aber von hohem Glanze, klar weil oder klar honiggelb, ferner crêmefarbig und graulich-weiß, sowie ron besonderer Härte. Es sind stark abgerollte Steine, die hier im Fluballuvium liegen. Das Lager folgt in verschiedener Breite dem Flußlaufe und wird zu einem guten Teile gebildet ron den schon oben erwähnten, ebenfalls stark abgerollten haselnufgroßen Eisensteingeschieben. Die Steine werden in bis zu 16 Fuf tiefen Gruben gewonnen, sind aber so unregchäßßg verbreitet, daß die Arbeit einem Gliicksspiele gleicht. Die Gruben scheinen nie besondere Wichtigkeit gehabt zu haben. 
Geht man von Cuddapah in westlicher Richtung das Panar-Tal noch weiter aufwärts und dann nach Norden, so gelangt man, sehon im Flußgebiet des Kistnah, in die Gegend von Bellary, in der zwei wichtige Diamantenfundorte, Munimadagu und Wajrah Karrur, liegen.

Beim ersten, II un ima d a g u, 30 Kilometer westlich von Banaganpilly und 76 Kilometer istlich von Wajrah Karrur, befindet sich im Umlsreise von einigen 37 Kilometern eine Anzahl von Gruben. Diese sind zwar jetzt erschöpft und verlassen, waren aber seinerzeit ertragreich und haben dem ausgedehnten Diamanthandel und den Schleifereien von Bellary hauptsächlich das Material geliefert, besonders am Anfange des 19. Jahrhunderts und bis 1833 . Jetzt warden hier nur gelegentlich noch einige Steine gefunden; die systematische Bearbeitung der Gruben, welche die eigentliche Diamantschicht ausheuteten, hat aufgehört. Diese schicht ist wenig mächtig; sie bedeckt die Granite, Gneise und andere ähnliche Gesteine des Untergrundes.

Die Lokalitït W a jrah Ka r r ur hat ebenfalls hauptsächlich in früheren Zeiten Diamanten geliefert, aber auch jetzt kommen noch solche vor. So hat man dort u. a. 1881 einen Stein von $67^{3 / 5}$ Karat gefunden, der einen schönen Brillant von 245/4 Karat im Werte von 12 (1)0 Pfund Sterling lieferte. Der Sage nach sollen sogar einige der grössten und beriihmtesten indischen Steine dorther stammen. Das Vorkommen der Diamanten ist hier eigentiimlich. Sie liegen einzeln auf dem Boden zerstreut, ohne daf eine bestimmte Diamantenschicht vorhanden wäre. Besonders hat man den diamantführenden Banaganpilly-Sandstein in jener Gegend noch nicht nachweisen können; Granit, Gneis und andere Lrgesteine bilden den Untergrund. Die Diamanten findet man entweder zufällig, namentlich nach heftigen Regengüssen, wobei sie aus dem Boden ausgewaschen werden, oder die Leute ziehen in der Gegend herum, um danach zu suchen.

Um diese eigentïmlichen Verhältnisse zu erklären, hat man angenommen, die Diamantenschicht sei in früheren Zeiten in der Umgebung von Wajrah Karrur weit verbreitet gewesen, sie sei aber völlig zerstört worden und die einzelnen Diamanten seien als ihre letzten unzersetzbaren Überreste zurückgeblieben. Dies ist nicht unmöglich, wird aber durch keine bestimmten Anzeichen bewiesen.

Spüter hat man das Vorkommen der Diamanten in dieser Gegend in anderer Weise auffassen zu miissen geglaubt. Man fand im Westen der Stadt Wajrah Karrur in einer Vertiefung im Granit oder Gneis ein blaues, einem vulkanischen Tuff ähnliches Gestein, welches nach Aussehen, Beschaffenheit und Vorkommen mit dem Gestein, das bei Kimberley in Südafrika so außerordentlich reich an Diamanten ist, dem ,blue ground", die srößjte Ähulichkeit hat. IIierin meinte man nun die ursprüngliche Lagerstätte der Diamanten von Wajrah Karrur, ihr cigentliches Muttergestein, entrleckt zu haben. Eine engrische Gesellschaft suchte dieses mit vielen Granit- und Gneisbrocken gremengte blaugrine Tuffugestein in groljem Maßstabe auf Diamanten auszubeuten, das Resultat war aber ein vollkommen negatives, es wurde kein einziger Stein gefunden.

In nenester \%eit chlaubte num der französische Reisende M. Chaper, der im Jahre 1582 im Interesse des Handels die Gegend nach Diamanten durchsuchte, das Geheimnis enthïllt und das Räitsel gelöst zu haben. Er fand den Gneis, der in der Umgebung von Wajrah Karrur vorwiegend den Untergrund des Bodens bildet, durchzogen von zahlreichen (rängen verschiedener Eruptivgesteine, besonders von Gängen eines grobkörnigen, rosenroten oder lachsfarbigen epidotführenden Permatits, einer besonderen Abart des Granites. In einem solchen Pegmatitgange, und zwar in dessen oberstem, stark verwittertem Teile, simmelte M. Chaper eigenhändig zwei kleine Diamantkristalle, die neben anderen Mineralien von unregelmäilig begrenzten Körnern blauen und roten Korunds (Sapphir und Rubin) begleitet waren. Die beiden Diamanten waren von oktä̈drischer Form mit 
vollkmmen scharfen Kanten und Ecken, völlige intakt, ohme jede Spur won Alrollunw. Die Ëingreborenen wollen ebenfalls unter denselben Verhältnissen schon zahlreiche Diamantr-n erefunden haben. ('haper zweifelt nicht, dafo seine Steine ursprunglich in dem l'rematit cingewachsen wewesen und dab sie erst durch dessen Verwitterung aus den Tusammenhange gelijst wordm sind. Dasselbe würde dam zweifellos auch für die ïbrigen ringsum gefundenen Diamanten gelten.

Die: Fund. Chapers und manentlich deren Deutung sind nachher von dem indischen Geologen Foote angezweifult worden, der einen von den eingeborenen Begleitern Chaper gespielten Betrug rermutet. Jedenfalls sind die Angaben thapers, der die Einwïnde ron Foote unerwidert lief, noch recht zweifolhaft. Eine Aufklïrung darüber wiire un so mehr erwünscht, als sie im Fall ihrer Beståtigung, wie wir weiter sehen werden, ein helles Licht auf das urspriingliche Ifuttergestein der indischen Diamanten iiberhaupt werfen kïmnten. Ditse wïrden wohl alle einem ähnlichen fiestein wie die von Wajrah Karrur entstammen und nach dessen Zersetzung in die diamantfiihrenden Sandsteine und Konglomerate gelanger sein, die unter krinen Lmständen als das urspriingriche Muttergestein der indischen Diamanten, in dem diese sich gebildet haben, betrachtet werden dïrfen. Zumunsten der ('haperschen Ansicht spricht jedenfalls die Tatsache, daf) die Diamanten im unteren Ianar-(xel)iet ron teilweise denselben Tineralien begleitet werden wie bei Wajrah Karrur, nämlich ron Rubin, Sapphir und Pistazit. womegen allerdings Foote bemerkt, dab inei Wajrah Karrur, auler an der Fundstelle der Diamanten und mit diesen zusammen, noch nie Rubin und Sapphir gefunden worten sei und dafo dis dort gefundenen stiicke Spuren ron Bearbeitung zeigen. Ferner spricht für Chaper der Umstand, dafi auch anderswo, so in Lappland, in Brasilien (Serra da Chapada in der Prorinz. Bahia) ete. die Diamanten in pegmatitischen Gesteinen vorkommen sollen. Freilich ist auch in diesen Gegenden eine weitere Bestiitigung der betreffenden Beobachtungen dringend erwïnscht; von weiteren Vorkommen dieser Art wird unten noch eingehender die Rede sein.

2) Die Nandial-Gruppe der Diamantlager zwischen Panar und Kistnah bei Banaganpilly.

Nur ungefïhr 15 geogr. Meilen gregen Norden von der vorigen Gruplue entfernt, am Tordende derselben Ebene, die auf der Westseite der Nalla-IIalla-Berge sich bis zur Stadt Nandial (220) Meter über dem Mreere) ausbreitet, liegt die zweite Reihe von Diamantgruben, die von anderen, so von V. Ball, auch als die Karnul-Diamantgruben bezeichnet werden. Die hierher gehörigen Fundorte liegen üstlich, südöstlich und west-

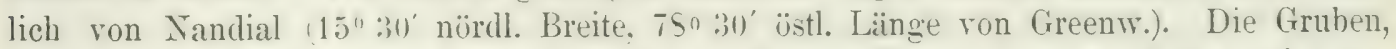
die teils die anstehende Diamantschicht, teils reifenlager aushenteten, sind jetzt meist rerlassen; sie gehören zum Teil zu den beriihmtesten, die in Indien je bekannt geworden sind. Hier können nur einige der wichtigsten erwähnt werden.

Die Gruben ron Ban a ga n pill y, wonach der diamantführende Sandstein seinen Xamen erhalten hat, liegen westnordwestlich von Condapetta und südwestlich von Nandial. Tach der Beobachtung von K ing hedeckt die Diawantenschicht mit den zugehörigen Sandsteinen diskordant, d. h. mit anderer Schichtenneigung, die älteren Sedimentïrschichten, besonders Schiefer und Kalke mit vulkanischem Trapp. Sie sind im ganzen 20 bis 30 Fuf mächtig: und werden an den Ahhä̈ngen der Hügel durchbrochen von höchstens 15 Fuf tiefen Schächten, ron deren Fuf aus das eigentliche Diamantenlager wegen der Festigkeit der darüber lagernden Gesteinshänke ringsum auf eine gewisse Entfernung verfolgt werden kann. Es ist 6-S Zoll mächtig und stellt ein grobes, sandiges und toniges Konglomerat oder eine Breccie dar, die haupt:iichlich von verschieden gefärbten Thonschiefer- und Hornsteinstïcken gebildet wird. Grobe Diamanten sind hier. wie es scheint, nie gefunden worlen; die hauptsäichlichsten Kristallformen. die beobachtet wurden, sind das Oktä̈der 
und das Dodekaëder. Heutzutage werden hauptsïchlich die alten Halden nach den bei der frïheren Bearbeitung übersehenen Steinchen durchsucht, doch sind die Gruben im anstehenden Sandstein ebenfalls noch im Gange.

Nordwestlich von Banaganpilly, ungefähr in der Mitte zwischen diesem Orte und Karnul, befinden sich die fruben von Ramulkota, 19 engl. Meilen im SW. von der letztrenannten stadt. sie liegen im Banaganpillysandstein und sind tiefer und ausgedehnter als die von Dschennur bei Cuddapah im Panar-Tal. Die jetzt hier gefundenen Steine sind meist klein und von nicht sehr regelmäfiger Form; ihre Farbe ist weib, grau, gelb und griinlich. Gegrenwärtig sind die Gruben im Sandstein nicht iu Betrieb, dagegen werden einige in der Nähe befindliche Seifenlager ausgebeutet. Newbold, der diese Gegend 1).10) besuchte, sah nur 20 Mann in Tätigkeit; in der trockenen Jahreszeit soll aber diese Zahl auf jo0 steigen. Auch jetzt noch greben diese Gruben wie die von Banaganpilly einen gewissen Ertrag, der aber nicht näher bekannt ist.

Die Gruben von Ramulkota sind wahrscheinlich identisch mit den von Tavernier erwähnten, frïher so reichen und beriihmten Gruben von Raoleonda, die zur Zeit der Anwesenheit dieses Peisenden (1665) schon seit 200 Jahren im Betriebe waren und grofe Schätze geliefert hatten. Nach den Mitteilungen von Tavernier fanden sich die Diamanten mit feinem Sand in kaum fingerbreiten Spalten eines ziemlich feinkörnigen harten Sandsteins, aus denen sie mühsam mittelst zugespitzter Eisenstangen herausgeholt werden multen. Der Ort war später vollkommen in Vergessenheit geraten; man hatte ilhn im Gebiet der Golcondagruppe, fünf Tagereisen westwärts von Golconda, gegen den mittleren Lauf des Kistnah, nicht fern von dessen linkem Nebenflusse Bhima und 8-9 Tagereisen von Yisapur, dem heutigen Bejapur, gesucht, bis V. Ball die Identität mit Ramulkota wahrscheinlich gemacht hat.

3) Die Ellore-Gruppe der Diamantenlager am unteren Kistnal oder die Goleonda-Gruppe.

Zu dieser gehören einige der ältesten und berïhmtesten indischen Diamantgruben, die sogenannten Diamantgruben von Golconda, welche die schönsten und grölten inclischen Steine geliefert haben. Sie liegen aber nicht, wie man nach dieser Bezeichnung. oft fülschlich glaubt, bei der alten Bergfeste Golconda (nahe IIyderabad), hier ist nur der Stapelplatz für die in weiterer Entferung gefundenen Diamanten, die da auch z. T. geschliffen wurden. Sogar die von Dschennur sind in frïheren Zeiten zum Verkauf hierher gebracht worden. Als Tavernier die Gegend besuchte, waren über zwanzig Gruben in fiange und gaben z. T. außerordentlich reichen Ertrag. Später wurden alle bis auf zwei oder drei verlassen, so daß heutzutage von den meisten und zum Teil gerade von den durch 'T'averniers Schilderungen am berihmtesten gewordenen nicht einmal mehr die Stelle bekannt ist.

Die reichsten dieser Gruben östlich von Golconda waren die von Kollur am rechten Ufer des Kistnah, westlich von Chintapilly, unmittelbar ehe er oberhalb der Nündung dess Nebenflusses Mundjair zu dem letzten Kinie nach Norden umbiegt. Kollur liegt unter s/10 $y^{\prime}$ östl. Länge von Greenw. und $16^{0} 42^{1 / 2}$ nördl. Breite. Der Ort wurde von Tavernier Gani Coulour genannt, er heißt daher jetzt zuweilen auch Gani. Dieses Wort ist einheimisch und soll "Grube bedenten. Coulour, woher der jetzt meist übliche Namen Kollur, stammt aus dem Persischen. Diese Gruben sind nicht identiseh, wie man vielfach meint, mit den ebenfalls hochberülumten Gruben von Partial; die letzteren liegen etwas weiter östlich am linken Kistnah-Ufer und werden unten eingehender besprochen werden.

Nicht mehr als 100 Jahre vor 'T'averniers Besuch, also etwa um 1560, waren die Diamantlager von Kollur entdeckt worden. Zuerst fand man durch Zufall einen Stein 
von 25 Karat, dem bald sehr zahlreiche andere folgten, darunter nicht wenige von 10-40 Karat und noch erö̈lere. Die Qualität entsprach allerdinges nicht durchaus der Menge und Grölive der gefundenen Steine, die vielfach nicht rein und klar waren. Der beriihmte ..Kohinur", jutzt im enclischen Kronschatz, und der "Grolimogul", dessen Verbleib) unbekannt und der vielleicht mit dem Kobinor identisch ist, stammen mit groler Wahrscheinlichkeit ven dort, dhenso die schönen blauen Diamanten, besonders der grolie des Bankiers Ifope. Zu Taverniers Zeiten haben nach dessen Bericht 60000 Menschen hier gearbeitet. heute sind aber die Gruben vollständig aufgegreben. Die Steine liegren in lockeren Alluvialmassen, es sind teifenlager. Zahlreiche verlassene Grähereien finden sich atch an Kistnah entlang in den Wäldern zwischen Kollur und Chintapilly, sowie zwischen letzterem Ort und Partial, so u. a. bei Kistapully.

Verfolgt man den Lauf des Kistnah, so trifft man etwas unterhalb der Mündung des Mundjair auf dem linken Lfer, etwas entfernt vom Flusse, östlich von Chintapilly die früher so reichen Gruhen von l'artial, aus denen wahrscheinlich der im französischen Kronschatz befindliehe ..Regent" oder "Litt" stammt. Die Gruben beuten die losen Zersetzungsmassen der Diamantschicht und Fluballuvionen aus; lange Zeit stand die Arbeit still, ohne dab aber die Ablagerungen ganz erschüpft wären. Im Jahre 15.5) waren nach Walker noch zwei (iruben in Betrieb. Nahe bei Partial liegen, zur selben Grupue gehöriğ, die alten (iruhen von Wustapilly, Codavetty-Kallu usw. Die Ietztere soll früher hesonders reich grewesen sein. Es sind Seifen, die aber jetzt nicht mehr bearbeitet werden. Der Sage nach hat man von dort Wagenladungen von Diamanten weggefahren.

Noch weiter östlich auf der linken, nördlichen Seite des Kistnah, aber fern vom Flusse liegen die ehemals ertragreichen Malavilygruben zwischen den Dürfern Maleli (Malavily) und Golapilly, nordüstlich ron Condapilly, sechs bis siehen Stunden westlich von Ellore. Die 15-20 Fuf tiefen Schïchte sind in einem konglomeratischen Sandstein oder in oberflächlichen Schuttuassen, die durch dessen Zerstörung entstanden sind, angelegrt. Dieser auf Gneis ruhende Sandstein gehört einer etwas jüngeren Schichtenreihe als die Karnulformation an und scheint aus den Überresten ron jetzt zerstürten Karnulschichten entstanden zu sein. Die Diamantenschicht ist nach manchen Beobachtern mit einer Kallitufflage bedeckt. Sie besteht zumeist aus Geröllen von Sandstein, Quarz, Jaspis, Fenerstein, Granit usw., sowie grö̉eren Stïcken eines Kalkkonglomerats, die keine Spur von Abrollung zeigen. Alle Nineralien, die bei Cuddapah den Diamant begleiten, sind hier ebenfalls vorhanden, es finden sich aber auferdem auch noch Chalcedon und Karneol. Die Gruben sind wenigstens bis in die dreibiger Jahre des 19. Jahrhunderts hinein im Betrieb gewesen haben jedoch zuletzt wenig Ertrag gegeben und sind nun alle gäinzlich verlassen.

In dem Gebicte dieser Gruppe, das wenigstens zum gröbten Teil zu Haiderabad grehört, lïßt die englische Hyderabad-Company arbeiten. Sie hat $1891 \mathrm{im}$ ganzen $862:, 1$ Karat Diamanten im Terte ron 15530 Tiupien gewonnen. Die Produktion der ganzen Gruppe ist noch etwas größer und betrug im Jahre vielleicht 1000 Karat.

Schreitet man rom Kistnah aus nach Norden fort, so kommt man in das Gebiet des Godavery. Als Fundort von Diamanten wird hier Badrachellum an diesem Flusse genannt. Das Turkommen ist aber unsicher und wird von manchen für sagenhaft erklärt. Jedenfalls sind hier, wenn übrrhaupt, nur wenige Steine gefunden worden. Die ganze Gegend ist sehr wenig bekannt, was mit ihrer Unzugänglichkeit infolge starker Bewaldung zusammenhängt. Viel wichtiger und ertragreicher ist (oder war wenigstens früher) das Flußgebiet des Mahanady, das die vierte Gruppe bildet.

4) Diesambalpur-Gruppeder Diamantlager nordostwärts des Godavery am mittleren Mahanadyflusse in Godwara. 
Die Diamanten des Mahanadysystems zwischen dem 21. und 22. Grad nördl. Br. und in ziemlich grober Entfernung von dem vorhergehenden Bezirk in den Zentralprovinzen gelegen, sind vielleicht diejenigen, die sehon den Alten bekannt waren. Der Diamantenflul des Ptolemäus wird in dieser Gegend gesucht; nach der Ansicht mancher Forscher soll es der Mahanarly selbst sein. Das Diamantenrevier beschränkt sich auf die Gegend ron Sambalpur; in seinem ganzen übrigen Laufe hat der Fluls keine Diamanten geliefert. Es dehnt sich in einer fruchtbaren Alluvialebene aus, die bei der genannten Stadt 130 Meter ïher dem M eere liegt und zwar ist es der Landstrich zwischen den Flüssen Mahanady und Bhramini, welcher letztere den ersteren im Nordosten begleitet. Niemand weif, wer die Steine hier zuerst aufgefunden hat und wann sie entdeckt wurden; sie waren seit undenklichen Zeiten bekannt.

Die Diamanten finden sich vorzugsweise im Mündungsgebiet einiger linksseitiger, nordsüdlich strömender Nebenflüsse des Mahanady, die in den nördlich vorliegenden Hügeln von Barapahar entspringen. Einer von ihnen ist der etwas oberhalb Sambalpur mündende Ebe, in dem ebenfalls manche den Diamantfluß der Alten sehen wollen, aber gerade von diesen scheint es nicht sicher festzustehen, daß Diamanten darin gefunden worden sind, während dies beim Mahanady keinem Zweifel unterliegt. Nach der Regenzeit wurden die Steine früher in den Flußbetten sesammelt. Sie fanden sich im Mahanady nur auf der linken, nie auf der rechten Seite, auch nicht oberhalb des Maund-Zuflusses bei Dschandarpur, nach mancher wahrscheinlich unrichtigen Angabe sogar nicht oberhalb der Mündung des Ebe, der daher vielfach als der Hauptdiamantenbringer angesehen wurde. Als untere Grenze der Diamantenführung gilt das Knie bei Sonpur; weiter talabwärts soll nie ein Diamant vorgekommen sein. Die ganze diamantfülırende Strecke des Mahanady wäre demnach etwa 50 Kilometer lang.

Einer der wichtigsten Punkte am Mahanady scheint früher die etwa $71 / 2$ Kilometer lange Insel IIira Khund in diesem Fluß bei Ihunan gewesen zu sein; ihr Name bedeutet auch Diamantgrube. Diese Insel teilt den Mahanady in zwei Kanäle. Jedes Jahr kamen zur trockenen Zeit, Ende März orler später, wenn der Fluß beinahe wasserleer war, Tausende von Leuten, um hier Diamanten zu gewinnen. Der nördliche linksseitige Kanal wurde durch einen Damm geschlossen und der diamanthaltige Kies und Sand aus dem nun fast trockenen Flußbett ausgegraben. Dieser wurde dann von den Frauen der Arbeiter, die den Sand ausgruben, auf Diamanten verwaschen. Den südlichen Kanal hat man niemals ausgebeutet, obgleich er nach der Ansicht mancher Sachverständiger chenfalls Diamanten, und zwar in reichlicherer Menge als der nördliche, enthalten müßte. In ihm ist aber die Wassermenge zu groß und die Strömung zu stark, so daß die Arbeiten hier mit sehr viel größeren Schwierigkeiten verbunden gewesen wären.

Bei Sambalpur liegen die Steine in einem zähen roten Schlamm mit Sand und Kieseln. Dies ist wahrscheinlich das mit den Diamanten flufabwärts gesehwemmte Verwitterungsprodukt der Gesteine, die in dem Ursprungsgebiet jener Fliisse, dem Ilügelland von Barapahar, anstehen. Nan kennt hier zwar keine Arbeiten auf Diamanten im anstehenden Gestein, aber diese Gesteine gleichen durchaus denen, die iiberall im südlichen Indien den Edelstein enthalten. Auch findet sich dieser in den dort entspringenden kleinen Bächen bei Raigarh, Jusehpur und Gangpur in einer gewissen Menge.

Große Steine sollen im Mahanady ziemlich häufig vorgekommen sein. Der größte, 210,6 Karat schwer, aber nur von der dritten (Qualitiit, wurde 1809 ) bei der Insel HiraKhund gefunden: sein Verbleib ist unbekannt. Im allgemeinen war die Qualitiit hier (ine sehr gute; die Diamanten rom Mahanady und von Tschota-Nagpux gehören zu den schönsten und reinsten Indiens. Sie werden im Mlahanady begleitet von Geschieben von Teryll, Topas, Grimat, Kanneol, Amrthyst und Berekristall. Diese stammen aber wohl 
nicht aus dem Muttergestein des Diamants, sondern aus dem Granit und Gneis, die der Flub streckenweise durchlïuft. Auch Fold führt der Mahanady in ziemlichel Menge, das mit den Diamanten gewonnen wurde.

IIeutzutage werden nur noch gelegentlich Jiamanten in dieser Gegend gefunden. Bis in die fünfziger. Jahre des vorigen Jahrhunderts hat man die Nachforschungen systematisch betrieben, dann aber wegen zu geringer Ergiebigkeit die Arbeiten eingestellt.

Wie Sambalpur gehört auch clas in sïdwestlicher Richtung etwas entfernt liegende Diamantvorkommen von Wairaghar im Distrikt Dschanda in den Zentralprovinzen der in Rede stehenden Gruppe an. Die Gruben, etwa 150) Kiloneter südöstlich von Nagjuur, sind sehr alt; sie sind identisch mit den von Tavernier erwïhnten Gruben von Beiraghar, ob) auch mit denen von Vena oder Wainganga ist unsicher. Ihre Reste erkennt man am Sathflusse, einem Nebenflusse des liophraguri, der seinerseits in den Wainganga, einen linken Zuflub des Codavery, geht. Die Gruhen waren rhemals reich, sind aber seit 1527 verlassen. Die Steine liegren in einer roten odter gelben, sandigen, lateritartigen Lrde, das ursprïngliche Gestein, aus dem diese Allvionen entstanden sind, ist aber nicht bekannt. Nach V. Ball haben die diamantführenden Schichten eine viel grïbere Ausdelınung, als man heutzutage vermutet, und künnen später vielleicht noch Bedeutung sewinnen.

Nach Torden schlieben sich an den Bezirk ron sambalpur die Diamantgruben der Division ron Tscliota $\mathrm{Nag}$ aur, dem aiten Kolirah in Nieder-Bengalen an. Diese sollen im 16. und 17. Jahrhundert viele srobe und schöne Steine geliefert haben, die den Berichten zufolge aus einem Flusse gewonnen wurden. Welches dieser Fluf war, weif man jetzt nicht mehr genau, es wird aber angenommen, daß es der Sank, ein linker Nebenflub des Bhramini sei, in dem sich auch später noch rereinzelte Diamanten gefunden haben. Heutzutage haben auch diese gelegentlichen Funde aufgehört.

In Bengalen liegen auch die zu Tarerniers Zeiten berihmten und ron ihm beschriehenen Gruben ron Sumelpur, deren Ort aber heute unbekannt ist. Die Steine wurden nach den Mitteilungen des g.enannten Reisenden aus dem Flusse Goël gewaschen. Man vermutet, dal) dies der nördliche Kö̈l ist, ein Nebenflul) des Sone (Schon), der in den Ganges fïllt und an dessen Ufer die Trümmer einer alten Stadt Semah oder Semul liegen, die man für Reste des alten Sumelpur (oder semelpur, nicht zu rerwechseln mit dem oben schon genannten Sambalpur am Mahanady) hält. Die Steine hätten dann denselben Ursprung wie die vorhergenannten, sie wïrden dem Hügelland entstammen, das die Quelle des Koël von der des Sank trennt. Nach Tavernier sind hier während seiner Anwesenheit in der trockenen Jahreszeit ron Anfang Februar ab 8000 Menschen mit der Gewinnung des Edelsteins beschäftigt gewesen. Man hält übrigens jetzt vielfach dieses und das vorhergenannte Vorkommen in Tschota Nagpur für eine auf falschen oder nicht richtig. verstandenen Mitteilungen beruhende Fabel.

5) Die Panna-Gruppe der Diamantlager im Bandelkhand $z$ wischen den Sonnar- und Sone-Flüssen.

In dieser nürdlichsten Gruppe (unter 25 Grad nördl. Br.) findet man heutzutage wie früher die Diamanten am nördlichen Rande des Hochlandes des Bandelkhand, das die Tiefebene des Ganges und Dschumna gegen Siiden begrenzt. Die Gruben liegen teils in der näheren Lmgebung ron Panna (Punnah), suidwestlich ron Allahabad am Ganges, teils in weiterer Entfernung von jener Stadt nach Westen, Sïden und Osten. Sie werden als die Pannagruben zusammengefaßt. Größere Steine kommen hier nicht ror und auch frïher hat man, wic es scheint, keine solchen gefunden, doch ist die Zahl der Diamanten beträchtlich und ihre Qualität gut. Ihre Form ist die des Oktaëders oder die des Dodekaëders. Sie liegen entweder in der eigentlichen Diamantschicht oder in deren oberfliichlichen losen 
Zersetzungsprodukten, aus denen sie auch in die Schuttmassen der Flïsse gelangt sind. Daf die Diamantschicht hier nicht der unteren, sondern der oberen Vindhyaformation angehört, ist schon früher erwähnt worden.

In der Umgebung von Panna liegen zahlreiche Gruben, namentlich nach Norden und Nordosten, die bedentendsten dicht bei der Stadt, wo sie auf einem Raume von kaum 21) Acker vereinigt sind. Die manchmal nur eine Spanne mächtige Diamantschicht liegt hier tiefer als an anderen Orten, wo sie abgebaut wird. Sie ist von einem Geschiehe- oder Blocklehm von erheblicher Mächtigkeit bedeckt, dessen Blöcke hauptsächlich aus Sandstein bestehen und an dessen Basis zahlreiche Stiicke von Lateriteisenstein liegen. Der Mangel an festen Gesteinslagen über der Diamantschicht macht es meist unmöglich, die letztere auch nur auf kurze Erstreckung von Schïchten aus unterirdisch zu verfolgen, Die Arbeiter sind daher genütigt, mit ungehenerer Mühe und Anstrengung weite und tiefe Lücher - bis $20 \mathrm{~m}$ im Durchmesser und 10-15 m Tiefe - zu graben, um das diamantführende Gestein zu gewinnen. Dies ist ein eisenschïssiger Ton, der aufer den Diamanten noch Brocken von Sandstein, Quarz, Hornstein, rotem Jaspis usw. enthält. Besonders zu erwähnen ist ein grïner Quarz (Prasem), dessen häufiges Vorkommen als gutes Zeichen für das Auffinden von Diamanten gilt. Eine Diamantgrube aus dieser Gegend ist auf Taf. T abgebildet. Man sieht die Arbeiter in den weiten Schacht unter der Aufsicht von Soldaten des einheimischen Herrschers ihr Werk vollbringen, indem sie aus dem mit Wasser bedeckten Grund das Gestein loshanen, das sie in dem links sichtbaren Korb nach oben ziehen, wo es weiter verarbeitet wird. Mittels des auf der rechten Seite dargestellten, aus Tonkriigen zusammengesetzten Paternosterwerks, das von Menschenhand getrieben wird, kann das zuströmende Wasser aus der Grube entfernt werden.

In den Gruben von Kameriya, nordöstlich von Panna, ist die Diamantschicht eine lockere, eisenschïssige Erde; sie wird von dem festen Rewahsandstein mit zwischengelagerten Tonschieferschichten in einer Mächtigkeit von $20 \mathrm{Fuß}$ bedeckt. Die Festigkeit dieser ïberlagernden Gesteine erlaubt hier eine unterirdische Gewinnung der diamantführenden Erde von der Basis von Schïchten aus, was die Arbeit viel leichter macht als bei Panna. Auch bei Babalpur sind zahlreiche Gruben, die aber jetzt alle verlassen sind.

Bei Birjpur (Bridschpur) üstlich von Kameriya und nahe bei Babalpur liegen die Gruben im Oberlauf des Baghin am rechten Ufer dieses Flusses, der das Diamantenfeld durehschneidet. Die Diamantschicht ist hier, abweichend von Kameriya, ein fester konslomeratischer Sandstein, der unnittelbar an der Erdoberfläche auf anderen Sandsteinen liegt, so daß die Gewinnung verhältnismäßig leicht ist.

Die grenannten Gruben beuten das anstehende Diamantlager aus, alle anderen in der Pannagrupye bearbeiten die daraus entstandenen verschieden beschaffenen Seifen.

Bei Majgoha (Majgama), dem westlichsten Punkte dieser Gruppe, südwestlich von Panna, ist das Vorkommen der Diamanten ein eigentïmliches. Sie liegen in einem grünen Lehm, der von Kalkspatadern durchzogen und von einer dicken Lage Kalktuff bedeckt ist. Dieser Lehm erfüllt zu ungeführ zwei Dritteln eine 100 Meter weite und 30 Neter tiefe kegelfïrmig nach unten sich verjüngende Einsenkung im Sandstein, vielleicht eine große alte Diamantgrube. Die Diamantgräber gehen bis 16 Meter tief hinab und behaupten, dals der Lehm immer reicher wird, je tiefer man kommt. Die Gruben sind jetzt zwar verlassen, sie gelten aber nicht für erschïpft, sondern für die Zukunft noch für aussichtsvoll. Das Vorkommen wird von De Launay mit dem Diamantenvorkommen in Suidafrika verglichen.

Gruben von einiger Bedeutung sind noch bei Udesna und besonders bei Sakeriya, wo der diamantführende Kies von gelbem Ton bedeckt ist, der zum Teil dem Laterit angehört; sie sind bis in die letzte Zeit bearbeitet worden und werden es vielleicht noch 


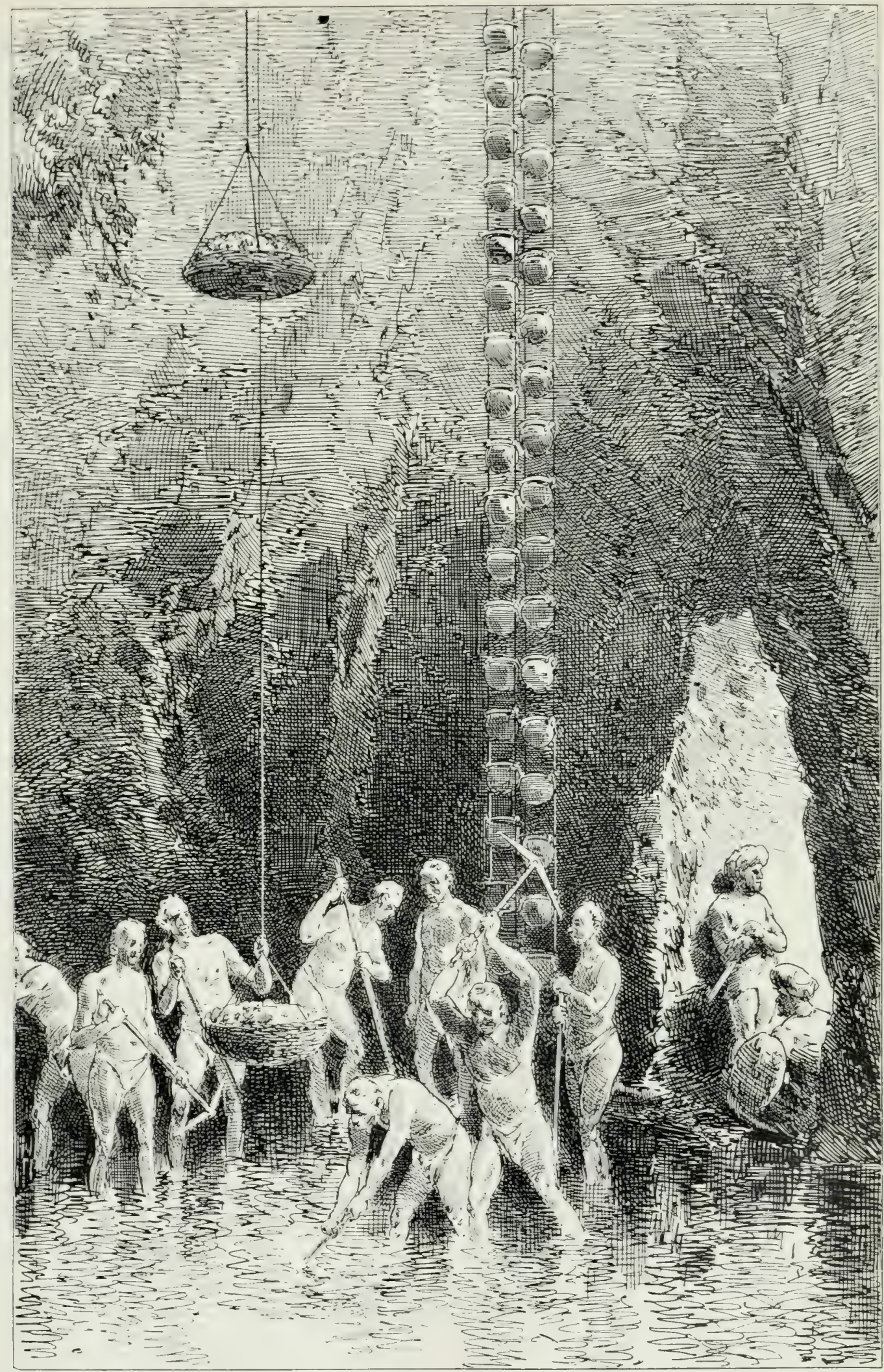

Diamantgrube bei Panna in Indien. 

jetzt. Bei Sahia Lachmanpur, 2t; Kilometer von Panna, findet man Diamanten auf drel Höhe des Hïgels Bindachul.

Endlieh sind noch zu erwähnen die Seifenlager in Tale des liaghinflusses, untrerhall, Birjpur. Eine clolie Strecke des Tales enthält solche. Die IIaupterulen liecren am unteren Ende des inneren Tales, wo etwa 4 Meter dlunkellorauner toniger Sand die diamantlïhrende (ieschielwsehicht bedeckt. Am oberen Ende des Tales sind zwei Wasserfïlle, jeder 3:3 Meter hoch, welehe Diamanten mit in die 'Tiefe führen, wo sie gesammelt werden, 230-300 Meter unter der anstehenden Diamantschicht.

Die Pannagruben sind hetutzutage die ertragreichsten in Indien. Sie kïnnten es noch mehr sein, wenn nieht die eingehorenen Fürsten, denen das Land gehïrt aufer Sahia Lachmanjur, selır beträchtliche $\Delta$ beaben erheben wïrlen (alle Steine ïher 6 Rati (iewieht und von den anderen ein Viertel de's Werte's). Trotzdem lebten früher über drei Viertel der Bewohner von Panna und den umliegrenden Dörfern von der Diamantengewinnung, beei der, infolge der druickenden Besteuerung der Arbeiter, grolje Betrügereien an der Tagesordnung sind.

(ranz isoliert und auljerhalh des vorstehend geschilderten Gebietes liegt der Fundort der Diamanten ron Sim la. Tier in den Vorbergen des Mimalaya, nördlich von Delhi, sollen am Anfang der siebziger Jahre des 19. Jahrhunderts in einem Bergstrom einige Iiamanten sefunden worden sein. Dies stimmt mit den Nachrichten alter indischer Ïberlieferungen ïherein, die gleichfalls Diamanten aus dem Himalaya erwähnen. Das Torkommen hat gar keine praktische Bedeutung und ist auch nicht unzweifellaft festgestellt.

Aus den zahlreichen Gruben dieser verschiedenen Dianantendistrikte stammt die unsceheure Zahl der vielfach sehr grofen und schünen Diamanten, die im Laufe der Zeiten mit anderen Edelsteinen in den Schatzkammern der indischen Fürsten und in den Tempeln als Schmuck der Gütterbilder aufgehüuft wurden. Bis zum zehnten Jahrhundert blieben alle in Indien gefundenen Diamanten im Lande, erst später wurden sie in andere Gegrenten des Orients, nachher auch nach Europa verbreitet, als die Eroberungs- und Plünderungszïge fremder Völker Indien verheerten. Den Anfang dazu machten die Perser unter dem Ghasneviden II a lr m u d am Ende des zehnten und am Anfang des elften Jahrhunderts. Welche sewaltige Massen von Diamanten in jenen Zeiten in Indien vorhanden waren, zeigt u. a. der Bericht des Persers F e r is c h ta, des Geschichtsschreibers der ron den Muhamedanern in Indien errichteten Reiche (bis 1606). Tach dessen Hitteilungen hinterlief Mruhamed der Erste, aus der persischen Dynastie der Ghuriden, der 1156 die muhamedanische Herschaft in Indien begrïndete. bei seinem Tode 500 Muns $1=400$ Pfund) Diamanten, die er im Laufe einer zweiunddreißigjöhrigen Regierung in dem Lande zusammengeraubt hatte.

Die Europïer wurden auf die in Indien gefundenen Schätze vorzugsweise durch die Berichte des italienischen Reisenden II a r c o Polo aufmerksam gemacht, der sich am Ende des 13. Jahrhunderts lange Jahre hindurch in Zentralasien, China usw. aufhielt. Nach C. Wr. K ing war jedoch der portugiesische Schriftsteller G a r c i a s a b H o r to der erste, der im Jahre 1565 authentische Nachrichten ïber indische Diamanten reröffentlichte. Gegen Ende des 17. Jahrhunderts lernte der französische Reisende T a vern i e r die Diamantenproduktion Indiens und die vom Großnogul Aurung Zeb zusammengehäuften Reichtïner an Edelsteinen genauer kennen, als er des Edelsteinhandels wegen sich ron 1665 bis 1669 in Indien aufhielt. Seine schon mehrfach erwähnten ausführlichen Reisebeschreibungen sind auf diesem Gebiete auch heute noch von großem Wert.

Als sich die Handelsbeziehungen Europas mit dem Orient allmählich mehr und mehr entwickelten, gelangten immer gröbere Mengen indischer Diamanten nach Europa. Der 
Hauptstapelplatz für diesen Handel und ïberbaupt für den Verkehr mit Edelsteinen war und ist noch heute Madras. Nicht wenige kamen auch als Kriegsbeute durch die Eroberungszïge der Engländer in deren Hände, so unter anderem einer der schönsten, gröliten und berïhntesten indischen Diamanten, der "Kohinur", der den Herrschern von Lahore gehörte, und den die englisch-ostindische Kompagnie 1850 der Königin Viktoria als Geschenk iilherreichte, nachdem sie den letzten jener Fürsten besiegt und entthront hatte.

Der alte Glanz ist aber nummehr ganz verblichen. Die Produktion Indiens ist heutzutage eine selur geringe. 1S:S betrug sie 170 Karat im Wert von 10573 Rupien, für 1 s99 sind die entsprechenden Zahlen 124 und S011. 1900 haben die Panna-Gruben 169 Karat geliefert, aus denen heute ïberbaupt fast der ganze Ertrag kommt und auch die besten Steine. Für 1903 werden 211,74 Karat im Wert von 2579 Pfund Sterling, für 1904 286,48 Karat in Trert von 2636 Pfund Sterling angegeben. Für die Ertrïge früherer Zeiten hat man keine genauen Zahlenangaben. Die Gesamtmenge der in Indien gewonnenen Diamanten ron Anfang an bis jetzt wird aber auf 10 Millionen Karat (oder 2050 Kilogramm), d. h. etwas mehr als 2 Tonnen, im Werte ron 350 Millionen Mark geschäitzt.

Die Ursachen des Riickganges sind verschiedenartig. Die reichsten Gruben wurden in frïheren Zeiten erschöpft, so daf nummehr nur noch die ärmeren Ablagerungen iibrig sind. Durch die unaufhörlichen Kriege, die lange das Land verwüsteten, wurde manche Grube auch vor der vollkommenen Erschüpfung verlassen und später vergessen, auch wurde daclurch die Nachfrage nach dem kostbaren Edelstein, die übrigens auch noch heute in Indien sehr srob ist, vermindert und die Produktion infolgedessen rerringert. In früherer Zeit - und in den noch unabhängigen Gebieten ist dies, wie wir schon gesehen haben, wenigstens zum Teil noch jetzt der Fall - multen die Arbeiter alle Steine über eine gewisse Größje dem Fürsten abliefern, dem das Land und damit die Grube gehörte, und ron den kleineren Steinen, je nach den Gegenden, noch weitere schwere Abgaben bezahlen. Ihr Gewinn war somit gering: daher wandten sie sich vielfach lohnenderen Beschïftigungen zu und verließen die Gruben, die ihnen unter giinstigeren Umständen vielleicht noch lange einen, wenn auch bescheidenen Ertrag geliefert haben würden.

Den Iauptstoh erlitt aber die Gewinnung der indischen Diamanten durch das $\Lambda$ uffinden der brasilianischen, die seit 1728 in den Mandel kamen und die aus Ablagerungen stammten, mit deren frischen, unberührten Reichtiimern die seit Jahrhunderten, ja wohl seit Jahrtausenden ausgebeuteten und der Erschöpfung nahen indischen in keinen Wetthewerb melur treten konnten. In neuerer Zeit hat der reiche Ertrag der südafrikanischen Diamantenfelder, namentlich an großen Steinen, die, im Gegensatze zu Brasilien, bis dahin Indien eigentiimlich gewesen waren, die Ungunst der Umstände noch wesentlich erhöht. Da auch seit langer Zeit, seit Jahrhunderten, in Indien keine reichen newen Ablagerungen gefunden worden sind, die als Ersatz für die alten ausgebeuteten dienen kïmnten, wie dies 7. 13. in Brasilien in so ausgezeichneter Weise der Fall ist, so ist wohl zu erwarten, daß Indien in nicht zu ferner Zeit ganz aus der Reihe der diamantenproduzierenden Länder wird ausscheiden müssen.

Nan hat wohl die IInffnung gehegt, daß die Produktion sich wieder heben kïnnte, wenn sie aus den ILänden der Eingeborenen in die von Europäiern ïbergehen würde. An einigen Orten ist eine systematische Bearbeitung der Ablagerungen in europäischer Manier versucht worden, aber bisher noch mit wenig Erfolg. Die natiirlichen, aber auch die sozialen und legislatorischen Verhältnisse lassen einen solehen von vornherein nieht gerade als sehr wahrscheinlich ansehen, am ehesten noch in den Dschennur-Gruben im I'anartale, in denen 
von Karnul und Nandial, von Sambalpur und Tschota-Nagpur, die alle in direktenn englischen liesitze sind, während die eingeborenen Fürsten gehörigen Gruben der Goleondaund der Panna-firuppe Europäern überhaupt nicht zugäinglich sein dïrften. Möglich ist allerdings, dab mit fortschreitender Kenntnis der geologischen Verhältnisse dess Landes doch noch neue Vorkommnisse der diamantenführenden Schichten mit grö̈lierem lieichtum an Steinen auforefunden werden, aber diese Moffnung hängt vorläufig ganz in der Luft.

Wie gering die jährliche Ibiamantenprodultion in Indien ist, wurde oben erwähnt; noch geringer ist die Menge indiseher Diamanten, die jührlich in den europäischen Handel kommt. Es ist überhaupt zweifelhaft, ob eine nennenswerte Menge das Jand verlälit, wahrscheinlich bleiben ziemlich alle jetzt gefundenen Steine in Indien, wie es schon vor Jahrhunderten war, und auch aus demselben Grunde. Wie frïher die indischen Fürsten und Vornehmen ihre Begierde nach Diamanten und anderen Edelsteinen trotz der grofen grefundenen Schätze kaum befriedigen konnten, so ist auch noch jetzt bei den reichen Eingeborenen das Verlangen nach diesen Steinen ein äulerst lebhaftes. Es ist um so eher anzunehmen, dab alle einheimischen Diamanten im Lande bleiben, als der großen Nachfrage wegen die I'reise in Indien oftmals höher stehen als in Europa, wo die Schätze der ganzen Welt zusammenströmen und sich Konkurrenz machen. Jedenfalls werden vielfach fremde Steine, besonders vom Kap nach Indien eingefuihrt, weil die einheimische Produktion den Bedarf des Landes nicht mehr zu decken imstande ist.

Eingehende Nachrichten iiber die Bes ch affen h e it der in Indien gefundenen Diamanten sind sehr spärlich. Einiges wenige hierïber ist im folgenden zusammengestellt.

Man trifft bäufig die Angabe, daß die indischen Diamanten vorzugsweise die Kristallform des Oktaëders haben, während die brasilianischen mehr vom Rhombendodekaëder begrenzt werden, und unterscheidet darnach, wie wir schon oben gesehen haben, einen indischen und einen brasilianischen Typus. Nach den wenigen wissenschaftlichen Untersuchungen, die man in neuerer Zeit an sicher aus Indien stammenden Diamanten angestellt hat, ist jene Ansicht aber offenbar nicht vollständig zutreffend. Darnach seheint in Indien im Gegenteil das Oktaëder selten zu sein, wälırend sich als Hauptformen der Pyramidenwïrfel und der Achtundvierzigflächner erweisen. Von 14 Kristallen, die F. R. M a llet in der Sammlung der Geological Survey of India in Kalkutta untersuchte, waren neun reine Pyramidenwürfel, zwei zeigten dieselbe Form mit untergeordneten Oktaëderflächen, zwei waren Oktaëder in Kombination mit Pyramidenwürfel und einer ein Oktaëder mit dem Dodekaëder. Der Pyramidenwürfel ist also an 13 von den 14 Kristallen vorhanden und an elf vorherrschend oder ganz selbständig, während das Oktaëder nur an dreien auftritt und nur an einem in überwiegender Ausbildung. Ton diesen 14 Kristallen sind fünf aus dem Karnuldistrikt (vier Pyramidenwürfel, ein Oktaëder mit Pyranidenwürfel), einer von Sambalpur (Pyramidenwürfel mit Oktaëder), vier von Panna (lauter verzerrte Pyramidenwiirfel), und die vier letzten sollen von Simla stammen. Auch unter den 31 indischen Diananten der Dresdener Mineraliensammlung sind nur etwa sechs Oktaëder und an zwei oder drei anderen sind Oktaëderflächen vorhanden, während die Mehrzahl die Form des Achtundvierzigflächners, einige auch die des Granatoëders haben. ¿̈́ber die Kristallformen der an den einzelnen Fundorten vorkommenden Diamanten sind schon oben einige Mitteilungen gemacht worden.

Daß große Diamanten früher in nicht unerheblicher Zahl in Indien rorgekommen sind, ist schon oben erwähnt worden; die größten und schönsten derselben sollen unten speziell beschrieben werden. Was heutzutage gefunden wird, ist meist nur von geringer Größe, so daß auch in dieser Beziehung, wie hinsichtlich des Umfanges der Produktion die jetzigen Funde mit denen frïherer Jahrhunderte keinen Vergleich aushalten können. Allerdings fehlen auch in gegenwärtiger Zeit sroße Steine nicht gänzlich, wie der oben 
erwähnte Fund eines $67:$, liarat schweren Diamanten bei Wairah Karrur im Jahre 1881 zeigt.

Auch über die Qualität der indischen Diamanten sind nicht viele ausfiilnrlichen Berichte vorhanden. Zweifellos hat Indien sehr viele Steine von allerfeinster Beschaffenheit geliefert, sehr zahlreiche. Diamanten ron einem Glanz, einer Reinheit des Wassers, einer Kraft des Feuters und ron der besten blauweiben Farbe sind hier vorgekommen, wie sie in Brasilien und besonders in Südafrika in dieser Menge nicht angetroffen wurden. Die Mitteilunщen, besonders iiber einzelne Gruben, berichten jedoch auch von schlechteren Steinen und namentlich ron vielen mit schwarzen Einschlïssen, aber trotzdem steht Indien allen anderen Ländern voran, was die vorzügliche Beschaffenheit seiner Diamanten betrifft. Namentlich stammen von hier fast alle die lebbaft und schön gefärbten blauen, grrinen und roten Diamunten, während die gelben ibre hauptsäehlichste Heimat in südafrika haben.

\section{Brasilien.}

Die brasilianischen Diamanten wurden etwa um das Jahr 1725 von Goldwïschern in der Gegend von Tejuco in der Provinz Minas Geraës in den groldhaltigen Sanden einiger Bäche und Flïsse entdeckt, den gewöhnlichen Angaben nach zuerst in Rio dos Marinhos, einem rechten Nebenflusse des Rio P'inheiro. (Fig. 43.) Die glänzenden Steinchen waren den Leuten bei ihrer Arbeit aufgefallen, jedoch nicht erkannt worden. Gleichwohl wurden sie aber gesammelt und gelegentlich (1728) nach Lissabon gebracht, wo sie der holländische Konsul, der sie zu sehen bekam, sofort für Diamanten der besten Qualität erklärte.

Nun begann eine eifrige Durchforschung jener Gegend, besonders der Wasserläufe, und es stellte sich heraus, daß alle Bäche und Flüsse dort mehr oder weniger reich an Diamanten waren. Die portugiesische Regierung grenzte zur Beaufsichtigung der Gewinnung des kostbaren Edelsteines, den sie für ein Regal erklärte, einen besonderen Diamantenbezirk, den Bezirk Serro do Frio, ab, erließ für ihn besondere Gesetze und Verordnungen und führte zur Verhinderung des unerlaubten Nachsuchens und des Schleichhandels eine scharfe militärische Überwachung ein.

Bei weiterer Nachforschung ergab) es sich, daß der Diamant nicht auf die Grenzen von Serro do Frio beschränkt war; auch in anderen Teilen von Minas Geraës wurden zahlreiche wichtige Funde gemacht, und ebenso in anderen Provinzen, nach Siiden in S. Paulo und Paraná, nach Westen in Goyaz und Mato Grosso und nach Norden in Bahia und vielleicht auch in Pernambuco. Bis in die neuere Zeit sind immer wieder von '/ceit zn Zeit neue und zum Teil sehr wichtige und ergiebige Ablagerungen bekannt geworden, so dal) wohl angenommen werden darf, daß die Zahl dieser Entdeckungen noch nicht abgeschlossen ist, $u m$ so mehr, als die bisher in Angriff genommenen Diamantenfelder zuin Teil in noch fast ganz unerforschten Gegenden liegen.

Der Staat Minas Geraës hat bis zum heutigen Tage seine Wichtigkeit behalten, wenn auch infolge der langjährigen starken Produktion die Ausbente segen friiher und namentlich gegen die Zeiten ummittelbar nach der Entdeckung stark zuriekgegangen ist. Dafuir sind besonders die crst im Laufe des vorigen Jahrhunderts und zum Teil sogar in den letzten Jahrzehnten desselben in Aufnahme gekommenen Fundorte der Provinz Bahia eingetreten, die gegenwärtig den reichsten Lrtrag liefern. Alle anderen Provinzen stehen gegen diese beiden zurïck: sie haben zum 'T'eil nur ganz unberleutende Mengen ergeben, zum Teil sind sie aber auch noch zu wenig bekannt, als daß man über ihre Verhältnisse schon rin abschliebendes Lrteil gewinnen könnte. Eine für den Juwelenhandel auf die Dauer ledentsame Produktion haben jedenfalls his jetzt nur jene erstgenannten beiden Staaten, 
Minas Geraës und Bahia, gellabt. Es ist zweifelhaft, ob in deell anderen heutzutagne uiberhaupt noch Diamanten in irgend nennenswerter Menge gewonnen werden.

Die wichtign I Diamantenbezirke von Minas Creraïs und Bahia sind auf der Kartre Fig. 12 nach lioutan übersichtlich zusammengestellt. Wir werlen die sämtlichen

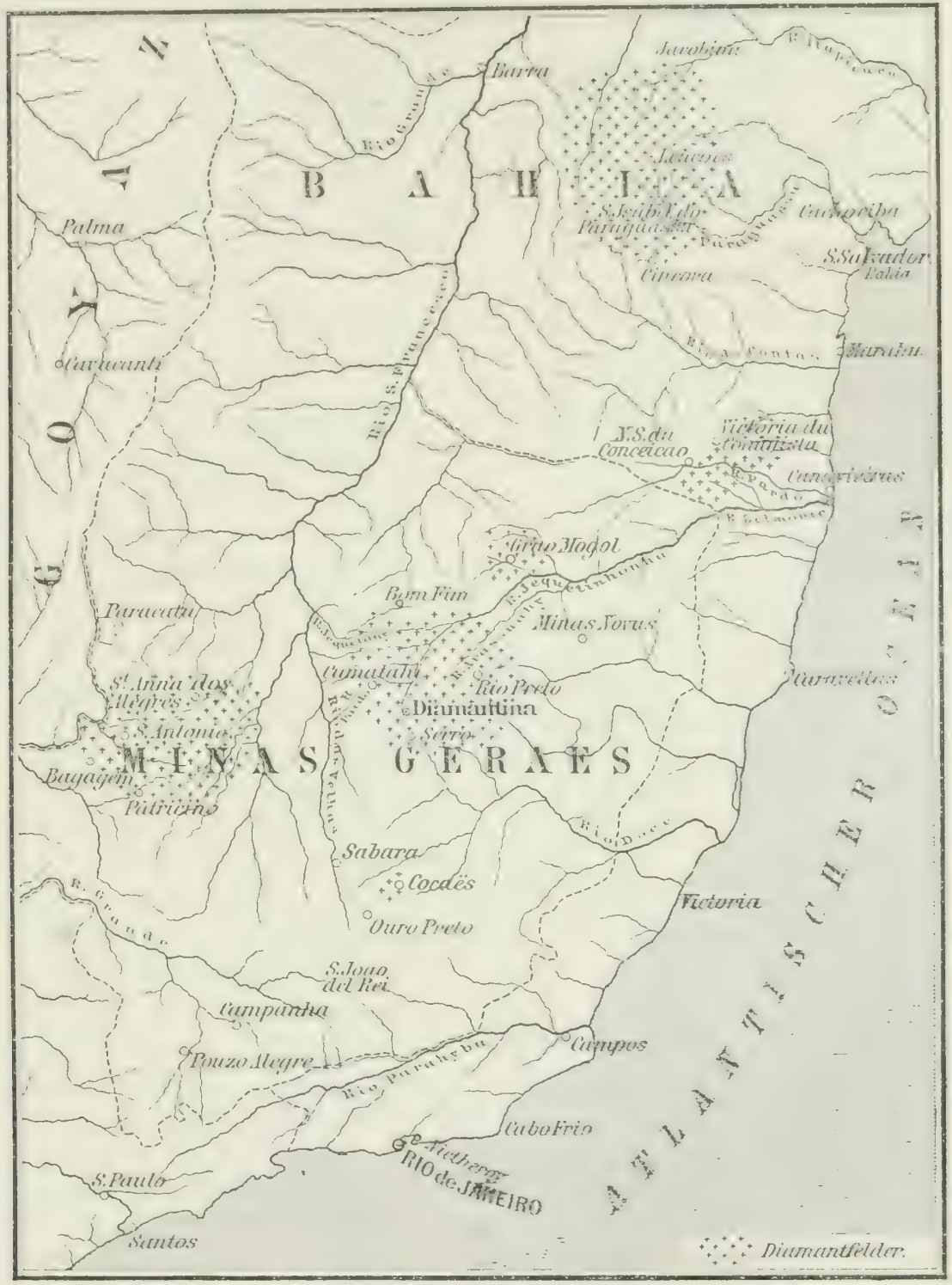

Fig. 42. Diamantenfelder in Brasilien. Maßstab 1:10,000,000.

brasilianischen Torkommnisse, nach Staaten geordnet, ihrer grüferen oder seringeren Wichtigkeit entsprechend und nach den mehr oder weniger eingehenden Nachrichten, die darïber vorhanden sind, mit verschiedener Ausführlichlieit behandeln. Den Anfang sollen die altberühmten Fundstätten ron Minas Geraës machen, ron denen die meisten selır "gut durchforscht sind. Die anderen sind diesen zum Teil mehr odler weniger ähnlich, so daß jene auch zugleich als Typus für sie dienen können. 
Man pflegt in der Provinz Minas Geraës vier Diamantenbezirke zu unterscheiden, von denen der von Serro do Frio oder Diamantina der bedeutendste ist; die andern sind die vom Rio Abaété, von Bagagem und von Grão Mogol.

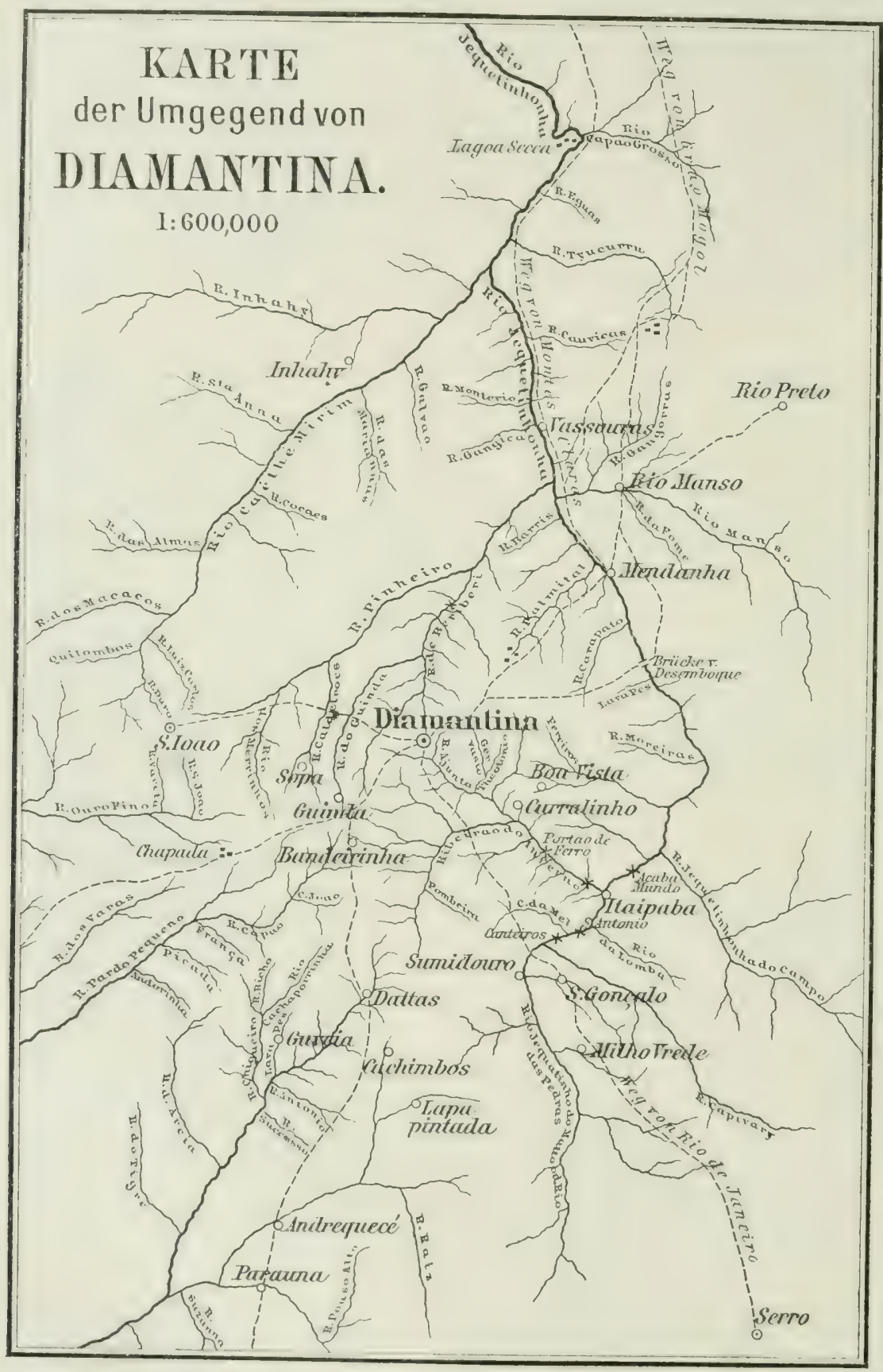

Fig. 43. Diamantenfelder des Bezirks Diamantina.

Eine Übersicht iiber den Distrikt von Serro do Frio oder Diamantina gibt die Karte Fig. 43 nach de Bovet. Er umfaßt in elliptischer Form ungefähr 100 Quadratmeilen. 
Die grolie, von Nord nach Sïd gerichtete Achse erstreckt sich etwa Sol km lang von Serro im Süden bis zum lío Caćthr. Mirim, wïhrend die andere Achse in einer Lä̈nge von $16 \mathrm{~km}$ vom Rio Jequetinhonha sich nach Westen bis zu einer Linie erstreckt, die parallel dem Rio das Velhas durch die Dörfer Dattas und Parauna hindurchgeht. Die Gegend ist ein wildes (iebirgstand auf der IIöhe und an den beiden Seiten des nördlichen Endes der Serra do Espinhago, die, in der Richtung des Meridians verlaufend, das Flufgenebiet des Rio S. Franciseo und seiner Nebenfluisse, besonders des Rio das Velhas, von dem des Rio Jequetinhonha und des Rio Doce trennt (Fig. 42). Es ist in der IIauptsache ein Plateau mit schroffen Rändern, in das die Täler tief und mit steilen Gehängen eingesehnitten sind. Auf der

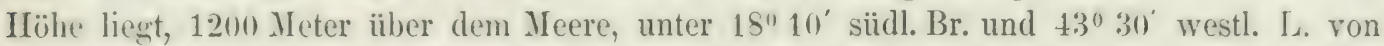
(Areenwich, die Ilauptstadt Tejuco, die nach der Entdeckung der Diamanten den Namen Diamantina erhalten hat, den sie heute führt. Nach ihr wird der Bezirk jetzt meist der von Diamantina genannt.

Die Diamanten finden sich zum Teil oben auf dem Plateau, zum Teil in den Tälern der Flüsse, die in dem Gebirgszuge entspringen. Der bedeutendste und zugleich der reichste von diesen ist der Rio Jequetinhonha mit den beiden Quellflïssen Jerfuetinhonha do ('ampo und Jequetinhonha do Matto (oder Rio das Pedras), die an der Serra do Itambe entspringen. Nach einem in der Hauptsache von Südwest nach Nordost gerichteten Laufe ergielit sich der Fluß bei Belmonte ungefälı unter $16^{0}$ siidl. Br. in den Atlantischen Ozean, nachdem er vorher seinen Namen in den des Rio Belmonte umgeändert hat. Er führt Diamanten von seiner Quelle bis nach Mendanha, aber nicht er allein, sondern auch seine Nebenfliisse. Von diesen sind aber die von rechts, der Rio Capivary, Rio Manso und andere, die nicht am Plateau von Diamantina entspringen, arm; reich erwiesen sich dagegen diejenigen, die hier ihren Ursprung nehmen und von links dem Hauptstrome zueilen: der Ribeirão do Inferno, Rio Pinheiro, Rio Caéthé Mirim und andere, sodann in geringerem Grade der Rio Arassuahy, der gleichfalls in den Jequetinhonha geht. Wichtig sind auch einige kleinere Wasserläufe, die von jenem Plateau aus nach Westen direkt oder indirekt in den Rio das Velhas, einen Nebenfluß des Rio S. Francisco, sich ergießen, der Rio das Dattas, Rio do Ouro Fino, Rio do Parauna mit seinem Nebenflusse Ribeirão do Coxoeira und andere, und vor allem der Rio Pardo Pequeño, der eine sehr grofe Menge besonders schöner und kostbarer Diamanten geliefert hat, und der wohl nach dem Jequetinhonha der wichtigste ist.

Hieran schließen sich dann die Ablagerungen des Rio Jequetahy und der Serra de Cabrol in Nordwesten vou Diamantina, die aber von den zuerst genannten durch eine diamantenfreie Zone getrennt sind, sowie eine kleine Grïberei im Jequetinhonha-Tal, $100 \mathrm{~km}$ abwärts von Diamantina. Endlich ist noch das Vorkommen weit im Süden dieser Stadt bei Cocaës, nur etwa $50 \mathrm{~km}$ nördlich von der Provinzialbauptstadt Ouro Preto, zu erwähnen, das zwar nur eine geringe Anzahl kleiner Diamanten geliefert hat, das aber wegen seiner isolierten Lage fern von anderen Diamantenfundorten bemerkenswert ist.

Zum Schluß verdient noch besonders hervorgehoben zu werden, daß das an der Ostseite der Serra do Espinhaço sich hinziehende Flußgebiet des Rio Doce, das von dem so dianantenreichen Gebiet des Jequetinhonha nur durch einen schmalen Gebirgsrïcken getrennt ist, noch nie auch nur einen einzigen Diamanten geliefert hat. Den Grund davon werden wir unten kennen lernen.

An den Distrikt von Diamantina schließt sich nach Westen hin der des Rio Abaété an, eines linken Nebenflusses des Rio S. Francisco mit seinen Quellflïssen Rio Fulda und Rio Werra und dem linken Zuflusse, dem Rio Andrade an. In den Rio S. Francisco gehen auch der Rio Indaia, der Bambuy, der Barrachudo und ebenso der Paracatú mit seinen Zuflüssen Santo Antonio, d'Almas, de Somno, de Catinga, de Prata usw. Die 
Diamanten dieser Frecrend wurden 1755 ron Schleichbündlern entdeckt und anfünglich ohne Konzession auswelpentet. Es wurde dabei in Rio Abaété einer der grribten brasilianicchen Steine ron 1351. Tiarat gefunden. Seit 1807 hat aber die Arbeit dort so sut wie ganz aufgehïrt. Ton 1795 an scheint rasch eine rollkommene Erschöpfung der Lagrer eingetreten zu sein, nachdem noch 1791 eine Schar von 1200 rechtmäfigen Arbeitern beschäftigt gewesen war.

Dieser Bezirk zieht sich in einer Länge von $500 \mathrm{~km}$ am Ostabhange der Serra da IIata da Corda lin, an der alle die gewannten Wasserläufe entspringen. Auf der anderen westlichen Seite descellon Gebirgszuges liegt, noch in Hinas Geraï, aber sehr nahe der Grenze gexen Goyaz. das Gebiet ron Bag a gem, das dieselbe Lüngenerstreckung wie der liezirk von Rio Abacte und mit diesem zusammen eine Breite von 400 Kilometern besitzt. I) ganze fiegend ist noch sehr wenig untersucht, sie liefert aber viele Diamanten. Ton hier stanmen melrere Steine ron bedeutender Grölie. unter anderem ein solcher ron 12013; Karat und namentlich der bis vor wenigen Jahren größte der bisher in Brasilien gefundenen, der ...Stern des Sïdens" oder ..Süidstern", der im Jahre 1853 gefunden wurde und der im rohen Zustande $254^{1 / 2}$ Karat wog.

In den letzten Jahren machte man hier Funde von mehreren ausnahmsweise großen Steinen (20-50) Karat), die aber häufig deformiert oder zerbrochen sind, in dem Flußsanden und auf dem (5) Meter hohen Plateau am Rio Douradinhos, einem Parallelfluf des Rio Bagagem, der sich wie dieser in den Rio Paranahyba ergieft. Die diamantfïhrenden Cascalholager erstrecken sich auch auf die rechtsufrigen Zuflïsse des letzteren (Rio P.), die schon zum Staate Goyaz gehören. Hier wurde noch am Einfluß des Rio Verissimo im Jahre 1906 ein grofer Stein, etwa von der Form einer Streichholzschachtel, eingewachsen im Canga-Konglomerat, gefunden, anscheinend ein Bruchstiick eines viel grüßjeren Kristalls, wie einige sagen ron 300 Karat. Er würde also den Stern des Süidens noch erheblich an Gröbe ïbertreffen. Leider wurde er von den Findern (Garimpeiros) aus Unwissenheit zerschlagen, gröfere Trümmer kamen aber dann doch in den Handel und wurden geschliffen. Auch die allerjüngste Zeit hat neue reiche Funde in diesem Bezirk gebracht, so in der Umgebung von Estrella do Sul in der Niederung des BagagemıFlusses und an anderen Orten.

Im Jahre 186i, ist in dieser Gegend, $30 \mathrm{~km}$ siidlich von dem Flecken Bagagem bei $\Lambda$ gua Suja, eine neue diamantenführende Ablagerung gefunden und seitdem ausgebentet worden. Der Diamant ist hier begleitet ron Blöcken der aus der nächsten Nähe anstehenden Gesteine und von viel Magneteisen, außerdem von Titaneisen, zersetztem l'erowskit, Pyrop und Rutil. Diese Begleitmineralien sind zum 'T'eil andere als in allen ïbrigen brasilischen Diamantenlagem, namentlich war Pyrop und Perowskit in einem solchen bisher noch nie wefunden worden. Das Mineralvorkommen erimnert an den ,blue ground" von Kimberley in Südafrika, von dem unten eingehend die Rede sein wird. Ebenso werden unten die Mineralien ausfïhrlich genannt werden, die sonst in Brasilien den Diamant begleiten.

Die Grube von $\Lambda$ gua Suja wird gegenwärtig von einer französischen Gesellschaft bearbeitet, nachdem in den letzten 3-4 Jahren enorme Aufbereitungsanstalten angelegrt worden waren. Die diamantfiihrende ,Tanä, ein Konglomerat, enthailt zwar viele kleine Diamanten, darunter jedoch zahlreiche graue, undurchsichtige, wïrlige Kristalle, die mit Lnrecht, da sie hïirter und nicht schleifwürdig sind, als Carbonado bezeichnet werden. Zuweilen finden sich aber auch Steme ron größerem Karatgehalt, die sich durch die prächtige blauweiße Farbe auszeichnen.

Endlich ist noch dic Grencend ron Grio Mogol foder Grào Mogor) zu erwähnen, das :30) Kilometer nordïstlich ron Diamantina in einer Bergkette liegt, die den . Tequetin- 
lonha auf seiner linken nordwestlichen Srite begleitet. In Jahre $141: 3$ wurde hier zuterst nachersucht, aber erst 1527 hat man Diamanten efunden. Dies ist fast der einzige Fundort, wo Diamantkristalle unter anderem anch in festen kongloneratischen Sand-tein. wie

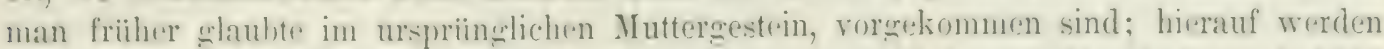
wir unten etwas näher eingehen. Der Ertraw war eine Zeit lane nicht unberleutend, 15:3e arbeiteten 2000 Leute, gegenwärtig ist er aber gering.

Die geologis chen Verhäl n isse in den Diamantengerenden der Provinz. Minas fitraïs, hesonders im Bezirk von I) iamantina, sind rielfach untersucht und daher, wenigstens die in letzteren, zienlich senau bekannt, duch hleiben allerding's noch manche dunkle I'unkte aufzuhellen. Zu Anfang des 19. Jahrhunderts haben sich besonders L. r. Eschwegu, etwas spittr spix und II artius, in den fünfziger Jaluren II eusser und Claraz, sodanu ('latusen und II elmreichen, in der neneren Zeit haujtsächlich die z. T. an Ort und stelle ansässigen Geologen Gorceix, de Boret, Orville A. Derby, E. Hussak u. a. um die Kenntnis der natïrlichen Verhältnisse jener Gegenden Verdienste erworben.

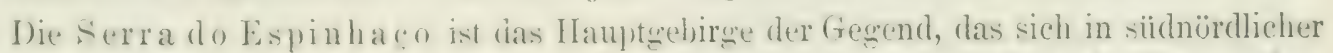
Jiehtung von Sabara über Dianantina und Grão Mogol bis in die C'hapada diamantifera ron Babia ununterbrochen hinzielst. Es bildet die srofe Wasserscheide zwischen den Cimässirn, die direkt in den atlantischen Ozean mïnden, und denen, die zunächst dem Uruguay, dem Parani und dem Rio São Francisco zufließen.

Nach den neuesten Untersuchungen ron Orville A. Derby liegen dort über der steil auferichteten Reihe der dem Cambrium oder Silur angehörigen resteine: Itabirit, whinmeriger (Quarzit, Itacolumit und quarzarmer Phyllit, die üfters ron Diabasen und uralitisierten (iabbros durchbrochen sind. diskordant Konglomerate und konglomeratische Sandsteine (jünterer (guarzit) und nur in diesen, nicht aber im Itacolumit, wie man wohl früher glaubte, wurden sowohl auf der Serra do (rão Mogol. wie auch jüngst in dex Chapada diamantifera ron Bahia, Diamanten eingewachsen gefunden. Oh die Konglomerate, stets fossilfrei, von der Serra do Grão Mogol mit denen ron Bahia gleichartigen Alters sind und welcher Formation sie angehören, ist noch ungewiß. I)ie von Grão Mowol sehen mehr deformiert aus, die Geschiebe von Quarzit sind geyuetscht und auf den Gleitflächen hat sich Sericit neu gebildet, während die von Bahia mehr die urprïngliche Form des Konglomerats erhalten zeigen. Der Diamant scheint nur in dem quarzigen Bindemittel des Konglomerats enthalten zu sein.

I a I Iauptrorkommen des Edelsteins in diesen Gegenden ist aber in Seifen und aus diesen wirl er ausschlieflich in gröferen Nengen gewonnen. Man pflegt dreierlei solcher diamantenführomlen Ahlagerungen zu unterscheiden, die wesentlich nach ihrer Lase, auf dem Plateau oder in den Tälern, und hier wieder unter oder ïber dem heutigen IIochwasserspiegel, roneinander abweichen. Ian bezeichnet danach als Flußablagerungen die, welche auf dem Grunde der heutigen Wasserlïufe innerhalb der jetzigen Hochwassergrenze sich befinden; als Gehängeablagerungen die an den Talabhïngen ïber dem heutigen Hochwasserspiegel liegenden; und endlich als Plateauablagerungen solche. die oben auf den Hochflächen mehr oder weniger weite Strecken bedecken.

Die beiden ersteren Arten von Ablagerungen sind ausnahmslos, die dritte Art zum Teil Allurionen, rom Wasser zusammengeschwemmte Schuttmassen mit mehr oder weniger stark abgerollten fresteinsstiicken, zwischen denen die Diamanten einzeln liegen. Je nach der stärkeren oder schwächeren Abrollung der beigemengten Gesteinsbrocken muf der Transport in Wasser auf gröfere oder lileinere Entfernung stattgefunden haben. Ein Teil der Hïhenablagerungen zeigt aber keine Spur ron Abrollung der Bestandteile durch Wasser und ïberhaupt solche Torhältnisse, daf man 
an ihrer Entstehung am Orte, wo sie sich heute befinden, nicht zweifeln kann. Es sind dann meist stark verwitterte, aber nicht durch Wasser von ihrer Stelle bewegte Gesteinsmassen, wie wir bei der speziellen Beschreibung einiger solcher Höhenablagerungen noch weiter sehen werden.

Bei aufmerksamer Betrachtung der Verbreitung der Höhenablagerungen und derjenigen in den Flußtälern fällt sofort ein bemerkenswerter Zusammenhang zwischen beiden auf. Die Gegrenden, in denen Diamanten auf der Höhe sich finden, sind auch die Ursprungsgrebiete der diamantenführenden Flüsse und Bäche, so daß man notwendig annehmen mul, daß die Edelsteine, die jetzt in den Ablagerungen der Täler, in den Seifen liegren, sich früher oben auf den Höhen befunden haben, von denen sie durch die Wasserliufe zugleich mit deren ganzem Vorrat an Kies, Sand und anderem Schuttmaterial in die Täler hinuntergeführt wurden. Dies tritt besonders bei Diamantina hervor. Das Plateall, das diese Stadt tı ägt, ist bedeckt von diamantenführenden Massen, und die Flüsse, die auf ihm ihren Ursprung nehmen, enthalten den Edelstein gleichfalls in mehr oder weniģer reichlicher Menge. Wasserläufe, die nicht in diesen diamantenreichen Höhen entspriugen, führen auch in ihrem Bette keine solchen, wie z. B. der Rio Doce und seine Nebenfliisse. Der Grund, warum diese keine Diamanten enthalten, liegt eben darin, daß sie in diamantenleere Gesteine eingeschnitten sind.

Auf diesen Zusammenhang der Plateau- und Talablagerungen weist auch der Unstand hin, daß in ganz Minas Geraës die den Diamant begleitenden Mineralien an allen diesen Lagerstätten, sie mögen auf der Höhe oder in der Tiefe der Täler liegen, im wesentlichen dieselben sind. In den in der Hauptsache aus größeren und kleineren Körnern und Bruchstiicken der umliegenden Gesteine und aus deren Verwitterungsprodukten bestehenden Diamantenablagerumgen findet man neben dem Edelstein gewisse, zum Teil noch frische, zum 'l'eil aber auch mehr oder weniger stark verwitterte Mineralien, von denen etwa die folgenden zu erwähnen sind: Quarz in seinen verschiedenen Abarten, zum Teil durchsichtig und farblos als Bergkristall, zum Teil in dichten Varietäten als Feuerstein, Jaspis usw., ist ïberall am häufigsten und massenhaftesten vorhanden. Ferner findet man die drei Dioxyde des Titans: Rutil, Anatas und Brookit (als Arkansit ausgebildet); Rutil in der Kristallform des Anatas (sog. captivos), Zinnstein als Holzzinn und in Kristallen, besonders bei Dattas, aber auch an anderen Orten; die Oxyde und Hydroxyde des Eisens: Magneteisen, Titaneisen, Eisenglanz mit Roteisenstein, Eisenglanz in der Kristallform des Magneteisens (Martit), Brauneisenstein; ferner Schwefelkies, frisch oder teilweise in Eisenhydroxyd (Goethit) umgewandelt und dadurch gebräunt; sodann Turmalin, versehiedene Arten von (rranat, Fibrolith, Klaprothin (Lazulith), Psilomelan, Talk, Glimmer, Yttrotantal, Xenotim und Monazit, Cyanit, wasser- und chlorhaltige Phosphate von komplizierter Zusammensetzung (Gorceixit, Harttit, Plumbogummit), ein wasserhaltiges Kalktonerdephosphat (Goyazit) Diaspor, Staurolith, Titanit, weißen und blauen, nicht aber auch gelben Topas und Gold, das häufig nit den Diamanten zusammen gewonnen wird. Mit dem Golde ist etwas Platin verbunden, das aber keine kommerzielle Bedeutung hat. Manche von diesen Mineralien sind dort mit besonderen Lokalnamen bezeichnet worden. So nennt man die kugelig und bohnenförmig orler flach scheibenförmig abgerollten schwarzen Turmalingeschiebe "Feijào" (d. h. schwarze Bohmen) und die oft jaspisähnlichen braunen oder braun- und rotgefärbten, selten weißen, häufiger grauen Gerölle der wasserhaltigen Phosphate oder der hydratisierten Titanoxyde ,Favas“ (d. h. Puffbohnen) usw.

Nicht alle die genannten Substanzen sind von gleicher Wichtigkeit. Als die konstantesten Begleiter des Diamantes neben dem Quarz in seinen verschiedenen $\Lambda$ barten werden die Oxyde des Titans (Rutil, Anatas, Brookit, Titanfavas im Gegensatz zu den Phosphatfavas usw.), Eisenglanz mit Martit und besonders Xenotim und Monazit, so- 
wie der schwarze 'Turmalin genannt. Dirse sind nicht gerarle alle iiberall häufig, ahore sie fehlen so gut wie nirgends in der Gesellschaft der Diamanten, währond andere strllenweise häufigere, an anderen Orten vergeblich gesucht werden. Man findet also keineswegrs immer diese sämtlichen Mineralien ïberall in derselben Weise zusammen, ihr Vorkommen schwankt bis zu einem wewissen Grade von einem Ort zum andern, ron einem Fluß zum andern und auch an versehiedenen Stellen rines und desselleen Flusses, was zum 'Teil damit zusammenhïngt, dab das Wasser die leichteren Mineralien raseher' und weiter stromahwïts führt als die schwereren, und dab manche beim Transport lejeht vollständig zerstört werden, während andere länger erhalten bleiben.

lirwähnt sei noch, dalo in Minas Geraës der Korund als becleiter des Diamants fast vollstïndig fehlt. Als Seltenheit findet sieh Korund, und zwar Rubin und Sapphir. in den Diamantsanden von Aqua Suja, Patrocinio de Sajuealyy und Douradinhos, wailurend er in den Ablagerungen von Salobro in Bahia mit unserm Edelstein zusammen häufiger vorkommt.

Die I iamantengräber nennen diese Bechleitmineralien ,Formation“ (boa formarão). Sie dienen ihnen zum Aufsuchen des Edelsteins, der sich wegen seines sparsamen Vorkommens und der Kleinheit der Exemplare leicht der Beobachtung entzieht, wïhrend die hïufigeren und zum 'Teil grö̈lieren Stiicke der ..Formation" leicht gefunden werden und in ihrer Begleitung dann bei genauerem Nachforschen der Diamant. Sur wo die .Formation" angetroffen wird, werden Anstalten zur Aufsuchung der Diamanten gemacht, freilich oft rergeblich, denn wenn auch der Diamant nie ohne die „Formation“ vorknmmt, so findet sich doch oft diese ohne Diamanten oder wenigstens olıne eine für die Gewinnung: genügende Menge derselben.

Den Diamantengräbern sind die einzelnen Bestandteile der Formation von verschiedener Bedeutung für ihre praktischen Zwecke. Als besonders wichtig und für die sichersten Kennzeichen der Anwesenheit von Diamanten halten sie die Turmalingeschiehe (Feijào), die Titansäuremineralien (Rutil und besonders Anatas, weniger Brookit), Eisenoxyde (Magneteisen, Titaneisen. Eisenglanz und Brauneisenstein), die Phosphate (Faras) usw., während anderen, z. B. dem Klaprothin usw., keine Wichtigkeit beigemessen wird. Die Ansichten hierüber scheinen aber nicht ganz allgemein dieselben zu sein, jedenfalls sind es im allgemeinen dieselben Nineralien, die wir als die konstantesten Begleiter des Diamants kennen gelernt haben.

Wir gehen nunmehr ïber zur näheren Betrachtung der drei Arten ron Diamantlagerstätten, wie sie im Bezirk Diamantina und auch sonst in Minas Geraës vorkommen. Es sind, wie schon oben erwähnt, die Fluß-, Gehänge- und Plateauablagerungen.

Die Flufablagerungen, welche die Täler innerhalb der heutigen Hochwassergrenzen erfüllen, sind von diesen die reichsten, zur Zeit die einzig wichtigen in diesen Gegenden und in ganz Brasilien überbaupt, zugleich sind jedoch die in ihnen vorkommenden Diamanten im allgemeinen Durchschnitt die kleinsten, kleiner als auf der Höhe. Auch in jedem einzelnen Fluß ist die Größe der Steine nicht überall dieselbe, sie nimmt talabwärts immer mehr ab, und allmählich hört das Torkommen ganz auf. Sehr auffällig ist diese Erscheinung im Jequetinhonha, wo die oben erwähnte $100 \mathrm{~km}$ unterhalb Dianıantina gelegene Diamantengrube nur ganz kleine Steine geliefert hat. Die Abrollung des die Diamanten einschließenden Schuttmaterials ist in diesen Flußablagerungen sehr stark, stärker als in den anderen, und gleichzeitig zeigen sich auch die Diamanten an den Kanten und Ecken merklich abgerundet. Die zerstörende Täitigkeit des Wassers wird natïrlich immer bedentender, je länger die Einwirkung erfolgt, es ist daher leicht begreiflich, daf auch die Diamanten talabwärts immer mehr an ihrer ursprünglichen Größe einbïßen und daß sie allmählich vollständig verschwinden, ganz ah)gesehen davon, 
dali die kleinsten Steinchen an leichtesten und daher am weitesten von dem Wasser fortbewegt werden.

Die den Boden der Wasserläufe bedeckenden und den Grund der Täler ausfüllenden diamantenführenden Schuttmassen bestehen in der Hauptsache aus abgerollten Stïcken der die Fliisse und Bäiche auf ihrem Wege ron der Quelle an talabwärts begleitenden Felsarten mit den oben als Gefährten des Diamants angeführten Mineralien, besonders Quarz in verschiedenen Alarten. Die Masse ist meist ziemlich stark mit Ton gemengt und bildet mit ihm zusammen das Produkt der Gräberei, den Cascalho. Dieser stellt gewöhnlich eine lose und lockere, vollkommen ungeschichtete Gesteinsanhäufung dar, die aber auch nicht selten durch den Ton eine festere Konsistenz erhält. Manchmal wird sie sogar, wenigstens in den obersten Lagen, in größerer oder geringerer Dicke durch ein cisenschïssiges Bindemittel zu einem festen, hauptsächlich aus abgerollten Quarzkörnern - bestehenden Konglomerat vereinigt, das entweder ausgedehntere Schichten oder auch nur einzelne Blücke bildet und das den Namen Tapan hoacanga oder Canga erhalten hat. Dieses Konglomerat schließt manchmal Diamankristalle ein. Stiicke desselben, wie in Tafel I, Fig. 1, mit einem eingewachsenen Diamant liegen nicht selten in den Sammlungen als vermeintliche Repräsentanten des Torkommens des Edelsteins auf seiner ursprünglichen Lagerstätte, in seinem Muttergestein; davon kann aber nach dem Vorstehenden keine Rerle sein.

Der Cascalho ist also ein Gemenge von abgerollten Gesteinsbrocken als dem gröberen Material mit dem Diamant und seinen Begleitmineralien als den feineren Bestandteilen, das Ganze mehr oder weniger stark mit Ton oder auch mit Brauneisenstein durchsetzt und dadurch zuweilen mehr oder weniger stark verkittet. Diese Masse liegt auf dem Grunde der Wasserlïufe, unmittelbar auf dem anstehenden festen Felsgestein. Aber der diamantenführencle edle Cascalho, der Cascalho virgem orler jungfräuliche Cascalho der Brasilianer, reicht nur in seltenen Fällen bis zur Oberfläche des Flußschuttes. Er hat nur eine gewisse stark wechselnde Mächtigkeit und ist gewöhnlich bedeckt von einer wenige Zentimeter bis zu 20 und 30 m mächtigen Lage eines diamantenfreien, sogenannten wilden Cascalho, dessen untersten Teil meist eine Anhäufung größerer Felsblücke bildet; im übrigen enthïlt er aber dieselben Bestandteile wie die tiefer liegende edle Schicht. Über dem wilden Cascalho fließt erst das Wasser; er muß entfernt werden, wenn man in den Gräbereien zu dem Edelstein gelangen will.

Der edle Cascalho füllt zwar im allgemeinen die Betten der Bäche und Flüsse ziemlich ununterbrochen auf größere Erstreckung, łloch ist er keineswegs durch die Talläufe hindurch gleichmäßig verteilt. An manchen Stellen ist er in grober Mächtigkeit und in bedeutenden Massen angehäuft, an anderen ist er nur in spärlicher Menge vorhanden und stellenweise fehlt er sogar ganz. Der Reichtum an Diamanten ist gleichfalls nicht iberall derselbe, weder in allen Fliissen, noch an allen Stellen desselben Flusses. Zwar sind nach frïheren Nachrichten in manchen Flïssen in Diamantina die Diamanten so regelmäßjig in dem Cascalho verteilt, daß man zum voraus mit großer Genauigkeit angeben konnte, wieviel Karat des Edelsteins eine gewisse Menge von dem beim Graben erhaltenen Materials liefern werde. Dies ist aber doch eine Ausnahme; meist sind einzelne Stellen reicher, andere ärmer, ja viele in derselben Schicht ganz diamantenleer.

Gewisse Umstände bedingen an einzelnen Punkten der Täler eine besonders massenhafte Anhïufung des edlen Cascalho und auch einen ungewöhnlichen Reichtum desselben an Diamanten. Diese Stellen werden natiirlich besonders eifrig aufgesucht und ausgebeutet. In deu Flubbetten sind nämlich da und dort dureh die Gewalt des stïrzenden Wassers mehr oder weniger tiefe Lïcher von runder zylindrischer Form in das anstehende feste Gestein eingebohrt, die nach ihrer ganzen Erscheinung nichts anderes sein können als 


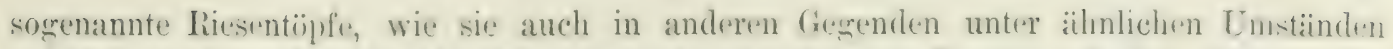

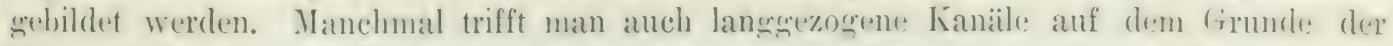

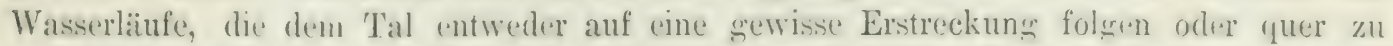
demselhen verlaufen. Sie werden zuweilen als „unterirdische Cañons" bezeichnet. Diese finden sich an stellen, wo das Wasser über besonders weiche Gestrinsschichten hinstrüntr,

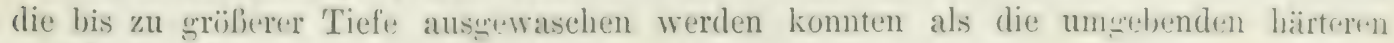
und festeren.

Solche stärker ausgetieften stellen, die manchmal nur klein sind, manchunal aber auch eine bedeutende Ausdehnung haben, sind es num, die vielfach mit besonders vielem und diamantenreichem ('ascalho ausgefüllt sind. Nan hat einmal in einem einzigen solehen Loch von geringen Dimensionen in dem Ribeirão do Inferno, der bei Dianantina in dem Jequetinhouha geht, sono bis 10000 Karat Diamant gefunden, wälırend das umgebende Flubbett arm war, und im Rio Pardo haben vier Neger in einem der kleinen Késel, die man als calderoes bezeichnet, in vier Tagen cine Ausbeute von 150 Karat gemacht. Auch die drei Cruben, die eine Zeitlang im Jeruetinhonha besonders ertragreich waren, die von S. Antonio und Canteiras oberhalb und die von Acaba Ifundo unterhalh der Einmündung des Ribeirão do Inferno, bauten auf solchen Vertiefungren; hier sind es aber langrezogene Kanäle der erwähnten Art. unterirdisehe Cañons.

Die Gehängeablạe rungen (Gupiarras der Brasilianer) sind meist ron geringerer Ausdehmung. Sie bestehen aus denselben Materialien wie die Lagerstätten in den Tälern, und der Diamant wird auch ron denselben Mineralien begleitet. Die Masse wird hier cleichfalls Cascalho, aber auch zuweilen frorgzulho genannt, duch ist der letztere Name hauptsäichlich für das Material der Plateauablagerungren gebräuchlich. Auch die Gehängeablagerungen folgen den Wasserläufen; sie liegen jedoch über den Hochwasserstande derselben an den Talgehängen, an denen sie meist etwas vorspringende Terrassen bilden. Solche trifft man nicht selten in einem und demselben Tal zu mehreren in rersebiedener IIöhe ïbereinander, so dalj die Flïchen der Terrassen unter sich und dem Talboden parallel laufen.

Das Material ist hier viel weniger abgerollt als unten im Tal. Man findet im allgemeinen, daf die Abrollung um so stärker ist, je tiefer die Terrasse an dem Talabhange liegt, und in jeder einzelnen Terrasse, je weiter man darin flußabwärts geht. Dieselben Täler, die an den Abhängen Gehängeablagerungen führen, sind auf dem Grunde ron Flubablagerungen erfüllt, die rom Wasser bedeckt werden; diese zeigen dann den hüchsten Grad der Abrollung. Danach können Kundige das Material der Gehänge- un! der Flufablagerungen auch in kleineren Proben meist mit Sicherheit unterscheiden.

Der Cascalho ruht an den Gehïngen, meist nicht unmittelbar auf dem festen Fels: er ist in zahlreichen Fïllen unterlagert ron einer gew ühnlich nicht sehr dicken Schicht feineren. mit Ton gemengten Sandes von verschiedener Farbe, dem sogenannten Ba rro. Iieser enthïlt ebenfalls Diamanten und geht allmählich und ohne scharfe Grenze in den eigentlichen Cascalho über. Der Barro ist jedoch stets deutlich geschichtet, während der Cascalho jeder Art niemals eine Spur von Schichtung zeigt, an den Gehängen so wenig wie anf dem Grunde der 'Tïler. Bedeckt ist die Masse vielfach, aber nicht immer, von einer Lage roter, lebmiger Erde.

Die Menge der Diamanten ist in dem Cascalho der Gehänge meist eine geringere als in dem der Flubbetten, dagegen findet man in dem ersteren, entsprechend dem schon oben erwähnten, verhältnismäßjig mehr größere und weniger abgerollte Steine als in den letzteren.

Die Plateauablagerungen finden sich an sehr zahlreichen Stellen auf den Ḧ̈hen ron Diamantina und in den anderen Diamantenregionen ron Minas Gerä̈s. Viele von 
ihnen haben frïher reichen Ertrag sebracht. Auch jetzt werden noch manche bearbeitet, doch stehen sie an Wichtigkeit hinter den Flußablagerungen zuriick.

Auf den Höhen ron Curralinho (Fig. 43) zwisehen dem Jequetinhonha und der Stadt Diamantina liegen in ungeführ istlicher Richtung von dieser die reichen Gruben Bom Successo und besonders Boa Tista. Anf dem Plateau siidwestlich von der genannten Stadt, welche das Flubgebiet des Rio Pinheiro von dem des Rio Pardo pequeno trennt, sind die Gruben ron La Sopa und Guinda im Gange, wo sogar zwei diamantenfülurende Ablagerungen, eine :iltere und eine jüngere, übereinander angetroffen wurden.

In derselien Richtung noch etwas weiter, 12 engl. Meilen westlich von Diamantina, liegt im Ursprungsgebiet des Caéthé Mirim und des Pinheiro die besonders merkwürdige Ablagerung von Sàn Joào da Chapada, die unten noch näher besprochen werden soll. Etwas südlich ron hier stölt man auf die früher ertragreichen Gräbereien von La Chapada im (Quellgebiet des Rio Ouro Fino, und damit ist die Zahl auch nur der bedeutenderen Ablagerungen dieser Art noch lange nicht erschöpft.

Was die Beschaffenheit der Plateauablagerungen anbelangt, so bestehen viele derselben wieder im allgemeinen aus dem nämlichen Material wie die andern. Doch spielen in sehr bezeichnender Weise unter den Begleitmineralien eine viel größere Rolle die spezifisch schweren, die das fließende Wasser weniger gut bewegen konnte, und die daher liegen blieben, während die leichteren weggeschwemmt wurden. Es sind namentlich die Titanoxyde (Titanfavas), die Eisenoxyde usw. neben den Quarzmineralien, die auch hier in größter Menge vorhanden sind. Die Masse wird hier nur Gorgulho genannt. Es sind meist horizontale Schichten, gebildet in der Hauptsache von groben Brocken der umgebenden Gesteine und einer roten mehr oder weniger tonigen Erde. Darin lieg'en die IBegleitmineralien des Diamants und dieser selbst so versteckt, daß sie erst nach dem Waschen zum Vorschein kommen, da die Erde alles gleichmäßjig ïberzicht und färbt. In den anderen Ablagerungen sind sie ohne weiteres deutlich sichtbar, da hier die Natur schon einen Waschprozef voronommen hat. Mineralien sowohl als Gesteinsbrocken sind im Goreulho gar nicht oder sehr schwach abgerollt, namentlich sind an den Diamanten sellost ihre scharfen Kanten und Ecken noch vollkommen erhalten und die Flächen zeigen ihre ursprüngliche natürliche Beschaffenheit.

Die Menge der Diamanten und der mit ihnen zusammen rorkommenden Mineralien ist hier an geringsten, dagegen findet man in den Plateauablagerungen größere Steine verhältnismäßig an häufigsten. Die Diamanten sind manchmal so verteilt, daßs sie in gröberer Menge in kleinen Nestern zusammen liegen, die schon bis zu 1700 und 2000 Karat greliefert haben, während der umgebende Gorgulho auf größere Erstreckung gar nichts oder nur sehr wenig enthält.

Unter dem diamantenführenden Gorgulho, unmittelbar auf dem anstehenden Gestein, liegt meist eine Tonschicht, die ebenfalls sparsam Diamanten einschließt. Bedeckt ist er wie in den Gehängeablagerungen mit einer diamantfreien Lage roten Tons von verschiedener Dicke, die indessen stellenweise auch fehlt. Dann bildet der Gorgulho unmittelbar die Erdoberfliiche, so daß oft Diamanten unter den Pflanzenwurzeln gefunden werden. Es wird erzïhlt, reiche Lager seien dadurch entdeckt worden, daß beim Ausreißen von Pflanzen einzelne Steine in den Wurzelballen mit zutage kamen; auch sollen Hühner Diamanten ausgescharrt und Kinder, an der Erte spielend, solche gelegentlich gefunden baben.

Ganz eigentiumlich und stark alıweichend liegen die Verhältnisse an anderen Orten auf den IÏ̈hen, so namentlich bei São João da. Chapada auf dem Plateau von Diamantina, $20 \mathrm{~km}$ westlich ron dieser Stadt. Die Grube liegt auf der Wasserseheide zwischen dem Jequetinhonha und dem Rio das Velhas, auf der geraden Fortsetzung einer 
Linie, die die wichtigen Ablagrerungen bei Boa Vista auf den IÏ̈hen von Curralinho und ron La Sopa (Fig. 43) miteinander verbindet. Die Entdeckung geschah in Jahre 15.3.3; (in auscredehnter Betrieb) hat lïngere Zeit stattgefunden, ist aber wegen Armut an Diamanten allmählich immer schwieriger geworden und hat später ganz aufgehört. Trotzdem ist die Stelle immer noch von grofer wissenschaftlicher Bedeutung, da lier wichtige Anhaltspunkte für die Beurteilung der Frage nach dem urspriinglichen Muttergestein, der primären Lagerstiitte der Diamanten jener Gegend gewonnen worden sind.

Der Ilamant findet sich hier in einem deutlich geschichteten Tone ron verschiedener Farbe, der mittels eines $40 \mathrm{~m}$ tiefen, 60-80 $\mathrm{m}$ breiten und $500 \mathrm{~m}$ langen Grabens orler Einschnits, ähnlich einem tiefen Eisenbahneinschnitt, durch den Abbau allmählich aufgeschlossen worden ist. Die Tonschichten sind steil aufgerichtet und unter j()" nach Osten geneigt. Bearleitet werlen sie von Itacolumitbänken, zwischen denen sie regelmäbigr und konkordant, d. h. mit srleicher Schichtenneigungr, eingrelagert sind. Alle diese Schichten, Ton sowohl wie Itacolumit, sind durchsetzt von zahlreichen kleinen Gängren, deren Ausfïllungsmaterial zum größten Teil aus (Quarz. (Bergkristall) mit Rutil und Eisengrlanz besteht.

Die Menge der Diamanten, die aus dem Tone gewonnen wurden, war sehr wechselnd, im sroßen und granzen war das Lager arm. Zwar berichtet Tschudi, der die Stelle 18 (i) besuchte, dalb in seiner Gegenwart in zwei Stunden 41 Karat gewonnen wurden, bei einer anderen fielexenheit hat man aber in 12 Tonnen des Tones nur zelın kleine Steine sefunden. Die Begrleitmineralien sind dieselben wie sonst und namentlich die drei oben genannten, daneben die anderen Eisenoxyde und Titanmineralien, ferner Turmalin usw, alles wie auch der Ijiamant sellst im allgemeinen spärlicher als im gewöhnlichen Cascallo und Gorgulho. Bemerkenswert ist, da\}, wo viele Exemplare von jenen Mineralien vorhanden waren, sich auch zahlreiche Diamanten einstellten, daß dagegen, wo jene sparsam waren oder fehlten, dies auch bei dem Diamant der Fall gewesen ist.

Alle diese Mineralien sind vollkommen scharfkantig und eckig, ohne eine Spur von Abrollung durch fließendes Wasser. Dies gilt für den Diamant selbst wie für alle seine Besleiter, auch für die allerweichsten, denen die geringste Bewegung ihre scharfliantige Begrenzung geraubt haben würde.

Diese Umstände führten Orville $\Lambda$. Derby und Gorecix, die das Lager eingehend untersuchten, zu dem allerdings nicht unbestritten gebliebenen Schlusse, daß hier der Diamant noch da liegt, wo er gebildet worden ist. Sie nehmen an, daf dies in den die Schichten durchsetzenden Quarzg̈̈ingen der Fall gewesen ist, in denen man zwar an dieser Stelle nie einen Diamant selbst, aher dessen Begleitmineralien in großer Menge gefunden hat. Das stete Zusammenvorkommen dieser Mineralien mit dem Diamant in der angegebenen Teise hier wic üherall sonst in Minas Geraës sprricht auch in der Tat dafür, daß sie alle den sleichen Ursprung und dieselbe Entstehung haben, und der Umstand, daß der Diamant hier in den Gängen nicht direkt neben seinen Begleitern beobachtet worden ist, kann bei der ïulbersten Seltenheit des Edelsteines nicht als Grund dagegen angesehen werden. Die Tone, in denen er liegt, sind die Verwitterungsprodukte der Gesteine, in denen die Gänge ursprünglich aufsetzen. Diese sind der Zerstörung und Zersetzung an Ort und Stelle ebenfalls zum Teil unterlegen, wie das mit den umgebenden Schiefern der Fall war, und dadurch wurde der Inhalt der Günge, der Diamant und seine Begleiter, dem aus den Schiefern enstandenen Tone beigemengt.

Große Ähnlichkeit mit der eben betrachteten Ablagerung von São. Toão scheint auch die von Cocaës bei Ouro Preto zu haben. Die Diamanten liegren hier auf einem aus Itacolumit bestehenden Plateau von ca $1000 \mathrm{~m}$ Meereshöhe. Der Itacolumit überlagert Glimmerschiefer, dieser Gneisgranit. Begleitmineralien des Diamants sind: Quarz, Titan- 
eisen, Anatas. Rutil, Magneteisen, Eisenglanz, Martit, Turmalin, Monazit, Cyanit, Fibrolith und Gold. Die drei zuerst genannten herrschen vor; von ihnen allen ist nur der Quarz abgerollt. Der Diamant mit seinen Begleitern tritt strichweise auf, und diese Striche sind von Ost nach West gerichtet. wie zahlreiche, Gold und die anderen genannten Mineralien führencle Gänge in Minas Geräis, so dals auch hier eine Abstammung des Diamants und seiner Gefährten aus solehen Gängen für wahrscheinlich gehalten wird.

Wieder anders sind die Verhältnisse bei Grão $\mathrm{Nogol} \mathrm{im}$ Bezirk Minas Novas. Die Stadt liegt im äufersten Norden des Staates Minas Geraës in einer Gegend, die als ein Teil der Surra do Espinhar:o anzusehen ist, 350 Kilometer nordöstlich von Diamantina am linken, nördlichen Ufer des R. Jequetinhonha. Hier sind aulier im normalen Gorgulho auch in einem festen konglomeratischen Sandstein mit viel grünem Glimmer besonders auf den Schichtflïchen J)iamanten gefunden worden. Nach manchen Nachrichten soll es ein einziger ungeheuerer isolierter Sandsteinblock sein, nach andern hat das diamantenführende Gestein eine Austehnung von 300$)$ bis 400 Meter. Namentlich in den dreißiger und vierziger Jahren wurde diese 1833 entdeckte Lagerstätte ausgebeutet, indem man mit Pulver Stïcke absprengte und diese weiter zerkleinerte. Fast sämtliche Sandsteinstiicke mit eingreschlossenen Diamantkristallen, die sich, allerdings sparsam, in den Sammlungen finden, stammen dorther; sie sind auch zum Teil gefälscht durch künstliches Einsetzen von Diamantkristallen in das Gestein, aber das Vorkommen ist zweifellos verbürgt.

Friiher wurde dieser diamantführende Sandstein für echten Itacolumit gehalten, und manche Geologen tun dies noch jetzt. Sie haben danach die Ansicht ausgesprochen, daf hier das Torkommen des Diamants im urspriinglichen Muttergestein zu beobachten und dab er ein Bestandteil des Itacolumits sei, wie jedes der diesen zusaumensetzenden Quarkörner usw. Neuerer Zeit ist aber wahrscheinlich gemacht worden, dab dieser Sandstein gar kein Itacolumit ist, sondern dab er zu dem sogen. jüngeren (2uarzit gehört, ron dem wir oben (S. 157) gesehen baben, daß er an der Serra do Espinharo den echten Itacolumit usw. diskordant bedeckt. Er würde also ein, wenngrleich :̈ulierlich ähnliches, doch geologisch versehiedenes und wohl viel jüngeres festein darstell'n und wäre wohl anzusehen als ein durch Verwitterung zerfallenes diamantführendes Gestein, dessen Bestandteile nachher wieder zu einem festen Gestein rerkittet worden sind.

betrachtet man diese sämtlichen Ablagerungen des Diamants in Zusammenhang, so sicht man, daf sie alle verschiedene Stadien eines und desselben immer weiter fortschreitenden Bildungsvorganges darstellen.

J'ei Śão Joào da ('hapada und an manchen anderen Orten oben auf den Plateaus liexen dir. Diamanten noch an der Stelle und in dem Gestein, in dem sie entstanden sind, nur ist dieses durch Verwitterung zerstört und, wenigstens zum Teil, in eine weiche tonige

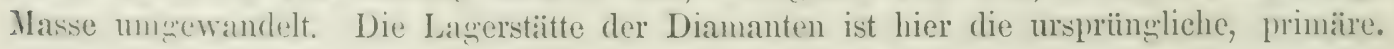

Die anderen Plateauahlagerungen mit ihren kaum oder doch nur wenig ahererollten Gesteinsmassen mïssen entstanden sein, als sich in früheren Zeiten die Wasserliufe erst wenig in die Ilochfliichen dinecenagt hatten, als demnach die heutigen Täler noch nicht existierten. I)as Wassel hat zwar den I)iamant und seine Beweleiter aus dem verwitterten Muttergestein, we es bei siar Joaio noch jetzt rorlicgt, herausgelöst und z. T. an ancleren Stellen wieder al)gelagert, alux der Transport esechah nicht auf grolie Entfernung, wie eben die selur geringe Abrollung beweist, und die Wiederablagerung erfolgte wahrseheinlich auf dem (irunde flacher serartiger Wasserbecken, in denen das Material seine Schichtung erlangete. I)ie I) iananten und ihre Bergleiter finden sich also an solehen Stellen auf ihrer zweiten, sekundären Lagerstätte. 
Als dann im Laufe der Zeiten die Wasserläufe sich immer tiefer in das Plateau rimnarten und allubihlich de: hentigen Talrinnen entstanden, bildeten sich zuerst die Gehängeablagerungen, deren Material zum Teil den ursprïnglichen Lagerstätten, zum Teil aber atuel den stekundioren Platrauablagerungen entnommen wurke. Die Diamanten, dis sich in den Gehïnceablatgrmugen finden, haben also wengstens teilweise zum zweiten Male ihre Lagerstätten sewechselt. Das Material arfuhr einen weiteren Transport rlurch dats Wasser und zeiet infolgedesing stärkert Abrollung. Die Täler wurlen mehr und

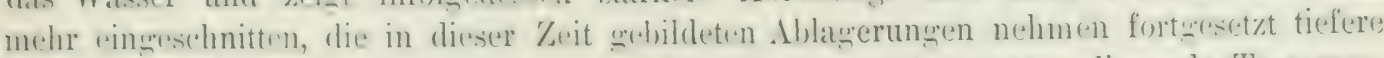
Yiveaus an den Talwehöngen ein und bilden immer weiter unten limende Terrassen, Dabei sehritt die dhrollung um su stïrker vor, je mehr die Massen in die Tiefe rïckten, his endlich dex Grund der hentigen T'iiler exreicht war, wo sich das am meisten abogeschliffene Traterial als Talablagerung absetzte und noch absetzt.

Fassen wir im folgenden die zum Teil schon oben erwälnten Angaben über das ursprïngliche Vorkommen des Diamants in Minas (ieraës zusammen, so ererilt sich das Nachstehende.

Dalf der Diamant im Lrsprungserelnet der oben wenannten Flüsse zu Ianse ist, seht man daraus, dali sie alle. soweit sie ïherhaupt I) iamanten führen. in der Xïhe der ILöhen-

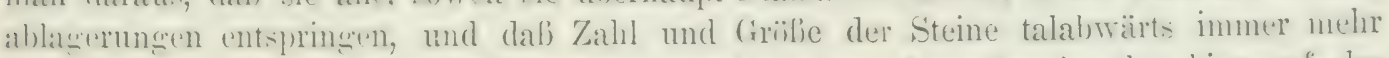
mul medr abminmt. his -in endlicle ganz rerschwinden. Das Gestein, das hier auf der

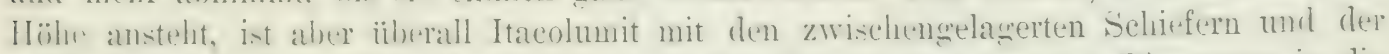
J)ekr ron jünerem Quarzit. Ietzterer ist das frestem, atus dem die Diamantem in die Schutmassen gekommen sein miissen. Dies wird bestïtigt durch die selom an Anfang

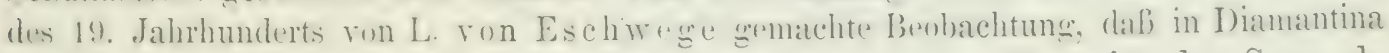
nur diejenigen Flïsse usw. Diamanten führen, die an der Westseite der Serra do

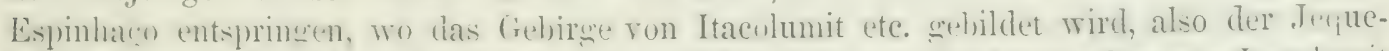
finhonha und die anderen when genamnten, während die am Ostabhans, ferm ron Itacolumit im Cineis. (ilimmersehiefer nsw. ilnen Lrsprume nehmenden Wasserläufe, wie der livo Duce: und sime Zuflüsie: kedine Sjut von Diamanten enthalten. Trir haben diese Tatsache schon olen mitereteilt: sir erliärt sich dadurch, daf diese Fliisse nieht die diamantenführenden, sondern nur diamantfreie Gesteine durchfließen.

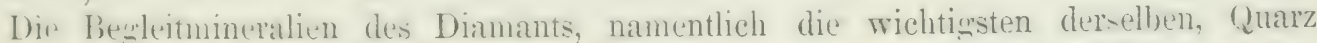
(Berekristally, di: Lisen- und Thitanmineralien, Turmalin usw. kommen nur auf den Cäingen ror, die jene Gesteine durchsetzen und die rorzugsweise von Quarz ausgefüllt sind. Sehom der T montand, dafi der Liamant stets mit diesen Mineralien und nur mit

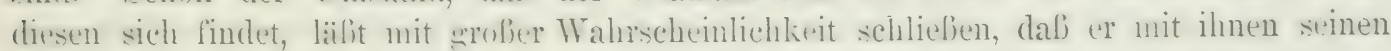
urspriinglichen Ort ebenfalls in den Gängen hat, wie zuerst Gorceix betonte. Dieser Schluf wird noch weiter erstiitzt dadurch, daff viele brasilianische Diananten auf das

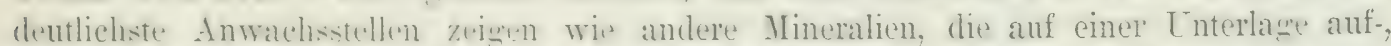

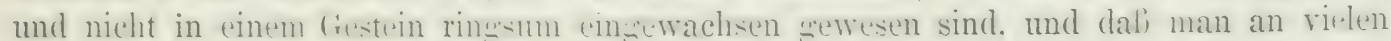
die Eindriicke von Quarzkristallen sieht, auf die sie aufgesetzt waren. Wir werden hierauf unten, bei der beschreibung der brasilianisehen Diamanten, noch eimmal zurïckkommen. Ferner finclet man Diamanten in Quarzkristallen oder in Anatas oder Eisenglanz ein- und an solchen angewachsen, was kaum anders als durch

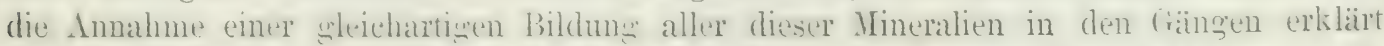
werden kann. Encllich berichtet forceix sowar, dalj an einigen Stellen Diamanten in den Gängen sellst angetroffen worden sind nud daf sie darin ausegebentet wurden, aller-

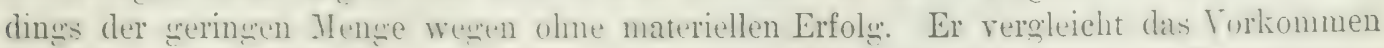
des Diamauts mit dem der wellen Topase bei Ouro Preto, die ganz sicher auf Quarzeringen in zerstzten Schiefern liegen, ein Vorkommen, das wir noch kennen zu lernen haben. 
Der Diamant wäre danach also in jenen Gegenden im Gegensatz zu anderen Fundorten, wo er als urspringlicher Gemengteil in kristallinischen Urgesteinen auftritt, ein Gangmineral, eine Ansicht, die aber freilich keineswegs allgemein geteilt wird.

Die Gewinmung der Diamanten ist in den erwähnten Ablagerungen je nach deren besonderen Verbältnissen etwas verschieden. Jede Diamantgewinnung wird in Brasilien "servico" genannt, und man unterscheidet, je nachdem diese in einer Fluß-, Gehänge- oder Plateauablagerung stattfindet, serviros do rio, servicos do campo und servicos da serra. Seit den frühesten Zeiten hat sich in dem angewendeten Verfahren wenig greändert; die Arbeiter waren und sind wohl noch meistens Neger, früher als Sklaven, seit Aufhebung der Sklaverei als Freie gegen Lohn tätig.

In den servicos do rio, in denen die Diamanten der Flußablagerungen gewonnen werden, muß das Wasser des betreffenden Flusses abgeleitet werden, damit man zu dem Cascalho gelangen kann. Man gräbt dem Flusse auf die meist kurze Strecke, die auf einmal abgebaut werden soll, ein neues Bett, oder man legt der Länge des Flusses nach einen Damm hinein, der die ganze Wassermasse zwingt, sich auf die eine Hälfte des Bettes zu beschränken; oder man leitet auch wohl das Wasser in hölzernen Kanälen ab. Aus dem trocken gelegten Teile des Bettes wird dann der edle Cascalho nach Entfernung: der iiberlagernden Schicht tauben Schuttes herausgegraben und außerhalb des Flußbettes, aber in dessen Nähe, angehäuft.

Der lose diamantführende Cascalho läßt sich leicht ğewinnen, die Konglomeratmassen der Canga sind aber oft so fest, daß sie mit Pulver gesprengt werden müssen, was die Arbeit sehr bedeutend erschwert, verzögert und verteuert.

Alle diese Gräbereien können nur in der trockenen Jahreszeit vom Mai bis Ende September ausgeführt werden, wenn die Wassermasse der Flüsse gering ist. In diesen Monaten wird so viel als nur irgend möglich von cem diamantführenden Cascalho gewonnen und an höher gelegenen Stellen, doch in möglichster Nähe der Bäche und Flüsse in Sicherheit gebracht. In der nassen Zeit steigt der Wasserspiegel oft sehr rasch und sehr hoch, so daß alles überflutet wird und keine derartige Arbeit möglich ist. In dieser Jahreszeit wird aber dann der früber ausgegrabene Casealho verwaschen, um aus ihm die Diananten zu gewinnen; eine solche Wäscherei wird von den Brasilianern eine Lavra genannt.

Bei den Terwaschen des Cascalho werden zuerst die gröbsten Gesteinsbrocken aus der Masse ausgrelesen oder durch Siebe von dem feineren Material getrennt. Aus diesem wird dann in besonderen Holzschiisseln, die den Namen Batêa fülıren, der feinste Ton und Sand durch Abschlemmen getrennt und aus dem Rückstande werden die Diamanten unter fortwährendem Schwemmen im Wasser mit der Hand ausgelesen. Die Arbeiter besitzen dabei eine ganz ungemeine Geschicklichkeit im Erkennen auch ganz kleiner zwischen den andern zurïckgebliebenen Mineralkörmern liegender Diamanten, die auch ein sonst geülotes Auge leicht übersehen würde.

Die Tïtickeit in einer brasilianischen Diamantenwäscherei ist auf Tafel VI dargestellt. Die Nerger links stehen in einem Bache und verarbeiten mit ihrer Batêa den Cascalho. Wenn eine Portion erledigt ist, holen sie sich neuen Vorrat aus den an beiden Ufern des Baches liegenden Massen, wie die Neger auf der rechten Seite, die teils den aufgehäuften Cascalho losgraben, teils die grefüllte Batêa zum Bache heranschleppen. Die ganze Arbeit steht unter scharfer Kontrolle, wie die peitschenbewaffneten Aufseher zeigen, die die Arbeiter zum Fleilße anspornen und Diebstahl gefundener Diamanten möglichst verhindern sollen. Zum letzteren Zwecke ist auch die Kleidung der Neger so leicht als mö̈glich. Wenn einer von diesen in seiner Batêa einen Stein sieht, sibt ex durch Erheben 


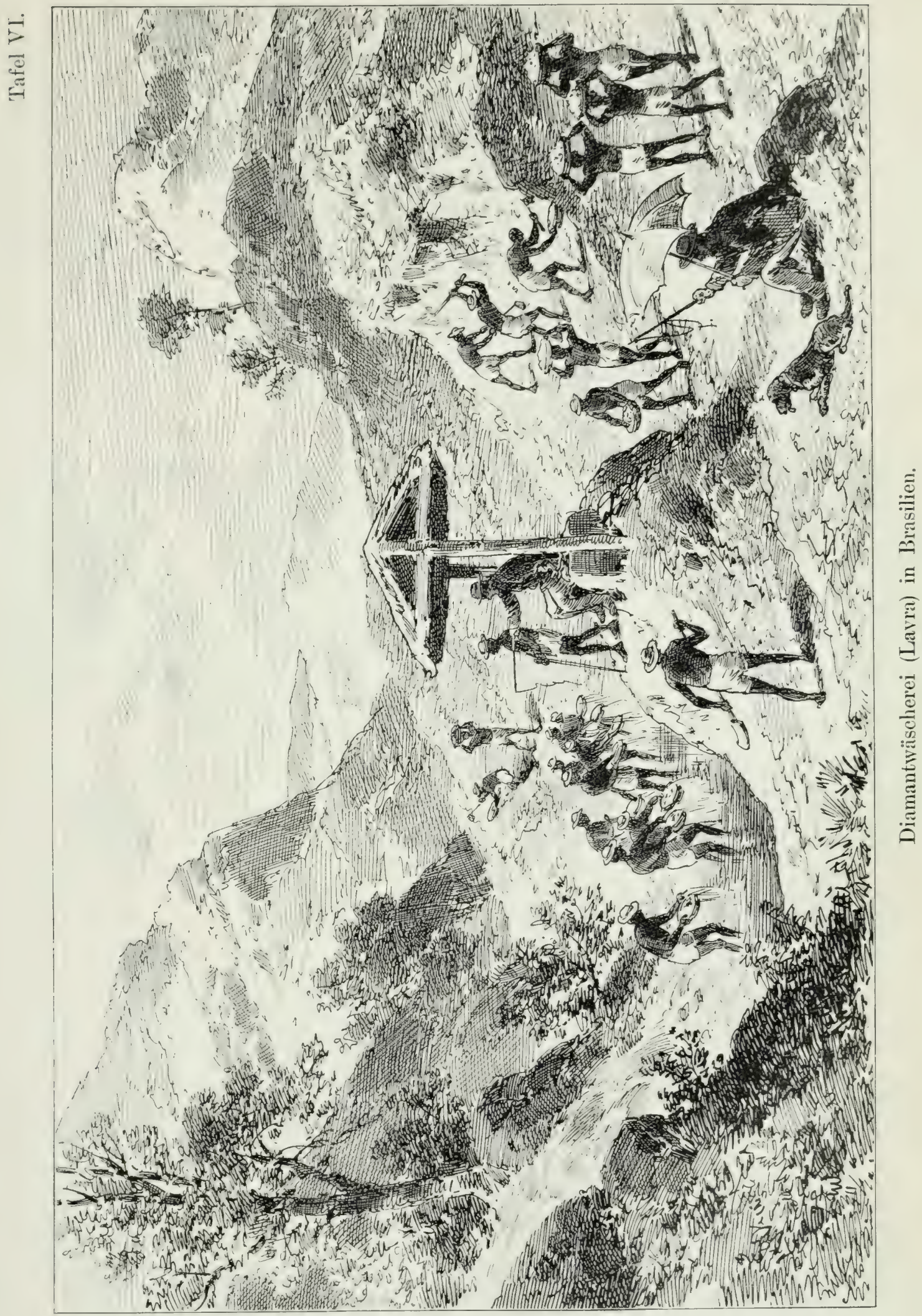



der Hand ein Zoichen, worauf ein Aufseher den Stein an sich nimmt. Die Peitschen der lotzteren zoigen, dab man es mit einer Darstellung der früheren Zustände zu tun hat aus der \%oit, wo die Sklaverei noch bestand. Jetzt nach Abschaffung derselben sind wohl dir l'eitschen verschwunden, im übrigen hat sich aber sicherlich an dem sanzen Treiben wenig geändert.

Die servicos do eampo an den Talgehängen über dem jetzigren hö̈chsten Wasserspiestel kïmnen zu allen Jahreszeiten betrieben werden, da hier das Wasser der Flïsse kein IIindernis bictet. Die den Casealho bedeckenden Ton- und Erdmassen werden entfernt, indem man einen nahen Bach ïber die Masse leitet, der alle diese leichteren Teile fortschwemmt, so dab die diamantführende Schicht dann unmittelhar zutage liegt. Da die Jäiche meist nur in der nassen Jahreszeit genïgendes Wasser haben, so ist im allgemeinen für diese Arbeit die Regenzeit vorzuziehen. Der gewonnene Cascallı, wird dann in :̈hnlicher. Weise wie bei den serviros do rio verwaschen und die Diamanten aus dem Rückstande ausgelesen.

Auch beim Abbau der Plateauablagerungen in den serviços da serra wird die Entfernung dex den Gorgulho bedeckenden tauben Sand- und Erdmassen durch fliefendes Wasser bewirkt. Da auf dem Plateau aber natürliche Wasserlüufe mit dem nötigen Gefïlle meist fehlen, so werden kiinstliche Sammelbecken angelegt, in denen das Regenwasser zuriickgehalten und aufgestaut wird. Den Inhalt dieser Becken leitet man dann in hölzernen Rinnen an die geeigneten Stellen und legt auf diese Weise die diamantführende Schicht so gut als möglich bloß, indem man die Sammelbecken immer wieder von neuem fïllt und auslaufen lïßjt. Aus dem Gorgulho werden auch hier wieder die Diamanten durch Waschen und Auslesen gewonnen.

In der arsten Zeit nach der Entdeckung der Diamanten in Brasilien erteilte die portugiesische Regierung die Erlaubnis zum Graben jedem Unternehmer gegen ein gewisses Kopf@eld für den einzeln arbeitenden Sklaven, deren Zabl kontraktlich beschränkt war. Diese Abgabe wurde immer weiter in die Höhe geschraubt, bis sich niemand mehr fand, der unter solchen Unständen arbeiten lassen wollte. Dann wurde von 1740 ab die Gewinnun konzessionierten Unternehmern gegen feste Pacht überlassen, aber die Regierung erzielte infolge von vielfachen Betrïgereien keine gïnstigen Resultate. Daher ïbernahm sie die P'roduktion ron 1772 an selbst und fuihrte sie auf eigene Rechnung bis zur Lostrennung Irasiliens von Portugal. Die besten, schönsten und größten und nach irgend (iner Richtung interessanten Steine wurden dem in Lissabon aufbewahrten portugiesischen Kronschatze einverleibt, so dafo dieser ein Sammlung von Diamanten enthält, die in der Welt einzig dasteht. Die grobe Masse der Ausbeute wurde an Händler verkauft und über Rio de Janeiro und Bahia nach Europa ansgeführt.

Teben der gesetzlichen Produktion her ging aber namentlich in früheren Zeiten eine sehr schwunghafte ungesetzliche durch die sogenannten Schleichhändler (damals garimpeiros genannt), die trotz der drakonischen Strafgesetze, gelockt durch den in Aussicht stehenden hohen Gewinn, im geheimen nach Diamanten suchten und den Sklaven der gesetzlichen Unternehmer verheimlichte oder gestohlene Steine abkauften. Die Menge der durch Schleichhandel gewonnenen und in den Verkehr gebrachten Diamanten sollte nach manchen Angaben, die natiirlich immer auf unsicherer Schïtung beruhen, der Nenge der auf gesetzlichem Wege gewonnenen mindestens gleichkommen. Namentlich sollen die Schleichhändler mehr grobe und schöne Steine gehabt haben als die ehrlichen, da nur bei solchen das Beiseitebringen für den Sklaven und das Risiko für den Händler lohnend war. Von anderer Seite wird dem Schleichlandel allerdings keine so große Bedeutung beigemessen, doch scheint allgemein der unerlaubte Handel bessere Geschäfte gemacht zu haben als die mit hohen Produktionskosten belasteten legitimen Produzenten. 
Seit 15:34, dem ersten Jahre der Selbständigkeit ron Brasilien, ist das frühere Diamantenmonopol der Regierung vollständig aufgehoben. Jeder kann seitdem Diamanten graben, wo und so viel er will, er hat nur eine geringe, ron der Größe der bearbeiteten Fläche abhängige Ahgabe an die Regierung und 25 Prozent des Rohertrags an den Eigentümer des Bodens zu zahlen. Auferdem wird ein Ausfuhrzoll von $1_{12}$ Proz. des Wertes der ausgeführten Steine erhoben.

I) Te Texersklaven, in deren Hünden früher die ganze Produktion lag, standen bei der Arheit unter der schärfsten Aufsicht, die aber den Diebstahl nicht zu beseitigen vermochte. L'm ilıren Eifer anzuspornen, erhielten die Arlociter für das Auffinden gröberer Steine besondere Belohnungen. Ein Sklave, der einen 17:2 Karat schweren Diamant fand, wurde früher, als tie Sklavenpreise niedrig waren, in Freiheit gesetzt, später nicht mehr. Andererseits wurden Sklaven, die Diamanten reruntreuten, mit barbarischen Strafen belegt. Die Arheit war wesentlich Handarbeit, der Cascalho wurde in Körben aus den Flußbetten locrausuretragen usw., wie dies schon oben bei der Betrachtung des Bildes auf Tafel VI Seite 196 geschildert wurde. Selten suchte man durch Maschinen das mühevolle Geschäft zu erleichtern, doch geschicht dies in der Neuzeit immer mehr durch europäische Geseilschaften. Indessen findet man auch heute häufıg im wesentlichen noch dieselben j)rimitiven Einrichtungen, da der Transport größerer technischer Vorrichtungen bei der Abgelegenheit und schweren Zugänglichkeit jener Gegenden enorme Kosten verursacht. Die Handarbeit kommt daher vielfach immer noch billiger zu stelen, um so mehr als die Maschinen selten lange an einem Platze bleiben künnen, da die einzelnen Gewinnungsorte ziemlich rasch ausgebeutet zu sein pflegen. Das Geschäft der Diamantengewinnung ist nur unter ausnahmsweise günstigen Umständen sehr lohwend, da die Kosten sehr hoch und auch jetzt noch die Verluste durch Veruntreuung bedeutend sind.

Als die ersten brasilianischen Steine in den II andel kamen, wurden sie ron dem Publikum nicht gïnstig aufgenommen. Es wurde zuerst behauptet, es seien gar keine Diamanten, oder es seien schlechte Steine, die eigentlich aus Indien stammten. Daher wurden anfänglich viele brasilianische Diamanten nach den portugiesischen Besitzungen in Indien, namentlich nach Goa geschickt und von dort aus als indische Steine in den Ilandel soluracht. Die Hollïnder wuliten sich diese Verhältnisse zu nutze zu machen und durch besondere Turträge ein IIonopol für den IIandel mit brasilianisehen Diamanten zu crlangen, die ron Rio de Janeiro und ron Bahia aus direkt nach Amsterdam geschickt wurden. Später sing die sanze Ausbeute infolge von Staatsverträgen mit der englisehen Tiegrierung nach London. In der neueren Zeit sind es hauptsächlich große französische Handdelshïuser, die den Diamantemmarkt in Brasilien beherrschen und die Diamanten über Paris in den Verkehr bringen.

In vorstehenden wurden vorzugswelse die Verhältnisse de's Staates Minas Gerä̈s und namentlich die des IIauptdiamantenbezirkes Diamantina geschildert, der allein mehr Diamanten geliofort hat als das übrigge Brasilien zusammen. Die Staaten. in denen atulerdem noch Liamanten exefunden werten, sind schon oben erwähnt; sie sind im allemeinen, Bahia auswenommen, viel weniger genau bekannt als die Umenegend ron Diamantina, anch ist die f'rodulition hier weit geringer gewesen als in Minas Geraës und bahia und hat jetzt wahrscheinlich überall sanz aufgrehört, deshall) sollen hierüher nur kurze Angaben gemacht werden.

In dem itate S. Paulo, südlich ron Minas Geraïs, hat man in den Flüissen, die den Iio Paraná zuströnen, Diamanten gefunden. Weitere Fundorte sind: Patrocinio de Sapucahy, Rio Canoas und Ituverava.

Der Statat Paraná hat vorzunsweise in Flubsebiet des Rio Tíbagy Diamanten seliefert. Diesur, ein Nebenfluß des lío l'arapanema. der in den l'araná fällt, durehströmt 
die (ampos von Guarapuavas. Nieht nur er selbst führt I bamanten, sondern auch seine

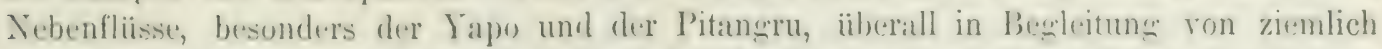
viel Gold. Auch in diesen Flüssen haben sich lokal kessel- und kanalartige Ventirfuneren des Beftes als hesonders reich erwiesen. Diamantfïhrende Ablagerungen hat man in dieser

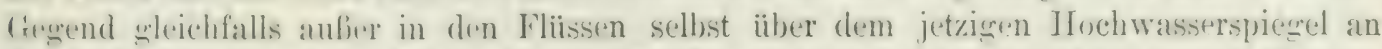
den Talabhängen und auf den Hähen gefunden. entsprechend den Gehänge- und I'latrauahlagerungen in Minas Graë. Die Entdeckung der Diamanten in Paraní geeschah durch cinen Zufall. Die steine, die gefunden wurden, waren durchweg klein; selten kamrn solche über einen Karat schwer vor, sie waren aber meist von guter Farbe und von groliem Glanz. Eine am Ende dies vorigen Jahrhunderts unternommene systematische Ausbeutung hat des geringen Ertrages wegen trotz des reichlichen Hitworkommens von

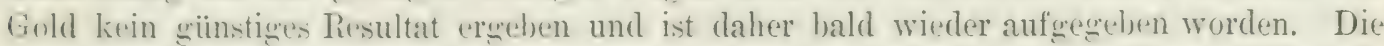
Strin. sollen hier aus deronischem Sandstein stammen, durch den die obengenannten Fliisse hindurchströmen.

Nach Westen zu in dem Staat Goyaz, auf der Grenze gegen Minas Geraës, wurden in den Fliissen Rio Verisimo bei Trahyras, Guritas, Guehre-Anzol, S. Marcos und Paranahyba Diamanten gefunden. Reich ist auch das (ied)iet lïngs dem Oberlauf des (irenzflusses Araguay erexen Mato Grosso, wo besonders der rechte Vebenfluli Rio Claro

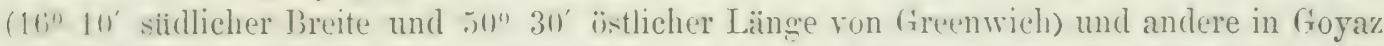
Erofe Schätz" geliefert haben. Die Gesamtmenge der im Rio (laro his zum Jahre 1950) gefundenen I)iamanten betrïgt 252001 Karat im Werte von S Millionen Mark.

Manche Fliisse in dem Staat Mato Grosso bis zur bolivianischen Grenze hin sind elenfalls mit Erfolg auf Diamanten untersucht worden und haben zum Teil eine reiche Ausherte anch gleichzeitig an Gold eroben. Die meisten Steine sind in der Xähe ron Diamantino (nicht zu verwechseln mit Diamantina, dem alten Tejueo in Minas fieraës) gefunden worden. in dem Lrsprungsgebiet des Paraguar und seiner Nebenflüsse, besonders des Rio ("uyabí auf seiner rechten Seite (15" 45 ' südlicher Breite und 56" üstlieher Lüngge ron Greenwich). I)ie ron hier stammenden Steine sind meist klein, aber zum Teil rom reinsten Wasser, viele allerdings anch gefürbt. sie sind mit einer sehr glainzenden Oberfläche rerselien, wie sie sonst hei hrasilianischen Diamanten nicht wieder vorkommt. Im Rio Coxim und Jauru werden Diamanten in Begleitung von Sapphiren wefunden. In Mato (irosso sollen lis 1550 im ganzen ungefähr 11916010 Farat in W'erte von 37 Millionen Mark gewonnen worden sein. Jetzt nach der Auflebung der Sklaverei wird wegen der zu hohen Löhne nur wenig gearbeitet, am meisten noch im Rio S. Anna grande.

Die geolowischen Verhältnisse ron Goyaz und Mato Grosso sind wenigh hekannt, doch wird rom licisenden angegeben, dab auch hier Itacolumit etc. verbreitet sei. Man kann also wohl annehmen, dafs das Torkommen des Diamants in diesen Staaten mit dem in Minas Geraës im wesentlichen übereinstimmt.

Der staat Bahia hat sich nehen Minas fierä̈s am diamantemreichsten erwiesen; während aber der letztere sich immer mehr ersehöjpt und im Ertrage zuriickgeht, sind in jenem erst neuerdings wieder reiche Lager gefunden worden, so dab die jührliche I'rodlulition jetzt in Bahia gröfer ist als in Minas Gerä̈s. Für die Gesamtmenge der gefundenen Diamanten von Anfang an ist dies aber noch lange nicht der Fall, da steht das alte Diamantina noch immer an der Spitze.

In Bahia sind schon im Jahre 1755 Diamanten gefunden worden, dhe Regierung verbot aber weitere Nachforschungen, damit die landwirtschaftlichen Terhältnisse dieser fruchtbaren Provinz nicht geschädint wïrden. Die Funde mehrten sich jedoch trotzdem; am Anfang des 19. Jahrhunderts wurde die Produlition nicht unwesentlich rergeröfert, und 
später hat gerade Bahia eine besondere Wichtigkeit erlangt und Minas Geraës im Jahresertrag überflügelt.

Die ersten Fundstellen waren auf der Ostseite der Serra da Cha pada und nördlich davon in der Serra do Assuâria, welche die nördliche Fortsetzung der den Bezirk von Diamantina und noch einen weiteren großen Teil von Minas Geraës durchziehenden Serra do Espinhaço bilden. Die Steine finden sich hier in Seifen, im Sande und Kiese der Wasserläufe. Die begleitenden Mineralien sind teilweise dieselben wie in Diamantina, namentlich kommen die dort wichtigsten, die Titanoxyde, Eisenoxyde, Turmalin, Quarz als Bergkristall usw. auch hier vor. Dazu treten aber noch einige, die in Minas Gerä̈s nicht rorkommen. In einem Sande aus der Serra da Chapada hat D a mour folgende Mineralien als Begleiter des Dianants nachweisen können: abgerollten Bergkristall, Kristalle von Zirkon, Turmalin, Iydrophosphate, Ittriumphosphate zum Teil titansäurehaltig, Diaspor, Rutil, Brookit, Anatas, Titaneisen, Magneteisen, Zinnstein, roten Feldspat, Zinnober, Gold; auch Granat und Staurolith sind hier beobachtet worden, und in neuester Zeit als Seltenheit Euklas. Feldspat und Zinnober sind bisher in Minas Geraës noch nicht mit dem Diamant zusammen vorgekommen. Aus diesen Mineralien, namentlich aus dem Zusammenvorkommen von Turmalin, Granat, Zirkon, Staurolith, Rutil u. s. w., schliebt Schrauf, daß die Gesteine, die in der Serra da Chapada den diamantführenden Sand geliefert haben, den Gneisen und Syeniten Norwegens ähnlich seien. In der Tat ergeben Tritteilungen, die man über den geologischen Bau jener Gebirge erhalten hat, daß sie aus derartigen Gesteinen bestehen. Doch sind die Nachrichten über diese Gegenden, wie überhaupt über das ganze Diamantenvorkommen in Bahia im ganzen recht spärlich, aber die Übereinstimmung der Begleiter des Diamants in Minas Geraës und in der Serra da Chapada läßt vermuten, daß das Vorkommen in dem letzteren Staate dasselbe ist wie in dem ersteren. Auch in festem Sandstein eingewachsene Diamanten, wie bei Grão Mogol (S. 194) hat man neuestens hier gefunden.

Besonders reiche Funde wurden im Jahre 1844 in der Serra da Cincorí (oder Sincorá) gemacht. Diese liegt ungeführ unter dem 41. Grade westlich von Greenwich und erstreckt sich von Südwest nach Nordost, von $13^{\prime} 1^{\prime \prime}$ bis $12^{\prime \prime} 15^{\prime}$ südlicher Breite. Sie bildet (Fig. 44) einen südöstlichen Ausläufer der Serra da Chapada, mit der sie an ihrem siidlichen Ende zusammenhängt. In ihrem Verlauf trennt sie das Flußgebiet des Rio de S. Francisco von dem des Rio Paraguassú, in dem sich alle von der Serra da Cincorá kommenden Gewässer sammeln. Das letztere Gebirge hat die größte Ähnlichlieit nit der Serra da Grão Mogol in Minas Geraës; es ist ebenso rauh und unwirtlich wie dieses, und der größten Wahrscheinlichkeit nach besteht auch die Serra da Cincorá aus Itacolumit wïhrend die umgelsenden Gebirge aus Granit und Gneis aufgebaut sind. Nach Orville A. Derby haben am oberen Lauf des Rio Paraguassí harte gelbe Sandsteine von $500 \mathrm{~m}$ Inähtigkeit eine grobe Verbreitung über Granit und Gneis. Seiner Ansicht zufolge stammen die Diamanten des Flusses aus mehreren Konglomeratbänken, die dem mittleren Teil dieses Sandsteins zwisehengelagert sind. E. II ussak fand neuerdings in einem Diamantensande vom Rio Paraguassú sehr viel Korund, Monazit und Xenotim, auch viel Granat, Itereynit und Fibrolith, wiihrend die für Minas Geraës bezeichnenden Mineralien, wie Anatas, Rutil, Turmalin, die Favas usw. fehlen.

Der Diamant wurde hier von einem aus dem Diamantenbezirk in Minas Geraies stammenden Sklaven entdeckt, dem beim Viehhüten die Ähnlichkeit der Bodenbildungen mit denen seiner Heimat aufgefallen war. Er fing an zu suchen und hatte in kurzer Zeit 7 (0) Karat gesammelt. Kaum war der Fund bekannt geworden, so kamen die Leute in Massen herbei, und schon in folgenden Jahre sollen 25000 , nach anderen Schätzungen aber nur 12000 bis 14000 Diamantensucher die Gegend bevölkert haben. Sie stammten 
aus der Serra da Chapada und der Serra do Assuâria, wo infolge dieser Auswanderungr die Diamantengewinnung fast ganz aufhörte. IIauptsächlich kamen sie aber aus Minas Geraïs, dessen Diamantenproduktion schon lange immer mehr zurïckgegangen war.

Der Ertrag der neu entaleckten Felder war sehr reich; er brachte die sinkende Diamantenausbeute Brasiliens wieder bedeutend in die Höhe. Am Anfang sollen im Durchschnitt tïglich 1450 Karat Diamanten gefunden worden sein, doch bald nahm die Menge auch hier ab und die Zahl der Arbeiter verminderte sich auf 50000 höchstens (j000) Bis zum Jahr 1949 waren in diesen Gegenden 932 411) Karat Diamanten gefunden und durch diesen reichen Ertrag war der Diamantenpreis in Brasilien auf die Hälfte herabgedrückt worden. Im Jahre 1858 lieferte Bahia nach der Schätzungr der Diamantenhändler 5.t ofo() Karat. wåhrend aus Diamantina nur 36000 Karat kamen.

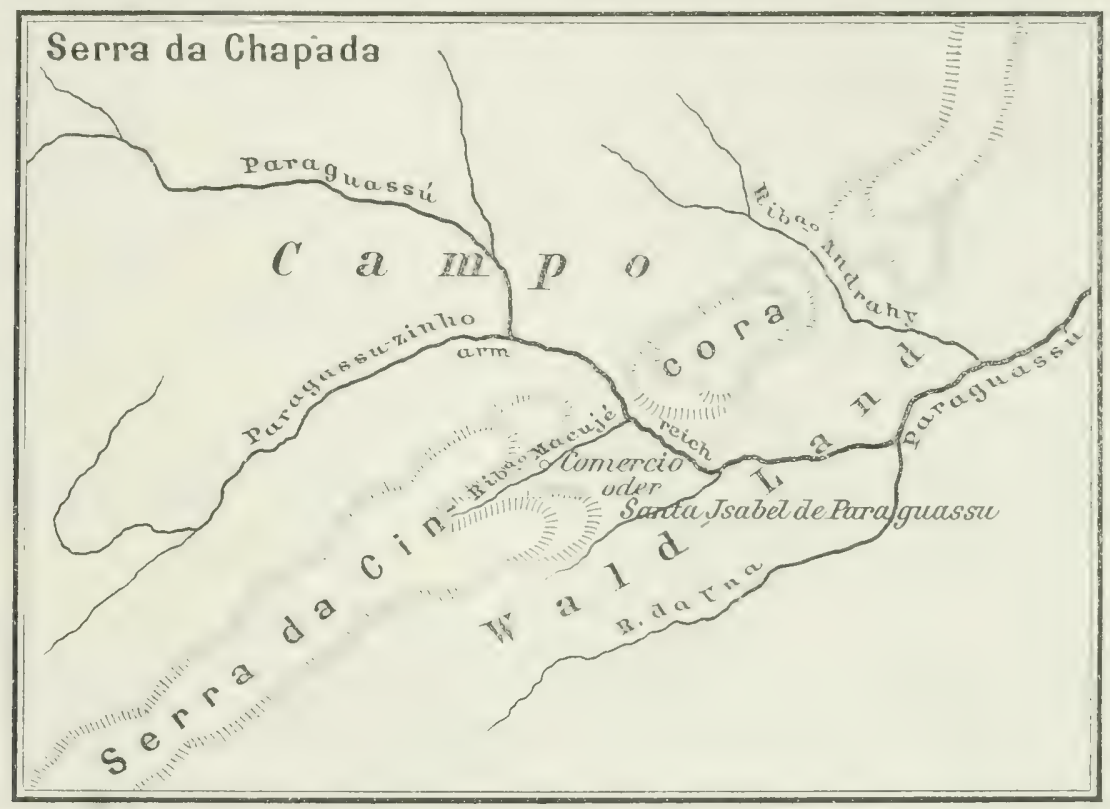

Fig. 44. Diamantenlager der Serra da Cinorá in Bahia.

Die Funde in der Serra da Cincorá gehören durchaus den Flußallurionen an. Nach den von J. J. von Tschudi veröffentlichten Berichten des Reisenden V. von Helm. reichen waren die ersten Entdeckungen an den Ufern des Macujé, eines kleinen rechten Nebenflusses des Paraguassú, gemacht worden. Hier entstand dann in der Folge der Hauptort des Bezirkes, 90 Legoas ron Bahia, der den Namen Comercio oder Santa Isabel de Paraguassú erhielt, sowie einige andere kleine Ortschaften. Später sind Diamanten auf 20 Legoas in der Umgebung von Santa Isabel gefunden worden. Der Hauptort weiter nördlich ist Lencoes (Fig. 42, S. 1S1), in dessen Nähe der als Fundort viel genannte Monte Venero liegt: Weitere wichtigere Lokalitäten sind Andaraby, Palmeiros, São Antonio und São Ignacio.

Die Wäschereien an der Westseite der Serra haben sich als arm erwiesen, bedeutende Mengen von Diamanten wurden aber aus dem Macujé selbst und an den Stellen grewonnen, wo der Paraguassí und der Andarahy das Gebirge durehbrechen. Am letzteren Flusse bestehen die Hauptwäschereien in den Bächen, die seinem rechten Ufer zufließen. Im Paraguassúbette sind ebensolche diamantenreiche Rinnen nachgewiesen worden, wie in den Diamantenflüssen von Diamantina. 
Die Diamanten aus der Serra da Cincorá werden als die "Cincorá- oder Sincorásteine" oder als "Bahias" besonders bezeichnet und ron den "Diamantinasteinen" unterschieden. Sie sind von erhehlich geringerer Qualitït als letztere und stehen wesentlich niedriger im Preise. Die meisten sind gelb, crriin. braun oder rot, auch haben sie fast alle eine längliche unregelnälbige Form, die für den Schliff wenig günstig ist. Steine vom reinsten Wasser sind hier im Verhältnis viel sparsamer vorgekommen als sonst in Brasilien, und die Größe ist meist gering. doch hat man im Anfang der fünfziger Jahre einmal einen Stein von $87^{1 / 2}$ Karat gefunden.

Dieser Diamantenbezirk ron Cincorá ist dadurch ausgezeichnet, daß fast ausschließlich nur hicr sich neben den gewöhnlichen Diamanten die oben schon mehrfach erwähnte besondere Abart findet, die man ihres abweichenden Aussehens wegen leicht für etwas ganz anderes loält und der man in Anbetracht ihrer schwarzen Farbe den Namen Carbonado oder Karbonat gegeben hat.

Er bildet im Gegensatze zum eigentlichen Diamant sehr selten Kristallformen von einiger Regehmäßigkeit, doch sind Oktaëder, Dodekä̈der und Würfel mit rauhen Flächen und mit abgerundeten Kanten und Ecken schon beobachtet worden. Ein solcher Kristall ron Würfelform ist Taf. I, Fig. 4 abgebildet. Meist sind es unregelmäßig rundliche Knollen. Sie gehen von Erbsengröße bis zu einem Gewicht von 700 und 800 Karat und zuweilen noch höher; im Mittel sind es 30-40 Karat. 1894 ist ein Stiick von 975, 1995 sogar ein solches von 3078 Karat oder 630 Gramm, etwa von der Größe einer Faust, gefunden worden. Dieser größte bis jetzt bekannte Karhonatklumpen entspricht fast genau dem gröliten Dianantkristall von der Premiermine in Transvaal, dem Cullinan. Solche große Gewichte sind aber selten. Die Karbonatstiicke sehen zuweilen aus, wie wenn es Fragmente größerer IIassen wären, die durch einen Stoß zersprengt wurden. Nanche zeigen f(ine Streifen, etwa wie Faserkohle; man glaubt, dab sie durch Reibung mehrerer Karbonatstïcke aneinander entstanden sind.

Der Glanz ist an der Oberflïche matt und zuweilen schwach fettig: das Innere ist gewöhnlich etwas glïnzender und mit zahlreichen lehbaft schimmernden P'inktehen durchsetyt. Die Farbe ist außen stets dunkelgrau bis schwarz, auf Bruchflächen ist sie meist ein wenig heller und zeigt einen Stich ins Bräunliche, Violette oder Rötliche.

Die Masse ist selten rollkommen kompakt; sie ist fast ausnahmslos mehr oder weniger stark porös, so dab sie das Aussehen eines Stïckes Kols hesitzt. Beim Erhitzen im Trasser werden infolge dieser Porositüt zahlreiche Luftblasen ausgetrieben. Der Zusammenhang der Stïcke ist meist ein fester, doch sind auch manche leicht zerreiblich. Das bei dem Zerreiben erhaltene feine Pulver hesteht, wie die mikroskopische Untersuchung lehrt, ans schr kleinen, selten wasserheilen, meist hellbräunlichen, halb durchsichtigen Oktä̈derchen echten Diamants, vielfach mit kleinen opaken Einschliissen. Der Karbonat ist also nichts anderes als ein poröses, feinkörniges bis dichtes $\Lambda$ grgregat von Diamantkriställehen also nicht amoryher Diamant, wie er zuweilen fälschlich genamnt wird. Er ist auch verschieden von dem schwarzen Diamant, der in regehmïßigen Kristallen von ganz kompakter Besehaffenheit an manchen Orten sich findet. Stellenweise sind manche Stiicke dieses Ascregats von hellgufïrbten, stïrker glinzenden, kompakten, nicht porösen Streifen eigentlichen Diamants durchzogen, auch lıat man beobachtet, daß eine Karbonatkugel einen kleinen farblosen, einheitlich (w) bildeten I)iamantkristall als Kern einschlob, der in die Karbonathülle allmählich ïh)reing, wie es auch die hellen Streifen von Diamant in die dunkle und poröse Nasse des umgebenden Karbonats tum. Selten sind die Wände der IIohlräume des letzteren mit kleinen farblosen Kristïllchen von Diamant besetzt.

Der Karbonat besteht, in der Hauptsache nur aus Kohlenstoff, wie der Diamant, doch ('nthält er mehr Aschenbestandteile als dieser, die beim Verbrennen in ganz gleicher Weise 
wie dort zuriickbleiben; zuweilen in der Form des verbrannten Stiickes Karbonat. Ihre Menge beträer 1 , lis ïber 4 Proz; drei Proben haben nach Rivot ererben: 96,-1, !19,10,

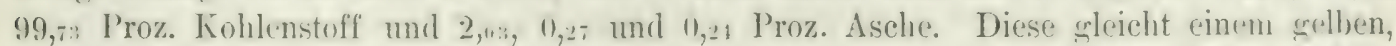
eisenhaltigen Ton mit einemeshlossenen unbestimmbaren mikroskopisch kleinen liristallehen. Behandelt man feines Karbonatpulver mit Köniowwasser, so löst sich etwas von der Asche auf und die Iössung enthïlt Eisen nehen wenier Kalk, aber keine Thonerde und Sechwefelsäure. Dan a giht fïr den Karbonat die Zusummensetzung: 97 Kollenstoff, 19,5 Wasserstoff und $i$, Sanerstoff, doch bediuf die Anwesenheit der beiden letztraen bestandteile noch der Bestiitigung. Ian hat auch die Ansicht ausesprochen, daf dem liristallisiorten Kohlenstoff in Karbonat amorpher beigemenget sei; die mikroskopische Untersuchung hat aber nichts davon erkennen lassen.

Die IÏ̈rte ist nicht nur chenso grof wie heim eigentlichen Diamant, sondern sie geht sogar noch darüber hinaus. Die Masse soll um so härter sein, je weniger dentlich kristallinisch sie ist. Karbonat kamn also mit gewöhnlichem Diamantpulver war nicht oder nur mit äuberster Schwierigkeit geschliffen werden, wohl aber ist das Lmaekelute migglich, und zwar nit hesomderer Leichtigkeit. Daher wird dieses poröse Diamantageregat vielfach zur IIerstelluner von Schleifjulver, ebenso aber auch zur Besetzuner der Bohrironen in Bohrmaschinen usw., kurz iiberall verwendet, wo man besonders hartes Material braucht. Der Karbonat ist dazu $\mathrm{nm}$ so gecigneter. als man daraus leicht Stïcke von passender Form und Gröfie herstellen kann, wïhrend man Kristalle meist nehmen mub, wie sie sind.

Das spezifische Gewicht ist we wen der Porositiit der Stiicke kleiner als bei Diamantkristallen; man hat die Werte: 3,$012 ; 3,141 ; 3,255 ; 3,416$ usw. gefunden. Die letzten drei Zahlen beziehen sich der Reihe nach auf die drei Exemplare, deren chemische Zusammensetzung oben angexweten worden ist. Die Substanz an sich, ahgesehen von den Poren, ist aber ebenso schwer wie der echte Diamant.

Daß das Vorkommen des Karbonats so gut wie vollständig auf den Bezirk von Cincorá beschränkt ist, wurde schon erwälunt. Hier ist el im Jahre 154: in den Gupiarren des Flusses San José zuerst gefunden worden, und von hier stammt alles, was von diesem Material im Handel vorkommt und was in der Technik verwendet wird. In Minas (jerä̈s fehlt der Karbonat so gut wie rollstïndig; ganz geringe Mrengen sind in Suidafrika gefunden worden, in Indien und Australien hat man noch keine Spur angetroffen. Etwas reichlicher, aber immer noch sehr sparsam, liegt er in den Diamantseifen ron Borneo, wo auch Karbonatstiicke mit einer Hïlle farblosen Diamants gesammelt worden sind. Z̈herall ist diese schwarze porïse MIodifikation des Diannants ron Kiristallen der gew ̈̈hnlichen Beschaffenheit bexleitet; sie lient ïherall in dem Gestein, das auch den eigentlichen Dianant heherbergt und ist also mit ilm wohl ron gleichem Lreprung und von gleicher Entstehung:

Die friiher schon beträchtliche Produktion ist neuerer Zeit noch bedeutend gewachsen und beträgt jetzt ca. 25)(1) Karat im Nonat. Trotzdem ist infolge des zunehmenden Verbranchs der Preis ganz enorm westiegen. Wührend er anfünglich 20 Pfennige für das Karat betrug, mub man gegenwïtig - -9 Pfund Sterling loro Karat für die besseren Surten bezahlen.

Schwer zu schätzen ist die Menge der jährlich hier gewonnenen eigentlichen Diamanten. Sie sind klein; Steine ron $31 / 2$ Karat sind sehr selten. 30 l'roz. der Cresantproduktion ist nicht schleifbar.

Auch im südlichen Teile der Provinz Bahia sind immerhalb des flachen und ebenen Küistensaumes zahlreiche Diamanten gefunden worden. Es ist der Grenzhezirls gegen Minas 
Geraës, der gewissermaßen eine nordöstliche Fortsetzung des Diamantenlandes von Diamantina ïber Grão do Mogol hinaus darstellt. Die Steine liegen hier im Alluvium bei Salobro (das Wort bedeutet „brackisch“), im Gebiete des Rio Pardo, der nahe dem kleinen Hafen von Canavieiras sich mit dem Diamantenflusse Jequetinhonha (Rio Belmonte) zusammen am Fuße der Serra do Mar in den atlantischen Ozean ergießt. Von dieser Mafenstadt sind die Gruben etwa zwei Tagereisen landeinwärts entfernt; sie heißen nach ibr auch die Canavieirasgruben.

Die Entdeckung geschah 1881 oder $18 \$ 2$ durch einen Waldarbeiter, der vorher schon in anderen Gegenden Diamanten gesucht hatte. Kaum war der Fund gemacht, so bevölkerte sich der Urwald trotz des ungesunden Malariaklimas mit 3000 und vielleicht noch mehr Diamantengräbern, welche die Schätze in einer Tiefe von 2 Fuß aus einem weißen Ton mit faulenden Blättern, also einer sehr jungen Bildung, hervorholten.

Dieses Diamantenlager ist viel toniger als irgendwo in Minas Geraës. Es hat durchaus den Charakter einer Höhenablagerung, doch führen auch die Flïsse Salobro und Salobrinho, linke Nebenflüsse des Rio Pardo, Diamanten, besonders an den Talgehängen ïber dem heutigen Wasserspiegel, in Gupiarras, wie sie in den Flufthälern von Diamantina vorkommen. In dem Thon sind nicht nur viel weniger, sondern zum Teil auch andere Mineralien als Begleiter des Diamants gefunden worden, wie in Minas Geraës. Diese sind wie in Diamantina überwiegend Quarz mit Jaspis und Kieseischiefer, dann viel Monazit in gelblichen und rötlichen Kristallbruchstïcken, sowie Zirkon von bräunlicher bis weißlicher, selten violetter Farbe; Titaneisen und ferner seltener Cyanit, Staurolith, Almandin, Eisenglanz, Magneteisen und Pyrit. Dazu tritt aber endlich in nicht unbeträchtlichen Mengen Korund, der in anderen brasilianischen Diamantlagerstätten nur spärlich und sporadisch vorgekommen ist, während alle die übrigen genannten Mineralien auch anderwärts in Brasilien nit dem Diamant zusammen auftreten. Im Gegensatz zum Korund hat man aber bisher die in Minas Geraës häufigen Begleiter Rutil und Anatas, sowie Turmalin und die Hydrophosphate in den Canavieirasgruben noch nicht gefunden.

Was den Ursprung dieser Diamanten anbelangt, so hat man sie aus dem Gneis, Granit und rlen anderen Urgesteinen des benachbarten Kïistengebirges, der Serra do Mar, abzuleiten gesucht Es fehlt aber in ihrer Begleitung jede Spur von Feldspat, Glimmer usw., sowie von den sonst in Brasilien in diesen Gesteinen vielfach vorkommenden farbigen Mineralien: Chrysoberyll, Andalusit, Turmalin, Beryll usw., so daß die vermutete Abstammung doch zweifelhaft ist. Das richtige Muttergestein zu ermitteln, ist noch Aufgabe weiterer Untersuchungen, jedenfalls scheint es nicht dasselbe zu sein wie in Diamantina, da die dortigen Gesteine in der ganzen Umgebung nicht anstehend bekannt sind.

Der Lrtrag dieser Gruben war gleich nach der Entdeckung so bedeutend, daß die anderen Diamantdistrikte mehr oder weniger verödeten. Die Steine sind durch Reinheit und schöne weilje Farbe ausgezeichnet und ebenso durch sehr regelmäßige, für das Schleifen außerordentlich gïnstige oktä̈drische Form, so daß das Spalten so gut wie überflüssig. ist. Eine Zeit lang berulıte die Diamantenproduktion von Brasilien zu einem guten Teil auf diesen Cruben. Wenn sie aber auch sehr reich waren, so waren sie es vielleicht doch nicht in dem Maße, als sie es schienen. Es wird nämlich behauptet, daß man viele Kapdiamanten nach Canavieiras schickt, un sie von hier aus als brasilianische Steine in den Handel zu bringen und teurer bezahlen zu lassen, ïhnlich wie man friiher brasilianische Diamanten nach Indien gehen lief, um ilmen als scheinbar indischen Steinen einen höheren Wert zu verleihen. Gegenwärti hat der Ertrag gegen frïher schon sehr erheblich abgenommen, und die Ablagerung scheint der vollständigen Erschöpfung schon sehr nahe. Dasselbe gilt aber mehr oder weniger für alle jetzt bekannten Diamantfelder in Brasilien, die fast sämtlich in der letzten Zeit nur schwach bearbeitet worden sind. 
Betrachtet man die Beschaffeuheit der brasilianischen Diamanten im grofen und ganzen, so zeigen sie neben einer Reile von gemeinsamen Eigenschaften auch viclfache Verschiedenheiten, die zuweilen dem Kenner den brasilianischen Lrsprung und manchmal sogar den speziellen Fundort verraten.

Die Gröbe ist fast immer gering. Brasilien steht in dieser Beziehung hinter Indien und namentlich weit hinter Sudafrika zuriick, wo sehr viel grolje Steine vorkommen. Weitaus die Mehrzahl der brasilianischen Diamanten wiegt 1/4 Karat und weniger. Kleinere als etwa von Stecknadelkopfgrölie werden nicht gewonnen, sie gehen bei dem grewöhn. lichen Waschprozeb verloren. Besondere Versuche haben aber gezeigrt, dab sie in reichlicher Menge vorhanden sind, es ist jedoch nicht lohnend, auf sie Riicksicht zu nehmen. Steine von $1 / 1$ bis $1 / 2$ Karat sind häiufig, solche von 1 bis 5 und (i Karat selten und mit steigender Größe immer seltener. Noch größßere gehören zu den ungewöhnlichen Erscheinungen. In Diamantina wurden in den besten Zeiten jährlich nur ungefähr zwei bis drei Steine von 16 bis 20 Karat, jüngstens in der Grube von Agua Suja mehrere von 20) bis 50) Karat gefunden, und bis ein noch schwererer vorkam, vergingen mehrere Jahre. Unter 10)(1)() brasilianischen Diamanten wiegt im Durchschnitt selten mehr als einer 20 Karat, und 8000 wiegen je 1 Karat und weniger. Während der ganzen direkten könighlichen Verwaltung von 1772 bis 1830 sind nur so Steine ron größerem Gewicht als eine Oitava $=171,2$ Karat gewonmen worden, abgesehen ron den defraudierten, deren Zahl unbekannt ist.

Der grö̈bte brasilianische Diamant ist der oben (S. 186) erwähnte von ca. 300) Karat aus dem Rio Verissimo in Goyaz. Bis zu dessen Entdeckung im Jahre 1906 war es der „Stern des Südens" oder .Siidstern“, der in den fünfziger Jahren hei Bagagem erbeutet wurde und der in rohen Zustande 2541/2 Karat wog. Er lieferte einen schönen Brillant ron 125 Karat. Ein Stein von 1381: Karat stammt aus dem Rio thaété und ein solcher von 120:4 Karat aus der Caxoeira rica bei Bagagem. Von Tabacos am Rio das Telhas wird ein Diamant ron 107 Karat erwähnt; andere ïber 100 Karat sind nicht bekannt geworden. Der vielgenannte ,Braganza“, der vermeintliche hühnereigroße Diamant von 1650 Karat im portugiesischen Kronschatz ist, wie wir gesehen haben, mit höchster Wahrscheinlichkeit nichts anderes als ein durchsichtiges farbloses Topasgeschiebe. Es ist aber nicht möglich, näheres zu erfahren, vla die portugiesische Regierung die Sache aus begreiflichen Gründen im Dunkel hält.

Die Kristallformen, die in Brasilien vorkommen, sind ziemlich mannigfaltig; dic einzelnen Fundorte sind darin vielfach verschieden. Auch die Regelmäßigheit der Formen ist nicht ïberall dieselbe, namentlich sind im Bezirk von Cincorí, wie schon oben erwälınt, die Kristalle in allgemeinen viel mehr verschoben und verzert als in Minas Geraës und bei Salobro.

Im Durchschnitt aller Lokalitäten sind die Hauptformen das Granatoëder und das Hexakisoktaëder mit rundlichen Flïchen, durch Verzerrung vielfach von der idealen Forn erheblich abweichend (Fig. $39 c$ bis f). RegelmäBige Oktä̈der finden sich auber bei Salobro seltener, anderwärts sind sie vielfach verschoben, zuweilen zu dïnnen Tafeln. Würfelformen (Fig. 39, " ) sind für Brasilien besonders charakteristisch; sie finden sich anderwärts sehr selten, sind aber hier häufig. Teträ̈der und andere hemiëdrische Formen, besonders Hexakistetraïler (Fig. 39, $7_{i}$ ) sind dagegen nur wenig gefunden worden. Zwillinge von Granatö̈dern kommen vielfach vor (Fig. 39, h), solche von Oktaëdern (Fig. 39, g) gehören zu den Seltenheiten.

Unregrelmäßige Verwachsungen mehrerer Diamantkristalle zu kleinen Gruplen trifft man in mroljer Zahl. Eine solche bildete ursprïnglich der oben erwähnte "Südstern", an den mehrere Eindriicke ron kleineren Diamanten sichtbar gewesen sind, die aber abgebrochen waren, als der Stein gefunden wurde. Nicht selten sind Bortlingeln (Tafel I, 
Figur 3), oft von ganz regelmäßBiger Kugelgestalt, die ringsum durch kleine hervorragende oktaëdrische Kristallspitzen rauh und infolge der Verwachsung aus zahlreichen kleinen Krist:ïllehen milehig trühe sind. Überhaupt gehören ungefähr ein Viertel aller in Brasilien gefundenen Steine zum .Bort“, der nicht zum Schmuck verwendet werden kann.

Die Oberfläche der rohen Diamanten ist teils glatt, teils gestreift oder rauls. Die Steine sind bald matt, bald onlänzend; bald undurchsichtig oder durchscheinend. Manche sind schon im rohen Zustande vollkommen durchsichtig und zeigen dann zuweilen vor dem Schleifen bereits ein schönes Farbenspiel, wie es sonst erst nach der Bearbeitung aufzutreten pflegt. Über den besonderen eigentïmlichen Glanz, der den Steinen von Nato Grosso aloweichend ron allen anderen brasilianischen eigen ist, wurde schon oben berichet. Zuweilen ist der ganze Stein von Hohlräumen durchzogen wie der Bimsstein. Auch regehmälige Vertiefungen an der Oberfläche kommen vor, die nicht selten die Form von Quarzkistallen haben, auf denen die betreffenden Diamantkristalle dann ursprïnglich aufgesessen haben müBten. Diamantkristalle mit Ansatzflächen, mit denen sie auf einem andern Mineral aufgewachsen waren, werden vielfach beschrieben. Ein solcher ist wohl der ... Sïlstern" (Figur 58); mit größter Wahrscheinlichkeit ist er mit der breiten unteren Fläche auf dem Gestein befestigt gewesen.

Die Farbe und die dadurch bedingte Qualitït variiert auljerordentlich und auch hierin sind verschiedene Fundorte verschieden. Ungefähr 40 Proz. sind vollkommen farblos, 25 Proz. vom reinsten Wasser und von der ersten Qualität. Das schönste und geschäizteste Blauweiß ist darunter nieht ganz selten. Weitere 30 Proz. haben einen leichten Anflug einer Färbung, und der Rest von wieder 30 Proz. zeigt eine ausgesprochene Farbe, doch sind schöne tief gefürbte Steine sehr selten. Neben den farblosen sind die matt weißlichen und die srrïnlichen am häufigsten. Die lichteren Farbentöne sind, wie wir schon oben bei der allgemeinen Betrachtung der Färbung des Diamants gesehen haben, vielfach nur auf der Oberfläche und verschwinden beim schleifen oder bei kurzem Glïhen an der Luft, wodurch der farblose Fern zum Vorschein kommt. Namentlich der Bezirk von Dianantina und besonders der Rio Pardo und ebenso anch die Serra da Cincorít haben derartige Steine geliefert. Zuweilen zeigen nur die Kanten und Ecken einen farbigen Anflug. Bei stärkerer Fïrbung geht die Farbe durch den ganzen Stein hindurch, doch hat man auch Steine angetroffen, die an verschiedenen Stellen versehieden gefürbt waren, wie gleichfalls schon when mitgeteilt wurde. Zuweilen sind dunkle, meist schwäirliche Flecken oder moosförmige Zeichnungen wie im Noosachat im Innern vorhanden. Auch andere fremcle Einschliisse sind häufig. Die Farben, die man beobachtet hat, sind gelb, rot, braun, griin, grau, schwarz. meist mit vielfachen Nuancen; blau ist selten, doch sollen einige schön blaue Steine vorgekommen sein.

Falit man die (gualität im allgemeinen, abgesehen von der Crößje, ins Auge, dann sind die brasilianischen Steine im Durchschnitt besser als die meist gelblichen rom Kap. Sie wleichen den indischen oder sind ihnen doch sehr nahe. Die schönsten blauweißen Diamanten von Brasilien stehen den besten indischen in keiner Weise nach.

Nicht alle brasilianischen Fundorte sind jerloch in Bezus auf die Qualität einander gleich. Am höchsten steht die Gergend von bagagem; von hier stammen aufer den grö̈liten auch die schünstrn und die weibesten, jecloch finden sich nehen diesen freilich auch viele gefiarbte, braune, sehwarze usw. Unter ihnen haben einige, aber freilich nur wenige (ine vorteillafte Farbe; diese sind damn sehre eresucht. Die meisten zeigen neben der schlechten Farhe noch zahbrohe kleine Fehler und vielfach eine unregelmäßjoge Form, so dalf sie wenig geschiätzt sind. Auf die Steme ron Bagagem folgen die aus den Canavieirasgruben, wo zwar kleine, aber fast durehaus sehön weibe und regrelmäßig stestaltete Diamanten mit nur wenigen Fehlern acfunden worden sind. Bei Tage haben sie cinen 
schönen frlanz und gutes Farbenspiel, sie verlieren aber davon crheblich bei Kerzenlieht und zeigen dann das weniger vorteilhafte Ausselten der Kapsteine. An dritter Stells kommen die I iamanten von Diamantina. die versehiedenen Fundorte mit geewissen Lnterschiedten. welche den Einheimischen genau bekannt sind. Einigre Cräibereien lieforn nur

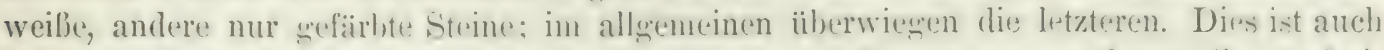

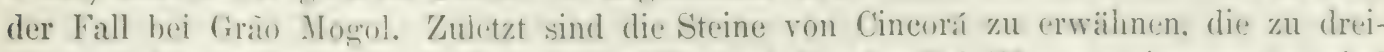

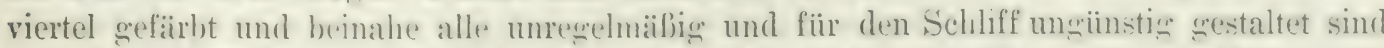
und die zur IIälfte ans Bort lestehen. Die Diamanten von bagagem und Canavirimas sind nur oberflächlich gef:irbt: sie sind ron Natur glänzend, selten matt. Die von Dia-

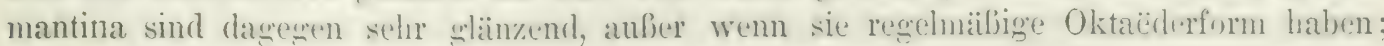
nicht selten haben sie eine ganz rauhe Oberfläche.

Die Diamantenpooduktion Brasiliens ron den frïhesten Zeiten ab ist rine: ungemein große. Für das 18. Jahrhundert und die ersten Jahrzehnte des 19. hat man genaue offizielle Nachweisungen; für die ersten Jahre nach der Entrleckung fehlen diese, ebenso siucl auch für die allerneueste Zeit keine ganz sicheren Nachrichten rorhanden. Viele Angaben beruhen daher auf mehr oder weniger unsichoren Schätzungen. Jene offiziellen Ermittehmen umfassen auch nur die auf legitimem Wrege sewommenen Diamanten. die Menewe der durch den Schleichhandel in den Verkehe geterachten nicht registrierten Steme soll nach der Annahme des früheren brasilianischen Oberherwhanptmanns IV. L. v. Eschwege wenigstens zeitweise chenso groli, wenn nicht noch grüfitr gewesen sein; audere nehmen hierfür allerdings nur ein Fünftel his ein Drittel an.

Nach den Mitteilungen von Dr. E. Hussak, friiher in S. Paulo, jetzt in Rio de Janeiro (Brasilien), die auf den älteren Angaben von v. Eschweg'e und Castelnau und den genaueren von Olyntho und Calogeras beruhen, ist unten die Gesamtdiamantenproduktion für die Ze it ron 17.41 bis 19113 angegehen. Nimmt man hinzu die

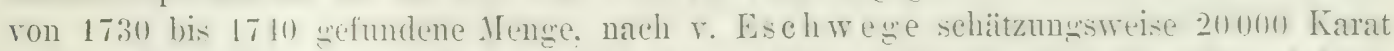
im Jahre, und fuir die ver Jahre von 1903 bis 1907 in Durchschnitt delnselloen Jahresertrag wie fuil die 37 Jahre von 1866 bis 1903, also 51739 Karat, so erhält man folgende Posten:

\begin{tabular}{|c|c|c|c|c|c|c|c|c|c|}
\hline $1730-1740$ & - & & • & . & - & . & & $200000]$ & Karat \\
\hline 17.41$)-1<4 !$ & . & . & . & & . & . & . & . & .. \\
\hline $1<.511-1<.52$ & . & . & . & . & & . & & f:31 (3)11 & .. \\
\hline $1-. i 2-1 \vee(i 2$ & . & . & . & . & . & . & . & . 191.29111 & ." \\
\hline $1-b i 2-14 t i t i$ & . & & . & . & . & . & & . T(1:3 1112 & .. \\
\hline 1-titi-1!m):3 & . & . & . & . & . & . & & . $1: 111::: 1$ & * \\
\hline $1903-1907$ & . & . & . & - & - & & - & 206956 & 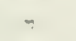 \\
\hline
\end{tabular}

oder sehr nahe 3140 Kilogramm, wovon die reichliche Hälfte auf Minas Geraës entfällt.

Die Erträe schwanken in verschiedenen Zeitabsehnitten erhehlich. Von 201)(0) isarat im Jahr zwischen 1730 und 1740 war die Jahresausbeute zwischen 1740 und 1772

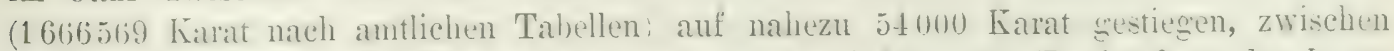
1772 und $1>24,1: 3191922$ Karat im sanzen) war sie infolse der Erschöpfung der Lager wieder anf 2:sollu Karat gesunken. Speziell zwischen 1511 und 1522 wird sogar nur

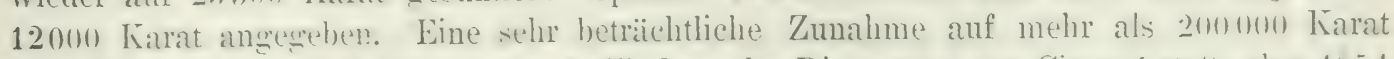

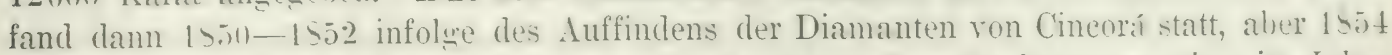

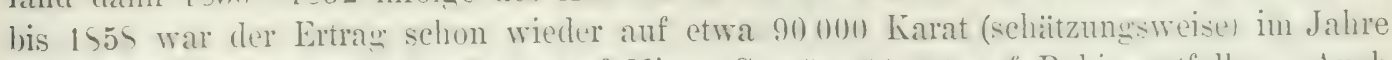

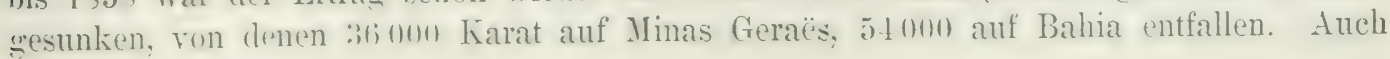


die Entdeckung des Canavieiras-Lagers hat nach 1881 eine vorübergehende Steigerung eintreten lassen, gegenwärtig kann man nach der obigen Tabelle etwa 50000 Karat im Jahre annehmen.

\section{Guayaua.}

Neuterdings sind auch in einem anderen Teile von Südamerika, in den Goldseifen von Britisch-, und allerdings in sehr viel geringerer Menge auch in denen von HolländischGuayana Diamanten gefunden worden. Die neuen Fundstellen liegen etwa 3700 Kilometer von den brasilianischen entfernt, gleichwohl ist aber mit den dortigen Diamanten namentlich mit denen von Agua Suja große Ähnlichkeit vorhanden, was die Beschaffenheit der Steine und ihr Vorkommen anbelangt. Das vor einigen Jahren gemeldete Vorkommen im Tipnani-Distrikt am Ostabhang der peruanischen und bolivianischen Kordilleren ist bisher noch nicht bestätigt worden.

In Britisch-Guayama sind gegenwärtig drei diamantführende Bezirke in verschiedenen Teilen des Landes bekannt:

1. im Gebiet des oberen Mazaruni und dessen Nebenflusses Putareng;

2. suidlich von Georgetown der Omai-Bezirk im Gebiet des Potaro, eines linken Nebenflusses des Essequibo;

3. im Norden am Oberlauf des Barima zwischen dem Jumbo- und dem Five Star Creek und 110 Kilometer südlich bei Jauna am Barima.

1. Der erste Fund geschah 1890 zufällig beim Goldwaschen am Putareng, einem Nebenfluß des oberen Mazaruni, wobei neben dem Gold einige Diamanten in der Schüissel (Batêa) zuriickblieben. Der Ort liegt unter $6^{0} 14^{\prime} \mathrm{n}$. Br. und $60^{\circ} 18^{\prime} \mathrm{w}$. L. von Greenwich, ungefähr 280 Kilometer oberhall der Stadt Bartica. Von Georgetown aus dauert die Reise dorthin 12 bis 20 Tage, je nach dem Wasserstand des Mazaruni, dessen Lauf häufig durch Stromschnellen und Wasserfälle unterbrochen wird. Die Fundstelle ist 7 bis 8 Kilometer vom Mazaruni entfernt; sie kann nur auf einem engen Pfad durch sumpfiges Land und dichten Dschungel erreicht werden, und alle Bedürfnisse mïssen von Indianern auf dem Kopf dorthin transportiert werden.

Die Gesteine des Mazaruni-Tales sind auf weite Erstreckung Granit und Gneis, die von Gängen von Diabas und ähnlichen Gesteinen durchsetzt werden. Die gegenwärtig betriebenen Diamantwäschereien liegen im Alluvium des Putareng an der Seite eines Hügels. Zu oberst findet sich reiner, weißer Quarzsand, 18 Zoll, über einer ebenso dicken Lage gelben sandigen Tons mit Quarzbrocken und Schmitzen von Sand und Kies, die durch Eisenoxyd verkittet sind und in denen gelegentlich kleine Diamanten gefunden werden. Dann folgen bis zur Sohle der jetzigen Gräberei 7 Fuß Ton, (ier nach unten mehr und mehr kiesigg wird, wobei die Gesteinsbrocken stetig an Größe zunehmen und um so häufiger dureh Eisenoxyd zementiert werden, je tiefer man kommt. Manche dieser Brocken erscheinen alggerollt und es sind ihnen kleinere Geschiebe und Sandkörner durch ein feldspatiges Bindemittel angebacken, wïhrend andere noch ihre scharfen Ecken haben. Einige bestehen aus Felsit, danchen finden sich Eisensteinkonkretionen, die meisten sind jedoch Quarz. In Gesellschaft dieser Gesteinsgeschicbe trifft man Körner von Ilmenit und kleine runde Gerölle von schwarzem Turmalin und Ceylanit, sowie von Topas und Korund (Sapphir). Den ausgegrahenen Kies bringt man in hölzernen Schüsseln nach einem nahen, kleinen Bach, wo er in engmaschigen Sieben ( $1 / 16$ Zoll Maschenweite) grewaschen wird; der Rückstand wird, solange er naß ist, ausgelesen. Die im Jahr 1890 zulerst gefundenen Diamanten stammen vom Fuße des Hiigels aus dem Grunde des Tales. Zwei Proben Kies von 100 und 150 Kubikmeter haben je etwa 1000) Steine geliefert. Die Ablagerungen auf der Ḧ̈he der Hügel sollen aber reicher und aussichtsvoller sein. Jedenfalls gilt es für sicher, 
dal die diamantenführenden Ablagerungen eine erheblich größere Verbreitung besitzen als die bis jetzt bekannt gewordenen.

Bis zum Jahre 19112 wurden 172844 Stïck Diamanten im Gewicht von 11718 1/s Karat angemeldet, so dafi also ein Stein im Durchschnitt 1/15 Karat wiegen wiirde. Die allermeisten sind alsu sehr klein, nur wenige wiegen 1 Karat, ganz vereinzelt gecht das Gewicht bis 11. Karat und ausnahmsweise bis 2 Karat und wohl auch noch darüher. Die Form pflegt die des Olitaieders zu sein. Die Steine sind ausgezeichnet rein und weiß und sehr stark gliinzend. I) (re Wert pro Karat betrïgt im Mittel ungefälır 50) Mark, also der Gesamtwert der funcle bis 1902 etwa 600000 Vark. 1904 begann die systematische Ausbeutung durch ein 1)uzend Gesellschaften, zum teil schon mit Maschinen, die trotz der enormen T'ransportschwierigkeiten herbeigeschafft worden sind. Der Gewinn ist aber noch šcring der enormen Kosten des Betriebs wegen, die nun durch Anlage einer Eisenbahn vermindert werden sollen; man kann erwarten, dal die Produktion dann einer raschen Entwickelung entgegengehen werde. Jedenfalls ist diese Gegend weitaus die wichtigste in ganz Guayana, alle anderen Funde sind den dortignen gregeniuber von ganz untergeorlneter Bedeutung.

2. Ein anderes Vorkommen von Diamanten wurde in den Goldwäschereien des 0 ma i flusses, eines kloinen Nohenflusses des Essequibo entdeckt, der sich 240 Kilometer von dessen Mündung mit ihm rereinigt. Ein kleiner Bach, der in den Omai fliefit, der Gilt Creek, hat beim rohen Waschen auf einer 500 Fub langen und 50 FuB breiten Strecke 60000 Unzen Gold und cinige hundert klcine Diamanten geliefert. Der goldhaltige Kies besteht hier aus melr oder weniger zersetzten Brocken des Hauptgesteins der Gegend, Dolerit oder Diabas, aus Eisensteinkonkretionen und eckigen Quarzstïeken. Aus ihm stammen auch die Diamanten, die allermeist vollkommen klare und farblose Oktaëder bilden, während die übrigen verschiedene Niüancen von rosa, grïn und hellgell) zeigen. Es wird vermutet, dab dieses Vorkommen ebenfalls genügende Aussichten für eine systematische Ausbeutung bietet.

3. Sehr wenig ist von der Gegend am Barima bekannt, die daher hier nur genannt werden soll.

Auch in IIolländisch-Guayana sind Diamanten entdeckt worden, und zwar gleichfalls gelegentlich beim Goldgraben. Die Lagerstätten sind im Mindreneti-Distrikt im Zentrum des Landes, zwischen dem Surinam- und dem Paramaca-Fluß, in der sog. ersten Goldzone. Vorläufig ist dieses Vorkommen noch ohne jede praktische Bedeutung, doch soll 1890 hier ein schöner Stein erbeutet worden sein.

Aus Französisch-Guayana werden neuestens ebenfalls vereinzelte Diamantenfunde gemeldet.

\section{Süilafrika.}

Die Diamantgruben ron Südafrika sind heutzutage weitaus die wichtigsten und reichsten. Vindestens neun Zehntel aller Diamanten, die jetzt in den Verkehr kommen, stammen von dort; es sind die sogenannten Kapsteine. Der Handel wird gegenwärtig vollständig von da aus beherrscht, und die früher so bedeutenden Fundorte in Brasilien, und mehr noch die in Indien, spielen jetzt eine untergeordnete Rolle.

Wir verdanken Emil Cohen, der den Diamantenbezirk am Kap im Jahre 1872 besuchte, die ersten genaueren wissenschaftlichen Nacbrichten dariber; und seine Mitteilungen sind auch jetzt noch ron größter Bedeutung. Zahlreiche andere Forscher haben seine Untersuchungen fortgesetzt und in manchen Einzelheiten vervollstïndigt, wesentliche neue Gesichtspunkte sind aber nicht zutage getreten. Von II oulle, Chaper, Boutan, 
Reunert, Stelzner, L. de Launay und anderen, aus neuester Zeit namentlich von Gardner F. Williams, dem fruheren Generaldirektor der De Beers-Gruben, besitzen wir zusammenfassende Darstellungen der dortigen Verhältnisse. Diese und die Originalarbeiten vieler sonstiger Forscher liegen den folgenden Betrachtungen zugrunde.

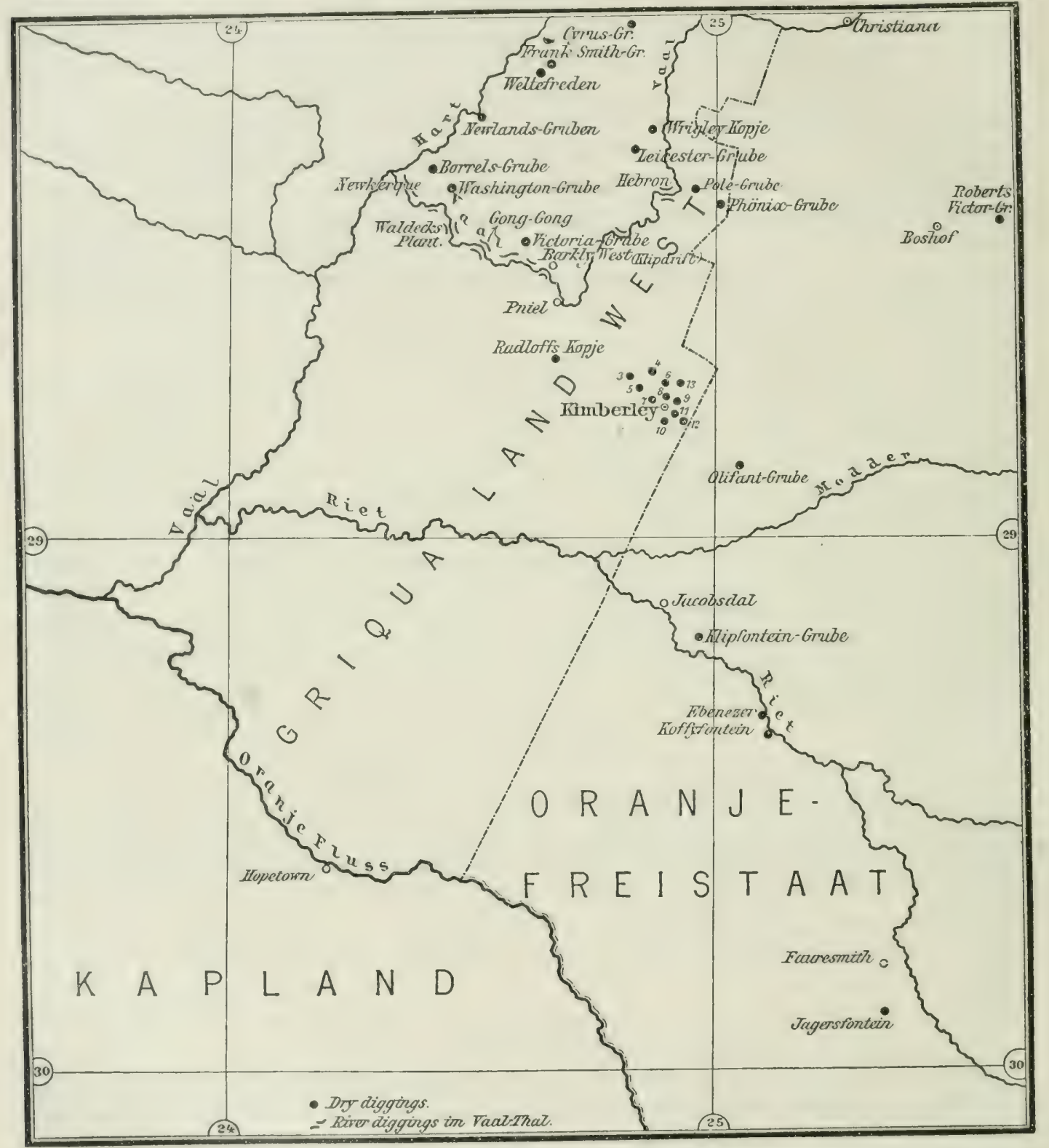

Fig. 45. Diamantvorkommen in Südafrika (westlicher Teil). (Maßstab 1:1500 000).

Die ersten Diamanten in jenen Gegenden wurden - wenn wir einige unsichere Anwaben aus früheren Jahrhunderten unberïcksichtigt lassen - im Jahre 1867 bekannt. Der Bur Daniel Jacobs hesab eine Farm „De Kalh" am Oranjefluß bei IIopetown (Fig. 15), etwa 50 Kilometer oberhalb der Einmïndung des Vaals gelegen. Unter den vielen bunten Flußkieseln bemerkten dessen Kinder einen farblosen, stark in der Sonne glänzenden 
Kristall, den sie mit sich nach Hause nahmen. Ein anderer benachbarter Bur, Schalk van Niekerk hatte eine unbestimmte Vermutung, dab hier etwas Besonderes vorliengen künnte. Eir liels sich den Stein schenken und übergab ilın dem herumziehenden IIändler John O'Reilly mit dem Aultrag, zu ermitteln, von welcher Art er wäre und ol) er sich vielleicht mit Vorteil verkaufen liefe. O'leilly wandte sich zu diesem Zwecke durch die Vermittlungr von Lorenzo Boyes in Colesberer an den sachverständigen Mineralogen Dr. W. Guybon Atherstono in Grahamstown, der sofort erkannte, dab er es mit einem Diamanten zu tun habe und der dessen (Gewicht $21121 \frac{1}{2}$ (genauer $21 \frac{1}{16}$ ) Karat bestimmte und seinen Wert auf 500 Pfund Sterling sehätzte. Um diesen Preis ging der Stein in den Besitz des damaligen Gouverneurs der Kapkolonie, Sir Philip, Woodhouse, über, nachdem er auf der Weltausstellung desselben Jahres (1867) in Paris zu sehen gewesen war.

Natïrlich erregte diese Entdeckung unter den umwohnenden Buren und Schwarzen einige Aufmerksamkeit, und auch andere Leute stellten Nachforschungen an. Aber erst zchn Monate später wurde, fern von der ersten Fundstätte, und zwar etwas unterhalb der Miindung des Vaal, im Oranjefluls ein zweiter Diamant festgestellt. Diesem folgte dann der prächtige weilbe 83\% Karat schwere Stein, den im März 1869 ein schwarzer Schäfer auf der Farm Zandfontein nahe dem Oranjeflub auf dem Boden auflas. Auch dieser Stein wurde von Schalk van Niekerk in den Handel gebracht; später gelangte er dann unter dem Namen „Stern von Südafrika“ zur Berühmtheit.

Weitere nennenswerte Funde wurden am Oranjefluß nicht gemacht. Inzwischen hatte aber auch der V a lf I u $\mathrm{B}$ eine Anzahl Diamanten geliefert. Er erschien bald aussichtsvoller und reicher als jener, und hierher richteten sich daher die Blicke der Leute, die, angereizt durch die bisherigen mehr zufälligen Funde, begannen, den Edelstein systematisch aufzusuchen. Eine erste gröliere Unternehmung dieser Art ging von Natal aus; die Gesellschaft erreichte den Vaal nach beschwerlicher Reise im November 1869 und fand hier, nach vielen vergeblichen Versuchen und schon fast gänzlich entmutigt, bei Klipdrift, jetzt Barkly-West, gegenüber der Missionsstation Pniel am 7. Januar 1870 den ersten Diamanten, dem bald zahlreiche andere folgten.

Diese günstigen Resultate bewirkten im Verein mit den früheren Funden ein immer massenbafteres Zusammenströmen von Diamantengräbern (diggers) auch aus der Kapkolonie und von anderen Gegenden. Bis 10000 sollen zeitweise dort versammelt gewesen sein. Sie ließen sich durch den wochenlangen Marsch in der wenigstens zur Winterszeit diurren Karru, wobei zahlreiche Zugtiere zugrunde gingen, sowie durch die Unwirtlichkeit der damals fast menschenleeren Diamantgegenden nicht abhalten, ihr Gliick zu versuchen. Nachdem zuerst nur die an der Erdoberfläche herumliegenden Steine aufgesammelt worden waren, kamen bald, zuerst unter den ungüinstigsten äußeren Verbältnissen, die Gräbereien und Wäschereien an zahlreichen Orten am Vaal zur Entwickelung. Allerdings erwies sich der Ertrag als unbedeutend, und so verließen die meisten diggers nach kurzer Zeit wieder ihre Arbeitsstätte in Vaaltal, um anderwärts lohnendere Beschäftigung zu suchen. Indessen haben die von ihnen gegründeten ,river diggings" doch immer noch, trotz der späteren viel wichtigeren Entdeckungen, eine gewisse, wenn auch untergeordnete Bedeutung. Wir werden sie später noch eingehender kennen lernen, vorläufig aber die Geschichte der Entdeckungen weiter verfolgen.

Bald zeigte nämlich die mit regstem Eifer fortgesetzte Durchforschung des Landes nach Diamanten, daß in jenen Gegenden nicht bloß die Fliisse den Edelstein führen. Auch oben auf der Hochfläche zwischen dem Vaal und dem Nodder, etwa to Kilometer suidöstlich von Pniel (Fig. 45) wurden in den Jahren 1869 bis 1SiL Funde gemacht. Man glaubte zuerst, daß man es mit alten Flußläufen oben auf der Höhe zu tun habe, es stellte sich aber bald heraus, daß es sich hier um ein ganz eigenartiges und von allen bis dahin 
bekannten völlig abweichendes Torkommen handelt. Es waren nicht die Schuttmassen der Seifen im Vaaltale, sondern die Diamanten lagen in einem eigentümlichen grünlichen Gestein eingeschlossen, das sich im Laufe der Zeit an zahlreichen Stellen in Südafrika in wesentlich derselhen Beschaffenheit wiederfand. Man gab ihm den Namen "blue ground" (blauer Grund, Blaugrund), mit dem es auch heute noch ganz allgemein bezeichnet wird. Dieses Gestein war auch nicht wie jene Seifen nur oberflächlich ausgebreitet, sondern es setzt, wie man später bei dem Abbau erkannte, als Ausfüllungsmasse schlotartiger Röhren und mehr oder weniger weit sich hinziehender Spalten quer durch die umgebenden Gebirgsschichten senkrecht in unbegrenzte Tiefe fort. Jedenfalls liat man durch den Bergbau, der in der Kimberleygrube, der tiefsten von allen, bis 900 Meter in die Erde eingedrungen ist, noch kein Ende erreicht. Die schlotförmigen Röhren, sog. pipes, haben einen kreisrunden, oralen oder nierenfürmigen Querschnitt von verhältnismäßig geringem Umfang. Der Durchmesser beträigt 25 bis mehrere hundert Neter; die höchsten Werte hat die ovale Premiergrube bei Pretoria ergeben: 600 und 900 Meter in zwei zueinander senkrechten Richtungen. Die Spaltenausfüllungen, echte Gänge, sind wenige Zentimeter bis 30 Meter mächtig und ziehen sich bis mehrere Kilometer weit im großen und ganzen geradlinig hin. Diese Gänge, teilweise oberirdisch nicht erkennbar, sind früher nicht beachtet worden, weil sie für die Diamantengewinnung nur wenig in Betracht kommen. Sie treten entweder ganz für sich allein, selbständig auf, oder sie stehen mit den "pipes“ in Verbindung; sie gehen von ihnen aus, so daf diese zuweilen auf einer Seite oder auf beiden ausgezogen erscheinen, oder sie verbinden wohl auch zwei solche Röhren miteinander, und nicht selten erweisen sich die pipes deutlich als lokal erweiterte Gänge.

Auf diesem ,blue ground", namentlich in den pipes der damals noch nicht vorhandenen, heutzutage aber so wichtigen Stadt Kimberley entwickelten sich dann die ungeheuer rasch zu so großer Bedeutung gelangten Gräbereien, die gegenwärtig die weitaus überwiegende Menge aller in den Handel kommenden Diamanten liefern. Sie wurden wegen der vollkommenen Trockenheit des diamantenführenden Gesteins als „dry diggings" (trockene Gräbereien) von den "river diggings", den Gräbereien im nassen Flußkies, unterschieden.

Kaum war das Auftreten von Diamanten in dieser Gegend bekannt geworden, so sammelten sich gewaltige Scharen, zeitweise bis zu 20000 Mann, die von allen Seiten herzuströmten, um sich an der Gewinnung dieser Schätze zu beteiligen. Namentlich eilten auch viele diggers rom Vaal herbei in der Hoffnung, an den neuen Plätzen unter vielleicht günstigeren Umständen größere Erfolge zu erzielen.

Eine solche plötzliche Ansammlung zahlreicher Diamantengräber an einem neuen Fundpunkt wurde ein ,rush" genannt. Die Ankömmlinge bedrängten die Buren, denen das Land gehörte und mit denen sie sich vielfach über die für das Graben auf deren Grund und Boden zu bezahlenden Entschädigungen nicht zu einigen vermochten. Die alten Besitzer waren daher froh, ihre Farmen an die zum Zwecke der Diamantgewinnung neu gebildeten Gesellschaften zu in ihren Augen sehr vorteilhaften Preisen verkaufen zu können, die aber angesichts der in dem Boden nachmals gefundenen ungeheuren Reichtümer lächerlich gering waren.

Aber die diggers, die dieser Schätze sich bemäichtigen wollten, waren in jenem abgelegrenen Landstrich nicht auf Rosen gebettet. In der heifen und schattenlosen, wenn auch nicht ungesunden, fast menschenleeren Gegend fehlten die notwendigsten Lebensbedürfnisse. Es gab kein trinkbares Wasser in der Nähe, Nahrungsmittel waren spärlich, der Staub und die Insekten quälten die Leute, die keine menschenwürdigen Wohnungen hatten and zumeist unter freiem Himmel oder in schlechten Hütten und Zelten kampieren mußten, so daß nicht wenige an den Enthehrungen bei der harten Arbeit und an Krank- 
leiten zugrunde gringen. Jedoch die schlimmen Zustände der ersten Zeiten besserten sich allmählich, die Gruben erwiesen sich als sehr reichlıaltig, und immer neue funde wurden gemacht, so dal trotz aller anfänglicher Schwierigkeiten und Widerwärtigkeiten keine Entmutigung Platz greifen konnte.

Den ersten Fund in der Nähe der jetzigen Stadt Kimberley machte, wie es scheint, der Bur Cornelius IIendrik du Plooy auf seiner Farm Bultfontein (Figr. 16), nach der gewöhnlichen Angabe am 6. Tovember 1569. Er zeigte in dem Dorf Jakobsdal mehrere ihm auffïllig ersehienene Steine vor, von denen einer als ein Diamant erkannt wurde. Auf dieser Farm steht jetzt die nach ihr benannte Grube Bultfontein. Es folgte die unmittelbar östlich anstoliende Farm Dorstfontein, wo im September 1570 der Eigentïmer, der Bur Adriaan

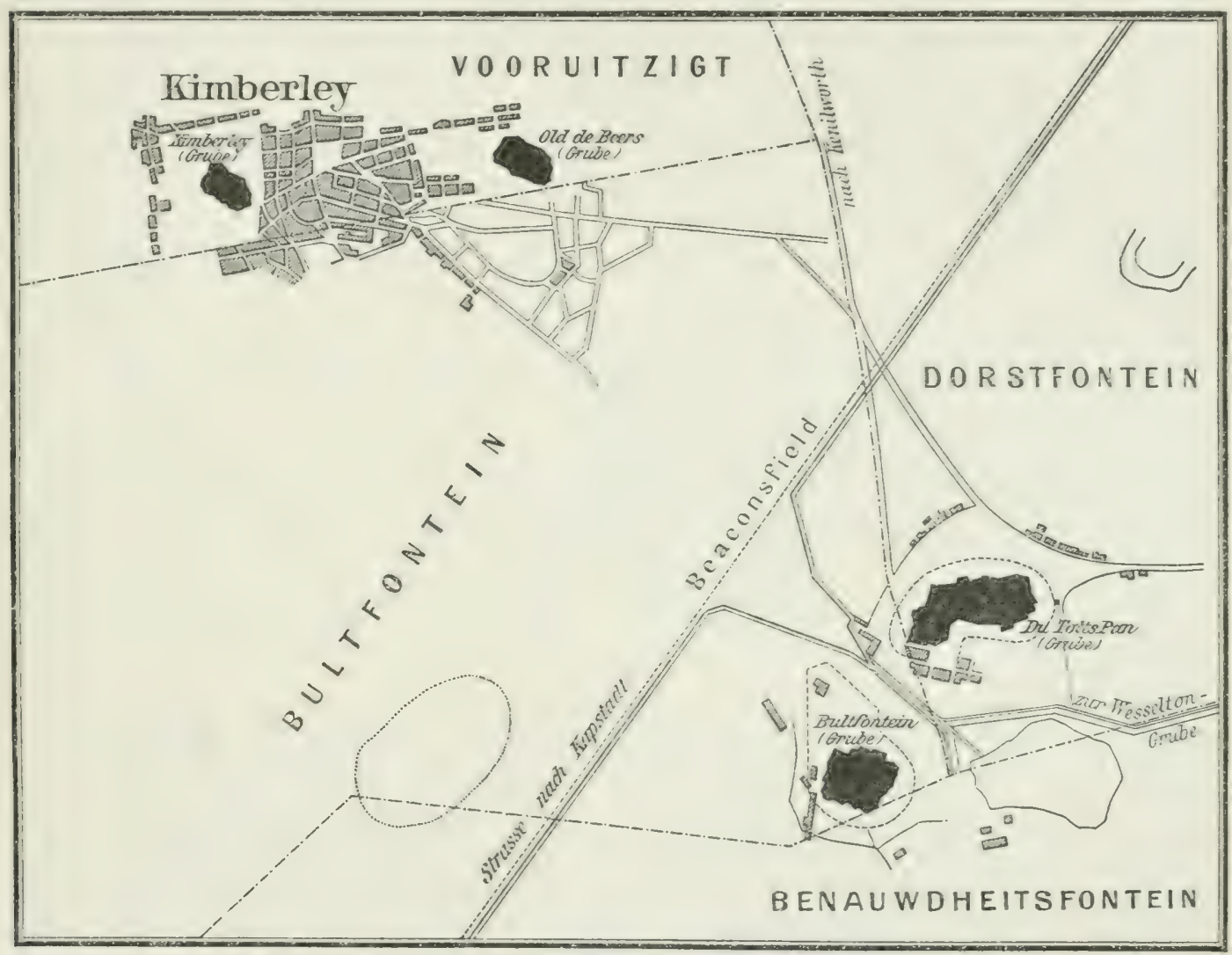

Fig. 46. Diamantgruben bei Kimberley. (Maßstab 1:40000).

J. van Wyk nahe bei seiner Wolnung auf einen am Boden liegenden Diamanten stieß; auch soll er eine Anzahl Steine aus den Wänden seines Hauses herausgelöst haben. die aus dem Schlamm eines benachbarten Teiches, einer "pan“, aufgeführt worden waren. An dieser Stelle wurde dann die nach dem Vorbesitzer des Wyk, Abraham Pauls Du Toit, benannte Grube $\mathrm{D} u$ to itspan angelegt. Als noch wichtiger erwies sich nachmals die etwa 3 bis 4 Kilometer weiter im Norden gelegene Farm Tooruitzigt des Buren de Beer, auf deren Gebiet in der Folge allmählich die Stadt Kimberley entstand. Der erste Fund, im Mai 1871, führte zur Begrïndung der Grube „De Beer's rush” oder "Old de Beer's* oder kurz De Beer's östlich von der Stadt. Im Juli desselben Jahres 1871 wurden Diamanten auch auf der Spitze eines kleines Hügels (kopje) westlich von der Stadt Kimberley entdeckt und hier entstand dann die vierte der großen und berühmten Kim- 
berleygruben, die zuerst als ..Colesherg Kopje" oder als „De Beer's new rush" bezeichnet wurde, die aber bald den Namen Kimberleygrube schlechtweg erhich und die sich späterhin als die reichbaltigste und wichtigste von allen vieren erwies.

Diese vier Gruben waren bis in die letzte Zeit die Hauptdiamantenfundorte, und von ihrer Eröffnung schreiht sich der riesenhafte Umsehwung in der Diamantengewinnung her. Ihnen hat sich erst juingst noch eine gleichwertige in einem andern Teile Südafrikas, in Transvaal angeschlossen. Aber auch jetzt sind sie noch von der größten Wichtigkeit und Bedeutung. Sie befinden sich sämtlich dicht bei der 1872 von den Diamantengräbern begriindeten Stadt Kimberley, dem Mittelpunkt der gegenwärtigen Diamantenindustrie, die jetzt etwa 50 000 Einwohner z:ïllt und mit der noch einige volkreiche Vorstädte: Beaconsfield, Wesselton und Kenilworth anschließen. Die beiden entferntesten Gruben liegen zirka 5) Kilometer auseinander; Fig. 16 gibt ihre gegenseitige Position an. Hier ist der Ort, der bis vor ganz kurzem fast alle aus Südafrika in den Handel kommenden Diamanten, ïber 90 Prozent der Gesamtmenge der ganzen Erde geliefert hat. Außer den vier genannten hat man aber später in engem Umkreis noch einige andere unbedeutendere Lagerstaitten entdeckt, die jedoch wegen zu geringer Reichhaltigkeit meist unbebaut geblieben oder bald wieder verlassen worden sind. Nur eine einzige von ihnen hat eine gewisse beschrïnkte Wichtigkeit erlangt und einen immerhin nennenswerten Ertrag geliefert. Es ist dies die Wesseltongrube, ungeführ 2 Kilometer östlich von Dutoitspan und etwa 7 Kilometer siidöstlich von Kimberley, die im September 1890 eröffnet wurde, also zwanzig Jahre später als die vier anderen jener Gegend. Sie hieß zuerst auch die Premier mine, dieser Tame ist aber zugunsten einer lange nachher, 1902, entcleckten und eröffneten Grube bei P'retoria in Transvaal fallen gelassen worden, die jetzt mit zu den allerwichtigsten in Siidafrika grebört und daher diesen Namen besser verdient. Nur im Vorbeigehen erwähnt seien die anderen, deren ungeführe Lage rings um die Stadt, bezeichnet durch die beigefügten Nummern, in Verbindung mit den schon erwähnten auf Fig. 45 daresestellt ist. Es sind: 3. Otto's Kopje, 4. Kamfers Dam, 5. Taylor's Kopje, (6. Doyl's Kopje, 7. Sainte Augustinegrube, 8. Kimberleygrube, ؛. De Beer's, 10. Bultfontein, 11. Dutoitspan, 12. Wesselton, 13. Belgravia.

Aber die Funde des Jahres $1 \delta_{\mathbf{~}} 0$ beschränkten sich nicht auf die Ungebung ron Kimberley. Fast gleichzeitig wie auf der Farm Dorstfontein (Dutoitspan), im August 1Si), wurden etwa 120) Kilometer weiter siidlich in Gebiet des Rietflusses auf der Farm Jagersfontein Diamanten nachgewiesen. Der Wirtschaftsinspektor Klerk daselbst beobalitete in einem zur Sommerszeit trockenen kleinen Wasserlauf (spruit) rote Granaten, von denen er sehört hatte, dals sie an Vaal auf die Anwesenheit von I)iamanten hinweisen. Fr bexamn darauf hier eine lileine Gräberei und traf in der Tiefe von 6 Ful einen Stein yon 50 karat. Wir iilerall nach einem solehen Ereignis gab es nun auch hier einen "rush", und es entstand dir nach der Farm benannte, auch jetzt noch wichtige Grube Jagersfontein, der sich spaiter nehen anderen die 60 Kiloneter weiter nordöstlich segen Jacobstal am Riet gelegene Grube Koffyfontein von geringerer Wichtigkeit anschloß.

So liegen also alle siddafrikanischen Jiamantgruben, soweit sie nach den ersten groben Entrleckungen un das Jahı 1870 bekaunt waren, auf einem verhältnismäßig kleinen Raum nördlich vom Oranjeflul) beisammen (Fig. 15). Sie sind in dem Landstrich verteilt, der von dem 26. Frade istlich von (ireenwich und der Gabel zwisehen dem Oranje- und dem Vaalfluf, den beiden IIauptfliissen Südafrikas, begrenzt wird, wobei aber das rechte nördliche Ifer des letzteren Flusses noch mit eingerechnet und wobei von den allerersten ganz vereinzelten Funden abgesehen werden mus, die zum Teil etwas siidlich rom Oranjeflub gemacht worden sind. Alle bis dahim bekannten Gräbereien und Wäschereien befinden sich in dem Quadrat, das von dem 29. und 30. Breiten- und von 
dem 21. und 26. Längengrad begrenzt wird. Die Stadt Kimberley liegrt ungefähr in der Mitte dieses Quadrats und die Grenze zwischen der Kapkolonie und dem friiheren OranjeFreistaat, bildet nahezu die Nordost-Siidwest-Liagronale. Auf diesem Gebiet ist die Vertoilung der Diamantfundpunkte (abgesehen von den Wäschereien im Vaalflusse) so, da!; sie alle auf einer 200 Kilometrer langen, fast geraden Linie liegen, die von Ford-Nord-West nach Süd-Süd-Ost getrichtet, ungefähr von der Mündung des Iartriver in den Vaal bis jenseits Fauresmith in der Oranjeflul-Kolonie, verläuft. Auf dieser Linie, die ron geologischer Wichtigheit ist und einer ausgedehnten Bruchspalte entspricht, liegt Kimberley, ung"efähr 40 Kilometer vom Taal entfernt unter $28^{\prime \prime} 42^{\prime} 54^{\prime \prime}$ siidlicher Breite und $24^{\prime \prime}$ 5()$\left.^{\prime} 1.\right)^{\prime \prime}$ östlicher Länge von Greenwich in eincr Meereshöhe ron 1232 Meter; Koffyfontein ist 60, Jagersfontein 120 Kilometer von Kimberley entfernt. Ein Stein von 7) Karat soll auch noch jenseits Jagrersfontein bei Mamusa am oberen Hart gefunden worden sein, man hat davon aber nichts weiteres mehr gehört. Yancher dieser Fundpunkte ist nicht genauer untersucht, da der Ertrag die Arbeit nicht lohnte, davon ist dann hier weiter nicht die Rede. An manchen anderen Orten beruhten die angeblichen Diamantenfunde sogar auf wissentlicher 'Täuschung. die von den Betrïgern zu dem Zweck unternommen wurde, um Spirituosen und andere Waren raseh und zu hohen Preisen an die hoffnungrswoll herbeiströmenden diggers zu verkaufen und so ein gutes Geschäft zu machen. Derartiges wurde daher als "canteen rush" bezeichnet.

I) ganze jetzt so wichtige Landstrecke war bis zur Entdeckung der Diamanten eine ïle, beinahe wïste Gegend ohne jeden Ertragswert, wo ein spärlicher Pflanzenwuchs wenigen Buren und Jägern einen kärglichen Lebensunterhalt gewährte. Sie gehörte zum Oranje-Freistaat. Tachdem aber die Gewinnung der unterirdischen Schätze einen so grewalticren Aufschwung genommen hatte und eine grobe Menschenmasse in der früler so diinn bevölkerten und allseitig fast unbeachteten Gegend zusammengeströmt war, bemächtigte sich die unglische Regierung des Landes unter dem Vorwand, in der zuchtlosen Gesellschaft der Diamanteräber Gesetz und Ordnung herzustellen. Am †. Jovember 18i1 wurde die englische Flagge in Kimberley grehibt, nachdem schon vorher (15ioj) die Diamantenfelder an Vaalflub in der Nähe ron Pniel usw. von den Engländern in Besitz Eenommen worden waren. Diese Annexionen waren Gewaltstreiche gregen den schwachen und schutzlosen Oranje-Freistaat, die das mächtige England schlieblich 1576 durch Zahlung (iner Entschädigungssumme ron 90000 Ifund Sterling zu sühnen suchte. Aus dem amnektierten Lande entstand dann die zuerst selbständige, seit 1SS() aler mit dem Kapliande vereinighte Kolonie Griqualand-West, die nummehr alle die damals bekannten reichen Dianantengruben enthält, mit einziger Ausnahme der beiden siidlichen dauernd zum OranjeFreistate, jetzt Oranjefluf-Kolonie, gehörigen, Koffyfontein und Jagersfontein, die aber nur etwa 6 bis 7 Prozent der gesamten südafrikanischen Diamanten liefern.

Wie das ganze Land furch die Diamanten erst eigentlichen Wert erhalten hat, so sind auch die einzelnen Landparzellen, mamentlich die, auf denen die Diamantsrulsen liegen, unom in Preise sestiegen. So wurde für die fast wertlose Farm Dorstfontein 26un Pfd. Sterling (520)(1) Mark), für die nicht wertyollere Farm Buitiontein 2000 I'fund Sterling (f) Uu( Mark) bezahlt. Die Farm Tooruitzigt, auf der jetzt Kimberley liegt, war ilnem Besitzer 1S71 um 6000 Pfund Sterling (ca. 120000 Mark) abgekauft worden; im Jahr 1S7j wurde sie von der englischen Regierung um 100000 Pfund Sterling (mehr als 2 Millionen Mark, erworlen, um den unaufhörlichen Streitigkeiten zwischen den Besitzern des Grund und Bodens und den darauf arbeitenden Diamantgräbern ïber die von den letzteren an jene zu zahlenden Gebïhren ein Ende zu machen.

Weitere Vorkommnisse von der Bedeutung der oben genannten wurden nun trotz vieler eifriger, aber allerdings planloser Nachforschungen zahlreicher Prospektoren zunäichst 
nicht mehr aufgedeckt; das Hauptaugenmerk richtete sich auf die Ausbeutung der um 1870 entdeckten Lagerstätten. Infolge des trotzdem ununterbrochen fortgesetzten rastlosen Prospektierens auf den kostbaren Edelstein ergab sich jedoch allmählich, daß der Diamantengrund keineswers in seinem Vorkommen so beschränkt sei, wie man wohl eine Zeitlang angenommen hatte, sondern daß er im Gegenteil sehr häufig und über ganz Südafrika verbreitet ist. Von der Nitte und dem Norden der Kapkalonie nach Griqualand-West, von Groß-Namaland in Deutsch-Siidwestafrika bis Rbodesia, nördlich vom Zambesi bis nach Ostafrika, im Pretoriadistrikt in Transvaal, im Blumhofdistrikt in der OranjeflußKolonie, kurz im ganzen Westen des Zuges der Drakensberge ist kaum ein Bezirk, wo nicht das Diamantengestein gefunden worden wäre.

Allerdings ist der Blaugrund keineswegs iiberall gleich reich an Diamanten. An zahlreichen Stellen haben die Gewinnungsarbeiten wegen zu geringer Ergiebigkeit bald wieder eingestellt werden müssen, und viele Vorkommen haben keinen einzigen oder doch fast keinen Stein geliefert. Daher sind alle diese neueren Entdeckungen jenen älteren gegenüber von untergeordneter Bedeutung, jedoch mit, allerdings sehr spärlichen, Ausnahmen. Die eine ist die schon erwähnte, aus dem Jahre 1890 stammende Wesselton-Grube bei Kimberley, die andere die 1902 bei Pretoria eröffnete Premier-Grube, die wegen ihrer Reichhaltigkeit rasch zu so großer Bedeutung gelangt ist, und von der unten noch weiter und eingehend die Rede sein wird. Es sei hier nur noch erwähnt, daß neben den Diamanten auf primärer Lagerstätte im ,blue ground" an zahlreichen Stellen in den genannten Gegenden auch solche auf sekundärer Lagerstätte, in Seifen, vorkommen, die zum Teil mit Blaugrundmassen in der Art in Verbindung stehen, daß die Abstammung der Steine aus diesen letzteren außer Frage steht.

Ilier soll zunächst nur eine flüchtige Übersicht über eine Anzahl dieser neu entdeckten, meist nicht abbauwürdigen Vorkommen gegeben werden, ohne näheres Eingehen auf die Zeit und die Umstände der Auffindung. Eine eingehendere Beschreibung der wichtigeren von ihnen wird dann unten zusammen mit der der oben erwähnten älteren erfolgen.

In der Kapkolonie wurden Mitte der neunziger Jahre des vorigen Jahrhunderts 60 Kilometer nordnordwestlich von Kimberley am Hart-Fluf die Newlands-Gruben aufgretan (Fig. 45). 20 Kilometer nordöstlich von ihnen ist die Weltefreden- und dicht dabei die Frank Smith-Grube, noch weiter in dieser Richtung die Cyrus-Grube. Ungefähr 20 Kilometer südwestlich von Newlands liegt auf derselben Geraden zwischen dem Hart und dem Vaal die Borrels-Grube, nahe dabei gegen Osten die Washington-, und immer in derselben Richtung auf Kimberley zu in etwas größerer Entfernung die Victoria-, endlich 4 Meilen daron die Russels-Grube (letztere ist nicht auf der Karte angegeben). Diese letztgenannten vier Gruben bilden wieder eine fast gerade Linie, die in ihrer Verlängerung von Barkly-West vorbei auf Kimberley trifft und die vielleicht die Fortsetzung derjenigen Linie ist, die, wie wir oben gesehen haben, Jagersfontein mit Kimberley verbindet. 13 Kilometer östlich vom Vaal und ungef:̈hr 28 Kilometer nördlich von der dortigen Hauptbahn (nach Rhodesia), dicht vor der Riverton RoadStation liegt auf der Farm Bultuan die Pole-, und etwas östlich davon auf der Farm Witpan die Phönix-Grube, nordwestlich von hier, jenseits des Vaal, gegen Frank Smith die Wrigley Kopje- und die Leicester-Grube. Jüngst ist auch Blaugrund im Gebiet des Vaalflusses nordwestlich von Kimberley gefunden worden.

In der Orange River-Kolonie (Fig. 45, 50) wurde ganz nahe bei Koffyfontein die Ebenezer-(Ebenhaezer-)Grube angelegt, 2 Kilometer weiter nördlich die wie diese jetzt rerlassene Klipfontein-(Regina-)Grube. Im Norden der Kolonie, 30 Kilometer in nordwestlicher Richtung von Kroonstad entfernt, liegt die Lace-Grube und westlich davon die Vorspoed-Grube. Nahe der Ostgrenze der Kolonie ist die nicht unwichtige 
II on astery-Grube, etwas westlich von Ficksburg und siidïstlich von Winbure. Weiter sïdlich, suidwestlich von Ladybrand, ist die Bethel-Grube. Die Driekopjes-Grube liegt nordwestlich von Winbur世. zwischen den Flüssen Zand und Vet etwas westlich von der siidafrikanischen Zentralhahn, und in derselben Gegend, in der Nähe von Smaldeel, dem Knotenpunkt der Seitenbahn nach Winburg u. a., die Robinson-Grube auf der Farm Kaal Valley, die einige Jahre lang bearbeitet wurde. Einige andere weniger interessante seien hier übergangen, nur die Roberts Victor-Grube bei Boshof, nordöstlich von Kimberley und die Olifant-(irube wenig sïdöstlich von dieser Stadt seien noch genannt.

In Transval wurden die ersten Diamanten 1897 auf der Farm Rietfontein gre. funden. Der kleine diamantenführende Landstrich liegt im Pretoria-Distrikt wenig östlich von der Hauptstadt auf der Ilochflïche zwischen dem Elands- und dem P'ienaars-Flusse. Die Gruben arbeiten teils in pipes, teils in Seifen; sie sind auf der Karte Fig. 51 dargestellt. Unbedeutend ist die Schuller- und die Kaalfontein-Grube im Süden, dann die Montrose-pipe und die Seife gleichen Namens. Von ungemeiner Wichtigkeit ist dagegen die nördlichste, die Premier-Grube, die ausgedehnteste aller bekannten, die selir große Steine, darunter den grölten ïberhaupt bisher gefundenen, den Cullinan geliefert hat und die durch ihre reiche Ausbeute mit der De Beer's-Gesellschaft in erfolgreiche Konkurrenz treten und deren Monopol bedrohen konnte. Westlich ron ihr liegen zwei unbedeutende Gruben in Seifen, deren Diamanten der Premier-pipe entstammen.

Die Anzahl der Blaugrund fuihrenden Schlote (und auch der wegen ihrer geringen praktischen Bedeutung hier noch nicht berïcksichtigten Gänge) ist also nicht klein. Wenigstens $60 \mathrm{der}$ ersteren, teils mit, teils ohne Diamanten (sog. ausgebrannte pipes) sind bekannt. Auch die diamantführenden sind praktisch von sehr verschiedener, die allermeisten von geringer Wichtigkeit, und die Mehrzahl der oben genannten Gruben steht nicht mehr oder doch nur in sehr geringem Betrieb oder ist iiberhaupt nie bearbeitet worden. Als die zur Zeit ertragreichsten seien besouders hervorgehoben: die fünf Gruben bei Kimberley (die Kimberley-, De Beers-, Bultfontein-, Dutoitspan- und die WesseltonGrube) im Kapland (Griqualand-West), die Jagersfontein-, die Roberts Victor- und die Vorspoed-Grube in der Oranjefluß-Kolonie, endlich die Schullers- und vor allem die Premier-Grube in Transvaal. Alles übrige ist von untergeordneter Bedeutung und das meiste daher oben nicht einmal im Vorbeigehen erwähnt. Wie weit die in Rhodesia und Deutsch-Südwestafrika bekanntgewordenen Diamantrorkommen ertragreich sind, wird erst die Zukunft lehren. Auch hierüber wird unten das bisher bekanntgewordene mitgeteilt werden.

Wir betrachten nummehr die einzelnen Lagerstätten genauer, und zwar zuerst die "river diggings" im Vaaltale, solann die hervorragenderen "dry diggings" in den verschiedenen Teilen Suidafrikas.

\section{River diggings (Flusswäschereien).}

Die reichsten liegen am Unterlaufe des Vaalflusses auf dessen beiden Seiten zwischen der Missionsstation Pniel und Klipdrift (Barkly West) einerseits und Delports Hope am Zusammenfluß des Vaal und des Hart Rirer andererseits (Fig. 45, S. 210). Klipdrift ist gegenwärtig der Mittelpunlit dieser ganzen Diamantgewinnung. Eine Anzahl Diamanten ist in Vaal auch weiter aufwärts bis Hebron (Windsorton), sogar bis Bloemhof und Christiana in Transval und ebenso flubabwärts bis zur Mündung in den Orange River und noch in diesem Flusse ron da bis Hopetown, sowie in einigen Nebenflüssen des Vaal, besonders im Modder und Vet, und des Orange River gefunden worden. Die Ergiebigkeit war jedoch an allen 
Orten so gering; daß die Ausbeutung jetzt fast ganz auf den zuerst genannten Abschnitt des Vaal beschränkt ist, eine Strecke des Vaaltales, die vom Zusammenflusse von Vaalund Hart River aufwärts etwa 90 Kilometer in der Luftlinie und etwa 130 Kilometer nach den Windungen des Flusses milt. Als besonders wichtig werden genannt die Bezirke von Newkerke, Waldecks Plant, Good Hope, Gongr Gong, Barkly West, Wedburg (hier, (6) Kilometer von Kimberley, am linken Ufer des Vaal, hat Zand Kopje in dem am 30. September 1903 endigendem Jahr für 60)000 Pfund Sterling (1200000 Mark) Diamanten geliefert) und Forteen Streams, alle in der Kapkolonie, sowie die Umgegend von Christiana. Aber auch hier ist eine ganze Reihe von Gruben auflässig geworden, als sich später der Strom der Arbeiter vom Flusse weg nach den unendich viel reicheren "dry diggings" bei Kimberley gezogen hatte. Die ganze Produktion der Flußwäschereien, die bis 1571 wichtig gewesen war, ist jetzt von untergeordneter Bedeutung. In ihnen finden wir eine kleine eigentïmliche Klasse von Diamantengräbern, welche mit großer Zähigkeit an diesen Gruben festhält, rastlos arbeitet, die zahlreichen Entbehrungen mit Gleichmut 'rträgt und trotz aller Miljerfolge und trotz des im günstigsten Falle immerhin kärglichen Crewinnes die Hoffnung auf bessere Tage nicht aufgibt. Ihre Zahl war lange Zeit gering: und wird wohl 200 bis 300 , Weiße und Schwarze, nicht überschitten haben. Sie arbeiten (inzeln, oder zu zweien oder dreien, nicht in größeren Gesellscbaften. Die Konzentration der . .lry diggings" in der Hand von großen Aktiengesellschaften, von der unten die Rede sein wird, hat aber zur Folge gehabt, daß die Zahl wieder größer wurde. Man zählt gegenwärtig hïchstens 1000 Weiße, vielleicht nur die Hälfte, mit zahlreichen eingeborenen Arbeitern. Gesellschaften zur Ausbeutung der Seifen haben wenig Erfolg gehabt. Die "river diggings" gelten als "poor men diggings".

Das bett des Vaal ist erfüllt mit Blöcken von diabasartigen und mancherlei wahrscheinlich metamorplischen Gesteinen, von denen die ersteren oft Mandelsteinstruktur besitzen. Diese Blöcke, die zum grroßen Teil sehr bedeutende Dimensionen haben, sind von den umgebenden Hügeln und Talabhängen herabgestiirzt. Zwischen ihnen liegt ein Gemenge kleinerer Geschiebe und Gerölle mit Kies, Sand und Lehm und hier finden sich die Diamanten, das ganze vielfach bedeckt ron einer melir oder weniger dicken Lage (ines roten Sandes, dem „rooi grund" (red ground) der ersten meist holländisehen Diamantsucher. Am reichsten sollen diejenimen Kiespartien sein, die ummittelbar auf dem anstehenden Untergrund aufliegen. Die Mächtigkeit der gesamten Ablagerung ist sehr verschieden und steigt his zu $12 \mathrm{~m}$ und mehr. Das Ganze ruht auf anstehenden Diabas. In diesem triff man an cinzelnen Stellen runde Becken oder Kessel oder auch langrgezogene hanaile mit senkrechten gexplätteten Wänden, manche von recht beträichtlichen Abmessungen. Sie sind durch die Taitigkeit des Wassers in dem festen und harten Bodengestein ausgearbeitet worden, und die runden Becken sind wahrscheinlich durch Fieschiebe ausgehöhlt die, im Sturz von Wasserfïllen herumgewirbelt, sog. Riesenkessel gethildet haben. Ähnliche Erscheinungen halen wir ja schon in den diamantenführenden Wasserläufen Brasiliens angetroffen (S. 1 (S) ). Wie dort ist auch in diesen Tertiefungen im Bette des Vaal der diamantführende Schutt hesonders massenhaft angehäuft und die Diamandführung ist nicht selte besonders reichlich. So hat ein solcher Kanal bei Waldeck's Plant, Sniths Gully wenannt,

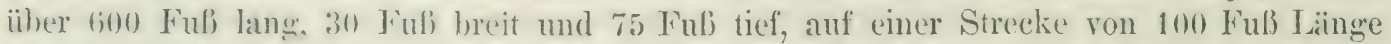
für 10 (60) Pfund Sterling (200) (060) Mark) Diamanten weliefert, darunter viele sroße und schöne Steine.

Zuerst wurde nur in dem Flubbette selbst gegraben, bald aber entdeckte man, dab die Sande und Kiese außerhall, desselben, in den lïngs des Flusses sich hinziehenden T'urrassen, (benso reich, jal wohl noch reicher sind, und so wurden auch diese in Angriff „2"enonnen. Von jenen Terrassen und den in ihnen befindlielıen Gräbereien liegen dıe 
meisten nur einige Iteter ïber dom jetzigen Wasserspiegel, einige erheben sich aber bis zu $60 \mathrm{~m}$ über diesen. Ihre Bearbeitung ist viel sicherer und beruemer als die des Flubhettes selbst, weil in diesem die Überschwemmungen den Gräberein vielfach den grïßsten Schaden zufü̈en und sie auch wohl zeitweise ganz unmögrlich machen. Es ist daher in neuester Zeit auch der Plan entstanden, den ganzen Vaalfluß aus seinem alten Bett, soweit es Diamanten birgt, ab- und in ein neues zu leiten, doch ist er noch nicht zur dusführung gelangt.

Die Diamanten, die zwischen den stroben Geschieben in dem sandigen Lehm lixgen. sind vielfach wie die anderen Flubgerölle und die Sandkörner deutlich. aber der strolien Iärte wegen wenicer stark als jene abgerollt. Sie werden von kleinen Geröllen zahlreicher Mineralien begleitet, so besonders ron rotem Granat und grïnem Olivin, die als günstiges Anzeichen für das Torkommen von Diamant gelten, von verschieitenen Quarzvarietiten, Achat, Jaspis, verkieseltem IIolz usw, die alle aus dem Olserlauf des Flusses stammen. Auch (ierölle ron hier anstehenden Gesteinen sind in grolier Menge beigenuischt. Sparsinner sind die meisten Mineralien rorhanden, die wir als Berrleiter der Diamanten in den "dry diggings" kennen lernen werden, doch fehlen sie nicht ganz. So werden aufer Granat und Olivin kleine Stïckehen von Titaneisen, dem Glimmer ähnlicher Taalit usw. gefunden. Zwischen diesen Mineralgeröllen liegt der Diamant, sanz in derselben Treise wie sie sellsst. Er ist sehr ungleichmähig verteilt, so dab ärmere und reichere Stellen miteinander abwechseln. Der Arbeiter, der auf eine reiche Stelle stößt, kann in kurzer Zeit sein Glïck machen, andere graben monatelang ron morgens bis abends, obne das Geringste zu finden.

Die Arbeit ist nicht wesentlich verschieden von der in den Diamantwäschereien anderer Lïnder und auch ron der in den sïdafrikanischen und australischen Goldwäschereien. Sie hesteht darin, daf) der Sand oder Lehm mit den Geschichen ausgegraben wird, was oft nur mit der crrößten Anstrengung müglich ist, da fiesteinshlüeke zum Teil fon sehr großem Lmfang häufig erst entfernt werden müssen, um zu den diamantführenden feineren" Iagen zu gelangen. Sehr tief liegende Kiese werden auch wohl mit Hilfe von Schäichten unterirdisch abgebaut. Das Material wird in Fïssern aufgeriihrt, sodann der feinste Schlamm in sogenannten cradles oder Wiegen durch IIinundherschaukeln unter fortwährendem begießen mit Wasser wegrewaschen und rleichzeitig durch Siebe die sroben und feinen Teile entfernt. Ein Rïickstand von mittlerem Korn bleibt dann schlieblich übrig, der die Diamanten enthält. Er wird in einer dïnnen Lage auf einem Tische ausgebreitet und die darin befindlichen Steine auscrelesen. die man schon bei geringer Übung namentlich in nassem Zustand an ihrem Glanze zwischen den anderen Sandkürnern und Geröllen leicht erkennt.

Jie Ausbeute ist im ganzen nicht sehr groli, sie beträgt im Mittel 15000 bis 20 (1m) Karat jährlich, weht aber auch zuweilen höher. Im Jahre 1990 wurden 2\$ 1223 ; Karat

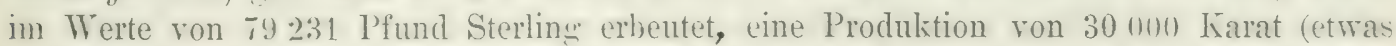

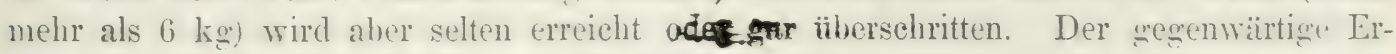
trag soll den Wert von 2 Millionen Mark erreichen.

Die geringe Henge wird aher wenigstens zum Teil wieder aufgewogen dureh cine ganz besonders schöne Qualitït. Diese ist bei den Flufsteinen aus den ...river dignings: in Durchschnitt sehr viel besser als bei den Produkten der „dry diggings" und nähert sich der der brasilianischen Steine. Sie besitzen eine gröfere Härte und ein stärkeres Fener, und wenn sie gefürbt sind, ist ihre Farbe ausgesprochen tiefer als hei den Steinen ron Kimberler. Daher sind die Preise für sie im Mittel sehr viel höher als die für die letzteren. So wurde z. B. in den achtziger Jahren für ein Karat Flussteine durch schnittlich 56 Mark bezahlt, während der Preis für ein Karat Steine aus den rier Kim. 
berleygruben im Durchschnitt nur 223/4 Mark erreichte, und ähnlich ist das Verhältnis noch jetzt. Es ist ein großer Prozentsatz farbloser fehlerloser Steine vorhanden, namentlich sind keine Sprünge da, weil nach solchen die Stïcke bei der Bewegung im Fluß schon vorher zerbrochen sind. Viele sind gelb; andere Farben sind tief orangegelb, blaßblan und -braun, rosa usw. Wenig Steine wiegen mehr als $30 \mathrm{Karat}$, viele jedoch über 10 Karat. Indessen lraben die "river diggings" auch einige besonders große Exemplare geliefert. Zu diesen gehört der schon erwähnte "Stern von Südafrika“, ein Diamant vom reinsten Wasser von 831/2 Karat im rohen Zustande, sowie der hellgelbe "Stewart" von $288^{3}$, Karat, der bei Waldeck's Plant am Vaal gefunden wurde. Von beiden wird unten noch weiter die Rede sein. Der größte bisher gefundene Stein, fast kugelig abgerollt, wog 330 3/s Karat und hatte einen Wert von 3500 Pfund Sterling (70000 Mark).

Diese river diggings sind Seifenlager, wie wir sie in Indien und Brasilien kennen ggelernt haben, in denen sich die Diamanten auf sekundärer Lagerstätte befinden. Man hat sich ihre Bildung zweifellos so zu denken, dafj eine ursprüngliche Lagerstätte wahrscheinlich von der Natur der unten zu besprechenden "dry diggings" oder auch mehrere solche in dem Gebiet des Oberlaufes des Vaal zerstört wurden und daß ihr Material in den Flußlauf hinein und in diesem talabwärts geschwemmt worden ist. Die Abrollung auch vieler Diamanten zeigt diese Bewegung im Flusse deutlich. Die ursprïngliche Lagerstätte war wohl nicht oberhalb Bloemhof in Transvaal gelegen, da man oberhalb dieser Stadt nie einen Diamanten gefunden hat. Eine Anzahl der Steine stammt vielleicht aus dem Blaugrund, den man, wie wir oben gesehen haben, neuestens im Gebiet des Vaal entdeckt hat. Man hat aber auch die Ansicht geäußert, daß die Steine wegen ihrer ganz anderen Beschaffenheit usw. als die der Steine aus den pipes, nicht aus solchen, sondern aus den den Vaalfluß begleitenden Diabasen stammen, weshalb sie auch vielfach nicht abgerollt wären. Nach gewissen Nachrichten hätte man in Südafrika auch schon Diamanten im Diabas eingewachsen gefunden, dies ist aber immerhin noch unsicher. Doch wird das Vorkommen im Diabas auch aus Neu-Süd-Wales gemeldet.

Daf ein 'Teil aus der Gegend von Kimberley hergekommen sein könnte, erscheint nach den örtlichen topographischen Verhältnissen ausgeschlossen. Bei der Beurteilung dieser Frage ist es nicht von erheblicher Wichtigkeit, daß so wenig von den Mineralien der dry diggings mit dem Diamant im Vaal vorkommen. Dies ist nicht weiter auffallenrl, da diese meist nicht sehr hart sind und daher beim Transport im Wasser leicht zerstïrt werden, leichter als die anderen im Gebiete des oberen Vaal vorkommenden Mineralien, die als Begleiter des Diamants im Fluße grenannt worden sind. Auch wäre es nicht undenkbar, dals cine Anzahl der in den dry diggings mit dem Diananten vorkommenden Mineralien hier schon von vornherein nicht oder nur sparsam vorhanden gewesen wïren. Die erheblich höhere (Qualität der „Flußsteine" im Vergleich zu der der Steine aus den dry diggings spricht ebenfalls nicht gegen die Abstammung aus diesen, da auch in einigen der letzteren, z. 13. in Jagersfontein, die Steine eine sehr viel bessere Beschaffenheit haben, als durchschnittlich in den anderen. Steine solcher besseren Qualität müßte dann auch die zerstörte Lagerstïtte, deren Material jetzt die Flußgeschiebe zum Teil bildet, enthalten haben.

\section{Dry diggings.}

a) Kapkolonie.

ILier sollen zunäelıst in der Uauptsache die Vorkommnisse der Gegend von Kimberley und zwar in erster Linie die pipes betrachtet werden. Dies empfiehlt sich, weil die dortigen (Aruben, resp. die pipes, auf denen sie angelegt sind, bis vor wenigen Jahren fitst alle siidafrikanischen Diamanten geliefert haben, weil sie wegen der starken Bearbeitung 
besonders gut bekannt sind und weil fast diesellen Verhältnisse mit nur geringen Abweichungen anderwärts überall wiederkehren.

Geologische Vorhältnisse. Das (iebict ist ein Teil der dort 1200 bis 15(0) Meter hohen unfruchtharen ebenen IIochfläche der Karru. Den Untergrund bilden die fast rlurehweg horizontalen schichten der danach benannten Karruformation, die dem Alter nach etwa dem Permokirton (Kohlenformation, liotliegendes und Zechstein) entspricht. Im besonderen jat es deren unterste Abteilung, die Eceagruppe, unterlagert von dem DwykaKonglomerat. Letzteres, von (iner sehr stark wechselnden Mächtigkeit bis zu 2,i) II teter, ist ein von Gletschern jener \%eit geblildeter, moränenartiger Blocklehm; die eigentlichen Eceabildungen bestehen atus ciner etwa 1000) Meter mächtigen Schichtenfolge von unten Schiefertonen, oben Sandsteinen, (welch' letztere aber bei Kimberley durch Erosion entfernt sind) mit zahllosen zwischengelagerten Bänken und hindurchsetzenden Cä̈gen von Diahas oder diabasähnlichen Eruptivgesteinen, die, ohne dab erhebliche Lnterschiede vorlägen, je nach ihrem äuferen Ansehen auch als Diorit, Melaphyr, Mandelstein, Traply, Lasalt, Dolerit usw. bezeichnet werden (Fig. 47, S. 222).

Pipes. In diese und die darunterliegenden älteren, an der Erdoberfläche in jener Gegend nicht sichtbaren Schichten der dem Devon zuwerechneten Kapformation usw. sind die mit Blaugrund (rfïllten Kanäle, Trichter odler Schlote, die „pipes"“. die Diatremen Dauhrées, eingesenkt. In Transtaal, wo die Eccabildungen fehlen und die Schichten der Kapformation an die Erdoherfläche treten, stehen die pipes in diesen. In der Oranjeflubkolonie sind die Eccabildungen vielfach von jüngeren Schichten der Karruformation, die im Alter unserer Trias entsprechen, überlagert, durch die hindureh sich die dortigen Blaugrundmassen dann in die Tiefe erstrecken. Einzelne von diesen beginnen oben in den Stormbergschichten, die mit unserer jüngsten 'Trias, dem Rhät, gleichaltrig sind.

Der Blaugrund der Trichter ist von dem umgebenden Nebengestein, dem sog. . Riff: auf das schärfste getrennt und das Material beider ist röllig verschieden. Nur im I3laugrund kommen Diamanten vor, in den Gesteinen des Riffs hat man noch nie auch nur einen einzigen gefunden, ob weich bei dem Betrieb der Diamantengruben gewaltige Massen davon abgegraben und entfernt werden muliten. Auch in den Riffgesteinsbrocken, die sehr zahlreich in dem blue ground liegen, hat man noch niemals einen Diamanten gesehen.

Das obere Ende dieser gesteinserfüllten Kanäle bildet meist kleine Erhebungen von einigen Jetern iiber die Umgebung, die von den umwohnenden Buren als "kopje" (Köpfchen) bezeichnet werden; vielfach in der Mitte mit einer flachen Einsenkung (pan). Erst durch die Ausgrabungen sind die jetzt vorhandenen großen Vertiefungen entstanden.

Der Querschnitt an der Erdoberfläche ist für die verschiedenen, im folgenden der Größe nach geordneten Gruben: Dutoitspan, 12:4 Mektar, flach hufeisenförmig, 655 m lang, $155 \mathrm{~m}$ breit; Bultfontein 912 Helitar, fast kreisrund mit einem Durchmesser ron $330 \mathrm{~m}$; De Beer's 51,2 Hektar, elliptisch, $292 \mathrm{~m}$ von Osten nach Westen, 192 m ron Norden nach Süden; Kimberley 4 Hektar, ein Oval von $274 \mathrm{~m}$ Länge und $164 \mathrm{~m}$ Breite und einem noch weitere $34 \mathrm{~m}$ nach Osten rorspringenden schmalen Sporn. Jagersfontein hat etwa 100000 Quadratmeter. Der größte Trichter ist der der Premier-Grube mit einem oberflächlichen Querschnitt von weit über 100000 Quadratmeter. Gegen unten zeigen die durch den Bergbau nach der Tiefe hin untersuchten Scblote z. T. eine Terengerung. In der De Beer's-Grube mißt der Querschnitt bei 270 Meter unter Tage nur noch 47000 Quadratmeter, er wird aber von 100 Meter Tiefe ab nicht mehr kleiner und die Röhre nimmt eine cylindrische Gestalt an. In der Kimberley-Grube ist der Querschnitt 300 Meter unter der Oberfläche noch 19000 , bei 600 Metern nur noch $\$ 000$ Quadratmeter nnd die oben 274: 164 Meter großen Durchnesser haben bei $600 \mathrm{~m}$ Tiefe bis 120: 50 Meter abgenommen. 
Damit ist aber die Verkleinerung des Querschnitts nach unten noch nicht zu Ende. Einen schematischen Längsschnitt durch den Kimberley-Trichter, der diese Verhältnisse andeutet, gibt Fig. 47, der im folgenden erläutert werden wird.

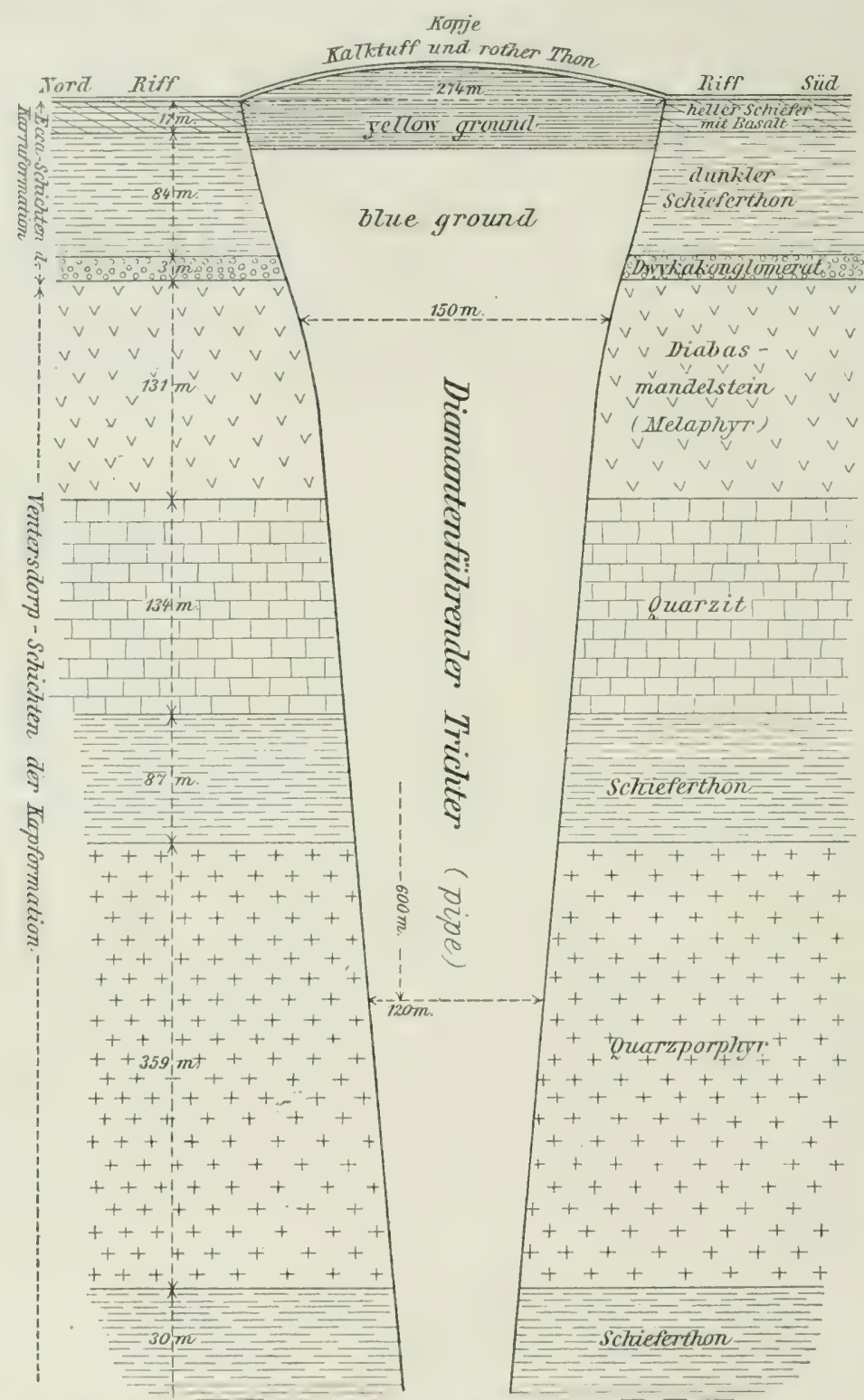

Fig. 47. Schematischer Durchschnitt durch die Kimberleygrube (Maßstab 1:4000).

Un Kimberley bedeckt (ine dïmne Lage roten Tones, 1 bis 5 Fulb mächtig, weite Landstrecken. Er liegt auf einer chenfalls weit verbreiteten 5 bis 20 Fuß mächtigen Schicht eines porösen Kalktuffs. Dies sind ganz junge alluviale Bildungen, die zu dem Iiff und dem diamantführenden 'Trichter gar keine nähere Beziehung haben. Sie überlagern diese beiden gan\% gleichmäßjig und dringen auch wohl auf Klïften und Spalten in die darunter liegenden Gesteine des Riffs und des Kanals ein, aber stets nur bis zu geringer Tiefe; unter ihnen beginnt das anstehende Gestein der Karruformation, das Riff. 
Das Riff besteht in der Kimberleygrube zu oberst aus einer 12 bis 17 m mächtigen Schichtenreihe von hellgefourbten, oben grïnlichgrauen, weiter unten gelblichen und graulichen Ecea-Schiefern ron verschiedener Itärte, denen an einzelnen Stellen der Grube feinkörnige bis dichte ()livindiabase, die vielfach als Basalt bezeichnet werden, zwischengelagert sind. Diese hellen Schichten werden unterlagert von ca. $\$ 4 \mathrm{~m}$ mäehtigen schwarzen bitumin̈̈sen Schiefortonen sanz von der beschaffenheit der Schiefertone unserer Steinkohlenformation; sie sind in einzelnen Lagen mit Schwefelkies imprägniert und schliefien vielfach Knollen von sphärosiderit, kleine Zwischenlager von Kalkspat und schwache Kohlensehmitzen (in. In der Tiefe von ${ }^{5} \mathrm{~m}$ ist den Schieferschichten eine $60 \mathrm{~cm}$ mächtige Diabastecke eingeschaltet. I) ie Unterlage der schwarzen Schiefer bildet das Dwykakonglomerat in der für dieses verhältnismälfig bedeutenden Mächtigkeit von $21 / 2$ Meter. Ihm folgen die Sehichten der Kapformation, zuerst ein harter grauer oder grïner Diabas-1landelstein (sog. Melaphyr). 1:31 Meter dick, sodann ebensovicl, 134 Meter, eines dichten, dunklen Quarzits ïber einer 35!) m starken gewaltigen Decke von Quarzporphyr, getrennt von dem Melaphyr durch Si Meter dunkler bituminïser Schiefer wie oben. Ebensolehe Schiefer unterlagern auch den Qtuarporphyr; man ist auf 30 Meter in sie eingedrungen, hat aber ihre untere Grenze noch nicht erreicht. Diese Schichtenfolge, im Ganzen ca. S50 Meter, wurde bis etwa 300 Neter Tiefe durch die oberirdische Gräberei, den Tagebau, von da an durch systematisch betriehenen unterirdischen Bergbau aufgeschlossen und festgestellt.

In den anderen Cruben bei Kimberley ist die Zusammensetzung des Riffs ganz ähnlich, nur die Mäichtigkeit der einzelnen Schichten und die Einlagerung der Eruptivgesteine zeigen einige, allerdings teilweise bedeutende Abweichungen.

In der gegen $700 \mathrm{~m}$ tiefen De Beers's Grube ist an einzelnen Stellen schon in den oberen Teilen des Riffs ein mächtiges Diabaslager von 17 bis $25 \mathrm{~m}$ rorhanden, der Quarzit ist weit mächtiger $(241 \mathrm{~m})$, dann folgt sofort ohne Schieferzwischenlage der ( (uarzporphyr, der $223 \mathrm{~m}$ weit verfolgt ist, dessen unteres Ende der Bergbau aber noch nicht erreicht hat. In Dutoitspan betrügt die Mächtigkeit der Ecca-Schiefer $115 \mathrm{~m}$; sie sind hier wie in den andern siidlich von Kimberley liegenden Gruben stärker entwickelt als dort, aber die Dicke des Dwykakonglomerats ist wie in De Beers und den übrigen Gruben bei Kimberley nur 1 bis $2 \mathrm{~m}$. Es folgen dann $27 \mathrm{~m}$ Quarzit und hinauf erst $104 \mathrm{~m}$ Melaphyr, dessen Ende in der ca. $300 \mathrm{~m}$ tiefen Grube noch nicht erreicht ist. In Bultfontein sind die Eccaschicfer fast ebenso mächtig, aber der zwischengelagerte Basalt tritt sehr zurïck, so daß die Trichterwände oben fast nur aus Schiefer bestehen, der hier, wie z. T. auch in de Beer's stellenweise stark gestört und unter einem Neigungswinkel bis zu $15^{\circ}$ gegen den IIorizont aufgerichtet ist. Unter dem hier nur 1 Meter mächtigen Dwykakonglomerat folgen $33 \mathrm{~m}$ Melaphyr, $47 \mathrm{~m}$ Quarzit, dann wieder Melaphyr, dessen Ende bei einer Tiefe der Grube ron ea. 200 m noch nicht erreicht ist. In der Wesselton-Grube sind die Ecca-Schiefer mit dem zwischengelagerten Basalt am mächtigsten, $130 \mathrm{~m}$, des Dwykakonglomerat ist auch hier nur $1 \mathrm{~m}$ stark; die ca. $200 \mathrm{~m}$ tiefe Grube stebt in dem num folgenden Melaphyr, der etwa 70 Meter tief durchsunken ist, sich aber noch weiter fortetzt.

Die Ausfüllungsmasse der Kanäle ist wie ihr Nebengestein in allen Gruben wesentlich dieselbe und auch an allen Stellen jeder einzelnen Grube, wenn man davon absieht, daf in allen Gruben die oberen Teile eine ziemlich weitgehende Verwitterung. erlitten baben. Unterschiede sind zwar vorhanden, so daf erfahrene Diamantgräber manchmal nicht nur die Grube, sondern sogar die Stelle der Grube angeben künnen, ron der ein Stück dieser Masse genommen ist. Aber diese Unterschiede, die auf der innerhall) gewisser Grenzen wechseInden Farbe, Härte und Zusammensetzung und dem Gehalt an eingeschlossenen Mineralien und fremden Gesteinstrimmern beruhen, sind im ganzen nur unbedeutend. 
Ton schichtenförmiger Abwechslung verschiedener Gesteine oder Gesteinsvarietäten, überhaupt von Schichtung, ist in den Trichtern keine Spur vorhanden. Doch hat man eine andere Art von bis zu cinem gewissen Grade regelmäßiger Anordnung von etwas, aber nur wenig voneinander verschiedenen Gesteinsmassen beobachtet. Nan hat in den Gruben ganz oder nahezu senkrechte, bis in die größte bekannte Tiefe reichende, böchstens $1 \mathrm{~m}$ weite, mit ciner talkartigen Mineralsubstanz ausgefülte Spalten getroffen. Diese zerteilen den wanzen Inhalt der Trichter in eine Anzahl von Abteilungen, die die Gestalt ron mächtigen senkrechten oder etwas greneigten Säulen haben. Innerhalb jeder einzelnen Sïule ist das Naterial dasselbe, die verschiedenen Säulen dagegen zeigen kleine Abweichungen innerhalb der vorhin erwähnten Grenzen.

Von der Art und Beschaffenheit des wechselnden Nebengesteins im Riff sind diese kleinen Abweichungeen und überhaupt die ganze Ausfüllungsmasse der Kanäle in jeder Ilinsicht vollkommen unabhängig. Man war wohl früher der Ansicht, daf diese Masse vom Nebenge'stein nach gewissen Richtungen und namentlich im Gehalt an Diamanten mehr oder wenicrer stark beeinflubt sein könnte. Namentlich hatte man, als man in der Kimberleygrube am unteren Ende der schwarzen Schiefer angekommen war, befïrchtet, der Diamantenreichtum möchte aufhören, da man die Entstehung der Diamanten auf den Kohlengehalt dieser Schiefer zurïckführen zu müssen geglaubt hatte. Der Wert des Grubenbesitzes der verschiedenen Eigentiimer war infolgedessen eine Zeitlangr bedeutend gresunken. Es trat aber gar keine Änderung cin, man fand in der Region des Melaphyrs dieselbe Menge Diamanten wie vorher.

Zwischen dem Riff und der Ausfüllungsmasse ist, wie schon erwähnt, stets eine scharfe Grenze, nie ein allmählicher Übergang vorhanden. Neist berühren sich beide Gesteine unmittelbar, doch sind oft auch Zwischenräume, zuweilen von ziemlich bedeutender Gröbe, zwischen ihnen rorhanden, die mit schünen Kalkspatkristallen ausgekleidet sind. Solche Neubıldungen finden sich auch auf den zahılreichen Klüften, die außer den die Säulen trennenden Spalten das Gestein durchziehen, und auf anderen IIohlräumen.

Wir wenden uns nun zur Betrachtung des diamantfïhrenden Gesteines selbst, das die Kanäle ausfïllt. Es besteht zu oberst aus einer hellgelben, mürben, sandigen, leicht zerreiblichen Masse, dem ,yellow ground" oder "yellow stuff" der Diamantgräiber, die 1s bis $24 \mathrm{~m}$ mächtig ist. Diese oberste Partie, die zuweilen wegen eines stärkeren Eisengehalts rot ist, dann auch wohl "red ground" genannt wird, ist in der Kimberleygrube durch die (irabarbeiten vollständig entfernt, aber in den anderen Gruben zum Teil noch zu beobachten. In srö̈lerer 'Tiefe bildet das Gestein eine einem vulkanischen Tuffe ähnliche Breccie von grüner, zuweilen bläulich-grüner Farbe, dem "blue stuff" oder "blue ground" (Blaurrund), oder kurz "blue", der in dieser Beschaffenheit oder mit geringen $\Lambda$ bweichungen überall bis in die größten bekannten Tiefen anhält.

Der ..yellow sround" und der ,blue ground" gehen meist sehr raseh ineinander ïber; die Grenzlinie ist nie vollkommen horizontal, sondern stets unter 5 bis 15 Grad geneigt. Manchmal findet man aber auch 5 bis $6 \mathrm{~m}$ einer rötlichen Zwischenmasse, den „rusty ground", der nach oben in das gelbe, nach unten in das grüne Gestein verläuft. Jene beiden sind nichts anderes als Verwitterungsprodukte des Blaugrunds. Dieser füllte urspriinglich die Kanäle bis zum Rande aus, erlitt aber nahe der Erdoberfläche durch die Atmosphärilien eine ziemlich weitgehende Unwandlung, wodurch der ,yellow ground" entstand. Eine in der Umänderung noch nicht so weit vorgeschrittene Zwischenstufe stellt der "rusty ground" dar. Der "blue ground" findet sich erst in einer Tiefe, in der diese Umwandlungsprozesse nicht oder nur wenig mehr tätig waren. Groß war der Schrecken der Grubenbesitzer, als die gelbe Farbe der blauen Platz machte. Auch dieser Wechsel hatte ("in Sinken des Wertes der Gruben zur Folge, da man ein Aufhören der Diamanten be- 
fürchtete. Es stellte sich hior aber ebenfalls heraus, dab zu dieser besorgnis gar keine Veranlassung war, demn das Gestrin erwies sich nach der Tiefe zu ehenso reich, ja zum Teil noch reicher als weiter oben.

Das cigentliche. Aufüillumgsestein der Kanäle ist also der B la u in rund, die anderen darin vorhandenen Massen sind aus diesem hervorgegangen. Er besteht aus einer grünen bis dunkelbläulicheriunen wder grauen, serpentinartigen Grundmasse, die dem ganzen die Farbe verleiht. Su macht den Eindruck eines getrockneten Schlammes, exweist sich jedoch unter dem Vikroskep nicht selten als auseresprochen porphyrisch durch zahlreiche Olivinkristïllchen, dir aber auch zum eroben Teil in Serpentin umgewandelt sind und die von Schwärmen winziger Magneteisenkïrnchen bergeitet werden. Diese Grundmasse rerkittet in erheblicher Ifenge vorhandene, srïbere oder kleinere, scharfkantige oder z. 'T'. auch grerundete Bruchstiicke eines srün- oder blauschwarzen gleichfalls serpentinartigen Gesteins. Beziiglich der stofflichen beschaffonheit sind die Grundmasse, die an II nowe stets iiberwiegt, und diese liesteinsbrocken nicht von einander verschieden, die erstere besteht in der Hauptsache aus frinsten Teilchen der letzteren. Zahlreiche Körner von allerlei Mineralien, und Bruchstiiclie fremoler (resteine oft in ungeheurer Menge sind in der Crundmasse

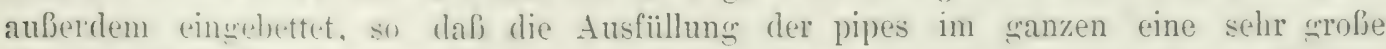
Iannigfaltigkeit und reiche Abwechslung in der Zusammensetzung zeigen kann. Sie hat im allemenen die Eigenschaft, an der Luft dureh Verwitterung in wenigen Wochen oder Monaten zu einer lockeren Erde zu zerfallen, was für die Gewinnunge der darin befindlichen Diamanten von sröbter Wichtirkeit ist. Ein Stïck des Blaugrunds mit seiner natürlichen Farbe und mit einem eingewachsenen Diamantkristall ist in Tafel I, Finur 2 zur Anschauung gebracht.

Der IBlaugrund besitzt zwar eine seringe Härte, aber eine ziemliche Fustigkeit. Er lälit sich daher schwer mit der Spitzhacke bearbeiten, aber leicht mit dem Messer schneiden und mit dem Nagel ritzen, und fühlt sich sogar etwas fettig an. Die chemische Zusammensetzung zeigt wohl quantitativ an verschiedenen Stellen gewisse Verschiedenheiten, ist aber im wesentlichen ïberall dieselbe. Alle Analysen haben neben wechselnden Mengen Kieselsäure strts shr viel Magnesia mit etwas Eisenoxydul, meist sehr wenig Kalk, ctwas Trasser und lohlensïure und sehr wenig oder gar keine Tonerde ercreben. Die Nasse ist also in der. Hauntsache ein Gemenge ron wasserhaltigen Magnesiasilikat mit kohlensaurem Kalk. Nach der Analyse von II askelyne bestand ein Stïck des Blaugrundes von der Kimberleyerube aus: 39,32 Kieselsäure; 2,309 Tonerde; 9,901 Eisenoxydul; 24,410 Magnesia; 10,162 Kalk: 6,556 Kohlensäure; 7,547 Wasser; Summa $=100,415$.

Die Kohlensïure genïgt sehr nahe, $u$ allen Kalk als kohlensauren Kalk anzunehmen. Zieht man diesen ah, dann hat das zurückbleibende Magnesiasilikat ungefähr die Zusammensetzun « des Scrpentins. Man pflegt daher das ganze Gestein auch wohl eine Serpentinbreccie zu nenuen. Diese Bezeichnung oder die als Tuff oder kurz Breccie soll auch hier in folmenden für das Muttergestein der Diamanten in der Hauptsache beibehalten werden.

Nicht immer hat das diamantfülırende Gestein die soeben geschilderte Beschaffenheit: zuweilen ist es hart und fest und besitzt dann auch nicht mehr die Fähigkeit, an der Luft erdis zu verwittern. Dies ist der , hard blue* (auch bard bank oder hardibank „2enannt) im (regensatz zum „soft blue“, dem gewöhnlichen gutartigen „blue ground".

Der ,hard blue" findet sich entweder inmitten des letzteren als eine melr oder weniger seschlossene Masse oder er bildet auch zuweilen eine mehrere Ful dicke Grenzschicht gegen das Vihengestein. In der Kimberley- und der De Beers-Grube, hei Jagersfontein usw. tritt er er'st in der Tiefe auf, andere pipes erfüllt er ganz bis zu ihrem Ausgang; so die der fchullergrube und die ron Zonderwater in Transvaal und andere. In der 
Schuller-Grube scheint sich in So Meter Tiefe "soft blue" unter den "hard blue" gefunden zu baben. Beide sind in der chemischen Zusammensetzung usw. nicht verschieden, doch macht der letztere oft gar nicht mehr den Eindruck eines 'Tuffs oder einer Breccie; es hat mehr den Anschein, als ob es ein ruhig an Ort und Stelle aus dem Schmelzfluß erstarrtes Eruptivgestein wäre.

Die in der Ausfuillungsmasse der pipes eingelagerten Bruchstiicke fremder Gesteine, die sogenamnten , boulders", sind teilweise, namentlich so weit sie aus Schiefer bestehen, scharfkantig und eckig, meistens aber, und zwar gerade die festeren, von rundlicher Form. Ilıre Dimensionen sind sehr verschieden. Von den kleinsten Splittern wachsen die Stiicke bis zu Felsunassen ron mehreren Tausend Kubikmetern Inbalt an. In der De Beers-Grube liegt in der Ausfïllungsmasse des Kanals eine Scholle von Olivindiabas, das sogenannte ,island“, die enen Querschnitt von $280 \mathrm{qm}$ besitzt und auf $216 \mathrm{~m}$ in die Tiefe verfolgt wurde, In Bultfontein war der sog. Mit. Ararat, $150 \mathrm{Ful}$ breit und $120 \mathrm{FuB}$ hoch; in der PremierGrube fand sich ganz oben ein ungeheuerer Block eines groben Konglomerats, und eine gewaltige Masse von Melaphyr in der Wesselton-Grube. Solche größere Massen, allerdings zum weitaus überwiegenden Teil von erheblich geringerem Umfang, als diese erwähnten, sind in sïmtlichen Gruben reichlich vorhanden. Man bezeichnet sie allgemein als ,islands“, oder meist als "f loating re ef", im Gegensatze zu dem ringsum anstehenden Riffgestein, dem „main reef". Sie sind besonders in den oberen Regionen angehäuft und verschwinden nach unten hin, während kleinere Bruchstücke derselben Gesteine bis zur größten bekannten Tiefe hinabgehen und iiberall einen reichlichen Bestandteil der Ausfuillungsmasse bilden, in der sie ganz regellos zerstreut liegen.

Diese fremden Gesteinsbrocken stimmen ihrer Beschaffenheit nach zum Teil vollständig mit den Gesteinen des anstehenden Riffes überein. So findet man sehr häufig Stiicke von Diabasmandelstein, Schiefer, Quarzit, Porphyr usw. Mit dem Wechsel des Nebengesteins im Riff findet man auch vielfach andere ilım entsprechende boulders in blue ground. An einzelnen Stellen sind stark bituminöse und kohlehaltige Schiefer in größerer Menge an. gehäuft, so daß zuweilen schon die aus Kohlenbergwerken bekannte Erscheinung der schlagenden Wetter in den Gruben beobachtet worden ist. Es wurde oben bereits angedeutet, daß auf diese Kohlenbestandteile die Entstehung der Diamanten in dem Tuff zuriickgefiihrt worden ist, weil man beobachtet haben wollte, daß nur da Diamanten in dem Tuffgestein vorkommen, wo es Stïcke dieser bituminösen kohlehaltigen Schiefer in reichlicher Nenge enthält. Wir werden aher weiter unten sehen, daß jene schwerlich in dem Tuffe der Kanäle entstanden, sondern wahrscheinlich durch vulkanische Kräfte fertig gebildet aus dem Erdinnern herausgebracht worden sind.

Teben den aus dem Riff stammenden Brocken findet man im Tuff aber auch vielfach Bruchstiicke von Gesteinen, die in der Nähe der Gruben anstehend nirgends bekannt sincl, und die man daher auch "exotische Fragmente" genannt hat. Viele stammen aus der Tiefe. So kommen, wenn schon nicht hïufig, Stïcke von Glimmerschiefer, Talkschiefer, und auch von Cranit vor. Letzterer, sonst selten und wegen starker Zersetzung zweifelhaft, fand sich in den oberen Teilen einer kleinen, bald wieder verlassenen Grube, Doyl's Iiush, 1; Stunde von Kimberley, in zahlreichen größeren Blöcken und kleineren Bruchstücken. Solche Gesteine sind in einer gewissen, allerdings nicht geringen Entfernung nürdlich von den Diamantfeldern an der Erdoberfläche anstehend hekannt. Es ist daher wahrscheinlich, dal sie sich in der Tirfe weiter nach Süden erstrecken und auch unter den Diamantrruben sich finden, wo sie die unterirdische Basis der Riffgesteine bilden. Andere solche fremdartigen Gesteinshrocken sind aber auch Überreste der Schichten, die einst die jotzt die Erdoherfläche bildenden überlagerten, die aber dann durch Erosion zerstört und abgetragen wurden. So fanden sich in der Kimberleygrube grole Blöcke eines grauen 
wher gelblichweilien Sandsteins mit kalkig-tonigem Bindemittel, wio er bei normaler

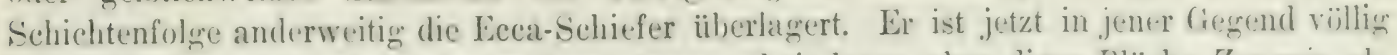
verschwunden, von seiner einstmaligen Anwesenheit legen aber diese Blïcke Zeugnis ab.

Die in dem Tuff cingeschlossenen Mineralien sind im ganzen spürtich vorhanden und betragen allerhöchstens ein Prozent der ganzen Masse des lilaugrunds, meist sehr viel weniger. In diesem treten sie vielfach gar nicht deutlich herror und kommen teilweise erst bei der Diamantenw äsche zum Vorschein; andere lassen sich auch nur chemisch nachweisen. Sie zeigen, den I)ianant ausgenommen, fast niemals regelnälfige Kristallflächen, sondern rundliche oder auch unregelmälig stumpfeckige Formen. Die fröle ist sehr verschieden. Einzelne sind iiberhaupt nur mit dem Mikroskop zu erkennen, andere: "rrejchen den Lmfan" einer Linse, Erbse, Nulj und sogar zuweilen, aber selten, z. B. in den Tewlands- und den Monastery-(xuben, eines Kopfes (Granat-, Pyroxen-, Glinmerknollen). Cirobe und kleine Stïcke auch ron einer und derselben spezies können in demselben Blaugrund-Vorkommen nebeneinander liegen.

Unter ihnen ist als wichtigstes, wemn auch bei weitem nicht verbreitetstes, vor allen anderen der IDiamant selbst zu nennen. Er findet sich in Form von vollständigen, ringsum ausgeblildeten Kristallen, jedoch merkwürdigerweise auch häufig in der von Bruchstïclen grö̈lierer Kristalle, von denen aher niemals zusammengehörige nebeneinander liegren. Ein solches ist u. a. auch der grölte bisher gefundene Diamant, der Cullinan ron ca. 600 Gramm Gewicht. Ton hier ab sinkt die Gröbe bis zur mikroskopischen herunter. Abrollung ist hier niemals auch nur in Spuren zu bemerken, die Kanten und Ecken sind stets vollkommen scharf im Gegensatz zu den steinen aus den river diggings. Die nähere Beschreibung der speziellen Eigenschaften der Kapdiamanten wird aber weiter unten folgen, hier soll nur die Art des Vorkommens betrachtet werden.

Der Diamant verhält sich in der Breccie genau wie die anderen Mineralien, er bildet frenau wie diese einen Bestandteil des Gesteines und unterscheidet sich in der Art des Vorkommens in nichts ron diesen, als durch seine stets regelmäßige Kristallform. Diese Kristalle oder Bruchstiicke ron solchen liegen einzeln und ringsum fest umschlossen in dem Tuff, aus dem sie sich ohne Schwierigkeit herauslüsen lassen. Sie haben dann meist eine ganz reine Oberfläche, zuweilen sind sie aber auch mit einem festen $̈$ C̈berzug von Eisenoxydhydrat oder ron Kalksinter verseben, der indessen stets leicht entfernt werden kann. Lange Zeit war niemals beobachtet worden, claß auch nur eine Spur eines fremden Minerals fest an einem Diamant angewachsen war. Der Fund ron mit Granat verwachsenen Diamanten, besonders im sogenannten Eklogit (S. 230), zeigte aber, daß dies doch in einzelnen Fällen vorkommt.

Diamanten finden sich von der Erdoberfläche durch den ..yellow s.round" und den .rusty ground" hindurch bis in die größten bekannten Tiefen der Gruben, aber nicht in allen Gruben und nicht an allen Stellen einer Grube in der gleichen Menge. Spezielle Zahlenangaben über den Diamantgehalt des Tuff's werden unten angeführt werden, hier folgen einige Mitteilungen ïher die allgemeinen Terhältnisse. Der Diamantgehalt wechselt vielfach mit der Tiefe. In der Kimberley- und der De Beers-Grube nimmt er grecren unten ab, in Bultfontein und Dutoitspan ist eine ziemlich rasehe Zunahme nach der Tiefe hin zu beobachten gewesen. In der Wesselton-Grube hat sich keine nemnen-werte Änderung gezeigt. In den verschiedenen säulenfürmigen Abtcilungen der Trichter ist der Diamantechalt ein verschiedener; in jeder eincelnen solehen Siiule ist aber die Diamantfïlıung. besonders in einer gewissen Tiefe, so konstant, dafi man genau berechnen kamn, wieviel Karat Steine man aus einer bestimmten Menge des Tuffs gewimnen wird. In allen fünf grofen Gruben bei Kimberley ist nur der üstliche Teil abbauwïrdig, der westiche ist zu arm, doch hat sich in der Kimberley-Grube das arme westliche Ende nach unten 
zu einer vom abbauwürdigen Ostteil abzweigenden Rippe verschmälert, während der letztere zwar auch stark zusammengeschrumpft ist, aber seine rundliche Form behalten hat. In der größten bis jetzt erreichten Tiefe dehnt sich der diamantarme Westteil zu einem Gang: aus, der ïber 100 Meter weit in westnordwestlicher Richtung in das Nebengestein hinein verfolgt worden ist, während der reiche Ostteil sich schlotförmig mit ganz schwach östlichen Einfallen noch weiter in die Tiefe fortsetzt. Auch die Beschaffenheit der Diamanten nach Form, Farbe, Größe und Qualität ist in verschiedenen Gruben und Teilen von solchen verschieden.

Dic Menge der Diamanten, die das Gestein beherbergt, ist von außerordentlich großer Wichtigkeit, aber diese ist in der Hauptsache eine volkswirtschaftliche wegen der großen Kostbarkeit des Edelsteins, weniger eine naturhistorische. In naturhistorischem Sinn hat der Diamant als Bestandteil des Gesteins keine große Bedeutung, wenigstens insofern er in so äuberst minimaler Menge vorkommt. Er tritt daher auch in dem Blaugrund selbst selten hervor, sondern wird meist erst in den Waschrïckständen sichtbar. Würde ein beliebiges anderes, weniger wertvolles Mineral sich nicht reichlicher finden als der Diamant, so würde es bei der Beschreibung des Gesteins kaum genannt werden. Wie gering der Vorrat an Diamianten ist, ersieht man daraus, daß er an der reichsten Stelle der reichsten Grube, der Kimberleygrube, ungefähr ein Zweimilliontel, oder 50 Milliontel eines Prozent, des ganzen Gesteins beträgt, und dieser Betrag sinkt in anderen noch bauwürdigen Gruben bis auf ein Tierzigmilliontel des Ganzen oder auf $2 \frac{1}{2}$ Milliontel Prozent herab. Die ersteren Zahlen entsprechen etwa $6 \frac{1}{3}$ Karat Diamant oder $11_{14}$ Gramm in einem Kubikmeter der Masse, was ein Würfelchen von 7 Millimeter Kantenlänge ergeben würde. Gruben mit $12 / 3$ Karat oder $1 / 3$ Gramm, gleich einem Würfelchen von $21 / 2$ Millimeter Kantenlänge, gelten noch als reich. Die bliihende Jagersfontein-Grube liefert nur 1/4 Karat oder 1/20 Gramm Diamant im Kubikmeter. Von da sinkt der Gehalt durch alle möglichen Zwischenstufen allmählich auf Null in manchen Blaugrund-Vorkommnissen herunter. Wenn darnach schon die absolute Menge eine so minimale ist, so fallen natiirlicb die kleinen Unterschiede an verschiedenen Stellen erst recht naturbistorisch nicht ins Gewicht, volkswirtschaftlich, d. h. für die Produktion, sind aber natürlich auch sie von höchster Bedeutung.

Interessant ist, daß in einigen Gruben, z. B. in Newlands, nördlich Kimberley, neben dem Diamant auch die andere kristallisierte Modifikation des Kohlenstoffes, der Graphit, vorkommt.

Die Mineralien, die den Diamant in dem Tuff begleiten, sind nicht überall alle in gleicher Häufigkeit vorhanden. Es bestehen auch hierin gewisse Verschiedenheiten für die einzelnen Gruben und für cinzelne 'Teile derselben Grube. Sie bilden entweder einheitliche homogene. Körner oder es sind auch Mineralien von verschiedener Art zu kleinen Gruppen mitemander verwachsen. Die am häufigsten vorkommenden Mineralien sind roter Granat, frischer oder meist in Serpentin umgewandelter Olivin, Pyroxen von verschiedener Art, brauner Magnesiaglimmer (Biotit) und Titaneisen, die anderen sind weniger verbreitet und einzelne bilden Seltenheiten. Im folgenden sollen die wichtigsten Begleitmineralien des Diamants ausführlicher besprochen werden.

Zuerst sei erwähnt dex Granat. Er findet sich konstant ïberall und auch stets in erheblicher Menge, zuweilen mit Kelyphitrinde. Ein Teil ist durch beronnene Zersetzung tribe und undurchsichtig und rotbraun geworden, ein anderer großer Teil ist noch ganz frisch, stark glïnzend, zuweilen harzartig, und durchsichtig. Die Farbe dieser frischen Granaten ist verschieden, an häufigsten tief weinrot und tief hyacinthrot, auch rot ins Tiolette, selten kommt die heller oder dunkler bräunlichgelbe, sowie eine prachtvolle rubinrote Farbe vor. Solche rubinrote Granaten werden als Edelsteine geschliffen und 
kommen unter dem Namen Kaprubin im IIandel vor. Die Granatkörner schwanken zwischen selır geringer und Wallnulgräbe und erreichen zuweilen Kopfgröbe. Alle bisher untersuchten siueke sind chrombaltige Magnesiatongranaten und bilden nach ihrer chemischen Zusammensetzung '/wischenglieder zwischen Pyrop, dessen Typus der allhekannte und so viel als Schunuckstein verwendete böhmische Granat ist, und Almandin, dem sog. edlen Granat, von denen unten eingehender die Rede sein wird.

Olivin ist vielfach noch in Form frischer, kleiner, fast farbloser Körner vorhanden, der meiste ist aber ungewandelt, zum greringen Teil in stark plecochroitisehe, dem Iddingsit nahestehende fasrie-biattrige $\Lambda$ ggregate, weitaus iiberwiegend in Serpentin. Beinahe der sanze, den Blaugrund zusammensetzende Serpentin stammt von dem Olivin, nur wenig ist aus dem Diopsid entstanden.

Von diliedern der Pyroxengruppe finden sich rorzugsweise Enstatit, Bronzit und ( h romdiopsid, alle drei wie der sofort zu erwähnenden Smaragdit, teilweise schön «enum zum Schleifen. Der Fnstatit hat die gewöhnliche Zusammensetzung, aber nicht immer das gewöhnliche Aussehen des Minerals. Er bildet meist bis haselnulbgrolje Körner olne deutliche Spaltharkeit, gelblichgrün oder von der Farbe des grïnen Bouteillenglases, ist durchsichtig und hat muscheligen Bruch. Dem Ansehen nach grleicht er oft sehr dem Olivin, mit dem er wohl auch gelegentlich rerwechselt worden ist. Er ist häufig mit Granat verwachsen, zum Teil in der Art, das einzelne Granatkörner rings rom Enstatit umschlossen sind. Diese Tarietät des Enstatit, die wolıl auch als Salit angeführt wird, ist rerbreiteter als der Granat. Es findet sich daneben aber anch, wenngleich seltener, Bronzit von grünlicher oder brauner Farbe und der gewöhnlichen Beschaffenheit mit deutlicher Absonderung in einer Richtung und nicht selten in Bastit umgewandelt. Sehr häufig, wenn gleich weniger als der Granat, ist der chromhaltige Diopsid, der auch vielfach sehr vollkommene ebene Absonderung in einer lichtung zeigt und dann wohl auch als chromhaltiger Diallag aufgefülırt wird. Er bildet Körner von derselben Grölje wie der Granat, smalragdgrïn, durehscheinend und in dïnnen Splittern durchsichtig. Ein Teil hat wie der Olivin eine Veränderung in Serpentin erlitten. Genannt wird auch Wollastonit.

Aus der Amplibolgruppe findet sich der grüne zum Teil sehleifwürdige S maragdit als Seltenlıeit; er ist vielleicht durch Umwandlung aus dem Chromdiopsid entstanden. Erwähnt werden auch zuweilen Tremolit und Asbest.

Überall sehr verbreitet und besonders deutlich herrortretend ist ein zersetzter II agnesiaglimmer, der in kleinen glänzeuden grünlichen oder bräunlichen bis rotbraunen, manchmal auch vollständig gebleichten, nahezu optisch einachsigen, bäufig regelmäßig sechsseitigen dünnen Plättchen oder niederen Prismen mit einem deutlichen IBlätterbruch, nicht selten mit starken Anzeichen erlittener Pressung; also verbogen und gekuickt und von Gleitflïchen durchsetzt, vorkommt. Der Lngeibte glaubt in diesen glänzenden Flittern in dem Tuff nicht selten beim ersten Anblick Diamanten zu erblicken. Ein graubraunes, zuweilen blaues Lmwandlungsprodukt ron chloritartiger Zusammensetzung und Beschaffenheit ist Vaalit genannt worden. Es bildet zuweilen hühnerei- bis kopfgroße braune Kugeln und Kinollen und ist stellenweise so angehäuft, daß es das Gestein beinahe allein zusammensetzt.

$\mathrm{Zu}$ den häufigeren Begleitmineralien des Diamants gehört auch ein stark magnesiahaltiges, nicht magnetisches Titaneisen (Ilmenit) in schwarzen, glänzenden Kürnern. Die Diamantengräber hielten dieses schwarze Mineral frïher für die bisher fast nur aus Brasilien bekannte schwarze Abart des Diamants, den Karbonat, und nannten es darnach Karbon. Sie ließen sich nur schwer davon überzeugen daß sie es mit einer ganz wertlosen Substanz zu tun haben; der Name Karbon ist aber auch nach der Aufklärung der Sache 
geblieben. Echter Karbonat ist am Kap zwar auch, jedoch nur sehr spärlich vorgekommen. Magneteisen in Körnern ron der gewöhnlichen Beschaffenheit, Chromeisen in schwarzen, lebhaft gïnzenden Küinern mit muscheligen Bruch und bis erbsengroß, und schwarzer Spinell treten stark zurick. Zirkon, der "dutch boart" der Arbeiter in Kimberley, lildet durchsichtige bis durchscheinende, ganz lichtgelbe bis fleischfarbige Kürner ron Linsen- bis Erbsengröle, die selten fehlen. Ferner finden sich Korund, Schwefelkies, Cyanit, Topas und manches andere. Apatit ist auf chemischem Whe nachorewiesen worden, Gold fand sich eimmal in einem Einschlub von Eklogit in Jacersfontein. Mikroskopisch wurde in dem Tuff unter anderem Turmalin, Rutil und I'erowskit beobachtet. Quarz ist dagegen noch nie vorgekommen, ebensowenig Feldspatb.

Die meisten genannten Mineralien kommen in allen Gruben teils mehr, teils weniger håufig vor, manche finden sich aber auch nur an gewissen Orten, an anderen nicht. Vom Gold ist es schon erwähnt, daß es nur in Jagersfontein angetroffen worden ist. Ob Korund überall vorkommt, ist zweifelhaft, in der Jagersfontein-Grube findet er sich als blaner Sapphir, in der Frank Smith-Grube als roter Rubin, wahrscheinlich ist er verbreiteter, als man bisher annahm, und bildet einen Teil des sogenannten dutch boart. Auch das allgemeine Vorkommen des Cyanits und anderer ist noch nicht festgestellt. Am gleichmäßigsten überall verbreitet scheint der Glimmer (Vaalit) und das Titaneisen zu sein; sehr arm an Pyroxen ist die Lace-Grube, arm an Pyroxen und Granat die PremierGrube in Transvaal.

Beim Waschen der Masse nach Entfernung der größeren Gesteinsstücke bilden vorzugs. weise die spezifisch schwereren dieser Mineralien, namentlich die roten Granaten, die grünen augitischen Mineralien und der Zirkon einen buntgefärbten Rückstand, der mit schwarzen Körnern von Titan- und Magneteisen und mit kleinen Gesteinsbröckchen vermischt ist. Alles andere ist selten oder wird durch den Waschprozel entfernt. In diesem Gemenge befinden sich auch die Diamanten.

Neist liegen diese Mineralien als vereinzelte Kö̈ner im blue ground, sehr häufig sind aber auch mehrere zu grobkörnigen knollenförmigen Aggregaten von verschiedener Größe, bis zu einem halben Heter Durchmesser, miteinander verwachsen. Augite scheinen darin vorzuherrschen, so daß man es häufig mit pyroxenitartigen Massen zu tun hat. Nicht selten sind auch Verwachsungen von Augit mit Granat, manchmal auch mit etwas Cyanit usw., die wohl fälschlich als Eklogit, auch als Griquait, bezeiclnet werden. Ein solcher sogenannter Eklogit von den Newlands-Gruben enthält zahlreiche Diamanten eingeschlossen auch sonst ist in sehr vereinzelten Fällen Diamant mit Granat, aber nie mit einem anderen der genannten Mineralien verwachsen gefunden worden. Diese Knollen sind, ebenso wie die Mineralien des Blaugrunds, nicht als fremde Einschlïsse zu betrachten, sondern es sind Urausscheidungen aus dem Timberlitmagma, ähnlich wie die Olivinfelsknollen im Basalt. Sie zeigen durch ilure Grobkörnigkeit, daß sie in großer Tiefe unter starkem Druck erstarrt sein miissen, und werfen so auch ein helles Licht auf die Entstehung der südafrikanischen Diamanten.

Alle die bisher genannten Mineralien bilden ursprüngliche Bestandteile des Gesteins die gleich bei seiner Entstehung in ihm vorhanden gewesen sind. Es finden sich daneben aber auch andere, die erst später durch die schon oben erwähnten Umwandlungs- und Verwitterungsprozesse in demselben neu entstanden sind. Hierher gehürt der schon gुenannte Kalkspat, der zuweilen in Form von Kristallen Hohlräume auskleidet, aber auch derbe Aggreerate bildet, und so auf Spalten und Kiliften, sowie in Form kleiner Nester die Masse auf größere Erstreckung durchieht und auf diese Weise einen nicht unwichtigen Bestandteil des Gesteins ausmacht. Auch Zeolithe finden sich, besonders Mesolith und Natrolith, zuweilen in schön ausgebildeten nadelförmigen Kristallen, ferner stellenweise 
(1)al und rauhe stiicke (ines blïulichen II ornsteines. Der als Seltenheit vorkommende: Schwerspat, sowie Ep id ot gohören wohl ebenfalls zu diesen neuentstandenen Mineralien. Alle solche stkundiare Bildungen, namentlich die Zeolithe, finden sich vorzugsweise in den läheren und hïghsten Teilen der Gruben, in denen die durch die Atmospluärilien herworgrerufenen Verwitterungsprozesse wirksam waren, nach unten zu verschwinden sie allmählich ganz vollständig.

Stanislas. He unier hat aus der Serpentinbreceie im ganzen achtzig verschiedene Mincralien beselnieben, von denen einzelne aber wohl noch genauerer Bestätigung bedürfen.

(äinge. Isetrachten wir nummehr die Gän re. Ilire Zahl soll noch weit grrölier sein als die der pipes, namentlich in der Oranje-Kolonie. Sie lassen sich nicht selten auf weite Entfernung leicht verfolgen, manchmal sind sie aber auch oberirdisch nicht zu sehen und konmen nur stellenweise in Wasserrissen, bei Gräbereien usw. zum Vorschein. Daf sit vielfich zu pipes in Bezichung stehen und dalo sie sich z. B. nicht selten örtlich zu solehen erweitern. haben wir in der Kimberley-Grube schon gesehen; auch das letztere geschicht in einzelnen Fällen erst mehr oder weniger tief in der Erde. Es ist sogar die Ansicht atuswesprochen worden, daßs sämtliche pipes auf Gängen stehen, was aber in vielen Fällen unerwiesen, in einzelnen sicher falsch ist Jedenfalls sind aber diese Beziehungen die Veranlassung gewesen, daf manche Prospektoren solchen Gängen nachgehen in der Iloffnung, so viclleicht auf einen diamantenführenden Schlot zu stoljen. Je nach der Richtung der Gebirgsfaltung und ihr entsprechend streichen auch die Gänge in verschieclenen Riclitungen.

Die Gänge durchsetzen dasselbe Tebengestein wie die pipes, und ebenso ist das dic Spalten erfïllende Ganggestein von dem in den Trichtern nicht wesentlich verschieden. Die Masse ist etwas härter, aber die Zersetzung ist oft sehr weit rorgeschritten. Nach F. W. Voit ist das Ganggestein ein im Tergleich mit dem sehr variablen Blaugrund cler pipes sehr monotones gelbliches oder bläuliches körniges Aggregat von gleichmäfig großen Serpentin- und Glimmerfragmenten. Jedenfalls ist die Struktur viel weniger deutlich breccienhaft als meist in den pipes, zuweilen tritt die Breceienstruktur sogar völlig zurïck und das Ganze sieht aus wie ein an Ort und Stelle erstarrtes vulkanisches Gestein, ganz ähnlich wie mancher hard blue in den pipes. Interessant ist in dieser Beziehung die völlige Übereinstimmung der Gesteine des Gangs in der Kimberley-Grube mit dem der pipe in demselben Niveau (S. 225). Der Blaugrund in den Güngen fülırt weniger Nebengesteinsbrocken und ist fast immer glimmerreicher. Die akzessorischen Wineralien der pipes finden sich auch hier, aber ziemlich selten und in kleinen Stücken, auch kommen gelegentlich Klumpen ron Pyroxenit und Eklogit ror. Diamanten jedoch hat man nur in einigen angetroffen, so in dem ziemlich reichen Gang von Graspan, 30 Meilen westlich von Kimberley (1 Gramm Diamant in 1000 Kilo Gestein), in dem ron Lion's Hill in der Oranje-Kolonie und in dem schmalen Verbindungsgang zwischen der Weltefreden- und der Frank SmithGrube nördlich von Kimberley. Diamantenproduktion ist aber auf den Gängen nicht mörrlicb, teils weil der Prozentgehalt zu gering ist, teils weil bei der geringen Mächtigkeit (Graspan auf 45-50 Kilometer Länge $1 / 2$ bis 1 Meter, der bei Lion's Hill löchstens 2 Meter mächtig) zu wenig diamandführende Masse vorhanden ist, so daß sich auch bei größerer Reichbaltigkeit die erforlerlichen, umfangreichen und kostspieligen Gewinnungsarbeiten nicht bezahlt machen. Daher haben auch alle die mehrfach unternommenen Versuche bald wieder eingestellt werden müssen. Wegen der hieraus sich ergebenden praktischen Bedeutungslosigkeit sollen hier auch nur einige charakteristische Beispiele aufgeführt werden, welche die allgemeinen Verbältnisse der Gänge und ihre Beziehungen zu den pipes zu erläutern geeignet sind. Aus dem Erwähnten ist auch zu ersehen, daß alles was im vorhergehenden 
und im folgenden von Gruben gesagt wurde, sich durchaus auf pipes, und nicht auf Gänge bezieht, wenn letzteres nicht ganz besonders hervorgehoben ist.

Solche Gänge wurden zuerst Ende des vorigen Jahrhunderts in den NewlandsGruben näher bekannt. Ein solcher setzt sich hier in S.W.-N.O.-Richtung $1 / 3$ bis 1 , stellenweise sogar his 21/2. Meter mächtig mehr als 1000 Meter weit fort und erweitert sich an mehreren Stellen, zum Teil nur unterirdisch, zu größeren und kleineren Sehloten. Einige von diesen haben die jetzt aufgelassenen Newlands-Gruben abgebaut. Verfolgt man jene Richtung weiter nach Nordost, so stößt man nach 20 Kilometern auf die Weltefredenund liurz darauf auf die Frank Smith-Grube. Es wird stark vermutet, daß diese beiden Trichter und ihre diamantführende, in dieselbe Richtung fallende Verbindung demselben Gang angehören, der sich wahrscheinlich noch weiter fortsetzt, da von der Frank SmithGrube aus sich mehrere schmale Gänge nach Nordosten foriziehen. Geht man von der siidlichsten Newlands-Grube in entgegengesetzter Richtung nach Siidwesten, so erreicht man die Borrels-Grube; es gilt nicht fïr unmöglich, daß auch sie auf diesem Gange steht, der damn also bis dorthin fortstreichen würde. Das Gestein des von dem KimberleyTrichter sich abzweigenden Ganges zeigt nicht den geringsten Unterschied von dem hard blue in derselben Tiefe der pipe. Es ist nicht breccienartig; sondern erscheint aus einem Guß erstarrt, eine basaltähnliche dunkelgrauschwarze Grundmasse mit Fragmenten und scharfen Kristallen von Olivin, Biotitblättchen mit Schmelzrand, Titaneisen und viel Perowskit. Gangförmige Fortsetzungen sieht man bei Jagersfontein, sowie in der Schuller- und in der benachbarten Kaalfontein-Grube in Transval. Die Klipfontein-Grube bei Koffyfontein besteht aus zwei ganz nahe gelegenen, fast kreisrunden pipes, die durch einen schmalen Gang verbunden sind, so daß das Ganze die Form einer Sanduhr hat.

IBesonder's interessant und lehrreich ist die Monastery-Grube in der OranjeflußKolonie. Zwei in der gleichen Richtung von Südost nach Nordwest hintereinanderliegende, stark verlängerte Trichter sind durch einen ebenso gerichteten schmalen Gang mit einander verbunden, der sich auch jenseits der beiden pipes im entgegengesetzten sinne noch weiter fortsetzt. Die Verlängerung von der einen pipe aus ist nach Südost auf 250 Mreter, von der anderen aus nach Nordwest auf 1300 Neter verfolgt und aufgesehlossen. Das (ranze stellt sich dar als ein bis 5 Meter mächtiger, vielfach allerdings schmälerer, S.O.-N.W. streichender Gang, der sich in den beiden pipes bedeutend erweitert und lokal ausgerlehnt hat. In dem gröheren, nordwestlich gelegenen Trichter von 300 Meter Länge betrïgt die größte Breite in S.W.-N.O.-Richtung ca. 70 Meter; in der kleineren im Südosten gelegenen ist die Länge ea. 90, die größte Breite 30 Meter. Sie schrumpft nach beiden Seiten hin canz allmählich ein und geht so stetig beiderseits in den schmalen Gang über.

IIierher gehört wohl auch der $1 / 2$ bis 2 Meter mächtige Gang, der den Blaugrund der I) e Beer's-Crube von N.O. nach S.W. durchsetzt und der wegen seiner starken Windungen den Namen ,snake“ (Schlange) erhalten hat. Das Gestein ist ein dunkelgrïner Glimmerperidotit und ron dem unten zu erwähnenden Kimberlit, dem Urgestein des blue ground, nicht wesentlich verschieden, enthält aber keine Diamanten und auch keine boulders. Es ist ein Eruptivgestein, das nach der Ausfiullung des Schlotes durch den Blaugrund auf einer Spalte in diesem als ein späterer Nachsehub emporgestiegen ist.

Was die Art und Weise der Ausfïllung der Trichter anbelangt, so ist es selbstverständlich, daß diese eigenartigen Bildungen mannigfache Erklärungsversuche veranlaßt haben. Die erste mit allen beobachteten Tatsachen in Einklang stehende Theorie verdanken wir Emil Cohen. Fast alle, die sich nach ihm (1873) mit diesem Gegenstande beschäftigt haben, sind ihm in der Hauptsache gefolgt und haben seine Ansichten nur unwesentlich modifiziert und zum Teil erweitert. 
Seine Meinung geht dahin, dal) die hesprochenen Kanäle vulkanische Trichter sind, die er mit den Mataren der Eifel vererteicht und die er jetzt vielleicht Vulkanembryonen

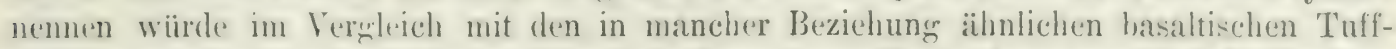
rähren der schwähischen Alh, und anderer Gexenden. Lr ist der Ansicht, dab die diese Kanäle ausfüllende Serpentinbreceie durch vulkanische Kräfte aus der Tiefe segen die Erdoberlaiehe heraushefördert worden ist. Wann das geschehen ist, d. h. zu welcher geologischen Zeit, war damals noch ganz unbekannt. Neuerer Zeit hat man jedoch Anhaltsjunkte dafür gefunten, u. a. durch die kntdeckung von Stiicken der charakteristischen Laven aus der Drakensberer-Kette in dem Blaugrund der Monastery-Grube. Man nimmt danach wohl mit H. S. Harger an, daß die Bildung der pipes nach, und zwar unmittelbar nach der lintstehumgr der Drakensbers-Vulkane stattgefunden habe, und daf sie den letzten Akt der vulkanischen Eruptionstätigkeit in Sïdafrika darstelle, der somit in die jüngere Trias- oder in die ältere Jurazeit fallen wïrde. Aus anderen Cründen wird die Entstehung der Schlote wohl in die ältere Kreidezeit oder gar in die postliretaceische Zeit verlert, so dalj auch jetzt noch eine gewisse Unsicherheit herrscht. Jedenfalls darf man aber wohl Angesichts ihrer geologischen Gleichartigkeit annehmen, daß sie alle ziemlich gleichalterig sind.

E. Cohen sehreilbt ïber die Bildung der mit blue ground erfüllten 'Trichter folgendermalien:

.. Ich nehme an, daf der diamantführende Bodlen ein Produlst vulkanischer Tätickeit ist, welehes wahrscheinlich in Form einer durehwässerten Asche, also vergleichlor den Auswurfsmassen der Schlammrulkane (bei verhältnismäBig nicht sehr hoher Temperatur), zur Eruption želanģte. Später traten dann in den oberen Regionen durch einsickernde atmosphürische Niederschlige, in den tieferen unter dem Einflusse steter Durchfenchtung mannigfache Veränderungen und Teubildungen ein. Die kraterförmigen isolierten Becken - richtiger viclleicht Trichter - , in denen allein die Diamanten sefunden werden, wären demgemäß wirkliche Krater, welehe teils direkt durch die Produkte des Auswurfs erfüllt blichen, teils durch Zurückschwemmung der über den Kraterrand fortgeschleuderten Massen erfïllt wurlen, wodurch allerlei Fremdartiges - lokal auch kleine Geschiebe und organische Tieste - in den Tuff selangen konnte. Das Material zur Tuffbildunw lieferten wahrscheinlich zum gröberen Teil in der Tiefe vorhandene kristalline Gesteine, von denen sich vereinzelt noch bestimmbare Reste finclen. Erst in betrïchtlicher Entfernung ron den Diamantenfeldern treten ähnliche Felsarten an die Oberfläche. Bei der durch rulkanische Kräfte bewirkten Zerstäubung dieser kristallinen Gesteine blieb der Diamant, der sich wahrscheinlich in ihnen gebildet hat, teils vollkommen erhalten, teils wurde er in Bruchstiicke zersprengt und in beiderlei Form mit dem T'uff emporgehoben. Für einen derartigen gleichzeitigen Auswurf von rollkommen ausgebildeten Kristallen und Fragmenten bieten manche der jetzt noch tätigen Vulkane Analoga, während es andererseits auch für die ïbrigen Fundorte von Diananten nicht unwahrscheinlich ist, dab ihre ursplüügliche Lagerstätte und der Ort ibrer Bildung in älteren kristallinischen Gesteinen zu suchen ist. Wenigstens treten vorzugsweise in letzteren die Mineralien auf, welche in der Regrel die Diamanten begleiten. Durch die Eruption wurden die Schichten der Schiefer und Sandsteine mit den eingeschalteten Diahaslagern geboben, durchbrochen und zertrümmert, und die Bruchstücke lieferten das Material für die zahlreichen vom Tuff eingeschlossenen kleinen Fragmente und großen zusammenhängenden Partien (floating reefs) der genannten Felsarten. Da man mehrfach bei Brunnenanlagen in der Nähe der Gruben auf den Schiefern eingeschaltete Kohlenschmitzen gestoßen ist, so sind auch auf diese sicherlich die Koblen zurïckzufïhren, die man gelegentlich im Diamantboden angetroffen und mit Unrecht in genetische Beziehung zu den Diamanten gebracht hat." 
Daß in der 'Tat die Ausfïllungsmasse der 'Trichter nicht durch fließendes Wasser in diese eingeschwenmt worden sein kann, folgt daraus, daß die in dem Blaugrund eingreschlossenen Mineralien und Gesteine keine Abrollung zeigen. B o n ney hat allerdings die rundliche Form der meisten auf solche Wasserwirkung zuriickführen und sie als Geschiebe ansehen wollen, aber mit Unrecht, denn gerade die weichsten, besonders die Schieferstïcke, die doch bei der geringsten Bewegung im Wasser zu allererst abgerollt werden mülbten, sind scharfkantig und -eckig. Die gerundete Form der übrigen, härteren, hat auch wohl, wie wir sehen werden, andere Grïnde. So bleibt also nur die E. Cohensche Ansicht von der vulkanischen Entstehung der pipes übrig und mit dieser, wenn schon mit einigen MIodifikationen, lassen sich auch die bisher beobachteten Tatsachen und namentlich die Bildung der Diamanten selbst, in großen und ganzen ohne Schwierigkeit erklären, wenn gleich wohl einzelnes in dieser Beziehung noch zu erledigen bleiben mag.

Nan stellt sich vor, daß durch die explosionsartige Wirkung hochgespannter Gase im Erdinnern, und besonders von Wasserdämpfen, welche überall die vulkanische Tätigkeit vermitteln, bei der Überwindung des gewaltigen Drucks der überlagernden Gesteinsmassen an cinzehnen Stellen geringsten Widerstands röhrenförmige, nach oben trompetenförmig erweiterte Öffnungen durch die Erdkruste gestoßen worden sind, wie sie eben die pipes zeigen. Daß dies möglich ist, suchte Daubrée durch Explosionsversuche im kleinen nachzuweisen; er erhicelt dabei Röhren, die denen der pipes ganz ähnlich waren. Noch überzeugender dafür ist die Existenz von sicher vulkanischen Bildungen, die sich von den südafrikanischen pipes in der Form in nichts unterscheiden, so die mit Basalttuff u. -breccie und z. T. auch mit Basalt erfüllten Röhren, die die Juraschichten der schwäbischen Alb bei Urach durchsetzen, so die Tuffröhren derselben Art in Schottland und in manchen anderen Gegenden, so die Maare der Eifel und so vor allem die mit den Tuffen und Breccien von Nelilithbasalt und teilweise mit diesem Gestein selbst erfüllten Schlote des Sutherlandbezirks im Kaplande. Alle diese Bildungen unterscheiden sich von den diamantführenden pipes nur durch die abweichende Beschaffenheit des Gesteins, das bei sämtlichen zweifellos rulkanisch ist, und das bei Sutherland sogar gewisse nahe Beziehungen zu dem sofort $\mathrm{zu}$ besprechenden Kimberlit nicht verkennen läßt.

Dieselben hochgespannten Gase und Dämpfe, welche die Trichter bildeter, haben rleichzeitig die in der Tiefe befindliche glühendflüssige Masse, das Magma, in der Röhre in die Höhe geprebt, an deren Nündung zerstïubt, und sie so, gemengt mit den Brocken der bei der Bildung der Röhre zertrümmerten Gesteine in die Luft geblasen. Dieses ganze Material fiel dann wieder auf die Erdoberfläche herunter. Dabei füllte ein Teil den zunächst offenen Schlot wieder aus, das zerstäubte Magma bildete den breceien- oder tuffartigen IBlaugrund und die Gesteinsbrocken die darin eingeschlossenen boulders, in ganz ähnlicher Weise, wie wir es in den vulkanischen Tuffröhren der oben zenannten Länder beobachten. Ein anderer Teil mulbte sich rings um die Mündung des Schlotes in mehr oder weniger grober Menge anhäufen. Davon ist jetzt allerdings nichts mehr zu sehen, man muß aber bedenken, daß das jetzige obere Ende der Röhren nicht das ursprüngliche ist. Die jetzt dort anstehenden Schichten waren früher von jüngeren Bildungen in erheblicher Mächtigkeit ülerlagert, diese sind aber in Laufe der Zeit zerstört und abgetragen worden zugleich mit dem entsprechenden oberen Teile der pipe und deren Umgebung.

Die Diamanten aus diesen zerstörten Partien der pipes sind zum Teil einfach in die Tiefe gesunken und haben sich in der nunmehr obersten Lage, einem die ganze Bildung vielfach bedeckenden roten Ton und vielleicht einem Teil des yellow ground angesammelt. Daher erhält man öfters, z. 13. in der Premier-Grube, ganz oben in den pipes aus den genamnten ljildungen einen ganz besonders reichen Ertrag infolge dieses natïrlichen Konzentrationsprozesses, der dem kïnstlichen Waschprozeß bei dem gegrabenen Blaugrund 
im wesentlichen entspricht. Ein anderer Teil dieser Diamanten wurle durch fliefendes Wasser in die Betten der benachbarten Baiche und Flisse hineingeschwenment und mit deren Sand und Kies gemengt. Hieraus werden sie nun in den river diggrings aus den Seifen an versehiedenen Orten gewonmen.

Die Bildung der pipes war aber mit einer einzigen Explosion vielfach noch nicht zu Ende. Solche wiederholten sich wenirstens in manchen derselhen mehrfach, und es entstanden auf diese Weise die verschiedenen oben erwähnten Säulen, wie sie z. B). in der Kimberley-Grube zu beobachten sind. Hicrauf beruht wohl äberhaupt wenigstens teilweic: die Versehiedenheit einzelner l'artien eines Trichters, namentlich auch hezuiglich der Diamantenfuilırung.

Außerdem drang das gliblendfluissige Magma in die Röhren und auch in die Crangspalten nach und mischte sich in den ersteren lokal mit den durch die Zerstäubung bei den Explosionen gebildeten feinen Asehenmassen. Durch solche Nachschübe entstanden dann die weniger ausgesprochen breceienartigen Partien der Ausfïllungsmassen, namentlich der hard blue, der ja z. 'T'. ganz den Eindruck eines an Ort und Stelle ruhig erstarrten Eruptivgesteins macht, und vor allem auch die Gänge in dem Blaugrund, wie z. B. der erwähnte in der De Beer's-Grube (the snake).

Das Gestein, das auf diese Weise entstand, war, in seiner tuffartigen und komplikten Ausbildung ganz gleich, aufänglich in der Hauptsache Olivin, es war ein Olivingestein, ein Peridotit, welcher wegen der dem Olivin beigemengten akzessorischen Mineralien einem auch sonst rielfach vorkommenden diamantfreien Olivingestein, dem Lherzolith oder auch dem Glimmer-Peridotit, nahesteht. Es wurde von Carvill Lewis nach seinem ausgezeichneten Vorkommen bei Kimberley mit dem besonderen Namen Kimberlit belegt und danach der Blaugrund auch Kimberlittuff oder Kimberlitbreceie genannt. Die Masse ist aber jetzt nicht mehr frischer, unverïnderter Olivin, sondern dieses Mineral ist, wie auch in den meisten sonstigen Olivingesteinen, zum größten Teil in Serpentin umgrewandelt, in dem nur vereinzelte Kö̈nchen des ursprünglichen Olivins als noch erhalten gebliebene Überreste des Urminerals liegen. Daher rührt die Bezeichnung des Blaugrund als Serpentintuff oder Serpentinbreccie.

Die dem Blaugrund beigemengten Mineralien waren jedenfalls zum gröbten Teil schon vor der ursten Explosion, als sich die gespannten Gase und Dänpfe noch nicht Luft gemacht hatten, im Innern der Erde unter hohem Druck als sogenannte intratellurische Ausscheidungen (Urausscheidungen) aus dem im übrigen noch im glïhenden Flub befindlichen Magma auskristallisiert, namentlich die größeren derselben und die grobkürnigen Knollen von Glimmer, Pyroxenit, Eklogit usw. Dies zeigt die Übereinstimmung mit den genannten anderwärts vorkommenden Peridotiten, die nach ihrem ganzen Verhalten sich zweifellos als in großer Tiefe erstarrte Eruptirgesteine, als sog. Tiefengesteine erweisen. Der Kimberlit unterscheidet sich von ilınen im wesentlichen nur durch das Vorkommen von Diamanten, das aber geologisch in dieser Hinsicht bedeutungslos ist. Nur bei der in der Tiefe stattfindenden langsamen Abkühlung konnten diese Mineralien in der beobachteten Größe und regelmäßigen Ausbildung sich aus dem Magma abscheiden. Allerdings haben die Mineralien des Blaugrund, der Diamant ausgenommen, ja keine regelmäßige Kristallform, sondern sie sind mehr oder weniger vollkommen gerundet. Dies rührt aber wohl daher, daß sie auf ihrem Weg gegen die Erdoberfläche in dem umgebenden, noch gliilıend flüssigen Magma eine oberflächliche Abschmelzung, eine Resorption erlitten haben, wie das unter gleichen Umständen bei anderen Gesteinen bäufig zu beobachten ist. Dasselbe ist natïrlich auch den eingeschlossenen Gesteinsbrocken widerfahren, und bei den kleinsten von diesen hat A. Bergeat ausgezeichnete Resorptionswirkungen in der Tat sicher nachzuweisen vermocht. Auf die Ausbildung in der Tiefe weist auch der Umstand hin, daß man in der Ausfüllung der 
'Trichter noch niemals auch nur die geringste Spur von glasigen Erstarrungsprodukten bat auffinden können, wie sie wohl sehr häufig bei oberflächlich fest gewordenen vulkanischen Ergulßgesteinen, nicht aber in Tiefengesteinen vorkommen.

Dab der Diamant, der ja nicht anders als seine Begleitmineralien im Tuff liegt, auch wie diese entstanden ist, erscheint sicher, da er ja z. B. in den Eklogitknollen mit diesen in ciner Weise verwachsen vorkommt, die jeden Zweifel an einer gleichartigen Fintstehung des Diamants ausschließt. Daß die freiliegenden Diamanten anders gebildet worden sein könnten, wird wohl niemand annehmen wollen. Auch sie müssen also in der Tiefe aus dem Magma auskristallisiert und dann mit seinen Begleitern in der oben beschriebenen Weise in die Röhre gelangt sein. Es hat auch keine Schwierigkeit, dies anzunchmen, da nach den Versuchen von J. Friedländer und R. von Hasslinger aus kohlenstoffhaltigen Schmelzen von der Zusammensetzung des Olivin oder auch, was dasselbe ist, des Blaugrunds beim Erstarren Diamant in der Form von Kristallen sich ausscheiden kann. Die beiden genannten haben mit kleinen Mengen gearbeitet und die Erstarrung der Schmelze ist verhältnismäßig rasch vor sich gegangen, daher haben sie nur Diamanten von mikroskopischer Größe oder wenig darüber erhalten. In den gewaltigen Magmamassen im Erdiunern und bei der dort nur langsam vor sich gehenden Erkaltung und Erstarrung konnten sich wie bei den anderen Mineralien auch grölsere Kristalle von Diamanten bilden. Diese sind iibrigens aber, wie wir gesehen haben, auch im Blaugrund zu allermeist klein und sogar z. T. mikroskopisch klein.

Jedenfalls müssen wir uns das Kimberlitmagma kohlenstoffhaltig vorstellen, was in verschiedener Weise möglich ist. Nach Stelzner war es mit Kohlensäure durchtränkt, andere denken an Kohlenwasserstoff oder an Metallkarbide als Quelle der Diamanten usw. Selhstverständlich wird das Magma nicht überall gleichviel Kohlenstoff enthalten haben, danach wird auch der Diamantgehalt nicht in allen Gruben und nicht in allen Teilen einer Grube der gleiche sein, und wenn an einer Stelle das Magma gar keinen Kohlenstoff enthielt, so konnten sich in einer an dieser Stelle entstandenen pipe auch keine Diamanten finden. Verschiedene physikalische Bedingungen bei der Abkühlung und Erstarrung des Magmas konnten die verschiedene Ausbildung der Diananten in den einzelnen Gruben nach Farbe, Größe, Kristallform usw. zur Folge haben.

Wir haben schon oben gesehen, daß man frïher versucht hat, sich die Entstehung der Diamanten nahe der Erdoberflïche zu denken, und zwar durch die Einwirkung des glühendflïssigen Magmas auf die bituminösen Schiefer. Diese schon von E. Cohen abgelehnte Ansicht ist auch in der Tat zu verwerfen, und zwar aus verschiedenen Gründen. Wïre sie richtig; so wäre wohl anzunehnen, daß Diamanten hauptsächlich oben in der Recrion dieser Schiefer im Riff sich finden, wo auch viele boulders der letzteren Art im. Blaugrund liegen, daß jedenfalls hier der Diamantenreichtum am größten ist. Tatsäichlich nimmt dieser aber in vielen pipes gegen unten, also mit der Entfernung von jenen Sehiefern nicht unbeträichtlich zu. Entscheidend ist aber die Tatsache, daß die transvaalschen pipes und vor allem die besonders reichhaltige der Premier-Grube in der Hauptsache durch Quarzit hindureh gehen und daß dort solche Schiefer und andere bituminöse Riffgesteine und boulders gänzlich fehlen.

Mit der Entstehung in der Tiefe finden dann auch die zahlreichen Bruchsticke von Diamantkristallen im Blaugrund ihre Erklärung. Bei dem unter heftigen Kraftwirkungen erfolgten 'I'ransport aus der Tiefe und in der Röhre entstanden sie durch Zerbrechen größ)erer Kristalle nach den Blätterbrïchen. Ähnliche Bruchstiicke bilden übrigens auch aus demselben Grunde häufig die Begleitmineralien.

Jer Kimberit, das ursprüngliche Muttergestein der Kapdiamanten, gehört zu den ganz besonders kieselsäurearmen, den ultrabasischen Eruptivgesteinen. Wir haben hier also das 
Iauptheispiel der Ausscheidung von Diamanten aus eincm ultrabasischen Magma vor uns, wie es in weit kleinerem Mabstab greichfalls in Borneo, Australien, Nordamerika usw. zu beobachen ist. Auch in Spanien, in der Nähe des I)orfes Carratracas, Provinz Malatra, soll ein Diamant mit Serpentingeröllen in einem Bachbett gefunden worden sin. Die letztere Entstelumer des I)ianants steht eregenüber der in sehr sauren Eruptirgesteinen mit hohem Kieselsïuregehalt, wie (ranit usw.; so ist diese, wenn cleich z. T. zweifellaft, in Brasilien, Lappland, low Bellary in Indien, im südïstlichen Borneo usw. zu beohachten.

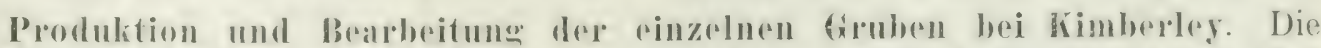

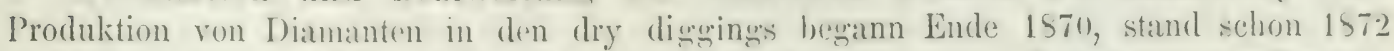
in höehster Blïte und hat sich seitdem immer mehr entwickelt. Zuerst war die Boarbei-

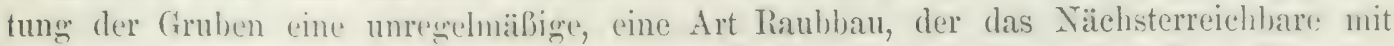
möglichst geringem Aufwand von Arbeit und Kosten nahm, ohne an kïnftige Zeiten zu denken. Das hatte zur Folge, daß man später grobe niihe und Opfer anfwenden mubte, um wertrollen (irund, der durch fribhere Arbeiten verschïttet worden war, wieder \% gänglich zu machen. In der zulctzt aufgefundenen Kimberleycrube wurde aber gleich von Anfang an ein rationellerer und rexelmäbigerer $\Lambda$ bloau eingefiilht, da man beim Betriebe der älteren Gruben schon durch Schaden klug geworden war.

Die Gruben wurden in quadratische Parzellen, sogenannte claims eingetcilt. wie es in den Goldfehlern Kaliforniens und Australiens und auch Südafrikas, sowie in den river dignings Sitte war. Diest claims waren in Kinberley und De Beer's 31 Fub enolisch = $30 \mathrm{Fub}$ hollindisch $=9,15 \mathrm{~m}$, in Dutoitspan und Bultfontein aber nur 30 Fulf engl. lang und breit. Jeder claim hatte also eine Grundfläche von etwas über $\delta($ (1m. Solcher Parzellen waren in Fimberley im sanzen 470, in De Beer's 622, in Bultfontein 1!67, und in Dutoitspan 1441. In den drei letztgenannten Gruben war zwischen den einzelnen claims war kein Zwischenraum gelassen, sie grenzten unmittelhar aneinander. Die nach innen zu gelegenen hatten also gar keinen direkten Zugang von aufen, was den Verkehr und Ahhau sehr ersehwerte. Um diese Übelstïnde zu rermeiden, ordnete der Regierungskommissar, damals noch der des Oranje-Freistaates, bei der Eröffnung der Kimberleygrube an, dalj hier 14 oder 15 von Norden uach Süden gehende, 15 Fuß breite Streifen in solehen Entfernungen ausgespart wurden, dals jeder claim an einen solchen Streifen zu liegen kam. Diese durften nicht in Angriff genommen werden; sie dienten zur Anlage von Verbindungswegen, sogenannten "road ways". Jeder Claimbesitzer verlor dadurch $7 \frac{1}{2}$ Fuf Boden, daher fand die Einrichtung zuerst großen Widerstand, hald aber schwand dieser, weil sich herausstellte, dab durch die Wege der Betrieb außerordentlich erleichtert wurde. Die Taf. VII gibt den Anblick der Kimberleygrube mit ihren Wegen, wie sie sich im Jahre 1872 darstellte.

Jeder „digger" durfte bis 1977 höchstens zwei claims besitzen, mit alleiniger Ausnahme des Entdeckers der betreffenden Grube, der drei zu nelmen berechtigt war. Jedermann hatte die Auswahl unter den noch freien claims und mußte dafür dem Grundeigentümer eine Entschädigng von 10 Schilling die Woche bezahlen. Bis 1873 galt die Bestimmung, daf jeder die ron ihm in Besitz genommenen claims umunterbrochen bearbeiten mulite. Ner aus irendeinem frunde acht Tage lang die Arbeit ruhen ließ. verlor sein Recht; ein beliebiger anderer konnte dann den nunmehr herrenlosen claim in Besitz nehmen.

Im Laufe der Zeit ergal) es sich, daf ein Mann nicht immer imstande oder willens war, einen ganzen claim allein zu bearbeiten. Es kamen Teilungen vor, und manche diggers hatten nur einen halben oder einen viertel und sogar einen sechzehntel claim. Die Besitzer solcher bruchteile von claims waren in allen Gruben sehr zahlreich. 
Wichtiger als die Teilung der claims erwies sich aber das Zusammenfassen mehrerer in einer IIand, nachdem die eben crwähnte entgegenstehende Bestimmung im Jahre 1877 beseitigt worden war. Es bildeten sich Aktiengesellschaften, die eine Anzahl claims zusammenkauften und gemeinsam bearbeiteten, und neben denen sich Eigentümer einzelner claims und namentlich solche von Bruchteilen eines claims im Laufe der Zeiten nur in sehr seringer Zahl unabhäingig erhalten konnten. In der Kimberleygrube waren so Mitte der achtzigre Jahre einige wenige große Gesellschaften im Besitze von fast sämtlichen claims, wïhrend Mitte der siebziger Jahre ungefähr 1600 Personen an der Grube huteilignt gewesen waren, und ähnlich hatten sich die Verhältnisse in den anderen Gruben westaltet. Der Besitz der einzelnen Gesellschaften wechselte zwischen erheblichen Grenzen, nimlich zwischen 4 und $; 0$ elaims. Die Verwaltung war bei vielen vollkommen rechtlich; manche waren aber auch Schwindelunternehmungen schlimnster Art, die zuweilen nach kurzem Betriebe ihre Arbeiten einstellen mußten.

Die nïchste Folge der Bildung dieser Aktiengesellschaften war eine starke Vermehrung dex Produktion. 1879 wurden im ganzen etwa 2 Millionen Karat Diamanten produziert, 1850 und 1851 stieg die Menge plützlich auf etwas ïber 3 Milionen. Dieses günstige Resultat in Verbindung mit den zahlreichen Schwierigkeiten, die die Bearbeitung der Gruben durch verschiedene Gesellschaften und daher in verschiedener Weise mit sich brachten, erweckte sodann das Bestreben, die Bebauung jeder Grube rollkommen einheitlich zu gestalten. Dahin zielende Versuche fanden anfänglich großen Widerstand, führten aber schließlich doch zum Ziel und zwar zuerst in der De Beers-Grube. Die 1880 mit einem Kapital von 21/2 Hillionen Pfund Sterling gegrïndete „De Beers mining company" dehnte sich allmählich immer mehr aus, indem sie die Anteile anderer Gesellschaften und einzelner Clainbesitzer aufkaufte und so nach und nach die ganze Grube in ihren alleinigen Besitz brachte. Nachdem dies erreicht war, konstituierte sie sich neu und verwandelte sich unter der Fiihrung des auch als Politiker bekannten, im Jahre 1902 verstorbenen Cecil John Rho des, der auch vorher schon im wesentlichen die Sache geleitet hatte, in die „De Beer's consoliclated mines company", die am 1. April 1589 mit einem Aktienkapital von $4 \frac{1 / 2}{2}$ Millionen Pfund Sterling ins Leben trat. Damit war der Anstoß zu der mächtigen Entwickelung der sürafrikanischen Diamantenindustrie gegeben. In ganz kurzer Zeit stand die Gesellschaft als Alleinherrscherin an der Spitze, und diese Stellung nimmt sie noch heute ein.

Zunächst erwarb sie im Jahre 1889 noch die ganze Kimberleygrube, seit 1859 und 1890 auch Bultfontein und Dutoitspan, denen endlich 1892 die Wesselton-Grube folgte, deren Eigentïmer sich allerdings noch bis 1896 das $\Lambda$ bbaurecht vorbehielt, so daf die Gesellschaft crst in diesem Jahre in den faktischen Besitz treten konnte. Damit waren nun also alle fünf ertrasteichen Gruben bei Kimberley in ihrer Hand vereinigt. Aufer ihnen war damals bloli noch Jagersfontein von einiger Bedeutung, aber auch hier wufte die Gesellschaft durch Erwerhung von Anteilscheinen ihren Einfluf geltend zu machen. Mit allen diesen Maliregeh hatte sie sich das Diamantenmonopol versehafft, und sie behielt es auch unbestritten, lis vor wenigen Jahren die Premier-Grube in Transvaal cröffnet wurde.

Wie sehr die Gesellschaft schon bald nach ihrer Grïndumg den Markt beherrschte, sieht man daraus, daß von den 2415655 Karat Diamanten, die vom 1. April 1890 bis 31. März 1891 in Südafrika gewonnen wurden, 2195112 Karat im Werte von 3287725 Pfund Sterling aus ihren (iruben kianen, also nahezu 90 Prozent des Ganzen. Gegen diese Menge versehwindet anch das aus anderen Ländern Kommende vollständig, sogar die Produktion von Brasilien, das hinter Siidafrika an zweiter Stelle stebt. Aber auch auf eimen Teil der dortigen Gruben, die Canavieiras-Gruben in Bahia, hat sich die De Beer's(rescellschaft ihre Einwirkmong gesichert. Mit weitem Blick und in ausgezcichneter Weise geteitet, hat sie sogar den Wetthewerb) der allein für sie guführlichen Premier-Grube zu 

beseitigen gewnfit, indem sie die Premier-(iesellschaft bestimmte, im Oktober lint waren eine angemessen. Entschäidigung. ihre l'roduktion einzuschränken, und sich dem untrn zu besprechenden I)iamintensyndikat und damit ihrer Preispolitik anzuschliefon. Allordings ist neuestens dir I'remier-Gesellschaft von dieser Abmachung sehon wieder zuriickgetreten.

Diese Politik besthlt darin, daß die De Beers-Gesellschaft ilıre ausschlargebendr. Macht dazu beniitz, dir. I'roduktion zur Vermeidung jeder Preisdriekerei der Nachfrage tunlichst anzupassen. Friilur als dle liesitzer der einzelnen claims und die zahlreichen kleinen Gesellschaften unahbäneip voncinander für sich arbeiteten, suchten alle rasch so viel Steine als nur möglich zu gewinne-n und zu verkaufen. I)adureh machten sie sich ggegenseitig Konkurrenz, und die Diamantempreis hlielun verhältnismäßjig niedrig. Die fesellschaft dagegen fïrderte nicht mehr und brachte nicht mehr in den IIandel, als zu den rersehiedensten Zwecken des Schmucks und der T'rehnik verbraucht wurde. Dies waren erfahrungrsmäbig efwa 200000 Karat im Nomat. Diese Mafregel in Verbindung nit dem bisherigen Nangel jeglichen ernsten IVetthewrohs machte es möglich, den Preis für 1 Karat Diamanten von anfänglich etwa 20 Schilling allmählich bis auf 60 Schilling und noch mehr hinaufzuschrauben und den Gesamterlïs fïr verkaufte Diananten von gols 1 s I'fund Sterling im Jahre 1559 bis anf 5607 T is Pfund im Jahre 1906 zu steigern. Gleichzeitig hatte die Veremigung der Kimberley-Gruben in einer IIand eine sehr beträchtliche Verminderung der Gewinnungskosten zur Folge. Wïhrend 1852 ein load Blaugrund ${ }^{1}$ ) die Gesellschaft auf 16 bis 17 Sehilling zu stehen kam, betrugen später die Unkosten nur noch 7 bis 9 Schilling im Durchschnitt. Alle diese Unstïnde bewirkten ein starkes Anwachsen der Gewinne, das sich in einem raschen Steigen der Dividende äuferte. Diese betrug im Jahre Iss9 nur 5, 1590 schon 20) Prozent, und ging, stetig grïber werdend, im Jahre 1596 bis auf 40) Prozent des Alitienliapitals in die Höhe. Dieser Stand hat sich bis hente nicht mehr geändert, nur für das Jahr, in dem die Belagerung ron Kimberley während des Burenkriegs stattfand, 1599 bis 1900, mußten die Eigentïmer der Aktien auf eine Rente rerzichten, da die Gesellschaft infolge dieser Vorgänge einen Verlust von $5-6$ Millionen Mark erlitt. Die Aktionäre wurden dafür aber durch auferordendliche Zuwendungen späiter einigermaßen entschädigt.

Dabei wurden nar nicht alle im Besitz der Gesellschaft befindlichen Gruben hearheitet. Anfänglich war es nur die Kimberley- und die De Beers-Grube, wozu 1596 noch die Wesselton-Grube trat, während seit Ende März 1990) Dutoitspan und Bultfontein stillgelegt waren. Sie erschienen zu wenig extragreich und konnten für später aufgespart werden, wemn der reiche Blaugrund der andem Gruben erschöpft sein wïrde. Von Dutoitspan sagte Cecil Rhodes beim Ankauf, die Grube sei zwar zum Betrieb zu arm, aber doch zu reich, als daf sie im Besitz eines andern gelassen werden künnte. Erst am Anfang dieses Jahrhunderts wurden sie, 1900) Bultfontein, 1903 Dutoitspan, wieder aufgenommen. Beide haben dabei die in sie gesetzten Erwartungen ïhertroffen, da der in den oberen Teufen geringe I)iamantgehalt nach unten beträchtlich wächst, während in den Hauptgruben, Kimberley und De Beers, der Ertrag in der Tiefe rasch abnimmt. Jene beiden anfänglich verachteten Gruben versprechen darnach nit der Zeit die Hauptdiamantenquellen der Gesellschaft zu werlen, namentlich auch angesichts ihres großen Lmfangs, der den der beiden letztgenannten erheblich ühertrifft. Gegenwärtig sind sie aber trotzdem der Krisis im Diamanthandel wegen wieder stillgelegt.

Un einen weiteren Blick in die Zukunft zu tun, sei erwähnt, daf die De Beers Gesellschaft in ihren fünf Gruben schon jetzt gegen 100) Millionen loads 1) Blaugrund durch

1) 1 load, das in Kimberley für derartige Zwecke allgemein übliche $\mathrm{Maß,} \mathrm{ist}=16$ Kubikfuß englisch $=0,454$ Kubikmeter. 1 load (Wagenladung) Blaugrund wiegt ungefähr 725 Kilogramm. 
beromännische Arbeiten 11. Versuchsschächte nachgewiesen und teilweise auch bereits für den Abbau aufereschlossen hat. Diese Anlagen gehen in der Kimberley-Grube etwa 900 Meter tief, in den anderen lange nicht so weit. Da die gegründete Hoffnung besteht, mit dem Berghaubetrieh bis vielleicht 2000 . Ieter vordringen zu können und auch dort noch brauchbares Material zu finden, so darf man wohl annehmen; daß die Produktion in ihrem heutigen Umfange auf eine ganze Reihe von Jahren gesichert ist.

Inı Anfanter, kurz nach der Eröffnung der Gruben, arbeitete jeder Besitzer eines claims oder (ines claim-snteils allein in seinem Grundstiick. Bald fanden sich aber verhältnismäfig billige Arbeitskräfte unter den umwohnenden Kaffern, die in grofer Zahl rerwendet wurden. In den foer Jahren waren allein in der Kimberleygrube 10000 bis $120(0)$ Kaffern als Arbeiter beschäftigt; manchmal wird die Zahl sogar auf das Doppelte angeweben. Ias Gestein wurde mit der Spitzhacke losgelöst oder mit Pulver, später anch mit Dynamit gesprengt und das Gewonnene auf die primitivste Art aus der Grube herausgefürlert, entweder getragen oder in Karren geführt. Dabei vertieften sich die verschiedenen Gruben immer melur, und zwar auch in dieser Zeit schon in den einzelnen claims in verschiedenem MIaße, da sie nicht alle gleich lebhaft bearbeitet wurden. So bildete bald ein stark bearbeiteter claim eine quadratische Vertiefung mit mehr oder weniger hohen senkrechten Wänden, von denen fortwährend Stücke sich ablösten und herunterfielen, und langsam bearbeitete claims bildeten quadratische Säulen, zuweilen von soleher Möhe, dab sie einstïrzten und die ganze. Nachbarschaft überschütteten. Die zwischen den claims hindurchfïhrenden roads in der Kimberleygrube, die nicht angehauen werden durften, bildeten bald Mauern, die hoch ïber die Umgebung hervorragten, so daß die ganze Grube den cigentïmlich pittoresken Anblick bot, den Taf. VII zeigt. Auch diese Mauem fingen der leichten Verwitterbarkeit des Tuffs wegen bald an zusammenzubrechen, daher mubte man schon 1872 anfangen, sie abzubauen. Die Grube erhielt dadurch ein ganz anderes Ansehen; sie glich num einem riesigen Loch, aus dem jetzt aber das gewonnene Material nicht mehr in der früheren Weise herausgeholt werden konnte. Daher wurden als Ersatz für die alten Verkehrswege, die roads, am Rande der Gruben, hohe Holzgeriiste mit Winden grebaut und die mit der diamantführenden Erde gefüllten Fellsäcke oder Eimer mittelst Drahtseilen heraufgezogen. Jeder Besitzer eines Teiles der Grube hatte seine besonderen Drahtseile, und so waren diese in sehr grofer Zahl, bis 1600, vorhanden. Die Grube bot in dieser Zeit (um 1874) einen Anblick, wie wenn sie mit einem Netz von Spinnenfäden überzogen wäre; die Figur Taf. VIII oben sucht diese eigentïmliche Erscheinung wiedelzugehen. Die Bewegung der Apparate geschah anfänglich bloß durch IIenschen orler Tiere, später wurden auch Dampfmaschinen angewendet. Daß dies nicht Weich in der ersten Zeit geschah, lag nur an den enormen Kosten der Maschinen und der zum Betrich (x) forlerlichen Steinkohlen. Anfangs 1550 waren aber trotzdem in den Gruben bei Kimberley schon 150) I)ampfmaschinen aufgestellt, deren Zahl sich bis 1552 auf 356 mit 4000) Plordekrïften vermehrt hatte, und neben denen im letzteren Jahre noch 150)0 Maultiere und Pferde verwendet wurden.

Schon allein durch die fortdauernden, mit zahlreichen Ungliicksfällen verbundenen Finstïrze in den fruben und das immer mühevollere Herausschaffen des gewomnenen Tuffs wurde die Bearbeitung der claims mit zunehmender Tiefe immer schwieriger und kostspieliger. Dazu kamen aber noch andere in derselben Richtung wirkende Umstände. Früher hatte man das die Gruhe umgebende Riff einfach stehen lassen. Bald jedoch fingren auch dessen Wände an einzustiilzen. Große Gesteinsmassen fielen und rutsehten in die Grube und überdeckten diese zum Teil so, daß der Betrich bedentend gehindert und "rst nach sehr langwierigen und kostspieligen Arbeiten zur Fortschaffung der abgestiirzten 
Massen wieder möglich wurde. So rutschte im September $18 \times 2$ in der Kimberleygrulue ein Stiick des Riffs im rewicht von $3500000000 \mathrm{~kg}$ ab, dessen Trümmer 6.1 claims üherschütteten; 1878 war sogar ein Viertel aller claims mit Trümmern des Riffs bedeckt. 18i!) und 1850 mulite man (i Millionen Mark für Beseitigung der ahgrestürzten Massen aufwenden, 1552 war dazu sogar eine Ausgabe von 10 Millionen Mark nötige, und doch komnte der Übelstand nicht vollstïndign beseitigt werden. Im ganzen wurden etwa 3 Millionen Kubikmeter Riff mit einem Aufwande von 40 Millionen Mark aus der Kimberleygrube entfernt. Wie weit diese Schwierigkeiten die der Einsturz des Riffes mit sich brachte, die Produktion becinflulit haben, sieht man daraus, dab die Kimberleygrube in den 1s Monaten vor der oben erwälnten Katastrophe $142972 s$ Karat Diamanten, in den darauffolgenden is Monaten aber nur \$50396 Karat geliefert hat. Durch diese Einstürze und die Entfermung der zwar noch stehenden, aber den Einsturz drohenden Riffteile wurde der obere Unfang der Grube immer gröber. So bildete die Kimberleygrube bis Nitte der achtziger Jahre allmählich eine $122 \mathrm{~m}$ tiefe, kraterartige Einsenkung von 3.50 $\mathrm{m}$ Länge und $300 \mathrm{~m}$ Breite, wie es Tafel VIII, untere Figur dargestellt ist.

Auch die Grubenwäisser fingen nun an lästig zu werden, und es wurde nötign, sie zu entfernen, als man immer mehr in die Tiefe eindrang. Dies war gleichfalls mit erhel)licher Mühe und großen Kosten verbunden.

Solche Schwierigkeiten zu besiegren, waren bald die Besitzer einzelner claims nicht melır imstande, un so mehr, als sie nicht die einzelnen claims, sondern die ganze Grube in ihrer Gesamtheit betrafen. Daher trat allmählich immer stärker das Bedïrfnis der Vereinigung mehrerer zu remeinsamer Arbeit hervor, und daraus entwickelte sich schon 187.1 die Einrichtung des, Kimberley mining board“, einer Behörde, die solche gemeinnützigen Unternehmungen, wie die Entfernung des eingestïrzten und den Einsturz drohenden Riffes, des Grubenwassers usw. auf gremeinschaftliche Kosten ausführte, und diese Schwierigkeiten waren auch der Grund, warum sich später die oben erwähnten Aktiengesellschaften bilden konnten. Früher war ein Besitzer eines claims nicht so leicht geneigt, sein Eigentum zu verïußern, da er daraus die größten Reichtiimer zu ziehen hoffte, und auch gegen die gemeinsame Bearbeitung mebrerer benachbarter claims durch alle Besitzer zusammen herrschte die größte $\Lambda$ bneigung. Bald fehlten aber vielen solchen kleinen Eigentiimern die Mittel zur Fortsetzung ihres Betriebes; sie muften ilıre Anteile verlassen oder verkaufen, und statt ihrer traten nun die Aktiengesellschaften ein, die mit wroßen Kapitalien arbeiteten und die daher alle jene Übelstünde leichter überwinden konnten, um so mehr, als sie nicht bloß ein kleines Eckchen der Grube, sondern ein größeres zusammenhängendes Stiick derselben besaßen. Sie waren auch imstande, den Betrieb durch Einführung der besten Maschinen und der zweckmäßigsten Einrichtungen fortdauernd zu vervollkommnen und anf die Höhe der modernen Technik zu erheben, und dadurch gleichzeitig auch billiger zu gestalten.

Inmer mehr und mehr drang aber allmählich die Überzeugung durch, daß in der bisherigen Weise nicht fortgearheitet werden künne, und daß die Einführung eines regelmäßjigen unterirdischen Bergbaues an Stelle des bisherigen oberirdischen Tagrebaues dringendes Erfordernis sei, um die Schätze der größeren Tiefe zu gewinnen. Erfolgreiche Anfïnge dazu sind in der Kimberleygrube schon 1845 gemacht worden. Hier wurde 1891 neben anderen Schächten cin solcher von 1261 en trieben. von den aus die Diamantlagerstïtte in verschiedenen Niveaus durch horizontale Strecken aufgeschlossen wurde. Fig. IS (S. 2.2) gibt ein Bild ron den damaligen bergmännischen Anlagen in der Kimberleygrube mit ihren Stollen und Schächten, die teils in dem Trichter selbst, teils im Nebengestein angelegt sind. Die größte Tiefe des Tagrebaues betrug etwa 880 Fub oder gegen 300 ITeter und stellt so die gröbte künstliche Ausschachtung in der Erdkruste 
dar. Bergmännisch ist man zurzeit bis etwa $2700 \mathrm{FuB}$, also über 900 Meter vorgedrungen (vgl. Fig. 47 S. 222). Man sieht daraus, in wie viel betrïchtlicherem Malstabe bei diesem neuen Betriebe der Abbau vor sich gehen konnte als früher. Ein Hauptvorteil des Bergbaues ist ferner der, daß nunmehr die Arbeiten nicht mehr durch Einstürze des Riffes gefährdet und gestïrt werden können. Daher waren auch im Jahre 1891 und später Malßregeln zur Bewältigung des Riffes früheren Jahren gegenüber nur in geringem Maße erforderlich.

Auch in den anderen Gruben ist der unterirdische Betrieb eingeführt worden. Die Anlage in der De Beers-Grube ist in Fig. 49 abgebildet. Der Hauptschacht ist hier jetzt 2076 Fuf oder ungefähr 700 Meter, die unterste Abbaustrecke 2040 oder nahezu 680 Meter tief.

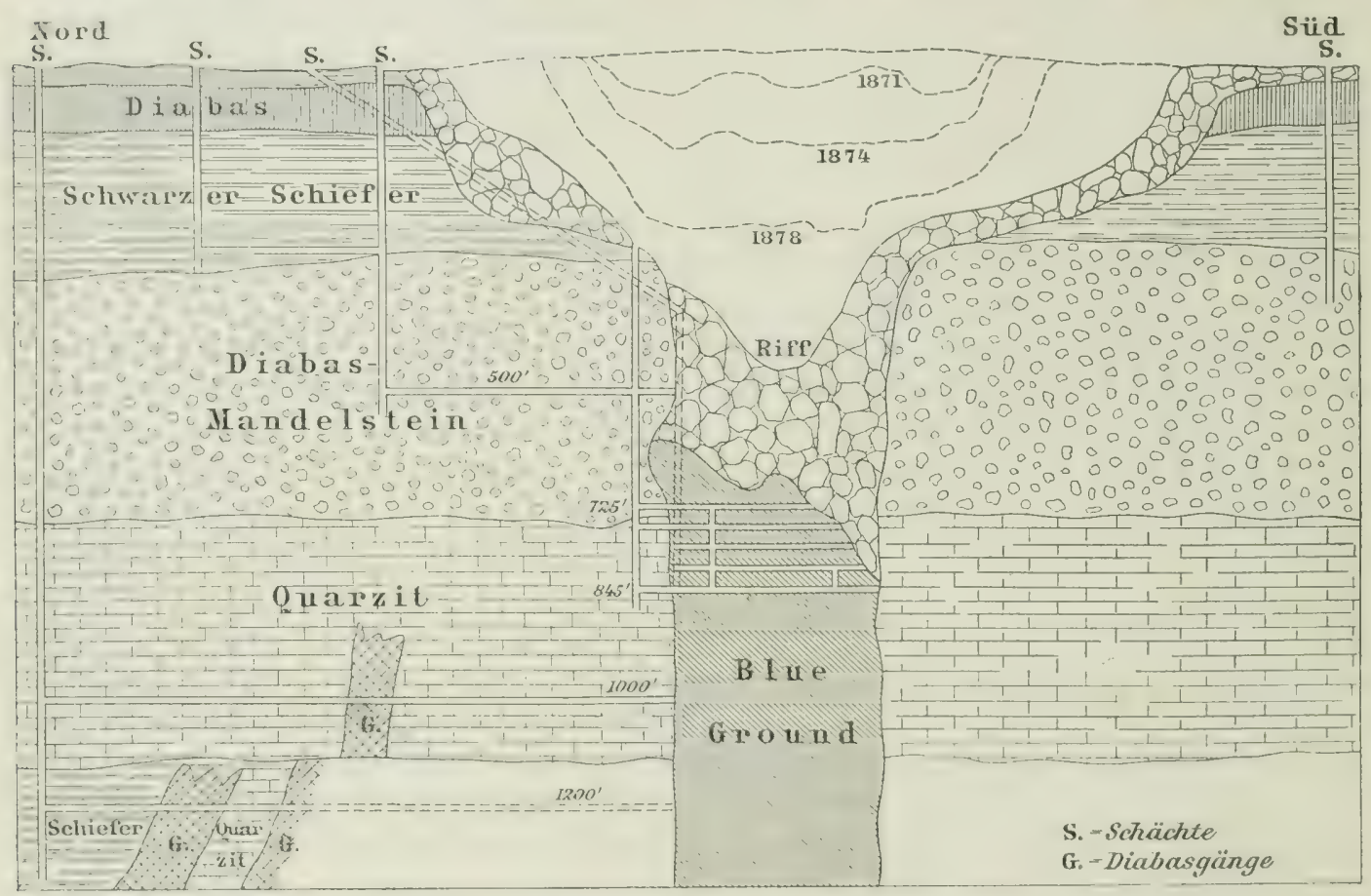

Fig. 48. Bergbauliche Anlagen in der Kimberley-Grube. $1: 4800$.

Wie die Gräberei zuerst in sehr primitiver Weise betrieben worden war, so wurde anfänglich auch die Gewinnung der Diamanten aus dem geförderten Gestein auf sehr rohe und olerflächliche Art ausgefiuhrt. Der zur Zeit der Entdeckung der dry diggings in der Gegend von Kimberley herrschende absolute Wassermangel, der so weit ging, daß man sogar das nötige Trinkwasser viele Kilometer weit vom Vaalflusse herbeifahren mubte, verbot das Wasehen wie in den river diggins von selbst. Daher wurde die diamantführende Nasse mit hölzernen Keulen gröblich zerkleinert, das Gröbste und Feinste durch zwei Siebe getrennt, der Rüickstand von mittlerem Korn wie in den river diggings in einer dünnen Schicht auf einem Tiseh ausgebreitet und nach Diamanten sorgfältig durchsucht.

Bei diesem Prozesse gingen matürlich alle die Steine verloren, die dureh äe etwa $2{ }^{1} / 2$ bis $4 \mathrm{~mm}$ weiten Maschen des feinen siebes hindurchfielen, es galt aber die $\Lambda$ nsicht, daß die Gewinnung auch dieser kleinen Diamanten die dazu nötige Zeit und Mühe nicht lohnen würde. Die größheren Gesteinsstiicke, die auf dem groben siebe mit 9 bis $15 \mathrm{~mm}$ Masehenweite liegen blieben, schlossen noch manchen Diamanten ein, der äußerlich nicht 
Tafel VIIT.

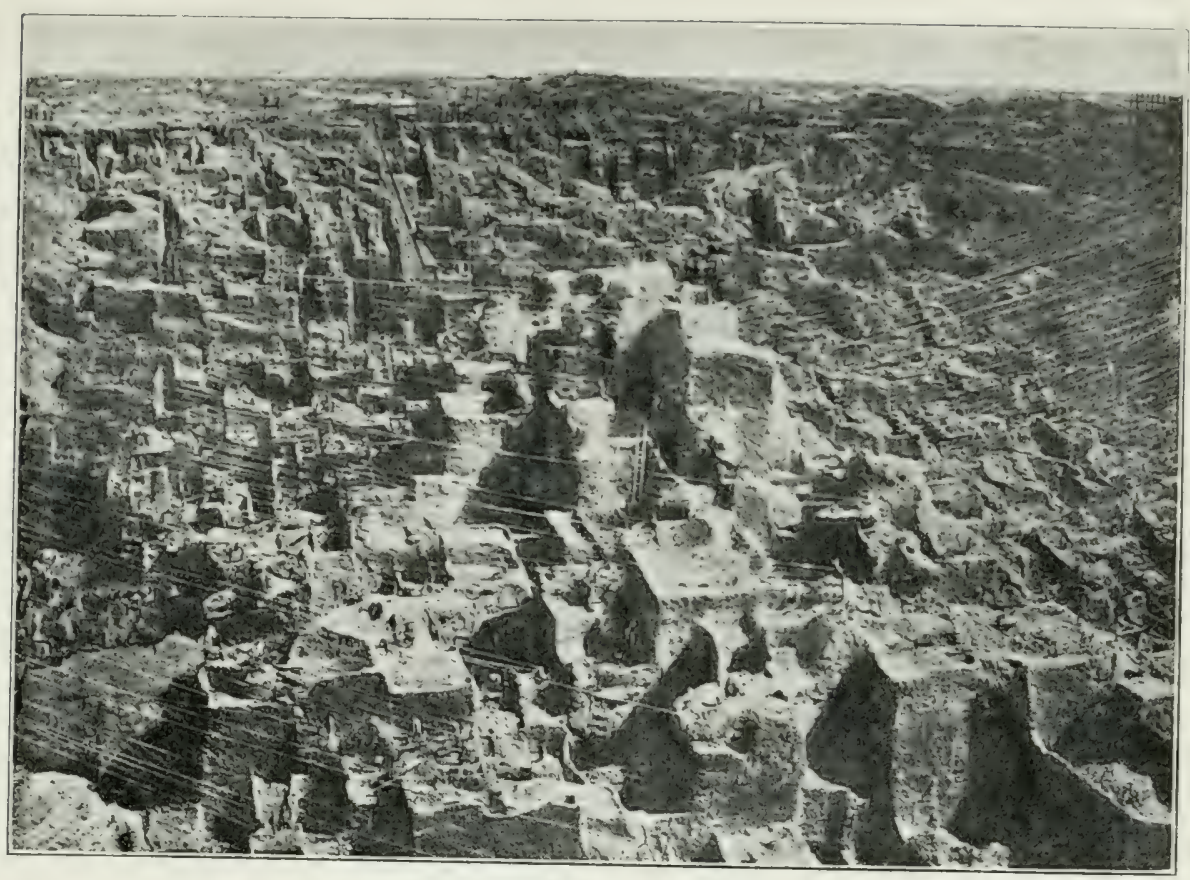

Kimberley-Grube 1874.

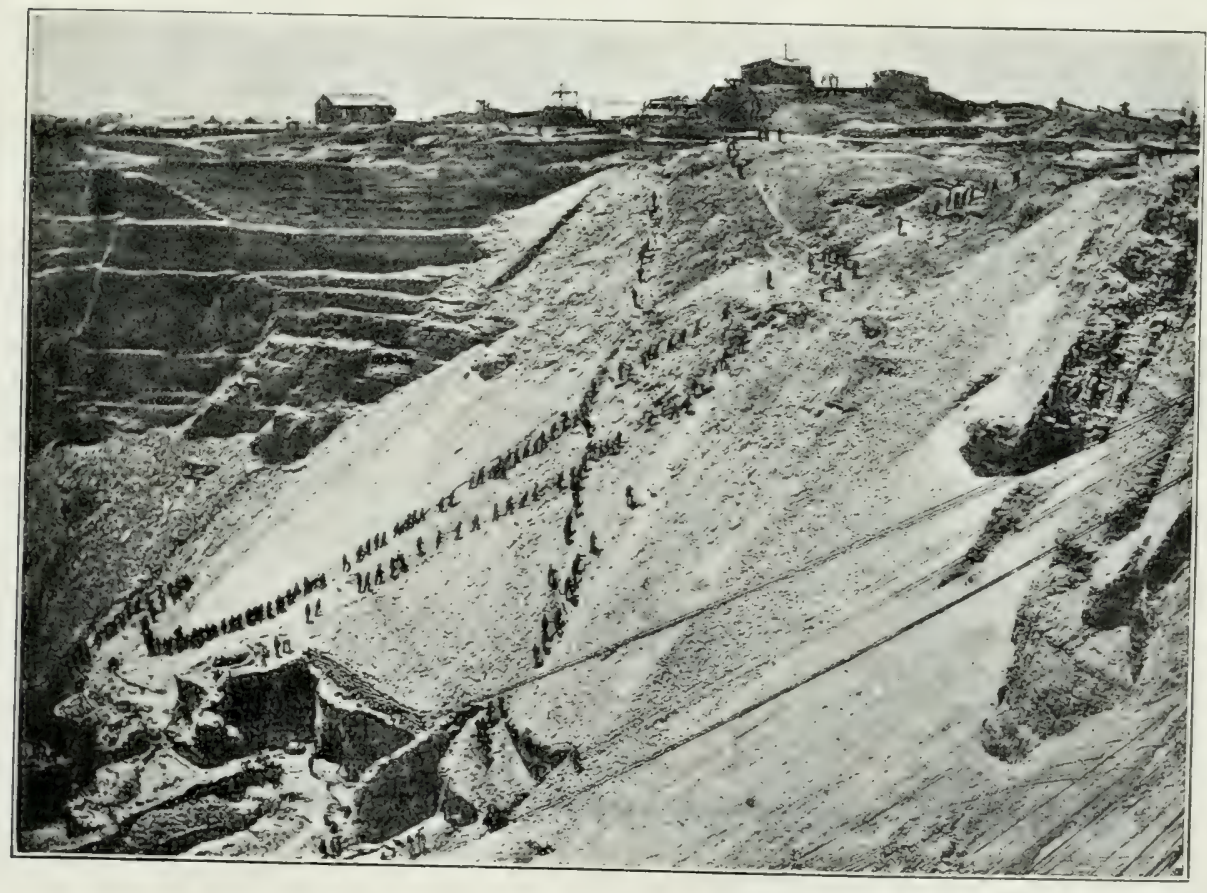

Kimberley-Grube (Westseite) 1885. 

bemerkbar war und der mit diesen stïcken beiseite geworfen wurde. Man glaubt, dalj in dieser ersten Zeit chensoviele Dlananten übersehen, wie gewomen wurden. So kam es, dafs die Diamantensucher in dem Abfalle, der sehon eimmal durchstöberten Diamantenerde, dem "debris", als er in Kimberley im Jahre 187:3 fortgeschafft werden mulite, noch eine reiche Ausheute an Diamanten machten. Ja, man hat sogar nach Einführungr besserer Methoden dieselben Massen, wenigstens soweit sie aus den reicheren Teilen der Grube stammten, noch ein drittes Mal mit Vorteil verarbeitet und noch vicle die beiden ersten Male ïbersehene Steine gefunden. Ifunderte von ärmeren Diamantengräbern, die lieinen Grubenanteil besaben, hatten friiher auf den alten Ialden ihre Arbeitsstätte und gewannen eine Zeitlang daraus ihren Lebensunterhalt in ähnlicher Weise, wie dies auch in Indien an manchen Stellen der Fall ist.

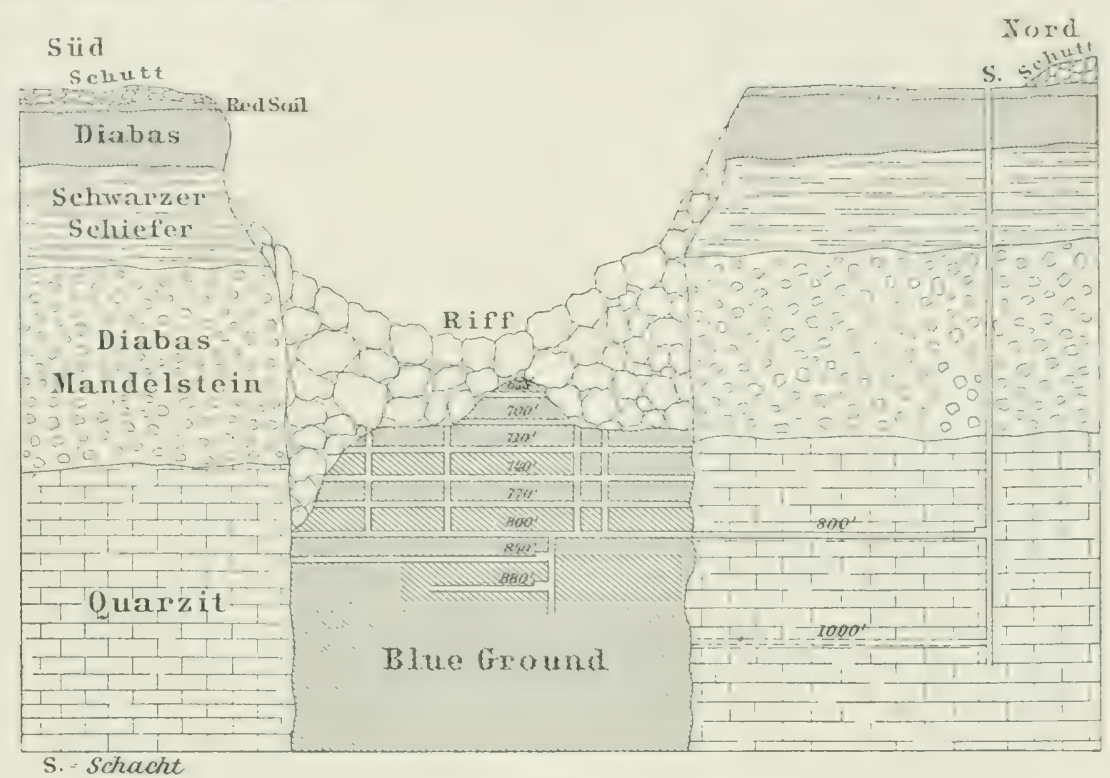

Fig. 49. Bergbauliche Anlage in der De 13eers-Grube. (1:4800.)

Seit 1900 hat dann die Gesellschaft selbst diese Massen, die „lébris", sowie die in der ersten Zeit der W äscherei erhaltenen massenhaften Rückstände, die „tailings" mit vollkommeneren Maschinen noch einmal durchgewaschen und reiche Erträgre dabei erzielt. Von 1900 bis 1907 wurden $12 \$ 32000$ loads débris und tailings auf diese Weise rerarbeitet und 2032000 Karat Diamanten im ITerte von 2551000 Pfund Sterling gerronnen, natiirlich fast alle klein, so daf der Mittelwert pro Karat in den letzten Jahren nur 25 bis 29 Schilling betrug. (Vgl. die Produktionstabelle weiter unten, S. 248).

Der anfängliche Wassermangel dauerte nicht lange an. Eine $22 \mathrm{~km}$ lange Wasserleitung rom Vaal her und zahlreiche gegrabene Brunnen, sowie die Gruben selbst lieferten bald Torrat genug, um die Wäscherei auch in den dry diggings einzufuihren. Das zerkleinerte Tuffgestein wurde anfangs ganz in derselben Weise und mit denselben eimfachen Apparaten gewaschen wie in den river disgings, bald aber folgten Verbesserungen. $187+$ kam zuerst eine Waschmaschine in Aufnahme, die mit der Hand gretrieben werden mubte. 1876 und 1877 wurde die Handarbeit durch Maschinenbetrieb ersetzt und weiter-

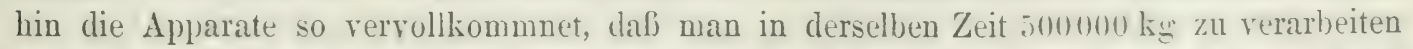
vermochte, die früher zur Bewältigung von 3000 bis $4000 \mathrm{~kg}$ nötig cewesen war. Beim Waschen, das zuletzt mit den sogr. P'ulsatoren geschieht, werden die feineren und leichteren erdigen Bestandteile des Blaugrunds entfernt und nur das Gröbere und spezifisch 
Schwerere bleibt zuriick, die Diamanten und die sie begleitenden Mineralien, namentlich Granat, Zirkon, Cyanit, Chromdiopsid, Enstatit und Olivin nebst den Eisenerzen (Titaneisen usw.). Aus diesen Waschriickständen, den sog. concentrates, etwa 1 Prozent des Blaugrunds, wurden dann frïher die Diamanten mit der Hand ausgelesen. Später konnte auch dies auf mechanischen Wege, durch die Separatoren, bewerkstelligt werden. Alle diese Maschinen arbeiten so vollkommen, daß auch die Gewinnung der kleinen Steine, die früher verloren gingen, ohne weitere Mühe möglich ist. Durch Kochen in einer Mischung ron schwefel- und Salpetersäure werden die Diamanten schließlich von allen anhaftenden fremden Körpern befreit, in Wasser und zuletzt in Alkohol gewaschen und dadurch marktfähig gemacht.

In den größeren Tiefen der Gruben ist der Tuff zu fest, um ohne weiteres verwaschen werden zu können. Dieser festere Tuff muß daher vorher einem Aufbereitungsprozeß unterworfen werden. Er wird zu diesem Zwecke in umzäunten größeren gepflasterten Feldstrecken, den sogenannten floors, in einer diinnen schicht auf dem Boden ausgebreitet und der Einwirkung der Atmosphärilien ausgesetzt. Durch den Einfluß von abwechselndem Tau, Regen und Sonnenschein wird der erst feste Tuff allmählich so aufgrelockert, daf er nunmehr durch Waschen verarbeitet werden kann. Diese Auflockerung, neben der ein Übergang der Farbe des "blue ground" in die gelbe des "yellow ground" hergeht, beansprucht einen bis neun Monate, je nach dem mehr oder weniger reichlich fallenden Regen. Aber auch die Grube, aus der die Masse stammt, also die Beschaffenheit des Gesteins, ist dabei von Einfluß; solches aus der Kimberleygrube soll in der Hälfte der Zeit locker und mürbe und zum Waschen geeignet werden, als das von De Beer's. Dieses braucht zuweilen einige Jahre, um ganz zu zerfallen, während das aus der Kimberleygrube meist in einigen Wochen oder Monaten genügend verwittert.

Immer aber bleiben dabei Stiicke übrig, die bei der Verwitterung nicht zerfallen (sog. lumps). Diese und der sich ebenso verhaltende hard blue werden in besonderer Weise behandelt, um die Diamanten auch aus ihnen zu gewinnen, indem man sie in besonderen Trichtermühlen zerquetscht und dann wäscht.

Der langsame Verwitterungsprozeß in den floors ist mit sehr großen Mißständen verknüpft, die den Ertrag der Gruben ganz beträchtlich vermindern. Der Wert der erforderlichen Bodenfläche ist sehr hoch, ebenso die Löhne für die Arbeiter und Wächter, und trotz der Bewachung und aller möglichen Vorsichtsmaßregeln kommen wälurend der langen Zeit, in der die Masse liegt, zahlreiche Diebstähle vor. Es wäre daher von größter Wichtigkeit, die langsame natïrliche Aufbereitung durch geeignete raschere künstliche Prozesse ersetzen und die Masse schneller für den Waschprozeß geeignet machen zu können; bisher ist dies aber noch nicht recht gelungen.

Ein Unstand, der die Diamantengewinnung in Südafrika lange Zeit aufs äußerste erschwerte und hinderte, war die große Teuerung, die in den Diamantenfeldern herrschte und zum Teil noch herrseht. In jenen Gegenden, die früher kaum eine höchst spärliche Bevölkerung notdiurftig zu ernähren vermochten, waren bald mindestens 30000 Weiße angesiedelt, die ihren Lebensunterhalt und die zu ihrem Geschäftsbetrieb nötigen Gegenstände zum gröliten Teil aus weiter Ferne, von Kapstadt, Port Elizabeth oder anderen Hafenstädten beziehen mußten. Der Transport geschah auf Wagen, die mit Pferden, Maultieren oder Ochsen bespannt waren und die wochenlang brauchten, um den weiten und beschwerlichen Weg nach Kimberley zurïckzulegen. Daher waren die Frachtkosten sehr hoch; sie betrugen pro 100 Pfund Waren von Port Elizabeth bis Kimberley für die Sirecke von $s 00 \mathrm{~km}$, die in etwa vier Wochen zurückgelegt wurden, 10 bis 30 Mark und von Kapstadt aus für den $1050 \mathrm{~km}$ langen Weg; zu dem etwa 6 Wochen nötig waren, noch erheblich mehr. Entsprechend hoch waren die anderen Preise. E. Cohen erzählt aus 
dem Jahre 1872, daß eine Flasche Bier damals 31/2 Mark, guter Pheinwein 1s Mark, cin Kohlkopf nie unter, oft aber ïber 3 Mark, Kartoffeln bis zu 2 Mark das Kilo, Eier his zu (i Mark das Dutzend kosteten, dab eine kleine Gurke Weilinachten mit 12 Mark bezahlt wurde, und daf man in manchen Jahreszeiten taiglich Futter im Werte von 15. Nark für ein P'ferd brauchte. Englische Kohle kostete 330) Mark per Tonne (11101) kgg), und rin Wagen IIolz nit etwa $4500 \mathrm{~kg}$ kam auf 600) Mark, also $100 \mathrm{~kg}$. Holz auf ungefïhr 13 Mark zu stehen. Der Preis für eine hundertpferdige Dampfmaschine, fertigr in Kimberley aufgestellt, betrug 160000 Mark. Man wundert sich bei diesen P'reisen für Maschinen und Kohle nicht, dab es lange dauerte, bis die Dampfkraft in dem Betrieb) zur Verwendung kam, um so mehr, als man in den ersten Zeiten nicht wissen konnte, dalf die reichen Ertrïgnisse so lange andauern würden und daß die Diamantenführung der blauen Erde bis in unbekannte Ticfen hinabgeht. Am billigsten war Fleisch von Antilopen; eine solche von der Gröle eines Rehes konnte man für :3 bis 8 Mark kaufen. Fleisch war daher das gewöhnlichste Nabrungsmittel, aber jeder Tropfen Wasser mulste teuer bezahlt werden.

Diesen Preisen entsprachen die Löhne, die den Aufsehern und Arbeitern gewährt werden multen. Aufseher und Beamte, nur Weiße, erhielten bis 40000 Mark im Jahre. Weilie Arbeiter, deren 1852 und 1553 etwa 1500 vorhanden waren, wurden mit 51 bis 160 Mark, Schwarze mit 22 bis 30 Mark in der Woche bezahlt.

Alle diese Angaben grelten für die Zeit, als Kimberley noch keine Eisenhahnen hatte. Seit 1555 ist aber diese Stadt durch einen 1100 Kilometer langen Schienenstrang m Kapstadt und durch einen solehen von $\delta(0)$ Kilometer Läinge mit Port Elizabeth verbunden. Dadurch haben sich selbstrerständlich die Preise vieler Gel)rauchsgegenstïnde grïnstigrer und normal gestaltet. Die Transportkosten für alle Bedürfnisse sind bedeutend ermäißigt, und es ist dadurch namentlich der ausgedehntere Gebrauch von Steinkohlen ermöglicht. die zum Teil aus England, zum Teil aber auch aus den einheinischen Lagern am Stormberg und im Indwedistrikt bezogen werden, welche beiden letzteren Orte mit Kimberley ebenfalls durch Eisenbahnen verbunden sind.

Entschieden gïnstig ist das Klima von Kimberley. Es ist im Winter sehr angenehm und mild, im Sommer, von September bis März, aber allerdings trołz der Lage von 1233 Meter über dem Meere häufig sehr heif. Regen fällt oft monatelang nicht, dann kommen aber auch wieder einzelne starke Güsse und sehr heftige Gewitter. Seit durch bessere Wolınungen und zweckmäßigere Lebensweise der Diamantengräber das frïher oft tïdliche Lagerfieber beseitigt worden ist, kann die Gegend durchaus nicht mehr für ungresund gelten, ein Cmstand, der selbstrerständlich von grober Bedeutung für die Produktion ist.

Wenn trotz mannigfacher ungünstiger Verhältnisse sich die Ausbeutung der Diamantenfelder in so grolartiger Weise entwickeln konnte, wie es tatsächlich der Fall ist, so mußte die Gesamtmenge der in Südafrikat gefundenen Steine trotz des relativ spärlichen Vorkommens in dem Tuff eine enorme sein. Daß dem so ist, werden die folgenden Mitteilungen über die Erträgnisse der sämtlichen dortigen Gruben zeigen, wie sie in der nachstehenden Tabelle nach Reunert zusammengestellt sind. Diese enthält die Menge der seit 1867 aus dem Kapland ausgeführten Diamanten und den Gesamtwert, sowie den mittleren Wert pro Karat in Pfund Sterling in den verschiedenen Jahren bis 1592 , zusanmengrestellt nach den besten hieriiber vorhandenen Quellen. Die Ausfulır ist natürlich nicht genau gleich der Produktion, aber doch sehr annähernd. Von anderen Angaben weichen diese Zahlen etwas, aber doch nur wenig ab, so dab sie jedenfalls ein nahezu richtiges Bild von der riesigen Produktion geben. 


\begin{tabular}{|c|c|c|c|c|}
\hline Jahr & Gewicht in Karat & Wert des Karats & $\begin{array}{c}\text { Gesamtwert } \\
\text { pro Jahr } \\
\mathscr{L}\end{array}$ & $\begin{array}{c}\text { Gesamtwert } \\
\text { für } 5 \text { Jahre } \\
\mathscr{E}\end{array}$ \\
\hline $\left.\begin{array}{l}1867 \\
1868\end{array}\right\}$ & 200 & - & 65 & \\
\hline 1869 & 16550 & $1 \neq 10 \mathrm{~s} .0 \mathrm{~d}$. & 24813 & \\
\hline $18 \% 0$ & 102500 & $1=10=0=$ & 153460 & \\
\hline 1871 & 269000 & $1=10=0=$ & 403349 & \\
\hline \multirow[t]{2}{*}{1872} & 1080000 & $1=10=0=$ & 1618076 & \\
\hline & & & & 2200348 \\
\hline 1873 & 1100000 & $1=10=0=$ & 1648451 & \\
\hline 1874 & 1313500 & $1=0=0=$ & 1313334 & \\
\hline 1875 & 1380000 & $1=2=6=$ & 1548634 & \\
\hline 1876 & 1513000 & $1=0=0=$ & 1513107 & \\
\hline \multirow[t]{2}{*}{1877} & 1765000 & $0=19=6=$ & 1723145 & \\
\hline & & & & 7746671 \\
\hline 1878 & 1920000 & $1=2=6=$ & 2159298 & \\
\hline 1879 & 2110000 & $1=4=6=$ & 2579859 & \\
\hline 1880 & 3140000 & $1=1=6=$ & 3367897 & \\
\hline 1881 & 3090000 & $1=7=0=$ & 4176202 & \\
\hline \multirow[t]{2}{*}{1882} & 2660000 & $1=10=0=$ & 3992502 & \\
\hline & & & & 16275758 \\
\hline 1883 & 2410000 & $1=2=9=$ & 2742470 & \\
\hline 1854 & 2263734 & $1=4=9=$. & 2807329 & \\
\hline 1885 & 2439631 & $1=0=5=$ & 2489659 & \\
\hline 1886 & 3135061 & $1=2=4=$ & 3504756 & \\
\hline \multirow[t]{2}{*}{1887} & 3598930 & $1=3=\pi=$ & 4242470 & \\
\hline & & & & 15786684 \\
\hline 1888 & 3841937 & $1=1=0=$ & 4022379 & \\
\hline 1889 & 2961978 & $1=9=3=$ & 4325137 & \\
\hline 1890 & 2504726 & $1=13=3=$ & 4162010 & \\
\hline 1891 & 3255545 & $1=5=8=$ & 4174208 & \\
\hline \multirow[t]{2}{*}{1892} & 3039062 & $1=5=8=$ & 3906992 & \\
\hline & & & & 20590726 \\
\hline Summe & 50910354 & Mittel $1 \mathscr{L} \quad 4$ s. 8 d. & 62600187 & \\
\hline
\end{tabular}

$\mathrm{Zu}$ dieser Tabelle ist noch zu bemerken, daß die für die Jahre 1867 bis 1882 angeführten Zahlen auf Schätzungen beruhen. Seit 1882, dem Jahre der Errichtung des "hoard for the protection of mining interests", hat man genaue statistische Angaben. Von der Mlenge der ausgeführten Diamanten erhält man vielleicht eine bessere Anschauung, wenn man die oligen Zahlen etwas anders faßt. Die Gesamtmenge der bis 1892 gewonnenen Steine beträigt beinahe 51 Nillionen Karat, die $10500 \mathrm{~kg}$ entspreehen, also $10^{1 / 2} \mathrm{t} \mathrm{zu}$ $1000 \mathrm{~kg}$, oder im ganzen 210 Zentner à $50 \mathrm{~kg}$. Sie würden eine Kiste füllen, die $5 \mathrm{Fuß}$ lang und breit und $6 \mathrm{Fub}$ hoch ist, oder die einen Würfel von nahezu $1 \frac{11 / 2}{\mathrm{~m}}$ Kantenlänge darstellt, und man könnte aus ihnen eine Pyramide errichten, deren quadratische Basis eine Seite von $9 \mathrm{Fuß}$ und die eine IIöhe von $6 \mathrm{Fuß}$ hätte. Der Gesamtwert in Mark beträgt 1252 Millionen; der mittlere Verkaufswert eines Karats war nahe 25 Mark.

Bis zum heutigen Tag hat sich die Gesamtmenge der in ganz Südafrika gewonnenen Diamanten nahezu verdoppelt, und der Wert der Gesamtproduktion von Anfang an bis jetzt ist in noch stärkerem Grade gewachsen, da die Diamantenpreise inzwischen erheblich gestiegren sind. Im ganzen sind in Südlafrika bis jetzt schätzungsweise ungefähr 90 Millionen Karat Diamanten im Verkaufswert von etwa 120 Millionen Pfund Sterling oder 2450 Millionen Mark produziert worden. 
Besonders genaue Nachweise ïber die Diamantengewinnung in ihren Gruben gibt von ilırer Grïndung an die De Becrs-(xesellschaft in ihren jährlichen Verwaltungsherichten mit allen Einzelleiten der l'roduktion, Reichlaltigkeit des Blaugrunds, der Preise, dor Ertrïge, der Unkosten usw., so dalj man daraus ein sehr klares Bild der Verhältnisse br. kommen kamn. Diese sind in den folgenden Tabellen ühersichtlich zusammengestellt, setrennt fiir die einzelnen (iruben, nur die Kimberley- und die De Beers-Grube sind von Anfang an zusammengefabt worden. Die Tabellen gehen bis zum Jahre 191)7. Ihre Berleutung ist ohne writeres verstïndlich, manches wird aher auch unten noch besprochen werden.

(Siehe die T'abelle S. 248.)

Die verhältnismäßig geringe Menge der anderwärts in Südafrika gewonnenen Diamanten wird bei der Betrachtung der einzelnen Gruben noch mitgeteilt werden, soweit sie bekannt und einigernaben erheblich ist. Die Produktionsverhältnisse der ,river diggings" bis zum Jahre 1592 sind schon oben (S. 219) erwähnt worden, der dort angegebene Betrag hat sich inzwischen nicht nennenswert geändert.

Einiges Licht auf die Entwicklung der Diamantenindustrie wirft außer den im Vorstehenden mitgeteilten Ertrïgen auch die Zahl der darin beschäftigten Arbeiter. Es sind teils Weibe als Techniker, Aufseher oder in sonstigen Vertrauensstellungen, teils Schwarze, meist Kaffern von den in mehr oder weniger weitem Umkreis wohnenden Stïmmen, zu einem nicht geringen Teil, über 1000, Strafgefangene (convicts), für die schwerere Handarbeit. Allein von der De Beers-Gesellschaft wurden beschäftigt:

$\begin{array}{cccc} & \text { Weiße } & \text { Schwarze } & \text { zusammen } \\ 1890 & 1281 & 5280 & 6561 \\ 1897 & 1626 & 7340 & 8966 \\ 1902 & 2000 & \text { über } 11000 & \text { ïber } 13000 \\ & \text { (zeitweise bis } 13750) & \\ 1907 & 3992 & 23769 & 27761\end{array}$

die beiden Zahlen für das letzte Jahr sehwankend zwischen 3766 und 4124, resp. zwischen 20870 und 26597.

Hicrzu tritt noch das Personal in den anderen Gruben, worüber keine so genauen Nachweise vorliegen.

Wenn die Arbeiterzahl nicht noch stïrker angewachsen ist, wie man vielleicht erwarten kïnnte, so liegt dies daran, daß in immer steigendem Maße Handarbeit durch Maschinen ersetzt worden ist.

Wir betrachten nunmehr noch die fünf Gruben bei Kimberley an der Hand der nachstehenden Tabellen und anderer bekannter Tatsachen etwas näher nach ihren speziellen Produktionsverhältnissen und den darin bestehenden Unterschieden, die zum Teil recht erheblich sind, was absoluten und relativen Diamantenreichtum, sowie Größe und Qualität der Steine anbelangt. Einzelheiten in letzterer Beziehung können allerdings erst mitgeteilt werden, wenn wir die Beschaffenheit der Kapdiamanten in allgemeinen kennen gelernt haben werden. Bei allen diesen Gruben hat der Burenkrieg und die Belagerung von Kimberley eine zeitweise Störung und z. T. Unterbrechung der Arbeiten zur Folge gehabt. so daß, wie wir gesehen haben, die De Beers-Gesellschaft für das Jahr 1899 bis 1900) keine Dividende verteilen konnte. Gleich nach dem Ende der Einschïießung der Stadt wurden aber die Arbeiten in alter Weise wieder aufgenommen.

Dic Kimberley-Grube, die kleinste ron allen, an der Oberfläche 4 Hektar groß, war von ihrer Entdeckung im Juli 1571 an die reichste und ist es auch bis jetzt geblieben. Mancher digger machte dort in der ersten Zeit in weniger als einem Monat sein Gliick; einer soll in 14 Tagen für mehr als 200000 Mark Diamanten gefunden baben. Daher w urde hier mit ganz besonderem Eifer gearbeitet, so daß zeitweise die anderen Gruben gänzlich verlassen waren. 
I. Produktion der De Beers- und der Kimberley-Grube von 1889-1908.

\begin{tabular}{|c|c|c|c|c|c|c|c|c|c|}
\hline $\begin{array}{l}\text { Jahr, } \\
\text { endigend am }\end{array}$ & $\begin{array}{l}\text { blue, } \\
\text { gefördert, } \\
\text { in loads }\end{array}$ & $\begin{array}{l}\text { blue, } \\
\text { ge- } \\
\text { waschen, } \\
\text { in loads }\end{array}$ & $\begin{array}{l}\text { blue, } \\
\text { vorritig } \\
\text { auf den } \\
\text { floors, } \\
\text { in loads }\end{array}$ & $\begin{array}{c}\text { Gesamt- } \\
\text { menge der } \\
\text { gewon- } \\
\text { nenen } \\
\text { Diamanten } \\
\text { in Karat }\end{array}$ & $\begin{array}{c}\text { Gesamt- } \\
\text { wert der } \\
\text { Diamanten } \\
\text { in } \\
\text { Pfd.Sterl. }\end{array}$ & 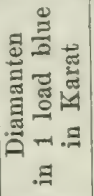 & $\begin{array}{c}\text { Wert für } \\
1 \text { Karat }\end{array}$ & $\begin{array}{c}\text { Wert } \\
\text { eines loads }\end{array}$ & $\begin{array}{l}\text { Pro- } \\
\text { duktions- } \\
\text { kosten } \\
\text { per load } \\
\text { blue } \\
\text { Pence }\end{array}$ \\
\hline z 1859 & & & & & & & 19 s. 9 d. & $25 \mathrm{~s} .4 \mathrm{~d}$. & \\
\hline irz 1890 & 219 & & & & & & & $37=$ & $8=10^{1 / 2}=$ \\
\hline irz 18 & & & & & & & $29=6=$ & $29=4=$ & $8=8=$ \\
\hline - Juni $1892^{2}$ ) & & & & & & & $25=6=$ & $23=$ & $7=4$ \\
\hline Juni 1593 & & & & & & & $29=1=$ & $30=6=$ & $6=12$ \\
\hline i 18 & & & & & & & $24=5=$ & $21=11=$ & $6=7$ \\
\hline i 18 s & & & & & & & $25=6$ & $21=8=$ & $6=11$ \\
\hline 1 & & & & & & & $26=9=$ & $24=$ & $T=0$ \\
\hline 189 & & & & & & & & $24=$ & $7=$ \\
\hline 18 & & & & & & & $26=6=$ & $21=2=$ & $6=$ \\
\hline i 1899 & & & & & & 71 & $29=7=$ & $20=12=$ & $6=$ \\
\hline i 190 & & & & & & & $35=10=$ & $23=7=$ & $7=$ \\
\hline i 1901 & & & & & & & $39=7=$ & $30=$ & $8=$ \\
\hline i 190 & & & & & & & $46=6=$ & $35=$ & $8=$ \\
\hline i 1903 & & & & & & 0,61 & $48=6=$ & $29=$ & $7=$ \\
\hline i 1004 & & & & & & & $48=11=$ & $26=$ & $7=$ \\
\hline i 1905 & & & & & & & $52=10=$ & $24=$ & $7=$ \\
\hline i 1906 & & & & & & & $61=0=$ & $24=$ & $8=$ \\
\hline i 1907 & & & & & & & $64=10=$ & $24=$ & $9=$ \\
\hline 30. Juni 1908 & 1208974 & 1130673 & 3323237 & $414121^{1 / 2}$ & 822288 & 0,37 & $58=1=$ & $21=$ & $6=8$ \\
\hline
\end{tabular}

\section{Produktion der Wesselton-Grube von $189 \%$ bis 1908 .}

30. Juni 1897

30. Juni 1898

30. Juni 1899

30. Juni 1900

30. Juni 1901

30. Juni 1902

30. Juni 1903

30. Juni 1904

30. Juni 1905

30. Juni 1906

30. Juni 1907

30. Juni 1908

271777
1146984
2032771
980210
1571631
1932140
1987543
1919304
2068278
2433905
2104308
1524099

\begin{tabular}{r|}
691722 \\
1662778 \\
736929 \\
1517981 \\
1752159 \\
1989598 \\
2134903 \\
2032582 \\
1935905 \\
1891461 \\
1719737
\end{tabular}

\begin{tabular}{r|l}
271777 & \multicolumn{1}{|c}{-} \\
727039 & 189356 \\
1097032 & $496762^{1 / 2} / 2$ \\
1340313 & $220762^{1 / 2}$ \\
1393963 & 447399 \\
1573914 & 521437 \\
1571859 & $594890^{1 / 2}$ \\
1356260 & 605241 \\
1391956 & 579152 \\
1859956 & 546754 \\
2102803 & $604915^{1 / 2}$ \\
1907165 & 457028
\end{tabular}

\begin{tabular}{r|l|l|r|r|}
196660 & 0,27 & $20=9=$ & $5=8=2=7=$ \\
567361 & 0,30 & $20=10=$ & $=10=10=2=3=$ \\
276191 & 0,30 & $25=0=$ & $=6=6=2=7,5=$ \\
610831 & 0,295 & $27=4=$ & $8=1=3=10=$ \\
873203 & 0,30 & $33=5=19=11=3=5=$ \\
1021276 & 0,30 & $35=4=10=3=3=3=$ \\
1055269 & 0,28 & $34=10=9=10=3=7=$ \\
1067475 & 0,284 & $36=11=10=6=13=10=$ \\
1196624 & 0,28 & $43=9=12=4=4=1=$ \\
1243360 & 0,32 & $41=1=13=2=5=9=$ \\
775088 & 0,27 & $35=11=10=6=4=9=$
\end{tabular}

\section{Produktion der Bultfontein-Grube von 1901 bis 1908.}

30. Juni 1901

30. Juni 1902

30. Juni 1903

30. Juni 1904

30. Juni 1905

30. Juni 1906

30. Juni 1907

30. Juni 1908

\begin{tabular}{r|r|r|r}
148086 & - & 148086 & - \\
353042 & 20194 & 480934 & $4486^{1 / 2}$ \\
318410 & 317185 & 482159 & 76573 \\
429729 & 514385 & 397503 & 148219 \\
605730 & 611491 & 391742 & 249003 \\
1771372 & 953296 & 1209818 & 346072 \\
2320538 & 1728047 & 1802309 & 547485 \\
1319720 & 1275838 & 1846191 & 411387
\end{tabular}

$6817 \quad 0,21 \quad 30$ s. 5 d. 6 s. 9 d. 6 s. 6 d. $118102|0,24| 30=10=7=5=5=9=$ $219711 \mid 0,29+29=7=8=6=5=9=$ $4349030,41 \quad 34=11=14=2=5=10=$ $743318 \quad 0,36 \quad 42=11^{1} / 2=15=7=5=5$ $11915520,3243=6=13=91 / 2=6=2=$ $704742 \quad 0,32 \quad 41=5 \quad 13=3=6=2=$

\section{Produktion der Dutoitspan-Grube von 1904 bis 1908.}

\begin{tabular}{|c|c|c|c|c|c|c|c|c|c|}
\hline uni 1904 & & & 15555 & 3032 & 6457 & 0,12 & & - & \\
\hline Juni 1905 & 311499 & 6575.1 & 261270 & $17121^{1}, 2$ & 59547 & 0,26 & $69 \mathrm{s.} 11 \mathrm{~d}$. & 185.2 & $12 \mathrm{~s} .3$ \\
\hline Juni 1906 & 355714 & $617(1) 25$ & $1329 ! 9$ & 151335 & 612608 & 0,25 & $S_{11}=12=$ & $19=10=$ & $1 / 2=$ \\
\hline 90 & & 15 & & & & 0,2 & $7 ! \quad 7=$ & $18=11=$ & 6 \\
\hline Juni 1908 & 1444898 & 839075 & 2878530 & 190738 & 612530 & 0,23 & $74=$ & $17=1=$ & \\
\hline
\end{tabular}


Bouton hat den Diamantengehalt einzelner Teile der Grube zusammengestellt. Darnach sehwankte er 155.7 in den ertragreichsten claims zwisehen 3,04 und 7,17 Karat im Kubikmeter Blaugrund oder zwischen 87 und 205 Karat in 100) loads, ungefähr entsprechend 2 bis 5 Milliontel (eines P'rozents. Dies gribt einen mittleren Gehalt von ungefïhr 5,104 Karat im Kubikmeter orler 1.4 Karat in 100) loads. Berücksichtignt man auch die ärmeren noch Ertrap liefernden l'artien der Grube, aber mit Ausschlub der den Abbau nicht mehr lohnenden, weil zu armen Westseite, so kann man im Mittel 4,55 Karat im Kubikmeter oder 130 Karat in 100 loads amnehmen. Wird endlich dieser ärmste Teil auch noch in Betracht gezogen, so ist der Durchschnitsertrag 4,20 Karat in 1 Kubikmeter oder 120) Karat Diamanten in 100 loads blue ground.

Eine Zunahne des Diamantgehalts nach der Tiefe oder auch nur ein Gleichbleiben in den verschiedenen Niveaus lälit sich nicht nachweisen, im Gegenteil deutet die Tahelle. die diese Verhältnisse gemeinsam mit denen der be Beers-(frube angibt, darauf hin, daß im Laufe der Zeit, d. h. mit zunehmender Tiefe der Ertrag immer geringer wird. Wir werden darauf bei der Besprechung der genannten Grube noch einmal zuriekkommen.

Die Qualität der Diamanten ist von der aus der De Beers-Grube nicht wesentlich verschieden, wie wir ebenfalls noch weiter sehen werden. Wie die Preise für 1 Karat in d'n obigen Tabellen ersehen lassen, ist sie beträchthch besser als bei deu Steinen aus der Wesscelton- und aus der Bultfontein-Grube, steht aber stark hinter der der Steine von Dutoitspan zuriek. Der gröbte Diamant, den die Kimberley-Grube geliefert hat, wog :03 Karat. ist aber voll von Fehlern; er wurde am 1. Juni 1890 gefunden und ist der grölte aus Griqualand-West und der sanzen Kapkolonie ïberhaupt. Ein anderer von 47t Karat wurde im Jahre 1892 gefunden; er gab einen schönen Brillant von 200 Karat.

Die De Beers-Gru be umfaßt $5 \frac{1}{2}$ Hektar, ist also etwa um ein Drittel gröfer als die Kimberley-Grube. Sie liegt 1600 Meter üstlich von dieser. Nach ihr ist sie die reichste dieser Gegend, doch ist der Lntersehied gegen jene nicht erheblich. Nach einer Mitteilung aus dem Jahre 1559 unmitteliar vor der Konsolidation, als beide Gruben noch getrennt verwaltet wurden, betrug der Gehalt in 100 loads Blaugrund

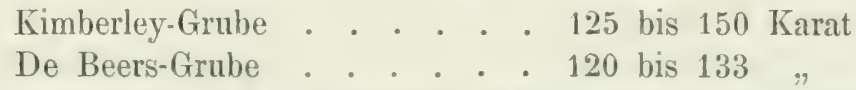

Nachrichten aus dem Jahre $18 \delta 5$ zufolge wäre damals allerdings der Lnterschied größer gewesen; es fanden sich in 100 loads Blaugrund wieder

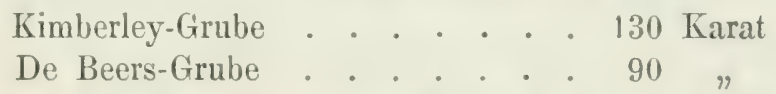

Diamanten. Auch hier sind die einzelnen Teile der Grube verschieden ergiebig; die reichsten stehen hinter Kimberley nicht zuriick. Dies ist besonders die Mitte, von der aus sich noch gute Partien nach Süden und Norden hinziehen, während ähnlich wie in der Kimberley-Grube, das westliche Ende, etwa ein Drittel des Ganzen, wenig ergiebig und zum größten Teil unbauwürdig ist.

Anfänglich sehien die Grube sehr arm und gab nicht mehr als 1/3 Karat im Kubikmeter oder $10^{1}, 2$ Karat in 100 loads. Der Gehalt nahm aber nach der Tiefe rasch zu und war bei 120 Meter ungefähr verzehnfacht, so daß aus einem Kubikmeter 31/2, aus 100 loads 100 Karat gewonnen wurden. 1582 bis 1854 schwankte die Zahl zwischen 1,28 und 3,52 Karat im Kubikmeter. Später stellte sich dann auch hier die aus der Tabelle zu ersebende rasche Abnahme ein. Indessen soll diese Verminderung der Produktion der beiden Hauptgruben nicht ausschließlich auf der Abnahme des Diamantengehalts im Blaugrund beruhen, sondern zum Teil auch auf äußeren Umstïnden, z. B. Einbruch von Schlammassen in die Gruben und vor allem darauf, daß früher beiseite gelassene ärmere 
Grubenteile in den Abbau mit hereingezogen wurden. Bis vor kurzem gelang es, den Minderertrag an Diamanten durch steigende Preise wieder auszugleichen, gegenwärtig ist das nicht melır möglich.

Die Qualität und der Wert der De Beers-Diamanten ist von denen aus der KimberleyGrube, wic schon erwähnt, nicht wesentlich verschieden, und zwar werden die ersteren um (ine Kleinigkeit höher geschätzt als die letzteren. Im Jahre 1887, also kurz vor der Vereinigung wurde 1 Karat von De Beers auf $17,75 \mathrm{M}$, von Kimberley auf $17,50 \mathrm{MI}$ geschätzt.

Grolse Steine hat die Grube in ziemlicher Anzahl geliefert, mehr als die KimberleyGrube. Ton hier stammt u. a. ein Oktaëder von 428 1/2 Karat, der sog. De Beers-Diamant (Fig. 60); ein Stein von 409 Karat nach dem Bericht von E. Cohen, also aus den friihesten Zeiten des Abbaues; der "Porter Rhodes", ein Oktaïder von 150, vielleicht von 160 Karat; der Tiffany-Brillant von $125 \%$ Karat (Fig. 61) usw.

Die Bultf onte in-Grube, 4400 Meter südöstlich von der Kimberley-Grube, hat einen Inhalt von etwa $9 \% / 2$ Hektar. Sie war zuerst sehr arm und gab nur kleine Teile eines Karats im Kubikmeter. Der Gehalt nahm aber gegen unten rasch und mit fast mathematischer Regelmäßigkeit zu und war bei ungefähr 70 Meter (200 engl. Fuß) schon verdreifacht. In den Jahren 1881 bis 1884 schwankte der Ertrag zwischen 0,56 und 1,27 Karat im Kubikmeter (16 und 36 Karat in 100 loads) und betrug im Mittel 1,05 (resp. 30) Karat für 1889. Unmittelbar vor der Konsolidation werden 0,70 bis 1,16 Karat im Kubikmeter (20 bis 33 Karat in 100 loads) angegeben. Von 1890 an wurde die Grube nicht mehr bearbeitet. Bis dahin war das im Tagebau geschehen, der 1887 eine Tiefe von 150 Meter (460 Fuß) erreicht hatte. 1900 wurde der Betrieb wieder aufgenommen. Da mächtige Massen eingestïrzten Riffs, die fast den ganzen Grubenboden bedeckten, etwas anderes unmöglich machten, unterirdisch durch Bergbau. Der Diamantenertrag stieg. dabei, wie die Tabelle zeigt, von 21 Karat im Jahre 1901 auf $36^{1 / 3}$ Karat in Jahre 1906 aus je 100 loads blue ground. Es wird indessen vermutet, daß diese Zahlen kein ganz richtiges Bild geben, da bis jetzt hauptsächlich verhältnismäßig arme Teile der Grube ausgebeutet worden sein sollen.

Die Diamanten von Bultfontein sind nit die geringsten von allen aus den Gruben bei Kimberley. Sie sind klein und gehen selten ïber 2 bis 3 Karat. Außerdem enthalten sie vielfach Einschliisse, die oft erst nach dem Schleifen hervortreten, weshalb sie nicht so leicht Käufer finden. Doch hat nicht nur die Quantität, sondern auch die Qualität in den tieferen Teilen der Grube eine Verbesserung gezeigt.

Die Dutoitspan-Grube liegt 1200) Meter von Bultfontein und 3220 Meter von De Beers entfernt. Sie ist mit $123 / 4$ Hektar gröber als alle anderen Gruben bei Kimberley. Außerdem zeichnet sie sich auch vor ihnen allen durch die besonders vortreffliche Qualität ihrer Diamanten aus, die in Südafrika nur von denen aus den river diggings im Vaal-Tale und aus der Jagersfontein-Grube ïbertroffen werden. Sie liefert nicht nur viele schöne, sondern auch eine erhehliche Zahl grober Steine. Allerdings ist sie auch die ärmste von allen und steht darin sogar noch etwas unter Wesselton. Die regelmäßige Bearbeitung begann 1880 mit lö̈chstens $1 / 4$ bis $1 / 3$ Karat im Kubikmeter ( 6 bis 10 Karat in 100 loads). 158?) schwankte der Gehalt zwischen $1 / 2$ und 3/4 Karat im Kubikmeter (12 und 18 Karat in 100 loads). Der Tagebau lö̈rte wie in Bultfontein im Jahr 1890 auf. Nach langer Unterbrechurg wurde der Betrieb unterirdisch von nenem aufgenommen. 1904 kamen die ersten Ertrïge, und zwar ctwa 11 Karat in 100 loads, was sich aber später in den Jahren 1905 und 1906 auf 26 und $24 \frac{1}{2}$ Karat in 100 loads steigerte. Eine erhebliche Zunahme nach unten ist also auch hier nicht zu verkennen. Im April 1908 ist aber diese, wie die Bultfontein-Grube abermals stillgelegt worden, weil infolge der schlechten allge- 
meinen Geschïftslagre namentlich in Amerika eine Überfüllung des Markts mit Diamanten eingetreten war.

Die Wesselton-firube, friher auch P'remier-, oler zum Unterschied von der gluchbenamiten in Transval, De Beers-Premiergrube genannt, umfaßt $93 /$ IIektar, ist also wenim gröber als Bultfontein. Sie liegt ungefähr 7 Kilometer von Kimberley entfernt, nahe der Grenze zwischen Grigualand-West (Kapkolonie) und der Oranjeflul-Kolonie auf der an Dorstfontein siidlich anstobenden Farm Benauwdheitsfontein (Fig. 46, S. 21:3). Von deren Besitzer, dem Buren Vessels, kaufte die De Beers-Gesellschaft im Jahre 1891 das ganze Anwesen, nachdem man dasclbst Blaugrund sefunden hatte. Sie konnte aber die Arbeiten erst $1 \$ 96$ begimnen, da bis dahin ein gewisser Itenry $\Lambda$. Ward hierzu berechtight war. Dies war die erste neue Entdeckung eines ertragsfähigen Vorkommens von Diamantenerde in Sïdafrika nach der langen zwanzigjährigen Pause seit Eröffnung der Gruben bei Kimberley.

Der anfängliche Tagebau erreichte eine Tiefe von 100 Metern; im Jahre 1900 wurde unterirdiseher Betriel, eingerichtet, und die bergmännischen Arbeiten gehen jetzt bis zu einer Tiefe ron 200 Metern. Die Tabelle zeigrt, daß der Ertrag sich ziemlich gleichmäßig mit ca. 30 Karat in 100 loads nach unten fortsetzt. Die Durchschnittsqualität der Diamanten ist infolge des Vorkommens vieler schlechter Steine eine untergeordnete: sie steht noch unter derjenigen von Bultfontein und ist somit bei Kimberley die geringste. 1905 ist dort der größte Stein im Gewicht von $187^{1 / 2}$ Karat gefunden worden.

Noch sei erwähnt, daß der blue ground von einer 8 Fuß dicken Kalksinterhaube bedeckt war, und daß sich in den oberen Teufen ein mächtiger Melaphyrblock von 350 und 200 Fuß Dicke in horizontaler Richtung als floating reef vorgefunden liat.

\section{Andere Gruben der Kapkolonie.}

Newlandsgruben. Sie liegen am Hart ungefähr 70 Kilometer nordwestlich ron Kimberley. In der Hauptsache wurden sie schon oben S. 232 besprochen. Es sind vier Gruben, die wohl alle als Erweiterungen eines 3 bis 8 Meter mä̈htigen Ganges anzusehen sind. Das Nebengestein ist dasselbe wie bei Kimberley und die pipes sind mit Blaugrund von der gewöhnlichen Art erfüllt. Alle sonst vorkommenden Mineralien sind attch hier vorhanden, besonders zu erwähnen sind die Elklogit-(Griquait-)Knollen, die z. T. Verwachsungen mit Diamanten zeigen (S. 230) und daher von besonderer theoretischer Bedeutung sind. Das Gestein des Ganges ist härter und fester und von zahlreichen Adern von Kalkspat und auch von Quarz durchsetzt. Der Betrieb ist wieder eingestellt worden.

Dasselbe ist der Fall bei den 20 Kilometer weiter nordöstlich gelegenen Gruben Weltefreden und Frank Smith. Es sind zwei benachbarte pipes, die durch einen diamantenführenden Gang miteinander in Verbindung stehen (S. 232).

\section{b) Oranjefluss-Kóolonie.}

Auch die Diamantengruben dieses Landes, deren Verbreitung aus der Karte Fig. 50 S. 252 zu ersehen ist, sind zum Teil ron erheblicher Wichtigkeit, wenn sie gleich hinter denen der Kapkolonie (Kimberley) und auch hinter denen von Transvaal (Premier-Grube) zurïckstehen. Für die Produktionsverhältnisse des Jahres bis zum 30. Januar 1905 werden folgende Zahlen angegeben:

\begin{tabular}{|c|c|c|c|c|c|c|c|c|c|c|c|}
\hline Gewaschener Blaugrund & $\cdot$ & . & . & & & & - & & & & 3556000 loads \\
\hline Gefundene Diamanten & • & . & & & • & & . & & & & $320548^{1 / 2}$ Karat \\
\hline Deren Wert . . & . & . & . & - & - & $\bullet$ & . & • & & & 938618 Pfund Sterling \\
\hline Diamanten in 1 load & . & . & . & . & . & • & - & . & - & . & 0,0899 Karat \\
\hline Wert eines Karats. & . & . & . & • & . & . & . & . & & & 58 s. 8 d. \\
\hline Wert eines loads & & 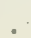 & & • & . & & • & & & - & 5 s. $3 \mathrm{~d}$. \\
\hline
\end{tabular}


Der Blaugrund ist demnach, wie der Vergleich mit den obigen Tabellen zeigt, im Durchschnitt in der Oranjefluß-Kolonie ärmer, zum großen Teil sogar erheblich ärmer als in den Gruben bei Kimberley, dagegen ist aber der Wert der gefundenen Steine beträchtlich größer, wie wir unten bei der Betrachtung der Jagersfontein-Grube noch näher sehen werden.

Die Zahl der Arbeiter in den Gruben war in demselben Jahre 526 Weiße und ungefähr 5000 Schwarze.

Weitaus die bedeutendste Grube dieser Kolonie ist die Jagersfontein-Grube. Sie ist eine der ältesten "dry diggings" und fast gleichzeitig mit denen bei Kimberley, im Tahre 1871, eröffnet. Sie liegt $5 \pm$ Kilometer westlich von der südafrikanischen Zentralbahn zwischen Kapstadt und Johannesburg, ist daher gegenwärtig noch unbequem zu erreichen. Das ganz nahe gelegene Fauresmith soll aber durch eine Zweiglinie mit der

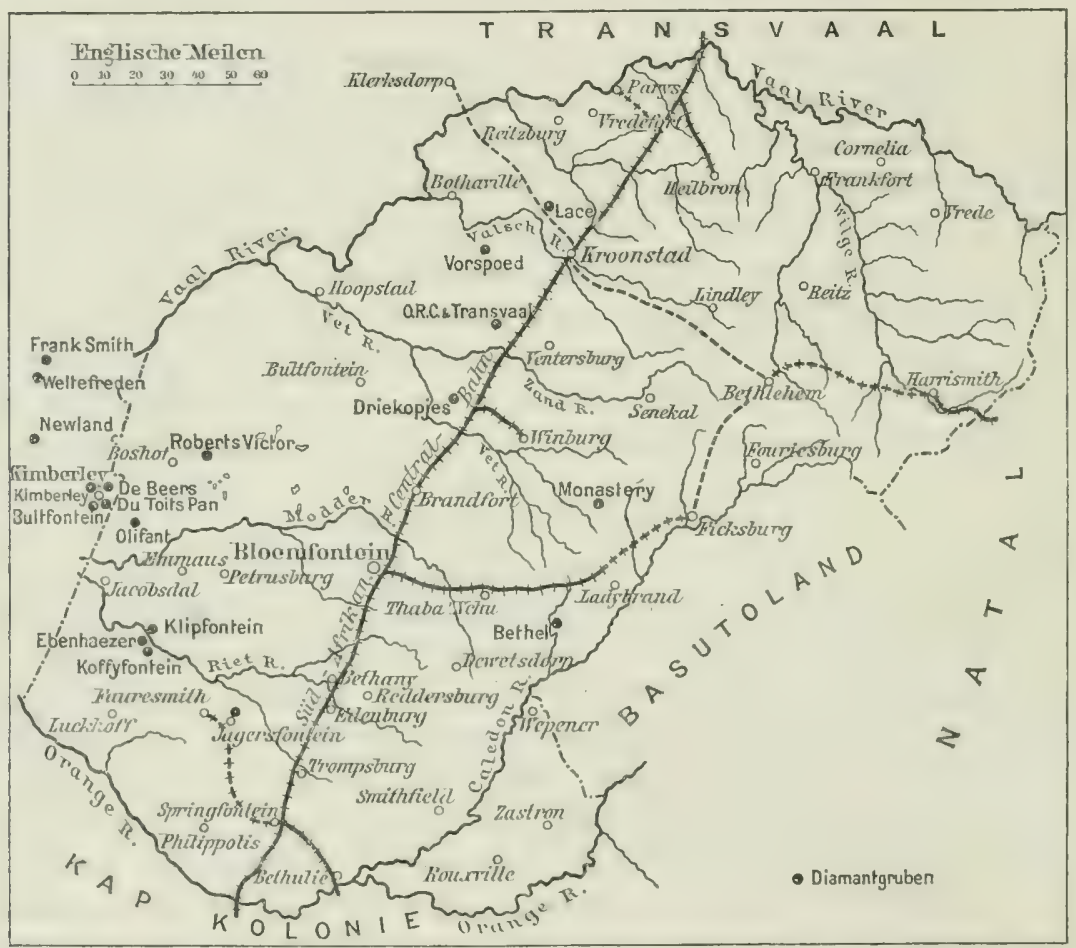

Fig. 50. Diamantgruben der OranjefluB-Kolonie nach Hatch und Corstorphine.

Station Springfontein der IIauptstrecke verbunden werden, wodurch auch diese wichtige Grube dem Terkehr näher rücken wïrde. Die Entfernung von Kimberley beträgt 120 Kilometer in südsüdöstlicher Richtung (Fig. 45 S. 210). Ihre Form ist die eines Ovals von ungefaihr 10 Hektar Inhalt (1124 claims) mit einer großen nach Nordwest gerichteten Diagronale von 500 Meter (150)(1) Ful engl.) und einer darauf senkrechten von 400 Meter (1200 Fuf). Die pipe steht in den Sandsteinen und Schiefern der Ecea-Formation ähnlich wie bei Kimberley, wie rlort auch mit Einlagerungen von Dolerit. Die Schichten fallen etwas nach Süden ein; die Sedimentgesteine bilden den südlichen, der Dolerit auf ungefähr zwei Drittel des Umfangs den nördlichen Teil des Grubenrandes. In einem Teil des Südens ist noch yellow ground vorhanden, sonst hat man überall schon den blue ground angeschnitten, der an der südüstlichen Ecke gangartig in das Nebengestein vorspringt. 
Die Grube wird terassenförmig in 'T'agrebau bearbeitet, der in der Mitte seine grölite Tiefe von nahezu 200 Metern hat. Der Einsturz von Riff spielt eine grofe Rolle, besonders in der nordïstlichen Partie, und hat die Arbeiten schon sehr gehindert und verzögert; man hofft aber doch den billigeren oberirdischen Betrieb noch eine Anzahl von Jahren fortführen zu können, whe es nötig ist, zum Bergbau ïberzugehen. Die Arbeit wurde gelegentlich schon früher, dann aber auch hier in Jahre 1599 durch den Krierr unterbrochen und konnte erst im Juli 1902 wieder aufgenommen werden; das Jahr bis zum 30. Juni 1904 brachte dann wieder den ersten vollen Ertrag.

Der Blaugrund enthält die gewöhnlichen Mineralien, und zwar oft in großen Stïcken, darunter auch als Seltenheit etwas Graphit, auberdem zahlreiche Stiicke der oben erwähnten Konkretionen (Eklogrit) usw. Der Diamantengrehalt ist grering und ühersteigt nicht 10 bis 11 Karat in 100 loarls. Doch sind diese Zahlen etwas zu klein, da die geförderte und gewaschene Masse nicht reiner Blaugrund, sondern stark mit Teilen des diamantenfreien Riffs remischt ist. Die angegebene Menge ist durch lange Jahre ziemlich lionstant dieselbe geblieben, allerdings mit einer kleinen Abnahme. In den Jahren 1595, 1896 und 1599 sind es 11.32, 11,6:3 und 11,20 Karat gewesen, 1905 und 1906 nur noch 9, 5 und 8 , 59 Karat in 100 loads. Gegenwärtig litfern die tiefsten Stellen des Tagebautes die besten Erträge.

Ist so der Diamantengehalt auch speziell in Jagersfontein erheblich geringer als bei Kimberley, so ist die Qualitït und der Wert der gefundenen Steine namentlich hier sehr viel besser. Dies zeigt am deutlichsten eine Vergleichung der Produktionsverhältnisse in demselben am 30. Juni $190 \pm$ endigenden Jahr fül die Jagersfonteingrube und die rereinigte Kimberley- und De Beer's Grube, für welche die folgenden Zahlen obiger Tabelle entnommen sind:

\begin{tabular}{|c|c|c|c|}
\hline & & $\begin{array}{l}\text { Jagers- } \\
\text { fontein }\end{array}$ & $\begin{array}{l}\text { Kimberley } \\
\text { u. De Beers }\end{array}$ \\
\hline Geförderter Blaugrund, & loads & 20764118 & 2440895 \\
\hline Gewaschener $" \quad$, & , & 1836634 & 2401099 \\
\hline Vorrät. Blaugrund auf den floors & $\eta$ & 975185 & 2175079 \\
\hline Gefundene Diamanten, Karate & & 167598 & 1303525 \\
\hline Wert derselben, Pfund Sterling & & 555696 & 3192795 \\
\hline Diamanten in 1 load, Karate & & 0,0968 & 0,54 \\
\hline Wert von 1 Karat & & 66 s. 4 d. & $48 \mathrm{~s} .11 \mathrm{p}$. \\
\hline Produktionskosten & & $2 \mathrm{~s} .11 \mathrm{~d}$. & $7 \mathrm{s.} 4 \mathrm{p}$ \\
\hline
\end{tabular}

Während also in Jagersfontein ungefähr drei Viertel so viel Blaugrund gewaschen wurde, wie in den anderen beiden Gruben, betrug die Menge der gefundenen Diamanten nur ein Achtel, ihr Wert jedoch ein Fünftel im Vergleich nit den dortigen Zahlen.

Im Jahre 1599, unmittell)ar vor dem Kriege, waren $2600(1001$ loads blue mit $2590(1)$ Karat Diamant in Gesamtwert von 500000 Pfund Sterling gefördert worden, der Wert eines Karats war also ungefähr 35 Schilling. Die niedrigen Produlitionskosten beruhen auf der verschiedenen Betriebsweise: billiger Tagebau bei Jagersfontein, teurer unterirdischer Bergbau bei Kimberley. Tergleiche wie oben lassen sich nach dieser Zusammenstellung leicht berechnen. Der Gesamtertrag der Grube bis Ende März 1901 wird zu 2165399 Karat im Wert ron 3923940 Pfund Sterling angegeben; hierzu tritt noch jährlich bis zur Jetztzeit der oben angegebene Betrag. Die sanze Jahresausbeute wird nach einem langfristigen Tertrag stets von der De Beers-Gesellschaft übernommen.

Die erwähnte ausgezeichnete Qualität der Diamanten von Jagersfontein beruht clarauf, dab viele Steine das schönste ,blauweib" zeigen, wie es bei den alten Diamanten vorkommt; und wenn auch der Wert der brasialianischen und noch melir der der besten indischen Steine nicht ganz erreicht wird, so wird, wje obige Gegenüberstellung zeigt. doch der der Steine aus den Gruben bei Kimberley ganz erheblich ïberschritten $(661,3$ gegen 
451/2 Schilling\%. Besonders berühmt ist die Grube auch wegen ihrer vielen großen Steine. Von hier stammt der 1593 gefundene „Excelsior" von 9713/4 Karat (Fig. 62), bis vor kurzem der größte, jetzt der zweitgrößte überhaupt bekannte Diamant, der nur von dem an 25. Januar 1905 in der Premicr-Grube gefundenen Cullinan übertroffen wird; sodann der Jubileeoder Reitz-Diamant von 6.10 Karat, $1 \$ 95$ ) gefunden, ein Stein von 600 und ein solcher ron 209:4 Karat; der sog. Julius Pan von 241/2 Karat usw. Auch auf einige dieser Riesensteine werden wir unten noch einmal speziell zurückkommen.

Ferner stehen im Betrich die Vorspoed-Grube 30 miles westlich von Kroonstad, und die

Roberts Victor-oder Dampląats-Grube, im Jahre 1906 entdeckt, 20 Kilometer iistlich von Boshof, das seinerseits 50 Kilometer nordöstlich von Kimberley liegt.

Dagegen ist von sebr untergeordneter oder gar keiner praktischen Bedeutung die

Koffyfontein-Grube, halbwegs zwischen Jagersfontein und Kimberley, ven beiden ungefülı 60 Kilometer entfernt. Es ist eine große pipe (etwa 1450 claims) im Ecca-Schiefer, bedeckt mit rotem Sand und Kalktuff. Gearbeitet wird nur schwach in einem Tagebau, der jetzt 40 Meter tief, ist und mit manchen Lnterbrechungen, wegen der Armut des Blaugrunds. Der Gehalt geht nicht ïber 5 bis 6 harat in 100 loads hinaus, aher die Steine sind von guter Beschaffenheit. Im Jabre 1896 wurden 3500 Karat Diamanten im durchschittlichen Wert von 30 Hark das Karat gefunden und damit ein sehr mäßiger Gewinn erzielt.

Dicht dabei liegt die kaum bearbeitete Ebenezer-(Ebenhaezer)Grube von 526 claims und von der Form eines menschlichen Fußes. Die Hauptausdehnung geht von Siid nach Nord.

$11_{12}$ Kilometer nördlich von dieser ist die verlassene Kỉpf ontein-(Regina-) Grube. Zwei ziemlich große Blaugrund-Bezirke sind durch einen mit demselben Material erfüllten Gang miteinander verbunden. Gleichfalls unwichtig sind die

Monastery-Grube, westlich von Ficksburg, von der schon oben die Rede war, die Lace-Grube bei Kroonstad, und alle die anderen auf der Karte verzeichneten Gruben.

Lace-Grube. Sie liegt auf der Farm Driekopjes, etwa 30 Kilometer nordwestlich ron Kronstad und umfaßt 400 claims. Die pipe durchbricht die Sandsteine der KarruFormation; in 12 bis 15 Meter folgt auf den "Gelbgrund" in scharfer Grenze der "Blaugrund", der segenwärtig etwa 16 Karat Diamanten in 100 loads liefert. Schon vor Entdeckung dieses Blaugrundvorkommens waren in der Nähe auf derselben Farm Diamanten in dem Rhenosterspruit, einem rechten Nebenfliifchen des Valschflusses, gefunden worden, nud zwar etwa 2 Kilometer oberhalb der Liundung an einer Stelle, wo der Bach einen 200) Meter mächtigen Diabasgang durchsetzt. Der Diamant war von schön rotem Granat (Kaprubin) begleitet. Dieses Vorkommen fübrte dann zur Entdeckung des etwa :3 Kilometer entfernten Blaugrunds der Lace-Grube.

Westlich davon ist auf der Farm liester's Kraal eine pipe aufgefunden, welche wie diejenige von Newlands eine lokale Erweiterung in einem Gang zu sein scheint.

Monastery-Crube. Sic liegt auf der gleichnamigen Farm, 65 Kilometer siidlich von Winbere. Die geologrischen Verbätnisse sind schon oben (S. 232) besprochen worden. Die beiden pipes bahen die Stormbareschehichten rom Alter des europäischen Rhät durehbrochen und werden ihrerseits von zwei Felsitporphyrgängen durehsetzt. Die Mineralien des Blaugrunds sind die gewöhnlichen. Der in Unmenge vorkommende, vielfach nit Kelyphitrinde versehene Granat, der grïne l'yroxen und der Glimmer bilden bis kopfgrolse Fragmente und Aggregate. Pyroxen und Magneteisen sind nicht selten pegmatitisch verwatchsen. Diese Crube ist zwar noht sehr ergiebig, sie ist aber die lehrreichste für die Erforschung der Natur der südafrikanischen pipes. 
Von den in der Nïhe von Smaldeel aufgefundenen Vorkommen von Blaugrund ist das auf der frarm Kaal Valley einige Jabre in der Robinsongrube ausgebeutet worden. Sie hat 6 Karat Diamanten in 100 loads blue ground geliefert (S. 217).

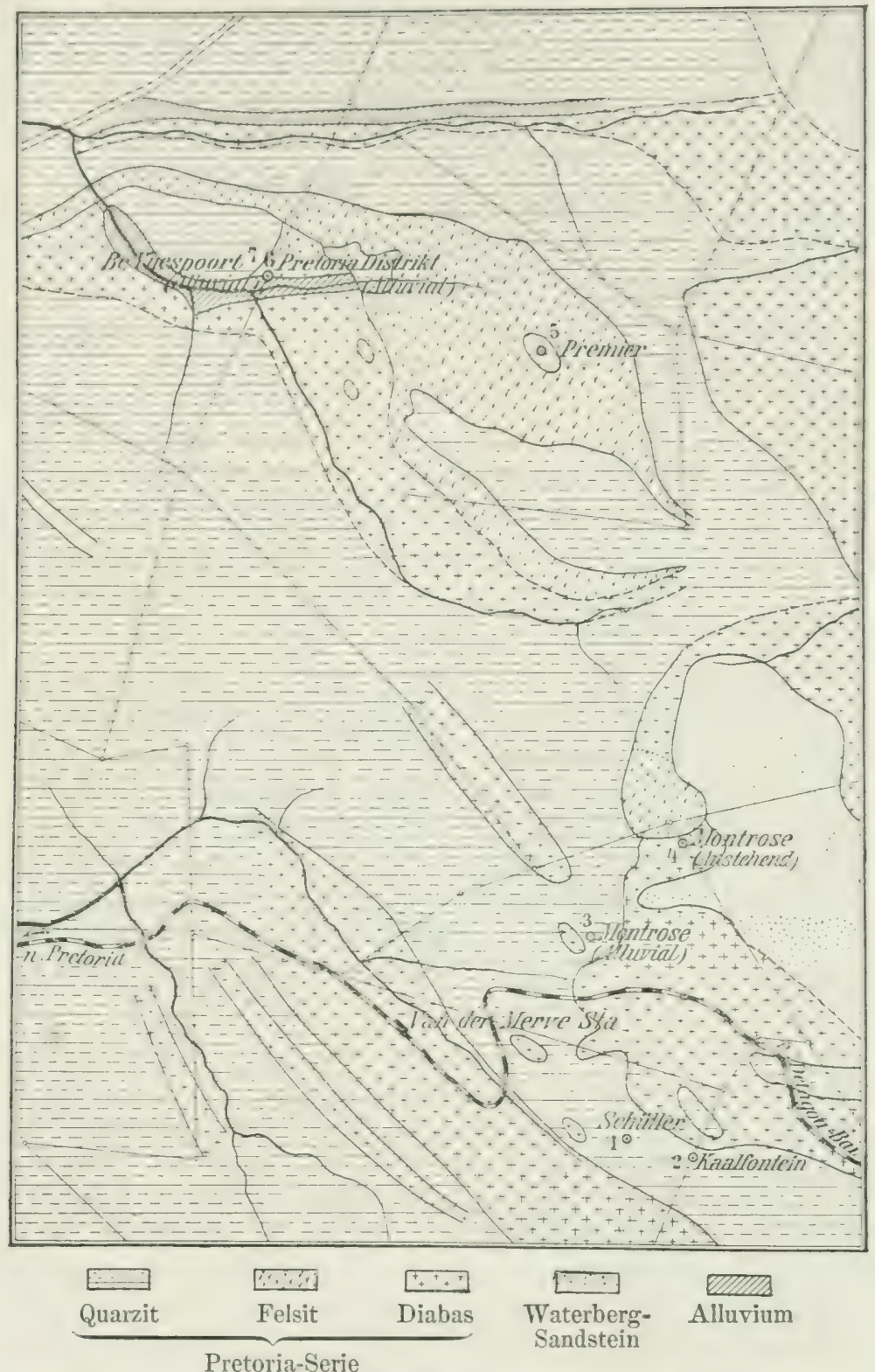

Fig. 51. Diamantgruben in Transvaal nach A. L. Hall (Malsstab 1:94720).

c) Transraal.

Wie wir schon oben gesehen haben, liegen die Diamantgruben ron Transvaal in einem kleinen Bezirk von ungefähr 140 Quadratkilometern in geringer Entfernung östlich von Pretoria in der Nähe der kleinen Station Van der Nerve der Eisenbabn nach der DelagoaBai. Es sind teils pipes mit echtem Blaugrund genau wie bei Kimberley, teils Seifen, von denen einige mit pipes derart in Verbindung stehen, dab an die Abstammung ihrer Diamanten aus diesen kein Zweifel sein kann. Die Karte in Fig. 51 stellt diesen Land- 
strich nach A. L. Hall, dem Landesgeologen von Transvaal, in einer Ausdehnung von etwa 9 $\frac{1}{2}$ und 1.1 Kilometer im Maßstab 1:94720 dar. Die Lage der Gruben, wie sie 1904 bekannt waren, geht daraus ohne weiteres hervor.

Die pipes durchbrechen vorzugsweise die Quarzite der zur Kapformation gehörigen Pretoria-Serie, die mit ihren Zwischenlagern von Diabas und Felsit eine Gesamtmächtigkeit von ungefähr 2500 Meter besitzt. Schwarze kohlige Schiefer, wie bei Kimberley fehlen hier gänzlich. Die Schichten streichen südöstlich und fallen unter $19^{\circ}$ nach Nordosten ein.

Nachdem im Jahre 1897 der erste Diamant auf der Farm Rietfontein gefunden worden war, entwickelte sich die Gräberei auf Grund unablässiger und erfolgreicher Nachforschungen rasch, und schon im Jahre 1898 wurden in Transvaal gewonnen

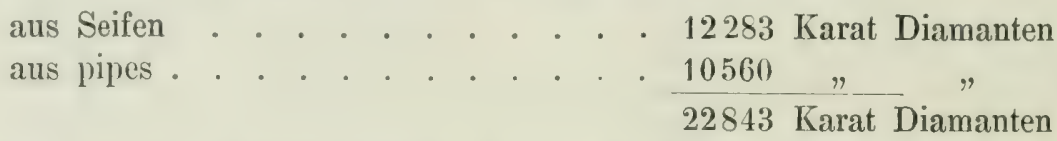

Die Steine waren im allgemeinen von guter Beschaffenheit, und wie in der Kapkolonie erwiesen sich auch hier die aus den Seifen im Durchschnitt als besser und größer.

1899 brachte der Burenkrieg einen gänzlichen Stillstand, dem jedoch nach dem Frieden ein ungeahnter Aufschwung folgte. Dieser ist in hervorragendem Maße, ja fast allein $\mathrm{zu}$ verdanken der so außerordentlich großen und ergiebigen

Premier-Grube. Diese baut auf einer 1902 entdeckten pipe und wurde im Mai 1903 eröffnet. Sie liegt auf der Farm Elandsfontein, deren Besitzer Joachim Prinsloo diese im Olstober 1902 für 50 (000) Pfund Sterling an T. M. Cullinan, den Direktor der Premier Company verkaufte. Ihre Entfernung von Pretoria beträgt 38 Kilometer gegen Osten, von der Station Van der Merve 9 Kilometer nach Norden. Auf einer Anhöhe, die sich 65 Meter iiber die Umgebung erhebt, bildet sie eine flache kesselförmige Vertiefung, die von niedrigen, aus Quarzit und Felsit bestehenden Hügeln umgeben ist. Die Form ist die eines Ovals von 900 Meter Länge und 600 Meter Breite mit einem Flächeninhalt von $281 / 2$ Hektar, der in 3570 claims geteilt ist. Damit ist sie weitaus die größte aller sïdafrikanischen Diamantgruben.

Die oberste Lage der pipe bildet, wie auch sonst, ein roter, tonig-sandiger Boden, der bis 2 Meter dick ist und sehr viele Diamanten enthält. Es ist wohl das Produkt einer intensiven Zersetzung des urspriinglichen Blaugrunds, in dem sich ein Teil der Diamanten aus dem obersten, jetzt zerstörten Teil des Trichters angesammelt und konzentriert hat. Die Kalktuffdecke der Gegend von Kimberley fehlt. Unter der roten Schicht, dem red soil, folgt Gelhgrund in einer Mïchtigkeit von 10 bis 15 Meter. Er gleicht einem grelblichgrauen Ton und ist sehr locker und weich, daher auch leicht durch Waschen zu verarbeiten. Nach unten geht er allmählich in hard blue über von derselien Art wie bei Kimberley. Dieser ist durch Bohrlöcher über 300 Meter tief verfolgt und nacbgewiesen worden.

Der Blaumrund ist hier dunkelolivenblaugriin, auch ins Graue, und zeigt sich oft ungewöhnlich fettig, so dab er auf den floors nicht zu feinem Pulver zerfälit, sondern noch weiter zerquetscht werden mul, ehe er gewaschen werden kann. Er enthïlt dieselhen Mineralien wie sonst. Besonder's genannt werden serpentinisierter Olivin, viel Titaneisen, Magneteisen, Magnesiaglimmer (Vaalit), Granat (Pyrop), diallagälnnlieher Chromdiopsid, Enstatit, Schwefelkies, Kalkspat usw. Als boulders findet man hauptsächlich Brocken ron rotem und braunem Quarzit, von Diabas und Felsit, sowie von Sandsteinen und Konglomeraten aus dem die Pretoria-Schichten iiberlagernden Waterberg-System. Von 


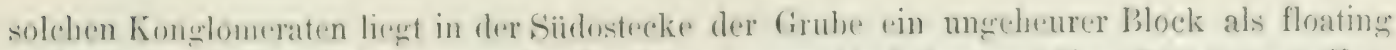

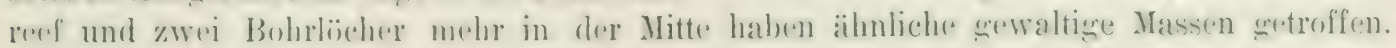

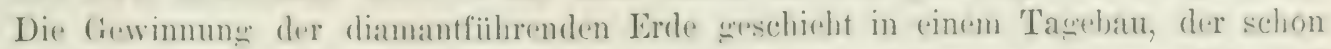

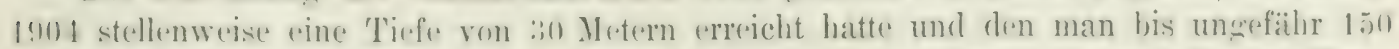

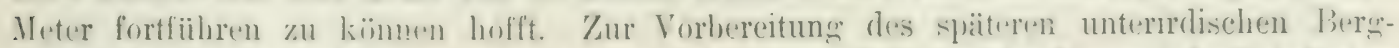

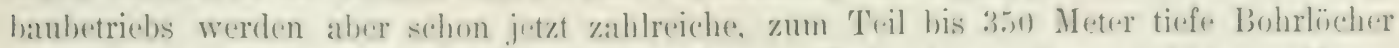

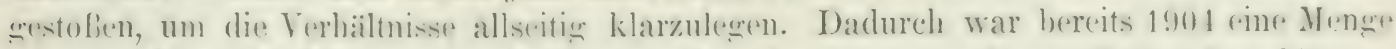
von ungefailn 125 Millionen loads Blangrund nacherewesen und zum Tril auforeschlossen,

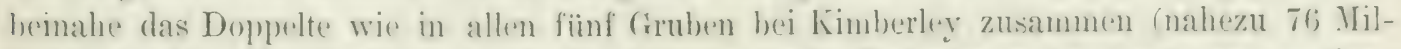

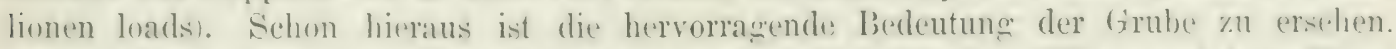
Sllein für den yellow wround ist der Diamantengehalt auf 82.3. Mill. Karat und deren Wirt, 24 Schilling pro Karat, auf 10400000 Pfund Sterling geschätzt worden.

Die Arbeit wurde anfänglich mit etwas prinitiven Hilfsmitteln betrichen, doch war man hestrebt. diese so rasch wie möglich durch die vollkommensten Apparate, Waschmatchinen, Pulsatoren, Separatoren nsw, wie sie bei Kimberley in Ciebrateh sind, zu ersetzen. Ylit ilınen sollen anch die älteren Rï̈ckstände noch einmal durchgearluitet werden, nm ihnen auch die letzten noch derin gebliebenen Diananten zu entziehen. Eine !) Kilo-

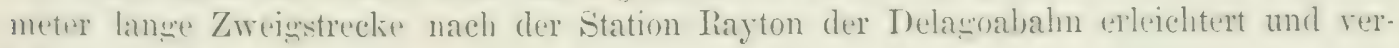
billigt den Betrieb wesentlich.

In der folmenden Tabelle sind die Ergelonisse der bisherigen Arbeit zusammengexteslt.

\section{Premier-Grube.}

\begin{tabular}{|c|c|c|c|c|c|c|c|}
\hline $\begin{array}{c}\text { Jahr } \\
\text { endigend } \\
\text { am }\end{array}$ & $\begin{array}{c}\text { blue, } \\
\text { gewasehen } \\
\text { in loads. }\end{array}$ & $\begin{array}{l}\text { Gefundene } \\
\text { Diamauten } \\
\text { in Karat. }\end{array}$ & $\begin{array}{l}\text { Wert in } \\
\text { Pfund } \\
\text { Sterling. }\end{array}$ & $\begin{array}{l}\text { Diamant } \\
\text { in } 1 \text { load } \\
\text { in Karat }\end{array}$ & $\begin{array}{c}\text { Wert } \\
\text { per Karat } \\
\text { in } \\
\text { Schilling }\end{array}$ & $\begin{array}{c}\text { Wert } \\
\text { eines loads } \\
\text { in } \\
\text { Schilling }\end{array}$ & $\begin{array}{l}\text { Produk- } \\
\text { tions- } \\
\text { kosten } \\
\text { per load. }\end{array}$ \\
\hline 31. Oktober 1903 & 76931 & 99205 & 137435 & 1,29 & 27 s. 9 d. & 35 s. S d. & $4 \mathrm{~s} . \mathrm{s}$ d. \\
\hline 31. Oktober 1904 & 939265 & 749653 & 566030 & 0,795 & $23=1=$ & $18=5=$ & $2=6=$ \\
\hline 31. Oktober 1905 & & 845652 & 994687 & 0,29 & $23=6=$ & $6=10=$ & $4=-$ \\
\hline 31. Oktober 1906 & & S99746 & 1303433 & 0,301 & $28=5=$ & $8=5=$ & $2=6=$ \\
\hline 31. Oktober 1907 & 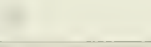 & $1 S 92000$ & 1702800 & 0,259 & $18=-$ & & \\
\hline Zusammen & & 4456259 & 5004385 & & & & \\
\hline
\end{tabular}

Danach ist der Gesamtertrag der Premier-Grube von ihrer Eröffnung bis Ende

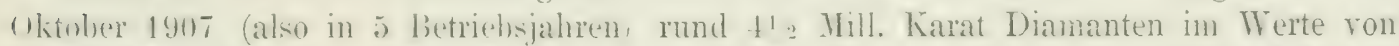
; Mill. ['fund Sterling. Der Diamantenewehalt des blangrunds war im ersten Jahre so loch wie anfïnglich in der Kimberley- und der De Berers-(irube, sank aher damn rascher. Der Minderertag im zweiten Jahre wurke einer hesonders ammen Partie blue cround zuweschriehen, die mit abeghaut und verwaschen werden mulite, in den nächsten Jahren war

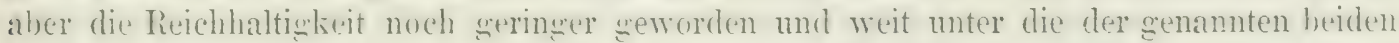
Gruben gefallen $(0,46,0,41$ und 0,37 in den Jahren 1905, 1906 und 1907). Die weitere Entwicklung muf abowartet werden; aus der Gleichheit der Zahlen für diese drei Jahre kann wegen der Kürze der Zeit noch neht anf die Zukunft geschlesidn werden.

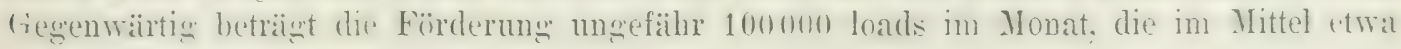
75000 Karat Diamanten liefern.

Tehen der Menge ist aber auch die Qualität und die Grölie der gefundenen Diamanten von Bedeutung. Die Beschaffenheit ist in allgemeinen Lurchschnitt nicht sehr vorteilhaft, so daß der Wert, der im Mittel 25 bis 30 Karat beträgt, sogar geringer ist als in der liultfontein- und in der Wesselton-Grube. Man findet sehr viele schlechte Steine und Bort, 
allerdings aber damehen auch schöne bis zu dem feinsten Blauweiß in nicht ganz geringer Menge. Die Gröbe ist gleichfalls im allgemeinen nicht unbedeutend, besonders berühmt ist aber die Grube wexen der verhältnismäßig zahlreichen sehr großen Diamanten, die sie in der kurzen Zeit ihres Bestehens schon geliefert hat. Am 27. Januar 1905 wurde hier der sröfte Diamant der Welt, der 3024:4 Karat schwere Cullinan und schon am 13. Februar darauf ein Stein von 334 Karat gefunden, dann einer von etwa 600 Karat und andere. Dadurch wird der Durehschnittswert natürlich nicht unerheblich beeinfluft. Eine Vergleichung obiger Tabelle mit den früheren gibt hierüber genaueren Aufschluß.

Die grewonnenen Diamanten gehen nicht wie die der De Beers-Gesellschaft an das Londoner Diamantensyndikat, sondern sie werden frei und unahhängig von jener in den IIandel gebracht. Dadurch ist das Monopol, das die Gesellschaft bisher unbestritten ausgeüht hat, erheblich bedroht und eine geführliche Konkurrenz hervorgerufen worden. Diese war kurze Zeit durch den Anschlul der Premier-Gesellschaft an das Londoner Diamantensyndikat vermieden. Letztere ist aber davon jetzt schon wieder zurückgetreten und hat den Wettbewerb wieder anfgenommen. Sie kann das um so eher, als ibre Produktionskosten pro Karat kaum mehr als den dritten Teil von denen bei Kímberley betragen, so daß sie imstande ist, ein Karat um 18 Schiling zu verkaufen, also um 4 Schilling billiger, als die Produktionskosten der De Beers-Gesellschaft betragen (fast 22 Schilling). Dabei nehmen die Produltionskosten bei der letzteren zu, in der Premier-Grube eher ab. Jedenfalls kann diese Konkurrenz ein Sinken des Preises der Rohdiamanten zur Folge haben. Unter diesen Umständen ist also wohl eine vergleichende Übersicht ïber die Produktionsverhältnisse beider Gesellschaften für die Jahre 1905 bis 1907 nicht ohne Interesse. Diese ist in runden Zahlen in der folgenden Tabelle enthalten, aus der u. a. auch die oben gemachten Angaben hervorgehen.

Premier-Grube.

\begin{tabular}{|c|c|c|c|c|c|c|}
\hline Jahr & $\begin{array}{c}\text { Gewonnene } \\
\text { Diamanten } \\
\text { in Karat }\end{array}$ & $\begin{array}{c}\text { Wert in } \\
\text { Pfund Sterling }\end{array}$ & $\begin{array}{c}\text { Diamanten in } \\
1 \text { load } \\
\text { in Karat }\end{array}$ & $\begin{array}{l}\text { Wert proKarat } \\
\text { in Sehilling }\end{array}$ & $\begin{array}{l}\text { blue auf floors } \\
\text { im Vorrat } \\
\text { in loads }\end{array}$ & $\begin{array}{l}\text { Produktions- } \\
\text { kosten per Karat } \\
\text { in Schilling }\end{array}$ \\
\hline $\begin{array}{l}190) 5 / 116 \\
190607\end{array}$ & $\begin{array}{r}904000 \\
1892000\end{array}$ & $\begin{array}{l}1300000 \\
1703000\end{array}$ & $\begin{array}{l}0,301 \\
0,289\end{array}$ & $\begin{array}{l}2 \mathrm{~s} \text { s. } 5 \mathrm{~d} . \\
18 \mathrm{~s} .\end{array}$ & - & $\begin{array}{r}13 \text { s. } 5 \mathrm{~d} . \\
8 \text { s. } 9 \mathrm{~d} .\end{array}$ \\
\hline Zusammen & 2792000 & 3003000 & & & & \\
\hline
\end{tabular}

\section{Do Beers-Gesellschaft.}

a) aus dem Blaugrund.

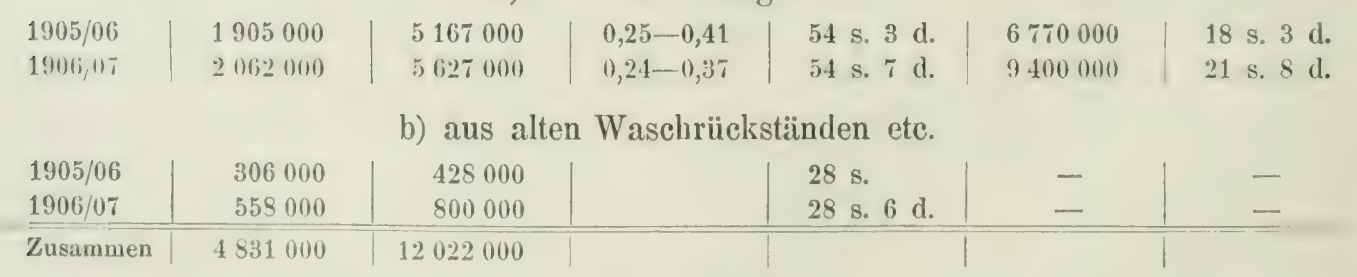

Man sieht, dab die P'remier-Crube etwas mehr als halb so viele Diamanten erzeugte, wie alle fünf De Beer's.Gruben zusammen, der Ertrag in Geld ist aber wegen des verschiedenen Wertes der Steine in der ersteren viel meringer und beträgt nur ein Viertel. Jedenfalls ist die P'remier-(trube erst in der Entwieklung begriffen, und es ist zu erwarten, daß die ihr giinstigen Unstände sich in der nïchsten Zeit noch weiter zu ihrem Vorteil versehieben werden 
Die Lompacnice, der die l'remier-frube grehört, arbeitet nur mit einen Aktienkapital

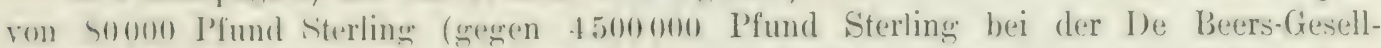
schaff). Deidem reichenErtrag dere Grube konnte die Gesellschaft in den vier Jahren ihres Liesteluens, frotzdem sie (i) $1 / 1$ ihres Reingewinns an die Regrierung ablicfern mul, .20)(101) Pfund sterling an die Alitionäre verteilen, also das (j-bis 7 -fache des Anlagekappitals. Für diss Jalur 1907 wurde (ine Ende Februar $1905 \mathrm{zu}$ verteilende Dividende in Aussicht genommen, und zwar für die versebiedenen Arten von Aktien teils "561" o, teils $4000^{0} \ldots$. Aikch in dieser IIinsicht ïbertrifft demnach die Premier-Grube alle. anderen siddafrikanischen Diamanteruben und wahrt sich das Recht auf ihren Namen und die Aussicht auf eine glänzende Zukunft, wemn auch die Gegenwart wegen der zeitweiligen Unverkiauflichlicit der I)iamanten infolge der allgemeinen Geschäftsstockung nicht gerade besonders befriedigend ist. Aus demselben Grunde mulite auch die Auszahlung der letztgenannten Dividende zunächst verschoben werden.

Neben der l'remier-(irube sind alle anderen in Transval unbedeutend, und ihr Ertrag ist gering. Daher sollen sie hier auch nur ganz kurz erwähnt werden.

Von dem Kessel der genannten Grube geht ein Bach nach Westen ab. In seinem Bett zicht sich ein Streifen diamantführenden Alluviums in einer Breite von Ion Metern hin. Es ist ein 11 - his 2 Meter mächtiger sandiger Ton mit Diabashrocken, bedeckt von einer :3 bis 4 Meter dicken Schicht schwarzer Erde. Diese Seife wird ausgebeutet durch die 3 bis 4 Kilometer talabwärts von der Premier entfernten Pretoria-DistriktGrube und der benachbarten Beynespoort-(Byeneest Poort-)Grube. (Fig. 51).

Noch wenig bekannt und bearbeitet ist die II o ntros e-pipe, die zweite in dieser Gegend entcleckte, suidlich von der Premier in der Nähe der Bahn. Sie steht in Diabas und Felsit. In ihrer Nähe gegen Van der Nerve liegt die alluviale Se if e von Montrose. Sic hat aber keinen Zusammenhang mit jener oder einer anderen bekannten pipe; ie Herkunft ibrer Diamanten ist zurzeit noch unbekannt.

Auf der Farm Rietfontein ist an der Stelle, wo im August 1897 der erste transvaalsche Diamant gefunden worden ist, 3 Kilometer südöstlich von Van der Merve die Schullerfirube angelegt worden. Die im l'retoria-Quarzit stehende pipe hat einen Querschnitt von unregelmäbig elliptischer Form mit Durchmessern von S1) und 71) Meter. Zuoberst liegt, etwa 10 Meter dick, yellow ground, dann folgt hard blue von der gewöhnliehen Beschaffenhuit und mit den auch sonst, z. B. in der Prenier, vorkommenden Mineralien und houlders. Er ist durch Bohrlöcher bis ïber 100 Meter in die Tiefe verfolgt worden. Die Grube hat bis zum 31. Januar $1902 \mathrm{im}$ ganzen 35015 loads mit einem Gebalt von 33,2s Karat in 100) loads, also 12651 Karat geliefert. Im Jahre 1903 wurden 3961 loads yellow mit s,t Kiarat in 100 loads und 3657 loads blue mit 6,2 Karat in 100 loads gewaschen und daraus 561 Karat Diamanten erhalten. Auch hier ist, wie diese Zahlen zeigen, eine sehr erhebliche Konzentration des Gehaltes in den jetzt obersten Teilen der pipe erfolgt, und zwar aus denselben Gründen wie in der Premier-pipe.

Eine noch etwas größere pipe mit einem ebenfalls unregelmäßjig ovalen Querschnitt von 135 und 100 Meter Durchmesser ist im Jahre 1898 nur 580 Meter östlich von jener entdeckt worden. Auf ihr arbeitet jetzt, und auch schon vor dem Kriege, die Ka a lfontein-Grube. Es ist viel weniger yellow ground vorhanden, darunter folgt hard blue, der durch ein Bohrloch in der Mitte gegen 201) Meter tief nachgewiesen worden ist. Dieser ist hier bedeutend weicher, rerwittert an der Luft und lïlt sich deswegen leichter bearbeiten als der in der Schniler-Grube. Der Betrieb ist daher in dieser eingestellt und wird nur in Kaalfontein fortgesetzt. 


\section{d. Rhodesia.}

In Rhodesia hat sich Diamant in nutzbarer Menge bisher nur in Seifen gefunden und zwar im So ma b u la forest, etwa 22 Kilometer von Gw elo. Dieser Ort liegt an der IBahn von Bulawayo nach saleshury ungefäh in der Mitte und ist der Knotenpunkt einer kleinen Seitenbahn nach Selukwe. Die Gegend gehört zum Quellgebiet des in den Zambesi mïndenderi Shanmani-Flusses. Die Diamanten liegen in groben, teilwerse tonigen Sanden und Kiesen. die stellenweise durch ein eisenschiissiges Bindenittel zu festem Sandstein und Konglomerat vereingt sind; es ist der sog. Willoughby's diamondiferous hallast. Dieser zieht sich bis etwa $10(10$ Meter an der Wasserscheide des Shangani gegen den Limpopo in die Höhe. ohne aber in das Gebiet des letzteren Flusses iiberzutreten. der keine Diamanten führt. Der Diamant ist kaum jemals etwas abgerollt, sondern bildet scharfkantige und eckige Kristalle von verschiedener Form. Fast durchweg ist die Farbe der rohen steine grinlich, beim Schleifen werden sie aber farblos; es ist also nur die iußerste Schicht gefärlbt. Die Qualität ist gut, z. T. sehr gut; eine größere Partie wurde zи 7 i Mark; eine audere kleinere zu 120) Mark pro Karat verkauft. Unter den Begleitern sind zahlreiche schön gerundete Gerölle von Quarz, vielfach Bergkristall; ferner findet sich Jaspis, Achat und Kieselholz, daneben Magneteisen und Eisenglanz, Granat, aber niemals hutrot wie Kaprubin, Beryll, sog. "Somabula blue" (wahrscheinlich blaner Topas), Zirkon, (Alimmer usw. Als besonders bezeichnend werden genannt: Staurolith. Cyanit, Chrysoberyll (zienlich vicl, nelsst Katzenauge und Alexandrit). Dageggen fehlen durchaus oder treten stark zuriick die charakteristischen Mineralien des Blaugrunds von Kimberley usw.: ()ivin, Enstatit und Bronzit, Titan- und Chromeisen usw. Die Diamanten werden also wohl schwerlich aus einer noch unentdeckten pipe von blue ground stammen, sondern lö̈lıst wahrscheinlich aus Pegmatitgüngen im Granit, resp. aus einem Kontakthof am Granit, denn die Nineralien, die sich mit dem Diamant zusammenfinden, sind eben gerade solche, wie sie in Pegmatitgängen resp. Kontakthö̈en vorkommen, und Granit ist das (xestein, das in der ganzen Gegend die diamantfuihrenden Seifen unterlagert. In allerjiingster Zeit hat man aber in dieser Gegend auch anstehenden Blaugrund entdeckt.

\section{e. Deutseli-Siidwestalrika.}

Schon seit lïngerer Zeit ist auch in dieser Kolonie Blaugrund bekannt, und zwar in den Bezirken von Gibeon am groben Fischfluf und yon Berseba, etwas weiter siidlich. hiex auf der Farm Mukerop. Tm ganzen sind es etwa 15 Stellen, aber nirends ist bisher din Diamant wefunden worden, wenigstens liegen keine sicheren Tachrichten darüber vor.

Dagegen wurde nenerdings ein ganz anderes, eigenartiges Diamantvorkommen entdeckt, diss his jetzt noch keinen Zusammenhang mit Blaugrund hat erkennen lassen.

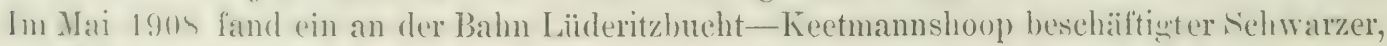
der frïhere in Kimberley gearbeitet hatte. in der Nähe von Kolmanskop, bei Kilometer 16 der Bahn, also ungefialn 15 Kiloneter in ästlicher Richtung vom Neer entfernt, in Sande des dortigen weit sicli hinzichenden dïrren Dünengürtels einen anl dem Boden liegenden I)iananten, de'n (er seinem Voresesetzten, dem Oberbahnmeister Strauch zeignte. Sofort entstand ein wahres Diamantenfieber. Zahlreiche Bewohner joner Gegend, sowie auswärtige Zuziighler lexten sich auf das I)iamantensuchen, und es wurlen auch vicle Steine grefundern, so dab sich die Itoffnumg auf einen reichen Ertrag inmer mehr steigerte. Sehurfscheine wuden von den Eigentimern des Bodens, von der hegierung sowohl als von der südwestafrikanischen Kolonialgesellschaft, in gröberer Zahl ausgegeben und die Nachforschungs-, sowie zum 'Teil auch die Gewinnungsarbeiten systematisch in Angriff grenommen. 
Jiese fïhrten zu der Erkenntnis, dals die I)iamanten auf weite Erstreckung verhoreitet smol. Sie bedecken einen zwar nur 3 enol. Neilen breiten, aber 20 bis 25 rngl. Meilen fon Vord nach siid sich erstreckenden Laundstreifen, in dem Kolmanskop ziemlich in der Mitte liegt. Dieser Streifen zidht sich halbmondfömign um Lüderitzhucht herum, be-

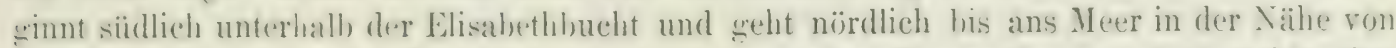

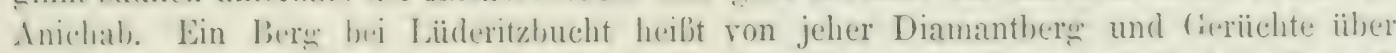

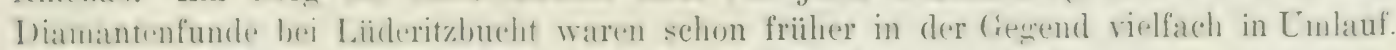
Aueh sollen Eingebrene ron lort seit riniger Zeit im Besitze ron I)iananten wewesen sein. die weder von Kimberley noch von Transvaal stammten.

Frrnor ereabs sich, daf die Diamanten alle lose in einem grobkïrnigen sande liegen und

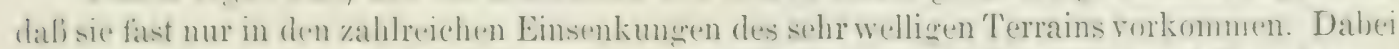
fmelen sie sich durchwe nur ganz oberflächlich und sind in der Iauptsache anf die äabersten vier \%entimeter des I)inensandes heschränkt; tiefer als ein Meter sind gar keine me-hr vorhanden. Man suchte zuerst nur die Erdoberfläche ab, bexann aher dann die obersten sandlawer dureh Anwendung ron Sielen und primitiven Waschapparaten zu bearbeiten. Dabei wird dats beim (iraben flacher Lëcher zutage tretende lirakwasser rerwendet, das in dieser fast rexenlosen, kein Trinkwasser liefernden Gegend allenthalben leicht und in genïgender Menge crlangt werden kann. Einige Diamantsucher haben so in der ersten Zeit mit einigen wenigen Arbeitern 50 und sogar 70 Karat täglich erbeutet.

Die Steine, die man findet, sind alle nur klein, von den meisten gehen 4 oder 5 auf (in Karat, riele sind kleiner, wenige größer. In Durchschnitt sind sie nicht über $1: 3$ Karat schwer. Der gröhte, der bisher vorgekommen ist, wiegt nicht ganz ein Karat (2- Karat, und ist ungefïhr exbsengrob, doch wird nenerdings ron einem über 2 Karat schweren stein berichtet. Die Form ist fast bei allen für den Schliff güinstig; es sind Granatoëder und Achtundrierzigflächner, aber auch riele Oktä̈der (Fig. 39). Die Qualität ist iu Durchschnit sehr gut. IIan trifft zahlreiche erstilassige Steme, danchen aber auch wie überall viele geringere, namentlich auch wefärbte, rote, gelhe, braune. graue, schwarze usw. In allgemeinen sind st besser als die Steine von Kimberley und nähern sich mehr den river stones. Ihre Härte soll die der australischen Diamanten erreichen.

In dem Sande ist der Diamant begleitet außer von den Quarzkörnern, die die Iimptmasse bilden, ron ungefälır jo Millimeter dieken größeren Kö̈nern, die zum Teil mleichfalls Quarz sinıl, zum Teil aber auch aus schwarzem Kieselschiefer, Jaspis, Chalcedon und Achat bestehen. Auch Granat fehlt nicht und scheint für lie Anwesenheit von Diamant leitend zu sein oder doch dafür gchalten zu werden; jedenfalls ist er infolge seiner lebhaft roten Farbe besonders leicht zu entrdecken. Alle diese Mineralkörner sind infolge der starken liewegung in ren häufigen und heftigen Sandstilmen sehr stark abgeschliffen und selbst ron den Diamanten zeigen manche Simuren ron Abrollung. Auch die nicht sehr zahlreichen, aus der mächtigen Sandïberdeckung herausracenden Felsen und Kilippen der anstehenden Gesteine sind durch den heftigen Anprall des fliegrenden Sandes stark greglättet.

I)iese Gesteine, die den Lntererund der Diinen bilden, sind auf weite Erstreckun und bis 150 Kiloneter landeinwärts Granite, Gneise, Hornblendeschiefer und andere Lrzebiressesteine. I)a und dort werden sie ron Gängen von Diabas (Grünstein) durchzogen. Genaueres hieruiber ist aber bis jetzt sehr weng bekannt, namentlich in dem Diamantenbezirk selbst, der noch fast gar nicht geologisch durchforscht ist.

Daraus folgt ganz von selbst, dalj sich auch die Frage nach den Lrsurung dieser Diamanten noch nicht beantworten lält; umsomehr verschiedene Veinungen sind daher hieriiber geäulert worden. Blaugrund wie bei kimberley hat man in der diamantführenden Zone des Lüderitzlandes noch nicht beobachtet, wenigstens nicht mit Sicherheit, doch wird gerüchtweise von dem Vorkommen von Gelbgrund berichtet und neuerdings sollen 
pipes bei Elisabethbucht aufgefunden worden sein. Wenn also die Diamanten aus Blaugrund stammen, wie manche meinen, so müßten sie durch die heftigen und andauernden Sïdwinde nach Norden getricben worden sein, oder die betreffenden pipes müliten jetzt unter dem Sande verschüttet liegen, es wäre denn, dab weitere Nachforschungen noch solche an der Oberflïche kennen lehrten. Es ist aber auch auferdem nicht gerade sehr wahrscheinlich, dab Blaugrund das Muttergestein des Diamants sei, da man nach den bisherigen Mitteilungen außer Granat noch keines von den zahlreichen Mineralien gefunden hat, die ihn in so charakteristischer Weise bei Kimberley begleiten. Granat kommit aber anch vielfach und stellenweise in Menge in Gneisen, Hornblendeschiefern und anderen :̈hnlichen Gesteinen vor, die im Hinterland von Lïderitzlucht verbreitet sind, und könnte daher auch aus solchen stammen, so dab diesem Mineral keine grrobe Bedeutung für die Beantwortung der vorliegenden Frage zukommt.

Das wahrscheinlichste ist, daß die Diamanten aus den oben genannten Grundgesteinen der Gegend um Kolmanskop abzuleiten sind, namentlich aus den dortigen Graniten. Die Begleitmineralien wïrden dem wenigstens nicht widersprechen, es sind sogar Berichte vorhanden, nach denen alle diese in dem dort anstehenden Granit vorkommen sollen. Auch anderweitig hat man ja Granit als Muttergestein von Diamant mit mehr oder weniger großer Sicherheit nachgewiesen.

Andere haben an die oben erwähnten Diabasgänge gedacht, da Diabase auch in Australien, sowie wahrscheinlich in der Kapkolonie Diamanten, wenn schon in spärlichster Menge, führen. Es wird dabei namentlich auf die Analogie mit den Flubsteinen aus dem Vaaltale hingeviesen, die ja wie die hier besprochenen von der feinsten Qualität sind und die ebenfalls aus Diabas stammen sollen.

Jedenfalls liegen die Diamanten nicht mehr an der Stelle, an der sie entstanden sincl. Das Muttergestein, gleichgültig welcher Art es gewesen ist, unterlag der hier sehr rasch und energisch fortschreitenden Verwitterung. Die Winde wehten die dadurch entstehenden feineren und leichteren Umwandlungsprodukte weg, und nur dic etwas gröberen Sandliörner mit dem Diamant und seinen widerstandsfähigen Begleitern blieben zurïck, letztere aber, und namentlich der Diamant selbst, in erheblich grölberer Menge als in dem Mutterrestein, in dem er sich bildete. Auch hier wären also die diantantführenden Sande Seifen, bei denen aber nicht das Wasser, sondern der Wind die Aufbereitung besoreste und die man daher als äolische Seifen von den früher betrachteten unterscheiden künnte.

Diese theoretischen Fragen künnen nur auf Grund einer genauen geologischen Durchforschung der ganzen Gegend bis weit um die diamantführende Zone herum beantwortet werden, event. durch einen Zufall bei dem weiteren Prospektieren in dem fast unbewohnten Lande, wobei das ursprügliche Muttergestein des Edelsteins entdeclit werden könnte.

Jedenfalls hat die Sache sehon jetzt eine gewisse praktische Bedeutung und verspricht diese für dic Zukunft in noch erhehlich höherem, vielleicht sogar in sehr hohem Malje zu (rangen. Bis September 1908 sind im (Aanzen mebrere Tausend Steine im Gesamtgewicht von 2720) Karat gefunden worden. Von da an hat die (rewinnung mit einiger Regelmïbigkeit cingesetzt. Hierdurch ist die Ausbeute seit dem 1. September in folgender Weise gestiegen: September 6644 Karat, Oktober S621 Karat, November 10225 Karat, D)ezember 11549 Karat, also bis Ende 1908 im Ganzen $397(i 2$, rund 40006 Karat mit einem Verkaufswert von efwa 11000000 Mark. Anfünglich wurde das Karat un 21 Mk., dann um 30 Mk., später 113 40 his $45 \mathrm{Mk}$. und sogar bis 60 Mk an Ort und Stelle verkauft. Da die Gewinnungskosten gering sind - sie betragen etwa 5 Mlk, nach anderen Angaben nur 1 Mark pro Karat - so bleibt dabei für den P'roduzenten unter allen Umstïnden ein schöner Gewinn, auch wenn, wie behauptet wird, angesichts der Unmöglichkeit strenger Kontrolle der Diebstahl hier wie in allen anderen Diamantfeldern eine bedeutende Rolle spielt. 


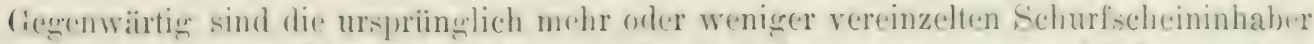
im lecerilf, sich zu gröbren und kleineren (iesellschaften zusammenzuschliefien und so

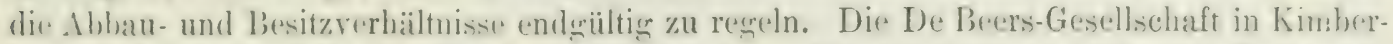
ley soll dahei chenfalls ihre Iland im fipele haben. Für sie wäre es auch eine Sache von

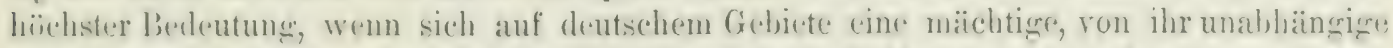
Diamantemproduktion entwickeln wïrle. Wie grob die II ffonmeren hieranf in Interessentenkreisen sind, kann man daraus ersehen, dab Anteilscherine von lou Mk., die die Gesell-

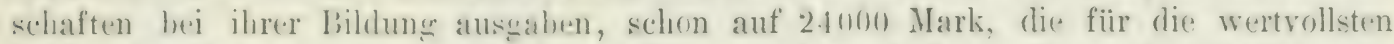
Folder hei Kolmanskop, wo in 1 load Dimensand 2-5 Karat Diamant enthalten sein

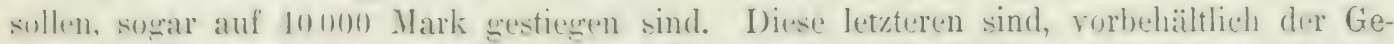
melumigung der Deutschen Kolonialgesellschaft in Berlin, Anfang 1909 ron einer ronglischen Aktiengesellschaft gepachtet worien und zwar in einer Ansdehnungron va. 16 anglischen Quadratmeilen oder 1111 Hektar. Die l'acht läuft vom 1. September 1905 an 50 Jahre. Die l'achtsumme beträgt 5) "in vom Marktwert der gewonnenen Diamanten, mindestens jedoch 600 Pfund Sterling im Jahr.

Den Diamantuproduzenten ist die Terpflichtung anferlegit worken, ihre cesamte Förderume einer vom Reichskolonialamt orler mit dessen Zustimmung rom fonverneur zu beredehenden Behörde oder P'erson zur Vermittlung der Verwertung zu iibergeben. Eine Gesellschaft hat sich zu diesem Zweek im Februar 1909 in Berlin gebildet.

Eigenschaften mol Qualität der sïdafrikanischen Ibiamanten.

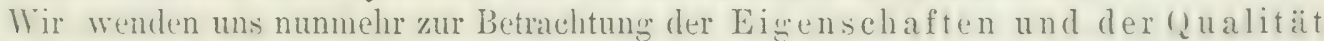
der in siidafriki gefundenen Diamanten selh)st, die sich in sehr verschiedenen Formen und Zuständen der Kristallisation, Farbe, Größe, Qualitåt usw. dort finden.

Die Liamanten der dry digreings bilden meist deutliche, ringsum regelmälige atsechildete Kristalle mit vollkommen scharfen Kanten und Ecken oder auch vielfach Bruchstiicke grö̈ferer Kristalle, die ringrs ron Spaltungrsfïchen umgeben sind und die also Siraltungsstiicke darstellen. Wie schon erwähnt, liegen diese stets einzeln in Tuffe ohne die zugete hörigen stïcke. Sie sind zuweilen von bedentender Gröbe und deuten auf ursprüngliche durch Zerbrechen zerstörte Kristalle von mindestens 3 his 500 Karat hin. Grüfere Stücke dieser Art werden als ..cleavages", kleinere unter einem harat als „sllints" bezeichnet. Auffallend ist die 'Tatsache, dali derartige Spaltungsstiicke hauptsächlich weif ofler doch sehr wenig gefürbt sind und um so spärlicher rorkommen, je dunkler die - übriwens, wie erwähnt, fast stets schr helle - Farbe ist. Bruchstiicke allsgesprochen geelber Diamanten werlen kaum gefunden; die Steine von dieser Farbe scheinen dem Zerbrechen einen erheblich größeren Widerstand entgegengesetzt zu haben, als weiße.

Dic Form der wanzen Kristalle ist vielfach sehr schön recelmäßig, aber auch häufig mehr oder weniger stark verzert und rundlich ohne bestimmt ausgesprochene Formen Die Kanten und Ecken sind nie abgerollt. wie in den river diggrings. Sehr häufig trifft man Oktaëder mit eingekerbten Kanten (Fig. 39 u und o), die im Handel als ..cristals" bezeichnet werden, wenn die Form regelmälfig ist. Etwas weniger verbreitet simd Dodekä̈der mit gewölbten Flïchen, nicht nur Dodekaïder selbst (Fig. 3!) e), sondern auch solche Formen mit einfach oder doppelt geknickten Flïchen (Fig. 39 7i. Kristalle dieser Art sind, wenn sie nicht stark verzert sind, besonders seschätzt, namentlich die Olitaëder, da man aus ihnen, ohne weiteres und ohne srö̈ßere Vorbereitungen durch Spalten, die beliebte Brillantform herstellen kann. Würfel (Fig. :19!1), die in Brasilien hauptsächlich zu Hause sind, fehlen am Kap so gut wie ganz. komuen aber doch vereinzelt vor. Hemiëdrische Formen, wie z. B. Fig. 39 $k$, findet man ebenfalls sehr selten. Pecht verbreitet sind Zwillinge nach dem gewöhnlichen Gesetz, entwedter ron zwei Oktaïdern (Fig. 39 y) oder von zwei Dodekaëdern oder Achtundvierzigflächnern (Fig. 39 h) 
gebildet und in der Richtung der Zwillingsachse stark verkürzt. Ihre äuljere Form ist je nach der Auslildung der Individuen sehr verschieden, tafelfürmig, linsenförnig, herzförmig. usw. Da Steine dieser Art ihrer geringen Dicke wegen nicht zu Brillanten, sondern meist nur zu Rosetten verwendbar sind, so werden sie weniger greschätzt als die anderen, namentlich die oktaëdrischen, und rin weiches Gewicht von ihnen wird weniger hoch bezahit als von diesen. Sie sind mit besonderen Namen belegt worden, und zwar heißen sie "twins", wenn die Zwillingsgrenze deutlich sichtbar, "macles" (maacle oder mackel; dagregen, wenn sie versteckt ist. Auch der Name nats (Nahtsteine) wird gebraucht.

Neben den ganz gesetzmäßig gebildeten Zwillingen sind unregelmäßige Verwachsungen zweier und mehrerer Individuen verbreitet, namentlich häufig sind die auch in Brasilien vorkommenden kugelförmigen Aggregrate, die Bortkugreln, mit sehr selten ganz y-latter, meist nit ranher Oberfläche, aus der die Ecken der zahllosen miteinander verwachsenen kleincen oktä̈drischen Kriställehen hervorragen (Taf. I, Fig. 3). Die Grölse dieser eigentïmlichen Bildungen ist zuweilen ziemlich bedeutend; ihr Gewicht geht bis zu 1 110 und sogar bis zu 200 Karat. Unter den Kugeln kommen auch vereinzelt solche vor, wo nur eine dünne äufere grauliche Schale durch solehe Verwachsung gobildet ist, wïhrend im Innern als Kern ein einheitliches gröberes Kristallindividuum steckt, das heim Zerschlagen der äußjeren raulen Schicht unverletzt herausfällt. Diese Bortkugeln sind zu technischen Zweeken sehr gesucht, namentlich seit der brasilianische Karbonat die steigenden Bedürfnisse der Technik nicht mehr in grentigendem Maße befriedigen kann. Ihr Preis beträgt bei Erbsengrübe bis 120 Mark das Karat. Alle diese Einzelheiten der Ausbildung in der Form spielen bei der Einteilung der Diamanten für den IIandel eine wichtige Rolle, wie wir unten sehen werden.

Die Größe der Kapdiamanten ist außerordentlich verschieden, man hat hier die größten und danehen anch die kleinsten gefunden, die bisher vorgekommen sind.

Dureh sorgfältiges Waschen kann man sehr zahlreiche kleine Steinchen bis 1/32 Karat (gegen 7 Milligramm) herab erhalten. Die verbesserten Waschapparate, Pulsatoren und Separatoren. geben solche kleine Steinchen jetzt ohne weitere Mühe, während sie früher bei der älteren Wäschereimethode verloren gingen. Daher war lange die Ansicht verloreitet, daß leichtere Diamanten als solehe von $1 / 1$ Karat am Kap nicht oder doch sehr selten vorkommen. Später hat man dann sogar sehr zahlreiche mikroskopisch kleine Kriställchen in dem Blaugrund beobachtet, die bis dahin ganz unbeliannt geblieben waren, und daneben ebenfalls mikroskopisch kleine Partikelchen von Karbonat und Craphit, die in dem diamantführenden Gestein bis dahin in jenen Gegenden sich ganz der Wahrnehmung entzogen hatten.

Die cinzig dastehende Inautmerkwürdigkeit, durch welche sich die sïdafrikanischen Diamantenfelder von allen übrigen unterscheiden, liegt aber in dem außerordentlichen lieichtum an grolien Steinen neben den allerdings auch hier überwiegenden kleineren und mittleren. Während 17 karitige Steine in Brasilien so selten waren, daß der Sklave, der das Gliiek hatte, (inen solehen zu finden, besehenkt und in Freiheit gesetzt wurde, koumen sie am Kap zu IIunderten und Tausenden vor, und beim Auffinden eines Diamants von 100 Karat ist liee die Aufrewug weit geringer, als wenn in Brasilien einer von 20 Karat vorkommt. Steine von st his 150 Karat sind noch sehr häufig, und es vergeht kaum ein Tag, an dem nicht ein solcher von 50 bis 100 Karat gefunden wïrde. In den 40 Jahren, seit denen man die Diamanten vom Kap kennt, sind dort weit melr große Steine gefunden worden als in Indien nach tausendjaihrigem und in Brasilien nach nahezu zweihundertjïhrigem Betriebe der Wäschereien und Gruben, und das gilt nicht nur für jedes dieser beiden Läinder einzeln, sondern ebenso für beide zusammen. Diamanten, die nach dem Schleifen 75 Karat und mehr wiegen, hat das Kapland jetzt schon erheblich 
mehr geliefert, als bis zur Entdeckung der dortigen Felder iiherhaupt bekannt gewesen waren. Die nittlerere Gröbe der brasilianischen Diamanten beträigt nicht voll 1 Karat, fiir die sibdafrikanischen ist das Mohrfache davon zu rechnen (wenn man von den aller-

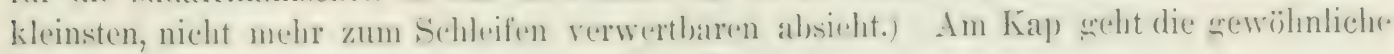
Handelsware im Gewicht bis zu 50 und 60 Karat.

Der grölite Jimmant rom Kaph, Eleichzeltig der grölite äberhaupt bekannte, ist der Cullinan, 3024\%, Karat schwer, aus der Premier-Grube; an zweiter Stelle stelat der Excelsior im Gewicht von $971{ }_{12}$ von Jagersfontein. Beide werden unten bei der Be-

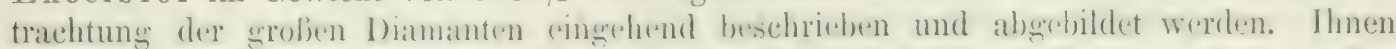

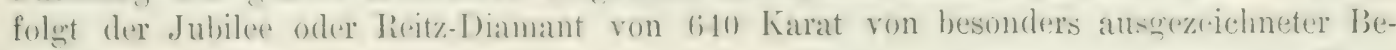
schaffenheit, ebenfalls von dort. Aus derselben Grube soll ein Stein von 600 Karat stammen, der aber als sehr unein beschrieben wirl. Ein Stein von 457' : Karat wurde

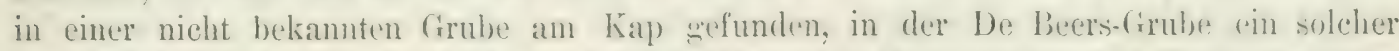

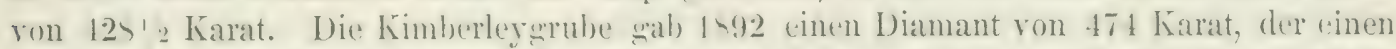

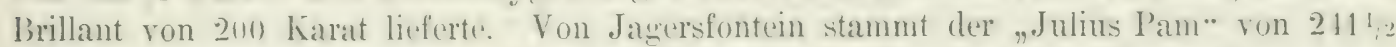
Karat, der nach dem schleifen noch 120 Karat wow. Eimige gröbere steine haben auch die river digreings geliefert, so ror allem den ...stewart" ron 255" - Karat und andere.

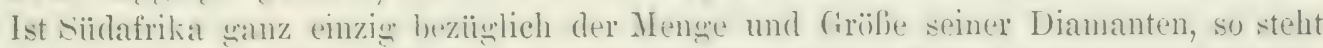
(s) leider auf einer niedrigen stufe bezïghich der Qualität. Kein Land produziert eine so grofe Ienge ereringer Steine. Sehr häufig sind dunkle, unansehnliche Farluen, deren Träiger nur als Bort Verwendung finden künnen. Ebenso trifft man häufig̣ .. Wollien“. sowie Risse, sog. "Federn“, auf denen nicht selten, besonders in Dutoitspan und in den river dignging am Vaal, eine dünne Lage von Brauneisen ausgeschieden ist. Ganz gewöhnlich sind die steine durch fremde Einschlïsse (spots) verunziert, die meist sehwarz sind und wie lohlenteilehen aussehen, aber wohl meist aus Eisenglanz oder Titaneisen bestehen. Auch srïne Finschlïsse ron eigentümlich wurmförmig̨er Gestalt, die nach E. ('ohen wahrscheinlich einer Kupferverbindung angebören, und rote ron unbekannter Vatur kommen vor. Steine nit sehr viel Einschlisse'n werden ,schmutzis" grenannt. Nach sitreeter sind im Mittel nur 20 Proz. der Kapsteine erstex (Qualität, 15 Proz. zweiter und :30 Proz. dritter Qualität, und 35 Proz. gehören zum Bost ; nach Kunz sind jedoch nur 8 Proz. vom ersten, 12 Proz. vom zweiten und 25 Proz. vom dritten Wasser; der Rest von 55 Proz. ist Bort.

Die Farbe ist von besonderer Wichtigkeit und sehr mannigfaltig. Man findet rollkommen farblose, reinweife bis sehr hell- bis tiefgelbe und orangefarbige, hell- mol dunkellraune, rauchgraue, blaß- und sehr selten dunkler griune und -blaue, rosarote, blaljviolette usw. Namentlich die gröberen Kapdiamanten pflegren etwas gefärbt zu sein, aber nicht die allergröbten. Dabei sind die Strine bald durchsichtig und klar, bald trübe und undurchsichtig bis vollkommen schwarz. Ileist ist die Farbe gleichmäßig verteilt, zuweilen ist aber auch ein Kern ron einer anders beschaffenen Hülle in paralleler Verwachsung umgeben. Auch kann es daher vorkommen, dafj ein farbiger roher Stein beim Schleifen ganz farblos wird oder umgekehrt.

Die reinweiben, absolut farblosen, sind sehr selten, doch fehlt das feinste Blauweif, wie es an indischen und brasilianischen Diamanten sich fundet, auch unter denen rom Kạ! nicht. Diese resuchtesten und geschätztesten ron allen, die "hochfeinen”, betragen aber nur 2 Proz. des Ganzen. Die Steine dieser Art bilden fast immer regelmäfige Oktaeder. Sie sind meist nicht grols und übersteigen selten 10 Karat. Doch gehüren auch einige von den größjeren und größten zu der ..hochfeinen“ Sorte. Einer der feinsten steine von Kay ist der "Porter Rhodes", der am 12. Februar 1880 in der Kinberleygrube sefunden wurde und dessen Gewicht zu 150 oder anch zu 160 Karat angegeben wird, ein Stein von allergröbter Schönheit. Auch die drei oben genannten gröbten Diamanten gehören hierher. 
Im allģemeinen sind jedoch die șroßen Steine gefleckt und umrein oder gefärbt, meist geelb und zwar oft schr stark und unschön, was ihren Wert erheblich reduziert. Besonders reich an grofien und schönen Steinen ist die sonst arme Grube Jagersfontein, und vor allem stammen solche von bester Beschaffenheit aus den river diggings. Aber auch die besten Kapsteine erreichen nicht ganz, das Feuer und das Farbenspiel der feinsten blawweifen brasilianischen oder gar der alten indischen, so daß sie an Wert und Preis doch hinterdiesen zuriickstehen.

Die meisten weifen Kapsteine haben einen mehr oder weniger deutlichen stich ins Gelbliche. Ein ungeibtes Auge hemerkt das zwar nicht und hält diese steine für vollkommen ungefïrlot, der erfahrene Juwelenbändler erkennt aber auch den allerschwächsten welblichen Sichein auf den ersten Blick. Steine dieser Art heifen „kapweif" (cape-white, kurz (ape), und man unterscheidet wieder nach dem etwas weniger oder mehr bemerkbaren farbigen Schein first eape und second cape. Nanche kapweilje Steine erhalten beim Schleifen als Brillanten einen besonders schönen Glanz und werden daher höher seschätzt als die anderen. Man hat ilmen den Namen "silver eapes" getegehen, andere werden als ..fine capes" hezeichnet. Ist die Färlung etwas deutlicher, aber immer noch ganz schwach gelblich oder auch grinlichgran, so spricht man ron "first und second bywater" (kurz first und second byei. Sehr verbreitet sind die deutlich, aber immer noch licht gefärbten gellorn Steine, deren Farbe rom Strohgelben und Kanariengelhen bis zum licht Kaffeebramen gelit. Sie bilden am Kap die Hauptmasse der schleifbaren Ware, sind aber schon (rhel)lich minder geschätzt als die kapweifen und die anderen schon erwähnten. Sie pflegen im allgemeinen mit viel weniger Fuhlern behaftet zu sein als die farblosen. Tach der Fürbung unterscheidet man von den hellsten bis zu den dunkelsten: offeoloured, light yellow; yellow und dark yellow, woran sich light brown und brown anschlieft. Das reichliche Vorkommen der schönen lichtgelhen Steine ist eine ganz besondere Eigentiimlichkeit der südafrikanischen Diamantfelder, nirgends sonst finden sie sich in dieser Menge. Frülier, ror der Entdeckung der Gruben am Ką̣. waren sie im Gegenteil so selten, daß sie als eine besondere Kostbarkeit angeselren wurden, wie die auch jetzt noch so sultenen schön roten, blauen und grünen. Solche sogen. "Phantasiesteme" (fancystones) sind am Kap) sehr weniw gefunden worden, vielleicht weniger als anderswo, und wenn je eimmal ein sch ̈̈ner Diamant von einer der zuletzt geenannten Farben vorkonmt, so ist er stets klein, doch wird ein rosavioletter Stein von 16 Karat erwähnt. Sehr schïn und tief gelb und orange gefairbte I)iamanten sind auch in Sürlafrika gar nicht häufig. Sie ggehören chenfalls zu den Phantasiesteinen und stehen hoch in der Wertschätzung, während die verschiedenen sehwach gelblichen usw. Nuancen der oben genannten Arten den Preis ungünstig beeinflussen. Durehsichtige dunkelbraune bis schwarze Steine sind sehr selten und teuer und werden, obwohl sie eigentlich jeder Schönheit enthehren, doch als knstharer Trauersehmuck greschätzt. I) ie zahlreichen unrein oder zu dunkel gefärbten gehören wie die trüben und undurehsichtigen zum Bort; sie werden nicht mehr geschliffen.

Ganz cigentuimlich und auber an Kap, besonders bei Kimberley, kaum jemals gefunden, sind die schon ohen erwähnten Steine, die kurze Zeit, nachdem sie dem Gestein entuommen sind, ganz von sellser und anscheinend ohne jede äußere f'eranlassung rissig werden und in einzelne Stïcke oder in ein Ilaufwerk feinen Pulvers zerfallen. Sie zeichnen sich aus durch (ine stets sehr regelmäbige oktaedrisehe Fiorm und eine eigentümliche rauchgraue Farbe, die entweder sleichmäßjig durch den ganzen Stein verteilt oder nur an den Kanten und Ecken angehäuft ist. An dieser Farbe und an einem eigentiimlichen starken Glanz kann man diese zerspringenden Steine stets sicher erkennen. Man nennt sie nsmoky stones" oder . "glassy stones with smoky corners", je nachdem die Farbe gleichmäßjig verteilt ist orler nicht. Ir ür den Besitzer eines solehen Steines ist ihr sonderhares Verhalten natïrich sehr uner wïnscht. Er sucht seinen Besitz dadurch zu erhalten, 
dali er ihn glejch nach dem Herausnehmen aus dem forestein in den Mund nimmt oder mbt Fett bestreicht usw. I)iese Mittel halten aber nur kurze Zeit vor, viceleicht nur so langere, bis es gedungen ist, den strin rinem unkundigen Käufer anzuhängen. I) ie Versendung wird vielfach im Innern einer Kartoffel vorerenommen: in einer solchen sollen sich diexe Steine besser laalten, wahrscheinlich weil sie dadureh vor jeder Berührung mit anderen

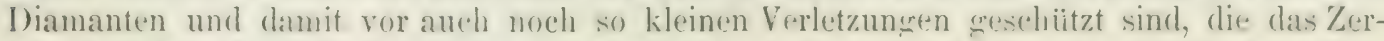
fallen aufierordentlich beginstigen. Nach den bisherigen Erfahrungen sind aber diese „.smoky stones" ihrem Schicksal rettungslos verfallen. Sie haben ïhrigens nur eine greringe Verbreitung. Die Lrache dieses regentiumlichen Verhaitens ist eine wahrecheinlich durch die Einlagermo des Farbstoffes rerursachte starke innere Spannung in diesen Kristallen, die eine kräftige anomale Doplellhrechung zur Folge hat, wie schon ohen bej der Betrachtung dieser Erscheinung gezeigt worden ist (S. 62).

Die Beschaffenheit der Steine ist in jedter firube und an den verschiedenen trellen jeder Grube eine andere, wemn man das lorkommen im grolien und ganzen ins Auge fafit, doch kommen cinzelne strine von jeder cualitait in allen Gruhen vor. Es ist raher in allemeinen nicht mïglich, aus der Beschaffenheit eines tinzelnen Steines die rirube zu crkennen, aus der ex stanmt: ein erfahrener Diamantenhändler in Kimberley ist jedoch imstande, aus einer Partie zusammen gefundener Diamanten nicht nur die Grube, sondern auch den betreffenden Teil der Grube zu bestimmen.

Nach Gardner. Filliams, dem lanģährigen general manager der de Beers-Gesellschaft, u. a. gilt für die Gruben bei Kimberley folgendes (vgl. auch S. $249 \mathrm{ff}$ ):

Die De Beers-firube ist ausgezeichnet durch einen groben Prozentsatz .yellows", wenige schöne , dark yellow", die schon als fancystones getten, eine heschränkte Anzahl ..silver eapes" und eine beträichtliche Anzahl, "light brown cleavage" ron schüner Farbe. Die Grube licfert Kristalle ron jeder Art und Farbe und deren Oberfläche ist fast stets fein „rekürnelt, schimmernol und von etwas fettigem Aussehen, was man in dieser Teise nur hei ihnen trifft. Bort ist selten. dagnegen Bruchstücke mit schw. rzen Flecken sehr häufiğ. Sehr reichlich lommen auch errobe, dodekatedrische Kristalle vor, dagegen fehlen rollkommen weiße Steine so gut wie ganz, fast alle sog. weilen sind kapweiß.

Die Kimberley-Grube liefert ein Produkt, das dem von de Beers zwar sehr ähnlich ist, aber doch anch wieder unterscheidende Merkmale erkennen läft. Man findet eine ziemliche Menge weifere "crystals", die in De Beers selten sind, einen ziemlichen I'rozentsatz "white eleavage". und rerhälmismäßig viele srobe flache, maacles". Die vielen "yellows" pflegen etwas heller zu sein als in De Beers. Viel, smoky stones" und eine Mrenge zum schleifen unbrauchlarer Bort, welche die Gesamt(qualitït herabdruickt. 90 Prozent alles siidafrikanischen Borts soll ron hier stammen. Im grrohen Durchschnitt sind die Diamanten von De Beers größer, die von der Kimberley-Grube weißer.

Die Dutoitsluan-Grube gibt einzelne schöne blauweile Steine und eine besonders feine Qualität ron ,silver capes", besser als die ron De Beers. Die Farbe ist häufig recht dunkel, doch findet man viele gewöhnliche weife Kristalle und .,clearages" und nicht wenig srofe grelbe Oktaeder ron enter Beschaffenheit und fast ohne Flecken. Therhaupt ist die Zahl der wrofen Steine rerhältnismälbig groß, die der ganz kleinen gering. Bort und smoky stones fuhlen fast ganz und Kristalle sind gut und regelmälbig ausgebildet. Im ganzen stanmen aus dieser Grube die schönsten Diamanten, die in der Lmgegend ron Kimberley gefunden werden.

Die Steine der Bultfontein-Grube sind zum großen Teile weiß, aber melır oder weniger gefleckt; nur selten sind sie schwerer als 2-3 Karat. Grobe Kristalle und Bruchstiocke kommen hier kaum vor, ebensowenig viele stark gefürbte Steine und Bort. Fast alle Diamanten von hier sind Oktaeder. 
In der Wess el t on-G r u be sind blauweiße Steine nicht ungewöhnlich, auch blaue, braune und grïne, sowie namentlich schöne dunkel- und orangegelbe Phantasiesteine, letztere nicht so ganz spürlich, sind vorgekommen. Charakteristisch ist das Auftreten einer großen Zahl von Olstaedern, namentlich auch von einzelnen größeren, sowie vieler Bruchstiicke von solchen, und das Vorkommen zahlreicher Zwillinge und unregelmäßjiger Kristalle, sowie vielen Borts.

Jagersfontein gibt, wie schon erwähnt, die weißesten und durchsichtigsten Steine, deren schönes Blauweiß sich dem geschätztesten brasilianischen und indischen zuweilen nïhcrt oder sogar gleichstellt, gleichzeitig aber auch einige der größten am Kap (siehe unten). Die Iniufigkeit der weißen Farbe in dieser Grube wird zuweilen dem Umstande zugeschrieben, daß hier gar kein Schwefellies rorkommt. der ïberall anderwärts sich findet und dort die gelbe Farbe verursacht haben soll. Diese schön weifen Steine haben leider sehr häufig häßliche Flecken und sonstige Fehler, und wenn auch ganz regelmäbige Kíristalle nicht fehlen, so sind doch Verwachsungen zu unregelmäifigen Gruppen gleichfalls nicht selten, sodal doch zahlreiche Steine von hier sich nicht zum Schleifen eignen. Die seltenen fehlerfreien Diamanten sind aber von sehr hohem Wert und erreichen die höchsten Preise. Man vergleicht die Qualität dieser Steine mit der von Bagagem in Brasilien.

Eine übersichtliche Zusammenstellung der Qualität der Steine der einzelnen Gruben gibt Williams in der folgenden Tabelle:

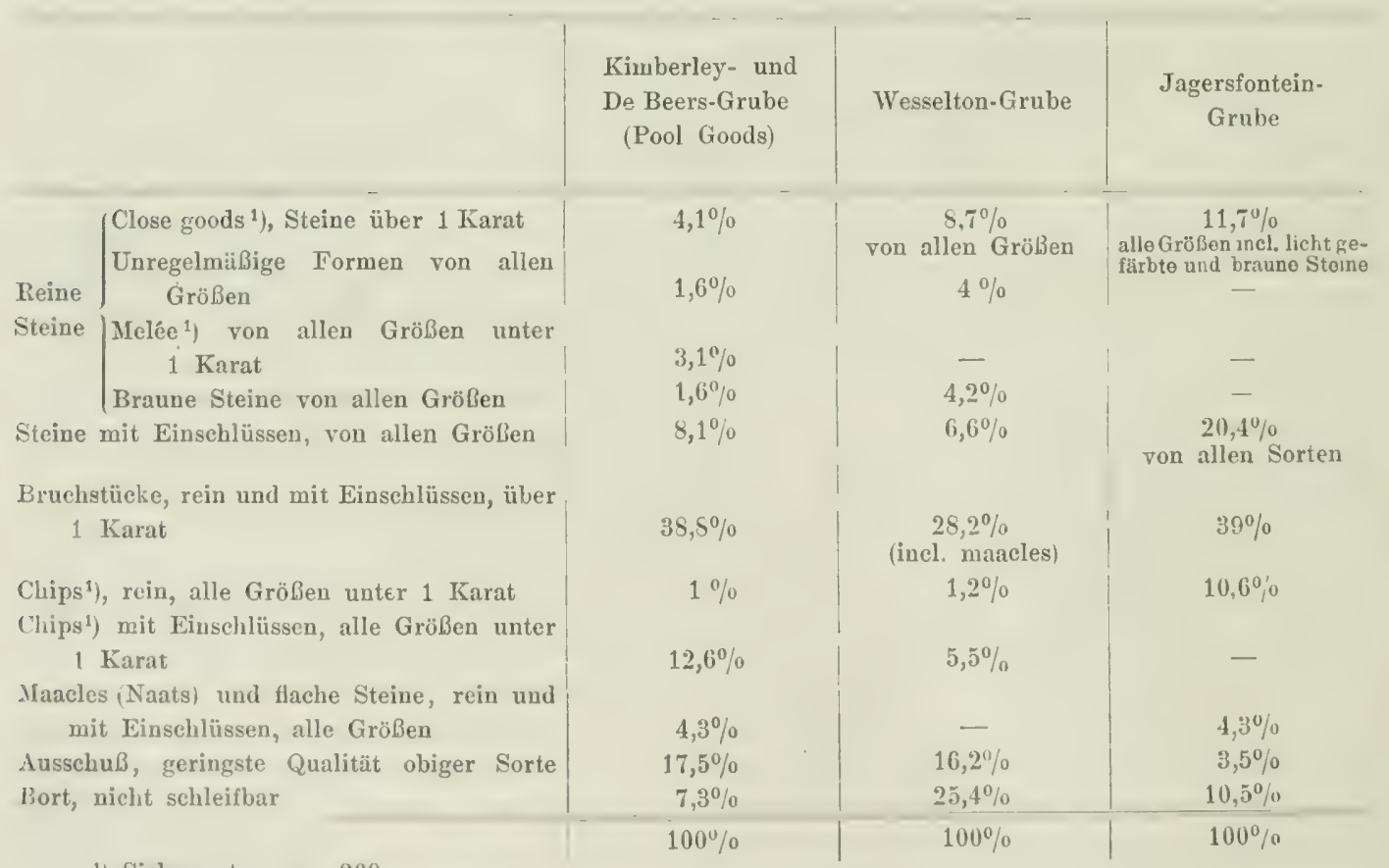

1) Siehe unten pag. 269.

$\mathrm{Zu}$ erwähnen ist noch, dal die J)iamanten von Kimberley, De Beers und Bultfontein fiir weniger hart gelten als die von Dutoitspan, Jagersfontein und aus den river diggings.

Hanlel. Der südafrikanische Diamantenhandel ist im wesentlichen in Kimberley konzentriert, wo die De Beers-Gesellschaft his vor kurzem ein Monopol auszuïben in der Lage war. Ilir Ilauptprodukt sind die Diamanten aus der Kimberley- und der De Beers-Grube, die 


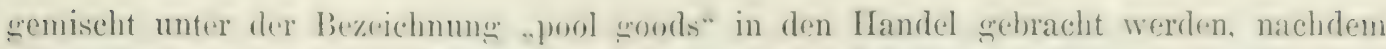
sie einer von besonderen sortierern bewirkten ersten Sortiexung unterzoren worden sind.

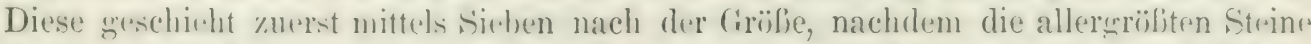
zuror mit der Iland auswesucht sind. Nach der Beschaffenheit im alleremeiner wird dann eine Einteilung in 10 Klassen vorgenommen. Das sind:

1. Close goods, reine wohlgeformte Steine,

2. Spotted stones, Steine mit wenig Einschlüssen,

3. Rejection stones, stark durch Einschlüsse entstellt,

4. Fine cleavage,

5. Light brown eleavage, zerbrochene Kristalle verschiedener Art.

6. Ordinary and rejection cleavage,

7. Flats, flache verzerrte Olitaeder,

8. Maacles, flache dreieckige Zwillinge,

9. Rubbish, Auschul, aber noch etwas besser als

10. Boart, nur noch zu technisehen Zwecken brauchbar: hicrher anch die Bortkugedn (round oder shot boart).

In den ersten acht ron diesen Klassen unterscheidet man dann nach der Farbe weiter: blue white, first cape, second cape, first bye, second bye, off color, light yellow, rellow, doch beriicksichtignt man nux bei den close groods der ersten Klasse alle dieste Nuancen, bei den anderen Klassen begnïgt man sich mit weniger.

Die gefundenen Diamanten werden seit einer längreren Reihe von Jahren nicht mehr wie friiher partienweise in den Handel gebracht, sondern das wanze Erzeusnis wird von dem zu diesem Zwecke aus den ersten Londoner I)iamantenfirmen geblikleten D i amantens yndikat, zu einem bestimmten von Zeit zu Zeit neu vereinbarten mittleren Karatureise übernommen. Von diesem wird ess damn für den Londoner Vlarkt von neuem sortiert. wobei 350 bis 400 Abteilungen gemacht werden und zwar in folgender Weise:

Pure goods,

Brown goods

Spotted goods,

Vollständig ausgebildete Kristalle.

Flat shaped goods.

Pure cleavage,

Spotted cleavage,

Brown cleavage,

Niats oder 1

Marcles. $\{$ flache dreieckige Kristalle, Zwillinge.

Rejections oder Boart.

Bruclistiicke von Kristallen (split stones).

Die meisten dieser Gruppen (außer dem Bort) werden nach der Farbe in 6 oder 7 Sorten celıracht, und jedte von diesen zerfällt wieder in s, 11 oder 12 Grüben, so daß die obige Anzahl ron dhteilungen heranskommt. Siteine der verschiedensten Beschaffenheit bis zum Gewicht von 20 Karat werden dann zu melı oder weniger großen Serien zusammengestellt, und in dieser Weise gelangen sie dann in den Verkehr.

Ton dem srudikat gehen die Steine an die (irosisten, an die Schleifer usw. immer wieder ron nemen nach anderen Gesichtspunliten sortiert. Es zeigt such dahei dats Talent des Ifändlers. der nach der mehr oder weniger gesebickten Zusammenstellung der verschiedenen Sorten zu grüberen und kleineren P'artien bessere oder schlechtere Geschäfte zu machen in der Lage ist. Nachdem die Diamanten endlich yeschliffen und wie vorher so anch nach dem Schleifen durch mehrere Hände gुesangen sind, ist ihr Preis gregen den urspringlich rom der De Beers-Gesellschafi erzielten rorzugsweise allein durch diesen 
Zwischenhandel $u m 200$ his 300 Proz. gestiegen, wenn schließlich die einzelnen Steine durch Vermittelung der Juweliere in die Hände des Publikums gelangen.

Aus dem bisherigen Verkehr hat sich für die gewöhnliche IIandelsware, die im Gewicht einzelner Steine bis 50, auch 60) Karat geht, eine größfere Zahl von besonders benannten IIandelssorten ljerausgebildet, die natïrlich ebenfalls in der Hauptsache auf den oben besprochnen Grundsätzen beruhen. Anfänglich waren es wenige, nur vier, allmählich sind es den fortschreitenden Bedürfnissen des Handels entsprechend, immer mehr geworden; gegenwïrtig unterscheidet man ungefähr die folgenden, die auch zum Teil oben schon genannt sind:

Crystals oder Glassies, vollkommene Oktaeder, weiß oder beinahe weil.

Roundstones, Kristalle mit gewölbten Flächen; Unterabteilungen nach der Farbe: first und second cape-white, first und second bywater (siehe oben).

Yellow clean stones, gelbe Steine, die je nach der melsr oder weniger tiefen Farbe in offecoloured (die hellsten), light yellow, yellow und dark yellow geteilt werden.

Míle besteht aus weilien bis gelblichen (bywater) und sogar oft braunen Kristallen, die im Durchschnitt nicht über 1 Karat wiegen. Kleines mêlée geht sogar bis 1/20 Karat herab. Alle hierhergehörigen Steine sind rund oder glassies, Bruchstïcke sind nicht darunter.

Cleavage setzt sich aus gefleckten Kristallen, Zwillingen usw. zusammen, die vor dem Schleifen gespalten werden müssen. Unterschiede nach der Farbe. "Black cleavage“ nennt man solche Stücke dieser Sorte, die auf den ersten Blick ganz von Flecken erfüllt sind, aber nach der Teilung doch noch schöne Steine geben können. "Speculative stones" sind die großen schwärzlichen Stücke; ihr Wert wechselt nach der Größe und besonders danach, ob man durch Teilen gute Stücke daraus gewinnen kann.

Chips heißen Steine dieser Art (cleavage) in allen Größen unter 1 Karat; unterschieden werden reine und solche mit Einschliissen (pure und spotted chips).

Das Gemenge ron schlechten gelben und braunen Stiicken, von black cleavage usw. bildet die parcels inferior, denen man oft auch den Bort noch beifügt. Das Ganze ist lieine schleifhare Ware mehr, sondern wird zu Schleifpulver zerstoßen oder sonst in der Technik verwendet.

Der Londoner Jnwelier E $\mathrm{E}$ w in W. Stre e ter gilot in seinem Edelsteinbuche die folgende etwas abweichende, nach dem Obigen aber im ganzen leicht verständiliche Einteilung:

White Clear Crystals.
Bright Black Cleavage.
Cape White.
Light Bywater.
Large White Cleavage.
Picked Mêlée.
Common and Ordinary Mêlée.
Bultfontein Mêlée.
Large White Chips.
Small White Chips.
Mackel oder Macle (flach, für Rosen).

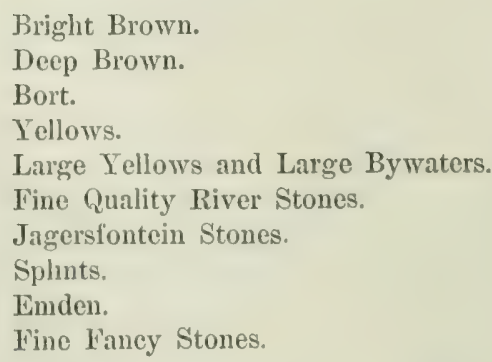

Diese verschiedenen Sorten reigen selbstverständlich die allergrößten Unterschiede im Preisce. Es ist klar, dal) dir kolossale Zumahme der Produltion nach der Entdeckung der sïdafrikanischen Dianıntfelder den ganzen bisherigen Diamantenhandel in der allerstiirksten Weise beeinflussen mulbte. Alle diejenigen Sorten, die am Kap besonders häufig rorkommen, fielen erheblich im Preise, wälırend die dort seltenen Sorten ihren alten Wert behielten. 
Danach sind vollkommen farblose Steine vom ersten Wasser (hochfein) durch das Auffinden der hapsteine im I'reise nicht reduziert worden, sie stehen jetzt noch mindestens rhenso hoch wie früher, sie sind in ihrem alten Werte seblieben. Dagergen sind vor allem strobe Diamanten von 10 his 150 Karat und von gelblicher bis gelber Farbe seln lillig geworden. Bei diesen verlor die alte Tavernier'sche Regel, wonach der Preis entsprechend dem Quarlat des firwichts in Karaten wachsen sollte, vollkommen ihre Geltung. I) Preis steigt bei ihnen nach dem einfachen Karatgewicht und sogar in noch geringerer P'roportion, so dalj ('in doppenttschwerer Stein nicht immer das Doppelte ron einem solchen vom einfachen Gewicht kostet, sondern häufig weniger.

Selbstrerstïndlich bedurfte es diner grewissen Zeit, um die Preise den neuen, anfünğlich noch nicht genau bekamnten Verhältnissen anzupassen. Die zuerst refundenen grö̈beren Steine wurden noch ungeführ nach jener alten Regel, also, wie sich bald heransstellte, viel zu hoch bezahlt, aber hald hatte sich die Sache reguliert. Schon 1576 waren rohe Steine guter (Qualutiat, kapweib und his zu ti Karat schwer, etwa 30-50 "0 weniger wert als zu Anfang und vor der Entedekung der Kapdiamanten, und zwar in der Art, daf die gröbten und die kleinsten die stärkste l'reisminderung erlitten. Dabei ist allerdings zu beriieksichtigen, daf das Kapweil) etwas hinter dem Weil der brasilianischen Steine zuriickstelit. Noch weit mehr, 1876 um $70 \%$ und vorher, 1873, sogar um $85 \%$, hatte sich der Preis der nicht schleifbaren Ware, des Borts, verringert, doch ist er später wieder beträichtlich gestiegen, wohl infolge vermehrter Verwendung zu technischen Zwecken.

Die im Handel bezahlten Preise sind, am Kap wie überall sonst, nicht nur von der Qualität. sondern auch ron Angehot und Nachfrage und manchen sonstigen Umständen abhängig: Es sind daher grobe Schwankungen bemerkbar, die oft sehr rasch aufeinander folgen; die leute geltenden Zahlen treffen häufig schon morgen nicht mehr zu. Nach den Mitteilungen von E. Cohen schwankte in den Jahren 1575 his 80 der Preis des Bort zwischen 1,80 und 5, S0 Mark, der kapweifen 2- bis 6 karätigen Steine zwischen 75 und 150 Mark, der 1 - bis 2 karätigen Bruchstücke zwischen $\delta$ und 24 Mark pro Karat usw.

Nach der durch E. Cohen mitgeteilten Zusammenstellung von Anton Petersen haben Ende 1852 rohe Steine per Karat in den Gruben folgendermaben im Preise gestanden: (1. Kolumne), während die Preise im Jahr 1908 nach George F. K un z in NewYork betrugen (2. Kolumne):

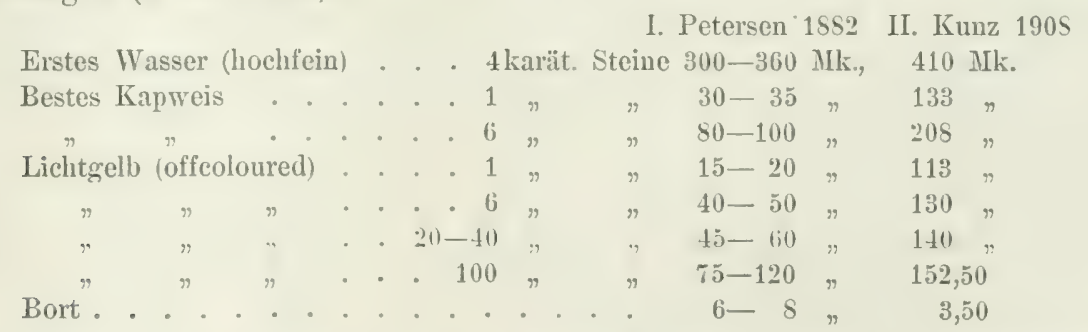

Diese Preise, von denen die in der ersten Kolumne infolge der damaligen ungïnstigen Geschäftslage ungewöhnlich niedrig sind, gelten für die Diamantenfelder, nicht aber direkt auch für Europa, wo oft ganz andere Verhältnisse berrschen als am Kap.

Für den 31. Juli 1s\$3 macht Boutan die folgenden Angaben über die in Kimberley per Karat bezahlten l'reise für Rohsteine der versehiedenen Sorten. Zum Vergleich und zur Teranschaulichung der seitdem eingetretenen Preissteigerung sind die entsprechenden Werte für 1901 beigefügt, die ich Herrn Dr. George Frederik Kunz in New - York verdanke und mit denen die mir von Dr. Arthur Dieseldorff in IIamburg mitgeteilten Zahlen sehr nahe übereinstimmen. 


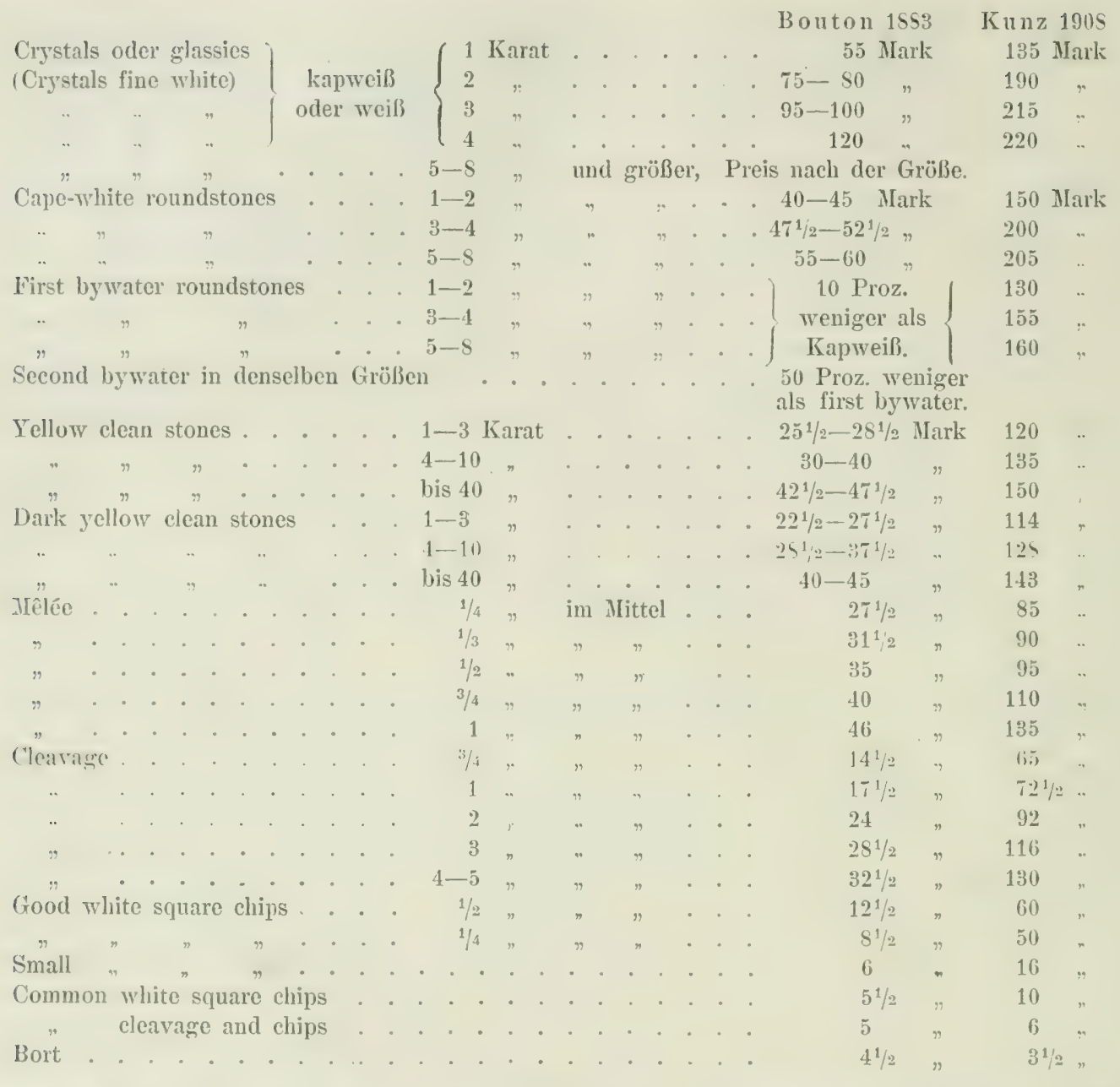

Auch E. Bo ut a n klagt ülere niedrige l'reise infolge der (xeschäftskrisis, die spätter noch zugenommen hat, so dab die Preise 1555 im allgemeinen noch um 20 Prozent gefallen waren. Von da an stiegen sie wieder. In den Jahren 1883 bis 1391 war der Wert eines Karats im Mittel, berechnet aus dem Gesamtexport und Gesamterlös:

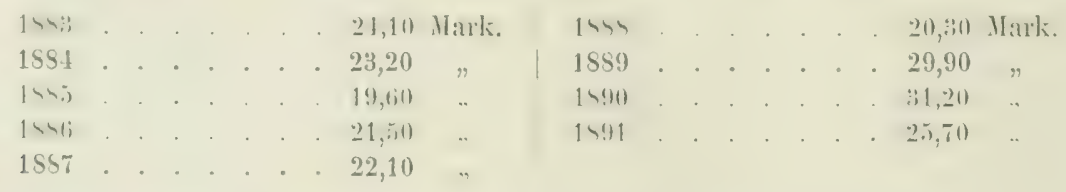

Von da ab betrugen diese Preise nach George F. Kunz:

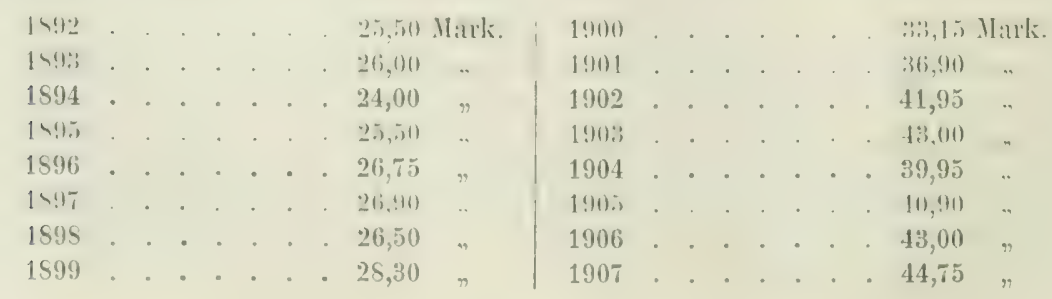


Ls ist daber zu bemerken, dal) die durchsehnittliche Qualität im Laufe dieser Jahre sich nicht wesentlich änderte, dali diese Zahlen also ziemlich annähornd den mittleren Marktpreis für die genamnte Periode darstellen. In den letzten 25 Jahren hat sich dieser Preis also, nachdem er anfänglich längrere Zeit ziemlich konstant gewesen war, ungrefähr verdoppelt.

Man begreift leicht, dali die kosthare und so leicht zu verbergende Ware zu zahlreichen Veruntreuungen verleitet, und aus diesen hat sich neben dem rechtmäljignen auch ein sehr umfangreicher illegitimer II andel entwickelt. Die Arbeiter, namentlich die Kaffern, wissen beim Graben, Waschen und Sortieren und in den floors trotz der unanfhörlichen scharfen Aufsicht Diamanten beiseite zu bringen. Sie verstehen die gestohlenen Steine trotz der beim Verlassen der Arbeitsräume vorgenommenen Leibesuntersuchung und der fast oder ganz fehlenden Kleidung durchzuschmugegeln und durch II hler in den Verkehr zu bringen. Der den rechtuäliggen Eigentümern durch Veruntreuungen zugefügrte Schaden wurde früher auf etra $30 \%$ des Gesamtertrages geschätzt.

Zwar hat man durch strenge Strafgesetze und scharfe Bestimmungen zur Rercelung des Diamantenhandels dem Unfug steuern wollen. Mehrjührige Zuchthausstrafe trifft Diamantendiebe und Itehler, die die gestohlenen Steine ankaufen. Schwarze dïrfen unter keinen Umstïnden einen Stein verkaufen und Weile mïssen eine schriftliche Genehmigungr zum Kaufen und Verkaufen haben, auch genaue Terzeichnisse führen usw. Aber der hohe Gewinn, den Diebe und besonders Itehler zu erwarten haben, wenn sie rom (iliick begiinstigt sind, macht, dalj weder der Dielstahl noch der illegitime Handel ganz rerhindert werden komnten, um so mehr als es nach den bestehenden Gesetzen sehr selten möglich war, einen Hehler seines Vergehens durch Zeugen usw. zu überführen.

Seit dem 1. März 155:3 hat man daher diese Gesetze dahin abgeändert, dalf nicht mehr wic früher der líchter den unrechtmäliggen Besitz der Diamanten, die in den IIänden irgendeines Mannes angetroffen werden, nachweisen muf, um ihn als Dieb oder Hehler zu verurteilen, sondern der Betreffende mul) seinen rechtmäligen Erwerh dartum. wenn ex der Terurteilung entgehen will. Auch kann seitdem jedermann olne Ausnahue einer körperlichen Cntersuchung unterworfen werden (searching system), was früher bei Wrifuen ganz unmöglich war.

Alle diese Bestimmungen gelten nicht nur für die Diamantfelder, sondern für das ganze englische Sïlafrika. So ist der illegitime Handel wohl sehr erheblich erschwert, aber ganz wird er sich doch kaum je verhindern lassen, denn die Kaffern wenden die hëchsteList an, um Steine beiscite zu bringen und zu verkaufen. Zwei Fülle aus dem Jahre 155 s mügen dies illustrieren. Ein Schwarzer wurde wegen des Terdachtes, unrechtmüfigerweise Diamanten zu besitzen, verfolgt. Als sich die Terfolger nahten, schob ur einen seiner Ochsen nieder. Kein Stein wurde bei ihm gefunden, als aber die Polizei abgezogen war, holte er aus dem toten Tiere die Diamanten wieder heraus, die er ilm in den Leib gejagt hatte. Bei einem anderen Einwerborenen, der in rätselhafter Weise gestorben war, stellte die Leichenschau als Todesursache bo Karat Diamanten fest, die er verschluckt hatte, um sie zu stehlen. Er hatte die l'ortion selhst für de lirifige Konstitution eines Kaffern etwas zu groß genommen.

In neuester Zeit ist nun aber eine Einrichtung getroffen worden, die greeignet ist, endlich den haulstiichlich durch die tinheimischen Arheiter betriebenen Diamantendiebstahl zu verhindern oder doch sehr bedeutend zu remindern. Es ist dies das soEnannte Compound-system. Die schwarze Arbeiterschaft der Kimberley. Gruben wird während der ganzen Daner ihres 3 Jonate währenden Arbeitskontraktes von jedem Verkehr mit der Aubenwelt abgeschlossen. sie leben in dicht umzälunten und sorsfältig" hewachten frehegen von mehreren Morgen Crübe, in denen sie alle ibre Bediurfnisse gre- 
liefert erhalten und kaufen können und wo für Wohlfahrtseinrichtungen aller Art bestens gesor ist ist. Sic kommen während ihres Engagements nur nit Beamten der Grubengesellschaft in Beriihrung und verlassen diese Gehege nur, um ihre Arbeit in den Cruben zu besorgen, und am Schlusse ihres Engagements nach genauer Untersuchung ihres Lürpers auch durch kräftig wirkende Laxiere. Trotz dieser Beschränkungen und der gïnzlichen Fernhaltung aller Spirituosen scheinen sich die Leute nicht iibel zu befinclen, da vicle nach Ablauf ihrer Zeit auf eine weitere Periode sich veruflichten. Es ist klar. dalj durch diese Einrichtung in der Tat die Möglichkeit der Veruntreuung sehr wesentlich eingeschränkt wird. Ganz beseitigt ist sie aber doch nicht; es kommen immer noch erhebliche Unterschleife vor.

\section{Borneo.}

Diamanten sind in Borneo im anstehenden Muttergestein noch nicht bekannt. Sie finden sich nur in einigen der zahlreichen Gold und Platin führenden diluvialen und alluvialen Seifen, und zwar sind es vielfach die reichsten Goldgebiete, die auch für den Diamant in Betracht kommen.

Die nachstehende Schilderung beruht in der Hauptsache auf den Mitteilungen, die I. D. If. Terbeek, der Direktor der Niederländisch-indischen greologischen Landesuntersuchung an E. Boutan gelangen lieb, sowie auf den Berichten von Th. Posewitz, der sich behufs geologischer und bergmännischer Forschungen jahrelang in den betreffenden Gegenden aufgehalten hat).

Die Diamantfelder von Borneo bilden zwei wohl unterschiedene (xruppen. Die eine liegt im Westen der Insel im Gebiete des Flusses Kapuas, der etwas unterhalb Pontianak in den Ozean mïndet, und zwar auf dessen nördlicher rechter Seite, sowie in Gebiet des Sarawak, der sich nach einem nördlichen Lauf ins Meer ergieft. Die andere ist im Südosten bei der Stadt Bandjarmassin in der Landschaft Tanab Laut bis nach Kusan, der Insel Laut gegenïler (Fig. 52). Alle Angaben über sonstige Torkommen sind unsicher und zweifelhaft.

Westliche Region. Die westliche Gruppe besteht aus drei getrennten Teilen am Südab)hang des (rrenzgebirges von West-Borneo gegren Sarawak: die zwei ersten in den Gebieten der Fluisse Iandak und Sikajam, die beide nach Süden gerichtet in den Kapuasstron münden und der dritte an diesen letzteren selbst nahe seiner Tereinigung mit dem Sikajam bei Sangau. Dazu kommt das Gebiet des Sarawak-Flusses, der am Nordabhang jenes (irenzgebirges nahe dem Sikajam sich gegen Norden zieht und bei Kuching in den Meerbusen von Sarawak (oder von Kuching) mündet.

Das berïhnteste Vorkommen der Insel und schon seit deren Besiedelumg durch die Malaien bekannt ist das von Landak. Die ersten holländischen Schiffer, die jene Ge. stade besuchten, sprechen schon davon. Je weiter man an dem Landak-Flusse talaufwärts kommt, destr) srö̈lbere Diamanten findet man. Doch sind die diamantenführenden Flußkiese lier verhältnismäßig arm an Gold, das an anderen Stellen sich reichlicher findet. Im Iande Sangau liexen einge wenige Gruben bei der gleichmamigen Stadt im KapuasTale in der Nïhe der Ifindung des Sikajam. Viel zahlreicher und wiehtiger sind aber die Cräbereien weiter oben in Tale des letzteren, sowie daran anschliefend im Gebiete des Merau und seiner Nohemarme an der Grenze ewegen Sarawak. In Nord-Borneo liegrt das J)iamantengebiet, das niemals einen beträchtlichen Ertrag seliefert hat, nur westlich ron dem Sarawak-Flusse, besonders wird hier der Nebenflub Sentha mit seinen zitronengelben Jiamanten genannt. Zwrifolhaft und jedenfalls schlecht bekannt sind Vorkommen im Gebiet des Kapuas oberhalb, östlich ron Sangau; aber auch die Ablayerungen bei dieser

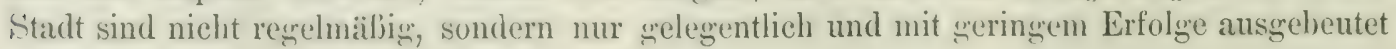
worden. 
Die Diamanten finden sich in Schichten, die dem Diluvium ancrehören, in Schuttmassen, die sich an Fube der berge hinziehen, ebenso aber auch im dlluvium in den Letten der Bäiche und Fliisse, welche die diamantenführenden Gergenden durchströmen.

Die I duvialbildungen lestrhen aus wohlgeschichteten Lagen ron Kies; ron Sand

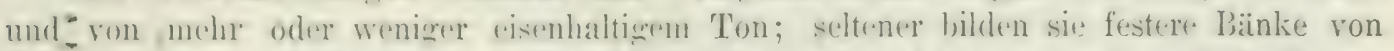
Konglomeraten und sandsteinen. Ihr Miichtigkeit schwankt zwischen 2 und 12 Metern. Die Diamanten sind auf die untersten Kieslagen beschränkt.

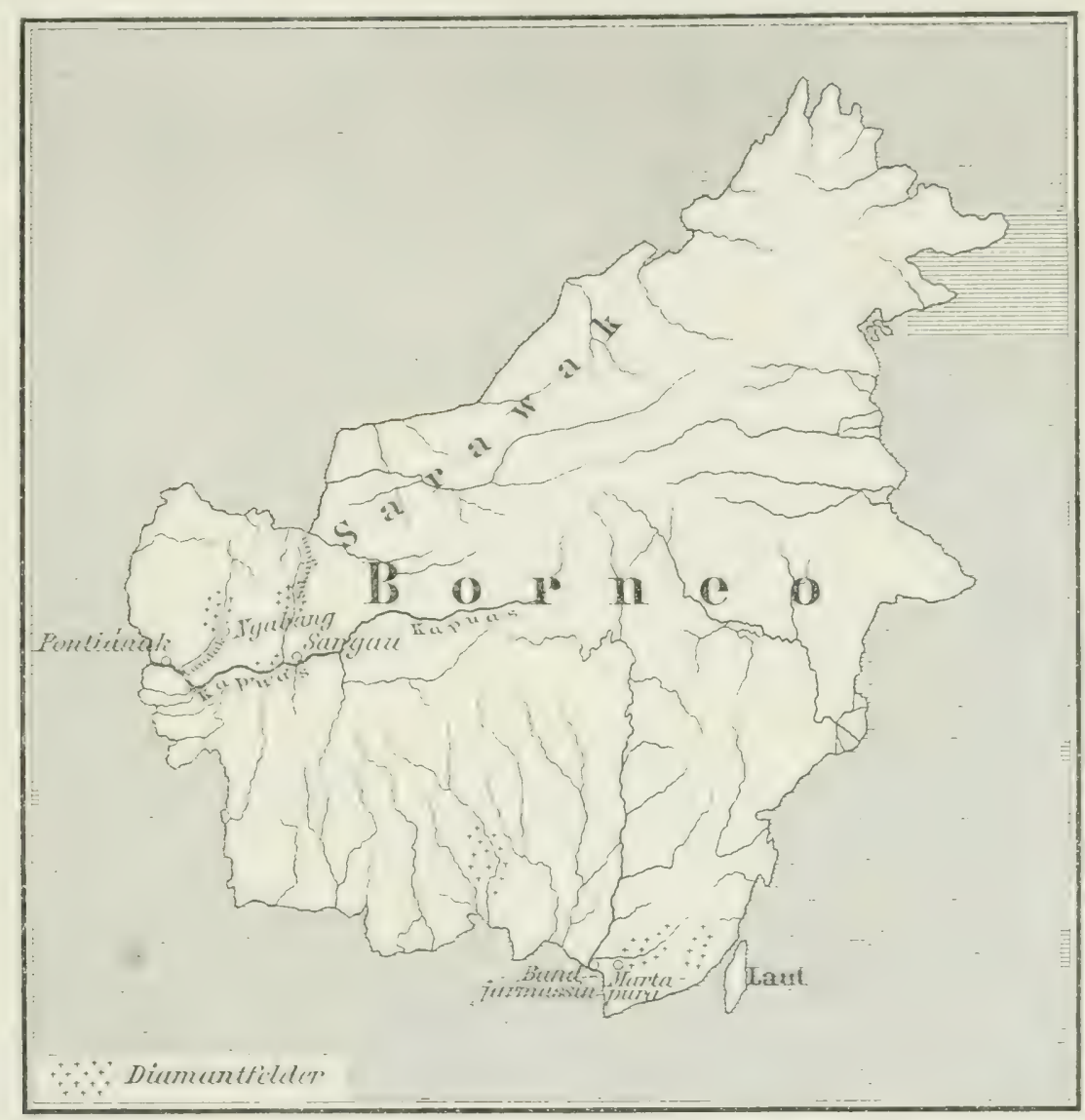

Fig. 52. Diamantfelder der Insel Borneo. Malistab 1:15000000.

Diese für sich nicht ocker duch nicht deutlich geschichteten alten Kiese bestehen aus stïker oder schwächer abgerollten (resteinsbrocken; es sind Flubbildungen, die in einzelnen kleinen Flecken an Fulje der Berge oder in den Tälern zerstreut sind, die aber immer ïber dem heutigen Hochwasserspiegrel liegen. Sie führen den Diamant durch ihre ganze Masse hindurch. I) erwähnten Gesteinssticke sind ron sehr verschiedener Tatur. Weiler und wellser Quarz, auch Fiosenyuarz herrschen ror, sodann sind es sehr harte und feste, graue und schwarze Quarzite, Quarzsehiefer und Tonschiefer, Quarz, Sandsteine und endlich, aber späirlich, Brocken ron Eruptirgesteinen, die jedoch meist so stark zersetzt sind, daf es schwierig ist, ihre ursprüngliche Natur zu erkennen. Von Mineralien werden genannt Hornblende, Blättehen von weifem Glimmer, Magneteisenkürner, vereinzelte Zinnoberstückchen, sowie etwas Gold und Platin. Blauer und violetter Korund gilt hier wie in der südüstlichen Region den Diamantgräibern als ein sicheres Zeichen für die Anwesenheit des Diamants. 
Die Diamanten in den Betten der Bäche und Flïsse stammen aus diesen Ablagerungen, aus denen sie herausgeschwemmt worden sind.

Die Gesteine, die man in der Gegend anstehend findet, sind die folgenden. Von sedimentärer Entstehung: Tonschiefer und Quarzitschiefer mit Quarziten; zum Devon gehörig; sodann Konglomerate und tonige Sandsteine, wahrscheinlich von sehr viel geringerem Alter, wohl dem ältesten Tertiär, dem Eocïn zuzurechnen. Von Eruptivgesteinen sind es Granite, Gabbros, Diabase, Melaphyre und Andesite.

C. van Schelle, ein Bergingenieur von der Insel Borneo, meint, daß die Diamanten in den Seifen aus jenen Eocänschichten stammen. Man findet die Edelsteine zwar kaum in dem noch an Ort und Stelle liegenden Verwitterungsschutt dieser Konglomerate und Sandsteine, in sogenannten Bergseifen, wohl aher in den durch fließendes Wasser zusammengeschwemmten Talseifen an den Abhängen und auf dem Grunde der Täler, und zwar nur da, wo das Eocän die Erdoberfläche bildet, während man noch nie auch nur einen einzigen Diamanten in solchen Schuttmassen angetroffen hat, die ihr Material vorzugsweise den devonischen Schichten entnommen haben oder auf diesen liegen, trotzdem sie wegen ihres Goldgehalts sehr vielfach und sorgfältig untersucht werden. Natïrlich bilden auch die Eocïnschichten nicht das ursprüngliche Muttergestein; dieses und die Bildungsweise des Diamants sind hier noch ebenso dunkel, wie vielfach anderwärts. Allerdings soll neuestens ein Diamant im Landak-Gebiet nahe der Mündung des Serak-Flusses im Serpentin eingeschlossen gefunden worden sein. Außerdem wird über das Vorkommen von ächtem Blaugrund wie in Südafrika im Gebiet des Labuk-Flusses in Nord-Borneo berichtet. Nähere Nachrichten hierüilser sind aber abzuwarten. Im Falle der Bestätigung würde aber der Ursprung des Diamants hier ein ganz anderer sein als im Südosten, in Tanah Laut, wo er aus granitischen Gesteinen, wahrscheinlich aus Pegmatiten, zu stammen scheint.

Die Diamanten dieser Gegend sind meist stark al)gerollt oder bilden unregelmäßige Bruchstücke, doch kommen auch regelmäßige Formen: Oktaeder, Dodekaeder und ähnliche, sehr selten Würfel, häufig dagegen Zwillinge, meist stark abgeplattet vor. Die Farbe weehselt stark, die Gröbe ist gering. Unter 100 Steinen wiegen 90 bis 95 weniger als 1 Karat, solche von 1 bis 5 Karat sind schon ungewöhnlich, schwerere sind grobe Seltenheiten. Immerhin ist eine gewisse Anzahl von solchen bekannt geworden. Der vielgenannte Stein des Sultans von Matan, der „Danau Radscha“, der größte aus Westbornco rom Unfang eines Taubeneis und von 367 Karat Gewicht ist allerdings vielleicht kein Diamant, sondern ein Bergkristall, doch soll sich im Besitz desselben Füirsten ciu echter Stein, der ,Sexgima“, von 70 Karat befinden. Am Ende der siebziger Jahre soll in Landak, den von dem gleichnamigen Fluß durchströnten Fürstentum, ein Stein von so Karat gefunden, gestohlen und in Sarawak um 30000 Gulden verkauft worden sein. In den fünfzigner Jaliren wurde in Landak ein 70 karätiger Stein vom reinsten Wrasser gefunden, der sich jetzt unter den Namen ,star of Serawak" in London befinclen soll. Der

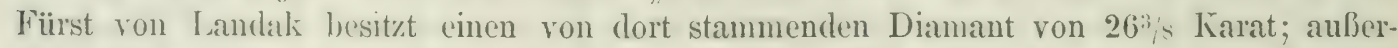
dem wird noch von Steinen von $67,54,12,23 \%, 22 \% / 1,15 \% / 4$ Karat berichtet, die ihre Heimat in Westborneo haben.

Im Jahre 1897 sollen in Westhorneo 1190, im Jahre 18991905 Karat Diamanten gefunden worden sein.

Sïdöstliche Region. Ias wichtigste Diamantrorkommen, das in der südöstlichen Ecke von Borneo in der Iandschaft 'I'anah Laut, ist am Ende des 17. Jahrhunderts entrleckt worden. In nenerer Zeit wurle es von dem französischen Bereingenieur Gaseuel genauer erforseht. Ls ist eine flachhügelige Gegend, von sehr zahlreichen, engen, tiefen, kurzen, stark ge- 
kriimmten Bächen durchzogen, dir dem sumpfigen Tieflande zuströmen. Dirser letztere Teil des I iamantenbegirks ist in der Regenzeit wanz überschwemmt und nur in der trockenen Jahreszeit zugünglich. Die diamantführendr: Region liegrt in den Tälern der beiden (zuellflüsse des Martapura, Riam Kiwa und Riam Kanan und in diesem selbst, an dem die gleichnamige Hauptstadt, der Hauptstapelplatz für den dortigen Diamanthandel, erbaut ist, sowie in den in sie einmiundenden Biichen. Shr wichtig ist ferner das Gebiet des Bandju Irang, das sich nördlich und sïdlich von diesem Flub über 20000 Ilektar ausdehnt, mit dem Ilauptort Tjampaka, dem Mittelpunkt der reichsten Fundstellen. Diamanten sind auch aus den Zuflïssen des bei Bandjarmassin ins Meer mündenden Barito, dem linken Mewien und dem rechten Djului, bekannt. Unsichere Nachrichten weisen auf weiter westlich gelegene Gegenden in Sïdhorneo. Von einiger Bedeutung seheint dagegen wieder das Vorkommen an der Ostkiiste in der Landschaft Kusan zu sein.

Die den Diamant enthaltende Schicht erfüllt nicht blob die Niederung und die Talsriunde, sondern sie zieht sich auch an den Talah)ïngen in die Höhe, stellenweise bis auf die Spitze der Hügel, deren Gipfel sie da und dort bildet.

Das Vorkommen ist iiberall im wesentlichen dasselle. Die Lagerstütte des Edelsteins besteht zu oberst aus rüthlichgelbem, mergeligem Ton, darunter sind weilje oder graue, rotgestreifte Tone, die nach unten in teilweise ganz lockere, teilweise noch etwas tonige Sande iibergehen. Diese werden nach der Tiefe immer grobkörniger und bilden so allmählich Kiese und Konglomerate, deren unterste Lage mit den grö̈bten Rollstiicken die Diamanten enthält. Diese Lage hat danach gegen oben keine hestimmte Grenze, sie ist auch nicht durch irgendwelche Merkmale sicher zu erkennen, sondern nur durch das Auffinden von Diamant und dessen charakteristischen Begleitern. Unter diesen spielen die gröbte Rolle derbe, triibe Korunde in der Form linsen- bis faustgruber Bruchstiicke von versehiedener, teilweise von blaner Farbe, die sich stets mit dem Diamant, aber auch nicht selten ohne ihn, finden. Die Diamantgräiber sehen zuerst nach ihnen, und wo sie vorkommen, wird genauer nach Diamanten gesucht.

Die Tieft der Diamantschicht unter der Oberfläche ist verschieden. Talahwärts betrïgt der Abraum 7 -S Meter und an der Grenze des sumpfigen Tieflandes bis 25 Meter, talaufwärts nähert sich die Schicht immer mehr der Erdoberflïche bis auf wenige Decimeter, doch sind vielfache Unregelmäbigkeiten zu beobachten. Auch beim Ansteigen an den Talabhängen verhält sie sich in dieser Weise und tritt bei einer gewissen Hühe zutage.

Die Mächtigkeit beträgt in der Niederung etwa I Meter, sie wechselt aber rasch und beträichtlich gegen die oberen Talenden hin. An den Talgehängen nimmt sie nach oben zı immer mehr ab. Gleichzeitig werden die dianıntfülurenden Kiese stets feinkürniger, und die Diamanten werden kleiner und seltener bis zum vollständigen Verschwinden.

I och hat an einzelnen Stellen, wo die Diamantschicht die Gipfel der Huigel bildet, durch die Regengüsse ein natïrlicher Waschprozefs stattgefunden, durch den die Zahl der Tiamanten in dem Sande rerhältnismäbig gröfer geworden ist. Diese relativ reicheren Sandmassen sind allerdings nur von geringer Ausdehnung und auch schon erschöpft, da sie durch ihre Lage ïher dem Grundwasser jederzeit leicht ausgebeutet werden konnten. In der Niederung hat das Lager eine beträichtliche und regelmäßige Auschehnung in die Breite. Diese wird in den engen Tälern aufwärts immer geringer, und vielfach wird der Zusammenhang unterbrochen: die Schickt hört da und dort auf, um anderwärts ron neuem zu erscheinen. Dem größten Wechsel ist auch die Diamantenführung unterworfen, und zwar sowohl nach der Zahl, als auch nach der Größe und Qualität der gefundenen Steine.

Die diamantfülırende Schicht besteht in der Hauptsache aus weiben, vielfach äuBerlich gelb und rot gefärbten Quarzgeschieben von der Größe einer Kinderfaust bis zu der 
eines Kopfes. Daneben findet man Gerölle von porphyrischen und von stark verwitterten granitischen Gesteinen, von wlimmerführendem Quarzit, von versteinerungsführendem Kalk und von aus diesem stammendem Hornstein. Brocken basischer Gesteine fehlen vollständig. Die ganze Mrasse ist von weißem oder gelbem, fettem 'Ton durchsetzt, der durch Verwitterung des Feldspaths der genannten Gesteine entstanden sein soll.

Ton den die Diamanten begleitenden Nineralien ist schon der Korund erwähnt als Merkzeichen für das Auftreten jener. Noch bezeichnender ist aber nach der Ansicht von Gaseuel der Rutil, der sich in verschiedenen dbarten zusammen mit etwas Brookit häufig findet. Außerdem sind zu erwähnen Gold und Platin als ständige Gefälırten des Edelsteins. Der schwarze Sand, der als Waschrückstand reichlich hinterbleibt, lesteht aus Magnet-, Titan- und Chromeisen, daneben findet man mikroskopische Kürnchen und Kriställchen ron Korund, Topas, Spinell, Zirkon und auch von Diamant.

Die Diamanten selbst liegen meist einzeln in dem Konglomerat, doch sind sie auch zuweilen mit anderen Bestandteilen des letzteren in Brauneisenstein eingebacken. Die meisten sind kamm merklich durch Abrollung angegriffen; sie bilden ganz scharf begrenzte Kristalle, häufig in der Form des Oktaeders, doch kommen anch Dodekaeder und andere ähnliche Formen sowie flache Zwillinge häufig vor, wälırend Würfel selten sind. Die Größe ist wie überall in Borneo im ganzen gering, doch ist 1865 be Tjampaka ein Stein von 25 Karat gefunden worden, der einen Brillant von 181/2 Karat im Wert von 15000 Gulden ergab. Ias Jahr 1850 lieferte den gröliten hier im 19. Jahrhundert volgekommenen Diamant von 77 Karat. Gerüchtweise wird noch ïber solche von 106 und it Karat aus früheren Zeiten berichtet. Früher sollen überhaupt grö̈ere Steine hïufiger gewesen sein als gegenwärtig. Darnach wären bei Martapura, wie übrigens auch in Landak, in den dreißiger Jahren des 19. Jahrhunderts 4-10karïtige Diamanten fast jeden Tag gefunden worden, während in den siebziger und achtziger Jahren $1-5$ karätige schon recht selten gewesen sind.

Unterlagert wird die diamantenführende Schicht in den Talengen und an den Seiten der II ïgel von rotem Ton, in den tiefer gelegenen und weiteren Tïlern von sehr festem, dunkelblaugrauem Lettenschiefer, dem mehrfach Sandstein und, stellenweise bauwürdige, Kohlenflötze zwischengelagert sind. Diese Schichten grehören wleichfalls dem Eocïn an, das auch hier weitverbreitet ist und die Hügel aufbaut. Da wo die Diamantschicht dem Eocïnschichten aufliegt, sind die roten Tone sandig und die dunklen Lettenschiefer sind zu einem schwarzen, bäulich oder grïnlich gestreiften Tonschlamm zersetzt. In den oberen Teilen der 'Tüler ist da und dort das diamantenführende Konglomerat noch unterlagert und von den Eocïnschichten getrennt durch ein anderes älteres Konglomerat, dessen Geschiebe aus z. 'I. stark zersetzten Grünsteinen bestehen.

Diese Eocänschichten liegen nach den Beohachtungen von Tooze im Hintergrunde der Täiler der diamantenfülirenden Flïsse und Bäche auf kristallinischen Sehiefern, Cilimmer-, ('hlorit-, 'Talk- und IIornblendeschiefern, von denen dessen Ansicht zufolge einzelne Zonen die ursprïgliche Lagerstätte des Edelsteins darstellen sollen. Aber die Anwesenheit oder die Nähe dieser Gesteine bietet keinerlei Gewähr für das Vorkommen von I) iamanten, und in dem diamantenfïhrenden Konglomerat findet man keine Bruchstiicke. von solchen, sondern, wie schon erwälnt, ron porphyrischen und von granitischen Gesteinen. Ëin solehes kieselsäurereiches, saures Eruptivestein, wahrscheinlich ein l'egmatit, ist also nach der Meinung von (xascuel wohl eher als das Muttergestein der Diamanten zu betrachten, im Geģensatz zu anderen Gegenden, besonders zu Südafrika, wo der 1)iamant aus lieselsüurcarmen, basischen Gesteinen dieser Art stammt. Lezteres ist, wie wir eben gesehen haben, vielleicht in Westborneo, in Landak usw. der Fall, so daf also dann in dieser Hinsicht zwischen den beiden Diamantbezirken der Insel Borneo ein 
interessanter (iemensat\% bestïncle. I)as Vorkommen in Südosthomeo wäre demnareh analog mit dem von Wajra Karrur bei Bellary in Indien, von Lappland ete. Allordings kennt man solche sauren granitischen (besteine noch nicht anstehend in juner Georend, aber diese ist eben zenlosisch überhaupt noch kaum untersucht und sehr schwer zugänglich. Jedenfalls muli wohl der Gebiresng, der das diamantfiilırende Fluberebiet des Martapura nach (Isten beerenzt, das Mutteresestein des Edelsteins enthalten, denn nicht nur die Täler de's Fluberehiets des Martapura usw. in Tanah Laut am Westabhang dieses Gelirges enthalten Diamanten, sondern auch diegenigen, die sich von dissen Ostabhang aus in das Meer ergieben, in der Landschaft Kusan bis zum Flubgebiet des Kusan, der gexenüber der Insel Laut mündet, und noch etwas weiter nördlieh his zum liankallan, der sich in die Klumpang-Bai ergieft. Die Cruben von Kusan, die seit den zwanziger Jahren des 19. Jahrhunderts bekannt sind, sollen nach manchen Nachrichten die reichsten in ganz Borneo sein, doch sind unsere Kenntnisse davon noch sehr unsicher.

Von der Grölje und ron der Kristallform der Diamanten in Borneor ist schon oben die Rede sewesen. Die (Mktaederform, die äberall die gewöhnlichste ist, findet man nicht selten sehr regehmibig ausgebildet. Diamanten dieser Art nennt iler Malaie ..vollkommene Steine", da sie in seinem Sinn fast gar keiner Bearbeitung durch Schleifen bediurfen. Erwähnt sei noch, dafs anch unreschmäljige Verwachsungen mehrerer Kristalle vorkommen, sowie sog. Bortkugeln ron der enwöhnlichen Beschaffenheit / Taf. I Fig. :3. Diese werlen ron den Eingeborenen unter den Tamen .Diannantseele" vielfach als Talisman benutzt.

C̈her die Qu a lität herrscht vielfach Lnsicherheit, da, wie man sagt, sehr viele Diamantrn rom Kap eingeführt und mit als einheimische verkauft werden. Lnter diesen letzteren tinden sich viele schöne klare und glïnzende neben zahlreichen seringsen, fehlerhaften und schlecht gefärbten, und zwar sollen Steine ron dieser Art rerhältnismälbig häutiger sein als in Brasilien, das sonst wegen der Kleinheit der meisten Steine an Borneo erimnert und auch wegen des Torkommens ron Karhonat, das in kleinen Körnern auf dex Insel zuweilen die anderen Diamanten begleitet. Tielfach gelten die guten Steine von Borneo für besonderss klar und glänzend, und das reschätzteste Blauweiß ist nicht ganz selten. Diamanten von dieser Beschaffenheit aus Borneo werden zuweilen für die schünsten der ganzen Erde erklärt.

Die meisten Diamanten sind farblos oder gelblich; daneben findet sich auch auseresprochenes gell) bis braun, ferner rot und bläulich sowie tiefes bouteillengrim ins schwarz. Fot und blau ist besonders selten und teruer; die schwarzen Kristalle, nicht zu verwechseln mit dem gleichfalls dunkeln Karbonat, sind sehr beliebt; sie geben kostbaren Tranerschmuck und zeichnen sich durch besonderen Glanz aus. Eigentümlich sind gewisse Strine, die in einer klaren und farblosen wohllkristallisierten Hülle einen trüben dunkeln Kern von derselben Kristallform einschliefen. Fieriilhmt wird namentlich auch die grofe Härte, worin die Liamanten ron Borneo denen von Australien gleichen. Die Steine sind daher schwer zu schleifen, erlangen aber dafür auch den besonders schönen und kräftigen Glanz, der an ihnen vielfach hervorgehohen wird. Manche Exemplare sollen sogar mit dem cewöhnlichen Diamantpulver sich gar nicht schleifen lassen. Für die lärtsten gelten die schwarzen, die daher, wie die anderen derartigen, nur mit ihrem eigenen Pulver bearbeitet werden können.

Die Produktion hatte ilure Bliitezeit unter der niederländisch-indischen Kompagnie. Damals wurden -ehr viele Steine nach Batavia ausgeführt, wo infolgedessen ein großer Diamantenluxus herrschte. Toch im 1S. Jahrhundert war der Ertrag der Gruben selı beträchtlich, nahm aber immer mehr ab und ist jetzt auf ein Minimum heruntergesunken. 
Die Gewinnung der Diamanten wird von den Malaien, und mit besonderem Gesehick namentlich auch ron Chinesen betrieben. In den Talniederungen arbeiten hauptsächlich die ersteren, und zwar auf sehr primitive Weise sehr ähnlich wie bei dem Aufsuchen der Rubine in Birma. Kleine Schächte, wenn nötig notdürftig ausgezimmert, werden in großer Zahl und in geringer Entfernung voneinander bis auf die Diamantschicht niedergebracht und diese dann von einem Schacht bis zu den benachbarten ausgegraben. Die Bewïltimung des zufließenden Wassers ist dabei meist sehr schwierig und oft unmöglich, so daß die Arbeiten auf die trockene Jahreszeit beschränkt werden müssen. Wenn das Material um einen Sehacht herum erschöpft ist, wird er verlassen und es werden immer neue gegraben. Solche alte Schächte finden sich in manchen Gegenden dicht gedrängt zu Tausenden und durchlöchern den Boden bienenwabenartig.

Der aus den Schächten geförderte Kies wird dann nach Entfernung der größeren Geröllstücke mittels Sieben in Körben gewaschen und aus dem hinterbliebenen Sand, der, wie wir oben gesehen haben, nur noch die spezifisch schwereren Mineralien enthält, werden die Diamanten mit der Hand ausgelesen.

Die Ablagerungen über dem Hochwasserspiegel der Täler werden vorzugsweise von Chinesen und zwar in offenen Gruben ausgebeutet. Diese können das ganze Jahr hindurch betrieben werden, hier ist aber häufig für die Wäscherei nicht das nötige Wasser vorhanden.

Versuche, einen Betrieb in europäischer Manier mit Maschinen usw. einzuführen wurden von einer niederländisch-französischen Gesellschaft gemacht, die 1852 in einem Landstrich von mehr als 2000 Hektar in Tanah Laut zwischen Tjampaka und Bandju-Irang eine Konzession auf 25 Jahre zur Diamantgewinnung erhalten hatte. Aber schon 1883 wurden die Arbeiten wieder eingestellt. Doch haben sich später andere Gesellschaften zum gleichen Zwecke gebildet. 1901 soll die „Borneo mining company" mit der De Beers-Gesellschaft in Kimberley übereingekommen sein, ihre Diamantgruben gegen eine jührliche Abstandssumme nicht zu bearbeiten, sie soll aber bald darauf den Vertrag wieder gekündigt haben.

Wir haben geselien, daß die Produktion in früheren Zeiten reichlicher gewesen ist als später. Die einheimischen Malaienfürsten haben davon Nutzen gezogen, indem sie den Diamantgräbern schwere Lasten auferlegten. Sie forderten, daß alle größeren Steine, in den meisten Landesteilen solche von 5 Karat und mehr, ihnen zu einem von ihnen festzusetzenden Preise überlassen würden und maßten sich auch für die kleinern ein Vorkaufsrecht zu niedrigen Preisen an. Die Folge war, daß die Funde namentlich größerer Steine nach Nöglichkeit verheimlicht und letztere unter der Hand an besser zahlende Käufer veraiufert wurden, um so mehr als auch jene niedrigen Taxpreise häufig nicht oder nur teilweise erlegt wurden. 1863 ühernahm die holländische Regierung die Verwaltung und machte verschiedene Versuche, wie sie das ïbrigens auch schon früher, 1823 und 1831, allerdings ohne Erfolg metan hatte, die Diamantgewinnung zu heben. Zu diesem Zwecke erlaubte sie u. a. jedem Eingeborenen die Gräberei gegen eine monatliche $\Lambda$ bgabe von 1 Gulden, die dann 1875 auf 3 Gulden erhöht wurde. Diese letztere Maßregel erwies sich als äußerst verhän nisvoll. Sie fiel zusammen mit dem Beginn der Einfuhr von billigen Kạ)diamanten, und diese beiden Ursachen zusammen hatten eine ganz gewaltige Abnalıme der Produktion zur Folge. Während früher jene Abgabe 44000 Gulden eingebracht hatte, war sie 1880) auf So() Gulden (xesunken. Von diesem Schlag hat sich die Produktion auch später trotz der Wiederherstellung des alten Satzes nicht wieder erholt, um so mehr als die Arbeiter leicht lohnendere Beschäftiwung in Reis- und Teebau, bei der Gewinnung von Waldprodukten, auch beim Goldwraben finden konnten. So liegen die meisten Gruben jetzt still. Wie erols der Rüekgang war, geht aus einigen sich allerdings teilweise wider- 
sprechenden Angaben ïher die Anzahl der Leute hervor, die sich in früheren 'Zeiten mit Diamantgraben beschïftigten. Danach waren in Südborneo in den dreibigrer Jahren des vorigen Jahrhunderts in einigen lundert (iruben 4-5000, in Landak $1>22$ in 10 Gruben 170, 1555 in 27 Gruben 57 Arbeiter beschäftigt. Andererseits liest man, daf) 1850 die Ablazerungen am Sikajam nur von etwa 10) Chinesen bearbeitet werden, während in den Gruben von Landak ungefähr 350 Arbeiter tätig gewesen sein sollen.

Nach der Ansicht der Sachlienner ist nicht viel Aussicht zur Besserunter der gregenwärtigen Verhältnisse vorhanden, namentlich auch, da die reicheren Seifen allnählich erschöpft und neue derartige nicht aufwefunden worden sind. So stehen jetzt nur noch ärmere Lager zur Verfïgung, in ilenen der Dianant doch wohl zu spärlich vorkommt, um auch unter günstigeren äuberen Bedingungen die Gewinnung genügend zu lohnen besonders angesichts des urdrückenden Wetthewerbs von Sïdafrika. Eine grïnstigere Wendung kömnte vielleicht stellenweise durch das Zusammenvorkonmen von fiold und Diamant eintreten, wenn sich diese beiden kostbaren Yaturprodukte gleichzeitig in denselben Gruben gewinnen ließen.

Zur Blïtezeit der Produktion unter der niederlïndisch-indischen Kompagnie gingen, wie erwähnt, die meisten Steine nach Batavia. Im Jahre 1738 sollen für S-12 Millionen holländische Gulden Diamanten ausgeführt worden sein. Suäter hat die Menge sehr erheblich ahgenommen. Genaueres ïber die Größe der Produktion zu ermitteln, ist nicht möglich, indessen sind ron der holländischen Regierung einige Zahlen bekannt gemacht worden, die den Betrag der Einfuhr nach Jara und ihren Wert für einige Jahre angeben:

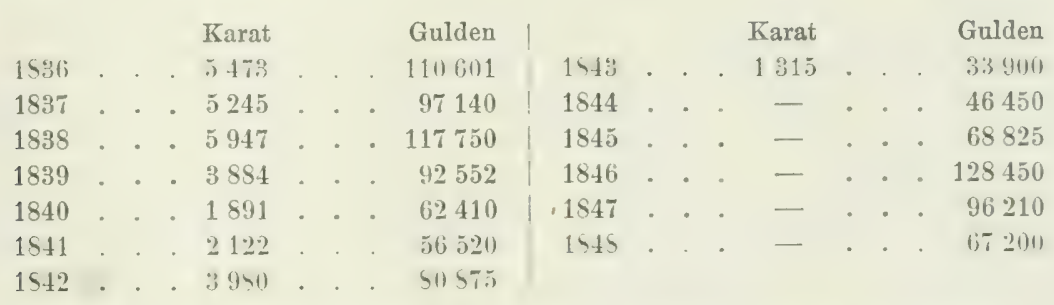

Diese den Zollregistern entnommenen Zahlen entsprechen wohl ann:̈hernd der Produktion und zeigen deren beträchtlichen Rïickgang. Ton 1StS ab hören die Angaben auf, da nun kein Zoll mehr erhoben wurde. Aus netterer Zeit hat man wieder einige Mitteilungen, die von Kaufleuten aus Ngabang, der Hauptstadt von Landak herriihren. Darnach wäre aus diesem Bezirk ausgeführt worden:

$1876 . .5062$ Karat
$1877 . .5271 \%$
$1878 . .5359 "$

Die heutige Jahresproduktion wird, wahrscheinlich zu hoch, auf 5000 Karat greschätzt.

Die meisten Steine wurden und werden schon im Lande von den Malaien in Tgabang und in Pontianak geschliffen, aber nicht in europäischen Formen, auch in Martapura sind Schleifereien. Die Eingeborenen kemnen die Bearbeitung des Edelsteins schon seit Jahrhunderten. Gegenwärtig findet fast gar keine Ausfuhr von Diamanten aus Borneo mehr statt, das Wenige, was gefunden wird, bleibt beinale ganz im Lande. Tas die Insel verlïßt, geht meist in die Länder des Orients, nach Indien usw., nach Europa kommt sehr wenig. 


\section{Anstralien.}

Auch $A$ ustralien hat seit 1851 in einigen seiner Goldfelder und spöter auch in manchen seiner Zinnseifen Diamanten geliefert, und zwar in nicht ganz geringer Anzahl. JBis 1905 sind im ganzen ungefähr 165000 Karat im Wert von 110000( Pfund Sterling wefunden worden. In besonderer Menge sind sie in Neu-Sïd-Wales, melr als Seltenheit in Victoria und Queensland, sowie in Süd- und Westaustralien vorgekommen. In NeuSïd-Wales sind 189516493 Karat in Wert von 6060) Pfund Sterling, 1S99 25874 Karat in Wert von 10350 Pfund Sterling gefunden worden. Die Steine sind alle klein; der errölite australische Diamant, aus Neu-Süd-Wales stammend, war bis vor kurzem ein (1ktaeder von $5^{5 / s}$ Karat; ein gleichfalls oktaëdrischer Kristall von Südaustralien wog $5^{5} / 16$ Karat; 1905 ist dann aber ein Stein von 29 Karat gefunden worden, und manche Bruchstiicke sollen auf firistalle ron 65 Karat schließen lassen. Das mittlere Gewicht der Diamanten von Neu-Süd-Wales, neben denen die seltenen von anderen Gegenden keine Rolle spielen, beträgt $1 / 5$ bis ${ }_{1 \%}$; Karat; es schwankt bei der iiberwiegenden Menge zwischen 1/4 und 1\%: Karat. Nach den Angaben der Schleifer sind die australischen Diamanten härter als die meisten aus anderen W'eltteilen und lassen sich daher nur schwer und mit großen Kosten schleifen, am besten mit ihrem eigenen Pulver, nicht mit dem von sonstigen Fundorten. Trotzdem sind sie vielfach stark abgerollt und zeigen dann an der Oberfläche einen eigentïmlichen starken Glanz, wie sie auch beim Schleifen einen besonders schönen Glanz annehmen. Immerhin ist diese große Härte der Verwendung als Schmuckstein nicht gïnstig, wohl aber der zu technischen Zwecken. Die Oktä̈derform ist die gewöhnliche, Zwillinge sind selten. Die Spaltbarkeit soll weniger vollkommen sein als sonst, das spezifische Gervicht etwas höher: $G_{0}=3,57$, gefunden an Steinen von Bingera. Die Qualität ist im Durchschnitt besser als am Kap und entspricht ungefülır der der brasilianischen Steine; als solche sollen sie auch zuweilen verkauft werden. Doch ist wegen ihrer Kkleinheit und ihrer schwierigen, daher kostspicligen Schleifbarkeit der I)urehschnittspreis pro Karat rerhältnismäßig gering und betrug um 1900 nur 7 bis s Tichilling gegen 10 Schilling in der Kimberleygrube am Kap. Nach ('urran sind etwa " 1 der gefundenen Diamanten (speziell im Bingera-Bezirk) mehr oder weniger vollkommene Schleifware, $1 / 4$ ist hierzu nicht geeignet. Die Verhältnisse sind so, dalj eine besonders hohe Entwicklung der Diamantenproduktion in Australien nicht zu erwarten ist, doch ist sie immerhin von einer gewissen Bedeutun..

In Nen-Sïl-Wales kennt man hauptsïchlich zwei Gegenden, in denen Jiamanten vorokekommen sind (Fig. 53). Es ist einmal der Landstrich westlich und nordwestlich von Sydncy im Flufgechicte des Macquarie, namentlich des Cudgegong, eines Nebenflusses des letzteren, der seincrseits un den Darling fiillt, hesonders hei IIndgee; ferner bei Bathurst, und westlich bis in das Gebiet des Lachlan, sowie südlich bis zum Shoalhaven. Todann ist es die nordïstliche Ecke der Kolonie im Flußgebiet des Gwydir, der chenfalls in den Darling oder Barwon River geht, bei Inverell und Bingera, und östlich davon in Neu-England.

Wie ïberall in Australien liegen die Diamanten in Seifen mit Gold, oder im Norden auch z. T. mit Zinnstein. In anstehenden Gebirge hat man sie mit Sicherheit noch nicht gefunden, und man kann daher auch nur vermuten, in welchem Muttergestein und unter welehen Umständen sie entstanden sind. Es sind alte Flubtäler, in denen sich die diamantführenden Kiese und Sande als Ablagerungen aus diesen früheren Wasserläufen finden. Sie liegen in gröfferer orler geringerer, zuweilen recht beträichtlicher Ï̈̈he über den heutigen Bäichen und Flïssen und in mehr oder weniger bedeutender Entfernung. von diesen und sie gehören der Tertiärformation, wahrscheinlich dem jüngsten Gliede, dem 


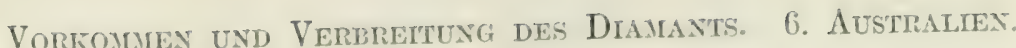

Pliocän, an. Grewöhnlich werden sie äberlarert ron Decken eines rlichten Basaltes, drex sich, ähnlich wie bei den kalifornischen foldseifen, als glïhrend flïssione Lava in dir. zur

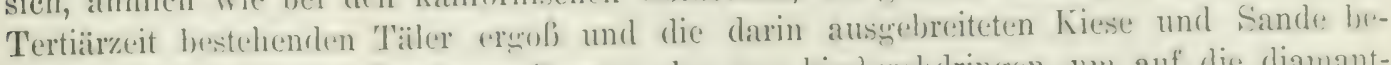
deckte. Durch diesen Basalt mulj man also nun hindurcholringen, um auf die dianant-

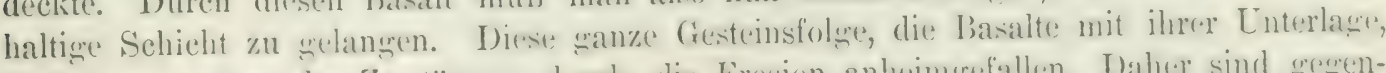

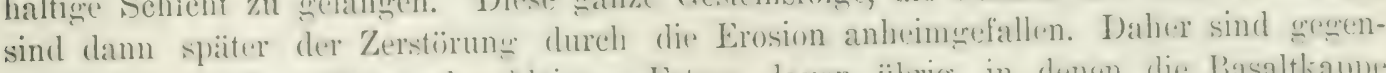

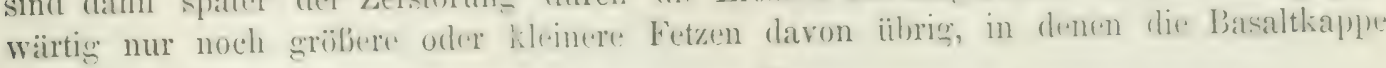

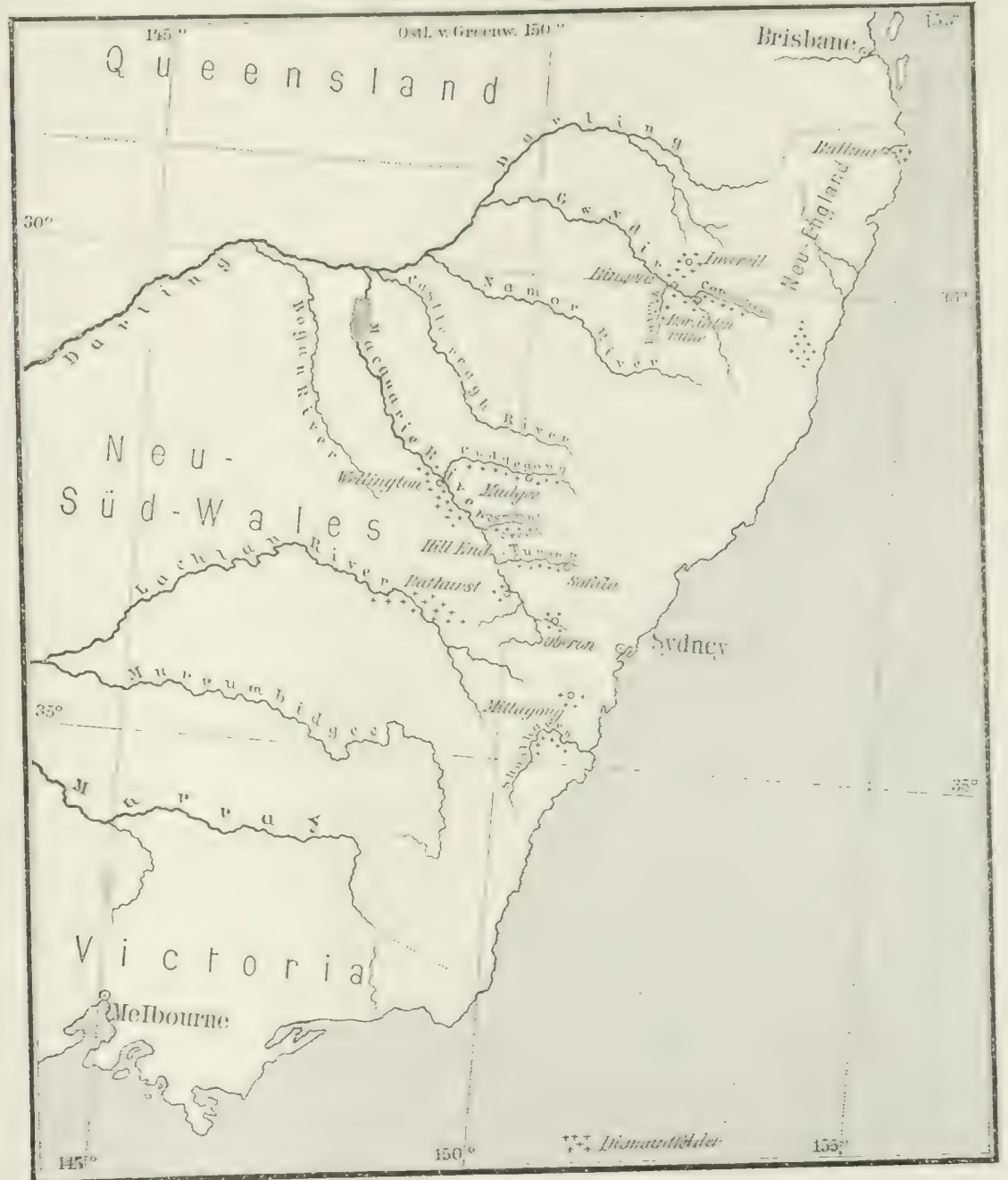

Fig. 53. Diamantfelder von Neu-Süd-Wales in Australien. Maßstab 1: 10000000.

die lockeren Massen dinunter for der Ternichtung bewahrt hat und die nun stellen- und strichweise ganz unabliängig von den heutigen Talzịgen unregelmälig auf den Höhen verteilt sind. Im Crunde der jetzigen Täler und auch stellenweise über dem Basalt liegen allerdings zuweilen gleichfalls diamantenfülrende Schuttmassen. Diese befinden sich aber nicht mehr an ihrem ursprïnglichen Ort es sind umgelagerte Seifen der eben erwähnten Art, die durch fliefendes Wasser, zuweilen sogar durch die Goldwäischerei aus einer ehemaligen hüheren Lage in die Tiefe geführt wurden. Sie bestehen aus demselhen Material wie jene, aber sie sind geologisch jünger und gehüren dem Pleistocän an. 
Die älteren sowohl wie diese jüngeren Seifen sind meist lose und locker, zuweilen sind sie jedoch auch durch ein griines, weißes oder graues kieseliges, oder aber durch ein braunes oder schwarzes, mangan- und eisenhaltiges Bindemittel zu einem festen Konglomerat ähnlich dem brasilianischen Cascalbo, verkittet. Die Mäichtigkeit des Diamantlagers wechselt stark und kann von wenigen bis $70 \mathrm{Fuß}$ betragen. Die Diamanten liegen darin sparsam und unregelmäßig zerstreut.

Sirdlicher Bezirk. Die ersten Diamanten der Kolonie, zugleich die ersten australischen ïberhaupt, wurden 1851 am Reedy Creek, einem Nebenflusse des Macquarie, 16 engl. Weilen von Bathurst und am Turon River, gefunden, 1852 traf man einige in derselben Gegend in Calabash Creek. 1859 entdeckte man sie im Macquarie bei Suttors Bar (Ḱristallform des Triakisoktaëders) und bei Burrendong; ein Hexakisoktaëder von 5 1/s Karat kam in gleichen Jahre im Pyramul Creek vor. Alle diese Punkte liegen in derselben Gegend, durchweg war aber das Vorkommen sparsam.

Den ersten gröferen Fund machte man 1867 bei Warburton oder Two-milesFlat am Cudgegong, 19 engl. Meilen nordwestlich von Mudgee. 1869 wurde hier die systematische Bearbeitung in einer Ausdehnung von etwa 200 Hektar begonnen, aber olme nennenswerten Nutzen. Die Orte, wo gearbeitet wurde, sind auler dem genannten: Rocky Ridge, Jordans Hill, Horse-Shoe Bend und Hassalt Hill. Der alte Flußschutt, in dem die Steine liegen, folgt unter einer Bedeckung säulenförmig abgesonderten Basalts dem Laufe des Cudgegong in einzelnen Fetzen, die mehr oder weniger weit vom heutigen Flusse entfernt und bis zu $40 \mathrm{Fuß}$ über dessen gegenwärtigem Wasserspiegel liegen. Seine Unterlage bilden senkrecht aufgerichtete Sedimentärschichten mit eingebetteten dichten Grünsteinen, wahrscheinlich dem Obersilur angehörig. Der Schutt selbst ist grober Sand und Lehm, gemengt mit Geschieben von Quarzit, Sandstein, Tonschiefer und Kieselschiefer, die von abgerollten Körnern und Kristallen von Quarz, Jaspis, Achat, verkieseltem Holz (dies in großer Menge) und anderen Kieselmineralien, ferner von Zinnstein als Holzzinn, Topas, gemeinem Korund (zum Teil lavendelblau, Demantspat, Sapphir, Rubin und einer eigentümlichen $\Lambda$ bart des Korunds, dem sogenannten Barklyit), Zirkon, Granat, Rubinspinell, endlich von Brookit, Magneteisen, Titaneisen, Turmalin, Magnesit, Knollen von Brauneisen und Körnchen von Osnium-Iridium und vor allen überall von Gold begleitet sind. Die Quarzgesehiebe sind häufig von Eisen- und Manganoxyden überkrustet. Die Menge und Größe der Diamanten ist für eine auf die Dauer lohnende Gewinnung zu unbedeutend, obwohl die Steine hier von besonders guter Qualität sind.

Allerdings wurden in den ersten fünf Monaten des Betriebes etwa 2500 Steine gefunden, sie waren jedoch alle klein. Der größte war jenes schon oben erwäibnte Oktä̈der von $5 \%$ Karat, welches einen schönen farblosen Brillant von $3 \% / 16$ Karat gab. Das Durchschnittsgewicht betrug aber nur 1/4 Karat. Die Farbe variiert erheblich; sie geht rom vollkommen Wasserhellen durch verschiedene Nuancen von gelb, hellgrïn und braun bis ins Schwarze. Einmal kam auch ein schön dunkelgrüner Oktaiederzwilling vor. Die gewöhnlichste Kristallform ist das Oktaëder in einfachen Kristallen und Zwillingen, sowie das Rhombendodekaëder, ferner das Triakis- und Hexakisoktäider; einmal ist auch ein Deltoiddodekaëder vorgekommen. Die Kristalle sind vielfach stark abgerollt und haben dann häufig die erwähnte grlatte und glänzende, vielfach aber auch eine rauhe und matte Oberfläche. Es scheint, daß sich in Australien grleichfalls kleine Bortkugeln von derselben Beschaffenbeit wie in Brasilien und Südafrika finden. Im Mittcl ist $G .=3,44$.

Noch an zahlreichen anderen (Orten jener Gegend hat man einzelne Diamanten gefunden. Am Turon River bei Bald IIill, IIill End, traf man einen Stein ron 5/, Karat; in den alten Goldgruben von Mittagong, etwa 75 miles südwestlich von Sydney, kam cine Anzahl Diamanten vor, zwar von geringer Größe, aber von ausgezeichneter Qualität, 
nicht selten strobgell, einige auch von sehr schöner, dunkler gelber Farbe. IIier will man auch auf eine von basaltgängen durchsetzte vulkanische Breceie, ganz ähnlich dem IBlaugrund im Suidafrika, gestolien sein. Noch ist nichts Genaueres darüber bekannt, doch sollen hier wie am Kap Brocken von Eklogit darin eingeschlossen sein. Nahe bei Bathurst fand sich ein erhsengrobes, beinahe kugoliges IIexakisoktaëder von schwarzem Diamant. Bei Monkey Ilill und Sally's Fleet, Grafschaft Wellington, traf man einen diamantführenden Sehotter unter Basalt ganz ebenso wie bei Mudgee. Auch Lralla, Oberon und Trunkey werden als Fundorte und zwar nicht nur vereinzelter Diananten grenannt. Am Mount Werong, 136 miles westlich von Sydney und 30 miles sïdlich von Oberon, wurde 1905 von foldgrähern der schon erwähnte gröbte australische I)iamant, ein 29 Karat schwerer, strohgelber, verzerrter Kristall ohne wesentliche Fehler, 12 Fulj tief im basalthedeckten alten Flußkies aufgefunden und auf 200 Pfund Sterling bewertet.

Alle diese Funde wurden im alten Flußkies gemacht. In jetzigen Wasserläufun werden Diamanten gefunden im Abercombie, Cudgegong, Mac(puarie, Brooks Creek, Sloalhaven, Lachlan und anderen. Diese Steine sind besonders stark abgerollt und auch zum Teil zerbrochen. Daher und weil der Kies dieser Fliisse dieselben Nineralien und (resteine führt wie die alten Flubablacerungen unter dem Basalt, ist kein Zweifel, daf man es hier in der Tat mit umgelagerten 'Teilen dieser letzteren zu tun hat.

Nördlicher Buzirk. Im Norden von Neu-Süd-Wales erstreckt sich die diamantführende Gegend nahe der Grenze gegen Queensland ungefäbr bis zum 151. Längeu- und bis zum 31. Breitegrad. Sie liegt im Flufmebiet des Gwydir, des Nebenflusses des Barwon oder obern Darling, und umfaßt hauptsïichlich die Grafschaften Hardinge und Wurchison. Von Bedeutung: sind vor allem die Distrikte von Bingera im Westen, wo der Diamant von Gold, und die von Inverell und Tingha mehr im Osten, wo er ron Zinnstein begleitet wird. Das IIauptgestein der Gegend ist Granit, der Schieferton der Kohlenformation durehbricht. Hierauf sind die basaltbedeckten Seifen abgelagert.

1872 kam die Dianantgewinumg in diesen Gegenden in Aufnahne. Wegen der Kleinheit der Steine und ihrer geringen Marktfähigkeit lief sie aber allmählich nach, gring" dann 1553 wieder in die Höhe und wurde bis jetzt fortgesetzt, allerdings nit mehrfachen, namentlich auch dureh Wassermangel bewirkten Unterbrechungen. Die Produktion ist gegenwärtig die wichtigste in Australien; nur hier ist sie üherhaupt nennenswert, und fast alles, was von Australien jetzt in den IIandel kommt, stammt aus diesen Bezirk.

Bei Bingera, 375 miles nördlich von Sydney, findet sich der Diamant nach Liversidge im Tale des Horton River, 7 bis $S$ englische Xeilen südlich von dieser Stadt, mit Gold ganz in derselben Weise wie bei Hudgee; als besonders ergiebig wird besonders die IIonte Christo Crube genannt. Die diamantführenden Ablagerungen, 2 bis 3 Fub mächtig, liegen in einzelnen, bei der Denudation übrigg gebliebenen Fetzen in jenem etwa 4 engl. IIeilen breiten, mach Norden geöffneten Tal, das ron den Ḧ̈geln der Drummondkette eingeschlossen wird. Fs sind sandige und tonige Massen, wahrscheinlich Ablagerungen des Horton aus frïheren Zeiten, die auf Schieferschichten der Kohlenformation und auf Granit liegen. In der Nïhe rorkonmende Basalte scheinen Ablagerungen wie die eben betrachteten zu überdecken. Die den Diamant begleitenden Vineralien sind wesentlich dieselben wie bei Murgee, es fehlt aber der Barklyit. Schwarzer Turmalin gilt für einen besonders charakteristischen (refïhrten des Diamants, aus dessen Vorkommen die Arbeiter auf reiche Funde schließen.

Die Diamanten bei Bingera sollen mit Serpentin in Terbindung stehen, und zwar sollen sie aus einem jaspisartigen Kontaktgestein zwischen diesen und den sandigen karbonischen Schiefern stammen. Darin wïrde eine gewisse Verwandschaft mit dem Vorkommien in Südafrika liegen. Am Rulby Hill, 12 miles sïdlich ron Bingera, wurde 1902 
sogar eine tufferfüllte Röhre gefunden, ganz ähnlich denen von Kimberley, die durch die Karhonschichten senkrecht in die Tiefe setzt. Die Ausfüllungsmasse dieser Röhre ist wie dort von Eruptirgängen, und zwar hier von Basalt durehsetzt. Sie besteht aus größeren und kleineren, meist eckigen Brocken von Melaphyr, aus Schieferstiicken und Fragmenten von sog. Kklogit, jenem Mineralaggregat, das auch am Kạ eine derartige Rolle spielt und ron dem auch Teile in dem Basalt eingebacken sind. Diese Gesteinstrümmer liexen in einer kürnigen Verwitterungsursse die in großer Mengre lose Körner von Mineralien enthält, die bei der Verwitterung besonders aus dem Eklowit losgelöst worden sind: sehr viel lyrop) (entsprechend dem Kaprubin!, grrïner Augit, etwas Magneteisen und Feldspat, sowie gelegentlich Quarz, Ceylanit, Zirkon und vielleicht Cyanit, daneben viel bei der Verwitterung neu gebildeter Kalkspat. Diese ganze Vineralmischung ist sehr ähnlich der in Niidafrika, aber Diamanten sind allerding noch nicht darin gefunden worden.

Die Diamanten der Gegend von Bingera sind etwa zur IIälfte farblos und strohgelb. Sie sind auch hier klein, der größte wog $2^{b ;}$; Karat. In einer Tonve der Schuttmasse wurden in Durchschnitt 20 Steine gefunden, und ein Vorrat von 1680) Stitck wog nur uncefälı 140 Karat. Etwas später wurden Diamanten auch bei Invere 11, ungeführ 40 miles, nordüstlich ron Bingera, in den Zinnseifen der Gegend entdeckt, und zwar in einer Ienge, die die systematische Gewinnung lohnend erscheinen läft. Außer von Zinnstein waren sie hegleitet von Bergkristall, Sapphir, Topas, Turmalin, Monazit usw.; Gold wird aber von bier nicht exw:ahnt. Mehrere Gesellschaften laben in verschiedenen Gruben vicle Tausende von Steinen in Durchschnittsgewicht von $1 / 4$ bis $1 / 3$ Karat gewonnen; der größte davon wog 3.4 Karat. In der Borah-Zinnseife, am Einflusse des Cope's Creek in den Gwydir, wurden in wenigen IIonaten 200 Steine gefunden, deren größter nahezu $11 / 2$ Karat wogn. In der Bengonover Zimnseife, wenige Meilen von der ebengenannten, fand sich ein Stein von fast 2 Karat. Diamantführend sind die Stannifer-, Ruby- und Britannia-Zinnseifen, überhaupt die meisten Zinnsande am Cope's Creek, Newstead-, Vegetable- und Middle Creek, alle in dieser Gegend. Auch im Gwydir sind einige Steine vorgekommen.

Im Tingah-Bezirk (Tingha ist südlich von Inverell unter $30^{\circ}$ südl. Breite) bei Copeton liegen zahlreiche Hügel mit einer Basalthaube, darunter die Sande und Kiese mit Zinnstein und Diamant, aber mit sehr wenig Gold. Einer dieser Hügel, etwa 10 miles siidlich von Inverell und 30 miles östlich von Bingera ist die berïhmte, $155+$ entcleckte und seitdem, wenn auch mit Unterbrechungen ausgebeutete Lokalität Bogrgy Camp am Big. River, Auburn Vale. 1S9S wurden hier etwa 150(00 Karat gewomnen, während gleichzeitign die Monte Christo-Grube bei Bingera ungefähr 1600 Karat lieferte. In dieser Gegrend wlaubt man eine gewisse Bezichung zwischen dem Vorkommen von Diamant und der (irenze zwischen dem Granit und den Schiefern der Kohlenformation nachweisen zu künnen. Nur westlich von dieser Grenze findet man in den zinnsteinfïhrenden Kiesen Diamanten, die also wohl ihren Ursprung in dieser Grenze, in dem Kontakt der beiden genannten Gestrinsarten hahen könnten, um so mehr als die weitaus reichste Grube der Gegend, die Daisey mine, «enau auf diesem liontakt steht. Östlich davon ist noch nie ein Diamant sefunden worden, obwohl alle sonst den Edelstein begleitenden Mineralien auch hier vorkommen.

Von Interesse ist, daf in dieser (regend, am Oakey Creek, 5 miles siidlich von Copeton, in dem früher sogenannten Basalt der Gä̈nge, die den Granit und die karbonischen Sehiefer unter den diamantführenden Kiesen und Sanden durchsetzen, im Jahre 190.4 zwei kleine Diamanten gefunden worden sind. Dieser gangförmige "Basalt" hat sich aber hei neuerer Untersuchung als IIornblendediabas erwiesen, den nun manche für das ursprïrgliche Muttergestein der dortimen Diamanten halten. Die Basaltbedeckung über den Seifen ist an der betreffenden Stelle enanz besonders dick und beträgt ungefähr so Fub. 
Zu erwihmen ist endlich noch das eigentiumliche Vorkommen von Iaallina in NowEngland, wo (:inzeln. I)iamanten am Meeresufer im Sande grefunden worden sind. Wahrscheinlich wurden sie aus rinere diamantführenden Ablagerung, die hier von den Ifeepeswellen bespïlt wird, ausgewaschen.

So bedentend verhältnismälige die Mrenere der in New-Siid-Wales gefundenen Diamanten ist, so gering ist ihre Anzahl on den anderen australischen Folonien. Man kann jerloch die Erwartung hegen, dalf die Funde sich noch vermehren werden. So hat man in Queensland ummittelhar nördlich ron Now-Süd-Wales bei Wallerawang und am Mary River Konglomerate entdeckt, die den diamantfïhrenden Ablagerungen ron II udgece und Binerera täuschend ähnlich sind, die aber allerdings bisher noch keine Steine oreliefert haben. Dagegen werden Diamantenfuncle aus Queensland vom Palmer liver und filbert River angegehen und nererer Zeit sind einige kleine Steine mit den Sapphiren von Anakie (s. u.) gefunden worden.

In Siidaustralien sind ungefähr 100 Steine in den Alluvialgoldwäschen von Echunga, 20 engl. Meilen sïdistlich von Adelaide, vorekommen, darunter das sehon eincrangs erwähnte Olitäeder von $5 \%$ is Karat. 15ti2 traf man einise Diamanten im Owensund im Arena-foldfelde in Victoria, eine gröbere Zahl, iiber (6) Kristalle, dagegen in Ieechworth-Distrikt in derselhen Kolonie, es war aber keiner dawn 1 Karat schwer. Auch aus der Gegend von Melbourne werlen Diamanten erwähnt, die in Begrleitung ron Rubin, Sapphir, Zirkon und Toplas vorkommen, sowie vom Mt. Kingston aus fonldwäschen.

Endlich hat auch IV estatustralien eine gewisse Anzahl Diamanten greliefert. Finicre kleine, fliichenreiche Kristalle fanden sich bei Freemantle in einem Sande mit Zirkon, Titaneisen, Burchistall, rotem, gelbem und weifem Topas und Apatit. Im Dezember 1595 wurde aus Perth herichtet, dab im Nordwesten der Kolonie bei Nullagina im Bereiche der Pillarra-(ioldfelder ein cröberer Fund gemacht worden sei, hei einer Cntersuchung habe man aber 1900 aus 230 Tonnen Cioldsand nur 25 kleine Steine grewinnen können.

Auch in Tasmanien ist im Jahre 1904 eine Anzahl Diamanten gefunden worden und zwar in dem foldfelde ron Corina, einem der ergiebigsten der Insel. Viele Versuche wurden gemacht, den Schatz zu heben, man hat aber seitdem nichts mehr daron gehört.

\section{\%. Norl-Amerika.}

Das Vorkommen von Diamanten in den Vereinigten Staaten von Nordamerika, seit 1550 bekannt, ist üherall ein recht spärliches und hat auf den Edelsteinhandel keinen Einfluß. Die Steine sind auch hier meist kiein bis zum Gewicht ron $23: 4$ Karat, und wenn schon recht gute Exmmlare nicht auseeschlossen sind, doch im Ganzen von unterenerdneter Qualität. Demnoch werden sie im Lande wexen ihrer wissenschaftlichen Bedeutung und als Erzetınis des vaterländischen Bodens geschätzt, eifrig aufgesucht und häufig weit über den wirklichen Wert hinaus bezahlt.

Das Forkommen ist rerschieden. Im lockeren Schuttgebirge, in Kies und Sand, finden sich die Diamanten in drei räumlich weit getrennten Gehieten, zum Teil mit Gold zusammen, und beim froldwaschen hat man sie auch rielfach mit angetroffen. Dies geschah zuerst im äufersten Westen der Union, in Talifornien, daran schlossen sich die Funde im Osten längs der Kette der südlichen Aplalachen, und endlich die im Norden, im Glazialgebiete der groben reen zwischen dem Oberen und dem Michigan-See. In allen diesen Gegenden liegen die Steine auf seliundïrer Lagerstätte fern ron dem Ort ihrer Entstehung. Ganz anders ist wahrscheinlich mit den neuerdings erst in Arkansas, also mehr in der Mitte des Iandes entrleckten Diamanten; hier scheinen sie noch in ihrem urspriinglichen Muttergestein zu liegen. 
George Frederik Kunz, der beste Kenner der amerikanischen Edelsteine, hat auch den Diamanten seiner Heimat ein eingehendes Studium gewidmet.

Im westlichen Gebiete sind es die Staaten Kalifornien, sowie Oregon, die am Westfulf der Sierra Nevada und der Cascade Range in den Flußgebieten des Sacramento und San Joaquin eine Anzahl Diamanten geliefert haben.

In Kalifornien hat man sie in den goldfïhrenden Schuttmassen angetroffen. Diese Seifen sind dort von zweierlei Art. In der Tertiärzeit und auch schon frïher haben mäichtige Ströme das Land durchflossen. Diese hatten ihren Ursprung in der Sierra Nevada und in der Cascade Range und erfüllten ihre Betten, die zum Teil auf größjere Erstreckung hin verfolgt worden sind, mit dem goldhaltigen Schutt der Gesteine dieser Gebirge. Später haben gewaltige vulkanische Eruptionen im nürdlichen Kalifornien und in Oregron die Erdoberfläche mit mächtigen Lavamassen überschüttet, welche jene alten Flußhetten vollends ausfüllten. In diese Lavamassen haben dann die jetzigen Fliisse ihre Betten eingeschnitten und in diese ebenfalls goldhaltige Schuttmassen aus den Bergen herabgeführt.

Aus solehen jüngeren Schuttmassen stammt in der Hauptsache der kolossâle Goldreichtum, den Kalifornien in den ersten Zeiten nach der Auffindung dieses Metalls im Jahre 1848 geliefert hat. Sie sind jetzt erschöpft; die heutige Goldgewinnung in jenem Lande hewegt sich in den zum Teil lavabedeckten Alluvionen der tertiären und vortertiären Gewïsser, und in diesen älteren Goldseifen findet man auch die Diamanten. Sie sind vielfach mit den die Schuttmassen bildenden Geschieben durch Eisenoxydhydrat zu einem festen Konglomerat verbunden, das der Tapanhoacanga der brasilianischen Diamantfelder sehr ähnlich ist. Da in der Nïhe dieses gold- und diamantenführenden Schwemmlandes vielfach Serpentine vorkommen, hat man, der Analogie mit Südafrika wegen, wohl vermutet, dalj die Diamanten aus solchen Serpentinen stammen, auch sollen bei Oroville am Feather River Diamanten im Serpentin vorkommen. Jedenfalls haben sie wie das Gold ihre Ileimat in den benachbarten Gebirgen, wenn auch senaueres noch nicht bekannt ist.

Der erste Fund wurde 1850 gemacht; es war der erste nordamerikanische Diamant ïberhaupt. Seitdem ist alljährlich eine Anzahl von Steinen angetroffen worden, meist von seringer Größe. Der größte wog $7 \frac{1}{1}$ liarat. Dic Zahl der wirklich rorhandenen Diamanten war aber wohl weit größer als die der gefundenen; sie sind jedoch vielfach zertrümmert worden und dadurch verloren gegangen. Das erwähnte feste goldhaltige Konglomerat wird nämlich behufs Gewimnung des Metalls in ein feines Pulver zerstampft und dabei werden auch die etwa mit vorkommenden Diamanten zerstört. In der Tat hat man in dem so erhaltenen Pulver mehrfach Diamantsplitter nachweisen können. Es ist sogar sehon die Vermutung: ausgesprochen worden, die so zerstörten Diamanten könnten mehr wert sein als das gewonnene Gold.

Auch aus einem anderen Grunde sind manche nordamerikanische Diamanten verloren gerangen. Bei den dortigen Arbeitern ist, wie anch vielfach sonst, die Meinung ziemlich verbreitet, dalj cin echter Diamant jedem Hammerschlage widerstehen könne. Sie erproben daher die Echtheit cines sefundenen Steines nicht selten dadurch, dab sie ihn auf dem Ambos mit dem Iammer bearheiten. Zerspringt der Sitein, so ist es ihrer Ansicht nach kein wirklicher Diamant gewesen. Das Irrige dieser. Meinung ist sehon oben bei der Betrachtung der IIairte und der. Spaltharkeit des Diamants auseinandergesetzt worden.

Im östlichen Grobiete hat namentlich der Ostrand der siidlichen Alleghanies in der sog. Piedmont Regron, also die Atlantischen Staaten von Alahama bis Virginia, eine beschräinkte Anzahl I)iamanten gerliefert. Sehr spälibh waren die Funde in Tennessee und Kontucky im Vesten des genannten Gebireszuges. Anfang der Fünfiziger Jahre des nemzchinten Jahrhunderts - nach anderen Nachrichten sogar schon Ende der vierziger Jahre 
- wurde in liuterford County, Nord-Carolina in einem alluvialen fooldsande cin grelbes

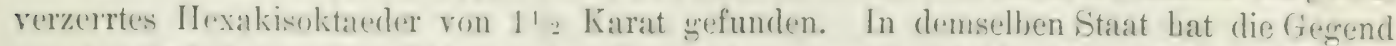
um den Ostfuli dex Blue Ridgere rinig̣e Liamanten, meist im Goldsande, geliefert. Die Gesteine des Gebireses sind hier liristallinische Sehiefer, unan trifft dort aber auch Itakolumit, deu man in den brasilianischen I iamantenuebieten eine so wichtige liolle zuschriel). Aber in beiden Gegenden hat man krine I damanten in diesem Gestein entrlecken kïnnen. Die hik angetroffenen steine sind meist Oktarler; der gröbte, 1846 grefunden, wog 41.2 Karat. Ein Stein im Trerte von fou Jollars soll in Süd-Carolina rorgekommen sein. Eine eröfere Zahl soll dam wieder Georeia ron mindestens sechs Orten eceliefert laben, wie in NordCarolina mit fold und in der Nachbarschaft von Itakolumit; aber alle diese dnwaben sind nicht vollkommen sicher. Verbiiret ist ein Stein von $33^{1} 2$ Karat aus Lee County, einige Kilometer ron Columbus. Aus Virginia stammt der grö̈ßte der Diamanten der Vereinigten Staaten, der sog. Dewey-[Hiamant. Ein Erdarbeiter fand ihn 1555 beim Craben in der Stadt Manchester in Boden. Es war ein Oktaeder mit gerundeten Kanten, das roh 23"1, Karat wow; eseschliffen hetrug das Gewicht noch 1111/16 Karat. Der stem ist nicht rom reinsten Wasser und fehlerhaft und hat daher nur cinen Wert ron 300)-fun Dollars, trotzdem ist er mu das Zehnfache verkauft worden. Ten nessee lat fast nichts geliefert; ein Stein ron 3 Karat. exeschliffen 11: Karat. ist 1599 am Siidufer des C'linch River, ein anderer ron 11\%1: Karat im orlechen Jahre bei Luttrell am Flat Creek. Union County, beide in der L'mgerend ron Knoxville gefunden worden. Aus Kentueky wird ein Steinchen ron i $1 ;$ Karat gemeldet. In diesen Staate, in Elliot County, hat man einmal Diamanten ähnlich wie am Kal) in (iängen eines Olivingesteins (Periclotits. Kimberlits) rermutet und aufgesucht, aher olme jeden Erfolm. In Ala bam a ist ein 41, Karat schwerer Stein etwa 50 Kilometer sïdlich von Bimingham, Shelby County, in der Gartenerde gefunden worden. Überall lagen die Diamanten im sind und Kies der Wasserlïufe oder lose im Broden. Wie in Kalifornien ist ilue urepringliche Lacerstäte unbekannt, aber man hat cliese sicher. in den Gesteinen der benachbarten G(rbirge zu suchen, aus denen sie herausgervittert und und nachher vom fließenden Wasser in die Tiefe transportiert worden sind.

Die Diamanten des Sernewbiets liegen alle in einem Landstreifen ron 600 miles Länge und 2010 miles Breite, der sich in nordwestlicher Richtung durch das Südende des Michigan-Sees hindurchzieht. Es waren schon 1899, nehen einer Anzahl kleinerer, 17 Steine ron 1.2 bis $21 \%$ Karat hekannt und sicher bestimmt worden. Alle haben in ilurem Torkommen das gemeinsan, dafj sie den in jenen Cegenden iiber weite Flïchen verbireiteten Gletscherbildungen der letzten Eiszrit eingelagert waren oder doch zu diesen in malien Beziehungen stehen. Professor William II. II ohbs in Madison hat sich hauptsäichlich mit diesen, wenn nicht für den Eandel: so doch für die Wissensehaft interessanten Vorkommen beschäftigt und uns damit näher bekannt gemacht.

Die erste Erwähnung eines Diamants von dort geschah im Jahre 155:). Trotz einiger Zweifel bezïglich der Echtheit des Vurkummens erregte er eine vorïbergehende Begeisterung für Diamantengräberei. I) Stem war schon 1576 hei Eagle, Waukesha County; nahe westlich bei Milwaukee in Trisconsin sefunden, aber nicht als Diamant erkannt worden, bis er 1583 dem Chrmacher und Juwelier Boynton in Milwaukee zu Gesicht kam, der das Richtige vermutete und darauf den stein für einen Dollar ankaufte. Es ist ein hlafgelbes, wenig rerzerrtes Ihhombendodelsamer von $1512 \ldots 2$ Karat, das jetzt in der Tiffanysammlung in Newyork liegt.

Im Frïhjahr is 66 fand sich dere gröbte Diamant jener Gegend, ein ebenfalls blafgelbes und ein wenie verdingertes Rhombendodekaeder, seinem Torgaingrer ron Eagle sehr ähnlich, aber 211, Karat schwer und 20, 13 und 10 Millimeter nessend. Er stamn.t ron Kohlsville hei Westend, Washington County, wenig nordwestlich ron Milwaukee. 
Daran schließen sich Steine ron mikroskopischer Kleinheit bis 2 Karat, die in den Jahren 1887 bis 1859 beim Goldwaschen in dem kleinen Plum Creek, Pierce County, vorgekommen waren, der eine kurze Strecke oberhalb der Mündung des S. Croix River von links in den Mississippi fließt, ebenfalls in Wisconsin. Es folgte im Oktober 1893 ein fast rein weißes, verzerrtes Rhombendodekaeder von $3^{1 / 1} / 1$. Karat aus der Nähe von Oregon, Dane County, Wisconsin, wenig siidlich von Madison, und ein Jahr darauf, 1894, der 107/s Karat schwere, 13, 9 und 11 Millimeter messende Stein von Dowagiac, Cass County, Michigan, dieser ron der östlichen Seite des Sees, nahe der Südspitze zwischen Niles und Kalimazoo. 1896 wurde ein $6^{13 / 32}$ Karat wiegender, weißer, aber etwas gelb gefleckter Stein, ein verzertes Triakisoktaeder, als Diamant erkannt, der schon im Jahre 1850 auf einer Farm bei Saukville, Ozaukee County, Wisconsin, 10 Kilometer nördlich von Milwaukee und 2 Kilometer vonı See entfernt, beim Ackern aufgelesen worden war. Eine kurze Strecke südlich von da wurde dann bei Burlington, Racine County, Wisconsin, unbekannt wann, ein schöner, grünlichweißer Diamant von 21/16, Karat, ein Tetraederzwilling, gefunden. Endlich sei noch der 6 karïtige Stein von dem östlichsten Fundort jener Gegend, von Milford, Clermont County, im Staate Obio, erwähnt, den man seit 1897 kennt, seit 1898 als Diamant. Er hatte wahrscheinlich die Form eines Oktaeders, ist aber jetzt zu einem schönen weißen Brillant geschliffen.

Weitere Funde wurden seitdem nicht mehr gemacht, doch ist zu vermuten, daß noch mancher Stein wegen seines hübschen Glanzes aufgelesen und verwahrt, aber nicht als Diamant erkannt ist. Einige sollen auch wieder verloren gegangen sein, weil man ihnen aus dem letztgenannten Grunde keine weitere Bedeutung beilegte, so, wie man berichtet, ein zweiter Diamant aus der Gegend von Eagle, noch größer als der erwähnte, sonst aber ihm in jeder Hinsicht ähnlich.

Betrachten wir nun diese Fundorte in ihrer Lage zu den Glazialbildungen der Seenregion, so ergibt sich, daß Oregon, Kohlsville und Eagle, sowie Saukrille, Burlington und Dowagiac in der der jüngsten Eiszeit angebörigen langgestreckten "Kettle-Moräne" liegen, die ersten fünf an deren südlichstem Rande, der letzte etwas weiter rückwärts gregen Norden, vom Rande entfernt. Jene entsprechen dem äuBersten Saum des letzten Gletschers jener Zeit. dieser einem späteren Stadium, als der Gletscher schon im Rückzuge begriffen war. Oregon, Eagle und Kohlsville gehören dem Teil der von diesem Gletscher hinterlassenen Moräne an, den man den „Green Bai-Lappen (Green bay lobe) nennt und der sich zungenförmig nahe der Westseite des Michigan-Sees bis über die Höhe von Milwaukee nach Sïden erstreckt, ohne aber den See zu berühren. Daran schließt sich unmittelbar und olne Zwischenraum die Westseite des Sees ganz schmal, die Ostseite breit umrandend und sich viel weiter nach Süden erstreckend, der "Lake Michigan-Lappen" (Lake Michigan lobe), dem die Fundorte Saukville, Burlington und Dowagiac, in weiterer Entfernung auch Milford anģehören. Ähnlichen Gletscherbildungen entstammen wohl auch die wenigen Steine, die man weiter im Osten, bei Syracuse im State New-Tork gelegentlich gefunden hat, und die daber hier mit erwähnt sein sollen.

Während alle die genamnten steine in der Moräne selbex gefunden wurden, lagen die aus dem Plum Creek vor den Moränen außerhall) des Cilazialgetrictes im Flußsand, wo sie neben Platin, Gramaten und zahlreichen anderen Mineralien beim Goldwasehen zufällig angetroffen worden waren. Lis ist aber kein Zweifel, daß sie von jenem kleinen Flub aus der Iloräne, einer westlichen Fortsetzung der "Kettle-Moriine", herausgewaschen worden sind und daß sie wie ihre liegleiter ursprïnģlich dieser ebenfalls angebört haben. In ähnlicher Treise wurden weiter siddlich in Indian a im goldhaltigen Sande einige Diamanten gefunden, besonders in Brown County und in Norgan County; namentlich wird von einem 
1) kaceler von $4^{3}$, Karat aus einem Arm des Gold Creek, 15 Kiloneter nörilich von Martinsville, Morgan County, berichtet.

Fragt man schliefilich nach der Abstammung der Diamanten aus den Moränen des Statates Wisconsin und der Seenregion ïberhaupt, so gehen uns die zahlreichen (jletscherschliffe eine Antwort, aus denen auf die Bewerung jener alten Gletscher geschlossen werden kamn. Darnach haben alle jene Diamanten dieselbe Heimat, die man nit einiger Wahrscheinlichkeit in den unwirtlichen Gegenden istlich von der James-Bai, dem südlichen Endr der IIudson-Bai vermuten darf. Von dort sind sie durch die Gletscher nit dem anderen Moränenmaterial nach Sïden greschoben und bei deren Rï̈ckzug am Ende der Eiszeit an ilrem jetzigen Fundorte liegen gelassen worden.

In Mrkansas sind Diamanten am 1. August 1906 entdeckt worden und bald waren "twa 140 Stiick im Gesamtgewicht ron 200 Karat gefunden. Sie sind auf den Lmkreis des Peridotitstocks von. Murfreeshoro, Pike County, annähernd eine Ellipse mit Durchmessern von 2100 und 1 S00 Fuf und mit einem Inhalt von 40 acres $=16$ IIektar, beschränkt. Die meisten wurden auf dem Boden aufgrelesen, einigre aus dem zu einer grauen und gelben Masse zersetzten (iestein ausgewaschen und einen hat man noch im Peridotit eingewachsen gefunden. Es ist also kein Zweifel, daß sie alle aus diesem stammen und daß das Vorkommen somit eine gewisse Ähnlichkeit mit dem in dem Hartgrund von Kimberey hat. Der Form nach sind die meisten rundflächige und gewöhnlich etwas rerlängerte Hexakisoktaeder(Fig. 39,e) auch flache Oktaederzwillinge (Fig. 39, g) sind nicht selten, und manche andere Gestalt ist beobachtet worden, darunter auch einige regelmäfige und unverzerrte Oktaeder. Schöne, rein weife Steine ron der vorzüglichen Beschaffenheit der südafrikanischen „river stones“ sind häufig, viele andere sind braun und grau, auch schön gelb, die Fürbung mehr oder weniger giinstign. Der größte bisher gefundene Kristall ist $61 / 2$ Karat schwer und milt $151 / 2,7^{3 / 4}$ und $t^{1}$; Millimeter; er ist rein weil, sowie vollkommen klar und durchsichtig, also von bester Qualität. Andere wiegen 61/4, 5, 4 und 3 Karat bis herunter zu 1/16 Karat.

Ist gleich auch dieser Fundort nicht praktisch wichtign, so ist er doch von grölter wissenschaftlicher Bedeutung als einziges nordamerikanisches Diamantenvorkommens auf ursprünglicher Lagerstïtte, und zwar nahe übereinstimmend mit dem in Südafrika, was zunüichst das Gestein anbelangt. Es ist nun die Aufgabe, zu untersuchen, ob die ïbrigen durchweg auf sekundïrem Lager befindlichen nordamerikanischen Diamaıten ihren Ursprung auch auf ein solches Muttergestein zurückführen.

Zum Teil nach der Ähnlichkeit der geologischen Verhältnisse mit denen diamantfiilurender Gebiete hat man auch in anderen Gerenden Nordamerikas das Vorkommen dieses Edelsteins rermutet. Aber teils haben sich an den betreffenden Orten überhaupt keine Diamanten gefunden, wie in dem oben erwïlnnten Peridotit ron Kentucky, teils waren es Steine auswärtigen Ursprungs, teils waren die rermeintlichen Diamanten Quarz wie in Montana.

Man hat auch die Diamantenvorkommnisse und die dadurch zuweilen hervorgerufene Erregung zu schwindelhafter Ausbeutung des Publikums zu benutzen verstanden, im grüßten, kaum glaublichen Maße im Staate Arizona.

Im Jahre 1sin hatte sich die Nachricht rerbreitet, dah irgendwo im Westen viele Edel. steine, darunter Diamanten in grröfter Menge, gefunden worden seien. Unter den bei einer Bank in San Franzisco deponierten Steinen waren ron dort sounu Karat Rubin und u. a. ein Diamant ron 108 Karat. Jedermann konnte die Steine besichtigen. Bald brachten diesclhen Leute, welche den ersten Fund gemacht hatten, eine zreite, etwas kleinere Partie Edelsteine in die Stadt. Nun begannen sich die Kapitalisten für die Angelegenheit zu interessieren. Am 10. Mai 1872 ging eine Bill zugunsten der Diamantensucher durch den Kongref, und eine Expedition von Interessenten begab sich mit einem Bergingenieur 
als Sachverrtändigem zu näheren Nachforschungen an den Fundort. Nachdem die Stelle mit Mühe aufgefunden worden war, sammelte jeder Teilnehmer zahlreiche Edelsteine. In einer Woche wurden zusammen 1000 Karat Diamant und 6-7000 Karat Rubin gewonnen, und die Expedition kehrte höcht befriedigt zurïck. Bald aber wurde die Sache aufgeklärt. Auch die mit der geologischen Untersuchung der Vereinigten Staaten betraute Behörde, die Geological Survey in Washington, hürte von den Funden. Sie rïstete zur genaueren Untersuchung des Vorkommens ebenfalls eine Expedition aus und diese stellte fest, daß cin riesiger Schwindel vorliege. Ein spekulativer Amerikaner hatte die Fundstätte, wie man zu sagen pflegt, „gesalzen". Die Rubine erwiesen sich als Granaten, der große Diamant von 108 Karat war ein Bergkristall, aber die kleineren Diamanten waren echt. Es waren in London gekaufte Kapdiamanten, die in solcher Menge an jener Stelle ausgestreut worden waren, dals man noch nach Jahren einzelne Steine fand. Nit Hilfe dieses Betruges war es gelungen, den interessierten Kapitalisten, die meist aus Kalifornien stammten, allmählich die Summe von 750000 Doliars abzunehmen, die den Wert der zum, ,Salzen" verwendeten Diamanten um das Vielfache iibertrifft.

Man tut in Amerika riel, um die einheimischen Diamanten zu sammeln. So werden namentlich an Leute, die bei ihrer gewöhnlichen Beschäftigung vielleicht Gelegenheit haben, deren zu finden, Erdarbeiter, Goldgräber und andere, Ringe mit kleinen Rohdiamanten ausgeteilt, um sie an das ausgezeichnete Aussehen dieses Minerals zu gewöhnen und ihre Aufmerksamkeit und ilır Interesse dafür zu wecken. Trotzdem ist die Zahl der gefundenen Steine klein geblieben, und nichts weist daraufhin, dab etwaige Hoffnungen auf späitere reichlichere Funde begründet sind.

\section{Ural und Sibirien.}

Die Diamanten des Urals wurden infolge der beriihmten Reise aufgefunden, die Alexander v. II u mbold mit Gustav Rose und Ehrenber guf Veranlassung des Kaisers Nikolaus in Jahre 1529 in jenen Gegenden ausführte. Humbold hatte schon 1523 in seinem „Essiti gुéognostique sur le gुisement des roches" wegen der vielfachen Ähnlichkeit der brasilianischen und uralischen Gold- und Platinwiischen die Ansicht ausgesprochen, dals auch in Ural der in Brasilien das Gold und das Platin vielfach hegleitende Diamant nicht fehlen werde. Er schlol dies aus dem Umstande, daß im Ural und in Brasilien die nit dem Gold und dem Platin vorkommenden Mineralien wesentlich dieselben sind. Die nämliche Ansicht hat aus denselben Gründen frïher schon und mabhängrig von If u mboldt der Dorpater Professor Horitz v. Fing elhardt ausgesprochen, der auch später das erste Diamentenvorkommnis im Ural eingehend untersuchte und ausfuhrlich schilderte. II umboldt war von der lichtigkeit seiner Ansicht so iiberzeugt, dab er beim Abschied seherzend zur Katiserin von liufland sagte, er werde nicht ohne die russischen Diamanten vor der Monarchin wieder erscheinen.

Die Rerisenden wandten auf dem eranzen Wege ihre volle Aufmerksamkeit der Auffindung des Jiamants zu, inden sie in allen Goldwäischen, die sie besuchten, die Gold enthaltenden sande mikroskopisch nach jenem Mineral durchforschten; ihre Mülse wurde aber nicht vom Erfolge gekrönt.

Gliicklicher war ein zitweiliger lieisebegleiter, ein Graf Poljer, den Humboldt in seine Ideen eingeweiht und fiir sie begeistert hatte. Nach der Trennung ron Humboldt setzte er daher, die gä̈nstige (ielegenheit benutzend, die Nachforschungen in den zum Bezirk der Iluitte Bissersk (etwa unter 5s/2 " n. Br. gehörigen Goldwäischereien auf den (iïtern seiner Frau, einer geborenen Fürstin Schachowskoi, fort. Hier ist es, wo am 5. Juli 1529 der exste uralische und zugleich der erste europäische Diamant grefunden wurde. 
Der sperinlle Fundpunkt ist die kleine Goldwäsche A dolphskoi in der Nähe der gröberen Krestowoswidschenskoi, 25 Werst im Nobdosten von Bissersk, 4 Werst rom fichirgskimmm entfernt anf der westlichen, emopäischen Alodachung des Crals. rie liegt in einer Seitenschlueht ler l'aludenka, eines (Quellhachs der Koiwa, die in die Tsehussowaja, einen Nebenfluß der Kama, fällt.

Der im ungewasehenen Zustande lehmig aussehende Goldsand von Adolphskoi ent-

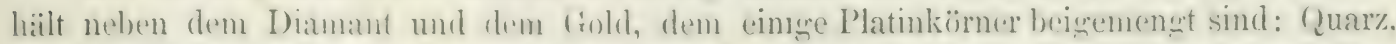

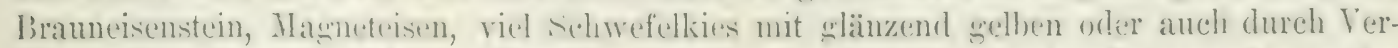
witterung braun serwordenen flïchen, Chalcedon, Anatas usw. nebst stiicken der in der Nähe vorkommenden Felsarten.

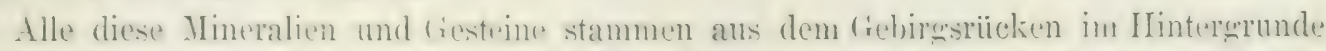

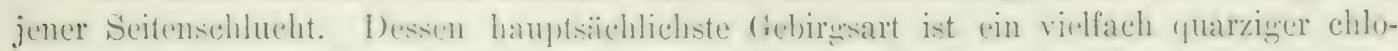
ritischer 'Talkschiefer, der wohl mit dem brasilianischen Itakolumit identifiziert worden ist, der aber nach den Cntersuchung von fi. liose damit keineswegrs äbereinstimmt.

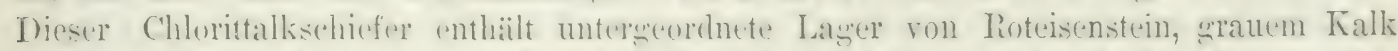
und namentlich sehwarzen, durch kohlige Teilehen gefäblen Dolomit, der die nmmittel-

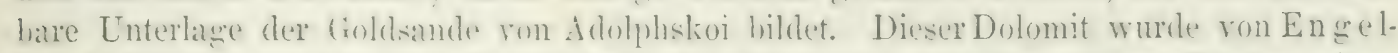

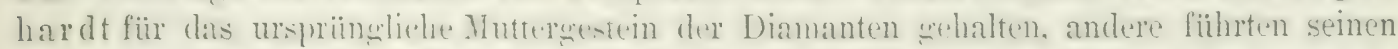
Lrsplung auf jemes als Itakolumit ameweselene restein zurïck. Wan hat aher noch nie cinen Diananten in seinem Huttrestein eingewachsen gefunten, immer nur luse im Sande.

Die Zahl der bisher in der Goldwïsche Adolphskoi vorgekommenen Diamanten be-

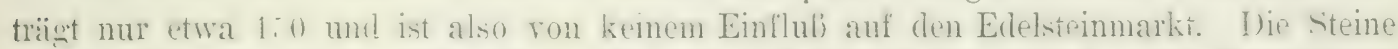
sind vollkommen durehsichtig. stark glänzend und farblos bis gelblich. Dit Fristallform

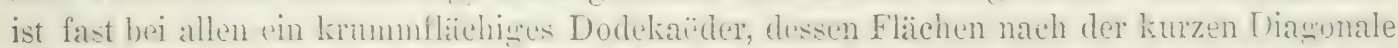
etwas geknickt sind (Fig. 39 c). Der größte wog 217/32 Karat, das Gervicht der fünf folgenden betrug $11 / 4,1^{1} / \mathrm{s}, 1 \frac{1}{16} \quad 1^{1 / 32}$ und 1 Karat, der Rest war kleiner, und zwar wog der kleinste 1, Karat. Dit 2) zuerst fefundenen steine hatten zusammen ein Gewicht von $17 " 16$ Karat. In einigen Kristallen findet man schwärychhraune Kohlenemschliisse. Ende des rorigen Jahrhundirts wurten wieder fünf Stïck yefunden, was Veranlassung zur Veranstaltung einer planmialitign Suche war, die bis dahin noch nie stattogfunden hatte, die aber bis jetzt ein größeres Resultat nicht ergeben hat.

Das Diamantrorkommen in Lral ist nicht auf Adolphskoi beschränkt geblieben. Schon 1531 wurlen in der (Goldwäsche des Mem Medscher, 14 Werst ästlich ron Katharinenburg, zwei kleine Diamanten, einer von 5/s Karat, gefunden. Im Jalıre $1838 \mathrm{kam}$ ein klemer Stein ron 's karat auf den Seifenwerken des Berereritrs Goroblagodatsk in der Grube Kuschaisk, 25 Thers von der IItitte Kuschwinsk und ustlich ron Bissersh, vor. 1 1 39 fand sich ein Kristall ron Z Karat auf der (Yrube Uspenskoi in einem Seifenwerke des Distrikts Werchne-Lratsk (iouv. Orenhurw). Auch an anderen Orten sind noch einzelne Steine vorgekommen, so in den Charitono-Kompaneiskischen Seifen am Flusse Serehrianaja, Kreis Kungur, fouvern. I'em in Lral. Ein hier rorocekommener $5 \mathrm{~mm}$ deker Fristall, en Zwilling. War rom mehreren Itexakisteträ̈dern benrenzt. Endlich ist noch zu erwähnen ein kleiner farbloser Stein aus der Grulhe Kamenka im Bezirk Troitzk, Gourernement Oreniurur, und der erste Diamant des sïdlichen Lral, der im Jahre 1 s.3 in der froldwïsche ron Katschkar gefunden wurde. Es ist ein gelber und rollkommen durchsichtien Achtundvierzieflächner ron 3 s. Farat. Der letztere Fund ist ron Interesse, eimmal weil er zeint, dah dex Diamant im Ural weiter rerbreitet ist, als man bisher anzunchmen berechtigt war, und sodann, weil auch im sïdlichen Lral die Begleiter unseres Edelsteins dieselben sind wie in Brasilien, woraus wieder auf ein ähnliches Vorkommen und eine :̈hnliche Bildune in beiden Ländern geschlossen werden darf. Ein 
neuer Fund ist der von vier Steinen im Goldsand des Baches Polojicha beim Dorf Kóltachi des Bezirks Newjansk.

Im ganzen sind jetzt an 16 uralischen Fundorten 222 Diamanten gefunden worden, deren schwerster 3 Karat wiegt. Sie sind fast durchweg rein, farblos und durchsichtig, aber klein.

Im allgemeinen trifft man Diamanten so selten und von so geringer Größe am Ural, dal es bis auf den heutigen Tag noch Leute gibt, die an dem wahren Vorkommen der selben in diesen Gegenden starken Zweifel hegen. Nach deren Ansicht handelt es sich um eine Täuschung, die ursprünglich geïbt worden wäre, um $\mathrm{Humboldts} \mathrm{Prophezeiung} \mathrm{in}$ Erfüllung gehen zu lassen. Hierfuir ist aber doch der entscheidende Beweis nicht erbracht, und die russischen Mineralogen, welche der Sache näher stehen, halten in ihrer überwiegenden Mehrzahl die Funde für echt, wofür auch die in der späteren Zeit wiederholt gemachten neuen Entdeckungen sprechen. Um die Auffindung der Diamanten im Ural zu fördern, hat auch die russische Regierung eine Anzahl echter Rohdiamanten von anderen Gegenden kommen lassen, um sie an die Grubenverwaltungen zu verteilen, damit sich deren Personal mit dem Aussehen des Edelsteines, wie er in der Natur vorkommt, bekanntmachen kann.

Auch Sibirien hat einige Diamanten geliefert. 1897 wurde ein kleinerer Stein in der nördlichen Taiga im Jenisseisk'schen Gouvernement in der Goldwäscherei von Baladin an der Melnitschnaja, einem Nebenfluß des rechtsseitig in den Jenissei mündenden Pit gefunden, und zwei Jahre später ein zweiter in einer benachbarten Goldwäscherei; der Fundort scheint hier aber nicht genau festzustehen.

\section{Lappland.}

Noch in einer anderen Gegend des russischen Reiches und zwar an dessen Westgrenze sind vor einicrer Zeit Diamanten vorgekommen, freilich ebenfalls nur klein und in geringer Menge, pämlich in Russisch-Lappland. Sie wurden auf mehreren in der zweiten Hälfte der achtziger Jahre ausgeführten Reisen von Ch. Rabot im Pasevig-Tale, das im Varangerfjord in das nördliche Eismeer mündet und unter dem 30. Grade östlich von Greenwich die Grenze zwischen Norwegen und Rußland bildet, in einem granatführenden Sande aufgefunden. Der genannte Fluß strömt über Gneis, der von zahllosen Granitund Pegmatitgängen durchsetzt wird; durch die Verwitterung dieser Gesteine ist jener Sand entstanden.

Nach der Untersuchung von Ch. Vélain enthält derselbe folgende, nach der IIäufigkeit des Vorkommens geordnete Mineralien: Granat (Almandin) in rosenroten abgerollten Körnern, die Hälfte der Masse bildend, viel Zirkon, braune und grïne IIornblende, Glaukopllan, Cyanit, grüner Augit, Quarz, Korund, Rutil, Magneteisen, Staurolitb, AndaIusit, 'Turmalin, Epidot, Feldspat (Oligoklas) und endlich als seltensten Gemengteil Diamant. Dieser ist wasserhell und bildet kleine eckige, seltener abgerollte Körner oder Bruchstiicke. Ihre Gröbe iibersteigt selten $0,25 \mathrm{~mm}$, doch wurde cin Kiristall mit einem Durchmesser von 1 , $\mathrm{nm}$ beobachtet. Sie führen viele fremde Einschlïsse teils von runden Gasporen, teils von mikroskopischen Kriställchen unbekannter Natur, was ihre Durchsichtigkeit stark becinträchtigt. Die Diamantnatur dieser kleinen Körper ist durch die Gesamtheit ihrer Eigenschaften, namentlich die große Härte, erwiesen und wurde noch weiter durch einen Verbrennungsversuch im Sauerstoff sichergestellt, hei dem das angewandte Bruchstiick rollkommen verschwand und reine Kohlensäure lieferte.

Die Begleiter des Diamants sind hier wesentlich dieselben wie in Indien und Brasilien, nux fehlt in Brasilien, nicht aber in Indien der Ejpidot (P'istazit), während umgekelırt in Lappland die in Brasilien so häufig vorkommenden wasserhaltigen Chlorophosphate nicht aufgefunden worden sind. Nach der Ansicht von Véla in ist hier, wie bei Wajirah Karrur unweit Bellary im siddichen Indien (nach ('haper) usw. der Pegmatit als das ursplüing- 
liche Nuttergestein des I)iamants anzusehen, in dem er sich erleichzeitie mit diesser fiebiressart gebildet hat. Jedenfalls muli er wohl aus einem der grenannten Uresesteine stammen, da andere Felsarten in jenen Gexenden weit und breit nicht bekannt sind. Teurere Tachrichten sind leider nicht vorhanden, es wäre aber trotz der geringen kommerziellen bedeutung von Wichtigkeit, wenn durch eingrehendere Untersuchungen das ursprïngrliche: Muttergestein der [appländer Diamanten nacherewiesen werden kënnte. Es würde hierdurch vielleicht auch ein weitteres Licht auf die vielfach angezweifelten Funde bei Wajrah Karrur geworfen. Jedenfalls ist die Entrleckung der Iferren Rabot und Véla in von gröbter theoretischer Bedeutung und verdient daher weiter verfolgt zu werden.

\section{Meteoriten.}

In interessanter Weise hat sich unsere Kenntnis von dem Vorkommen des Diamants erweitert durch das Auffinden kleiner, meist mikroskopischer Körnchen des Minerals von stets grauer oder schwarzer Farbe, also von einer Beschaffenheit ähnlich der des Karbonats, in einer Anzahl ron Ueteoriten, die zum Teil der Gruppe der Meteorsteine, zum Teil der des Meteoreisens angehören. Wir haben es also beim Diamant nicht mit einer Substanz zu tun, die nur der Erde angehört; sic kommt ebenso auch in anderen IIimmelskürpern vor, ron denen Bruchstücke von Zeit zu Zeit auf die Erde fallen. Von Bedeutung für den Edelsteinhandel ist dieses Vorkonmen der erwähnten Beschaffenheit der meteorischen Diamanten und ihrer äufersten Spärlichkeit wegen in keiner Weise, aber für die Kenntnis der natïrlichen Verhältnisse des Diamants ist es doch so wichtig, daß es eine kurze Erwähnung rerdient; um so mehr als Ansichten ïber die Entstehung der irdischen Diamanten darauf gegrüindet worden sind.

Der erste Meteorit, in den Diamanten gefunden worden sind, ist der II eteorstein, welcher am Morgen des 11). Septembers 1856 auf einem Felde drei Meilen ron dem Dorfe Novo-Urei am rechten Ufer des Alatyr im Krasnolobodschen Kreise des Permschen Gouvernements in Rufland gefallen ist. Mr. von Jerofejeff und P. von Latschin off fanden ihn $1 \delta 85$ zusammengesetzt aus Bruchstiicken der beiden Mineralien Olivin und Augit mit zwischengelagerter kohliger Substanz und etwas Nickeleisen. In der kohligen Substanz waren kleine grauliche Körner enthalten, die sich nach Härte, spezifischem Gewicht, mikroskopischem Aussehen und nach der chemischen Zusammensetzung zweifellos als Diamant (oder Karbonat) erwiesen. Andere Forscher baben dieses Resultat durchaus bestätigt. Die IIengre dieser außerirdischen Diamanten heträgt ungefähr 1 Prozent des ganzen Steines ron 1762,3 g, nämlich ca. $17 \mathrm{~g}$ oder 55 Karat. Ein Jahr später, 1559 hat F. Sandberger schwarze Körnchen in dem Meteorstein von Carcote in der Wüste Atacama in Chile als Diamant bestimmt.

Später wurde dann vorzugsweise im Meteoreisen Diamant gefunden, und zwar zuerst 1859 durch Weinschenk in dem ron Magura (Arra) in Lngarn. Dann ist namentlich das Meteoreisen von Canyon Diablo in Arizona durch seinen verhältnismäßig großen Diamantgehalt beriihmt geworden. zuerst durch die Untersuchung ron Foote (1891), dessen Resultate durch IIuntington, Mallard, Friedel, besonders durch II issan durchaus bestätigt wurden. Der Diamant ist hier in Form schwarzer Körnchen und durchsichtiger Kriställchen vorhanden, ex wird außer ven anderen Mineralien auch ron Graphit und amorphem Kohlenstoff, sowie ron Siliciumkarbid (Moissanit) hegleitet, das mit dem künstlichen Karhorundum rollständig ïbereinstimmt. Auch in einigen anderen Meteoreisen hat man sehr harte Körnchen gefunden, die vielleicht zum Teil ebenfalls Diamant sind, so u. a. in dem im Dezember 1908 im Dorfe Cubella bei Burgos in Spanien gefallenen. 
Vielleicht hat der Diamant sogar eine noch weitere Verbreitung in den Meteoriten, und zwar in Meteoreisen, oder hat sie wenigstens früher gehabt. Man findet nämlich in manchen Stïeken des letzteren kleine Graphitpartien von würfeliger Form, die ganz mit der Kristallform vieler I)iamanten übereinstimmt. Soleher würfelfürmiger Graphit, den man als Cliftonit bezeichnet hat, kommt vor in dem Meteoreisen von Magura (Arva) neben dem Diamant, in dem von Toluea in Mexiko, von Penkarring Rock (Youndegin, Westaustralien), ron Coshy's Creek (Cocke Co. und Sevier Co. in Tennessee, sogenanntes Seviereisenj und von smithville in derselhen Gegend, letzteres wahrseheinlich mit dem vorhergenannten demselhen Falle ancrehörig; vielleicht noch in einigen anderen. Es ist im höchsten Grade wahrscheinlich, daf der Cliftonit früher Diamant gewesen ist, der dimn eine Limwandlung in Craphit erfithren hat; eine solehe kann ja auch künstlich durch Erhitzen dex Diamantliristalle bei Luftabschlulj herbeigeführt werden. Man darf erwarten, dafich sich bei senauerer Xachforsehung auch noch in manchen anderen Meteoriteu Jiamanten finden werden, nachdem man einmal auf ihr Vorkommen aufmerksam geworden ist: in manchen anderen fehlen sie allerdings auch mit Bestimmtheit, wie die darauf gerichteten Untersuchungen gezeigt haben.

An das Vorkommen in Meteoreisen schließt sich das im Stahl an; manche Sorten enthalten ihn, und zwar in Form oktaedrischer Kriställehen bis zur Grölbe von 0,5 Millimeter.

\section{c) Entstehung und Nachbildung des Diamants.}

Sehr viele Gelehrte haben die natiurliche Entstehung des Diamants zum Gegenstande der Forschung und noch häufiger der Vermutung semacht. Zahhreiche Meinungen, zum Teil der widersprechendsten $\Lambda \mathrm{rt}$, sind darüber geä̈Bert worden, vielfach ohne jeden Versuch einer wissenschaftlichen Begründung durch die natülichen Verhältnisse des Edelsteines. Derartiene Ansichten sind selbstrerständlich vollkommen willkürlich und wertlos.

Friilher war man gar nicht in der Laše, sich ein klares Bild ron der Entstehung des Diamants zu machen, da man weder sein urspriingliches natïliche's Vorkommen kannte, noch verstand, ihn kïnstlich nachzulihlen. Auch heute ist man darin noch nicht viel weiter gekommen, namentlich war die künstliche Nachbildung bis ror liurzem unmöglich und ist auch jetzt noch in ihren ersten Anfangsstadien; die Frage ist daher auch jetzt nuch nicht spruchreif. Demn nur wenn man über das Vorkommen eines Minerals auf seiner ursprïnlichen Lagerstätte genau unterrichtet ist, kennt man die Art und Weise suiner Eintstehung in alluemeinen. Versuche über seine kïnstliche Herstellung unter Vorhältnissen, die den natïlichen nöglichst entsprechen, künnen dann zur Lufliärun@ dus speziellen Bildungsoreänge dienen. Dabei lassen sich oft die in der Natur mit rorkommenden Mineralien gleichen Ursprungs, namentlich solehe, deren Entstehung sehon bekannt ist, als Leitsterne beniitzen.

Alle Arten der Entstohung, die bei Mineralien iiberhaupt möglich sind, hat man sehon fiir den liamant hehaupten wollen, inclem man dabei nur einzelne seiner Eigenschaften beriicksichtigte, oder auch, inclem man enewise an sich denklare l'rozesse ohne weiteres auf den Diamant ïbertruæ. I)ie einen dachten an eine Bildung desselben dureh den I.ebensprozeli der l'flanz'n, andere liefen iln wenigsstens aus organisehen liesten entstehen, während wieder andere ilm von unorganischen Substanzen abzuleiten versuchten. Manche nehne'n eine hohe Temuperatur hei der Entstehung an, manche andere halten diese im Gecrenteil für völlig ausceschehlossen, da sich Diamant in starker IIitze in Graphit verwamdelt. In folgenden sind einige Ansiehten über die Bildung des L)iamants zusammengestellt, die Zahl derselben könnte leicht noch vermehrt werden.

Der erste, der eine direkte Abscheidung ats l'flanzen durch deren I.ebensprozel) 


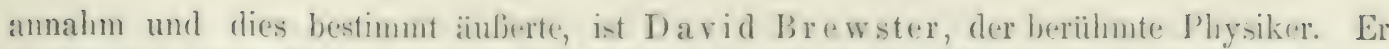
dachte an einen Vorgang wie dir. Bildung des fimmmi und sprach dem I) banant eine ursprïglich weiche Beschaffenheit \%u, wie jonem. Ehenso war der bekannte Mineraloge J a meso n der Ansicht, dab sich der Diamant aus den Säften irgendeiner l'flanze abueschieden habe, ähnlich wie sich Kieselsäure in der Form des somenannten Tabaschir in tlen Knoten der Bambusstämme ausseheidet. Petz holdt hatte ähnliche Anschauungen.

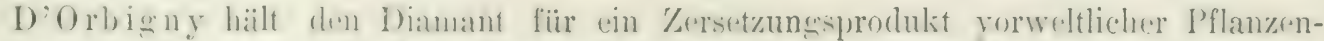

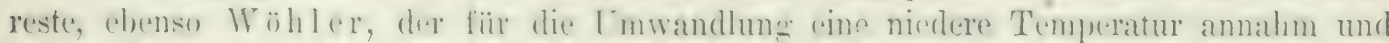

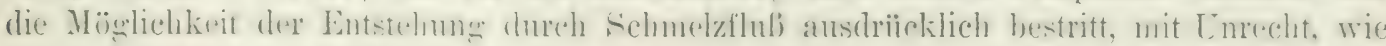
wir jetzt wissen. J. D. Dana hielt in Gegensatze dazu höhere Temperatur für erforderlich oder doch fïr moghtich: er dachte sich I)iamant ans oreanischen substanzen

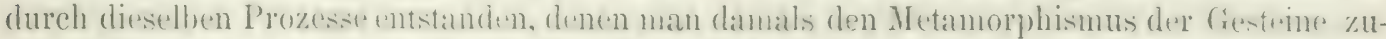

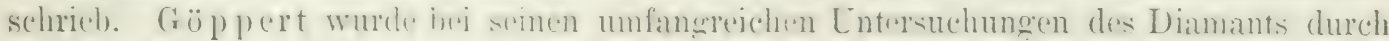

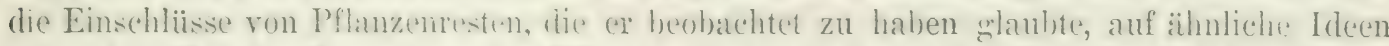

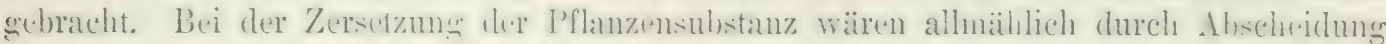
der anderen bestandteile inmer linhlenstofireichere l'rodukte entetanden und endlich reiner Kohlenstoff. Dieser wïre zuerst in antorphem und weichem Zustande gewesen und crest

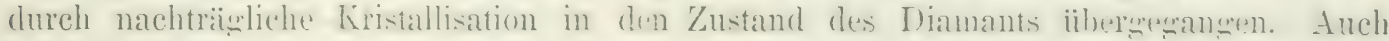
nach G. Wilson wäre aus der Holzsubstanz allmählich immer mehr Wasserstoff und Siluerstoff answetreten: dadureh wär eine dem Anthacit miteprechende subsan\% entstanden, und dieser Anthrazit hätte dann durch weitere ähnliche Umwandlung den Diamant geliefert. Diese Prozesse wären bei niederer Temperatur vor sich gegangen, bei höherer hätte sich statt Diamant Graphit bilden miissen. Nach G. B is ch of läßt sich gegen die Ansichten der Eutstehung des Diamants aus Pflanzensulstanz nichts einwenden, doch ist er nicht in der Lage, etwas Bestimmtes ïber seinen Ursprung zu äußern. Jedenfalls hält er aber wie Wöhler die Nitwirkung hoher Temperaturen für ausgeschlossen.

Parrot nahm im Gegenteil eine Umwandlung von Holzsubstanz bei hoher Temperatur an. Er diachte sich likine Kohlenteilchen durch vulkanische filut stark ehitzt und

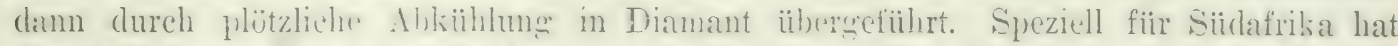
Carrill Lewis eine ähnhche Ansicht answeplochen. Tach ihm wïre dort der Diamant in dem Dianantegestein, lem Kinnixelit, den er sich in whiihendflïssigem Zustande in Form eines Eruptivgesteins ilureh die Röhren an die Erdoherfläche emporgedrungen denkt, aus dem Kohlenstoffe der zahlreich darin eingeschlossenen stiicke bituminüser, also kohlenstoffhaltiger Schiefer dureh die Ilitze jenes Gestems feloldet worden. Yach der Ansicht mebrerer anderer Forscher wäre der him!erlit selhst kohlenstoffhaltig gevesen, und der Diamant hätte sich aus ihn bei der Erstarung ans dem gliihenden Flusse als urspringlicher Gemengteil answescheden. C. C. von Lemblard nahm ehenfalls die rulkanische

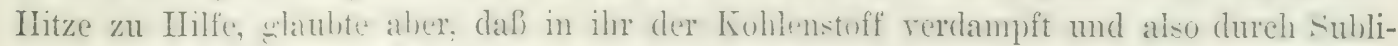
mation zur Kristallisation als Diamant gebracht worden sei.

Liebig remutet, dab in einem fliissigen liohlenstoffeichen Kohlenwasserstoffe dureh eine Ant ron Terwesungsprozef sich immer kohlenstoffreichere rephindungen bildeten, aus dench sich schliefilich reiner Kohlenstoff in kristallisierter Forn ausscheiden mußte. Er kann sich nur in einer solchen Weise und bei niederer Temperatur den Diamant entstanlen denlien, da höhere Temperatur und Gegenwart ron Sanerstoff mit seiner Verbremlichleit nicht vereinhar scien. Im Gerensatz dazu behauptet Berthelot, daf eine Ausscheidung von Kohlenstoff aus einer solchen Flïssigkeit nur in der Hitze stattfinden könne; rom Diamant speziell spricht er dabei allerdiugs nicht. C'hancourtois 
läft den Diamant aus Emanationen von gasförmigen Kohlenwasserstoffen bei deren langsamer Oxydation an der Tuft entstehen, wobei aller Wasserstoff in Wasser übergeht, aber" nur ein Teil des Kohlenstoffs Kohlensäure liefert; der Rest würde als Diamant kristallisieren. Er erinnert dabei an die bekannte Bildung von vulkanischem Sehwefel aus Schwefelwasserstoff, wobei ganz analog dessen gesamter Wasserstoffgehalt unter Ausscheidung von Schwefelkristallen sich zu Wasser oxydiert.

Von einigen Forschern wurde der im Immern der Erde an vielen Stellen massenhaft vorhandenen Kohlensäure eine wesentliche Rolle bei der Bildung des Diamants zugeteilt, aber in rerschiedener Weise. Schon der bekannte Mineraloge J. N. Fuch s hatte derartige Vorstellungen, später auch A. Stelzner bezüglich der Kapdiamanten.

Nach Göbel sollte Kohlensäiure bei hoher Temperatur durch gewisse Metalle, wie Aluninium, Magnesium, Calcium, Eisen, auch durch Silicium usw. reduziert und dabei Kohlenstoff als Diamant ausgeschieden worden sein. Simmler kniipfte an die zuweilen im Diamant eingeschlossenen kleinen Tröpfchen flïssiger Kohlensäure an. Nach seiner Ansicht könnte flüssige Kohlensäure bei hoher Temperatur und starkem Druck Kohlenstoff auflösen und aus dieser Lösung liönnte letzterer als D)iamant wieder auskristallisieren. Bei den Untersuchungen von Gore und ebenso von Doelter konnte aber allerdings eine Löslichkeit von Kohlenstoff in flüssiger Kohlensäure nicht konstatiert werden.

Auch an Clorkohlenstoff als Quelle des Kohlenstoffs wurde bei den Iypotbesen über die Entstehung des Diamants gedacht. A. Favre, später H. St. Claire Deville nelımen die Möglichkeit dex Bildung von Diamanten aus der genannten Terbindung an. A. Favre wurde zu seiner Ansicht dadurch gebracht, dafs einige der Mineralien, die den Diamant in Brasilien begleiten, sich aus Chlorverbindungen ihrer Bestandteile bilden können. G o r c e ix nimmt ebenfalls, speziell für Brasilien, dessen Diamantlager er genau kennt, gewilj mit Recht eine gleichartige Bildung des Diamants und seiner Begleitmineralien an, für die er als Quelle Chlor- und Fluorverbindungen vorausetzt. Dieselbe Gleichartigkeit der Bildung in Brasilien durch gegenseitige Umsetzungsprozesse aller möglicher Substanzen denkt sich auch D a mo u r, obne aber über diese Prozesse sich näher zu äufern. Endlich sollte nach einer von G a n n el aufgestellen Hypothese auch Schwefelkohlenstoff imstande sein, bei seiner Zersetzung Diamant zu liefern. Einige weitere Ansichten über die Möglichkeit der Entstehung von Diamanten ergeben sich noch unten bei der Betrachtung der Versuche, die zur künstlichen Nachbildung unseres Edelsteines unternommen worden sind.

Legrt man, um eine auf die natiirlichen Verhältnisse des Diamants gegrïndete Anschauung yon seiner Entstehung zu erhalten, die Beschaffenheit der urspriinglichen Lagerstiitten, soweit man sie bis jetzt kennt oder doch zu kennen glaubt, zugrunde, so wird man zu der Ansicht gebracht, daß der Diamant nicht ïberall auf die nämliche Art und Weise gelsildet worden ist. Soweit unsere jetzigen Kenntnisse reichen, müssen wir für verschiedene Gegenden verschiedene Bildungsvorgänge annehmen.

Ist der Diamant in Indien, Lappland im sïdlichen Borneo, usw. wirklich in den die Gneisschichten zangfömig durchsetzenden granitischen Eruptivesteinen, am Kap in dem Olivingestein als ein IBestandteil derselhen eingewachsen gewesen, dann ist wohl kein Zweifel, daß der I)iamant auf dieselbe $\Lambda \mathrm{rt}$ entstanden ist wie diese Gesteine selbst.

Leider gehört aber deren Bildungsweise noch mit zu den dunkelsten Fragen der ganzen Geologie, so dali mit jener Erkenntnis für die Entstehung des Diamants nicht viel gewonnen ist. Ilïhst wahrseheinlich sind jene granitischen (Pegmatit-) Gäinge aus einer mit Wasser durchtrïnkten, bei vermutlich nicht sehr hoher Temperatur geschmolzenen Silikatmasse erstarrt, und dasselbe gilt hüchst wahrseheinlich für das Olivingestein, das am 
Kap die I biamanton ursprünglich enthielt und nach seiner Umwandlung in Serpentin noch enthält. Ist dieses (iestein ein Eruptiverestem, dann ist seine Bildung von drer des Peogmatis ïherhalut nicht wesentlich versehieden und der siidafrikanische I)iamant in dereselhen Wrise entstanden wir der in Indien und Lappland. Der Lnterschied besteht bloff darin, dafi sich der Kohlenstoff in ersten Fall aus emen sehr sauren (kieselsiburereichens, in zweiten aus einem sehr hasicchen (kiesclsäurearmen) Schnolyflub beim Ersturren in Form ron regennäbigen Kristailen ansegescheden hat. Ifan hat sich dahei den Schmelzflulf mit Kohlenstoff in ircendeiner Form imprägniert zu denken. sei es, dab dieser als soleher in dem Schmelzfluli foreliblit ist, oder in Verbmdung mit anderen Elementen als Karbid oder als Kohlensäure. In letzterer IInsicht denkt man an die mikroskopischen Einschlüsse flïssiger Kohlensïure, die die Mineralgemengteile jener Gesteine, besonders der Quarz der Granite, aher auch der Olivin des P'eridotits und der Diamant selfst oft in erheblicher Anzahl beherberen. Dafj sich aus kohlenstoffhaltigen ultrabasischen silikatschmelzfliissen nach Art des Kimberlits in der Tat Diamant in kristallisiertem Zustande auszuscheiden rermag, haben die Versuche von J. Friedländer und von v. R. Ifablinger und J. Wolf, bewiesen die wir unten noch näher kennen lernen werden.

In ganz anderer Weise mul) der Diamant, der, wie es den Anschein hat, mit duarz und anderen Kristallen aufgewachsen auf Spalten im Itakolumit Brasiliens, vielleicht auch Nordamerikas vorkommt, entstanden sein. Es ist nicht der mindeste Zweifel möglich, daß die Kristalle des Quarzes und der ihn begleitenden Mineralien auf wässerigrem Wege, durch Auskristallisieren aus wïsserigen Lösungen, vielleicht in der Kälte, sich gebildet, haben. Dieselbe Entstehung müßte dann - immer die tatsïchliche Richtigkeit des ganzen Vorkommens rorausgesetzt - auch dem Diamant zugeschrieben werden. Wie jene Lüsungen beschaffen waren, ist allerding's zurzeit noch ganz umbekannt, wahrscheinlich aber waren sie warm. Goreeix, der zuerst die Gleichartigkeit der Entstehung der brasilianischen Diamanten mit den hier und schon oben genannten Begleitmineralien ausgesprochen hat, denkt sich diese allerdings nicht durch wässerige Lüsungen, sondern durch Cimsetzungr von aus dem Erdinnern aufsteigenden (iasen und Dämpfen gebildet, und zwar, wie wir vorhin gesehen haben, ron solchen chlor- und fluorhaltiger Verbindungen. In heiden Fällen würden wir es mit einer sog. pneumatolytischen Bildung zu tun liaben.

Im Lral sollen die Diamanten ron Adolfskoi ursprïnglich in einem bituminösen Dolomit eingewachsen gewesen sein. Tach der Annalime von Engelhardt, der diese Art des Torkommens zuerst für das Wahrscheinlichste erklärte, wäre der Diamant durch Umwandlun der dem Dolomit beigemengten bituminösen Bestandteile entstanden. Wie man sich den Prozelj im speziellen zu denken hätte, das steht allerdings ebenfalls noch dahin.

Das Torkommen des Diamants im Meteorstein von Nowo-Lrei ist wegen des Mitrorkommens von Olivin und Augit vergleichbar nit dem von Südafrika. Es liegt nahe, auch eine ähnliche Bildung in einem fremden Hinmelsk̈̈rper anzunehmen wie am Kap. Anders ist es mit den Diamanten im Meteoreisen. Scheidet sich Kohlenstoff ans greschmolzenem Gulfeisen ans, wie es in jedem Hochofen geschieht, so kristallisiert er als Graphit, im Stahl üfter's als Diamant. Es wäre nieht uudenkbar, dafj unter den bei der Bildung des Meteoreisens herrschenden besonderen Lmständen, vielleicht wegen des in demselben stets rurhandenen Nickel- und Phosphorgehalts, sich der Kohlenstoff als Diamant auscreschieden hätte. Ilier kamn vielleicht eine weitere Ausbildung der greichfalls noch zu erwähnenden Versuche von Moissan Aufklärung verschaffen.

Es seht aus dem Lrwähnten hervor, dab beziiglich der natïrlichen Entstehung des Dianants noch manche Cnsicherheit herrscht. Nur weitere Beobachtungen des ursprüng- 
lichen Torkommens des Diamants und seiner Begleitmineralien, sowie Versuche über lï̈stliche Dilrstellumg desselben werden instande sein, uns klare Vorstellungen zu verschaffen.

Alle Bestr(ebmene die nach verschiedenen Richtungen hin bisher in dieser Beziehung: gemacht worden sind, waren noch vor kurzem erfolglos. Mit zweifelloser sicherheit hat man dabei erst in der jüngsten Zeit Diamant erhalten, wenn man auch friiher schon rinigemal der Meinung gewesen war, das Ziel erreicht zu haben. Man versuchte, den Kolnenstoff durch Schmelzen oder durch Terdampfen, also bei sehr hoher Temperatur, besonders durch Yermittelung dex Elektrizität, sodann dureh Abscheiden aus kohlenstofflıaltigen Flïssigkeiten in der Kïlte oder in der IItze und bei starkem Druek als Dianant zum Liristallisieren zu bringen. Ton einigem Interesse sind rielleicht die älteren Untersuchungen von Despretz und die von Ilannay; sehr viel wichtiger, ja allein von Bedeutung sind die nemeren rom MIoissan, von Friedländer. von v. Haflinger und Wolf, und endlich auch die ron Ludwig. Allerdings ist diese Bedeutun worläufig noch eine rein wissenschaftliche, theortische, da die bisher auf kïnstlichem Trege erhaltenen Diamanten dhrehweg klein, ja somar zum grolien Teil mikroskopisch klein und auch tribe und undurchsiehtig gewrsen sind. Bis zur Herstellung schöner und grolier, zum Schmuck brauchbarer Steine ist wohl noch ein weiter Weg, doch kann auch jeder Tag die Lösung dieses Problems bringen.

Despretz lick ïber einen Monat lang ununterbrochen im luftleuren Ram starke (dektrische Funken von einem Kohlenzylinder auf Platindrihte ühersehlagen. Diese letzteren bedeckten sich dahei mit Kohlenteilchen, in denen bei 3ofacher Termriferung kleine Oktaederehen beobachtet wurden, die nach der Angabe Kormol ritzten. Bei einem anderen Versuche ließ er zwei Monate lang in angesäuertem Wasser den Strom von einer Kululenspitze auf einen Platindraht übergehen. Auch dabei beschlug sich der Draht mit einer diinnen linhlensehicht, in der zwar keine Oktaederchen beobachtet werden konnten. dir aber deenfalls Korund ritzen sollte, allerdines weniger leicht, als das Produkt des ersten Versuches. Beide Nale fehlt der zweifellos sichere Nachweis, daß die erlaaltenen Körnchen wirklich Diamant gewesen sind.

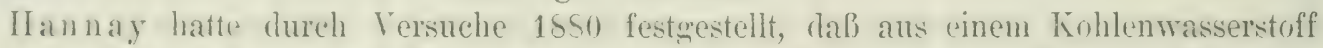
bei hoher 'Temperatur durch Natrium-, besser durch Lithiummetall Kohlenstoff ausweschieden wird. Znerleich ranhte er nacbgewiesen zu haben, dab bei starker Hitze und hohem Druck liohlenstoff in stickstoffhaltigen orenischen Sulstanzen sich auflüse. Daher lieli ar Lithim in riner zugeschweiften schmiedeciscrnen Rïhre auf Paraffin, dem er eine kine Mrenge Walfischtran bejeremiseht hatte, einwirken, und zwar bei sehr hoher Temper-

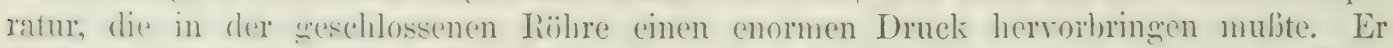

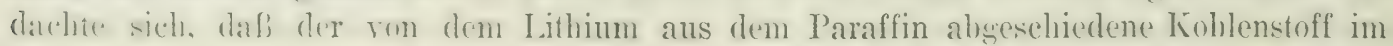
Entstehuntwoment rom dem stickstoffhaltigen Walfischtran anfectiost werle und bei dex Erkaltuno ak J)iamant sich ausscheiden könne. Der Versuch ereab auch eine kristallinische Masse mit at I'roz. Kohlenstoff, aber auch hier ist die Zugenörigkeit zum Diamant durchaus zweifelhaft.

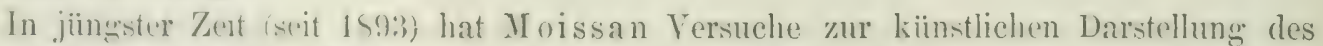

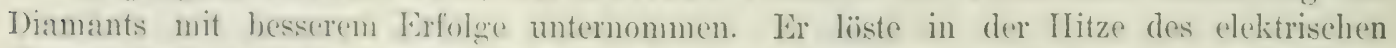
Flammenhogens Kohlenstoff in Eisen und bewerkstelligte eine schr rasche Erstarrung der Masse, indem er den Tiegrel, in dem sie seschmolzen wurle, in kaltes Wasser tauchte, oder inclem er die Schmelze in eine in Fisenfeile gemachte Itöhlumg goh, oder auf noch andere Weise. Durch dit rasche Erstarrung dire Aubenschicht der s'ehmelze sollte nach der Ansicht von Moissan auf das zunächst noch flïssige Innere ein starker Druck ausgeibiht werden, ond dieser sollte den bei der Erkaltung sich ausseheidenden Kohlenstoff 
veranlassen, als Diamant, statt wie untır gewöhnlichen Lmständen als Graphit, zu kristallisieren. Jedenfalls whielt "r, als (re das Eisen nach der vollstïndigen Erkaltung" auflöste, einzelne teils schwarze, teils aleer auch vollkommen wasserhelle bis $1_{2}^{2}$ mm grofie Kömehen und Kirställehen von der Form und Beschaffenheit des Diamants, die im Saucrstoff zu Kohlensïure verbrannten. Ifier ist kein Zweifel an der Dianantennatur des rothaltenen l'roduktes mehr mïglich. Schmelzendes Sillor lieferte dasselbe Pusultat wie Eisen.

Diese Versuche von Uoissan erklären das Vorkommen kleiner Diamanten in gewissen Stahlsorten und in den erwähnten Meteoreisen.

Dab anch aus kohlenstofflaltigen Schmelzflissen ultrabasischer Silikate, wie des siirafrikanischen Kimberlits, der Koldenstoff in Form ron Diamant auskristallisieren kann, hat uns zuerst, 1595, Inanuel Friedländer gezeigt. Er rülırte in eingr dïnnflïsigen Schmelze ron Olivin mit einem Kohlenstäbchen herum und fand nach dem Abliilhlen die mit der Kohle in Beriihrune exwesenen Teile der erstarten Masse schwarz we fürlte. Unter dem Mikroskup enteckte er nehen zahlredchen Magneteisenkriställehen winzise his 0.001 Millimeter grofe braune, schr stark lichthrechende, durchscheinende Oktaederchen, auch Tetraterehen und Tetraterlewillinge, die Topas und liubin ritzten und auch alle amderen Merkmale des Diamants zeigten. Beim Erhitzen unter Luftzutritt verschwanden sie, blieben aber im Kohlensäurestrom unverändert. Zu demselben Frgel)nis gelangte 19n)2 R. v. Hablinger. Als er in einer dem natürhchen Mutteresestein der südafrikanischen Diamanten gleichen, dureh Thermit geschmolzenen Masse liohlenstoff auflöste, erhielt ur

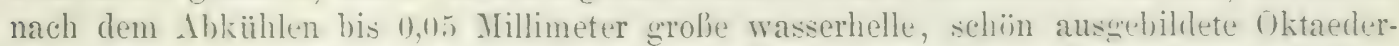
chen ron Diamant. Er hat dann den P'rozeß im Terein mit J. Wolf eingehender studiert. Beide berichten 19(1):, dafs ein (rehalt von Alkalien und alkalischen Erden, besonders halk und Magnesia, zur Entstehung ron Diamant notwendig ist, dafi aber zu kieselsäurereiche Sehmelzen keine Diamanten mehr liefern. Da der siidafrikanische Kimberlit kieselsäurearm und zugleich manesiareich ist, so entsprechen diese Versuche canz den natiulichen Terhältnissen der Diamanten am Kap. Man kann damach nicht mehr zweifeln, dafs diese als Ausscheidung aus dem Kimberlitmagma sich enebildet habev, wobei der darin befinclliche Kohlenstoff, ehenfalls diesen Versuchen zufolge, wahrscheinlich in For'm ron Karbiden Forhanclen gewesen ist. Der Annalume einer Entstehung ron Diamant in dem sehr kieselsäurereichen Pegmatit würden die von v. R. IIaflinger und J. Wolf erbaltenen liesultate allerdings nicht ginstig sein; in Beziehung darauf wären also noch fernere Lntersuchungen nötig.

Zum Schluß sei noch erwähnt, daß im Jahre 1901 Albert Ludwig ein Verfahren beschrieb, Kohle durch Schmelzen unter hohem Druck direkt in Diamant umzuwandeln. Der Prozeb wirl durch Anwesenheit von Diamant befördert. Er leitete durch eine in Retortenkohlenpulver eingeluttete Eisenspirale in Wasserstoff unter einem Druck ron 1300 Atmosphären den elektrisshen Strom und erhitzte dadurch das Eisen zur Rotglut. Sach wenigen Minuten schon fanden sich an einzelnen Kohlenuartikelchen winzige hellọlinzeide Friställehen ron der Beschaffenheit des Diamants. Ohne Eisen muf der Kohlenstuff in einer sehr hoch gespannten Atmusphä̈re geschmolzen werden. Unter solchen Cmstimden geschmolzenter Kohlenstoff ist für Elektrizitit nichtleitend wie Diamant, während die angewandte liohle leitend war. Dianant wurde dabei anch in kleinem, bis erbsengrofen Kö̈nchen von der Beschaffenheit des Karbonats tatsiichlich erhalten. Dies erweckte bei Ludwign die Iloffunge, daf diese Realition dazu leerufen sei, .. die Darstellung des Dianants im Grolien zu bewerkstelligen und mit den natïrlichen Diamanten in seharfen Wettbewerl) zu treten". 


\section{d) Verwendung des Diamants.}

Die IIauptanwendung des Diamants, neben der jerle andere von geringer Bedeutung ist, ist die als Schmuckstein. Nur die Steine, die wegen Undurchsichtigkeit oder schlechter Farbe oder sonstiger ungünstiger Beschaffenheit hierzu untauglich sind, werden in anderer Weise, und zwar wegen ihrer großen Härte in der Technik benützt.

\section{Verwendung zu Schmucksteineu.}

I) Schönheit des Diamants beruht sehr selten auf einer eigentïmlichen vorteilhaften Kör]erfarbe. Sie ist bedingt durch den hohen Glanz und das ausgezeichnete, unvergleichliche Farbenspiel, das durch die Brechung des Lichts auch in dem nicht oder schwach gefürbten Steine hervorgerufen wird. Je schöner dieses Farbenspiel, desto wertvoller unter sonst gleichen Verhältnissen der Diamant. Die Erscheinung ist jedoch abhängig ron dem Schliff. Rohe Steine mit ihren rauhen und meist wenig regelmäßigen Flächen zeigen sie meist gar nicht oder in geringem Maße. Erst bei geschliffenen Diamanten tritt sie hervor, und auch bei ihnen in verschiedenem Grade und in verschiedener Schönheit, je nach den durch das Schleifen hervorgebrachten Formen, die nicht alle in gleichem Maße günstig wirken.

Wieweit man im Altertum schon rerstand, Diamanten zu schleifen, oder doch vorhandene Kristallflächen durch Politur zu verbessern, ist nicht mit Sicherheit bekannt. Aus den iiberlieferten Berichten geht aber hervor, daß diese Kunst den Alten wohl nicht ganz unbekannt war.

In Indien, dem alten IIeimatlande des Diamants, verstand man schon in den ältesten Zeiten Diamantflächen zu polieren, und später hat man dort auch gelernt, Facetten anzuschleifen. Am Encie des siebzehnten Jahrhunderts, zur Zeit der Anwesenheit von Tavernier (1665), wurden jedenfalls Diamanten in dieser Weise bearbeitet. Wann und wie das Verfahren crfunden oder eingefïhrt wurde, ist nicht bekannt. Die Indier wandten den Schliff aber meist nur an, um schlechte Stellen an den Steinen zu entfernen. Sie bevorzunten natiirliche Oktä̈der, deren Flïchen sie polierten. Allerdings stellten sie auch andere Schlifformen her, so vielfach Dicksteine (S. 96, Taf. TV, Fig. 15 ${ }^{\text {a }}{ }^{\text {b) }}$ ), deren Form daher als "indischer Schnitt" bezeichnet wurde, daneben Tafelsteine, Dïnnsteine und ähnliches. Alle diese Gestalten sind nicht nur in Indien, sondern auch sonst im Orient, in Persien, Arabien, Bagdad usw. sehr geschïtzt. Formen mit zahlreichen Facetten fehlten gleichfalls nicht. Die s'chleifer schmiegten sich dabei aber der natiirlichen Begrenzung des rohen Steines an, um Materialverlust möglichst zu vermeiden. Letzteres war und ist noch heute im Gexensatz zu den europäischen Steinschleifern die IIauptsorge ihrer indischen Kollexen, die aus diesem Grunde vielfach unförmlich dicke, für die Lichtwirkung ungüinstige sogenannte "klumpige Steine" oder „Kieselsteine" herstellen. Diese Steine kamen nachler zum Teil in europaiische I:ïnde und wurden dlann unter großem Gewichtsverlust neu geschliffen, um ihre: Schöuheit zu heben. Ein solches Schicksal hatte neben anderen der "Kohinur", der grolje I)iamant der englischen Krone, desse'n friihere in Indien hergestelle Form auf Taf. X, Fig. 4, b, die jetzige europäische in Fig. 5, , , c abgebildet ist.

Wir treffen indessen in Indien nicht nur einheimische Diamantschleifer, sondern auch Europäer. So berichtet Tavernier von dem Venezianer IIortensio Borgis, dab er den wrofien Diamant des Beherrschers von Dethi, der nach seinem Besitzer später "Grofmoenl* genamnt wurde, mit wenie Erfolg eschliffen lıabe. Die seit dem Ende des Mittelalters in Europa zur Entwicklung und zur Blïte crelangte Diamantschleiferei ist also nicht ganz olne Einflub auf Indien seblichen, und vielleicht ist die Kunst in Indien von Europa aus eingeführt oder doch neu geweckt worden. 
Im Abendlande wurde im Mittelalter der Diamant noch zanz roh oder oberflächlich poliert oder auch in den in Indien ïblichen einfachen Formen von Spitzsteinen, I)ickund Tafelsteinen usw. heniitz. Er diente so anfänglich nicht zum Frauenschmuck sondern zur Verzierune von Staats- und Prachtgewändern, wie z. B. des Krïnungrsmantels Karls des Groben, von Reliquiensehreinen, Seeptern, Kronen, Schwertscheiden usw. Von Diamantschleifereien aus jenen Zeiten ist in Europa so grut wie gar nichts Cienauces bekannt, bis am Anfank des 15. Jahrhunderts ein geschickter Künstler Namens Irermann in Paris auftrat, wo sich nunmehr die Diamantschleiferei entwickelte. Schon 1373 wurden Diamantpolierer in Nïrnberg erwähnt, man weif aber nicht näher, in welcher Weise sie die Steine bearbeitet haben.

Mit der allmählich sich vervollkommnenden und verbreitenden Kunst, die Schönheit der Diamanten durch Schleifen, wenngleich zun̈̈ehst nur wenigr zu erhöhen, geht wohl auch die allgemeiner werdende Verwendung zum Frauenschmuck IIand in Hand. Dies geschah zuerst am franzïsischen IIofe unter Karl VII. durch $\mathbf{A g n e s}$ Sorel (nach 1131) Die dortigen Damen entwickelten dann schon unter Franz I. einen großen Luxus darin und dieser nahm bald so zu, dab Karl IX. und Heinrich IV., allerdings vergeblich, eigene Terordnumgen dagegen erlassen muliten. Von Frankreich aus verbreitete sich hierauf die Sitte, Diamanten zum Sichnuck des Körpers ständig zu tragen, allmählich über ganz Europa.

Der starke Terbrauch hatte zur Folge, daß die Diamantschleiferei neut Impulse erhielt. In der Tat machte diese Kunst noch im Laufe des 15. Jahrhunderts einen ihrer gröbten Fortschritte durch den niederlïndischen Steinschleifer Ludwig ran Berquen in Brïgre. Seine Erfindung fällt in das Jahr 1476. Manche stellten die sache nach einer Mitteilung seines Enkels Robert ran Berquen so dar, als wäre er der Entdecker des Verfahrens, Dramanten mit ihrem eigenen Pulver zu schleifen, also der eigentlichen Diamantschleiferei. Aber diese Kunst ist, wie wir gesehen haben, wahrscheinlich schon längst in Europa bekannt gewesen. Was L. van Berquen erfand, war wohl nur eine Terlesserung des Schleifverfahrens und eine streng regelmäbige Anordnung der Facetten, wodurch das Farbenspiel, das an den frïher hergestellten Spitz- und Tafelsteinen beinahe gleich Null war, sehr wesentlich gesteigert wurde.

Die ersten und berïhmtesten Diamanten, die L. von Bercfuen schliff, sollen die Karls des Kïhnen von Burewnd gewesen sein, welche der Herzog zum Teil in seinen unglïclilichen Schlachten gexen die Schweizer verlor. Einige dieser Steine sind wahrscheinlich noch heute in der damals erhaltenen Form vorhanden und bekunden den hohen frad der Geschicklichkeit des Künstlers, der sie geschliffen. Nach Schrauf sind der ..Florentiner"

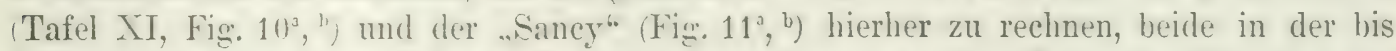
dahin unbekannten, ron L. van Berquen zuerst angewandten Form der Brioletts oder Pendeloques. Bei der speziellen Betrachtung der grolien Diamanten werden wir auf diese beiden noch einmal zurïckkommen.

Die Form dieser Diamanten ist später nicht gar zu oft nachgeahmt worden; gegenwärtig ist sie ziemlich ungebräuchlich und liommt an neugeschliffenen Steinen wenig vor. Dagegen kam im 16. Jahrhundert, etwa 1521), die jetzt für den Diamant so wichtige Form der Rose olter Iiosutte mit ihren versehiedenen Abarten (Taf. IV, Fig. I his 7 und Fig. 37 und 35, S. 97 auf. Diese war lingere Zeit sehr belieht und wird anch jetzt noch sehr häufigr angewendet. Sie hat den Vorteil, daß sie beim Sichleifen dïnner und flacher, sog. schwacher Diamanten, einen nur ganz unbedeutenden Materialverlust verursacht und daß sie einen sehr starken (ilanz zeigt. Andererseits leidet sie aber an den Übelstand, dab ihr das schöne Farbenspiel giinstiger geschliffener Diamanten abgeht.

Bald wurde auch die Form der Rose überholt durch eine andere, welche die hüchsten (irade der Vollkommenheit darstellt, die der Diamant nach unseren jetzigen Erfahrungen 
erlangen kann. Es ist die Form des Brillants, deren Erfindung in der Mitte des 17. Jabrhunderts, wie wir schon oben gesehen haben, dem Kardinal II a zarin oder doch wenigstens seinem Einfluß zugeschrieben wird. An den Brillanten von MI a zarin hatte das Oberteil (außer der Tafel) 16 Facetten, es war der zweifache Brillant (Taf. II, Fig. $1^{a}, b, c$. Am Ende des 17. Jahrhunderts stellte der Venetianer Vincent Peruzzi zuerst dreifache Brillanten mit 32 Flächen am Oberteil (Fig. $3^{\text {a }, ~ ", ~}{ }^{c}$ ) her, die eine noch efwas gïnstigere Lichtwirkung haben. Später sind dann die Facetten, wie in Fig. $4^{\text {a }}$, ${ }^{b}$, derselhen 'Tafel, gleichnälbiger gestaltet worden, auch hat man neuerer Zeit bei den Brillanten die Tafel machmal göinzlich durch rosettenartig angeordnete Facetten ersetzt. An Steinen dieser Art werden in Amerika zur Frhöhung des Glanzes zuweilen flache Vertiefungen statt der Facetten angeschliffen, und ähnlich werden auch Steine von anderen Formen manchmal mit solchen Vertiefungen versehen. Andere Schlifformen, die man seitdem noch erfunden lıat, sind nur unwesentliche Modifikationen der genannten, so der Sternschnitt von Caire (Taf. III, Fig. $1^{\text {a }},{ }^{\text {b }}{ }^{c}$ ), der daraul berechnet ist, ohne Verschlechterum der Lichtwirkung den dureh die Herstellung der Brillantform bedingten Verlust zu vermindern, der amerikanische Brillantschliff (Fig. 34, S. 92) und der Jubiläumsschliff oder Schliff des 20. Jahrhunderts (Fig. 35, S. 94).

Der Materialverlust ist allerdings beim Brillant sehr bedeutend und beträgt ein Drittel, oft die Hälfte des rohen Steines, manchmal noch mehr. So betrug z. B. bein "Regent", einem der vollkommensten Brillanten, den man kennt, das Rohgewicht 110 Karat, der geschliffene Stein wiegt jetzt $1366^{\top}$, Karat, weit weniger als die Hälfte. Beim "Kohinur" sind die entsprechenden Zahlen $186^{1 / 16}$ und $1061 / 16$ Karat, und der roh 2541/2 Karat wiegende „Siidstern" wurde beim Schleifen in einen Brillant von 1251,2 Karat verwandelt. Im Jittel rechnet man, dab für einen Brillant von 1 Karat ein roher Diamant von 21/2 Karat nötig ist. Dafür ist aber auch das Farbenspiel beim Brillant das Herrlichste, was man sich denken kann, präichtiger als bei irgendeiner anderen Schlifform. Dieses Umstandes wegen erleidet man den Verlust gern, und man seliätzt einen etwas kleineren Dianant mit grutom Brillantschliff und Farbenspiel weit höher als einen etwas größeren, aber schlechter geschliffenen, der wegen seines ungïnstigen Schliffes ein nur unbedeutendes Farbenspiel zeigt.

Der Brillant wird stets so gefabt, daß die breite Tafel nach vorn und dem Beschaner zugekehrt ist. Nur selten und wenn der Stein Fehler hat, die man verdecken will, geschicht das Ungekehrte (indische Fassung). Die Strahlen des auffallenden Lichtes machen dann den schon frïher (S. 52, Fig. 20) dargelegten Weg. durch den stein lindurch und bewirken so das prachtvolle Aussehen. Teben einem Brillant sicht jeder andere Diamant matt und tot aus, die Anordnung. der Facetten an anderen Schlifformen verändert die Lichtstrahlen bei ihrem (kang dureh de'l Stein weniger guinstig, und namentlich kann sich das Farbenspiel keiner anderen Diamantform mit dem des Brillants messen. Aher auch jeder Brillant, der nicht die olen (S. 93) angregebenen Dimensionen hat, der also nicht genau nach der liegel geschliften ist, wirkt weniger vorteilhaft. Ein soleher ist z. B. der "Kohinur" in sciner neuen Form. Lr ist zu niedrig und daher seine Wirkung erheblich geringer als die des ,Regent". dessen form genau in den richtigen Vurhältnissen gehalten ist.

Die II irkung cines Brillants hänget aber nicht allein von der Form und Beschalfenheit dess Steines, sondern his zu cinem hohen Grade auch von der Art der Beleuchtung al). Die Lichtquelle darf nicht zu swrolj sein, sonst ïberdecken sich die einzelnen durch die Brechume entstandenen farbigen 'Teilstrahlen und machen in Auge den Eindruck von Weil). Bei kiinstlicher Beleuchtung darf die Flanme nicht durch eine matte Glasglocke verdeckt sein. An vorteilhaftesten fïr das Aussehen eines Brillants ist es, wenn er von 
allen seiten her durch zahlreiche kleine Flammen beleuchtet wird. Sohr bedeutend wird die Wirkung gesteigert, wenn die Brillanten etwas hin und her schwanken, was durch Aufsetzen auf dïnne metallene Stähchen bewirkt werden kann; ein durch fortwährende rasche Änderung des Furbenspieles hervorgebrachter besonders prachtvoller Anblick ist die Folge davon.

Werden auch dem Diamant erforderlichenfalls alle Formen gegeben, die sonst bei Edelsteinen ïblich sind, so sind doch geerenwärtig die beiden Hauptsehlifformen des 1)iamants in erster Linie und von weit überwiegender Bedeutung die des Brillants, sodann, ebenfalls weit verbreitet, die der Iiosette (Rose); alles andere tritt daregen zurück und kommt höchstens gelexentlich einmal ror. Bei keinem anderen Edelsteine werden diese beiden Formen so häufig und in so vorwiegender Weise angewendet wie beim Diamant, so dab, wenn man von Brillanten und Rosetten schlechtweg spricht, darunter immer solche von Diamant verstanden sind.

Zu Brillanten (s.91) werlen alle Steine der verschiedensten Größe verschliffen. von den gröbten bis zu Bruchteilen eines Karats, wenn es die rohe Form irgend ohne zu grofen Verlust erlaubt. Auf Tafel IX sind Brillanten von 1'4 Karat bis 100 Karat in natiirlicher Gröbe, von der Tafel des Oberteils aus gesehen dargestellt, die ein ühersichtliehes Bild von der den versehiedenen Gewichten zukommenden Grölje getsen. Man hat besondere Instrumente, sog. Diamanten-oder Brillantenlehren, mittels deren man die Größe der Steine in Millimetern messen kann. Hieraus lälbt sich dann mit Hilfe geeigneter Tabellen das Gewicht ermitteln, was häufig; besonders bei gefaßten Steinen, von Wert ist. Bei vollkommen regelmäbig geschliffenen Brillanten ist diese IIthode recht zuverlïssig; wenn unregehmäßige Facetten vorhanden sind, kann das so gefundene Gewicht von dem richtigen, das die Waage angibt, um $1 / 16$ bis $1 / 32$ Karat abweichen.

Zu Rosen (S. 96) werden im allgemeinen nur kleine und schwache, d. h. diinne Steine, sowie bei der Herstellung größerer Brillanten abgespaltene Stïcke verarbeitet, größere nur, wenn sie zu einem Brillant nicht dick genug sind. Man zieht es sogar zuweilen vor, aus einem solchen dïnnen Steine von einiger Größe durch Zerteilen mehrere kleinere Brillanten statt einer grölieren Rose herzustellen. In Fig. 54 sind wie oben bei den Brillanten einige Rosen von verschiedenem Gewicht ( 1 bis 50 Karat) in natïrlicher Größe abgebildet. Rosen mit noch regelmäßiger Flächenanordnung werden von viel geringeren Dimensionen hergestellt als Brillanten. Sie gehen bis zu einer Kleinheit herab,

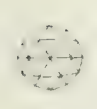

I.

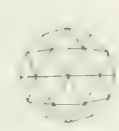

21

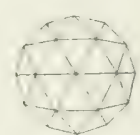

,

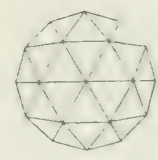

10

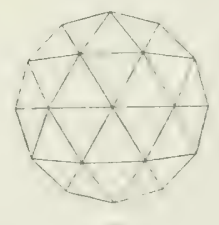

25

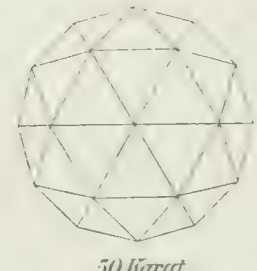

joliarrit.

Fig. 54. Natürliche Größe der Rosetten aus Diamant von 1 bis 50 Karat.

sodaß 1500 und noch mehr auf ein Karat gehen. Kleine Rosen, von denen 100 bis 160 und noch mehr Stiick ein Karat wiegen. werden Stückrosen genannt. In der Kunst, Steine von dieser geringen Größe zu schleifen, sind namentlich die Holländer bewandert. Solche minimale Splitterchen werden oft auch nur nit einigen wenigen unregelmäbigen Facetten versehen und bilden dann die sogenannten ș en a ille; sie, wie die kleinsten Rosen benützt man zum Einfassen (Karmoisieren) anderer gröberer Edelsteine. Hier schließen sich endlich noch die Porträtste in e (Kasken, Brillantglas) an, sehr dünne, auf beiden Seiten abgeschliffene Plättchen aus Diamant, deren Rand meist mit kleinen 
Facetten versehen ist. Sie dienen zum Bedecken kleiner Portrïts usw. in Ringen usw. und bringen auf diese Weise eine sehr gute Wirkung liervor. Erwähnt mag noch werden, daß man, wenn schon selten, auch aus Diamant in der Mitte durchbolsrte ovale Formen zum Aufreihen auf Schnüren herstellt.

Zum Schluß seien hier noch einige Ausdrücke erwähnt, die von den Juwelieren zuweilen angewendet werden. Sehr kleine Diamanten heißen Salzkörner, sehr große und schöne Solitairs, auch Nonp areils oder Parangons. Solitairs wurden früher alle geschliffenen Diamanten über 50 Karat genannt, solche über 100 Karat hat man wohl auch als majestätische Diamanten bezeichnet. Steine unter ein Karat bilden das Karatgut, die von einem, zwei usw. Karat werden als Karatsteine, Zweikaratsteine usw., auch als ein-, zweikarätig usw. unterschieden.

\section{Diamantschleiferei.}

Die allgemeinen Verhältnisse der Edelsteinschleiferei sind schon oben (S. 99) besprochen worden. Bei der Bearbeitung des Diamants ist aber seiner großen Härte und seiner Spaltbarkeit wegen manches zu berücksichtigen, was bei anderen Edelsteinen wegfüllt.

Die Form des Brillants wird jetzt, wie wir gesehen haben, am häufigsten hergestellt. Diese gleicht in den allgemeinen Umrissen einem Oktaëder, an dem zwei gegenüberliegende Ecken abgestumpft sind. Hat man eine solche Form, dann sind nur die Facetten anzubringen, und der Brillant ist fertig. Die günstigste Ausgangsform für diesen Schliff ist daher das Oktaëder. Kristalle von den Formen der Fig. $39 n$ und $o$ sind somit für die Brillanten besonders geeignet, aber auch die Granatoëder und Achtundvierzigflächner (Fig. $39 c$ und $d$ ) sind noch günstig. Haben jedoch die rohen Steine eine vom Oktaëder stark abweichende Form, wie z. B. Fig. $39 e$ und $f$, dann wird von den oktaëdrischen Blätterbrüchen der Diamanten Gebrauch gemacht, um aus ihnen durch Spaltung erst ein Oktaëder herzustellen und daran weiterhin die Brillantfacetien anzubringen. Das Spalten ist also eine wichtige Prozedur bei der Diamantschleiferei. Es fördert die Arbeit sehr bedeutend, denn es ist sehr rasch geschehen, während es sehr zeitraubend und kostspielig wäre, die betreffenden Teile statt dessen abzuschleifen. Außerdem sind die abgespaltenen Stiicke noch ganz und können weiter zur Herstellung kleinerer Steine, und zwar ihrer geringen Dicke wegen namentlich zu Rosetten, Verwendung finden. Das Spalten wird auch sehr viel angewandt, um unreine äußere Teile von einem inneren besseren Kerne zu trennen, um einen größeren Stein von ungünstiger Form in mehrere kleinere zu zerlegen usw. Dabei ist aber die äußerste Vorsicht nötig. Der Arbeiter muß verstehen, aus der Form der rohen Diamanten die Lage der Spaltungsflächen zu beurteilen und muß imstande sein, Zwillingsbildungen zu erkennen, bei denen die Spaltungsflächen nicht ununterbrochen durch den ganzen Stein hindurchgehen. Sucht man einen Stein letzterer Art zu spalten, oder einen anderen Stein in falscher Richtung, so ist er der Gefahr der Zertriimmerung ausgesetzt, was immer großen Verlust zur Folge haben kann.

Die eigentliche Spaltung, das "Klieven" der Diamantschleifer, wird von besonderen Arbeitern besorgt, und zwar ist der Vorgang der folgende: der zu spaltende Stein wird mit einer Mischung von Schellack, Terpentin und feinstem Ziegelmehl oder einer ähnlichen Masse, dem sog. Zement, oder auch mit Schnellot am Ende eines Kittstockes befestigt, und zwar so, daß die herzustellende Spaltungsfläche in die Verlängerung des letzteren fällt. Dann wird ein zweiter Diamant mit einer hervorstehenden Kante in derselben Weise auf einen anderen Kittstock gesetzt, so daß die Kante nach oben gekehrt ist. Mit dieser wird nun über den zu spaltenden Stein an der Stelle, wo die Teilung vor sich gehen soll, und in der Richtung der herzustellenden Spaltungsfläche so lange stark hin und her geriehen, bis eine kleine Rinne von grenügender Tiefe entstanden ist. In dieser wird ein scharfes, 


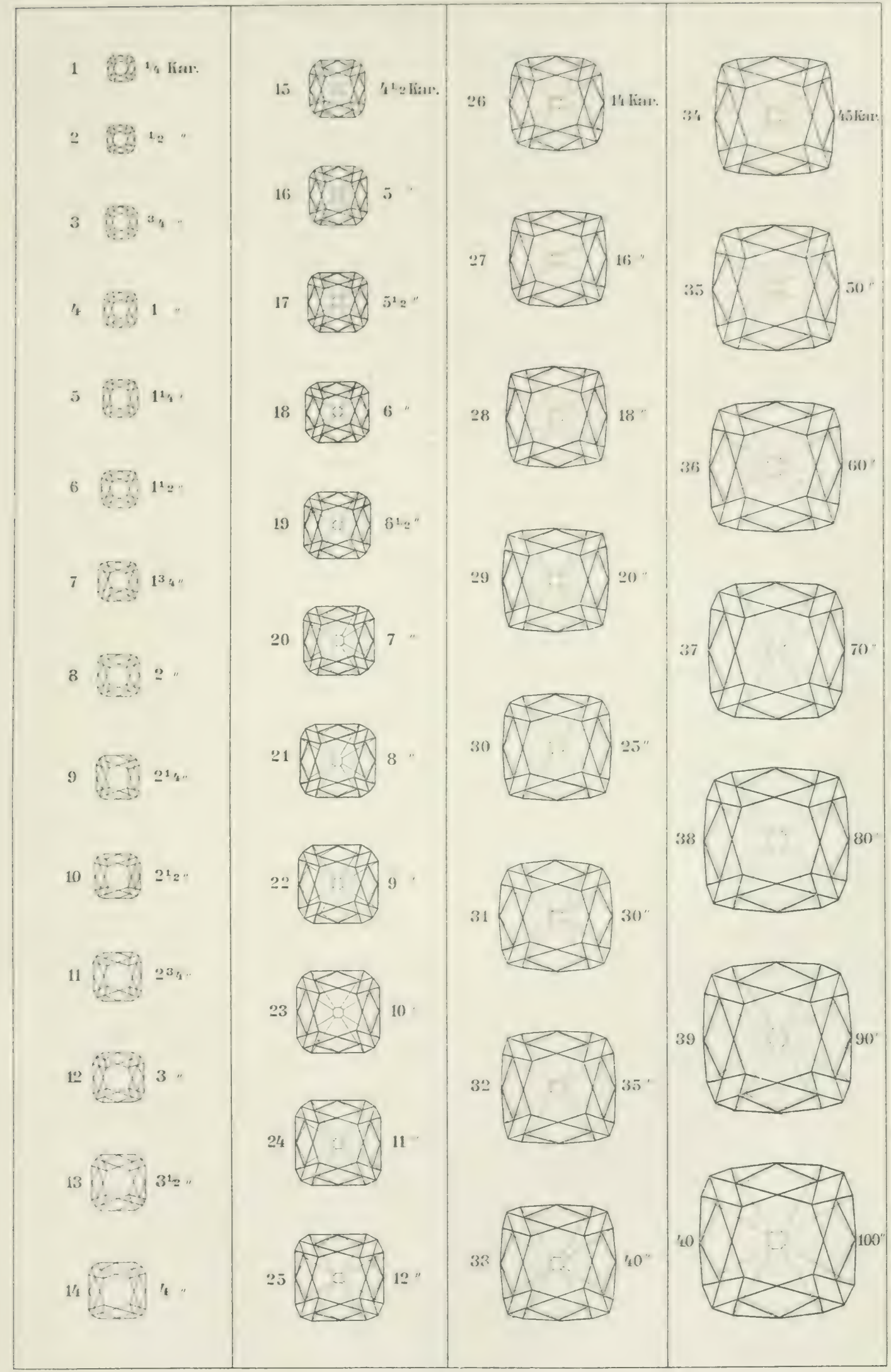



starkes Messer wieder genau in dor Richtung der herzustellenden Trennungsfläche auforesetzt und darauf, nachdem der Sticl des Kittstockes auf eine feste elastische Unterlage grestellt ist, mit dinem Ifammer ein kurzer enerrischer Schlar ausgeführt. Die Spaltung gelıt so wanz leicht vor sich. Durch IItrumdrehen des Steines, indem man den Kitt dureh Erwärmen weich macht mol jenen von neuem in der Richtung einer zweiten usw. Spraltungsfläche einsetzt, kann man in derselben Weise die Spaltung nach den anderen Richtungen ausfïlıren. Jan mul dabei das durch das Einreiben der Rinnen entstehende Pulver in einem kleinen Kistehen, der Schneidebiichse auffangen, da es wertvoll und zum eigrentlichen Schleifen brauchbar ist.

Neuerdings hat man auch Maschinen zum Spalten der Diamanten hergestellt.

I)as Spalten ist in Indien, der Mitteilung Tavernier's zufolge, schon seit alten Zeiten bekannt und allgemein im Gebrauch. In Europa scheint es aber erst seit neuerer Zeit von den Diamantschleifern angewendet zu werden, und zwar, wie erzählt wird, nach dem Tormange des englischen Physikers Wollaston, der um die Wende des 18. und 19. Jahrbunderts (1766-152S) lebte. Von ilım wird berichtet, da\} er grole Diamanten mit äuljeren Fehlurn kaufte, die fehlerhaften Stellen durch Spaltung entfernte und dann die Steine mit großem Nutzen wieder verkaufte.

IIat der Stein, wenn nötig, durch Spalten, die oktaëdrische Grundform des Brillants erhalten, dann handelt es sich darum, noch die Facetten anzubringen. Dies geschieht nicht direkt durch Schleifen; diesem geht zur Beschleunigung und Erleichterung der Arlecit erst noch eine andere der Diamantschleiferei eigentuimliche Operation voraus, die wieder von besonderen Leuten besorgt wird, das Schneiden, Formen, Reiben, Bruttieren. Cramen oder Graumachen des Steines, wodurch die Facetten im rohen vorgebildet werden. Der Arbeiter nimmt dabei gleichzeitig zwei Steine in Angriff, die er mittels Schncllots, einer leicht schmelzbaren Legierung von Blei und Zinn, oder mittels des beim Spalten verwendeten Kittes auf Kittstöcken befestigt, so daß nur die Stelle herausragt, an der die Facette entstehen soll. Dann werden die beiden Diamanten an diesen Stellen, zum Auffangen des Pulvers über der Schneidebüchse, mit starkem Druck aneinander gerieben, his die Facetten in ihren Umrissen, ziemlich eben, aber noch rauh an beiden Steinen in ihrer ungefähr richtigen Stellung vorliegen. Bei diesem Reiben entsteht ein eigentïmliches Geräusch, das so charakteristisch sein soll, daß ein Kenner daran ohne weiteres merken kamn, ob zwei Diamanten oder zwei andere harte Steine aneinander gerieben werden. Die so vorbereiteten Facetten haben ein granes, metallisches Ausseben, daher der Name Granen oder Graumachen. Dabei ist immer darauf zu sehen, daß der Stein durch die Reibung nicht zu stark erhitzt wird, weil er sonst eisige Flecken erhält.

Ist an den beiden Steinen die erste Facette in rohen fertig, dann wird das Schnellot oder der Kitt erwärmt und erweicht, und die Steine werden so gedreht, daß eine zweite Stelle heraussicht, die eine Facette tragen soll. Das Reiben wird wiederholt und damit in derselben Weise so lange fortgefahren, bis alle größeren Facetten vorgezeichnet sind. Die Steine sind dann von einem System ziemlich ebener, rauher, grauer, etwas metallisch glänzender Flïchen umgeben; sie haben nun gar nicht mehr das Aussehen von Diamanten, sondern eher das von matten, grauen Metallkörnern von der allgemeinen Form des herzustellenden Brillants oder der betreffenden anderen Form, die man ihnen zu geben beabsichtigt.

Auch für das Grauen hat man jetzt Maschinen, die das Geschäft sehr gut besorgen. Sie werden daher vielfach mit Nutzen als Ersatz für die Handarbeit angewendet und baben außerdem den Vorteil, daß beinahe alles abgeriebene Pulver gewonnen wird, während beim Grauen mit der Hand wenig mehr als die Hälfte in der Schneidebiichse aufgefangen werden kann, so daß beinahe die Hälfte verloren geht. 
Früher wurde auf diese Weise auch die breite Tafelfläche der Brillanten durch Reiben vorbereitet. Heutzutage versteht man, die betreffende Ecke durch Sägen in der oben (S. 103) besprochenen Weise zu entfernen. Diese Ecke bleibt dabei erhalten, während sie früher ganz verloren ging, und der Terlust ist dadurch viel geringer. Auch in anderen Richtungen werden die Diamanten jetzt zersägt, um z. B. aus einem größeren Stïck von ungünstiger Form zwei kleinere besser gestaltete zu erhalten usw. Beim Schleifen des "Regent" hat man iibrigens rom Sägen bereits Gebrauch gemacht. Die Oktaëderecken beim Herstellen ron Brillanten hat man schon friiher auch in der Weise entfernt, daß man an der passenden Stelle den Stein ringsum einkerbte, wie beim Klieven und dann die Feke durch einen raschen Schlag abtrennte; dies ist aber immerhin nicht ungefährlich.

Dem Reiben folgt nun erst das Schleifen oder Polieren. Diesem ist es vorbebalten, die rauhen Reibflächen glatt und glänzend zu machen und ihnen genau ihre richtige Lage zu geben, die an den gegrauten Flächen noch nicht vollkommen erreicht ist, sowie die noch fehlenden kleinen Facetten anzubringen, die beim Grauen nicht beriicksichtigt werden. Dies geschieht in der bei allen Edelsteinen üblichen Weise (S. 100), indem man die Steine in eine Doppe einsetzt und auf die Schleifmühle bringt, die in unserem Falle stets nit Diamantpulver als Schleifmittel versehen werden muß. Wegen der Gleichheit der IIärte des Steines und des Schleifmittels fällt beim Diamant Schleifen und Polieren zusammen; die Facetten erhalten beim Schleifen sogleich ihren höchsten Glanz, ein besonderer Polierprozef ist überfliissig. Der Stein braucht zum Schlusse nur noch behufs Beseitigung der anhängenden Unreinigkeiten mit feiner Knochenasche oder Tripel abgerieben zu werden, um marktfähig zu sein.

Bei dem Schleifen ist es keineswegs gleichgïltig, in welcher Richtung die stets wagrecht laufende Schleifscheibe über die herzustellende Facette weggeht. In manchen Richtungen wird der Stein verhältnismäßig leicht angegrifien, in anderen ist dies kaum möglich. Dieses Verhalten hängt, wie wir gesehen haben, damit zusammen, daß beim Diamant wie bei anderen Edelsteinen die Härte in verschiedenen Richtungen verschieden ist. Der Diamant muf daher "nach dem Wuchs" geschliffen werden, sonst können leicht Steine und Schleifscheiben zerstört werden. Der Arbeiter muß also diese Richtungen leichter Angreifharkeit genau kennen, sonst rückt sein Geschäft im günstigsten Falle äußerst langsam vorwärts. Soll z. B. an einem Oktaëder die Tafel eines Brillants angeschliffen werden, so mul3 die Schleifscheibe über die Kanten des Oktaëders weg: angreifen. Greift sie ïber die Flächen (in Fig. 55 von nahezu rombischer Form mit den gekreuzten Pfeilen) weg an, dann ist es fast unmöglich, die Facette zustande zu bringen, weil in dieser Richtung die IIärte des Diamants erheblich größer ist als in der andern.

In der Fig. 5) geben die Pfeile die Richtung geringster IIärte auf sämtlichen Flächen eines Brillants an, also diejenigen Richtungen, nach denen mit dem besten Erfolge geschliffen werden kann. Auch dieses dritte und letate Stadium in der Bearbeitumg eines I liamants, das Schleifen und Polieren, wird von besonderen Arbeitern besorgt.

Die Reihenfolge, in der die Facetten eines Brillants hergestellt werden, ist nicht gleichgilltig. Jedenfalls wird, wenn man von der oktaëdrischen Grundform ausgeht, immer zuerst die Tafel und die Kalette angrebracht. Dabei mulb, um die richtigen Grölsenverhältnisse zu erhalten, stets, wie es in Fig. 56 dargestellt ist, an der Seite der Tafel die Ecke genau auf $" / 3$ der halhen Höhe, an der Seite der Kalette auf 19 derselben abgeschliffen werden, sonst entspricht der Stein nicht der Regel für die vollkommenste Brillantform, bei welcher der Oberteil ein Drittel, der Unterteil zwei Drittel der gesamten Dicke von der Tafel bis zur Kalette einnimmt. 
Bei manchen rohen Steinen ist die Gestalt so, daf man ihnen statt der gewöhnlichen Form besser die der ovalen oder der dreieckigen Brillanten gibt. Dann modifizieren sich die obigen Operationen etwas nach den speziellen Terhältnissen. Dasselbe geschieht auch, wenn es sich um andere Schlifformen als den Brillant handelt, z. B. um eine Rosette. In diesem Falle spielt dann die Spaltbarkeit keine so grolje Rolle mehr, im übrigen wird aber ebenso verfahren wie beim Brillant.

Der Ilauptsitz der Diamantschleiferei hat mit den Zeiten vielfach gewechselt. Die L, udwig van Berquen zugeschriebene grobe Entdeckung wurde 1476 in Brügge gemacht, doch bestanden im 15. und 16. Jahrhundert die meisten Schleifereien in Antwerpen, wohin Arbeiter von L. van Berquen übergesiedelt waren. Ton da kam die Kunst nach Amsterdam, und hier hat sie sich bis zum heutigen Tage immer weiter und großartiger entwickelt, freilich nicht ohne mancherlei Wechselfälle. In dieser Stadt sind jetzt die meisten Anstalten für Diamantschleiferei und die meisten Arbeiter. Gegenwärtig befinden sich dort etwa 70 große und kleine Fabriken mit allen Einrichtungen der modernen

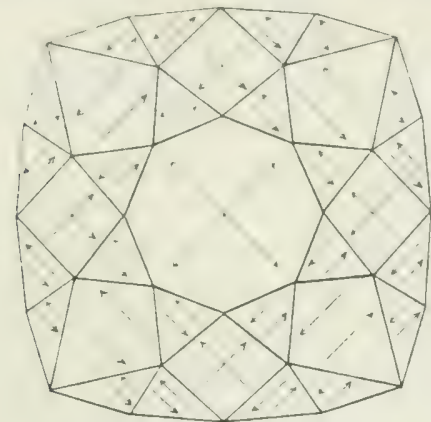

Fig. 55. Richtungen geringster Härte auf den Facetten eines Brillants.

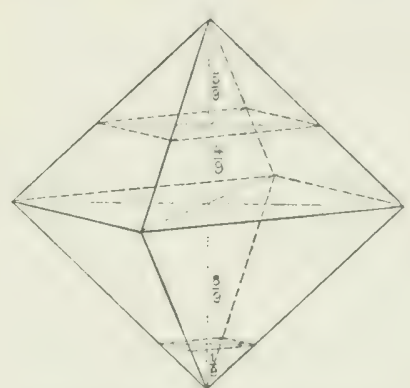

Fig. 56. Diamantoktaeder mit Tafel und Kalette als Vorbereitung für den Brillantschliff.

Technik und mit Dampfluetrieb, sowie mit mehr als 12000 Arbeitern, durchweg Juden. Eine dieser Anstalten hat allein 450 Schleifmühlen und 1000 Arbeiter. Im ganzen sollen in Amsterdam ungefähr 7000 Schleifapparate (Skaifs) im Betrieb sein. Allerdings ist Amsterdam nicht mehr, wie lange Zeit hindurch, der einzige Sitz dieser Industrie. Es gibt jetzt geschickte Schleifer, namentlich in Antwerpen, aber auch in Gent, Paris, st. Claude und anderen Orten im französischen Jura, London und vor allem in Deutschland, besonders in Ianau, sowie in Berlin und in Idar bei Oberstein a. Yahe, wo, wie bekannt ist, und wie wir unten noch eingehend sehen werden, die Bearbeitung der farbigen Edelsteine, namentlich auch des Achats und anderer Quarzmineralien ihren Hauptsitz hat. In Nordamerika hat sich dieser Industriezweig seit einiger Zeit, begünstigt durch den bohen Zoll auf geschliffene und die Zollfreiheit für rohe Edelsteine, sowie durch den infolge des stark zunehmenden Reichtums rasch steigenden Juwelenluxus bedeutend entwickelt. Auch manche neue Einrichtungen, z. B. die der mechanischen Doppen, in denen die Steine nittels Klammern festgehalten und beliebig gedreht werden künnen. und einige neue Schlifformen sind hier aufgekommen, während in Europa der Betrieb olıne Verbesserungen stets in der alten Weise stark stagnierend weitergeführt wurde. Immer aher steht Amsterdam noch an der Spitze: Amsterdamer Schleifer gelten noch immer für die gresehicktesten, daber werden ihnen meist die gröliten und kostbarsten Steine, wie z. B. der Excelsior und der Cullinan, anvertraut; auch verstehen sie am besten, ganz kleine Steinchen mit regelmäßigen Facetten zu versehen.

Daß bei der Herstellung eines Brillants die Hälfte des rohen Steins, selten weniger, häufig mehr verloren geht, ist schon erwähnt. Die zum Schliff erforderliche Zeit ist 
recht erheblich und wächst mit der Größe der Steine. So brauchte z. B. Marry G. II orse in Boston 31.2 Monate, um einen 125 Karat schweren sïdafrikanischen Diamant zu einem 77 Karat schweren Brillant zu schleifen. Die sehr erheblichen Kosten gehen daraus von selber hervor.

Während das Schleifen des Diamants von der größten Wichtigkeit ist, kommt das Schneiden oder Gravieren desselben, das bei weicheren Edelsteinen so viel geubt wird, bei ihm der großen Ïärte wegen kaum vor. Ob im Altertum auf Diamant graviert wurde, ist mindestens sehr zweifelhaft, aus 'späteren Zeiten sind aber einige geschnittene Diamanten bekannt, so ein solcher mit dem Bildnisse des Don Carlos und ein anderer mit dem für Karl V. hergestellten spanischen Wappen. Heutzutage wird der Diamant jedenfalls nicht mehr in dieser Weise bearbeitet, da die Ausführung zu schwierig und die Wirkung der geschnittenen Steine nicht der angewandten Mühe entsprechend ist. Dab die Kunst auch im Orient nicht unbekannt war, zeigt unter anderem ein von Boutan angeführtes Beispiel, wo auf einer Fläche eines schönen indischen Oktaëders von 30 Karat ein religiöser Spruch in orientalischen Buchstaben eingraviert war. Nach dem Bericht von G. Rose war der unter dem Namen "Schah" bekannte ungelmäßig geformte Diamant des russischen Kronschatzes (Taf. X, Fig $3^{a}{ }^{\prime \prime}$ ) auf einigen Flächen mit persischen Inschriften versehen, die Namen von persischen Königen angebend. Ein anderer großer Diamant, der "Akbar Schah", war auf zwei Flächen mit arabischen Inschriften versehen, die aber wie bei dem "Schah" durch einen Neuschliff verschwunden sind.

Auch das Durchbohren von Diamanten zum Auffassen auf Schnüren kommt vor, aber gleichfalls nur als Seltenheit. Diese Kunst soll heutzutage noch in Genf und Venedig betrieben werden, in letzterer Stadt als letzter Überrest alter Diamantschleifereien die ehemals hier im Gange waren. Das Bohren setzt wie das Schleifen die Anwendung von Diamantpulver voraus. Die erste Öffnung wird mit einer feinen Diamantspitze bewirkt, dann wird mit einer Stahlspitze und Diamantstaub bis zur völligen Durchbohrung weiter gearbeitet.

\section{Verwendung in der Technik.}

Die Anwendung der Diamanten in der Technik beruht zum kleinen Teil auf der starken Lichtbrechung, am meisten wird von der enormen Härte Gebrauch gemacht.

Wegen der starken Lichtbrechung hat man versucht, den Diamant zu Linsen für Mikroskopobjektive zu verwenden. Solche Diamantlinsen brauchen nur eine gieringe Trïmmung zu haben, um dieselbe Vergröferung zu geben wie sehr stark gekrümmte Linsen aus schwächer lichtbrechender Substanz, wie Glas usw. Die mit der starken Kriummung der Linsen verbundenen Übelstände werden also beim Dianant vermieden, auch sind Diamantlinsen ihrer großen Härte wegen nicht der Gefahr ausgesetzt, von Staub und Schmutz angegriffen zu werden. Die Versuche wurden hauptsïchlich von Pritchard auf Antrieb des Dr. Goring 1824 bis 1826 gemacht, aber obwohl es Pritchard gelang, einige brauchbare Linsen herzustellen, so wurde diese Verwendung wegen der Schwierigkeit der Arbeit und wegen des hohen Preises solcher Fabrikate nieht weiter verfolgt.

Sehr verbreitet ist die Anwendung der Diamanten zum Glassehneiden. IIierzu muß der Stein eine von zwei krummen Kristallflächen gebildete gebogene, nicht zu stumpfe Kante besitzen, die man mit schwachem Druck an der Oberflïche des Glases hinführt. Dadurch entsteht in diesem ein sanz flacher, feiner Sprung, der etwa 0,15 Millimeter Tiefe hat, der aber genügt, um ein Zerlorechen genau in seiner Richtung zu ermöglichen. Wenn die Kante in geeigneter Weise aufgesetzt ist, d. h. parallel der Richtung, in der der Diamant über das Glas hinbewegt wird, dringt sie wie ein Keil in das Glas ein und treibt die oberflächliche Schicht auseinander. Ist der Diamant nicht richtig aufgesetzt, dann 
giht es keinen Sprung; er schneidet nicht, sondern er ritzt. Dasselhe geschieht auch, wron man einen Diamantsplitter mit einer scharfen Splitze verwendet. Diese macht eine limne, indem oberflïchlich Glasteile losgerissen werden, was beim richtigen Schneiden niomals eneschicht. Längs einer solchen eingerissenen Rinne springt das Glas nicht wie lïngrs cines eingeschnittenen Simunges. Wollaston hat hieribur eingrehende Versuche anerestellt und gefunden, daf nicht nur natïrliche runde Kanten sich zum Glasschneiden rignen, sondern auch kïnstlich anteschliffene und sogar schon von wenigrer harten steinen als I)iamant. Er sehliff solehe an Rubin, Sapphir, Bergkristall usw. an und konnte damit dieselbe Wirkung hervorbringen, während cine gerade, von zwei chenen Flaichen gebildete Kante cines I)iamants zum Selneiden ganz untauglich war. Man benutzt zu sog. (t)laserdiamanten kleine natürliche Kristalle ron geerigneter Form, etwa Granatoëder odter ähnliche (Fig. 39, c, d usw.), die man mittels Schnellots in geeigneter Stellung in eine eiserne Fassung einsetzt, sodal\} die zum Schneiden geeignete Kante gerade aus dem Lot herausragt: die Fassung wird dann an einer hölzernen Handhabe befestignt. Die Anwendung ist Sache einiger Clbung, die für jeden einzelnen Diamant besonders erlangt werden mul, da eine auch nur geringe Abweichung von der richtigen Stellung die Wirkung des Schneidens verhindert. Die meisten Glaserdiamanten sollen aus Steinen ron Borneo und Bahia gemacht werden.

Übrigens werden auch scharfe Diamantsplitter, wie sie z. B. vielfach beim Spalten der zum Schleifen bestimmten Steine abfallen, in ähnlicher Weise gefaßt und als sog. Sehreibdiamanten zum Sehreiben und Zeichnen auf Glas und andere harte Gegenstände verwendet. Solche Diamantspitzen werden auch zum Gravieren und Bohren harter Edelsteine. wie Rubin, Sapphir usw. benützt, und dasselbe ist schon im Altertum geschehen. In der Neuzeit wird die Diamantspitze beim Gravieren allerdings woul meist durch sehr rasch rotierende, mit Diamantjulver in Olivenöl bestrichene Scheibchen (Zeiger) oder Spitzen ersetzt.

Ferner wird der Diamant wegen seiner großen Härte noch verwendet zum A bdreh en des Randes von Uhrgläsern und von Zapfen aus ganz hartem Stahl, die für Präzisionsinstrumente aller Art bestimmt sind, zum Abdrehen von Kanonenrohren z. B. in den Werkstïtten von Krupp in Essen, zur Herstellung von Werkzeugen aller Art für die Feinmechanik, zum Auskleiden von Öffnungen, durch welche Gold, Silber usw. behufs Herstellung feiner Drähte hindurchgezogen werden, zum Abdrehen und zur sonstigen Bearbeitung harter Gesteine, wie Granit, Gneis, Porphyr usw., zu Zapfenlagern der feinsten Uhren und anderer ähnlicher Instrumente usw.

Unfangreicher ist aber wohl die Anwendung von Diamanten zur Herrichtung der scharflantigen Furchen auf den Reibflächen von II ühlsteinen, zu welehem Zwecke man nenerer Zeit besondere Maschinen konstruiert hat, und vor allem bei der Bohrung ron Lüchern in Gesteine. Namentlich die Gesteinsbohrung mit Diamant ist seit ibrer Erfindung im Jahre 1860 wichtig geworden, besonders wo es sich un recht harte und feste Felsarten handelte, sowohl bei Tiefbohrungen als beim Bergwerksbetrieb, beim Tunnelbau usw. Eine mit Diamanten besetzte rotierende Bohrkrone reibt auf dem Gestein und dringt mit außerordentlicher Geschwindigkeit darin vor, so daß die Arbeit sehr viel mehr gefördert wird als bei irgendeiner anderen Bohrvorrichtung. Man benutzt dazu und iiberhaupt in der Technik zum Schleifen untaugliche schlechte Diamanten, Bort und Karbonat.

Besonders zu erwähnen ist die Verwendung des feinen Pulvers zum Schleifen nicht nur von Diamanten, sondern auch von anderen Edelsteinen, selbst ron nicht so selır harten, die sich auch mittels schmirgel schleifen ließen; die Arbeit mit Diamant fördert aber viel besser und ist daher trotz der Kostspieligkeit des Schleifpulvers billiger. Auch 
zum Durchschneiden harter Steine wird aus demselben Grunde jetzt Diamant vielfach benutzt, indem man die vertikal rotierenden runden Schneidescheiben aus Metall am Rande, der den Stein angreift, mit Diamantpulver bestreicht oder feine Diamantsplitterchen dort einsetzt.

\section{Grobe und beriihmte Diamanten.}

Besonderes Interesse knüpft sich an eine Anzahl besonders großer und schöner Diamanten, deren Geschichte, mehr oder weniger genau erforscht, zum Teil bis in ziemlich weit zurückliegende Zeiten hinaufreicht. Bei einigen der durch Größe und Schönleit berühmten Steine sind allerdings die früheren Schicksale nicht genauer bekannt. Andererseits wissen wir aus zuverlaissigen alten Beschreibungen und Abbildungen von manchen solchen Steinen, von denen keine neuere Kunde mehr vorhanden ist, sei es, daß sie zerstört oder verloren gegangen sind, sei es, daß sie in den Schatzkammern irgendeines orientalischen Fürsten, die stets eine besondere Vorliebe für Diamanten und andere Edelsteine hatten, verborgen liegen.

Diese Diamanten, die wegen ihrer ungemeinen Kostbarkeit vielfach mit besonderen Namen belegt worden sind, stammten früher alle aus Indien, erst vor verhältnismäßig kurzer Zeit, in den fünfziger Jahren des 19. Jahrhunderts, hat auch Brasilien einige wenige hierher gehörige Steine geliefert. Aus Südafrika kommen zwar jetzt in wenirg Jahren mehr große Steine als aus Indien und Brasilien in vielen Jahrzehnten und Jahrhunderten zusammen. Aber die meisten von ihnen sind wegen ihrer gelblichen Färbung weniger geschätzt, so daß nur einige wenige von den vielen großen Kapdiamanten wegen ihrer besonderen Schönheit eine hervorragende Stellung einnehmen und einen eigenen Namen erhalten haben. In der folgenden Zusammenstellung spielen also indische, meist in früheren Jahrhunderten gefundene Steine eine besonders große Rolle.

Der Wert dieser kostbaren Steine ist natürlich ein ganz enormer, man findet sie daher nur unter den Kronjuwelen einiger Länder und in den Händen einiger besonders reicher Privatpersonen im Abend- und besonders auch im Morgenlande.

Der Londoner Juwelier Edw in W. Stre eter hat ein eigenes Buch über diese berühmten großen Diamanten herausgegeben, auch Boutan hat ihre oft komplizierte und schwierig zu entwirrende Geschichte sorgfältig studiert. Ihre und die betreffenden älteren Berichte sind den nachfolgenden Mitteilungen zugrunde gelegt. Die meisten dieser Steine sind auf Tafel X und XI im geschliffenen Zustande in natïrlichen Verhältnissen abgebildet und geben so eine Übersicht ïber ibre Größe und über die Formenmannigfaltigkeit, die durch den Schliff an ihnen hervorgebracht worden ist, bei in der Hauptsache gleichbleibenden allgemeinen Schlifformen. Die meisten sind Brillanten, aber im speziellen von erheblich rerschicener Form. Auch die Gestalt des ursprünglichen rohen Steines ist bei mehreren dargestellt.

Einige der größten dieser Steine, von denen die Berichte zu erzählen wissen, sind übrigens mit höchster Wahrseheinlichkeit gar keine Diamanten, sondern andere Mineralien, die damit verwechselt wurden. Uierher gehört vor allem einer der größten, je als Diamant erwähnten Steine, der aus einem unbekannten brasilianischen Fundorte stammende hïhnereigroße "Braganza" von 1680 Karat, von dem oben schon mehrfach die Rede war und der jetzt allgemein für ein Stïck Topas gehalten wird. Er wird im portugiesischen Kronschatz aufbewahrt und ist näherer Untersuchung aus leicht begreiflichen Grinden nicht zugänglich, denn wïrde er sich mit Bestimmtheit als Topas erweisen, so würde der Wert von 22.4 Millionen Pfund Sterling, den man ihm früher zuschrieb, auf ein Minimum heruntersinken. 
Fur ein Stiuck Bergkristall wird jetzt der ebenfalls schon erwähnte grolje "Diamant" des Rardschah von Mattan auf Borneo, der dort sog. .Danau Radschah" gehalten. Im Falle der Echtheit wïre es weitaus der größte Diamant von jener Insel; er hat ein Gewicht von 367 Karat. Der birnförmigre, etwa taubeneigrobe Stein soll im Bezirke Landak in Westhorneo gefunden worden sein, der Name Danau Radschah weist aber mehr auf den Sïdosten der Insel, wo der Fluf Danau ist. Lr soll 1865 in Pontiának untersucht und als Bergkristall erkannt worden sein. Manche meinen aber, der Eigentiimer habe damals den echten Stein gar nicht vorgelegt, sondern nur eine Nachbildung.

Zweifellos echt sind alle die folgenden, von denen zuerst die indischen, dann die brasilianischen und endlich diejenigen vom Kap erwähnt werden sollen.

Die groljen indischon Diamanten werden zuweilen für sphr alt grehalten, höchstwahrscheinlich sind sie aher, wenigstens zun Teil, in garnicht w) sehr frïher Zeit grefund'n worden. Jedenfalls gribt es keine bestimmten Nachrichten aus dem Altertum, im Gerrenteil weilj man ziemlich sicher, dal) die im Besitze der Römer befindlichen Steine eine nur geringe Gröbe batten.

Der größte Diamant, der aus Indien erwähnt wird, wenigrstens in seiner ursprïnglichen, freilich nur vermuteten Gestalt, ist der in seiner Geschichte allerdings vielfach unklare Grobmogul. 'Tavernier sah ihn 1665 in der Schatzkammer des Grobmoguls Aurung Zeb in Delhi und gab eine Abbildung nebst genauer Beschreibung davon. Der Stein hatte danach die Form einer sehr holten runden Rosette (Taf. X, Fig. 2) und war von gutem Wasser. Er wog $319^{1 / 2}$ Ratis, was Tavernier, 1 Rati $=i / 8$ Karat gesetzt, in 280 Karat umrechnete. Nach anderer Ansicht wäre aber ein Rati kleiner anzunehmen und das Gewicht nur etwa gleich 188 Karat zu setzen. Der rohe Stein soll zwischen 1630 und 1650 in den Gruben von Kollur gefunden worden sein und ursprïnglich $787 \%$ Karat gewogen haben. Von dem oben schon erwähnten, in Indien ansässigen renetianischen Schleifer Hortensio Borgis soll er dann so ungünstig geschliffen worden sein, daf das Gewicht auf den genannten kleinen Betrag herabsank. Den Wert des geschliffenen Steines berechnete T avernier auf nahezu 12 Millionen Franken. Was später aus dem nur aus Taverniers Beschreibung bekannten Grolbmogul geworden, ist rollkommen unbekannt. Man hat daher vermutet, daß er mit einem jetzt unter anderem Tamen bekannten großen Stein identisch sein könnte, so mit dem „Orlow" oder dem ..Kohinur“", von denen unten die Rede sein wird, oder daß er irgendwo unter den Schätzen eines indischen Fürsten verborgen gehalten wird, wenn er nicht gar im Laufe der Zeiten vollständig verloren gegangen oder zerstört worden ist. Manche vermuten, daß der Stein sich jetzt in dem Schatze des Schah von Persien befindet.

Einen großen Diamanten von demselben Gewicht, 320 Ratis, beschreibt auch der Stifter der Moguldynastie, Babur, in seinen Memoiren. Danach wäre dieser Stein seit den ältesten Zeiten in Indien bekannt und beriilımt gewesen und wäre, nachdem er, meist als Kriegsbeute, durch die Hände vieler indischer Fürsten gegangen, 1556 in den Besitz Baburs gelangt. Nach der Ansicht des englischen Mineralogen II a skely ne, die seitden riele Anhänger gefunden hat, ist dieser Stein derselbe, den T a verni e r in Delhi sah und als "Großmogul" beschrieb, und gleichfalls derselbe, der sich jetzt unter dem Tamen Kohinur im englisehen Kronschatz befindet. Dieser letztere wurde 1739 von dem Perser Nadir Schah erbeutet, als er das Reich der Grobmoguls zerstörte und eroberte. Im Jahre 1513 kam er in die Hände des Fürsten ron Lahore und wurde dort 1550 bei Gelegenheit eines Aufstandes die Beute der englisch-ostindischen Kompagnie, die ihn der Königin Victoria überreichte. Das Gewicht betrug 1S6:16 Karat, war also sehr nahe gleich dem oben für 320 Ratis angenommenen kleineren Betrage. Der Stein hatte damals die sehr ungiinstige Form einer unregelmäßigen Rosette (Taf. X, Fig. 4 ${ }^{a}$, b), oben mit angeschliffenen 
Facetten, unten mit einer breiten Spaltungsfläche; eine zweite kleinere Spaltungsfläche lag an der Seite. Um die Schönheit besser hervortreten zu lassen, wurde er in einen Brillant umgeschliffen, ein Geschäft, das der Diamantschleifer Voorsanger in dem Etablissement von Coster in Amsterdam im Jahre 1852 in 38 zwölfstündigen Arbeitstagen für den Preis von 8000 Pfund Sterling bewerkstelligte.

Der Kohinur ist nunmehr ein ziemlich schöner Stein von $106^{1 / 16}$ Karat, aber die nene Form (Taf. X, Fig. $5^{3},{ }^{b},{ }^{c}$ ) ist für einen vollkommenen Brillant zu niedrig, das Wasser ist nicht wanz rein und die Farbe etwas graulich, also die Beschaffenheit keineswegs ganz tadellos. Trotzdem wird der Wert jetzt auf 2 Millionen Mark geschätzt.

Welche Ansicht die richtige ist, ob der Kohinur und der Großmogul derselbe Stein oder ob beide von einander verschieden sind, wird sich wohl kaum mit Sicherheit jemals entscheiden lassen. Für die Identität beider spricht sich auch $\mathrm{T}$ e n a nt aus, der weiterhin der Meinung ist, daß der Kohinur und der sogleich zu besprechende Orlow Stiicke des von Tavernier erwähnten rohen Steines von 787\%. Karat seien, und dazu sollte dann als drittes Stück eine mehrfach von Schriftstellern erwähnte Diamantplatte von 132 Karat gehören, die Abbas Mirza bei der Eroberung von Coocha iu Khorossan mit den Schätzen von Reeza Kuli Khan erbeutete. Tennant bildete das Ganze in Flußspat nach, der dieselbe Spaltbarkeit wie der Diamant besitzt, und schrieb danach jenem rohen Steine die Form eines hühnereigroßen Granatoëders von $793^{5} / \mathrm{s}$ Karat $\mathrm{zu}$, welche letztere Zahl mit der von Tavernier angegebenen sehr nahe uibereinstimmt.

Meinungsverschiedenheiten sind auch bezüglich des Namens Kohinur vorhanden. Dieser, der „Berg des Lichts" bedeutet, soll dem Steine von Nadir Schah gegeben worden sein. Nach einer anderen Ansicht wäre es eine Korruption des Fundortes Kollur und wiirde den großen Diamanten von Kollur bedeuten, unter welchem Namen der Diamant angeblich früher in Indien bekannt war.

Der erwähnte Orlow oder Amsterdamer ist der größte Diamant des russischen Kronschatzes; für gewöhnlich befindet er sich an der Spitze des Reichsszepters. Er ist vom schönsten Wasser, vollkommen rein und zeigt den lebhaftesten Glanz. Die Form ('Taf. X, Fig. 1 a , ", c) ist sehr älnnlich der des Großmoguls nach Taverniers Zeichnung, eine hohe, fast halbkugelige, runde Rosette, unten mit einer Spaltungsfläche, wie das auch beim Kohinur in der alten Form der Fall war. Die Höhe beträgt 10, der größte Durchmesser 15/2 Linien, das Gewicht $\left.194^{3 /}\right|_{4}$ Karat. Früher soll er ein Auge der Statue des Brahma im Tenıpel auf der Insel Scheringham im Caveryfluß in Maysur in der Nähe von Trichinopoli gebildet haben. Hier wäre er von einem französischen Soldaten in den ersten Jahren des 18. Jahrhunderts gestohlen und durch Vermittelung eines englischen Schiffskapitäns von Madras nach Europa gebracht worden. Der Stein kam nachmals nach Amsterdam, wo er 1791 vom Fürsten Orlow für die Kaiserin Katharina II. um 1400000 holländische Gulden gekauft wurde. Auch er soll, wie erwähnt, ein Stuick des Großmogul sein.

Zuweilen wird berichtet, daf der Stein durch Vermittelung eines Armeniers Schafras in den Besitz der russischen Krone gekommen sei. Dies soll aber, nach anderer Meinung, nicht für den Orlow zutreffen, sondern für einen anderen grolen Diamanten der russischen Krone, den Mond der Berwe. Diesen, 120) Karat schwer, hatte Nadir Schah in Indien crbeutet; er zierte seinen Thron und wurde bei seiner Ermordung nit anderen Juwelen von einem afghanischen Soldaten geraubt, von dem er in den Besitz des Armeniers Schafras kam. Letzterer verkaufte ihn 1775 für 450000 Rubel, eine Leibrente von 4000 Rubeln und einen $\Lambda$ delsbrief an die Kaiserin Katharina 11. Die Geschichte dieses Steines wird iibrigens 

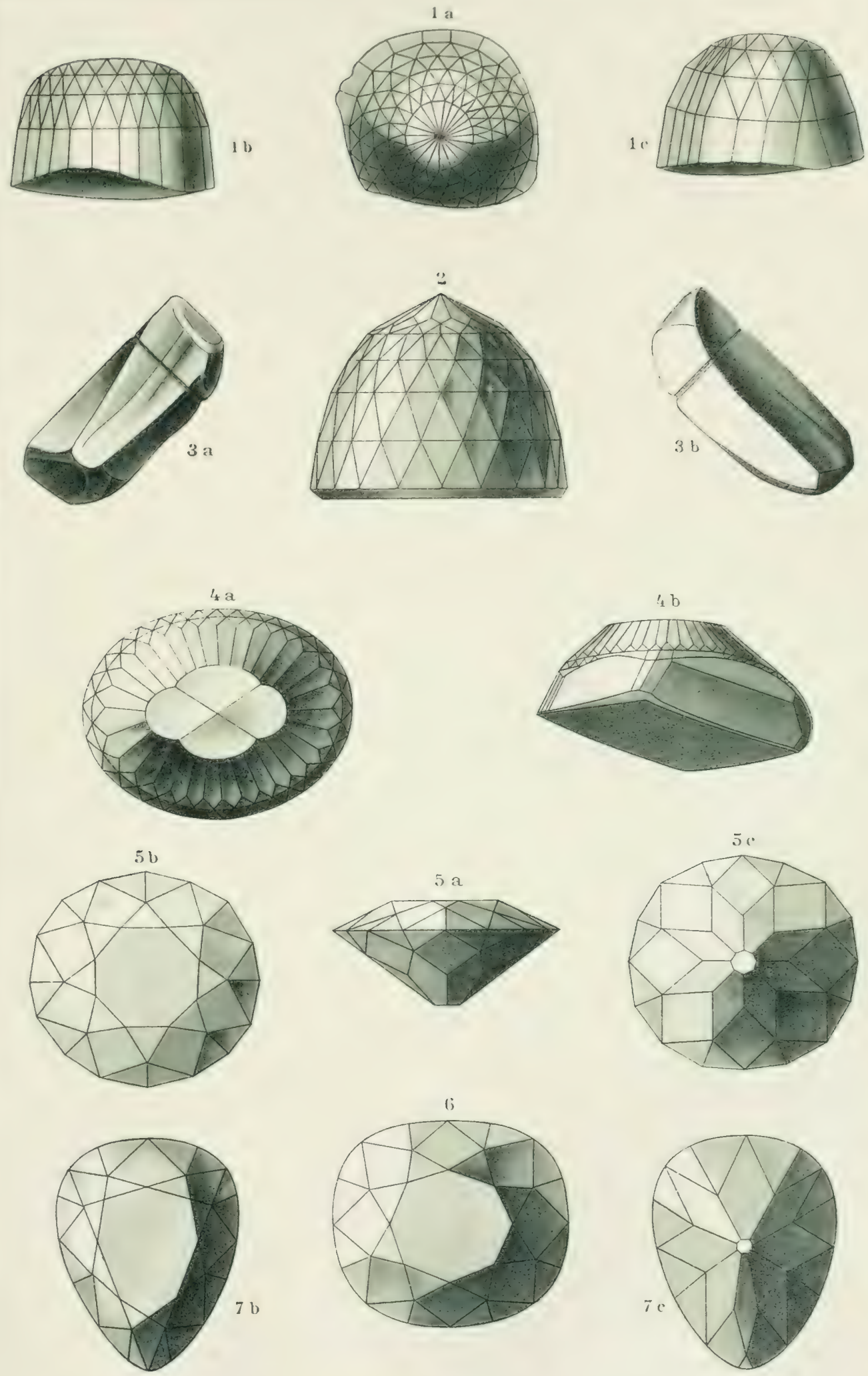

1. Orlow. 1a. von oben. 1b, c. von zwei verschiedenen Seiten. 2. Grossmogul. 3a, b. Schah. 4, 5. Kohinur. 4a, b. alte Form. 5a, b, c. neue Form. 6. Stewart (Kap). 7 b, c. Diamant des Herrn Dresden (Brasilien). 

vielfach, auch aberesehen von der Butriligung des Schafras, mit der des orlow verwechselt und vermengt. Modern eseschliffen würde er einen Brillant von 120) bis 125 Karat genesen.

Gleichfalls der russtschen Krone gehört der Polarstern, ein schöner lirillant von 40 Karat (Taf. XI, Fig. 15).

Ein eigentümlicher Stein ist der Schah, den der persische Prinz Chosroës, der jüngere Sohn von Abhas Mirza, im Jahre 1529 dem Kaiser Nikolaus von Iiuliland

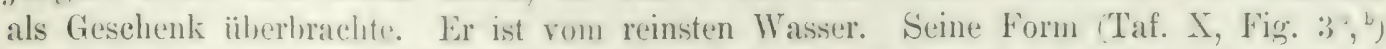

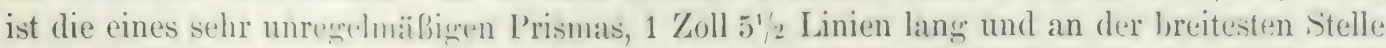
S Linien breit. [) Be Begrenzung wird teils von Spaltungsflächen, teils von angeschliffenen Facetten gelbildet. Auf drei der letzteren sind die Namen von drei persischen Künigen eingraviert, er bildet also eines der wenigen Beispiele ron gravierten Diamanten. G. Ros e, der den Stein kur\% nach dessen Ankunft in St. Petershurg sal, gibt das (tewicht auf so Karat an. Suäter soll er oberflïchlich iiberschliffen und sein Gewicht dabei erst von 95 auf 86 Karat reduziert worden sein, was also mit f. Roses Angaben nicht ganz stimmt. Auch die interessunten Inschriften sollen bei diesem Prozeb verschwunden sein.

Ein anderer gravierter Diamant ist der $\mathrm{Akbar}$ Schah, genannt nach seinem ersten Besitzer, den Grofmogul Akhar. Dessen Nachfolger Jehan lief ihn auf zwei seiten mit arabischen Inschriften versehen. Er gring dann verloren, tauchte aber, kenntlich an diesen Inschriften, yor kurzem in der Türkei unter dem Namen des „Steines von Shepherd“ wieder auf. Er wom 116 Karat, wurde aber 1566 umgesehliffen und 1867 an den Gaikwar von Baroda um 35 (1011 lfund Sterling verkauft. Sein jetziges Gewicht ist 71 oder 72. Karat; auch er hat beim Umschleifen die eingravierten Inschriften verloren.

Einer der größten indischen Diamanten ist der $\mathrm{Nizam}$, von dem aber nicht viel be. kannt ist. Es soll in der Gegend von Golconda von einem Kinde auf dem Boden gefunden worden sein. Man weif ron ihm seit 1535. Das Gewicht ist 277 Karat. Es wird ihm aber auch eine andere Fundgeschichte und ein ursprïngliches fewicht ron t40 Karat zugeschriehen. Er soll sich jetzt im Besitze des Nizam ron Haiderabad befinden.

Die grobe Tafel ron Tavernier (Fig. 5 7 ) ist, wie der Grobmogul, verschwunden. Der Reisende sah sie 1612 in Golconda; es war der gröbte Dianant - 2423/16 Karat -, den er in Indien im Privatbesitze antraf. Gegen ein Angebot von 400000 Rupien wurde sie damals nicht abgegeben.

Wenig Nachrichten hat man von den zwei großen Diamanten im Besitze des Schah von Persien. Der eine, der Dary a-i-n ur (Meer des Lichts), wiegt 186, der andere, der T a j-e-mah (Krone des Mondes), 146 Karat. Beide sind vom reinsten Wasser und als Rosetten geschliffen. Sie schmückten früher zwei Armbänder, deren Wert auf 20 Millionen Mark geschätzt wurde.

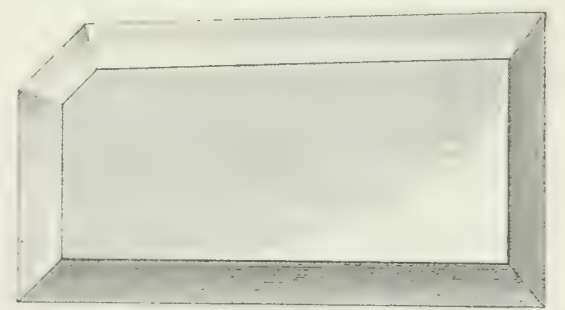

Fig. 57. Große Diamanttafel von Taverniex.

Einer der ausgezeichnetsten und schönsten Diamanten, die man kennt, zugleich auch, wenigstens im Rohgewicht, der srößte voin allen sicher nachgewiesenen indischen, ist der Regent oder Pitt. friilher auch der ...Millionär" genannt, der dem franzüsischen Kronschatze angehört. Er wurde 1701. in den Gruben von Partial gefunden (nach anderer Lesart auf der Halbinsel Malakka) und an den Gouverneur Pitt des Forts St. Georg in Madras um 20400 Pfund sterling verkauft. 1717 erwarb ihn der damalige Regrent von Frankreich, der Herzogr von Orleans. um zwei Millionen Franken und die etwa beim schleifen abfallenden Stiicke. Dieser lief ihn um 1751 in London bearbeiten. Der Schliff dauerte zwei Jahre, kostete 5000, nach anderen Nachrichten S(100) Pfund Sterling und reduzierte das Gewicht 
ron 410 auf $136^{14}{ }_{16}$ Karat. Es ergab sich aber dabei ein fast vollständig fehlerloser Brillant von der vollkommensten Form (Taf. XI, Fig. $8^{a},{ }^{b},{ }^{c}$ ), bei dem freilich die Farbe den allerhöchsten Anforderungen nicht ganz entspricht. Bei der Schätzung der französischen Kronjuwelen 1791 wurde der Wert auf 12 Millionen Franken festgesetzt. 1792 ging der Stein mit vielen anderen Edelsteinen aus dem französischen Kronschatz durch Diebstahl verloren, wurde aber später in seinem Versteck wieder aufgefunden. Während der Kriege der Republik war er verpfündet, Napoleon löste ihn aber wieder ein, und scitclem ist er ununterbrochen bis heute in Paris geblieben als wertvollstes Stiick des franzïsischen Kronschatzes. Bei der vor einigen Jahren erfolgten Veräußerung der im Besitze der französischen Regierung befindlichen Edelsteine ist er als ein Objekt von allgemeinem Interesse nicht mit verkauft worden.

Der Florentiner oder "Großherzog von Toskana", auch der "Österreicher" genannt, befindet sich in der Schatzkammer der Wiener Hofburg. Er hat die Form eines Brioletts (Taf. XI. Fig. 10 a ${ }^{1}$ ) mit neunfacher Anordnung der Facetten. Sein Gewicht ist 1331/5 Wiener Karat $(27,454 \mathrm{~g})$; die Angabe von 1391/2 Karat, die man zuweilen trifft, bezieht sich auf das leichtere florentiner Gewicht. Der Stein ist sehr schön klar und hat ein Feuer ersten Ranges, die Farbe geht jedoch deutlich etwas ins Gelbe. Nach der gewöhnlichen, aber auch bestrittenen Annahme wurde er von Ludwig van Berquen für Karl den Kühnen geschliffen, von diesem in der Schlacht von Granson verloren und von einem Schweizer auf dem Schlachtfelde gefunden. Später gelangte er nach mehrfachem Besitzwechsel in die Hände des Großherzogs Franz Stephan von Toskana, der ihn später mit nach Wien nahm, wo er seitdem ununterbrochen geblieben ist.

Sehr ähnlich dem vorigen in der Form ist der sehr viel kleinere Sancy von $53^{12 / 16}$ Karat, der wie jener nach einer gleichfalls bestrittenen Ansicht von L. van Berquen für Karl den Kühnen geschliffen worden sein soll. Der Besitzer soll ihn in der Schlacht hei Nancy bei sich getragen haben, und aus den Händen eines Soldaten, der ihn hier nach dessen Tode fand, soll er nach Portugal und dort an einen Herrn von Sancy in Frankreich gekommen sein, der ihn gegen das Jahr 1600 an die Königin Elisabeth von England verkaufte. Von England brachte ihn 1649 die Gemahlin Karls I. nach Frankreich, wo er anfänglich als Pfand in den Besitz des Kardinals Mazarin kam, der ibn mit 17 anderen großen Diamanten an Ludwig XIV. vererbte. 1791 wurde bei der Schätzung. ler französischen Kronjuwelen sein Wert auf eine Million Franken angegeben. In der Revolution wurde er 1792 wie der Regent gestohlen, aber nicht wie dieser vom früheren Eigentümer wieder aufgefunden. Er blieb verschollen, bis er 10 Jahre später unter den Edelsteinen der spanischen Krone wieder auftauchte. Von 1828 bis 1 S65 gehörte er dem Firsten Demidoff, der ihn für 20000 Pfund Sterling verkaufte. Jetzt soll er dem Maharadscha von Guttiola gehören, also nach vielen Irrfahrten in sein Vaterland zurückgekehrt sein. 1867 war er auf der Pariser Weltausstellumg zu sehen. Seine Form ist Taf. XI, Fig. 11 ", abgebildet. Demselben Steine werden zum Teil auch andere Schicksale zugeschriehen, die aber nicht besser verbürgt sind, als die oben erzählten. Es ist nicht undenkbar, daß mehrere Steine unter dem Namen Sancy miteinander verwechselt wurden.

Der Nassak hat seinen Namen daher, daß er längere Zeit im Schiwatempel zu Nassak am oberen Godavery auflbewahrt wurde. Später bemächtigte sich seiner der letzte unabhängige Fürst von Peischwa, dem er 1818 von der ostindischen Kompagnie als Beutestiick abgenommen wurde. Er hatte damals eine ungiinstige Gestalt und wog $891 / 2$ Karat; man gab ihm daher die in Taf. XI, Fig. 13 ${ }^{\text {a }}$, ${ }^{\mathrm{c}}$ dargestellte neue Form eines dreiseitigen Brillants. 1831 erwarb ihn der Juwelier Emanuel in London um 7200 Pfund Sterling und verkaufte ilın bald darauf an den Marquis von Westminster, in dessen Familie er sich noch befindet. 
Der Diamant der Kaiserin Eugenie ist ein schöner Brillant unbekannten Ur. sprunges von 51 Karat. Er gedörte der Kaiserin Katharina II. von Ruliland, die ilın ihrem Giinstlıngr l'otemkin schenkte. In dessen Familie vererbte er sich, bis ihn Napoleon III. ais IIochzeitsgeschenk für seine Gemahlin Eugenie kaufte. Diese veräufjerte ihn nach ihrer Entthronung an den Gaikwar von Baroda in Indien.

Der Pigott ist ein Brillant von geringer Dicke, den Lord Pigott um 1775 aus Indien nach kngland brachte und der nachnals in den liesitz des Vizekünigs Ali I'ascha ron Ägypten grelangte. Später gingr seine Spur vollständig verhoren; nach einem Bericht soll "r zerstört worden sein. Sein Gewicht war nach Mawe, der den Stein kurz vor dem Terkauf an Ali I'ascha sah, 19 Karat, es werden aber auch andere Zahlen bis zu $511^{\prime 2}$ Karat angegeben.

Einer der schönsten bekannten Diamanten ist der $45:, 4$ Karat schwere, weilie sächsische Brillant". Sein Lmriß bildet ein Quadrat ron 11/12 Zoll. August der Starke soll cine Million 'Taler dafuir bezahlt haben.

Der Pascha von $\ddot{A} g y p t e n$ ist ein schöner achtseitiger Brillant von 60 Karat, den der Vizekönig Ibrahim von Ägypten um 28000 Pfund Sterling kaufte.

Durch besondere Schönheit ist ein verhältnismäligig kleiner Diamant, der Stern ron Este, den meisten genannten ïherlegen. Er ist vollkommen fehlerlos und hat eine auswezeichnet regelmäfige Brillantform. Das Gewicht beträgt nur $255^{1: 3}: 2$ Wienter Karat (52.32 Milligramm), also nur etwa balb so viel als bei dem „Diamant der Kaiserin Eugenie” uder dem ,Sancy". Trotzdem ist er nur unbedeutend kleiner als diese beiden, und dies ist ehen ein Beweis für die Proportionalität seiner Verhältnisse und die Regrelmäbigkeit seines schliffes. Er befindet sich zurzeit im Besitze des Erzherzogs Franz l'erdinand ron Cisterreich-Este, des ältesten Solnes des Erzherzogrs Karl Ludwig. Sein Wert wurde in Jahre $1>76$ anf 64000 österreich. Gulden gesehätzt; früher, im Jahre 1591, war sein Wert auf 200000 bis 250000 Franken festgestellt worden.

Schön gefürbte grolje Diamanten gibt es auber den vielen gelben vom Kap nur wenige, alle indischen Ursprungs. Yon ihnen ist der nächstfolgende der berïhmteste.

Der Diam ant ron Hope hat eine prachtrolle sapphirblaue Farbe, wie sie an anderen Diamanten kaum wieder vorkommt, daneben einen präichtigen Glanz und ein herrliches Farhenspiel und Feuer. Er wurde seit 1830) bekannt und gehürte später dem Londoner Bankier Henry Thomas Hope, der ihn für 1 S1)00 Pfund Sterling kaufte. Es ist ein schöner Brillant von 441/2 Karat.

Im französischen Kronschatze war bis 1792 ein schön blauer dreiseitiger Brillant von $67^{2}$ 16 Karat, der 1791 auf 3 Millionen Franken geschätzt worden war. 1792 wurde er mit dem liegent und anderen Edelsteinen gestohlen und nicht wieder grefunden. Er war greschliffen worden aus einem rohen Steine von 112\%/1; Karat, den Tavernier für Ludwig XIT. aus Indien mitgebracht hatte. Man hat frund zu der Annahme, dafj der Diamant von II ope ein Stïck des letztgenannten Steines ist, den man zertrümmerte, un die Spur des Diebstahls zu verdecken und den man nachher in neuem Schliff 183u wieder auf den Markt brachte. Wahrscheinlich ist auch der blaue Diamant des Diamantenlerzogs Karl ron Braunschweig (gestorben 1873 in Genf), ein Stein ron $13^{*}+$ Karat und ron derselben Farbe wie der Hope, der 157.t in Genf für 17000 Franken verkauft wurde, ein Stiick jenes franzüsischen Steines, und ebenso ein gleichgefïrbter kleiner Diamant von 1', K Karat, der für 300 Pfund Sterling in den Besitz einer englischen Familie gelangte.

Der grüine Diamant von Dresden, im grünen Gewölbe aufbewahrt, ist der berühmteste Repräsentant der grünen Farbe. Er ist sehr schün hell apfelgrïn und steht in der Färbung etwa zwischen dem Smaragd und dem Chrysopras in der Mitte. Seiner 
Qualität nach ist er fehlerlos und rom reinsten Wasser. Die Gestalt ist mandelförmig; er ist 11/2.2 Zoll lang und 11/12 Zoll dick und das Gewicht beträgt 40, manche sagen fälschlich 311/1 oder 45 Karat. Seit 1743 ist er im Besitze der sächsischen Krone. August der Starke soli ihn für 60000 Taler gekauft haben.

Aus Brasilien stammen nur wenige der großen berihmten Diamanten. Zu erwähnen sind hauptsïchlich die zwei folgenden, die beide in den fünfziger Jahren dieses Jahrhunderts im Bezirke Bagagem im westlichen Teile von Ninas Geraës gefunden wurden und die schließlich beide in den Besitz des Gaikwar von Baroda übergegangen sind.
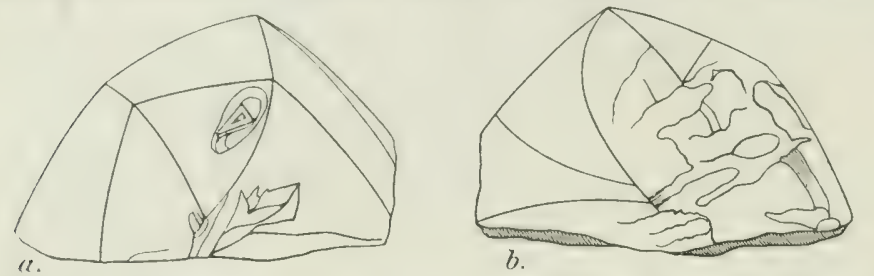

Fig. 58. Südstern, Gestalt des rohen Steines in natürlicher Größe, von 2 Seiten gesehen. Indien ist eben nicht mehr imstande, dem Verlangen seiner Großen nach schönen Diamanten selber zu genügen. Diese müssen sich jetzt auswärts umsehen.

Der Sü d stern (Stern des Südens) wurde Ende Juli 1853 gefunden. Er bildete nach der Untersuchung des französischen Mineralogen D ufrén oy ein unregelmäßiges Dodekaëder mit bauchigen Flächen (Fig. 58, welche die natürliche Größe darstellt), von 25t1/2 Karat Gewicht. Der Stein hatte an einigen Stellen oktaëdrische Eindrücke von anderen kleineren Diamanten, die früber damit verwachsen waren. An einer Seite befand sich eine platte Stelle, an der Spaltbarkeit erschien. Das Ganze machte den Eindruck, als wäre es eine Gruppe von Diamantkristallen gewesen, die mit jener platten Stelle auf einer Unterlage aufgewachsen war. Einige eingeschlossene schwarze Plättchen wurden für Titaneisen gehalten, das ja auch sonst im Diamant eingeschlossen vorkommt. Der rohe Stein ging um 430 Contos de Reis (etwa 800000 Mark) an ein Konsortium über. Er wurde in Amsterdam mit einem großen Kostenaufwande geschliffen und gab dabei einen schönen reinen Brillant von 1251/2 Karat (Taf. XI, Fig. 9 ${ }^{\mathrm{a}},{ }^{\mathrm{b}},{ }^{\mathrm{c}}$ ), den jener indische Fürst um 80000 Pfund Sterling ankaufte.

Kleiner ist der Diamant des Herrn E. Dresden, der fast zur gleichen Zeit und ziemlich am gleichen Orte wie der Südstern gefunden wurde. Er wog 1191/2 Karat, schien aber nur ein Bruchstück eines größeren Kristalls zu sein. Beim Schleifen gab er einen länglich eiförmigen Brillant (Taf. X, Fig. $7^{\text {b }}{ }^{c}$ ) von $76 \frac{1}{2}$ Karat, er verlor also dabei ganz auffallend wenig von seinem Gewichte.

Der Pseudodiamant „Braganza" ist schon eingangs erwähnt worden. Einige andere größere Steine aus Brasilien wurden bei der Beschreibung der dortigen Lagerstätten kurz angreführt, so der große Stein, der am Anfange dieses Jahrhunderts am Rio Abaété in Minas Geraës gefunden worden ist, dessen Verbleib man aber nicht kennt, und andere.

Auch von den vielen großen Diamanten aus Sïdafikil sind einige zur Beriihmtheit gelangt und demzufolge mit besonderen Namen belegt worden. Es sind teils die ersten Steine, die dort gefunden worden sind, teils solche, die durch außergewöhnliche Grölse und Schönheit ïber die anderen hervorragen. Schon bei der Betrachtung des Diamantenvorkommens am Kap ist von einigen derselben die Rede gewesen.

Der Stern von Sïdafrika, 1869 gefunden, ist der erste in jenem Lande entdeckte gröbere Diamant. Er wog roh $\$ 31_{2}^{\prime}$ Karat und lieferte einen oval dreiseitigen Brillant (Taf. XI, Fig. 14) von 46\% Karat und vom reinsten Wasser, der für nahezu eine halbe Million Mark an die Grïin Dudley verkauft und daher auch „Dudley-Diamant" genannt 

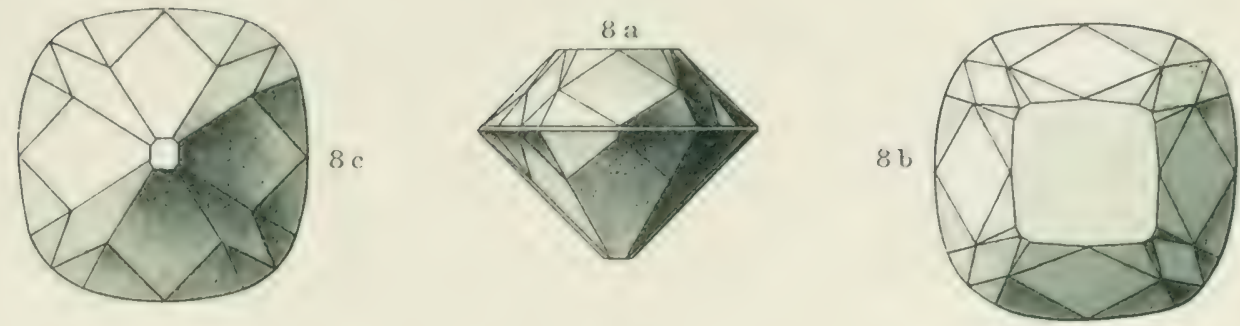

(9) 1
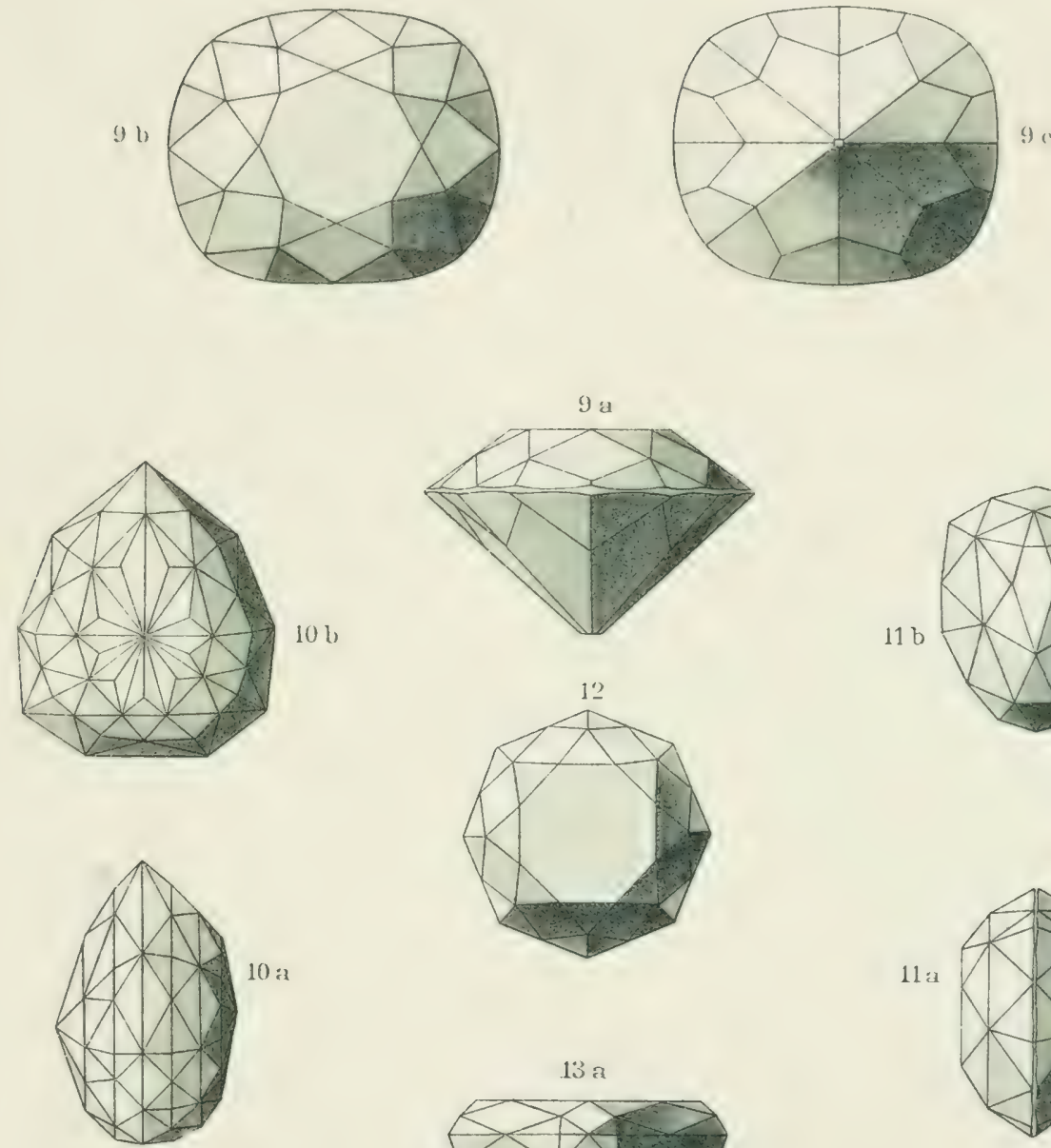

\section{$10 b$}

13 a
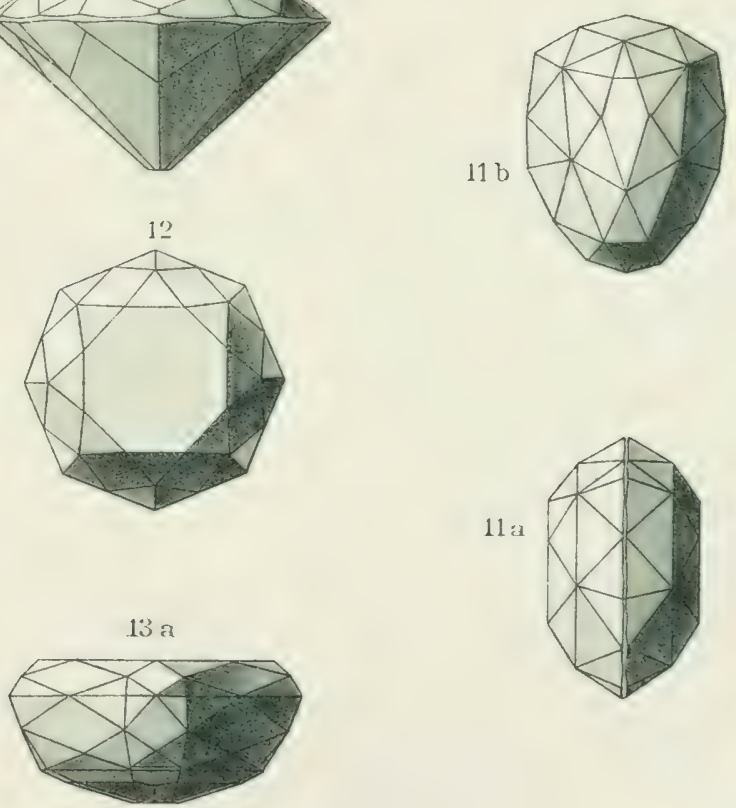

14
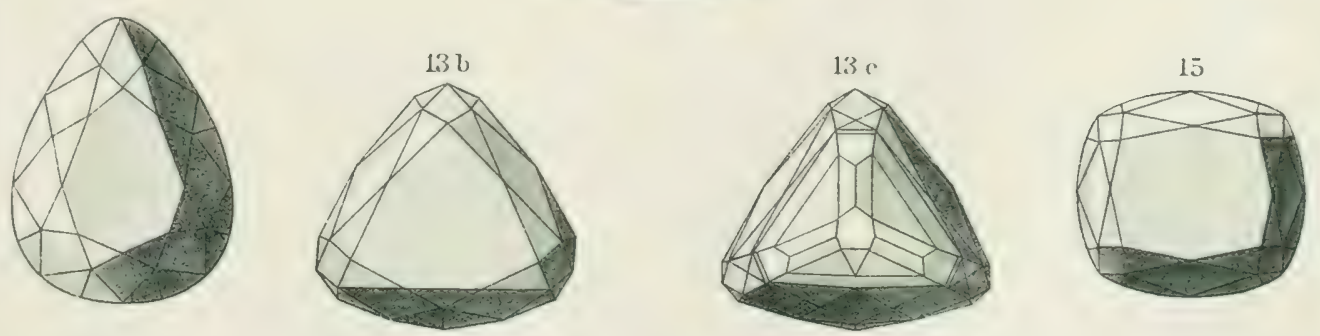

8a, b, c. Regent. 9 a, b, c.Südstern (Brasilien). 10 a, b. Florentiner. 11 a, b. Sancy. 12. Pasclia von Egypten. 13 a, b, c. Nassak. 14. Stern von Südafrica (Kap). 15. Polarstern. 

wurde. Wie wir schon oben gresehen, ist es ein Flubstein, der in Beziehungr auf seine Qualifït sich mit den hesten indisehen und brasilianischen Diamanten messen kann.

Viel errilier ist der Stewart, der 1572 in den river dignings von Waldecks plant am Vaal sefunden wurde. Roh wog er $2581 / 2$ Karat und war daher mehrere Jahre der crö̈bte Kapdiamant, bis er in neuerer Zeit von anderen, weit grö̈feren überholt wurde. Im rohen Zustande wurde er zuerst für 120000), dann für 180000 Jark verkauft und gab) gesehliffen rinen Brillant von 120 Karat von etwas gelblicher Farbe, der Taf. X, Fig. 6 abgebildet ist.

Der Porter Rodes ist ein 150, nach anderen Angaben 160 Karat wiegendes, vollkommen farbloses, ,hlauweibes" Oktaëder, das am 12. Februar 1851) bei Kímberley in der De Beers-Grube gefunden wurde. Seiner ganzen Beschaffenheit nach ist er einer der schönsten Diamanten, die je am Kap vorgekommen sind. Tach der Schätzung des Eigentiimers sollte er 200000 Pfund Sterling wert sein.

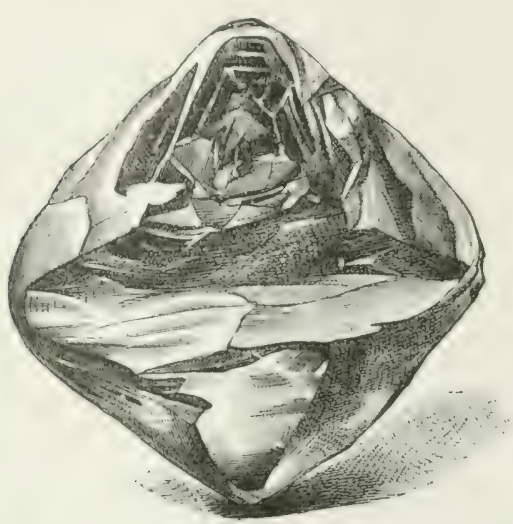

Fig. 59. Victoria-Diamant von $457^{1 / 2}$ Karat vom Kap; natïrliche Form und Größe.

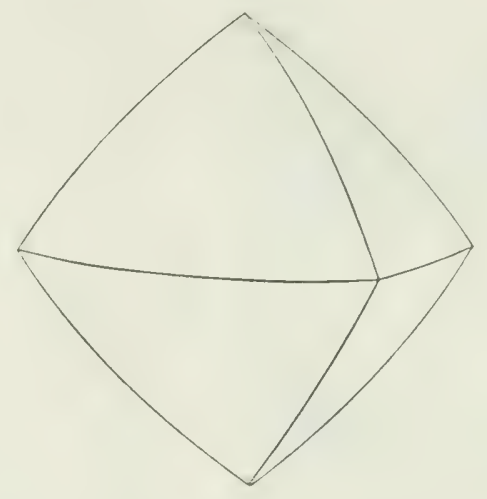

Fig. 60. De Beers-Diamant von $428^{1 / 2}$ Karat, schematische Form in natürlicher Größe.

Ein Stein von $4571_{2}$ Karat kam 1884 nach Europa, wie es hieß aus einer der Gruben hei Kimberley, aber ohne nähere Angaben. Überhaupt lag über seiner Herkunft ein geheimnisvolles Dunkel. Die Form im rohen Zustande war die eines unregelmäßigen Oktaëders. Fig. 59 ist sie in richtiger Größe und auch sonst naturgetreu dargestellt. Beim Schleifen erhielt man einen sehr schönen farblosen Brillant von 180 Karat, der den Namen Victoria oder "Imperial" oder "Great White“ erbielt und der für 400000 Pfund Sterling an den Nizam von Haiderabad verkauft wurde. Er wird jetzt darnach auch als "NizamDiamant" bezeichnet.

Einen Brillant, einen der größten bekannten, von 225 Karat erhielt man aus einem im Jahre 1857 in der De Beers-Grube gefundenen blaß gelblichen Steine ron 4281/2 Karat, also mit dem ungewöhnlich niedrigen Schleifverlust von nicht ganz der Hälfte des Rohgrewichts. Er hatte die Form eines sehr regelmäßigen Oktaëders, das in Fig. 60 sehematisch in natürlicher Größe abgebildet ist und dessen längste Achse 1i/s Zoll (engl.) maß. Geschliffen wurde er von einem indischen Fürsten gekauft. Tach seinem Fundorte wird er der De Beers-Diamant genannt, da er der größte aus dieser Grube ist.

Aus derselben Grube (von 187i) stammt der prächtige, schön kanariengelbe TiffanyBrillant von 125\% Karat im Besitz der großen Juwelierfirma Tiffany \& Co. in New-York, der zu den herrlichsten Steinen aus den Kimberley-Gruben gehört. Seine Form ist in Fig. 61 S. 320 in natïrlicher Größe dargestellt. 
Der größte in den Gruben bei Kimberley jemals vorgekommene Stein wurde am 1. Juni 1896 in der De Beers-Grube in 870 Fuß Tiefe gefunden. Es ist ein blaßgelbes,

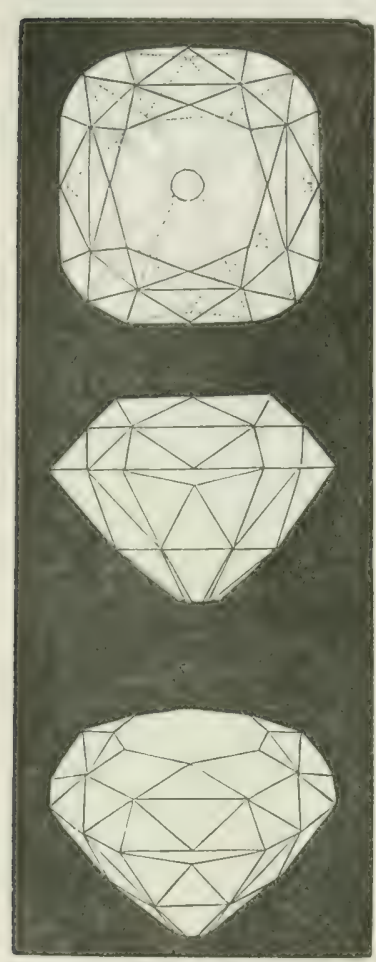

Fig. 61. Tiffany-Brillant von $125^{1 / 2}$ Karat; natürl. Größe. aber durch Fehler entstelltes Oktaëder von 5031/4 Karat. Siehe auch S. 249.

Die beiden größten bis vor kurzem bekannten Diamanten, die jetzt allerdings durch einen neveren Fund in Transvaal weit übertroffen werden, hat aber die Jagersfontein-Grube in der Oranje-Kolonie geliefert. Der eine davon, der größte bis dahin, 9713/4 Karat schwer, hat aus diesem Grunde den Namen Ex celsior erhalten; jetzt ist er an die zweite Stelle gerïckt. Seine natürliche, ziemlich unregelmäßige Form und Größe stellt die Fig. 62 dar.

Er ist demnach schwerer als der sagenhafte "Großmogul", dem in seiner hypothetischen Rohform nur ein Gevicht von $7871 / 2$ Karat zugeschrieben wurde. Die ganze Begrenzung des Excelsior wird von Kristallflächen gebildet, auch die breite Fläche unten ist eine solche, keine Spaltungsfläche. Seine Maße betragen $3 \frac{1}{2}$ Zoll (engl.) in der Länge, 11/2 Zoll in der Dicke und $2^{1 / 2}$, bez. $1 \frac{1}{3}$ Zoll in der größten und kleinsten Breite.

Am 30. Juni 1893 wurde er von einem Kaffern gefunden, der dafür eine Belohnung von 500 Pfund Sterling nebst einem Pferd samt Sattel und Zaum erhielt. Eine Firma in Kimberley hatte mit den Grubenbesitzern einen Vertrag geschlossen, wonach ihr für eine bestimmte Zeit alle gewonnenen Steine olne Ausnahme zu einem vereinbarten Preise pro Karat überlassen werden sollten. Dieser Vertrag endete mit dem 30. Juni; einer der letzten an diesem Tage gefundenen Steine war der Excelsior, der durch seinen ungeheuren Wert jenen Kaufleuten unter allen Umständen ein glänzendes Geschäft sicherte, zumal da er von der schönsten „blauweißen" Farbe und überhaupt von der besten Beschaffenheit ist.

Die Sachverständigen haben seinen Wert sehr verschieden beurteilt; ihre Schätzungen schwanken von einer Million bis 20 Millionen. Es war aber unmöglich, einen Käufer aufzutreiben. Daher wurde er im Jahre 1904 in 10 Stïcke zerlegt. Die drei größten wogen 158, 147 und 130 Karat, also zusammen etwa die Hälfte des Ganzen. Beim Schleifen in $\Lambda$ msterdam wurden Steine von verschiedener Form, alle von bemerkenswerter Schönheit erhalten. Ihre Grölse betrug $68,45^{30} / 32 \quad 45^{26} / 32,39^{10} / 32$, $34^{2} / 32,27^{30 / 32}, 25^{22 / 32}, 23^{24} / 32,16^{12 / 32}$ und $1317 / 32$ Karat, also das Gesamtgewicht aller nach dem Schleifen $340^{13 / 32}$ Karat. Demnach ergab der rohe Stein von $971^{3 / 4}$ Karat nur eine Ausbeute von 35 Proz.

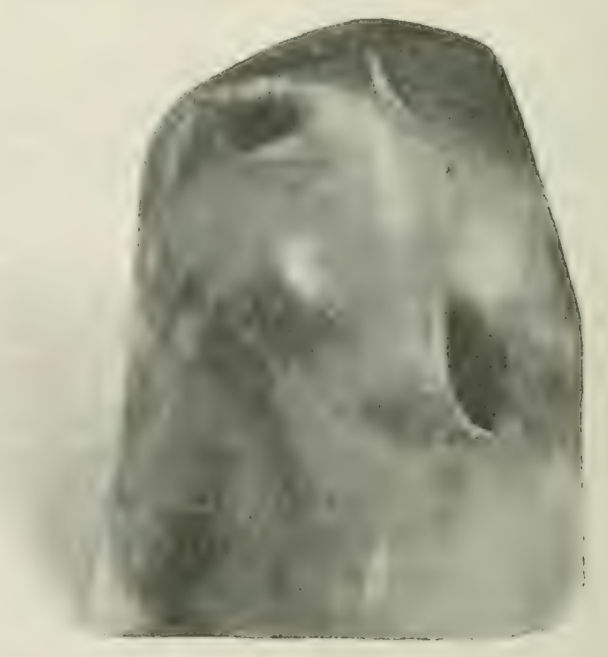

Fig. 62. „Excelsior" von $971^{3 / 4}$ Karat ans der Jagersfontein Grube in Südafrika; nat. Form und Gröbe.

Ein zweiter sehr groljer Dlamant von regelmäßiger Form und von 640 Karat wurde 1895 in Jagersfontein gefunden. Zuerst wurde er nach dem damaligen Präsidenten des 


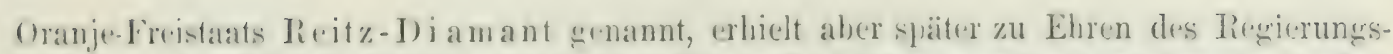
jubilïuns der Königin Vietoria 15997 ) den Namen Jubilee, manchmal ward er auch ..Imperial" Eemannt. Im Jahre 1900 war er auf der Pariser Weltausstellung zu selen. Beim

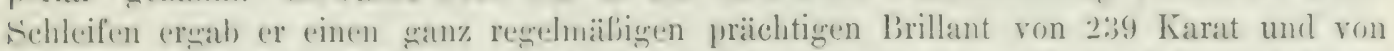

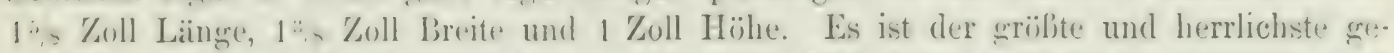
schliffene Diamant, der his vor kurzem, his zum Schleifen des ('ullinan, existierte, von hïehster. Vollkommenlerit in Farbe, (ilanz und Wasser, ohne den geringsten Fehicr, vin Stein ron unverwleichlieher Pracht und Schönheit. Anfänglich wurde er zuweilen nit dem „Excelsior" verwechselt.

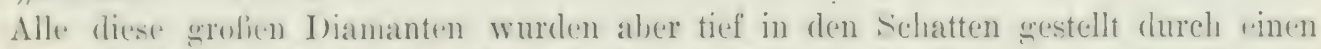
ne'uen Fund, der am Nachunttag des 26). Januar 1965) in dex I'remiemine hei I'retoria

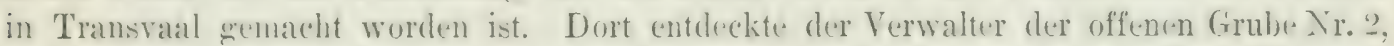
Mr. Fred Wells in der Tiefo von is FuB einen mit einer Ecke atus dem yellow ground

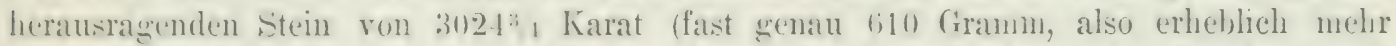
als ein I'fund, der dann nach dem Vorsitzenden der dir Grube ausheutenden Premier-Gesellschaft dep "('ullinan"-Diamant oder auch nach dieser Grube dex "Premer"-Diamant genannt wurde. Es war ein ganz einheitlicher Kristall, der in drei aufeinander senk-

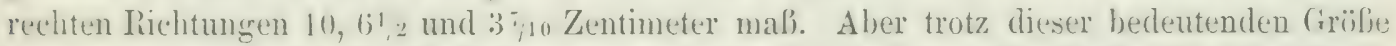
ist er duch nur ein Bruchstïck, wahrscheinlich weniger als die Hälfte, eines grö̈feren Individumus. Dies zeight die Berrenzung, die zunächst von vier unverkennbaren ausgedehnten oktä̈drischen Blätterbrüchen gebildet wird, zu denen sich noch eine natürlichte Oktä̈rlerfläiche, stehs krtumme Dodekä̈derflächen und eine kleine Würfelfläche gesellen. Die Form und croife wird durch die zwei groben Figuren auf Taf. XI a dargestellt. Zwillingsbildung irgend einer Art ist nicht vorhanden.

Optisch ist der Stein dadurch austezeichnet, dal er auf das polarisierte Licht einwirkt. Diese anomale Doplellurechung weist auf innere Spannungen hin, die vielleicht mit an dem Zerbrechen des ursprïngrlichen gröferen Kristalls schuld sind. In ïbrigen ist die Beschaffenheit ausgezeichnet. Der Stein ist vollkommen durchsichtig und „wasserweil", fast ,blauweif", sodab er täuschend einem ganz reinen und klaren Stücke Eis wleicht. Er ist der reinste der sehr grofen Diamanten. Einigge kleine schwarze und braune Finschliisse (rielleicht (rraphit und Brauneisen) waren wohl rorhanden, ehenso einige kleine Federn und andere derartige unbedentende Fehler, diese lagen aber so giunstig in der Nïhe der Oberfläche, daf sie den Wert als Edelstein nicht beeinflufiten. Nach der Iiegel von Tavernier ist dieser anf 9 Millionen Pfund Sterling berechnet worden. Die 'T'ransvaal-Regrierung hat ihn im Jahre 1907 dem Ǩ̈̈nig Eduard von England geschenlit, der ihn 1945 in Amsterdam durch die berïhmte Steinschleiferei Asscher u. Co. zerlegren und in einzelnen Stïcken schleifen ließ.

Dabei entstanden aufer mebreren kleineren besonders drei gröfere Steine, die in Figg. 62a in ihrer Form und Größe abgebildet sind. Der größte, Cullinan I genannt, in der Mitte des Bildes, ist ein Pendeloque von 5161,2 Karat, der größte jetzt existierende geschliffene Diamant; der zweite, Cullinan II, ist ein vierseitiger, nach einer Richtung etwas verlïnBrillant ron 309 Karat, der also ebenfalls den oben erwähnten Jubilee noch beträchtlich ïbertrifft. Auch der dritte, wie die ïbrigen ein beim Schleifen abgespaltener Splitter, ist ein Pendelofue allerdings ron etwas spitzerer Form, 92 Karat schwer. Daran schlielit sich weiter em Brillant ron 62 Karat usw. Das Gesamtgewicht aller aus dem Cullinan erhaltenen geschliffenen Steine beträgt 980 Karat.

„Die Schünheit dieser Steine übertrifft jede Erwartung. Sie hesitzen ein Fener, einen Glanz, eine so selten schöne blauweilje reine Farbe, ein so wunderbares Spiel der Lichtbrechungen, daf man kaum seinen Augen traut. Die Steine sind absolut rein, und die 
Art des Schliffes ist greeignet, die wunderbare Schönheit und das seltene Feuer zu höchster Wirkung zu bringen, so dal) der Fachmann überwältigt ist ron dem Eindrucke der auf ilın einwirkenden ITunder der Natur und der höchsten Leistungen einer voll entwickelten Technik. Es giht in der Tat an diesen Steinen nichts auszusetzen, weder hinsichtlich der Farhe, der Reinheit, des Feuers, noch auch des Schliffes; was man sich je ertrüumen konnte von ideal schönen Brillanten, sieht man hier verwirklicht".

Der Cullinan I soll die Krone, Cullinan II das Scepter der englischen Könige zieren. Die zahlreichen abgespaltenen kleineren Stïcke werden als Brillanten geschliffen verkauft und aus dem Erlös die namhaften Kosten des Schleifens der größeren Steine gedeckt.

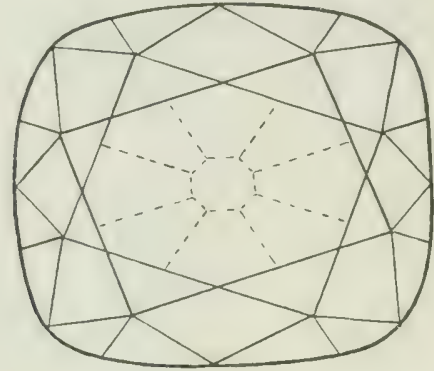

Cullinan II, 309 Karat

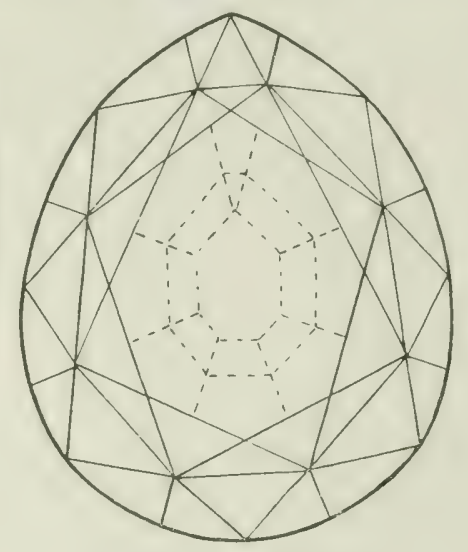

Cullinan $x, 516^{1 / 2}$ Karat

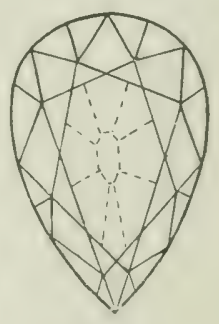

92 Karat

Fig. 62a. Die drei größten aus dem Cullinan geschliffenen Steine (natïrl. Größe).

Auf der Tafel XIa ist neben dem Cullinan zum Vergleiche noch ein kleinerer Stein von 334 Karat aus derselben Grube in natïrlicher Form und Größe abgebildet. Auch ein solcher von 600 Karat ist dort kürzlich gefunden worden.

\section{Wert der Diamanten.}

Der Wert dex Diamanten hängt von selır vielen Umständen ab, deren rasches und scharfes Erfassen die Kunst des.Juwelenhändlers ist. Einzelne Eigenschaften eines Steines kïnnen seinen Wert sehr wesentlich erhöhen oder vermindern, und so handelt es sich darum, alle Punkte, die auf den Preis von Einflub sein können, in gebührendem und ihrer Bedeutung entsprechenden Maße bei der Schätzung in Betracht zu ziehen. Dabei kommt immer nur der IVert eines Diamants als Edelstein in Betracht; Steine, die nicht mehr zum Schmuck, sondern nur noch zu technischen Zwecken dienen können, werden einfach wie andere Iraren nach de'n Tagespureisen dem Gewicht nach verkauft. Finige spezielle Angaben über die Preise der Kapdiamanten sind schon oben, S. 271, gemacht worden.

Von dien Eienschaften, die den Wert eines Diamants mit in erster Linie bestimmen, ist vor allem die Grö Be zu nennen. Je größer cin Stein, desto wertvoller ist er bei

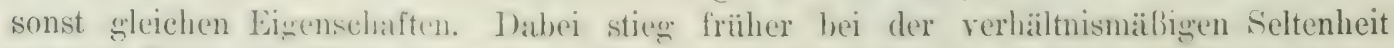
gröberer Steine der Wert in rascherem Tempo, als die durch das (xewicht in Karat ausgedriickte Größe. Ileutzulage ist dies nur noch teilweise der Fall. Bei der Angabe der Preise wird hiervon weiter unten noch ferner die Iiede sein. I)er Wert nieht zu grofer Steine, wie sie häufiger sefunden und wie sie auch vom P'ublikum nicht zu selten verlangt werden, wird durch die allereneinen Verhailtnisse des Handels bestimmt. Aufergewöhnlich grolie und schë̈ne Steine, die sogenannten Solitairs, l'arangons oder Nonpareils, 


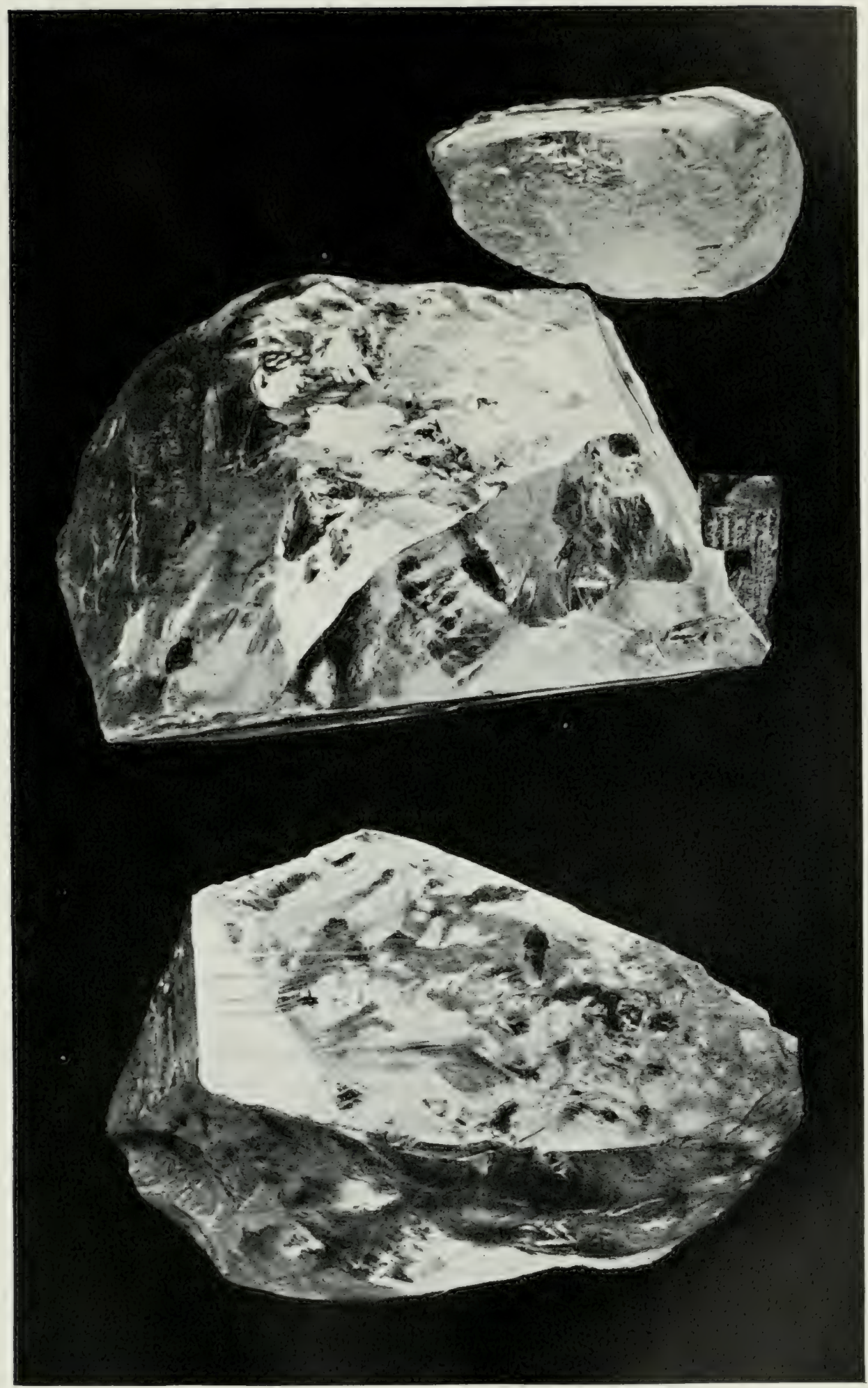

Cullinan-Diamant.

(Natürliche Grősse.) 

hahen anch rinen der. Seltenheit ihres Vorkommens entsprechenden exzeptionellen Wert, der sar keiner livenl unterworfen ist und sich von Fall zu lall nach den speziellen Verhältnissen richtet.

Sehr wesentlich wird der Wert eines Diamants durch das Schleifen rrhöht. Trotzdem ein stein durch diese operation einen beträehtlichen Teil seines Gewichts, meist die Hälfte und noch mehr, verliert, ist er doch nach dem Schleifen bedentend wertwoller als vorhere, da erst dureh den sichliff seine sanze Schö̈nheit hervortritt. W'eil dies aber nicht in wleich hervorragendem Mabe bei allen schlifformen der Fail ist, sofern ein Brillant bedeutend wirkungsvoller ist, als dine Rosette oder ein irendwie anders asechliffener Diamant, ein Brillant auch im allgemeinen am schwierigsten herzustellen ist, so ist (in Brillant mehr wert als eine linsette usw. Ehenso ïbertrifft anch ein Brillant von vällig rextelmäliger und den Vorschriften genau entsprechender form einen weniger rexcelmäbigen an Wert oft nicht unbedentend. Die Zahl der angesehliffenen Facetten ist grleichfalls von Einfluls in der Art, dafs der Wert mit der Zahl derselben steint. „Einmal semacht" heilit ein Brillant, wenn er trar keine Querfacetten an der Kiilasse besitzt, sonder'n bis zur Kalette flach zugeschliffen ist; ,doppelt geemacht", wenn er eine Reihe Facetten am Lnterteil hat, und ,dreimal gemacht", wenn er oben und unten alle Facetten nach der liexel hesitzt. Der Wert eines steines wird nach diesen Alstufungen sehr verändert; el steigt um so höher, je mehr derselbe "remacht" ist. In derselloen Weise ist natürlich auch fïr jede andere schlifform die Zahl und die Regelmäßigkeit der Anlage der Facetten, sowie ihre wohlproportionierte Gestalt und Gröbe für den Wert des Steines mit bestimmend. Ein vollkommener Brillant ron 1 Karat ist mindestens viermal melır wert als ein roher Stein ron demselhen Gewichte und der gleichen Beschaffenheit, und eine ebensolche Rosette hat im Mittel etwa vier Fünftel des Wertes eines gleichschweren Brillants.

Wie wir gesehen haben, sind die Formen der rohen Diamanten für den Schliff bald mehr, hald weniger grïnstig, daher ist auch die Gestalt des rohen Steines auf den ITert nicht ohne Einfluli. Dies ist auch im Torbeigehen schon mehrfach bei speziellen Beispielen hervorgrehohen worden. Okitaëdrische und dodekaëdrische Kristalle, die sich leicht und olne zu viel Terlust zu Brillanten schleifen lassen, sind mehr wert als verzerrte Steine, von denen bei der Bearbeitun viel abf:illt, oder die man zerteilen muß, um für den s'chliff vorteilhafte Stïcke zu bekommen, und namentlich auch als flache Steine von der Form der in Fig. 39, g und h darcestellten Zwillinge, die gar keine Brillanten, sondern nur noch Rosetten geben. Auch die sualtharkeit wird in Betracht grezogen. Einfache Kristalle, die sich spalten und daher leichter bearbeiten lassen, sind wertwoller als Zwillinge \%. B. ron der Fin. 39, $i$ dargesteliten Form und unregelmällige Kristallgrupnen, bei denen dies nicht möglich ist und die daher vielfach zum hort weworfen werden müssen, aus dem sich Schmucksteine überhaupt nicht mehr herstellen lassen.

Vom allerbedeutendsten Einflub auf den Wrert der Diamanten ist aber ihre Durchsichtigkeit, Klarheit und Reinheit, sowie die An- und Abwesenheit ron Fehlern aller Art und nicht zum mindesten auch die Färbung.

I) Durehsichtigke it und Klarheit steht dahei in erster Linie. Je durehsiehtiger und klarer ein Stein, je reiner sein Wasser, desto wertvoller.

Fehler, die die Durchsichtigkeit und den Glanz beeinträchtigen, drïckeu den Wert stets hedeutend herah. Sie sind heim Diamant sehr mannigfaltig. Recht häufig findet man cröfere Einschlïsse von schwarzer und brauner, aber auch ron anderer Farbe. Auch Einlagerungen von Sand oder von Asche, sowie gelbe Flecken, die man als Stroh bezeichnet, sind weit verbreitet. Wolken ron weiber, grauer und brauner Farbe verhindern vielfach die feine Politur, wenn sie an die Oberfläche treten. Dasselbe bewirken die durch zu starke Erwäimung beim Schleifen herrorgebrachten eisigen Flecken ohne bestinmte Farbe. Sehr 
wichtig sind die Federn, die den Spaltungsflächen folgenden kleinen Risse, die nicht nur die Durchsichtigkeit beeinträichtigen, sondern auch das Zerbrechen des Steines beim Schleifen und später heim Gehrauch verursachen können. Alle diese Fehler wirken, auch wenn sie nur klein und unbedeutend sind, sehr störend, da sie in dem klaren und durchsichtigen Steine an den zahlreichen Facetten gesplegelt, in vielfacher Wiederholung sich dem Auge zeimen. Nehmen sie an Fröbe und IIenge zu, dann ist der Stein zum Schleifen nicht mehr zu gebrauchen, er gehört zum Bort.

W'nn die Fehler nur in den äußersten Teilen des rohen Steines sind, lassen sie sich oft durch den Schleifprozel entfernen, und sind dann von keinem Belang. Es ist die Kunst des Iändlers und des Schleifers, dies richtig zu erkennen und vorteilhaft zu verwerten.

Je nach den speziellen Verhältnissen günstig oder ungiinstig wirkt die Farbe. Im allgemeinen sind die vollkommen wasserhellen, farblosen Steine am wertvollsten, besonders die sogenannten blauweißen, also von der Beschaffenheit, die am Kap sehr viel seltener ist als in Indien und auch in Brasilien. Schon ein ganz geringer, für den Laien kaum bemerkbarer Stich in irgendeine Farbe, besonders in die jetzt durch die Kapsteine so verbreitete gelbe, vermindert den Wert erheblich. Dies geschieht noch mehr, wenn die Farbe etwas dentlicher wird Dabei sind die blauen, grauen, roten und gelben Farbentöne noch geschätzter als die braunen und schwarzen. Am meisten wird aber der Wert durch unreine Farben vermindert, die gleichzeitig die Durchsichtigkeit beeinträchtigen, sehr viel mehr, als dies bei zwar etwas gefübten, aber sonst klaren und durchsichtigren Steinen der Fall ist.

Vollständig ändern sich jedoch die Verhältnisse, wenn ein Diamant neben vollkommener Durchsichtigkeit und Klarheit eine ausgesprochen schöne Färbung besitzt. Solche tieferen Farben sind besonders geschätzt und teuer, weil derartige Steine ganz ungemein selten sind, namentlich blane, dann aber auch rote und grïne; weniger gilt dies für grelbe, wie sie jetzt an Kap) hänfiger vorkommen. Der Wert solcher schön gefärbter Diamanten geht oft weit über den der schönsten farblosen hinaus. Die wenigen Steine dieser Art, die sog. Phantasiesteine, sollen bei den nachfolgenden Betrachtungen unberïcksichtigt bleiben. Ihre Zahl ist den anderen gegenüber eine vollkommen verschwindende; sie sind zum Teil schon oben bei der Beschreibung der besonders bemerkenswerten großen Diamanten sowie bei der Betrachtung der Farbe des Diamants ewähṇt worden.

Auf dem Grade der Klarheit und Durehsichtigkeit und der Abwesenheit oder dem Vorhandensein voll Fehlern und Färbung beruht die Qualität der Diamanten. Man unterscheidet danach vielfach drei Abteilungen, nämlich die Steine vom ersten, zweiten und dritten Wasser. Doch werden auch zuweilen vier und noch mehr Unterabteilungen gemacht; in jeder wäichst der Wert mit der Größe.

Die steine voun ersten Wasser (1. Qualität) sind vollkommen farblos, durehsichtig und wasserhell, ohne eine spur von Fehlem irgendwelcher Art. Sie sind die wertvollsten. Die vom zweiten II asser (2. Qualitait) sind entweder auch noch farblos, haben aber unwesentliche kleine Fehler, oder sie sind ohne Fehler, zeigen jedoch eine ganz geringe Spur irgendeiner Färbung. Die vom dritten Wasser sind farblos mit größeren Fehlern oder auch gefärbte (couleurte Diamanten). Je nach der Stärke der Färbung und der Größe der Fehler unterscheidet man wohl eine 3. und 4. Qualitait. Zu dieser gehören die geringsten Diamanten, die noch als Edelsteine Verwendung finden. Man darf aber nicht glauben, dab diese Abteilungen ganz fest abgegrenzt wären, sie sind im Gegenteil zienlich willkürlich. Nancher Juwelier erklärt einen Stein für einen solchen zweiten Wasser's, den ein anderer noch als ersten Wassers gelten läßt, und ähnlich in anderen Fällen. Wie die Qualitait auf den Wert der Steine einwirkt, geht bis zu einem gewissen Grade aus folgrenden Angaben hervor: Ein Brillant vom zweiten Wasser hat nur etwa 
$\because$ ron dem Wert aines solchen vom rrsten Wasser und bei zwei entsprechenden Rosetten verhalten sich die Werte wie 3 zu 4.

feht man von dem Werte eines Brillants vom 1. Wasser als Einheit aus, dann ist der Wert fïr einen solehen vom 2. Wasser etwa $2 /:$, für eine Rosette vom 1. Wasser grleich Is und fïr eine solche vom 2. Wasser shleich 3/;. Zu bemerken ist, dab diese Qualitiitsunterschiede erst nach dem Schleifen sicher erkannt werden können; die rohen Steine lassen die ligenschaften vielfach norh nicht mit der orforderlichen Schärfe hervortreten und kömmen daher nicht mit geniizender Bestimmtheit nach der Qualität klassifiziert und einer der obigen Abteilungen zugewiesen werden.

Wir laben schon oben gesehen, dab der Diamant zwar im Altertum nach den Angaben ron Plin i us der kostbarste Edelstein, ja das kostbarste menschliche Besitztum ïherhaupt gewesen ist, dab dies aber gegenwärtig nicht mehr gilt. Es sei hier daran erinnert, dafi schöne Rubine, namentlich wenn das fewicht über ein Karat oder gar über mehrere Karat himausgeht, viel wertvoller sind als gleichschwere Diamanten von der entsprechenden Qualitait. Dasselbe gilt auch im allgemeinen für Smaragd, und selbst einzelne besonders schöne blaue Sapphire können die Diamanten im Preise ïbertreffen. Wir werden hicranf bei der Betrachtung der Preise für Rubin usw. noch weiter zurïckkommen.

Die für die Diamanten unter normalen Verhältnissen bezahlten Preire bängen jederzcit ron ihrem Werte ab, wie er in dem Vorhergehenden näher gekennzeichnet wurde. In jelem Augenblicke steht ein nach den obigen Regeln wertvollerer Diamant auch büher im Preise als ein minder wertvoller. Aber diese Preise sind nicht zu allen Zeiten dieselhen, sie schwanken und zwar sehr stark, wie dies schon oben hei der Betrachtung der Edelsteinpreise im allgemeinen auseinandergesetzt wurde, worauf hier verwiesen werden soll, ebenso auch auf die Darstellung des Handels mit Kapdiamanten (S. 268).

I) älteste Preisangabe für Diamanten, die man kennt, ist die des Arabers Te if a sehius, der im 12. Jahrhundert einen Stein ron 1 Karat auf 2 Dinar (etwa 120 Mark) schätzte. Benvenuto Cellini gibt in Jahre 1550 den Preis eines schönen Steines von demselben Gewicht auf 100 Goldtaler (scudi) an; diese Summe übersetzt Sehra uf in 200 isterr. Gulden $=400$ Mark, Boutan dagegen in 1100 Franken $=$ s 50 Mark. Letzterer Betrag wiirde ein so abnorm hoher sein, daß er gewiß unrichtig ist und auf falscher Annahme des Wertes eines Goldtalers beruht. 1609 gibt Boëthius de Boodt den Wert eines Karatsteines auf 130 Dukaten oder etwa 440 Nark an, während das 1672 in London anonym erschienene Werk: "The history of jewels" den Preis von 40 bis 60 Kronen oder 160 bis 240 Mark festsetzt. Dazwischen lag der 30 jührige Krieg, dessen zerstörende Wirkung wohl allein die Schuld an dem groBen Preisriickgange trug. Tavernier gibt 1676 den Preis des Karatsteines zu 160 Mark, und damit stimmen auch andere Taxen aus derselben Zeit ron Holland und Hamburg. 1733, bei der großen Panik nach den brasilianischen Entdeckungen, war der Preis roher Diamanten auf 20 Mark pro Karat gesunken, der sich aber schon 1734 wieder auf 30 Mark für den Karatstein hob und dabei damn mehrere Jahre stehen blieb. 1750 wird von dem seiner Zeit berühmten Londoner Juwelier David J effries, dem Yerfasser einer ,Abhandlung über Diamanten und Perlen“, für schöne geschliffene Karatsteine wieder der 1676 von Tavernier und anderen angegebene Preis von 160 Mark genannt, und "der aufrichtige Jubelier", ein 1772 in Frankfurt a. M. erschienenes Werk über Edelsteine, gibt für diese Zeit den hohen Preis von 120 Taler oder 360 Mark für einen solcben Stein.

Nach den bei Ausbruch der französischen Revolution bedeutend gesunkenen Preisen konnte der mit der Abschätzung der französischen Kronjuwelen betraute Ausschuß 1791 einen geschliffenen Karatstein im Mittel nicht höher als zu 120 Mark bewerten. Nachdem aber bald, wesentlich infolge des ron Napoleon und seinem Hofe getriebenen und 
veranlabten Luxus der l'reis wieder gestiegen war, kostete im Jahre 1532 ein schöner Brillant ron I Karat 1 S0 Mark, während rohe Steine von guter schleifwiirdiger Qualität zu 42 bis 15, hïchstens (i) Mark das Karat verkauft wurden. Im Jahre 1559 wurden rolıe Steine dersethen Art mit $\delta \mathrm{I}$ bis zu 10.) Mark für das Karat bezahlt, und für geschliffene Faratsteine findet man aus den Jahren 1860) und 1865260 und 360 Mark angegeben.

Für das Jahr 1869, also kurz vor der Entdeckung der Kapdiamanten, trifft man bei S c h r a uf folgende Preisangaben: Rohe gute, schleifwürdige Ware, wie sie in grölieren Partien aus den Produktionsländern in den Handel kommt, kostete 100 Mark pro Karat, Sorten, die wenig schleifbare Ware enthalten, und von denen der gröfte Teil nur als Bort verwendet werden kann, waren 20 bis 40 Mark wert, und Bort allein wurde mit 4 lis 6 Mark bezahlt. Die Angabe der Preise geschliffener Steine zeigt den großen Einfluf des Schliffes und der Schlifform, sowie der Qualität. Ein Brillant von 1 Karat vom ersten Wasser wurde $\mathrm{um} 400$ bis 500, ein solcher von zweiten Wasser um 300 Mark verkauft, während eine einkarätige Losette vom ersten Wasser nur 300 bis 360 Mark wert war. Ein Brillant von 1,2 Karat kostete 120 Mark, ein soleliel von 3/4 Karat 240 Mark solche ron 1/10 Karat 20 Mark. Von kleineren Rosetten, von denen 50 Stiuck auf ein Karat gehen, wurde das Karat mit 300 Mark, von noch kleineren, von denen 1000 Stïck 1 Karat wiegen, das Stiick mit 1/2 Mark bezahlt. Nur in den gliicklichen Zeiten im 16. und am Anfange des 17. Jahrhunderts, herrschten ähnlich hobe Preise für Diamanten wie 1869. Dies zeigt die folgende Zusammenstellung der Preise von Brillanten von 1 bis 5 Karat in den Jahren 1606, 1750, 1865 und 1867. Diese Tabelle, die den Preis in Franken ausdrückt, wurde zusanmengestellt von L. Dieulafait und vervollsiändigt für das Jahr 1875 aus der unten folgenden Aufstellung von V a n d er hey m, um zu zeigen, wie die Preise nach der Auffindung der südafrikanischen Diamanten infolge des starken Angebotes heruntergegangen waren, nachdem 1867 bis 1869 noch steigende Tendenz geherrscht hatte.

\begin{tabular}{|c|c|c|c|c|c|}
\hline Brillant von & 1606 & 1750 & 1865 & 1867 & 1878 \\
\hline $\begin{array}{l}1 \text { Karat } \\
2\end{array}$ & $\begin{array}{l}545 \text { Frkn. } \\
2152\end{array}$ & $\begin{array}{l}202 \text { Frkn. } \\
807\end{array}$ & $\begin{array}{r}453 \text { Frkn. } \\
1639\end{array}$ & $\begin{array}{r}529 \text { Frkn. } \\
2017\end{array}$ & $\begin{array}{l}220 \text { Frkn. } \\
700\end{array}$ \\
\hline$\eta$ & 4916 & 1815 & $3151 \quad$ & 3529 & 1250 \\
\hline 4 & 6.554 & 2470 & & - & 1950 \\
\hline $5 \quad n$ & 8753 & 5042 & 8067 & 8823 & 2750 \\
\hline
\end{tabular}

Die Ende der siebziger Jahre geltenden Diamantenpreise für die marktfïhige Ware, also für niedrige Gewichte, sind am besten zu ersehen aus der folgenden Zusammenstellung, die der Pariser Juwelier Vanderheym für die Weltausstellung von $157 \mathrm{im}$ Auftrage des Syndikats Pariser Juweliere angefertigt und durch je zwei Steine von der hetreffenden (rrölie und Beschaffenheit illustriert hat. Die in Franken ausgedruickten Preise gelten je für ein Paar Brillanten, das Gewicht steigt immer um 1/2 Karat und geht bis zu 12 Karat; dabei werden vier Qualitäten unterschieden.

Diese den heutigen Verhältnissen allerdings nicht mehr entsprechenden Zahlen sind keine Phantasiegebilde, sondern es sind im Handel zu jener Zeit wirklich bezahlte Summen. In den letzten 20 Jahren haben sich die Diamantenpreise mehr als verdoppelt.

Man erkennt aus der folgenden Tabelle den groben Unterschied der Preise von Steinen desselben Crewichts für die verschiedenen Qualitäten, namentlich zwischen der ersten und zweiten. Dieser ist schon bei einem Karat grö̈ljer als der Unterschied zwischen der zweiten und 


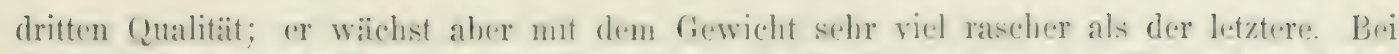
einem Stem von 12 Karat ist dem P'reis für urstr. Gualitait nahezu das I)reifache wie bei einem ebenso grolien stuine ron der zweiten Gualitiit, während die Preise ron zwei zwölfkarätigen Steinen sich nur verhalten wie 9 zu S, wenn sie der zweiten und dritten, wie 6 zu 5, wenn sie der dritten und vierten Qualität angehören. Der Grund davon ist, dalj am Kap sehr wenge Steine ron der ersten Gualität, namentlich sehr wenige gröliere vorkommen, während von den anderen (gualitïten auch grolie steine dort bäufig sind.

\begin{tabular}{|c|c|c|c|c|c|}
\hline Nr. & $\begin{array}{c}\text { Gewicht } \\
\text { in Karat }\end{array}$ & 4. Qualität & 3. Qualität & 2. Qualität & 1. Qualität \\
\hline 1 & 1 & 120 & 150 & 180 & 220 \\
\hline 2 & $11 / 2$ & 200 & 250 & 300 & 400 \\
\hline 3 & 2 & 400 & 480 & 600 & 700 \\
\hline 4 & $21 / 2$ & 525 & 625 & 800 & 950 \\
\hline 5 & 3 & 660 & 780 & 1020 & 1250 \\
\hline 6 & $3^{1 / 2}$ & 720 & 945 & 1225 & 1600 \\
\hline 7 & 4 & 960 & 1120 & 144!) & 1950 \\
\hline 8 & $4^{1 / 2}$ & 1050 & 1305 & 1642 & 2350 \\
\hline 9 & 5 & 1250 & 1500 & 1900 & 2750 \\
\hline 10 & $5^{1 / 2}$ & 1430 & 1705 & 2117 & 3250 \\
\hline 11 & 6 & 1620 & 1920 & 2340 & 3700 \\
\hline 12 & $61 / 2$ & 1820 & 2112 & 2567 & 4250 \\
\hline 13 & 7 & 1995 & 2310 & 2765 & 5000 \\
\hline 14 & $71 / 2$ & 2175 & 2550 & 3000 & ว\$\$00 \\
\hline 15 & 8 & 2360 & 2800 & 3240 & 6700 \\
\hline 16 & $8^{1 / 2}$ & 2550 & 3060 & 3485 & 7600 \\
\hline 17 & 9 & 2700 & 3330 & 373วั & 8500 \\
\hline 18 & $9^{1 / 2}$ & 2897 & 3562 & 3990 & 9400 \\
\hline 19 & 10 & 3050 & 3800 & 4250 & 10300 \\
\hline 20 & $10^{1 / 2}$ & 3255 & 4042 & 4515 & 11400 \\
\hline 21 & 11 & 3465 & 4290 & 4840 & 12500 \\
\hline 22 & $11^{1 / 2}$ & 3737 & 4600 & 5175 & 13700 \\
\hline 23 & 12 & 3900 & 4500 & ว4400 & 15000 \\
\hline
\end{tabular}

Man sieht auch, wie wenig die sogenannte Tavern i er'sche Rescel, wonach der Preis mit dem Quadrat des Gewichts zunimmt, den wirklichen Verhältnissen beim Dianant entspricht. Tach obiger Tabelle wäre der Preis eines zwölfliarätigen Steines von der ersten Qualität $=12.12 .220=31680$ Franken, während er faktisch nur 15000 Franken kostete, also nicht ganz die IIälfte der berechneten Zahl. Ebenso ungenaue Resultate gibt die Regrel bei kleineren Steinen. Ein sechskarätiger Diamant erster Qualität wiircle danach $6.6 \cdot 220=7920$ Franken wert sein, während der wirkliche Preis 3700 Franken betrug. Heutzutage ist die Preiszunalame größerer Steine noch greringer als 15is. Bis zu 15 Karat etwa ist der Preis dem Gewicht ungefähr proportional, so daB ein Zweikaratstein das Zweifache, ein Dreikaratstein das Dreifache eines einkarätigen kustet, wenigstens gilt dies für die drei letzten Qualitïten, für die erste ist die Zunahme stärker.

Nach der Regel von Schra uf, wonach der Preis eines Karatsteines mit dem Produkt aus der balben Karatzahl und der um zwei vermehrten Karatzahl multipliziert wird, würde ein zwölfkarätiger Stein erster Qualität: $6.14 .220=18+50$ ) Franken statt des wirklichen Preises von 1500 (1) Franken kosten. Diese Regel gibt also immer noch um 3450 Marh zu viel, ist aber doch weitaus zutreffender als die von Tavernier. Dies gilt aber nicht mehr für kleinere Steine. Ein Sechskaratstein erster Qualität kostet nach Schrauf 
3. S. 220=5250 Franken, der wirkliche Preis ist aber wie oben nur 3700 Franken. Gegenwärtig rechnet man für einen Brillant mittlerer Qualität von 1 Karat 300 Mark, nur bei den allerschönsten Steinen, wie sie als Seltenheiten im IIandel vorkommen, kann man 1 Karat zu 400 und sogar 600 Mark rechnen.

Der Preis der großen Steine, die über das Gewicht der gewöhnlichen Handelsware, also etwa ïher 20 Karat hinausgehen, ist überhaupt nicht in Regeln zu bringen. Manchmal wurde für einen solchen mehr, manchmal weniger bezahlt, als die Tavernier'sche Iiegel angibt, manchmal wohl auch ziemlich ebensoviel. Die Preise, die für solche großen Steine und ehenso für sehr schön gefürbte blaue, rote, grüne usw. bezahlt werden, sind Liebhaberpreise, die auch von der Möglichkeit abhängen, solche besonders wertvollen Stïcke an den Mann zu bringen, und eine solche Möglichkeit ist oft gar nicht vorhanden, da die Käufer für derartige Kostbarkeiten ebenso selten sind wie diese selber. Man pflegte früher solche Steine besonders fürstlichen Personen und namentlich vor in Aussicht stehenden Festlichkeiten, Vermählungen usw. anzubieten, selbstverständlich häufig ohne Erfolğ. Ein solcher Stein, der vielfach angeboten, aber nicht verkauft wurde, soll dadurch nicht unerheblich im Werte herabsinken. Später fanden sich vielfach in Amerika Abnehmer.

Übrigens ist es auch für kleinere Steine kaum möglich, Normalpreise anzugeben, da alles von der Qualität abhängt, die obigen Zahlen werden aber immerhin einigermaßen orientieren. Man hat stets scharf zwischen den Preisen geschliffener und roher Steine zu unterscheiden; letztere kommen nicht einzeln, sondern nur in größeren Partien, und zwar vom Kap genau nach Qualitäten sortiert, von Brasilien unsortiert, wie sie gefunden werden, in den Handel. Eine starke Zunahme erfahren die Preise durch den wiederholten Zwischenhandel, bis die Steine endlich im Juwelierladen in die Hand des Publikums gelangen.

\section{Nachahmung und Verfilschung.}

Der hohe Preis schöner Diamanten hat vielfach Versuche zur Folge, unkundige Käufer durch andere ninderwertige Steine oder Nachahmungen aus Glas zu täuschen. Es sind namentlich einige farblose Edelsteine oder farblose Varietäten von solchen, die hierzu verwendet werden können: farbloser Topas, durch Glühen entfürbter Hyacinth, weißer Sapphir und Spinell, Beryll, Turmalin, ferner Phenakit, Bergkristall und andere. Bei allen diesen fehlt das schöne Farbenspiel und, vielleicht den farblosen Hyacinth und Sapphir ausgenommen, der hohe Glanz. Ein Kenner wird daher niemals einen dieser Steine mit Jiamant verwechseln. Sie unterscheiden sich von diesem sicher durch die Härte und die meisten auch durch die Lichtbrechung; von den genannten allen ist nur der Spinell einfachbrechend wie der Diamant. Der Diamant allein läßt die Röntgenstrahlen vollkommen durch; ihm nähert sich darin allerdings der Phenakit. Auch das spezifische Gewicht mibt ein Erkennungsmerkmal, wie wir bei der Betrachtung der versehiedenen farblosen Edelsteine und ihrer Unterscheidung im dritten Teile dieses Buches noch weiter sehen werden. Seltener als mit farblosen wird der Diamant mit gefärbten Edelsteinen verwechselt; auch dafür werden wir später die unterscheidenden Kennzeichen speziell kennen lernen.

In Beziehung auf Farblosigkeit, Durchsichtigkeit, Glanz und Farbenspiel haben manche Glassorten, besonders der Straß, die größte Ähnlichkeit mit dem Diamant. Dieser wird daher häufig zur Nachahmung des Diamants benutzt, und es ist wohl auch einem Kenner nicht leicht möglich, frisch geschliffenen Straß von einem echten Diamant durch das bloße Ansehen sicher zu unterscheiden. Hier gibt aber die Iürte leicht die Entscheidung. Straß wird schon von einer harten Stahlspitze leicht geritzt und von der Feile angegriffen, ebenso auch von der Ätztinte, die auf echten Diamant nicht im geringsten einwirkt. 
Nicht selten sind Verfälschungen durch Dubletten, bei denen \%. B. nur der Obertid cines Brollants aus I)iamant, der Unterteil dagregren aus Gulas oder einem farblosen Steine, etwa weiljem Sapphir, besteht. Von dem Betrug, der durch Verdeckung der gelblichen Farbe der Diamanten mittels leichter Öberdeckung mit einer blauen Substanz geüht wird, ist schon ohen die Rede gewesen. Durch Iiestreichen der Unterseite von Glas oder weiljen Steinen mit Farben kann bis zu einem gewissen Frade, aber doch nur in zirmlieh roher Weise das Farbenspiel des Diamants nachgeahnt werden. Sachen dieser Art werden exerenwïtig unter dem Namen Iris vielfach in den Ifandel grebracht, ohne daß aber dabei eine 'Täuschung beabsichtigt wird oder möglich wäre.

\section{Korund.}

Zu der Mineralspezies Korund gehören einige der schönsten und wertrollsten Edelsteine, die man kennt, vor allen der rote $\mathrm{R} u$ b in und der blaue sapph ir, daneben noch zahlreiche weitere von anderer Farbe. Alle diese Steine sind nach der Gesamtheit ihrer im mineralogischen Sinne wesentlichen Eigenschaften, also nach ihrer chemischen Zusammensetzung, ihrer Kristallform und ihrem ganzen physikalischen Terhalten einander in jeder Winsicht gleich. Sie unterseheiden sich lediglich durch die Farbe, die auf der Beimischung kleiner Mengen frender Substanzen beruht, und die daher für ihre Betrachtung als IIneralien unwesentlich ist, die aber allerdings für ihre Verwendung als Edelsteine die allergrößte Wichtigkeit und Bedeutung besitzt.

Was die ehemische Zusammensetzung betrifft, so ist der Korund reine Tonerde, also cin Oxyd des jetzt so viel verwendeten Metalls Aluminium. Er hat die Formel $\mathrm{Al}_{2} \mathrm{O}_{3}$, was einem Gehalt von 53,2 Proz. des genannten Metalls und von 16,8 Proz. Sauerstoff entspricht. Aber diese ideale Reinheit ist wohl nie vorhanden; stets ergibt die Analyse kleine Mengen anderer Substanzen als Verunreinigungen, und zwar um so weniger, je klarer und durchsichtiger die Steine sind, je mehr sie sich also zu Edelsteinen eignen. Sind größere Mengen solcher fremder Stoffe vorhanden - und diese betragen manchmal zehn und noch mehr Prozente - , daun sind die Steine tribe und unansehnlich, so dab sie keine Verwendung zum Schmuck mehr zulassen. Die chemische Untersuchung hat neben der Tonerde etwas Eisenoxyd, Kieselsäure usw., zuweilen auch eine Spur Chromoxyd nachgewiesen. Ein schün durchsichtiger roter Korund, sogenannter orientalischer Rubin, und ein ebenso beschaffener blauer, ein orientalischer Sapphir, beide mit allen für einen Edelstein erforderlichen Eigenschaften in ausgezeichneter Weise ausgestattet, haben dabei die folgenden Zahlen ergeben:

\begin{tabular}{|c|c|c|c|c|}
\hline & & & Rubin & Sapphir \\
\hline Thonerde & . & & 97,32 & 97,51 \\
\hline Eisenoxyd. & . . & . & 1,09 & 1,89 \\
\hline Kieselsäure & . . . . & . & 1,21 & 0,80 \\
\hline
\end{tabular}

Auf diesen kleinen Mengen fremder Substanzen, namentlich auf dem Gehalt an Eisenoxyd und zum Teil auch an Chromoxyd, beruhen, wie wir unten noch weiter sehen werden, die verschiedenen Färbungen.

Der Korund zeigt nicht selten deutliche, schön ausgebildete Krystalle, die dem hexagonalen System, und zwar dessen rhomboïdrisch-hemiëdrischer Abteilung angehören. Eine 
Anzahl der häufiger vorkommenden Kristallformen ist in Fig. 63, a bis $i$ dargestellt. Sie sind in zweierlei verseliedener Weise ausgebildet. Bei vielen herrscht ein sechsseitiges Prisma mehr orler wenicer stark vor, das an beiden Enden durch eine gerade Endfläche senkiecht zu den P'rismenflächen geschlossen ist und auf dessen Kanten abwechselnd oben und unten die Flächen cines lihomboëders aufgesetzt sind. Die meisten Flächen sind glatt, nur die geraden Endflächen tragen eine regelmäßig dreiseitige Streifung. wie es der auf Tafel I, Figur 5 abgebildete Kristall zeigt. An den Figuren " bis $c$ sind nur die genamten Formen, aber in verschiedener Ausdehnung vorbanden, in Figur d tritt dazu noch eine dopreltsechsseitige P'yramide, ein Dihexaëder, dessen Flächen auf die des Prismas nach oben und nach unten gerarle aufgesetzt sind. Solche Pyramiden bilden in den Figuren 63, "bis $i$ allein oder doch überwiegend die Begrenzung, allein in Figur $e$, mit
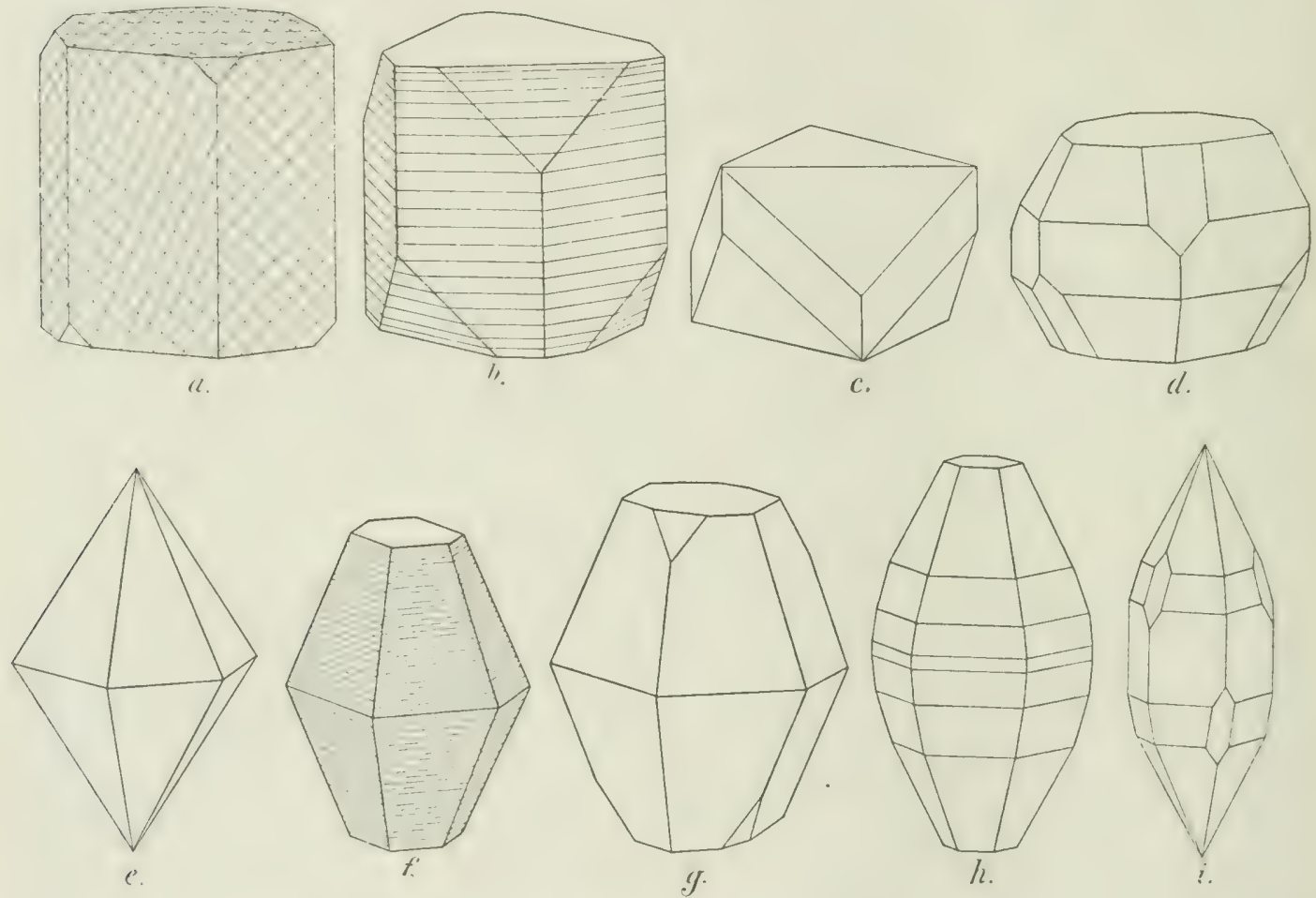

Fig. 63. Kristallformen des Korunds (Rubin, $a-d$; Sapphir, $e-i$ ).

der geraden Endfläche in Figur f, und mit dieser und den kleinen auf die Endkanten abwechselnd oben und unten gerade aufgesetzten Flächen eines Rhomboëders in Figur \%. Die Flächen dieser Pyramiden sind, wenn sie den Tiristall allein oder vorwiegend begrenzen, in iler Weise wie in Figur / stark horizontal gestreift. In Figur $h$ sind drei solche Dihexaïder mit verschieden steilen Fläichen ïbereinander ausgebildet, deren Endecken auf beiden Seiten durch die gerade Endfläche und deren Seitenkanten dureh die Flächen eines hexagonalen Prismas gerade abgestumpft sind. In Figur $i$ sind zwei Dihexaëder mit dem sechsscitignen Prisma und einem Rhomboüder kombiniert. Man hat also, wie schon oben angedeutet, zwei Ausbildungsformen der Kristalle; bei der ersten (Fig. a bis (l) sind die Prismen, bei der zweiten (Fig. $e$ bis $i$ ) die Pyramiden vorzugsweise entwickelt. Die erstere findet sich ïberwiegend bei dem roten Korund, dem Rubin, die zweite mehr bei dem blauen, dem Sapphir. Ein Rubinkristall ist auch auf Tafel I, Figur 5, 
ain Salphlirkristall auf derselben 'Tafel in Figur 7 abgebildet, beide in ihrer natiorlichen Beschaffenheit.

Ilïnfig, allerdings meist nur bei dem träben, undurchsichtigen Korund, wenioner hei

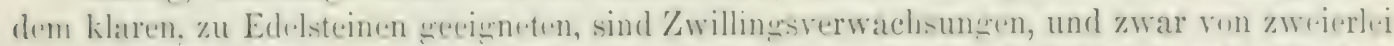
Art. Xatch der einen sind diime, deme Latuedlen in grolier Zahl parallel mit den Flächen

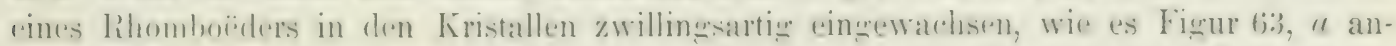
deutet. Nach der zweiten Art ist dies parallel der geraden Endfläche der Fall, wie in Figur b. Die verschiedenen Flichen erhalten dadurch rine oft sshe frine seradlinige

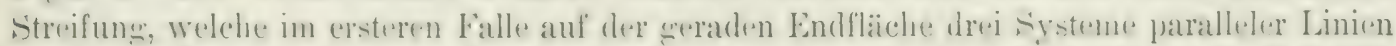
bildet, dies sich unter Winkeln von 610 Grad oder 120 Grad durchschneiden, während im zweiten Falle dir Streifen auf den I'rismenflïchen in horizontaler Richtung senkrecht zu den Kanten verlaufen.

Mit diesen in recelmäbiger Wrejse zwillingsartion den Kristallen eingelagerten diinnen und stets rollkommen elenen l'lättehen oder Lanellen lä̈ngt eine scheinhare Sfaltharkeit des Korunds nach den Flächen des Rhomboüders und auch nach dele geradon Endfläche zusammen. Diese Lamellen hängen oft nicht sehr fest aneinander; sie trennen sich dann leicht nach ihren ebenen Beogrenzunesflächen beim Zerschlagen ler Kristalle, welche sich mach eliesen noch leichter mit dem MeiBel spalten lassen. Man hat es aher danach lierbei nicht mit einer wrklichen Spaltbarkeit zu tun, sondern mit einer socrenannten

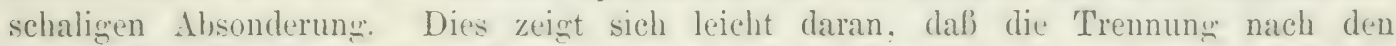
Flächen des Rhomboüders oder nach der geraden Endfläche nicht an allen Kristallen möglich ist, sondern nur an solehen, in denen sich auch Zwillingslamellen nach der betreffenden Flïche finden, und daf die Absonderung stets der Grenze einer solchen Lamelle folgt. Fehlen die Zwillingslamellen, so fehlt auch jede Spur efenflächiger Trennung oder scheinbarer Spaltbarkeit, der Truch ist muschelig, wie bei so vielen anderen nicht spaltbaren Mineralien.

Der Korund ist sprüde. Unter seinen physikalischen Eigenschaften ist, wie heim Diamant die hervorragendste die $\mathrm{Harte}$. Er ist nach diesem das härteste Mineral, wenn er auch hierin nicht entfurnt jenen Edelstein erreicht; alle anderen Hineralien sind weicher als der Korund, wenngleich manche nur um weniges. Wegen dieser Ligenschaft ist der Korund als Material zmu Schleifen und Polieren harter Körper sehr geeignet; seine trüben Yarietaten, namentlich der dichte schwarze Schmirgel, werden auch, wie wir geselen haben. hierzu vielfach benutzt, ebénso beruht darauf die Terwendung zu Zapfenlagern für Lhren und andere feine Instrumente usw. Indessen sind nicht alle Abarten des Korunds in Beziehung auf die Härte einander ganz gleich; es sind zwischen ihnen kleine Cntersebiede vorbanden. Am härtesten von allen ist der hlaue Korund, der Sapplir und hier wieder, wie man sagt, der australische.

Das spezifische Gewicht ist sehr hoch. Bei reinem Material ist es sehr nahe $=4$ grefunden worden; die Zahlen schwanken zwischen 3,at und 4,in. Größere Abweichungen ron $4, \cdots$ berulen auf Irrtïmern oder auf der Lnreinheit der zur Bestimmung angewandten Stïclie. Die einzelnen in der Farbe verschiedenen Tarietäten sollen kleine Differenzen erkennen lassen. Der Korund ist einer der schwersten Edelsteine, man kann ilın daher durch das spezifische Gewicht meist sicher ron anderen ähnlich ausselıenden unterscheiden. Er sinkt in reinen Methylenjodid und sogar noch in der schwersten Flïssigkeit $\left(\mathrm{G} .=3, t_{1}\right.$ ) sofort und rasch zu Boden.

Von Säuren, auch von Ätztinte, wird das Nineral weder in der Kälte noch in der Wärme angegriffen; vor dem Lütrohr ist es vollkommen unschmelzbar. Beim Erhitzen im Dunkeln zeigt sich, dab riele Korunde sehr schön phosphorezzieren. Reiben mit Tuch oder Leder erzeugt positive Elektrizität, die sehr lange erLalten bleibt. 
Die äucre Erscheinung des Korunds ist sehr mannigfaltig. Am häufigsten ist er trïbe und dann als Schmuckstein nicht zu verwenden. Nur ein kleiner Teil ist klar und durchsichtig genug zu diesem Zweck. Man bezeichnet den klaren und durchsichtigen als edlen, den trüben und undurchsichtigen als gemeinen Korund. Nur von dem ersteren, dem Edelkorund, kann hier eingehender die Rede sein. Er ist im Gegensatz zu Imitationen auch für Röntgenstrahlen noch gut durchlässig:

Der edle Kortund hat cinen sehr kräftigen und schönen Glanz, der an Lebhaftigkeit de'm de's Diamants sehr mahe steht und namentlich auf angeschliffenen Facetten stark hervortritt. Es ist aber nicht die charakteristische Art des Glanzes wie beim Diamant, also nicht der Demantglanz, sondern der gewöhnliche Glasglanz. Kein anderer Edelstein, abgesehen vom Diamant und vielleicht dem farblosen Hyacinth, hat einen so kräftigen und vollen Glanz, ein so ausgezeichnetes Feuer, wie der edle Korund, der danach vielfach auf den ersten Blick von gleichgefürbten anderen Steinen unterschieden werden kann. Die grobe Härte bewirkt, daß die Oberfläiche den Glanz auch unverändert beibehält, so daß die Schönheit eines geschliffenen Korunds dauernd bestehen bleibt; es findet kein allıähliches Matt- und Trübwerden der Flächen beim Gebrauch statt. Wegen des hohen Glanzes werden auch Korunde noch geschliffen, deren Farbe hell oder sonst weniger ansehnlich ist; sie geben immer noch vorteilhaft aussehende Steine.

Alle Korunde sind doppeltbrechend mit einer optischen Axe. Die Lichtbrechung ist ziemlich stark, aber doch bedeutend geringer als beim Diamant. Die Doppelbrechung ist dagegen gering; die Brechnungsköffizienten des ordentlichen und des außerordentlichen Strahles sind nur wenig voneinander verschieden. Sie wurden an einem Kristall von Ceylon im gelben Natriumlicht bestimmt und gefunden: $\omega=1,009 ; \varepsilon=1,7595$. Auch die Farbenzerstreuung ist sehr gering; die Brechnungskoëffizienten weichen für die verschiedenen Farben des Spektrums nur wenig voneinander ab. Deswegen ist beim Korund niemals das Farbenspiel des Diamants zu sehen, das eben wesentlich auf der energischen Farbenzerstreuung des letzteren beruht.

Die starke Lichtbrechung und geringe Farbenzerstreuung verbunden mit der bedeutenden IÏ̈rte hat die Anwendung farblosen oder sehr hellgefärbten, durchsichtigen Korunds zur Herstellung von Linsen für Mikroskope veranlaßt. Pritchard, der, wie wir gesehen hahen, auch den Diamant in dieser Weise benutzte, stellte 1827 solche Linsen aus sehr hellblauem Sapphir her, er hat aber keine Nachfolger gefunden. Die umfangreichste Verwendung des edlen Korunds, die auf der Durchsichtigkeit beruht, ist die zu Schmucksteinen. Diese wirken außer durch die letztere Eigenschaft und den starken Gilanz vornehmlich durch die prächtige Farbe; viele der am schönsten gefärbten Edelsteine gechören zum Korund. Wir werden uns daher jetzt der Betrachtung der Farbenverhältnisse dieses Minerals zuwenden.

Die ganz reine kristallisierte Tonerde ist vollkommen farblos, wasserhell. Es ist dies der Leukosapphir. In dieser Weise kommt' aber der Korund selten vor. Meist ist eine mehr oder weniger intensive Färbung zu beobachten. Diese ist in vielen Fällen nur fleckenweise vorhanden, so daß farbige Stellen rings von farblosen umgeben sind, und nicht selten zeigt ein Stück an verschiedenen Orten abweichende Farbe. Daß die Färbung der einzelnen Stücke sehr verschieden ist, wurde schon oben erwähnt.

Aus allen diesen Erscheinungen folgt, daß die Farbe durch Beimischungien kleiner Nengen von fremden Körpern zu der an sich farblosen Grundsubstanz hervorgerufen wird. Noch ist es aber nicht gelungen, für jede einzelne Farbe den färbenden Stoff mit Sicherheit oder auch nur mit Wahrscheinlichkeit nachzuweisen. Die Veränderung der Farben durch Radiumbestrahlung siehe S. 72. 
Die Farhen sind bald licht und blal, hald dunkel, tief und gresiittigt. Steine der ersteren Art werden als "weibliche", solche der letzteren Art als "männliche" bezeichnet.

Der Dichroismus ist stets mehr oder weniger bemerkbar, wenn die Farbe nicht gar zu hali ist. Bei starkgefähten Steinen ist er sehr deutlich, und zwar un so nuehr. je tiefer die Färbung ist.

Nach der verschiedenen Farbe werden beim edlen Korund mehrere Varietäten unterschieden, die mit besonderen Namm belext worden sind und die in Eilelstemhandel seln verschiedene Wichtignkeit und sehr verschiedenen Wert haben. Verhälnnismälbig häufig ist der rote korund oder Rubin und besonders der blaue oder Sapplir. Alle anderen Farbenvarietäten bilden im V'eregleich mit diesen sparsam und sogar zum 'Teil sehr spürlich vorkommende Seltenheiten. Sie werden mit denselben Namen brnannt, wie gewisse Steine yon wanz abweichender Beschaffenheit, aber je unit derselbicen Farbe, indem man zur Interscheidung die Bezeichnung "orientalisch" beifïgr, welehe die besonders edle Beschaffenheit, wrolie Ifärte und sehönes Aussehen andeuten soll. Gerade die verschieden gefärbten Korunde sind es vorzussweise, die durch dieses Adelsprärlikat den anderen seleichgefürbtrn Edelsteinen gegeniiber ausgezeichnet werden, auch der Iithbin und der Sapphir. Lnter letzterem Namen werden zuweilen im erweitertem Sinne auch alle farblosen und anders als rot wefäribten Korunde zusammengefaßt und als gelber Sapplir, Violettsapphir usw. unterschied(’n.

Die verschiedenen Farbenvarietäten des Korunds sind nun die folgenden:

Rubin (orientalischer Rubin): rot.

Sapphir (oriental. Sapphir): blau bis farblos (Leukosapphir).

Oriental. A quamarin: hell bläulichgrün bis griunlichblau.

Oriental. Smaragd: grïn.

Oriental. Chrysolith: gelblichgruin.

Oriental. Topas: gelb.

Oriental. Hyacinth: morgenrot.

Oriental. Amethyst: violett.

Diese Farben behalten meist auch bei kïnstlicher Beleuchtung ihre volle Schönheit, was bei den Steinen, die den Korundvarietäten ihren Namen gegeben haben, viclfach nicht der Fall ist. Diese werden zum Teil im Kerzenlieht unansehnlich und stehen anch aus diesem frunde hinter den entsprechenden gleichgefärbten Korund erheblich zurïck. In der Glïhhitze wird die Farbe des Korunds zuweilen, aber nicht immer, veründert oder auch zum Teil ganz zerstört, wie wir unten bei der Betrachtung der verschiedenen Varietäten noch weiter sehen werden.

Der Korund findet sich in seinen einzelnen Abarten teils in unregelmäßig begrenzten Körnern, teils in regelmäbig ausgebildeten Kristallen im Gestein eingewachsen, und zwar vorzugsweise im Urgebirge, im Granit, sowie im Gneis und anderen ähnlichen Gesteinen, ebenso, und vor allem auch in schleifbaren Exemplaren, in dem durch Beriibrungr mit einem Eruptivgestein veränderten Kalk als Kontaktmineral. Aus diesen ursprünglichen Iagerstätten gelangt er in die Seifen, und gerade aus diesen werden in allen seinen Ursprungsländern die schönsten Stiicke der verschiedenen oben genannten Tarietïten gewonnen. Nenerer Zeit hat man auch gelernt, den edlen Korund in rerschiedenen Farben, besonders rot, gelb und violett, sowie auch farblos, nicht aber blau, in vollendeter Schönheit mit allen Eigenschaften der natürlichen Steine künstlich nachzubilden, wovon unten noch weiter die Rede sein wird.

Wir gehen nunmehr, nachdem wir die allen Korunden gemeinsamen Eigenschaften kennen gelernt haben, zur Betrachtung derjenigen Varietäten über, die zur Verwendung als Schmucksteine passend sind. Wir werden dabei die einzelnen Farben trennen und begrinnen mit dem kostbarsten aller Edelsteine, dem Rubin. 


\section{Rubin.}

Eigrnschafton. Unter den verschieden gefürbten tharten des edlen Korunds ist die rote, der Rubin (orientalische Rubin), die wertvollste und gesehätzteste. Überhaupt ist zurzeit der Rubin und daneben der Sapphir und der Smaragd am beliebtesten und gesuchtesten unter allen farbigen Edelsteinen. Es ist wahrscheinlich der Anthrax des Theophrast und bildet cinen Teil dessen, was man im Mittelalter Karfunkel nannte. Alle die oben erwähnten Eigenschaften des Korunds kommen auch ihm zu; von den anderen Varietäten desselben unterscheidet er sich lediglich durch die rote Farbe, wie sie Tafel I, Figur 5 an einem natiirlichen Kristall, Figur 6 der nämlichen Tafel an einem geschliffenen Steine dargestellt ist.

Die Farbe zeigt an verschiedenen Stiicken verschiedene Nuancen; bald ist sie tief, dunkel und gesättigt (männliche Rubine), bald hell und licht (weibliche Rubine), mit allen möghlichen Übergüngen. Die lichten Nuancen sind hellrosenrot bis rötlichweiß, so daß zuweilen nur ein schwacher Stich ins Rote auf dem fast farblosen Stein vorhanden ist. Die dunkleren Farben sind entweder rein rot, oder karminrot, oder blutrot, die meisten Rubine haben aber einen mehr oder weniger deutlichen Stich ins Bläuliche oder Violette, namentlich beim Hindurchsehen. Sehr läufig ist ein Stich ins Bräunliche, weniger ein solcher ins (relb. Die geschätzteste Farbe ist die tief und zwar rein karminrote. Diese ist von den Birmanen mit der des frischen Taubenblutes verglichen worden, man hört daher vielfach, daß die Steine von der Farbe des Taubenblutes die wertvollsten seien. Sie ist recht selten, und Steine dieser Art stehen daher auch am höchsten im Preise, wenn sie fehlerlos, klar und durehsichtig sind. Alle diese Nuancen des Rubins sind dadurch ausgezeichnet, daß sie im Gegensatze zu anderen roten Steinen bei Kerzenlicht an Kraft und schönheit der Färbung nichts verlicren, daß sie bei kïnstlicher Beleuchtung in ebenso prächtigem roten Licht erglänzen wie im hellen Tageslicht. Durch Radiumbestrahlung leidet die Farbe nicht.

Vielfach ist die Färbung nicht ganz gleichmäBig. Zwischen den roten Stellen sind häufig einzelne sröbere oder kleinere weibe Flecken, die aber zuweilen beim Erhitzen verschwinden und einem gleichmäßjgen Rot Platz machen. Durch zweckmäßige Behandlung. im Fener (Brennen) läßt sich zuweilen auch die Farbenunance ändern. So verlieren manche crylanische steine dabei ihren stich in's Violette und werden dadurch wertvoller. Der Riubin kann, wie alle anderen Korunde die höchsten Temperaturen ertragen, ohne zu zer_ springen, wenn man ihn nur vor zu plützlichen Änderungen hütet. Dahei beobachtet man vielfach die schon bei der Betrachtung der Farbe der Edelsteine im allwemeinen erwähnte cigentümliche Farbenänderung. Der glïhende Stein wird bei der Abkühlung erst weib, dam swiin und endlich wieder rot, wie vorher. Die rote Farbe wird also bei starkem Erhitzen nicht dauernd verändert olex zerstört, wie die des Sapplhirs, auch bei der höchsten Glut ist dies nicht der Fall, nicht einmal in der Schmelzhitze.

Es ist daher sicher anzunehmen, dalb der rote Farbstoff des Rubins nicht organiseher Natur ist, wie es bei so' manchen anderen Edelsteinen der Fall zu sein seheint, deren Farbe heim Glïhen zerstïrt wirl. Die Ursache des Rot ist wohl ein kleiner Chromgehait, den man in manchen Ruhinen nachewewiesen hat. Man shlaubt dies um so mehr annehmen zu diirfon, als Glasfliisse durch Boimischung einer geringen Menge Chromoxyd eine dem Tubin sehr ähnliche Farbe erhalten kïnnen. Auch haben die unten zu besprechenden Versuche von fremy und anderen ïlere die künstliche Darstellung des Rubins erwiesen dal) in der 'Tat kristallisierte Tonerde durch etwas Chromoxyd eine schöne rubinrote Färhmong erlangt. Bei diesen Nachlildungsversuchen sind zuweilen Kristalle entstanden, die 


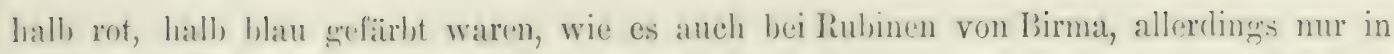
seltenen Fïllen, vorkommt.

Jer Diehroismus des liubins, namentlich des dunkelgefäbten, ist nicht germe. In verschiedenen Richtungen dureh die Kristalle hindurchesehen, ist die Färbung riemlich verschieden, und nur bei selu hellen Steinen ist ein soleher Lntersehied nicht deutlich zu bemerken. Jie kristallformen des liubins sind, wio wir schon oben gestehen haben, in

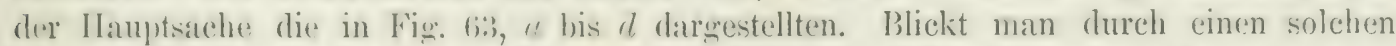
Kristall von dunkler Farbe senkrecht zu der ereraden Endfläehe hindurch, so erseheint er intensiv dunkelrot, entweder rein oder meist etwas ins Violette ziehend. Feht dagegren das Licht senkrecht zu den Flächen des Prismas hindureh, so erscheint der Stein virel lerller. Setzt man die I)ichrolupe von Haidinger auf eine Prismenflïche auf und lyetrachtet das bindurcherengangene Licht, so ist bei der Stellung des gröblen Unterschierles beider Bildur das eine hellrot, das andere dunkelrot, meist etwas ins Tiolette. In jeder anderen Tichtung gibt die Dichrolupe ebenfalls zwei rote Bilder von mehr oder weniger rerschiedener Intensitiit. Nur wenn die Lupe auf die gerade Endflache aufgesetzt wird, sind beide Bilder immer cinander shleich, und zwar intensiv rot, serade wie wenn man in derselhen Riehtung ohie Lupe hindurchsehen würde. Dieser kräftige Dichroismus lïbt den echten, schön gefïrbten Ruhin immer sicher von gewissen anderen roten Steinen unterscleiden, die regulär kristallisieren und daher keinen I)ichroismus besitzen, so vom Spinell und ron den verschiedenen Arten des Granats.

Die Verschiedtenheit der Färbung beim Ifindurehsehen nach versehiedenen Richtungen hat zur Folge, dalj man den Rubin in ganz bestimmter Weise schleifen mub, um die schönste Farbenwirkung zu erhalten. Die IIauptausdehnung des geschliffenen steines, also die Tafel, nuf so nahe wie müglich der zeraden Endfläche des Kristalls parallel gelegt werden; in jeder anderen Richtung geschliffen gibt derselbe Rubin eine weniger intensive und rlaher weniger geschätzte rote Farbe, die am unscheinbarsten wird, wemn die Tafel einer Prismenfläche parallel geht.

Rubme von Siam flu oreszieren in violettem Licht wenig, während die viel wertvolleren ron Birma einen lebhaften roten Lichtschein aussenden und daher zwischen den anderen viel heller erscheinen.

Manche Rubine zeigen auf der geraden Endfläche und noch besscr auf einer in deren ungefährer Richtung geschliffenen, rundlich gewölbten Oberfläche bei auffallendem Lieht einen suchsstrahligen sternförmigen Lichtschimmer. Wan nennt sie Ste r n r u b i ne oder auch Ruhinasterien und Rubinkatzenauten. Die Erscheinung ist dieselbe wie beim Sternsapphir; bei diesem ist sie aber noch ausgezeichneter, es soll daher bei der Beschreibung des Sapphirs näher darauf eingegangen werden.

Wrrt. Der gleichmäbign, tief und rein liarminrote, taubenblutfarbige, klare und durchsichtige, vollkommen fehlerlose Rubin ist der weitaus wertrollste Edelstein, den man heutzutage kennt, besonders wemn er einen sammetartigen Schimmer und ein lebbaftes Fener zeight. Wenn auch die Wertschätzung der versehiedenen Arten der Edelsteine mit der Zeit in nicht unbeträichtlichem Maßje schwankt, so hat der Rubin, aufer im Altertum, doch wohl fast immer an der Spitze zestanden. Dies gilt aber nicht für die fehlırhaften und anch nicht für die hellroten Rubine, die wesen der geringeren Schönheit der Farbe niectriger im I'reise stehen, namentlich aber auch deswegen, weil sie in zitmlicher IIenge und auch in gröberen Stïck'n vorkommen, während vollkommen durchsichtige und fuhlerfreie Rubine ron der schönsten Farbe schon hei ganz bescheidenter Gröfe zu den selır seltenen Funden gethören. Zu dunkle Farben, welche die Durchsichtigke betintrïchtigen, sind gleichfalls ungünstim, ebenso die Nuaucen ins Blaue oder Violette. und noch mehr die ins Gelbe oder Braune, wie sie in Siam besonders häufig sind. 
Daher stehen Rubine von der besten Sorte im Preise weit über ebensolehen Diamanten vom gleichen Gewicht, auch wenn beide nur ein Karat wiegen. Tadellose Diamanten von der ersten Qualität sind schon bei dieser Größe häufiger als entsprechende Rubine. Steigt aber das fewicht höher, so verschiebt sich das Verhäiltnis immer mehr zu Ungunsten des Rubins. Ein schön taubenblutroter fehlerfreier Rubin von 3 Karat ist schon eine große seltenbeit, nach der man lange suchen nuß, während ein ebensolcher Diamant eine nicht ungewöhnliche Erscheinung ist. Diamanten von 10 Karat werden noch in ziemlicher Menge grefunden, gleichschwere Rubine kommen kanm mehr vor, und noch größere sind nur in einzelnen Exemplaren hekannt, immer Steine von hoher Vollkommenheit und Schönheit vorausgesetzt. Daher steigt der Preis der Rubine sehr viel stärker als das Gewicht, und zwar soll dies für nicht zu schwere Steine, wie sie die gewöhnliche Ilandelsware bilden, ziemlich der sogenannten Tavernier'schen Regel gemäß der Fall sein, während beim Diamant die Zunahme des Wertes mit dem Gewicht in sehr viel geringerem Grade stattfindet. Ein Karatstein von Rubin kostet etwa das Doppelte von einem einkarïtigen Diamant und zwar kaun ein einkar:ïtiger Rubin erster Qualität gegenwärtig im Juwelierladen auf 750 bis $10(10)$ Mark geschätzt werden, während ein ebenso schwerer schöner Brillant mit 3010, ein solcher von bester Sorte mit bis (bo) Mark bezahlt wird. Bei Steinen von 3 Karat ab ist ein Rubin von vollkommener Sehönheit mindestens zehnmal teurer als ein Diamant. Ein Brillant aus Diamant erster Qualität von 3 Karat wird in Juwelierladen etwa mit 3000() Mark berechnet, ein cbensolcher Rubin knstet mindestens 30000 Mark. Ton zwei entsprechenden Steinen von 5 Karat sind die Preise etwa 600)( Nark beim Diamant und (iv) (0)0 Mark beim Rubin. Es ist dabei zu berücksichtigen, dab diese Steine von 3 und 5 Karat geschliffen sind und dalj sie im urspruinglichen rohen Zustande ein etwa doppelt so grofes Gewieht hatten. Noch größere, sowie besonders schöne Rubine haben überhaupt keinen eigentlichen Marktpreis mehr; es werden dafür Liebhaberpreise oft von unglaublicher Hühe bezahlt, namentlich wenn ein soleher Stein zu irgendeinem Zweeke gebraucht und zu kaufen gesucht wird. So wurde im Jahre 1599 (in etwas über 2 Kirat schwerer Rubin von der allerersten Sorte für 27000 Mark verkauft, wïhrend sonst ein selir guter Zweikaratstein mit 10000 Mark bewertet wird. Ein schöner Rubin von 9\% Karat wurde von dem amerikanischen Edelsteinkenner Kunz auf 33000 Dollars, also etwas über 130000 Mark geschätzt. Nach den Berichten des Londoner Juweliers Streeter hat man in London für einen schönen geschliffenen Rubin ron 325/16 Karat 10000 Pfund Sterling (200000 Mark) und für einen ebensolchen von 38", 16 Karat sogar das Doppelte, nämlich 20000 Pfund Sterling (f00 000 Mark) gelöst. Diese beiden Steine waren vou ganz besonderer Schönheit, ausgezeichneter Farbe und ohne Fehler. 1)er schönste seit Einführung des europäischen Betriebes in Birma, der Heimat der meisten und besten liubine, im Jahre 1899 gefundene Stein wog 77 Karat und wurde roh um 1 Lack Rupien $=26660$ Pfund Sterling oder 533500 Mark verkauft. In allgemeinen kann man sagen, daß für einen schön geschlifienen Rubin mindestens das 21 , fache des rohen Steines bezahlt werden muß.

In der Mitte des 16. Jahrhunderts gibt Benvenuto Cellini den Preis eines Karats Rubin achtmal höher an als den eines Karats Diamant. Er nennt für jenen 800, für diesen nur 100 Goldtaler (scudi). Heutzutage ist, wie wir greschen haben, der Untersehied weit geringer, er beträgt nur etwa das Doppelte.

Wie sehr die Preise beim Rubin von der Beschaffenheit, besonders von der Farbe abhängen, ist daraus zu ersehen, dalj mit dem Lichterwerden der Wert sehr raseh auf ein Minimum herabsinkt, so daß ein Karatstein hellrosenroten Rubins hüehstens auf 20 Mark bewertet werden kann. Nur zeitweise werden diese hellen Steine etwas höher geschätzt. Ehenso niedrig stehen die gelb- und braunroten Steine von Siam im Preis. 
bei der Preishildung spielen natürlich die Feh l e r eine sehr grolie loblle. Nur für vollkommen fehlerfeie steine gelten die obigen l'reise; wenn aber Fehler vorhanden sind. sinkt der Wert bedeutend. Solche sind: trübe Besehaffenheit, wolkige stellen (Wolken) und solehe mit Sedidenglanz, die besonders bei lichtgefürbten steinen häufig vorkommen, milchartige halbdurchisichtige Flecken (Chaleedonflecken), kleine Risse und Sprünge (Federn), ungleiche Verteilung der Farbe und andere mehr. Die Wolken und der seidenartige (xlanz entstehen durch eingeschlosiene winzige und nur bei starker Vereröberuner sichthare Nädelchen. Vereinzelt fehlen diese nur wenigen Iiubinen, denen sie dann nicht scharlen, zu IIaufen vereint wirken sie ungiinstig. Sie sind es wohl auch, die in recelmälfiger Anordnung den schönen Lichtschein der Asterien oder Sternsteine verursachen.

Wie einge besonders grofe I)iamanten allgernein bekannt geworden sind und überall beschrieben und gemannt werden als Reprësentanten der hö̈hsten Kostbarkeit, so ist dies in ähnlicher Wreise auch der Fall mit einer gewissen Anzahl von liubinen von aubergewöhnlicher Gröbe. Tavernier erwähnt zwei Steine, die er beim König ron Visapur (Bijapur) in Indien gesehen hat, den einen von 50.3, den anderen von 1712 Karat, die er zu 6000000 und 7.5500 Franken schätzt. Auch von anderen in Indien befindlichen grolien Rubinen ist gelecentlich die Rede, und noch mehr von solehen in Birma, aber alle diese Berichte sind unsicher und zum Teil falsch. So wird erzählt, dafo der Köniğ von Ava einen Stein von der Grölie eines kleinen Hühnereies in einem Ohrgehä̈nge trugr. In Europa befinden oder befanden sich gleichfalls einige ungewöhnlich große und schöne Exemplare. Einen Rubin von Hühnereigröle und von vollkommener Schönheit besaß der deutsche Kaiser Rudolph II.; nach der Schätzung des edelsteinkundigen Boëthius de Boodt, war er 60000 Dukaten wert. Der König Gustav III. von Schweden hat, wie erzïhlt wird, 1777 der Kaiserin Katharina II. von Rubland einen prächtigen Rubin ron der Größe eines Taubeneies überreicht, dessen Verbleib allerdings unbekannt zu sein scheint Ton den schünen Rubinen des franzüsischen Kronschatzes wogn nach einer Liste von 1791 der schwerste 7 Karat und wurde zu so0)(0) Franken taxiert. Der schwerste überhaupt war ein hellroter Stein ron 2511/16 Karat, für den aber, der lichten Farbe wegren, nur ein Wert ron 25 000 Franken angenommen wurde. Von anderen großen und schönen Steinen war schon oben die Rede. Einen schün roten, teilweise durchsichtigen Rubinkristall von 162:3 Karat besitzt die Mineraliensammlung des British Museum in London.

Eine Anzahl größerer Rubine wird noch unten bei der Beschreibung der einzelnen Fundorte erwähnt werden. Der größte überhaupt bekannte, angeblich aus Tibet stammend, wiegt zwar 2000 Karat, ist aber nicht vollkommen klar und durchsichtig. Der grü̈bte ron Birma ist ebenfalls nicht ganz durchsichtig; er wiegt nach Edwin W. Streeter 1184 Karat.

Rubiu als Schmuclisteiu. Die Rubine werden in ganz ähnlicher Weise wie die Diamanten auf roticrenden eisernen Scheiben geschliffen. Als Schleifmittel dient in Europa jetzt wohl allgemein Diamantpulver, das die Arbeit rasch fördert. Tach dem Anschleifen der Facetten miissen diese, damit sie den vollen Clanz erhalten, noch poliert werden, was mit wasserbefeuchtetem Tripel auf Kupferscheiben geschieht. Hauptsitz dieser Industrie ist London, doch werden auch in Paris und Antwerpen, in Idar, im französischen Jura usw., sowie in Norlamerika viele Rubine geschliffen. überall zusammen mit anderen kostharen farbigen Edelsteinen, Sapphir usw. Das Schleifen geht wegen der groben Härte langsam und ist infolge daron tener. Die Kosten betragen bis zu 40 Prozent des Werts des rohen Steins. Es wird angenommen, dab für das schleifen eines Postens Rubine im Wert von 100 (1)00 Mark 42001 Mark bezahlt werden müssen. Das Gewicht kann dabei bis auf die Hälfte und unter Lmständen noch erheblich tiefer herabsinken. Nan scheut aber auch hier den Verlust nicht, um dem Stein eine gä̈nstige Form zu geben, die seine Schünheit müshlichst hebt. 
Auch die facettierten Formen, die man gibt, sind gewöhnlich die bei dem Diamant bevorzugten. Die Brillantform (Taf. I, Fig. 6) wird häufig gewählt, da diese beim Rubin ebenfalls die Schönheit des Steines am besten zur Geltung kommen läßt. Nur werden die Rubinbrillanten bei tiefer Färbung zur Erhöhung der Durchsichtigkeit vielfach etwas niederer, flacher und duinner gehalten, als es die strenge und beim Diamant genau einzuhaltende Regel erfordert. Auch beim Rubin liißt infolge der starken Lichtbrechung die Unterseite des Brillants die von vorn einfallenden Lichtstrahlen nicht nach hinten austreten, sondern fuihrt sie infolge der Totalreflexion wieder nach vorn und in das Auge des Beschauers, nachdem sie die prïchtige rote Farbe des Steines angenommen haben. Diese Eigenfarbe ist es, auf der in Verbindung mit dem sehönen und starken Glanz die Wirkung des Rubins beruht, das prächtige Farbenspiel des Diamants fehlt hier dagegen vollständig wecren der auberordentlich greringen farbenzerstrenenden Kraft des Korunds. Daher ist auch eine sehr häufig angewandte Form der Treppenschnitt (Taf. III, Fig. 2-4), der iiberhaupt für farbige durchsichtige Steine sehr gut paßt und der ihre Wirkung beinahe ebenso erhöht wie die Brillantform, wenn der Stein nicht jenes Farbenspiel zu geben imstande ist. Ähnlich ist es mit dem gemischten Schnitt, wo der Oberteil Brillantfacetten, der Unterteil solche wie beim Treppenschnitt trägt (Taf. III, Fig. 5). Auch der Schliff mit rerlïngerten Brillantfacetten (Taf. III, Fig. T) ist gegrenwärtig sehr beliebt und ebenso die mugrelige Form (en cabochon). Diese letztere pflegte man in Europa frïher nur den Asterien zu geben, deren eigentiimlicher Lichtschein dadurch am besten zur Geltung kommt. Tafelsteine, Spitzsteine und ähnliche Formen werden heutzutage wohl kaum noch hergestellt, sie finden sich aber zuweilen an Steinen, deren Schnitt aus früheren Jahrhunderten stammt. Dagegen werden aus flachen und dünnen Rubinen vielfach Rosetten geschliffen, die bei geringem Substanzverlust doch eine schöne Wirkung hervorbringen. Ganz kleine Steinchen erhalten auch hier eine unregelmäßige Facettierung; sie dienen zum Einfassen größerer Edelsteine andrer Art.

Reine, klare und durchsichtige Steine von gesättigter Farbe werden meist à jour gefalit: solche ron geringerer Qualitiit erhalten oft eine Folie von Gold- oder Kupferblech, oder. ron rotem Glas, welche die Wirkung sehr erhöht. In Birma werden die mugeligen Steine zu diusem Zwecke nicht auf Folien gesetzt, sondern unten ausgeschliägelt und die Vertiefung mit Gold ausgefüllt.

Der Schliff ist übrigens nicht die einzige Bearbeitung, die der Rubin erfährt. Manche Steine sind, namentlich im Orient, mit eingravierten Inschriften versehen, und in andere sind Figuren eingeschnitten worden. So kennt man aus dem Altertum einen Rubin mit dem Koppe des Jupiter Serapis, einen anderen mit der Figur der Minerva. Aus Indien wird von einem Ring berichtet, der ganz aus einem einzigen Rubin herausgeschnitten war. Dort wurden Rubine auch zum Aufreihen auf Schnïren durchbohrt.

Vorkommen. Ruisin ist an zahlreichen Orten gefunden worden, aber doch nur an wenigen in so guter (Qualität, dal's es lohnt, ihn als Edelstein zu versehleifen. Von kommerzieller Bedentuner ist wohl nur das Vorkommen in Ober-Birma, in Siam und auf Ceylon, alle anderen Fundorte sind, wenigstens zurzeit, unwichtig und zum Teil auch nur wenig bekannt.

Die sehönsten und die meisten Rubine, die gröbere IIälfte der Gesamtmengre, kommen gexpenwärtig und kamen von jeher aus Ober-Birma. Die Verbreitung der dortigen Edelsteine (Rubin, roter Turmalin, Jadeit und Bernstein) gilot Fig. 6.4, die Fundorte des Rubins etwas spezieller Fin 65 (S.3.11). Die Rubingruben dieses Landes werden mindestens schon seit dem 15. Jahrhundert auscrebeutet und haben wohl seitdem in der Iauptsache die .Juweliere mit unserem Edelstein, wenigstens mit den schönsten Exemplaren desselben, versorent. Es ist aber wahrscheinlich, dab die Erträge der Gruben geren frïher abgenommen haben und 
dalj jetzt zum 'Teil die seit alten Zeiten angesammelten Vorräte allmählich in den europåischen Verkehr gelangen.

Schon 'Tavernier erwähnt die birmanischen liubingruben. Nach seinem auf wahrsclecinlich miliverstandenen Mitteilungen anderer, nicht auf eigener Anschauung beruhenden Berichte sollten sie in den Capelanbergen in Peru, 12.2 Tagemärsche in nordiostlicher Richtung von der Stadt Siriam, jetzt einem elenden Dorfe dicht bei dem heutigen Rangun, liegen. Der Ertrag war zu jenen Zeiten (zweite Hälfte des 17. Jahrhunderts) offenbar nicht sehr grol. Tavernier schätzt ihn auf 100000 écus im Jahre und erziihlt, dals er mit der Einfulr von Rubinen aus Europa nach Indien ein gutes Gescbäft gemacht habe. Jene unrichtige Fundortsangabe kehrt in der einschlïgigen Litteratur bis zum heutigen Tage immer wieder. Es ist nicht der mindeste Zweifel, daß Tavernier die noch jetzt im Betriebe befindlichen Gruben in Ober-Birma im Sinne gehabt hat, trotzdem diese sehr viel weiter von Siriam (Sirian oder Rangun) entfernt sind. Die Entfernung von hier bis Mandalay beträgt schon mindestens 36 'lagemärsche, und von da sind es noch weitere acht bis in den Hauptrubinendistrikt von Mogouk, während die weniger wichtigen Sadschijin-Hügel allerdings

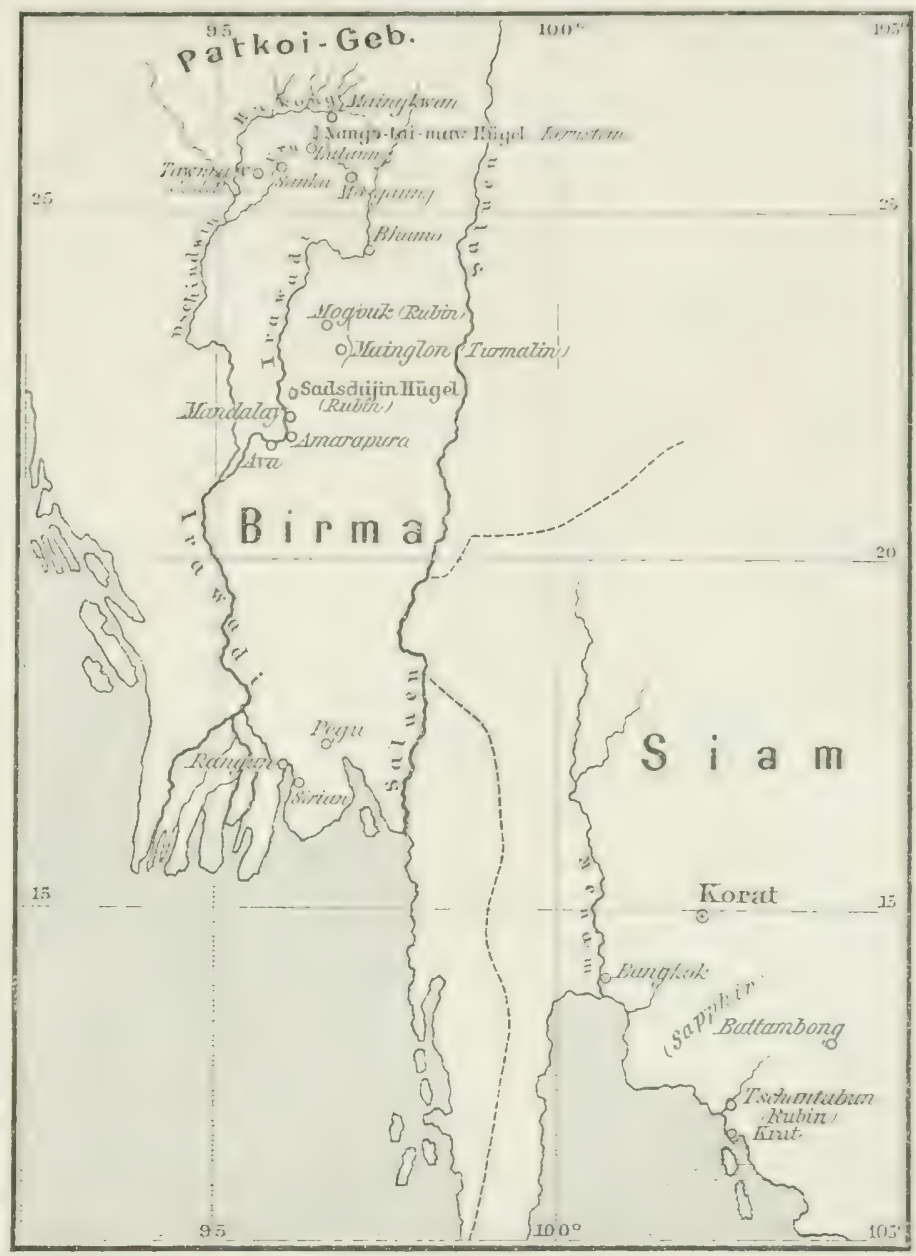

Fig. 64. Vorkommen des Rubins und Sapphirs in Birma und Siam. Maßstab 1: 15000000 . näher bei letzterer Stadt liegen. Bis vor kurzem hat die Eifersucht der Birmanen diese Gruben ängstlich gehïtet und für Europäier so gut wie unzugänglich gemacht. Erst seit der Besitzergreifung des Landes durch die Engländer in Jahre 1ss5 sind sie etwas genauter bekannt geworden, und seitdem haben auch Europäier einen Teil des Betriebes in die Hand geuommen. Es ist schon die Vermutung geäufert worden, daf die Englïnder wesentlich mit durch den Wunsch, die für unermeslich reich gehaltenen Rubinlager in ihre Iand zu bekommen. zu der Besitzergreifung ron Birma reranlabt worden sind.

Der wichtigste rubinführende Bezirk, der von $1 \mathrm{~g} g \mathrm{~g}$ o $\mathrm{k}$, umfaßt viele, dem Berichte des Ingenieurs Lockhardt zufolge, der nach der englisehen Okkupation als Angestellter der ., Burma Ruby Mining Company“ zwei Jahre lang an Ort und Stelle gelebt luat, 400) (engl.) 
Quadratmeilen auf der linken östlichen Seite des Irawadi. Nach anderen Nachrichten ist der Umfang dieses ron den Engländern als „Distrikt der Ruby mines" oder als „ruby tract" oder "stone tract" hezeichneten Gebietes aber nur 45, oder mit Einrechnung der verlassenen Gruben $66^{\circ}$ (engl.) (Quadratmeilen, so weit es bis jetzt bekannt ist. Allerdings ist es sehr wahrscheinlich, daf sich die Rubinfelder noch mehr nach Sïden und Osten und

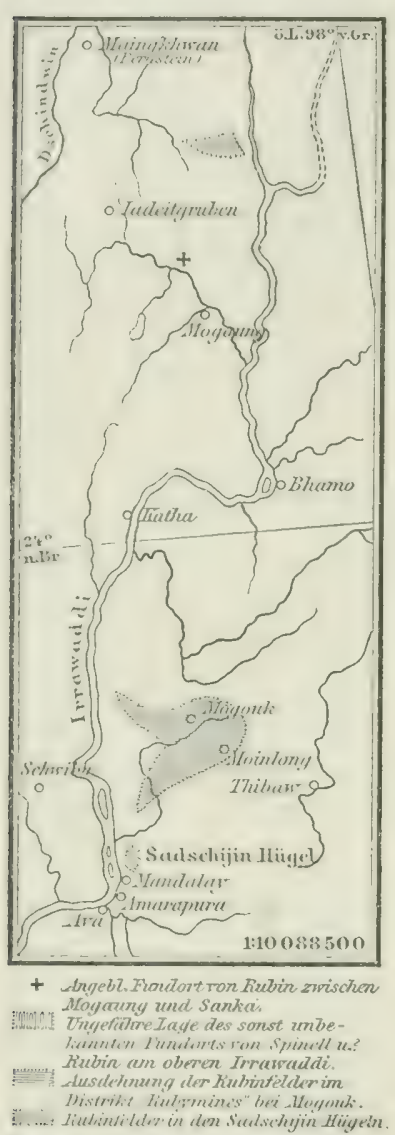

Fig. 65. Rubinfelder in Birma. bis in die unabhängigen Schan-Staaten hinein erstrecken, wenigstens ist eine alte Gräberei vor kurzem im Nampay-Tale bei dem Dorfe Namseká in dem Mainglon- (oder Moinlong)Staate aufgefunden worden. Der Bezirk der Rubingruben ist ein Bergland, in dem Höhenzïge mit Tälern abwechseln, und das vom Irawadi durch eine 30 (engl.) Meilen breite Niederung getrennt ist, in der gleichfalls noch einige wenige unbedeutende Rubingruben von Eingeborenen betrieben werden.

Die Hauptstadt dieses seit 1637 zu Birma gehörigen Landstrichs und auch der Hauptpunkt des dortigen Handels mit Edelsteinen, besonders mit Rubinen, ist Mlogouk (oder Mogok). Sie liegt unter $22^{\circ} 55^{\prime}$ nördl. Breite und $96^{\circ} 30^{\prime}$ östl. von Greenwich, etwa 34 englische Meilen in der Luftlinie oder 58 Meilen auf der in gutem Zustande befindlichen macadamisierten Straße östlich von dem Flußhafenplatz Thebetyan (oder Thabeitkyan) am Irawadi, dem Ausgangspunkt fiur die Reisen in das Rubinenland, und 90 (engl.) Meilen nordöstlich von Mandalay oder von der etwas weiter flußabwärts gelegenen alten Hauptstadt des Landes, Ava, die als Hauptstapelplatz für den Edelsteinbandel des ganzen Landes früher auch den Namen Amarapura oder Ratanapura (d. h. Edelsteinstadt) führte. Die Meereshöhe des in sehr lieblicher Umgebung gelegenen Mogouk mit etwa 6000 Einwohnern beträgt $4100 \mathrm{Fuß}$ (engl.), die der ebenfalls viel genannten benachbarten Städte Kapyun oder Kyat-pyen und Kathé 5000 Fuß. Trotz ihrer bedeutenden bis zu 7775 Fuß ansteigenden Höhe ist diese teils mit dichten Dschungel, teils mit Reisfeldern bedeckte Gegend für Europäer und Eingeborene sehr ungesund. Nach den Untersuchungen von Prinsep ist es keinem Zweifel unterworfen, dab unter Taverniers Capelanbergen die Berge um Kyat-pyen oder Kapyun (Kapyunberge) zu verstehen sind.

Das Muttergestein des Rubins und der begleitenden Mineralien, namentlich des Spinells, ist ein weilfer dolomitischer körniger Kalk oder Marmor, der in den Rubingehieten ganze Berge bildet und der nach den Untersuchungen von Fr. Noetling der oberen Kohlenformation angehört. Hindurchgedrungene Eruptivgesteine (Granit usw.) haben den anfänglich dichten Kalkstein in den zum Teil sehr grobkörnigen Marmor umgewandelt und in dem ursprïnglich rubinfreien Gestein die Entstehung des Edelsteines und seiner Begleiter veranlabt. Es hat, geologisch gesprochen, eine Kontaktmetamorphose stattgefunden, wie das unter den genamnten Unständen in ähnlicher Weise häufieg geschieht, wobei sich wohl an vielen Orten liorund, aber nur selten der kostbare liubin bildet. Nach den Mitteilungen von Brown und Judd wären allerdings die Verhältnisse andere und der rubinführende Kalk wäre eine Einlagerumg im Gneis. Die weiter unten mitzuteilenden Beobachtungen hei Nanya-zeik sprechen aber mit orober Bestimmtheit für Lontaktmetamorphose. In dem festen anstehenden Gestein sind die Edelsteine nux sehr sparsam 


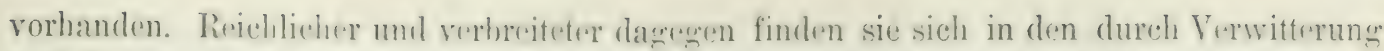
und zarsetzune des Muttergestrins entstandenen tonigen und sandien Massen, in Sufen,

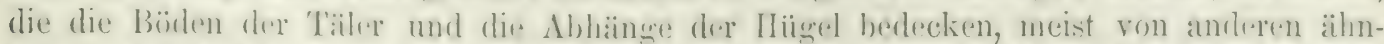

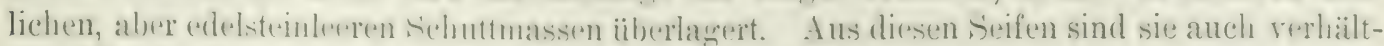

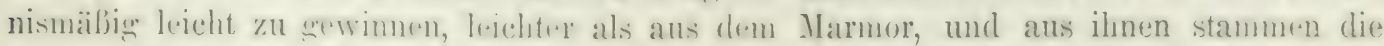
meisten, die in den Handel kommen.

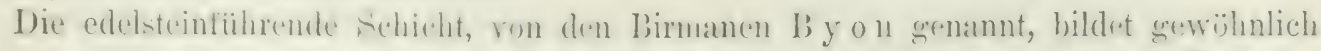

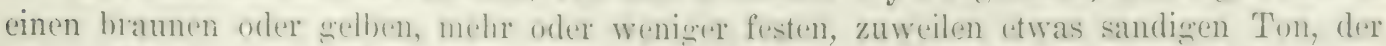
als ein Lï̈ckstand bei der Anflizung des Kallies infolge der Verwitterung betratehtet werden mub. Ex enthäit neben den liubin noch sapphir und andere Korundarten, spinell de

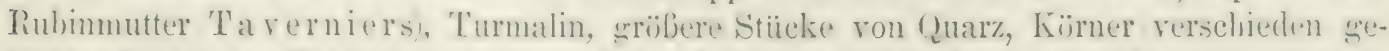
fïrbter Foldspate, Knollen verwitterten schwefolkiests und andere mehr oder weniger wertvolle Mineralien, endlich Brocken der in der Gexpend anstehenden Gesteine. In dieser Weise bedeckt er die Abhänge der Berese. Wird nun der Byon durch flieljendes Wasser aufgeriihrt und in die Tiefe geführt, so werden daraus die Tonteilchen und die leichteren Mineralkiömer wegreschwemmt, und es hinterbleibt eine mehr sandige Masse, welche die spezifich sehwereren liubine enthailt und die in den Talgriunden zur Ablagerung grelangt. Zuwcilen findet man so in den Flufalluvien statt jener tomig-sandigen Massen reine Edelsteinsande, die aus lauter winzigen, im Sonnenlicht lebhaft glanzenden Rubiukömehen bestehen.

Die Edelsteinerde liegt gewöhnlich auf einem weichen, „verfaulten" Gestein von charakteristischer Beschaffenheit. Wenn die Eingeborenen dieses Gestein mit ihren Grubeu erreichen, so nehmen sie an, daf sie durch die Schicht des Byon völlign durchgethohrt haben und dafi weiteres Eindringen in die Tiefe aussichtslos ist. Der Byon ist auf dem Grunde der Tiiler 1-5 Fuls mäichtigr, verdruickt sich aber auch celegentlich auf wenige Zoll und liegt etwa (i-21) Fulf unter Tag. An den Abhängen der Hügel steight die Mäichtighkeit nicht selten bis auf 15 -20, sogar bis auf $50 \mathrm{FuR}$.

Eicentümlich ist das Torkommen des Byon in den Ifühlen, welche die Kallfelsen in grofer Zahl durchziehen, und die sich in diesen zuweilen auf meilenweite Erstreckung verfolgen lassen, bald ausgedehnte und hohe Gewölbe, bald schmale Kliifte und enge Spalten bildend. Dise Höhlen sind vielfach teilweise odler ganz mit hineingeschwemntem Byon erfüllt, und dieser ist nicht selten mit einer dicken Schicht von Kalksinter bedeckt, der die wunderbarsten Tropfsteinformen bildet.

Frïher, bis 1S-6, wurden die Edelsteine ausschlieblich von den Eingeborenen gewonnen. Diese gehen dahei in den verschiedenen Ablagerungen verschieden vor. In den Tälern werden quadratische Schächte von 6-9 Ful im Querschnitt bis auf die Byonschicht getrieben. Ist die äherlagernde Masse nicht fest, so werden die Schächte mit Bambus ausgezimmert; ist das Gestein haltharer, so greschieht das nicht. Man geeht dann im Tiefsten dieser Schächte in horizontaler Richtung mit Strecken von einem Schacht zum andern, um auf diese Treise so riel als müglich ron der edelsteinführenden Erde zu gewinnen. Von dieser werden hierauf die lockeren und leichten erdigen Bestandteile weggewaschen und der zurückblubende Sand nach Edelsteinen durchsucht. In dieser Weise kann nur in der trockenen Jahreszeit gearbeitet werden.

An den Bergechängen werden in der Richtung der Neigung. Einschnitte bis anf die Rubinschicht hergestellt, und zwar in der Hauptsache in der Weise, daf man Wasser oft mit grober Mïhe und aus großer Entfernung in Bambusröhren herbeileitet und dieses mit mọ̈lichst starkem Gefälle durch seine Strömun@ auf die Schuttmassen einwirken läßt. Alle leichteren Bestandteile werden so fortgreschwemmt, und die grä̈heren und schwereren Stiicke, darunter die Edelsteine, bleiben zurick. Hier arbeitet man in der Regenzeit und benützt die größeren Wassermassen, die da zur Verfügung stehen. 
Endlich werden auch die mit Byon erfïliten Höhlen und Spalten aufgesucht, dieser herausgegraben und die Edelsteine, wie es immer geschicht, durch Waschen isoliert. Zuweilen kommen solche Höhlen zufällig bei den Arbeiten an den Bergabhängen zutage. Um das Jahr 1870' wurde eine besonders große in dem Berge Pingudaung nahe bei Kyat-pyen entdeckt und ausgebeutet.

Ton diesen drei Arten von Gräbereien sind die in den Alluvien der Flußtäler am wichtigsten. Am meisten Ertrag geben die Gruben in den Tälern, in denen die drei oben genannten Städte Kyat-pyen, Kathé und besonders Mogouk liegen. Für die Zukunft, nach Einführung eines rationellen Bergbaues auf europäische Art, gelten auch die Arbeiten in den Hühlen, die gegenwärtig, bei dem primitiven Verfahren der Eingeborenen, sehr große Gefahren mit sich führen und den Verlust zahlreicher Menschenleben veranlassen, als sehr aussichtsreich.

Die Edelsteingräberei war früher nur gegen einen Erlaubnisschein der birmanischen Regierung und gegen Erlegung von Abgaben gestattet. Außerdem gehörte jeder Rubin im Wert von 1000 Rupien und darïber dem König, der ihn ohne jede Entschädigung an sich zu nehmen berechtigt war; was er etwa dafür geben wollte, war ganz freiwillig und hing nur von seinem eigenen Ermessen ab. Daß deswegen viele größere und daher wertvolle Steine zertrümmert und in Bruchstiicke von einem geringeren Wert als dem genannten zerlegt wurden, ist selbstverständlich. Auch Unterschlagung der besseren Steine und Verwertumg derselben auf dem Wege des unerlaubten Handels war aus demselben Grunde an der Tagesordnung.

Der Handel mit Tiubinen war ebenfalls von einer Erlaubnis der birmanischen Regierung: abhängig und mit Abgaben belegt. Die gewonnenen Steine - im Wert von etwa 50000 bis 100000 Rupien im Monat - multen zuerst in die Rubinenhalle in Mandalay gebracht werden; erst von da aus gelangten sie an das Publikum. In dieser Stadt ist noch heute der Itandel mit Rubinen von großer Bedeutung; und die Birmanen verkaufen jährlich für ctwa 30 Lack Rupien, etwas über 4 Millionen Mark Steine, wozu auch IÏ̈ndler aus Europa herbeikommen. Natürlich ging neben diesem legitimen Handel ein emsiger Schmuggel mit Rubinen her, namentlich wurden viele, besonders auch wertvolle Steine im ('nglisehen Unter-Birma, sowie in Indien, vornehmlich in Calcutta, zum Verkauf gestellt. In der Zeit des letzten Königs von Ober-Birna sollen jührlich für 2-3 Lack Rupien Tiubine unerlaubt in Unter-Birma verkauft worden sein.

Seit der englischen Besitzergreifung 1585 änderten sich alle diese Verhältnisse vollständig. Das ILnopol der Eingeborenen hörte auf, und anch Europäier beteiligten sich nunmelır an der Gewinnung der Rubine. Es bildete sich zuerst eine englisch-italienische, damn eine englische Gesellschaft, die Burma Ruby Mining Comp., Limited, welche seit 15S:) die Arbeiten zur Ausbeutung der rubinhaltigen Schichten in der Umgegend ron Mogouk in großem Maßstabe betreibt.

biese fiesellschaft suehte die I'roduktion dadurch zu heben, dab sie nicht nur die Alluvionen in dem 'Tal ron Mogrouk anshentete, die schon seit Jahrhunderten Rubine gelirfort haben, sondern auch die bis dahin noch nicht in Anoriff genommenen Ablagerungen an dem oben genamnten, 16 Kilometer von Mogouk entfernten Berg l'ingutaung bei Kyatpyen und die des Bereses Kyuktung. Doch sind auch bei ihr die Arbeiten in den Talsründen des Mogouk-Flusses die ergiebigsten und wichtigsten. Sie läbt nur in offenen Tagrabaten den loyon gewinnen, bedient sich aber dabei in immer steigendem Nabe europaiischer Ietriehsmittel, besonders rationeller Förderapjarate, und namentlich sind mäehtige l'umpen in Gang, un das Wasser aus den Gruben zu entfernen und diese trocken zu halten. Auf solche Wrise kann die chlstemführende Sehicht bis zu jeder beliebigen Tiefe und diese geht bis $\%$ a 50 Meter - vollständig gewonnen werden. Reichlich rorhandenc 
Wasserkrïte liefern den elektrischen Strom, der nicht nur die genannten Maschinen treibt, sondern auch zweckmäßlig konstruierte Waschapparate, die den aus den Gruben gewonnenen Byon verarbeiten. Aus dem von diesen grelieferten edelsteinführenden Rïickstand werden dann die Rubine und die anderen wertvollen Strine mit der Hand auserelesen, und zwar ausschlieblich von zuverlïsigen Europäern zur Verhütung des I)ichstahls. Dieser soll aber von den Eingreborenen dennoch in ausgedehntem Mafstabe hetrieben werden, trotzdem noch andere strenge Maliregeln zur Verhïtung desselben getroffen und sehr empfindliche Strafen gegen die Diebe festgesetzt sind.

Anfünglich gingen die sehr hochgespannten Erwartungen, die an dieses Lnternehmen gekniipft worden waren, in keiner Weise in Erfïllung. Die Gevellschaft arbeitete sogar lange Jahre mit Verlust, um so mehr als die englisch-indische leerierungr eine hohe jühr-

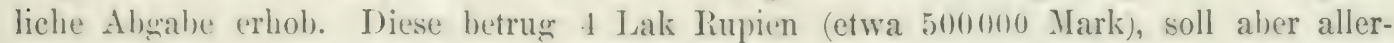
dings niemals vollstïndig bezahlt worklen sem. Indessen wurde der Betrieb fortdauernd rerbessert und dadurch eine Steigerung der Produktion und gleichzeitig eine Ermäligung der (iewimungskosten bewirkt. Auch lief sich die Regierung herbei, die noch nicht bezahlten Abgabenreste niederzuschlagren und den Betrag der Steuer auf die IIälfte, also auf 2 Lak Rupien zu ermäljigen. wozu allerdings noch 30 Prozent des etwa als Dividende zur Verteilung kommenden Geschäftsugewinns treten sollten. Durch alle diese Mabregeln haben sich die Aussichten der Gesellschaft allmählich inmer giunstiger gestaltet, der Verlust in (lem Betrieb) hat aufgehört, und seit 1699 kann sogar eine stetig wachsende Dividende verteilt werden, die schon bis zu erheblichen. Beträgen gestiegen ist.

Die Einnahmen der Gesellschaft bestehen aus verschiedenen Teilen. Es sind einmal die Ababen, die ihr die eingreborenen Edelsteinsucher zahlen müssen, welche gregen eine Taxe von 20 Rupien im Monat für jeden von ihnen beschäftigten Arbeiter in besonderen Gebieten nach ihrel alten Weise das Geschä̈t betreiben dürfen. Bis 2000 Leute sind dabei taitig und finden ihr reichliches Auskommen. Die Gesellschaft nimmt daron etwa f(1) (100) Mark im Jahre ein. Vor allen ist es aber der Verkaufspleis der ron der Gesellschaft selbst gewomnenen Rubine, die stets roh und ungeschliffen, besonders in London auf den Markt gebracht werden. Dieser Verkaufspreis betrug:

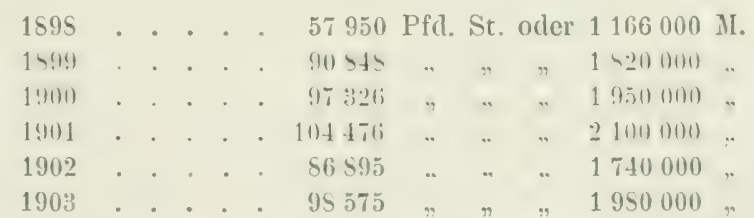

Ton dem Lrlïs des letzten Jahre's war ungefähr die Hailfte 44950 Pf. St.) oder etwa

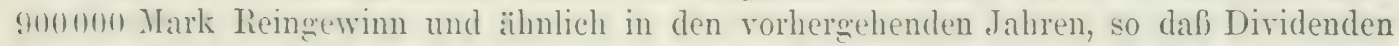
ron ea. 20 " " verteilt werden konnten. Jedenfalls zeigen diese Zahlen, daß seit 1599 die Produktion einen crheblichen Aufschwune genommen hat, der bis heute, wenn auch nicht wanz selehmäbig. andautert. Immerhin betrïgt aber der Wert der jührlichen Ausbeute noch nicht sanz 2 Mill. Mark. Gefürdert werden jïhrlich ungefähr $5000(0)$ Wragenladungen loads) Bron. Einer Schätzung nach wïrde dabei der jetzt bekannte Torrat nach 20-25 Jahren erschöpft sein.

Die hei Mogrouk gewonnenen Edelsteine sind neben den an Mengre und Wert weit iiberwiegenden Rubinen die anderen Farbenvarietäten des Forunds, in erster Linie Sapphir, sodam auch orientalischer 'Topas und Amethrst, denen gewenüber die grüinen Abarten orientalischer Suraged, Aquamarin und Chrysolith, sehr selten sind. Auch gemeiner Forund fehlt nicht und von Steinen anderer Art ist vor allen der Spinell, sodann auch der Turmalin zu erwähnen. Nach friiheren Mitteilungen sollte auf jolo Rubine nur ein 
Sappliir vorkommen und die anderen Edelkorunde sollten noch weit seltener sein. Ein Bericht aus dem Jahre 1902 meldet, daß gewonnen wurden: 210754 Karat Rubine 9786 Karat Sapphir (wohl cinschließlich der andersfarbigen Edelkorunde), auferdem noch 10241 Karat, Spinell.

Wenn so also der Sapphir der Zahl nach sehr stark zurïcktritt, so sind darunter doch verhältnismäßiğ viele schöne und große Steine. Demgregeniäber sind die Rubine meist klein, größere Exemplare sind sehr selten. Der größte Teil wiegt nicht über 1/s Karat; schwerere Steine pflegen voll von allen möglichen Fehlern zu sein. Fehlerfreie Steine von 6 bis 9 Karat kommen kaum jemals vor, und solche im Gewicht von 30 Karat hat man nur in sehr vereinzelten Exemplaren erbeutet. Im Jahre 1857 wurde ein Stein von 49 Karat, im Jahre 1890 ein solcher von 304 Karat gefunden; aus früheren Zeiten wird über von Steine im Gewicht von 172 und von 400 Karat berichtet. Die schönsten Rubine, die vor der englischen Eroberung von Birma nach Europa kamen und die schon oben erwähnt worden sind, wurden im Jahre 1875 vom König dorthin rerkauft. Der eine wog roh 37, der andere 47 Karat, beide sind von prächtiger Farbe. Für den kleineren wurden, wie wir gesehen haben, nach dem Schleifen in Europa 200000 , für den grrößeren 400000 Mark gelöst (S. 336). Größere Stücke, deren ungünstige Beschaffenheit, mangelnde Durchsichtigkeit usw. aber die Anwendung als Edelstein ausschließt, sind sogar in Gewicht von über 1000 Karat vorgekommen. Streeter bildet einen solchen Stein ab, der 1184 Karat wiegt und der nebst zwei Stïcken von ähnlicher Größe seit der englischen Besitzergreifung gefunden worden ist. Überhaupt sollen in der letzten Zeit in Birma verhältnismäßig zahlreiche große Rubine gefunden worden sein, aber fast alle von ungünstiger Beschaffenheit.

Das Jahr des Aufschwungs, 1899, ist aber auch in dieser Hinsicht bemerkenswert. Es lieferte drei besonders schöne und große Steine, darunter den kostbarsten seit Einführung des europäischen Betriebs im Gewicht von 77 Karat, von dem schon oben die Rede gewesen ist.

Die Farbe des birmanischen Rubins ist meist tiefrot, aber mit verschiedenen Nuancen. Sehr selten ist der ganz reine Karmin, die Taubenblutfarbe, die auch in Lande an höchsten geschätzt wird, so daß mit aus diesem Grunde derartige Steine schon an Ort und Stelle, in der Grube sehr tener bezahlt werden, wenn sie durchsichtig und fehlerfrei sind. $\Lambda \mathrm{n}$ verbreitetsten ist ein Stich ins Violette oder Blaue, durch den der Wert schon beträchtlich vermindert werden kann. Noch ungünstiger wirkt ein Stich ins Bräunliche, der sehr häufig angetroffen wird, wïhrend ein ebenfalls wenig beliebtes, etwas ins Gelb ziehendes Tiot selten ist. Mellgefärbte Exemplare fehlen auch in Birma nicht, aber sie treten gegen die dunkleren zurück, was in Ceylon umgekehrt ist. Die birmanischen Rubine haben die besondere Eigentïmlichkeit, daß sie im violetten Licht lebhaft rot fluoreszieren, was die Steine namentlich von Siam, aber auch von anderen Fundorten gar nicht oder doch nur sehr schwach tun.

Im ursprïnglichen Gestein eingeschlossen haben die Rubine immer deutlich ausgebildete Kristallform. Es sind die in Figur 63, a bis a abgebildeten Gestalten. Aus dem Muttergestein werden jedoch die Rubine kaum in größerem Maßstabe goewonnen, da sie dabei leicht zerbrechen. Jieselben Formen sind aber auch noch bei zahlreichen Steinen in der Edelsteinerde zu beobachten, die noch nicht vom Wasser von ihrer ursprünglichen Lagerstitte fortgeschwemmt worden ist. Uier sind die Steine jedoch vielfach ganz unregelmäßig begrenzt, und in den Seifen der Flußtäler, sowic in dem Byon der Möhlen sind sie meist oberflaichlich stark abyerollt, zum Beweis daß sie cinen weiten Weg zurückgelegt haben und dabei sich aneinander abgerieben haben. 


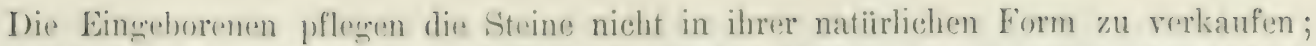

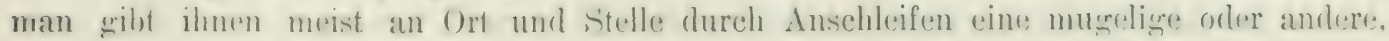
fast immer wenig regelmäßige und unvorteilhafte Form.

Das Hauptbestreben der birmanischen Schleifer geht im Gegensatz zu den europäischen dahin, das (iewicht des rohen stemes mö̈glichst zu erhalten und frö̈bere Schleifverluste zu vermeden, wemn dabei anch eine ungünstige Form herausommt. Iful diese auch in Europa stets einer hesioren, vorteilhafteren weichen, so hat die slatte ()berfläiche doch immerhin für den Läufer den Vorteil, dals er die innere lieschaffenheit der Strine viel besser prïfen und efwaige Fehler weit leichter bemerken kann, als das unter dem ranhen

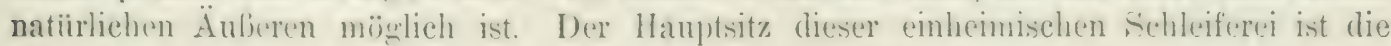
Stadt Mandalay.

Die Geenend ron Mogrouk liefert fast alle jotzt aus Birma in den Itandel kommenden Rubine. Viel woniger wichtien und vulleicht vollkommen erschöpft ist aine nicht fern davon aufgefundene, friaher lange Zeit betriebene Grube im Gebiete des Flusses Nampa i bei dem Iorfe Namseká (22" $46^{\prime}$ nïrdl. Breite, $96 " 44^{\prime}$ ïstl. Lïnge von (rreenwich), 15) engl. Meilen siidwestlich von der Stadt Mainglon (Fig. 61. S. 33!), die ihrerseits siidüstlich von Mogouk liegt. Die IRubine sollen hier, begleitet von Spinell, in einem hauptsächlich aus Milchouarzkörnern bestehenden Flufisande in einer kleinen Seitenschlucht des $\mathrm{Nampai}$ vorkommen, in welche die ganze Masse wahrscheinlich durch Hochfluten des Mogoukflusses hineingeschwemmt wurde. F. Noetling konnte jedoch an dieser Stelle keine Rubine finden.

Einen zweiten in Birma gelegenen Rubindistrikt, aber weniger wichtig als der von Mogouk, bilden die Sadschijin-II ü grel (Sagjin Hills). Diese liegen viel näher bei Mandalay, nur 16 encl. Meilen nördlich von dieser Stadt und 2 Meilen rom Irawadi, aus dessen Alluvialebene sie als ganz isolierte Massen aufragen. Es ist derselbe weibe Marmor wie bei Mogouk, der wie dort meist mit rotem Ton bedeckt ist. Der Kalk ist stark zerklïftet und mit Höhlen durehzogen. Das Vorkommen des Rubins ist hier ein doppeltes. Eimmal sieht man Spalten im rubinfreien oder -armen Marmor erfüllt mit rubinreicheren Stiicken desselben Gesteins, die zu einer festen Masse verkittet sind. Sodann sind die Spalten und Höhlungen hier wie bei Mougouk mit einem braunen tonigen Verwitterungsdetritus erfüllt, der auch hier aus dem Kalk entstanden ist und der daher gleichfalls die in diesem enthalten gewesenen, nicht verwitterbaren Edelsteine und sonstigen Mineralien umschlielit: Rubin, Sapphir, roten und schwarzen Spinell, Amethyst, braunen Chondrodit, sehr hell bläulichen Apatit in kleinen Körnchen und Kriställehen, braunroten Glinmer usw, die man übrigens alle auch noch im Kalk eingewachsen findet. Dureh Waschen werden die Edelsteine gewonnen, und man vermutet, daf bei zweckmäliger Bearbeitung noch bedeutender Ertrag möglich wäre. Die Rubine sollen hier aber im Durchschnitt heller und daher weniger wertroll sein als in dem Hauptrubinbezirk von ILogouk: was jedoch von manchem Beobachter bestritten wird.

Tach den Berichten der Eingeborenen sind Rubine und Spinelle in dem Kalk zweier Hügel, die sich etwas nördlich von den Sadschijin-Hügeln erheben, vorgekommen. Auch ist man etwa 30 (engl.) Meilen südlich von Mandalay, in der Nähe der Stadt Kauksay, beim Bau der Eisenbahn, die Mandalay mit Rangun rerbiudet, auf alte Rubingruben gestoßen.

Einige Punkte weiter nördlich, in Ober-Birma, deren ungefähre Lage aus dem Kärtehen Figur 65 (\$. 340) zu ersehen ist, haben gleichfalls Rubine geliefert. Genaueres ist nur von dem Vorkommen in der Gegend ron Nanya-zeik, ca. 100 Kilometer nordwestlich von Mogaung gegen die Jadeitgruben von Sanka hin im Bezirk Myitkyina, bekannt geworden. Die dortigen Rubinfelder liegen ungefähr bei + der Karte zwischen $96^{\prime \prime} 3: 3^{\prime}$ bis $96^{0} 43^{\prime}$ 
östl. L. von Greenwich und $25^{0} 20^{\prime}$ bis $25^{\circ} 40^{\prime}$ nördl. Br. und erstrecken sich von NO. nach SW. von dem genannten Dorf bis Man- We. An beiden Orten liegen zahlreiche verlassene Rubingruben; neuere Versuche haben nur geringe Ausbeute geliefert, doch sollen früher schöne Steine gefunden worden sein. Es gilt nicht für unmöglich, daß diese Gegend einmal einen crnstlichen Konkurrenten von Mogouk abgeben könnte, doch hört man auch die Ansicht, daß diese nördlichen Lagerstätten schon erschöpft seien. In dem östlich rom Indawfluß begrenzten Gebiet von Nanya-zeik steht auf große Erstreckung Granit an, dazwischen liegen kleine, linsenförmige Stöcke von Marmor, der an der Berïhrungsstelle mit dem Granit alle die Hineralien enthält, die sich auch in dem rubinführenden Kalk ron Mogouk usw. finden. Fs ist bei Nanya-zeik nicht der mindeste Zweifel, daß diese Mineralien, wie auch der Rubin selbst, durch Einwirkung des Granits auf den der Karbonformation angehörigen Kalk, also durch Kontaktmetamorphose, in dem letzteren entstanden sind. Man muß daher schließen, daß auch bei Mogouk, wo die geologischen Verhältnisse in allgemeinen dieselben sind, die Rubine unà ihre Begleiter auf diese Weise entstanden sind. Durch Verwitterung des Marmors und des benachbarten Granits entstand auch in diesem nördlichen Gebiet der rubinführende Byon, der hier zu einem großen Teil aus Feldspatkörnern besteht und aus dem auch hier ausschließlich die Edelsteine gewonnen werden. Die Byon-Lager sind durchaus an die Nähe von Marmor gebunden; darin angelegte Gruben sind namentlich aus der Umgegend von Nanya-zeik und Man-We bekannt. Über die noch weiter nördlich am oberen Irawadi gelegenen angeblichen Fundorte wissen wir gar nichts Näheres.

Daß auch in Siam Rubine und Sapphire sich finden, ist schon länger bekannt, aber erst seit kurzem ist das Torkommen etwas genauer untersucht und eine systematische Gewinnung eingeleitet, nachdem das Aufsuchen von Edelsteinen in diesem Lande durch Privatpersonen lanere Zeit wegen eines königlichen Privilegs erschwert oder ganz verhindert gewesen war. In einigen Gegenden herrscht der Rubin, in anderen der Sapphir ror. Die rorzugsweise rubinführenden Bezirke sind von den sapphirreichen scharf getrennt durch den Kamm des Patat-Gebirges. Die ersteren liegen im Siiden in den Provinzen 'T'schantabun und Krat, die anderen wichtigeren im Norden in dex l'rovinz Battambong (Fig. 64, S. 339).

Die Rubingruben von 'T s chan ta bu n können von Bangkok aus auf einer etwa zwanzigstïndigen Dampferfahrt erreicht werden. Sie liegen in südöstlicher Richtung in der Nähe der Ilauptstadt der Provinz, die gleichfalls Tschantabun heißt, nicht fern von der Küste des Golfes von Siam (Fig. 66). Die höheren Berge des Landes bestehen aus graulichem Granit, während die niedrigeren Teile von Kalk webildet werden, in dem vielleicht, wie in Birma, das bis jetzt noch unhekannte Muttergestein des Tiubins zu sehen ist. Vorläufig weib man nur, daf die Edelsteine in Seifen liegren, die bisher in sehr primitiver Weise von den Eingeborenen und vorzugsweise von Birmanen mittels (iruben ausgebeutet wurden, von denen kieine mehr als 24 Fulj Tiefe erreicht. In früheren Zeiten war der Reichtum der Gegrend an Edelsteinen sehr grob. Östlich von der Stadt T'schantabun ist (in In̈̈gel, der. Edelsteinhiigel" genannt wird. Nach dem Berichte eines Missionars yon 1859 konnte man dort in einer halben stuncle leicht eine Handvoll Rubine sammeln; jetzt ist der Vorrat hiex wie in allen anderen so leicht zugäinglichen Ablagerungen der Gegend erschöpft, doch ist die Stadt 'T'schantahun nach wie ror der Mittelpunkt des Edelsteinhandels in jener Gegend.

Über die Provinz K rat, deren meichnamige IIauptstadt siidüstlich von Tschantabun und ziemlich nahe am Meere liegrt, hat man u. a. durch $D$ e m e t r i einige nähere Nachrichten (rhalten. Die Rubingruben dieser Gexend sind auf einem weiten Raume der Unterprovinz Kilung zerstreut. Sie bilden zwei efwa 30 engl. Meilen voneinander entfernte Gruppen, die 
als die Gruben von Bo Navang und von Bo Tschanna bekannt geworden sind. In beiden Bezirken zusammen waren beim liesuch De metris ungeführ 1250) Arbeiter tätig.

Die Gruben von Navang (Fig. 66), nahe der Ostgrenze der Karte, bedecken etwa 2 engl. Quadratmeilen. Lis sind 2-4 Ful tiefe Löcher in der Umeregend des Dorfes Navang. Ein grober, scelber oder brauner sand, der auf weite Strecken die Erdoberfläche bedeckt, überlagert eine Tonschicht. Da wo der Sand den Ton beriihrt, enthält er in einer Dicke von 6-10 Zoll die Rubine, hier wie in den anderen Gegenden von Siam mit Sapphiren. Die Gruben werden erst seit 1875 systematisch ausgebentet. Die Steine, die sie liefern, sind von viel besserer Qualitåt, jedoch meist kleiner als die sonst in Siam vorkommenden. Sie liefern auch, wenn schon in geringerer Menge Sapphir. Im Jahr 1906 waren 3000 Arbeiter tätig.

Die Gruben von T s e han na (Hauptort Ban Yat) liegen iiber unsef:ïhr eine Quadratmeile zerstreut etwa 30 .Meilen nördlich von den vorigen entfernt. Sie werden seit 1855 bearbeitet. Del rubinführende Sand ist 6-24 Zoll mächtig und einige Gruben erreichen eine Tiefe bis zu 24 Fuß. Nach der Heinung der Eingeborenen sind die Steine durch den Flub rom Berge Kao Sam Nam herabgeschwemmt

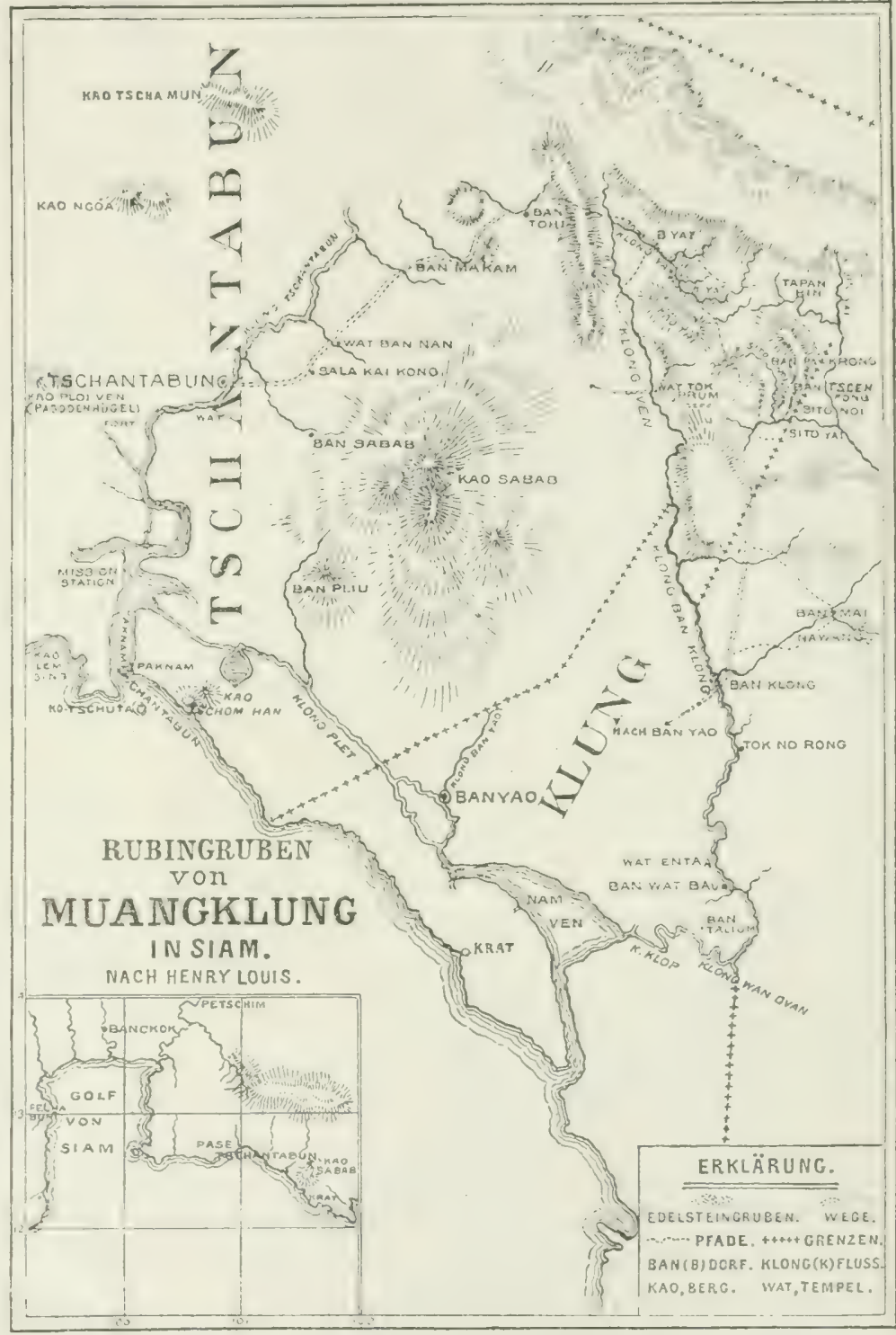

Fig. 66. Rubin- und Sapphirgruben von Muang Klung in Siam. worden, und am Fulbe dieses Beress sollen auch schon zahlreiche schüne Rubine sefunden worden sein. Das büchst ungesunde Kilma ist der Arbeit dort aber sehr wenig gïnstig.

Die fremend ist hïgelig. die Talsohlen erheben sich 600-Son) Fuf iiber das Meer,

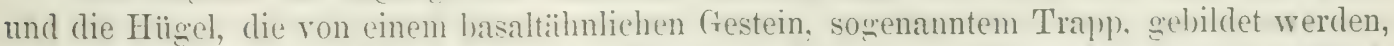
sind noch etwa 500 Fub höher. Die Bäche sind in ihrem Oberlauf ungemein reißend, so daß sie erst in ihrem Unterlauf. wenn sie sich dem Hauptfluß, dem Klong Ven nähern, rubinfïhrende Alluvionen ablagern künnen. In diesen Seifen arbeitet ein Teil der Gruben, 
aber nur in der trockenen Jahreszuit. In der Recenzeit wendet sich der Betrieb den Ablagerungen zu, die sich an den Talabhängen und an den Seiten der Hügel über dem heutigen IIochwasserspiegel hinziehen. Die edelsteinführende Schicht ist hier 5 Zoll bis 5 Fub mächtig und wird ron einer $21_{2}^{2}$ bis 1.2 Fub dicken, roten, sanderen und tonigen lateritartigen Masse iblherlagert, die keine Edelsteine liefert. Diese wird, genau wie in den Rubingruben von Mogouk und auch meist von Birmanen aus der dortigen Gegend mittels kleiner Sehächte von etwa 4 Fuß Durchmesser durchbohrt, um zu jener zu gelaneren. Han holt die Erde mit den Edelsteinen heraus, einen mit vielen Brocken des Traply gemengten braunen Ton, der für das direkte Terwitterungsprodukt des ersteren gehalten wird. Dieses Gestein mülite dann das IIttergestein der Edelsteme sein, was aber noch in keiner Weise sichergestellt oder anch nur wahrseheinlich gemacht ist. Nan findet in dem Ton Rubin und Sapphir, nebst gemeinem Kiorund, daneben seliöne Bergkristalle, Zirkon- und Titaneisenkristalle in Menge und als Seltenheit Topas. Nur die beiden ersteren sind zu Schnucksteinen brauchbar und daher von Wert. Rubine kommen doppelt so viel vor als Sapphrre. Dic Rubine sind zum Teil hell; alle haben einen diistern Glanz und viele einen wenig geschäitzten Stich ins Orange, Gelb und Braun. Die Sapphire sind dunkel bis undurchsichtig: Gute Exemplare sind bei beiden selten. Zweihundert Mann arbeiten gegenwärtig in den Gruben; sie fördern die Erde aus dem edelsteinhaltigen Lager, waschen sie und lesen in der allgemein üblichen Wreise die Rubine und Sapphire aus dem Rückstande aus. So gewinnen sie im Jahre etwa eine halbe Million Karat Steine, deren Gesamtwert aber im Nittel nicht über $2000-3000$ Pfund Sterling (10000-60000 Mark) hinausgeht, da, wie schon erwähnt, überwiegender minderwertiger Ware nur wenige gute, wertvolle Stiicke beigemengt sind. Der auf der Fluoressenz beruhende Unterschied von den wertvolleren birmanischen Rubinen ist schon oben erwähnt. Auch im Dichroismus ist der siamesische Rubin anders als der von Birma; das eine Farbenbild ist bei beiden karminrot, das andere im ersten Fall braunrot, im anderen gelbrot.

Auf der Insel Ceylon (Fig. 69) finden sich sparsam Rubine neben erheblich größeren Mengen von Sapphiren und anderen Edelsteinen in den dortigen Seifen. Die Steine haben vielfach noch ihre deutliche Kristallform, die mit der am Liubin von Birma beobachteten vollkommen ïbereinstimmt (Fig. 6:3, a bis (d), meist sind es aber abgerollte Körner. Die Seifen liegen entweder über dem jetzigen Iochwasserstand am thhange der Berge oder in den Flußtälern; besonders bei Ratnapura und Rakwana, auch am Fufe des Adamspiks werden daraus Rubine gewonnen. Die meisten derselben sind von zu heller, himbeerroter Farbe und daher von geringerem Wert als die birmanischen, doch finden sich zuweilen auch in Ceylon Steine von schöner Farbe, die aber die birmanischen doch niemals wanz erreichen, so dalf ihr Preis immer niedriger ist. Andererseits kommt in Ceylon der so wenig reschätzte bräunliche Farbenton vieler lima-Rubine kaum vor. Nicht selten sind auch Steine mit abwechselnd blauer und roter Farbe. Eine bläuliche Nuance vieler liubine von dort kann durch Brennen beseitigt und so deren Farbe wesentlich verbessert werden. Die meisten Ceylon-Rubine konmen daher in gehranntem Zustande in den IIanclel. I)as Vorkommen von Sapphir ist weit wichtiger als das von Rubin; bei der Beschreibung des Sapphirs mub daher hierauf noch einmal zuriekgekommen werden. Das Nuttergestein der Rubine ist nach Tennant in Ceylon wie in Birma ein kristallinischer dolomitischer Kalk oder Marmor, der u. a. bei Bullatotte und Badulla ansteht. Beim Sapphir ist das Vorkommen wahrscheinlich ein anderes; er soll aus gneis- und granitartigen Gesteinen stammen.

So reich das Festland von Vorderindien an gemeinem Korund ist, so sparsan ist bisher schleifwïrdiger edler Korund, speziell Rubin dort gefunden worden. Einige wenige brauchbare Steine sind aber in Maysur und im Salemdistrikt in Madras mit dem gemeinen 
Korund vorecekommen. whenso im Fluballuvium des Kavary, der siidlich von P'ondichery in den Mererhusen von bengalen mündet, und dessen sande und Kiese in Vorkommen von Edelsteinem anferordentlich grolie Ähulichkeit mit den Flufalluvien von reylon haben sollen. Es werden noch einige andere Orte in Vorderindien, namentlich noch einige andere Flïsse als Funderte von Rubin Eelegentlich erwähnt, die Angaben bruhen aber zweifollos zum 'Teil auf Virwerlsiblung des Rubins mit rotem Ciranat, der in dem Lande sehr verbreitet ist. Jeclenfalls komenten die indischen Grolien die vielen Rubine ibrer Schatzkammern nicht alle aus dem Lande. solbst bezehen, die steine stammten fon IBrma und anderen Fundorten. namentlich den nachlier zu betrachtenden in Badakschan.

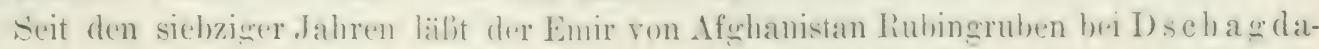

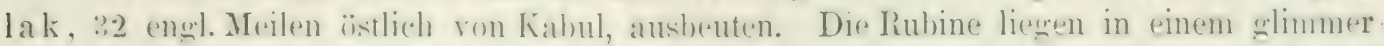
führenden kristallinischen Kalk. Sie sind zum Teil selır deutlich kristallisicrt, und zwar wieder in denselhen Formen wie die von Birma. Man hat sie friber für Spinell gechalten und als solehen beschrieben, doch ist es natch den in kuropa belsannt getwordenen Txemplaren zweifellos Ronbin, der aher vielleicht, wie in Birma und Ceylon, ron spinell begleitet wird. Das Vorkommen wïre dann dem ron Birma auferordentlich ähnlich.

Ein liubin vom 101'. Karat wurde durch einen englischen Reisenden ron frandamak nach Europa gebracht. Diexer ()rt liegt 20) englische Meilen ron Dschagclalak entfernt unter etwa $34{ }_{13}$ " nördl. Breite und 70 " ̈̈stlicher Länge von Greenw. Vielleicht beziehen sich beide Namen auf dassellue Vorkommen. Näheres ist bis jetzt noch nicht dariber bekannt geworden.

In früheren Jahrhunderten sind die Rubingruben in Badaks ch a n berühmt gewesen; aus ihnen haben die Grobmownls ihre Schatzkammern mit diesem Edelsteine bereichert. Sie liegen (Fig. 67) in Schignan, in dem nach Südwest gerichteten Knie des oberen Oxus, etwa unter $71^{1}{ }_{i 2} 0$ östl. Länge von Greenwich und $37^{\circ}$ nördl. Breite, zwischen dem Oberlaufe des Oxus und seinem rechten Nebenflusse Turt, wahe dem Orte Gharan oder Guran (was aber "Grube" bedeuten soll), 16 Meilen unterhalb der Stadt Barschar, in den niederen, nicht in den höheren Bergen. Die Lage des Orts ist aber keineswegs genauer bekannt, ebensowenig die Verhältnisse, unter denen die Rubine vorkommen. Sie sollen in einem roten Sandstein oder, was wahrscheinlicher. ist, wie in Birma in einem stark magnesia-

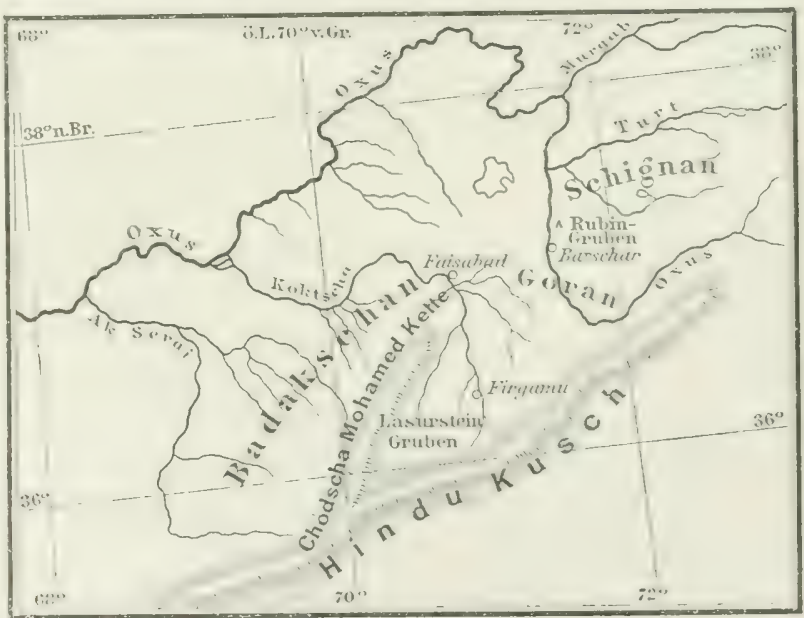

Fig. 67. Rubingruben in Badakschan am oberen Oxus. Maßstab : 1:6000000.

haltigen Kialk liegen; wieder andere Berichte sprechen von einer weiben Erde, aus der die Edelsteine gewonnen werden.

Rubine sollen sich frïher, elenfalls von Spinell, und zwar dem sogemannten Balasrubin begleitet, in grofer. Irenger in diesen fruben gefunden haben. Lm aher den Wert der Steine nicht herabzudriicken, liefen, nach dem Bericht ron Marco Polo, der die Gruben im 13. Jahrhundert besuchte, früher die Fürsten des Landes nur eine beschränkte kleine Menge wewinnell, die zum Teil als Tribut an die mongolischen Kaiser in Delhi gelangte, zum Teil anderen Herrsehern als Geschenk dargeboten und nur ztm kleinsten 
Teil in den Handel gebracht wurde. Später scheint der Ertrag ganz nachgelassen und die Gewinnung endlich vollstänảig aufgehört zu haben. 1866 soll der Betrieb von neuem aufgenommen worden sein, es ist aber nicht bekannt, ob heute noch dort gearbeitet wird; jedenfalls haben die Erträge keine Bedeutung für den jetzigen Edelsteinhandel. Nach einem Bericht aus neuerer Zeit sind die Gruben ziemlich erschöpft. Es arbeiten etwa 30 Leute dort, die ihre Funde dem Emir von Kabul abliefern. 1873 soll ein Stein von der Grölie eines Taubeneies gefunden worden sein. Vielleicht kommen aus diesen Gruben die Rubine, die gegenwärtig mit Spinell zusammen über Taschkent in den Handel gebracht werden, und die der Angabe der Händler nach aus dem Tianschan stammen. Ebenso ist vielleicht auch der 2000 Karat schwere Rubin, den Streeter aus "Thibet" erhalten hat, in den Gruben am Oxus gefunden worden. Jedenfalls hat man keinerlei nähere Nachrichten über Rubingruben im Tianschan oder in Thibet.

So wichtig das Vorkommen von Rubin in Asien ist, so geringfügig ist es in allen anderen Erdteilen.

Kleine schleifwïrdige Rubine kommen wohl auch aus $\Lambda$ ustralien, besonders aus den Goldsanden, wo sie zum Teil als Begleiter des Diamants gefunden werden. Aber so häufig der Sapphir dort ist, so selten ist der Rubin; er gehört zu den seltensten Edelsteinen dieses Landes. In Neu-Süd-Wales findet man ihn im Sande des Cudgegong (Fig. 53) und einiger seiner Nebenfliisse, im Mudgee und an mehreren anderen Orten. In Victoria trifft man Rubine in den Goldseifen von Beechworth, bei Pakenham und sonst. Überall ist aber der Rubin seltener als der mitvorkommende Sapphir. Vielfach ist auch in Australien irrig roter Granat für den so viel wertvolleren Rubin gehalten worden. So glaubte man vor mehreren Jahren zahlreiche Rubine in den Nacdonnel Ranges im Nordterritorium von Siidaustralien gefunden zu haben, zu deren Gewinnung sich in kurzer Zeit 24 G'esellschaften bildeten. Die gewomnenen Steine erwiesen sich aber bei genauerer Untersuchung als dem Rubin gegenüber fast wertlose rote Granaten von allerdings sehr schöner Qualität, die nun zuweilen als Adelaide-Rubine bezeichnet und verkauft werden.

Auch A merika liefert in den Vereinigten Staaten sparsam Rubin als seltenen Begleiter des gremeinen Korunds und des Sapphirs, der sich in diesem Lande in größerer Menge von edler Beschaffenheit findet. Hiervon wird bei der Betrachtung der amerikanischen Sapplire die Rede sein. Von Bedeutung für Rubin ist nur das Vorkommen im Sande des Cowee Creek und seiner Nebenfliisse, der von rechts (Osten) in den Little Tennessee River mïndet, 5 bis 6 (engl.) Meilen nördlich ron Franklin, in Macon County, Nord-Carolina. Wie in Birma stammen auch hier die Steine aus Kalk. Begleitet wird der Rubin von Sapphir, auberdem von viel Granat und zahlreichen anderen Mineralien, darunter etwas Gold, es fehlt aber der in Birma mit dem Rubin vorkommende Spinell. Die Kristallform ist tafelig bis kurz prismatisch. Die Farbe wechselt von dunkel- bis hellrot und weilj; viele Steine haben die echte Rubinfarbe. Auch Asterien kommen häufig vor. Fehler sind sehr verbreitet, so seidenglänzende Wolken und Einschlïsse von rotem Rutil und schwarzem Ilmenit, sowie von Granat in der Abart des Rhodolith. Die Anwesenheit dieses letzteren prächtig roten und klaren Minerals vermindert aber die Schönheit des Riubins nicht. Die Produltion wird systematisch betrieben und ist nicht gering. Der gröbte hier gefundene Stein von guter Beschaffenheit wiegt $61 / 2$ Karat. Auch andere Fundorte von einzelnen Tinbinen in dem an Korund so reichen State Nord-Carolina werden genannt, so die Corundum Hill-M ine bei Cullasagee in Macon County, südöstlich von Franklin, und andere, sie sind aber ohne jede grröbere Bedentung. Auch in Amerika hat man nicht selten Granaten für liubine gehalten und als solehe gresammelt und verkauft.

In Brasilien haben die Diamantensande des Rio Coxim in Mato Grosso und die Spinellsande des lío Pinua in Espirito Santo einige schleifbare Rubine und Sapphire geliefert. 
In Europa sind schleifwürdige Rubine so grut wie gar nicht vorgekommen, ebensowenig in $\Lambda$ frika. Der sogenamnte Kaprubin, der Begrleiter des Diamants in Südafrika, ist kein Rubin, sondern Granat.

Küustliche Nachbilıhne. I)er liubin ist der einzige der kostharen Edelsteine, von dem man sicher weil), dal) ('s möglich ist, ihn mit allen seinen Eigensehaften in Kristallen von einiger (irölbe nachzubilden, odler, wie man zu sagen pflegrt, kïnstlich herzustellen. Dem Pariser Chemiker Fromy ist dies nach vielen mit $\Lambda$. Terneuil zusammen ausgreführten Versuchen endlich (1891) vollkommen gegrliickt. Er schmol\% in einem Tontiegel, der wesen seiner porïsen Beschaffenheit der Luft namentlich in der Hitze leichten Durchgang gestattet, bei sehr hoher Temperatur (1500) " ( $\vdots$ ) ein Gementre vollkommen reiner Tonerde $\left(\mathrm{Al}_{2} \mathrm{O}_{\text {.. }}\right.$ ) nit etwas kohlensaurem Kali, Fluorbaryum Coder Fluorcalcium) und einer kleinen IIenge von chromsaurem Kali zusammen, und hielt diese Masse acht Tage lang im Flul). Wahrseheinlich bildete sich dabei Fluoraluminium, dits dann von der zutretenden feuchten Iuft und den Ofengasen zersetzt wurde: und das so Kristalle ron Tonerde lieferte, die sich durch Aufnahme von Chromoxyd aus dem chronsauren Kali rot färbten. Diese ruten Kristalle, dir demmach nichts anderes sind als richtiger kïnstlicher Rubin, lagen in nehr oder wenimer grober Menge in der schmelze, aus der sie isoliert werden konnten (sogenannte rubis scientifiques).

Sie hatten stets die in Fin. lis dargestellte Form eines lihombö̈ders mit sehr stark ausgedehnter gerader Endflïche, auch waren vielfach noch andere von den in Fi (1-d daresestellten Flächen vorhanden. So bildeten sie stets dïmne Tafeln ron allerdings nur geringer Größe l,is zu höchstens 1 : Karat fiewicht. Sie wurden um so gröber, je umfangreicher die angerwendeten Tiegel und je bedeutender die Massen der zusammengeschmolzenen und im Schmelzflusse aufemander einwirkenden Substanzen. Die Farbe war je nach den speziellen Unstiinden heller oder dunkler rot. :3 bis 4 P'rozent doppelcbromsaures Kali gaben die sehönste und reichste Rubinfarbe. Häufig gring aber die Nuance mehr oder weniger ins Violett oder die Kristalle waren auch zuweilen ganz blau, so daß solche aus demselben Tiegel diese verschiedenen Färbungen zeigten. Manchmal hatte sogar ein und derselbe Kristall ein rotes und ein blaues Ende. Frémy schloß hieraus, daß Chrom nicht nur die rote Farbe des Rubins, sondern auch die blane des Sapphirs hervorzurufen vermöge, und dals vielleicht auch der natïrliche Sapphir durch Chrom gefärbt sei, Mehr als 3 bis 4 Prozent des Chromsalzes wurde von der 'T'onerde schwer aufgenommen, und die Kristalle erhielten dadurch eine violette, von der der natiirlichen Rubine stark abreichende Farbe.

Diese künstlichen Rubine sind wie die natïrlichen geschliffen,

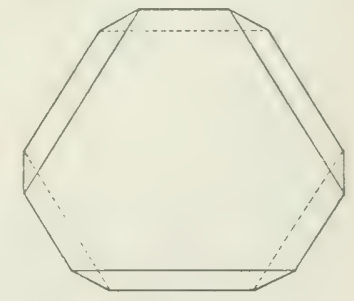

Fig. 68.

Künstlich hergestellterRubin nach Frémy. aber auch in ihrer urspringlichen Kristallform gefabt und zum Schmuck verwendet worden. Zu Zapfenlagern für Lhren ete. sind sie ebenfalls brauchbar, da ihre Härte der der natiirlichen Steine in nichts nachgibt.

Im allgemeinen sind die Rubine ron Frémy jedoch für den praktischen Gebrauch zu klein und namentlich zu dïnn, indessen hat F rémy die Ioffnung gehegt, mittels Tiegeln von 50 Liter Inhalt erheblich größere Kristalle herstellen zu können

Schön karminrote Steine, zum Teil ron beträchtlicher Größe, waren schon frïher, etwa um das Jahr 1655, von Genf aus in den Irandel gehracht worden. Ihre Farbe glich bei der spektroskopischen Lntersuchume mehr der der Rubine von Frémy als der natïlichen. Gewisse andere Eigenschaften wisen dentlich auf künstliche Entstehung hin. sie sind etwas weicher als natiirliche líubine und zum Teil einfach lichtbrechend. Wrahrscheinlich 
sind sie durch \%usammenschmelzen kleiner echter Steine und von Rubinpulver mit Schmelzmitteln (etwas Kieselsäure oder Borsäure) hergestellt worden und haben daber den Namen rubis reconstitués (auch wobl rubis de Genêve) erhalten.

In Jahre 1902 machte $\Lambda$. Verneuil ein Terfahren bekannt, Rubine von Edelsteinqualität kïnstlich herzustellen, und zwar ähnlich wie Fromy, durch Zusammenschmelzen reiner Tonerde mit etwas Chromoxyd. Sein Verfahren war aber etwas anders; er erhielt keine reggedmälig begrenzten Kristalle, sondern runde Kügelehen, die jedoch alle Eigenschaften des kristallisierten Rubins zeigen. Diese Methode wurde dann, zuerst namentlich in Paris, weiter auswebildet und durch den Ban zweekmäßiger Apparate sehr vereinfacht und verbilligt, so daß nun eine systematische gewerbsnäßige IIerstellung schöner und großer künstlicher Rubine für den Handel zu mäljigen Preisen möglich ist. Feinstes Pulverv on Ammoniakalaun mit etwas Chromoxyd fällt durch ein feines Sieb in regelmäljigen Zwischenräumen mit ganz kurzen Pausen auf ein senkrecht stehendes Knallgasgebläle und zersetzt sich hier vollständig: Die ïbrig bleibende verstäubte Tonerde schmilzt zusammen und wird so auf einem kleinen in der Achse des Geblïßes befestigten Tonerdezylinder aufgefangen der nahe bis zur Schmelztemperatur der T'onerde erhitzt ist. Auf diese TVeise sondert sich allmählich eine gewisse Menge neugebildete Rubinsubstanz an, wobei man sich nur vor einer zu starken Stégerung der Temperatur zu härten und für Verwendung chemisch reiner Materialien zu sorgen hat. Zahlreiche schöne zum Schleifen taugliche stïcke sind auf diese Weise erzeugt worden (rubis synthétiques). Gegenwärtig kommen von dort flaschenförmige Schmelztropfen von 2 bis 10 Gramm in den Handel, am dicken Ende kugelig mit einem scharf ahgegrenzten, diinnen, trïben, weiben oder grauen Boden, au anderen Ende lang ausgezogen und an der Spitze zuweilen deutliche Kriställchen von der Form des natiirlichen liubins. Die Flasche selbst hat zuweilen die Gestalt eines sechsseitigen Prismas mit etwas rundlichen Flïchen und Kanten, in denen sich die Flächen unter Winkeln von $120^{\circ}$ schneiden. Die Hauptmasse ist prachtvoll rot und durchsichtig. Die Tropfen sind ziemlich spröde und zerbersten zuweilen sehr leicht bei einer geringen äußeren Verletzung, ähnlich wie die sog. Glastränen, denen sie auch in der Form gleichen. Die Härte ist die des Korunds, an der Oberfläche etwas geringer; das spezifische Gewicht $\left(\mathrm{G}_{0}=3,97\right.$ bis 4,05) und alle optischen Eigenschaften, namentlich auch der Dichroismus sind die des Rubins in der Weise, daß der ganze Tropfen nicht etwa ein Agregegat von Rubinkörnern, sondern ein homogenes, einbeitliches Kristallindividuums darstellt, dessen Iauptachse der Mittellinie der Flasche von der Spitze nach der Mitte des Bodens entspricht. Es liegt hier künstlicher Rubin vor, der sich in nichts wesentlichem von dem natuirlichen Iiubin unterscheidet und der auch ganz dessen schönes Aussehen besitzt. Die rote Farbe zeigt verschiedene Nuancen; die bei den natïrlichen Steinen so seltene Taubenblutfarbe ist bei diesen künstlichen verhältnismäßig häufig; nicht ungewöhnlich ist ein eigentïmlicher Stich ins Gelbe, der in der Natur kaum vorkommt, der bei echten Ribinen verbreitete Stich ins Bläuliche und Violette fehlt auch hier nicht. Die flaschenförmigen Schmelztropfen sind ohne Zusat\% einer Chromverbindung farblos. Die schönste Rubinfarbe entsteht bei Zusatz der 21:2 Proz. Chromoxyd. Bei einer geringeren Menge des letzteren erhält man cine liosafarbe, die zuweilen der des roten gebrannten Toprases sehr ähnlich ist. Steine dieser Art werden daher sehr unriehtiger Weise, „synthetischer Topas" genannt.

Aher diese kïnstlichen liubine werden ungeachtet ihres im allgemeinen erheblich schöneren Aussehens nicht als eleichwertig mit den natürlichen betrachtet. Diese sind in Gefahr, ihre herorzugte Stellung zu verlieren und entwertet zu werden. Denn die künstlichen Steine, die im Gewicht von 1/10 his 15 Karat heroestellt werden können, sind erheblich billiger und kosten gexenwärtị: höchstens 12 Mark das Karat der tadellosen geschliffenen Ware. 
Um dieser Konkurrenz nach Möglichkeit zu begrement hat das Syndikat der Edelsteinhändler in Paris (iexenmalirexceln beschlossen. Unter dem Namen Tiubine sollten nur aus natürlichem liohmaterial ereschliffene Steine zu verstehen sein, jeder Elelsteinhiindler sollte zur Doklaration von ihn verkanfter, sowie zur liiicknahme etwa von ihm unwissentlich abgegebener künstlicher Steine verpflichtet werden.

Derartige Bestimmungen sind natürlich geeignet, den Vertriel) der künstlichen Steine zu hemmen, ob in erheblichem Malie und auf die Dauer, wirci erst die Erfahrung lehren mïssen, denn ein innerer (trund für diese scharfe Unterscheirlung liegr rigentlich nicht vor bei der vollkommenen (bleichheit mit den natïrlichen, auch bezijenlich der sichïnheit. Jedenfalls sind kïnstliche Steine schon in recht erheblicher Zahl im IIandel, und selten wird dem Kä̈ufer mitgetrilt worden sein, dali er es mit Kunstprodukten zu tun hat.

I'nter allen Umständen sind aher diese Mabnahmen nur wirksam, solange irgendwie bemerkhare Unterseheidungsmerkmale vorhanden. Vit dem blofen Auge einen gruten Kunststein stets mit voller Sicherheit zu crkennen, ist wohl auch dem erfahrensten Juwelier kaum möglich.

Manchmal sind die kïnstlichen Steine vielleicht an der erwähnten, etwas ins frelbliche gehenden Farbennuance, an einer eigentimlichen leichten Tribung und namentlich an dem Auftreten von Schlieren und Streifen in etwas abweichender Farbe kenntlich. Als einzige sichere Nerkmale sind aher die Einschlïsse zu betrachten, die man mit einel scharfen Lupe, besser unter dem Mikroskop, wahrnehmen kann. Beim kïnstlichen Tiul,in sind es kleine rundliche Bläschen, ofters in erhehlicher Menge, die bei dem natürlichen durchaus fehlen. Lmokeht triff man nur in diesem, aber keineswegs in allen Exemplaren, mikroskopisch kleine Fliissigkeitseinschliisse ron mehr eckiger Form, sowie winzige braune Xïdelchen, die oft scharenweise angeordnet sind, die einzehnen Scharen sich unter Winkeln von 60" durchkrenzend. Auch Einschlïsse von Kriställehen anderer Art fehlen nicht, doch sind sie seltener. Die Kennzeichen der künstlichen Steine haben aher den swöbten Teil ihrer Bedeutung eingebuißt, da man durch fortschreitende Verbesserung der Iterstellungsmethoden allmählich dahin gelangt ist, sie zu vermeiden. Derartige fehlerlose, blasenfreie Rubine lassen sich dann von ebenso vollkommenen einschlubfreien natiurlichen überhaupt nicht mehr sicher unterscheiden.

Neben den bisher besprochenen französischen kïnstlichen Tubinen sind aber auch die mindestens gleichwertigen dentsehen zu nennen. Sie werden hergestellt von der Deutschen Edelsteingeselischaft in Idar in Verbindung mit Professor A. Miethe in Charlottenburg und zwar nach einem verhältnismälfig einfachen Verfahren, ähnlich dem von Verneuil, aus reiner Tonorle mit piner kleinen IInge ron Chromoxyd, das die Farbe gibt. Das erhaltene l'rodult ist in chemischer Zusammensetzung, IIärte und allen anderen Eigrenschaften dem natïrlichen Rubin rollkommen suleich und liefert blasenfreie Steine von höchster Vollkommenheit der Durchsichtickeit und des Glanzes. Ton Farben lann das sn boch seschätzte Taubenblutrot mit d.r lenchtenden Pracht des Karmins, die in Birma, Siam oder Ceylon gewöhnliche Nuanee, rot mit einem stich ins Violett oder ausgesprochen violett und ganz helles liosa weliefert werden, und taubenhlutfarbige Steine nicht cinmal erheblich teurer als andere.

Unterscheidune von anderen roten steinen. T) a der Timbin ein sehr liostharer Stein ist, so werden ihm nicht selten andere minderwertige Steine untergeschoben. Es kann sich dabei in erster linie nur um Spinell und Granat, weiterhin um roten Turmalin und für blaßrote liubine um ebensolche Topase handeln. Fonterefärbter Quarz (sog. craruelés) und Rosenquar\% werden kaum als Verfülschung vorkommen, dagegen kamn das Unterschieben von Glasfliissen versucht werden.

Ba uer, Edelsteinkunde. 2. Aufl. 
Spinell und Granat, ebenso alle Glasflüsse, unterscheiden sich vom Rubin leicht durch ihre einfache Lichtbrechung und den Dichroismus des letzteren. Roter Turmalin und ebenso roter Quarz baben ein viel geringeres spezifisches Gewicht als der Rubin; sie schwimmen leicht auf Methylenjodid, während Rubin sofort sinkt. Roter Turmalin ist stark pyroclektrisch, Rubin nicht; letzterer ist für Röntgenstrahlen erheblich durchlässiger als alle die anderen roten Steine und als die roten Pasten. Rosenroter Topas. künnte nur den hellrosenroten Rubin ersetzen; beide sind wohl im Wert nicht sehr voneinander verschieden, und so wird eine sichere Unterscheidung selten von großem praktischen Interesse sein. Sie kann vorgenommen werden auf Grund des spezifischen Gewichts $(G .=3,5$ bei Topas und $=4$, beim Rubin), wonach Topas in der schwersten Flïssigkeit noch schwimmt, während Rubin darin untersinkt. Eines der wichtigsten Unterscheidungsmittel beruht aber auf der großen Iärte des Rubins, der als zweithärtestes Nineral unmittelbar hinter dem Diamant folgt und der daher alle die genannten Steine mit Leichtigkeit ritzt Bei Glasflïssen und bei rotem Flußsp)at ist dies sogar mit der harten stahlspitze müglich.

Rote Steine anderer Art werden zuweilen unter Zufügung eines unterscheidenden Beiworts ebenfalls als Rubin bezeichnet. So versteht man unter bühmischem Rubin den Rosenquarz, brasilianischer Rubin ist roter Topas, Kaprubin und Adelaide-Rubin roter Granat, sibirischer Rubin roter Turmalin, falscher Rubin ist roter Flußspat usw. Rubinspinell und Balasrubin gehören zum Spinell.

Die Glasfliisse, die in der Farbe dem Rubin nahe stehen, das sogenannte $R$ ubinglas, hat man durch verschiedene Pigmente hervorzubringen versucht. Mangansalze geben eine ähnliche, aber doch stark violette Farbe. Am besten sind Goldsalze, Goldpurpur usw. die man mit dem Glasfluß, Straß usw. einschmilzt. Hierzu ist bei Goldsalzen große Vorsicht nütig, danit das Glas nicht trübe wird. Nach dem Erstarren sind solche Goldgläser gelblichnrïn; durch Anwïrmen, das sogenannte "Anlaufen“, erlangen sie erst ihre schöne rote Farbe. Es entsteht darlurch der Rubinfluß von der schönsten Rubinfarbe, den man durch mehr oder weniger grofen Zusatz von Goldsalz in verschiedener Intensität erbalten kann. Interessant ist, dafj sich schöne rubinfarbige Gläser schon in alten keltischen Gräbern finden.

Rubinmutter. In Nord-Carolina finden sich am Buck Creek in Clay County rosa und roter Rubin in einem grïnen Mineral der IIornblendegruppe (Smaragdit) eingewachsen. Diese werlen so geschliffen, daß die roten Kürner von einem grünen Rande umgeben sind. Wegen des Farbengegensatzes bieten derartige Steine, die $\mathrm{Rubinmutter}$ genannt werden, einen hïlsschen Anblick, trotzdem der Rubin von der gewöhnlichen trüben Beschaffenheit des gemeinen Korunds ist.

\section{Sapphir.}

Eigensehaften. Der Sapphir (orientalische Sapphir) ist der blaue Korund. Er unterscheidet sich vom Rubin wesentlich nur durch diese Farbe, doch ist er auch etwas härter - er ist der härteste aller Korunde - und auch das spezifische Gewicht soll um einen geringen betrag höher sein als bei den anderen, nämlich grleich 4, ws, während es für Rubin zu 3,96 bis f,w; angegeben wird. Die Kristalle des Sapphirs sind bei vollkommen gleichen allgemeinen Verhältnissen etwas anders ausgebildet als die des Rubins indem bei ihm die P'rismen und Rhombö̈der des letzteren zurücktreten und dafür die hexagonalen Doppelpyramiden vorherrschen, wie es in der Fig. 63, e bis $i$ schematisch, und Taf. I, Fig. 7 nach der natürlichen Beschaffenheit dargestellt ist.

Während beim Rubin die rote Farbe meist über den ganzen Stein gleichmäßig verteilt ist, sind die Sapphire auberordentlich häufig fleckig, indem rein weilbe oder gelblich- 
weibe mit blauen Stellen abwechseln, die entweder ziemlich scharf zegenemander ab. setzen oder allmählich in inander überechen. In der farblosen Hauptmasse des steins sind die blawen Flecken mehr oder wenigrer zahlieich, bald ganz vereinzelt, bald dicht gedrängt. Nur Wenn der Stein ununterbrochen blau ist, wird er als Edelstein geschätzt, fleckige Sapphire haben nur geringen Wert.

Treten die blauen Flecke immer mehr zurück und verschwinden endlich franz, dann hat man farblose oder andbliche steine, die aber in der angedenteten Wreise durch alle

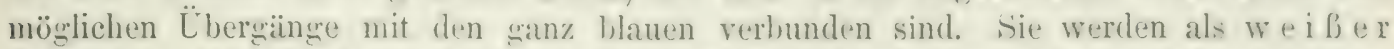
S ap p h i c coder Leukosapphiry bezeichnot. Vollstïndig farblose, klare und durchsichtiser, also tadellos wasserhelle Exemplare sind aher selur selten, meist ist immer noch ein bläulicher Schein oder eine mehr oder wenieger deutlich gelbe Färbung forhanden, welche letztere dann zu dem unten zu besprechenden orientalischen Topas hinüberfülurt.

Die erwähnte Verteilumg der blauen stellen in der farblosen oder gethen Masse ist meist rollkommen gesetzlos, manchmal sind jedoch allerdings auch beile in irgendeiner Wreise regelmälbig getereinanter angeordnet. So ist zuweilen das eine Ende des Steines blau, das andere farblos, oder beide Enden sind blau und lassen ein farbloses Mittelstiuck zwischen sich, oder farblose und blawe Schichten liegen mehrfach ïbereinander usw. Übrigens wechseln beim Sapplir nicht blos blau und weib (oder farblos) an demselben stiick miteinander al, sondern zuweilen auch verschiedene Nuancen von l,lau, z. B. rein blau und grtinlichblat, wie bei den dunkeln Sapphiren ron Siam, und sogar verseliedene sonstige Farben. So kennt man Sapphire, die ein blaues und ein rotes Ende lıaben. solehe, die an beiden Enden blau und in der Mitte gelb sind usw. Ein Sapplirliristall von $19 \div 16$ Karat mit der letzteren Farbenzeichnung liegt z. B. in der Mineraliensammlung des Museums im Jardin des plantes in Paris.

Von dieser Farbenvertulung wird zuweilen bei der Verwendung der Steine Gebrauch gemacht, um gewisse Effekte zu erzielen. Im IIseum in Gotha wird eine Fignr des Confucius aufbewahrt, die aus einem mehrfarbigen Sapphir in der Weise hergestellt wurde, daf der Kopf weil) ist, während die Beine eine gelbe Farbe haben; der zwischenliegende Körper ist hellblau.

Das Blau des Sapplirs, die eigentliche Sapplirfarbe, zeigt alle müglichen Abstufungen von der hellsten bis zur dunkelsten, rom beinahe Farblosen bis zum annähernclen Sehwarz. Diese sehr dunkle Farbe nennt man tintig. Die sehr hellen, weiblichen Sapphire werden zuweilen Trassersapphire, die sehr dunkeln Indigosapphire oder auch Luchs- oder Katzensapphire genannt. Im allgemeinen ist der Stein am wertrollsten, je dunkler er ist, doch darf dies nicht.so weit gehen, daß die Durchsichtigkeit darunter leidet. Aber nicht nur die Tiefe der Farbe ist verschieden, sondern auch die Nuance, die zwischen indigoblau, berlinerblau, smalteblau, kornblumenblau, graulichblau und vor allem grünlichblau wechselt. Die geschätzteste Farbe ist ein lebhattes und gesättigtes reines Kornblumenblau. Ein schöner Sapphir muß wie blauer Sammet aussehen, und je deutlicher der eigentïmliche Glanz des Sammets mit der schönsten Farbe verbunden ist, desto höher ist der Wert. Steine dieser Art sind, wenngleich im allgemeinen der Sapplin ziemlich verbreitet ist, recht selten. Ein schün blaner sapplirkristall ist Taf. I, Fig. 7, ein geschliffener stein in Fig. 8 derselben Tafel abgebildet.

Daß beinahe stets dem Blau mehr oder weniger Grïn beigemischt ist, hanu man besonders konstaticren. wenn man durch einen sapphir nach verschiedenen Richtungen hindurchsieht. Man heobachtet dabei wie beim Rubin einen deutlichen Dichroismus, um so stärker, je dunkler der Stein ist; bei ganz heller Farbe ist die Erscheinung kaum mehr wahrzunehmen. Sieht man durch einen nicht zu hellen Sapplir in der Richtung der IIauptaxe, also in der Richtung der Terhindungslinie der Endecken einer der sechs- 
seitigen Doppelpyramiden, oder senkrecht zu der geraden Endfläche hindurch, dann ist die Farbe rein blau, je nach der Beschaffenheit des Steines mehr oder weniger tief und gesaittigr und zuweilen etwas ins violette spielend. Sicht man aber senkrecht zu der ersteren Richtung durch d(n Sapplir hindurch, so ist die Farbe stets heller und meist deutlich griinlichblatr. Besonders ist dies der Fall bei den jetzt viel im Handel vorkommenden Sapphiren von siam, bei denen von Le Puy in Frankreich (Auvergne) und bei manchen anderen. In zwischenliegenden Richtungen ist auch die Farbe eine intermediüre.

Diesclben Farbenunterschiede gibt die Beobachtung mit der Dichrolupe. Betrachtet man den Stein mit dieser in der ersteren Richtung, dann erhält man bei jeder Stellung: des Instrmments zwei snleiche, rein blaue, vielleicht etwas violette Bilder. In der zweiten Tichtung sind die beiden Bilder im allgemeinen verschieden; beim gröliten Farbenunterschiede erscheint ein dunkleres, rein blaues Bild, wie die von vorher, und ein helleres, meist grünlichblaues bis grïnes (Steine von Siam), aber auch zuweilen gelblichgrïnes und gelbes (Steine von Birma und Ceylon).

Wie beim Rubin ist es also auch beim Schleifen des Sapphirs, der dieselben Formen erbält wie jener, zweckmäßjg, eine ganz bestimnte Richtung cinzuhalten, damit die Farbe des Steines in der besten Weise zur Erscheinung kommt. Auch hier muf die Hauptausdehnung des Steines, die Fläche, die dem Beschaner entgegengehalten wird, also z. B. bei einem Brillantschliff, wie er Taf. I, Fig. $8 \mathrm{zu}$ schen ist, die Tafel, die große Flïche des Oberteils, möglichst nahe der Richtung der geraden Endfläche in den Kristallen sein. dann präsentiert sich der Stein in seiner reinsten und lebhaftesten blauen Farbe.

Bei kïnstlicher Beleuchtung verhalten sich die Sapphire verschieden. Manche behalten dahei ihre Farbe unverändert bei, manche werden dunkler, andere werden rötlich orler jurpurn und wieler andere endlich mehr violett. Namentlich die Steine, die diese Farbenänlerung in guten Stïcken zeigen, sind selten und wertvoll. Das Verhalten ist ähnlich wie beim Alexandrit; deswegen werden solche Sapphire in Colombo gelegentlich als „blaue Alexandrite" verkauft. Sie finden sich $u$. a. auch in Montana.

Für Rïntgenstrahlen ist der Sapphir wie alle anderen Edelkorunde gnt durchläissig.

Beziiglich des Verhaltens der Farbe in der Wärme ist der Sapphir vom Rubin wesentlich verschieden. Während die Rubinfarbe sehr grofer Ilitze siegreich widersteht, wird dadurch die Sapphirfarbe zerstört. Durch nicht zu starkes Glïhen werden die blauen Sapphire, ohne dalj sie sich sonst irgendwie verändern, farblos wie der Leukosapphir, blan gefleckter Leukosapphir wird dadurch einheitlich farblos. Bei sehr hoher Steigerung der T'emperatur wird der Sapphir grau und trübe. Der Verlust der Farbe geht indessen nicht durchweg mit geleicher Leichtigkeit vor sich. Am leichtesten sollen sich dic indischen (ntfürben, hei manchen anderen wird die Farbe sogar nur heller blau, ohne aber ganz zu rersehwinden. Wexen dieser Ieichten Veränderliehkeit hat man den I'rsprung der blauen Farbe wohl in der beimengung (iner geringen Nenge einer organisehen Suhstanz gesucht, die in der Witze zerstïrt wird. Nan hat sie aber auch auf den kleinen Eisengehalt zuriickzeführt, dex, wie die eingangs mitgeteilte Analyse zeiont, beim Sapplir vorhanden ist. Endlich glaubte man ihren Grund in einex geringen Menge einer Chromverbindung wefunden zu haben. besonders mach den oben erwïhnten Versuchen von Frémy zur kïnstlichen Darstellung des Lubins, bei denen er in demselben Tiegel nebencinander rote und cinzelne blaue Kristalle crhelt, die beide durch Chrom geförht waren. stolche kiinstliche Sapphire sollen zuweilen so intensiv blan sein, wie es bei natiurliehen niemals vorkommt. Die Reprodulition lianstlicher silpphire in derselben Weise wie beim Rublin steht indessen moch in weitem Fulde, da man wohl scelegentich und zufällig blaue Steine nehen roten

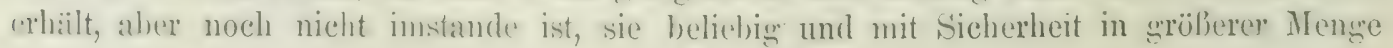
herzustellen. 
Die blaue Farbe des Silpphirs wird nicht nur durch die Ilitze veräindert und zerstiort, sondern auch durch Siadiumbestrahlumg. So werden dabei die: Steine von Ceylon crelh usw. Siehe hierïber Näheres S. 72.

Eine Erscheinung besonderer Art benerkt man an den Asterien. Viele sapplires zeigen wie manche liubine namentlich in intensivem somnen-orler Kerzenlicht auf der greraden Endfläche der hristalle oder einere dieser Lage fentsperehenden Bruchfläche einen leuchtenden, mehr oder weniger rewhöbigen, sechsstrahligen, selten auch einen zwölfstrahligen stern. Die Ersehemunge ist besonders schön. Wemn der Kristall kugelige greschliffen ist, so dafo die Mitte der hathkugedigen oder vielledeht noch stäkeren Krimmung ïber der geraden Endfläche in der Achse des Kristalls lient. Die Strahlen verlaufen von einem Mittelpunkt aus nach dem Liande. Lein I)rehen des Steines wandert der Stern ïber dessen rundliche Oberfliiche hin, so dafo der Mittelpunkt stets deen Licht zuchkehrt ist. Iräufiger als einen vollständigen stern sieht man Teile eines solehen, su nanentlich

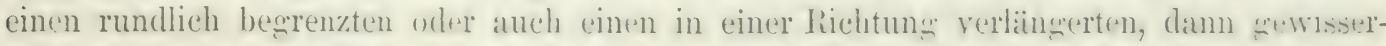
mafien einen Arm des Sternes darstellenden Lichtschem ron der fleichen Besihaffenheit wie dieser, der sich beim Drehen des Stemes ganz in derselhen Weist äber desen Oberflïche hinbewegt, genau wie bei dem unten zu betrachtenden katzenauge, wher auch mehrere solche Arme. Ist der stein so seschliffen, dab sich die stets ziemulich steile Träbung ïber einer Prismenfläche des Kristalls erhebt, so entsteht stets nur eine 1eluchtende Linie in der Richtung der Kristallachse. Die Strahlen des Stemes und die anderen ofenannten Erscheinungen werden exthildet von einem hellen, meist weiben, zuweilen auch rötlichen odter bläulichen milchigen Lichtschein. Dieser ist entwerler schmal und auf der

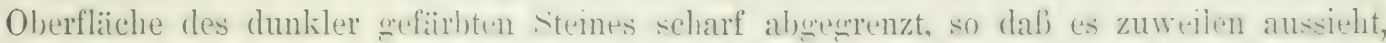

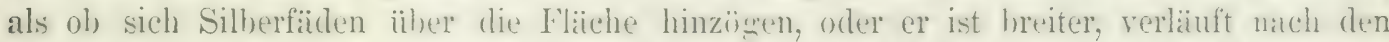
Seiten hir ohne hestiumte (irenze und rerliert sich allmählich in die dunklere Lmechun.: Das erstere Terhalten, die scharfe Aborenzung der strahlen nach beiden suiten, ist das gesehätztere. Sapphire mit deutlichem Stern werden als Sternsapphire Asterien ode-1 Sternsteine, und zwar spezieli Sapphirasterien oder Sapphirsternsteine) bezrichnet, während solche mit einem rundlichen oder in einer Lichtung verlängerten Lichtschein orientalischer Girasol oder Satplu irkatzenauge. auch opalisierender Sapplir genamnt

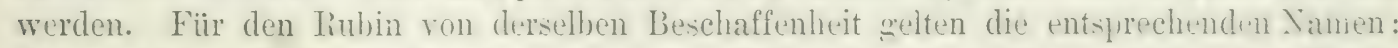
Sternrubin, Iiubinasterie oder -sterustein, Tubinkatzenange odtre opalisierender Rubin. Dieselhe Erscheinung zeigt sich ïbrigens auch zuweilen, wenn schon seltener, an den noch zu betrachtenden gelben horund, dem orientalischen Topas. Steine dieser Art zällen, wie dis liubinkatzenauge, elenfalls zu dem orientalischen (Firasol. Wenn sie einen rundlichen oder länglichen Lichtschein zeigen; sie heilen dinn Topaskatzenauger, und wem ein deutlicher Stern auftritt, Topasasterie. In Preise stehen diese Strine im allgemeinem

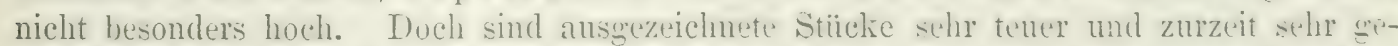
schätzt. Ein schüner Sternsapphir hat etwa den Wert eines sonstizen schönten silpplirs,

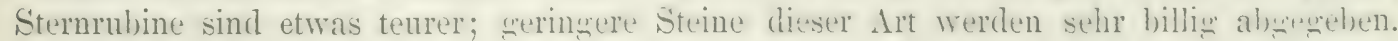
Alle Asterien usw. finden sich wohl mit den anderen Varietäten des edlen Korunds an desien sämtlichen Fundstellen. kommen aber doch vorzugsweise, die guten Extuphlare fast ausschließlich, von der Insel Ceylon.

Die Lisache dieser Lichterscheinungen wird rerschieden angegehen. Manche fiihren sie auf die Beugung des Lichts an diumnen Zwillingslamellen zuriek. die; wie es oben

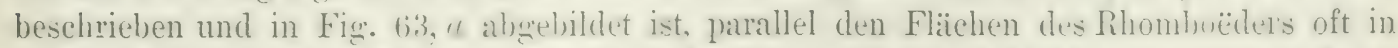
grober Zahl den Kristallen eingelagert sind. Diese dünnen Schichten erzengen auf der geraden Endfliche eine dreifache Streifung unter Winkeln vou fio Grad, die nach Babinet den Stern hervorbringt. Sach anderen ist der Grund aller dieser Lichteffekte eine grobe 
Anzahl mikroskopisch kleiner röhrenförmiger IIoblräume, die in der Basis nach drei Richtungen, parallel den Flächen des Prismas, in den Korundkristallen eingeschlossen sind. Am wahrseheinlichsten beruht die Erscheinung aber auf den schon beim Rubin (S. 337) erwähnten, beim Sapphir in derselben Weise vorkommenden und meist nach denselben drei Richtungen eingrewachsenen Kristallnädelchen, die auch den seidenartigen Glanz mancher unregchmäbis hecrenzter Stellen auf vielen solchen Steinen bewirken, dem gefürchtetsten Fehler der Edelkorunde. Wenn diese Näidelchen in Menge und regelmäßjig eingelagert sind, bewirken sie die Erscheinung des Sterns und seiner Abänderungen; sind sie dagegen unregelmäßig eingewachsen, so erzeugen sie den seidenartigen Schimmer. Daß es wohl diese Nïdelchen sind, die das Asterisieren bewirken, geht daraus hervor, daß die Erscheinung: nur an Steinen auftritt, die solche Einschlüsse in großer Zahl enthalten, und zwar in so grober, dab sie trübe sind und an der Oberfläche sogar einen metallischen Schiller zeigen, sowie auch daraus, daß andere Mineralien, Granat, Rosenquarz, Zirkon usw., die zuweilen ähnliche Kriställehen in derselben Art eingewachsen enthalten, dann auch die gleichen Erscheinungen der Sterne der Asterien usw. erkennen lassen.

In der Tat sind auch Sternsteine niemals ganz klar und durchsichtig, wenigstens nicht durch die sanze Masse hindurch, häufig sind sie auch aus abwechselnd blauen und weißen Schichten aufgebaut. Nan beobachtet sogar dieselbe Erscheinung an vielen rollständig undurchsichtigen Stiicken des gemeinen Korunds, besonders des sog. Demantspats von brauner Farbe, die dann ebenfalls manchmal geschliffen werden. Einschliisse der erwähnten Art sind beim blauen Sapplir häufiger als bei den anders gefürbten Korunden, bei welchen letzteren Asterien auch nur ausnahmsweise vorkommen, jedenfalls verhältnismäßig seltener als beim Sapphir.

Für die Sehlifform des Sapphirs gilt dasselbe, was für den Rubin angegeben wurde. Asterien werden stets en eabochon geschliffen. Auch die Fassung wird in derselben Weise vorenommen wie beim Rubin; zur Verbesserung der Farbe wird nicht selten ein blaugefärbtes Silberplättchen als Folie untergelegt.

Wert. Der Sapphir ist auch in den schönsten und vollkommensten schleifbaren Stiicken weit häufiger und rerbreiteter als die Rubine der besten Sorte. Auch gibt es im Veruleich mit Rubin viel zahlreichere große Sapphire von der vollkommensten Qualität. I)aher sind Sapplire immer weit billiger als entsprechende liubine von derselben Größe und (Fïte. Ein Karat von der schönsten und gleichmäßBgsten, tief kornblumenblauen Farbe und mit sammetartigem Glanze wird bei vollkommener I)urchsichtigkeit und Fehlerlosigkeit selten höher als mit 200-300 Mark bezahlt, ein Preis ron 500 Mark und mehr, wie leem Riubin, kommt hier nicht vor. Ein solcher Sapphur ron 2 bis 3 Karat hat ungeführ den Wert eines guten Diamanten von demselben Gewicht. Ungleichmäßiæu und hell gefärbte, orler Steine mit Fullern sinken dann bis auf einige Mark pro Karat herab. I)a grobe Steine ron vollkwmmener Qualität nicht selten sind, so dab das Gewicht ron 10 Fiarat, das beim Jiubin fast schon das Maximum darstellt, beim Sapphir ein gar nicht so ungewöhnliches Torkommen ist, wächst der Preis für gröbere Steine sehr viel langsamer als beim Rubin, und zwar ungefïlır dem forwicht entsprechend. Ein doppelt so schwerer itein kostet danach etwa das Inoplete nsw. Die Fehler, die den Wert des Sapphirs beeintriehtigen, sind im allgemeinen diesclben wie heim Rubin: Wolken, milchige, halb durchsichtige Stellen, weife glasige Streifen, seidenglänz.nde Flecken und ungleichmäßige Färbung usw.

Auch ron Sapplhir worden einige besonders grobe und schöne Steine als Merkwiirdigkeiten zuweilen erwähnt. Üher einen der schönsten und grö̈len Sapphire. die bekannt geworden sind, cinen Stein von 951 Karat, berichtet eine englische Gesandtschaft, die ihn $1 \zeta 27$ im Schatze des Könies ron Ara gesehen hat; er stammt aus Birma, soll aber nicht fanz fehlerlos sein. In der Sammlung des Jardin des plantes in Paris befindet sich ein 
roher Stein von 1:32116. Karat, der sogenannte ,IIolzlöffelverkïufer", der von einem Manne mit dieser Beschäftigung in Bengalen erefunden sein soll; er heilit auch der ..Ris)ipoli" nach der Familie, in deren Besitz er friber war. Lis ist einer der schönsten blauen Sapphire, ohne alle Flecken und Fehler. Dieselles sammlung be wahrt noch einen zweiten

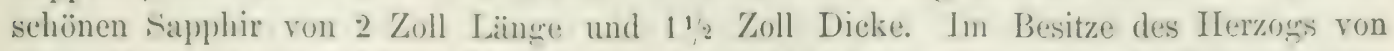
Devonshire ist ein selë̈ner Sapplir von ïber 100) Karat, drer oben als Brillant, unten trepuenförmig exeschliffon ist. Noch mehrere andere werden geleerentlich erwähnt, so ein dunkler, tintiger, fehlerloser ron 252 Karat, der 1862 in London, und ein 2.5 Karat schwerer, schön blauer, mit cinem getleen Fleck anf einer Seite, der 1 sfi in l'aris ausgestellt war. Ein grolier prachtruller Sapphir liegt in der Schatzkammer in Wien.

Torkommen. Das Vorkommen des Sapphirs ist geenau dasselhe wie das des laubins. Er findet sich in der nämlichen Weise im anstehenden Gestein, häufig mit liubin zusammen und ebenso auch in seifen. Es gibt wohl keinen einzigen Fundort, wo nur Rubin oder nur Sapphir vorkïme; beide sind stets nebeneinander vorhanden, allerdings bald der eine, bald der andere: stark iiberwiegend und daneben meist auch zueleich alle die verschiedenen anderen edlen und gemeinen Varietiten des Korunds. C̈herwiegrend ist der Rubin in den oben als Fundorte für dicsen Edelstein genannten Gergenden. Überwiegend Sapphire kommen aus Siam (aber in der. Iauptsache aus anderen Gruben als der Rubin), ron Ceylon, von Zanskíl in Kaschmir, aus de'l Gold- und Diamantsanden von Australien, besonders von Neu-sïd-IVales, sowie aus. Ilontana in Nordamerika. Einige andere Fundorte, namentlich die europäischen, sind ganz bedeutungslos.

IT eitaus an meisten Sapphire kommen gegenwärtig aus Siam. wo der grope edelsteinführende Bezirk ästlich ron Tschantahun (am Meerbusen von Siam, ungefähr 121/2" nördlicher Breite), dessen IIandelsmittelpunkt diese stadt bildet, ungeführ 10n (englische) (Quadratmeilen umfulit. Die Iiubingruben haben wir schon (\$. 346) betrachtet. Seharf getrennt ron ihnen liegen weiter nürdlich jenseits des Gebirgskammes die Sapphirwruben. Sie sind nicht so lange belsannt wie jene; die Entdeckung der dortigen blauen Edelsteine fällt etwa in das Jahr 1866 ; seit dem Anfang der siebziger Jahre werden die Gruben stärker bearbeitet und seit $15 !(1)$ hat eine englische Gesellschaft den Betrieb iibernommen. Tenn die sapphirgräberei auch jünger ist. so ist doch ihr Ertrag weitans bedeutender, ihre Wichtigkeit erheblich gröfer." Allein die (iruben ron Bo-Pie-Lin sollen mehr als die Hälfte aller jährlich auf der wanzen Erde g̈ewonnenen Sapplhire liefern; die sümtlichen anderen Fundorte treten dagegen mehr oder weniger zurück.

Der sapphirführende Landstrich ist, sowert man ihn kennt, 6 iengl.) Meilen lang und und 2 Meilen breit. Er enthält 13 Dörfer mit etwa 3500 Einwohnern, die ron der Gräberei leben, meist Birmanen, die das Geschïft auch durchaus auf birmanische Art betreiben; europäische Methoden haben hier noch keinen Eingang gefunden. Der Hauptort ist Pailin, daher spricht man häufig ron dem Sapphirbezirk ron Pailin. Er ist ungeführ halbwegs zwischen Tschantahun und Battaubong, 43) (encl.) Meilen von der ersteren, 50 Meilen von der anderen Stadt entfernt (Fig.61, pag. :3:39). Die (xruben liegen etwas üstlich von der Linie, die beide miteinander verbindet, in der l'rovinz liattambong. Die Steine, weit überwiegend Sapphire mit wenigen Ruljinen und sonstigen Edelkorunden, finden sich in einem lis 1S Zoll dicken, roten, schwach sandigen Lehm 15 bis $25 \mathrm{Ful}$ unter dem Boden. Treniger tiefliegende Torkommen, die zun 'T'eil die Erdoberfliiche erreichten, so daß man nur den Boden abzusuchen brauchte, sind längst erschüpft. Es sind durehwegr Seifen in den Flußtïlern und an den unteren Teilen dex Abhänge der Berge und Hügel, wie wir es bei der Betrachtung des Iiubins liennen geternt haben. Das Muttergestein hat man auch beim siamesischen Sapphir noch nicht entdeckt.

Seine Cualitït ist zum Teil sehr gut. Zahlreiche Steine sind ron dem schönsten Blau und 
zeigen den meschïtzten sammetartigen Schimmer besser als irgrendwelche andere. Daneben finden sich allerdings auch sehr viele dunkelblaue, in reflektiertem Licht fast schwarze sog. tintige. Merkwürdigerweise sind die größeren, über ein Karat schweren Stïcke auch in der Qualität besser als die kleineren, die daher auch vielfach nur zu Uhrensteinen u. s. w. verarbeitet werden. Der Handel gecht hauptsächlich nach Calcutta, doch gelangt auch viel nach Europa. So erzählt Edwin IV. Streeter, dal schon 1890 ein Posten von 30000 Karat nach London gekommen ist und dab einer der grölten Londoner Edelsteinhändler im Jahre 1889 für 71) (1)0 Pfund Sterling (ungefïhr 1/2 Millionen Mark) siamesische Sapphire verkauft hat. 1906 waren 4000 Arbeiter mit der Sapphirgräberei beschäftigt.

Über das Vorkommen des sapphirs in Birma ist dem oben bei der Betrachtung des Rubins Gesagten wenig himzuzufügen, da das Torkommen und die Fundstellen dieselben sind. Ist auch die Zahl gering, so sind doch die einzelnen Steine nicht selten von erheblicher Größje. Berichtet wird über grobe Sapphire im Gewicht von 1988, 951, 820, 253 usw. Karat. Solche von 6 bis 9 Karat sind gemein, aber allerdings meist nicht ohne Fehler. Der grölte bisher in Birma gefundene fehlerlose Stein soll $79 \frac{1}{2}$ Karat wiegen,alle grö̈heren zeigen Fehler meist in beträchtlicher Zahl. Leider ist die Farbe der Sapphire gewëühnlich zu dunkel, fast sehwarz, so daf sie selten die höchsten Preise erzielen. Mit denen von Sian können sie sich in der Qualität nur selten messen.

In Ceylon wird der Sapphir von vielen anderen Edelsteinen begleitet, so von Rubin und anderen Edelkorunden, von Zirkon in mannigfachen Farben, besonders Hyacinth, von Turmalin, Spinell, Chrysoberyll, Amethyst und anderen Quarzarten, namentlich Katzenauge, Crranat und zwar Almandin und Kaneelstein, Cordierit und anderen selteneren und unwichtigeren. Unter ihnen spielt der Sapphir stets die Hauptrolle, die anderen stehen sergen ihn an Menge und Wert mehr oder weniger zurïck.

Die Fundorte liegen hauptsüchlich auf der West- und Südseite der Insel. Der eigentliche Edelsteinbezirk ist die Provinz Sabaragamuwa, und hier vor allem der Distrikt Saffragam, das Beroland an Südful) des Adamspiks mit der IIauptstadt Ratnapura (oder Anarhadnapura, d. h. Stadt der Rubine). Hier ist der Mittelpunkt der Edelsteindustrie der Insel. Die edelsteinführenden Ablagerungen ziehen sich aber südlich bis Rakwana und ïber die dortigen Beroe hinaus bis ans Meer zwisehen Point de Galle und Matarì (Matura) und weiter etwa bis zum Magama- (Mahagam- oder Kirinda-)Ganga. Auch in der Westjrovinz fehlen sie nicht, besonders um den etwas nördlich von Colombo mündenden KelaniGanga, dhensowenig in der Zentralprovinz, wo besonders die Umgegend von Nuwara Elliya genamnt wird. An vielen Orten hat aber die Gewinnung wegen Erschöpfung der Lagerstïtten sänzlich anfgehört. Heutzutage findet sie in größjerem Maßstabe nur noch in dem Bezirk ron Ratnapura und in der Umgegend von Rakwana sowie in dem (ralleDistrikt statt; ain wenig wird auch noch in Ilatton, in seringer Entfernung nordïstlich vom Adamspik, frearbeitet. Crößere Ausheute gaben früber die Umgebung von Nuwara Elliya und die Horton Plains.

An allen diesen Ortın finden sich die Sapphire mit den sie begleitenden Edelsteinen nur in Seifen, und sie werden ausschlielblich nur aus solchen gewonnen. Es sind dies tonig-sandigre Ablacerungen auf dem Grunde der Täler und der weiten, vielfach mit siimpfen und lidisfehdern bedeckten Niederungen, zuweilen auch über dem Hochwasserspiegel der Wasserläufe an den Talabhängen. Anstehend in dem Muttergestein hat man in Ceylon Edelsteine mit Ausnahme des Almandins und des Hondsteines noch nicht heobachtet, da eine genauere Unter'suchung des mit dichtem Dsehungel bedeckten Landes schwierig ist und Aufschliisse vollstindig fehlen. Die meologischen Verhältnisse, sowie kleine Partien den Edelsteinen angewachsenen Muttergesteins zeigen aber, daß sie in der 
Hauptsache aus granitischen und besonders aus grneisartigen Gesteinen sowie aus den diesen letzteren eingelagerten Kalken stammen. Die Verwitterungsprodukte dieser Gesteine sind es, die jene Seifen bilden.

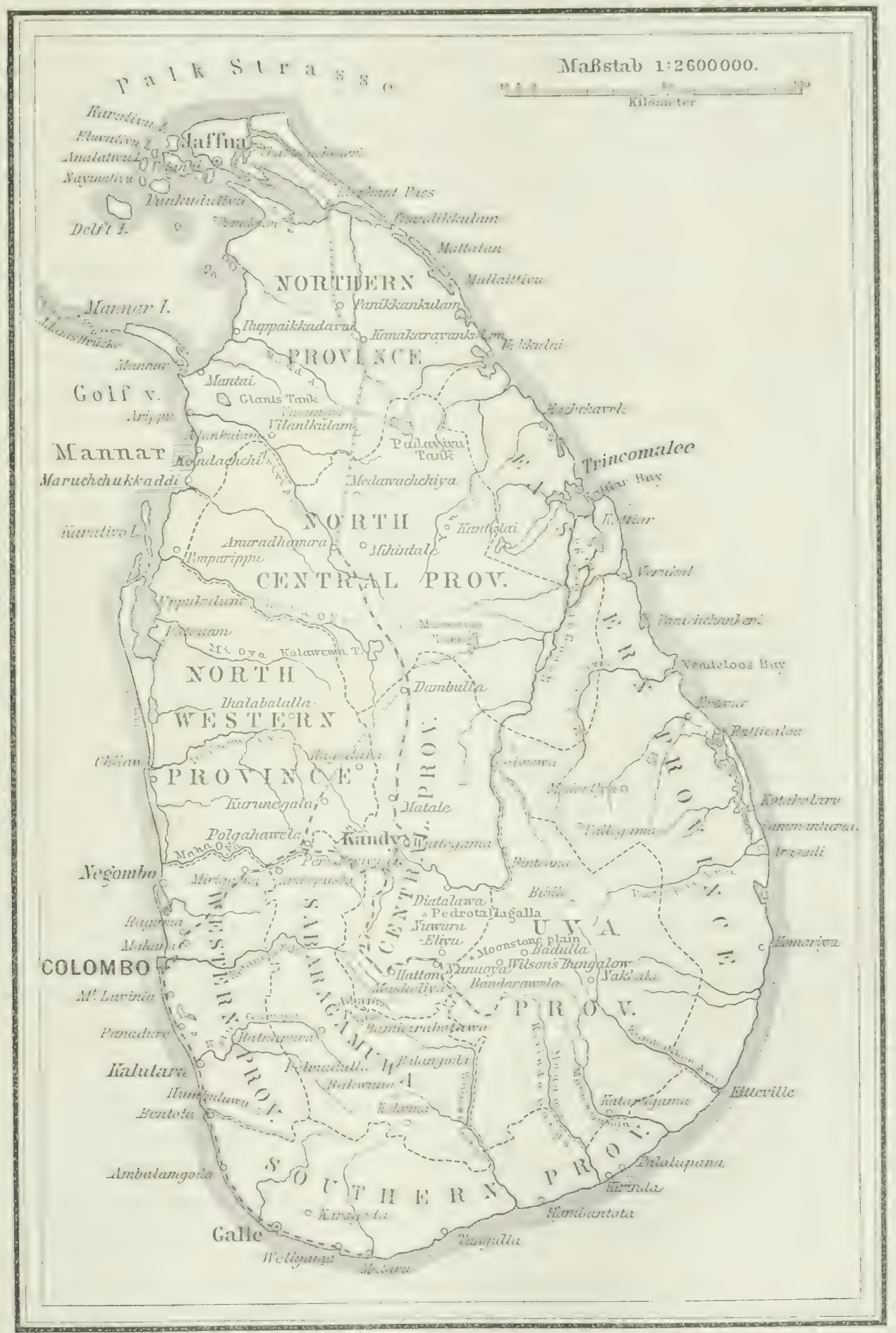

Fing. 69. Torkommen des Silphlirs und anderer Edelsteine anf der Insel Ceylon. 
Die edelsteinführende Sehicht, Illam der Eingeborenen, höchstens 1-2 FuB mächtig, liegt auf dem mehr oder weniger stark zersetzten anstehenden Gestein. Bedeckt wird sie gewöhnlich ron 5-(; Fuß eines meist schlammigen Alluviums, doch liegt sie nicht selten flacher, aber auch häufig viel tiefer, bis 50 und 60 und sogar 120 Fuß unter der Oberfläche. Manchmal sind zwei Lager von Illam vorhanden, die durch eine tonige Zwischenschicht retrennt werden. Der Illam besteht in der Hauptsache aus Quarzkörnern, von Schrot- bis Kopforüße, die wie die beigemengten Edelsteine meist stark abgerollt sind. Sie sind dann wohl vom Wasser aus größerer Entfernung herbeigeführt und haben sich dabei gregenseitig abgescheuert. In diesem Falle ist die Masse oft rein sandig. In anderen Ablagerungen haben die Steine aber ihre Kristallformen noch erhalten; sie sind kaum oder gar nicht abgerieben und noch frisch und glïnzend und können dann nur wenig ron ihren ursprünglichen Lagerstätten im Muttergestein entfernt sein.

Der Abbau ist sehr einfach und liegt fast ganz in den Händen der Eingeborenen; eine zu diesem Zwecke gegründete europäische Gesellschaft hat keinen Erfolg gehabt. Jeder Ceylonese kann gegen eine kleine Abgabe „genmmen"; vicle tun dies unerlaubt bei Nacht. Heist vereinigen sich mehrere zu kleinen Gesellschaften, die gemeinsam arbeiten. Die Cräbereien werden "gem pits" genannt und man unterscheidet Wasser-pits und Land-pits, je nachdem sie in den Flïssen und Niuderungen im Wasser, oder an den Talabhängen auf dem trockenen Lande betrieben werden.

Die Wrasser-pits, die wichtigeren von beiden, lassen sich nur in der trockenen Jahreszeit bearbeiten. Nit langstieligen, rechtwinkelign abgebogenen Schaufeln (Krïcken) holt man den Illam aus dem Boden unter dem Wasser hervor und wäscht ihn in zweckmälig konstruierten, 22 Ful weiten und 1 Fub tiefen, engmaschigen, legelfürmigen Körben aus hohrsceflecht durch Herumschwenken im Wasser, wobei die Leute bis zum Leib im Flusse stehen. Dadurch wird alle tonig-schlammige Beimengung nebst den leichteren Mineralien rasch und vollständig entf(rnt, und zusammen mit Gesteinshrocken bleiben die schweren Mineralien, darunter namentlich die Erlelsteine, rein zuriick. Größere wertlose Stiicke werden sofort entfernt und damn derselbe Prozed mit einer neuen Schaufel voll Illam wiederholt. Tachdem so etwa 15 bis 20 oder auch mehr Schaufeln verarbeitet sind, wird der Korl) ungeleert, aus dem Inhalte das zum Schleifen Geeignete ausgrelesen und das Unbrauchbare, die „refused stones" oder ..nambu" der Eing̈eborenen weggeworfen. Es sind hauptsä̈chlich Quarzgerölle, denen aber mancherlei andere Mineralien, vielfach ron grofem wissenschaftlichen Interesse, beigemengt sind. Liegt der Illam tiefer, so muß die dahin fülurende Grube durch Zimmermong vor den Einfallen gesichert werden. In diesem Falle treten dann häufig auch Taucher in Tätignkeit, die in der Tiefe die Masse mit Brechstangen lockern, so (lal) sie mit den Krïcken herausbefördert werden kann. Manchmal ist es nötig, den Fluß mittels cines Ditmmes nach der Seite abzuleiten, um den Wasserzutritt in einen ergiebigen pit zu vermindern.

In den Land-pits wird ähnlich gearbeitet. Hier müssen zur Ansammlung von Wasser für die Wäscherei oft tiefe Löcher gegraben werden.

Der fesamtwert des gewonnenen Edelsteimmaterials wird zuweilen auf nur 10000 Pfund Sterl. (etwa 201) (100) Nark) im Jahr eneschätzt, doch findet man auci, und zwar mit weit gröfierer Wrahrscheinlichkeit, sehr viel höhere Kahlen angegehen; der genaue Betrag ist aber wohl sehr schwerig festzustellen. I)ie Steine kommen teilweise in rohem Zustande zum Verkauf. Sehr viele werden aher auch von den einheimisehen Schleifern ähnlich wie die Rubine in Birma mit unrexchäbig mugeligen oder facettierten Formen versehen, die dann in Europa vorteilhafteren weichen müssen. Steine dieser Art, gefaßt und lose, meist ron mutergeordneter Qualität, untermischt mit allen möglichen wertlosen Nachahmungen, bieten damn die kleinen einheimischen Händler den Ceylon besuchenden Fremden und den 
lieisenden auf den Colombo berïhrenden Dampfern um hohe Preise zum Kaufe an. Der eirentliche, richtige und frusthafte Edclsteinhandel wirkt dagegen in der Stille und tritt nicht in dieser Weise an die Öffentlichkeit.

Die Farbe der (eylon-sapplhire ist meist ziemlich blal) und häufig nicht sleichmälig verteilt, so dali die hlaurn I'artion mit farblosen und gelblichen abwechseln, meistens ganz unregelmäßjig, nicht selten auch schichtenförmig nach ganz bestimmten Pichtungen. Selten ist rot neben blau an demselben Steine. Vollkommen tadellose Exemplare von sleichmälliger dunkler Farbe und sanz fehlerlos sind wie iiberall nicht gerarle häufieg, aher doch auch nicht allzu selten. Die meisten sind nur klein, doch werden auch gröbere Steine mehrfach gefunclen. Sternsapplin ist nicht ungewöhnlich; er stammt fast ausschlieblich aus Ceylon. Der wasserhelle ..weibe Sapphir" ist gleichfalls ziemlich häufig und erheblich billiger als der haue, ebenso auch der schön gelhe, meist ganz gleichmäbigr gefärbte „orientalische 'Topas". Er wird dort oft kur\% Topas genannt, eigentlicher, echter schleifbarer gelber Topas kommt aher in Caylon nicht vor. Eine dieser Insel eigrentïmliche Abart des edlm Korunds ist der rötlichnelle, fleischfarbige, bis hellrosa .. Künigstopas": der rötlicherelhe ist der ..patparachan" der Fingehorenen. Nicht ungewöhnlich sind violette ,orientalische Amethyste." selten dawegen die anderen ,orixtalischen" fiteine.

Von Bedeutun" sind auch die Sapphire, die seit $15 \$ 1$ oder $1>52$ in dem ZanskárI) istrikt in Kaschmir in crober Menge gefunden worden sind. Der Fundort, wo diese schönen Steine gewommen werklen, war lauge Zeit nur ungenau bekannt, da er von den Entdeckern geheim sehalten und spaiter ron der Regricrung ron Kaschmir ängstlich, besonders vor den Augen der Eurnüier, crehïtet wurde. Lange war es keinem Sachverständigen möglich, Zutritt zu erlangen, bis der indische Geologe T. D. Latouche am Sichluse der achtziger Jahres undlich die Gruben besuchen und Bericht dariber erstatten konnte. Sie sollen übrierens jetzt erschüpft, aher sehr viele gute Steine noch ron früher her rorbanden sein, die, un cinen l'reissturz zu verhüten, nur alluählich in den Itandel gebracht werden. Andererseits wirl gremeldet, dab die cruben in der letzten Ztit wieder eröffnet worden seien.

Die Stelle, wo alle die blanen steine herstammen, liegt in dem Bezirke ron Padam (Padar, einige rengl. Meilen iistlich ron dem Dorfe Machél, dieses unter 33 "25' nördl. Broite und $76 " 21$ ' astl. Längre ron Greenwich. Sie ist seln nahe der Grenze des ewigen Schnees, otwa eine halbe Tacreise won der Ilöhe des Lmasi-Passes entfernt. Tach einer anderen Mitteilung wird der (1rt am leichtesten ron dem Pentse-Pab zwischen Zanskár und Rangdum) aus erreicht.

Die ersten Funde sollen hei (ielerenheit eines Bersturzes gemacht worden sein, dureh den die sapphirhaitigen Fel:arten hlofigelegt wuren. Zahlreiche Exemplare sind aus ihwen gewonnen worden. Gleichzeitig entileckte man aber auch, dab die lockeren Terwitterungs-

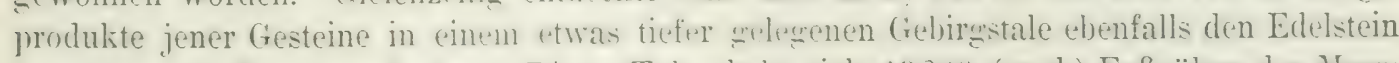
in reichlicher Ifenge enthalten. Dieses Tal erhelut sich 1320) (engl.) Fuf über das Meer; es ist 1001) Yards lang und fun Yards loreit und liegrt zwischen dem genannten Dorfe Machél und Sumjan, nordwestlich ron diesm hüchstgedegenen Dorfe an der Siidseite des Febirgszuges, der Zanskír ron dem Dschinalital scheiclet, 13 Tagereisen ron Sirinagrar,

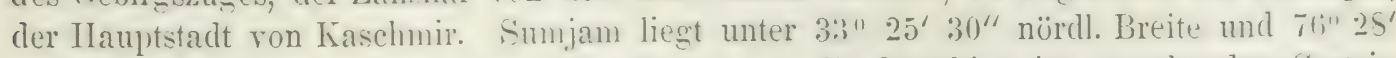
$10^{\prime \prime}$ östl. Länge von Greenwich. Die Stelle, wo die Sapplhire im anstehenden Gestein eingeschlossen sind. liest noch llun Fub über jenem Tal, also im gamzen 1.1 ant Fub über dem Neere und ist schwer zugänglich.

Die Gesteine, die diese frexend zusammensetzen, sind Glimmerschiefer und granatführende Gneise mit eincrelagertem liristallinischen Kalk; sie werden ron Ciängren von Granit (Pegmatit) durchsetzt. In diesen letzteren findet sich der sapphir in Gesellschaft 
von Bergkkistall, Spodumen, Lazulith, Beryll, Glimmer, grïnem Turmalin, usז. Die granitischen Verwitterungsmassen in jenem Tale, in denen die Sapphire ebenfalls vorkommen, werden beschrieben als eine wenig mächtige weiße Schicht, die von rotbrauner Erde bedeckt ist. Aus dieser Schicht künnen die Edelsteine ohne besondere Gerïte ,wie Kartoffeln" einfach mit den Händen aufugelesen, alver auch durch Waschen gewonnen werden. In den Seifen ist brauner Turmalin ein Begleiter der blauen Steine.

Zuerst wurden diese wegren ihrer schönen Farbe von den Umwohnern gesammelt und in Lnkenntnis des Wertes riclfach zum Futuerschlagen benutzt. Sie waren anfünglich so häufiğ, dals die Leute grolie Vorräte davon einsammelten. Man brachte sie dann den Edelsteinhändlern von Simla und Delhi, die in kurzer Zeit eine erhebliche Zahl dieser vermeintlichen blauen Quarze oder Amethyste sehr billig kaufteu. Bald wurde aber der richtige sachverhalt bekannt; zahlreiche Handelsreisende kamen nach Zanskár, um möglichst viule ron den wertvollen Steinen zu erwerben. So stieg der Preis rasch und erreichte für eine Cnze guter Stïcke den dem Sapphir auch sonst entsprechenden Satz ron 20) Pfund Sterling, der allerdings später infolge des starken Angebotes wieder etwas zurickging. Balll hatte auch der Maharalscha ron Kaschmir, in dessen Gebiet die Fundorte liegen, begonnen, sich fïr die Angrelegrenheit zu interessieren. Er besetzte die Gruben, ließ den Leuten die schon gुefundenen steine wegnehmen und verbot den Betrieb der Cräbereien olne seine, durch eine Abgrabe zu crlangende Erlaubnis, und so liegren die Verhältnisse noch gegenwärtig.

Die Sapphire von Zanskár bilden nicht selten dentliche Kristalle ron den Formen der Figuren 6:3, e his $i$. Zahlreiche kleine dunkelbraune und grüne Turmaline sind häufigg an ihrer Oberflitche angewachsen oder in ihrem Inneren eingeschlossen. Die firistalle sind zuweilen sehr groh; man kennt schleifbare Steine von j Zoll Länge und :3 Zoll Dicke, und es sollen solche bis zur Länge eines Fußes rorgekommen sein. Toch häufigrer sind unregehülljige Körner und Bruchstiicke, die wohl vielfach beim Herausarbeiten erst durch Zerschlagen der Kristalle entstehen. Die Steine ans dem lockeren Verwitterungsgrus sind meln oder weniger abgerollt, also jedenfalls auf gröbere Entfernung im Wasser fortgeschwemmt worden. Einige dieser Gerölle wogen 100, sogar 300 Karat.

Die Farbe ist vielfach bläulichweilj oder blïulichgrau, häufig aber auch viel reicher und schöncr. Oft sind die Steine an verschiedenen Stellen verschieden gefärbt, zuweilen die Mitte fröblierer Kristalle schön blau und die beiden Enden weil usw. Dic meisten sind sanz oder teilweise milchig trübe oder haben einen für die Benutzung ungünstigen seidenartigen Glanz. Nur die schön blanen und klaren Stïcke geben wertvolle Steine. Sie stellen viejfach nur T'eile grö̈ferer, aber sonst trüber Exemplare dar, die von den Steinschleifern sorgofältig herausgeschnitten und geschliffen werden. (rellbe, braune oder rote Farbe ist selten.

Clbrigens sind diesc Gruben nicht die einzigen Orte, wo sich in jenen fernen Gegenden schleifw ürdige Sapphthe finden. In der Nachbarsehaft jener Fundorte und in gröberer Lntfermung daron sind noch mehrere andere Vorkommen unter wanz entsprechenden Terhälnissen weniestens oberflichlich bekannt geworden, so am Lacha-Pali, von wo

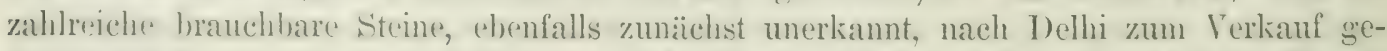
bracht wurden; im Gneis und Glimmerschiefer des oberen Raini-Tales, unterhall) des IIantiPasses in Kulu, lou (engl. Moilen sïdïstlich vom Umasi-Pab, und noch an anderen Orten.

Auch die Vereinigten Staten von Nordamerika sind reich an Sapphiren, und zwar vor allem der statat Montana, wo versehiedene Bexirke teilweise hohe Erträge liefern. Auch hier ist der Sappluir von den anderen Edelkorunden begleitet.

J)e Steine sind alle klein; ihr (iewicht ïhersteignt nicht 9 Karat, so dab sie geschliffen selten iiber 2-3 Karat, nie iiber 5-6 Karat gehen. Die Form ist meist mehr oder weniger ahgerollt, doch fohlen anch regelmälige Kristalle nicht. Es sind, abweichend ron 
anderen Sapphiren, kurze Prismen mit der gerarlen Endflaiche und diinen 'Tafeln, auch Rhomboëder mit stärker oder schwächer ausgebildeter Basis.

Die meisten sind nur zu trehnischen Zwecken, besonders zu Lhrsteinen zul qrebrauchen, zu denen sie sich weren der Form der Kristalle und ween der von den Steinschleifern festgestellten besonderen Iärte vorzitghich ejgnen. Inoch finclet man auch sflur viele schün durchsichtige und zu Schmucksteinen verwendbare.

Die Farhe ist meist ziemlich blali: tief und gesïttigt ist sie nur ausnahmsweise, st

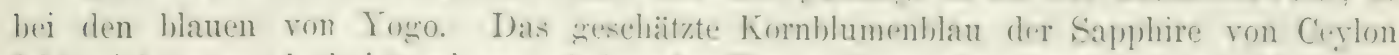
fohlt nicht eranz, doch ist, wir es scheint, das Taubenhlutrot der birmanischen Iiubine noch nie beobachtet worden. Inagegen ist rle Firbung anderordentlich manigfaltig. mohr als irend wo anders. Alle heim edlen Korund sonst hekannten Nuaneen kommen anch hier vor, danehen noch manche besondere. liot, Rosa. Lachsfarbe und dieron l̈herean- ins

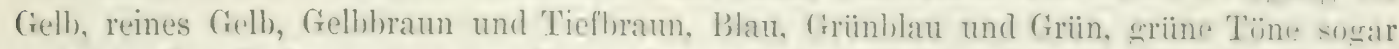
recht häufig; finden sich in gröberer oder geringerer Virbeitung. Manche strine sind

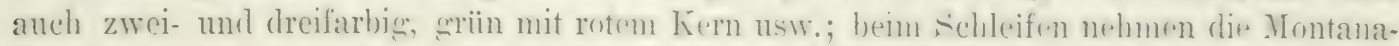
Salphlire einen hesonders schönen Glanz an, und viele erhalten dadurch rinen eigentiimlichen, für dieses Vorkonmen charaliteristischen motallischen fichimmer. Bei ereschliffenen Steinen gewinnt die Farher dureh kïnstliche Belenchtung auberordentlich, und manche blane und grüne werden im Lampenlicht rot, ähnlich wie der ..blaue Alexandrit"

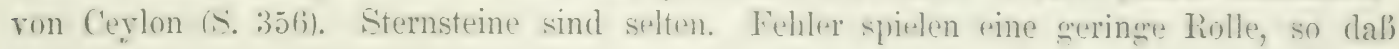
hier ein zu Schmucksteinen besonders geeignetes Material vorliegt.

Das Vorkommen ist z̈herall ziemlich übereinstimmend daselbe. Die Steine liewen an der Basis der goldfuihrenden Gílazialsande, die viulfach auscerluhte Terrassen an den Talabhängen längs der Wasserläufe ïher deren hentigem Hochwasterspiegel bildern. Das

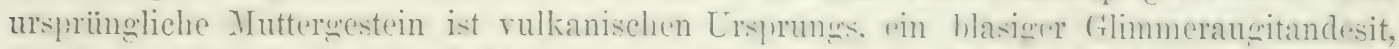
der die aus Schiefer hestehende Tnterlage der Glazialsande in frängen durehsetzt. In diesem Andesit sind die Sapphire auch eingewachsen crefunden wordm, ähnlich wie in manchen Basalten an Rhein und an anderen Orten. I)urch Verwitturung wurden sie damn herausgelöst und in jene Sande hineingeführt mud dahei nit dem anderen Material derselhen mehr oder weniger ahgerollt. Beim Goldwachen sind sie zuerst entdeckt worden. und daraus hat sich dann allmählich die heute selhständige. sehr umfantreche und wichtige Produktion entwickelt.

Schon seit dem Jahre 1 S6jo kennt man so die Sappluire aus der Gegend ästlich von

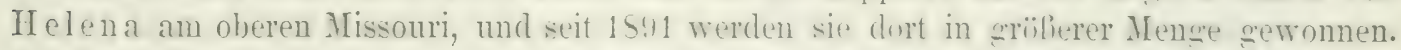
Die Schutt-Terrassen, in denen sie vorkommen, die sogenannte .har's, ziehen sich his zu

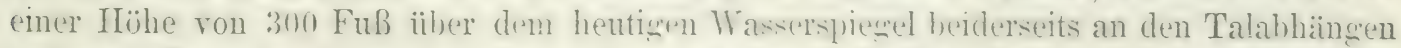
entlang. Besonders reich ist die unterste. Wenice Zull dicke Lage his 40 und 50 Fub minter der Oherfliche. Bexleitet wird der liomd von vielen anderen Mineralien: weifem Topas, zum Teil in Form kilemer Kriställchen, alhecerolten Kä̈rnern von sehön rotem Granat, der anfangs für Rubin gehalten wurke, won (yanit, ah gerollten Zinnsteinkömem istronzinn, von in Brameisenstein umpewandeltem schwefellies, fon Chalcedon, Kallisplatteröllen usw. Die rerschiedenten. Supphir und (iold fuilnrenden ..hatrs" sind mit besonderen Samen belegt worden. Spokane har bei Stuhbs Ferry, 12 fengl. Meilen ron Felena, ist

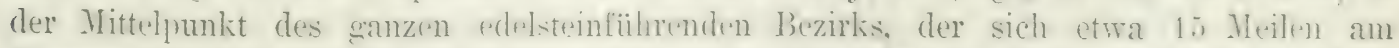

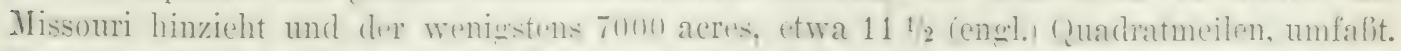

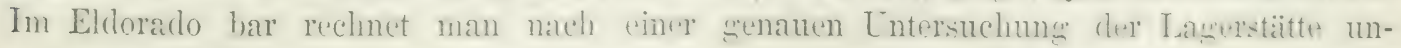
gefähr 2000 Unzen Sapphire auf einen acre, die vorhandene Menge ist also sehr er-

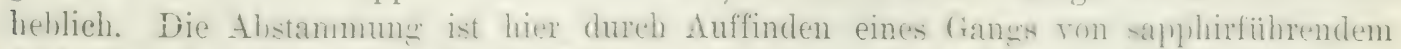

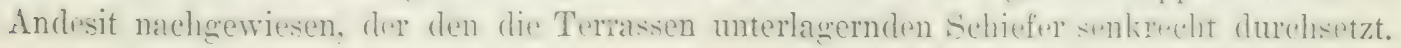


Südwestlich ron Helena liegen die zurzeit wenig wichtigen Fundorte im Ursprungsgebiete des Rock Creek in Granit County am Nordostabhang der Bitter Root Range, 35 (engl.) Meilen nordïstlich von Phillipsburg. Auch hier findet man die Steine an der Basis einer glazialen Goldseife. Sie sind nicht sehr stark abgerollt und stammen also aus der Nähe. Die Farbenmannigfaltigkeit ist bei ibnen besonders groß. Eine 1900 in Paris ausgestellte Brosche war mit mehr als 200 dieser Sapphire im Gewicht von $1 \frac{1}{4}$ bis 3 Karat besetzt, von denen jeder eine etwas andere Nuance zeigte. Halbwegs zwischen hier und Helena hat man gleichfalls eine beschrïnkte Anzahl von Sapphiren zusammen mit Granaten am D ry Cottonw ood Creek, 18 (engl.) Meilen von Deer Lodge in Deer Lodge County, gewonnen.

Östlich rom Missouri liegt der besonders wichtige Bezirk am Judith River.

Ohne Bedeutung sind hier zunächst die Fundorte in Choteau County. Die Steine werlen aus einer alluvialen Goldseife gewonnen; sie sind sehr ähnlich denen von Melena, aber im ganzen mehr blau und nicht selten ebenso schön wie in Ceylon.

Seit der Mitte der neunziger Jahre bekannt und inzwischen von großer Wichtigkeit geworden, weit mehr als alle die anderen bisher genannten Lokalitäten in Montana, ist dagegen der $\log _{0}$ - Bezirk in Fergus County, 75 (engl.) Meilen östlich von Helena zwischen Yogo und Utica. Auch hier wurden die Sapphire zuerst im Flubsand gefunden, gewonnen werden sie aber jetzt anders als sonst in jener Gegend, aus dem anstehenden Muttergestein, dem obengenannten Andesit. Dieser bildet einen 4-16 Fuf mächtigen, beinahe senkrechten, ungefähr ostwestlich streichenden Gang in einem harten grauen Kalk, und auf diesem Gang werden die Grähereien betrieben. Das Ostende liegt am Ostabhang der Little Belt Mountains, 10 (engl.) Meilen westlich von Utica. Von hier an ist der Gang auf eine Erstreckung von 5 Meilen his jenseits des Yogo Creek in westlicher Richtung aufgeschlossen. Zwei Gesellschaften gewmnen dort den Sapphir in ausgedehnten, bis 1200 Fuls langen und bis 90 Fuß tiefen Tagebauen und teilweise auch unterirdisch in Schächten und Stollen. Diese Arbeiten zusammen stellen eine der größten Edelsteingräbereien der Welt dar.

Der Andesit, das Muttergestein der Sapphire, ist in den oberen Teilen des Ganges bis 50 Fub tief zu einer weichen und lockeren, gelben, braunen oder roten Erde verwittert, wird aber nach unten zu allmählich frischer, härter und fester und damit ändert sich die Farbe in bläulich oder grau. Die zersetzte Masse wird wie gewöhnlich gewaschen und die Steine werden aus den Riickstïnden mit der Hand ausgelesen. Das feste sapphirhaltige Gestein muß durch Sprengen mit Pulver gelockert werden; die Stïicke lälst man dann, ähnlich wie den Blaugrund in den floors bei Kimberley an der Luft verwittern, wozu ein Monat bis ein Jahr erforderlich ist. Das erdige Verwitterungsprodukt wird dann ebenfalls weiter durch Waschen rerarbeitet. Die Verteilung der Edelsteine hat sich dabei als sehr wechselnd erwiesen; zwei gleich grole Gesteinsmassen haben die eine 10000 Karat, die zweite nur 74 Karat, andere haben zwischenliegende Werte ergeben.

Der Ertrag ron 1901 wird zu 38529 Karat Schleifware im Wert von 30170 Dollars (ca. $125000($ Mark) und sos 404 Karat Uhrsteine im Wert von 11570 Dollars (ca. 50000 Mark) angegelen, also Gesantwert der Produktion 41740 Dollars (ca. 175000 Mark). Der ganze Ertrag hat gegen früher etwas abgenommen, da die weiche erdige Zersetzungsmasse zum Teil erschöpft ist und die Arbeiten nunmehr vielfach auf das feste Gestein angewiesen sind. Der Ausfall wird aher durch etwas höhere Preise ausgeglichen, da die Nachfrage nicht vollständig befriedigt werden kann; daher ist auch eine Steigerung der Produktion zu erwarten. Die ganze Masse des abbaufähigen edelsteinführenden Andesits wird bis zur Tiefe von 2000 Fuß auf 10 Millionen Kubikyards geschätzt.

Die Steine von Yogo, fast durehwer regelmälige Kristalle, sind meist Rhombnëder mit der Geradendfläche, die manchmal bis zur Bildung dünner Tafeln ausgebildet ist. 
Die Farbe ist hell bis sranz dunkelblau, einzelne Stiicke mit dem schïnsten Kornblumenblau von Ceylon, andere sind violeft und rot. Der beste bisher gefundene Stein ist tiefhlau und wiegt $3 \frac{1}{2}$ Karat, das hüchste frowicht beträint a Karat. Die Preise von 1 Karat geschliffen schwanken zwischen 5 und 25 Dollars (20 und 100 Nark).

Neben diesen Fundorten sind die anderen nordamerikanischen olne jede Bedeutungr. Einige gute blane Sapphire sind u. a. mit dem gremeinen Korund, von Corundum Hill bei Culsagee, südöstlich von Franklin in Macon County, Nord-Carolina refunden worden, auch einige schöne gelhe und wrïne. In Delaware ('ounty iu staate I'ennsy'l ranien sind Sternsteine in geringer Zahl roreckommen usw. Aber an diesen wie auch an einigen anderen Lokalitiiten ist der Ertrag ein minimaler und daher hier nicht weiter zu berïcksichtigen. Veuestens werden Funde guter steine in den froldwäischen ron Washington County in Idaho erwähnt.

Nicht ganz gering ist auch die Zahl guter schleifwerter Korunde, hesonders Sapphire, die aus Australien in den Handel kommen. Sie finden sich dort in den froldseifen mit Diamant zusammen, sowie in den Zimnseifen und anderen ähnlichen sand- und Kiesablagerungen in Victoria, Süd-Australien, Queensland und in Neu-SïdrWales, hier namentlich in der Nordostecke des Landes, in Neu-Enchand-Distrikt, bei Bingera, Inverell usw.. aber auch sonst an allen für den Diamant angegubenen Fundorten (Fig. 53. S. 2 s3) und noch verbreiteter wie dieser, aher ganz in derselben Weise. Leider sind die australischen Steine meistens zu klein und zu dunkel, um grofien Wert als Edelsteine zu haben, doch findet man auch schön blane Exemplare von bester Farbe als weniger häufice Vorkommnisse. Die Farbe geht ron ganz farblos und durchsichtig durch verschiedene Tuancen von blau und sriin bis dunkel und fast undurchsichtign blau. Daneben kommen auljer einisen Rubinen besonders schïn eriine Korunde von der Farbe des orientalischen smaragds vor. Unter 100 Stiick Korund sind immer zwei oder drei von der letzteren Art. Auch schöne Sternsapphire sind gar nicht ungewïhnlich. Die Kristallform, Dihexaëder wie in Fig. 63, e usw. ist häufig noch deutlich erhaltem, meist sind es aher unregehäßige Körner oder abgerollte Geschiebe, wie die Sandkörner.

Das ganze australische Sapphirvorkommen war lane Zeit nicht von sehr grober Wichtigkeit, doch hat seit kurzem wenigstens ein Fundort in der Xïhe der Zentralbahnstation $A$ nakie in Queensland eine größBere Bedentung erlangt. Die Lokalitiat liewt östlich ron der Drumond Range unter 23-23 ${ }^{1} 2^{\prime \prime}$ sïdl. Breite und his zu 145" östlicher Länge von Greenwich. Es sind edelsteinführende Sande und kiese in alten Fluftïlern, die spüiter mit Basalt erfüllt wurden. Dieser bildet das Muttergestein der sapphire, und durch dessen fast vollständige Verwitterung sind sie in den Flubsand gelangt, aus dem sie in der üblichen Weise durch Waschen gewonnen werden. Der Ertrag ist etwa 1-6 Lnzen und sogar bis 13 Lnzen aus einer Wagenladung (load!. 19014 waren etwa 200 Mann an verschiedenen Stellen in Tätigkeit, und die Gesamtproduktion wurden auf 14000 Karate geschätzt. Die Steine, häufig ron regelmäßigrer Kiristallform, sind meist klein, ein schön grüner wog $\delta^{3 \prime}{ }_{4}$ Karat. Die Farbe ist manimfaltig, ihnlich wie in Montana, und vielfach auch blaß wie dort. Hellblau, grïn und gell, ist häufig, rot und violett selten. Das reine Kornblumenblau ist noch nicht vorgekonmen, dawegen sind Steine mit zu dunkeln Farben häufig. Mit der Farbe schwankt natïrlich der l'reis betrïchtlich, der aber im allgemeinen nicht sehr boch ist. Begleitet wird der sapphir in dem Sande von renig Gold. schwarzem Turmalin, kleinen Spinellen und Granaten, sowie ron Topas und Zirkon; ron letzterem sind einige schöne schleifbare Stücke gefunden worden.

Auch in Tasmanien kommt sapplir ror, doch sind tadellose Steine selten. Die Farben sind blau in allen Yuancen, tiefgriin, purpur und gelb. Auch Sternsteine fehlen nicht ganz, doch hat man noch keinen Rubin angetroffen. 
Ein Vorkommen von Sapphir in Europa wird vielfach genannt, das von der Iserwiese, dem Ursprungsgebiete des Iserflusses im Isergebirge im nördlichen Böhmen. Man findet dort in dem Terwitterungsgrus des ringsum anstehenden Granits usw. Sapphir in Gesellschaft ron Ceylanit, Zirkon, Granat und Iserin, die alle in jenem Gestein eingewachsen waren und durch deren Zersetzung in die lockeren Alluvien gelangten. Der Sapphir bildet zuweilen kleine hexagonale Prismen, meist aber mehr oder weniger abgerollte Kïrner von verschieden blauer Farbe und verschiedenem Grarle der Durchscheinenheit. Manche sind nur blaß und dann gewöhnlich trübe und undurchsichtig; manche andere sind tiefblau und diese meist auch schön durchsichtig. Es sollen einzelne Steine ron erster Qualität dort vorgekommen sein, doch waren solche über 4 Karat inmer sehr selten. Jetzt findet man kaum melır etwas, nachdem die beschränkte Lagerstätte im Laufe langer Tahre sehr sorgfültig durchsucht worden ist; friiher hat sie immerhin eine gewisse Anzahl schöner Sapphire geliefert.

Außer an den erwähnten Orten werden noch einzelne schleifbare Sapplire aus dem Granatsande von Melonitz im Böhmen, aus dem Goldsande von Ohlapian in Siebenbürgen, vom Ural, von Madagaskar, Borneo und anderen Gegenden angeführt. Die Menge ist aber dort ïberall so gering, dab eine eingehendere Schilderung dieser Lokalititen nicht erforderlich ist.

Kïustliche Darstellumg. Frémy berichtet, daß er gelegentlich bei der Herstellung der Rubine anch einzelne blaue Korundkristalle erhalten habe, es war ihm aber nicht möglich, hlauen Sapphir beliebig zu reproduzieren. Inzwischen ist es zwar gelungen, sehr schön durehsichtigen und prachtvoll glänzenden farblosen Korund (Leukosapphir), sowie gelben Korund, den „orientalischen Topas “ von vorzïglicher Beschaffenheit auf demselben Wege wie den Rubin künstlich darzustellen. Für den blauen Sapphir ist aber das gecignete Verfahren trotz zalulreicher Versuche immer noch nicht entcleckt. IIan kann wohl blaue Schmelztropfen von derselben Form erhalten, wie beim Rubin, wenn man der Tonerle etwas Kobalt zusetzt. Die Masse wird jedoch beim Erkalten nicht kristallinisch, sondern sie erstart amorph und hat dann ein specifisches Gewicht, ea. 3,5 statt 4,0, sowie eine geringere IIärte und schwächere Lichtl)rechung. Es liegt also kein kïnstlicher Sapphir mit allen Eigenschaften des natürlichen ror, namentlich steht auch die Farbe dieses Schmelzflusses weit linter der des letzteren zuriick und dasselbe ist mit dem Glanz der geschliffenen Steine der Fall. Diese sind, der amorphen Beschaffenheit entsjirechend, nicht dichroitisch und unterseheiden sich auch dadurch von echten Sapphiren. Die Masse ist sehr spröle und hat daher vielfach große Neigung zu zerspringen, wie die sog. Glastränen. Wie diese zeigt sie auch anomale Doppelbrechung.

Vrrlailschungen. Die blauen Steine, die dem Sapphir untergesehoben und damit verwechselt werden können, sind der Cordierit, Cyanit (Sapparé), der blaue Turmalin und dere 'Topas von derselhen Farbe. In manchen Fïillen kann der Aquamarin ähnlich aussehen. Verwechselung wäre wegen der blauen Farbe vielleicht noch mit dem IIauyn und dem blauen Diamant möglich. Alle ohne Ausnahme sind etwas, die meisten sogar erheblich leichter als der Sapplhir; sie sehwimmen in der schwersten Flïssigkeit, in der der letztere rasch sinkt. Nur der Cyanit steht auf der Grenze mit dem spezifischen Gewicht:3, Ehenso ist die IIärte bei sämtlichen mit Ausnahme des Diamants erheblich geringer, so daß sie vom Korund leicht geritzt werden, die meisten sogar schon vom Topas.

Der T'urmalin wird wohl in den meisten Fällen schon an seiner abweichenden blauen Farbe und seinem viel stïlieren I)ichroismus untersehieden. D) Cyanit ist fast immer

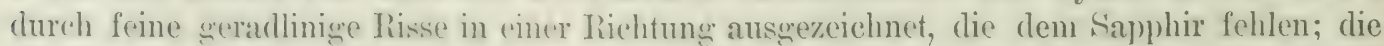
Farhe ist der des letzteren sehr ähnlich, daher der Name. Sapparé, aber die Durehsichtigkeit ist gering. Cordierit zeigrt einen schr starken Dichroismus; der des Sapphirs ist stets weit 
schwächer. 'Topas wird an sperifischen Gewicht am leichtesten erkannt. Diamant und Hauyn brechen das ficht anfach und haben gar keinen lochroismus. Beides grilt in eqleicher Weise fïr blate Cilasfliisse, dir wie immer auch nur greringe Härte besitzen.

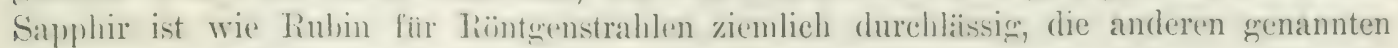
Edelsteine außer Diamant nicht.

I) Sapphir in der Farbe entsprechende (xläser kimmen leicht durch Zusatz von etwas liobaltoxyd zu dem farblosen strafi crhalten werden. Ein Teil Kobaltoxyd auf 7o-so Teile des letzteren uibt win sehr schönes Sapplhirblau. Auch Eisen färbt (xlas unter Umstanden in derselloen IV eise, wie die blanen Eisenschlacken zeigen, und wie man aus einer schön blanen mit weilien Basreliefs versehenen antiken Vase des britischen Musemus sieht, in der die chemische Analyse nur Eisen, koin Kobalt nacherewiesen hat. Ifeutzutage wird allerding's Eisen zum Blaufärben von Gläsern nicht mehr angervendet.

Weiloer Sapplir kann mit L)iamant, farbiosem Spinell, Iy yacinth und Topas, mit Bergkristall und Phemakit, sowie mit weiljen Glasfliissen verwechselt werden. Ifyacinth und Spinell sinken mit dem Sapplnhir in der schwersten Fliissigkeit unter, alle anderen schwimmen darin. Nur der Diamant ritzt den Leukosapphir, während die übrigen von ihm leicht geritzt werden. Glas, Diamant und Spinell brechen das Licht einfach. Man wird bei Berücksichtigung aller dieser Eigensehaften nicht leicht in den Fall kommen, den farblosen Sapphir mit einem der genannten Steine oder mit einem Glasflul zu verwechseln.

Auf die Lnterscheidung aller blauen und aller farblosen Steine voneinander werden wir im dritten Abschnitt noch einmal ausführlich zurïckkommen.

\section{Andere Varietäten des edlen Korunds.}

Teben dem orientalischen Iiubin und Sapphir gibt es noch einige andere Varietäten des edlen durchsichtigen fiorunds, die sich ron diesen beiden und roneinander lediglich durch die Farbe unterscheiden. Sie werden, wie wir schon oben gesehen haben, benannt mit den Namen einiger anderer gewöhnlicherer, in der Färbung mit ihnen übereinstimmender Edelsteine, indem man diesen Namen das Beiwort "orientalisch" zusetzt. Man spricht so von orientalischem Aquamarin, Smaragd, Chrysolith, Topas, Hyacinth und Amethyst. Yon den mit diesen Tamen schlechtweg bezeichneten sogrenannten ,occidentalischen" Steinen unterscheiden sich diese orientalischen meistens sehr leicht durch die Härte $(\mathrm{H} .=9)$ und das spezifische Gewicht ( $G_{0}=1,(1)$ ). sowie durch ihre starke Durchlässigkeit für Röntgenstrahlen. Eigentlicher Aquamarin, Smaragd und alle die anderen genannten occidentalischen Edelsteine sind weicher als Korund und werden ron diesem mit Leichtigkeit geritzt. Auch im spezifischen Gewicht stehen sie hinter den orientalischen steinen zurïck, welch letztere in der sehwersten Flïsinkeit alle rasch sinken, während jene in dieser und zum Teil auch im reinen Methylenjodid schwimmen. Einzig und allein der Hyacinth macht hier eine Ausnahme. Er ist schwerer als die forundvarietäten, es ist aber selten nütig, hierauf Rïcksicht zu nehmen, da er nur spärlich vorkommt. Wir werden im dritten Abschnitte noch einmal auf die Unterscheidung aller dieser Edelsteine einzugehen haben. Bei einiger $\ddot{i b m g}$ erkennt man die orientalischen Steine aber meist schon an ihrem sehr viel hïheren trlanz, weleher den der entsprechend gefüilsten occidentalischen Steine stets weit ïbertriff. Ilierauf und anf der grofen Härte beruht jene edlere Beschaffenheit diesen gesenüher, die durch die Bezeichnung ...rientaliseh" geehrt wird.

Man hat es bei fast allen diesen Varietäten mit Seltenheiten zu tun, die mehr oder wenigter vereinzelt init Ibubin und sapphir an den Fundorten diesor Edelsteine in Birma, 
Siam, auf Ceylon, in Montana und Nord-Carolina, in Australien usw. sich einstellen. Nur der orientalische Topas und Amethyst kommen etwas reichlicher vor. Sie alle werden mit jenen zusammen gewonnen und wie sie geschliffen und gefaßt, so daß hierïber keine besonderen Bemerkungen nötig sind.

Der orientalische Aquamarin ist der licht bläulichgrrüne oder grünlichblaue Korund, der in Farbe und Durchsichtigkeit dem später zu betrachtenden Aquamarin, einer Abart des Berylls, ähnlich ist. Die Farbe zieht bald mehr ins Blaue, bald mehr ins Grïne. Es gibt auch, besonders in Montana, dunkel griinlichblane Korunde, die sich in der Farbe unmittelbar an den Sapphir anschlieben und zwischen diesem und dem orientatalischen Aquamarin einen Übergang in der Farbe vermitteln. Diese dunkel grïnlichblauen Steine sind durch einen besonders starken Dichroismus ausgezeichnet.

Nähert sich die Farbe dem reinen Grün, so erhält man den orientalis chen $\mathrm{S}$ m a $\mathrm{r}$ a $g$ d, den ausgesprochen grïnen edlen Korund von mehr oder weniger intensiver Färbung. Diese hat meist einen Stich ins Gelbe und besitzt selten die Schönlıeit des echten Smaragrls, der dagegen in der Durchsichtigkeit und der Kiraft des Glanzes zuriicksteht. Der orientalische Samaragd ist die seltenste aller Korundvarietäten, ja einer der seltensten aller Edelsteine überhaupt, so daß man sogar schon an seiner Existenz grezweifelt und Verwechslung mit echtem Smaragd usw. vermutet hat. Dies ist aber unrichtig, das Vorkommen dieses Edelsteines ist doch wohlverbïrgt. Nicht nur in Birma, Siam und Ceylon, auch in Australien ist er, wenn schon iuberall spärlich, gefunden worden, und ebenso kennt man ihn in einzelnen guten Exemplaren von Montana und von Franklin in New Jersey, sowie ron Culsagee in Nord-Carolina, wo ein Exemplar von 100, 50 und 35 mim Lïnge, Breite und Dicke gefunden worden ist. Wegen der groljen Seltenheit steht er im Preise weit über den besseren Sapphiren, erreicht aber nicht den Rubin. Vom echten Smaragd unterscheidet er sich auber durch Ilärte und spezifisches Gewicht auch durch den viel kräftigeren Dichroismus, dessen Farben zwischen grïn und blau schwanken. Zuweilen zeigen diese Steine in aufallenden Lichte eine andere Farbe als im durchgehenden. So ist ein Stein von Tschantabun in Siam auf der Oberfläche dunkel bouteillengrün, beim Hindurchsehen bläulichviolett befunden worden.

Der orientalische Chrysolith oder orientalische Peridot ist hell gelblichgrün. Er geht viel mehr ins Gell als der zuletzt betrachtete Edelstein und entspricht in der Farbe dem Chrysolith oder Peridot oder anch dem hellen Chrysoberyll oder Cymophan. Er ist viel häufiger als der orientalische Smaraged. Mit demselben Namen wird übrigens auch der klare und durchsichtige, nicht schillernde grïnlıchelbe Chrysoberyll bezeichnet, der sich grleichfalls durch viel größjere Härte von dem eigentlichen Chrysolith unterscheidet, und von dem unten noch weiter die Rede sein wird.

Ist die Farbe rein grelb, dann nennt man den Stein orientalischen Topas (Topassapphir, gelher Sapphir). Lr ist ein sehr geschätzter Edelstein, wenn er ein lehhaftes Gelh zeight, der Wert ist aber je nach der Nuance versehieden. $\Lambda$ m höchsten gestellt wird das rtwas ins liot gehende Safrangelh, daneben aber auch das reine Zitronengelb. Die meisten Steine sind ziemlich hell strohgelh, häufig zieht sich die Farbe auch stark ins Bräunliche oder ins Grïnliche. Im letzteren Falle nähert er sich dem vorhergehenden Edelsteine. Wenngleich meln oder weniger ausgesprochen gelher Korund ziemlich verbreitet ist, so ist doch sehön gefärhter orientalischer Topas seltener als der orientalische Chrysolith und ïbertriff in seiner Farbe letzteren an Schönheit und daher auch im L'reise. Auch bei kräftiger gresiittigter lä̈rbung ist dieser nicht so hoch wie der sehöner Sapphire; er greht damn bis etwa 20 Mark pro Karat; die weit häufigeren hellgelben Steine sind erheblich billiger. Ein Fehler, der den Wrert zuweilen nicht unerheblich herunterdrïckt, ist ein eigentiimliches avanturinartiges Flimmern, das wahrscheinlich von Einschlïssen kleiner fremder Körper herriihrt. 
Bei manchen 'Topassapphiren tritt, wio schon oben crwähnt, derselbe sechsstrahlige stern

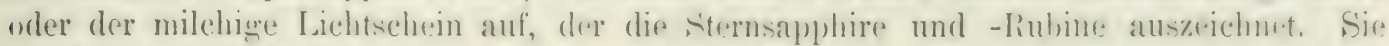
werden analog den letzteren als Topasastrerion orler 'Topaskatzenaumen bezelchnet. 'T'a vernier berichtet, dafi) ex im schatze des (irolimoguls cinen orientalischen Topas von 1573.4 Karat enseluen hat, den (re auf 271600 Franken schätyte. Einen anderen schönen Stein dieser Art von 29 Karat besal der Pariser Juwelier Ca ire. Er war durch eine arabische Inschrift ausqezeichnet, deren buchstaben aber nicht eingraviert, sondern durch die sanze Dicke des Steines hindurchenghort waren. Vermutlich war es ein orientalisches Amulett. Ist in Ceylon häufig. Prächtige Steine mit allen Eigenschaften der natiurlichen werden nach demselben Verfahren wie der Tiubin kïnstlich herestellt. D)ese kiinstlichen

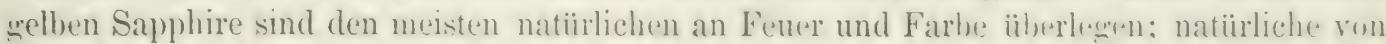
solcher Farbenfrische und Schünheit kommen kaum vor. Lnter der Einwirkung von Radiumstrahlen nehmen farblose und hellblaue) sapphire eine sehr schöne, wleichmäbig gelbe Farbe an; manche sog. kïnstliehe gelbe Sapplhire sollen durch Radium gefairbtr natïrliche weiße sein.

Der orientalisehe Hyacinth (orientalische Vermeille $=$ vermeille orientale) ist hell morenrot bis rötlichbraun; die Farbe unterseheidet sich dureh einen merklichen Stich ins Gelbe oder Braune von der des Rubins. Auch hier ist zuweilen ein dentlicher Schiller vorhanden wie beim orientalisehen Topas. Sein spezifisches Gewicht ist niedriger als das des echten Hyacinths, bei dem es 4,: his 4,: beträgt. In der Farbe :̈hnlich ist der sogenannte $\mathrm{K} \ddot{\mathrm{n}} \mathrm{igstop}$ as von Ceylon (S. 363).

Wichtiger ist endlich wieder der orientalis che A met hyst (Violettrubin oder Violettsapphir, Amethystsapphir oder P’urpursapphir, der violette Edelkorund. Die Farbe ist nicht selten schön und lebhaft violettblau und steht der des eigrentlichen Amethysts in ihren verschiedenen Abarten recht nahe. Zuweilen spielt sie stark ins Rosarote oder ins Purpurfarlige; im letzteren Falle gleicht der Stein dann sehr manchen Almandingramaten und namentlich auch manchen Spinellen. Überhaupt kann die Farbe alle cresittignten und blassen Nuancen zwischen dem Rot des Rubins und dem Blau de's Sapphirs zuiwen: die Farben dieser beiden Edelsteine sind grewissermalen bei ihm gemischt. Durch starkes Erhitzen bis $2000^{\circ}$ erfährt die Farbe einen Umschlag nach Rot zu. Gegenwärtig kommen Steine von einer ganz merkwürdigen, diister violettroten Farbe in d:un Handel, die angeb)lich durch starkes Gliihen ron in Ceylon naturlich vorkommenden, urspriinglich schwarzvioletten Steinen entstanden sein sollen. Durch Radiumbestrahlung wird die Farbe sehmutzig graublau. Terschieden rom eigentlichen Amethyst hat der orientalische einen sehr starken Dichroismus, der schon mit blofem duge beim Ilindurchsehen nach verschiedenen Richtungen deutlich bemerkbar ist. Blickt man senkrecht zur geraden Endfläche durch einen Kristall, so erscheint er lebhaft violett: in einer Richtung parallel mit der geraden Endfläche, also senkrecht zu der Hauptaxe, ist er sehr licht, fast farblos. Beim Scbleifen muf dieses Terhalten in der Weise beriicksichtigt werden, dals die Tafel des geschliffenen Steines der geraden Endfliiche des Kristalls parallel gelegt wird, sonst ist er blaf und unansehnlich. Kommt gleichfalls in Ceylon häufig vor. Auch sehr schöne Violettrubine lassen sich nach dem oben erwïhnten Verfahren künstlich herstellen.

Die stets schon bei gewöhnlichem Lichte mehr oder weniger deutlich zum Rot neigende Farbe des Violettrubins geht im Kerzenlicht vielfach noch stärker ins Rot und wird schüner als bei Tage. ('a ir e beschreibt einen solchen Stein, der bei Tag blau war, wie Sapphir, der aber hei künstlicher Beleuchtung eine schöne Purpurfarbe annahm. Im Gegensatz zum orientalischen wird der gewöhnliche Amethrst im Lampenlicht meist grau und unansehnlich. Als die beste Schlifform für den orientalischen Amethyst wird das Taf. III, Fig. 8 abgebildete Maltheserkreuz angeted)en, im übrigen werden alle die bein Rulbin und Sapplin 
erwähnten Formen der farbigen Edelsteine anch hier angewendet. Der Preis eines Steines von schöner cesiattigter Farbe erreicht nicht den eines guten Sapphirs und geht bis etwa 20 Nark pro Karat.

Die bisher betrachteten Varietäten des Korunds sind alle klar und durehsichtig. Nanchmal worden auch trübe stïcke gesehliffen, wenn sie eine schöne Farbe haben oder aus einem anderen (irunde hierzu geeignet sind. Zu erwähnen ist vielleicht der Demantspat, ein halbdurchsichtiger haarbrauner Kormud, auf dessen gerader Endfläche an manchen Kristallen sich, ebenso wie bei den Asterien, ein schöner bläulichwerßer Lichtschein zeigt. Solche Steine werden zuweilen in dieser Richtung mugelig geschliffen und schlieben sich dann im Aussehen an die Sternrubine an. Das Vaterland des Demantspats soll China sein, doch kommen ähnliche Sachen auch anderswo mit edlem und gemeinem Korund zusammen vor.

\section{Spinell.}

An den Korund und besonders an den Rubin schlieben sich diejenigen Edelsteine an, die zu der Mineralgruppe des Spinells gehören. Sie haben meist eine rote Farbe in verschiedenen Nuancen wie der Rubin, werden daher auch gelegentlich mit dem Rubin verwechselt und ihm untergeschoben und fälschlicherweise nach dem Rubin genannt (Rubinspinell, Balasrubin), obgleich beide Substanzen in allen Eigenschaften, außer in der Farbe, roneinander verschieden sind. Auch blaue Spinelle von der Farbe des Sapplirs kommen vor, diese sind jedoch von geringerer Bedeutung, ebenso die schwarzen.

Unter dem Namen Spinell wird wissenschaftlich eine größbere Reihe von Mineralien zusammengefaßt, die sämtlich dieselbe allgemeine chemische Formel, aber doch eine im speziellen sehr verschiedene Zusammensetzung haben, die jedoch in Beziehung auf die Kristallformen miteinander übereinstimmen. Von allen diesen, mit der Zusammensetzung auch in der Färte, Farbe, Durehsichtigkeit usw. sehr weit voneinander abweichenden Mineralıen, die die Spinellgruppe bilden, findet aber eigentlich nur ein einziges als Edelstein häufigere Ferwendung, das daher auch als "edler spinell" bezeichnet wird.
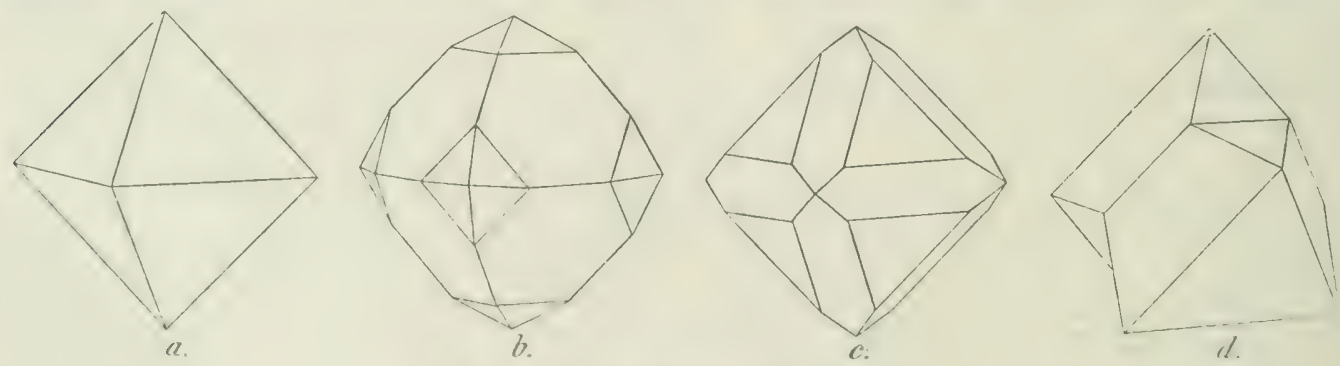

Fig. 70 . Kristallformen des Spinells.

Der edle Spinell ist aine Verbindung von Tonerde, die für sich allein den Rubin bildet, mit Magnesia nach dor Formel $\mathrm{XIg}_{2} \mathrm{O} . \mathrm{Al}_{2} \mathrm{O}_{3}$ oder $\mathrm{MI}_{2} \mathrm{Al}_{2} \mathrm{O}_{4}$. Neben diesen haupts:ïchlichen Bestandteilen finden sich aher stets kleine IIeneen anderer, auf denen die sehr mannigfaltige Färbume der an sich farblosen Substanz beruht. Besonders wichtig seheint in dieser licziehung anch hier ain kleiner (xehalt an Chromoxyd zu sein, der beim edlen Spincll die so häufige rote Farbe hervorbingen soll, ganz ebenso wie beim Rubin. Der 


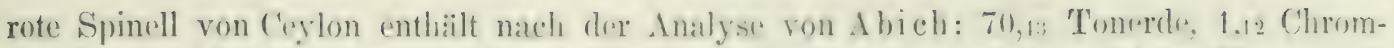

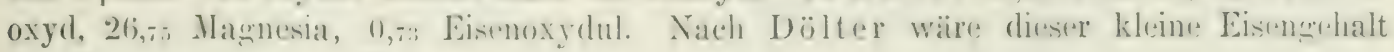
die Ursache der roten Farbe.

Das Mineral ist in den allermeisten Fällen deutlich kristallisiert, und wenn auch die dem regulären System angehörigen Kristalle vielfach aboerollt sind, so ist doch ilire Form

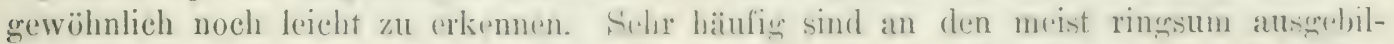

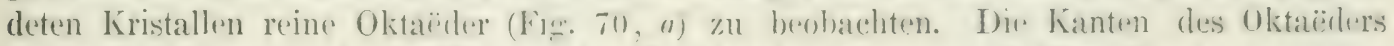
sind nicht selten durch die Flächen des Dodekaëders abgestumpft iFirg. To, c), ungewöhnlich ist die mehr bei dem unten zu erwïhnenden schwarzen Spincell vorkommunde Form,

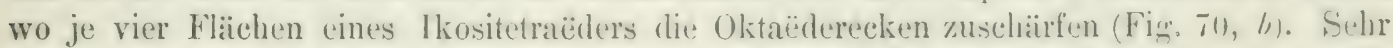
häufig sind Zwwillinge von der Form, die in Figur 70 , d abgeblildet ist, bee denen zwei Oktaëder nach einer ihrer Flächen derart synetriseh aneinander gewachsen sind, dadi die anderen Oktä̈derflächen an der (irenze beider Individuen je drei abwechselnd aus- mol einspringrende Winkel miteinander bilden. Diese Zwillinge zweier Oktaïder, die man nach ihrem häufigen Vorkommen beim Spinell. anch wenn sie bei anderen Vineralien, \%. B. beim Diamant (Fig. 39, g), vorkommen. Spinellzwillinge nennt, sind oft nach der gemeinsamen Oktaëderfläche sehr dïnn tafelförmign auscrehildet. Hanchmal ist an das zweite Oktaëder in derselben Weise noch ein drittes, an dieses noch ein viertes usw. angewachsen, so dal) zuweilen sehr komplizierte Gruppen entstehen.

Spalten lassen sich die Spinellkristalle nicht oder doch nur sehr unvollkommen. Ihr Bruch ist unregelmä̈big muschlig. Sie sind spröde und hart und stehen in letzterer IIinsicht in der Teihe der Edelsteine an vierter Stelle unnittell)ar hinter dem unten zu erwähnenden Chrysoberyll und noch um etwas Weniges über dem Topas (I. = 5!. Das spezifische Gewicht ist ziemlich hoch und ron dem des Diamants nicht sehr verschieden; e's ist G. $=3,60$ bis $3,6: 3$. Durch Reiben wird der Spinell positiv elektriseh, erlangt aber durch Erwärmung oder Abkühlung keine pyroëlektrische Erregung. Ton Säuren, auch ron Ätztinte wird das Mineral nicht angegriffen, ebensowenig schmilzt es vor dem Lütrohr.

Der Glanz ist der gewöhnliche Glasglanz, er ist aber schön und liriffig̨, besonders auf geschliffenen Flïchen. Der Spinell nimmt zwar eine sehr gute Politur an, steht aber doch auch in dieser Beziehung hinter dem Rubin zuriick. Es ist jedoch wohl nur dem geübten Auge eines erfahrenen Kenners möglich, an der stärke des (x)lanzes einen Rubin von einem Spinell sicher zu unterscheiden. Iranche dieser Steine sind sehr sehön, liar und durchsichtig, andere wieder trübe und undurchsichtig. Nur die ersteren haben als Edelsteine einen höheren Wert. Die Lichtbrechung ist, dem regulären Kristallsystem entsprechend, einfach, und ziemlich stark; der Brechungskoüflizient ist nicht sehr werschieden für verschiedene Farben des Spektrums. Ein hellroter Spinell ergab: 1,:1 fuir rotes, 1,:2 für gelbes und 1,i:; für blaues Licht. Der Spinell verhält sich also auch in Beziehung auf die Stärke der Lichtbrechung und auf die geringe Farbenzerstreuunğ dem Rubin sehr ähnlich. Man kanu aus letztgenannter Eigensehaft von vornherein erkemnen, daß der Spinell nicht das lebhafte Farbenspiel des Diamants zeigen wird, und das ist in der Tat auch nicht der Fall. Für Röntgenstrahlen sind alle Sppinelle nur wenig̣ durchlässign.

In vollkommener Reinheit ist die Substanz des Spinells ganz farblos, und man findet auch zuweilen, allerdings als Seltenheit, farblose Oktaëder des Minerals. Diese kïnnen dann Oktaëdlern rom Diamant ähnlich sein, erreichen aber doch nicht den hohen eigenartigen Glanz des letzteren. Indessen ist eine sichere Unterscheidung nur auf Grund der weit geringeren Härte 1 ̈̈̈̈glich, da beide Jineralien einfach lichthrechend sind und, wie wir gesehen haben, auch sehr nahe dasselle spezifische Gewicht haben. D uf énoy herichtet von einem vollkommen farblosen Spinell, der geschliffen von Indien kam und der cin Gewicht von $12,011 \mathrm{~g}\left(61^{1 / 2}\right.$ Karat) hatte. 
Die eigentliche Farbe des edlen Spinells ist aber die rote, doch findet sich auch Blau, Grün und Lila. Das Rot zeigt verschiedene Nuancen bis ins Violette und Blaue einerseits und bis ins Gelbe anderseits. Alle roten Spinelle sollen sich bezïglich der Farbe namentlich darlurch rom Rubin unterscheiden, daß die durch Reflexionen aus dem Inneren, besonders der geschliffenen Steine spielenden Lichter ins Gelbe gehen, die Nuance des Steines mag sonst sein, welche sie will. Auch ist dic Farbe stets nach allen Richtungen genau dieselbe. Dichroismus ist nicht vorhanden.

Zwischen dem Farblosen und dem intensirsten Rot gibt es alle möglichen Zwischenstufen in bezug auf die Tiefe der Farben. Manche Kristalle sind so dunkel gefärbt, daß sie fast ganz undurchsichtig erscheinen, und von hier aus werden die Farbentöne immer lichter, so daß ein wanz allmählicher Übergang zum Farblosen hergestellt wird. Im Gegensatz zum Rubin ist die Farbe beinahe immer vollkommen gleichmäßjig; Flecken treten sehr selten auf, so dal) unter einer Partie Spinell immer erheblich weniger Ausschuß sich findet als unter der gleichen Anzahl von Rubinen. Auch sonst hat der Spinell weniger Fehler als der Rubin. In der Hitze ist die Farbe beständig, wie bei dem letzteren. Allerdings wird auch der Spinell bei hoher Temperatur weiß, aber beim Abkihlen wieder rot, ohne jerloch wie der Rubin eine grüne Zwischenstufe zu durchlanfen. Ührigens ist hierbei Torsicht nötigr, da der Spinell leicht Risse bekommt. Dichroismus ist der regulïren Kristallisation entsprechend nicht zu beobachten; auch hierdurch unterscheidet sich der Spinell bestimmt rom Rubin, ebenso durch die Lichtbrechung; die Brechungskoeffizienten sind bei Spinell etwas kleiner ( $\mathrm{n}=1,72)$, als bei den roten Granaten ( $\mathrm{n}=1,76-1,80$, vgl. S. 66). Von der blauen und der seltenen grünen Farbe wird unten die Rede sein.

Im allgemeinen sind die Spinelle um so geschätzter, je tiefer sie gefürbt sind, sofern darunter die Durchsichtigkeit nicht leidet. Die intensiv roten Kristalle bilden den Rubinspinell, da sich ilure Farbe der des Rubins zuweilen bis zur Ununterscheidbarkeit nähert (vol. Taf. I. Fig. 5, 6 u. 10). Sie werden nicht selten als Rubine verkauft, kïmnen aber an der einfachen Lichtbrechung und an dem Mangel einer jeden Spur von Dichroismus erkannt werden. Die geschätztesten Farben des Rubinspinells sind die karmoisinroten, blutroten und ponceauroten. Die schönsten Steine von cochenille- oder blutroter Farbe werden von den Juwelieren als ,gouttes de sang" bezeichnet.

Lnter dem Tamen Balasrubin (rubis balais) werden die rosenroten und in anderen lichtraen Nuancen gefärbten roten Spinelle zusammengefalit. Sie zeigen meist einen Stich ins Blate oder Violette und daneben nicht selten eine eigentiumliche milehige Trübung, die de'n Wert nicht merheblich vermindert. Ein solcher Balasrubin ist auf 'Taf. I, Fig. 9, al)gebildet. Freht die Farbe sehr entschieden ins Blaue oder Violette, so ist sie ähnlieh Rer mancher Ahnandine, nur viefach blasser. Derartige Steine heißen Almandinspinell. IV ('nn die Farhe nicht zu hell ist, nähern sich diese violetten Spinelle auch vielfach dem Amethyst und dem orientalischen Amethyst, unter weleh letzterem Namen sic dann nicht selten in den Irandel rehracht werden. Auch hier ist die Lnterseheidune leicht möglich durch dir rinfache Lichflorechung und den Mangel an Dichroismus beim Spinell. Schwierigrer fostzustellen ist der. Lntersehied der Spinclle von dem Almandin und anderen roten Granaten, die das Licht (henfalls einfach und fast gleich stark brechen und keinen Dichroismus zeigen. Beim (Granat ist die Fäbune aber meist viel tiefer, und das spezifische Crewicht des Almandins ist gröber als 4, dagegen ist die Iärte geringer ( $71 / 2)$. Dem Rosatopas nähert sich der balasrubin in der Farbe zuweilen sehr und wird auch häufig dafür ausgegehen, der Topas ist ahere doppelthechend und stark dichroitiseh. Hanche Juweliere meinen sogar, dalf Balaspubin nur ein anderer Name für Losatopas sei, und dab es gar keinen wirklichen Balastubin celoe. C̈hrigens sind Rubinspinell und Balastubin mit Almandinspinell nicht durch scharf: (trenzen voneinander getrennt, sondern sie zeigen sanz allmähliche l̈̈hergänge. 
Geht die Farbe des Spinells stark ins Gelbe, damn laat man die Alart des li ubicells, der hyacinthroth, orangerelh) und selbst strolugell, ist. Er wird nur wenig freschätzt. Der brasilianische. Fubicell, der die Topase und die anderen Edelsteine in Minas novas begleitet, hat wexen seiner gedloroten, an die des Essigs erinnernden Farbe den Nimuen Essigspinell rralten; in seiner II imat wird er seiner Farbe wewen auch als "IIyacinth" bezeichnet. (Eeht die Farbe entschieden in das Orangerote, dann wird der Stein anch woll! Vermeille genannt, doch wird dieser Name gewöhnlich für gewisse (rranaten, auch für den orientalischen Hyacinth, angewendet.

Die Formen, die der spinell beim sichleifen erhält, sind im wesentlichen die des Tiubins. Schön gefärbte durehsichtige Steine werclen als Brillanten, segenwärtig auch en cabochon

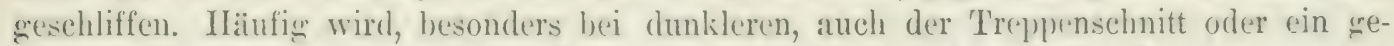
mischter sichnitt angewendet, an dem der Oherteil mit gemischten Brillantfacetten rersehen ist. Zur Verbesserung der Farhe und des (xlanzes pfleagt man Folien von glänzendem Goldoder Kupferblech unterzulegen.

Kleine Spinelle von guter Beschaffenheit sind häufigr. Dis srolien, die den Lmfang einer Faust erreichen können, sind meist trühe. Schöne iteine bis zu einem Karat grehören zu den gewöhnlichen Vorkommnisien, auch solche his zu 4 Karat sind nicht grerade selten. Gröbere jedoeh finden sich nur sparsam, und ïber $\delta$ his 10 Karat gehen sie nicht leicht hinaus. Jedenfalls sind aber zute Spinelle ron tadelloser Beschaffenheit häuficer als ebensolche Rubine rom gleichen Gewicht, umsomehr als die Spinelle, wie wir gresehen haben, in rerhältnismäßig viel pröherer Zahl frei ron Fehlern sind als die Rubine. Ticht selten sind IIohlräume von oktä̈drischer Form, wie sie weder bei künstlichen noch bei natürlichen Rubinen vorkommen.

Der Preis de's Spinells ist jederzeit geringer als der des Rubins, er wechselt aber bedentend mit der Farhe und Kilarheit der Steine. Am höchsten werden schöne Iiubinspinelle und schön rosenrote Spinelle bezahlt, und zwar his zu etwa + Larat bei vollkommener Durchsichtigkeit 1 Karat ungefähr mit 100 bis 150 Mark, meist aber weit greringer (10-2j Mark). Balasrubine der besten Sorte sind etwa halb so viel wert als Rubinspinelle, und wenn die Farbe unansehnlich ist und der milehige Lichtsehein störend einwirkt, sinkt der Wert noch erheblich tiefer. Dasselbe ist bei den anderen Varietäten der Fall, die als Edelsteine aber keine grobe Bedeutung haben. Tom farblosen Spinell kostet 1 Karat bis 12 Mark.

Wenn beim edlen Spinell auch kleine Steine weitaus überwiegen und grobe sehr ungrewöhnlich sind, so fehlen sie doch nicht sanz. Das Verzeichnis der franzüsischen Kronjuwelen ron 1791 gilst einen Rubinspinell ron $5(012,16$ Karat, der damals auf 50 (10)0 Franken seschätzt wurde, und einen Balasrubin von 2014, Karat im Werte ron 10 000) Franken, neben zwei kleineren ron $12^{6,16}$ und 12 Karat, deren Preis trotz des gleichen Gewichtes sehr verschieden und zwar auf : zweiten festgesctzt wurle. Ein berïlumter grolier Spinell ist auch der sogrenannte „Rubin des schwarzen l'rinzen" im englischen Kronschatze im Tower in London. der vielfach für einen wirklichen Rubin rehalten und ausgegeben wird. Die größten bekannten Spinelle sind aber wohl die zwei, die auf der Ausstellung von 1862 in London zu sehen waren. Beide waren mugelig geschliffen, von vollkommener Farbe und ohne Fehler. Der erste wog 197 Karat und gab nach dem Lmschleifen einen sehr schünen Stein ron S1 Tarat; beim anderen war das Gewicht ursprünglich 1021,1 , nach dem neuen schliff $721 ; 2$ Karat. Ball berichtet ïber zwei grobe Rubinspinelle unbekannten indischen Lrsprungs mit eingravierten persischen Inschriften; der eine wiegt 1331.2 Karat und hat die Form einer durchbohrten lïnglichen Perle, 1,62 Zoll lang und 1,9 Zoll dick. Der andere ist unregelmäßig rundlich, nur oberflächlich poliert und 197 Karat schwer. 
In Beziehung auf das Vorkommen steht der Spinell, wie wir schon oben gesehen haben, in engster Beziehung zum Korund. Er findet sich in derselben Weise und in der Hauptsache auch an denselben Orten wie der Rubin und der Sapphir und die anderen oben besprochenen Varietäten. IVie der Korund, so ist auch der Spinell ein Mineral des Urgebirges. des Gneises und anderer kristallinischer Schiefer. Er findet sich namentlich auch in dem den Gneisen eingelagerten Kalk, sowie als Kontaktbildung in Kalken, die in der Nähe ron Eruptivresteinen eine Veränderung erlitten haben. Im folgenden sind die wichtiesten Fundorte kurz angefiihrt, für die Einzelheiten sei auf die Beschreibung derselben Lokalitäten beim Rubin und Sapphir verwiesen.

In $\mathrm{Ober-Birma}$ ist der edle Spinell in seinen versehiedenen Varietäten ein sehr verbreiteter Genosse des Rubins, sowohl eingewachsen im Kalk, als auch in den Seifen. Von den Edelsteinen, die aus den benachbarten Schan-Staaten von den Eingeborenen zum Verkauf gebracht werden, sind dreiviertel Spinelle. Neben Birma ist Ceylon in seinen Edelsteinseifen hauptsächlich wichtig als Heimat zahlreicher Spinelle, schöne Kristalle sind aber nicht gewöhnlich. Das Muttergestein ist hier gleichfalls ein körniger Kalk. Ceylon ist auch die Heimat eines schön durchsichtigen blauen Spinells, von dem unten noch weiter die Rede sein wird, im ïbrigen ist die Färbung sehr mannigfaltig: rot, blau, griin, lila, oft von eigentümlichem dïsteren Ton und die Größe sehr wechselnd vom kleinsten Körnchen bis zu der einer Faust. Viele Spinelle finden sich in den Rubingruben von B a d a ks chan. Schon der berühmte venetianische Orientreisende des 13. Jahrhunderts, Marco Polo, sammelte in der Provinz Balascia am oberen Oxus, die mit dem heutigen Badakschan identisch ist, Spinelle, wohl gleichzeitig mit Rubinen, und von Balascia soll der Name Balasrubin abgeleitet sein. Die in Taschkent verkauften Rubine, die aus dem Tianschan stammen sollen, befinden sich gleichfalls in der Gesellschaft von Spinell, und ebenso ist der Rubin von Dschagdalak in Afghanistan von Spinell begleitet. Dasselbe ist bei den Rubinen und Sapphiren von Siam der Fall und nicht minder bei denen von A ustralien, wo sie mit diesen besonders in den Edelsteinseifen von Neu-Süd-Wales und hier wieder vorzugsweise in denen des Bezirkes von Neu-England, dann aber auch im Cudgegong, Macquarie und in anderen Fliissen meist als abgerollte Körner vorkommen. Sie fehlen aber in Victoria (Owen's River) und anderen australisehen Kolonien gleichfalls nicht, und einzelne Steine sind auch schon in Tasmanien gefunden worden. Daß in Brasilien, und zwar in den Edelsteinseifen von Minas novas, der gelbe sogenannte Essigspinell vorkommt, ist schon erwälınt. Spinelle von verschiedener Farbe, meist blaugrau, aber auch schöne Rubinspinelloktaëder, finden sich reichlich im Sande des Rio Pimua bei der Stadt Itapimirim im Staate Espirito Santo, sowie anstehend im Marmor am Kontakt mit Granit bei Con(quista in S. Paulo und bei Carangola im südlichen Mlinas Geraës. Auch die Vereinigten Staaten von Nordamerika liefern gelegentlich einige schleifbare Steine; so sind z. B. wenige ziemlich dunkel gefärbte Steine bei Hamburgh in New-Jersey vorgekommen, dagegen sind die Sapplire von Montana nicht von Spinell begleitet. Alle anderen Fundorte sind noch weniger wichtig als die genannten und von gar keiner kommerziellen Bedeutung, sie sollen dlaher hier übergangen werden. Zu erwählhnen sind vielleicht noch die zum Teil durchsichtimen grïnen Spinelle von Mitchell County in Nord-Carolina und ebensolche aus einer Bleigrube in Neu-Mexiko, von denen einzelne Exemplare zum Schmuck verwendet werden; aber auch sie haben keine praktische Bedeutung.

Rote sowie blaue Spinelle von großer Schönheit von der Beschaffenheit der natiirlichen lassen sich nach derselben Methode wie der Rubin kïnstlich herstellen.

Blauer Spincll. Die blaue Farhe spielt beim Spinell eine sehr untergeordnete Rolle. Der blaue Spinell, der, entsprechend der Bezeichnung Rubinspinell, Sapphirspinell grenannt werden lï̈nnte, der nicht selten auch den falschen Namen Sapphirin führt, enthïlt neben 
der mit der Tonerde verhundenen Magnesia etwas Fisenoxydul, welches die Farbe veranlabit.

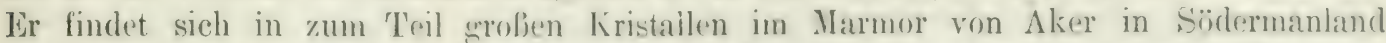
(Schweden); diese sind aber zumeist trïhe und werden wohl kamm geschliffen. Dagewen begleiten einzelne durehsichtige blaue Exemplare den roten Spinell an den oben grenamnten Fundorten, so in Birma, namentlich aber in Ceylon. Von hier und zwar von Ratnapura und aus dem Distrikt Kandy kommen neben erianen namentlich auch sehr schöne dunkelblaus Oktaëder, die geschiffen Eilelsteme von krïfterem Granze und ziemlich hohem Wrarte liefern, und die an schö̈nheit linter vielen sapphiren nicht zuriekhlriben, nur ist bei den letzteren der Glanz noch stärker. Beide unterscheiden sich voneinander wie die roten Spinelle vom Rubin.

Sehwarzer spinell (Ceylanit oder Pleonast). Bei diesem ist ein gröberer Teil der Magnesia durch Eisenoxydul und rin 'Teil der Tonerle durch Eisenoxyd ersetzt, ess

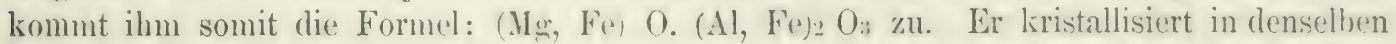
Formen wie der edle spinell, auberdem lommt aber bei ihm anch nicht selten die in Fig. 70,1, abgebildete Kombination vor. Der ('ylanit ist wrinlichschwarz, in wanz dïnnen Sehichten dunkelgriin und wirl, da er wie alle Spinelle eine gute Politur annimmt, ab und zu geschliffen und zu Trauerschmuck verarbeitet. Er findet sich in losen Körnern von zum Teil recht bedeutender Gröbe, bis über zollhang, in den Edelsteinseifen von Ceylon, besonders bei Kandy; ferner in kleinen glïnzenden Kristallen in manchen Auswürflingen des alten Vesuvs, der somma, und an vielen Stellen als Kontaktmineral im Kalk, da wo dieser mit Granit und anderen ähnlichen Gesteinen zusammenstüft. Besonders grobe Kristalle dieser Art, Oktä̈der nit 3 bis 1 Zoll langen Axen, findet man bei Amity im Staate Newyork, sodann kleine, aber in grofer Zahl, in Fassatale in Tirol und an vielen anderen Orten. Die meisten sind aber zum Schleifen wenig geeignet und der Preis ist niedrig, bis etwa 4 Mark das Karat.

\section{Chrysoberyll.}

So mannigfaltig die Färbung des Korunds ist, der daher dem Juwelier eine ganze Reihe verschiedener Edelsteine liefert, so einförmig ist sie beim Chrysoberyll, der dem Auge fast nur einige grüne Nuancen und nahestehende gelbe und braune Fürbungen darbietet. Wie sich der Spinell wegen der vielfach ïbereinstimmenden Farbe an den Kormd, speziell den Rubin anschloß, so schließt sich auch der Chrysoberyll an dasselbe Mineral an, aber nicht der Farbe, sondern der nahe gleichen Härte wegen.

Der Chrysoberyll wird in der IÏ̈rte, aufer selbstverständlich rom Diamant, nur noch vom Korund ïbertroffen: nur von diesen beiden wird er geritzt, alle anderen Mineralien sind weicher. Nach der Mohs schen IIärteleska kommt ihm der Grad 81.2 zu; er steht mitten zwischen Korund und Topas und ist in der ganzen Reihe der Mineralien der IIärte nach das dritte.

Wie der harte Korund nur aus Tonerde besteht und der kaum einen Grad weichere edle Spinell außer einer ïberwiegenden Nenge von Tonerde nur noch Magnesia enthält, so nimmt auch an der Zusammensetzung des gleichfalls durch große Härte ausqezeichneten Chrysoberylls die Tonerde einen besonders bohen Anteil. Unser Edelstein besteht aus 80,2 Proz. Tonerde und danehen aus 19, a Proz. Beryllerde, entsprechend der chemischen Formel: Be $\mathrm{O}_{\mathrm{Al}} \mathrm{Al}_{2} \mathrm{O}_{3}$ oder Be $\mathrm{Al}_{2} \mathrm{O}_{4}$. In dieser idealen Reinheit findet sich der Chrysoheryll freilich nie, 
die Analysen weisen stets kleine Mengen von Eisen nach, und in den Kristallen vom Ural, dem Alexandrit, findet man auch etwas Chromoxyd. Der eigentliche Chrysoberyll von Brasilien und der Alexandrit aus dem Ural haben bei der Analyse ergeben:

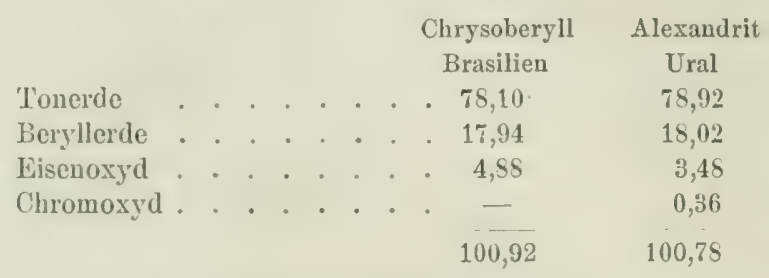

Die Kristallformen des Chrysoberylls gehören dem rhombischen System an, doch sind einfache Kristalle selten, die meisten sind mehr oder weniger komplizierte Zwillinge. Die ersteren bilden niedere rhombische Prismen, die beiderseits durch eine in einer Richtung sehr deutlich gestreifte gerade Endfläche geschlossen sind. Nach diesen gestreiften Flächen sind die Tristalle tafelförmig, wie Fig. 71, a zeigt, in der außerdem noch einige andere Flïchen eingezeichnet sind. Nach einer Prismenfläche sind häufig zwei Individuen mit-
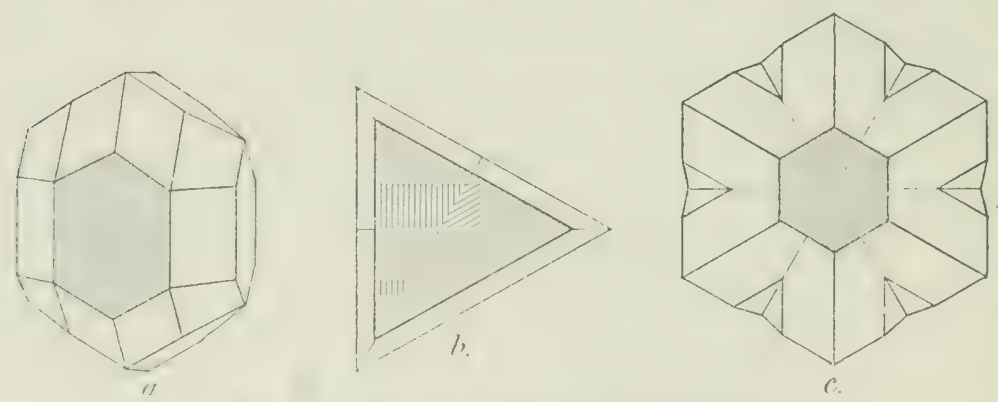

Fig. 71. Kristallformen des Chrysoberylls. einander zwillingsartig verwachsen. Die breite Endfläche fällt dann für beide Individuen in eine Ebene; in jedem der beiden ist die Streifung anders gerichtet, und die Streifen stoßen in der Zwillingsgrenze unter einem Winkel von 60 Grad zusammen (Fig. 71,6 und Taf. XII,

Fig. 1(1). Drei soleher Zwillinge wachsen manchmal aneinander und dureheinander hindurch, so dafo komplizierte Gruppen wie in Fig. 71, $c$ und Taf. XII, Fig. 8 entstehen, an denen aber die verschieden gerichtete Streifung der Tafelfläche die Grenze der einzelnen Individuen stets leicht erkennen läßt.

Deutliche Sualtharkeit ist nicht vorhanden; der Bruch ist muschelig. Die Substanz ist spriide und, wie schon erwälhnt, sehr hart (II. $=81 / 2$ ). Das spezifische Gewicht ist $3, ; 5$ lis $3, \pi$. Von Süuren wird das Mineral nicht angegriffen, in der Lötrohrflamme ist es unsehmelzhar. I)urch lieiben wird positive Elektrizität erregt, die mehrere Stunclen lang anhält.

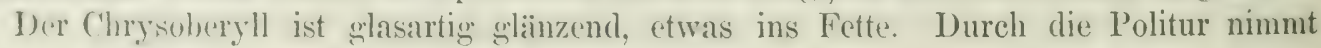
er eimen sedir schönen und starken Glanz an, der der bedeutenden Ilärte wegen unverändert bestehen bleibt. Die Durchseheinenheit ist schr verschieden; manche Stïcke sind schön durchsichtig und klar, andere trübe und undurchsichtig. Die Durchsichtigkeit ist aber meist nur an exechliffenen Steinen deutlich zu erkennen, da die natürlichen Stücke sehr viclfach äulferlich abgerollte Geschiehe sind, die unter allen Umständen trübe und unklar atısschen. Fïr liöntgenstrahlen ist der Chrysoberyll noch ziemlich gut durehlässig.

An durchsichtienen Stiick'n kann man im Polarisationsinstrument leicht die Doppelbrechung erkennen: sie ist aher nicht sehr stark, der größte Brechungskoëffizient ist vom kleinsten nur wenig rersehieden. I)ie Lichtbrechung sellost ist ebenfalls nicht besonders kräftig und ziemlich ähmlich der des Rubins. Die Brechungskoëffizienten wurden sehr nahe wie bei diesem Nineral gefunden, und zwar der größte $=1, ;$; 


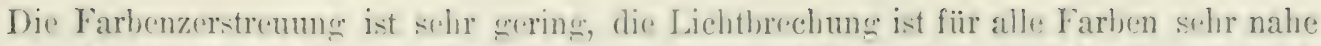

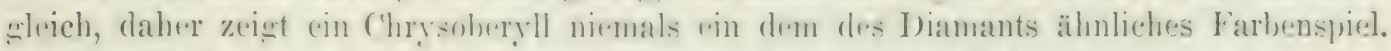

Die Farbe, die durch Radiumstrahlen nicht verïndert wird, läßt nur geringe Verschiedenheiten erkemen. Sire ist hei manchen Vorkommis-an, namentich bei dem wich-

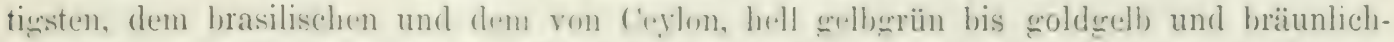
grelb his bram. Bei den uralischen kristallen ist sie intensiver grïn, gras- his smaragderiun.

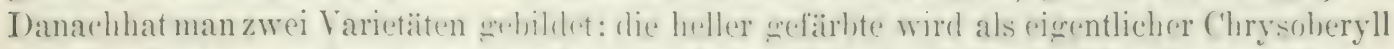

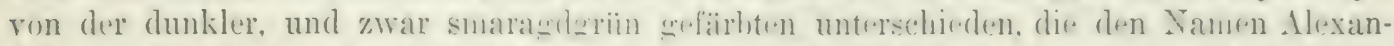

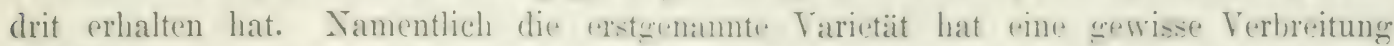
und Wichtigkeit. die zweite ist wegen ihres weit sparsameren Vorkommens ron geringerer Bedentung.

\section{Chrysoberyll.}

Der eigentliche Chrysoheryll ist durch sfine hellere Farive ausqegeichnet. Dirse ist griin, meist mit einem starken Stich ins Gelbe (Taf. XII, Fig. 10 und 11), mehr oder wenigur lebhaft lauchgriin. sparedgrin, grasgün, anch grïn ins fraue oder Weile. Sie geht zuweilen bis zum schönen (Foldgell, IIellgell), frünlichgell) und (redhlichgrün, sowie ins Olivengrün, Bräunlichgell) und manchmal socar his ins Brame und Schwarze. Nach verschiedenen Riehtunèn ist die Farhe nichî wesentlich rersehieden, der Dichroismus ist gering und ist auch mit der Dichrolupe ron II aidinger nicht sehr bestimmt wahrzunehmen. In der Hitze wird die Farbe nicht verändert. Die besonders hä̈ufige crelh)lich grïne Nuance ist sehr ähnlich der eines anderen Eiblstrines. des Chrysoliths, daher werden auch Steine dieser Art von den Juwelieren vielfach als Chrysolith bezeichnet. Die auberdem beim Chrysoberyll am håufigsten vorkommende Farbe ist die bräunlichgelbe.

Die Durchsichtigkeit ist sehr verschieden. Nanche Chryoherylle sind schön klar und durchsichtin, und es fehlt ihnen dam der sofort zu prwähnende Lichtschein, der sonst bei diesem Edelsteine so verbreitet ist. Gelblicheriune Steine dieser Art werden im Handel zu-

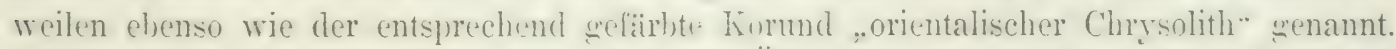
Andere sind, mit jenen durch alle minglichen C̈herwinge verbunden, trible und unklar.

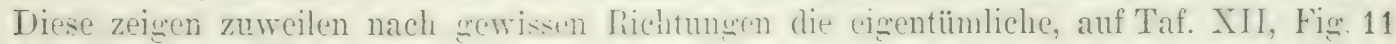
darestellte Lichterseheinung. die man als Chatorieren bezeichnet, und die selur ähnlich an

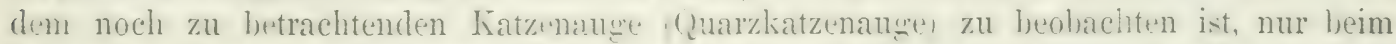
Chrysoleryll meist viel sehöner. Dieser chatovierende Chrysoheryll ist der Cymophan der Mineralogen, der als Edelstein erate dieser Lichterscheinung wegen sechätzt wird und der im Edesteinhandel unter dem Namen Chrysoberyllkatzenauge oder orientalisches oder ceylonesisches oder indisches Katzenauge oder auch wohl kurz als Katzenauge oder opaleszierender oder schillernder Chrysolith bekannt ist.

biese Erscheinung, durch die sich der Cymophan auszochnet und ron dem gewöhnlichen Chrysoheryll unterscheidrt. ist win milehierer, weifer, häulich-oder grünlichweifer, selten solderelher, wogender Lichtschinmer, dur sich beim Drehen des steines ïber desen Oberfläche hinbeweent, hesonders -chüin. Wenn diese mugelig geschliffen ist. Man sieht

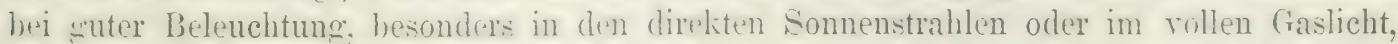
einen hellen Lichtstreifen. anf schïn Strinen eine fast silberartig whinzende Lichtlinie üher die runde Oberfläiche von einem his zun anderen Ende sich hinziehen. Diese ist manchmal, aber gewöhnlich nur hei liteinen, seltener bei grölieren Exempliaren, schmal und nach den Seiten hin scharf bererenzt. si daf sie gewissermalien einen Liehtfaden bildet; dann ist der Stein unter sonst chleichen Yerhältnissen am geschätztesten. Oder der Lichtstreifen ist breiter und rerflieft allnählilich nach der Seite hin olne scharfe Grenze, indem er nach rechts und links ganz stetig an IIelligkeit abnimnt und in die Lngehung ver- 
läuft. Dies ist wenimer beliebt, (ebenso wenn nur ein breiter, unregelmäßimer, ringsum allmählich inmer trüb)er werdender Lichtfleck an derjeniçen Stelle des Steines erscheint, die dem Lichte zucelehrt ist. Steine der ersteren Art werden wohl Katzenauge im engeren Sinne, solche der letzteren Cymophan im engeren Sinne genannt.

Die Form dieser Lichterscheinun@ hängt zum 'Teil von der Beschaffenheit des Steines ab, zum Treil wird sie aber auch bedingt dureh die Gestalt seiner Oberfläche. Man kann also durch siinstigen Schliff die Schönheit wesentlich steigern, durch unzweckmäßige Form sie betrïichtleh remindern. Am lesten ist 's im allgemeinen, wenn die mugelige Oberflïche stark gewölht ist. Je niedriger die Wölloung ist, desto breiter und desto mehr an den Rändern verschwommen ist der Lichtschein. Ist die Oherflïche ganz eben, so glänzt dieser ïber ibre Erstreckung weg vollkommen gleichmäßig.

Das Chatoyieren ist ausschlieblich nur an trüben Chrysoberyllen, nie an durchsichtigen zu sehen. Es ist im allgemeinen um so deutlicher, je trüber der Stein ist. Die trübe Beschaffenheit wird hervorgebracht durch änßerst zahlreiche, mikroskopisch kleine Hohlräume, yon denen der englische Physiker David Brewster einmal 30000 auf $1 / \bar{\tau}$ Quadratzoll beobachtet hat, und diese kleinen Höhlungen sind auch wohl die Ursache der Lichterscheinung. Sie sind vornehmlich nach gewissen Richtungen den Steinen eingelagert, und dementsprechend mul auch die Anordnung der Schliffläche gewählt werden, wenn der Schiller auf ihr in seiner vollen Schönheit auftreten soll; in anderen Richtungen geschliffen, läbt der Stein die Erscheinung nur schwach oder auch gar nicht hervortreten.

Die Schönheit des Chrysoberylls beruht auf seinem hohen Gianz und seiner meist immer noch lebhaften Farbe. Von den durchsichtigen sind die hellgefürbten wenig ge. sucht, die mit lebhafter Fä̈bung jedoch sehr geschätzt. Noch höher geht aber der Wert der schillemden C'hrysoberylle, des Chrysolithkatzenauges, wenn diese Erscheinung in ihrer höchsten Schönheit auftritt. Auch hierbei ist die Körnerfarbe nicht ohne Bedeutung, die hier dieselben Nuancen zeigt wie bei dem anderen Chrysoberyll. Doch wechseln alle diese Verhältnisse bedeutend nit der auf diesem Gebiete sehr der Veränderung unterworfenen Morle. Diese stellt zuweilen den Chrysoberyll in allen seinen Abänderungen tief in der lieihe der Edelsteine, indem sie andere lebhafter gefärhte höher schätzt. Sie hebt ihn dann aber auch wieder, bald die durchsıchtigen, bald die schillernden bevorzugend. Welchen Einflulj auf die Verwendung des Chrysoberyllkatzenauges der Verlobungsring ausiibte, den der Herzog von Conna ugh seiner Braut schenkte, wurde schon oben erwähnt. Der J'reis stieg infolge der wachsenden Beliebtheit des Steines bedeutend und ist etwa chensohoch, wie der eines gleich großen Balasiubins. 1 Karat von schün schillerndem braunen Katzenauge kostet bis 100 Mark.

Das schönste und gröbte Chrysoberyllkatzenauge, das bis vor kurzem bekannt war, ist ein Stein ron dunkler Farbe, aber nicht ganz tadelloser Lichtlinie (sie ist in der Mitte geknickt), 351 : mm lang und 35 $\mathrm{mm}$ dick, der in der Ilope's Collection des South Kensington Museums in London aufbewahrt wird. Inzwischen sind noch andere ebenbiurtige Steine gefunden worden. Ein präehtiges Exemplar derselben Art wird von Nordamerika aus, wohin es rerkauft wurde, beschrieben. Es ist $23 \mathrm{~mm}$ lang und breit und $17 \mathrm{~mm}$ diek und wient $50: "$, Karat. Die Farbe ist gelblichbraun und die Lichtlinie so vollkommen scharf, schmal und gerade, wie man es nur irgend von einem so großen Steine erwarten kann.

Der durchsichtige, namentlich der gesehätzteste von diesen, der schön goldgelbe, wird ebenso wit die anderen durchsiehtigen Edelsteine als Brillant gresehliffen, oder man wendet den Treppenschnitt oder den gemischten Sehnitt an. Die Fassung ist selten à jour und nur wenn die Färbung schön, lebhaft und intensiv ist. Ist dies nicht der Fall, ist die Farbe hell und blalj, so wird zu ihrer IJehumg dem in einen liasten gefaliten stein eine Folie 


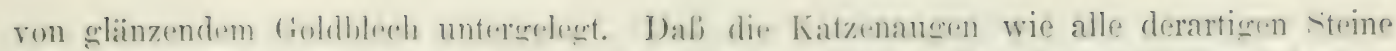

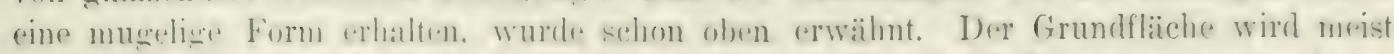

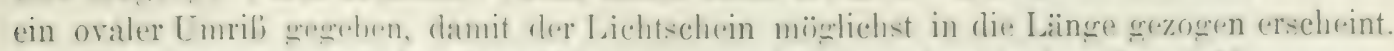

Teel chryoberyll liefort lirasilien, wo er sich besonders in dem bezirk Minas novas in der Provinz Jinas cieraios mit Berghristall, Amethyst, rotem (guarz, wrïnem Turmalin,

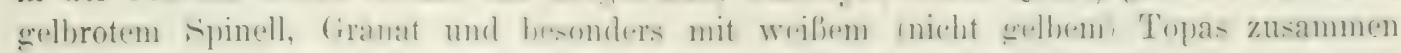
findet. Näheres über das Vorkommen wird beim Topas mitgeteilt werden.

Zum Chrysoberyll entriren mit die schönsten farbigen steine, die in lirasilien bekannt sind. Er wird rom den Eingerborenen als Clarysolith bezelonet, in derselben Weise. wie dies im Edelsteinhandel ziherhanut zn exescheten pllowt. Die Farbe ist ziemlich mannig-

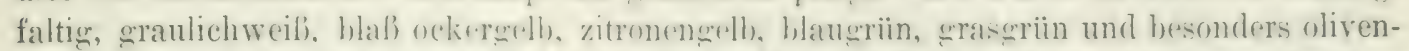

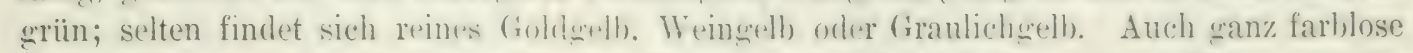
Steine kommen zuweilen vor, dir an Durchisichtıkeit und Feuer dem Diamant nahe kommen. Die gefärbten sind nicht selten sanz lilar und durchsichtig, viclfach zeizen sie aber auch meist melir oder weniger ausererïgt den Lichtschein des hatzenauges. Der Chrysoberyll ist in Brasilien sehe exechätzt und daher zimmlich tener. meist teurer als in Europa; hesonders helieht sind die rein crïnen und schön goldgellen. Das Mineral

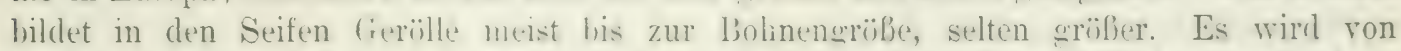
einem 16 Pfund schweren stiick berichtet, ron dem es aber nicht feanz fest steht. ols ess wirklich (hrysoberyll oder nicht vielmehr lieryll (Arquamarm) ist. Die Siteine lassen trotz ihrer Abrolling die breite esestreifte Tafelfliache noch velfach deutlich erkennen. Auch als Begleiter der Diamanten in Minas Geraës kommt Chrysoberyll in seringer Nenge vor.

Sehr ähnlich wie in Minas novas ist das allerdines kommerziell ranz unbedentende Torkommen unseres Edelsteines in den foldwöischereien der Umeregend des Flusses Sa narka in Lande der orenhureischen Kosaken im südlichen Ural. Die meist schün schwefelgethen, seltener graulichen oder crïnlichen steine finden sich dort mit Euklas, rosenrotem Topas und anderen Wincralien zusammen: sie bilden fast stets nur sehr kleine Gerülle, die ron solchen der anderen Ahart des ('hrysoberylls. des Mexandrits, in spärlicher Menge begleitet werden.

Der meiste schleifhare Chrysoheryll kommt aus Ceylon; es ist gröftenteils solcher mit Lichtschein. Da diese Steine häufio kurz als Katzenaugen hezeichnet werden, ohne bestimmte Lnterscheidung von der ehenso genannten Varietät des Quarzes, die in C'eylon in besonders auscezeichneter. Weise sich gleichfalls findet. so ist man bei der Beschreibung der in Ceylon rorkommenden Elelsteine nicht selten im Zweifel, welche ron diesen beiden Arten von Katzenange eigentlich wemeint ist. Jedenfalls scheint früher der echte Chrysoberyll in seinen rerschiedenen Varietiten mit und ohme Lichtschein in Cerlon seltener im Handel gewesen zu sein. Erst als nederding der stein wieder in Aufnahme kam, wurde eifrig danach gresucht und auch eine wrofie Zahl der schönsten Exemplare gefunden: tieforoldwelbe, hellgelhe, gelblichgrïne. sraulich grïne, dunkelgrine, grïnlichbraune und andere Farben, mit und ohne Lichtschein. Die dunkelgrünen haben die Eigenschaften und hesonders den ausgezeichneten Pleochroismus und Farbenwechsel des Alexandrits, von dem unten noch weiter die Rede sein wird. Aus Ceylon stammt das oben erwähnte, größte bisher be-

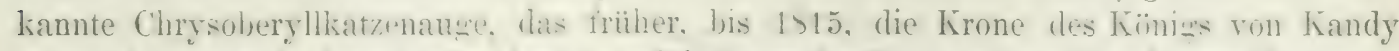
schmïckte. Auch der zweite dort angeführte grofe Stein ist wohl auf jemer Insel grefunden worden. Thas fewicht dersteine schwankt im Übrien zwischen 1 und 100 Karat. Sie begleiten den Sapphir in den Eil. Ltemseifen. Die I Iauptfundstellen sind in dem Alluvium des Bezirkes Saftragam und im sibden der Insel in der Gegend ron Matara: dor Lateranga-

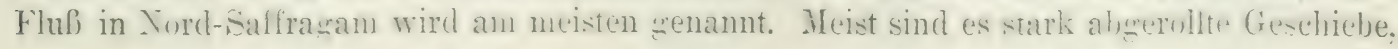


doch kommen zuweilen auch ziemlich wohlerhaltene Kristalle vor, deren Kanten und Eckun beim Transport in den Seifen wenig gelitten haben.

Auch Birma (Penul wird als Ileimat des Clirysoberylls erwähnt, die Angaben sind aher unbestimmt; mit völliger Sicherheit ist der Edelstein von dort jedenfalls nicht bekannt. Dasselbe gilt auch von Vorderindien, wo er, wenn er je vorkommt, eine nur untergerordncte Rolle spielt. Dageren scheint er sich in einigen Diamantwäschereien von Borneo etwas reichlicher zu finden, aber auch hier ist er für den Edelsteinhandel ohne größere Bedeutung.

Es ist schon oben erwähnt, daf der Chrysoberyll mit dem Chrysolith verwechselt und daher mit demselben Namen henannt worden ist. Die Verwechslung kann nur vorkommen bei Steinen ohne den Lichtschein, der beim echten Chrysolith (Olivin) niemals sich findet. Die Unterscheidung ist möglich mittels der IIärte, die beim letztgenannten Steine viel geringer ist als beim ('brysoberyll, nämlich nur ghleich 61 bis 7 . Anch die spezifischen Gewichte sind ziemlich verschieden: $G_{0}=3,34$ bis 3,37 beim Chrysolith und $G_{0}=3,65$ bis 3,75 beim Chrysoberyll. Beide Mineralien sinken daher zwar im Methylenjodid unter, ahes der Chrysoberyll auch in der ersten, sehwersten Flüscienkeit, auf der der Chrysolith schwimmt. Die optischen Eigenschaften sind in beiden sehr ähnlich und geben keine rasche und sichere Unterscheidung.

Das Chrysoberyllkatzenauge kann mit dem Quarzkatzenauge verwechselt werden. trotzdem ersteres meist viel schöner und glänender ist. Beide unterscheiden sich ebenfalls durch die IIärte, die beim Quarzkatzenauge nur gleich 7 ist, und besonders durch das spezifische Gewicht, das bei letzterem, wie bei allem Quarz, 2, ij betrïgt. Das Quarzkatzenauge schwimmt daher in Methylenjodid, während das C'hrysoberyllkatzenauge darin rasch untersinkt.

\section{Alexandrit.}

Der Mexandrit ist der dunkel srasgrüne bis smaragdgrïne Chrysoberyll; die Farbe ('Taf. XII, Fig. 8) entsteht wahrscheinlich durch den eingangs erwälınten kleinen Chromoxydghehalt. Die Färbung dieses Edelsteines zeigt manches Merkwürdige. Zunächst bemerkt man einen schr ausgesprochenen Pleochroismus, den er im Gegensatz zu dem hellgefärbten Chrysoberyll besitzt. Die Farbe auf der srofen, nach oben gekehrten gestreiften Fläche: ist grïin, von vorn bei « (Fig. 71 , a) hindurchgesehen rütlichgelb. Um die schüne grüne Farhe müglichst gut zu erhalten, empfiehlt es sich daher, die Steine so zu schleifen, dab die Tafelfläche in der Richtung der gestreiften Kiristallfläche zu liegen kommt, oder doch von ihr in der Richtung nicht viel abweicht. Untersucht man den Pleochroismus mit der Dichrolupe, so erhält man auf dieser gestreiften Fläche ein griunes Bilı, den Licht• schwingungen in der Richtung der Streifen, und ein orangegelbes Bild, den Schwingungen senkrecht dazu entsprechend. Die Lichtschwingungen, normal zu der gestreiften Fläche geben ein kolumbinrotes bis violettes Bild.

Noch merkwürdiger ist der Farbenunterschied je nach der Art der Beleuchtuns. Betrachtet man einen in der angegehenen Weise geschliffenen Alexandrit bei Tage, so ist er wie wir ess schon gresehen haben, schün erün; bei künstlicher Beleuchtung verschwindet aber diese Farbe und machit einer ausgesprochen blutroten oder violetten Platz. Dersellue Stein ist also, wie man zu sagen pilegt, bei Tage ein Smaragd (Taf. XII, Fig. 9, u), in der Nacht bei Lampenlicht ein Amethyst ('Taf. XII, Fig. 9, h). Die Dicke darf dabei nicht zu gering sein; je dünner, desto geringer die Unterschiede.

Man hat diesen aufallenten Farbenwechsel friiher auf den Pleochroismus zurïickzufïhren gesucht, nach den Untersuchungen von A. Hicthe beruht er aber auf den Absorptionsverhältuissem, wie sie bei der Beobachtung mit dem Spektroskop hervortreten. Iäfift 
man das Licht, das einen Alexandrit passiert bat, auch noch durch ein sipektoskop) hindurchrehen, indem man ein solehes auf dessern Tafel aufsetzt und ins IJelle sirht. so bemerkt man zwei äuferst starke Absorptionsstreifen, den reinen im gedhen, den anderen

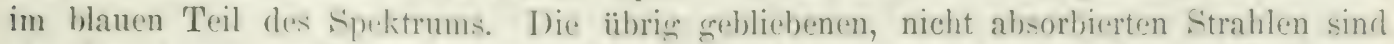

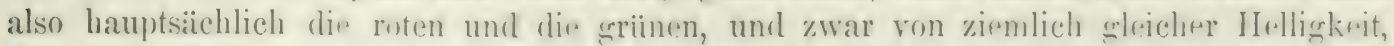

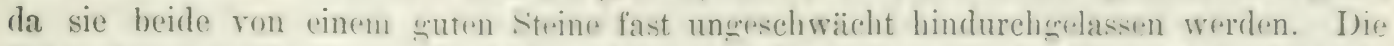

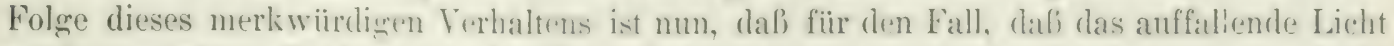
reich an grïnen Sitrahlen ist, der Strin fast rein griin erscheint. Ist dageren das Licht reich an roten Strahlen, so wird er eine mehr oder weniger rein rote Farbe zeigen miissen.

Diese Erscheinuneen lassun sich leicht mittels Fliissigkeiten nachahumen, die dieselben Absorptionsverhältnisse besitzen, bei denen aber natïrlich der Pleochroismus fränzlich ausgeschlossen ist. A. Miethe lïste 0,1 (iramm Cyanin C'hinolin-Lepodin-Jod-Amyli in s0 cm absoluten Alliohols und anderersteits 1 Gramm Tartrazin in Wasser. Fïgt man

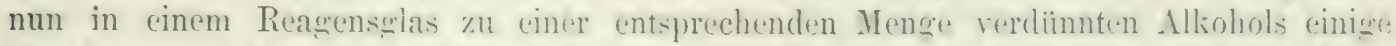

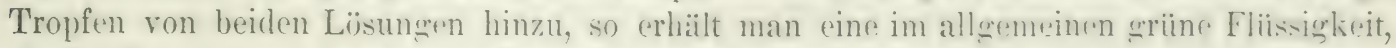

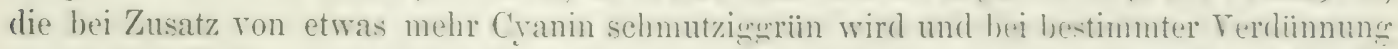
genau den Farbenwechsel des dlexandrits zeiot, und zwar genau aus demselben Crundr. I. Hlawatsch erhielt dieselhe Erscheinung, inclen er einer verdiinnten rioletten Lïsung von Chromalaun einige Tropfen einer durch Erhitzen grïin gemachten sqleichen Lïsung in Wasser hinzufügte. Auch eine solehe grïne Lösung allein zeigt den Farbenwechsel.

Noch sei bemerkt, daf man in Colombo zurveilen „blaue Alexandrite ${ }^{6}$ verkauft. Diese Farbe hat aber der wirkliche Alexandrit niemals. Es sind dies die schon oben erwähnten seltenen Sapplire, die aihnlich wie der letztere auch bei Laupenlicht ihre blaue Farbe in eine violette verwandeln.

Bis vor nicht sehr langer Zeit kannte man den Alexandrit ausschließlich nur aus Ruliland, und zwar aus der Smaraglgxube an der Tokowaja, ostlich von Katharinenburg im Ural, von der unten bei der Beschreibung des Smarageds noch weiter die Rede sein soll. Hier findet er sich aufer mit diesem noch mit zahlreichen anderen Nineralien im Glimmerschiefer eingewachsen. Er hildet meist bis zu $4 \mathrm{~cm}$ grofe und sogar zuweilen noch erheblich größere, sternförmige Drillingskristalle ron der Form der Fig. 71, c. oder Taf. XII, Fig. S, oder doch dieser sehr nahe stehend, während einfache Fristalle und Zwillinge, wie in Fig. 71 , a und h, sehr selten sind. Diese Drillinge sind oft zu mehreren regellos zu Gruppen verwachsen; man kennt eine solche Gruppe, in der 2.2 grobe und mehrere kleine derartige Fristall: miteinander vereinigt sind. Jene Fundstelle wurde im Jahre 1S:0 am Tage der Grobjährigkeitserklärunщ des nachmaligen Kaisers Alexander II. zufällig entcleckt; daher stammt der Nane des Minerals und zum 'Teil auch das Interesse, das man ihm in Ruliland untgegenluringt. Da der Stein, wie wir oben gesehen haben, grleichzeitig die Hauptmilitïrfarben Ruflands, criin und rot, zeigt und es ein damals ausschlieblich russisches Torkommen war, so wird er in jenem Lande besonders gern getragen. Aber die meisten russischen Alexandrite sind rissig und trübe, vielfach mit Glimmerplättchen durchwachsen und zu Schmucksteinen unbrauchbar; nur selten findet man in den Kristallen reine und klare, durchsichtige, rissefreie Stiicke, die dann die erwähnten Farben erscheinungen deutlich zeiren. Nur solche Partien werden geschliffen; die Steine wiegren von 's bis höjchst selten ïloer 5) Karat. Das schleifbare Haterial ist also immerhin recht sparsam vorhanden, um so mehr als heutzutage die Gruben überhaupt nicht viel liefern. Aus allen diesen friinden steht der Alexandrit hoch im Preise, viel höher als der andere Chrysoberyll; ein Karat wird mit 6nu II. und bei tadelloser Beschaffenheit des Steins noch höher bezahlt. 
Lange Zeit war der genannte der cinzige Fundort des Alexandrits, später hat marı ilm auch noch in anderen Gegrenden angetroffen. Als Seltenleit begleiten, wie schon erwïhnt, Alexandritareröle mit solchen von gewöhnlichen Chrysoberyll die anderen gelegentlich noch zu erwähnenden Edelsteine in den Goldseifen an der S a n a r k a im sïdlichen Cral. Neuerdings hat man den Alexandrit, und zwar in einiger Menge, auch in Ceylon, besonders in den Edelsteinablagerungen von Morawak-korale gewonnen. Es sind dunkelwrïne Gerölle mit dem charakteristischen Dichroismus und Farbenwechsel der uralischen Steine, von denen sogar einige die bei den letzteren niemals vorkommende Lichterscheinng des Cymophans, das Chatoyieren, zeigen. Dies sind richtige Alexandritkatzenaugen, wie sie bis dahin nicht bekannt gewesen waren, und wie sie inzwischen auch anderswo nicht wieder gefunden worden sind. Die ceylanischen Alexandrite sind iiberhaupt noch schöner als die uralischen, namentlich gilt dies für die bei kïnstlicher Beleuchtung hervortretende kolumbinrote Farbe, während die grüne etwas blasser zu sein pflegt als am Ural. Die Steine wiegren kaum unter \& Karat, einer hat sogar ein Gewicht von $63^{3} / 4$ Karat ergeben. Dies ist der größte bisher bekannt gewordene Alexandrit von Ceylon. Er wurde mit

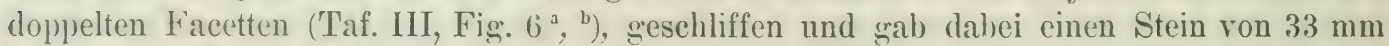
Länge und $: 32 \mathrm{~mm}$ Breite in der Rundiste mit einer Dicke von $17 \mathrm{~mm}$. Seine Farbe bei Tage ist grasgriu ins Gelbe, bei künstlicher Beleuchtung wird sie himbeerrot. Ein sehr schöner kleinerer Stein ebendaher wiegt $28^{23 / 32}$ Kalat; seine drei Dimensionen betragen 32, 16 und $9 \mathrm{~mm}$. Bei 'l'age zeigt er eine sehr schöne, saftig grüne Farbe mit etwas Rot, bei Gasbeleuchtung ist es ein gesättigtes Kolumbinrot; der Stein kann dann kaum von einem purpurroten siamesischen Spinell unterschieden werden. Alexandrit ist neuerer Zeit auch im Noldosten von $\mathrm{T}$ a s m a n i e $\mathrm{n}$ in dem zinnerzführenden Sand des Weld River vorgekommen. Er stammt aus Granit; die Farbe ist hellgrïn und beim Hindurchsehen rot. Auch mit den Diamanten in $\mathrm{R}$ ho oles i a sind einige Alexandrite in Begleitung anderer Chrysoberylle gefunden worden.

Sogenannter Alexandrit wird seit einiger Zeit nach der beim Rubin beschriebenen Methode hergestellt. Er zeigt den Farbenwechsel bei kïnstlicher und natürlicher Beleuchtung in ausgezeichneter Weise, ist aber bei Tageslicht nicht so intensiv grün als der natür. liche aus dem Ural, sondern mehr graulichgrün und bei Lampenlicht mehr rosa. Die bei den natürlichen Steinen so häufigen Risse fehlen, er ist ganz klar und durchsichtig. Neuere Untersuchungen haben aber ergeben, daß dieser "künstliche Alexandrit" optisch einachsig ist und (las spezifische Gewicht $G_{0}=4,0$ hat, dals er also neben den kïnstlichen Rubin zum Korund zu stellen und daß demnach jene Bezeichnung unrichtig ist.

\section{Beryll.}

Das Mineral Beryll unfalit außer einigen anderen namentlich zwei wichtige Edelsteine, den smaraged und den Aquamarin. Beide unterscheiden sich voneinander und von den anderen hierher sehörien edlen Varietäten, welehe letzteren auch die Juweliere als Beryll zu bezeichnen plfegen, ähnlich wie Rubin und Sapphir, ledieglich dureh die Farbe und sind sonst in allen Fimensehaften einander chleich. Wir werden hier zuerst dasjenige Verlaalten kemnen lirnen, das dem licryll iilrerhaupt zukommt, und daran die Besprechung der Beschaffenheit jener Varietäten anschließen.

Was die chemische Zusammensetzung anbelanght, so enthält auch der Beryll noch eine Exwiste Menge Tonerde, die in den zuletzt hetrachteten Edelsteinen, den zum Korund schärigen, den spinell und dem ('hrysoberyll, eine so grobe Rolle enespielt hat, die aber 
nun gegen die anderen Destandteile zuriicktritt. Diese sind Kirselsäure und die nach dem hier vorliegenden Mineral so benamnte lieryllerde, wolche wir auch beim Chrysoberyll schon als Bestandteil kemen gerernt haben. Ier Beryll ist aler ein Beryllium-Tonerde-Silikat,

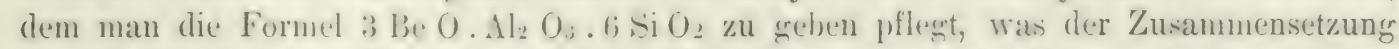
14,11 Beryllerde, 15,..; Tonerde und bi,-1 Kieschäure entspricht. Mehrere Analysen haben aber noch kleine Mengen anderer Bestandteile nachgewiesen, so etwas Wasser, Alkalien, wenig Eisen und Chromoxyd; endlich wird auch eine geringe Spur orwanischer Substan\% in manchen Beryllen angerethen, wie $m$ dem sehönen Smaraged ron Vuzo in Kolumbien

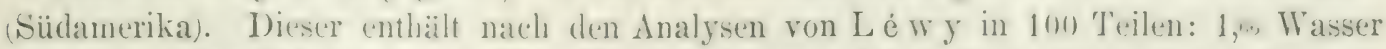
1),12 organische Substanz und 95,-2. Mineralsubstanz; die letzter" ilnerseits besteht aus: 67,9 Kiesels:̈ure, 17,: Tonerde. 12,1 Beryllerde, 0,: Magnesia, 11,: Natron und einer Spur Chromoxyd, von welchem andere Analysen bis über 3 Prozent ergeben haben. Der Ayuamarin ron Adun-'Trehilon in Sibirien ist nach der Lntersuchung von P' en f i eld zu-

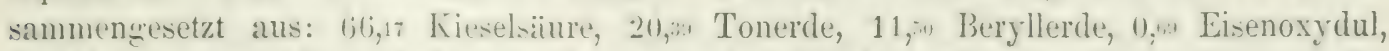
1,24 Natron. einer syur Lithion und 1,14 in der Glïhhitze flïchtige liestandteile, in der Hauptsache Wasser; Chromoxyd fehlt hiter vollständigg, im fiegensatz zum smaragd. Von einem kleinen Caesiumgehalt mancher Berylle wird unten noch die Rede sein.

Die Kristalle des Berylls (Fig. 72, $a$ bis e) gehören dem hexagonalen System an. Es sind meist ziemlich langgezogene sechsseitige Prismen mit ghatten Flächen, deren Endbegrenzung in vielen Fällen, so meist beim smaragd, allein durch die cerade Endfläche grebildet wird (Fig. 72 , , $)$. Nicht selten sind die Kanten des hexagonalen Prismas durch

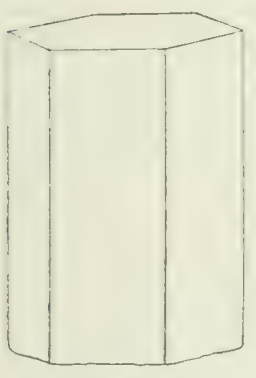

a.

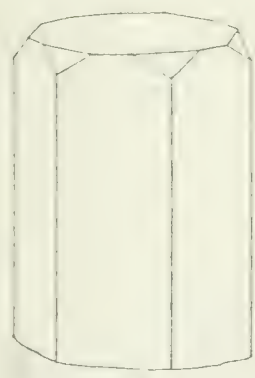

b.

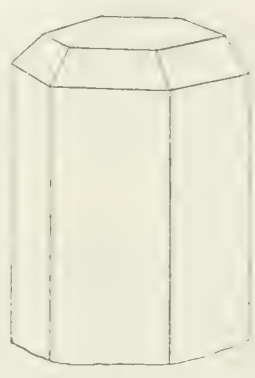

c.

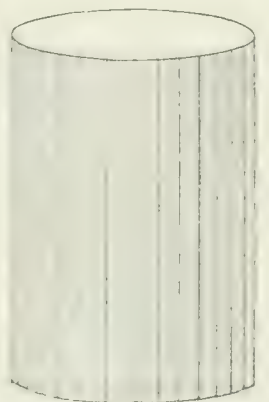

!!

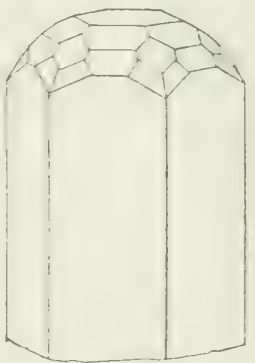

$e$

Fig. 72. Kristallformen des Berylls (Smaragd, Aquamarin usw.).

Flächen des anderen hexagronalen Prismas abgestumpft und durch solehe ron zwölfseitigen Prismen zugeschärft, so daf scheinhar walzenförmigy runde, stark längsgestreifte Säulen entstehen, die aber doch ron lauter ebenen, wenngleich sehr schmalen Flächen begrenzt sind (Fig. 72, d). Auch die Enden sind an vielen Kristallen flächenreicher, indem statt oder neben der geraden Endfläche Flächen von sechsseitigen und zwölfseitigen Pyramiden mit dem Prisma kombiniert sind (Fig. $\left.72, l, c^{\prime}, c^{\prime}\right)$. Derartige komplizierte Formen finden sich hauptsächlich beim Aquamarin.

Die Kristalle sind entweder an einem Ende aufgewachsen und bilden dann oft schöne Drusen, oder sie sind auch zuweilen ringsum vollkommen in dem Gestein eingebettet. In ersteren Falle sind sie nur an dem freien Ende mit regelmäßigen Kristallflïchen verselen; im letzteren Falle ist dies an beiden Enden der Fall, doch ist die Endhegrenzung vielfach auch an beiden Enden unregelmäßig.

Spalthar sind die Burylliristalle nach verschiedenen Richtungen, aher nicht hesonders deutlich. Am leichtestem ist dies der Fall nach der geraden Endflïche, sehr unvollkummen parallel mit den Flïchen eines hexagonalen Prismas. Der Bruch ist im allgemeinen 
muschelig und das Mineral ist spröde. Bezüglich seiner Härte steht es etwas über dem Quarz, aber dloch noch unter dem Topas. Der Härtegrad ist: $H_{0}=71 / 2$, also für einen Edelstein ziemlich niedrig. Der Beryll ist unter den besseren Steinen einer der am wenigsten harten, die einzelnen Varietäten sollen aber hierin kleine Unterschiede zeigen: der Smaragd von Muzo gilt für etwas härter als der sibirische Aquamarin. Ist die Härte aber auch nicht besonders hoch, so genügt sie doch, um eine sehr schöne und feine Politur zu ermöglichen, die sich aber beim Gebrauch allerdings nicht so gut erhålt, wie bei den härteren Juwelen.

Wie die Iärte, so ist auch das spezifische Gewicht niedrig, niedriger als bei irgend cinem anderen der wertvolleren Edelsteine; Stïcke von einem gewissen Gewicht sind daher verhältnismäßig groB. Man findet im Nittel 2,7 , bald etwas mehr, bald etwas weniger und der Wert schwankt bei den als Edelsteine brauchbaren Beryllen zwisehen 2,67 und 2,75; durchweg erhebt es sich also, wenngleich nur wenig über das des Bergkristalls $\left(G_{0}=2,65\right)$. Speziell für den Smaragd von Muzo wurde gefunden: G. $=2,6,7$ f für den sibirischen Aquamarin werden die Zahlen $G_{0}=2,69$ bis 2,75 angegeben. Jedenfalls schwimmt der Beryll immer in reinen Methylenjodid und steigt, wenn untergetaucht, darin sehr rasch wieder an die Oberfläche, während er in der vierten, leichtesten Fliissigkeit vom spezifischen Gewicht des Quarzes langsam untersinkt. Man kann ihn an diesem Terhalten von manchen ähnlich aussehenden Steinen sehr leicht unterscheiden.

Von Säuren wird der Beryll nicht zersetzt, nur Flußsäure (Ätztinte) greift ihn etwas an. Vor dem Lötrohr ist er nur sehr schwer schmelzbar und gibt dabei eine weifje, trübe, blasige Schmelze.

Dem äuferen Ansehen nach sind die Berylle sehr verschieden, namentlich bezüglich der Farbe und der Durchsichtigkeit. Viele sind vollkommen trïbe und undurchsichtign, wenige schön klar und durchsichtig, und dazwischen findet man alle möglichen Übergänge. Die ersteren, die "gemeinen Berylle“, kommen meist im grobkörnigen Granit in Kristallen von zuweilen bis über 6 Ful Länge und bis zu $2 \frac{1}{2}$ Tonnen Gewicht vor, sind aber als Edelsteine nicht zu gebrauchen, da auch ihre meist gelblich- oder grïnlichweilße Farbe stets zu unansehnlich ist; von diesen soll hier nicht weiter die Rede sein. Verschliffen werden nur die durchsichtigen oder doch stark durchscheinenden „edlen Berylle“, die anch meist cine angenehme, vorzussweise griine oder blaue oder auch wohl eine gelbe Farbe besitzen. Selten ist Braun und Rosa oder auch vollkommene Farblosigkeit. Der Glanz ist bei allen Varietäten der gewöhnliche Glasglanz, welcher nur auf den der verhälinismäßig deutlichsten Spaltung parallelen geraden Endfliichen etwas ins Perlmutterartige geht und durch das Schleifen und Polieren sehr kräftig wird. Röntgenstrahlen werden nicht hindurchgelassen.

Der Beryll zeigt, seiner Kristallisation entsprechend, doppelte Lichtbrechung; die Doppelbrechung ist aber sehr schwach, der grröfte nnd der kleinste Brechungskoëffizient fiir dieselhe Farbe sind nur wenig voneinander versehieden. Die Lichtbrechung ist ebenfalls žrering, die Zahlen für die Brechungskoëffizienten sind sehr niedrig. Beim Smaragd von

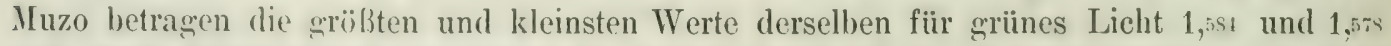
und beim sibirischen Aruamarin 1,54: und 1,57\%. Auch die Farbenzerstreuung ist sehr gering, die Brechungrskoiffizienten fiir verschiedene Farben weichen uur sehr wenig voneinander al). Dies geht aus folgenden Zahlen hervor, die man an einem Beryllkristall für rotes, gelbes und grünes Licht erhalten hat:

\begin{tabular}{|c|c|c|c|}
\hline & & Rot & Gelb \\
\hline die größten & . & . 1,566 & 1,570 \\
\hline die kleinsten & & . 1,562 & 1,566 \\
\hline
\end{tabular}


Fieraus folget, dals der beryll niemals ein Farbenspiel ähnlich dem des Diamants zeigen kann. Seine Schönheit beruht in der Iauptsache auf dem starken Glanz und auf der Körperfarbe. Diese ist, wie wir gesehen haben, ziemlich mannigfaltig, wenn auch weit nicht so wie beim Korund. Nach der Farbe werden mehrere mit besonderen Namen belegte Varietiten unterschieden. I) dunkelgrüne Beryll ist der S Smaragd, die anders, und zwar beinahe immer hellgefärbten können unter dem Namen „edler Bery ll" zusammengefalit werden. Von diesen heibt der hellblaue oder bläulichgrïne oder grünlichblaue Aquamarin, der gelblicherrine geht unter dem Namen A quamarinchrysolith, und der gelbe wird von den Juwelieren speziell Beryll, der zuweilen vorkommende schön goldgelbe Goldbery 11 genamt. Als Edelsteine sind besonders wichtign der Aquamarin und vor allem der Smaragnd, der mit zu den kostbarsten Steinen gehört, die wir gegenwärtig besitzen. Die anderen sind von geringerer Bedeutung.

Alle diese durehsichtigen Berylle, die Farbe magn sein wie sie will, wenn sie nur nicht zu blaf ist, zeigen deutlichen Pleochroismus. Wenn man auch beim Hindurchsehen mit blobem $\Lambda$ uge nach verschiedenen Iichtungen Farbenuntersehiede selten deutlich erkennt, so treten solehe doch bei der Beobachtung mittels des Dichroskops meist unzweideutig hervor. Mit Hilfe des Pleochroismus kann man echte Berylle von oft in der Farbe täuschend ähnlichen Glasimitationen und auch von einzelnen anderen grrünen Steinen mit Sicherheit unterscheiden, die speziellen Verhältnisse künnen aber erst bei der Betrachturg der einzelnen Varietäten angegeben werden.

Wir haben nummehr die versehiedenen nach der Farbe aufgestellten Abarten des Berylls gesondert kemnen zu lernen. Diese haben für den Edelsteinbandel eine sehr verschiedene Wichtigkeit, da sie an Wert auberordentlich stark voneinander abweichen. Weitaus am kostbarsten ist der zunächst zu betrachtende Smaragd, hinter ihm stehen die anderen weit zuriick.

\section{Smaragd.}

Unter dem Namen Suaragd versteht man, wie schon erwähnt, die in ihrer schönsten Färbung rein und intensiv grünen Berylle. Diese Farbennuance ist nach ihrem prachtvollen Auftreten an unserem Edelsteine als smaragdgrin bezeichnet worden. Neben deu reinen Smaragdgrün kommt aber auch Grasgrün, Grün mit einer kleinen Beimischung von Gelb, und Seladongrïn, mit etwas Grau, vor; ins Blaue gelende Nuancen sind aber rränzlich ausgeschlossen. Viele Smaragde sind allerdings sebr licht, bis zum Grünlichweißen herab, diese werden aher nicht geschliffen, nur die schön und tief smaragdgrünen bis grasgrünen sind hoch geschätzt. Ihre Farbe, die aus Taf, XII, Fig. 1 bis 3 zu ersehen ist, gehört mit zu den lieblichsten und prïchtigsten, welche die Edelsteine darbieten: sie ist nicht selten mit dem frischen Grün einer Wiese im Frühling verglichen worden. Die schönsten Steine haben einen eigrentïmlich sammetartigen Schimmer, wie er ähnlich auch an manchen dunkelblauen Sapphiren auftritt. Bei künstlicher Beleuchtung ist die Farbe ebenso schön wie am Tage. Durch Radiumbestrahlung geht das dunkle in ein sehr lichtes Griin über.

Ein Smaraged aus der Grube von Muzo in Kolumbien zeigte nach einem Tersuch ron F. Wöhler bei einstündigem Erhitzen auf eine Temperatur, bei der hupfer leicht schmilzt, keine Veränderung der Farbe. Diese kann daher nicht, wie Léwy meinte, von der kleinen Menge organischer Substanz herrühren, die er in dem Smaragd von demselben Fundorte nachgrewiesen hatte, sondern sie stammt hüchst wahrscheinlich von dem kleinen Chromoxydgetalt ron 0,15t Proz., den Wühler in dem untersuchten Stück fand. Daß 
cine so kleine Nenge Chromoxyd in der Tat eine so kräftige girüne Färbung erzeugen kann, wurde durch Zusammenschmelzen von weißem Glas mit derselben Ienge Chromoxyd bewiesen; das Glas nahm dabei eine ebenso intensiv grïne Farbe an, wie sie der schönste Smaragd zeigt. In dem Smaragd vom Ural und in dem ägyptischen wurde späterhin elyenfalls Chromoxyd als die wahrscheinlichste Ursache der Färbung nachgewiesen.

Der Pleochroismus des Smaragals ist bei lebhafter Färbung dentlich; die dichroskopische Lupe giebt ein smaragdgrünes orler gelblichgriines und ein blaugrünes Bild.

Übrigens ist die Färbung der Smaragdkristalle keineswegs immer ganz gleichmäßig; läufig̨ wechseln farblose oder unansehnlich gefürbte Stellen mit schön smaragdırünen ab, meist unregelmäßßig, nicht selten ist dieser Wechsel aber auch regelmäßßg schichtenförmig; so daß die einzelnen versehieden gefärbten Lagen senkrecht zu den Prismenkanten, also in der Riehtung der geraden Endfläche, aufeinanderfolgen.

Die Durchsichtigkeit des Smaragds ist nur in sehr seltenen Fällen eine rollkommene. Die meisten Kristalle sind mehr oder minder rissig und dadurch weniger klar, ebenso werden auch durch stellenweise angehäufte mikroskopisch kleine Flüssigkeitseinschliisse wolkige Trubungen hervorgerufen. Fremde Mineralkörper, die die Reinheit und Klarheit stören, fehlen ebenfalls nicht; so findet man namentlich vielfach Gilimmerblättchen eingewachsen. Wenn die Stïcke trübe und und undurchsichtig werden, nimmt meist auch die Schönheit der Farbe erheblich ab, und die Smaragde nähern sich dadurch in ibrer Beschaffenheit dem gemeinen Beryll; sie sind dann als Edelsteine nicht mehr brauchbar. Am kostbarsten ist der vollkommen klare und durchsichtige Smaragd, aber anch der etwas trübe, rissige hatt noch seinen Wert, wenn nur die Farbe schön smaragdgrün ist.

Es gibt keinen anderen Edelstein, bei dem fehlerhafte Exemplare so verbreitet, vollkommen tadellose, fehlerfreie so selten wären, als beim Smaragd. Die Art dieser Febler ereibt sich aus dem vorgehenden. Vor allem spielen die erwähnten Risse eine sehr große Rolle; rissige und dadurch etwas trübe Steine werden "moosig“ genannt. Trübe wolkige Stellen kommen häufig vor, und ebenso ist UngleichmäBigkeit der Färbung durch hellere Flecken sehr verbreitet. Einschlüsse fehlen nie vollständig.

Der Preis der Smaragde ist sehr verschieden und wechselt ganz außerordentlich mit den Moden und stets mit der Qualitiit. Der Smaragd folgt in tadellosen Stiicken im Preise gergenwärtig hinter dem Rubin und übertrifft ihn sogar zuweilen, jedenfalls steht er aber über dem Diamant. Ein vollkommen fehlerfreier, durchsichtiger, tadellos gefürbter Stein der allerbesten Sorte im Gewicht von einem Karat kann auf 1000 Mark gesehätzt werden, und der Preis nimmt der Seltenheit größerer Stïeke wegen mit der Größe sehr viel stärker zu als das Gewicht. Ein solcher Stein von nur wenigen Karaten ist, wie beim Rubin, so selten, daß gar kein Marktpreis mehr maßggebend ist; er wird nur nach Liebhaberpreisen sehr hoch bezahlt. Fehlerhafte, rissige Steine von etwas trüber Beschaffenheit sind auch bei schüner Färbung viel billiger, und wenn gleichzeitig die Farbe heller wird, sinkt der Wert eines Karats auf 100, ja auf 50 Mark und noch weiter herunter. Er steigt dann auch nicht oder doch nicht viel raseher als das Gewicht, da Steine dieser $A$ rt von beträchtlicher Größe nicht ungewöhnlich sind.

Wenn nun auch volkommene Snaragde ohne jeden Fehler in geschliffenem Zustande fast stets nur klein sind, und wenn auch die natülichen Smaragdkristalle meist eine nicht sehr beträchtliche Gröbe haben, so gribt es doch auch Exemplare der letzteren von bedeutenderem Umfange, die aber dann meist an Qualität zu wünschen übrig lassen. Erzählt wird allerdiness von sehr eroben smaragden, man hat aber dabei zu berücksichtigen, dab in frïheren Zeiten, namentlich im Altertume, andere griine Steine ebenfalls mit dem Namen Smaragd belegt worten sind. Die alten Peruaner sollen einen Smaragrd von der der Ciröbe emes Straubeneies als Gottheit verehrt haben. Lin Stein von 2205 Karat soll 
in der Schatzkammer in Wien aufhewahrt werden; Sehrauf berichtet von rinem aus einem einzigen strin geschmittenen Tintenfali, das neben groliem, als Tafulsteine eneschliffenen Smaraçlen chendorf sich befindet. Ëiner der gröliten und schïnsten, sicher brekannten Sinaragde ist der des Heroges von Dovonshire in Lngland. Lis ist ungeschliffen und hat die gewöhnliche Form der Smaragde, nämlich die eines sechsseitigen Prismas, hier von 2 Zoll Dicke, mit der geraden Endfläche, wie es in Fig. 73 in natiirlicher Gröbe dargestellt ist. Das Gerwicht betrïgt 818/20 Unzen oder 1350 Karat. Die schönste Farbe zeichnet ihn aus, atch ist er beinabe fehlerlos, klar und durch. sichtig. Seine Heimat ist die Smaragdgrube von Muzo in Kolumbien. Die von hier stammenden Kristalle sind allerding's meist kleiner, doch sind fingerlange und -dicke nicht gar zu selten. Ebenso große Kristalle wie hier finden sich im Ural gleichfalls nicht besonders sparsam; ein solcher von 8 Zoll Länge und 5 Zoll Dicke wird in der Sammlung des kaiserlichen Bergeorps in St. Petersburg aufbewahrt und von noch größeren wird berichtet. Der größte von allen dortigen ist wohl der im Besitz des Kaisers von Rußland, dessen Länge zu 25 und dessen Dicke zu $12 \mathrm{~cm}$ angegeben wird. Einige besonders große, frülıer für Smaragd gehaltene

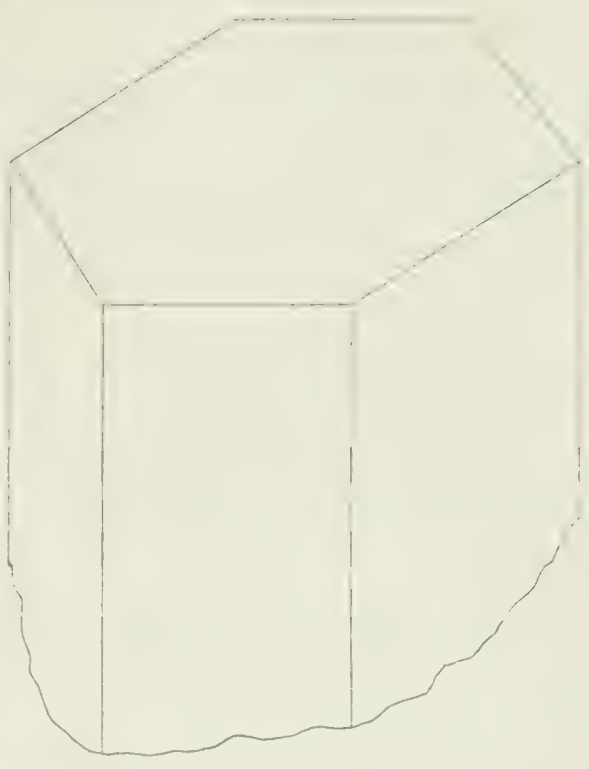

Fig: 73. Smaragd des Herzogs von Devonshire, natiïliche Größe.

Stiicke, haben sich bei wenauterer Untersuchung als grines Glas erwiesen, so ein solches von 283/4 Pfund Gewicht im Kloster auf der Insel Reichenau im Bodensee.

Die Form, die man dem Smaragd beim Schleifen gibt, hängt durchaus von der Beschaffenheit (ler Stiicke ab. (janz fehlerlose durchsichtige, namentlich nicht zu dunkle. werden als Brillanten oder auch als Rosetten geschliffen. Am läufigsten wird aber wohl der 'Treppensehnitt angewendet (Taf. XII, Fig. 33), vielfach oben mit Brillantfacetten. Auch als ganz einfache Tafelsteine sowie en eabochon werden Smaragde nicht selten geschliffen und Baroque-Formen sieht man ebenfalls zuweilen. In Farbe und Durchsichtigkeit tadellose, tiefgefärbte Steine faft man meist ì jour, hellere erhalten häufig eine wrine Folie, rissige und sonst fehlerhafte setzt man in einen innen sehwarzen Kasten. Zuweilen werden rohe Smaragde, sog. Matric's, abwechselnd mit Perlen, zu Fächer- und Lorgnettenketten usw. verwendet, ehenso Barorues, die auch ungefalit als Anhänger rerschiedener Art getragen werden.

Beim Schleifen werden Stilcke von geeigneter Größje von den meist das erforderliche Maß ïbersteigenden natürlichen Liristallen sorgfäitig und unter tunlichster Vermeidung̈ jeglichen Substanzverlustes abgexïgt. Besondere Sorgfalt ist nütig, wenn ein gröbtenteils fehlerhafter Kristall einzehe schön gefürbte fehlerlose Stellen enthält. Diese werden dann ron ihrer Umgebung getrennt und für sich rerschliffen und es wird ihnen die für ihre spezielle Beschaffenheit geeignetste Form gegeben.

Bezuighich des Torkommens unterseheidet sich der Smaragd sebr wesentlich ron den sämtlichen bisher betrachteten Edelsteinen dadurch, dab er sich in der Hauptsache stets nur auf sciner ursprüinglichen Lagerstäte findet, in dem Muttergestein, in dem er sich gebildet hat. Er ist rorwiegend ein Mineral der kristallinischen Schicfer; man trifft ihn an mehreren Stellen in Glimmerschiefer und ähnlichen Gesteinen eingewachsen. Nur 
das beriihmte Vorkommen von Muzo in Kolumbien ist anders; die Kristalle finden sich mit Kalkspat ete. auf Spalten in Kalkstein. Man hat daher auch, aber ohne Grund, die Ansicht geäufert, daß diese Smaragde ebenfalls ursprïnglich in Glimmerschiefer eingewachsen rewesen und daß sie später erst in diese Spalten hineingeschwemmt worden seien. In eigentlichen Seifen, wie Diamant, Rubin usw., hat man den Smaragd so gut wie niemals angetroffen.

Fundorte. Die am frühesten bekannten Fundstätten sind wohl die in Oberägypten in der Nähe der Küiste des Roten Meeres, südlich von Kosscir, etwa unter $24^{1} / 2^{0}$ nördl. Breite, ïstlich ron Assuan. Schon im Altertum wurde Äthiopien als Ileimat des Smaragds gुenannt. Die Fundorte waren aber im Laufe der Zeiten vollkommen in Vergessenheit geraten, so daß die Nachrichten der Alten vielfach für irrtümlich galten. Nanche meinten, daß echte Smaragde zuerst am Ende les 16. Jahrlunderts aus Amerika nach Europa gekommen seien, es ist aber zweifellos, daß solche schon in ägyptischen Mumien, in den römischen Ruinen, in Herculanum und Pompeji usw. gefunden worden sind.

Alle diese vor dem Ende des 16. Jahrhunderts (1566) bekannt gewesenen Smaragde können nicht aus den nachher hauptsächlich wichtig gewordenen südamerikanischen Fundstätten stammen, sie mïssen, soweit wir bisher unterrichtet sind, aus Ägypten oder aus den von den Alten ebenfalls erwähnten scythischen Ländern, also vielleicht aus dem auch heute noch Smaragde liefernden Uralgebirge geholt worden sein.

Die alten ägyptischen Gruben wurden im zweiten Jahrzehnt des 19. Jahrhunderts von Cailliaud auf einer von II ehemed A li Pascha in Ägypten angeordneten Expedition wieder aufgefunden und seitdem mehrfach von europäisehen Reisenden besucht. Es waren teils oberirdische, teils unterirdische Werke mit vielfach noch wohl erhaltenen Gebäulich. ketten. Ihre sroße Ausdehnung bezeugt, daß sie in bedeutendem Umfange betrieben worden sein müssen. Einzelne Gruben sind so geräumig; daß darin gleichzeitig 400 Menschen nebeneinander arbeiten können. Wann und aus welchen Gründen der Betrieb eingestellt wurde ist unbekannt. Handwerkszeug und Gerätschaften, die man in den Gruben auffand, weisen darauf hin, daß diese mindestens schon zu den Zeiten des Sesostris, 1650 v. Chr., abgebaut wurden. Inschriften melden, daß zur Zeit Alexanders des Großen griechische Bergleute die Gruben bearbeiteten. Auch während der Regierung der Kleopatra müssen sie noch im Betriel, gewesen sein, denn diese Königin pflegte Smaragde, in denen ihr Bildnis eingraviert war, zu verschenken (daher Kleopatragruben). Nach den Ägyptern haben die Römer, Araber und Türken gearbeitet, letztere wohl bis in die Nitte des 18. Jahrhunderts.

Aus diesen Zeiten sind keine genaueren Nachrichten bekannt bis zur Wiederauffindung durch Cailliaud, unter dessen Leitung Mehemed Mli die Arbeiten durch altanesische Bergleute (1816) wiederaufnehmen ließ. Bald wurde aber auch dieser nene Versuch (1819) aus unbekannten Gründen, vielleicht wegen unbefriedigender Qualität der refundenen Steine, wieder aufgegeben, und der Betrieb ruht bis zum hentigen Tage. Untersuchungen der alten Gruben, die vor einer Reihe von Jahren vorgenommen wurden, haben zur Entdecknng einer Anzahl Körbe geführt, in denen jene albanesischen Bergleute das von ilınen gewonnene Material zur Förderung verpackt hatten, die aber dann doch in der Grube stehen geblieben sind. Man hat hieraus auf ein plötzliches Verlassen der Gruben schließen wollen, es ist aber hieriiber nichts Nüheres bekannt geworden.

Diese alten Gruben liegen in einer Depression des langen Gebirgszuges, der sich längs der Westküste des Roten Mecres hinzieht. Man findet in diesem Gebirge zahlreiche alte (ioldbergbaue, ebenso auch alte Topasgruben, und danchen die erwähnten Smaragdgräbereien. Sie bilden zwei getrennte Bezirke, den südlicheren 15 (engl.) Meilen vom Meer entfernt, am Dschebel Sikait (auch Sakketto oder Sekket genannt) und den etwa 10 (engl.) Meilen nördlicher welegenen am Dschebel Sabara (Sebara, Zabara, Zubara usw.). 
Der bedentendere und auswedehntere dieser beiden Bezirke ist der von Sikait, der durch den Wadi I)schamal mit seiner der IIïndungr vorliegenden Insel mit dem Meere in Verbindung steht. Man findet hier die lieste zahlreieher Tempel und anderer (iebüude,

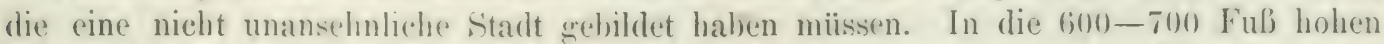
IIïgel sind II underte ron mehr wher weniger tiefen Sehäichten tretrieben. Ähnlich, wenngrleich weniger aukgedehnt, sind atteh die Üherreste der alten (irähereien am Dschebel Sabara.

Das Muttergestein dieser vielfach schön, aber meist nieht sehr tief gefefïrbten Smaragde. neben denen u. a. auch Aquamarin vorkommt, ist an beiden Grten ein dunkler Glimmerschiefer, der in 'T'alkschiefer vingelagert zu sein scheint, und der iun Bezirk von Sikait Augit und Hornblende aufnimmt. Es ist eine Felsart, die dem Muttergestein des unten näher zu besprechenden Smaragds in Cral und in den Salzhureger Alpen vollkommen gleicht.

Schöne, gut gefürlote Smaragde werden nicht selten mit anderen Edelsteinen am Strande bei Alexandria rom Mecre ausweworfen, zum Teil im bearbeiteten, zum 'Teil in rohen Zustande. Es scheint, als ob dort bei irgendeiner (iclegenheit größere Mengen Edelsteine ins Meer versenkt worden wären, das sie jetzt wieder zurückgibt. Mit höchster Wahrseheinlichkeit stammen alle die hier gefundenen smaragde aus den oberïgyptisehen Gruben; nach ihrer Beschaffenheit und der ihrer Begrleitmineralien stimmen sie mit den dortigen auf das vollkommenste überein.

Zu Ende des 16. Jahrhunderts kamen die ersten Smaragde aus S ï a merika, das nachlier durch einige Jahrhunderte, bis zum Jahre 1530, die sämtlichen im Handel vorkommenden Exemplare dieses Edelsteines lieferte.

Die zuerst bekannt grewordenen amerikanischen Smaragde sind die peruanischen. Die spanischen Eroberer sahen in Peru zahlreiche schöne und große Steine dieses kostbaren Juwels bei den Bewohnern des Landes in Gebrauch, sie waren aber trotz der gröliten Mühe nicht imstande, die Gruben zu finden, in denen der Edelstein grewonnen wurde. Es sclıcint, dals diese beim Einfalle der Spanier von den eingeborenen Arbeitern verlassen und verschïttet wurden: vielleicht sind sie auch schon früher erscbüpft gewesen. Sie sollen in dem Iantatale bei Puerto viejo gelegen halen, von wo der Sage nach auch der schon oben erwälnte Smaragd von der Gröbe eines Straubeneies herstammite, den die alten Peruaner als Gottheit verehrten. Jedenfalls wird heutzutage gar kein Smaragd mehr in Peru gewonnen. Ungeheuer muß aber die Menge der Steine gewesen sein, die die Spanier nach der Eroberung des Landes den Eingeborenen abnahmen und nach Europa schickten. So erzählt Joseph d'Acosta, daß auf dem Schiffe, mit dem er 1557 ron Peru nach Spanien fuhr, zwei Kisten mit je einem Zentner Smaragde befördert wurden. Diese massenhafte Zufuhr aus Peru in Verbindung mit dem Ergebnis der bald nachler in Kolumbien aufgefundenen Gruben driickte den Preis der bis dahin in Europa so seltenen Steine auferordentlich. Die amerikanischen Smaragde waren viel schöner als die bisher in Europa benutzten, die wohl aus den schon genannten Gruben in $\ddot{A} g y p t e n$ stammten. Daher wurden die besten Smaragde als "peruanische" oder auch als "spanische" bezeichnet, ganz ebenso wie die wertrollsten Edelsteine anderer Art orientalische genannt werden, gleichniultig, ob sie aus dem Orient stammen oder nicht. Viele der jetzt in Gebrauch stehenden Smaragde sind schon damals von Südamerika nach Spanien und ron dort aus nach anderen Teilen ron Europa gebracht worden, haben aber seit jener Zeit ihre Gestalt durch Umschleifen in die jeweilig der Mode entsprechende Form, wahrscheinlich mehrfach, geäindert, so daß sie ron ihrem urspriinglichen Eigentïmer nicht mehr erkannt werden wiirden. Die Spanier sollen in Peru viele Steine durch Hammerschläge zertrümmert haben, da bei ihnen die Meinung herrschte, nur die seien echt, die dabei nicht zerbrechen. 
Auch in Hexiko fanden die Spanier zahlreiche Smaragde bei den Eingeborenen, einzelne ron hervoragender Schönheit und bedeutender Größe und zum Teil in charakteristischen, anderweitim nicht wieder vorkommenden Formen mit großer Kunst bearbeitet. Namentlich wirl von fünf in der Form von phantastischen Blumen, Fischen und anderen ähnlichen Gestalten geschnittenen Steinen berichtet, die $\mathrm{Cor}$ tez von dort mit nach Europa crebracht hat. Da aber niemals etwas über das natïrliche Vorkommen von Smaragden in jenem Lande hekannt geworden ist, so ist es wahrscheinlich, daß die Mexikaner ihre Snaragde aus l'eru oder auch aus den sofort näher zu schildernden Gruben in Kolumbien bei sich eingeführt und dann in ihrer Art verarbeitet haben.

Nicht lange waren die Spanier genütigt, ibre Begierde nach dem prachtrollen grünen Edelsteine an den in den Schatzkammern, Tempeln und Grabstïtten der alten Peruaner und Nexikaner angehäuften Torräten zu befriedigen. Fast gleichzcitig mit Peru bemächtigten sie sich der Lünder, die jetzt den Namen K o l u m b i e n (Colombia oder NeuGranada) führen, und hier wurden auch die Lagerstättten gefunden, aus denen die Einwohner dieser Gegrenden die bei ihnen verbreiteten griinen Edelsteine holten, Lagerstïtten, die noch heute von großer Bedeutung sind, und die auch den Juwelieren unserer Zeit den größten Teil der neu in den Handel kommenden Steine liefern.

Diese kolumbischen Fundorte des Smaragds sind die einzigen, die in Südamerika wirklich bekannt und nicht bloß gerïchtweise durch mehr oder weniger zuverlässige Mitteilungen der Landeseinwohner angerleutet worden sind, wie dies bei den peruanischen der Fall war. Daher ist auch die Ansicht ausgesprochen worlen, daß die Smaragdgruben in Kolumbien überhaupt die einzigen gewesen seien, die in Südamerika je im Betriebe standen, daß jenes Land allen in Mexiko und in Südamerika gefundenen Smaragd geliefert habe, und daß namentlich in Peru, dann aber auch ebenso in Bolivia, Venezuela und Ectador, die als Ileimat des Steines gleichfalls crwähnt werden, niemals auch nur ein einziges Exemplar auf seiner natürlichen Lagerstätte vorgekommen sei. Danach wïrden alle die sogenaunten ,peruanischen Smaragde“ ihren Namen, wenigstens soweit er die Heimat und nicht im oben angegebenen Sinne die Qualität ausdrücken soll, mit Unrecht fiihren, sie mïssten cigentlich als kolumbische bezeichnet werden. Jene Annahme ist nicht sehr wahrscheinlich, doch soll cine Diskussion dieser Streitfrage hier nicht versucht werden, da sie von keiner praktischen Bedeutung ist. Gegenwärtig liefern ja jedenfalls peruanische usw. Gruben keine Smaragde mehr, und für den heutigen Edelsteinhandel ist es gleichgültig, ob dies je in früheren Zeiten der Fall gewesen ist oder nicht.

Am 3. März 1537 Iernten die Spanier die kolumbischen Smaragde zuerst kennen durch ein ihnen von den Indianern dargebrachtes Geschenk. Sie erfuhren zugleich auch den Fundort derselben, der mit dem noch jetzt gebräuchlichen Namen Somondoco bezeichnet wurde. Er liegt 9 Leguas von Guatequé entfernt, dicht bei dem Wasserfalle des Namar, wo der Garagoa herabstiirzt, um sich mit dem Guario zu verbinden, der in den Upia, einen Nebenfluf des Rio Meta, mündet. Der Ort liegt auf der Ostseite der Kordillere von Boggotá, ungef:ilı unter $5^{0}$ nördl. Breite und etwa eimen halben Grad östlich von Bogotá, in einer so wilden und unzugänglichen Gegend, daß die Spanier trotz der Menge der allerdings nur durch schwere Arbeit zu erlangenden Smaragde nieht lange dort verweilten. Seitdem ist dann auch jede genauere Kunde der dortigen Vorkommnisse und der alten Gruben verloren gegangen, und bis auf den heutigen Tag hat man nichts wieder davon gehört, so daß auch dieser Fundort trotz bestimmter Nachrichten dariiber zuweilen für cinen zweifelhaften gehalten wird. Es ist aber sicher, daß ein nicht gaeringer Teil der frïher in Kolumbien gerabrabenen grïnen Edelsteine wirklich von hier stammt.

Kurze Zeit darauf wurde in nicht zu grofier Entfernung ron jener ersten Fundstelle rine zweite entdeckt, die den Spaniern reiche Vorrïte lieferte und die noch jetzt wichtiger 
ist als irgendeine andere auf der wanzen Erde. Sie ist zucroleh fast die cinzige die

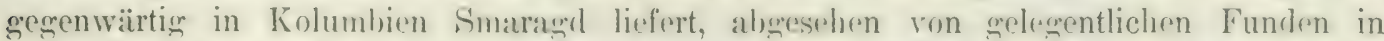
Graibern oder in den friiher als Opferstäten benutzten Bereseren. Die an solchen ()rten vorkommenden Steine sind aber durchwes ron untergeorlneter Beschaffenheit, während die in den Gruben exwonnenen nach Farbe und Durehsichtienkeit zum Treil vom sröbiter Schönheit und vielfach von erster Qualitäit sind.

Diese Smaragdlager befanden sich im Lande der willen Muzo-Indianer, dis: von den Spaniern lange Zeit nicht besient werden konnten. 155) erelange dies endlich, wenn auch nur unvollstïndig, dem Fïhrer Iatiz Lanchero, der in diesem Jahre die Start Santissima Trinidad de los Muzos griindete, das heutige Dorf Muzo (oder Muso), an rechten Ufer des Rio Minero in dem dambals so genannten Gebirge von Itoco, das nachler von jener Stadt den Namen erhalten hat.

Die Smaragdewewnung begann hier loss und wurde trotz der hestïndigen Angrifes der Indianer fortgesetzt, zurst in einer alten Grube in den liergen, von der jetzt livine: Spur mehr vorhanden ist. An dem Orte, wo später der Mittelpunkt des Betriebes lag, etwa eine Legua ron dem Orte IIuzo entfernt, begann man die Arbeit im Jahre 1594. Zahlreiche Gruben wurden in diesem Bezirke im Laufe der Jahre angelent und aus verschiedenen Grïnden zum Teil auch wieder verlassen, zum Teil werden sie noch heute ausgrebeutet.

Nach den Mitteilungen von Ricardo Lleras Codazzi in Bogrotí liegren die Smaragrlgruben ron Colombia in der Cordillera Oriental von Bogroti, die sich bei Popayan von der Hauptkette abzweigt und das rechte isstliche Ufer des Rio Vagdlalena auf seinem Laufe nach Norden begleitet. Sie bilden zwei Zonen parallel der Achse dieses (tebirgszuces zu beiden Seiten der Ehene von Boyací. Die westliche Zone umfaft die der Regierung gehörigen Gruhen IIuo und andere ron geringerer Bedeutung; in der östlichen Zone liegt u. a. die alte Crube ron Somondoco und die von Chirar, alle z. Z. guinzlich verlassen. Außerhalb dieser Zone ist nur das Vorkommen bei der Saline ron Temocon erwähnenswert, die aber wenig brauchbares Naterial enthält.

Die gegenwärtiw allein in lextracht kommenden Gruben sind die der Regierung gehörigen in der westlichen Zone, die auf der Karte Fig. 74 (S. 394) dargestellt sind. Sie liegen alle auf der linken Seite des Rio Minero (oder Rio (arare), der nach nürdlichem Lauf in den Rio Magdalena mïndet, nicht weit vom Dorf Muzo. Es sind die folgenden: Mina Real de Muzo, Nina de Coseuez, Mina de la Chapa und Mina de Peña Blanca oder Cerro Fambrias. Jede dieser Gruben enthält eine Anzahl smaragdfülrender Kallsspatgänge, die ebenfalls mit hesonderen Namen belent werden, so z. B. die Mina Real de Muzo die Gänge San Antonio, El Plaron, La Isla, Miğuel Ruiz, Jaramillo Fequendama und Gerena; die Grube Coscuez. die Gänge Dona Urraca, Guacamayas und Don Jareos usw. Die in der Karte nicht verzeichnete Mina de Camancha in der Talschlucht des Rio Villamizar, einem Nebenfluf des Minero, nahe dem Dorf Coper, enthält nur ein einziges System bauwürdiger Adern.

Die Gruben stehen in den ammonitenführenden Kalken und feinkörnigen schwarzen Kalkschiefern der unteren Kreide, die durch zahlreiche Falten und Verwerfungen grestört und von den erwähnten Kalkspatadern durchsetzt werden. Diese sind, soweit sie smaragdfïhrend sind, dïnn, kompakt und von kristallinischer Struktur, und sie verzweigen sich vielfach und unregelmäßig in dem Nebengestein (Fig. 76, S. 396). Andere mächtigrere Kallspatgänge, die sogen. ciniceros, die sich nicht rerzweigen, führen fast niemals Smaragd. Die Mineralien, die den Edelstein in jenen ersteren Adern begleiten, sind: das seltene Ceriumkarbonat Parisit in grö̈feren und kleineren Kristallen, farbloser und wasserletler Kalkspat von der Art des islïndischen Doppelspats (Taf. XII, Fig. 1), Rihomboëcler von meist 
schwarzem Dolomit, farbloser Flulisplat, schün kristallisierter Bergkristall, zuweilen mit Einschlïssen kleiner Kristalle von Smaragd und Parisit, sowie Quarz von grüner Farbe, Schwefelkies in Form von Pyritoeder und Würfel, grïner Gips usw.

Das Torkommen des Smaragds in diesen Adern ist ein doppeltes. Einmal sind die Kristalle, mit denen der Begrleiter, namentlich mit Doppelspat, Bergkristall und Dolomit in Drusen aufiewachsen. und zwar fast stets auf einer Kruste von Schwefelkies oder von Killisplat. Die Smaragdkristalle sind dann meist nur an einem Ende regelmäßig ausgebildet. In dieser Weise finden sich die schönen und großen, cenatillos genannten Prismen. Zum andern trifft man den Smaragd in Nestern, sogen. guarruceros, Hohlräumen

\section{Gegend der dem Staate gehörigen Smaragdgruben in Colombia .}

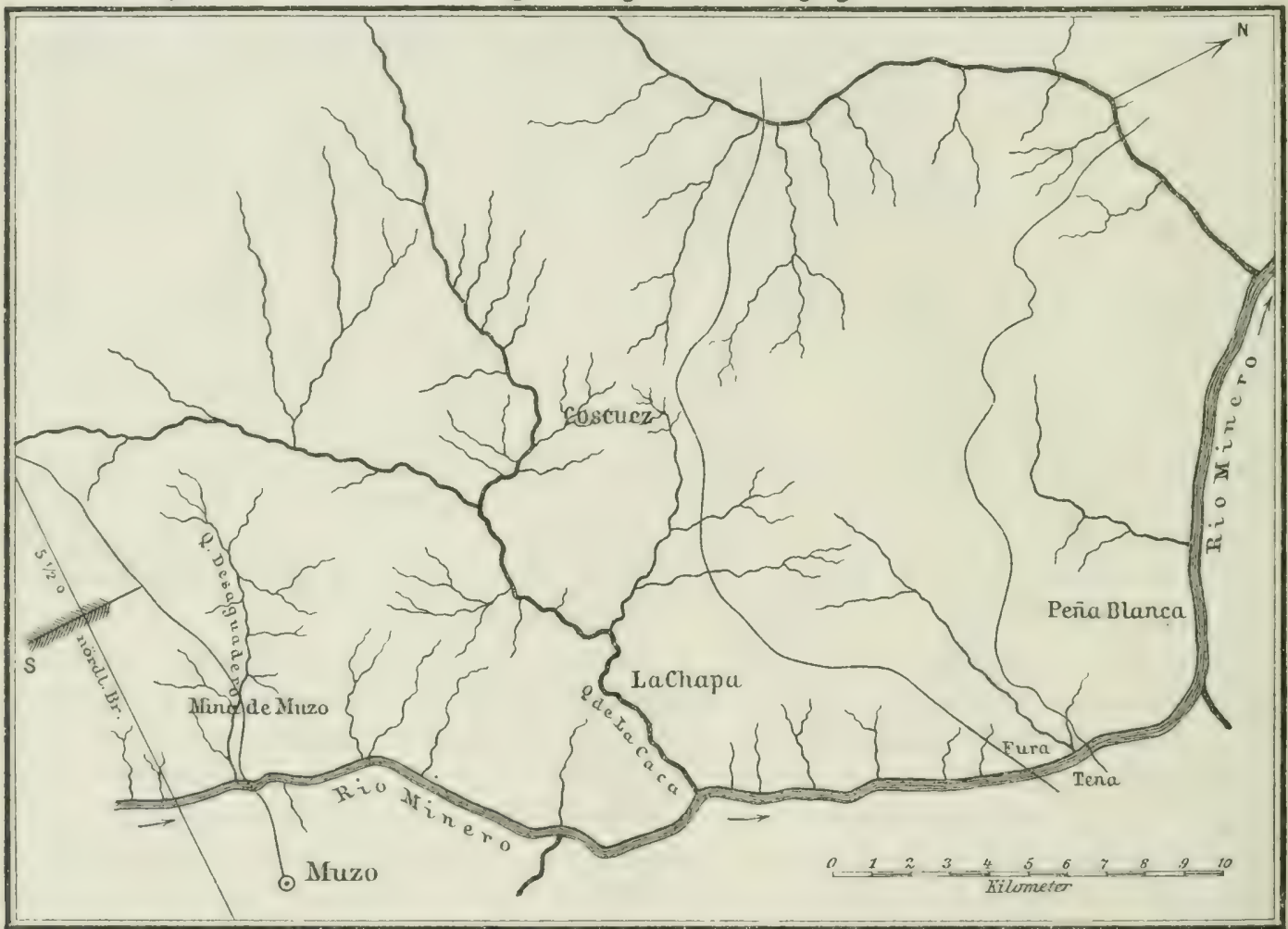

Fig. 74. Smaragdgruben im Besitz der Regierung von Colombia (nach R. L. Codazzi).

in den Adern, deren Wände mit Liristallen von Schwefelkies, Quarz usw. besetzt sind und deren Inneres mit einer sehr feinen weißen, aus Kieselsäure, Tonerde und Berylliumoxyd bestehenden Lrde ausgefuillt ist; in dieser liegen Smaragdkristalle, die dann beiderseitig regelmäbige Begrenzung zeigen. Diese Verbältnisse sind in den einzelnen Gruben etwas verschieden.

Steine von höchster Yollkommenheit finden sich nur in der Mina Real de Muzo und in der Grube von Coscuez. I.etztere wird aber wie die übrigen dem Staate gehörigen Gruben seit der Zeit der spanischen IIerrsehaft nicht mehr bearbeitet, trotzdem ihr Material hinter dem von Muzo nicht zuriicksteht. Dagegen ist diese von der größiten Bedeutung, sie ist es, die die schönen kolumbischen Smaragrde liefert. Sie steht zur Zeit allein im Betrieb, doch werden anch in ihr nicht alle Adern abgebaut, da bei Gerena die Massen 
des Sihwefels und des Pyrits, dur ..ciniceros" sich entzündet haben und seit mehreren Jahren brennen. Die Lage der (iruben bei Muzo sind aus der Karte (Fig. 75) zu ersehen.

Die jetzige Iraunterube lierrt rinize Kilometer westlich vom Dorf Muzo auf der anderen linken seite des Rio Minero, am rechten siidlichen Tababbange geren die (zuebrada

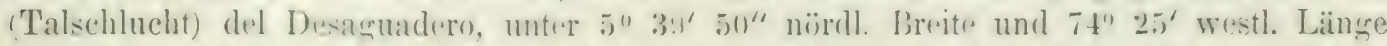
von Greenwich, ungefähr $110 \mathrm{~km}$ mordwestich von liogotí, in ciner Meereshähe von $878 \mathrm{~m}$. Sie ist seit langer Zoit im Betrieb, aber nicht ununterhochen. Mehrfach muliten die Arbeiten eingestellt werden, so in der Mitte des 1). Jahrhunderts. wie herichtet wird, infolge einer sroben Fenersbrunst. Erst is 11 wurle der Abhau wiederaufgenommen, und balıl durch die

\section{Smaragdgruben von Muzo.}

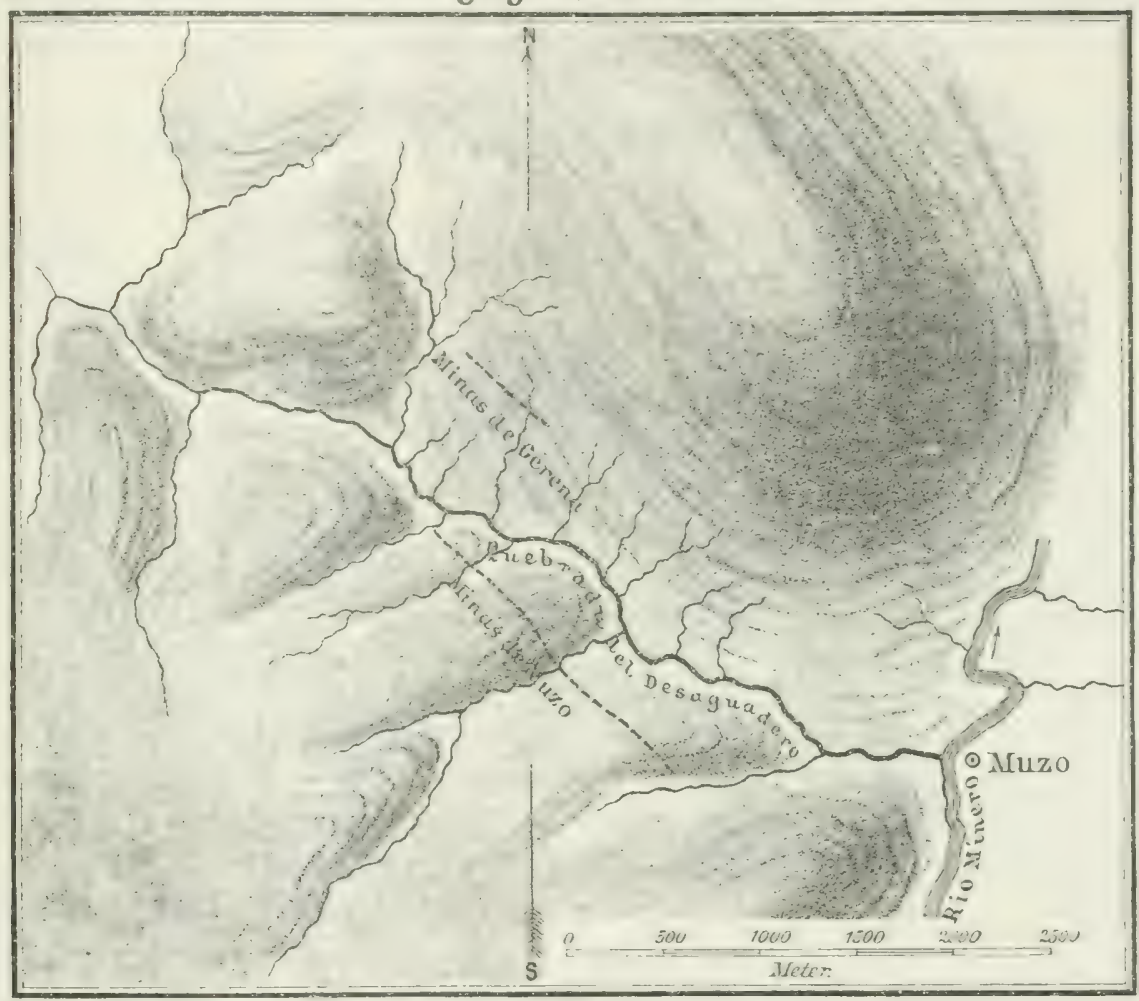

Fig. 75. Smaragdgruben bei Inzo, Colombia (nach R. L. Codazzi).

kolumbische Regierung sellsst, hald durch einheinische Pächter oder auswärtige, europäische Gesellschaften fortgeführt. Namentlich diese Pächter umgaben in ihren Interesse die ganze Fundstätte mit einem undurchdringlichen Geheimnis, so dab iiber manche wichtige Punkte nur ungenügende, dürftige Nachrichten rorhanden sind. 1549-1561 war es eine englische Gesellschaft, die der Regierung 14200 Dollars Pacht und 5 Prozent des Reingewinns erlegte. 156.1 - 1575 bezahlte eine französische Gesellschaft unter der Leitung von fustav Lehmann für das Recht der Ausbeutung sämtlicher dem Staate gehöriger Gruben 14700 Dollars im Jahr und die Steine, dhe früher nach London geschickt wurden, kamen vorïhergehend in Paris auf den Markt. Später traten andere Unternehmer an die Stelle, die weit böhere Pachtsummen zu entrichten hatten. Gegenwärtig fordert die Regierung eine so hohe Pacht, dab Privatpersonen überhaupt kaum instande sind, die Gruben mit Nutzen auszubeuten, auch wenn so schöne Kristalle wie die ron Muzo und Coscuez gefunden werden. Zur Zeit arbeitet ein einheimisches Syndikat. 
Der schwarze Kalkschiefer, in dem die Grube steht, wird ron rotem Sandstein und Sehieferton unterlagert. Ein Teil der Crube ist in Fig. 76 abgebildet. Ihre Höhe über der Taliohle beträgt (i0) m. Sie bildet einen trichterförmigen Tageban mit einem oberen Durchnesser von $200 \mathrm{~m}$ und einem unteren von $50 \mathrm{~m}$. An der einen bergaufwärts gelegenen Seite ist die Thiefe etwa $120 \mathrm{~m}$, an der entgegengesetzten nach abwärts gerichteten nur $20-30 \mathrm{~m}$. In frïhren Zeiten, jedenfalls während der spanischen Herrschaft, war der Betrieb unterirdisch in schäiehten und Stollen; später zog man, zum 'Teil um den grolien Unterschleifen durch die Arbeiter durch schärfere Beaufsichtigung besser entgegentreten zu kümnen, den offenen Tagebau vor. Die jetzige Gewinnungsmethode wurde von der erwïhnten englischen Gesellschaft eingreführt. Sie besteht darin, dab die Arbeiter, von oben nach unten fortschreitend, grofe treppenförmige Einschnitte (banqueos) in den Schiefer machen, und so die ganze Felswand allmählich systematisch abtragen, um alle smaragdführenden Kalk-

\section{Ansicht einer Ader in der Mina Réal de Muzo.}

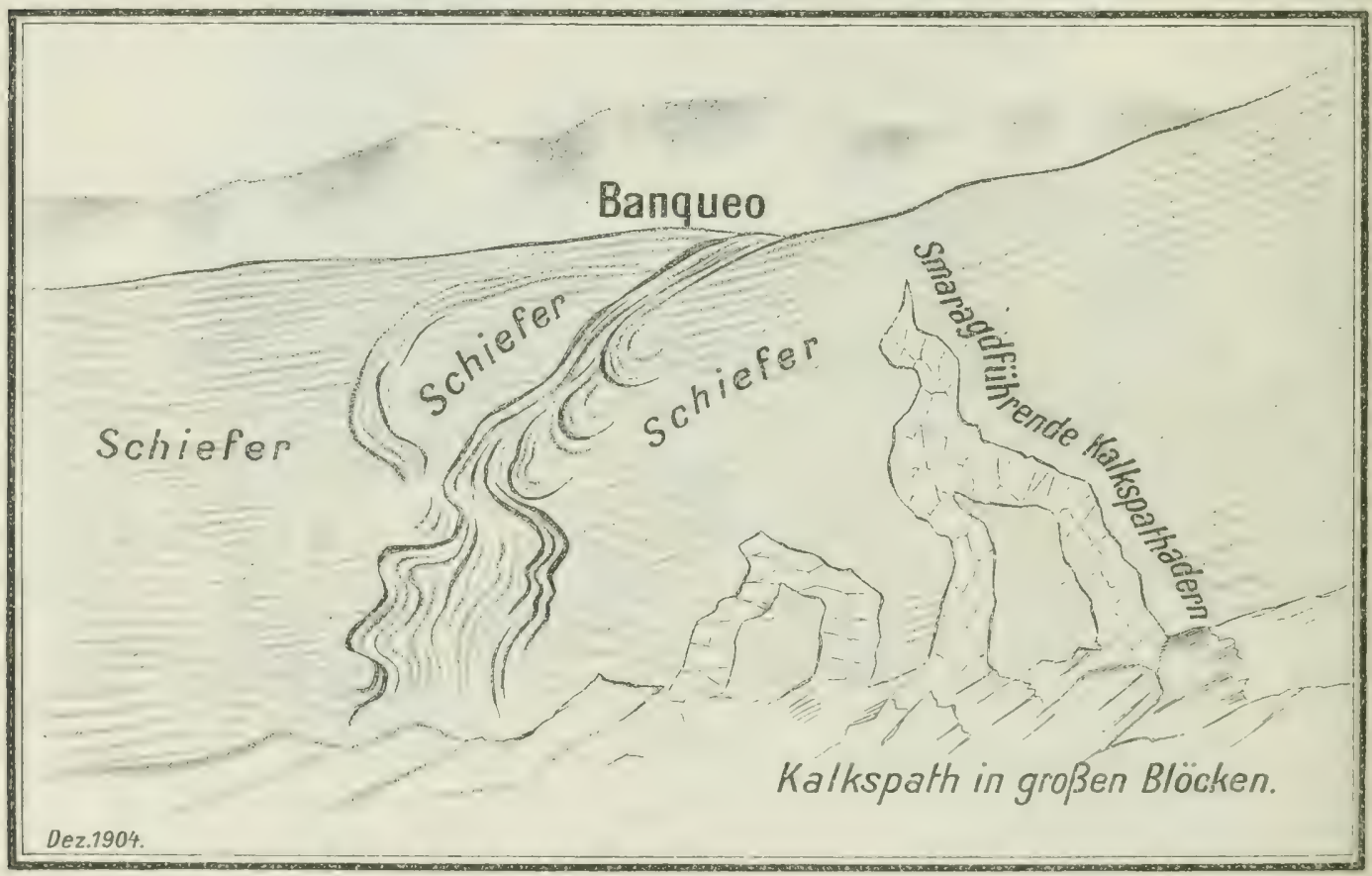

Fig. 76. Teil der Smaragdgrube bei Muzo, Colombia (nach R. L. Codazzi).

spatadern aufzufinden. Aus diesen bricht man mittels eiserner Stangen grobe Blöcke, die an geeigneten Orten sesanmelt und in kleinere Stiicke zerlegt werden. In ihnen sucht man dann die Smaragle auf, die durch das Vorkommen von griinen Quarzkristallen angedeutet werden sollen. Die Cberreste und üherhaupt aller $\Lambda$ braum sammelt sich unten in der Grube an. Fon Zeit zu \%cit wird dann aller dieser Schntt mittels in der Iöhle zu diesem Zweck angestauter Wassemassen durch einen digens hiezu hergestellten Kanal aus der Grube hinausgeschwemmt und diese dadurch gereinigt.

Das Auffinden ertrawreicher Stellen ist sehr unsicher, da keine bestimmten Kennzeichen die Anwesenheit der unregelmibig im Schiefer verteilten Kalkspatadern und der in diesen nur sporadiseh vorhandenen smaragdführenden Drusen und Nester ankïndiren. Man muß daher immer aufs Geratewohl vorehen und alles dem Zufall iiberlassen. So findet man manchmal monatelang carnichts, andererseits kounte ein Tag einen Ertrag von 1000(10) Mark bringen. Infolgedessen ist auch die (iesamtproduktion, soweit man sie 
kennt, sehr schwankend. Sis betrug z. B. im Jahre 1819 im Durchschnitt 12 40) Karat in Monat, in den fünfziger Jahen im Mittel 22.346 Karat im Jahr, doch ist es ummöglich canz zuverlässige Aneaben zu erhalten. Auch jetzt spielt die Veruntreuung von Steinen durch die Arbeiter eine arolie Rolle; sie soll ungefähr ein Viertel der ganzen Ausbeute betragen.

Die Kristalle des kolumbicchen Smaraeds haben fast alle die cinfache Form des hexa-

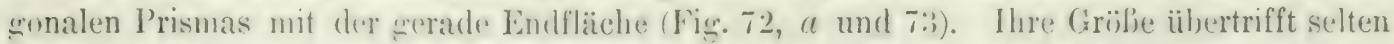
die eines Daumens, meist ist sie erhehlich geringer. Iäufig sind sie ein-oder mehrere Male quer durchechrochen; die rinzelnen Bruchstiicke sind durch feine, auf den Spalten eingedrungene Kalkspathäutchen voneinander getrennt, werden aber durch die umgebende Masse festgehalten, so dafb der liesitzer den Sehaden crist nerkt, wenn er anfängt. seinen Kristall herauszuarbeiten. Ilt den deutlichen Kristallen kommen manchmal auch ab)gerundete Stücke ror, die als beweis für die früher wohl grehegte Ansicht angesprochen wurden, dal die Smaragle nieht in den Kalkspatadern entstanden, sondern von anderswoher, aus einem Gneis- oder (iranitgebiet. in diese hineingeschwemut worden seien, cine Ansicht, gegen die aber durchschlagende Grïnde sprechen.

Eigentümlich ist, dafi manche Kristalle nach dem Herausnchmen aus der Grube ohne erkennbaren äuferen Anlab in stiicke zerspringen. Man sucht sich hiergegen, allerdings vielfach obne Frfolgr, dadurch zu schiitzen, dab man die gewonnenen Smaragle einige Tage in undurehsichtigen verschlossenen Gefälen vor den Sonnenstrahlen behiutet und sie so langsam austrocknen lïfit. Mit jener Eigenschaft steht wohl auch im Zusammenhang, daß die meisten frisch aus der (rube gewonnenen Smaragde ganz klar und durchsichtig und frei von Spriingen sind; erst nach einiger Zeit werden sie rissig und nehmen dadurch die schon oben sreschilderte grewöhuliche, etwas trüh) Beschaffenheit an. Im Gegrensatz dazu sollen sie, wie ührigens auch die Smaragde anderer Fundorte die ihnen eigentïnliche Härte erst erhalten, nachdem sie einig'e Zeit die Grube verlassen haben.

Die kolumbischen Smaragde sind bäufig ron der schönsten, dunkelgrimen Farbe, doch gibt es noch viel mehr hellere bis fast farblose; manchmal sind die Kristalle auch außen grün und innen farblos. Bei zahlreichen Frristallen geht die Farbe stark ins Schwärzliche, und diese zeigen dann besonders schön den sammetartigen Schimmer. Auch Sternsteine, ähnlich den oben beschriebenen Sternsapphiren (S. 35i) kommen als Seltenheit vor. Die Durchsichtigkeit wechselt stark und geht vom vollkommen Klaren bis zum ganz Trüben.

Der Handelswert der Smaragde beruht auf der Farbe, dem Glanz und auf der Durchsichtigkeit und Klarheit. In dieser Bezichung zeigen sie auch in Kolumbien die weitestgehenden Unterschiede, und nach diesen Eigenschaften werden sie in rerschiedene Klassen oder Sorten eingeteilt.

Die smaragle des $\mathrm{L}$ ral stammen alle aus einigen wenigen der Krone gehörigen Gruben, die auch blalggrïnen Aquamarin, Alexandrit und den noch zu besprechenden Phenakit liefern. Sie liegen zu mehreren Gruppen rereinigt in einem schmalen Landstrich, ungefähr S5 Werst (Kilometer) nordïstlich ron Katharinenburg an Oberlauf der Starka Tokowaja und anderer rechter Tebenflüsse des in die Pyschma mïndenden Bolschoi (Großen) Reft.

Was Schünheit der Farbe und Durchsichtigheit anbelangt, so stehen die schönsten uralischen Smaragde den sïdamerikanischen nicht nach, doch kommen auch sehr viele trühe, undurchsichtige und rissige, sowie hell, ungleichmälig und unscheinhar gefärbte vor, die als Edelsteine nicht rurwendet werden können. Die meisten sogar sind nur halbdurchsichtig und haben sehr viele Risse, rollkommen durchsichtige sind dagegen sehr selten. Die Kristallform ist das hexagnonale Prisma, vielfach an den Enclen unregrelnälbig; 
zuweilen auch, wie in Kolumbien, durch die gerade Endfläche begrenzt; andere Formen kommen kaum vor. An Grölje iibertreffen die uralischen Smaragde vielfach die Funde von anderen Orten, namentlich die von Südamerika. Wir haben schon oben einige besonders große uralische Smaragde kennen gelernt. Die größten sind bis $40 \mathrm{~cm}$ lang und $25 \mathrm{~cm}$ dick, doch sind diese großen weist nicht schleifbar, auch bilden sie Aus. nahmen neben der überwiegenden Zahl der kleinen.

Die Smaragde finden sich im Ural wie in Ägypten und abweichend von den Verhältnissen in Kolumbien in einen dunkeln, dem Chloritschiefer zwischengelagerten Glimmerschiefer eingeschlossen, wie es Taf. XII, Fig. 2 darstellt, die sich allerdings auf einen andern, unten zu besprechenden Fundort (im Habachtal in den Salzburger Alpen) bezieht. Glimmerblättchen sind wie in $\ddot{g}$ ypten und an dem letztgenannten Fundort nicht selten an die Kristalle an- oder in sie eingewachsen. Die Kristalle sind entweder einzeln, oder es sind mehrere in paralleler Stellung aneinander gereiht, oder in anderer Weise zu gröljeren Gruppen vereinigt. Namentlich findet man zuweilen radialstenglige Aggregate, in denen die einzelnen Kristallindividuen von einem gemeinsamen Mittelpunkte ausstrahlen.

Zusammen mit dem Alexandrit wurden die Smaragde von der Tokowaja im Jahre 1830 zufällig von einem Bauern entdeckt, der einige kleine grïne Kristalle in den Wurzeln eines vom Winde umgerissenen Baumes bemerkte. Er brachte sie nach Katharinenburg, wo schon 1755 die Kaiserin Katharina II. Schleifereien zur Verarbeitung der im Ural so vielfach gefundenen schönen Steine aller Art angelegt hatte, und wo noch heute der Ilauptsitz des russischen Edelsteinhandels ist. Von dort aus wurden dann umfassende Nachforschungen angestellt und einige Gruben angelegt, in denen Smaragd zusammen mit Beryll, Alexandrit und Phenakit seit 1832 systematisch gewonnen wurde. Die Ausbeute stiegr bis 1837, fiel dann aber, und 1852 wurde infolge zu starken Wasserzuflusses und zu großer Kosten der Betrieb fast gänzlich eingestellt Später wurden einige Gruben an Unternehmer verpachtet, die aber ebenfalls keinen Erfolg batten und daher 1882 die Arbeiten einstellten. Um die Jahrhundertwende ernetterte eine englische Gesellschaft die Versuche. Die Gruben haben bis 1882 mindestens $4000 \mathrm{~kg}$ Smaragd und Aquamarin gegen $100 \mathrm{~kg}$ Alexandrit und $82 \mathrm{~kg}$ Phenakit geliefert, und die Jahresprodulstion hatte einen Wert, der bis nahezu auf 200000 Mark stieg.

Auf diese Stelle ist das Vorkommen größerer Mengen von Smaragd im Ural beschränkt. Nur ein einziges Mal hat man einen schön gefärbten und durchsichtigen Stein in ciner Goldseife im Tal des Flüßchens Schemeika im Katharinenburger Bergrevier rrefunden. Daß schon im Altertume Smaragde aus dem Lande der Scythen erwälunt werden, ist bereits im Vorbeigehen mitgeteilt. Möglicherweise stammten sie aus uralischen Fundorten, doch ist Näheres darüber nicht bekannt.

Ganz ähnlich wie an der 'Tokowaja ist das Vorkonımen des Smaragdes in den Salzburger $\Lambda$ lpen, nur sind hier die Kristalle viel kleiner, das Ganze ist viel unbedeutender und spielt im Handel eine ganz untergeordnete Rolle.

Die Fundstelle liegrt obersalb der Sedlalp (oder Söllalp), an einer steilen Felswand. dem Suraragdpalfen, an östlichen Abhange des Legbachgrabens, einer Seitenschlucht des Habachtales, 13 Kilometer von Habach. IIier wurden die Steine mit Lebensgefahr, trotzdem sogar zeitweise dureh regelmäligen Bergbau gewonnen, der Ertrag war aber für einen ausgedehnten Betrieb zu gering. besonders bei den ungünstigen Verhältnissen, die zum Teil auch die grofe Meeressöhe von 7500 Fulb mit sich brachte. Indessen gilt das Vorkommen immer noch als aussichtsvoll: 1902 sind 68000 Karat gefunden worden. Schon die alten Römer sollen den Edelstein an dieser Stelle gewonnen haben. 
Der Smaragd bildet hier geleichfalls sechsseitige Prismen, auf den Seitenflächen und an den Enden vielfach mit Glimmerblättehen und schwarzen Turmalinnädlelchen bedeckt, die auch oft in das Innere der Kristalle hineinewachsen sincl. Die Farbe ist zuweilen sehr schön dunkel smaragdgrïn, ̈̈fter aber heller grasuriün his grrünlichweil) und häufig nicht gleichmäßig über den Stein verteilt. In den moisten Fällen ist der ganze Kiristall triibe, hallolurchsichtig, durchscheinend bis undurchsichtig, selten durchsichtig. Nur wenime sind für die Verwendung als Edelstein schün genugr grefïrlot und genügend rein und klar. Die weiben oder hellgefärbten Kristalle sind im allgemeinen sröfier und reiner als die griinen. Diese sind ron einer Linie bis zu einem Zoll lang, selten lïnger, bei einem Durchmesser von 1/, bis 3 Linien, in Ausnahmefaillen auch mehr. Das Intteresestein, in dem die kiristalle eingewachsen sind, ist ein feinkömiger, tonschiteferartiger, dunkelbräunlicher bis -gïnlicher Glimmerschiefer, der in einen grünen, teils an Chlorit, teils an IIornblende reichen Glinmerschiefer eingelagert ist. Das Vorkommen ist in Fir. 2, Taf. XII abgebildet. Begleitet wird der Smaragd ron Schwefelkies. In den feinsten Glimmeradern von 1 bis 3 \%oll Dicke sollen die schönsten und gröften Steine sich finden. Manche Handstïcke sind von solchen aus dem Ural ununterscheidbar.

Ubrigens ist dieser Punkt nicht der einzige Fundort des Edelsteines in jener Gegend; man trifft ihn anch an einigen anderen Stellen in der Nähe, die aber von noch geringerer Bedeutung sind.

Von europäischen Smaragdvorkommen ist vielleicht noch kurz das von Eidsvold am Südende des Mjösensees in Norwegen zu erwähnen, wo die Kristalle im Granit eingewachsen sind. Sie sind aber fast alle sehr hell gefärbt und trïbe und deshalb bisher noch nicht oder nur in geringer Menge verschliffen worden. Versuche bei Arendal in Norwegen, Smaragd zu entdecken, haben keinen Erfolg gehabt.

Auch alle anderen Fundorte von Smaragden, die auljer den erwähnten noch bekannt geworden sind, haben geringere Bedeutung, teilweise sind sie sogar zweifellaft. Man findet vielfach Indien und Birma als Heimat unseres Edelsteines angegeben, aber, wie es scheint, mit Unrecht. Selbst die verhältnismäßig zuverlässigen Nitteilungen über spärliche Smaragdfunde in Ratschputana im nordwestlichen Indien beziehen sich vielleicht nicht auf diesen Edelstein, sondern anf Chrysoberyll. Der Smaragd ist in Indien sehr beliebt, es ist aber so gut wie sicher, daß die dort jetzt vorhandenen Exemplare nicht aus dem Lande selbst stammen, sondern von Südamerika, vielleicht auch vom Ural eingeführt sind. Noch heute liefert der Londoner Edelsteinmarkt zahlreiche Smaragde nach Indien, auch wird erzählt, dab suidamerikanische Steine nach Indien geschickt werden, um sie dort in landesiiblicher Weise anschleifen zu lassen und sodann als von indischer Herkunft in den Handel zu bringen.

In Algier soll ebenfalls Smaragd rorgekommen sein, und zwar als Gerölle in den Flïssen Harrach und Bouman, und auch anstehend in deren Nähe. Nach neueren Nachrichten sind aber die Steine von dort grüner Turmalin.

Unbedeutend ist das Vorkommen in Australien. Nan findet Smaragde sparsam in Südaustralien an Mt. Remarkable und an einigen Orten in Neu-Sïd-Wrales. Hier könnte vielleicht das neuentdeckte Torkommen am Vegetable Creek in Neu-England, der Nordostecke der Kolonie (Fig. 53), wo sich der Edelstein mit Topas und anderen Mineralien in einem Zinnerzgang auf der Grenze zwischen Granit und Tonschiefer findet, ron einiger Bedeutung werden, ebenso das im Pegmatit am Glen Creek, 7 miles nordïstlich ron Emmaville (151 1/20 östliche Länge und 291/20 südlicher Breite), wo aher die Härte des Muttergesteins ein wesentliches Hindernis für die Gewinnung ist.

Eine gewisse Zahl schöner Smaragde hat auch Tordamerika seliefert. Kleine Exemplare sind an zahlreichen Stellen in den östlichen Unionstaaten gefunden worden 
Im Staate Nord-Carolina sind sie an mehreren Orten in Alexander County auf Drusen im Gneis rorgekommen, besonders wird Stony Point genannt, wo der Smaragd von andersgefärbtem edlem Beryll und von Hiddenit, dem später noch zu betrachtenden sogenannten Lithionsmaragd, begleitet wird. Die Emerald and Hiddenite Mining Company hat hier im Laufe weniger Jahre für 15000 Dollar's von diesen Steinen gewonnen, aber damit, wie es scheint, die Fundstelle erschöpft. Nur wenige von den hier gefundenen Smaragden waren schleifwürdig; der grölte und schönste der gewonnenen Steine wiegt geschliffen (6) Tiarat. Auch Russel Gap Road in derselben Grafsehaft wird erwähnt, sowie der Big ('rabtree Mountain in Nitchell County. Der meist nicht schleifbare Smaragd bildet hier velfach schöne, grïne, unregelmäßice, dünne Äderchen im Feldspat und Quarz; die ganze Nasse wird dann ähnlich der Opalmutter unter dem Namen Smaragdmutter zu Sehmucksteinen (en eabachon) und zu kleinen Gebrauchsgegenständen verarbeitet. Einige gute Smaragde sind bei Iladdam in Connecticut und bej Topsham in Maine gefunden worden, aber die Gesamtmenge aller nordamerikanischen Smaragde ist doch im ganzen stering und fïr den Edelsteinhandel ohne liedeutung. Sie werden als Produkte der Heimat ausschlieflich im Lande verwendet und als einheimische Edelsteine hochgeschätzt.

In friiherer Zeit galt auch Brasilien für reich an schönen Smaragden, und bald nach der Eroberung durch die Portugiesen wurden ausgedehnte Expeditionen ausgesandt, um die Edelsteine aufzusuchen. Man hat aber in jenem Lande trotz aller aufgewendeten Miihe und Anstrengung bis heute keinen einzigen Smaragd gefunden, und es ist wahrscheinlich, daß eine Verwechselung mit grïnem Turmalin vorliegt, der in Brasilien, wie wir sehen werden, reichlich vorkommt.

Im Altertum sind offenbar die verschiedenartigsten grünen Steine mit dem Namen Smaragd bezeichnet worden, so der grüne Jaspis, das Kupfergrïn (Chrysokoll), der Malachit und andere. Aber auch jetzt noch wird der Name Smaragd für andere grüne Edelsteine gebraucht, die man dann durch einen Zusatz vom echten Smaragd unterscheidet. So ist der „orientalische Snaragd" der grine Korund; "Kapsmaragd" heißt der grüne Prehnit; der "Lithionsmaragd" ein grünes, zur Pyroxengruppe gehöriges Mineral, das als solches mit dem Namen Hiddenit bezeichnet wird und das wir als Begleiter des Smaragds in Nord-Carolinia schon im Vorbeigehen kennen gelernt haben; der „Kupfersmaragd", als Mineral Dioptas genannt, ist eine schön grüne Kupferverbindung. Von den beiden letzteren, die als Edelsteine zuweilen Verwendung finden, wird unter noch weiter die Rede sein.

Manche grüne Mineralien können unter Umständen mit dem Smaragd verwechselt und ihm untergeschoben werden, namentlich der orientalische Smaragd, der unter dem Namen Demantoid bekannte grüne Granat, der eben erwähnte Hiddenit und der Diopsid, der Alexandrit, der griine T'urmalin und vielleicht auch der Chrysolith und der Dioptas. Alle diese Steine hahen ein höheres spezifisches Gewicht als der Smaragd und sinken in der dritten und sogar einige in der schwersten Flüssigkeit unter, auf denen beiden der Smaragd schwimmt. Auferdem ist der orientalische Smaragd viel härter. Der Demantoid, dessen Farbe meist etwas ins felbe geht, aber doch manchmal der des Smaragds sehr ähnlich ist, bricht das Licht einfach. Der Hiddenit kommt nur als grobe Seltenheit vor und wird so gut wie ausschlichlich nur in Anerika als Edelstein benutzt; er wird am höheren Gewieht erkannt. Die Farbe des Diopsids ist viel mehr bouteillengrïn als die des Smarageds. Der Alexandrit ist dureh die viel gröbere IIärte und den sehr starken Pleochroismus neben dem Smaragd ansgezeichnet. Die rrüne Farbe des Turmalins geht häufig stark ins Blaue, ist aber auch oft derjenigen der helleren Smaragde nicht unähnlich; den besten Unterschied wiht das sperifische (rewicht des Turmalins $\left(\mathrm{G}_{.}=3,07\right.$ ), das sich noch ein wenig iiber das dex dritten Fliissigkeit erhebt, so dab er darin sinkt. 
1) (Chrysolith int gedblichgrin und kann an der Farbe und an seinem auberordentlich geringen Pleochroismus wohl stets leicht untersehieden werden. Endlich sei der Kupfersmaragd (I)ioptas) noch genannt, der stets schr dunkel smaragrdgrün geförbt und sehr wenion durchsichtig, sowie (rheblich weicher und schwerer ist als der Smaragrl. Eingehend ist de Unterschembng der mit dem Smaraged ctwa verwechselharen durchsichtigen grrünen Steine im dritten Teile in der 11. Tabelle dargestellt, in der noch cinige andere, hier nicht erwähnte, berücksichtigt sind.

Ein schönes smaragderiines (x)as kann unter anderem erhalten werden, wenn man 4608 Teile Strab, 42 Teile reines Kupferoxyd und 2 T'eile Chromoxyd zusammenschmilzt. Tom Smaragd wird es leicht durch die einfache Lichtbrechung und die Abwesenheit einer jeden Spur von Pleochroismus, sowie durch die weit geringere Härte unterschieden. Eine Nachahmung des Smarageds kommt gegenwärtig zuweilen im Handel vor, die sich durch schöne Farbe, aher nicht kanz vollständige Durchsichtigkeit, zahlreiche kleine Lufthläschen, Mangel an Dichroismus und das spezifische Gewicht 3,19, sowie endlich durch einen Gehalt an Beryllerde ( 7 bis $\delta$ Proz.) wie im natiirlichen lieryll auszeichnet. Man hat es offenbar mit einem Glas zu tun, dem der letztgenannte Bestandteil zugesetzt wurde, um die Masse den echten Beryll chemisch ïhnlich (analysenfest) zu machen. Solche und ähnlichr: Nachahmungen sind Smaragdolin genannt worden. IIäufig werden zurzeit von Paris aus geschliffene Imitationen in den Handel grebracht, welche die Beschaffenheit der Dubletten (S. 116) zeigen. Nan hat sie als "Émeraudes soudées" bezeichnet. Sie sind in verschiedener Weise zusanmengesetzt. Meist werden zwei Teile von der gewïnschten Form aus Bergkristall, ein Ober- und ein zugehöriger Unterteil mittels eines zwischenliegenden grïinen Chromglases, wie es ohen erw:ähnt wurde, aneinander geschmolzen. Zuweilen ist auch der Obertell ein hell bläulich grrüner Aquamarin und nur der Unterteil ist Bergkristall. Manchmal ist die srüne Zwischenschicht, die dem Ganzen die Farbe verleiht, ein durchsichtiges grünes Gelatineplättchen, das dann beim Gliihen zersetzt wird und an diesem Verhalten erkannt werden kann. Von der Seite betrachtet, benerkt man, namentlich mit dem Mikroskop), wenn der Stein aufrecht in einer stark lichtbrechenden Flüssiglieit (Methylenjodid, Monobromnaphthalin) usw. steht, sofort die Schichtung und die Farblosigkeit der beiden Ilauptteile. Im Polarisationsinstrument erkennt man öfters sofort den Quarz an seinen charakteristischen Eigenschaften. Wenn der Stein gefaßt ist, ist die richtige Beurteilung schwieriger, da die Farbe der echten Smaradfarbe sehr nahe kommt. Für gute Exemplare dieser gänzlich unechten Nachachmungen hat man bis zu (i) Mark pro Karat bezahlt, jetzt sind sie allerdings erheblich biiliger zu haben.

Auch der kïnstlichen Herstellung des echten Smaragd mit allen seinen natïrlichen Eigenschaften und mit Edelsteinqualität soll man schon auf der Spur sein, aber man hat jedenfalls das Ziel noch nicht erreicht.

\section{Edler Beryll.}

\section{(Aquamarin, Aquamarinchrysolith und Goldberyll).}

Unter den durchsichtigen edlen Berrllen sibt es wenige farblose und rosenrote, die jedoch nur ausnahmsweise einmal geschliffen werden. Um so häufiger geschieht dies mit dem dunkel-, aber meist nur licht blauen oder hell grü̈lichblauen und blïulichgrünen A(puamarin, und auch der gelblichgrine Aquamarinchrysolith, sowie der gelbe Beryll, der in seiner schönsten $A$ bart als Goldberyll bezeichnet wird, baben eine beschränkte Verwendung. Alle diese Varietäten unterscheiden sich rom Smaragd wesentlich nur durch die Farbe, dazu 
kommt aber auch eine etwas kompliziertere Kristallisation, so daß sie die flächenreicheren Formen der Fig. 72, $b$ bis $e$ und von Taf. XII, Fig. 4 und 5 zeigen, während, wie wir gesehen haben, am Smaragd kaum eine andere als die in Fig. 72, a dargestellte einfache Gestalt auftritt. Wir werden im folgenden den Aquamarin etwas eingehender betrachten und daran im Vorbeigehen die anderen Varietäten des edlen Berylls anschließen, die sich in allen wesentlichen Beziehungen wie jener verhalten, und deren Fundorte zum Teil dieselben sind.

Aquamarin. Der Aquamarin ist durch seine reine himmelblaue oder auch bläulichgrüne oder grünlichblaue Farbe charakterisiert. Diese wurde mit der Farbe des Meerwassers verglichen, und nach einer alten Sage sollte Aquamarin im Meerwasser wegen der vollkommen gleichen Färbung gar nicht sichtbar sein, was eben den Namen Aquamarin veranlaßte. Die Aquamarine sind fast stets ziemlich hell, dunklere gibt es nur sebr wenige, so z. B. schön und tief sapphirblaue in geringer Menge bei Royalston in Massachusetts in Nordamerika und bei Rio de Janeiro. Zuweilen unterscheidet man den himmelblauen Beryll als eigentlichen Aquamarin (Taf. XII, Fig. 5 und 7) von dem grünlichblauen bis bläulichgrünen (Taf. XII, Fig. 6), der dann speziell als "sibirischer Aquamarin" bezeichnet wird. Meist führen aber alle bellgefärbten Berylle der erwähnten Art ohne weitere Unterscheidung den Namen Aquamarin. Die Farben aller dieser edlen Berylle, so namentlich die des Aquamarins, sind besonders bei künstlicher Beleuchtung schön und glänzend. Durch Radiumstrahlen werden sie nicht verändert.

Die Ursache der Färbung ist beim Aquamarin und ebenso auch bei den anderen edlen Beryllen nicht dieselbe wie beim Smaragd. Sie ist nicht auf Chrom, sondern wahrscheinlich bei allen auf einen kleinen Eisengehalt zurückzuführen, der niemals fehlt und der zwischen 1/2 und 2 Proz. schwankt. Diese Farbe wird, nach Versuchen an grünem und gelbem Beryll aus dem Granit der Gegend von Dublin in Irland, durch einstündiges Erhitzen auf 357 Grad fast ganz zerstört, die Kristalle bleiben aber dabei durchsichtig. Beim Schmelzen erhält man eine ganz farblose trübe Masse.

Wenn der Stein nicht gar zu blaß gefärbt ist, ist der Pleochroismus noch recht merklich. Mit der dichroskopischen Lupe erhält man ein rein hellblaues und ein sehr hell gelblichgrünes, fast farbloses Bild. Ist die Farbe etwas tiefer, dann treten Farbenunterschiede beim Hindurchsehen nach verschiedenen Richtungen schon mit bloßem Auge hervor.

Der Aquamarin, wie überhaupt der edle Beryll, ist meist recht gleichmäßig durch die ganze Masse gefärbt; verschiedene Färbung an verschiedenen Stellen desselben Kristalls ist ungewöhnlich. Viel häufiger als beim Smaragd sind die Steine durchaus klar und durchsichtig und vollkommen fehlerlos. Zuweilen treten aber allerdings auch hier Risse und trübe wolkenartige Flecken auf, welche letztere wie beim Smaragd von zahlreichen, dicht gedrängten, mikroskopischen, leeren oder flüssigkeitserfüllten Hohlräumen herrühren. An solchen wolkigen (moosigen) Stellen ist es unmöglich, eine feine Politur herzustellen; die Steine bleiben auf ihnen trotz aller Bemühung stets mehr oder weniger matt, obwohl der Beryll sonst wie der Smaragd einen sehr starken Glanz anzunehmen vermag. Zuweilen wechseln durchsichtige Partieen mit undurchsichtigen trüben ab; man muß dann vor dem Schleifen die letzteren vorsichtig entfernen, um die ersteren für sich allein zu bekommen.

Die Gestalt, die man dem edlen Beryll und speziell dem Aquamarin beim Schleifen zu geben pflegt, ist nehen allen möglichen anderen, auch mugeligen Formen, die des Brillants oder der Treppensehnitt in einer seiner verschiedenen Modifikationen. Einige sind in Fig. 6 und 7 auf Taf. XIl abgebildet. Da die Farbe, wie erwähnt, meist sehr hell ist, so mul man, damit sie noch deutlich hervortritt, den Steinen eine nicht zu geringe Dicke geben. Kur Ilebung des Glanzes und der Farbe wird der Beryll bäufig auf einer Folie aufgebracht, die zu seiner Farbe palit. Die Aquamarine erbalten eine Silberfolie 

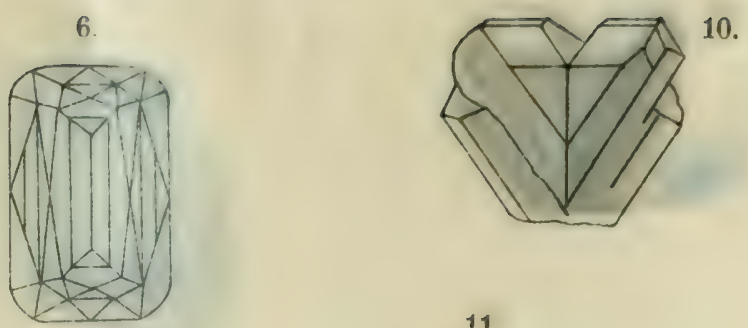

10.

7.

11.

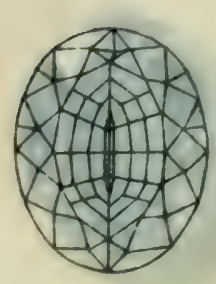

8.
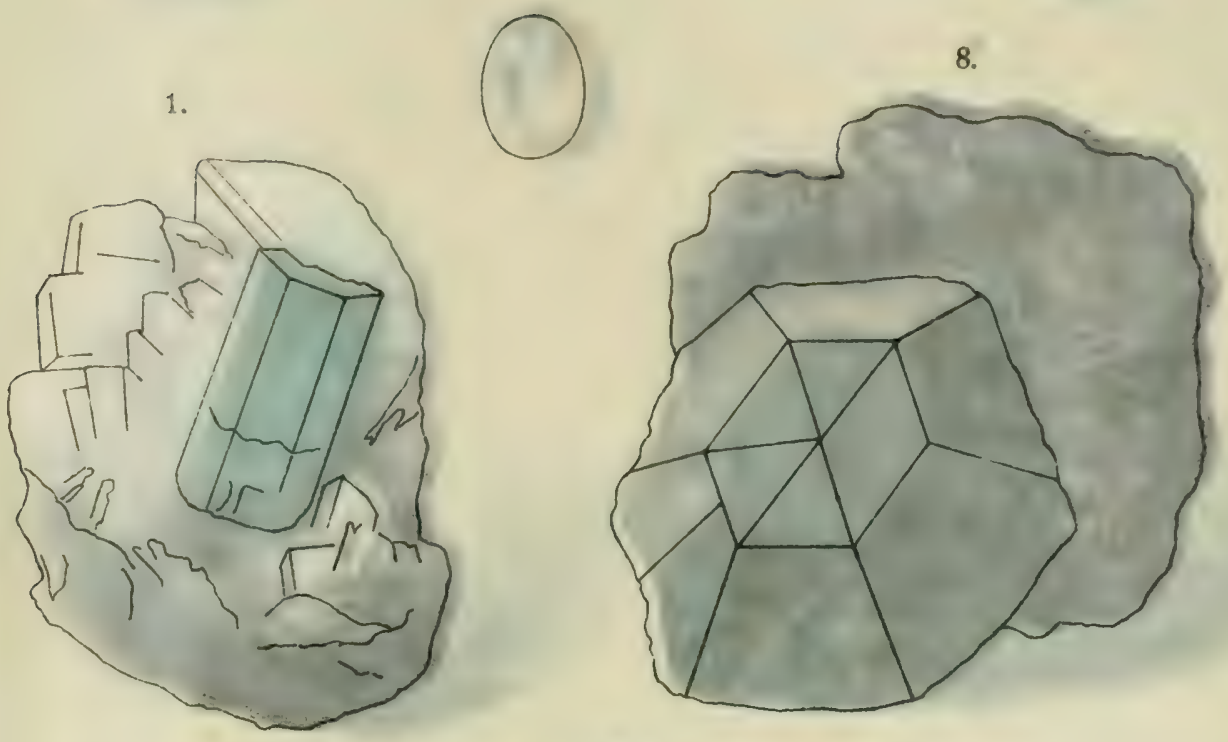

9 b.

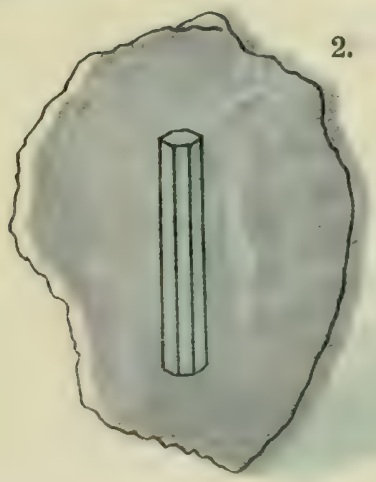

9 a.

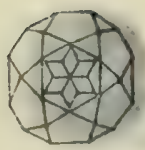

5.

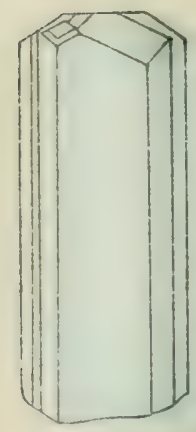

3.

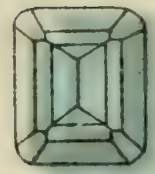

4.
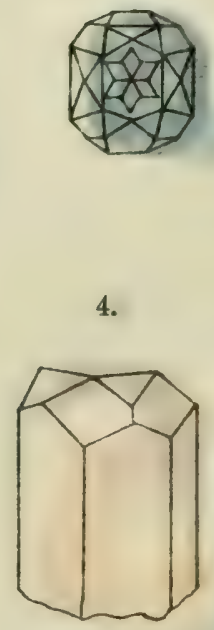

1. Smarag (Krystall, im Kalkspath, Musogrube). 2. Smaragd (Krystall, im Glimmerschiefer, Habachthar?. 3. Smaragd (geschliffen). 4. Beryll (Goldberyll, Krystall). 5. Aquamarin (Krystall. Ain-Tschilon). t. 7. Aquamarin (geschliffen). 8. Chrysoberyll (Alexandrit, Krystall inkowoia). 9a. Chry soberyll (Alexandrit, geschliffen, bei Tag). 9b. Chry soberyll (Alexan $x^{2}$ i. geschliffen, bei Kerzenlicht). 10. Chrysoberyll (Krystall, Brasilien). 11. Chrysoberyll (Cymophan, oder orient. Katzenauge, geschliffen). 


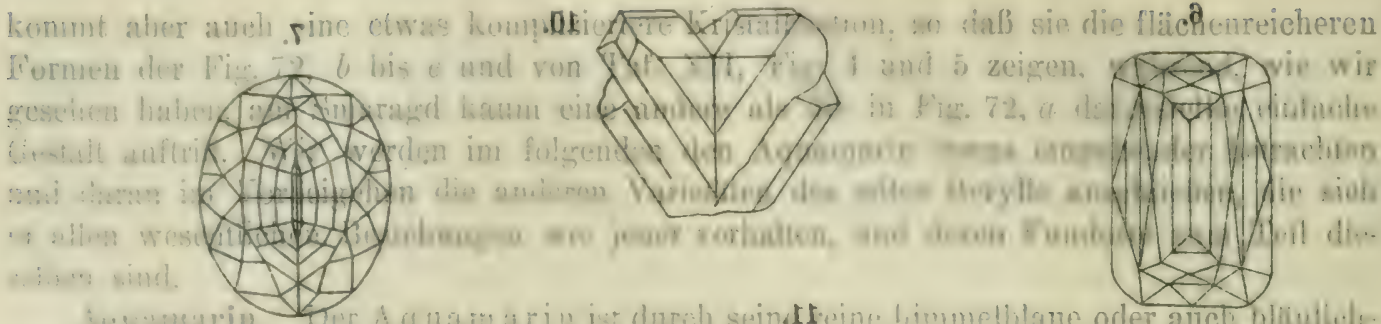

Guamarin.

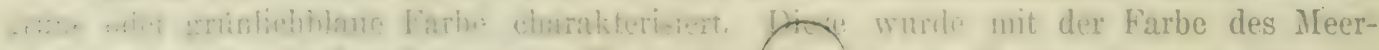

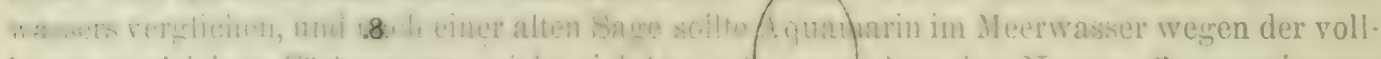

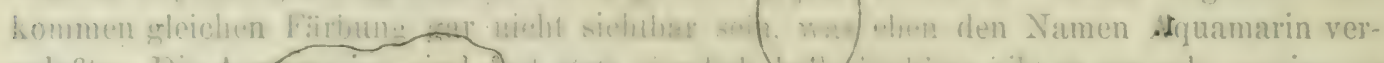

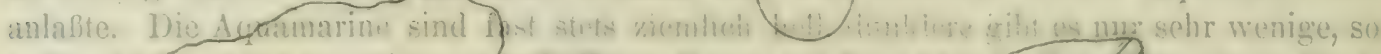

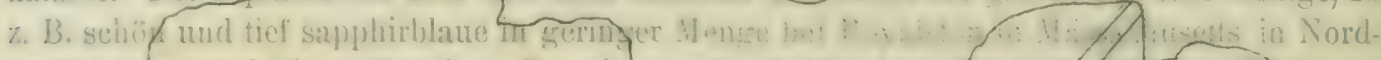

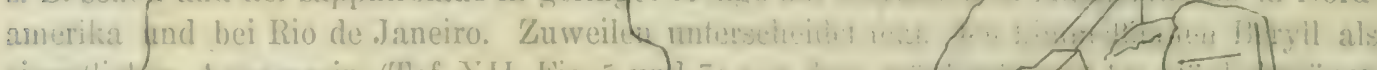

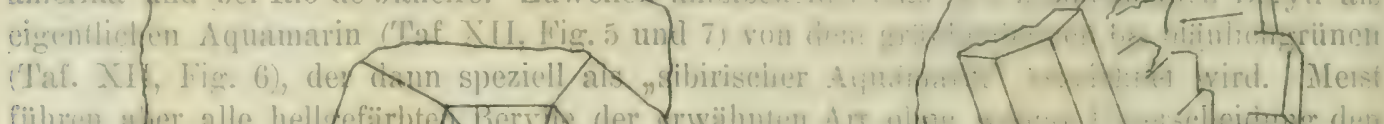

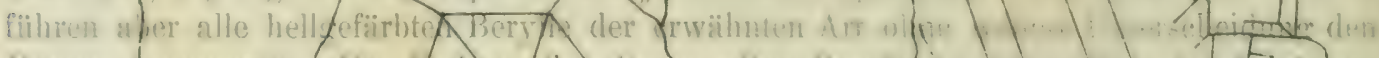

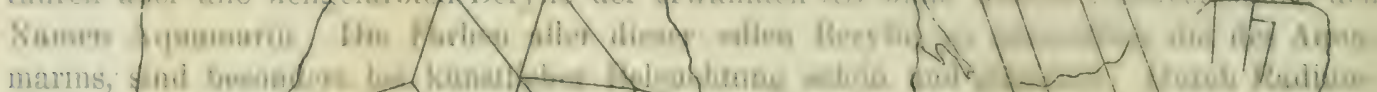

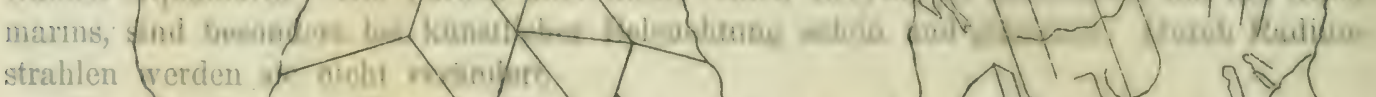

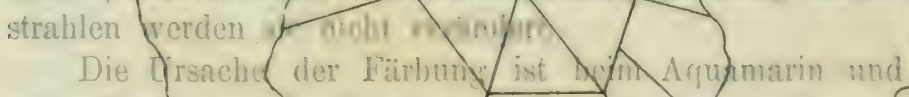

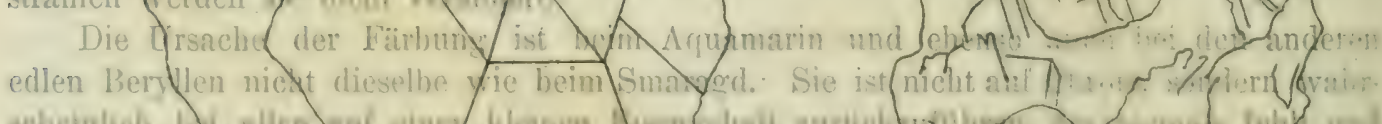

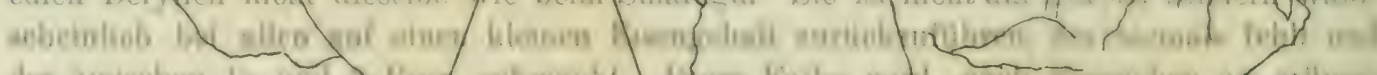

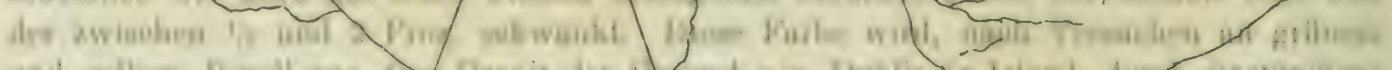

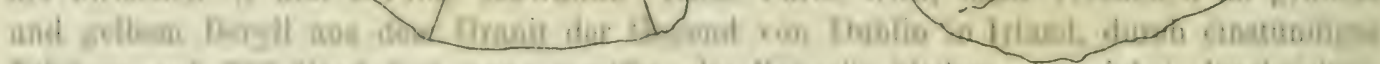

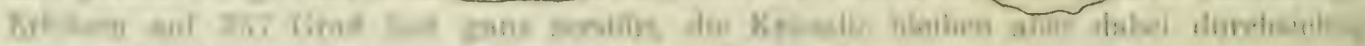

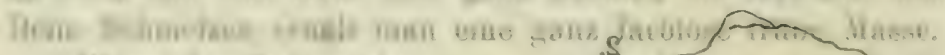

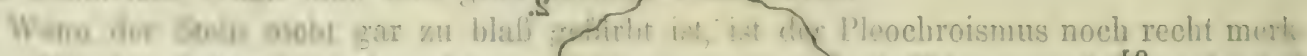

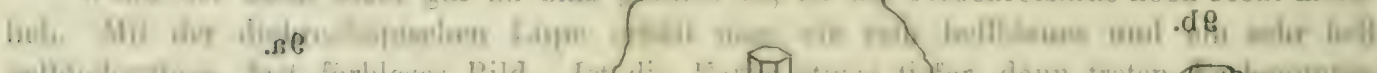

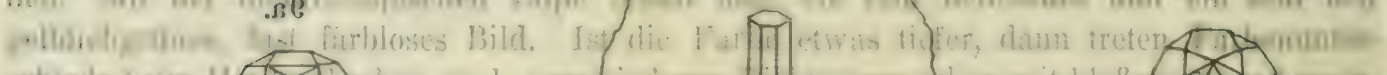

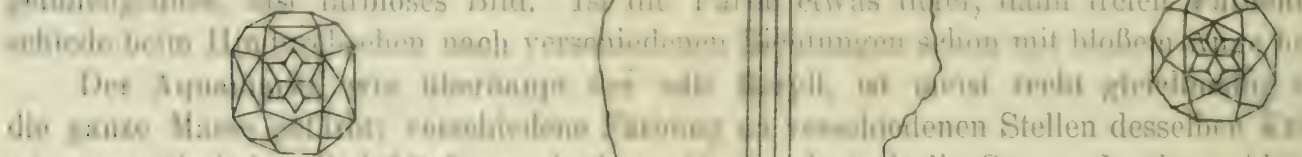

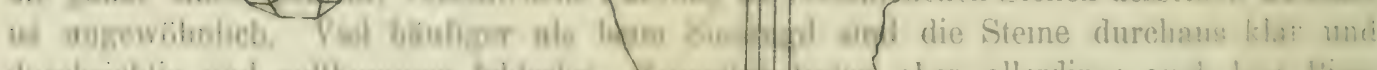

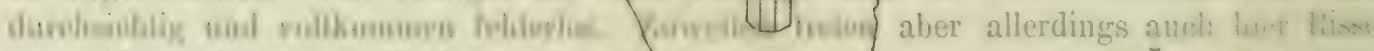

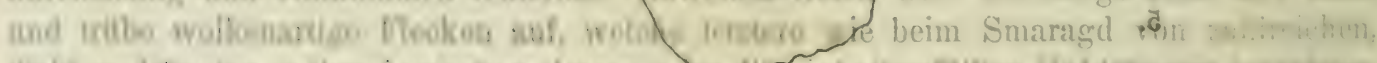

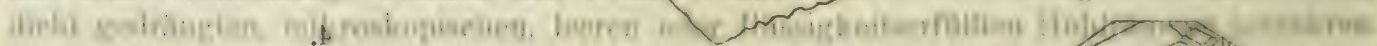

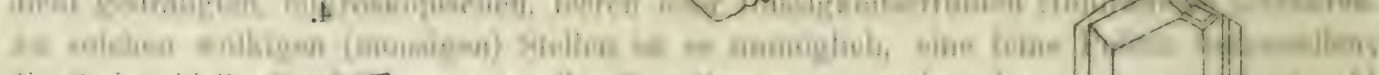

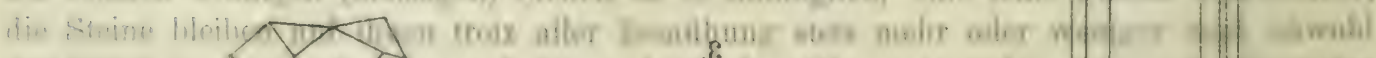
Acy theyll son

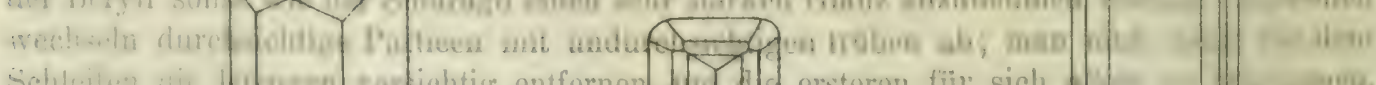

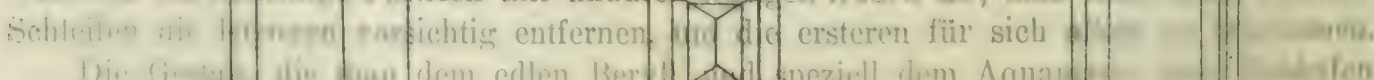

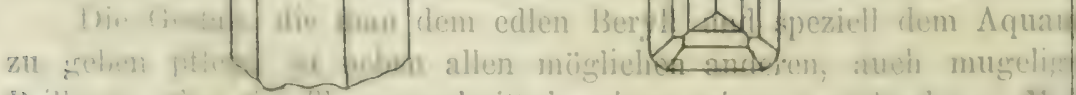

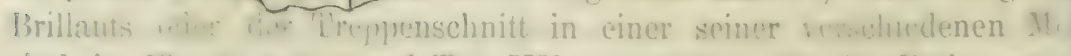

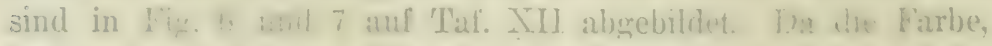

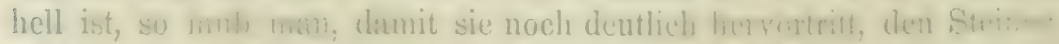

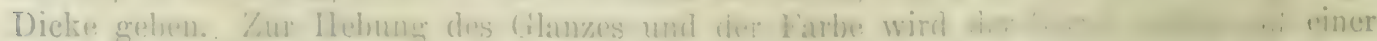

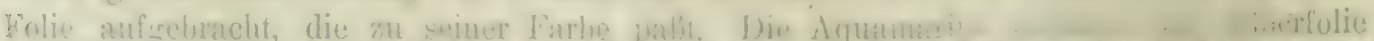

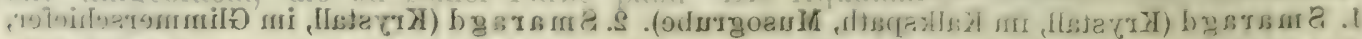

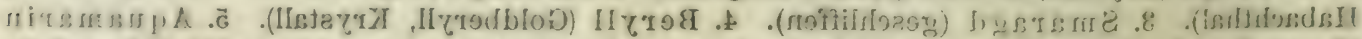

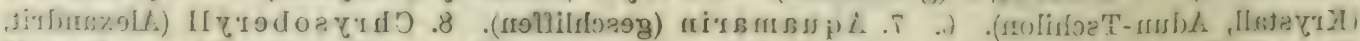

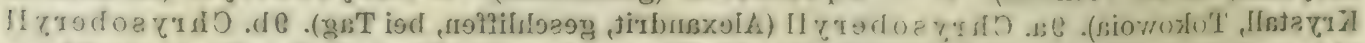

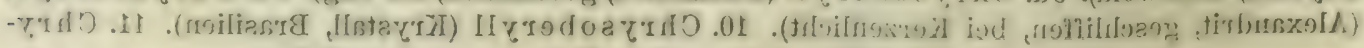

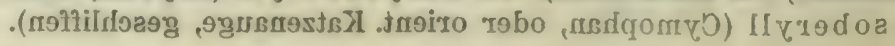


TAFEL XII.

6.

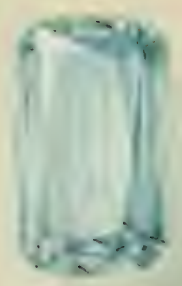

1.

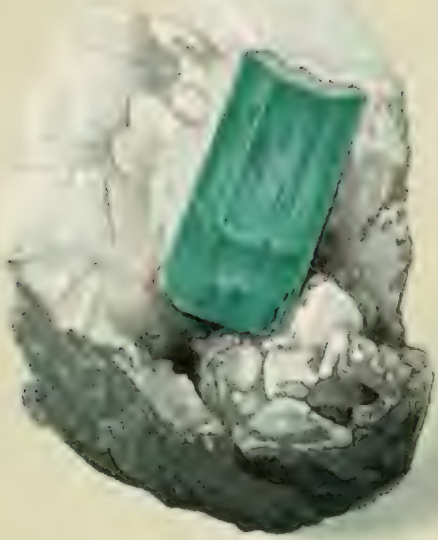

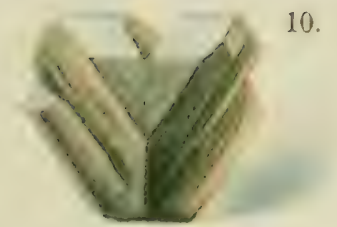

11.

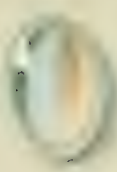

7.

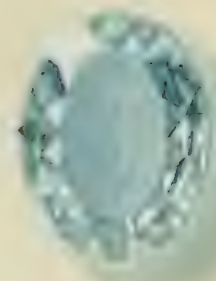

8.

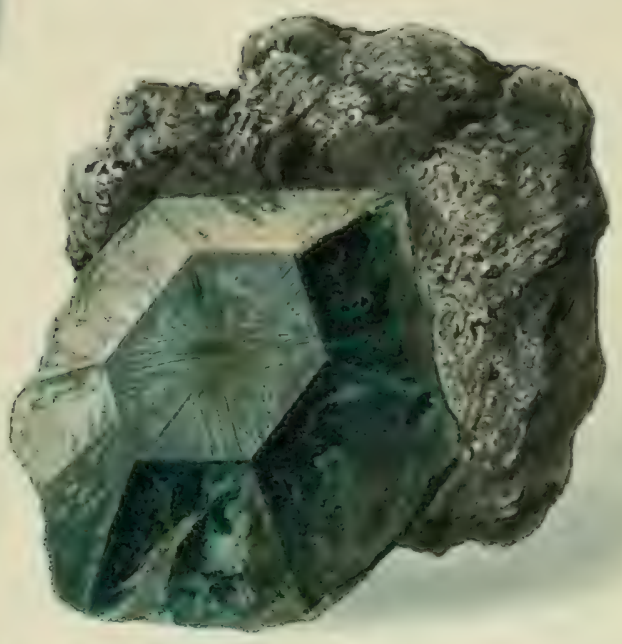

$9 \mathrm{~b}$.

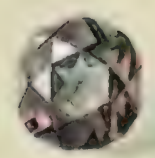

5.

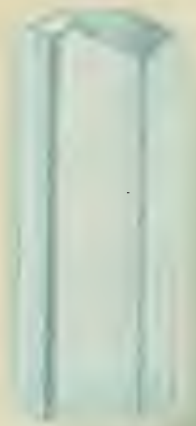

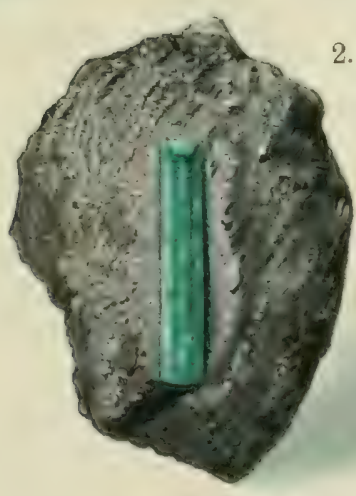

3.

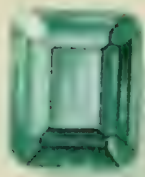

9 a.

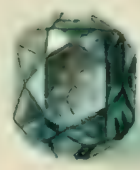

4.

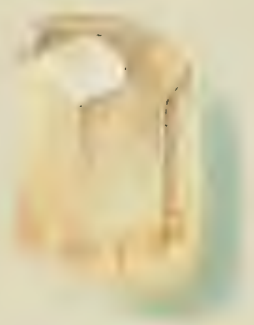



oder werden in einen selıwarzen Kasten gesetzt, sehïne, fehlerlose und grut, namentlich nicht zu blaß gefärbte Steine aber auch à jour gefalbt.

Die greschliffemen Steine sind hä̈ufig nach einer Iichtungr etwas in dir Länge gezogen, da sie meist ans langen und verhältnismälbig diinnen Prismen herauspeschnitten sind, wie cines in Fig. i, Tat. XII, dargestellt ist. In solehren länglich gestaltefen Steinen wibt die Längsrichtung die Lage der Ilauptaxe des Kristalls an, wovon man sich unschwer durch Beobachtung des I'leochroismus äberzengen kann. Gröljere Kristalle von dieser Form werden im Orient nicht selten zu Dolcherriffen und anderen derartigen Getgenständen verarbeitet. Zum Eingravieren von Figuren ist der Aguamarin viclfach und auch schon im Altertum benutzt worden; die mälibe Härte ist dieser Anwendung srïnstig. In alten Zeiten soll der Beryll auch zur Ilerstellung von Augengläsern geedient haben, und daher soll das Wort „Brille" stammen,

Vom edlen Beryll, hesonders vom Ayuamarin gilot es in Lntersehied vom Smaragd zahlreiche durchsichtige, schön geförbte, fehlerfreie Exemplare von beträchticher Grölje. Prismen von beryll in tadellosicr schleifharer Ware von Dammenlänge und -dicke sind ganz gewöhnlich, und sowar erbebluch gröbere sind noch keine Seltenheit. Der frübere Pariser Juwelier Barbot erwähnt in scinem Werke über Edelsteine einen rohen Aquamarin von seltener Schönheit im Gewicht ron ungrefülır 10 kær, für den 150)(0) Franken verlangt wurden; in Minas novas in Brasilien wurde 1511 ein schönel grascrüner stein von 15 Pfund gefunden, und ron anderen groljen und schünen stïcken wird nicht gatr zu selten berichtet. Es ist daher sellsstverständlich, dafj der Preis der Ayuamarine und der edlen Berylle ïberhaupt ein recht niedriger ist. Sie gehören zu den lilligsten Edelsteinen, aber wegen seiner liehlichen und angenehmen Farbe und seines schïnen Glanzes ist namentlich der Aynamarin sehr rerbreitet und geschätzt. Ein Karatstein mittlerer Beschaffenheit kostet bis zu y Mark; die Farbe mul schon selı schön und die Qualitiit dabei in jeder Ifinsıcht vollkommen sein, wenn der Stein einen höheren Wrelt haluen soll, 20 bis (i5 Mark pro Karat. Wenn unter solehen besonders griustigen Lmständen ein vorzüglicher Aquamarin auch einen ziemlichen Wert haben kann, so erreicht er doch wohl nie den Minimalwert des guten smaragds. Auch steigt der Preis nur in demselben Verhältnis wie das Gewicht.

Der Beryll und namentlich der Aguamarin ist ein verbreitetes Mineral, das an vielen Orten in schleifwerter Beschaffenheit rorkommt. Auch er wird, wie der Smaragnd, hauptsächlich auf ursprünglicher Lagerstätte, und zwar im Unterschied von diesem fast nur auf Drusen grobkürniger Granite (Pegmatite) und in anderen ähnlichen Gesteinen gefunden. Das Vorkommen auf sekundïrer Lagerstïtte, in Seifen, ist dagegen minder gewöhnlich, es ist jedoch immerbin wichtiger als beìm Smaragd.

Vorkommen. Zahireiche schöne kiare. meist blal gelblichgrüne, aber auch bliuliche Steine, Kristalle sowohl als Geschiehe, kommen aus Brasilien, in beiderlei Form nicht selten ron beträichtlicher Grölje. Die Kristalle sind äuferlich häufig stark zerfressen. Das Muttergestein ist derselbe grobkörnige Granit (Pegmatit), der auch die anderen farbigen Edelsteine Brasiliens, Turmalin, weifen Tojas, Chrysoberyll usw. beherhergt, aus dem sie dann als Geschiche in die Flïsse gelangen. Die Heimat ist der Bezirk Minas Noras in der Nordosteclie des Staates Minas Geraes. Bei der Betrachtung des farblosen Topases werden wir dieses Torkommen genauer kennen lernen. Als Fundorte, die dort gegenwärtig schöne Aquamarine liefern, werden besonders genannt: die Insel lhla Alegre im Jequetinhonha nahe der Stadt Calhao (Arassuahy, woher zurzeit die besten kommen sodann die Briiche bei Pecanha am Rio Doce in Minas Geraes und weiter talabwärts im Staate Espirito Santo. Die Fristalle wachsen ron geringer Größe bis zu beträichlichem Umfance an. 1912. ist einer ron 15,:: Pfund im Tert von ca. jo00100 Mark, und ein 
anderer von :) I'fund gefunden worden. Dem entsprechend sind auch die Geschiebe zuweilen sehr grob. wie das oben erwähnte 15 Pfund schwere Stück zeigh, das im Jahre 1811 im Quellowelnet des Rio s. Matheus in Minas Novas gefunden wurde; kurze Zeit darauf folgte ihm dhendort ein anderes schönes Stiick von 4 Pfund. Die meisten sind aber weit kleiner, ihr grrölter Durchmesser schwankt zwischen zwei und höchstens fünf Linien.

In der Nähe von Rio de Janeiro kommt gleichfalls Aquamarin, und zwar auch auf Gängen von grobkörnigem Granit im Gneis vor, so z. B. bei Vallogo, wo 1825 ein schöner Kristall von 4 Pfund gefunden wurde, für den der Besitzer 600 Pfund Sterling forderte, und noch früher ein durchsichtiger, reiner und fehlerloser Stein von 7 Zoll Länge und 9 Linien Dicke. Im Jahre 1903 wurden bei einer Station der Leopoldina-Eisenbahn schr schöne tiefblaue Kristalle gefunden und daraus einzelne prächtige Steine von 100 Karat geschliffen.

Verbreitet ist der Beryll im Ural und auch sonst in Sibirien, wo er an mehreren Orten, wie in Brasilien in Begleitung von Topas, in geeigneter Beschaffenheit gewonnen wird, so dab diese Gegenden sich zum 'Teil bezïglich der Wichtigkeit für unseren Edelstein mit Brasilien messen können.

In Ural hat sich derselbe an verschiedenen Stellen in der Gegend von Katharinenburg im Gouvernement Perm und am Ilménsee im Ilméngebirge, sowie in den Goldwäschen an der Sanarka im südlichen Teile des Gebirges gefunden.

In der Nähe von Katharinenburg ist es hauptsächlich die Nachbarschaft der Dörfer Mursinka (Mursinsk) und Schaitanka (Schaitansk), wo diese Steine vorkommen, ïberall auf Drusenräumen im grobkörnigen Granit, der feinkörnigen Granit in Gängen durchsetzt.

Der bei Mursinka vorkommende Beryll ist der schönste im ganzen Ural. Seine Farbe ist verschieden: weingelb, grünlichgelb, gelblichgriin, bläulichgrïn und blaßblau. Gewöhnlich ist er durchsichtig und sehr regelmäßig kristallisiert; die Prismen sind von einigen Millimetern bis 65 Zentimeter lang und bis 26 Zentimeter dick. Manchmal kommen Verwachsungen mehrerer Kristalle vor, zuweilen in paralleler Stellung, zuweilen auch unregelmäßig. Eıne solcbe Gruppe von schön gelbgrïnen oder spargelgrïnen, tadellos durchsichtigen, parallelverwachsenen Kristallen, $27 \mathrm{~cm}$ lang und $31,2 \mathrm{~cm}$ im Umfang, wurde im Jahre 1828 gefunden. Sie befindet sich jetzt in der Sammlung des St. Petersburger Berginstituts; ihr Wert wurde auf etwa 43000 Rubel geschätzt. Die Höhlungen, in denen die Kristalle sitzen, sind meist mit einem braunen Ton ausgefüllt, der als Anzeichen reicherer Anbriiche gilt. Begleitet wird der Beryll von Quarz, Feldspat, Glimmer, schwarzem Turmalin und namentlich von den ebenfalls als Edelsteine wichtigen Mineralien Topas und Amethyst, ron denen unten eingehender die Rede sein wird. Diese "bunten Steine" der dortigen Steinsucher werden in zahlreichen Gruben gewonnen und zum größten Teil in den Schleifereien von Katharinenburg verarbeitet. Die Gruben waren früher alle bei dem Dorfe Mursinka selbst, später wurden solche auch einige Kilometer entfernt, bei den Dörfern Alabaschka, Sisikowa, Juschakowa, Sarapulskaja und anderen angelegt, deren Bewohner zum großen 'Teil von der Edelsteingewinnung leben. Im Jahre 1815 wurden die Berylle von Schaitanka bekannt; diese sind aber alle farblos oder hellrosa und daher als Edelsteine von geringerer Wichtigkeit, sie bilden jedoch, wie jene Mineralien alle, auch von den anderen genannten Fundorten, prächtige Stufen, die man in allen Mineraliensammlungen zu bewundern felegenheit hat. Die Lage der Gruben in der Nähe von Mursinka ist auf dem Kärtehen Fig. 77 angegeben; bei der Betrachtung des Amethysts sollen noch einige weitere Nachrichten über dieselben mitgeteilt werden.

Im Granit der Malaja Tesma im Bergrevier von Slatoust wurden drei neue Aquamarinfundorte festgestellt; die reichste Grube ist Tschernyschew-Grube genannt worden. 
Von geringerem Werte sind die hell apfeteriinen Berylle, die den Sinaraged von der

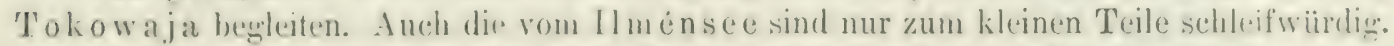
Sie finden sich am östlichen Uler dieses Sees, 6 Werst Kilometer) nordijstlich von der

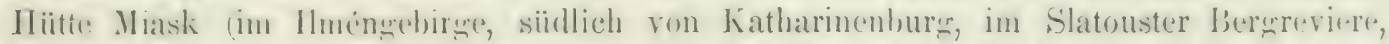

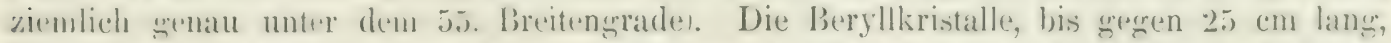
bläulichyriun ins Latucheriune, aluer sehr rissign und gröbtenteils nur durchscheinend, liegen mit ebenfalls rissigen 'Topaskristallen in Quarzgängen mit grünem Feldspat (Amazonenstein), die das Miascit genannte Gestein durchsetzen.

Unwichtig ist auch das Vorkommen in den Goldwäschen am Flusse Sanarka im sïdlichen Ural, wo sich der Beryll in Form von Geschieben als Begleiter des 'I'opases, Chrysoberylls usw. findet.

Der Beryll vom Altai zeichnet sich mehr durch Größe als durch Schönheit aus. $\mathrm{Er}$ findet sich in bis $1 \mathrm{~m}$ langen und bis $15 \mathrm{~cm}$ dicken Kristallen von der Form eines sechsseitigen Prismas mit gerader Endfläche (Fig. 72, a u. 73) und von himmelblauer bis griinlichblauer Farbe in braunem, sehr rissigem Quarz; der Fundort liegt in den T'igeretzker Bjelken. Da diese Kristalle gewöhnlich höchstens durchscheinend sind, so sind sie zu Edelsteinen selten brauchbar.

Wichtiger ist wieder das Vorkommen im Nertschinsker Kreise in Transbaikalien. Nertschinsk liegt am Oberlauf des Flusses Schilka, der sich weiter abwïrts als Amur fortsetzt, etwa $116^{\circ}$ östlich von

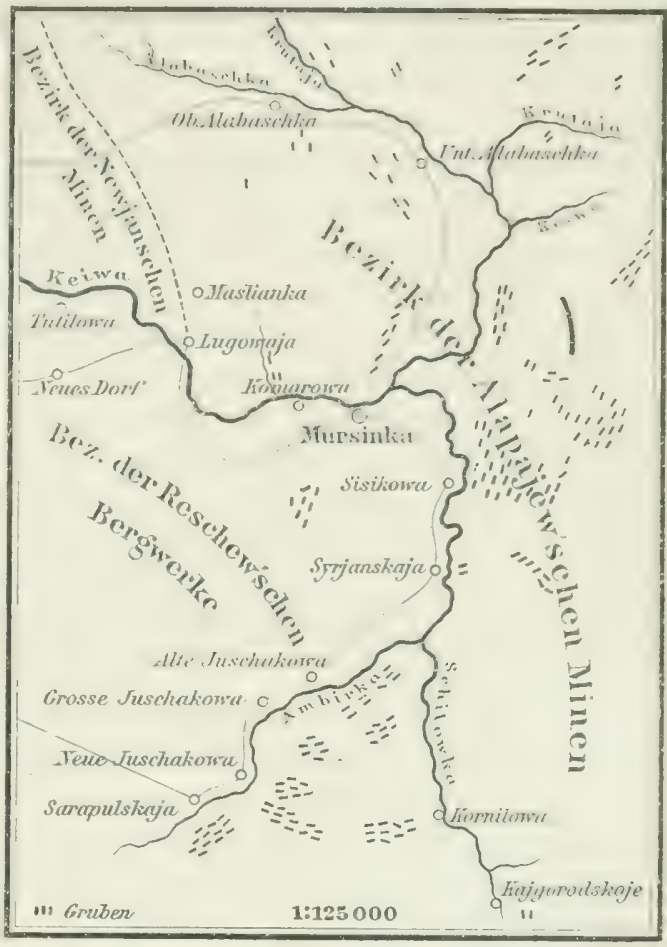

Fig. T. Vorkonmen des Berylls bei Mursinka im Ural. Greenwich. Es sind hier zwei Landstriche, in denen zahlreiche Berylle, und zwar vorzugsweise Aquamarine vorkommen: der Gebirgsiicken Adun-Tschilon mit seiner siddlichen Fortsetzung im Bergzuge von Kuchuserkensk und die Umgegend der Urulga am nördlichen Abhang des Borschtschowotschnoi-Gebirgszuges.

Die Berylle und die anderen „bunten Steine“ ron A dun-Tschilon, einem granitischen Bergzun zwischen dem Onon und dem Onon-Borsja, sind schon seit 17\%3 bekannt. Die Ausbeute war früher sehr betrïchtlich, am höchsten im Jahre 1796, wo allein 5 Pud (= $52 \mathrm{~kg}$ ) reine und zur Verarbeitung taugliche Aquamarine gefunden wurden. Die Kristalle sitzen auf den Wänden von Ilohlräumen einer Gebirssart, des sogrenannten Topasfelses, der hauptsïchlich aus feinkörnigem Quarz und kleinen Topaskristïllchen gemengt ist und der den Granit gangfürmig durehzieht. In diesen Hohlräumen ist der Aquamarin stets begleitet ron Topas und Rauchtopas, bäufig auch ron anderen Mineralien. Der hüchste Berg des Gebirgszuges Adun-Tschilon, der Adun-'Tschilon im engeren simne oder 'I'utchaltni, besteht aus zwei durch ein enges Thal getrennten Giffeln, deren westlicher Hoppewskaja Gora oder Schüriberg leilbt. Dieser, in der Hauptsache von Topasfels gebildet, ist durch die Gräbereien nach Beryll derart durchwählt, daßs man darauf lieinen unberührten Fleck mehr finden kann. Die Edelsteine sind aber nicht auf diesen Berg. allein beschränkt, zahlreiche Gruben finden sich auch in der Umgegend zerstreut und 
nehmen im ganzen etwa zwei Quadratwerst ein. Es sind höchstens drei Faden tiefe offene Schürfe primitivster Art ohne Zimmerung, von denen aus kurze horizontale Strecken nach allen Richtungen in das Gestein hineingetrieben werden.

Am siudlichen Abhange des Hoppewskaja Gora findet man den Aquamarin mit dem ihn stets begleitenden Topas in schönen Exemplaren lose in einer lockeren, durch Verwittermug des Topasfelses entstandenen, viel Eisenocker enthaltenden Erdschicht, unmittelbar unter der Rasendecke.

Die Berylle von Adun-Tschilon bilden, abweichend von den glattflächigen Prismen vom Ural und rom Borschtschowotsehnoi-Gebirgsug (oder von der Urulga), stark vertikal grestreifte Säulen wie in Fig. 72, $\pi$. Sie sind gewöhnlich grïnlichblau, doch auch himmelblau, gelblichgrïn, weingelb usw.; auch ganz farblose kommen zuweilen vor. In der Durchsichtigkeit variieren sie vom vollkommen Klaren bis zum Kantendurchscheinenden. Die vielfach zu Gruppen verwachsenen Kristalle sind häufig mit einer diinnen Schicht eines braunen Eisenockers bedeckt, mit dem auch die Drusenrïume ausgefïllt zu sein pflegen.

In dem Borschtschowotschnoi-Gebirgsuge zwischen den Flüssen Schilka und Unda hat man um die Mitte dieses Jahrhunderts viele schöne Berylle gefunden, hauptsäichlich in den Granitbergen längs den Ufern der Urulga, eines rechten Nebenflusses der Schilka. Die Berylle aus der Nähe der Urulga sind ganz besonders ausgezeichnet durch ihre bedeutende Größe, ihre Klarheit und Durchsichtigkeit und durch ihre angenehme und schïne Farbe. Die meisten sind gelblichgriin, doch gibt es auch farblose, blaue nnd gelbe. Die Größe geht bis $10 \mathrm{~cm}$ Länge und $5 \mathrm{~cm}$ Dicke; die Kristallform ist häufig sehr schön regelmäßig. Im allgemeinen ist der Beryll von der Urulga dem von Mursinka sehr ähnlich.

In anderen Teilen von Asien ist der Beryll und speziell der Aquamarin nur sparsam vorhanden. Ostindien hat zwar an manchen Punkten blaß gefärbten Aquamarin geliefert, und Gegenstïnde daraus findet man dort in alten Gräbern, Tempeln usw. nicht selten, gegenwärtig ist aber die Produktion gering. Am meisten scheint im Distrikt Coimbatur in der Prïisdentschaft Madras gewonnen worden zu sem, so manche Steine von beträchtlichem Wert bei Padgur (Pattalai). Hier wurde am Anfange des 19. Jahrhunderts Aquamarin gecraben, der auf Hohlräumen eines grobkörnigen Granits vorkam. Die Grube wurde später verlassen, nachdem alle leicht erreichbaren Steine herausgebrochen waren. In der Nähe boi Kaneayam in demselben Distrikte hat man dann später Aquamarine entdeckt, ron denen Jroben auf der Wiener Weltausstellung in Jahre 1873 zu sehen waren. Hier wurde ('inural (in $184 \mathrm{~g}(=900)$ Karat ungeführ) schwerer Stein von der vollkommensten Durchsichtigkeit gefunden, der für 12500 Franken verkauft worden ist.

Ifellh)laue zum Teil ziemlich grobe, bis $3^{1 / 4}$ Zoll lange Kristalle finden sich an mehreren Stellen auf Granitgängen im Gneis im Pendsehab, sie sind aber iiberall meist sehr risige und nur ansnahmsweise zu Schmucksteinen geeignet. Im Dschaipur-Stante in Radschputana wurde Aquamarin im Asehmir-Distrikt in den Toda Hills und bei Radschmahal am lianas, anch bis 38 (engl.) Meilen entfernt von dieser Stadt an versehiedenen Orten gefunden und gewonnen, die Steine sind aber meist zu klein, so daß sie trotz schöner Farbe wenig Wert haben. Sie wurden in Schwemmlande aufgelesen und stammen wahrscheinlich aus den Granitgängen, die in Radschputana die Gebirgsschichten in grober zahl durehsetzen. Kleine Kristalle von gelbem Beryll sind im Distrikt IIazaribagh in Bengalen in einem mäichtigen Gange emgeschlossen, und noch mehrere andere Fundorte edler Berrlle werden angegeben, die aher zum Teil noch zweifelhaft sind. Einige Berylle finden sich in den Glimmergruben von Nellore und Behar.

In Birma sollen Aquamaringeröle im Irawadi gefunden worden sein, die Nacliricht ist aber unsicher. Jedenfalls ist das Vorkonmen von A(juamarin in Birma spärlich, 
und dasselbe gilt für das edelsteinreiche f'eylon. wo der edle Beryll aber immorhin in einzelnen fehlerfreien Exemplaren angetroffen wird.

Europa ist geleichfalls sebr arm an sehleifharen licryllen, wenn auch mancher Fundort bekannt ist. Vielleicht kann der schön und ziemlich tief blau erefärbte, aber selten durehsichtige Beryll aus dem Cranit der Mourne Mountains in Irland erwähnt werden.

Zahlruich sind die Lokalitiiten in Nordamerika, in den Vereinigten staaten. Einigre dieser fundorte haben sehïne sehleifbare steine von verschiedenen Farben geliefert, jedoch keiner in erheblicher Menge. So findet sich Beryll mit dem Smaraged von IIaddam in Connecticut und von Stony Point, Alexander ('ounty in Nord-('arolina. Bei Russel Gap) lioad in derselben Grafschaft wurden melır schleifbare Aquamarne gewonnen als irgendwo sonst in den Vereinigten Staaten. Schön blaue Aquamarine finden sich auch in Mitchell County, in Nord-Carolina, so in der Spruce Pine-Region, hier mit Goldberyll, Varietäten von verschiedenen Farben älınlich den Uralischen auf Drusen in Pegmatit von Topsham in Iaine, srine Berylle bei Stoneham, Oxford County in Maine, wo ein schönes bläulicherrïnes Stïck erbentet wurde, das einen prachtrollen, beinahe fehlerfreien Brillant von $35 \mathrm{~mm}$ Länge und Breite und $20 \mathrm{~mm}$ Dicke im Gewicht von 133:/ Karat lieferte, einige gute Steine bei Grafton in New Ilampshire, schöne Aquamarine und Goldberylle bei New Milford in Connecticut. Rei Royalston in Massachusetts fanden sich neben anderen z. T. edlen Beryllen solehe, die so schön blau waren wie gute Sapphire, aber leider nur in kleinen Kristallen; es sind das die schönsten blawen Berylle, die je beobachtet worden sind, und ein hiristall wurde auf 200 Dollars geschätzt. Am Mit. Antero, 10 Hiles nördlich von Salida, in Colorado kommt Beryll mit Phenakit und anderen Mineralien 12000 bis $14000 \mathrm{Fuß}$ hoch vor. Hell- bis dunkelblaue Kristalle sitzen auf Drusenräumen im Granit. Sie sind 1 bis 4 Zoll lang und ${ }^{1}, 10$ bis 1 Zoll dick und geben bis 5 Karat schwere geschliffene Steine. Ein eigentïmliche tiefblaue Varität ist neben andersfarbigen von Rineon, 91/2 Miles südöstlich von Pala, San Diego County, im südlichen Kalifornien bekannt geworden. Nanche trübe Steine von hier von verschiedener Färbung geben en cabochon geschliffen einen Lichtschein wie das Katzenauge (Beryllkatzenauge). An dieser Stelle ist der Beryll ohne'Turmalin. Mit diesem, sowie mit Hessonit und Topas findet er sich bei Ramona, ebenfalls in San Diego County und zwar ist hier neben anderen Farben (Aquamarin, Goldberyll) die sonst so seltene rosenrote ziemlich reichlich vertreten, und dasselbe ist in dem Jacumba-Distrikt in der Ungregend der Jacumba Hot Springs, 70 miles istlich von der Stadt San Diego, der Fall. Alle diese Edelsteine finden sich in jener Gegend auf Drusen in Pegmatit mit Turmalin, bei dessen Besprechung davon eingehender die Rede sein wird. Anders, und zwar in einem vulkanischen Quarztrachyt kommt der himbeerrote Beryll von Simpson-County in Utah vor. Die Zahl der Fundorte ist damit noch nicht erschöpft, aber sie werden nicht weiter erwähnt, weil sie, wie iuhrigens auch die meisten genannten nordamerikanischen, für den Edelsteinhandel nur von untergeordneter Wichtigkeit sind.

In A ustralien kommt Beryll ebenfalls in kleiner Menge ror, so an mehreren Orten in Neu-Siid-Wales usw. Auch die australischen Funde sind für den Handel vollkommen belanglos.

Was den gelben Edelberyll betrifft, so stammt der wenig gebrauchte gelblichgrine Aquamarinchrysolith, auch wohl kurz Chrysolith genannt, meist, und zwar in grö̈feren Exemplaren, aus Brasilien, doch findet man ebenso gefürbte Steine ron schöner Beschaffenheit auch an manchen der oben erwähnten Orte, so in Sibirien als Begleiter des Aquamarins. Der schön gelbe Beryll, von dem ein Stein auf Taf. XII, Fig. 4 abgebildet ist und der in seiner schönsten und am tiefsten und reinsten getben Abänderung Goldberyll genannt wird, findet sich in guten Exemplaren außer an den schon genannten Orten bei Albany in Maine, in Coosa County in Connecticut und in der Tähe der Stadt 
New-York, sowic auch an anderen Orten der Vereinigten Staaten, wo dieser Stein hoch geschïtzt wird. Überall hier wie auch anderswo ist aber das Vorkommen stets spärlich. Ein 2 Zoll langer Kristall von Goldberyll ist aus einem alten Indianergrab nahe dem Tesanty Creck in Macon County, Nord-Carolina ausgegraben worden; er stammt walurscheinlich aus der nahe gelegenen Littlefield-Beryllgrube. In den South Mountains in Burke County, Nord-Carolina, begleitet er den Aquamarin. Ganz unbedeutend ist das Vorkommen von Pisek in Böhmen.

Die gelben Berylle stehen sonsi im allgemeinen nicht hoch im Preise; nur besonders ausgezeichnete Steine werden höher als mit einigen Mark für das Karat bezahlt.

Gewisse farblose, bläuliche oder hellrosafarbige Berylle von den Fundorten in Maine wurden wegen ihres kleinen Cäsiumgehalts Cäsiumberylle genannt; ein guter geschliffener Karatstein ist 20 bis 80 Mark wert.

Der edle Beryll kann mit mehreren anderen Edelsteinen dem Aussehen nach verwechselt, aber bei genauerer Untersuchung, namentlich durch das ganz besonders niedrige spezifische Gewicht meist leicht und sicher unterschieden werden. Der Aquamarin gleicht der Farbe nach dem orientalischen Aquamarin, dem Euklas, und wohl auch manchen Turmalinen, ganz besonders aber dem blauen Topas und zwar so sehr, daß der letztere im Edelsteinhandel ebenfalls unter dem Namen Aquamarin zu gehen pflegt. Alle diese genannten Steine sinken aber in der dritten Flüssigkeit $\left(G_{0}=3,0\right)$ unter, während der Beryll schwimmt. In gleicher Weise unterscheidet man den gelben Beryll, den Aquamarinchrysolith sowohl als den Goldberyll von ähnlich aussehenden gelben und grünlichgelben Steinen vom gelben Topas, vom orientalischen Topas und Chrysolith, vom eigentlichen Chrysolith und vom Chrysoberyll, die alle in jener Fliissigkeit ebenfalls untersinken. Schwieriger ist die Unterscheidung von dem gelben Quarz, dem Citrin, der im spezifischen Gewicht und in der IIärte nur sehr wenig unter dem Beryll steht. Diese beiden Eigenschaften mïssen zu dem vorliegenden Zwecke etwas genauer untersucht werden. In der vierten Fliissigkeit $\left(G_{0}=2,0 \%\right.$ ), in der der Citrin schwebt, sinkt der Beryll noch langsam unter, und eine glatte Quarzfï̈che, die der Citrin nicht angreift, wird vom Beryll noch merklich, wenn auch nicht stark geritzt. $̈$ tztinte wirkt stark auf Citrin, aber schwach auf Beryll ein, und die Brechungskneffizienten des letzteren sind nicht unerheblich höher als die des Quarzes. Auch der stärkere Pleochroismus des Berylls kann einen Anhaltspunkt und zuweilen die Entscheidung geben.

Ein Glasflub von der Farbe des Aquamarins wird u. a. erhalten, wenn man 3456 Teile Straß, 24 Teile spießglanzglas und $1 \frac{1}{2}$ Teile Kobaltoxyd zusammenschmilzt. Von den echten Steinen unterscheiden sich derartige Imitationen durch die einfache Lichtbrechung und den vollständigen Mangel des Dichroismus, sowie durch die geringere Härte.

\section{Euklas.}

Der Euklas gehört mit zu den seltensten Mineralien, er kommt daher auch nicht im gewöhnlichen Edelsteinhandel vor, sondern wird nur gelegentlich einmal geschliffen und zu hohen Liebhaberpreisen (ein Karat bis 200 Mark und mehr) verkauft. Er hat in mehr als einer Hinsicht große Ähnlichkeit mit dem Beryll, besonders mit dem Aquamarin. Dies zeigt sich schon in der chemischen Beschaffenheit, denn beide enthalten dieselben Bestandteile, nur in versehiedenen Mengen, der Euklas außerden etwas Wasser. Seine Zusammensetzung wird durch die Formel: $\mathrm{H}_{2} \mathrm{O} .2 \mathrm{BeO} \cdot \mathrm{Al}_{2} \mathrm{O}_{3} \cdot 2 \mathrm{SiO}_{2}$ ausgedruickt. 
Die Kristallform gehört dem monoklinen System an. Es sind stark vertikal grestreifte Prismen, die oben und unten durch schief angesstzte Flächen beerenzt sind, wie Fig. 78 zeigt. In einer IRichtumg, parallel mit der Symmetriechene, können die Kristalle stehr leicht gespalten werden; die vollkommenen Blitterbriiche stumpfen die seitlichen Kanten der Prismen gerade ab. Diese Eigrenschaft hat zur Folere, dal) die Steine leicht lisise bekommen, leicht zerbreehen und beim Sichleifen am liande splittern, sie müssen also sehr in acht grenommen waden. Die Ifärte ist nahe grleich der des berylls, nämlich grleich $7 \frac{1}{2}$, der Euklas ïbertriff aber doch hierin den Beryll um etwas. Das spuezifische fiewicht ist riemlich grols, ghleich $3, n ;$ bis $3,1 \ldots$. Durch. Iieiben wird rine nicht unbedeutende elektrische Spannung erzeugt.

Der Euklas ist glasglinzend, in der Richtung des Blätterbruches tritt häufig P'erlmutterglanz auf. Durch das Schleifen und Polieren kann ein schr schöner Glanz hervorgebracht werden. Die Steine sind vielfach vollkommen klar und durehsichtig. Die Lichtbrechung ist gering, ebenso die Doppelbrechung und Farbenzerstreuung; die Brechungsindices liegen zwischen 1,65 und $1,6 \mathrm{i}$. Die Farbe hat viel Ähnlichkeit mit der des edlen Berylls; sie ist entweder grün ins Blaue, wie es Taf. XIII, Fig. 5 zeigt, oder sie geht ins Gelbe; sie zeigt die verschiedensten Nuancen, die aber beinahe stets blaß sind. Tief und dunkler gefärbte Steine finden sich fast gar nicht, ebenso sind auch farblose ungewöhnlich. Am geschätztesten sind blaugriine Steine von etwas kräftigerer Farbe, wie in obiger Figur, die dem entsprechend gefärbten Aquamarin und dem blauen 'Topas oft sehr nahe stehen. Von diesen beiden unterscheidet sich aber der Euklas leicht durch das spezifische Gewicht; auch der trotz der ziemlich schwachen Färbung nicht unbeträchtliche Dichroismus, namentlich der blauen, kann zu diesem Zivecke dienen.

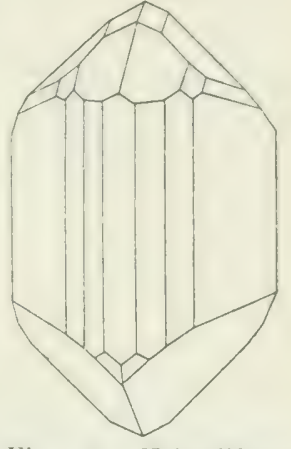

Fig. is. Lrisistallform des Euklases.

Die Zahl der Fundorte ist sehr beschränkt, und überall kommt der Stein nur in sehr spärlicher Menge vor. Zuerst wurde er in Brasilien bekannt, wo er die gelben Topase in der Gegend von Villa Rica (Ouro preto) in Minas Geraës begleitet, die sich nesterweise auf Quarzgäingen in dem mit dem Itakolumit verbundenen Tonschiefer finden. Allerdings kommen, wie es scheint, niemals Topas und Euklas in einem und demselben Neste nebeneinander vor, sondern beide für sich in verschiedenen Drusen. Die Hauptfundorte sind Capao do Lane und Boa Vista (Fig. S1, S. 420). Im Jahre 1904 sind hier etwa zwei Dutzend 10 bis 33 Millimeter lange Kristalle gefunden worden, und vor zwei Jahren hat ein Obersteiner Steinschleifer neben 50 Kilogramm Topas 5 Kilogramm Euklas gesammelt. L. v. Eschwege berichtet von einem über 11:2 Pfund schweren Euklas aus dieser Gegend; die meisten sind aber klein und die Kristalle gewöhnlich dureh Abbrechen von Stïcken nach dem vollkommen Blätterbruch verstimmelt. Übrigens fehlt das Mineral auch in den brasilianischen Diamantseifen nicht, ist aber als Begleiter des weilen Topases in Minas Novas bisher noch nicht vorgekommen.

Eine zweite Fundstelle des Euklases in losen Kristallen sind die Goldwäschereien am Flusse Sanarka im Ural im Gouvernement Crenburg. Die Steine, wie in Brasilien meist Spaltungsstiicke. sind bis $1^{1}, 2$ Zoll lang, aber meist kleiner. Ihre Farbe ist grasgriin bis griinlichblau, manche sind auch farblos. Als Begleiter finden sich hier ebenfalls Topas, sodann der schon oben betrachtete Chrysoberyll und andere Mineralien.

Kleine hellgelbliche Kriställchen, auf Glimmerschiefer aufgrewachsen, sind neuerer Zeit im Gebiet des Großglockners in den Alpen rorgekommen, sie haben aber lediglich mineralogisches Interesse. 


\section{Phenakit.}

Der Phenakit ist als Edelstein ebensowenig wichtig, wie der Euklas, spielt aber doch immerhin wie dieser eine gewisse Rolle.

Er enthïlt gleichfalls viel Beryllerde, aber neben dieser keine Tonerde, sondern nur Kieselsäure nach der Formel $2 \mathrm{BeO}$. $\mathrm{SiO}_{2}$. Das Kristallsystem ist das hexagonale, und zwar sind die Kristalle nach der rhomboëdrischen Tetartoëdrie entwickelt. Meist sind es niedere Prismen, die als Endbegrenzung die Flächen eines Rhomboëders oder einer hexagronalen Pyramide, zuweilen daneben auch noch schmale Flächen anderer Formen tragen, wie es Fig. 79, $a$ bis $c$ zeigt.
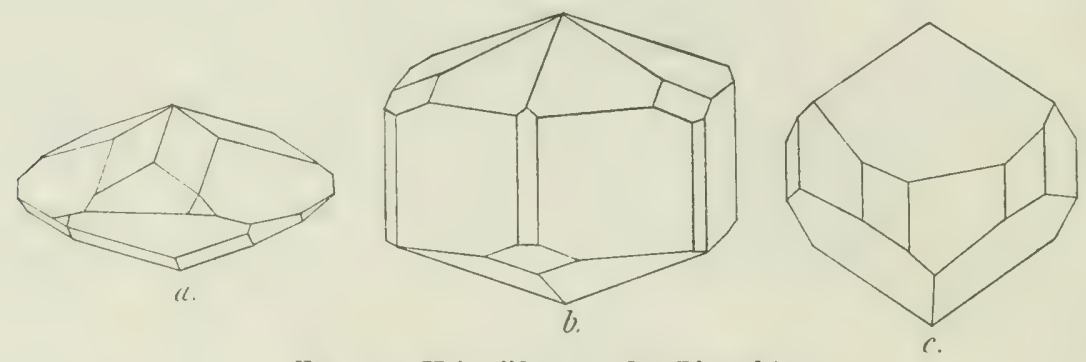

Fig. 79. Kristallformen des Phenakits.

Die Spaltharkeit ist im Gegensatze zum Euklas sehr unvollkommen; der Bruch ist muschlig. Der IIärte nach steht auch der Phenakit etwas höher als der Beryll, er geht sogar noch um ein Weniges über den Euklas hinaus (H. $=71 / 2$ bis 8 ). Das spezifische Gewicht liegt etwas unter dem des Euklases; es beträgt $G_{0}=2,95$ bis gegen 3, , so daß der Phenakit noch eben in der dritten Fliissigkeit $\left(G_{0}=3,0\right)$ schwimmt.

Der Glanz ist besonders auf den frischen Bruchflächen ein lebhafter Glasglanz, wïhrend die natïrlichen Kristallfächen vielfach matter sind. Durch Schleifen wird er schr gehohen, so daß gut polierte Phenakite mit zu den glänzendsten Steinen gehören und mit sapphir rivalisieren können. Das Mineral ist vielfach wasserhell und klar, öfter jedoch trïhe und nur durchscheinend, so dal vollkommen fehlerfreie Steine sehr selten und losibar sind. Röntgenstrablen läbt der Phenakit noch etwas besser durch als der Diamant; er ist für sie der durchläissigste aller Edelsteine. Meist ist er farblos, seltener geelh. haun und rosenrot. Ahgesehen von dem schöneren Glanz gleieht der farblose wasserhelle J'henakit dem Berekristall sehr. Er ist schwach, aber doch etwas stärker lichtbrechend als dieser, dageenen ist seine Doppelbrechung schwächer. Wasserhelle Phenakite erhalten wie alle derartigen Steine meist Brillantsehliff. In dieser Form tritt das Feuer besonders schön hervor, und der Stein bokommt darlureh eine grewisse Ähnlichkeit mit Diamant, hat aber nie dessen schönes Farbenspiel.

Die Zahl der Fundorte des P'henakits ist kaum größer als die des Euklases; er ist aber doch etwas häufieer als dieser. Zuerst bekannt war der weiße von der Tokowaja im Katharinenburger Revier im Tral, wo er mit dem Smaragd und Chrysoberyll in his mehr als $10 \mathrm{~cm}$ dicken und bis 11/2 Pfund schweren Kristallen im Glimmersehiefer eingewachsen ist. Weniger wichtig ist das Vorkommen mit Topas und grünem Feldspat (Amazonenstein) bei Miask am Ilménsee in Ural. Die Steine von der Tokowaja namentlich werden, wenn sie durehsichtig genug sind, in Katharinenburg geschliffen und wie die anderen russischen Edelsteine durch die Messe von Nischny Nowgornd zu hohen Preisen in den IIandel gehracht. Sie werden hauptsächlich in Rußland getragen, 
pinige gehen aher durch Vermittelung jener Messe auch in den Orient (nach I'ersien, Indien usw.).

Seit kurzer Zeit crst bekannt ist das Vorkommen von Phenakit in Nordamexika, und zwar vorzugsweise in Colorado. Er findet sich hier in flachen rbomboëdrischen Kristallen, wie bei Miask in leegleitung von Topas und Amazonenstrin auf rï̈nen im (iranit. Die Fundorte sind Topaz Butte bei Florissant, 16 (rnol.) Meilen vom Pikes Peak entfernt, und mit beryll und (Luarz am Mt. Antero, Chaffee County, 10 (renerl.) Ifeilen nördlich von Salida, in zolllaneren I'rismen. Auch diese amorikanischen Phenakite werden geschliffen und als einheimische Steine seeschätzt und vielfach im Lande setragen. Von anderen amerikanischen Vorkommen ist noch ein solches in Brasilien zu erwähnen, das in der letzten Zeit wertwolles Material geliofert hat. In Europa ist I'lonakit früher auf den Fisengruben von Framont in den Vogesen vorgekommen; es sind kleine braune Tristalle, die aber kaum jemals geschliffen worden sind. Die kleinen Kiristalle, die in den Jetzten Jahren im Granit von Striegau und auf Glimmerschiefer aufrewachsen im Kanton Wallis gefunden wurden. sowie die von Kragerö in Norwegen sind nur mineralngrische Seltenheiten. Überhaupt hat der I'henakit sm Edelsteinhandel keine srofie Bedeutung.

\section{Topas.}

Der 'T'opas gilt für den Typus der gelben Steine, daher werlen auch die gelben Steine, die einer anderen Iineralspezies angehören, vielfach mit demsellsen Namen bezeichnet. Der gelbe Korund heibt, wie wir gesehen hahen, orientalischer Topas, der gelbe Quarz (Citrin) wird böhmischer, zum Teil auch spanischer, der gelle Flulispat falseher Topas genannt. Der Mineralspezies Topas gehören dagegen diejenigen Edelsteine an, die als edler, brasilianischer, s:ichsischer, siburischer and taurischer Topas hezeichnet werden. Der Topas im Sinne des Mineralogen umfaft aber nicht nur gelbe Steine, sondern auch farblose, blaue und rote, die dann als Edelsteine vielfach andere Namen führen.

Das Nineral Topas ist eine fluorhaltige Verbindung von Kieselsäure mit Tonerde, die man durch die chemische Formel: $\mathrm{Al}_{2} \mathrm{Si}_{4} \mathrm{~F}_{2}$ darstellen kann. Diese entspricht 33,:3 Kieselsïure, 56,5 Tonerde und 17,6 Fluor. Die Analysen goben aber stets eine kleine, zwischen 0,1 und 2,:5 Prozent schwankende Menge Wasser, die bei Glühbitze erst entweicht. Sie beruht nicht etwa auf beginnender Verwitterung, sondern gehört wesentlich zur Substanz des Topases und becinfluft auch die pliysilialischen Eigenschaften, spezifisches Gewicht, Lichtbrechung usw. Man nimmt daher an, dafo ein Teil des Fluor durch Hydroxyl (IIO) ersetzt sei, und schreibt die Formel allgemeiner: $\mathrm{Al}_{2} \mathrm{Si} \mathrm{O}_{4}\left(\mathrm{~F}, \mathrm{IIO}_{2}\right.$. Nicht selten findet sich neben den genannten noch irgendein anderer Bestandteil, aber stets nur in sehr geringer Mene, so Spuren von Eisenoxydul, Kalk, Alkalien usw. Jedenfalls spielt aber auch beim Topas die 'T'onerde, wie in den meisten bisher betrachteten kostbaren Edelsteinen (Ruhin, Saphir, Spinell usw.), eine hervorragende Rolle.

Die Kristallformen des 'Topases, die dem rhombischen System angü̈̈ren, bieten neben grofer Ühereinstimmung in manchen Einzelheiten auch vielfache Verschiedenheiten. Stets sind zwei rhombische Prismen miteinander kombiniert, die zusammen eine meist langgestreckte achtseitige, stark läugsgestreifte S:̈ule bilden. Die Endbegrenzung wechselt dagegen ron einem Fundort zum anderen. Sic ist fast stets nur an dem einen Ende regelnä̈lic entwickelt, da dic Kristalle immer mit dem anderen drusenförmig auf einer Lnter- 
lage aufurewachsen sind. Finigne solcher Topasformen stellt die Fig. 80, $a$ bis $d$ dar. Die Fig. S", " und elsenso die Figuren 2 und 4 auf 'l'af. XIII geben die einfache Ausbildung: mancher Kristalle von Kileinasien und besonders von Brasilien; die Begrenzung des einen Encles wird nur von den Fliichen eines Oktä̈ders grebildet. An dem in Fig. 81, Z abgebildeten Kristalle freten dagexen hauptsäichlich zwei grobe Domenflïchen auf, die ihn oben dachförmig besrenzen und neben denen die kleinen dreieckigen Oktä̈derflächen fast vollständig verschwinden; derartig ausgebildete Kristalle stammen aus den Adun-TschilonGebirene bei Tertschinsk in Transbaikalien. An den Kristallen von Mursinka in Ural (Fig. SI), c und Taf. XIII, Fig. 1) tritt zu diesen Fliichen noch eine ausgedehnte grerade Fndfläche, und dasselbe ist der Fall bei den flächenreichen Kristallen vom Schneckenstein in Sachsen (Taf. IIII, Fig. 3 und Fig. S), d), an denen mehrere Oktaëder mit den schon genannten Formen kombiniert sind. An anderen Orten kommen noch viel flächenreichere Kristalle vor, die angeführten können jedoch als Beispiele für die natürlichen Formen des T'opases geniigen.

Die Grülje der Topaskristalle ist auferordentlich verschieden. Man kennt solche von Stecknadelkopfüröbe, aber auch manche von vielen Pfunden Gewicht. So wurde in der Nähe des Flusses Urulga in Sibirien ein schöner durchsichtiger Topas von mebr als 25 Pfund gefunden.
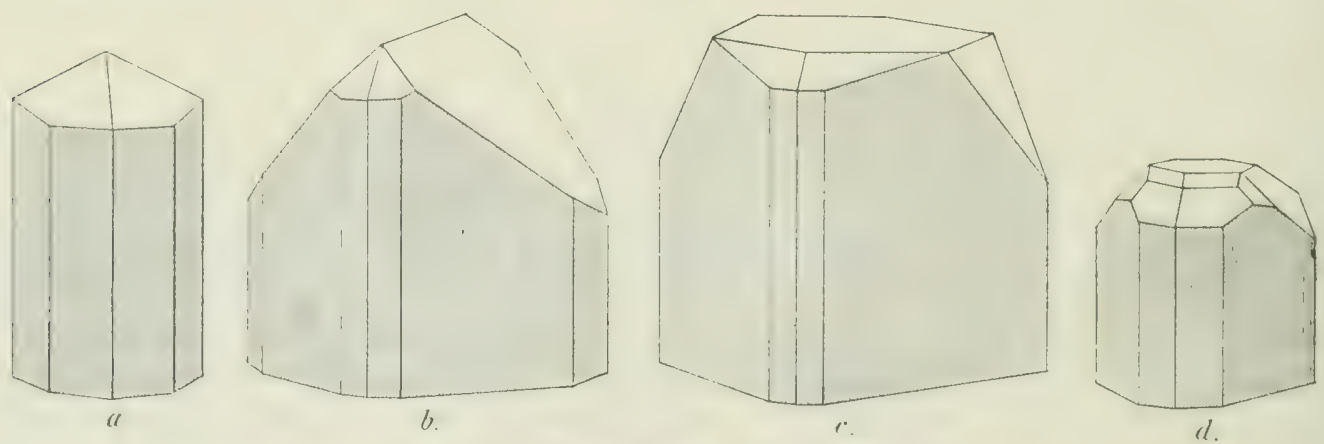

Fig. 80. Kristallformen des 'Topases.

Eine hervormgende Eigenschaft des Topases bildet seine ausgezeichnete Spaltbarkeit, die bei ihm vollkommener ist als bei den meisten anderen Edelsteinen. Sie geht in einer Richtung, und zwar jarallel mit der geraden Endfläche, also senkrecht zu den langgezogenen sestreiften P'rismen. Infolge dieser leichten Spaltbarkeit brechen auch die Kristalle bei ilırex Entfernung von der Unterlage fast stets nach einer zanz ebenen, lel)haft slïnzenden und spiegelnden Fläche ab, wie dies die obigen Figuren am unteren Ende zoigen. Nach dem Blätterbruche können Toplase, die, wie es bäufig vorkommt, zur Iferstellung eines einzigen Schmucksteines zu lang sind, leicht und ohne Mïhe und frefahr durch Zerspalten mit dem Meißel in mehrere Stiicke von passender Gröbe zerlent werden, was für die Bearbeitung von grobem Vorteil ist. Andererseits entstehen aber in den Topasen leicht grerallinige Risse in dieser Richtung, welche die Schönheit und den Wert der Steine: (rheblich beeinträichtigen. Lis ist daher dringend geboten, Topase sorwfältig vor dem Fallen, vor Stöben usw. zu bewahren; schon ein leichter Zufall dieser Irt kann sehr störende Sprünge verursachen, die namentlich dureh lebhaftes Irisieren stark hervorzutreten pflegen. Beim Schleifen ist gleichfalls Vorsicht geboten, da infolge der vollkommenen Spaltharkeit am Rande der Steine leieht Splitter ausspringen, und da auch durch die Einwirkung der Sehleifseheibe leicht Risse entstehen. Manchmal zerhrechen die Steine sogar dabei in mehrere Stiicke. 
Die Iärte des 'Topases ist geringer als die der meisten bisher betrachteten steine, aber immer noch betrïchtlich. Er reprësentient den 8. Giad der Härteskala und ritzt also (quarz noch mit Leichtigkeit, während re seinerseits vom liorund ehenso leicht geritzt wird. Infolse dieser groben IIärte nimmt or eine sehr grute Politur und damit einen starken (ilanz an, der iibrigens auch auf den natïlichen Kiristallflächen vieliach zu sehen ist.

Sehr hoch für eine nicht metallische Substanz ist das sperifische fiewicht. Es beträgt nach verschiedenen Angaben und bestimmt an verschiedenen Varietiiten 3,50 bis 3,55 . Bei farblosem Topas ist es etwas höher als bei grefürbtem; für den rrsteren findret man

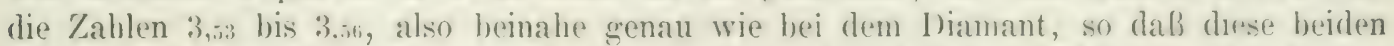
im geschliffenen Zustande manchmal einander recht ähnlichen Edelstene durch ibre Dichte nicht mit Sicherheit voneinander unterschieden werden kïnne'n. Fïr den rötlichgelben Topas von Brasilien und Kleinasien (Taf. XIII, Fig. 2 und 2, a) wurde gefunden $G_{0}=3,50$ bis 3,55 ; für den grünlichblauen von Nertschinsk: $G_{0}=3,53$. Man trifft zuweilen Angaben, die bis 3,4 herah und bis 3,6 linauf (xuhen; diese sehr weit von $3, ;$ ab)weichenden Zahlen beziehen sich aber entweder auf unreines Vaterial, oder die Bestimmung ist fehlerhaft.

Durch Reibung wird der Topas stark elektrisch, so daf er leichte regrenstände Papierstickchen usw. anzicht. Gewisse Varictäten, so z. B. die rom Schneckenstein in Sachsen, sind in dieser Beziehung besonders empfindlich. sie werden schon dureh Reiben zwischen den Fingern lehhaft errewt. Bei manchen brasilianischen Topasen renügt hierzu schon ein Druck zwischen den Fingern, lesonders in der Richtung der Axe der prismatischen Kristalle. Beim langsamen Abkühlen erhitzter Topase tritt sehr energische Pyroëlektrizität auf, stärker als bei den meisten anderen Edelsteinen, etwa ausgenommen den Turmalin. Die Steine bleiben manchmal bis :30 Stunden elektriseh und sind es oft noch lange, nachdem eine völlige Erkaltumg eingetreten ist. Diese leichte Elektrizitïtserregung ist unter Umständen ein wichtiges Kennzeichen für den Topas und kann dazu dienen, ihn von anderen ähnlichen Steinen zu unterscheiden.

In der Lötrohrflamme ist der Topas unschmelzbar, doch wird er dabei unter Verlust von Fluor und Wasser trübe und undurehsichtig, und gefärbte werden farblos. Säuren wreifen den Topas nicht im mindesten an, weder in der Kälte noch in der Würme.

Wichtiger als alle diese Eigenschaften sind aber für den Topas als Edelstein die optischen, das Terhalten gegen das Licht. In dieser Bezichung hat man zunäichst zwei Abteilungen von Topas zu unterscheiden: den ron Natur trüben und undurchsichtigen sogenannten „gemeinen“ Topas ron dem klaren und durehsichtigen .edlen“ (Edeltopas). Der erstere ist zum Schmuckstein um so weniger greeignet, als er auch stets nur eine unansehnliche schmutzigweiße Farbe besitzt. Er findet sich hauptsächlich unter dem Namen Pyrophysalith in grofen Kristallen in der Nähe ron Falun in Schweden im Granit, und in stengligen Agegregaten als sogenannter Pyknit auf den Zinnerzlagerstïtten des Erzgebirges. Von diesen geneinen Varietäten wird im Nachfolgenden nicht weiter die Rede sein, wir haben uns hier nur mit dem edlen Topas zu beschäftigen, der außer durch seine Klarheit und Durchsichtigkeit durch hohen Glanz und häufig auch durch schöne Farben ausgezeichnet ist, so daß er sich zum Schmuckstein ganz besonders gut eignet. Für Röntgenstrahlen ist der Topas noch etwas durchlässig.

Der Glanz ist der gewöhnliche Glaşlanz, nur auf den Spaltungsflächen ist er perlmutterartig. Daf er auf den natïrlichen Kristallflïchen vielfach sehr stark ist. ist schon erwähnt; es ist dies besonders auf den Prismenfliichen der Fall. Der hohe Glanz, der durch das Schleifen und Polieren erzeugt werden kann, ist es hauptsächlich, durch den der Topas zuweilen dem Diamant im Aussehen sehr nahe komnt, so dal' ein wuter Topas 
sich auch nehen einem Diamant immer noch sehen lassen kann, wenn er ihn an Schönheit auch nie ganz erreicht.

Die Lichthrechung ist nicht sehr stark; die Brechungskoëffizenten sind im Gegensatz zum Diamant verhäilnismäßig niedrig und erheben sich nur wenig über 1, fi. Dem rhombischen Kristallsystem entsprechend besitzt der 'Topas Doppelbrechung, aber auch diese ist grering, die Brechungskoëffizienten für versehiedene Richtungen weichen nur wenig voneinander al). Dasselbe ist für verschiedene Farben der Fall: die Farbenzerstreung; die Dispersion, ist eleichfalls nur unbedeutend. Fin geschliffener 'Topas kann demnach nur ein sehr geringes Farbenspiel haben und unterscheidet sich auch dadureh bei aller sonstigen grolien Ähnlichkeit sehr wesentlich vom Diamant. Diese Verhältnisse gehen am besten hervor aus der Gröbe der Brechungsindices für verschiedene Richtungen und für verschiedene Farben. Die grö̈ßten, mittleren und kleinsten Werte derselben sind für rotes und violettes Licht, gemessen an einem und demselben Kristall, die folgenden:

$\begin{array}{llll}\text { rot: } & 1,618 & 1,610 & 1,608, \\ \text { violett: } & 1,635 & 1,627 & 1,625 \text {. }\end{array}$

Für andere Kristalle, namentlich für solche von anderen Fundorten und von anderer Farbe, sind die entsprechenden Zablen zwar etwas, aher doch nur wenirg von den angegebenen verschieden.

Die Färbung des Topases ist recht mannigfaltig, die Farbenreihe ist ziemlich grob.

Der reinste Topas ist vollkommen farblos, und so kommt er auch häufig vor, ganz durchsichtig und klar, wasserhell. Er bildet in dieser Beschaffenheit Kristalle, wie bei Miask im Ural, in Sibirien und an anderen Orten. Noch häufiger aber sind es abgerollte Geschiehe, vorzugsweise in den Bächen und Flïssen von Diamantina und besonders von Minas novas im Staat Minas Geraës in Brasilien, ebenso in Australien, vor allem in Neu-Süd-Wales, aber auch in Tasmanien und in anderen Gegenden. Diese Geschiebe sind vielfach vollkonmen wasserklar, so daf sie von den Brasilianern als "pingos d'agoa" (Wassertropfen) bezeichnet werden. Im Edelsteinhandel fülıren die farblosen Topase zuweilen den entsprechenden französischen Namen „goutte d'eau", werden wohl auch als Edeltopase in engerem Sinne bezeichnet.

Der vielgenannte große Diamant der portugiesischen Krone, der Braganza, von 1650) Karat Gewicht, ist der Vermutung nach nichts anderes als ein solches Topasgeschiebe von besonderer Schönheit und Klarheit. In Brasilien werden diese Steine der schon erwïlınten Ähnlichkeit mit Diamanten wegen vielfach Sklavendiamanten genannt. Man sucht sie im geschliffenen Zustande auch nicht selten dem Diamant unterzuschieben. Die Unterscheidung ist nicht immer ganz leicht; da ihr spezifisches Gewicht fast genau dasselbe ist, so lälit dieses sonst so bequeme Hilfsmittel hier im stich, man kann aber den Topas an seiner Licht- und Doppelbrechung und an seiner geringeren IIärte erkennen. Das spezifische (iewicht ist jedoch zur Unterscheidung des farbloses Topases von anderen wasserhellen steinen geeignet, so namentlich vom Bergkristall und auch vom Phenakit, die leichter sind als Topas, und vom farblosen Sapplir, der erheblich sehwerer ist. Im gewö̈hnlichen Methylenjodid schwimmt der Bergkristall, dessen Gewicht $=2$, und ebenso der Phenakit, wo $\mathrm{C}_{0}=2,9-3,0$, während der Topas sehr schnell untersinkt. In der schwersten Fliissigkent sinkt der farblose Sapphir unter, der Topas bleibt an der Oberflïche. Auch die starke Elektrizitiitserregung, die dem Topas, nicht aber den anderen genannten Mineralien eigen ist, kann zur Erkennung des ersteren dienen.

Wenn Färbumg vorlaunden ist, ist diese oft nur sebr bialb, manchmal aber auch linaftig und intensiv. In letzterem Falle bemerkt man damn einen nicht unbedeutenden Pleochroismus, allerdings kaum mit blobem Auge, aber leicht mit der dichroskopischen Lupe. 
An den gefärbten Topasen tritt vielfach die bla ue Farbe auf, entweder rein, oder manchmal mit einem mehr oder wenierer dentlichen Stich ins (iriine, fast nie aber rein griin. Ein natiorlicher Stem dieser Art ist Taf. XIII, Fig. 1, ein greschlifener chenda Fig. 1, " abebebildet. Dunkelblaue Topalse sind bisher kaum vorgekommen, meist ist die Farbe ziemlich lieht, und manchmal ist sie so heell, dali man die betreffenden Steine auch farblos mit einem leichten blïulichen IIatuch nennen kïnnte. So findet man es unter den Kristallen von Mursinka bei Katharinenburg in Ural. Nach diesem letzterem Fundort heiben die sehr lichtbläulichen, fast farblosen Steine sibirischer oder tauriseher Topas. Ist die Farbe etwas dunkler, aher immer noch lichtblau, dann hat man den brasilianischen Sapphir, ein Name, der allerdings auch dem blauen Turmalin von lirasilien, einem der Begleiter der dortigen weiben und blauen 'Topase, geegeben worden ist. Die Farbe mancher blauer 'T'opase, namentlıch der grüulichblauen und bläulichgriinen, ist der de's Aquamarns oft so überaus ähnlich, dalb eine Erkennung und Unterscheidung beider vielfach nur durch genauere Untersuchung möglich ist. Sie bewerkstelligt sich aher leicht mit IIlfe des spezifischen Gewichts: der schwere 'Topas sinkt im reinen Methylenjodid, wälurend der leichte $\Lambda$ quamarin schwimmt. Solche aquamarinähnlichen Steine, wie sie unter anderen namentlich in der Gegend ron Nertsehinsk in Transbaikalien vorkommen, werden stets unter dem Namen Aquamarin verschliffen. Echter Aquamarin ist erheblich häufiger und verbreiteter als der 'I'opas und besonders als der ebenso gefürbte. Man hat also hier die Erscheinung, dab der seltenere Stein dem verbreiteteren untergeschoben und nach ihm benannt wird; gewöhnlich ist das Verhältnis umgekehrt. Der Pleochroismus der blauen Topase tritt un so stärker hervor, je mehr die Farbe ins Grïne geht. Er ist derart, daß für den Fall der wrößten Farbendifferenz der beiden Bilder, welche die dichroskopische Lupe liefert, das eine fast oder ganz farblos, das andere blaugrün bis fast rein grün ist. Beim Aquamarin sind diese Farben etwas anders: gelblichwelb und hell himmelblau. Selten ist beim 'Topas eine gelblichgrüne Farbe, ähnlich der des Chrysoliths; diese Nuance führt uns aber nun zur Hauptfarbe unseres Edelsteines, der g elben.

Diese ist von allen Farben die verbreitetste und findet sich in den verschiedensten Nuancen, vom hellsten fast farblosen reinen Gelb bis zum Dunkelbraungelb, meist mit einem mehr oder weniger deutlichen Stich ins Rote, das zuweilen auch in der Farbenmischung überwiegrt. Nur der gelbe Topas wird von den Juwelieren nit diesen Namen schlechtwegr bezeichnet. Nach der verschiedenen Nuance hat wan einzelne zum Teil besonders benannte Varietäten unterschieden. Diese besitzen nicht alle den gleichen Wert, und innerhalb jeder einzelnen Varietät steht der Preis um so höher, je tiefer und gesüttigter die Farbe ist, vollkommene Klarheit und Durchsichtigkeit der Stïcke vorausgesetzt.

Ein schön safrangelber sogenannter indischer Topas soll sich nach manchen Angaben auf der Insel Ceylon finden, aber nicht häufig, und vielfach wird vermutet, daf es sich hier um gelben Sapphir handle, daß echter Topas in Ceylon iiberhaupt nicht vorkonme. Als grobe Seltenheit soll er auch in Brasilien beobachtet sein. Dunkelgelbe, mit einem Stich ins Rote oder Braune, kommen zahlreich und in großer Schönheit an einigen der später eingehender zu betrachtenden brasilianischen Fundstätten vor. 'Taf. IIII, Fig. 2 gibt das Aussehen eines Kristalls dieser Art, Fig. -2, " das eines geschliffenen Steines von einer etwas anderen Nuance. Daneben finden sich in Brasilien aber auch, wennschion in geringerer Menge, goldgelbe, honigrelbe, weingelbe und andere. Von diesen hat speziell der schün goldgelbe den Namen brasilianischer Topas erbalten.

Hellweingelb, wie der Kristall Taf. XIII, Fig. 3 und der geschliffene Stein Taf. XIII, Fig. 3. u, ist der sächsische Topas rom Schneckenstein bei Auerbach im sächsischen Voigtlande. Diese Farbe spielt zuweilen ins Grünliche; die Abart beißt dann sä chs is cher Chrysolith. 
Die dunkelgelhen Topase zeigen ziemlich starken Pleochroismus. Die Bilder, die in der dichroskopischen Ixpe entstehen, sind hell- und dunkelgelb, oder gelb und rot bis gelblichrot. Je heller die Farbe, desto weniger ausgesprochen ist dieser Unterschied, und bei ganz hellgelben Steinen ist er sehr schwach und sogar kaum merklich.

Von anderen gelben Steinen, die mit Topas verwechselt werden können, ist besonders der sellse Sapplir, der orientalische Topas, und der gelbe Quarz, der Citrin wichtig. Von diesen wird namentlich der leztere, der in denselben schönen Nuancen sich findet wie der Topas, diesem vielfach untermeschoben, wie wir bei der Betrachtung des Citrin noch weiter sehen werden. Durch sein geringes spezifisches Gewicht kann er vom gelben Topas gleich leicht unterschieden werden, wie der Bergkristall vom wasserhellen Topas. Ebenso unterscheidet sich der orientalische vom eigentlichen Topas in derselben Weise wie der farblose 'Topas von dem farblosen Sapphir; es sei in dieser Beziehung auf die frülieren Bemerkungen verwiesen.

Selten ist der 'Topas von Natur ausgesprochen rot; in Brasilien kommen rote Kristalle zuweilen als Begleiter der gelben vor. Die Farbe ist meist ziemlich licht rosenrot bis lila, zuweilen sehr ähnlich der des Balasrubins, der sich aber durch seine einfache Lichtbrechung und den Mangel an Pleochroismus leicht von dem doppeltbrechenden und ziemlich stark pleochroitischen roten Topas unterscheidet. Dieser heißt bei den Juwelieren Rosatopas; er ist auf 'Taf. XIII, Fig. 4 und 4, a als Kristall und in geschliffenem Zustande abgebildet. An einzelnen Exemplaren ist die Farbe etwas intensiver und gesättigter, ähnlich der mancher Rubine. Diesen roten Topasen hat man den Namen brasilianischer Rubin gegeben, ihr Wert ist höchstens etwa ein Drittel von dem gleichgroßer und gleichgefärbter echter Rubine. Der dunkel gelbrote Hyacinthtopas ist kein Topas, sondern Zirkon.

Die seltene natürliche Färbung des Rosatopases kann auf künstlichem Wege täuschend nachgeahmit werden, und zwar durch vorsichtiges und nicht zu starkes Glühen der gelben, besonders der brasilianischen Topase. Dabei verschwindet diese Farbe und verwandelt sich in die der roten Topasvarietät. Die meisten in den Juwelierläden liegenden Exemplare des Rosatopases sind nicht natiirlich, sondern es sind durch Gliiben veränderte, "gebrannte", gelbe Topase. Je dunkler gelb der Stein vor dem Glühen war, desto dunkler rot wird er in allgemeinen nachher. Die Erhitzung und die Abkïhlung muß sehr allmählich und langsam erfolgen, weil der Stein sonst rissig und unbrauchhar wird. Es gibt verschiedene Methoden, die Umwandlung der Farbe zu bewerkstelligen: man kann die Steine mit Kiohlenpulver, Sand, Asche, oder einer anderen pulverigen Substanz in einen Tiegel packen, diesen langsam erhitzen und ebenso auch wieder abkühlen; oder man umwickelt einen gethen Stein dick mit Feuerschwamm und zündet diesen an; wenn er ahgebrannt ist, ist der Stein rot. Man hat dabei aber immer darauf zu achten, daß die Temperatur nicht iiber dunkle Rotglut steigt, weil hierdurch leicht eine vollständige Entfärbung eintritt und die Steine trïbe und rissig werden.

Die gehrannten Rosatopase sind ganz besonders stark pleochroitisch, mehr als die von Natur roten und auch mehr als solche von anderer Farbe. Die Bilder in der dichroskopischen Iupe sind im Maximum der Verschiedenheit kermesinrot und honiggelb. Wegren der Seltenheit von Natur roter 'T'opase lat man wobl die Ansicht ausgesprochen, dalb alle Rosatopase nur gecoliihte gello 'Topase seien. Es ist alber unter anderen von L. r. Eschwege und anderen Kemmern Brasiliens gut bezeugt, dal dies nicht richtig ist, dal von Ilaus aus rote Kristalle neben den gelben ecelexentlich vorkommen; sie lassen sich indessen nur schwer von den gebrannten unterscheiden.

Aher es bedarf gar keiner hohen Temperatur, um die Farbe wenierstens mancher T'opase zu verändern. Diese verschwindet schon oder wird wenigstens blasser, wenn man 
den Stein einige Zeit dem Sionnenlichte aussetzt. Eine solehe Entfärbung ist namentlich an manchen dunkelweinerelben Kristallen vom Flusse Lrulgra in Sibiren beobachtet worden; wenige Monate geniigten, um die Farbe in cin schmutziges Weil zu verwandeln. An manchen blafhlaten Steinen ist eine Umwandlung der Farbe in blafgelh im Sonnenlicht beobachtet worden. Dieses Aushleichen deutet darauf hin, dal) die Färbung durch eine orwanische Substanz hervorgebracht wird, die dem an sich farblosen Topas beigemengt ist. Anders lient die Sache bei denjenigen Topasen, deren Farhe sich im Iichte nicht ver:̈indert, so namentlich beim gelben brasilianisehen. Iieser ist wohl dureh ein Metalloxyd sefëirbt, denn seine Farbe wird zwar in der Hitze in Rot verwandelt, versehwindet aber nicht bei ciner Temperatur, wo organische Substanz schon ganz zerstïrt sein würde, und bei der also im Falle eines organischen Pigments der Stein ganz entfärlst werden mübte. Die Farbenverïnderung durch Radiumstrahlen siehe S. 72.

Alle diese edlen Topasvarietïten werden zu schmucksteinen benutzt, doch sind nur schön und gleichmäßig gefärbte, klare und durchsichtige, fehlerfreie Exemplare von höherem Werte, während solche, die sich von dieser Beschaffenheit zu weit entfernen, nicht mehr geschliffen, sondern höchstens als sogenannter "Topasbrack" zur Iterstellung eines harten Schleffulvers zerstoben und zerrieben werden. Der farbige Topas wird mit Torliebe als Treppenstein, und zwar mit einer kleinen Tafel und feinen und schmalen, greichweit voneinander entfernten Treppen geschnitten. wie die rier geschliffenen und auf Taf. XIII, Fig. 1, a, 2, a, 3, a, 4, a abgebildeten Topase zeigen. Seltener ist der Brillantschliff, doch ist auch dieser nicht ungewöhnlich. Letztere Form ist mehr die der farblosen Topase, der pingos d'agoa usw. Der gelbe erhält auch nicht selten die Gestalt rines Tafelsteines, und wenn lichtgefärbt, wie der sächsische, wird ihm beim Fassen zur Hebung des Feuers und der Farbe eine glänzende Goldfolie untergelegt; manchmal wirkt eine rote Folie noch besser. Blaue Topase erhalten stets eine hellblaue glänzende, niemals eine dunkle Folie; letztere wiirde das Aussehen fremdartig und unansehnlich machen. Nur die schönsten und klarsten Topase aller Farben werden à jour gefaßt.

Der Preis richtet sich nach der Klarheit, Durchsichtigkeit und Schünheit und nanentlich nach der Farbe. Er wächst nicht stärker als das Gewicht und ist ïberhaupt nicht sehr hoch, da gute Exemplare, auch von bedeutender Größe, immerhin häufiğ genug gefunden werden und der Topas gegenwärtig von der Mode nicht sehr begüinstigt ist. Namentlich der gewöhnliche gelbe Topas steht aus diesem letzterem Grunde mit höchstens 5 Mark, der seböne honiggelbe mit 15 Mark pro Karat, niedrig im Werte, viel niedriger als in früheren Zeiten, wo er sich größerer Beliebtheit erfreute. Rote, sosicie besonders auch schön blaue sind jetzt gesuchter und es wird bis 25 Mark für das Karat bezahlt. Für die farblosen steigt der Preis nicht über 6 Nark, für dunkelbraungelbe nicht über 3 Mark für ein Tarat und für weniger gute Steine geht dieser Preis noch sehr herunter. Noch vor etwa 15 Jahren war der Preis des Topases etra dreimal so hoch wie jetzt. Für gelben Topas schwankt jetzt der Preis im Großhandel zwischen 2 und 41) Mark für das Kilogramm roher Steine.

Auf den Preis sind namentlich auch die Fehler der Steine von Einfluf, die vorzugsweise in unreiner Farbe, Rissen in der Richtung der Spaltbarkeit (Federn) und wolkigren 'Trübungen bestehen. Anch größere Bläschen findet man vielfach eingeschlossen, die zum 'Teil leer, zum 'T'eil auch mit Flussigkeiten verschiedener Natur erfüllt sind.

Künstliche Darstellung des Topases ist bisher noch nicht sicher gegluickt. Dagegen kann man den gelben Topas sehr tïuschend ins Glas nachahmen, indem man den Sitraf mit etwas SpieBglanzglas (Antimonoxyd) und mit einer Spur Goldpurpur oder mit jenem und etwas Eisenoxyd zusammenschmilzt. Goldpurpur gibt ein dunkleres, mehr rötliches, Eisenoxyd ein helleres Gelb. Ton dem eigentlichen Topas sind diese Gläser durch viel 
geringere IIirte, niedrigeres spezifisches Gewicht, einfache Lichtbrechung, IIangel an Pleochroismus usw. leicht zu unterscheiden. Was neuerdings als synthetischer "Rosatopas" in den Handel gebracht wird, ist ein rosenrother künstlicher Rubin (S. 352).

Was das Vorkommen des Topases anbelangt, so findet er sich vorzunsweise in älteren kristallinischen Silikatgesteinen, im Gness und anderen kristallinischen Schiefern. sowie in Granit (Pegmatit). Die Kristalle sitzen in diesen Gesteinen auf spalten und sind darin nicht selten von Zinnerz, ebenso auch von Beryll (Aquamarin) usw. begleitet. Das ganze Verhalten ist so, daß man den T'opas als eine pneumatolytische, eine Art Fumarolenbildung ansehen muB, entstanden dureh gegenseitige Einwirkung fluorhaltiger Dämpfe, die bei der Bildung jener Gesteine, besonders bei der Eruption der Granite sich auf jenen Spalten entwickelt haben. Aus der Verbindung mit seinem Muttergestein ist der 'Topas vielfach durch Verwitterung losgelöst und in die Seifen grelangt, in denen er sich dann in Form stark abgerollter Geschiebe findet. In neuerer Zeit entrleckte man zwar auch in manchen jüngeren Eruptivgesteinen von trachytischer Natur auf Drusenräumen einzelne Topaskristalle; dies ist aber immerbin eine Seltenheit und olne jede Bedeutung für den Edelsteinhandel.

Die Fundorte schöner schleifwürdiger Topase sind ziemlich zahlreich. Sie wurden zum Teil bereits oben im Vorbeigehen kurz erwähnt, hier sollen nun einige der bedeutenderen etwas eingehender geschildert werden.

In Europa ist das wichtigste Vorkommen das vom Schneckenstein bei Gottesherg in der Nähe von Auerbach im süchsischen Voigtlande, $4 \mathrm{~km}$ südöstlich vom Bahnhofe Hammerbriick. Der Schneckenstein stellt eine nahezu $24 \mathrm{~m}$ hohe, steil aus dem umgebenden Glimmerschiefer emporragende Felswand dar, gebildet von einem Trümmergestein, dem 'Topasfels, dessen einzelne bis faustgroße Zusammensetzungsstücke cines quarz- und turmalinreichen Schiefers durch Quarz und Topas zu einer sehr festen Masse verkittet sind. Auf zum Teil mit weißem oder gelben Steinmark ausgefüllten IIohlräumen ist neben Quarz, Turmalin usw. vorzugsweise auch Topas auskristallisiert, in der Weise, wie es Taf. XIII, Fig. 3 zeigt. Die Kristalle sind mit einem Ende auf der Drusenwand aufrewachsen; sie bilden kurze Prismen, welche am anderen Ende die in Fig. 80, , abgebildete, ziemlich komplizierte Begrenzung tragen. Die Gröbe ist sehr verschieden; von wenigen Linien geht sle bis zu dem Maximum von 10 Zentimeter Lïnge und 5 Zentimeter Dicke. Im Mittel betragen diese Dimensionen etwa je $1 \mathrm{~cm}$; größtere Kristalle sind ungewöhnlich.

Die Färbung ist meist hell weingelb, selten etwas tiefer bis dunkel weingelb, oder auch ganz farblos oder weil; je dunkler die Farbe, desto wertvoller. Manchmal geht sie auch etwas ins Grünliche (sächsischer Chrysolith); dem gegenïber heißt der weingelbe speziell „sächsischer Topas“. In früheren Zeiten, gleich nach seiner Entdeckung im Jahre 1737, war dieser sogen. „Sehneckentopas" von den säehsisehen Kurfürsten sehr bevorzugt und daher auch sonst bedeutend geschätzt und hoch bezahlt. Gegenwärtig ist dies nicht mehr der Fall; für Stïcke die damals 300 Mark wert waren, würde man heute höchstens 8-10 Mark lösen.

Die prachtrollen Topasgarnituren, die im grünen Gewölbe in Dresden aufbewahrt werden, legen Zeugnis al, von der frïlieren Vorliebe für dieses Vorkommen zugleich aber auch von der groben Schönheit, die einzelne der dortigen Steine erreichen, während die große Mehrzahl allerdiness leider zu hell und unansehnlich gefärbt ist. Im 18. Jahrhundert wurden die Schmeckensteintopase systematisch gewommen und verkauft; jetzt gesehieht dies seit langer Zeit nicht mehr. Damals wurde das erbeutete Naterial nach Gröbe und Reinheit in drei fiorten reteilt. Die Steine der ersten Qualität, also die reinsten und größten, hichen limgsteine, die geringeren Schnallensteine und die schlechtesten noch als Edelsteine 
verwendbaren Karmusirgut. Diese Namen sind aber mit der ganzen Industrie, die frühr eine nicht ganz geringe Bedeutung hatte, längst vergessen.

Brasilien, das wir schon als Ifeimat des Diamants, Perylls und Chrysoberylls kennen geternt haben, und das noch mancherlei andere Edelsteine liefert, enthält reiche Funderte auch ron Topas, und zwar von Topas von verschiodenen farben, besonders in dem Staat Minas Geraës.

Der hrasilianische Topas ist teils farblos oder viel seltener hellblau oder auch woll griinlich, oder er ist gell, oder rot. Die gelben und roten Topase finden sich zusammen, sind aber in Vorkommen vollkommen gretrennt von den andern, die ihrersests wieder zusammenliegen.

Die $\mathrm{farblose}$ Varitait ist von den letzteren weitaus die verbreitetste, blau ist viel seltener; es ist hell und weitaus nicht so schön wie bei den sibirisehen Topasen. Solche blauen Geschiebe, wie sie z. B. in dem Rio P'iauhy, einem Zuflub des Jerputinhonha vorkommen, sind in Brasilien als ..safiras" bezeichnet worden, doch sind auch kürzlich Kristalle gefunden worden, z. B. bei Theophilo Ottoni. Den farblosen Topas haben wir schon als spärlichen Begleiter des Diamants bei Diamantina, sowie in Toribergehen als Gefälırten des Chrysoberylls und des Berylls im Municipio von Minas novas kennen geternt: wir werden dieses ausgedehnte Vorkommen schöner farbiger Edelsteine, der .esmeraldas" der Brasilianer, z. T. nach Mitteilungen ron E. II ussak etwas eingehender betrachten.

Der auspedehnte Bezirk ron Minas novas liegt im Nordosten ron Minas Geraës und von Diamantina, um das mittlere Flußgebiet des Diamantenflusses Rio Jequetinhonha, der in seinem Unterlauf Rio Belmonte genannt wird. Hier ist die Heinat des weifen und blauen Topases und der farbigen Edelsteine, des Berylls (Aquamarins), des grimen, roten ete. Turmalins, des Chrysoberylls, Spodumens, Andalusits usw. Lange Zeit war ihr Muttergestein unbekannt; man fand sie, namentlich den Topas, nur in Form ron Geröllen, mehr oder weniger abgeschliffen im Sande der Flüsse und Bäche, in Seifen. Jetzt hat man auch die ursprünglichen Lagerstätten, die für alle gemeinsam sind, aufgefunden. Es sind Gänge eines glimmerreichen, bald II sscovit, bald rosaroten Lepidolith führenden grob)körnigen Granits oder Pegmatits, die Gneis und Glimmerschiefer durchsetzen. In Hohlräumen dieser Gänge sind die Kristalle der genannten Mineralien, oft ron beträchtlicher Gröfe, neben anderen, die als Edelsteine keine Bedeutung haben (Quarz, Zinnstein, Columbit usw.), drusenfürmig aufgewachsen und bilden in dem Pegmatit unregrelnäßjo zerstreute Nester nicht selten von recht erheblichem Umfang. Die Jineralien in den Drusen wechseln in der Art sehr; bald findet man darin nur grrüen und roten Turmalin, bald nur Aquamarin, wieder andere sind reich an Topas und Chrysoberyll usw.

Das permatitische Ifuttergestein ist aber nicht mehr durchaus frisch, sondern nabe der Oberfläche vollständig zersetzt und in einen glimmerreichen lockeren erdigen Kaolin umgewandelt, der nun jene Kristalldrusen umhïllt. Diese werden herausgegraben und die Gruben verlassen, sobald das unverwitterte feste Gestein erreicht ist. Aus diesen Gängen gelangen die Edelsteine dann weiterhin auch in die Wasserläufe, in denen sie zu rundlichen Gerïllen ah)eschenert werden. Zwei von ihnen sind sogar bis heutzutage nur in dieser Form als Flulgreschiebe bekannt, der Andalusit und der Spodumen; diese sind auf ihrer ursprünglichen Lagerstätte bis jetzt noch nicht aufgefunden worden.

Die ältesten Fundorte der esmeraldas. wo neben schönen Aquamarinen und gelben Chrysoberyllen usw. farblose, neuerer Zeit als Seltenheit anch hellblaue Topaskristalle, zum Teil von enormer Gröfe vorkommen, ist die alte deutsche Kolonie Theopbilo Ottoni, die aber jetzt von ihren deutschen Bewohnern gänzlich verlassen ist. Sie liegt am Oberlauf des Rio Mucury, der bei l'orto Necre ins Meer mündet, nahe der Grenze gegen Bahia am Nordabhang der Serra dos Aymores, ron der ein Teil danach auch den Namen 
Serra das Esmeraldas erhalten hat. Als besonders reich wurde früher in jener Gegend der Landstrich zwischen den Quellbächen des Rio S. Matheus bezeichnet, die gewöhnlich ,as Americanas" gemannt werden. Auch im Flußgebiet des Rio Doce, in der Gegend von P'eanha, siidwestlıch von Theophilo Ottoni und suidüstlich von Diamantina, sowie weiter flußalbwïrts im Staate Espirito Lanto wurden Funde gemacht, die gegenwärtig ausgrebeutet werden.

Die zur Zeit wichtigsten Fundstellen sind aber weiter nördlich in der Nähe der kleinen Stadt Arassuahy am oberen Jequentinhonha, die jetzt Calhão heißt, weil südwestlich daron in demselben Municipio noch eine zweite Stadt nit jenem Namen, Villa de Arassuaby, liegt, in deren Umgehung zwar Gold rorkommt, aber keine farbigen Edelsteine. Diejenigen der Gegend von Calhào stammen aus dem dem genanntem Fluß zuærekehrten, nördlichen Abhang der Serra do Chifre, finden sich aber auch auf der entgegengesetzten.

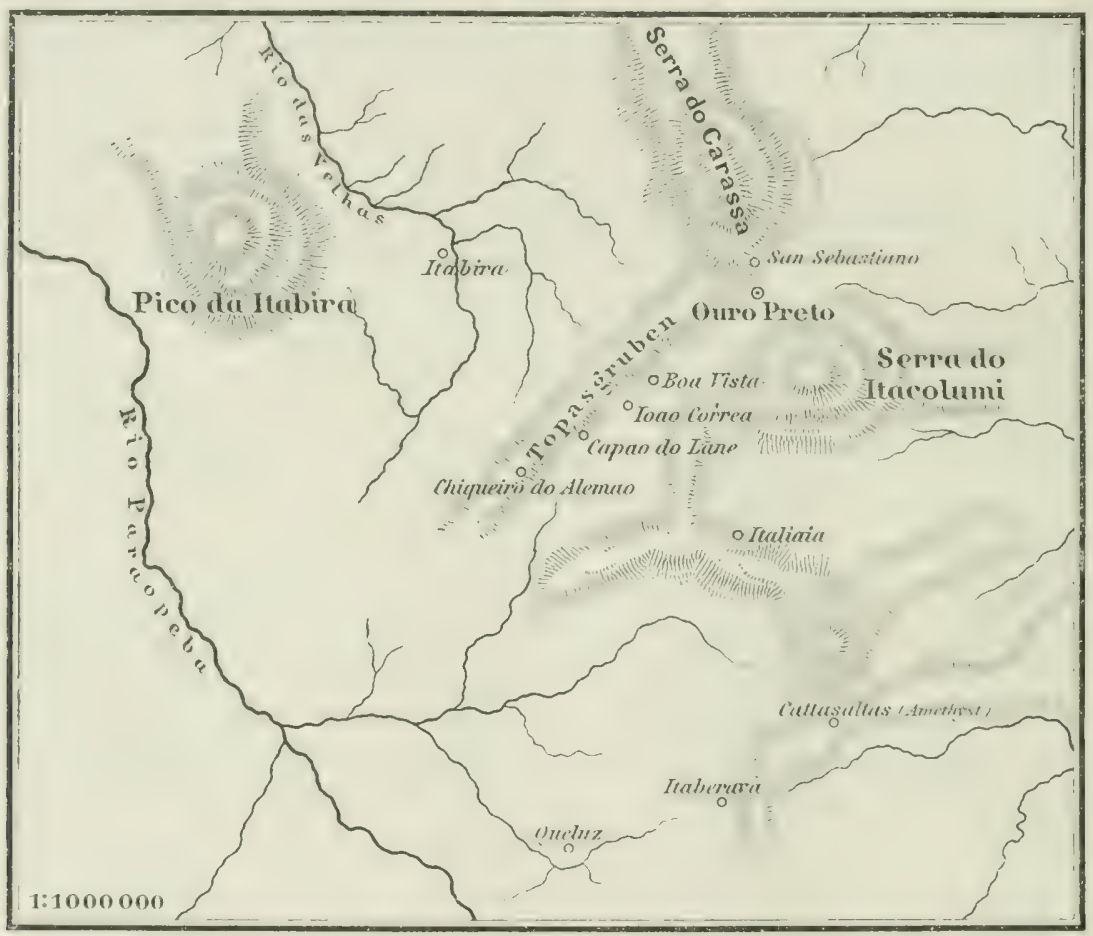

Fig. 81. Vorkommen der gelben Topase bei Ouro Preto in Brasilien.

linken oder nördlichen Seite des Jequetinhonha, bei Salinas, Ibitinga usw., ehenso auf einer kleinen Insel, die bei Calhão im Flub liegt, der Ihla Alegre (S. 403). Auch in der Gegend von Calhão erreichen manche Topaskristalle eine ganz bedeutende Größe.

Unter den Flubeschieben, die nach ihrer Heimat auch zuweilen ,.minas novas" genannt werden, ist die Menge der Topase sehr grols und ïbertrifft die der anderen genannten Steine. Sic hilden wie jene Bruckstïcke oder noch häufiger vollständig ringsum abgeriebene Gerïlle, meist von der Größe einer Linse bis zu der einer Kastanie. Selten sind sie noch grö̈ber, doch sind auch schon Stïcke von Faust-bis Kopfgröße und bis zu mehreren Pfunden Gewicht grefunden worden. Die beste Qualitiit des weißen Topases soll in dem lío Utingra rorkommen, doch sind die pingos d'agoa durchaus nicht auf dessen Bett beschränkt; blaue freschiebe finden sich wie erwähnt im Rio Piauhy.

Ganz anders ist das Vorkommon und die Verbreitung der gelben brasilianischen Topase. Ihre Ileimat ist in Figr. S1 dargestellt. Sie wurden etwa 1760 in der Nähe 


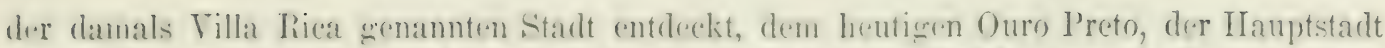

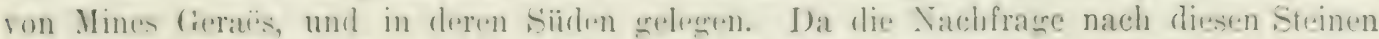

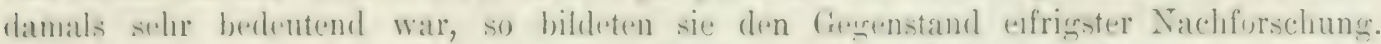

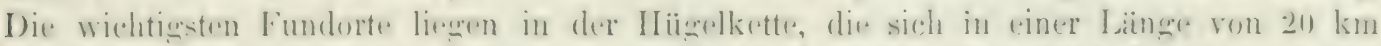

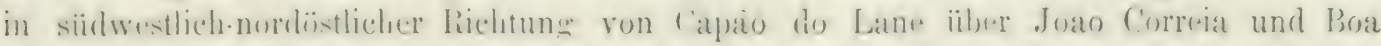

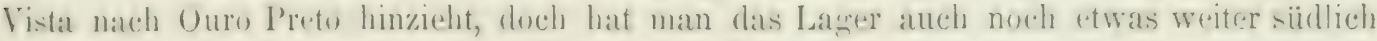
bis Chiqueiro do Alemão verfolgt. Der Topas findet sich hier nur auf einem wenige

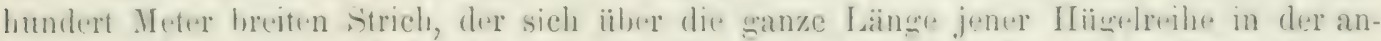

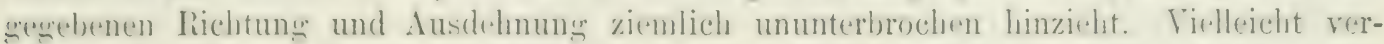

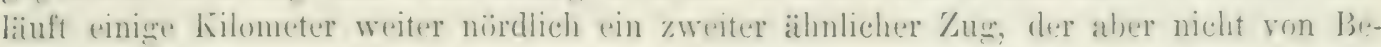
deutung ist.

Diese gethen Topase kommen fast durchaus nur auf ihrer ursprïnglichen Lagerstäte.

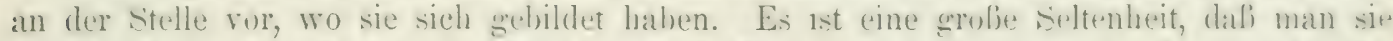

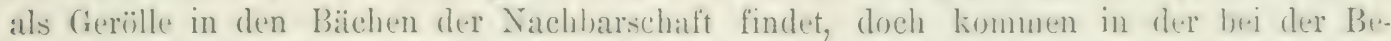

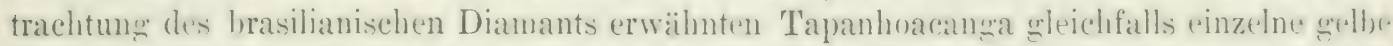
Topasererille vor. Wenn aber auch die Lacerstätte die ursprüngliche ist. sn wilt dies doch nicht mehr für dass Mutteresterin. Dirses befindet sicht nicht mehr in seincm frühren frischen Zustande, sondern ist vollständig zersetzt. Wahrscheinlich ist dias Vorkommen der gelhe Topaste dasselhe wie das der Diamanten in Diamantina, auf Ifohliäumen der. wie jene IÏ̈henzïge von Südwest nach Xordost sich erstreckenden Quarzäinge in den Gesteinen, die jene IIïgel bilden. Es sind dies mit Itakolumit in Verlindung stelende Tonschiefer, die an diesen Stellen durch die Verwitterung in eine dunkel gefärbte shlinmerigschuppige weiche tonige Hasse umirewandelt wurden. In einzelnen I)rusen und Testern, die lose in diesem Tone zerstreut sind, und die als Bruchstïcke der Quarzäinge angerehen werden miissen, lieren zahlreiche ansnahmslos abgebrochene Topaskristalle in einem weilien his dunkelhraunen, schuppisen Steinmark eingebettet, aher auch vielfach direkt in (lex tonigen Verwitterungsmasse selbst. Xach Orville A. Derby würde der Topas ans einem zersetzten Cangr eines Eruptirgesteins stammen, der die schefergesteine durchschneidet. Es sind jedenfalls noch weitere Untersuchungen nütig, un den Sachverhalt volliommen lilar zu legen.

Die Begleiter des Topases sind in der Itauptsache dieselben wit die des Diamants, die so vielfach auf den den Itakolumit und die bexpleitenden festerine durchsetzenden Quarzeïngen beohachtet werden. Es sind auber dem (guarz (Berekristall und Rauchtopas) noch 'l'itaneisen, Eisenglanz, Rutil, Zirkon, Florencit und schwarzer Turmalin. Alle lieten in dem Ton als abgebrochene Bruckstïcke durcheinander gemengt. Auch den schon oben betrachiteten seltenen Euklas findet man dort in derselben Weise, aber nach I. v. Eschwez: nicht mit Topas zusammen, sondern auf besonderen Drusen fïr sich.

Etwas abweichend ist das Vorkommen bei Saramenha, 1/2 Stunde von Ouro Preto. Hier ist ein beträchtliches Lager von mit Eisenglimmer sremengtem Brauneisenstein, in dem Topaskristalle allerdings im allgemeinen ron blabgelber Farbe, aber in wrober Menge eingeknetet sind, die beim Herausnehmen spiegulflïchige, scharfkantige Abdrïcke in dem Muttergestein hinterlassen.

Die Farbe der Topase von Ouro Preto geht vom ganz blassen his zum dunklen Weingelben und Bramen; sie pfleggt um so dunkler zu sein, je dunkler braun das Steimmark ist, in dem die Kristalle eingelagert sind. Taf. IIII, Fig. 2 zeigt einen schün gefürbten hristall ron dieser Gerend, auch der in Fig. 2, a derselben Tafel abgebildete weschliffene Stein stammt von dort. Am schönsten sind die dunkel weingelben von der Farbe eine's alten Malaga. Auch rote von natürlicher Färbung kommen ror Taf XIII, Fig. ti. Sie sind mist blabrosa (Rosatopas) (Fig. 4, a!, aber auch zuweilen dunkelrot, ähnlich wie Rubin brasilianischer 
Rubin, wortunter man aber auch die entsprechenden künstlich rot gefürbten, gebrannten Steine versteht). Namentlich diese „brasilianischen Rubine“ sind sehr gesehätzt. Sehr selten ist die violette Farbe des Amethysts.

Die Durchichtigkeit ist mehr oder weniger groß. Durchaus nicht alle Kristalle sind zum Schleifon geeeignet; unter tausend Stiick ist vielleicht ein einziger ganz tadelloser Stein, alle anderen sind fleckig, rissig oder sonst fehlerhaft und daher zum guten Teil als Edelsteine überhaupt nicht verwendbar.

Die Kristalle sind von verschiedener Größe. L. v. Eschwege erwähnt solche von 6 und sogar von 10 Zoll l.änge und 2 resp. 4 Zoll Dicke. Diese großen sind aber sehr selten zum Schleifen tauglich, sie sind fast alle mehr oder weniger fehlerhaft. Die meisten sind viel kleiner, höchstens etwa so lang und dick wie ein kleiner Finger. Die Kristallform ist wohl erhalten und stets die ganz einfache, die außer in den zuletzt genannten Abbildungen in Fig. 80, $a$ wiedergegeben ist.

Bei der Growinnung dieser Topase wird in den Gruben die ganze tonige Masse aufgehackt. Wenn man dabei auf ein größeres Nest stößt, wird es vorsichtig herausgenommen und seöffnet. Die einzeln im T'one liegenden Kristalle erbält man, indem man die losgehauenen 'T'onmassen durch in die Gruben hineingeleitetes Wasser aufweicht und die feineren tonigen Bestandteile fortschwemmt. Die Topase werden mittels ausgespannter Netze zurückgehalten.

Der Ertrag, der besonders bei den Landgütern Capão do Lane, Caixambu und Boa Vista reichlich war, steigerte sich zeitweilig bis zu 18 Zentnern, betrug aber im Mittel nur 7 bis 9 Zentner im Jahre. Bis 50 Arbeiter sollen gleichzeitig bei den Gräbereien beschäftigt gewesen sein. Die Steine werden über Rio de Janeiro in den Handel gebracht und dort zum Teil auch geschliffen. Zahllose alte Gruben, von den Bergleuten sogenannte Pingen, im Tale von Ouro I'reto legen noch heute Zeugnis ab von der früheren regen Tätigkeit in dieser Gegend. Aber allmählich hat die Nachfrage und damit auch der Ertrag nachgrelassen, und seit längerer Zelt ist die systematische Bearbeitung so gut wie ganz eingestellt. Viele sind der Ansicht, daß der Fundort ziemlich erschöpft sei, von anderer Seite wird dies aber auf das Entschiedenste bestritten und behauptet, daß noch reiche Schätze dort verborgen liegen. In der Tat hat auch vor 2 Jahren ein Obersteiner Steinschleifer aufer 5 Kilogramm Euklas noch 50 Kilogramm Topas dort herausgeholt.

Technisch unvichtig ist das Vorkommen von teils farblosem und wasserhellem, teils blabgefürbtem Jopas in Mexiko. Er findet sich bei San Luis Potosi und La Paz im Staate Cuanajuato auf Zinnerzlagerstätten und bei Durango in zinnerzfiihrenden Sanden.

Auch in den Vereinigten Staaten von Nordamerika ist das Vorkommen guter schleifharer 'Topase trotz großer Verbreitung des Minerals nur spärlich; die besten kamen friilser aus den ïstlichen Unionstaaten. $\Lambda \mathrm{m}$ Harndon Hill bei Stoneham in Maine und an einigen anderen Orten jener Gegend finden sich schöne klare, zuweilen wasserhelle, zuweilen blïuliche und grünliche Kristalle mit Beryll und anderen Nineralien im Granit, ebenso bei North Chatham in New IIampshire. Im Granit von Trumbull in Connecticut kommen 'Topaskristalle vor, die den säehsischen sehr ähnlich, aber meist trïbe und selten schleifwürdip sind. In Colorado findet man schöne farblose und wasserhelle, sowie blaßblaue 'Topase zuweilen von ziemlicher Größe mit Phenakit und anderen Nineralien auf Drusenräumen im Granit an verschiedenen Stellen im Gebiete des Pikes Peak in El Paso County, z. B. hei Florissant, 14 (engl.) Meilen nördlich rom Peak, aufgewachsen auf grïnem Feldspat ( $\Lambda$ mazonenstein); chenso etwa 30 (engl.) Meilen vom Pikes Peak in der Nähe des Devils IIead Mountain farblose, rötliche, weingelbe und blaßblaue, ähnlich denen von Mursinka im Ural, im Gestein und lose in Boden. Auch der Mt. Antero, etwa 10 (engl.) Mrilen nördlich von Salida, in Chaffee County ist ein nicht unwichtiger Fundort. Die 
limblorte in Colorado liefern gregenwärtig die besten nordamerikanischen Schmucksteine von 'oupas, von denen zwei nach dem Schleifen 125 und 193 Karat wiegen. Vor kurzem (rst entdeckt wurden die farblosen, gelben und blauen Topase des Ramona-Distrikts in San Diexo County in siidlichen Kalifornien, die, mit Feldspat, Granat, Beryll usw. O)rusen in rinem P'exmatit bildend, in der Surprice- und Iittle Three-(xrube crewonnen werden. 1)as Vorkommen ist wie bei dem dortigen 'Turmalin (siehe diesen) auf Drusen im Permatit, aber niemals sind 'Topas und Turmalin miteinander in derselben Druse. An mehreren Stellen hat man anch Topase auf Drusenräumen von jüngeren trachytischen Eruptivgesteinen, sogenannten Rhyolithen gefunden, so bei Nathrop, Cliaffee County und am ('balk Nountain in Colorado, blafogelbe und sehr schöne farblose in Thomas Range, 41) engl. Meilen nördlich rom Sevier Lake in Utah, und in derselhen Entfernung westmordwestlich von der Stadt Deseret am Sevier River, im Gestein selbst und lose in der Verwitterungskrume desselten. Das ist wohl das schönste Topasvorkommen eler Vereinierten Staten. Ton allen diesen Fundorten und noch von manchen anderen werden wohl selecrentlich einige Exemplare geschliffen und als einheimische Steine gretragen, einen wichtigeren Handelsartikel bildet aber der nordamerikanische Topas nicht.

Durch die Schönheit und Größe der Kristalle ist der r us is che Topas besonders bemerkenswert. Es sind solche von schöner Beschaffenheit bis zu 31 Pfund Gewicht Erefunden worden. Der T'opas wird mit den anderen russischen "farbigen Steinen" zum T'eil in Katharinenburg im Ural geschliffen und von den dortigen Hä̈dlern durch die Messe ron Nischny Nowgorod in rohem und geschliffenem Zustande in den Handel gehracht.

Wie in Minas novas, so kommen auch an den meisten russischen Lokalitäten Topas und Beryll miteinander vor. Die Fundorte beider Mineralien sind hier durchaus identisch; nirgends findet man das eine ohne das andere, mit Ausnahme des Altai, wo bisher noch kein Topas neben dem Beryll vorgekommen ist. Die allgemeine Übersicht über die Verbreitung der russischen Berylle kann daher auch für die des russischen Topases gelten, hier sollen nur noch einige den Topas speziell betreffende Angaben gemacht werden.

In der Gegend von Katharinenburg im U ral findet man Topas besonders in der Nïhe des Lorfes Alabaschka bei Mursinka (Fig. 77, S. 405) auf Drusen im Granit, die durch das Zusammenvorkommen schöner Kristalle von Rauchtopas, großer gelber Feldspatkristalle, kugelig übereinander gehäufter weiber Albitkriställchen und roter Tafeln von Lepidolith neben dem T'opas ein besonders schönes Ansehen gewähren. Die Topaskristalle sind von der Größe eines Stecknadelkopfes bis zu mehren Zentimetern Länge. Die Farbe ist bläulich, wie in Taf. XIII, Fig. 1 und 1, ", doch auch zuweilen licht blïulich rrün oder graulichweiß, seIten farblos. Meist sitzen die Kristalle einzeln neben denen der anderen senannten Jineralien in den Drusen, manchmal sind sie auch zu mehreren in paralleler Stellung zu größeren Gruppen miteinander verwachsen. Eine der sewöhnlich sehr einfachen Kristallformen ist in Fig. 80, c, eine etwas andere auf der ohen zitierten Tafel, Fig. 1 dargestellt. Die Durchsichtigkeit ist verschieden; manche sind ganz klar, andere nur durchscheinend. Die durchsichtigen erlangen im Handel ('inen ziemlich hohen Preis. Von den Gruben bei Mursinka wird bei Betrachtung des Amethyts noch einmal die Rede sein.

Am $11 \mathrm{~m}$ énse findet sich der T'opas auf der Ostseite, in der Nähe der Hüitte II i a sk ebenfalls auf Drusenräumen in Pegmatitgängen. Diese sind zuweilen mit weißem Ton erfüllt, in dem die abgebrochenen Kristalle eingebettet liegen. Die Günge setzen an vier Stellen im elïolithfreien Miascit auf. Begleitet wird der Topas von grrïnem Feldspat (Amazonenstein), auf dem er vielfach aufgewachsen ist, von Phenakit, Glimmer und 
anderen Mineralien. Er kommt hier in zwei Varietäten vor: einmal farblos, durchsichtig: und rein wasserhell, wie die ,pingos d'agoa", in regelmäßig und flächenreich ausgebildeten Kristallen; sodamn in solchen ron schmutzig gelblichweißer Farbe, nur kantendurchscheinend, rissig. oft zersetzt, wie man dort sagt, verfault, schon mit den Fingern zerdrïckible und blofj von wenig Flächen begrenzt. Kristalle dieser letzteren Art haben natiurlich als Eldsteine keine Bedeutung; für beide șind die Größenverhältnisse dieselben wie bei Alabaschka.

Topas findet sich auch in den Goldwïschen des Kaufmanns Bakakin im Tal der S a n a r k a (Nebenfluß des Ui, der in den 'T'obol fällt) und einiger Nebenflüsse im sïdlichen Ural (Gouvernement Orenburg, Bezirk Troizk). Er gleicht so sehr dem gelben brasilianischen, daB man den uralisehen Ursprung der hristalle anfangs bezweifelte. Ihre meist wohlerhaltene Form ist einfach, ungeführ wie in Fig. S(), (. Die Farbe ist gewöhnlich gelb, in verschiedenen Nuancen, sowie rosa bis violblau, manche sind auch vollkommen farblos. Viele sind schön durchsichtig: Die Größe geht bis zu einer Länge von $21 / 2$ und einer Dicke von $3 / 4 \mathrm{~cm}$. In den Seifen wird der Topas von zahlreichen anderen zum Teil schon erwähnten Mineralien und Edelsteinen begleitet, so von Quarz, zum Teil als Amethyst, Korund (Rubin), Chrysoberyll (Alexandrit und Cymophan), Spinell, Chalcedon (Karneol, Achat, usw.), Staurolith, Cyanit, Euklas, Turmalin, Granat, Beryll usw. Für den Topas, und zwar speziell für den rosafarbigen ist auch das ursprüungliche Vorkonmen bekannt. Er findet sich mit grünem, chromhaltigem Turmalin und grïnem, gleichfalls chromhaltigem Glimmer (Fuchsit) auf (Quarzgängen oder -Nestern im Kohlenkalk, der in jenen Gegenden weite Strecken einnimmt.

Der Topas vom Adun-Tschilon-Gebirge im Gebiete von Nertschinsk in Trasbaikalien (vergl. S. 4115) ist meist wenig durchsichtig und stark rissig und daher von geringer Bedeutung. Er bildet, mit (Duarz gemengt, den sogen. Topasfels, der den Granit grangförmig durchzieht und der, wie wir gesehen haben, auf unregelmäßigen Drusenräumen die dortigen Berylle, und mit ihnen und mit Rauchtopas zusammen Kiristalle von echtem Topas beherbergrt. Mit diesem gemeinsam liegt Topas auch in dem bei der Besehreibung des erstgenannten Edelsteines erwähnten Verwitterungsgruse lose im Ackerfeld. Die Kristallform ist stets die von Fig. $80 \mathrm{~b}$.

Im Gebirgszuge Kuchuserkensk sind die Topase anfangs der fünfiger Jahre entdeckt worden. Trotzdem dieses Gebirge als eine Fortsetzung des Adun-TschilonGebirges zu betrachten ist, sind doch die aus ihm stammenden Steine nicht den dortigen grleich, sondern, soweit man bis jetzt weiß, am ähnlichsten denjenigen aus dem Gebiryszuge Borsehtschowotsehnoi, die dort an vielen Orten, aber vorzugsweise in den am Flusse Crulga sich hinziehenden Bergen mit Beryll zusammen in Granit rorkommen. Der Topas ron hier zeichnet sich durch ganz besondere Schönheit in Farbe und Durchsichtigkeit, sowie durch bedeutende Grölie aus. Er ïbertrifft alle anderen russischen Topase durch seine zuweilen enormen Dimensionen : ein vollkommen durchsichtiger, dunkelhoniggelber Kristall von hier wog 3 Pfund, ein anderer schön durehsichtiger, von angenehmer dunkdweingelber Farbe sogar iiber 25 Pfund, und bei einem dritten, weniger schönen, nur durchscheinenden, schmutziggelben, $19 \mathrm{~cm}$ langen und $21 \mathrm{~cm}$ (in der größten horizontalen Dimension) dicken betrug das Gewicht31 Pfund; dieser ist sehon oben kurz erwähnt. Die Farbe wechselt meist zwischen der braunen des Rauchtopases und der gelben des brasilianischen 'T'opases. Manchmal ist sie dunkel honiggelb, vielfach anch heller in dieser und in anderen grelben Nuancen; zuweilen findet man sie auch hellblau und blïulichweif sowie ganz farblos und wasserhell. Die Kiristalle sind teils vollkommen einheitlich gebildete Individuen, teils sind es aus mohreren solehen parallel verwachsene Gruppen.

Topas beherbergt anch die Landschaft Darien, der südliche Teil von Transhai- 

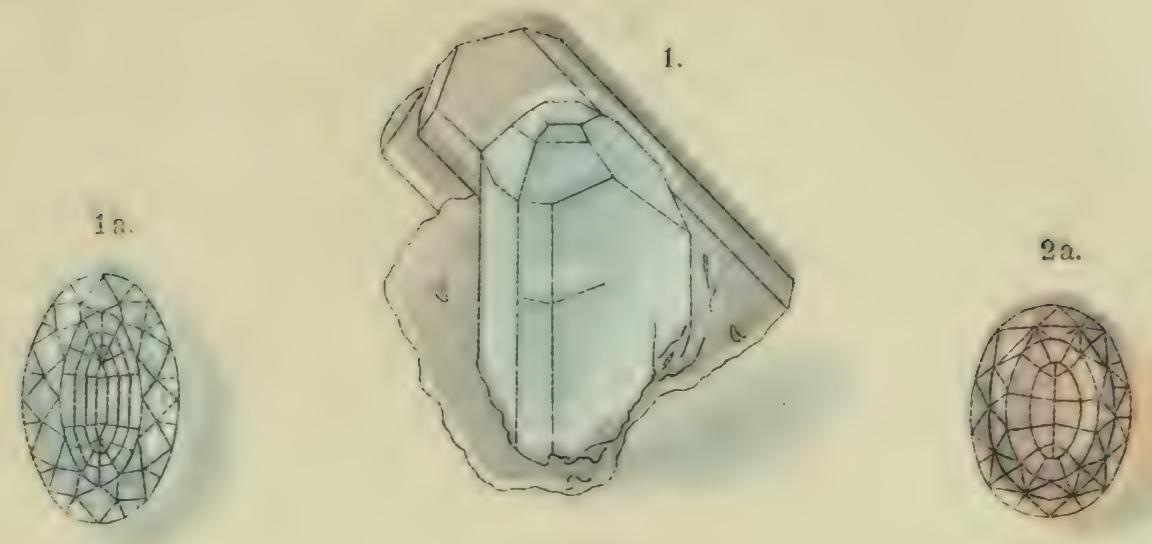

3.

$4 a$.
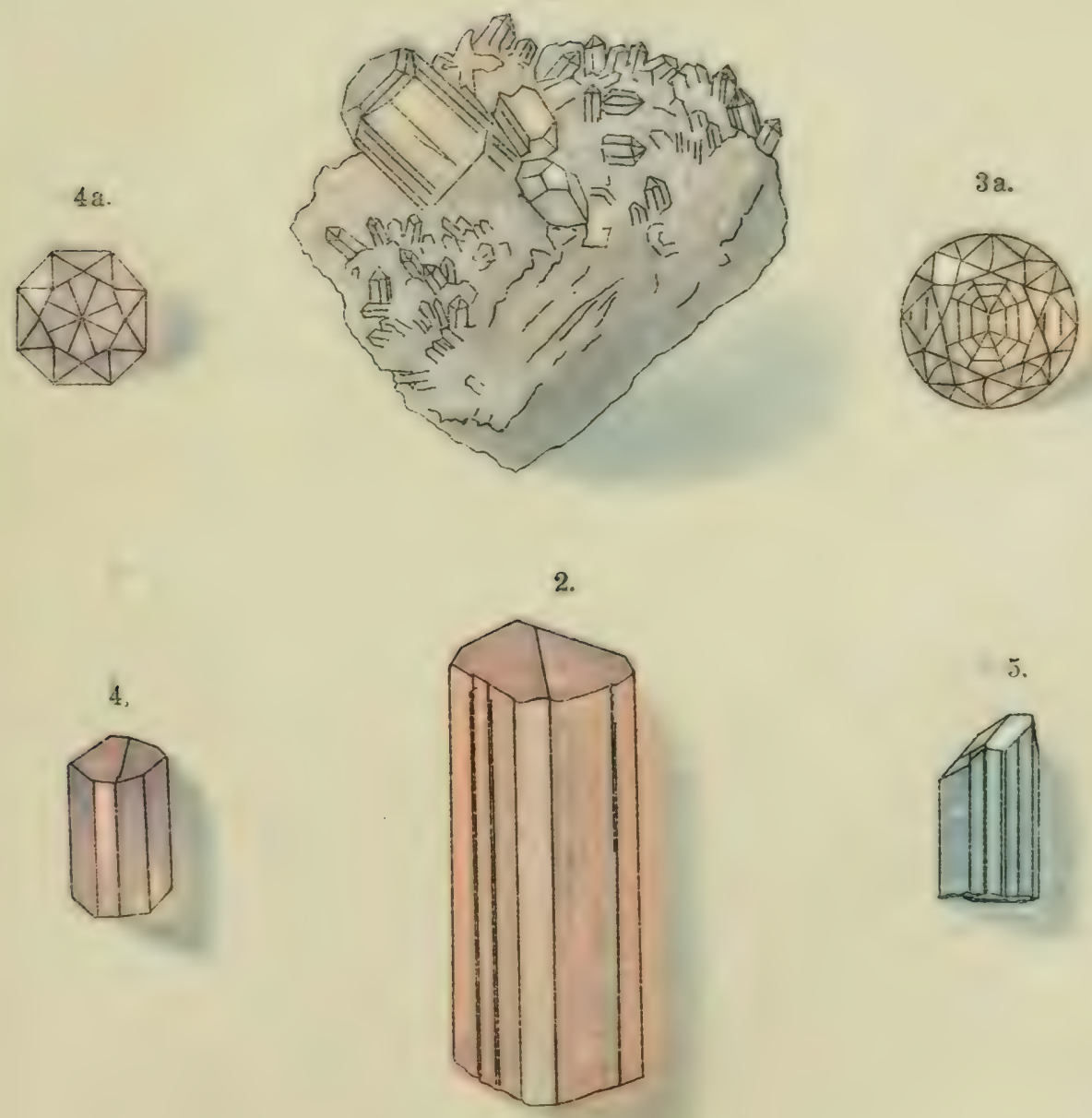

5.

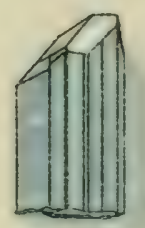

1. Topas (Bluu, Rrysial, Miursinla). 1s. Topas (blau, geschliffen). 2. Topas (dunkelgelh, Krystall, Trasilien). 2a. Topas (dunkelgelb, geschliffen.) 3. To pas (hellgelb, Krystall, Sachsen). :a. Topas (Gachon, geschlifien\}. 4. Rosatepas (Krystall, Brasilien). 4a. Rosatopas (geschiliften). 5. Euklas (Krystall, Brasilien). 


\section{$\operatorname{I1x} 137 \mathrm{MT}$}

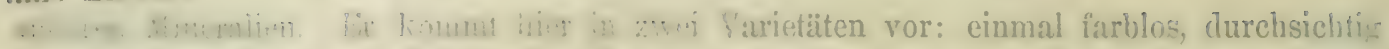

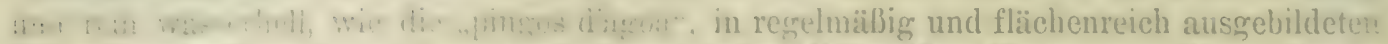

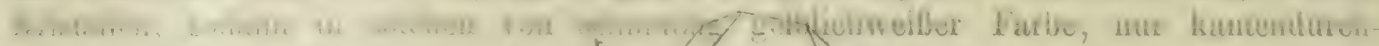

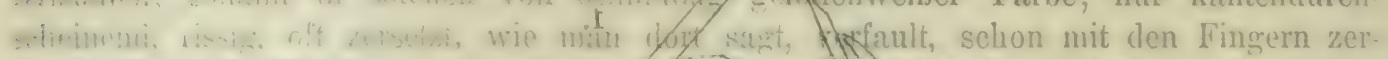

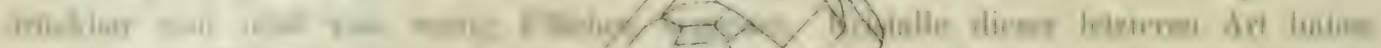

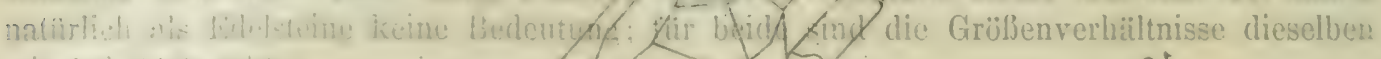

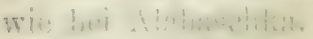
. B I

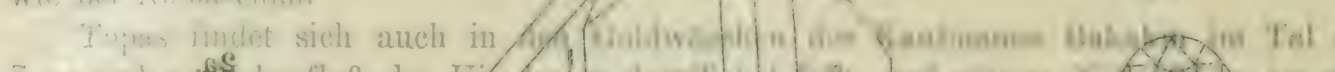

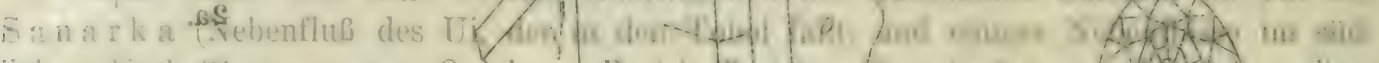

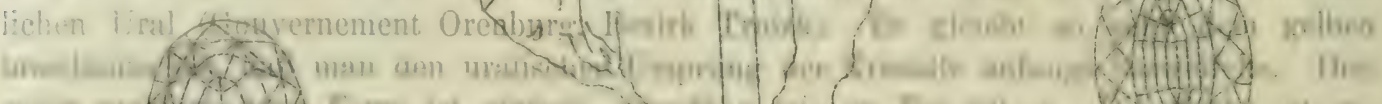

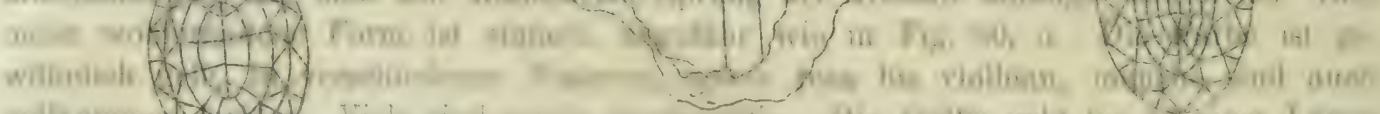

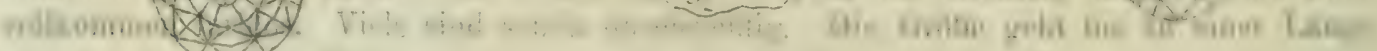

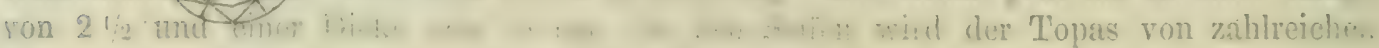

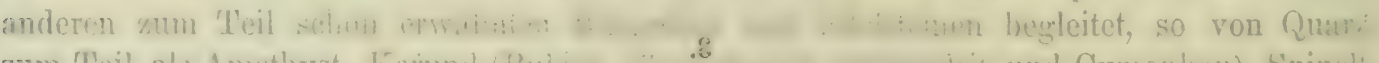

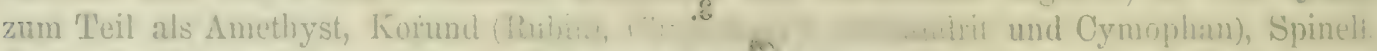

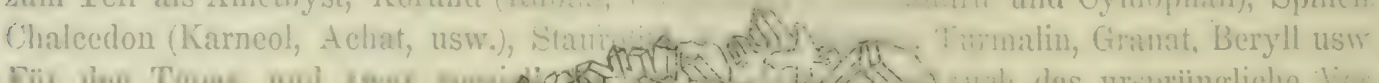

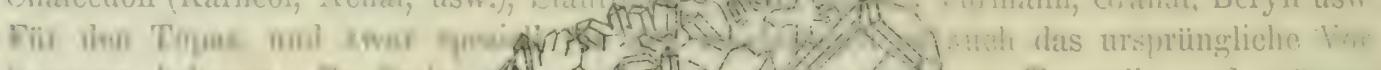

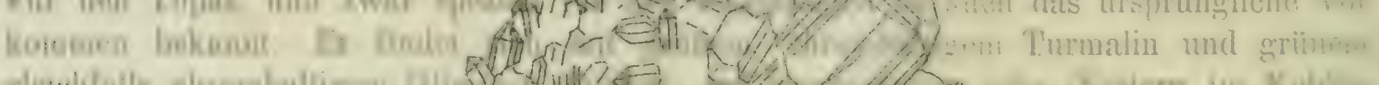

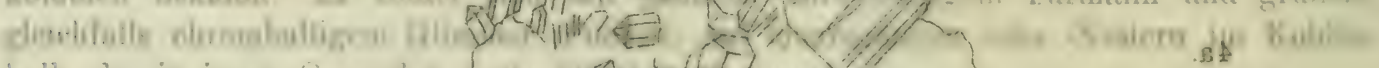
kalk, der in i.sen Gemenden film men

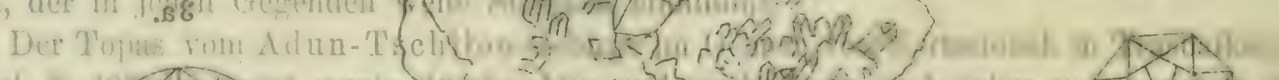

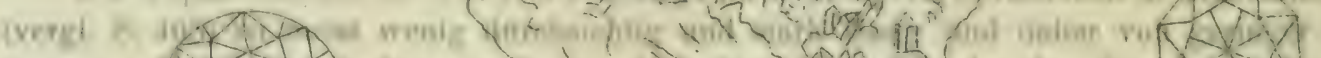

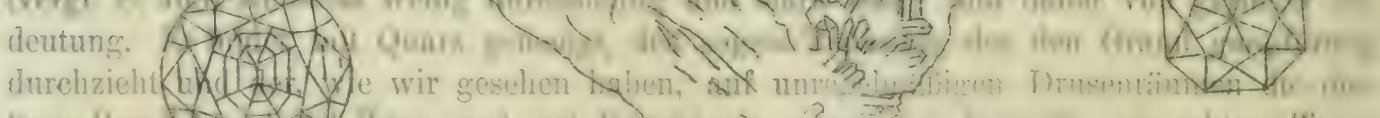

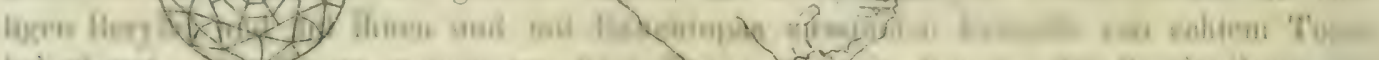
helivinogh.

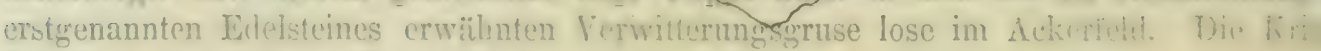
form ist stets die ron Fig. 8() 6 .

Tm Gebirgszuge Kuehuserkensk sind die Tupase anfangs der funfaimer Ja:

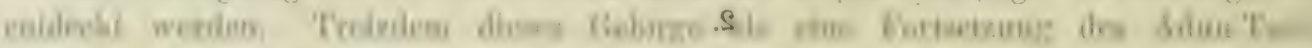

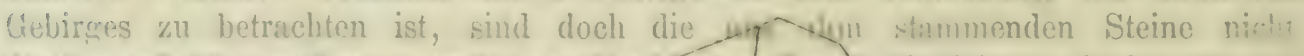

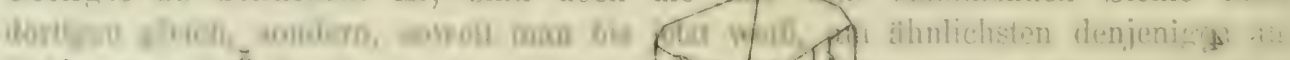

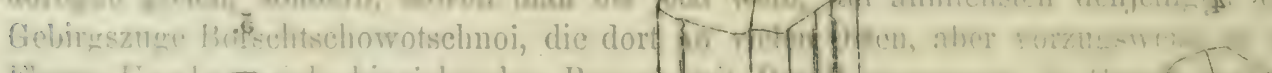

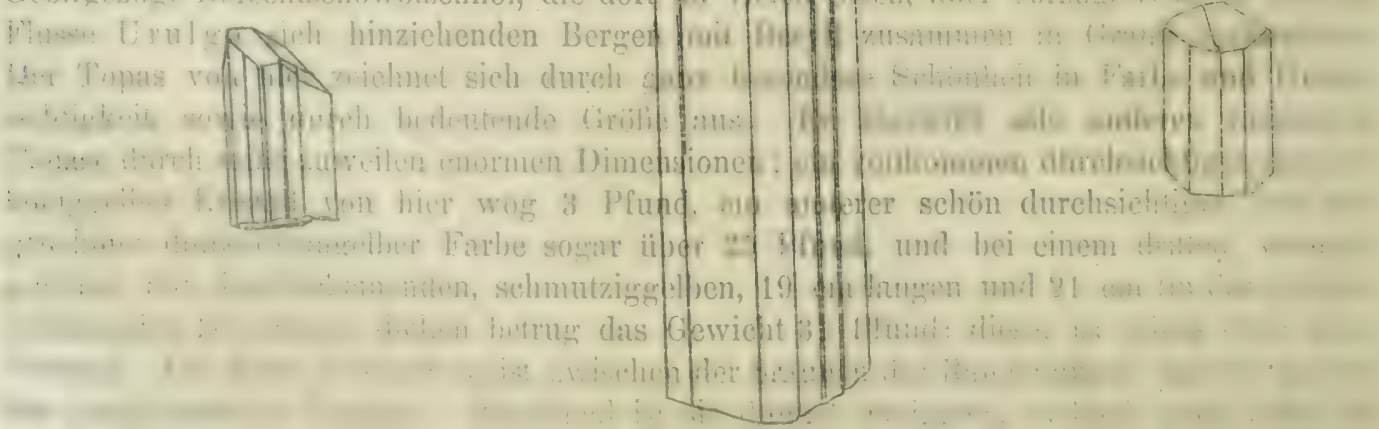


TAFEL XIII.

$1 \mathrm{a}$.

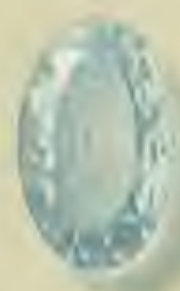

4 a.

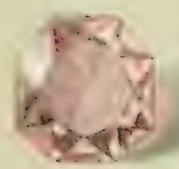

4.

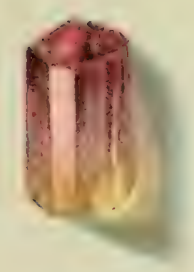

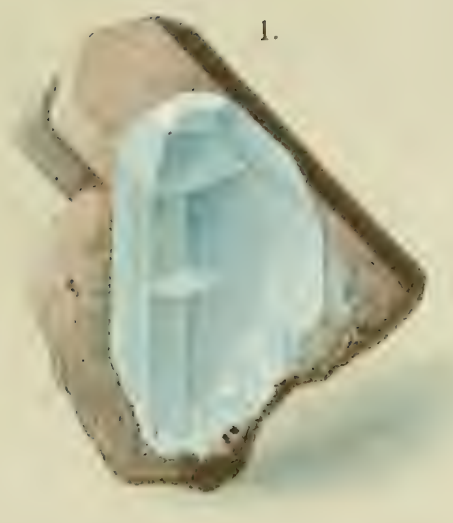

3.

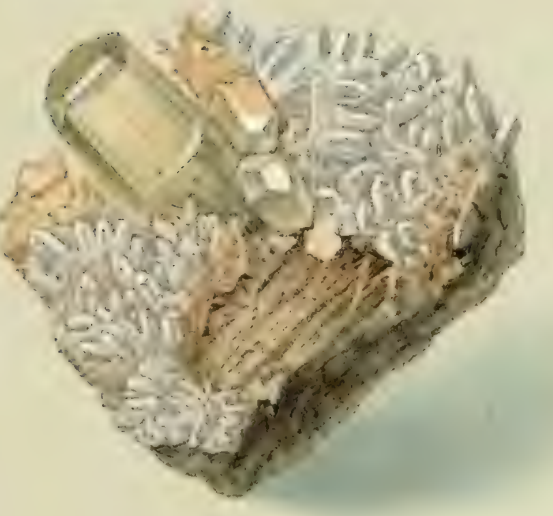

2.

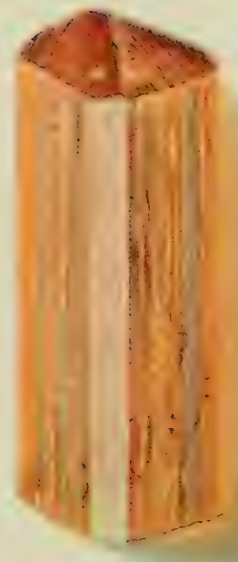

2 a.

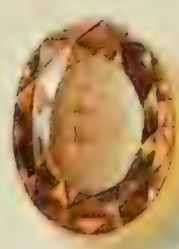

3 a.

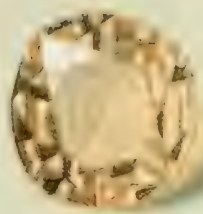

5.

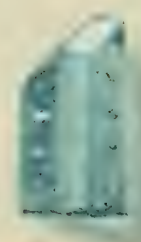



kalien. Mehrfach semannt werden wasserhelle, schin kristallisierts: Steines ron der Schilka, dem Oberlauf (oder Haupt(quellfluß) des Amur.

In Asien ist auch sonst schöner Topas noch verbreitet. Sehr ähnlich dem gelben brasilianischen, ja von ihm was form und Farbe anbedanget, nicht zu unterseleciden, ist der aus der fiegend rom II likla oder Muglat in Klemasion. Fundort und Vorkommen sind nicht näher bekamm, auch fiir len Edelstrinlandel nicht wichtig. D)ie Kristalle sind dunkelhonigerelb bis blalweingelb, zuweilon rosenrot. seltener bau; dir Form ist wie die der brasilianischen in Fig. 80, a und Taf. XIII, Fig. 2 u. 4 abgebildet.

In Ostindien ist Topas mit Sicherheit nicht nachgewiesen. Alle Berichte über ostindische Topase sind zweifelhaft oder sicher falsch und beruhen zum Teil auf Verwechshungen mit Quarz und anderen Mintrahen. Zweifelhaft ist das Vorkommen auf Ceylon, wo nach manchen Berichten meereriine, farblose, hell- und dunkelyedhe Topasgeschiebe sich mit den anderen Edlstoinen, namentlich mit dem Sapphir, zusammen finden sollen. Man ist jedoch bei den Beschreibungen stets unsicher, oh echter oder nicht viehmehr „orientaliseher" 'Topas gemeint ist, so dalj an dem Vorhandensein des ersteren auf dieser Insel stark gezweifelt werden muls. U. a. soll hier eine schön safrangentbe Varietait, der bereits erwähnte .indische Topas" rorkommen. Auch der :36!1 Karat schsere farblose ,Maxwell-Stuart"-Topas, ein sehr sehinner Brillant, soll von Ceylon stammen; vor dem Schleifen hatte er die Größe einer starken Männerfaust. G. $=3$, ,

Aus Japan kommt neuerer Zeit ebenfalls Topas, zum 'Teil in ziemlich grofien, wassexhellen, hellgelben und grïnlichblauen Kristallen, die an verschiredenen Orten aus Pexmatitgängen im Granit und Gneis stammen. Die japanischen. Topase haben noch lieine Bedeutung in Edelsteinhandel, kömnen diese aber mit der Zeit wohl noch erlangen, da viele von ihnen durchans schleifwürdiog sind. Blaue, grine und gethe Topase sind anch in Kamschatka gefunden worden.

In Afrika, und zwar in İygten wurden in friberen Zeiten in densellen fegenden, am Gebel Sabara nahe dem Roten Meere, Topase gegraben, wo dic Smaragrle vorkommen. Eine große Zahl alter Topasoruhen hat man dort aufopfunclen, aber kaum eine später wieder in Betrieb gesetzt, da der Toplas für solche Versuche cerenwïrtig zu wenig Wert besitzt. Tur bei Risk Allah soll in jener fexend zur Zeit Topas gewonnen werden. Anch die Topase aus dem deutschen Selutzerebete in Sii dwestafrika, zuweilen wolkig und trübe, meist wasserhell und klar, selten bläulich, auch weingelb bis bramgelb, sind bisher wohl kaum verschliffen worden. Geschiebe ron schön blanem Topas begleiten den Diamant in der Gegend von Somabula in Rhodesia (sog. Somabula blue).

Endlich ist noch Australien als Heimat des Topases zu erwithnen. Dieser Edelstein ist hier recht verbreitet, besonders in Seifen. Farblose, bläuliche und griuliche, auch gelbe Geschiebe, vielfach sanz den hrasilianischen gleichend, finden sich in der Granitregion ron Neu-England, der nordïstlichen Ecke ron Neu-Siid-Wales, sowie in den dortigen Zinnseifen als Begleiter des Zinnsteines und des Diamants, so bei Oban, Jnverell, am Glen Creek, $\tau$ miles nordüstlich von Emmaville und besonders bei Tingah. Wie der Zinnstein stammt der Topas wohl sicher aus dem Granit (Pegmatit) in dem bei Oban auch schöne Kristalle beobachtet worden sind. Fanz ähnlich wie in Neu-England kommt der Topas aber auch in den Flïssen weiter sïdlich (siehe die Karte Fig. 53, S. 2S3) als Begleiter des Diamants vor. Es sind hier ebenfalls Geschiebe, und zwar oft von bedentender Schönheit und Größle, bis zu mehreren Lnzen Gewicht, bald farblos, bald blau, zuweilen auch gell). Gelbe und blaue Geschiebe hat man auch in Owens River in Tictoria gefunden, und in sehr grobkürnigem Pegmatit bei Londonderry in dem Coolgardie-Goldfeld in Westaustralien, vor kurzem bis 6 Fuf lange und bis $21 / 2$ Zoll dicke Kristalle, die aher wenig sehleifbares Material geliefert haben. Tiele von diesen 
australischen Topasen werden gesammelt und geschliffen. Dies ist auch der Fall mit den schönen wasscrhellen, gelt)en, blauen und grü̈lichen Topasgeröllen aus den Zinnseifen von Tasmanien, die dort sehr verbreitet sind und die gleichfalls aus Pegmatit stammen. Große Mengen sollen von hier nach China ausgeführt werden.

\section{Zirkon.}

(Hyacinth.)

Dieser Edelstein gehört noch zu den wertvolleren, namentlich benutzt man neben andersfarbigen vielfach die durchsichtige gellorote Varietït, die den Namen Hyacinth erhalten hat. Immerhin steht aber doch der Zirkon an Wichtigkeit dem Topas und den anderen schon beschriebenen Edelsteinen bedeutend nach, da er viel seltener verschliffen wird als diese.

Der Zirkon ist zusammengesetzt aus den beiden Bestandteilen Kieselsäure und Zirkonerde, und zwar enthält er 32,s Proz. von der ersteren, 67,2 Proz. von der letzteren, entsprechend der Formel $\mathrm{ZrO}_{2} \mathrm{SiO}_{2}$.

Die Kristallformen, von denen einige der bäufigsten in Fig. 82, a bis $d$ abgebildet wurden, sind gewöhnlich sehr einfach; sie gehören dem quadratischen System an. Es
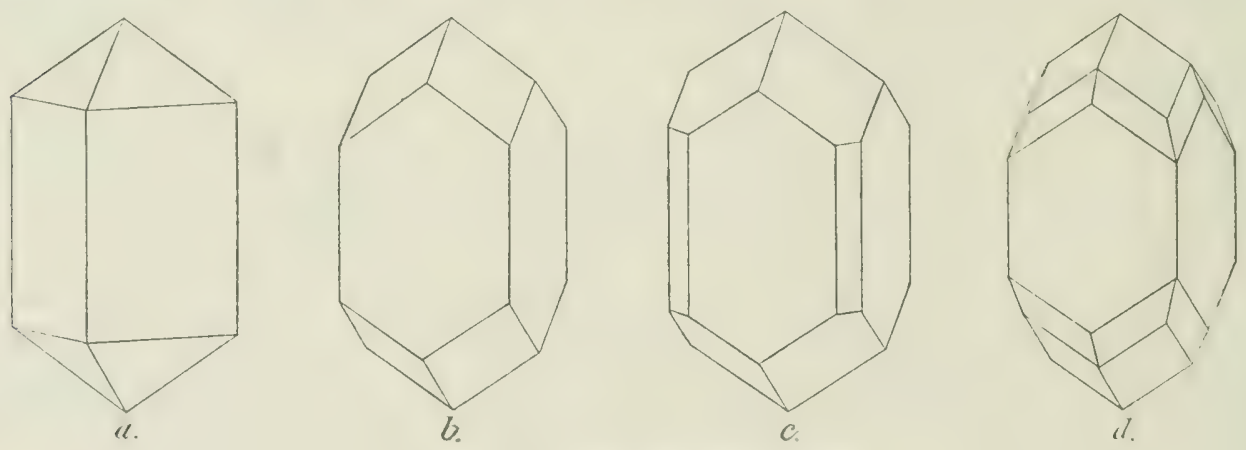

Fig. 82. Kristallformen des Zirkons.

sind meist kurze und verhäiltnismäßig dicke, ringrsum von regelmäßigen Flächen umgebene Kristalle, begrenzt von quadratischen P'rismen und Oktaëdern in verschiedener Anordnung. Die schon genannte Varietät des Hyacinth findet sich kaum anders als in der Fig. 82, $b$ und $c$ und Taf. I, Fig. 11 und 12 dargestellten Form eines quadratisehen Prismas, zuweilen mit abgestumplten Kanten, auf wolche die Flächen eines quadratischen Oktaëders der anderen Stellung gerade aufgesetzt sind, so daß sie oben und unten vierflächige Zuspitzungen bilden. Die anderen Figuren gehören dem eigentlichen Zirkon an.

Das spezifische Gewicht ist sehr hoch. Ohne daß ein ansreichender Grund dafür bekannt wäre, ist es sehr verschieden und steigt von 3,905 bis 4,525. Grïne Steine sind im allgemeinen leichter, gelbe und braune schwerer, doch nicht ohne Ausnahmen. Manche Exemplare, namentlich von mittlerem spezifischem Gewicht nehmen beim Glühen ein crheblich höheres an. Die höheren Zahlen werden für die normalen gehalten. Diese finclet man u. a. bei der Varietït des IIyacinths von G. $=4,610-4$, s25. Das sind die höclsten Werte, die bei Edelsteinen, ïberhaupt bei Mineralien ohne eine größere Menge von 
schwerem . Ietall, enefunden wurden. Die Zirkone sinken alle auch in dere schwersten Flïssigkeit rasch zu Boden.

Die Spaltbarkeit ist beim Zirkon sehr unvollkommen, ja kaum zu bemerken. Der

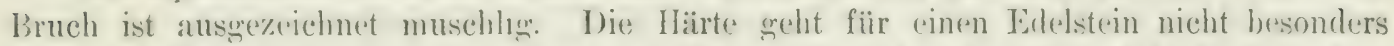
hoeh; sie liegt zwischen der des (quarzes und Topases, es ist also II. $=71 \%$; bei manchen, und zwar besonders bei den leichteren, ist sie auch wohl etwas geringer als beim Ouarz. Sie: ist aber jedenfalls stets geniigend, um eine selır wute Politur zu gestatten, so daß Schliffiläehen eine'n ausgezeichneten Glanz, und zwar, wie die Kristallflächen, einen diamantartigen Glasglanz besitzen.

Der Zirkon ist zum 'Teil trübe und undurchsichtig und bildet dann den gemeinen Zirkon, dem der durchsichtige edle segenïhersteht, aber auch der durchsichtigste läbt Rönterenstrahlen nicht hindureh. Der ge meine Zurkon ist meist von bramer oder grauer, auch von wrïner bis schwarzer Farhe, wird aber seiner Undurchsichtigkeit wegen wenig als Edelstein benutzt. Eine feuerrote trübe Varietät, die zuweilen geschliffen wird, ist nach ihrer Iremat als „ceylonischer Zirkon" bezeichnet worden. Auch der edle Zirkon ist zuweilen nicht sehr vollkommen durchsichti $\stackrel{m}{,}$ aber doch in hohem Grarle durchscheinend. Wegen seiner sehr mannigfaltigen, meist recht hiibsehen Farbe und seines besonder's holien Glanzes und Feners, bezïglich dessen er hinter dem Diamant nur wenign zuriickstelit, newïhrt er einen angenehmen Anblick. Nur selten ist er vollkommen farblos und wasserhell, wie z. I3. die auf dem Chloritschiefer des Wildkreuzjoches in Tirol aufgewachsenen Krystalle und manche von C'ylon. Iräufiger ist er grïn, hell und dunkel in verschiedenen Nuancen, auch bräunlich und gelblich, rosenrot, braunrot (sog. Hyacinthtopas), braun und bräunlichgelb, sowie, in sehr seltenen Fällen, rein gelb und violett; nur blau fehlt sänzlich. Die verbreitetste Hauptfarbe des edlen Zirkons ist ein etwas ins Bräunliche grehendes, aus ziemlich gleichen Teilen rot und gelb gemischtes Orange, das an verschiedenen Exemplaren bald etwas mehr ins Rote, bald etwas mehr ins Crelbe spielt und an verschiedenen Kristallen etwas dunkler oder etwas heller sein kann. Der Zirkon ron dieser Färbung̣, wie sie Taf. I. Fig. 11 und 12 zur Anschauung bringt, bildet die Varietät des schon erwähnten Myacintlıs. Fin grïnlichgelher Zirkon ist auf derselben 'Jafel in Fin. 13 abgebildet; derartige Steine werden m Ilandel zuweilen für Turmalin gehalten und auch danach benannt. Die Farbe des Zirkons ist manchmal sehr leuchtend und feurig, besonders bei gewissen roten und braunen steinen, manchmal aber auch eigentiumlich diister, wamentlich das dunkle Grïn. Nicht selten ist die Farhe auch etwas ungleichmälig. und zwar in feinen Streifen und Lagen abwechselnd verschieden.

Nach dem Ifyacinth heift die erwïhnte rotgelbe Farbe hyacinthrot. Sie kommt sanz in derselben Weise noch bei einem zweiten Edelstein vor, der auch als Begleiter des Hyacinths an dessen Iauptfundort, auf der Insel Ceylon, auftritt. Es ist der der Granatfanilie angehörige Tianeelstein oder Hessonit (Taf. XIV, Fig. 7 u. 8), von dem unten noch ausführlich die Rede sein wird. Beide werden sehr häufig miteinander verwechselt; der Kaneelstein wird von den Juwelieren ebenfalls Hyacmth genannt und dem echten Iyacinth untergeschoben. Dies soll in so hohem Maße der Fall sein, daß manche whaupten, im europäischen Edelsteinbandel komme überhaupt so gut wie kein echter Hyacinth ror, fast alle sogenannten Hyacinthe seien Kaneelsteine. Bei einer großen Zahl derselben ist dies sicher der Fall; viele der letzteren werden als IJacinth verkauft, obwohl sie im Glanze und Fener hinter dem in dieser Hinsicht besonders ausgezeichneten echten Steine, dem hyacinthroten Zirkon, erheblich zuriickstehen. Die Hilfsmittel, durch die man beide Steine leicht und sicher zu unterscheiden rermag, werden wir bei der Betrachtung des Hessonits kennen lernen. Sie beruben vornehmlich auf der einfachen Licht- 
brechung des Kanedsteines gegeniiber der doppelten des Hyacinths, sowie auf dem charakteristischen Absorptionsspektrum des letzteren (S. 7i).

Besonder's zu erwathnen sind die sehr blak strohgelben bis vollkommen farblosen Zirkone ofler Hyacinthe von der Insel Ceylon, von denen oben schon im Vorbeigeben kurz die Rede gewesen ist. Sie werden von den Juwelieren zuweilen als "Cerkonier" oder ... Jargon de Ceylon" bezeichnet. Sie haben einen ausgezeichneten Glanz und stehen darin dem I Diamant sehr nahe, dem sie daher gelegentlich untergesehoben werden. Noch im vorigen Jahrhundert hat man sie geradezu für schlechte Diamanten gehalten und daher" nach dem Fundort Matara (Matura) auf Ceylon als "Matara- oder Maturadiamanten“ bezrichnet. Wie den Kaneelstein, so kann man aber auch den Dianıant rom Uyacinth an der einfachen Lichtbrechung unterscheiden, auferden den Diamant auch noch dureh die Hiirte und das spezifische Gewicht. Der Diamant schwimmt noch in der schwersten Flüssigkeit, in welcher der Hyacinth rasch untersinkt.

Solche farblosen Zirkone von natürlicher Besclıaffenheit sind allerdings sehr selten, man kann sie aber in beliebiger Zahl kïnstlich herstellen durch Erhitzen (Brennen gefürbter Hyacinthe nicht nur von Ceylon, sondern auch von anderen Fundorten (Tasmanien, Queensland usw). Der hyacinthrote Zirkon lıat nämlich die Eigenschaft, dab er bei einer Temperatur von ungeführ 50()" ('. sehr leicht seine Farbe verliert, dabei aber erheblich an Glanz gewinnt. Wenn man einen solchen Stein der Spitze der Lütrohrflamme nähert, so verschwindet das Rot plötzlich und ex wird mit einem Ruck farblos. Doch sind nicht alle Exemplare gleich leicht veränderlich in der Wärme, und auch ihr sonstiges Verhalten beim Erhitzen ist nicht immer dasselbe. Einzelne wenixe verändern ihre Farbe iiberhaupt nicht oder verlieren sie doch nicht ganz, so daß sie einen Stich ins Rosenrote bis Strolıgelbu behalten, oder statt farblos graulich werden. Andere nehmen längere oder kiirzere Zeit nach dem Erkalten das ursprüngliche Aussehen zanz oder dioch zum Teil wieder an, wenn auch die Nuance vielfach eine andere, meist hellere ist; doch darf die Erhitzung: nicht zu weit gegangen sein, sonst bleibt die Entfärbung bestehen. Die Wiederherstellung" der früheren Farbe wird dureh Radiumbestrahlung sehr erleichtert und beschleunigt. Sie erfolgt nach kurzer Zeit, wohei zugleich in der Dunkelheit eine lebhafte Phosphoreszenz zu beolachten ist, die in ähnlicher Weise auch die Farbenänderung und Entfärbung in der Wärme begleitet. Die natürliche Körperfarbe der Zirkone wird durch derartige Strahlen nicht becinflulit, eine andere als die gelbrote IIyacinthfarbe auch nicht dureh die W:äme; grüne Steine z. B. bleiben bei mehr als $700^{\circ}$, wie sie waren.

In der Praxis wird diese Farbenänderung nicht nur benutzt, un farblose Zirkone herzustellen (rechannte Hyacinthe, künstliche Hataradiamanten), sondern auch un zu dunkle Steine heller und durchsichtiger zu machen, z. B. solehe von Tasmanien. Man steigert dabei die Hitze vorsichtien und nicht zu stark, z. B. dureh Einwickeln der Stïcke in Fenerschwamm, der damn algeberannt wird. Mit der Veränderung der Farbe ist Wenigstens manchmal auch eine solche des sperifischen Gewichts verbunden. So stieg dabei das de's bramgelben Zirkons von Tasmanien voul 1,301 auf $1,6 \pi$, und ähnlich ist es bei dem Hyacinth von Ceylon.

Nanche IIyacinthe ändern ilıre Farbe und ihren Glanz anch schon bei crewöhnlicher Temperatur. Sie blassen oft schr rasch ab, wemn man sie dem Lichte, besonders den direkten somnenstrahlen ausscetzt. Bei anderen, allerdinges selteneren, geht dabei die Farbe in eine bräunlichrote über, die nit der Zeit immer entsehiedener braun wird. Gleieltzeitig wird dabei der Diamantelanz immer mehr glasïhnlich. Verwahrt man solehe veränderten Steine im Dunkeln, dam nähern sie sich in Farbe und Glanz allmählich wieder ihrer ursprünglichen Beschaffenheit, aher vollkommen wird der frühere Zustand doch nie nolur crreicht. Wemn auch nicht alle Hyacinthe dieser Teränderung ausgesetzt sind, so ist 


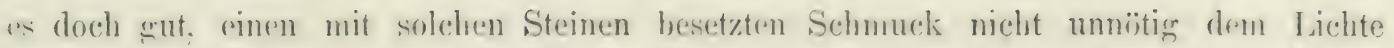

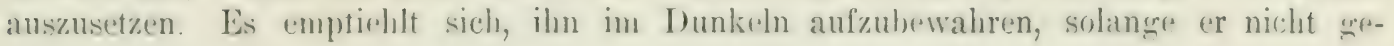
tragen wird.

Dir Lichthrechung des Zirkons ist sehr stark und wird hïchstens noch von der des 1)iamants ïbertroffen. Dem quadratischen Kristallsystem eremäl) ist er dopueltbrechend. Fïr den gröffen und kleinsten brechungskoiffizienten eines IJyacinthkristalles von Ceylon hat man die Werte 1,97 und 1,92 erhalten. Die Differenz beider creribt 0,os als das Malf der Doppelbrechung, die danach ebenfalls ganz besonders enererisch ist. Dagergen weichen die brechungskö̈ffizienten für die verschienlenen Farben nicht viel vonemander ah, die Farbenzerstremung int also gering und kann sich nicht entfernt mit dor des Diamants messen. Wenn dalser auch der farblese IIyacinth bezüglich des Glanzes den Verelcich mit dem I Diamanten nicht zu scheuen hat, so steht er hinter diesem doch hezïglich des Farbenspieles weit zuriick; ein solches tritt bei ihm auch unter den günstigsten Umständen so gut wie gar nicht hervor.

Auffallend crering ist beim IJyacinth, wie iiberhaupt beim Zirkon, der Pleochroismus. Die beiden Bilder in der I)ichrolupe sind auch bei sehr intensiver Färbung der Steine so nahe einander gleich, dalj man kamm Unterschiede zu erkennen vermag. Man kann also diese sonst so bequeme Erscheinung nicht gut benutzen, um beispielsweise den Ilyacinth ron dem gar nicht dichroitischen Kaneelstein zu unterscheiden. Etwas stärker als der Pleochroismus des Hyacinths ist allerdings der der anders crefürbten Zirkone, aber auch bei diesen ist er schwächer als bei allen anderen doppeltbrechenden farbigen Elelsteinen. Manche Zirkone zeigen eine Lichterscheinung wie das Katzenange.

Von den sonstigen Eigenschaften des Zirkons sei noch erwähnt, dab er vor dem Lütrohr unschmelzbar ist und daß er von Sïuren, selbst von der Flußsäure nicht angegriffen wird. Beim Reiben wird er etwas elektrisch, aber nicht in dem Grade, daf diese Eigenschaft zur Erkennung und Unterscheidung von anderen ähnlichen Steinen dienen könnte.

Was das Yorkommen des Zirkons betrifft. so ist er im Crgehirge, in den älteren kristallinischen Sillkatgesteinen, wie Granit. Gneis und anderen ähnlichen fehiresarten zı Hause und namentlich in der Varietït des gemeinen Zirkons vielfach sehr verbreitet, aber auch der durchsichtige edle Zirkon und besonders der Hyacinth hat darin seine eigentliche Heimat. Die Kristalle sind in der ïberwiegenden Mehrzahl der Fälle in den (iesteinen ein-, selten auf Drusen in denselben aufgewachsen. Einige ron diesen Gesteinen enthalten Zirkon, allerdings die gemeine Varietät, in solcher II enge, daß sie danach bezeichnet werden, so die Zirkonsyenite des südlichen Norweyens in der Gegend von Federiksvïn und Laurvik; und manche andere Fundorte, namentlich in Nordamerika, liefern viele Zentner gemeinen Zirkons. Aber auch jüngere vulkanische Gesteine, besonders Basalte enthalten zuweilen Zirkon in rereinzelten deutlichen eingewachsenen Kristallen von der Tarietiit des Ifyacinths. Bekannt ist in dieser Beziehung der Basalt ron Espaly bei Le Puy in Velais (Departement Haute-Loire) in Frankreich, ferner in Deutschland die sogenannte. Mühlsteinlava von Niedermendiøn nahe dem Laacher See, der Basalt von Unkel am Rhein. mancher Basalt im Siebengebirge usw. Einen im schwarzen Basalt eingewachsenen und teilweise von der Umhüllung hefreiten Iycainth gibt Tafel I, Fig. 12. Es ist nicht unwahrsebeinlich, daf die in dieser Weise rorkommenden Iyacinthe nicht mspriinglich in dem basaltischen Gestein entstanden sind, sondern dab sie sich darin auf sekundïrer Lagerstätte befinden. Sie waren vielleicht anfänglich ebenfalls in einem granitischen oder anderen älnlichen Gestein eingewachsen. von dem dann Bruchstiicke in die gliihend flïssige Basaltmasse gelangten. Diese wurden darin bis auf den ron allen Bestandteilen allein widerstandsfühigen Hyacinth eingeschmolzen, und so blieb dieser als letzler Rest jenes alten Gesteines ïhrig, als scheinbarer Gemengteil des Basalts. 
Aus seinem Mutterestein gelangte der Zirkon, speziell der Hyacinth, auch in die aus jenem entstandenen Verwitterungsmassen, und weiterhin in den Schutt der Fliisse und Bäche, (r lildet einen Bestandteil der Seifen. Die Unverwitterbarkeit der Substanz macht, dalf die Kristalle auch bei diesem Vorliommen vollkommen frisch, glänzend und durchsichtig sind. Aus den Seifen werden die als Edelsteine verwendeten Zirkone ausschlidblich gewomnen, niemals aus dem festen anstehenden Gestein. In ihnen sind sie wie die anderen Edelsteine dort stark abgerollt, doch ist vielfach die Kristallform noch deutlich zu erkennen.

I) grö̈lten Teil der im IIandel vorkommenden Zirkon liefert die Insel Ceylon, und zwar stammen sie aus denselben Seifen, in denen auch die anderen ceylonesischen Elclsteine, Spinell, Sapphir, Katzenauge usw. gresammelt werden. Der Zirkon begleitet diese in erheblicher Menge und wird mit ihnen sleichzeitig gewonnen. Das Hauptvorkommen ist in den Ablacerungen des Bezirkes Saffragam mit der Hauptstadt Ratnapura, bei Rakwana, sowie im süden der Insel in denen am Walawe Ganga nnd bei Matara (IIatura), von welch letzterem Ort die farblosen, auch die gegliihten Hyacinthe den schon erwähnten Namen "Matura- oder Mataradiamanten" erhalten haben. (Fig. 69, S. 361.) Die Größe del Iyacinthkristalle ist fast stets grering; die meisten sind höchstens linsengroß, erbsengrofe sind schon selten und über 10-12 Karat geht das Gewicht kaum hinaus. Als besondere Seltenheiten werden einige große Hyacinthe erwähnt, so ein solcher von 5 1/2 Linien Länge und $4 \frac{1}{2}$ Linien Dicke und ein zweiter, bei dem die entsprechenden Dimensionen 6 und 7 Linien betragen. Größjer sind häufig die Zirkone von anderer Farbe, grïin, gelb, rötlich, hellbraun, dunkelbraun bis schwarz, auch die durchsichtigen edlen, die in Ceylon den Hyacinth begleiten; schöne Steine von Zentimeterlänge sind bei ihnen nichts übermälig Seltenes und Ungewöhnliches. Charakteristisch für die edlen Zirkone von Ceylon ist neben der gleichmäßigen Farbe eine hauchartige Trübung, die durch feinste mikroskopische Einschlüsse hervorgebracht wird. Daß die zahlreichen Zirkone aller Art in den ceylonesischen Seifen aus denselben Gneisen und aus den diesen eingelagerten Kalken stanmen, wie z. B. die mit vorkommenden Sapphire, ist zweifellos, man hat sogar in seltenen Fïllen IIyacinthkristalle noch im Muttergestein beobachtet. Die bei der Betrachtung des Sapphirs hierüber gemachten Mitteilungen treffen auch hier zu.

Unwichtig sind die Fundorte, die noch sonst in Indien angegeben werden, und die sogar zum Teil selrr zweifelhaft sind. So soll Hyacinth im Alluvium von Ellore, Prïsidentschaft Madras, und im Granit von Kedarnath am oberen Ganges vorkommen, aber die Sache ist nicht ganz sichergestellt. Ebenso ist es mit dem Hyacinth, der den Rubin in Ober-Birma nach manchen Nachrichten begleiten soll.

Neben Ceylon ist besonders Australien zu nennen. In Queensland finden sich Zirkone mit den Sapphiren von Anakie, meist klein, doch auch nicht selten groß und schïn genug zum Schleifen. Einige sind farblos und sehr grlïnzend und daher zuerst für Diamanten gehalten worden. Die meisten zeigen verschiedene Nuancen von braun, rot und gelb, und sind dann gegen die Finwirkung von Licht und Wä̈me besonders empfindlich. Die hellgelben sollen zum Teil durch Brennen blau werden. Berichtet wird ron einem sehr schönen roten, seschhffenen Uyacinth von 15 Karat, doch sind gute Steine hier nicht hüufig. In Neu-Süd-Wales kommt der Edelstein in den Gold und z. 'T'. auch Diamanten führenden Seifen ïber ein ausgedehntes basaltisches Gebiet verbreitet vor. Besonders werten Glen Innes und Inverell als Fundorte grenannt; schöne Exemplare sollen auch von Mugdee stammen. Die meisten sind stark alogerollt und vielfach zerbrochen; sie gehen vom Farblosen und Wasserhellen bis ins Dunkelrote. Aus 'Tasmanien kommt in neuerer Zeit viel Zirkon in den Ilandel. Ei ist in den Zinnseifen des Nordostens in Form bis zollgroler, stark abgerollter, nur selten noeh 
Kristallflïchen zeigender Gerölle schr verbreited. Besonders gelbhraune bis rote Varietäten, vielfach sehr dunkel in der Farbe, doch ateh z. T. den Ilyacinthen von Ceylon sehr ähnlich, sind häufien. die geschliffen ein sehr schönes Aussehen haben. Auch beei ihnen ändert sich die Farbe sehr leicht.

Sicher bekannt, abor höehst unbedentend ist das Vorkommen des Edelsteines in Europa, in Seifen, die drenen in Ceylon sehr ähnlich sincl. Im Sande der Iserwiese, die bei Betrachtung der Fundorte des sapphirs rorwilhnt wurde, wirl der letztere granz :ihnlich wie in Ceylon von IIyacinth bexlettet, dessen Ilenge und Grible aber gering ist. Beide Edelsteine mit den anderen dort vorkommenden stammen wohl auch an dieser Stelle aus Gneis. In den Bäichen hei Espaly in Frankreich findet sich Hyacinth aus dem Basalt auswewittert; er ist ganz shleich dem von Ceylon, aber das Vorkommen ist spürich und die Kristalle sind klein, höchstens 2 bis 3 Millimeter lang.

Endich funden sich auch schäne reich gefärbte Zirkone in den Goldsanden von Nord-Carolina, die Kristalle sind aber zum Schleifen leider zu klein.

Betrachten wir zum Schluf noch die Art der Verwendung des Zirkons zum Schmuckstein! Der gefärbte wird am öftesten als 'Tafelstein odter Dickstein, zuweilen auch als Treppenstein und sogar manchmal als Brillant geschliffen, je nach der mehr oder weniger tiefen Färbung und klaren Durchsichtigkeit. Gute reine Steine reflektieren das Licht selir schön von innen heraus und brauchen keine weitere Verbesserung, creringere Exemplare erhalten bei der Fassung eine Goldfolie oder werden in einen schwarzen Kasten gesetzt. Die weifen farblosen, besonders die gebrannten, erhalten meist die Form von Rosetten, wozu sie sich ihres starken Glanzes und des fehlenden Farbenspieles wegen besser eignen als zu Brillanten, aber auch diese letztere Form wird zuweilen angewendet. Solche gebrannte Hyacinthe waren wexen ihres eirentïmlichen düsteren Glanzes in vorigen Jahrhundert zu Trauerschmuck statt Diamanten beliebt.

Der Wert des Hyacinths ist gegenwärtig verhältnismäßig grering. Der Stein wird jetzt viel weniger begehrt als friher, und der echte ist, wie schon oben erwähnt, im IIandel selten. Die ganz kleinen sind weģen ihrer IIäufigkeit niedrig iu Preise, srößere stehen höher, ja nur diese haben überhaupt einen gewissen $W^{r}$ ert. Ein Karat eines gut geschliffenen Steines ist auf höchstens 10 bis 12 Mark zu schïtzen, wenn er schün gefü̈rbt ist. Entsprechende Zahlen gelten auch für die anders gefürbten Zirkone. Früler waren die Preise viel höher.

Es ist schon oben bemerkt worden, daß der gelbrote Granat, der Messonit oder Kaneelstein, dem Hyacinth auferordentlich ähnlich ist und viel mit ihm verwechselt wird. Ebenso ist die Ähnlichkeit des gebrannten Hyacinths mit Diamant schon herrorgehoben und die M̈̈glichkeit einer Unterscheidung der beiden genannten Edelsteine vom echten Hyacinth angegeben worden. Es gibt aber noch andere steine, die dem letzteren in seiner ursprïnglichen hyacinthroten Farbe mebr oder weniger gleichen und die daher ebenfalls als IIyacinthe bezeichnet werden. Mierher gehört vor allem der schon früher besprochene „orientalische Iycainth", der gelbrote horund mit ebenso lebhaftem Glanz und Feuer wie der eigentliche Hyacinth, der sich aber durch grö̈lere Härte $\left(\mathrm{H}_{0}=9\right)$ und kleineres spezifisches Gewicht $(\mathrm{G} .=4, \cdots)$ von dem letzteren unterscheidet. Auch an seinem nicht starken, aber deutlich bemerkbaren Dichroismus lälit sich der orientalische Hyacinth erkennen, da diese Erscheinung an dem echten nicht zu sehen ist.

Mit dem Vamen Hyacinth werden auch zuweilen rote Quarzkristalle bezeichnet, so namentlich die im Gips von S. Jago di Compostella in nördlichen Spanien eingewachsenen als Пyacinthe von Compostella. Geschliffen können diese schon wegen ihrer trüben Beschaffenheit und dem geringeren Glanz von Iyacinth unterschieden werden, mit völliger Sicherheit aber an ihrem geringen spezifiseben Gewicht, das nur 2, ${ }_{6}$, betrïgt. Der Stein 
schwimmt daher in Methylenjodid. Dasselbe tut der Turmalin, dem in manchen Abänderungen allerdings weniger der Пyacinth, als gewisse anders gefärbte Zirkone nicht unähnlich sind. Der Turmalin ist auferdem noch dureh einen sehr kräftigen Pleochroismus charakterisiert. Auch der Rosatopas soll zuweilen für Hyacinth ausgegeben werden; bei ihm ist aber die Farbe ganz anders und der Dichroismus sehr stark.

Endlich ist noch zu erwäl!nen, daß man zuweilen Gläser herstellt von der Farbe des Iyacinths, die diesem betrïgerischerweise untergeschoben werden können. Sie lassen sich an ihrer einfachen Lichtbrechung und an der geringen Härte leicht erkennen.

\section{Granat.}

Der Granat ist ein außerordentlich viel benutzter Edelstein, der sowohl in kostbaren Schmuckstïcken als in der gewöhnlichen ordinären Marktware Verwendung findet, doch ist die Mode hier von großem Einfluf. Wenn man noch vor kurzem das Schaufenster eines Juwelierladens betrachtete, so sah man wenigstens in der Hälfte der ausgestellten Schmucksachen Granat in seinen verschiedenen Abarten, heute ist er fast gänzlich verschwunden.

Granat ist nicht ein einzelnes Mineral von ganz bestimmter Zusammensetzung und Beschaffenheit wie Diamant, Topas und andere. Man fabt unter diesem Namen eine ganze Gruppe von Mineralien zusammen, die sümtlich in Beziehung auf die Kristallform und manche physikalische Eigenschaften, sowie in betreff der allgemeinen Verhältnisse der chemischen Zusammensetzung miteinander übereinstimmen. Sie weichen jedoch hierin im einzelnen stark voneinander ab, sofern in den zahlreichen Gliedern der Gruppe versehiedene Einzelbestandteile miteinander in Verbindung getreten sind und hiervon ist dann namentlich die äußere Erscheinung ablüngig. Der Granat bildet also eine sogenannte isomorphe Reihe, wie sie so vielfach im Mineralretch und namentlich auch unter denjenigen Mineralien vorkommen, die als Edelsteine für uns von besonderem Interesse sind.

Alle Granate sind Verbindungen der Kieselsäure, es sind Silikate. Die Übereinstimmung der allgemeinen chemischen Verhältnisse besteht darin, daß stets drei Moleküle Kieselsäure, Si $\mathrm{O}_{2}$, mit einem Molekuil Sesquioxyd von der Zusammensetzung $\mathrm{R}: \mathrm{O}_{3}$ und mit drei Molekülen Monoxyd, MO, vereinigt sind. Die allgemeine chenische Formel, welche die Zusammensetzung der ganzen Reihe ausdrückt, ist demnach: $3 \mathrm{MO}$. $\mathrm{T}_{2} \mathrm{O}_{3}$. $3 \mathrm{SiO}_{2}$. Die Verschiedenheit der einzelnen Gieder der Granatgruppe besteht dagegen darin, daß das Monoxyl bald Kalk (CaO), bald Eisenoxydul ( $\mathrm{FeO}$ ), bald Magnesia ( $\mathrm{MgO}$ ), manchmal auch Mangonoxydul ( $\mathrm{MnO})$ ist, während gleichzeitig als Sesquioxyde die Tonerde $\left(\mathrm{Al}_{2} \mathrm{O}_{3}\right)$ das Eiscnoxyd $\left(\mathrm{Fe}_{2} \mathrm{O}_{3}\right)$ und zuweilen das Chromoxyd $\left(\mathrm{Cr}_{2} \mathrm{O}_{3}\right)$ in die Verbindung eintreten.

Diese verschiedenen Monoxyde und Sesquioxyde könnten sich nun in der mannigfaltigsten Weise miteinander vereinigen. Die Analysen haben aber gezeigt, daß nicht jedes einzelne Monoxyd mit jedem einzelnen Sesquioxyd zusammen vorkommt, sondern dals nur eine geringe Anzahl der theoretiseh möglichen Verbindungen faktisch existiert, die man nach den in ihnen vorhandenen Oxyden mit besonderen Namen belegt. Von einigen weniger wichtigen abgesehen sind es die folgenden:

1. Kalktongranat: $3 \mathrm{CaO} \cdot \mathrm{Al}_{2} \mathrm{O}_{3} \cdot 3 \mathrm{SiO}_{2}$.

2. Eisentongranat: $3 \mathrm{FeO} \cdot \mathrm{Al}_{2} \mathrm{O}_{3}-3 \mathrm{SiO}$.

3. Magnesiatongranat: $3 \mathrm{MgO}-\mathrm{Al}_{2} \mathrm{O}_{3} \cdot 3 \mathrm{SiO}_{2}$

4. Kalkeisengranat: $3 \mathrm{CaO} \cdot \mathrm{Fe}_{2} \mathrm{O}_{3} \cdot 3 \mathrm{SiO}_{2}$.

5. Kalkchromgranat: $3 \mathrm{CaO} \cdot \mathrm{Cr}_{2} \mathrm{O}_{3} \cdot 3 \mathrm{SiO}_{2}$. 
Diese cinzelnen Verbindungen sond weniestens zum Teil in ziemlicher Jiemlerit in der Natur nacherewiesen worden. In den meisten Granaten findet man aber nicht blos ein einziges Monoxyd wie (a) oder FeO oder ein einzelnes siesquioxyd $\mathrm{Al}_{2} \mathrm{O}$ oder $\mathrm{F}_{2} \mathrm{O}$ : nsw, sondern zwei oder mehrere nedpeneinander, und zwar an den verschiedenen Exemplaren in wechselnden Menzenverhailtnissen. So tribt es also (iranate, die aulber siO: und $\mathrm{N}_{2} \mathrm{O}$. die bejden . Monoxyde CaO und FeO neloneinander enthalten, und zwar bald wehr von dem einen bald mehr von dem anderen. I)ie beiden ersten der obigen Verbindungen, der Kalk- und der Eisentongranat, sind demnach hier miteinander gemischt, und zwar so, dal) die CaO-reicheren eine äberwiegende Menge von dem ersten, die FeOreicheren mels von dem zweiten enthalten. Cranate, die nehen CaO greichzeitig $\mathrm{N}_{2} \mathrm{O}_{3}$ und Feg $\mathrm{C}_{3}$ enthalten, sind Hischungen von Kalkton- und Kalkeisengranat usw. Die.

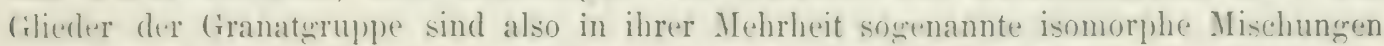
einiger der obigen fünf und noch anderer seltenerer firundverbindungen ron sanz entsprechender allgemeiner Zusammensetzung, die wir zum Teil bei der Betrachtung der einzelnen Granate noch kennen lernen werden. Hauptsächlich nach dem auf diesen Mischungen beruhenden chemischen Bestande wird die grolie (iruple de's rranats in eine Anzahl von besonders benannten Arten eingeteilt. Ein Bild ron deren wechselnder Zusammensetzung gibt die folgende Tabelle, in der die Ergethnisse der Analysen einiger als Eilelsteine dienender Glieder der Granatgruppe zusammengestellt sind, die nach dem oben Erwälınten leicht bezighlich ihrer Mischungsverbïltnisse gedeutet werden kïnnen. Namen und Heimat dieser Granate sind je am Kopfe der Kolumnen angegeben.

\begin{tabular}{|c|c|c|c|c|c|c|c|c|}
\hline & & & $\begin{array}{c}\text { Hessonit } \\
\text { (Kaneelstein) } \\
\text { Ceylon }\end{array}$ & Almandin & $\left|\begin{array}{c}\text { Demantoid } \\
\text { (smaragdgrün) } \\
\text { Syssertsk }\end{array}\right|$ & $\begin{array}{c}\text { Pyrop } \\
\text { Böhmen }\end{array}$ & $\begin{array}{c}\text { Pyrop } \\
\text { (hyacinthrot) } \\
\text { Kap }\end{array}$ & $\begin{array}{c}\text { Pyrop } \\
\text { (dunkelrot) } \\
\text { (Kaprubin) }\end{array}$ \\
\hline Kieselsäure . & . . & . . & 40,01 & 40,56 & 35,50 & 41,35 & 40,90 & 39,06 \\
\hline Tonerde . & . & . . & 23,00 & 20.61 & - & 22,35 & 22,81 & 21,02 \\
\hline Eisenoxyd . & . & . . & - & 5,00 & 31,51 & - & - & 2,69 \\
\hline Chromoxyd. & . & , . & - & - & 0,70 & 4,45 & 1,48 & - \\
\hline Kalk . . & . & . . & 30,57 & - & 32,90 & 5,29 & 4,70 & 5,02 \\
\hline Magnesia . & . & . & 0,33 & - & 0,21 & 15,00 & 16,43 & 12,09 \\
\hline Eisenoxydul. & . & . . & 3,31 & 32,70 & - & 9,94 & 13,34 & 18,70 \\
\hline Manganoxydul & . & . . & 0,59 & 1,47 & - & 2,59 & 0,38 & 0,58 \\
\hline Sumn & & . . & 97,81 & 100,34 & 100,82 & 100,97 & 100,04 & 99,16 \\
\hline
\end{tabular}

In fast allen seinen so rerschiedenartig zusammengesetzten Arten kommt der Granat ausguzeichnet kristallisiert vor, nur von wenigen Tarietäten sind noch keine dentlichen Kirstalle gefunden worden. Diese sind bald im Gestein eingewachsen und dann ringsum rollständig mit Flächen ausgebildet, wie z. B. der Taf. XIY, Fig. 3 abgebildete, zum Teil aus seiner Lmgebung herausgearbeitete Kristall. Oder sie sind, zu Drusen vereinigt, auf einer Interlage aufgewachsen und dann an der Anwachsstelle selbstrerständlich nicht mit ebenen Flächen versehen, wie dies bei dem Fig. i derselben Tafel dargestellten Granat der Fall ist. Die Formen, deren wichtigste in Fig. $\$ 3$, a bis a wiedergegeben sind, gehören dem reculären Kristallsystem an. Sehr rerbreitet ist das Rhombendodekä̈der Fig. 53. r), das nach seinem besonders ausgezeichneten Torkommen am Granat ron den Kristallographen auch Granatoëder genannt wird. Ï̈ufig sind bei diesem die sïmtlichen Kanten mehr oder weniger stark abgestumpft durch Flächen. die gewöhnlich der Länge nach zart gestreift sind, wie es Fig. 5:3.7. sowie Tafel XIT Fig. 3 zeigt. Bald sind die Dodekaëderflächen stärker entwickelt als die Abstumpfungslïchen, wie in den Figuren, bald ist es umgekehrt, so daß ron den ersteren oft nur kleine rhonibisch gestaltete Tieste übrig sind.

B a u $\mathrm{r}$, Edelsteinkunde. 2. Aufl. 
Diese Abstumpfungsflächen gehören dem Ikositetraëder an, das auch selbständig mit entsprechend gestreiften Flächen häufig beim Granat vorkommt (Fig. 83,c). Am Granatoëder sind in viden Fällen nicht nur die Kanten abgestumpft, wie in Fig. 83, 7, sondern die Kanten zwischen den Flächen des letzteren und den seine Kanten ersetzenden Ikositetraëderflächen sind ehenfalls sämtlich abgestumpft, so daß Formen entstehen wie die in Fig. 83, d darerestellte. Diese letzteren Abstumpfungsflächen sind häufig in derselben Richtung zart gestreift wie die ersterenannten, dem Ikositetraëder angehörigen; sie bilden miteinander die flächenreichste einfache Kristallform des regulären Systems, einen Achtundvierzigflächner, der aber für sich allein beim Granat noch nicht beobachtet worden ist. Andere Formen als diese kommen kaum vor, namentlich fehlen hier so gut wie ganz die flächenärmsten einfachen Körper des regulären Systems, das Oktaëder und besonders der Würfel, die bei anderen regulären Mineralien am häufigsten zu sein pflegen.
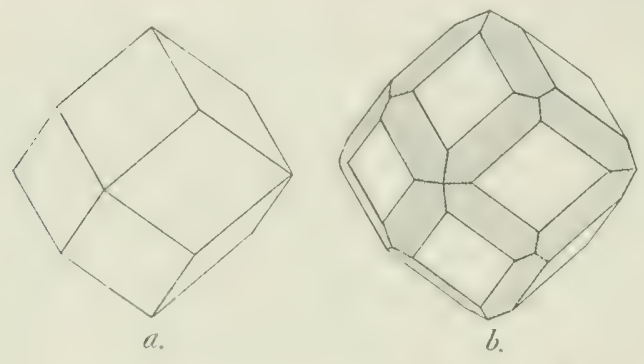

Fin.

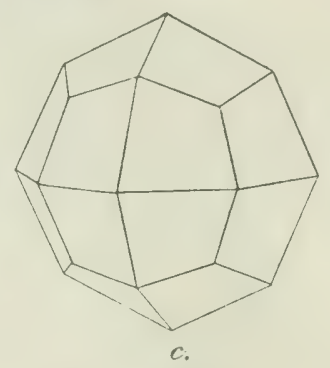

c.

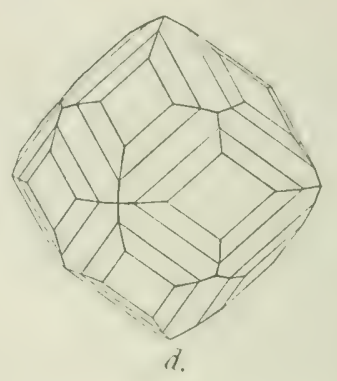

Blätterbriche zeigen die Kristalle nicht. Die Spaltbarkeit ist sehr unvollkommen, mehr als bei den meisten anderen Mineralien. Der Bruch ist kleinmuschelig bis uneben. Die Härte ist bedeutend. Bei allen roten Granaten, und das ist die Mehrzahl der als Edelsteine verwendeten, übertrifft sie die des Quarzes, ohne aber die des Topases zu erreichen. Sie werden alle von 'Topas geritzt, ritzen aber ihrerseits Quarz etwas; es ist also $H .=7-\delta$. Etwas abweichend verhalten sich einige griine Granate. Der als Edelstein zuweilen benutzte Demantoid steht noch unter dem Quarz und wird von diesem geritzt $(H .=61 / 2)$, er ritzt aber, wie die roten Steine dieser Gruppe, mit groler Leichtigkeit Glas, was zur Unterscheidung von Glasimitationen dienen kann. Besonders grob und sehr nahe wie beim Topas ist die Härte des schön smaragdgrünen Kalkchromgranats, den die Mineralogen Uwarowit nennen, der aber selten verschliffen wird. Wegen der großen Härte wird der Granat vielfach in Form von Pulver zum Schleifen anderer Edelsteine und sonstiger harter Gegenstände verwendet, auch zur Herstellung von sog. Schmirgelpapier usw. Er ist von den Mineralien mit gröljerer IIärte als Quarz cines der verbreitetsten und leicht zu billigen Preisen in Ilasse zu beschaffen. Reine Steine ohne Risse dienen auch zur Herstellung von Zapfenlagern für Uhren usw.

Wie die IIärte, so schwankt auch das spezifische Gewicht, und zwar in ziemlich weiten Grenz'n. Es ist, wie jene, von der Zusammensetzung der einzelnen Arten abhängig und um so höher, je melır sehweres Metall, besonders Eisen, in der Verbindung vorhanden ist. Am niedriesten hat man es bei dem lialktongranat gefunden, wo es etwa 3, beträgt; am hö̈hsten ist die Zahl bein Eisentongranat, nämlich 4,3. Zwischen diesen beiden Grenzen 3, , und 4,3 liegen die Werte für die ïbrigen Granate; bei der Betrachtung der einzelnen Varietäten werden hierïber noch nähere Mitteilungen gemacht werden. Das hohe spezifische Gewicht läßjt den Granat meist leicht und sicher von ähnlichen Steinen unterscheiden, namentlich wieder von Glasimitationen, die leichter sind.

Hit der Zusammensetzung indert sich anch die Farbe. Diese ist stets der Substanz 
rigrentiimlich und wird nicht retwa durch eingemengte Pigmentteilchen veranlalit. Sice ist daher durch die enanze Masse vollkommen gleichmälig verteilt und zeigrt keine Flecken. Auch hält sie sich heim Erhitzen oder ändert sich dabei doch nur vorïbercehend, um bein Erkalten in der urspriinelichen Weise wiederzukehren. Reiner Kalktongranat ist vollkommen farblos; dieser woifer sogenannte Leukogranat wird aher niemals ereschliffen. An verhreitetstru ist die rote Farbe, die in den verschiedensten Abstufungen zwischen sanz hell und beinalse schwarz und in den verschiedensten Nuancen meist mit einem Stich ins liraune, felbe oder Violette vorkommt. Rot sind, wie schon erwälnt, namentlich anch die meisten Granate, die zum Schmuck verwendet werden. Diese bilden das odur wenizstens einen 'Teil dessen, was man früher Karfunkel nannte: wahrseheinlich rerstand man darunter alle roten Edelsteine olme Ausnahme, nicht nur droll Rubin. drer jetzt allerdings vorzugsweise unter diesem Namen begriffen wird. Von der roten Farhe soll auch der Name Granat stammen; sie wurle frïher mit derjenigen der Blïten und Körner des Granathatumes verglichen. Neben den roten Granaten dienen zum Schmuck, jedoch selı viel weniger, anch sulche von grïner Farbe, die zum 'Teil der des Smaragrds gleicht, meist aber mehr gellgriin ist oder ins Brïunliche geht. Leider ist der am schïnsten smaragdwrïn «efürbte Granat, der schon genannte Kalkchromgranat oder Uwarowit, als Edelstem kaum zu webrauchen, da die Kristïllchen, die er bildet, meist viel zu klein und auch zu wenig durchsichtig sind. Das färbende Prinzip bei den Granaten ist der Eisen-, in geringrerem Mabe der Mangan- und Chromgehalt. Das Eisen verursacht die rote und gelb)lichørüne, sowie die sehr verbreitete gelbe und braune, das Chrom die schön smaragdgrüne Farbe. Anch schwarze, gleichfalls durch die Eisenbestandteile gefürbte Granate kommen vor; sie werden wohl gelegentlich einmal zu Trauerschmuck verwendet. Die blaue Farbe fehlt aber in der Granatgruppe gïnzlich. Von der Farbe wird bei der Betrachtung der einzelnen Arten des Granats gleichfalls noch weiter die Rede sein.

Die D urch si chtigk eit ist sehr verschieden, aber alle Granate, auch die durchsichtigen, sind für Röntgenstrahlen wenig oder gar nicht durchlässig. Die meisten Granatkristalle sind tribe und undurchsichtig, es gibt aber beinahe unter allen Varietïten auch mehr oder weniger zahlreiche Exemplare von vollkommener Klarheit und Durchsichtigkeit selbst bei der tiefsten und dunkelsten Farbe. Nur die edlen durchsichtigen Steine der verschiedenen Arten werden geschliffen, niemals trübe und undurchsichtige. Der Glanz ist auf natiirlichen Kristallflïchen zuweilen sehr stark, manchmal auch weniger; jedenfalls sind die durchsichtigen Steine auf frischem Bruch lebhaft glänzend, wenn sie es auch an der Oberfläche infolge von deren rauher Beschaffenheit oder aus anderen Gründen nicht sind. Durch das Schleifen und Polieren wird der Glanz bei ihnen stets noch beträichtlich erhöht und zu einem schïnen Feuer gesteigert. Der Qualität nach ist es der gewöhnliehe Glas. glanz, der allerdings vielfach stark ins Harzartige neigt, so daß manche Granate sich im Aussehen einem Stiick Harz sehr nähern.

Nit der regulären Kristallisation hängt es zusammen, daf der Granat das Licht einfach bricht; nur in einzelnen Fällen beobachtet man anomale Doppelbrechung; aber kaum bei den als Edelsteine in Betracht kommenden vollkommen klaren und durchsichtigen. Die Brechungskoëffizienten sind bei allen Granaten ziemlich groß, aber ebenfalls mit der Zusammensetzung ron einer Art zur anderen etwas schwankend; die Zahlen gehen ron 1,70 bis 1,90 für rotes Licht. Die Farbenzerstreuung ist fast stets gering, so daf niemals ein Farbenspiel entsteht wie beim Diamant; nur der als Demantoid bezcichnete grüne Kalkeisengranat zeint eine derartige Erscheinung, wenn auch weitaus nicht so stark wie der letztere. Die meisten Granate wirken demnach als Edelsteine ledigglich durch ibren starken und lebhaften Glanz und ihre meist sehr schöne tiefe und gresüttigte Farbe. Manche geben beim Hindurchsehen nach einer Kerzenflamme oder auf einer runden Ober- 
flïche einen vier- oder sechsstrahligen Lichtstern, ähnlich wie die Sternsapphire; diese Erscheinung ist aber selten und erhöht nicht die Schönheit des Aussehens und den Wert als Edelstein.

Die cinfache Lichthrechung erlauht meist, den Granat sicher von anderen ähnlich aussehenden Steinen, so roten (iranat von liubin, wrïnen von Smaragd usw., aber nicht von (Alasflïssen zu unterscheiden. Dieselbe Untersebeidung ist möglich infolge des ebenfalls anf der regulären Kristallisation beruhenden Nangels an Dichroismus. Die Farbe ist lreim Hindurchsehen nach allen Richtungen die nämliche, und die Dichrolupe zeigt keine Yerschiedenheit der Bilder. Dies ist besonders wichtig bei der Unterseheidung des Rubins ron dem oft recht ähnlıch gefärbten roten Granat. Die Ähnlichkeit der Farbe ist hier zuweilen so grof, daf auch ein geübter Kenner bei der Betrachtung mit bloßem Auge cetäuscht werden kann; wir haben schon bei der Beschreibung des Rubins gesehen, daß solehe Verwechselungen in der Tat vorkommen. Wegen dieser Farbengleichleit ist auch ein schön roter Cranat, der die Diamanten am Kap begleitet, "Kaprubin" genannt worden.

Vor dem Lötrohr ist der Granat meist ziemlieh leicht schmelzh)ar, nur bei einigen Arten ist dies schwieriger oder auch ganz unmöglich. Durch das Schmelzen erlangen die Stiicke die Fähigkeit, von Sïuren zersetzt zu werden, was bei dem ungreschmolzenen Granat nicht der Fall ist. Das spezifische Gewicht wird dabei stark erniedrigrt; so wurde bei einem hell gelbroten Kalktongranat gefunden: vor dem Schmelzen G. $=3,63$, nachher $\mathrm{r}_{\mathrm{r}}=2$, Besonders leicht schmelzhar sind die sehr eisenreichen. Diese wirken auch etwas auf die Nagnetnadel, und die Schmelze, die sie geben, wird vom Magnet angezogen. Alle Granate werden beim Reiben mit Tuch usw. schwach positiv elektrisch.

Der Schliff, den die Granate erhalten, ist der mehr oder weniger dunklen Farbe angepalit. Den meisten Varictäten gibt man gern die mugelige Form meist mit rundem, nicht selten auch mit ovalem Umriß; die Wülbung wird meist sehr hoch und steil hersestellt, so daf halhkugelige Gestalten entstehen. Wenn der Stein sehr dunkel ist, wird er durch Aushöhlungr der Unterseite, durch Aussehlägeln, dünn und dadurch durchsichtiger gemacht, ein Verfahren, das beim Granat besonders häufig Anwendung findet. Solche ausgeschlizgelte Granate werden Granatschalen genannt. Sie wurden sehon im Altertume angefertigt, wie zahlreiche Funde in römischen Ruinen zeigen. Häufig ist der Schliff als Tafelstein oder in der Treppenform, auch der gemischte Schnitt wird nicht selten angewendet. Alle diese Formen muß man bei dunkel gefürbten steinen möghchst niedrig. halten. Die große Tafelflïche wird vielfach nicht, wie gewöhnlich, eben, sondern mugelich greschliffen. Bei manchen Arten ist auch die Form der Rosette und des Brillants nicht selten, ebenso trifft man ganz unregelmäßige Phantasieformen. Einige greschliffene (iranate sind Taf. XIV, Fig. 4, 6, 6 u. 10, sowie Taf. XVIII, Fig. 7 abgebildet. Die Fassumg geschieht nur bei nicht zu dunkel grefärbten Steinen à jour, dunklere erhalten oft eine glänzende Folie von Silber oder Kupfer, die das Aussehen nicht wenig hebt. Vielfach werden die Granatkörner mit ringsum ogleichmälig symmetrisch, aber auch regellos verteilten kleinen Facetten versehen, in der Mitte durehbohrt und zur Iterstellung von Arm- und Halsbändern auf Schnüre gezogen.

Der Wert der einzelnen Granatrarietäten ist sehr versehieden. Fr hängt in der Iauptsache ab von der Schönheit der Farbe und von der IIäufigkeit des Vorkommens. Bei der Beschreibung der cinzelnen Arten werden hierïber sperzielle Angaben semacht werden.

Ton Fehlern, die den Wrert verringern, sind hauptsächlich kleine Risse vorhanden, nach denen die Steine leicht weiter springen. Iläufig sind aber die Granate von geradezu idealer Reinheit, Klarheit und Fehlerlosigkeit, wie nicht leicht ein anderer Edelstein. Steine von dieser Beschaffenheit sind natülich besonders hochgeschätzt. 
Dur Granat gehört in seiner fexamtheit zu den mineralogisch wichtiessten Substanzen, da er, wenigstens in seinen undurchsichtimen gerieinen Abarten, eines sehr grolfe Verbreitumg in der Erdkruste besitzt. Siltener sind allerdings de klaren und durchisichtigen edlen, die Art und Weise ihres Vorkommens ist aber von der jener anderen nicht wesentlich verschieden. In der Ilauptsache ist der franat ein Mineral der alten kristallinischen Silikatersteine, besonders dur kristallinisehen Schiefer, des fineises, filimmerschiefers, auch des Serpentins usw. In diesen sind die Kristalle, wite schon cinganess mitereteilt wurde,

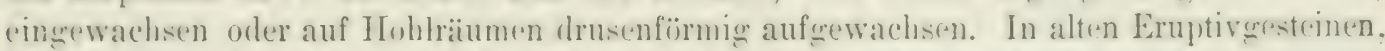
wie Granit und anderen, ist der Granat sehon viel weniger rerberetet, und in jïnceren vulkanischen Felsarten ist er, den selswarzen Melanit abgerechnet, nur spärlich forlıanden. Auberdem findet er sich in manchen Kalken an stellen. wo diese mit Granit und ähnlichen Eruptivesteinen in Berïlumm stehen, als sogenamntes Kontaktprodukt. Alle diese ursprünglichen Arten des Vorkommens sind aber für die edlen. durchsichtigen Steine, wie sie zum Schleifen benutzt werden, nicht von Belang. Aus dem festen Gestein werden wenigre derselben heransgelöt; man nimmt wie bei so vielen anderen Edelsteinen meist nur die von del Natur sellsst isolierten, die mehr oder weniger abgerollt lose im Terwitterungsuruse jener Gesteine, in Senfen, legen und die man aus diesen durch Waschen und Auslesen gewinnt.

Wir haben schon oben gresehen, dak man nach der speziellen chemischen Zusammensetzung eine grïßere Zahl von Arten des Granats aufgestellt hat. Ebenso wird auch innerhalb der einzelnen, auf der chemischen Zusammensetzung beruhenden Art nach der äuberen Beschaffenheit eine Anzahl von Varietäten unterschieden und mit besonderen Namen belext. Die meisten von diesen haben blob mineralogisches Interesse: nur ron wenigen gibt es so durchsiclitige Exemplare, daf sie als Edelsteme benutzt werden können, und diese haben wir nunmehr eingehender zu betrachten. Es ist der hell gelbrote IIessonit oder Kaneelstein, der meist dunkel violettrote Amandin, der blutrote Pyrop aus Böhmen mit dem prachtvollen Kaprubin, und der schün grüne Demantoid aus dem Lral, zu denen als Seltenheiten im Edelsteinhandel noch der rote Khodolith, der chenfalls gellorote Spessartin. der bräunlichgrüne Grossular und der schwarze Melanit hinzutreten.

\section{Hessonit (Kaneelstein).}

Der Hessonit oder Kaneelstein ist nach der in obiger Tabelle ancefülurten Analyse in der Hauptsache ein Kalktongranat, der aber geringe Mengen Eisenoxydul und Janganoxydul enthält und dem also eine kleine Quantität Eisentongranat und Mangantongranat beigemischt ist. Diese beiden Bestandteile verursachen eine angenehme warme gelbrote Färbung des an sich farblosen Kalktongranats. Die Farbe ist ein Hyacinthrot, das zuweilen in das Orangefarbige oder in das Honiggelh zieht. Sie ändert sich etwas je nach dem Abstand, in dem man den Stein rom Auge hält. Nur in einiger Entfermung ist dieser deutlich rot, dicht an das Auge gehalten erscheint er oft fast rein gell), das Rot verschwindet beinahe rollstïndig. Der Hessonit ist noch weiter dadurch auserezeichnet. dab die Farbe bei Lampenlicht erheblich leuchtender und feuriger wird als am Tage. Sie ist aus den Figuren $T$ und $S$ auf Taf. XIV zu ersehen. deren erste eine Drust ron Kristallen in der beim Hessonit nicht seltenen Form der Fig. S3, /, die zweite einen geschliffenen Stein darstellt.

Man hat den Hessonit, seiner Farbe und seines Aussehens wegen, mit Kandiszuclier verglichen, hauptsächlich aber mit Zimmetrinde (Taneel). Daher hat er den Tamen Kaneelstein erhalten, ein Terorleich, der sehr nahe lag, da der edle Hessonit, wie 'r zum Schmuck verwendet wird, der Hauptsache nach der Zimmetinsel Ceylon entstammt. Am meisten Ähnlichkeit hat er aber mit dem schon oben betrachteten Iyacinth. Diese 
Ähnlichkeit geht so weit, dab es den Mineralogen erst Ende des 18. Jahrhunderts gelungen ist, beide auseinander zu halten. Bis dahin nahm man auch den Ilessonit für echten Hyacinth, welcher Irrtum um so schwerer zu vermeiden war, als der letztere den rrsteren in den Edelsteinseifen jenes Landes ganz ständig begleitet. Die Edelsteinhändler unterscheiden beide Steine auch heute noch nicht; der Hessonit wird unter dem Namen IIyacinth rerkauft, so daß ein großer 'T'eil dessen, was unter der letzteren Bezeichnung in den Mandel gebracht wird, seinen Namen mit Unrecht führt. Namentlich gilt dies für die srïberen Stiicke, denn echte Hyacinthe finden sich wenigstens in Ceylon kaum anders als in kleinen Kristallen, während von Hessonit auch Exemplare von beträchtlichem Thufange und von schöner Beschaffenheit häufig vorkommen. Wenn im Edelsteinhandel ju cin Unterschied gemacht wird, so wird von dem dunkler gefürbten Hessonit, dem der Namen Ilyacinth verbleibt, der hellere als Kancelstein abgetrennt. Dieser mehr oder weniger bewubten Verwechselung beider Steine liegt indessen nicht, wie man meinen kiimnte, betrïgerische Absicht zugrunde. Wenn auch der Hyacinth in Beziehung anf den Glanz dem Hessonit weit voransteht, so ist doch bei beiden die Farbe gleich schön, und vollkonmen klare, durchsichtige, schön gefärbte und fehlerlose Kaneelsteine stehen anch bei richtiger Kenntnis der Sachlage im Preise hinter dem echten Iyacinth kaum zurïck, ebensowenig wie in der Schönheit des Aussehens; kleine fehlerhafte und schlechter grefärbte Hessonite besitzen allerdings nur geringen Wert.

Wenn auch Hyacinth und Kaneelstein im Handel häufig verwechselt werden, so ist 's doch unter Berücksichtigung aller Eigenschaften beider nicht schwer, sie sicher zu unterscheiden. Das spezifische Gewicht des Hessonits ist gleich 3, ; bis 3,7 gegenüber dem viel höheren des Hyacinths, das 4,6 bis 4,7 beträgt. Der Hessonit ist cinfach lichtbrechend, der Iyacinth zeigt starke Doppelbrechung. Der Glanz des letzteren ist viel stärker und schön diamantartig, während der des Hessonits ein stark ins Marzartige sehender Glasglanz ist. Namentlich derbe Stiicke haben ein harzähnliches Aussehen. Auch die Iärte des Hyacinths ist etwas größer $\left(H_{0}=71 / 2\right)$ als die des IIessonits, die sich nur wenig über die des Quarzes erhebt $\left(H_{0}=71 / 4\right)$. Schwierig ist dagegen die Unterscheidung des Hessonits von dem gelbroten Spinell, dessen Farbe sich zuweilen der des Kaneelsteines sehr nähert. Er ist regulär kristallisiert und daher einfach brechend wie letzterer, und die Brechungsindices beider sind fast genau gleich. Auch die Härte beider ist kaum verschieden und ebenso das spezifische Gewicht, das beim Spinell nur sehr wenig seringer ist $\left(G_{.}=3, c_{i \prime}\right.$ bis 3,63$)$. Es wird unter diesen Umständen manchmal unmöglich sein, zu erkennen, ob ein geschliffener Stein oder ein unregelmäßigres Bruchstück Hessonit oder Spinell ist. Bei Kristallen ist dies meist leicht, da der letztere stets in Oktäidern kristallisiert, der erstere selten. Daß Härte und spezifisches Gewicht Glasfliisse von derselben Farbe leicht erkennen lassen, ist sehon oben angegeben worden.

Einige Eigenschaften des Kaneelsteins seien hier noch erwähnt, die für den Gebrauch desselben als Edelstein allerdings keine grobe Bedeutung besitzen. Die Lichtotbrechung ist etwas geringer als bei anderen Granaten; der Brechungskoüffizient ist $=1,76$ für rotes Licht und die Dispersion sehwach. Zuweilen wird anomale Doppelbrechung beobachtet. Der Ilessonit schmilzt ziemlich leicht vor dem Lütrohr zu einem grïnlichen Glase. Trotz des geringen Eisengehaltes wirkt er etwas auf die Magnetnadel.

Dal3 der Hessonit auf der Insel Ceylon vorkommt, haben wir schon gesehen. 1)iesses Land (Iig. 69, S. 361) ist fast die einzige Ileimat schön gefärbter, durchsichtiger mol daher schleifwürdiger Stiicke, und wahrscheinlich stammen so gut wie alle im IIandel bufindlichen Steine von hier. Sie finden sich, wie berichtet wird, nur in Form abgerollter (ieschielee, die in verschiedener Gröbe bis zum Gewichte von mehreren Pfunden in den Edelsteinseifen liegen, und die besonders in der Südprovinz, so bei Weligama und Matara 
häulig sein sollen. Die Gerölle sind zwar sehöner und reiner und weniger rission als die religen, nicht im Wasser geschwemmten Stiicke, sind aber doch zum Teil ehenfalls noch stakk von Sialten und kiliften durchsetzt. Diese machen den wesentlichsten Fehler des Kaneelsteins aus, der, davon abgesehen, meist vollkommen klar und rein ist.

Der anderwïts vorkommende Inessonit ist zum Schleifen weniger geedgnet als der

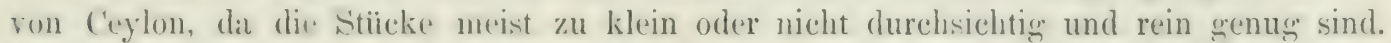
Inoch werden anch in Europa, namentlich in den Alpen einige Orte erwähnt, die zuweilen schleifbare Steine in geringer Menge liefern oder frïher greliefert haben.

In älteren Zeiten wurden die schönen „Hyacinthgranaten von Dissentis“ oder ..vom st. Gotthard" zuweilen geesehliffen, die an der Alpe Lolen im Maigelstale auf der Grenze zwischen den liantonen Uri und Graubïnden mit Epjidot im Ruarz auf einer sehmalen Lagerkluft im Glimmeroneis vorkommen. Es sind Kristalle von verschiedener, aber die einer Erbse kamm überschreitender Größe, die meist im Innern ein Quarzkorn ringeschlossen enthalten. Ileutzutage werden sie kaum noch benutzt. Ton sehr geringer Bedeutung ist auch das Vorkommen an der Mussalp im Alatal in Piemont, wo sehïne Kristalldrusen, deren eine auf Taf. XIV, Fig. 7 abgebildet ist, auf Spalten im Serpentin sitzen. Die Hessonitkristalle sind hier von dunkelgrünen Chlorit- und hellwriinen Diopsidkristallen begleitet: eine Anzahl der letzteren ist neben dem Granat auf dem abgebilkleten Stïck zu sehen. Diese Drusen sind ebenso wie die ganz ähnlichen von Achmatowsk im Ural eine Zierde aller Sammlungen und geben ein schönes Bild von dem natiurlichen Vorkommen unseres Edelsteines. In Nordamerika hat der Ramona-Distrikt in Diegro County, im südlichen Kalifornien, einigres schöne Material geliefert; bei der Betrachtung des Turmalins, den der Hessonit teilweise begleitet, wird davon noch die Rede sein. Andere nicht unwichtige Fundorte dort, liegen im Jacumba-Distrilit, in der Lmgegend der Jacumba Hot Springs, 70 miles üstlich von der Stadt San Diego, z. T. im Pegmatit wie in Ramona, z. T. im Kalk. Aucb der Hessonit von Kalifornien wird vielfach IIyacinth genannt. Manchmal geht er unter dem Namen Spessartin, doch scheint eigentlicher Spessartin in jener Gegend nicht vorzukommen.

Geschliffen wird der Hessonit meist mit Facetten in den oben angegebenen Formen (Taf. XIV, Fig. 8), oder anch en cabochon. Wegen der hellen Farbe ist es nicht nötig, ihn unten auszuschlägeln oder die Steine besonders dünn zu halten. Die Fassung geschieht zur Hebung des Feuers meist mit einer glänzenden Folie, seltener à jour.

\section{Spessartin.}

Dem Hessonit in der Farbe sehr ähnlich ist der Spessartin von Amelia Court House in Virginia. Es ist ein Mangantongranat, in dem statt des Kalkes Manganoxydul in die Verbindung eingetreten ist. Er findet sich an dem genannten Fundorte auf den Glimmercruben im Granit in schönen klaren Kristallen, die Steine von 1 bis 100 Karat und von sehr guter Qualität gegeben haben. Spessartin von anderen Lokalitäten wird kaum geschliffen. Die sog. Spessartine des südlichen Kialiforniens sind wohl alle Hessonite (siehe diesen).

\section{Almandin.}

Der dunkelrote Almandin ist derjenige Granat, der hauptsächlich mit zu dem gehört, was mau friber Karfunkel nannte. Nach der gewöhnlichen Annahme ist das Wort Almandin vestïmmelt aus dem Namen: Carbunculus alabandicus, den Plinius dem Steine gab, weil dieser nach seiner Mitteilung bei der Stadt Alabanda in Karien (Ǩleinasien) gefunden und dort auch geschliffen wurde. Heutzutage wird er in seinen durchsichtigen Exemplaren vielfach als der edle Granat schlechtweg und im engeren Sinne bezeichnet. 
Der Almandin ist, wie die eingangs angeführte Analyse zeigt, ein Eisentongranat. der aber stets neluen den Mauptbestandteilen noch etwas Eisenoxyd, Manganoxydul usw. enthält.

Seine stets dunkle, wohl von dem beträichtlichen Eisengehalt herriihrende Farbe ist an verschiedenen Stïcken etwas verschieden. Sie geht meist deutlich ins Violette und wird dann als kolumbinrot bezeichnet (Taf. XIV, Fig. 3 u. 4 und Taf. XVIII, Fig. T), doch ist er auch nicht selten bräunlichrot bis rotbraun. Die bräunlichroten Steine werden von den Jnwelieren zuweilen als Vermeille bezeichnet, doch ist dieser Begriff etwas schwankend und umfaßt auch andere dunkelrote Granate mit einem Stich ins Gellse, namentlich den unten zu erwähnenden böhmischen Granat, den Pyrop. Bei künstlicher Beleuchtung geht die Farbe aller Almandine mehr ins Orange oder Hyacinthrote; sie nähert sich der des Hessonits, und der Stein verliert nicht unerheblich an seiner Schönheit. Beim Erhitzen wird der Almandin schwarz, aber nach der Abkühlung wieder rot wie vorher, doch soll er sein ursprïngliches schönes Aussehen nicht vollkommen zurïckerlangen.

Der Almandin nähert sich in seiner Farbe oft sehr den Rubin, er wird aber in der früher erwïhnten Weise durch seine einfache Lichtbrechung und den Nangel an Dichroismus leicht erkannt. Einen Unterschied gibt auch das spezifische Gewicht, das beim AImandin höher ist als bei allen anderen Granaten. Es ist auch etwas höher als heim Rubin und schwankt zwischen 4,1 und 4,3, während es bei diesem kaum iber 4," hinausgeht. Die Härte ist ebenfalls ein Mittel der Unterscheidung; sie steht beim Almandin nur wenig ïber der des Quarzes, und es ist $\mathrm{H}=71 / 4$, Der Almandin wird also schon ron Topas und noch mehr vom Korund stark geritzt, ist aber seinerseits imstande, den Quarz etwas zu ritzen.

Wie das spezifische Gewicht, so ist auch das Lichtbrechungsvermögen größer als beim Uessonit. Der Brechungskoëffizient ist für rotes Licht gleich $1, \pi$. Vor dem Lötrohr schmilzt der Almandin ziemlich leicht zu einer magnetischen Schlacke. Auch der ungeschmolzene Almandin wirkt etwas auf die Magnetnadel ein, und zwar des höheren Eisengehaltes wegen ein wenig stärker als der Hessonit.

Beim Schleifen wird der $\Lambda$ lmandin sehr schön glänzend, bleibt aber darin doch hinter dem Rubin zuriick. Die Formen, die er erhäilt, sind die auch sonst beim Granat angewendeten; eine Rosette aus Almandin ist Taf. XIV, Fig. 4, abgebildet, doch ist die mugelige Form (Taf. XVIII, Fig. 7) hier häufiger, mehr als beim Hessonit, und namentlich trifft man vielfach Granatschalen mit ausgeschlägelter Unterseite. Bei diesen scheint dann die rote Farbe trotz ihrer Dunkelheit sehr schön durch. Sie vereinigt sich mit dem auf der runden Oberfläche konzentrierten Glanz zu einem präichtigen Anblick. Folien von glänzenden Metallplättchen sind von sehr günstiger Wirkung.

Der Wert hängt außer von der Größe, der Reinheit und der Abwesenheit aller Fehler, namentlich der von Rissen, sehr wesentlich von der Farhe ab, die auch bei dickeren Stücken noch lebhaft leuchten muß. Je näher sie dem schön galänzenden sammetartigen Purpur des Rubins steht, desto höher ist der Preis, der aber doch kaum auf 2 Mark pro Karat steigt. Die ins Bräunliche gehende Farbe der Vermeillegranaten ist wenig geschätzt; Steine dieser Art sind sehr billig, ebenso solehe von geringer (tröße und alle mit unreiner Farbe, mit Rissen und anderen Fehlern. Wertvoller sind die kolumbinroten Steine.

Der Almandin ist in trïber undurchsichtiger, nicht schleifwärdiger Beschaffenheit der verbreitetste aller Granaten. Ir bildet so den gemeinen Granat der Mineralogen, der meist in sehr gut ausgebildeten, manchmal viele Pfund schweren Ǩristallen im Gneis, Glimmerschiefor u.s.w. in kleineren Individuen auch zuweilen im Granit und ähnlichen Gesteinen sich (ingewachsen findet. Diese Art des Vorkommens ist in Taf. XIV, Fig. 3, abgebildet. Teben den trïben kommen aber in derselben Weise, wenn gleich spärlich, auch exile 
durehsichtige Exemplare vor, und diese sind es, welche geschliffen werden. Indessen ist der Almandin. wie so vele andere Edelsteine, nicht immer noch anf seiner urspringlichen Lagerstitte; anch er ist vielfach aus dem Mufterowentein herauswewittert und bildet me-ist

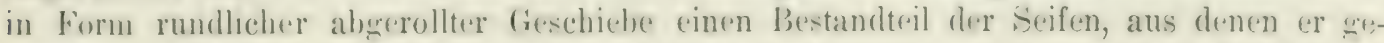
womnen wird. Vieht nur iiberhaupt, sondern auch speziell in schleifwërligen stiicken ist aber der Almandin verhereiteter, d. h. er findet sich an zahlreicheren Orten als der Kanerelstein. Im folgenden sollen die wichtiperen Fundstellen etwas eingrhender betrachtet werden.

Zuerst ist auch für den Almandin Ceylon zu erwähnen. Er findet sich hier in den Steifen mit Hessonit und den anderen Edelsteinen zusammen in der Form ron durchsichtigen, schleifwïrdien Geschieben, die zwar sehr zahlreich, aber im granzen kleiner sind als die des Kancedsteins. Auch als Gesteinstemenentell hat er eine weite Verbreitung, ist aber als solcher für den Edelsteinmarkt olne jeden Belang. Ween der Älndichkeit mit Rubin wird er wohl zuweilen mit diesen Edelsteine verwechselt und dafiir ausgereben. Er wird daher auch gelegentich als "eeylanischer Rubin" bezeichnet, welcher Tane also nicht den in Ceylon ebenfalls vorkommenden echten Rubin bedeutet.

Sehr häufı findet man als wichtirsten Fundort der schönsten Almandine der Welt Sirian, die alte Hauptstadt des früheren Königreichs Pegu, angeführt, das späiter durch Eroberung dem Reiche der Birmanen einverleibt wurde. und dessen ranzes fiebiet jetzt einen Teil der englischen Kolonie Birma bildet. Die alte Iauptstadt wurde in der Mitte des 15. Jahrhunderts zerstört und rerlassen, und dafïr sanz in der Xähe das jetzt so wichtige Rangun, die erste Handelsstadt ron Birma, gegrüudet. Rangun und mit ihm Sirian, jetzt ein elendes Dorl, liegen in der Niederung des Irawadi, in den ganz jungen Alluvionen des ron diesem Flusse gebildeten Deltas. Hier liönnen nach der Mitteilung von Fr. Joetling (Kalkutta), einem genauen Kenner des Landes, niemals Granate vorgrekommen sein und sind auch tatsächlich nicht vorgekommen. Der Almandin, der von hier stammen soll, muf also eine andere Heimat haben, von der aus er vielleicht frïler über die danals wichtige Handelsstadt Sirian in den Verkehr gehracht wurde. In Pegru, dem Gebiete des unteren Irawadi, findet man überhaupt keine Edelsteine, in Oher-Birna kommen allerdings neben Pubin und Spinell, beide rot, und dem srleichfalls roten Turmalin Almandine in geringer Menge vor, namentlich bei Namseka, anch bringen die Bewohner der ̈̈stlich an Birma stobenden Grenzländer, die Schans, nicht selten Almandine nach Birma, um sie als Rubine zu verkaufen. Doch hat die Angrabe von sirian als Funclort von Granat etwas Rätselhaftes, das noch der Aufklärung bedarf.

Infolge des vermeintlichen Vorkommens bei Sirian wird der Amandin auch .siriseher Granat" genannt (nicht syrischer, mit Syrien hat der Name nichts zu tun). Im Laufe der Zeiten hat aber diese Benennung allmählich mehr den Sinn einer Qualitätsbezeichnung angenommen, sofern man vielfach unter "sirischen Granaten" ins V'iolette gehende Almandine besreift, die in der Farbe dem Rubin oder auch dem orientalischen tmethyst recht nahe stehen und die daher nit zu den besten und kostharsten aller Granate gehüren. Sie wïrden also in einem gewissen Sinne eimen Gegensatz zu den weniger beliebten Vermeillegranaten bilden, deren Farbe etwas ins Bräunlicbe geht.

Verbreitet ist der Granat in Vorderindien. Speziell der edle Almandin kommt dort in so groler Menge vor, dal er ein nicht ganz unwichtices Erzeugnis des Landes darstellt. Er wird an manchen Orten gesammelt und in Delhi und Dschaipur sowie an manchen Orten im Kischengrarh. Staate geschliffen. Ob alle indischen Cranate zum Almandin gehüren, ist allerdings wegen Mangels an Analysen zweifelhaft. sie werden aus dem losen Verwitterungsprodukt des Muttermesteins herausgegraben, in der Hauptsache Fneis, Glimmerschiefer und andere älınliche Felsarten. Die Zahl der heliannten Fundorte, die früher ausgebeutet wurlen und auch jetzt rielleicht noch einizen Ertrag liefern, ist 
recht beträchtlich. Yon Bedeutung sind gegenwärtig aber nur die Gräbereien in Radschputana (rgl. Fig. 11 S. 170). Tiel genannt werden die Gruben von Serwar (Sarwar) im KischengarhStaate (26" $1^{\prime}$ nürdliche Breite und $75^{0} 4^{1}{ }^{\prime} 2^{\prime}$ üstl. Länge), deren Granate zwar klein, aber an Glanz und ziemlich stark ins Violette gehender Farbe unübertroffen sind. Eine grofje Anzahl ron Arbeitem scheint hier beschiffigt zu sein. Hieran schliebt sich die Gegend von Radschmahal in (lem benachbarten Dschaipur (25 $023^{1 / 2}$ nördl. Breite und $75 " 21 \frac{1}{2} 2^{\prime}$ östl. Länge), wo grofe Irengen aus Glimmerschiefer gewonnen werden. Üher den Wert der jährlich in den Handel gebrachten indischen Granaten hat man keine genauen Nachrichten; Schätzungen schwanken zwischen 2000) und 10000 Pfund Sterling. Jedenfalls übertrifft dieser Wert den der daselbst gefundenen Diamanten um das Mehrfache.

Von Fundorten in Amerika sind zuerst die brasilianischen zu nennen. Der Almandin findet sich hier in zwar kleinen, aber schön grefürbten und durchsichtigen abferollten Körnern als Begrleiter des 'Topases im Bezirk Minas novas im Staate Minas (Feraës. Auch von Uruguay sollen schöne schleifbare Stïcke kommen. Zahlreiche Fundstellen sind in den Tereinigten Staaten bekannt, von denen einige auch durchsichtige und schleifbare Steine liefern, aber allerdings nur in geringer Menge. Zu erwähnen sind vielleicht die purpurroten Gerölle des Columbia River in Washington und Oregon, die sich dort ron zum Teil sehr suter Beschaffenheit, in der Größe von einem halben Karat bis zu einex halben Unze, in bedeutender Menge finden. Wichtiger ist Grönland, wo größere Stiicke ron sehr schöner Farbe und Durchsichtigkeit, aber allerdingss vielfach sehr von Rissen durehzogen, meist in Chlorit- und Glimmerschiefer eingewachsen vorkoumen; zahlreiche Steine von guter Beschaffenheit stammen hierher.

In Australien ist der Almandin (wahrscheinlich neben anderen Granaten) sehr verbreitet. In Südaustralien finden sich Stiicke, die grölieren lebhaft kirschrot und gelblichrot, die kleineren lichtrot ins Violette, in den Flüssen des Yordterritoriums sehr häufig. Sie wurden zuerst für Rubine gehalten, in dem Kiese des Maude, Florence und Hale in großer II nge systematisch gewonnen und teuer verkauft. Nicht weniger als 24 Rubingesellschaften mit einigen II undert Grubenfeldern hatten sich gebildet; sie gringen alle in dem Augenblick zugrunde, wo die Steine als Granat erkannt und dadurch gegen früher beinahe wertlos geworden waren. In demselben Nomente wurden auch alle Arbeiten zur Gewinnung eingestellt, und heutzutage wird in Australien nur noch wenig Granat zum Schleifen gesammelt. Jener Verwechslung zufolge werden die australischen Steine zuweilen als "Adelaiderubine" bezeichnet. Schöne dunkelrote Steine kommen gegenwärtig aus Queensland.

Auch Europa besitzt schleifbaren Almandin, wenngleich nicht gerade in großer Menge und besonderer Qualität. Vor allem ist es das Gebiet der Alpen, das jührlich einen gewiss'n Trorat liefert. Ilier sind wieder besonders bervorzuheben die dodekaëdrischen, brüunlich-hyacinthroten, bis zollgroßen Kristalle aus dem dunkeln Glimmerschiefer und dem Chloritschicfer des oberen Zillertales in Tirol, namentlich am Roßrucken gegenïber der Berliner Hïtte im Zenmmgrund. Sie werden dort gexraben und durch gregenseitiges Abschleife in einem sich drehenden Fasse vom Muttergestein befreit. Alsclann gehen sie größtenteils nach Böhmen, wo, wiu wir unten bei der Betrachtung des P'yrops noch weiter sehen werden, eine bedeutende Granatindustrie sich entwickelt hat. Hier strömen die Granate der camzen Velt zusammen und werden im Verein mit den einheimischen und mit allen möglichen anderen Edelsteinen und IIalbedelsteinen geschliffen und zu Schmucksachen verarbeitet. Die aus Böhmen selher stammenden Granate gehören allerdings zum grö̈ßten Teil nicht zum Almandin, sondern zum Pyrop, es gibt aber dort auch schleifbaren Almandin, der besonders im aufgeschwemmten Lande in der Gegend ron Kiuttenberg und Kollin gefunden und gewonnen wird. Danach werden diese Steine auch als „Kolliner 
Granaten" bezeichnet. Wichtig ist das Vorkommen nicht, ehenowenig wie die anderen cmropäischen Almandine, so die von Mittelwald im Rohoznabach in Cngarn, zuweilen von ansehulicher firible dir von Alicante in Siranion und manche andere, die arelegentlich erwähnt und verarbeitet werden.

\section{Pyrop (böhmischer Granat).}

Der I'yrop oder böhmischo Granat ist durch eine prachtwolle, leuchtende, dunkelblutrote Farhe ausgereichnet, die stets einen unverkemubaren stich ins frelbe hat (Taf. XIV, Fis. 5 u. 6) und die zuweilen sogar fast his zum Iyacinthrot selit. Violette Töne sielit man hier nie. Man ist also bei einem ins Violette gethenden Granat sicher, Almandin vor sich zu haben, bei anderen Nuaneen kann es zweifelhaft sein, ob Pyrop oder Almandin vorlinent. Wegen des gelleen Seheines der Farbe wird auch der Pyrop zum Vermeillegranat frerechnet, ja manche praktische Edelsteinkenner bezeichnen nur den Pyrop nit diesem Namen. Daf anch er früher mit unter Karfunkel verstanden wurde, ist hüchst wahrscheinlich. Auch der P'rop ist manchen Ruhinen in der Farbe sehr ähnlich, kann aber anf dieselbe Weise durch Lntersuchung der Lichthreehung und des Dichroismus erkannt und ron diesen unterschieden werden, wie der Almandin, ebenso durch das spezifische (iewicht, das aber lier nicht höher, sondern niedrigner ist als das des Rubins, es beträgt nur $3,6 ! 3-3,-$. . Hierdurch unterscheidet sich, wenn nicht schon durch die Farbe, der Pyrop auch sicher von dem erheblich schwereren Almandin, dessen spezifisches Gewicht zwischen 4,1 und 4,3 schwankt.

Dor Pyrop ist in der Inuptsache ein Magnesiatongranat, doch ist er liomplizierter zusammengesetzt als die anderen schon betrachteten Granate, da er neben der Magnesia nicht unerbebliche Iengen ron Kalk, Eisenoxydul und Manganoxydul und endlich auch meist ron Chromoxyd enthïlt. Auf dem kleinen Eisen- und Mangangehalt, vielleicht auch auf dem Chromgehalt beruht die beinahe stets recht tiefe und gesättigte Farbe.

Im Gegrensatze zu fast allen anderen Granatarten findet sich der Pyrop so sut wie nimuals in deutlichen Kristallen; nur wenige solche sind bisher gefunden worden, und zwar haben diese, ebenfalls anders wie sonst beim Granat, eine lirummflächige Würfelform. Meist bildet der Pyrop unregelmäßige Körner mit rauher matter Oberfliiche, aber ;) Hinzendem muscheligen Bruch. Die anderen Eigenschaften stimmen aber mit denen, die smnst beim Granat vorkommen, üherein. Die Härte ist etwas größer als beim Quarz II. $=7^{1 / 1}$ ); das Lichtbrechungsvermögren ist bedeutend (Brechungkoëffizient gleich 1, für rotes Licht, gröber als bei irgendeinem anderen roten Granat) und die Lichthrechung vollkımmen einfach olıne jede anomale störung. Abweichend ist dagregen wieder, daf der Pyrop vor dem Lötrohr sehr schwer und nur an den feinsten Spitzen schmilzt, und zwar zil einem magnetischen schwarzen Glas. Er unterscheidet sich dadurch von allen anderen roten Granaten, die såmtlich leicht schmelzbar sind.

Der Pyrop ist meist rollkommen klar und durchsichtig, soweit es die dunkle Farbe Festattet. Der von Bühmen ist durchgängig und ohne Ausnahme von idealer Reinheit; $\because$ ist das einzige Edelsteinvorkommen, wo alle Steine gleich frei sind von fremden Einschliissen und Verunreinigungen. Auch durch Risse, wie bei anderen Granaten, ist die Klarheit selten gestürt. Beim Erhitzen werden die Körner, ähnlich wie der Almandin, undurchsichtig und schwarz, beim Erkalten kehrt aber, anders wie bei diesem, die ursprüngliche Durchsichtighkeit und die schöne rote Farbe ganz unverkïrzt wieder.

Was das Torkommen des Pyrops anbelangt, so ist er stets an Olivingesteine oder den daraus durch Umwandlung entstandenen Serpentin gebunden. In diesen Gesteinen ist er in Form unregelmäßiger Körner eingewachsen, wie z. B. an Granatherg bei Petschau 
in Böhmen, bei Zühlitz in Sachsen, woher das in Taf. XIV, Fig. 5, abgrebildete Stück stammt, und an vielen anderen Orten. Aus diesem festen Gestein wird aber der Pyrop, wenigstens in Europa, nicht gewonnen, nur aus dem lockeren Verwitterungsprodukt, so an zahlreichen Orten im nördlichen Böhmen, von wo der zeitenweise außurordentlich behebte Pyrop, der daher so genannte böhmische Granat, fast ausschließlich herstammt. Hier ist auf frund und aus Veranlassung dieses anderwärts kaum irgendwo in ähnlicher Weise bekannten Torkonmens eine wichtige Industrie entstanden, die aher jetzt nicht mehr bloß die in Lande gefundenen Granate verarbeitet, auch nicht bloß Pyrop, sondern die Crranate der verschiedensten Arten aus allen Teilen der Erde, aus dem Zillertal, aus Ostindien, Ceylon, Kleinasien, Australien, den Vereinigten Staaten, von Grönland usw. einführt und daneben auch alle möglichen anderen Edelsteine, mit einziger Ausnahme des Diamants, in ibren Bereich gezogen hat.

Die bühmische Granatschleiferei ist sehr alt, hat sich aber mit der Zeit vermindert und erst Ende des 18. Jahrhunderts einen neuen Aufschwung genommen. Dieser fiel zusanmen mit der Zeit, als die böhmischen Bäder Karlsbad, Teplitz usw. anfingen, Weltbäder zu werden und Tausende von Fremden alljührlich dort zusanmenströmten. Die Badexisiste brachten die niedlichen Granatschmucksachen mit nach Hause, und es dauterte nicht lange, so war ein wichtiger Exportartikel daraus geworden. Wie bedeutend dieser Industriezweig geworden war, sieht man daraus, daß darin noch vor kurzem in Böhmen ungefähr 3000) Granatschleifer, einige Hundert Granatbolser, und in etwa 500 Goldund Silberschmieden 3500 Schmuckarbeiter beschäftigt wurden. Rechnet man hierzu die etwa 350 bis 100 Arbeiter, die in Bühmen den Granat gewannen, und alle die zahlreichen sonst in dieser Industrie und in deren Nebenzweigen in verschiedener Weise tätigen Personen, so kann man wohl sagen, daß 9-10000 Menschen ihren Lebensunterhalt diesem Edelstein verdankten. Gegenwärtig lieğt die Industrie aber allerding's sehr darnieder, da sich die IInde von dem Granat gänzlich abgewendet hat. Granatschmuck ist zur Zeit unmodern.

Die Schleifereien befinden sich zum kleineren Teile in Prạ, sehr zahlreich sind sie dagegen namentlich in der Gegend zwischen Reichenberg und Gitschin, wo die Orte Rovensko, Semil, Sobotka und Lomnitz zu nennen sind. Weitaus am wichtigsten ist aber Turnau an der Iser; hier ist der Hauptsitz der Industrie, und hier hat daher auch die Regierung eine Fachschule für die Bearbeitung und Fassung der Edelsteine eingerichtet. Übrigens finden sich auch einzelne Schleifereien jenseits der Grenze, so u. a. in Warmbrunn in Schlesien und an anderen Orten. Geschliffen werlen die Granate vielfach auf kleinen Scheiben von feinkörnigem Sandstein mit Schmirgel und Öl.

In jenem Bezirke kommen zwar Granate vor, so bei Neu-Paka etwas östlich von Gitschin, wo die wenigen Kiristalle, die bisher rom Pyrop in Böhmen bekannt geworden sind, gefunden wurden. Die hauptsïchlichsten Gewinnungsorte, die das Material für die Schleifereien so gut wie ausschließlich liefern, liegen aber in ziemlicher Entfernung nach Westen am Südahhange des böhmischen Mittelgebirges und nördlich vom Egerfluf, sowie westlich ron dem Stiildehen Trebnitz (südwestlich von Leitmeritz). Die granatführende Sehicht ist dort iiber eine Fläche von mehr als $70 \mathrm{gkm}$ ansgebreitet, und etwa auf dem zehnten 'Teil derselloen ist das Vorkommen ein reichliches. Ein ganz isolirter Fundpunkt ist der Stiefelberer bei Meronitz, sodann in einigree Entfernung östlich davon der cröbere Bezirk, der die Umgebung von ('hodolitz, Dlaschkowitz, Podseditz, Chrastian, Trzemschitz, Starrey, Leskay, Schöppenthal, Schelkowitz, Trziblitz und Sollan umfaßit. Im Jahre 1590 waren hier in diesem eranatreichen (xebiete 1.2 Eigentïmer von Granatfeldern vorhanden, die mit 362 Arbeitern für etwa 80000 Gulden Steine gewannen. Mit dem Granathandel befaliten sich 17 l'ersonen. Seit dem Jahre 1890 ist die Gewinnung der Granate aus 
dem angegebenen Grunde wesentlich eingeschränkt worden. Die Nachfrage ist zurzeit sehr

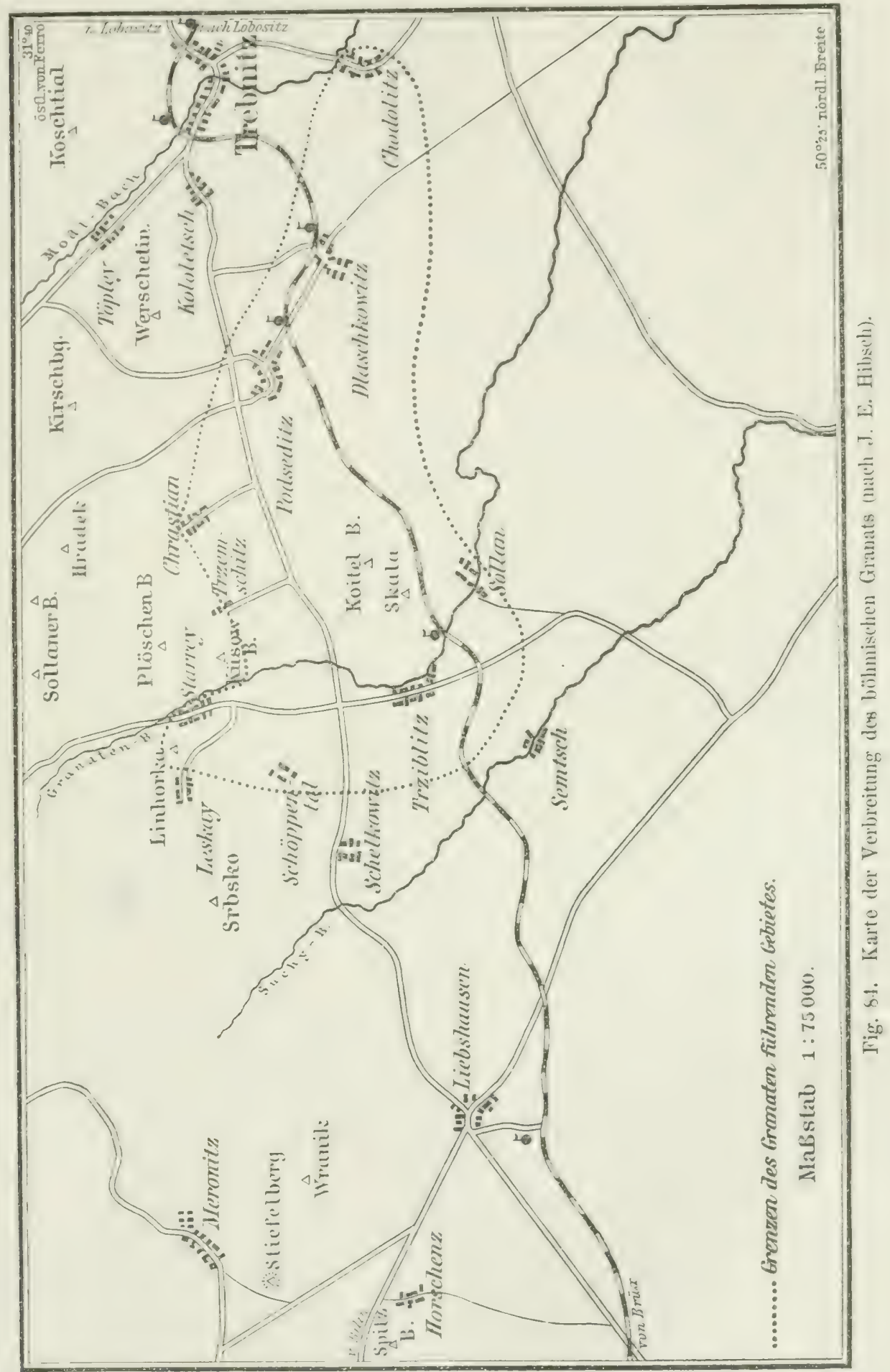

gering und die Preise sind gedrückt. Gegenwärtig (Frühjahr 1908) befassen sich nur noch vier Personen mit dem Aufkauf ron Granat im Gebiete, und der Wert des im letzten 
Halbjahre (Herbst 1907 bis Frihjahr 1908) gewonnenen Materials betrug nur etwa 9000) Kronen, während im Betriebsjahre 1857/88, in der Zeit der hö̈hsten Blüte der Granatindustric. jälırlich Steine im Werte von 400000 Kronen gewonnen worden waren. Infolge dieses frïheren starken Bedarfs soll auch eine gewisse Erschöpfung der Lagerstätten eingetreten sein.

Die Pyrope liegen meist in einem tonigen und sandigen Kies orler Schotter, der dem Diluvium angehört und der auf den Schichten der Kreideformation ruht. In diesem Schotter sind lose Granatkürner in grofer Zahl frei von allem Muttergestein eingeschlossen, man findet aber auch solche in einem braunen Halbopal, der in Stiicken bis zu Kopfgrïle aus dem das ursprüngliche IInttergestein bildenden, jetzt fast vollkommen zersetzten Serpentin durch Umwandlung entstanden ist, und in dem auch oft noch Überreste dieses Serpentins erhalten geblieben sind. Die Granatkörner in dem Opal sind nicht verwendbar; gesammelt und geschliffen werden fast nur die, welche lose in dem Boden liegen.

Die Schotterablagerungen, die den Pyrop beherbergen, sind an den zahlreichen Stellen ihres Vorkommens etwas verschieden. Bei Chrastian liegen auf den Verwitterungsletten der Tommergel der oberen Kreideformation (Oberturon, Stufe des Inoceramus Cuvieri) $4 \mathrm{~m}$ Pyropschotter mit gelbbraunen, tonigem Bindemittel, darauf folgen $2 \mathrm{~m}$ Pyropschotter mit lichtgrauem, lettigem Bindemittel und das Ganze wird von der $1 \mathrm{~m}$ mächtigem Ackerkrume bedeckt. Bei Meronitz hingegen treten die Granate in einer basaltischen Eruptivbreccie auf, die einen Eruptivschlot erfüllt. Außer einzelnen losen Granaten finden sich als Einschlüsse in der Breccie Brocken von mehr oder weniger zersetztem Serpentin mit frischen Pyropen und verschiedene Varietäten von Granulit. Die Eruptivbreccie setzt als zylindrischer Körper senkrecht in die Tiefe. Hier wurde bis vor 50 Jahren das granatführende Gestein bergmännisch gewonnen. Aus der zerdrückten Masse sammelte man dann durch einen Waschprozeß die Granate. Hente ist ist in Meronitz die Granatgewinnung vollständig eingestellt. Gegenwärtig kommt für die Gewinnung der Pyrope in Betracht nur noch das oben genannte, zwischen den Dörfern Schelkowitz, Starrey, Chodolitz und Sollan gelegene zusammenhängende Gebiet, in welchem der granatführende diluviale Schotter auftritt. Der aufgeschlossene Schotter erinnert in seiner Struktur einigermaßen an cine Grundmoräne; größere Gesteinsblöcke, insbesondere von Basalt, Geschiebe von Quarz u. s. w. liegen eng verpackt in einem sandigen oder tonigen Bindemittel. Letzteres schlielit die Granate und ihre Begleiter (Zirkon, Sapplir, Rubin usw.), sowie zahIreiche verkieste Kreideversteinerungen ein.

Auch die jetzt lose im Schotter der genannten Gegend eingebetteten Granate stammen aus einer basaltischen Eruptivbreccie, die den \#̈̈gel „Linhorka" zwischen den Dürfern Starrey und Leskay bildet. In der Breccie treten Einschliisse von Gneis, Glimmerschiefer und zersetztem Serpentin mit Granaten auf. Erst durch Zersetzung der sehr leicht verwitterharen Breceie und des Serpentins sind die Granate in die diluvialen Ablagerungen gelangt. Deshalb findet sich Granat in den Schottern nur von Leskay und Starrey ab)wärts in abnehmender Nenge bis zum Egerfluß.

Auf dem IIïgel "Linhorka" werden die Tuffe nach den granatführenden Serpentineinschlïssen, hier "Granatmuttergestein" genannt, durchsucht. Man gräbt zu diesem Zwecke mehr oder weniger tiefe Gruben. Im Jahre 1884 hatte man eine schachtartige Grube vom Gipfel des Berges bis über 50 Meter abgeteuft. Dabei waren Serpentinblöcke ron mehr als einem halben Kubikmeter Größe gefunden worden. Heute sucht man auf iler Linhorka nur in der Tiefe ron wenigen Metern nach dem granatführenden Serpentin. Auberdem werden Granate aus dem oben beschriebenen Diluvialsehotter südlich von Starrey gewonnen. Aus der lockeren Schottermasse und der den Schotter bedeckenden 


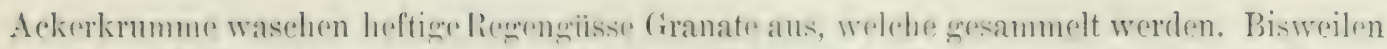

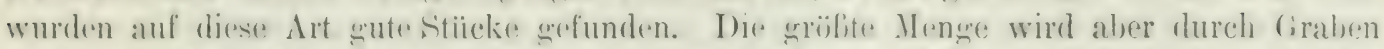

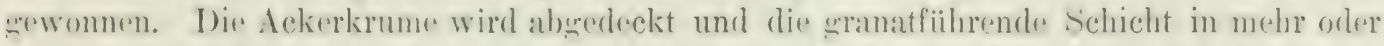
weniger tiefen Löchern auferestucht, die wieder zugeworfon werden, wenn das darm ront-

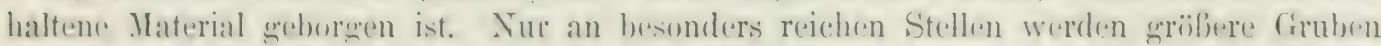
lerrestellt, und es wird auch wohl erenentlich ein kloiner unterirdischer beremännischer

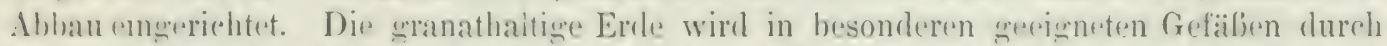
Waschen rom den leichtesten tonigen Teilehen befreit, die Strine auscrelesen und durch

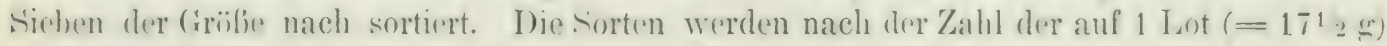

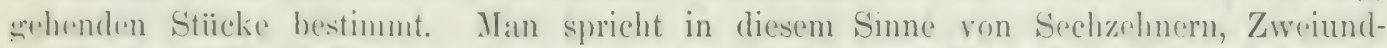
dreibigern, ILundertern usw. je nachdem 16, 32, 100 Steine 1 Lot gerben. Die meisten sind sehr klein, so dals 500 und mehr auf 1 Lot gehen. Solche, von denen 400 ein Lot wexen, sind noch :ublierst zahlreich und wenig wert. Reiskorngröbe dagergen wird schon gern gesehen, Erbsengröbe kommt nicht jeden Tag ror, und bis ein Stein von der fröble riner Haselnuß grefunden wird. können mehrere Jahre vergehen. Man rechnet, da\} auf $100 \mathrm{~kg}$ Granaten 2-:3 Dreilimer und auf $2000 \mathrm{~kg} 1$ Sechzehner kommt. Lin $1896 \mathrm{ge}-$ fundener Stein von $1 / \mathrm{s}$ Lot wurde als etwas Besonderes hervorgehoben.

Hirraus ist zu ersehen, daß grö̈fere Granate zu den Seltenheiten gehören, doch sind wenigstens einzelne yon bedeutenderem Umfang bekannt geworden. So erwähnt Boëthius de Boodt in seiner 1609 erschienenen IHistoria gemmarm einen in Besitz des Kaisers Rudolf IT. befindlichen taubeneigrolien Pyropl, dem er einen Wert von 45000 Talern beilegt. Noch jetzt bewahrt die k. k. Schatzkammer in Wien einen ausgezeichneten Stein ron der Gröle eines Hïhnereies, und im Grünen Gewölbe in Dresden befindet sich ein soleher ron $35 \mathrm{~mm}$ Längere is num Breite und $27 \mathrm{~mm}$ Höhe, also etwas gröber als ein Taubenei und im Gewicht von $468 \frac{1}{2}$ Karat, der in einen Orden des goldenen Vließes gefaßt ist.

Da alle böhmischen Pyrope gleich schön und rein sind, so hängt ihr. Wert fast nur von der Größe ab. Kleine Steine sind sehr billig, der Preis steint aber sehr bedentend mit dem Cewicht, wie aus den erwähnten Größenverhältnissen ron selbst hervorgeht. Del böchste Preis für einen in den letzten Jahren gefundenen rohen Stein soll aber 50)( Gulden nicht überstiegen lıaben. Boëthius gibt an, dab größere Steine den Preis des Tibins erreichen; heututage ist dies jedenfalls nicht mehr der Fall, trotzdem das Aussehen, wenigstens was die Farbe betrifft, nicht weit hinter dem mancher Rubine zurïcksteht. Böhmische Pyrope vom Gewicht von 1/16 Lot (etwas über 1 Gramm, sog. Sechzehner), werden heute im Granatgebiet vom Mändler mit 60 bis 100 Kronen pro Stiick bezahlt, je nach der Form und sonstigen Beschaffenheit. Für Granate, ron denen 24 Stiick 1 Lot wiegen (sog. Vierundzwanziger), gibt man nur 6 bis 8 Kronen.

Die allerkleinsten Körnchen werden nicht als Schmucksteine verwendet, sie dienen zum Tarieren beim Wiegen mit feinen Wagen, zur Iterstellung von Schleifjulver und sosar als Ziersand für Gartenwege. Man sieht hieraus, in relcher Massenhaftigkeit sie vorkommen. Erst von einer gewissen Größe ab werden sie geschliffen. Die im rohen Zustande unansehnlichen Steine erlangen dadurch ihre leuchtende Farbe, die um so prächtiger hervortritt, je kleiner der Stein ist. Die Gestalt, die der Pyrop erhält, ist mannigfaltig, fast alle bekannten Schlifformen werden bei ihm angewendet. Sehr häufig ist hier, wie beim Almandin, die mugrelige Form, meist unten ausgeschlägelt und nit oder olıne Facetten am Rande. Auf der runden Oberflïche spielt dann von dem dem Lichte zugekehrten Punkte aus ein besonderes feuriges Rot. Noch gewöhnlicher ist aber der Schliff mit Facetten: Tafelsteine, niedere Treppensteine mit nicht zu wenig Stufen. häufig wie bei den anderen Granaten mit rundlicher Tafel; auch Brillanten und Rosetten sieht man häufig; ebenso Phantasieformen, an denen die Facetten ohne bestimmte Regel angeordnet 
sind. Das Fassen geschieht entweder in schwarzen Kasten mit glänzender Kupfer- oder Silberfolie, odter en paré, d. h. zahlreiche Steine werden mit Stiftchen über Löchern in der Metallplatte befestigt, die die Grundlage des ganzen Schmuckstückes bildet, so daß sie dicht gedrängt nebeneinander stehen. Durchbohrung kommt hier mehr vor als bei anderen Granaten. aber nur bei kleinen Steinen, die dann ringsum symmetriseh angeordnete Facetten erhalten und auf Schnüre aufgereiht werden.

Aufer den böhmischen werden nur noch wenige andere Pyrope geschliffen, so in Europa die von Ely in Five in Schnttland, die sogenannten "Ely-Rubine“, die aber nur lokale Bedeutung haben. Wichtigrer ist das Vorkommen im Westen der Vereinigten Staaten, besonders in Arizona, Neu-Mexiko und im südlichen Colorado, wo die Granate, wie sonst so vielfach, sleichfalls für Rubine gehalten und als solche bezeichnet worden sind; es sind die ,Arizona- und Colorado Rubine“ des dortigen Handels. In Neu-Mexiko findet man eckige und abgerollte Körner im Sande bei Santa Fé. Das Hauptvorkommen ist aber zusammen mit Olivin und Chromdiopsid in der Reservation der Navajos-Indianer. Der Pyrop wird hier von den Indianern aus dem Sande der Ameisen- und Skorpionenhaufen ausgelesen und auch mittels Steinen aus dem Muttergestein herausgeklopft. In Arizona kommt er ebenfalls lose im Sande und im nordöstlichen Teile des Staates auch im Gestein vor und wird in der gleichen Weise von Indianern, sowic gelegentlich ron den dort stationierten Soldaten gesammelt und verkauft. Die rundlichen oder eckigen Körner sind 1,4-1, Zoll groß, solche von $1 / 2$ Zoll sind rar. Die Qualität ist im allgemeinen gut; die Hälfte der Funde ist schleifwürdig, ein Viertel liefert gute Steine, aber sehr feine finden sich recht selten, namentlich solche über 3 Karat. Viele enthalten ein Netzwerk feiner Nïdelchen, wahrscheinlich von Tutil. Im Durchschnitt sind sie kleiner als die gleich zu besprechenden sog. Kaprubine. Beide sehen bei Tage gleich schön aus, aber bei künstlicher Beleuchtung sind die amerikanischen diesen afrikanischen Steinen ïberlegren; ihre Farbe gewinnt im Kerzenlicht, während die Kaprubine etwas dïsterer werden. Die Verwendung der sog. "Arizona- und Coloradorubine" ist ziemlich ausgedehnt; weniger ist dies mit den Pyropen der Fall, die in den Goldwäschereien der Grafschaften Burke, Mac Dowell und Alexander in Nord-Carolina und an noch anderen Orten in den Vereinigten Staaten vorkommen. In der Stadt Brooklyn hat man kürzlich bei einem Tunnelbau in einem zersetzten Serpentingestein schleifbare Pyrope gefunden. Gering ist auch die Bedeutung der mexikanischen Pyrope, die im Staate Sonora bekannt sind, und die in derselben Weise wie in Arizona in Chihuahua, besonders am JacoSee vorkommen, wo sie von den Commanches-Indianern gesammelt werden.

Einer der schönsten aller Granate ist der dunkelblutrote Pyrop, der die Diamanten im Kaplande in Südafrika begleitet. Auch er wurde anfïnglich für Rubin gebalten und längere Zeit als solcher ausgegeben und verkauft, daher führt er noch jetzt den Namen Kaprubin; er ist der Stein, von dem oben im Torbeigehen schon mehrfach die Rede gewesen ist.

Der Liamant wird am Kap von verschiedenen Granaten begleitet. Man findet nicht selten tief weinrote und hyacintlirote ungefähr von der Farbe des Iressonits, auch farblose, brïunlichgellse und scolbe, häufig violette und gesättigt blutrote. Letztere sind die geschätzten Kaprubine, die allein von allen geschliffen werden. Wie die oben angeführten Analysen zeiggen, sind die sämtlichen roten Granate, die mit dem Diamant am Kap vorkommen, von dem böhmischen in der Zusammensetzung kaum verschieden. Es sind etwas Mangan- und Eisenoxydul enthaltende Magnesiatonerdegranate wie der Pyrop aus Böhmen mit einer gewissen Annäherung an den Nlmandin. Zum Pyrop ist also wohl der Kaprubin zu rechnen und keinesfalls zum Almandin, wie es fälschlicherweise vielfach aeschicht. Dies zeight ebenso sein spezifisches Gewicht, das 3, bi beträgt, während 
TAFEL XIV.
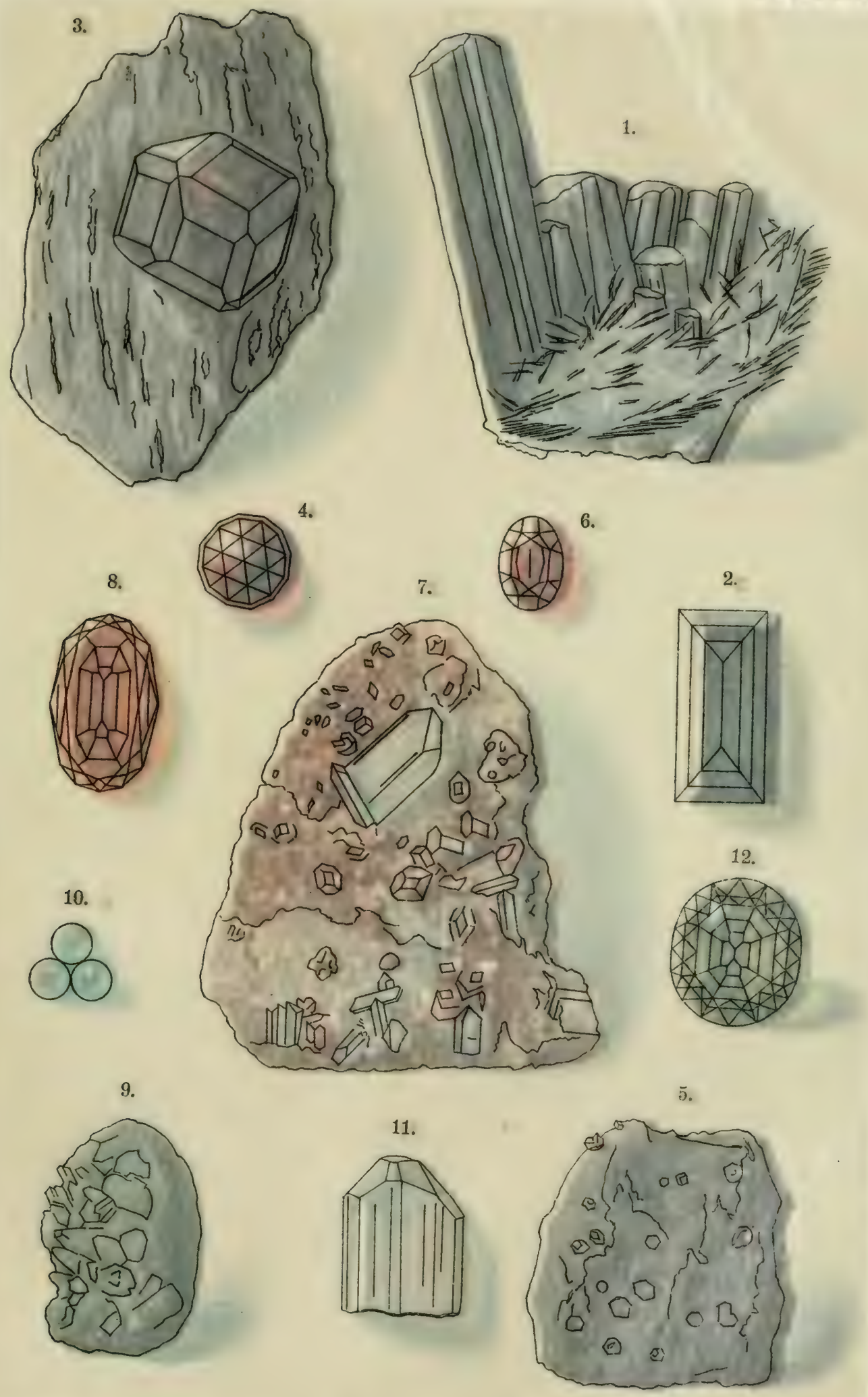

1. Epidot (Krystall, Knappenwand). 2. Epidot (geschliffen). 3. Almandin (Krystall). 4. Almandin (geschliffen). 5. Pyrop (böhmischer Granat, im Gestein). 6. Py rop (Kaprubin, geschliffen). 7. Kaneelstein (Krystalle, Mussaalp in Piemont). 8. Kaneelstein (geschliffen). 9. Demantoid (roh). 10. (Dem an toid (geschliffen). 11. Chry solith (Krystall). 12. Chry solith (geschliffen). 


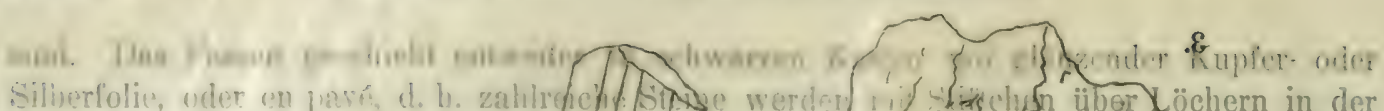

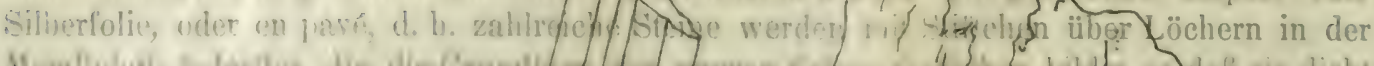

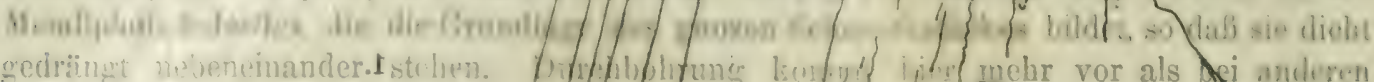

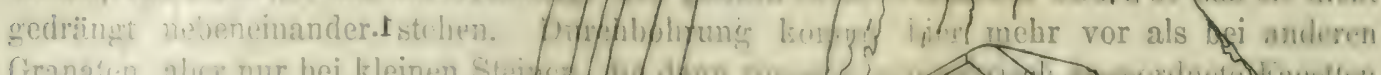

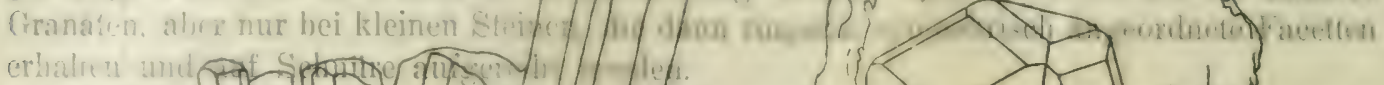

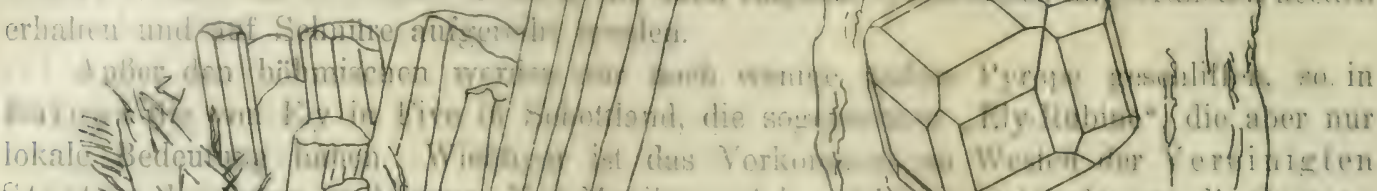

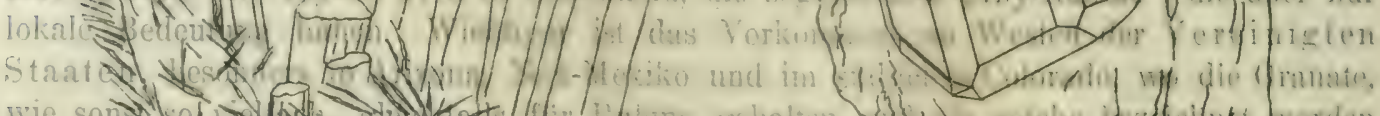

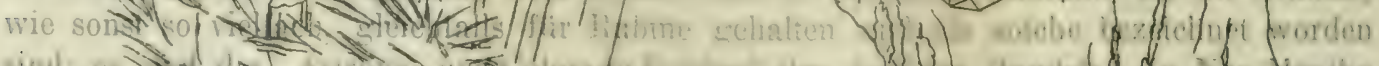

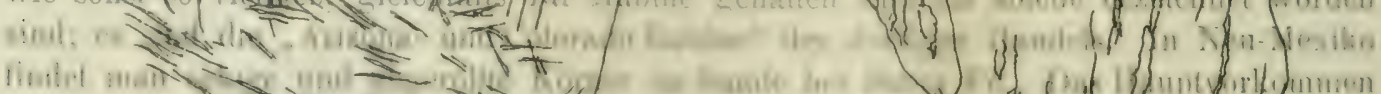

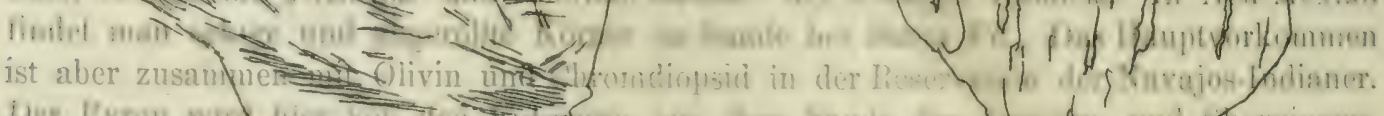

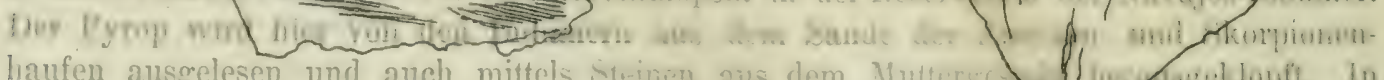

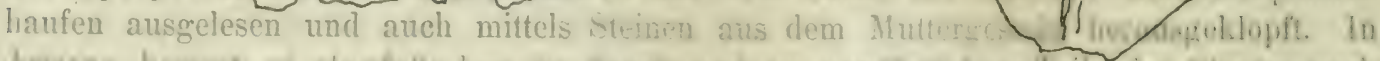

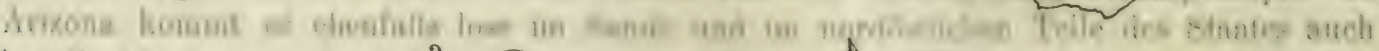

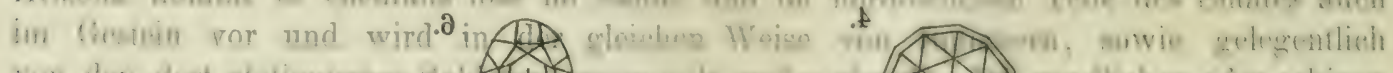

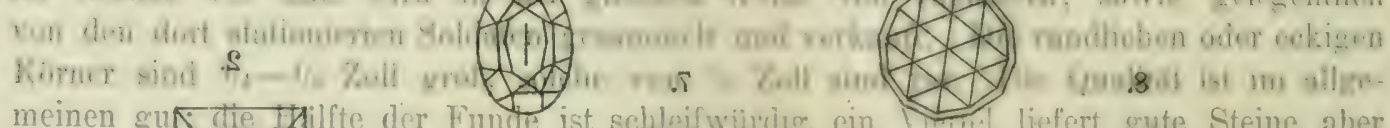

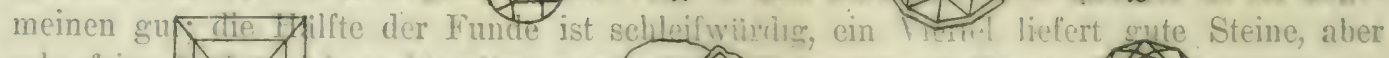

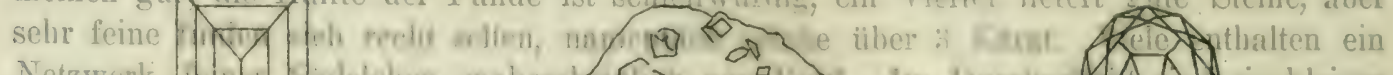
Netzwerk 14 : : Whblom, wahrghl,

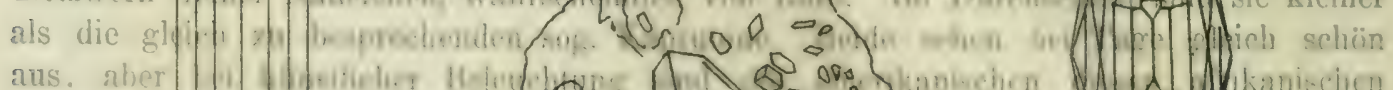
aus. aber $\left\{\begin{array}{l}000 \\ \text { sol }\end{array}\right.$

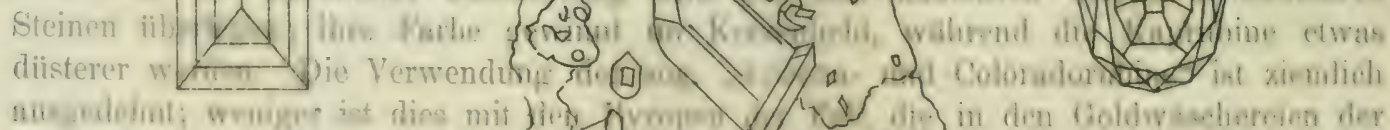

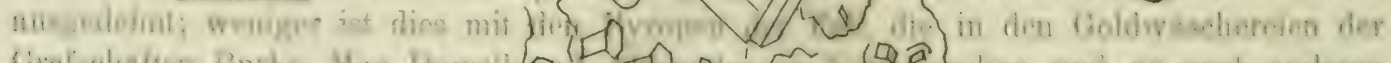

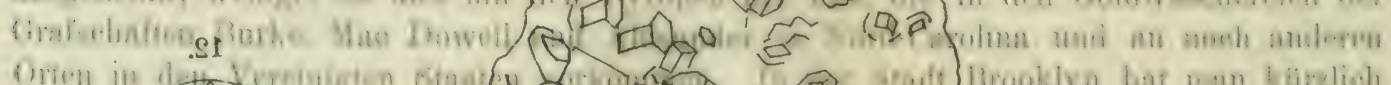

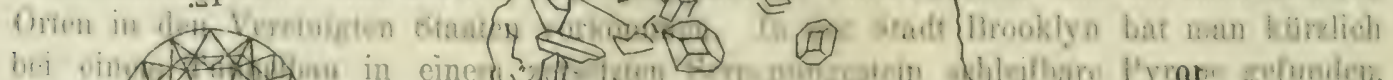
bring in cine

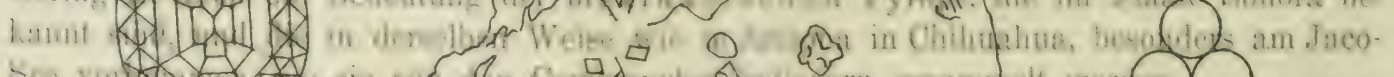
Ba. xom 28

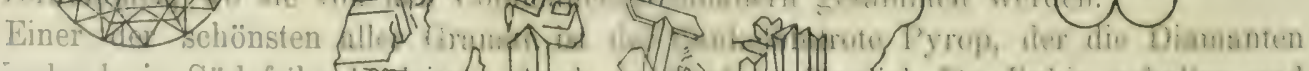

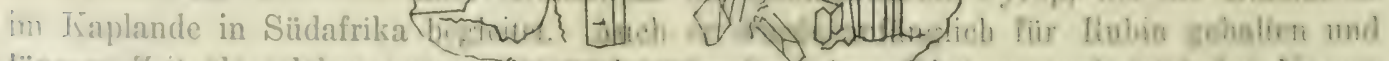

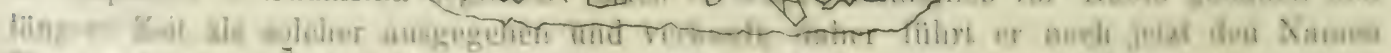

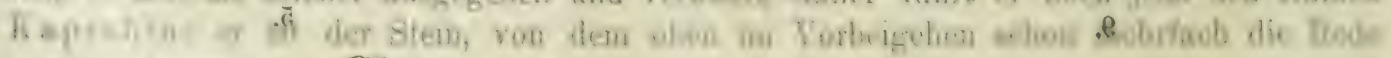

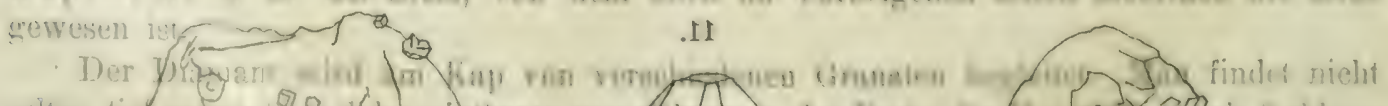

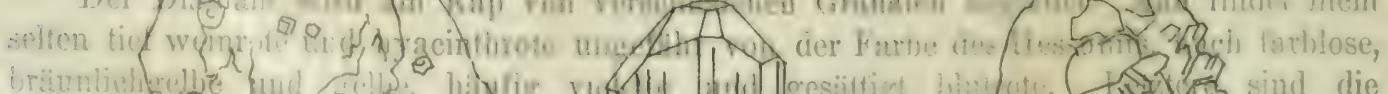

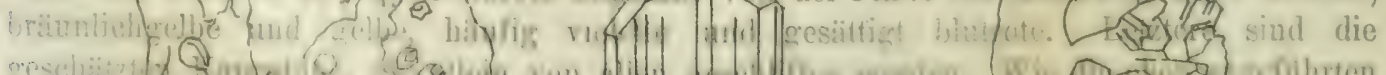

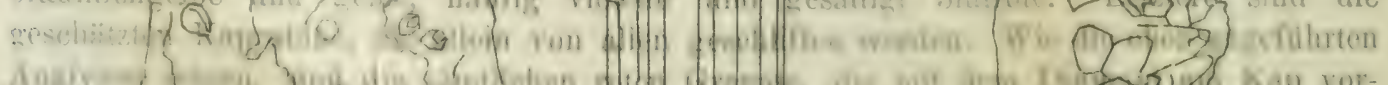

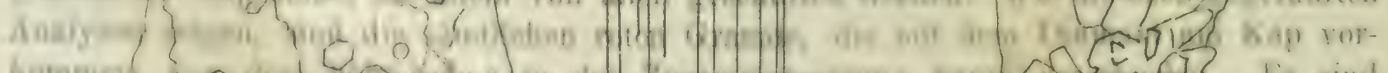

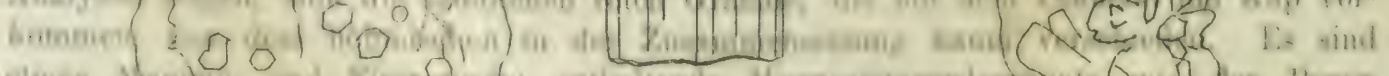

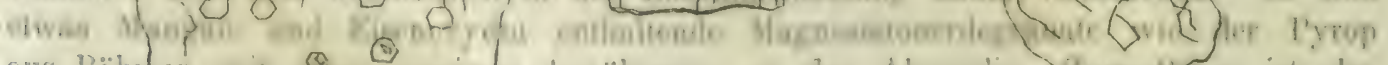

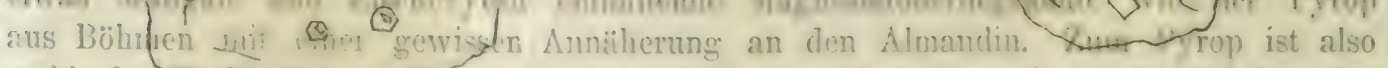

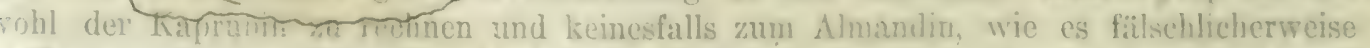

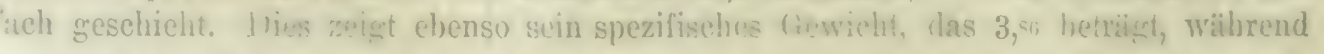

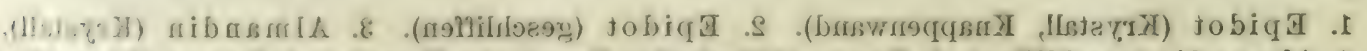

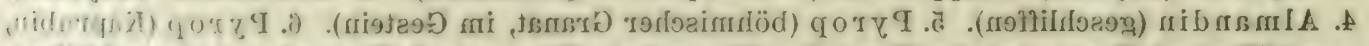

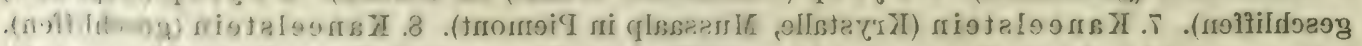

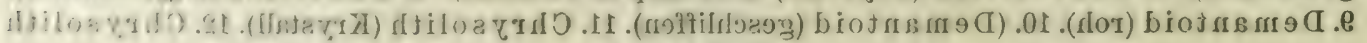


TAFEL XIV.
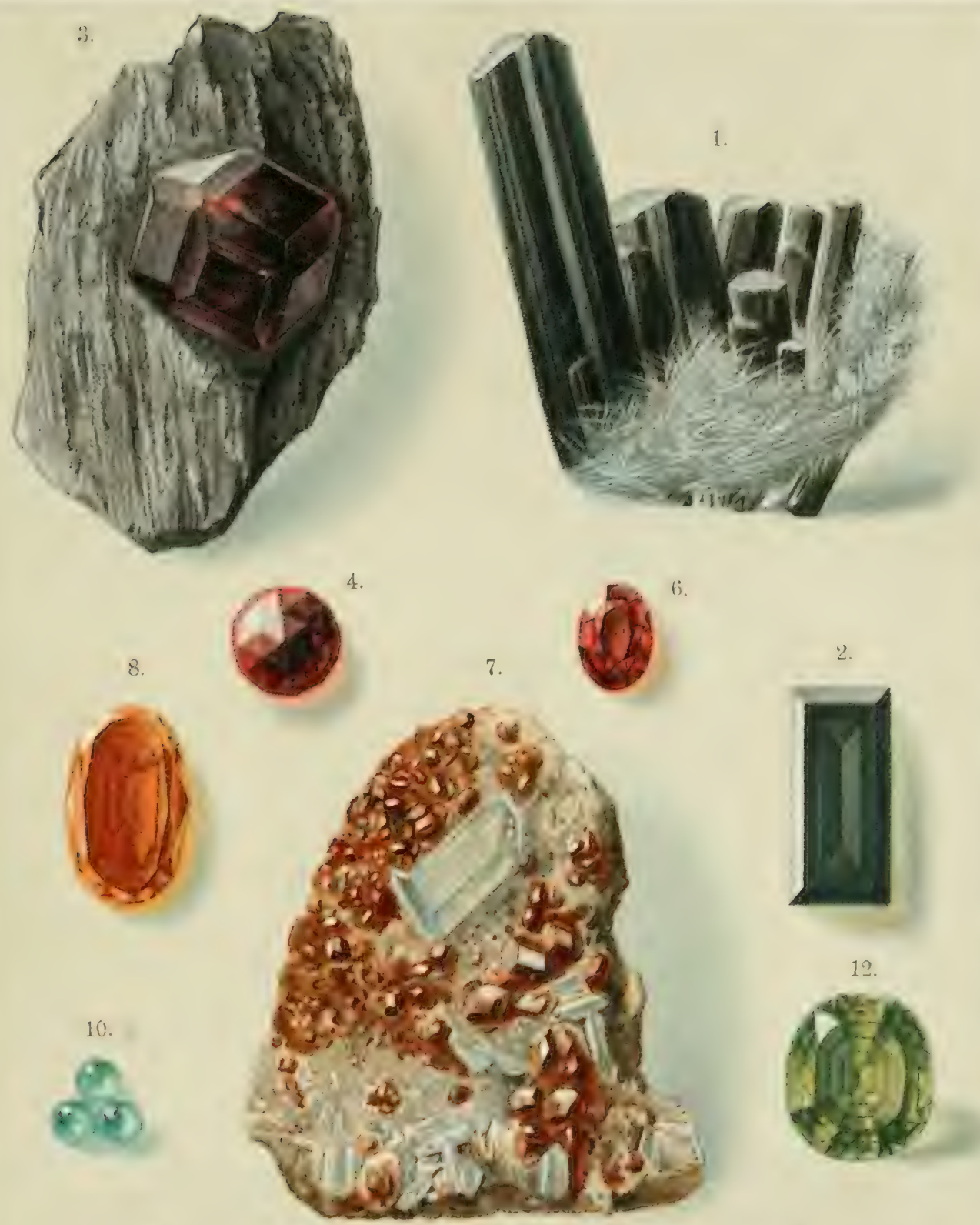

2.

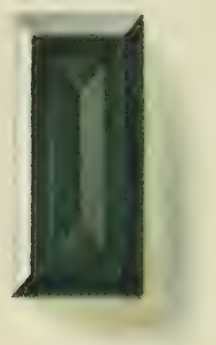

12.

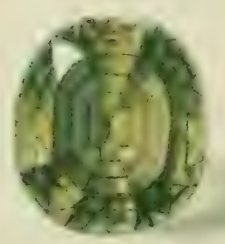

5.
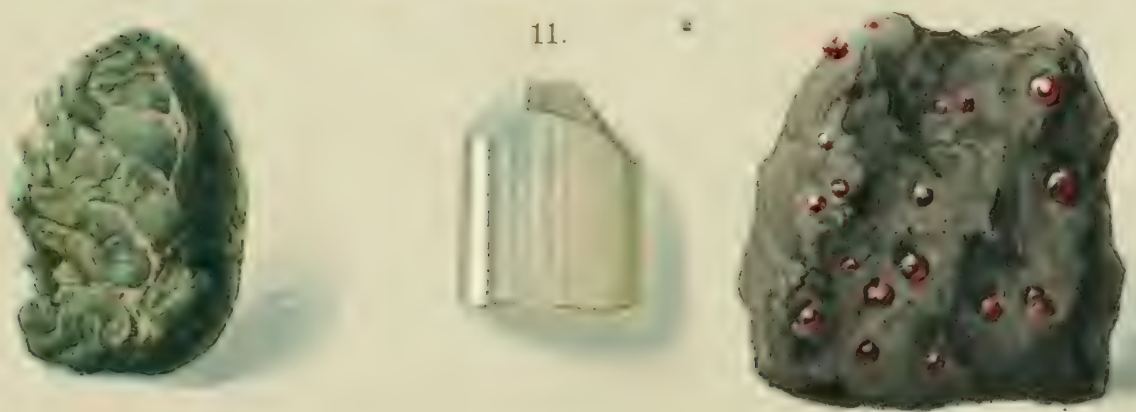



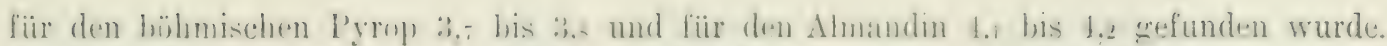

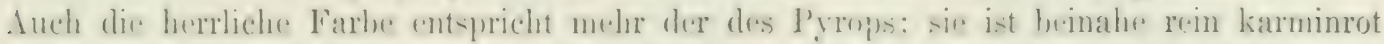

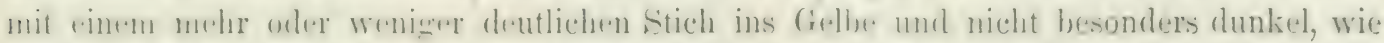

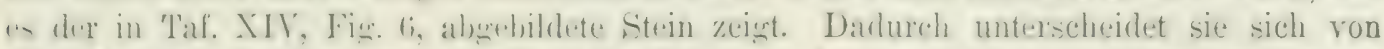

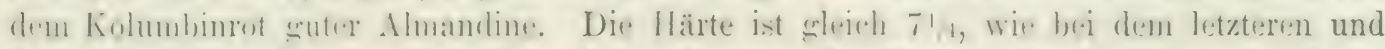

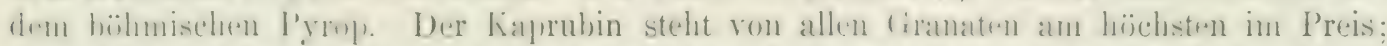
won nicht zn klemen Stiicken beser Qualitait wird ein Karat mit wwa 2 Mark bezahlt.

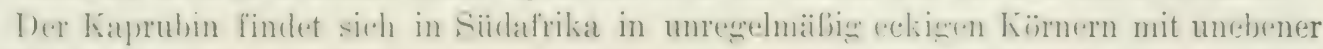
Oberfläche in dem diamantführenden Gestein, dem "blue ground" und dem nyellow

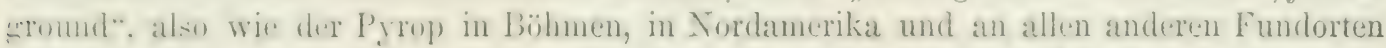
in einem olivin- resp. Serpentingestein. Er ist in weit geringerer Menge vorhanden als

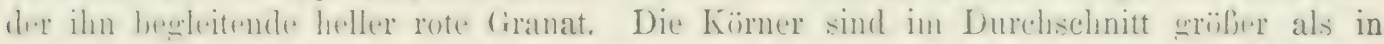

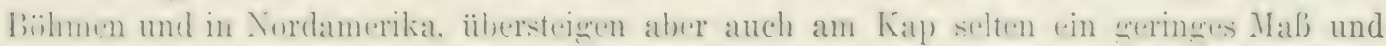

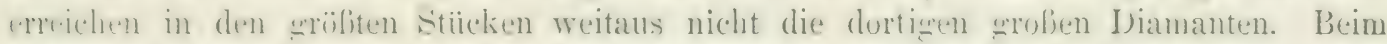

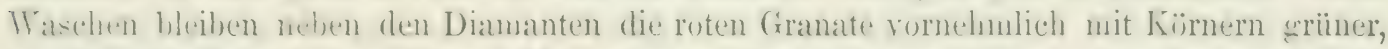
zur Familir des Ausits we höriger Mineralien zurïck, und aus diesen schön bunten Waschribliständen, den concentrates, werden dann die wenigen Kapmubine auscelesen. Verhält-

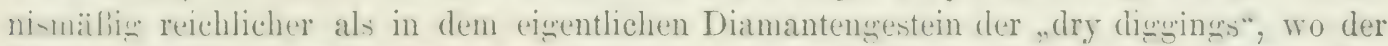
Strin immerhin als Seltenheit anzusehen ist, aber auch hier nicht gemein, ist das Vorkommen des hatprubins in den diamantführenden Sanden und Kiesen des Vaalflusses, in den ..river dimenes." Bei der Diamantwäscherei werden die Steine als Nebenprodulit hier wie in den .. dry diggings" grewomnen. Die Steine aus dem Taal sind manchmal so glatt und gleichmäßig abgerollt, daß sie wie poliert aussehen.

An den Kaprubin schließt sich der um die Jahrhundertwende in Deutsch-Ostafrika gefundene auserezeichnete Granat an, der in der Zusanmensetzung sich kaum von dem dunkelroten Kaprubin der obigen Tabelle S. 133) unterscheidet, und der auch das niedrige spezifische Gewicht $(G,=3, \rightarrow i)$ der Pyrope zejogt. Der Fundurt liegt im Finterland ron Lindi in ler Landschaft Namaputa, wenig nördlich rom Roruma unter 39" üstl. Länge und etwas südlich vom 11. Breitegrad, am rechten Ufer des in den Rovuma mündenden Muitibaches, der den Westabhang des Makonde-Plateaus entwässert, westlich von Newala. Der Granat führende Bezirk ist Luisenfelde senaunt worden. Iier liegen zahlreiche meist bis hastelnufgroße, nicht selten auch noch erhehlich griifere, lis kartoffelzrolje Stïcke lose herum oder stecken im Boden in der Verwitterungskrume des Muttergesteins. eines Hornblendegneises, in dem man sie auch eingewachsen beobachten kann. Die hier gesammelten Granate sind meist sehr schün durchsichtig und die Farbe ist kolumbinrot mit einen stich ins Braunrot oder ins Gelbe, auch nicht selten rein Karmin und nicht zu dunkel. sodab auch noch grobe Steine genügend durchsichtig sind. Die Farbe, hald etwas heller mit Nejoung zu der des Almandin. bald etwas dunkler mit Jeigung zum l'yrop, tritt beim Schleifen sehr schön hervor. und es ze'set sich, daf sie in kïnstlicher belenchtung nicht nur nicht verliert, sondern eher gewinnt. Ebenso erhalten die Steine durch das Schleifen einen sehr kräftigen Glanz, so daf sie sich in ihren Edelstein(jegensebaften allen anderen Granaten entschieden iiberlegen erweisen. Da sich geschliffene Exemplare bis zu lo und 15 Karat ron wröbter Schönheit daraus herstellen lassen, so finclet die wesamte nicht geringe P'rodulition willige Abnehmer in den deutschen und den böhmischen Schleifereien, in denen dieses ausgezeichnete Vorkommen den Namen "Faschoda-Granat" erhalten hat. Auch ganz im Norden der Kolonie am Siidabhang.

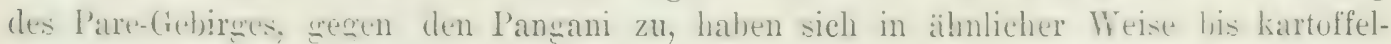
grofie Cramate gefunden, die aus Granit stammen. Sie sind aber zu dunkel und daher nicht zum Schleifen verwendbar.

$\mathrm{B}$ a u $е г$, Edelsteinkande. 2. Aufl. 
Gleichfalls dem Pyrop) in der Zusanmensetzung nahestehend, aber im Aussehen rersehieden ist der vor einigen Jahren entdeckte R hodolith. Er findet sich meist in Form abgerollter Stïcke unbekannten Ursprungs im Gewicht bis :3 1/2 Pfund mit Rubin, mit dem er zuweilen rerwachsen ist (S. 350) und anderen Mineralien im Cowee Valley, IIacon County, Nord-Carolina. Die Farbe ist rosenrot, zuweilen ziemlich dunkel, aber ohne das diistere Ansehen der meisten Granate, und auch bei künstlicher Beleuchtung vorteilhaft zur Geltung gelangend. Die Durchsichtigkeit ist vielfach vollkommen, so daß präichtige Steine erhalten werden können, allerdings meist nur kleine, aber man kennt doch auch solche von 59, 13, 25 und 23 Karat. Die Jahresausbeute betrug 1901 ungefähr 2000001 Karat, davon war aher nur ein kleiner Teil schleifbar, und hatte geschliffen einen Wert von etwas iiber 100000 Mark. Schon 1902 war dieser WVert auf 6000 Mark gefallen.

\section{Demantoid.}

Der Demantoid ist ein schöner grïner Edelstein aus der Gruppe der Kalkeisengranate, wie die Analyse in der obigen Tabelle zeigt. Die Farbe wechselt nach Art und Intensitiit vom schünsten Smaraggdgrün bis zum Bräunlich- und Gelblichgrün und bis zur annähernden Farblosigkeit. Einige der vorkommenden Nuancen sind in Fig 9 und 10 auf Tafel XIS an geschliffenen Steinen und an einem rohen veranschaulicht. Am verbreitetsten scheint ein lichtes Gelblichgriin zu sein. Die smaragdgrine Tarietait, zu der die obige Analyse sehört, zeigt einen kleinen Chromgehalt, der wohl die schöne Farbe hervorgerufen hat. Dagegren enthalten die heller und die gelblichgrün gefärbten kein Chrom; bei ihnen ist die Färbung auf Eisen zurückzuführen.

Der Glanz ist ein starker, etwas ins Fette gehender Glasglanz, der sich dureh die Politur noch wesentlich steigert. Die Durchsichtigkeit und Reinheit der Substanz ist meist vollkommen, das Lichtbrechungsvermögen ist sehr stark, und bei künstlicher Beleuchtung zeigt sich an greschliffenen Steinen häufig ein schönes Farbenspiel nach Art dessen beim Diamant.

Die Ïärte ist geringer als bei allen anderen Granaten; sie ist gleich 61,2 und erreicht also nicht ganz die des Quarzes. Das spezifische Gerricht beträgt $3, \varsigma^{3}$ bis $3, \uparrow .5$. Vor dem Lötrohr schmilzt der Demantoid nur in den feinsten Splittern zu einem schwarzen magnetischen Glase, und in Säuren wird er, abweichend von allen anderen Granaten, schon im natürlichen Zustande, ungeschmolzen, leicht und vollständig zersetzt.

Der Demantoid ist bisher fast nur im Ural gefunden worden. Entdeckt wurde er in den sechriger Jahren in Form von grimlichweiben bis beinahe farblosen Geschieben in den Goldserfen von Nischne Tagilsk. Später ist er auch im Syssertsker Bezirke am Westabhange des (rebirges an dem zum oberen Fluligebiete der Tschussowaja gुehürigen Bache Bobrowka, in etwa 10) Werst Entfernung südwestlich von dem Dorfe Poldnewaja oder 20) Werst sïdlich vom Hüttenwerk Polewskoy, sïdlich von Katharinenburg und ron Beresowsk, vorekommen, zuerst unter den Geschieben einer Goldwäsche, dann auch in deren Untergrund auf seiner ursprüinglichen Lagerstïtte im Mutterogestein. Nach diesem Fundorte hat er auch den Namen Bobrowka-Granat erhalten.

Ifier liegrt er mit Dolomit, etwas toniger Substanz und Magneteisen in vorwaltend Serpentinasbest fülırenden Klüften eines digentümlichen grauen bis grünlichgrauen Serpentinzesteins, zugleich aber auch mehr oder wenimer deutlich in diesem selbst. Der Granat ist in den Spaltenausfïllungen in dem holzartigen, den Kluftflïchen parallel gefaserten Serpentinasbest eingebettet und von Häuten desselben eingeschlossen, entweder in einzelnen unregelmäbigen Körnern, oder weit häufiger in 1, bis 2 Zoll groben rundlichen, äußerlich wenigr glämzenden, fettig und triib atusschenden Knollen mit unregelmälbig gestreifter und 
enefurchter Oberfläche, wie rine solche in Taf. XIV, Fir. 9, aberebildet ist. Diese Kinollen

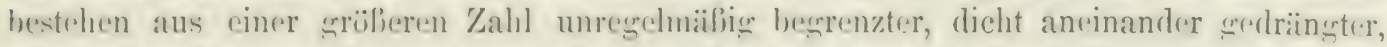
wie ineinander sepreliter, sanz regellos creordneter, aber stets durch serpentinhäute vonninander getrennter Kärner mit stark slänzendem, rollkommen muscheligem Bruch. In der Regel erscheinen die knollen durch ticfer eingreifendr oberflächliche Furchen in einzelne gröliere Partien gegrliedrert: auf jeder solchen wreden durch ein engeres Notz feinerer Furehen die Trennungsliaben der einzelnen Körner angereben. Deutliche Kristallformen finden sich sehr selten, doch sind Granatoëder und Ikositetraïler, sowie Kombinationen beirler beobachtet: auch die rundliche Oberfläche der Körner scheint teilweise son mancellaft entwickelten unvollkommenen Kristallflächen gebildet zu soin. Finice Körner sind auch im Goldsand ron Ekbatana in Medien gefunden worden.

Der Demantoil wird rielfach weschliffen und als Edelstein getraenen. namentlich in seiner Heimat, im Lral und auch sonst in Rufland: auforhalh) dieses Landes wird or

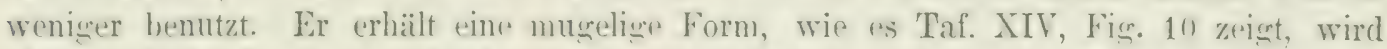
aber auch häufig in versehiedener Wrise mit Facetten versehen. Weren seiner meist grelherïnen Farbe wurd. er anfänglich für Chrysolith gehalten und wird auch noch jetzt mach Erkennung des wahren Sachverhalts im Lral mit diesem, sowie mit dem Tamen Olivin oder Peridot helegt. Er unterscheidet sich aber ron dem echten Chrysolith durch seine einfache Lichtbrechung und sein hohes spezifisches frewicht, rermöghe dessen er in der schwersten Fliissigkeit untersinkt, während der Chrysolith schwimmt.

Die chromhaltige smaragdgrime Varietüt ist dem Smaragd sehr ähnlich: sie wird daher auch als ..malischer Smaragd" bezeichnet, wobei man aber nicht vereessen darf, dal) der Cral auch echten Smaragd liefert. Dieselben beiden Merkmale, die den Demantoid von Chrysolith unterscheiden, lassen auch eine Verwechslung mit Smaragd als unmüplich arscheinen. Leider steht der Verwendung des Demantoid der Unstand entrecren, daf die Kürner infolge der oben beschriehenen Struktur der größjeren Knollen stets sehr klin sind, sonst wäre er durch seinen starken Glanz, die angenehme Farbe und das Farbenspiel gewif einer der geschätztesten Schmucksteine, dessen Benutzung wohl auch durch seine reringrere Iärte nicht stark beeinträchtigt würde. richön, tief und rein refürbte Steine, namentlich von einiger Gröfe, sind selten und werden teuer bezahlt, bis zu 120 Mark das Karat der besten Ware; für geringste Qualitïten kann der Preis bis auf 11 Mark heruntersinken.

Ebenfalls chromhaltig ist der schün smaragdgnrïne Kalkchrom-Granat, der Uw a rowit. Er findet sich aber nur in Form ganz kleiner Kriställehen und dünner Krusten, so daß (’r kaum jemals geschliffen wird, wozı er nach seiner Farbe sehr gut geeignet wäre, obwohl er niemals gut durchsichtig ist.

Außer den erwïhnten wichtigeren werden manchmal auch noch einige andere Granatvarietïten zum śchmuck benutzt. Bräunlich@rüner Kalktongranat, der als Mineral den Namen Grossular führt, namentlich der vom Wiluifluf in Sibirien, wird zuweilen unter dem Namen Stachelbeerstein geschliffen. Auch ein schön rosenroter, aber selten ganz klar durchsichtiger Kalktongranat, der beim Rancho de San Juan in Mexiko in gut auscrebildeten dodekä̈drischen Kristallen in einem feinkörnigen Kalke rorkommt, findet zuweilen Verwendung. Dasselbe gesehieht manchmal mit dem II elanit, einem schwarzen Kalkeisengranat, der wegen seiner Farbe gelegentlich in Trauerschmuck gefaßt wird. Er findet sich im Gegensatz zu allen anderen Granaten ausschlieflich in vulkanischen Gesteinen, so im Kaiserstuhl bei Freiburg im Breisgau und bei Frascati im Albaner Gebirge bei Rom. Bei ihnen allen ist die Terwendung so geringfügig, dab diese kurzen Bemerkungen genügen können. 


\section{Turmalin.}

Dor Thunalin ist ebensoweng wie der Granat ein durch eine ganz bestimmte, stets wiederkthrende chemische Zusammensetzung definiertes Nineral, sondern er bildet we jenor anr Gruppe isomorpher Sulstanzen, die in ihrem ehemischen Bestande erheblich romeinander abweichen, dagegen in der Kristallform sehr nahe miteinander ïbereinstimmen. J) wechsehden chemischen Zusammensetzung entsprechend sind auch manche physikalische Eigenschaften bei den Turmalinen verschieden, so das spezifische Gewicht und namentlich Durchsichtigkeit und Farbe, von denen besonders die letztere eine grole Mannigfaltigkeit zeigt. Die Mineralogen haben nach allen diesen Eigenschaften eine sröbere Anzalıl mit besonderen Namen bezeichneter Varietäten untersehieden, von denen die nicht zu dunkel gefürbten und zugleich durchsichtigen mannigfache Anwendung als Edelsteine finden. Den Juwelieren ist jedoch der Hineralname Turnalin kaum bekannt, und (b) husowenigh kennen sie die in der Wineralogie gebräuchlichen sonstigen Bezeichnungen fiir die verschiedenen Abarten. Sie haben die als Edelsteine bratchbaren Turmaline nach ihrer Farbe getrennt und danach mit besonderen Edelsteinnamen versehen, unter denen sie in Handel fast ausschlieblich gehen. Diese snllen unten bei der Beschreibung der einzelnen Varietäten angefuihrt werden.

Yon der chemischen Zusanmensetzung hängen alle anderen Eigenschaften mehr oder weniger direlit ab, sie soll daher zunächst betrachtet werden. Um eine Vorstellung davon zu geben, seien zunächst hier die Ergrebnisse einiger Analysen zusanmengestellt, die sich auf Stiicke von verschiedener Farbe beziehen. Es ist angeführt: 1. farbloser Turmalin rom Elba; 2. roter Turmalin von Schaitanka im Ural; : griuner Turmalin ron Brasilien; 1. brauner Tumalin von Dobrowa bei Unterdrauburg an der Drau in Kärnten; 5. dunkelbater 'Turmalin von Goshen in Massachusetts; 6 . schwarzer Turmalin ron T nity in New Hampshire, beide in Nordamerika.

\begin{tabular}{|c|c|c|c|c|c|c|c|}
\hline & & & \\
\hline & & $\begin{array}{c}1 . \\
\text { Farblos } \\
\text { Elba }\end{array}$ & $\begin{array}{c}2 . \\
\text { Rot } \\
\text { Schaitanka }\end{array}$ & $\begin{array}{c}3 . \\
\text { Grün } \\
\text { Brasilien }\end{array}$ & $\begin{array}{c}4 . \\
\text { Braun } \\
\text { Dobrowa }\end{array}$ & $\begin{array}{c}5 . \\
\text { Dunkelblau } \\
\text { Goshen }\end{array}$ & $\begin{array}{c}6 . \\
\text { Schwarz } \\
\text { Unity }\end{array}$ \\
\hline Fluor. . . & . . & 0,70 & 0,70 & 0,70 & 0,64 & 0,82 & - \\
\hline Kieselsüure . & . . & 38,85 & 38,26 & 38,06 & 38,09 & 36,22 & 36,29 \\
\hline Borsäure . . & . . & 9,52 & 9,29 & 10,09 & 11,15 & 10,65 & 9,04 \\
\hline Tonerde. . . & . . & 44,05 & 43,97 & 37,51 & 32,90 & 33,35 & 30,44 \\
\hline Eisenoxydul . & . & - & - & 5.83 & 0,66 & $11,9 \check{z}$ & 13,23 \\
\hline Manganoxydul & . & 0,92 & 1,53 & 1,13 & - & 1,25 & - \\
\hline Magnesia . . & . & 0,20 & 1,62 & 0,92 & 11,79 & 0,63 & 6,32 \\
\hline Kalk . . . & . . & - & 0,62 & - & 1,25 & - & 1,02 \\
\hline Natron . . & . . & 2,00 & 1,53 & 2,21 & 2,37 & 1,75 & \\
\hline Kali . . . & . . & 1,30 & 0,21 & 0,42 & 0,47 & 0,40 & 1,94 \\
\hline Lithion . & - & 1,22 & 0,48 & 1,30 & - & 0,54 & - \\
\hline Wasser & & 2,41 & 2,49 & 2,23 & 2,05 & 2,21 & 1,72 \\
\hline Spez. Gewicht & . . & $\begin{array}{c}101,17 \\
3,022\end{array}$ & $\begin{array}{r}100,70 \\
3,052\end{array}$ & $\begin{array}{r}100,70 \\
3,107\end{array}$ & $\begin{array}{r}101,37 \\
3,035\end{array}$ & $\begin{array}{r}100,07 \\
3,203\end{array}$ & $\begin{array}{r}100,00 \\
3,192\end{array}$ \\
\hline
\end{tabular}

Man sicht daraus, diali der 'T'urmalin cin Silikat ist, und zwar eines ron recht komflizierter Yusammensetzung, da sehr viele bestandteile mit der kieselsäure vereingent sind. Der Turmalin ist vielleicht der am kompliziertesten zusammenesetzte ron sämtlichen Lidelsteinen und steht hierin dem Diamant, dem cinfachsten von allen, gerade gererenüber. I)iese Virhälnisse werden noch rerwickeltex dadurch, dali nicht immer aile vierzehn 


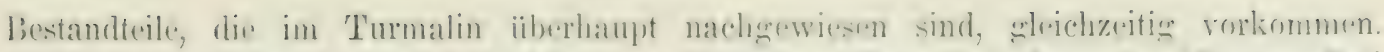

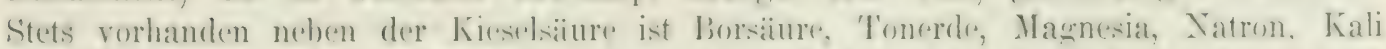

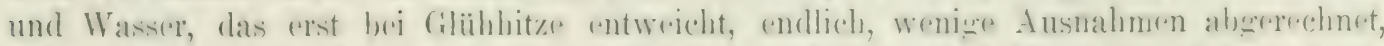
Fluor. Nur in einzelnen 'Turmalinen fimlet man Lithion und Manganoxydul, und ror allem ist das Eisenoxydul ein wiehtiger wechsehnder liestandteil, der bald granz fohlt,

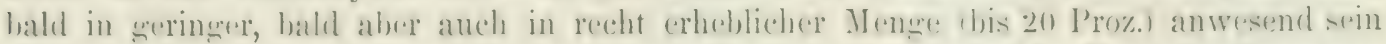

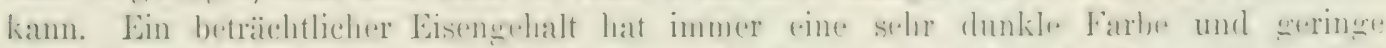

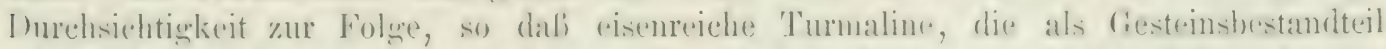

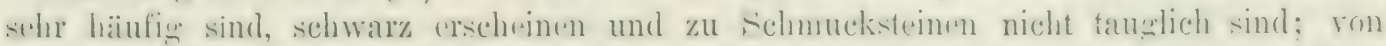
solehen wird also hier im folsenden nicht mehr weiter die liede sein. Aluer auch sonst

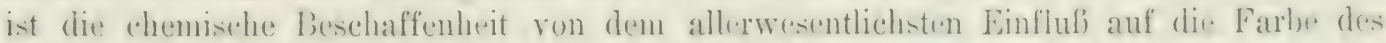
T'urmalins. wie ans den angefiilurten Analysen schon ohne weiteres hervorgeht und ww wir unten auch noch weiter sehen werden.

Wegen der zahlieichen Bestandteile, die sich bei der Analyse zum Teil nur schwierim und nicht mit wrober Genanigkeit bestimmen lassen, und weeen der wechselnden Verhältnisse, in denen sie auftreten, ist es bisher noch nicht gelungen, eine allseitig befriedigende und sämtlichen Terbältnissen Rechnung tragendre chemische Formel für den Tumalin zu ermitteh. Man hat wohl versucht, alle Tumaline auf die Formel: II:Al: (B.UH): Si, O1: zu bezichen, wobei die neun Wasserstoffatome durch wechselnde, :iquivalente Mengren Aluminium, Alkalimetall, Magnesium und Eisen. ein Teil des (OII) durch Fluor ersetzt werden; oder man hat atnenommen. dab alle Tarictäten des Minerals Mischunwen aus einer kleinen Anzahl von (srundverbndungen ron ganz bestimmter Zusammensetzung sind, die, ähnlich wie beim Granat, in wechselnden Mengen zusammentreten und so die Verschiedenheit des chemischen Bestandes und mancher physikalischen Eigenschaften reranlassen. Toch ist es eine der Aufgaben der Mineralchemie, die Yatur dieser (irundverbiudung, überhaupt die chemische Konstitution des Turmalins mit Bestimmtheit festzustellen.

Trotz der groben Unterschiede in der chemischen Zusammensetzung ist doch die Kristallisation bei allen Turmalinen wesentlich die gleiche. Die Kristalle. die dem hexagronalen System in seiner rhomboëdrischen Aushildung anærehören, sind meist mehr oder weniger lange Prismen. An den Enden werden sie begrenzt ron Rhomboïlem, Slialenoëdern oder der seraden Endfläehe, allein oder in Kombination miteinander. Entsprechende Flächen dieser Formen schneiden sich unteremander und mit den Prismenflaichen in Winkeln, die au den verschiedensten Kristallen nur um gauz geringe Beträ que, höchstens etwa um einen (irad differieren, die Zusammensetzung mag noch so sehr abweichen. Diese nahe kristallographische Übereinstimmung chemisch verschiedener Substanzen ist eben das, was man als Isomorphismus bezeichnet; daher wurde auch oben geesagt, dan die T'urmaline eine Gruppe isomorpher Mineralien darstellen.

Die Kristallformen des Turmalins zeigen eine Eigentümlichkeit, die für sie sanz hesonders charakteristisch ist. Diese besteht dain, dab die Gruppierung der Flïchen an dem einen Ende der Prismen eine andere ist als an dem entgegengesetzten. Dieser verschiedene Ausbildung von Kristallen an beiden Enden einer Richtung wird in der Fristallographie als IIemimorphismus bezeiclinet; der Turmalin ist also hemimorph. Allerdings ist dieses Verhalten nur selten deutlich zu sehen, da die Kristalle meist an cinem Ende aufarewachsen und daher nicht mit Flächen versehen sind. Häufig genug sind sie aber doch auch schon beiderseitigr ausgebildet vorgekommen. man kann sie dann niemals mit Kristallen ähnlicher Mineralien rerwechseln. Einige solehe deutlich henimorphe Kristalle sind in den Figuren 85, " bis ', S. 454 , dargestellt. Die hemimorphe Aushildung ist hesonders an den drei mittleren Figuren ausgeprägt, wo oben riel mehr Flächen entwickelt 
sind als unten. Sic zeigt sich aber auch in den Prismen. Statt dab diese, wie es den Verhältnissen des hexagonalen Systems entsprechen würde, sechsseitig sind, sind sie nur dreiseitig, wie in Fig. 85 ", oder statt zwölfseitig sind sie nemseitig, wie in Fig. $85, b$ bis $c$. Dies ist fiir die Kristalle unseres Minerals so bezeichnend, daf man daran Stïcke olne jede Endhexrenzung mit Leichtigkeit und Sicherheit als Turmalin erkennen kann.
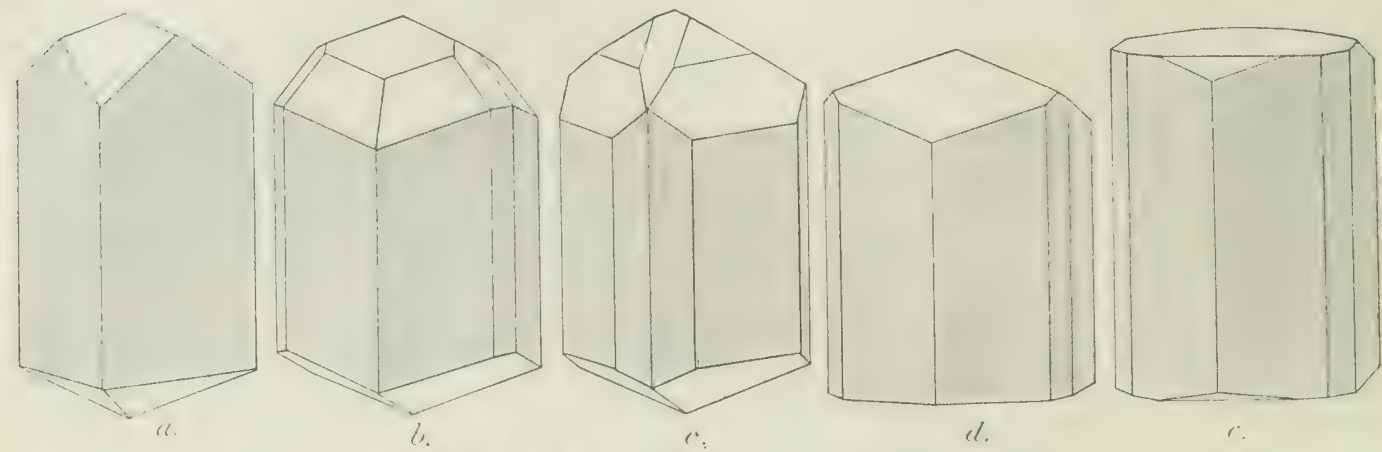

Fig. S. Kristallformen des Turmalins.

Die l'rismenflächen sind meist mehr oder weniger deutlich der Länge nach gestreift, wie es die Figuren andeuten. Am meisten tritt dies hervor bei Prismen, an denen noch mehr als nem Flächen ausgebildet sind und die daher oft walzenförmig rund erseheinen. Ein soleher Kristall von grünem Turmalin ist Taf. XV, Figur 9, alogebildet, während in Fig. $\delta$ anf derselben Tafel die charakteristische gerundet dreiseitige Form des Prismas deutlich hervortritt. Die Flïchen, welche die Enden der Prismen begrenzen, sind meist grlatt und nicht gestreift, einzelne sind dagegen rauh und dam matt, während die anderen, wit anch die Prismenflächen lebhaft glänzen. Die Kristallformen sind etwas, aber nicht wesentlich mit dem Fundort rerschieden; die Abbildungen in Fig. S.j stellen der Iicihe nach dar: a) cinen braunen 'Turmalinkristall von Ceylon; b) und e) zwei griine von Brasilien; d) einen roten von Schaitanka im Lral und e) einen rosenroten von Elba. Die Kristalle des durehsichtigen edlen, zu Sehmucksteinen taughlichen 'Turmalins sind maist klein und übertreffen selten in der Länge und Dicke die Grölbe eines kleinen Fingers.

Spaltbarke it ist beim Turmalin nicht in bemerkbarem Grade vorhanden. Der Bruch ist meleen bis unvollkommen muschelig. Da die Masse sehr spröde ist, so werden die meisten liristalle von zahlreichen unregehnäßigen Rissen durehsetzt, die natiurlich der Verwendung als Edelstein sehr hinderlich sind. Die Härte ist etwas gröber als die des (!uarz:s. den dere Turmalin serade noch ritzt; dagegen wird letzterer stark vom Topas geritzt. Es ist daher: H. $=7$ bis $71 / 2$ oder auch $=71 / 4$.

Das spreifische (iewieht ist sehr verschieden und schwankt zwischen etwas, wemn

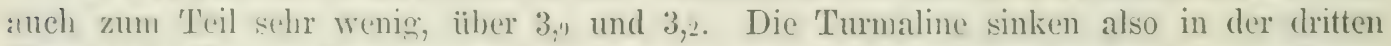

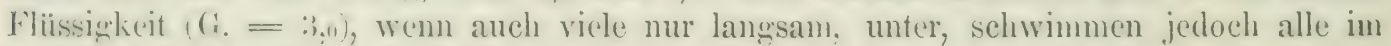
reinen Methylenjodid. Die Dichte ist von der Zusammensetzung abhängig in der Weise, dab sie in allgeneinen mit dem Eisengehalt wächst, wie man aus den oben angeführten, den Analysen heignefiigten Zahlen ersieht. Nur in einzelnen Ausnahmefällen werden Werte

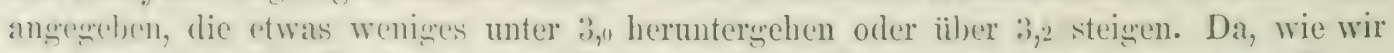
Eresehen hahen, die I)unkelheit der Farbe und die Undurchsichtigkeit mit dem EisenFrhalte zunchmen, so sind im allgemeinen die dunkleren 'Turmaline, die nieht geschliffen werden. die sehwereren. die helleren, zu bdelsteinen tauglichen, die leichteren: ihr fewicht steigt ron der unteren Grenze an nur wenig über 3,1 . 
Ier Glanz ist der gewöhnliche diasplanz. Er wird durch das Schleifen erheblich

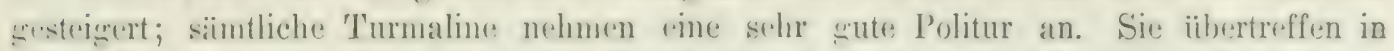

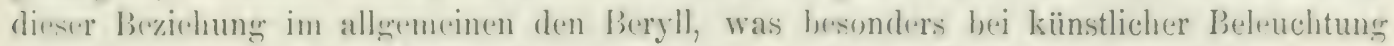

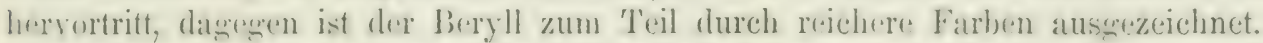

Die Durchsichtigkeit und Farbe schwanken, wie wir schon gesehen haben, innerhalh, sehr weiter (Erenzen, anch die durehsichtigsten Turnaline sind für Rë̈ntegenstrahlen fast undurchlässig. Die meisten sind in dicken Stücken vollkommen undurchsichtign und diann selıwar\% odle doch sehr dunliel gefärbt. Alser alle diese werden in dünnen Schichten durchsichtig. Soltener sind auch in srölieren Stiicken durchsichtige Varietäten, die dann rine antsurechend hellere Farbe labben. Diese letzteren allein sind zu Edelsteinen greesignet. Nie werden als ,edle 'Turmaline" hezeichnet im Gegensatze zu dem dunkel grefürbten mondurchsichtigen ...gemeinen Turmalin”. Auch von den edlen Abarten sind vollkommen klare und fohlerlose Exemplare selten und werden im alleremeinen mit ziemlich hohen l'reisen bezahlt. Die Farbe der edlen T'urmaline ist schr mannigfaltig, mehr als bei den moristen anderen $\%$ Schmucksteinen rerweudeten Mineralien; sie sollen in fulgenden etwas eingehender besprochen werden.

Jem schwarzen Turmalin, dem sogemannten Schürl, steht der farblose gegenüber, d.1. aher, wenn er meich durchsichtig ist, doch meist nicht als wasserhell angesehen werden kamn, da er gewöhnlich einen, wemn auch schwachen Stich ins Rï̈liche orler Grïnliche zeiget. Der farblose Turmalin ist ron den Mineralogen Achroit genannt worden. Er wird wohl nur sehr scelten als Edelstein geschliffen, ist auch üherhatupt nicht hiaufig. Ton

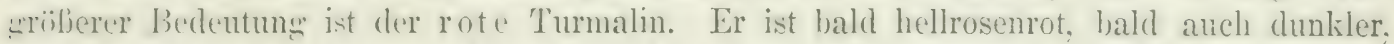
zuweilen hat (re sogar cine schöne Rubinfarbe und wird dann als Rubellit oder wegen suines Vorkommens in Sibirien als siberit bezeichnet. Durch Beimischung ron etwas Blau geht die Farbe manchmal ins Violette. Nur der dunkler rote Turmalin ist als Edelstein wichtige, nicht der rosenrote. Tiel häufiger ist der grüne edle Turmalin. Er ist teils hellgriin, teils dunkler in rerschiedenen Nuancen. Selten ist die Farbe rein smaragdsriun, häufiger sind bä̈ulich- und namentlich gelblichgrïne Nuancen. Der weniestens in durchsichtigen Stiicken seltene bla ue Turmalin führt den Mineralnamen Indigolitlı; er ist meist ziemlich tief šefärbt, bald rein indigoblau, bald mit einem starken stich ins (irïne. Sehr verbreitet sind auch braune Kristalle, die mineralogiseh zum Teil als Dravit bezeichnet werden. Sie sind entweder rein braun, oder griunlich-oder rötlichbraun. Die Farbe ist bald dunkler, hald heller und greht bis in ein ziemlich helles (relb, Bräinnlichgelb) und Strohgelb.

Teist sind die Kristalle gan\% gleichmäliog gefärbt, doch kommen auch rerschiedene Farben an einem und demselben Stïck vor. So findet man auf der Insel Elba farblose oder lwell gefärbte Turmaline, denen in raschem Übergang, jecloch ohne scharfe (irenze ein kurzes schwarzes Ende angesetzt ist, die sogenannten II o h len küpfe. Zuweilen ist die Sache auch swrade mugehehrt: schwarze Kristalle sind in derselben Teise mit einem weifjen Ende versehen. I'rismen mit einem rosemroten und einem grünen Ende, wie Taf. XV, Fig. 5, trifft man uleichfalls nicht selten; beide Farben gehen in der Mitte allmählich ineinander über. Interessint sind die Kristalle ron Chesterfield in Massachusetts und ron anderen Orten, besonders in Brasilien. an denen ein roter Kern in sanz scharfer Grenze von einer griunen Iliille umechen ist, wie das Fig. S und !) auf Taf. XV darstellt. Solehe Farbenverschiedenheit an demselben Kristall ist auch sonst an dem brasilianischen Turmalin sehr verbreitet und mannigfaltig (S. 462).

Jie Farbe der Turmaline beruht nicht auf einem mechanisch beigemengten, der Subsimz fremden P'ignent. Jeder, auch der dunkelste Kristall, zeigt rullkommen sleichmälirece Fürbung ohne Flectsen. Die Farbe ist der Substanz eigentiunlich und eine Folge 
ihrer chenischen Zusammensetzung. Die oben erwähnten Grundrerbindungen haben ilure bestimmten Farhen, mol durch Mischen derselben werden wieder gewisse andere Nuancen hervorgebracht, die von dem speziellen Mischungsverhältnis abhängen.

Enthält der Turmalin kein oder beinahe kein Eisen, dagegen etwas Manganoxydul und Lithion neben den andern konstant widerkehrenden Bestandteilen, dann sind die Kristalle farblos, rosa oder dunkler rot oder auch lichtgrïn. Welche ron diesen Farben auftritt, scheint auf dem speziollen Mischungsverhältnis des Eisens zum Mangan zu beruhen. Das dunklere Rot wird wohl durch einen rerhältnismäßig bedentenden Mangangehalt hervorehenacht. Tritt eine etwas srö̈here Menge Eisenoxydul hinzu, dann wird die Farbe dunkeluriun, wie so häufig, wenn diese Substanz in Silikaten vorhanden ist; doch enthalten einzelne grïine Turmaline auch etwas ('hromoxyd, also dieselbe Sulstanz, die am Smaragd die prachtrolle griine Färbung hervorbringt. Die braunen Turmaline enthalten fast kein Eisenoxydul, auch kein Manganoxydul und ebensowenig Lithion, aber viel mehr Maฏnesia, als alle die vorher genamnten. Für die blane Farbe ist offenbar wieder eine gröbere Menge Eisenoxydul nötig; doch scheinen durchsichtige blaue 'l'urmaline bisher noch nicht analysiert worden zu sein. Die eisenreichsten Turmaline sind, wie wir schon wissen, alle schwarz und in dickeren Stïcken undurehsichtig; ganz dïnne Plättchen sind jedoch stets mit brauner, grïner oder blauer Farbe durchscheinend.

In der Wäme sind diese Farben recht beständig; sie werden oft sogar beim Gliihen nicht wesentlich geändert, manchmal aber geschieht dies allerdings. So werden z. R. dunkelgrüne Steine beim schwachen Glühen hellgrïn oder graugrïn und dadureh zum Schmuck weniger geeignet oder auch wohl ganz unbrauchbar. Das Verbalten der Farben des Turmalins beim Bestrahlen mit Radium ist schon oben (S. T2) mitgeteilt worden. Eine sehr bezeichnende Eigenschaft des Turmalins ist der starke Dichroismus, der selbst bei ganz hlaß gefärbten Steinen noch merklich ist, aber mit zunehmender Tiefe der Farbe erheblich an Stärke wächst. Am 'Turmalin ist diese Eigenschaft wohl stärker ausgeprïgt als an irgendeinem anderen Edelsteine, den selten geschliffenen Dichroit vielleicht ausgenommen; sic ist daher zur Unterscheidung ron anderen Steinen besonders geeignet. Ganz durchgängig ist die Farbe, die man beim Itindurehsehen in der Riehtung der Prismenkante erhält, dunkler als die in der Richtung senkrecht dazu, auf den Prismenflächen. Wenn die Farbe des Kristalls dunkel und die Sehicht nicht zu dünn ist, kann man in der ersten Richtung überhaupt nicht mehr hindurchsehen, wohl aber bei derselben Dicke in der zweiten. Meist sind auch die Farben in den beiden Richtungen nicht dieselhen, wie schon bei der allgemeinen Betrachtung des Dichroismus (S. 7: $)$ buispielsweise angeführt wurde. Sehr häufig kann man daher den Dichroismus ohne weiteres mit bloliem Auge erkemnen; ebenso tritt er aber auch naturlicherweise mit der Dichrolupe deutlich hervor. Am meisten verschieden sind die Bilder, die man mit dieser erhält, wenn man in der lichtung senkrecht zu den P'rismenkanten dureh die Kristalle hindurehblickt. Dann ist dem oben (iesagten entsprechend ein Bild dunkler als das andere und beide sind je nach der Färlumg des Kristalls versehieden. Bei braunen Kristallen sind die Bilder dunkelbraun und hellbraun bis gelb, bei roten dunkler und heller rot usw., ist der Kristall tief grefürht, damn ist das dunklere Bild beinahe oder ganz schwarz. das hellere zeigt irgendeine der genannten Farben.

Infolge des starken Dichroisnus dürfen Turnalinkristalle von auch nur einigermaben dunkler Farbe nicht anders greschliffen werden als so, dab die dem Beschaner zugekehrte IIauptfläiche, die Tafel des gesehliffenen Steines, der Prismenkante parallel geht. Nur dann sieht jener in der liichtung senkrecht zu den Prismenkanten hindureh und der Stein zeigt eine klare und schöne Farle. Wäre jene Fläche senkrecht zu den Prismenkanten, also der geraden Endflïele parallel, damn wiirde man in der Richtung der Prismen- 


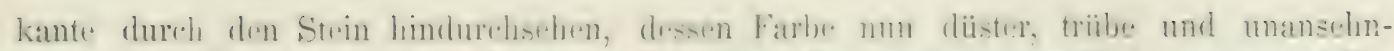

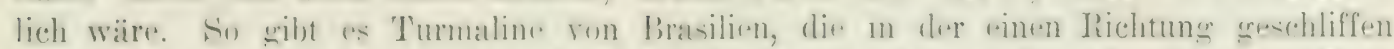

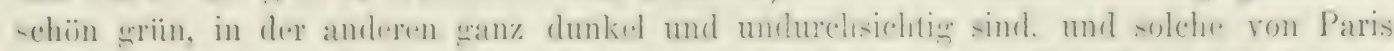

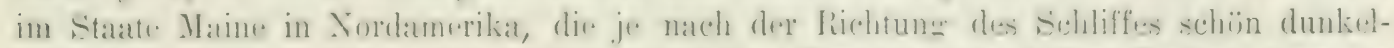

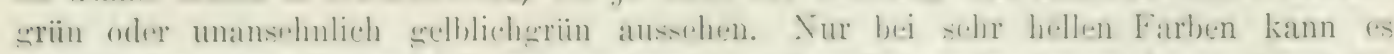

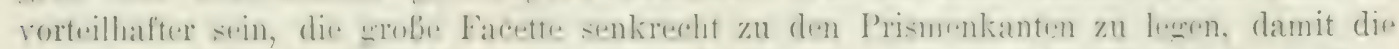
steine etwas dunkler rercheinen. Der Sethleifer hat es also in der Iland, einem Stein

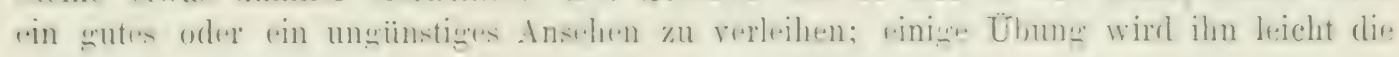
richtige Anordnung der Schliffläche finden lassen.

Dit Lichthrechung ist nicht sehr stark; stärker ist die durch das hri-talloystem be:-

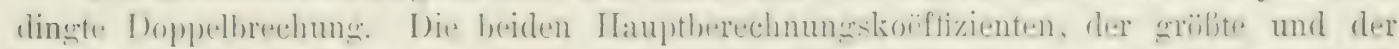
kleinste, und dimit die Lichthrechung und die Doppolhrechung sind nit der Farbe des Steines und also mit descen chenischer Zusammensetzung etwas schwankend, und zwar indet in allewemen mit zumehmender Inunkelheit der Farbe, also mit steigendem Eismerehalt, eine Znmahme der Brechung-kreffizienten statt. Man hat jene zwei brechunstekoëffizienten gefunden:

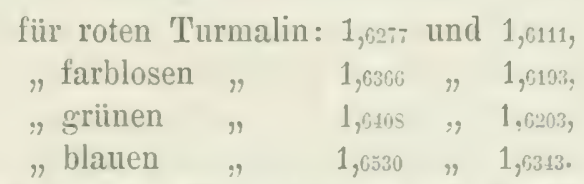

Ilïchst charakteristisch für den Turmalin ist auch die Fähigkeit, ieicht ulektrisch zu werden. I)ureh lieiben mit 'Tuch odter Seide wird er rasch und zimulich stark und auch für länerere Zeit erregt. Toch mehr aher ist dies der Fall bei der Abkïhlung nach rorangegangener Erwärmung. Er ist also stark proelektrisch, und zwar der hemimorphen Ausbildung der Kristalle entsprechend polar, d. h. so, dalj diese stets an einem Ende der Prismen und bei geschliffenen Steinen an din diesen entsprechenden stellen positive, an anderen entgegengesetzten Ende negative Elektrizität zeigen. Am stärlisten ist die prroelektrische Erregung bei den durchsichtigen und hellwefärloten edlen 'Tumalinen, doch dïrfen sie nicht zu stark rissige sein. Die Erregung ist unter grünstigen Lumstïnden so stark, daf kleine Papierschnitzel und andere leichte Gegenstïnde energisch angezogen werden. Dieses Verhalten wurde schon bei der Entdeckung des Turmalins an Infange des 15. Jahrhunderts in Ifolland beol)achtet, wo man bemerkte, dalj erwïrmte Fristalle beim Erkalten Aschenteilchen anzogen: das Mineral wurde danach Aschentrecker (Aschenzieher) genannt. Kein anderer Edelstein, der mit Turmalin etwa verwechselt werden lï̈nnte, ausgenommen vielleicht der Topas, wird bei der Abkühlung in auch nur entfernt ïlınlichen Grade elektrisch, man kam also dieses Verhalten mit Vorteil zur Unterscheidung benutzen, so z. B. von rotem Turmalin und Rubin usw., wie wir schon oben S. S.3 gesehen haben. Sehlieblich sei noch erwähnt, dab der Turmalin ron süuren nicht angerriffen wird. Vor dem Lütrohr sind die farblosen, hellgriinen und roten nicht schmelzhar, die dunkleren schmelzen oder sintern zusammen und gehen dabei weifje his dunkelbraune Schlacken.

Was das Vorkommon des Turmalins anbelanent. so ist dies fart ganz auf die $\mathrm{Cr}^{-}$ sesteine, Granit, Gneis und ähnliche beschränkt. Das Auftreten im kömicen Dolomit rom Campo longo am St. Gotthard und im Binnental in der Schweiz und in noch anderer Weise ist dagegen untergeordnet und hat jedenfalis für den Turmalin als Edelstein keine Bedeutung. Die edlen Varietäten sind wohl so grut wie ausschlieflich auf jene erstgenannten Gesteine beschränkt, rorzugweise auf den Granit, besonders in seiner grobkörnigen Ausbildung: die als Pegmatit bezeichnet wird. Hier sind die hellgefürbten Kristalle auf Drusenrïumen aufgewachsen, und zwar kommen solche ron rerschiedener Farbe, auch schwarze. mitemander, wenn nicht in derselben I rum, so doch in derselben 
Gesteinsmasse an rerschieden Stellen vor. Ton Fundorten, und zwar besonders ron solchen, die schleifloare Stcine liefern, wird unten noch die Rede sein. Dunkler gefärbte Kiristalle. braune. blau und namentlich vielfach schwarze sind häufig in dem Gestein selbst cingewachsen und ringsum von der Masse umschlossen. Aus den ursprünglichen Lagerst:iitten, auf denen er sich gebildet hat, wird auch der Turmalin vielfach durch Verwitterung losgelïst und kommt so in die Seifen, aus denen gerade die schönsten und für die Verwendung zum Schmuck geeignetsten Exemplare an verschiedenen Orten, besonders in Brasilien und auf der Insel Ceylon, mit anderen Edelsteinen zusammen gewonnen werden.

Jeder Turmalin ist zum Schmuckstein geeignet, wenn er nur durehsichtig und schön Eefärbt ist. In der Tat wird auch Material von der verschiedenartigsten Beschaffenheit verschliffen. Zu helle Farben sind wenig geschätzt, beliebter sind gesättigte rote, grïne, Wlaue auch hrame Steine, von denen die schön roten am wertvollsten, die grïnen und bratmen am häufigsten sind, während blaue keine so grofe Bedeutung besitzen.

Die Schlifform ist meistens der Tafelstein oder ein niedriger 'Ireppenstein; als Brillant wird der Turmalin selten verarbeitet. Die vielfach etwas matte Farbe wird gern durch (ine passende Folie verbessert. Außer den schon erwähnten, allerdings häufig vorkommendeu Tissen (Adern) haben die T'urmaline wenig Fehler, namentlich trifft man Einschlïsse irgendwelcher fremder Substanzen so gut wie niemals.

In folgenden sollen die als Edelsteine verwendbaren Tarietïten des Turmalins etwas eingehender betrachtet werden, wobei zu beachten ist, dab meist verschiedene Farben an demselben Fundort nebeneinander vorkommen.

Der fiulolose ' $\mathrm{I}$ urmalin oder Achroit ist namentlich in vollkommen oder naliezu wasserbellen Stücken selten grob genug; um brauchbare Steine zu geben. Er findet sich meist in kleinen diinnen Nadeln mit dem anders gefürbten Turmalin auf der Insel Elba und kommt in schönen Fristallen auch in dem Dolomit von Campo longo neben grinem Turmalin ror, chenso noch an manchen anderen Orten, ïberall jedoch als Seltenbeit. Schleifwürdige Exemplare in einiger Fröße und Menge liefert vielleicht nur die Gegend yon Richville bei De Kalb, Lawrence County im Staate New York, wo sie, wie auf Elba, auf Drusen im Granit aufgrewachsen sind. Er hat ror anderen farblosen Steinen nicht scerade viel voraus, ist aber vor manchen durch seinen schönen Glanz ausgezeichnet. Sein pyroekektrisches Verhalten, auch sein spezifisches Gewicht von :, , unterseheidet ihn leicht von allen anderen farblosen und durchsichtigen Steinen: er sinkt langsam in der dritten Flïssigkeit $\left(\left(G_{0}=:, ",\right)\right.$ und sehwimmt in der zweiten, dem reinen Methylenjodid (G. $\left.=3,3\right)$. Phenakit, farblosor Beryll und Berekristall schwimmen auch in der ersteren, Diamant, sowie farbloser Topas, Spinell. Sapplir und IIyacinth sinken in der letzteren. Von Glasfliissen unterscheidet sich rler farblose wie alle anderen Turmaline durch die Doppelbrechung.

I) rel' rote 'T'urmalin (Rubellit) finclet sich in versehiedenen Nuancen von hellrosa bis dunkelliarminrot und bis zum Violetten (Siberit). Nanehmal ist die Farbe derjenigen gewisser Iiulnine so ähnlich, dafo eine Unterscheidung mit bloßem Ange selbst für den Kenner schwierig ist. Auch manchen spinellen, besonders dem Balasrubin, und ebenso dem Rosatopas. gleicht er dex Farbe nach in einzelnen Fxemplaren zum Verwechseln. Von allen diesen unterscheidet ilın aher stets das spezifisehe Gewicht, das hier wleich 3, wist Jene sinken alle im reinen Mrethylenjodid unter, auf dem der 'Turmalin seliwimmt. Der Dichroismus ist hei nicht zu hellen Steinen sehr ausgesprochen. Die Farben rler Bilder in der dichroskopischen Lupe schwanken zwischen hellrosa und dunkelrot; die erstere Nuance greht zuweilen etwas ins frelhe, die letztere meist etwas ins Violette. Auch diese Eigenschaft gribt manchmal eine siehere Unterseheidung von den iibrigen roten Edelsteinen, bei denen andere Farben auftreten. 
Sehr wichtige Fundorte dieses sehönen Stemes liegen in Katharinenburger Revier im Ural, in der weiteren und näheren Lmeghung des Dorfes Mursinka (Fign. 7 S. S105), wo er mit Amethyst, Topas, Beryll und anderen ,bunten Steinen" geeraben und vorzugsweise in den Schleifereien in der stadt Katharinenburer verarbeitet wird. Wegen diexes Vorkommens lat er den Mineralnamen Siberit und den Edelsteinnamen ,sibirischer 'T'urmalin", orler auch wegen seiner Ähnlichkeit mit Rubin ..sibirischer Rubin" erhalten. Besonders zenamnt werden die Fumdorte heim Dorfe Schaitanka, is km südlich von Mursinka und $72 \mathrm{~km}$ nördlich von Katharinonbure, wo er mit Albit, Quarz, crünem Glimmer und roten Lithionghlimner auf I)rusen eines sehr grohlsörnigen firanits sitzt, meist dem Albit und dem Lithonglimmer an-oder aufgewachsen. Zuweilen liegen die Kristalle auch in einem sellen 'Ton, wahrscheinlich einem lerwitterunesprodulit des firanits. Es sind

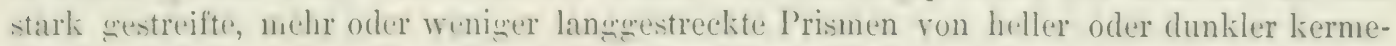
sinmeter, katminroter lis riolettblauer, meist an beiden Enden etwas versehiedener Farbe. dimeben finden sich aber anch hell obivengrine und hell leberbrame bis dunkel braun*hwarze Kristalle. Bei Sarapulskaja, $12 \mathrm{~km}$ von Mursinka, liegen dunkel kermesinrote, meist kleine Kristalle, die parallel ofler exzentrisch verwachsene Gruppen bilden, in einer mit Granitgrus gemengten Dammerde am Fufie eines (iranithügels. ehenfalls ron andersfarbicun Turmalinen begleitet. Ein sparsameres Torkonmen ist das im Gebiete von Nert-chinsk in 'Transhaikalien. Der ,sibirische Rubin", besonders der dunkelrote, ist ein als hemisches Produlit besonder's in Rufiland gesehätzter und gern getragener Edelstein, der hier auch einen recht erheblichen Wert hat, um so höher, je rubinähnlieher die Farbe ist. Auferhalh Ruflands sieht man ihn, wenigstens in Europa, nur wenig. Ein schön grefärbter sibirischer Kristall ist in Taf. XV, Fig. 6 dargestellt.

Aufer in dieser seiner hauptsïchlichen Heimat in Sibirien findet sich der rote Turtuilin auch noch an anderen Orten, wenn anch in geringerer Menge, in schleifwiurdigen Lxenplaren. So kennt man ihn ron Ceylon, wo er den Rulin, Sapphir. Spinell, Irya(inth usw. in den Edelsteinseifen begleitet, und besonders von Birma, wo er aber einen anderen Verbreitungshezirk hat als der Iiubin. Hier kommt er bei Iainglon (oder Mroinlongr) ror (Fig. 64 und 65, S. 339 und :310;, 20) engi. Meilen suidüstlich ron der Rubinstadt Mogrouk. Die Turmaline liegren im Tale des Flïßchens Nampai nahe dem Dorf Namseka luse in dem Flubsande. Toter Turmalin ist da mit schwarzen rergesellschaftet; beide sind stets stark abgerollt. Er wird seit 1.50 bis 200 Jahren ron Chinesen in zahlreichen flachen und kleinen Löchern gegrahen und besonders in der nassen Jahreseit dureh Waschen gewonnen. Das gresamte Iaterial geht dann nach China, wo die Steine zur Herstellung ron Kü̈pfen auf Mandarinenmiitzen dienen. Sie werden sehr wohl von dem in der Xähe vorkommenden Rubin unterschieden. Etwas weiter talanfwärts liewen zahlreiche alte Gruben, die jetzt aber günzlich verlassen sind. Der Nampai kommt aus einem Gneisgelbiet, und der Tiubellit stammt aus zersetzten Granit-1Pegmatit)-sängen, die diesen (ineis durchsetzen. In der Literatur wird von einigen hesonders sehënen und groben roten Turmalinen berichtet, dit bei verschiedenen Gelewenheiten aus Jima in englische Sammlungen gelaugt sind. (1) diese elenfalls ron dem genamnten Fundorte stammen, ist unbekannt: man weif von ihrer speziellen IIeimat nichts. Iner Ertrag limmas an rotem 'Turmalin betrug 1S9s: :591 Lfund: 19100: 12.10 P'fund, 1903: 196 Pfund; 19015: 161 Pfund im Wert ron 3011011 Mark; 1906: 193 Pfund im Wert von 20000 Mark.

Schöne und große rote Turmaline z. T. mit grïner Hülle, wie Taf. XV, Fig. 8 u. 9, sind neuerdings in Madagaskar gefunden worden.

Aus A ustralien kommen elenfalls sehleifhare rote Turmaline. z. T. nit priner Lmhüllung; z.um Teil ganz wrin oder sonst versehiedenfarbig. so von dem Kangaroo Island in Südaustralien und ron (oconarup) in Kent-Distrikt in Westaustralien, an heiden Orten ebenfalls in Pegmatit. 
Ausgezeichnete Vorkommen edler Turmaline finden wir in Nordamerika, wo im Jahr 1907 etwa 2140 Pfund schleifbare Kristalle gewonnen worden sind. Die Orte. die schüne steme weliefert haben, liewen \%. 'T. wanz im Westen, in den NenenglandStaaten, z. 'T. ganz im ()sten in Kalifornien, und dazwisehen ist so gut wie nichts bekannt. In beiden Gexenden ist trotz ilırer weiten Entfernung die Art des Auftretens der Kristalle wesentlich diesellue. Wie fast iiberall trifft man sie in (rängen von Pegrmatit, auf Drusen oder in das fammgestein eingerwachsen, begleitet manentlich von anderen lithionhaltigen Mineralien. Lithionglimmer (Lepidnlithı, Amblygonit. Spodumen (Kunzit) usw., auch von etwas Berrll. Granat und anderen. Die Farbe ist meist vorwiegend rot in verschiedenen Nuancen. Doch ist grün. blau, gell) usw. in versehiedenen 'Tünen gleichfalls nicht selten, und auch vollkommene Farblosigkeit kommt vor. Die meist lang prismenförmigen Kristalle sind in vielen Fällen an verschiedenen Stellen, meist an beiden Enden, rerschieden gefärbt, ebenso ist eine schichtenförmige Abwechslung zweier Farben wie in Brasilien (Taf. XV,Fig. 8 u. 9) ziemlich verbreitet.

Im Osten ist vor anderen der Staat Maine zu nennen und hier als die wichtigste Lokalität der Mount Mica, eine engl. Meile östlich von Paris Court House. Oxford County. meist kurz Paris genannt, wo die Kristalle, wie bei Schaitanka im Ural, mit rotem Lithionglimmer, dem Lepidolith der Mineralogen, auf Drusen im Pegmatit aufgewachsen sind. Seit der Entdeckung im Tahre 1520 sind hier bis jetzt fïr wenigstens 50000 Dollars rerschiedenfarbige Turmaline gewomnen worden. die als cinheimische Edelsteine in den Vereinigten Staaten, serade wie in Rußland, sehr beliebt sind. In Oxford County finden sich gute schleifwürdige Kristalle auch im Pegmatit ron Rumford Falls. Yäist dem rom Mount Nica ist der in derselben Weise vorkommende, im Jahre 1852 entdeckte Turmalin vom Nount Apatite in Auburn, Androseogrgin County in Maine von Bedeutung. Seit jener Zeit werden dort zahlreiche schöne schleifwürdige Krystalle gefunden. farblos, rosa, lila. hellblau, auch dunkelblan, griun und gelb, die beim Schleifen Steine bis 6 und sogar S Karat lieferten, aber nie mehr. Einige der 'Turmaline von hier zeigten die eigentimliche Erscheinumg, dab sie nach dem Schleifen dunkler wefärlot waren als vorher. Die roten Kristalle sind bei l'aris zuweilen mit einer Rinde ron grïnem Turmalin überwachsen. Dieselbe Erscheinung findet sich aber noch ausgezeichneter bei Chesterfield im Staate Massachusetts an den sroßen Prismen, wie sie auf Taf. CV , Fig. S u. 9, abgebildet sind, sowie an manchen brasilianischen Steinen. Bei der Verarbeitung wird zuweilen nur der rote Kern benutz, der wie der rote amerikanische Turmalin überhaupt nicht selten eine dem Rubin sehr ähnliche Farbe hat. Zuweilen wird aber auch der Sehliff quer zu den Prismen welegt und dic grüne Rinde beibchalten. wodurch ein sanz eigentimlicher, auf dem Farbenkonstrast beruhender Eindruck hervorgebracht wird. Weniger benerkenswert, aber doch immerhin zu erwähnen ist das Vorkommen im Staate Connecticut, wo bei Haddam Neck rote, doch meist crriine, anch bunte Kristalle in einem pegmatitischen Quarzfeldspatgestein vorkommen, ebenso bei Portland.

Besonders hervorragend, wohl die: schönsten, die bisher bekannt geworden. sind die aus dem Ende des voriegen Jahrhunderts stammenden Funde im Westen. In siidlichen Kalifornien, und zwar in den febiren von San Diego und ron Riverside County wurden sehr viele rote, danchen auch in gocringerer Zahl andere Edelturmaline von ungewöhnlicher Pracht und Gröbe, atberdem, in derselhen Weise vorkommend, noch sonstige Edelsteine. Kunzit, Beryll. (iranat und Topas enteleckt und ausgereutet. Sie finden sich alle in

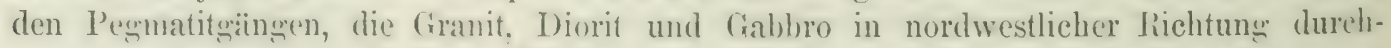
setzen und unter verschiedenen 11 inkeln nach Sïdwest einfallen. Bei aller allgemeinen Ähnlichkeit ist aher doch (ine dopuelte Verschiedenheit des Torkommens zu beobachten. An einigen Orten triff man Lithiommineralien, besonders Lithionglimmer (Lepidolith) z. 'T. 


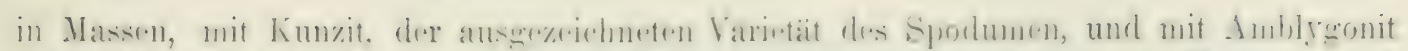

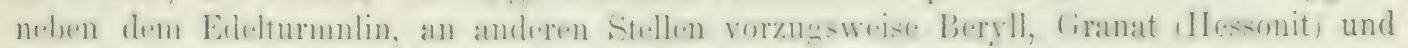

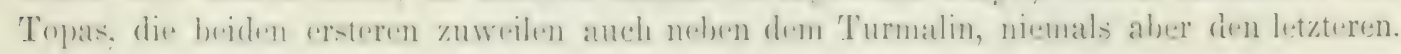

Weitaus am bedeutendsten sind in Diego County die Gruben des Mesa Grande-

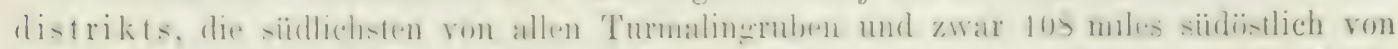

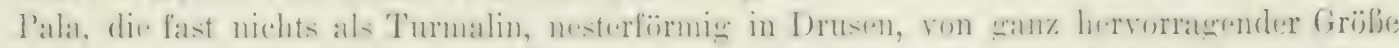
und Schönheit der Kristalle geliefert haben. Sie liegen bis 5000 Fulb hoch am Mesa

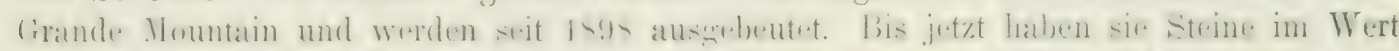

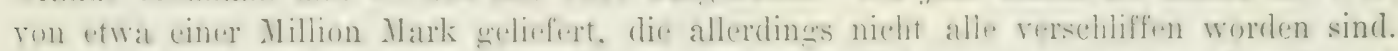

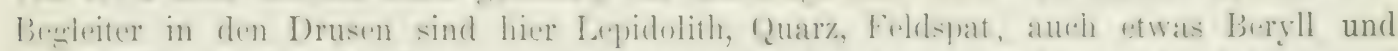

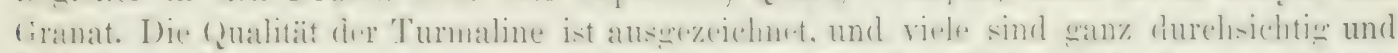

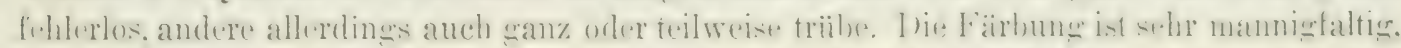

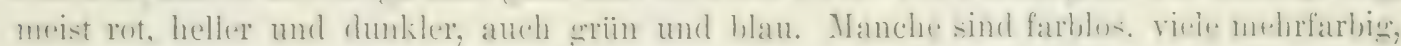

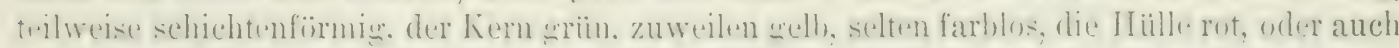

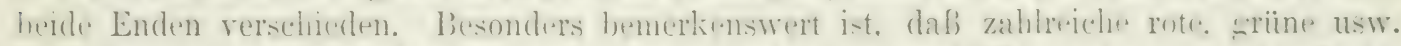

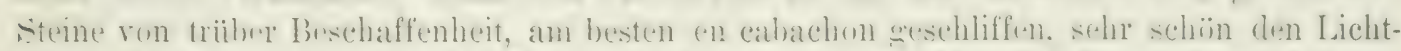

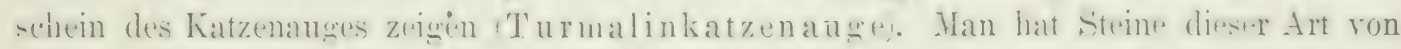
25 bis 30 Karat erhalten. Der größte, bisher gefundene Kristall von hier war $45 \mathrm{~mm}$ lang und $42 \mathrm{~mm}$ dick (Durchmesser). Geschliffene Steine wiegen bis 50 Karat.

Eine zweite wichtige (iegend in derselhen Grafsehaft ist der Paladistrikt um die Stadt Pala. wo die Edelsteingruben in drei farallelen Gehirgaiigen liesen. Der wetlichste ist der J'ala Mountain, wo ein Ciange in der Hauptsache von dunkel-lilafarbigem Lepidolith answefuillt ist, in dem etwas hellere, rusenrote, lange und diinne Turmalinprismen in radialer Anordnung sehr zahlreich einerewachsen liesen. Ist anch der Turmalin trühe und für sich siten brauchibar, so entsteht doch heim sechleifen mit dem umgebenden Lepidolith wergen

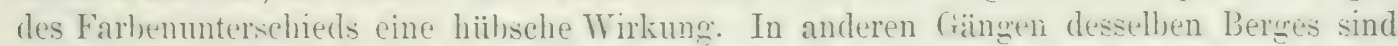
die Verliälnisse wie hei Mesa Grande. Damn folgt gegen Osten etwa $1^{1}$ a miles nordïstlieh roin Jala der Pala C'hief Mountain, wie der näehstfolgende, der Heriart Mountain. rin Ausläufer des Iena Tibia Mountain. Das Torkommen ist ebenfalls wieder entsprechend dem von Mesa Cirande; die Kristalle sitzen auf Drusen in Pegmatit, smd aber z. T. so schön und noch eröfer als dort, nicht selten einen Fub lang und mehrere Zoll dick. Auch hier ist die Farhe wieder vorherrschend rot in rersehiedenen Tönen, dann blau, grün, sowie hunt, z. B. rot und blau an den Enden und mehrlach auch schalenfürmig; auben blau und innen rot mit einer schmalen weifen Zwischenschicht. Als Begleiter ist hier besonders der Kunzit wichtig, denso in dem dritten, dem üstlichsten frebirgszug, dem Heriart Mountain, der auch sonst wesentlich dieselben Terhältnisse bietet wie der vorhergehende. Eine neue Entreckump ist endlich der Fundort am Moosa Cany on, nahe den Moosa Falls, 10 miles sïdwestlich von Pala.

Wenig wivhtig ist der Ramonadistrikt, wo cine cewisse, aber nicht sebr erbebliche Menge edlen Tumalins rom allen Farben ohne Lithiommineralien in den Beryll- uncl Hessonitgruben mit vorgekommen ist und wo Topas eine größere Rolle spielt.

In Riverside County, nördlich von San Diego County, ist die Gegend nördlich und ästich von Coahnila ron einiger Bedentung. Die Gruben liegen in der san Jacinto Liange bis nahe am Kamm 1500 bis jol00 Fufj hoch. Hier sind $14 i 2$ die ersten kalifornischen Edeiturmaline gefunden worden, wieder zusammen mit Quir\%, Funzit und anderen Lithiommeralien. sowie mit viel Beryll. Die Kristalle sind z. T. rot und rosa. aber iiberwiend blan und srün, zuweilen innen rot und auben soriun, nit sehmalcr farbloser Zwischenschicht. sowie nicht eranz selten durchaus farblos. Zwischen hier und Mesa 
Grande sind noch mamche andere Fundorte bereits bekannt und noch weitere mit einem bohen Grad von Wahrscheinlichkeit zu vermuten.

In Colorado sind rote, enrïne und blaue Turmaline bei ('anyon in der Gegend ron Royal Gore mit Quarz, Amazonenstein und etwas Beryll gefunden worden. Seit 1906 wird das Vorkommen auch ausgebeutet.

Virle schöne rote Turmaline begrleiten die griinen, die in Brasilien so häufig sind. sie liaben aber letzteren gegenüber geringere Bedeutung. Ticht selten bildet auch hier der rote einen Kern im grünen.

Die roten Turmaline ron Elba, Penig in Sachsen usw. sind zum Schleifen zu hell und meist auch zu klein; nur selten findet sich hier ein Exemplar, das zur Verwendung als Edelstein tief genug gefärbt ist.

Der griine Turmalin ist unter den edlen der verbreiteste und steht daher nicht so hoch im Preise wie die anderen. Er ist selten smaragderiin und dann nicht weniger tief geffïrbt als der schöne echte Smaragd. Gewöhnlich șeht die Farbe mehr ins Gelbliche, sie ist grasgrüin, gelblichgrün bis grïnlichgelb in allen möglichen Nuancen, bald lichter. laald dunkler (Taf. XV, Fig. 7, sowie $S$ u. 9). Der Dichroismus ist auch hier sehr ausgepräigt; neben gelblichgrünen und bläulichgrünen Tünen, die bis beinahe zun Schwarz. zrehen, treten in der dichroskopischen Lupe auch gelbe, braune und violette auf.

Die hauptsächlichste. Ifeimat ist Brasilien, wo grïne und andersfarbige Turmaline in Säulen bis zu mehreren Zoll Länge und entsprechender Dicke besonders in dem kleinen Ribeirão da Tolha, 10 Leguas von Chapada, aber auch anderweitig im Bezirk Minas novas in der Provinz Minas Geraës, mit den weifen Topasen usw. zusammen vorkommen (S. 419). Die Farbe, bald heller, bald dunkler grïn, zuweilen ausgesprochon gelblich grün, ist hier nicht selten sehr schön smaradgrün. Man hat diese Steine anch früher für wirkliche Smaragde grehalten und sie mit grofem Eifer aufgesucht, bis man bemerkte, dal man es nicht mit diesem kostbaren Edelstein, sondern mit dem weit weniger wertvollen Turmalin zu tun hat. Von dieser Ähnlichkeit hat der grüne Turmalin auch den Edelsteinnamen ..brasilianischer Snaragd oder auch Chrysolith" erhalten. Er wird in Brasilien viel getragen, namentlich ist er als Ringstein bei der dortigen Geistlichkeit geschätzt, als deren Emblem er gilt. Im Übrigen ist die Farbenmannigfaltigkeit sehr groß, vielleicht noch größer als bei den Turmalinen von San Diego County in Kalifornien, denen die brasilianischen Steine sonst im Vorkommen und Aussehen sehr ähnlich sind. Neben den ïberwiegenden grïnen finden sich mehr oder weniger tahlreiche farblose, rosa, rote und blaue. Viele sind mehrfarbig. IÏufig sind die beiden Enden verschieden: rot und srïn, srün und blau, rot und farblos etc., ebensohäufig ist ein Kern von einer andersfarbigen IIïlle umgeben: Kern rot und Iïlle yrün (Taf. XV, Fig. 8 und 9), seltener mmgekehr, zuweilen mit einer farblosen Zwisehenschicht oder rote Hülle mit farblosem Kern, oder in noch anderer Anordnung. Vielfach sind die Farben tief und gesättist, häufig auch sehr blab und zart. Ganz ähnlich wie in Brasilien ist das Vorkommen schöner 'T'urmaline von verschiedenen Farben in Ma dag a s k ar.

Ein anderes Vorkommen ist das in den Edelsteinseifen von Geylon, wo eine gelbe und gelblichgrïne, dem Chrysolith (oder Peridot) ïhnliche Varietät den dort meist braunen Turmalin begleitet. Sie ist mit ihm durch Übergäinge in der Farbe verbunden. Einzelne Stücke sind nur auf der einen Seite in dieser Weise grefärbt, auf der anderen sind sic weil) und zeiren hicr einen milchigen Lichtschein. Tach dem Fundort wird diese felblichgrïne Abart als Edelstein „eeylonesischer Chrysolith" oder auch „eeylonesischer Peridot" genannt. Er ist meist wenicer tief erefürbt als der brasilianische und wird auch in ('eylon von noch anders sefärbten 'T'urmalinen beckleitet. Von dieser Insel stammit der 


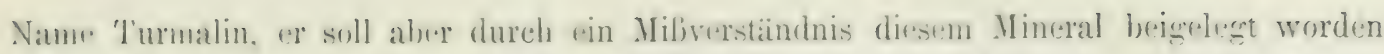
sein. Die Singalesen sollen unter turmali den Hyacinth verstehen.

Dab auch in Nordamerika schön grüne Turmaline vorkommen, ist schon oben

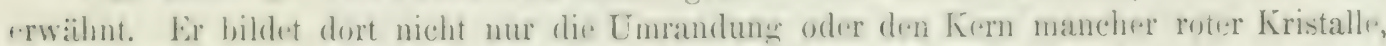
sondern es finden sich atteh ganz griine, die wie die roten vielfach zu Schuncksteinen ver-

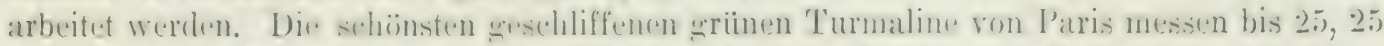
und 1 s mus in der Lïnge, breite und loicle. Auch in Norden wom l'ortland rounty, Con. sind schüne grine 'Turmaline gefunden worden.

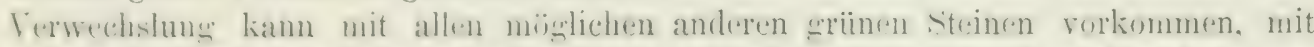

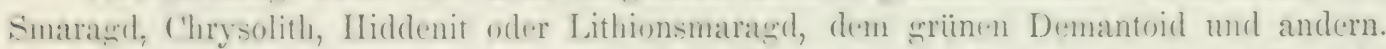
Von simtlichen unterscheidet sich auch diex Turmalin durch das spezificche frewicht

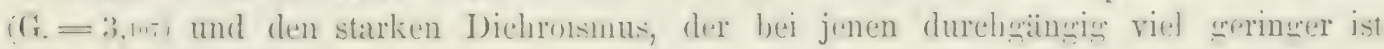
oder auch ganz fehlt.

Der haur Turmalin oder Indigolith nicht häufig. Er ist hald hell, hald dunkel achärbt, meist rein indigu-oder auch wohl smalteblau, zuweilen nit einem mehr orler weniger starken Stich ins Griane. Ein geschliffener blauer Turmalin ist Taf. XV, Fïg. 11, abgetrildet. Die Farbe ist zuweilen ron der des Sapphthirs nicht zu unterscheiden, manchmal gelecht sie auch mehr der mancher Ayuamarine. Ob man is mit einem won diesen beiden Edelsteinen oder mit 'Turmalin zu tum hat, erkennt man auch hier an spezifiechen Gewicht, das bein Indigolith 3,1, betrïgt, und namentlich an dem Dichroismus, der bei diesem gleichermaben sehr stark ist. Diese Varietait kommt ebenfalls, wennschon seltener, mit der grïnen in Brasilien ror; sie leeilit daher bei den Juwelieren .. hrasilianischer" Sapphir". Einzelne schleifhare Exenplare sind auch bei Paris und an anderen Orten in Maine, hei (ioshen in Massachusetts und sonst in Yordamerika, besonders am Mt. Mica, vorgekommen, ebenso bei Mursinka im Ural. Schöne Stïcke werden mit LepridolithGlimmer und Quarz als Begleiter griunen Turmalins aus dem Granit südlich ron Pahira ber Ilazaribagh in Bengalen erwähnt; es sind hier Fristalle ron einer Länge bis über einen Zoll, die zum 'Teil innen indigoblau, aufien grä̈n sind. Auch mit dem Sapphir' von Zanskár kommt blauer Turmalin in Begleitung von sgelbem und braunem vor Überall sind aber gut durchsichtige Stiicke von schöner blaner Farbe selten und stehen hoch im Preise, viel höher als die grïnen.

Ferner ist noch der branne Turmalin zu erwähnen, der zumeilen hell und durchsichtig genug ist, um geschliffen werden zu künnen. Er gibt dann recht hübsche Steine. Die Farbe geht rom Dunkelbraun in verschiedenen Abstufungen durch das Hellbraune bis ins ('ellue (,L'eridot von Ceylon", honiggelb bis grelblichgriin) oder auch ins Rütlichbraune. Schöne durchsichtige braune, wohl auch gelbe stïcke, sind besonders häufig auf Ceylon. wo die iiberwiegende Mehrzahl der Turmaline in den Edelsteinseifen die braune Farbe zeigt. Ton dieser Insel stammt auch der Tafel XV, Fig. 10, dargestellte stein. Die meisten anderen sind zum Schleifen nicht klar genug, es finden sich aber doch unter den bei Dobrowa unweit Unterdrauburg an der Drau in Kärnten im Glimmerschiefer eingewachsenen meist trüben immer einige schleifwärdige klarere, ebenso unter den ganz ähnlich rorkommenden ron Crawford im Staate $\mathrm{New}$ Tork. Auch unter den rotbraunen Turmalinen atus dem Kalk ron Gouverneur und ron Newcomb in New York triff man solche, die genïgend klarr und frei von Rissen sind. um gute Steine zu geben. Brame nordamerikanische Turmaline sind aber allerdings noch wenig geschliffen worden.

Schwarzer. 'Turmalin ist sehr verbreitet. Er wird ebenfalls zuweilen greschliffen und gibt dabei sehr gölüzende, undurehsichtige Steine, die zu Tranerschmuck greeignet sind. 
Im Jahre 1 !lot wurden für rohe T'umaline ungefähr folgende Preise pro Pfund bezahlt: fïr kleine rote, grïne und blaue Steine 130 Mark; für größere grüne 650 Mark; für schr grolje sriine und blane 1300 Mark; für sehr große schöne rote 2600 Mark. Für das Kallat suter geschliffener Ware wird im Detailhandel bezahlt: rot: bis 25 Mark, rosa: bis 16 Mark, dunkelviolett: bis 12 Mark, grïn: lois 10 Nark, blaugrün und blau: his 12 Mark. farblos: bis 8 Mark, mehrfarbig (eriin, blau, gelb, rot): bis 25 Mark, braun: bis 3 Mark, schwarz: bis 1 Mark.

\section{0 pal.}

Der Opal, dieses in der Natur so verbreitete Mineral, ist wie der noch häufigere ()uarz, der uns weiter unten eingehend beschäftigen wird, in der Itauptsache Kieselsäure, aber im Gegensatz zum Quar\% ist er nicht kristallisiert, sondern amorph. Neben der Kieselsïure ist stets noch eine gewisse Nenge Wasser vorhanden, die aber von einem Stiick zum ander'n wechselt; auch Verunreinigungen durch zuweilen nicht unerhebliche Quantitäten fremder Substanzen finden sich sehr häufiğ. Solche unreine und dadurch trübe und meist mehr orler weniger intensiv gefürbte Opalvarietäten werden aber fast gar nicht zur Herstellung von Schmucksteinen verwendet; hierzu dient beinahe ausschlieflich der „edle Opal". Dieser zeichnet sich ror allen anderen durch einen prächtigen bunten Farbenschiller aus, der durch Brechung und Spiegelung der Lichtstrahlen in der an sich farblosen Substanz zustande kommt. Dieser Edelopal wird uns daher hier rorzugsweise beschäftigen. Ihm gegenüber stehen alle die anderen nicht farbenspielenden Varietäten, die man als , gemeinen Opal" zusammenfassen kamn, und von denen unten die hier in Betracht kommenden ebenfalls kurz beschrieben werden sollen.

Im folgenden sind einige der als Schmucksteine brauchbaren Opale in Beziehungr auf ihre chemische Zusammensetzung in einer Tabelle vereinigt, aus der der wechselnde Wassergehalt und die bei diesen nur geringe Nenge fremder Beimengungen ohne weiteres deutlich zu ersehen ist.

\begin{tabular}{|c|c|c|c|c|c|c|c|}
\hline & & $\begin{array}{c}\text { Edler Opal } \\
\text { Ungarn }\end{array}$ & $\begin{array}{c}\text { Feueropal } \\
\text { Zimapan }\end{array}$ & $\begin{array}{l}\text { Milchopal } \\
\text { Kosemütz }\end{array}$ & $\begin{array}{l}\text { Kascholong } \\
\text { Füröer }\end{array}$ & $\begin{array}{l}\text { Menilit } \\
\text { Paris }\end{array}$ & $\begin{array}{l}\text { Hydrophan } \\
\text { Hubertusburg }\end{array}$ \\
\hline Kieselsäure & . & 90,0 & 92,0 & 98,75 & 95,32 & 85,50 & 93,13 \\
\hline Tonerde . & . . & - & - & 0,10 & 0,20 & 1,00 & 1,62 \\
\hline Eisenoxyd & . . & - & 0,25 & - & - & 0,50 & - \\
\hline Kalk . . & . . & - & - & - & 0,06 & 0,50 & - \\
\hline Magnesia & . . & - & - & - & 0,40 & - & - \\
\hline Natron . & . . & - & - & - & 0.13 & - & - \\
\hline Kali . & . . & - & - & - & 0,13 & - & - \\
\hline Wasser . & . . . & 10,0 & 7,75 & 0,10 & 3,47 & 11,00 & 5,25 \\
\hline Organisehe & ibstanz & - & - & - & - & 0,33 & - \\
\hline
\end{tabular}

I) a der Opal nicht kristallisiert ist, so fehlen regehmäbige ehenfliehige formen bei ihm ganz, daweren bildet re häulig rundliche Knollen, traubige, sinterartige Überzïge, längliche, tropfsteinälnnliche '/alpfen und andere derartige Gestalten. Ton Spaltbarkeit ist keire Spur

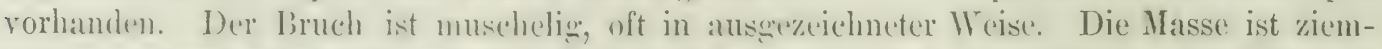
lich, manchmal sogar schr spröde und leicht zersprenghar und zerbrechlich. Die Ifärte ist nicht sehr grol, geringer als beim Quarz; es ist $H_{0}=51 / 2-61 / 2$, so daßb also zwar die 
TAFELL XV!

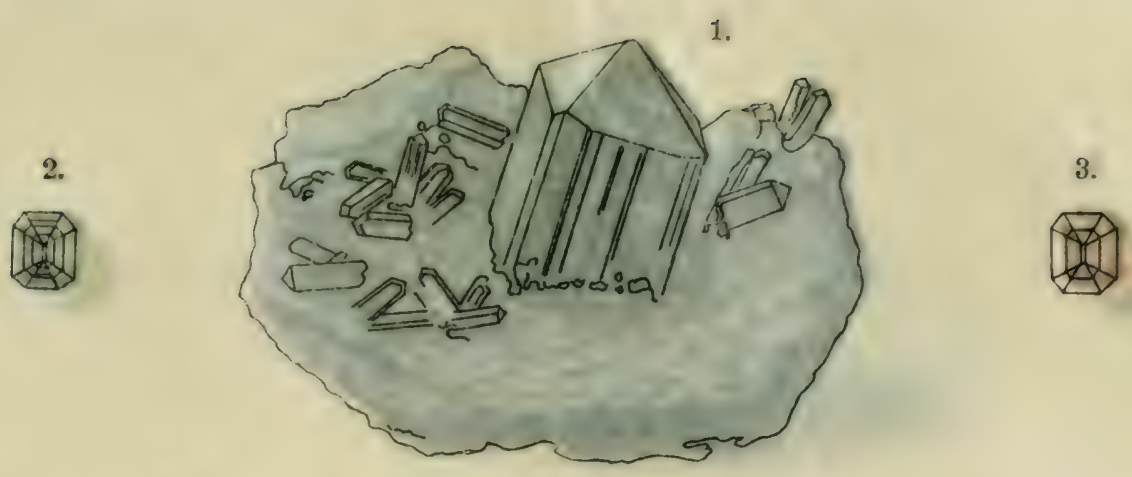

4.

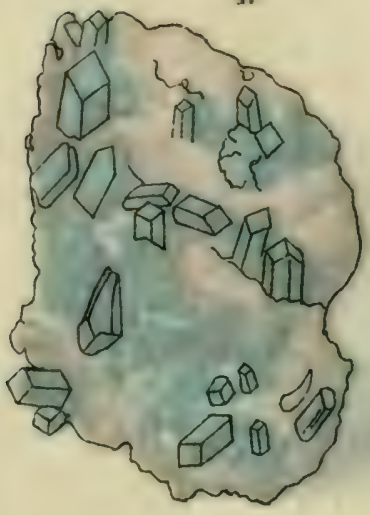

5.

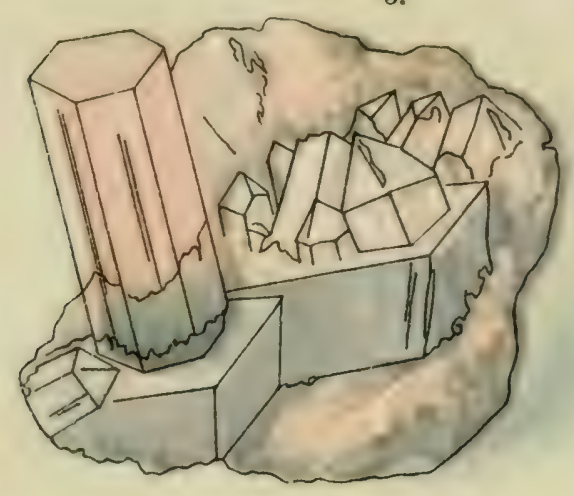

10.

6.
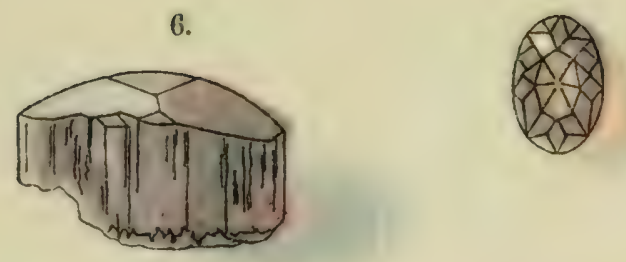

7.

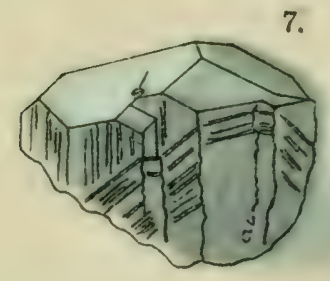

11.

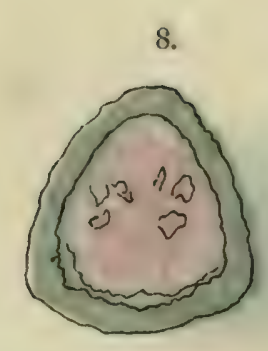

9.

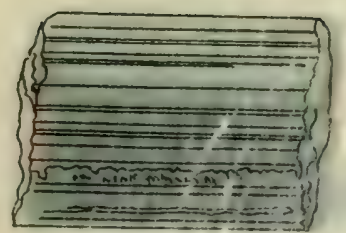

1. Vesuvian (Krystalle). 2. 3. Vesuvian (geschliffen). 4. Dinptas (natürliches Vorkommen). 5 bis 9. Turmalin (Krystalle). 10. 11. Turmalin (geschliffen). 


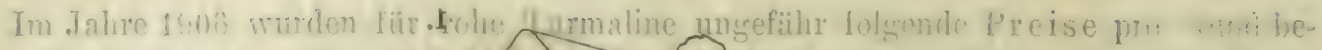

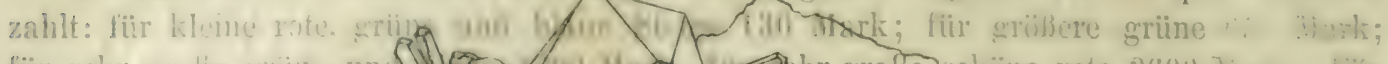
fiir schr smit thine ims

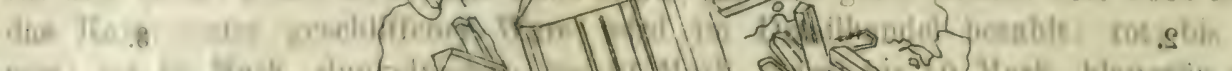

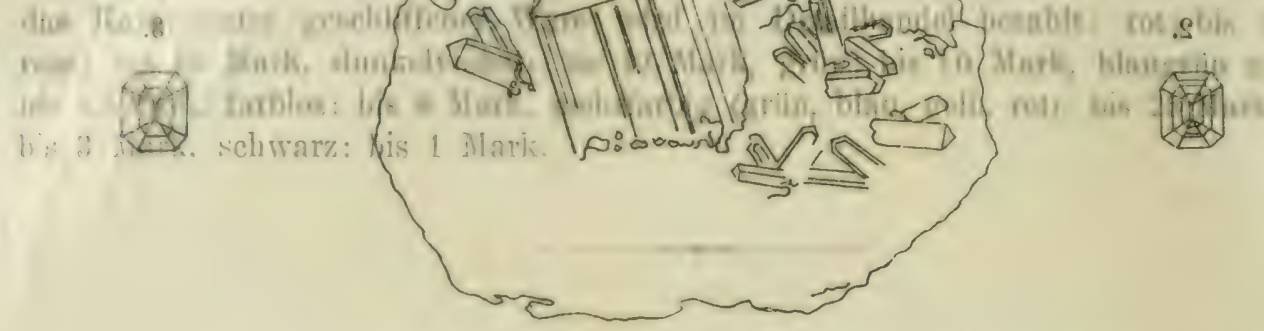

.

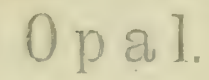

t Quar a shen un sof

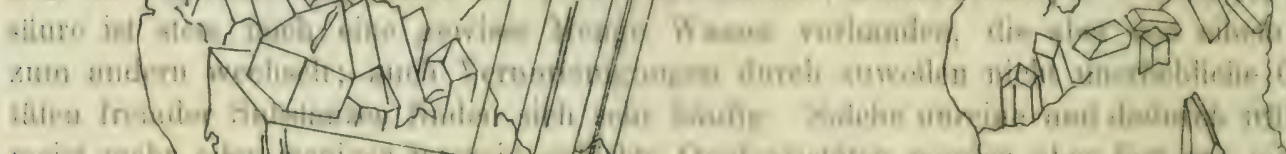
13ira in (a) mo i. toob) है

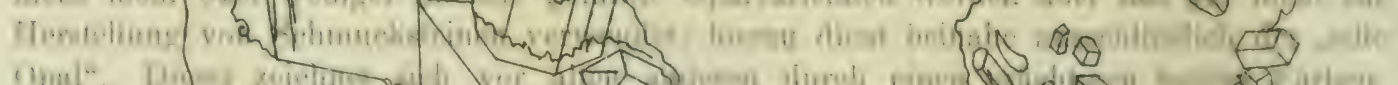

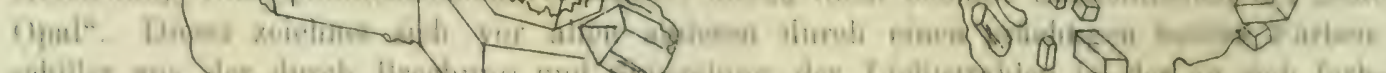

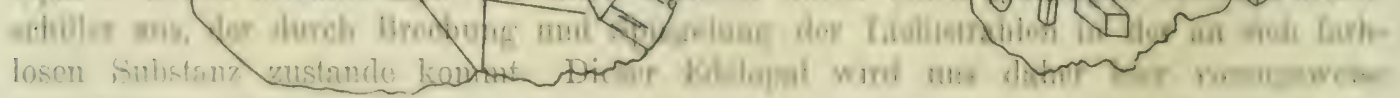

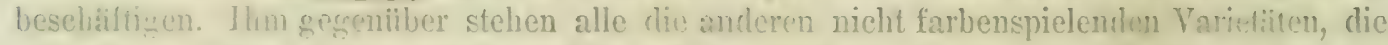
man als sencinen Opal"s zusammenfassen or nn, und von denen unten dise hier in betracht kommendes ehenfalls kurz beschieben weon sollent.

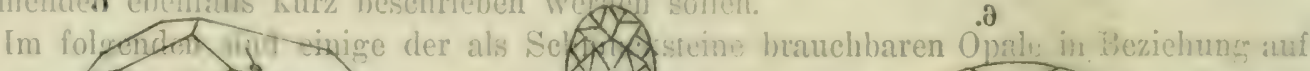
ibre chen dentlich 2 (

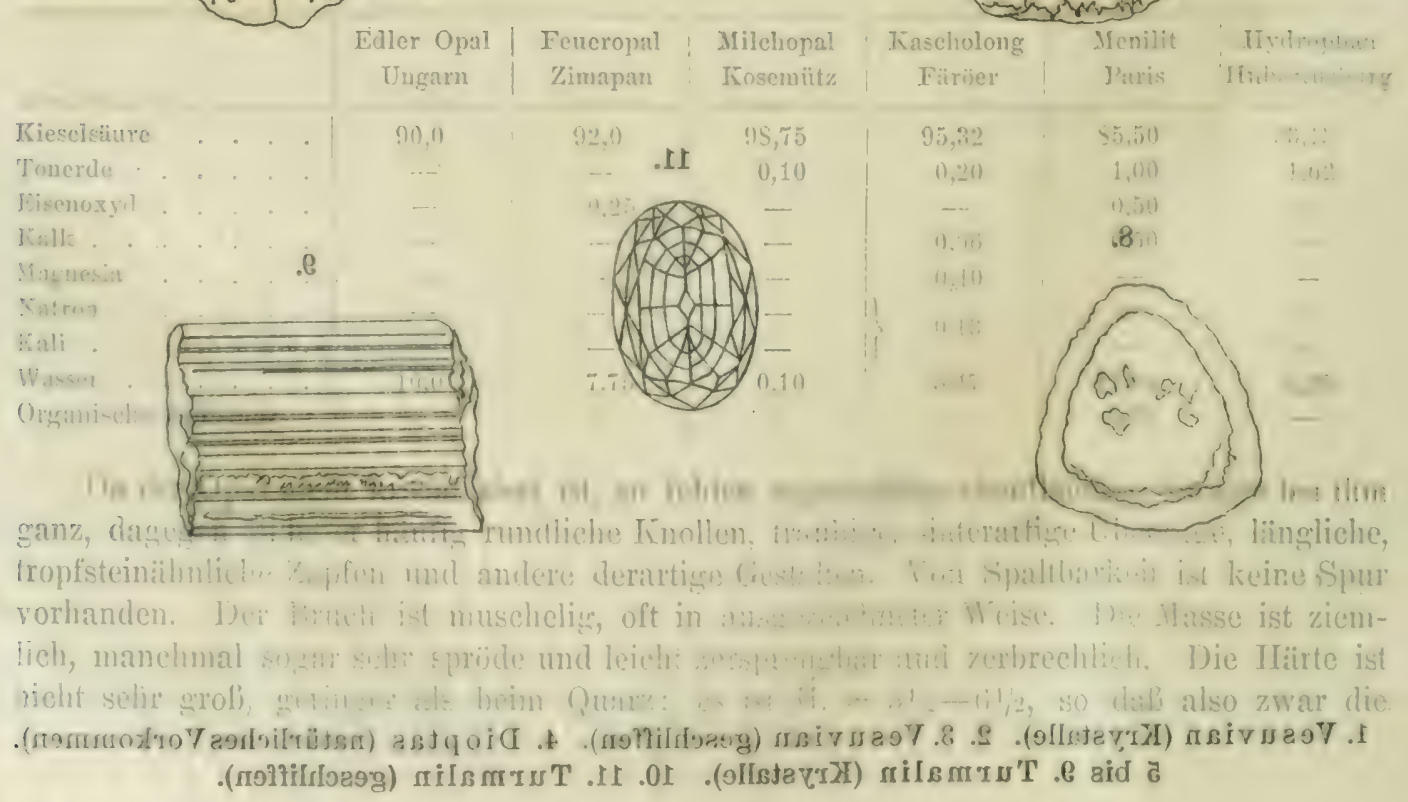


TAFEL XV.
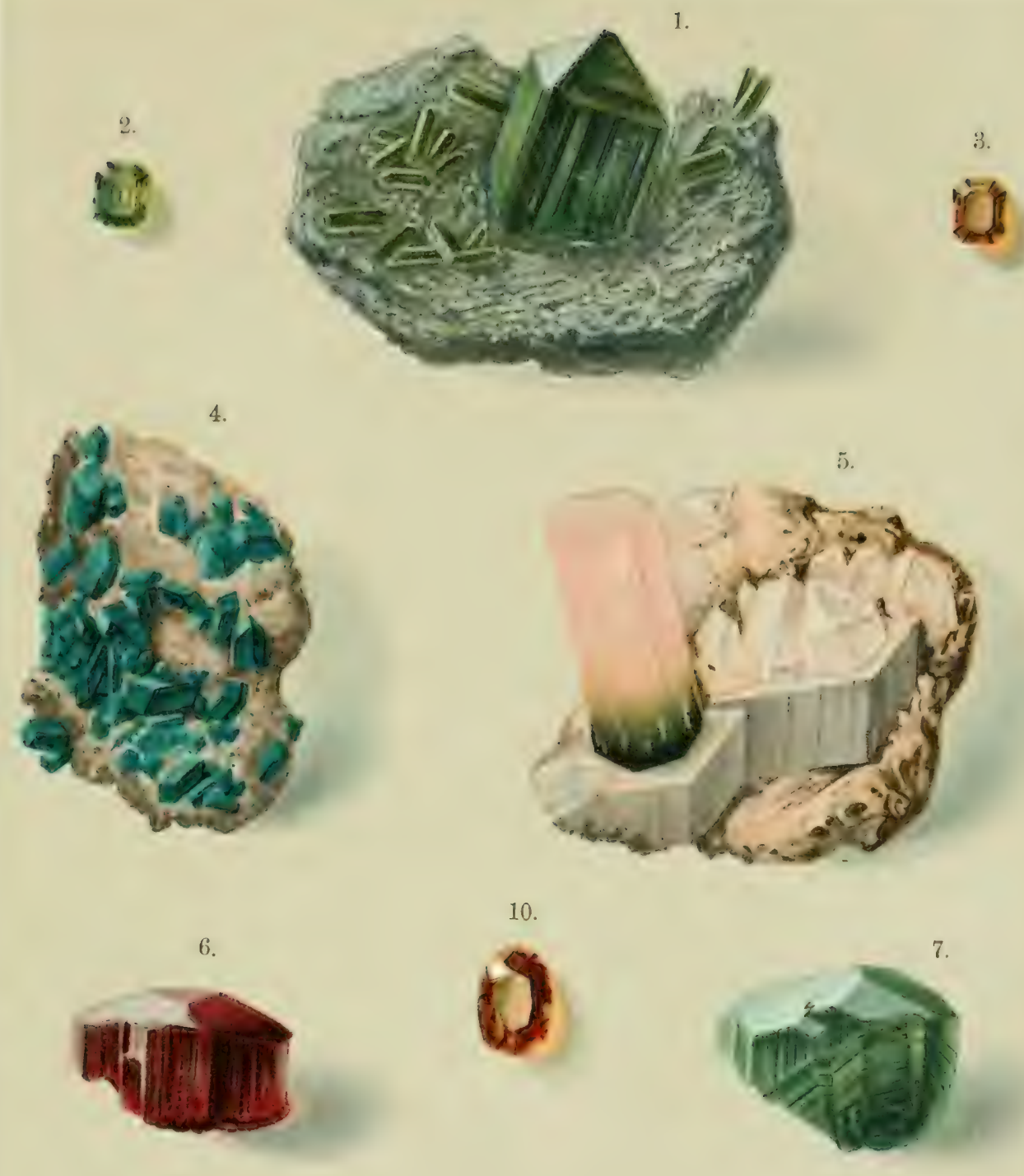

10.
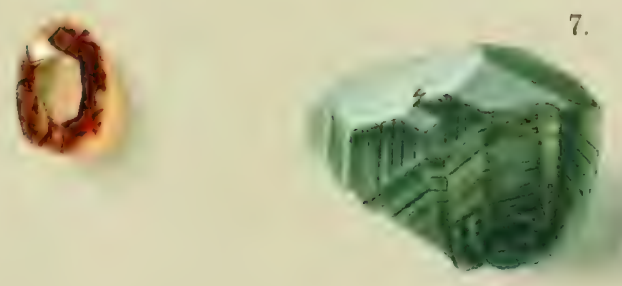

11.
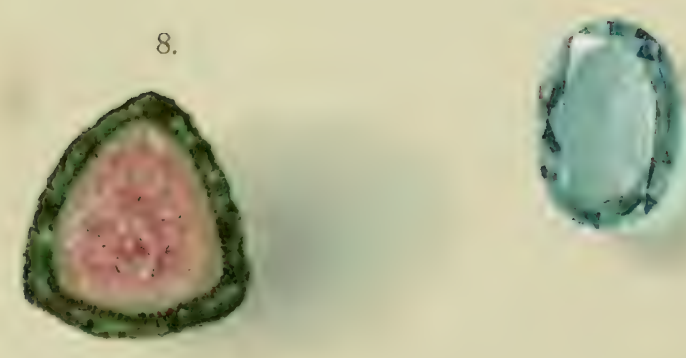

9.

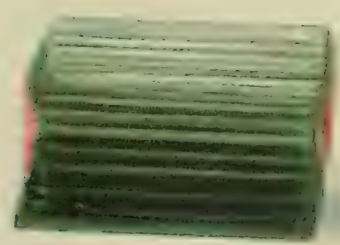





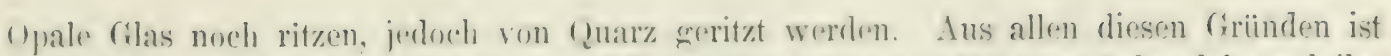
w nuition, einen als Schmuckstein enschliffenen Opal sehr sorofältig zu behandeln und ihn vor Stälen und vor lieriihrung mit härteren Körpern, sowir ror Sitaul) tunlichst zu schiltzen, damit er nicht zerbrochen oder zerkratzt wird.

Wir die Märte. so ist auch das spezifisehe fewicht nichlriger als das des guarzes. E ist von der chemischen Zusammensetzunæ, ron dem Wassercelialt und der Menge fremder Verunreinigunwen ahhängig. und schwankt mit diesen ungroühr zwischen 1,9 und $2,3$.

Der (ilanz ist meist der gewöhnliche Glaswlanz, doch kommen anch fettig, sowie har\%- und wachs:ähnlich stïnzende Opale ror. Ei ist vielfach ron Satur schon ziemlich -tark. wirl aler durch das rehleifen und Polieren noch wesentlich, wenn auch nicht his zu besonders hohem (irate erestrigert. Die I)urchsichtigkeit ist bei einer Varietät,

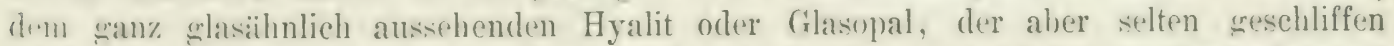
wird, rollkommen. Die meisten Opale sind jedoch trïhe und hächstens durchscheinend his halhdurehsichtig. In dieser letzteren Weise verhält sich auch der edle Opal. Für lïintenstrahlen siud alle Opale noch ziemlich durchlässig. An sich und im reinsten Zu-tande ist die Masse vollkommen farblos. Die dureh die beigemengrten fremden Substanzen lurvorelinachten Farben sind meist hraun, gell) und rot in versehiedenen Nuanern. seltener friin: schwarze Opale kommen ebenfalls vor, aber auch die weife Farbe ist bei unreinen, triiben Varietaiten, wie z. I3. hei dem unter den Analysen erwähnten Vilchopal, nicht ungwöhnlich. The Lichthrechung, der amorphen Beschaffenheit wegen einfach. ist schwach;

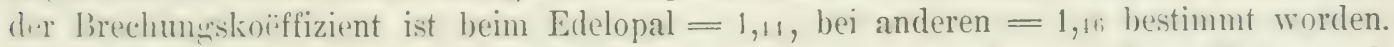

Beim Erhitzen zerspringt der Opal sehr leicht, daher sind geschliffene Steine auch rı. Temperaturveränderungen, namentlich vor raschem Erwärmen durch Berïhrung mit hrilien (iegenstiinden zu hïten. Das IVasser entweicht sehon unter der rilihhitze und dit Masse wird dabei, wenn sie es nicht schon vorher war, trübe und unklar. Schmelzhar ist der Opal ror dem Lötrohr nicht, wohl aber im Knallgasgeblïse. In säure lüst er sich nicht, auljer in Flulsä̈ure; ron Ätztinte wird er stark angegriffen. Im Fegensatz zum Quarz ist dies auch bei der Behandlung mit Kalilauge der Fall.

Der Opal kommt fast ausschlieflich auf spalten, Klüften und sonstigen IIohlrïumen in basaltischen, trachytischen und anderen vulkanischen Gesteinen, seltener im Serpentin usw. vor. stets aber nur in Kieselsäure enthaltenden Gebirgsarten. In diesen finden sich die verschiedensten Varietäten nebeneinander und zusammen mit anderen Kieselsäuremineralien, wit Chaleedon und Quarz. vielfach mit diesen mehr oder weniger innige Gemenge bildend. Der Opal und diese anderen Mineralien sind stets Zersetzungsprodukte jener Gesteine. Das in diesen zirkulierendle Wasser, das zuweilen sehr heif ist, löst aus ihnen Kieselsäture auf. und diese scheidet sich auf Hohlrïumen oder an anderen seeisneten Orten. je nach den speziellen Verhältnissen in einer der genannten Formen wieder aus, wenn das Lösungsmittel verdunstet oder erkaltet. Mit dieser Art der Entstehung hängen die oben beschrielene'n rundlichen Gestalten zusammen. welche an die Formen der in ähnlicher Weise aus IVasser abgesetzten Tropfsteine erinnern. Der Opal bildet zuerst eine weiche gallertartige Masse, $r$ ist nichts anderes als eine eingetrocknete Kieselgallerte. Man findet sogar zuweilen in den Gesteinen die Kieselsäure noch fencht in ihrem ursprünswlichen weichen, wallertartigen Zustande und sieht sie erst zu Opal erhärten, wenn sie an der Luft liegend einen Teil ihres TWassers verloren hat.

Im Vorstehenden sind die allen Opalen gemeinsamen Eigenschaften zusiammengestellt. In folgenden sollen $n u m$ alle zu Schmucksteinen verwendeten Tarietïten des Minerals je nach ihrer Berlentung mehr oder weniger eingehend geschildert und dabei namentlich disjenime Verhalten betont worden. wodurch sie sich als zum Schmuck hesonders geeignet erweisen und wodurch sie sich von anderen Varietäten unterscheiden. 


\section{Edler Opal.}

Die wichtigste und wertrollste Varietït des Opals ist der edle Opal, auch Edelopal, orientalischer Opal, Element- oder Firmamentstein genannt. Zwar sind alle Eigenschaften, die sonst den Trert und die Schönheit eines Edelsteins ausmachen, bei diesem Mineral nur in ungreordnetem Maße vorhanden. Es ist nicht durchsichtig, hat keine ausgeprägte Farbe, einen im Vergleich mit anderen feinen Steinen nicht sehr starken Glanz und nur greringe Härte, aber das auf seiner Oberfläche auftretende prächtige Farbenspiel stellt ihn doch in die Reihe der kostharsten Juwelen. Kein anderer Edelstein zeigt eine ähnliche Erscheinung, so daß der Edelopal unter seinen Genossen eine ganz einzigartige Stellung einnimmt. Seiner Wichtigkeit als Schmuckstein entsprechend, werden wir hier seine Figenschaften und seine sonstigen Verhältnisse etwas eingehender kennen zu lernen haben.

Der Edelopal ist stets nur durchscheinend bis höchstens halbdurchsichtig, zuweilen allerdings der Durchsichtigkeit sich stark nähernd. Das Licht scheint meist mit rötlichgelber Farbe lindurch. In auffallenden, an der Oberfläche zurückgeworfenen Lichte ist er meist farblos und erscheint milchartig trübe, milchweiß, vielfach mit einem leichten bläulichen, zuweilen auch perlgrauen Schein. Viel seltener ist eine ausgesprochene Körperfarbe, gelb, rot und blau, auch grin und schwarz. Unter diesen ist gelb, und zwar weingelb bis schwefelgelb, nicht ganz nngewöhnlich, auch rot kommt nicht gar zu sparsam ror, besonders gelblichrot. Sehr selten ist dagegen rosenrot; ron dieser Farbe wird ein prachtvoller Stein im Grünen Gewölbe in Dresden aufbewahrt. Blau, grün und schwarz ist ungewöhnlich. Von großer Schönheit sind zuweilen die seltenen sehwarzen Opale, bei denen auf dunklem Hinterorunde das Farbenspiel in besonders herrlichem Glanze strahlt.

Dieses Farbenspiel besteht bei allen Opalen darin, dab der Stein in dem an der Oberfläche zurïckgeworfenen Licht, nicht aber beim Hindurchsehen, in den lebhaftesten und brennendsten Regenbogenfarben erglänzt. Diese bedecken zuweilen den ganzen Stein oder es sind nur einzelne farbenglänzende Stellen, welche in die nicht mit Farbenspiel versehene Umgebung allmählich übergehen. Die ganze Oberfläche zeigt manchmal ganz einheitlich eine und dieselbe Farbe, wobei namentlich Gelb und Griin geschützt ist, oder man sielıt einzelne größßere gleichmäßig gefärbte, aber in der Farbe miteinander abwechselnde Flecke, die meist gleichfalls allmählich ineinander verlaufen. Zuweilen sind aber auch winzige verschiedenfarbige Flitterchen unregelmäßig und in größter $\Lambda$ nzahl über die Oberfläche des Steines verteilt und gewähren so ein kaleidoskopartig buntes Bild, das man namentlich bezïglich des Glanzes der Farben mit dem Halsgefieder mancher Tauben oder mit einer I'fauenfeder vergleichen kann, während die mehr einheitlich spielenden Steine größere Ähnlichkeit mit farbenglänzenden Perlmutterplättchen haben. Die Farben sind aber bei guten Edlelopalen durchgängig feuriger als bei allen diesen zum Vergleich herangezogenen Gegenstïnden. Finige farbenspielende Edelopale sind auf Taf. XVI, Fig. 6 bis 9, abgebildet.

Man pflegent, in Anlehnung an die Schilderung des Opals und seines Schillers bei Plinius, rielfach zu sagen, daß in dem Farbenspiel dieses Edelsteines das feurige Rot des Rubins, das prïchtige Grün des Smaragds, das goldige Gelb des 'Topases, das tiefe Blau des Sapphirs und das lebhafte Violett des Amethystes miteinander vereinight seien. Alle diese Farben kommen auch in der Tat vielfach an einem und demselben Steine nebeneinander vor, häufig fehlen aber auch einige, und manchmal sieht man, wie schon erwähnt, die sanze Oberfläche nur in einer einzigen Farbe glänzen. Die Verschiedenartigkeit des Farbenspiels, wie es an den einzelnen Steinen auftritt, von denen sich keiner genau so verhailt wie der andere, wird dadurch bedingt. Dieses ist zum 'Teil in hestimmter Weise an gewisse Fundorte geknüpft. Während z. B. beim ungarischen Opal meist nur kleine Flecken und Flitterehen ron versehiedener Farbe remellos und rasch miteinander ab- 


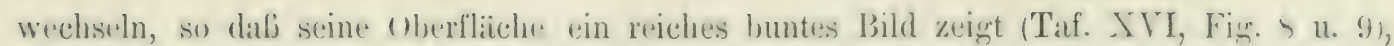
ist der australische ('Taf. XVI, Fig. (i) u. T) bäufig darlureh ausgereichnet, dalf die Farbe:11 ïber grölere Flächen dieselben bleiben.

Auf der Art des Farbenspiels beruht die: Lintergcheidung einer Anzahl von Varietäten des edlen Opals, dir besondere Namen erhalten haben. Beim Harley uin-orler Flimmeropal sind zahlreiche kleine eckige Farbenflitterchen so dicht gedrängt, dab sie gewissermalien ein sehr feines buntes Ilusaik bilden. Auch solche Opale, wo der Farbenschiller nicht auf einem weilien, sondern auf einem geslbroten, dem nachlier zu betrachtenden

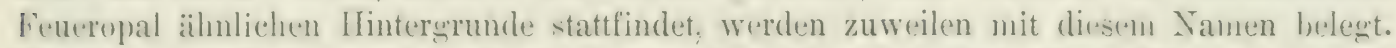
Wrehseln die Farben mehr reihen-oder streifenweise, so heibt der Stein Flanmenopal. Lst die ganze Fliiche mit einem goldig grlänzenden gelben, Schein bedeckt, so hat man den Goldopal. Ein fast durchsichtiger Opal, aus dessen Innern ein lebhaft wogendes blautes Licht strahlt, ist zuweilen Girasol genannt worden, welcher Vame übrigens auch für andere Edelsteine benutzt wird. Opalonyx heilit ein Stein, der aus einer suchicht farbenspielemden edlen und aus einer Fehicht nicht farbenspielenden geneinen Opals zusammengesetzt ist. Isei dem Knopfopal von Neu-Mexiko ist werber, sehwach oder gar nicht farhenspielender Opal mit einer śchicht schwarzen Chaleedons verwachsen, was schr hiilsche Steine liefert. In einzelnen Fundorten kommen noch andere Surten ror, die zum Teil bei der Beschreibung der rerschiedenen Lokalitäten noch besonders erwähnt werden sollen.

Auf die Schünheit der Farben gुründet sich im wesentlichen die Wertschïtzung. Nicht auf allen Steinen ist das Spiel derselben gleich prächtig. Hanchmal sind die Farbenreflexe zu matt und trïbe, manchmal auch zu klein und zu vereinzelt oder zu einheitlich, als dab sie einen besonders vorteilhaften Eindruck hervorbringen lï̈nnten. In einem solchen Falle ist natürlich der Wert des Steines gering. Dieser wächst aber rasch nit der Leblnaftickeit und Pracht der vielfach mit einander abwechselnden und in einander übergehenden Farben und mit ihrer mehr oder weniger vollstïndigen Ausdehnumg über die sanze Oberfläche hin, so daß das bunte Farbenspiel möglichst wenig durch nicht schillernde Stellen unterbrochen sind.

Das Farbenspiel ist nicht ganz unveränderlich. Beim Erhitzen der Steine bis zur Vertreibung des Wassers versehwindet es, weil dadurch die Masse zu triib wird. Manche Steine verlieren ihr Wasser allmählich sehon in der Kälte und werden dadurch unansehnlich, so daß ihr frïherer Wert stark herabsinkt. Durch Trïnken mit (̈) soll sich das Farbenspiel wieder erhöhen lassen, durch die allmähliche Zersetzung des ïls sollen sich aber die so behandelten Steine mit der Zeit schmutzi@ braun färben, womit die Farben vollkommen verschwinden, und wodurch die Stïcke selbstverständlich wertlos werden. An wenimsten sind die ungarischen Edelopale solchen Veränderungen ausgesetzt, was ihren höheren Wert anderen gegeniiber mit bedingt.

Die Farben, die das glänzende bunte Bild hervorbrinæen, das ein Edelopal uns zeigt. luaben nichts Körperliches, sie sind in der an sich farblosen Masse nicht hervorgebracht durch irgendwelchen beigemischten oder beigemengten Farbstoff. Ihr Ursprung beruht lediglich auf der Veränderunæ, welche die auffallenden Lichtstrahlen in der Opalsubstanz erleiden, durch einen Vorgang. der wahrscheinlich nicht wesentlich verschieden ist ron denjenigen, der das Irisieren in manchen Quarzen und anderen Mineralien herrorbringt. Beim Eintrocknen der feuchten Kieselerde, beim Festwerden der Gallerte, die der Opal zuerst im noch weichen Zustande bildet, entstehen leicht nach allen Richtungen hio sich durchkreuzende Spältchen nnd Risse. Auf diesen dringt Luft in den Stein, die sieh darin in so dïnnen Schichten ausbreitet, dafs auf ihnen die brennenden Farben der diunnen Plättchen erglänzen. Durch mikroskopische Untersuchung ist nachgewiesen, dalf auf 
solchen liksen anch nachträglich diinne P'lättchen einer anderen Opalmasse ron abweichenden Lichthrechun wsverhältnissen eingelagert worden sind, die wahrscheinlich sich an der Entstehmor des Farbenspieles ebenfalls beteiligen. Dieses ist beim Opal prächtiger und lehhafter, als bei ircendeinem der irisierenden Mineralien, und es ist daher die Frage, oh heim Opale nicht noch andere Ursachen vorhanden sind, die bei jenen fehlen. Vielleicht ist die Erscheinung, die der edle Opal bietet, noch nicht nach allen Seiten vollkummen richtig erkannt und erklärt, jedenfalls sind schon mehrfach abweichende Ansichten hinüber geäubert worden. Fest steht aber jedenfalls das Tatsächliche, daß das Farbenspiel nicht durch l'igmente, durch beigemengte Farbstoffe, hervorgebracht wird, sondern dab es eine auf der Teränderung der einfallenden Lichtstrahlen beruhende sogenannte Interferenzerscheinung ist, wonit das Abblassen oder Verschwinden beim Hindurchselıen auf des Beste iibereinstimmt.

Wegen der nie fehlenden vielen Risse ist es geraten, den edlen Opal, wenn er auch vielleicht etwas härter ist als der gemeine, noch sorgfältiger zu schützen als andere Opalsorten. Namentlich muß man ihn, noch mehr als andere Opale, vor starken und unregelmäßigen Temperaturänderungen besonders ängstlich behüten. Deshalb ist ror allem auch das Schleifen mit größter Vorsicht auszuführen, wenn der zu bearbeitende Stein nicht in Gefahr kommen soll, zu zerbrechen.

Beim Schleifen erhält der edle Opal fast immer eine runde nugelige Forn ohne Facetten, auf der das Farbenspiel sehr schön hervortritt. Facetten würden dieses letztere nicht verbessern, eher stören, auch könnten sie bei der geringen Härte des Steines nicht lange scharf bleiben. Daher sind Edelopale nur selten mit solchen geschliffen worden, immerhin kommen aber zuweilen Tafel- und Treppensteine und andere Formen vor. Je nach der Gestalt des rohen Stïckes wird die Grundfläche des geschliffenen Steines kreisrund oder oval, und je nach dessen Dicke wird die Wölbung höher oder niederer, sodaf die Form einer halben Lrbse, Bohme oder Mandel ähnlich ist. Auch Perlen werden hergestellt, nicht selten mit Durchbohrung zum $\Lambda$ uffassen auf Schniiren. Das Bestreben des Schleifers ist immer, das Farlenspiel tunlichst zu steigern, wozu nicht selten große Geschicklichkeit und reifliche Überlegung und Erwägung aller Umstände erforderlich ist. Die Aufgabe besteht häufig mit darin, angewachsenes II uttergestein und nicht farbenspielende Opalpartien mit möglichst geringem Verlust edler Teile von einem Stein zu entfernen, damit er über die ganze Oherfliche hin sein Farbenspicl ununterbrochen in möglichster Schönheit zeigen kann. Matt gूewordene Opale künnen durch Polieren mit Wassertripel auf der Hand aufgefrischt werden.

Kïnstlich kann das Farbenspiel etwas gesteigert werden, indem man dem Stein, der allerdings nicht zu dick und nicht zu wenig durchseheinend sein darf, beim Fassen eine Folie von buntschillernder Seide, oder ein Stïck Pfauenfeder, oder auch ein glänzend poliertes Perhmutterplïttehen unterlegt. Das Fassen geschieht selten a jour; am besten in ('inem schwarzen Kasten, wobei man wrößere Steine zur IIebung des Glanzes geern mit cinem Kranze vou kleinen Diamanten oder farbigen durehsichtigen Steinen umgibt. Umwekehrt werden aber auch vielfach größere Diamanten, Rubine, Sapphire usw. mit kleinen Edelopalen in derselben Weise eingefaßt oder, wie man sagt, karmoisiert.

Der Preis des edlen Opals ist sehr beträehtlich; or wehört mit zu den belielitesten und besthezahlten Edelsteinen. Wir wir aber schon im Vorbeigehen gesehen haben, hängt seine Wretschätzung in allererster I inie von der Sehönheit des Farbenspiels ab; die rot und auch die griun spielenden sind die teuersten, doch ist die besondere Beginstigung gerate dieser Farben mehr Salche der aunenblicklichen Mode. Die Steine sollen nieht zu stark durchscheinend, chensowenign aber zu trübe sein, weil durch diese beiden Imstände

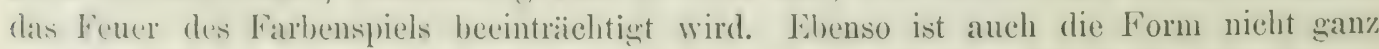
ohne Einflub; zu grolie und zu geringe D)icke der mugeligen Steine ist unerwïnscht. 
bis vor kurzem ist in IIandel fiir jedes gröbere und bessere Stiick der l'reis nach seiner

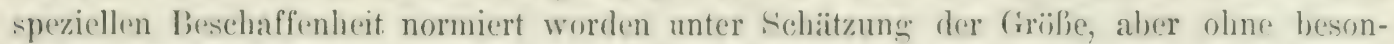
dere Berïeksichtigung des Gewichtes. Erst in neuerer Zeit wirl rlas letztere, in Karaten ausgedrüekt, mehr in Betracht gezogen. Der Wert sehönster ungrarischer Steine erreicht ungefälur den sheich schwerer brillanten. (Grobe Opale, namentlich solche, die auch eine 'ntsprechende I bicke haben, sind wegen der verhältnismäbigen feltenheit ihres Vorkommens selur tener, der Preis witehst sebre viel rascher als die Gröbe. Kleinere Steine sind rentsprechend billiger; ein lebhaft farbenspielender Karatstein mulb mindestens auf 50 Mark werschätzt werden. Ist das Farbenspiel geringer, so vermindert sich der Preis sehr schnell his 7.11 ganz kleinen Beträgen, wie dies namentlich zum Teil bei den aus Mittelamerika stammenden sogenannten ..mexikanischen" und den australischen Opalen, von denen unten die Rede sein wird, der Fall ist. Im Mittelalter waren schïne Edelopale vielleicht noch höher seschätzt als jetzt, und die alten Römer haben einen groben Luxus auch mit diesim Edelstein getrieben.

Trotz des zu erwartenden Gewinnes ist es noch nicht gelungren, den edlen Opal dureh Glasfliisse nachzuahmen; das kïnstlich in Glas erzeugte Farbenspiel wird jedermann leicht von dem des echten Steines unterscheiden. Dagegen sucht man zuweilen nicht farbenspielende gemeine Opale als edle erscheinen zu lassen, indem man sie mit denselben Folien wie die edlen in einen schwarzen Kasten falt. Das Farbenspiel wird dadurch manchmal dem Steine bis zu einem ziemlich hohen Grade mitgeteilt. Schön farhenspielende slänzende schwarze Opale befinden sich zurzeit im Handel, auf denen der V'erdacht ruht, daf an ilnen irgendeine kïnstliche Verïnderung stattgefunden hat; doch ist bisher nichts Nälıeres darüber bekannt geworden.

Das Vorkommen des edlen Opals und seine Entstehung ist iberall genau ebenso, wie beim Opal überhaupt und wie es oben auseinandergesetzt worden ist. Überall ist er ron semeinem Opal in seinen verschiedenen Abarten, sowie ron anderen aus Kieselsüure bestehenden Mineralien, wie Chalcedon, auch Quarz begleitet. Er bildet im gemeinen Opal und in ihn allmählich übergehend kleinere Partien, die bei der Gewinnung aufgesucht, ron den nicht farbenspielenden abgetrennt und in den Handel gebracht werden.

Eine der wichtigsten Fundstätten, die gegenwärtig, wenn auch nicht die meisten, so doch die schünsten und wertvollsten edlen Opale liefert, liegt im nördlichen Inngirn. nicht weit von der galizischen Grenze in der Gegend von Kaschau und Eperies im Siudosten des Śíroser Komitats, nahe der Scheide gegen das Komitat Zemplén. Der hier gewonnene Opal ging in friiheren Zeiten nach Konstantinopel und kam rou dort meist iiber Amsterdam in das Abendland zurïck. Daher war bis zum Ende des vorvorigen Jahrhunderts die Meinung verbreitet, unser Edelstein stamme aus dem Orient, weshalb er auch als .orientalischer Opal" bezeichnet wurde. Noch heute ist der Ausdruck zuweilen für be. sonders schöne Stiicke im (rebrauch, entsprechend der gleichen Gepflogenheit bei anderen Edelsteinen, obwohl man jetzt seit langer Zeit mit Sicherheit weib, daß die in Ägyten, Arabien, Cypern, Ceylon usw. vermuteten orientalischen Fundorte tatsächlich nicht existieren. Allerdings hatte schon am Ende des 17. Jahrhunderts der französische Reisende und Edelsteinhändler Tavernier auf Grund seiner Reiseerfahrungen die damals ganz richtige Behauptung aufgestellt, daß nur in Ungarn Edelopal vorkomme, sie ist aber lange Zeit unbeachtet geblieben. Das Folgende beruht z. T. auf den Mitteilungen von K. Ziman yi.

Die Opalgruben befinden sich in dem Kaschan-Eperieser Gebirge in einem wilden, fast menschenleeren Bergland nahe dem 466 Meter iiber dem Meer gelegenen und $24, \bar{\imath}$ Kilometer in südöstlicher Richtung von Eperies entfernten Dorfe Czerwenitza (magyarisch Törüsvígás). Eine kleine Ansiedlung, 3 Kilometer nördlich ron dem genannten Dorfe, bildet den Mittelpunkt der Opalgewinumg und der Opalgruben. Sie dient nur dieser 
Industrie und hat daher den ungarischen Namen Opalbanya erhalten; die durchweg slovakischen Cmwohner nennen sie Dubnik. Ihre Meereshöhe beträgt 700 Meter. Hier ist die Stiitte des Opalberghanes; von hier kommen die vielen schönen ungarischen Steine, die noch immer, auch nach Entdeckung anderer, reicherer Quellen, eine nicht unerhebliche Rolle im Erlelsteinhandel spielen. Einen Kilometer westlich von Dubnik ist der Berg Libanka, in dem heutzutage ausschließlich die Gräberei vor sich geht. Etwas weiter entfernt, T Kilometer nördlich von Czerwenitza, liegt der Berğ Simonka, der früher wichtig gewesen ist. Er bildet die höchste Erhebung jener Gegend und steigt bis zu einer Neereshöhe von 1092 Meter an.

Das Gestein der Libanka ist ein vulkanisches, ein Pyroxenandesit von brauner, grauer bis schwarzer Farbe. Es wird ron zahlreichen, in verschiedener Richtung verlaufenden Silalten und Klïften durchsetzt und beherbergt eine große Menge größerer und kleinerer IIohlyäume von verschiedener Form. Der Opal findet sich in einer Breceie, die aus fest miteinander verkitteten Brocken dieses Gesteins besteht. Sie schneidet nach Osten und Westen in senkrechten Grenzen gegen den umgebenden opalfreien anstehenden Andesit ab, getrennt ron ihm beiderseits durch eine Lage ziemlich kompakten roten Tons. Die Opal führende Gesteinsmasse ist immer mehr oder weniger stark verwittert. Namentlich ist der Feldspat stark verïndert und in Kaolın oder auch in Opal umgewandelt. Tor allem sind aber die in Gestein befindlichen IIohlräume, Poren und Spalten, mit Opal ausgefüllt, ofters ron Schwefelkies und Narkasit. seltener auch von Antimonglanz und Schwerspat begrleitet. Die mit Opal erfüllten Nester sind, scharf rom Nebengestein geschieden, überall in der Andesithreceie, soweit sie aufgeschlossen ist, vorhanden; sie nehmen auch in der größjten bekannten Tiefe nicht ab, aber allerdings sind sie sehr sporadisch und unregelmäßig darin verteilt. Indessen hat die Erfahrung gelehrt, daß da, wo das Gestein Schwefelkies führt und wo es in der Nähe der IJohlrïume ron kompakterer Beschaffenheit ist, der Edelopal sich reichlicher findet als sonst.

Die Opalmasse ist in den Hohirämmen meist horizontal ahgelagert. Dies tritt namentlich dort dentlich hervor, wo die Ausfüllung nicht vollstaindig ist. Die obere Begrenzung wird in diesem Fall ron einer mehr oder weniger elenen, vollkommen horizontalen Fläche genbildet. Den gröliten Teil des Raumes nehmen die gewöhnlichen Opalarten ein, meist Nilchopal, auch Wachsopal, zu denen sich zuweilen Hyalit gesellt. Mit dem Milchopal ist der Edelopal verwachsen und geht allmählich in ihn iber; zuweilen sieht man auch beide in unregehmäßigen, horizontalen Schichten miteinander wechsellagern. Anders ist das Vorkommen des durchsichtigen IIyalits. Er hängt in den von den anderen Opal Jeer getassenen Räumen in Form kleiner Zapfen und zierlicher Stalaktiten von der Decke der In libäume herab, zuweilen auBerordentlich feine bart- und spinnwebenartige Gewebe bildend; vielfach bedeckt el die obere Begrenzungsfläche jener Opale und füllt auch nicht selten den äher ihnen befindlichen Raum vollstïndig aus. Er ist offenbar jüngeren Trsprumes als diese, während der Milchopal und der Edelopal als gleichalterig anzuschen sind.

Wrenn das Nuttergestrin oberflichlich vollständig verwittert, bleibt der widerstandsfïhigere Opal unverïndert übrig und liegt dann lose im Erdboden. Aus diesem grelangt er in die Wasserliufe und ist deren Sand und Kies in Form von freröllen beigemengt. Auch diese wurden früher aufgesucht und gewonnen.

Der Elelopal ist meist nur in ganz kleinen l'artien mit dem gemeinen Opal rerwachsen. Diese werden damn aus der Masse herausgeschnitten und geschliffen. Stuicke ron der Größe einer Bohne oder einer IIaselnuß sind schon sehr selten, noch größere kommen äußerst vereinzelt vor. Das größte, aus früherer Zeit bekannte Stiick wird im mineralogischen IIofmuseum in Wien aufhewalıt. Es ist ungeschliffen, aber beinahe ganz 
vom Inttergestein befreit und zeigrt fast dunchweg das schönste Farbenspicl. Die Form ist die eines Keils, die Grölie ungefälı die einer Mannesfaust, 1:, 1/oll lang, 21.2 Zoll breit und 1,2 bis : Zoll hoch. Das Gewicht beträigt 34 Lot oder nahezu bon Gramm (etwa 3000) Karat). Ein Ansterdaner Edelsteinhändler wollte, wie crzïhlt wird, $500(000)$

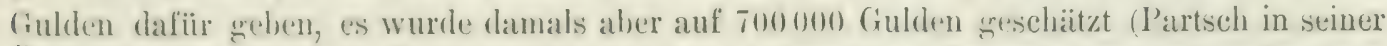
Uhersicht der im k. k. Ifofmineralienkabinett aufgesteflen Sammlungen gribt allerdings 14.55 nul 70000 Gulden an, welche Zahl dann auch in andere Werke ïbergergangen ist). (iefunden wurde das stäck in den siebziger Jahnen des 15. Jahrhunderts bei C'zerwenitza als Gerölle von einem Fenersteinsucher. Der noch anhängende Andesit zeight, dal's es aus den höheren 'Teilen des Libankabereses stammt. Ein kleineres, ebenfalls durch lieinheit und Farbenpracht ausgezeichnetes ereschliffenes Stiick von der Form und Gröbe eines Hiihnereis, vielleicht von dem vorigen ahgetremnt, befindet sich in der k. k. Schatzkammer in Wien. 1s6s wurden zwei jetzt birnförmig geschliffene prächtige Opale ron 186 und 16t) Karat in der Libanka zefunden; der letztere soll der schönste Iarlequinopal sein, den man bis jetzt kennen gelernt hat.

Ehenfidls in der Libanka und zwar an einer der tiefsten dort aufgeschlossenen Stellen fand man in Januar $18 s 9$ die sröbte jetzt bekannte Opalmasse von einem ganz auberg̈wö̈hnlichen Umfang. Die Form ist nahezu elliptisch, die Länge beträgt 1), S() Meter, die Breite 1,40 und die Dicke 0,30) Meter, das Gewicht nahezu 200 Kilogramm. Sie lag in einem Hohlraum, ron dem aus zahlreiche Klüfte und Spalten in den umgebenden Indesit lineinliefen, die ebenfalls Opal enthielten. Der Hohlraum ist in seinem oberen Viertel leer seblieben, die obere (irenzfliche des Opals ist wie gewöhnlich etwas wellig, jedoch im ganzen elueu und rollkommen horizontal. Ein feines weißes Pulver von Opalsubstanz bedeckt sie. Der Opal selbst war in der Hauptsache Milchopal, gegen den der edle Opal stark zuriicktrat, und zwar wechselte letzterer in drei ziemlich goleichweit voneinander abstehenden dïnnen horizontalen Lagen, die dickste 1 Zentimeter messend, mit dem Milchopral alb. Die ganze Masse lag wieder mit einer ebenen horizontalen Fläche auf einer Partic eines stark zersetzten und dadurch etwas weicher gewordenen Opals ohne alles Farbenspiel. Auch der Opal in den von der Hauptmasse ausgehenden Kilüften und spalten War vorwiegend Milchopal mit geringen Mengen Edelopal. 13 Steinschleifer hatten rier Ilonate Arbeit, bis der aus diesem Funde herribrende Edelopal geschliffen war. Dieser, meist von der Art des Ilarlequinopals, ist von ausgezeichneter Beschaffenheit, nur an der Grenze stellt sich sogrenannter Oculus ein, eine infolge beginnender Zersetzung;, etwas weniger lebhaft farbenspielende Abart. Dazu tritt stellenweise eine für diese Geagend besondere Erscheinung. Während der ungarische Opal sonst durehweg dadurch auscrezeichnet ist, dab das Farbenspiel durch kleinere verschiedenfarbige Flecken und winzige Flitterchen zustande kommt, wurde an diesem Stiick da und dort eine größere Ausdehnung von Flecken in gleicher Farbe beobachtet, wie sie sonst hauptsïchlich dem unten zu beschreiluenden australischen Opal eigentümlich ist. Dieser Lnterschied ist aus Tafel XV zu ersehen, auf der Fig. 6 und $T$ australische. Fig. 8 und 9 ungarische Steine darstellen.

Teben dem reinen Opal wird in Ungarn noch die Opalmutter gewonnen. Das (iestein, in dem sich der Opal eingewachsen findet, ist stellenweise mit zahlreichen winzicen Upalpartikelchen durchwachsen, die trotz ilner Kleinheit das Farbenspiel auf das Schünste zeigen. Sie künnen wegren ihrer zu geringen Gröbe nicht aus der Masse losgetë̈st werden, teilen dieser aber ihren Farbenglanz mit, der nun auf dunklem Hintersrunde reflektiert wird und dem ganzen Gestein ein recht hübsches Ansehen verleiht. Diese Masse bezeichnet man als Opahmutter. Auch sie wird, wenn sie an farbenflimmernden Teilchen recht reich ist, zu sichmucksteinen, öfter aber zu kleinen Galanteriegegen- 
ständen, wie Dosen usw., verarbeitet. Das Aussehen dieser Stücke und ihr Farbenspiel kann zuweilen noch erhöht werden, indem man die stets mehr oder weniger poröse Masse mit (i) durchdränkt und dieses bei gelindem Fener zersetzt. Das Muttergestein wird dadurch sehwarz gefürbt, und auf dieser schwarzen Unterlage bringen dann die Farben der unverïndert gebliebenen Opalpartikelchen eine noch schönere Wirkung hervor als auf der ursprüinglich helleren. Vielleicht werden auf solche Weise die oben erwähnten schwarzen Opale gewonnen, deren künstliche Ilerstellung vermutet wird; indessen ist es zweifellos, daß auch echte, natiirliche schwarze Edelopale, wenngleich als große Seltenheit volkommen.

Auch den Hydrophan findet man bei Czerwenitza nicht selten. Er zeigt in der Grube häufig noch das lebhafte Farbenspiel, das aber an der Luft infolge Wasserverlusts rasch verschwindet (sog. Weltauge, oculus mundi). Wir werden ihn unten noch näher kennen lernen. Aber auch die entgegengesetzte Erscheinung will man beobachtet haben. Manche Opalstiicke sollen in den Gruben, von Bergfeuchtigkeit durchsetzt, kein Farbenspiel zeigen, das erst bei der Austrocknung über der Erde sich allıählich einstellt. Einzelne derartige Proben sollen sogar im Gestein ursprïnglich noch gallertartig weich gewesen und erst allmählich an der Luft erhärtet sein.

An der Simonka sind die Verhältnisse im wesentlichen dieselben, wenn anch mit gewissen Abweichungen im einzelnen. Das Muttergestein ist ebenfalls ein Andesit, aber nach Szabo kein Pyroxen-, sondern ein Glimmerhornblendeandesit von dunkelgrauer Farbe und von etwas höherem geologischem Alter. Der Opal füllt, etwas anders als an der Libanka, Spalten und Gänge aus, die durch eine Tonlage von denı Andesit getrennt sind. Im Hangenden dieser Spaltenausfüllungen, in der Nähe der dortigen Tonlage, findet man hauptsächlich den Edelopal, wie sonst in Verbindung mit Milchopal. Die Simonka war früher der Mittelpunkt des Opalbergbaus, und in alten Zeiten scheint man hier daneben Zinnober gewonnen zu haben, der in der Gegend auch sonst den Opal in spärlichen Mengen begleitet. Im Jahr 1859 wurde aber der Betrieb wegen großen Wassereinbruchs und wegen Schwierigkeiten der Förderung gänzlich eingestellt; er findet jetzt nur noch in der Libanka statt.

Die natiirliche Beschaffenheit und die Art und Weise des Vorkommens deuten mit Sicherheit darauf hin, daf anch in dieser Gegend der Opal sich aus wässerigen Lösungen gebildet hat. Wahrscheinlich ist die Zersetzung des Gesteins durch heiße (Quellen erfolgt, wie sie häufig in vulkanischen Gegenden vorkommen. Heutzutage fließen sie allerdings nicht mehr bei Czerwenitza, aber in geringer Entfernung von da sind solehe noch jetzt zu beobachten.

Nachdem wir die natürlichen Verhältnisse des ungarischen Opals kennen gelernt haben, wenden wir uns nunmehr der Produktion zu.

Die Gewinnung des Edelopals geht in sehr alte Zeiten zuriek. Es ist wohl kein Zweifel, dals schon die alten Römer ihre Opale hier geholt haben. Nach den ausgedehnten, mächtigen, mit großen Bäumen bestandenen Halden und namentlich nach aufgefundenen Berenwerksgeräten zu urteilen, mulj jedenfalls sehon vor 800) Jahren ein Abbau stattgefunden haben. Daß der Betrieb im Jahre 1400 im Gang war, ist urkundlich beglaubigt; 300 Arbeiter haben damals Opal (und vielleicht auch den oben erwälinten Zinnober) gewonnen. Früher grehörte das ganze Gebiet einer Familie Keczer, seit dem Jahre 1687 ist es Eigentum des ungarischen Staates. Der neuere Betrieb begann unter dem Kaiser Joseph II. in Jahre 1771 und wurde unter sehr wechselnden Verhältnissen und nicht oline Unterbrechung lis zur Gexenwart fortgesetzt. Zuerst konnte jedermann das Recht der Opalgewinnung gegen eine jährliche $\Lambda$ bgabe von 5 Gulden erwerben; einige Jahre darauf fand eine Verpachtung an Unternehmer statt. Von 1788 bis 1517 nahm die Regierung selber die Sache in die Hand und führte einen regelmäßigen unterirdischen Berg- 
hau ein, nachdem bis dahin nu unordentlieh und ausschliefilich in mehr oder wenigrer tiefen oberirdischen Gruben und Tagebauen seetrbeitet worden war. Dann trat eine lïngre l'ause ein; der betrieb wurde winzlich eingestellt und alles Graben nach Opal verboten, bis später die fruben wieder pachtweise an Lnternehuer vergeten wurlen. Von 1515 an war es mehr als 30 . Tahre lang die Fanilie cioldschmidt, ron da an bis 1896 die Familie Eürer. I)er jährliche Pachtzins stimer in dieser Zeit ron 10000) auf 22300 (iulden, die Gewinnungskosten betrugen ungrefïhr 60000 Gulden, so dali sich also die Selhstkosten der Opale war nicht niedrig stellten. Seit dem 1. November 15:46 hat die Regrierungr selbst wieder den Betrieb) ühernommen, der jetzt nur noch in den Bergwerksanlagen an dex Ost. seite des Lihanka-Berges stattfindet. Wier haben schon die frïheren oberirdischen Tagebane mächtige IIalden hinterlassen, die sich viel Kilometer weit von Süd nach Nord hinzichen und die auf die grobe bedeutung der Opalgräberei in älteren Zeiten hinweisen. Wie unfangreich der gegenwïrtige Bergbau ist, geht daraus hervor, daf das opalführende Gestein in 14 rerschiedenen Niveaus durch Stollen angefahren ist. die eine Gesamtlänge von 10 Kilometer haben. Der Möhenunterschied zwischen dem obersten Stollen und dem tiefsten, dem Wilhelm-Erbstollen, betrïgt 135 Meter. Man ist aber noch unter den letzteren herunter gegangen und 5 Meter tiefer hat man 1899 die oben beschriebene grolje Opalmasse gefunden. ̈̈berhaupt hat sich herausgestellt, dab ein Abnehmen des Edelopals nach der 'liefe nicht zu bemerken ist, eher ungekehrt. In den tiefsten Horizonten wird jetzt auch ausschließlich gegraben, obwohl in den höheren ebenfalls noch genug brauchbares Material vorhanden ist.

I)ie Arbeit in den Gruben ist nicht schwierig und verhältnismäßig wenig lsostspielig, weil das Gestein leicht zu gewinnen und doch so fest ist, daß in den Stollen kaum Holzzimmerung nötig wird. Eine Erschwerung des Betriebs wird dadurch verursacht, daß infolge des sporadischen und unregelmäßigen Vorkonmens des Edelopals die Ausbeute sehr dem Zufall unterworfen ist. Man findet oft in Honaten nur unbedeutende kleine Stiickelen, dann aber auch auf einmal wieder größere Stufen, deren Wert die Kosten des ganzen Jahres deckt. Das opalhaltige Gestein wird mit grober Vorsicht losgesprengt und die edlen Teile sorgfältig von dem anbaftenden und unbrauchbaren Material gretrennt. Sie kommen dann in die an Ort und Stelle in Dubnik befindliche Schleiferei, die geschliffenen Steine werden dem ungarischen Finanzministerium eingesandt und von diesem verkauft $\mathrm{Zu}$ geringe Exemplare mit zu schwachem Farbenschiller werden vernichtet.

Der Menge nach ist die Produktion in den letzten Jahren entschieden zuriickgegangen, besonders klein war sie in den Jahren 1903 und 1904. In den letzten Jahren der Verpachtung (1890 bis 1896) betrug sie durchschnittlich im Jahre 12000 bis 14000 ) Karat, es gab aber auch Jabre, in denen sie auf 20000 und sogar auf 25000 Karat stieg. Einen besonders groljen Erfoly erzielte Goldschmidt auf der Wiener Ausstellung 1573, wo rohe und greschliffene Steine zu sehen waren und die gröbte Bewunderung erregten. Besonders hervorragend war ein Halsband im Wert von 65000 Gulden, ein Diadem zu 20000 Gulden und 2 Kameen zu 26000 und 15000 Gulden. Den Ertrag während der Selbstverwaltung der Regrierung gibt die folgende auf amtlichen Angaben beruhende Tabelle:

\begin{tabular}{|c|c|c|c|c|c|c|c|c|c|c|c|c|c|c|c|c|c|c|}
\hline & & & & Stück & & & & & $\begin{array}{c}\text { Gesamtgewicht } \\
\text { in Karat }\end{array}$ & & & & Stück & & & & & $\begin{array}{l}\text { Gesamtgewicht } \\
\text { in Karat }\end{array}$ \\
\hline 1597 & . & . & . & t6i6s 7 & . & . & . & . & . $\quad 65.53$ & $1910: 3$ & . & . & 5.569 & . & . & & & . $\quad 12+45$ \\
\hline 1895 & . & . & . & 28862 & . & . & . & • & $2177+16$ & 1904 & . & . & 6366 & . & . & . & . & $105 \mathrm{~S}$ \\
\hline 1599 & . & . & . & 28695 & . & . & . & . & $3325+11$ & 1905 & . & . & 11556 & . & . & . & & 2020 \\
\hline 1900 & . & . & . & 22609 & - & . & - & - & $3553^{14 / 16}$ & 1906 & . & - & 10537 & . & . & . & . & 2422 \\
\hline 1901 & . & . & . & 24576 & . & . & . & . & $4095^{3} 16$ & 19117 & . & . & 111557 & . & . & . & . & $1172^{10} / 10$ \\
\hline 19012 & . & . & . & 26800 & . & . & . & . & . . $311: 14: 16$ & & & & & & & & & \\
\hline
\end{tabular}


In . Jahre 1590 waren 2 Beamte, 3 Unterbeante, 5 Aufseher und 130 Grubenarbeiter angestellt; regenwïrtig sind es 2 Beamte, 1 Aufseher, 1 Maschinist, 3 Schleifer und 54 Arbeiter.

Zur Zeit soll die ungarische Regierung damit umgehen, die Opalgewinnung wieder zu verpachten oder die ganzen Bergwerksanląen nebst Zubehör zu rerkaufen.

Ehenso schöner edler Opal wie bei Czerwenitza findet sich auch noch anderwärts in nürdlichen Ungarn, und zwar in ähnlicher Weise wie dort. So kommt er u. a. in einen Quarztrachyt bei Nagy-Mihali östlich von Kaschan an der Laborcza nahe der östlichen Cirenze des Komitats Zemplén vor. Die Menge ist gering, und das Vorkommen hat keine kommerzielle Bedeutung. Dasselbe gilt für die äußerst spärlichen Funde, die sonst in Europa gemacht worden sind: bei Frankfurt a. M. und auf den Färöern im Basalt, bei Neudeck in Böhmen, in Irland usw.; diese sollen daher nicht näher beschrieben werden.

Ist auch das ungarische Vorkommen des Edelopals das hauptsächlichste, was Schörheit und Wert der Stiicke anbelangt, so daf die weitaus geschätztesten der im Handel befindlichen Steine hierher stammen, so sind doch einige andere, und zwar außereuropäische Fundstellen wegen der Menge der dort gefundenen, wenngleich meist minderwertigen Steine nicht ohne Bedeutung und werden es vielleicht mit der Zeit in noch höherem Maße werden. Sie liegen alle in Amerika und in Australien; ihre Betrachtung soll unsere nächste Aufgabe sein.

Zunächst seien die Fundorte in dem mittelamerikanischen Staate II o nduras erwähnt, die zwar in diesen Augenblicke noch keine bedeutende Wichtigkeit für den Iandel haben, aber doch, wie es scheint, größere Aussichten für die Zukunft eröffnen. Die Steine von dort zeigen in der Art des Farbenspiels Ähnlichkeit mit den ungarischen, die meisten sind jedoch mehr durchsichtig und weniger feurig als diese. Ein besonderer Übelstand ist aber, dal diese Farben nicht so bestïndig sind. Sie vergehen wenigstens bei sehr vielen Exemplaren allmählich beim Liegen in der Luft, doch sind auch in Honduras zahlreiche Steine rorgekommen, die sich mit den ungarischen in jeder Hinsicht, was Schönheit und Beständigkeit anbelangt, messen können. Der Edelopal findet sich hauptsächlich im Departement Cracias im westlichsten Teil des Landes ganz auf dieselbe Art wie in Ungarn in verwitterten trachytischen Gesteinen. Er wird auch hier begleitet von allen möglichen anderen Opalsorten, die an einzelnen Stellen in jener Gegend sich in gewaltigen Massen srebildet haben. Besonders erfïllt im mittleren Teile des genannten Departements der Opal in seinen verschiedenen Varietäten Gänge und Lager, zum Teil von großer Mächtigkeit und Ausdehnung in meist dunklem Trachyt. In diesen Opalmassen ist an mehreren Stellen Edelopal cingesprengt, der dann in Gruben gewonnen wird. Diese liegen aber meist weit al) ron den Verkehrsstraßen, deswegen werden sie zum Teil wenig bearbeitet, um so mehr, als das Produkt aus den erwähnten Gründen weniger gesucht ist als das ungarische.

Die bekanntesten Gruben sind in der Nähe der Stadt Gracias (oder Gracias o Dios), andere in der fiegend von Intibukat und einige der wichtigsten bei Erandique gelegen. Aber auch hicr ist die I'rodulition geringer, als sie möglich wäre, sie könnte jedoch wahrscheinlich dureh einen rationellen Berghau mit Vorteil erweitert werden. Der Edelopal bildet mit anderem Opal kleine moregehnälige Gïnge in Trachyt, die beinahe senkrecht stehen und häufig sich auskeilend und wieder cinsetzend von Nordost nach Siidwest streichen. Er liegt in (inzelnen Platten in dem gemeinen Opal und wechselt auch zum Teil mit diesem in äuberst diinnen $\mathrm{Lagen}_{\mathrm{ab}}$, wodurch ein onyxartiger Stein ron eigentiumlichem hïbschem Aussehen entsteht ( $\mathrm{Op}$ alongr); manehmal sind es aber auch gröbere zusammenhängende Partien. Die IIauptgruben befinden sich in einem 250) Fuli hohen und 3 engl. Neilen langen Hü̈gel, der von rotem Trachyt gebildet wird; 


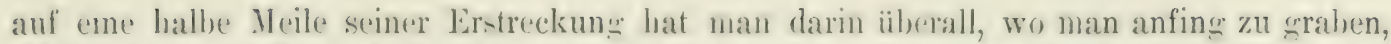
Edelopal angetroffen. Aulier hire wurde alore auch noch an manchen anderen titellen bei Erandique der Edelstein gefunden, olne dab jeduch irgendwo bis jetzt eine regrelmälige systematische Gewinnung eröffnet worden wäre.

An den genannten Orten ist der Opal mit Sicherheit nachgewiesen, und gewisse If newen sind dort auch schon grewomen worden. Lis gribt aber in jenem Lande noch manche stellen, wo man auf Gruad von zu diesem Zwecke angestellten Untersuchungen der budenverhältnisse und des Vorkommens anderer Gualsorten auch Edelopal mit Wahrschemlichkeit und sogar mit ziemlicher Sicherheit erwarten darf. So erscheinen manche I'litze zwischen Intibukat und Las Pedras aussichtsreich, ehenso die Gegrenden ron Le Pasale und Yukusapa und die Abhänge des grofien lierges bei Santa Fosa. Fast sicheren Erfolg für Inlage ron Opalgruben soll das Tal versprechen, das sich zwischen Tamba und dem l'aß ron Guayoea hinzieht, wo besonders grolie Massen von allen möglichen Opalsorten vorkommen. Irier ist auch sehon ein perlorauer Opal nit roten Reflexen sefunden worden, der allerdings keinen Handelswert hat, aber doch das Vorkommen besserer iteine erwarten lälit.

Dak es in Honduras manches Opalvorkommen gibt, das den Weilien bisher noch nicht bekannt geworden ist, sieht man daraus, daf) häufig Inclianer schöne Steine zum Terkauf in die Stadt bringen. Vielleicht erstrecken sich die Fundstellen ïher die Grenzen von Honduras hinaus nach Guatemala. Edle Opale von hier liexen mehrfach in den Simmmlungen, doch sind, wie es scheint, spezielle Fundorte nicht bekannt, und jedenfalls weif man nichts ron der Gewinnung ron Opal für den Handel in dem letzteren Lande. Eine Zone von Opal und auch Edelopal führenden trachytischen Gesteinen soll sich ron IImduras aus sogar noch über Guatemala hinaus bis weit nach Norden und wenigstens bis Mexilio fortziehen, und in der Tat ist unser Edelstein in diesem Lande mehrfach rorgekommen und gewonnen worden.

Von geringer Wichtigkeit in dieser Hinsicht ist in Mexiko zunäichst das Gehirge rom Real del Monte an der Peña del Carilan, nürdlich ron dem durch seinen Obsidian bekannten ferro de las Navajas, dem MIesserberg.' Bedeutender sind die im folgenden zu heschreibenden Gruben ron Esperanza. wo der Edelopal so verbreitet ist, daf man kleine Flitter davon sogar vielfach in den Mauersteinen eingewachsen findet. Das Vorkommen ist hier wie in Nordamerika ron dem in Ungarn in keiner Weise wesentlich verschieden.

Die Opalgruben von Esperanza liegen 10 Leguas nordwestlich von San Juan del Tiu im staate Queretaro, wo sie ïber cin ausgedehntes Gebiet von s0 Leguas Liinge und 21) Letruas Breite verteilt sind. Das Torkommen wurde $15: 35$ ron einem Ackersmann durch Zufall entdeckt, aber crst seit 1570 ist eine regelmäbige Gewinnung im Gange. Der Opal findet sich in einem trachytischen Gestein ron porplyyrischer Struktur und ron riitlichgrauer Farbe, das dort unter anderen den ron Nordwest nach Sïdost sich hinziehenden IIügel ron Ceja de Leon und den von Pë̈neta bildet, an denen viele Gruben liegen. Diese sind wenigstens zum T'eil durch die Massenhaftigkeit und Mannigfaltigkeit ilıres Produlits auszeichnet. So hat ein einzig̨es Stiick Gestein aus der Simpaticagrube gewöhnlichen Edelopal, Harleıuinopal, Lechososopal (eine sofort zu erwähnende Art), sowie Nilchund Feneropal geliefert. Eine der sröftein Gruben ist die Juradogrube. Sie bildet eine 150 Fulf tiefe, 100 Fuß weite und einige hundert Fub lange Ausschachtung im Trachyt. Kleinere sind noch viele vorhanden, doch werden gegenwärtig nur wenige bearbeitet.

Das opalhaltige Gestein wird nach dem 25 Leguas entfernten Queretaro gebracht, wo ctwa -20 eingeborene Schleifer in drei Schleifereien fast das gesante in den Gruben wtwonnene Material in sehr roher Teise verarbeiten, so dafo die Steine oft recht geringen Effekt machen. Nach auswärts kommt nur wenig zum Schleifen. In den Gruben selbst 
sind etwa 100 Indianer beschäftigt, aber ebenfalls in wenig rationeller Weise. 50)(100) geschliffene Steine werden jührlich verkauft, und leicht könnte diese Produktion verdoppelt werden. Sie rehen vielfach nach den Vereinigten Staaten, wo sie in manchen Gegenden an den Bahnstationen den Reisenden als einheimisches Produkt verkauft werden, aher auch nach Europa, besonders nach Deutschland, wo sie zur Anfertigung billigen Schmuckes dienen. Der Preis der mexikanischen und ebenso der mittelamerikanischen Opale ist sehr verschieden und im allgemeinen weit geringer als der der ungarischen; er geht ron wenigen Cents bis zu 100 Dollars. Posten von 100 und mehr Stiick werden oft um weniger als 10 Cents jedes verkauft. Höhere Preise werden nur für ausnahmsweise schöne Exemplare bezahlt, sie erreichen aber nicht den Betrag der für ungarische Steine bezahlten Summen.

Der mexikanische Edelopal bildet meist zwischen oder auf gemeinem Opal ohne Farbenspiel dïnne Lagen, oft so dïnne, daß es zum Schleifen zu wenig ist. Die Massen liegen auf IIohlräumen im Gestein, die zuweilen nur zur Hälfte oder zu zwei Dritteilen ausgefuillt sind und in denen der Opal abwechselnde horizontale Lagen bildet, die nicht selten nach oben durch eine traubige Decke von glasartig hellem, durchsichtigem Hyalit abgeschlossen werden, ganz ähnlich wie in Ungarn. Man kann nicht leicht einen schüneren Beweis für den Absatz des Opals aus kieselsäurehailtigen Lösungen sehen.

Die Zahl der hier vorkommenden Varietäten von Edelopal ist recht beträchtlich. Bei vielen ist die Intensität der Farbenreflexe nicht sehr ausgezeichnet und selten mit der bei ungarischen Steinen zu vergleichen. Häufig findet man ausgedehnte gleichfarbige Flächen, zuweilen nur eine einzige glänzende Farbe auf einem Stein: rot, grïn, gelb, die entweder beim Drehen des Steines dieselbe bleibt, oder auch zuweilen sich ändert und in eine andere übergeht.

Der mexikanische IIarlequinopal ist vielfach durch ganz besonders bunte Abwechslung der Farbenflimmer ausgezeichnet. Mäufig und sehr schön ist ein feuerroter Opal mit prachtroll smaragdgrünem, daneben zum Teil auch karminrotem und dunkelviolettblauem Farbensuiele; es ist die Art, die man in Mexiko Lechosos-Opal nennt. Auch sehr schöne, dunkel ultramarinblane Reflexe kommen in Verbindung mit smaragdgrünen vor. Ein großer Stein mit prïchtigem rosenrotem Farbenspiele war 1587 in Paris ausgestelit. Einzelne dieser Varietäten sind besonders schön in gewissen Gruben, weniger schön in anderen; das Produkt mancher Fundorte hat ein ganz besonderes Gepräge.

Man erhäilt aus den vorhandenen Schilderungen der mexikanischen Opalgruben den Eindruck, als ob durch einen rationellen Betrieb der Gräbereien und der Schleifereien die Opalproduktion in diesem Lande, wie auch in Honduras zu einer hohen Bliite gebracht werden könnte, so daß von Amerika aus der ungarischen und australischen Industrie, die jetzt beinahe einem Monopole gleicht, eine erhebliche Konkurrenz erwachsen wïrde. Aber dic mexikanischen Opale zeigen wie die zentralamerikanischen den Mißstand, dalj riele ron ihnen allmählich durchsichtig oder auch ganz undurchsichtig werden und dabei ihr Farhenspiel in beiden Fällen mehr oder weniger vollständig verlieren, das dann zwar durch Tränken mit (̈) für einige Zeit, aber doch nicht für immer wiederhergestellt werlen kann: Ianche haben auch die 'Tendenz, im Laufe der Zeit zu zerspringen und in Stïcke zu zerfallen, ohne dab eine äubere Ursache zu erkennen wäre. Da derartiges bei ungarischen Steinen kaum zu befürchten ist, so werden sie immer einen gewissen höheren Wvert behalten. Iedenfalls ist es angezeigh, frisch gelorochene mexikanische Opale nur unter Vorsichtsulakregeln zu kaufen.

Dal) mexikanische Opale in den Vereinigten Staaten zuweilen als cinheimisehe verkauft werden, ist schon erwähnt. Eis gibt aber auch in dem letzteren Iande cin mbedeutendes Vorkommen in der Nähe des John Davis River in Crook County, Orenen. 
Die treine ron hier sind craulichweil) nit rotem, friinem und frelbem Farben-piel, das dem mancher mexikanischer Steine sehr ähnlich ist; eine eigentliche l'roduktion scheint aber nicht stattzufinden. Inhedeutend sind auch die spätre entedecten Vorkommusise in

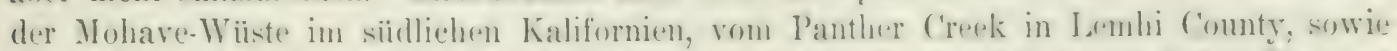
von Moseow, Owylue (onnty, Idaho, ferner vom Burnt River, siddlieh von Baker City und

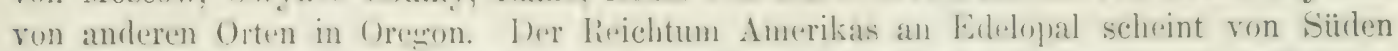
nath Forden abzunchmen. Nach dem, was wir jetzt wissen, ist Honduras am reichsten, Mexilio erheblich ärmer und die Vereinigenten staten beherbergen nur verschwindende Mengen.

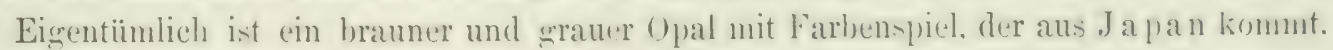

Edler Opal findet sich endlich auch in ausgezeichneter Weise in Australien an verschiedenen Stellen, und zwar vorzuswerese m Ven-Süd-Wales und Gutensland. Auf den milchig-triiben Steinen erolänzt das schönste likau, firün und Rot, aber vieffach nicht in den feinen Farbenflitterchen wie beim ungarisehen ()pal, sondern in sröberen, wheichgeföirbten Flächen, die an den Grenzen ineinander äberegehend abwechseln oder auch eine und dieselbe Farbe äber den granzen Steiu wex. Dies bedingt cin wesentlich verschiedenes Aussehen der ungarischen und allstralischen Opale (Taf. XVI, Fig. 8 und 7 . Nohen diesen kummen aber auch alls Australien zahlreiche Steine mit rerselben Farbenverteilung wie bei den ungrischen und thenso schön wie diese, nur geht die Crundfarbe oft etwas mehr ins tielbe. Viele sehr sute Schmuchsteine sind schon aus australischem Opal geschliffen worden.

In Teu-Sïd-Wales findet sich der schönste Opal am Rocky Bridge Creck, Aber(rombie River, County Georgina (34" südliche Breite, 149' üstliche Längre in einem feinkörnigen, bläulichgrauen, mandelsteinartigen Basalt oder Trachyt von 31) Fub Dicke, der so zersetzt ist, daß er sich mit dem Fingernaget ritzen läßt. Der edle Opal hat sich auf den Blasenräumen und in Spalten abgelagert, begleitet wie sonst von gremeinem Opal whe Farbenspiel und ron Iyalit. Die gröbte Masse bildet der gremeine, in dem nur kleine Partien edlen Opals ausgeschieden sind. Dieser ist milchigweiß und zeigt hauptsiichlich grïne, rote und rosenfarbige Reflexe. Das Torkommen ist hier nur spärlich, aber zum Teil sehr schön.

Weit wichtiger ist aber das Vorkommen von Edelopal in nichtrulkanischem Gestein, das iiber weite Strecken hin bekannt ist und eine sehr reiche Ausbeute liefert.

Der Mittelpunkt der Industrie in Neu-Siid- Vales ist die kleine Stadt White Cliffs in Tungnulgra County, 65 miles nordwestlich ron Wilcannia $(31 \%$ " nürdliche Breite und 14312 " östliche Länge, da wo die von virdney kommende Elsenbahn den Darling- oder Barwon-River iberschreitet). In dieser Gegend findet pegenwärtig die ausgedehnteste und ertragreichste Opalgewinnung der ganzen Erde statt. In nicht ganz 20 Jahren wurde hier schon mehr Edelopal sefunden als in Lnearn in den Jahrhunderten des Bestehens der dortigen Gruben, und das Ilaterial ist zum Teil ebensogut. In einem einzigen Jahr wird nun mehr Opal rerkauft als früher in jo) Jahren. Die Jahresproduktion in NeuSiid-Wales bat zurzeit einen Wert ron nicht ganz 106(1)(1) Pfund Sterling und die Gesantausbeute seit der Entdeckung einen solehen von etwa einer Million Pfund sterling. Ein beträchtlicher Teil daron geht nach Idar, wo sehr viel australischer Edel-Opal geschliffen wird.

Aufgefunden wurde der Edelopal von White Cliffs zufällig von einem Jäger im

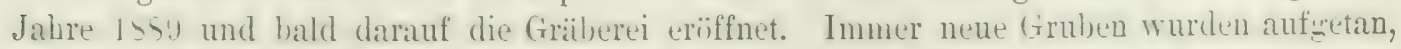
in denen mehrere hundert Arbeiter besehaiftigt sind, und die Produlition hat, wenn auch mit Cnterbrechungen, andauternd zugenommen, obwohl zeitenweise stark behindert durch empfindlichen Mangel an Wasser in dem dürren Land. 
Durch diese Unternehmungen wurde die Opalführung eines Landstrichs ron 15 miles Länge und 2 miles Breite ringrsum White Cliffs genauer festgestellt. Der Edelstein ist aber noch auf sehr weite Erstreckung nachgewiesen worden, so in Neu-Siid-Wales bei Malparinka, 160 miles von White Cliffs und bei TVallangulla, 300 miles von dort, sowie mamentlich weit nach Queensland hinein, überall wesentlich in derselben Weise vorkommend.

Der. Opal, in der IIauptsache gemeiner Opal, meist Milchopal, dem stellenweise mehr oder weniger srobe Mengen Edelopal heigemengt sind, findet sich in einem weißen, zum Teil sehr foldspatreichen, kieseligen Gestein vom Alter der oberen Kreide, entsprechend dem Desert sandstone in Queensland. Es wechselt in seinem Charakter von einem teilweise sehr festen, glasig aussehenden, teilweise weicheren und lockeren Sandstein bis zu einem feinkürnigen Konglomerat von verschiedenem Aussehen. In diesen Gesteinen liegt der Opal in Form dïnner l'lïttchen oder auch stellenweise dickerer Partien auf den Schichtflaichen, oder er erfüllt meist sehr schmale, zuweilen aber auch sich etwas erweiternde Ḱlüfte und Spalten zwischen diesen und bildet auch das Bindemittel, das die Sandkürner miteinander vereinigt, sowie etwas grüßere Knollen zwischen diesen. Iläufig ist er das Versteinerungsmittel fossiler Saurierknochen, von Muschel- und Schneckenschalen, ron Belemniten und von Krinoidenstielgliedern, die jetzt alle ganz aus Edelopal bestehen. Ebenso ist IIolz oft in Opal umgewandelt, und zwar so, dalj gemeiner Opal die IIauptmasse bildet, während in radialen Spalten, die von der Mitte der Stamm- und Aststiicke auswehen, sowie in anderen Iroblräumen der Edelopal auftritt. In den Sandsteinen liege $n$ vielfach his zu 100) Pfund schwere schwarze Konkretionen, innen häufig hohl oder auch mit einem Pflanzenrest in der Mitte, von der sich klaffende Risse nach außen ziehen wie bei den sog. Septarien. Alle diese Hohlräume pflegen gleichfalls mit Opal ausgefüllt zu sein, der auch lionzentrische Lagren um den Mittelpunkt herum bildet, abwechselnd mit dem tonig-sandigen Material, das die Konkretionen in der Hauptsache zusanmensetzt. Eigentïmlich sind endlich bis faustgroße Knollen, gebildet durch radiale Terwachsung zahlreicher hristalle eines noch nicht genauer bekannten Minerals, das jetzt ganz verschwunden und ohne Ïnderung der Form vollstïndig in allerdings nie sehr stark farbenspielenden Eldelopal umgewandelt ist. Wahrscheinlich waren es Kristalle von Gips, die auch soust unverändert in den Opal führenden Schichten vorkommen. Das eigentlich wertvolle Edelsteinmaterial bilden die etwas größeren Partien auf den Schichtfliichen, in den Spalten und Kliffen des weichen Sandsteins und in diesem selbst. Im Gegensatz zu den Vorkommen in Queensland löst sich hier der Opal leicht vonı Nebengestein und kann ohne Mühe rein erhalten werden.

An der Erdoberflïche ist von dem Opal selten etwas zu sehen. Bei der Nachforschung ist man auf den Zufall und auf Schürfen angewiesen, was, wie die Gräberei iüberhaupt, durch die Beschaffenheit des Nebengesteins sehr erleichtert wird. Wo eine Spur von Opal erscheint, werden die Arbeiten eröffnet, in sehr vielen Fällen allerdings ohne Erfolg. MIeist liegrt das Mineral sehr nahe der Oberfliiche, so daß früher die Ansicht verbreitet war, dal tiefer als $12 \mathrm{FuB}$ kein Opal mehr zu erwarten sei. Es hat sich indessen später in Schächten zezeigt, daß bei 50 Fulb noch Funde gemacht werden künnen, und es soll sogar die Menge sowohl als die Qualitait mit der Tiefe sich verbessern. Wird Opal angetroffen,

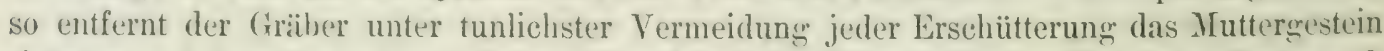
ringsum und legt ihn mit müglichster Sorgfalt frei. Gelegentlich werden dabei Nester aufsedeckt, die einen Wert von mehreren tausend l'fund Sterling haben. Einmal soll ein (einziger soleher Fund für 12000 bis 15000 P'fund Sterling Opal geliefert haben. Yon der

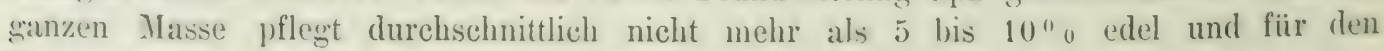
Handel verwendbar zu sein. 
Der edle Opal von White Cliffs ist ziemlich klar, aber immerhin im allgemeinen etwas triber als der von Queensland. Die Kiirperfarbe ist meist hell und zwar hellgrelth in durchgehenden, bläulich in auffallenden Licht. Der Farbenschimmer ist sehr mannigfaltigr. Es kommt dabei auf die Iiflexfarben selbst sowie auf die Farbenverteilung, das Muster. an. Von den Farben ist grïn und blau am hïufiesten, erell, und rot sind selteril. Am ereschitztesten ist rot entweler allein, oder anch mit erell), eriin oder blau zusanmen.

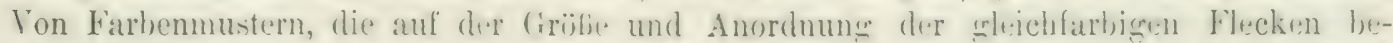

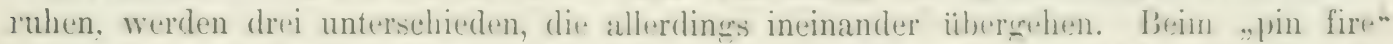
bilden die Farbenflecken kleinste I'ünktehen: bei .. harleruin" sind es kleine runde ode.

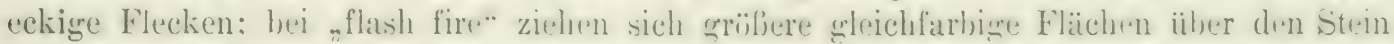
hin. IIarleguin ist an seltensten und eresuchtesten. Fis fohlt nicht an Strinen. die sich mit den besten ungarischen messen kïmnen, doch ist solche arstklassige Ware recht spärlich vorhanden.

Auf der Schönheit des Farbenspiels lexpht im allewemeinen und in der Hauptsache der Wert, der natïrlich bei lehbaftem und liäftigem Farbenglanz gröber ist als bei mattem und schwachem Sehmmer. Fiir Steine der besten Qualität werden his jom Mark fro Unze bezahlt, bis herab zu minimalen Betrïgen bei geringerer Beschaffenheit. Sehr von

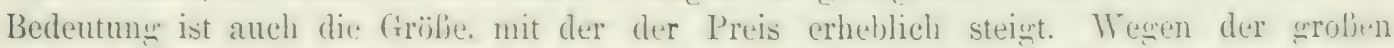

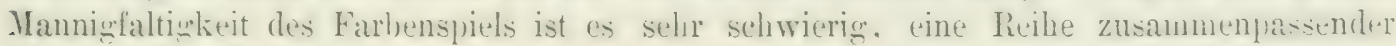
unleichartiger Steine für eine Schmuchisache zu beschaffen, wenn sie nicht aus einem und denselben sröberen stück herausesehnitten werden. Weshalb stehen solche ron bester beschaffenheit besonders hoch im Preis. Eines von 1',2 Lnzen ist mit 1111, ein anderes von 9 Unzen mit 700 Pfund Sterling bezahlt worden.

Die Verarbeitune geschieht im allgemeinen in derselben Weise, wie sonst heim Opal, virlfach schon an Ort und Stelle. Teilweise ist aber das Material zu Schmucksteinen rewöhnlicher Art nicht rerwendhar. Vielfach sind die Opallagen zu diün, dann klebt man sie auf schwarzen Onyx, was den filamz sehn erhöht. Kleine stïckehen werden nicht selten in dieser Weise auf Onyx oder Schiefer mosaikartig miteinander verhunden. Sandsteinstiicke mit riclen kleinen, darin rerteilten Opalflitterchen werden wie die unarische Opalmutter rerwendet (sogr. Opalin), meist zu Perlen reschliffen oder auch zu kleinen Gebrauchscerenständen verarbeitet. Manchual schmilzt man auch kleine Opalstiickchen mit Glas zusammen und verwendet diese hübsch aussehende Masse zu Stockknüpfen usw.

Auf dem schon länger bebauten Gebict von Wallangulla in County Finchi, 30u miles nordöstlich von White Cliffs und 51) miles nördlich von Walgrett (30" südliche Breite, und 14y" üstliche Länge, wurde die Gräberei etwa 1902 eröflnet. Die Produktion ist jetzt noch gering, ein erheblicher Teil der Erzeugnisse ist aber schönster Ifarlequinopal. Die natürlichen Verhältnisse de's Vorkommens usw. sind nicht anders als bei Thite Cliffs und in Queensland. In der abrelegenen und wenig bekannten Gegrend zwischen Walgett und der Grenze von Queensland werden noch manche gute Opallager vermutet.

In (Queensland ist Edelopal lïngst bekannt, und seit $187 \mathrm{~s}$, also liuger als in NeuSüd-Wales wird er gewonnen. Aleer trotzdem und trotz des gröferen Reichtums der Lager hat sich der Industriezweig doch nicht so entwickelt wie dort, und der Irert des Jahresertrags, der 1594 noch 12001$)$ l'fund Sterling betrug, ist jetzt auf weit unter (1) (1)1) Pfund herabgesunken (1900 bis 1903: 7000 Pfund).

Der Opalbezirk in Queensland steht mit dem von Yeu-Süd-Males in Verbindung und zieht sich ron der Grenze beider Fulonien zwischen dem 111. und 1.16. Lüngengrad nürdlich his zum 21. Grad siidlicher Breite. Die Opalfelder liegren also alle in westlichen und siidwestlichen Tel von Gueensland. Ihre Zahl und noch mehr die der einzelnen Gruben 
ist sehr sroß: in der Beschreibung und auf der Karte von C. F. V. Jackson in Brisbane sind sie nach dem Stand von 1902 zusammengestellt.

Die ersten Funde wurden im Coopers Creek gemacht, Die dortigen Gruben liegen in der Crabel zwischen dem Coopers Creek (Thomson River) und dem in diesen mündenden Kyabra Creels, südlich von dem 26. Breiten- und östlich, aber hauptsächlich westlich von dem 14\%. Iängengrad, wenig östlich von dem Yamma-Yamma-See. Östlich davon, nahe dem 14. Längrengrade liegen die Valdare-Gruben und nahe dabei die rom Bulls Creek. Ietztere, 79 miles nordwestlich von Toompine, geben einen sehr reichen Ertrag und liefern gerenwärtig wohl den srößten Teil des Queensländer Opals. Nordwestlich von der Bahnstation Cunnamulla sind die Gruben des Toompine-Bezirkes und wenig westlich von dieser Station die von Jowah mit der ergiebigen Great Extended-Grube. Weiter im Norden ist das Jundah-Opalfeld, 17 miles westlich ron der Stadt Jundah am Thomson River, und noch etwa 100 miles weiter nach Norden, 60 miles süd-westlich von der Bahnstation Winton, liegt in der Mueller Range, etwas südlich vom 23. Breitengrad, das Grubengebiet von Opalton oder Fermoy, das $18 \varepsilon 8$ entdeckt wurde und lange Zeit sehr gute Erträge lieferte, aher jefzt verlassen ist. Endlich sei noch das nördlichste Vorkommen erwähnt, das Gebiet der Kynuna-Gruben, in denen aber jetzt auch nicht mehr gearbeitet wird. Überhaupt sind viele frühere Gruben gregenwärtig verlassen, auch hier zum Teil wegen Wassermangels, andererseits sind aber auch noch viele Opalfundorte bekannt, an denen noch keine Abbauversuche gemacht worden sind.

Die Art des Vorkommens ist im wesentlichen ganz wie bei White Cliffs. Der Opal bildet schmale Bänder und Adern, sowie unregelmäßige Knollen in einem meist stark (iisenschüssigen Kieselsandstein und einem damit in Verbindung stehenden harten Ton der oberen Kreideformation, des sogr. Desert Sandstone, der in durch die Erosion getrennten einzelnen Fetzen ïber weite Strecken verbreitet ist. $\Lambda$ m manchen Stellen, besonders in dem (irubenfeld von Bulls Creek, bildet der Opal anch die Nitte von z. T. recht großen Toneisensteinnieren. Die Opallagen sind oft so dïnn, daß man keine Steine en cabochon daraus herstellen kann; es werden dann ebene Platten in der obenerwähnten Weise geschliffen. Die Körperfarbe ist milchweib und die Durchscheinenheit soll meist etwas besser, aber die Qualität im allgemeinen etwas geringer sein als bei White Cliffs. Als Tieflexfarben treten ein dunkleres Blau und Grïn, auch Rot auf. Die Hauptmasse ist hier chleichfalls gemeiner (O)al, der edle bildet nur einen geringen Bruchteil des ganzen.

Edelopal ist übrigens auch in Queensland in einem vulkanischen Gestein in kleiner Menge vorgekommen, und zwar in dem Basalt von Springsure, wo sogar eine Zeitlang ein Abbau versucht wurde.

In Westaustralien ist schöner Opal in einer gewissen Menge in einem konwlomeratartigen (iestein bei Norseman gefunden worden; er hat aber keine kommerzielle Bedeutung erlangt.

\section{Feueropal.}

An den edlen Opal sehliebt sich der Feneropal an, der nach seiner zuweilen sehr schönen, fenerroten Farlue benannt worden ist. Auch als Sonnenopal hat man ilın aus demselben firmonde bezeichnet. Der Name Girasol, den wir schon bei einigen anderen Edelsteinen kennen gelernt haben, ist auf diesen Stein gleichfalls übertragen worden.

Die Farbe weht vom Hellbrïunlichellen, beinahe Farblosen und weiterhin auch Bläulichen bis ins auswesprocheme Blan und his zum ticfen liäunlichrot. In dünnen Splittern ist sie inmer schr viel blasser als in dickeren stïcken und beim Ilindurchschen heller als in reflektierten Lichte. Die schënsten Nuaneen sind dre mancher welber Topase und die des Hyacinths. Nicht selten sind an cinem und demselben Stiick mehrere Nuaneen mit- 
einander vereinigt, die an den Grenzen allmählich ineinander und in das vollkommen Farblose iibergehen. Die Farbe riihrt wohl von dem kleinen Eisengehalt her, den die eingangs angeführte Analyse ergeben hat.

Der Stein ist stark durchseheinend bis fast vollkommen durchsichtig. Auf dem stets ausgezeichnet muscheligen Bruch ist der Glanz sehr stark, und dieser wird durch das Polieren noch erhöht. Mugelig orler in Facetten geschliffen gibt er daher einen sehr hiibschen Schmuckstein, wenn die Farbe nicht zu licht ist. Auf Taf. XVI ist in Fig. 10 ein roher, in Fig. 11 ein geschliffener Feueropal dargestelit.

An zahlreichen Stïcken tritt auch beim Feueropal ein Farbenspiel ähnlich dem des edlen Opals auf. Beide unterscheiden sieh dann nur durch die Körperfarbe des Feuer-

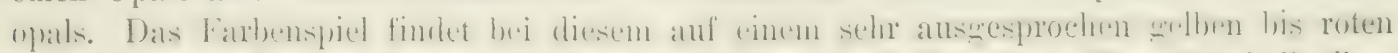

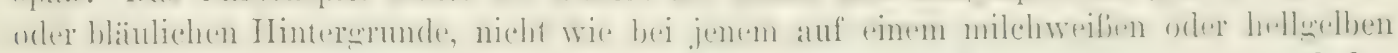
und rötlichen statt; indessen sind zwischen den gelben und roten Edelopalen und den

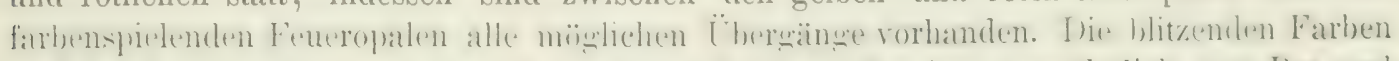

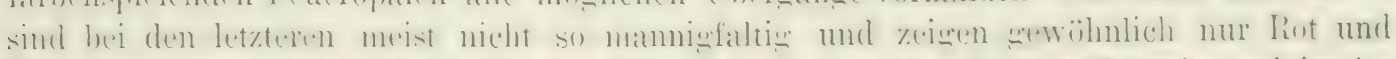

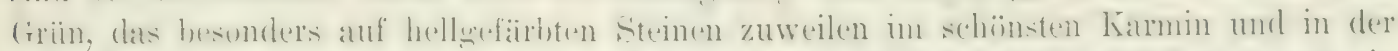

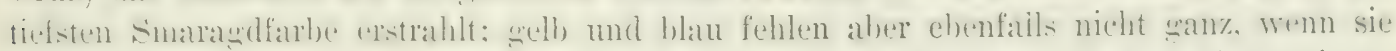

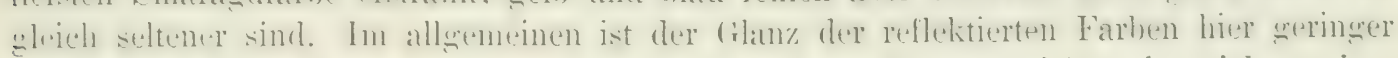
als beim weißen Edelopal und überhaupt das ganze Farbenspiel meist viel weniger prächtig wie bei diesem.

Der Feneropal ist eine der schönsten unter allen Varietäten des Opals, gleichzeitig al)er auch empfindlicher als alle anderen. Häufige wird er schon dureh Beriuhrung mit

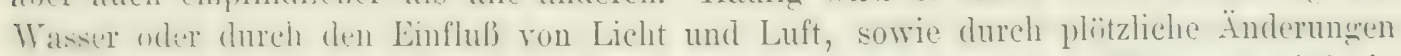

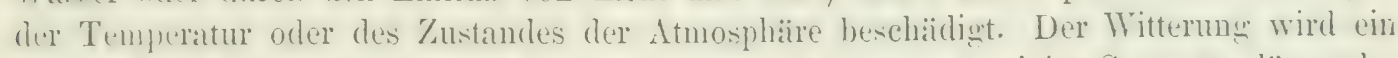

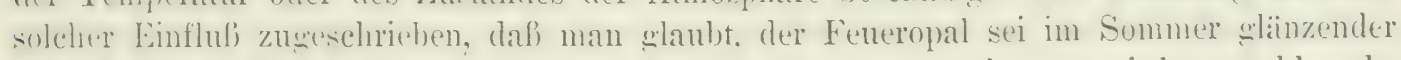
als im Winter. Wenn dieser Unterschied wirklich vorhanden ist, so wird er wohl mehr mit dem esröferen (ilanz der Somne in der warnen Jahreszeit zusammenhängen. Viele Steine lassen allerdings solehte srobe Empfindlichkeit nicht erkemen, andere dagecen werden sehr leicht rissig und verlieren frlanz und Farbe ohne jede erkennhare Lrsache, auch wenn sie vor allen genannten Einwirkungen so gut als nur irgend möglich gesehuitzt werden. Es sind dies besonders stïker durchsichtige steine nit Farhenspiel, die sich in dieser Wrise verhalten und die darlureh zur Verwendung als sichmuchsteine untauglich werden.

Diese ist aber überhatupt nicht bedeutend; del Feneropal ist im Ilandel trotz seines guten Auschens wenig rerbreitet. Demtungeachtet ist aber der l'reis nicht gering, wahrscheinlich weil schöne und doch dauerhafte Steine von einiger firöfe immerhin ziemlich selten sind. Es wird angegeben, daß ein Stein von $4^{1 / 2}$ Linien Länge und $3^{1 / 2}$ Linien Breite nit 1200 Franken bezahlt worden sei. Ein Karat kostet jetzt bis 10 Mark.

In der Hauptsache ist der Feueropal ein Produkt Mexikos, von wo ibn am Anfange des 18. Jahrhunderts A lexander v. Humboldt zuerst nach Europa gebracht hat. Hier allein findet er sich in Menge, und zwar in einem puphyrartigen Traebre hei Villa seca

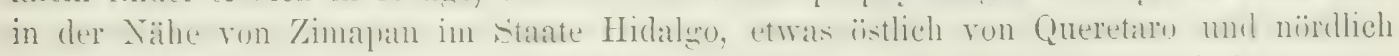
von der Stadt Mexiko, unter $20^{\circ} 44^{1 / 2} 2^{\prime}$ nördl. Breite und $\delta 1^{0} 41^{3 / t^{\prime}}$ westl. Länge von Greenwich. Er füllt in seinem Muttergestein mit anderem, gemeinem Opal zusammen Spalten und Kliifte aus und bildet in diesem auch einzelne größere Stücke, die dann in der oben angegebenen Weise verschieden gefärbt zu sein pflegen. Viele sind mit einer

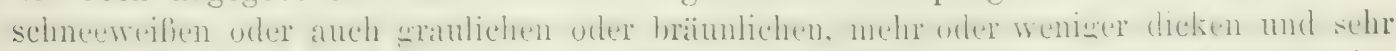
stark porösen Verwitterungrsinde bedeckt, wie es auf Taf. XVI, Fig. 10 dargestellt ist. Aufer bei Zimapan findet man den Eidelstein noch nit dem when bechriebenen Edelopal 
im Staate Querctaro. Hier ist es, wo die Farbe zuweilen ins Bläuliche und sogar ins ausśesprochen Blaue olne jede Spur von Rot ül)ergeht und wo diese bläulichen Varietäten manchmal ein schünes Farbenspiel zeigen; ferner bei Tolima in Mexiko, in Honduras, in Guatemala, ferner an einzelnen Orten in Nordamerika, bei Telkibanya in Ungarn, auf den Färöern und noch in anderen fregenden, stets in wesentlich derselben Teise wie bei Zimapan mit anderem Opal zusammen. Alle diese Vorkommen sind aber dem von Zimapan gegenüber unwichtig und baben im Edelsteinhandel sar keine Bedeutung, so dab sie hier nicht weiter betrachtet zu werden brauchen.

Der nicht farbenspielende, rïtliche, gelbe und bräunliche Opal, der den Feueropal von Zimapan begleitet, wird zuweilen im Handel ebenfalls Goldopal genannt.

\section{Andere Opalvarietäten (Gemeiner Opal, Halbopal usw.).}

Alle anderen Opalsorten stehen hinter dem edlen und dem Feneropal an Schönheit weit zuriick. Sie werden zwar auch noch gelegentlich zu billigen Schmucksachen verarbeitet, bilden aber doch schon mehr das Material zur Verfertigung gröberer Gehrauchsgegenstïnde oder sogenannter Galanteriewaren, wie Stockkn̈̈pfe, Dosen, Siegelstïcke, Messergriffe usw. Daher sollen sie hier nur in Vorbeigehen kurz und im allgemeinen und olne Eingehen auf Einzelheiten betrachtet werden.

Der nicht farbenspielende Opal findet sich häufig vollkommen durchsichtig und dann atcel gewöhnlich rollkommen farblos und wasserhell, oder etwas weniges ins Rïtliche oder Blïuliche spielenr, in Form meist dünner, zuweilen auch dickerer Krusten mit traubigw Oherflaiche, basaltische und andere kieselsäurehaltige Gesteine oft als eine ganz nene Bildung ïherziehend. Es ist dies die oben schon erwïhnte, wegen ihres glasartigen Aussehens als II yalit (Clasopal, Müllersches (Blas) bezeichnete Tarictät. Diese reinste und klarste Abart des Opals wird wohl sehr wenig zu Schmucksteinen verschliffen, zeigt aber damn rinen sehr schönen Glanz. Beinahe vollkommen farblose, etwas ins Bläuliche nder Gelbliche spielende Opale und fast ebenso klare wie Iyalit. nur mit einer selur unbedeutenden milchisen Trübung, kommen ebenfalls vor; sie führen zu den anderen, den gemeinen und Halbopalen hinüber, mit denen sie sich zusammen finden.

Durch Beimengungen ron mancherlei Art wird die im reinsten Zustande wasserhelle () palsubstanz in den verschiedensten Graden trïbe und undurchsichtig und nimmt wechselndle Färbung, auch abweichenden Glanz und überhaupt das mamnigfaltigste Ausschen an, ohne dali die wesentlichen Eigenschaften, wie sie eingangs geschildert sind, sich änderten. IIirauf beruben die von den Nineralogen unterschiedenen, aber allerdings nicht scharf aberegrenzten und vielfach ineinander iibergehenden Unterabteilungen. Der wemeine () pal ist stark durchseheinend und fast stets wenig gefïrbt; der II albopal ist weniger durehseheinend, farblos bis stark gefärbt; der Opaljaspis oder Jaspopal ist infolge sehr starker Verunreinigungen, namentlich durch eisenhaltige Substanzen, intensiv rot, braum und gelb, anch erriin lis schwarz und nur sehr wenie durchseheinend. Manche Opale baben statt des gewöhnlichen Glasglanzes Fettglanz, der bald mehr wachs-, hald mehr pechartion ist; darnach werlen gelbe, wachsglainzende Opale Wachsopal, braune, peeh-

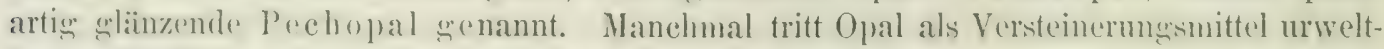
licher Bäume auf und bildet so den Holzopal. Ahnliche Unterarten gibt es noch mehrere. sie sollen aber hier nicht weiter anfereählt, aber zum tecil unten noch kurz beriieksichtigt werden.

Diese verschiedenen Arten von Opal finden sich meist in der oben schon erwähnten

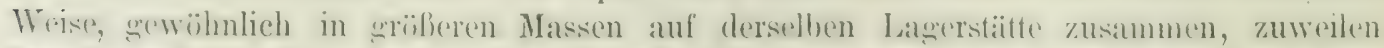

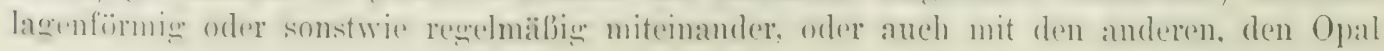




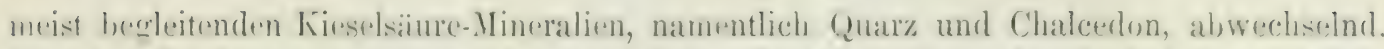

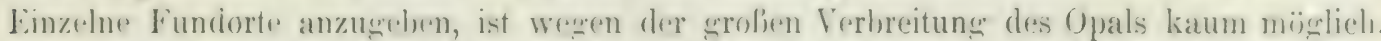

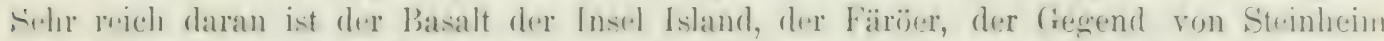

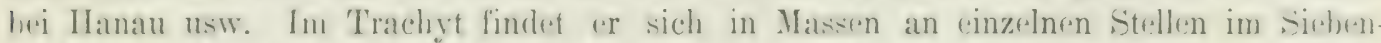
gebirme, in den vulkanisehen (indirgen des nördlichem Engarn und Sirbenbürgen, in Itonduras, durelı ganz Zentralanerika und Mexiko hindurch bis in die Vereinigten staaten limein an vielen brten. Auch der Serpentin der Geepend von Frankenstein in sichlesien beherberet grolic Quantitäten des Minerals. Andere Arten des Vorkommens sollen nocle weiter gelegentlich genannt werden.

Opale rom all den erwähnten Sorten nehmen beim Śchleifen meist cinten quten filan\% an, und die Farbe ist nicht selten recht hïhseh, so dab die Steine, denen man reine mugelige Form gewöhnlich olune Facetten zu geben pflegt, ein ganz vorteilhaftes Auscilum haben. Wegen des meist massenhatten Torkommens des Rohmaterials ist der l'reis durehsuimgig sering, so daf derartige Steine, einzelne Ausnahmen abgerechnet, nur in den hilligsten schmuckichen Verwendung finden, um so mehr, als sie wegen ilirer geringen Härte und groljen Fprödigkeit nur wenig Widterstandsfïhigkeit besitzen. So wurle früher

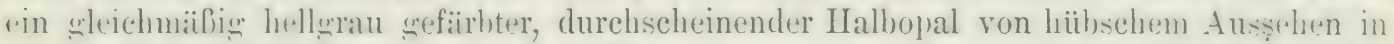
Erolier Menge bei Steinheim unweit Hanau gewonnen und zum Schleifen nach filar sebracht. Als die Masser erscheijft war. kam ein ähnliches Material aus drm viebengebirge in derselben Weise zur Verwendung.

Im folgenden sollen einige besondere, zuweilen zu Schmucksteinen verschliffone sonrten des gemeinen und des Halbopals kurz angeführt werden.

Milchopal ist ein milchweifer, also bläuliehweißer, zuweilen auch srünlichweiber, triiber, aber stark durchseheinender Opal, der in Menge in dem zersetzten seruentin bei Losemiitz in der Naihe ron Frankenstein in Schlesien, bei Steinheim, aber auch an anderen Orten vorkommt. Zuweilen enthält der Milchopal sehwarze baumartige Fisuren, sogenannte Dendriten, wie mancher Chalcedon (rol. Fig. 1(1), die beim Schleifen der Oberflïche möglichst genähert werden. so daß sie deutlich durchscheinen. Dies ist der Moosopal; er gehört mit zu den später noch zu erwähnenden Baumsteinen. Besonders schüne :3 bis 4 Zoll grolie Stiicke dieser Art finden sich z. l3. in Trego County in Kansas. auch in Cuba.

Beim Opalachat wechseln hellere und dunklere Schichten von Opal, oder auch solche ron Gpal und ('hakedon miteinander streifenfömig ab. Derartige Bildungern sind sehr ähnlich dem onyx und werden auch in derselben Weise rerarbeitet. Sie finden sich in besonderer Schönheit bei Guayoca in Honduras in derselben Weise, wie dies oben bei der Betrachtung des Edelopals jener Gegend im Vorhergehen erwähnt worden ist. Sulcher webanderter Opal ron steinheim hat friber in Iom vielfach zur Herstellun: von Fameen Verwendung gefunden.

Opalkatzenauge Krokydolithopal) bat man eine eigentïmliche Verbindung von ()al mit Katzenauge von Yarra Yarra in Westaustralien genannt. Es ist ein brauner, oder auch wohl gether und griner Opal, der von schmalen Bändern von Krokvdolith durchzogen wird. Letzterer ist meist braun mit einen goldigen Schiller, zuweilen auch dunkelgriin mit einem weilien. oder brïunlichrot mit einem bernsteinroten Lichtschein. Er grleicht in jeder Beziehung dem Katzenauge von Siidafrika (s. IV.) auch darin, dab der ursprïng-

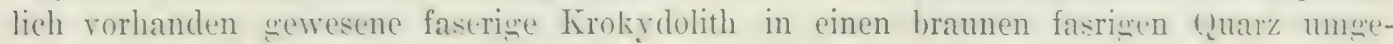
wandelt worden ist. Es ist ein schüner, ganz eigenartiger Stein, der sich somst nirenends in dieser Weise findet und del um 1900 entdeckt wurde.

Der Prasopal ron Linsemitz. hei Frankenstein ist ein stark durchseheinender. durch

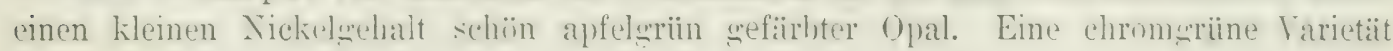


wurde hei Port Matepuaric in Neu-Sïd-Wales gefunden. Schön rosenroter, wahrscheinlich durch or wanische Substanz gefüirbter Italbopal kommt bei Quiney unweit Mehun (Dep). Cher) in Frankreich in Suifwasserkalk eingelagert vor, ein ebensoleher in Bernardino county in Kalifurnim. In Llar wird ein Material ron derselben Beschaffenheit geschliffen, für das der Fundort Mokiun in Oberïgypten ançesceben wird. Ein bunter Opal ron rosenroter, gevther und griner Farbe und ron grober schönheit ist im Staate Jaliseo in Mexiko in bedentender Menge gefunden worden.

Dw IF achsopal ist durch eine gelbe, wachsähnliche Farhe und durch einen wachsartigen (ilanz auswezeichnet. Er findet sich ausgezeichnet in der fegrend ron Toliaj und hesonders von Telkibanya in Ungarn in trachytischen Tuffen und hat ron dem letzteren Fundorte auch den Namen Telkibanyastein erhalten. Ebendort kommt der dunkelbraune, heller geaderte, pechartig glänzende I'echopal in Masse vor, der teilweise vollkommen ainer eingetrockneten Kalbsbratenbrühe gleicht. Ganz ähnliches findet sich auch sonst. z. P. bei Felsherg und an anderen Orten im niederhessischen Basaltwebict, z. T. in grofen Massen.

II olzopal ist ein bald heller, bald dunkler gefärbter Opal, der als Tersteinerungsmittel ron Hölzern auftritt, deren Struktur auf angeschliffenen Flächen zuweilen in sehr hiilsschen Zeichnungen hervortritt. Er begleitet stellenweise den unten zu hetrachtenden, aus (Wuarz bestehenden Holzstein und findet sich in grofer Menge in der eben genannten Gegend in Ungarn, ehenso auch am Quegstein und bei Oberkassel am Sichengebirece. in Chesterficld County, Vircinia, an Clover Creek, Lincoln County, Idaho, im üstlichen Teil von El Paso County in Colorado und an vielen anderen Orten.

Der Ifenilit bildet graubraune runde Knollen im Klebschicber von Ménilmontant und yon St. Ouen bei Paris. Bein Schleifen nimmt er einen lebhaften Glanz an, und da die Farbe zuweilen zwischen trau und braun streifenförmig abwechselt, so gewähren manche Steine einen recht hiibschen Anblick.

Der Hydrophan ist ein schmutzigweißer, gelblicher, bräunlicher oder auch wohl rütlicher und stünlicher Opal. der in seinem gewöhnlichen Zustande wenig Glanz und sehr geringe Durchscheinenheit besitzt. In dickeren Stiicken ist er fast undurchsichtig und lïlit auch an den ciïnnen Rändern wenig Iicht durch. Er hat aber eine sehr merkwürdige Eirentïmlichkeit, auf der seine gelegentliche Verwendung als Schmuckstein beruht. Diese besteht darin, daf der Hydrophan, wenn er in Wasser gelegrt wird, eine grobe Menge davon in sich aufnimmt und dabei allmählich fast vollkommen durchsichtig wird. Einzelne Steine erlangen dabei sograr das Farbenspiel (les Edelopals; sie werden W eltauge (oculus mundi) grenannt. Diese Änderumgen beruhen auf der groljen Porosität der Substanz, die infolge dessen an der feuchten Zunge klebt und mit Begierde Wasser aufsaugt, wobei zuweilen mit cinem zischenden (iräusch zahlreiche Luftblasen entweichen, dic beim Eindringen des Wassers aus den Poren des Steines vertrieben werden. Nimmt man den nahezu durehsichtign oder doch stark durehscheinend gewordenen Hydrophan dann aus dem Wasser heraus. so wird (r mit fortschreitender Verdunstung der aufgenommenen Fliissignceit allmählich wieder trïbe wie vorher, und das Farbenspiel beim Weltauge verschwindet. Der Vorgane kann aber beliebie oft wiederholt werden, wenn man nur stets canz remes Wasser anwendet. D)ir Stiieke. dir zuweilen zu Selumueksteinen Verwendung finden, werden mit rundlicher (Oberfläche in Form diüner Linsen exeschliffen und a jour medistens in Ringe

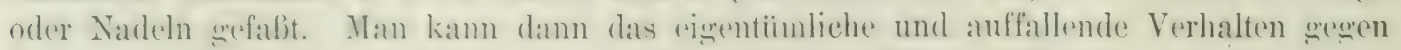
Wasser stets leieht zeigen. Dieses ist auf den ersten Bliek rïtselhaft und wunderbar, und darin liegt wohl auch der Grund, warum der. Hydrophan anf Java und den um-

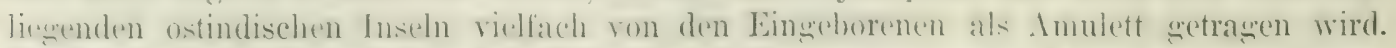
Lis sollen fährlich ron Europa, namentlich rom ldar ans. zahledehe Exemplare dorthin verkauft werden. 
TAFEL EXVhYVI.

2.

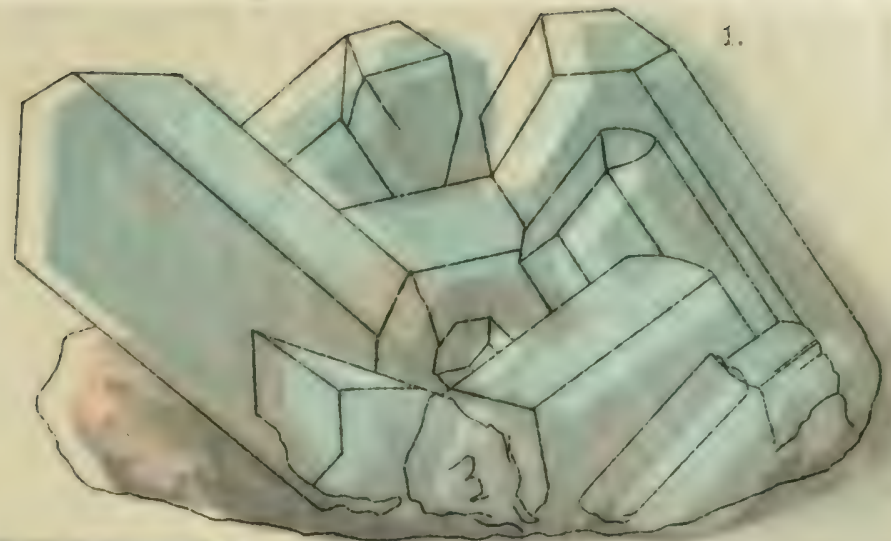

3.

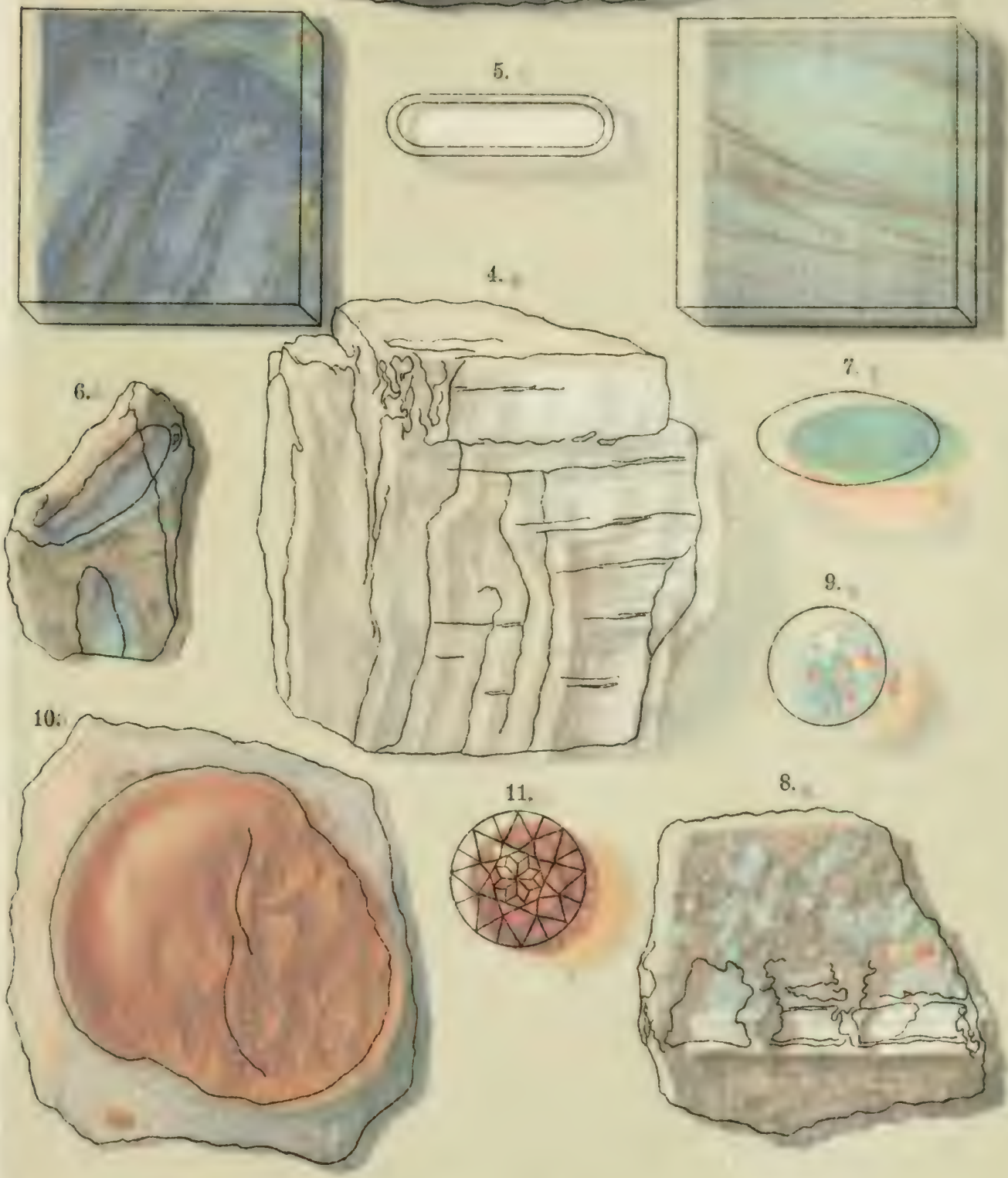

1. Amazonenstein (Krystalie). 2. Labradorit (angeschiffen). 3. Farhenspinlender Feldspath (angeschliffen). 4. Adular (roh). 5. Adular (ges hliffen, Momustein). B. Wilor Opal (Australien, roh). 7. Edler Opal (Australien, gesehliffen). 8. Edler Opal (Unsam, roh). 9. Edier Opal (Ungarn, geschliffen). 10. Feneropal (roh). 11. Feneropal (meschiife;? 

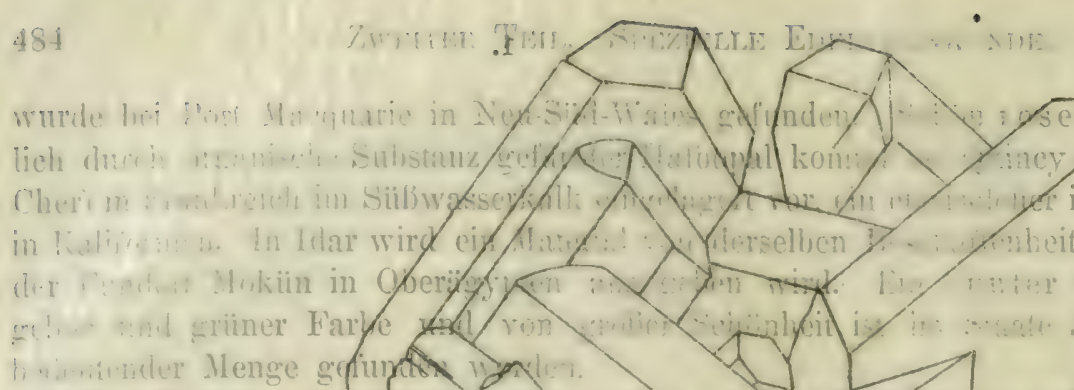

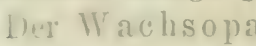

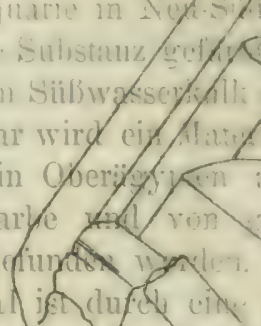

artigen Glanz ausgezeidunet. ErVimit

hesonders von 'Telkibanya in Ungate

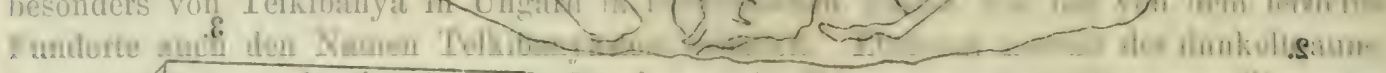

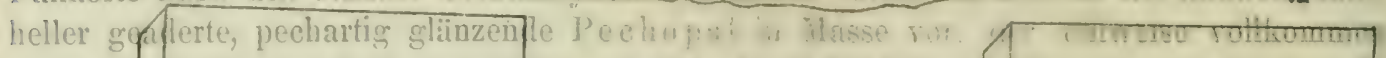

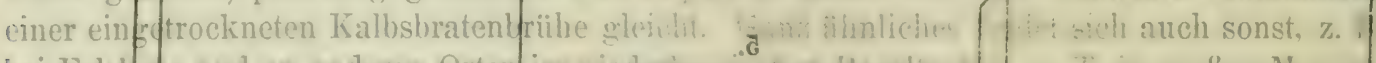

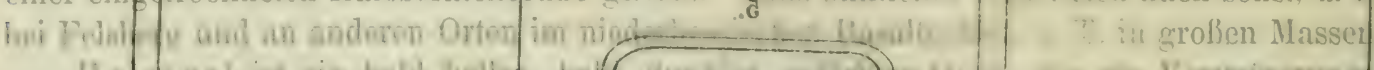

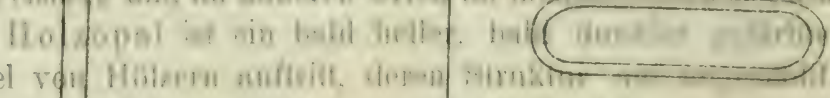

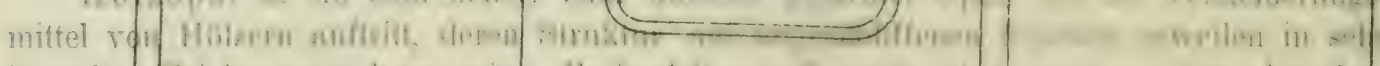

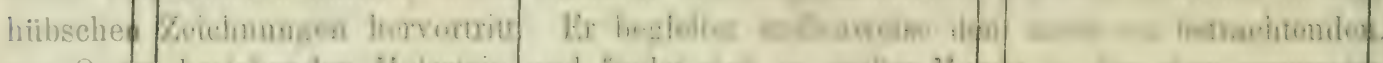

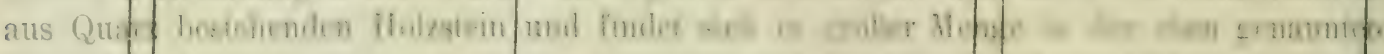

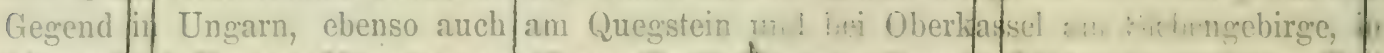
ron El

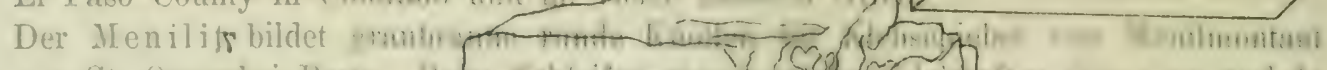

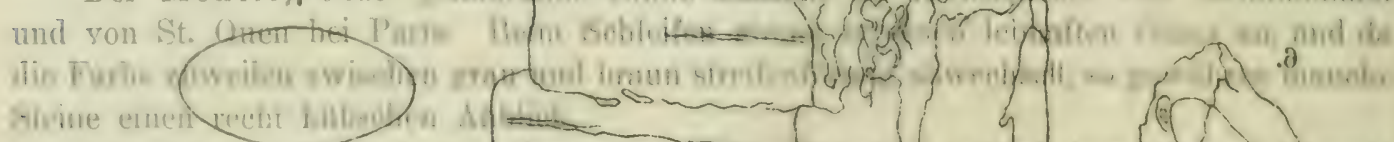

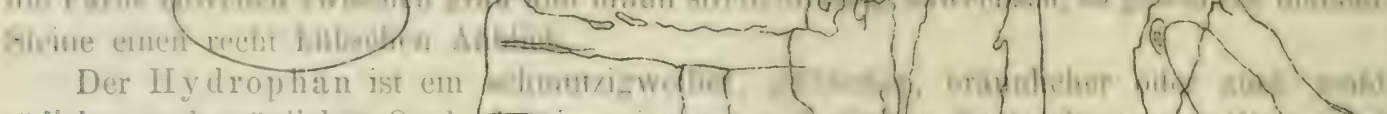

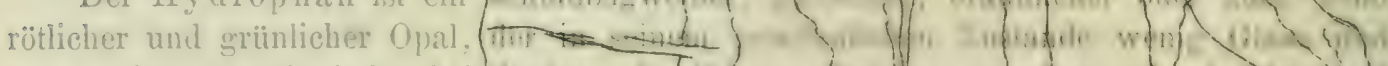

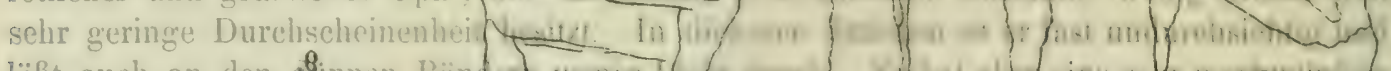

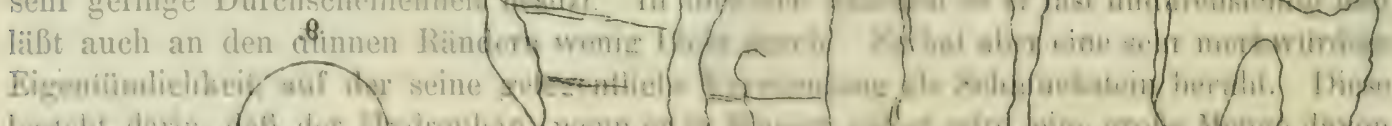

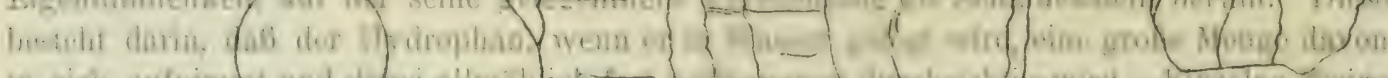

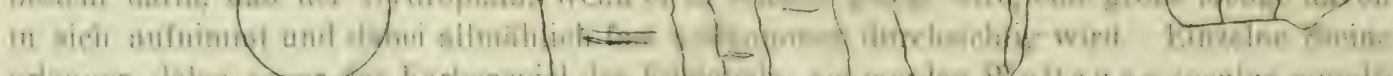

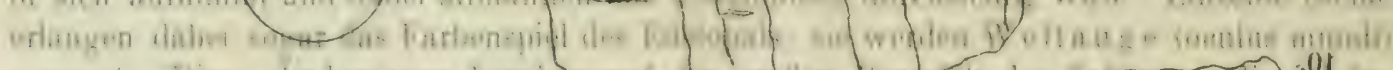

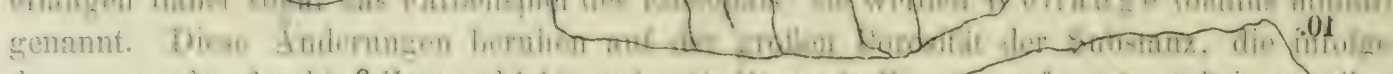

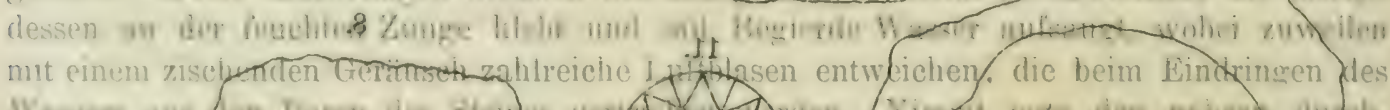

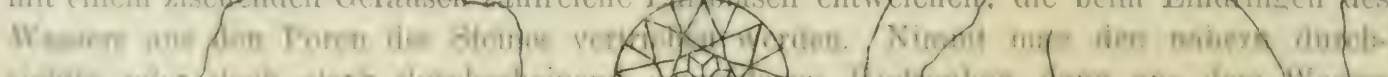

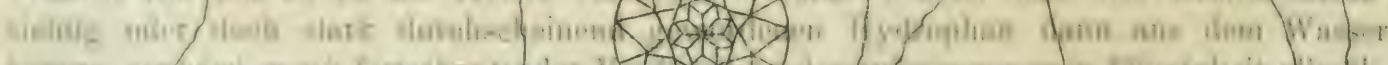

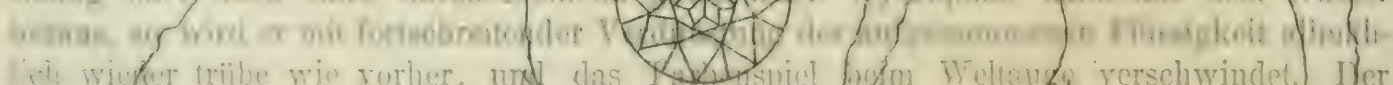

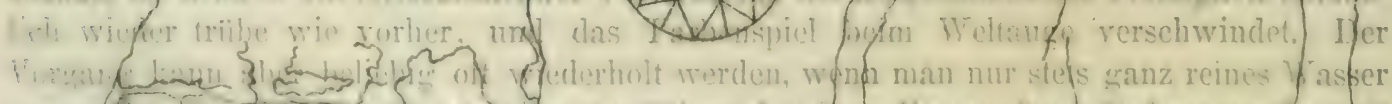

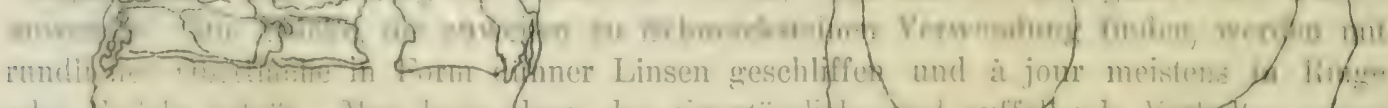

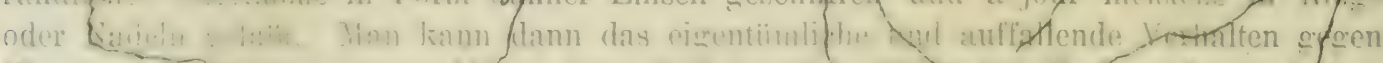
W. soler ....... nund darin lime $\because$ :

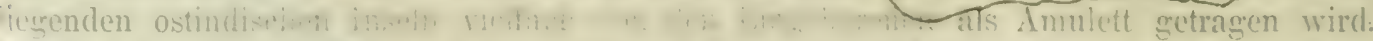

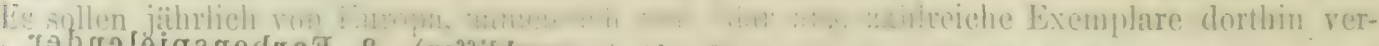

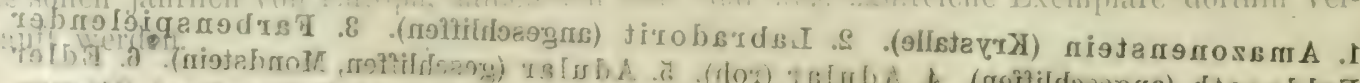

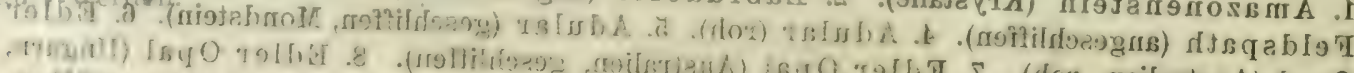

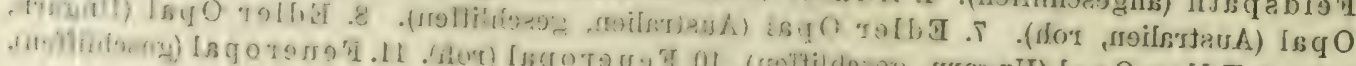
. 
TAFEL XVI.
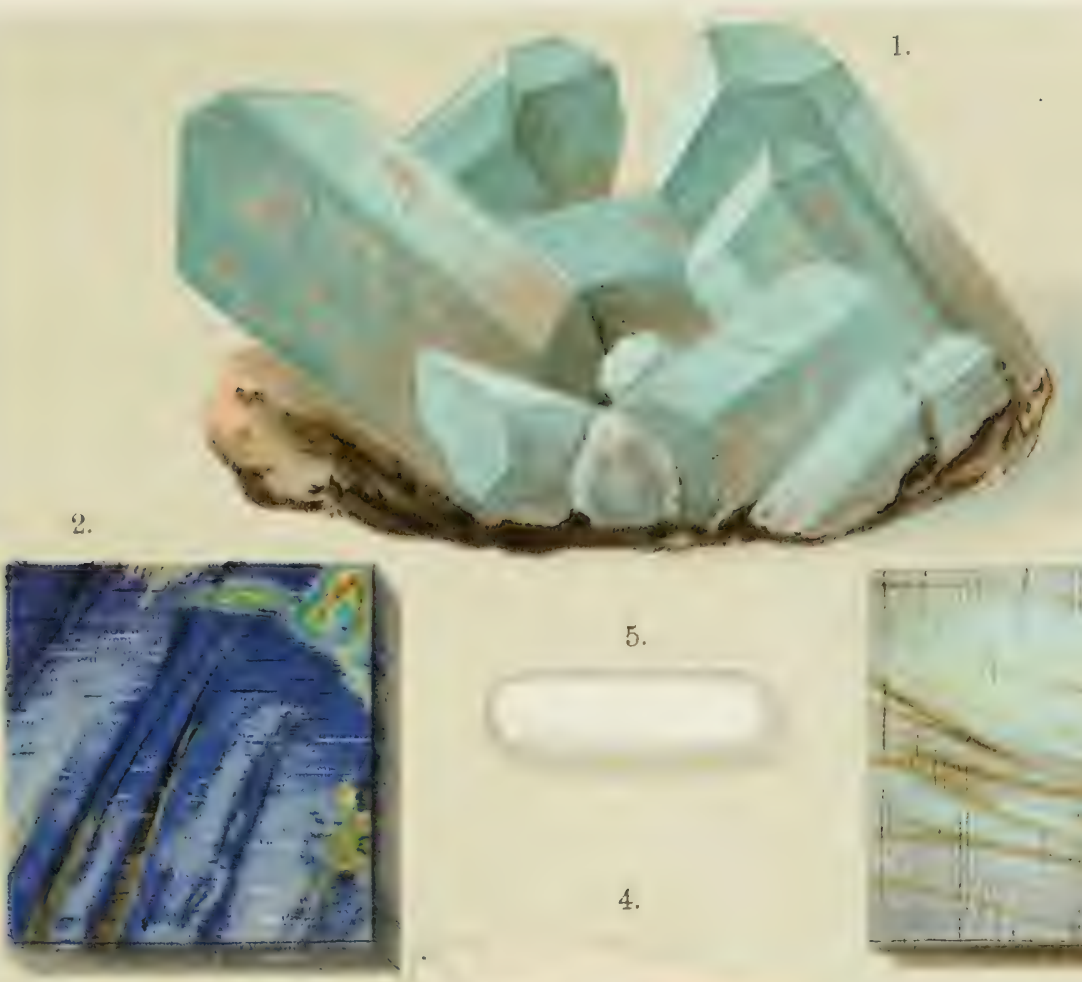

3.
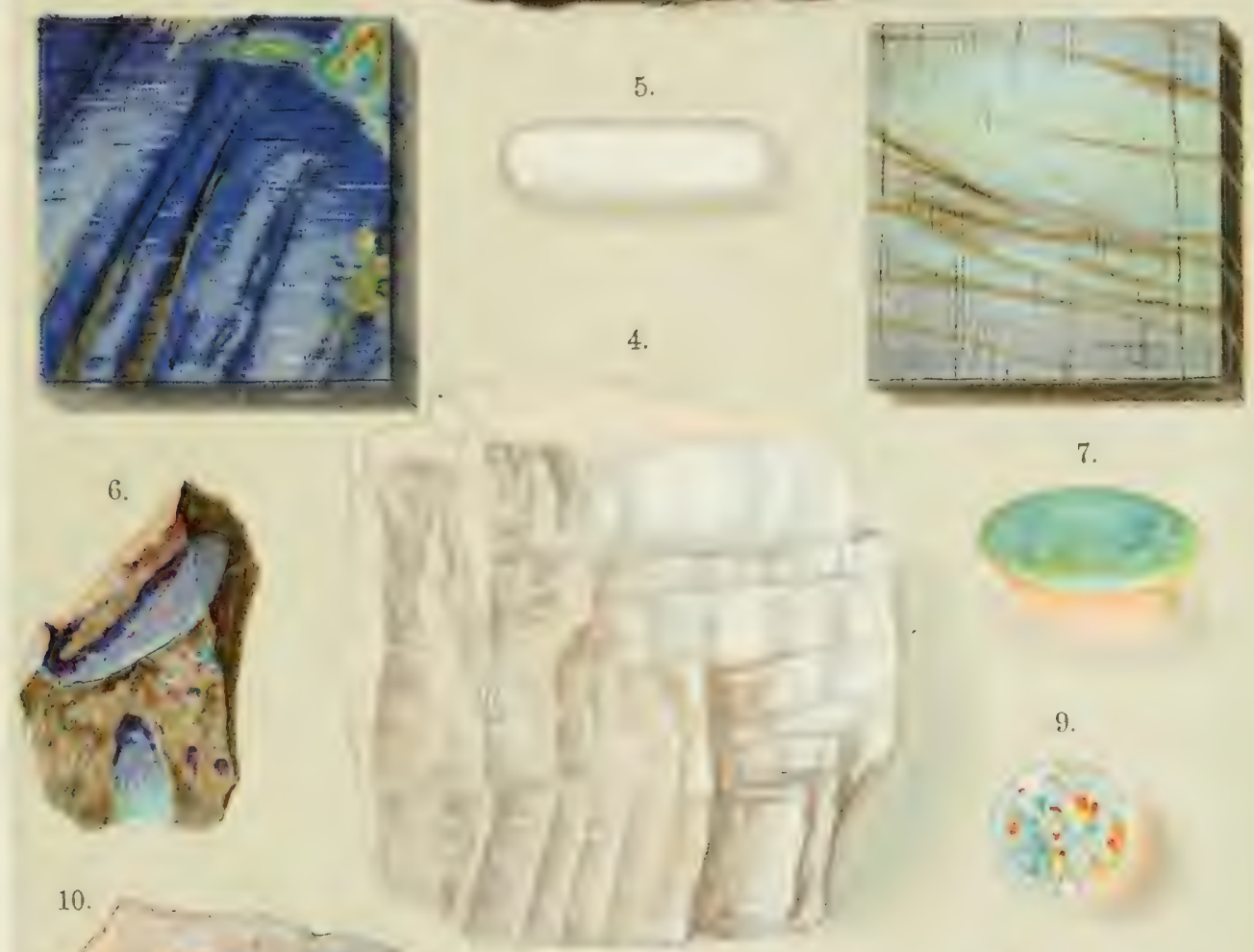

7.

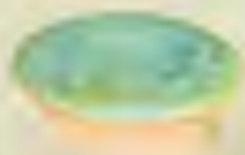

9.
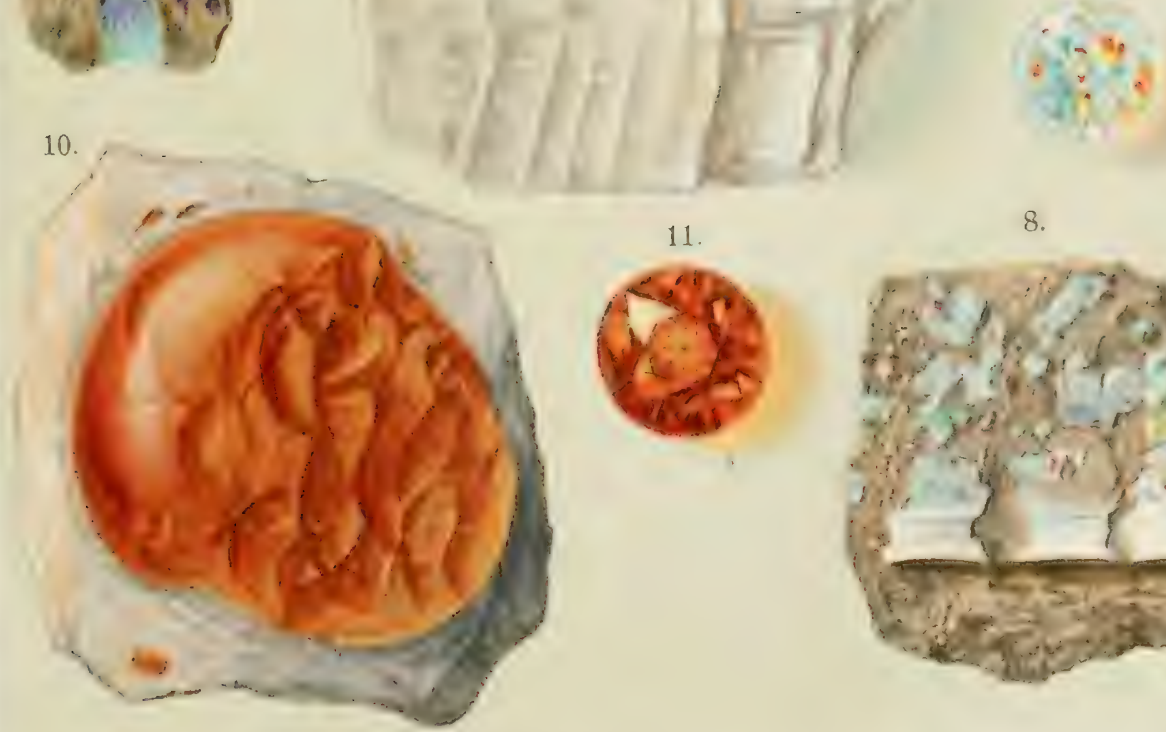

11.

8.
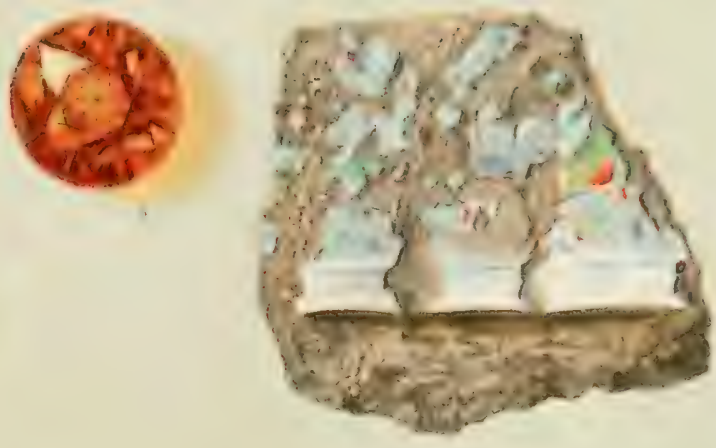

Bei Anwendung von Wasser ist die Durchsichtigkeit immer nur raseh voribergehend

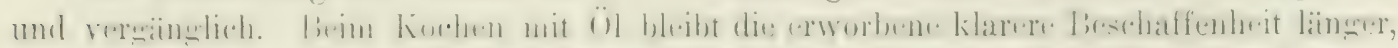
sogar jahrelang bestehen. MIan kann aber auch noch in etwas anderer Weise den Versuch austellen. Imprïgniert man die poröse Nasse mit reinem Wachs oder Walrat, dann ist

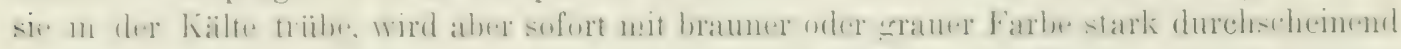
bis durchsichtig, wenn nan sie etwas erwärmt und dadurch das Wachs zum Sehmelzen bringt. Daher wird der Stein zuweilen auch Pyrophan genannt. Durch Tränken mit

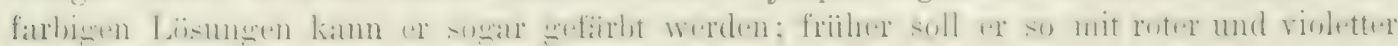
Farbe in den Handel gebracht worden sein.

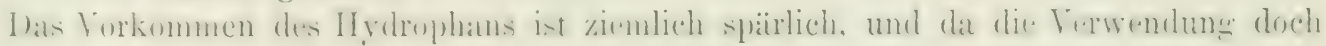
immer einen gewissen Umfang hat, so ist der Preis nicht ganz gering und geht bis 3 Mark pro Karat. Er ist um so höher, je größer der Stein ist, je schöner durchsichtig er im Wasser wird und je glänzender das dabei etwa auftretende Farbenspiel ist.

Der Hauptfundort ist wohl bei Hubertusburg in Sachsen in einem Porphyr oder

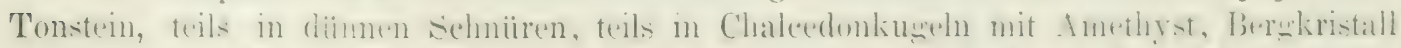

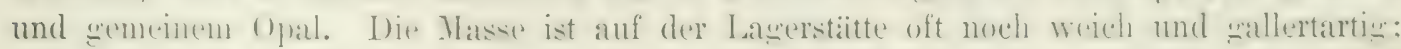
sie trocknet erst an der Luft allmählich aus und wird dadurch zu Hydrophan. Eine

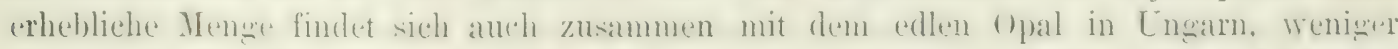
wichtign ist dats Vorkonmen nit dem Feneropal bei Zimapan in Jexilso unol mit den rer-

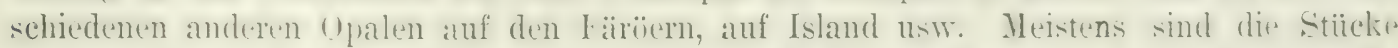
nur ganz klein: die Mtehrzahl der in Handel befindlichen steine sull die Linsengrölo. nicht iibersteigen. Der Ifydrophan soll z. T. durch beginnende Verwitterunge aus anderen () palarten, IV eltauge aus Edelopal usw. entstanden sein und daher spine besonderen Eigenschaften erhalten haben. Wohl aus diesem Grunde ist er auch etwas weicher.

Der Kascholonщ (Cacholong, Perhutteropal, Perhutterachat. Kahmiickenopal oder -Achat, ist ein sehr weniw durchscheinender, matter, oder schwach perhmutterolänzender. grelblicher, zuweilen auch milchweißer oder rötlicher Opal mit sehr glattem, großmuscheligem Bruch. Er ist ehenfalls stark porïs und hängrt an der Zunge, wird aber in II asser nicht wie der IIydrophan durchsichtig. Man verwendet ihn zu allen möglichen kleinen Gegenstïnden und Geritschaften, und benutzt iln zuweilen auch mugh weschliffen zum Schmuck. Manche steine sehen infolere der hübschen Farbe und des beim sichleifen terhaltenen schönen Glanzes recht wut aus. Bei cinzelnen stiicken weehseln hellere und dunklere Streifen wie beim Onyx miteinander ab, oder es sind diunne bläuliche oder srrünliche Chalcedonschichten dazwischen selagert. Auch dieses Material wird zuweilen wis onyx zu Kameen verarbeitet.

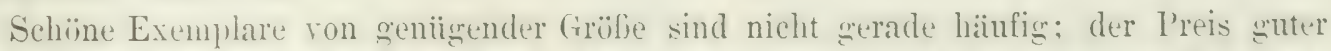
Stïcke betrïgt etwa eine Mark pro Karat. Der hascholong findet sich in geringer Mrenge an rerschiedenen Orten, meist in diumnen Lagen ron (iner bis vier Linien, selten bis zu $2{ }^{1}$ ㄹ cm, mit Chalcedon wechstelnd. Der Xame ist mongoliseh und bedentet ...schüner Stein”: er" soll herrïhren von dem seit langer Zeit in der Literatu erwïhnten, aber nicht nälete bekannten Vorkommen :m Flusese Cach in der Bucharei, wo er berichten zufolge in losen Geschiehen umherliegr. Nach der unwohnenden Vülkerschaft ist er früher als Kalniickenopal, oder da man ihn fïr eine Art Achat hielt, als Kalnüickenachat bezeichnet worden. Man findet ihn ferner in den Thasalten der Färöter und von Island, in nierigen und traubigen L'berzügen auf dem Brauneisenstein von Hüttenbere in Kärnten, bei Ruditz und Olonuezan in Mähren, sowie an der Fundy Bay in Neu-Schottland, äberall mit Gpil und Chalcedon zusammen. Cirolie. liedeutung hat er nirends. Er ist wohl durch noch weitergehende Zersetzung anderer Opale entstanden als der Hydrophan. 


\section{Türkis.}

1) 'T'ïrkis (orientaliseher, echter oder Mineraltürkis, Türkis vom alten Stein oder furpunise de la vieille roche) wird als Mineral auch Kalait oder Kallait genannt, unter liemutzun eines alten plinianischen Namens für ein grünes Mineral, das man auf unseren Edelstein bezicht. Dieser ist stets undurchsichtig, meist grïn, in den besten Qualitäten blau, und niemals in deutlichen Kristallen ausgebildet. Fr unterscheidet sich in diesen Beziehungen von fast allen anderen wertvollen Edelsteinen, die sämtlich, mit Ausnalime des (Mpali, durehsiehtig und vollkommen kristallisiert sind. Von ihmen und von allen ïhrigen wichtigen Edelsteinen überhaupt ist er namentlich auch durch seine chemische Zusammensetzung versehieden, sofern er zur Mineralgruppe der Phosplate gehört, von der liein anderes Cilied die für einen guten Edelstein nütigen Eigenschaften besitzt.

Was zunächst diese seine chemische Beschaffenheit betrifft, so ist der Türkis in der Ilauptsache cine wasserhaltige Terbindung der Tonewde mit der Phosphorsïure, der man die Formel: $2 \mathrm{Al}_{2} \mathrm{O}_{3} \cdot \mathrm{P}_{2} \mathrm{O}_{5} \cdot 5 \mathrm{H}_{2} \mathrm{O}$ zu geben pflegt. Diese erfordert im reinsten $\mathrm{Zu}$ stande: 47,n Proz. Tonerde, 32.5 Proz. Phosphorsäiure und 20,5, Proz. Wasser, die Analysen ergehen jedoch nicht immer genau dieses Mischungsverhältnis, sondern etwas schwankende Zahlen, wie es bei solchen nicht deutlich auskristallisierten Substanzen auch sonst lüufign der Fall ist. Aufer jenen Hauptbestandteilen enthält aber der Türkis immer noch weringe Hengen anderer Substanzen. Man findet namentlich stets zwisehen 1 und 4 Proz. Eisenoxyd und zwischen 2 und 8 Proz. Kupferoxyd, die deswegen von Wichtigkeit sind, weil sie die Farbe vermitteln. Ein blater orientaliseher 'T'ürkis, wahrscheinlich aus l'ersien stammend, hat nach der Analyse von II ermann eroeben: 47,45 Proz. Tonerde, 1,10 Proz. Eisenoxyd, 2,02 Proz. Kupferoxyd, 1,85 Proz. Kalk, 0,50 Proz. Manganoxydul, 28, Proz. Phosphorsiure und 18,1s Proz. Wasser. Da die Eisen- und Kupferhestandtcile niemals fehlen, so hat P'enfield die Ansicht ausgesgesprochen, dab ihre Anwesenheit nicht auf fremden Vermeeinigungen beruht, sondern dab sie dem Mineral wesentlich angehören. Lir liat daher statt jener eine dies berïclisiehtigende Formel:

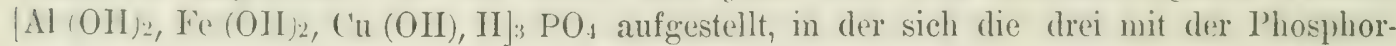
säure vereinitemelen basisclen Verbindungen in wechselnden Verhältnissen vertreten kümnen.

Das Wasser läßt sich durch Glïhen eines kleinen Stückes in einem engen Glasrïhrelen leicht anstreiben und beschlägt dann die Winde des letzteren mit Tropfen; dabei zreprungt das Stiickehen unter lautem Knistern in kleine Splitter, es dekrepitiert, wie man

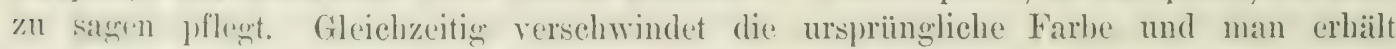
rine schwarzhraune Masse, deren Zusammenhang oft so lose ist, dab sie beim leisesten I) ruck in J'ulver \%erfillt, oder das angewandte Stiick wird auch gleich von vornherein in (in solches braunes l'ulver verwandelt. Sehmelzbar ist der Tiirkis selbst in der Flamme des Lätrolnes nicht; (2r färbt aber in feinen Splittern die Lötrohrflamme oder die Flamme des bunsenschen (iashremers oder der Spirituslampe infolere seines Gehalts an l'hosphor-

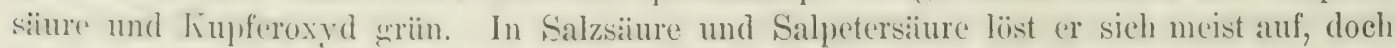
scheinen in disser Beziehume sich versehiedene Sorten und Stïcke von versehiedenen Fundorten abweichend zu verhalten, da manche P'roben von diesen beiden Sïuren nicht angereriffen werden. Diese wirken aber immer so weit ein, dab die Farbe des Steines zerstört wird und verschwindet.

Daß man keine Kristalle des Türkis kennt, ist schon oben erwähnt worden. Er

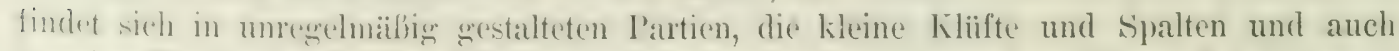
sumstige Ifohlräume in dent Muttergesteine ganz oder teilweise ausfüllen. Ist die Aus- 


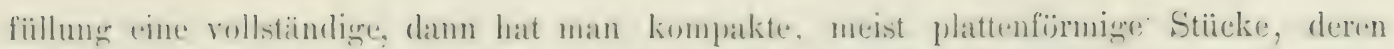
Dicke dis Malj ron wenien Millimetern selten ïluerschreitet, die sich aber manchmal in

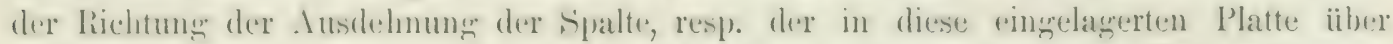
gräbliere Flächen ausbreiten. Ist die Ausfüllumger der Spralten nur zum Teil erfolgt, su)

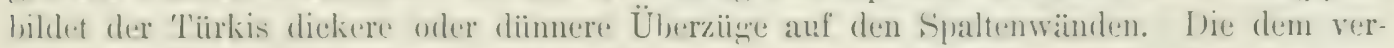

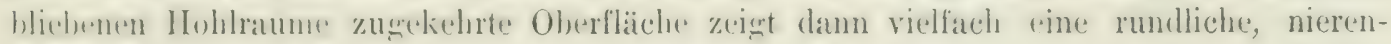
förmige, traubige oder auch tropfsteinähnliche Gestalt.

Mit dem Manged bestimmter Kristallform hängat das Fehlen jeder Spur von Spaltbarkeit zusammen. Der Bruch ist kleinmuschelig bis unelen. Er zeient iun frischen Zustande cinen wenig lehhaften, wachs- oder seifenähnlichen, an manchen steinen auch mehr Glatsigen Gianz, der aber dureh śchleifen und Polieren etwats, jedoch nicht sebr hoch, gewesteigert werden kann und der dann in Verbindung mit der schönen Farbe dein steine: sein eigentiinliches, angenelmes Aussehen verleiht, auf dem dessen Wert beruht. I)ie Sulstanz ist in einigermalfen dicken Stïcken undurchsichtign und lïlit nur an den feinsten

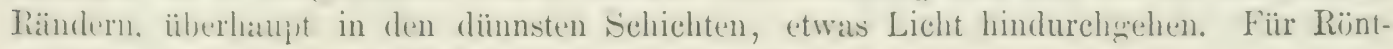
genstrahlen ist der echte 'Türkis ziemlich durchlässig.

Auf einem frischen bruch und noch mehr auf einer angeschliffenen und polierten Fliiche stellt sich der Türkis dem bloben Auge dar als eine vollkommen einheitlich gethatute. welehartige Masse. Betrachtet man aber einen Dïnnschliff unter dem Mikrosliop luei starker Vereröberung, so sieht man, dab sie aus einer unendlichen Zahl wirr durch-

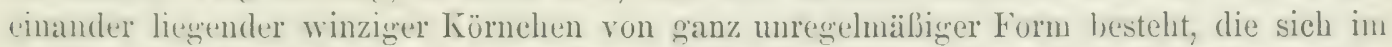
polarisierten lichte als doppelbrechend und damit als kristallisiert erweisen. In anderen Fällen Los Cerillos in Neu-Uexiko) ist sie aus feinsten doppellorecheuden Fästerchen zusammengesetzt, die entweder alle untereinander parallel und senkrecht zu den Wöinden der (iesteinsspalten ferichtet sind, in denen der Türlis vorzuliommen pflewt, oder die zu zahlreichen rundlichen radialfasrigen Gebilden, sog. Sphïiroliten, vereinget sind. ans denen dann der ganze Stein besteht. Der 'Türkis ist also trotz des Mangels an regelmäbigen äußeren Formen nicht amorph, sondern er bildet ein dichtes Aggresat miliroskopisch kleiner kristallisierter Individuen. Man benerkt dabei ferner, dals der im Dünnschliff durchsichtigen eigentlichen Türkismasse nicht selten kleine, weniger durchsichtige Partien, zuweilen von ring- vder kreisförmigger, oder auch von röhrenfürmiger Gestalt eingelagert sind, die wahrscheinlich von beginnender Verwitterung herrïhren. Auch kleine fremdartige Kürperchen, vielleicht dem Mineral ('halcedon angehörigr, lïbt das Mikroskop zuweilen als Einschliisse erkennen.

Die Farbe des Türkis ist entweder grün oder blau; das erstere ist viel häufiger der Fall als das letztere. Sie berulit auf dem oben erwähnten kleinen Kupfer- und Eisengehalt. Im Dïmschliff unter dem Ilikroskop) sieht man nur selten, hesonders bei dem blauen jersischen Türkis, sefürbte Parthien als fetzen- oder staubfömige l'eilchen, manchmal anch als wolkige Stellen ron unbestimmter Begrenzung gregen die farblose Lmgebung deutlich sich abheben. Beinahe immer ist im blauen und wrïnen Türkis die Fürbung wanz chelehmäbig durch die Masse verteilt. Diese erscheint in der diunnen Schicht des Schliffes fast vollkommen farblos, vielleicht schwach gelblich, das firin und Blau tritt (rist in dickeren Laygen hervol. Es ist dies dasselbe Terhalten, das viele stark grefärbte und zuweilen fast undurchsichtige Mineralien zeigren, die im Dïnnschliff durchsichtig und farblos erscheinen.

Die Suancen der Farbe wechseln zwischen himmelblau und bergeriün, einem blassen Grïn, dem grau und blau beigemischt ist. Überhaunt sind die l'iurkise fast stets ziemlich blafs getärbt, sehr intensive Färbungen kommen kaum vor, aber in diesen blassen Nuancen finden sich zwischen dem blanen und grï̈nen Endgyliede alle möglichen Übergänge, 
die man zu dince stetign sich ändernden lieihe zusammenstellen kann. Von allen diesen Farben ist alyer nur die rein und möglichst tief himmelblaue von Bedeutung. Nur Türkise, die diese Farbe haben, werden gegenwärtion als Edelsteine in Europa und dem größten Teile des Orients hochgesehätzt. Mit zunehmender Beimischung von Griin nimmt die Wertschätzung und der Preis mehr und mehr ab, und ganz grüne Steine werden in der alten Wrelt nur in einigen Teilen ron Arabien als Schmucksteine verwendet. In friiherer Zeit scheint aber wenigstens an manchen Orten, besonders in alten Nexiko, auch die grïne Farbe beliebt gewesen zu sein, und wir werden bei der Betrachtung der mexikanischen Fundorte sehen, daf auch jetzt noch in jenen Gegenden von den Eingehorenen grü̈ne Türkise als Schmucksteine viclfach und mit Vorliebe getragen werden.

Die himmellblatue Farbe ist meist ïber die gamze Oberfläche hin vollkommen gleichartig; und nur Steine von dieser Beschaffenheit sind wertvoll. Bei den Steinen von gewissen Fundorten, besonders bei denen vom Sinai, bemerkt man aber auch zuweilen feine netzartiø angeordnete hellere Streifen, die besonders an geschliffenen Steinen scharf auf dem dunkleren Grunde hervortreten. Auch braune Adern und Flecken treten vielfach auf. Stets hat jedoch die blaue Farbe des echten Türkis die wertvolle Eigenschaft, daß sie ihre Schönheit auch bei kïnstlicher Beleuchtung im Lampenlicht vollkommen beibehält, während andere, dem Türkis ähnliche blaue Substanzen unter diesen Umständen unansehnlich grau ausselien.

Bei manchen 'T'urkisen ist die blaue Farbe sehr unbeständig. So werden viele Steine aus dem Megharatal am Sinai und aus Neu - Mexiko, bald nachdem sie aus den Gruben genommen sind, matt und blaß, und die Farbe ist nach kurzer Zeit fast ganz verschwunden. C̈berhaupt soll die blaue Farbe ziemlich unbeständig sein und allmählich an Sonnenlicht ausbleichen, wobei das Blau gleichzeitig eine grïne Nuance annimmt. Dies ist aber jedenfalls nicht immer der Fall, viele Tïrkise behalten doch ilıre Farbe recht lange unverändert bei. So erzählt Sir Richard F. Burton von einem sehr schönen blaten Stein, den er an der Flinte eines Beduinen gesehen und der in der Färbung nicht im mindesten gelitten hatte, trotzdem er mindestens 50 Jahre lang der Sonne und Wind und Wetter schutzlos ausgesetzt gewesen war. Durch deu Schweil soll die Farbe besonders stark angegriffen werden. An der Sonne gebleichte oder sonst beim Tragen als Schmuckstein in ihrer Farbe veränderte Steine nehmen zuweilen ihr früheres schönes Blan wieder an, wenn man sie mit Ammoniak behandelt oder auch befettet, ja, wie man sagt, schon dadurch, daß ein Ring mit dem Stein nach der inneren IIandfläiche zu gretragen wird, so daß er vielfach mit der etwas fettigen, aber nicht mit Schweib bedeckten Hand in Berïhrung kommt. Aber diese Farbenernenerung ist nicht dauerhaft, das frisch hergestellte Blau verschwindet bald wieder, und man hat sich in dieser Beziehung vor Betrug zu hüten. Da sich die Farbenänderung meist langsam ron der Oberfliiche aus nach innen erstreckt, so kann der Stein oft dureh Überpolieren verbessert werden, doch muß man diese Operation immer von Zeit zu Zeit wiederholen.

Vollständig versehwindet die Farbe und der Glanz bei der Verwitterung, die in manchen Steinen von der Oberflïche an nach innen allmählich fortschreitet. Nan findet zuweilen rohe Türkise, die im Innern schön blau, aber außen von einer matten weißen bis gelben und braunen Verwitterungsrinde umgeben sind. Diese muß man dann erst entfernen, um zu dem wertyollen, schöngefürbten, frischen Kerne zu gelangen. Manchmal ist auch der V'erwitterungsprozel3 so weit vorgesehritten, dab er das ganze Stiick ereriffen hat, das dann in eine lockere, leicht zerdriekbare Masse verwandelt ist, in der vielleicht noch einzelne blaue Körnchen liegen.

Da der Wert mit der Schı̈nheit der blauen Farbe sich bedentend erhöht, so hat man anch schon versucht, schlechtere Steine kïnstlich blau zu färben. Diese betrügerische 
Operation ist auch bis zu einem grewissen Grade gelungen, indem man die Steine mit

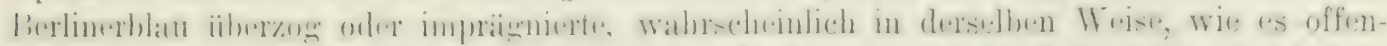

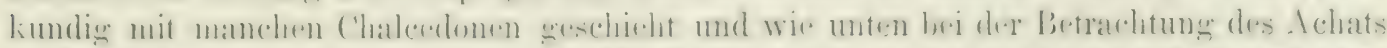

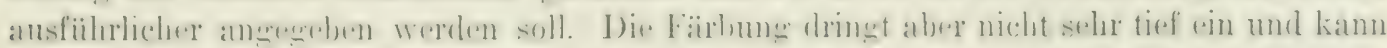

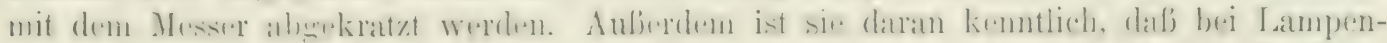

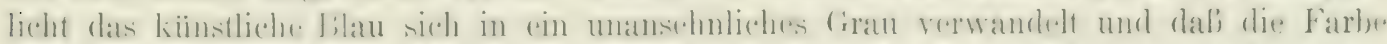

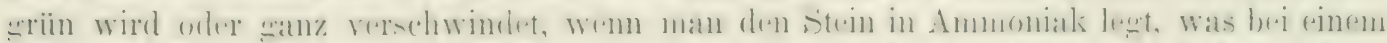

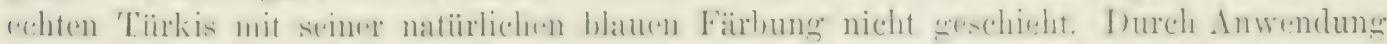
des letzteren Hilfsmittels kann man sich leicht vor Betrug schïtzen.

In Beziehung auf das spezifische Gewicht schwankt der Türkis etwas; man hat für

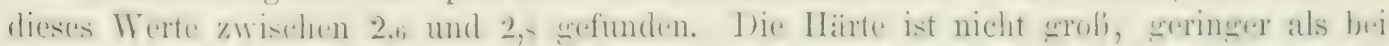
fist allen anderen wertwollen Edelsteinen. Sie ist whele ti und entspricht der des Feldspats. Von Quarz wird er also leicht geritzt und von der Feile stark angegriffen; er

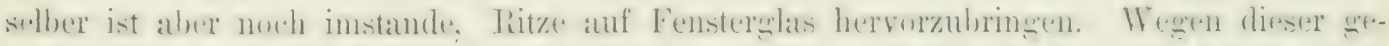

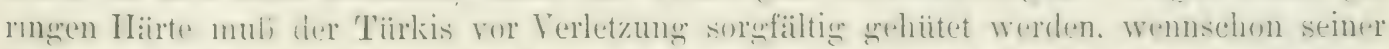
Endurehsichtigkeit wexen ein kleiner Ritz nicht so viel schateet als bei einem durchsichtigen Edelstein.

Ob der Tiükis schon im Altertum bekannt war, ist zweifellaft, jedenfalls war er es im Mittelalter. (iexenwärtig hat er vielleicht eine auswebreitetere Anwendung als cichnuckstein als irerendein anderer der wertrolleren Edelsteine, da er im Morgenlande und im Abendlande in gleicher Weise beliebt ist. Namentlich im Orient, in der Türkei, in Agrpten. Arabien und l'ersien wird er viel getragen, da ihn die orientalen für cribekiringend halten. Lr findet sich dort, wem anch oft nur in einem kleinen schlecteten Stiickehen als Ringstein in Zimn gefaft, an jeder Hand, dient aber ehensu auch zur Verzierung der (iriffe und Scheiden von Dolehen und säbeln, des Sattelzengs und zu ähnlichen Zwecken. Der Name Türkis soll von dieser hïufigen Verwendung in der Tuirkei her-

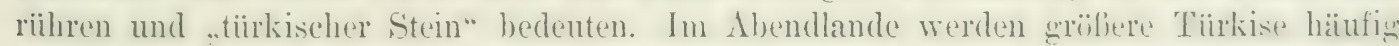
beim Fassen mit kleinen Diananten umgeben, während kleine Tïrkise umgekelirt riclfach zur Einfassung anderer Edelsteine dienen.

Wie alle undurchsichtigen Steine wird der Türkis fast nur mugelig, en cabochon, ohne alle Facetten geschliffen, und zwar meist mit einer chenen, lireisumden oder ovalen Unterflïche, wie es Taf. XX, Fig. 2- dargestellt ist. In dieser Form tritt der Glanz und namentlich die Farbe des Steines hesonders vorteilhaft hervor. Es wird zwar angegeben. dalj auberewewöhnlich schöne und grolie Stiicke auch zu Tafelsteinen oder zu Dicksteinen verarbeitet werden. Dies ist aber jedenfalls nur sehr selten der Fall, da wegen der Indurchsichtigkeit die schönheit durch Facetten nicht wehohen wird. Manchmal werden Figuren eingraviert, im Orient häufig Spriiche aus dem Koran, deren Buchstaben man auch wohl mit Gold auslegt. Steine, die wraviert werden sollen. erhalten statt der runden vielfach auch eine ganz ebene Oberfläche.

Der Wert unseres so allgemein und so hochereschätzten Edelsteins ist ein recht beträchtlicher, im Mittelalter ist er noch erheblich höher sewesen. Der Preis hänget sehr wesentlich ron der Grölie und der Farbe ab und wechselt mit diesen beiden Faktoren sehr bedeutend. I) er Einflul; der Farbe ist zum 'Teil sehon oben erwähnt worden. Am teuersten sind nicht zu dïnne tief und gleichmäljig geförbte rein himmelblatue Steine ohne Flecken: mit zunchmenden (irïn sinkt der l'reis allüählich bis auf Null herab. Was den Linflub der (rö̈be anbelanget, so sind kleine Tiurkise leicht und in Irenge zu haben und daher billig. Aler schon erbsengrofe stiicke sind selten und werden daher, wenn sie gut gefö̈rlst sind, tener hezahit. Kleine Steine werden nach Tausenden, etwas gröbere nach Dutzenden, solche von einer gewissen Größe ab stïckweise gehandelt. Ein Karat 
der besten (Iualitait ist etwa auf 150 Mark zu schätzen. Der Preis steigt der Seltenheit gröferer stiicke entsprechend in erheblich höherem Grade als das Gewicht. Bei rohen Fteinen ist es sehr wesentlich, daß auch eine genügende Dicke vorhanden ist, da nur dam sich ein guter, nicht zu flacher mugeliger Schliff herstellen läßt; dies ist unmïglich, wem der 'Türkis nur eine dïnne Lage auf seinem Muttergestein bildet.

Aulergewöhnlich grolbe Türkise von schöner Farbe und Beschaffenheit sind, wie es scheint, nur sehr wenige bekannt. Beschrieben wird unter anderen ein zwei Zoll langer herzförmiger Stein, der vor einiger Zeit sich im Besitz eines Moskaner Juweliers befand und den früher Nadir Schah als Amulet getragen hat. Lr war mit einer goldverzierten Inschrift aus dem horan versehen und sein Wert wurde auf 5000 Rubel geschätzt. In der. Sammlung der kaiserlichen Akademie in Moskau liegt ein Türkis von mehr als :) Zoll Lïnge und 1 Zoll breite. Die gröbten und schünsten Stiicke sollen sich aber in der Schatzkammer des Schah von Persien befinden. In seinem Lande liegen die wichtigsten 'I'ürkisgruben, und aus deren Erträgnis pflegte er frïher die besten Exemplare fïr sich zu entnehmen.

Üher das Vorkommmen des Türkis in der Natur wurde schon oben mitgeteilt, dab er, wie es Taf. XX, Fig. 3, zu sehen ist, dünne Adern von mehr oder weniger bedeutender Ausdehnum: in manchen Gesteinen bildet. Diese sind so entstanden, daß sich das Mineral aus wïsseriger Lösungु auf ursprünglich offenen Hohlrämmen, meist schmalen Filüfen und Spalten absetzte, und diese entweder ganz oder auch nur zum Teil erfüllte. War du A usfïllumg unvollständign, damn überzieht nur eine dünne Türkiskruste beide W:inde der Spalte, und diese Krusten zeigen die erwähnte rundliche, nierenfürmige usw. Oberfläche. Das Muttergestein, in dem die jetzt mit T'ürkis erfüllten Spalten aufsetzen, ist an den einzelnen Fundorten des Edelsteines verschieden; bald ist es schwarzer 'Tonschiefer oder Kieselschiefer, bald Sandstein, hald sind es auch vulkanisehe, und zwar trachytische Gesteine, von denen die letzteren namentlich als 'Träger der edelsten Vorkommnisse von Wichtigkeit sind. Im Kalk scheint sich der Stein noch nie gefunden zu haben; diesbezügliche Angaben haben sich als irrig erwiesen.

Was die Verbreitung des Türkis anbelangt, so fehlt er zwar auch in Europa nicht, doch ist in unserem Erdteil bisher fast nur die griüe, als Edelstein unbrauchbare Varietiat vorgekommen; die Farbe geht wohl zuweilen etwas ins Blaue, schön himmelhaue Steine sind aber noch nicht gefunden worden. Die Zahl der Fundorte ist ziemlich

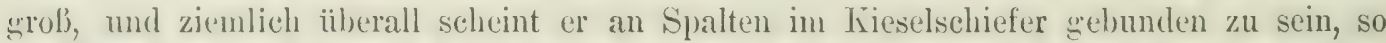
hei (i)snitz im säthsischen Toightande, bei Steine und Domsdorf unweit Jordansmïhl in Schlesien usw.

Wohl die wichtigsten Fundorte scböner blauer Türkise liegen in Asien. Von franz ïberwiegender Bedentung ist hier Persien. daher werden die Steine von der besten Beschaffenheit anch wohl als "persische 'Türkise" bezeichnet. Die Perser nennen diesen ihren Lieblingstein Piruzeh (arabisch Firuzeh), und nach der Mitteilung von C. Ritter wäre das Wort 'Türkis eine Verstümmelumw davon. Diese 'T'ïrkise kommen zum Teil von Persien äber Indien nach Europa, weshall, man öfters die falsche Angabe findet, dab der Edelstein auch in Indien vorkomme.

Die bedeutendsten persischen Türkisgruben, die das kostbare Material fast ausschlieflich lieferm, liegen im Bezirk von Nischajur, 15 geogr. Meilen westlich von Me-ched in der l'rovinz ('horassan, 750 Kilometer östlich von Theheran. Wir haben über diese in neuerer Zeit hauptsächlich dureh Tietze, Bogdanowitsch und den persischen Cieneral Cl. II outum Sehindler Nachrichten erhalten, ron denen der letztere am Anfange der achtziger Jahre eine Zeitlang Gouverneur des Grubenbezirks und Leiter des Betricbes in den Gruben gewesen ist. 
Jie berere der Gexend bestrehen aus Nummulitenkalk und Sandstein, die auf Tonselhiefer ruhen und die grolbe Massen Cips und Steinsalz einschlieben. Alle diese Schichten

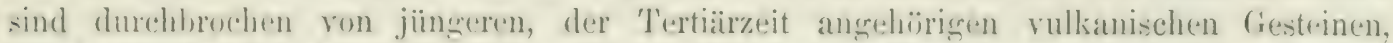

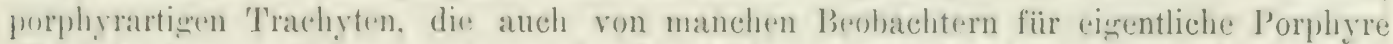
Felsitporplygrei wehalten worden sind. Sie bilden eine (iebiraskette, die sich zwischen Kotschan und Mischapur von Westen nach Osten erstreckt. In diesen Zuge liegt der

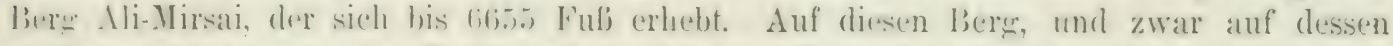

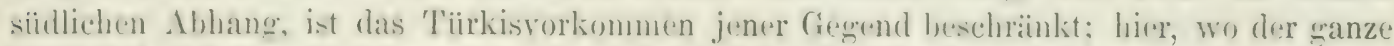

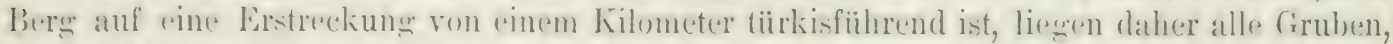
die in fribleren, zum Tril weit zuriickliegenden Zeiten bearbeiteten, nun moistrus rexlassenen sowohl. wie die jetzt in Betrieb befindlichen. Am Fube des berges zieht, im Nittel in einer Höhe von $4540 \mathrm{Ful}$, ein Tal hin, in dem, $5100 \mathrm{FuB}$ hoch, unter $36^{\prime \prime}$

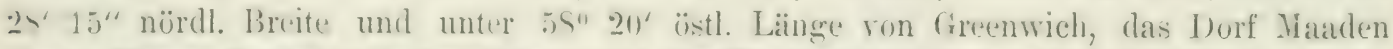
liegr. I)ieses Dorf bildet den Mittelpunkt der Tärkisgewimnung. Die Gruben liexen in

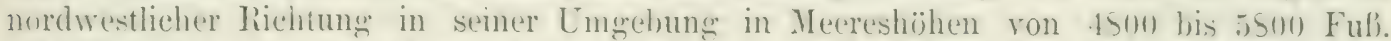
Alle: Einwohner von Maaden und den umliegenden Dörfern leben von unsorem Edelstein, ron der Arbeit in den Gruben, von dem Sehleifen und von dem Verkauf.

Das urspringliche Mutteraestein des T'irkis ist ausschlielilich jener, im Zustande der lewitterung befindliche porphyrartige 'lachyt und eine breceienartige 'Trümmermasse, ans stïcken derselhon Felsart bestehend, die dureh Braunejenstein miteinander verkittet sind. Der' 'T'ïrkis ist in Menge vorhanden und macht sich allenthathen dirch blane und

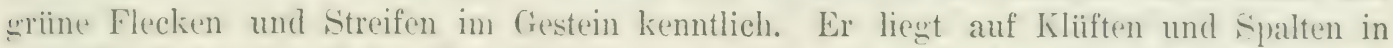
dem Trachyt und auf den \%wischenrïumen zwischen den Brocken, die jene Breceit zusammitnsctzen, letzteres in der W'eise, dal) er dem Brauneisenstein als jünste Bildung eingevagert ist. Dieser erfüllt häufig die Zwischenräume in dem Gestein nicht ganz, und die (webliebenen Ilöhlungen nimmt dann der Türkis ein. Er findet sich so in mehr oder weniger ausgedehnten Platten oft ron ziemlich ebener Gestalt, die meist nur eine Dicke ron 2 bis 6 , höchstens ron $13 \mathrm{~mm}$ besitzen und die beiderseitig von einer mehr oder weniger dicken Lage ron Brameisenstein begleitet sind, die aber auch zuweilen sanz fehlen kann. In anderen Fällen bildet der Edelstein tinzelne unregrelnäßjige kleine Massen ron Erbsen- bis hächstens Bohnengrüße, die hald regellos in Gestein zerstrent sincl. labld aber auch in dem Brauneisenstein nebeneinauder liegend sich eleichfalls zu f)attenfürmigen Gebilden vereinigen können. Endlich erfiillt der Türkis in dem auf den eribleren Kiliften angesammelten Brauneisenstein kleine Spalten, die quer zu diesen Kliiftem verlaufen. Er erstreckt sich damn auch vielfach iiher den letzteren hinaus und in die umgebenden 'Trachytstiicke hinein, wo er nun nicht ron Brauneisenstein begleitet ist. Selten ist es. dafo der Türkis Inohlrätume im Innern der Trachytstücke der Breccie ansfiillt. Nineralogisch interessaut ist die Erfïllung soleher Höhluneren im Trachyt, die durch Answitterung ron Feldspatkristallen entstanden sind; in diesen nimmt der Türkis di. Form de's zerstörten Feldspats an und bildet so Afterliristalle von Türkis nach dem letzteren Mineral.

Die 'Türkise finden sich aber nicht blob in dem festen Trachyt oder der Trachythreceie, sondern auch in ziemlicher Zahl in den durch Verwitterung dieser festeine ent-

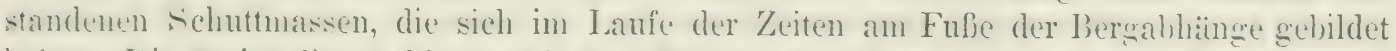
hahen. I) ie teine liewen hier lose in dem schutte, vielfach mit einer weilien Verwitterungsrincle ïberzogen, nach deren Entferumge erst die schüne blaue Farbe zum Vorschein kummt. oder auch wohl vïllig zersetzt. Diese türkisfïhrenden alluvialen Schuttablagerungen

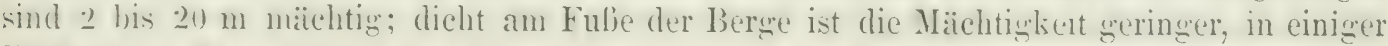
Entfermung daron bilden sie kleine IIügel, die durch Erosion aus der ursprünglich zu- 
sammenhängendin Masse entstanden sind. Man findet darin aber nux in den obersten 2 Mrter whte 'Tiirkise. bis zu 4 m findet man schlechte, sriinliche und weibliche, noch tiefer grar keine melnr.

Die Zahl der Gruben in jener Gegend ist sehr beträchtlich; sie beträgt mehrere Ilundert, die meisten sind aber nicht mehr im fiange. Im Jahre 1576 wurle auf 266 (iruben gearbeitet. Der Betriel) bestelit bereits seit Jahrhunderten; schon in der im Jahre 1:301 (xichienenen Abhandlung über. Jineralogie des Arabers No hamed ibn Mansur wird davon gesprochen. Nach seiner krzählung ging frïher die Sage, dali die beste dieser Ciruben ron Isaak, dem Solın Abrahans, aneclegt worden sei; sie wurde danach die Isaakssrube genannt. Lange Zeit hindurch hat man nach richtigen bergmännischen Regehn ge-

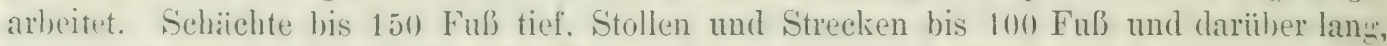
allerdings von geringer IHöhe und Weite, die unterirdischen Baue dureh stehengelassene Pfeiler gestïtzt und, wo nötig, Wetterschäichte zur Zufuhr von gruter Luft, alles das findet man in den alten Gruben, deren Anlage somit eine vollkommen zweckensprechende ist.

Bis 1725 wurde nach der Meinung von Schindler der Bergbau wahrscheinlich von der fersischen Regierung und damals sachgemäl in der erwähnten Weise betrieben. Später iiberlieb man ihn den Umwohnern, namentlich den Einwohnern von Maaden zu eigener Verwaltung, und von da an beginnt der Verfall. Der rationelle Betrieh hörte allmählich auf, die stïtzenden Pfeiler wurden weggehanen, um den darin befindlichen Tiurkis zu gewinnen, jede Vorsichtsmabregel wurde vernachlässigt und so ein schlimmer liaubhau eingreführt, der die Arbeit in den Gruben sehr gefährlich machte und der notwendig zum Rïickgange der Produktion führen mußte. Tiele Grubenbaue stürzten ein und wurden unzugïnglich, und an manchen Stellen, wo früher ein wohl iu Stande gehaltenes System von bergmännischen Anlagen war, sieht man jetzt bis zu bu und sll Fuf tiefe und bis 250 Fub weite trichterförmige Vertiefungen, die sich durch den Einsturz jener frïheren Schächte und Stollen gebildet haben.

In manchen jener alten Gruben ist der Bergbau noch jetzt im Betrieb, teils indem de Arbeiter in dem tïrkisfïhrenden Gestein noch weiter vorwärts dringen, teils indem das von frïher her in den Gruben lose herumliegende Gestemsmaterial und dasjenige der Halden, meist von Franen und Kindern, auf Türkist durchsucht wird. An Ende des vorigen Jahrhunderts soll nur noch in einer alten tirube grearbeitet worden sein. Aber immer nete Gruben werden angelegt, fast stets mit Lirfolg, da eben der T'ürkis den ganzen Berg durchsetzt.

Die 'Türkise der alluvialen Schuttablagerungen werden gleichfalls nicht unhenutzt

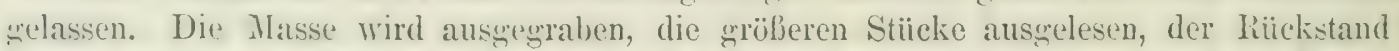
gewaschen und der Türkis auf diese Weise sichtbar gemacht. Früher waren diese (irähereien nicht von hesonderer Wichtigkeit, aber mit zunehmender Verwilderung des Berwhatues gewannen sie an loedentung immer melor und spielen jetzt eine nicht ganz untergeordnete Rolle.

In den achtziger Jahren waren etwa 200 Arbeiter uit der Gewimumg des Eilelsteines beschüftigt, dawon etwa 130 in den Berewwerken auf der ursprünglichen Lagerstitte, die iibrigen in den Gräbereien in dem alluvialen Schutt.

Die gewomnenen Steine werden meist gleich an Ort und Stelle in roher Wejse mugelig Eeschliffen und sodann von den 15 bis 20 Dorfältesten so rasch wie müglich nach Ilesched sebracht. Hier ist der Markt fïr unseren Edelstein. und deswegen wird Meselsed auch zuweilen fälschlich für den Fundort gehalten. Ton da aus geht der Türkis, anf ITarzstähchen auferekleht und diese zu Bïndeln zusammengebunden, zum swöbten T'eile durch Virmittelun bucharischer Kanfleute, nach Rulbland, und zwar nach Moskau oder auf die Messe von Nischny Nowgorod, von wo er sich uiber die ganze Welt verbreitet. In 


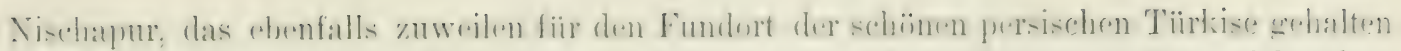
wird, bekommt man den Edelstein selten zu sehen und zu kaufen, worüber sich schon

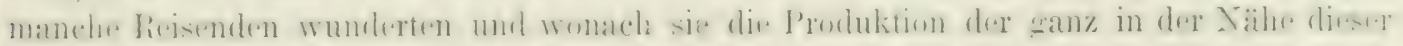

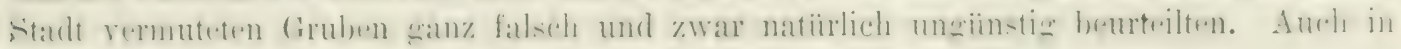
Mesched ist er schwer zu kaufen und teuer, oft teurer als in Europa.

Der Wert des Ertrages der Gruben betrug am Ende der siebziger Jahre etwa 250(00)

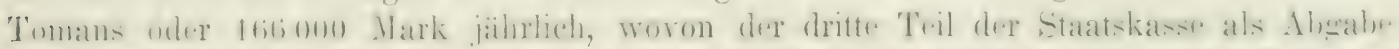

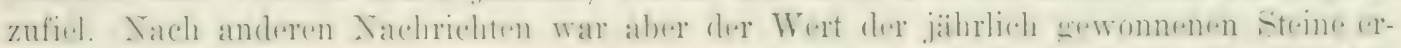

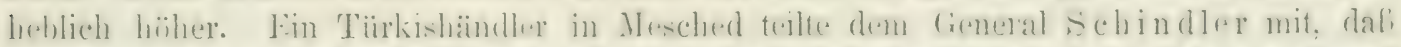

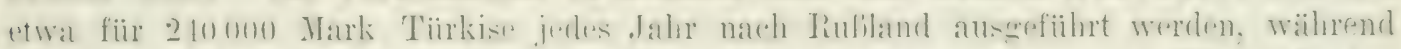

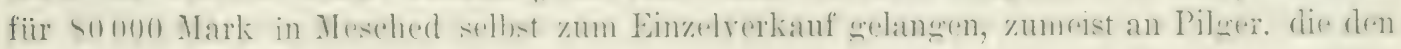
Glücksstein, in einen zinnernen oder silbernen, niemals aber in einen goldenen Ring: gefaßt, mit in ihre Heimat bringen wollen. Viele Steine werden auch über Iezd am persischen Golf nach Konstantinopel und Bagdad exportiert.

Im Jahre $18 S 2$ beschloß der persische Minister für den Kultus, die Bergwerke und

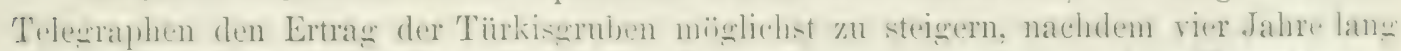

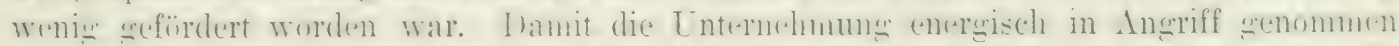
werde, stellte er den General Schindler als Leiter des Bergbaues an die Spitze und

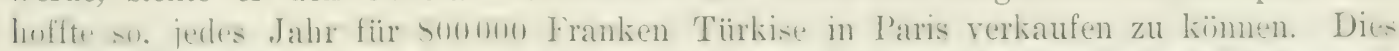
gwang allordings nicht in dem wewinseliten Grade. wentestens nicht in ersten Jahre. Wo nur fiir 300000 Franken Steine gewonnen wurden, aber immerhin bedeutet die kurze

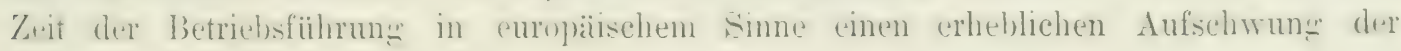
Gruben.

Tor einiger Zeit hat die Lombloner Juwelierfirma sitreeter die Gruben zu pachten und

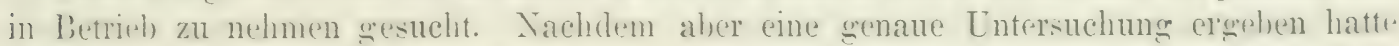

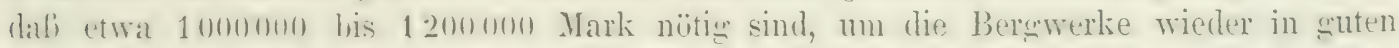
hetriehsicheren Zustand zu versetzen, gine sir ron ihrem Plane ab. Spüter sull eine amerikanische Firma demselben Unternehmen nälsergetreten sein.

Was die Dualitit der persischen Steine ron dem erwähnten Fundorte hetrifft, so ist wirklich Feines selten. Dic Farbe ist vielfach schion dunkelhlau, häufig aber auch hlabblau und griin. Besonders schön blau sollen manche Steine mit einer weißen Verwitterungrinde aus den alluvialen Schuttmassen sein. Die Farbe ist im allwemeinen dautrhaft. in einigen der neneingerichteten Gruben sind aber auch Türkise rorockommen. die kure Zeit. nachdem sie aus dem fiestein der Grube herausgenommen waren, abblabten nnd weiß wurden. Diese werden daher bis zum Verkauf in feuchter Erde aufbewahrt; dur Käufer wird dann hald sewahr, dab er hetrogen ist. Da es kein Wittel gibt, diese schlechten Steine ron den guten zu unterscheiden, so ist ein gewisses Vilitrauen in den Irandel mit persischen Türkisen sekommen, das selhstrerständlich der Produktion nicht gerade förderlich ist.

Die Steine aus den einzelnen Gruben sind im allgemeinen von verschiedener Beschaffenheit. Man teilt sie an Grt und stelle nach der Grïfe. der Form und besonders

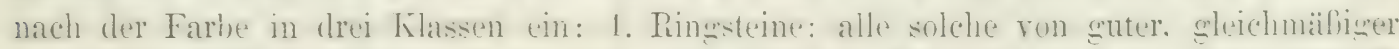

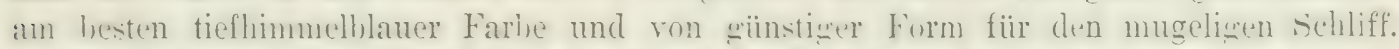

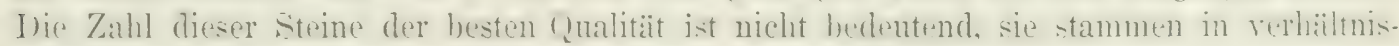
mälbig größter Zahl aus den alluvialen Schuttmassen. 2. Steine mittlerer Qualität mit rure I nterabteilungen: nur die besten rom ibnen kommen noch nach Europa. dit andren werden in Persien oder oder sonst im Orient verbraucht. 3. Arabische Steine: schlecht

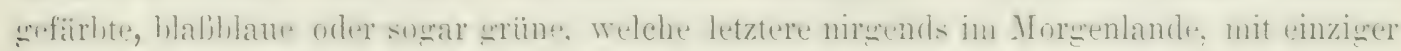
Ausnahme von Arabien, benutzt rerden, wo man, anders als iiberall sonst, mebr auf die 
Gröhe als auf die Farbe und die Beschaffenheit sieht. Der Preis ron einem Pfund Steine der ersten (qualität beträint in den Cruben etwa 1800 Mark, während dieselbe Menge Strine der dritten Qualität nur etwa 100 Mark kostet. In Europa ist der Preis weit höher. Man hat berechnet, daß man für cinen Stein, der in der Grube 10 Mark kostot. in Europa 25, Mark zahlen muf; ein Karatstein wird hier je nach der Qualitait mit 5 his 10 Mark, nur bei der besten Beschaffenheit höher berechnet. Der Jahresexport wird gegenwärtig auf 200000 Mark geschätzt; es ist etwa ein Drittel des ganzen Ertrages, der Rest bleibt im Lande.

Das Türkisvorkommen von Maaden ist nicht das einzige in Persien; es gibt deren noch mehrere, die aber alle weniger bekannt und, wie es scheint, sehr viel weniger reichhaltig sincl. In der Provinz Chorassan wurden auch hei Tabbas Türkise, allerdings von nicht sehr suter (Qualität, gefunden, und Bogdanowitsch spricht von einem unlängst entdeckten Türkislager irgendwo weit im Süden von Mesched, 18 Tagereisen ron dieser Stadt entfernt. Länger, aber freilich nur sehr oberfächlich bekannt ist das Türkisvorkommen in der im Innern von Persien gelegenen Provinz Lermân, an verschiedenen titellen nordwestlich von der Stadt gleichen Namens in den großen, von Nordwest nach Südost streichenden vulkanischen Gebirgszïgen. Bei Tschemen i Mô $\Lambda$ span, vier Farasch von Pâriz und gegenüber Gôd i Alhmer, liegt eine bis vor kurzer Zeit betriebene Türkismine mit hellen, etwas ins Grünliche gehenden Steinen. Bei Kîrik, nordïstlich von Schehr i Bâbek, sind alte Gruben mit zwei Schä̈hten, deren einer erst vor wenig Jahren durch ein Erdbeben verschüttet wurde, wïhrend der andere schon seit langer Zeit nicht mehr im Betriebe war. Unweit Maschîz an dem Abliange des ïber 12000 Fuß hohen Tscheheltangehirges sind vor etwa 20 Jahren helle Tiurkise grefunden worden. Auch in der fiegend von Taft, unfern lezd am persischen Golfe, soll Tïrkis vorkomnen und frïher gewonnen worden sein.

Weiter nach Yordosten, außerhall) der persischen Grenzen, werden ebenfalls Türkiswruben meist mit grïnen Steinen zwischen Herat und dem westlichen Turkestan angegeben. Nach :ilteren Nachrichten arabischer Schriftsteller findet sich der Edelstein in der Nähe von 'hodschent, von wo auch des Plinius grüner Callais (Callaina) stammt, den man später mit Tïrkis identifizierte. Auch noch andere Fundorte aus jener Gegend werden genannt, so in neuerer Zeit (1857) der Gebirgsug Kara Tube, 50 km von Samarkand, wo in einer unbekannten Vergangenheit auf Tïrkis, der mit Brauneisenstein im Kieselschiefer rorkommt, Gruben angelegt worden sind. Später wurden in jenen Regionen wieder Funde semacht, so im Gebiet des Syr Darja in Bezirke Kuraminsk (in den Bergen KaraMazar), (benso im Bezirke Karkaralinsk in der Kireisensteple (Revier Semipalatinsk). Alle: diese: und noch andere dortige Vorkommnisse sind fiir den Handel bis jetzt rollkommen belanglos und werden daher hier nicht eingehender betrachtet.

Nach den persischen Fundorten des Türkis sind in der Alten Welt die auf der Sinaihalhinsel am meisten von Bedeutung. Sie liegen in der Nähe der Westküste, meist im Gebiete des Serbâl.

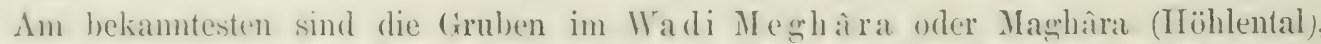
die schon von den alten $\mathrm{Igy}$ tern in wröferem Malistabe ausgebeutet wurden, nach II. Brusch hereits zur Zoit des der dritten 1)ynastie angehörimen Königs Snefru im vierten Jahrtausend vol (buristus, und lis zur Zeit von Ramses II., 1300 Jahre vor Christus, wie as scheint, nicht länger. Zahlreiche Inschriften und Geritschaften rersehictener Art.

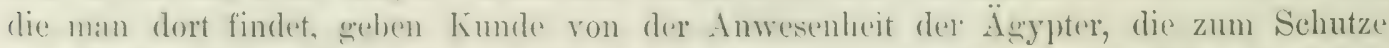
dor Tïrlismine und cines bedentenden Kupferberwhanes, der in der Nähe betrieben wurde, eine Garnison in jener Gegend unterhielten. Der englische Major C. K. Mac

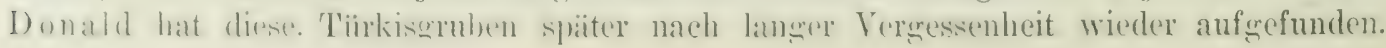


Er hat sie von neuem in Betrieb gesetzt und aus ihrem Ertrage schöne und grolie

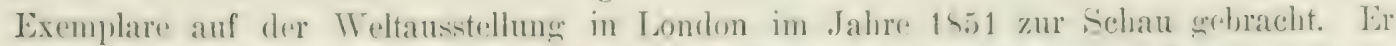

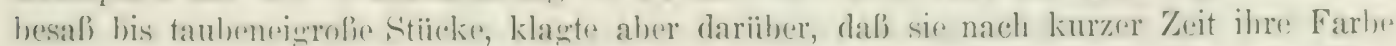

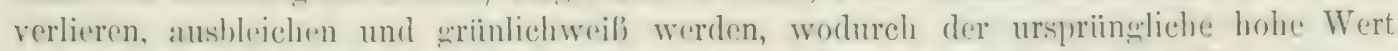
anf Tull heruntersinkt. Dieses Śchicksal hatten anch, wenigstens zum Teil, die in london anserestellten strine: einer von ihnen war schon nach Verlanf ennes Jahres wanz weib und danit wertlos eneworden, nachdem er vorher um einen lobhen Preis verkauft worden war:

Die alten firuben des Meghitatales liegren an dessen nördlichem dbhangere, der aus rotem Sandstein der Carbonformation, dem som. nubischen sandstein, besteht, 150 Fuli über der Talsolile. Der Porphyr, der die segeniuberliegende Talwand zusammensetzt, enthält dort keinen Tiirkis. Das Vorkommen ist ähnlich wie in Persien. Der Edelstein erfüllt kleine spalten und Klïfte in dem Gestein, und die meist plattenfürmigen Stideke haben ungeführ diesulben Dimensionen wie dort. Besonders wertvoll sind bis haselnuferolie Ausscheidungen in einem ockerien, roten bis bramen Eisencr\%. Jo roter, also wasserärmer, dieses Erz, desto blauer ist der Türkis, je brauner das Erz, um so blasser der stem, der in dieser Lmgehung iffers auch die wrïne Farbe zeigt. Auch später waren wieder Arbeiten zur Gewinnung der Türkise im Gange.

Der Tiurkis der sinaihalhinsel ist aber nicht auf den Sandstein des Wadi Meghárar beschränkt, w findet sich auch auferhalb dieses Tales, so nördlich davon bri Sarbut-el. ('hadem, ebenfalls im Sandstein und auch schon ron den alten Ägyptern wewonnen, sowie in dem Porphyr, der den Serbail telweise bildet, auch diesen in dïnnen Platten durchziehent. Die hier rorkommenden Steine sind schön blau und zeichnen sich ror andern dort in derselben Weise in Sandstein rorkommenden darlurch aus, dafi sie die Farbe gut halten. Sie werden von den in der Gegend nomadisierenden Beduinen gesammelt und in den Handel gebracht, und auch ein Teil der ron II ac Donald nach Europa reschickten Türkise soll nicht den alten Gruben im IIeghàratal, sonder'u dem Serbiilporphyr entstammen. Das Vorkommen ist nicht nöher bekannt, da die Eingeborenen ihre Gruben sorgsam verborgen halten, doch wird ein Fundort hesonders genannt, der Josesbrunnen, auch Naseb- oder Nasaiphquelle, zwischen Suez und dem Sinai. Die ron hier stammenden Steine zeigen unter dem IIikroskope eine eigentünliche, von der der anderen Türkise etwas abweichende Struktur, so dali hier zweifellos eine sanz bestmmite Fundstätte vorliegt. Es ist aber nicht mïglich, sie aus dem Namen näher zu erkemen, da die Beduinen jeden Brunnen, der trinkbares Wasser liefert, Moseshrumen nennen. Nach einer Angabe ron II. Fischer lige der Fundort wenau unter dem 2!). Breitengrade etwa 5) Meilen rom Serbâl. Die ron hier stammenden Steine sind mit eisenschiissigem, hraunrotem, miirhem, kïmigem Quarz verwachsen und stammen daber vielleicht ebenfalls aus Sandstein, wie im Wadi Meghâra.

In ihren enten Sorten stehen die Türkise ron der Sinaihalhinsel an Schönheit und Tiefe dex Farbe hinter den persischen nicht zuriick; einzelne Stiicke ïbertreffen diese sogar zuweilen noch darin. Im Durchschnitt ist aber die Farbe heller und geht mehr ins Weiblichblaue, der Glanz ist mehr masig und sie sind etwas spröder. Sehöne steine ron hier kommen unter dem Namen ...̈̈ryptische" orler ..Alessandrinen-Türkise” in den Itandel. Ian hat diese friber für Kunstprodulte grehalten, sie haben sich abor bei wenatuer Lntersuchung als echte natürliche Nineraltürkise erwiesen.

Auch im eigentlichen Arabien sull Türkis vorkommen, wenigstens werden in .. Lande der Midianiter" drei Türkiscruben erwähnt. von denen zwei noch jetzt im Betriehestehrn sollen. Die Steine ron bier verlieren aber bald ihre Farbe. Sonst ist in Asien kein T'ïrkisvorkommen bekannt. 
Gehen wir nunmehr zur N euen Welt über, so treten uns hauptsächlich die Türkislakerstiiten in den siidwestlichen Staaten der nordamerikanischen Union in Colorado, Nevala, Arizonia, Kalifornien und Yeu-. Yexiko entgegen. Diese waren zum Teil besonders in friiheren Jahrhunderten von Wichtigkeit, sind aber anch heute noch von srober Bedentung. Im Jahr 1907 sind dort etwa 600 Pfund ausgewählte rohe T'ürkise und nahezu 3000 Pfund Türkismutter (Türkis im Muttergestein) gewonnen worden.

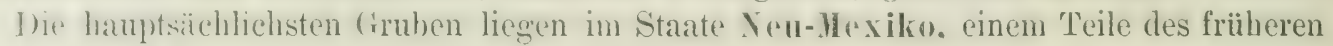
mexikanischen Aztekenreiches. Sie haben schon den alten Mexikanern den von ihnen

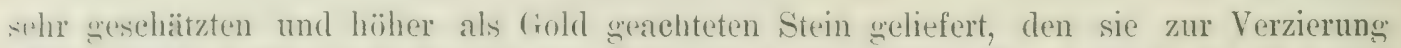
aller müglichen frexenstiinde und zum sehmuck verwendeten. Man seheint aber dort den ?-rïnen 'Türkis, nicht den lianen, besonders in Ehren gehalten zu haben. Tach der Ansicht mancher Forscher ist der ron den alten Vexilsanern so hoch geschätzte grïne Edelstein Chalchihuitl nichts anderes als T'ürkis; nach anderen bezieht sich der Name aber nicht auf diesen, sondern auf einen anderen griinen Stein, Malachit, vielleicht auf Smaragd oder Nephrit oder grünen Jaspis usw., oder überhaupt auf wertvolle grüne Steine.

Auch später, nach der Zerstörung des mexikanischen Reiches, ist der Türkis der Liehlingstein der Ureinwohner jener Gegenden, der P'ueblos- und Navajos-Indianer, geblieben. Diese nennen ihn, nach der Mitteilung von W. P. Blake, Chal-che-rve-te, was nur eine Verstümmelung des alten Namens Chalchihuitl sein soll. Noch vor nicht zu langer Zeit schätzten sie den Stein so hoch, dab sie nur selten und nicht anders als durch die hüchsten Anerbietungen vermocht werden konnten, ihre tiirkisgeschmückten Gerätschaften an Weibe abzutreten. Sie gaben aber den Leichen ihrer Verstorbenen solche fast stets als Totengabe mit ins Grab, wie die Untersuchung alter indianischer Friedhöfe in jenen Gegenden gezeigt hat.

Es sind jetzt in Neu-Mexiko vier tïrkisfiuhrende Bezirke bekannt, in denen allen die Indianer und spläter zum T'eil auch die Spanier mehr oder weniger intensiv gearbeitet haben. 1. Bei Los Cerillos in Santa Fè County; 2. in den Burro Mountains siidwestlich von Silver City; in Grant ('ounty; 3. bei Eureka (Old IIachita) ebenfalls in (irant County; 4. in den Jarilla Mountains in Otero County. Die neu-mexikanischen truben sind jetzt die ertragreichsten der Welt und hahen die persischen längst überholt. Auch die Qualität ist, wemn schon zahlreiche Steine griun und unansehnlich sind, vielfach die beste und nicht gringer wie bei Mesched. Allerdings sollen die blanen Steine teilweise ihre Farbe nicht behalten, doch wird dem auch, wenigstens für die Produkte mancher Gruben, entschieden widersprochen. Der Wert des Jahresertags soll seit 1893 schitzungsweise 1500000 Dollars betragen.

Die am frïhesten - von William P. Blake in den fünfziger Jahren - wieder aufwefundenen altmexikanischen (xruben liegen in dem nach diesem Steine nenerer Zeit soEenamnten Mt. ('laalchihuitl (oder Mt. Clialehuitl), einem Ausläufer des Crand Central

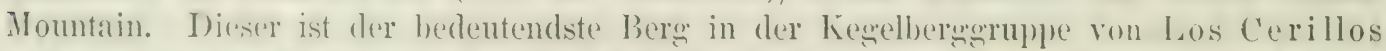

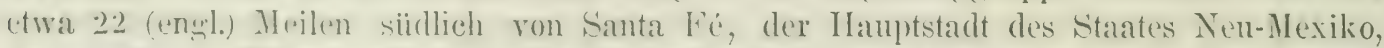
am nördlichen lifur des cialisteo Jiver, der in westlichem Laufe in den liio crande seht mond der den J)istrikt von Los cerillos ven dem wichtigen Minendistrikt der l'lacer- oder Gold Mountains trennt.

Jene Kegelberge und speziell der türkisfiilırende Mt. Chalchihuitl bestehen in der Ianptsache ans porphyrartien ansebildeten vulkanischen Trachrtwesteinen, sogenamnten Augitandesiten. Diese Andesite und ihre 'T'uffe, die in demselben Berge stellenweise nicht unbeträichtliche Mengen von Blei-, Kupfer- und Silbererzen, wie auch Gold-

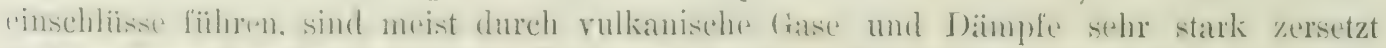

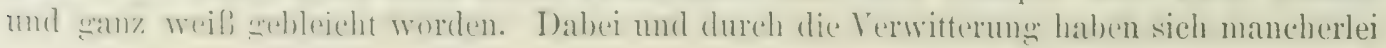


nene Mineralien gedildet, unter anderen namentlich auch der Törkis, der seine T'onerde aus dem in Kaolin umerewandelten Feldspat, seine Phosphorsäine aus dem Apatit des Andesits und seinen liupferewalt den dent Gesteine eingewachsonen Küpererzen entnommen hat. Aller Türkis scheint ursprünglich Kaolin gewesen zu sein; die Tïrkisbildung folgte der des Kaolins. Das Mineral bildet hier wir aiberall sonst in dem weiben oder enelblichen, tonälunlichen, zersetzten Andesit oder 'Tuff kleine Kinollen und dïnne: Adern, zuweilen nit rundlicher oder nierenförmiger Oberfläche. Lass Gestein enthält den T'ürkis an so zahlreichen stellen, dali man allenthalben blaur und grine Flecken an den Bergwäinden sieht.

W. P. Blake beschreibt die alte mexikanische Grube, die zweifellos schon vor der Entreckung ron Amerika angelegt worden ist, als ein ungeheures trichterförmiges Loch. dessen Wände in steilen Gehängen schroff in die Tiefe stüzen. An einer Stelle bängen die Felsen sogar über und bilden auf diese Wreise eine Art ron IIïhle; an einer andleren sind div. Abhänge durch die von oben hineingrefallenen Schuttmassen sanfter. Auf den Gehïngen wachsen mehrere Jahrhunderte alte Pinien, Kedern und sonstige liaime; die das hohe Alter dieser kïnstlichen Ausschachtung erkennen lassen. Das Loch ist etwa 200 Fuß tief und 3010 Ful weit, und viele Tausend Tonnen Gestein sind aus dem festen Fels herauswebrochen worden. Ähnliche, aber kleinere Löeher sind noch mehrere vorhanden, ja ess scheint, als ob die ganze Oberfliiche des ïberall türkisführenden Berges nach diesem Edelsteine durehwïhlt worden wäre. Auch unterirdische beremännische Arbeiten der alten Mexikaner von zum Teil nicht unbedeutender Ausdehnung wurden ('ntcleckt, als man später die alten fruben wieder in Betriel) zu setzen versuchte; es fanden sich darin zahlreiche Steinhämmer und andere Gerätschaften, die in alten Zeiten beim Berchau verwendet worden waren. Alles machte den Eindruck, als seien jene unterirdischen Baue vor dem Verlassen seitens der Fing̨eborenen von diesen sorgfältig versteckt und rerschlossen worden, wohl um sie vor dem Zutritte Unberufener zu schiitzen. Wie ansgedehnt die Arbeiten in diesen Gruben gewesen sein müssen, zeignt unter anderem der Lnistand, daf die durch das herausgeworfene taube Gestein grebildeten Halden eine Fläche von mindestens 20 acres einnehmen. Auch auf diesen wachsen grole Büume in Menge als Beweis ihres hohen Alters.

Das Verlassen der Cruben durch die Indianer wurle durch ein grofes nationales Lnoliick hewirkt, das im Jahre 1680 eintrat. In einer Seite des lereres fand ein bedeutender Frdsturz statt, Welcher eine beträchtliche Zahl der Arbeiter in den Türkisgruben vernichtete. Das war nicht nur die Lrsache des Auf hürens der Türkišrewinnung, sondern anch der spanischen Inerschaft in jener Gegend, wider die sich die Indianer, aufgeregt durch dieses Ereignis, mit Erfolg erhoben.

Am Anfang der achtziger Jahre des 19. Jahrhunderts, nachdem das Tal des Rio Crande durch eine lisenbahn zugänglicher greworden war, hat sich eine Gesellsehaft zur Wriederaufnalıme der einige miles nördlich von der Stadt Los cerillos geterenen Türkisgruben

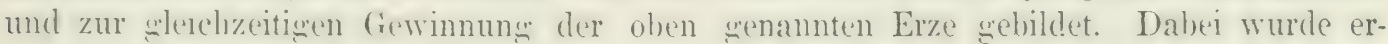
mittelt, dafi schöner blaner Türkis zwar nicht fehlt, daf der meiste aber wriun oder blaufriun ist und dab man viele Tonnen (iestein zerschlitgen muf, um auch nur einen einzigen

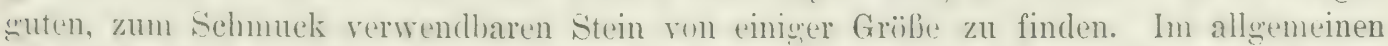
ist die Lualitait jodenfalls erering. und die Folece davon war, dafo jene Gesellschaft bald

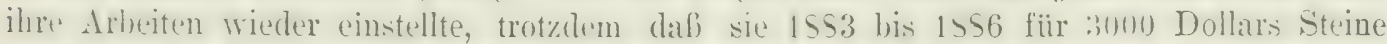
grewomnen hatte. Später trieben nur noch einzelne arme 1 teife nnd Indianer dort Raubhan, indem sie den Fels durch Feuersetzen miirbe machten und so zur Gräberei vorrichteten.

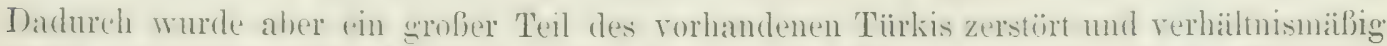
wenig sewomen. Die Ausheute wurle damn in roher Weise zu rinden oder herzförmigen, 
durchbohrten Zieraten verarbeitet und in Santa Fé oder auf den Stationen der dortigen Eisenbahnen an die Reisenden als merkwiirdiges Landesprodukt verkauft. Der Preis war sehr niedrig, und die indianischen Händler gaben einen Mundvoll solcher Steine um 25 Cents (etwa 1 Mark). Nur wenige derselben gelangten von hier in die Läden der Juweliere, da überhaupt nur wenige wirklich gute Exemplare gefunden wurden und da ein versuchter Betru@ das Vertrauen zu den dortigen IÏ̈ndlern stark erschütterte. Sie hrachten nämlich schön dunkelblaue Türkise in den Verkehr, die aber G. F. K unz bei der genaueren Untersuchung als in der oben schon erwähnten Weise durch Berlinerblat an der Oberfläche künstlich gefärbt erkannte.

Die IIauptprodulition findet jetzt nicht mehr an dem Nit. Calchihuitl statt. Sie ist auf das Anfangs 1890 aufgefundene Vorkommen an dem benachbarten Turquoise IIill (Turquesa) übergegangen, der giinstigere Verhältnisse bietet. Auch hier haben die Indianer schon gegraben und die wichtigsten neneren Gruben sind hier angelegt. Es ist eme kaum bemerkbare Erhebung 3 miles nordöstlich vom IIt. Calchihuitl und 7 miles von Los Cerillos am Wege nach Santa Fé und 11/2 miles von Bonanza. Das Gestein ist derselbe Andesit wie dort und auch das Vorkommen des Türkis ganz ïbereinstimmend, jedoch seine Qualität besser, vielfach derjenigen des persischen gleich, auch sind grölbere Steine nicht zu selten.

Wichtig sind ferner die Gruben in den Burro Mountains. Sie liegen in der Südwestecke von Neu-Mexilso, 15 miles suidlich von Silver City, in Grant County. Auch hier haben die Ureinwohner bereits stark gearbeitet, wie die alten Halden zeigren. Der Stein lildet an dieser Stelle gleichfalls Schnïre, Adern und kleine Knollen, und zwar in einem Granit, dessen Feldspat in Kaolin umgewandelt ist. Nan hat unter anderem eine Platte von 8 Zoll im Durchmesser und $1 / 8$ bis $1 / 4$ Zoll Dicke gefunden. Es wird berichtet, daß in einem Monat 10 $\mathrm{kg}$ schöner, meist nierenförmiger, mit einer diinnen kieseligen Haut überzogener Türkise erbeutet worden sind. Präichtige geschliffene Steine von 20 Karat und mehr stammen von hier aus versehiedenen Gruben, aber auch viele grüne. Andere Fundorte in dieser Gegrend sind im Cow Springs-Bezirk im Trachyt und in demselben County im Eureka (Old Hachita)-Distrikt, hier ebenfalls mit alten Gruben.

150 miles von den Burros und 50 miles von Las Cruzes am Rio Grande del Norte in östlicher Richtung entfernt, 55 miles nordöstlich von El Paso an demselben Fluß und 200 miles südlich von Los Cerillos, in Otero County, ist das Tiirkisvorkommen in den Jarilla Mountains, wo gleichfalls alte oberflächliche, bis auf den festen Fels gehende Baue angetroffen worden sind, die, nach den darin gefundenen Gefäßen und Geräten zu urteilen. schon vor Jahrhunderten verlassen wurden. Auch hier liegt der Edelstein in derselben Weise wie sonst auf dïnnen, nahezu vertikalen Fugen und Spalten im Trachyt, zum Teil von kupferkies begleitet. In der shoo-ar-mé Mine of the Jarillas hat man in einem 7) Fuß tiefen Schacht iiberall Türkis gefunden. Er bildet meist halbkugelige und nierenförmine $\Lambda$ grgregate, doch auch kompakte Massen, die die Hohlräume ganzansfüllen. Einmal wurde eine kleinnierige Tïrkisplatte von 3/4 Zoll Dicke und 3 Fub im Quadrat aufredeckt. Die Farbe ist meist blan, näher der Oberflache auch vielfach griun, und zwar wahrscheinlich infolge von Verwitterung des blauen. So sehön blau, bis indigoblau, die Steine in der Tiefe sind, so werden sie doch an der Luft beim Austrocknen vielfach milfarbig und kleben dann an der Zunge. Man findet aber auch zahlreiche schöne und daturhaft wefärbte Exemplare, so dab in einer einzigen, neu in Betrieb wesnommenen alten Grube in sechs Monaten mehr als $50 \mathrm{~kg}$ gut rerkïuflicher Türkise gewonnen worden sind.

Noch manche andere. 'Tiurkisvorkommen sind in Neu-Mexiko gefunden worden, und viele von ihnen haben schon die alten Mexikaner abgebaut und immer dann verlassen, 
wenn sie aus der iulberen, durch Verwitterung aufgelockerten Umhiillung der Berge bis auf das harte und feste frische Folsgestein durchgedrungen waren, das sie mit ihren schwachen Nitteln nicht zu bewältigen vermochten.

Andere Staaten im Westen der Union haben ebenfalls Türkis geliefert; einige der Fundorte sollen hier noch kurz erwähnt werden.

Viel Türkis wurde in Coehise County, ungefähr 20 engl. Meilen von Tomstone in Arizona in einem Auslïufer der Dragoon Mountains, nicht weit von der früheren Apachenhauptstadt Cochise und siddistlich von der heutigen Hauptstadt Tuscon, von den Alten gewonnen. Der betreffende Berer heilit jetzt Turquoise Mountain. und da auch Silhererze in der Nïhe vorkommen, so ist dort ein Berewwerkshezirk unter dem Vamen 'Tiirkisdistrikt entstanden. In den Berg sind mehrere grobe Höhlungen hincingehauen, aher iberall ruht jetzt der Betrieb, und zwar seit langem. Der Reichtum an Türkis, der hier in einem weißen Quarzit, vielleicht einem völlig zersetzten Feldspatgestein, liegen soll, wie in Kalifornien, ist nicht so grob wie am Mt. C'halchihuitl, auch sind die alten Arbeiten nicht so ausgedehnt wie dort. Die Farbe der Türkise ist meist grün in verschiedenen Nuancen. Im Staate Arizona, und zwar in Mohave County, lient auch der Fundort Mineral Park, wo schün gefärbte Türkise auf drei etwa 100 Yards roneinander entfernten Gängen von 1 bis 4 Zoll Mächtigkeit sich naliezu '.2 Meile weit verfolgen lassen. Auch hier haben die alten Mexikaner und später die Spranier die Steine in frïheren Zeiten in grober Menge gewonnen. Ein neuer Fundort wurde an Colorado River entdeckt.

5 (engl.) Meilen nördlich von Columbus, 1/2 (engl.) Meile südlich von der Xorthern Bell Mine im Columbus-Distrikt im südlichen Nevada, findet man Türkis in Adern und kleinen Körnern, in einem braunen Sandstein. Die einzelnen Türkise ron hier sind zwar meist klein, sie gehören aber nach Farbe und Qualität zu den besten, die in Nordamerika vorkommen. Einige wertvolle Stïcke von der vortrefflichsten Beschaffenheit und Farbe sind schon gewonnen worden. Die meisten dieser Steine gehen nach San Francisco. Außer den einzelnen reinen Steinen wird hier auch der Sandstein mit den darin liegenden kleinen Türkisen zu einem hühschen bunten Schmuckstein verschliffen (Tiurkismutter). In Esmeralda County, Tevada findet sich schön blaner Türkis in Adern von 1, Zoll und mehr einem dunkelgranen Chalcedon eingewachsen. Dieses Torkommen dient zur Herstellung von Kameen, bei denen der Chalcedon den IIntergrund für die aus dem Türkis geschnittenen Figuren etc. bildet. Ein neuer Fundort am ('actus Mountain, 50 miles üstlich von Butler in Nye County, ist ohne Bedeutung.

In Colorado ist der Türkis vom Holy Cross Mountain schon länger bekannt. Auferdem wird schöner Türkis in einigen Cruben bei La Jara, 112 miles westlich rom lio Frande, in Conejos County. nahe der siidlichen Grenze des Staates, etwa 106 " westlich ron Greenw., in einem kleinen rulkanischen Hügel grewounen, in dem auch alte Gruben mit Steinhämmern usw. angetroffen wurden. 1907 wurden am Carrizo Creek in der Coloradowïste Tiurkis entdeckt.

In Kalifornie n ist das Vorkommen von Taylors Ranch, ('howchillas River, Fresno) County, nur ron mineralogischem Interesse, da hier der Türkis in sechsseitigen Prismen von Zollänge als Afterkristall nach Apatit sich findet. Von einer gewissen Wichtigkeit für den Edelsteinhandel ist dagegen der seit 159y näher bekannte Türkis ron San Bernardino County. Er findet sich auf einem weiten, schwer zugänglichen. Wasserarmen, 500() bis 60100) FuB hohen, vulkanischen Gebiet von 30 bis 40 miles Ausdehnums, die besten Gruben aber zusammengedrängt in einem 14 miles langen und 3 bis 4 miles breiten Streifen. Es ist ein Teil der groben Wïste in der nordïstlichen Ecke von San Bernardino County nahe Death Valley und westlich rom Colorado River, 50 bis bo miles 
nordwestlich von der Bahnstation Manvel und 100 miles nördlich von der Station The Needles. D)as 'Türkisvorkommen greift noch etwas über die Grenze der henachbarten Staaten Arizona (Mohave) und Nevada hinïber. Es sind viele alte Gruben ron früheren Bewohnern jener fiegend vorhanden, die außer diesen maneherlei Gebrauchsgegenstände für den licrobau, Steinhämmer usw., sowie zahlreiche Felseninschriften und Bildwerke hinterlassen haben. Der Türkis findet sich auf Klïften und Spalten, sowie in Form runder, von einer weiben blasigen oder tonigen Masse umgebener Knollen von Bohnengröbe in einem nürben Yuarzgestein, das in Schiefer und Sandstein eingelagert ist; zahlreiche vulkanische Massen durchbrechen diese Schichten. Es ist dasselbe Auftreten, das der T'ürkis von 'Turquoise Mountain in Arizona zeigt. Die alten Gruben, höchstens $15 \mathrm{Fuß}$ tief und von geringer Ausdehmungr, lağen an den Talgehängen, die neueren Arbeiten gingen mit Schächten tiefer. Dabei stellte sich heraus, daß die (Qualität der Steine, die nahe der Oberfläche stark durch Verwitterung gelitten hat, nach unten zu sich verbessert, die Menge aber allmäblich abnimmt, so dali in einzelnen Stellen bei 40 Fuls, an anderen bei 100 Fuß keine spur ron Türkis mehr vorhanden ist. Die Produktion ist ziemlich reichlich und hatte schon 1900 einen Wert von 20000 Dollars im .Jahre. Viele Steine sind von guter Art, und manche auch nicht klein. Einmal wurde ein soleher, allerdings blaßBblau, gefunden, der geschliffen ein Oral ron 32 und 54 Millimeter Durchmesser im Gewicht von 203 Karat gab. Geschliffen wird auch hier unter dem Namen T'ürkismutter der weiße Quarz mit den blanen Einschlüssen und Adern, was durch den Farbengegensatz einen hübschen An. blick gewährt.

Teuestens wird gemeldet, daf die T'ürkisgewinnung in den suidwestlichen Unionsstaaten stark abgenommen hat und daß auch die Qualitït der Steine geringer geworden ist.

Auch an einigen Orten im Osten der Vereinigten Staten ist Türkis grefunden worden, so in A labama in Clay County und in New. Iersey bei Sommerville in einer Kupfergrube, ebenso in Mexiko bei Bonanza im Santa Rosa-Distrikt im Staate Zacatecas in einer Bleierzsrube. Alle diese Vorkommen sind aber unbedeutend und Gräbereien haben in früheren Zeiten nirgends stattgefunden.

In alten Ruinen aus der Inkazeit in Peru und Bolivia hat man wohl geschliffenen 'Türkis, aber in diesen Lïndern, ïberhaupt in Siidamerika, kein natürliches Vorkommen angetroffen.

Auch in Australien, und zwar in der Kolonie Victoria, ist blaner Türkis aderfürmig in schwarzem Tonschiefer vorgekommen, der in einer "New Discovery" genannten Grube srewonnen wird. Es ist aber noch nichts Genaueres dariiber beliannt. Der sog. 'Türkis aus West-Australien ist Chrysokoll (siehe unten).

Wie alle kostbareren Edelsteine hat man anch den Türkis auf billigem Wege mit allen seinen natïrlichen Eigenschaften künstlich herzustellen versucht. Bis zu einem gewissen firade ist man auch dabei zu einem gïnstigen liesultate gelangt, sofern es unzweifelhaft greluneren ist, eine Masse zu erhalten, die sich in der chemischen Zusammensetzung nicht wesentlich vom echten Tiirks unterscheidet und deren physikalische Eigensehaften, Farbe, Calanz, Irïte, Dichte, Bruch und auch das Anssehen dieselben sind wie bei dem letzteren. I)ie Fabrikation soll hauptsächlich in Wien, in Frankreich und in England betrieben werden, und zwar in der Weise, dalb die lockere Masse eines durch rine Kupferverbindung hlangefarbten chemischen Niedersehlags von phosphorsaurer Tonerde stark zusammencererelit wird. Die Einzelnheiten des Verfahrens sind aber nicht bekannt.

Diese kïnstlichen Tïrkise werden neben den natiurlichen in den Ilandel gebratelt. Sie haleen stets eine schr gute Farbe und können kaum von echten untersehieden werden. Dahlere tritt häufien der Verdacht auf, dab man es mit einem solchen Kunstprodulit zu tun 
halee, wenn eimmal von cinem Orte ein ungewölnnlich grober Vorrat guter stïcke in den IIandel kommt. Sio war es vor einer liejhe von .lahren mit persischem Tïrkisen, dann auch mit den ohen erwähnten sogenannten ïgytischen oder Alessandrinen-Türkisen, die sich aber, wie schon erwähnt, alle als echte erwiesen haben.

Dic. Möglichkeit der Enterscheidung echter und nachemachter Tïrkise breruht auf den versehiedenen Verhalten beider in der Ititze. Dieses Verfahren ist natürlich nur anzuwenden, wenn es erlaubt ist, etwa von einer bedeutenden Anzahl einen oder den anderen Stein herauszunehmen und durch Erhitzen zu zerstïren, was bei Ankïufen srö̈berer Posten wohl immer möglich sein wird, odex wenn sich auf der IInterseite eines frröberen Steines ein kleines Splitterchen loslösen lälit, das zum Versuch genügt. Ias Verhalten des echten Türkis im Feuer ist oben schon angegeben: er zerknistert heftị und zerfällt beim Glühen in ein sehwarzbraunes Pulver oder gibt ohne zu schmelzen eine lockere Masse von dieser Farbe, die sich leicht zu Pulver zerdrücken lälit. Alles dies tut der kïnstliche Tïrkis nicht; er zerknistert nicht und giht kein schwarzhraunes Pulver. sondern er schmilzt oder sintert zu einem harten Körper zusammen, der wenigstens im Innern seine blaue oder blaugriine Farbe beibehält. Manche Stiicke schmelzen sogar ziemlich leicht zu einer schwarzen Kugel. Ferner sollen die küinstlichen Steine daran erkannt werden, dab sie beim Liexen im Wasser sofort dunkler blau werden und dab ihre Oherflïehe im nassen Zustande viele kreuz und quer verlaufende Risste zeigrt: auch sollen sie in Wasser und Alkohol weicher werden. Als ein besonders sicheres Kennzeichen der echten Steine galt lange das Anhaften kleiner Partikelehen des Muttergesteins, namentlich brauner Flecken des mit dem Türkis so bäufig verwachsenen Brauneisensteines. Ian hat aber gelernt, auch die kïnstlichen Türkise mit kleinen braunen, ebenfalls von Eisenhydroxyd herrïhrenden Flecken zu versehen, und so ist dieses Merknal wieder unsicher geworden.

Aufer diesen kïnstlichen 'Türkisen, welche die Yatur in allen wesentlichen Punkten nachzuahmen suchen und die den echten äußerlich so ähnlich sind, daß eine Lnterscheidung durch die gewöhnlichen Hilfsmittel kaum möglich ist, werden unseren Edelsteine zuweilen auch noch andere Körper untergeschoben, so namentlich eine tiirkisähnliche Glaspaste. Diese kann man erhalten, wenn man der undurchsichtigen Glasmasse:; Proz. Kupferoxyd. 11,2 Proz. Braunstein und eine Spur Kobaltoxyd zusetzt. Solches Glas ist aber wohl stets rom echten Stein leicht zu unterscheiden. Der Glanz ist hier der gewöhnliche Glasglanz, der namentlich au Rande unschwer zu erkennen ist, wo beim Sebleifen stets kleine Splitterchen ausbrechen, die auch den dem Gilase zukommenden muscheligen Bruch zeigen. Auch wird man meistens Luftbläschen beobachten künnen. wenn die Imitation nicht ganz sorgfultion gemacht ist. Einige weitere Substanzen, die zuweilen für Türkis gehalten und ihm untergeschoben werden, sollen im folgenden betrachtet werden. Sie wie die blate Paste sind im Gegensatz zum echten Türkis für Röntgenstrahlen ganz undurchlässig.

An den echten Türkis schlieBt sich zunächst eine eigentiimliche oreanische substanz an. die wegen ihres ähnlichen Aussehens vielfach mit unserem Edelsteine rerwechselt und für ihn verwendet worden ist, die sogar denselben Namen erhalten bat. -

Es ist der

\section{Zahntürkis.}

Der Zahntiirkis heißt auch Beintiirkis, occidentaliseher Türkis, Türkis rom nenen Stein, turyuoise de la nouvelle roche, Odontolith, fossiler Türkis. Man versteht darunter Knochen und besonders Zühne vorweltlicher Säugetiere, namentlich von Mastodon und 
Dinotherium, die beim langen Lagern in der Erde durch Aufnahme von phosphorsaurem Eisen, sogenannter Blaueisenerde, schön himmelblau, zuweilen auch dureh Kúpfersalze griin seworden sind. Letztere Farbe ist aber hier die seltenere, und da sie bei dieser Sub):tanz weichlalls nicht geschätzt ist, so soll von ihr nicht weiter die Rede sein.

Solche blaugefärbte Zähne und Knochen sind an versehiedenen Orten vorgekommen, besomders reichlich in den Miociinschichten von Simorre, Auch u. s. w. in der Gascogne (I) ej). (lu (Gers) in Frankreich, wo sie hauptsächlich dem Mastodon angustidens angehören. bei Simorre ist sogar eine Zeitlang ein förmlicher Bergbau darauf getrieben worden. Der Schmelz der Zühne ist hier in Boden ursprïnglich mansehnlich graublau, wird aber beim Erhitzen schön hinmelblau. Auch die Mammutzähne, die sich in Sibirien so håufig finden, sind zuweilen schön blau gefärbt.

Dieser Zahntuirkis wird, wie der echte, vielfach in mugeligen Formen geschliffen. Er ist zwar erheblich weniger wertvoll, aber schöne Stiicke von einiger Größe sind doch immer nicht ganz billig. Seine Farbe ist nahezu dieselbe wie beim Mineraltürkis, sie behïlt aber ihre Schönheit bei künstlicher Beleuchtung nicht, sondern wird im Kerzenlicht trïbe und grau. Auch soll sie bei Behandlung mit Alkohol und Wasser allmählich abblassen. Auf geschliffenen und polierten Flächen bemerkt man vielfach hellere Streifen auf dem dunkleren Farhengrunde, die ron der Struktur der Zahnsubstanz herrïhren. Diese tritt im Dünnschliffe unter dem Mikroskop deutiich hervor, und man sieht dabei gleichzeitig, daß das fürbende Pigment auf kleinen Kanälchen eingelagert ist. Die Farbe wird auch nicht selten durch braune oder schwarze moosförmige Flecken, sogenannte Dendriten, beeinträchtigt und dadurch der Wert des steines beträchtlich verringert.

Einige Kennzeichen lassen stets mit Sicherheit den Zahntïrkis vom echten Mineraltiirkis unterscheiden. Ersterer entbält bis zu 11 Proz. kohlensauren Kalk; man sieht daher, wenn ein kleines Stïckchen mit Salzsäure übergossen oder ein größeres mit einem 'Tropfen Salzsäure betupft wird, ein lebhaftes Aufbrausen. Wegen seines Gehaltes an organischen Stoffen entwickelt er beim Erhitzen einen brenzlichen Geruch, beim Reiben wirl er lange und andauernd elektrisch. Die Härte ist geringer als beim echten Steine und daher die Politur weniger fein. Dagegen ist das spezifische Gewicht grölier, gleich 3 bis : ${ }^{1}, 2$, so daf ein Stiick Zahntïrkis in der dritten Flïssigkeit vom Gewicht 3,0 untersinkt, während Nineraltürkis schwimmt.

Auch der Zalıntiirkis kann künstlich nachgemacht werden, indem man kalziniertes Elfenbein eine Woche lanğ in eine warne Lösung des tiefblauen, schwefelsauren Kupferoxyd-Ammoniaks legt. Das Elfenbein nimmt dadurch dieselbe schöne Farbe an.

Finige andere Vineralien aus der Gruppe der Phosphate werden zuweilen wie der Türkis wegen ihrer schönen Farbe als Schmucksteine verwendet, haben aber nur eine ganz untergeordnete Bedeutung.

\section{Variscit (Utahlith, Wardit).}

Der Variscit ist ein dem grünen Türlsis sehr ähnliches, nicht sehr hartes, dureh etwas Eisen oder Chrom gefärhtes wasserhaltices 'Tonerdephosphat mit der' Formel: $\mathrm{Al} \mathrm{PO}_{1}$. $2 \mathrm{I}_{2} \mathrm{O}$, von dem zwei amerihanische $A$ barten zuweilen gesehliffen werden und als einheimische Fteine eine gexwisse beschränkte. Terwendung finden. Beide sind sehön hellgrün und ganz molurchsichtign, so dab sie die in diesem Falle ïbliche mugelige form erhalten.

Jie eine Hhart, nach ihrer Iledmat V tahlith ganannt, da sie bis jetzt nur im Staate lath rorgekommen ist, wurde zuerst, 1594, hei Mereur in ('edar Valley, Tooele County,

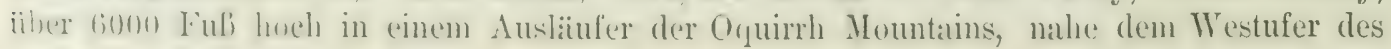


Ltah-Lake, ecefunden; nachlıer, 1905 , auch 20 miles nordwestlich von dort, im Clay Canyon, Ltah County, \& bis 9 miles westlich von Stockton und to miles südwestlich ron Salt Lake ('ity, am istlichen Fulj der Stanshury Mountains. An beiden ()rten bildet das Mineral wall- bis kokosnulierobe, rauhe, dureh lisenhydroxyd braune Knollen mit einem präehtigen

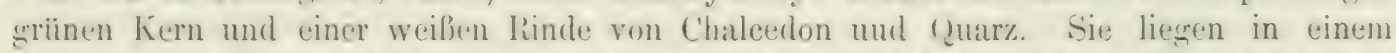
rothraunen von Kalkichichten einereschlossenen Kieselschefer. Schönes Material ist nicht zu häufig und wird mit (j0) Dollars pro l'fund verkauft. Zuerst ging das meiste nach ('hina, wo derartige sriune steine sehr eneschätzt werden, jetzt bleibt auch viel im Lande. Die Gesamtproduktion beträgt gegenwärtig etwa 20000 Karat im Jahr.

Der Wardit ist rom Ltahlith in der Zusammensetzung etwas, aber im Aussehen kaum rerschidelen. Er findet sich nur nit diesem zusammen an dem ersten der grenannten (orte

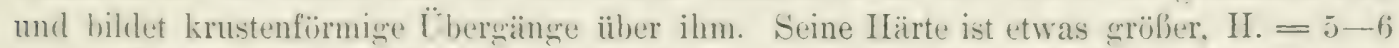
geren II. = 1-5 beim Ltahlith, die Farbe ist ein sehr sehönes helles, manchmal bläuliches Griin. Das Verkommen und ebenso die Verwendung ist spärlich.

Unter dem Namen Amatrix (= american matrix), Variscit- oder Utahlithmutter, wird genwätig in Amerika Ltahlith und Wardit in ('halcedon und guarz eingewachsen vielfach aseschliffen. Da beide Mineralien zuweilen oolithische Struktur haben und ron ähnlichen gellsen und grauten substanzen begleitet sind, die auf dem weißen, grauen, grelblichloramen bis dunkelbraumroten Muttergestein in bunter Abwechslung berrortreten, so bieten diese Steine oft ein sehr hübsches Ausseben und werden als ausschlieblich amerikanisches Produkt geschätzt.

\section{Kallainit (Kallais).}

Der Kallainit ist gewissermaßen ein prähistorischer Edelstein, der sich in mebreren Beziehungen eng an den Türkis anschliebt. Er fand sich bisher nur in einem alten keltischen Grabe zu Manć-er-H'rock bei Lockmariaquer in der Bretag'ne in der Form rundlicher Stïckchen ron der Größe ron Leinsamen bis zu der eines Taubeneies. Die Farbe ist fast stets grüin und zwar apfelgrün ins Smaragdgriine, der Stein ist aber im Gegrensatze zum Türkis stets stark und schön durchscheinend und gewewährt einen recht hühschen Anblick. Manchmal ist er auch weif und bläulich und zuweilen sehwarz und braun geadert und gefleckt. Die Zusammensetzung ist sehr nahe der des Türkis, es ist ebenfalls wasserhaltige phosphorsaure Tonerde, aher die Bestandteile sind in etwas anderen Mrengen vorhanden. Die Substanz ist, wie der Türkis, nicht deutlich kristallisiert und bildet wie dieser ein dichtes Aggregat mikroskopisch kleiner Kürnchen, dessen Irärte $=31 \frac{1}{2}$ bis 4 und dessen spezifisches Gewicht $=2, ; 11$ bis $2, \ldots 2$ ist. Bisher ist es noch nicht gelungen, den ursprüinglichen Fundort dieses Minerals zu entdecken, das offenbar den alten lielten jener Gegend als Sehmuckstein gredient hat und das, wenn es in einiger Menge vorhanden wïre, auch heute noch, wenigstens bis zu einem gewissen (irade, als solcher dienen künnte. Wahrscheinlich ist ess eine thart des Minerals Tariscit, die sich aber ron den anderen, auch den genannten Varietäten durch schönere Farbe und größere Durchsichtigkeit unterscheidet.

\section{Lazulith.}

Ton Vineralien ist nur eines, das greschliffen vielleicht mit dem Tïrkis rerwechselt werden künnte und das ihm zuweilen untergeschoben werden soll. Dieses Mineral, das unter seinem eigentlielien Namen wohl niemals als Edelstein Verwendung findet, ist der Lazulith (nicht zu verwechseln mit Lapis lazuli. dem Lasurstein, der uns weiter unten beschäftigen soll). Er bildet himmelblaue, monokline Kristalle oder auch derbe, feinkürnige Massen, die als Blauspat bezeichnet werden. Die Zusammensetzung ist auch hier älnnlich wie beim Türlis; es ist ebenfalls ein Wasser, aber zugleich Magnesia und Eisen 
enthaltendes Tonerdephosplhat. Die Härte ist gleich 5 12, also etwas geringer als beim Türkis; das spezifische Gewicht ist erheblich grölser, gleich 3,1, so daß auch der Lazulith in der dritten Flüssigkeit von 3, spezifischem Gewicht sinkt. Der Glanz ist, anders als beim Türkis, der wewöhnliche Glasglanz, ohne Übergang zun wachsähnlichen. Schöne Kristalle finien sich in einem mürben Sandstein in den Graves Mits., Lincoln County, Georgia in den Vereinigten Staaten, sowie auf Quarz, der den Tonschiefer von Werfen im Salzburgischen in einzelnen diunnen Adern durchsetzt; am letzteren Orte kommt auch der derbe Blauspat vor. Man trifft den Lazulith nur äußerst spärlich im Edelsteinhandel. Der vermeintliche Lazulith aus den Diamantsteifen von Diamantina in Minas Geraës hat sich als Spodumen erwiesen.

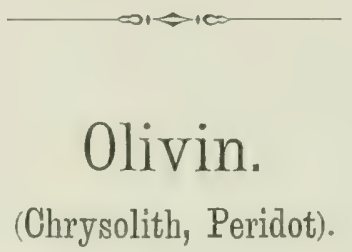

Die Gruple des Olivins umfaßt eine größere Anzahl von Mineralien, von denen aber nur eines, der Olivin im engeren Sinne, als Edelstein Verwendung findet. Er heißt als solcher Chrysolith, bei den französischen Juwelieren Peridot. Der Name Chrysolith kommt von der schïnen gelblichgriinen Farbe her, er würde aber eher auf einen ausgesprochen goldgelben Stein, etwa den gelben Topas, passen, für den er auch früher unter anderen von Plinius angewendet wurde. Der Name Olivin ist ebenfalls ron der Farbe abgeleitet, und zwar wurde die Nuance, die der Olivin zeigt, mit dem viel Gelh und Braun enthaltenden Grün der Frïchte des Ölbaumes, der Oliven, verglichen, das als olivengrün bezeichnet wird. Keine andere Farbę, auch keine andere von der genannten stark verschiedene Nuance, kommt bei dem als Edelstein verwendeten Chrysolith in Betracht. Hierdurch unterscheidet er sich wesentlich von vielen anderen, z. B. den sehon betrachteten Diamant, Korund, Topas usw., bei denen eine große Reihe von Farben und Farbenabänderungen zu beobachten ist; er gleicht hierin mehr dem Türkis, bei dem ebenfalls nur eine einzige Farbe im Edelsteinhandel vorkommt.

Der Olivin und mit ihm die edle Varietät, der Chrysolith, ist

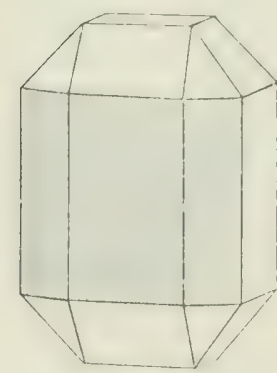

Fig. sli.

Kristallform des Olivins (Chrysoliths). chemisch sehr einfach zusammengesetzt. Er ist ein Magnesiasilikat von der Formel: $2 \mathrm{MgO}$. Si $\mathrm{O}_{2}$; ein Teil der Magnesia ist aber stets durch die entsprechende Menge Eisenoxydul ersetzt. Bei der Analyse eines schön durehsichtigen und als Edelstein brauchbaren gelblichgrünen Chrysoliths aus dem "Orient" hat Stromeyer gefunden: 50,15 Magnesia, 9,19 Eisenoxydul und 39,73 Kieselsäure neben minimalen Mengen von Mangan- und Nickeloxydul und von Tonerde. Diese brauchen hier nicht weiter beriicksichtigt zu werden. Der Eisengehalt schwankt etwas weniges und mit ihm auch die grüne Farbe. Diese schreibt sich, wie bei den grïnen Weinflaschen, lediglich von der kleinen Menge Eisenoxydul her; wenn diese etwas gröber ist, so ist die Farbe etwas dunkler und umgekehrt. Es gibt auch ein zur Gruppe des Olivins gehöriges Mineral, den Forsterit, der das ganz eisenfreie reine Magnesiasilikat von der angegebenen Formel darstellt; er ist dem fehlenden Eisengehalt entsprechend vollkommen farblos. Von dem Chrysolith ist er eben nur dadureh versehieden, daß er gar kein Eisen enthält. 
I) Olivin ist zuweilen in deutlichen Kristallen auscerbildet, die dem rhombischen System angehören. Eine hei dem durchsichtigen, als Edelstein verwendharen Chrysolith nicht selten vorkommende Form ist in Fig. Sti darostellt. An einem rhombischen Prisma, dessen Flïchen sich unter 130" $3^{\prime}$ schneiden, sind die stitlichen Kanten durch die schmalen Flïchen des Brachy-, und die vordere und hintere Kante durch die breiten des Makropinakoids gerade ahgestumpft, so dab ein nach dren Flächen des letzteren etwas hreiter ausgedehntes achtspitiges P'risma entsteht. Die Flïchen des Makropinakoids und die des Prismas sind der Iänge nach, also in der Iidchtung der Prismenkanten deutlich gestreift. Auf die Prismenflächen sind die dreieckigen Flïchen eines rhombischen Oktäiders, auf die P'inakoidflichen dir vierseitigen Flächen eines ausgedehnten Makrodomas und eines kïrzeren Brachydomas aufgesetzt. Endlich ist der Kristall nach oben und unten durch die langrezogene, aber schmale gerade Endfläche oder Basis bewrenzt, welche die Endecken des Oktä̈ders und zu greicher Zeit die obere und untere Kante der Domen grerade abgestumpft. Andere Formen, die zuweilen vorkommen, sind dieser mehr oder weniger :̈hnlich, wie z. B. die, welehe auf Taf. XIT, Fig. 11, dargestellt ist. Die Kristalle sind gewöhnlich ringsum ausgebldet; sie sind meist nicht auf Drusenrïumen auf-, sondern in Gestein eingewachsen oder doch frïher eingewachsen gewesen.

Eine sehr deutliche Spaltbarkeit ist beim Olivin nicht vorhanden; am besten ist sie noch in der Richtung des Brachypinakoids. Der Bruch ist stets muschelig. Die Härte entspricht etwa der des Quarzes, ist aber stets ein wenig geringer; man gibt meist $\mathrm{H}_{.}=$ (i:, an. Der Olivin wird also rom Quarz geritzt, ritzt aber seinerseits Feldspat und noch leichter gewöhnliches Fensterglas. Verglichen mit anderen Edelsteinen ist demnach die IIärte nur gering: trotzdem nimmt der Chrysolith, wenn auch etwas schwierig, eine sehr gute Politur an. Er wird aber beim (Gebrauch leicht angegriffen, die Facetten werden matt, die Kanten und Ecken runden sich ab und werden stumpf. Der Stein ist daher auch nicht gerade besonders geschätzt und wird wenig getragen, namentlich selten als Ringstein, da er beim Tragen an der IIand zu leicht zerkratzt wird. Jedenfalls mul er stets sehr in Acht genommen werden.

Das spezifische Gewicht des reinen, klaren und durehsichtigen Olivins schwankt zwischen 3,329 und 3,$3 ;$. Es ist um so höher, je grö̈ler der Eisengehalt und also je dunkler die Farbe, und sinkt in dem Maße, wie die Steine heller werden. Die schwereren Olivine sinken demnach im reinen Methylenjodid langsam unter, schwimmen aber in der schwersten Fliissigkeit $\left(G_{.}=: 3,6\right)$. Die leichteren Steine haben oft ziemlich genau das Gewicht des Methylenjodids. Sie schwehen in ihm an jeder beliebigen Stelle, sinken darin beim Erwärmen, schon durch Beriihren des Gefïlfes mit der Hand, zu Boden und steigen beim Erkalten an die (1herflïche. Jedenfalls kann man den Chrysolith mit Hilfe des spezifischen Gewichtes von mehreren anderen grïnen Steinen mit Sicherheit unterscheiden.

Viele Olivine sind ganz klar und durchsichtig, ron der vollkommensten Reinheit und ohne die geringsten 'Trübungen und Fehler. Nur diese werden unter der Bezeichnung „edler Chrysolith" zu Schmucksteinen verwendet, nicht aber der viel verbreitetere trïbe, durchscheinende bis undurchsichtige .gemeine Olivin". Aber auch der durchsichtigste Olivin ist für Röntgenstrahlen fast undurchlïssig. Der Glanz, der, wie erwähnt, durch die Politur sehr gesteigert werden kann, ist der gewöhnliche Glasglanz, aber stets mit einem Stich ins Fettige. Die Lichtbrechung ist nicht sehr stark. Dem rhombischen Krystallsystem entsprechend wird das Licht doppelt gebrochen, und zwar ist die Doppelbrechung selır kräftig, melr als bei irgendeinem anderen Edelstein, ausgenommen den Zirkon (Hyacinth), bei dem sie noch erheblich höher geht. Die Größje der Brechungskoüffizienten gibt ein Bild ron diesen Terbältnissen. Der kleinste und größte dersell)en sind: für gelbes Licht: 1, wit und 1,w, also ihre Differenz, welche die Gröle der Doppel- 
brechung ansibt, sleich 0,,3t; der mittlere Brechungsexponent ist $=1, \pi$. Dic Brechungsexponenten fiir Lichtstrahlen von anderer Farbe weichen nicht wesentlich von den obigen Werten ab, die Farbenzerstreuung ist also gering, und es kann daher von einem lebhaften Farbenspiel nicht die Rede sein.

Von der gelblichgriunen Farbe und ihrer Abhängigkeit von dem Gehalt des Steines an Eisenoxydul ist schon oben die Rede gewesen. Sie geht bald etwas mehr ins Gelbe oller auch manchmal ins Braune, bald mehr ins Grïne, doch sind die Unterschiede stets wring; der gemeine Olivin ist auch nicht selten ausgesprochen gell). Sehr tief und gesiittigt ist die Farbe nie. Eine Vorstellung von der gewöhnlichen Färbung des Chrysoliths gibt Fig. 11 und 12 auf T'af. XIV, die cinen Kristall und einen geschliffenen Stein darstellen. Je nach der Tuance werden zuweilen besondere $\Lambda$ barten unterschieden, die aber keineswegs allgemein angenommen und bekannt sind. Danach ist der eigentliche Chrysolith blaß gelblichgrün, der Peridot tief olivengrün und der Olivin gelblich oder licht olivengrün.

I)er Pleochroismus ist stets schwach; die Farbe der Bilder in der Dichrolupe schwanken zwischen gelblich ölgriin und rein grasgrün ohne wesentliche Beimischung von Gelb.

Andere Eigenschaften, die mit dem Aussehen nichts zu tun haben, aber bei rohen Steinen mit zur Lrkennung und Unterscheidung von anderen dienen können, sind die Unschmelzbarkeit vor dem Lötrohr und die leichte Zersetzbarkeit durch Säuren. Nur sehr eisenreiche Olivine, wie sie als Edelsteine nie angewendet werden, sind etwas, aber doch immer schwer schmelzbar, und alle Olivine werden, namentlich in Form eines feinen Pulvers, von Salzsäure und Schwefelsäure, besonders beim Erwäirmen, unter Abscheidung gallertartiger Kieselsaiure leicht und rasch zerstört. Unter, wahrscheinlich unbewußter, Anwendung dieser letzteren Eigenschaft wird dem Chrysolith die letzte Politur häufig durch Schleifen mit Schwefelsüure statt mit Wasser gegeben; die Facetten werden dadurch ganz besonders glatt und glänzend. Auch Ätztinte greift die Steine sehr stark an.

Man gibt dem Chrysolith meist die Form des Tafelsteines oder es wird der 'Treppenschnitt in seinen verschiedenen Modifikationen angewendet (Taf. XIV, Fig. 12). Auch Brillanten und Rosetten kommen zuweilen vor. Bei den erstgenannten Formen wird die 'Tafel nicht selten rundlich geschliffen und so der Übergang zu dem eigentlichen mugelichen Schliff mit oder ohne Facetten hergestellt, den man bein Chrysolith ebenfalls zuweilen antrifft. Farbe und Glanz werden vielfach durch eine Goldfolie, bei sehr blassen auch durch eine grüne Folie verbessert.

Der Olivin ist ein in den Gesteinen der Erde viel verbreitetes Mineral. Er ist ein Bestandteil des Basalts, in dem er in Form scharf begrenzter Kristalle, häufiger in der unregehmäliger Körner, und oft in unfangreichen, faust- bis kopfgrolen, ja noch größeren kïrnigen Aggrexraten vorkommt, in denen einzelne kleine unregelmäßige Olivinkörner in iiherwiegender Menge mit sparsameren Körnem anderer Mineralien gemengt sind (Olivinknollen). Auch in sonstigen Gesteinen: Diabasen, Gabbros usw., ist vielfach Olivin enthalten, und ïherwiegt sogar nicht selten in ihnen, so dab fast reine Olivinmassen von grolem Umfang entstehen, und ebensolehe sind auch manchmal dem Gneis und anderen derartigen Felsarten aus der Reihe der kristallinischen Schicfer eingelagert. Aus dem festen Gestein grelangen einzelne Olivinkörner auch in den aus jenem grebildeten Verwitterungsgrus und in die seifen. Endlich ist noch zu erwähnen, dalj auch in vielen Meteoriten Olivin als wesentlicher Bestandteil sich findet.

Aber der in dieser Weise rorkommende Olivin wird wohl kaum jemals als Edelstein verwendet. Der aus dem Diabas und (abboro stanmende ist triibe und undurehsichtig; der aus dem Basalt und ähnlichen (xesteinen ist wohl vielfach klar und rein, wie z. B. der rom Vesur, aber es sind fast stets nur Kö̈rnchen von ganz geringem Unfang. Auch

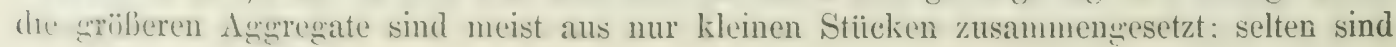


dies. etwas stöfer wie in dem Basalte rom Berge Kosakow bei Semil an der lser im nïrdhehen Böhmen. Hier finden sich zuweilen bis hassenuligrolie vollkommen durchsichtige und schön gelblicherine Körner, die häufig als Edelstrine geschliffen werden. Klar und

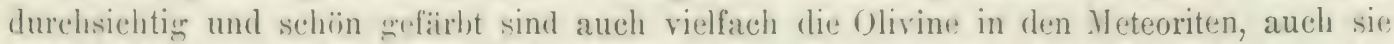
inden jedoch nur kleine Kristäldehen. Nur in einigen wenigen dieser der Erde fremden Ilimmelskörper hat man klare und durchsichtige Exemplare von einer Gröfe gefunden, dali man daraus fteine von 1 Karat schleifen kïnnte, die dann in eigentlichen Sinne himmlische Edelsteine wären.

Auf der Ilerkunft der im Edelsteinhandel vorkommenden und zu Schmucksteinen rerschliffenen ('hrysolithe lag ein grwisses I)unkel. Man sieht in den Mincraliensammlungen nicht selten rundlich abmerollte Stiieke von vollkommener lieinheit und Klarheit und von schöner farbe, bis zu Irallnulgeröle, die offenbar aus irozendemem Flublies, einer Seife stammen. Diese stimmen in ihrer Beschaffenheit mit den ereschliffenen Chrysolithen, wie sie meistens vorkommen, derart üherein, dalj sie wohl heide dieselbe Ileimat haben kïnnen. Wo diese aber zu suchen ist, war durchaus nicht mit Sicherheit bekannt.

Man sprach von ,.Pen" und dem "Lande der Birmanen”; die Nachrichten über das Vorkommen von sehleifwürdigem Chrysolith elort und in Indien iiborhaupt sind alser äußerst unsicher. Dasselbe gilt für Ceylon, wo der mit Chrysolith so häufig verwechselte Chrysol)eryll sich findet. sowie für Brasilien, wo Chrysolith unter den farbigen steinen von Minas Novas zuweilen gemannt wird. Es ist aber höchst wahrscheinlich, dab es sich dabei ghelehfalls stets um Chry soberyll handelt, den die Brasilianer allgemein als Chrysulith zu bezeichnen pflegen.

Auch aus dem "Orient", aus "Natolien" und aus der "Levante“, sollte der als Edelstein verschliffene Chrysolith stammen und ïber Konstantinopel und Österreich in den abendlïndischen Irandel geloracht werden. Ebenso findet man "̈̈gypten" als Fundort angecreben. namentlich von klaren, schön grünen Kristallen etwa von der in Taf. XIY, Fig. 11 abgebildeten Form, die grleichfalls in den Sammlungen häufig zu sehen sind. Crenatuere Angaben sprachen von Oherägypten und von einer Lokalitït üstlich ron Esneh, zwischen dem Xil und dem Loten Meere; als Muttergestein wurde Granit oder syenit angegeben. Alle diese Nachrichten waren jedoch durchaus vag und unsicher.

G. F. Fi nz, der bedeutende amerikanische Edelsteinkemner, hatte nach seinen reichen Erfahrungen in Edelsteinhandel die Ansicht gewonnen, dab schleifbarer Chrysolith gegenwärtic überhaupt kaum mehr gefunden werde, und dals alle Steine, die sich zurzeit im Handel hefinden, aus Kirchen und Klöstern und alten Schmucksachen aller Art stammen, die oft schon vor 200 . Iahren hergestellt worden sind. Da sich namentlich in den alten Kirchengerïten vielfach schöne Olivine finclen, so hat man wohl auch geglaubt, sie seien von den Kreuzfahrern mitgebracht worden. Vielleicht habe man damals die Fundorte gekannt; sie wïrden dann wohl erschöpft ofier aus anderem Grunde verlassen sein und die genauere Kenntnis davon wäre im Laufe der Zeiten allmählich verloren gregangen. Allerdings berichtet er auch gleichzeitig ïber das Vorkommen schleifharer Chrysolithgeschiebe, die mit (iranaten sich in den Sanden des nordwestlichen Neu-Mrexiko und des nordüstlichen A rizona finden, wo sie ron den Lmwohnern, den Navajos-Indianern, mit den begreitenden framaten gresammelt werden. Aber diese sind erst seit kurzem bekannt und auch meist nur klein und ron keiner guten Farbe, so daf sie tatsïchlich nur wenig benutzt wurden, da die jetzige Mode grolse und mögrichst dunkel gefäirbte Steine von schöner Durelisichtigkeit verlangt. Erst im Jahre 1904 sind dann im Peridot Canyon in Arizona

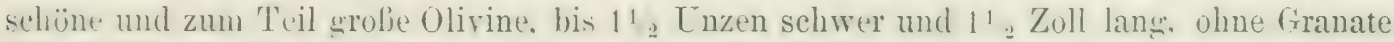
in einem porösen Lavagestein sefunden worden, die vielleicht für den Edelsteinhandel Bedeutung erlangen. 
Von weit gröberer Wichtigkeit ist jedoch die Entdeckung prächtiger Olivine, die 1900 auf der Kleinen vulkanischen Insel Selorerot (auch Zebirget oder St. Johns) an der ägyptischen Kü̈ste des Roten Meeres, südöstlich vom Vorgebirge Ras Benas (2.3 " $36^{\prime}$ nördlicher Breite, 36" $10^{\prime}$ üstlicher Länge von Greenwich) gemacht wurde. Der Olivin findef sich hier in Form von ausgezeichneten Kristallen, die auf den Wänden ron Hohlräumen eines stark zersetzten Oiivingesteins, das dadurch zu Serpentin geworden, aufgewachsen sind. Nach Europa kommen teils hristalle, fast stets mehr oder weniger zerbrochen, oder unregelmäßige Bruchstïcke, meist klein und nicht über 1 bis 2 Karat; doch findet man ganz reine Kristalle von $40 \mathrm{Gramm}$ und noch größere Bruchstücke. Das Material ist zum Teil trübe zum Teil von tadelloser Klarheit und Reinheit, und es kïnnen geschliffene steine von höchster Vollkommenheit auch des Glanzes und der Fürbung bis zum Gewicht von nahezu 40 Karat erhalten werden. Da zahlreiche alte Gruben aus unbekannten friiheren Jahrhunderten vorhanden sind, so ist wohl kein Zweifel, daß wir Lier den verloren gegangenen Fundort der immer schon als aus Ägypten stammend bezeichneten Kristalle und der Olivine in alten Schmucksachen und Kirchengeräitschaften vor uns haben.

Der echte Chrysolith, der edle Olivin, wird mit manchen anderen Steinen verwechselt, die dieselbe oder eine ähnliche grïne Farbe haben. Manche Chrysolithe werden für Smaragd gehalten und ausgegeben, der aber durch sein riel niedrigeres Gewicht und sein Schwimmen in reinem Methylenjodid leicht unterschieden werden kann. So sind z. B. die sogenannten Smaragde, welche den Schrein schmiicken, der die Reliquien der heiligen drei Könige im Kölner Dom birgt, in Wirklichkeit keine solchen, sondern Chrysolithe von aubergewöhnlicher Größe (200 bis 300 Karat). Besonders häufig ist aber die Verwechselung mit dem Chrysoberyll. Daß die Brasilianer diesen Stein Chrysolith nennen, wurde schon erwähnt; auch der Chrysolith der französischen Juweliere und der „orientalische ('brysolith" des Edelsteinhandels ist, wenigstens zum Teil, Chrysoberyll. Dieser letztere kann an seiner viel gröberen Härte und dem bedeutend höheren spezifischen Gewicht vom echten Chrysolith unterschieden werden; in der schwersten Flïssigkeit sinkt er, während der letztere darin schwimmt.

Noch manche andere hellgriune Edelsteine werden gelegentlich als Chrysolith mit verschiedenen Beinamen bezeichnet: Ceylanischer Chrysolith ist olivengrïner Turmalin, orientalischer Chrysolith wird auch der gelblichgrïne Korund genannt, sä̈chsischer Chrysolith ist der griinlichgelbe Topas vom Schneckenstein in Sachsen, falscher Chrysolith der grïne Bouteillenstein oder Moldawit odler Pseudochrysolith, ron dem noch die Rede sein wird; Chrysolith vom Kap ist die grüne Modifikation des Minerals Prehnit usw. Auch der Demantoid wird häufig Chrysolith genannt, ebenso zuweilen der Vesuvian. Wir werden in dritten 'T'eile (Tabelle 12 bis 14) die Art und Weise kennen lernen, wie man alle diese Steine voneinander unterscheiden kann.

In neuerer Zeit wird ein melblich rrrïnes Glas unter dem Namen Chrysolith oder auch Obsidian ziemlich viel rerschliffen und an sewöhnlicheren Schmucksachen in den Handel gebracht. Es ist dem echten Chrysolith sehr ähnlich, aber an seinem geringen spezifisehen Gewicht, sowie an seiner einfachen Lichthrechung im Polarisationsinstrument leicht zu unterscheiden.

Was den l'reis des Chrysoliths betrifft, so werden grole, reine und verhältnismäbig dunkel gefärbte Stiicke am besten bezahlt. Frïher war der Stein böher geschätzt als jetzt, wo er im allgemeinen dem Topas grleich steht. Im Mittel ist für 1 Karat cines größeren Stückes kaum mehr als 4 bis 7 Mark zu rechnen. 


\section{Cordierit.}

\section{(Dichroit, Jolith.)}

Der Cordierit, der außer den genannten noch verschiedene andere Mineralnamen

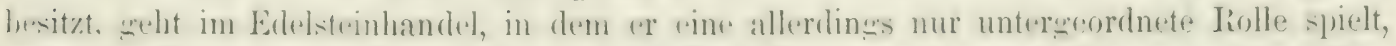

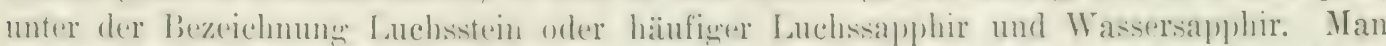
sieht daraus. dalf man es mit einem blanen steine zu tun hat, und in der Tat grejehen

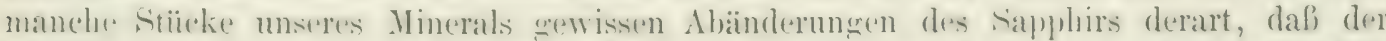

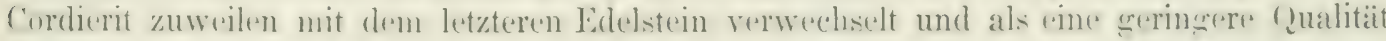
desselben verkauft wird.

Auber der Farbe haben aber beide Steine sehr weniw miteinander qumein. ilne sämtlichen anderen Eigenschaften sind sehr wesentlich voneinander verschieden.

Die Zusammensetzung des Cordierits wird durch die chemische Formel ausgedrückt: $\mathrm{H}_{2} \mathrm{O} .4(\mathrm{Mg}, \mathrm{Fe}) 0.4 \mathrm{Al}_{2} \mathrm{O}_{3} .10 \mathrm{Si} \mathrm{O} 2$; es ist ein etwas Wasser enthaltendes TonerdeMagnesia-silikat, in dem ein Teil der Magnesia dureh Eisenoxydul ersetzt ist. Die Analyse: rines aus dem „Orient", wahrscheinlich von der Insel reylon stammenden Stückes hat

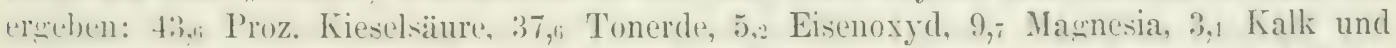
1." Walsser, zusammen 100,2 I'roz. Spätere Lntersuchungen haben jedoch gezeignt, dah das Eisen nicht als Oxyd, sondern durchans als Oxydul im Cordierit vorhanden ist. Der Eisengebalt ist wohl jedenfalls das färbende Prinzip.

Gut ausgebildete Kristalle sind nicht sehr häufig: die Flächen sind meist rauh und die Kanten nicht hesonder's scharf. Das Kristallsystem ist das rhombische; gewöhnlich bilden die liristalle niedere J'rismen mit ausgedehnter gerader Endfläche wie in Fig. Si. Teutliche Spaltbarkeit ist nicht rorhanden; der Bruch ist unvollkommen muschlig. Die IÏrte ist $=7 \%$, übertrifft also die des Quarzes um ein Geringes. Der Stein ist sprïle und schmilzt sehr schwer vor dem Lötrohr. Von Säuren wird er nicht merklich angegriffen. Das spezifische Gewicht ist wahrscheinlich mit. dem nicht immer gleichen Eisengehalt etwas schwankend; es betrïgt 2,60 bis 2,66, auch etwas grölere und und kleinere Zahlen werden angegeben, jedenfalls ist es von dem des Quarzes nur wenig verschieden, und zwar im allgemeinen etwas niedriger.

Der Cordierit ist meistens kaum durchscheinend, zuweilen jedoch auch vollkommen durchsichtig; nur Stücke von der letzteren Beschaffenheit werden als Schmucksteine verwendet. Der Glanz ist Glasglanz, der aber auf Bruchflächen etwas ins Fettige

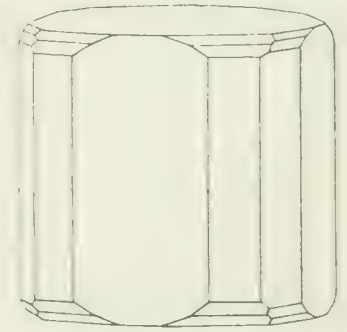

Fig. 87. Krystallform des Cordierits. weht. Durch die Politur wird er beträchtlich erhöht, doch bleiht er hinter dem des ächten Siaphhirs stets weit zuriick. Die Lichthrechung ist sehwach, ebenso die Doppelbrechung. letztere schwächer als bei irendenem anderen Edelsteine. Der gröbte und kleinste Brechungsindex für Orange sind $=1,545$ und 1,535.

Die Farbe ist wechselnd. Manche stiecke sind fast farblos, andere gell, griin, braun, sehrererbreitet ist ein meist ziemulich clunkles Blau, das zuweilen etwas ins Tinlette greht. Nur solehe blatue Stïcke werden geschliffen. Am schönsten grefärlot und zugrleich am besten durchichtig sind die Gerïlle ron Crylon, won denen oben die ehemische Zusammensetzung angegerehen worden ist. Sie allein dienen den Edelsteinschleifern in der Ilauptsache als Material, während stiicke ron anderen Urten meist zu schlecht grefürbt und zu triibe sind. Die Farbe diesel (Ferölle schwankt zwischen himmelhlau und indigro; nach der Tirfe der Färbung unterschedet man zuweilen die helleren als Wassersapphir ron 
dem dunkleren Luchssapphir. Bei allen diesen Cordieriten tritt aber eine Eigenschaft in granz besonder's ausgezeichnetem Grade hervor, nïmlich die Versehiedenheit der Farbe in verschiedenen Richtungen eines und desselben Steines, der Dichroismus. Dieser ist hier stärker als bei den meisten anderen Mineralien, so daß der Cordierit danach auch den Namen Dichroit erhalten hat. Die größte Farbendifferenz zeig't sich beim Hindurchsehen nach den drei aufeinander senkrechten kristallographischen Achsen. In der einen Richtung tritt ein schönes dunkles Blau auf, in einer zweiten ist der Stein viel heller blau und in der dritten licht gelblichgrau bis fast farblos; in zwischenliegenden Richtungen erhält man intermediäre Farben. Bei der Untersuchung mit der dichroskopischen Lupe zeigen die Bilder Färbungen, die jenen drei Hauptfarben sebr nahe stehen, oder Mischfarben aus ihnen, jederzeit aber große Verschiedenheit innerhalb der genannten Grenzen: dunkelblau, hellblau und graulichgelb bis farblos, was für die Unterscheidung von anderen blauen Steinen von Bedeutung ist.

Auch beim Schleifen muß auf den Dichroismus Rücksicht genommen werden, um einen schön blau aussehenden Stein zu erhalten. Je nach dem Schliff kann aus einem und demselben Stein ein Luchssapphir oder ein Wassersapphir entstehen. Am läufigsten wird die Treppen- oder Tafelform angewendet, die Steine dïrfen aber wegen der Dunkelheit der Farbe nicht zu dick sein. Die Tafelfläche muß auf der dem dunkelsten Blau entsprechenden Richtung senkrecht stehen, dann gehen die in das Ange des Beschauers gelangenden Lichtstrahlen in dieser Richtung durch den Stein hindurch, und dieser zeigt sich in der schönsten blauen Farbe, die er überhaupt erhalten kann. Je weniger jene Richtung eingehalten wird, desto unscheinbarer, hellblau oder gelblichgrau, ist die Färbung. Auch mugelige Steine werden häufig hergestellt, wobei in ähnlicher Weise auf die richtige Lage der runden Oberflïche Bedacht zu nehmen ist. Auf dieser bemerkt man bei manchen Steinen eine Lichterscheinung ähnlich wie am Sternsapphir. Zuweilen sucht man beim Schliff gerade den Dichroismus, diese ausgezeichnete Eigenschaft des Steines, deutlich zu zeigen, indem man Würfel herstellt, deren Flïchen auf jenen drei Achsen senkrecht stehen. Diese werden mit einer Ecke auf einer Nadel befestigt und zeigen dann beim IIndurchsehen durch die verschiedenen Flächen abwechselnd jene drei Hauptfarben und damit eine für die meisten Beschauer sehr auffallende und merkwürdige Eirscheinung.

Vom Sapphir ist der Cordierit durch die Gesamtheit seiner Eigensehaften leicht zu unterscheiden. Der Dichroismus ist beim Sapphir viel geringer, die Härte sehr viel größer und ebenso das spezifische Gewicht; der letztere sinkt in allen schweren Flüssigkeiten, während der Cordierit in allen, zuweilen vielleicht mit Ausnahme der leichtesten schwimmt. Dadurch unterseheidet er sich auch von den anderen blauen Steinen, dem blauen Diamant, dem Turmalin und dem noch zu betrachtenden Cyanit oder Sapparé, die alle erheblich schwerer sind.

Wras das Vorkommen in der Natur anbelangt, so ist der Cordierit fast durchaus an den Granit und besonders an den Gneis gelbunden; in kleinen Mengen ist er allerdings auch in manchen vulkanischen Gesteinen gefunden worden. Ringsum ausgebildete Kristalle, aber trübe und von zu dunkler Farbe, sind in dem Granit von Bodenmais in! bayrischen Walde eingesehlossen; Stïcke von meist unregrelmäßjiger Begrenzung, jedoch zum Teil seḧ̈n blau und manchmal auch gut durchsichtig, liegen unter anderen im Gneis von Arendal, Kragerö, Tvedestrand und anderen Orten in Norweenen, in dem von Orijürfvi be Aho in Finland usw. Ein schönes Vorkommen ist anch das von IIaddam in Connecticut in einem Granitgang in Gneis und das ron Edencley in Nord Dakota, wo bis fünf Millimeter grobe durchsichtige blaue Kömer in Glimmerschiefer eingewachsen sind. Die (ierille von Ceylon, von denen schon oben die liede war, sind bis nulgerroli; sie finden sich als Seltenheit mit anderen Edelsteinen in den dortigen Edelsteinseifen. Ïhnlich soll der C'melierit auch in Minas novas in Brasilien zuweilen mit den weiben Topasen rorkommen. 
I) urch Zusammenschmelzen der obenerwälınten (irundbestandteile kann man cine: durchsichtige elizerne Masse mit der blauen Farbe, dem spezifischen frewicht $\left(2, f_{i}\right)$ und dem Brechungsvermögen des Cordierits herstellen.

\section{Vesuvian.}

\section{(Idokrası)}

Der Name Vesuvian stammt von dem Vorkommen ausgezeichnet schöner durchsichtigner brauner Kristalle dieses Minerals am Vesur, die in Teapel zuweilen als Schmmeksteine reschliffen werden. Im IIandel ist für sie daher auch die Bezeichnung "vesurische Gemme" gebräuchlich. Die Verwendung des Steines ist alser geringfügig und in der Ifauptsache auf Italien beschränkt. Hier liegt im Alatale in den piemontesischen Alpen noch ein zweiter Fundort schleifwïrdiwer Kristalle, und zwar soleher von srïner Farbe, die von dem benachbarten Turin aus in kleiner Zahl in den Edelsteiuhandel grebracht werden. Da Vesuriane von anderer IIerkunft kaum zu schmucksteinen benutzt werden, so hat man es hier mit eineni spezifisch italienischen Edelstein zu tun.

Der Vesurian ist ein etwas Wasser und Eisenoxyd, sowie geringe Mengen anderer Bestandteile enthaltendes Kalk-Tonerde Silikat. Früher nahm man ihn für gleich zusammengesetzt wie den Kalktongranat, es hat sich aber dann herausgestellt, daf dies nicht ganz richtign ist und dal ihm die kompliziertere Formel: $\left.2 \mathrm{H}_{2} \mathrm{O}\right) .12 \mathrm{CaO}_{0.3}\left(\mathrm{Al}_{1} \mathrm{Fe}_{2} \mathrm{O}_{3} .10 \mathrm{SiO}_{2}\right.$ zukommt. Die Analysen ron Fristallen der beiden genannten Fundorte haben folgende Zahlen ergeben:

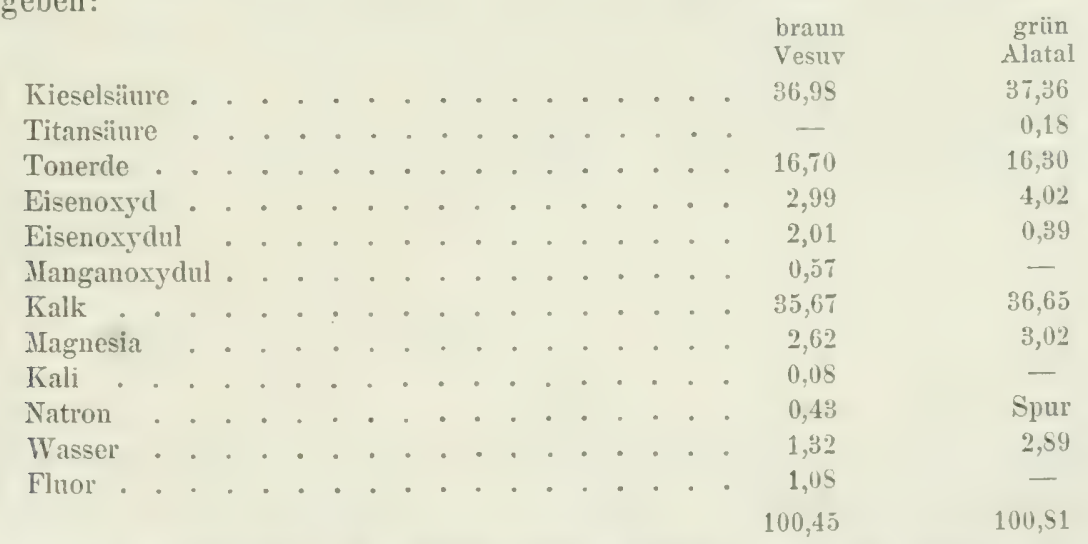

Fehr häufig findet man gut ansçebildete Kristalle, die dem quadratischen System :ngehören. Gewöhnlich sind sie unter Bildung schöner Drusen mit einem Ende auf eine'r Unterlage aufgewachsen. Zwei derselben sind in den Figuren 88 , $a$ und $b$ abgebililet, der erste vom Alatale, der andere vom Vesuv. Es sind fast immer mehr oder weniger stark verlängerte Säulen mit deutlich vertikal gestreiften Flächen, deren Zahl acht oder mehr beträgt. Wenn die Säulen von sehr vielen und dann sehr schmalen Flächen
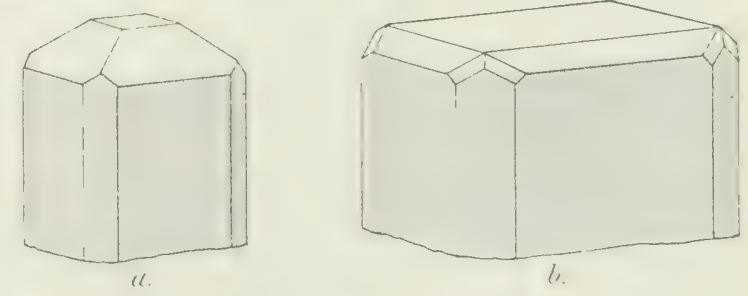

Fig. Ss. Kristallformen des Vesuvian. begrenzt sind, erscheinen sie walzenförmig rund. Die grerade Endfläehe schlielit die Kristalle meist in ziemlicher Ausdehnung nach oben ab, und zwischen ihr und den 
Prismenfläch liexen noch Flächen von Oktaedern und Dioktaedern, zum Teil nur sehr klein, aber dann zuweilen in solcher Anzahl, daf manche Vesuviane zu den flächenreichsten Kristallen gehören, die man im Mineralreich überhaupt kennt.

Die Spaltharkeit ist nur sehr gering. Der Bruch ist unvollkommen muschlig bis mnchen. I) as Mineral ist spröde, die Härte ist nicht ganz die des Quarzes (If. $=61 / 2$ ), cliv. Schmelzbarkeit ist ziemlich leicht, und ein geschmolzenes Stück wird ron Säuren zersetzt, nicht aber ein ungeschmolzenes. Das spezifische Gewicht ist der etwas wechseluden chemischen Zusammensetzung entsprechend ebenfalls schwankend und geht ron $\therefore$ bis.., ; die braunen Kristalle sind etwas schwerer als die grinen. Für die braunen Vesuviane vom Vesuv fand man: $G_{0}=3,45$, für die grïnen vom Alatale: $G=3,39$ bis 3..:; beide sinken also langsam im reinen Methylenjodid, schwimmen aber in der schwersten Flüssigkeit.

Die Durchsichtigkeit ist sehr verschieden, aber stets gehen Röntgenstrahlen wenig hindurch. Die meisten Kristalle des Vesuvians sind nur durchscheinend bis halbdurchsichtig, rielfach das freie Ende durchscheinender als das aufgewachsene. Nur durchsichtige oder stark durchscheinende Stiicke werden geschliffen, wobei sie einen recht guten Glanz annehmen, und zwar ist dieser der gewöhnliche Glasglanz, der aber auf Bruchflächen etwas ins Fettige geht. Die Lichtbrechung ist zienlich stark, die Doppelbrechung schwach. Die beiden Hauptbrechungskoeffizienten sind $=1,723$, und 1, -2, , gemessen an Kristallen vom Alatal. Von großer Mannigfaltigkeit ist die Farbe, die von dem Eisenund Mangangehalt herriburt. Es gibt fast farblose und gelbe, auch blaue und rote Vesuviane, am rerbreitetsten ist aber der braune und grïne in verschiedenen Nuancen, und Steine von dieser Art sind es, wie wir gesehen haben, die wohl ausschließlich als Edelsteine benutzt werden. Der Dichroismus ist ziemlich stark; bei dem grïnen Vesuvian rom Alatale ist bei der größten Farbenverschiedenheit der beiden Bilder der Dichrolupe das eine rein grün, das andere gelblichgrün.

Was das Vorkommen anbelangt, so findet man den Vesuvian an zahlreichen Stellen entwerler als Kontaktmineral im Kalk eingewachsen, oder aber in kristallinischen Schiefern, wie Gneis, oder endlich im Serpentin; seltener ist das Auftreten des Minerals ein anderes und dann jedenfalls für unsere Zwecke unwichtig. Für zwei Arten des Vorkommens geben gerade die Kristalle von den erwähnten beiden Lokalitäten gute Beispiele.

Der grïne Vesuvian des Alatales findet sich an der Testa Ciarva, einem kahlen, steilen Felsen auf der Mussaalp in einer mehr als metermächtigen Bank im Serpentin, wo die Kristalle mit Chlorit zusammen auf hellgrïnem, derbem Vesuvian aufgewachsen sind. Der Ort ist derselbe, wo auch der früher betrachtete gelbrote IIessonit-Granat vorkommt (S. 1:39), beide Jineralien liegen aber getrennt. Das Vorkommen von hier ist Taf. XV, Fin. 1 abegebildet, ein eresehliffener Stein ebendaher Fig. 2. Die Farbe desselben ist sehün

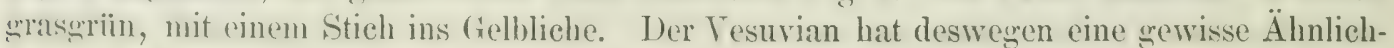
kiit mit Chrysolith und wird daher zuweilen sogar als Chrysolith bezeichnet; die Farbe des letzteren geht aber noch mebr ins Gellee, und sein Dichroismus ist im Gegensatz zum Tesuvian kaum merklich. Jine enewisse Ähnlichkeit ist auch mit den anderen grïnen Steinen, Diopssid, Epidot, Iemantoid usw., vorhanden, die Unterschiede sollen im dritten T'eile (Tabelle 13 und 14) angegeben werden.

Der Vesurian vom Vesur findet sich mit zahlreichen anderen, sehön kristallisierten Mincralien in den Kalkstrinauswiirflinen des alten Vesurs, der jetzt sogenannten Somma, dir bei der stroben Eruption vom Jahre 79 n. Chr. unter Bildung des jetrigen Vesuvs zamm wrolien 'T'ail zerstört worden ist. Diese in Kalk eingewachsenen Kristalle sind braun

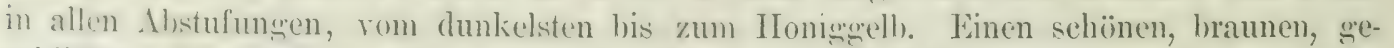
rehliffenen Vesuvian rom Vesuv stellt die Fig.: a auf Taf. IV dar. Gewisse heller braune 
Steine von dort ghteichen in der Farbe manchen Hyacinthen; diese werden daher auch wohl als Ilyacinthen bezoichnet und sind besonders geschätzt. Einen sicheren Unterschied zwischen beiden giht vor allem das sehr verschiedene spezifische (jewicht. Wie der braune V'esuvian ron anderen braunen Steinen, Rauchtopas, braunem ''urmalin, Axinit usw., unterschieden werden kamn, soll ebenfalls spaiter angegeben werden (Tabelle 9 und 11).

Vichts anderes als dunkelgelhlichlorauner Vesuvian ist das als $\mathrm{X}$ a $u$ th it bezeichnete Vincral ron Amity, Orange County, New York, aus dem zuweilen kleine Schmucksteine herestellt werden, die aber wohl ausschlieblich in Nordamerika Verwendung finden. Selten wird auch der himmelblaue Vesurian von Telemarken in Norwegen, der Cyprin geschliffen.

Die Schlifformen sind fïr die braunen und die grïnen Steine dieselben, es ist dic Treplen- und die Tafelform, andere kommen kaum vor. Für beide Farben ist der Preis der mäßigen Benutzung: wegen gering.

\section{Kalifornit.}

Der Kalifornit ist ein dichter Vesuvian mit splittrigem Bruch, oliven- bis fast wrasmriin, vielfach mit helleren Streifen und Flecken, der beim Schleifen einen kräftigen Glanz annimmt. Er fand sich zuerst 1859 in derben und linsenfürmigen Massen zwischen Kalk und Serpentin anstehend am Piz Longhin bei ('asaceia im Bergell in der Schweiz und von dort abgestiirzt im Talschutt des benachbarten Ordlegna-Baches. Spüter traf man ihn auch in Tirol, sowie in Kalifornien an, woher er seinen besonderen Namen hat. Hier ist er gleichfalls mit Serpentin in Verbindung. Die Fundorte liegren in Siskiyou County ganz im Norden und in Fresno County in der Mitte des Staates, nürdlich rom Tulare-See, sowie in Tulare County. Man hat ihn zuerst für Jadeit grehalten, dem ex zun Verwechseln :̈̈nnlich sieht. Muglig greschliffen kann er hübsche Schmucksteine geben, wegen seines massenbaften Vorkommens ist er auch zur Herstellung grülierer Gegenstände geeignet.

\section{Axinit.}

Auch vom Axinit werden zuweilen einzelne durchsichtige Kristalle als Edelsteine, und zwar meist en cabochon geschliffen, die meisten Exemplare des Minerals sind aber nur durchscheinend und dann unbrauchbar. Dex Axinit hat eine hübsche nelkenbraune Farbe, die zuwcilen stark ins Violette zieht, doch kommen auch umansehnliche, stark mit Grau gemischte Färbungen vor. Der Dichroismus ist ziemlich stark; die Bilder, die man mit der Dichrolupe erhält, schwanken zwischen violblau, zimmtbraun und olivengrün. Hierdurch ist ein sicherer Cnterschied ron dem bäufigsten braunen sichmuckstein, dem Rauchtopas gegeben, dessen Dichroismus sehr gering ist, aber ebenso von dem braunen 'Turmalin, der zwar gleichfalls stark dichroitisch ist, aber andere Farben zeigt. Beide sind auch erheblich leichter.

Der Zusammensetzung nach ist der Axinit ein wasser- und borsäurehaltiges Silikat von Tonerde und Kalk, in dem aber auch noch geringe Mengen Eisen und Mangan vorkommen, welche die Färbung vermitteln. Die Formel wird: $\mathrm{H}_{2} \mathrm{O} .6 \mathrm{CaO} \mathrm{B}_{2} \mathrm{O}_{3} .2 \mathrm{Al}_{2} \mathrm{O}_{3}$. $5 \mathrm{Si} \mathrm{O}_{2}$ geschrieben.

Der Axinit findet sich meist in derben Massen, die nie zum Schleifen geeignet sind, aber auch nicht selten in schönen Kristallen des triklinen Systems. Eine häufig vor- 
kommende Form mit den Flächenstreifungen zeigt Fig. 89. Die Kristalle haben die Eigentïmlichkeit, dalj die Flächen sich unter sehr spitzen Winkeln schneiden, so dafi sehr scharfe Kanten entstehen. Besonders deutliche Spaltbarkeit ist nicht vorhanden. Das Mineral ist

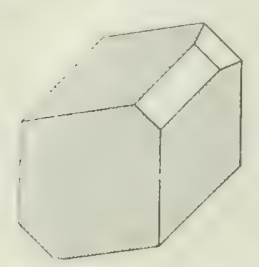

Fig. 4?. Kristallform des Axinits. spröde, die Härte ist annähernd die des Quarzes (H. $=61 / 2$ bis 7 ), und das spezifische Gewicht ist 3,29 bis 3,30 . Die natïrlichen Flächen sind häufig sehr stark glasglänzend; auch durch die Politur wird ein schöner Glanz erzielt.

Der Axinit findet sich in alten Silikatgesteinen verschiedener Art, in denen die Kristalle auf den Wänden von Hohlräumen aufgewachsen sind, so z. B., und zwar die besten von allen, im Gneis von Le Bourg d'Oisans im Dauphiné in Frankreich (Departement de l'Isère) und an anderen Stellen der westlichen, weniger der östlichen (tiroler) Alpen; ferner bei Botallack in Cornwall in England, im siidlichen Kalifornien und an anderen Orten. Die Verwendung und der Wert sind nicht sehr bedeutend und die geschliffenen Steine stets klein, da die meisten Kristalle nur geringe Größe und namentlich Dicke besitzen.

\section{Cyanit.}

Der Cyanit oder Disthen ist ein zuweilen weißes oder hellgelbes, auch grünes, graues oder schwarzes, meist aber, wie der Name sagt, blanes Mineral. Die Farbe ist zwar in der Regel zientich blaß himmelblau, aber doch auch nicht selten dunkel kornblumenblau. Derartige Exemplare geben recht hübsche Schmucksteine, wenn sie geniigende Durchsichtigkeit haben, was aber allerdings nicht allzu oft der Fall ist.

Diese gleichen dann bis zu einem gewissen Grade dem Sapphir und werden wohl auch zuweilen für solchen gehalten und verkauft. An den Sapphir erinnert auch der Edelsteinname dieses Minerals, Sapparé oder Sappar. Dieser stammt von einem Schreihfehler her, den der jüngere Sa ussure, der bekannte Genfer Mineraloge, machte, als er die Etiquette, die bei einem fälschlich für Sapphir gehaltenen Stück Cyanit lag, als Sapparé las. Trotzdem dieser Irrtum längst erkannt ist, blieb der letztere Namen doch bestehen, da er sich allmählich zu fest eingebürgert hatte, besonders bei den französischen Edelsteinhändlern.

Wie der Topas ist der Cyanit ein Tonerde-Silikat, er unterseheidet sich aber ron jenem durch den Mangel des Fluorgehalts. Seine chemische Formel ist: $\mathrm{Al}_{2} \mathrm{O}_{3}$. Si $\mathrm{O}_{2}$, ein kleiner Teil der 'T'onerde ist jedoch durch Eisenoxyd ersetzt, das trotz seiner geringen Menge doch wahrscheinlich die Farbe bedingt. Der sehön blaue Cyanit vom St. Gotthard enthält: 36,67 Kieselsäure, 63,11 Tonerde und 1,19 Eisenoxyd (zusammen 100,97).

Vielfach ist das Mineral deutlich kristallisiert. Die Kristalle, an denen eine der häufigsten Formen die in Fig. 90 abgebildete ist, gehören dem triklinen System an. Es sind breite, langgestreckte, nicht selten etwas gebogene, meist im Gneis, Glimmerschiefer und anderen ähnlichen Gesteinen eingewachsene Prismen, gewöhnlich von sechsseitigem Querschnitt. Der breiten, in der Figur nach vorn gekehrten Fläche entspricht ein sehr vollkommener Blïtterbruch; ein weniger deutlicher geht

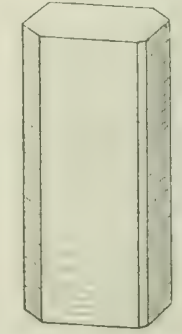

Fig. 90. Kristallform des Cyanits. der einen der beiden seitlich an diese anstoßenden schmäleren P'rismenfläichen parallel. Die beiden letzteren Flächen sind vertikal gestreift, während die breite Hauptspaltungsfläche 
vine horizontale Streifung trïgt. Die Endbegrenzung ist uneist unregelmälig; dio I'rismen zeigen an den Enden eine sehr vollkommene querabsonderung, infolge deren sie hïufig ziemlich chenflaichig durchbrechen, wie es in der Figur darestellt ist. Dieser Absonderung entiprechend entstehen auf den Flïchen des Prismas, namentlich auf der breiten vorderen, zahlreiche feine horizontale lisse, die in der Figur thenfalls angedeutet sind. Iläufiger als in deutlichen Kristallen findet sich der Cyanit ïbrigens in Form ron derben Massen, oft ron beträichtlicher Gröbe und zuweilen auch von schön blauer Farbe, sowie mit sehr deutlicher Spaltbarkeit, in denselben Gesteinen wie jene.

Sehr spröde ist der Cyanit nicht, auch necht sehr hart, doch zeigh er in Beziehung auf die Irïte das eigentiimliche Verhalten, dals er in gewissen Richtungen schon vom Feldspat leicht geritzt wird. an anderen Stellen dagegen kamm vom Quarz. Die Hürtesrade schwanken also zwischen jo und $\bar{\tau}$, und es besteht somit ein Härteunterschied für rerschiedene Stellen und Richtungen eines und desselben kristalls, wie er in diesem betrage an heinem anderen Mineral wieder vorkommt. Jedenfalls muls ein ereschliffener Cyanit sorefältig behandelt werden, damit er beim Tragen nicht zerkratzt wird.

Das spezifische Gewicht steht zwisehen 3,56 und 3,60. Letztere Zahl gilt für die dunkelblauen, die als Schmucksteine allein verwendet werden. Ihr Gewicht unterscheidet sich also nicht wesentlich ron dem der schwersten Flüssigheit $i r_{,}=3, s$. For dem Lütrohr ist der Cyanit nicht schmelzbar und von Säuren wird er nicht angegriffen.

Der meiste Cranit ist höchstens stark durchscheinend. Tollkommen durchsichtige Steine sind nicht gerade häufig, namentlich nicht solche, die mit der Durchsichtigkeit eine schüne dunkelblaue Farbe rerbinden. Diese ist meist etwas ungleichmäßig verteilt, so daß die Kristalle fleckig erscheinen; bäufig ist eine dunkelblaue Mittelpartie von einer hellblaten Rinde umgeben. Beim Schleifen werden die hellgefürbten und nicht ganz durchsichtigen Teile möglichst vollstïndig entfernt und nur die dunkelblauen benutzt. Für Röntgenstrahlen ist der Cyanit ziemlich durchlässig.

Der Dichroismus ist merklich, aber nicht stark; er ist um so kräftiger, je dunkler die Farbe. Die zwei Bilder in der Dichrolupe schwanken zwischen einem helleren und einem dunkleren Blau. Die Lichtbrechung ist beträchtlich. Der Glanz ist Glasglanz, auf dem Ifauptblätterbruch Perlmutterglanz; an natïrlichen Stiicken ist er vielfach nicht besonders stark, er gewinnt aber durch die Politur, jedoch nicht sehr erheblich.

Der Cyanit wird als Tafelstein oder in Treppenform oder wohl noch bäufiger mugelig greschliffen und kann sich dann nit seiner schönen Farbe neben echtem Sapphir immerhin noch sehr wohl sehen lasien. Er unterscheidet sich aber von diesem leicht durch seinen viel schwächeren Glanz, seine viel geringere Häite und sein niedrigeres spezifisches Gewicht. Auferdem sicht man auf vielen geschliffenen Cyaniten den oben besprochenen Rissen entsprechende feine Linien dicht gedrängt in wanz paralleler Lage hinziehen, die zuweilen, besonders auf mugeligen Steinen, einen schwachen Lichtschein derselben Art wie beim Crmophan hervorrufen. Auch kleine Spültchen in der Richtung des Hauptbliitterbruchs kommen nicht selten vor. Je tiefer die Farbe und je durchsichtiger und reiner der Stein, desto wertvoller ist dieser, aber der Wert ist nie sehr grof und die Verwendung, wenigstens in Europa, sehr beschränkt.

Das Vorkommen des Cyanits ist reichlich und die Zahl der Fundorte grob, doch greben nur wenige ron ihnen schleifwürdige Exemplare und auch diese nur in geringrer Menge. Solche trifft man unter anderen am Monte Campione bei Faido im Livinertal am südlichen Abbange des St. Gotthard im Kanton Tessin, wo deutliche Kristalle, deren chenische Zusammensetzung oben angegeben ist, mit dem sofort zu besprechenden roten Staurolith zusammen in großer Zahl, aber allerding meist ron heller Farbe, in einem weifen bis gelben feinschuppigen Glimmerschiefer liegen. Im Zillertal und Pfitschtal in Tirol findet man, eben- 
falls im (thmmerschiefer, derbe Massen, die zuweilen schleifwürdige Partien einschließen. Nahe der Spitze des Yellow Mountain bei Baskerville, sowie bei Seven Mile Ridge, Mitchell County in Tord-Carolina, kommen auf einer weißen Quarzader im Granit schöne dunkelblaue Kristalle vor, von denen einige geschliffen werden. Schöne grüne und blaue, aus dem Mnttergestein ausgewitterte Exemplare findet man bei Red Bluff, Madison County, Iontana. Schleifwïrdige Stïcke kommen zuweilen auch in brasilianischen Flufsanden vor; unter anderen begleitet der Cyanit den Diamant in Diamantina. Die besten sollen aber an noch unbekannten Lokalitäten in Indien gefunden werden, wo der Stein auch mehr Verwendung findet als in Europa. Zweifellos kommt in Indien an selır vielen Stellen Cyanit vor, es wird aber auch behauptet, daß die in Indien getragenen Exemplare alle aus Europa stammen.

\section{Andalusit.}

Der Andalusit stimmt mit dem Cyanit in der chemischen Zusammensetzung vollständig ïberein; auch ihm kommt die Formel: $\mathrm{Al}_{2} \mathrm{O}_{3}$. Si $\mathrm{O}_{2}$ zu. Er unterscheidet sich aber von jenem durch die Kristallisation, inden seine Kristalle nicht dem triklinen, sondern dem rhombischen Systeme angehören. Diese sind alle sehr einfach begrenzt (Fig. 91); sie bilden langgezogene, beinahe rechtwinklige Sïulen, deren Flächen ein ziemlich deutlicher Blätterbruch parallel geht und die oben meist nur durch die gerade Endfläche geschlossen sind, zu der selten andere Flächen noch hinzutreten.

Solche Kristalle finden sich an vielen Orten und in großer Zahl besonders im Gneis und in anderen kristallinischen Schiefern. Sie sind oft von bedeutender Größe, aber stets beinahe undurchsichtig und von unansehnlicher matter, grauer, grüner, roter usw. Farbe, so daf sie nicht als Schmucksteine dienen künnen. Hierzu eignen sich ausschließlich die durchsichtigen, meist grïnen, zuweilen auch gelblichbraunen Geschiebe, die sich mit dem weißen Topas in den Edelsteinseifen des Bezirks Hinas novas in Brasilien

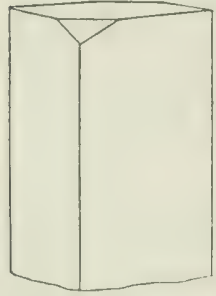

Fig. 91.

Kiristallform des

Andalusits. finden, wo aber im Gegensatz zum Topas usw. das urspriingliche Vorkommen im Muttergestein noch nicht bekannt ist. Die weit häufigeren grünen erscheinen im auffallenden Lichte ziemlich dunkel, oder auch heller grasgrün mit einem Stich ins Gelbe und zeigen beim Hindurchsehen einen sehr starken Dichroismus, der schon mit bloßem Auge deutlich bemerkbar ist. In der Richtung der beiden horizontalen Achsen des Prismas, das auch an den Geschieben durch die Spaltbarkeit erkennbar ist, erscheinen zwei grine Nuancen, von denen die eine etwas ins Gelbe geht; in der Richtung der Prismenkante sieht man ein hïbsches Bräunlichrot. Zwischen diesen Farben bewegen sich auch die Bilder, die man mit der Dichrolupe erhält. Es sind dieselben, die auch der Alexandrit zeigt, bei dem aber das Grün melır smaragdiihnlich und das Rotbraun tiefer und gesättigter erscheint, während die Farben beim Andalusit meist zienlich licht sind. Die Ähnlichkeit zwischen beiden ist aber doch so grof, daß der Andalusit zuweilen dem kostbareren Alexandrit untergeschoben wird. der aber an seiner größeren Ihärte und dem höheren spezifischen Gewicht unschwer erkannt werden kann, das beim Andalusit $=3,1 \mathrm{i}$ bis 3,19 ist.

Wie, beim Cordierit, so muls auch beim Andalusit der Schleifer auf diese Farbendifferenz Rücksicht nehmen, man geht aber auch hier wie beim Cordierit vielfach ab- 


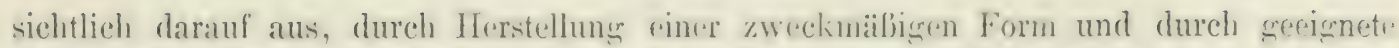
Fassung den Stein beim Ifindurchsehen nach verschedenen Richtungen in verschiedenen Farben erscheinen zu lassen. Die Verwendung und ebenso dex l'reis ist gering. Der Glanz des Andalusits ist Glasglanz, der durch die Politur nicht sehr gesteigert werden kann. Die Härte ist etwas gröber als die des Quarzes $(H .=71 / 4)$. Vor dem Lötrohr und gegen Siuren ist das Mineral ebenso beständig wie der Cyanit.

Erwähnenswert ist noch diejenige eigentümliche Abart des Andalusits, die man mit dem besonderen Namen Chiastolith (Hohlspat) bezeichnet hat. Es sind unregedmäbige, lanewerowene, stets in schwarzem Tonschiefer eingewachsene Prismen, bis zu 1 Zoll dick und mit allen wesentlichen Eigenschaften des Andalusits, von heller Farbe, fast weils. Die Besonderheit besteht darin, daß der 'Tonschiefer die Prismen nicht nur umgibt, sondern an den Kanten mehr oder weniger weit in sie eindringt und sie in der Mitte der Länge nach in einer an verschiedenen Stellen verschieden dicken Achse durchzieht. Die Tonschieferpartien an den Kanten stehen mit der in der Nitte in Verbindung, und es erscheint daher auf jedem Querschnitt eine schwarze kreuzförmige Figur auf einem weißen Hintergrunde, wie es Fig. 92 zeigt (Kreuzstein). Man sieht hier, wie je nach der an den versehiedenen Stellen desselben Kristalles nicht ranz gleichen Ausdehnung der schwarzen Einschliisse diese Figur in den einzelnen Querschnitten verschieden ist, bald das Schwarz, bald das Weiß vorherrschend.

Derartige Durchschnitte wurden vor einigen Jahren als Schmucksteine unter dem Namen Stealith verkauft.

Auf der Kreuzfigur beruht ihre Verwendung als Amulette, die besonders in den Pyrenäen getragen werden. Dort sind auch mehrere Fundorte brauchbaren Materials von geniigender Gröbe der Kristalle, ebenso in der Bretagne bei Salles de Rohan unweit Brieux, in Madera County in Kalifornien und noch an vielen anderen Orten. Der Chiastolith ist namentlich da, wo der Tonschiefer mit Granit in Berïhrung steht, als Kontaktmineral in großer Menge im ersteren
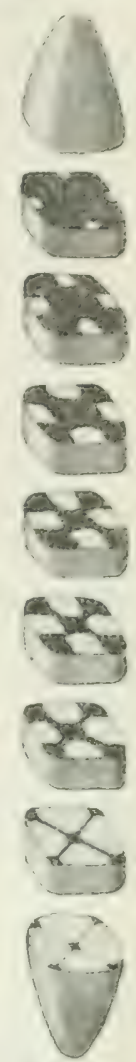

Fïg. 92. eingewachsen, es sind meist aber nur madelförmige dünne Prismen, die wegen ihrer geringen Dicke unbrauchbar sind, wie z. B. bei Gefrees unweit Berneck im Fichtelgrebirge: so grofe Kristalle wie in den oben grenannten Fundorten sind seltener.

\section{Staurolith.}

Der Staurolith ist in der Hauptsache ein Magnesia-Tonerde-Silikat mit einem kleinen Eisengehalt. das stets in gut ausgebildeten Kristallen des rhombischen Systems rorkommt. Diese bilden verlängerte. meist sechsseitige Prismen, von denen häufig zwei sich unter (j)" oder 90" zwillingsartig durchkreuzen. Sie sind stets dunkelbraunrot. aber selten für Schnucksteine durchsichtig genug. Wegen der Farbe ist der Staurolith manchen Granaten ähnlich, unterscheidet sich aber von diesen durch die doppelte Lichtbrechung; er wird auch meist wie Granat geschliffen. Auch wie dunkle gelbbraune Topase sollen manche Exemplare aussehen. Die Härte ist $=7 \frac{1}{2}$, das spezifische Gewicht $3, ;$ bis $3,-$. Die Kristalle sind meist im Glimmerschiefer, Tonschiefer und ähnlichen Gesteinen eingewachsen, aber gewöhnlich durch viele fremde Einschliisse verumreinigt und dann un- 
brauchbar. Rein genug sind einzelne von den Kristallen, die in großer Zahl den oben besprochenen Cyanit in dem weißen Glimmerschiefer vom Monte Campione bei Faido im Kanton Tussin hegleiten, auch die Gerölle aus den Goldwäschen an der Sanarka im Gehiete der (Irenburgischen Kosaken, wo sie mit dem Euklas und anderen Edelsteinen vorkommen, und ebenso einige der Körner in den Diamantseifen von Salobro in Brasilien. Die Verwendung ist sehr spärlich und der Preis niedrig. Auch der den Rubin von Cowee County in Nord-Carolina begleitende Staurolith ist zuweilen von guter Beschaffenlıeit.

\section{Epidot.}

(Pistazit.)

Auch der Epidot gehört zu den Mineralien, von denen nur gelegentlich besonders schöne Exemplare als Schmucksteine geschliffen werden. Vor allem sind die prachtvollen, starkglänzenden, schön gefürbten und meist vollkonmmen durchsichtigen Kristalle von der Tinappenwand, im obersten Teile des Untersulzbachtals im Pinzgau im Salzburgischen, hierzu geeignet; die anderen sehr zahlreichen Fundorte des Minerals liefern kaum Steine, die schön genug gefärbt und gleichzeitig genügend durchsichtig sind.

Die chemische Zusammensetzung wird durch die Formel: $\mathrm{H}_{2} \mathrm{O} .4 \mathrm{CaO} .3(\mathrm{Al}, \mathrm{Fe})_{2} \mathrm{O}_{3}$. $6 \mathrm{SiO}_{2}$ ausgedriickt; es ist also ein etwas Wasser enthaltendes Kalk-Tonerde-Silikat, in dem eine wechselnde Menge Tonerde durch Eisenoxyd ersetzt ist. Der Epidot von dem genannten Fundorte besteht aus: 37,s:3 Kieselsäure, 22,63 Tonerde, 14,02 Eisenoxyd, 0,93 Eisenoxydul, 23,27 Kalk und 2,05 Wasser (zusammen 100,73).

Kristalle sind sehr häufig. Die Formen gehören dem monoklinen Kristallsystem an. Es sind langgezogene und gleichzeitig meist in einer Richtung etwas abgeplattete Prismen, die ihre Längserstreckung parallel der Symmetrieachse haben. Die langen Prismenflächen
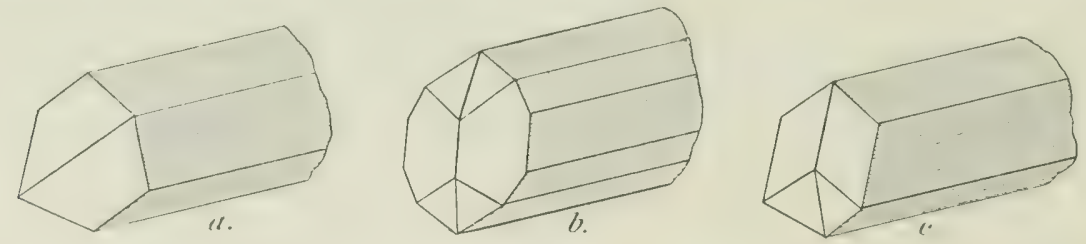

Fig. 93. Kristallformen des Epidots.

tragen meist eine deutliche Lüngsstreifung, während die kleinen Endflächen glatt zu sein pflegen. Vielfach sind zwei solche Prismen zwillingsartig aneinander gewachsen, so dalb an dem Ende einspringende Winkel entstehen. Meist sind nur auf der einen Seite der Prismen Endflächen ausgebildet, da die Kristalle gewöhnlich mit dem anderen Ende auf ihrer Unterlage aufgewachsen sind. Einige am Epidot häufig vorkommende Formen sind aus Fig. 93, $a$ bis $c$ zu ersehen; in den ersteren beiden, $a$ und $b$, sind einfache Kristalle, in der dritten, $c$, ist ein Zwilling dargestellt.

Mit einer der P'rismenflïchen geht ein deutlicher, mit einer zweiten ein etwas weniger deutlicher Blätterbruch parallel. Die Härte ist gleich $6^{1} / 2$, steht also noch etwas untel der des Quarzes. Das spezifische Gewicht schwankt mit dem Eisengehalt zwischen 3,25 und $;,$... Bei den verhältnismälßig cisenveichen Kristallen von der Knappenwand ist: $G_{0}=3,17$ bis $3, ;$; diese sinken also im reinen Mrethylenjodid zu Boden, schwimmen aber 
in der schwersten Fliissigkeit. Der Ejidot schmilzt vor dem Lötrohr, und die geschmolzene Masse wird von Süuren zersetzt, nicht aber die frische, ungeschmolzene.

Die Durchsichtigkeit sehwankt zwischen allen fraden, doch sind schön klare, namentlich von dunkler Farbe nicht häufig, auler ehen an der Knappenwand. Für Röntgenstrahlen ist aller Epidot undurchläissig. Die Lichthrechung ist stark und chenso die Doppelbrechung. Der grölite und der kleinste brechungskoeffizient für rotes Licht sind $=1,73 \ldots$ und 1,76; . Die Fïrbung ist sehr mannigfaltig, die Farbenreihe ziemlich grof. Die Farbe, die bei der Verwendung zu Schmucksteinen nicht zu dunkel sein darf, hängrt genau von dem Eisengehalte ab und ist um so dunkler. je gröber dieser ist. Selten findet man beinahe farb. lose Kristalle, häufiger hellgellse, zuweilen auch rote, am verbreitetsten ist eine bei anderen Edelsteinen kaum wieder in derselben Weise vorkommende, mehr oder weniger dunkel pistaziengrïne. Nuance (ein dunkles (rrün mit einem Stich ins Gelbe und Brame), die zu einem anderen Namen des Minerals, Pistazit, Veranlassung gegeben hat. Zu diesen dunkelgefärbten gehören auch die Kristalle von der mehrfach grenannten Lokalität, ron wo eine Druse auf 'Taf. XIT, Fig. 1, ein creschliffener Stein auf derselben Tafel, Fig. 2, abgehildet ist. Die Salzburger Epidote sind an der Oberfläche im zurückgeworfenen Lichte dunkelgriin, fast schwarz, wenigstens in dickeren Stïcken. Sieht man aber durch die Prismen hindurch, so sind sie in einer Richtung schön grin und in einer darauf senkrechten grelbbraun, zuweilen ins Rote. Die Bilder im Dichroskop wechseln zwischen grrün, gelb und einem sehr dunkeln Braun, der Dichroismus ist also sehr stark. Der Epidot gehört zu den am stäiksten dichroitischen Mineralien.

Die Schliffformen sind die gewöhnlichen der dunkelgefärbten Steine, niedriger Treppenund Tafelschnitt; ein solcher ist Taf. XIV, Fig. 2 dargestellt. Die Dicke darf nicht zu beträchtlich sein, sonst ist die Farbe düster und unansehnlich, sie kann aber durch eine glänzende Folie verbessert werden. Je nach der Richtung der Tafelfläche wird der geschliffene Stein mehr grïn oder braun erscheinen, jedenfalls erhält er beim Schleifen stets einen sehr schönen glasartigen Glanz.

Von anderen grünen und braunen Steinen unterscheidet sich der Epidot leicht durch den starken Pleochroismus und das hohe spezifische Gewicht. Grüner und branner Turmalin, die grleichfalls stark dichroitisch sind, sind viel leichter $\left(G_{0}=3,1\right.$ bis 3,1$)$ und schwimmen daher im Methylenjodid. Grïe Steine, mit denen eine Verwechselung möglich wïre, Diopsid, Chrysolith und andere haben, einen viel schwächeren Dichroismus, ebenso der braune Rauchtopas. Braune Steine kommen indessen weniger in Betracht; der Epidot wird meist so geschliffen, daß er auf der Tafelfläehe die grïne Farbe zeigt.

Das Mineral findet sich hauptsächlich in älteren Silikatgesteinen, in denen die Kristalle entweder auf IIohlräumen aufgewachsen oder auch vollkommen eingewachsen sind. An der Knappenwand im Untersulzbachtal sitzen sie auf Spalten in derbem Epidot, sogenanntem Epidotschiefer. Die Fundstelle unterhalb des Pobergkammes wurde 1866 entdeckt; es ist das herrlichste Epidotvorkommen und überhaupt eines der schönsten Mineralvorkommen der sanzen Welt. T'ausende von Kristallen wurden daraus gewonnen und in die Nineraliensammlungen aller Länder verbreitet, eine Anzahl derselben ist auch geschliffen worden. Einzelne sind von bedeutender Gröise, bis $45 \mathrm{~cm}$ lang und 3 bis $4 \mathrm{~cm}$ dick, die meisten allerdings weit kleiner. Begleitet wird der Epidot neben einigen anderen Mineralien, von Kalkspat, Apatit- und Feldspatkristallen, sowie von Asbestnadeln, welche um die Anwachsstellen der Epidotprismen herum zuweilen eine Art dichten Filzes bilden, wie es in Fig. 1 der zitierten Tafel deutlich zu sehen ist.

So zahlreich die Fundorte in Europa auch sind, so kann sich doch keiner mit dem genannten messen; keiner von ihnen liefert eine solche Menge schöner schleifwürdiger Steine. Vielleicht sind aber einige amerikanische Lokalitäten noch erwähnenswert, von 
denen zuweilen ein Stein geschliffen wird. Kristalle, sehr ähnlich denen von der Knappenwand, sind von Rabun Gab, Rabun County, Georgia bekannt geworden; schïn dunkelgriune ron Roserille, Sussex County, New Jersey, andere von Haddam in Connecticut, aus den sïdlichen Kalifornien und von Alaska. Ebenso finden sich schöne, grofe, durchsichtiç Kristalle von grüner Farbe mit dem grïnen Turmalin in Brasilien. Sicherlich wäre es möglich, an manchen der vielen Fundorte schleifbare Stïcke zu finden, wenn ein Bediüfnis danach vorhanden wäre. Dies ist aber keineswegs der Fall, der Verbrauch und auch der Wert als Edelstein ist gering.

\section{Manganepidot.}

Es gibt noch eine Abart des Epidot, bei der statt Tonerde in der Hauptsache Manganoxyd in der Verbindung enthalten ist. Dieser Manganepidot bildet zuweilen prachtfoll kirschrote Kristalle, von denen der eine oder der andere geschliffen wird, wenn er durchsichtig genug ist. Der Hauptfundort ist die Manganerzlagerstätte ron San Marcello in den Piemontesischen Alpen, woher das Mineral auch den Namen Piemontit erhalten hat.

\section{Zoisit.}

Der Zoisit steht dem Epidot in der Zusammensetzung sehr nahe, enthält aber kein oder doch sehr wenig Eisen. Er kristallisiert rhombisch und bildet meist undurchsichtige, sraue, im Quarz eingewachsene Prismen. Es gibt indessen dloch eine schön rosenrot grefärbte, etwas durchscheinende Varietät, die zuerst bei Kleppan, Kirchspiel Souland in Telmarken im südlichen Norwegen gefunden und daher Thulit genannt wurde. Später hat man diesen auch an einigen Orten in Mähren gefunden. Er wird zuweilen geschliffen, namentlich in Form kleiner Kugeln.

\section{Dioptas.}

(Kupfersmaragd.)

Der Dioptas ist ein tiefgrünes Mineral, dessen Farbe der des Smaragnds nahe steht; er ist aber stets dunkler als dieser. In der Zusammensetzung weichen jedoch beide weit voneinander ab. Der Dioptas ist ein wasserhaltiges Kupfersilikat von der Formel: $\mathrm{H}_{2} \mathrm{O}$. ('uO . $\mathrm{SiO}$. Ein Kristall von dem altbekannten Fundort in der Kirgisensteppe ergab: 36, Ku Kieselsäure, 18, 49 Kupferoxyd, 2, , En Eisenoxydul, 12,29 Wasser (zusammen 99, $;$ ). Wegen des grofen Kupfergehaltes, der hier die smaragdgrüne Farbe hervorbringt, hat das Mineral den Namen Kupfersmaragd erhalten.

Meist findet sich der Dioptas in deutlichen Kristallen, die indessen stets klein, selten ïber erbsengrob sind. Sie grehören wie die des Smaragds dem hexagonalen Systeme an: sechsseitige Säulen mit rhomboedrischer Endbegrenzung, an denen in seltenen Fällen die Kanten zwischen den gestreiften Rhomboeder- und den glatten Prismenfläehen abwechselnd oben und unten abgestumpft sind, wie es der rhomboedrischen Tetartoedrie entspricht. Fig. 91 zeigt diese Form an einem Kristall von dem erwähnten Fundort. In der Richtung (ler Abstumpfungsflächen der Endkanten des Rhomboeders geht ein deutlicher Blätterbruch, so dab die Kristalle an diesen Kanten einen aus dem Inneren leuchtenden Perlmutterglanz hesitzen, wïhrend sie sonst glasglänzend sind. Die Härte ist gering; der Dioptas wird 


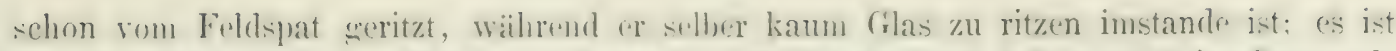

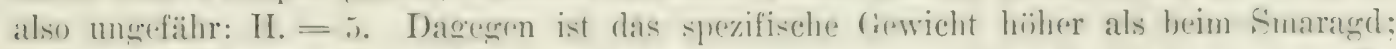

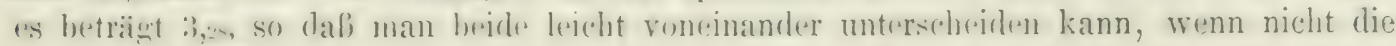
weit dunklere Farbe und die infolge zahlreicher kleiner Risse stets selır geringe Durchsichtigkeit den Dioptas auf den ersten Blick erkennen lassen.

Der Hauptfundort, früher der einzige größerer Kristalle, ist der Berg Altyn 'Tübe, ein westlicher Ausläufer des Altai in der Kirgisensteppe in Sibirien. Dieser Bere hesteht aus kalk, der von zahlreichen Klïften durchzogen ist. In ihnen sitzt der Dioptas in sparsamer Menge auf dem Kalkspat, der sie zum größten Teil erfüllt (Taf. XV, Fig. 4). Auch in manchen Goldwäschen im Jenisseischen Gouvernement sind einzelne größere Dioptaskristalle vorgekommen, hier lose als Geschiebe und mehr oder weniger abgerollt.

So waren also größere Dioptase lange Zeit ein spezifisch russisches Vorkommen. Auf Rußland, sowie auf die den Hauptfundort um. gebenden Länder: Persien usw. war auch die Verwendung als Edelstein in der Hauptsache beschränkt. Letzteres ist auch noch

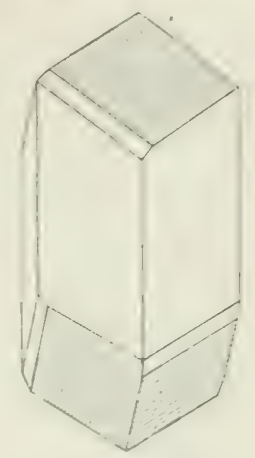

Fig. 94.

Kristallform des Dioptases. heute der Fall. trotzdem in nenter Zeit zahlreiche schöne und rrolje Kristalle auch anderwïrts, so namentlich im franzïsischen liongogebiete, entdeclit worden sind. Der umfänglicheren Benutzung steht aher trotz der schönen Farbe die seringe Härte und Durchsichtigkeit entgegen, die auch den Preis wohl stets in bescheidenen Grenzen halten werden.

\section{Kieselkupfer.}

Dem Dioptas steht in der Zusammensetzung sehr nahe das amorphe Kieselkupfer oder der Chrysokoll. Das Mineral ist teils griin (Kupfergriin. Kieselmalachit, oder blau (Kupferblau) und wïrde der schönen Farbe wegen sich trotz seiner sehr geringen Durchsichtigkeit gut zu Schmucksteinen eignen, wenn die Härte nicht gar zu nieder und meist nicht einmal gleich der des Kalkspats wäre $\left(H_{0}=2-3\right.$. Trotzdem werden einzelne Steine, namentlich aus den Kupfererzlagerstätten ron Nischne Tagilsk im Ural, geschliffen. In der Allonez-Grube bei Houghton in der Kupferregion am Oberen See tindet sich ein mit Quarz gemengtes und daher viel härteres und zum Schleifen besser geceignetes Kieselkupfer, das prïchtig blaugriine Steine von einem halben (Quadratzoll Oberfliiche zu liefern rermag. Blanes Kieselkupfer ist schon mehrfach für Türkis gehalten und auch als solcher verkauft worden; z. B. das schön himmelblaue von Phönixville in Arizona und andere.

\section{Garnierit.}

Schön grün, aber ebensowenig durchsichtig wie das Kieselkupfer ist auch der rarnierit oder Numeait. Es ist ein gleichfalls amorphes wasserhaltiges Nickelsilikat, das auf der Insel Neu-Kaledonien in großen Massen vorkommt und ron dem zuweilen einige Steine geschliffen werden, deren IÏ̈rte aber wie beim Kieselkupfer die des Kalkspats nicht ganz erreicht.

\section{Titanit. (Sphen.)}

Der Titanit ist eine Terbindung ron Kalk nit Kieselsäure und Titansäure ron der Formel: Ca 0 . si Oz. Ti O. Die Formen der sebr häufig schön ausgebildeten Kíristalle 
gehïren dem monoklinen Systeme an. Diese sind entweder in gewissen Silikatgesteinen eingeschlossen und dann undurchsichtig, meist braun oder gell) und zu Schmucksteinen nicht gecignet: oder sie sind auf Kliiften derartiger Gesteine aufgewachsen und dann häufigr selı schïn klar und durchsichtig. Diese aufgewachsenen durehsichtigen Titanite werden mit dem besonderen Namen Sphen von jenen anderen unterschieden; sie sind es allein, die zuweilen geschliffen werden, wenn die Durchsichtigkeit vollkommen und die Farbe schön ist. Diese ist meist grïn, zuweilen auch gelb und braun, manchmal sogar rot, immer mit deutlichem Dichroismus. Die grünen gleichen dem Chrysolith, Vesuvian, Demantoid, Chrysoberyll und anderen grünen Steinen, aber nie dem Smaragd, da ilre Farbe stets ins Gelbe geht und nicht sehr tief und gesättigt ist. Die gelben stehen in der Farbe manchen hellgelben Topasen nahe.

Die Härte ist gering: $H_{0}=5^{1 / 2}$. Das spezifische Gewicht ist ziemlich grob: $G_{0}=3,35$ bis 3,45 , so daß also der Titanit im reinen Methylenjodid zu Boden sinkt. Schöne schleifwürdige Kristalle finden sich an verschiedenen Stellen der Alpen auf Spalten im Gneis usw., besonders in Tirol, und hier namentlich im Pfitschtale und in Zillertale, aber auch in der Schweiz, z. B. im Binnental. In Nordamerika kommen besonder's große und schöne Kristalle bei Bridgewater, Bucks County in Pennsylvanien, vor. Diese sind bis über 1 Zoll lang und zum Teil vollkommen durchsichtig, so dals man sehr schöne Steine von 10 bis 20 Karat daraus schleifen kann. Die Terwendung des Sphens als Edelstein ist beschränlit und sein Preis gering.

\section{Benitoit.}

In Beziehung auf die chemische Zusammensetzung schliebt sich der Benitoit nahe an den Titanit an. Er hat die Formel: $\mathrm{BaO}_{3} 3 \mathrm{SiO}_{2}$. TiO. und kristallisiert hexagonal in rhomboëdrischen, bis $2 \mathrm{~cm}$ großen Formen. Die Kristalle finden sich, eingewachsen in weißem Natrolith, auf engen Spalten in einem dem Serjentin der kalifornischen Coast Range linsenförmig eingelagerten basischen Eruptivgestein oder einem stark zersetzten kristallinischen Schiefer. Sie sind zuweilen, wenn klein, ganz farblos, größere Individuen sind ganz oder meist nur zum Teil blau, und diese blauen Partien geben geschliffen Steine, die an Farbe dem Sapphir gleichen, an Glanz ihn ïbertreffen. Die Farbe, oft an demselben Kristall nicht an allen Stellen die gleiche ist, wenn blals, rein blau, geht aber, wenn sie dunkler wird, ins Violette. Der Pleochroismus ist sehr stark. In der Iichtung der Achse, also auf die Geradendfläche gesehen, sind die Steine fast farblos, senkrecht dazu, auf den Prismenflächen, tritt die blate Farbe am tiefsten und schünsten hervor. Der Schliff mulb also, entgegengesetzt wie beim Sapphir, so geschehen, dalf die 'Tafelfläche der Steine der kristallographischen IIauptachse parallel geht. Die Iicht- und die Doppelbrechung sind stark; die beiden Iauptbrechungskoeffizienten wurden für gelbes Natriumlicht bestimmt: der kleinste $=1, ; i$ und der größte $=1$, sw. Die Härte ist: II. $=6 \frac{1}{4}$ bis $61 / 2 . \quad$ G. $=3$, ,it -3, ,ijo. Eine deutliche Spaltbarkeit ist nicht vorhanden; der Bruch ist muschelig. Der Fundort liegt in der Nount Diablo Range, im Ursprungsgebiet des San Benito River in San Benito County in Kalifornien, und zwar nahe der Eisenbahnlinie San Benito-Fresno, etwa unter $36^{\prime \prime} 20^{\prime}$ nrdl. Br. Von ihm ist der Name des nenen Eilelsteins hergeleitet, von dem aber bis jetzt nur spärliches Material gefunden wurde. Im Jahre 1907 sind 15 Pfund rohen Benitoits gewonnen worden, aber ein großer Teil larom war nicht zu Schmucksteinen brauchbar. Bis zum 1. Januar 1905 hat man Steine 
im Gesamterewicht von 350 Karat geschliffen. Die Sprörligkeit des Materials bedingt dabei große Vorsicht und die Verluste sind ziemlich bedeutend.

\section{Prehnit.}

Der Prehnit wird zuweilen seiner sehrinen gelblicherrinen. der des Chrysolith ähnlichen Farbe wegen geschliffen, hat aber keine umfangreiche Verwendung. Es ist ein Kalk-TonerdeSilikat mit einem kleinen Wassergehalt, das zuweilen in tafelfürmigen Kristallen des rhombischen Systems ausgebildet ist. Diese sind meist zu kugelfümigen oder nierenförmigen und traubigen, im Innern strahligen bis faserigen Agregregaten verwachsen; in dieser Form pflegt der Prehnit bauptsïchlich in der Natur vorzukommen. IIan findet ihn so auf Hohlräumen von Mandelsteinen und Diahasen, ïberhaupt von älteren vulkanischen Gesteinen, zuweilen in ziemlich grofen Stiicken, an manchen Stellen in den Alyen, so an der Seiser Alp, im Fassatal in Tirol, am St. Gotthard usw., soclann am Kap der guten IIoffumng' (daher der Name Kapchrysolith oder Kapsmaragd), in Amerika am Oberen See und an vielen anderen Stellen, besonders schün bei Bergen IIill und Paterson in New Jersey.

Die Härte des Prehnits ist etwas üher 6, das spezifische Gewicht gleich 2,- bis 3,10 Er ist durchscheinend, selten durchsichtig, glasglänzend und farblos, gelb oder wriin. Nur die letztere Farbe, ein reiches Ölgriin, ist zuweilen hübsch genug für einen Schmuckstein, Stiicke von anderen Farben werden daher nicht benutzt. Der gesehliffene grüne Prehnit gleicht nach Glanz und Farbe zuweilen sehr dem Chrysoplas, der aber härter und viel leichter ist. Er wird höchstens mit 1 Mark pro Gramm bezahlt.

Für einen faserigen Prehnit oder auch für eine Varietät des Thomsonits wird der C'hlorastrolith gehalten, dei in kleinen rundlichen Kugeln von licht bläulichgriner Farbe in den Mandelsteinen der zum Staate Michigan grehörigen, im Oberen See gelegenen Inseln Isle Royale und Green Stone Island vorkommt. Diese Kugeln wittern vielfach aus dem Gestein heraus und werden am Strande rom Wasser abgerollt. Sie liegen dort als Geschiebe herum und werden so gesammelt. Wegren ihrer Faserigkeit zeigen sie vielfach eine Lichterscheinung wie das Katzenauge, nur meist unvollkommener, manche aber auch in groljer Schönheit, wenn sie eine passende mugelige Form erhalten haben. Sie werden fast ausschließlich in Nordamerika getragen. Die größten Kugeln, die man kennt, haben 1 1/2 Zoll im Durchmesser, die meisten sind jedoch viel kleiner. Schöne Stïcke kosten bis 10 Mark das Karat.

Eime ähnliche Substanz ist der Zonochlorit, in dem Mandelstein der Neepigon Bay am Oberen See in Canada. Die rundlichen, bis 2 Zoll im Durchmesser haltenden Ausfüllungsmassen der Mandelräume bestehen aus abwechselnd heller und dunkler grïnen Lagen, die beim Schleifen hübsch hervortreten. Auch der Zonochlorit wird kaum außerhalb Amerikas geschliffen und auch dort nicht viel benutzt.

\section{Thom sonit.}

In ähnlicher Weise, als Ausfüllung der runden Hoblräume in einem Yandelsteine, und zwar an der Good Harbour Bay des Oberen Sees, und aus dem Gestein herausgewittert, als isolierte Kugeln, die dort lose am Strande herumliegen, findet sich eine schüne radialfaserige und gleichzeitig aus einzelnen konzentrischen, der äuberen Begrenzung dieser Kungeln entsprechend verlaufenden Lagen aufgebaute Varietiit des Minerals Thomsonit, das sonst keine, für einen Schmuckstein erforderlichen Eigenschaften besitzt. Diese einzelnen 
Tagen zeigen aber hier zarte Töne von milchweiß, gelb und grün, die miteinander abwechseln, so daf der Stein einen sehr hübschen, an Achat erinnernden Anblick gewährt. I)as Schleifen besteht fast nur im Polieren der vom Wasser abgerollten, bis 1 Zoll großen Kugeln. die am Strande gesammelt werden; die im Gestein noch eingeschlossenen werden nicht henutzt. Nur in seiner Heimat wird auch dieser Stein zuweilen getragen und etwa mit 1 Mark pro Karat bezahlt.

Der Lintonit rom nämlichen Fundorte ist vielleicht eine Abart dieses Thomsonits, an der griune und fleischrote Lagen miteinander abwechseln. Er wird in schönen Exemplaren mit 2 Mark pro Karat bezahlt.

Natrolith.

Dem Thomsonit rerwandt und wie dieser ein wasserhaltiges Natron-Tonerde-Silikat aus der Gruppe der Zeolithe ist der Natrolith. Er findet sich nicht selten in schönen, wasserhellen Einzelkristallen von langprismatischer Gestalt, die aber nie als Schmucksteine verwendet werden. Zuweilen kommen jedoch radialfaserige und konzentrisch-schalige Aggregate vor, deren einzelne Lagen in mehreren Farben miteinander abwechseln. Besonders schön ist dies bei dem Natrolith vom Hohentwiel in Hegau zu sehen, wo die aufeinanderfolgenden Schichten isabellgelb und hellgelb bis weiß sind. Da die Steine eine gute Politur annehmen, so werden sie zuweilen geschliffen, und zwar so, daß der erwähnte Farbenunterschice möglichst deutlich lervortritt. Die Verwendung und der Wert ist aber unbedeutend, und eigentliche Schmucksteine werden kaum daraus dargestellt, mehr kleine Gebrauchsgegenstände, Platten zum Belegen von Wänden usw.

\section{Kieselzinkerz.}

Das Kieselzinkerz, auch Kieselgalmei genannt, ist ein wasserhaltiges Zinksilikat, das zuweilen in farblosen und durchsichtigen Kristallen des rhombischen Systems vorkommt, noch häufiger jedoch radialfaserige und konzentrisch-schalige Aggregate mit rundlicher, nierenförmiger Oberfläche bildet. Diese sind nicht selten durch einen kleinen Kupfergehalt schön gefüibt, namentlich lebhaft grïn und blau, zuweilen ähnlich wie Türkis. Derartige, durch ihre Farbe ausgezeichnete Stiicke werden manchmal meist mugelig geschliffen und als Schmucksteine verwendet. Ihre Härte ist aber gering ( $H_{.}=4$ bis 5 ), so daß sie wenig Dauerhaftigkeit besitzen; das spezifisehe Gewicht ist gleich 3,35 bis 3,5 . In diesen beiden Eigenschaften weicht das Kieselzinkerz erheblich vom Türkis ab und kann daran von ihm unterschieden werden. Schön gefärbte Stïcke finden sich in den Bergwerken von Laurium in Attika, bei Santander im nördlichen Spanien und bei Nertschinsk in Transbaikalien, aber auch bei Raibl in Kärnten und an anderen Orten. Die Verwendung ist sehr beschränkt. Das Gramm kostet bis 1 Mark.

\section{Zinkspat (Galmei, Smithsonit).}

Das Kieselzinkerz wird beinahe an allen den genannten Fundorten von einem anderen zink haltigen Mineral, dem kohlensauren Zink, begleitet, das als Mineral den Namen Zinkspat oder Galmei erhalten hat und das als Zinkerz eine grole Rolle spielt. Es findet sich (henfalls zuweilen in lebhaft grün, blau, auch wohl violett gefïrbten Aggregaten, genau wie das Kieselzinker\%, die dann auch wie dieses zuweilen geschliffen werden. Namentlich das Vorkommen von Laurim wird, wie das Kieselzinkerz von dort, zuweilen zu Broschen, 
Rimesteinen, l'atten usw. verarbeitet. Eine prïchtig goldgethe Varietait (lokal bekanrit als .'l'urkey fat" von Tellville in Arkansas, wird thenso verwendet. Schön himmelblaues Material konme gemenwärtig in ziemlicher Menge aus der Kelly mine in Veu-Mexilos. Des' Preis ist derselbe wie beim Kieselzinkerz.

\section{Gruppe des Feldspats.}

Die Feldspatfamilie unfalit eine (xruppe ron Mineralien, die wenigstens zum Teil in der Erdkruste eine aulerordentlich scrolie Verbreitung besitzen, so daf sie mit zu deren wichtigsten Bestandteilen gehören. Die meisten Feldsplate sind zwar trübe, undurehsichtig und unansehnlich gefürbt und besitzen durchaus keine Limenschaften, die eine Verwendung zu Schmucksteinen zulassen. Einige derselben bieten jedoch einen so schünen Anblick, dalj sie hierzu sehr sreeignet sind und auch tatsäichlich vielfach benutzt werden. Diesen ist unten eine eingehende Schilderung gewidmet, vorher aher sollen die allgemeinen Eigenschaften aller Feldspate, soweit sie hier von Interesse sind, eine kurze Darstellung finden.

Alle Glieder der (rruppe sind Silikate, Verbindungen der Kieselsäure, in denen diese stets mit Tonerde verbunden ist. Hierzu tritt aber noch entweder Kali oder Natron, oder Kalk, oder aber Natron und Kalk gleichzeitig. Man unterscheidet darnach Kali-, Natron und Kalkfeldspat, sowie die Kalknatronfeldspate, in denen bald das Natron über den Kalk überwiegt, bald das Umgekehrte der Fall ist. Die verschieden zusammengesetzten Feldspatmineralien haben zum Teil besondere Namen erhalten,

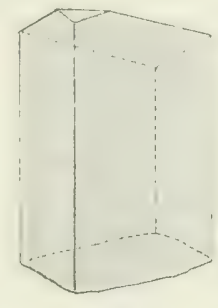

(l.

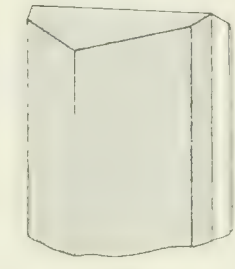

b.

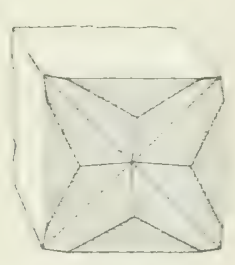

i.

Fig. 95. Kristallformen des Feldspats.

von denen einige unten noch angefiihrt werden sollen.

Sèn häufig bilden die Feldspate ausgrezeichnete Kristalle oft von bedeutender Gröbe. Von diesen gehören die des Kalifeldspats dem monokinen System, die iibrigen alle dem triklinen an. Sämtlich sind sie aber in ihren allgemeinen Formverhältnissen einander sehr ähnlich und unterscheiden sich wesentlich nur durch die (iröfe der Winkel, unter denen die Flächen zusammenstoßen. Diese Differenzen sind aber stets ganz gering und betragen hüchstens wenige Grade. Einige Formen sind in Fig. 9., "bis c und in Fig. 96 al)gebildet. Bei allen findet sich ein rhombisches Prisma; bei den einfachsten Kristallen ist auf die vordere und hintere stumpfe Kante je eine schiefe Endfläche aufgesetzt (Fig. 95, a). Nicht selten treten aber hierzu noch andere Flaichen, namentlich sind meist die seitlichen scharfen Prismenkanten durch die Längsfliiche gerade abgestumpft (Fig. 95, 7 .

Sehr häufig sind zwei oder mehrere Individuen nach rerschiedenen Gesetzen zwillingsartiw miteinander verwachsen, so daß zuweilen komplizierte Gruppen entstehen, wie in Fig. 95, c. Die Feldspate sind entweder in den Gesteinen, wie Granit, Gneis, Trachyt usw., als Bestandteile derselben eingewachsen und bilden hier meist unregelmä̈jig begrenzte Körner, seltener mit ebenen Flächen rersehene Formen; oder es sind regelmälig ausgebildete Kristalle, die auf den TÏ̈nden von Spalten und anderen Hohlräumen in denselben Gesteinen aufgewachsen und zu Drusen, nicht selten ron grofer Schünheit, vereinigt sind. 
Einige physikalische Eigenschaften sind für die Feldspate besonders bezeichnend. tlle hahen, ahgesehen ron einigen undeutlichen, zwei leicht herstellbare Blätterbrüche. Der eine sehr vollkommene geht in der Richtung der vorderen schiefen Endfläche; auf ihm z.rigen die Kristalle Perlmutterglanz und oft lebhaftes Irisieren, während sonst iuberall flasclanz vorhanden ist. Die zweite, weniger deutliche Spaltungsfläche stumpft die scharfen scitlichen Kanten des Prismas al) und geht der Längsfläche parallel.

Die Spaltbarkeit ist im wesentlichen bei monoklinen und triklinen Kristallen dieselbe, đoch ist ein kleiner Unterschied vorhanden. Beim monoklinen Kalifeldspat stehen beide Blätterbrüche genau aufeinander senkrecht; er hat daher den Namen Orthoklas, der Senkrechtspaltende, erhalten. Bei den triklinen Feldspaten stehen sie nicht mehr genau aufeinander senkrecht, diese heißen daher die Plagioklase, die Schiefspaltenden. Die Abweichung des Winkels beider Spaltungsrichtungen ron einem Rechten ist jedoch nur «ering; der Winkel ist nahe gleich 930. Diese beiden Blätterbrïche lassen derbe Feldspatstiicke leicht als solche erkennen, namentlich wenn man noch die Härte hinzunimmt, die bei allen gleich 6 ist; der Feldspat ist ja der Typus des 6. Härtegrades. Der unregelmäßige Bruch des Feldspats nach anderen als den Spaltungsrichtungen ist kleinmuschelig 'bis uneben.

Das spezifische Gewicht schwankt etwas mit der Zusammensetzung und geht von 2,5 bis 2,7. Es ist $1 \mathrm{~m}$ so höher, je größer der Kalkgehalt, und am grö̈ßten ber dem reinen Kalkfeldspat, dem Anorthit. Vor dem Lötrohr sind alle Feldspate schwer schmelzbar. Von Salzsïure werden reine Kali- und Natronfeldspate nicht zersetzt, dagegen sehr leicht der Anorthit und alle viel lialk enthaltenden Kalknatronfeldspate. Je mehr der Kalkgehalt zunimmt, desto leichter wirkt die Säure ein und desto rascher und vollständiger findet die Zersetzung statt. Von Ätztinte werden sie alle sehr stark angegriffen.

Was das äubere Ansehen der Feldspate anbelangt, so sind sie, wie erwähnt, zu allermeist trühe und undurchsichtig und unansehnlich gefärbt. Dies sind die sogenannten gemeinen Feldspate. Die verbreitetsten Farben sind gelb, braun, rot, meist sehr hell, beinahe oder auch ganz weib, sehr häufig aber auch intensiver. Alle diese Farben sind wenign geschätzt; vielmehr ist dies der Fall mit dem schönen Grün, das an einer Abart des Kalifeldspats, dem Amazonensteine auftritt, der wegen dieser Farbe zuweilen als Schmuckstein geschliffen wird. Gerade bei manchen jener trüben gemeinen Feldspate findet sich aber zuweilen ein Farbenschiller, ein prïchtiges Farbenspiel, das den betreffenden Stiicken ganz besonderen Wert als Schmuckstein verleiht. Es gibt indessen auch vollkommen farblose Varietaiten, die vielfach gleichzeitig mehr oder weniger vollkommen durchsichtig sind. Bei zahlreichen Exemplaren derselben tritt ein lieblicher milchiger Lichtschein auf, und sie sind es, die ebenfalls als Schmucksteine benutzt werden, nicht aber die noch weit zạhlreicheren Stücke derselben Abart, an denen diese Erscheinung fehlt. Für Röntgenstrahlen sind alle Feldspate noch halbdurchlässig.

Die Edelsteine aus der Feldspatgruppe sind weder besonders häufig im Gebrauch, noch sind sie sehr knstbar, aber immerhin haben sie eine gervisse Wichtigkeit. Im folgenden sollen sie, nach ihrem Aussehen gruppiert, etwas eingehender besprochen werden, und zwar zuerst der; welcher nur durch die Farbe wirkt, der schon erwïhnte Amazonenstein; sodann die, welche einen Lichtschein oder einen Farhensehiller zeigen, der Sonnenstein, der IIondstein, der labradorisierende Feldspat und der Labradorit. Andere Glieder der Gruppe werden nicht zu Schmucksteinen verschliffen.

\section{Amazonenstein.}

Die Farbe des Amazonensteines ist ein zuweilen etwas ins Blaue gehendes Spangrün von verschiedener Intensität, bald seh1 blaß, beinahe weiß, bald, durch alle Übergänge 
hiermit verbunden, tiof und dunkel. Ausschlieblich Steine von dieser letzteren Art werden reschliffen. aber auch diese nur, wenn sie rollkommen rein sind. Triufigr sind weilie, gelbe und rote Flecken und streif(en, dann ist der Stein unbrauchbar. Da der Amazonenstein weder durchsichtign, noch auch nur stark durchscheinend ist, und da er auch beim Schleifen keinen besonders kriffigen Glanz annimmt, so ist das sehr angenehme Griin die einzige Quelle der Schönheit. und die Stïeke sind um so geschïtzter, je schöner, tiefer und reiner diese Farbe ist. Sie sull von emem kleinen kupferechalt, nach anderen von einer organischen Substanz herrïhren.

Der Amazonenstein ist ein Kalifoldspat. Er findet sich in derhen Massen als fremengteil pegmatitischer (resteine, häufin aher auch in regelmäißig ausgel)ildeten, his 25 cm langen Kristallen, die auf Spalten und Kliiften dieser nämlichen (iesteine prachtrolle Urusen bilden. Eine solche ist 'Taf. XVI, Fig. 1, ein einzelner Kristall in der nehenstehenden Fig. 96 abgebildet. Die wesentlichen Eigenschaften sind, abgesehen von der Farbe, dieselben wie bei den anderen Feldspaten; das spezifische Girwicht ist der Zusammensetzung entsprechend ziemlich nieder, es ist $G_{0}=2,55$ bis 2,66 .

Der Name Amazonenstein ist zuerst $\mathrm{mm}$ die Vitte des rorigen Jahrhunderts einem grïnen Nineral rom Amazonenstrom in Sïdamerika gecgeben worden. Es erscheint aber fraglich, ob darunter die jetzt allgemein so genannte Substanz verstanden gewesen ist, und nicht vielmehr der Nephrit oder der Jadeit, die unten noch beschrieben werden sollen, oder irgendein anderer grüner Mineralkörper. Jedenfalls weif man heutzutage nichts mehr von einem Vorkommen des spangrïnen Feldspats in jenen Gegenden. Mit Sicherheit ist dieser dagegen bekannt vom Ural, wo er sich in derben Körnern und in schönen Kristallen auf der Ostseite des Ilmensees bei Miask mit Topas und anderen Mineralien in pegmatitischen Gesteinen findet. Später bat man ihn auch an einigen Stellen in Nordamerika angetroffen. Am schönsten ist das Vorkommen am Pikes Peak, Teller County, in Colorado, wo er mit grauem Quarz und fleischrotem Feldspat in einem grobkörnigen Pegmatit eingeschlossen ist, ebenfalls zum Teil in schönen

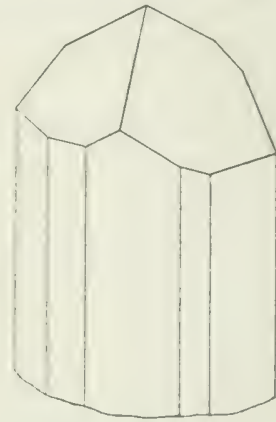

Fig. 96. Kristallform "des Amazonensteins. und grofen Kristallen (Taf. XVI, Fig. 1). Auch bei Florissant im gleichen County wird Amazonenstein gewonnen und ein neues Vorkommen ist kürzlich in Custer County in Colorado entdeckt worden. Gut gefärbte Exemplare kommen auch aus dem grobkürnigen Granit der Allens Glimmergrube bei Amelia Court House im Staate Virginia, wo schon Hunderte von Tonnen prachtroll grïner Spaltungsstïcke, bis 6 und S Zoll groß, gewonnen worden sind, eine geringe Nenge auch aus Pennsylvanien.

Die Schlifform ist meist die einer ovalen oder runden ebenen Platte, deren obere Fläche auch wohl ganz flach nugelig hergestellt wird. Der Stein kommt aber im Edelsteinhandel nicht häufig vor: am verbreitetsten ist er noch in den Lrsprungsländern, Rußland und Nordanerika. Nur besonders kräftig gefürbte größjere Stiicke haben einen etwas höheren Wert, der bei ungewöhnlıch schönen und reinen Exemplaren bis auf mehrere hundert Mark steigen kann. Man stellt iibrigens nicht bloß Schmuckstiicke, sondern auch andere kleine Gegrenstände aller Art, wie Schalen, Vasen, Siegelstücke usw. daraus dar. Amazonenstein findet man schon an altägyptischen Kunstgegenstïnden; das Material dazu soll aus Oberägypten stammen.

\section{Sonnenstein (Avanturinfeldspat).}

Unter dem Tamen Sonnenstein versteht man Feldspate verschiedener Art, die auf einem wenig durchsichtigen, hellgefärbten, meist beinahe weißen bis lachsfarbigen Hintergrunde leb- 
haft metallisch glïnzende Lichtreflexe, meist rot, selten von anderer Farbe, grün und blau, zeigen. I)iese sind besonders intensiv im direkten Sonnenlicht oder bei starker künstlicher Belenchtung. Sie sind bald nur sparsam und einzeln in dem Feldspat zerstreut, bald sind sie aber anch zahlreich und dicht gedrängt, so daß die ganze Oberfläche mehr oder wanger einheitlich in dem metallischen roten Lichte glänzt, das dann einen sehr lï̈bschen Anblick hervorbringt. Der Name Sonnenstein soll eben auf diese glänzend roten Lichtreflexe hinweisen.

Die Erscheinung rührt her von winzigen und sehr dünnen Täfelchen des Ninerals Eisenglanz, die alle untereinander paralell in der Richtung der Hauptspaltungsfläche dem Feldspat eingewachsen sind. Diese Fläche ist daher die Schillerflïche, auf anderen Flächen, fehlt die Erscheinung; da ihnen keine solche Einschlïsse entsprechen. Die Täfelchen sind regelmälfig sechsseitig oder rbombisch oder auch ganz unregelmäßig begrenzt. Infolge ihrer sehr geringen Dicke sind sie mit roter Farbe durchsichtig, wie die Betrachtung von diinnen Schliffen nach der Schillerfläche unter dem Mikroskop deutlich zeigt. Ibre Oberfläche reflektiert ein rotes, metallisch glänzendes Licht, das den Sehiller hervorbringt, und zivar um so schöner und lebhafter und ununterbrochener, je zahlreicher und je gleichnäßiger sie in dem Steine verbreitet sind. Fehlen sie ganz, so ist auch keine Spur von dem Lichteffekt zu sehen, ebensowenig wenn die Schillerflïche nicht die geeignete Lage gegen die einfallenden Lichtstrahlen hat. Daher bemerkt man abwechselndes Auftreten und Verschwinden des Schillers, wenn die dem Lichte zugekehrte Flïche hin- und hergedreht wird. Meist schillert nicht das ganze Stïck oder doch nicht in gleicher Schönheit, da fast immer die Eisenglanztäfelchen nur an einzelnen Stellen zahlreich genug eingeschlossen sind. Diese besseren Partien werden dann gewöhnlich allein benutzt, nicht aber die umgebenden Teile, die nur wenig oder gar keine Einschlïsse enthalten Die Erscheinung hat die größte Ähnlichkeit mit derjenigen, die an dem Avanturin genannten Quarz, den wir noch zu betrachten haben, beobachtet wird. Diesem Namen entsprechend hat man den Sonnenstein auch als Avanturinfeldspat bezeichnet.

Am. Anfange des vorigen Jahrhunderts war der Sonnenstein eine große Seltenheit und Kostbarkeit. Nur einige wenige Stïcke davon waren bekannt, und als einziger Fundort wurde die Sattelinsel (Setlowatoi Ostrow) im Weißen Meer bei Arehangel angegeben. Das Vorkommen wird beschrieben als kleine Partien von Feldspat, die in einer trüben, weiblichen, durchscheinenden Nasse unregehmäßig zerstreute, goldig schimmernde, aber sonst gleich beschaffene Teile zeigen. Wohl nur vermutungsweise wurde später als Heimat des Sonnensteins Ostindien und Ceylon genannt, genauer bekannt sind dagegen die folgenden Fundorte.

Im Jahre 15.31 wurde das Vorkommen bei Werchne Udinsk an der Selenga, einem Zuflulb des Baikalsees, entdeckt. Der Sonnenstein findet sich hier in einigen senkrechten Gängen von Feldspat, die ein schwarzes Nebengestein durchsetzen. Auf der Hauptspaltungsfläche des nelkenbraunen Steines liegen auch hier die Eisenglanztäfelchen, die den Schiller veranlassen. Sie sind in rrö̈lter Menge vorhanden, so daß bei richtiger Lage der Sehillerfläche gegen das Licht unzählige goldig glänzende Flitterehen sich zeigen. In veränderter Lage ist der Stein einförmig braun und ohne Glanz, in gecigneter Weise gedreht, erseheint er dann plïtzlich wie vergoldet, was eine überrasehend schöne Wirkung hervorbringt. Schon das an der Erdoberflïehe durch den Einfluls der Verwitterung stark zerbröckelte Mineral lieferte Stücke, die besser waren als die bis dahin bekannten. Weiter in Innern wïrden sich aber gewilj noch gröbere zusammenhängende Massen finden, die, nach der nicht geringen Mäehtigkeit der Gänge zu schließen, auch zu umfangreicheren Gixenständen, zu Schalen, Vasen usw., verarbeitet werden könnten. Als Gerölle in der Selenga kommt der Sonnenstein gleichfalls vor. Solche sind schon frïher gelegentlich 
von vorüberyiehenden Katufleuten exesammelt, und auch ereschliffen worden, als man das Mineral auf seiner urspriinglichen Lagerstätte noch nicht kannte.

Am typischsten und schïnsten ist der in den fünfziger Jahren auf seiner Lagerstätte entdeckte Sonnenstein von ITvedestrand im siidlichen Norwergen. Ein ranz ähnliches Vorkummen ist auch das von IItterö ehendort, am Kristianiafjord. Schon früher wurde Sonnenstein aus jener Gerend, von Fredriksvärn erwälnnt, wahrscheinlich ist damit aber das Mineral von 'Tyedestrand gemeint. Auch hier sind as unrexcelmäligig benrenzte derbe Massen, nie regehmäbige Kristalle, die im Gemenge mit weiliem Quarz eine aderartige Ausscheidung im Gneis bilden. Diese hat im Mittel die Dicke von einer halben Klafter und ist auf eine Länge von mindestens 3 Klafter aufgeschlossen. Sie folgt den beinahe senkrechten Gneisschichten, die in ihrer unmittelbaren Nïhe in sehr glimmerreichen Glimmerschiefer orler eigentlich in reinen Glimmer ïbergehen. In jener Ausscheidung ist der Sonnenstein begleitet ron Eisenglanz, Cordierit, Hornblende, Zirkon und wahrscheinlich auch ron Apatit. In der Nachbarschaft der Crenze ist der Feldspat beinahe ganz farblos und zeigt nicht den charakteristischen Sehiller; nach der Nitte hin treten darin allmählich immer mehr Eisenglanztäfelchen auf, und gleichzeitig wird das prächtige Funkeln und Flimmern immer stärker. Die schünsten Stïcke liegen am meisten nach der Witte zu; sie bilden stets nur kleinere, unregelmäßig begrenzte Partien, die von weniger guten umgeben sind und in diese allmählich ïbergehen. Die besseren Teile werlen bei der Bearbeitung sorgfältig herausgeschnitten und von den schlechteren getrennt.

Auch in Nordamerika ist Sonnenstein an mehreren Orten vorgekommen, so bei Statesville in Yord-Carolina, wo er zum Teil ebenso schön ist wie der norwegische, aber noch kleinere glänzende Flecken hat; ferner am Blue Hill bei Fairfield in Pennsylvanien und an anderen Stellen desselben Staates. Bei Middletown, Delaware County, Pennsylvania, findet man sehr schöne Stücke, die den norwegischen wenig nachgeben, zusammen mit dem noch zu betrachtenden Mondstein lose im Boden liegen. Bei Media in derselben Grafschaft trifft man neben dem rot schillernden Sonnenstein einen Feldspat, der ganz älnnliche, aber von Einschlïssen anderer Art herriihrende grïne Lichtreflexe zeigt.

Der Sonnenstein von allen den genannten Fundorten ist ein triklin kristallisierter Kalknatronfeldspat, bei dem der Natrongehalt über den Kalkgehalt ïberwiegt. Feldspate dieser Art werden mineralogisch Oligoklas genannt. Der bisher betrachtete Avanturinfeldspat ist also eine Abart des Oligoklases, und zwar eben die, welche durch die erwähnten Einschliisse und den von ihnen hervorgerufenen Schiller ausgezeichnet ist und sich dadurch von dem übrigen Oligoklas unterscheidet. Wie die triklinen Feldspate überhaupt, so zeigt auch der zum Oligoklas gehörige Sonnenstein auf der Schillerfläche, die der Hauptspaltungsfläche entspricht, eine feine geradlinige, in der Richtung der zweiten Spaltungsfläche verlaufende Streifung infolge einer eigentümlichen Zwillingsbildung, die bei den nun zu erwähnenden $\Lambda$ vanturinfeldspaten nicht vorkommt. Diese Streifung kann daher zur Unterscheidung dienen, sofern es sich um rohe Stiicke handelt; beim Schleifen verschwindet sie, und die Möglichkeit der Unterscheidung hört damit auf.

Die Erscheinung, die den Sonnenstein charakterisiert, ist nämlich nicht auf den Oligoklas beschränkt, sie zeigt sich auch an anderen Feldspartarten, namentlich an einzelnen Exemplaren des Kalifeldspats odler Orthoklases, und zwar ganz in derselben Treise und aus demselben Grunde: dïnne Täfelchen von Eisenglanz sind auch hier parallel der Hauptspaltungsfläche eingewachsen und erzeugen auf dem Stein den Schiller, der dem früher beschriebenen in jeder Hinsicht gleicht. Solche Orthoklassonnensteine werden hauptsächlich von Nordamerika erwähnt, so z. B. von Gleen Riddle, Delaware County in Pennsylvanien, wo der Feldspat lachsfarbig und zum Teil durchsichtig ist; von Crown Point und anderen Orten im Staate New York, mamentlich sind hier die kleinen Stücke 
von Greeley Tarm heinahe ebenso schön wie die norwegischen; endlich von Amelia Court House in Amelia County, Virginia.

Alle diese Sonnensteine werden in der Richtung der Schillerfläche entweder ganz ebcn oder flach schildförmig geschliffen. Die Verwendung ist sehr spärlich und der Preis nux bei ausgewählt schönen Stiicken etwas höher bis 3 Mark pro Karat.

Die Avanturinfeldspate sind von dem eigentlichen Avanturin oder dem Avanturinytuarz schon durch das bloße Ansehen genïgend unterschieden, so daß eine Verwechselung heider wohl selten vorkommt. Im Zweifelsfalle bietet die IIärte ein sicheres Unterscheidungsmerkmal: der Avanturin hat wie jeder Quarz die Härte $\bar{\imath}$, der Avanturinfeldspat nur die IIärte 6, so dals also letzterer vom Quarz deutlich greritzt wird. Von dem Avanturinglas, das den roten metallischen Farbenschiller nachzuahmen sucht, wird bei der Betrachtung des Avanturinquarzes die Rede sein.

\section{Mondstein.}

Mit dem Namen Mondstein bezeichnet man farblose und stark durchscheinende bis beinahe vollkommen durchsichtige Feldspate, die in einer Richtung ein bläulichweibes milchiges Licht scheinen lassen, das man mit dem Lichte des Mondes verglichen hat. Selten ist die Körperfarbe grau bis schwarz und der Stein bis ganz undurchsichtig. Wie der Farbenschiller des Sonnensteins, so ist anch diese Lichterscheinung, das Chatoyieren, nicht ausschließlich auf eine bestimmte Art der Feldspatgruppe beschränkt. Aber wenn sie auch an einzelnen Exemplaren aller möglicher, verschieden zusammengesetzter Feldspate vorkommt, so ist dies doch am schönsten bei dem farblosen, durchscheinenden Orthoklas der Fall, dem der Name Adular beigelegt worden ist. Der Mondstein wird daher vielfach als eine Abart des Adular aufgefaßt, und die Erscheinung ist infolgedessen als Adularisieren bezeichnet worden. Die Beschränkung auf den Adular entspricht aber nicht voliständig den Tatsachen; auch der farblose und durehsichtige Natronfeldspat, der Albit der Mineralogen, zeigt in einzelnen, wenngleich weit sparsameren Exemplaren denselben Lichtschein, ebenso manche Feldsplate von der Zusammensetzung des Oligoklases, den wir schon bei der Betrachtung des Sonnensteins kennen gelernt haben. Alle diese adularisierenden Feldspate mit dem mondartigen Lichtschein werden auch wohl zuweilen Girasol, oder Fisch- und Wolfsauge, oder endlich Ceylon- und Wasseropal genannt.

Der Adular, der am liäufigsten von allen Feldspatvarietäten die Lichterscheinung des Mondsteines zeigt, ist der reine Kalifeldspat, dessen chemische Zusammensetzung durch die Formel: $\mathrm{K}_{2} \mathrm{O} \cdot \mathrm{Al}_{2} \mathrm{O}_{3}$. $6 \mathrm{Si} \mathrm{O}_{2}$ ausgedrïckt wird. Er ist sehr häufig in schönen und großen Kristallen ausgebildet. Die Formen derselben sind häufig sehr einfach, wie z. B. in Fig. 95, " und 7. Zuweilen sind es aber auch komplizierte Zwillingsverwachsungen; eine solche, wo vier Individuen miteinander gesetzmäßig zu einem Vierling verbunden sind, ist in Fig. 95, $c$ dargestellt.

Das spezifische Gewicht ist gleich 2,55, wie beim Orthoklas überhaupt, von dem der Adular eine farblose und durchscheinende bis durchsichtige Abart darstellt. Geschliffen werden nur diejenigen Exemplare, die den Lichtschein zeigen. Dieser ist nicht über die ganze Oberflïche der Steine verbreitet, sondern er erscheint blok in einer ganz bestimmten Richtung; nämlich sehr nahe den Flächen, die an Kristallen die vordere und hintere Kante der Prismen gerade ahstumpfen wïrden, an derben Stïcken an der entsprechenden Stelle. Nur wenn man auf diese Fliiche blickt, erscheint der Schimmer, und auch auf ihr nur damn, wenn sie die erforderliche Lage gegen das Auge und gegen die Lichtquelle hat. Dreht man die Fläche aus dieser Stellung heraus, dann verschwindet allmählich die ganze Frscheinung, um bei der entgegengesetzten Drehung sofort wieder aufzutreten. Auf 
Taf. XVI ist sie in Fis. 4 an einem unregelmäligen Spaltungsstiicke von Adular darzustellen versucht worden.

Sach der Lage der Schillerflïche mub auch der schliff ererichtet werden. Am vorteilhaftesten arscheint der Lichtsehein auf einer mugeligen Flächr. die sich über der genannten Schillerfläche in ziemlich starkır Wölbung erheht. Facetten dïrfen nicht anenebracht werden, diese stëren die Erscheinung. Seln wirkungswoll sind auch Kugeln ans Mondstein, also gewissermalien zwei nit ihrer Grundflaiehe vereinigte mugelige Steine. Siolehe kugeln werden exexenwïrtign vielfach heresestellt und, auf schnüren aufEezogen, an Ilabbändern usw. getragen, sowie sonst zu Schmucksachen verwendet. Sie gleichen einigermaben weiben Perlen. Schleift man an einem Adular eine chene Fläche an genau in der Riehtumg, in der der Lichtschein auftritt, so geht dieser iiber deren granzen Imfang gleichmäbig wes. Stellt man aber in der angegebenen Weise eine rundliche Fläche her, so sieht man auf dem farblosen und fast durchsichtigen Iintergrunde einen blïulichen Lichtfleck (Taf. XVI, Fig. 5), innerhalh) dessen die Durchsichtigkeit des Steines fast vollständig verschwunden $z u$ sein scheint und der umgeben ist von einem Rande, innerhalh, dessen dieser seine gewöhnliche Beschaffenheit und keine Spur ron Schiller zeigt. Der schillernde Fleck geht in die nieht schillernde Lmgebung ziemlich rasch, aber ohne scharfe Grenze tiber. Er ist um so kleiner, aber auch um so schöner und intensiver, je stärker die Krümmung der Schlifiläche ist, die man so wählen mul, dal der Schiller nicht zu klein, aber auch nicht zu matt wird. Eine sehr grofe Intensität hat aber die Erscheinung niemals, es ist stets ein mildes wogendes Licht, das sich bei ler Drehung des Steines über dessen Oberfläche hinbewegt und bei zu starker Neigung endlich am liande versehwindet. Jan kann die Wirkung noch steigern, wenn man die Fassung in einem schwarzen Kasten vornimmt. Die Erscheinung ist vergleichbar mit der an Cymophan und auch an dem noch zu besprechenden Quarzkatzenauge, nur ist bei dem letzteren der Glanz des Lichtscheines mèr seidenartig, beim Mondstein mehr perlmutterartig.

Der charakteristische Lichtschein, das Chatoyieren des Iondsteines, ist an den verschiedenen Exemplaren des Adulars melur oder weniger deutlich ausceprägt und fehlt an den meisten vollständig. Auch an einem und demselben Exemplare schillern rielfach einzelne Stellen besser als andere. Diese besseren werden dann herausgeschnitten und für sich geschliffen. Je kräftiger der Schiller hervortritt, um so geschätzter sind die Steine. Ein solcher von der Gröle einer Bohne mit schönem Lichtschein hat einen Wert von 25 bis to Mark, und mit der Größe steigt der Preis bedeutend. Am greschätztesten ist ein ausgesprochen blauer Lichtschein. In Allgemeinen beträgt der Preis bis etwa 2 Mark pro Gramm.

Die Ursache des Schillers sind wahrscheinlich miliroskopisch kleine farblose, lebhaft glänzende Kristalltaifelchen, die alle untereinander parallel den Kristallen in der Richtung: der Schillerfläche in großer Anzahl eingewachsen sind und die für Koolin gehalten werden. Nur die Adulare, in denen das Jlikroskop solche Plättehen erkennen läbt, schillern, und zwar um so stärker, je größer dic Zahl derselben ist; fehlen sie ganz, so ist auch kein Schiller vorhanden. Die Anwesenheit dieser kleinen fremden Körperchen ist auch die Ursache, warum die schillernden Adulare niemals vollkommen klar und durchsichtig sind; eine kleine, wenn auch noch so unbedeutende Tribung ist stets vorhanden.

Der Adular findet sich in auscezeichneter Weise in den verschicdensten Teilen der Tiroler, Schweizer usw. Alpen, wo er in schönen Kristallen von den ohen angegrehenen Formen mit Bergkristall und anderen Jineralien auf den Wïnden ron Spalten im Gneis und ähnlichen Gesteinen aufgewachsen ist. Hier ist die hauptsäichlichste Heimat des Ninerals, aber nur eine kleine Zahl der vielen alpinen Adulare zeigt den Schiller, und 
bei verschwindend wenigen ist dieser so kräftig, daß sie als Schmucksteine verwendet werden könnten. Dur schön und kräftig schillernde Mondstein, der verschliffen wird, stammt fast aller ron der Insel feylon (Fig. 69, S. 361), wo aber das Vorkommen anders ist als in den Alpen. Er findet sich hier in pegmatitischen Gängen, und zwar z. T. in prachtvollex schriftgranitischer Terwachsung mit Quarz, z. T. in Form rundlicher bis faustsmolier Partien oder porphyrischer Kristalle in dem mürben kürnigen Gestein. Klarere Stïcke zeigen einen schönen blauen Schimmer, während die mürberen, trüben l’artien cinen mehr silberweißen, stärkeren Schiller aufweisen, den man oft über eine große Gesteinsfliiche einheitlich auftretend verfolgen kann. Unregelmäßig begrenzte, derbe bis faustgroße Stïcke liegen in einem weilen kaolinähnlichen Ton, der durch Verwitterung des Gesteins entstanden ist; die Nondsteinstiicke sind der unveründert gebliebene Überrest. In dieser Weise findet er sich u. a. bei Nuwara Elliya, wo eine etwas westlich gelegene Stelle auf manchen Karten als "moonstone plain" bezeichnet wird. Das Hauptvorkommen ist aber in Dumbara- und im Kandy-Distrikt der Zentralprovinz; als Fundort wird u. a. der Mondstein-Pit bei Jatore nördlich von Wattegama, an der Babn von Kandy nach Norden, genannt. Der Mondstein wird, als der einzige Edelstein in Ceylon, aus dem anstehenden Gestein gewonnen. Aus diesen ursprïinglichen Lagerstïtten im anstehenden Gesteine gelangt er dann auch in die Edelsteinseifen, in denen er sich in Form abgerollter Geschiebe findet, die mit den anderen Edelsteinen zusammen gewonnen werden. Am häufigsten soll, er in dieser Weise im Siiden, bei Weligama zwischen Galle und Matara an der Südküste der Insel, vorkommen. Die gegenwärtig von Ceylon zum Schleifen nach Europa gebrachten Stücke sind, jedenfalls zu einem großen Teile, unregelmäßig begrenzt aber nicht abgerollt; diese stammen also wohl nicht aus den Seifen, sondern aus der ursprünglichen Lagerstätte. Häufig werden sie schon in Ceylon rundlich geschliffen, jedoch meist in unzweckmäßiger Weise, so daß sie in Europa umgeschliffen werden, um ihre Schönheit besser hervorzuheben.

Andere Gegenden liefern dem Edelsteinhandel ebenfalls einiges, aber bedeutend weniger Material. In Brasilien kommen in der Nähe ron Rio de Janeiro im Gneise schöne Kiristalle vor, von denen manche einen genügend kräftigen Schiller zeigen. Auch in Nordamerika findet sich Mondstein an verschiedenen Orten. Die schönsten Exemplare kommen von der Allens-Glimmergrube bei Amelia Court House, Amelia County, in Virginia. Die fast durchsichtigen und farblosen, bis $\mathrm{zu} \mathrm{1/2}$ Zoll großen Stücke, von welchen viele sich mit denen von Ceylon in der Qualität messen können, sind in einem grobkörnigen Granit eingewachsen, aus dem sie beim Graben nach Glimmer mitgewonnen werden. Mrerkwïrdig ist das Vorkommen sehr schön blau schillernder Mondsteinkristalle in einem vulkanischen Gestein, einem Rhyolith, bei Rialto in den Funeral Mountains, Inyo County, Kalifornien, nach der Grenze gegen Nevada, leider sind sie aber zu klein. Schöne Mondsteingeschiehe hat man auch gelegentlich in Bows River in West-Australien gefunden.

In Nordamerika findet man nun auch andere Feldspate als Adular mit dem Lichtschein des Mondsteines, wennschon nur in geringer Menge. Diese sind zum Teil von dem bisher betrachteten $\Lambda$ dularmondstein im Aussehen nicht zu unterseheiden, zum Teil haben sie aber allerdings auch einen etwas anderen Charakter. Namentlich ist es der' farblose und durchsichtige Natronfeldspat, der Albit, der zuweilen die Erscheinung zeigt und dessen schimmerude $A$ bart wohl als $A$ lbitmondstein bezeichnet werder könnte. Ein sehr schönes Torkommen dieser Art bildet der Albit von Mineral Hill bei Media, Delaware County, Pennsylvanien, der zuweilen geschliffen wird, und ebenso der mit dem besonderen Namen Peristerit leceichnete Albit ron Macomb, St. Lawrence County, New Jork. Viele Kristalle dieses letzteren mit gewöhnlichem Feldspat zusammen vorkommenden Minerals, nicht alle, haben den Schiller, und zwar manche so schön wie die von Ceylon; 
er gent abor hier zuweilen etwas meler ins Ifellgriine und Gelbe und zeiget auch wohl versehiedene Fatben gledehzeitig. I)ieser Peristerit findet als Schmuckstrin ebenfalls Anwendung. Adularisierender Albit, der wie dor oben erwähnte als P'eristerit bezeichnet worden ist, findet sich auch in Form von Kristallen und gröberen derben Massen auf Gïngeen grrobkörnigen (iranits in fineis bei Pathurst unweit l'erth in Kanada und an verschiedenen anderen Orten.

Lin Oligoklas mit Lichtschein, also ein Oligoklasmondstein, wurde vor kurzem am Fulf des Medlock Mountains, 1 Meile nördlich ron Bakersville, Mitchell County, Nord('arolina, auf cinem (iranitgang im Schiefer gefunden. Er ist weil) oder grau und stellenweise ganz durchsichtig. Da er parallel der Sualtungsfliehe Ëisenglimmerschiippehen cingeschlossen enthält, so zeigt er in dieser Richtung die Erscheinung. des Sonnensteins, wiihrend er in der oben beschriebenen Richtung als Mondstein erscheint.

Sehr viel seltener als diese Mondsteine sind durchsichtige Feldspate von gelblicher Farbe, die ein rötlichess Adularisieren zeigen. Auch sie werlen zuweilen als Sonnenstein bezeichnet, sind aber von dem oben beschriebenen, eigentlich so genanuten schmucksteine dieses Namens wohl zu unterscheiden. Die Fundorte sind rliesellyen wie die des Mondsteines.

Der Mondstein wird neuerdings sehr täuschend in Gilas nachgeahmit, so daf die Unterscheidung der in billigen Schmueksachen häufigg vorkommenden Intitationen von den echten Steinen durch bloßes Ansehen schwierig ist. Das Glas hat jedoch immer ein höheres spezifisches Gewicht als die letzteren und namentlich eine geringere M̈̈rte, so daß ein unechter Mondstein ron Feldspat geritzt wird. Auch ist der echte Mondstein deutlich doppelthrechend, während die Glasimitation einfache Lichtbrechung zeigt.

\section{Labradorisierender Feldspat.}

Einen schünen Schiller sicht man auch auf dem Kalifeldspat, der einen Bestandteil der im südlichen Norwegen zwischen dem Kristiania- und dem Langesundfjord rerbreiteten, frïher zum Teil Zirkonsyenit genannten Augitsrenite, namentlich der dieses Gestein durchsetzenden grobkörnigen Gänge einer ganz ähnlichen Felsart bildet. Als spezielle Fundorte werden vielfach Laurvik und besonder's Fredrilistärn angegehen. Die etwas fettglänzende Schillerflïche hat dieselbe Lage wie heim Nondsteine, aber in Gegensatz zu diesem ist der Feldspat grau und undurchsichtig und der Schiller ist nicht blof b]ïulich, sondern sehr schön blau, seltener grrïn, gelb und rot. Er ist viel intensiver als beim IIondstein und nähert sich mehr dem des sofort zu betrachtenden Labradorfeldspats, ohne ihn aber an Farbempracht ganz zu erreichen. Wegen dieser Ähnlichkeit hat das norweurische Mineral den Namen ., labradorisierender Feldspat" erbalten. Eine geschliffene Platte davon ist in Fig. 3, Taf. XVI, zu sehen. Allerdings wird diese Abart des Feldspats selten zu eigentlichen Schmucksteinen benutzt, da sie ron dem reichlich vorkommenden wahren Labradorfeldspat an Schönheit weit ïbertroffen wirct. Dagegen verwendet man das granze Gestein zuweilen zu kleinen Architekturstiicken, zu Grabdenkmïlern usw., die durch den Schiller des Feldspats ein sehr hüilsches Aussehen erhalten.

\section{Labradorit (Labrador, Labradorfeldspat, Labradorstein).}

Der präichtigste aller Feldspate ist der, der naeh seinem besonders ans:gezeichneten Vorkommen an der Küiste von Labrador die genannten Namen erhalten hat. Er ist durch ein außerordentlich lebhaftes Spiel in intensiven, metallisch clänzenden Farben auf einem unansehnlich grauen Körper ausgezeichnet, das dem Stein ein wunclervolles Aussehen verleiht und das dessen Verwendung als Schmuckstein bedingt. 
Der Lahradorit ron dem angegebenen Fundorte ist wie der Olicoklas von Tredestrand, der sogenannte Sonnenstein, ein Kalknatronfeldspat, es überwiegt jedoch im Gegensatz zu jenen der Kialk über das Natron. Bei der Analyse wurde gefunden: 55,59 Proz. Kieseĺsäure, 25,11 Tonerde, 2,;: Eisenoxyd, 11,10 Kalk, 4,5:3 Natron, 0,3:2 Kali; Summe 100,2s. Alle andersartigen kalkreicheren Feldspate von dieser oder nahestehender Zusammensetzung wexden nach dem speziell hier in Rede stehenden als Labradorit oder Labradorfeldspat, odcr auch wohl kurz als Labrador bezeichnet, auch wenn sie von anders woher als von Labrador stammen.

Sie finden sich selten in deutlichen und regelmäßigen Kristallen ausgebildet, die dem triklinen System angehören. Meist sind es derbe Massen, und speziell bei dem Feldspat von der Labradorküste ist dies stets der Fall. Wie bei allen anderen Feldspaten sind zwei deutliche Blätterbriche vorhanden, die einen Winkel von etwa $9+$ Grad miteinander machen. Von diesen ist der vollkommenere deutlich perlmutterg]änzend und zeigt dieselbe Zwillingsstreifung, die wir beim Sonnenstein von Tvedestrand kennen gelernt haben, nur sind beim Labradorit diese Streifen meist breiter und weniger zahlreich und regelmäßig. Eine ganz älunliche geradlinige Zwillingsstreifung beobachtet man indessen hier nicht selten auch auf der zweiten Spaltungsfläche.

Auch in Beziehung auf die ïbrigen Eigenschaften stimmt der Labradorit mit den anderen Feldspaten im wesentlichen überein. Die Härte ist auch hier gleich 6; die Schmelzbarkeit vor dem Lötrohr ziemlich schwierig. Das spezifische Gewicht ist ebenfalls niedrig, aber doch etwas höher als beim Kalifeldspat und beträgt 2,70. Ein Unterschied von diesem liegt außer in der erwähnten Zwillingsstreifung auch in der Zersetzbarkeit durch Salzsäure, die beim Labradorit wegen des großen Kalkgehaltes ziemlich leicht vor sich geht, wobei die Kieselsäure in Form eines schleimigen Pulvers ausgeschieden wird.

Die Farbe des Labradorits ist ziemlich dunkel rauchgrau oder aschgrau. Er ist von Natur wenig glïnzend, nimmt aber eine gute Politur an und ist vollkommen undurchsichtig. Dreht man aber ein Stiick nach allen Seiten herum, so sieht man auf der dïster gefërbten Oberfläche plötzlich das erwähnte prächtige Farbenspiel aufleuchten, wenn man die richtige Lage erreicht hat. Dies ist der Fall, wenn die Lichtstrahlen auf der Fläche des zweiten, weniger deutlichen Blätterbruches reflektiert werden, außerdem tritt es auch noch auf einer zweiten Fläche auf, hier aber sehr viel weniger ausgezeichnet. Nur wenn jene Fläche dem Auge zugekehrt ist, erscheint das Farbenspiel in seiner ganzen Pracht, besonder's wenn die Sonne oder starkes künstliches Licht den Stein direkt bestrahlt. Nach dieser Flïche muß also der Stein geschliffen werden, aber nicht mit Facetten, die eher stïrend wirken, sondern entweder vollkommen eben oder ganz flach mugelig, schildfürmig. Weicht die Śchliffläche ron jener Richtung zu weit ab, so sieht man keine Farben. Es ist aber noch außerdem nötig, daß die genannte Flïche gegen das Auge und das einfallende Licht eine bestimmte Stellung einnimmt. I)reht man sie aus dieser heraus, so verschwinden die Farben und man sieht nur das unscheinbare Grau des Steines. Bringt man ihn wieder in die richtige Lage, so tritt der herrliche Schiller plützlich und mit einem Schlage wieder auf.

Dieses plötzliche Auftreten und Terschwinden und Wiederaufleuchten der gllänzenden Schillerfarben ist für die Erscheinung sehr charakteristisch und macht sie besonders auffallend und üherraschend. Daher wird der Stein von den Juwelieren auch Changeant genaunt, und das Farbenspiel wird als Farbenwandlung, sonst auch als Farbensehiller oder Labradorisieren bezeichnet.

Die Farben des Schillers sind stets brennend und intensiv metallisch grlänzend. Keine Kunst ist imstande, sie auch nur amnähernd nachzuahmen und eine Vorstellung davon zu getien. In ihrer Art erinnern sie an die heim Irisieren und am Edelopal auftretenden 
Farben, nur sind es nicht, wie bei den besten Sorten des letzteren, kleine, rasch miteinander abwechselnde Flitterchen von verschiedener Färbung, sondern man sieht gröbere eleichgef:̈irbte Flächen oder Fläehenteile. Am meisten erinnern sie an die Art der Färbung gewisser tropischer Schmetterlinge, deren Flügel nach Art unserer Schillerfalter, nur viel feuriger miznzen: Morpho Cypris und Morpho Achilles, schïn blau, Apratura Seraphina, griin, beide aus siidamerika, und andere, oder auch an den IIals der 'Tauben.

Die Mamnigfaltigkeit der Farben ist sehr trolb. Man sieht Blau in allen Nuancen vom reinen Smalteblau bis zum Violett; Grün vom reinsten Smaragregrïn an in verschiedenen Nüancen und mit allen möghlichen Übergängren zum Blau und Gelb; das glänzendste Goldgell, und das leuchtendste ('itronengelb, das in dis tiefste Orange und weiterhin in das kräftigste Kupferrot und 'Tombakbraun verläuft. Nicht selten ändern sich die Farben etwas beim Drehen des steines, namentlich geht gell, zuweilen in grün über; meist bleiben sie aber, wie sie sind, bis sie ganz verschwinden. In Fịn. 2, Taf. XVI, ist versucht worden, diese präichtige Farbenerscheinung nachzubilden.

Diese versehiedenen Farben sind keineswers alle gleich häufigr; am öftesten sieht man blan und griü, am seltensten gelb und rot. Es ist nicht gewöhnlich, dab dieselbe Farbe über die ganze Schillerflïche eines Steines verbreitet ist. Dies kommt wohl zuweilen vor, wie bei dem blauschillernden Labrador von Brisbane in Australien, der in der grenannten Figur dargestellt ist. Meist wechseln aber grö̈bere und unregelmälige Flecken und langgezogene Streifen von verschiedener Färbung mehr oder weniger bunt miteinander ab, indem sie ziemlich rasch, aber doch meist nicht mit scharfen Grenzen ineinander iihergehen. Der Pariser Juwelier Caire erwähnt einen allerding's nicht von Labrador, sondern aus Rubland stammenden Stein mit einer eigentiimlichen Farbenzeichnunی. Diese zeigte, der Beschreibung zufolge, ein vollkommen deutliches Bildnis Ludwigs XVI., der Kopf rom schönsten Azurblau auf einem goldiggrïnen Hintergrunde, darïher schwehend eine schön granatrote Krone mit regenbogenfarbigem Rande und einem kleinen, silberartig̣ glïuzenden Federbusch. Der Besitzer dieser Kuriosität verlangte dafür (1799) 250000 Franken!

Nicht inmer schillert die ganze Flïche eines Steines, recht häufig sind farbenglianzende Stellen unterbrochen ron nicht farbigen Flecken. Namentlich sieht man häufig langgezogene schmale Streifen mit geradlinig paralleler Begrenzung von der unscheinbar grauen Fï̈rperfarbe des Steines mit ebensolchen abwechseln, die in den schönsten Schillerfarben erscheinen. Manchmal werden die grauen Stellen, besonders diese Streifen, beim Drehen des Steines schillernd, während die vorher farbig gewesenen ihren Schiller und damit ihre Schönheit vollkommen verlieren und ihrerseits unscheinbar grau werden und so abwechselnd, wenn man dem Stein die frühere Stellung wiedergibt. Derartige Unterbrechungen, namentlich durch ganz schillerlose Stellen, schaden der Gesamtwirkung sehr und driicken den Preis wesentlich herunter. Steine ganz ohne solche, mit völlig ununterbrochenem Schiller, finden sich selten und sind stets klein.

Die Wertschätzung ist um so größer, je glänzender und leuchtender die Farben. Gute Steine mit lehhaftem Farbenspiel für Manschettenknöpfe usw. kosten etwa 4 Mark das Stiick. Steine mit diisterem Schiller stehen weniger hoch im Preise; sie werden als Ochsenaugen (oeil de boeuf) bezeichnet. Auch die Art der Farbe ist wegen deren verschiedener Häufigkeit nicht ohne Einflul auf den Preis. Dieser ist bei ganz fehlerfreien Stücken nicht unbetrïchtlich, geht aber für weniger vollkommene stark herunter. Die besten Exemplare werden zu Schmucksteinen verschliffen; größere Stïcke finden Verwendung zu kleinen Gebrauchsgegenständen, wie Dosen. Stockknöpfen usw. Bei Mosaiken rerden farbenschillernde Gegenstände, wie Schmetterlinge usw. aus Labradorit hergestellt, auch dient er zu Spielereien rerschiedener Art. So waren am Anfang des 19. Jahrhunderts 
kleine Reliefs ies unter dem Namen Mandrill bekannten Affen beliebt, die so aus unserem Edelstein herauseschnitten waren, dab nur die Schnauzen und diejenigen anderen Körper teile in Farteen schillerten, auf denen das auch bei den lebenden Tieren der Fall ist.

ITas die Ursache der Farbenwandlung beim Labrador anbelangt, so sind dafür schon verschiedene Erklärungen versucht worden. Es scheint, als ob die gelbe und griine Farbe auf andere Weise entstïnden als die blaue. Jene gehen von winzigen, bräunlich durchschcinenden Täfelchen von rhombischem, hexagonalem oder auch ganz unregelmäßigem Tmrisse aus, die dem Feldspat, wie man unter dem Mikroskop sieht, oft in großer Zahl in ganz paralleler Lage eingewachsen sind, und die den Mineralien Eisenglanz, Magneteisen und Titaneisen anzugehören scheinen. Die blaue Farbe ist nicht an solche Einschliisse gebunden; sie tritt manchmal sehr kräftig hervor, wenn diese fast ganz fehlen. Alan hat es dabei wohl mit einer komplizierten optischen Erscheinung der Interferenz zu tun, deren völlige Erklärung der Zukunft vorbehalten ist.

Enteckt wurde dieser schöne Stein zuerst am Ende des achizehnten Jahrhunderts von den Mermhuter Missionaren unter den Lskimos der Labradorküste; 1775 wurde das erste Stiick nach Europa gebracht. Dort bildet der Labradorit mit dem noch zu besprechenden Hypersthen, dem schön kupferrot glänzenden Nineral aus der Augitgruppe, ein Norit genanntes Gestein, das in Form von Geröllen große Verbreitung hat. Da es sehr grobkürnig ist, so sind in den meist nicht sehr grofen Geschieben sehr selten beide Bestandteile noch miteinander verwachsen; fast immer ist jeder derselben einzeln und bildet ein Stïck für. sich allein. Über das Vorkommen, namentlich auf der ursprïnglichen Lagerstätte im anstehenden Gebirge, sind nur spärliche Nachrichten vorhanden. Die Bai von Nunaengoak, die das Festiand von Labrador bei Nain gegen Norden begrenzt, wird als reich an „sogenanntem Labradorgestein“ bezeichnet. Östlich vom Festlande liegt die kleine Paulsinsel ('Tunnularsoak), die namentlich in friiheren Zeiten als ergiebiger Fundort viel genannt wurde. Auferdem wird ein Binnensee, der Tesseksoak-See, westlich von Nain als Hauptfundstelle angegeben. 12 miles von Nain soll das Labradoritgestein in einem sehr grobkörnigen hornblendeführenden Granit eingeschlossen sein, von dem auch Teile zuweilen noch an den in den Sammlungen befindlichen Stïcken angewachsen sind. Nach anderen Ansichten ist dieser sogenannte Granit ein grobkürniger Gneis; dann wäre die den Labradorit enthaltende Gesteinsmasse als eine Einlagerung im Gneis, also als ein Glied der kristallinischen Schiefer anzusehen. Nach der Nitteilung von G. F. K unz ist in jenen Gegenden seit mehr als einem Jahrhundert das Mineral bergmännisch grewonnen worden. 150 Millionen Kubikfuß des Gesteins sind aufgeschlossen, und man könnte grolje Blöcke gewinnen.

Der bisherigen Betrachtung lagen ausschließlich die Terhältnisse des Labradorits ron der Labradorkïste zugrunde, wo fast aller Feldspat des Gesteins Farbenschiller zeigt. Das Nineral hat jedoch eine sehr grobe Verbreitun@ als Bestandteil der verschiedenartiosten Gesteine. Aher in der weitaus üherwiegenden Mehrzahl der Fälle fehlt ihm der Farbenschiller vollständig; die Stiicke sind meist grau oder weiß und durehaus ungeeignet zum Schmuckstein. Indessen sind doch im Laufe der Zeiten noch andere Fundorte farbenspielenden Labradorits entrleckt worden, die zum Teil schönes Material in solcher Massenhaftigkeit geliefert haben, daß die Preise auch guter Steine erheblich zuriickgingen und daß die betreffenden Gesteine: zu großen Säulen und anderen ähnlichen Arehitekturstiicken, ja sogar zu Bausteinen Verwendung finden konnten.

Schon bald nach den ersten Funden in Labrador, im Jahre 1751, wurden Stïcke von :ihmlicher Beschaffenheit wie dort in Rußland entdeckt, das sich später als besonders ruich an diesem schönen Material erwies. Zuerst fand man lose Blöcke als Gerölle bei Peterhof unweit St. Petershurg, deren Farbenspiel jedoch das der Steine von Labrador 
nicht erreieht und meist blan ist. Besonders grolie liollstiicke, mohr als 2 Ellen hreit und 1 Elle hoch, werden vom T fer der l'aulowka bei Zarskoje-Selo erwähnt. Auch bei Miolï in Finnland liegen zahlreiche Gerölle. In diesen Lande fand sich das Mineral in den zwanziger Jahren des vorigen Jahrhunderts bei der Wiederaufnahme einer sehr alten Eisenergeruhe bei ojamo im Kirchspiel Lojo in der fiegend ron tho. Es ist hier ron etwas anderer Beschaffenheit als in Labrador, sofern es beinale farblos ist statt errau, und sehr stark durchscheinend. Andirdem schillert es in mehr Farben, und diese sind zuweilen zu regelnäbigen Figuren angerdnet, indem sich um einen nicht schillernden dunkeln Kern ringsum gleichschillemde konzentrische Zomen herumzielen, deren Farben nach auben him ziemlich rasch wechseln. Fleischfarben mit schönem Farbensohiller ist ein Labradorit von IIsingfors.

Das bedeutendste Vorkommen von schillerndem Labradorit in Riuliland und wohl iiberhaupt ist aber das in Tollynien bis in die Gegend ron Kiew. Er bildet hier mit anderen Mineralien, besonders dem Diallas, ein von den Petrographen (iabbro genanntes Gestein von wenigrstens teilweise seln grobem Korn, so daf die einzelnen Lab)radoritindividuen, die aber keinesweus alle den schiller zeigen, bis is Zoll messen, aber allerdings stellenwejse auch auf wenige Linien heruntersinken. Die Farbe des Minerals ist verschieden, dunkelgrau oder grün in mehreren Nuancen, zuweilen hell- und dlunkelgrün an einem Stiick. Auf der gewöhnlichen Schillerfläche erscheint ein sehr schönes Farhenspiel in grünen, blauen, gelben und roten 'Tönen. von denen die beiden ersteren vorherrschen: gelb tritt besonders zwischen grïnen Streifen auf.

Der Gabbro mit dem schillernden Labradorit bildet einen Teil des grofien siidrussischen Gebiets der granitischen Gesteine und ist in dieser Gegrend keine seltene Erscheinung. Er ist auf große Erstreckung verbreitet und an zahlreichen Orten anstehend, und wird hier und dort in Steinbriichen gewonnen. So findet er sich an den Ufern des Baches Bystriewka bei Kamennoi Brod unweit Kiew im Distrikt von Radomysl: Material von hier hat man zu den farbenschillernden Siiulen der Heilandskirche in Moskau verwendet. Später wurde das Vorkommen westlich von Kamennoi Brod bei Gorosehki und an mehreren anderen Punkten des Distrikts Schitomir bekannt, und weiter hat man das Gestein bis in das Gouvernement Cherson verfolgt, wo es 1567 hei Towo-Pawlowsk aufgefunden wurde.

Tenerdings sind sehr schön und einheitlich blau schillernde Labradorite mit dem Fundorte Brishane in Queensland (Australien) in den IIandel getracht worden; sie wurden schon oben im Torbeigehen erwïhnt. Terbreiteter ist aber das Mineral in den Vereinigten Staaten von Tordamerika. Tamentlich scheint der Staat Tew York daran reich zu sein, wo in den (irafschaften Essex und Lewis der farbenschillernde Labrador sowohl anstehend als in Form von Geschieben im glazialen Dilurium vorkommt. Derartige Geschiche gehen noch durch ganz Long Island und New Jersey. In einem Flusse in Lewis County hat man so schön schillemde Gerülle gefunden, daß dieser darnach den Tamen Opalescent Tiver erhalten hat. Bei Keeseville in Essex County wird ein labradoritführendes Gestein in Briichen gewonnen und zu ormamentalen Zwecken sowie zu Bausteinen verwendet. Auberdem ist das Material noch an rerschiedenen Orten in Pennsylvanien, Arkansas und Tord-Carolina, sowie in Kanada angetroffen worden, aber alle diese Torkommnisse werden gुegenwärtig kaum jemals zu Schmucksteinen verschliffen, da diese teurer zu stehen kommen als diejenigen aus dem Mineral von der Labradorkiiste, das zudem einen riel schüneren Schiller zeigt und eine besstre Pulitur annimmt. 


\section{Eläolith.}

Der Klïolith gehört zu der Mineralspezies Nephelin. Es ist ein Natron-TonerdeSilikat ron hexagonaler Kristallform, das durch die Härte $5 \frac{1}{1 / 2}$ bis 6 , das spezifische Gewicht 2,: bis 2,61 und durch die Eigenschaft charakterisiert ist, von Säuren außerorduntlich leicht zersetzt zu werden. Der Nephelin findet sich in der Natur in zweierlei Tarictäten von sehr verschiedenem Aussehen, aber mit den gleichen wesentlichen Eigenschaften. Zunächst bildet er in Form von glasglänzenden, nicht oder doch nur schwach sefärbten Kristalleu oder einzelnen unregelmäßig begrenzten Körnern einen Bestandteil mancher jüngeren vulkanischen Gesteine oder ist auf Hohlräumen in denselben drusenförmig aufgewachsen. Dies ist der eigentliche oder "glasige Nephelin". Die schönsten Kristalle desselben findet man in der Form hexagonaler Prismen meist mit der geraden Endfläche und von vollkommener Farblosigkeit und Durchsichtigkeit in den Auswürflingen des alten Vesuvs, der sogenannten Somma Dieser "glasige Nephelin" wird nie geschliffen; er hat keine Eigenschaft, die ihn zum Schmuckstein empfehlen würde.

Anders ist es mit der zweiten Abart, die als Bestandteil älterer plutonischer Gesteine, namentlich der darnach so genannten Eläolithsyenite, in einigen Gegenden in ausgezeichneter Weise, aber fast nur in Form unregelmäßig begrenzter Körner, kaum in der von Ḱristallen vorkommt. Dieser ältere Nephelin unterscheidet sich von dem jüngeren glasigen wesentlich durch seinen ausgesprochenen Fettglanz, wonach er den Namen Eläolith oder Fettstein erhalten hat. Außerdem ist er nicht durchsichtig, sondern triibe und höchstens durchscheinend; auch nicht farblos, sondern lebhaft bläulichgriun oder braun bis ziegelrot. Beim bloßen Betrachten scheint der Elïolith etwas ganz anderes zu sein als Nephelin, er stimmt aber mit dem glasigen" Nineral in Beziehung auf Kristallform, Zusammensetzung; spezifisches Gewicht usw. vollkommen überein, so daß ein wesentlicher Unterschied zwischen beiden nicht vorhanden ist.

Die abweichende Beschaffenheit des Eläoliths beruht auf der $\Lambda$ nwesenheit sehr zahlreicher Einschlïsse mikroskopisch kleiner Kriställchen, die wenigstens zum Teil dem Augit und der Hornblende, zum Teil auch anderen Mineralspezies angehören. Diese verursachen den Fettglanz und die Farbe und sind auch die Veranlassung eines zarten milchigen, wogenden Lichtscheins, der namentlich an manchen mugelig geschliffenen Steinen deutlich hervortritt. Ganz ähnlich wie beim Katzenauge bildet er ein breites Lichtband, das sich ïber den Stein hinzieht und sich beim Drehen über diesen hinweghewegt. Exemplare, bei denen diese Erscheimung auf einer kräftigen und reinen Körperfarbe schön auftritt, machen cinen schr angenehmen Eindruck und sind nicht ohne Wert, da sie immerhin selten vorkommen, so häufig das Mineral auch sonst ist. Jedenfalls sind sie im Edelsteinhandel nicht viel zu finden. Geschliffen werden meist nur Steine von wrïner Farbe, seltener solche von roter oder brauner. Der Preis steigt bei beiden Sorten bis 3 Mark pro Karat.

Solehe Stiicke kömnen dem Aussehen nach mit Cymophan und mit Katzenauge verwechselt werden. Diese beiden sind aber härter und werden von Quarz nicht geritzt, wohl aber der Eläolith. Sehwerer sind sie ebenfalls, so dab sie in der vierten Flüssigkeit untersinken, in der der Nephelin eben noch schwimmt.

$\Lambda \mathrm{m}$ längsten bekannt ist der Eläolith des südlichen Norwegens, wo ein bis faustgrobe Stiicke des Minerals enthaltender Eliiolithsyenit an mehreren Stellen vorkommt. $\Lambda$ is Fundorte werden auch hier Laurvik und Fredriksvärn genannt, und zwar kommen am ersteren Orte vorzugweise braune und griine, am anderen vorzugsweise rote Stiicke vor. In einem Ghnlichen Gestein am üstlichen Ufer des Ilménsees im Ural in der Näihe des IIüttenwerkes Miask finden sich gleichfalls gröhere Stïcke Elïolith ron roter und grïner Farbe, feruer 
in Siid-(röinland und in den Vereinigten stataten. Hier sind die Hauptfundorte Magnet Cove in Arkansas, wo schön fleischrote, zimmt- und welbhraune, als Edelstein. brauchbare: Stiicke in Menge vorkommen, sowie Gardiner und Litehficld in Maine, wo das Mineral schön wriin ist. Auch Salem in Massachusetts kann noch erwähnt werclen. C̈berall ist der Elaiolith ein Bestandteil eines ähnlichen (iesteins wie in Norwegen und im Lral.

\section{Cancrinit.}

Der grelbe Canerinit, der den Elïolith von Litehfield becrleitet, wird wegen seiner hübschen Farbe zuweilen geschliffen und in Amerika als Schmuckstein getragren. Er enthält dieselben Bestandteile wie der Eläolith, daneben aber noch etwas Kohlensäure und Wasser; auch lisistallisiert er in denselben hexagonalen Formen wie der Tephelin. Er ist höchstens stark durchscheinend, nie vollkommen durchsichtig und seine Farbe geht vom Hellgell, bis zum Dunkelorangegeelh. Das nämliche Material, aber vielfach nicht gelb, sondern rosa, grïn usw. findet sich noch an anderen Orten; es wird aber aufer in den Vereinigten Staaten nirgends benutzt und auch hier nur sehr wenig.

\section{Lasurstein}

(Lapis lazuli, Lasurit).

Der Lasurstein oder Lapis lazuli, auch orientalischer Lasurstein oder orientalischer Lapis lazuli genannt, ist ein vielfach prachtvoll blanes, undurchsichtiges Mineral, das in derben, äußerst feinkörnigen bis dichten Massen mit unebenem Bruch in der Natur rorkommt. Äußerst selten sind Kristalle von Erbsen- bis Bohnengröße, die die Form ron Rhombendodekaedern haben und also dem regulären System angehören.

Besonders wichtig ist die Farbe; auf ihr allein beruht die Schönheit des Steines. Sie ist meist blau, und zwar in den schönsten und besten Stiicken dunkellasurblau, zuweilen ins Schwarzblaue. Eine schöne lasurblaue Farbe, die nicht zu sehr ins schwarze ggeht, zeigt Taf. XX, Fig. 1. Die tiefblauen Stücke werden fast allein zu Schmucksteinen verarbeitet; ihre Farbe ist weit schüner und reicher als die aller anderen undurchsichtigen blanen Steine und namentlich stets dunkler als die des Türkis, der sich dadurch leicht unterscheidet. Nicht selten ist das Nineral aber auch hellblau, sehr blaf bis beinahe ins Farblose; diese weniger dunkeln Stücke, die manchmal mit Türkis verwechselt werden könnten, haben aber als Edelsteine geringe Bedeutung. Man bezeichnet manchmal die helleren Exemplare hier wie bei anderen Edelsteinen als weibliche, den dunkelblauen, männlichen gegenüber. Zuweilen ist das Blau rollkommen gleichmïßig rerteilt, so daß dit ganze Masse ununterbrochen dieselbe Farbe hat; vielfach wechseln aber weiße und blaue Schichten oder Flecken in mehr oder weniger bunter Mannigfaltigkeit mitemander ah. Auch ist die blaue Farbe nicht selten durch gelbe, metallisch gläinzende Punlite unterbrochen, die nicht, wie Laien manchual glauben, Gold sind, sondern dem Mineral Schwefelkies angehören. Wenn sie sich zersetzen, dann entstehen statt der grelben Punkte rostbraune Flecken, die die Steine stark verunstalten. Der blaue Lasurstein ist wahrscheinlich der Edelstein, den die Alten unter dem Namen Sapphir verstanden, nicht der jetzt so benannte blaue Korund.

Die reine blane Farbe ist indessen nicht die einzige, die beim Lasurstein rorkommt. Verbreitet ist namentlich an gewissen Fundorten ein etwas ins Grünliche gehendes Blau; auch 
auscesprochen sriune Steine kommen vor, sind jedoch viel seltener als blane. Dasselbe gilt für die violette und rötlichviolette Färbung, die ebenfalls auf gewisse Fundorte beschränkt zu sein scheint. Mreist reigt ein Stein nur eine von diesen Farben, zuweilen kommen auch blau, griin und rot oder violett nebeneinander vor. Stets ist das Pulver zwar lichter als die dicken Stïcke, aber doch deutlich und in denselben Tönen gefärbt wie diese.

Die Farbe des Lasursteines bleibt nicht unter allen Umständen dieselbe, namentlich ändert sie sich beim Erhitzen. Wird die Temperatur eines Exemplares von hellblauer Farbe his zur schwachen Rotglut erhöht, so wird es häufig schön dunkelblau; das anfänglich zu Schmuelisteinen nicht verwendbare und daher ziemlich wertlose Stiick wird schleifwiirdig, und der Wert steigt erheblich. Allerdings geht beim Erhitzen manchmal auch die reine hell- oder dunkelblaue Farbe in ein wenig angenehmes grïnliches Blau iuber, und wenn die Temperatur zu sehr gesteigert wird, tritt nicht selten vollkommene Entfärbung ein. Dasselbe geschieht bei griinen und violetten Steinen, die aber, wenn die Erwärmung immerhalb der geeigneten Grenzen bleibt, also nicht über schwache Rotglut steigt, wie die hellblauen nicht selten tief und gesättigt dunkelblau werden, wodurch auch hier der Wert nicht unbedeutend zunimmt. Aus Chile kommt ein grünlichblauer Lasurstein, der beim Erhitzen farblos wird, bei der Abkühlung aber seine ursprïngliche Farbe wieder annimmt. Manche Stücke zeigen beim Lirwärmen lebhafte Phosphoreszenz.

Der Lasurstein besitzt in ganzen Stiicken keine Spur von Spaltbarkeit; er hat einen kleinmuscheligen bis unebenen Bruch, auf dem meist schon für das bloße Auge die feinkörnige Struktur hervortritt. Der Glanz auf frisehen Bruchflächen ist glasartig und meist schwach; er wird wohl bei manchen Vorkommnissen etwas kräftiger, geht aber bei manchen anderen bis zum vollständig Natten herunter. Auch durch das Schleifen wird kein besonders lebhafter Glanz erzeugt, am wenigsten bei unreinen oder gefleckten Stiicken, an denen härtere und weichere Stellen miteinander ahwechseln. Die erlangte P'olitur hält sich der geringen IIärte wegen nicht lange; die geschliffenen Steine werden durch den Gebrauch bald matt und unansehnlich. Durchsichtig ist der Lasurstein nicht, höchstens an den feinsten Kanten etwas durchscheinend.

Die Härte geht, wie schon erwähnt, nicht sehr hoch; sie ist etwa gleich $51^{1 / 2}$. Der Lasurstein wird also leicht von Quarz, sogar noch von Feldspat geritzt, ritzt aber seinerseits noch Fensterglas. Auch das spezifische Gewicht ist sehr gering, es ist beinahe am kleinsten unter allen zu Edelsteinen verwendeten Mineralien. Man hat $G_{0}=2,3$ bis 2,12 sefunden und sieht daraus, daf der Lasurstein auch auf der leichtesten Fliissigkeit rom Gewicht des Quarzes $\left(G_{0}=2,65\right)$ noch schwimmt.

Von Salzsäure wird das Mineral zersetzt. Die vielfach beigemengten weißen Partien lösen sich unter Aufbrausen durch Entwicklung von Kohlensäure auf und erweisen sich dadurch als Falkspat. Gleichzeitig wird die blane Farbe allmählich zerstört und dabei oft ('in kriftiger Creruch nach Schwefelwasserstoff, also wie bei faulen Eiem, entwickelt. Kieselsäure wird gallertartig ausgeschieden. Vor dem Lötrohr schmilzt die Substanz sehwer $\mathrm{zu}$ einem farblosen und ziemlich klaren blasigen Gase.

Schon beim Betrachten des Lasursteines mit dem bloßen Auge, oder besser mit der Lupe, erkennt man deutlich, daß er kein einheitliches, homogenes Mineral darstellt wie der Diamant, der Rubin und andere. Man bemerkt, daß in ihm mehrere Substanzen mitcinander gemengt sind. Noch bestimmter tritt dies hervor bei der genaueren ehemischen Untersuchung und bei der Beohachtung von Dünnschliffen unter dem Mikroskop.

Die Analysen zeigen, dab alle Lasursteine zwar dieselben Bestandteile enthalten, aber nicht immer in denselben Verhältnissen; es finden hierbei im Gegenteil recht bedeutende Gehwankungen statt. In der IIauptsache findet man stets Kieselsäiure, aber die Menge 
geht rom 3 bi bis $1 ;$ T Proz. und entsprechend die anderen Bestandteile, die aus der in

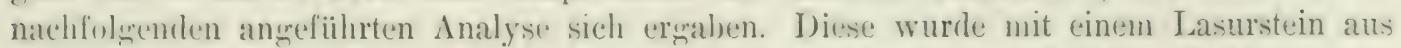

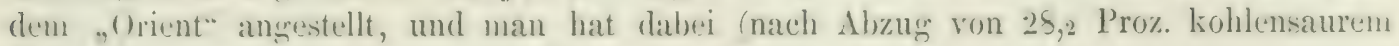
Kalk und 4,5 Proz. kohlensaurer Magnesia) erhalten:

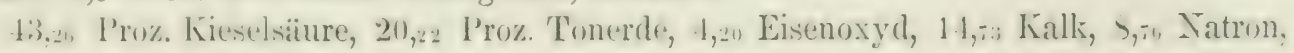
5,6 : Schwefelsäure, 3,16 Schwefel (Summa auf 100,00 berechnet).

Manche andere Stiicke ereden noch einen kleinen (ichalt an Chlor, der bis auf ein halles Prozent steigen kann.

Ifat die stark wechselnde Zusammensetzung des Lasursteines vermuten lassen, daf er ein (itemente versehiedener Muhstanzen ist, so erheht dies die Betrachtung von I) iinnschliffen unter dem Mikroskop) zur vollen Gewifheit. Die einzelnen Bestandteile und ihre Beziehungen zueinander treten dabei deutlich hervor. Meist bildet weileer Kalkifuat oder Kalkstein von feinkörniger Struktur aine Crumdmasse, in der alle die anderen Gemengeteile eingewachsen sind: er ist zuweilen in zrober Menge vorhanden, tritt aber auch vielfach bis zum Verschwinden zuriick. Seine Anwesenheit bedingt rlie weiben Flecken und Streifen, sowie das Aufbrausen mit Salzsïure, ron dem schon ohen die Rede war; daß der Kalk manchmal etwas dolomitisch (magnesiahaltig) ist, ersicht man aus der obigen Analyse.

In dem Kalk erkennt man eine nicht unerhebliche Zahl anderer ganz odter nahezu farbloser Hineralkörper, ron denen die meisten dem Augit und der Ilornblende angehören. Besonders wichtign sind aber gefürbte Körner, die die oben erwähnten Farhen des Lasursteins zeisen. Diese sind mehr oder weniger reichlich rorhanden. Bald rertrüngen sie alles andere und setzen die Steine beinahe für sich allein zusammen, bald sind site aber auch nur vereinzelt dem Kalkspat eingelagert. Sie bilden die eigentliche Lasursteinsubstanz, die dem Kalkspat ihre Farbe und bis zu einem gewissen Grade ihre anderen Eimenschaften mitteilt. Sind viele farbige Kö̈ner vorhanden, dam ist auch die Farbe der Stïcke tief und gesättigt, und je nach ihrer Verteilung sind die letzteren gleichmäßiğ gefürbt oder blau gefleckt und gestreift. Wenn die Kö̈ner blau, grün oder violett sind, dann ist dies auch bei den ganzen Stïcken der Fall. Manche Körner erweisen sich unter dem Jikroskop als sehr intensiv und dunkel gefärbt, manche andere sind hell bis fast farblos, was ehenfalls von Einfluß auf die Fürbung der ganzen Stücke ist. Diese farbigren Einschliisse sind meist nicht regelmäbig begrenzt, sondern fast immer rundlich oder zackig und lappig mit zahlreichen Aus- und Einhuchtungen. Allerdings fehlen auch zuweilen deutliche Kristallformen nicht, die offenhar, wie die oben erwälınten grö̈leren Kristalle, Rhombendodekateder bilden und also gleich ihnen dem regulären system angehören. Damit stimmt anch die einfache Lichtbrechung der meisten ïberein; einzelne brechen die Lichtstrahlen allerdings doppelt, es ist aber wohl zweifellos, daß hier eine anomale Erscheinung vorliegt. Auch Andeutungen von Spaltbarkeit nach den Flächen des Rhombendodekaeders sieht man zuweilen. Nicht selten ist eine gewisse Anzahl kleiner blauer förnchen zu rundlichen Gruppen vereinigt.

Die firbenden Bestandteile des Lapis lazuli sind, wie es den Anschein hat, nicht alle von derselben Beschaffenheit. Tir haben schon gesehen, daß sie in der Farbe und in anderen Eigenschaften gewisse Lnterschiede zeigen, dasselbe ist auch bezïglich ihrer chemischen Zusammensetzung der Fall. Es ist den beiden Nineralogen Brögger und Bäckström bei ihrer wichtigen Lntersuchung des Lasursteines gelungen, die Pigmentlörner nach ihren speziellen Eigenschaften in mehrere Portionen zu tremnen. Ton diesen hat die eine $(\mathrm{H})$ die Zusammensetzung des blauen Minerals Hauyn, das wir noch zu betrachten haben werden, da es ebenfalls zuweilen geschliffen und als Edelstein rerwendet wird; eine zweite (U) hat die Zusammensetzung der künstlichen Terbindung, die 
wir als viel bentuten blaten Farbstoff unter dem Namen Ultramarin kennen, so daß der Lasurstuin his zu einem gewissen Grade nichts anderes ist als natiirliches Ultramarin.

Daneben sind zwar zuweilen einzelne blaue Körner von noch etwas anderer chemischer Natur Forhanden, jene beiden sind aber von diesen Pigmenten die wichtigsten. Ihre Zusammensetzung wird durch die folgenden beiden Formeln gegeben:

$$
\begin{aligned}
& \mathrm{H}=3\left(\mathrm{Na}_{2}, \mathrm{Ca}\right) \mathrm{O} .3 \mathrm{Al}_{2} \mathrm{O}_{3} \cdot 6 \mathrm{Si} \mathrm{O}_{2} .2(\mathrm{Na}, \mathrm{Ca}) \mathrm{SO}_{4} . \\
& \mathrm{U}=3 \mathrm{Na}_{2} \mathrm{O} .3 \mathrm{Al}_{2} \mathrm{O}_{3} .6 \mathrm{Si} \mathrm{O}_{2} .2 \mathrm{Na}_{2} \mathrm{~S}_{3} .
\end{aligned}
$$

In beiden findet sich also das Natron-Tonerde-Silikat $\mathrm{Na}_{2} \mathrm{O} . \mathrm{Al}=\mathrm{O}_{3} .2 \mathrm{Si} \mathrm{O}_{2}$, in welchem beim Hauyn etwas Natron durch die äquivalente Menge Kalk ersetzt ist und zu den beim Hauyn noch eine gewisse Menge Natronsulphat, beim Ultramarin etwas Schwefelnatrium hinzutritt.

In dem Lasurstein, dessen Analyse oben angegeben ist, finden sich nach der Berechnung 76,3 Proz. Hauyn (H) und 15,i Proz. Ultramarin (U); daneben sind noch $7, \pm$ Proz. blaue Körner vorhanden, die nach ihrer Zusammensetzung mit dem Mineral Sodalith übereinstimmen, in welchem anstatt des Natronsulphates oder anstatt des Schwefelnatriums etwas Chlornatrium mit demselben Natron-Tonerde-Silikat verbunden ist, das auch beim Hauyn und Ultramarin die Hauptrolle spielt. Dieses Mengenverhältnis der drei Pigmente ist aber keineswegs immer dasselbe, es schwankt im Gegenteil stark. Der Hauyn überwiegt wohl immer, das Ultramarin tritt zurïck und fehlt auch wohl manchmal ganz, und dasselbe gilt in noch höherem Grade für den Sodalith; aber für das Aussehen der Steine ist dies von keinem erheblichen Belang, da alle drei Körper bezüglich der Farbe im wesentlichen miteinander übereinstimmen. Auf der Zersetzung dieser Silikate beruht die Entfärbung durch Säuren.

Nach den vorstehenden Auseinandersetzungen ist also der Lasurstein, wie er in den Handel gebracht und in der verschiedensten Weise verwendet wird, ein Kalkstein, der von den erwähnten Pigmenten mehr oder weniger reichlich imprägniert ist. Es ist wabrscheinlich, daß diese und die anderen in dem Lasurstein nachgewiesenen Mineralien (Augit, Hornblende usw.) sich durch die Einwirkung eines Eruptivgesteins, eines Granits oder eines ähnlichen, auf den Kalkstein, gebildet haben, daß der Lasurstein also ein sogenanntes Kontaktgebilde ist, wie wir schon manche kennen gelernt haben. Seine Verbreitung auf der Erde werden wir nunmehr betrachten.

Über die Fundorte des Lapis lazuli sind zahlreiche Angaben vorhanden, die aber meist ungeniigend und zum Teil sicher unzuverlässig und sogar falsch sind. Dies hängt damit zusammen, daß manche der betreffenden Gegenden überhaupt noch wenig erforscht und alle wegen ihrer Abgelegenheit wissenschaftlicher Untersuchung wenig zugänglich sind. Namentlich scheint es auch, wie wenn viele als Fundorte angeführte Lokalitäten nur IIandelsplätze wären, über die das allgemein geschätzte Material in den Verkehr gebracht wird. Ton einigen Gegenden sind aber sichere Nachrichten dariber vorhanden, wo und wie sich das Mineral in der Natur findet und wie es gewonnen wird. Die wichtigsten und ergiebigsten liegen in Asien; von hier kommt der meiste und zugleich der schönste, der in der Industrie Verwendung findet. Nicht ganz unwichtig ist auch das Vorkommen in Südamerika, und zwar in Chile, ganz bedeutungslos das in der Gegend von Rom und Neapel.

Am längsten bekannt sind die Lasursteingruben in Badakschan in der nordöstlichsten Ecke von Afghanistan am Oberlauf des Amu Darja (Oxus). Sie liegen ganz in dex Nähe des oben schon erwähnten Fundortes der zentralasiatischen Rubine und Spinelle ind sind wie diese schon 1271 von dem berihhten renetianischen Reisenden II areo l'olo besucht und beschrieloen worden. Späterhin liaben dann noch mehrere andere Forseher Nachrichten ïber das Vorkommen und die Gewinnung des Minerals gregeben. 
Die uralten Iasursteingruben, die aber bis in die Gegenwart im Betrieb geblieben sind, liegen im oberen Teile des Tales des Kokcha (Koktscha) (Fig. 97), eines linken

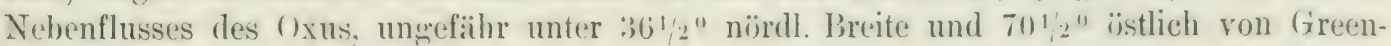
wich, nïrdlich rom Hindukusch zwischen diesen Gebirge und der Chodscha-MohamedKette. Wahrseheinlich gibt is in dieser wenig zug̈̈̈ngliehen Gegend, besonders im IIindukusch, noch manche andere Lagerstïtten des schönen Mincrals, es scheint aber, als of nur die im oberen Koktschatale gelegenen genauer bekannt geworden wären.

Dieses Tal ist da, wo die (rruben sich befinden, sehr eng, nur 200) Yards breit und auf beiden Seiten von hohen, nackten Felsen eingefalit. Die Gruben liegen etwa 1500) FuB iiber dem Flußbette in einem weißen und schwarzen Kalkstein, der das Huttergestein des Lasursteins bildet. Man unterscheidet dort drei Qualitïten, eine von indigroblauer, eine zweite von lichtblauer und cine dritte von grïner Farbe. I) ganze Jaluresproduktion beträigt jetzt ungeführ 36 P’ud oder 600 $\mathrm{kg}$, das gesante gegenwärtig gewonnene Material soll aber im ganzen von geringerer Qualität sein. Friuher war die Produktion erheblich stärker und die Qualitåt besser; Nachrichten aus den zwanziger Jahren des vorigen Jahrhunderts zufolge betrug sie damals ungefähr 300 Pud oder etwa $5000 \mathrm{~kg}$.

Der größte Teil des Lasursteins und besonders die besten Stiicke gehen nach Buchara. Von hier gelangt dann eine große Menge nach Rußland, wo die Weiterverbreitung besonders durch die Messe in Nischny Nowgorod bewirkt wird. Der Preis ist hier schon erheblich höher als in dem Ursprungsgebiet. Außerdem wird von den Gruben viel nach

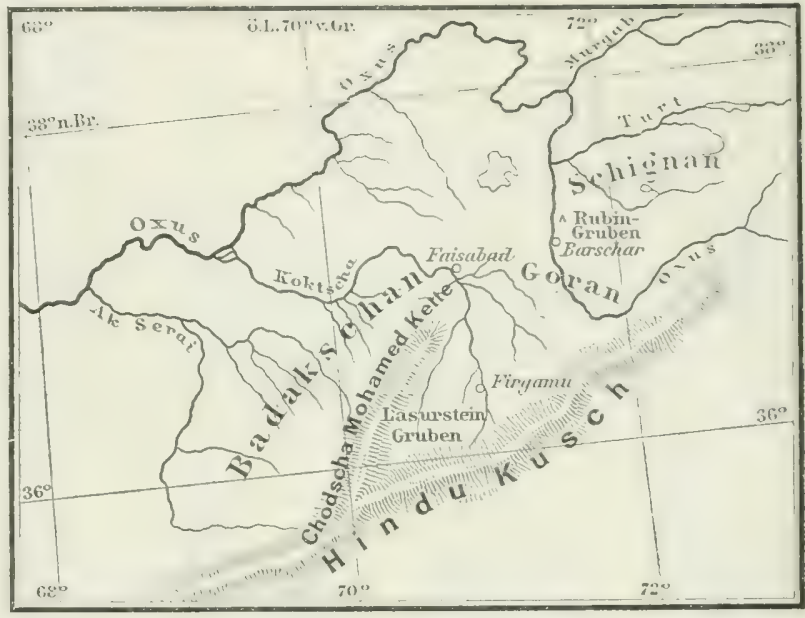

Fig. 97. Lasursteingruben von Baclakschan am oberen Oxus. Malistab: 1: 6000000.

China und mit den Rubinen jener Gegenden zusammen auch nach Persien ausgeführt. Es ist daher wohl möglich, daß die Angaben von Lasursteinvorkommen in Persien, in der kleinen Bucharei, in Tibet und China sich alle nur auf Lasurstein beziehen, der durch den Handelsverkehr aus Badakschan nach den genannten Ländern ausgefülırt worden ist. Jedenfalls sind die Nachrichten über das Vorkommen daselbst, die man in der Litteratur findet, stets nur ganz vag; bestimmte Jitteilungen iber Fundorte usw. sucht man vergeblich. Auch derjenige Lasurstein, der in anderen Teilen von Asien, in Afghanistan, Beludschistan, Indien usw. zum Verkauf gelangt, und der nach der Meinung mancher Reisenden in diesen Gegenden gefunden wird, stammt wahrscheinlich ausnahmslos von den erwähnten Fundstellen im Gebiete des oberen Oxus.

Die Gewinnung des Materials geschieht hier in wenig zweckmïßiger Weise durch Feuersetzen, jetzt noch wie schon vor Jahrhunderten oder gar Jahrtausenden, denn der Lapis lazuli, aus dem die alten Ägypter Skarabïen schnitten, Lat seine Heimat wahrscheinlich gleichfalls in Badakschan und ebenso der sonst im Altertum vielfach benutzte. An dem Orte, wo Lasurstein vermutet wird und wo gearbeitet werden soll, werden große Feuer angezuindet und die erhitzten Gesteine mit Wasser begossen. Im Winter sind die kalten Felsen für diesen Prozeb besonders empfindlich, deswegen ist jener die für den Grubenbetrieb besonders geeignete Jahreszeit. Das Gestein wird dadurch locker und 
bröcklig. Ist das in geniigender Weise bewirkt, dann werden die dabei entstandenen, oft ungeheuren Blöcke mit großen Hämmern zerschlagen und die tauben Massen entfernt, lis man auf ein Nest des gesuchten Minerals stößt. Rings um dieses werden dann tiefe (irmben angelegt und der Lasurstein nebst seinem Nebengestein mittels Brechstangen losgesprengrt. Dabei lassen sich zuweilen große zentnerschwere Tafeln abspalten, die der Schichtung des Gesteins entsprechen. Es wurde die Meinung ausgesprochen, daß die tiefblaue Farbe, die der Lapis lazuli von Badakschan vielfach zeigt, von der starken Erhitzung beim Feuersetzen herrührt, entsprechend der oben erwähnten Erfahrung, daß IIcllblau bei diesem Mineral in der Hitze in Dunkelblau übergeht. Es scheint aber doch, daß dies jedenfalls nicht in voller Allgemeinheit gilt und daß am Oxus von vornherein dunkelblane Stïcke neben hellblauen vorkommen. Nicht selten ist es gerade hier, daf der Lapis lazuli mit gelben Punkten von Schwefelkies durchsprengt ist, die sich manchmal zu größeren Nestern und Streifen zusammenhäufen.

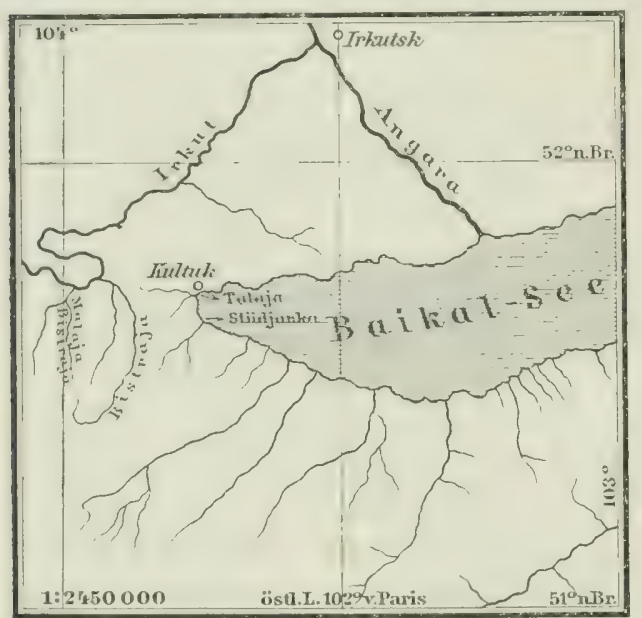

Fig. 98. Lasursteingruben in der Gegend des Baikalsees.

Ein zweites Gebiet von Lasursteingruben liegt am Westende des Baikalsees in Sibirien (Fig. 98), von wo das Material zu den Säulen in der Isaakskirche in St. Petersburg stammt. Das Mineral findet sich hier an mehreren Stellen; an den Bächen Talaja und Malaja Bistraja (kleine Bistraja), sowie an dem Flüßchen Slüdjanka. Der Lasurstein liegt hier in Blöcken bis zu 3 Pud im weißen körnigen Kalk oder Marmor, da wo dieser an Granit stößt, eine Art des Vorkommens, die wahrscheinlich, wie wir gesehen haben, fuir unseren Edelstein iiberall dieselbe ist. Am Baikalsee ist der Lapis lazuli nur an wenigen Stellen so schön und tief blau wie der meiste von Badakschan, enthält auch viel weniger Schwefelkies eingesprengt als dieser. Er ist dagegen fast durchweg frischer und glänzender und stärker durchscheinend. Neben der blauen Farbe ist hier die violette, dunkelgriune und hellrote gleichfalls vertreten. An einzelnen Stücken ist die äußere Rinde tief blau und matt, der Kern rot und glänzend. Es scheint darnach, als ob der rote oder violette Lasurstein erst durch Verwitterung schön blau gefärbt würde. Vielleicht ist auch der dunkelblaue Stein von Badakschan nur stärker verändert und war ursprünglich violett und rot wie der vom Baikalsee.

Der Grubenbetrieh) seheint nirgends besonders lohnend zu sein und ist jedenfalls sehr unsicher. Man hat keine Anzeichen, um durch Versuchsbauten neue Lagerstätten aufzusuchen, und ist daher lediglich auf den Zufall angewiesen.

In dem engen Tal des kleinen und schmalen, 30 Werst langen Flüßchens Talaja, das 2 Werst siddlich von Kultuk in den See mündet, herrscht auf der linken Seite in steil abfallenden W:̈̈nden weilier, dolomitischer Kalk, der stellenweise von granitischen Gesteinen überlagert wird. Den Kalkstein durchziehen Gänge oder Adern, ausgefüllt von einer mehligen, mit Glimmer vermischten Kalkmasse, in der neben Brocken von festem Kalk Kinollen und Bruchstïcke von Lasurstein liegen, wie es das in Fig. 99 dargestellte J'rofil zeigt. Bis zum Jahre 1553 waren hier drei Gruben im Betrieb, die später, nach der Entdeckung der reichhaltigeren Lagerstïtte an der Malaja Bistraja und wegen der ungenïgenden Beschaffenheit des gewonnenen Materials, verlassen wurden. 
1)asselbe geschah, ebenfalls wegen der schlechten Qualität des Lasursteins und wegren der Miirte des umgebenden Gesteins mit den langre Zeit hindurch bearbeiteten Gruben an der Slïdjanka, 12 Werst sïdlich vom Dorfe Kultuk, die aber später wieder geöffnet wurden. Auch hier findet sich der Lasurstein nesterartig im weißen Marmor auf der Grenze zum Granit und Gneis, die dort mit dem Marmor häufig abwechseln. Aber nicht nur anstehend im Felsen, sondern auch als Gerölle im Flusse trifft man den Stein auf einer Erstreckung von 35 Werst (etwa 5 deutsche Meilen). $\mathrm{Er}$ variiert in den schönsten $\mathrm{Ab}$ -

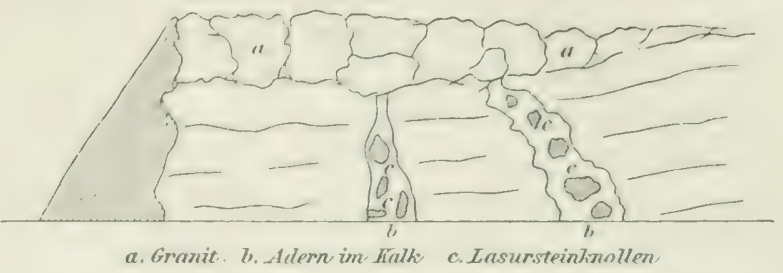

Fig. 99. Vorkommen des Lasursteins an der Talaja (Baikalsee). änderungen rom dunkelsten, gesüttighten Ultramarinblau bis zum Blaßwolkigen, mit den reizendsten Übergängen in Violett, Seladongrün usw.

Am reichsten sind die 1554 entdeckten Ablagerungen an dem Flülehen II a laja B istraja. Die dortigen Gruben sind daher längere Zeit allein bearbeitet worden, um so mehr, als das von hier stammende Material rortrefflich und von großer Schönheit ist, und eine ganz besondere Gleichmäßigkeit besitzt. Die besten Steine der ganzen Gegend stammen aus diesen Gruben, die an dem linken Arme des Baches liegen, der sich 10 Werst oberhall) der Mïndung mit dem rechten Quellbach vereinigt. Hier herrschen granitische Gesteine. In dem Gebirgsrïcken, der die rechte Seite des Tales bildet, lagern sicb an diese in beinahe senkrechter Stellung Schichten von verïndertem weifem, dolomitischem Kalke mit körniger Struktur an, in dem der Lasurstein eingesehlossen ist, und zwar ebenfalls auf Spalten und $\Lambda$ dern, die mit lockerem Material ausgefuillt sind. Je weiter man in diesen in die Tiefe vordringt, desto mehr nimmt der Lasurstein an Menge und Schönheit zu. An den Schurfstellen sieht man, daß er sich dort auf einem Raume ron 7000 Quadratfuß findet. Hin und wieder bemerkt man anch etwas Schwefel in der Nachbarschaft. Auch in der Kleinen Bistraja sind Knollen von Lasurstein vorgekommen, darunter solche, die ein Gewicht von $3 \mathrm{Pud}(60 \mathrm{~kg}$ ) haben; ebenso trifft man derartige Geschiebe in dem in die Malaja Bistraja mïndenden Flïßchen Turluntaj, was auf eine weitere Terbreitung des Minerals hinweist. An der Malaja Bistraja kommen gleichfalls violette und mehr oder weniger dunkelgrüne Varietäten neben der blauen vor.

Endlich finden sich größjere Mengen von Lasurstein in den chilenischen Anden. Nach der Nitteilung von P hilippi liegt die Fundstätte bei den Quellen der Bäche Cazadero und Tias, kleiner Zuflüsse des Rio Grande, in der Kordillere von Oralle, wenige Cuadras ron der Strafe entfernt, die nach den argentinischen Provinzen führt und in geringer Entfernung von der Wasserseheide, noch auf chilenischem Gebiet. Das Mineral kommt, von Schwefelkies begleitet, in Stïcken von verschiedener Größe in einer mächtigen Schicht von weißem und grauem Kalkstein eingeschlossen ror. Dieser Kalkstein ruht auf Tonschiefer und wird seinerseits bedeckt ron einem anderen geschichteten Gestein, reich an Eisenerz und Granat. Über dieser letzteren Schicht liegt Granit, der den. oberen Teil der Berge bildet. Auch auf sekundärer Lagerstätte, herausgelöst aus dem Zusammenhang mit seinem Iuttergestein, findet sich der Lasurstein in einzelnen Stiicken in einer kleinen Ebene, zugleich mit Fragmenten von Granit, Schiefer und Eisenerz in einem Lager ron Geröll, das durch Verwitterung der anstehenden Gesteinsmassen entstanden ist. Der chilenische Lasurstein, der an der genannten Stelle in einiger Menge gewonnen wird, ist meist blaßblau ins Grïne und ron weißen Streifen durchzogen. Er wird daher viel weniger geschätzt und schlechter bezahlt als der asiatische.

B a uer, Edelsteinkunde, 2. Anf. 
Geringe Mengren Lasurstein von erdiger Beschaffenheit, also zu Schmucksteinen nicht geeignet, findet man in den Kalkanswürflingen des alten Vesuvs, der Somma, sowie in den Kalkeinschlïssen der vulkanischen Tuffe im Albaner Gebirge bei Rom; hiervon soll hier nicht weiter die Rede sein. Jedenfalls zeigt aber dieses Vorkommen, wie alle anderen. dafs die oben erwähnte Auffassung des Lasursteins als Kontaktmineral im Kalk große Wabrscheinlichkeit für sich hat.

Der Lasurstein war im Altertum sebr beliebt, namentlich wurde viel in ihn graviert und erhabene Figuren aus ihm geschnitten. Auch jetzt noch ist er, wenngleich weniger als früher, sehr geschätzt und dient namentlich zu Ringsteinen, Broschen und zu ähnlichen Zwecken. Auch im Orient, in China usw. wird der Stein sehr vielfach verwendet. 1) a die Schönheit ausschließlich auf der blauen Farbe beruht, so sucht man diese recht rein zu erhalten und schneidet daher aus den rohen Stücken möglichst gleichartig blaugrefärbte Teile heraus, um sie zu schleifen. Man gibt dabei entweder eine ganz ebene Flïche oder wählt eine flach mugelige Form; Facetten sind wegen der vollständigen Undurchsichtigkeit ohne jede Wirkung.

Der Preis war früher, als noch eine umfangreiche Verwendung in der Malerei stattfand, höher als jetzt. Er wird bestimmt durch die Größe des Steines und durch die Reinheit und Gleichmäßigkeit, sowie durch die Tiefe und Sättigung der blauen Farbe; eine andere als diese ist nicht beliebt. Das reine, nicht zu tiefe Lasurblau ist am wertvollsten, weiße und gelbe Flecken driicken den Preis sehr herunter; am wenigsten geschieht dies, wenn sie ganz gleichmäßig und regelmäßig verteilt sind. Sehr niedrig im Preise steht der blaßblaue und der grünliche Lapis lazuli.

Das Rohmaterial für die Schleifereien bilden meist kleinere Stiicke, die nach dem Kilogramm verkauft werden. Solche von Nußgröße gehören schon nicht mehr zu den gewöhnlichen Vorkommnissen. Derartige Stücke von der besten Sorte kosten 300 MIark das Kilogramm; größere einheitlich und schön gefärbte Stïcke sind noch viel teurer, bis über 500 und sogar gegen 600 Mark das Kilogramm im europäischen Handel. Für geschliffene Steine zahlt man $2_{1 / 2}^{1 / 2}$ bis $4^{\prime / 2}$. Iark pro Gramm, je nach Farbe, Größe und Form, ja sogar bis 10 Mark pro Stück.

Viel häufiger als zu Schmucksteinen wird der Lasurstein zu allen möglichen kleinen Gegenständen, Briefbeschwerern, Leuchtern und anderen Galanterieartikeln verarbeitet auch zu kleinen Schalen, Vasen usw. Frïher machte man jeden solchen Artikel meist aus einem einzigen Stïck; sie waren daher sehr teuer, da eine hierzu erforderliche Größe ler rohen Blöcke selten ist, auch wenn man sich, wie es bei solchen Gegenständen der Fall zu sein pflegt, mit einer geringeren Sorte begnügte. Gegenwärtig werden derartige Sachen aus Metall hergestellt und mit dünnen Plättehen von Lasurstein belegt (fourniert). Auch gröfere Gegrenstände sieht man zuweilen in dieser Art mit Lasurstein geschmïckt. So wurden im Winterpalais in St. Petershurg und im Schloß von Zarskoje Selo Zimmer mit Lasurstein getäfelt und anderer ähnlicher Luxus getrieben. Von den Säulen in der Isaakskirche in St. Petersburg ist schon oben die Rede gewesen. Bei der Herstellung von Steinmosaik findet das Mineral ebenfalls Verwendung, wobei vielfach die gelben, glänzenden Schwefelkiespunkte die Gestirne auf dem durch den Stein gebildeten blauen Himmel vorstellen. Schon Plinius vergleicht den Stein mit dem sternbedeckten Firmament. Jedenfalls kontrastiert der Schwefelkies mit seiner goldgelb grlänzenden Farbe sehr schön gegen den tiefblauen Stein.

In frïheren Zeiten hatte der Lasurstein eine sehr wichtige Anwendung in der IIalerei; man verfertigte aus ihm das natïrliche Ultramarin. Dunkelgefärbte Stiicke wurden pulverisiert und die blauen Bestandteile unter möglichster Entfernung der nicht gefö̈rbten gereinigt, was allerdings stets nur in sehr geringem Maße gelang. Das feine Pulver, 
seinerzeit der einzige schion blane Farbstoff, famd dann unter dem Vamen Lltramarin als Malerfarbe Verwenclung. Dies hat aber jetzt fast ganz aufgehört, seit man eine ebenso schion blane Farbe fabrikmälfig herstellen kann. Dies ist das schon oben erwähnte, kïnstlielse Cltramarin, das sehr nahe dieselhe Zusammensetzun und dieselbe Beschaffenheit hat wie das natiuliche. Es unterscheidet sich aber vorteilhaft von dem letzteren, das sehr hoch bezahlt werden mußte, durch einen viel niedrigeren Preis.

Mit dem Lasurstein kïnnen verschiedene andere blaute undurchsichtige, Steine und kïnstliche Substanzen verwechselt werden. und diese werden ihm wohl gelegrentlich auch betrügerischer Weise mutereschohen. Sehr tïuschend kann Ialsurstein in Glas nachgemacht werden, aluer beim Glas ist die Farbe geringer und das spezifische fiewicht höher, und auf jeder, auch der kleinsten Bruchfläche, erkennt man den glänzenden muschligen Bruch des Glases im Gegensatz zu dem unelenen matten Bruch des Lasursteins. Achat wird zuweilen kïnstlich hlau gefärbt und dann im Handel wohl gelegentlich als Lasurstein bezeichnet; bei dem blanen Achat ist aher IIärte und squezifisches Gewicht gröber als beim echten Lasurstein, auch ist die Farbe hier mehr ein dunkles Berlinerblau, nicht das leuchtende Lasurblau des Lasursteins. Die blane Kupferlasur soll ebenfalls zuweilen als Lasurstein auftreten; sie ist weicher, aber viel schwerer als dieser ( $\mathrm{f}$. $=3,3$, und lüst sich in Salzsäure, wegen der Entwicklung von Kohlensäure unter andauernden Blasenwerfen, aber ohne Abscheidung einer Kieselgallerte, leicht und vollständig auf. Mit dem stets helleren Türkis komut wohl selten eine Terwechslung vor, auch der blaue Lazulith wird wohl kaum zur Täuschung des Publikums benutzt oder mit Lapis lazuli verwechselt. Der sog. Lasurstein von Ditro in Siebenbïrgen ist Sodalith (S. 548).

\section{Hauyn.}

Der obengrenannte, in dem Lasurstein als färbende Substanz vorkommende Uauyn findet sich in manchen vulkanischen Gesteinen in Form unregelmäßiger, meist schün lasur- bis himmelblauer Körner, viel seltener in regelmäßigen Kristallen ron der Form des Rhombendodekaeders. Hauptfundorte sind die Gegend des Laacher Sees bei Andernach am Rhein (Niedermendig usw.), das Albaner Gebirge bei Rom (San Marino usw.), die Auvergne in Frankreich usw. Dieser reine Hauyn wird zuweilen wegren seiner schönen Farbe, die nun aber hier mit vollständiger oder doch annähernder Durchsichtigkeit verbunden ist, geschliffen. Namentlich in Frankreich soll der Stein tine gewisse Verbreitung haben; er ist jedoch im Edelsteinhandel sehr wenig wichtig, hat aber trotzdem, wenn er nach Farbe und Durchsichtigkeit zum Schleifen taugt, einen nicht ganz gering'en Preis.

Die Hauynkristalle oder -Körner sind nach den Richtungen der Dodeliaederflächen deutlich spaltbar, durchsichtig bis durchscheinend und einfach lichtbrechend. Die Härte ist gleich $5 \frac{1}{2}$, das spezifische Gewicht ungefähr gleich 2,t. Mit Hilfe dieser Eigenschaften kann man den Hauyn von anderen blauen Steinen unterscheiden.

\section{Sodalith.}

Außer dem Hauyn hat auch wohl die blane Tarietät des sodaliths eine beschränkte Terwendung als Schmuckstein gefunden. Er spielt wie jener cine allerdings geringe Rolle unter den färbenden Bestandteilen des Lasursteins, findet sich aber auch in Kristallen des recrulären systems, sowie in größeren derben Kïrnern, die jedoch meist farblos oder unansehnlich gefürbt sind, aber doch manchmal auch eine ausgesprochene Farhe besitzen. Von diesen sind namentlich die blauen zuweilen recht schön und manche Stiicke werden dem Lasurstein sehr älınlich. Sie sind es, die zuweilen geschliffen werden, namentlich 
die aus einem syenitischen Gestein, das bei Litchfield im Staate Maine in den Vereinigten Staaten in losen Blöcken herumliegt; sie finden dort als heimische Steine eine beschrïnkte Verwendung. Ähnliches Material liefern Gesteine derselben Art von Ditro in Siebenbüren und von Miask am Ilménsee im Ural. Sehr schön blau und ganz ähńlich dem Lasurstein ist der um 1900 aufgefundene Sodalith von Bancroft, Dungannon Township, Hastings County, Ontario in Kanada. Der Sodalith spielte schon unter dem Schmuck der Ureinwohner des bolivianischen Hochlands eine gewisse Rolle. Der Reisende Alfons Stübel hat in dem Trümmerfeld von Tiahuanaco in der Nähe des Titicacasees, einer der ältesten Stätten sïdamerikanischer Kultur, Schmuckperlen aus blauem Sodalith gefunden, zusammen mit Pfeilspitzen aus Quarz und Obsidian usw. Der dortige Sodalith ist nicht in der Umgegend gefunden, sondern aus unbekannter größerer Ferne herbeigeschafft.

\section{Obsidian.}

Der Obsidian ist kein eigentliches Mineral, sondern eine glasartig erstarrte Lava aus der Gesteinsfamilie der Trachyte, ein vulkanisches Gesteinsglas, das zuweilen zu Schmucksachen verarbeitet wird. Dieser seiner Natur entsprechend, wird er von den Steinschleifern auch als Lava, schwarze Glaslava, vulkanisches Glas, Glasachat usw. bezeichnet.

Wie das künstliche Glas ist auch dieses natïrliche, der Obsidian, vollkommen amorph und daher einfach lichtbrechend. Er zeigt den schönen großmuscheligen Bruch; den man immer an größeren Glasstücken sieht, und ebenso deren charakteristischen Glanz, der allerdings zuweilen auch ins Fettige geht. Typischer Obsidian ist dem gewöhnlichen Glase in allen Beziehungen außerordentlich ähnlich, nur die Farbe und die Durchsichtigkeit machen einen Unterschied. Der Obsidian ist nämlich fast stets mehr oder weniger stark und dunkel gefärbt, schwarz, grau, braun, gelb, rot, grïn, zuweilen auch blau. Dieser tiefen Färbung entsprechend sind dicke Stiicke beinahe immer vollkommen undurchsichtig, nur dünne Splitter und die feinsten Ränder der Bruchstücke sind durchsichtig und dann auch vollkommen farblos, oder doch sehr licht gefärbt in einer der genannten Nuancen. Die Farbe ist entweder über das ganze Stiick hinweg gleich, oder es wechseln mehrere Farben in Flecken, Streifen und anderen Zeichnungen ab. Eine fein braun und grau gestreifte Varietait aus Nordamerika hat den Namen „Bergmahagoni“ (mountain mahogany) erhalten; sie zeigt geschliffen eine Maserung, ähnlich der des Mahagoniholzes. Wichtiger und verbreiteter ist aber der einförmig schwarze Obsidian; beinahe nur dieser wird zu Schmucksteinen verarbeitet, jedoch bloß, wenn er vollkommen gleichmäßjig gefärbt und homogen erscheint; er ist um so beliebter, je gleichartiger und je mehr sammetartig schimmernd die Farbe ist.

Nicht immer zeigt der Obsidian die erwähnte Beschaffenheit, sehr häufig findet man zahlreiche Kristalle, oft von erheblicher Größe darin eingewachsen. Derartige unreine Stiicke werden nie benützt. Aber auch die scheinbar vollkommen homogenen Massen sind es nicht in aller Strenge. Unter dem Mikroskop erkennt man, daß auch der für das blobe Auge ganz gleichartig aussehende Obsidian eine große Zahl winziger runder IIohlräume (sogenannte Dampfporen) und Kriställchen aller Art, sowie verschiedene sonstige Linschlüsse beherbergt. Diese schaden wegen ihrer geringen Größe der Schönheit des Ausseltens nicht das mindeste, sie bewirken aber zuweilen den schon erwïhnten Fett- 
glanz, und in einzelnen Fiallen verleihen sie den Stiicken einen eigentümlichen sehönen rötlichen, silbelweiben oder grïnlichgelben, und dann'manchmal prächtig goldgrünen Schiller auf der dunkeln Körperfarbe. Dieser schillernde Obsidian ist viel höher gresehiitzt als der, dem diese Erscheinung fehlt, er ist aber nicht besonders häufig. Der Wert ist um so größer, je reicher und kräftiger der Schiller ist.

Der Obsidian hat wie das kïnstliche Glas ein niedriges spezifisches Gewicht, das meist zwischen 2,3 und 2,; schwankt und 2,i; selten erreicht oder gar übertriff. Die chemische Zusammensetzung ist der Lavanatur gemäls nicht immer konstant dieselbe, sondern bei jedem Vorkommen etwas anders, aber alle Obsidiane sind Alkali-TonerdeSilikate, in denen namentlich ein kleiner Kaligehalt nie fehlt. Die Kieselsiiure schwankt zwischen 60 und 80 Proz. und demgemäß auch die Menge der ïbrigen Bestandteile, die im wesentlichen die gleichen sind wie in den grewöhnlichen Glassorten, nur sind die Mischungsverhältnisse etwas abweichend. Ein schön schwarzer Obsidian von der Insel Lipari hat bei der Analyse von Abich ergeben: 74,05 Proz. Kieselsüure, 12,97 Tonerde, 2,73 Eisenoxyd, 0,12 Kalk, 0,2s Magnesia, 5,11 Kali, 3,ss Natron, 0,31 Chlor, 0,22 Gliuhverlust (Wasser), Summe $=99,67$.

In Übereinstimmung mit Glas ist die Masse sehr spröde und zerspringt leicht in äßerst scharfkantige Stiicke. Beim Schleifen muß daher große Sorgfalt angewendet werden, damit nicht am Rande kleine Splitter ausspringen; aus demselben Grunde ist auch beim 'Tragen von Obsidianschmuck Vorsicht geboten. Die Härte ist ungefähr die des Fensterglases und beträgt 5 bis $5 \frac{1}{2}$; der Obsidian wird daher von Feldspat und noch leichter von Quarz geritzt, während er selbst Fensterglas wenig oder gar nicht angreift. Säuren, mit Ausnahme von Flußsäure (Ätztinte), sind ohne jede Einwirkung. Der Obsidian schmilzt nicht besonders schwierig vor dem Lötrohre unter Aufschäumen und erstarrt dann zu einer porösen grauen Masse.

Beim Schleifen nimmt er stets eine sehr gute Politur an und daher wird zu den verschiedensten Schmucksachen verarbeitet. Die schillernden Exemplare erhalten eine mugelige Form, auf der der Schiller am schönsten und kräftigsten hervortritt. Die schwarze Varietät dient häuptsächlich zu Trauerschmuck aller Art, zu Broschen, Manschettenknöpfen, Hals - und Armbändern usw., während Ringsteine und älnnliches nur selten aus diesem Material hergestellt werden. Gewöhnlich gibt man den Steinen eine ebene oder schwach gewölbte Oberfläiche, seltener eine stärker gekrimmte, eigentlich mugelige Form. Auch Facetten sieht man wegen des starken Glanzes vielfach angebracht, und diese sind meist in der Art wie bei den Rosetten angeordnet. Ebenso werden aus Obsidian vielfach runde oder facettierte, in der Mitte durchbohrte Perlen von verschiedener Form angefertigt und auf Schnïre aufgefaßt getragen.

In friiheren Zeiten war die Benutzung des echten natürlichen Obsidians umfangreicher als jetzt. Gegenwärtig ist man imstande, künstliche schwarze Glïser herzustellen, die ihn an Schönheit, Tiefe und Gleichmäßigkeit der Färbung und in dem sammetartigen Schimmer des Glanzes meist erheblich ïbertrefien. Diese werden daher vielfach vorgezogen; es ist meist unmöglich, an geschliffenen Stiicken mit Sicherheit zu erkennen, ob nan es mit einem kïnstlichen oder natiirlichen Produkt zu tun hat. Leichter ist die Unterscheidung von einer anderen vielfach zu Trauerschmuck verarbeiteten schwarzen Substanz, dem Gagat oder Jet. Wie wir unten sehen werden, ist es eine Art Koble, die, wie alle derartigen organischen Körper, die Wärme schlecht leitet und sich daher warm anfühlt, während der Obsidian wegen seiner besseren Wärmeleitung bei der Berührung mit der Hand ein Kältegefühl erzeugt. Alle anderen schwarzen Steine, die ge legentlich im Edelsteinhandel vorkommen, wie schwarzer Turmalin, Spinell (Ceylanit) und andere, haben ein höheres spezifisches Gewicht, als der Obsidian und sinken in der 
vierten Flïssigkeit, auf der letzterer schwimmt; der schwarze Hämatit, den man nicht selten als Ringstein trifft, ist außerdem noch ausgesprochen metallisch glänzend und gibt auf einer rauhen Porzellanplatte einen roten Strich, Obsidian einen farblosen.

In seinen rerschiedenen Abarten ist der Obsidian außerordentlich verbreitet und tritt in manchen fregenden in großen Mengen auf. Wenn auch die überwiegende Masse, die meist aus mehr oder weniger scharfkantigen, oder auch unregelmäßig rundlichen, an Tler Oherfläche häufig rauhen Blöcken oder Stücken, zuweilen aus runden Kugeln besteht, iibcrall unrein und zum Schleifen ungeeignet ist, so findet man doch dazwischen reine und lomogene Stiicke von jeder zu den obengenannten Zwecken wünschenswerten Größe so reichlich, daß der Materialwert auch der schönsten Steine sehr niedrig ist. Der Preis der Schmuckstiicke geht daher über den ebenfalls nicht sehr betrïichtlichen Schleiferlohn wenig hinaus. Der großen Verbreitung wegen ist es unmöglich, alle Fundorte aufzuführen, es sollen daher hier nur einige der wichtigsten kurz erwähnt werden.

In Europa ist die Insel Lipari sebr reich an schönem Obsidian. Ein hauptsächlich aus diesem Gestein bestehender Lavastrom erstreckt sich in einer Mächtigkeit bis zu 100 Fub und in einer Breite von einer Achtelmeile vom Monte Campo bianco bis ans Meer bei Capo Castagno. Auch die Nachbarinsel Vulcano beherbergt viel Obsidian. Auf den Ponzainseln durchsetzt schwarzer Obsidian iu Gängen die vulkanischen Tuffe. Sehr verbreitet ist das Gestein in Ungarn und auf der Insel Island, wo namentlich, wie in Lipari, viel schönes, schleifwürdiges Material gesammelt werden kann. Nach jenem Torkommen wird der Obsidian von den Steinschleifern auch vielfach als ,isländischer Achat" bezeichnet.

Das Land, wo, wenigstens in früheren Zeiten, die umfangreichste Verwendung zu allen möglichen Zwecken stattgefunden hat, ist jedoch Mexiko. Die Ureinwohner verfertigten sich, wie noch jetzt manche dort heimischen Indianerstämme, Pfeil- und Speerspitzen, Messer und andere Geräte und Waffen aus Obsidian. Messer wußten sie einfach durch zweckmäßjiges Abschlagen langer und dünner Splitter von größeren Stïcken mit einer solchen Schärfe herzustellen, dafs sie sogar zum Rasieren geeignet waren. Auch Spiegel, Masken und andere Figuren, sowie Schmucksachen haben sie daraus angefertigt, wie die Funde in alten Wolnn- und Begräibnisstätten usw. zeigen. Obsidian ist zwar in Mexiko sehr verbreitet und zieht sich von hier aus noch weit nach Siiden und Norden. Es scheinen aber doch hauptsächlich einige Punkte gewesen zu sein, die den alten Mexikanern das Rohmaterial lieferten. Am bekanntesten ist der jetzt sogenannte Cerro de las Navajas, der Messerberg, der zuerst durch die Beschreibung von Alexander von Uumboldt genauer bekannt wurde. Er liegt bei Real del Monte in Staate Hidalgo, nördlich von der Stadt Mexiko und in der Nähe der Stadt Atotonilco; noch beute sind die alten Gruben, deren Anlage bis weit vor die Zeit der Eroberung des Landes durch die Spanier hinaufreicht, deutlich zu sehen. Die Farbe der hier vorkommenden Stiicke ist mannigraltig, aher meist schwarz; von hier stammen auch sehr schöne schillernde Obsidiane.

In Nordamerika sind hauptsïchlich der Silver Peak im Staate Nevada und der Obsidian Cliff in dem Nationalpark am Yellowstone River als Fundorte massenhaften schönen Materials zu erwïhnen. Der oben genannte, braun und grau gestreifte „Ber@mahagoni" findet sich mit anderen Obsidiansorten längs des Pitt River in Kalifornien; braun und schwarz gefleckt ist der Obsidian von Drewsey in Oregon, und so gibt es in jenen Lande noch manche Lokalität, deren Produkt zuweilen geschliffen wird.

In A sien ist von einiger Bedeutung der Kaukasus, wo ebenfalls schillernder Obsidian nehen anderem gewonnen wird. Ein soleher vom Ararat mit sehr reichem Schiller wird in Tiflis außer zu Schmucksachen auch zu Vasen, Schalen und anderen größeren Kunst- 
gexenstïnden verarbeitet. Eine gewisse beschräinkte Verwendung haben die schïn und teils gleichmäljig urefirbten, teils bunten Obsidiankugeh von brauner und grauer, iofters anch welber und roter Farbe, sowie von allen Graden der Durchscheinenheit von Flusse Marekanka bei Ochotzk in Ostsibirien, die unter dem Namen Marekanit den Mineralogen bekannt sind. (xanz älınliches Material findet sich ïlrigens auch anderwärts, so an manchen Orten in Mexiko und sonst.

Dem Obsidian sehliefit sich eine ähnliche grlasartiene Substanz an, deren Entstehung aber noch nicht genïgend aufgeklärt ist und die man daher, sowie wegren ihres ab)weichenden Aussehens, von jenem getrennt bält. Auch sie wird in Edelsteinhandel meist als Obsidian bezeichnet. Es ist dies der

\section{Moldawit.}

Der Moldawit wird von den Mineralogen wegren seiner Ähnlichkeit mit griinem Bouteillengrlas, sowie mit dem oben beschriebenen grinen Olivin oder Chrysolith auch Bouteillenstein oder Pseudochrysolith genannt. Aus den letzteren Grunde heibt er bei den Steinschleifern zuweilen Wasserchryolith, meist aber Obsidian. Die Ühereinstimmung mit den beiden erstgenannten Substanzen im Aussehen ist in der Tat auferordentlich grol, so daf eine Unterscheidung ohne genauere Untersuchung bei geschliffenen Steinen nicht immer mit Sicherheit möglich ist.

Der Moldawit ist wie der Obsidian ein dem Glase analog zusammengesetzter und beschaffener Körper, der sich von dem Obsidian für das bloße Auge nur durch die vollkommene Durchsichtigkeit und die meist grüne Farbe der frischen Stücke unterscheidet. Letztere, in auffallenden Licht fast schwarz, geht im durchfallenden vom Lauchgrïnen bis ins Pistaziengrüne und Olivengriine und ist nie sehr tief und dunkel. Einzelne Stiicke sind auch lichtgrïn und lichtbraun oder dunkler bräunlicbgriin. Verwitterte Exemplare sind triib, hellgelblichbraun bis schmutzigweif. Zu Schmucksteinen werden ausschließlich nur ganz klare und durchsichtige und meist nur schön grïne Moldawite verschliffen, aber auch bei den besten Stiicken hat die Farbe etwas Duisteres. Die Nasse ist amorph und daher einfach lichtbrechend und nicht dichroitisch. Die Lichtbrechung ist gering; der Brechungskoeffizient ist ungefähr: $n=1,5$, also wesentlich kleiner, als beim grïnen Bouteillenglas, wo ungeführ $\mathrm{n}=1,6$ ist. Beim Zerschlagen erhält man wie beim Obsidian leicht scharfkantige Bruchstiicke und grofmuschelige Bruchflächen mit starkem Glasglanz. Die Härte ist auch hier etwa gleich $5 \frac{1}{2}$, aber das spezifische Gewicht geringer als meist beim Obsidian und beim Flaschenglas $\left(G_{0}=2,58\right)$, nänlich nur gleich 2,36.

Wenn sich so der Moldawit für das bloße Auge wie ein Stück Bouteillenglas oder wie ein grïner durchsichtiger Obsidian darstellt, so sind doch auch bestimmte Lnterschiede von diesen beiden Substanzen vorhanden. Bei der Untersuchung unter dem Mikroskop sieht man die ganze Masse durchseizt von zahllosen winzigen Lufth)läschen oder Dampfporen, die in dieser Weise weder im Glas, noch im Obsidian vorkommen. Dagegen fehlen im Pseudochrysolith durchaus die im Obsidian fast stets vorhandenen mikroskopisch kleinen Kriställchen. Ferner zeigt die chemische Analyse, daßf der Moldawit in der Zusammensetzung mit dem grimen Flaschenglase so wenig übereinstimmt wie mit dem Obsidian. Der von Trebitsch in Mähren enthält nach C. von John: iS, bi Proz. Kieselsiiure, 12,01 Tonerde, 0,16 Eisenoxyd, 3,09 Eisenoxydul, 0,11 Manganoxydul, 1,6. Kalk, 1,30 Magnesia, 0,44 Natron, 3,06 Kali; zusammen 100,49. Der Kieselsäuregehalt sinlit zwar bei einzelnen Stiicken auf etwa 76 Proz., steigt aber dagegen bei anderen auf S3 Proz. Auch in der Schmelzbarkeit zeigt der Moldawit ein anderes Verhalten als Glas und 
Obsidian: er schmilzt im Gegensatz zu diesen sehr schwer, ohne sich aufzublähen, und gibt nach dem Erkalten eine vollkommen klare Masse.

Aus allen diesen Unterschieden ist $\mathrm{zu}$ ersehen, daß der Bouteillenstein weder durchaus die Beschaffenheit eines grünen Glases noch die eines durchsichtigen Obsidians hat. Trotz großer Übereinstimmung nach beiden Seiten sind doch zu bedeutende Abweichungen vorhanden, und so wurde lange darüber gestritten, ob der Moldawit eine natürliche Glaslava, oder aber nicht vielmehr ein Kunstprodukt, und zwar ein Überbleibsel einer alten Clasindustrie sei, die in seiner Heimat in Böhmen und Mähren frïher betrieben wurde und die dort zum Teil noch jetzt im Gange ist. Vor einigen Jahren ist noch eine dritte jetzt wohl am meisten verbreitete Ansicht geäußert worden. Die Stücke des Moldawits haben eine eigentïmlich gestaltete Oberfläche, wie sie bisher nur an echten Meteoriten beobachtet worden ist. Man hat daher aus diesem sowie aus anderen Gründen auch dem Moldawit einen außerirdischen, meteorischen Ursprung zugeschrieben.

Was die Art und Weise des Vorkommens auf der Erde anbelangt, so hat man den Moldawit noch nie in einem festen Gestein ein-oder an ein solches angervachsen beobachtet, jedenfalls sind Angaben hieriiber recht zweifelhaft. Immer findet er sich oberflächlich im Boden, und zwar in Form einzelner loser Stücke, die nie Faustgröße erreichen, meist sogar viel kleiner sind. Sie haben eine rundliche, mehr oder weniger elliptische oder flach tafelförmige Gestalt und eine charakteristische, eigentiumlich rauhe, runzelige oder narbige, wie zerfressen aussehende matte Oberfläche. Daher sind auch ganze Stiicke dunkel und wenig durchsichtig; die schöne Durchsichtigkeit, die zarte Farbe und der kräftige Glasglanz von Schmucksachen aus Bouteillenstein kommt erst beim Schleifen zum Vorschein.

Seit langer Zeit bekannt sind die böhmischen Fundorte. In der Gegend zwischen Moldauthein und Budweis im Süden des Landes an der Moldau (daher der Name Moldawit) liegen die Stücke als Geschiebe in Bach- und Flubablagerungen, oder in der Dammerde, aus der sie bei der Bestellung der Felder vielfach ausgeackert werden. Besonders reich ist das Terrain zwischen Prabsch, Klein-IIorozek und Zahoritsch, doch war frïher die Menge größer als jetzt. Die Steine werden zusammengelesen und in die Schleifereien verkauft. Auch bei Radomilitz, westlich von Budweis, findet sich Bouteillenstein, hier ist er aber von lichterer Farbe, als sonst in Böhmen. Die Stiicke sollen an dieser Stelle in der Grundmoräne eines alten Gletschers aus der Eiszeit liegen, was die Annahme einer künstlichen Entstehung gänzlich ausschließen würde. Unter ganz ähnlichen Umständen wie in Böhmen findet sich Moldawit auch bei Kotschichowitz unweit Trebitsch im Iglawatale und an anderen Orten in Mähren, z. B. bei Mährisch Kromau. Sehr reichlich ist er aber nirgends vorhanden.

Abgerollte Geschiebe, bis 1 Zoll Durchmesser, ganz ähnlich den böhmischen Bouteillensteinen, aber nicht so schön gefärbt, finden sich bei Santa Fé in Neu-Mexiko in den Vereinigten Staaten; hier hat man es aber wohl mit einem echten, zweifellos natiirlichen Obsidian zu tun.

Der Pseudochrysolith wurde anfangs nicht gerade häufig benutzt, doch kam er in den letzten Jahren etwas mehr in Aufnahme. Der Preis ist gering; für ein Pfund des Rohmaterials wurde bis 75 Mark bezahlt und bei geschliffenen Steinen wird ein Gramm ungeführ auf eine halbe Mark geschätzt. Die Schliffformen sind die beim Olivin angerebenen; besonders häufig sind Tafelsteine, doch sieht man auch Treppensteine und ähnliches, vielfach mit etwas gerundeter Tafel.

Da infolge steigender Nachfrage nach solchen Steinen der Bedarf aus dem natiirlichen Rohmaterial nicht mehr gut gedeckt werden konnte, trat an seine Stelle ein künstliehes grïnes Glas, das dann auch unter dem Namen Obsidian in den Handel kam. Es 
zeigt mehrere Nuancen, und die Farbe ist heller und freundlicher als bei dem natïrlichen Moldawit. Steine aus diesem kïnstlichen Obsidian sieht man gegenwärtig sehr lı̈ufig in billigen Schmucksachen. Zuweilen soll auch einfach grüines Bouteillenglas zu diesem Zweek verwendet verden. Von diesen kïnstlichen Gläsern ist natürlich der echte Moldawit schwer mit Sicherheit zu unterscheiden aufer etwa durch die mikroskopische Untersuchung oder durch die Lichtbrechung, die bei den kïnstlichen Gläsern durchgängig höher ist. Der Brechungskoeffizient jenes den Moldawit unter dem Schleifernamen Obsidian ersetzenden grünen Glases ist: $\mathrm{n}=1$, ,i:i für grelbes Licht. Leicht ist dagegen die Unterscheidung aller dieser künstlichen und natïrlichen Gläser von den echten kristallisierten grrünen Edelsteinen, von denen Chrysolith, grüner 'Turmalin, Vesuvian und der Demantoidgranat wohl die ähnlichsten sind; manche Exemplare nïhern sich anch etwas dem Smaragd. Andere kommen zur Vergleichung weniger in Betracht. Bei allen diesen Stemen ist das spezifisehe Gewicht erheblich höher, so daß sie in der vierten Fliissigkeit untersinken, was Bouteillenstein nicht tut. Außerdem sind sie alle lärter und mit einziger Ausnahme des Demantoids auch doppeltbrechend und dichroitisch, so daf eine Verwechslung mit Bouteillenstein bei genügender Aufmerksamkeit niemals vorkommen kann.

\title{
Gruppe des Pyroxens und des Amphibols.
}

\section{Hypersthen}

\author{
(mit Bronzit, Schillerspat und Diallag).
}

Es sind dies diejenigen Glieder der Mineralgruppe des Pyroxens oder Augits, die auf einer Fläche einen eigentümlichen metallischen Schiller zeigen, der den Grund zu ihrer Verwendung als Schmuckstein bildet.

\section{Hypersthen.}

Der Hypersthen ist dadurch ausgezeichnet, daß auf einer dunklen Körperfarbe ein prächtiger, kupferroter, metallischer Schiller auftritt. Namentlich in Frankreich sollen derartige Steine beliebt sein. Allerdings zeigt sich der Schiller nicht bei allen Exemplaren des Minerals; die, an denen dies nicht der Fall ist, haben dann keine Eigenschaften, die sie als Schmucksteine verwendbar erscheinen lassen.

Die schönsten Stïcke, wohl die einzigen aus denen manchmal Schmucksteine, vorzugsweise Ringsteine und ähnliches hergestellt werden, stammen von der Labradorkïste, namentlich wird die kleine Insel St. Paul vielfach als Fundort genannt. Daher hat man das Mineral auch Paulit genannt; von den Steinschleifern wird es wohl als „Labradorhornblende" bezeichnet. Es begleitet dort den farbenspielenden Labradorfeldspat (S. 533), indem es mit ihm das bei der Beschreibung des letzteren erwähnte Gestein bildet. Das, was für das Torkommen und die Verbreitung jenes scbönen Minerals gilt, das gilt daher auch in der IIauptsache für den Hypersthen. Die Menge, die man findet, ist ziemlich beträchtlich; auch gute fehlerfreie Stiicke, namentlich solche ohne. Risse, können ohne Schwierigkeit erlangt werden, indem man aus größeren Massen die besten Teile herausschneidet 
und für sich schleift. Wegren dieser verhältnismäßigen Häufigkeit ist der Hypersthen auch nicht von mrolien Werte. Das Karat geschliffener Steine wird mil 1 bis 2 Mark bezahlt.

Der ehemischen Zusammensetzung nach ist das Mineral im wesentlichen ein Magnesiasilikat von der Formel $\mathrm{MgO}_{\mathrm{g}} \mathrm{SiO}_{2}$, in dem aber ein erheblicher Teil der Magnesia durch Eiscnoxydul ersetzt ist. Der Hypersthen von Labrador besteht aus 49.56 Proz. Kieselsïure: 6,17 'Tonerde, 2,25 Eisenoxyd, 14,11 Eisenoxydul, 0, $; 5$ Manganoxydul, 24,27 Magnesia, 2.3; Kalk (zusammen 100). Er gehört zu den rhombisch kristallisierten Pyroxenen; deutliche Kristalle findet man aber in der genannten Gegend nicht, sondern nur derbe, bis faustgroße, vielfach abgerollte Stiicke, an denen einige mehr oder weniger deutliche Blätterbrïche oder Absonderungsflächen vorhanden sind. Namentlich nach einer Fläche lassen sich die Stiicke sehr leicht teilen, und zwar infolge davon, daß parallel mit dieser Fläche unzählige mikroskopisch kleine kristallinische Täfelchen mit lebhaftem Metallglanz, vielleicht dem aus reiner Titansäure bestehenden Mineral Brookit angehörig, dem Hypersthen eingelagert sind. Die Absonderung nach dieser Fläche ist so vollkommen, daß die Steine in dieser Richtung leicht Risse bekommen. Beim Schleifen ist daher große Vorsicht nötig; da solche Risse der Qualität sehr sehädlich sind.

Aber jene kleinen Einschliisse sind nicht nur die Ursache der Absonderung, sondern auch die des metallischen Schillers. Dieser geht von jenen Täfelchen aus, er zeigt sich nux auf der Absonderungsflïche, der die Täfelchen parallel liegen; auf anderen Flächen ist keine Spur dieser schönen Lichterscheinung zu sehen, und ebenso fehlt sie ganz an den Stücken, die keine solchen 'Täfelchen eingeschlossen enthalten. Der Lichtschein wird sehr gesteigert, wenn man die Schillerfläche eben schleift und poliert, wobei der Stein einen schönen Glanz annimmt. Noch mehr geschieht es, wenn man ihm eine flach schildförmige Gestalt gibt, so daß seine runde oder ovale Grundflïche mit jener Fläche parallel geht. Im ersteren Falle ist der Schiller über die ganze Fliche gleichmäßjig ausgebreitet, im anderen ist er auf die dem Lichte entgegengekehrte Stelle beschränkt, aber an dieser verstärkt und gleichsam konzentriert. Facetten können die Wirkung der Steine nicht heben, sondern nur beeintrïchtigen. Geschwächt und gestört wird der Schiller auch, wenn der Stein nicht genau in der angegebenen Weise geschliffen ist.

Die eigentliche Körperfarbe des Hypersthens, auf der sich der kupferartige Schiller kräftig abhebt, ist an sich unansehnlich, dunkel braunschwarz, sie wirkt aber durch ihren Kontrast zu dem lebhaften Lichtschein. In einigermaßen dicker Sehicht läßt das Mineral kein Licht hindurch, es ist vollkommen undurchsichtig; diinne Schliffe sind aber so durchsichtig, daf man imstande ist, eine mikroskopische Untersuchung vorzunehmen, bei der dann die erwähnten tafelförmigen Einschlüsse deutlich hervortreten.

Wras die sonstigen Eigenschaften des Hypersthens anbelangt, so ist das spezifische Gewicht gleich 3,1. Die IÏ̈rte ist gleich 6, er wird also vom Quarz geritzt, ritzt aber seinerseits Glas. Er ist sprïde und schmilzt nicht schwer vor dem Lötrohr, wobei er ein schwarzes, magnetisches Glas gibt; von Säuren wird er nicht angegriffen.

Noch einige andere dem IIypersthen mehr oder weniger nahestehende Mineralien aus der Pyroxengruple sind bekannt, die alle, wie er, einen auf der Anwesenheit fremder Einschliisse beruhenden metallischen Schiller in einer Richtung leichter Absonderung zeigen, der aber bei manchen dieser Steine schon stark in das Perlmutterartige geht. Sie sind alle weniger schön als jener, werden aber ebenfalls zuweilen geschliffen. Die Körperfarbe ist hier nicht mehr die dunkelbraune des Iypersthens, sie ist meist heller: braun, grau, srün usw. Die betreffenden Mineralien sind der lBronzit, der Schillerspat und der Diallag; sie sollen hier nur ganz kurz geschildert und namentlich die Unterschicde ron Hypersthen hervorgehoben werden. 


\section{Bronzit.}

Der Bronzit ist nichts anderes als ein etwas eisü̈̈merer Hypersthen, daher ist sein spezifisches Gewicht niedriger, etwa gleich 3,3 . Er ist aus demselben Grunde auch weniger dunkel gefärbt, und ebenso ist der Schiller, wenn er vorhanden ist, heller, melr bronzegelb, er tritt dann aber immer noch recht kriftig mit leblaftem, metallischem Glanze auf dem meist hraunen steine hervor. Dieser hat zuweilen eine Anlage zum Fasrigen, und dinn nimmt der Schiller eine gewisse Plhnlichkeit mit dem des Katzenauges an. Man findet den Bronzit in Stïcken, die zum Schleifen groli und schïn genug sind, unter anderem mit Feldspat zusammen bei Kupferbers im Fichtelgebirge, in Serpentin fom Gulsen bei Kraubat in Steicrmark und an der Secfeldaly im Lltenthal in Tirol, sowie in dem Blaugrund von südafrika (S. 229). Die V(rwendung ist aber noch beschränkter als beim Hypersthen und der Preis ziemlich der gleiche.

\section{Schillerspat.}

Der Schillerspat ist vom Bronzit kaum anders als durch das Aussehen versehieden; mineralogisch ist er wesentlich dasselbe. Er ist hell graulichgrïn, und der Schiller, der schon stark von dem Metallischen in das Perlmutterartige greht, ist ebenfalls grünlich. Der Hauptfundort ist die Baste im Radautale bei Harzburg im Harz, woher der Stein auch als Bastit bezeichnet wird. Dort sind einzelne Körner nicht selten ron ziemlicher Größje in einem dunkelgrünen bis schwarzen Serpentin eingewachsen. Der hellgrefürbte Schillerspat tritt auf diesem dunkeln Hintergrunde sehr hiibsch hervor. Die schillernde Flïche ist dabei nicht ganz ununterbrochen, sondern es wechseln einzelne schillernde Flecken ron Bastit mit dem nicht schillernden Serpentin ab, so daß das Bild mannigfaltiger wirt. Alle schillernden Stellen solcher Stiicke, die eben oder flach mugelig oder schildfürmig. geschliffen zu werden pflegen, zeigen den Schiller gleichzeitig; bein Drehen verschwindet er, und zwar ebenfalls gleichzeitig über die ganze Fläche weg. Der Schillerspat wird aber nur selten zu Schmucksteinen rerarbeitet, eher noch zu Dosen und anderen ähnlichen kleinen Geräten.

\section{Diallag.}

Der Diallag steht dem Iypersthen mineralogisch etwas ferner, kann ihm aber im Ansehen recht ähnlich werden. Er enthält außer den Bestandteilen des letzteren noch viel Kalk, und seine Kristalle grehören nicht dem rhombischen, sondern dem monoklinen Kristallsystem an. Meist sind es anch hier unregehmäßig begrenzte derbe Stiicke, die mit den zuletzt genannten Mineralien die deutliche Absonderung in einer Richtung und auf dieser den metallischen Schiller gemein haben. Die Farbe ist hier mannigfaltiger: dunkelbraun, griin in verschiedenen Nuancen, bis sehr hell grünlich und graulich. Der Schiller ist meist mit dem Steine gleichfarbig und geht um so mehr ins Metallische, je clunkler, und um so mehr ins Perlnutterartige, je heller die Farbe ist. Der Diallag bildet mit Feldspat ein Gestein, das den Namen Gabbro erhalten hat. Dieses ist an manchen Stellen so grobkörnig, daß die Diallagstïcke grol genug zum Schleifen sind, die Verwendung ist aber sehr spärlich. Man findet solchen grobkörnigen Gabbro unter anderem bei Volpersdorf unweit Neurode in Schlesien, bei Le Prese im Veltlin und an manchen anderen Stellen der westlichen Alpen, bei Prato unweit Florenz, sowie auch sonst in den Apenninen und noch an vielen anderen Orten.

\section{Diopsid.}

Eines der bestgefürbten und durchsichtigsten Mineralien aus der Gruppe des Augits bildet der Diopsid, der infolgedessen zuweilen als Schmuckstein geschliffen wird. Er ist 
ein Kalkmagnesia-Silikat, in dem Kalk und Magnesia zu gleichen Teilen enthalten sind, wo aber (in Teil der Magnesia durch Eisenoxdul ersetzt sein kann. Die chemische Formel ist: $\mathrm{Ca}(\mathrm{Mg}, \mathrm{Fe}) \mathrm{Si}_{2} \mathrm{O}_{6}$ oder $\mathrm{CaO} .(\mathrm{Mg}, \mathrm{Fe}) \mathrm{O} .2 \mathrm{Si} \mathrm{O}_{2}$.

Die Kristalle gehören dem monoklinen Systeme an. Es sind meist ziemlich lange, sïulenförmige Prismen von oblongem Querschnitt, deren Kanten durch die schmalen Flächen cines rhombischen Prismas etwas abgestumpft werden. Mit dem einen Ende sind sie stets aufgewachsen, am anderen sind mehr oder minder zahlreiche Flächen ausgebildet, manchmal ist die Endbegrenzung aber auch ganz unregelmäßig. Nicht selten ist Zwillingsbildung und ebenso sind unregelmäßige Verwachsungen zu stengligen Aggregaten eine häufige Erscheinung.

Eine ziemlich deutliche Spaltbarkeit geht in der Richtung der Prismenflächen. Die Kristalle sind spröde und haben fast genau die Härte des Feldspats, $H .=6$; sie werden also von Quarz stark geritzt, ritzen aber ihrerseits leicht Fensterglas. Das spezifische Gewicht beträgt 3,2 bis 3,3 ; es ist um so höher, je eisenreicher der Diopsid. Für die durchsichtigen, eisenreichen, bouteillengrünen Kristalle von Tirol, aus denen hauptsächlich zuweilen Schmucksteine geschliffen werden, gilt die letztere Zahl. Von Säuren wird der Diopsid nicht angegriffen.

Der Glanz ist ein starker Glasglanz, der durch die Politur nicht unwesentlich gesteigert wird. Die Durchsichtigkeit schwankt zwischen weiten Grenzen. Bei vielen Exemplaren ist sie sehr vollkommen; wenn dies nicht der Fall ist, werden sie nicht gesehliffen. Für Röntgenstrahlen ist der Diopsid höchstens halbdurchlässig. Die Farbe ist grün, aber mit dem Eisengehalte verschieden. Die fast eisenfreien Exemplare sind beinahe vollständig farblos, mit zunehmendem Eisenoxydul wird die Farbe immer kräftiger, und bei den eisenreichsten, dem sog. Hedenbergit, ist sie ein schönes tiefes Bouteillengrün. Charakteristisch ist, daß auch bei der tiefsten Färbung der Dichroismus sehr gering ist. Die Brechungskoeffizienten sind: der kleinste $=1, \pi 32$, der größte $=1, \pi$, für gelbes Licht, also die Lichtbrechung und die Doppelbrechung ziemlich stark.

Nur wenige Fundorte sind es, deren Produkt zuweilen geschliffen wird. Die hell graugrïnen Kristalle, die den Hessonitgranat vom Alatal in Piemont begleiten (Taf. XIV, Fig. 7, und S. 439), werden in 'Turin, teilweise auch in Chamonix zu Schmucksteinen verarbeitet und besonders in Italien in Ringen usw. getragen. Ganz ähnliche Kíristalle, von hell ölgrïner Farbe von de Kalb in Lawrence County im Staate New York finden in Nordamerika eine beschränkte Verwendung. Schöner als diese sind die dunkelbouteillengriinen Kristalle von der Alpe Schwarzenstein im Zillertal in Tirol. Sie sind bis 5 Zoll lang und bis 1 Zoll breit und sitzen im Chloritschiefer mit einem Ènde aufgewachsen. Manche, namentlich die kleineren Exemplare, sind sehr gut durchsichtig, und ebenso ist die Farbe recht schön, aber vielfach nicht über den ganzen Kristall dieselbe. Sehr gewöhnlich ist das aufgewachsene Ende dunkelgrïn, das freie fast farblos, nie umgekehrt. Diese Kristalle waren früher ziemlich häufig; ihr grünes Ende wurde geschliffen und die Steine wie die vom Alatale werden namentlich in Italien mit Vorliebe getragen. Gegenwärtio ist das Vorkommen seltener und auch die Wertschätzung des Steines hat abgenommen.

Zum Schleifen geeignet ist auch ein Teil des Chromdiopsids aus dem Blaugrund von Kimberley sowie der gleichfalls schön grüne Smaragdit von dort (S. 229)

Die Formen, die man dem Diopsid beim Schleifen gibt, sind die gewöhnlichen der farbigen, durchsichtigen Steine: Treppen- und Tafelsteine in ihren verschiedenen Modilikationen. Die Treppen müssen bei dunkel gefärbten Steinen niedrig gehalten werden.

Der Diopsid kann unter Umständen mit grünem Glas und anderen grïnen Steinen verwechselt werden. Das Glas ist einfachbrechend. Vom Smaragd unterseheidet sich 
der Diopsid durch die andere Farbe und das viel höhere spezifische Gewicht. Der Chrysolith ist oft sehr :ihnlich gefärbt und zeigt auch denselben schwachen Dichroismus und ein sehr ihnliches spezifisches Gewicht; aber der Diopsid ist merklich weicher und wird vom ('hrysolith leieht geritzt. Der grïne Turmalin, der Epidot und der Alexandrit sind durch ihren starken Dichroismus von ihm untersehieden, letzterer ist auch erheblich schwerer und dasselbe gilt für den grünen Vesuvian. Der Dioptas wird wohl kaum mit Diopsid verwechselt werden, die Farbe beider ist zu sehr verschieden.

\section{Spodumen.}

Der Spodumen ist ein lithionhaltiges Glied der Pyroxengruppe, ein Lithion-Tonerde-Silikat mit der Formel: $\mathrm{Li}_{2} \mathrm{O}_{0 . \mathrm{Al}_{2}} \mathrm{O}_{3} .4 \mathrm{SiO}_{2}$, entsprechend der Zusammensetzung: 64,5 Kieselsäure, 27,4 Tonerde und 8,1 Lithion, wozu in einzelnen Fällen noch seringe Mengen anderer Substanzen treten künnen. Er bildet wie die meisten Pyroxene prismatische Kristalle des monoklinen Systems, an denen häufig die vordere und hintere Kante des Prismas stark abgestumpft sind, so daß auf diese Weise breit tafelfürmige Gestalten entstehen, mit einer mehr oder weniger komplizierten, zuweilen auch mit einer ganz unregelmäßigen Begrenzung an den Enden. In der Richtung der beiden Prismenflächen, die nahezu aufeinander senkrecht sind, gehen ziemlich vollkommene Blätterbrüche. Die Härte ist: H. $=6 \frac{1}{2}$ bis 7 , so daß das Mineral eben noch rom Quarz geritzt wird; G. $=3,1:$ bis 3,19 , so daß es noch in der zweiten Flüssigkeit $\left(\left(x_{0}=3,0\right)\right.$ rasch untersinkt, aber im reinen Methylenjodid schwimmt. Von Säuren wird der Spodumen nicht angegriffen, auch von Ätztinte nicht. Vor dem Löthrohr schmilzt er ziemlich leicht und färbt dabei die Flamme schwach rot.

Der Spodumen ist ein Mineral der Pegmatitgänge, des Gneises usw. Er findet sich in diesen meist in matten, undurchsichtigen, unansehnlich gefürbten, graulich- orler grïnlichweißen Massen und Kristallen nicht selten von ganz beträichtlicher Größe, und ist dann nicht als Schnuckstein zu verwenden. Man hat aber in einzelnen Fällen im Innern solcher umfangreicher Partien einen vollkommen durchsichtigen und schön gefärbten Kern ron Edelsteinqualität gefunden, der in die trübe, weiße Umhïllung ganz allmählich ühergeht. Hieraus und aus der allgemeinen Eigenschaft des Spodumens, sich leicht durch Verwitterung zu verändern, hat man geschlossen, dals jene triiben, gemeinen Massen ursprünglich ganz die schöne Beschaffenheit des jetzt in einigen noch vorhandenen edlen Kernes gehabt und daß sie erst im Laufe der Zeit ganz oder docb zum allergrö̈ten Teil ihr jetziges Aussehen dureh eine allmählige Umwandlung angenommen haben. G. F. K unz hat dieses Verhalten in bezeichnender Weise so ausgedriickt, daß er sagt, der Spodumen ist ein abgestorbener Edelstein.

Diese klaren und durchsichtigen Kerne in trüben Spodumen, die allerdings stets sehr rissig und daher nicht schleifbar sind, zeigen nun eine verschiedene Farbe. Grïn lat man sie an einigen Orten im Staate Massachusetts, violett bei Branchrille in Connecticut grefunden. Nun ist es aber im Laufe der letzten 25 bis 30 Jahre geglïckt, an einigen wenigen Orten als Seltenheit Spodumen zu entdecken, der noch durchaus seine edle Beschaffenheit mit vollkommener Klarheit und Durchsichtigkeit und mit schöner Färbung besitzt, und zwar auch wieder griin (oder gelb) und violett, sehr spärlich auch blau. Diese edlen Spodumene, bis jetzt im Vorkommen fast ganz auf Amerika beschränkt, geben, da sie bein Schleifen einen sehr kräftigen Glanz annehmen, ausgezeichnete Schmucksteine und werden auch, namentlich in ihrer Heimat, nicht selten dazu rerwendet. Sie sind nach ibrer Farbe besonders benannt worden, der grüne oder gelbe Hiddenit, der 
violette Kunzit. Ihre allgemeinen Eigenschaften sind die des Spodumens überhaupt, ihr besonderes Verhalten werden wir nun getrennt betrachten.

\section{Hiddenit. \\ (Spodumen- oder Lithionsmaragd,)}

Der IIiddenit ist die grïne bis gelbe Abart des Spodumens mit allen oben erwähnten allgemeinen wesentlichen Eigenschaften dieses Minerals. Die Farbe ist zuweilen ein ausresprochen schönes, aber nicht sehr tiefes Smaragdgrün, daher die oben angegebenen Beinamen, sie geht aber auch vielfach mehr oder weniger ins Gelb und ist nicht selten ausgesprochen gelb, letzteres vorzugsweise bei den Steinen aus Brasilien.

Die Ursache der smaragdgrünen Farbe ist ein kleiner Chromgehalt $0,18 \%$ Chromoxyd), der in manchen Proben gefunden ist, die gelbe Farbe beruht wohl auf der Beimischung einer geringen Menge $(0,25 \%)$ Eisenoxyd. Je schöner grün nun die Farbe, desto höher ist der Wert. Diese ist aber nie so gesättigt wie beim Smaragd, außerdem unterscheidet sich der Hiddenit von diesem sowie auch von dem oben besprochenen grünen Diopsid noch durch einen recht deutlichen Plcochroismus, von dem letzteren auch durch eine geringere Lichtbrechung, sofern beim Spodumen die Brechungskoeffizienten für gelbes Licht nur zwischen 1, ,i51 und 1,677 schwanken. Ein wesentlicher Unterschied vom Smaragd ist auch das spezifische Gewicht, das bei diesem 2,i, beim Hiddenit 3,17 beträgt. Im ïbrigen sind die Unterschiede von ähnlich aussehenden Steinen aus dem dritten Abschnitt zu ersehen.

Die Durchsichtigkeit ist meist vollkommen, Röntgenstrahlen werden aber wie bei den meisten Silikaten nicht hindurchgelassen. Der Dichroismus ist kräftig.

Wenn der Hiddenit geschliffen wird, nimmt er einen schönen Glanz an. Es muß dabei aber mit großer Vorsicht verfahren werden, da die Steine wegen der vollkommenen Spaltbarkeit Risse bekommen und sogar leicht zerbrechen oder wenigstens am Rande splittern. Die Schliffformen sind die gewöhnlichen der farbigen Edelsteine. Man hat bei der Anlage der Facetten Rücksicht auf den Pleochroismus zu nehmen, infolgedessen die Farbe mit der Richtung von hellgrün, fast farblos bis dunkelgrün wechselt.

Der Hiddenit ist in grïnen und gelblichgrünen Exemplaren bisher fast nur in den Vereinigten Staaten, in gelben auch in Brasilien gefunden worden.

In den Vereinigten Staaten ist der einzige wichtigere Fundort seit 1881 bekannt. Er liegrt bei Stony Point, Alexander County, Nord-Carolina, 16 miles nordwestlich von Statesville. Der Hiddenit begleitet dort die schönen Smaragde und Berylle, die mit Quarz, Granat, Rutil und anderen Mineralien drusenförmig auf Hohlräumen eines granitischen Gesteins, eines Pegmatits, sitzen (S. 400). Die ersten Exemplare, die gefunden wurden, lagen, aus der ursprïnglichen Lagersätte ausgewittert, lose im Boden. Sie wurden wegen ihrer grünen Farbe und ihrer Durchsichtigkeit anfänglich für Diopsid gehalten, denn bis dahin war der Spodumen noch niemals in dieser Beschaffenheit gesehen worden, die genauere Untersuchung stellte jedoch alshald den wirklichen Sachverhalt fest. Später hat man dann heim systematischen Nachgraben nach Smaragd Hiddenitkristalle auch auf ihrer ursprünglichen Lagerstätte im Gestein angetroffen und aus diesem gewonnen. Ihre Gröfe sehwankt (rhehlich, geht aber nie über eine Iänge von ea. 8 Zentimeter und über die Dieke von 1 Zentimeter hinaus; das gewöhnliche Maß ist 1 bis 2 Zentimeter lang und 2 bis 4 Millimeter dick. Die Form ist meist prismenförmig, manchmal auch etwas tafelig nach der Jiingsfläche. An der Außenseite sind die Kristalle meist sehr raub, zerfressen dureh die Jinwirkung natiirlicher Lösungsmittel. Die Farbenreile umfaßt alle Nuancen zwischen 
smaragdgriin und gelblichgriin, die letztere ist die häufigere. Die geschliffenen Stene sind als aussehließlich einheimisch in Amerika sehr ereschätzt. Daher ist auch fast das granze bisher gefundene ziemlich spörliche Material dort geblieben, und nur sehr wenign nach Europa grekommen. Der Preis für schön grüne und durchsichtige Exemplare geht von 50 bis 100) Dollars für I Karat und wird wohl cher steigen als fallen, da die (irube erschöpft, oder doch jedenfalls seit lange nicht mehr im Betrieh ist, so dal neues Material nicht mehr in den IIandel kommt. In sanz geringer Menge begleitet der Itiddenit wohl auch stellenweise den häufigeren Kunzit. Schön grrüner IFiddenit, älınlich dlem von NordCarolina, wurde neuerdings auch in MIadagaskar gefunden.

Im Gegensatz zu dem mehr oder weniger ausgesprochen griinen IFiddenit von Nordamerika ist der aus Brasilien fast durchweg gell) und zwar ziemlich hell; ein Stich ins Grïn kommt hier kaum vor.

Auch bei ihm ist die Durchsichtigkeit vollkommen. Der brasilianische Iriddenit wurde der Ähnlichkeit der Farbe wegen früher mit Chrysoberyll rerwechselt und auch mit diesem Namen bezeichnet; mancher geschliffene Chrysoberyll aus Brasilien diurfte sich bei der genaueren Untersuchung als Hiddenit erweisen. Die Unterscheidung ist leicht mittels der Härte sowie mittels des spezifischen Gewichts : im reinen Methylenjodid schwimmt der Hiddenit, der Chrysoberyll sinkt rasch und ist viel härter. Beide Mineralien kommen in Brasilien im Bezirk Ninas novas auch zusammen vor (\$. 351 und 419). Im Gegensatz zum Chrysoberyll ist aber der Hiddenit bis jetzt ausschließlich als Geschiebe in den Nebenflüssen des Rio Jequetinhonha gefunden worden, auf der ursprïnglichen Lagerstätte im Gestein hat man ihn bis jetzt noch nirgends angetroffen.

Blauer Spodumen findet sich selten in den Diamantseifen von Diamantina und ist früher für Lazulith gehalten worden.

\section{Kunzit.}

Der Kunzit ist nach dem bekannten und auch in diesem Buche viel genannten Mineralogen und Edelsteinkenner George Frederick Kunz in Neu Iork benannt. Innerhalb einer bestimmten Grenze ist er ziemlich mannigfaltig gefürbt. Er geht von dunkellila bis violett, fast amethystfarben, durch verschiedene Nuancen ron rosa bis herunter zum beinahe Farblosen. Analog wie beim Hiddenit könnte man hier der Ähnlichkeit mit Amethyst wegen von Spodumen- oder Lithionamethyst sprechen. Die erwähnten Farben zeigen eine auffallende Beziehung. Die Stiicke sind um so kräftiger gefärbt, je tiefer die Stelle in der Grube ist, aus der sie stammen, je näher der Oberfläche, desto blasser. Man sieht deutlich, daß hier die beginnende Verwitterung die Färbung beeinflußt und verïndert. Diese ist wohl durch einen kleinen Nangangehalt (0,11 \% Manganoxydul, in einer anderen Probe 0,15\% Manganoxyd) verursacht.

Mit der ausgesprochenen Farbe ist wie heim Hiddenit ein kräftiger Dichroismus verbunden. Am tiefsten ist die Färbung, wenn man in der Richtung der Prismenkanten durch die meist nach der Querfä̈che tafelförmigen Kristalle bindurchblickt. Hier tritt dann ein schönes, nicht zu dunkles Lavendelblau mit großer Annäherung an das Violett und damit das amethystähnliche Aussehen besonders dentlich hervor. Quer dazu, also u. a. senkrecht zur Tafelflïche ist die Farbe viel heller, meist blaß rosa, und verschwindet $\mathrm{z}$. T. fast ganz. Auch mit der Dichrolupe ist ein Wechsel zwischen schön lila bis violett und fast farblos zu beobachten. Selbstrerständlich ist der Pleochroismus um so geringer, je blasser die Farbe des Steins. Bei kräftig gefürbten Exemplaren ist aber beim Schleifen hierauf in leicht erkennbarer Weise Rïcksicht zu nehmen: Die Tafelflïche der Schliffformen muß quer zu den Prismenkanten gehen, sonst ist der Stein unansehnlich. 
Nit der schönen Farbe vereinigt sich meist eine vollkommene Durchsichtigkeit und Fehlerlosigkeit. Durch den Schliff erhalten die Steine, die Farbe mag hell oder dunkel sein, einen auscrezeichneten Glanz, so daß sie unter allen Umständen einen prächtigen Anblick gewähren. Am häufigsten werden die Brillantform oder gemischte Schliffformen angewendet.

Sehr merkwürdig ist der Kunzit durch gewisse optische Eigenschaften, durch die er sich nicht nur von den iibrigen, besonders von den violetten Edelsteinen, sondern namentlich auch von den anderen Varietäten des Spodumens, vor allem von dem Hiddenit unterscheidet. Es ist dies die starke Lumineszenz, die in ihm durch verschiedene äußere Einwirkungen hervorgebracht wird. Durch mechanische Angriffe, Reiben mit Tuch usw. kann er allerding's nicht zum Leuchten gebracht, wohl aber elektrisch erregt werden. Dagegen sendet er beim Erwärmen schon weit unter der Glühhitze in der Dunkelheit ein orangefarbiges Licht aus. In der Funkenstrecke zwischen den Polen eines starken elektrischen Induktionsapparats kommen ganze Kristalle mit orange-rosa Farbe zum Leuchten, das 45 Minuten anhält; gleichzeitig erlangen sie die Fähigkeit, auf die photographische Platte einzuwirken. Kunzit, der einige Minuten der Einwirkung stark aktiven Radiumbromids ausgesetzt war, zeigt wundervolle Phosphoreszenz, die auch nach der Entfernung des Radiumsalzes noch einige Ninuten lang anhält. Gegen Radiumemaution ist Kunzit dagegen wenig empfindlich. Wie Radium wirkt auch Aktinium. Für Röntgenstrahlen ist der Kunzit wie der Hiddenit höchstens halbdurchlässig, er wird aber durch ihren Einfluß stark phosphoreszierend, stärker als irgend ein anderes Mineral, und zwar ist das Leuchten erst goldigrosa, dann 10 Minuten lang weils, bei anderen Exemplaren erst rosa-orange, dann blaß rosa und endlich weiß, und noch nach 45 Minuten ist ein schwaches Glimmen bemerkbar. Das Stiick wirkt dann noch rascher auf die photographische Platte. Auch ultraviolette Strahlen bringen das Mineral zum Leuchten.

In anderen Eigenschaften stimmt der Kunzit ganz mit dem Hiddenit überein. Die Brechungskoeffizienten sind dieselben, ebenso die Härte und das spezifische Gewicht (G. = 3,17 bis $3,1 \varsigma_{7}$ ), sowie die Spaltbarkeit, die hier wie dort große Vorsicht beim Schleifen nötig macht. Durch Reiben wird er elektrisch wie Topas.

Während der Hiddenit aufer in Nordamerika auch noch, wenn schon in einer geringeren Abart, in Brasilien vorkommt, ist der Kunzit bisher fast nur in den Vereinigten Staaten gefunden worden; er ist ein spezifisch nordamerikanischer Edelstein, der deshalb im Land sehr geschätzt ist und mit 6 bis 20 Dollars, meist allerdings mit weniger als 10 Dollars pro Karat bezahlt wird. Er ist erheblich billiger als Hiddenit, da er in betrïchtlichen Mengen und auch in größeren, mit den Erfordernissen eines Edelsteines versehenen Kristallen gefunden wird als dieser. Wenn die Kristalle des Hiddenit höchstens fingerlang und -dick werden, kennt man solche vom Kunzit, die bei vollkommener Durchsichtigkeit die Dimensionen einer Männerhand haben. Einer der größten bekannten mißt nach drei Richtungen 18, 8 und 3 Zentimeter und wiegt ein Kilogramm. Es sind daher aus Kunzit schon schöne Steine bis zu 150 Karat schwer geschliffen worden. Allerdings bilden hier wie sonst diese großen Individuen Ausnahmen, die meisten sind nicht mehr als 10 Zentimeter lang. Wie beim IHiddenit zeigen sie namentlich an den Enden ein stark zerfressenes Aussehen, mit vielen kleinen, narbenartigen Vertiefungen, infolge der langen Einwirkung von natürlichen Lösungsmitteln; die Kristalle sind auf natürlichem Wege sehr stark geätzt worden, oder, wie man sagt, korrodiert.

Die Fundorte, die das Material zum Schleifen liefern, liegen fast ausschließlich im Westen der Vereinigten Staaten, im südlichen Kalifornien, in Riverside und in San I) iego County, wo der Kunzit die schon früher von dort beschriebenen Edelsteine, und namentlich den Turmalin in den Pegmatitgängen begleitet (S. 460) und mit ihnen zu- 


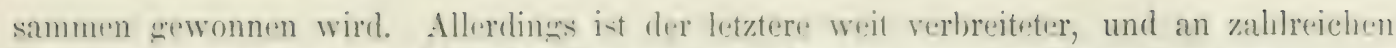
Stellen, wo er vorkommt, fehlt der Kunzit, so in dem ganzen, für Turmalin so wichtigen Bezirk von Mesa Grande. Die Geimtproduktion in den Vereinienten staten war 1907 etwa 125 I'fund auswesuchten Materials, worunter aber anch die geringe Menge farblosen, gelben und griinen edlen Spodumens.

Von geringerer bodentumg ist zunïchst das Vorkommen im Coahuila-Distrikt in Riverside (County, wo das Mineral namentlich in der Fano-Grube, 20 miles nordïstlich von Pala, in einem Auslüufer der Jacinto Ramge, mit schïnem Turmalin, Beryll usw. gresraben wird. Neben violetten bis farblosen Kristallen sind hier als Seltenheiten auch gelbe, griine und blaue beobachtet worden. Wichtiger ist San I)iego county und hier wieder der P'ala-Bezirk. aber nicht der nächst Pala geelextene Pala IIountain sellst, wo sich so wenig Kunzit findet wie im Mesa Grande-Distrikt. Am meisten von Bedeutung sind die Gruben am Pala Chief Mountain, 11.2 miles norliestlich ron Pala und die Pala Chief Mountain-Grube selbst, von wo der sröbte Teil des schönen, durehsichtimen schleifwürdigen Kunzits stammt, und wo der Kunzit von etwas Hiddenit bergleitet wird. Doch hat auch der Heriart Mountain sehr gutes Material geliefert, so u. a. die Naylor-, die Caterina- und die Vanderburg-(rube, sowic die White Queen-Grube, in der 1902 zuerst der anfänglich für Turmalin gehaltene Kunzit mit Beryll entdeckt wurde.

Späilich ist Kunzit bisher im Osten der Vereinigten staaten vorgekommen, doch hat man ihn zusammen mit etwas Hiddenit bei Andover, Oxford County, Maine, entdeckt und hofft, in der Tiefe größere Mengen anzutreffen.

Neuerdings hat sich Kunzit ebenso schön wie in Kalifornien auch in II ad a gaskar gefunden.

Ton anderen ähnlich aussehenden Edelsteinen ist der Kunzit leicht zu unterscheiden. Es kann da eigentlich nur der Amethyst, der violette Quarz, in Betracht kommen. Dieser ist aber nie so glïnzend als der Kunzit, und sein Dichroismus ist kaum bemerkbar. Er ist zwar etwas härter, aher sehr viel leichter als der letztere, so dab der Kunzit in der ersten Flïssigkeit, in der Amethyst schwebt, rasch zu Boden sinkt. Lila Kunzit ist schon an seiner Farbe kenntlich; es gilbt keinen anderen durchsichtigen Edelstein dieser Art. Farbloser Kunzit kommt geschliffen kaum vor.

\section{Rhodonit.}

Der Rhodonit (Mangankiesel) ist ein durch seine schün rosenrote, der der Himbeere ähnliche, zuweilen etwas in das Lichtkastanienbraune gehende Farbe ausgezeichnetes Glied der Pyroxengruppe. Zu Schnucksteinen, aber auch zu allen möglichen Gegenständen der Kunstindustrie (Schalen, Vasen usw.) dient hauptsächlich die feinkörnige bis dichte Masse von meist zartsplittrigem Bruch, die sich bei den Dörfern Malaja Ssedelnikowaja und Schabrowa in der Nähe von Katharinenburg im Ural findet und die auch vorzugsweise hier verschliffen wird. Aus diesem Material ist u. a. der Sarkophag des Zaren Alexanders II. hergestellt. Der Fundort liegt auf der Ostseite des Urals südwestlich ron dem erstgenannten Dorfe, am rechten Ufer der Amarilka, die sich von rechts in den Isset ergießt. Wenige Werst ron der Goldwäscherei Schabrowskoi entfernt bildet hier der Rhodonit in zwei dicht nebeneinander gelegenen Brïchen ein etwa 2,7 Meter mäichtiges Lager, wie es scheint im schwarzen Tonschiefer. Nur die unteren Partien werten benutzt, nach oben hin ist die Masse zu sehr durch Quarz verunreinigt. Stellenweise ist das Korn ziemlich grob) derartige Stellen lassen dann zwar die mineralogische Natur der Substanz deutlicher erkennen, aber zum Schleifen sind sie ungeeignet. Als selır störend erweisen sich viele Klüfte und sipalten, die das Lager weithin durchziehen und die Masse in kleine Stiicke zerlegen. Diese sind dann auf den Kiluftflïchen durch Terwitterung schwarz gefïrb)t. 
Von dersulhen Beschaffenheit, aber in geringerer Menge, findet sich der Rhodonit anch auf den Ylanganerzlagerstätten in Wermland in Schweden, wo er aber nicht zum schleifen benutzt wirl. Wichtiger ist das amerikanische Vorkommen bei Cummington in Massachusett, wo mehrere hundert Pfund schwere Blöcke von schön rosenroter Farbe in (iner (tualitiit gefunden werden, die der des russischen Rhodonits nicht nachsteht. Sie knumbu anch in derselben Weise zur Verwendung wie dieser. In Australien ist kürzlich gleichfalls Rhodonit gefunden worden.

Chemisch ist der Rhodonit ein Mangansilikat, woher er auch den Namen Mangankiesel führt. Im reinsten Zustande hïtte er die Formel $\mathrm{MnO}$. $\mathrm{SiO}_{2}$, aber meist sind noch andere Bestandteile vorhanden, namentlich eine mehr oder weniger große Menge Kalksilikat. Die an anderen Orten als im Ural nicht gerade seltenen Kristalle, die sich z. B. auf den Manganerzgruben in Wermland finden, gehören dem triklinen Kristallsysteme an; sie werden aber trotz ihrer prächtigen roten Farbe und schönen Durchsichtigkeit kaum geschliffen, sondern eben nur die erwähnten dichten Massen. Diese haben die Härte 5 bis 6 und ein spezifisches Gewicht gleich 3,5 bis 3,6 . Sie sind wenig durchscheinend und schwach glänzend, nebmen aber eine genügende Politur an.

Zuweilen wird der Mangangranat als Mangankiesel und das hier vorliegende Mineral als Manganspat bezeichnet. Dies ist aber falsch; der letztere Name kommt dem kohlensauren Mangain zu, das häufig ebenfalls hübsch rosenrot ist, aber wegen zu geringer Ilärte wenig geschliffen wird.

Anhangsweise sei hier kurz erwäbnt der nicht zum Pyroxen, sondern zum Glimmer gehörige

\section{Lepidolith.}

Er schlieft sich durch seine hellrote Farbe hier an, die aber durch einen Stich ins Blaue oder Violette sich von der des Rhodonit unterscheidet, und die daher als Lila zu bezeichnen ist. Der Lepidolith ist eine Abart des Lithionglimmers, von der sich bei Tiozena in Mähren eine feinkörnige bis dichte Varietät in ziemlicher Menge findet, und diese ist es, die wegen ihrer hïlsschen Farbe trotz ihrer geringen Iärte $(H .=21 / 2)$, infolge deren sie sich mit dem Messer, ja schon mit dem Fingernagel ritzen läbt, zuweilen geeschliffen wird. Die Terwendung geschieht aber allerdings mehr zu kleinen Gegenständen des Kunstgewerbes als zu eigentlichen Schmucksachen. Der Lepidolith von Pala in Kalifornien, das Muttergestein des dortigen roten Turmalins, ist schon oben (S. 161) besprochen worden.

Ein anderes Mineral der Glimmergruppe ist der durch einen kleinen Chromgehalt nrïne Muscovit oder Kaliglimmer, der Fuchsit oder C $\mathrm{homglimmer.} \mathrm{Er} \mathrm{findet} \mathrm{sich}$ in feinbliittrigen bis dichten Massen, die als Material zu römischen Kunstwerken und zu Schmuckperlen aus alten Gräbern in Guatenala gedient haben, beides als Seltenheit. Heutzutage findet eine derartige Verwendung nicht mehr statt.

\section{Nephrit. Jadeit. Chloromelanit.}

Diese drei Mineralien, die zuweilen unter dem Namen der Nephritoide oder auch wohl als Jade zusammengefaft werden, sind gewissermaßen prähistorische Edelsteine, die wenigstens in Europa ihre Haupthedeutung gehabt haben schon in Zeiten, über die keine Überlieferung sichere Kunde bringt. Ileutzutagre ist ihre Verwendung zu sichmucksteinen sering, und auch die lienutzung zu anderen Zwecken ist so ziemlich auf einige aubereuropäische Länder beschränkt. 
Das erste dieser Minuralien. der Véphrit, gehïrt zu der Gruppe der IIornblende orker des Amplhibols, wïhrend die beiden anderen, der Jadeit und der Chloromelanit, die sich ïbrigens nur unwesentlich voneinander unterscheiden, der Familie des Augits orler Pyroxens zuzurechnen sincl. Trotz dieser aus den mineralogischen Eigenschaften sich erowenden Zugehörigkeit zu zwei verschiedenen, allordings sehr nahestehenden Abteilungen des Mineralreichs zeigen doch vielfach alle drei in ihren Aussehen und ihrer beschaffenheit und daher auch in ihrer Verwendung sholie C̈h reinstimmung. Es sind äulerst feinfaserige bis dichte Agrgregate, deren cinzehe Bestandteile nur in dïnnen Schliffen unter dem Mikroskop erkannt werden kïnnen. Die Stiicke sehen oft, besonders wenn die Oberflïche fein geschliffen ist, für das blole Auge aus, wie wemn sie vollkommen homogen und getwissermalien aus einem fusse wären. In Dïnnschliffen bemerkt man aber bei starker Vergröberung, daß sie aus zahllosen winzigen, wirr durcheinander liegrenden Fäiserchen aufgehaut sind. Wegen dieser verworrenfaserigen Strulitur haben die drei Vineralien, trotz ihrer nicht sehr bedeutenden IIärte, die zwisehen dem sechsten und siebenten frade liegt, eine auferordentlich grofe Zähigkeit und Festigkeit; sie sind mit die zähesten und schwerst zersprengharen Mineralkörper, die man kennt; vor allem ist der Nephrit durch diese Eigenschaft ausgezeichnet. Infolge ihrer Zähigkeit und auch ihres hübschen Aussehens sind die Vephluitoide sehon in den Urzeiten zu Prunkwaffen in Form von Beilen und Meilieln, zu Zierraten aller Art, zu Idolen usw. verarbeitet worden. Dnese Gegenstïnde finden wir heutzutage in Europa in den Pfahlbauten, in alten Gräbern usw. und aus diesen auch vielfach lose im Eraboden liegend und ähnlich in anderen Ländern.

Bis vor kurzem kannte man in Europa und ebenso in Amerika die Tephritoide nur im rerarbeiteten Zustande. Rohmaterial auf seiner ursprünglichen Lagerstätte war in der Hauptsache nur in Zentralasien und in Teuseeland sefunden worden. Daraus hatte sich, namentlich durch die Bemühumgen ron II ein rich Fischer in Freiburg i. Br., die Ansicht entwickelt, dalj alle in Europa und Amerika rorkommenden Cieräte oder doch das Ruhmaterial dazu, aus jenen fernen Gegenden, besonders aus Zentralasien stammen, und daß dureh ausgredehnte Handelsverbindungen und durch Viilkerwanderungen schon in prïhistomschen Zeiten diese bereits damals hochesechätzten Steine an dit Orte befürdert worden seien, wo man sie heute findet.

In netterer Zeit hat man aber anch rohen Nephrit usw. in manchen Gegenden gefunden, wo bis vor kurzem nur rerabbeitete Stiicke bekannt gewesen sind. Man hat ferner beobachtet, daß die Gerïte einer Gegend in Beziehung auf die mikroskopische Struktur des Materials zwar untereinander ïbereinstimmen, sich alere von anderen Vorkommen, namentlich ron den asiatischen unterscheiden. Daher und aus manchen anderen Gründen ist jene Ansicht nach den Vorgange von Fr. Berwerth in Wien und besonders von A. B. Meyer, s. Z. in Dresden, jetzt zieulich vollstïndig aufgegeben und mit der vertauscht worden, daß die da und dort rorkommenden verarbeiteten Gegenstïnde durchweg aus einheimischem orler doch in der Tähe gefundenem Rohstoffe lergestellt worden seien. In manchen Gegenden sind allerdings auch jetzt noch keine Fundorte roher Tephritcide bekannt, es ist aber immerhin möglich, daf solche bei genaueren Tachforschungen noch sefunden werden, wenn die Latgerstätten nicht schon von den alten Creinwohnern bis zur völligen Erschöpfung ausgebeutet worden sind.

In Luropa ist die Verwendung des Tephrits und seiner Verwandten heutzutage gering. Sie sind alle undurchsichtiğ, höehstens durchscheinend, und die Farbe ist, wenn auch zuweilen schün, doch meist unansehnlich, gewöhnlich grün, dann aber auch grau his ins Farblose: sie stehen also weit hinter anderen Jineralien zuriick, was die schünheit und die Brauchbarkeit zum Schmuckstein betrifft. Dagegen verarbeiten und benutzen einige am Anfaner der Zivilisation stehende Tülkerschaften anderer Weltteile diese Materialien noch 
jetzt ganz in derselben Weise, wie dies die Ureinwolıner Europas in prïhistorischen Zeiten getan hah)en, su vor allen die Maoris in Neuseeland den dort vorkommenden Nephrit und die Birmanen den Jadeit. Die größte Wertschätzung genießen aber die Nephritoide heutzutage in China, wo sie, vielleicht zusammen mit einigen anderen ähnlich aussehenden Mineralsulistanzen den nationalen Lieblingsstein bilden, der mit dem Namen "Yü“ bezeichnet wird. Der Stein Yü, der in versehiedene Varietäten zerfällt, wird dort nicht nur zu Śchumuckgegenständen, sondern auch zu Tellern, Schïsseln, Vasen, Schreibzengen, Säbel„uriffen, Götzenbildern und ähnlichen Dingen verarbeitet, die zum Teil mit einer staunenerregenden Kunstfertigkeit und Geschicklichkeit hergestellt sind. Auch sonst im Orient, in Indien, Zentralasien, der Türkei usw. sind Gegenstände aller Art aus Nephrit und Jadeit sehr geschätzt, aber China steht in dieser Industrie obenan und exportiert auch eine Menge der Erzeugnisse derselben.

Eine wundervolle Sammlung von Kunstgegenständen aus Nephrit und Jadeit nebst dem zugehörigen Rohmaterial ist in der letzten Zeit von Heber Reginald Bishol) mit sehr großen Kosten zusammengebracht und dem Metropolitan Museum in New York geschenkt worden. Diese Sammlung wurde dann von einer Anzahl Sachverstaindiger unter der Redaktion von G. F. Kunz wissenschaftlich bearbeitet und in einem großen, vorziiglich ausgestatteten und mit den herrlichsten Abbildungen gezierten Prachtwerk: Investigations and Studies in Jade beschrieben. Hier ist nun von kundigster Hand alles zusammengestellt, was bis 1906 in irgendeiner Beziehung über die in Rede stehenden Mineralien bekannt war. Es ist ein unentbehrliches Quellenwerk ersten Ranges für alle, die sich damit beschäftigen wollen.

\section{Nephrit.}

Der Nephrit (Beilstein, weil er häufig zu Beilen verarbeitet gefunden wird, auch Nierenstein, weil er vielfach als Amulett gegen Nierenleiden diente und auch jetzt noch dient, französisch Jade und englisch Jade, worunter man aber nicht selten den Jadeit mit versteht) ist ein zur Familie der Hornblende oder des Amphibols gehöriges Mineral, dessen Zusammensetzung durch die Formel: $\mathrm{CaO}_{3} 3 \mathrm{MgO}_{4} 4 \mathrm{SiO}_{2}$ ausgedrickt wird, wobei aber ein wechselnder Teil der Magnesia durch die entsprechende Menge Eisenoxydul ersetzt ist. Ein Nephrit von Ost-Turkestan ergab bei der Analyse: 58,

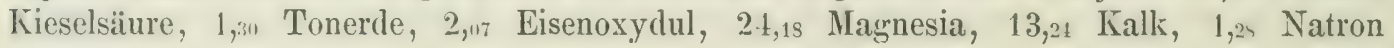
(zusammen 100,07).

Diese Zusammensetzung ist genau dieselbe, wie die eines anderen Minerals aus der Amphibolgruppe, das man als Strahlstein oder Aktinolith zu bezeichnen pflegt. Dieser findet sich nicht selten in Form von einzelnen dïnnen und langen rhombischen Prismen des monoklinen Kristallsystems im 'T'alkschiefer, z. B. des Zillertals in Tirol, eingewachsen, oder als strahliges $\Lambda$ gorrecrat zahlreicher nadelförmiger Kristalle an vielen Orten als Strahlsteinoder Aktinolithschiefer. Alle Eigenschaften des Nephrits, sofern sie von wesentlicher Bedeutung sind, stimmen mit denen des Strahlsteines vollkommen überein, namentlich das spezifische Gewicht, die Härte und die Spaltbarkeit, aber anch die bei beiden meist mehr oder weniger intensiv grüne Farbe. Man sieht daraus, daß der Nephrit nichts anderes ist als ein äuljerst feinfaseriger bis dichter Strahlstein, dessen Prismen hier mikroskopliseh feine Fäserchen darstellen. In diinnen Sehliffen erkennt man diese unter dem Mikroskop) als zum Strahlstein gehörig, und man benerkt, dab sie ganz regellos kreuz und quer durcheinander ¿Evachsen sind. Auf der besonderen Art und Weise dex Verbindung dieser Fäserehen mitcinander beruht zum Teil die charakteristische von einem Fundort zum andern etwas wodhelmo mikrosknpische Struktur, sowie die enorme Zähigkeit des Nephrits. 
Bei dieser Beschaffenheit ist es sellstrerständlich, dab der Nephrit niemals rectermäbige hristallformen zeigt. Er bildet eröfere und kleinere Vassen von stets franz unregrel-

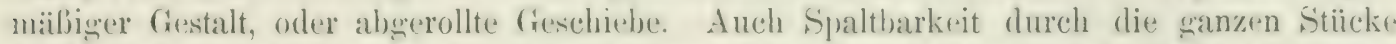
hindurch kann nieht vorhanden sein, doeh matht sich zuweilen wine deutliche schieferige Absonderung nach einer Richtung bemerkbar. In dieser lichtung lasson sich dann viele Stiicke mit verhältnismäbiger Lejehtigkeit zerschlagen. während dies nach anderen Richtungen wegen der enormen Zïhigkeit äuberst schwjerig ist. Die Druckfestigkeit des Neplurits wurde höher grefunden als die des besten Stahls. Grölere Nephrithlïcke kann man mit IIämmern überhaupt nicht mehr zerteilen, namentlich wenn sie die hierfür besonders ungüinstige runde Oberfläche von fieröllen haben. Man verfährt dann wohl in der Weise, dab man sie stark erhitzt und in kaltes Wasser wirft. Infolge der rasehen Temperaturänderung entstehen zahlreiche Risse, nach denen die Masse in einzelne Bruchstiicke zerfällt, die nun ihrerseits mit dem IJammer weiter zerlegt werden können, wobei unchene Bruchflächen von charakteristischer splitteriger Beschaffenheit entstehen.

Dieser auberordentlichen Zühigkeit gegenüber ist die IIärte des Nephrits gering; sie ist nicht ganz die des 6. Grades $\left(H_{0}=5 \frac{1}{1 / 2}\right.$ bis 6$)$. Jedenfalls ist sie aber höher als die des Glases, das ron Nephrit geritzt wird, und niedriger als die des Quarzes, der stets den Nephrit zu ritzen imstande ist. Die Masse ist ziemlich spröde, läßjt sich aber doch auf der Drehbank bearbeiten, wenn auch selbstverständlich mit Nühe und unter hesonderen Vorsichtsmaßregeln und mit geeigneten Instrumenten.

Das spezifische Gewicht ist sehr nahe gleich 3, es schwankt aher etwas, wahrscheinlich mit dem grleichfalls innerhalb gewisser Grenzen wechselnden Eisengehalt. Meist liegt es ein wenig unter 3 , seltener steigt es um einen geringen Betrag dariber hinaus. Gewöhnlich werden 2,91 und 3,"1 als Grenzen angegeben, doch trifft man auch Werte von 3,1 und 3,2, die aber wohl immer auf fremden Beimengungen (von Magneteisen usw.) oder gar auf falschen Bestimmungen beruhen. Der meiste Nephrit schwimmt also ehen noch auf der dritten Flïssigkeit $\left(G_{0}=3,1\right)$, mancher sinkt jedoch darin auch schon langsam unter. Das spezifische Gewicht ist ron Bedeutung, da es den Nephrit von dem oft zum Verwechseln ähnlichen, aber viel schwereren Jadeit $\left(G_{0}=3,3\right)$ zu unterscheiden gestattet, der also in jener Flïssigkeit unter allen Umständen rasch untersinkt und der kaum im reinen Methylenjodid schwimmt.

Säuren greifen den Nephrit nicht an, auch die Ätztinte nicht. Vor dem Lötrohr wird er triibe weiß, und schmilzt schwer zu einer grauen Scblacke. Auch hierin liegt ein Unterschied vom Jadeit, der sich durch eine besonders leichte Schmelzbarkeit schon in der gewöhnlichen Gasflamme auszeichnet, wobei er in Gegensatz zum Nephrit die Flamme lebhaft gelb färbt.

Der Nephrit ist nie durchsichtig und nur in dünnen s'chichten stïrker durchscheinend, also unter anderem an den scharfen Rändern der Bruchstiicke. Rüntgenstrahlen werden nicht durchgelassen. Dickere Stücke sind vollkommen undurchsichtig bis höchstens schwach durchscheinend. Bruchflächen sind wenig glänzend, durch die Politur hebt sich der Glanz jedoch bedeutend; er geht auf den glatten Schliffflächen etwas ins Fette.

Die Farbe ist wie beim Strahlstein im allgemeinen mehr oder weniger kräftig grin infolge des kleinen Eisengehaltes. Sinkt dieser, so wird sie heller und verschwindet in allerdings seltenen Fällen mit dem Eisen beinahe ganz bis zum Weil; nur eisenreichere Varietäten haben eine lebbaftere Färbung. Das Grïn zeigt die mannigfaltigsten Abstufungen vom hellsten bis zum schwärzlichen und die rerschiedensten Nuancen: graulichgrün, meergriin, lauchgrïn, grasgrïn usw. Daneben findet man Gelb und Braun sowic Grau, zuweilen mit einem stich ins Bläuliche, Rötliche oder Grïnliche. Eine vielfach sehr gesehätzte blaugraute Fürbung ist mit der der Molke verglichen worden. Meist ist die 
Farbe sanz whichmibiw. seltener sind melnere Farben oder Farbennuancen an demselben Stücke vorhunden, so daf dieses gestreift, grefleckt, seadert, marmoriert oder in anderer Treise erexichne erscheint. Die Färbung ist nicht an allen Orten des Vorkommens dieselbe; an manchen überwiegt mehr die eine, an manchen mehr eine andere Nuance. Diese kamn daher neben der mikroskopischen Struktur und der speziellen chemischen Zusammunsetzung bis zu einem gewissen Grade dazu dienen, den Fundort eines Stiickes 7.1 bestimmen.

Wass clas natüliche Vorkommen des Nephrits anbelangt, so gehören seine urspurünglichen Laşerstïtten überall den kristallinischen Schiefern an. In Hornblendeschiefern, aber auch im Pyroxenfels. und vor allem in Serpentin und in anderen hierher gehörigren Gesteinen bildet er mehr oder weniger mächtige und ausgedehnte Einlagerungen. Aus Serpentin soll er auch da und dort dureh den Gebirgstruck, durch die bei der Gebirgsbildung zur Wirksamkeit gelangenden dynamometamorphen Prozesse entstanden sein. Allerdings ist bezïglich des Vorkommens und der Bildung des Nephrits noch manches in Dunkel wehiillt. Anstehenden Nephrit kennt man vorzugsweise in Ost-Turkestan und den nach Osten daran sich anschliefenden Gegenden in China, ferner in Cisbaikalien und auf Neuseeland. Geringere Mengen hat man in Sehlesien, etwas größere in Ligurien gefunden, und auch sonst ist er wohl sparsam in dieser Weise vorgekommen. Sehr häufig liegen lose Blöcke als Gerölle in den Flußanschwemmungen der Gegenden, wo sich die urspriinglichen Lagerstiitten befindeu. In dieser Form, als Gerölle, ist der Nephrit dann u. a. auch im norddentschen Flachlande angetroffen worden. Wir werden im folgenden das Vorkommen und dir Verbreitung des Nephrits etwas eingehender betrachten und dabei nicht nur das Rohmaterial, sondern auch die verarbeiteten prähistorischen Objekte beriicksichtigen.

In Europa ist der Nephrit besonders in verarbeiteten Zustande verbreitet. Nephritobjekte, namentlich Beile und Meißel vou prähistorischem Alter, sind vor allem in der Sehweiz wichtig, wo sie vorzugsweise in den Pfahlbauten am Bodensee, Ziiricher See, Bieler und Neuenburger See in grober Zahl vorgekommen sind, vielfach mit einem dunkeln Überzug, einer Patina bedeckt, die aus Markasit besteht. Ehenso finden sie sich auch in den benachbarten Gegenden des südlichen Badens (am Überlinger See bei Maurach) und Bayerns. Die hier gesammelten Steine haben eine ganz besondere mikroskopische Beschaffenheit, die sie von allen anderen bekannten Nephriten unterseheidet. Es ist daher durchaus wahrscheinlich, dab das Material nicht von fern her, sondern vielleicht aus den Schweizer Alpen stammt. Allerdings hat man bisher trotz aller Nachforschungen hier noch keinen anstehenden Nephrit entdecken künnen, aber man hat doch am Ufer des Neuenhurger Sees einige abgerollte Geschiebe dieses Minerals gefunden, die zweifellos aus einer noch zu entdeckenden ursprïnglichen Lagerstiitte jener Gegend, vielleicht aus dem Wallis, stammen. Ob dabei auch das erwähnte primäre Torkommen in Ligurien mit in Betracht kommt, stelit noch dahin.

Auch weiter östlich, im Samntal oberhall, Cilli und im Murtal in Steiermark, sind Geschiche von Nephrit in ziemlicher Anzahl aufgelesen worden, deren urspriingliches, zweifollos in der Nähe befindliches Lager man greichfalls nicht kemnt. Sieher deuten sie aber clarauf hin, dalj dex Nephrit in den Alpen cine größere Verbreitung hat. Bei weiteren Fortsehritten in der seologischen Frforschung dieses vielfach noch wenig bekannten Gebirges relingt es vielleicht, das Anstehende dieses Nephrits anfzufinden. Die Lücke zwischen der Sehweiz und Steiermark füllen einige verarbeitete tiroler Nephritstiicke aus; Rohmaterial kennt man aber von hier noch nicht.

Aulierhalh der Schweiz und den genamnten benachbarten Gegenden sind bisher noch wenig prihistorische Nephritsachen in Juropa gefunden worden; Jadeitgeräte, die auch in

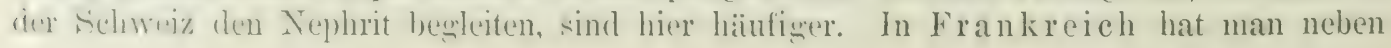




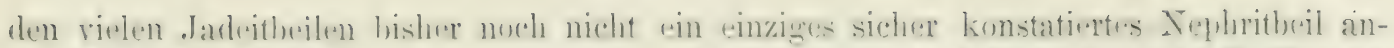

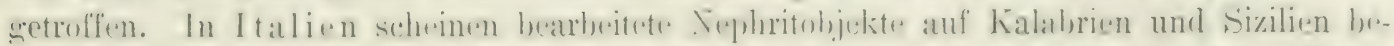

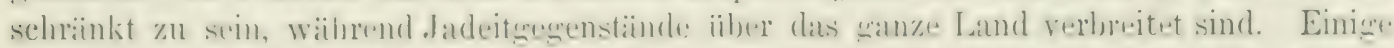
wenime Funde sind in triechenland gemacht worden. Ionhuaterial hat man in dirsen Iändern noch nicht entrleckt anlier in Italien in rex regend von siestri levante in siid-

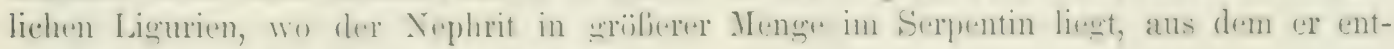
standen sein soll.

Deutschland hat neben denen aus dem sudlichen Baden und Bayern nur einige

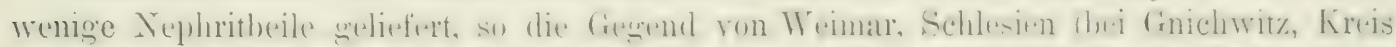
Breslau) usw. Hex ist der lohmephrit wichtiger, der in verschiedener drt des lonkmmens im Lande bekannt wurde.

Zunächst sind einiwe erratische lilïcke und freschiebse im nordischen Diluvium ein-

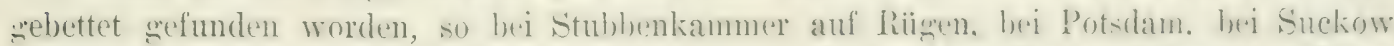

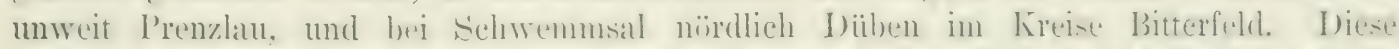
Nephrite entstanmen, wie alle anderen Diluvialgeschiche in unserem Flachlande, von denen sie sich in Vorkommen in nichts unterscheiden, zweifellos aus dem skandinavischen Norden und gehören höehst wahrscheinlich den dort so rerbereiteten kristallinischen Schiefern an.

Anstehender Nephrit ist in Deutschlaud anf Schlesien beschränkt. Er wird von hier schon ron I,inné 1707-17T) erwähnt, aber dessen Mitteilung weriet in Laufe der Zeit in Vergessenheit. In den achtziger Jahren des 19. Jahrhunderts ist damn das Vorkummen von neuem entdeckt worden, und zwar an den von Linné angegebenen Orten. Der erste befindet sich in Gebiete des Zobtengebirges bei Jordansmiilul. Wo bis uiber fufimächtige, zuweilen weithin sich erstreckende Lager von meist dunkelgrüner Farlue zwischen Granulit und Serpentin einerebettet und rundliche bis 5 em grofe Kinollen sowie breitere und schmälere Bänder von weifer bis hellgriiner Farbe im letzteren Gestein sellst eingeschlossen sind. Hier hat G. F. Kunz 1999 für die Sammlung des oben genamnten If he ter R. Bishop in New York neben kleineren Stïcken einen Block von 2140 Kilumramm erhalten. Der Nephrit des oben erwähnten Beils von Ginichwitz, zwei stunden ron Jordansmühl, stimmt gut mit dem hier anstehenden überein. I)ie zweite Lokialitiit liegt bei dem durch seinen Bergbau bekannten Reichenstein; hier trifft man das Mineral aber nicht in großer Menge. Bis zu 7 em dicke Lagen eines dichten, hellgraulichgrinen, zuweilen etwas rütlichen Tephrits mit sehr unvollkommener schieferung finden sich in dem Diopsidgesteine des Fïrstenstollens eingeschaltet. Einen Pflasterstein aus Tephrit ron unbekannter Herkunft liat man in Breslau entdeokt.

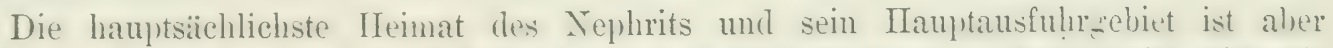
Asien, und zwar ror allem Mst liuliestan (kleine Bucharei. Wichtigs ist hier die Gegend südlich von Yarkand und Khotan. Besonders bekannt sind die jetzt allerdinges nicht mehr oder doch nicht mehr andauernd im Betrieb stehenden Nephrifbrïche Konakán und Karalí am rechten Abhange, 500 Fuß ïher dem Masser, 1'.. Meilen daron entferunt im Tale des Karakasch, des Oberlaufs des Khotan Darja, in der (iegend ron Ciullaschén und 9 (engl.i Meilen istlich von Schahidulla, das an dem scharfen, nach Wisten gekehrten

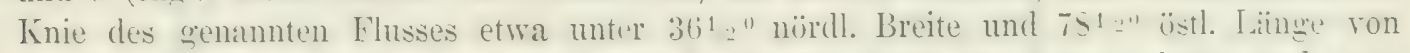
Greenwich liegrt. Es ist die Gegend des westlichen Endes der Kirenlunkette. nnd zwar deren südlicher Abhans. Der Tephrit bildet nach frïheren Beschreibungen in diesen Briichen 20 his fo Fuli mächtige Lager im tineis und IIornblendeschicfer, es wirl jetzt aber rermutet, dalj er auch hier im Serpentin rorkomme und aus cliesem tuntstanden sei. Wrie an südlichen, so ist aber auch am nördlichen thhange jenes Gehirwes an mehreren Stellen Vephrit anstelrend vorgekommen, so weiter albwïts am Khotan Darja und am 
-irikia, und wenso als Gerölle in allen dortigen Wasserläufen am nördlichen und südlichen (iehängr. I) Yeph Yrit von Ost-Turkestan ist im allgemeinen beller als aller andere.

Ein forncrer Fundpunkt anstehenden Nephrits wurde weiter westlich im Osten des Pamirgelietes in Gruben am Raskem Darja ausgebentet, der, ron Westen kommend nul mit dem ron Süiden zufließenden Tasch Kurgan sich rereinigend, den Yarkand Darja hilkct. Die Gruben liexen am rechten Ufer des Raskem, etwas nördlich ron Taschkhana, wo el, ein Kinie bildend, sich plötzlich von Nordwest nach Norden umbiegt, ungefähr unter $37^{\prime \prime} 4^{\prime}$ nördl. Breite und $76^{\circ}$ östl. Länge von Greenwich. Ein solches Vorkommen in dieser Gegend war lange vermutet worden, da man weiter unten im Tale des Yarkand Darja immer schon viele Nephritgerölle gefunden hatte. Im Jahre 1580 wurde dann das Anstehende und die Gruben entdeckt, deren Material mit dem der Gerölle vollständig iibereinstimmt.

Die bis jetzt bekannt gewordenen Lagerstätten des Nephrits in diesem Teile ron ('hina sind indessen nicht auf die wenigen genannten Punkte beschränkt; sie erstrecken sich rom Raskem Darja aus über fünf Längengrade nach Osten bis zum Kiria (etwa $81^{1}$.2" istl. von Greenwich), ja wohl noch erheblich weiter, und zwar liegen sie überall an beiden Abhängen des Kwenlun-Gebirges.

Ausführlich berichtet in neuerer Zeit Bogdanowitsch über den Nephrit jener riegenden. Nach seinen Mitteilungen sind im Kiwenlun zwischen dem Berge Mustagat (etwa $76^{\circ}$ östl. von Greenwich) und dem Meridian des Lob-Nor (etwa $89^{\prime \prime}$ östl. Länge) nicht weniger als sieben Bezirke ursprünglicher Lagerstätten des Nephrit bekannt, die dem nürdlichen Abfall des Gebirges und dessen unmittelbarem Torlande angehören. Der Nephrit ist besonders in Pyroxengesteinen eingelagert. Fast alle Wasserläufe Kaschgariens führen Nephritgeschiebe. Ständige Nachgrabungen nach solchen finden in den Tälern des Jurunkasch, Karakasch und des Tisnab statt. Besonders bekannt sind die bei Kumat am erstgenannten Flusse unterhalb Rhodan. Sie bewegen sich sowohl in den neuesten Anschüttungen des Flusses, der zum Zwecke der Nephritgräberei oft auf weite Strecken abgeleitet wird, als auch besonclers in den älteren, terrassenförmig über dem Fluf sich erhebenden Schuttablagerungen aus der Diluvialzeit. Oberhalb Kumat ist die Talebene ganz durchlöchert von 1 bis $1^{1 / 2} \mathrm{~m}$ tiefen Gruben. Seit alter Zeit durch ihren Nephritreichtum berühnt sind die Karangu-Tag-Berge südlich von Khotan, etwa $791^{12}$ ".̈stlich ron Greenwich, wo sich das Mineral aber nicht auf ursprünglicher Lagerstïtte findet wie im Karakaschtale an den oben erwähnten Orten, und bei Balyktschi. Das gleiche gilt für die von dem genannten Reisenden neu aufgefundenen Ablagerungen bei Schanut am Tisnab und von Ljuschei im Gebiete des Kiria Darja und ebenso von dem Vorkommen an dem berïhnten Berge Mirdschai oder Midai im oberen Flubgebiete des Asgensal, (eines Yebenflusses des Yarkand Darja. Die Fundorte anstehenden Nephrits werden seit dem Aufstande der Iuhamedaner in den sechziger Jahren und der Vertreibung der Chinesen nicht mehr bearbeitet; sie gelten bei diesen für erschöpft und, soweit es sich um das zutage liegrende Material handelt, nicht mit Unrecht. Alle ursprünglichen Lagerstätten des Nephrits gehören dem IIochgebirge an; manche liegen jedenfalls noch jenseits der rehneegrenze in für Menschen unerreichbaren Höhen, von denen viele Blöcke in die Tiefe rollen oder von den Gewiissern und den Gletschern zutale gefuihrt werden.

Nach dem Vorkommen und der Art der Gewinnung werden hier in dem Rohmaterial (lrei Varietiaten unterschieden: 1) aus der ursprünglichen Lagerstätte im Steinbruche gewomnene Stiicke; 2) nicht von Menschenland gebrochene, sondern von unzugänglichen Hähen durch das Eis der Gletscher mitgehrachte Stiicke, die noch ihre urspringlichen Kinten und Ecken haben; 3) Rollstiicke aus älteren diluvialen oder jüngeren alluvialen Fluliablagerungen. I) ie letzteren waren beim 'Transport Stöben und ähnlichen Einwirkungen 
alm meisten auscesetzt; sie sind daher wahrscheinlich freitr ron unsichtharen inneren Lissen, da sie sonst nach ihnen wohl hätten zerbrechen müissen. Aus diesem Grunde sind sie wertvoller als alle anderen, natürlich grleiche Farbe und sonstige lieschaffenheit vorausgesetzt, die bei der P'reisbildung von erröliter Wichtigkeit sind. Am wenigrsten Wert haben die aus Steinbriichen kommenden Stïcke, die der erolien Festigkeit der Nephrits wegen dureh Fenersetzen gewomnen werden. Dadureh verliert das Material an (zualitait, und namentlich zerspringt die Masse in verhältnismälig kleine Teile, so dab grö̈bere Blïcke, wie der resige Monolith rom (irabmal des Tamerlan in Samarkand in der CiurEmir-Moschee zu den groben Seltenheiten sehören. Einen solchen Block in Form eines unfürmlichen Klumpens von 13\%,1 em Lä̈nge, 111,2 cm Broites und 91,5 cm Dicke und trotz aller im Laufe der Zeiten daran verül)ten Zerstürungen nur um ein I)rittel kleiner als jener Monolitb, wahrscheinlich aus den erwähnten Grähereien von Sehanut stammend, fand Bogdanowitsch beim Dorfe l schaktal zwischen Karasch und Toksun. Er war dort schon in der Mitte des vorigen Jahrluunderts auf dem Wegre nach Peking aus irgendeinem Grunde liegen gelassen worden.

Im Jahre 1591 wurde ein noch viel weiter im Osten neu entrleckter Funduunkt anstehenden Tephrits bekannt gemacht. Er liegt in Norden der Kwenlun-Kette auf dem Wege vom Kuku-Nor nach dem nürdlich davon gelegenen Nanschangebirge in der chinesischen Provinz Kansu. Es ist der Beschreibung nach ein Veplritgang, der in einem nicht näher hek:annten weichen Gestein aufsetzt und rou dem wohl die vielen Geschiehe stammen, die ron friiheren Reisenden in den Bächen und Flïssen jenes Landstriches gefunden worden sind. Am Tordabhange des Tanschan, z. B. in den Iö̈rfern Kan-Tschu und In-Tschu wird ein lebhafter Handel mit Nephrit betrieben, und in beinahe allen Dörfern der Gegrend verarbeiten die Landleute den stein für die Chinesen. Auch in der Stadt Su-Tschu-Fu (etwas südlich vom 40. Breitengrade) bestehen mehrere Werkstïtten. Der an vielen Stellen im Nanschangebirge vorkommende Nephrit ist trübe bis durchscheinend, von lichtgrüner, milchweißer bis schwefelgelber Farbe.

Es ist nicht unwahrscheinlich, daß in der langen Kette des Kwenlun und des Tanschan noch an anderen Orten anstehender und geschiebefürmiger Nephrit den Einheimischen bekannt ist und daß dasselbe auch in anderen Gegrenden Chinas, z. B. in Yïnan, der Fall ist. Jedenfalls liefern aber jene genannten Lagerstätten (oder haben wenigstens früber geliefert) einen sehr ansehnlichen Teil des in China so viel verarbeiteten und so hoch geschätzten Steines Yü. Von diesen Fundorten kommt auch der meiste. sonst in Asien, namentlich in Zentralasien, zu allen möglichen Zwecken verwendete Nephrit. Ob aber alle in Asien gefundenen bearbeiteten Nephritgegenstände aus OstTurkestan oder den anderen genannten Gegenden in China stammen, steht dahin. Funde dieser Art wurden im Amurlande, an Ostkal, auf der Tschuktschenhalbinsel, in Japan usw., aber auch in Syrien und Kleinasien gemacht; in dem letzteren Lande hat Schliemann bei seinen Ausgrabungen Nephritgeräte zutage gefördert. Wahrscheinlich ist es, daß alle diese Gegenstïnde auf jeweils in der Tähe gefundenes Rohmaterial zu beziehen sind.

In der Tat sind außer den erwähnten noch manche sonstige Nephritrorkommen in anderen Teilen von Asien bekannt geworden.

Zunächst sei hier die Gegend am westlichen Ende des Baikalsees im Gouvernement Irkutsk genannt, wo Tephrit von vortrefflicher Beschaffenheit und mannigfacher Fürbung in Menge vorkommt und gewonnen wird. Die cisbaikalischen Fundorte liegen in dem zu der Gebirgskette ron Sajan gehörigen Felsengebirge Botogrol und in den ron dort ausgehenden Wasserläufen. Die Bewohner jenes Landstruchs, die Sojoten, tragen vielfach Tephrit als Schmuck, die Weiber um den Hals, die Männer am Tabaksheutel. Tiel ge- 
nannt und mit :mm läingsten lekannt ist das Vorkommen in der Umgebung der seit 1555 aufgelass(men (rulu, die den lange Zeit ron der großen Faberschen Bleistiftfabrik in Nürnherw veruherten beriihnten Alibert-Graphit geliefert hat. Graphit und Nephrit sind hier imnim mitrinanler rerhunden, sofern der letztere vielfach Graphitplättchen eingewachsen mollialt. Lampe Zeit waren aus jener ganzen Gegend nur mehr oder weniger stark abgerollte stilcke, manchmal Blöcke bis zu 1000 Pfund Gewicht, unter den Geschieben in den Jlhwimen der dortigen Bäiche und Flüsse bekanut. Die Gewässer, die solche führen, sind die Fliisse Bjelaja mit dem Urik und Onot und der Kitoj, die beide von links in die Angara münden, der erstere etwas weiter vom See entfernt als der letztere; ferner die Bistraja, rechter Nebenfluß des Irkut, von dem Berge Clawar-Daban kommend, der die scharfe Ecke zwischen dem See und der Slïdjanka ausfüllt (Fig. 98, S. 541); sodann der letztere Fluß selber. Anstehend wurde schöner, fast smaragdgriiner Nephrit schon 1850 am Onot aufgefunden, und zwar von Alibert, dem Entdecker des Graphits und des erratischen Nephrits. Tiele Pfunde prächtigen Materials von Nephrit sind seitdem dort gewonnen und verarbeitet worden, und namentlich in der letzten Zeit wurde viel nach Europa und besonder's in die russischen Schleifereien (Peterhof) geliefert. Kurze Zeit nachher wurden die Lager am Flüßchen Sachanger (Sagan-Char), das in den Kitoj mündet, bekannt. Gegen Ende des 19. Jahrhunderts ( 1597 ) hat man dann dort noch eine Reihe von anderen Vorkommen auf urspriinglicher Lagerstätte entdeckt, so als teilweise bis 4 Meter mächtige Lager im Flußsystem des Urik und des schon genannten Onot, solann am Kitoj selbst und endlich im Gebiet des Baches Chara Scholga, der in den Chorok fließt. Diese neuen Entdeckungen, die man L. von Jaczews si verdankt, wurden veranlaßt durch den Wunseh der russischen Regrierung, schönes Naterial zum Grabdenkmal des Zaren Alexander III. zu erhalten. Der Nephrit des letztgenannten Fundorts, teils blalj grefürbt, teils lebhaft grün, wurde in Terbindung mit Rhodonit dazu verwendet. Der ostsibirische Nephrit, der ïbrigens auch in Transbaikalien am Anur anstehend beobachtet worden sein soll, ist recht mannigfaltig in Färbung und Aussehen und meist von guter, vielfach von vortrefflicher Qualitiit. Er gilt als ein dynamometamorphes Umwandlungsprodukt von Strahlsteinschiefer, der ein Glied der Reihe der kristallinisehen Schiefer darstellt. Terarbeiteten Nephrit (Beile) hat man in Ostsibirien auch gar nicht selten in Boden und in Grabstiitten der Ureinwolnnex gefunden, so in alten Tschudengräbern bei Tomsk und am Altai.

In Ostindien ist Nephrit oder doch nephritälunliches Material ebenfalls gefunden worden, das aber im Lande offenbar nicht in größerem Maßstab gewonnen und verarbeitet wurde. Das Vorkommen ist daher nicht sehr wichtig. Es beschränkt sich auf den siidlichen Teil des Bezirks Mirzapur in Bengalen.

In Amerika tritt, wie in Europa, der Nephrit an In̈ufigkeit geegen den Jadeit weit zurïck. Verarbeitete Nephritolyjekte kennt man aus Zentralamerika, Venezuela, Britiseh Columbia und Alaska. Anstehendes oder doch rohes Material sollte vom Amazonenstrom kommen, und rin 'Teil dessen, was Amazonenstein genannt wird, sollte Nephrit sein; vlies ist jerloch sehr unsicher. Mit Bestimmtheit nachgewiesen ist jedoch das Vorkommen rohen und anstehenden Vephlurits an verschiedenen Orten in Alaska und in bemachbarten reilen von Britisch Columbia. Aus Alaska stammt wohl auch das Material zu den bei den Tschulitschen und sonst in jenen fiegenden auf beiden Seiten der Behringsstrabe bei den Fingehorenen gefundenen Nephriterenenstïnden, so dalf also die amerikanisehen Steine vielleicht über jene Stralje hinüber his mach Asien verbreitet worden sind. Dal die in Siidannerika, in Tenezuela, Colmmbia und Brasilien vorkommenden Nephritgegenstände aus

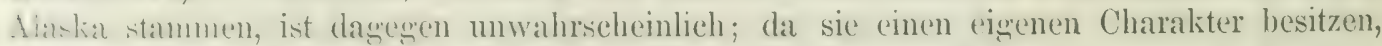
ind sir wohl aus einheimischem Material hergestellt, dessen findorte man allerdings noch nicht kennt. 


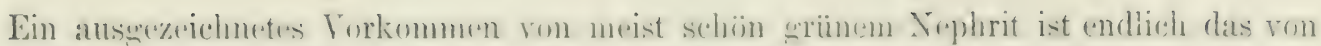

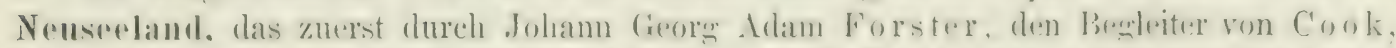
bekannt geworden ist. 1)er Nephrit findet sich nach F. II ocelestetter teils anstelend, trils

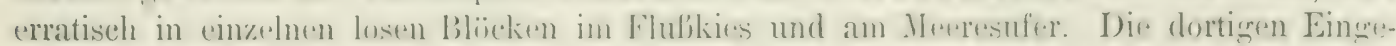

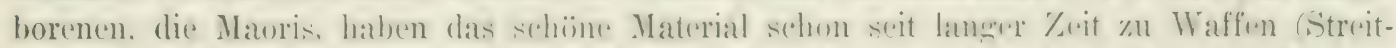

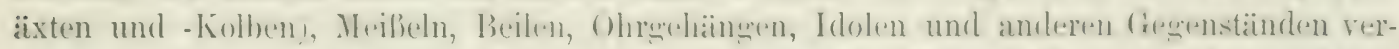

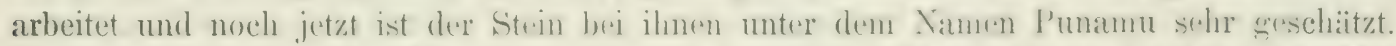

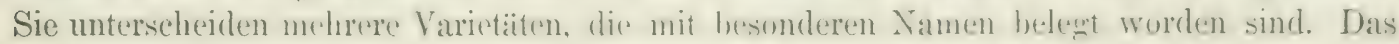
Vorkommen ist noch nicht wenauer hekannt. Lis seheomen drei Hauptfundorte zu sein, die alle auf dex Westseite der Sïdinsel bexen. Der erste ist am Arahanta- oder Brunnerfludi, wo der Nephrit 15 engl. Meilen von der Mïndung entfernt in mehreren Fuli mächtigen

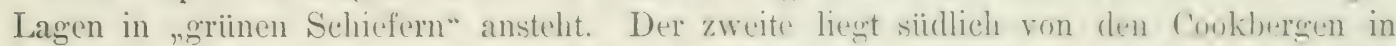

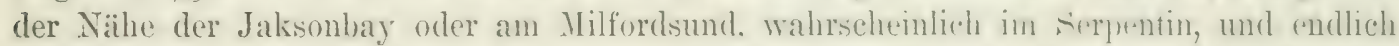
der dritte am see P'unamu in der P'rovinz Otazia. Das Vurkommen ansteluenden Nephrits in Neuseeland war allerdings anch vielfach bezweifelt worden, da alle zur Verarbeitung kommenden Stiicke Gerölle sincl. Neuerdings ist aber der Nephrit in Serpentin de' D'Urville-Insel von A. Dieseldorff mit Bestimmtheit nachwewiesen worlen, wenn greich nur in geringer Menge. Der Neuseeländische Nephrit geht anch nach Europar, um dort zu allen möglichen Gegenständen verschliffen zu werden. Man findet auf jener Insel noch andere srüne, dem X'ephrit :̈hnliche Substanzen, die jedoch eine abweichende Zusammensetzung haben, so z. B. die steine Kawakawa und Tangwiai, die vitlach mit Nephrit verwechselt und wie dieser benutzt werden.

Auch sonst kommt Nephrit roh und verarbeitet in jenen Gegenden vor, so auf NeuKaledonien (anstehend), in Teu-Guinea, auf den Marquesas-Inseln, den Neu-Mebriden. in Otaheiti, Tasmanien usw.; das Vorkommen in Nenseeland ist aber weitaus das wichtigste.

Auberordentlich zahlreich sind die Mineralien, die fälschlicherweise unter dem Namen Nephrit in den Sammlungen liegen oder als Schmucksteine usw. Verwendung gefunden Laben, und die als Falsonephrite bezeichnet werden. Beinahe alle Mineralien. die dicht, nur durchscheinend und in der oben angegebenen Weise gefärbt, also vorzusweise grim sind, hat man schon für Nephrit gehalten. Es sind versehiedene Varietïten des Minerals Quarz und Achat, Serpentin, Zoisit und viele andere. Härte und spezifisches Gewicht lassen den Lnterschied meist ohne besondere Schwierigkeit erkennen. In China wird (oder wurde) der Nephrit durch eine stark bleilualtige Glaspaste nachgeahmt, die man als "pâte de riz" bezeichnet und die dem echten Nephrit sehr ähnlich, aber schwerer ist als er. Sehr lange wurden namentlich Jadeit und Chloromelanit mit Nephrit rerwechselt, oder besser für Nephrit gehalten. Bei der speziellen Beschreilumg dieser beiden Mineralien wird der Unterschied angegeben werden.

Wie wir oben gesehen haben, hat der Nephrit im grauen Altertum grobe Bedeutung gehabt, und im Orient, besonders aber in China, hat ex diese noch, und ehenso bei gerrissen halbwilden Völkerschaften. Im heutigen europäischen Juwelenhandel kommt der stein aber kaum vor. Man verfertigt aus schön grünen Varietïten, besonders dem ron Teuseeland und vom Baikalsee wohl melegentlich einen meist mugelig geschliffenen Ring- oder Nadelstein, auch zuweilen einen ganzen Ring, aber viel häufiger kleine Gebrauchsgetenstïnde, wie Papiermesser usw. Vielfach wird der Tephrit auch heute noch als Amulett geegen manche Krankheiten, besonders Nierenkrankheiten, getragen. aber in der Irantsache hat das Mineral eine untergeordnete Wichtigkeit und die daraus hergestellten Schmucksteine weringen Wert. Sehr kosthar sind allerdings viele der im Orient und besonders der in China hergestellten Kunstgegrenstïnde aus Nephrit, in Europa freilich weniger des Materials als der zum Teil außerordentlich kunstrollen Arbeit wegen. 
Dies ist in ('hina anders; hier hat der Nephrit auch an sich, abgesehen von der darauf verwendeten Arheit, cinen hohen Wert und bildet einen wichtigen Handelsgegenstand. Jede Farbe und jede schattierung des Steines Yü hat bei den Chinesen ihren eigenen Namen und ihren besonderen Preis. Am höehsten schätzen sie die Sorte von rein milchweißer Farlue und, wie sie sich ausdruicken, mit dem fettigen Glanz des Schweineschmalzes. Für Jiollstiicke von dieser Beschaffenheit werden nach den Mitteilungen von Bogdanowitsch lis 200 Riubel bezahlt. Die Schwierigkeit der Bearbeitung des zähen Materials erhöht aber schon in China den Wert verarbeiteter Stiicke noch bedeutend. Für die Arbeit wird das doppelte Gewicht der entfernten Steinmasse in Silber bezahlt. Dies gilt aber nur für rohe Schleiferei; die Faronnierung mub noch, je nach ihrer Feinheit, besonders bonoriert werden. Man erkennt hieraus leicht den Grund des hohen Preises, den die chinesischen Nephritwaren in ihrer Heimat und noch mehr in Europa haben.

\section{Jadeit. Chloromelanit.}

Der . Tadeit und der Chloromelanit sind lange mit Nephrit verwechselt worden, da sie ihm im äußeren Ansehen, in der Zühigkeit, Härte usw. sehr ähnlich sind. Die französischen und englischen Mineralogen haben sie vielfach alle drei unter dem Namen Jade zusammengefaßt, der aber jetzt, wo der Unterschied erkannt ist, fast ganz auf den Nephrit beschränkt wurde. Am besten wäre es, diesen Namen überhaupt nicht mehr zu verwenden, da er immer mit einer gewissen Unsicherheit verknüpft ist. Er stammt ron dem spanischen: Piedra de la hijada $=$ Nierenstein.

Erst durch die chemischen Analysen, des französischen Mineralogen Damour und durch die mikroskopische Untersuchung ist ermittelt worden, daß von dem echten Nephrit, wie wir ihn kennen gelernt haben, der Jadeit und der Chloromelanit als bei aller äuferen Ähnlichkeit wesentlich verschiedene Mineralkürper abgetrennt werden müssen, und daß die letzteren beiden nicht wie jener zur Gruppe der Hornblende, sondern zu der des Augits gehören. Untereinander sind Jadeit und Chloromelanit nur unwesentlich verschieden. Der letztere hat bei der Analyse, seiner dunkleren Farbe entsprechend, einen höheren Eisengehalt ergeben, während der erstere ziemlich eisenfrei oder doch sebr eisenarm ist. Die übrigen Bestandteile sind in beiden dieselben und ebenso alle anderen charakteristischen Merkmale, so dab also der Chloromelanit wohl als ein eisenreicher Jadeit anzusehen ist.

Der Jadeit ist chemisch sehr ähnlich dem Spodumen (S. 557), nur enthält er in derselben Formel Natron statt Lithion. Er ist in der IIauptsache ein Natron-Tonerde-Silikat: $\mathrm{Na}_{2} \mathrm{O} \cdot \mathrm{Al}_{2} \mathrm{O}_{3}, 4 \mathrm{SiO}_{2}$, dem aber stets kleine Mengen anderer Bestandteile beigemischt sind, so dal die Analysen für verschiedene Stïcke ziemlich schwankende Werte ergeben. Die chemische Intersuchung des Chloromelanits hat bisher allerdings noch nicht genau auf dieselbe, überhaupt nicht vollkommen ungezwungen auf eine einfache chemische Formel gefuihrt, so daß hiier noch weitere Nachforschungen zur Ermittelung der richtigen Verhältnisse nütig sind. Wie nahe sich aber die beiden stehen, ist aus den zwei folgenden Analysen zu ersehen, von denen die erste sich auf einen rohen Jadeit von Birma, die andere auf einen zu einem Beil verarbeiteten Chloromelanit aus dem Dep. Morbihan (Bretagne) in Frankreich bezieht. Beide Analysen geben außerdem dureh Trergleichung mit den oben anģeführten Zahlen für den Nephrit den großen chemischen Tinterschied von diesem, dem namentlich Tonerde und Natron beinahe vollkommen fehlen, wiihrend umgekehrt der Jadeit und Chloromelanit fast keinen oder nur wenig Kalk und keine Magnesia enthalten. 


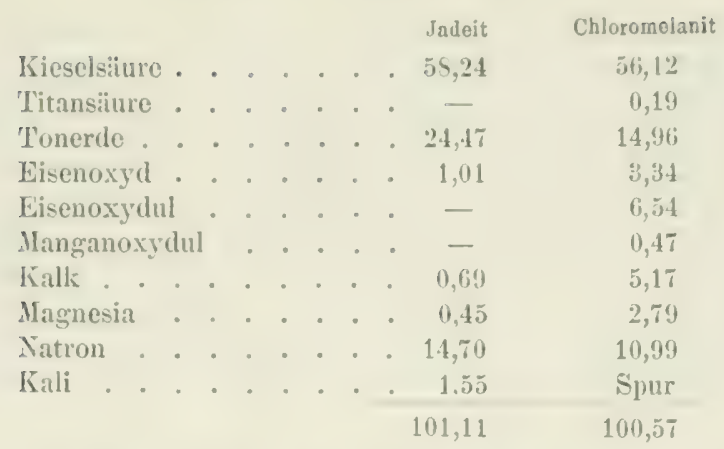

Wie der Nephrit, so bildet auch der Jadeit und der Chloromelanit ein sehr feinfaserimes bis dichtes Gewebe olne bestimmte, regelmäbige äufere Forn, dessen refüge nur in Dünnschliffen unter dem Mikroskop) deutlich hervortritt. Die feinen Fïserehen liegen wie beim Nephrit kreuz und quer durcheinander; auf dieser verworren faserigen Struktur berulıt die grobe Zühigkeit und Festigkeit auch dieser beiden Mineralien, sowie der unehene, splitterige Bruch, den beide mit dem Nephrit gemein haben.

Wie bei diesem, so sind auch hier die Stïcke nie durehsichtisn, höjchstens durchscheinend bis kantendurchscheinend. Der Glanz ist auf Bruchfliichen zering, durch die Politur wird er sehr verstärkt und geht dabei vielfach etwas ins Fettige. Denselben rlanz zeigen auch manche abgerollte Geschiebe an ihrer Oberfläche. Die Suhstanz des Jadeits ist farblos, und so sind zahlreiche Stiicke vollkommen oder doch nahezu weif, nicht selten mit einem Schein ins Rosenrote. Doch findet er sich auch häufig grefïljt, aber meistens ziemlich licht: graulich, grïnlichweiß, bläulichgrün, lauchgrün, apfelgrïin, jedoch auch schön smaragdgriin. Wenn letztere Farbe vorkommt, ist sie gewöhnlich in einzelnen meist nicht sehr großen, ziemlich scharf abgegrenzten Flecken auf weiljem Hintergrunde verteilt. Das Smaragdgrïn wird durch einen in den. Jadeiten von dieser Farhe stellenweise rorhandenen kleinen Chromgehalt verursacht, sonst ist aber die griine Farbe die Folge des kleinen Eisengehaltes. Daher ist auch der Chloromelanit viel dunkler als der Jadeit. Er ist nie farblos oder licht gefärbt, sondern stets dunkelgrün bis beinahe schwarz.

Wir haben im Vorhergehenden die Punkte hervorgehoben, in denen der Jadeit und Chloromelanit mit dem Nephrit mehr oder weniger übereinstimmen; im folgenden sollen die unterscheidenden Eigenschaften angegeben werden.

Hierher gehört vor allem das spezifische Gewicht, das beim Jadeit hüher ist als beim Nephrit. Es beträgt beim Jadeit 3 , ,im bis $3, \%$, beim Chloromelanit, des größeren Eisengehaltes wegen mehr, nämlich $:,{ }_{1}$. Allerdings sinkt bei manchen Jadeiten infolge von zahlreichen fremden Beimengungen das Gervicht his auf den für den Nephrit geltenden Wert herunter, und wenn dies auch eine seltene Ausuahme ist, so folgt doch daraus, dafs ein niederes spezifisches Gewicht nicht zur sicheren L'nterscheidung des Jadeits rom Nephrit dienen kann, doch spricht das hohe Gewicht von 3,3 immer gegen Nephrit.

Auch die Härte ist beim Jadeit etwas grölier als beim Nephrit; es ist H. $=61 / 2$ bis 7 .

Ein charakteristisches Merkmal dem schwer schmelzbaren Nephrit gegenüber ist die sehr leichte Schmelzbarkeit des Jadeits und des Chloromelanits. Feine Splitter typischen Jadeits schmelzen schon in der. Weingeistflamme ohne Anwendung des Lütrolures zu einem durchsichtigen, etwas blasigen Glase, wobei sich die bläuliche Flamme infolge des Natrongehaltes des Jadeits lebhaft gell) färbt. Dasselbe gilt für den Chloromelanit. Allerdings ist dieser niedere Schmelzbarkeitsurad ebenfalls nicht ganz konstant, sofern einzelne Jadeite und ('hloromelanite etwas schwerer schmelzen, aber doch nie so schwer wie Nephrit, der auch niemals die Flamme gelb färbt, da er kein Natron enthält. 
Die sicherste Lnterscheidung gibt jedoch neben der chemischen Analyse die Untersuchung diünn Schliffe unter dem Mikroskope, bei der die einzelnen Fäserehen nach ilirem ganzen Verhalten, nach ihrer Spaltharkeit, ihren optischen Eigenschaften usw. sich unzweidentig als zum Augit grehörig erweisen, während, wie wir gesehen haben, die des Yephrits dir Eigenschaften des Amphibols zeigen. Selbstverständlich kann aber die Schmmlzharkeit, die chemische Zusammensetzung und das mikroskopische Verhalten bei harbeiteten Gegenständen häufig nicht untersucht werden, da hierzu die Ablösung eines, w'mn auch nur kleinen Splitters, erforderlich ist. In diesem Falle ist man dann ganz aluf das spezifische Gewicht beschränkt, wobei aber die oben gemachte Mitteilung zu beachten ist.

Was das Torkommen anbelangt, so hat man bearbeitete Jadeitobjekte aus prähistorischer Zeit in Europa, Asien, Amerika und auch in Afrika und Australien vielfach gefunden, die Sitellen, wo das Rohmaterial herstammt, sind aber meist noch so gut wie unbekannt. Der einzige bekannnte und wissenschaftlich untersuchte Ort, wo größere Massen von Jadeit anstehend und erratisch vorkommen und gewonnen werden, liegt im nördlichen Birma. Yon hier aus wird der Stein wie der Nephrit von seinen asiatischen Fundorten aus als sehr geschätztes Material durch den ganzen Orient verbreitet und mit dem Nephrit, häufig ohne bestimmte Lnterscheidung beider, riel verarbeitet. Wie beim Nephrit ist dies be-

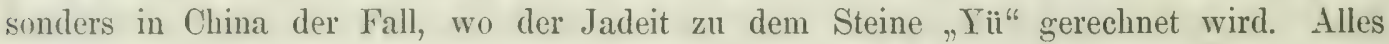
was iiber die Wertschätzung und die Verwendung von Nephrit in diesem Lande mitgeteilt wurde, gilt auch fuir den Jadeit. Wie jener ist auch der Jadeit in Europa weniger geachtet und wird hier selten zum Schmuck verwendet.

Der Chloromelanit begleitet in bearbeiteter Form den Jadeit in Frankreich, der Schweiz, Mexiko, Neu-Granada; ein großes Beil aus diesem Materiale stammit von der Iumboldt-Bay in Neu-Guinea u. s. w. Rohen Chloromelanit hat man aber bis jetzt noch kaum gefunden, die aus ihm hergestellten Sachen sind alle prähistorisch; sie sind seltener als Nephrit und Jarleit. Er ist als besonderes Mineral zuerst an einem französischen Beile erkannt und von Damour nachgewiesen worden. Im folgenden sollen einige genauere Mitteilungen über die Verbreitung des Jadeits und Chloromelanits gemacht werden.

In Europa haben prïhistorische Jadeitgegenstände eine große Verbreitung wie beim Nephrit vorzugsweise in Form von Beilen, die sich aber durch ihre geringe Dicke als sogenannte Flachbeile von den meist dickeren Nephritbeilen unterscheiden. In der Schweiz begleitet der Jadeit und Chloromelanit den Nephrit in den Pfahlbauten, und zwar ist die Verbreitung der Nephrit- und Jadeitäxte so, daß in den Stationen der westlichen Schweiz die aus Jadeit, in denen der Ostschweiz die aus Nephrit ïberwiegren, so daß hier auf zehn Nephritgegenstände nur ein solcher aus Jadeit gefunden wird. In Frankreich sind bisher nur Jarleit- und ('hloromelanitgegenstände, aber keine aus Nephrit gefunden worden. In Deutschland folgen Jadeitobjekte dem Laufe des Rheins und finden sich iiberhaupt in Westen des Landes, im Elsal, Baden, Württemberg, IIessen, Nassau, Westphalen Kheinland, und im Anschlulb hieran in Belgien, sowie bis nach Itannover und Oldenhurg und im Osten bis Braunschweig und Thüringen. Während sie im östlichen Deutschland fehlen, sind sie in den österreichischen Läindern, in Oberösterreich, Käirnten, Krain, Südtirol und balmatien wieder vorhanden. In I talien sind Jadeitbeile usw. durch das ganze Land verhreitet. In Grie ehen land und daran sich anschließend in Kleina sien (Troja, mit Nephritsachen von Sehliemann ausgergraben) sind gleichfalls zahlteiche Stiicke vorgekommen und in alten $\ddot{\mathrm{A}} g \mathrm{y} p$ ten diente der Jadeit vielfach als Material zu Skarabien und anderen ähnlichen Gegenständen.

Luropiaisches Rohmaterial von Jadeit hat sich bisher blob in ken Schweizer und firementesischen Apen in geringer Menge gefunden. So sind unter den aus den Mlpen 
stammenden fieschieben des Neuenburger sees und abenso bei Ouchy unweit Laumsanne am Genfer See neben einigen Nephritereriblen auch solche aus . Iadeit angetroffen worden, und an einzelnen Stellon in den Alpen selhst, so am Monte V'iso iun Aostatale und be. St. Marcel in Piemont hat man unzweifelhaften Jadeit auch anstehend den kristallinischen Sehiefern ringelagert gefunden. Alle diese Vorkommmisse sind aber äuberst unbedeutend und nur deshalb wichtire, weil sie zeigen, dalj liohjarleit auch in Europa nicht fohlt.

In Imerika finden sich von den Creinwohnern verfertigte Jadeit- und Chloromelanitgeriatschaften in erolber Zahl in II xiko. Ilier, mol zwar in der Stalt Mexiko, hinter der Kathedrale, im Lonkreis des erroben alten Tempels, sind in den Jahren 1960) und 1901 Tausende von Jardeiteregenstïnden, Perlen, Tafeln usw. ausgegraben worden, eluenso zur gleichen Zeit eine Anzahl solcher sachen in den Ruinen von Ilount Alhan 5 miles sïdwestlich ron Oaxaca. In Mittelumerika ist Costariea, besonders aber Guatemala zu nennen, wo zahlreiche Beile, l'erlen usw. von Jadeit und ('hloromelanit in alten (iräbern liegen; im nördlichen Südamerika ist es hauptsätchlieh Venezuela. Der in Mexiko vorkommende Jadeit wird von manchen für den Stein Calchihuitl der alten Ifexikaner grehalten, andere glauben aber, dals mit diesem Yamen dort früher der Türkis bezeichnet worlen ist. Irgendwelche sichere Spur von Rohmaterial hat man bisher in wanz Amerika noch nicht angetroffen, es ist aber anzumehmen, daf der Ruhstoff zu jenen fiegrenstïnden aus den betreffenden Gegrenden stammt. Unter dem Amazonenstein vom Amazonenstrom soll neben tanderem auch Jadeit zu verstehen sein, doch ist das durchaus unbestimmt. In Alaska soll roher Jadeit neben Nephrit sich finden.

Wie beim Nephrit, so ist auch bein , Jadeit das Vorkommen in Isirn das wichtigste. Hier spielt das Mineral auf seiner urspriinglichen Lagerstätte die Hauptrolle. Yon untergeorlneter Bedeutung sind zunïchst die Fundorte in Ost-Turkestan, wo der Jadeit den Nephrit, allerdings in geringerer Menge und Häufigkeit, begleitet, oder doch in dessen Nähe vorkommt, wie dieser dem Amphibol- und Pyroxenschiefer, vielleicht dem Serpentin eingelagert. Bei Gulbaschén in Karakaschtale hat man in den Tephritgruhen Jadeit mit Nephrit verwachsen gefunden. In Pamirgebiet ist der Jadeit anstehend in Tal der Tunga, eines linken Tehenflusses des Raskem Darja, bekannt. Hier wurde er von den Chinesen in Steinbriichen gewonnen, die etwa unter 37" 40' nürdl. Breite und $76 "$ üstl. ron Greenwich liegen und die 30 bis 40 Werst ron den Tephrithriichen im Rasliemtale entfernt sind. Wie diese, so sind auch jene seit der Tertreihung der Chinesen aus Yarkand verlassen.

Sehr viel wichtiger dagegen ist das Vorkommen des Jadeits in Mhor-Birma. wo er auf einem eng begrenzten Fleck an Oberlaufe des Lruflusses in den Katschin-Bergen bekannt geworden und 1592 ron Fr. Noetling zum ersten Male wissenschaftlich in sachverständiger Weise untersucht worden ist. Ton ihm stammen zum cröbten Teile die folgenden Mitteilungren. Yeuere Nachrichten haben wir von A. W. G. Bleeck, der die Gegend im Jahre 1907 besucht hat.

Die Jadeitgruben liegen in dem Bezirke (Sub-Division) Mogromng des MyitkynaDistrikts, etwa 70 engl. Meilen von dieser stadt. im Gebiete des genannten Flusses, der in den Dschindwin mündet (vergl. Fig. (j), S. 339)). Die Art der Gewinnung ist eine dreifache. Einmal wird das Mineral in einem Steinhruch von dem anstehenden Felsen losgebrochen; sodann werden die abgerollten Blïcke aufgestucht, die im śchutte des Lru zerstreut liegen und die wahrscheinlich ron zurzeit noch unbekannten anstehenden Lagerstïtten in der Nïhe des Flusses stammen, endlich wird ein Jadeitgerölle fülurendes Konglomerat bei Hweka ausgebeutet.

Die Gewimnung aus dem L'ru ist die alteste und wird schon seit Hunderten von Jahren betrieben. Sie ist durchaus an die Ufer des Lruflusses getbunden und auf die 
Strecke rom Dorf und Fort Sanka an bis Mamon, etwa 15 bis 20 (engl.) Meilen stromahwärts. heschrïnkt. Weiter oberhalb, jenseits Sanka, fehlen Jadeitgeschiebe ganz, unterhalb Mamon werden sie so selten, daß die Gewinnung nicht mehr lohnt. Auf dieser sanzen sirecke sind die Flußufer an beiden Seiten nach dem kostbaren Mineral durchwïhlt, olme daf bisher eine Erschöpfung eingetreten wäre. In dem Flußalluvium werden an dem Fuße der die Talränder bildenden Hiigel bis $20 \mathrm{Fub}$ tiefe Gruben angelegt und ans ilnen der von Geröllen aus Quarzit und anderen Gesteinen begleitete Jadeit zutage refürdert. Auch das im Flusse selbst liegende Material wird zum Teil von mit den modernsten Apparaten versehenen Tauchern herausgeholt. Die Stiicke sind alle stark ab)gerollt und von sehr verschiedener Grölje; es wird ein Block erwähnt, zu dessen Bewegrung drei Mann nötig waren, doch sind solche Dimensionen Ausnahmen. Heutzutage ist die Gewinnung auf den am weitsten talabwärts liegenden Punkt Mamon, 10 Meilen siidlich von Tammaw, beschränkt.

Gute Stiicke werden, allerdings nur als Seltenheit, auch in einer, lïngs dem Uru anstehenden, roten thonähnlichen Verwitterungsmasse, dem sogenannten Laterit gefunden. Diese sind durch den letzteren in ihren äußeren Teilen auf ziemliche Tiefe ebenfalls rot gefïrbt und zeigen dadurch einen schönen Schiller. Wegen des hübschen Anblickes, den sie gewähren, sind sie sehr geschätzt; sie werden als ,roter Jadeit" besonders unterschieden und von den Chinesen hoch bezahlt. Im Inneren der Stiicke steckt meist noch ein ungefärbter Kern; man sieht daran deutlich, daß die Färbung von außen allmählich eingedrungen ist.

Der in jener Gegend anstehende Jadeit ist erst seit dem Ende der siebziger Jahre bekannt; er wurde etwa 15 Jahre vor Noetlings Besuch wahrscheinlich durch Zufall aufgefunden. Seitdem wird er von dem Dorfe Tammaw oder Tawmaw (Fig. 64) aus in einem großen, jetzt etwa $600 \mathrm{~m}$ langen, $300 \mathrm{~m}$ breiten und bis $50 \mathrm{~m}$ tiefen Steinbruch von 500 bis 600 Leuten aus dem Stamme der Katschins ausgebeutet. Jene nur in der trockenen Jahreszeit bewohnte Niederlassung liegt unter $25^{\circ} 44^{\prime}$ nördl. Breite und $96^{\circ} 14^{\prime}$ östl. Länge von Greenwich, 6 engl. Neilen von Sanka, $500 \mathrm{~m}$ über dem Uru und $1000 \mathrm{~m}$ iiber dem Meeresspiegel. Der Jadeit bildet eine ziemlich mächtige Einlagerung, nach anderer Annahme einen Gang, in einem dunkelgrïnen, fast schwarzen Serpentin, der in Gestalt einer kleinen Kuppe aus den umgebenden miocïnen Sandsteine hervorragt.

Der Steinbruchbetrieb geschieht zum größten Teil oberirdisch aber auch in flachen Schäichten. Nach Beendigung der Regenzeit, etwa im Dezember, kommen die Arbeiter und beginnen die voll Wasser gelaufene Grube nit Eimern miihselig zu entleeren. Vor März kann der Betrieb nicht beginnen, so daß im güinstigsten Falle drei Monate für die Gewinnung des Jadeits übrig bleiben. Diese erfolgt durch Fenersetzen. Durch große Fener wird der Jadeit erhitzt, in der Nacht kïhlt er rasch ab und zerspringt dabei in einzelne Blïcke, die dann mit rroljen IIämmern weiter zerkleinert werden können. Diese rohe Prozedur hat einen sehr schädlichen Einflub auf die Beschaffenlseit des gewonnenen Materials. Daher steht die Qualität des Jadeits aus dem steinbruche hinter derjenigen der (ieschiebe aus dem Flusse, die keinem Feuer ausgesetzt gervesen sind, erheblich zurïck. Es wird jedoch im Steinbruche viel mehr gewonnen als in den Gruben am Flusse.

Die dritte, recht ertragreiche Lagerstïtte ist bei dem Dorfe II éka, fast genau südlich von 'Tammaw unter $255^{\prime \prime} 29^{\prime}$ nördl. Breite und $966^{\prime \prime} 16^{\prime}$ östl. Lä̈ge in einem engen Gebirestal gelegen, und ehenfalls nur in der trockenen Jahreszeit bewohnt. An dem ganzen, wohl fon m hohen, das I)orf im Torden ïberragenden Berog wird Jadeit aus einem sehr wroben Konglomerat gewomnen, in dem sich zum Teil nach Kubikmetern messende Bï̈cke dis llinerals finden. Derartige Konglomerate liegen auch noch weiter nach Westen, werden aber zurzeit nicht mehr ausgebeutet. 
Ende März kommen zahlureiche Chinesen in diese fiegenden, zum Teil um sich selbst an der Gräberei zu beteiligen, besonders aber $u m$ den von den Katschins gewonnenen Jadeit zu kaufen, enute Stiicke zu hohen Liebhaberpreisen. An Ort und Stelle findet keine Terarbeitung statt. I)as beste Material wird mit Maultierm auf dem nächsten Landwegte direkt nach China seschafft. das der Hauptabnehner ist und wo der Jadeit nach den obigen Mitteilungen. wie äbrigens auch in Birma selhst, sehr gechä̈tzt wird. Ein anderer T'eil wird nach Mogeung und ron dort auf Kähnen nach Bhanes an Irawarli grebracht, das daher vielfach fälschlicherweise als Fundort des birmanischen Jadeits grilt. Ton da echt es hierauf weiter auf dem Flusse nach Mandalay, wo dir stücke zum Teil in wrofen Schleifereien verarbeitet, zum Teii auch nur angreschliffen und danach auf ihre Qualität und auf ihren Wert untersucht werden. Üher Langrun wird der Jadeit dann, soweit er nicht in Lande Verwendung findet, auf dem Seewege nach China und auch nach Furopa spediert. Nach offiziellen Nachrichten sind im Jahre 1903 2635 Zentner Jadeit im Wert von 55435 Pfund Sterling, 190437 is Zentner im Wert ron 50726 I'fund und 1905 2655 Zentner im Tert von 45474 Pfund in den Katschin-Berien gefunden und meist nach China ausgeführt worden.

Die Hauptmasse des Jadeits, der dort von den Eingeborenen und ron den Chinesen meist nit dem birmanischen Namen .. Kyauk-tsein" bezeichnet wird, ist weif und ron marmorähnlichem Aussehen. er hebt sich daher in dem Steinbruch scharf gregen das beinahe schwarze Nebengestein, den Serpentin, ah. Die weile, durchscheinende Masse des Jadeits ist durchsetzt mit größeren und kleineren Partien ron schün smaragclgriiner Farbe, die sich aber im übrigen ron dem weiben Jadeit in nichts unterscheiden. sie sind es, die das wertrollste Material bilden. Man schneidet sie heraus, um Ringsteine u. s. w. zu schleifen, oder man macht davon ganze Ringe, besonders Armringe, die an einer Stelle einen wrünen Fleck haben, sonst aher weil sind, orler man rerwendet den Farbenunterschied in anderer zweckmäßiger Weise zum Schmuck. Grüfere Stïcke liefern Gefäbe verschiedener Art und andere Gerenstiinde, was aber hier nicht weiter berücksichtigt werden liann.

Der Preis schöner Stücke, weifer sowohl als hesonders wrïner, ist schon an Ort und Stelle sehr hoch. Fïr einen Block mit viel grïnem Material ron noch lange nicht einem Kubikyard Grübe wurden 10000) Pfund Sterling verlangt und ein chinesischer Iändler war hereit, sono Pfund zu weben. Ein grofes Geschiebe von Hwélia mit einzelnen prachtvollen grïnen Stellen, an dem mehrere Iränner zu schleppen hatten, wurde 1907 mit yono) Rupien bezahlt. Ein kleiner grüner Stein, grob genug für einen Siegelstein, wird bei bester Qualität mit 400 bis 500 Rupien bezahlt, während er in Europa sehr wenig kosten würde. Der Gesamtwert des ganzen, anscheinend so grut wie unerschöpflichen Lagers ist also enorm, wenn auch selbstrerständlich so kosthare Stiicke, wie die erwähnten nicht alle Tage gefunden werden.

Diese Fundstelle anstehenden Jadeits bei Tammaw ist die einzige, die gegenwärtị. den Europäern genauer bekannt ist. Es ist aber höchst wabrscheinlich, daf deren in (Oher-Birma, und weit nach China hinein in der Provinz Tünnan noch mehrere rorhanden sind und daf sie auch ron den Eingeborenen zum Teil in ähnlicher Weise, wie hei Tammaw abgebaut werden. Ebenso werden dort wohl vielfach in den Wasserläufen die ron den anstelıenden Massen abstammenden Gerölle, wie an Cru, aufgesucht, aher zurzeit sind sichere Tachrichten hierïher nicht vorhanden. Solche Gerölle von weiber und sraulichgrüiner Farbe, die aus "Tibet im nördlichen Himalaya" stammen sollen, sind vor einigen Jahren in Idar verschliffen worden. Der Fundort ist nicht näher bekannt: ibrer sanzen Beschaffenheit. namentlich ihrer ziemlich dunkel graulich-grünen Farhe nach. stammen sie nicht rom Truflusse. In den Sammlungen trifft man zuweilen Jadeit ron Tay-hy-fu oder Talifu in Yunuan 100" ̈̈stl. ron Greenwich, 211" nördl. Breite. Diese Lokalität 
ist aber kein Fundort des Minerals, sondern nur eine Etappe auf dem Landwege von den oben beschrichenen birmanischen Fundorten nach China (Peking); in der Tat stimmt auch der angehlich dort gefundene Jadeit ganz mit dem birmanischen überein.

Auch in Neu-Guinea findet sich Jadeit und Chloromelanit anstehend und als Beile.

\section{Quarz.}

Kiein anderes Mineral wird so häufig und zugleich in so zahlreichen, durch Struktur, Farbe, Durchscheinenheit usw. unterschiedenen Varietäten als Schmuckstein benutzt wie der Quarz. Von diesem Gesichtspunkte aus gehört also der Quarz mit zu den wichtigsten Edelsteinen, weniger seines Wertes wegen, der bei den meisten Abarten gering, bei keiner sehr bedeutend ist; höchstens werden gelegentlich für einzelne Stiicke von besonderer Schönheit und Vollkommenheit etwas höhere Preise bezahlt. Der Grund hierfür liegt in der verhältnismäßig großen Verbreitung, ja dem sogar zuweilen geradezu massenhaften Vorkommen auch der schönsten Varietäten, die deswegen, aber allerdings zum Teil noch aus anderen Gründen, alle nur zu den sog. Halbedelsteinen gezählt werden.
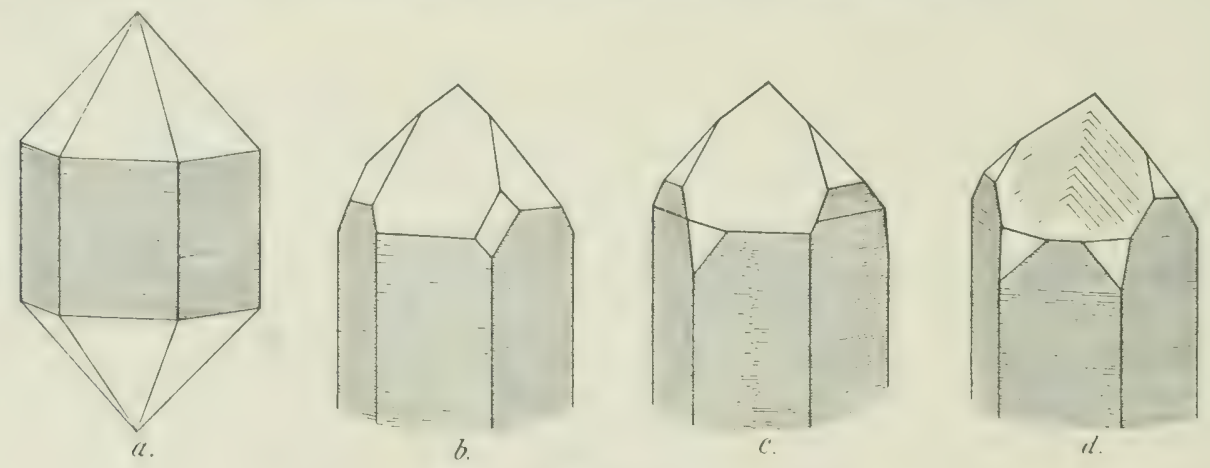

Fig. 100. Kristallformen des Quarzes.

Ehe wir zu diesen als Schmucksteine benutzten, meist mit besonderen Namen unterschiedenen Abarten des Quarzes speziell übergehen, haben wir dessen allgemeine Eigenschaften zu betrachten, die allen Stiicken dieses Minerals ohne Ausnahme zukommen und die dann später nicht mebr wiederholt zu werden brauchen.

Der Quarz ist reine Kieselsäure (Siliciumdioxyd), $\mathrm{SiO}_{2}$, und besteht demzufolge im reinsten Zustande aus 46,7 Proz. Silicium und 53,3 Proz. Sauerstoff. Vielfach enthält er aber mehr oder weniger starke Verunreinigungen durch fremde Substanzen aller Art, die wie wir unten sehen werden, mannigfaltige Färbungen hervorbringen. Von dem ebenfalls aus Kieselsäure bestehenden Opal unterscheidet sich der Quarz chemisch dadurch, daß ihm Wasser stets vollständig fehlt.

Im Gexensatz zum Opal - und darin liegt ein weiterer wesentlicher Unterschied zwischen beiden - ist aber der der Quarz nicht amorph, sondern kristallisiert. Außerordentlich häufig findet man sehr schön ausgebildete Kristalle, meist mit leblıaft glänzenden Flächen. Die Formen gehören dem hexagonalen System an (Fig. 100, « bis d). Es sind fast ohne Ausnahme regehmäßig sechsseitige P'rismen, deren Flächen durch eine sehr dentliche horizontale Streifung senkrecht zu den Prismenkanten ausgezeichnet sind. Oben (Fin. 10), h, his (1), und an vollständig ausgebildeten Kristallen auch unten (Fig. 100, a) 
findet sich eine sechsseitige pyramidale: Zuspitzung, deren Flächen gerade ïber den Prismenflächen liegen. Auberdem sind noch viclfach kleine Flächen schief oder gerade auf die l'rismenkanten aufgesetzt, wic in Fig. 100, l, bis 1 . Aus deren Anordnung folgt, dafs der Quarz der trapezoëdrisch-tetartoëdrischen Abteilung des hexagonalen Systems zugerechnet werden mub. Die spezielle Ausbildung der rinzelnen Kristalle ist etwas verschieden. Bei manchen sind die Prismenfliichen lang, wie an den in den Figuren darosestellten, manchmal sind sie auch kurz oder fehlen sogar ganz, so dab der Kristall nur die sechsflächige pyramidale Zuspitzung zeigrt. Auch die auf die Kanten des Prismas aufresetzten kleinen Flichen fehlen häufig, und Zwillingsbildung ist eine verbreitete Erscheinung. Diese hat unter anderem eine ganz unregelmäßjge Verteilung der letztgrenannten kleinen Flächen zur Folge, die bei einfachen Kristallen auf den abwechselnden Kanten oben und unten sitzen und an den zwischenliegenden fehlen. Die Zuspitzungsflüichen an d•n Enden sind manchmal alle greich groß (Fig. 100 (1), manchmal sind sie abwechselnd gröber und kleinex (Fig. 100, l, bis $($ ), und nicht selten ist die Aufeinanderfolge groljer und kleiner Fläcben ganz unregelmäßig (Taf. XVII und Taf. XVIII, Fig. 1 und 2).

Die Kristalle sind entweder in einem Muttergestein eingelagert und haben dann die ringsum ausgebildeten Formen wie in Fig. 100,, . Oder sie sind auf einer Cnterlage aufgewachsen und besitzen dann gewöhnlich nur am freien Ende eine regelmäßige Begrenzung, wie es in Fig. 100, $b$ bis $d$ dargestellt ist. Meist sind auf derselben Unterlage mehrere Kristalle vereinigt und bilden dann zuweilen sehr schöne Drusen. Eine solche zeint Taf. XVII. Bei ihr sind die einzelnen Individuen lang säiulenförmig. Manchmal sind die Kristalle solcher Drusen auch ganz kurz und als Begrenzung sind nur die sechsflächigen Endspitzen vorhanden, die dann dicht gedrängt nebeneinander liegen.

In Form derber Massen ist der Quarz gleichfalls sehr verbreitet. Einzelne unregelmäßig begrenzte Körner bilden einen wichtigen Bestandteil vieler und rerbreiteter Gesteine, wie der Granite, Gneise usw. Häufig sind zahlreiche Kürnchen zu einem Agrregat vereinigt, dessen Zusammensetzungsstiicke sehr oft mikroskopisch klein sind; sie bilden so die verschiedenen Varietäten des dichten Quarzes, wie Iornstein zu dem u. a. der als Schmuckstein benutzte grïne Chrysopras gehört), Jaspis und andere. Auch stengliche Aggregate kommen nicht selten vor. Sind die einzelnen Stengel sehr dünn, dann wird die Masse faserig, wie z. B. bei dem Tigerauge, das wir als vielbenutzten Schmuckstein noch weiter kennen zu lernen haben. Überhaupt hat man nach der Struktur unter diesen derben Aggregaten mancherlei Varietäten unterschieden, von denen zum 'T'eil unten noch die Rede sein wird, da sie vielfach zu Schmucksteinen verarbeitet werden.

Deutliche spaltbarkeit ist beim Quarz nicht vorhanden. Der Bruch ist in Kristallen und größeren derben Stïcken muschelig, fast so vollkommen wie beim Glas, in dichten Aggregaten ist er uneben oder eben und zuweilen splitterig. Die Härte ist die des $\mathbf{7}$. Grades, also noch nicht eigentliche Edelsteinhärte, aber der Quarz ist unter den weit verbreiteten Mineralien das härteste. Er ritzt die meisten anderen und namentlich auch das Fenster ralas und gibt mit dem Stahl sehr starke Funken. Daher ist auch früher eine Abart des dichten Quarzes zum Fenerschlagen benutzt und wegen dieser Verwendung als Feuerstein bezeichnet worden. Seinerseits wird der Quarz von den meisten wertvolleren Edelsteinen geritzt, so zunächst vom Topas, der ihm in der Härteskala unmittelbar folgt, und noch leichter rom Korund und Diamant. Er ist sehr spröde und daher verhältnismäßig leicht zersprengbar, wenigstens lassen sich von größeren Kristallen unschwer Splitter abschlagen; schwieriger ist dies vielfach bei den feinkörnigen bis dichten Aggregaten.

Das spezifische Gewicht ist beim reinen Quarze G. $=2$, bei unreinen Varietiten ist es davon etwas verschieden, so daß die Zahl für den Quarz im allgemeinen etwas 
schwankt. Auch im spezifischen Gewicht liegt ein Unterschied rom Opal, der stets erheblich leichter ist.

Vor dem Liitrohr ist der (Quarz unschmelzbar, schmilzt aber leicht im Kinallgasgeb]äse. Ton Säuren wird er nicht angegriffen, außer von Flußsäure, die ihn vollstïndig auflöst. Auch \&uen Kalilauge ist der Quarz sehr widerstandsfähig, während der Opal von dieser leicht aulgelöst wird. Durch Reiben wird er elektrisch und behält seine Elektrizität bis eine Stunde lang.

Das äußere Ansehen der zahlreichen, in der Natur vorkommenden Arten des Quarzes ist schr verschieden. Es wird außer durch die Struktur wesentlich durch den Glanz, die Durchscheinenheit und die Farbe bedingt.

Der Glanz ist meist der ganz gewöhnliche Glasglanz, doch zeigen manche Stiicke auch Fettglanz (Fettquarz), und faserige Aggregate haben zuweilen einen sehr schönen Seidenglanz. Alle diese Arten von Glanz sind vielfach auf natïrlichen Flächen und Bruchflächen nicht sehr stark, werden aber durch das Schleifen und Polieren meistens sehr lebhaft: alle Quarze nehmen eine sehr gute Politur an.

Die Durchscheinenheit ist sehr verschieden; sie geht von der vollkommenen Durchsichtigkeit bis zum Undurchsichtigen. Der Quarz in seinem reinsten Zustande ist ganz durchsichtig und farblos, aber auch gefärbte Quarze lassen vielfach das Licht ungehindert hindurch. Die durchsichtigen Abänderungen werden als edle Quarze von dem trüben oder ganz undurchsichtigen gemeinen Quarze unterschieden. Für Röntgenstrahlen ist auch der klarste und durchsichtigste Quarz nur halb durchlässig, ähnlich wie der Topas.

Die Farbe beruht auf fremden Bestandteilen, die der im reinen Zustande vollkommen wasserhellen Quarzmasse beigemengt sind, und die bei der chemischen Untersuchung des Quarzes als Verunreinigungen erseheinen. Bald ist es ein Pigment von zum Teil noch nicht näher bekannter Natur, das in feinster Verteilung (dilut) die ganze Masse gleichmälig durchdringt und dessen einzelne Teilehen selbst bei der stärksten Vergrößerung nicht getrennt hervortreten. Bald sind es kleine, unter dem Mikroskop deutlich sichtbare Nädelchen, Fäserchen, Körnchen und Plïttchen anderer Mineralkörper, die in Menge dem Quarz eingerachsen sind und ihm ihre Farbe mitteilen. Auf der ersteren Ursache beruht die braune Farbe des mit dem Namen Rauchtopas belegten Quarzes, des violetten Amethysts, des gelben Citrins, des rosenroten Rosenquarzes usw.; auf der letzteren das Griin des Prasems, das Blau des Sappbirquarzes und andere. Die Farbenreihe ist eine sehr reiche; keine der bekannten Farben fehlt canz, und die meisten sind in mehreren lichteren und dunkleren, sowie anderen Farben sich nähernden Nuancen vertreten. Nicht selten ist es, dalk ein und dasselhe Stïck Quarz eine stellenweise verschiedene und zuweilen sogar recht bunte Färbung und mannigfaltige Farbenzeichnung zeigt, die ihren höchsten Grad bei den zu Schmucksteinen so viel verwendeten Achaten erreicht. Sehr gewöhlich ist die Färbung der Kristalle nicht ganz gleichmäßig, sondern durch mehr oder weniger vollständiges Fehlen oder Überhandnehmen des Farbstoffes an einzelnen Stellen fleckig. Auch nach der Farbe werden zahlreiche Varietäten mit besonderen Namen untersehieden, von denen die wichtigsten schon ohen genannt sind. Über die Ver:inderung der Farben durch Radiumstrahlung siehe S. 72 .

Die Lichtbrechung des (Uuarzes ist dem hexagonalen Kristallsysteme entsprechend die doppelte, aber die Doppelbrechung ist nicht sehr stark, ebensowenim wio die Lichthrechung iiberhaupt. Daf in der Tat die Brechunsskoëffizienten nicht hoch, und die zu derselben Farbe wैhörigen grö̈bten und kleinsten Werte derselben nicht viel voneinander versehieden sind, crsicht man aus der nachfolgenden Zusammenstellung, wo in der ersten Reihe o die keinsten, in der zweiten e die größten Betrï̈e der Brechungskoëlfizienten für die verschiedenen Farben des Spektrums aufeinanderfolgen. 


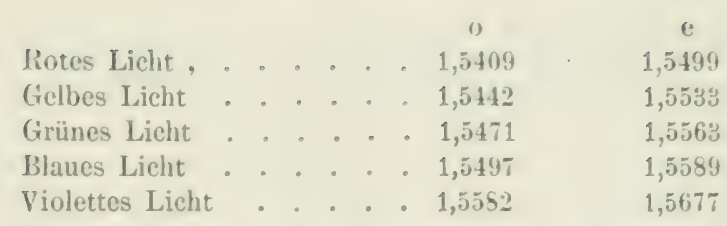

Ist die Doppelbrechung auch nicht sehr bedeutend, so ist sie doch stark genur, dalf man dureh einen geschliffenen durchsichtigen (guarz hindurch doppelte Bildter eines Gegenstandes, z. B. einer Lichtflamme sieht, wie es die Fig. 2t). " zeiz. Dies lälit ohne weiteres einen (guarz ron einem ähnlich gefärbten Cilasflub unterscheiden. bei dem die Flammenbildehen einfach sind, wie in Fig. 26, 1\%. Die obigen Zahlen zeigen auch, dafs die Brechungskoëffizienten für verschiedene Farhen sehr nahe diestllyen sind; es folst daraus, daß die Farbenzerstreuung gering ist, so dalf der Quarz nur ein schwaches Farbenspiel, niemals ein solches ähnlich dem des Diamants zeigen kann.

Eine besondere optische Eigentümlichkeit des Guarzes, die aulfer ilın nur noch wenigen anderen Ylineralien zukommt, ist die, dalf er das Licht zirkular polarisiert. Da dies aber lediglich in physikalischer IInsicht von Interesse ist, so wird hier davon weiter nicht die Rede sein.

Im bisherigen wurden die Eigenschaften angegeben, die dem Guar allgeme-in zukommen. Im folgenden sollen die zu Schmucksteinen verwendeten Arten speziell betrachte-t und diejenigen ihrer Eigentïmlichkeiten aufgeführt werden, auf denen diese- Verwendung beruht und durch die sie sich roneinander unterscheiden. Ifan hat hier zumïchst die Gruppe der kristallisierten (Quarze, die regelmälfige Kristalle oder auch Agrregate einzelner, mit bloßem Auge noch erkennbarer. wenn schon unregelmäßig be viduen bilden, zu betrachten. Daran schließen sich die dichten Varietiiten, die aus einer groben Zahl mikroskopisch kleiner Quarzteilchen zusammengesetzt sind. Bei dem kristallisierten Quarz erfolgt die weitere Einteilung nach der Farbe, bei den Aguregaten nach der Struktur und nach der sonstigen Beschaffenheit. Den Beschluf macht die Gruppe der Chalcedone, deren besondere Verhältnisse unten erlïutert werden sullen. Die Verschiedenheit der so erhaltenen Tarietiten des Quarzes ist zuweilen derart, daf man olne genauere Kemntnis die Zugeliürigkeit der Stïcke zu einer und lersellhen Mineralspezies nicht vermuten wïrde.

Wir betrachten demnach die zuı Guarze gehörigen Edelsteine in der nachstehenden Reihenfolge:

\section{A. Kristallisierter Quarz.}

Bergkristall.

Rauchtopas.

Amethyst.

Citrin.

Rosenquarz.
Prasem.

Sapphirquarz.

Quarz mit Einschlüssen.

Katzenauge.

Tigerauge.

B. Dichter Quarz.

Hornstein mit Holzstein und Chrysopras.

Jaspis.

Avanturin.

C. Chalcedon.

Gemeiner Chalcedon.

Achat mit Onyx.

Karneol.

Plasma mit Heliotrop. 


\section{A. Kristallisierter Quarz.}

Bergkristall.

Berchkristall wird der vollkommen wasserhelle, farblose und durchsichtige Quarz genannt. Er zeichnet sich durch seine Klarheit und Durchsichtigkeit ganz besonders vor anderen Materialien aus und übertrifft in dieser Hinsicht sogar häufig den Diamant, der aber dafür seinen wundervollen Glanz und sein prächtiges Farbenspiel voraus hat. Ein unregelmäßig begrenztes Stück Bergkristall gleicht am ersten einem Stïcke farblosen Glases, weshalb ihm auch wohl der Name Glasquarz beigelegt worden ist, oder ganz reinem Eis. Für Eis ist er auch im Altertum und sogar noch im Mittelalter gehalten worden. Man war der Ansicht, daß man es mit Wasser zu tun habe, das durch die große Kälte der höchsten Gipfel der Alpen, wo der Bergkristall vielfach vorkommt, so stark gefroren sei, daß es auch in rer böberen Temperatur der niedrigeren Regionen nicht mehr schmelzen könne. Jetzt weiß man, daß der Bergkristall Quarz ist und daß er sich vom gewöhnlichen gemeinen Quarz lediglicb durch die Klarheit und Farblosigkeit unterscheidet; er stellt die Quarzsubstanz in ibrer vollkommenen Reinheit dar.

Vielfach findet sich der Bergkristall in ausgezeichneten Kristallen, an denen fast ausnahmslos das Prisma stark entwickelt ist, so daß sie einen langsäulenförmigen Habitus besitzen (Fig. 100, a bis d). Dann kommen gerade bei dieser Varietät die auf die Prismenkanten aufgesetzten kleinen Flächen vor, wie in den Fig. 100, $b$ und $c$, die einige auf der Unterlage aufgewachsen gewesene und von ihr abgebrochene Bergkristalle darstellen. Indessen sind auch ringsum ausgebildete Kristalle von der Form der Fig. 100, a keineswegs selten. Diese Ausbildungsformen unterscheiden sich in einigen Punkten von denen des gemeinen Quarzes, bei dem die Kristalle vielfach nur mit den niedrigen sechsflächigen Endspitzen ausgebildet sind und an dessen Kristallen, auch wenn sie eine langsäulenförmige Gestalt haben, doch die an den Kanten des Prismas auftretenden kleinen Flächen so gut wie niemals vorkonmen. Die Bergkristalle bilden nicht selten prächtige Drusen, wie die auf 'Taf. XVII abgebildete aus der Gegend von Bourg d' Oisans in den Dauphinéer Alpen in Frankreich. Nicht besonders selten sind eigentïmlich gewundene Kristalle, bei denen namentlich zwei gegenüberliegende, besonders stark ausgedehnte Prismenflächen eine starke spiralige Krümmung zeigen. Nicht selten zeigen die Flächen in der Mitte eigentiimliche kastenförmige Vertiefungen, anch sind die Kristalle häufig oberflächlich durch natiurliche Mittel angeätzt oder auch ringsum mehr oder weniger stark zerfressen.

Die Grölse der Kristalle ist sehr verschieden. Bald haben sie nur einige Millineter Lïnge und einige Milligramm Gewicht, bald, aber selten, erlangen sie mehrere Meter Umfang. und sie wiegen mehrere Zentner. Am hïufigsten ist wohl eine gewisse mittlere Größe von der Länge und Dicke eines Fingers und wenig darüber.

Wie der Quarz üherhaupt, so ist namentlich auch der Bergkristall vielfach reich an Einschliissen fremder Kö̈rper der verschiedensten Art. Diese treten grerade bei ihm am deutlichsten hervor wegen der auferordentlichen Klarheit der Substanz, die nicht den kleinsten in ihrem Innern befindlichen Körper zu verbergen vermag. Nicht selten sind es leere Tiäume und IIöhlungen, die mit einer Flüssigkeit erfüllt sind. Die Füllung ist bei diesen meist nicht ganz, vollständig, so daf ïber der Flïssigkeit eine kleine Luftblase sich befindet, die beim Bewegen des Kristalles hinundher schwankt, eine sogenannte Libelle. Manchumal sind diese mit Fliissigkeit angefüllten Hohlräume so groß, daß man sie vollkommen deutlich mit blobem Auge sehen kann (Wassertropfen(puarz, s. u.), meist sind sie aber mikroskoprisch klein. In diesem Falle sind sie dann gewöhnlich in ganzen Scharen oder

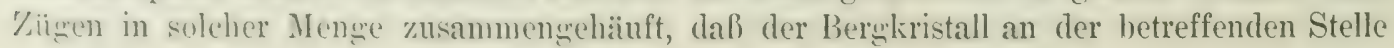


oftmals völlig trube arscheint. I)ies ist namentlich vielfach an dem Ende der Fall, mit dem er aufgewachsen ist, wïhrend das obere freie Ende vollkommen klar ist. Das Mikroskop zeigt, dals nur am trüben aufgewachsenen Ende IJuft- und Flüssigkeitsbläschen in gröberer Henge in den Kiristallen vorhanden sind, nicht aber in dem freien, durchsichtigen und klaren. Die Flüssigkeit ist in virlen Fällen, wie sicher nachgewiesen werden konnte, flïssige Kohlensäure, in anderen Fïllen ist es aher auch irgend etwas anderes, Wasser oder eine Kochsalzlösung usw.

Wichtiger als diese flüssigen Einschliisse sind die von festen Kürpern, nanentlich von Kristallen, die anderen, fremden Mineralspezies angehören. Diese sind zuweilen äuferst klein, jedoch so massenbaft vorhanden, dalj sie den ganzen Kristall gleichmäßjig fürben, wie bei dem grïnen Prasem und dem blanen Sapphirquarz. Manche andere sind aber größer und dann gewöhnlich nur in geringer Zahl vorhanden. so dab sie sich deutlich einzeln in der wasserhellen Quarzmasse präsentieren, namentlich wenn sie ausgesprochen grefärbt sind. So findet man vielfach zahlreiche l'ättchen von grünem Chlorit den Bergkristallen ein- oder ihrer Oherfläche angewachsen, und häufig durchdringen sie die granze Masse, so dab diese grün gefärbt erscheint und daß zwischen dem grünen Chlorit nur noch wenig von der wasserhellen (Quarzsubstanz zu sehen ist. Weiße Strahlen des Minerals Tremolit durchziehen manche Kristalle, in wieder anderen sieht man grüne Nadeln von Strahlstein (Taf. XVIII, Fig. 2), rote oder gelhe von Rutil usw. Alle diese Einschliusse von Mineralien -... und ihre Zahl könnte noch stark vermehrt werden - und ebenso auch die von Fliissigkeiten, spielen zuweilen für die Verwendung des betreffenden steines zum Schmuckstein eine gewisse Rolle, wir werden daher unten darauf noch einmal zurückkommen.

Der Bergkristall wurde frïher recht häufig zu Schmucksteinen verschliffen, heutzutage ist diese Terwendung sehr zurïckgegangen. Die Form, die man ihm gab, war gewöhnlich die des Brillants, auch Tafelsteine und Rosetten trifft man nicht selten. Bein Schleifen erhalten die Steine einen lebhaften Glasglanz, der durch Glïhen noch etwas gesteigert werden kann, und unter günstigen Umständen anch ein gewisses, wenngleich stets nur bescheidenes Farbenspiel. Davon macht man Gebrauch, indem man Leuchter, Lampen, Kronleuchter und ähnliche Beleuchtungsgegenstände mit geschliffenen Bergkristallen behängt, die meist eine langgezogene Berloquen-, Pyramiden-oder Prismenform erbalten. Die von den Lichtflammen ausgehenden Strahlen brechen sich in diesen Bergkristallen und zeigen das Farbenspiel, das namentlich wegen des fortwïhrenden Wechsels in den hinundher schwingenden Anhängen eine angenehme Wirkung ausïht.

Kileine Gegenstände der Kiunstindustrie werden ebenfalls nicht selten aus Bergkristall dargestellt, Kugeln, Briefbeschwerer, Siegelstöcke usw. Auch zu diesem Zwecke ist das Mineral im Altertum und im Dittelalter sehr viel wichtiger gewesen als gegenwärtig. Namentlich hat man damals alle möglichen Gefülje, Schalen, Vasen, Trinkbecher usw. daraus herwestellt und nicht selten mit figïrlichen Darstellungen prächtig verziert, so daß sie vielfach Gegenstände ron hohem kïnstlerischem Werte darstellen. Diese Industrie blïhte in einer Zeit, als die Fabrikation vollkommen klarer und farbloser Glasmassen von einigem Umfange noch in den Windeln lag. Damals war der Bergkristall dasjenige Material von solcher Beschaffenheit, das noch am leichtesten und in verhïltnismälig großen Stiicken zu haben war. Später hat sich die Glasindustrie zu immer höherer Vollkommenheit entwickelt und grleichzeitig ist die Terarbeitung des Bergktristalls zu größeren Girfüfen usw. zurückgegangen, weil man solche aus Glas (sog. . Kristall") viel leichter und billiger, und (h)enso schün herstellen lernte als aus dem härteren, schwerer zu hearbeitenden, aber deswegen allerdings auch riel haltbareren und dauerhafteren Mineral. Von der hohen Lntwickelung der alten, auf die Terarbeitung des Bergkristalls gerichteten Industrie legen 
viele Kunstsammlungen deutliches Zeugnis ab, und die Geschichte erzällt von wertvollen Bergkristallgefäßen, die im Altertum hergestellt worden sind.

Heutzutace wird der Bergkristall statt zu künstlerisch wertvollen Gegenständen viel mehr zu praktisch brauchbaren Dingen verarbeitet, bei denen die ziemlich große Härte und die Unangreifbarkeit durch chemische Agentien von Bedeutung sind. So dient er vielfach zur IIerstellung von "Glïsern" zu Brillen, Fernrohren und anderen optischen Instrumenten, die dann vor dem Zerkratzen ziemlich geschïtzt und daher den aus Glas hergestellten "Gläsern" weitaus vorzuziehen sind. Auch zu anderen Zwecken der Optik wird das vollkommen durchsichtige Material benutzt; ferner zur Fabrikation von feinen Gewichten, wie sie auf sehr empfindlichen, zu wissenschaftlichen Zwecken dienenden Prïzisionswagen gebraucht werden, um Gewichtsbestimmungen von der höchsten erreichbaren Genauigkeit zu erhalten; dann zur Herstellung harter Zapfenlager für feine Instrumente und zu manchen anderen ähnlichen Zwecken.

Wie die Verwendung, so ist auch der Wert des Bergkristalls gegen früher erheblich zurückgegangen. Dieser hängt ab von der mehr oder weniger großen Reinheit, Durchsichtigkeit und Farblosigkeit der Stiicke und von der An- oder Abwesenheit von Fehlern, welche in die Schönheit beeinträchtigenden fremden Einschlüssen, in Rissen, in trüben oder gefürbten Stellen und in anderen ähnlichen Störungen der gleichmäßigen Beschaffenheit bestehen. Ferner steigt er mit der Größe; kleine Stiicke von vollkommener Qualität sind nicht selten, daher übersteigt der Preis eines geschliffenen Ringsteines, auch von der besten Sorte, wohl kaum jemals 10 Mark. Im Gegensatz dazu sind gute Stiicke von erheblicherem Unfange gar nicht so leicht zu beschaffen, und zwar un so schwieriger, je größer sie sind; solche stehen daher im Preise verhältnismäßig hoch. Für gutes Rohmaterial wird in Jdar bis 50 Mark, bei Stücken von 1/4 Zentner 200 bis 300 Mark pro Kilogramm bezahlt. Schöne und gut geschliffene Steine kosten $1 \frac{1}{1} 2$ bis 3 Mark das Karat.

Der Bergkristall ist ein sehr verbreitetes Mineral. Er findet sich mit anderen Mineralien zusammen, vorzugsweise aufgewachsen auf Spalten und Kliiften versehiedener Urgesteine und bildet hier oft Drusen von außerordentlicher Größe. Diese Art des Vorkommens in Verbindung mit den häufigen, ja so gut wie nie fehlenden Flïssigkeitseinschliussen, von denen oben die Rede gewesen ist, läßt nicht daran zweifeln, daß die überwiegende Menge des Minerals dureh Ausscheidung und Auskristallisieren aus einer kieselsäurehaltigen, wässerigen Lösung entstanden ist. Die bekannten Fundorte auch nur einigermaßen vollstïndig anzugeben, ist, ihrer groben Zahl wegen, ummöglich, es sollen daher hier auch nur einige wenige hesonders wichtige spezieller erwähnt werden.

In Europa ist die hauptsächlichste Heimat des Bergkristalls das Hochgebirge der tiroler, schweizer, italienisehen und französischen Alpen. Die Kristalle sitzen auf Klïften und Spalten im Granit, Gneis und anderen ähnlichen Gesteinen. Sie werden von den Kristallsammlern, den in der Schweiz so genannten Strahlern, aufgesucht und in den IIandel gebracht. Dieses Gesehäft ist ein äußerst miilısames, da die Fundorte der Kristalle vielfach an den höchsten und unzug̈̈̈nglichsten P'unkten des Gebirges liegen, die nur unit Lebensgefalı erreicht werden kömnen. Bei der Aufsuchung kristallführender Drusen lassen sich die Strahler leiten durch die Quarzyänge, die sich als weiße Bänder iiber die Felswinde hinziehen; auf Drusenräumen in diesen Gängen pflegen die Bergkristalle zu sitzen. Dureh den Ton, der beim Sehlagen mit einem Hammer entsteht, kann man das Vorhandensein eines solchen Hohlraumes im Innern erkennen, der dann mit der Spitzhaue, oder eventuell dureh sjprengen mit Pulver oder Dynamit, geöffnet und ausgebeutet wird.

Diese Höhlungen und damit auch die in ihnen sitzenden liristalle sind meist nicht besmulers roli, zuweilen sind sic aber von recht erheblichen Dimensionen, und dasselbe 
gilt dann auch für die darin hefindlichen Kristalle. Solche ansegedehnte Drusenräume werden Kristallkeller oder Kristallgewölbe grenannt. Manchmal sind in einem einzigen solchen Loche IIunderte von Zentnern Berckristall gefunden worden, und zahlreiches Kristalle haben Gewichte von einem und sogar von mehruren Zentnern ergeben.

Ein berïhmter fund dieser Art ist der im Jahre 1719 aufgererabene: Fristallkeller vom Zinkenstoek im Berner Oherland in der Nähe der Grimsel. In diesem fand sich ein Kristall von S Zentnern, viele wogen 1 Zentner usw.; im ganzen wurden 10(0) Zentner Bererkristalle aus dieser einen Riesendruse gewonnen. Ein anderer Keller in Viesch tale zwischen Münster und Laax im Ober-Wallis lieferte im Jahre 1757 grolbe und prächtige Kristalle von 50 bis 1400 Pfund Gewicht. Auch sonst ist der Kanton Wallis reich an liergrkristall, ebenso das St. Gotthardgebiet, das Berner Oberland sowie andere der 'Teile der schweizer und weiterhin auch der italienischen und ïsterreichischen Alpen. Viel genannt wird das Vorkommen der Bergkristalle in den allerdings nur kleinen Drusenräumen des etwas coldhaltigen Quarzganges von La (xardette bei Bourg d'Oisans im Dauphiné (Dep. de lisire) in den französischen Apen. Von hier stammt die auf Taf. XVII abgrebildete Gruppe, deren Fristalle, wie alle von diesen Fundorte, durch eine eigentiumliche schiefo und unsymmetrische Endbegrenzung vor anderen Torkommnissen ausgrezeichnet und daran kenntlich sind. Frïher wurden schöne Kristalle in den Gräbereien, sog. cristalliere's, besonders in der Verlängerung der Grandes-Rousses zwischen den Flïssen Eau d'Olle und Romanche im Territorium von Huez gewonnen. Eine der berïhntesten war dic cristallière von Huez, 2700 Meter boch am Fulje des Grandes-Rousses-Gletschers, andere liegen am Fufe des Pic de l'Etendard und an zahlreichen anderen Orten. Nach der Eröffnung der (irube La Gardette am Ende des 15. Jahrhunderts scheinen aber alle diese erzfreien (Luarzgïnge vernachlässigt worden zu sein. Die Bergkristalle von hier sind mit anderem Material dieser Art am Anfang unseres Jahrhunderts in einer Schleiferei zu Briançon an der Durance, Dep. des Hautes Alpes, verarbeitet worden; jetzt hat sie ihre Taitigkeit lïngst eingestellt. Die hier geschliffenen wasserhellen Steine wurden darnach als "Diamanten von Briancon" bezeichnet. Alle diese alpinen Berghkistalle haben jetzt fuil die Industrie nur noch geringe Bedeutung; sie sind vorzugsweise durch die Funde in Brasilien und Madagaskar verdrïngt worden, die meist viel reiner und auch billiger sind als jene.

Aus dem Hochgebirge werden mit dem durch die Verwitterung entstandenen Gebirgsschutt durch die Gletscher und die Gewässer auch Bergkristalle in die Tiefe gefuilhrt. Sie gelangen in die Bäche und Flüsse, werden hier auf ihrem Wege talabwärts allmählich immer mehr abgerollt und nehmen mit der Zeit die Form vollkommen runder Geschiebe an, die wegen ihrer zerkratzten Oberfläche trübe aussehen, im Inneren aber vollkommen klar und durchsichtig sind. So finden sie sich z. B. im Rbein in der Gröle bis zu der einer Nub. Sie werden dureh die Aar in diesen Fluß hineingeschwemmt und wurden früher in Baden an mehreren Stellen beim Goldwaschen als Nebenprodukt unter den Namen Rheinkiesel mit gewomen und verschliffen. Man hat diese Rheinkiesel in frïheren Zeiten wohl für schüner und reiner gehalten als Bergkristalle, die auf anderem Irege aus den Alpen heruntergebracht wurden, jedoch mit Unrecht. Ähnliche Geschiebe werden noch an manchen anderen Orten grefunden und gelegentich in derselben Weise verwendet, so bei JIédoe und bei Alencon (Diamanten ron Alencon) in der Tormandie in Franliteich, bei Fleurus in Belgien, bei Cayenne usw.

Auch auberhalb der Alpen ist der Berghristall sehr verbreitet, es sollen aber auch von diesen auberalpinen Vorkommuissen nur einige wenige genannt werden. Prachtroll klar sind die meist nicht sehr groben Kristalle, die in Ifoblräumen des beriilımten Marmors von Carrara sitzen. Ringsum ausgebildet und vielfach ohne deutlich bemerkbare Anwachsflïche sind die sehr sehön wasserhellen Kristalle, die auf der frenze der II ar. 
marosch im nordïstlichen Ungarn gegen Galizien hin auf Kliiften eines dunkeln Karpathensandsteins oder des diesem eingelagerten 'Tonschiefers auf Kalkspat aufgewachsen sind. Als Fundorte dieser stecknadelkopf- bis nußgroßen Kristalle, die vorzugsweise nach starken Regrengiissen auf der Erdoberfläche zusammengelesen werden, sind besonders Veretzke, das Tal des Nagyagflusses und Bocsko zu nennen, doch haben sie in jener Gegend weitere Verbreitung. Nach ihrer Heimat werden sie als "Narmaroscher Diamanten", sonst auch wohl als Dragomiten (von dem walachischen drago = lieb, wert) bezeichnet. Kleine liergkristalle, allerdings vielfach nicht tadellos klar und nur zum kleineren Teile schleifbar, finden sich auf Klïften im Lettenkohlennergel der hessischen Grafschaft Schaumburg an der unteren Weser. Sie wurden unter dem Namen ,Schaumburger Diamanten" früher nicht selten zu Schmucksteinen verarbeitet. Die kleinen Kristalle aus dem Porphyr von Stolberg am Harz sind "Stolberger Diamanten" genannt worden.

So reich auch Europa an schönen Bergkristallen ist, so wird es doch von den massenhaften Vorräten in anderen Weltteilen weit in den Schatten gestellt.

Schon seit der Mitte des 17. Jahrhunderts liefert die Insel Madagaskal große Torrïte, und auch noch jetzt kommt viel von dort. Das Mineral ist hier besonders rein und klar und bildet oft Blöcke von ganz besonderer Größe, von denen die größten bis zu $8 \mathrm{~m}$ Unfang erreichen. Es sind ganz isolierte Stiicke, zum Teil in den Flüssen vom Wasser abgerollt, und solche werden allein fiir den Verbrauch gesammelt. Tadellose 13löcke im Gewichte von 50 bis 100 Pfund sind hier keine Seltenheit. Diese Funde haben bewirkt, daß größere Bergkistalle von vorzüglicher Beschaffenheit, die in den Alpen selten und daher früher teuer waren, zu billigen Preisen in den Handel gelangten. Der Bergkristall findet sich in dem ganzen von Gneis gebildeten 'Teil der Insel, besonders im Osten und Nordosten, und hier vorzugsweise bei Vohémar und von da bis Mahanoro an der Küiste und mehr oder weniger weit landeinwärts. Genannt wird auch die Insel Sainte Marie. Die von Nosi-Bè kommenden Schiffe brachten vielfach den Quarz mit, daher wurde diese Insel nicht selten fälschlich als Fundstelle angesehen. Anstehend im Muttergestein scheint das Mineral in Nadagaskar nicht ïberall bekannt zu sein, doch ist es nach den begleitenden Mineralien sicher, daß es wenigstens zum Teil aus Gä̈ngen grobkörnigen Granits (Pegmatits) stammt, zum Teil allerdings auch aus Spalten, ähnlich wie in den Alpen.

Auch in Indien ist der Bergkristall verbreitet. Er wurde früher dort verarbeitet, und dasselloe ist heute noch der Fall, wenn auch keine so ausgezeichneten Gegenstände mehr daraus dargestellt werden wie in alten Zeiten. Noch jetzt ist diese Industrie im Gange zu Vellum im Tandschor-Distrikt des Gouvernements Madras, wo unter dem Namen „Vellum-Diamanten“ Brillanten, Rosetten usw., aber auch Brillengläser und anderes aus lBergkristall geschliffen werden. Dieser wird in der Nähe in Geschiebeform aus einem Konglomerat der Tertiärformation gewonnen. Dagegen ist die friber beriilumte Verarbeitung unseres Minerals in Delli jetzt ganz zum Erliegen gekommen. Gefälse aller Art, Schalen, Vasen, Trinkbecher usw. und andere Gegenstände wurden dort ehemals in äußerst kunstvoller Weise daraus hergestellt; das Material stammte von Aurangpur, 15 engl. Meilen siidlich von I) dhi, wo die alten Gruben noch jetzt zu sehen sind. Einiges Material zum Schleifen liefern auch die zweispitzigen Kristalle aus dem Gips des Salzmergels bei Kalahagh am Indus, ebenso wird in Kaschmir Bergkristall zu billigen Schmucksachen verschliffen. Andere der zahlreichen Fundorte haben, wie es scheint, und hatten keine industrielle Bedeutung.

Besonders reich ist Amerika und hier vorzusweise Brasilien. Dieses Land liefert neben vielen geffirbten Quarzen, von denen noch weiter die Rede sein wird (Amethyst,

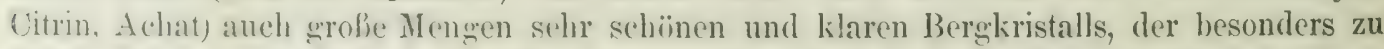
brillengliisern und anderen optischen Instrumenten, aber auch zu allen möglichen sonstigen 
E

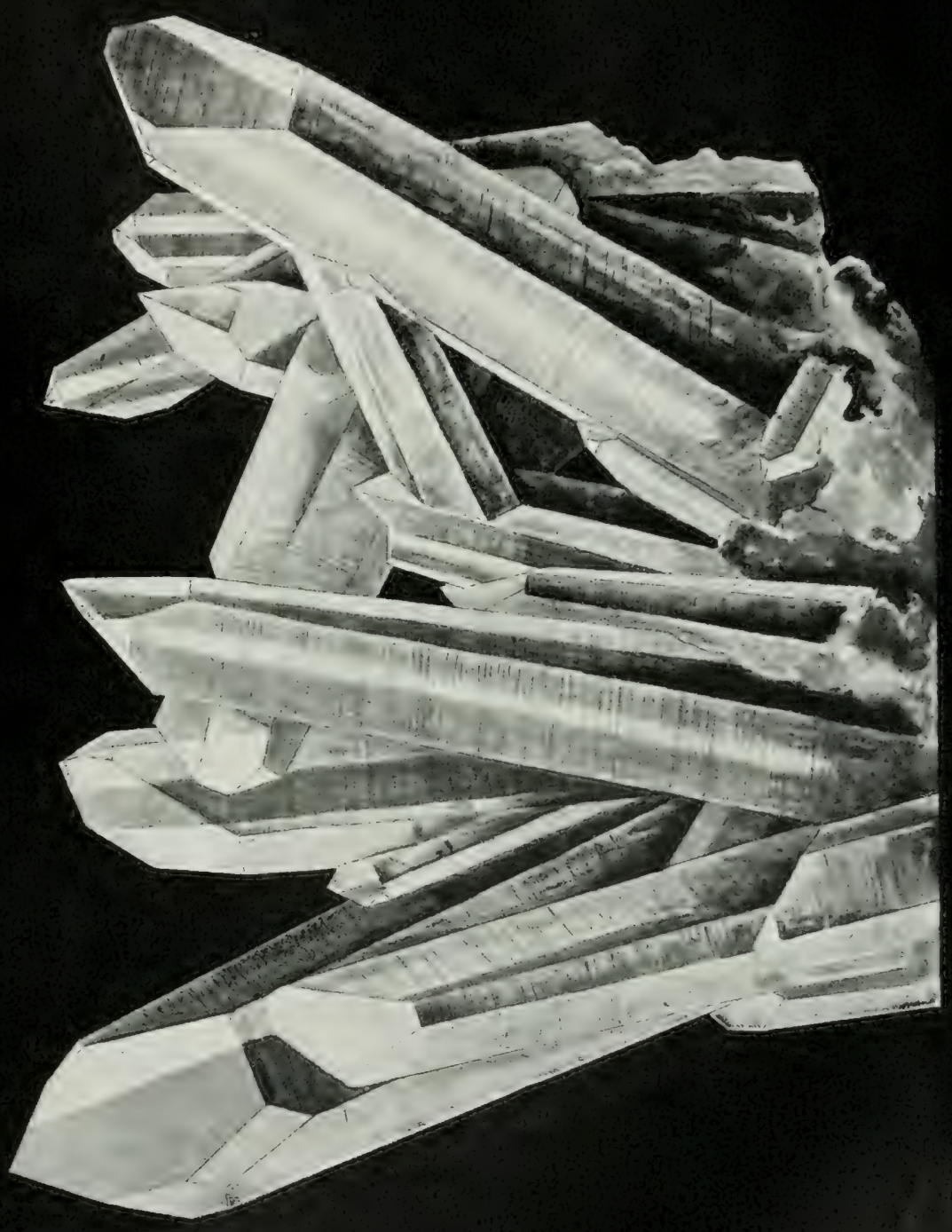

(1) 

Zwecken verschliffen wird. Der brasilianische Berckristall ist besonders billig und z. T. leicht zul gewinnen; daher. und wegen seiner vorzïglichen Beschaffenheit bat er den von den meisten anderen Fundorten fast völlig aus dem IIandel verdrängrt. Ein fertiges Brillenglas, das in Brasilien aus dortigem Bergkristall geschliffen worden ist, stell sich nach der Angabe von $k$ u $\mathrm{n}$ \% in New York hilliger als der Schleiferlohn für ein Brillenglas in dieser Stadt. Es sind die Provinzen Minas Cieraies, S. Paulo und namentlich Goyaz, die als Heimat des Bergkristalls Bedeutung haben.

Tach den Mitteilungen des Edelsteinhändlers $A$ ugust Leyser II in Idar liegren die Fundorte in Goyaz in der Serra dos Cristä̈s, einem Hochlande zwischen den Fliussen São Mareos und São Bartholomeo. Der erste, der Grenzflulf gecegen den Staat Minas Geraës, ergießt sich nach südlichem Lauf in den nach Westen flielienden Rio I'aranahyba; der andere, mit jenem parallel, ist ein Nebenfluf des Rio Corumba, der sich weiter abwärts, gegen Westen, ebenfalls mit dem Paranahyba vereinigt. Die Gegend, etwa 350) Kilometer wegen Osten von der Hauptstadt f'oyaz entfernt, liegt siidlich vom 16. Breitegrad und ungeführ 1S" westlich ron Greenwich. Der Hauptort heift são Sebastiäo, die näichste Bahnstation ist Entrerios, das gegenwärtige Ende der Mogiana-Bahn. Die Kristalle finclen sich auf Adern, die einen Sandstein von enormer Härte und Festigkeit durchziehen, so dab bei der (rewinnung Dynamit nötig ist, und nicht selten rersagt auch dieser. Diese Adern sind stellenweise so dïnn, daß sie sich in dem Nebengestein oft nur als foine Linien hinziehen. Man kamn dann mitunter monatelang arbeiten, ehe man eine Druse triff, in der Kristalle (denticão) sitzen. Ton diesen ist nur der kleinste Teil reiner Bergkristall, der weitaus sröfte Teil ist trüber gemeiner Quarz. Man kann froh sein, wenn der zehnte Teil klar und durchsichtig und für die Schleiferei brauchbar ist. Jede Ader hat ihre besondere Eigentïmlichkeit, was die Gröle und die Form der Kristalle anbelangt. In der einen sind es langestreckte Zapfen, in der anderen sind sie kurz und dick, bald sind sie grof, bald klein, bald regelmäbig ausgebildet, bald mehr oder weniger stark verzerrt. Die Dicke ceht häufig bis zu der eines Armes, öfters anch darüber. Ähnliches gilt für die Farbe. Die Adern, die ganz farblose, wasserhelle Kristalle liefern, sind sehr selten; in ihnen kommen niemals farbige Exemplare vor. Am häufigsten ist ein Anflug von Farbe, rauchgrau, griinlich oder gelblich, flaschenfarbig, wie die Arbeiter sagen. Steine dieser Art werden an der Sonne oder durch Erhitzen gebleicht. Manche Adern liefern hell- bis dunkelbraunes, ja yanz schwarzes Material (Rauchtopas), das durch Erhitzen gelb und dann als Citrin nder Topas rerkauft wird. Natürlich gelbe Kristalle (Citrin) sind auf diesen Adern selten, häufiger finden sie sich wie in Rio Grande do sul in einem vulkanischen Gestein (tapiaganga), die Ausbeute ist aber auch liee gering und die Produlition nicht lohnend. Adern. die sich nahe liegen. sind sich so ähnlich, daß man bei einiger Erfahrung mit Sicherheit hestimmen liann, aus welcher Gegend oder Ader eine Partie von Ḱristallen stanmt. Aufer auf der ursprünglichen Lagerstätte in den Adern findet sich der Quarz, Berckistall und alle die andern Qualitäten und Farben, auch in Rollstïcken (oro de Ema) his zum Gewicht ron $6+$ Pfund, lose im Boden und an der Erdoberfläche liegend. Bis ror ganz kurzem wurden uu diese gewonnen und in zwei Jahren sind ron 200 Leuten 7our Tomnen gesammelt worden. Da aber derartige Fundstellen sehr leicht zu bearbeiten sind. so war der Vorrat bald erschüuft und ecegenwärtig wird fast nichts mehr gefunden. Es muf nunmehr alles aus den Adem losgesprengt werden. Die ganze Ausbeute beziffert sich zurzeit auf etwa 25000 Kilogramm im Jahre; sie wird zum srö̈ßten Teil ron der oben genannten Firma in den Handel gebracht.

Auch in Nordamerika ist Berghristall an sehr vielen Stellen gefunden worden. In Chestnut Iill im Staate Nord-Carolina sind reine zentnerschwere Kristalle rorgekommen. Der schwerste wom $131 \mathrm{~kg}$. Dies ist der größte, der in Nordamerika bekannt geworden 
ist; der zweitcribte ron $86 \mathrm{~kg}$ stammt aus Alaska. Am Lake George in Herkimer County und auf größere Erstreckung in der Ungegend liegen im Staate New York zahlreiche rinģsum ausgebildete Kristalle, allerdings meist von geringer Gröle in Hohlräumen eines Kallisandsteines. Sie rivalisieren nach Glanz, Klarheit und Reinheit mit den Bergkristallen von Carrara. Man sammelt sie seit mehr als 50 Jahren in Menge und rerkauft sie in der Gegend, gescbliffen und roh, meist an Touristen, unter dem Namen ...Lake Geore-Diamanten". Sie schließen zuweilen größere Wassertropfen ein, was ihren Wert crhöht, oder die beherbergen schwarze Körner einer bituminösen Substanz, zuweilen von erheblicher Größe, was die entgegengesetzte Folge hat. Massenhaft ist das Vorkommen und die Verwendung wasserheller Bergkristalle am Crystal Mountain und auf 40 engl. Meilen rings um Hot Syrings in Arkansas, wo sie auf Spalten in einem roten Sandsteine vorkommen. Wagenladungen dieser sogenannten "Arkansas-Diamanten" bringen die Farmer nach Hot Springs und Little Rock, wo um Tausende von Dollars davon an die Badegäste verkauft wird. Bei Hot Springs finden sich im Washita River auch rheinkieselartige Geschiebe, die von den Touristen so gesucht sind, dal\} man durch Abrollen in rotierenden Füssern Bergkristallstücke kïnstlich in diese Form bringt, um den Bedarf zu decken. Reichlich ist auch das Vorkommen von Bergkristall in Kanada.

Der Bergkristall kann unter Umständen mit sämtlichen wasserhellen Edelsteinen verwechselt und ihnen als der billigste von allen untergeschoben werden. Am hä̈nfigsten wird er mit dem Diamant in Beziehung gebracht, und viele Namen deuten, wie wir gresehen haben, auf die Ähnlichkeit in Durchsichtigkeit und Farblosigkeit bei beiden hin. Man nennt den Bergkristall Scheindiamant oder Similidiamant, und spricht nach dem Fundorte, aufer von den schon genannten marmaroscher, schaumburgisehen und Arkansasusw. Diamanten, auch von bühmischen, irischen und Paphos-Diamanteh, von Diamanten von Fleurus, Bristol, der Insel Wight, von Quebeck usw., auch ganz allgemein von occidentalischen Diamanten. Alle diese Pseudodiamanten sind Bergristalle; aber da sie selbst in den schönsten Stïcken nicht den herrlichen Glanz und das prächtige Feuer und Farbenspiel der echten Diamanten zeigen, so ist eine Verwechselung kaum möglich. Einen sicheren Unterschied gribt im Notfalle die schwache doppelte Lichtbrechung des Bergkristalles, sowie die bedeutende IÏ̈rte, die starke einfache Lichtbrechung und das hohe spezifische Gewicht des Diamants, der im reinen Methylenjodid raseh untersinkt, während Bergkristall schwimmt. Auch alle andereren farblosen Steine lassen sich durch das spezifische Gewicht sicher von Bergkristall unterseheiden. Nach der abnehmenden Größse desselben geordnet sind es rorzugsweise farbloser Hyacinth, Sapphir, Topas, Spinell, Turmalin und Phenakit. Der letztere, der leichteste von diesen, hat ein spezifisches Gewicht von 2:1!, bei allen anderen ist dieses höher, so daß sie in der leichtesten Flüssigkeit, in der Ber@isistall schweht, rasch zu Boden sinken. Wichtig ist auch die Unter'scheidung von weißem, farblosem Glas (S. 551). So verloreitet und billig Bergkristall ist, so wird ihm doch das letztere untergeschoben, und mancher sogrenannte Similidiamant ist nichts anderes als (xlas. Es ist aber einfach lichthrechend, und daher im l'olarisationsinstrumente leicht von dem doppeltbrechenden Berokristalle zu unterscheiden, der zudem stets erheblich härter, nicht selten auch leichter ist als das Glas.

Erwähnt sei zum Śchluß, daß der Bergkristall auch gefärbt werden kann. Irirft man ihn in salïhendem Zustand in eine farbige Flïssigkeit (rote oder blane Tinte usw.), so erhält or infolge der raschen Abkühlung an der Oberfläche unz:̈̈hlige kleine Risse, durch die die Flïssigkeit eindringt und so dem Stück ihre Farbe mitteilt. Man kann auf diese Wreise lire farbigen (Quarze, Amethyst, Citrin, Rosenquarz, P'rasem usw. kïnstlich nachahmen, die Sache hat aber keine grobe praktische Bedeutung, und die Falsifikate können an den Sprüngen stets leiclit erkamnt werden. Derart gefärbte Bergkristalle werden eraquelées genannt. 


\section{Rauchtopas.}

Jer launchtopats ist nicht, wie es dem Xamen nach scherinen kïnnte, eine Ahart des Toplases, es ist der durchsichtige Quarz von brauner bis bemahe schwarzer Farbe. Der gemeine braune Quar\% wird als Rauchyuarz bezeichnet. Wenn der Rauchtopas sehion durchsichtig ist, wird or nicht solten sesehliffen und macht dann mit seiner oft recht tiefen und gesättigten Farbe einen sehr guten Eindruck.

Die Farbe ist nelkenbraun bis raucherau. Sie ist bald sehr zart mit allen Übrogängen his zur vollkommenen Farb]osirkeit des Bergkristalls; bald ist sio aber auch dunkler und geht wenigstens in dickeren Stiicken his zum vollstïndigen Schwarz. Solcher dunkle Rauchtopas wird Morion genannt. Manchmal ist die Farbe nicht ganz gleichmälfigr; hellere und dunklere Stellen wechsehn miteinander ab. An sehr dunkel garfärbten Stiicken ist ein dentlicher, aber doch immer nicht sehr starker I)ichroismus zu hemerken: die Farbe wird ron der dichroskopischen Lupe in getblichbraun und in hell nelkenbraun mit einem stich ins Violette zerlegt. Je heller die Farbe des Steines, desto greringer ist der Farbenunterschied, und bel sehr blassen Stïcken ist er ïberhaujt nicht mehr zu bemerken. Eine Kristalldruse von Rauchtopas ist Taf. XVIIT, Fig. 3, ", ein geschliffener Stein von lichterer Farbe Fig. 3, $b$ und $c$ dargestellt.

Die Lrsache der Fürbungr soll eine flüchtige, brenzlich riechende, kohlenstoff- und stickstoffhaltige, organische Substanz sein, die sich als eine trübliche Flüssigkeit von der Quarzsubstanz abdestillieren läßt, doch denkt man auch an unorganische, namentlich an Titanverbindungen; jedenfalls ist die kleine Menge des Farbstoffs ganz in der Kieselsäure aufurelöst (dilut) und auch bei der stärksten Verörößerung nicht mit dem Mikroskop zu erkennen. Ein Geruch macht sich manchmal schon bemerklich, wenn man einen dunkelgefïrbten, also vicl ron diesem Stoff enthaltenden Rauchtopas zerbricht, oder wenn man zwei derartige Stücke stark geweneinander reibt. Beim Glühen an der Luft, ja schon beim Erhitzen auf 300" C. wird der Rauchtopas infolge des Entweichens der färbenden Substanz rollkommen farblos und wasserhell und ist dann vom Bergkristall nicht mehr zu unterscbeiden. Beim Erwärmen auf eine niedrigere Temperatur wird die braune Farbe gelb bis braungrelb, wie die des unten zu betrachtenden (itrins, und nicht wenige der in Handel rorkonmenden gelben Quarze sind nichts anderes als "rebrannte" Rauchtopase. Durch Radiumbestrablung wird die urspriingliche Farbe wiederhergestellt.

In allen anderen Eigenschaften als bezüglich der Farbe stimmt der Rauchtopas mit dem Bergkristall bis auf das kleinste überein. Wir werden sehen, daß dies bei dem violetten edlen Quarze, dem Amethyst, nicht in diesem Ifalbe der Fall ist, aber der Rauchtopas ist nichts anderes als braun gefürbter Bergkristall. Dies zeigt sich besonders in der speziellen Art der Kristallisation und des Torkommens, wie wir dies anch schon bei der Betrachtung des Bergkristalls von Goyaz gesehen haben.

Die Kristallformen sind ganz genau die des Bergkristalls, und alles, was oben hierïher angeführt worden ist, gilt in dersellen Weise für den Rauchtopas, für den also namentlich auch die Fig. 100, l, und ¿ zutreffen. Was das Torkommen anbelangt, so sitzt der Rauchtopas ebenfalls auf Spalten der gneis- und granitartigen Gesteine an vielen Grten der Alpen, begleitet von denselben Jineralien wie der Bergkristall, und anderswo sind die Verhältnisse ähnlich. Auch der Rauchtopas findet sich zuweilen in den großen kellurartị erweiterten Drusen, die viele Zentner des scbönsten Materials enthalten können.

Das wrobartigste Torkommen ron Rauchtopas, und zwar teilweise ron schönsten, in grüberen stücken tiefschwarzen Morion, bildet die im August 1565 am Tiefengletscher im Kanton Cri nahe der Furkastrabe im verwitterten Granit entcleckte, 6 Meter lange, 4 ILeter hreite und 1 his 2 Meter hohe Kristallhöhle. 300 Zentner Kristalle wurden in kurzer Zeit 
hier gewonnen, darunter 200 Zentner schöner durchsichtiger Schleifware und 100 Zentner Kabinetstiicke. Unter letzteren waren einige Kristalle von besonderer Größe, die jetzt im Berner IInseum aufgestellt sind. Ihrer Merkwürdigkeit wegen hat man sie mit besonderen Namen belegt.

Der "Yroßvater" ist $69 \mathrm{~cm}$ lang, sein Umfang beträgt $122 \mathrm{~cm}$ und sein Gewicht $133^{1} \mathrm{z} \mathrm{kg}$. Etwas diinner und leichter, aber länger und am besten von allen erbalten, sowie am regelmiiljigsten auskristallisiert ist der "König". Er ist $87 \mathrm{~cm} \mathrm{lang,} \mathrm{hat} 100 \mathrm{~cm}$ Umfang und wient $127^{1}=\mathrm{kg}$. Die zwei kleinsten der sechs in Bern aufbewahrten Kristalle sind "Kastor" und "Pollux" von 72 und $71 \mathrm{~cm}$ Länge und 65 und $621 / 2 \mathrm{~kg}$ Gewicht. Alle diese genannten zeigen an einem Ende eine Anwachsstelle. Einer der sechs Kristalle, der „große Zweispitz", ist dageegen ringsum vollständig ausgebildet und überall von regelmäßigen Flächen umgrenzt; man kann an ihm durchaus nicht die Stelle finden, nit der er auf der Unterlage befestignt war, und doch muß er ursprünglich wie die anderen aufgewachsen gewesen sein. Er ist $82 \mathrm{~cm}$ lang, hat $71 \mathrm{~cm}$ im Umfange und wiegt $67 \mathrm{~kg}$.

Diesem massenhaften Vorkommen des Rauchtopases in den Alpen gegenüber sind alle anderen Funde unbedeutend. MIan begegnet ihm als Begleiter der Edelsteine: des Topas, Berylls und besonders des Amethystes bei Mursinka im Ural; ferner neben Beryll und Topas in der Gegend von Nertschinsk in Transbaikalien usw. Auch als Geschiebe findet er sich nach Art der Rheinkiesel, so bei Aleneon in der Normandie mit den Bergkristallkieseln zusammen und ebenso in den Edelsteinseifen von Ceylon.

Zu erwähnen ist noch das Vorkommen am Berg Cairngorm auf der Grenze von Inverness-shire und Banff-shire siidwestlich von Banff im nördlichen Schottland und in der Umgegend. Man findet dort einen durchsichtigen weingelben bis braunen, zuweilen schwarzen Quarz in Kristallen bis zu 25 Pfund, die in England nach der Lokalität als "Cairngorms" bezeichnet werden (schottischer Topas zum Teil). Der Stein war früher namentlich in Schottland sehr beliebt und wurde in Menge gesammelt. Das war ein sehr einträ̈rgliches Geschäft in der Gegend der großen Granitmassen in diesem Teil des Landes, es hat aber jetzt fast ganz aufgehört, da die Nachfrage allmählich bedeutend nachgelassen hat. Die Kristalle wurden in flachen Löchern und Gräben aus dem zersetzten Granit und dem daraus gebildeten Schutt gewonnen, der die meisten der dortigen niedrigen Hügel bedeckt und finden sich auch in vielen Wasserläufen daselbst, so z. B. im Avon, wo Stücke bis zu 40 Pfund vorgekommen sind. Die Rauchtopase sitzen mit großen OrthoklasKristallen und Muscovittafeln und zuweilen mit Beryll auf Drusen in Gängen eines feinkörnigen Granits, die den grobkörnigen Granit durchsetzen, oder sie liegen lose in dem durch Verwitterung des Granits entstandenen Kaolin.

Erwähnung verdienen schließlich noch einige amerikanische Fundstätten, die schleifwïrdiges Material liefern. In grrobkörnigen Granit von Pikes Peak in Colorado finden sich auf Drusenrïumen grolie Mengen von Rauchtopas als Begleiter des Amazonensteines und jührlich werden für mehrere Tausend Dollars Steine dort gewonnen und versehliffen. Der grröbte hier grefundene Kristall ist mehr als 4 Ful lang. In nicht greringer Menge wird Rauchtopas auch am Mount Antero in Colorado, bei Magnet Cove in Arkansas und in den Crrafschaften Burke und Alexander in Nord-Carolina gewonnen. Geschiebe von Rauchtopas zusammen mit solchen von Bergkristall finden sich nicht selten im PotomacFlusse, sowie an der Küiste von Lonen Branch sïdlich von New York; sie werden als Andenken geschliffen. Es ist nicht möglich, aber auch nicht erforderlich, alle die vielen Fundorte von Rauchtopas in diesem Lande aufzuzïhlen; auch hier sind Kristalle bis über 100 Pfund vorgekommen und Stiicke von der vollkommensten Durchsichtigkeit und Klarheit, die zu den schönsten Schmucksteinen tauglich sind. In Goyaz in Brasilien begleitet, wie schon erwähnt, Rauchtopas den Bergkristall. 
Wenn der Rauchtolas als Schmuckstein geschliffen wird, erhailt er hïufign die fiestalt des Brillants oder auch die des Tafel- oder Treppensteines, die Forn mit verlängerten Brillantfacetten, die des Maltheserkreuzes (Taf. XVIII, Fig. 3, l, c) usw. Im übrigen wird er auber zu Schmucksteinen in ähnlicher Weise wie der Bergkristall auch zu Siegelstioken und anderen derartigen I)ingen verarbeitet. Wrenn dis Farbe nicht zu blabs ist, crewïhrt ex mit seinem starken und schönen (Blanze stets einen sehr hübschen Anblick.

Der Rauchtopas ist einer der wenigen braunen Edelsteine, die man kennt, und ron diesen im allgemeinen der klarste und durchsichtigste und auch der häufigste. Die anderen, die der Farbe nach noch in Betracht kommen und mit ihm verwechselt werden können, sind Axinit, Vesurian und brauner Turmalin; andere braune Steine gehen mehr ins Gelhe und unterseheiden sich dadurch schon auf den ersten lBlick vom Pauchtopjas. Der Untersehied der grenannten drei Steine von dem letzteren wird an sichersten durch das spezifische Gewicht gregehen, das bei ihnen allen üher 3 hinausgeht. Sie sinken daher in der dritten Fliissigkeit rom Gewicht 3,", auf der Rauchtopas schwimmt. Auch der schwächere Dichroismus des letzteren gegenüber dem starken bei den drei anderen lïßt jenen von diesen leicht und sicher unterscheiden. Zicht man etwa noch den braunen Diamant in Betracht, so ist dieser an seinem starken und charakteristischen Glanze meist von rornherein sicher zu erkennen, auferdem aber auch durch seine einfache Lichthrechung und den vollstïndigen Mangel an Dichroismus, sowie durch das hohe spezifische Gewicht, vermüge dessen er sogar im reinen Methylenjodid rasch untersinkt.

\section{Amethyst.}

Der Amethyst (occilentalischer Amethyst) ist der violette Quarz. Die Farbe geht zuweilen rom Violett ins Purpurrote; steine dieser Art werden wohl Purpurachat genannt. Sie ist bald blaß, beinahe weil, bald tief und gresättignt. Häufig ist sie nicht gleichmäßjig über den ganzen Stein verteilt, sondern fleckigr, heller und dunkler violett oder violett und farblos unregelmäßig, zuweilen jedoch auch in regelmäbigen Streifen miteinander abwechselnd. In einzelnen Fällen hat man sogar Kristalle beoabachtet, an denen neben dem Violett noch eine zweite Farbe, gelb oder grïn, auftrat.

Die meisten Amethyste sind trübe und hüchstens durchscheinend, viele sind allerdings auch vollkommen klar und durchsichtig. Nur diese letzteren, die edlen Amethyste, werden als Edelsteine geschliffen. Hellgefïrbte und gefleckte Steine haben wenig Wert, sie werden aber, wenn sie in größeren Stiicken vorkommen, zuweilen zu allen müglichen kleinen Gebrauchsgegenstïnden rerarbeitet, bei denen es auf jene genannten Eigenschaften weniger ankommt. Schmucksteine sind um so greschätzter, je durchsichtiger und tiefer und gleichmäßiger gefärbt sie sind.

Die Farbe steht der des „orientalischen Amethysts“, des Violettrubins, sehr nahe, hat aber diesem violetten Korund gegenüber den großen Nachteil, daß sie bei künstlicher Beleuchtung meist sehr verliert und unansehnlich und wrau wird, wälırend jener seine violette Farbe in voller Schönheit beibehält. Nur wenige Amethyste sind in dieser Beziehung ron besserer Beschaffenheit und behalten ihre schöne Farbe auch bei Licht.

Der Amethyst ist meist nur schwach dichroitisch; selten ist der Farbenunterschied sehr deutlich, bei manchen ist er sogar sehr gering, ja kaum wahrnehmbar. Die violette Farbe zerfällt in einen mehr rötlichen und einen mehr blauen Teil, und die Dichrolupe gribt 2 wei mehr orler weniger deutlich verschiedene Bilder von den genannten beiden Farbennuancen.

Die violette Farbe ist nicht bestïndig; sie verschwindet beim Erhitzen und nacht bei weiter steigender Temperatur einer mehr oder weniger ausgesprochen gelben oder braungelben 
Platz. Bei efwa :300" pflegent die Entfärbung zu beginnen und bei etwas iiber $4000^{\circ}$ sind die Steine meist anz farblos. Über $500^{\circ}$ tritt die gelhe oder braune Färbung auf, die beim Erliaiten fewöhnlich intensiver, ja in einzelnen Fällen dann erst deutlich wird. Ilie Intensität dere selben oder braunen Farbe entspricht der der ursprïnglichen violetten. I) ureh lialiumbestrahlung wird die violette Farbe wiederhergestellt. Indessen verhalten sich durchaus nicht alle Amethyste dabei ganz gleich, z. B. kann an denen alls der Auvergne kaum ein helles Gell erzielt werden; auch die Temperaturen her denen die Farbenänderung eintritt, sind nicht immer dieselben. Die durch höhere 'Temperatur erzeugte braune und gelbe Farbe ist übrigens ebenfalls nicht bestïndig und verschwindet bei noch weiterem Erhitzen, wie wir unten bei der Betrachtung des Citrins noch sehen werden. Ührigens muß beim Erhitzen des Amethystes große Vorsicht ansewendet werden, da er dabei leicht zerspringt. Daher werden die Steine in Sand eingebettet und die Erhitzung sowie die Abkühlung wird möglichst stetig und langsam bewirkt. Man nennt diesen Prozeß das Brennen des Amethystes. Der Farbenwechsel von violett in geelb hat nämlich eine gewisse praktische Bedeutung, da man hierdurch den häufigeren violetten Quarz in den selteneren gelben (Citrin) verwandeln kann. In der Tat sind auch viele gelbe Quarze oder Citrine nichts anderes als "gebrannte Amethyste". Jiese gelben Steine sind im Edelsteinhandel gleichfalls sehr geschätżt; wir kommen hierauf unten noch einmal zurück.

Auch beim Amethyst ist die Färbung wie beim Rauchtopas eine dilute; sie wird hervorgebracht durch ein in der Quarzmasse vollkommen aufgrelöstes Pigment, das auch bei stärkster Vergrößerung nicht in einzelnen voneinander deutlich unterscheidbaren Teilchen in den Kristallen hervortritt. Nicht selten ist es an einzelnen Stellen stärker angehäuftdie dann in der oben geschilderten Weise als dunklere Flecken erscheinen, während es an anderen Stellen fehlt, die dann ganz farblos sind. Die Ursache der Färbung des Amethysts ist in verschiedener Weise zu erklären versucht worden. Man hat geglaubt, daß es eisensaures Kali sei, auch organische Substanz wurde angenommen, meist wird aber die Farbe auf einen kleinen Mangangehalt zuriickgeführt, den die Analysen ergeben, der aber allerdings zuweilen äußerst gering ist. Beispielsweise wurde in einem dunkelgefärbten brasilianischen Amethyst nur 1/1\% Proz., und in einem helleren gar kein Nangan gefunden, so daß die Fragre nach der Ursache der Färbung noch nicht als gelöst betrachtet werden kann.

Auch die Kristalle des Amethysts stimmen in allen wesentlichen Beziehungen mit denen des Berghristalls iiberein; manchmal ist auch die Ausbildung dieselbe, sofern man beim Amethyst zuweilen gleichfalls die langprismatische Form, wie bei jenem, aber meist ohne die kleinen auf die Prismenkanten aufgesetzten Flächen, findet (Fig. 100, ( )is $d$ ). Dies ist namentlich der Fall, wenn die Kristalle auf Kliiften in Gesteinen, wie Gneis usw. aufsewachsen sind. Nehen der allgemeinen Ühereinstimmung mit dem Bergkristall sind aber doch anch auch vielfach kleine Untersehiede in der Ausbildungsweise vorhanden. Sehr cewöhnlich ist es, daß ron den ganzen Kristallen nur die sechsflächigen Endspitzen ausswebildet sind, wie es im (iegrensatze zum Bergkristall so häufig beim gemeinen Quarze vorkommt (spitzenamethyst). Diese splitzen sitzen dann stets in wrober Zahl dicht zusammenfredrängt auf ihrer Unterlage und laufen oft in ein stengliches Aggregat aus, indem jede sich mach unten in ein unregelmäligig begrenztes Prisma verlängert, das nicht mit ebenen Flächen hatte auskristallisieren kïnnen, weil es von den zahlreichen, ringsum sich gleichzeitig

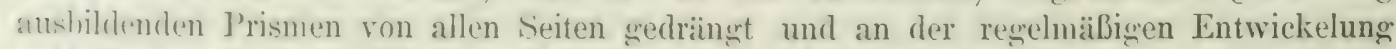
chhindert worden war. IIäufig sind an den sechsflächiren Endspitzen nur drei abweehselnde I'lïhen stob und und ausgedehnt; die zwischenliegenden sind dagesen sehr klein brler fehlen auch ganz, so dals die Individuen zuweilen aussehen, wie wenn sie Würfel 
wären. Derartige wïrfelähnliche Amethyste tindet man, von ihrer Lnterlage und den benachbarten Kristallen abgebrochen, häulige unter der aus sürlamerika in Itenge zu uns gebrachten Schleifware.

Eine ligentümlichkeit, die bei Amethystkristallen besonders häufige vorkommt und die: sie elenfalls nit denen des gremeinen Quarzes teilen. ist, dals sir aus vielen cibereinander.

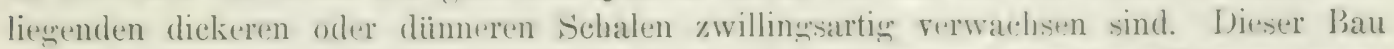
sibt sich nicht selten durch linienweise abwechselnd hellere und dunklere färbung zu erkennen, oder anch durch eine zarte winkelfömige streifungr auf den Endflächen, wie sie in Fig. 100 d angedeutet ist. Zarte Linien, dieser Sehichtenbildung entsprechend, treten auch auf unreggehmäBigen Bruchfliichen deutlich hervor und erzeugen dort eine eigentümliche Streifung; die man mit den Linien auf der Innenfläche der Hand verglichen hat. Auffallend sind die sogenannten Scepterquarze (Fig. 101), die beim Bergkristall zwar nicht fehlen, beim Amethyst aber viel häufiger sind. Auf einem langen und dïnnen, meist farblosen, durchsichtigen oder auch trüben Quarzprisma sitzt an einem Ende, in paralleler Stellung, ein dickerer Quarzkristall, der häufig durchsichtig und violett gefärbt ist.

Amethystkristalle erreichen zuweilen eine beträchtliche Größe; bis fußlange Exemplare sind schon vorgekommen. Dicse großen sind aber selten ganz durchsichtig und von embeitlicher Färbung und daher zu Schmucksteinen nicht verwendbar. Man findet jedoch auch eine Menge schön und gleichmäßig gefärbter Amethyste von einer Größe, daß sich für jeden im

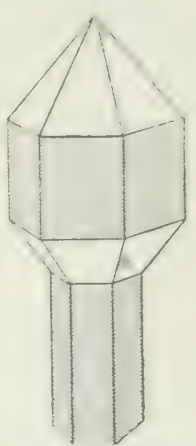

Fig. 111 . sicepterçuar\%. Handel vorkommenden Schmuckstein das Rohmaterial ohne Schwierigkeit beschaffen lälit.

Was die allgemeine Art des Vorkommens des Amethysts anbelangrt. so haben wir schon gesehen, daß zuweilen Kristalle, und zwar meist von langprismatischen Habitus, wie Bergkristalle, auf den W:inden von Klüften und Spalten im Granit, Gneis und anderen Gesteinen aufgewachsen sind. Anders finden sich die Amethyste, von denen meist nur eine sechsflächige oder eine dreiflächige, würfelähnliche Endspitze aušrebildet ist. Sie sitzen so auf den Wänden mandelförnig gestalteter Höhlungen in den mehr oder weniger stark zersetzten schwarzen unter dem Namen Melaphyr bekannten Eruptivgresteinen. Diese Höhlungren wurden von Dampfblasen erzeugt, welche durch die noch in glïhendem Flusse befindliche Masse hindurchzudringen suchten, die aber bei der Erstarrung des Gesteins stecken blieben. Sie waren zuerst leer, haben sich aber allmählich mit neugebildeten Mineralsubstanzen ganz oder teilweise ausgefüllt, indem sich die letzteren auf den Wänden der Blasenräume absetzten. Diese Neubildungen sind ziemlich manniwfaltig und von verschiedener Natur je nach den speziellen Verhältnissen; unter ihnen spielt der Amethyst, häufig mit dem später zu besprechenden Achat zusammen in demselben Hohlraume, eine Hauptrolle. Die meist im Innern hohlen Ausfiullungsmassen der Mandelräume, die von den neugebildeten Mineralien zusammengesetzt werden, haben natïrlich ebenfalls eine mandelförmıge Gestalt, sie werden daher auch Mandeln genannt. Man spricht so von Amethyst-, Achat- usw. Mandeln. Sie sind erbsengroß bis zu bedeutenden Dimensionen und Zentnergewicht. Gesteine der genannten Art, die solche Mandeln einschließen, werden Mandelsteine genannt.

Wird das irgendwie beschaffene Muttergestein des Amethysts vollständig zersetzt, so grelangen die Kristalle in den dadurch entstehenden Terwitterungsschutt und weiterhin in die Alluvionen der Bäche und Flüsse, in die Seifen, in denen sie als abgrerollte Kürner den anderen Geschieben beigemengt sind.

Frïher kannte man hauptsïchlich den Amethyst aus den Mandeln in den Melaphy'gesteinen (Mandelsteinen) des Nahetales bei Oberstein und an anderen Orten in dieser 
(xegend. In Oberstein und Idar wurde er auch früher in großen Mengen verschliffen, und dies seschieht in den dortigen weltberihmten Schleifereien, die wir bei der Betrachtung des Achats nüher kennen zu lernen haben, in großem Unfange noch gegenwärtig, wenn auch dir einheimischen Amethystlagerstätten jetzt schon lange so gut wie vollständig erschïj)ft sind. Das heute zur Verfügung stehende fremde Naterial ist aber noch vorzüglicher, als das frïhere einheimische. Gegenwïrtig werden größere Stiicke von ausgezeichneter Beschaffenheit in Menge gefunden, während früher meist nur kleinere Kristalle vorhanden waren, so daß die sparsamen größeren, wenn sie nach Farbe und Durchsichtigkeit tadellos waren, verhältnismäßig viel höher im Preise standen als gegenwärtig. Es ist darnach begreiflich, daß die Schleifereien im Idartale durch die Erschöpfung der Fundorte in der Nahegegend keine Schädigung erlitten haben.

Das Land, das heutzutage die meisten Amethyste, das Rohmaterial der jetzigen Schleifereien, liefert, ist das siidliche Brasilien mit dem benachbarten Uruguay. Von dort kommen die Steine in Fässern oder in Säcken aus Tierhäuten zu Tausenden von Zentnern nach Europa, besonders nach Idar, und zwar nicht nur Amethyste, sondern anch anders gefärbte Quarze, gelber Citrin, farbloser Bergkristall und andere.

Im südlichen Brasilien (Rio Grande do Sul) und in Uruguay findet sich der Amethyst und ebenso der im folgenden zu betrachtende gelbe Citrin in gleicher Weise, wie der in denselben Gegenden massenhaft vorkommende Achat, der für die Schleifereien in Idar usw. noch wichtiger ist, als der Amethyst. Sie bilden auch hier Mandelausfullungen im Melaphyrmandelsteine. Bei der Betrachtung des Achats wird von diesem Vorkommen eingehender die Rede sein. Im Jahre 1900 etwa wurde in der Serra do Mar, $600 \mathrm{~m}$ über dem Meere, 20 engl. Meilen nördlich von Santa Cruz in Rio Grande do Sul eine solche Amethystmandel von ganz ungeheuren Dimensionen gefunden. Sie maß in drei Richtungen 10 Meter, 5 Meter und 3 Meter, und die in ihr enthaltenen, bis faustgroßen Amethystkristalle, wunderschön dunklelblau-violett und glänzend, wurden auf 700 Zentner geschätzt. Sie wurde, soweit sie nicht zerstört war, von der Firma C. W. Kessler in Illar erworben und war auf der Ausstellung in Düsseldorf 1902 unter der Bezeichnung „Amethystgrotte" zu sehen.

Es gibt aber auch einige Ametlyystfundorte anderer Art in nördlicher gelegenen Teilen von Brasilien, wo unser Edelstein nicht von Achat begleitet wird, und diese sollen nun zunäichst hier besprochen werden. Sie liegen in der Provinz Minas Geraës. Der Amethyst bildet dort schöne Kristallgruppen auf den danach so genannten Campos dos Cristaës in der Nähe von Diamantina. Die feurigsten und schönsten Exemplare stammen jedoch vom Ribeirão da Paciencia bei Itaberava unweit Cattas altas siidlich von der Hauptstadt Ouro Preto (Fig. S1, S. 420), wo sie sich in ähnlicher Weise finden wie der gelbe Topas derselben Fegend, von dem oben die Rede war. Zahlreich ist auch das Vorkommen von Amethystgeschieben in den Edelsteinseifen des Bezirks Minas Novas als Begleiter der ebenfalls frïher schon betrachteten weißen (und blauen) Topase, der Turmaline, des Chrysoberylls usw. Wie diese Steine also, so stammit auch der Amethyst hier aus Pegmatitgängen.

Auch die Vereinigten Staaten von Nordamerika beherbergen schleifwürdigen Amethyst in einiger Nenge, der aber wohl aller im Lande verarbeitet und als einheimischer Edelstein geschätzt wird. Am meisten findet er sich an Deer Hill bei Staw in Maine, aber verhältnismäßjg wenig schleifhare Exemplare. Gute Kristalle, manche von besonderer Grölbe und zum Teil sehr schön gefärbt und durchsichtig, trifft man im Staate Pennsylvanien, so besonders in Providence Township, Delaware County, aber auch in Chester County und in anderen Gegrenden. Schöne, zu Schmucksteinen sehr gecignete Exemplare sind dann besonders in IIaywood County bei Tesanty, Macon County in Nord-Carolina vorgekommen. Die prächtigen Amethyste von Rabun County in Georgia sind dadurch 
ausgrezeichnet, dab sie vielfach erroße Flüssigkeitseinschlïsse enthalten, während in den anderen Amethysten nur mikroskopisch kleine Crebilde dieser Art sich finden. Am Oberen See ist Amethyst sehr verbreitet, besonders auf der kanadischen reite, wo unter anderen die darnach so benannte Ortschaft Amethyst Ilarbour liegrt; der meisteaus dieser Gergend ist aber allerdinges nicht sehleifwert. Auch der von Neuschottland ist selten zu Selmucksteinen brauchbar, der von der Fundy bay und anderen Orten jener (regend wird aber zu grö̈feren Gegenstïnden der oft genannten Art verarbeitet.

Ferner ist in Amerika noch zu erwähnen der Amethyst von Fuanajuato in Mexiko. Die Kristalle sind bis fuljlang, aber meist blaf und nur an der Spitze dunkler und selten durehsichtig genug zum Schleifen. Es muß aber noch andere, jetzt unbekannte Amethystfundorte in Mexiko gegeben haben, da man schöne schleifwürdige Steine von ganz anderer und schönerer Beschaffenheit als die von Guanajuato vielfach in alten Aztekengräbern findet.

Großen Ruf als die besten und schönst gefärbten unter den bekannten haben noch vor den brasilianischen die Amethystgeschiebe aus den Edelsteinseifen von Ceylon, die dort mit den anderen Edelsteinen zusammenliegen und auch gemeinsam mit diesen gesammelt werden, in der Weise, wie es bei Betrachtung des Sapphirs (S. 360) erwähnt wurde. Die Steine stammen aus den granitischen und gneisartigen Gesteinen jener Gegend. Ebenso findet man Amethyst in einigen Fliissen in Birma, aber dieses Vorkommen ist ohne Bedeutung. Dasselbe gilt für Vorderindien, wo das Mineral zwar gleichfalls vorkommt, jedoch in geringerer Mengre.

Von größerer Wichtigkeit sind die Fundstellen im Ural, namentlich bei Mursinka (oder Mursinsk) in Revier der Alapajewschen und Reschewschen Bergwerke, Kreis Katha-

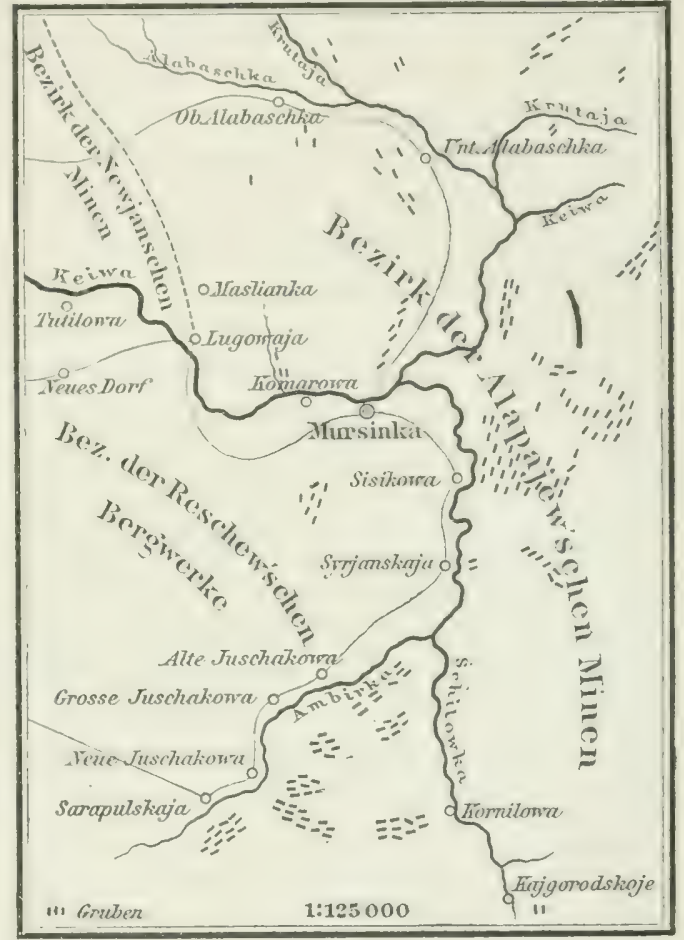

Fig. 102. Amethystgruben bei IIursinka im Lral. rinenburg im Permschen Gouvernement, wo das genannte Dorf unter 57" 40' nürdl. Breite und $30^{\circ} 37^{\prime}$ östl. von Pulkowa liegt. Hier findet sich der Amethyst nahe der Erdoberfläche in Drusenräumen auf wenig mächtigen Quarzgängen im verwitterten Granit, oft unmittelbar unter dem Rasen. Er begleitet den schon oben erwähnten Beryll und Topas, die ebenfalls auf Gängen oder in Nestern im Granit sitzen, aber nicht mit dem Amethyst zusammen in denselben Hohlrämmen, sondern meist in viel größerer Tiefe, so daß ihre Gewinnung erheblich schwieriger ist als die des Amethysts. Zurzeit werden in dortiger Gegend jährlich ungefähr 140 Pfund Ametbyst gegraben ineben 15 Pfund Beryll und Topas und mehr als 200 Pfund Goldquarz).

Die Gewinnung der farbigen Steine findet vorzugsweise im Winter statt, wo 150 bis 200 Personen in den Gruben arbeiten, während diese Zahl im Sommer auf etwa 25 herabsinkt. Die Lage der Gruben, die dem Kabinet des Kaisers von Rußland grehören, ist Fig. 102 angegeben. Ihre Zahl ist ungefähr 75 , von denen aber nur neun gegenwärtig bearbeitet werden. Sie zerfallen der Lage nach in drei Gruppen: 1. die Gruben bei Mursinka; 
2. die Alabaschka-Gruben am Flïßchen gleichen Namens; 3. die Gruben am Flüßchen Ambirka, die auch als die Sarapulka-Gruben bekannt sind. Die auf der Ostseite der Flïse Alabaschka und schilowka liegenden Gruben, besonders die bei Sisikowa, sowie die bei Mursinka greben vorwiegend Amethyst, die zwischen den Dörfern Unter- und OberAlabasehka gelegenen vorzugsweise Topas und Beryll, ebenso die bei Juschakowa und Sarapulskaja, wo aber auch noch roter Turmalin vorkommt. Die dortigen Steine und so auch der Amethyst werden zum größten Teile in Katharinenburg geschliffen und in Rußland verbraucht, doch gelangen auch zahlreiche Stücke durch die Vermittelung der Messe von Nischny Nowgorod in den westeuropäischen IIandel. Die meisten uralischen Amethyste sind hell gefïrbt, oder fleckig und gestreift usw., doch sind auch manche sehr schöne dunkel violette darunter, die mit denen von Brasilien und Ceylon, den besten Amethysten die man kennt, wetteifern können.

Neben Ceylon, dem Ural und Brasilien mit Uruguay, den gegenwärtigen Hauptproduktionsgebieten unseres Edelsteins, haben andere Fundorte geringes Interesse. Man findet den Amethyst an mehreren Stellen der Alpen, meist auf Kliiften im Gneis, so unter anderen im Zillertale in Tirol, das früher Schleifware geliefert hat; ferner auf den Erzgïngen von Schemnitz in Ungarn. In Spanien kommt Amethyst mit Quarzen von anderer Farbe mehrfach und auch in schleifwürdigen Exemplaren vor, so bei Carthagena in der Provinz Murcia, sowie in der Provinz Katalonien, wo die Stadt Vich als Fundort angegeben wird; an der erstgenannten Stelle hat er die Form von abgerollten Geschieben, wie auf Ceylon. Australien liefert an mehreren Orten gute Amethyste. Überall ist aber die Produktion gering, oder es findet eine regelmäßige Gewinnung iiberhaupt nicht oder nicht mehr statt.

Geschliffen wird der Amethyst seltener als Brillant, häufiger als Treppen-oder Tafelstein (Taf. XVIII, Fig. 1, b). Dunkel und gleichmäßig gefärbte Steine sind die gesuchtesten ; sie werden obne Folie à jour gefaßt, hellere und etwas fleckige erhalten eine Folie von der Farbe des Steines. Schöne große, dunkle und fleckenlose Steine der besten Qualität werden jetzt mit bis 2000 Mark pro Kilo bezahlt, hell gefärbte, fleckige sind weit billiger. Frïher war der Preis viel höher. Wie sehr dies der Fall war, sieht man an dem anfangs des 18. Jahrhunderts beriihmten und vielgenannten Amethysthalsbande der Königin Charlotte von England, das damals auf 2000 Pfund Sterling geschätzt wurde, während es heute kaum um 100) Pfund einen Käufer finden würde. Die großen Mengen schöner südamerikanischer Steine, die im Laufe des 19. Jahrhunderts entdeckt wurden, haben diesen Preissturz veranlaßt. Der Amethyst hat seitdem aufgehört, ein kostbares Material für feine Schmuckstiicke zu sein; er wird jetzt in der Hauptsache zu einfacheren und billigeren Sachen dieser Art verwendet. Sehönste geschliffene Steine kosten jetzt bis 10 Mark das Karat.

Im Altertum wurde häufig in Amethyst graviert und Siegelsteine daraus hergestellt. Auch größere Gegenstände hat man daraus gefertigt, wie die Trajansbüste, die von Napoleon in Berlin greraubt worden ist. Heutzutage ist diese Verwendung des Amethysts nur untergeordnet.

Wegen der Ähnlichkeit der Farbe könnte der echte Amethyst nur mit dem orientalischen verwechselt werden, andere violette Edelsteine gibt es kaum. Der letztere ist aher viel härter und schwerer und sinkt im Methylenjodid, worin der erstere sehwimmt. Von dem hïchst spärlich im IIandel vorkommenden violetten Flußspat, dem "falschen Amethyst", unterscheidet sich der echte durch doppelte Lichtbrechung, größere Härte und geringeres spezifisches Gewicht. Die Doppelbrechung ist auch ein sicherer Unterschied rom violetten Crlas, das dem Ansehen nach von Amethyst oft kaum zu unterscheiden ist. 


\section{Citrin.}

Unter dem Namen Citrin rersteht man den gethen (quar\%. Vanche ('itrine entsprechen in allen ihren Eigenschaften auBer der Farbe durchaus dem Berekristall und dem Rauch. topas. Wohl die meisten sind aber in ihrer Leschaffenheit fanz dem Amethyst analog; sie zeigen dieselbe Ausbildung der Kristalle, dieselbe winkelartige Streifung auf den Endflïchen (Fig. 100, d), sowie dieselbe Zeichnung auf manchen Bruchflïchen, und unterseheiden sich von dem Amethyst lediglich durch die getbe Farbe. Aber auch hierin sind gewisse Beziehungen vorhanden, sofern das Violett des Amethysts durch Erhitzen in das Gelb des Citrins ïberecht, wie das schon bei der Betrachtung jenes Edelsteins erwähnt worden ist. Man hat deshalb auch angenommen, dab der ron IIaus aus gelbe Quarz in der Natur überhaupt nicht oder doch nur selır sparsam vorkomme, und dafj aller Citrin, oder doch der größte T'eil sogenannter ngebrannter" Amethyst, oder wohl auch "get)rannter Rauchtopas" sei, welcher letztere, wie wir gesehen haben, beim Erhitzen zum Teil seine braune Farbe ebenfalls in Gelb umwandelt. Diese Annahme ist aher sicher nicht richtig; es ist zweifellos, daf Citrin ron natïrlicher Bildung an einigen der unten zu nennenden Orte in der Tat rorkommt, und zwar an einzelnen derselben in ziemlich erbeblicher Menge, so dab er einen nicht unwichtigen Handelsartikel bildet, doch ist die Bezeichnung Citrin als Handelsname wenig iblich. Nicht immer ist es leicht zu erkennen, ob ein solcher Stein ron Anfang an grelb grewesen oder erst durch Erhitzen von Anethyst oder Rauchtopas gelb geworden ist; es herrscht hierin bezïglich der gelben Schleifware recht vielfach Unsicherheit.

Die Farbe ist nicht an allen Stücken genau dieselbe, hald heller, bis ins Farblose, bald dunkler wein- bis honiggelb, safrangelb und noch in anderen Tuancen. Oft zieht sie mehr oder weniger ins Braun. Namentlich ist eine tief brïunlichgelbe Farbe an vielen Steinen prächtigr ausgebildet, die der Farbe des Taf. XIII, Fig. 2, a, abgebildeten Topases ähnlich ist. Steine dieser Art werden Madeiratopas genannt, da die Farbe mit der des Madeiraweines rerglichen worden ist. Andere Stiicke zeigen einen herrlich goldigen Glanz, so dab sie hinter dem echten gelben Topas an Schünheit nicht zuriickstehen und daß oft ein Kenner dazu gebört, einen Citrin ron einem Topas durch das Ansehen zu unterscheiden. Der Dichroismus ist, wie wir unten noch sehen werden, zuweilen stärker, manchmal jedoch nur unbedeutend.

Daher wird auch der Citrin vielfach dem Topas untergeschoben, mit dem er aber außer der Farbe nichts gemein hat. Ja der gelbe Quarz geht im Edelsteinhandel gewöhnlich nicht unter seinem eigentlichen mineralogischen Namen, sondern sehr häufig unter den Namen Topas, dem man vielleicht zuweilen noch einen unterscheidenden Beinamen gibt, wie occidentalischer, indischer, böhnischer, spanischer Topas. Der indische Topas in diesem Sinne ist nicht zu verwechseln mit dem ebenso genannten safrangelben Topas ron Ceylon, der S. 415 erwähnt wurde. Lnter spanischem Topas rersteht man die tief bräunlichgelben Steine, von denen soeben die Rede war. Goldtopas wird auch der schön groldgelbe Citrin genannt. Der Tame "falscher Topas" kommt ebnfalls vor, er ist aber mebr für gelben Flußspat üblich.

Beide Steine, Citrin und echten Topas, kann man an rerschiedenen Eigenschaften, besonders am spezifischen Gewicht und auch an der Härte immer leicht voneinander unterscheiden. Der Topas ist härter $\left(H_{0}=8\right)$ und ritzt daher Quarz, was Citrin nicht tut, da er eben selber Quarz ist. Der erstere ist auch viel schwerer und sinkt im reinen Methylenjodid rasch unter, während der letztere darauf schwimmt.

Selbstverständlich wird der Citrin nur geschliffen, wenn er vollkommen klar und durchsichtig ist. Je rollstïndiger dies zutrifft, je schöner, gesättigter und reiner die Farbe ist, desto wertvoller ist der Stein, der in seinen schönsten Exemplaren mindestens den Wert 
der besten Amethyste erreicht, während die gewöhnliche Mittelware wie beim letzteren um wenige Mark jro Kilogramm verkauft wird. Die Schliffform ist wie beim Amethyst oder auch beim Topas, und ïberhaupt bei farbigen Steinen, am häufigsten Treppen- und Tafelform mit ihren verschiedenen Modifikationen.

Das Vorkommen des Citrins galt früher für spärlich und beschränkt. Man kannte als Fundort die schottische Insel Arran, wo er bei Goatfield auf Spalten im Granit aufgewachisen ist (schottischer Topas zum Teil); ferner wußte man, daß er den Bergkristall bei Bourg d'Oisans im Dauphiné begleitet, und ebenso wurde er von einigen Lokalitäten in Ungarn, Kroatien usw. erwälınt. Bei Mursinka im Ural trifft man in den Edelsteingruben neben viel Amethyst auch etwas gelben Citrin. In Nord-Carolina sind gleichfalls eminge schöne schleifwürdige Stiicke gefunden worden, aber die Menge ist auch hier sowie an manchen anderen Orten in Nordamerika unbedeutend. In Menge ist er erst im Handel seit seiner in den dreibiger Jahren des 19. Jahrhunderts erfolgten Entdeckung in Brasilien (Rio Grande do Sul) und Uruguay (besonders in der Gegend von Salto Grande am Uruguay-Fluß). Von hier kommt er seitdem mit Amethyst und Achat in großen Massen zum schleifen nach Europa, vorzugsiveise nach Oberstein und Idar, deren zahlreiche Schleifereien auch dieses Material verarbeiten. Von dem Vorkommen in Staate Goyaz in Brasilien ist schon S. 587 die Rede gewesen.

Der gelbe Quarz spieit im Handel immerhin eine nicht unbedeutende Rolle, und namentlich die schönen feurigen, dunkel und braungelben Steine sind sehr beliebt. Es seien daher die wichtigsten Sorten mit ihren Handelsnamen nach R. Brauns noch kurz aufgezählt. Bei manchen ist, wie wir gesehen haben, die gelbe Farbe ursprünglich, bei manchen anderen ist sie erst durch Erhitzen hervorgebracht oder verbessert und verstärkt. Gelber Kristall, zitronen- bis orangegelb, mit starkem Dichroismus, ohne die charakteristische Zeichnung der Bruchflächen und die anderen Eigenschaften des Amethyst, also wie Bergkristall sich verhaltend und wie dieser lang prismenförmig; kommt, allerdings nicht sehr häufig, in Bruchstücken meist ohne Endflächen aus Brasilien. Goldtopas, in der Farbe vom vorigen kaum verschieden, doch auch sehr hellgelb; die im IIandel meist vorkommenden Bruchstücke zeigen die Zeichnung und die optischen Eigenschaften des Amethysts und kaum bemerkbaren Dichroismus. Er wird in diesem Zustande aus Brasilien in Menge eingeführt und soll ein Amethyst sein, der dort schon durch Brennen seine gelbe Farbe erhalten hat. Das Pfund wird je nach Klarheit und Größe der Stücke mit 20 bis 60 Mk. bezablt. Brauner Topas, auch wohl Brasilian- oder Uruguay-Topas, ist dunkelbraungelb, klar und feurig und einer der schönsten Steine dieser Gruppe; die rohen Stücke sind entweder Bruchstücke mit den Endflächen der Quarzkristalle, die zuweilen einen opalartigen, milchigen Schein zeigen, und sie werden beim Erhitzen farblos, um beim Erkalten ihre urspruingliche Farbe wieder anzunehmen; oder sie sind mebr stengelig mit farblosen Enden und matten weißen Endflächen. Bei beiden Arten ist der Dichroismus schwach; das optische Verhalten ist wie bei Bergkristall. Es sind wohl ursprïnglich braune Steine, deren Farbe durch Brennen reiner und schöner geworden ist, die aus Brasilien und Uruguay kommen und von denen das Pfund mit 20 bis 50 Mark bezahlt wird. Span is cher 'T opas ist ein ganz besonders schöner, vollkommen klarer, feurig gelbbrauner Stein, der kräftiges Feuer mit satter Farbe verbindet; er kommt im Handel in Form bramer, stark dichroitischer, pyramidal begrenzter, prismatischer Kristalle vor, die von Hinojosa, I'rovinz ('ordoba, vom Nordabhaner der Sierra Morena in Spanien stammen. Sie werden dort in kleiner IIenge, einige Zentner jährlich, gewonnen und erhalten durch vorsichtiges (Alïhen ihre schöne Farbe (Topas von Hinojosa oder auch von Salamanca). Auch in Fen-Sectand soll ähnliches rorkommen. Er ist von allen diesen gelben Quarzarten der kostbarste und das Pfund klarer und großer Stiicke kostet bis zu 500 Nark. 


\section{Rosenquarz.}

Der Rosenquarz (böhmischer Rubin) ist ein hïchstens durchscheinender bis halbdurchsichtiger, etwas fettolänzender derber (Quarz von schïn rosenroter Farbe, die allerdings zuweilen so zart und blalj ist, dalf sie in allen möglichen Übercaingen bis ins. Wilchweisse verlïuft. Diese Farhe, die in äulferster Feinheit durch die ganze Masse verteilt ist, ist nicht beständig; sie bleicht im Lichte rasch aus, auch beim starken Erhitzen verschwindet sie. Sie wird also wohl von oreanischer Suhstanz hervorgebracht, doch hat man sie auch auf eine kleine Menge Titansäure zurïekgefïhrt, die im hosenyuarz gefunden wurde. Inundlich geschliffene Steine (Kugeln, Eier, Barorues usw.), hesonders von möglichst kräftiger Farbe, die freilich nicht hesonders häufig sind, sehen recht häbsch aus und zeigen zuweilen einen sternförmigen Lichtschein, ähnlich dem der Asterien. Der Verbrauch ist gering: der Preis auch besserer steine ist sehr niedrig und betrïnt etwa $1_{2}$ Mark pro framm. Trotzdem werden sie in Glas nachgeahmt, und zwar so tüuschend, daf der echte manchmal nur an seinem geringeren spezifischen Gewicht und seiner größeren Märte zu erkennen ist. Der Rosenquarz findet sich in größeren unregelmäßig begrenzten Stïcken, unter anderem im Granit der Gegend von Bodenmais im bayrischen Wald, aber auch in schottland bei Clora (Aberdeenshire) auf drei nahezu parallelen (xïngen, mehrorts auf den IIebriden sowie auch auf den Shetlands-Inseln, in Irland bei Belfast, in der Nïhte von Katharinenburg im Ural, auf Ceylon, in Ostindien, Brasilien usw. doch gechörte das Material immerlin zu den weniger verbreiteten Tarietiiten des Quarzes. Neuerdings wurden jedoch grolje Massen gefunden, die 25 Meilen westlich von Fort Collins in Larimer County. Colorado einen bis 3 Veter mächtigen Gang im Granit bilden; 1905 wurden hier 210110 Pfund gewonnen, aber allerdings nicht alles zu Schmucksteinen. Eine andere reiche Lagerstätte, die viel schünes Material lieferte, ist die in den Black Hills in C'uster County, Sïd-Dakota, sowie die ron Yokohol. Tulare County, Kalifornien. Auch in den Coahuila Mountains in Riverside County, Südkalifornien, ist Rosenquarz in 4 bis 6 Fuli mïchtigen Gängen gefunden worden Im Jahre 1907 betrug die Gesamtproduktion in Siid-Dakota und Colorado $513(4)$ Pfund.

Ein rotweinfarbiger, schön schleifbarer derber Quarz findet sich reichlich in einer Zone chloritischen Quarzgesteins, die ron Fortingal durch Ben Lawers und die zentralen Perthshireberge bis zum Loch Eck in Argyllshire hinzieht, an mehreren Orten, ebenso noch an einigen Stellen in Inverness-shire.

\section{Prasem.}

Der Prasem, im Edelsteinhandel zuweilen auch Smaragdmutter genannt, weil er friiher für das Huttergestein des smaragds gehalten wurde, ist ein lauchgrüner, etwas fettglïnzender, nur durchscheinender Quarz, der seine Farbe von unzähligen mikroskopisch kleinen Fäserchen und Nädelchen des Minerals Strablstein erhalten Lat, die in der sonst farblosen und reinen Quarzmasse eingewachsen sind. Der Prasem wurde schon im Altertum zur Herstellung ron schmucksteinen, auch ron Laubwerk an Mosaiken usw. benutzt; die Schmucksteine waren vielfach graviert. In römischen Ruinen wird er in dieser Treise nicht ganz selten angetroffen. Man kennt aber die Orte, ron denen die Rënter ihr Rohmaterial bezogen, nicht mehr, hat dagegen später andere entdeckt. So finden sich Kristalle und kristallinische Massen von derselben Beschaiffenheit wie die uns aus dem Altertum iiberkommenen Steine bei Breitenbrunn zwischen Schwarzenberg. und .Johanngeorgenstadt im sächsischen Erzgebirge auf den Kies- und Blendelagern, ferner in Habachtale in den Salzburger Alpen, an mehreren Orten in Schottland und Finnland usw. Die Terwendung ist jetzt gering und mit der im Altertum ganz übereinstimmend. Wegen des spärlichen Verbrauchs und des reichlichen Vorkommens ist sein Preis mäßig. 


\section{Sapphirquarz.}

I) Sapphinguarz (Lasurquarz oder Siderit) ist ein kristallisierter Quarz, der durch eine reichlich eingemengte blaue, faserige bis erdige Substanz, wahrscheinlich dem Mineral Trokvilolith anchürig. dieselbe Farbe angenommen hat. Er ist wenig durchscheinend, etwas fettglïnzend und nicht sehr zum Schleifen geeignet. Daher ist auch seine Verwendung hoinahe meich Tull und ebenso sein Preis. Er findet sich aderförmig im Gips des Gipsherwes bei Mooseck nächst Golling im Salzburgischen, in ziemlich großer Menge.

\section{Quarz mit Einschlüssen.}

Wie schon erwähnt, umhüllt der Quarz sehr häufig andere Mineralien und sonstige Sulsstanzen. Diese Einschliisse sind teils nur vereinzelt vorhanden, teils in großer Nenge, manchmal sogar so reichlich, daß die ganzen Quarzkristalle dadurch vollkommen gleichmälig gefärbt erscheinen, wie es z. B. bei dem eben erwähnten grünen Prasem und dem blauen Sapphirquarz der Fall ist. Von solchen massenhaften Einlagerungen ist jedoch hier nicht die Rede, sondern nur von vereinzelten, die sich von dem umgebenden Quarz durch ihre Farbe oder ihre sonstige Beschaffenheit in besonderer Weise ablieben, so daß dadurch nicht selten ein huibsches Ausseben hervorgebracht wird. Es ist dazu notwendig, daß der (Quarz möglichst vollkommen durchsichtig ist, weil nur dann die Einschlüsse deutlich hervortreten. In nur durchscheinender oder ganz undurchsichtiger Masse eingewachsen, würden sie ja mehr oder weniger verhïllt und verdeckt werden und gar nicht oder nur sehr wenig sichtbar sein, wenn sie nicht ganz an die Oberfläche treten. Die Farbe des Quarzes ist dabei ganz gleichgültig; in farbigen durchsichtigen Stiicken, z. B. von Amethyst, können Einschlïsse dieser Art ebenso schön zur Geltung kommen wie im farblosen Bergkristall. Am wichtigsten und verbreitetsten sind sie gerade in den beiden genannten Varietäten des Quarzes. Je nach der Natur der eingeschlossenen Körper haben die Steine ein sehr verschiedenes Aussehen, und manche von ihnen werden gerade wegen ihrer Einschlüsse mit besonderer Vorliebe zu Schmucksteinen verarbeitet. Von diesen soll hier etwas eingehender die Rede sein.

Haar- und Nadelsteine. Unter diesem Namen versteht man Quarze, die einzelne nadel- oder haarförmige Kristalle anderer Mineralien eingeschlossen enthalten, wie es Taf. XVIII, Fig. 2, zeigt. Hier sind es griine Nadeln des Minerals Strahlstein, die den (Quarz durchziehen; in anderen Fällen sind es weiße Fasern von Asbest, oder gelbe bis rote, dünne und langgezogene, zuweilen wie Strohhalme aussehende Rutilkriställchen und andere mehr. Manchmal haben derartige Einschlïsse eine gewisse Dicke und sind gerade, dann spricht man von Nadelsteinen; oder sie sind haarförmig dïnn und lang, dann erhält das Stiick den Namen Haarstein. Sind derartige haarförmige Einschlüsse rotbrauner bis gelher Rutil, dann heißen sie Venushaare; solche kommen neuerer Zeit hesonders schön aus dem Staate Goyaz in Brasilien (S. 587) und aus den Monazitgruben von Shelhy, Cleveland County, auch von Alexander County und anderen Orten in NordCarolina und sind in den Schweizer $\Lambda$ lpen gleichfalls gefunden worden. Ist es grïne IIornblende oder strahlstein oder Asbest, dann werden sie wohl auch als $\mathrm{T}$ h e $\mathrm{t}$ is h a a r e bezeichnet. Sie sind entweder wie die Nadeln ebenfalls gerade gestreckt oder gekrümmt und gehogen und nicht selten zu einem Knäucl zusammengeballt. Grüne Härchen, wahrscheinlich von $\Lambda$ shest, in dieser Anordnung verursachen oft ein Aussehen, wie wenn Moos in dom (Luarz eingewachsen wäre; Steine dieser Art werden dann Moossteine genannt. Wir haben ähnliche, wir Moos aussehende Einschlüsse bei der Betrachtung des Achats norh rimmal kemnen zu lernen; die Achate, die sie beherhergen, heißen dementsprechend Moosachate. Denselhen Namen sibt man auch zuweilen eigentlichem Quarz mit derartigen Einlagerungen. 
Solehe Bildumgen im Bergkristall kommen nicht selten in den Alpen und an den anderen Fundorten dieses Minerals vor. In nanchen Stïcken Berckeristall von Madagaskar sieht man lange graue, metallisch glänzende Kriställehen des Minerals Manganit Ein durehscheinender Milehquarz aus dem Calumet Hill-steinhruch bei Cumberland im Staate Rhode Island (Nordanterika) mit zahlreichen Nadeln schwarzer IIornblende kam bis 1s૬3 in Ilenge zum Schleifen nach Idar und Oherstein a. Xahe, seitdem wird er nicht mehr grewomnem. Ähnliches stammt auch aus Japan und aus Madagraskar. In dem hellen Amethyst, der in den Höhlungen eines Mandelsteines, meist aber lose in Boden auf der Wolfsinsel im onegasee, nordöstlich von St. Petershurg in Ruliland, gefunden wird, liegen lange diinne Kriställchen des braunen Minerals Goethit (Nadeleisenerz), wie in Fig. 103, und derartiger Beispiele gibt es noch viele.

Die letztgenannten Steine werden in St. Petersburg und Moskau unter dem Namen Liebespfeile (flêches d'amour) geschliffen. Derselbe Name ist aber auch auf andere ähnliche Gebilde übertragen worden, wie man sie z. B. in Nord-Carolina in Nordamerika in großer Schönheit findet. Gleich allen derartigen Sachen erhalten sie eine flachrundliche Oberfliiche und zuweilen Herzform. Überhaupt schleift man alle solche Steine, wenn sie einen hübschen Anblick gewähren, ohne Rücksicht darauf, was die eingeschlossenen Körper in mineralogischer Hinsicht sind. Man sucht hierbei die Einschlüsse der Oberfläche so gut es geht zu nähern und

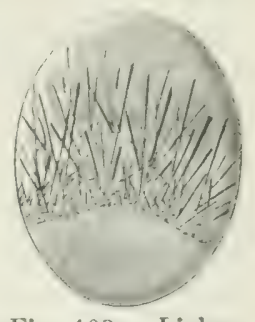

Fig. 103. Liebespfeile von $d$. Wolfs. insel im Onegasee. dadurch eine möglichst günstige Wirkung des Ganzen hervorzurufen. Doch sind solche Steine lieine eigentliche marktfühige Ware, es sind mehr Merkwürdigkeiten, die von Liehhabern geschätzt, vom großen Publikum jedoch kaum beachtet werden. Schöne Steine dieser Art sind aber trotzdem nicht billig, sie werden mit 50 Mark und höher bezahlt.

Wassertropfenquarz. Man versteht darunter Bergkristalle mit einem eingeschlossenen, deutlich sichtbaren Tassertropfen, in dem bei der Bewegung des Steines eine Luftblase (Libelle) hinundherschwankt. Größere, auch in einiger Entfernung schon erkennbare Einschlïsse dieser Art sind nicht häufig. Besonders schön hat man sie in Madagaskar angetroffen, doch kommen sie auch in den Alpen und an anderen Fundorten des Bergkristalls vor. Fenannt werden namentlich auch die oben erwähnten Bergkristalle von Herkimer County im Staate New York und ron Hot Springs in Arkansas, sowie die Amethyste von Rabun County in Georgia wegen der grossen Flïssigkeitseinschlïsse, die sie vielfach enthalten und wegen der sie nicht selten geschliffen werden. In noch höherem Maße als ron den Haar- und Tadelsteinen gilt es von diesem Wassertropfenquarz, daß er nur zuweilen einmal von einem Liebhaber als Merkwürdigkeit zum Schleifen gebracht wird.

Goldquarz. Es ist durchsichtiger oder stark durchscheinender Quarz, der Adern oder K̈̈̈rner ron gediegenem frold oder auch wohl vielfach durcheinander gewachsene haarfürmige Kristïllchen von Gold (sog. Dendriten), sowie ebensolche, knäuelförmig ineinander greschlungen, einschließt. Gegenwärtig wird er in Amerika, und zwar vorzugsweise in San Francisco, weniger in den anderen großen Städten der westlichen Staaten, vielfach geschliffen und daraus namentlich Platten zu Broschen, für Stockknöpfe, Manschettenknöpfe usw., sowie Briefheschwerer und andere kleine Gebrauchsgegenstïnde dieser Art hergestellt. Einige der Goldquarzgruben in Kalifornien, Oregon, Idaho und Montana baben sehr schöne Stiicke geliefert. Der Preis hängt wesentlich rom Goldgehalt ab, der mit Hilfe des spezifischen Gewichtes bestimmt wird. Weiterhin kommt aber anch naturlich die Schönheit der Exemplare sehr mit in Betracht. Einzelne Ringsteine kosten so ron 2 bis 10 Dollars, ausnahmsweise schöne noch mehr.

Der Goldquarz wird jetzt sehr viel zum Schmuck verwendet. Wie groh der Umsatz in diesem Artikel und dessen gegenwärtige Bedeutung ist, sieht man daraus, daß in 
manchen Jahren in jenen Gegenden für 40000 bis 50000 Dollars rohe schleifwürdige Goldquarze verkauft werden. Eine einzige Schleiferei zu Oakland in Kalifornien verbraucht jährlich für ctwa 10000 Dollars roher Steine, und eine große Juwelenhandlung in San Franciseo verkant in derselben Zeit für etwa 15000 Dollars geschliffene. Die Steine müssen snryfültig ausgesucht werden, da sie sehr zerbrechlich und schwer zu bearbeiten sincl, so daß nur ungefähr die Hälfte der rohen Ware schließlich geschliffen in den Handel gebracht werden kann.

Nicht aller Goldquarz ist übrigens durchsichtig, mancher ist auch trübe und neuerer Zeit ist sogar ein ganz schwarzer, sowie blauer und grïner gefunden worden. Ein rosenroter ist ein Kunstprodukt; der Quarz ist mit Karminlösung rot gefürbt. Man hat sogar den Goldquarz selbst künstlich herzustellen versucht durch Zusammenschmelzen von Quarz und Gold mit Hilfe der Elektrizität, die Sache hat aber nicht zu einem günstigen Resultate geführt.

Auch außerhalb Amerikas wird zuweilen Goldquarz geschliffen, aber weitaus nicht in so großem Unfange. Die Goldquarze von Australien, Südafrika usw. sind aber jedenfalls hierzu ebenso geeignet wie die kalifornischen. In Europa ist der mehrfach schon erwähnte, etwas Gold enthaltende Quarz von La Gardette bei Bourg d'Oisans im Dauphiné in friiheren Zeiten geschliffen worden, derselbe Quarz, auf dem die schönen Bergkristalldrusen aufgewachsen sind, deren eine auf Taf. XVII abgebildet ist. Auch bei Mursinka im Ural wird, wie wir schon oben gesehen haben, Goldquarz gewonnen, und zwar ungefähr 200 Pfund im Jahre.

Regenbogenquarz (Iris). Dieser ist von geringer Bedeutung. Der Bergkristall ist vielfach von unregelmäßigen feinen Sprüngen durchsetzt, zuweilen von ziemlich großer Ausdehnung, auf denen bei ihrer Entstehung etwas Luft eingedrungen ist. Diese bildet in den Spalten eine äußerst dïnne Lage und spielt infolgedessen, wie alle solche dünnen durchsichtigen Schichten, z. B. Seifenblasen, in den glänzendsten Regenbogenfarben. Es ist die Erscheinung, die man allgemein als Irisieren bezeichnet, daher die beiden obengenannten Namen. Meist ist dieses Farbenspiel, das somit nicht der Substanz des Bergkristalls selbst zugehört, sondern in der von ihm eingeschlossenen Luft durch einen physikalischen Vorgang, die Interferenz der Lichtstrahlen, hervorgebracht wird, nicht sehr ansehnlich. Die schillernden Flächen sind gewöhnlich klein. Manchmal sind die glänzenden Farben aber doch auf einen größeren Umfang ausgedehnt, und dann gewähren die Steine oft einen, sehr bübschen Anblick. Man schleift solche flach mugelig, die Oberfläche der stets mehr oder weniger stark gekrümmten, schillernden Fläche entsprechend und ibr möglichst genähert. Der Wert ist dann höher als für gewöhnliche Bergkristalle und zuweilen nicht gering, namentlich wenn das Farbenspiel auf die Mitte des Steines beschränkt ist, ohne an irgendeiner Stelle den Rand zu erreichen. Dies gilt für die höchste Schönheit und ist beim Schleifen, so gut es irgend geht, zu beriicksichtigen. In den meisten Fällen ist das Irisieren auf einzelne Stellen der Bergkristalle beschränkt, die dann zum Behuf der Verarbeitung vorsichtig herausgeschnitten werden. Manchmal ist aber auch ein dickerer Kristall von vielen irisierenden Spriingen durehsetzt, so daß man größere Stiieke daraus herstellen kann. Ein Beispiel dafür ist ein Kandelaber in den vatikanischen Sammlungen, der aber vielleicht aus mehreren Teilen zusammengesetzt ist.

Man findet solchen Regenbogenquarz von natïrlicher Entstehung in grïßerer oder geringerer Schönheit gelegentlich an allen den vielen Stellen, an denen Bergkristall vorkommt. Die Erscheinung kann aber auch künstlich hergestellt werden, indem man gewöhnlichen licrgkristall vorsichtig mit einem Hammer schlïgt, wobei irisierende Sprünge entstehen. Eine andere Methode ist die, dafj man geschliffene Bergkristalle stark erhitzt und in 
kaltes IVasser wirft. Bei der raschen Abkühlung bilden sich ebenfalls leicht Sprünge, die die Sehillerfarben zeigen. Es ist klar, dab hierbei häufigr Stiicke zerbrechen; wergen des geringen Wertes des gewöhnlichen Bergkristalls ist dies aber von greringer bedeutung. Auch manche andere durchsichtige Steine zeigen das Irisieren oft recht biibsch. Sie können ebenso versehliffen werden und fallen dam gleichfalls unter den liegriff "Iris". Ebenso werden auch geschliffene Berghristalle und Gläser genannt, die durch hinten aufgetragene bunte Farben das Irisieren nachahmen. In billigen Schmucksachen sieht man sie sehr häufig.

\section{Katzenauge.}

Unter Katzenauge (Quarzkatzenauge, oceidentalisehes Katzenaute, Schillerquarzj versteht man einen derben Quarz, der auf steiner Oberfläche, namentlich wenn sie rundlich geschliffen ist, vermöge seiner inneren Beschaffenheit einen wogenden, milchirgen Lichtschein zeigt. Dieser ist durchaus ähnlich demjenigen, den man auf manchen rundlich geschliffenen Exemplaren des Chrysoberylls sieht, die den speziellen Tamen Cymophan erhalten haben, und die ebenfalls als Katzenauge, aber zum Lnterschied als orientalisches Katzenauge bezeichnet werden. Wenn diese Unterscheidung nicht gemacht ist, wenn einfach von Katzenauge gesprochen wird, dann kann man häufig nicht erkennen, welches von beiden gemeint ist. Aus der Literatur läßt sich in der 'Tat nicht immer ersehen, ob unter diesem Namen das orientalische oder occidentalische Katzenauge verstanden wird, was namentlich bei der Angabe des Vorkommens manchmal zu Unsicherheiten führt.

Und doch ist es nötig, beide Sorten scharf auseinander zu halten, denn sie haben zum Teil selır verschiedene Eigenschaften; sie sind an Schönheit einander keineswegs gleich, und demzufolge weichen auch die Preise wesentlich voneinander ab. Das orientalische Katzenauge ist viel schöner, es ist glänzender, und der Lichtschein tritt wirkungsvoller hervor. Das Quarzkatzenauge steht hiergegen im allgemeinen weit zurück; auch die besten Exemplare davon erreichen den Cymophan an Schönheit nicht, und der Preis des letzteren ist stets erheblich höher, um so mehr, als er auch viel seltener vorkommt. Ein sicherer Untersehied beider liegt in der viel größeren Härte des Chrysoberylls, die, wie wir gesehen haben, noch über die des Topases hinansgeht, vermüge deren das orientalische Katzenauge auch eine viel böhere Politur annimmt als das occidentalische. Ferner weichen die spezifischen Gewichte erheblich voneinander ab; der Chrysoberyll, bei dem es $3, ;$ betriigt, sinkt raseh im Methylenjodid, das Quarzkatzenauge, wo G. $=2,6.5$ schwimmt darin.

Der Quarz, auf dem sich jene Lichterscheinung, das Chatoyieren, zeigt, bildet derbe, einheitlich gebaute, also nicht etwa aus einzelnen Körnern zusammengesetzte Massen. Er ist etwas fettglänzend und mehr oder weniger durchscheinend, nie durchsichtig. Die Farbe ist zuweilen weiß, bäufiger aber olivengrün bis dunkellauchgrün, vielfach stark ins Graue, heller oder dunkler, oder rot ins Braune oder Gelbe in verschiedenen Nuancen oder auch ausgesprochen braun, gelb oder grau. Auch blaue Steine kommen als Seltenheit vor.

Die Ursache des Lichtscheines ist eine Menge feiner Asbestfasern, die in dem Quarz in vollkommen paralleler Richtung eingewachsen sind und die wan an manchen Stiicken deutlich mit der Lupe erkennen kann. Häufig kommt es vor, dalj diese Fasern durch Verwitterung zerstört und vollkommen verschwunden sind, so daß der Quarz statt ihrer von einer großen Zahl feiner hohler Kanälchen durchzogen ist, von denen jedes einzelne einer Asbestfaser entspricht. Die ganze Quarzmasse hat dann eine faserige Beschaffenheit, die Lichterscheinung ist aber dieselbe, wie wenn die Fasern noch vorhanden wären.

Der Lichtschein zeigt sich am schönsten, wenn der Stein eine ziemlich hochgewölbte mugelige Form erbäit, die sich iiber den in der Richtung der ehenen Grundfläche hin- 
ziehenden Fasern erhebt. Es entsteht dann auf der gerundeten Seite ein mehr oder weniger breites Band wogenden Lichts, das sich senkrecht zu den Fasern über den ganzen Stein hinwexzieht, beiderseits von nicht schimmernden Flächenteilen begrenzt. Beim Drehen des Steines wandert das Licht über dessen Oberfläche hin, bis es bei zu starker Neignum secren die einfallenden Strahlen allmählich am Rande verschwindet (vgl. Taf. XVIII

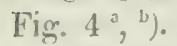

Es ist ein seidenartig glänzender Schiller von weißer, etwas ins Gelbliche oder Bläuliche gehender Farbe, der mit dem Lichtschein in dem Auge der Katzen verglichen worden ist. Man pflegt den Steinen cine etwas länglichrunde, ovale Form, wie die einer Kaffeebohne zu greben, über deren Oberfläche das Lichtband längs des größten Durchmessers hinweggeht, was die vorteilhafteste Wirkung hervorbringt. Für die schönsten Katzenaugen gelten wie beim Chrysoberyll die Steine, auf denen sich das Lichtband in möglichst scharfer Abgrenzung nach rechts und links und in nicht zu großer, aber recht gleichmäßiger Breite ron der umgebenden Oberfläche kräftig abhebt. Unterbrechungen des Lichtstreifens wirken ungünstig, ebenso verschwommene seitliche Grenzen, sowie eine zu große Breite desselben, da er dann auf den zu schmalen nicht schimmernden seitlichen Teilen des Steines zu wenig ausgeprägt hervortritt. Nicht beliebt ist es auch, wenn statt eines Lichtbandes nur ein Lichtfleck entsteht. Am geschätztesten von allen sind gegenwärtig in Europa die braunroten Katzenaugen mit einem zart bläulichweißen Schiller. Steine dieser Art kosten bis zu 50) Mark, doch müssen sie dann sehr schön und von nicht zu geringer Gröle sein. Im allgemeinen ist aber der Wert niedriger und bei Stiicken ron untergeordneter Qualität sehr gering, während die orientalischen Katzenaugen stets hoch bezahlt werden, auch wenn die Qualität nicht die allerfeinste ist. Opalkatzenauge siehe S. 483.

Die Fundorte der schönsten Exemplare unseres Katzenauges liegen in Asien, in Ostindien und auf der Insel Ceylon. Hier ist der Stein auch vorzugsweise beliebt, namentlich bei den Malayen, mehr als in Europa, wo er sebr der Mode unterworfen ist. Meist wird angegeben, daf die rotbraunen vom ostindischen Festlande, die grünen und grauen von Ceylon kommen, doch ist dieses Verhältnis nicht ganz konstant.

In Ostindien wird hauptsächlich die Malabarküste, die westliche Küstengegend der Südspitze, als Heimat unseres Edelsteins genannt, es scheinen aber sehr wenig genaue Nachrichten hieriiber vorhanden zu sein. Die Art des Vorkommens ist fast ganz unbekannt, man weil nicht, ob die Stiicke noch im Gestein sitzend oder lose als Geschiebe gefunden werden, und kann darüber um so weniger urteilen, als sie meist schon angeschliffen nach Europa kommen. Die Fundorte sollen bei Quilon und Cotschin liegen, doch schwebt auch hierüber noch ein gewisses Dunkel. Nördlich von der Malabarküste bei Ratanjur im Radschpiplastaate (Fig. 41) nordnordöstlich von Bombay kommt der Stein in Form von Geschieben mit dem dortigen Achat usw. vor; dieses letztere Mineral, also sicher auch das Katzenauge, stammt hier aus den dortigen basaltischen Gesteinen, dem 'Trapp von Dekkan. Fernere Fundorte sollen in der Nähe von Madras, sowie im unteren Kistnahtale in der Nïhe des Palanathagebirges nordwestlich von Gunturu, liegen. Auch aus B irm a werden einige Exemplare erwähnt. Jedenfalls ist das Vorkommen auf dem Festlande, wenigstens in der Jetztzeit, minimal, und die Steine iiberschreiten nieht das Gewicht von zwei Unzen.

Wiehtiger sind die Funde in C'ylon, wo das Quarzkatzenauge das orientalische learleitet. Auf dem Festlande fehlt dieses letztere, wenigstens ist es von dort nicht mit Wicherheit bekannt. Das erstere bildet in C'eylon bis hacelnubgrobe, selten grö̈bere Körner, die vorzugsweise den durch Verwitterung granitischer Felsarten entstandenen Edelsteinsoifen von Saffragam und Matara in größerer Zahl beigemengt sind. Die grüne Farbe ist 
hier jedenfalls am häufigsten, doch fuhlen auch braunrote und gelbe nicht. Von reylon stammt die zrobe Irehrzahl dex in Europa befindlichen Exemplare; sie werden wie die rom Festlande in rundlich geschliffenem Zustaude ausweführt und in den IIandel grebracht, aber auch im Lande riel verwendet, und zwar, ebenso wie in Indien iiberhaupt, vorzugsweise als fingrstein. Die Cuylonesen schätzen die rein oliveneriinen mit schmalem, scharf berrenztem Lichtscheine am meisten; sie sind ïberaus stolz auf das Vorkommen des Katzenauges in ihrem Lande, da sie glaulern, dafi es sich anderwärts nicht findet. Wir haben schon gesehen, daf diese Ansicht unrichtig ist, und werden uns noch weiter davon überzeunen, demn auch Eu rop a beherheret diesen Elelstein, wenn es auch nur Exemplare von untergeordneter Beschaffenheit liefert. Dis Material, meist won hellgrianer Farbe, findet sich bei Treseburg im IIar\% nit Asbest auf kleinen rangtrïmmern im Serjentin. aber schleifwürdige Stiicke kommen kaum vor. Etwas besser sind die Steine aus dem Diabas von IIof und ron anderen Orten im Fiehtelgebirge, die auch häufiger verarbeitret werden, ohne dab sie aber nur annähernd die indischen an Bedeutung erreichten. In Ungarn kommen keine schleifharen Katzenaugen ror, trotzdem wird der Stein von den Juwelieren zuweilen „ungarisches Katzenauge" genannt.

Auch in Europa wird das Katzenauge meist als Ringstein, Narlelstein usw. benutzt, und die geringe Größe der schönen indischen und eeylanischen steine läßf auch eine andere Terwendung kaum zu. Doch fehlen größere Stïcke nicht ganz. So bewahrt die Wiener Schatzkammer eine Schale aus gelhlichbraunem Katzenauge von j Zoll Länge, die einen rohen Stein von verhältnismälig sehr bedeutendem Unfange voraussetzt.

Dem Katzenauge sehr ähnliche Steine kann man k̈̈̈nstlich erhalten, wenn man Stiicke des sofort zu betrachtenden gelbbraunen Tigrerauges mit Salzsäure behandelt. Der Farbstoff wird danu aufgelöst, und es hinterbleibt eine grauliche Masse, die beim Schleifen die Lichterscheinung des Katzenauges zeigt (S. 607). Unter den braunen Katzenaugen von Ceylon kommen zuweilen Steine mit ganz ähnlichem Lichtscheine vor, die aus Faserkalk bestehen. Diese brausen mit Salzsäure auf, was echtes Katzenauge nicht tut, sie sind auch viel weicher. Manche graue IIuschelschalen geben rundlich geschliffen einen ähnlichen Lichtschein wie das Katzenauge und werden in Ceylon zuweilen diesem untergeschoben; auch sie brausen mit Salzsäure, lassen sich mit dem IIesser ritzen und zeigen meist auf der Oberfläche Regenbogenfarben, was echtes Katzenauge nie tut. Aus Glas wird Katzenauge nachgeahmt, indem man eine weiße Glasschicht beiderseits mit einer srïnen verbindet und in geeigneter Weise. über die Grenze hinweg; rund schleift; die scharfen unverïnderlichen Linien zwischen Grïn und Weiß lassen diese Falsifikate erkennen.

\section{Tigerauge.}

Tigerauge nennt man einen feinfaserigen Quarz von gelber bis brïunlicher Farbe, der, in der Richtung der Fasern geschliffen, einen präichtigen goldigen Glanz zeigt. Ein Stïck dieses Steines ist auf Taf. XVIII, Fig. 5, dargestellt.

Das Mineral bildet diinne, parallelflïchig begrenzte Platten, die selten mehr als einige Zentimeter dick sind. Die untereinander vollkommen parallelen Fasern steben auf den Begrenzungsflächen der Platten senkrecht. Sie sind aber ,nicht immer ganz geradlinig, sondern häufig gebogen oder vielmehr geknickt.

Schon auf einer gewöhnlichen Bruchfläche in der Richtung der Fasern zeigt sich der mit der faserigen Beschaffenheit zusammenhängende Seidenglanz. Dieser wird aher sehr erhöht durch das Schleifen und Polieren. Kehrt man eine solche polierte Fläche gegen das Licht, dann erscheint der prächtige Glanz in der schün gelben Farbe des Minerals, aber meist nicht gुleichmäfign iiber die ganze Schlifflïche hinweg, sondern nur in einzelnen. 
mit den natiurlichen Wänden der Platte parallelen Streifen. Zwischen diesen liegen dunklere, mehr braune streifen von geringerem und weniger seidenartigem Glanz. Dreht man nun den Stein etwas herum, so zeigen die vorher braunen Streifen den schönen goldigen Scidenglanz, und die zuerst glänzend gewesenen gelben Streifen werden braun und matter. Bei fortgesetztem Hinundherneigen der Platte wechselt so das Aussehen dieser Streifen, die mit den Knickungen der Fasern zusammenhängen, fortwährend ab. Eben dasselbe finclet auf jedem in einem Schmuckgegenstande gefaßten Stiick Tigerauge statt, das den Bewegungen des Trägers folgt; die Schönheit des Anblicks wird durch diese fortwährende Veränderung wesentlich erhöht.

In der Begleitung des Tigerauges findet sich ein anderer Stein, der mit ihm bis auf die Farbe in jeder Hinsicht übereinstimmt. Er ist ebenso feinfaserig und seidenglänzend, der Glanz und das Aussehen auf polierter Fläche wechselt ebenso streifenweise ab, die IIärte ist dieselbe usw. Dagegen ist die Farbe nicht gelb, sondern dunkel indigoblau. Auch dieses blaue Mineral wird geschliffen; es fübrt den Namen F a lk e n a u ge. Die genauere Untersuchung zeigt, daß man es hier mit farblosem und durchsichtigem Quarz zu tun hat, dem eine Unzahl feiner Fasern des blauen, zur Amphibolgruppe gehörigen Minerals Krokydolith eingewachsen sind, alle untereinander parallel und senkrecht zu den Flächen der Platte. Es ist dieselbe Substanz, die auch den Sapphirquarz blau färbt; in diesem sind aber die Fasern nicht parallel, sondern sie liegen kreuz und quer durcheinander.

Das Tigerauge steht nun zum Falkenauge bezilglich seiner Entstehung in einem ganz bestimmten Zusammenlıange. Betrachtet man ein Stück des letzteren, so findet man es nicht immer über seine ganze Fläche hin gleichmäßig blau, häufig wechseln gelbe Stellen mit den blauen ab. An manchen Stiicken sind nur einzelne gelbe Faserbündel zwischen den blauen, an anderen Stiicken ist Gelb und Blau ziemlich im Gleichgewichte, und bei wieder anderen sieht man nur noch einzelne blaue Partien zwischen der überwiegend grelben Masse. Die ganze Erscheinung läßt keinen Zweifel, daß die gelbe Substanz, die in jeder Hinsicht mit dem Tigerauge übereinstimmt, dureh Umwandlung aus der blauen, dem Falkenauge, hervorgegangen ist, und zwar ist es der Krokydolith, der diese Veränderung erleidet. Alle seine Bestandteile werden aufgelöst und fortgeführt, nur die Kieselsäure bleibt als Quarz in der fasrigen Form des urspriinglichen Minerals zurück, durch eine kleine IIenge zwischen den Fasern abgelagerten Eisenhydroxyds gelb gefärbt. Ist dieser Prozeß noch im Beginne, dann sind nur einzelne Stellen gelb gefärbt; je melır er fortschreitet, desto größèr und zusammenhängender werden die gelben Partien, und endlich ist das Falkenauge ganz in Tigerauge übergegangen, die ganze ursprünglich blaue Masse ist gelb geworden, ohne daß aber dabei die Faserstruktur im mindesten gelitten bätte.

Diese Steine sind Heimatgenossen des Kapdiamanten. Wie letztere kommen auch sie in Westgriqualand vor, aber die Fundorte liegen anderswo, und zwar westlich von Kimberley, dem Zentrum der Diamantenproduktion, in der Gegend der Stadt Griquatown. In frïheren Zeiten wurden als solehe genannt: Lakatoo am Oranje-Fluß, wo Amianth (Krokydolith) und Brauneisenstein als Begleiter mit vorkommen, sowie Tulbagh, von wo die faserige Beschaffenheit und die Schönheit des Materials in älteren Berichten besonders gerïhmt wird.

Nach den Mitteilungen von E. Coh en liegen die Fundstellen der beiden hier in liede stehenden Nineralien, soweit sie gegenwärtig zur Gewinnung derselben von Wichtigkeit sind, nördlich vom Oranje-Fluß in dem Gebirgszuge, der nahe westlich von Griquatown anfangs in nordsüillicher, dann in nordöstlich-siidwestlicher Richtung sich hinzieht, und dessen nördliche Fortsetzung jenseits des Orange River die Doornberge bildet. Der (iehirgsug nördlich von dem genannten Flusse heißt auf der großen offiziellen Karte der Kitpkolonic von 1576 Asbestos-IIountains, auf den gew ̈̈̈hnlichen Karten wird dieser Name 
fïr einen sehr viol kïrzeren, ctwas weiter nach Osten zu gelewenen Höhenzug angewendet, wälırend jene die Langen Berge genannt werden.

In jenen Bercen findet sich das Tigrerauge an zahbreichen Stellen, unter anderen nahe bei Griquatown. Die Platten sind in einem häufig sehr dïnngeschichteten, feinkörnigen (Quarzestein von rothrauner, kaffechrauner bis ockergeltor Farbe cingelagert, das man am besten als. Iaspisschiefer bezeichnet und das die IIanptmasse des nicht selor hoch über das Platrau ansteigenden Berezuges bildet. Hier wird das Materual grepraben, das jetzt massenhalt nach Europa kommt und das namentlich in Oberstein a. Nahe und dem benachbarten Idar verschliffen wird.

Es ist noch nicht lange her, daf das Tligerauge in Europa eine grolie Seltenheit war. Vor etwa 30 Jahren kostete ein Karat 25 Mark und mehr. Die starke Konkurrenz zweier Händler hat es aber dahin gebracht, dab die Steine in schr crrofer Mengre auf den Markt geworfen wurden, wodureh der Preis bis auf wenig mehr als 1 Mark für das Pfund fiel.

Wenn auch alles jetzt in Handel vorkommende Tigerauge und Falkenauge aus den Ashestos-Mountains stammt, so sind sie doch beide nicht ganz auf jene Gegend beschränkt: im Gegenteil scheinen sie in Sïdafrika eine weite Terbreitung zu besitzen. So hat der Reisende II a u e h Tigerauge viel weiter östlich am oberen Marico, einem Tebenfluf des oberen Orange River gefunden. Außerhalb Siidafrikas wird 'Tigerange nur noch rom Yarra-Yarra-Creek in Westaustralien erwähnt.

Anfänglich, als diese Substanzen noch spärlich zu haben und daher teuer waren, wurden sie nur zu kleineren Schmucksachen aller Art verarbeitet. Tamentlich wurden Ringsteine und älınliches daraus dargestellt, die eine ebene oder flach grerundete Oberfläche erhielten. Später, nachdem der Preis so stark gesunken war, fing man an, aufer den renannten Schmucksachen auch kleine Gebrauchsgegenstände, Stockknöpfe usw. daraus zu fabrizieren. Auch zu Kameen und Intaglien findet der schöne Stein gegenwärtig zuweilen Terwendung. Namentlich lat das Tigerauge eine sehr grohe Terbreitung gewonnen, während das in viel geringerer Menge vorkommende Falkenauge auch in der Verwendung stark zuriicksteht. Bei beiden muß stets der Schliff so ausgeführt werden, dab die Schlifffläche den Fasern möglichst nahe parallel geht. Nur in dieser W'eise tritt die šchönheit des Steines hervor, um so weniger, je mehr die Fläche von jener Richtung ahweicht. Die verschiedenen, nebeneinander vorkommenden Farben werden zuweilen zur Herstellung von Fischen, Vögeln und anderen Tiergestalten usw. benutzt. Durch Glïhen wird das Tigerauge mehr rotbraun. Daß durch Behandlung des Tigerauges mit Salzsäure ein dem grauen Katzenauge ähnlicher Stein hergestellt werden kann, wurde schon bei der Betrachtung des Katzenauges erwähnt: das Eisenhydroxyd wird dabei ausgezogen und die fasrige Kieselsäure bleibt zurïck. Die entfärbte graue Masse ist porös und kann durch Imprägnieren mit farbigen Flïssigkeiten verschieden gefürbt werden, wodurch die Äbnlichkeit nit Katzenauge oft noch gesteigert wird. Der Name Katzenauge hat auch die Bezeichnung. Tigerauge und Falkenauge veranlaßt, da mugelig geschliffene Steine genau dassell)e Chatoyieren zeigen wie jenes, nur mit anderer Farbe. Opalkatzenauge oder Krokydolithopal siehe S. 483.

\section{B. Dichter Quarz.}

Hornstein.

Der Hornstein ist ein sehr feinkürniger bis vollkommen dichter Quarz, der aus einer Nenge mikroskopisch kleiner Quarzkürnchen zusammengesetzt ist und der durch einen ausgezeichnet splittrigen Bruch, sowie durch einen geringen Grad ron Durchschemenheit 
charakterisiert ist, vermöge dessen nur an den scharfen Rïndern der Bruchsticke etwas Licht hindurchscheinen kann. Die beiden letzteren Eigenschaften unterscheiden den IIornstein rom Jispis, der einen glatten Bruch hat und rollkommen undurchsichtig, also auch nicht mehr kantendurchscheinend ist. Die Farbe des Hornsteins ist meist unansehnlich srau, braun, grelb usw. Nach dem Aussehen wurde die Masse verglichen mit einem Kuhhorn, mit dem sie namentlich in Beziehung auf die geringe Durchscheinenheit ïber'instimmt, daher der alte Bergmannsname Hornstein, der aber bei den Steinschleifern ganz unbekannt ist. Diese kennen wohl die einzelnen Arten des Hornsteins, die sie verarbeiten, den Holzstein und den Chrysopras, sie fassen sie aber nicht unter jenem Sammelnamen zusammen, wie es die Mineralogen mit den beiden genannten und noch manchen anderen ähnlichen Steinen tun, die nicht verschliffen werden, und von denen hier also nicht weiter die Recle ist.

Der meiste Hornstein, wie er sich massenhaft auf manchen Erzlagerstätten, als Einschluß im Kalk, Ton usw. findet, hat nicht die für einen Schmuckstein erforderlichen Eigenschaften, es gibt aber einige Varietäten, die besser gefürbt und auch sonst so beschaffen sind, daß sie einen hübschen Anblick gewïhren, und diese werden dann geschliffen. Von diesen schöneren Abänderungen sind es hauptsächlich zwei, eine grüne, die den Namen Chrysopras fuihrt, und diejenige, die zuweilen als Versteinerungsmittel fossiler ח̈̈lzer auftritt und dabei deren eigentümliche Struktur bewahrt hat. Diese sogenannten II olzsteine bieten daher manchmal auf ihrer Oberfliiche hübsche Zeichnungen dar, von denen zur IIerstellung von Schmucksteinen Gebrauch gemacht wird. Es ist eine Substanz, ähnlich wie der Holzopal, den wir schon kennen gelernt haben; der Unterschied besteht darin, daß das Versteinerungsmittel hier nicht Opal, sondern Quarz ist.

Holzstein (versteinertes oder verkieseltes Holz). Die Holzsubstanz vorweltlichel Pflanzen ist in Quarz umgewandelt und damit imprïgniert. Dieser Quarz hat im ganzen eine Beschaffenbeit, die ihn am meisten dem Hornsteine, aber auch nicht selten dem Chalcedon nähert. Die Holzstruktur ist dabei deutlich erhalten geblieben und auch of die äufere Form. Man findet zuweilen noch ganze Stämme, Äste usw. und noch bäufiger Stiicke von solchen, deren charakteristische Form jedermann zweifellos erkennt. Noch deutlicher tritt meist die Holznatur auf Flächen hervor, die man der Länge und der Quere nach anschleift. Auf Lüngsschnitten in der Richtung der Achse des Stammes sieht man die Zellen und Gefäße des IIolzes in verschieden gefärbten Lagen vielfach miteinander abwechseln. Auf Querschliffen treten häufig ringförmige Figuren hervor, welche Durchschnitte durch die Gefäße darstellen. Man kann so oft noch die Natur der betreffenden Pflanze erkennen, wenn man Dünnschliffe unter dem Mikroskope untersucht, und hat so versteinerte Palmen, Nadelhölzer und manches andere nachzuweisen vermocht.

Die Färbung der Holzsteine ist meist dïster grau und braun, da die Wände der Gefäße diese Farbe haben; die Ausfüllung der Gefäle und der Zwischenräume zwischen ihnen ist gewöhnlich etwas oder auch viel heller. Auf diese Weise kommen auf den Steinen die eben besprochenen Zeichnungen zustande, die auf gut polierten Flïchen zuweilen einen recht angenehmen Anblick gewähren, um so mehr, als die Stüeke beim Polieren einen kräftigen Glanz annehmen. Die auf Querschnitten hervortretenden Figuren erinnern nicht selten an das gefleckte Gefieder der Stare, weshalb derartige IIolzsteine als Starsteine bezeichnet werden. Man schleift manchmal einzelne Schmucksteine daraus, hïufiger ist aber die Anwendung zu Dosen, kleinen Gefäßen und anderen ähnlichen (iegenständen. Aber auch diese Benutzung ist jetzt gewen friiher bedeutend zurücksegingen. Die alten Babylonier verfertigten daraus einen Teil ihrer Cylindergemmen.

Das Rohmaterial ist sehr verbreitet und daher der Preis dieser Gegenstände kaum höhne als der Arbeitslohm. In Deutschland ist hauptsächlich das Kyffhäusergebirge als 
Fundort bekannt, wo srobe ctämme in den Sandstemen und Konglomeraten des liotliegenden eingeschlossen sind. Andere der iuberst zahlreichen Fundstellen anzufiihren, ist hier kaum von Interesse, es sei nur noch erwähnt, dalj Kieselhölzer, zum Teil in ungeheuren staimmen, in den westlichen staaten der amerikanischen Union frolorado, Kalifornien und Arizonal sehr verbreitet sind und dals sir dort vielfach zeschliffen werden, aber allerdings mehr zu Tischplatten. Piedestals und anderen ähnlichen grofen Gexpenstïnden als zu Schmucksteinen. Das Vorkommen dieses schönon Matrrials ist ein so massenhaftes, daß es der wertyollste Fund dieser Art auf der Wolt zu wrerden verspricht; besonders bekannt ist das Torkommen in Arizona. in den drei sog. verkieselten Wälderm im Chalcedony Park an der Atlantic- und Pacific-Eisenbahn in der Nähe von Inollorook, s miles südlich ron der Station Corrizo jener Bahn, in Apache County. Der der Bahn nächstgelegene umfaßt etwa eine englische Quarlratmeile. Das Material ist hier in der Iauptsache Chalcedon (Holzachat). Ganze Stämme und kleinere Truimmer liegen massenhaft umher auf feinkörnigem Sandstein, aus dem sie ausgewaschen worden sind. Zwei weitere Lager, o und 16 miles von Chalcedony Park entfernt, liefern wenimer feines Iaterial; sie sind an versehiedenen Stellen der grenannten Bahn entblüßt. Ein kleiner fossiler Wald, dessen Kieselholz ganz mit dem des Chalcedony Park übereinstimmt, liegrt. etwa 3 miles von Los Cerillos entfernt, in Neu-Mexiko. Endlich sei auch der "versteinerte Wald" im Dschebel Mokattam siidöstlich von Kairo erwähnt.

Auch in Hornstein versteinerte Korallen, deren Gehäuse mit weißer Farbe auf einem schön fleischroten Hintergrunde hervortreten, werden gegenwärtig unter dem Namen Korallenachat geschliffen. Das Rohmaterial soll nach den Angaben der Idarer Steinschleifer aus Arabien, und zwar aus der Gegend von Aden stammen, doch finden sich ähnliche Sachen auch anderwärts. Mineralogisch sind solche verkieselte Korallen wohl als Beekit bezeichnet worden. Auch hier ist die Substanz öfters Chalcedon.

Chrysopras. Der Chrysopras ist ein schön apfelgrüner, ziemlich stark durchscheinender, deutlich, aber sebr fein körniger Hornstein mit rauhem, splitterigem Bruch und den sonstigen Merkmalen des genannten Minerals. Die Farbe ist bald heller, bald dunkler, niemals sehr tief und geht bis ins Farblose. Weiße, auch braune Flecken liegen vielfach zwischen dem Grün. Die Farbe ist dadurch ausgezeichnet, daß ibre Schünheit bei künstlicher Beleuchtung sich nicht vermindert.

Die Ursache der Färbung ist eine kleine Menge Nickeloxyd, die etwa 1 Proz. beträgt. Die färbende Substanz ist höchst wahrscheinhlı eine wasserhaltige Verbindung dieses Nickeloxyds mit Kieselsäure, die in der Wärme ihr Wasser und damit ihre Farbe verliert, Man schließt dies aus dem Terbalten des Steines, der beim Erhitzen immer blasser und allmählich ganz weiß wird. Die hierzu nötige Temperatur liegt gar nicht sehr hoch. Schon wenn man einen Siegelstock aus Chrysopras häufiger benutzt, verschwindet allmählich die grüne Farbe und ebenso, wenn man einen Stein den direkten Sonnenstrahlen aussetzt, die hierbei auch durch ibr Licht wirken, denn auch ohne Temperaturerhöhung bleicht die Farbe allmählich aus.

Daß es in der Tat der kleine Wasserverlust ist, anf dem die Entfärbung beruht, sieht man daran, dab ein entfärbter Stein seine ursprüngliche Farbe nach und nach wieder annimmt, wenn man ihn in feuchte Erde oder Baumwolle legt. Das verlorene Irasser wird dabei allmählich wieder aufgenommen und der fruhere Zustand hergestellt. Die. Farbe der entfärbten Chrysoprase lïbt sich erneuern und die von solehen, die von Anfanın an zu hell und zu blaß gefärbt waren, etwas steigern, wenn man sie statt mit Wasser mit einer grïnen Lösung von Nickelvitriol in Berïhrung bringt. Man kann auf solche Weise sogar eine Art von Chrysopras kïinstlich herstellen, indem man ein Stïck des noch zu betrachtenden Chalcedons, der nicht selten stark porös ist, einige Zeit in eine grïne Chronı- 
lösung lecrt. Es wird dabei eine gewisse Menge derselben absorbiert und der Stein beim Eintrocknen schïn apfelgrün, genau wie echter Chrysopras. Oft ist es nicht leicht, derartige kiinstlich gefärbte Steine, die gegenwärtig statt des echten Chrysoprases sehr viel im IIandel vorkommen. als solche zu erkennen und von echten zu unterscheiden, aber die Unterscherdung ist auch nicht von grober Bedeutung, da der echte Chrysopras und der kïnstich srïn wefärbte Chalcedon in fast allen ihren Eigenschaften vollkommen übereinstimmen. Der letztere hat vor den ersteren sogar manches voraus und wird daher in der lienutzung zu Schmucksteinen vielfach bevorzugt; seine Farbe ist meist schöner und gleichmäliger, und sic ist echt und dauerhaft, da sie weder bei der Erwärmung verschwindet noch am Lichte ausbleicht.

Die Bearbeitung des echten Chrysoprases ist nicht so ganz einfach. Er erhält wegen s.roßer Spröoligkeit leicht Risse und splittert am Rande; namentlich muß man ihn aber vor zu starkem Erhitzen bewahren, da dies, wie wir gesehen haben, seiner Farbe schadet. Wird er in dieser Beziehung unvorsichtig behandelt, dann geht die grïne Farbe in eine unreine grauliche über, der Stein verliert seine Durchscheinenheit zum größten Teile und wird undurchsichtig. Zweckmäßiges Schleifen läßt dagegen die Farbe vollständig ungeändert und der Stein erhält bei der Politur einen sehr schönen Glanz. Den Schmucksteinen gibt man eine mugelige Form, vielfach mit einer oder zwei Reihen von Facetten am Rande. Beim Fassen wird zur Erhöhung der Farbe meist eine Folie von grünem Tafft untergelegt. Der Chrysopras dient zu Nadelsteinen, Ringsteinen usw., aber zu Siegelringen, Siegelstücken usw. paßt er aus dem oben schon erwähnten Grunde nicht. Früher war er mehr geschäłzt als gegenwärtig. Ein schöner Stein von der besten, möglichst tiefgrünen rrleichmäßigen Farbe und bedeutender Durchscheinenheit wurde mit 100 Mark und mehr bezahlt; hente wiirde der Preis kaum die Hälfte und für blaß 'gefärbte unreine Stücke noch sehr viel weniger betragen. Doch ist auch jetzt noch der Chrysopras die bestbezablte und wertvollste unter den dichten Varietäten des Quarzes, die zu Schmucksteinen verschliffen werden; überhaupt ist er unter den sogenannten Halbedelsteinen einer der beliebtesten und geschätztesten. (Taf. XX, Fig. 8.)

Aber nicht nur zu kleinen Schmucksteinen dient dieses schöne Material, auch größere Gegenstände aller Art werden daraus hergestellt. Namentlich wurde der Chrysopras friiher zum Belegen von Tischplatten, von Wandflächen und zu ähnlichen Zwecken, sowie zu eingelegten Mosaikarbeiten benutzt. So ließ Friedrich der Große zwei Tische dieser Art in Sanssouci aufstellen, und an den schönen Mosaikwänden der aus dem 14. Jahrhundert stammenden Wenzelskapelle auf dem Hradschin in Prag sieht man Chrysopras verwendet.

Der Chrysopras findet sich in dünnen P'latten und Adern zuweilen von ziemlicher Ausdehnung meist im Serpentin, durch dessen Verwitterung er entstanden ist und dessen kleiner Nickelgehalt die fürbende Substanz geliefert hat. (Yröbere Stiicke sind selten gleichmälig gefärbt. Stellen von dunklerer und sehönerer Farbe gehen allmählich in ausgedehntere hellere oder ganz weiße, oder auch in gelben und braunen gewöhnlichen IIornstein über. Bei der Bearbeitung werden jene herausgeschnitten und für sich verschliffen. Vielfach ist nicht dir ganze Masse eigentlicher Hornstein, sondern dieser verlätuft stellenweise in andere dichte Quarzvarietäten, in Chalcedon, auch in Opal, die siveh selechzoitig mit dem ('hrysopras und in derselben Weise grebildet haben, und die (chenfialls manchmal grïn gefïlot sind, wie z. B. der Prasopal, den wir sehon oben (S. 15:3) kennen gelernt haben.

Dir hauptsizchliehste. Ireimat unseres Edelsteins ist Sehlesien, wo er an verschiedenen stellen in der Xähe von Frankenstein, südlich von Breslau, vorkommt. Bei liosemiitz mond Ziilzendorf findet man tief-. manehmal auch nur hellogrïnen ('hrysopras mit Chalcedon 
TAFEL UXVIII.

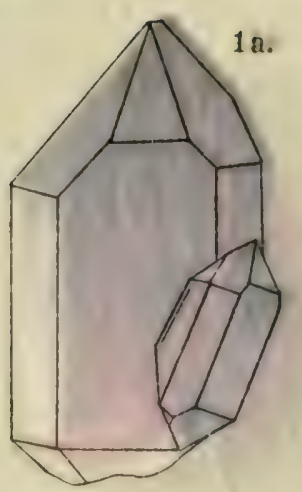

$3 \mathrm{~b}$.

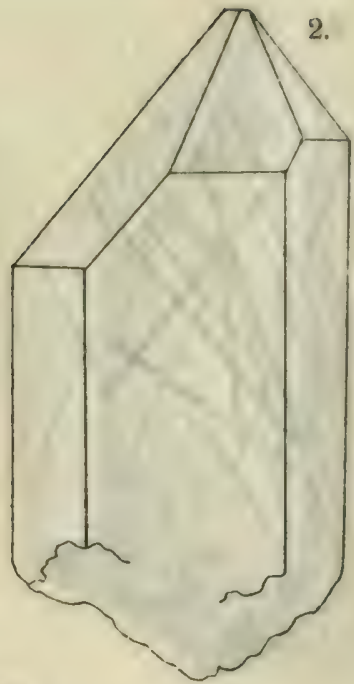

$1 \mathrm{~b}$.

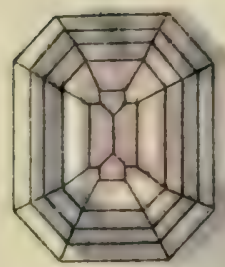

$3 c$.
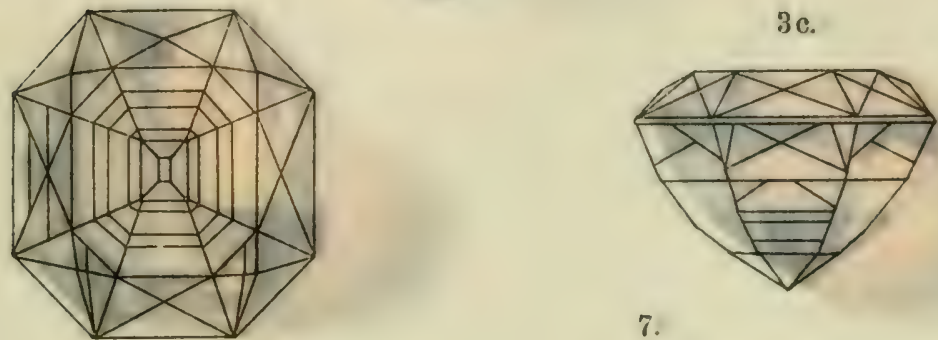

7.

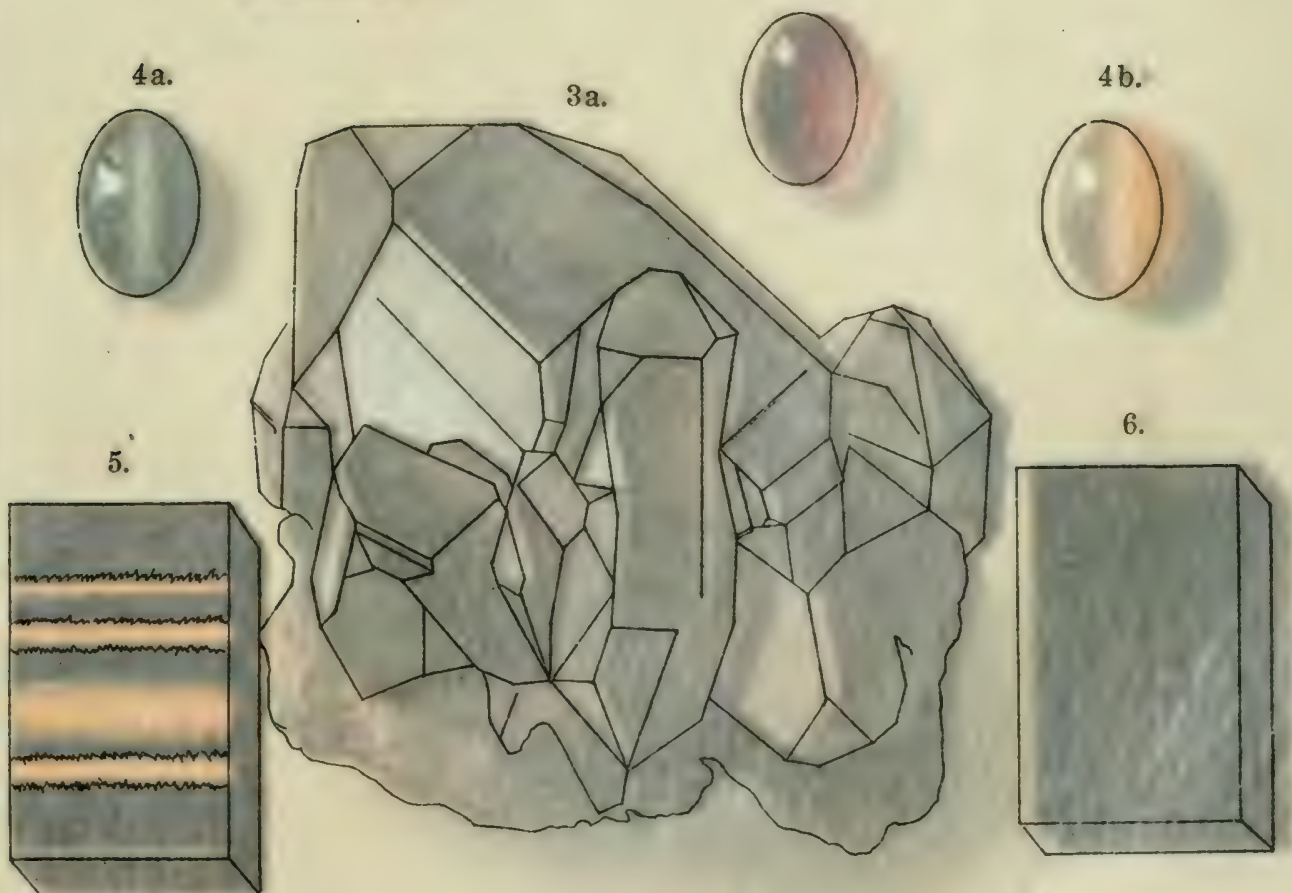

1a. A methyst (Krystall). 1b. Amethyst (geschlifien). 2. Bergkrystall mit Einschlüssen (Nadelstein). 3a. Rauchtopas (Krystalle). 3b und 3c. Rauchtopas (geschliffen, von olicn und von der Seite gesehen), 4a. und 4 b. Kotzenauge (grün und braun). 5. Tigerauge.

6. Heliotrop (beide angeschliffen). 7. Almandin (geschliffen). 


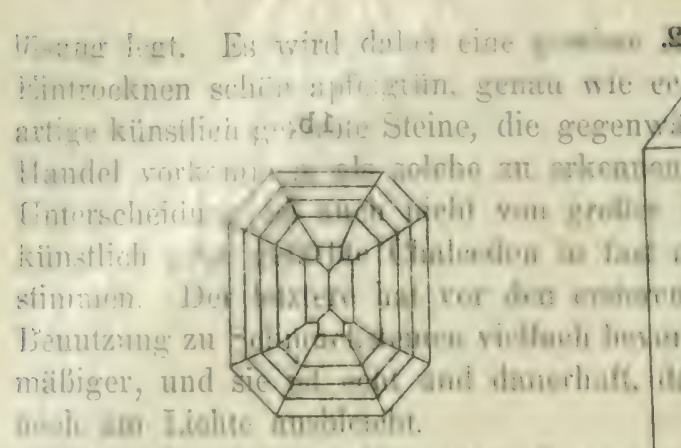

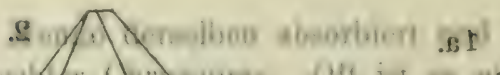

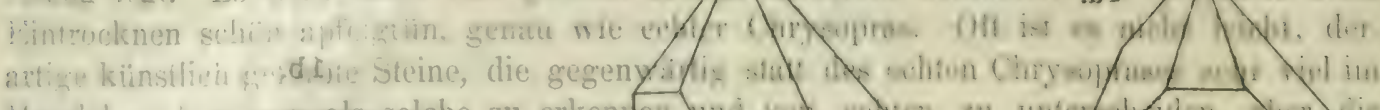

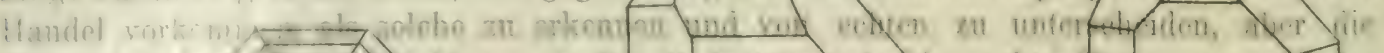

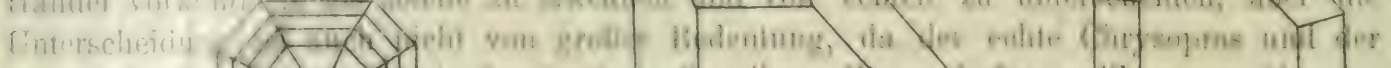

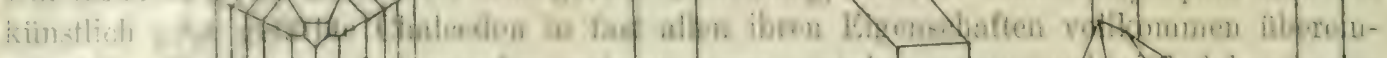

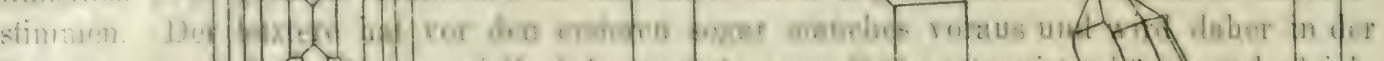

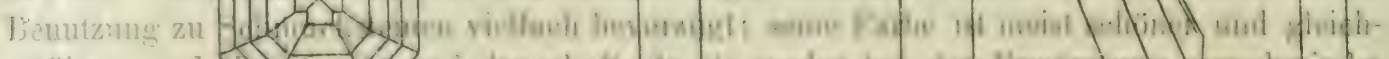
maibiger, und sinter.

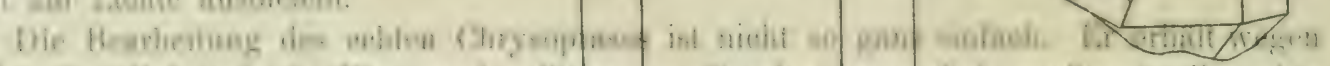

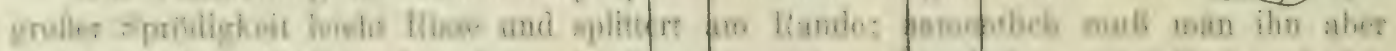

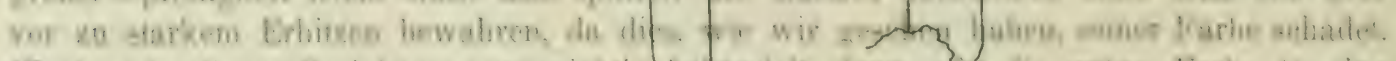

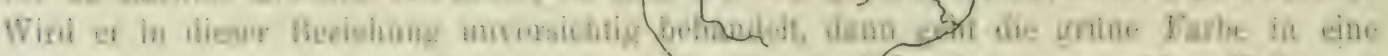

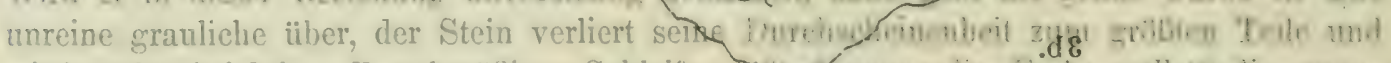

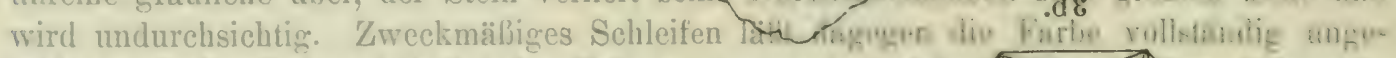

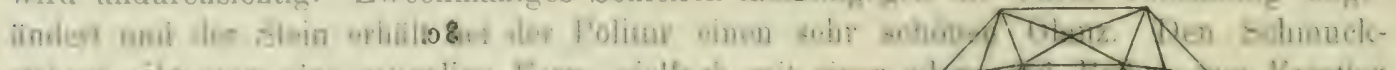
atenem silat wan win.

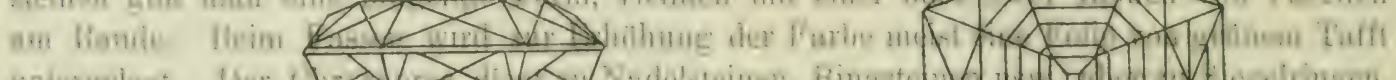

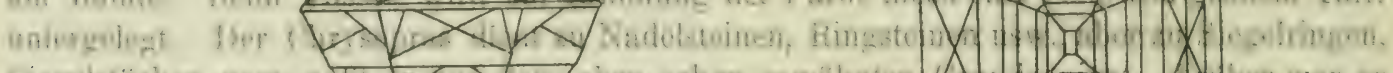

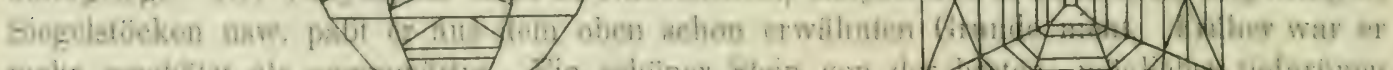

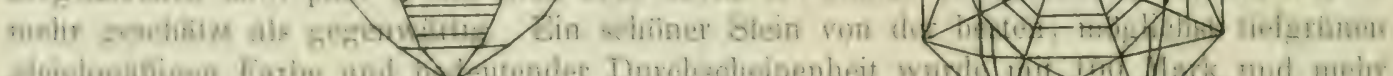

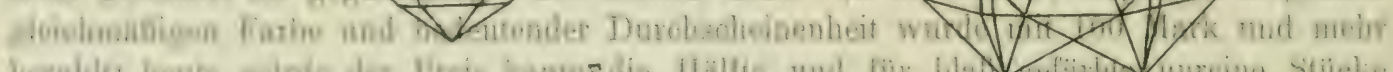

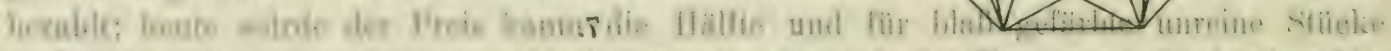

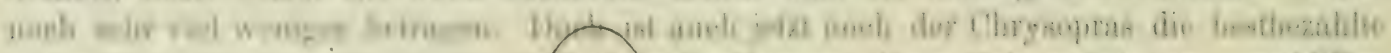

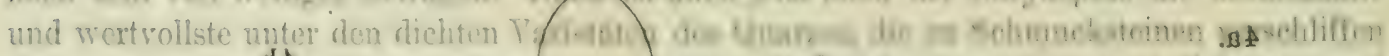

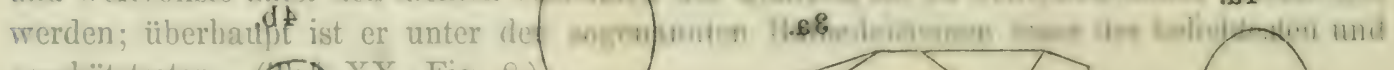
ceschïztesten.

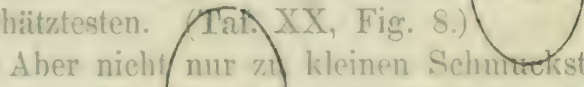

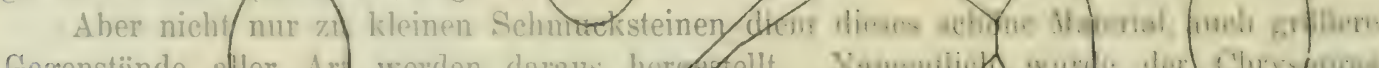

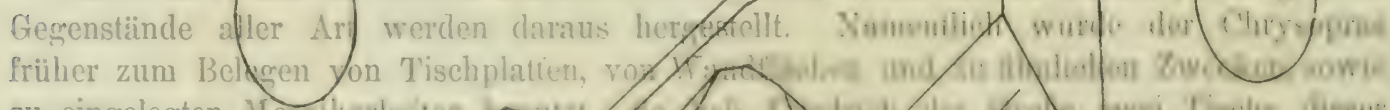

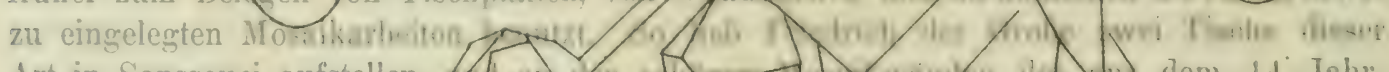

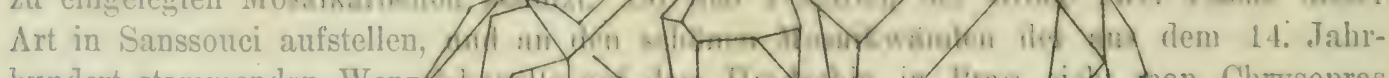
hundert stammenden Wenz
rerwendet. .2
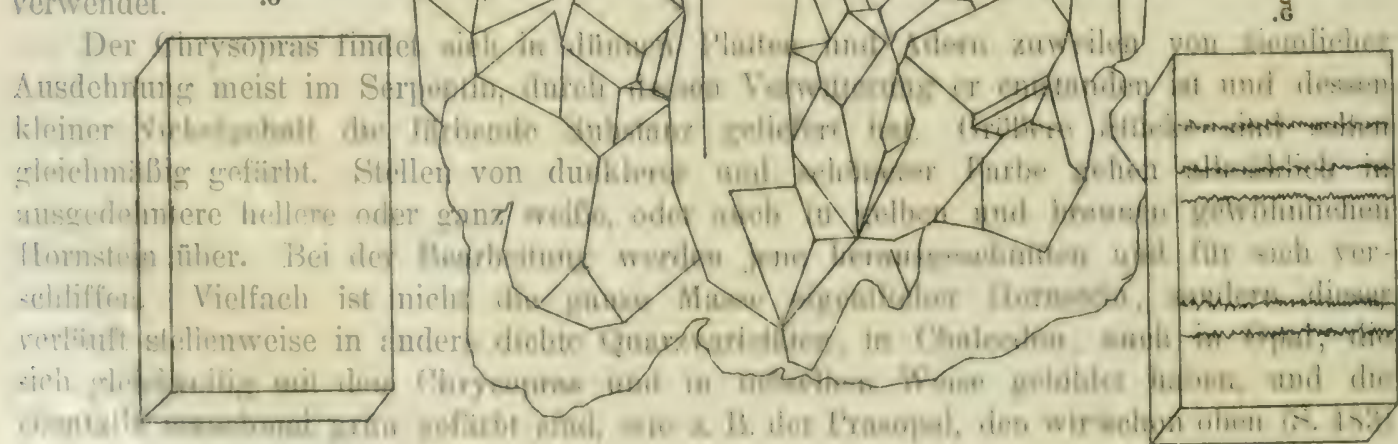

whit lialuen.

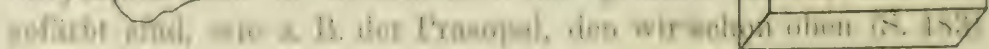

Ireimat unseres Edelsteins ist Schlesien, wo or an verschiedene-1. Trankenstein, siddlich von Breslau, vorkommt. Bei hosentitz 
TAFEL XVIII.

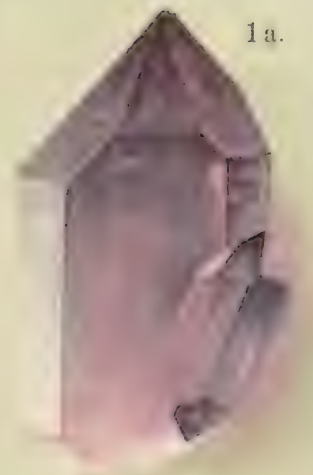

2.

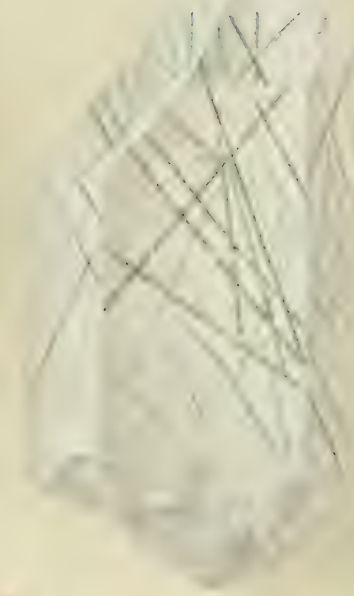

$1 \mathrm{~b}$.

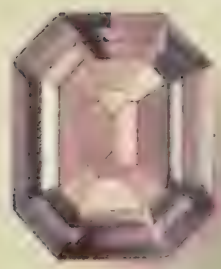

31).

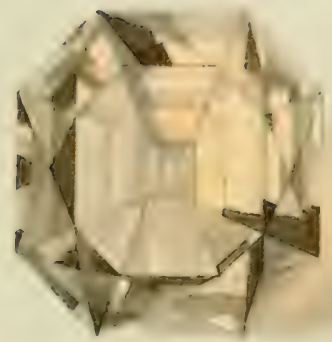

3c.

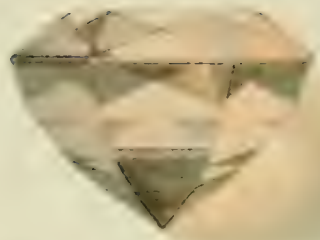

7.

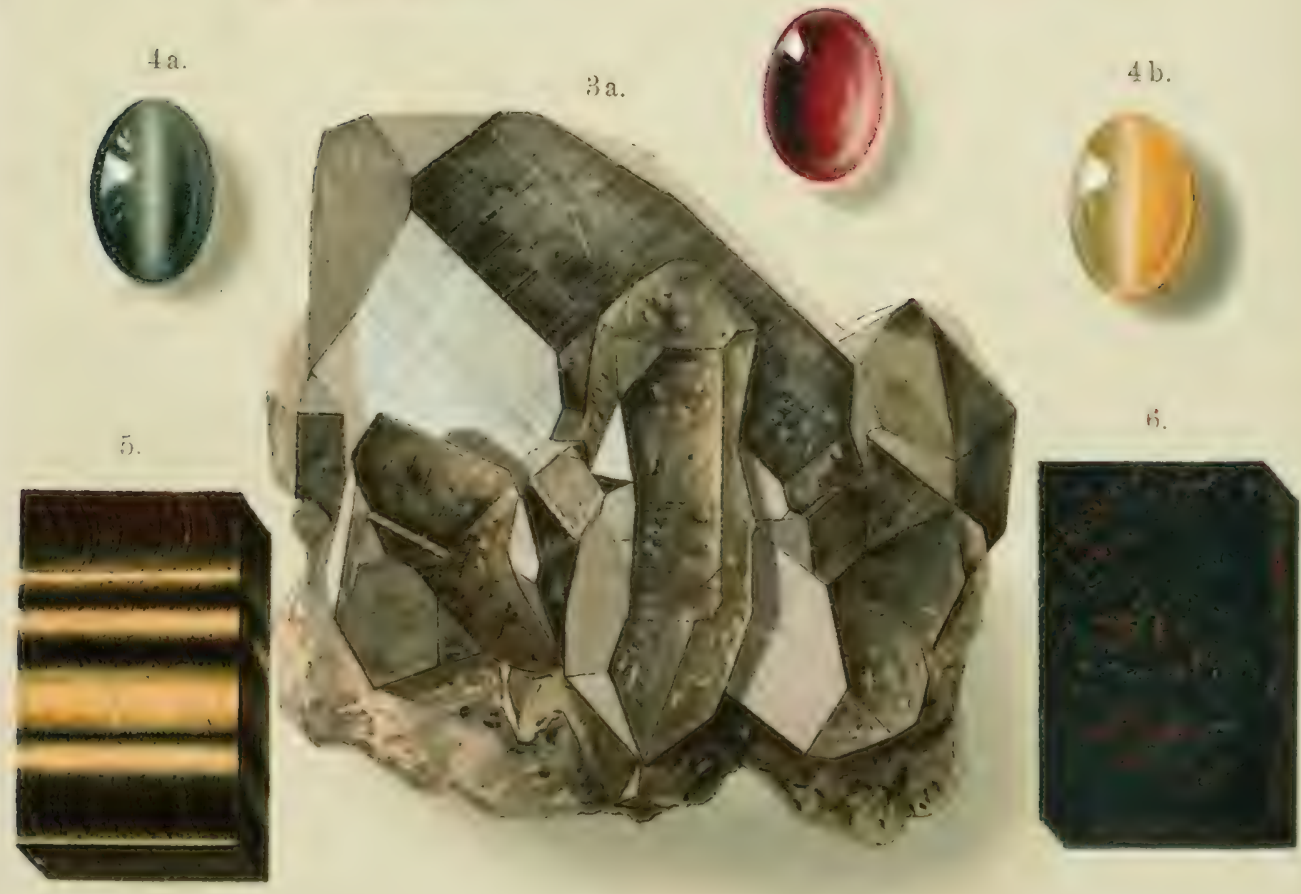



und opal, mit Isbest und anderen Mineralien auf Kliiften iun Serpentin, ähnlich auch bei Batumgarten und Grochau, wïhrend bei Crläsendorf, l’rotzan und Schrebstorf das Mineral in (iner selblichbraunen tonigen Erde liegt, die den Surpentin heedeckt und die durch Zersetzung aus ihm entstanden ist. Man findet den Chrysopras vielfach ganz oberflaichlich, so daß er durch liegengüsse auszewaschen und bei dem liestellen der Folder ausgepflügrt wircl. Bei Frankenstein kann man ziemlich erobe Stïcke gewinnen, die aber in der schon rwähnten IVeise meist unrein und licht gefärbt sind; sehïn grine Exemplare sind scelten und meist klein; die schönsten stammen von Gläsendorf.

Vach einer früheren Beschreibung (1505) geht in jener (remend rine drei Meilen lange Chrysoprasader durch den Serpentin und die begrleitenden fiesteine hindurch. Diese: wurde 17.10 an ihrem nördlichen Ende bei der Windmühle von kosemiitz von einem preulischen Offizier zufällig entdeckt. In der Folge interessierte sich Fridrich der (irolje fïr diesen schlesischen Stein und verwendete ihn, wie schon ohen anscerleutet, mit zur Ausschmiickung ron Sanssouci. Bei der Entdeckung wurde auf unser Minural der Tanu. ('hrysoplas ïbertragen, der zwar im Altertum sehon bekannt, aber für ein sanz anderes Wineral in Gebrauch gewesen war. Auch die Entdeckung des preufisehen offiziers war keine neue, der sehöne grïne Stein wurde nur durch ihn langjähriger Vergessenheit entzugen, denn es ist kein Zweifel, daß der Chrysopras der Prager Wenzelskapelle gleichfalls aus Schlesien stammt, daß das Torkommen also im 14. Jahrhundert schon bekannt wewesen sein muß.

Andere europäische Fundorte sind kaum von Bedeutung. Dunkel apfelyrine Stiicke kommen bei Wintergasse im Stubachtale im Salzburgischen vor, ebenso findet sieh c'hrysopras vielleicht bei Ruda in Siebenbïrgen, beide Vorkommen sind aber spä̈rlich.

Auferhalh, Europas kommt der Chrysopras ebenfalls, und zwar stellenweise in nicht gratuz geringer Menge ror. Aus Ostindien stammen sehr schöne Steine, deren genauerer Fundort aber nicht bekannt zu sein scheint. Auf der Nickelockerorube zu Redwinsk, ̈stlich von Katharinenburg im Ural, ist Chrysopras gefunden worden, und endlich in Nordamerika an rerschiedenen Stellen. Die wichtigste von diesen war die Nickelgrube von Nickel Mount bei Riddles, Douglas County im Staate Oregon. Er bildet hier bis zolldicke Adern in dem im Serpentin liegenden Nickelerz. Die Farbe ist ein dunkles Apfelgrün, und schöne Platten von einigen Quadratzoll Oberflïche kann man leicht erhalten. Newere Fundorte hat man in Kalifornien angetroffen, wo der Chrysopras ebenfalls in Serpentin vorkommt. Sie haben viel gutes Material geliefert. Die hauptsäichlichste Gewinnung findet $S$ miles suidöstlich von Peterville in Tulare County statt, wo im Jahre 1906 drei Tonnen Rohmaterial 300 Pfund schöne Steine lieferten. Weniger wichtig sind die Gruben am Venice Hill, 10 miles östlich von Visalia und bei Exeter. Auch sonst hat man in Kalifornien da und dort Chrysopras gefunden. Ein schüner grïner bis blauer Stein dieser Art, durch Kupfer gefürbt, findet sich in der Kupfererzerrube ron (ilobe in Arizona. Er ist aber wohl Chalcedon und wird weiter unten eincehender betrachtet werden.

\section{Jaspis.}

Der Jaspis ist ein durch viele fremde Bemengungen rerunreininter dichter Quarz. Er unterscheidet sich rom IIornstein durch seinen glatten, nicht splitterigen, grofmuscheligen bis unchenen Bruch, seinen matten Glanz auf den Bruchflächen, die vollständige Lndurchsichtigrkeit auch an den Rändern und die meistens intensire Fö̈rbung. Ein scharfer Lnterschied liegt darin aber nicht, und ebenso ist der Jaspis ron anderen unreinen dichten Quarzvarietäten, wie Eisenkiesel usw. nicht mit Bestimmtheit zu trennen. Fon manchem Situcke bleibt es zweifelhaft, ob man es besser zum Jaspis oder zum Hornstein, Eisen- 
kiesel usw. stellen soll. Man hat es eben bei allen mit einem aus mikroskopisch kleinen Körnchen bestehenden, dichten Quarz zu tun, der in seinen auf fremden Beimengungen beruhenden speziellen Eigenschaften bald mehr mit der einen, bald mehr mit der anderen dieser cenannten Abarten des dichten Quarzes übereinstimmt. Die Unsicherheit hat aber keine Bedeutung; denn diese Quarzvarietäten sind überhaupt nur unwesentlich voneinander verschicen und gehen vielfach ganz allmählich ineinander über, so daß sogar zuweilen das eine Ende des Stiickes mehr der einen, das andere mehr einer anderen derselben zugeschrieben werden muß, während die zwischenliegenden Partien alle möglichen Zwischenstufen darstellen. Gegen die im folgenden Abschnitte zu betrachtenden Chalcedone ist der Jaspis ebenfalls nicht scharf abgegrenzt; auch hier sind alle möglichen Übergänge zivischen dem typischen Jaspis und dem typischen Chalcedon vorhanden, von denen es zweifelhaft bleibt, ob sie zu dem einen oder anderen gerechnet werden sollen. Ist die Masse vollkommen, sogar an den scharfen Rändern undurchsichtig, dann nennen sie die Steinschleifer Jaspis, ist sie, wenn auch nur wenig, durchseheinend, Chalcedon. Mineralogisch sind allerdings zwischen Chalcedon einerseits, sowie Hornstein und Jaspis andererseits noch sonstige wichtigere Unterschiede vorhanden, die wir bei der Betrachtung des Chalcedons kennen lernen werden.

Daß im Jaspis der Quarz ziemlich stark verunreinigt ist, wurde schon erwähnt; die Menge der fremden Beimengungen beträgt häufig 20 Proz. und kann noch höher steigen. Sie bestehen in der Hauptsache aus Tonerde und Eisenoxyd; die Quarzmasse umschließt Tonteilchen und Eisenhydroxyd in mehr oder weniger feiner Verteilung, auch organische Körperchen verschiedener Art wurden schon beobachtet. Auf der großen Menge dieser fremden Bestandteile beruhen die speziellen Merkmale des Jaspis, die Undurchsichtigkeit, der großmuschelige, glatte, wenig glänzende Bruch, die intensive Färbung usw. Nehmen jene $a b$, dann wird auch die Färbung lichter, der Bruch wird mehr uneben und splitterig, die Masse wird etwas durchscheinend, und das Ganze nimmt mebr die Beschaffenheit des Hornsteins an, zu dem, wie wir gesehen haben, alle möglichen Übergänge hinfiuhren.

Für die Verwendung des Jaspis ist vorzugsweise die Farbe von Wichtigkeit. Sie ist sehr mannigfaltig und in der Hauptsache lediglich von dem Eisengehalte abhängig. Wenn dieser sehr gering ist, dann ist der Stein so gut wie farblos, zeigt aber durch den 'Tongehalt die charakteristischen sonstigen Eigenschaften des Jaspis. Ein solcher weißer Jaspis rom Aussehen des Elfenbeines soll als große Seltenheit aus der "Levante" kommen und schöne Schmucksteine geben. Gefärbte Stiicke sind selten ganz einheitlich, meist sind mehrere Farben oder Farbennuancen auf demselben Stück vorhanden, entweder regelmäßig in parallelen oder konzentrischen Lagen miteinander abwechselnd, oder in geaderten, geflammten oder sonstigen, zuweilen ganz unregelmäßigen Zeichnungen verteilt. Manchmal ist auch die Masse von mehr oder weniger geradlinigen Spalten und Kilüften durchzogen, die mit anders gefärbtem und vielfach auch sonst anders beschaffenem Quarze ausgefiilt sind. Von den vorkommenden Farben ist Braun, Gelb und Rot am verbreitetsten, Grïn ist ebenfalls noch häufig, seltener ist Blau und Schwarz. Man unterscheidet danach Farbenvarietïten, die zum Teil mit besonderen Namen belegt worden sind und die weiter unten noch eingehender betrachtet werden sollen.

Auch bezüglich der Art des Vorkommens zeigt der Jaspis erhebliche Tersehiedenheiten. Er findet sich entweder schichtenförmig in anderen Gesteinen eingelagert oder in unregrelmälign begrenzten Knollen auf manchen Erzlagerstätten, besonders mit Eisenerzen zusammen, wher ah)er auf Klïften, Spalten und sonstigen Ilohlräumen kieselsäurehaltiger Gesteine, oder entlich an Stellen, wo gewisse Eruptivgesteine von der Gruppe der Grünsteine (Diabase) mit Tonschiefer zusammenstoßen, als Umwandlungsprodukt (Kontaktprodukt) der letzteren. 
Diese unregelmälige begrenzten Massen werden unabhängrigr von der meist grelhen, braunen oder roten Farbe als ge me in e oder deutscher Jaspis von dem roten oder kastanienbraunen Ku ueljaspis unterschieden, der regrelmäbign runde Knollen oder Kugeln bildet, die, wie wir sehen werden, im Bohnerz eingelagert sind oder lose auf dem Boden herumliegen. Selbstverständlich finden sich alle diese Jaspisarten auch nicht selten als abgerollte Geschirhe im Sande oder als Kiesel der Bäiche und Fliisse.

Den Jaspis in seinen verschiedenen Abarten hat man besonders im Altertum viel verwendet zu Schmucksteinen, die teilweise graviert wurden, zu Mosaiken, sowie auch zu grrïberen Gegenstïnden. Im Mittelalter und bis in die Jetztzeit hinein ist die Benutzung ehenfalls noch sehr umfangreich gewesen, sie hat aber doch allmählich abgenommen, und gregenwärtig ist der Stein ohne Bedeutung. Man stellt wohl aus besonders schön und gleichmäbigng gefïbten Stïcken noch Schmucksteine dar, die trotz der Mattigkeit der Bruchflächen durch die Politur einen ziemlich lebhaften, wenn auch nicht sehr kräftigen Glanz erhalten. Die Iauptyerwendung ist aber zu Dosen, Schalen, Tasen, Tischplatten, zu Mosaiken und sograr zu kleinen Architekturstïcken. Diese werden von größeren Blöcken aus einen Stïcke hergestellt, oder aus mehreren Teilen zusammengesetzt, wobei die Farbenzeichnung berïcksichtigt werden muß, danit eine schöne Verbindung der einzelnen Stücke entsteht. Wegen der Massenhaftigkeit des Vorkommens ist der I'reis des Jaspis im allgemeinen grering; nur recht schöne und gleichmäßig gefärbte Exemplare haben einen etwas höheren Wert.

Im folgenden sollen nun die Farbenvari etäten des Jaspis, nebst den verwandten Arten des dichten Quarzes, und ihr Torkommen etwas genauer beschrieben werden. Manche von ihnen finden sich an einzelnen Orten für sich allein, anderswo liegen verschieden gefärbte .Taspise an derselben Stelle zusammen. Der großen Verbreitung des Jaspis wegen ist es nicht möglich, auch nur einigermaßen die Fundorte erschöpfend anzugeben, man findet daher hier nur die wichtigsten Beispiele erwähnt.

Der typische rote Jaspis ist der Kugeljaspis von Auggen und Liel bei Mrühlheim im Breisgau. Er bildet dort nuß- his kopfkroße runde Knollen, die im Bohnerze eingelagert sind und mit diesem gewonnen werden. Der Aldinger Stollen bei Auggen bat in früheren Zeiten große Mengen davon geliefert, die Knollen sind außen mit einem Anflug eines weißen Mehles bedeckt, innen sind sie dunkel ziegelrot mit weißen, gelben auch zuweilen grünlichen Streifen und anderen Zeichnungen. Häufig ist ein roter Kern von einer mehr oder weniger dicken gelben Hïlle umgeben.

Schön und gleichmäßig gefärbten roten Jaspis (oder Eisenkiesel), zuweilen von weißen Quarzadern durchzogen, trifft man nicht selten im hessischen Hinterlande westlich von Narburg, in Nassau, im Kellerwald usw. auf ziemlich weitem Lmkreise als Kontaktprodukt zwischen T'onschiefer und Diabas. Die Farbe ist dunkelblutrot und macht geschliffen einen ganz guten Eindruck. Man findet meist kleinere Stiicke, aber zuweilen auch kopfgroße und noch größere Blöcke. Besonders bei Löhlbach unweit Frankenberg in Hessen ist diese Art von Jaspis früher in vorzüglicher Größe und Schönheit vorgekommen und danach als $\mathrm{L}$ öhlbach er Achat bezeichnet worden. Man hat ehemals einen ziemlich ausgedehnten Gebrauch davon gemacht, und in den Kasseler Sammlungen sind noch heute zahlreiche aus diesem Materiale hergestellte Kunstsachen zu sehen. Jetzt wird schon seit langer Zeit nichts mehr von dort geschliffen. Schöner roter Jaspis (neben andersgefärbtem) findet sich auf den Eisensteingängen des säichsischen Erzgebirges an vielen Stellen, in der Gegend von Oberstein und Idar und noch an manchen anderen Orten. Es ist ïberflïssig, die Verbreitung dieses heute unwiehtigen Materiales weiter zu verfolgen.

B ra uner Jaspis bildet vor allem die sogenannten Nilkiesel, die aber keineswegs im Nil, jedoch allerdings in den Nilländern rorkonmmen. Es sind rundliche, meist bis etwa 
faustgrobe Knollon mit ein wenig rauher Oberfläche. Auf den glatten Bruchflächen heben sich konzentrische bräiunlichgelbe streifen in wechselvollem Verlauf gegren die schöne dunkelkastanienluraune Farbe der Stiicke ab. Diese Knollen, die urspriinglich in den Schichten de. Nummulitenformation eingelagert waren, bedecken in großer Menge dicht gedrängt jecle Sserir-Fläche (Kieswüiste) im Gebiete der ägyptischen Wïsten. In der Nähe von Kairo finlet sich sscrir östlich auf den Abhängen des Mokattam und noch viel weiter verbreitet westlich in der lybischen Wüste, deren Randgebiete auf Tagereisen nur von solchen abgerundeten Jaspisstiicken bedeckt sind. Die rundliche Oberflïche ist hier nicht durch $\mathrm{Ab}$ rollen in Wasser zustande gekommen, sondern dadurch, daß die sturmbewegten Sandkürner die scharfen Kanten und Ecken der ursprünglich unregelmäßig gestalteten Jaspisbrocken im Laufe der Zeit vollkommen abgeschliffen haben.

Braunen Jaspis von vorzüglicher Beschaffenheit findet man in Nordamerika in Begleitung von gelbem und rotem bei Sioux Falls in Dakota in großer Menge. Jälrlich wird für etwa 30000 Dollars von diesem schönen Materiale verschliffen in großen Werken, die an demselhen Orte errichtet worden sind. Namentlich stellt man architektonische Ornamente und ähnliches daraus her. Dieser Stein, der in Amerika unter dem Namen "Sioux Falls Jasper" bekannt ist, kommt schichtenförmig in unerschöpflichen Mengen vor und wird in Steinbrichen gewonnen.

Gelber Jaspis wird bei der Herstellung der Florentiner Mosaiken vielfach angewendet. Er hat bräunliche und weiße Streifen auf ockergelbem Grunde und stanmit von der Insel Sizilien, auch vom Dauphiné, aus der Gegend von Smyrna usw. An den Kúugeln von rotem Jaspis von Auggen bildet er vielfach die äußere Zone. Er ist im iibrigen wenig wichtig.

Griiner Jaspis kommt hauptsïchlich im Ural vor und wird dort verarbeitet. Er bildet unter anderem bei Orsk am Uralfluß oberhalb Orenburg ein mächtiges Lager im Gneis, das Blöcke von beliebigem Umfange liefert, so daß man daraus sogar größere Gegenstände, wie Vasen und ähnliches massiv und aus einem Stïcke herstellen kann. Die Verarbeitung geschieht auch für dieses Material in den großen Schleifereien zu Katharinenburg. Die Farbe ist dunkel lauchgrün, der stein geht daher unter dem Namen des Plasma, dem er :iuferlich ziemlich ähnlich ist, das aber zum Chalcedon gehört und das wir daher erst unten kennen lernen werden. Grüner Jaspis ist in China sehr geschätzt; er bildet einen Teil der Steine, die dort unter dem Namen "Y $\ddot{u}$ " zusammengefalit werden, und ron denen bei der Betrachtung des Nephrits und Jadeits zum Teil schon die Rede gewesen ist.

Bla uer Jaspis ist immer unansehnlich und zeigt stets eine grauliche, die sogenannte lavendelblaue Nuance; er wird kaum benutzt. Hierher gehört auch der sogemannte Porzellanjaspis, kein eigentlicher Jaspis, sondern ein lavendelblater, zum Teil ziegelroter und grelber, durch Braunkohlenbrïnde gefritterter und dadurch grehärteter Ton, der u. a. in der Gegend von Großalmerode in IEssen massenhaft vorkommt, der aber namentlich im nördlichen Böhmen eine weite Verbreitung hat und von dem zuweilen ein Stiick zu einem Schmucksteine Verwendung findet.

Beim Bandjaspis wechseln versehieden gefürbte, geradlinigr verlaufende diinne Lagen remolmäfin miteinander ab. Die Masse ist sehr unrein und kann kaum mehr zum Jaspis zerechnet werden. Sie hat eher die Beschaffenheit eines Kieselschiefers, steht aber wie der Porzellanjaspis doch im Aussehen dem echten Jaspis nahe und ist von ihm nur dadurch verschieden, dab die Kieselsäure bei ihm ganz besonders viele fremde Beimengungen ('nthält und diff die Substanz daher vor dem Lötrohr schon etwas schmelzbar ist. Soleher liandjaspis findet sich vielfach, doch ist meistens die Farbenversehiedenheit der einzelnen

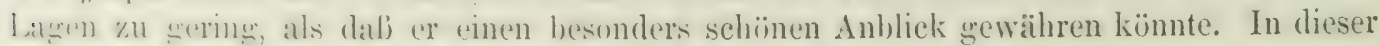


Weise findet er sich schichtenförmie bei Lautenthal am IIarz. bei finandstein unweit Kohren in Sachsen und an anderen orten. Schïn ist vor allem der sibirische bandjaspis, bei dem dunkelblutrote und -lauchgräne werade Streifen sehr regrelmäbig miteinander alternieren. Er soll in der Nähe von Werchne. Lralsk an! Einflufj der Cralsela in den Cralflul, vorkommen, aber nur in kleineren losen Stiicken, so dab keine zröbleren Geegenstände aus einem einzigen Stäcke hergesteflt werden können. Derartige Sachen werden aleer viel-

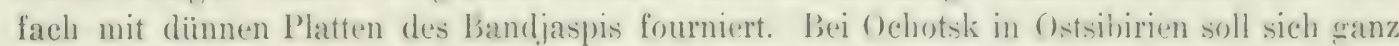
ähnliches Material finden. Auch (Istindien, und zwar der Pezirls Tschota Varpur in Bengalen, wird als Hemat wuter Lxemplare angegeben. Schion.r Bandjaspis, an dem braune, rote und gelbe mit weiben Streifen abwechseln, findet sich in crolier Menge in Nordamerika, so bei Collyer, Trego Comnty in Kansas, und älnnlich ist der Bandjasplis von Brackettrille, Kinney County, Texas; rot, gelb und grau gestreift ist der von I)ulzura, San Diego County, Kalifornien. Er bildet ein ausgezeichnetes Material zu Kannen, wozu Bandachat überhaupt wegen seiner regelmälige lagenförmigen Struktur sehr gut greeignet ist.

Den C̈bergang des Jaspis zu den ('haleedonen, die im näichsten Abschnitte is. 61 T betrachtet werden sollen. bildet in einem gewissen sinne der Jaspachat, bei dem undurehsichtige, stark sefärbte Teile mit durehscheinenden weniger gefürbten in der mannigfaltigsten Weise verwachsen sind. Es ist der ehemals viel grenannte , jaspe fleuri" der Juweliere. Friher wurde er ähnlich wie Jaspis verarbeitet: das Material kam vorzussweise und in crofur Jenge aus Sizilien, wo nach Farbe und Farbenzeichnungen 1010 Varietïten unterschieden wurden. Ein schüner Jaspachat ist auch der in Amerika vielgenannte.. Trxas-Achat", der in Texas an rerschiedenen Stellen rorkommt. In allen diesen Steinen iiberwient in dem Gemenge bald der durchscheinende Achat, bald der völlig undurchsichtigne Iaspis; man macht daher, um dieses Verhältnis auszudruicken, zuweilen noch einen Ĺnterschied zwischen Jaspisachat und Achatjaspis, je nachdem das erstere oder das letztere der Fall ist. Alle diese Steine sind aber von sehr geringer Wichtigkeit und kommen heututage als. Schmucksteine überhaupt kaum mehr im Handel vor.

\section{Avanturin.}

Der Avanturin (Avanturinyuarz) ist ein schwach durchscheinender, feinkïrniger bis dichter Quarz mit muscheligem und meist splitterigem Bruche, auf dessen Gherfläche punktweise ein meist braunroter, aber auch gelber und weifer und selten sogar blatter und grtiner, vielfach metallartiger schiller spielt. Wie man unter dem Milsroskupe sieht, geht dieser Schiller aus von einer großen Zahl kleiner, silberglänzender, weilier, odler, was viel häufiger ist, rotbrauner Glimmerschüppehen, die dem an sich farblosen Quarze eingrewachsen sind, oder ron zaliJreichen, mit Eisenhydroxyd erfiillten Spä̈ltchen, die sich zwischen den I tuarzkürnchen durchziehen, oder endlich ron winzigen Plättehen ron wrïnem ('hromglimmer (Fuchsit) oder ron solchen unlekannter Beschaffenheit von blauter Farbe. Jeder solche Einschluß, jedes einzelne Glimmerplättchen oder Spältchen gaibt einen metallähnliehen Glanz, und der Schiller des ganzen stiickes ist un so ununterbrochener. je whichmälinger jene der Masse eingestreut und je weniger Zwischenrïume zwischen ihmen vorhanden sind. die keine Finschlïsse enthalten. Die Frocheinung des meist rothraun schillernden Avinturins ist sehr ähnlich der bej dem Sonnenstein, der danach auch als Aranturinfeldspat bezeichnet wird, während der echte Aranturin diesem gesenüber auch Avanturinyuarz heilit. Letzterer kann neben dem anderen stets an seiner gröbteren Härte erkannt werden: er wird rom Quarze nicht geritzt, wohl aber der Sonnenstein.

Der Avanturin wird vielfach zu Ring- und Nadelsteinen, Broschen, Manschettenknöpfen usw. verschliffen. Die Steine erhalten eine ebene oder flach mugelige oberfläche 
ohne Facetten und nehmen durch die Politur einen schönen kräftigen Glanz an. Derartige Steine gelten für um so schöner, je gleichmäßiger und ununterbrochener der metallische Schiller ist. ('ute Stellen von dieser Beschaffenheit werden aus den größeren unregelmäficeren Stïcken, wie sie in der Natur meist vorkommen, herausgeschnitten und für sich geschliffen. In früheren Zeiten war diese Verwendung des Avanturins bäufiger und der Stein als Schmuckstein geschätzter, heutzutage wird er mehr zu Schalen, Vasen und anderen :̈hnlichen Gegenständen verarbeitet, über deren große Fläche hin die Gleichmäßigkeit des Schimmers selbstverständlich weniger vollkommen ist als bei den kleineren Oberflächen der Schmucksteine. Zu letzterem Zwecke sind am geschätztesten die rotbraunen, kupferartig rot schillernden Avanturine; braune, rotgelbe und weiße mit silberartig weißem Schimmer, schwarze mit weißen Punkten, sowie grüne und blaue sind zwar seltener, aber darum doch nicht mehr gesucht. Bei allen Avanturinen gehört es zur besonderen Schönheit des Steines, daß die metallisch glänzenden Flitterchen wie einzelne, wohl unterschiedene Sterne aus der Masse herausfunkeln.

Die Verbreitung des Avanturins ist ziemlich bedeutend, und man trifft auch gar nicht selten Stiicke von beträchtlicher Größe an, doch sind Steine mit allen Merkmalen der vorzïglichsten und schönsten Qualität recht sparsam und daher auch nicht billig. An den verschiedenen Fundorten kommt der Avanturin entweder auf seiner ursprïnglichen Lagerstätte oder in Form von losen Geröllen vor. Nicht überall ist er schleifwürdig.

Am reichsten ist wohl der Ural, wo er sich an mehreren Stellen findet, so in dem Bergzuge des Taganai, nördlich von Slatoust am Ui, einem Nebenfluße der Ufa im südlichen Teile des Gebirges. Der Avanturin bildet hier ein mächtiges Lager im Glimmerschiefer. Ferner trifft man ihn bei Kossulina, 28 Werst westsiidwestlich von Katharinenburg. Letzterer iibertrifft in Rücksicht auf die Farbe und den Schiller den ersteren, er ist aber mehr wie dieser von Kliiften durchzogen und daher nicht in so großen Blöcken zu haben. Beide Vorkommen werden in Katharinenburg geschliffen. Ein schön grüner Avanturin kommt neuerer Zeit aus dem Gouvernement Irkutsk in Sibirien. In Altai findet sich weißer und rötlich weißer Avanturin 30 Werst von dem Sitze der altberïhmten Steinschleifereien in Koliwan (etwa unter $51^{\circ}$ nördl. Breite) entfernt bei Beloretzkaja. Das Material von dieser Lokalitït wird in Koliwan verarbeitet. Es liefert zusammen mit dem uralischen die schönen Schalen, Vasen usw., die man als Geschenke der russischen Kaiser in den europäischen Fürstenschlössern bewundert. Stücke dieser Art können, wenn sie ron tadelloser Beschaffenheit und von einiger Größe sind, einen Wert von vielen tausend Mark haben.

In Indien trifft man Avanturin zum Teil in sehr schönen Exemplaren, doch scheint das Vorkommen und die genaue Lokalitït noch im Dunkel zu schweben. Namentlich wird mehrfach von einer sehr hübschen, grün glänzenden Varietät berichtet, von der u. a. ein Stïck von 7,3 und 2 Zoll Lä̈nge, Breite und Höhe beschrieben wird, wahrscheinlich aus dem Distrikte von Bellary im südlichen Teile des Landes stammend. Auch bei ihn sind es Glimmerblättchen, die den Glanz bedingen, und zwar Plïttehen des griunen Chromglimmers oder Fuchsits. Grobe Verbreitung scheint allerdings der Stein in Indien nicht zu haben.

Solcher grüner Avanturin ist namentlich in China sehr boch angesehen. Er wird dort mit zu dem steine .. Y ü $^{\prime \prime}$ gezählt und von anderen hierher gehörigen Mineralien als der katiserliche Yïstein unterschieden. Das Reichssiegel soll aus solchem Materiale hergestellt sein. Lis ist aber unbekannt, woher die Chinesen diesen Stein beziehen, dessen Wert sie sehr viel höher stellen, als den des Nephrits.

Fundorte des Avanturins in Europa werden viele. genannt, keiner scheint aber hervorragende Stiicke seliefert zu haben und alle sind unbedeutend. Hierher gehören die 
Gerend von Aschaffenbure in Bayern, Mariazell in Steiermark, Veillane zwisehen Susa und T'urin in Piemont, wo er sich in Form von Geschieben findet. Nantes in Frankreich, Glen Fernate in Perthshire und andere Orte in Schottland. Bei Madrid liegen Geschiebe von Avanturin zwischen solchen von Granat usw.

Es gibt eine prächtige (xlassorte, die in hohem Malee dem Avanturin ähnlich, aber noch schöner ist als dieser, der künstliche Avanturin oder das Aranturinglas. Es ist ein farbloses Glas, in dem sehr zahlreiche keine rote Oktä̈derchen cingrewachsen sind. Diese lassen sich an ihrer scharf aus!eprägten Kristallform, an ihren regrelmïßjg dreieckigen Flächen, sowie an der roten Farbe und dem starken Metallglanze, und endlich durch die chemische Analyse leicht als metallisches Kupfer erkennen. An der Form der Einschlïsse, die schon unter der I,upe deutlich hervortritt, sowie an der weit geringeren Irïte kann man in allen Fällen das Avanturinglas von dem echten tvanturin oder anch ron dem Sonnenstein unterseheiden.

Der nicht sehr wahrscheinlichen Sage nach soll ein Glasmacher von Murano bei Venedigr das Glas durch Zufall (par aventure) entdeckt haben, dadureh, daf ihm Kupferfeilspäne in einen Topf mit gesehmolzenem Glase fielen. Von dieser Zufälligkeit soll der Name Avanturin (Aventurin) stammen, der dann später auf die natiirlichen Steine von ähnlichem Aussehen übertragen wurde. Wahrscheinlicher ist, daß die Fabel ersonnen wurde, um das in den Fabriken von IIurano ängstlich gehütete Geheimnis der Herstellung dieser prächtigen Glassorte dadurch zu wahren, dab man andere auf eine falsche Fïhrte zu lenken suchte. Später geriet das Verfahren auch in Murano wieder in Vergessenheit, bis im Jahre 1927 der Cilasfabrikant Bibaglia dort nach langen Anstrengungen die Herstellung des Aranturinglases in alter Schönheit von neuem entdeckte. Die Schwierigkeit bestand wesentlich darin, die ausgeschiedenen Kupferkriställchen zu verhindern, sich in einen Klumpen zusammenzuballen, sondern sie möglichst gleichmäßig und in der richtigen Nenge in der Glasmasse zu verteilen, wie es nötig ist, wenn diese einen vorteilhaften Anblick gewähren soll. Auch jetzt noch ist das Verfahren Fabrikgeheinnis. Das Produkt wird wie der natürliche Avanturin viel benutzt zur Herstellung kleinerer Schmucksachen usw. und größjerer Gegrenstände, denn es ist möglich, große Blöcke davon zu gewinnen, von denen das hilogramm früher mit 40 bis 60 Mark bezahlt wurde. Das hierzu benutzte Glas ist besonders leichtfliissig, so daf es lange vor dem Kupfer schmilzt, das in einer Menge ron etwa 21: Proz. darin enthalten ist.

\section{Calcedon.}

Die Gruppe des Chalcedons umfaßt eine Anzahl von Kieselsäure-Mineralien von dichter Struktur und feinsplitterigem Bruch, die sich durch eine rersteckte, manchmal schon mit blofem Auge oder mit der Lupe erkennbare, meist aber erst in Dïnnschliffen unter dem Mikroskope deutlich hervortretende feine Faserigkeit auszeichnen. Das spezifische Gewicht ist etwas kleiner, nämlich $\mathrm{C}=2,59$ bis 2,60 ; die Härte ist etwas geringer, höchstens findet man: $\mathrm{H}=6 \frac{1}{2}$, so daf Chaleedon rom Quarz noch etwas geritzt wird, aber seinerseits Feldspat ritzt und noch starke Funken am Stahl gibt; endlich wird die Masse erheblich leichter von Kalilauge angegriffen, als es bei Quarz der Fall ist. Diese Unterschiede riihren daher, daß dem faserigen Quarz des Chalcedons eine geringe Menge des etwas leichteren und weicheren Opals beigemengt ist.

Da der Chalcedon ein faseriges Aggregat ist, so hat er niemals eine regelmäßige äußere restalt, es sei denn, daß er in der Form anderer Mineralien als Afterkistall oder Pseudomorphose vorkommt, was nicht selten der Fall ist. Er nimmt aber dann den von einem anderen Kristall gebildeten regelmäßigen Raum ein und hat die ebenflächige Form nicht 
selbst durch die ihm innewohnenden Kräfte hervorgebracht. Dagegen zeigt der Chalcedon sehr häiffig eine sinterartige rundliche, nierenförmige, traubige, zapfen- oder tropfsteinförmige Olserflïehe. auf der die Fäserchen alle senkrecht stehen. Außerdem sieht man noch vielfach, (dal) die wanze Masse aus einer oft sehr großen Anzahl einzelner, sehr diinner Lagen besteht, die, larallel mit der äußeren rundlichen Oberfläche verlaufend, übereinander geschichtet sind. Diese Schichtung fehlt wohl nie gänzlich, wird aber allerdings oft sehr undeutlich. Je nachdem sie mehr oder weniger bestimmt hervortritt, zeigt sich auf einer Bruch- oder Sichliffläche, am besten senkrecht zu der rundlichen Oberfäche in der Faserrichtung, eine ansgesprochene oder auch nur zart angedeutete Bänderung oder Streifung, die wohl nur selten granz fehlt. Danach unterscheidet man gestreiften und ungestreiften Chalcedon, ron denen der erstere grewöhnlich als A chat bezeichnet wird; daß eine scharfe Grenze zwischen beiden nicht vorhanden ist, geht aus dem erwähnten von selbst hervor.

Zerschlïgt man ein Stiick Chalcedon, so findet zuweilen, aber durchaus nicht immer, eine Trennung nach den übereinanderliegenden rundlichen Schichten statt; die Trennungsflächen sind dann ebenfalls rundlich und häufig sehr glatt und glänzend. Neist hängen aber diese einzelnen Schichten so fest zusammen, daß die Stücke durch einen Hammerschlag nicht nach deren Grenzflächen auseinanderfallen. Sehr leicht bewerkstelligt sich dagegen das Zerschlagen stets in der Richtung senkrecht zu der runden Oberfläche, oder was dasselle ist, nach den Fasern. Diese Längobbrüiche entstehen stets, wenn man ein Stück Chalcedon zertrümmert. Sie sind uneben und feinsplitterig, und nur wenig, und zwar häufig etwas wachsartig glïnzend. Durch die Politur nach dem Schleifen wird der Glanz sehr gehoben; er geht dann in einen selır schönen und kräftigen Glasglanz über. Die Nasse ist nie vollkommen durchsichtig, stets trïbe und höchstens durchscheinend bis halbdurchsichtig, zuweilen wohl dem Durchsichtigen stark genähert. Dabei ist die Durchscheinenheit in der Richtung der Fasern größer als senkrecht dazu, so daß also in der Faserrichtung geschliffene Platten weniger Licht hindurehgehen lassen als ebenso dicke aus demselben Steine, deren Fläche auf den Fasern senkrecht steht. Übrigens verhalten sich nicht immer alle Lagen, aus denen ein Stiick besteht, in Beziehung auf die Durchscheinenheit gleich. Einzelne können fast durchsichtig, andere so gut wie undurchsichtig sein, und verschieden klare und triihe Schichten können so vielfach miteinander abwechseln.

Die meisten Chalcedone sind nicht, oder doch nur sehr wenig gefärbt: graulich, gelblich, bläulich, zuweilen auch, wenn Farblosigkeit oder sehr schwache Färbung mit ziemlich vollkonmener Undurchsichtigkeit verbunden ist, milchweilb. Indessen fehlen auch ausgresprochenere und sogar intensive Farben nicht durchaus; man findet Gell), Braun, Schwarz, Rot, Grïn, in seltenen Fällen auch Blau. Die Färbung ist entweder durch das zanze Stiick hindurch dieselbe, oder es herrscht eine bunte Abwechslung in der Farbe der einzelnen Lagen, die aber alle auf ihrer ganzen Erstreckung sich immer gleich verhalten. Je grröber die Untersehiede der Farben der einzelnen Layen sind, die den Chalcedon zusammensetzen, desto deutlicher und schärfer tritt die schon oben erwähnte Streifung und Bänderung hervor.

Aber man ist bei den (halcedonen nicht auf die natïrliehen Farben heschränkt. Viele kïnnen auch kï̈stlich gefä rbt werden, indem man sie mit einer farbigen Flïssigkeit durchträinkt. Diese lailst dam beim Verdunsten ihren Farbstoff in dem steine zuriick und teilt so diesem ihre Farbe mit. Der Vorgang beruht anf einer mehr oder weniger vollkommenen I'orositiit der Masse, die zuweilen so auseresprochen ist, dalj kleine Stïcke an der fenchten Zunge klehen, indem sie deren Feuchtigheit rasch einsausen, und dafo sie, in Wascer selent. unter zischenden Geräusch die Flïssigkeit in sich aufnehmen und gleichzeitig zahleciche Luffblasen ausstolien. Man crkennt nicht selten unter dem Mikrosl:ope mol sugar manchmal schon mit der Iupe die Poren in Form runder Bläschen oder lang- 
gezogener Kanälehen zwischen den Fasern. I)abei werhalten sich meistens die Stüeke nicht durch ihre ganze Masse hindurch gleich, sondern einzelne I aren sind porös und nehnen leicht Farbstoffe auf, andere tun dies infolge ungeniigender oder mangeinder Porositït durchaus nicht oder nur in sehr geringem Grade.

Auch die nicht sehr häufigen intensiveren natiirlichen Färbungen der Chalcedone beruhen gewils in vielen Fälen anf einer nachträglichen, nach der Bildung erfolgten Ihurchtränkung mit irgendeinem natïrlichen Farbstoffe.

Die kïnstliche Färbung der Chalcedone ist für die heutige Achatschleifered von granz hervorragender Bedentung geworden. Sie wird in so grofen Mafistabe angewendet, dafs unter den eseschliffenen steinen die in ihres Farbe kiüstlich veränderten chalcedone, namentlich delate, an Menge die vollständig natïrlichen ïhertreffen. Wir haben daher auf diesen Zweig der Technik noch weiter zurïckzukommen, wenn wir dis: Vurarbeitung. der hier in Rede stehenden Materialien kennen lernen werden.

Der Chalcedon bildet entweder über den Gesteinen sinterartise Überzï oben erwähnten rundlichen Oherfläche, oder er hängt in zapfen- oder tropfsteinfürmigen (iebilden an greeigneten Stellen, oder er füllt spalten und kliifte oder andere IIohlrämme in der Gesteinen aus. Es sind dies meist kieschsïurehaltige vulkanische Gehirgsarten, die, wenn Chalcedon in ihnen in einiger Henge sich findet, stets schon emen ziemlich hohen Grad ron Verwitterung und Zersetzung erkennen Iassen. Daraus kam man ersehen, dal die Chalcedone Verwitteruners- und Zersetzungsprodukte der Gesteine sind, in denen sie vorkommen, ganz ähnlich wie wir dies unter anderem bein Opal und Amethyst gresehen baben. Aus den kieselsäurehaltigen Lüsungen, die sich bei der Verwitterung hilden, scheidet sich Kieselsäure, und zwar je nach den speziellen Lmständen, als Opal oder Chaleedon oder auch als Quarz in einer seiner vielen Abarten aus, bäufig bilden sich sogar alle diese verschiedenen aus Kieselsäure bestehenden Mineralien gleichzeitig nebeneinander. Es ist daher natürlich, daf der Chalcedon auf seinen zahlreichen Lagrerstätten nicht selten ron Opal und ron Guarz begleitet wird. Mineralogische L'ntersuchungen haben es wahrscheinlich gemacht, dab der Chalcedon wenigstens zum Teil durch Lmwandlung aus Opal entstanden ist, der dabei aus dem amorphen in den kristallinischen Zustand überging. Werden durch den ferneren Verlauf der Verwitterung die Gesteine, die den Chalcedon beherbergen, vollkommen zerstört, dann liegt der letztere in einzelnen Stïcken lose im Boden und diese werden nachler vielfach vom fliefenden Wasser ergriffen, abgerollt und abgerieben und in der Form von Geröllen dem Flußschutte beigemengt.

Nach semer äuleren Beschaffenheit und nach seinem Aussehen, wesentlich also nach der Strulitur, sowie nach der Farbe und der Art ihrer Terteilung, wird der Chalcedon von den Steinschleifern in eine Anzahl von Lnterarten eingeteilt, die besondere, zum Teil schon aus dem Altertum stammende Namen erhalten haben. Diese rerschiedenen Abteilungen sind aber nicht besonders scharf roneinander geschieden, manche sind auch bezïglich ihres Aussehens gewissen Varietiten des Jaspis, des Hornsteins usw. so ähnlich, daf man zweifelhaft sein kann, wo gewisse Stiicke unterzubringen und wie sie zu benennen sind. Dies ist aber von geringem Belang für die Terwendung zu śchmucksteinen, wo e's doch in der IIauptsache nur auf die Schönheit des Aussehens ankommt und wo es leichsültig ist, welche Beschaffenheit das Material zeigt und wie es gebildet wurde. Mineralogrisch bedingen die oben grenannten Eigenschaften, namentlich die feine Fastrigkeit, die Zugrehörigkeit zum Chalcedon. Der Hauptunterschied, den die Steinschleifer bei diesen dichten Ouarzmineralien machen, beruht, wie wir bei der Betrachtung des Jaspis gresehen haben, auf der Durchscheinenheit. Sie nennen Jaspis alles vollkommen Lndurchsichtige. Chalcedon in seinen verschiedenen Abarten alles mehr oder weniget Durchscheinende, ohne besondere Rïcksicht auf andere Eigenschaften. 
Die Varietäten, die hier beim Chaleedon unterschieden werden sollen, sind die folgenden:

Gemeiner Chalcedon, einheitlich, aber meist schwach gefärbt.

Karneol, einheitlich rot, mit dem braunen Sarder.

Plasma, einheitlich dunkelgrün, mit dem rot getüpfelten dunkelgriinen Heliotrop.

Achat, deutlich aus einzelnen Lagen aufgebaut, die nicht selten verschiedene

Färbung haben und dann die erwähnte Streifung hervorbringen. Es ist der "gestreifte Chalcedon", zu dem auch der vielgenannte Onyx gehört.

Die meisten dieser Tarietäten zerfallen wieder in Unterabteilungen, die wie bei der speziellen Beschreibung zum Teil näher kennen lernen werden.

\section{Gemeiner Chalcedon.}

Dies ist der Chalcedon im engeren Sinne, der gewöhnlich Chalcedon schlechtweg genannt wird. Die Farbe ist fast stets sehr licht, weiß, grau, gelb, braun, blau, selten auch grïn. Sie ist in der Iauptsache einheitlich, überall dieselbe, doch sind einzelne Stiicke auch mehr oder weniger deutlich wolkig (Wolkenchalcedon) gefleckt, sowie undeutlich gebändert. Wenn an einem Exemplare eine deutliche Schichtung und Streifung vorhanden ist, wird es nicht zum Chalcedon, sondern zum Achat gerechnet. Vollkomnen aus einem Guß ist aber dieser Chalcedon im engeren Sinne meist gleichfalls nicht; er besteht wie der Achat gewöhnlich aus einzelnen dünnen Lagen, die aber infolge ibrer fast gleichen Färbung für das bloße Auge stark zurïcktreten und undeutlich werden. Manchmal ist die Farbe etwas ausgesprochener, dann entstehen Varietäten, die zum 'Teil ebenfalls besondere Namen erhalten liaben. So wurde ein seltener blauer, sich zuweilen manchem Sapphir in der Farbe nähernder Chalcedon von Nertschinsk in Transbaikalien, von Tresztya in Siebenbürgen, von Eagle Point, Jackson County, Oregon, und von Indien von den Steinschleifern fälschlich Sapphirin, ein wachsähnlich gelber und ebenso glänzender Cerachat (Wachsachat oder Halbkarneol), ein trüber milchweißer weißer Karneol genannt. Ein schön rosa- und lilafarbiger Chalcedon findet sich bei Aurora in Nevada in Mandeln eines Melaphyrs. Auch ein Teil der oben (S. 623) in Zusammenhang beschriebenen Holzsteine besteht aus Chalcedon (Holzachat).

Die faserige Beschaffenheit ist ziemlich deutlich, der Bruch typisch uneben und zart splitterig, und ebenso ist der Glanz des frischen Bruches und der gesehliffenen und polierten Stiicke grenau so, wie es schon eingangs erwähnt wurde. Die Durchscheinenheit ist oft sehr groß; selbst dicke Stücke lassen zuweilen das Licht fast ungehindert hindurch, aber vollkommen klar ist keines. Dagegen sind viele auch sehr wenig durchscheinend und fast undurchsichtig, namentlich die milchweißen. Die schön durchscheinenden Stücke werden als "orientalische Chalcedone" von dem weniger stark durchscheinenden "occidentalischen" untersehieden. Aber auch bei den schönsten orientalischen Exemplaren ist die Durchscheinenheit nicht immer und iiberall dieselbe; auch bei diesen treten häufig zarte, etwas trühere Flecken auf, die jedoch die Schönheit nicht beeinträchtigen, sondern im Gegenteil eine recht gefällige Wirkung hervorbringen können, so daß der Wert dadurch im allgemeinen nicht verringert wird.

Dex gemeine ('balcedon bildet nierenförmige, traubige oder zapfenförmige Überzige, oder 're erfüllt IFohlräume in den Gesteinen, wie wir'es schon eingangs kennen gelernt hathen. In dieser IVeise findet er sich ziemlich häufig, doch sind oft die vorbandenen Ilengen sehr gering und die Überzügre zu dünn, so daß sie sich nicht zum Schleifen "ignen. Diekere Massen von großer Reinheit und Schönheit liefert unter anderem die 
Insel Island und die Fïrïeroruppe. Das meistr Schleifmaterial kommt aber aus Ostindien und namentlich atus Brasilien (Rio Grande do Sul) und Uruguay: auf diese beiden Torkommen soll bei der Betrachtung des Achats näher eingegangen werden.

Die Verwendung des ('halcedons war frïher und schon im Altertum häufiger als jetzt, wo er dureh andere steine in den IIintergrund gedrängt worden ist. Man stellte daraus Rimg- und Siegrelsteine, Petschafte, riegrelstüeke, Stockknöpfe usw., ahr.r auch Tassen, T'eller, frchalen, Vasen usw. dar. Die Verarbeitung geschieht in Europa vorzugsweise in den unten noch weiter zu besprechenden Schleifereien von Idar und Oberstein a. Tahe und ron Waldkirch in Baden mit den äbrigen Chalcedonarten und anderen ähnlichen Steinen zusammen, aber u. a. auch in größerem Mabstabe in Ostindien an manchen Orten, die jedoch alle an Wichtigkeit hinter Oberstein mit dem benachbarten Idar zurlickstehen.

Beliebt ist gregenwärtign der schon oben im Vorbeigehen erwähnte, zuweilen fälschlich Sapphirin genannte blaue Chalcedon von Tresztya (Köteles Mezii) im Lápos-Gelirge im nördlichen Siebenbürgen, südlich von Kapnik und südüstlich ron Felsübanya. Die Farbe des Chalcedons von hier ist verschieden: grau, bläulichweib, sowie hell und dunkel smalteblau. Je schöner blau, desto mehr werden die Steine greschätzt. Das Mineral findet sich in losen plattenförmigen und Schalenbruchstiicken, zuweilen in ganzen hohlen Kugetn in Feldern, aus denen es herausgeackert wird. Der Innenrand der Kugeln oder eine Fläche der plattenförmigen Stiicke zeigt gewöhnlich eine glänzende, flachnierige Oberfläche, oder auch mehr oder weniger scharfkantige Würfelformen, die man für Pseudomorphosen (Afterkristalle) nach Flußspat hält. Auch andere solche Afterbildungen, Chalcedon, in der Form anderer Mineralien. wurden beobachtet. Die Gegenseite der Stiicke zeigt verschiedene, \%. T. auch regelmäßige Eindrücke und ist oft wie zerhackt. Der Chalcedon greht vielfach in derben oder stengeligen Quarz unvermerkt über. Diese ganzen Bildungen stammen aus Klïften und rundlichen Hohlräumen eines jetzt ganz verwitterten vulkanischen Gesteins, eines Andesits. Aus dem blauen Material werden runde Perlen, Baroques und andere Schmucksachen geschliffen.

Der Wert des Chalcedons, der übrigens nur bei ganz besonders großen und schönen Stiicken etwas bedeutender ist, beruht hauptsächlich auf der Durchscheinenheit, sowie auf der Schönheit und bis zu einem gewissen Grade auf der Gleichmäßigkeit der Färbung. Sehr wichtig ist, dab keine Sprünge und andere derartige Fehler vorhanden sind. Trübe, schlecht und und ungleichartig gefürbte rissige Stücke sind so gut wie wertlos. Trotz des im ganzen greringen Preises des Chalcedons und der Leichtigkeit, ihn auch in größeren Stücken zu erhalten, hat man ihn durch einen Glasfluß recht täuschend nachgeahmt, der sich aber durch geringere Härte und höheres spezifisches Gewicht vom echten Chalcedon unterscheidet.

Einige durch gewisse Besonderheiten ausgezeichnete Abarten, die beim gemeinen Chalcedon zuweilen unterschieden werden, sind die folgenden:

Der Punktachat (Punktchalcedon, Stephanstein) ist ein weißer oder graulicher Chalcedon, mit kleinen roten Flecken und Punkten von Eisenoxyd. Er ist am schönsten, wenn diese so klein sind, daß sie nur rote Punkte bilden, die gleichmäßig über die ganze Oberfläche des Steines verteilt sind, welche dann aus einiger Ferne eine gleichmäßige rosenrote Farbe zu haben scheint.

Der Ba umstein (Dendrachat, zuweilen auch Mocha- oder Mokkastein) ist ein weiber oder srauer Chalcedon, in dessen Innerem sich braune, rote oder schwarze Dendriten finden, Bäume und Gestrüucher nachahmende Zeichnungen, die dadurch entstanden, daf eisen- oder manganhaltige Lösungen auf feinen Spältchen sich ausbreiteten, darin verdunsteten und ihre färbenden Bestandteile in der angegebenen Form zuriickließjen. Eisenhaltig. sind die braunen und roten, manganhaltig die schwarzen Figuren dieser Art. Dab solche. baumförmige Zeichnungen in der Tat entstehen, wenn auf feinen Spältchen Flüssigkeiten 
sich ausbreiten, kann man durch Versuche mit gefärbten Lösungen zwischen zwei Glasscheihen leicht nachweisen. Die Krunst des Schleifers, der einen solchen Baumstein verarbeiten soll, bestelst darin, über der stets in einer ziemlich ebenen Fläche ausgebreiteten Zeichmung so viel wegzunehmen, daß diese vollkommen klar sichtbar, aber der Dauer-

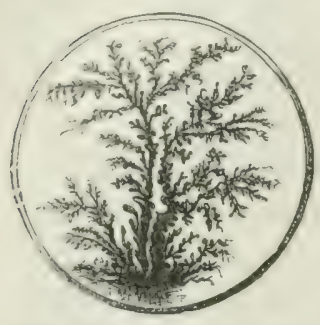

Fig. 104. B allmstein (Mokkastein). haftigkeit wegen doch noch von einer dïnnen Chalcedonhaut bedeckt ist. Die Oberfläche des Steines ist eben oder etwas weniges gewölbt und der Umriß, je nach der Form der Figur, rund oder oval. Ein solcher Baumstein, der etwa zu einer Brosche gefaßt werden könnte, ist in Fig. 104 in natürlicher Größe abgebildet. Besonders schön sind gewisse seltene Baumsteine, bei denen der weiße oder graue Chalcedon wie beim Stephanstein von roten Punkten durchsetzt ist. Ursprünglich sollen Baumsteine aus dex Gegend von Mokka in Arabien, am Eingange in das rote Meer, zu uns gekommen sein und daher ihren Namen erhalten haben. In neuerer Zeit wird er vorzugsweise aus Ostindien gebracht, wo er, zusammen mit anderen Chalcedonarten, sein Lager in einem vulkanischen, basaltartigen Gestein, dem sogenannten Dekkantrap) hat (siehe bei Achat). Nan findet schöne Stiicke als Geschiebe im Fluße Dschumna, dann kommt er in Menge nördlich von Radschkot auf der Halbinsel Kathiawar (Gutscharat) und im Bette des Flusses Majam in der dortigen Gegend vor. Hier findet man Blöcke bis zum frewichte von 40 Pfund von sphärischer, traubiger und mandelartiger Form, sowie abgerollte Geschiebe. Auch in Nordamerika kommt schönes schleifwürdiges Material an verschiedenen Stellen vor, so z. B. bei Central City in den Rocky Mountains.

Der Baumstein ist um so wertvoller, je klarer und dentlicher die Form von Bäumen und Gesträuchern hervortritt; Steine mit unregelmäßjigen schwarzen und braunen Flecken sind wenig geschätzt. Er kann auch künstlich nachgeahmt werden. Einem Obersteiner Achathändler ist es gelungen, auf der Oberfläche geschliffener Chalcedone schwarze Zeichnungen der erwähnten Art dauerhaft herzustellen, welche die auf den meisten natürlichen liaumsteinen vorhandenen an Schönheit weit übertreffen, sonst aber von ihnen schwer zu unterscheiden sind. Eine Zeitlang wurden die Baumsteine viel benutzt und hoch bezahlt, wenn die Zeichnung die pflanzliche Form grut nachahmt; ein schöner Stein dieser Art kann bis 60 Mark kosten.

Manchmal werden auch tierische Gebilde in derselben Weise nachgealimt, z. B. Miicken; derartige Steine werden Miickensteine genannt; sie kommen aus Montana.

Der Moos achat, ebenfalls vielfach Mokkastein genannt, ist durch melir oder weniger zahlreiche Einschliisse eines grünen Minerals ausgezeichnet, ebenso, wie es auch in manchen Bergkiristallen vorkommt. Es sind meist langgezogene, vielfach ineinander verschlungene, wirre Knäuel bildende Härchen und Fäscrehen, die nicht selten täuschend den Eindruck hervorbringen, als ob der Stein Moos eingeschlossen enthielte. Der danach so genannte Moosachat ist häufig in den vulkanischen Gesteinen, dem Dekkantrapp des westlichen Ostindiens, zum Teil mit dem Baumstein zusammen, so u. a. bei Radschkot, wo er unregelmäßjge Spalten im zersetzten 'Traply ausfüllt. Er wird hier in Stïcken von $1 / 2$ bis :3) l'fund gewonmen. Bei Ratanpur kommt er gleichfalls vor und ebenso als Geschiebe in manchen Flïssen: Nerbudda, Dschumna, auch in Godavery usw. Seit einiger Zeit kommt sriiner natürlicher, sowie gelber und roter kïnstlicher Moosachat aus China, der den anderen im IIandel zum 'Teil verdrängt hat. Sehöne Moosachate finden sich mollich auch in nicht geringer Menge in den Staaten Oregon, Utah, Wyoming (im'Hartvill... J listrikt in den Black IIills), Colorado und Montana in den Vereinigten Staaten.

Finflyllos. Besonders eigentümlich ist der als Schmuckstein allerdings nur wenim henutzte Enhydros (Wasserstein oder Mydrolith). Man versteht darunter flach ovale, 
nieren- oder z. T. brotlaibförmige, also unten fast cbene. hohle, dïnnwandige Knollen von durehscheinendem, beinahe farblosem Chaleedon, die teilweise mit einer Fliissignteit (Wasser erfiillt sind. Diese scheint durch die dïnnen Wändle durch, namentlich deutlich, wenn sie etwas bewegt wird, und schliget beim Schïtteln deutlich hörbar an diese an. Die Knollen liegen in vulkanischen (iesteinen, werden jetzt aber z. T. in tonigen Jassen ggefunden. Diese waren gleichfalls ursprünglich feste fiesteine dieser Art, die in Lanfe der Zeiten allmählich vollständig rerwitterten und so jene Tone bildeten. Die Enhydroskugeln, die in derselben Weise wie andere Chaleedone und wie es oben auscinandercresetzt wurde, in diesen vulkanischen Steinen entstanden, und die als Auskleiduneren von IIolilrïumen in dem Gestein mit einer dïnnen Chalcedonschicht anzusehen sind, blieben dahei erhalten und künnen nun aus dem weichen tonigen Verwitterungsprodukte herausgegraben werden. Wäre man genötigt, sie aus dem harten frestein herauszuschlagren, so wïrden sie wolil meist durch die Erschïtterung zerspringen. Zuerst kannte man diese Bildungen vom Monte Tondo in den Colli Berici bei Tieenza in Oberitalien, wo sie als Seltenheiten, und kaum die Gröbe einer Xuß ïbersteigend, im verwitterten Basalt vorkamen. Schon Plinius berichtet hieriiber. Gegenwärtig bringt man prächtige, meist halbhandgrobe Exemplare in einiger Menge aus Uruguay; sie finden sich hier mit dem Achat zusammen in einem Melaphyrmandelsteine. Einige Exemplare haben einen Durchmesser bis zu 1 Meter und ein Gewicht ron mehreren Zentnern. Ehenso schöne Exemplare kommen zuweilen von der indischafghanischen Grenze, sowie von Neu-Süd-Wales.

Setzt man einen solchen Enhydros der trockenen Luft aus, so verdunstet allmählich das Wasser. Unter gewissen Umständen wird e's aber nachber in die leeren Knollen wieder aufgenommen, wenn man sie in ein Gefäß mit Wasser legrt. Dabei erfolent der Aus- und Eintritt der Fliissigkeit durch die Wände selbst, ohne daß Spalten oder grö̋ere Öffnungen darin vorhanden wären. Auch dieser Vorgang beweist die schon erwähnte grolbe Porosität des Chalcedons, wenigstens mancher Exemplare desselben, und die Fühigkeit, sich mit Flüssigkeit zu durchtränken. Diese Entleerung und Füllung ist daher imstande, ein grewisses Licht auf die später zu betrachtende Bildung der Achatmandeln zu werfen.

Tenn der Enhydros auch keine Wichtigkeit als Schnuckstein hat, so wird er doch zuweilen geschliffen. Die Aubenwand kleiner bis haselnußgrober Exemplare wird geglättet und poliert, was des leichten Zerbrechens wegen sehr vorsichtig geschehen muß. Man sieht dann die Fliissigkeit sehr deutlich im Innern des Steines sich bewegren. Solche Steine werden in Ringe, Nadeln usw. gefaßt, aber allerdings wohl mehr der Merkwürdigkeit wegen, als zum Schmuck getragen.

\section{Karneol.}

Der Karneol ist der rote Chalcedon (Taf. XX, Fig. 6). Er ist bald, wenigstens anscheinend, ganz einheitlich gefürbt, bald unterscheidet man deutlich die einzelnen Lagen, aus denen er besteht und die bäufig in der Färbung etwas voneinander verschieden sind. Karneole, auf denen infolge dessen eine deutliche, scharfe und bestimmte Streifung zu sehen ist, werlen von den Steinschleifern in Idar Wackler genannt. Die charakteristische Farbe ist fleischrot, mehr oder weniger gesiittigt, rom tiefsten Blutrot bis fast rein weils und gelb. Es ist schon oben erwiihnt, daf weiße Chalcedone auch weilbe Karneole genannt werden, namentlich geschieht dies, wenn sie noch einen rötlichen oder gelblichen Schein zeigen. Sie sind mit den roten durch alle möglichen Übergänge verbunden. Zuweilen sind hellere und dunklere Flecken rorhanden, und nicht selten sind die Stïcke auben an den liändern dunkler und werden nach innen hin immer heller. Die schön dunkel und gleichmäßjig gefürbten, von aller Streifung freien, stark durchscheinenden Steine heifen "Karneole rom alten Stein" oder "männliche Karneole". Für die besten gelten die, welche 
beim Hindurchsehen tief blutrot sind, und an denen das auf der Oberflïche reflektierte Licht schwärzlichrot erscheint, die also, im auffallenden Lichte betrachtet, schwärzlichrot aussehen. Steine dieser Art kommen aus Indien. Die beller roten und gelbroten werden ., weibliche Karneole" oder Karneole schlechtweg genannt. Die männlichen sind selten und wexen ihrer großen Schönheit sehr geschätzt. Unter vielen Tausenden von Karneolstiicken sind stets nur sehr wenige, die jene Bezeichnung wirklich verdienen, die anderen alle sind blab, oder gelblich, oder brïunlich, oder graulich, oder gefleckt, oder sie sind durch Sprünge und Risse fehlerbaft. Alle Karneole aber sind, die Farbennuance mag' sonst sein wie sie will, mehr oder weniger durchscheinend, im Gegensatze zu dem in der Farbe oft recht ähnlichen, aber vollkommen undurchsichtigen roten Jaspis.

Die Farbe des Karneols rührt nicht, wie man frïher wohl glaubte, von organischen Substanzen, sondern von Eisenverbindungen her. Vorwiegendes Eisenoxyd färbt mehr rot, Eisenhydroxyd mehr braun und gelb. Beim Erhitzen verliert das letztere sein Wasser; es bildet sich Eisenoxyd, und damit geht das Gelb in ein mebr oder weniger reines Rot iiber. So erhalten viele Steine erst beim Erhitzen ihre eigentliche Karneolfarbe, und viele, die im natiirlichen Zustande unscheinbar gelb und zum Schmuck unbrauchbar sind, erlangen in der Hitze mit der roten Farbe ibre Schönheit und einen oft nicht geringen Wert.

Diese Farbenveränderung ist nur möglich und eine intensivere Färbung überhaupt nur dann vorhanden, wenn der Stein von Natur eine nicht zu geringe Menge Eisen enthält. Zu wenig von jenen Eisenverbindungen gibt immer eine blasse unseheinbare Farbe, die sich auch beim Glühen nicht in ein intensives Rot verwandelt. Deshalb ist es zuweilen wünschenswert, noch etwas Eisen zuzuführen. Dies geschieht, indem man die Stiicke zuerst mit einigen eisernen Nägeln zusammen in Salpetersäure erwärmt. Das Eisen der Nägel löst sich dabei auf, und die eisenhaltige Flüssigkeit wird von dem porösen Steine aufgesaugt, der nunmehr, wenn er geglüht wird, eine schöne rote Farbe annimmt. Es genïgt auch, die Steine vor dem Erhitzen mit einer Lösung von Eisenvitriol zu tränken, was jedenfalls einfacher und ebenso wirksam ist. Bei allen diesen Versuchen hat man zu hohe Steigerung der Temperatur zu vermeiden. Bei zu starkem Glühen wird der Karneol weiß und matt und kann dann leicht zu Pulver zerrieben werden.

Der Karneol kommt in derselben Weise in der Natur vor wie der gemeine Chalcedon und der Achat, bald als Überzug mit rundlicher Oberfläche, bald als Ausfüllung von Spalten und anderen Hohlräumen, namentlich von Mandelräumen in vulkanischen Gesteinen, sodann nach der Verwitterung der letzteren als rundliche Kinollen oder unregelmäßige Bruchstiicke lose im Boden oder auch als abgerollte Geschiebe in Sande und Kiese der Bäche und Fliisse. So ist der Karneol auch bei uns ziemlich verbreitet, aber derjenige, der in den Steinschleifereien verarbeitet wird, stammt fast ausschließlich aus Indien, Brasilien und Uruguay, wo er mit Chalcedon anderer Art, namentlich mit Achat zusammen gefunden und gesammelt wird. Die allgemeinen Verhältnisse des Vorkommens werden unten bei der Betrachtung des Achats auseinandergesetzt werden; der speziellen Fundorte schöner. Karneole soll hier kurz Erwähnung geschehen.

In Indien findet man in den Bergen von Radsehpipla, und zwar bei Ratanpur am unteren Nerbudda (Fig. 41), bis zu 3 Pfund schwere abgerollte Steine. Diese haben in den (Gruben, in denen man sie gewinnt, alle möglichen Farben, schwärzlich, olivenfarbig, milehweil usw, rot ist aber fast keiner. Die schöne rote Farbe kommt erst beim Erhitzen zustande, das teils durch lïngeres Liegen an der Sonne, teils in Feuer bewirkt wird. Dabei werden namentlich die im rohen Zustande olivenfarbigen Stiicke schön rot, und geben die in der Nachloarschaft, in Cambay westlich von Baroda vielfach geschliffenen, besonders geschätzten Karneole. 
Diese (iruben sind abor nicht die cinzigen, auch nördlich von Barorla am Maliflul' liegen fräbereien, und noch an zahlreichen anderen titellen des vulkanischen Gebites des westlichen Indiens koumt das Mineral vor, wenn es auch nicht überall gesammelt unil geschliffen wird. Tielfach findet sich der Karneol auch als Greschiebe in den Flüssen. ïberall in Gesellschaft mit anderen Chalcedonarten, von Jaspis usw. Ein ganz ähnliches Vorkommen ist in Rengalen in den vulkanischen Radschmahalhüigeln am Ganges, das aber, wie es scheint, geringere kommerzielle Wichtigkeit besitzt.

In Sü dame rika ist als Fundort von Karneol vorzugsweise das Campo de Maia bekannt. 5 () Meilen siidlich rom Rio Pardo, der bei Porto Alegre in das dortige Iaff mündet. Dir: ans dieser Gegend stammenden Steine sind meist durch eine ziemlich regrelmälbige Kugelgestalt ausgezeichnet. Überall, wo dort Achat vorkommt, ist er von Karneol begrleitet, so daß dieser eine ziemliche Verbreitung hat.

Andere Fundorte schöner Stuicke, die gelegentlich genannt werden, liegen in Surinam. bei Warwick in Queensland, in Sibirien usw., aber sie alle haben den indischen und brasilianischen gegenüber keine Bedeutung. In früheren Zeiten wurde in Japan viel einheimischer Karneol zu durchbohrten Perlen verarbeitet, die auf Schnüre aufgezogen wurden. Sie spielten in dem ehemaligen Handel der Holländer mit diesem Lande eine gewisse Rolle.

Verarbeitet wird der Karneol in ähnlicher Weise wie der gemeine Chalcedon zu verschieden gestalteten runden, oralen, eckigen usw. Steinen mit ebener oder flach schildförmiger Oberfläche mit und olne Facetten und zu den anderen bei der Betrachtung des Chalcedons genannten Gegenstainden. $\mathrm{Er}$ ist im allgemeinen weniger spröde als dieser und eiguet sich daher besser auch zum Cravieren. Ringsteine und andere Schmucksteine werden vielfach mit einer Gold- oder Silberfolie versehen, die den Glanz und die Farbe bedeutend hebt; der Verbrauch, namentlich zu billigen Schmucksachen, ist nicht unbedeutend, jedenfalls wohl stärker als der des eigentlichen Chalcedons. Auch schon im Altertum wurde Karneol vielfach verwendet.

Wie wir gesehen haben, geht die Farbe des Karneols vielfach ins Braune. Ausgesprochen hell- bis dunkelbraune Stïcke, oft schïn und glänzend kastanienbraun, somie solche, deren Braun mehr oder weniger ins Orangefarbige zieht, bis fast schwarze haben den besonderen Namen Sarder (oder Sard) erhalten. Eine scharfe Grenze zu dem roten Karneol ist aber nicht vorhanden; bei manchen Stïcken kann man zweifelhaft sein, ob man sie in der einen oder der anderen Weise benennen soll. Als der schönste Sarder wird der angesehen, der bei einem ausgesprochenen, aber doch etwas ins orangefarbige rehenden Braun, gegen das Licht gehalten, schön rot durchscheint. Manche Stiicke werden durch Erhitzen besser gefärbt und erhalten zuweilen erst dadurch ihr charakteristisches glïinzendes Braun. Nicht selten sind die Steine mit zahlreichen undurchsichtigen Punkten ron dunklerer Farbe durchsetzt; diese Abart wird als sandiger Sarler" bezeichnet. Schöner Sarder kommt nicht viel vor und ist recht wertvoll. Er findet sich an den genannten Fundorten des Karneols und mit dem noch zu betrachtenden Achat zusammen und wird mit diesen beiden zusammen gewonnen. Gegenwärtig ist ein Mittel bekannt und wird viel angewendet, Chalcedon auf kïnstlichem Wege schön, tief und gleichmäßig braun zu färben, wie wir bei der Betrachtung des Acbats noch weiter sehen werden. Derartige gefärbte Steine dienen jetzt unter dem Namen Sarduin vielfach als Ersatz für den natïrlichen Sarder, hinter dem sie in keiner Weise zurïckstehen. Auch der echte Sarder war schon im Altertum sehr beliebt. Er wurde aus Indien nach Griechenland ïber Sardes eingeführt, daher der Name. 


\section{Plasma und Heliotrop.}

Plismal lieißt der grüne Chalcedon. Die Farbe ist meist dunkellauchgrün (Taf. XVIII. Fig. 6, olne die roten Punkte), seltener heller, apfelgrün und ganz ins Weiß verlaufend, zuweilen mit gelben und weißen Flecken. Die färbende Substanz ist die sogenannte Grïnerde, eine dem Chlorit oder dem Glimmer ähnliche Substanz, oder manchmal grüner Asbest, ähnlich dem, der auch in dem Moosachat enthalten ist. Aber während man es bei diesem mit einzelnen grünen Einschlüssen in der sonst farblosen Substanz zu tun hat, ist heim Plasma der ganze Stein gleichmäßig von Körnchen und Schüppchen dieser Minerale durchsetzt und infolgedessen durch die ganze Masse hindurch übereinstimmend gefärbt. I)as Plasma ist der vielen Einschlüsse wegen viel weniger durchscheinend als der übrige ('halcedon und nähert sich dadurch im Aussehen den grïnen Jaspis, mit dem es auch den wenig splittrigen, fast glatten Bruch gemein hat. Bei der mikroskopischen Untersuchung erweist sich das Mineral aber als ebenso faserig wie echter Chalcedon, und dadurch ist es wesentlich von dem feinkörnigen grünen Jaspis unterschieden, wenn es auch zuweilen unmöglich ist, ein vorliegendes Stück durch bloßes Ansehen mit Sicherheit als das eine oder andere zu erkennen.

Das Plasma war frïher nur verarbeitet aus den Trümmern des alten Rom und anderer römischer Niederlassungen bekannt gewesen, und man weiß heute noch nicht, woher die Rümer das Rohmaterial erhalten haben. Später hat man das Mineral dann an verschiedenen Orten gefunden, und gegenwärtig kommt es in einiger Menge aus Ostindien, wo es besonlers schön und häufig, ganz ähnlich wie Karneol, in den vulkanischen Gesteinen des Dekkan sich findet, namentlich in der Gegend südlich vom Fluße Bhima (Fig. 41) in Haiderabad, ferner als Geschiebe in diesem Flusse, im Kistnal, Godavery und anderen. Sehr ähnlich ist der sog. grüne Avanturin von dort, der über Bombay in den Handel kommt. Auch am ersten Nilkatarakt in Oberägypten soll schönes Plasma gefunden werden. Plasma, ïl- und lauchgrün, zuweilen von seltener Schönheit liefert auch der Schwarzwald, wo es, abwechselnde Schalen bildend, mit Chalcedon, Quarz und anderen Mineralien in den Porphyrkugeln am Hauskopf und Eckefels bei Oppenau vorkommt. Ein anderer Fundort von Plasma in jener Gegend ist auch der Sauersberg bei Baden-Baden, wo das Mineral mleichfalls in Porphyrkugeln eingeschlossen ist. Für die Edelsteinschleiferei ist aber das Schwarzwälder Plasma ohne größere Bedeutung.

Gleichfalls ein griiner Chalcedon ist der Heliotiop. der auch als orientalischer Jaspis oder als Blutjaspis oder Blutstein bezeichnet wird. Er ist vom Plasma nur dadurch unterschieden, daf der grünen Masse schöne blutrote Punkte, Flecken oder Streifen eingesprengt sind (Taf. XVIII, Fig. 6). Diese wurden mit Blutstropfen verglichen und daher rïhrt der erwähnte Namen Blutjaspis. In einer vielgenannten Skulptur aus Heliotrop, die in der Nationalbibliothek in Paris aufbewahrt wird und welche die Geilelung Christi darstellt, sind diese roten Punkte mit großer Kunst zur Darstellung der Blutstropfen auf den Gewändern benutzt worden. Der Stein gilt für um so wertvoller, je schöner rot die Punkte sind, je mehr sie sich in der Grölje gleichen und je regelmäßiger sie auf dem «rïnen Hintergrunde verteilt sind. Rote Streifen oder größere rote Flecken sind weniger belicht. Stets ist hierbei wie auch beim Plasma eine schöne, tiefe, gleichmäßig grüne Crundmasse vorausgesetzt. Diese ist durchweg erheblich weniger durchscheinend als die (ingesprengten roten Partien. Auch gelbe Punkte und Flecken statt der roten finden sich zuweilen in der grïnen Grundmasse; diese Abart des Heliotrop ist aber viel Weniger schïn, sie ist daher nicht sehr gesehätzt und wird kaum zu Schmucksteinen bemutzt. Dasegen wird der rot punktierte ILeliotrop wie das Plasma zu Ring- und Nadelsteinen, Broschen und ähnlichen Schmucksachen, aber auch zu kleinen Gefäßen, Etuis usw. 
verarbeitet. Das lohbmaterial stamut wohl fast aussehlieflich aus Ostindien, wo es mit Chalcedon, Achat, Kameol. I'lasma usw. zusammen vorkommt. Namentlich wird als Fundort die (iecend nördlich von liadschkot auf dor Ilalbinsel Kathiawar, westlich von Cambay, und die von Puna siidiestlich rom Bombay wenannt; am erstreren Orte sollen bis 40) Pfund schwere Stïcke ronkommen. Es wird rielfach angexelyen, dalf diese oder andere ähnliche Steine ïber Calcutta nach Europra auspreführt werden. Dies ist für Steine, die auss dem westlichen Indien stammen, wenig wahrscheinlich, vielleicht werden iiber ('alcutta l'rodukte von ïstlicher gelegrenen Gergenden, etwa ron den Tiadschmahalhïgreln am Ganges exportiert; über das dortige Vorkommen ist aber näheres nicht bekannt. Vehen den ostindischen sind die europäischen Vorkommnisse ohne Bedentung. Neuerer Zeit wurden aber schöne IIeliotrope aus Australien bekannt. Auch ron Brasilien kommen zahlieiche Exemplare, die dort den Karneol, Achat usw. begleiten. Viel schïner IIeliotrop finciet sich auch bei Chugwater, 50) miles nordwestlich von Cheyenne in Wyoming.

\section{Achat.}

Der Achat ist der wichtigste aller Chalcedone, derjenige, der am allerläufigsten verarbeitet und am meisten benutzt wirl. Es ist der gestreifte Clialcerlon, dessen cinzelne ïhereinanderliegrende Schichten deutlich verschieden sind und der daher auf Bruchflächen tine mehr oder weniger ausgesprochene Bänderung erkennen läft. Die Selichten sincl in ihrem durch Färbung und Durchscheinenheit bedingten Aussehen einander oft sehr ähnlich, so dal) das ganze Stïck ziemlich einheitlich erscheint; häufig weichen sie aber auch sehr stark roneinander ab, lann tritt die Streifung und Bänderung besonders deutlich hervor.

Die Dicke dieser Lagen ist meistens auf ihrem ganzen Verlauf dieselbe und in allen Fällen auferordentlich gering, wie man besonders sieht, wenn man eine dünngeschliffene Platte unter dem Mikroskop untersucht. Der englische Physiker Brewster hat auf diese Weise in einem Achat auf 1 Zoll Dicke 17000 einzelne wohl unterschiedene und scharf gegeneinander abgregrenzte Schichten gezïhlt. Allerdings ist die Dicke nicht inmer so gering. Die Folge dieser äuferst feinschaligen Struktur ist, daß an manchen senkrecht zu den Schichten geschliffenen, recht dïnnen Platten mit selır feinen Lagen beim Hindurchsehen nach dem Lichte Regenbogenfarben auftreten, da die hindurchgehenden Lichtstrahlen an den feinen Streifen ein Gitter- oder Beugungsspektrum erzeugen. Achate, an denen dies der Fall ist, werden Regenbogenachate genannt; sie haben als Schmuchsteine aber keine Bedeutung.

Die Durchscheinenheit der einzelnen Lagen ist sehr verschieden; sie schwankt zwischen beinahe durchsichtig und so gut wie undurchsichtig. Die Farben, die beim Achat auftreten, sind dieselben wie beim Chalcedon überhaupt. Manche Schichten sind fast farblos, milchweilb und dann stets so gut wie undurchsichtig; oder sehr licht gefürbt, graulich, blaulich, gelblich, bräunlich. Andere sind intensiver und mit einer ausgesprochenen Farbe versehen: gelb, rot, braun, grrau, während grïn und blau selten vorkommen. Jede einzelne Schicht ist meist auf ihrer ganzen Erstreckung gleich gefürbt, sie gehört also einer der im Vorhergehenden betrachteten, nach ihrer Farbe besonders benannten Chalcedonvarietiiten an; die lichtgefärbten stimmen ganz mit dem gemeinen Chalcedon, die roten mit dem Karneol, die braunen mit dem Sarder usw. überein. Man sagt daher auch wohl, daf beim $A$ chat die verschiedenen einheitlich gefürbten Chalcedonvarietüten lagenweise miteinander abwechseln. Umgekehrt sieht man nicht selten, dab die letzteren aus lauter gleich oder nahezu gleich gefürbten dïnnen Lagren bestehen, wie z. B. der oben erwïhnte Wackler. Zuweilen unterscheidet man Chalcedon-, Karneol- usw. Achat, je nach dem in dem Stïck der Chalcedon, Karneol usw. an Menge überwiegt. Auch der Jaspis- 
Achat (Jaspachat), ron dem früher schon die Rede war, gehört zum Teil bierher, bei ihm wechseln durchscheinende Chalcedonpartien mit undurchsichtigen Jaspispartien ab.

Auf der Farbenverschiedenheit, auf dem angenehmen Gegensatz zwischen den rerschicdenen Schichten in bezug auf die Färbung beruht die Schönheit des Aussehens und also die Verwendbarkeit des Achats zum Schmuck. Nach ihrer Schönheit und namentlich nach dem Grade ibrer Durchscheinenheit unterscheidet man auch die Achate zuweilen als "orientalische" und „occidentalische". Die ersteren sind die schön gefärbten und stark durchscheinenden, die letzteren die minder ausgezeichneten. In ihrem natürlichen Zustande sind die meisten Achate allerdings unansehnlich und licht gefärbt, so daß sie zur Herstellung von Schmucksteinen sehr wenig geeignet erscheinen; nur bei verhältnismäßig wenigen ist die natürliche Farbe kräftig und intensiv genug, besonders Rot in verschiedenen Nuancen, auch Gelb und Braun. Man kann aber den Achaten wie anderen Chalcedonen alle möglichen schönen Farben künstlich mitteilen, wie wir bei der Betrachtung der Art und Weise der Verarbeitung in den Schleifereien eingehender sehen werden.

Die einzelnen Lagen, aus denen die Achate bestehen, bilden namentlich auf angeschliffenen Flächen verschiedene Zeichnungen, indem sie, bald in gerader Richtung, bald mannigfaltig gebogen und geknickt und in der verschiedenartigsten sonstigen Weise verlaufen, wie das die beiden Figuren auf Taf. XIX für einige Beispiele zeigen. Hierdurch werden vielerlei Gegenstände in ihrem Aussehen nachgeahmt und danach hat man die Achate mit verschiedenen Namen belegt.

Beim Bandachat sind die einzelnen Lagen untereinander parallel entweder ganz eben oder stetig gebogen, ohne stark aus- und einspringende Stellen. Auf Schlifflächen senkrecht zu den Schichten bilden diese eine regelmäßige geradlinige oder gebogene Bänderung. Ein solcher Bandachat, in dem milchweiße truibe Lagen mit andersgefärbten in scharfer Abgrenzung abwechseln, heißt im allgemeinen Onyx (Taf. XX, Fig. $5^{\mathrm{a}},{ }^{\mathrm{b}}$ ). Je nach der Farbe der neben den weißen auftretenden Streifen unterscheidet man verschiedene Unterabteilungen desselben. Wechseln die weißen Schichten mit schwarzen ab, dann hat man den kurzweg so genannten $\mathrm{Onyx}$ im engeren Sinne. Grauliche wie der gemeine Chalcedon, also sehr licht gefärbte Schichten neben den weißen geben den Chalcedonyx, rote und weiße den Karneolonyx, brame und weiße den Sardonyx. Der Onyx in seinen verschiedenen Abarten ist bei der Verarbeitung der Achate ron ganz besonderer Bedeutung; wir werden unten daher darauf noch weiter zurïckukommen haben. Eine spezielle Modifikation des Bandachats ist der Kreisachat, wo die Streifen einzelne verschiedenfarbige runde Ringe von grö̈lerem oder kleinerem Durchmesser bilden, die um einen Mittelpunkt herumlaufen. Iat die mittlere Partie eine besondere, namentlich eine dunkle Farbe, dann ist das Aussehen eines solchen Ringes oft nicht unähnlich dem eines Auges, daher für solche Steine der Name $\Lambda$ ugenachat. Eine Art von Kreisachat kann auch künstlich aus anderem $\Lambda$ chat oder Chalcedon nachgeahmt werden. Man setzt die Spitze eines Stahlstäbchens, eines sog. Kürners, auf die geschliffene Fläche eines solchen und übt auf dieses einen kräftigen IIammerschlag aus. Dann entsteht um die Ansatzstelle der Spitze herum ein System von konzentrischen Kreisen, die dem Stein ein ganz hïbsches Aussehen geben.

Maben die Streifen aus- und einspringende Ecken, vergleichbar mit den Bastionen eines Festungswerkes, dann heißt der Achat Festungsachat (Fortifikationsachat). Beim Landschaftsachat sieht man Zeichnungen, die an ein Landschaftsbild erinnern, und wenn die Streifen Ruinen nachahmen, was besonders bei dem unten noch zu betrachtenden T'rümmerachat der Fall ist, dann nennt man ihn Ruinenachat. Der Wolkenachat zeigt wolkenartig gestaltete trübe Stellen auf einem besser durchscheinenden Hintergrunde; heim Sternachat sieht man sternförmige Figuren; der M uschel-oder Koralle nachat 
erweckt den Anschein, als hätte man es mit versteinerten Muscheln und Korallen zu tun. was allerdings auch tatsächlich zuweilm rorkommt. Es gribt noch eine Anzahl solcher Namen, die meist leiehtverständlich sind. Da sie keine grofe: Bedleutung haben, werden sie hier nicht weiter erwähnt.

Was das Iuftreten dres lehats in der Yatur anbelangt, so findet er sich als Seltenheit gangförnig, Spalten im Gestein ausfüllend. Ilierher grehört das Vorkommen von Halsbach bei Freibere in Sachsen, wo der Gang besonders Korallenachat führt, und vor allem das von Schlottwitz bei Wesenstein im Müglitztale in Sachsen (Amtshauptmannschaft Dippoldiswalde). Ilier hat man es mit einem ausgezeichneten Bandachat zu tun, dessen feine und lebhaft grefärbte Lagen den Wänden der Spalte parallel grehen, in der neben dem Achat auch gemeiner ('halcedon, Jaspis, Quarz und Amethyst vorkommt. An einer Stelle ist auf der einen Seite die Ausfïllung der Spalten durch den Gebirgsdruck vollkommen zertrümmert worden und die einzelnen scharfliantigen Fragmente, namentlich ron tehat, sind durch Amethyst zu einer festen Nasse wieder verkittet, die durch ibre Farbenkontraste ein sehr hïbsches Aussehen zeigt. Dies ist der vielgenannte Trümmerachat, dessen Achatbruchstïcke zuweilen Ruinen von Gebäuden nachahmen, daher der schon erwähnte Name Ruinenachat. Der Trümmerachat ist $17 \overline{1}()$ gefunden, in Menge Fewennen und wie andere sächsische Achate, so z. B. der aus dem Porphyr stammende Altendorfer und Rochlitzer, zu allen möglichen Sachen verarbeitet worden. Aus dem Korallenachat von Halsbach bereitete man frïher einen schönen rosenroten Streusand. Gegenwärtig sind die Gruben meist nicht melır zugänglich, da sie beinahe inmmer unter Wasser stehen.

Allermeist erfüllt aber der dchat rundliche Blasenrïume, in gewissen vulkanischen Gesteinen, so in manchen Porpliyren, Basalten usw., namentlich aber in vielen Melaphyrmandelsteinen. Es sind dieselben länglich ovalen Hohlräume, die sogenannten Mandelräume, die wir schon bei der Betrachtung des Vorkommens des Amethysts kennen gelernt haben, die auch die Hauptmasse des Achats beherbergen. Im Gegensatze zu dem auf spalten vorkommenden Achat wird dieser als Mandelachat bezeichnet; er ist der wich. tigste aller Achate, da er fast allein den Schleifereien das Material liefert. Solche Mandeln, die überwiegend aus Achat bestehen, werden Achatmandeln genannt. Sie haben fast stets eine sehr rauhe, löcherige Außenfläche und eine kugelige, birn- mandel- oder brotlaibförmige Gestalt.

Der Aufbau dieser Mandeln ist so, daf die Lagen des Achats, der sie zusammensetzt, meist mehr oder weniger genau parallel der Wand der Mandelrïume verlaufen. Ist dies in vollkommener Weise der Fall, dann entsteht der Bandachat; auf kleinen Abweichungen hiervon beruhen die verschiedenen anderen Achatvarietäten, die nach dem Verlaufe der Streifen auf den Schlifflächen in der oben angegebenen Weise unterschieden worden sind. Eigentiimlich ist das Verhalten, das viele aus Südamerika stammende Mandeln zeigen. Die Lagen folgen ganz regelmäliig der Wand des Mandelraumes, biegen aber an einer Stelle plötzlich un und gehen ganz geradlinig quer durch den Mandelraum hindurch bis zur entgegengesetzten Wand, wie Fig. l, Taf. XIX, zeigt. Dieses Terhalten ist nur am südamerikanischen Achat zu beobachten. Bei dem von anderen Fundorten, aber auch bei vielen südamerikanischem Mandeln gehen die Chalcedonschichten ununterbrochen rings herum und folgen überall den Wänden der Mandeln, wie es in Fig. a, Taf. XIX, dargestellt ist. Achate wie in Fig. 7 werden von den Idarer Steinschleifern wohl auch als Sardonyx und die ebenen Lagen unten in der Figur als Sardlagen bezeichnet.

Der Achat grenzt in den Mandeln nur selten unmittelbar an das Gestein an; sehr läufig ist eine meist dünne Schicht eines grïnen, erdigen, chlorit- oder glimmerïhnlichen Minerals dazwischen, die sogenannte Griinerde, die sich auch in dem Moosachat einge- 
schlossen findet und die das Plasma und den Heliotrop grün färbt. Nach der Grünerdeschicht folnt, Lage auf Lage, der Achat, aber selten bis ins Innerste hinein, den ganzen Mandelraum erfiillend. Meistens bleibt innen ein leerer Raum, dann wird die Mandel wohl auch eine Geode genannt.

Gegen diesen inneren Hohlraum ist der Achat zuweilen mit einer nierenförmigen orler traubigen Oberfläiche abgegrenzt, wie sie dem Chaleedon in allen seinen Varietäten (eigen zu scin pflegt, oder er hängt in tropfsteinähnlichen Zapfen von oben her in den leeren Raum hinein. Zuweilen ist dieser dann schließlich noch von zuletzt gebildeter Achatmasse vollends ausgefüllt worden, in die nun die Zäpfchen des früher grebildeten Achats röhrenfürmig hineinragen. Dies ist der sogenannte Röhrenachat. Aber in den seltensten Fïllen beherbergt eine solche Mandel nur Achat; meist sitzt auf der innersten Achatschicht eine dïnnere oder dickere Lage ron kristallisiertem Quarz, oft ron Amethyst, der seine Endspitzen in den innersten leer gebliebenen Raum hineinsteckt, oder diesen auch als kristallinisch derbe Masse vollkommen erfüllt (Taf. XIX, Fig. b, oben). Bald ist in einer solchen Mandel das meiste Achat und nur wenig oder auch gar kein Anıthyst; bald ist umgekehrt nur eine diinne Schicht von Achat vorhanden und der Mandelraum in der Hauptsache erfüllt von Amethyst, dessen Vorkommen in dieser Weise schon oben (S. 593) erwähnt wurde. Je nachdem pflegt man von Achat- und Amethystmandeln zu sprechen; Amethyst- und Achatmandeln sind also nichts wesentlich Verschiedenes, sondern nur besondere Ausbildungsformen einer und derselben Erscheinung, nämlich von Nandelausfüllungen mit Kieselsäuremineralien. Hüufig ist auch der Amethyst noch nicht das Innerste; auf dessen Kristallen sitzen in zahlreichen Fällen noch solche von Kalkspat und anderen Mineralien, besonders von wasserbaltigen Silikaten aus der Gruppe der Zeolithe, die aber hier nicht eingehender besprochen zu werden brauchen.

In vielen Achatmandeln sind auf manchen Durchschnitten, die durch das Innere hindurchgelegt werden, noch gewisse Besonderheiten $\mathrm{zu}$ erkennen, die für die Erklärung der Ausfüllungsweise dieser Mandeln von Wichtigkeit sind. An einigen Stellen unterbrechen nämlich die Achatschichten ihren Lauf parallel der MIandelwand, biegen von beiden Seiten her scharf um und ziehen sich direkt auf die Mandelwand zu, zwischen sich einen meist nur schmalen Kanal lassend, wie es Fig. a, Taf. XIX oben links zeigt. Von diesen Kanïlen, die man Spritzlöeher nennt, findet man bei genauer Untersuchung an jeder Mandel mindestens einen, sehr häufig sind deren aber auch mehrere vorhanden, wie in der erwähnten Figur $a$.

Die Spritzlücher erstrecken sich rom Innern der Mandel bis an die Mandelwand, an der sie aufhüren. Thre äußere Mündung ist zuweilen durch eine trichterförmige Vertiefung an der Aufenseite der MIandeln deutlich zu erkennen, zuweilen liegen sie auch mehr versteckt und treten nur auf den Durchschnitten hervor. Bald sind diese Kanäle leer und verbinden das hohle Innere der Mandeln mit ihrer äuljeren Begrenzungsfläche; bald sind sie aber auch vollständig mit Achatsubstanz erfüllt, und zwar mit derselben, die auch in der Mandel die imnerste Stelle einnimmt und die sich durch den Kanal hindurch bis zur äußeren Grenze der Mandel hinzieht.

Die ganze Beschaffenheit der Achatmandeln und die Art und Weise ihres Torkommens gibt ohne große Schwierigkeit eine Erklärung ihrer En tsteh ung, die alle Einzelheiten der Lirscheinungsweise zu deuten imstande ist und die wir hier wenigstens in ihren Grundzügen betrachten. Zuerst laben wir aber noch eine Eigentiimlichkeit des Vorkommens kennen zu lernen, die darin besteht, dab ausgrefüllte Nandeln fast nur in solchen der genamnten Gesteine sich finden, die schon stark verwittert und dadurch eines Triles ihrer liestandteile beraubt sind. Je weiter die Zersetzung voreschritten ist, die vielfach bis zur vällien Erweichung des (iesteins gerht, desto mehr pflegen die Mandel- 
Tafel XIX'.

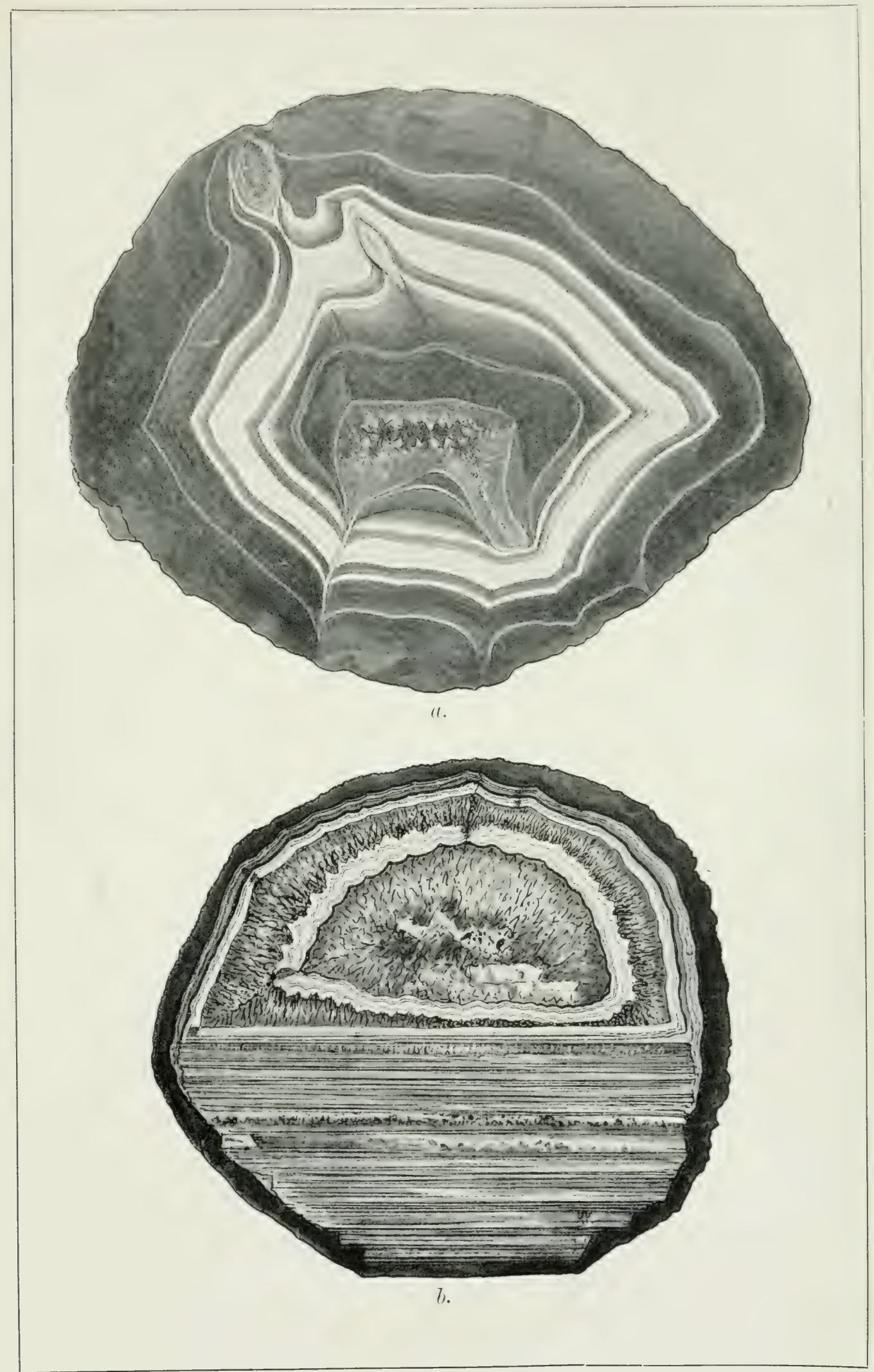

Achat. a. von Oberstein, b. von Brasilien. 

rïume enefiillt zu sein, je weniger zersetzt jenes ist, desto weniger Achat finclet sich in diesen IÏ̈lılungen, und in ganz frischen unverinderten fiesteinen sind sie meist vollkommen leer.

Ilieraus folgt unzweifelhaft, dab das Material, das dir Mandelräume erfüllt, die Kieselsäure, wenigstens zum Teil den Cresteinen entmommen ist, die die Mandeln beherbercren. Das die Verwitterung vermittelnde Wasser hat Kieselsäure neb.n anderen Bestandteilen

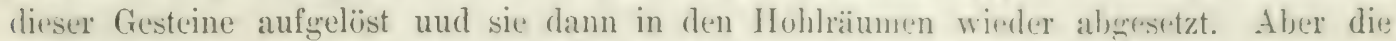
Schichtung der Mandeln zeignt, dalj diese Ablagerumg nicht kontinuierlich und ununterbrochen vor sich gegangen ist, sondern dab zwischen der Bildung von je zwei aufeinander folgenden Lagen eine mehr oder weniger lange l'ause stattgefunden hat, sonst hätte die fanze Mandel eine vollkommen gleichmälige, ungeschichtete Masse bidden müissen.

L'm diese Schichtung und die daraus zu schliefende unterbrochene Ausfüllung zu erklïren, hat man intermittierende, nur mit Pausen flieliende, leife Springryuellen, etwa ron der Art der bekannten Geysirs zu IIilfe genommen, wie sie unter anderen auf der Insel Island und im nordamerikanischen Nationalpark am Tellowstone Fiver in so ausegezeichneter Weise zu beobachten sind. Das wesentlichste dabei ist, daf warmes oder heiBes Wasser aus der Tiefe aufsteigt, die Gesteine durchtränkt, später aher wieder zurücksinkt, so daf die Gesteine wieder trocken werden. Dieses Wasser zersetzte die ganze Gesteins. masse', durch die es hindurchging, belud sich allmählich mit Kieselsïure und bildete eine Kieselsäurelösung. Wenn die Gesteine Mandelräume enthielten, so dran@̣ das emporsteigende heile Wasser in diese ein und füllte sie aus. Beim Zurüicksinken entleerten sich die Mandelräume, aber an der Wand blieb ringsum eine Schicht kieselsäurehaltigen Wassers hängen. Dieses erkaltete und verdunstete zum Teil und setzte so eine dïnue Lieselsïurchaut ab, die erste, der Wand des Mandelraumes nächstgelegene Achatschicht. Eine zweite Füllung der Hohlräume bei dem nächstfolgenden Aufsteigren der Quelle gab die zweite Haut und so jedes Aufsteigen und Zurückweichen des Wassers eine neue dünne Schicht bis zu der mehr oder weniger vollständigen Ausfüllung der Mandelräume, wobei die Flïssigkeit durch die Spritzlöcher, aber wohl auch durch den porüsen Achat selbst, ein- und wieder austrat. Selbstverständlich mußten auf diese Weise auch Spalten und andere Hohlräume in den Gesteinen mit Achat usw. erfüllt werden.

Die Gröle der so entstandenen Mandeln entspricht natürlich genau der der Mandelrïume. Sie geht von der einer Erbse oder HaselnuB bis zu den schon erwähnten bedeutenden Dimensionen. Das Gewicht der Mandeln hängt auber ron der Gröfe noch von der mehr oder weniger rollständigen Ausfüllung derselben ab. Die schwerste Mandel, die bisher bekannt geworden ist, wiegt ungefähr 40 Zentner; sie stammt aus Brasilien.

In dieser Weise findet man Achat an sehr zahlreichen Orten; nur an wenigen kommt er aber in solcher llenge und Schünheit ror, daß er von Bedeutung für die Herstellung ron Schmuckwaren ist. Nur von diesen Fundorten kann hier die Rede sein.

Am wichtigsten war früher das Vorkommen in den Talnegerenden. besonders in dem jetzt oldenburgischen Fürstentum Birkenfeld und den umliegenden preubischen Gebietstrilen. Ein Teil dieses Landstriches gehürte früher zu Pfalz-Zweibrïcken. Weshalb man auch jetzt noch zureilen die unrichtige Angabe findet, die Fundorte dieser Achate lägen in der Pfalz oder bei Zweibrïcken. Melaphyre und Mandelsteine sind dort sehr verbreitet, und fast überall enthalten die letzteren Achat, wenn auch nicht üherall in rleicher Schünheit. Sehr ausgezeichnet sind die Exemplare ron der Struth bei Oberstein und rom Galgenberg bei Idar, beide Orte, der erstere an der Nahe, der andere dicht dabei in dem kleinen Seitentälchen des Idarbaches gelegen; ferner die rom Rosengarten am Weibelstein bei St. Wendel auf preufischem Gebiete und ron manchen anderen Stellen. Jahrhunderte- 
lang wurden diese Achate systematisch gegraben und in den zahlreichen Schleifereien der dortigen Gugrend, besonders in Oberstein und Idar, verarbeitet, die wie noch jetzt, die granze Welt mit Achatwaren versorgten. Gegenwärtig sind diese Fundorte im Wesentlichen crschüpft. Wir werden auf diese wichtige Industrie noch weiter zurïckkommen.

Andere europaiische Fundorte, aber von weit geringerer Bedeutung sind in nördlichen Bühmen, wo der Achat in den Mandelsteinen am Jeschkenberg bei Friedstein, am Kosalower Gebirge bei Semil, am Tabor-Gebirge und am Morzinower Berg bei Lomnitz, sowie iu Lewiner Gebirge bei Neu-Paka vorkommt, außerdem aber auch, aus den Gesteinen ausgewittert, lose im Erdboden und als Geschiebe in den Flüssen (Iser und Elbe). Das hier gefundene Material, nicht nur eigentlicher Achat, sondern auch Karneol und andere Chalcedonvarietäten, Jaspis usw. wird in den Schleifereien von Turnau, Liebenau Gablonz usw. verarbeitet.

Viel wichtiger als diese und andere europäische Vorkommnisse sind aber jetzt einige außereuropäische, namentlich die sïdamerikanischen und zum Teil auch die ostindischen. Besonders die ersteren sind für die Achatindustrie von Idar und Oberstein von gröbter Bedeutung geworden, da sie nach völliger Erschöpfung der einheimischen Fundstätten dieser die überwiegende Menge des Rohmaterials liefern, und zwar solches von ausgezeichneter Beschaffenheit.

In Sïdamerika ist die brasilianische Provinz Rio Grande do Sul und das siddich anstoßende Uruguay die Heimat der Achate, die vielfach unabhängig von ihrer speziellen IIerkunft als "brasilianische Achate" bezeichnet werden. In ihrer Begleitung finden sich die schon früher erwähnten kristallisierten Quarze, wie namentlich Amethyst und Citrin sowie Chalcedon von anderer Art als Achat, besonders Karneol. In jenen Gegenden sind ganz ebensolche Melaphyre und Mandelsteine wie an der Nahe massenhaft verbreitet, und in diesen haben sich auch dort die Achate und die anderen genannten Mineralien gebildet. Sie liegen vielfach nicht mehr in dem eigentlichen Muttergestein selbst, sondern dieses ist häufig durch die Verwitterung mehr oder weniger vollstïndig zersetzt und dadurch nicht selten in einen roten bis braunen stark eisenhaltigen Ton verwandelt, der dann die von der Verwitterung nicht angegriffenen Amethyst- und Achatmandeln usw. einschließt. Wenn der Regen den Ton wegschwemmt, liegen diese lose auf dem Boden herum; vielfach gelangen sie auch in den Schutt der Bäche und Flüsse und werden in diesem zu Geschieben abgerollt. Die Form der Mandeln ist meist die eines Brotes, also auf einer Seite flach, auf der entgegengesetzten gewölbt. Ihre Größe ist nicht selten recht erheblich; von Brasilien stammt die oben erwähnte Mandel von 40 Zentner Gewicht.

„Das Gebirgsland, das der Uruguayfluß umflielt und das an der Mündung des La Plata beginnend, sich durch Uruguay und den brasilianischen Staat Rio Grande do Sul nach Norden hinzieht, um weiter in die Serra do Mar aufzusteigen, besteht größtenteils aus stark verwittertem Melaphyr, insbesondere der Gebirgszug, der sich nördlich von Porto Alegre vom $28^{\circ}$ südlicher Breite und $34^{\circ}$ westlicher Länge von Ferro bis in den Distrikt ron Salto am Uruguay $\left(31 \frac{12^{0}}{}\right.$ siidliche Breite) erstreckt. Dieser Zug von 90 bis 100) deutschen Meilen Länge, der im Norden bewaldet ist und von den zu dem System des IIaffs von P'orto Alegre gehörigen Flüssen Taquarie und Rio Pardo durchströmt wird, bis zu den baumlosen Campos von Salto, liefert seit den dreißiger Jahren des 19. Jahrhunderts sowohl die oben besprochenen (Quarzmineralien, Amethyst und Citrin, als auch das Rohmaterial für die Achatschleiferei, Chalcedon, Karneol, Achat usw. In den Betten und Tüleru der genannten Flïsse werden die Karneole gefunden, auf den dort gelegenen Höhen die streifigen Steine. Tom Campo de Maia, 50 Meilen vom Rio Pardo, kommen die zentnerschweren Sardonyxe. Die Nebenflüsse des Uruguay, der Grenzfluß Quarein, der große 
und kleine Catalan, der Arapay, der grobe: und kleine Quaro, die Distrikte Tres cruces und Meta perro liefern neben streifigen die bläulichen Achate."

Von Achaten kamen aus Südamerika lange Zeit nur bläulichgraue in den Handel. Dirse sind an sich sehr unscheinhar, aber sie haben zwei äufierst wortwolle Eigenschaften vor den vielfach bunteren von Oberstein voraus. Einmal sind sio solur leicht zu färben, sodlann haben sie meist die auf Taf. XIX, Fig. l, darerestellten vollstündig greradlinigren Lagen, die ron den Steinschleiffrm zur IItrstrllung von Onyxsteinen besorders greschätzt werden. Reeht wenig verbreitet sind naturschwarze Steine; unter Tausenden von Zentnern knmmt kaum einmal ein solcher vor. Sehr selten sind schön smaraggdgrüne Laren, stets unmittelhar unter dem den Achat bedeckenden Amethyst; ungewöhnlich ist auch die rosenrote Farbe, wogegen das beim Karneol gewöhnliche tiefere Fleischrot auch bei brasilianischen Achaten häufiger vorkommt.

Die Entdeckungr dieser Steine gesehah im Tahre 1527 durch nach Brasilien aus:rewanderte Obersteiner, die sofort die bis dahin verachteten Schätze zu heben begrannen, indem sie den Achat und seine Beggleiter an der Erdoberfläche zusammenlasen oder aus dem tonigen Boden herausgruben. Sie schickten grobe Mengen daron nach ilhrer Heimat, und es entwickelte sich bald ein lebhafter Inandel in diesem Artikel. Aber trotz der vorhandenen grofen Menge ist die Gewinnung nicht gerarle leicht, da die Fundstellen zum Teil in unwirtlichen Gerrenden liegen und der Transport der Steine nach der Küiste hüchst beschwerlich ist. Lngeachtet dieser Schwierigkeiten konmen jährlich große Massen nach Oberstein und Idar, wo gegenwärtig fast nur noch südamerikanische Achate geschliffen werden.

Lm eine Anschauung ron der Bedeutung dieses Handelszweiges zu geben, sind im folgrenden die allein aus Rio Grande do Sul ausgreführten Mengen Achatsteine (inbegriffen Karneol- und alle anderen Chalcedonarten; für eine Anzahl ron Jahren angegeben; die aus Uruguay stammenden sind dabei noch nicht berücksichtigt:

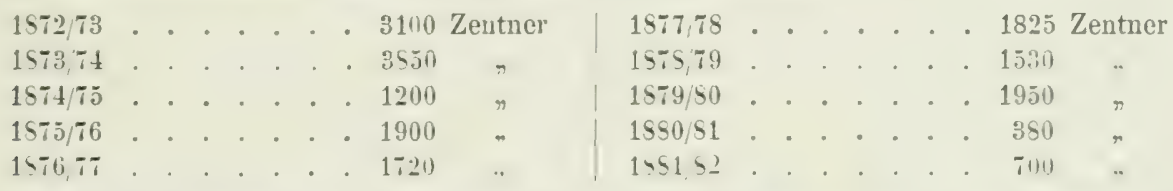

Die Menge wechselt also sehr bedeutend, ebenso der für die rolen Steine bezahlte Preis. Bei den Versteigerungen in Idar-Oberstein bewegt sich der Wert des Zentners Rohachat im Durchschnitt ron 5 bis 15 Mark, es gelangen aber dabei gelegentlich einzelne Mandeln zum Terkauf, die bis 1000 Mark zu stehen kommen. 1566 z. B. wurde eine solche aus Porto Alegre von über 2000 Kilogramm Gewicht für etwa 2500 Taler erworben. In Brasilien selbst ist es nicht gelungen, die Schleiferei ins Leben zu rufen. Einige ausgewanderte Obersteiner haben zwar einen Anfang dazu gemacht, aber die Sache kam nicht zum Gedeihen und hörte bald wieder ganz auf, so daß die Brasilianer geschliffene Acbatwaren aus Oberstein und Idar bezieben müssen, wobin sie selber das Rohmaterial liefern.

Auch in Ostindien ist ein Mandelstein, der dort als Trapp bezeichnet wird, das Muttergestein der Achate und der anderen dort vorkommenden schon oben genannten Chalcedonvarietäten, die alle zusammen als ..hakik" bezeichnet werden. Tamentlich ist es das Hochland von Dekkan, das auf Tausende von Quadratmeilen aus solchen Gesteinen, dem Dekkantrapp, besteht, ebenso die umliegenden Gegenden, das alte Königreich Gutscherat mit der Hauptstadt Surat und mit der jetzt Kathiawar genannten Halbinsel westlich vom Golf von Cambay, ferner ein Teil von Radschputana usw. Sodann sind weit im Osten die Radschmahal-Hügel zu erwäbnen, die in dem großen nach Nordost gerichteten Gangesknie unter dem 25. Grade nördl. Breite liegen. Diese werden ron einem ähnlichen 
vulkanischen C'esteine gebildet wie das Hochland von Dekkan, und ebenso die benachbarten Gegenden von Bengalen.

In diesen (iestein füllen die Achate, Karneole usw. überall Mandelräume und Spalten aus. Wenn durch Verwitterung des Muttergesteins die Massen ihren Zusammenhalt verlieren, liegen die Chalcedonstücke, wie in Brasilien, an vielen Stellen massenhaft lose auf dem borlen herum und gelangen als Geschiebe in alle Flïsse, die das Dekkan durchziehen oder in ihm entspringen, wie der Godavery mit dem Wanda, der Kistnah, Bhima und viele andere. Auch bilden sie an zahlreichen Stellen ausgedehnte und zum Teil wichtige Schichten von Konglomeraten, in denen die Chalcedonbrocken, eckig oder abgerollt, durch ein eisenschïssiges Bindemittel mehr oder weniger fest miteinander verkittet sind. Gerade diese Konglomerate, in denen sich der Achat auf sekundärer Lagerstätte befindet, sind die Hauptıuellen für die zur Verarbeitung gelangenden Steine.

Wenn num auch Chalcedone in Indien eine sehr weite Verbreitung haben, so finden sie sich doch nicht überall in gleicher Schönheit und Brauchbarkeit, und wenn auch an zahlreichen Stellen schleifbares Material gesammelt wird, so sind doch zwei Gegenden hierfür vor allem wichtig, die wir auch schon als Fundorte für Moosachat, Moksasteine, Heliotrop, Karneol usw. kennen gelernt haben. Es ist die Umgebung von Ratanpur am unteren Terbudda in dem Staate Radschpipla und das Land nördlich von Radschkot auf der Halbinsel Kathiawar; uberall begleitet hier Achat die vielfach schon genannten Steine.

Am bekanntesten sind die Lager von Ratanpur. Hier baben seit mehr als 2000 Jahren die einheimischen Schleifer ibr Material an Karneol, Achat usw. geholt. Die besten und greschätztesten Stïcke kommen alle aus einer dünnen Schicht eines Konglomerats mit eisenschïssigem Bindemittel, dessen Eisenbestandteile wahrscheinlich die schöne 1 ote Fïrbung der darin eingeschlossenen Steine bewirkt haben. Diese Schicht wird durch $4 \mathrm{FuB}$ weite und im Mittel $30 \mathrm{Fub}$, höchstens aber $50 \mathrm{Fub}$ tiefe Schächte aufgesucht und ron diesen aus mittels horizontaler bis 100 Yards langer Strecken nach allen Seiten hin verfolgt und ausgebeutet. Die gefundenen Steine, unter denen auch Katzenauge eine Rolle spielt, sind selten mehr als ein Pfund schwer. Wir haben schon gesehen, daß sie zum Teil gebrannt werden müssen, damit ihre schöne Farbe zum Vorschein lommt; andere haben diese aber schon von Natur. Das gesammelte Material geht zu Schiff nach den zahlreichen Urten der einheimischen Schleiferei, vor allem nach Cambay, dem Hauptsitz der indischen Achatindustrie; ferner nach Europa, besonders reichlich (iiber London) nach Oberstein und Idar, sowie in großer Menge nach China, wo viel indischer Chalcedon, besonders Karneol, geschliffen wird.

Einheimische Schleifereien entstanden an vielen Orten, wo brauchbares Rohmaterial zur IIand war, so bei Dschabalpur in den Zentralprovinzen (Fig. 11), selur nahe dem 81. Grade ästlich ron Greenwich und bei Banda am Ken, einem Nebenflusse der Dschumna, der eine Menge Chalcedongeschiebe führt. Sehr wichtig waren wenigstens früher die Werkstiitten von Broach oder Bbarotsch bei Baroda im Mündungsgebiete des Nerbudda. Yon dem Namen Broach soll das Wort Brosche stammen. Auch Ahmedabad, etwas weiter nördlich, wird genannt. Die gegenwärtig wichtigsten Schleifereien, die einzigen, die jetzt überhaupt noch Bedeutung haben, sind die von Cambay (Khambat) am Meerbusen wleichen Namens, nördlich von Bombay. Sie, wie auch die übrigen, arbeiten grleichzeitign für den indischen, arabischen und europäischen Geschmack und senden neben dem Rohmaterial auch fertige Waren in diese Länder, die allerdings in Europa vielfach umgeschliffen werden.

Lus den genamiten Gegenden Indiens und zwar ron Ulein (oder Ouzeih) $\left(23^{\circ} 10^{\prime}\right.$ nürdl. Breite und $7 f^{\prime \prime} 11^{\prime}$ isstl. ron Greenwich), sollten die im Altertum berühmten murrinischen (refälie stammen. Diese künnten daher nur aus Chalcedon (Achat usw.) bestanden 
haben, nicht, wie man wohl amnahm, aus Flulspat, der in jener fiegend gar nicht bekamnt und iiberhaupt in Indien selten ist.

Achatschleiferei. Idal-0hersteiner Industrie. Der Achat und die anderen Chalcedone werden zu den allerverschiedenartigsten Gegenstïnden des Schnuckes oder sonstigen Crebrauches verarbeitet; es gribt keinen anderen stein, der eine so vielscitign Terwendung hätte als er. Diese Mannigfaltigkeit hängt zum Teil damit zusammen, dals für die Form der schmucksteine die Mode von grober Bedeutung ist. Sie bringt einen oft sehr raschen Wechsel in den aus Achat daresestellten Artikeln hervor, so dafi mancher, der in eimem Jahre in Millionen von Exemplaren heresestellt wurde, in folgenden war nicht mehr verkauft werden kann. Auch in Beziehung auf die Anwendung der rerschiedenen Arten des Chalcedons und Achats in speziellen spielt die Mode in holiem Mafe: unit: bald ist der rote Karneol, bald der griune Ifeliotroll oder das P'lasma, bald schwarzel' Achat oder Onyx usw. am beliebtesten. Besonders grolje Verbreitung fanden Achatschmucksachen aller Art in der Zeit von 1815 bis Mitte der fünfziger lahre; dies ist die goldene Zeit der Achatindustrie gewesen. Im allgemeinen sind die von ilır gelieferten Gegenstände ganz auberordentlich billig. Nur wenn besonders grofe stïcke rerarbeitet werden oder besondere Kunstfertigkeit für einen Gegrenstand nötig ist, treten hohe Preise ein. Trotz der Billigkeit des echten Achats wird er doch durch eine eigene Glassorte, das sogenannte Achatglas, recht gut nachgeahmt; der Achat kann aber an seiner grüberen Härte leicht davon unterschieden werden.

Schmucksachen sind bei der Verarbeitung des Achats die Hauptsache. Man rerfertigt sie zu dem verschiedenartigsten Gebrauch und in zahlreichen Mustern. Die wichtigsten dieser Artikel sind: Manschettenknöpfe, Busen- und Haarnadeln, Ohrgeh:̈nge, Gehänge an Uhrketten, die übrigens zurzeit nicht sehr ron der Mode bevorzugt werden, Hals- und Armbïnder, Schnallen, ganze Ringe und Ringsteine, zum Teil graviert als Siegrelsteine, zum Teil auch mit erhabenen Figuren (Kameen), Petschafte und anderes. Mehr Gegenstände des täglichen Gebrauches als Schmucksachen sind: Kungeln als Griffe für Schirme und Stöcke, sowie Brief beschwerer, Streichholzbïchsen, Toilettekïsten, Dosen; ferner Siegelstöcke. Federhalter, Messergriffe, Schachfiguren, Spielmarken; sodann Schalen und Tasen von jeder Form und Größe, Weihwasserkessel, Tassen, Dessertteller, Saucenschüisseln usw., weiterhin Leuchter, Kinderspielzeuge, wie Klicker, Kanonen und anderes. Aus rerschiedenen farbigen Calcedonen werden Mosaikarbeiten zusammengesetzt, die zu Tischplatten und ähnlichen Dingen Verwendung finden. Für technische Zwecke wichtig sind Reibschalen aus Achat, ferner Polierzïhne für Goldarbeiter und Buchbinder, Glättsteine für Papier- und Kartenfabriken, Walzen für die Herstellung von Bändern, Zapfenlager für Wagen und andere Produkte der Feinmechanik usw. Eigentümlich ist ein schwunghafter IIandel mit Anuletten aus braunem oder sehwarzem Achat. sogenannten Oliven, nach Zentralafrika, der sich rom Jahre 1550 an entwickelt hat. Es sind 1/2 his :3 Zoll lange. diinne, braune bis schwarze, der Länge nach durchbohrte Zylinder, die in der Mitte einen weiben Ring haben müssen. In der Mitte der sechzigger Jabre wurde daron für viele liundertausend Taler nach dem Sudan verkauft, und manche Firmen haben daron für 40)(1)0 Taler exportiert. In jener Zeit hat die Idar-Obersteiner Industrie fast nur diesen Artikel fabriziert, später hat aber die Nachfrage immer mehr abgenommen, nachdem 1561 ; der Höhepunkt ïberschritten war. Indessen spielen doch auch heutzutage noch diese sudanartikel eine gewisse Rolle. Es sind die gemannten Oliven, in der Mitte etwas auscebaucht, und die Halboliven mit einem etwas diinneren weifen und einem dickeren schwarzen Ende, entsprechend einer in der Mitte durebgeschnittenen Olive; ferner Wal\%en, cylindrisch, dicker als lang, etwa 1 Zentimeter dick und ea. 1.2 Centimeter lang, endlich II ütchen (Zündhütchen). im Gegensatz zu den Walzen lïnger als dick, etwa 1 his 
$1_{1}^{1} .2$ Zentimeter lang und 1.2 Zentimeter dick, und ebenfalls cylindrisch, braun oder schwarz, in der Mitte mit cinem weiben Ring und der Länge nach durchbohrt. Rote, anch gelbe und griine Amulette usw ron den verschiedensten Formen gehen nach Westafrika. Ausschließlich weiße Artikel dieser Art werden für die Nordküste von Afrika fabriziert.

Die Arbeiten, die am Achat behufs Herstellung der genannten Gegenstände, deren Zahl sich noch vermehren ließe, ausgeführt werden müssen, sind von verschiedener Art. Lis ist das Schleifen, das Bohren, das Gravieren und dann das Färben der Steine. Die Industrie, die sich damit befaßt, ist eine echt deutsche. Sie hat ihre Stätte in Waldkirch in Schwarzwalde, wo aber weniger Achat als andere Edelsteine und Halbedelsteine aller Art geschliffen werden, vorzugsweise aber in dem melrfach schon genannten 0 berstein

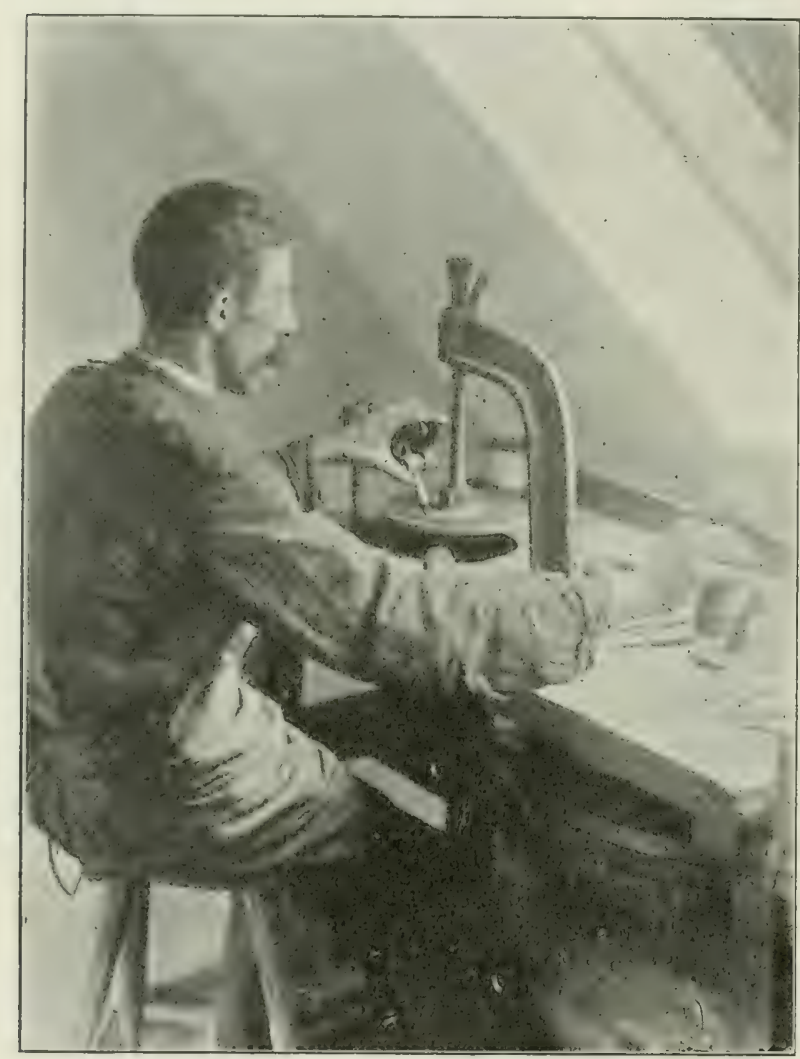

Irigr. 105. Moderner Edelsteinschleifer (Lapidiir), Itar. an der Nahe mit dem benachbarten Idar und einer Reihe umliegender Ortschaften (Herrstein, Obertiefenbach bis Allenbach, Enzweiler usw.). Hier spielt der Achat mit den anderen Chalcedonen und den Quarzarten die Hauptrolle, wenngleich auch hier andere Steine (Malachit, Lasurstein usw., und neuerer Zeit sogar alle feinen Edelsteine, einschließlich des Diamants) geschliffen werden. Am wichtigsten von allen bleibt aber immer der Achat. Von hier aus wird die ganze Welt mit Achatwaren versehen, die allerdings an zablreichen Orten, an denen sie zum Verkauf kommen, in Bädern, Touristenorten usw., als einheimische Produkte ausgegeben werden. Die Gegend von Oberstein hat jahrhundertelang die Pflege und Entwicklung dieses Geschäftszweiges, die Achatschleiferei, derart für sich monopolisiert, daß kaum andere Orte mit ihr erheblich konkurrieren können, auch die oben erwähnten indischen nicht. Wo man auf der ganzen Welt einen geschliffenen Achat sieht, spricht die Wahrscheinlichkeit dafuir, daß er in der Obersteiner Gegend bearbeitet worden ist. Die Steine werden dort nicht nur geschliffen, gebohrt, graviert und gefärbt, sondern zum Teil auch, wenn erforderlich, gefaßt, meist in vergoldetes Messing. Dieser letztere Industriezweig wurde am Anfange des 18. Jahrhunderts cingefülıt, doch werden noch jetzt neun Zehntel aller geschliffenen Steine ungefaßt an auswärtige Juweliere verkauft. Die dortigen Arbeiter haben sich durch weitgehende Arbeitsteilung bei der Bearbeitung und dem Fassen der Steine eine derartige Geschicklichkeit in ihrer speziellen Tätigkeit erworben, dab die Obersteiner und Idarer AchatWaren in solcher Tollkommenheit der Ausführung und zugleich zu solch niederen Preisen hexpestellt werden können wie sonst nirgends. Wir werden daher im folgenden diese cifenartige Inclustrie etwas näher betrachten, auch die bisherigen Bemerkungen über 
die Verarbeitung des Achats beziehen sich wesentlich auf die Verhältnisse von Idar und Oberstein.

Die dortige Achatindustrie entstand durch die demals in grofere Menge und Schïnheit in jener fegend efefundenen rohen Steine. Die frïheste urkundliche Erwälnung stammt ron 1497, die tichleiferei ist aber jedenfalls noch älter. Sie kam nach wechselvollen Schicksalen im Laufe der Jahrhunderte allmïhlich in V'erfall, da seit dem Beginn des 19. Tahrhunderts das einheimische Rohmaterial sich immer mehr ersehïpfte und daher die Nachfrage nicht mehr befriedigt worden konnte. Gleichzeitig fanden vorübergehend ron $1824 \mathrm{ab}$ billige und schöne Edelsteinmitationen durch die feinen bühmischen Glasflïsse wroben Absatz, die in dieser Zeit den ächten Steinen erhebliche Konkurrenz machten. Da

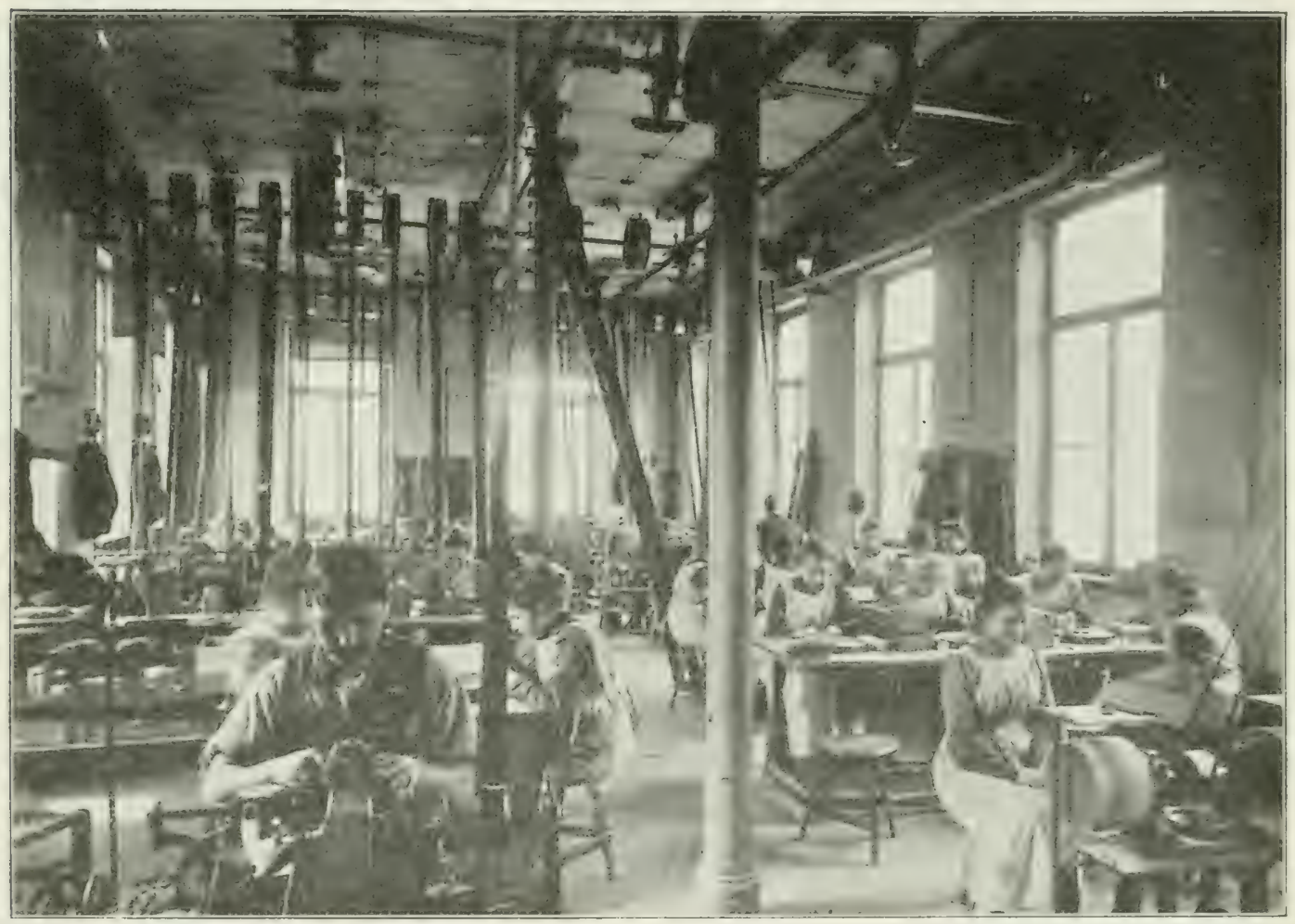

Fig. 106. Innere Ansicht einer modernen Edelsteinschleiferei in Idar.

kam Rettung durch auslïndisches Material, zuerst durch den englischen Puddingstein, sog. Schottländer, ein aus nufgrofen verschiedenfarbigen Geröllen ron Feuerstein etc. bestehendes festes Konglomerat, das damals zu Dosen und anderen Galanteriewaren viel verarbeitet wurde, besonders aber durch die um dieselbe Zeit über London eingefülırten indischen Karneole. Teue Blïte brachte jedoch erst die Auffindung der brasilianischen Achate, Imethyste usw. im Jahre 1 $\$ 27$, die noch durch das kurz vorher erfolgte Bekanntwerden der auf die neu entdeckten Achate besonders rorteilhaft anwendbaren Fürbungsmethoden wesentlich erhüht wurde. Es wird gegenwärtig kaum noch einheimisches Naterial dort geschliffen, sondern überwiegend brasilianisches und indisches. Überhaupt werden schleifbare Steine iiberall hergeloolt, wo sie sich finden, und zwar nicht nur Achat und Chalcedon in seinen rerschiedenen Abarten, sondern auch Amethyst, Citrin, Bergkristall und neuerdings auch alle möglichen anderen Edelsteine, sogar Diamant, namentlich sind auch noch seit 1597 die australischen 
Opale und Sapplire wichtig geworden. Oberstein-Idar ist jetzt für alle Edelsteine mit Ausnalıme des Diamants ciner der wichtigsten Märkte. Es existieren dort Händler, die das Rohmaterial in Massen in den Lrsprungsländern persönlich einkaufen und es dann in einzelnen Partien an die Schleifer reräußern. Dies geschieht, einer alten Gewohnheit gemäß, vorwiegend in üfentlichen Auktionen, die von Zeit zu Zeit in Idar oder sonst in der Gegend veranstaltet werken. 1590 betrug der Wert der so verkauften rohen Steine 230900 Mk., doch wechselt diese Zahl stark; 1819 waren es 22800 , 1873 dagegen $640000 \mathrm{Mk}$, der höchste und niedrigste Trert zwischen 1S4S und 1890. In den Tahren 1906 bis 1907 betrug der Umsatz

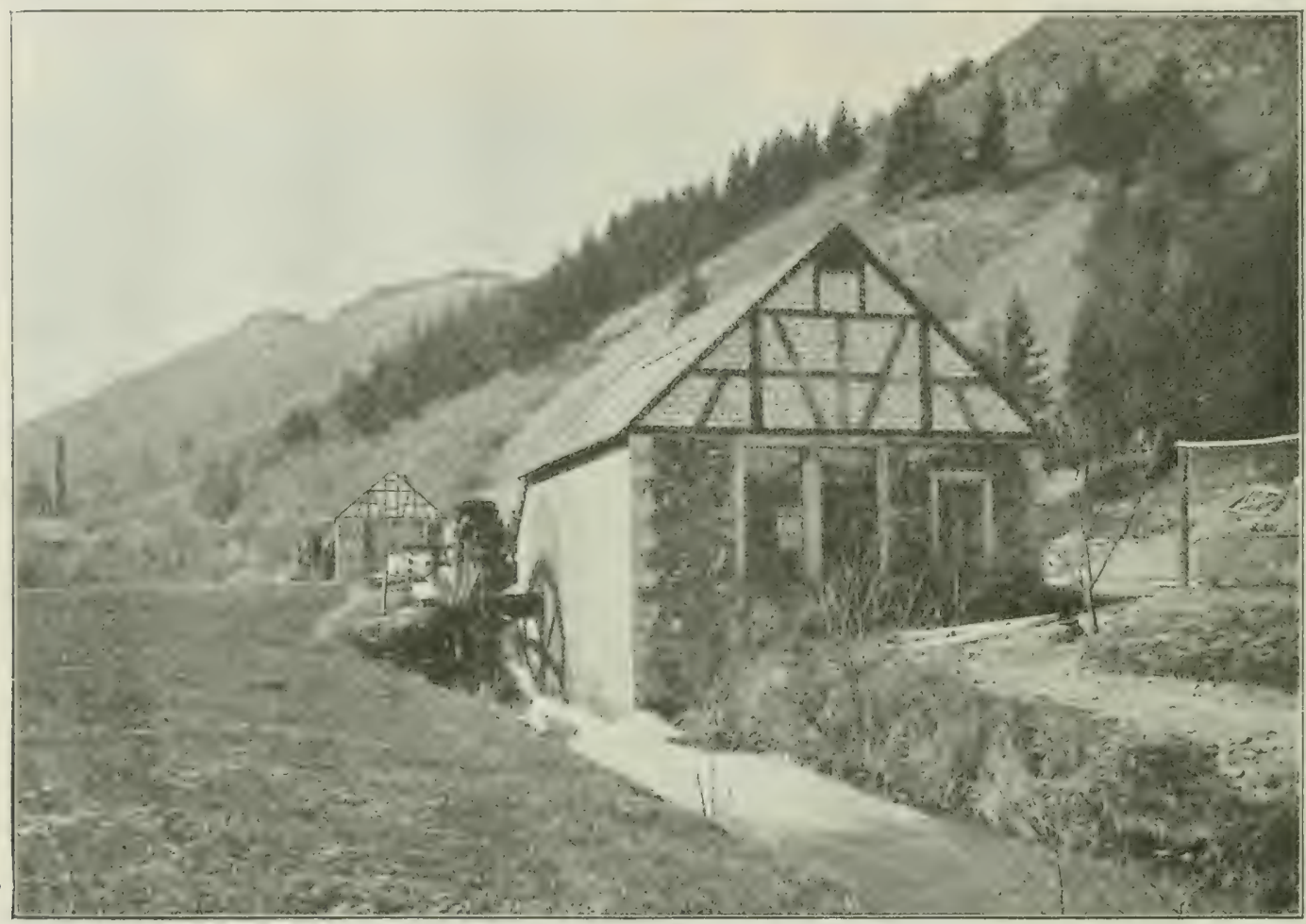

Fig. 107. Äußere Ansicht einer alten Achatschleife im Idartal.

in Idar bis ungeführ 1200000 bis 1500000 Mark im Jahr. Für Achate, Amethyste und Citrine war der Wert der auf Auktionen verkauften Ware:

$$
\begin{aligned}
& \text { 1906: } 840018 \text { Mark } \\
& \text { 1907: } 758095 " \\
& \text { 1908: } 415770 "
\end{aligned}
$$

IIiezu kommt der Wert der freihändig verkauften Steine, der schätzungsweise unsefälı die II:älfte der angegebenen Zahlen beträgt, sodaß die Gesamtsumme, die in brasilianischen Steinen in Idar umgesetzt wurde, sich ungefähr belaufen würde:

$$
\begin{aligned}
& 1906 \text { auf } 1300000 \text { Mark } \\
& 1907 \text { " } 1150000 \quad " \\
& 1908 \text { " } 630000 "
\end{aligned}
$$

Hie starken Schwankungen beziehen sich in der Iauptsache auf Citrin und Amethyst.

J)ie Werkstitten, in denen die Terarbeitung des Achats und der anderen genannten Steine stattfindet, sind zum Teil in neuerer Zeit vollkommen modern und mit allen 
Maschinen und Apparaten dor Gerenwart, mit horizontal sich drehenden metallenen Schleifscheiben und mit anderen derartiren Gerïtschaften ausgestattet. Der Betrieb geschieht mit L)ampf, Gas und Elektrizitait, und die ganze Einrichtung ist von riner anderen modernen Edelsteinschleiferei im Wesen nicht rerschieden. Von der Linführuner dieser neuzeitlichen Einrichtung, zu Anfang der siebenziger Jahre des 19. Jahrhunderts, stammt der stets steigende Aufschwung der Oberstein-Idarer Industrie. Die Schleifer, die mit IIilfe dieser neuen Maschinen auch feine Edelsteine zu bearbeiten verstelen, werden im Ceerensatz zu den anderen Lapidïre renannt. Ein soleher ist in Fir. 10.) S. 13.36 mit seiner Maschine, (ine moderne Edelsteinschleiferei in Idar in Fig. $106 \mathrm{~S} .637$ abgebildet (vgl. auch S. 101).

ther nehen diesen noch nicht lange existierenden Finrichtungen der Gegenwart sind auch die seit alten Zeiten grehrauchten und allnïhlich immer mehr verbesserten Schleif-

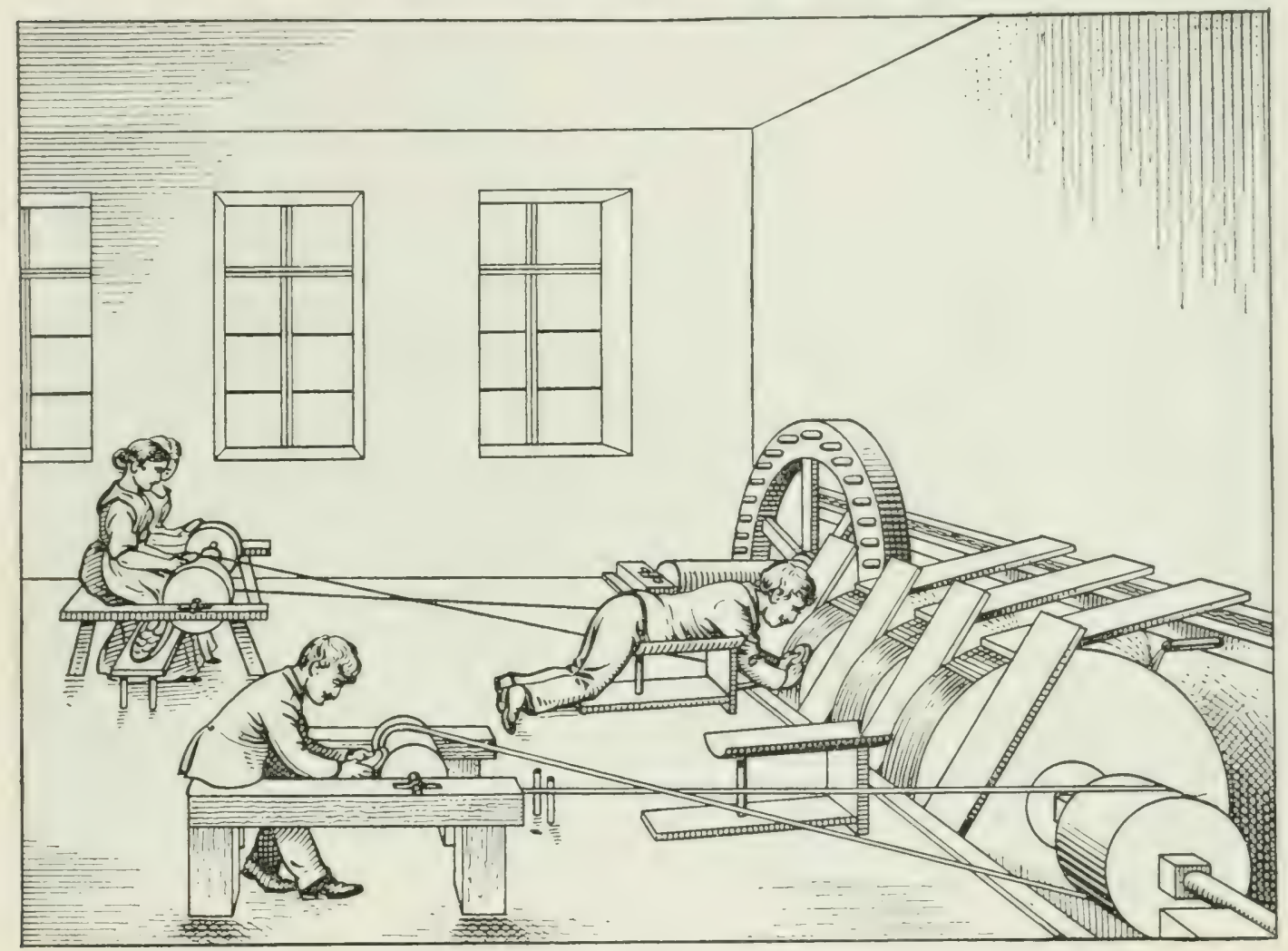

Fig. 108. Achatschleiferei in Oberstein.

mühlen (kurz Schleifen genannt) noch im Gange. Sie werden durch Wasser betrieben. An dem bei Oberstein in die Nahe mündenden Idarbache, an dem das St:idtchen Idar liegt, folgt eine solche Mühle auf die andere, auch sonst finden sie sich an anderen benachbarten Bächen, besonders an dem Fischbach und Vollmersbach, so daf ungefäbr 100 solcher älterer Schleifereien in jener Gegend vorhanden sind. In ihnen wird vormiegend die eigentliche Achatschleiferei rorgenommen. Das Bohren und Gravieren wird von anderen Arbeitern in besonderen Werkstätten besorgt.

Eine solche Schleifmiihle am Idarbach ist in Fig. 1117 yon außen, Fig. 10 s von innen abgebildet. Drei bis fünf, in der Abbildung drei, Schleifsteine aus Sandstein sitzen auf einer horizontalen Welle, die durch ein Wasserrad in Bewegung gesetzt wird. Der größte dieser Steine hat 1,70 Meter Durchmesser; in jeder Sekunde werden drei Um- 
drehungen ausgreführt. Die Steine sind an den beiden Rändern mit Hohl- und Rundlehlen rersehen, mittels deren den zu schleifenden Steinen mit Leichtigkeit gewisse Formen gegeben werden künnen. Die obige Abbildung gibt mehr schematisch die Einrichtung einer Schleifmiihle. Eine solche, wie sie wirklich aussieht, und zwar die von $\Lambda \mathrm{ug}$. Wintermantel in Waldkirch, ist in Fig. 109 nach einer Photographie abgebildet.

Tachdem die Achate usiv. durch Zuhauen mit Hammer und Meißel, oder bei wertvolleren Stiicken durch Zersägen mittels einer mit Schmirgel bestrichenen oder neuerer Zeit auch mit Dianıanten besetzten Metallscheibe (Fig. 110) ihre Form im Rohen erhalten haben, werden sie geschliffen, indem sie der Arbeiter mit Gewalt gegen die zylindrische Stirnfläche des durch einen Wasserstrahl stets naß gehaltenen, rotierenden Schleifsteins oder gregen die an diesem angebrachten Iohlkehlen drückt. Dies geschieht, indem er sich mit dem Leib

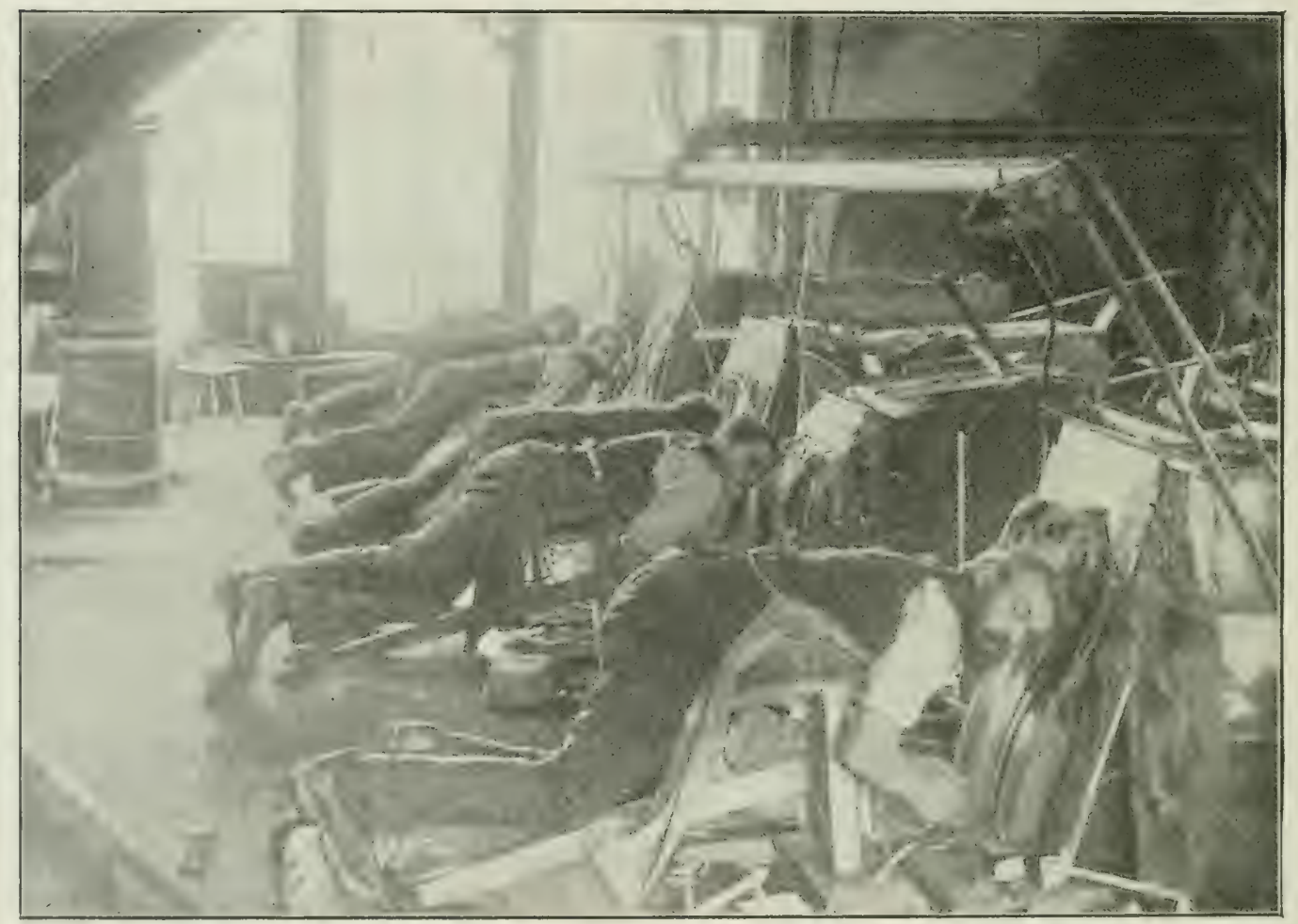

Fig. 109. Achatschleiferei von Aug. Wintermantel in Waldkirch (Baden).

in ein trogfürmig ausgehöhltes, vor dem Schleifstein stehendes Brutt, den Küraß, legt, und die Beine gexen dahinter auf dem Boden befestigte Stiitzen stemmt. Das zu schleifende Stïck wird mit den Iäinden auf dem Sehleifstein hin- und hergedreht, bis es die gewiinschte Form hat. Tor jedem der etwa einen Fulb breiten Schleifsteine können, wenn es nötig ist, mleichzeitig zwei Arbeiter tïtig sein, einer an der rechten, der andere an der linken Kante. Dahei sieht man, daß die Achate eine schr sehöne Phosphoreszenzerscheinung zeigen, indem sic beim Reiben an dem Sandstein ein lebhaftes rötlichweibes Licht ausstrahlen.

Das Vertieftschleifen oder Aushöhlen (Iohlmachen oder Auskolben) von Schalen und Tasen usw. geschicht stets von stehenden Arbeitern, den $\mathrm{Hoh}$ l ma che rn, an kleinen Schleifsteinen. und auch für andere $\Lambda$ rbeiten sind noch die entsprechenden Vorrichtungen vorhanden.

Zum Polieren ist eine besondere Maschine bestimmt, an der die geschliffenen Steine vollends marktfertig semacht werden. Sie erhalten dadurch einen sehr hohen Grad von 
Clanz. Die Poliermaschine besteht aus einem Zylinder aus hartem Holz, oder aus einer J Blei- oder Zinnscheibe. I)as Poliermittel ist Tripel, der in feuchtem Zustande aufgetragen wirl. Die Arbeit selber ist so leicht, dab sie von Kindern besorgt werden kann. Arbeiter und Arbeiterinnen, die das Polieren besorgen, sind auf Fig. 1115 links in sitzender Stellung abgebildet.

Die zu gewissen Zwecken bestinmten Steine müssen nach dem Schleifen noch durchhohrt werden. Das Bohren (Fig. 111 ) geschieht mittels rasch sich drehender Stahlspitzen oder Rü̈ıren, die mit Schmirgel- oder Diamantpulver versehen werden oder an deren Ende ein feiner Diamantsplitter sitzt (S. 104) ist. Der Bohrer macht so u. a. anch ganze Ringe aus Achat.

Sehr wichtig ist die Verwendung des Achats zum Gravieren (Fig. 112, vgl. auch pag. 106). Schon die alten Römer benutzten dieses Mineral zu solchen Zwecken; sie trieben mit geschnittenen Steinen aller Art, namentlich mit geschnittenem Achat (Onyx), einen sehr großen Luxus. Wenn dies auch heutzutage nirgends mehr geschieht, so ist doch eine derartige Benutzung mancher Achatsorten auch gegenwärtig noch immerhin von einer gewissen Bedeutung (S. 104).

Die zum Gravieren, zur Herstellung von Intaglien und Kameen besonders gerne, aber doch nicht etwa ausschließlich verwendeten Achatvarietäten sind die verschiedenen Onyxe, der eigentliche Onyx, der Chalcedonyx, Karneolonyx und Sardonyx. Sie dienen dazu, eine weiße oder doch helle Figur auf dunklem oder farbigem Hintergrunde hervortreten zu lassen. Der Onyx ist um so besser, je ebener und regelmäßiger die einzelnen Lagen sind (Tafel XX, Fig. 5 ${ }^{a, b}$ ), deswegen sind die brasilianischen Achate mit

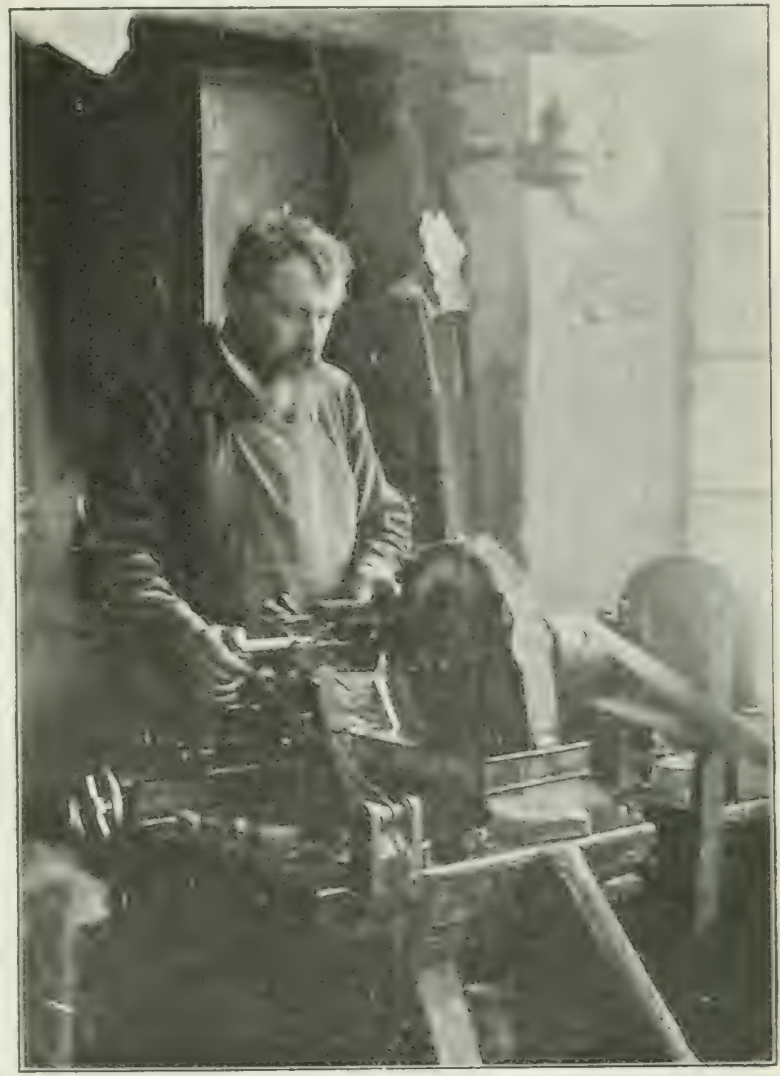

Fig. 110. Zerschneiden von Edelsteinen. ibren ebenen Schichten (Taf. XIX, Figr. l, zu Onyzsteinen vorzugsweise geeignet und daher auch besonders wertroll. Die zum Gravieren bestimmten Steine werden aus den ebengeschichteten Teilen dieser Achate in Form ron ausgedehnten Platten so herausgeschnitten, daß die Plattenflächen der Schichtung parallel gehen, und daf die Platte in ihrer wanzen Erstrecknng aus einer weißen und aus einer farbigen Lage besteht. Das Gravieren wird dann so aus. geführt, daf auf einer schwarzen, roten oder sonst gefärbten Unterlage als Hintergrund sich die aus der weißen Lage herausgeschnittene Figur, meist ein menschliches Bildnis, erhebt, wie es bei der in Fig. 7, Taf. XX, dargestellten Kamee aus Karneolonyx und in den Textfigruren 114 und 115 (S. 6-4) der Fall ist: oder dab durch die schwarze Schicht hindurch gegraben und aus der darunter liegenden weifien die Figur herat:searbeitet wird, wie bei der Intaglie, Fig. 113. Auch hier stellt sich dann die Figur hell auf dunklem Hintergrunde 
dar. Ein Siegelstein aus Karneol mit einem eingravierten Buchstaben ist Taf. XX, Fig. 6, dargestellt. Besonders geschätzt ist es bei der Anfertigung von Kameen, wenn die weiße Schicht ron tiner weiteren, wenn auch nicht über die ganze Platte ausgedehnten roten Lagre bedeclit wird, aus der man dann die Haare, Teile der Gewandung usw. schneiden kann. Die antike sog. Ptolomäerkamee ist aus einem Stein mit neun Lagen geschnitten unter geschickter Benützung der verschiedenen Farben der einzelnen. Die Arbeit geschieht mit IIilfe der sogenannten Zeiger, wie wir dies schon im früheren gesehen haben. Die Ilauptsitze der Herstellung gravierter Achate sind gegenwärtig in Paris und besonders in Italien, aber die dazu bestimmten Onyxplatten werden in Idar hergestellt. Indessen werden in Italien die echten Onyxplatten vielfach durch anderes Material ersetzt; so werden viele

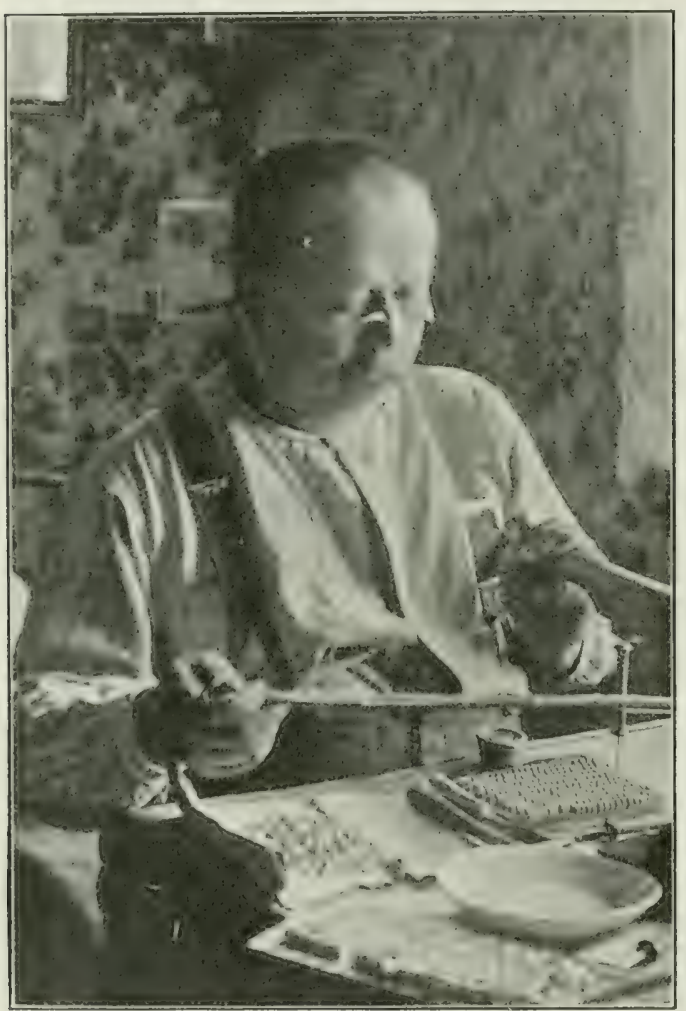

Fig. 111. Edelsteinbohrer. Kameen aus den dicken Schalen gewisser großer Meeresschnecken geschnitten, die wie der Karneolonyx aus roten und weißen Lagen bestehen und die sich ihrer weit geringeren Härte wegen viel leichter bearbeiten lassen als der echte Stein. (sog. Muschelkameen). Seit 1870 blüht die Kunst des Gravierens auch in der ObersteinerGegend, wohin sie durch im Krieg aus Paris vertriebene Arbeiter verpflanzt wurde.

Übrigens werden nicht blob in ebene Platten Figuren geschnitten, wie bei den Kameen. Aus älterer Zeit sind uns einige aus Onyx dargestellte Gefäße überliefert, bei denen die Lagen so gehen, daß auf der durch den Gefäßkörper gebildeten Unterlage von der einen Farbe Figuren und Bilder von der anderen Farbe des Steines sich in erhabener Arbeit abheben. Hierher gehört unter anderem die berühmte Onyxvase, die in den Sammlungen in Braunschweig aufbewahrt wird.

Von allergrößter Wichtigkeit für die Obersteiner Achatindustrie ist die Färbung der Steine, des Achats sowohl als des Chalcedons, namentlich seitdem das Rohmaterial vorzugsweise aus Brasilien kommt. Die meist im natïrlichen Zustande ganz unansehnlichen, licht graulich gefärbten Achate von hier wären zum Schleifen gar nicht geeignet gewesen, wenn nicht, wenige Jahre vor ihrer Entleckung, eine Methode bekannt geworden wäre, ihnen künstlich eine schöne Fürbung mitzuteilen. Zuerst lernte man die Steine schwarz zu färben. Ein Idarer Achathändler soll diese Kunst von einem seiner römischen Kollegen, die alljährlich nach Oberstein und Idar kommen, um Onyxsteine zu kaufen, erfahren haben. Seitdem ist das in liom seit langer Zeit bekannte Verfahren in der Nahegegend in großem Maßstab ausgeübt und vielfach weiter entwickelt und ausgebildet worden. Lange Zeit war nur das Schwarzliirlen lekannt, späiter lernte man aber auch braune, gelbe, blaue und grine Farben an den steinen anzulbringen; das Rotfärben wurde schon beim Karneol erwähnt.

Die Jïglichleit der Fïrloung beruht auf der Porosität, die nicht nur den Achaten, sundern auch allen anderen Chalcedonen ,zukommt und diese befïhigt, farbige Flüssig- 
keiten in sich aufzunehmen. Allerdings ist dies nicht bei allen Stïcken in gleichem Maße der Fall und auch nicht bei allen Schichten eines und desselben Stückes. Manche sind sehr porüs, saugen daher die Farbstoffe leicht und in grober Menge auf und fürben sich dadurch intensiv. Die Farbstoffe dringen, wenn die Steine nur lange genugr in den färbenden Flüssigkeiten liegren, bis ins Innerste der der Färbung zugänglichen Teile hinein, die Färbung ist also nicht blol oberflïchlich, sondern sie geht durch und durch. Dabei hat man die Erfahrung gemacht, daß das Aufsaugen der Fliissigkeiten stets in radialer Richtung, senkrecht zu den Streifen, viel rascher erfolgt als in der Richtung der Streifen selbèr, was mit der radialen Ausdehnung und Anordnung der Poren zusammenhängt, die wir oben kennen gelernt haben. Andere Stücke oder Streifen in solchen sind gar nicht oder doch weniger porös, nehmen keine oder doch schwierig Farbstoffe auf und dann nur in geringer Menge und oft erst nach langer Zeit, ihre Färbung ist daher nur unbedentend. Chalcedon der ersteren Art nennen die Steinschleifer weich, solchen von der anderen hart. Durch bloßes Ansehen kann man diesen Unterschied nicht immer erkennen, doch erweisen sich die harten Chalcedone unter dem Mikroskop als besonders feinfaserig, während die weicheren erheblich gröbere Fasern zeigen, und damit hängt wohl der höhere oder geringere Grad von Porosität zusammen. Niemals zu färben sind die milchweißen, trüben Streifen, die nicht selten mit den stets besser durchscheinenden, färbbaren grauen usw.

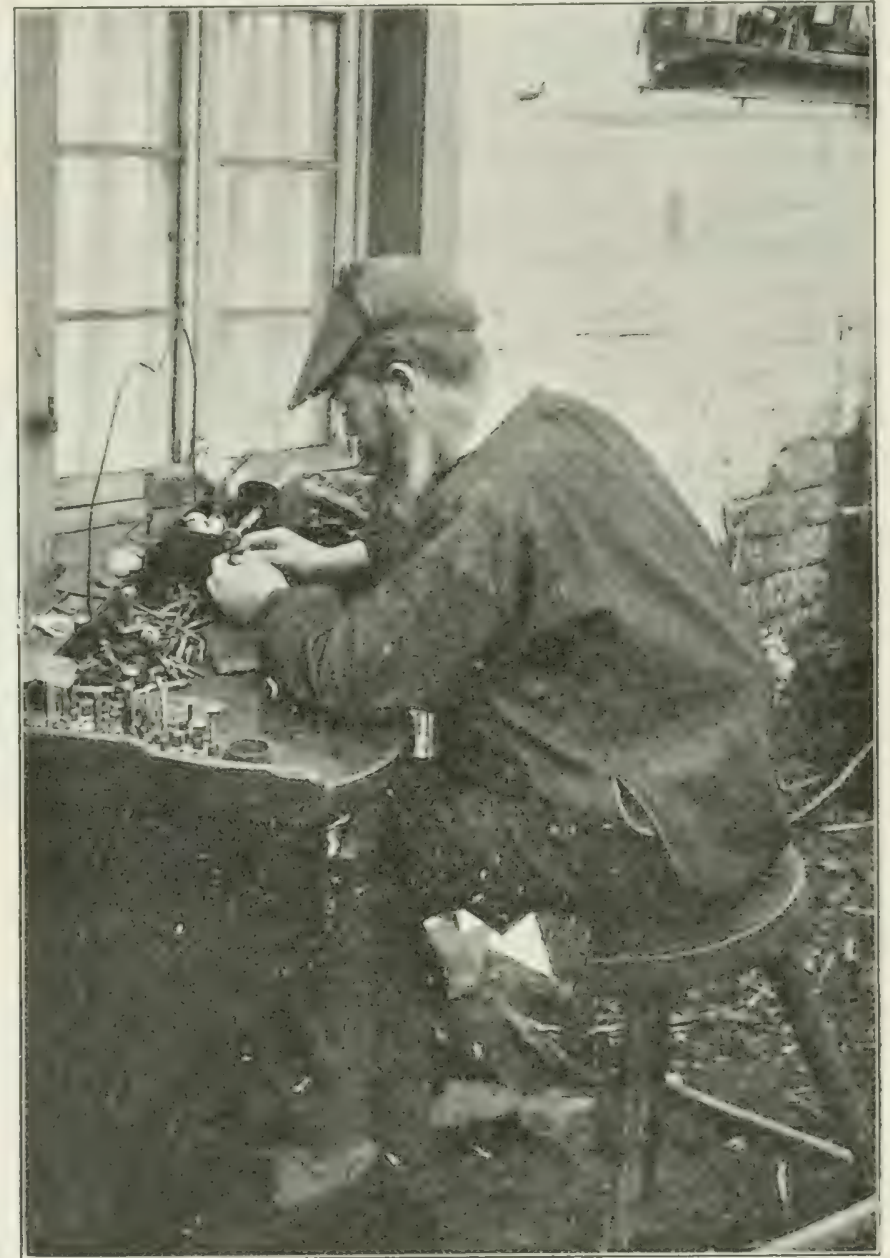

Fig. 112. Edelsteingraveure. abwechseln. Sie sind gar nicht porös und können daher Farbstoff überhaupt nicht aufnehmen. Unter dem Mikroskope erweisen sie sich als besonders reich an beigemengtem Opal. Die Obersteiner Achate sind im allgeneinen in dem obigen Sinne härter als die siidamerikanischen, die sich meist zum Färben ganz besonders gut eignen, wenngleich auch bei ihnen Lnterschiede vorbanden sind. Tamentlich sind durebgängig die äuberen Teile der Mandeln, die Iaut, schwerer zu färben als die inneren. Solcher Chalcedon, der in sich sehr gleichmälig beschaffen, ungestreift und dabei geniigend porös ist, um Farbstoff aufunehmen, wird in Idar und Oberstein Massikstein Coder Serra-Massik, nach dem Vorlsommen in der Serra do Mar) genannt, während der aus abwechselnd porösen und nicht porösen Sehichten 
zusammengesetzte Chalcedon Serra-Stein (auch streifiger Stein) heißt. Letzterer wird durch die Färhung deutlich gebändert, während sich jener gleichmäßig färbt; im natürlichen Zustand sind sie meist beide ziemlich einheitlich grau.

Die Methode der Färbung ist danach im allgemeinen einfach, doch sind in der Praxis vielerlei Dinge dabei zu berücksichtigen, wenn die Sache gut gelingen soll. Daher sind es immer nur wenige, die auf diesem Gebiete besonderes leisten. Vor allem gehört eine genaue Kenntnis der Steine dazu. Jedenfalls sind die Vorgänge bei der Färbung noch lange nicht vollständig im einzelnen aufgeklärt. Es kommt vor, daß sich aus einer ganzen Masse von Steinen bei derselben Operation nur einige wenige gut färben, trotzdem daß sie sich anscheinend alle ohne Ausnahme ganz gleich dazu eigneten, und manchmal erhalten einzelne Steine in derselben Beize z. B. eine grüne, andere eine blaue Farbe, olne daß ein Grund dafür bemerkbar wäre. Vielfach ist das Verfahren auch noch Geheimnis gewisser Personen, die dasselbe ängstlich hüten, wie auch schon das am frühesten bekannte Schwarzfärben erst allmählich allgemein zugänglich und Gemeingut aller geworden ist.

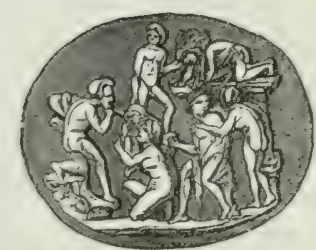

Fig. 113. Antike Intaglie.

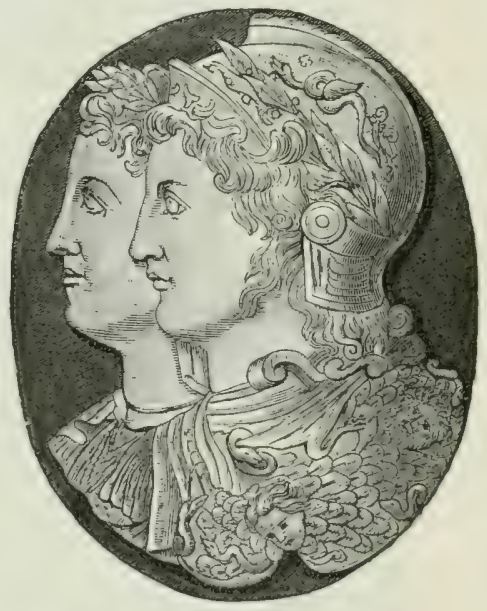

Fig. 114. Antike Kamee.

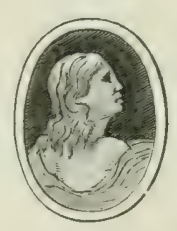

Fig. 115. Antike Kamee.

Das Schwarzfärben wurde 1519 in Oberstein bekannt. Das Verfahren, wie es sich seitdem ganz allgemein entwickelt hat, ist das folgende: Die sauber gewaschenen Steine werden in der Kälte getrocknet und in eine wässerige Honig- oder Zuckerlösung gelegt, die sich in einem ganz reinen neuen Topf befindet. Dieser wird mit dem darin befindlichen Achat 2 bis 3 Wochen erhitzt, aber nicht bis zum Sieden. Dabei ist darauf zu sehen, daß die Steine immer mit der Flüssigkeit bedeckt sind, die daher stets nachgegossen werden mul. Hierauf werden sie herausgenommen, abgewaschen, in einen anderen Topf mit käuflicher Schwefelsäure (Vitriolöl) gebracht und mit dieser ebenfalls erwïrmt. Die vom Stein aufgesogene Schwefelsäure zersetzt den mittels der zuerst angewandten Flüssigkeit hineingebrachten Zucker oder Honig und scheidet daraus Kohlenstoff ab, der die Fürbung hervorbringt. Die weicheren Stiicke sind oft bereits wenige Stunden, nachdem sie in die Schwefelsäure gelegt worden sind, tief und schön schwarz, andere brauchen länger; einen Tag oder auch mehrere und manche nehmen sogar nach geraumer Zeit nur eine schwache Färbung an. Nachdem die Farbe die höchste mögliche Intensität erreicht but, werden die Steine aus der Flüssigkeit herausgenommen, auf dem Ofen scharf getrocknet, solamn geschliffen und poliert und endlich mit öl eingerieben oder auch einen Tag in Öl gelegrt und das ülrige nicht aufgesaugte Öl mit Kleie entfernt. Das Öl verdeckt kleine Risse und verbessert den Glanz. 
Auf diese Weise entstehen die schön schwarzen Achate, die im Handel vorkommen und von denen so gut wie keiner natïrlich ist, ebenso aber auch die Onyxe (Taf. XX, Figr. $5^{\mathrm{a}} \mathrm{b}$ ), bei denen die schwarzen, ursprünglich graulichen oder bläulichen schichten mit den nicht gefärbten weilien, den sogenannten Onyxstreifen, die den Steinen den eigentlichen Wert geben, abwechseln. Aber nur stark porise Steine oder Schichten werden tief sammetschwarz, weniger poröse nur dunkler oder heller braun je nach dem Grade der Porositït. Auch die ursprïngliche Farbe der gefärbten Schichten ist dabei von Einfluß; eine ursprünglich rote Lage hat auch nach der Färbung noch einen roten Schein usw. Wie wichtigr die Möglichkeit, Farben anzunehmen, bei den Achaten ist. sieht man daraus. daß der P'reis eines Zentners von 100 bis $50(00)$ Mark schwanken kann, je nachdem sich die Steine mehr oder weniger schön schwarz färhen. Es ist daher vielfach Brauch, vor dem Ankauf Probefürbungen kleiner Splitter vorzunebmen. um die Qualitït des betreffenden Materiales sicher festzustellen.

Neben der schwarzen spielen die übrigen künstlichen Farben der Achate eine verhältnismäßig geringe Rolle. Einige von ihnen sollen hier noch kurz erwähnt werden.

Ein schönes Zitronengelb, wie es als natürliche Farbe niemals vorkommt, läft sich auf künstlichem Wege herstellen, indem man gut getrocknete Achate in einen Topf mit Salzsïure legt und unter den Ofen schwach erwärmt. In 14 Tagen ist die Färbung vollendet.

Blau, und zwar vom schönsten tiefen Indigo und Lasur bis zum zarten Himmelblau, wie es gleichfalls die Natur in den Achaten nicht darbietet, erhält man, indem man die Steine zuerst mit gelbem Blutlaugensalz imprägniert und hierauf in einer passenden Eisenlösung kocht. Beicle setzen sich im Innern des Steines zu Berliner Blau um, das diesem seine Fürbung mitteilt. Es gibt aber für die Blaufärbung auch noch andere Mittel. Der blassrötliche Jaspis von Nunkirchen, Kreis Merzig, gibt, in derselben Weise grefürbt, den trüben lasursteinähnlichen „deutschen oder falschen Lapis“. Er unterscheidet sich aber doch immer in der Nuance von dem echten Lasursteine und wird daran, sowie an der erheblich größeren Härte leicht erkannt.

$\mathrm{Zu} \mathrm{Grün} \mathrm{benutzt} \mathrm{man} \mathrm{eine} \mathrm{Chromsäure} \mathrm{enthaltende} \mathrm{Lösung,} \mathrm{z.} \mathrm{B.} \mathrm{eine} \mathrm{durch} \mathrm{Erwärmen}$ grün gewordene Lösung von Chromalaun; nach der Imprägnation mul der Stein einer starken Hitze ausgesetzt werden. Auf diese Weise entsteht der dem Chrysopras ähnliche Chalcedon, der schon oben erwähnte künstliche Chrysopras.

Eine rotbra une Farbe wird beim Achat in derselben Weise wie beim Karneol erhalten, indem man ihn mit Eisenritriol imprägniert und hierauf glüht. Daß kïnstlich braun gefärbte Achate vorkommen, haben wir bei der Betrachtung des Sarders gesehen; sie sollen dabei mit einer Lösung von braunem Kandiszucker imprägniert und dann gebrannt werden.

Ein hübsches Rosa kann durch eine Anilinfarbe hervorgerufen werden. Mit Hilfe derartiger Pigmente lassen sich alle möglichen Färbungen herstellen, die dann aber wohl teilweise nicht sehr haltbar sein werden.

Auch durch bloßes Erbitzen, durch Brennen, werden manche Achate schon günstig verändert; die lichtbläuliche oder grauliche Farbe wird dabei zuweilen milchweiB und Gelb und Braun geht in ein schönes Rot über. Manche graue Chalcedone können durch Behandeln mit Kalilauge milchweiß gemacht werden.

Die Verarbeitung des Achats und der anderen verwandten Mineralien ist aber natürlich nicht ausschließlich auf Oberstein.Idar und Waldkirch beschränkt, sondern findet auch anderwärts, wenngleich in sehr viel geringerem Umfang, statt. Erwähnt sei hier nur, daß in Japan entzückende Tiere und andere Sachen aus Achat hergestellt werden, bei denen die Zufälligkeiten (Färbung usw.) des Materials in sehr geschickter Weise zur Verwendung kommen. Dasselbe geschieht jetzt auch in Oberstein. 


\section{Malachit.}

Dor Malachit ist ein Mineral, das wegen seiner prachtvollen grünen Farbe als Schmuclsstein rerwendet wird, trotzdem daß er nach seinen ïbrigen Eigenschaften hierzu wenig geeignet erscheint.

$\mathrm{Er}$ ist ein wasserbaltiges Karbonat des Kupfers von der Formel: $\mathrm{H}_{2} \mathrm{O} .2 \mathrm{Cu} \mathrm{O} \cdot \mathrm{CO}_{2}$, das im reinsten Zustande aus 71,95 Proz. Kupferoxyd, 19,90 Proz. Kohlensäure und 8.15 Proz. Wasser besteht. Das letztere kann durch Erhitzen leicht vertrieben werden, wobei die grüne Farbe einer schwarzen Platz macht. Die Kohiensäure entweicht unter Aufbrausen, wenn man ein Stückchen in Salzsäure wirft oder wenn man einen Tropfen Salzsïure darauffallen läßt; man kann dadurch leicht den Malachit im rohen Zustande von anderen ähnlichen grünen Mineralien unterscheiden. Wird ein größeres Stückchen ganz in Salzsäure aufgelöst, so erbält man eine grüne Flüssigkeit, von der ein Tropfen einer Spiritus- oder farblosen Gasflamme eine prachtvolle blaue Färbung mitteilt.

Zuweilen ist der Malachit deutlich auskristallisiert und bildet dann meist kleine Nädelchen, die dem monoklinen Kristallsysteme angehören. Solche einzelne Kriställchen sind aber selten; meistens findet man derbe Massen von größerem oder geringerem Umfange, die durch ihre radialfaserige Beschaffenheit ihre kristallinische Struktur noch erkennen lassen, die aber auch vielfach vollkommen dicht, scheinbar unkristallinisch und sogar häufig ganz erdig sind.

In seiner schönsten Ausbildung, wie er zur Verarbeitung als Schmuckstein ausschließlich benutzt wird, hat der Malachit die Form von Knollen, oft von sehr erheblicher Größe, die außen vielfach eine rundliche, nierenförmige, traubige oder zapfenförmige Oberfläche und stets im Inneren eine schalige und faserige Bildung zeigen. Die äußere rundliche Fläche ist oft schwarz und matt. Auf Bruchflächen in der Richtung der Faserung ist der infolge der Faserbildung etwas seidenartige Glanz ebenfalls gering, hier tritt nun aber stets die schöne grüne Farbe hervor. Diese ist indessen nicht über die ganze Fläche weg dieselbe, sondern es wechseln dunklere und hellere Lagen von geringer Dicke, die in der Richtung der rundlichen Oberfläche verlaufen, vielfach miteinander $a b$, in ähnlicher Weise, wie es bei dem Achat der Fall ist. So entsteht eine Art Maserung, oft von großer Schönheit, von der bei der Verwendung des Malachits vielfach Gebrauch gemacht wird. Auf Taf. XX, Fig. 4 ", ist ein solcher Malachitknollen in seinem natürlichen Zustande, in Fig. $4^{\mathrm{b}}$ derselben Tafel eine von einem solchen Knollen abgeschnittene und polierte Platte dargestellt.

Betrachten wir die Eigenschaften des Malachits, so ist wegen des großen Kupfer. gehaltes das spezifische Gewicht sehr hoch. Es werden für verschiedene Stücke ziemlich abweichende Werte angegeben, die zwischen 3,5 und 4,0 schwanken; im Mittel wird meist $\mathrm{G}_{0}=3, z$ bis $3, \mathrm{~s}$ angenommen. Die Härte ist gering; es ist nur etwa $H$. $=31 / 2$, so daß der Stein schon von Flußspat geritzt wird. Da er aber undurchsichtig ist, so schadet ein kleiner Ritz nicht besonders, immerhin ist es aber nötig, Malachitgegenstände aller Art vor Verletzung sorgfültig zu schützen. Infolge der geringen Härte kann man zwar eine sanz gute Politur, aher keinen starken Glanz der geschliffenen Flächen herstellen. Die Masse ist nicht spröde und läßt sich daher auch auf der Drehbank bearbeiten.

Der Malachit ist ein sehr verbreitetes Mineral, aber er kommt meist nur in kleinen l'artien vor, die mit anderen, besonders mit kupferhaltigen Mineralien verwachsen sind. Diese unreinen Stücke sind zum Schleifen ungeeignet, sie bilden aber an manchen Orten (nin nieht unwichtiges Kupfererz. Der Grund der weiten Verbreitung des Malachits ist der, daß die anderen kupferhaltigen Mineralien und Erze, der Kupferkies, das Rotkupfererz 
usw. sich sehr leicht in Malachit umwandeln; wohl aller Malachit ist auf diese Weise durch Umwandlung aus anderen kupferhaltigen Mineralien entstanden. Wenn so also der Malachit eine weite Verbreitung besitzt und wenn er auch an zahlreichen Orten in bedeutender Mengre vorkommt, so sind doch die größeren reinen Stüicke, die sich zur IIerstellung von Schmucksachen eignen, nur sparsam und an wenigen Stellen grefunden worden, die im folgenden speziell angegeben werden sollen.

Unter allen Gegenden der Erde ist es der Ural, der am meisten schleifwiirdigen Malachit geliefert hat und von wo auch die gröliten reinen Massen des Minerals stammen, die sich bisher gefunden haben. Der Malachit ist in diesem Sinne ein spezifisch russisches Vorkommen, andere Lïnder treten dagegen vollkommen in den Hintergrund. Der Ural ist sebr reich an Kupfererzen, aher nur wenige Lagerstätten sind für die hier in Betracht kommenden $\mathrm{Z}$ wecke von Bedeutung, die meisten liefern nur als Erz verwendbaren Malachit. Zu erwähnen sind allein die Kupfererzbergwerke bei Nischne-Tagil und bei bogoslowsk im nördlichen Teile jenes Gebirges, und die bei Gumeschewsk weiter im Suiden. In frïheren Zeiten, am Anfance unseres Jahrhunderts, war die Produktion schleifwïrdigen Materials eine recht bedeutende, ging aber dann allmählich immer mehr zurïck, und heutzutage ist es nur noch die Grube Medno-Rudiansk bei Nischne-Tagil, die brauchbare Stuicke liefert, die anderen sind erschöpft oder geben doch in diesem Augenblicke keine genügend reinen Exemplare. Meistens liegt der Malachit nesterförmig auf Klüften im Kalkstein, aus denen er durch den Bergbau herausgebolt wird. Die Verarbeitung des so erhaltenen Materials geschiebt in den Schleifereien von Katharinenburg, soweit es nicht im rohen Zustande in den Handel gebracht wird.

Die Gruben von Gumeschewsk waren in fruheren Zeiten die wichtigsten; sie lieferten den meisten brauchbaren Malachit und auch die besten Qualitäten. Der Ort liegt 56 Werst südöstlich von Katharinenburg, sehr nahe dem 58. Grad östlich ron Paris, im Quellgebiet der Tschussowaja. Der Malachit in seiner schönsten Ausbildung hat die Form der erwähnten nierigen, tropfstein- und röhrenartigen Massen, die hier in verschiedener Größe und in einer Pracht vorkamen, wie es an anderen Orten nicht bekannt ist. Der Ruf der Gumeschewskschen Gruben beruhte hauptsächlich auf dem Vorhandensein dieser herrlichen Malachitstiicke, die dort in einem roten Letten lagen. Sie hatten ein Gewicht bis zu $10 \mathrm{Pud}$ (a $16 \mathrm{~kg}$ ), sind jedoch meistens kleiner. In der Sammlung des Bergkorps in St. Petersburg liegt die größte zusammenhängende Malachitmasse, die aus dieser Grube je gefördert worden ist. Sie stellt eine platte, nierenförmige Masse mit einer Höhe von $3 \mathrm{FuB} 6$ Zoll und mit fast derselben Breite dar, deren Gewicht etwa 90 Pud (gegen $1500 \mathrm{~kg}$ ) beträgt und deren Wert auf 525000 Rubel geschätzt worden ist.

Bei Nischne-Tagil, im nördlichen Ural, wenig sïdlich vom 58. Breitegrad und ungefähr $571 / 2$ Grad östlich von Paris, kommen ganz ähnliche Kupfererze in derselben Weise vor wie bei Gumeschewsk, aber der schöne zum Schleifen geeignete faserige und nierenförmige Malachit ist hier viel sparsamer und meist weniger schön wie dort. Dagegen hat man hier im Jahre 1835 eine zusammenbängende Nalachitmasse von einer Größe gefunden, wie bis dahin und auch seitdem niemals wieder, die namentlich das große Stück von Gumeschewsk, von dem eben die Rede war, noch weit überragt. Sie war 10 $1 / 2$ Fuß lang, $8 \mathrm{FuB}$ breit und $3_{1}^{1 / 2} \mathrm{FuB}$ hoch und im Inneren vollkommen kompakt, so daß das Gewicht auf nicht weniger als 500 bis 600 Zentner geschätzt wurde. Die Farbe war sehr schön smaragdgrïn und so die Irasse zum Schleifen ganz besonders geeignet. Hier in dem Reviere von Nischne-Tagil liegt die Grube Medno-Rudiansk, die jetzt allein noch nennenswerte Mengen von schönem Malachit liefert. Die Reichtiimer der anderen gehören, wie schon erwähnt, früheren Zeiten an. 
Dies wilt anch für die noch weiter nördlich gelegenen Gruben von Bogoslowsk, (ungefähr 59:23 (irad nürdl. Breite und 57\%/3 Grad östlich von Paris, an der oberen Turja). Diese Gruben befinden sich 15 bis 18 Werst weiter östlich an demselben Flusse, woher sie auch die Turjinskschen Gruben heißen. Auch hier bildet der Malachit nierenförmige Massen, das Torkommen ist jedoch auch in diesen Gruben erbeblich weniger schön und reichlich wie in Gumeschewsk. Stïcke von besonderer Größe sind hier nie vorgekommen.

Neben dem Ural ist vor allem Australien noch als Heimat schönen schleifbaren IIalachits zu erwälınen. Auch hier bildet das Mineral meist kleinere unansehnliche Massen, die nur als Kupfererze brauchbar sind, aber es finden sich doch zuweilen größere Partien, die den uralischen an Schönheit in keiner Weise nachstehen und die auch in der Form und Beschaffenheit mit diesen vollkommen übereinstimmen. Besonders reich ist Queensland, wo die Peak Downs Kupfergrube liegt, die schon prachtvolle Stücke geliefert hat. Auch in Neu-Süd-Wales kommt schöner schleifbarer Malachit in ziemlicher Menge vor. In Nordamerika haben die Gruben von Morenci in Arizona schöne Stücke geliefert.

Was die Verwendung des Malachits betrifft, so verarbeitet man ihn verhältnismäßig selten zu Ring- und Nadelsteinen, läufiger schon zu Broschen, Ohrgehängen und ähnlichen Schmucksachen. Man gibt den Steinen meist eine ebene oder flach gerundete Oberfläche, Facetten werden seltener angebracht, da sie keine besondere Wirkung hervorbringen, doch trifft man auch Tafel- und Treppenschnitt. Die Ohrgebänge erhalten häufig eine drebrunde, keulenförmige oder ähnliche Gestalt.

Sehr viel häufiger ist die Verwendung zu allen möglichen Galanteriewaren: Briefbeschwerern, Tintengefüßen, Leuchtern, und zu Dekorationsstücken, wie Schalen, Vasen, Kamingesimsen, Tischplatten usw., oft von erheblicher Größe. Die Sachen werden aber nicht massiv aus Malachit hergestellt, sondern die Form des betreffenden Gegenstandes wird in Kupfer oder einem anderen Material vorgebildet und dann mit dünnen Malachitplättchen belegt (fourniert), die man durch Zersägen der größeren Stücke erhält. Die Kunst besteht darin, diese Plättchen so zusammenzusetzen, daß die Fugen möglichst wenig sichtbar sind, was sich namentlich durch eine geschickte Benutzung der erwähnten Maserung bewerkstelligen läßt. Diese Industrie ist namentlich in Rußland entwickelt, der Heimat des dazu gehörigen Materials. Hier sieht man die schönsten und größten Gegenstände derartiger von Malachit, und hierher stammen als Geschenke der russischen Kaiser die zahlreichen Sachen aus diesem Material, die sich in den europäischen Fürstenschlössern befinden. In Petersburg werden besonders die sehr großen Malachitsäulen in der Isaakskirche viel bewundert. Große Säulen aus demselben Stoffe hat aber auch das Altertum schon gekannt. In dem Dianentempel zu Ephesus hat sich eine Anzahl derselben gefunden, die jetzt die Sophienkirche in Konstantinopel zieren.

Der Malachit hat so eine ganz ähnliche Verwendung wie der Lasurstein, aber er ist leichter in größeren Stücken zu erhalten und sein Preis ist bis zehnmal geringer. Niedrigr ist der Preis kleinerer Stiucke; die Produktion an solchen befriedigt den vorhandenen Bedarf immer noch leicht. Dagegen werden größere Massen wegen ihres viel sclteneren Vorkommens viel höher bezahlt, und zwar um so mehr, je schöner die Farbe und je kompakter die Masse.

Der Malachit kann kaum mit einem anderen Steine verwechselt werden, so charakteristisch ist seine ganze Erscheinung. Nur das grüne Kieselkupfer, der danach so genannte Kieselmalachit (S. 521), sieht zuweilen ähnlich aus. Ein kleines Tröpfehen Salzsäure an einer rer-teckiten Stelle, das, wenn es rasch wieder entfernt wird, keinen Schaden tut, bringt die Lutscheiduner: gewöhnlicher Malachit zeight in dem Tropfen Aufbrausen wegen Entwickelung: von Kohlensäure, Kieselmalachit nicht. 


\section{Kupferlasur.}

Eine sehr ähnliche Zusammensetzung wie der Malachit hat die Kupferlasur. Sie ist aber durch eine schön dunkelblaue Fart)e ähnlich der des Lasursteins ausgezeichnet, auf die der Name hinweist. Die Kupferlasur ist jedoch viel schwerer $\left(\left(\frac{1}{x_{0}}=3, r\right)\right.$ und weicher $\left(H_{0}=3^{3^{\prime}}\right)$ als der Lasurstein und unterscheidet sich von diesem auch noch dadurch, dal' sie wie der Malachit mit Salzsïure aufbraust. Der Stein ist in dickeren Stiicken kaum jemals vollständig durchsichtirg, höchstens durchseheinend. Der Glanz ist Glasgrlanz und kann auch durch die Politur nicht sehr gesteigert werden. Die Verwendung ist nur beschränkt.

Azumalathit werden in Amerika Steine genannt, in denen grüner Malachit mit blauer Kupferlasur gemengt sind. Sie werden hergestellt aus stalaktitischen, kugeligen olter nierigen Massen, die aus abwechselnden Lagen beider Mineralien bestehen und die je nach der Lage der Schlifflächen verschieden gezeichnete Steine greben. Das Rohmaterial stammt aus der Kupfererzgrube von Bisbee und anderen Orten in Arizona.

\section{Faserkalk. Fasergips.}

Faserkalk. Das Mineral Kalkspat bildet zureilen sehr feinfaserige Platten, in denen die Fasern untereinander parallel und auf den Wänden der Platten senkrecht stehen. Sind die Fasern selur fein, dann zeigen Bruchflächen in der Richtung derselben einen sehr schönen Seidenglanz, der durch die Politur noch gehoben werden kann. Daher wird der Faserkalk, besonders wenn er nit dem Seidenglanz vollkommene Farblosigkeit verbindet, zuweilen geschliffen und namentlich zu keulenförmigen Ohrgehängen und ähnlichen Schmucksachen verarbeitet. Auf der rundlichen Fläche bemerkt man dann eine Lichterscheinung ähnlich der des Katzenauges, aber nur wenn der Schliff frisch ist; denn da der Kalkspat sehr geringe Härte hat $\left(H_{0}=3\right)$, so werden solche Sachen leicht zerkratzt und sind dann sehr unansehnlich.

Körniger Kalk ist der Marmor, der aber zu Schmucksachen keine Verwendung findet und der daher hier nicht betrachtet werden soll.

Ganz dem Faserkalk ähnlich ist der faserige Aragonit, der wie jener kohlensaurer Kalk ist, der aber anders kristallisiert und auch sonst abweichende Eigenschaften hat. Er ist manchmal weiß und wird dann ebenso benutzt wie der Faserkalk, ron dem er durch das Aussehen nicht zu unterscheiden ist. Zuweilen ist er aber auch rot, braun und weiß gebändert, wie z. B. der Karlsbader Sprudelstein, der für die Badegäste zu allen möglichen kleinen Gegenständen verarbeitet wird. Ebenfalls zum Aragonit, aber teilweise auch zum Kalkspat, gehört der Onyx-Alabaster aus Ägypten und der OnyxMarmor von Tecati in Mexiko und von anderen Orten, der sogenannte ..mexikanische Achat, mexikanische Onyx". Auch dieses weisse, gelbe oder grïne Material wird fast nur in der Großsteinschleiferei, beinahe nie zu Schmucksachen verarbeitet.

Daß unter den Katzenaugen von Ceylon zuweilen brauner faseriger Kalk mit vorkommt, ist schon oben erwähnt worden.

Fasergips. Wie der Kalkspat, so bildet auch der Gips nicht selten parallelfaserige Platten mit schönem Seidenglanz, die wie der Faserkalk zuweilen benutzt werden. Hier ist aber die Härte noch geringer $(H .=2)$ und daher die Schönheit noch vergänglicher. Material dieser Art ist häufig in den großen Gipsbrüchen der Gegend ron Paris, in dem 
der Triasformation angehörigen Gips von Derbyshire und Nottinghamshire in England und an vielen anderen Orten.

Körniger Gips bildet den Alabaster, der aber wie der Marmor nie als Schmuck. stein dient.

\section{Flussspat.}

Der Flußspat oder Fluorit ist für einen Edelstein viẹl zu weich; trotzdem wird er zuweilen zu Ringsteinen und zu anderen Zwecken dieser Art geschliffen wegen der prachtvollen Farben, die manche Varietäten zeigen, und zwar benutzt man ihn vorzugsweise zur Nachahmung wertvollerer Edelsteine, denen er in der Färbung nahesteht. Die Verwendung ist aber gering, umfangreicher ist die zu allen möglichen größeren Gegenständen, die wegen der lebhaften Farben eine sehr gute Wirkung hervorbringen.

Das Vorkommen des Flußspates ist ein sehr reichliches. Derbe und dichte Massen erfüllen, namentlich mit Schwerspat zusammen, Spalten und Gänge in allen möglichen Gesteinen. Regelmäßig ausgebildete Kristalle, stets auf einer Unterlage aufgewachsen und zuweilen herrliche Drusen bildend, schön gefärbt und durchsichtig, wie es zur Verwendung als Schmuckstein erforderlich ist, finden sich in großer Zahl auf Erzgängen in den verschiedensten Gegenden. Am ausgezeichnetsten ist das Auftreten derselben in England, besonders im Norden, auf den Bleierzgängen in Cumberland, Derbyshire usw. aber auch im Süden, in Devonshire, Cornwall usw. Auf den Erzgängen im Harz, im Erzgebirge, im Schwarzwald usw. sitzen ebenfalls schöne Exemplare. Die Verbreitung ist so groß, daß es nicht möglich ist, auch nur die wichtigsten Fundstellen in Kürze anzugeben.

Im reinsten Zustande besteht der Flußspat aus 48,72 Proz. Calcium und 51,25 Proz. Fluor. Er ist also Fluorcalcium, dessen Zusammensetzung durch die Formel $\mathrm{CaF}_{2}$ ausgedrückt wird. Schöne Kristalle sind sehr häufig; sie gehören dem regulären System an. Die gewöhnlichste Form ist die des Würfels, doch finden sich auch Oktaeder und andere einfache reguläre Gestalten, teils für sich, teils in Kombination miteinander. Nicht selten sind Zwillingskristalle, namentlich findet man Würfel zwillingsartig durcheinander gewachsen. Sehr verbreitet sind auch derbe kristallinische Aggregate von körniger und stengliger Struktur, sowie vollkommen dichte Massen, die aber nur in der Technik verwendet werden.

Nach vier Richtungen, die den Flächen des Oktaeders parallel gehen und die also an den Würfeln die Ecken gerade abstumpfen, findet eine leichte Spaltbarkeit statt. Das Nineral ist spröde und hat nur die Härte des vierten Grades, so daß es schon von Fensterglas leicht geritzt wird. Das spezifische Gewicht schwankt zwischen 3,1 und 3,2 , er sinkt also jederzeit in der dritten, schwimmt aber auf der zweiten Flüssigkeit. Beim Erhitzen vor dem Lötrohr zerknistert der meiste Flußspat heftig und zerfällt in kleine Splitterchen, die mit ziemlicher Gewalt nach allen Seiten hinausgeschleudert werden. Er enthält gewöhnlich eine Menge kleiner, hohler oder mit Flüssigkeit erfüllter Einschlüsse, deren Inhalt sich in der Hitze stark ausdehnt und so das Stück zersprengt. Die Schmelzbarkeit ist nicht besonders leicht, doch hat er eine große Neigung, mit anderen Mineralien 2nsammenzuschmelzen, weshalb er bei manchen Hüttenprozessen den Erzen zur Erleichterung des Schmelzflusses zugesetzt wird. Daher stammt auch der Name Flußspat. i. Tanche Tarietäten haben die Eigenschaft, beim Erwärmen noch unter der Glühbitze ein 
schönes grrïnliches oder bläuliches Licht auszustrahlen, das aber nach kurzer Zeit erlischt und bei einer Wiederholung des Versuchs nicht wiederkehrt; sie phosphoreszieren. Von Schwefelsïure wird der Flußspat vollkommen zersetzt und dabei Flubsïure entwickelt, die vielfach zum Ätzen des Glases und mancher Edelsteine, namentlich von Quarz, Achat usw. benutzt wird.

Für die hier besonders interessierenden Zwecke ist das Verhalten gegen das Licht von der größßten Bedeutung. Der Glanz ist ein charakteristischer feuchter Glasglanz. Die Durchscheinenheit greht durch alle Grade hindurch, von der vollkommensten Durchsichtigkeit bis zum Durchscheinenden und Undurehsichtigen. Am wichtigsten ist die Fürbung. Diese ist außerordentlich mannigfaltig; kein anderes Mineral hat eine so grolje und schöne Farbenreihe, in der keine sonst im Mineralreich vorkommende Farbe fehlt. Der vollkommen reine Flußspat ist ganz farblos und durchsichtig, er ist vollkommen wasserhell; dies ist aber selten. Durch feinste Beimengung fremder, zum 'Teil organischer Substanzen in sehr kleinen Mengen entstehen die Farben, die beim Erhitzen meistens gränzlich verschwinden oder sich ändern. Häufig ist die Farbe licht und zart, vielfach jedoch auch außerordentlich tief und gesåttigt, so daß3 sie nur in dïnnen Schichten deutlich hervortritt, während dickere Stücke fast schwarz erscheinen. Immer aber ist das Pulver (der Strich) weiß oder doch sehr hell. Der Farbstoff ist häufig unregelmäßig verteilt, so daß die Steine ein fleckiges Aussehen erhalten. Manchmal wechseln sogar an einem und demselben Stücke mehrere Farben regelmäßig schichten- oder streifenförmig miteinander ab, wie beim Achat, namentlich bei derben kristallinischen Aggregaten. Kristalle enthalten zuweilen einen andersgefärbten Kern, so sieht man z. B. gelbe im Innern violett usw.

Zu Schmucksteinen können nur solche Kristalle dienen, die genügende Durchsichtigkeit mit schöner gleichmäßiger Färbung verbinden. Im Handel werden solche Flußspate mit dem Namen des entsprechend gefärbten, wertvollen und echten Edelsteins bezeichnet, dem man den Zusatz "falsch" beifügt. Man spricht so von falschem Topas, Rubin, Smaragd, Sapphir, Amethyst usw. Selbstverständlich kann der Flußspat aber nicht nur den hier genannten Edelsteinen untergeschoben werden, sondern ebenso anderen ron derselben Farbe, so der gelbe nicht nur dem Topas, sondern auch dem Citrin, der rote auch dem roten Turmalin usw.

Sehr häufig ist gelber Flußspat, der "falsche Topas", welcher Namen indessen auch für den gelben Quarz, den Citrin, zuweilen gebraucht wird. Er findet sich im sächsischen Erzgebirge bei Freiberg, Gersdorf und an anderen Orten. Das Gelb hat verschiedene Nuancen, weingelb, honiggelb, bis ins Braun. Es ist meist ziemlich licht, doch fehlen auch tiefere Färbungen nicht. Rote Kristalle, meist an der Oberfläche mehr oder weniger angefressene Oktaeder, kommen in den Schweizer Alpen mehrfach, doch nicht gerade häufig vor, meist auf Spalten im Gneis, so am St. Gotthard, wo Göschenen vielfach als Fundort genannt wird, am Zinkenstock nahe der Grimsel, im Tavetschtale in Graubinden. im Wallis, im Tessin usw. Die Farbe dieser "falschen Rubine" ist meist licht, rosenrot; dunkleres Rot kommt weniger vor. Die grüne Farbe der "falschen Smaragde" ist zuweilen sehr schön und geht bis ins reiue Smaragdgrün, so an manchen englischen Kristallen, an denen aus dem Porphyr vom Petersberg bei Halle, an solchen aus den Erzgängen von Badenweiler usw. Bekannt ist auch das in neuester Zeit aufgefundene Vorkommen von Nacomb, St. Lawrence County, New York, wo in einer großen Höhlung Tausende schöner grüner Kristalle im Gesamtgewichte von $15 \mathrm{t}$ gefunden worden sind. Blaue "falsche Sapphire“ finden sich vorzugsweise in den Zinnerzlagerstätten des Erzgebirges; die Farbe ist hier ziemlich dunkel bis beinahe schwarz. Schöne hellblaue und rote Kristalle sind kürzlich in Illinois entdeckt worden. Auch in den Steinsalzablagerungen 
von Hall in Tirol kommt blauer Flußspat vor. Eigentiimlich sind die Flußspatwürfel von Alston Hoor in Cumberland in England. Diese sind beim Hindurchsehen schön grïn, wïhrend das an der Oberfläche zuriickgeworfene Licht dunkelblau erscheint. Diese Erscheinung ist nach dem Auftreten am Flußspat, dem Fluorit der Mineralogen, als Fluoreszenz bezeichnet worden. Sie ist besonders lebhaft bei der Beleuchtung mit Röntgenstrahlen. Man faßt derartige Steine zuweilen à jour in Nadeln, Ringe usw., um den Farbenunterschied beim Hindurch- und Daraufsehen als Merkwürdigkeit zeigen zu können. An anderen Orten hat die blaue Farbe oft einen deutlichen Zug ins Violette, namentlich an sanz dunklen Kristallen, es gibt aber auch solche von lichterer, ausgesprochen violetter Färbung, die der des Amethysts zuweilen zum Verwechseln ähnlich ist. Solche „falsche Amethyste" finden sich unter anderem in großer Schönheit auf den Bleierzgängen von Weardale in Durham in England.

Alle diese "falschen" Steine werden wie die echten geschliffen. Sie nehmen dabei eine gute Politur an, müssen aber beim Schleifen und beim Tragen an der Hand usw. wegen der Sprödigkeit, der geringen Härte und der leichten Spaltbarkeit sebr sorgfältig in Acht genommen werden, denn es entstehen gerne geradlinige Risse in der Richtung der Blätterbrïche, oder es springen kleine Splitter aus, und die Steine werden an der Oberfläche zerkratzt und dadurch unansehnlich. Der Wert ist stets sehr gering und der Preis niedrig. Von den echten Steinen können diese Flußspate immer leicht durch die geringe Härte unterschieden werden. Auch das verschiedene spezifische Gewicht des echten und falschen Steines gilut die Möglichkeit einer leichten Unterscheidung, sowie die einfache Lichtbrechung des Flußspats gegenüber der doppelten der anderen. Diese zeigen daher auch meist mehr oder weniger deutlichen Dichroismus, eine Eigenschaft, die dem Flußspat, seiner regulären Kristallform entsprechend, ebenso abgeht wie die doppelte Lichtbrechung.

Als Schmuckstein wird der Flußspat aus den erwähnten Gründen wenig benutzt. Etwas umfangreicher ist die Verwendung zu größeren Ziergegenständen, wovon hier nur kurz in Vorbeigehen die Rede sein soll. Man verfertigt daraus Schalen, Vasen, Leuchter, Briefbeschwerer, sogar Architekturstücke, wie Säulen, Kamingesimse usw. Derartige Gegenstände sind namentlich in England unter dem Namen spar ornaments beliebt und verbreitet. In England ist auch das hierzu brauchbare Material zu Hause, und zwar findet es sich in größter Menge und Schönheit vorzugsweise bei Tray Cliff nahe Castleton in Derbyshire. Es sind derbe, großkörnige Massen von sehr dunkelblauer, etwas ins Violette gehender Farbe, vielfach mit hindurchziehenden weißen und gelben Schichten; sie werden dort als blue John bezeichnet. Man bringt die Stücke durch Schleifen in die gewünschte Form, man kann sie aber auch auf der Drehbank bearbeiten, doch ist dabei große Vorsicht erforderlich, da aus den schon oben genannten Grïnden leicht Stiickchen ausspringen, wodurch die Glätte und der Glanz der Oberfläche wesentlich beeinträchtigt wird. Die Arbeiter haben aber im Laufe der Zeiten - die Industrie begann im Jahre 1765 - gewisse Kunstgriffe erfunden, um diesen Übelstand zu vermeiden. Der wichtigste besteht darin, daß der Flußspat bei der Bearbeitung mit Пarz imprägniert wird, das einen größeren Zusammenhalt der Teilchen veranlaßt. So lassen sich aus dem hierzu so ungünstigen Materiale sehr dünnwandige Gefäße drehen, die oft nur 1 bis $1 \frac{1 / 2}{2}$ Linien stark sind. Diese geringe Dieke ist deshalb nötig, weil nur dann durch die tiefgefärbte Substanz eine genügende Menge Licht hindurchgrehen kann, so dal die schöne Farbe deutlich in die Erscheinung tritt. Wenn man diesen Flußspat bis annähernd zur Rotglut erhitzt, dann geht die dunkelviolblaue Farbe in ein schönes, amethystähnliches Violett über, das als natiurliche Farbe dort nicht vorkommt. Es muß dabei aber mit größter Sorgsamkeit verfahren werden, denn die Stiicke bekommen leicht Risse, und bei zu hoch 
gesteigerter Temperatur geht die Farbe ginzlich verloren, sie wird weil). Wegen dem geringen Werte des massenhaft vorkommenden und leicht zu gewinnenden Rohmaterials geht der Preis dieser Waren nur wenig über den Arbeitslohn hinaus, der aber, der Schwierigkeit der Arbeit wegen, nicht unbedeutend ist.

Es ist die Vermutung ausgesprochen worden, dals die rätselhaften vasa murrina der alten Römer aus Flußspat bestanden haben, doch ist hierfür kein bestimmter und ausreichender Anhalt vorhanden. In Gegenteil ist es wahrscheinlich, daf diese kostbaren Gefälie aus einem anderen Materiale gefertigt gewesen sind, wie bei der Betrachtung des Achats (S. 634) erwähnt worden ist. Jedenfalls ist der Flufspat schon in selır alten Zeiten zum Schmuck verwendet worden. Neben Perlen von Sodalith sind auch solche von Flußspat in der uralten Trümmerstätte von Tiahuanaco auf dem IIochlande von Bolivia in der Nähe des Titicacasees (S. 5t8) gefunden worden.

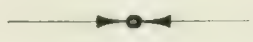

\section{Apatit.}

In ähnlicher Weise wie der Flußspat ahmt auch der Apatit mit seinen in manchen Varietäten sehr schönen Farben gewisse Edelsteine nach. Durchsichtige Exemplare werden daher ebenfalls zuweilen geschliffen. Der Apatit ist hierzu sogar noch geeigneter, da er etwas härter ist als der Flußspat (er hat den fünften Hürtegrad), und da er keine deutliche Spaltbarkeit besitzt. In chemischer Hinsicht ist es chlor- und fluorhaltiger phosphorsaurer Kalk, der im hexagonalen Systeme kristallisiert und sich sehr häufig in schünen Kristallen, meist sechsseitigen Prismen mit der geraden Erdfläche oder anderweitiger Endbegrenzung, findet. Die Farbenmannigfaltigkeit ist nicht so grols wie beim Flußspat. An sich ist die Substanz wie dort vollkommen farblos, und viele Kristalle sind auch in der Tat ganz wasserhell. Durch beigemengte Pigmente wird sie jedoch in verschiedener Weise gefürbt: lila oder violett oder hellgrïn wie die Kristalle auf den Zinnerzlagerstätten des Erzgebirges, z. B. von Ehrenfriedersdorf in Sachsen und besonders schön auf einer alten Kupfergrube von Kiräbinsk in der Nähe von Miask im Ural; oder hellgelb wie der sogenannte Spargelstein im Talkschiefer der Tiroler Alpen; oder tiefblaugrïn, wie die Moroxit genannte Abart, die an vielen Orten, so in Nordamerika und besonders in Kanada, an der Sliidjanka in Transbaikalien (Fig. 98), bei Arendal in Norwegen, in Deutscl-Südwestafrika usw. in kristallinischen Silikatgesteinen und in Narmor eingewachsen vorkommt; oder himmelblau wie gewisse australische Kristalle usw. Von ganz besonders schöner Färbung und hoher Vollkommenheit sind die durchsichtig grünen, rosenroten und violetten Apatite, die mit Turmalin zusammen auf Spalten im Granit am Mount Apatite bei Auburn, Androscoggin County im Staate Maine in den Vereinigten Staaten gefunden werden und die man früher zum Teil für Turmalin gehalten hat. Von allen diesen verschiedenen Vorkommnissen werden gelegentlich schön gefürbte Exemplare geschliffen, wenn sie, was aber nicht besonders häufig ist, vollkommene Durchsichtigkeit besitzen. Am meisten werden vielleicht die grïnen kanadischen MIoroxite benutzt, doch ist auch bei ihnen die Verwendung bescbränkt und der Wert nicht hoch. Zur Unterscheidung von ähnlich gefürbten Steinen kann neben der Härte das spezifische Gewicht dienen, das sehr nahe wie beim Flußspat gleich 3.2 ist. Letzterer kann neben dem doppeltbrechenden und etwas dichroitischen Apatit an seiner einfachen Lichtbrechung und an dem vollständigen Mangel an Dichroismus erkannt werden. Von Beryll und Smaragd, denen manche ge- 
schliffene Apatite sehr ähnlich sind, unterscheidet sich der letztere sehr leicht durch das spezifische Gewicht: der Apatit sinkt in der dritten Flüssigkeit $\left(G_{0}=3,0\right)$, in der jene schwimmen.

\section{Sehwefelkies.}

Der Schwefelkies oder Pyrit, von den Juwelieren auch wohl Markasit genannt, ist das einzige der metallisch glänzenden Schwefelmetalle, das zuweilen einmal geschliffen wird. Er ist Zweifachschweîeleisen, FeS:, von regulärer Kristallform. Das spezifische Gewicht ist sehr hoch, $G_{.}=5,0$. Die Substanz ist spröde, die Härte liegt nur wenig unter der des Quarzes, H. $=61 \frac{1}{2}$. Vor dem Lötrohr gibt der Schwefelkies schweflige Säure, die an ihrem stechenden Geruch leicht erkannt wird. Mit dem Stahle geschlagen erzeugt er lebhafte Funken, indem die durch die Reibung losgerissenen Teilchen unter demselben Geruche ebenfalls zu schwefliger Säure verbrennen. Von Salzsäure wird er nicht angegriffen, von Salpetersäure aber vollständig zersetzt.

Die Farbe ist ein hübsches, etwas ins Graue gehendes Gelb, das man als Speisgelb bezeichnet. Der Glanz ist ein lebhafter Metallglanz, der besonders auf geschliffenen Steinen, denen man meist die Form niederer Rosetten zu geben pflegt, schön hervortritt. Wegen der ziemlich großen Härte hält sich auch der Glanz lange, und die Kanten der geschliffenen Steine verlieren ihre Schärfe nicht. Dagegen wird die äußere Erscheinung vielfach durch eine mehr oder weniger rasch vorschreitende Verwitterung beeinträchtigt, die die Oberfläche matt und unansehnlich macht.

Im 18. Jahrhundert war der Schwefelkies namentlich in Frankreich geschätzt und viel verwendet, da er wegen seines hohen Glanzes und seiner hübschen Farbe einen guten Eindruck macht. Er diente vorzugsweise zur Verzierung von 'Toilettegegenständen, wie Schubschnallen und Strumpfbändern, von Dosen usw., wurde aber auch in Broschen, Armbänder und andere Schmucksachen eingesetzt. Später nahm die Vorliebe für diesen Stein sehr ab, und endlich hörte seine Verwendung so gut wie ganz auf. Es hat aber nicht an Versuchen gefehlt, ihn in seine frühere Stellung wieder einzusetzen. So wurde im Jahre 1846 eine große Menge von geschliffenen Schwefelkiesen nach Paris gebracht, die alle aus Genf und dem Jura kamen und die nach der Mode der Zeiten, in denen der Stein frilher beliebt gewesen, gefaßt waren. Die Sache machte eine Zeitlang großes Aufsehen, aber bald geriet der Versuch ins Stocken, und die Steine fanden keinen Absatz mehr, da sie trotz des geringen Materialwertes teuer waren und die Fassung nicht dem modernen Geschmack entsprach. Schon friiher einmal, nach der Eroberung Perus, war der Schwefelkies in der Mode gewesen. Man hatte in alten Inkagräbern große polierte Platten davon gefunden, die wohl als Spiegel benutzt worden waren. Dies lenkte die Aufmerksamkeit auf das Mineral, das dann zuweilen als Inkastein bezeichnet wurde. Man schrieb ilrm damals heilbringende Kräfte zu und nannte es daher auch Gesundstein oder Elementarstein. Der Schwefelkies wurde aus diesem Grunde als Amulett und anch in IIalsketten, Nadeln, Ohrringen usw. vielfach getragen und manchmal teuer bezahlt. Die Verbreitung des Schwefellieses in der Natur ist sehr grol, er gehört mit zu den häufigsten Mineralien der Erdkruste. Nenestens hat man versucht, kleine grlänzende Schwefelkieskristalle in ihrer natürlichen \$eschaffenheit als Schmucksteine zu verwenden. 


\section{Hämatit.}

Der Iïmatit oder Blutstein ist ein durch Metallglanz und dunkelstahlgraue bis eisenschwarze Farbe, sowie durch vollkommene Undurchsichtigkeit ausgezeichnetes Mineral. Er gehört zum Eisenglanz, dem natïrlichen Eisenoxyd, $\mathrm{Fe}_{2} \mathrm{O}_{3}$, das in reinem Zustande aus 70,0 Proz. Eisen und 30,0 Proz. Sauerstoff besteht. Nicht selten kommt er in rhomboedrischen Kristallen vor, die sich in besonderer Schönheit unter anderem auf den ausgredehnten und wichtigen Eisenerzlagerstätten der Insel Elba, auf Spalten und Klüften im Gneise der Hochalpen und an anderen Stellen finden.

Die Kristalle sind aber nur in dickeren Stïcken lebhaft metallisch glänzend und schwarz, ihr feines Pulver, wie man es am leichtesten durch Ritzen mit einer Feile oder durch Überstreichen über eine rauhe Porzellanplatte erhalten kann, ist dagregen dunkelkirschrot und sehr kleine Kriställchen sind mit schöner roter Farbe durchsichtig. Daraus ist der Name Blutstein und dessen griechische Übersetzung Hämatit entstanden. An der roten Farbe des Strichpulvers kann man das Mineral von allen andern ähnlich aussehenden schwarzen metallisch glänzenden Steinen, z. B. rom Titaneisen, unterscheiden.

Kristalle werden wohl kaum geschliffen. Aber der Hämatit findet sich nicht bloß in dieser Form, sondern auch vielfach und in größeren Quantitïten als derbe unregelmïßjig begrenzte Massen, die jedoch sonst alle Eigenschaften der Kristalle besitzen, nicht nur die oben genannten, sondern auch dasselbe spezifische Gewicht $\left(G_{0}=4, \pi\right)$ und dieselbe Härte, die des Feldspats $\left(H_{0}=6\right)$. Diese Abart wird in den Schleifereien von Idar-Oberstein usw. zur Herztellung von Schmuckgegenständen verwendet, und zwar soll das Rohmaterial, das Stücke von erheblicher Größe bildet, aus Ostindien stammen. Auch in Brasilien, und zwar in den Provinzen São Paulo und Minas Geraës, kommt Ähnliches vor.

Vielleicht noch ausgedehnter ist jedoch die Verwendung des feinfaserigen Eisenglanzes. Dieser hat meist nicht mehr den intensiven Metallglanz der Kristalle und der erwähnten derben kristallinischen Massen, auch geht die Farbe schon stark ins Rote und nähert sich der des Pulvers. Wenn letzteres aber nicht zu sebr der Fall ist, sind geschliffene und polierte Flächen immer noch lebhaft metallisch glälnzend und dunkelstahlgrau bis schwarz, und die faserige Beschaffenheit verschwindet für das Auge vollständig. Derartige Stiicke können daher ebensogut geschliffen werden wie jene derben, dagegen finden die ausgesprochen roten Abänderungen nur noch als Erz zur Herstellung* des Eisens Verwendung. Der fasrige Eisenglanz hat meist eine rundliche, traubige oder nierenförmige Oberfläche und wird dann als roter Glaskopf bezeichnet. Er findet sich in kleineren Partien zwischen dichtem Roteisenstein von ausgesprochen roter Farbe, Wände von Hohlräumen in demselben in mehr oder weniger dicken Lagen überziehend. Schleifbaren Hämatit von dieser Beschaffenheit hat man in dem jetzt allerdigss so gut wie erschöpften Eisenerzgang bei Kamsdorf unweit Saalfeld in Thüringen gewonnen, ebenso in den alten weltberiihmten Eisensteinablagerungen der Insel Elba, die auch die oben erwähnten schönen Kiristalle, oft in prachtrollen Drusen, beherbergen; aus den Eisenerzlagerstätten von Schottland kommt gleichfalls schleifbares Material. Der gegrenwärtig in Idar und Oberstein geschliffene faserige Hämatit stammt jedenfalls zum Teil atls Neuseeland, teilweise auch von Platten in Böhmen usw.

Der Hämatit wird in verschiedener Weise zu Schmucksteinen verwendet, die stets um so schöner sind, je büher und vollkommener der metallische Glanz und je tiefer schwarz die Farbe. Man verfertigt daraus Ring- und Siegelsteine, in deren ebene Flächen meist eine Figur, ein Buchstabe, oder irgend etwas anderes eingrariert wird, also Siegelsteine 
von mannigfalticer Art. Der Hämatit ist iiberhaupt einer derjenigen Schmucksteine, die am meisten zum Gravieren verwendet werden. Mugelige Steine für Ringe und andere Schmuckstiicke zeigen zuweilen infolge ihrer faserigen Struktur einen allerdings stets nur trïhen und matten Lichtschein, ähnlich dem des Sternsapphirs. Steine von dieser Form werden zur Verzierung von Broschen, Armbändern, Medaillons usw. hergestellt, meist wie auch die Ringsteine mit nur wenig erhabener, schildförmig krummer Oberfläche. Zuweilen verfertigt man runde Kugeln, die zu Hals- und Armbändern usw. auf Schnüre grezogen werden. Sie zeigen dann ebenfalls nicht selten den genannten Lichtschein, so daß sie manchmal in Glanz und Farbe echten schwarzen Perlen recht ähnlich sein können. Kleine Wïrfel aus Hämatit werden auf Nadeln aufgesteckt usw. Hämatit wird seiner schwarzen Farbe wegen vielfach zur Anfertigung von Trauerschmuck verwendet. Die Benutzung ist aber nicht besonders ausgedehnt, und die Steine erreichen nur geringe Preise, da das Rohmaterial wegen seines zu diesen Zwecken mehr als reichlichen Vorkommens beinahe wertlos ist.

Der Hämatit ist eine der Substanzen, die in den allerfriihesten Zeiten schon zum Schmuck benutzt wurden. In den Ruinen von Babylon sind viele Zylindergemmen, zum Teil mit Gravierungen, aus diesem Steine gefunden worden, und ebenso fanden sich Schmucksachen aus Hämatit in alten ägyptischen Gräbern. Auch im klassischen Altertum hat der Stein zur Herstellung von Intagilien und $\mathrm{zu}$ anderen ähnlichen Zwecken in ausgedehntem Naßstabe Verwendung gefunden, da er sich leicht bearbeiten läßt und schön aussieht.

Für die Bearbeitung der Edelsteine, namentlich einiger weicherer Sorten, ist der Hämatit von Wichtigkeit, weil sein feines Pulver, allerdings auch vielfach das von künstlich hergestelltem Eisenoxyd, unter dem Namen Englisch-Rot häufig als Schleif- und Poliermittel benutzt wird. Sodann ist er für Goldarbeiter nicht olıne Bedeutung, weil auch aus ihm, und zwar aus derselben faserigen Abart, dem roten Glaskopf, die zu Schmucksteinen verschliffen wird, die Gerïte zum Polieren des Goldes und des Silbers an den Schmucksachen, die sogenannten Polierzähne, hergestellt werden (S. 635).

Ganz ähnlich wie der Hämatit wird zuweilen auch die Titansäure enthaltende Varictät des Eisenglanzes, das Titaneisen, zu Schmucksteinen verschliffen. Es wird zuweilen auch als Iserin bezeichnet, weil schwarze abgerollte Körner desselben als Begleiter des Sapphirs an der Iserwiese sich finden. Das Titaneisen hat außer der Faserigkeit wesentlich dieselben Eigenschaften wie der Eisenglanz, es nimmt aber beim Schleifen einen noch hïheren Glanz an als dieser. Die Verwendung ist jedoch zu spärlich, als daß weitere Nitteilungen nötig wären. Erwähnt sei nur noch das hübsche Vorkommen von Cumberland in Rhode Island in Nordamerika, wo weiße Quarzkörner in das schwarze Titaneisen eingewachsen sind, so daß die geschliffenen Stücke einen angenehmen Farbenkontrast seben. Tom IIämatit unterscheidet sich das 'Titaneisen dadurch, daß die Farbe des Strichpulvers nicht rot, sondern braun oder schwarz ist; außerdem ist das Mineral zum Teil magnetisch, was beim Hämatit nie der Fall ist.

\section{Rutil.}

Der Rutil ist ein Mineral, das aus 'Titansäure, $\mathrm{TiO}_{2}$, besteht und sich häufig in Kristallen des quadratischen Systems findet. Er hat meist eine dunkelbraune, rote bis schwarze Farbe und vielfach einen kräftigen metallartigen Demantglanz, so daß er wenigstens in 
TAFELLYX:

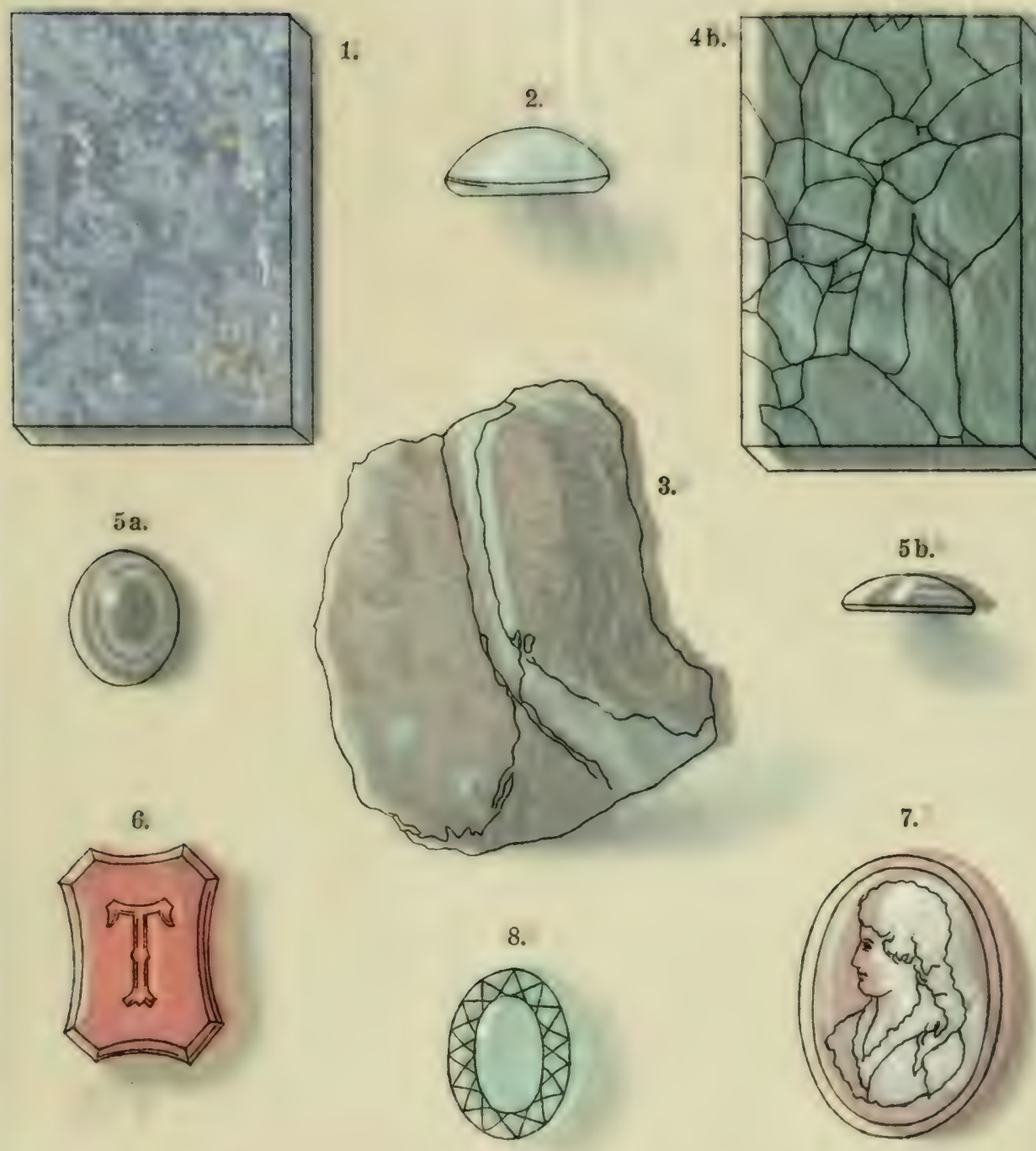

9.
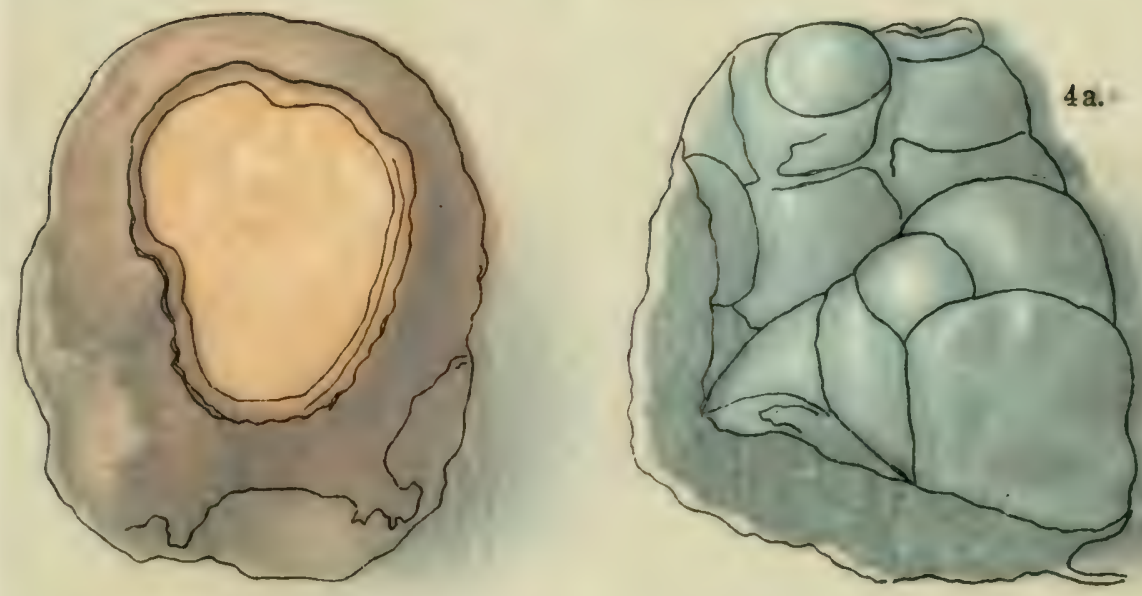

1. Lasurstein angeschliffen). 2. Türkis (geschliffen). 3. Türkis (im Gestein). 4a. Malachit (natürl. Vorkommen). 4b. Malachit (angeschliffen). 5a und 5b. Onyx (von oben und von der Seite gesehen). 6. Karneol (geschliffen und graviert). 7. Achat (Karnolonyx, als Kamec geschnitten). 8. Chrysopras (geschliffen). 9. Bernstein (angeschliffen). 


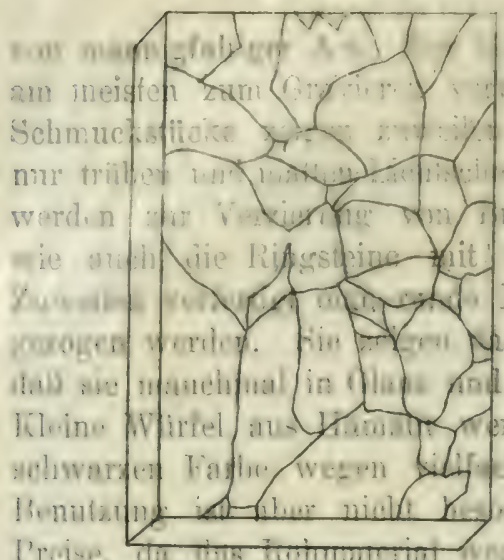

hommens theinale werllos int.
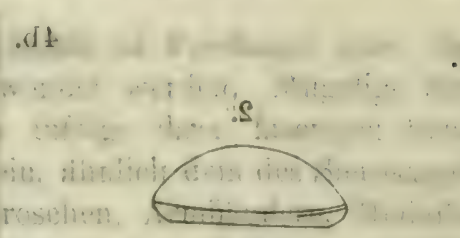

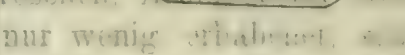

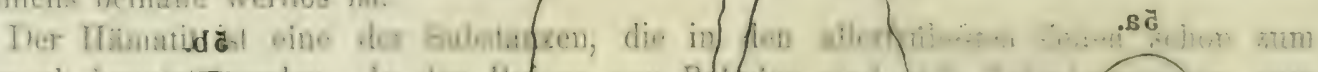

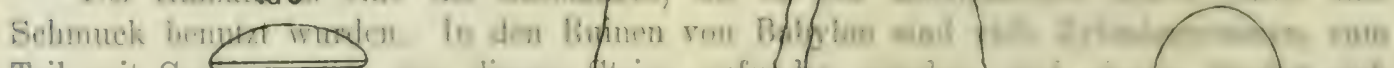

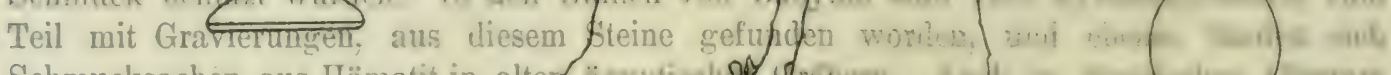

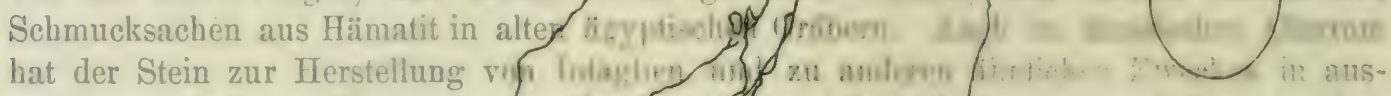
gedehntem Maßstabe Verwendun
aussieht.

Fiir die Bearbeitung der Edelstix namefflich einich

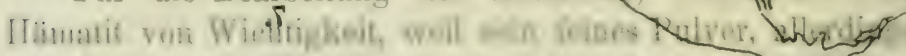

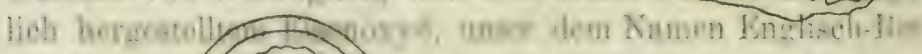

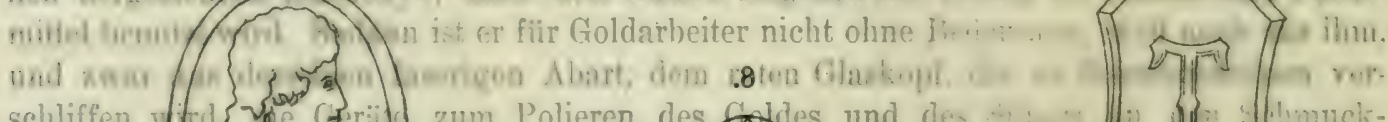

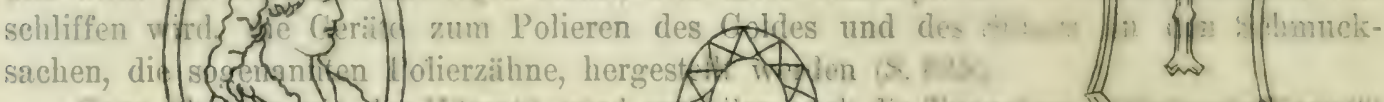

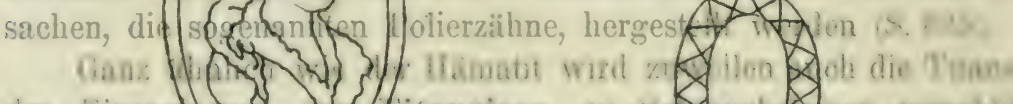

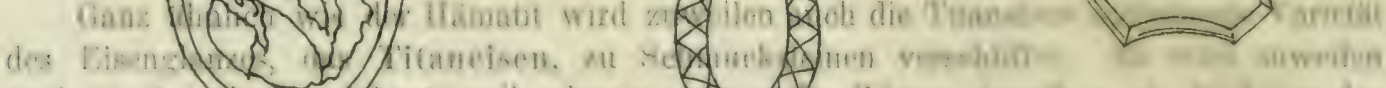

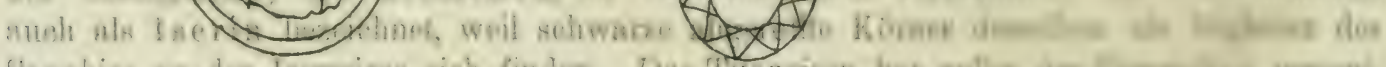

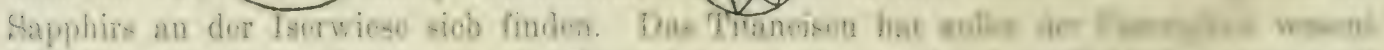

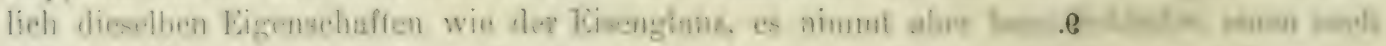

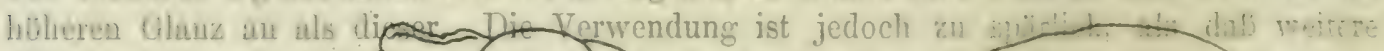

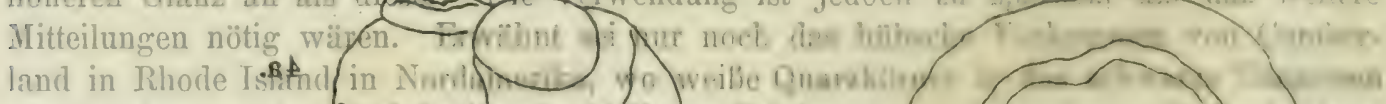

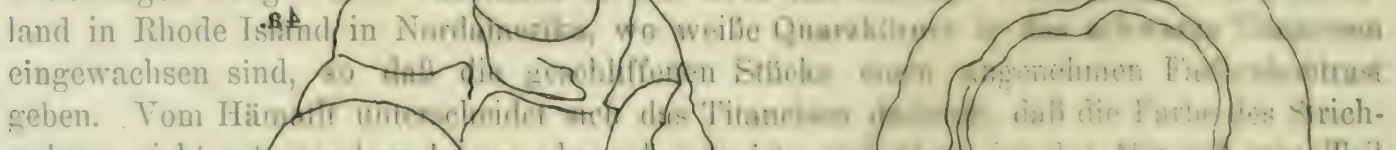

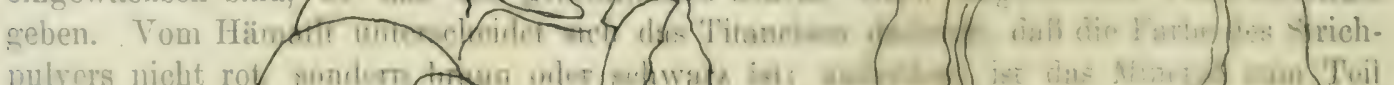

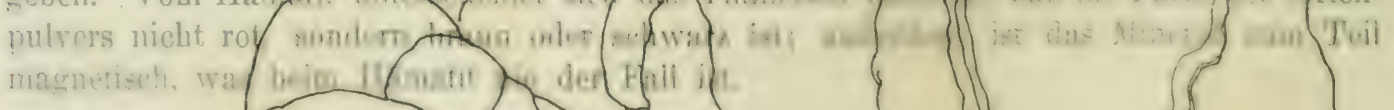

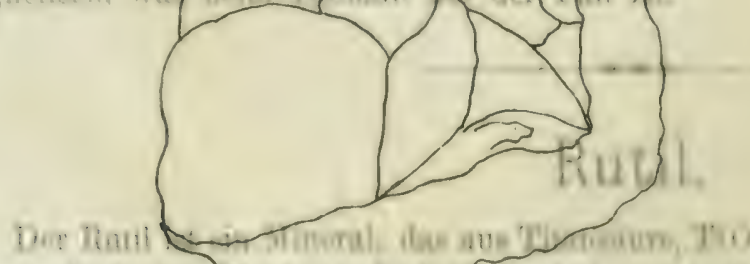

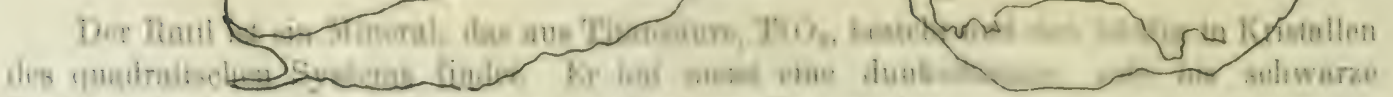

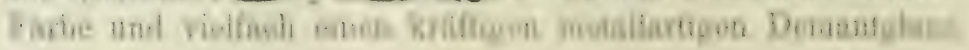

eveniputeas in

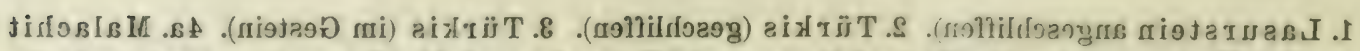

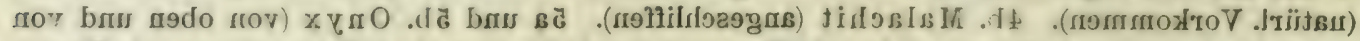
coms

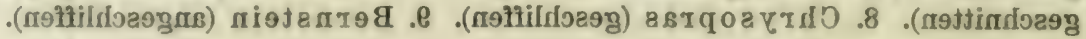


TAFEL $X X$

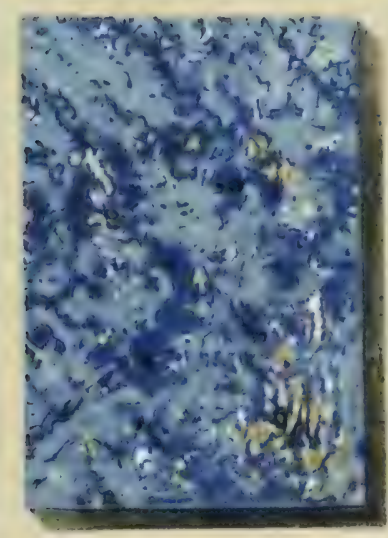

1.
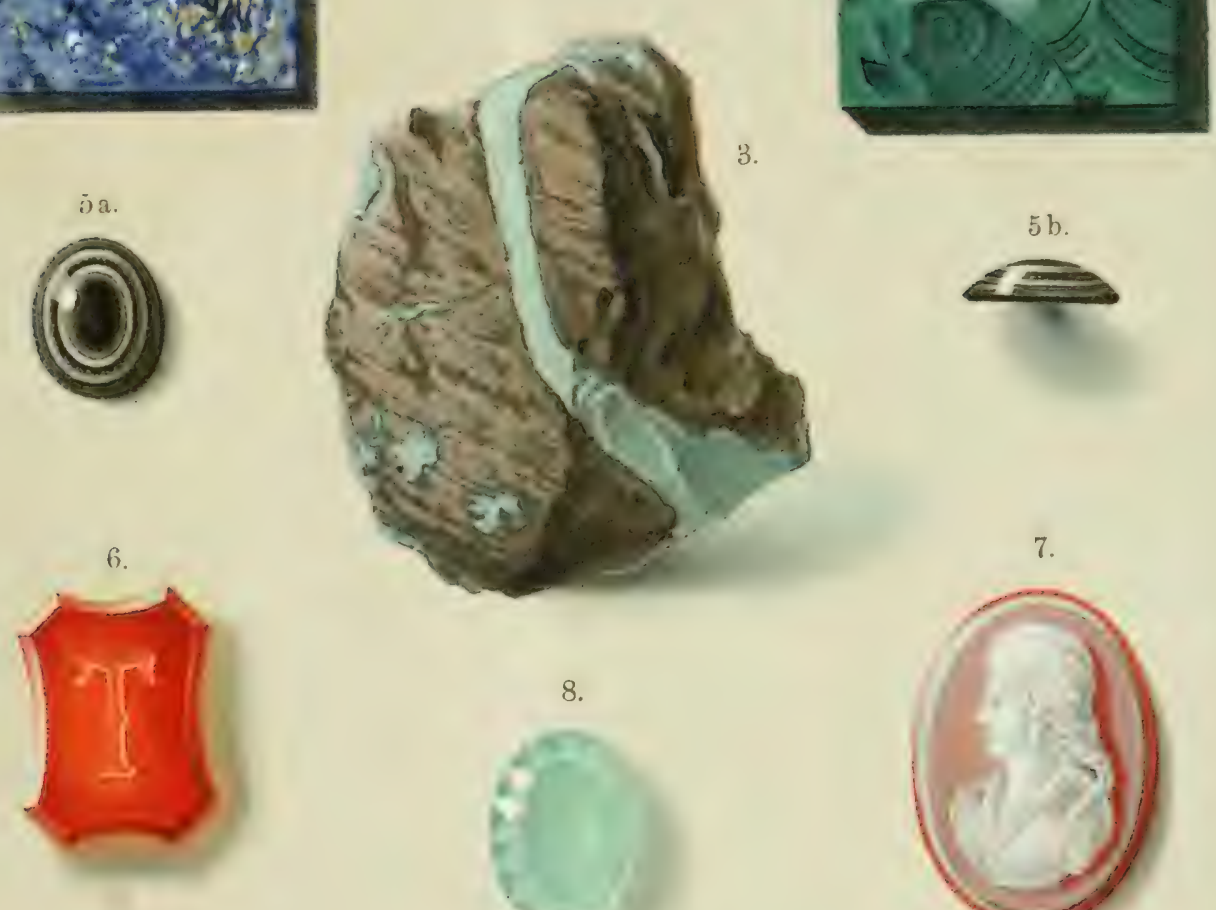

$4 \mathrm{~b}$.

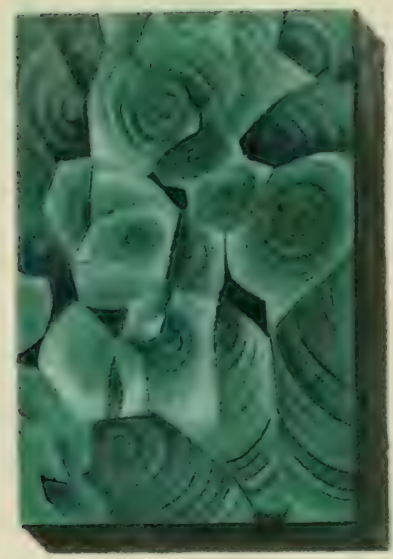

$5 b$.

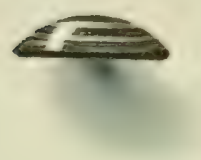

7.

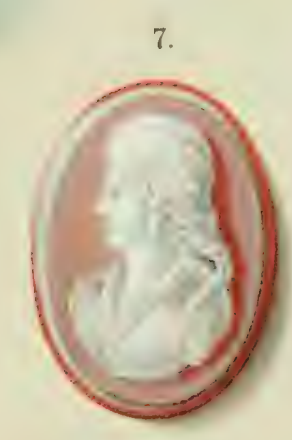

8.

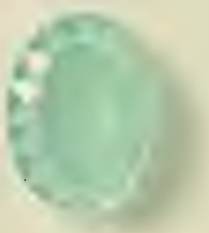

9.
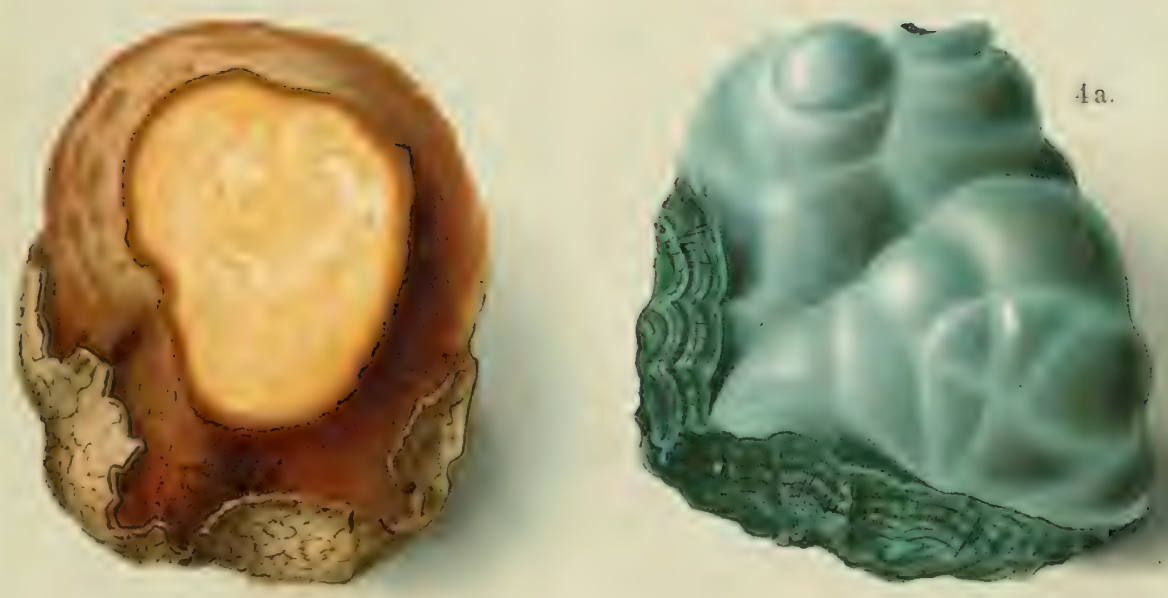

einzelnen Exemplaren schön senug ist, um Erechliffon zn werden. Ein derartiger Stein Gheleht dann oft in so bohem Grade cinem schwarzen I)iamant, dafj er bein ersten Anblick damit verwechselt werden kann. Lnterscheidende Merkmale sind die viel geringere

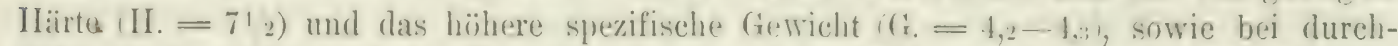
sichtigen Exemplaren starke I)oppelhrechung und merklicher I)ichroismus. Der liutil ist suhr verbreitet. aber doch meist nieht zum Schmuckstein greegnet, man sirht ihn daher nur selten geschliffen.

\section{Bernstein.}

Der Bernstein, dieser viel benutzte selbe selumuckstein, zehërt nicht zu den eirentlichen Mineralien. Er ist pflanzhehen Lrsprungs, ein mehr oder weniger stark verïndertes IIarz vorweltlicher biaume, das aber wie ein Vineral in den Schichten der Erdliruste eingeschlossen vorkommt und das daher wenierstens anhangsweise den Mineralien zugeziihlt wird, wie andere fossile Baumbarze, deren wichtigstes er ist.

Eigenschaften und Beschaffonheit. Dab der Bernstein ein solches Ilarz ist, geht unzweifelhaft aus der Gesamtheit aller seiner Eigenschaften hervor. Irïufig findet man ihn sogar noch im Zusammenhang mit Teilen der fossilen Nadelholzbïume, aus denen er entstanden ist und die unter den Namen der Bernsteinfichte (Pinites succinifer Goepluert) zusammengefaßt werden. Im folgenden ist zunächst vorzugsweise nur der eigrentliche echte Bernstein, der Suceinit der Mineralogen, beriicksichtigt, dessen hauptsüchlichste Heimat das ostpreulische Samland ist. Andere diesen ähnliche oder auch z. T. mit ihm in allen wesentlichen Eigenschaften ibereinstimmende, und in derselben Weise wie er benutzte, aber viel spärlicher vorkommende Harze werden daran angeschlossen.

Was die chemische Zusammensetzung anbelangt, so besteht der Bernstein wie die anderen Harze in der Hauptsache aus Koblenstoff, Wasserstoff und Sauerstoff, die aber in etwas schwankenden Verhältnissen miteinander verbunden sind. Im Mittel findet man 79 Proz. Kohlenstoff, 10,: Sauerstoff und 10,5 Wasserstoff, was der Formel $\mathrm{C}_{111} \mathrm{H}_{10} \mathrm{O}$ entsprechen wïrde. Auch geringe Mengen Schwefel sind zuweilen vorhanden, sowie etwas unorganische Substanz, die beim Verbrennen als Asche zuribchbleibt. Der reine Bernstein enthält davon nur etwa 1/5 Proz., durch die Anwesenheit fremder Einschlïsse kann aber diese Zahl wesentlich erhöht werden.

Der liernstein ist jedoch kein homogener und in jeder Beziehung durchaus gleichartiger Körper. Er ist auch, abgesehen von den Aschenbestandteilen, ein Gemenge mehrerer Substanzen, die sich durch chemische Operationen roneinander trennen lassen. Dureh Destillation erhält man eine kleine Quantität eines ätherischen (̈)s, des Bernsteinüls, und namentlich den charakteristischen Bestandteil, die Bernsteinsäure, die in dem echten preußischen Bernstein stets, aber in wechselnden Mengen, vorhanden ist. In den vollkommen klaren, durchsichtigen Stiicken findet man 3 his + Proz., in den trüben mehr, steigend bis zum Höchstbetrage ron $\delta$ Proz., der sich in den vollkommen schaumigen Massen findet. Durch Behandeln des feinen Pulvers mit Alkohol, Äther und anderen Lïsungsmitteln lassen sich vier in der Zusammensetzung und dem schmelzpunkt roneinander abweichende IIarze ausziehen. Der unlüsliche Rüchstand, 44 bis bo Prozent, ist ein bituminüser Stoff, das sogenannte Bernsteinbitumen, ron Berzelius Succinin grenannt.

In Wasser ist der Bernstein rollkommen unlöslich. Ganze stïcke werden auch ron Alkohol, Schwefeläther, Essigäither und anderen ähnlichen Lösungsmitteln nur wenig und erst nach längerer Enwirkung angegriffen. In konzentrierter Schwefelsäure ist das feine

B a tu or, Edelsteinkunde. 2. Aufl. 
I'ulver schon in dur Kälte rollkommen löslich und durch kochende Salpetersäure wird es vollständig zersetzt.

Beim Erhitzen wird der Bernstein weich, bläht sich auf und giht einen charakteristischen. angenehmen Geruch von sich. Bei 350 bis $375^{\circ} \mathrm{C}$, also bei einer höheren Temperatur als andere Harze, schmilzt er und wird gleichzeitig zersetzt, unter Entwickelung weißer Dämpfe, wobei die oben genannten flüchtigen Bestandteile, Bernsteinöl und Bernsteinsäure, entweichen, zuweilen auch etwas Wasser. Diese Dämpfe zeigen ebenfalls jenen Geruch und reizen, der in ihnen enthaltenen Bernsteinsäure wegen, stark zum Husten. Als nicht flüchtiger Rückstand hinterbleibt eine glänzend schwarze Substanz, das Bernsteinkolophon, das sich in Terpentinöl und Leinöl auflöst und so den Bernsteinlack und Bernsteinfirnis liefert, die vielfach zum Anstreichen benutzt werden. Der Lack ist durch seine große Härte nach dem Trocknen ausgezeichnet. Beim Erhitzen in öl wird der Bernstein weich und biegsam; wir werden sehen, daf von dieser Eigenschaft eine nicht unbedeutende praktische Anwendung gemacht wird.

An der Luft erhitzt, entzündet sich der Bernstein und brennt mit heller rufender Flamne. Daron kommt der Name Bernstein (Börnstein), der brennbare Stein. Es entsteht dabei wieder jener aromatische Geruch, der so charakteristisch ist, dab man daran dieses Harz leicht von anderen ähnlich aussehenden unterscheiden kann. Er ist auch der Grund einer beschränkten Verwendung des Bernsteins als Räucherwerk.

Die physikalischen Eigensehaften sind ebenfalls ganz die eines Harzes. Der Bernstein ist vollkommen unkristallisiert, amorph. Die Stiicke haben daher auch nie eine regelmäfige ebenflächige Gestalt, sie sind entweder ganz unregelmäbige rundliche Knollen, oder sie haben die Form von Zapfen, 'Tropfen, Platten usw. mit rundlicher Umgrenzung. Auch Blätterbriiche fehlen vollständig, der Bruch ist muschlig, aber die Stiicke sind vielfach von unregelmäßigen Rissen durchzogen. Zuveilen ist eine schalige Absonderung, eine Zusammensetzung aus einzelnen diinnen Lagen zu beobachten. Diese Verschiedenheiten der Form und der Struktur stehen im engsten Zusammenhang mit der Entstehung des Bernsteins und sind völlig abhängig von der Art und Gelegrenheit des Ausflusses des Harzes aus den Bernsteinbäumen. Wir sehen in dieser Beziehung beim Bernstein alles, was an den IIarzen der Nadelhölzer der Gegenwart beobachtet werden kann. Freihängend haben sich Tropfen gebildet, deren regelmälig' rundliche, oft birnenförmige Gestalt als Seltenheit geschätzt wird, oder Knollen, die manehmal zu bedeutender Gröfe heranwuchsen. Man nennt den auf diese Weise entstandenen Bernstein nat ürlichen Bodenstein od. Grundstein, natürliches Rund und Knibbel. Oder das Iarz sammelt sich an den Stämmen - unregelmäßige St ïcke; oder zwischen Bast und Holz - I'latten und Flieben; oder es erfüllt Hohlräume in dem Holz, entweder durch Zusammenflieben oder dureh Unwandlung des Parenchyms in IIarz - - sogen. Varkienung und \%. T. ebenfalls Flieben und un regelmäßige Stäeke. Wie bei den Koniferen unserer hentigen Wälder war das dem lebenden IIolz bei der Verkienung odex Verschorfune entquollene Ilarz mit Zelisaft gemengt, der es emulsionsartig durehsetzte und daher trübte. Wenn aber dis im Harz befindlichen. das Licht reflektierenden kleinen Bläschen zusammenflossen, oder dias aheresonderte IIarz nochmals umschmolz, wurde es klar. Bei der erröberen Ititze des siommers entstanden hierdurch langzapfige und, im Gegensatz zu jenen einheitlich geblikleten, kompakten, in Lamellen geflossene Burnsteinsorten, die dadurch, dalb ein Erowab oberflächlich sehmell erhärtete und den nachfolegenden nicht mehr gut haften liefo, eine schalige Absonderung, eine Zusammensetzung aus einzelnen diinnen Lagen, zeigen. Darnach unterscheidet man die zwei IIauptsorten des Bermsteins. Die eine, kompakt und wie aus einem (tub, wird als massiver Bernstei n bezeichnet, die andere, ans rinzeln ühereinander abgelagerten und leicht romeinander trennbaren 
Sehichten hestehend, führt den Samen der šchlanhben. In den Extremen sind diests

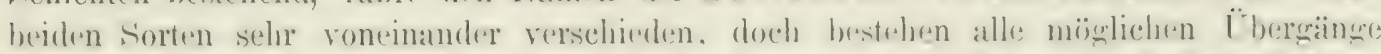
zwischen ibmen. Alich unterschedidet man diesen beiden eregeniiber noch fine dritte Sorte, Rohbernstein, die dadurch entstanden ist, dab woiches Harz entweder auf den einst moorigen Waldhoden oder in ron Mulm erfïllte Hählungern des Stammes flofi und sich mit dem fremden Material so menente, dalf diese Masse schwar\% wurde. Man begrichnet diese Art des Bernsteins als Schwarzfirnis.

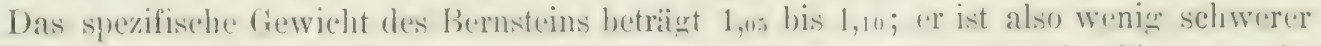
als Wasser, manentlich als Srewasser. Die Härte steht etwas iber dor des fripses, es ist also etwa II. = 21.2; der Fingrernaged bringt daher beim litzen kamm noch einen Eindruck hervor. Die IIärte ibertrifft somit die der meisten anderen Irarze. was wenfalls als unterscheidendes Iterkmal dienen kann. Die Masse ist nicht sehr sprö̈le, sir lälit sich diher mit dem Messer schneiden und sehnitzen, auf der I)rehbank bearbeiten. durehbohren usw. was alles für die Bearbeitung sehr wichtig ist. Schneidet man mit dem Utessir am Rande eines stiickes, dann crhält man keine zusammenhängenden Späne, sondern ein Pulver.

Durch Reiben mit T'uch lälit sich starke negative Elektrizität erzeugen. so daf kleine l'apierstiickehen usw. angezogen werden. Von dem alten Namen des Bernstrins, Elektron, stammt die Bezeichnume für diese Erscheinung. Bei sehr starkem Reiben entsteht ehenfalls der schon mehrfach erwähnte Geruch; die Masse wird dahei aber niemals klehrig wie andere Harze, weil der Schmelzpunkt weit über der dureh die Reibung erzeugrten Temperatur lient. Beim Berihhren mit der IIand fühlt sich der Bernstein warm an, da "l' ein sehr schlechter Wärmeleiter ist. Mierdurch unterscheidet er sich leicht ron ähnlich aussehendem Glas und ron Jineralien, die alle in der Hand das Gefühl der Kälte herrorbringen.

An den meisten Stïcken ist dex Glanz ein schöner echter Harzglanz, der durch die Politur noch wesentlich gesteigert wird. Diese hohe Politurfähigkeit macht den Bernstein zu Schmucksachen ganz besonders geeignet. Allerdings ist sie nicht immer in gleichen Maße vorhanden; manche Stücke sind mehr oder weniger matt und werden auch durch Polieren nicht glänzend; sie sind dann zum Schmuck ungeeignet.

Die Durchsichtigkeit geht rom vollkommen Klaren durch alle ت̈bergänge hindureh l,is zum ganz Triben und Undurchsichtigen. Aber auch die undurehsichtigen Stiicke sind fïr liöntgenstrahlen vollkommen durchlïssiæ. Sehr häufig sind an demselben Stiicke klarere und trülsere Stellen vorhanden, die stets ganz allmählich incinander überohehen und sehr selten scharf gegreneinander absetzen. Dies ist ein sehr charakteristisches Kennzeichen des echten Bernsteins in seiner natürlichen Beschaffenheit; er unterseheidet sich dadurch sehr bestimmt ron anderen ähnlichen Substanzen, die wir später kennen lermen werden. An durchsichtigen Stïcken kann man beobachten, dab der Bernstein seiner amorphen Beschaffenheit gemäß einfach-lichthrechend ist. Zuweilen bemerkt man allerdings eine schwache anomale Doppelbrechung, besonders um fremde Einschlïsse hertm, die kleine spannungen im Inneren des Stückes hervorbringen. Die Lichtbrechung ist schwach; für mittlere Strahlen betrïgt der Brechungskoeffizient, schwankend an rerschiedenen stïcken, 1,530 bis 1,547 .

Die Farbe ist sehr einförmign. In der groben Masse des baltischen Bernsteins hat man bisher fast nur Gell, gefunden, das aber in zahlleichen Nuancen rom beinahe vollständig Farblosen bis zum Dunkeloelb und Braun verlïuft. Rot konmt an frischen Stiicken äuferst selten ror, entsteht aber stets mit der Zeit durch eine oberflïchliche Umwandlung. Griin und Blau ist gleichfalls sehr selten; hiervon soll unten noch weiter die Rede sein. 
Fabt man die Fürbung im Zusammenhange mit der Durchsichtigkeit ins Auge, so sind trotz der Einfürmigkeit der ersteren beim Bernstein doch grobe Ferschiedenheiten der :̈ußeren Erscheinung vorhanden, und das Aussehen der Stiicke ist demzufolge von einem zum andern sehr wechselnd. Auf Grund dieser Eigenschaften hat man eine Anzahl ron hesonders benannten Varietiten aufgestellt, die sich zum Teil auch hinsichtlich der mehr oder weniger vollkommenen Politurfähigkeit voneinander unterscheiden. Danach und nach ihrem Aussehen sind diese Varietïten zum Schnucke in verschiedenem Grade geeignet und greschiitzt und daher für den Handel von gröberer oder geringerer Bedeutung.

Der durchsichtige Bernstein wird im Handel als Klar bezeichnet. Klar sind beinahe ausnahmslos die Schlauben; vollständig trüb sind diese niemals, und sclion eine Abwechslung von hellen und trïben Stellen ist bei ihnen sehr selten. Im Gegrensatze dazu sind die massiven Steine beinahe immer mehr oder weniger trübe. Vollkommen durchsichtige massive Steine gehören zu den ungewöhnlichen Erscheinungen. Sie werden hoch bezahlt. Bei dem Klar des massiven Steins unterscheidet man verschiedene Farbennuancen. Am geschätztesten sind die fast wasserhellen, im Handel eisf arbige genannt. Sie finden sich an den Bernsteinbeigaben altheidnischer Gräber, im Bernstein der sogen. gestreiften Sande und in dem der mehr sandigen Glieder des Diluviums. Davon wird unten noch weiter die Rede sein. Hier muß ein Umwandlungs-, ein Bleichungsprozeß vor sich gegangen sein, denn in seinem eigentlichen urspriinglichen Muttergestein, der sogenannten "blauen Erde" findet sich eisfarbiger Bernstein niemals. Näichst diesem letzteren zililen die sehr dunkelgelben Nuancen zu den seltenen Sorten, man nennt sie Braun. schweiger Klar. Die Hauptmasse besteht aus dem gewöhnlichen Gelben. Je nachdem bei diesem, aber auch bei dem im nachfolgenden betrachteten Trüben, die äußere Rinde heller oder dunkler ist, unterscheidet man Gelbblank und Rotblank. Das erste wird für die Lackindustrie ganz besonders bevorzugt.

Der flohmige Bernstein ist nur leicht, wie durch einen feinen Staub, getribt. Wie der klare nimmt er eine rorzügliche Politur an. Der Name flohnig kommt ron der ostpreufischen Bezeichnung Flohmfett für das halbdurchsichtige gelbliche Fett der Gänse und Enten, dem diese Bernsteinsorte im Aussehen gleicht.

leim Bastard ist die Trübung schon stärker, aber die Politurfähigkeit noch sehr grut. Je nachdem die Trübung das ganze Stiick durchsetzt oder nicht, sind verschiedene Bezeichnungen üblich. Ein durchweg trïber Bernstein ist der eigentliche Bastard. Sind sesättigt und schwach trübe Stellen wolkig verteilt, dann hat man den wolkigen Bastard. Auch nach der Farbe wird der Bastard eingeteilt. Die rein weise bis graulichgelbe Nuance heißt perlfarbig; die helleren Töne davon werden in Handel "blauer Bernstein" genannt (nicht zu verwechseln mit den seltenen wirklich blauen Stïcken). Die gelbe und brïunlichgelbe Varietät bezeichnet man als kumstfarbig (von dem ostpreußischen Namen Kumst für Kohl, Sauerkohl); die erstere heißt hell-, die letztere dunkelkumstfarbig. Kumstfarbig ist das Taf. XX, Fig. 9, dargestellte Bernsteinstïck, das auf einer tieite eine angeschliffene ebene Fläche, sonst seine natïrliche rundliche Begrenzung hat.

IIalbbastard steht zwischen dem Bastard und dem folgenden, dem knochigen Bernstein in der Mitte. Er verbindet mit dem Aussehen des letzteren die l'oliturfähigkeit des ersteren. Der knochige Bernstein, kurz K nochen genamnt, ist undurchsichtig, weicher als die vorhergehenden, steht diesen an Politurfühigkeit nach und besitzt, wie es der Name andeutet, ein knochen- his elfenbeinähnliches Aussehen. Die Farbe variiert von weils bis braun. Durch die Kombination der Eigenschaften der im vorhergehenden aufgeführten Sorten entsteht eine ungeheure Mannigfaltigkeit von Bernsteinfarben, dic unter dem Namen ,huntknochiges Klar" und , buntknochiger Bastard" zusammengefaßt werden. 
Der schaumige Bernstein endlich ist undurchsichtig, sehr weich, nicht mehr politurfähige und vielfach reich an Anscehedongen von Schwefolkies in Kristallen.

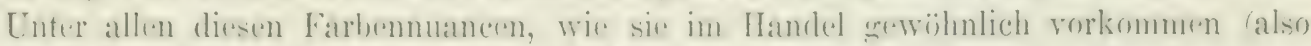

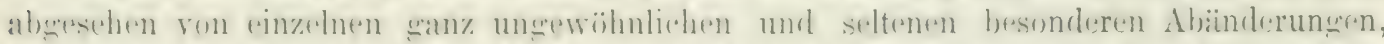

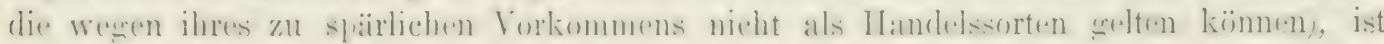

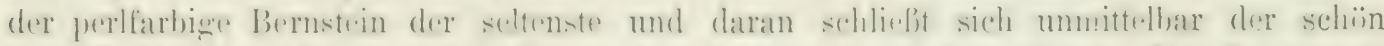

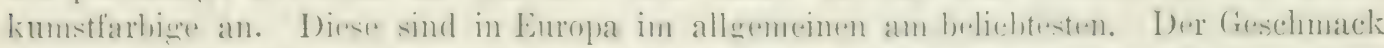

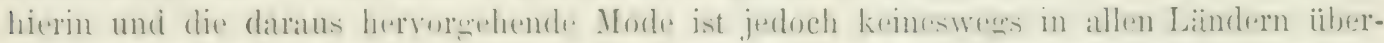
einstimmend; wir werden hieriber unten noch weitere Mitteilungen zu machen haben.

Die Mannigfaltigkeit dieser Varietäten ist früher auf einen kleinen Wassergehait

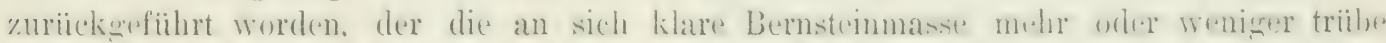

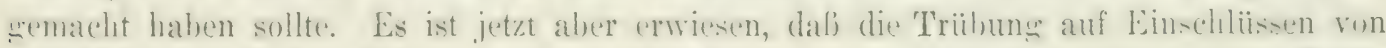
unzähligen rundlichen bläschen von verschiedener, wem anch stets sehr geringer Grible berulst, die daher anch nicht mit blobem Ange orler mit der Lape, sondern nur in diinnen Schliffen bee starker Vergröferung unter dem Mikroskope wahrewenomen werden kïnnen. Dhese Blikehen sind in der Grundmasse des Bermsteins verteilt, die immer von dem reinen

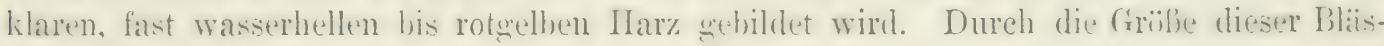
chen, deren Durchmesser zwischen 0,000 s und $0,02 \mathrm{~mm}$ schwanken, sowie durch ihre bed!-utendere oder geringere Anzahl und mehr oder weniger getdrängte Lage wird das verschiedenartige Auschen des Bernsteins hervoreberacht. Tie Summe der Bläschendurchsehnitte geht ron $10,(1$, his $11,+2$ der wanzen Fläche. An kleinsten sind die Blïschen heim Knochen (0, mu his (1, (m) 1 mm Durchnesser), dagegen sind sie hier am zahlreichsten: rine Cutersuchung unter dem Mikroskope hat auf 1 gmm der feinen Sehicht des Dïmm-

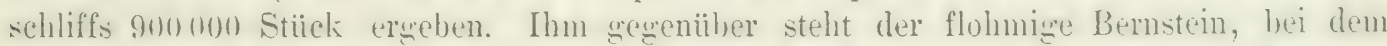
die geringste Zahl 606 im Quadratmillineter! vorhanden ist, bei dem aher dir Blit:chen den grüften Durchnesser (11,2 mmi haben. Dizwisehen liegen alle anderen Sorten, durch deren tudium sich ergehen hat, dah der Bermstein um so stïrker getriilst ist, je zahl-

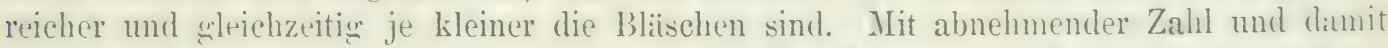
Heichzeitig zumehmender Größe derselhen wird die Masse immer klarer, und wemn sie. gar keine Bläschen enthält, ist sie vollkommen ungetrübt durchsichtig.

Die kleinen Bläschen bewirken die Triibung dadureh, dab das Licht nicht muchehindert durch sie hindurchwehen liann. Beim Lintritt in sie aus der munet) nden Bernsteimmasse werden die Lichtstrahlen zum Teil durch Totalreflexion abgelenkt, so dab sie nicht alle in das Ang'te gelangen. Wäre es müglich, diese kleinen IIohlriume statt mit Luft mit tinem durchsichtigen Körper ron annähernd gleichen Brechungsverhältnissen wie der Bernstein selbst zu exfïllen, dann mülbte die Trübung verschwinden, die trühen Stïclie mïilten klar werden.

Dies lälit sich in der Tat ohne erolbe Schwierigkeit erreichen durch eine Operation. die man das Klarkochen des Bernsteins nennt. Auch in der Technik wird dieses Verfahren manchmal angewendet, um triibe Stiicke durchsichtig zu machen, wodurch sie zuweilen an Wert wewinnen. Man bewirkt dies dadurch, daf man die roben Steine in einem eisemen Gefiif mit Rïbül übergieft, so daß sie von diesem vollständig überdeckt sind und dann äußerst langsam erhitzt unseführ bis zu der Temperatur, wo das (i) siedet und sich zu zersetzen begrinnt. Wie die Erwärmung muli nachher auch die Erkaltung sehr langsam und vorsichtig geschehen, da sonst der zu klärende Bernstein leicht Risse erhält oder ganz zerspringt. Je kleiner die Stiicke, desto rascher ist in allgemeinen der Prozeb heendigt; bei gröberen mul) das Erhitzen längere Zeit fortge'esetzt und nicht selten mub es sogar mehrere Male wiederholt werden. Es kommt dabei aber auch auf die innere Beschaffenheit des Bernsteins an, da gleichgroße Stiicke vielfach verschieden 
range Zeit brauchen, um klar zu werden. Dies beginnt stets an der Oberfläche und schreitet allmählich nach innen vor.

I)er Vorgang besteht darin, daß sich das Rübül auf den feinen sjuältchen, die den Bernstein durchsetzen, allmählich in das Innere der Stiicke hineinzieht und dabei die Blïschen ausfüllt. Da das Rüböl den Brechungskoeffizienten 1,1i; hat, der von dem oben erwähnten des Bernsteins weng abweicht, können nun die Lichtstrahlen so gut wie uncrehindert hindurchgehen und in das Auge gelangen. Die anfänglich tribe Masse erscheint daher jetzt klar und durchsichtig. Ist dem $\ddot{\text { I }}$ ein Farbstoff beigemischt, so dringt auch dieser ein und färbt den Stein entsprechend.

Beim Klarkochen entstehen, wenn nicht mit größter Vorsicht verfahren wird, leicht vigentïmliche Sprünge, die in ihrem Aussehen an Fischschuppen erinnern. Sie sind zuerst so fein, daß sie kaum merklich hervortreten, mit der Zeit werden sie aber immer deutlicher und beginnen zu irisieren, bis sie endlich im Verlaufe des Kochens ganz scharf sichtbar und goldig glänzend werden. Derartige goldig glänzende Sprünge nenmen die Bernsteinarbeiter Sonnenflinten; an ihnen kann man nicht selten klargekochten Bernstein von natürich klarem unterscheiden.

Wir haben bisher vorzugsweise die gelben Farbennuancen des Bernsteins betrachtet. Ton einicem Interesse sind die als Seltenheit vorkommenden fast stets trüben, selten klaren grïnen und blauen Stiicke. Das Grïn ist hellgrün, olivengrïn bis zum Apfelgrün des ('hrysoprases, auch zuweilen mit weiben Wolken; das Blau schwankt zwischen lasurblau, himmelblau und stahlblau. Dieses Blau beruht nicht auf eincm besonderen Farbstoffe, sondern es ist nur die Folge einer eigentïmlichen Veränderung, die die Lichtstrahlen beim Ilindurchgehen durch Stiicke erleiden, in denen feine Bläschen, ähnlich wie beim Bastard oder Tinochen in ganz dünnen Lagen angeordnet sind. Es ist eine ähnliche Erscheinung, wie sie auch sonst bei trïben Medien beobachtet wird. You "schwarzen Bernstein" wird unten die Rede sein.

Noch eine andere Farbenerscheinumg tritt bei manchen Bernsteinstiicken in aus. grezeichneter Weise herror, die Fluoreszenz. Beim Hindurchsehen sind diese Stücke (nelb) bis braun, an der Oberfläche wird aber ein oft sehr dunkles blïuliches bis griinliches Licht reflektiert. Unter dem preußischen Bernstein sind fluoreszierende Stiicke sehr selteı, um so gewöhnlicher sind sie unter den bernsteinähnlichen IIarzen anderer (regenden (Sizilien, Birma usw.). Besonders schön ist die Fluoreszenz bei dem sogenannten Bernstein von San Domingo. Für die Verwendung zum Schmuck ist diese Erseheinung: jedoch ungünstig.

Ein Clbelstand ist es, daß die gelbe Farbe des Bernsteins nicht sehr konstant und dauerhaft ist. Sie ändert sich mit der Zeit, indem mit dem Bernstein eine von außen nach innen fortschreitende chemische Cmwandlung vor sich geht. Namentlich werden helle Stücke dunkler und die grelbe Farbe wird rot oder brïunlichrot, was für den Gebrauch als Schmuckstein wenig erwünscht ist. Schon nach wenigen Jahren kann man diese Farhonänderume der Bernsteinstiocke bemerken, aber je nach der Sorte ist sie etwas verschieden. Mit ihr gehen auch noch andere Erscheinungen Hand in Hand. Klar wird schwach dunkler, und mehr rot, und es bilden sich zahlreiche scharfe Risse. Bastard iiberzieht sich auben mit einer wachsgliänzenden bräunlichen Sehicht. Ḱnochen wird porzellanartig glänzend und rissig; und schaumiger Bernstein ändert sich derart, daß er sich mit einer dïnnen, scharf hecgrenzten Schicht von ganz klareu Aussehen und sprörler Beschaffenheit bedeckt. Alle diese Verïndermgen gehen allmählich immer tiefer und ziehen sich namentlich auf Spalten in das hnere hinein. Man hat diese Vorgänge früher auf die Wirkung des Lichtes geschoben, es hat sich aber herausgestellt, daß Dunkelheit sie nicht hindert, daß sie aber durch Iuftabschlub, z. is. durch Einlegen der Stlicke in 
Wasser, vermieden werden können. Man hat es also mit einer einfachen Verwitterungserscheinung durch die Einwirkung der Luft auf den Bernstein zu tun.

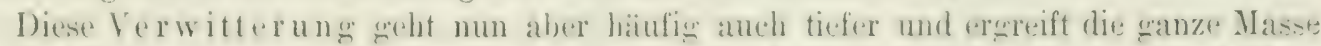
his ins Innerste hinein oder doch einen wroljen 'Teil davon, su dali nur noch ein kleinet unverändert friseher kern ïbring ist. Bei solehen stark verwitterten stïcken ist die Auliensehicht vielfach nach allen licehtungen zelsprungen und zerkliaftert, und oft entstehen dadureh an der Oberfläehe bienenwabenailunliche flache Sliulpturen, wie es Tat. XX. Figr. !, darrestellt ist. I) ie äubere verwitterte Lage trement sich meist leicht und scharf ron dem imneren frischen Kern. I)abei entstehen auf diesem sehr häufig flach kegenfömige Vertiefungen, die dicht gedrängt neheneinander liegen. Diese Verwitterungserscheinungen sind durchaus auf Stücke heschränkt, die trockinn in der Erde gelegen haben, so bei prähistorischem Bernsteinschmuck und bei stiicken, die in das Diluvium verschleppt worden sind. Vielleicht spielt auch die Wirkung kalkhaltigen Wassers dabei eine Rolle. Solche. die in ganz trockenem Sande cingebettet sind, sind stets sehr stark und vielfach bis ins Innerste himein zersetzt und zeigen namentlich jene bienenwabenähnliche leschaffenheit der Oberflïche meist sehr sehön, während solehe, die im Wasser lagen, oder die in der nassen Erde usw. eingebettet und dadurch vor dem Luftzutritt greschiitzt waren, wenig oder gar nicht verändert sind und auch die heschriebenen Oberflächenformen nicht erkennen lassen.

Kinschlïsse. Wir baben gुesehen, dab der Berustein häufig Luftbläschen einhüllt, die einen wesentlichen Einfluß auf sein Aussehen ausïben. Daneben findet man aber auch vielfach Einschlïsse von verschiedener anderweitiger Beschaffenheit, die zum Teil von zanz. besonders charakteristischer Bedeutung sind. Nicht ganz selten beherberert der Bernstein kleine Wassertropfen, viel bäufiger sind in ihm aber feste Körper unorcanischen und organisehen Ursprungs.

Von unorganischen Einsehlüssen ist bauptsächlich Schwefelkies zu erwähnen, der in manchen Stücken Klüftchen und Spültchen in Form ganz dünner Lamellen trfüllt. namentlich in den Schlauben. Daß er sich auch vielfach im schaumigen Bernstein findet, ist schon erwähnt. Der Verarbeitung ist er natiirlich stets hinderlich, und Stiicke, die damit durchsetzt sind, baben daher für den Bernsteindrechsler seringen Wrert. Sehr viel wichtiger sind die Einschlïsse organischen, teils pflanzlichen, teils tierischen Ursprungs.

Die pflanzlichen Einlagerungen bestehen oft, wie wir das beim Schwarzirnis bereits geseben haben, aus feinem Holzmehl, das eine Schwarzfürbung des an sich gelben Bernsteins bewirkt. Bernstein, dessen Harzmasse selbst schwarz ist, gibt es nicht. Als grobe Seltenheiten kommen unter dem Namen "schwarzer Bernstein" beinabe schwarze Harze mit dem Bernstein zusammen in Ostpreufen vor. Diese stehen aber, wie ibre Mikrostruktur zeigt, dem Bernstein gäuzlich fern. Ein schwarzharz, das den Bernstein häufig begleitet, der sogen. Stantienit, ist von diesem total verschieden, und auch zur Herstellung von Schmucksachen nicht brauchbar. Was vielfach im Mandel als „schwarzer Bernstein" verkauft wird, ist Gagat oder schwarzęuärbter Preßhernstein, auf die wir noch zu sprechen kommen werden.

Aber nicht immer sind die Holzteilchen so klein und zahlreich, daf sie zur Bildung des Schwarzfirnisses Veranlassung geben. Mehrfach hat sich Holz in so großen Stiicken im Bernstein gefunden, daß man aus deren Schliffen die Art dieses Holzes, also die Mutterpflanze des Bernsteins bestimmen konute. Daraus ergah sich eben mit Sicherbeit, daß dieses IIarz einem Nadelholz entfloßs. Ebenso wie Holz hat man aber auch Tadeln und andere 'l'eile ron Koniferen als Einschlïsse beobachtet. Die Taleln gehören sicher mehreren Spezies an, aber es ist bis jetzt noch nicht möglich, Nadeln und Holz der Art 
nach zusammenzul)ringen. Man bezeichnet in diesem Sinne nit Güppert die sogenannte Bernsteinfichte allgemein mit dem schon erwähnten Namen: Pinites succinifer.

Deutlich erkennbare Reste anderer Pflanzen fehlen aher gleichfalls nicht, wenn sie auch zu den gatnz ungewöhnlichen Erscheinungen gehören. So sind namentlich Blätter und Bliten gefunden worden, die in der Harzumbiillung ihre Form und ihr Aussehen bis in die kleinsten Einzelheiten auf das herrlichste konserviert haben, trotzdem daß sie häufig in Schwefelkies umgewandelt sind.

In noch auscrezeichneterer Weise sind aber die Tierreste erbalten, die man im Bernstein in grober. Menge und Mannigfaltigkeit findet und die man mit den wohlerhaltenen Pflanzenresten zusammen als Inlilusell zu bezeichnen pflegrt. Es sind namentlich Inseliten der rerschiedensten Art, besonders Fliegen (Dipteren), aber auch Ameisen, Motten usw. auferdem Spinnentiere, Tausendfüßer usw. Selten sind Schnecken und Haale von Beuteltieren oder Nagern, sowie überhaupt alle anderen Tiere außer den genannten. Die Inklusen sind fast aussehließlich auf den klaren Bernstein der Schlauben beschrïnlit, im trüben massiven haben sie sich so gut wie niemals gefunden. Alle diese Einschlïsse, die tierischen sowohl wie die pflanzlichen, sind den jetzt bei uns rorkommenden Tieren und Pflanzen zwar vielfach sehr ähnlich, aber der Art nach von ihnen doch vollkommen versehieden. Sie haben in einer weit zurückliegenden, lïngst vergangenen Zeit, in der ïlteren Tertiärzeit, gelebt und sind damals von dem Harze eingehüllt worden, das dem derselhen Periode angehörigren Bernsteinbaume entfloß und das sie bis auf den heutigen Tag so rollkommen erhalten hat, daß die Zoologen ihren äußeren Bau mit ebensolcher sicherheit studieren können wie den von jetzt lebenden Wesen. Daher bilden die Inklusen Schätze ron höchster wissenschaftlicher Bedeutung für die Kunde der Vorwelt. Auch für die Terwendung des Bernsteins zum Schmuck sind die Einschliisse nicht ohne Bedeutung, da dieser nicht selten so geschliffen wird, daß die von ihm umhüllten Geschöpfe in die Nïhe der Oberfläche treten und dem Beschauer deutlich sichtbar sind.

Vorkommen. Die eigentliche Heimat des echten Bernsteins, des Succinits, ist das ostpreulbische Samland, die nach Westen vorspringende Halbinsel nördlich ron Künigsberg. Er liegt hiex vorzugsweise in einer marinen, von einem Meer der Tertiärzeit abgelagerten Schicht graulichgriner, sogen. graukonitischer oder Grünsande, zuweilen etwas verhärtet, die der unteren Abteilung der Tertiärbildungen, dem Unteroligocän, vielleicht dem Eneän, angehört und die man als die blaue Erde zu bezeichnen pflegt. Auberdem findet er sich aber auch noch in den dariberliegenden, etwas jüngeren Schichten, den "gestreiften Sanden" der gleichfalls tertiären Braunkohlenformation.

Weitaus an wichtigsten und reichsten ist jedoch die ,hlaue Erde". In iln sind die Bernstein in einiger Menge führenden Lagen nur wenige Meter mächtig und der eigentliche ...Stich", der weren seiner besonderen Reichhaltigkeit einen Abbau allein wirklich lohnend macht, kaum einen halben. Es ist eine Umlagerung des ehemaligen Waldbodens, auf dem die Bernsteinfiehte wuchs und in dem sich das kosthare Harz bei der Verwesung des Holzes aufspeicherte.

Die Verbreitung der bernsteinreichen blauen Erde ist gering und nur in einem kleinen Teil des Samlands westlich von einer Linie von Cranz nach dem sïdlich von Palmniken an der Westkïste gelegenen Nodems bekannt. Auch hier ist der Bernsteingehalt nicht ïherall derselbe und für einen Abbau geeignet. So nimmt dex Gehalt nördlich von P'almniken an der samländischen Westliüste gegen Brüsterort bedeutend ab, doch hat man neuerdings ein reiches Vorkommen bis in das mittlere Samland nachgewiesen, während im südlichen Samland, gegen fï̈nigsherg hin, die Ablagerung fehlt. Sicher hat aber die Bernsteinfichte an Anfang der 'Tertiärzeit eine größere Verbreitung gehabt, demn man findet etwas Bernstein enthaltende blaue Erde noch weit östlich bis 


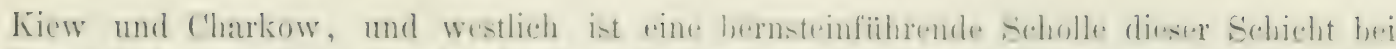

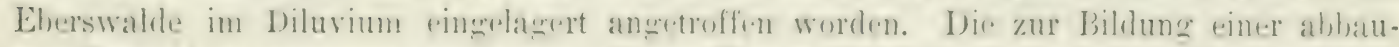

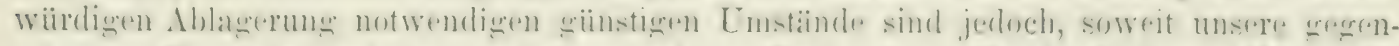

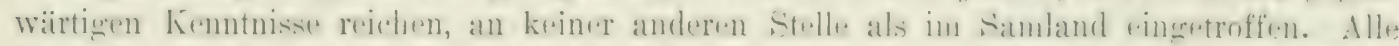
Versuche, die man anderswo angestellt hat, haben zwar dat und dont die der .. haluen Erde"

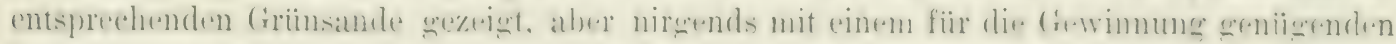
Bernsteingehalt.

Diese ältesten bernsteinführenden Schichten der „blauen Erde" sind dann später,

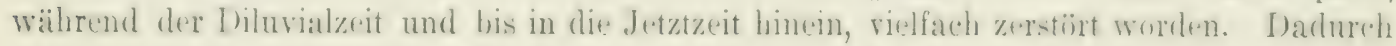
wurde der darin enthaltene Bernstein verschleppt und an einem anderen Ort in einer

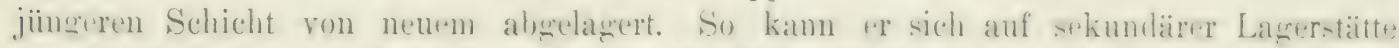
ïberall da finden, wo diluviale und alluviale Bihlungen anftretend, die in Zusanmentanng

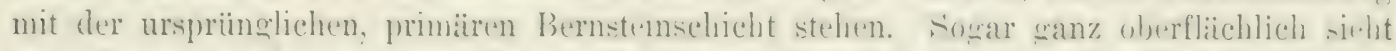
man bermstein oft in Menge liegen. I) rer samlïndische Strand ist nicht sthten anf weite

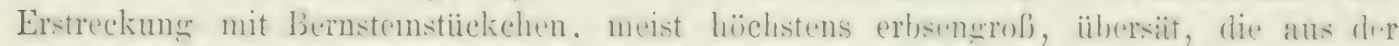
untermeerischen Bernsteinschicht auscewaschen und an das Land geworfen worden sind.

Auf sekundiarer Laeverstättr hat man auch auferhalh des Samlands schon vielfach

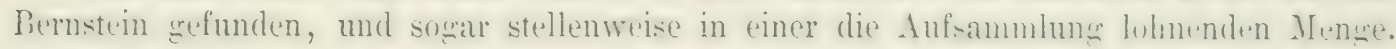
Hiervon wird bei der Betrachtung der Gewinnungsarten noch weiter die Rede sein.

Hier sei auch noch die Größe der in diesen verschiedenen Ablagerungen sich findenden Bernsteinstïcke erwähnt. Diese ist innerhalb ziemlich weiter Grenzen verschieden. Wenige wiegen mehr als 100 Gramm, die meisten viel weniger. Solehte von Erbsemerölie und darunter sind am häufigsten. Im allgemeinen sind die Stidcke um so seltener, je grö̈fer sie sind. Das grölite bisher bekannt grewordene Exemtular witert $9,-\mathrm{kg}$ und ist $45 \mathrm{~cm}$ lang und $20 \mathrm{~cm}$ breit und dick; es hat selır schöne Bastardfarbe und wird auf 4000 Mark reschätzt. Gefunden wurde es nicht im Samlande, sondern bei Kamnin in Pommern; aufbewalirt wird es gegenwärtig in Ifuseum für Naturkunde in Berlin.

Ebendort liewt ein zweites, etwas kleineres Stiick, das ron Schlapuachen zwischen Insterburg und Gumbinnen in Ostpreufen stanmt; es wiegt $6.3 \mathrm{~kg}$ und niff 3.5, 2.2 und $14 \mathrm{~cm}$ in der Länge, Breite und Dicke.

Gewinnung. Zuerst und schon in den ältesten Zeiten wurde offenbar derjenige Bernstein gewonnen, der aus unterseeischen, streckenweise den Vfeerescrund bildenden bernsteinfïhrenden schichtenablagerungen ron dem Wasser lerauserewaschen und auf dem Boden des Meeres ausgrebreitet oder an das Land geworfen worden war. Auch noch lucute bildet dieser sogenannte Seebernstein oder kurz Seestein einen wenurleich Eegenwärtig kleinen Teil der Produlition. Er ist dadurch ausezeichnet, dafs er nicht von einer Terwitterungsrinde bedeckt ist. Diese war wohl, solange die Stiicke noch in der blauen Erde steckten, urspriinglich teilweise vorbanden, aber sie wurde beim Hiu- und IIerrollen im Sande durch die Meereswowen ahgerieben und blieb hüchstens spurenweise in Vertiefungen der Oberfläche erhalten, an Stellen, wo die Sandkörner nicht wirken konnten. Bei diesem Vorgange der Hin- und Herbewegung im seichten Kïstenmeere werden die Bernsteinknollen namentlich während heftiger stïme starken Stölien auswesetzt, infolge deren sie nach den in ihnen etwa rorhandenen Klüften und sprïngen zerlorechen. Die Stiicke des Seebernsteins sind daher im allgemeinen gesund und frei ron schädlichen, bei der Verarbeitung zu Schmucksachen hinderlichen Rissen.

Die Gewinnung des Seesteins ist wenigstens zum Teil besonders leicht, da iln am flachen Strande das Meer selber dem Menschen iiberliefert. Besonders bei stürmen, die rom Meere gexen das Land wehen. Werlen grobe Mengen Bernstein vom Meereshoden aufgerihht und an das Ufer greworfen. Namentlich sind die bei solchen Crelegrenheiten 
massenhaft an den strand getriebenen Bündel von Seetang vielfach mit Bernstein beladen. Die so ans Land gespülten Bernsteinstiicke werden gesammelt. Sodann werden vor allem auch die Tangmassen durchstöbert, um ihren Inhalt zu gewinnen. Aber man begnügt sich nicht mit den, was der Wind an das Ufer treibt; die Leute gehen, wenn eine gewisse Ruhe in dem Sturm eingetreten ist, so weit als nur möglich in das Wasser hinein und ziehen den flottierenden Tang, das sogenannte Kraut, mit langgestielten Netzen anf das Land, damit er nicht wieder vom Wasser zuriickgerissen wird und so sein Inhalt verloren geht. Diese Arbeit heißt das Schöpfen; der Bernstein, der dabei gewonnen wird, ist der Sch öpfstein. Was die See auf den Strand wirft, wird als Strandsege n bezeichnet.

Man beschrïnkt sich jedoch nicht auf das, was das Meer freiwillig hergibt, sondern man holt auch die Stïcke heraus, die auf dem Neeresgrunde liegen, und wendet hierzu verschiedene Hilfsmittel an.

Ein solches ist das Stechen des Bernsteins. Von einem Boote aus wird der Meeresgrund abgesucht, wo die Tiefe des Wassers in der Nähe des Ufers noch nicht zu groß ist; die gefundenen Stücke werden dann mit kleinen Netzen (Käschern), die an langen Stielen befestigt sind, heraufgreholt. Dabei müssen die großen erratischen Blöcke, die den Frund des Meeres vielfach bedecken mit besonderen, ebenfalls an langen Stangen befestigten Instrumenten weggewälzt werden, um die zwischen und unter ihnen liegenden Bernsteinstücke zu gewinnen. Auch diese erratischen Blöcke selber werden vielfach aus dem Neere herausgeholt, um sie in dem steinarmen Lande als Baumaterial usw. zu verwenden; dabei wird dann nicht selten Bernstein in einiger Menge nebenher gewonnen. Dies war frïher unter anderem an der Nordwestecke von Samland bei Briisterort in hervorragendem Maße der Fall, wo man, nachdem die großen Steine herausgehoben waren, den so geglätteten Meeresgrund mit Schleppnetzen nach Bernstein absuchte. Das Bernsteinstechen ist auf die samländische Küste beschränkt, an Ger westpreußischen sind die Versuche ohne Erfolg geblieben; hier wird der Seebernstein nur durch Auflesen am Strande und durch Schöpfen gewonnen.

Aber nicht nur im Samlande, sondern an der ganzen Ostseckïste von Livland und Kurland durch Ost- und Westpreußen, Pommern mit Rügen, Mecklenburg und längs des ganzen Strandes der jütischen Halbinsel, in Holstein, Schleswigr und Jütland wird auf diese Weise eine gewisse Menge Bernstein gewonnen, an manchen Stellen mehr, an manchen weniger; streckenweise fehlt der Bernstein allerdings auch wohl ganz. Neben dem Samland ist wohl vor allem die jütische IJalbinsel mit Schleswig und Holstein von einiger Bedeutung. Mehr als an der Ostküste findet sich hier an der von der Nordsee bespiulten W'estkïste, wo an zahlreichen Orten der Strandsegen gewonnen wird. Als reich wird besonders die Halbinsel Stavning und die Insel Fanö genannt. Weniger Ertrag scheinen die nordfriesischen Inseln Romö, Sylt, Amrum, Föhr usw. zu liefern, eine größere Mengre dagegen wieder der Strand der Eiderstädtischen Ialbinsel, wo bei der Ebbe viel Bernstein in den Watten liegen bleibt und gesammelt wird. Reich ist vor allem die Hitzbank, eine Untiefe, die von jener Halbinsel aus sich weit in das Meer hinauszicht. Die Bernsteinsucher werden daher hier II itzläufer grenannt. Auch die Eidermündung ist günstig; von hier gieht sich die Bernsteingewinnung noch weiter südlich bis Büsum, ist aber in Süderdithmarsehen, in der Elbmündung und an der hannoversehen, oldenburgisehen und holländischen Küiste gering. Wegen der Flut ist die Arbeit in den Watten mit großen Gefahren verbunden. Deswegen gehen in Norderdithmarschen die Leute mit ablaufender Flut vielfach zu I’ferde hinaus, sammeln so viel sie können und retten sich, wenn das Meer zurïckkehrt, so schleunig als möglich wieder auf das feste Land. Dies sind die Bernsteinreiter. Vielfach wird das Sammeln hier auch von Booten aus betrieben. Gegen früher soll jetzt der Ertrag bedeutend nachgelassen haben. 
Diese Gegenden haleen wohl im Altertum den Bernstein geliefert. Die Inseln an der holländischen, der ost- und der nordfriesischen Küste werden daher von Plinius .,insulate ghessaliae", d. h. Bernsteininseln genannt: auch als die Elektriden wurden sie bezeichnet. Das viel reichere Samland selbst ist den lï̈mern erst spitter bekannt weworden, aber schon in Beginn der Kaiserzeit treten sie in direkte Ilandelsheziehungen zu Ostpreulien, un dats von ihmen sehr hochgeschätzte. IIarz zu erhalten, das damals wohl ledigheh durch Aufsammeln der vom Meere ausceworfenen Stïcke, hëchstens noch etwa durch Sichijpfen gewonnen wurde.

Alle diese bisher erwähnten Methoden, den auf dem Meerestrunde liegenden Bernstrin zu gewinnen, sind etwas primitiv. Jan ist aber nicht bei ihnen stehen geblieben und lat später namentlich die rationellere und ertragreichere $\mathrm{T}$ a ucherei cingeführt. Seit 1869 stiegen mit allen Hilfsmitteln der modernen Technik ausgestattete Taucher der damaligen großen Königsberger Bernsteinfirma Stantien \& Becker in das Mcer, un den auf dessen Grunde herumliecrenden Bernstein aufzusammeln und den in Ireereshoden steckenden herauszugraben. Zuerst wurde bei Brüsterort, sowie bei denn nahe ästlich davon grelegenen Dorfe Grob-Dirschkeim getaucht, nach der Ersehöpfung des dortigen Vorrates suidlich davon bei Palmnicken. Ifeute ist diese (iewinnungsart aber ganz auffregeben zugunsten des viel reicheren Ertrag liefernden bergmännischen Betriebes. Ehe wir aber hierzu übergehen, haben wir noch das Baggern und die oberirdische Gräherei nach Bernstein zu betrachten.

Das Bawgern, das ausschließlich ron der eben genannten Fima hetrieben wurde. seschah nicht im Meere, es blieh stets ganz auf das kurische Haff beschränkt. Dessen Boden bildet bei dem Dorfe Schwarzort, etwas südlich von Hemel auf der kurischen Jehrung gelegen, eine sehr bernsteinreiche, dem älteren Alluvium angehörige Schicht, die sich nach Osten hin über den Wasserspiegel des Haffs erhebt und die auf dem festen Lande bei Prökuls zu einer umfangreichen Gräberei Veranlassung gregeben hat. Der Beginn des Baggerns fällt in das Jahr 1\$60, und von da ab datiert wegen der grolen Ergiebigkeit dieses Betriebes ein Wendepunkt in der Bernsteingewinnung. Während bis dahin der Seestein den Markt beherrscht hatte, ïberwog hald das durch Bagrern erhaltene massenhafte Material, der Baggerstein, der allerdings in der Beschaffenheit sich rom Seesteine in keiner Weise wesentlich unterschied, sofern bei ihm gleichfalls die Verwitterungsrinde fehlte, und auch bei ihm die Stïcke in der Hauptsache getsund, d. h. frei ron Rissen und Spalten waren. Vit drei kleinen IIandbaggern begann die Arbeit, zuerst unter ungünstigen Verhältnissen; als aber die richtigen Stellen gefunden waren, entwickelte sich das Lnter. nehmen zu ungeahnter Blüte. Mehr als 20 grobe Dampfbagger holten spüter mittels kräftigner Maschinen den Haffhoden bis zu einer Tiefe von $T$ bis $11 \mathrm{~m}$ heraus; dieser wurde nach Bernsteinstïcken durchsucht und so lange Zeit hindurch ungefähr die Hälfte des Jahresertrages an ostpreußischem Bernstein gewonnen. Etwa 10010) Arbeiter waren dabei beschäftigt; das kleine Fischerdorf schwarzort erlangte eine erhebliche Bedeutung: und seine Einwohnerzahl vermehrte sich um das Tielfache. Jetzt ist dies alles aber voriiber und das Baggern hat seit Ende November 1890 aufgehört.

Teben dem Sammeln, Schöpfen, Stechen, Baggern usw. des Seesteins ging seit alter Zeit die Bernsteingräberei am Strande und im Innern des Landes her. Der auf diese Weise gewonnene Bernstein, der sogenannte Grabstein, ist rom Seestein durch eine meist dicke Verwitterungsrinde unterschieden, auch hat er im Innern viel mehr Risse als der letztere, die aber wegen jener Rinde äuferlich nicht sichtbar sind. Nicht nur in Ostpreußen, sondern auch in allen Teilen des oben bezeichneten Verbreitumgsbezirkes des Bernsteins wurde gegraben und auf diese Weise das in den Schichten der Tertiïrformation und umgelagert in Diluvium und Alluvium eingeschlossene Material gewonnen. Die Menge 
des Crabstrins war in früheren Zeiten neben der des Seesteins gering, gegenwärtig hat sich dieses Terhältnis aber ungemein zu ungunsten des Seesteins geändert, namentlich seit vom Jahre 15:3 ah die ,blaue Erde" durch unterirdische fräherei, also durch bergmännisch'n Betriel), abgebaut wird. In der Jetztzeit ist es infolgedessen der Grabstein, der den Markt heherrscht, der Seestein tritt ihm segenïber an Menge und Bedeutung vollständig in den Hindergrund.

In oberflächlichen Alluvialablagerungen wurde zuerst Bernstein gegraben im Sïdosten von Ostpreuben, sïdlich von der Linie Ortelshurw-Johannesburg (an der Eisenhahnlinie Allenstein-Lyk) in einem Gebiet, das östlich von der Pissek und westlich vom Omulewflusse begrenzt wird, das sich aber noch weit nach Polen hinein erstreckt, bis gegen Ostrolenka am Narew. Hier und an verschiedenen anderen Orten in Polen hat man namentlich in friheren Jahrhunderten gleichfalls viel Bernstein durch Graben gewonnen. In ähnlicher Weise ist auch in Ostpreußen viel gegraben worden, so namentlich bei Steegen auf der Danziger Nehrung. Hier und in der wichtigsten aller dieser alluvialen Ablagerungen, bei dem schon erwïhnten Prökuls, begann die Firma Stantien \& Becker in kleinem Maßstabe ihre nachmals, allerdings an anderen Orten, zu so riesiger Entwickelungr grelangten Gräbereien, durch die, nachdem sie später in fiskalischen Besitz ühergetwangen sind, heute die ganze IVelt mit Bernstein versorgt wird. Prökuls liegt südlich von Memel, Schwarzort gegenüber, auf dem Festlande an der Bahnlinie Memel-Tilsit. Die Ablagerung ist dieselbe, die in ihrer westlichen Fortsetzung unter den Ilaffspiegel hinab, bei schwarzort, durch Baygern ausgebeutet wurde; die Gräberei hat aber nicht entfernt den Ertrag geliefert wie das Baggern.

In Diluvium ist Bernstein überall in norddeutschen Flachland vorhanden, meist in geringer Menge, aber stellenweise doch auch in größeren Quantitäten, besonders da, wo in der Tiefe die ,blaue Erde" ansteht. Das Vorkommen ist aber, wie das im Alluvium, praktisch ron geringem Wert, da die vereinzelten reicheren Stellen durch keine Merkmale grekennzeichnet sind, so daß das Auffinden derselben Iediglich Sache des Zufalls ist. Man trifft sie gelegentlich bei Anfurabungen zu anderen Zwecken, hei Meliorationen, in Sand- und Kiesgruben, beim Torfstechen usw. Kleinere Ablagerungen und Nester wurden an vielen Stellen in Ost- und Westpreußen, Pommern, Mecklenburo, Schleswis-Holstein, Dïnemark, in der Mark und weiter nach Westen hin, sodann in der Provinz und in Königreich Sachsen, in Schlesien (vor 4 Jahren bei Breslau mehrere Zentneri usw. gefunden und ausgreheutet, und auch nach Osten hin, in Rußland, wird ziemlich viel Bernstein in Diluvium gergraben. Einige besonders reiche Stellen sind in Ost- und Westpreulen, sowie in Pommern angetroffen worden, so namentlich die folgenden: Bei Krebswalde unweit Elbing lieferte ein kleines Nest 700 I'fund; für die Grähereien von Schillehnen bei Braunsherg wurden ehemals 400 Dukaten jährliche Pacht bezahlt; bei Gluckau, unweit Danzig, hat man in friiheren Zeiten, mindestens 170 Jahre lang, Bernstein aus dem I)iluvium gregraben und noch 1858 wurde ein gutes Stïck von 11 Pfund 26 Lot gefunden. Nesterweise in Lehm kam bei Karthaus viel Bernstein vor, und von einiger Bedeutung sind die Orte Berent, Konitz, Czersk, Tuchel und Polnisch-Krone in Westpreuben, sowie Treten und Rohr nördlich von Rummelshurg in Pommern, wo man schon seit über 100 Jahren Bernstein in lehmigen $A$ dern gräht, die sich his zu einer Tiefe von "2:3 $\mathrm{m}$ im Diluvialsande hinziehen.

Die Ciesamtmenge des aus dem Alluvium und Diluvium gewonnenen Materials verschwindet aber gexen die Vorräte, die den Tertiärschichten, den .gestreiften Sanden" der Braunkohlenformation und vor allem der .blauen Lrde“" selbst entstammen. Diese letztere liefert heutzutage, von geringen Quantitäten abgesehen, alles, was von echtem Bernstein in den Handel gebracht wird. Gräbereien, offene Tagebaue sowohl als unterirdiseher 
Bererbau, in diesen sichichten sind durehaus auf dir. Fordwestedere ron sianland und aluch hier auf die liferkante ästlich und südlich von Brösterort heschränkt; im Binnenlande fohlen sie gänzlich und whenso an der ganzen übrigen Ostsecküste, sowie längs der Nordsee.

Schon in früheren Jahrhunderten und bis in die Neuzeit hinein wurde in den

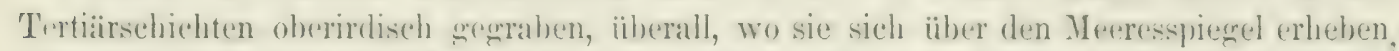
ocler sich doch nicht zu tief unter ihn hinabsenken. Orte, wo wichtige (rribereden betrieben wurden, sind Kraxtepellen, Groß- und Kleinkuhren, Georerswalde, Rauschen, Sassen Wannenkrug usw. Wirklich grolartige liesultate hat aber das Bernsteingraben in der blatuen Erde bei Lappehnen geliefert; vierspämnige Wagen waren nïtige, das gewonnene Material wegzufahren.

Wann die oberirdische Gräberei in der "blauen Erde" begonnen hat, ist unbekannt, doch ist mit Sicherheit anzunehmen, dal) schon um 1660) mit Erfolen an den Cferberen von Warniken und Grob-Hubniken Pernstein aus der ,hlauen Erde" und anderem Tertiärschichten gegraben wurde. In groliem Mafstabe begannen derartige Arbeiten im Jahre 1837.

Bei diesen Tagebauen ist es nötign, die oft viele Meter mächtige C̈herdeckung der Bernsteinformation durch die Schichten des jüngeren Tertiürs ider Braunkohlenformationi und des Diluriums abzuräumen, um auf dee nur etwa $1^{1}{ }_{2}$ Spatensticbe mächtige eigrentliche Bernsteinschicht zu kommen; auljerdem war man vielfach gezwungen, den Einbruch des Neeres in die Gruben durch Abdämmen zu hindern. Die dadurch verursachten ungeheuren Arbeitskosten geben einen Begriff von dem Reichtum der ..hlauen Erde“ an Burnstein, der alle diese Auslagren ersetzen mußte. Allerdings lieferten oft schon die in den ...estreiften Sanden" über der "blanen Erde" unregelnä̈̈ig rerteilten Bernsteinnester einen reichen Ertrag: aber trotz alledem war die Gräberei eben jener Lnkosten wegen nicht immer lohnend. Daher hat heutzulage diese Gewinnungsmethode fast ganz aufcehört; sie ist jetzt ersetzt durch den hereminnischen Betrieb. der in unterirdischen Bauen der "blauen Erde" ihre Schätze raubt.

Berømännisch wurde schon von 1781 ab durch die Regierung am Espenwinkel zwischen Hubniken und Kreislacken am samländischen Weststrand der Bernstein der gestreiften Sande" gewonnen, man hat aber das Unternehmen nach vierundzwanzigjährigem Betriebe wieder aufgegeben. Ein Verdienst der früheren Firma Stantien \& Becker ist es, zuerst den unterirdischen Abbau der "blauen Erde" rersucht zu haben, der dann mit durchschlagendem Erfolge, sowie mit immer steigenden Erträgen, später vom Fiskus. bis zum heutigen Tage fortgesetzt worden ist.

Am Anfange der siebziger Jahre des 19. Jahrhunderts fanden gleichzeitig zwei Tersuche nach dieser Richtung hin statt. Der eine wurde von seiten der kgl. preufischen bergwerksverwaltung bei Nortycken unweit Rauschen am samländischen Nordstrande, mehr im Innern des samlandes, unternommen. Er scheiterte, weil es unmöglich war, die aus dem Triebsande, einer wasserreichen, die ..blaue Erde" überlagernden Schicht zuströmenden Gewässer in dem Schachte zu bewältigen. Das zweite, eben von jencr Firma ins Werk gesetzte Lnternehmen an der Westküste des Samlandes bei Palmnichen zwischen Pillau und Briisterort gelang in der glänzendsten Wreise. Sie hatte dort ummittelbar am Strande zur Bernsteingewinnung im Jahre 1570 einen großen Tagebau angelegt, aus dem sich bis zum Jahre 1875 allmählich der berçmännische Betrieb entwickelte, der an jener Stelle, wo die Bernsteinschicht 6 bis 5 m unter den Ostseespiegel lient. sich immer weiter ausdehnte. Die alte Grube bei Palmnicken wurde dann um das Jahr 1590 verlassen und etwas weiter nördlich, zwischen Kraxtepellen und Hubniken, die neue "Grube Anna" angelegt, die bis in die Jetztzeit herein den Bernstein liefert. 
Der unterirdische Bergbau brachte den enormen Vorteil, daß die gewaltigen Abraumarbeiten der oberirdischen Gräberei mit ihren riesigen Kosten nicht mehr notwendig sind, daß keine großen Flächen wertvollen Bodens der Landwirtschaft entzogen werden und daf die Arbeiten in der kalten Jahreszeit nicht mehr unterbrochen werden müssen, wie das beim Tageban der Fall ist. Jetzt wird hier die gesante Bernstein führende ..blane Frde" aus Schäichten, Stollen und Strecken gefördert und ihr nutzbarer Inhalt dureh Waschen in eigenen, zweckmäßig eingerichteten Apparaten von der anhängenden Erde befreit.

Der so erhaltene und gereinigte Bernstein, der sogenannte Dammstein hat, wie aller Grabstein, eine dicke Verwitterungsrinde, die in der Tonnenwäsche entfernt wird, indem man die Stiicke mit Wasser und zum Teil mit scharfem Sand in rotierenden Fässern oder T'onnen so lange hin- und herwälzt, bis die letzte Spur der undurchsichtigen Kruste entfernt ist. Eine nochmalige, die sogenannte K lebssche Wäsche vollendet die Zurüstung des Rohmaterials, das nun ganz dieselbe reine Oberfläche hat wie der Seestein. Man kaun den Dammstein jetzt wie diesen auf seine innere Beschaffenheit (Farbe, Durchsichtigkeit) und die etwa in ihm vorhandenen Risse untersuchen und danach seinen Wert taxieren, sowie die beste Art der Verarbeitung feststellen, was alles bei dem Grabsteine mit anhängender Rinde nicht möglich ist. Nach der Beschaffenheit werden die gewonnenen und gereinigten Steine solann sortiert und die einzelnen Sorten, von denen unten noch weiter die Rede sein wird, getrennt in den Handel gebracht.

Die hergmännische Gewinnung des Bernsteins und die aus der See und rom Strande, durch Lesen, Fischen und Stechen, sind gegenwärtig die gebrïuchlichen Gewinnungsmethoden. Schon in den letzten Jahren ihres Betriebs waren von der Firma Stantien \& Becker, die durch ihre kaufmännischen Unternehmungen sich ein Geschäftsmonopol der liernsteinproduktion herausgebildet hatte, die anderen Betriebe außer ihrer Anna-Grube eingestellt. Im Jahre 1899 erwarb der preußische Staat von Stantien \& Becker das Bergwerk, die Ländereien und alle Anlagen zur Herstellung des für die versehiedenen Bernsteinindustriezweige geeigneten Rohsteins, sowie die vorhandenen Vorräte für S7.) (1) Mark. Auch er ließ die anderen Betriebe ruhen. Erst neuerdings ist der Entschlul grefalit, im Jahre 1910 mit einem groben Tagebau zu beginnen, diesen aber nicht wie frühır an dem Seeufer, sondern im Binnenlande, östlich von Palmnicken, anzulegen.

Die gesante Produktion der fiskalischen Bernsteinbetriebe betrug 1903: $434300 \mathrm{~kg}$, 1907: 401300 kg; dazu kommen jührlich noch etwa $20000 \mathrm{~kg}$ im Wert von $230000 \mathrm{Mk}$. Rohbernstein als Ertrag sämtlicher Sträinde der Ostsee. In den 20 Jahren vor 1903 sind im ganzen $8.156840 \mathrm{~kg}$ Bernstein in Ostpreußen gewonnen worden, darunter $1716178 \mathrm{~kg}$ große, $1920450 \mathrm{~kg}$ mittlere und $4820212 \mathrm{~kg}$ kleine Stücke.

I) Be Bernsteingewinnung ist eine uralte Beschäftigung der Anwohner der Ostsee. Schon die in Ostpreußen aufgedeckten Gräber aus der Steinzeit beherbergen Beigaben aus Bernstein und zeigen, wie hoch dieses Harz schon damals gesehätzt wurde. Es ist daher kein Wunder, dab schon früher die Beherrscher jener Gegenden die Gewinnung dieses kostharen Materials möglichst in ihre Hand zu bekommen suchten. Zu diesem rwweck wurdu der Bernstein von dem deutsehen Orden zum Regal erklärt, oder vielleicht anch nur ein älteres Regal etwas weiter entwickelt und ausmebildet. Dieses Reural besteht noch hente in allen den Landesteilen, die dem Orden später nicht dureh die Polen entrissen wurden, also in Ostpreußen, nicht aber in Westpreußen und in anderen Gegenden. Ifier waren andere Rechtsverhältnisse zum Teil von älnhlieher Art, zum 'I'eil war aber die Barnstringewinnung vollkommen frei, letzteres nach polnischem Recht noch heute in Westpreußen.

Das Regal wurde bis 1511 vom Staate selbst ausgenutzt, indem er die Strandbewohner geconeln eine bestimmte Entschädisungr zum Sammeln namentlich des Strandsegens zwang 
und den so sewonnenen Bermstein rerkaufte. Die diunit verbundenen C̈brelstïndr, namentlich die infolge der unvermeidliehem I) fratulationen eingeri-sene und sich inmer melır steigernde Demoralisation der Stranddörfer veranlabte die Iegierung 1811, dir Bernstringewinnung zu rerpachten, und zwar zuerst an eine Gesellschaft, dann an einen frenceralunternehmer. 1)ie's dauerte bis $14: 37$. In dieser Zeit war es jedem Lnbefugten streng verboten, atuch nur das kleinste Stïck liernstein aufzunchmen, und dir Ibewoliner di.r Dörfer am Strande durften nur auf besonderen Wexen und an r.inzeluen bezedicheten stellen sich der See nähern. Zuwiderhandlungen gregen diest Bestimmungren waren mit schweren Strafen bedroht.

Lim alle durch diese Einrichtuneren veranlabten Belästigungen der Anwohner zu hr.. seitigen und den durch sie erheblich geschädigten Stranddiorfern aufzuhelfen, wurrle 1 1 :37 der ganze Strand von Nimmersatt an der russisehen Grenze bis Polsk ëstlich von Danzig tron da bis Weichselmünde war diese letztere Stadt von altersher berechtint) an die strandgemeinden selber veruachtet, die nun das Recht des Sammeins, des sichüpfons, rtechens und des Crabens in den Uferbergen hatten, und die den lohbernstein frei verkaufen durftrn. an wen sie wollten. Das Recht zu graben wurde aber 1565 davon wieder ahgetrennt, weil es nicht ein für die armen Strandbewohner, sondern für kapitalkräftige Enternehmer passender Betrieb ist, dessen zweckmäbige Einrichtung und Fortführung wrofle Anlageund Betriebskosten verursacht, weil infolcedessen die Arbeiten von den Strandbewohnern wenig rationell und hïufig auch ohne jeden Reingewinn greführt wurlen und weil dir trä̈bereien in einen namentlich durch Zerstörung von Ackerflächen schäillichen Raubhau ausarteten. Daß mzwischen die Neuerungen in der Bernsteinproduktion. wie Baggern, Tauchen und Bergwerksbetrieb), ron der Firma Stantien it Becks eingeführt wurten. ist schon oben erwähnt. Auch diese Firma hatte, wie jeder, der sich in jener Gegend mit der Gewinnung ron Bernstein beschäftigt, die in dem Regal begriindeten Abgaben an den Fiskus zu entrichten. Sie und die Genehmigung des Besitzers von Frund und Boden sind die Bedingungen für die Bernsteingewinnung. Diese Abgaben und die Einkïnfte des Staates aus dem Regal überhaupt liefern ein sehr interessantes Bild der Entwicklun! der Bernsteinproduktion.

Während der Selbstverwaltung durch den Staat bis 1511 brachte das Regal durchschnittlich jährlich etwa 2.2010) Mark ein; in der Zeit der Generalpacht his 15:37 betrugr diese Summe etwa 30000 Mark. Die Verpachtung an die Kommunen ergab ungefähr 3 1000) Mark; seitdem ist die Einnahme allmählich auf 700000 Mark im Jahre crestiecten. und der preußische Staatshaushaltsetat für 159495 hat als Einnahme aus dem Bernstein.

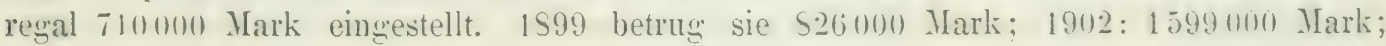
1906: 1182000 Mark.

Verarbeitung. Alle Bernsteinstiicke, deren lräjbe und Beschaffenheit es irond grestattet, werden zu Rauchrequisiten und zu rehmucksachen verarbeitet. Die Nachfrage nach solchem Robmaterial ist so bedeutend, dali die Produktion manchmal damit nicht gleichen Schritt halten kann. Die Verarbeitung geschieht meist auf der Drehbank. Auf ihr werden die Stiicke äuferlich abgedreht und nach Bedarf durchhohrt. Vielfach wird auch durch Schnitzen mit dem Schnitzmesser und durch Inschleifen ron Facetten die gew ünschte Form gregehen. Letzteres @eschieht, abweichend ron dem Yerfahren bei Edelsteinen, stets auf horizontal sich drehenden feinen Sandsteinscheiben: das Anschleifen ron Facetten mit der Iand auf einer feststehenden Scheibe bringt stets stumpfe Kanten hervor. Für die Politur wird eine Stelle der Schleifsteine mittels eines polierten Fenersteins so vollkommen wie möglich geeglättet und an diesen stellen der Facette die letzte Tollkommenheit gegeben. Sonst wird zum Schlub mit Schlemmkreide, Tripel, Bolus und Wasser poliert. Die meisten Perlen werden in Polangen und Krottingren, jenseits der ost- 
preufischen Grenze in Rufland, geschliffen. Sehr wichtig für die Bernsteinindustrie ist, daß sich der Bernstein in kochendem Leinül erweichen und dann biegen läßt, sowie daß man trübe Stücke klarkochen und schlechtgefärbte bleichen kann.

Entscheidend für die Rentabiliäit der ganzen Bernsteinindustrie ist die Fabrikation von Rauchrequisiten. Man kann mit ziemlicher Sicherheit annehmen, dab dem Geldwerte nach eine achtmal gröbere Nenge Bernstein zu Ansatzspitzen für Pfeifen und zu Zirarrenspitzen verarbeitet wird als zu schmuck. Für die Fabrikation von Artikeln zum Rauchen ist besonders Wien wichtig, das in dieser Beziehung auf dem Weltmarkt an der Spitze steht und seine Produlte in alle Gegenden der Erde rersendet. Diese jetzt bis in die lileinsten Details in Wien ausgebildete Massenfabrikation für Rauchrequisiten besteht dort seit 1826. Erst Mitte der sechziger Jahre folgten in Deutschland Nürnberg und Rubla. Seit etwa 10 Jabren hat sich in New York eine nennenswerte Industrie derselben Art entwickelt. Kileinere Industrien befinden sich in Paris und in St. Claude im Jura, in Konstantinopel, London und mehrorts in Holland. Der Verbrauch aller dieser Plätze an Rohbernsteiu ist aber von geringer Bedeutung, sie beziehen ihren Bedarf an Bernstein in schon bearbeitetem Zustande von Wien, Nürnberg und Ruhla, und beschränken sich mehr auf die IIerstellung von Holzpfeifen, die sie mit Bernsteinspitzen montieren. In beschränktem Maße kaufen Polangen und Schitomir in Tolbynien besonders knochigen Bernstein, den sie, vielfach mit Tulasilber, zu Zigarrenspitzen verarbeiten.

Für den Handel von Rohbernstein ist die Fabrikation von Schmucksachen zwar nicht so von hoher pekuniärer, aber doch von volkswirtschaftlicher Bedeutung. Bei dem rerhälitnismäßig geringen Preis für das Rohmaterial lieznt der größte Wert im Arbeitslohn, und es finden eine große Anzahl von Arbeitern in der Herstellung von Bernsteinschmuck ihre lohnende Beschäftigung. Als Hauptorte für diese Industrie sind Danzig, sodann Polangen und Krottingen in Rußland, ferner Stolp in Pommern und Berlin zu nennen.

Von besonderem Interesse ist die Mannigfaltigkeit der Schmucksachen. Jedes einzelne Land bevorzugt besondere Formen und auch besondere Bernsteinsorten. Während in zivilisierten Ländern der Schmuck im wesentlichen die gleichen bekannten Formen zeigt und nur nach Farbe und Schliff eine Vorliebe einzelner Länder auftritt, machen sich in den Landstrichen an den Grenzen der Kultur andere eigentiumliche und zum Teil wunder bare Geschmacksrichtungen geltend. Von den verschiedenen Sorten lieben England und die T'ürkei besonders die Perlfarbe und den feinen Bastard, Holland und Amerika das feurigste Kilar. In China und Korea bilden Ketten von hundert je etwa $1 \frac{1}{12} \mathrm{~cm}$ im Durchmesser haltenden, meist klaren, aber auch trüben Perlen den Schmuck wohluabender Mandarinen. Ansehnliche Quantitäten von Bernstein werden zu Betkränzen für Katholiken und Mohammedaner verarbeitet, namentlich ist der Verbrauch der Mekkapilger grob.

Von den Formen, die der Bernstein bei der Bearbeitung zu Schmucksachen erhäilt, sind einige besonders wichtig, weil sie auf dem Weltmarkt sehr viel verlangt und daher in Mengen zum Verkauf und zur Verwendung ium Groben fabriziert werden. Dies sind vor allem die Perlen, runde abgedrehte Stiicke von mehr oder weniger bedeutender Größe, kugelig oder in einer Richtung in die Länge gezogen, vielfach auch mit Facetten versehen und stets zur Aufreihung auf Schnüren, in der Mitte durchbohrt.

Unter den so für den (xrobhandel hergestellten Perlen unterscheidet man nach der Form sechs Sorten:

1. Oliven, länglich-elliptische Perlen.

2. Zotte $\mathrm{B}$, zylinderförmig, an beiden Enden schwach zugerundet, fast eben.

3. Grecken, wie Zotte, nur kürzer.

4. Eigentliche Perlen, kugelförmig rund.

5. Korallen, mit geschliffenen Facetten versehene Perlen. 
6. Pferdekorallen, flache klare Perlen, die auf den zwei entgegrengesetzten Seiten mit Facetten versehen sind.

Die ordinäreren dieser Perlen und Korallen werden falsch gredreht, d. h. mit einem elastischen Messer, das sich möglichst den Formen des Bernsteinstückes anpabt, worlurch viel an Rohmaterial gespart wird. Die fertigen Perlen werden dann auf sichnüre aufgezogen und so Ketten rom ungefähren Umfang eines Halses gebildet. An diesen pflegt die mittlere Perle, der sogen. Bodenstein, am grrößten zu sein; von hier ab werden sie dann nach den beiden Enden allmählich immer kleiner. Je nachdem eine solche Kette allein ein l'fund wiegt, oder zwei, drei usw. zusammen, unterscheidet man die Ketten als Einer, Zweier usw. bis Fünfzehner. Beim Handel sind je eine, zwei, drei usw. bis fünfzelın solcher Ketten an einem Ende in einem Handerriff zu einem je ein Pfund wiegrenden Bündel zusammengefaßst. Natiurlich sind die Perlen um so größer, je weniger Ketten auf ein Pfund gehen. Bei den Einern hat der Bodenstein fast die Grölje einer kleinen Faust. Diese gehen in flohmigen oder flohmig-knochigen Färbungen nach Zentralafrika, in ihren schmutzig kumstfarigigen Nuaneen nach Nordwestafrika. Seclıser bis Achter in knochigem Bernstein bezieht Arabien, in minderwertigem Bastard die Türkei.

Ein anderer in grobem Maßstabe hergestellter Artikel sind die Ma nellen. flache polierte Scheihen, in deren Mitte eine Perle aufgekittet ist. Diese ist klar, wenn die Platte aus Bastard besteht oder umgelsehrt. Der Perle wird nicht selten zur Erhöhung des Clanzes eine Zinnfolie untergelegt und die Unterseite durch eingravierte Blumen usw. rerziert. Die Manellen dienen als Mittelstiicke für Hals- und besonders für Armbänder und sind namentlich in Persien, Armenien und in der Türkei beliebt.

Endlich sind als Massenartikel rielleicht noch bis $5 \mathrm{~cm}$ lange und bis $2 \mathrm{~cm}$ dicke $Z$ y linder mit etwas breiterer Basis zu erwälnen, die bei gewissen Stämmen in Zentralafrika und Südamerika als Schmuck für die durchbohrten Ohrlappen eine Zeitlang beliebt waren. Sie haben jetzt allerdings an Wichtigkeit sehr verloren. Alle die vielen anderen Schmucksachen aus Bernstein, außer den genannten, bilden keinen Gegenstand der Massenproduktion, brauchen daher hier nicht eingehend im einzelnen betrachtet zu werden.

Es sind in neuester Zeit mehrfach Versuche gemacht, um den Bernstein in dem wirklichen Kunstgewerbe mehr Eingang zu verschaffen. So brachte die Pariser Weltausstellung 1900) ganze Ameublements, Spiegrel und Uhren, bei denen Holz mit Platten ron Bernstein ausgelegt war. St. Louis zeigte verschiedene Schnitzereien aus Bernstein, die in Berlin, große Silberarbeiten mit Bernstein, die in Berlin und Stuttgart, sowie Taschenuhren mit Bernstein, die in der Schweiz hergestellt waren. Trotz alledem aber ist die Fabrikation des Bernsteinschmucks entschieden zurückgegangen. Dahingegen hat sich eine neue Industrie entwickelt, die in den letzten Jahren so gewaltig angewachsen ist, und von der jetzt der gesamte Bernsteinhandel abhängt. Dieses ist die Fabrikation des Preßbernsteins, der wie Naturstein verarbeitet wird und auf den wir bei der Imitation des Bernsteins näher eingehen werden.

Die Abgänge bei der Terarbeitung des Bernsteins und die kleinsten Stïcke aus der Produktion werden zu Bernsteinlack verbraucht. Bei Erhitzung des Bernsteins bis etwa 400" Celsius schmilzt er unter Zersetzung, wobei er Bernsteinsäure und Bernsteinöl liefert. die als Nebenprodukte gewonnen werden, und eine in Terpentin- und Leinöl leicht lösliche Masse, das Bernsteink olophon, zurïckbleibt. Die Auflösung dieses Kolophons gibt einen dauerhaften und sebr harten, allerdings etwas dunklen Lack. Da das Schmelzen des Bernsteins feuergefährlich ist und größere maschinelle Anlagen verlangt, bringt man jetzt leicht in öl löslichen reschmolzenen Bernstein in den Handel. 1596 wurden beispielsweise $277612 \mathrm{~kg}$ Rohbernstein verschmolzen und daraus $176000 \mathrm{~kg}$ geschmolzener Bernstein, $40000 \mathrm{~kg}$ Öl und $8000 \mathrm{~kg}$ Säure hergestellt. 
In den letzten Jahren ist die Konkurrenz der afrikanischen Kopale sehr füblbar.

Der Gesamtkonsum der ganzen Erde an Rohbernstein hat einen Wert von 2-3 Millionen Mark. Daran waren die einzelnen Länder 1907 in folgender Weise beteiligt:

Dieses entspricht einem Quantum von

\begin{tabular}{|c|c|c|c|c|c|}
\hline Österreich & bezog & für & 1389122 & Mark & $\begin{array}{c}\text { Rohbernste } \\
44302,81\end{array}$ \\
\hline Vereinigte Staaten von Nordamerika & $"$ & " & 801227 & , & 24859,05 \\
\hline Deutschland & ” & , & 532472 & " & 31246,38 \\
\hline Rußland & ", & $"$ & 213035 & $"$ & 14609,30 \\
\hline Frankreich & $"$ & " & 284361 & , & $6 \mathrm{~S} 65,56$ \\
\hline Türkei & " & $"$ & 85105 & " & 1920,51 \\
\hline England & 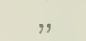 & , & 34210 & , & 405,00 \\
\hline China und Korea & $"$ & $"$ & 5591 & , & 103,30 \\
\hline
\end{tabular}

Bernsteinhandel. Wir haben oben geschen, daß die Firma Stantien \& Becker die Bernsteinproduktion auf eine vorher nicht geahnte Höhe brachte. Es ist klar, daß sie diesen Massen schnell Absatz verschaffen und ihnen neue Wege bahnen mußte, namentlich da man dem gegrabenen Steine anfangs ein nicht unberechtigtes Mißtrauen entgegenbrachte. For Stantien \& Becker iiberwog der Seestein, und der Grabstein trat an Nenge zuriick. Der Seestein ist, wie wir gesehen haben, frei von Rinde, gesund und arm an Rissen, so daß der Käufer jedes Stück nach seiner Beschaffenheit richtig taxieren und den Wert und die Verwendbarkeit beurteilen konnte. Dies ist beim rohen Grabstein seiner Rinde wegen nicht möglich und daher der Ankauf einer Partie von dieser Ware, die früher nur mit der Rinde verkauft wurde, eine gewagte Spelsulation. Wegen der greringen Menge des in den Handel gebrachten Grabsteins war das in älteren Zeiten nicht von Belang. Als aher der Grabstein immer mehr in den Vordergrund trat, machte sich eine Abneigung gegen ihn geltend, die auf der Unmöglichlieit beruhte, seine Qualität zu erkennen.

Hierin lag die Veranlassung, im Gegensatze zu der früheren Gepflogenheit, dem Grabsteine seine Rinde zu nehmen, ehe man ihn in den Handel brachte, und dies wurde in der oben angegebenen Weise ausgeführt. Nun hatte der Grabstein keine erheblichen Nachteile mehr, und er ist jetzt daher ebenso geschätzt wie der friber in erster Linie gesuchte Seestein, um so mehr, als beim Sortieren die größeren Stiicke nach den in ihnen etwa rorhandenen Sprüngen zerspalten werden, so daß auch vom Grabstein nur gesundes Material in den Handel kommt. Hand in Hand mit dieser wichtigen Änderung ging sodann die Aufstellung einer Reihe für den Großverkehr zweckmäßig gewählter, den Bediirfnissen der verschiedenen Zweige der Bernsteinindustrie sich anjassender Handelssorten, die auf der Farbe und der Beschaffenheit, sowie auch auf der für die Verwendung sehr wichtigen Form der Stiicke beruhen und die nach Grölie. Stückzahl auf das Pfund und allen den renannten Eigensehaften bis in das kleinste Detail sich stełs gleichbleiben, so dafj sie dem Fabrikanten eine sehr genaue Berechnung ermöglichen. Zwar waren schon früher gewisse Sorten untersehieden und wie die heutigen mit besonderen Namen helegt worden, aber diese alte Einteilung erwies sich allmählich immer mehr als ungenügend und unbrauchbar. Sie ist daher seit 1868 allmählich überall verdrängt und durch die von jener mehrfach genannten Firma neu eingeführten ersetzt worden, von denen wir unten eine Übersicht kennen lernen werden. Wir werden dabei die Mitteilungen von R. Klebs benutzen, dessen wichtige Untersuchungen über den Bernstein auch sonst hier zugrunde gelegt sind.

Bei der Verarbeitung des Bernsteins ist es, wenn sie mit mörlichstem Vorteil geschehen soll, erforderlich, den Verlust durch den Abfall auf ein Minimum herabzudriicken. ILan muf also zu einer langren und dünnen Zigarrenspitze ein ebenfalls langes und dünnes 
Bernsteinstiick und nicht etwa ein kugrelförmig rundes verwenden. Neben der Qualitiit ist somit die Form der Stiicke von aussehlagrechender Wichtigkeit: nach ihr wird der Bernstein daher in erster Linie eingereilt, Qualität und Gröbe seben diann die Unterabteiluneren, namentlich wird Klar und Trüb besonders ausqremustert. Die im folgrenden mitgeteilte Sortierung bezielit sich aber nur auf massive Steine, nicht auf Schlauben und Knochen. I)iese werden nach :̈hnlichen Prinzipien für sich eingwteilt. Auch besonders seltene Farben werden für sich ausgehalten, sie bilden aher eben der Seltenheit wexen keine eigentlichen Handelssorten, denn dazu gehört ein nicht zu sparsames Vorkommen.

Nach diesen Grundsätzen wird nun der Bernstein in der folgenden Weise in I Iandelssorten eingreteilt; im granzen werden, nach Cröße, Farbe und Reinheit der Stïcke etwa 150) unterschieden.

1. Flieben. Plattenfürmige Stücke, bei denen sich die Länge zur Breite verhält wie etwa 3 zu 1 und die mindestens $75 \mathrm{~mm}$ dick und breit und $25 \mathrm{~cm}$ lang sind. Am meisten geschätzt sind die, deren Flïchen annähernd parallel verlaufen. Sie heiben Arbeitssteinfließen und werden in fünf Sorten gehandelt:

$\begin{array}{crrrrrr}\text { Arbeitssteinfließen } & \text { Nr. } 1 & 10 & \text { bis } & 12 & \text { Stiick auf } & 1 \\ \text { kgg }\end{array}$

Fließen. die nicht die regelmäßige rechteckige Form der Arbeitssteinfliefen haben, bilden die gewöhnlichen Fließen. Man unterscheidet dabei zehn Handelssorten, die erste Nr. 0 mit 2 bis 3 Stuick, die letzte Nr. 7 mit 360 Stück auf $1 \mathrm{~kg}$.

Die Fließen werden zu Rauchgegenständen. wie Zigarrenspitzen, Ansatzspitzen zu solchen usw. verarbeitet.

Was die Preise betrifft, sn wird $1 \mathrm{~kg}$ gewöhnlicher Fließen Nr. 1 mit 220 Mark, Nr. 5 mit 41 Mark bezahlt. (Nr. 0 ist so selten, dab sie eigrentlich keine Handelssorte bilden.) Von den besonders ausgelesenen Arbeitssteinflielen werden Nr. 1 und 2 etwa $331_{33}$ Proz., Nr. 3 50, Nr. 425 . Nr. 5 10 Proz. löher berechnet als die entsprechenden gewöhnlichen.

2. Die Platten, Bernsteinstïcke von ähnlicher Gestalt, aber nicht so dick wie die Fließen. Man unterscheidet sieben Plattensorten:

Platten Nr. 0: Stücke mit einer Oberfläche von 40 bis 60 qcm, $1 \mathrm{~kg}=132 \mathrm{Mark}$

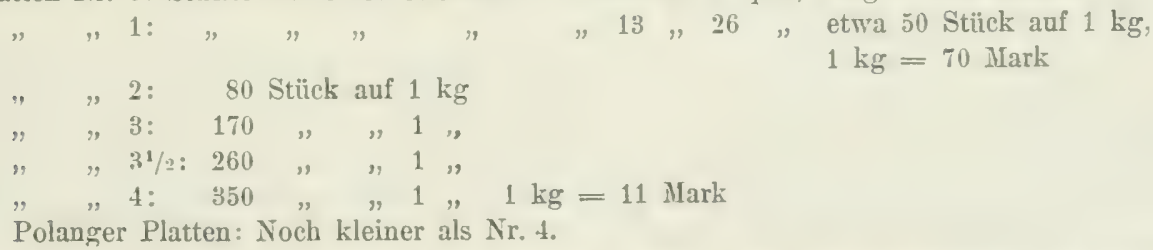

Die Platten werden in erster Linie ebenfalls noch zu Rauchrequisiten, namentlich zu Zigaretteneinsteckern verarbeitet, dann aber auch zu Schmuckgegenstïnden, wie Manellen, Pferdekorallen. Kreuzen, Glocken zu mohammedanischen 'Tesbib (Rosenkränzen verbraucht.

3. Bodenstein. Große rundliche Stücke Bernstein von beliebiger Farbe:

Feiner Bodenstein, 10 Stück auf $1 \mathrm{~kg}$
Ordinärer " 14 bis $16 \quad, \quad, 1$,

Die erstere Sorte kostet 75 Mark, die letztere 50 Mark pro Kilogramm.

Aus Bodenstein werden außer Schnitzereien und anderen Gegenständen von geringer Bedeutung für den Großhandel die Mundstïcke für die türkischen Wasserpfeifen hergestellt, die vielfach mit Gold und Türkisen verziert in den Handel kommen. 
1. Runder Bernstein. Die runden Bernsteinsorten teilt man nach der Farbe in Klar und Trüb (Bastard). Man unterscheidet danach und nach der Größe 18 Handelssorten, darunter :

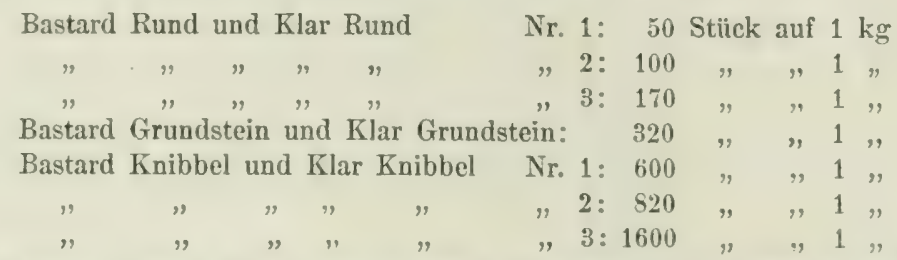

Klar und Bastard Rund Nr. 1 werden mit 60 Mark, Nr. 3 mit 38 Mark, Klar und Bastard Knibbel Nr. :3 mit 4 Nark 60 Pfg. bez. 5 Mark 25 Pfg. pro Kilogramm bezablt.

5. Knochiger Bernstein. Wird aus allen Bernsteinsorten besonders ausgeschieden; wenn der Knochen Übergänge in Halbbastard und Bastard zeigt, unterscheidet man nach der Form: Runde große feine Knochen, die 135 Mark, und große Knochen, die 85 Mark das Kilogramm kosten. Sind sie mehr knochig, so spricht man von weißen großen Knochen, 100 Mlark das Kilogranm. Kleine Arbeitsknochen, 150 Stiick auf ein Kilogramm, kosten 10 Mark.

6. Schlauben. Sie werden nach der Möglichkeit ihrer Verwendung in Spitzenscblauben, das Kilogramm zu 35 Mark, in Grecken 20 Mark und in kleine flache Schlauben 5 Mark das Kilogramm eingeteilt. Sie werden wenig verarbeitet, abgesehen von den durch Inklusen, namentlich von Insekten, ausgezeichneten Stücken, die für Sammlungen zur wissenschaftlichen Untersuchung, aber auch zum Schmuck zugerichtet werden. Früher mebr, jetzt in geringerer Menge, werden Schnüre und Armbänder hergestellt, in denen jede einzelne Perle ein schönes Insekt enthält. In neuerer Zeit werden aus den Schlauben viel sogenannte Naturspitzen angefertigt, zu denen man die Steine von der Rinde befreit, nach äer Form der rohen Stücke poliert, durchbohrt und mit einem Brenner versehen in den Handel bringt.

7. Firnis (Tirniß). Die kleinsten Stücke Bernstein. Sie werden in viele Sorten eingeteilt, die unter verschiedenen ibre Qualität bezeichnenden Namen, wie: Gelbblank, Rothlank, Spitzblank, Knochenfirnis, Korallenbruch, Rasura, Schwarzfirnis verkanft und zu Lack verarbeitet werden. In neuester Zeit ist aber der Handel mit Firnis (Virniß) sehr eingeschränkt, weil er zu Preßhernstein verarbeitet wird und der Fiskus bestreht ist, allein Preßhernstein (in Palmnicken) herzustellen. Zur Lackindustrie wird daher möglichst geschmolzener Bernstein verkauft.

8. Endlich sei noch der Brack erwähnt, größere Bernsteinstücke, die im Innern rissig und blasig oder von fremden Verunreinigungen so durchzogen sind, daß nur einzelne Teile noch gesunden Stein geben. Sie werden daher auf Spekulation gekauft, oder auch als große billige Stïcke zu Untersätzen oder zur Herstellung von Bernsteinfelsen zu Nippsachen usw. verwendet. Er zerfällt in Groß Brack (die reinsten Stiicke) und Ordinär Brack.

Im rorstehenden sind für einige Sorten die Preise angegeben, die sich auf $190 \mathrm{~S}$ beziehen. Vergleicht man diese mit solchen aus friberen Zeiten, so sieht man, daß der rohe Bernstein im ganzen im Preise, namentlich bei den kleineren Sorten sehr in die Ï̈̈be gegangen ist. Diese Steigerung beruht auf der Fabrikation des Preßbernsteins. Bei seiner Herstellung ist es möglich, sorten, die früher mit 3 Mark und darunter verkauft wurden mit 25 Mark und mehr zu verwerten.

Imitationen und Verfälschungen. Sehr häufig wird der Bernstein durch ähnlich aussehende billigere Substanzen nachgeahmt und verfälscht, und dadurch der legitime Bernsteinhandel nicht unerheblich geschädigt. Diese Nachahmungen sind bald mehr, bald 
weniger geschickt, bei einiger sachkenntnis ist e's aber nicht schwer, sie durch einfache Beobachtungen und Versuche vom echten Bernstein zu unterscheiden.

Am plumpsten ist die Nachtildung namentlich des klaren Bernsteins durch grefärbtes frlas, das allerdings jetzt kaum noch zu lauchrequisiten, viel dagegen zu Perlen usw. Yerwendung findet. In kleineren Orten liublands sieht man auf jeder Mesise grolie Mengen ron l'erlen und anderen Schmuck, welcher letztere genau so wie der Danziger aus echtem liernstein aussieht, aher aus klarem und triihem gellyem folas bestelit. Die Ansatzspitzen zu Opiumpfeifen für China werden meist thenfalls aus bernsteinfarbigem Glas statt aus echtem Bernstein heroestellt. (irölere IIärte, häheres spezifleches Gewicht und das Kältegrefüh bei der Beruihrung mit dem Finger lassen das Glas leicht erkennen, ebenso) der glasglänzende muschelige Bruch überall da, wo an den Ränd+rn ein splitterchen abgesprungen ist.

Zelluloid wirl vielfach so enefürbt, dab es flohmigem oder kumstfarbigem Bernstein selır äbnlich ist. Seine Verwendung zu Ansatzspitzen für Pfeifen ist verhältnismäljig häufig. am häufigsten verarbeitet man es aber zu den gröberen Negrerkorallen, Einern und Zweiern (S. 673). Besonders stellt man die Bodensteine daraus her und vermengt ihn in Ketten mit Perlen aus echtem oder Preßhernstein. Schmuck aus rötlicherelbem Zelluloid hat man nambre antique" genannt. Beim Reiben entwickelt Zelluloid fast keine Elektrizität, dagexen einen merlilichen Kamphererech. Mit dem Messer lassen sich Spätune abschneiden, während Bernstein beim schnedden Pulver gribt. Yit einem heiljen Platindraht herïhrt, haften diese Spähne sehr leicht an diesem und verbrennen in der Lichtflamme explosionsartig rasch unter Entwickelung eines sïuterlichen Geruches. Bernstein baftet seiner schwereren Schmelzbarkeit wegen nicht am heifen Platindraht, verbrennt lanesam und hinterläßt das charakteristische Bernsteinaroma. In Schwefeläther wird Zelluloid schon in der Kälte leicht und rasch angegriffen und oberflächlich gelöst, während Bernstein ohne jeden Schaden eine Viertelstunde lang in der Flüssigkeit liegen kann.

Tor diesen Zelluloidimitationen kann ihrer grofen Feuergefährlichleit wegen nicht entschieden genug gewarnt werden, namentlich sind sie aus diesem Gruncte zu Rauchrequisiten vollkommen ungeeignet. Von den Zelluloidfabrikanten wird diese Gefahr allerdings geleugnet, aber durchaus mit Lnrecht. Alle Versuche, die Masse durch Zusatz anderer Körper feuerbeständig zu machen, sind bis jełzt gescheitert.

Aus dem Kasein abgerahmter Wilch stellt man durch Farbezusatz eine Bernsteinimitation her, die Galanith grenannt wird und die dem Aussehen nach sehr einem massigren grelben Bastard ähnelt. Das Galanith ist hornartig und splittert nicht wie der Bernstein, es ist unschmelzbar und riecht beim Erhitzen unangenehm.

Tielfach werden dem Bernstein andere Harze untergeschoben. Ton diesen allen unterscheidet er sich aher meist sehr leicht durch höheren Schmelzpunkt, größjere Härte, geringere Löslichkeit in Alkobol, Äther usw., sowie durch den Gehalt an Bernsteinsäure und durch den charakteristischen Geruch beim Reiben und namentlich beim Verbrennen.

Vielfach wird dem Bernstein Kopal untergeschoben, ein Harz, das in Menge aus Ost- und Westafrika, Südamerika und Australien bei uns eingeführt und das zum Teil wie der Bernstein aus der Erde gegraben wird. Vom Kopal unterscheidet sich der letztere sofort durch das Aussehen. Jener ist so hellırelb und glasig, wie es beim Bernstein nur vielleicht als große Seltenheit gelegentlich einmal vorkommt. Dieser hat auch einen höheren Schmelzpunkt, gröljere Härte und ist in Essigäther, Cajeputül usw. viel schwerer löslich. Ferner besitzt der Bernstein den charakteristischen Geruch beim Reiben und namentlich beim Terbrennen. Die Bernsteinsäure, die dem Bernstein eicrentïmlich ist. kann nur bedingungsweise als Erkennungszeichen angesehen werden, weil man sie in betrügerischer 
Absicht (rweichten Kopalen künstlich zusetzt, um die ehemische Reaktion zu verwischen. Sïntliche Arheiten aus Kopal sehen schmutzig aus, und sie lassen sich leicht daran erkennen, daf sie wegen ihrer leichteren Schmelzbarkeit in der Hand oder an Tucb, etwa am Rockïmel, gerieben, klebrig werden, daß sie, wegen ihrer geringeren Härte schon Eindrüicke mit dem Fingernagel annehmen, und daß sie, in Essigäther gelegt, ihren Glanz verlicren und aufquellen, was alles beim Bernstein nicht der Fall ist. Beim Reiben mit Tuch wird dex Kopal weniger stark elektriseh als der Bernstein. Der Kopal kann übrigens nicht in allen Punkten den Bernstein ersetzen, denu er ist zu spröde, um das Schnitzen und das Anschneiden von Schraubengewinden usw. zuzulassen, wie es beim Bernstein möglich ist.

Die angeführten Imitationen und Terfälschungen des echten Bernsteins haben gegenwärtig wohl kaum eine größere kommerzielle Bedeutung, sie werden zwar hier und dort gebraucht, aber nur in geringer Ausdehnung. Dagegen hat der "Preßbernstein" im letzten Dezennium so an Verbreitung zugenommen, daß er, wie wir bereits oben gesehen haben, den ganzen Bernsteinhandel stark beeinflußt. Auch kommt seit zivei Jahren unter dem Namen ,gehärteter Kopal" ein Bernsteinsurrogat so rielfach auf den Markt, daß es ernstliche Befürchtungen erregt.

Der Prebbernstein wurde zuerst von Wien aus in den Handel grebracht. Es sind dies größere Stücke, die durch Zusammenpressen vieler kleiner Bernsteinbröckchen unter starkem Druck und bei höherer Temperatur gewonnen werden. Schon seit Jahren sind Versuche nach dieser Richtung gemacht worden, um so die massenhaften kleinen Bernsteinstïckchen, die sonst nur zur Firnisbereitung zu brauchen sind, besser nutzbar zu machen. Lange Zeit experimentierte man.

Schon 1969 hatte ein in Paris lebender Deutscher durch Zusammenpressen kleiner erhitzter Bernsteinstiicke größere Olivenperlen hergestellt, deren Qualität dem heutigen Preßbernstein wenig nachgab. Die Methode wurde von Stantien is Becker unterdriickt und ging in Feldzug 1870-71 verloren. 1573 nahm R. Klebs diese Versuche wieder auf, und es grelang, ihm ein mittelmäßiges Fabrikat zu erzeugen. Einen wirklichen Erfolg aber erlangten erst etwa $b$. Tahre später zwei Wiener Firmen Spiller und Trebitsch.

Das Verfahren, mehrere Stïcke Bernstein zu einem größeren zu vereinigen, beruht auf dessen Eigenschaft, bei einer Temperatur von 200-250 " weich zu werden. Die von allen Unreinigkeiten befreiten Stückchen des Rohbernsteins legrt man in flache Stahlformen und schließt diese ganz hermetisch mit einem Stahldeckel. Diese Stahlformen mit ihrer Füllung kommen in grenau temperierte Öfen oder in Bäder von Glycerin, Paraffin usw; der Deckel wird unter sehr starkem hydraulischem Druck von $400-606$ Atmosphären auf die in der Hitze erweichte und an der Oberfläche jedes Bernsteinpartikelchens geschmolzene Masse gepreßt und dadurch das Ganze ineinandergeknetet und zusammengekittet. Auf diese Weise erhielt Spiller flache Kuchen von Preßbernstein, der jedoch nur sehr mäßigen Ansprïchen grenügte. Trebitsch schloß die in der Gestalt etwas geänderten gefüllten Formen mit einem sehr starken hohỉen Stahltopf, dessen Boden dünne Durchbohrungren besaß und daher siebartig wirkte. Durch sehr hohen Druck wurde dieser Topf in den erhitzten Bernstein gepreßt und dieser gezwungen, durch die Öffnungen zu treten und sich inniger zu mischen als bei der Spillerschen Art. Iierdurch erzielte er ein bedeutend schöneres, gleichmäßigeres Produkt.

Der preubische Fiskus hat nach der Übernahme der Bernsteinwerke diese Art der Herstellung auch in seinem Betriebe eingeführt.

Man kann die jährliche Produktion von Preßbernstein auf mindestens 35000 Kilogramm veranschlagen, wozu über 110000 Kilogramm Rohbernstein notwendig sind. Der Preis des Preßbernsteins ist je nach Qualitït 75-100 Mark das Kilogramm. Dadurch, 
dalf man dem liemstein in den Stahlformen Farben zusetz, erhält man crefärbten I'refjbernstein, von dem namentlich der schwarge viel Verwendung, beispielsweise zu Trauer-

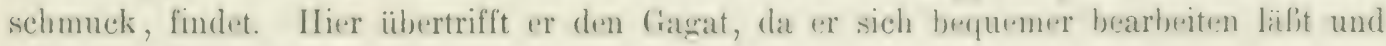
schnellen 'J'emperaturwechsel besser verträgt.

Es wird mehrfach versucht, Fabrikate aus Prefibernstein als echten Bernstein in den IIandel zu hringen. Das ist natiorlich unrichtig, wenn anch das Waterial zu ersterem anscheinend nur aus echtem Naturbernstein besteht. Zunäblost wäichst der P'reis des Bermstrius nut Zunahme der Gröbe ererade eines Stückes, und zwar verhältnismälige schell und bedeutend. Von

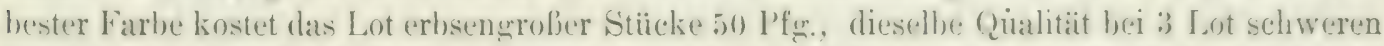
Stïcken das Lot $6-7$ Mark. Sodann besteht der l'velbernstein frar nicht hronosen nur aus Bernstein. Wie erwähnt, bilden sich beim Erhitzen in der Form vielfach dünne Sechichten von Kolophon, das je nach der verwendeten Temperatur gell, his rothraun wird. Es durchsetzt den P'refbernstein und kittet die unveränderten Bernsteinstïckehen zusammen, wodurch ein Gemenge ron weich grewesenem und gesehmolzenem Bernstein entsteht. Ninch viel weniger kann uan bei grefärbtem, schwarzen usw. von echtem sehwarzen Bernstein, sondern nur yon schwarzgefärbtem Preßbernstein sprechen. Viele Eigenschaften, wite In̈̈rte, hohe Schmelzbarkeit, starke Reihungselektrizität, der charakteristische (ieruch, die schwere Lïslichkeit usw. sind natïrlich beim Preßhernstein dieselben wie beim natïrlichen. Indessen eribt es eine Reihe von Merkmalen, an denen man beide sicher voneinander unterscheiden liann. Die klaren Stïcke Prelbbernstein sind nie glasartig blank, sondern stets sind Wolken und Streifen, sogenannte Schlieren vorbanden, wie sie auftreten, wenn sich verschiedene Fliissigkeiten mischen, oder wenn Zucker in Wasser aufgelüst wird. Dieses berulıt auf der verschiedenen Lichtbrechung ron unzersetzten und reschmolzenem Rohmaterial.

Die flohmigen und Bastardstïcke des Preßbernsteins erkennt man daran, dafo die Trübungen in parallelen Streifen übereinanderliegren, etwa wie bei den Cirruswollen. Be'i echtem Bernstein kommt diese Erscheinung nie vor. Kann man einen Splitter des fraglichen Fabrikates unter dem Mikroskop betrachten, so ist der Untersehied beider sofurt mit vollstïndiger Sicherheit deutlich. Beim echten Bernstein besteht die Trübung aus Bläschen, die vollständi@ kugelrund sind und durch die klare Grundmasse unregrelmäßig verteilt liegen. Der Preßhernstein dagegen zeigt deutliche Fluidalstruktur. Streifen mit sehr kleinen, verschieden gestalteten Bläschen, Rissen und dunkel gefürbten Partikelehen, die sich selbst bei sehr starker Vergröberung nicht auflösen, umschlieljen hellere, eckige Partien unzersetzten Bernsteins, bei dem man vielfach noch die kreisrunden Blïsehen wahrnehmen kann. War der Preßbernstein gefürbt, so liegt der Farbstoff nur in diesen Streifen, die eingeschlossenen Partien sind farblos.

Ein sehr gutes Mittel, um in den meisten Fällen beide zu unterscheiden, ist es, den fertigen Gegrenstand so lange mit einem Wolllappen mit Öl und Wiener Kalk. Schlemmkreide oder Bol, kräftigr zu polieren, bis er tiichtig heib wird. Echter Bernstein wird dadurch glïtter und blanker, während Preßbernstein stellenweise seinen Glanz verliert und dadureh, dafj sich das entstandene Kolophon im öl auflüst, ein ..crütziges" Aussehen bekonımt. Durch Polieren mit Schlemmkreide, Bol usw. und Wasser wird auch Prelbernstein sehr schön glänzend.

Gehärteter Kopal entsteht dadurch, daß reine Kopalstiicke unter hoher Dampfspannung in Wasser, dem man oft Bernsteinsäure hinzugesetzt hat, längere Zeit erhitzt werden. Bei dieser Behandlung trübt sich der Kopal allmählich und wird härter. Ein greübtes Auge erkennt schon an der blassen Färbung und an den mit unbewaffnetem Auge erkennbaren Bläschen leicht, daßj man es mit diesem Surrogat zu tun hat. Mit Sicherheit zeigt es das Mikroskop an der unregelmäßigen Form der Bläschen und dem Mangel an 
Fluidalstruktur, daß man es weder mit Natur-, noch mit Preßbernstein zu tun hat. Eine Sorte gehärteten Kopals zeigt sehr regelmäßige elliptische Bläschen. Stellt man eine hieraus grearbeitete Spitze in Essigüither, so wird man schon nach 24 Stunden bemerken, daß sie an ihrer ganzen Oberfläche klar geworden ist, und dal diese Klärung bei längerer Dauer der Einwirkung fortschreitet, eine Erscheinung, die nie bei Natur- oder Preßbernstein vorkommt.

Im vorhergehenden war in der Hauptsache nur vom eigentlichen echten Ostseebernstein, dem Succinit, die Rede, dem einzigen, im wesentlichen ausschließlich deutschen Edelstein, dem deshalb hier ein breiterer Raum gewährt worden ist. Daneben existieren aber noch zahlreiche andere Harze, die diesem sebr ähnlich sind, die auch wie dieser verwendet werden und die daher zum Bernstein im weiteren Sinne zählen und meist Bernstein genannt werden, obwohl sie sich durch manche Eigenschaften, namentlich durch den Mangel an Bernsteinsäure, von ihm unterscheiden. Deswegen sind sie in neuerer Zeit auch von den Mineralogen, jedoch ohne genügenden Grund, durch besondere Namen vom succinit unterschieden worden. Im Edelsteinhandel spielen sie jedenfalls alle diesem gegeniiber eine untergeordnete Rolle, sind jedoch zum Teil in ihren Heimatländern nicht ganz olne Bedeutung, deshalb sollen von diesen meist außerdeutschen Harzen wenigstens die wichtigsten eine kurze Erwähnung finden.

\section{Gedanit.}

Mit dem Succinit zusammen finden sich mehrere andere Harze, die aber bis auf eines nicht zu Schmuckgegenständen geeignet sind. Dieses eine ist der Gedanit, den die Bernsteinarbeiter auch als "spröden", „mürben" oder „unreifen" Bernstein bezeichnen. Er ist im allgemeinen mehr oder weniger hell weingelb und durchsichtig oder wenigstens stark durchscheinend, seltener schmutziggelb und undurchsichtig. Die meisten Stiicke erscheinen außen wie abgerollt und abgerieben und sind mit einem schneeweißen Mehle bestäubt, das sich abwischen läßt. Bernsteinsäure fehlt, daher entsteht durch die bei der Verbrennung sich bildenden Dämpfe, deren Geruch dem des Bernsteins sehr ähnlich ist, kein Hustenreiz. Der Schmelzpunkt liegt niedriger als beim Bernstein, aber höher als beim Kopal, etwa bei 1400 C. Auch die Härte ist geringer als bei dem ersteren $(H .=11 / 2$ bis 2$)$. Die Löslichkeitsverhältnisse sind ähnlich wie bei diesem, von Terpentinöl wird er aber leichter angegriffen als Bernstein. Durch Reiben mit Tuch wird auch hier starke negative Elektrizität hervorgerufen, so daß leichte Körperchen, Papierschnitzel usw. angezogen werden.

Was den Gedanit bezüglich der Verarbeitung ungünstig vom Bernstein unterscheidet, ist die große Sprödigkeit. Er läßt sich zwar wie dieser auf der Drebbank zu allen mögrlichen Gegrenständen berrichten, und wird auch hierzu ganz wie der echte Bernstein benutzt, aber er lälit sich seiner spröden Beschaffenheit wegen nicht gut bohren, gar nicht schnitzen, und man kann keine Schraubengewinde anbringen, auch mïssen die daraus dargestellten Sachen ihrer leichten Zerbrechlichkeit wegen sehr in acht genommen werden. Daher steht der Gedanit im Preise hinter dem Bernstein zurück; er wird um ein Drittel geringer bezahlt als die entsprechenden Sorten des letzteren. Im Iandel gehen daraus hergestellte Schmucksachen usw. unter dem Namen Bernstein und werden mit solehen aus echtem Suecinit ohne Unterschied verkauft; nur der Kenner ist zur Not imstande, festzustellen, ob irgendein bearbeitetes Stück Gedanit oder echter Bernstein ist.

Das Vorkommen ist auf die Gräbereien beschränkt, in denen er den Grabstein in geringer Menge begleitet. Unter dem Seestein kommt er nicht vor, wahrscheinlich, weil 
er dem spiele der Wellen und der Abreibung im Sande keinen Widerstand leisten kann und seiner Sprödigkeit wegen dabei vollständig zertriimmert wird.

\section{Rumänischer Bornstein (Rumänit).}

Der rumänische Bernstein unterscheidet sich in keiner wesentlichen Eigenschaft vom ostpreubischen Suecinit. Wenn man gröljere Mengen vergleicht, findet man bei ihm dieselben Unterschiede der Farbe und Durchsichtigkeit wie bei dem letzteren, kann also dieselhen Sorten erkennen. Allerdings ist in Rumänien die Farbe gewöhnlich brïunlichgelb bis braun, seltener gelb, und klare Stïcke sind häufiger als trübe. Eine vielfach für charakteristisch gehaltene braunrote Farbe ist nicht ursprünglich; sie und die damit verbundene Anwesenheit vieler Risse und besondere siprüdigkeit beruhen auf einer I mwandlung an der Luft, wie wir sie auch beim succinit kennen geternt haben (sogen. gebräunter Bernstein). Einzelne Stücke zeigen Fluoreszenz, oft schöner als der dadurch besonders ausgezeichnete sizilianische Bernstein. Die Härte ïbertrifft die des Bernsteins um etwas. Bernsteinsäure ist in wechselnder Menge vorhanden (bis 3;; Proz.), aber im Durchschnitt in geringerer als im Bernstein. Charakteristisch ist auch ein verhältnismäßig groljer Gehalt an schwefel, der 1,15 Proz. beträgt. Lüsungsmitteln gegenüber ist der Rumänit noch widerstandsfähiger als der Succinit. Beim Erhitzen entwickelt er einen eirentümlıch aromatischen Geruch, grleichzeitig. einen solchen nach Schwefelwasserstoff (faulen Eiern), der sich aus dem Schwefel bildet. Ohne sich aufzublähen, erweicht er bei $3(0)$ "C. und stöbt dabei Dïmpfe aus, welche wie die des Bernsteins zum Husten reizen.

Das Harz findet sich, mit einer stets nur sehr dünnen, fest anhaftenden Verwitterungssschicht von dunkel gelblichgrauer bis rotbrauner Farbe bedeckt, in kohligen, blïtterigen Schiefern als Nester oder in unterbrochenen Lagern in Sandsteinschichten ausschieflich im Bezirke Buzeu. Die zahlreichen Fundorte liegen alle in der Nähe der nach Südosten vorspringenden siebenbïrgischen Grenze. Die Schichten, in denen der Rumänit vorkommt, oder aus denen er ursprüngrlich stammt, gehören wie im Samlande dem älteren Tertï̈r. und zwar dem unteren Oligocïn an. Er wird meist nach Wien gebracht und dort unter dem Namen „rumänischer Bernstein“ zu Zigarrenspitzen und anderen Gebrauchs- und Luxusgegenständen verarbeitet. Dem echten Bernstein macht er so eine gsewisse, aber keine starke Konkurrenz, da er im allgemeinen nicht sehr häufig ist; etwa 400) Kilogramm werden jährlich grewonnen. Seiner verhältnismäfigen Seltenheit wegen wird er auch etwas hüher bezahlt.

Eine in Rumänien als schwarzer Bernstein bezeichnete Substanz ist kein Bernstein, sondern wie der unten zu betrachtende Gagat eine schwarze Loble (Lignitpechliohle).

\section{Sizilianischer Bernstein (Simetit).}

Der sizilianische Bernstein ist im Aussehen vom Ostseebernstein ziemlich verschieden. $\mathrm{Er}$ ist meist durchsichtig, und die Farbe ist im allgemeinen dunkler. Rotgelb bis hellweinrot ist nicht selten, auch kommen granatrote Stücke ror, und ferner so dunkelrote, daB sie im auffallenden Lichte schwarz erscheinen. Hell- und dunkelbraun fehlt nicht, ebensowenig gelblichweiß. Neben den überwiegenden durchsichtigen Stiicken trifft man auch manche nur durchscheinende oder undurchsichtige. Die Fluoreszenz, bei der das an der Oberfläche zurïckgeworfene Licht blau und grïn ist, bildet hier eine ausgezeichnete und häufige Erscheinung. Charakteristisch ist eine dünne Terwitterungsrinde ron gelbroter, dunkelroter bis schwarzer Farbe, unter der der innere frische Kern allmählich in bellere Nuancen übergeht.

Härte, Bruch und Elektrizität ist wie beim Ostseebernstein, auch das spezifische Gewicht ist sehr nahe dasselbe. Beim Erhitzen schmilzt er, ohne sich vorher aufzublähen. Er gibt 
dabei starke weibe 1)ämpfe, aber keine Bernsteinsäure. Der Geruch ist daher etwas anders als der des Ostseebernsteins und reizt nicht zum Husten.

Der sizilianische Bernstein findet sich, außer an einigen anderen Orten, in losen, abgrerollten Stïcken im Mündungsgebiete des Flusses Simeto, südlich von Catania, daher der Name Simetit. Aus Schichten tertiären Alters, in denen er ursprünglich eingeschlossen war, wurde er durch das Wasser des Flusses herausgewaschen. In der eben genannten Stadt wird er, aber neben ihm auch viel Ostseebernstein, zu Schmucksachen usw. verarbeitet. Mit ihm finden sich zuweilen schwarze, im Bruche glänzende Harzstïcke von seringerer IIärte als die durchsichtigen. Sie geben beim Erhitzen einen anderen Geruch und sind wohl eine andere Substanz als die letztere.

\section{Birmanischer Bernstein (Birmit).}

Auch in Birma findet sich ein von dem Ostseebernstein nicht wesentlich verschiedenes Marz, das zu Schmucksachen verwendet wird. Die Färbung ist ziemlich einförmig. Als Grundfarbe tritt ein glänzendes blasses Gelb auf, ähnlich dem von hellem Sherry. Dieses geht in dunkleren Stücken ins Rötliche und weiter ins Schmutzigbraune, wie es die meisten zeigren, die dann ihrem Aussehen nach mit Kolophonium oder mit festgewordenem Petroleum verglichen werden können. Wenige Stiicke sind klar und dann sehr hell strohgelb bis fast farblos; die meisten sind etwas trübe und zeigen eine sehr starke bläuliche oder grünliche Fluoreszenz, die den Gebrauchswert stark vermindert. Stücke genau vom Aussehen des ostpreußischen Bastard kommen niemals vor.

Der Birmit ist etwas härter als Succinit, spröde, aber leicht zu bearbeiten. Vielfach ist er von Rissen durchzogen, die mit Kalkspat erfüllt sind; es ist daher schwierig, größere zusammenhängende Stïcke zu finden, was den Wert ungünstig beeinflußt.

Die Heimat des birmanischen Bernsteins ist der Bezirk Myitkyia im Norden des Landes (siehe die Karten Fig. 64 und 65). Die altberïhmten Gruben liegen nicht zu fern von den Jadeitgruben in einem Hügel, 3 (engl.) Meilen südwestlich von Maingkwan im Becken des IIukong, des Oberlaufes des Dschindwin, unter $26^{0} 15^{\prime}$ nördl. Breite und $96^{\prime} 30^{\prime}$ ̈̈stl. von Greenwich. Die Stücke finden sich in einem blaugrauen, dem unteren Miocïn der Tertiärformation angehörigen Tone, in dem sie nesterweise eingebettet sind. Sie sind stark abgerolit, flach, meist plattenförmig, zum Teil bis kopfgroß. Das Material ist von den Eingeborenen und von den Chinesen gleich geschätzt. Es werden Perlen und Zylinder zum Einstecken in die Ohrlappen daraus gedreht und Figuren von Tieren, Götzen usw. daraus geschnitzt. Die Produktion war stets gering, und es ist schon aus diesem Grunde, ganz abgesehen von den obengenannten ungünstigen Eigenschaften, wenig wahrscheinlich, dalj der birmanische Bernstein je auf den europäischen Markt kommt. Im (xegenteil wird jetzt viel Ostseebernstein ïber Indien nach Birma eingeführt und dort als "indischer Bernstein" billiger verkauft wie der einheimische. Nan hat sogar behauptet, dal) die Gruben jetzt gar nicht mehr bearbeitet werden und der noch im Handel vorkommende Birmit aus alten aufgesammelten Vorräten stamme. Doch wurden nach amtlichen Mitteilungen der indischen Regierung in der Zeit von 1898 bis 1903 jährlich im Durchschnitt 51 Zentner in Wert von 362 Pfund Sterlingr gewonnen. Später nahm die Produktion, wahrseheinlich infolge der friedlichen Verhältnisse des Landes, erheblich zu. Sie betrug 1904: 86 Zentner im Wert von $\$ 38$ Pfund, 1905: 126 Zentner im Wert von 945 Pfund. Gleichzeitig wurde aber die Qualitït geringer, und der Preis des Zentners fiel von 9 Pfund 15 Schilling auf 7 Pfund 10 Schilling. 


\section{Kanadischer Bernstein (Cedarit).}

Der kanadische Bernstein kommt in Kömern bis zu Wallnuliegrifie in den Triebsandgeholeten des Saskatchewan, besonders an Cedar-Lake vor. Lir findet sich dort mit

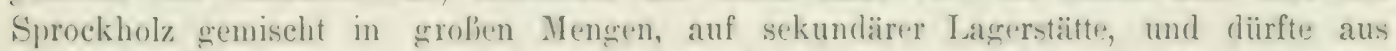
Kreidegestein ausgewaschen sein. Die kanadische liegierung hat die harzführenden Flïchen anfereteilt und die Bernsteingewinnung an Indianer vergehen. Seine Löslichkeitsverhältnisse sind ähnlich denen des baltischen Bernsteins, er schmilzt unter Zersetzung bee a $35^{\prime \prime}$. Unter den Cedaritkörnern finden sich 5 Prozent Bastard, 35 Prozent klar, geths und rotreell); 1 Prozent knochig, das ïbrige ist schwarzhraun klar oder granz unrein. Die Farbe des klaren steht zwischen der der Zanzebar-Kopals und des hellen Bernsteins. Er ist frei von Bernsteinsäure, läbt sich leicht bearbeiten und gut und schnell polieren. Ob) die klaren Varietäten zu P'erlen verarbeitet werden, ist nicht bekannt, jedenfalls würden sie sich @ut dazu eignen, da sie genügende Härte und starkes Feuer besitzen. Geschmolzen liefert der Cedarit einen Kolophon, aus dem sehr dunkler und harter Lack herestellt werden kann.

\section{Bernstein von San Domingo.}

Der sog. Bernstein von San Domingo ist ein zum Retinit gehüriges fussiles IIarz, das zwar in einzelnen Varictïten dem Bernstein nahe steht, jedoch lieine Bernsteinsäure enthält, in andern aber mehr dem Kopal mleicht. Er ist nur klar bekannt, Bastard scheint nicht vorzukommen. Die Farbe geht ron gelh bis zu einem schönen Braun. C'harakteristisch ist für ihn die starke petroleumartige Fluoreszenz; fertige Zigrarrenspitzen sehın schon in den Auslagen der Ladenfenster bläulich aus. Dieses Harz wird in Amerika mehrfach verarbeitet. Es findet sich in ziemlicher Menge in rundlichen Stiicken, meist bis 2 Zoll dick, oder in flachen bis zur Größe einer Mannshand mit fossilen IIolzresten (Lignit) in Schichten der Tertiärformation. Der Hauptfundort ist auf der 1801) m hoch gelegenen Spitze des Berges Palo Quemado in der Provinz Santiago, im Gebiet des Oberlaufes des Licey River, etwa 30 miles ron der Kïste, 10 miles nordwestlich ron Tamponil und 7 miles nördlich von Santiago.

Auch andere Länder liefer'n solche bernsteinähnliche Harze, so scheint namentlich das südliche Mexiko sebr reich daran zu sein, es ist aber zurzeit noch nichts Xäheres dariiber bekannt. Der ,mexilsaniscbe Bernstein" wird ron unbekannten Fundorten im Innern des Landes durch die Eingeborenen an die Küste gebracht und im Lande zu kleinen Bijouterien rerarbeitet. Er kommt in solchen Mengen vor, daf die Indianer Fener damit anmachen. Die Farbe ist ein reiches froldgelb, und die stiicke fluoreszieren stark. Seiner Beschaffenheit nach ist er zu den Kopalen zu rechnen.

\section{Gagat.}

Der Gagat (Agstein, schwarzer Bernstein. Jet (engl.), Jais franz.), ist eine Art fossiler Kohle, die vielfach zu Trauerschmuck und anderen Dingen verarbeitet wird. Wenn Koble hierzu tauglich sein soll. so muß sie verschiedene besondere, nicht gerade häufig nebeneinander rorkommende Eigenschaften in sich vereinigen. Sie muß ganz dicht, kompakt und homogen sein, was sich durch einen vollkommen muscheligen Bruch ausspricht. 
Ungleichartige Partien dürfen nicht zwischengelagert sein, namentlich wird sie durch eingewachsenen Schwefelkies, der die Kohlen so häufig verunreinigt, zum Schleifen unbrauchbar. Ebensowenig darf die urspriingliche innere Holzstruktur noch deutlich erbalten sein, was ahel nicht hindert, daß vielfach die äufere Gestalt der Stämme unit ihren Ästen usw. vollkommen sichtbar geblieben ist, zum deutlichen Merkzeichen der Entstehung aus vorweltlichen Hölzern, die im Laufe der Zeiten eine sehr starke Umwandlung durch Verkohlung erlitten haben.

Die Farbe mul gleichförmig ohne Flecken und möglichst tief und rein sehwarz sein. Je schöner sammetartig schwarz ein Stiick ist, desto mehr ist es greschätzt; eine ins Bräunliche grehende Nuance ist weniger beliebt. Gute geschliffene Stuicke müssen lebbaft glïnzen, solche, die nur matt schimmern, haben keinen Wert; der Glanz ist meist ein ziemlich ausgresprochener Fettglanz. Endlich muß die Masse möglichst wenig spröde, jedoch so fest sein, daß sie sich mit dem Messer schneiden (schnitzen) und auf der Drehbank sowie mit der Feile bearbeiten und in der gewöhnlichen Weise schleifen läßt. Auch mulj sie genügende Härte haben, damit die durch die Bearbeitung hergestellten Formen gut erhalten bleiben und beim Gebrauche nicht zu rasch abgenutzt werden.

Diese Beschaffenheit besitzt der Gagat in ausgezeichneter Weise. Er hat, wie alle Kohlen, die Eigenschaft vollkommener Undurchsichtigkeit, ist aber für Röntgenstrahlen rollkommen durchlässig. Das spezifische Gewicht steigt bis 1,3i, doch sollen einzelne Gagatstiicke auch auf dem Wasser schwimmen, wahrscheinlich aber doch nur infolge von poröser Beschaffenheit. Die Härte des echten Gagats schwankt zwischen 3 und 4 . Vor dem Lötrohr entzündet sich die Masse leicht, da sie sehr inniğ von bituminösen Teilen durchtränkt ist; sie brennt einige Zeit mit stark rauchender, rubender und riechender Flamme und linterläßt einen glänzenden, porösen, koksälınlichen Rückstand. Ein eigentliches Schmelzen tritt dabei nicht ein. Die Wärmeleitungsfähigkeit ist sehr gering, daher fühlt sich der Gagat, wie alle Körper organischen Ursprungs, mit der Hand warm an, was namentlich beim Vergleich nit schwarzen Steinen und Gläsern sehr deutlich hervortritt und eine rasche Unterscheidung ermöglicht.

Die hauptsächlichsten Gagatschleifereien, die gegenwärtig existieren, sind in Whitby in Yorkshire, am nördlichen Teile der Ostküste von England. In diesen Lande gibt es auber den grenannten keine weiteren, und die festländischen sind jetzt so unbedeutend, daß sie den englischen gegenüber nicht in Betracht kommen. Whitby ist also das Zentrum der Gagatindustrie überbaupt und hat für den Gagat etwa dieselbe Bedeutung wie Oberstein für den Achat.

Gagat scheint nach überlieferten Berichten in England schon in vorrömischer Zeit zum Schmuck verwendet worden zu sein. In grofer Menge wurde or in den Klippen der Yorkshire-Küiste gegraben, besonders in der Nähe von Whitby, aber auch sonst, so in Eskdale, in Danby Dale und in einigen andern tiefern Taleinschnitten, die die Moorländereien des östlichen Yorkshire durchziehen; besonders ercriebig sind die Lager bei Robin Iloods Bay, 4 (engl.) Meilen südöstlich von Whitby. Der Gagat liegrt in den schwarzen stark bituminösen und kalkreichen Posidonienschiefern des oberen Lias (Zone des Ammonites [Harpoceras] serpentinus), nicht selten in der Form flacher ausgedehnter Massen, die in seltenen Fällen eine Länge bis zu $6 \mathrm{Fuß}$ erreichen. Eine Abteilung dieser Schiefer ist so reich an Gagat (engl. Jet), daß sie speziell als Jet-rock bezeichnet wird.

Die Menge des jährlich gewonnenen Rohmateriales ist nicht gering; sie stieg im Jahre 1880 auf 6720) Pfund. Es sind zwei Sorten, die in Whitby verarbeitet werden. Eine härtere und bessere und daher auch teurere schwankt im Preise zwischen 4 und 21 Sehilling (oder Mark) pro Pfund; sie wird noch jetzt in der Hauptsache von einheimischen Gräbereien geliefert, doch ist das Vorkommen der Erschöpfungr nahe. Gagat 
von ausgremeloneter Qualitit wird jetzt in froben Blöcken und zu geringen Preisen aus Sipanien, und zwar besonders aus Aragonien, nach Whitby eingeführt - im Jahre 190n im sanzen 2 Tonnen im Werte vom 250) Pesetas - wodurch die engrlische Produktion von Rohagat wesentlich reduziert worden ist. Der Gromtjahresumsatz in Gagatwaren

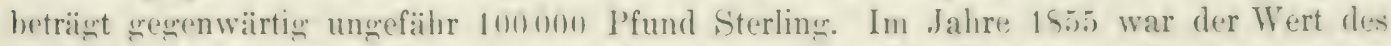
in Whithy verarbeiteten (iagats 20000 Pfund Sterling. Die Zahl der in England mit der Gewinnung und Verarbeitung des Gagats heschäftigten Personen betrïgt zurzeit ungeführ $1200-1500$.

Statt echten Gagrats wird indessen in Whitly noch ein anderes ähnliches encrlisches Material verarbeitet, die Kännelkohle. Sie ist mehr eraulich-oder bräunlichschwarz, weniger glïnzend und auch weniger politurfähign, sowie sprïder. Dieste findet sich in großen Massen in der Steinkohlenformation von Newcastle und an andern Orten in Encland und Schottland. Wegen des Torkommens in größjeren l'latten kïnnen daraus auch Furniere zur Bekleidung größerer Flächen, z. B. von Wandflïchen, hergestellt werden. Beim echten Gagat kommt dies. der geringeren firïbe der rohen Stiicke wegen, nur in unbedeutendem Umfange vor.

Auch auf dem europäischen Kontinent haben einige Länder Gagat sreliefert, und dieser ist dort auch verarbeitet worden. Daß Spanien Rohmaterial nach England liefert. ist schon erwähnt, aber auch in seinem Heimatlande wurcle der spanische Gasnat früher in einiger Menge verarbeitet; diese Industrie scheint indessen jetzt zienlich erloschen zu sein. Die Fundorte liegen, wie wir gesehen haben, in Aragonien. aher auch in Galicien und Asturien. Die Terarbeitung gescbah vorzugsweise in Asturien an mehreren Orten.

In Frankreich ist der Sitz der auch dort uralten Gagatindustrie im Languedoc, und zwar im Departement de l'Aude. wo der Gagat in dem Grünsande der oberen Kreideformation vorkommt. Er bildet wie in Yorkshire dünne Platten. die selten ein Gewicbt ron 15 Pfund erreichen. Die Hauptfundorte sind bei Ste. Colombe sur l’Hers, bei Monjardin unweit Chalabre am Berg Commo-Escuro und bei Bugarach am Berc Cerbeiron, wo ein unregelmäBiger Bergbau betrieben wurde. Doch lieferten diese Pliitze nicht das ganze Material. Wie noch jetzt in Whitby, so mußte auch in Frankreich der spanische Gagat aushelfen, der ron dort kommende soll sogar zum Teil besser gewesen sein als der französische.

Die Blütezeit dieser Industrie in Frankeich fällt in das 18. Jahrhundert. 17S6 waren in jener Gegend noch 1200 Leute dabei beschäftigt, vorzugsweise in der Gemeinde Ste Colombe, dann in Dourban, Segure. Payrat, Bastide und andern. Es wurden damals im .Tahre etwa 10100 Zentner Gagat (franz. Jais oder Jaret) einheimischer und auswärtiger rerarbeitet. Die fertigen Gegenstände gingen zu einem guten Teil ins Ausland. besonders nach Spanien, das jedes Jahr etwa für 150000) Franken bezog, sodann nach Italien, Deutschland, und in den Orient, namentlich in die Türkei. Später trat infolge einer ̈̈nderung der Mode ein starker Rückgang ein. 1521 betrug der Reingrewinn aus dem Graben und der Verarbeitung des Gagats nur noch 35000$)$ Franken, und heutzutage ist von diesem Industriezweige beinahe gar nichts mehr übrig.

In Württemberg findet sich das Rohmaterial in denselben Schichten und in derselhen Weise wie bei Whitby, in den Posidonienschiefern des oberen Lias. so bei Schömbergr, Balingen, Boll und an manchen andern Orten der schwähischen Alb. Man kïnnte durch Tachgraben leicht Gagat genug gewinnen, um eine der englischen ähnliche Industrie zu betreihen. Es hat auch nicht an Versuchen gefehlt, eine solche einzurichten, und die Recrierung hat diese Bestrebungen lebhaft gefördert, der Erfolgr blieb aber aus. Die in Gmïnd, Balingen und andern Orten angelegten Werkstätten konnten sich nicht halten, 
sie sind der Konkurrenz von Whitby erlegen, wo unter güunstigeren Bedingungen gearbeitet wird. Kleine Mengen hat auch die fränkische Alb (Gegend ron Staffelstein) geliefert.

In Yordamerika findet sich Gagat, ebenso schön wie bei Whitby, im südlichen ('olorado im Wet Mountain Valley, und besonders in El Paso County im gleichen Staate, neuerdings auch in Maryland. Er wird aber nicht oder doch äußerst wenig zur Herstellung von Schmuck verwendet. Dasselbe ist der Fall mit dem schönen Vorkommen von Pictou in Pictou County in Neu-Schottland. Dagegren wird die schwarze, etwas metallisch glänzende Steinkohle, die man Anthrazit nennt, namentlich die von Pennsylvanien, zuweilen in der Weise wie der Gagat benutzt. In Amerika wird als Trauerschmuck statt des Gagat allgemein „schwarzer Onyx", d. b. küinstlich schwarzgefärbter Onyx oder Achat, getragen, der glänzender, schöner schwarz, härter und haltbarer ist und der sehr billig ron Oberstein und Idar bezogen wird. Eine Gagatindustrie hat hier somit wenigstens gegenwärtig keinen Boden, trotz des schönen und in genügender Menge vor kommenden Rohmaterials.

Der Gagat dient zur Anfertigung von Schmucksachen aller Art, wie Broschen, Armund Halsbändern, Anhängern in Kreuzform und von anderer Gestalt usw., die, wie oben angedentet wurde, in der Hauptsache in der Trauerzeit getragen werden. Man verfertigt aber aus demselben Material auch Gebrauchsgegenstände, die nicht dem Schmuck dienen, Rosenkränze, Dosen und andere kleine Gefäße, Tintenfässer, Leuchter, Stockknöpfe usw., die sich alle durch ihre große Leichtigkeit auszeichnen. Die Sachen werden zuerst mit dem Messer oder der Feile im Rohen geformt, dann auf der Drehbank oder der Schleifscheibe weiterbearbeitet, oder auch mehr oder weniger kunstreich geschnitzt und endlich fein poliert, zuletzt bloß auf dem Ballen der Hand.

Trotzdem daß die Gagatgegenstände auch von der besten Beschaffenheit keinen loohen Wert haben und im allgemeinen, wenn nicht an ein Stück besondere Kunstfertigkeit gewendet worden ist, zu mäßigen Preisen im Handel abgegeben werden, hat man sie doch durch andere Substanzen nachzuahmen gesucht, oder man hat doch wenigstens Trauerschmuck und die sonstigen erwähnten Gegenstände aus anderen schwarzen Materialien hergestellt, die ebenfalls als Gagat bezeichnet werden und die von Unkundigen mit Gagat verwechselt werden können. Diese Materialien und ihre Unterschiede von dem letzteren sollen daher hier kurz angegeben werden. Häufig sieht man Trauerschmuck, der aus schwarzem Glas, künstlichem oder natürlichem (Obsidian), hergesteilt ist. Man wird kaum je im Zweifel sein, ob man es mit Glas oder Gagat zu tun hat. Frsteres ist viel glänzender, härter und schwerer als letzteres, und im ersten Augenblicke bemerkt man den Unterschied, wenn man das Stück berührt. Glas fühlt sich auffallend kalt, Gagat dagegen warm an. Aufer Glas liefern zuweilen der schon erwähnte schwarze Onyx, schwarzer 'T'urnalin oder Granat (Melanit) usw. das Material zu derartigen Sehmucksachen. Gagat kann von allen diesen Steinen durch dieselben Mittel unterschieden werden, wie von Glas. Ein Kunstprodukt, aus dem ganz ähnliche Sachen hergestellt werden, wie aus Gagat, ist der Hartgummi. Das Aussehen beider ist sehr ähnlich, auch das warme Anfühlen. Der Ilartgummi wird aber schon beim schwachen Reiben an Tuch so stark elektrisch, daß er kleine Papierschnitzel mit größter Leichtigkeit anzieht, was beim Gagat nicht der Fall ist. IIartyummi läßt sich im weichen Zustande in Formen pressen, und man kann so sehr leicht eine Art von Kameen usw. herstellen, die aber durch ihre stumpfen Konturen dem Kundigen sofort zeigen, daß er es nicht mit geschnitzten Gagatwaren zu tun hat, die sich durch bestimmte Umrisse, sowie durch scharfe Kanten und Ecken auszeichnen. 


\section{DRITTER TEIL.}

Erkennung und Unterscheidung der Edelsteine. 

Schon bei der Beschreibung der einzelnen Fdelsteine ist angeget)en worden, wir man jeden erkennen und von allen ähnlich aussehenden unterscheiden kann. Die dabei aufeestellten Regeln lassen sich benützen, um zu untersuchen, ob ein Stein, der z. B. für einen I)iamant auswegehen wird, auch wirklich ein soleher ist oder nicht, vielleicht irgendein anderes, dem Diamanten ähnliches Mineral oder gar nur eine Imitation aus Glas.

Es sind aber auch Fälle möglich, wo bei einem Edelsteine von einer grewissen Farbe - der Eigenschaft, die immer zuerst und hauptsächlich ins Auge fällt - kein bestimmter Anhaltspunkt vorhanden ist, welcher Art man ihn zuzurechnen hat. Es kann also z. B. vorkommen, daß ein roter Stein vorliegt und man nicht ohne weiteres sofort crkennen kann, ob man es mit Rubin, Spinell, Granat, Topas, Turmalin, Flufsppat usw., oder mit Glas zu tun hat.

Ein erfahrener Juwelier oder Mineraloge wird dabei allerdings wohl selten im Zweifel sein. Schon das äußere Ansehen, das auf den mit bloßem Auge oder mit der Lupe wahrnehmbaren, in den beiden ersten Teilen eingehend erörterten Eigenschaften der Durchsichtigkeit, des Glanzes, der Farbennuance usw. beruht, ermöglicht einem solchen meist die Erkennung auch geschliffener Steine auf den ersten Blick, und wenn es sich um ungeschliffene, rohe Stïcke handelt, kommen als weitere, ohne experimentelle Untersuchung erkennbare Merkmale, wenigstens für den Kenner, noch Kristallformen, Form der Bruchflächen, Blätterbriche usw. hinzu, um eine sichere Bestimmung zu erleichtern.

Glas kann von einem echten Edelstein vielfach durch sein wärmeres Anfühlen sowie durch Behauchen unterschieden werden. Dahei nimmt es den Hauch leichter an und beschlïgt sich rascher mit Feuchtigkeitstropfen, und es behält ihn auch lïnger als der Stein (S. 81).

Führen aber alle diese dem bloßen Auge oder dem Gefühl zugänglichen Kennzeichen nicht zum Ziele, dann miissen auch noch solche Eigenschaften mit zu Hilfe genommen werden, die nicht durch bloßes einfaches Betrachten, eventuell mit der Lupe, hervortreten, sondern die erst durch gewisse Versuche mit geeigneten Instrumenten erkannt werden können.

Diese Versuche müssen einigen Bedingungen genügen, wenn sie nicht nur für den wissenschaftlichen Mineralogen, sondern auch für den praktisch gebildeten Juwelier brauchbar sein sollen. Sie müssen sich einmal ohne Beanspruchung besonderer Handfertigkeit und eingehender theoretischer Kenntnisse leicht anstellen lassen, und die erforderlichen Instrumente müssen einfach und solide und möglichst billig sein. Weiter ist noch durchaus erforderlich, daß die Steine bei der Untersuchung nicht beschïdigt rerden. Dies ist besonders wichtig, wenn dieselben geschliffen sind; bei rohen Exemplaren schadet meist eine kleine oberfliichliche Verletzung nicht viel, doch ist auch bei ihnen eine solche tunlichst zu vermeiden. Gut ist es ferner, wenn sich diese Tersuche auch an gefaßten Steinen anstellen lassen. Sie können dann noch in manchen Fällen eine sichere Erkennung 
ermüglichen, aber vielfach wird die Fassung eine solche vereiteln, da sie die allseitige Untersuchung lindert. Man kann somit eine in jeder Hinsicht genïgende Beobachtung aller Eigenschaften im allgemeinen nur an ungefaliten Steinen vornehmen, und man wird daher einen wertvollen Edelstein vorsichtigerweise nur ungefaßt kaufen.

Am besten genïgen diesen Anforderungen das spezifische Gewicht und das optische Terhalten, die daher auch für die vorliegenden Zwecke besondere Bedeutung haben, in beschränktem Umfang auch die Pyroelektrizität. Sie sind im ersten Teile (S. 12 bis 29 und S. 38 bis 81 , sowie S. 8:3) ausführlich besprochen worden. Hier sollen nur einige für die Erkennung und Unterscheidung der Edelsteine besonders wichtige Verhältnisse kurz rekapituliert werden, im übrigen aber sei auf jene Auseinandersetzungen verwiesen und ebenso auf die Beschreibungen der einzelnen Edelsteine im zweiten Abschnitte dieses Buches.

Das spezifische Gewicht wird am besten und bequemsten bestimmt mit Hilfe der schweren Flüssigkeiten, besonders des Methylenjodids, das man so weit mit Benzol verdünnt, his der Stein gerade schwebt. Das Gewicht der Flüssigkeit und damit das des zu untersuchenden Steines wird dann mittels der Westplıalschen Wage (Fig. 7) ermittelt. Die Steine dürfen dabei aber nicht schwerer sein als das reine Metbylenjodid, dessen spezifisches Gewicht bei gewöhnlicher Zimmertemperatur gleich 3,3 ist. Sinken die Steine in diesen zu Boden, so kann man unter Umständen statt des reinen Methylenjodids solches benutzen, das mit Jod und Jodoform gesïttigt ist, und damit in der gleichen Weise verfahren wie mit jenem, oder man muß eine der anderen Methoden (mit dem Pyknometer, der hydrostatischen Wage, der Westphalschen Wage mit der in Fig. 5 dargestellten Einrichtung usw.) anwenden. Wenn das spezische Gewicht über 3,6 hinausgeht, so daß der Stein auch in dem mit Jod und Jodoform gesättigten Methylenjodid zu Boden sinkt, kann man sich vielfach noch des geschmolzenen Thalliumsilbernitrats (S. 26) bedienen. Da in den allermeisten Fällen eine vollkommen genaue Bestimmung des spezifischen Gewichts nicht erforderlich ist, so verwendet man in der Praxis am bequemsten die vier Normalflüssigkeiten (S. 27), mittels deren sämtliche Edelsteine bezüglich ihrer Dichte in die fünf Abteilungen gebracht werden können, von denen unten bei der Betrachtung der Unterschiede der einzelnen Edelsteine ein ausgerdehnter Gebrauch gemacht werden wird.

Das spezifische Gewicht läßt sich gleichermaßen bei rohen und geschliffenen Steinen anwenden, sie dïrfen nur keine Beimengung fremder Substanzen haben und selbstrerstïndlich nicht gefafit sein. Mittels der Methode des Schwebens in Methylenjodid, Thalliumsilbernitrat usw. kann man das spezifische Gewicht an den kleinsten Steinchen bestimmen; ist es nötig, die Wage anzuwenden, müssen die Stücke etwas größer sein.

Von grober Bedeutung ist das optische Verhalten. Es handelt sich hauptsäehlich darum, ob der zu untersuchende Stein die Lichtstrahlen stark oder schwach, einfach oder doppelt bricht.

Das stäkere und schwächere Li ch tbre chungsverm ögen, die Größe der Brechungskoeffizienten, kann bei durchsichtigen Edelsteinen mittels des Refraktometers leicht grenau festgestellt werden (S. 62). Nicht selten grenïgt dabei eine amnähernde Bestimmung oder die Ermittlung, ob die Brechungskoeffizienten sehr grofj oder klein sind, oder bei zwei zu unterscheidenden Steinen, wolcher das Licht stärker oder schwiicher bricht. In den folgenden Tabellen sind die Brechungskoeffizienten für mittlere Strahlen angegeben.

Die Doppelbrechung ist zuweilen schon direkt dentlich zu sehen, wenn man durch den Stein hindurch nach einer Lichtflamme blickt. Jede einzelne Facette gibt dann mit derjenigen, die gerade vor dem Auge liegt, ein Prisma, und in diesem entsteht ein kleines farbiges Flammenbild, das einfach ist bei einfach brechenden (Fig. $26^{\text {b) }}$, doppelt bei doppelthrechenden Steinen (Figr. 26, S. 57). Da aber bei Edtelsteinen mit sehr geringer 
Doppellorechung die Flammenbilder einfach scheinen kïnnen, weil die beiden zu einem Doppethilde zusammengehörigen Einzelbildchen beinalse ganz iibereinanderfallen und sich fast vollstiondig decken, so ist nur die sichere beohachtung der Joppelforechung durch deutliche Dopuelbilder entscheident. Unter allen Lmständen müssen die steine bei dieser Beobachtung ganz durchsichtiy und von ebenen und grlatten Kristallflichen, oder won angeschliffenen ehenen Facedten begrenzt sin; unrexelmäbige Bruchstiicke oder rundlich geschliffene Flïchen weben keine scharfen Bilder der Flamme und lassen daher den Unterschied, um den es sich hier handelt, nicht erkennen.

Fïhrt die direkte Beobachtungr aus irgendeinem frunde nicht zur doutlichen Erkennung der doppelten oder einfachen Lichtbrechung. dann lälit sich dies mittels des I'olarisationsinstrumentes (Fig. 27, S 55) feststellen. Man legt den Stein auf den Ohjekttisch des Instrumentes, dessen Polarisationsebenen gekreuzt sind und dessen Sohfeld daher dunkel erscheint, und dreht ihn mit dem Objekttisch herum. Wenn bei einer vollen Comdrehung um 360 (xrad eine viermalige Aufhellung und Verdunkelung eintritt, dann bricht der Stein das Licht zweifellos doppelt. Wenn er dagegen wie das ganze iibrige Sehfeld bei einer vollen Drehung oleichmälbigr dunkel bleibt, dann kann er einfachbrechend sein, er muß es aber nieht sein, da auch in doppeltbrechenden Kristallen eine oder zwei Richtungen, die optischen Achsen, vorhanden sind, in denen sich dieselhe Erseheinung zeigt, nach denen gesehen also der doppeltbrechende Körper einfach brechend erscheint. Wenn demnach ein Stein bei einer gewissen Lage auf dem Objekttisch des Polarisationsinstrumentes bei der Drehung unverändert bleibt, dann bringt man ihn ein zweites Mal in riner anderen Lage auf diesen, so dab die Lichtstrahlen in einer anderen Richtung hindurchgehen. Wird der Stein nunmehr beim Drehen abwechselnd hell und dunkel, dann ist er doppeltbrechend; bleibt er auch jetzt wieder dunkel, dann braucht man nicht mehr zu zweifeln, dab er wirklich einfachbrechend ist, eine absolut sichere Erscheinung hat man aber nur. wenn deutlich Doppelthrechung beobachtet ist. (ieschliffene Steine legt man dabei auf zwei Facetten, ron denen aher keine der anderen parallel sein darf. Man mulj bei derartigen Beobachtungen jedoch im Auge behalten, dalj bei stark lichtbrechenden Steinen die Lichtstrahlen leicht durch Totalreflexion gehindert werden kïnnen, an deren oberer seite auszutreten. Solche erscheinen dann bei der Drehung dunkel, trotzdem dab sie in der Tat doppeltbrechend sind. Um diese Unsicherheit zu vermeiden, hringt man den Stein, eventuell durch Aufkleben mit Wachs an dem Rande auf ein Objektglas, so in das Polarisationsinstument, dalj eine möglichst grofe Fliiche, bei Brillanten die Tafel, bei Rosetten die Grundfläche usw., dem Beschauer zugekehrt ist, oder man beobachtet den Stein in einem Glasgefäb mit ebenem durchsichtigen Boden, in welehem man ihn mit Methylenjodid, Monobromnaphthalin oder einer anderen stark liehtlorechenden Substanz ïbergossen hat. Man kann auf diese Weise in Polarisationsinstrument nicht nur mit ebenen Facetten geschliffene Steine, sondern auch mugelige und ebenso ganz unregelmäbign gestaltete Stiicke untersuchen. Es ist dabei nicht einmal rollkommene Durchsichtigkeit nötig, es genügt schon ein erbeblicher Grad von Durehscheinenheit, um Helligkeitsunterschiede beim Drehen zu erkennen, wenn sie nicht zu gering sind. Zu berïcksichtigen sind die optischen Anomalien (S. 61). die aber wohl kaum jemals einen Irrtum veranlassen werden. Bei allen diesen Versuchen mit dem Polarisationsinstrumente ist es durchaus nötig, das störende Seitenlicht durch eine über den Stein auf den Objekttisch gresetzte undurchsichtigre Pappröhre oder auch durch Vorhalten der Hand vor den Stein abzublenden.

Die Brechungskoeffizienten werden auch hier mittels des Refraktometers (S. 62) bestimmt; der orößte und der kleinste sind für jeden Edelstein unter der Form $\mathrm{n}_{\mathrm{i}}-\mathrm{n}_{\approx}$, also z. B. für Bergkristall 1,55-1,56, in den folgenden Tabellen angegehen; aus ihnen folgt die Stärke der Doppelbrechung ohne weiteres. 
Auch die Beobachtung des Dichroismus, eventuell mit der dicbroskopischen Lupe, kann bei durchsichtigen, nicht zu licht gefärbten Steinen sichere Merkmale der Doppelbrechung geben. Entstehen in diesem Instrumente (S. 74) beim Hindurchsehen durch einen Edelstein gegren das Licht zwei verschieden gefürbte Bilder, dann ist dieser dichroitisch und damit auch doppeltbrechend. Bleiben beide Bilder gleich gefärbt bei einer vollen Umdrehung des Steines oder der Lupe, dann ist die Beobachtung, ähnlich wie bei der Untersuchung der einfachen oder doppelten Lichtbrechung, nicht entscheidend. Der Stein kann in diesem Falle entweder wirklich nicht dichroitisch und dann einfachbrechend sein, oder der Unterschied in der Färbung der Bilder ist so unbedeutend, daß er nicht deutlich wahrgenommen werden kann. Es ist aber auch möglich, daß man zufällig in einer Richtung hindurchgesehen hat, in welcher der sonst dichroitische Stein keine Farbenverschiedenheit zeigt. Man darf sich also auch hier nicht mit der Beobachtung in einer Richtung begnügen, wenn das erstemal Farbengleichheit vorhanden war, sondern man muß den Stein in einer anderen Lage vor die Lupe bringen und nach einer anderen Richtung noch einmal untersuchen. Zeigt er nun verschieden gefärbte Bilder, dann ist er sicher dichroitisch und doppeltbrechend, sind oder scheinen dagegen auch jetzt beide Bilder wieder gleich, dann kann der Stein wohl undichroitisch, d. h. einfach lichtbrechend sein, die Sache ist aber nicht vollkommen sicher entschieden. Ein bestimmtes, unzweideutiges Resultat gibt nur der sichere Nachweis des Dichroismus. Auch bei der Beobachtung dieser Erscheinung ist es zur Vermeidung von Totalreflexion zweckmäßig, den Stein mit möglichst grolien ebenen Flächen (Facetten) vor die Öffnung des Instrumentes zu bringen.

Manche Edelsteine sind so stark dichroitisch, daß man schon mit bloßem Auge beim Hindurchsehen nach verschiedenen Richtungen Farbenunterschiede wahrnimmt. Dadurch ist dann schon die Doppelbrechung ohne weiteres erwiesen und die Dichrolupe ist überflüssig und lıöchstens noch zur Bestätigung der direkten Beobachtung wünschenswert, ebenso auch zur Konstatierung der verschiedenen auftretenden Farbentöne der Bilder, die für die einzelnen Steine bis zu einem gewissen Grade charakteristisch sind und die daher auch bei den unten folgenden Tabellen zum Teil Berïcksichtigung finden sollen. Die Beobachtung des Dichroismus bietet den Vorteil, daß sie oft an gefaßten (a jour gefaßten) Steinen ganz ebensogut vorgenommen werden kann wie an ungefaßten, und an rohen so gut wie an geschliffenen.

Für die Erkennung des Almandins und des Zirkons ist unter Umständen das Absorptionsspektrum (S. 77) von Bedeutung:

Für einen Mann, der mit Edelsteinen zu tun hat, sind also die schweren Flüssigkeiten mit der Westphalschen Wage, ein Polarisationsinstrument von der besehriehenen Finrichtung oder besser ein Mikroskop) mit Polarisationsvorrichtung, ein Refraktometer und eine dichroskopische Lupe zweckmäßige, ja notwendige Gegenstände und Apparate, um zweifelhafte Edelsteine zu bestimmen und sich so vor Verlusten zu schïiten, in beschrïinktem Maße kann auch ein Taschenspektroskop und eine Vorrichtung zur Erkennung der Pyroelcktrizität von Nutzen sein. Sie lassen sich alle ohne Schwierigkeit anwenden und führen bei zweckmäßjger Benutzung und olne zu großen Aufwand ron theoretischen Kenntnissen und praktischer Geschicklichkeit und Erfahrung in fast allen Fällen zum sicheren Ziele, wenigstens denjenigen, der die natürliche Beschaffenheit der Edelsteine kennt, oder doch imstande ist, sich in einem passenden Buche darïber zu belehren.

Manchmal ist es aber doch wünschenswert und in einzelnen fällen sogar notwendig, auch noch andere Eigenschaften zu Rate zu ziehen, auch solche, bei denen der Stein unter Umständen etwas verletzt wird, besonders die II ärte und, von viel geringerer Bedeutung, die Schmelzharkeit, die höchstens bei rohen Steinen getegentlieh benutzt werden kamn, sowie das Verhalten gegen Säuren. Selbstverständlich mul auch hiebei jede Be- 
schädigung vermieden werden, wemn es sich um einen vinzelnen Stein von hohem Werte handelt, namentlich wemn er geschliffen ist. Anders liegren jedoch die Verhältnisse, wenn ein grober I'osten geleichartiger Steine, wie sie die Juweliere zur Verwendung in ihrem (ieschäfte zu kaufen pflegen, z. B. eine griöfere Menge Türkise, zur Lntersuchungr vorliegen. Dann ist oft der Vorteil riner sicheren Bestimmung so grolb, dalf ein oder das andere als Stichprobe beliebig herausgenriffene Exemplar zu diesem Zwecke etwas besehädigt oder auch granz zerstïrt werden kann. In diesem Falle lassen sich die letzteremannten Kigenschaften, vielleicht sogar die chemische Analyse, ohne Bedenken anwenden, und elrenso ist dies in den meisten Fällen auch an rohen steinen zulässign. Von ihnen kann man nicht selten einen Splitter zur genaueren Untersuchung ablïsen, und ein kleiner Ritz, oder ein von der Beriihrung mit einer siure herrührender Fleck schadet nichts, da sie beim Schleifen wieder verschwinden. Alle diese Untersuchungsmethoden werden bei greschliffenen Steinen am besten ganz vermieden und nur dann angewendet, wenn die anciern nicht mit Sicherheit zum Ziele führen, aber auch in diesem Fall mit der durch die Verhältnisse gebotenen Sorgfalt und Vorsicht.

Bei der Härte kann es sich nur um die Feststellung grö̈berer Unterschiede handeln, kleine sind nicht entscheidend, da nicht selten auf einer und derselben Fläche und auf verschiedenen Flächen eines und desselben Kristalls kleine IÏ̈rtedifferenzen sich ercreben. Die Untersuchung wird am besten so vorgenommen, dafs man mit einer hervorragenden Ecke oder Kante des zu prïfenden Steines die erforderlichenfalls durch Anschleifen und Polieren mit glatten Flächen versehenen Iineralien der Ïirteskala zu ritzen versucht. Von diesen genügen, wie wir S. 31 gresehen haben, für die praktischen Zwecke der Lntersuchung der Edelsteine in fast allen Fällen die Nummern 6 bis 8, also je ein Stiick Feldspat, Quarz und Topas, am besten mit einer angeschliffenen und glänzend polierten Fläche; Nummer 5 kann durch eine kleine Glastafel ersetzt werden. Die weicheren Nummern sind meist überflüssig, ebenso auch die Nummern 9 und 10. Die zum Ritzen bestimmte Ecke wïhlt man bei einem geschliffenen Steine zweckmäßig am Rande, der bei der Fassung rerdeckt wird. Aber auch so ist mit der größten Behutsamkeit zu rerfahren, da infolge des beim Ritzen anzuwendenden Druckes an dem zu untersuchenden Steine leicht splitter ausspringen, namentlich wenn deutliche Blätterbriche in ilım vorhanden sind.

Zuweilen ist es auch nicht zu vermeiden, daß ein geschliffener Edelstein seinerseits geritzt wird. Man benutzt dann hierzu gewöhnlich an liebsten die scharfe Spitze eines stark gehärteten Stahlstäbchens, die Quarz eben noch ein wenig, Glas dacregen stark angreift. Jan kann auf diese Weise namentlich Glasimitationen von echten harten Edelsteinen, wie Diamant, Rubin, Sapphir usw. sicher unterscheiden; diese werden nicht geritzt, wohl aber das Glas, bei dem die dadurch verursachte Beschädigung wegen seines geringen Wertes keinen wesentlichen Schaden verursacht. Torsicht ist nur bei weicheren Edelsteinen, Chrysolith usw., geboten, jedenfalls tut man aber stets gut, eine möglichst versteckt liegende Stelle für die Härteuntersuchungen auszuwählen, die durch die Fassungr dem Anblick entzogen wird. Besonders achtsam hat man bei durchsichtigen Steinen zu verfahren, bei denen ein Ritz auch auf einer versteckt liegenden Facette die Schönbeit sehr heeinträchtigen kann, während ein solcher auf der Hinterseite eines undurchsichtigen Steines gar nichts schadet. Unbedenklich ritzen kann man rohe Steine. Bei ibnen läßt sich auch die Härte auf verschiedenen Flächen und in verschiedenen Richtungen untersuchen. Statt der Stahlspitze wird häufig auch eine harte Stahlfeile benutzt, die den weichen Stein stärker angreift und einen weniger hohen Ton hervorruft, als es bei einem bärteren der Fall ist. Geschliffene Steine werden am besten nur am Rande mit der Feile geprüft und auch hier nur mit größter Vorsicht. Wegen aller dieser Schwierigkeiten wird im folgenden von der Härte nur ein beschränkter Gebrauch gemacht werden. Nur 
spärlich ist auch die Anwendung von Säuren (Ätztinte usw. S. 8), die aber doch in einzelnen Fällen (ebenfalls nützlich sein kann. Dies gilt namentlich, wenn es sich um die sichere Erkennung kohlensïurehaltiger Steine, wie z. B. Malachit. handelt. Ein auf einen rohen Stein oder an eine unschädliche Stelle eines geschliffenen gुehrachtes Tröpfchen Salzsäure erzeugt starkes Aufhrausen. Die auf die Untersuchung roher Steine beschränkte Bestimmung der Schmelzbarkeit ist für die vorliegenden Zwecke von noch geringerer Bedeutums. Gelegentlich wird auch von den elektrischen und magnetischen Eigenschaften der Steine Gebrauch gemacht werden, hesonders von der Pyroelektrizität (S. 83).

In neuerer Zeit hat man die Entdeckung sremacht. dah auch die Röntgenstrahlen zur Interscheidung mancher Edelsteine voneinander und ron Imitationen benutzt werden künnen. (\$. 40). Dies ist besonders wichtig für den Diamant, der diese strahlen hindurchgehen läbt, was beim Glas und den meisten anderen farblosen Edelsteinen nieht der Fall ist. Eine Glasimitation, sowie ein Topas, Bergkristall usw, wird also bei der Pbotosraphie im Kathodenlicht in scharfen Umrissen erscheinen, der Diamant dagegen nicht. Ähnlich läbt sicb auch der halbdurchlässige Korund (Rubin, Sapphir usw.) ron ganz undurchlïssigen Steinen, wie Spinell, Turmalin usw., sowie von Glas unterscheiden. Auch Phenakit, ferner Bernstein und die ähnlichen Harze, sowie Gagat bieten diesen Strahlen nur ein geringes Hindernis. Vorläufig ist diese Erkennungs- und Unterscheidungsmethode noch wenig ausgebildet, man darf aber erwarten, daf sie vor allem zur sicheren Erkennung des Diamants noch wichtig werden wird. Da der Stein dabei in keiner Weise Beschädigungen ausgesetzt ist, so ist sie ganz besonders geeignet, um so mehr, als auch die Fassung nicht immer ein Hindernis ihrer Anwendung ist. Hier soll zunächst nur darauf hingewiesen werden.

Alle diese Eigenschaften werden nun im folgenden in der angegebenen Weise dazu benutzt, die greich oder ähnlich aussehenden Edelsteine voneinander zu unterscheiden. Letztere werden zu diesem Behufe in drei Abteilungen betrachtet werden:

a) die durcbsichtigen,

b) die durchscheinenden und undurchsichtigen,

c) die mit einer besonderen Lichterscheinung versehenen.

Zwischen den durchsichtigen und durchscheinenden ist eine scharfe Scheidung nicht zu machen, da geringere Exemplare der sonst durchsichtigen Arten zuweilen nur durchscheinend sind. Daher sind zuweilen bei dem praktische'n Gebrauch der nachfolgenden Anleitungen steine, die man wegen mangelnder Durchsichtigkeit vergeblich in der zweiten Abteilung gesucht hat, in der ersten nachzuschlacen. In zahlreichen Fällen ist der betreffende Stcin an verschiedenen Stellen zu finden. In diesen beiden Abteilungen ist nach der Farbe eine weitere Unterscheidung gemacht, in der dritten nach der speziellen Art der Lichterscheinung.

\section{a) Durchsichtige Steine.}

Sie werden nach der auffälligsten ihrer Eigenschaften, nach der Färbung, unterschieden in farblose, srrünlichblaue oder bläulichgrïne (meergrine), hellblaue, blaue, violette, lila- und rosenfarbiene, rote, rotbraune und braunrote, raucheraue und nelkenbraune, rotgelbe und gelbrote, selbbraune und braungelbe, gelbe, gelblichgrüne und griine. Unter einer von diesen vierzehn Farbenänderungen sind im folgenden alle irgend bemerkenswerten durchsichtigen Edelsteine aufgeführt. Wenn einer von ihnen in mehreren Farben oder Farbennuancen vorkommt, wie z. B. der Topas und viele andere, oder wenn es zweifelhaft sein kamn, in welcher Abteilung ein Stein seiner Farbe nach untergebracht werden muls. kehrt dieser an verschiedenen Stellen wieder. Innerhalh jeder einzelnen Farbe sind die zugehörigen Edelsteine zunächst nach ahnehmendem spezifischem Gewichte tahellarisch angeordnet und in die mehrfach erwähnten fünf Abteilungen (I bis $V$ ) gebracht. 
Jedem einzelnen Steine ist die genaue Zahl für das spezifische frewicht in der nach dern Namen folgenden Kolumne beigefügt, die nächste lidihe enthält die Härtegrade, und in den drei letzten findet man die Art der Lichtbrechung (einfach oder doppelt, Brechungskoffizient, sowie, auszenommen bei den farblosm, den Dichroismus angegeben, diesen nach der stärke und zum Teil auch nach der Art der Färbung der Bilder in der

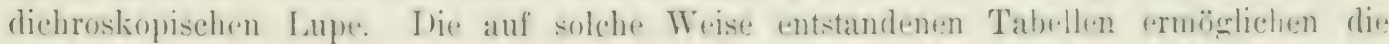
Unterseheidung der nach der Farhe zusammengehörigen Edelsteine meist ohne weiteres: rinige jeder einzelnen Tabelle beigefiigte erläuternde Bemerkungen auch iiber das Verbalten gregenuiber den Röntgenstrahlen. P'yroelektrizität usw.) werden dif Bestimmung noch erleichtern und vervollständigen. Diese Bemerkungen bezichen sich meist nur auf die zu einer und derselben der fünf Ahteilungen I his T gehöricren Steine, da sich dicjenišen, die zu verschiedenen Ahteilungen gehören, fast ausnahmslos durch ihr Verhaltron geren die vier schweren Fliissigkeiten mit Sicherheit auseinanderhalten lassen. so dali bei ihnen jede Verwechselung ausgeschlossen erscheint. Immerhin ist es zweckmäfig. die Bemerkungen auch bei den anderen $A$ hteilungen anzusehen, wo dieselbe Kombination von Edelsteinen, wenn auch mit andern Farben, wiederkehrt. Anf manche unterscheidenden Merkmale ist, um zu bäufige Wiederholungen zu vermeirlen, nur an der einen oder anderen Stelle hingrewiesen. Im übrigen werden die Angaben der Tabellen meist für sich allein schon genügren.

Bemerkt sei noch, dab bei jeder Farbe die wichtigeren und verbreiteteren der zugehïrigen Edelsteine durch etwas gröberen Druck hervorgehoben sind und dalj in den Erläuterungen auf ihre Unterschiede besondere Rücksicht genommen ist.

\section{Farblose Steine.}

\begin{tabular}{|c|c|c|c|c|c|c|c|}
\hline Abteilung & Namen & & & $\begin{array}{l}\text { Spezifisches } \\
\text { Gewicht }\end{array}$ & Härte & $\begin{array}{c}\text { Licht- } \\
\text { brechung }\end{array}$ & $\begin{array}{l}\text { Brechung:- } \\
\text { koeffizienten }\end{array}$ \\
\hline $\begin{array}{c}\text { I. } \\
\text { G. über } 3,6\end{array}$ & $\begin{array}{l}\text { Zirkon (Hyacint } \\
\text { Sapphir . . } \\
\text { Spinell . . }\end{array}$ & & & $\begin{array}{c}4,0-4,7 \\
3,9-4,1 \\
3,60-3,63\end{array}$ & $\begin{array}{c}71 / 2 \\
9 \\
5\end{array}$ & $\begin{array}{l}\text { doppelt } \\
\text { doppelt } \\
\text { einfach }\end{array}$ & $\begin{array}{c}1,92-1,97 \\
1,76-1,77 \\
1,72\end{array}$ \\
\hline $\begin{array}{c}\text { II. } \\
\mathrm{G}_{0}=3,3-3,6\end{array}$ & $\begin{array}{l}\text { Topas. . } \\
\text { Diamant . . }\end{array}$ & . . & $\begin{array}{l}\cdot^{i} \\
\cdot\end{array}$ & $\begin{array}{l}3,50-3,56 \\
3,50-3,52\end{array}$ & $\begin{array}{r}5 \\
10\end{array}$ & $\begin{array}{l}\text { doppelt } \\
\text { einfach }\end{array}$ & $\begin{array}{c}1,62-1,63 \\
2,43\end{array}$ \\
\hline $\begin{array}{c}\text { III. } \\
\mathrm{G}_{.}=3,0-3,3\end{array}$ & Turmalin . & . . & . & 3,02 & $7^{1 / 4}$ & doppelt & $1,62-1,64$ \\
\hline $\begin{array}{c}\text { IV. } \\
(i .=2,65-3,0\end{array}$ & $\begin{array}{l}\text { Phenakit . } \\
\text { Beryll . . }\end{array}$ & $\begin{array}{l}\cdot . \\
. \\
.\end{array}$ & & $\begin{array}{c}2,95 \\
2,69-2,75\end{array}$ & $\begin{array}{l}7^{3 / 4} \\
7^{3 / 4}\end{array}$ & $\begin{array}{l}\text { doppelt } \\
\text { doppelt }\end{array}$ & $\begin{array}{l}1,66-1,68 \\
1, a ̄ 7-1,59\end{array}$ \\
\hline \multirow[t]{2}{*}{$G_{.}=2,65$ und darunter } & $\begin{array}{l}\text { Bergkristall } \\
\text { Opal (Hyalit) }\end{array}$ & .. & . & $\begin{array}{l}2,65 \\
2,15\end{array}$ & $\begin{array}{l}i \\
6\end{array}$ & $\begin{array}{l}\text { doppelt } \\
\text { einfach }\end{array}$ & $\begin{array}{c}1,55 \text { Ј }-1, \text { ว̌ } 6 \\
1,46\end{array}$ \\
\hline & Glas . . & . & . & schwankend & $j$ & einfach & schwankend \\
\hline
\end{tabular}

Die Steine der ersten Abteilung lassen sich durch ihr hohes spezifisches Gewicht sie sinken in der ersten Fliissigkeit - leicht ron den anderen trcinen. Innerhalh dieser Abteilung sind Zirkon (Hyacinth) und Sapphir dureh ihr Verhalten im Polarisationsinstrumente als doppeltbrechend, der Spinell als einfachbrechend zu erkennen. Letzterer ist eine große Seltenheit; er konmt als Schmuckstein kaum ror. Die beiden ersteren sind häufiger; sie dienen namentlich nicht selten als Verfälschung für Diamant, der aber an seinem geringeren spezifischen Gewicht - er schwimmt in der ersten Flüssigkeit - leicht unterschieden wird. Hyacinth und Sapphir lassen sich, wenn es gröbere steine sind, nach dem genauen spezifischen Gewicht unterscheiden, sonst kann hierzu auch die Härte dienen: Sapphir ritzt eine glatte Topasfläche leicht und deutlich, Hyacinth nicht. Farbloser 
Hy acinth ist durch einen intensiven Diamantglanz und sein Absorptionsspektrum charakterisiert, während der starke Glanz des farblosen Sapphirs glasartig ist. Geschliffene farblose Hyacinthe sind fast ausnahmslos klein, höchstens erbsengrolj, und die Farbe, meist erst nachträglich aus dem ursprünglichen Hyacinthrot durch Erhitzen entstanden, hat oft noch einen, wenngleich nur sehr schwachen Stich ins Rötliche, der bei dem farblosen Sapphir vollkommen fehlt. Letzterer ist für Röntgenstrablen halbdurchlässig.

Die zweite Abteilung umfaßt Topas und Diamant, von denen der erstere durch seine Doppelbrechung sich im polarisierten Licht von dem einfachbrechenden Diamant unterscheiden lïßt, der seinerseits für Röntgenstrahlen vollkommen durchlässig ist. Das spezifische Gewicht ist bei beiden fast vollständig übereinstimmend, dagegen kann unter Umständen die enorme Härte des Diamants zur Feststellung des Unterschiedes dienen; Diamant ritzt Topas sehr stark und leicht. Für das bloße Auge schon ist der Diamant durch seinen starken und charakteristischen Glanz, und wenn geschliffen, meist durch sein prächtiges Farbenspiel so gut gekennzeichnet, da\} er mit Topas kaum verwechselt werden kann, desto leichter aber mit dem farblosen Glas, dem Straß, der jedoch von der Stahlspitze stark geritzt wird und der sich wärmer anfühlt als ein echter Diamant.

Farbloser Turmalin, sehr wenig im Edelsteinhandel, wird schon durch seine Zugehörigkeit zu Abteilung III sowie an der Pyroelektrizität erkannt. Die beiden farblosen Steine der Abteilung IV, Phenakit und Beryll, lassen sich mit Sicherheit nur durch die genaue Bestimmung des spezifischen Gewichtes unterscheiden, die im Methylenjodid und daher an den kleinsten Stückchen vorgenommen werden kann. Für das Ansehen ist Phenakit durch besonders starken Glanz gekennzeichnet und unterscheidet sich dadurch nicht nur von dem ïbrigens sehr selten geschliffen vorkommenden farblosen Beryll, sondern auch vom Turmalin und vom Bergkristall, ebenso auch durch seine fast vollkommene Durchlässigkeit für Röntgenstrahlen. Der Bergkristall gehört der Abteilung $V$ an und ist daher mit den genannten schwereren Steinen nicht zu verwechseln.

Von allen den zuletzt genannten Steinen unterscheidet sich Glas stets durch seine einfache Lichtbrechung. Diese kommt außer dem Spinell nur noch dem Opal zu, der aber in seiner farblosen und durchsichtigen Varietät, dem Hyalit, so gut wie niemals als Edelstein verwendet wird. Er wird daran erkannt, daß er Glas ritzt, daß er aber seinerseits von der Stahlspitze stark geritzt wird. Auch die anı wasserhellen Opal (Hyalit) stets vorhandene schwache anomale Doppelbrechung kann zur Unterscheidung von Glas dienen.

2. Griinlichblaue oder bliulichgrine (meergrỉne) Steine.

\begin{tabular}{|c|c|c|c|c|c|c|c|c|c|}
\hline $\mid \begin{array}{c}\mathrm{Ab}- \\
\text { teilung }\end{array}$ & \multicolumn{4}{|c|}{ Namen } & $\begin{array}{l}\text { Spezifisches } \\
\text { Gewicht }\end{array}$ & Härte & $\begin{array}{l}\text { Licht- } \\
\text { brechung }\end{array}$ & $\begin{array}{l}\text { Brechungs- } \\
\text { koeffizienten }\end{array}$ & Dichroismus \\
\hline 1. & \multicolumn{4}{|c|}{$\begin{array}{l}\text { Sapphir } \\
\text { (orient. Aquamarin) }\end{array}$} & $3,9-4,1$ & 9 & doppelt & $1,76-1,77$ & nicht sehr stark \\
\hline II. & $\begin{array}{l}\text { Topas . } \\
\text { Diamant . }\end{array}$ & . & $\begin{array}{l}\cdot . \\
\cdot .\end{array}$ & . & $\begin{array}{l}3,50-3,56 \\
3,50-3,52\end{array}$ & $\begin{array}{l}8 \\
10\end{array}$ & $\begin{array}{l}\text { doppelt } \\
\text { einfach }\end{array}$ & $\begin{array}{c}1,62-1,63 \\
2,43\end{array}$ & $\begin{array}{l}\text { deutlich } \\
\text { (farblos u. grünlichblau) } \\
\text { fehlt }\end{array}$ \\
\hline III. & $\begin{array}{l}\text { Flußspat . } \\
\text { Turmalin . } \\
\text { Euklas . }\end{array}$ & $\begin{array}{l}\cdot \\
\cdot \\
\cdot\end{array}$ & $\begin{array}{l}\cdot \dot{ } \cdot \\
\cdot \\
\cdot\end{array}$ & $\begin{array}{l}\cdot . \\
. \\
.\end{array}$ & $\begin{array}{c}3,0-3,2 \\
3,0 \\
3,05-3,1\end{array}$ & $\begin{array}{c}4 \\
71 / 4 \\
71 / 2\end{array}$ & $\begin{array}{l}\text { einfach } \\
\text { doppelt } \\
\text { doppelt }\end{array}$ & $\begin{array}{c}1,44 \\
1,62-1,65 \\
1,65-1,67\end{array}$ & $\begin{array}{l}\text { fehlt } \\
\text { deutlich } \\
\text { merklich }\end{array}$ \\
\hline \multirow[t]{2}{*}{ IV. } & Aquamarin . & - & - & . . & $2,68-2,75$ & $7^{3 / 4}$ & doppelt & $1,57-1,58$ & $\begin{array}{l}\text { deutlich } \\
\text { (bläulich und gelblich) }\end{array}$ \\
\hline & Glas . . & • & . & . & schwankeud & $\tilde{5}$ & einfach & schwankend & fehlt \\
\hline
\end{tabular}


Aquamarin und Topas haben nicht selten ganz dieselbe Farbe: sie werden am häufionsten zu unterscheiden sein, was sich durch das sperifische fiewicht mit Sicharelarit bewerkstelligen lïbt. Auf demselben Wrepe erkennt man den seltenen, den grenannten in der Fïrbung ebenfalls oft sehr ähnlichen Euklas. Fïr die Unterscheidung von Sapphir, Diamant und Topas geelen die Bemerkungen der ersten Tabelle. Flufspat wird dureh das Gewicht, die geringe Ilärte, und die einfache sowie besonders schwache Lichtbrechung leicht erkannt. Seine Farbe pflegt dunkler zo sein als die stets lichtere von Aquamarin, Topas und Euklas. (Hlas ist einfachbrechend und viel weicher als alle hierher gehörigen Steine, außer Flulispat.

3. Hellblane Steine.

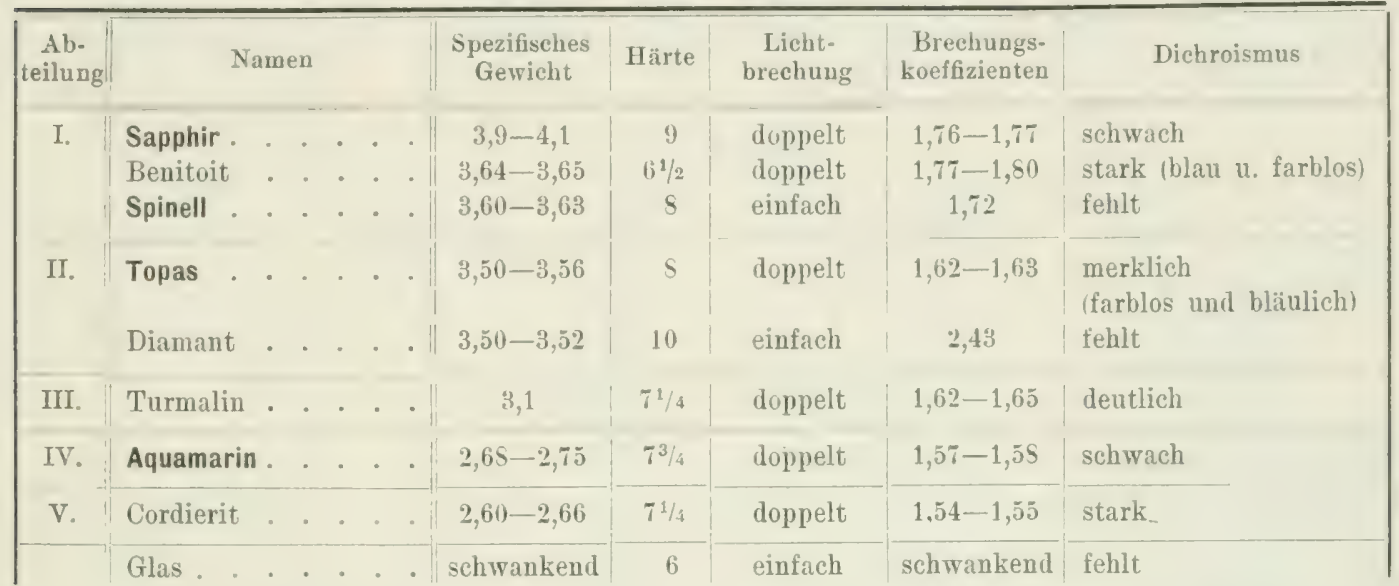

Unter Berïcksichtigung der zur ersten und zweiten Tabelle gregrebenen Erläuterungen können die hierher gehörigen Steine leicht unterschieden werden; die häufigeren erkennt man ohne weiteres am spezifischen Gewichte. Benitoit schweht in der ersten Fliissigrkeit, in der Sapphir rasch sinkt, und ist viel stärker dichroitisch als dieser.

\section{Blane Steine.}

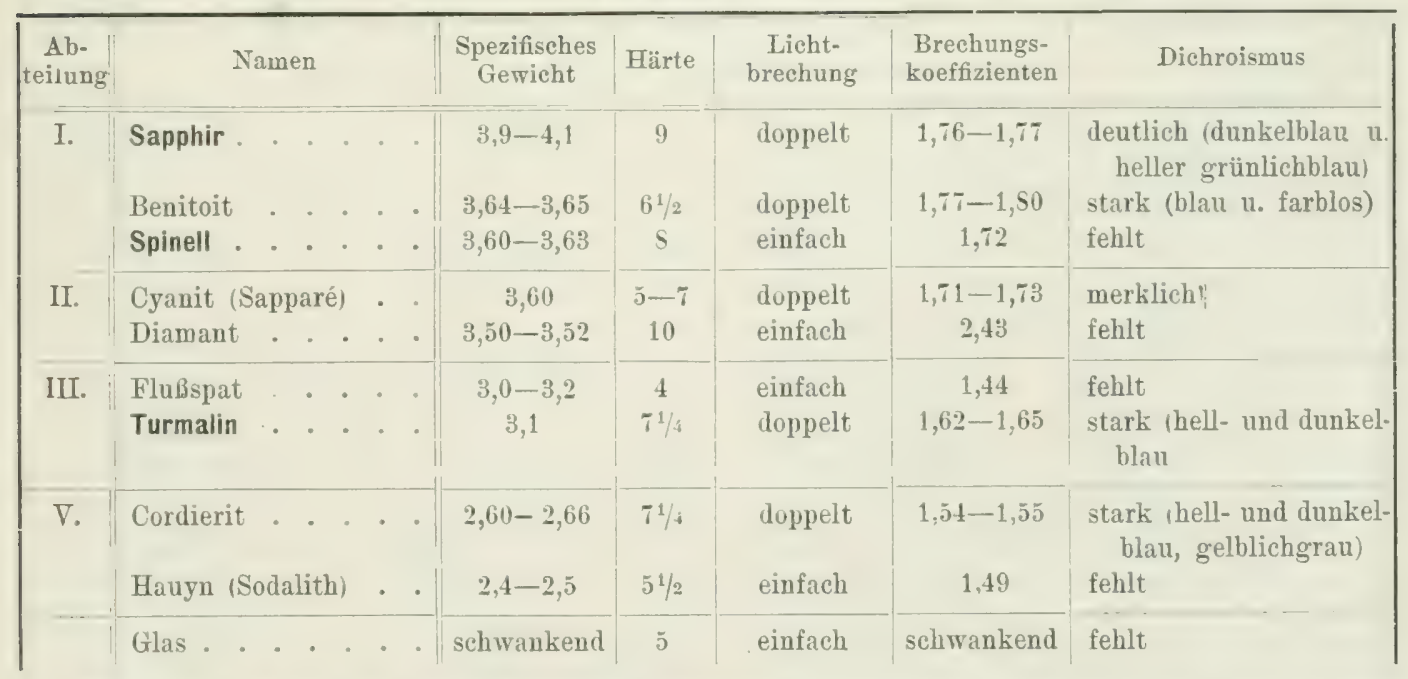

Wichtig ist hier vor allem Sapphir; daneben spielt nur noch Turmalin eine grewisse Rolle. Beide unterscheiden sich genügend durch das spezifische Gewicht. Turmalin ist 
meist sehr dunkel, und die Farbe geht etwas ins Grüne; die des Sapphirs ist meist reiner blau. Sehr bezeichnend ist hier der Dichroismus, der beim Turmalin sehr viel stärker ist, und dessen Pyroelektrizität. Cyanit (Sapparé) zeigt so gut wie ausnahmslos feine geradlinige Risse in einer Richtung; er ist gewöhnlich nicht ganz vollkommen durchsichtig und im Vergleiche mit Sapphir wenig glänzend. In der ersten Flüssigkeit schweht er sowie der Benitoit, oder sinkt langsam unter, was beim Sapphir sehr rasch gesehieht. Dunkelblaner Diamant ist eine äußerste Seltenheit; er wird an Gewicht, Märte und einfacher Lichtbrechung erkannt. Corderit kommt im Edelsteinhandel nur wenig vor; sichere Erkennungsmerkmale sind das niedere spezifische Gewicht sowie der starke und in den Farbentönen charakteristische Dichroismus. Glas und Hauyn sind einfachbrechend und nicht dichroitisch, aber ersteres hat stets ein erheblich löheres spezifisches Gewicht als der letztere, der meist undurchsichtig ist. Benitoit unterscheidet sich vom Sapphir auch durch seinen viel stärkeren Dichroismus.

5. Violette Steine.

\begin{tabular}{|c|c|c|c|c|c|c|c|c|c|}
\hline $\begin{array}{c}\mathrm{Ab}- \\
\text { teilung }\end{array}$ & Name & & & & $\begin{array}{l}\text { Spezifisches } \\
\text { Gewicht }\end{array}$ & Härte & $\begin{array}{l}\text { Licht- } \\
\text { brechung }\end{array}$ & $\begin{array}{l}\text { Brechungs- } \\
\text { koeffizienten }\end{array}$ & Dichroismus \\
\hline I. $\|$ & $\begin{array}{l}\text { Zirkon } \\
\text { Almandin } \\
\text { Violettrubin } \\
\text { Benitoit . } \\
\text { Spinell . }\end{array}$ & $\begin{array}{l}\dot{ } \\
\dot{ } \\
\text {. } \\
\text {. }\end{array}$ & $\begin{array}{l}\dot{\cdot} \\
\dot{\cdot} \\
\dot{\cdot}\end{array}$ & $\begin{array}{l}\dot{\cdot} \\
\dot{\cdot} \\
\dot{\cdot}\end{array}$ & $\begin{array}{c}4,0-4,8 \\
4,1-4,2 \\
3,9-4,1 \\
3,64-3,65 \\
3,60-3,63\end{array}$ & $\begin{array}{c}71 / 2 \\
7^{1 / 4} \\
9 \\
61 / 2 \\
8\end{array}$ & $\begin{array}{l}\text { doppelt } \\
\text { einfach } \\
\text { doppelt } \\
\text { doppelt } \\
\text { einfach }\end{array}$ & $\begin{array}{c}1,92-1,97 \\
1,77 \\
1,76-1,77 \\
1,77-1,80 \\
1,72\end{array}$ & $\begin{array}{l}\text { sehr schwach } \\
\text { fehlt } \\
\text { deutlich } \\
\text { stark } \\
\text { fehlt }\end{array}$ \\
\hline III. & $\begin{array}{l}\text { Axinit . - } \\
\text { Apatit . } \\
\text { Flußspat . } \\
\text { Kunzit . }\end{array}$ & $\begin{array}{l}. \\
. \\
.\end{array}$ & $\begin{array}{l}\cdot \\
\cdot \\
\cdot \\
\cdot\end{array}$ & $\begin{array}{l}\cdot \\
\cdot \\
\cdot \\
\cdot\end{array}$ & $\begin{array}{c}3,29-3,3 \\
3,2 \\
3,0-3,2 \\
3,18\end{array}$ & $\begin{array}{c}63 / 4 \\
5 \\
4 \\
61 / 2-7\end{array}$ & $\begin{array}{l}\text { doppelt } \\
\text { doppelt } \\
\text { einfach } \\
\text { doppelt }\end{array}$ & $\begin{array}{c}1,68-1,69 \\
1,64-1,65 \\
1,44 \\
1,65-1,68\end{array}$ & $\begin{array}{l}\text { stark (viol., braun, grün } \\
\text { schwach } \\
\text { fehlt } \\
\text { kräftig }\end{array}$ \\
\hline V. & Amethyst . & . & . & - & 2,65 & 7 & doppelt & $1,55-1,56$ & schwach bis deutlich \\
\hline & Glas . & $\cdot$ & . & . & | schwankend & 5 & einfach & schwankend & fehlt \\
\hline
\end{tabular}

Apatit und Flubspat kommen kaum vor; sie unterscheiden sich von den ïbrigen violetten Steinen durch das spezifische Gewicht und voneinander durch die Verhältnisse der Lichtbrechung. Der zur nämlichen Abteilung gebörige Axinit, dessen Farbe stark ins Braune geht, ist durch besonders kräftigen Dichroismus gekennzeichnet. $\Lambda \mathrm{m}$ häufigsten ist der echte $\Lambda$ methyst, den sein niederes spezifisches Gewicht in Verbindung mit dem sehr geringen Dichroismus nicht schwer erkennen und von den hierher gehörigen Steinen der ersten Abteilung unterscheiden läßt. Von diesen ist Almandin dureh seine Farbe ausgezeichnet, die mehr ein etwas ins Blane grehendes Rot als ein eigentliches Violett ist, sowie durch sein Absorptionsspektrum. Er unterscheidet sich außerdem vom Amethyst und vom Violettrubin durch die einfache Lichtbrechung, sowie vom letzteren durch geringere IHärte. Violettrubin, Amethyst und spinell werden vielleicht am bequemsten durch den Dichroismus unterschieden, der am ersteren stark, am zweiten schwach ist, und am dritten ganz fehlt. Violettrubin und Spinell ritzen Quarz, was Amethyst nicht tut. Spinell wird neben den beiden anderen an der einfachen Lichtbrechung erkannt. Glas wird vom Stahlstift stark reritzt, was bei den gebräuchlicheren violetten Steinen nicht der Fall ist; von Violettrubin und Amethyst unterscheidet es sich auberdem noch durch seine einfache Lichthrechung. Spinell und Almandin zeigen wesentlich nur im spezifischen Gewicht größere Unterschiede: der erstere schwebt oder sinkt langsam, der andere sehr rasch in der ersten Fliissigkeit. Auch die kleine Differenz der Härte und der Brechungskoeffizienten kann die Unterscheidung ermöglichen; unter Umständen ist es aber schwierig, den einen 
neben dem anderen zu erkennen. Kunzit unterschedidet sich won dem in der Farbe sehr ähnlichen Amethyst leicht durch soinen loshen Glanz, seine stärlire Lichthrechung und sein spezifisehes (iewicht, durch letzteres auch von liolettrubin und den anderen Steinen der ersten Abteilung, von allen anderen Ededsteinen durch sein auscezeichnetes optisches Verhalten (S. 560).

\section{Lila- und rosalarbige steine.}

\begin{tabular}{|c|c|c|c|c|c|c|c|c|c|}
\hline $\mid \begin{array}{c}\text { Ab- } \\
\text { teilung }\end{array}$ & Name & & & & $\begin{array}{c}\text { Spezifisches } \\
\text { Gewicht }\end{array}$ & Häirte & $\begin{array}{c}\text { Licht- } \\
\text { brechung }\end{array}$ & $\begin{array}{l}\text { Brechungs- } \\
\text { koeffizienten }\end{array}$ & Dichroismus \\
\hline I. & $\begin{array}{l}\text { Zirkon } \\
\text { Rubin } \\
\text { Spinell (Balas }\end{array}$ & & & & $\begin{array}{c}1,0-4,5 \\
3,9-4,1 \\
3,60-3,63\end{array}$ & $\begin{array}{c}71 / 2 \\
9 \\
8\end{array}$ & $\begin{array}{l}\text { doppelt } \\
\text { doppelt } \\
\text { einfach }\end{array}$ & $\begin{array}{l}1,92-1,97 \\
1,76-1,77 \\
1,72\end{array}$ & $\begin{array}{l}\text { sehr schwach } \\
\text { schwach } \\
\text { fehlt }\end{array}$ \\
\hline II. & $\begin{array}{l}\text { Topas . } \\
\text { Diamant . }\end{array}$ & . & . & & $\begin{array}{l}3,50-3,56 \\
3,50-3,52\end{array}$ & $\begin{array}{c}8 \\
10\end{array}$ & $\begin{array}{l}\text { doppelt } \\
\text { einfach }\end{array}$ & $\begin{array}{l}1,62-1,63 \\
2,43\end{array}$ & $\begin{array}{l}\text { stark (rot und gelb) } \\
\text { fehlt }\end{array}$ \\
\hline III. & $\begin{array}{l}\text { Flußspat . } \\
\text { Kunzit . } \\
\text { Turmalin . }\end{array}$ & . & $\begin{array}{l}. \\
. \\
\text {. }\end{array}$ & . & $\begin{array}{l}3,0-3,2 \\
3,15 \\
3,02\end{array}$ & $\left\{\begin{array}{c}4 \\
6^{1 / 2}-7 \\
7^{1 / 4}\end{array}\right.$ & $\begin{array}{l}\text { einfach } \\
\text { doppelt } \\
\text { doppelt }\end{array}$ & $\begin{array}{l}1,44 \\
1,65-1,69 \\
1,62-1,65\end{array}$ & $\begin{array}{l}\text { fehlt } \\
\text { kräftig } \\
\text { deutlich } \\
\text { (heller und dunkler rot) }\end{array}$ \\
\hline $\mathrm{V}$. & Rosenquarz & . & . & & 2,65 & 7 & doppelt & $1,555-1,56$ & sehr schwach \\
\hline & Glas . & . & . & . & schwankend & ว & einfach & schwankend & fehlt \\
\hline
\end{tabular}

Häufiger kommen nur Rubin, Spinell, Topas und Rosenquarz vor und daneben vielleicht noch der rote 'Turmalin, alle anderen sind seltene Erscheinungen auf dem Edelsteinmarkte. Rosenyuarz ist sehr hellrosa und nie vollkommen klar und durchsichtig. Der Balasrubin bat nicht selten eine milchige Trübung. Die stark dichroitischen Topas und Turmalin zeigen verschieden gefärbte Bilder in der Dichrolupe, der letztere zeigt Pyroclektrizität. Das spezifische Gewicht unterscheidet sie mit Sicherbeit, ebenso den Topas rom Rubin und Spinell, die ihrerseits an den Verhältnissen der Lichtbrechung und dem Dichroismus nebeneinander erkannt werden lï̈nnen. Diamant ist für Rüntgenstrahlen vollkommen, Rubin halbdurchlässig. Zirkon zeigt das Absorptionsspektrum. Glas 1st durch die geringe Härte und die einfache Lichtbrechung leicht $\mathrm{zu}$ erkennen.

7. Rote Steine.

\begin{tabular}{|c|c|c|c|c|c|c|c|c|c|c|}
\hline $\begin{array}{l}\text { Ab- } \\
\text { teilung }\end{array}$ & $\mathrm{Nan}$ & men & & & & $\begin{array}{l}\text { Spezifisches } \\
\text { Gewicht }\end{array}$ & Ḧ̈rte & $\begin{array}{l}\text { Licht- } \\
\text { brechung }\end{array}$ & $\begin{array}{c}\text { Brechungs- } \\
\text { koeffizienten }\end{array}$ & Dichroismus \\
\hline I. & $\begin{array}{l}\text { Zirkon } \\
\text { Almandin } \\
\text { Rubin . } \\
\text { Kaprubin } \\
\text { Böhmischer } \\
\text { Hessonit } \\
\text { Spinell. }\end{array}$ & $\begin{array}{c}\cdot \\
\cdot \\
\cdot \\
\cdot \\
\cdot \\
\cdot \\
\cdot\end{array}$ & $\begin{array}{l}\cdot \\
. \\
\text { nat } \\
\text {. } \\
\text {. }\end{array}$ & $\begin{array}{l}. \\
. \\
.\end{array}$ & & $\begin{array}{l}4,0-4,8 \\
4,1-4,2 \\
3,9-4,1 \\
3,86 \\
3,7-3,8 \\
3,65 \\
3,60-3,63\end{array}$ & $\begin{array}{l}71 / 2 \\
71 / 4 \\
9 \\
71 / 4 \\
71 / 4 \\
71 / 4 \\
9\end{array}$ & $\begin{array}{l}\text { einfach } \\
\text { einfach } \\
\text { einfach } \\
\text { einfach }\end{array}$ & $\begin{array}{l}1,92-1,97 \\
1,77 \\
1,76-1,77 \\
1,80 \\
1,50 \\
1,76 \\
1,72\end{array}$ & $\begin{array}{l}\text { sehr schwach } \\
\text { fehlt } \\
\text { deutlich } \\
\text { (hell- und dunkelrot) } \\
\text { fehlt } \\
\text { fehlt } \\
\text { fehlt } \\
\text { fehlt }\end{array}$ \\
\hline II. & $\begin{array}{l}\text { Topas . } \\
\text { Diamant }\end{array}$ & $\begin{array}{l}\cdot \cdot \\
\cdot \cdot\end{array}$ & & & & $\begin{array}{l}3,50-3,56 \\
3,50-3,52\end{array}$ & $\begin{array}{r}8 \\
10\end{array}$ & $\begin{array}{l}\text { doppelt } \\
\text { einfach }\end{array}$ & $\begin{array}{l}1,62-1,63 \\
2,43\end{array}$ & $\begin{array}{l}\text { stark (rot und gelb) } \\
\text { fehlt }\end{array}$ \\
\hline III. & $\begin{array}{l}\text { Flußspat } \\
\text { Turmalin }\end{array}$ & $\begin{array}{l}\cdot \cdot \cdot \\
\cdot \quad \cdot\end{array}$ & $\cdot$ & . & & $\begin{array}{l}3,0-3,2 \\
3,0 \mathrm{~S}\end{array}$ & $\begin{array}{l}4 \\
71 / 4\end{array}$ & $\begin{array}{l}\text { einfach } \\
\text { doppelt }\end{array}$ & $\begin{array}{l}1,44 \\
1,62-1,65\end{array}$ & $\begin{array}{l}\text { fehlt } \\
\text { stark (rosa u. dunkelrot) }\end{array}$ \\
\hline \multirow[t]{2}{*}{$\mathrm{V}$} & Feueropal. & . . & ${ }^{\circ}$ & . & & 2,2 & 6 & einfach & 1,45 & fehlt \\
\hline & Glas . . & . . & . & & & schwankend & 5 & einfach & schwankend & fehlt \\
\hline
\end{tabular}


Roter Fulisplat und Diamant und ebenso der Feueropal sind selten. In der ersten Abteilung stehen die Granate: Almandin, Kaprubin und böhmischer Granat, die beiden letzteren nicht wesentlich verschieden und zum Pyrop gehörign, sowie der Hessonit oder Kaneelstein. Diese, sowie der Spinell unterseheiden sich rom Rubin durch die einfache Lichthrechung und den Mangel an Dichroismus, untereinander durch die Farbe: Almandin ist purpurrot (etwas ins Bläuliche und zeigt das charakteristische Absorptionsspektrumı), Kaprubin und böhmischer Granat dunkelblutrot (mit einem Strich ins Gelbliche), und Hessonit ist hell gelbrot. Außerdem liaben diese verschiedenen Arten des Granats, wie die Tabelle zeigt, auch nicht unwesentlich verschiedene spezifische Gewichte und z. T. Brechungskoeffizienten. Spinell ist in der Farbe oft dem Rubin ähnlich (Rubinspinell), unterscheidet sich aber leicht in der genannten Weise. Dagegen ist er vom Granat schwer zu trennen, namentlich der gelblichrote Spinell (Rubicell) vom Kaneelstein, da beide in gleicher Weise einfache Lichtbrechung und keinen Dichroismus zeigen und Farbe und spezifisches Gewicht beinahe genau übereinstimmen. Die Brechungskoeffizienten sind selur wenig, aber doch etwas verschieden, so daß unter Umständen diese eine Unterscheidung ermöglichen. Bei geschliffenen Steinen kann, wenn auch schwierig oft die Härte und der Brechungskoeffizient entscheiden; bei rohen die Kristallform, (stets Oktaëder beim Spinell, fast nie Oktaëder beim Kaneelstein), oder die Schmelzbarkeit (Kaneelstein ziemlich leicht schmelzbar, Spinell nicht). Durch die Schmelzbarkeit sind auch Hessonit und Almandin von dem unschmelzbaren Pyrop verschieden. T'urmalin und Topas sind einander und dem Rubin zuwellen in der Farbe sehr ähnlich alle unterscheidet aber das spezifische Gewicht mit Sicherheit. Auch im Dichroismus liegt ein Unterschied: das bei dem Topas sehr bemerkbare Gelb tritt in den beiden Bildern der Dichrolupe beim Turmalin und Rubin nicht auf. In der dritten Abteilung unterscheiden sich Turmalin und Flufspat, in der zweiten Topas und Diamant je durch die doppelte Lichtbrechung und den starken Dichroismus der einen und durch die einfache Lichtbrechung und den Mangel an Dichroismus der anderen. Feneropal hat stets ein sehr viel geringeres spezifisches Gewicht als alle anderen, ist meist etwas trübe und einfach, sowie schwach lichtbrechend und zuweilen farbenspielend wie edler Opal. Glas unterscheidet sich in der gewöhnlichen Weise von allen hierher gehörigen Steinen; der Unterschied von Opal und Glas wird am besten durch das Gewicht gegeben, das beim letzteren kaum unter 2,6 heruntergeht. Für Diamant, Zirkon, Rubin und Turmalin siehe auch Nr. 6.

S. Rotbraune und brannrote Steine.

\begin{tabular}{|c|c|c|c|c|c|c|c|c|}
\hline $\begin{array}{c}\mathrm{Ab}- \\
\text { teilung }\end{array}$ & \multicolumn{3}{|c|}{ Namen } & $\begin{array}{l}\text { Spezifisches } \\
\text { Gewicht }\end{array}$ & Härte & $\begin{array}{l}\text { Licht- } \\
\text { brechung }\end{array}$ & $\begin{array}{l}\text { Brechungs- } \\
\text { koeffizienten }\end{array}$ & Dichroismus \\
\hline I. & $\begin{array}{l}\text { Zirkon } \\
\text { Almandin } \\
\text { Staurolith } \\
\text { Hessonit }\end{array}$ & $\begin{array}{ll}\cdot & \cdot \\
. & \cdot \\
\cdot & \cdot \\
\cdot & .\end{array}$ & $\begin{array}{lll}\cdot & \cdot & \cdot \\
\cdot & \cdot & \cdot \\
\cdot & \cdot & \cdot \\
\cdot & \cdot & \cdot\end{array}$ & $\begin{array}{l}4,0-4,8 \\
4,1-4,2 \\
3,73 \\
3,65\end{array}$ & $\begin{array}{l}7^{1 / 2} \\
71 / 4 \\
7^{1 / 2} \\
7^{1 / 4}\end{array}$ & $\begin{array}{l}\text { doppelt } \\
\text { einfach } \\
\text { doppelt } \\
\text { einfach }\end{array}$ & $\begin{array}{l}1,92-1,97 \\
1,77 \\
1,75 \\
1,76\end{array}$ & $\begin{array}{l}\text { sehr sehwach } \\
\text { fehlt } \\
\text { schwach } \\
\text { fehlt }\end{array}$ \\
\hline II. & Topas . . & . $\cdot$ & . . . & $3,50-3,56$ & 8 & doppelt & $1,62-1.63$ & stark (gelb und rot) \\
\hline III. & Turmalin & - $\cdot$ & $\cdot \cdot \cdot$ & 3,1 & $7^{1 / 4}$ & doppelt & $1,62-1,65$ & $\begin{array}{l}\text { stark (hell- und dunkel- } \\
\text { briunlich) }\end{array}$ \\
\hline V. & $\begin{array}{l}\text { Citrin (span } \\
\text { Feueropal . } \\
\text { Bernstein . }\end{array}$ & $\begin{array}{l}\text { aisch } \\
. \\
.\end{array}$ & $\begin{array}{c}\text { erTopas) } \\
\text { - . . } \\
\end{array}$ & $\begin{array}{l}2,65 \\
2,2 \\
1,08\end{array}$ & $\begin{array}{l}7 \\
6 \\
2-3\end{array}$ & $\begin{array}{l}\text { doppelt } \\
\text { einfach } \\
\text { einfach }\end{array}$ & $\begin{array}{l}1,55-1,56 \\
1,45 \\
1,53-1,55\end{array}$ & $\begin{array}{l}\text { schwach bis deutlich } \\
\text { fehlt } \\
\text { fehlt }\end{array}$ \\
\hline & Glas . . . & .. &.$\quad$. & schwankend & 5 & einfach & schwankend & fehlt \\
\hline
\end{tabular}


Staurolith kommt selten vor; er ist meist nicht vollkommen durehsichtig und stets sehr dunkel gefärbt. T'urmalin und Almandin von dieser Farbe werden selten greschliffen, und Zirkon, Ilessonit und Topas können nach der Tabelle und nach den Erläuterungen zu der vorigen und zu frïheren Tabellen leicht untersehieden werden, ebenso Citrin, der entsprechend erefärbte (Quarz, ron diesten. Bernstein ist allen anderen gregenüber durch sein warmes Anfühlen, sein geringes spezifisches Gewicht, und die stelur starke Reibungsselektrizitiit ausgezeichnet. (ilas und opal siehe vorige Tabelle. Zirkon und Almandin zeigen charakteristische Absorptionsspektra.

\section{Rauchgraue und nelkenbraune Steine.}

\begin{tabular}{|c|c|c|c|c|c|c|c|c|c|c|}
\hline $\begin{array}{c}\mathrm{Ab}- \\
\text { teilung }\end{array}$ & Nam & & & & & $\begin{array}{l}\text { Spezifisches } \\
\text { Gewicht }\end{array}$ & Hürte & $\begin{array}{l}\text { Licht- } \\
\text { brechung }\end{array}$ & $\begin{array}{l}\text { Brechungs- } \\
\text { koeffizienten }\end{array}$ & Dichroismus \\
\hline II. & $\begin{array}{l}\text { Zirkon . } \\
\text { Diamant . } \\
\text { Epidot . } \\
\text { Vesuvian . }\end{array}$ & & . & . & . & $\begin{array}{l}4,00-4,70 \\
3,50-3,52 \\
3,47-3,50 \\
3,4\end{array}$ & $\begin{array}{l}71 / 2 \\
10 \\
61 / 4 \\
61 / 2\end{array}$ & $\begin{array}{l}\text { doppelt } \\
\text { einfach } \\
\text { doppelt } \\
\text { doppelt }\end{array}$ & $\begin{array}{c}1,92-1,97 \\
2,43 \\
1,73-1,77 \\
1.719-1,722\end{array}$ & $\begin{array}{l}\text { sehr schwach } \\
\text { fehlt } \\
\text { stark (grün, gelb, braun) } \\
\text { deutlich }\end{array}$ \\
\hline III. & $\begin{array}{l}\text { Axinit : } \\
\text { Andalusit . } \\
\text { Turmalin . }\end{array}$ & & . & . & - & $\begin{array}{l}3,29-3,30 \\
3,17-3,19 \\
3,2\end{array}$ & $\begin{array}{l}63 / 4 \\
71 / 2 \\
71 / 4\end{array}$ & $\begin{array}{l}\text { doppelt } \\
\text { doppelt } \\
\text { doppelt }\end{array}$ & $\begin{array}{l}1,65-1,69 \\
1,65-1,64 \\
1,62-1,65\end{array}$ & $\begin{array}{l}\text { stark (viol., braun, grün) } \\
\text { stark (gelb und rot) } \\
\text { stark }\end{array}$ \\
\hline $\mathrm{V}$. & Rauchtopas & & ${ }^{\circ}$ & . & & 2,65 & 7 & doppelt & $1,55-1,56$ & schwach bis deutlich \\
\hline
\end{tabular}

Von den Steinen dieser Farbe ist eigentlich nur der Rauchtopas verbreitet und wirklich wichtig. Braune Diamanten sind nicht gerade selten; dagegen gehören Andalusit, Vesuvian und Epidot und noch mehr Axinit zu den ungewöhnlicheren Vorkonmmissen des Edelsteinmarktes. Die Angaben der Tabelle lassen sie meist unschwer voneinander und rom Gilas unterscheiden; einige Schwierigkeit künnte aher die Erkennung von Vesurian nehen Epidot machen, wobei jedoch der sehr viel stärliere Dichroismus des letzteren entscheidet. Zwischen Andalusit und Axinit geben die mehr ins Grïnliche gehende Nuance des ersteren und die ganz anderen Farben in der Dichrolupe einen Unterschied.

10. Rotgelbe und gelbrote Steine.

\begin{tabular}{|c|c|c|c|c|c|c|c|}
\hline $\begin{array}{c}\text { Alb- } \\
\text { teilung }\end{array}$ & Namen & & $\begin{array}{c}\text { Spezifisches } \\
\text { Gemicht }\end{array}$ & Härte & $\begin{array}{c}\text { Licht- } \\
\text { brechung }\end{array}$ & $\begin{array}{l}\text { Brechungs- } \\
\text { koeffizienten }\end{array}$ & Dichroismus \\
\hline I. & $\begin{array}{l}\text { Zirkon (Hyacinth) } \\
\text { Orient. Hyacinth } \\
\text { Pyrop . . . } \\
\text { Hessonit . } \\
\text { Spinell (Rubicell) }\end{array}$ & 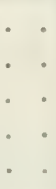 & $\begin{array}{l}4,6-4,7 \\
3,9-4,1 \\
3,7-3,9 \\
3,65 \\
3,60-3,63\end{array}$ & $\begin{array}{l}7^{-1 / 2} \\
9 \\
7^{1 / 4} \\
7^{1 / 4} \\
8\end{array}$ & $\begin{array}{l}\text { doppelt } \\
\text { doppelt } \\
\text { einfach } \\
\text { einfach } \\
\text { einfach }\end{array}$ & $\begin{array}{l}1,92-1,97 \\
1,76-1,77 \\
1,60 \\
1,76 \\
1,72\end{array}$ & $\begin{array}{l}\text { sehr schwach } \\
\text { deutlich } \\
\text { fehlt } \\
\text { fehlt } \\
\text { fehlt }\end{array}$ \\
\hline II. & . . . . & . . & $3,50-3,506$ & S & doppelt & $1,61-1,62$ & stark (rot und gelb) \\
\hline V. & Feueropal. . & . . & 2,2 & 6 & einfach & 1,45 & fehlt \\
\hline & Glas . . . . & . . & schwankend & 5 & einfach & schwankend & fehit \\
\hline
\end{tabular}

Für die Cnterscheidung ron Pyrop), Hessonit und Spinell siehe Tabelle $\neg$. Hessonit und Hyacinth sind in der Farbe zuweilen sehr ähnlich und werden oft verwechselt, obwohl der letztere einen sehr viel kräftigeren diamantartigen Glanz hat. Der sichere 
Unterschied liert in der Lichtbrechung und in dem Absorptionsspektrum des letzteren. Der orientalische Ifyacinth ist deutlich dichroitisch, der zum Zirkon gehörige eigentliche Hyacinth kaum merklich. Der Topas ist schon allein durch sein spezifisches Gewicht von allen anderen Steinen dieser Farbe geschieden und außerdem noch durch starken Dichroismus charakterisiert.

11. Gelbbraune und braungelbe steine.

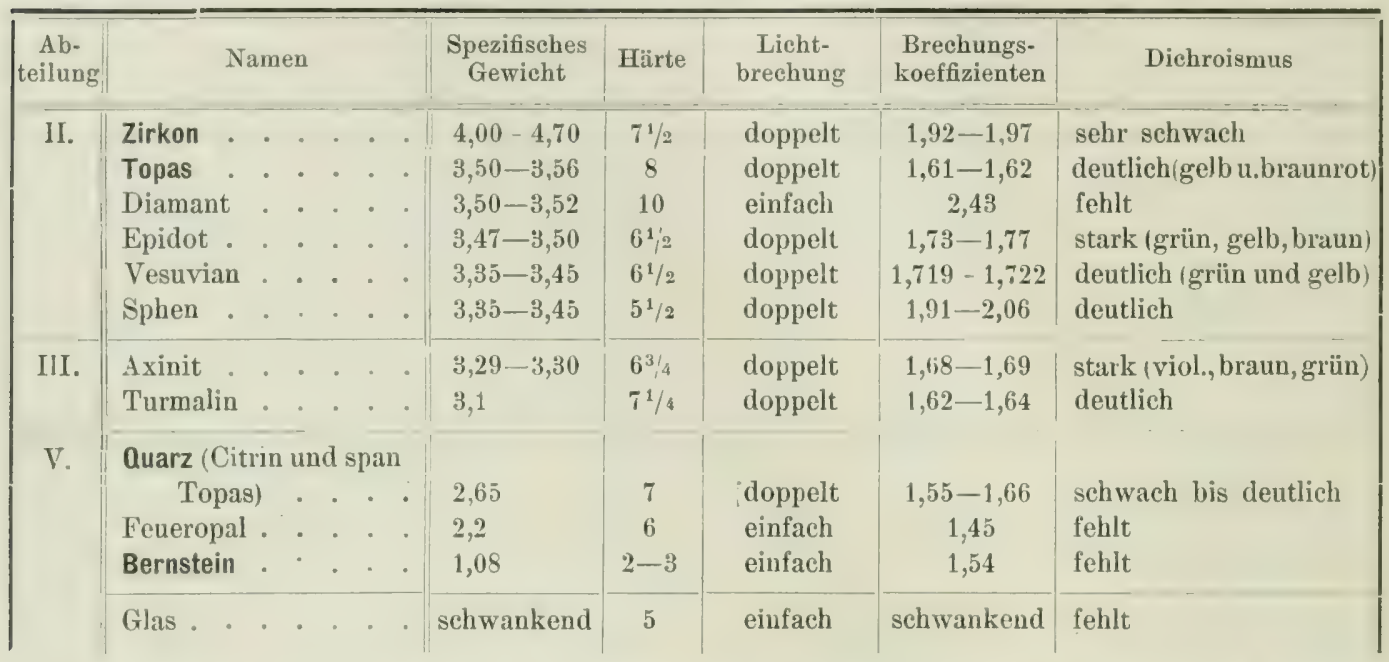

Von Steinen dieser Farbe ist Topas, Citrin nebst Goldtopas und besonders Bernstein rerbreitet. Letzterer fühlt sich warm an, ist sehr leicht und weich und wird beim Reiben so stark elektrisch, daß er kleine Papierschnitzel anzieht; er kann infolgedessen kaum mit einem der anderen Steine dieser Tabelle verwechselt werden. Die Unterschiede des Glases von dem Bernstein und den anderen Harzen (Reibungselektrizität der Harze usw.) sind bei der Beschreibung des Bernsteins (S. 677) ausführlich angegeben. Echter Topas und Quarz unterscheiden sich mit Sicherheit durch das spezifische Gewicht, ebenso auch durch die größere Ilärte des ersteren und dessen starken Dichroismus. Vesuvian, Epidot und Sphen, die ïbrigens geschliffen sehr selten sind, lassen sich neben jenen beiden und auch nebeneinander wohl nur durch die Unterschiede der Härte und der Brechungskoeffizienten erkenuen. Zwischen Epidot und Vesuvian kann unter Umständen die genaue Bestimmung des spezifischen Gewichts entscheiden, die sich noch mittels des mit Jod und Jodoform gesäittigten Metlıylenjodids bewerkstelligen läßht. Doch kann auch der Dichroismus hierzu dienen, der beim Epidot besonders stark ist, stärker als bei den beiden anderen, die sich jedenfalls dureh die Härte unterscheiden: Topas ritzt Quarz; Citrin, Epidot und Vesuvian ritzen nur noch Feldspat; Sphen endlich kamm Glas. Citrin ist leichter als alle anderen, außer Bernstein und Feueropal; letzterer läßt sich vom Citrin durch geringere Iärte, Schwere und Durchsichtigkeit, vom Bernstein in der ohen angegebenen Weise unterscheiden.

\section{Gelbe Steine. (S. Tabelle S. 703.)}

Am häufigsten hat man Citrin, Topas und die gelbe Varietät des Korunds, die man als orientalischen Topas bezeichnet, zu unterseheiden. Die spezifischen fewichte geben die Entscheidung zwischen diesen dreien. Außer ihnen kommen aber doch noch verschiedene andere gelbe Steine nicht zu selten im Edelsteinhandel vor. Die Farbe des Hyacinth geht stets deutlich ins Rot, rein grelb ist er nie. Letzteres ist auch bei den meist grünlichgellen Chrysoberyll und Chrysolith selten der Fall. Von dem orientalisehen Topas unter- 
I'abelle 12. (Gelbe Steine.)

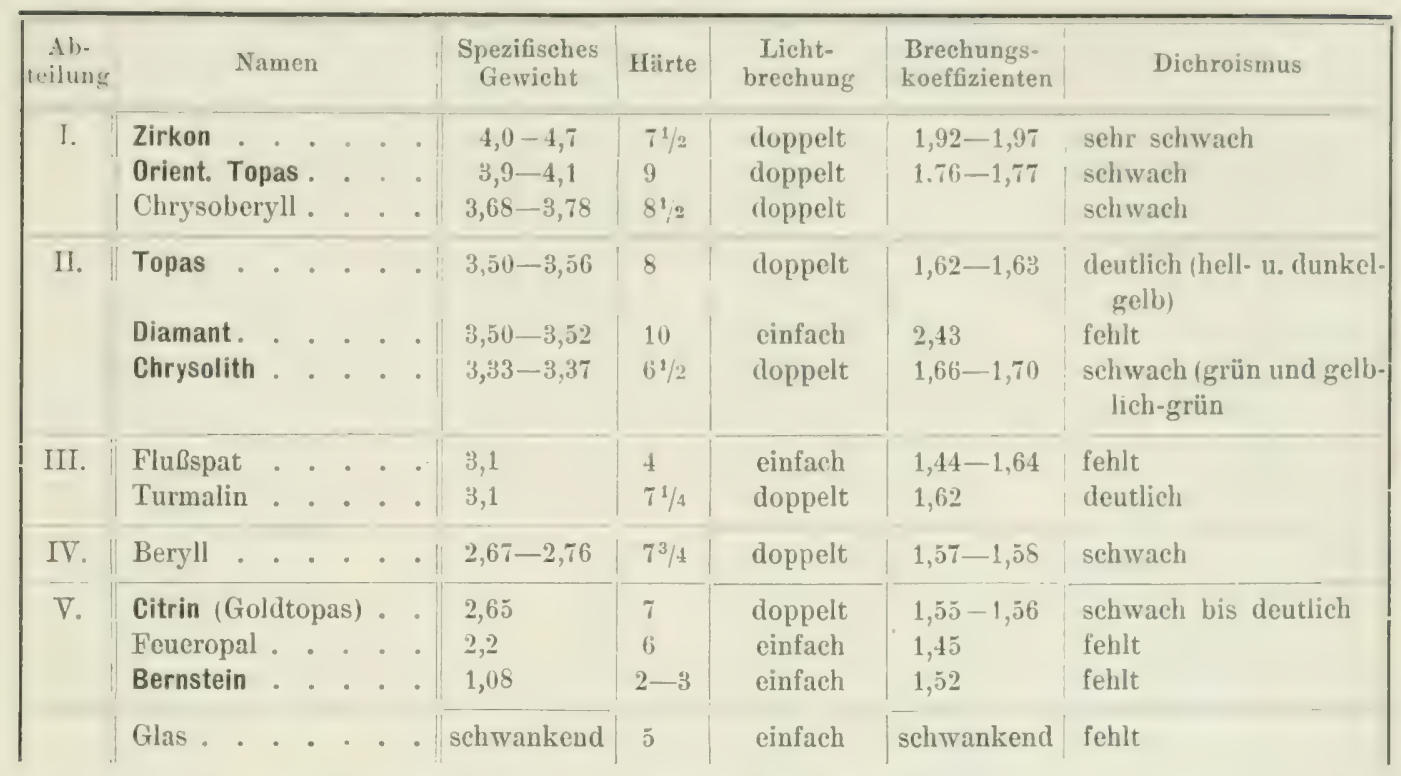

scheidet, wenn die Steine nicht gar zu klein sind, das spezifische Gewicht, aber auch die II:irte. Hyacinth ritzt den Topas nicht, dagegen tut dies der orientalische Topas und der Chrysoberyll; der orientalische T'opas ritzt auch einen, vielleicht zu diesem Zwecke vorrätig. gehaltenen Chrysoberyll. Topas, Diamant und Chrysolith sind voneinander nach Lichtbrechung und Härte, wie es die Tabelle zeigt, von den anderen durch das spezifische Gewicht zur Geniige unterschieden, ebenso namentlich echter und orientalischer Topas, letztere beide auch durch die Härte. Topas und Diamant haben verschiedene Lichtbrechung und Härte (Tabelle 1). Auch Topas und Citrin lassen sich nebeneinander durch das spezifische Gewicht und die Härte sicher unterscheiden: ersterer sinkt im Methylenjodid und ritzt Quarz, letzterer nicht. Bergll und Citrin gehören nach dem spezifischen Gewichte zwar in verschiedene Abteilungen, die Größe desselben ist aber bei beiden so nahe dieselbe, daß dabei unter Umständen Unsicherheiten bleiben künnen; indessen ist der Beryll doch wohl stets etwas schwerer als Citrin (Quarz) und sinkt in der vierten Flüssigkeit unter, in der dieser noch schwebt. Wenn darnach noch Zweifel bleiben, kann die Entscheidung wohl ron der Härte kommen: Beryll ritzt Quarz, Citrin nicht. Beryll ist feichter, aber härter als der Chrysolith, sowie bedeutend schwächer lichtbrechend. Für den Bernstein siehe die Erläuterung zu Tabelle 11, für Feueropal und Glas die zu Tabelle 7.

\section{8̉. Gelblichgrine Steine. (S. Tabelle S. 704.)}

Unter den schwersten ist Chrysoberyll häufig; er wird an seiner großen Härte erkannt, vermöge deren er Topas leicht ritzt. Der orientalische Chrysolith tut dasselbe, ist aber viel stärker dichroitisch als der Chrysoberyll, der sich anch bäufig durch einen milchigen Lichtschein auszeichnet. Zirkon ist selten; er ist stark diamantartị glänzend, und übertrifft die anderen in Beziehung auf das spezifische Gewicht so sehr. daf er durch genauere Bestimuung desselben, dann auch durch den sehr schwachen, kaum wahrnehmbaren Dichroismus untersehieden werden kann. Demantoid ist der einzige einfach lichtbrechende Stein der ersten Abteilung. In der zweiten zeichnet sich der Topas durch seine Härte aus; er ritzt leicht Quarz, was Epidot, Vesuvian, Sphen und Chrysolith nicht tun. Für Epidot, Vesuvian und Sphen vergleiche die Erläuterungen zu Tabelle 11. 
Tabelle 13. (Gelblichgrüne Steine.)

\begin{tabular}{|c|c|c|c|c|c|c|c|c|c|c|}
\hline $\begin{array}{c}\mathrm{Ab}- \\
\text { teilung }\end{array}$ & \multicolumn{5}{|c|}{ Namen } & \multirow{2}{*}{$\begin{array}{c}\begin{array}{c}\text { Spezifisches } \\
\text { Gewicht }\end{array} \\
4,0-4,7 \\
3,9-4,1 \\
3,85 \\
3,68-3,78\end{array}$} & \multirow{2}{*}{$\begin{array}{l}\text { Härte } \\
7^{1 / 2} \\
9 \\
7 \\
81 / 2\end{array}$} & \multirow{2}{*}{$\begin{array}{l}\begin{array}{c}\text { Licht- } \\
\text { breehung }\end{array} \\
\text { doppelt } \\
\text { doppelt } \\
\text { einfach } \\
\text { doppelt }\end{array}$} & \multirow{2}{*}{$\begin{array}{c}\begin{array}{c}\text { Brechungs- } \\
\text { koeffizienten }\end{array} \\
1,92-1,97 \\
1,76-1,77 \\
1,90 \\
1,75-1,76\end{array}$} & \multirow{2}{*}{$\begin{array}{l}\text { Dichroismus } \\
\text { sehr schwach } \\
\text { deutlich } \\
\text { fehlt } \\
\text { schwach (gelblich und } \\
\text { grünlich) }\end{array}$} \\
\hline I. & $\begin{array}{l}\text { Zirkon } \\
\text { Orient. Ch } \\
\text { Demantoic } \\
\text { Chrysobery }\end{array}$ & $\begin{array}{l}\text { irys } \\
\text { il }\end{array}$ & $\begin{array}{l}\text { solith } \\
\text {. } \\
\text {. }\end{array}$ & $\begin{array}{l}\dot{ } \\
\dot{.} \\
\dot{ }\end{array}$ & . & & & & & \\
\hline II. & $\begin{array}{l}\text { Topas . } \\
\text { Epidot . } \\
\text { Vesuvian } \\
\text { Sphen . } \\
\text { Chrysolith }\end{array}$ & $\begin{array}{l}\cdot \\
\cdot \\
\cdot \\
\cdot\end{array}$ & $\begin{array}{ll}\cdot & \cdot \\
\cdot & \cdot \\
\cdot & \cdot \\
\cdot & \cdot \\
\cdot & \cdot\end{array}$ & . & & $\begin{array}{l}3,50-3,56 \\
3,47-3,5 \\
3,35-3,45 \\
3,35-3,45 \\
3,33-3,37\end{array}$ & $\begin{array}{l}8 \\
61 / 2 \\
6^{1} / 2 \\
51 / 2 \\
6^{3} / 4\end{array}$ & $\begin{array}{l}\text { doppelt } \\
\text { doppelt } \\
\text { doppelt } \\
\text { doppelt } \\
\text { doppelt }\end{array}$ & $\begin{array}{c}1,62-1,63 \\
1,73-, 177 \\
1,719-1,722 \\
1,91-2,06 \\
1,66-1,70\end{array}$ & $\begin{array}{l}\text { deutlich } \\
\text { stark (grün, gelb, braun) } \\
\text { deutlich (grün und gelb) } \\
\text { deutlich } \\
\text { schwach (grün und } \\
\quad \text { gelblichgriin) }\end{array}$ \\
\hline III. & $\begin{array}{l}\text { Hiddenit ( } \\
\text { smaragd } \\
\text { Andalusit } \\
\text { Turmalin }\end{array}$ & Li & $\begin{array}{l}\text { hion- } \\
\cdot . \\
\cdot \\
\cdot \\
\cdot\end{array}$ & & & $\begin{array}{l}3,17-3,20 \\
3,17-3,19 \\
3,1\end{array}$ & $\begin{array}{l}6^{3 / 4} \\
71 / 2 \\
71 / 4\end{array}$ & $\begin{array}{l}\text { doppelt } \\
\text { doppelt } \\
\text { doppelt }\end{array}$ & $\begin{array}{l}1,65-1,68 \\
1,63-1,64 \\
1,62-1,64\end{array}$ & $\begin{array}{l}\text { schwach (hell- und } \\
\text { dunkelgrün) } \\
\text { stark (gelb, grün, rot) } \\
\text { stark (gelb und grün) }\end{array}$ \\
\hline IV. & Beryll & . & . . & & & $2,67-2,76$ & $7^{3 / 4}$ & doppelt & $1,57-1,58$ & deutlich \\
\hline V. & Moldawit & - & - $\cdot$ & & & 2,36 & $51 / 2$ & einfach & $1, \tilde{a}$ & fehlt \\
\hline & Glas (sog. & $\mathrm{Ob}$ & sidia & & & schwankend & 5 & einfach & 1,69 & fehlt \\
\hline
\end{tabular}

Chrysolith ist viel härter als Sphen, und viel weniger dichroitisch als letzterer, und besonders als Epidot und Vesuvian. Der Chrysolith hat nicht selten genau dasselbe Gewicht wie das reine Methylenjodid; er schwimmt darin in der Kälte und sinkt beim Erwärmen, schon bei längerer Berührung des Gefäßes mit der Hand, langsam zu Boden. Der orientalische Chrysolith ist viel schwerer, viel härter und viel stärker dichroitisch als der eigentliche. Leichter als dieser letztere sind Hiddenit, Andalusit und Turmalin; alle drei sind deutlich dichroitisch, am stärksten Andalusit mit einem charakteristischen roten Farbenton. Hiddenit ritzt Quarz nicht, dies tun aber die beiden anderen. Beryll wird an dem niederen Gewicht und dem schwachen Dichroismus erkannt; es ist die Varietät des Aquamarin.Chrysoliths. Moldawit ist einfachbrechend und hat ein sehr niederes spezifisches Gewicht; er unterscheidet sich durch dieses letztere und den kleineren Brechungskoeffizienten von dem meist schwereren künstlichen gelblichgrünen Glas, sowie durch seine düstergriine Farbe.

\section{Griine Steine. (S. T'abelle S. 705.)}

In der ersten Abteilung ist die orientaliseher Smaragd genannte Varietït des Korunds sehr selten; Zirkon und Demantoid sind spärlich, der dunkelgriine Chrysoberyll, der Alexandrit, ist allein etwas verbreiteter. Sein starker Dichroismus unterseheidet ihn vom Zirkon und vom orientalischen Smaragd, in dessen Farben bei der Untersuchung mit der dichroskopischen Iupe der charakteristische rote Ton des Alexandrits nicht vorkommt. Zirkon ist zwar doppeltbrechend, aher beinahe gar nicht dichroitisch. Demantoid ist dureh einfache Lichtbrechung ansgezeichnet. In der zweiten Abteilung ist allein Diamant einfachbrechend. Für Epidot, Vesuvian, Sphen und Chrysolith siche Erlaiuterungen zu Tabelle 11 und 13. Der stets ziemlich dunkelgrine Epidot unterscheidet sich von den beiden anderen durch ein dunkelbraunes Bild in der Dichrolupe, das bei diesen nicht vorkommt; doch kann die Feststellung, ob Vesuvian oder Epidot vorliegt, unter Umständen schwierig sein. Diopsid und Chrysolith sind zuweilen nach Farbe und spezifischem Ge- 
a) Durcistchtige Steine. Grüne.

'Tabelle 14. (Grüne Steine.)

\begin{tabular}{|c|c|c|c|c|c|c|}
\hline $\begin{array}{l}\text { Ab- } \\
\text { teilung }\end{array}$ & Namen & $\begin{array}{l}\text { Spezifisches } \\
\text { Gewicht }\end{array}$ & Härte & $\begin{array}{c}\text { Licht- } \\
\text { brechung }\end{array}$ & $\begin{array}{l}\text { Brechungs- } \\
\text { koeffizienten }\end{array}$ & Dichroismus \\
\hline I. & $\begin{array}{l}\text { Zirkon . . . } \\
\text { Orientalischer Smaragd } \\
\text { Demantoid . . . } \\
\text { Chrysoberyll . . . }\end{array}$ & $\begin{array}{l}4,0-4,7 \\
3,9-4,1 \\
3,95 \\
3,68-3,78\end{array}$ & $\begin{array}{l}71 / 2 \\
9 \\
7 \\
81 / 2\end{array}$ & $\begin{array}{l}\text { doppelt } \\
\text { doppelt } \\
\text { einfach } \\
\text { doppelt }\end{array}$ & $\begin{array}{l}1,92-1,97 \\
1,76-1,77 \\
1,90 \\
1,75-1,76\end{array}$ & $\begin{array}{l}\text { sehr schwach } \\
\text { deutlich (grün u. braun) } \\
\text { fehlt } \\
\text { stark (grün, gelb, rot) }\end{array}$ \\
\hline II. & $\begin{array}{l}\text { Diamant . . . . } \\
\text { Epidot . . . . } \\
\text { Vesuvian . . . . } \\
\text { Sphen . . . . } \\
\text { Chrysolith . . . . }\end{array}$ & $\begin{array}{l}3,50-3,52 \\
3,47-3,50 \\
3,35-3,45 \\
3,35-3,45 \\
3,30-3,37\end{array}$ & $\begin{array}{l}10 \\
61 / 2 \\
61 / 2 \\
51 / 2 \\
\\
63 / 4\end{array}$ & $\begin{array}{l}\text { einfach } \\
\text { doppelt } \\
\text { doppelt } \\
\text { doppelt } \\
\text { doppelt }\end{array}$ & $\begin{array}{c}2,43 \\
1,73-1,77 \\
1,719-1,722 \\
1,91-2,06 \\
1,66-1,70\end{array}$ & $\begin{array}{l}\text { fehlt } \\
\text { stark (grün, gelb, braun) } \\
\text { deutlich (grün und gelb) } \\
\text { deutlich (gelb, grïn, rot- } \\
\text { braun) } \\
\text { schwach (grün und gelb- } \\
\text { lichgruin) }\end{array}$ \\
\hline III. & 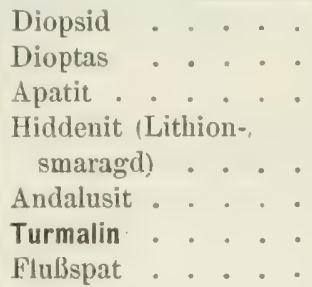 & $\begin{array}{l}3,2-3,3 \\
3,29 \\
3,2 \\
3,17-3,20 \\
3,17-3,19 \\
3,1 \\
3,1\end{array}$ & $\begin{array}{l}6 \\
5 \\
5 \\
\\
61 / 2 \\
71 / 2 \\
71 / 4 \\
4\end{array}$ & $\begin{array}{l}\text { doppelt } \\
\text { doppelt } \\
\text { doppelt } \\
\text { doppelt } \\
\text { doppelt } \\
\text { doppelt } \\
\text { einfach }\end{array}$ & $\begin{array}{l}1,67-1,70 \\
1,67-1,72 \\
1,64-1,65 \\
1,65-1,68 \\
1,63-1,64 \\
1,62-1,64 \\
1,44\end{array}$ & $\begin{array}{l}\text { schwach } \\
\text { schwach } \\
\text { schwach } \\
\text { deutlich (hell- und } \\
\text { dunkelgrün) } \\
\text { stark (gelb, grün, rot) } \\
\text { stark (gelb u. blaugrün) } \\
\text { fehlt }\end{array}$ \\
\hline IV. & Smaragd & 2,67 & $73 / 4$ & doppelt & $1,57-1,58$ & $\begin{array}{l}\text { deutlich (grün und } \\
\text { blaugrün) }\end{array}$ \\
\hline V. & Moldawit & 2,36 & $5^{1 / 2}$ & einfach & 1,5 & fehlt \\
\hline & Glas (sog. Obsidian) . & schwankend & 5 & einfach & $\begin{array}{c}1,69 \\
\text { (schwankend) }\end{array}$ & fehlt \\
\hline
\end{tabular}

wichte fast völlig gleich; die Erkennung wird ermöglicht durch die Härte: ein Chrysolith ritzt einen vorrätig gehaltenen Diopsidkristall, ein Diopsid selbstverständlich nicht. Dioptas ist stets sebr tief gefärbt und wohl nie vollkommen klar. Chrysolith wird von Ïtztinte angegriffen. Flußspat ist einfachbrechend. Apatit meist dunkelgriin ins Bläuliche. Diopsid nur unmerklich dichroitisch. Andalusit und Turmalin besitzen die Eigenschaft des Dichroismus in viel höherem Grade; bei dem ersteren tritt stets ein charakteristischer roter, bei dem letzteren ein blaugrüner Farbenton auf, der je dem auderen fehlt. Beide ritzen Quarz, was der deutlich, aber doch weniger stark dichroitische Hiddenit nicht tut. Der echte Smaragd gehört der IT. Abteilung an und kann daher wit den in der Färbung ähnlichen Steinen, mit dem orientalischen Smaragd, dem Dioptas, dem Hiddenit und dem Chrysoberyll nicht verwechselt werden. Manche stark rissige Smaragde gehen im spezifischen Gewichte noch etwas unter den Quarz herunter und treten dann in der fünften Abteilung auf; bei fehlerlosen Steinen ist dies aber nicht der Fall. Für die Unterscheidung ist eine kleine Abweichung nach der angegebenen Richtung nicht von Belang, denn die anderen grünen Edelsteine haben nie die schöne grüne Färbung des Smaragds. Moldawit ist einfachbrechend wie künstliches Glas und von diesem zuweilen schwer zu unterscheiden, doch ist er im allgemeinen etwas härter und leichter, und der Brechungskoeffizient ist erheblich kleiner. Sehr ähnlich sind der grüne Andalusit und der Alexandrit, sowohl in der Farbe als im Dichroismus. Das spezifische Gewicht unterscheidet sie mit Sicherheit, ebenso die Härte: Alexandrit ritzt Topas, Andalusit nicht. Zirkon macht sich wie immer durch seinen ausgezeichneten diamantartigen Glanz, sein Absorptionsspektrum und sein hohes Gewicht kenntlich und unterscheidet sich durch letztere beide rom Diamant. Die häufigeren grïnen Steine, Chrysoberyll, Turmalin und Smaraged sind durch das 
spezifische Gewicht genïgend geschieden; jeder gehört einer anderen Abteilung an. Glas wird in der früher schon mehrfach angegebenen Weise erkannt. Noldawit siehe Nr. 13.

\section{b) Durchscheinende und undurchsichtige Steine.}

Auch bei der Unterscheidung der durchscheinenden und undurchsichtigen Edelsteine spielt das spezifische Gewiebt eine Hauptrolle, dagegen fallen hier die Verhältnisse der Lichtbrechung so gut wie ganz als Merkmale aus. Sie werden einigermaßen ersetzt durch die Härte, die gerade wegen dem Mangel an vollkommener Durchsichtigkeit bei ihnen besser verwendet werden kann, da ein kleiner Ritz an einer verborgenen Stelle des Steines, besonders auf seiner Hinterseite nicht schadet. Auch Säuren (Ätztinte usw.) können hier besser als bei durchsichtigen Steinen angewendet werden. Nach Farbe und Glanz sind die folgenden Gruppen unterschieden, in denen die einzelnen Glieder wie oben nach abnehmendem spezifischem Gewichte tabellarisch geordnet und in dieselben fünf Abteilungen gegliedert sind: Weiße und sehr lichtgefärbte, sowie graue, sodann blaue, grüne, schwarze, gelbe und braune, rosenrote nebst rot und lila, mehrfarbige und metalliseb glänzende. In jeder einzelnen Gruppe sind die Unterschiede je nach den speziellen Verhältnissen angegeben.

1. Weisse und lichtgefirbte, sowie graue Steine.

\begin{tabular}{|c|c|c|c|c|c|c|c|c|c|c|c|c|}
\hline Abteilung & \multicolumn{10}{|c|}{ Namen } & $\begin{array}{c}\text { Spezifisches } \\
\text { Gewicht }\end{array}$ & Härte \\
\hline III. & Jadeit & - & • & - & - & - & - & • & . & . & 3,3 & $6^{1 / 2-7}$ \\
\hline IV. & Nephrit . & . & . & . . & & 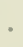 & 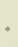 & - & . & . . & 3,0 & $5^{1 / 2}-6$ \\
\hline V. & $\begin{array}{l}\text { Chalcedon } \\
\text { Opal . . }\end{array}$ & . & . & $\begin{array}{l}\cdot . \\
.\end{array}$ & . & . & 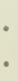 & 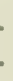 & • & $\begin{array}{l}. \\
.\end{array}$ & $\begin{array}{l}2,6 \\
1,9-2,2\end{array}$ & $\begin{array}{l}6^{1 / 2} / 2 \\
6\end{array}$ \\
\hline & Glas . & . & . & . & & & & & $\theta^{\circ}$ & - & schwankend & 5 \\
\hline
\end{tabular}

Die Steine dieser Gruppe sind durch ihr spezifisches Gewicht untersehieden. Jadeit hat, wenn rein, beinahe das Gewicht der zweiten, Nephrit das der dritten Fliissigkeit; sie schwimmen in dieser meistens eben noch, einzelne Stücke sinken auch schon langsam zu Boden. Voneinander lassen sich geschliffener Jadeit und Nephrit meist nur durch das spezifische Gewicht, unter Umständen auch durch die Härte unterscheiden, rohe Stiicke noch durch die Schmelzbarkeit, da der erstere in feinen Splittern schon in einer gewöhn. lichen Kerzenflamme, ohne Anwendung des Lötrohrs, schmilzt (vergl. S. 573). Chalcedon und Opal unterscheidet man an der größeren Härte und dem höheren Gewichte des ersteren. Glas ist stets weicher als Chalcedon und schwerer als Opal; letztere beide werden, im Gegensatz zu den anderen, von Ätztinte leicht angegriffen.

\section{Blaue Steine.}

\begin{tabular}{|c|c|c|c|c|c|c|c|c|c|c|c|c|}
\hline Abteilung & \multicolumn{10}{|c|}{ Namen } & $\begin{array}{l}\text { Sperifisches } \\
\text { Gewicht }\end{array}$ & Hïrte \\
\hline I. & Kupferlasu & . & . & & - & • & & & - & - & 3,8 & $33 / 4$ \\
\hline III. & $\begin{array}{l}\text { Lazulith } \\
\text { Zahntürkis }\end{array}$ & & . & 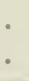 & $\cdot$ & • & & & • & $\begin{array}{l}\cdot . \\
. \\
.\end{array}$ & $\begin{array}{l}3,1 \\
3,0-3,5\end{array}$ & $\begin{array}{l}51 / 2 \\
5\end{array}$ \\
\hline IV. & Tuirkis . & . & . & & . & . & & & • & . . & $2,6-2,8$ & 6 \\
\hline V. & $\begin{array}{l}\text { Achat und } \\
\text { Lasurstein }\end{array}$ & laspi & & & & & & & & & $\begin{array}{l}2,6 \\
2,4\end{array}$ & $\begin{array}{l}61 / 2 \\
5^{1 / 2}\end{array}$ \\
\hline & Glas . & . & - & & . & & & & . & . & schwankend & 5 \\
\hline
\end{tabular}


Alle, auber dem Achat, werden von Ätztinte leicht angengrifen. Kupferlasur ist durch hohes Gewicht und geringe IÏ̈rte sowie durch Aufbrausen mit einem Tröpfohen Salz* säure den anderen hierher gehörigen Steinen dieser Gruppe fregrenïber unzweidentig grekennzeichnet, ebenso auch durch die stets sehr dunkle Farbe. Lazulith und besonders Türkis sind stets heller, und Türkis nie stark glänzend. Beide unterscheidet das spezifische Gewicht. Tïrkis und Zahntïrkis siehe Seite 502; aus den dort angeführten Kennzeichen ergibt sich auch die Unterscheidung des Zahntürkis vom Lazulith, für den in der Hauptsache das vom Türkis Gesargte grleichfalls gilt. Stets dunkelblau, in manchen Stiicken mehr oder weniger ausgesprochen ins Grüne ziehend, ist der Lasurstein, häufig mit grelben metallenen Flitterchen von Schwefelkies und nicht selten auch mit weiben Flecken und Adern von Kalkspat durchsetzt. Spezifisches Gewicht und Härte, sowie leichte Angreifbarkeit durch Säuren unter Entwicklung eines Geruchs nach faulen Eiern (Schwefelwasserstoff) lassen ihn von den obengenannten Steinen unterscheiden, besonders auch von dem kïnstlich blaugefärbten Achat. und dem Jaspis, dem falschen Lasursteine. Türkis und Lasurstein werden zuweilen durch Glas nachgemacht. Die Untersebiede siebe S. 501 und S. 547.

\section{Griine Steine.}

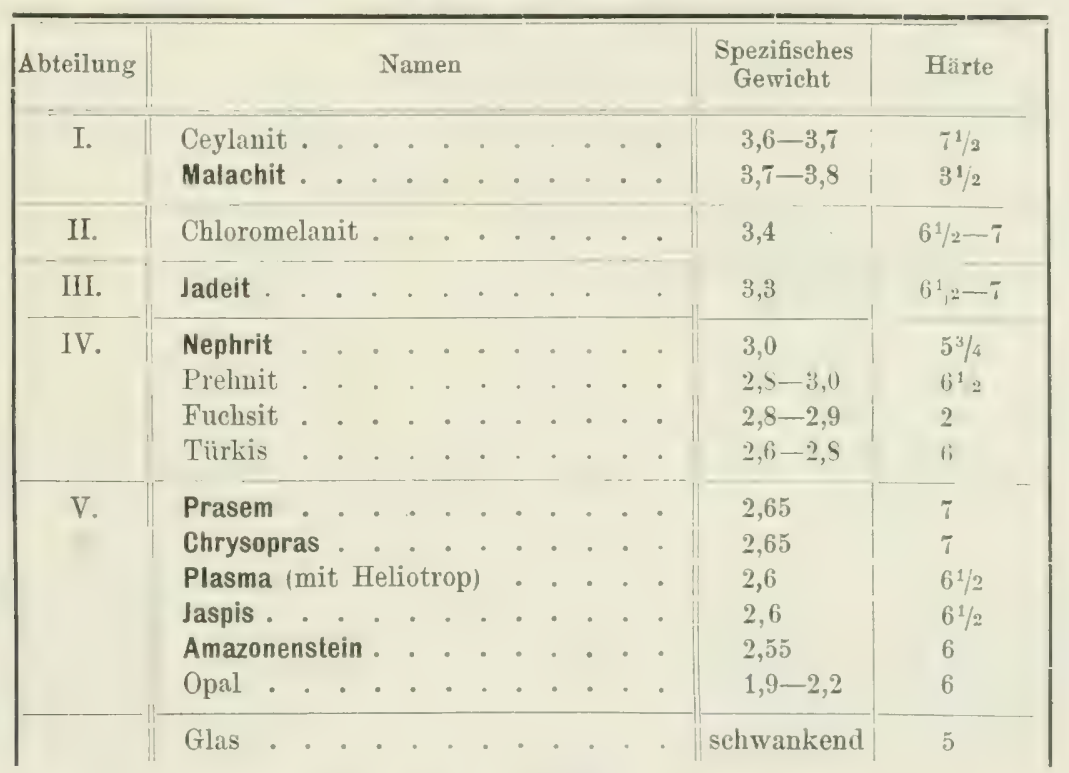

Malachit braust mit einem Tröpfchen Salzsäure auf; er ist stets aus heller und dunkler grünen krummen Schichten aufgebaut. Ceylanit ist dunkel schwarzeriin, fast schwarz; er ist der härteste und schwerste von allen. Nephrit und Jadeit, vergleiche Tabelle 1 (S. 706). Cloromelanit ist nichts anderes als ein eisenreicher und daher etwas schwererer und ziemlich dunkel gefärbter Jadeit mit allen Eigenschaften dieses letzteren. Prehnit steht im spezifischen Gewichte zwischen Türkis und Nephrit, er schwimmt und schwebt also jedenfalls in der dritten Flüssigkeit. Feldspat ritzt er noch, was Türkis und Nephrit nicht tun. $\mathrm{Er}$ ist meistens ausgesprochen gelblichgrün und faserig; letzteres ist beim Nephrit nicht der Fall, auch geht seine grïne Farbe mehr ins Grau. Der Türkis ist ebenfalls nie faserig. Die Steine der fünften Abteilung sind zunächst die vier Quarz. mineralien: Prasem von dunkellauchgrüer und Chrysopras von hell apfelgrüner Farbe, sorlann Plasma und grïner Jaspis, rein grün und stets dunkel. Echter Chrysopras wird seiner Farbe wegen nicht leicht mit einem anderen Steine verwechselt als mit dem kïnst- 
lich apfelgrïn gefürbten Chalcedon, der aber mit jenem völlig gleichwertig ist. Die drei anderen, Prasem, Plasma und grïner Jaspis, können geschliffen kaum mit Sicherheit unterschieden werden, aber in rohen Stiicken und Dünnschliffen unter dem Mikroskop. Da sie als Schmucksteine ziemlich gleichwertig sind, so ist eine sichere Unterscheidung anch nicht sehr wiehtig. Prasem hat ein etwas höheres Gewicht und größfere Härte als die beiden anderen. Von diesen pflegt man die ganz undurchsichtigen als Jaspis, die noch etwas durchscheinenden als Plasma zu bezeichnen. P'lasma mit roten P'unkten ist der Heliotroj). Amazonenstein ist bläulichgrün und nie sehr dunkel; seine Härte ist einen ganzen Grad geringer und läßt ihn leicht von den vorhergehenden unterscheiden, außerdem, namentlich an rohen Stiicken, die deutliche Spaltbarkeit, die aber auch an geschliffenen, vielfach durch geradlinige Risse sich kenntlich macht. Charakteristisch sind feine weiße Streifen, die fast nie ganz fehlen. Der nicht sehr verbreitete griune Opal (Prasopal) von der Farbe des Chrysoprases, ist durch das besonders niedrige spezifische Gewicht, Glas durch die geringere Härte von allen sonstigen grïnen Steinen dieser Art verschieden. Ceylanit, Chloromelanit und Jadeit, sowie Nephrit werden von Ïtztinte gar nicht, Prasem, Chrysopras, Plasma und Jaspis schwer, alle übrigen mehr oder weniger leicht angegriffen. Fuchsit läßt sich schon mit dem Fingernagel ritzen.

\section{t. Sehwarze Steine.}

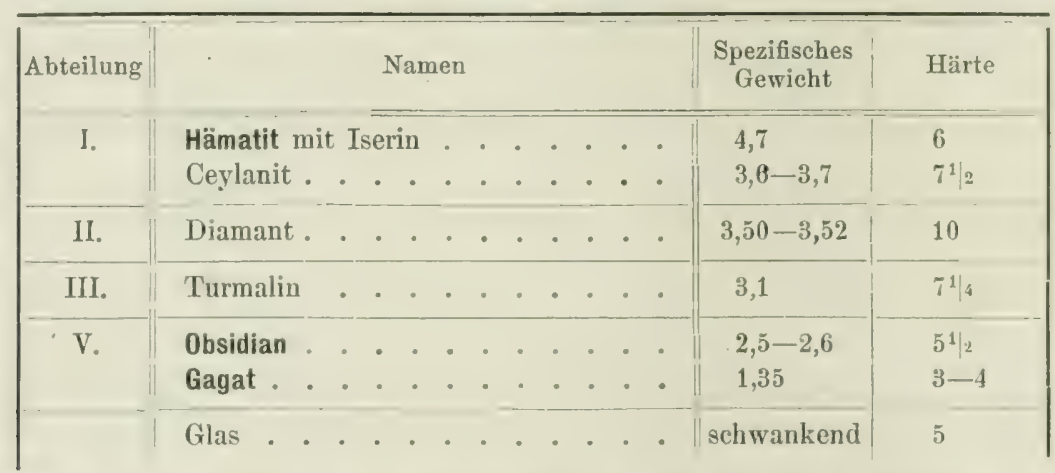

Von diesen, vorzugsweise zu Trauerschmuck verwendeten Steinen ist Hämatit metallisch glänzend und hat roten Strich; Ceylanit ist durch seine große Härte und hohes spezifisches Gewicht genügend gekennzeichnet, ebenso wie schwarzer I)iamant durch seine alles andere übertreffende Hürte und, wenn geschliffen oder in einzelnen Kristallen, durch besonders bohen Glanz. Schwarzer Obsidian und schwarzes Glas stehen im Gewichte hinter allen anderen Steinen dieser Gruppe weit zurïek, sind aber voneinander, außer durch die Untersuchung von Dünnschliffen unter den Mikroskop, schwer zu unterscheiden, jedenfalls durch blobes Ansehen im greschliffenen Zustande kaum. Gagat fühlt sich warm an und lïft sich mit dem Messer schneiden; den Unterschied von Hartsummi siehe S. 686. I Hamant und Gagat sind im Gegensatz zu den anderen für Röntgenstrahlen durchlässig. 'Turmalin ist pyroelektrisch. Obsidian und fllas werden leicht von Ätztinte angegriffen.

\section{Gelbe und braune Steine. (S. 'Tab. S. 709 oben.)}

Schwefelkies nimmt in dieser Gruppe durch Metallghlanz und spezifisches Gewicht (ine besondere Stellung (rin. Karneol ist gelb bis gelbbraun und rotbraun, auch zuweilen ausgesprochen kastanienbraun (Sarder), häufig verschiedene Nuancen streifenförmig ab)wechselnd; seine größere IÏ̈rte und sein höheres spezifisehes Gewicht unterseheiden ihn von dem ähnlich gefüirbten, aber nie grestreiften Feueropal. Natrolith ist isabellgelb (ins 
b) Durchscheixende uxd ux̃drchisichtige Steine.

Tabelle 5. (Gelbe und brame Steine.)

\begin{tabular}{|c|c|c|c|c|c|c|c|c|c|c|}
\hline Abteilung & \multicolumn{8}{|c|}{ Namen } & $\begin{array}{c}\text { Spezifisches } \\
\text { Gewicht }\end{array}$ & Härte \\
\hline I. & Schwefelkies & . & & 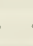 & . & - & . & - & 5,0 & $6^{1 / 2}$ \\
\hline \multirow[t]{5}{*}{ V. } & Karneol nelost & Sarde & & . & . & . & . & . & 2,6 & $6^{2} / 2$ \\
\hline & Natrolith . & . . & & . & . & . & . & . & $2,2-2,3$ & $51 / q$ \\
\hline & Feueropal . & . & & . & . & . & . & - & $1,9-2,2$ & 6 \\
\hline & Bernstein & . . & & & 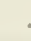 & . & - & 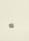 & 1,05 & $2-3$ \\
\hline & Glas . . & . & & . & & . & - & . & schwankend & 5 \\
\hline
\end{tabular}

Braune), wenig gänzend und stets faseriw. Bernstein fühlt sich warm an, wird durch Reiben sehr stark elektrisch und liilit sich mit dem Messer schneiden. I)adurch unterscheidet er sich leicht von Glas. Dieses übertrifft den Vatrolith und den Feneropal stets an Gewicht und wird von Karneol stark geritzt.

6. Rosenrote, rote und lila Steine.

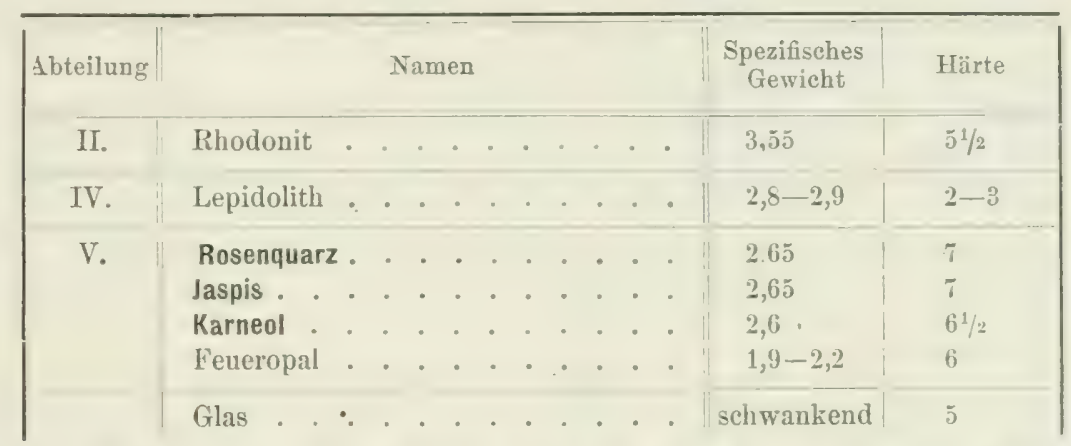

Rhodonit ist rosenrot, aber dunkler als der grleichfalls rosenrote Rosenquarz, der luärter und glïnzender, aber weniger schwer und stärker durchscheinend ist als der erstere. Lepidolith ist lila und läßt sich schon mit dem Fingernagel, jedenfalls aher sehr leicht mit einem gewöhnlichen Messer ritzen. Jaspis ist ganz undurchsichtịn und dunkelrot bis braunrot, Karneol durchscheinend und meist dunkler oder heller gelbrot. Feneropal ist leichter und weicher als Karneol, dem er bezüglich der Farbe zuweilen sehr ïhnlich ist. Glas ist weicher als alle Glieder dieser Reihe außer Lepidolith. Opal und Glas werden von Ätztinte leicht angegriffen.

7. Mehrfarbige steine.

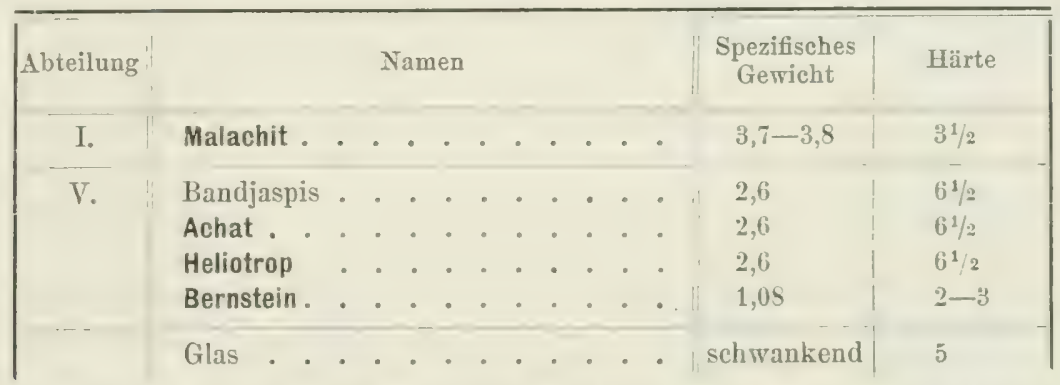

Beim Malachit wechseln heller grüne und dunkler grïne bis beinahe schwarze Schichten in krummliniger Begrenzumg regelmäßig miteinander ab. Das hohe Gervicht und die geringe Härte zeichnen ihn aus: an dem Aufbrausen mit einem Tröpfehen Salzsïure, das 
dann die Spiritusflamme blau färbt, wird er mit Sicherheit erkannt. Beim Bandjaspis wechseln grïne und braunrote, zuweilen auch andersfarbige Streifen meist geradlinig miteinander ab; er ist undurchsichtig. Der Achat ist wenigstens etwas durehscheinend; die Farbenstreifen bilden bei ihm verschiedene Zeichnungen und zeigen in der Farbe mehr oder minder große Unterschiede. Heliotrop ist dunkelgrün (Plasma) mit roten Punkten. Bernstein (unterschieden nach Tabelle 5, S. 709) ist zuweilen braun und gelb gefleckt, wolkig usw. Glas spielt bei den mehrfarbigen Steinen kaum eine Rolle, doch kommt allerdings auch solches zuweilen vo:"

\section{Metaliglainzende Steine.}

Schwefelkies, gelb (Tabelle 5, S. 709).

Haimatit und Iserin, schwarz (Tabelle 4, S. 708).

Rutil, S. 656 .

\section{c) Steine, die eine besondere Lichterscheinung zeigen.}

Diese Lichterscheinungen sind meist so bezeichnend, daß die Steine daran leicht erkannt werden können und daß die hier im folgenden angegebenen Unterscheidungsmerkmale kaum jemals angewendet werden müssen.

1) Steine mit einem Lichtstern: Sternsapphir, Sternrubin, Sterntopas usw. Diese Steine, die zum Korund gehören und die als Sternsteine zusammengefaßt werden, müssen die Härte 9 haben und also Topas noch ritzen. Das spezifische Gewicht ist etwa 4, sie sind nur durch die blawe, rote, gelbe usw. Farbe voneinander verschieden. Bei anderen Edelsteinen ist diese Erscheinung selten; sie können nach einer der obigen Tabellen erkannt werden.

2) Steine mit wogendem Lichtschein, der sich beim Drelen des Steins über dessen Oberfläche hinbewegt: Girasol-Sapphir,-Topas und-Rubin, Demantspat; Chrysoberyll (Cymophan), Katzenauge; Tigerauge und Falkenauge; Mondstein; schillernder Obsidian.

Girasol-Sapphir, -Topas und -Rubin, sowie Demantspat gehören mit den unter 1) genannten zum Korund und haben alle Eigenschaften, nanıntlich die große Härte dieses Minerals. Der Demantspat unterseheidet sich durch seine geringe Durchscheinenheit und die haarbraune Farbe von den drei anderen, die zwar ebenfalls nicht durchsichtig, aber doch nur leicht getriibt sind. Alle anderen hier genannten Steine sind weicher und spezifisch leichter. Sehr ähnlich ist Chrysoberyll (Cymophan oder orientalisches Katzenauge) dem gewöhnlichen Quarzliatzenauge. $\Lambda$ ber die Härte der beiden ist $81 / 2$, resp. 7 , und das spezifische Gewicht ist 3,7 , resp. 2,65, so dal3 sie schon bei oberflächlicher Untersuchung nicht verwechselt werden können. Der höhere Glanz und die bessere Durchsichtigkeit des Chrysoberylls läßt beide meist schon von vornherein unterscheiden. Dem Chrysoberyll in Beziehung auf die Lichterscheinung ähnlich ist auch der Mondstein, der aber farblos und fast durchsichtig ist, nicht grün oder rot, und nur durchscheinend wie bei jenem. Der Mondstein ist viel leichter $\left(G_{0}=2,{ }_{1}\right)$ und weicher $(H=6)$ als der Cymophan, ınd sein Lichtschein bläulich. Wie das Quarzkatzenauge ist auch Tigerauge und Falkenauge Quarz mit allen Eigenschaften dieses Minerals $\left(\mathbf{G}_{0}=2,65\right.$ $\mathrm{H}=7$ ); sie haben ausgezeichnete Faserstruktur, das Tigerauge ist schön goldig glänzend, zuweilen künstlich anders gefärbt, das Falkenauge dunkelblau. Das Katzenauge hat nie den prächtigen Goldglanz des natürlichen Tigerauges, der Jichtschein ist mehr milehig weiß. Beim schillernden Obsidian ist der Schiller stets geringer; der Unterschied von den anderen Steinen dieser Abteilung ist durch das niedrige Gewicht $\left(G_{0}=2,5-2,6\right)$ und die geringe IIärte $\left(\mathrm{H}=5^{1 / 2}\right)$, sowie durch die leichte Wirkung der Ätztinte sicher gegeben. 
3) Steine mit metallisehem Sehiller. Hypersthen, Bronzit, Schillerspat, Diallag. Alle gehören zu der Augitgruppe; ihre Härte erreicht nicht ganz den 6. Grad und das spezifische Gewicht beträgt 3,3 bis 3,1 . Hypersthen hat einen kupferroten, Bronzit einen bronzegelben, griinen oder braunen, Schillerspat und Diallag einen griinen bis braunen Schiller. Hypersthen wird leicht erkannt werden, die anderen sind zum Teil schwer von einander zu unterscheiden; die Unterscheidung hat keine Bedeutung (vgl. die Beschreibung S. 567)

4) Steine mit metallisch sehillernden Punkten. Avanturinquarz und Sonnenstein (Avanturinfeldspat), unregelmäßig begrenzte, metallisch schillernde rote Punkte und kleine Fleckchen. Der Unterschied liegt in der IÏ̈rte, die beim ersten $=\bar{\tau}$, beim anderen $=6$ ist. Ïhnlich ist das künstliche Avanturinglas, das an der Gestalt der den Schiller bedingenden Einschlüsse erkannt wird. Es sind kleine Oktaüderchen, deren regrelmäßig dreiseitige Flächen unter der Lupe deutlich hervortreten (S. 617). Sonnenstein und Avanturinglas werden von Äztinte leicht angegriffen. Als Seltenheit gibt es auch grünen und blauen Avanturinquarz mit allen wesentlichen Eigenschaften des roten.

5) Steine mit buntem Farbenspiel. Edler Opal, Regenbogenquarz und Labradorfeldspat. Opal ist meist hell, weib, auch gelb und rot, selten schwarz, und die farbenschillernden Stellen sind von verschiedener Größe. Das spezifische Gewicht ist 1.9 bis 2,2 und die IIärte $=6$. Dadurch unterscheidet er sich sicher von dem stets wasserhellen Regenbogenquarz mit der Härte 7 und dem Gewicht 2,65. Labradorfeldspat ist dunkelgrau, das Farbenspiel ist auf eine Fläche beschränkt und vielfach in geraden Streifen abwechselnd. Die IIärte ist $=6$, das Gewicht $=2$, ; und an rohen Stücken ist die vollkommene Spaltbarkeit nach einer Richtung stets zu bemerken. Labrador und Opal wird niemand verwechseln, eher ist das zwischen edlem Opal und Regenbogenquarz möglich; die angegebenen Merkmale geben aber den Unterschied unzweideutig. Labradorisierender Feldspat ist dem Labrador sehr ähnlich, hat aber kein so schünes Farbenspiel. 

ANHANG.

Perlen und Korallen. 



\section{Perlen.}

Eigenschaften und Entstehung der Perlen. Neben den kostharsten Juwelen stehen gleichberechtigt die Perlen. Sie sind die wertvollen Erzeugnisse unscheinbarer bewohner des Wassers, und zwar gewisser Muscheln, die in warmen Neeren, aber auch in den Fliissen und Bächen mancher Gegenden leben. Sie gehören also nicht zu den Edelsteinen. dienen aber wie diese seit unvordenklichen Zeiten zum Schmuck des menschlichen Körpers sowie zur Verzierung aller möglichen Prunkgeräte und wetteifern mit jenen an Kostharkeit, Gerade gegenwärtig sind sie sehr geschätzt und werden ungemein hoch bezahlt. Es sind kugelrunde, ovale oder birnförmige, zuweilen sogar ganz unregelmäbig rundliche Gebilde von verschiedener Größe, die niemals durchsichtign, höchstens durchscheinend und meistens farblos, weib, seltener grefärbt sind, und die vorzugsweise durch den eigenartigen lieblichen Glanz ihrer Oberfläche das Auge des Beschauers entzuicken. Ln die Schönheit der I'erle zu genießen, ist es natïrlich nicht erforderlich, zu wissen, wie sie beschaffen ist und wie sie entsteht. Das Verständnis mancher Eigenschaften, namentlich des inneren Baues der Perlen, wird aber wesentlich gefördert, wenn wir wissen, wie sie sich im Innern, jener Muscheln bilden. Wir werden daher zuerst ibre Entstehung kennen lernen und daran die Betrachtung ihrer Eigenschaften anschließen.

Mit den Perlen im engsten Zusammenhang steht eine andere Substanz, die auch ron den Perlen ihren Namen erhalten hat und die gleichfalls nicht selten zu Schmucksachen und anderen kleinen Gegenständen verarbeitet wird. Es ist die Perlmutter. die sich durch einen ganz ähnlichen Glanz wie die Perlen und vielfach durch ein mehr oder weniger intensives, hübsches Farbenspiel auszeichnet. Sie kleidet bei vielen Muscheln die Innenseite der Schalen in einer mebr oder weniger dicken Schicht aus; eine Masse von ganz ähnlicher Beschaffenheit finden wir auch in der Schale einer bestimnten Abteilung von Schnecken; wir wollen uns aber bier auf die Muscheln beschränken, da die Bildung von Perlen in Schnecken zwar vorkommt, aber doch nur in vereinzelten Fällen, die für die Gewinnung ohne jede Bedeutung sind.

Betrachten wir eine Muschelschale, so bemerken wir an der äußeren Oberfläche eine dünne hornige IIaut, die sogenannte Epidermis, dereu Substanz Konchyolin genannt wird. Darunter folgt die eigentliche Schale. Sie besteht aus kohlensaurem Kalk, der mit einer organischen Substanz durchzogen ist. Diese Schale setzt sich aus zwei Lagen ron wesentlich rerschiedenem inneren Bau zusammen, den man allerdings meist erst bei einer gewissen Vergrößerung unter den Mikroskop deutlich erkennen kann. Nach außen hin. unmittelbar unter der Epidermis, liegt eine Schicht, die aus einer großen Zabl diunner, dicht nebeneinander stehender kalkiger Stäbchen besteht, deren Längenerstreckung auf 
der Oberfläche der Schale senkrecht steht. Dies ist die Säulen- oder Stäbchenschicht. Auf sie folgrt, den inneren Teil der Schale bildend, eine Lage, die aus sehr feinen, stark durchscheinenden l'lättchen aufgebaut ist. Diese liegen in wroßer Zahl ühereinander und verlaufen der Schalenoberflïche annähernd parallel, also senkrecht zu den Stäbchen der Mittelsehicht. Dieser imnerste der drei Teile der II uschelschale, von blätteriger Beschaffenheit, der bei manchen Muscheln nur dünn, bei anderen von erhel)licher Dicke ist, hat für uns das größte Interesse; es ist die Perlmutterschicht, kurz das, was man als Perlmutter bezeichnet. Wir werden sie etwas genauer betrachten.

Was zunächst die Substanz der feinen kalkigen Plättchen anbelangt, welche die Perlmutter zusammensetzen, so gleicht sie nach ihrer IIärte, ihren spezifischen Gewicht und nach allen sonstimen Eigenschaften durchaus derjenigen Abänderung des kohlensauren Kalkes, die man in der Mineralogie als Aragonit bezeichnet. Die Perlmutter besteht also aus Aragonit im Gegensatz zu der Stäbchenschicht, die nach ihrem ganzen Wesen mit dem ebenfalls aus kohlensaurem Kalk bestehenden Nineral Kalkspat übereinstimmt, und die also etwas weicher und spezifisch leichter ist.

Die dïnnen Plättchen ziehen sich niemals ununterbrochen durch die ganze Schale hin, sondern es sind einzelne kleine Fetzen, die nach geringer Erstreckung aufhören, wïhrend andere sich dafür einschieben, die sich dann ihrerseits ebenso verhalten. Dieser feinblätterige Bau ist die Ursache des eigentümlichen Glanzes, der die Perlmutter auszeichnet, und den man darnach Perlmutterglanz genannt hat. Er kehrt, wie wir schon im ersten Teile dieses Werkes (S. 42) geselien haben, bei allen Substanzen wieder, die in derselben VTeise heschaffen, d. h. aus lichtdurchlassenden dïnnen Plättchen aufgebaut sind.

Die feinen Plättchen, welche die Perlmutter bilden, haben zum Teil einen ziemlich ebenen Verlauf. zum Teil sind sie auch mehr oder weniger stark gekrimmt und gebogren. Sie gehen nie ganz parallel mit der Oberflïche der Perlmutterschicht, und schneiden daher die letztere. Dadurch entsteht auf dieser, die für das bloße Auge vollkommen glatt erscheint, eine sehr feine, zuweilen schon mit der Lupe, zuweilen auch erst unter dem Mikroskop bemerkbare Streifung; die Ränder der Plättehen ragen etwas hervor, und zwischen zwei benachbarten Plïtchen sind sehr zarte Furchen, die einander bis iuf 1/:3no Zoll nahe riicken können. Diese Furchen, deren Entfernung übrigens etwas wechselnd ist, verlaufen krumm und zackig und oft ganz unregelmäßig und bilden zuweilen kleine greschlossene Ringe. Wie der blätterige Aufbau den Perlmutterglanz hervorruft, so ist diese feine Streifung die Ursache des Farbenspiels, das auf der meist farblosen, zuweilen allerdings auch gefärbten Perlmuttersubstanz vielfach in prächtiger Weise auftritt. Es beruht nicht auf einem besonderen Farhstoff, sondern es entsteht dadurch, daß das gewöhnliche Tages- oder Kerzenlicht auf der feingestreiften Oberflïche in besonderer Weise sespiegelt und in seine farbigen Bestandteile zerlegt wird, die dann einzeln in das Auge srelangen. IIan erkennt dies, wenn man die natürliche Oberflïche einer Perlmuttersehale oder hesser eine schief gegen diese gefïhrte Schlifffläche in Siegellack abdriekt. Dieser Abdruck erhält dadurch eine Oberfläche mit ebenso zarter Streifung, und auf ihr bemerkt man dann das gleiche Farbenspiel wie auf der Perlmutter selbst.

An jeder Muschel wird die Sehale dureh den sogenannten Mantel des Tieres gebildet, der den im Wasser gelïsten lialk ausscheidet und aus ilım die Stäbchenschicht sowie die P'rlmutterschicht aufbaut. Dieser Mantel besteht aus zwei häutigen Lappen, die das Muschelfier von beiden Seiten her umbïillen und die unmittelbar an der Innenfläehe der Schalen anliexen. Zwischen dem Mantel und der sichale seht die Ablagerung des Kalkes vor sich, und immer neue Sehichten desselben setzen sich auf der inneren Fläche der Schale an, wodurch diese immer dicker wird. Aber nicht alle Teile des Mantels haben dabei wanz die grleiche Verrichtung; der äußerste Rand scheidet die äußere IIaut der Sehale, 
die Epidermis, ab; die Aubenflïehe des Mantels liefert die l'erlmutter, und eine sehmale äubere Zone riness um den Rand des IIantels herum bildet die zwischen Epidermis und Perlmutter liegende Ståbchenschicht.

Dies ist der Vorgang bei den Tieren, die sich in ihrem normalen Zustande, in ilırer gewöhnlichen ungestörten Lebenstätigkeit befinden. Sulange dies der Fall ist, entstehen keine Perlen. Ihre Bildung ist ein abnormer, in gewissem Sinne ein krankhafter Vorgang, der sich allerdings von der Bildung der Schale in nichts Wesentlichem unterscheidet, der aber einer äuberen Ursache, einer von auben kommenden Anrecrungr bedarf. Auch die Prolen sind Ausscheidungen in der Hauptsache von Kaik aus dem Mantel, und zwar von Kalk mit der Beschaffenheit der Perlmutter, aber nicht in einer auspredehnten Śchicht. wie bei der Bildunger der Inschelschale, sondern in konzentrischen Lagen, rings um einen gemeinsamen Mittelpunkt herum. Auch die Perle ist Perhmutter, nur ron anderer Struktur als in der gewöhnlichen Muschelschale. Jede Perle entsteht durch eine von lokalen Ursachen veranlaßte, besonders starke Absonderung von Perlmuttersulstanz oder granz allgemein von Schalensubstanz um einen Punkt herum. Diese Ausscheidung erfolgt nur an Stellen, wo ein besonderer Reiz auf den Mantel ausgeibt wird. Die Muschel sucht diesen Reiz zu beseitigen, und das Mittel, dessen sie sich dazu bedient. besteht eben darin, daß sie die Ursache des Reizes in Perlmutter einhuïlt. Die Produlite dieser Einhüllung" sind dann die Perlen und deren Mittelpunkt die Punkte im Mantel der Muschel, wo der Reiz wirkte. Daß die Perlenbildung nicht zu den normalen Lebensprozessen der Muscheln gehört, sondern einer besonderen abnormen Anregung bedarf, sieht man daran, dali nicht alle Permuscheln Perlen liefern, sondern nur einzelne wenige Exemplare derselben. Bei der eigentlichen Perlmuschel findet man im Durchschnitt in 30 bis 40 Stiick kaum eine einzige Perle. Daß der Torgang ein krankhafter ist. dafür sprechen die Beobachtungen der Perlfischer. Darnach hat man in wohlgebildeten, regelmïßig grestalteten Muscheln wenig Aussicht, Perlen zu finden. Viel mehr Hoffnung geben solche von unregelmäßiger Form und gestörtem Wachstum, solche, die Auswïchse tragren, die von bohrenden Parasiten durchlöchert sind usw. Es ist darnach unzweifelhaft, daß dic Perlbildung auf einer Störung des normalen Wachstums beruht.

Wohl noch nicht für alle Fälle ist es genügend aufgeklärt. was die Muscheln reranlaßt, in ihrem Innern die, wie wir sehen werden, in einzelnen Fällen ziemlich grroße, bis über taubeneigroße Kalkmasse der Perlen auszuscheiden.

In zahlreichen Fällen sind es kleine fremde Kürper; die durch irgendeine Lrsache in das Innere der Inschel hineingekommen sind. In vielen Perlen findet man als innersten Kern ein Sandkörnchen, das vielleicht der Wellenschlas zwischen die geöffneten Schalen hineingespült hat. Hier ist es offenbar das Sandkorn grewesen, das einen Reiz auf den Mantel der Muschel ausgeiibt und ihn zur Ausscheidung ron Kalk um das Körnchen herum veranlaßt hat, in ähnlicher Weise, wie ein kleines Stäubchen im Auge eine abnorm reichliche Ausscheidung von Wasser bewirkt, und wie sich eine in einen Muskelstrang eingewanderte Trichine mit einer Kalkhülle umgibt. Nach manchen Beobachtern sollen Sandkörner die häufigste Ursache der Perlenbuldung sein; den Forschungen ron Möbius zufolge, wie sie in dessen wertvollem Werk: "Die echten Perlen", niedergelegt sind, war aber in 5! ron ihm untersuchten, aus dem Meere und aus dem Süßwasser stammenden Perlen kein Sandkorn zu finden; bei einer kleinon Anzahl hatte die innerste Partie die Beschaffenheit eines kristallinisch kïrnigren Kalkes; bei den allermeisten zeigten sich organische Kerne von brauner Farles, die vielleicht Reste von kleinen Eingeweidewürmern der Muschel sind. Daf derartige l'arasiten, und zwar nicht selten solche von mikroskopischer Kleinheit, die Bildung von Perlen in der Tat bewirken künnen, ist lange vermutet worden. 
Ausgredehnte Untersuchungen der neueren Zeit hahen nun in der 'Tat einen Zusammenhang zwischen der Perlenbildung und eneystierten (eingekapselten) Parasiten mit voller Sicherhest nachgewiesen und gezeigt, daß letztere sogar für die Perlenbildung in erster Linie verantwortlich gemacht werden müssen. Zuerst bekannt wurde dies von der Miesmuschel (Mytilus edulis), in welcher ja nicht selten Perlen auftreten. Es handelt sich hier um die I arve eines Saugwurmes, des Leucithodendrium somateriae, welche in das Bindegewehe des Mantels der Muschel gelangt und hier von einer zelligen Kapsel umschlossen wird, um welche sich nun die Perlnuttersubstanz in konzentrischen Schichten ablagert und so eine Perle bildet. Bei der echten Seeperlmuschel von Ceylon ist es die Larve eines Bandwurmes, des Tetrarhynchus unionifactor, die unter ähnlichen Encystierunırs. (Einkapselungs-)vorgäingen die fast alleinige Ursache der Entstehung der echten Perlen ist: bei der Perlmuschel des Tuamotu-Archipels gleichfalls die Finne eines Bandwurnew, des Thylocephalum margaritiferae.

Je nach der Stelle, an der die Ausscheidung der Perlsubstanz stattfindet, ist die Perle ron verschiedener Gestalt und Beschaffenbeit. Geschieht dies innerhalb der Weichteile des Mantels, etwa rings um einen dort sich aufhaltenden Eingeweidewurm, dann entsteht eine mehr oder weniger regelmäßig runde Perle, die frei und lose im Mantel liegt. Geschieht es in unmittelbarer Nähe der Schalenwandung, dann verwächst die Perle fest mit der Perlmutterschicht und bildet auf dieser eine größere oder kleinere rundliche, warzenförmige Erhabenheit. Im ersteren Falle erbält man eine eigentliche echte Perle, die ohne weitere Bearbeitung zum Schmuck verwendet werden kann. Die festgewachsenen Perlen heifen bei den Juwelieren Perlenwarzen. Ihre Form ist stets sehr unregelmäßig. Auch sie werden aber benutzt, indem man sie von der Schale losschneidet; sie liefern dann die sogenannten $\mathrm{Phantasieperlen.} \mathrm{In} \mathrm{einzelnen} \mathrm{Fällen} \mathrm{sind} \mathrm{sie} \mathrm{im} \mathrm{Innern} \mathrm{hohl}$ und schliefen zuweilen eine schöne Perle ein, die lose darin liegt und die dann bei der ïffnung des Hohlraumes herausfällt. Die ursprünglich lose Perle ist zuerst an dieser Stelle gebildet und nachher beim weiteren Wachstum der Schale von der an der Innenfläiche derselben sich ablagernden Perlmuttersubstanz umhüllt worden und so festgewachsen.

Auch die Zahl der in einer Muschel sich findenden Perlen ist verschieden. Wird der Mantel nur an einer Stelle gereizt, dann entsteht auch nur eine einzige Perle. Geschicht dies an mebreren Stellen, dann bilden sich mehrere und sogar unter Umständen in einzelnen Fällen viele Perlen. Die größte Zahl derselben, von der berichtet wird, waren $\$ 7$ von guter Beschaffenheit in einer Perlmuschel aus dem indiscinen Ozean, in einer solchen von Ceylon lagen 67 von verschiedener Größe usw. Selbstverständlich werden die Perlen im allgemeinen um so kleiner sein, je zahlreicher sie sind.

Der erste, welcher zeigte, daf die Perlen in ihrem Bau nit der Muschelschale übereinstimmen, war der beriihmte franzïsische Naturforscher Réaumur (1683-1757). Dieser Bau wird am besten erkannt, wenn man einen Dünnschliff mitten durch eine Perle hindurch bei genïgender Veræröljerung unter dem Mikroskop untersucht. Dabei sieht man, dal) die Perlen wie die Perlmutterschicht der Muschelschalen aus einzelnen sehr dïnnen Lagren bestehen, die, ähnlich wie die Schalen einer Zwiebel, der rundlichen Oberfläche parallel aufeinander folgen, rings um den gemeinsamen Nittelpunkt herum. Über dem Kern bildet sich eine erste Perlmutterschicht, über dieser eine zweite, dritte und so fort, bis zur äufersten, letzten und jüngsten. Selten bildet aber eine solche Lage eine ununterbrochene Kugelflïche, fast immer sind es nur kleine Partien, die nach kurzem Verlauf aufhören und statt deren dann andere einsetzen, also ebenfalls wieder genau wie bei der Perlmutter. Man kann aus diesem feinblïtterigen Bau erkennen, daß der Absatz yon Kalk in den beiclen genannten Substanzen nicht ganz kontinuierlich stattgefunden hat, 
sondern daß vielleicht mit den Jahreszeiten zusammenhängende kïrzere oder längere Unterbrechungen stattgrefunden haben, in denen die Ahlagerung von Kalk und damit das Wachstum aufhörte. Jeder Wachstumperiode entspricht eine solche feine Lage, jeder Unterbrechung ein Zwischenraum zwischen zwei benachbarten Lagren. Diese übereinanderliegenden dünnen Kalkhäutchen werden ïbrigens manchmal auch direkt für das bloße Auge sichthar. Erhitzt man eine Perle bis zum Gliihen, dann blättern diese einzelnen feinen Lagen ab, indem sie sich nach Aufhebungr ihres Zusammenhalts roneinander absondern. Dasselbe geschiebt auch an durchlochten Perlen, die langre Zeit auf Schnüren getragen werden. Wegen der geringen Härte, die zwischen dem dritten und vierten Grade liegt, werden die Mündungen der Bohrlöcher allmählich auscreweitet, und zwar in der Weise, dal rings um diese Offnungen einzelne dïnne Blïttchen von der Außenfläche der Perlen schuppenförmig abfallen.

In dieser Weise sind die meisten und auch die schönsten Perlen beschaffen; sie bestehen auber dem Kern gewöhnlich nur aus Perlmutterschichten. Aher nicht alle haben diese ausgesprochen feinblätterige Struktur; es gibt auch Ausnahmen davon. Nicht selten ist der Kern von einer dunkeln Schicht umgeben, die ganz mit der Epidermisschicht der Muschelschalen ïbereinstimmt, und darauf folgt eine Lage von faseriger oder säuliger Beschaffenheit, die in jeder Hinsicht an die Stäbchenschicht erinnert. Erst diese ist dann von der feinblätterigen Perlmutterschicht umhüllt, die das Ganze nach außen abschliebt. Eine solche Perle ist gewissermaßen eine umgekehrte Muschelschale. Sie besteht aus denselben Teilen wie diese, sie liegen aber in entgegengesetzter Reihenfolge, zu innerst die Epidermis, zu äußerst die Perlmutter. Indessen kommt es auch zuweilen vor, daß die Perlmutter vollständig fehlt und daß die Stäbchenschicht die äufere Oberfläche bildet; in diesem Falle, oder wenn die äußerste Schicht aus Epidermis besteht, ist die Perle dunkel, braun oder schwarz gefärbt und ohne Glanz und damit auch ohne Wert. Nicht selten sieht man auch eine mehrmalige Wiederholung von Perlmutterlagen, die durch Epidermis- oder Stäbchenschichten voneinander getrennt sind.

Man kann leicht ermessen, mit welchen Bildungsvorgängen diese Verschiedenheiten in der Struktur zusammenhängen. Wenn eine Perle, wie es meist der Fall ist, caanz in dem Perlmutter liefernden Bereich des Mantels entsteht und hier durch Ablagerung immer neuer feiner Schichten an ihrer Oberfläche allmählich wächst, so wird sie ganz aus Perlmuttersubstanz ron der mehrfach erwähnten Beschaffenheit bestehen. Aber eine solche Perle bleibt nicht immer während ihres ganzen Wachstums an derselben Stelle liegen; sie kann aus verschiedenen Ursachen ibren Platz wechseln, und dadurch muß auch die Beschaffenheit der abgelagerten Substanz eine andere werden. Kommt sie in denjenigen Bereich des Mantels, der die Stäbchenschicht bildet, dann wird auch auf ihrer Oberfläche eine solche entstehen und ebenso eine Epidermisschicht, wenn sie eine Zeitlang ganz am Rande des Mantels verweilt. Liegt der Kern zuerst hier, dann wird er sich mit Epidermis bedecken, und wenn die im Entstehen begriffene Perle hernach allmählich langsam nach innen wandert, wird auf die Epidermis eine Stähchen- und auf diese zuletzt eine Perlmutterschicht folgen. Bewegt sie sich abwechselnd ron außen nach innen und dann wieder zurück; dann werden sich diese verschiedenen schichten ganz der Bewegung entsprechend ein- oder mehrere Male wiederholen. Fs kann auf diese Weise eine große Mannigfaltigkeit in dem speziellen Bau der Perlen hervorgebracht werden.

Wie bezüglich des Baues, so stimmt die Perle auch bezïglich der chemischen Zusammensetzung der Substanz, der Härte und des spezifischen Gewichts vollkommen mit der Perlmutter überein. Sie besteht aus kohlensaurem Kalk wie diese, und zwar in derjenigen Modifikation, die in allen Eigenschaften mit dem Mineral Aragonit 
ühereinstimmt. Daneben sind aber immer noch geringe Nengen anderer unorganischer Substanzen vorhanden, und vor allem fehlt nie eine gewisse Quantität, bis 12 Prozent, eines ormanischen Stoffes, der mit der Oberhaut- oder Epidermisschicht der Muschel übereinstimmt; er ist ebenfalls Konchyolin. Dieses durchzieht das Kalkkarbonat aufs innigste und verbindet die unorganischen Teile fest miteinander. Das spezifische Gewicht frischer, weißer, glänzender Seeperlen betrügt 2,i5n-2,ess, und die Härte ist nahe an 4, jedoch bei verschiedenen Exemplaren etwas verschieden und stets etwas geringer als bei der Perlmutter. Härte und Gewicht sind beide etwas kleiner als beim Aragonit, was von dem beigemengten weicheren und leichteren Konchyolin herrührt. Infolge ihrer Zusammensetzung lösen sich Perlen in Säuren leicht unter Kohlensäureentwickelung auf, die ein lebhaftes Aufbrausen verursacht. Schon Essigsäure hat diese Wirkung. Hierauf beruht die Erzählung, daß die ägyptische Königin Kileopatra bei einem Gastmahle eine kostbare Perle in Essig aufgelöst und die Lösung getrunken habe. Im gewöhnlichen Speiseessig ist aber die Essigsüure so verdünnt, daß eine Perle auch von geringer Größe recht lange Zeit braucht, bis sie vollständig gelöst ist, viel länger als ein Gastmahl zu dauern pflegt. Die Perlen verschwinden in den Säuren übrigens nicht ganz; nur der Kalk wird ausge'ogen, das damit gemengte Konchyolin bleibt dagegen in Form einer häutigen weichen, etwas aufgequollenen, noch perlmutterglänzenden Masse von der Form und Größe und auch von der Farbe der Perle zurïck, auf welche die Sïure nicht weiter einwirkt.

Wie von Säure, so werden die Perlen auch vom Schweiß angegriffen. Wenn sie längrere Zeit auf der bloßen Haut getragen oder viel mit den Fingern berührt werden, verlieren sie allmählich ihren Glanz und ihr schönes Aussehen, sie werden trübe und unansehulich. Alte, getragene Perlen besitzen nie mehr die Frische der neugefischten, sogrenannten Jungfernperlen. Die zarten Schichten blättern ab, und zwar, wie wir schon gesehen haben, am meisten um das Loch herum, das behufs Auffassen auf eine Schnur hindurchgebohrt wird; hier erfolgt der Angriff am stärksten. Wegen ihrer geringen Iärte reiben sich die auf eine Schnur aufgefaßten Perlen gegenseitig ab und werden dadurch matt und unansehnlich. Sehr alte Perlen werden dadurch zerstört, daf die darin enthaltene organische Substanz wie andere tierische Körper vollständig verwest. Ein Beispiel dafür bilden die zahlreichen Perlen, die man im Jahre 1544 in dem Grabe der im Jahre 400 gestorbenen Töchter des römischen Staatsmannes und Feldherrn Stilicho in Rom fand. Nach einem Aufenthalte von mehr als 1100 Jahren in der feuchten Grahesluft zerfielen sie bei der Berührung in Staub. Wir sehen aus diesem ganzen Verhalten, daß sich die Perlen, was die Beständigkeit anbelangt, in keiner Weise mit den unter solchen Umständen unverwüstlichen, ewig dauernden Edelsteinen messen können.

Die leichte Angreifharkeit der Perlen sowohl infolge ihrer geringen Ilärte als auch durch die Wirkung des Schweißes ist um so bedauerlicher, als ilıre Schönheit lediglich an ihrer Oberfläche hängt. Ist diese im Laufe der Zeiten verändert, hat die Perle infolgedessen jhr schönes Ausschen eingebiilbt, so ist dieses unwiederbringlich rerloren. Während man einen verdorbenen Edelstein durch abermaliges Polieren wieder in seinen ursprünglichen Zustand versetzen und ihm seine frühere Schönheit wiedergeben kann, ist dies bei den Perlen nicht möglich. Sie müssen daher beim Gebrauch als Schmuck mit jeder Vorsicht so behandelt werden, daf sie unter allen Umstiinden ihre Oberfläche in ihrer ursprünglichen Beschaffenheit mögrlichst beibehalten. Manchmal ist es allerdings wohl mïglich, die äußerste Schicht einer Perle, die mißfarbig oder verdorben ist, abzulösen und so eine kleinere, aber schönere Perle herzustellen. Diese Operation erfordert aber die höchste siorefalt hesonders gesehickter Arbeiter und gelingt selten vollkommen. 
Diese Oberfliche ist nicht vollkommen glatt, sondern mit zahlreichen mikroskopisch kleinen, feinen Erhabenheiten und Vertiefuneren bedeckt. oder man bemerkt zarte, unregelmälbig gekrimmte Furchen, ähnlich wie bei der Perluntter, die wie hier eine Folge des Wachstums sind. Ihre Beschaffenheit ist, wie wir weiterhin sehen werden, für das Aussehen der Perlen von großer Wichtigkeit.

Auf der Oberfläche zeigt sich vor allem der eigentümliche, nicht sehr starke, aber schïne und zarte, mit Worten nicht näher zu schildernde Glanz, den die Juweliere als .Orient" zu bezeichnen pflegen und der dem Feuer der Diamanten entspricht. Es ist ein Perlmutterwanz, der auf dem oben beschriebenen feinblätterigen Bau beruht. wie bei der Perlmutter selbst. Die einzelnen dünnen, nicht ganz durchsichtigen, nur stark durchscheinenden Lagen lassen etwas Licht hindurch, das von den tieferen Schichten wieder nach auljen reflektiert wird. An der Außenseite der Perlen tritt es aus, mischt sich hier mit den an der Oberfläche direkt zurückgeworfenen Strahlen, und diese Mischung von innerlich gespiegeltem und an der Oberfläche zurïckgeworfenem Licht bringt auf der Perle den Eindruck des Perlmutterglanzes, des echten Perlenglanzes, im Aucre herror. Je schïner dieser Glanz ist, desto wertvoller ist die Perle. Er wird um so ausrrezeich. neter, je dïnner die Kalklagen sind, aus denen sich die Perlen zusammensetzen. Diese zeigen sich hierin sehr verschieden; ganz besonders übertreffen die Perlen der Seeperl. muschel diejenigen der Flußmuscheln. Neben einer echten indischen Perle sieht eine Flufperle kalt und matt aus, während jene Wärme und Leben hat. Perlen mit schüner glänzender Oberfläche sind etwas härter als andere, matte, was mit der mehr oder weniger innigen Aufeinanderlagerung der einzelnen Schichten zusammenhängt.

Der Glanz der Oberfläche ist mit dieser vergänglich und der Wert der Perle da. durch einer starken Verminderung unterworfen. Nan hat daher alle möglichen Mittel versucht, alten und verdorbenen Perlen den ursprünglichen Glanz, die erste Frische der Jungfernperlen, wiederzugeben, aher alle vergeblich. Tersucht man die unscheinbar gewordene Oberfliiche zu entfernen, in der IIoffnung, unter der obersten Kallischicht cine zweite mit ebenso schönem Glanz anzutreffen, so findet man sich gewöhnlich gretäuscht. Das Innere ist meist dunkel und trübe, etwa vergleichbar einem toten Fischauge. Nur selten kommt es vor, daß eine Perle einen besseren Kern einschlielit, so daß sie durch vor. sichtiges Abschälen der obersten Sichichten verbessert werden kann. Daher bat man andere, zum Teil unsinnige Mittel versucht, um ohne Verletzung der trïb und matt gewordenen Perle ihre erste Schönheit zuriickzugeben. IIan hat sie längere Zeit in die Tiefen des Meeres versenkt, hat sie Hühnern und Tauben zu fressen gegreben usw, aber ohne Erfolg. Die unnachahmliche Zartheit des Perlglanzes ist, wenn einmal verschwunden, für immer und unwiederbringlich dahin.

Keine Perle ist völlig durchsichtig, doch gehürt zur vollkommenen Schünheit ein hoher Grad von Durchscheinenheit, der allerdings vielen Perlen fehlt. Auf der mehr oder weniger großen Menge des hindurchgehenden Lichtes beruht auch bei der Perle wie hei den Diamanten das, was man das. Wasser" zu nennen pflegt. Man spricht auch bei den Perlen vom ersten, zweiten usw. Wasser.

Von sehr großer Wichtigkeit für den Wert einer Perle ist die Farloe. Die meisten schmuckperlen sind weiß, gelblichweiß oder bläulichweiß, seltener rütlich oder schwärzlichgrau. Eine vollkommene, perlmutterglänzende oder, wie die Juweliere sagen, "reife“ Perle hat die Farbe der Perlmutterschicht ihrer Muschel, doch beruht die Färbung auch zuweilen auf individuellen, jeder Perle eigentümlichen. von der Schale unabhängigen Ursachen, namentlich stimmt sie dann mit derjenigen der letzteren nicht überein, wenn die Perlmutterschicht fehlt. Die Perlen der echten Seeperlmuschel (Avicula oder Meleagrina margaritifera) sind weif und diese weißen, und zwar die silberartig milchweißen, sind 
die wertvollsten. Die Farbe ist un so schöner weif, je feiner und regelmäfiger die kleinen Unebenheiten der Oberfläche sind. Das auffallende Licht wird durch diese zarten Erhöhungen und Vertiefungen nach allen Richtungen so vollkommen zerstreut zurückgeworfen, daß die Perle fast leuchtend weiß erscheint. Es gehört aber auch noch dazu, daß die Perle bis in das Innerste hinein aus farbloser Perlmuttersubstanz besteht; ein etwa vorhandener, größerer, brauner Kern aus Stäbchensubstanz schimmert immer durch die stark durchscheinenden äußeren Perhmutterschichten hindurch und übt so einen schädlichen Einfluf, indem er die Perle düster und trübe macht, besonders wenn über dem Kern nur eine dünne Perhmutterlage sich befindet. Solche grau oder braun durchscheinenden Perlen werden „unreif" genannt. Von einer großen und schönen indischen Perle wird berichtet, daß sie "wie eine Quecksilberkugel" auf weiliem Papier hinrolle, das Metall an Glanz und an Weiße übertreffend. Solche silberartig perlglänzenden, weißen durchscheinenden Perlen sind die "Perlen vou schönsten Wasser"; sie haben außen stets eine dicke Perlmutterschicht. Viele echte Perlen zeigen indessen auch einen stich ins Gelbliche oder eine ausgesprochenere gelbe Farbe, und zwar häufiger die von Persien als die von Ceylon. Diese gelbliche Farbe ist in Asien, Indien, China usw. vielfach beliebt; gelbliche Perlen sind hier geschätzter als weife, weil sie für dauerhafter gelten als die letzteren. Man sagt, daß weiße Perlen beim Aufenthalt in der faulenden Muschel gelb werden; nach besonderen in dieser Richtung angestellten Versuchen ist dies jedoch nicht, oder jedenfalls nicht immer der Fall. Auch ein leichter blauer Schein kommit vielfach vor, der wie der gelbe mit der Gesamtfärbung der Perlmutterschale zusammenhängt.

Zuweilen kommen aus der Südsee und aus dem mexikanischen Meerbusen auch schöne schwarze Perlen, die wahrscheinlich in der Nähe des Mantelrandes entstanden sind. Sie sind die härtesten von allen und haben bei schüner und gleichmäßiger Farbe und guter Gestalt fast denselben Wert wie die rein weißen. In Europa sind sie zu Trauerschmuck nicht unbeliebt. Zwischen den weißen und den schwarzen Perlen stehen die nicht seltenen bleifarbigen, die sich bald mehr den ersteren, bald mehr den letzteren im Aussehen nähern. Rotbraune, etwas eisenhaltige Perlen stammen aus Vexiko, bronzeartig schimmernde liefert die IIammermuschel (Malleus) von den Gambia-Inseln. Graubraune Perlen enthält nicht selten unsere Flußperlmuschel (Marmaritana margaritifera); es fohlt ihnen die Perlmuttersehicht. In der Steckmuschel (Pinna nobilis) trifft man hell- und dunkelbraune Perlen, die, zum Teil ebenfalls ohme Perlmulterlage, von der Stäbchenschicht gegen außen begrenzt sind. Indessen enthält dieselbe Muschel auch perlmutterä̌inzende Perlen von granatroter Farbe, die bei den semitischen Völkern wie bei den Indiern als besonders kosthar galten. Ifellrosenrote Perlen mit zarten, weilien Wellenlinien, dem schönsten rosenroten Sammet gleichend, sollen von den Bahama-Inseln stammen. Hellblatue Perlen trifft man vielfach aus der eßbaren Miesmuschel (Mytilus edulis), weißswriine und schwach rosarote aus Spondylus gaederopus, violette aus der Arehenumschel (Area Noa(e), purpurfarbige aus Anomia cepa, bleifarbige aus Placuna placenta. Nattweife Perlen, also ohne den schönen Glanz der echten Perlnuscheln, können wahrscheinlich alle Mollusken liefern, die eine weibe Innenfläche haben, in einzelnen Fällen sogar, wenn ihnen eine Perlmutterschicht fehlt; bekannt sind solche unter anderem aus der Pilgermuschel (Pecten jacohaeus), der Riesemmuschel (Tridacna sigas), aus manchen Arten der gewöhnlichen Malermuschel (Unio), oder bei unserer gemeinen Teichmuschel (Anodonta), ferner aus der sogrenannten Messerscheide (Solen), und anderen. Auch die ebjare Auster (O)strea edulis) hat sehon, trotz des Fehlens der Perhutter, solehe mattweise Perlen geliefert; von einem Austernesser wird erzählt, daß er beim Verspeisen einer solehen Nuschel in dieser eine Perle fand, die er fuir 2-2 Taler verkaufte. Dali man auch in manehen sichnecken Perlen findet, ist schon erwähnt. Der grobe westindische Strombus gigas und 
die ostindische Turbinella scolymus liefern sehr schöne rosenrote Fxemplare, allerdings whe Perlmutterschicht und daher keine eigentlichen echten Perlen. Sie sind dadurch auserecichnet, dalf sie, wie die Schmeckenschalen, aus denen sie stammen, die Farbe mit der Zeit verlieren, was bei einer wahren Perle niemals vorkommt.

Ianche Perlen zeigen auch einen Anflug von P'ermutterfarben und schillern beim Drehen, wenn gleich nur sehr sehwach, blïulich, graulich und rö̈lich. Sie haben auf ihrer Oberfläche umregehmäljog hegrenzte Felder diinner Permuttrmasse, welche die unterliesende Schicht nicht gileichmäbigr bedecken. Man bemerkt auf ihrer Oberfläche aulier jenen kleinen Vertiefungen Erhabenheiten, zarte unregelmälig grekrümmte Furchen, die entweder mit anderen ziemlich parallel laufen oder kleine geschlossene fiurven won unregelmäBiger Gestalt bilden, genau wie wir es oben bei der P'erlmutter kennen gelernt baben. Die Farbenerscheinung hat auch die nämliche mit diesem Bau in Verbindung stehende Ursache wie bei der letzteren.

Auch die Form der Perlen ist für ihre Verwendung und für ihren Wert keine'swegs gleichgiiltig. Es zeigen sich hierin mannigfache Verschiedenheiten. Few ̈uhnlich ist sie ganz regetmäßig kugelig rund oder mehr oder weniger oval oder auch birnförmig, an einem Ende dick, am anderen dünn. Diese letzteren, die birnförmigen und die länglichovalen Perlen heißen l'e rlenbirn en, die birnförmigen speziell auch frlockenperlen. die kuggelförmig runden Tropfen oder Perlena ugen. Die oralen Perlen enthalten manchmal zwei Kerne, deren jeder von Perlmutterlagen umgreben ist und die dann weiter nach außen hin von Perluutterschichten bedeckt werden, die um beide Kerne herum gehen. Es sind hier offenbar zwei ursprïnglich getrennte kleinere Perlen zu einer srößeren miteinander verwachsen. Perlen, die auf einer Seite ron Natur flach sind, heiben Boutonperlen.

Nicht selten ist eine größere oder geringere Abweichung von den erwäilnten Gestalten; sehr unregelmäßig geformte Perlen werden Barockperlen genannt. Sie finden sich verhältnismäßig besonders häufig in der Perlmuschel des süben Wassers. Auch sie werden noch zum Schmuck und zu anderen Zwecken benutzt, doch sind sie weniger geschätzt als regelmäßiger rundliche ron den oben genannten Formen. Wie weit die Abweichung der Barockperlen in der Gestalt gehen kann, zeigen unter anderem zwei derselben, die der Pariser Juwelier Caire heschreibt. Dic eine ron ihnen ahmt täuschend den Kopf eines Hundes, die andere den Orden des heiligen Geistes nach.

Sehr wechselnd ist die Größe. Die größte Perle, die man erwähnt findet, ist eine im Besitz des Schah ron Persien. Sie bat eine birnförmige Gestalt und ist $35 \mathrm{~mm}$ lang und 25 mm dick. Ebenfalls für die größte bekannte Perle wird die in der Sammlung von Beresford II ope im South Kensington. Ituseum in London erklärt. Diese wiegt :) Unzen oder ungeführ 455 Karat; sie miljt zwei Zoll in der Länge und $4^{1} 2$ Zoll im Umfang, ist also nicht ganz $1^{1}:$ Zoll dick; demnach würde sie etwa die Gröfe eines Iniihmereies hahen. In der österreichisehen Kaiserkrone ist eine Perle von 3mu Karat, aber von mittelmäßiger Qualität. Eine Perle, die im 16. Jahrhundert von Panama an den spanischen Hof kam, soll die (xröhe eines Taubeneies gehabt haben. Für die schönste unter den großen Perlen gilt die in Museum von Zosima in Moskau befindliche indische die den Tamen La Pellegrina erhalten hat. Sie ist rollkommen kugetrund, sehr schön weiß und beinahe durchsichtig und wiegt 25 Karat. Solcher gröberer Exemplare gibt "s noch mehr, doch ist die ïberwiegende Ifehrzahl kleiner his sehr klein. Je nach der Größe baben die Perlen besondere Tamen erhalten. Die außergewöhnlich grroßen, die nur in einzelnen Exemplaren vorkommen, etwa die von den Dimensionen einer Walnuß und dariber, heißen Parangonperlen, solche von der Größe einer Kirsche 
Kirschperlen. Z ahlperlen oder Stüekperlen sind kleiner, aber immer noch so groß, daß sie einzeln dem Stïck nach bezahlt und gehandelt werden; es sind dies Perlen über ein Karat. Saat-, Lot-oder Unzenperlen kommen nicht mehr einzeln in den Handel, sondern nur noch in Partien. Die kleinsten und unscheinbarsten werden Sand., Stoß- oder Staubperlen genannt. Ihre Größe geht bis zu der eines Hirsekorns und noch weiter herunter. Die gewöhnlichste Größe schöner indischer Perlen ist das anderthalb- bis dreifache einer Erbse.

Im Handel werden die Perlen mittels Sieben nach der Größe sortiert. Regelmäßig runde Perlen von einem gewissen Durchmesser haben stets sehr nahe dasselhe Gewicht. Dieses läßt sich mit Hilfe der sog. Perlenleeren, bestimmen, Nickelplättchen mit runden Öffnungen von verschiedener Größe, deren Durchmesser steigenden Gewichten von 1/2 Grän an entsprechen Der Durchmesser jeder Perle läßt sich dadurch leicht ermitteln, und bei jedem Loch steht das entsprechende Gewicht angeschrieben.

Verwendung der Perlen. Die Verwendung der Perlen ist im wesentlichen dieselbe wie bei den Edelsteinen. Schon im frühesten Altertum sind Perlen zum Schmuck sehr beliebt gewesen. Welcher Luxus damit namentlich bei den Römern getrieben wurde, ist aus den Erzählungen der Schriftsteller jener Zeit zu ersehen und zum Teil allgemein bekannt.

Wenn aber auch die Verwendung bei Perlen und Edelsteinen im allgemeinen dieselbe ist, so ist doch ein großer Unterschied insofern vorhanden, als die Perlen keiner Pearbeitung, keinem Schleifprozeß unterzogen werden dürfen. Durch das Sichleifen erhält ein Edelstein erst seine Schönheit, erst dadurch wird er zum Schmuck geeignet. Eine Perle wïrde dadurch ihre Schönheit verlieren, die durchaus an ihre natürliche Oberfläche gebunden ist; sie muß so benutzt werden, wie sie aus der Hand der Natur hervorgegangen ist. Eine oberflächlich matte Perle kann nicht durch Polieren verbessert und eine solche von unregelmäßiger Form nicht durch Abschleifen günstiger gestaltet werden, weil dadurch der eigentümliche Glanz verloren gehen würde.

Das Fassen der Perlen geschieht auf verschiedene Weise, aber der geringen Durchsichtigkeit wegen nie à jour, wie bei den kostbarsten Edelsteinen. Schöne große Perlen sieht man häufig mit kleinen Diamanten oder farbigen Steinen karmoisiert; umgekehrt umgibt man Edelsteine der verschiedensten Art zur Hebung des Effektes mit kleinen Perlen. Am häufigsten werden aber die Perlen in der Mitte durchbohrt und auf Schnüre gezogen. Die Bohrung geht der geringen Härte wegen leicht von statten, wir haben aber schon oben gesehen, daß auf Schnüre aufgefaßte Perlen leicht der Zerstörung unterliegen, besonders durch Abbröckeln an den beiden Mündungen der Bohrung. Bei solchen Perlschnïren ist es sehr wichtig, nach Form, Größe und Beschaffenheit (Farbe usw.) gut zusammenpassende Exemplare aneinanderzureihen, da im anderen Falle leicht ein wenig angenehmer Anblick hervorgebracht wird. Dabei brauchen aber nicht alle Perlen einer Schnur einander ganz gleich zu sein. Wenn sie auch kleine Verschiedenheiten zeigen, kïnnen sie, dicht aneinander gereiht, gleich aussehen, indem sich die kleinen Unterschiede des Aussehens gegenseitig aufheben und einem gleichmäßigen Anblick aller Platz machen. Auch Perlen geringerer Qualität können so zuweilen noch eine gute Wirkung ausüben. Es ist daher bei der Untersuchung und Preisbestimmung einer wertvollen Perle, die mit anderen auf eine Schnur gezogen ist, Regel, die übrigen Perlen zu bedecken, damit keine gregenseitige Beeinflussung stattfinden und jede für sich allein wirken kann.

Kleine Perlen (bis 2 mm Durchmesser) werden nicht selten in der Mitte durchgeschnitten, und die so erhaltenen II albperlen in Schmuckstiicke eingesetzt. Die Herstellung von Italbperlen wird u. a. in Idar in großem Umfang betrieben, wo der Handel mit Perien neben dem mit Edelsteinen eine bedeutende Rolle spielt. 
In eigentimlicher Weise benutzt man zuweilen die Barockperlen mit ihren mannigfaltigen und oft wunderlichen, unreselmäbig rundlichen Formen. sie dienen zur Herstellung kleiner liunstegenenstände, namentlich von Karrikaturen, indem man sie durch Zufügung der fehlenden Teile zu fiestalten aller Art ergünt. Eine reiche Sammlung soleher Sachen, einige Perlen von ungrewöhnlicher Gröbe enthaltend, findet man im Grünen Gewïlbe in Dresten. Beispielsweise ist darunter die Figur eines Hofzwereses, dessen Leib) von einer passend gestalteten barockperle in der Gröbe eines Hïhnereies getbildet wird. Auch die fegenwart hat den Geschmack der Rokokozeit an derarticen Absonderlichleiten noch nicht ganz verloren; noch jetzt stellt man zuweilen ähnliche Dinge aus Barockperlen dar.

Auch die auf den Schalen festgewachsenen Perlenwarzen, die gleichfalls unrer. $]$ mälije gestalteten Phantasieperlen, sind zuweilen von soleher Schönheit, dalj sie zu Schmucksachen Verwendung finden können. Sie werden von der Lnterlage Insereschnitten und bilden dann im groljen und granzen halbkugelige Formen. Vielfach werden zwei von diesen mit ihrer Rüickseite aneinander gekittet und so zu Halsschmuck, Ohrgehängen usw. benutzt. An dem ganz abweichenden Glanze der Schnittfläche, mit der diese Perlen an der sichale saljen, lassen sich derartige einseitig flache Phantasieperlen leicht ron natürlichen in dieser Form unterscheiden.

Was den Preis der Perlen anbelangt, so steht er hinter dem der feinsten Edelsteine nicht zurïck und ist gegrenwärtig sehr boch. Man findet riesige summen angegeben, die für einzelne, besonders schöne grole Perlen bezahlt worden sind. Wie bei den Edelsteinen, so ist auch hier der Wert abhängig rou der Gröbe, der Form und dem rorzugsweise auf Glanz und Farbe beruhenden Aussehen. Schöne Formen heben den Preis, unregelmäßıge Gestalten vermindern ihn, und unter sonst gleichen Verhältnissen, also bei gleicher Beschaffenheit und Größe, ist eine unregrelmäBig gestaltete Perle erheblich weniger wert als eine solche von regelmäßjger Form. An meisten geschätzt ist die reine Kugelgrestalt, darnach eine ganz symmetrische, ringsum gleiche Birnform, auf welche die orale oder Eiform folgt. Besonders wichtig ist das Ausseben. Eine Perle ron der besten sorte (vom ersten Wasser) muf eine glatte Oberfläche und einen vollkommenen ..Orient" haben, was mit einer recht dünnblätterigen, feinen struktur zusammenhänıt; sie darf keine Flecken und keine Risse zeigen, und sie muß endlich einen hoben Grad von Durchscheinenheit und eine schöne weiße Farbe besitzen, verbunden nit einem möglichst vollkommenen Perlenglanz. Allerdings stehen anch schïne schwarze Perlen sehr hoch im Preise und nicht weniger solche mit einer schönen und kräftigen sonstigen Farbe. rot, gell) usw. aber immer nur, wenn der Glanz gut ist. Perlen ohne "Orient" haben auch bei der schönsten Farbe und der vollkommensten Form nur einen geringen Wert.

Die Preise der grolien und schönen Perlen sind Liebhaberpreise, für die es keine allgemeinen Regeln gibt; sie wechseln und werden von Fall zu Fall nach den speziell vorliegenden Verhältnissen festgesetzt. Für kleinere Perlen, die im gewïhnlichen Handel umlaufende $\mathrm{W}$ are, haben sich Marktpreise herausgebildet, die ebenfalls mit der Zeit veränderlich sind und die sich jeweilig wie sonst nach Angebot und Nachfrage regulieren. Es getten hierfür dieselben allgemeinen Grundsätze wie bei den Edelsteinen. Dabei entspricht der Prcis ziemlich genau der sogenannten Tavernierschen Regel, d. h. er steigrt im Quadrat des Gewichts, wobei man von den Grän (-Viertelkarat) auszugehen pflegt. Eine Perle von 1 Gräin der gewöhnlichen Handelsware (sclinurware) kostet gegenwärtig je nach der Qualität (Form und Schönheit, mindestens 2-10 Mark. Jehmen wir beispielsweise die Sorte, von der ein Grän 6 Mark wert ist, dann kostet eine Perle von: 


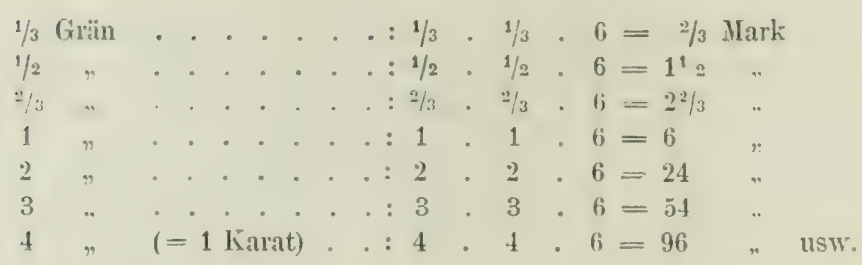

L'm eine ungefähre Anschauung von Perlen verschiedenen Gewichts zu geben. sei erwïhnt, daß eine solche von drei Karat ungefähr die Größe einer Erbse hat.

Im Preise der Perlen ist ein Unterschied, ob man eine solche einzeln kauft oder eine größere Anzahl, die nach Form und Beschaffenheit auf einer Schnur vollkommen zueinander passen. Solche werden höher berechnet als einzelne von derselben Qualität, da es meist schwierig ist, zusammenstimmende Exemplare in genügender Menge zu erhalten. Oft ist eine lange Sammelzeit erforderlich, während der die schon vorhandenen und bezahlten ungeniitzt daliegren. Möbius berichtet, daß seiner Zeit (Ende der fünfziger Jahre) eine Schnur von 70 bis $\delta 0$ dreikarätigen (also erbsengroßen) Perlen bis 6000 Taler gekostet habe, was für die einzelne Perle etwa io Taler ausmacht. Dies ist ungefähr das Doppelte des damaligen Preises einer einzelnen Perle von derselben Größe und Beschaffenheit.

Zum Schlusse sei der Wert einiger großer und schöner Perlen erwähnt. Die oben schon besprochene Perle aus der Hope-Kollektion im South-Kensington-Insem in London wird auf 250000 Mark geschätzt. Bei der Taxierung der dem französischen Kronschatz gehïrigen Perlen im Jahre 1793 wurde der Wert einer 275/16 Karat schweren runden Jungfernperle von prachtvollem Schmelz und Wasser auf 200000 Franken festgesetzt, der von zwei wohlgeformten birnenförmigen Perlen von sehr schönem Wasser, zusammen $5711 / 16$, Karat schwer, auf 300000 Franken, von vier verschieden gestalteten Perlen von $164^{6 / 16}$ Karat auf 60000 Franken usw. Jener zuerst genannten gegenüber betrug der Wert einer $36^{10 / 16}$ Karat wiegenden birnenförmigen, aber auf einer Seite flachen Perle nur 12000 Franken, woraus der große Einfluß von der Gestalt und der Beschaffenheit zu ersehen ist. Auf der internationalen Fischereiausstellung in Berlin im Jahre 1880 hatten Berliner Juweliere eine Schnur gelblicher indischer Perlen ausgestellt, die soo(00 Mark wert war, eine Schnur weißer Perlen von Panama, welche 1000000 Mark kostete, und eine Schnur schwärzlicher Perlen aus dem pazifischen Ozean, die auf 120) (11) Mark geschätzt wourde.

Porlenfischerei. Wenn auch, wie wir gesehen haben, zahlreiche Schaltiere Perlen erzeugen können, so sind es doch vorzugsweise nur zwei Arten von Muscheln, die so viel von diesen kostharen Körpern liefern, daß das systematische Einsammeln derselben einen lohnenden Industriezweig bildet. Es ist dies ror allem die echte Seeperlmuschel (Meleagrina oder Avicula marcaritifera), die in den warmen Meeren vieler tropischer Gegenden lebt; sodann in zweiter Iinie und unendlich weniger wichtig die Flußperlmuschel (Unio, Nargaritana oder Alasmodonta margaritifera) und einige nahe Verwandte, welehe zahlreiche Bäiche meist nordiseher, jedenfalls stets aufertropiseher Lïnder hewohnen. Die Seeperlmuschel liefert den. Juwelieren weitaus die meisten und auch die sehönsten Perlen und hat das auch schon im Altertum getan. Ebenso kommt von ihr die größte Menge der P'erlmutter, die in den Mandel gebracht und von der Industrie in der allgemein bekannten Weise verarbeitet wird. Die Zahl der Perlen, die das siiße Wasser liefert, ist klein und deren Qualität im allgemeinen gering.

Wenn wir uns zuerst zu der der Seeperlmuschel wenden, so ist es nach der Annahme der meisten ('onchyliologen fast ïherall eine und dieselbe spezies. welche die 


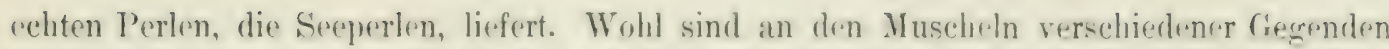
gewisse Abänderungen in der Gröbe und Dicke der Schalen, in der Tiauhighteit der Aulienfläche, der Färbung der Innenflaiche usw. vorhanden, abur diesce Merkmale sind doch zu wenig bestimmt, als dab sich darauf wohl abereorenzte Arten triinclen lieben. Manchmal werden die kleinen und dïnnsehaligen, daher nicht als l'erhmutter brauchbaren Muscheln unter dem Namen Avicula margaritifera von den erofen und dickschalieren unterschieden, die dann Meleagrina marearitifera genannt werden, aber es sind doch zahlreiche Übergänge vorhanden, die gegen eine scharfe Trennung sprechen.

Die Seeperlmuscheln leben stets in großer Zahl zusammen und bilden, wie die Austern, sogenannte 13 änke. Diese liegen meist nur $6-9 \mathrm{~m}$, manchmal auch $111-15 \mathrm{~m}$ unter dem Meeresspiegel, nur selten noch tiefer. Der Untergrund ist meist kalkig. und zwar am häufigsten Korallenboden. Die Muscheln sind nicht frei beweglich, sondern mittels eines Bündels zäher horniger Fäden, des sogenannten Bartes oder Brssus, der durch einen Ausschnitt am Schlobrande der einen Schale aus dem Innern derselhen heraus. tritt, an irgendeinem festen Körper des Meeresgrundes festgewachsen. Die Perlmuschelbänke sind noch von Korallen. Schneckin und vielen anderen Seetieren belebt Dis Temperatur des darüber stehenden Wassers beträgt kaum weniger als $25^{\circ} \mathrm{C}$.

Lm diese Muscheln rom Meeresgrunde Ioszureißen und aus dem Wasser herauszuholen, steigen Taucher in die Tiefe hinab, zum Teil fast ohne jede kïnstliche Lnterstïtzung ihres schweren und gefahrvollen Berufes, zum Teil aber auch mit den besten Apparaten ausgestattet, die das Betreten nicht zu grrofer Meerestiefen verbältnismäßig leicht und gefahrlos machen und ein längeres Verweilen unter dem Wasser ermüslichen. Es hat sich dahei herausgestellt, daß die Perlmuscheln nicht iiberall, wo sie rorkommen, so reich an Perlen sind, daß die Gewinnung lohnend ist und daß namentlich nicht immer dieselben Juscheln zahlreiche Perlen und gleichzeitig Perlmutter ron guter Beschaffenheit liefern. So kommt die beste Perlmutter, die man kennt, und von der eine Tonne $(=1000 \mathrm{~kg})$ 1600-3000 Mark wert ist, von den Perlmuscheln aus dem die Sulu-Inseln (zwischen den Philippinen und der Nordspitze ron Borneo umgebenden Meere, die aher verhältnismäßig wenig Perlen enthalten. Im Gegensatz dazu liefert die Insel Ceylon in dem Golf von Mannar die meisten und schönsten Perlen der Welt, die Schalen der dortigen Perlmuschel sind aber wegen zu geringer Dicke in der Permutterindustrie fast unbrauchbar.

Die weitaus bedeutendsten Perlfischereien von allen sind die in der Strafe von Mannar an der Nordwestspitze ron ('eylon (Fig.69, p.361), die nach einem alten Fort auch die Fischereien von Arippi genannt werden. Auch an der regrenüberliegenden Koromandelkiiste des indischen Festlandes werden Perlen, aber in geringer Menge, gewonnen. Das Neer in dieser Gegend ist durch die nördlich rorliegenden Inseln und sandbänke sehr geschützt, so daß sich die Perlnuscheln darin in voller Ruhe entwickeln kïnnen. Die

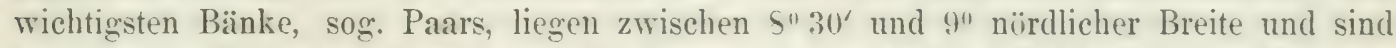
3 (englische) Meilen von der Küste entfernt gegrenüber von Maruchchukkaddi, dem Hauptort des Perlenhandels in Ceylon. Die gröften haben eine Länge von 2 (engrl.) Meilen und eine Breite von 2's Meilen. Im ganzen ziehen sich die Muschelbänke 90 Meilen weit an der Küste hin bis zu einer Entfernung von 12 Meilen rom Lfer. Die vorzüglichsten Iuscheln liegen 6-13 Meter tief unter dem Wasserspiegrel. Von diesen Bänken wurden schon im Altertum Perlen bezogen; seit unvordenklichen Zeiten wird hier nach Perlen getaucht, und zwar jetzt noch im wesentlichen auf dieselbe Weise, wie schon zur Zeit der alten Römer und noch frïher. Die Perlfischerei stand seit friihester Zeit stets unter der Kontrolle der jeweiligen Landesregierung, zuerst der einheimischen, dann der portugiesischen. der holländischen und jetzt der englischen. Die Hauptstation der Taucher in diesen 
Gegenden ist Kondachchy. Dieser Ort ist zur Zeit der Fischerei, während 6 Wochen der Monate März und April, in denen das Meer am ruhigsten ist, von Menschen aus allen Teilen Indiens belebt. 15000-20000 Taucher, Fischer, Haifischbeschwörer, Händler usw. bevölliern dann den sonst menschenleeren Strand. Eine große Zahl von Booten, bis 300, je mit 10 Tauchern, fahren auf die von der Aufsichtsbehörde genau abgegrenzten Fischgründe und suchen so viel Perlmuscheln als möglich zu erlangen. Jedes Boot kann an einem Tage im Durchschnitt 20000 Muscheln sammeln. Es kommt auf seine Kosten, wemn in 1000 Muscheln fïr 2-3 Mark Perlen sich finden, ein um die Hälfte größerer Ertrag gilt schon für einen guten Fang. Die Muscheln werden selten sofort am Lande geöffnet. Meist kommen sie in abgeschlossene Rüume, in denen sie absterben und unter Terbreitung eines entsetzlichen Geruches verwesen. Die faulenden Massen bringt man dann in hölzerne Gefäße, in denen sich die in den Muscheln vorhanden gewesenen Perlen sanmeln. Schon an Ort und Stelle werden diese mit Hilfe von verschieden weiten Sieben nach der Größe in Sorten geteilt, häufig auch gleich gebohrt und so verkauft. Doch ist die Zahl der zum Schmuck tauglichen unter der Gesamtzahl sehr beschränkt. Die allermeisten eignen sich hierzu nicht; sie werden in Indien, wie auch sonst im Orient, zu medizinischen Zwecken benutzt und dienen unter anderem z. B. auch als kostbarer Ersatz des gewöhnlichen Kalkes bei der Bereitung des Betels, ein Luxus, den sich natïlich nur die Reichsten erlauben können. Die Nuschel von Ceylon bleibt klein und erreicht etwa die Grölje der flachen IIand ohne die Finger. Ebenso ist auch die Dicke stets gering, so dal sie als Perlmutter keinen Wert hat, obwohl der Glanz und das Aussehen der Innenfäche sehr schön ist.

Neuerdings werden die gefischten Muscheln mittels Röntgenstrahlen auf Perlen untersucht, die dabei als schwarze Punkte deutlich hervortreten. Es ist dabei nicht nötig, Ifuscheln ohne Perlen unnützerweise zu töten, und von den sehr kleinen Perlen, die man bemerkt, kann man wohl annehmen, dals sie noch weiter wachsen, wenn man das Tier wieder in das Meer wirft.

Die Perlenfischerei ist in jenen Gegenden nicht auf den Golf von Mannar beschränkt, sie findet auch bei Trincomalee an der Ostküste von Ceylon statt und noch an anderen Orten, die aber wie der letztere wenig wichtig sind. Überall wird der Betrieb der Fischerei so grehandhabt, daß eine Stelle, die befischt worden ist, 6-7 Jahre lang in Ruhe bleibt, damit sie sich ungestört von neuem bevölkern kann. Dieser Zeitraum ist genügend, um die ganz jungen Perlmuscheln zu völlig entwickelten Tieren heranwachsen zu lassen. Viel älter als 7 Jahre scheinen sie nicht zu werden, denn wenn man eine Bank länger als 7 Jahre ruhen läßt, findet man viele tote Tiere in derselben.

Von groler Bedeutung und gleichfalls schon im Altertum bekannt und ausgebeutet, sind die Perlmuschelbänke im persischen M eerbusen, besonders auf der westlichen, arabischen Seite. Die Fischerei ist hier gänzlich in den IIänden der Araber, die jede Konkurrenz fernzuhalten wissen. Sie wird in ganz ähnlicher Weise betrieben wie in Ceylon.

Besonders wichtig ist die Umgebung der Bahrein-Inseln an der arabischen Kiuste (etwa unter 26" nördlicher Breite), indessen sind hier auch weiter südlich auf eine Erstreckung von io geographischen Meilen ertragreiche Muschelbänke bekannt, die hier wie bei Bahrein meist in etwa 12-13 Meter Tiefe liegen. An der gegenüberliegenden persischen Küste werden ggleichfalls schöne Perlen gewonnen, so unter anderem aus groler Tiefe zwischen den Inseln Kharak und Gorgo, nordwestlich von Abuschir (= Bender Buschir oder kurz Buschir). Die Perlmuscheln des persischen Meerbusens sind doppelt so groß wie die von Ceylon, und dicker, sowie außen grlatter. Die P'erlen von hier haben einen gelblichen Schein gegenüber den reinweißen indischen, sonst stehen sie aber in der Qualität hinter den letzteren nicht zurück. 
Im Roten Ifer seheint die I'erhuschel, aufer im südlıchsten Teil, überall verbreitet $z u$ sein. und an mehreren Stellen findet auch eine nicht unbedeutende Fischerei statt. Wiehtig ist diese namentlich bei der Insel Dahlak unweit Massaua, sowie bei den «erentiber an der arabiscleen Kü̈ste liegenden Farsan-Inseln. P'erlen von geringer Qualitït liefert auch das Meer bei Dschidda, westlich ron Mekka in Arabien. An der afrikanischen Küste weiter südlich werden sïdlich von soffalit bei den Bazaruta-Inseln (2131" siidl. Br.) ebenfalls Perlen gewonnen. I)ie Perlmuscheln des Roten Veeres liefern auch sehr viel gute Perlmutter.

Perlunschelbïnke sind über den ganzen Indischen Ozean zerstreut, doch hahen sie nicht die Bedeutung der schon grenamnten. Perlen von greringer Gröbe und Qualität liefert unter anderem der Meerbusen von Katsch (Cutch) an der Nordkiiste der IIall)insel Guzerate oder Kathiawar und das Meer bei Karratschi in Indusdelta. Etwas bessere kommen von den Kïsten des Mererui-Archipels westlich von Tenasserim auf der IIalbinsel ron Malakki. Schon genannt sind die Sulu-Inseln an der Nordostspitze von Borneo. Ton diesen und den benachbarten Taui-Taui-Inseln kommen Perlen, die an Giute den indischen gleichkommen. Hier und in den umliegenden Ileeresteilen ist aber besond.rs auch die Perlmutter wichtig. Die schalen sind hier sehr groli und wiegen im Durchschnitt 3,4 Pfund, gehen jedoch bis zu 2 Pfund. Außer durch die Größe sind sie aher auch durch die Reinheit und den Glanz der Perlmuttersehicht hervorragend. Man hezeichnet sie gewöhnlich als Makassarschalen, da sie vielfach über Makassar (südl. Celebes) in den Handel kommen. Perlen kommen auch ron den Küisten von Yeu-Guinea und einigen nahe gelegenen Inselgruppen, besonders von den Aru-Inseln.

Der ganze Stille Ozean scheint nach Möbius ein großes Perlenmeer zu sein, denn auf den meisten Inseln, süalich und nördlich der Linie, trafen die Seefahrer Eingreborene, die sich mit Perlmutter und Perlen schmückten und die mit aus Perlmutterschalen geschnittenen Angelhaken fischten. Seit einiger Zeit, wahrscheinlich seit 1527 Lat sich die Fischerei von Amerika aus entwickelt und liefert Perlen und Perlmutter. Siidlich rom Äquator kennt man die Perlnuschel bei den Salomons-, Gesellschafts- und Marquesas-Inseln, sowie bei den Tuamotu- oder Xiedrigen Inseln. Hier liegt die kleine Gambier-Insel, die als besonders wichtig bezeichnet wird. Nördlich rom Äquator kommen Perlmuscheln bei dem Marianen- und dem Marschall-Archipel ror. Die kleinen und schlechten Perlen, die die Sandwich-Inseln liefern. stammen nicht aus dem Meere, sondern aus den Wasserlïufen des festen Landes, z. B. aus dem Perlenfluf, dre deutsche Meilen von Honolulu auf der Insel Oahu.

Neuestens wird von reichen Perlenfunden bei Sachalin berichtet. In Laufe eines Ionats sollen Anfangs 1909 etwa fuir eine halbe Nillion Mark ron den Japanern gewonnen worden sein, fast durchweg rein in der Farbe, vom schönsten Glanz und von verhäiltnismäßig bedeutender Größe. Die meisten hatten einen grauschwarzen Schimmer, es fanden sich aber auch ganz schwarze und gelbe.

An der zentralamerikanischen und mexikanischen Westküste liegen weitausgredehnte Perlmuschelbänke, die schon vor der Entdeckung der Teuen Welt ron den Creinwohnern ausgebeutet wurden, so besonders bei Tototepec in der mexikanischen Provinz Oajaca. Auch aus dem kalifornischen IIeerbusen und aus den Golfe von Panama erhielten die Spanier riele Perlen, und jetzt noch gewinnt nan hier Perlen, sowie namentlich auch viel Perlmutter. Im Golfe ron Panama ist die Cmgebung des Archipels del Rey und von Taboga reich an Perlmuscheln; es sind die Perlinseln (Islas de las Perlas) der ersten Eroberer, deren Bänke aber jetzt der Erschöpfung nahe sind. An der Küste von Costarica wird die Bucht von Nicoya genannt. 
Sehr beribmt waren auf der Ostseite von Amerika früher die Perlenfischereien bei den Inseln ('ubagua und Margarita im Antillenmeer an der Nordküste von Venezuela, deren Perlen alle anderen amerikanischen an Größe und Schönheit übertrafen. Gleichwohl sind aber diese „occidentalischen“ Perlen alle niemals ganz so schön wie die „orientalischen" oder indischen. Sie sind zwar oft größser, aber meist weniger regrelmäßig rund und mehr bleifarbig. Jetzt findet um jene beiden Inseln keine Fischerei mehr statt, die Bänke sind erschöpft, und die von Diego Columbus, dem Sohne des Entdeckers, 15019 gegriindete, einst durch den Perlenhandel reiche Stadt Neu-Cadix auf Cubagua zwischen Margarita und dem Festlande ist vollständig verschwunden. Nur an der kolumbischen Küste zwischen Rio Hacha und Maracaibo werden jetzt noch schöne Perlen gewonnen, und zwar mehr als an der amerikanischen Westküste. Sie stammen aber von einer anderen IIuschel, der Avicula squamulosa, deren Schalen wegen ihrer geringen Dicke, trotz ihres schönen Glanzes nicht für die Perlmutterindustrie geeignet sind. In den westindischen Meeren wird die Insel St. Thomas genannt, sie hat aber geringe Bedeutung.

Möbius schätzt, daß im ganzen im Jahre ungefähr 20 Millionen Seeperlmuscheln «efischt werden, die Perlen und Perimutter liefern. Ungefähr 4 Millionen von diesen II uscheln enthalten Perlen. Kommt nur auf 1000 Muscheln eine mit einer schönen großen Perle, so liefert das Jahr deren etwa 20000 Stiick, die zu kostbaren Geschmeiden Verwendung finden können. Wenn sich diese Zahlen auch mit den Jahren ändern, so geben sie doch noch jetzt ein ungefähres Bild von der jährlichen Perlenproduktion. Aus den oben angegebenen Preisverhältnissen der Perlen erhellt, wie große Werte man dadurch jedes Jahr gewinnt. Aber mindestens ebensogroß wie der gesamte Wert der Perlen ist derjenige der Perhmutter wegen der ungeheuren Menge von Schalen, die jührlich die Industrie verbraucht. Trotz der Millionen von Muscheln, die ohne Unterlaß dem Meere entnommen werden, scheint eine Erschöpfung der Bänke nicht einzutreten. Wenn auch an einigen Orten die Fischerei infolge zu starken Betriebes aufgehört hat, so ist doch im groljen und ganzen ein Nachlassen der Produktion nicht zu bemerken und, wie es scheint. auch nicht zu befürchten.

Mehrfach, namentlich in den holländisch-ostindischen Neeren, sind schon Versuche gremacht worden, künstlich e Perlmuschelbänke anzulegen, indem man, ähnlich wie es mit der eßbaren Auster zuweilen geschieht, Muscheln an geeigneten Stellen aussetzte und sie der natürlichen Entwicklung überlief3. Es seheint aber, als ob noch keine erheblichen Resultate erzielt worden wären. Eine Schwierigkeit liegt jedenfalls darin, daß, wenn auch die Tiere gedeihen, sie darum doch noch nicht notwendig Perlen liefern, denn dazu bedarf «, wie wir gresehen haben, gewisser Störungen in der Entwicklungr, welche die Ausscheidung der Perlen bewirken, und diese sind nicht iiberall vorhanden. Es wäre also notwendig, auch die Schmarotzertierchen mit zu verpflanzen, die dies in den meisten Fällen veranlassen.

Süsswasserperlon. Neben den Meeresperlen spielen die Siißwasserperlen, wie wir schon gesehen haben, eine ganz untergeordnete Rolle. Die Flubperlmuschel, die hier zuerst zu nennen ist. gleicht der enewöhnlichen Malermusehel sehr und zeigt namentlich dieselle Zerfressenheit der Außenfläche der Schale um den Wirbel herum, sie wird aber etwas größer. Man nimmt an, daß etwa 100 MLuscheln eine Perle liefern und daß unter 100) Perlen einc gute ist. Aber die Reschaffenheit auch der besten Flußperlen steht hinter der der Meeresperlen im allgemeinen zurïck, da sie einen bleifarbigen Schimmer haben, da sie oft der Perlmutterschicht entbehren und dann glanzlos und graubraun sind. Auch hier werden wie bei der Seeperlmuschel in vollkommen regelmäßig grebildeten Schalen keine Perlen gefunden; nur in solchen, die in ihrer Entwicklung gestört worden sind, was sich durch eine runzliche, höckerige, gefaltete oder sonst unregelmälbige Gestalt zu erkennen silst, kann man Perlen erwarten, oft aber auch in diesem Falle vergeblich. 
Flubperhuscheln finden sich in allen Weltteilen, aber der Seeperhuschel entgerengetesetzt melır in kalten als in warmen Gegrenden, und zwar in Bächen und kleinen Flüssen mit klarem und frischem Wasser.

In Europa fehlt sie in den südlichen Ländern und in Alpengebiet. Innerhall, Deutschlands bewohnt sie hauptsächlich manche Wasserläufe, die vom böhmischen und bayerisehen Wald, sowie vom Fichtel, Erz- und Riesentelirge kommen. Bekannt als perlenführend sind vor allem die $\mathrm{Hz}$ und der leegen in Neederbayern; die C̈lsnitz oberhalb Berneck und der Perlenhach im oberen Maingebiet; die Elster 1 m sächsischen Vogtlande mit ihren Zuflüssen, namentlich in der Nähe der Stadt C̈̈snitz; der Oueili und die Juppel in Schlesien; die Ioldau oberhalb Frauenbere und deren Zuflul' Wattawa in B̈̈hmen. Seit Jahrhunderten wird der Perlmuschel in diesen Gergenden von Seiten der Regrierungen die bestmöglichste Pflege zugewendet, namenlich in Sachsen, der Ertrag ist aber trotz alledem minimal, und wird durch Überschwemmungen vielfach sehr beeintrïichtight. Er hat, wie es scheint, nach Zahl und Güte mit der Zeit immer mehr und mehr abgenommen. Wie gering der Ertrag der vogtländischen Perlfischerei gregrenwärtig ist, ersieht man aus den folgenden Angaben: Im Jahre 1 \$.3 wurden 55 Perlen abgreliefert, 1814 sogar nur 13, während das Jahr 1895 deren 65 ergab. nämlich 21 helle, 22 halbhelle und 25 ganz trübe oder verdorbene. Neuerdings hat man die Flubperlnuschel auch in der Ruwer und in anderen Bächen des Ilochwalds bei Trier sowie im suressart entdeckt. In der Elster ist die Perlfischerei ein Regal.

Die berïhmten Sammlungen des griinen Gewölhes in Dresden zeigen, daf früher sehr schöne Perlen in den vogtländischen Gewissern vorgekommen sind. Ein Halshand von 177 Elsterperlen, das hicr aufbewahrt wird, ist anf 30on Taler geschätzt worden, und eine Herzogin von Sachsen-Zeitz soll ein Halsband aus vogtländischen Perlen be. sessen haben, für das ein Juwelier 40000 Taler bot.

Auch im nördlichen Deutschland haben sich einige Perlen gefunden, so in der echten Flußperlnusehel in der Lüneburger Haide zwischen Celle und Ïlzen, in der Wipperau, Gerdau und Barubeck. Aus einer anderen Nuschel, und zwar aus I'nio crassus, stammen die wenigen Perlen, die in der Tapps-Aa bei ('hristiansfeld an der schleswigschen Vordgrenze. und auch z. B. in der Gegend von Rheinsberg, sowie in dem see bei Lindow in der Provinz Brandenburg gelegentlich gefunden worden sind.

Seit den Zeiten des Altertums bekannt sind die Flußperlen von England, Sch ottland und Irland. Es wird behauptet, Juli us ('äsar habe seine Expedition nach Britannien wesentlich dieser Perlen wegen unternommen Die echte Flufperlnuschel findet sich in Wales, Cumberland, Schottland und dem nördlichen Irland. Besonders wird der Flub ('onway im nördlichen Trales als eine Hauptquelle der britischen Perlen genannt, die, besonders die schottischen, schon im 12. Jahrhundert in Paris und Antwerpen Handelsartikel waren. Ehenso wie in England usw. ist aber die Perlmuschel auch in Schweden und Norweren von Schonen und Christiansand bis Lappland, und im nördlichen Rußland vom Quellgebiet des Don und der Wolga bis zum Weißen Meer vorhanden und liefert eine gewisse Zahl ron Perlen, worunter manche gute Exemplare.

Eine Perlmuschel, die sich von der europäischen Margaritana margaritifera in keinem P'unkt wesentlich unterscheidet, findet sich auch in Nordamerika, besonders in den Neu-Englandstaaten. Sie fülirt allerdungs sehr wenig Perlen. Dagegen triff man im Flußgebiete des Wississippi und in den atlantischen Staaten eine Anzahl Arten der nahe verwandten Gattung Unio, die viele Perlen enthalten. Schon die ersten europäischen Entdecker dieser Länder fanden dort im 16. Jahrhundert eine ungeheure Menge von Perlen bis zur Größe einer Nub. Heutzutage ist dem gegenüber der Ertrag gering. Schon erwähnt sind die Flußperlen der Sandwich-Inseln. 
Von besonderem Interesse ist die Perlenindustrie in Ostasien, besonders in China. Im Schmucke der Chinesen spielen Perlen eine große Rolle, daher werden sie in jenem Lande seit Jahrhunderten eifrig aufgesucht. Namentlich in einigen Flüssen der Mandschurei, wie übrigens auch in Ostsibirien, sollen perlenführende Muscheln leben, doch ist es noch nicht genauer bekannt, welchen Gattungen und Arten sie angehören. Weiter im Süiden, in den Wasserläufen bei Kanton und Hutschefu, ist es die Cristaria plicata, die Perlen liefert. Sie ist von besonderem Interesse, weil sie seit Jahrhunderten zu Versuchen benutzt wird, Perlen künstlich zu erzeugen, d. h. die Muscheln durch gewisse Mittel zur Produktion zu zwingen. Tausende von Chinesen treiben dieses Geschäft, ohne es aber bis zur Entstehung wirklicher runder Perlen bringen zu können. Sie gehen in der Weise vor, dal sie in die vorsichtig geöffnete Muschel ohne Verletzung des Tieres zwischen Mantel und Schale kleine Halbkügelchen oder dünne Buddhabildchen aus Zinn schieben. Diese werden dann durch die Ausscheidung des Nantels mit Perlstoff iberzogen und nehmen so ein perlenartiges Aussehen an. Nach zehn Monaten bis drei Jahren ist der Überzug $1 / 10$ bis $1 / 5 \mathrm{~mm}$ dick, dann können diese Gebilde zum Schmuck benutzt werden. Man schneidet sie von der Schale, mit der sie stets verwachsen sind, ab und faßt sie in geeigneter Weise.

In ähnlicher Weise hat man auch sonst schon versucht, künstliche Perlenbildung hervorzurufen. Man hat Sandkörner oder abgedrehte Perlmutterkügelchen in die Schale eingeführt und gehofft, daß sie sich mit Perlsubstanz überziehen wïrden, die erlangten Resultate sind aber bisher sehr gering. Es wird erzählt, der große Linné habe eine Methode der kïnstlichen Perlbildung gekannt und die Beschreibung derselben schriftlich niedergelegt; es ist jedoch nichts Näheres darüber bekannt geworden.

Neben den genannten Versuchen gingen aber vielfach solche her, Perlen aus anderem Naterial nachzubilden, d. h. Körper herzustellen, die den echten Perlen so ähnlich wie möglich sehen, ohne aber den hohen Preis zu haben. Mit diesen Versuchen haben wir uns nun zum Schluß noch in Kürze zu beschäftigen.

Falsche Perlen. Imitationen. Versuche zur Nachahmung von Perlen sind schon vielfach angestellt worden. Sehr nahe läge es, Perlnutter rund abzudrehen und zu polieren, Dies gibt aber keine den Perlen ähnliche Körper, da hier nicht, wie bei der echten Perle, die feinen Perlmutterlagen ringsum der Oberfläche folgen, so daß das Aussehen solcher Perlmutterkugreln ein ganz anderes ist. Ein geeigneteres Mittel hat im Jahre 1680 (vielleicht schon früher, urn 1656) der Pariser Rosenkranzmacher Jacquin entdeckt, um Perlen herzustellen, die den natïrlichen sehr ähnlich sind und die namentlich auch den schönen Perlenglanz der letzteren zeigen. Sein Verfahren wird auch heutzutage noch sehr vielfach angewendet und bildet die Grundlage einer blübenden Industrie. Man verfertigt aus einem besonders zu diesem Zwecke hergesteliten farblosen und leicht schmelzbaren Glase, das im IIandel Gir a sol grenannt wird, hohle dünnwandige Kügelchen. Je nach der Form, die man diesen ganz beliebig geben kann, lassen sich runde, ovale, birnförnige oder Barockperlen nachahmen. Ihr perlenähnliches Aussehen erhalten diese Glaskugeln, indem man ihre Innenfläche mit einem weißen, silberig glänzenden Farbstoff überzieht, den man aus den Schuppen des Weiffisches oder Uklei (Cyprinus alburnus - Alburnus lucidus) gewinnt. Er liegt unter den Schuppen und wird durch Schïtteln derselben mit Wasser von ilinen getrennt. Unter dem Mikroskop sieht man, daß dieser Silberglanzstoff aus zahllosen, äußerst dünnen und schmalen, unregrelmäßig rhombischen Plättehen besteht. Durch Anrüluren mit aufgelöster Hausenblase kann man einen dünnen, klebrigen Brei erhalten, der als Perlenessenz oder Essence d'Orient bezeichnet worden ist. 7 Pfund Fischschuppen geben davon ein Pfund, wozu 18 bis 20000 Fische nötig sind. Dieser Brei wird in die hohlen Glaskugeln hineingebracht und srleichmäßig anf deren Innenseite 
auserebreitet. Wenn er dann eintrocknet, so ist die ganze Kugel innen mit einer dünnen, silberigr slänzenden Schicht ïherzogen, die ein dem der echten Perlen sehr ähnliches Aussehen hervorbringt, so dal) auch ein Kenner den Unterschied erst nach genauerer Untersuchung bemerkt. Künstlich ist hier also nicht der Perlenglanz, sondern nur die Form der perlenartig glïnzenden Fläche. Zur Erhöhung der Festigkeit wird schlieflich noch der ganze IIohlraum mit Wachs ausgegossen. Sorcfältig hergestellte Perlen dieser Art, sog. Bourguignonperlen, sind den truten indischen usw. überaus ähnlich; sie werden auch statt dieser häufig retragen. Sie stehen ziemlich hoch im Preise, da die Ilerstellungskosten nicht gering sind. Ist die Ausführung weniger sorgfältign, so ist der Preis allerdings niedriger. Man kann derartige Kunstprodukte dann schon zu billigeren Schmucksachen rerwenden. Wenn sie die echten Perlen auch nicht mehr so vollständier nachahmen wie die besseren, so geben sie deren sehönes Aussehen doch immer noch im großen und ganzen wieder und verschaffen so auch dem Unbemittelten die Möglichkeit, sich am Glanze der Perlen zu erfreuen. Von den echten Perlen unterscheiden sie sich dadurch, daf sie, mit einem Tröpfchen Salzsäure betupft, nicht aufbrausen.

Eine andere Art von imitierten Perlen besteht aus gepulverter Perlmutter. Diese sog. perles a nacre oder des Indes sind nicht wie die oben beschriebenen hohl und verhalten sich gegen Salzsäure wie die echten.

Recht schöne atlasglänzende künstliche Perlen werden zuweilen aus den Schneidezähnen des zur Gruppe der Seekühe gehörigen Dugong, eines wie die Wale im Wasser wohnenden Sïugetieres, hergestellt. Es lebt in der Nähe der bei Massaua im Roten Meer liegenden Insel Dahlak, die wir schon als Perlfischerstation kennen gelernt haben. Viel verbreitet sind aber wohl derartige Perlen nicht.

In neuerer Zeit werden künstliche Perlen auch aus dem sogenannten Opalinglase hergestellt, dem man durch vorsichtige Behandlung mit Flußsäure das ungefähre Aussehen der echten gibt.

Sehr täuschend können die schwarzen Perlen mittels des Hämatits oder Blutsteins nachgeahmt werden, wie wir schon bei der Betrachtung dieses IInerales gesehen haben. Eine polierte Kugel oder Birne aus diesem Material nähert sich oft im Aussehen einer schwarzen Perle sehr, namentlich wenn die Politur nicht bis zum höchsten möglichen Grade getrieben wird. Zu unterscheiden ist sie aber leicht an dem viel höheren spezifischen Gewicht und an dem Kältegefühl beim Berïhren mit der Hand. Rote Kugeln mit etwas perlarticrem Glanz künnen auch aus den dicken Schalen der großen westindischen Meeresschnecke Strombus gigas gedreht werden; sie werden aber wohl eher den Korallen als den Perlen untergeschoben.

Alles was uns über Perlen und ihre Verwendung zum sichmuck bekannt ist, ist zusammengestellt in dem 191$) 8$ in New-York erschienenen prächtigen und reich illustrierten Werke von George F. Kunz und Charles H. Stevenson: The book of the pearl. Leider ist es zu spät in meine Hände gekommen, daß es bei der Revision des vorstehenden Abschnittes nicht mehr benuzt werden konnte.

\section{Korallen.}

Die rote oder edle Koralle oder kurz die Edelkoralle, die in den Läden der Juweliere nehen den eigentlichen Edelsteinen und den Perlen eine gar nicht unwichtige Rolle spieit. bildet die inneren Martteile eines niedrig organisierten Tieres aus der großen Klasse der Anthozoen oder Korallenpolypen, das ganz oder doch beinahe ausschlieflich das Mittelmeer bewohnt. Hier wird es in weitaus üherwiegendem Maße ron Italienern aus der 
Tiefe herausereholt, und ebenso wird das Produkt dieser Fischerei zum allergrößten Teil in Italien verarbeitet, so daß wir es hier in diesem Sinne mit einem Erzeugnis jenes Landes, mit einer beinahe ganz italienischen Industrie zu tun haben, neben der die Leistungen der anderen Länder eine untergeordnete Rolle spielen.

Die Edelkoralle wird von den Zoologen nach dem Vorgange des französischen Naturforschers Lamarck Corallium rubrum genannt; Bezeichnungen, wie Corallium nobile, Isis nobilis und andere, die gelegentlich angewendet wurden, sind jetzt nicht mehr gebrïuchlich.

In einer vollständigen Koralle sind zahlreiche Einzeltierchen, die sogenannten Polypen, vereinigt, die miteinander einen gemeinsamen Organismus, eine Kolonie, bilden. Dieser dient der feste, rote, kalkige Korallenstock zur Stütze oder, wie die Zoologen zu sagen pflegen, zur Achse. Er ist beim lebenden Tier von einer dïnnen, fleischigen, ebenfalls roten Rinde oder Haut, dem von den Zoologen sogenannten Sarkosom oder Coenenchym, iiberzogen. In diesem sind da und dort, mehr oder weniger gedrängt, die einzelnen Polypen eingesenkt, die sich durch ibre weiße Farbe dentlich von dem roten IIintergrund abheben. Das Sarkoson mit den darin sitzenden Polypen ist der eigentlich lebende Teil der ganzen Kolonie; hier spielen sich die sämtlichen Lebensprozesse ab, auf denen die Ernährung und Fortpflanzung der Koralle beruht, und von ihm wird auch der Kalk ausgreschieden, der zum Aufbau des Stockes dient. Von diesem lält sich das Sarkosom wie eine Haut abziehen, „wie die Rinde von einem Weidenzweige im Frübjahr"; man hat dann den reinen Korallenstock, also das, was man gewöhnlich als Koralle bezeichnet und was zu Schmucksachen und zu allen möglichen anderen Gegenständen verarbeitet wird. Wir werden den Korallenstock zunächst genauer kennen lernen, da er für uns hier allein ron wesentlichem Interesse ist, und daran eine kurze Schilderung des Lebens und der Fintwicklung der Korallen anschließen. Endlich soll die Art und Weise ihrer Gewinnung und ihrer Verarbeitnng, die Korallenindustrie, etwas eingehender betrachtet werden.

Der Korallenstock. Der kalkige oder knochige Stock der Edelkoralle ist nach seiner Form mit einem kleinen roten, selten weißen oder schwarzen Bäumchen oder einem Strauch zu vergleichen, der zwar Äste und Zweige hat, aber keine Blätter. Dieser Baum oder Strauch ist mit einem breiten scheibenartigen Fuß auf irgendeinem festen und harten Gegenstand im Meere wie mit einer Wurzel festgewachsen. Man findet so die liorallen auf dem den Meeresgrund bildenden Felsen, auf einzelnen Steinen, aber auch auf allen möghlichen anderen Dingen, auf Kanonenkugeln, Flaschen, Museheln usw., ja sogar auf einem Stiick eines menschlichen Schädels hat man eine Koralle aufgewachsen wesehen. Zuweilen sitzt eine Koralle auf einer anderen, was man dann besonders deutlich erkennt, wenn beide in der Farbe nicht miteinander übereinstimmen.

Durch den Ful ist der Korallenstock sehr fest mit der Unterlage verbunden. Er breitet sich ïber der Oberfläche der letzteren aus und erfüllt wohl auch in ihr vorhandene Vertiefungen, aher er ist nicht im stande, wie eine Pflanzenwurzel in das Innere einzudringen. Auf dem Fufe erlebt sich der verästelte und verzweigte, selten gerade, sondern meist zierlich hinundher rrebogene Stamm. Dieser erreicht selten eine Läng̨e, die über einen Fuß hinausgeht. Die Dicke bleibt hinter einem Zoll meistens mehr oder weniger weit zurück und übertrifft dieses Mals nur in seltenen Ausnahmefällen und auch dann nur um einen germengen Betrag. Nicht immer trägt eine Fußplatte nur einen einzigen Stamm; vielfach, an manchem Fundorte, z. B. in der Provence sehr hä̈ufig, erhehen sich ïber demselben Fuf mehrere und sogar viele Korallenstöcke, die damn allerdings nur geringe Dimensionen anzunehmen pflegen.

Die Korallen streben bei ihrem Wachstum nicht, wie die Pflanzen, nach oben, dem Lichte, 7u. Der Stamm ist stets senkrecht zu der Unterlage, auf der er festerewachsen ist. 
Sitzt er auf dem flachen Neereshoden, so ragt (2x in dic II ïhe; ist er an einer senkrechten Felswand befestigt, dann kehrt er seine Spitze in warrechter Richtung nach der Seete; von der Unterseite ïherhängender Felsen und von der Deckt unterseeischer Hählen im LferEestein hängt er lotrecht herab, und gerade diese letatere Stellung ist eine besonders häufige.

Der Stamm, der aus dem Fub herauswächst, wird nach dem entgegengesetzten Ende hin allmählich dïnner und sehlielit mit einer stumpfen, unregerelmäliow gestalteten Spitze. Das Dünnerwerden greht aber sehr langsam vor sich, so dafj rin kürzreres Stammstück eine zylindrische Gestalt zu laben scheint.

Manchual in ganz geringer Entfernung über dem Fuf, zuweilen auch arst 1 m Abstand von einigen Zentimetern, beginnt die Verzweigung. Ton dem stamme grelen die Äste aus, diese tragen die Zweige und von den letzteren kïnnen wieder kleinere Ab. zweigungen ausgehen und so fort. Alle diese Seitenteile verlaufen, wie der Stamm. meist nicht gerade, sondern gleichfalls mehr oder weniger stark hinundher gebogen, und endigen, wie jener, stumpf und unregelmäßig, selten in einer scharfen Splitze. Die Verästelung und Terzweigung richtet sich nicht nach einem ganz bestmumten fiesetz. sie scheint aher im allgemeinen so vor sich zu grehen, daß die Äste und Zweige sich müglichst weit ausweichen. Die İste gehen rom Stanme nach allen Seiten ab, aber fast niemals zwei oder mehr Äste auf gleicher Höhe, d. L. in der nämlichen Entfernung vom Fuls. Ebenso verhalten sich die Zweige zu den Ästen, indem auch sie, fast stets in derselhen Höhe nur ein einziger Zweig, sich nach allen möglichen Richtungen hin erstrecken, so daß also nicht eine oder einige bestimmte Richtungen in dieser Hinsicht besonders aus. gezeichnet sind.

Die Veigung der Äste gegen den Stamm und der Zweige gegen den Ast. auf dem sie sitzen, ist sehr verschieden. Sie beträgt häufig to bis jo Grad, loch kann der Winkel auch größer und sogar stumpf werden, so daß der betreffende Seitenteil gewissermafen nach rïckwärts gerichtet ist. Im Gegensatz dazu kann der Abstand aber auch selır klein werden, und der Ast dieht neben dem Stanm, der Zweig dicht nehen dem Ast hinlaufen. In diesem Fall kommt es sogar nicht selten vor, dab zwei solche Teile sich beriuhren und wenigstens für eine gewisse Strecke ganz miteinander verwachsen, um sich oft nachleer wieder zu trennen. Eine solche Verwachsung kann, wie zwischen zwei an verschiedenen Stellen abgehenden $\ddot{A}$ sten oder Zweigen eines und desselben Stockt's, auch zwischen Teilen zweier nebeneinander wachsender getrennter Stöcke vor sich gehen.

Wir haben gesehen, daß genau in derselben Höhe sehr selten zwei verschiedene. Seitenteile alzweigen, aber allerdings kann der Zwischenraum zwischen zwei nächstbenachbarten Ästen eines Stammes oder Zweigen eines Astes sehr crering sein. so dalj er oft nur wenige Millimeter beträgt. Dagegen ist es aber auch nicht selten, daf die Entfernungr zweier Äste oder Zweige verhältnismäßig crrob ist und einige Zentimeter ausmacht. Im allgemeinen ist das Verhalten so, daß am dicken Ende der Stämme mehr Aste auswehen als gegen das diinnere freie Ende hin und entsprechend bei den Zweigen. aber eine durchgehende Regel ist dies nicht.

Überall, wo ein Ast oder ein Zweig abgeht, ist der Stock etwas, wenn auch oft nur sehr wenig, abgeplattet. Während er sonst im grofen und ganzen einen lireisförmiw runden Querschnitt hat, ist dieser an jenen Stellen mehr oder weniger ausgejurägt elluptisch. Dieselhe Erschemung der Ahplattung ist ïhrigens auch an mancher Stelle zu bemerken. wo keine Verzweigung stattfindet und wo auch sonst keine Crsache dafül zu erkennen ist. Jan hält dies vielfach für die Folge einer zeitweiligen lirankhaften Entwicklung des ganzen Tieres.

Die Häufigrkeit der Terzweigungen und ebenso auch ibr mehr oder weniger krummer oder geradliniger Verlauf, ïberhaupt die ganze Gestalt der Korallenstïcke, indert sich 
nach dem Ort, an dem die Koralle wächst, nach der Tiefe unter dem Meeresspiegel usw. Es ist so, daß Stricke, die unter denselben Lebensbedingungen der Polypen entstanden sind, im allgemeinen auch gleiche oder doch ähnliche Formenentwicklung zeigen. Man muß daraus schließen, daß es höchstwahrscheinlich gerade diese Lebensbedingungen sind, auf denen die Form der Stöcke beruht. Diese ist für die verschiedenen Gegenden des Mittelmeeres so charakteristisch, daß es einem Kenner, wenigstens wenn er einen grïljeren Torrat von demselben Fundort vor sich hat, mörlich ist, nach dessen Gesamtcharakter seine Heimat zu bestimmen. Die Korallen von der algerischen und tunesischen Kïste. von Sizilien und besonders von Sciacca, von Spanien und von der Provence, zeigen in dieser Hinsicht bemerkenswerte Versebiedenheiten, die deswegen wichtig sind, weil die Form einer Koralle auf ihre Verwendung und damit auch auf ihren Wert nicht ohne Einfluß ist. Wir werden unten bei der Betrachtung der einzelnen Fundorte derartige Unterschiede noch kennen zu lernen haben.

Eine charakteristische Erscheinung bei den Edelkorallen sind die feinen Furchen, die dicht gedrängt die Oberfläche der Stöcke bedecken. Sie verlaufen im allgemeinen ziemlich gradlinig in der Längsrichtung der Stämme und ihrer Verzweigungen, doch gehen sie auch vielfach mehr in der Richtung von Schraubenlinien. Da, wo Äste und Zweige abgrehen, ziehen sie sich um die Ansatzstelle herum, um hinter derselben wieder in der ursprünglichen Richtung weiterzugehen. Manchmal gabeln sie sich und bilden zwei gretrennte Furchen, die sich vielfach nach kurzem Verlauf wieder vereinigen. Ihre Zahl ist gewöbnlich gegen die Basis hin am größten und nimmt allmählich nach den dünnen Enden der Stöcke zu ab, indem einzelne Furchen aufhören. Die Entfernung benachbarter Furchen ist immer gering; sie beträgt nie weniger als $1 / 4 \mathrm{~mm}$ und kaum mehr als $1 / 2 \mathrm{~mm}$.

Ebenso bezeichnend wie diese Furchen sind für die Beschaffenheit der natürlichen Oherfläche eines Korallenstockes kleine, rundliche, flache Vertief ungen von höchstens $2 \mathrm{~mm}$ Durchmesser, die bald dicht nebeneinander liegen, so dal, sich die Ränder berühren, bald etwas weiter voneinander entfernt sind, so daß sie bis zentimeterweit voneinander abstehen. Sie zeigen die Stellen an, über denen in der Rinde der lebenden Koralle die verschiedenen Polypen gesessen haben, welche die Kolonie zusammensetzen.

Jene Furchen und die oben betrachteten Vertiefungen gehören zu den stets vorhandenen, niemals fehlenden Eigenschaften eines Stockes der edlen Koralle. Wo sie nicht sind, hat dieser nicht mehr seine natürliche Oberfläche, sondern ist, etwa durch künstliche (slättung bei der Verarbeitung zu Schmuckgegenständen oder auf irgendeinem anderen Wege verändert worden. IIäufig sieht man aber neben den erwähnten Vertiefungen noch kleine, meist nur nadelstichgroße Löcherchen in das Innere der Stïcke hineingrehen, die indessen vielfach, und zwar namentlich bei ganz frischen Exemplaren, auch fehlen. Hier hat man es nicht mit einer zu der natürlichen Beschaffenheit der Korallen gehörigen Erscheinung zu tun, sondern mit Bohrlöchern, die von irgendwelehen bohrenden Meeresbewohnern, Bohrwïrmern, Bohrschwämmen usw., in den Korallenstöcken angebracht worden sind. Namentlich abgestorbene Stöcke sind oft dermaken zerbohrt und zerfressen, dals sie nicht mehr in der Industrie verwendet werden können.

Die Korallenstöcke erscheinen, wenn sie nicht angebohrt sind, in einiger Entfernung von ihrer Ansatzstelle, von dem Fuße, vollkommen homogen, kompakt und ohne Hohlräume im Innern. Allerdings kommt es auch zuweilen vor, daß sie fremcie Körper verschiedner $\Lambda$ rt eingeschlossen enthalten, die beim Wachstum der Koralle ron der Kalksubstanz eingrehüllt wurden, wenn sie sich zufällig in der Nähe befanden. Die Bruchflächen frischer Korallen sind uneben und splitterig. Schon mit bloßem Auge und noch mehr mit der Lupe tritt auf manchen Querbriichen, nicht auf allen, sowohl in den 
St:immen, als auch in den Verzweigungen die Erscheinung hervor, daf die Stijcke aus einer Anzahl dïnner Schichten bestehen, die sich konzentrisch umeinander herumlecren. Die sanze Masse besteht aus einer Anzahıl incinander steckender hohler lïihren, die, nach aulien hin immer waiter werdend, sich gerenseitig dicht berïhren. liesonders deutlich sieht man diesen Aufhau aus einzelnen Schichten und die daher rührende schalige Struktur, und zwar auch dann, wenn mit dem bloben Auge orler mit der Lupe gar nichts zu benerken ist, wenn man einen sehr dünnen Querschnitt bej senü griißerumg unter dem Mikroskop betrachted. Man erkennt gleichzeitier, dab jede einzr. Ine der sich konzentrisch umgebenden Schichten aus, zahllosen feinen Fäserchen besteht, die, allerdings nicht immer sehr regrelmäbig und grerarlinig, in radialer Richtung, also vom gemeinsamen Mittelpunkt aller Schichten aus nach der Peripherie hin verlaufen. Diese Fasern sind auberordentlich stark doppelbrechend, sie selechen in diesar Hinsicht dem Mineral Kalksjuat, dem auch die anderen noch zu betrachtenden Eigenschaften fontsprechen und dem sie hïchstwahrscheinlich zuzurechnen sind. Auch durch Gilïhen von Stiicken eines Korallenstocke's tritt dessen schaliger Bau deutlich hervor, indem dabei die einzwhen Lagen, oft ron äuljerst geringer Dicke, sich durch Abb) ïttern roneinander trennen.

Bei der mikroskopischen Betrachtung eines foinen Qulurschnittes erkennt man auch, dal die rote Farbe nicht steichmäbig über die wanze Fläche verbreitet ist, somdern daf mehr oder weniger lebhaft rot gefürbte konzentrische kinge nit granz farblosen ron aulien nach innen abwechsehn. Bei sehr dünnen Schliffen scheint sogar der srïlite Teil der Masse granz farblos zu sein, erst hei einer gewissen Dicke der Schicht tritt die rote Farbe hervor, um so deutlicher, je dicker diese ist, am deutlichsten bei den ganzen stijcken Die Farbe ist aber bei diesen nicht stets dieselhe', sondern sie zeigt mannicfache Verschiedenheiten. Bei frischen. lebenden liorallen. also in ganz unveränderten Zustande

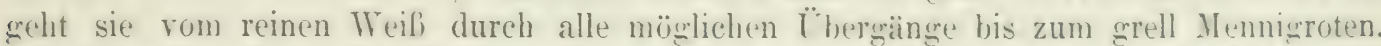
Die reinweilje Farbe ist allerdings seln selten; sie sull die Folge einer Krankheit sein. Auch die gelbe Farbe tritt nur in wenigen Fällen auf. Für die rote Farbe hat man in Italien, wo die Korallenindustrie eine so grolie Rolle spielt, eine Reihe von mit besonderen Tamen belecrten Nuancen unterschieden. An das reine Weil (bianco schliebt sich die Engelhautfarbe (pelle d'angelo!, ein schönes, frisches, helles Fleischrot an; darauf folgrt allmählich, immer dunkler werdend, blabrosa (rosa pallido), lebhaft rosa (rosa vivo), zweite Farbe (secondo coloro), rot (rosso), dunkler rot rosso scuro: und endlich als dunkelstes Rot das Karfunkelrot oder Erzdunkel (carbonetto oder arciscuro!. Selten ist es, daf an (inem Stock zwei rerschiedene Farben nebeneinander auftreten, dab er also z. B. hall rot und halb weif gefärbt ist; auch zwei wesentlich verschieden rote Nuancen sind ungewöhnlich.

Die Farbe des feinen Pulvers (der Strich) der roten Korallen ist blafrïtlich, und zwar um so ausgesprochener, je dunkler rot das stiick und um so mehr dem weißen sich näbernd, je blasșer dieses ist.

Tenn die Koralle tot ist, ändert sich meist die Farbe. Abgestorbene stijcke, die längere Zeit auf dem (irunde des Meeres lasen, namentlich wenn dieser ron schlammiger Peschaffenheit ist, sind fast immer mehr oder weniger dunkelbraun bis schwarz oder wie die Italiener sagen, verbrannt (bruciato). Die schwarze Koralle des Mandels ist aber zum Teil etwas ganz anderes; wir werden unten noch davon zu sprechen haben. In einzelnen Fällen werden tote Korallen allerdings auch allmählich weib oder gelb. Sehr häufig sind sie, ihre Farbe magr sonst sein wie sie will, ron anderen Meerestieren durchbobrt und zerfressen und dadurch zur Verarbeitung nicht mehr brauchbar.

Die schwarze oder braune Farbe der toten Korallen erstreckt sich nicht immer auf den ganzen Stock. Manchnal bildet sie nur einzelne unregelnä̈bige Flecken, oder wenn 
das ganze Stiick schwarz erscheint, so ist doch vielfach das Innere noch rot und nur die Oberfläche hat bis zu einer gewissen größeren oder geringeren Tiefe ihre Farbe verändert. Nicht selten ist allerdings auch gerade das Umgekehrte der Fall: der Kern ist schwarz geworden und die Außenschicht ist rot geblieben, und in manchen Fällen wechseln rote und schwarze Schichten miteinander ab, so daß z. B. zwischen einem schwarzen Liern und einer ebenso gefärbten Außenschicht eine rote Zwischenlage sich findet, die auf dem Querbruche einen roten Ring auf schwarzem IIinterørunde bildet. Man hört manchmal die Behauptung, die schwarz gewordenen Korallen können durch abwechselndes Liegen im Wasser und an der Sonne ihre ursprüngliche Farbe wieder annehmen. Versuche haben aber gezeigt, daß dies jedenfalls nicht immer der Fall ist, und höchstwahrscheinlich geschieht es überhaupt nie.

Was die Substanz der Korallen anbelangt, so besteht sie, wie mebrere Analysen zeigen, in der Hauptsache aus kohlensaurem Kalk, und zwar, wie wir schon oben geseben haben, wahrscheinlich aus Kalkspat, dem aber kleine Mengen fremder Kö̈rper beigemischt und beigemengt sind; namentlich ist der Kalk von organischer Substanz durchzogen, und wird daher beim schwachen Glühen schwarz.

Das spezifische Gewicht steht jedenfalls sehr nahe dem des Kalkspats, viel näher als dem der anderen kristallisierten Modifikation des kohlensauren Kalks, des Aragonits $(2,4)$. Während für den reinen Kalkspat $\mathrm{G}_{.}=2,72$ ist, hat man bei der Edelkoralle für alle Farben stets Zahlen zwischen 2,6 und 2,7 gefunden; so wird von Canestrin i angegeben: $\mathrm{G}_{0}=2,671$ und 2,68. Dagegen ist die Härte etwas höher als beim Kalkspat, was aber, wie die Verminderung des spezifischen Gewichts, durch die fremden Beimischungen verursacht sein kann. Sie steht zwischen dem dritten und vierten Grade der Mohsschen Skala, und zwar dem letzteren näher, so daß $\mathrm{H}_{0}=3 \frac{3}{4}$. Diese geringe Härte ermöglicht die leichte Bearbeitung mit Messer, Feile usw. und auf der Drehbank. Dabei wird aber die Politur niemals sehr fein; die Korallen bleiben immer matt, aber der Glanz ist doch genügend, um in Verbindung mit der schönen roten Farbe einen recht angenehmen Anblick hervorzubringen.

Die chemische Zusammensetzung der Korallen wird durch die folgenden Analysen von Tischer angegeben, der rote und schwarze Stöcke untersuchte. Er fand:

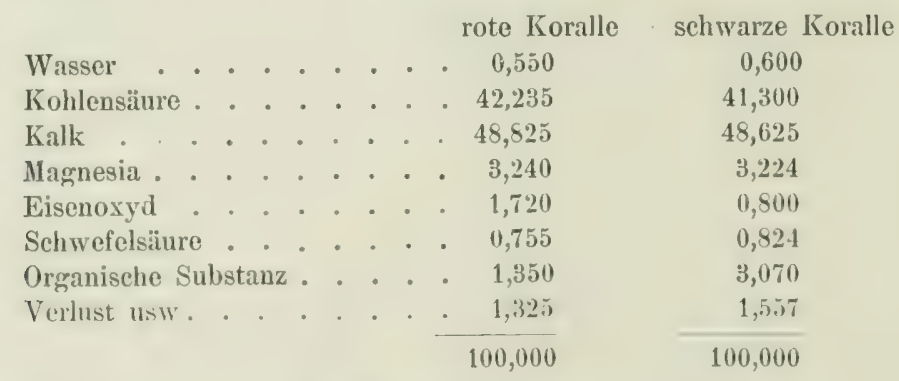

Hieraus kann man folgende Bestandteile berechnen:

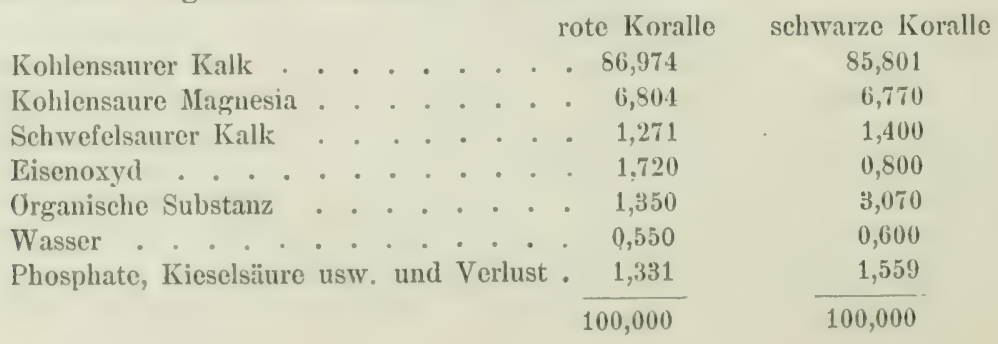


Ähnliche, zum Teil allerdings aber auch swas abweichende Resultate haben die früheren, freilich wenier zahlreschen Analysen erewen. Jedenfalls sieht man aus allem. dab man es immer mit kohlensaurem Kalk zu tun hat, dem neleen etwas organischer Sulstanz namentlich eine kleine Menge kohlensaurer Magnesia beigemischt ist. Das Terhältnis dieser beiden Bestandteile ist indessen nicht immer dassellue; bei jungen Korallen sinkt der Gehalt an Magnesiakarbonat bis auf I Prozent, während er bei alten bis auf is Prozent steigen kann. Damit wird grleichzeitigg die Härte etwas grïber, so dab der Ïlber-chub über den dritten Härtegrad wohl ron dem Magnesiagrehalt ahhängt. Die obigen Analysin zeigen auch, dal die roten und die schwarzen Korallen in ihrer Zusammensetzungr nur unwesentlich voneinander abweichen; die IIauptdifferenz besteht darin, daß in den schwarzen sich mehr und wohl auch andere organische Substanz findet als in den roten.

Diese organische substanz ist also wohl die Ursache der schwarzen Färbung. Man hat letztere auch auf einen Gehalt an Mangansuperoxyd zurïckzufüliren gesucht, aber die obige Analyse gibt keine Spur ron Mangan. Ebenso sollte die Einwirkung von Schwefelwasserstoff auf die roten Korallen die Änderung der Farbe rerschulden, aber auch dafür ist kein durchschlagender Grund vorbanden. Die Ursache der normalen roten Fürbung hat man greichfalls auf ehemischem Wege zu ermitteln gresucht. Ifan hat wohl gemeint, dab sie anf der kleinen Menge Eisenoxyd beruhe, die in der Analyse ron Tischer 1,72n Prozent betrïgt, die aber andere Chemiker bis zu 4,-5 Prozent gefunden haben. Dies ist jedoch nicht sebr wahrscheinlich, denn beim Gliihen verschwindet sowohl die rote als auch die schwarze Farbe und die Masse wird weil3. Der rote Farbstoff ist also vermutlich wie der schwarze, und wie dies bei den buntgefärbten schnecken und Wuscheln der Fall ist, ein organischer, der beim Absterben fault und schwarz wird und dadurch die Farbe der toten Koralle hervorruft, die bei noch weiter fortschreitender Zersetzungr in eine schmutziggelbe übergehen kann.

Die lebende Korralle. Wie wir schon oben gesehen haben, sind die Korallenstöcke im lebenden Zustande mit einer roten fleischigen, schliipfrigen, sich an der Oherfläche sammetartig anfühlenden Haut, dem Sarkosom oder Cünenchym, überzogren. Diese Haut ist stets sehr diinn und erreicht kaum die Dicke einer Linie. Sie ist von sehr zahlreichen isolierten roten Kalkkörperchen durchsetzt, die eine äuferst geringre Längre von bei weitem nicht einem Millimeter und eine eckige Form mit vielen herrorragenden kleinen Spitzen haben. Bein Zerdrücken eines Stückes der Haut zwischen den Fingrern fühlt man sie deutlich, ihre Form tritt aber erst unter dem Mikroskop hervor. In Vertiefungen des Sarkosoms sitzen die einzelnen Polypen, welche die Kolonie bilden. Die Haut ïberzieht den ganzen Stock bis über die Enden der Verzweigungen weg. die daber weich und biegsam sind und mit einem scharfen Messer durchgeschnitten werden künnen, was weiter hinten nicht mehr möglich ist. Bei jungen Stïcken ist auch der Fulf danit bedeckt, bei älteren ist dies nicht immer der Fall; cr und de benachbarten Teile des Stockes sind rielfach ibrer Rinde beraubt, abgestorben und stark zernagt und zerfressen, wie ganz tote Stöcke, bei denen die Haut rasch vollständigr verschwindet. Läbt man einen lebenden Korallenzweig an der Luft eintrocknen, so bildet die Haut eine ziegrel- bis mennigrote, raub sich anfühlende diinne Rinde, auf der da und dort kleine Wärzchen sich erheben. Diese tragen in der Mitte ein rundes Loch, von dem aus acht kurze Kerben ausstrahlen, die die ganze Warze in acht radial gestellte Teile sondern. In diesen Warzen, die so an ihrer Oberseite die Form eines achtstrahligen Sternes haben. sitzen, rersteckt im Innern, die Polypen.

Auch im Wasser sieht man ron dem Polypen nichts, wenn dieses einigermalen bewegt ist. Eine lebende Koralle ist dann ganz gleichmäßig rot. Aber anch an ilı treten die 
dem Sitz der Polypen entsprechenden Wärzchen auf, von denen eben die Rede war. Läßt man aber einen solchen lebenden Korallenzweig längere Zeit in rollkommenster Ruhe in einem mit Meerwasser gefüllten Glase stehen, dann sieht man allmählich die kleinen Erhöhungen an der Spitze sich öffnen. Es erhebt sich aus jeder ein kleiner weißer, fleischiger Zylinder, an dessen oberem Rande ringsherum acht grleichfalls weiße, wenige Millumeter lange, an beiden Seiten mit zahlreichen feinen Wimpern besetzte Arme stehen, die sich lebhaft hinundher bewegen. Dies sind die einzelnen I'olypen, unter denen der Stock überall die schon oben erwähnten flachen Vertiefungen trägrt. Die Polypen sind gegen äußere Reize sehr empfindlich. Wird das Wasser bewegt oder werden sie selber auch noch so sanft berïhrt, so ziehen sie sich rasch zusammen und verschwinden vollständig in der Haut, und zwar gleichzeitig alle Polypen eines Stockes, auch wenn nur ein einziger berührt worden ist. Der Stock hat dann wieder dasselbe Aussehen wie frïher, und erst nach längerer Ruhe, oft erst nach mehreren Stunden, kommen die Polypen wieder heraus, um bei der geringsten Beunruhigung wieder zu verschwinden. Sie haben in der Form eine gewisse Ähnlichkeit mit manchen Blumen; man hat daber die Korallen frïher für Pflanzen und die Polypen für ihre Bliiten gehalten, bis der französische Arzt und Naturforscher Peyssonel im Jahre 1723 den wahren Sachverhalt und die Zugehörigkeit zum Tierreiche erkannte, ohne aber sogleich die Zustimmung der anderen Zoologen zu finden.

Teder Polyp hat im Innern einen einzigen Leibesraum, in den von der Aubenwand her acht Hautfalten hineinragen und der durch ein besonderes Schlundrohr mit der von den acht Armen oder Tentakeln umgebenen Mundöffnung in Terbindung steht. In diesem Leibesraum gehen die sämtlichen Lebensprozesse, namentlich die Ernährung und Fortpflanzung, vor sich.

Die Ernährung wird dadurch bewirkt, daß die Fangarme durch ihre fortgesetzte Bewegung der Mundöffnung alle möglichen winzigen Organismen zuführen, die im Meerwasser schwimmen und die durch das Schlundrohr in den Leibesraum gelangen, wo sie verdaut werden. Die so gebildete weiße, milchälnnliche Ernährungsflïssigkeit strömt in einem komplizierten System von Röhren durch die ganze Rinde hindurch, so dalb alle in dieser sitzenden Polypen gleichmäßig an der Ernährung der ganzen Kóonie teilnehmen. Diesem Röhrensystem verdanken auch die feinen Rinnen ihre Entstehung, die, wie wir gesehen haben, die Oberfläche der Korallenstöcke bedecken; in ilınen verlaufen die dem Stock zunächst liegenden Gefäße.

Von besonderer Wichtigkeit ist die Fortpflanzung. Sie bewerkstelligt sich auf doppelte Treise, durch Eier und durch Knospung, und zwar in der Weise, dals die Bildung jeder netuen Kolonie, jedes Stockes, durch ein Ei, die Enstehung neuer Polypen in der Kolonie durch Knospung bewirkt wird.

Teder ainzelne Polyp ist von einem bestimmten Geschlecht, entwedler männlich oder weiblich. Die Anordnung ist in den allermeisten Fällen so, dals die Polypen eines rund desselloen Stockes entweder alle männlich oder alle weiblich sind. Tur in Ausnahmefällen kommt es vor, daß eine Kolonie teils weibliche, teils männliche Polypen beherberget, von denen aber dann immer je die gleichen auf verschiedenen Verzweigungen zusammensitzen, so daß auch noch in diesem Falle eine gewisse Trennung der Gesehlechter durehgefiihrt ist.

In dem Leihesraum der weiblichen Individuen entstehen winzige runde Eier, die in diesen durch den Samen der männlichen befruchtet werden. Es bilden sich dadurch sehr kleine, mit bloßem Auge kaum sichtbare, wurmförmige Larven, die, nachdem sie im Muttertiere einen grewissen Grad der Entwicklung erlangt haben, durch dessen Mundöffuung austreten und frei im Neere herumschwimmen. Nachdem dies eine Zeitlang gedauert hat, setzen sich die Larven an irgendeinem harten Gegenstand fest. Die Gründung 
einer Kolonie ist dadurch erfolert und die weitere Entwicklunger der Larve lälit einen neuen Korallenstock entstehen.

Unmittelbar nachdem die freischwimmende Larve geren ein festes Uindernis trestolien ist und sich an diesem festresetzt hat, zeigt sie die fiestalt einer winzigen Halhkugel. Diese word allmählich gröber und durch Ausbildung der oben erwähnten Kalkkïrperehen rot. Bei der weiteren Entwicklung wïchst an dem der Ansatzfläiche: geeteniiberliegenden P'unkte der erste Polyp heraus, der sich immer mehr aushnldet, bis er zum vollstindig fertigen seschlechtsreifen Tier herangewachsen ist. Filejehzeition scheidet sich an der Ansatzfläche das harte kalkigre Fubhlatt aus, mit dem der Stock an seiner Lnterlage befestigt ist. Mit dem weiteren Wachstum geht eine fortschreitende Absonderungron Kallisubstanz aus dem Meerwasser im Innern des Tieres vor sich, aus der teilweise die ainzelnen eckigren Kalkkïrperchen, teilweise aber die für uns vor allem wichtigren Korallenstöcke entstelsen. Diese vereröbern sich, indem in dem Tiere immer neur diunne Kalkschichten ringsum auf dem schon vorhandenen Stocke abgelagert werden, der sich auch allmählıch verästelt und rerzweigt und der die Fortsetzung des immer weiter sich ausbreitenden Fußblattes bildet. $\mathrm{Er}$ ist beim lebenden Tiere ron dem Sarkosom ïberzugen, das in der festsitzenden Larve durch deren gesamte Körpersubstanz repröisentiert wirrl. Die Ausscheidung des Kalkes geht aber nicht ganz gleichmäßig und ununterbrochen vor sich, wie man aus dem schichtenfïmigen Aufbau der Korallenstöcke sieht. Wahrscheinlich sind gewisse . Tahreszeiten der Kalkbildung günstiger als andere. In diesen bildet steh dann eine dïnne Kalkschicht, und in der darauffolgenden ungïnstigen Zèt scheidet sich nichts oder nur wenig aus und in dieser Weise abwechselnd, so dafj jede einzelne Schulit einer Wachstumsperiode entsprıcht, wie die Jahresringe der Biiume, deren finde man in ihrer Wirksamkeit beim Wachstum des IIolzes bis zu einem gewissen firade mut drm kalkausscheidenden Sarkosom der Korallen vergleichen kann.

Der Korallenstock ist also das Produkt der Kalkausscheidung in Innern des Sarkosoms. In demselben Mabe wie dieses, wächst auch der Stock in die Längre und in die Dicke, indem sich an der Spitze und ringsum immer neue dünne Kalkschichten über den schon vorhandenen absetzen. Damit gleichzeitig geht aher auch eine Termehrung der Polypen vor sich, welche die ganze Kolonie zu bilden und dieser die zu ihrer Ernährung nütigen Stoffe zu liefern haben. Zuerst war nur ein einziger Polyp rorhanden, der wenuigte, solange die Koralle noch klein war. Dies ist aher nicht mehr der Fall. wenn das Wachstum weiter rorgeschritten ist. Dann sprossen an verschiedenen Stellen der Haut allmählich immer mehr neue Polypen heraus, die sich sanz ebenso wie der erste nach und nach zu sreschlechtsreifen, fertigen Korallentieren entwickeln und die sich nun mit den schon frïher vorhandenen an der Ernährung und weiteren Ausbildung der Kolonie und des ihr zur Stütze dienenden Stockes, sowie an der Produltion neuer Larren beteiligren. Dieser Prozeß kann mit der Bildung der Knospen in der Rinde eines Bammes verglichen werden und ist daher von den Zoologen auch als Knospung bezeichnet worden. Er hat, wie wir geseben haben, für die Entwicklung der ursprïnglich aus dem Ei entstandenen Koralle eine ganz besondere Wichtigkeit.

Für die Kenntnis der Korallen und besonders auch für den rationellen Betrieb der Fischerei ist es wichtigr, zu wissen, wieviel Zeit ein Stock zu seiner vollständigen Entwicklung, also bis zur Erreichung seiner Maximalgröße nütig hat. Die Angaben hieruber sind sehr verschieden. Wahrscheinlich hängt das mit den mehr oder minder günstigren Lehensbedingungen zusammen, unter denen das Wachstum ror sich geht, vor allem scheint die Tiefe hierbei eine wichtige Rolle zu spielen.

Nach der Meinung mancher Sachverständiger erreicht eine Koralle erst in 30 Jahren ihre volle Größe. Andere behaupten dagegen, daß man auf einer befischten fiorallen- 
bank schon nach sehr viel kürzerer Zeit wieder große, brauchbare Stöcke trifft. So sollen an der nordafrikanischen Küste zu Anfang des 18. Jahrhunderts die Korallenfelder nach nur vierjähriger, durch die Kriege veranlaßter Ruhe einen ganz ungeahnten Ertrag gegeben haben, wobei zahlreiche Stöcke eine ganz außergewöhnliche Größe erlangt hatten.

Bei Vico Equense, in der Nähe von Sorrent, ist 6 Meilen (Miglien) von der Küste eine Korallenbank; man nimmt an, daß die Korallen hier in einer Tiefe von 60 Fuß acht Jahre brauchen, um die gehörige Größe zu erreichen und bei bedeutenderer Tiefe längere Zeit. Bei Messina wachsen Korallen von der Spitze des Faro bis mehrere Stunden südlich ron der Stadt. Dieser ganze Strich ist in zehn Abteilungen eingeteilt, ron denen jedes Jahr eine befischt wird, so daß man immer nach zehn Jahren zu derselben Abteilung zurïckkehrt. Diese Zeit genügt hier, um die Korallen zu ihrer vollen Größe heranwachsen zu lassen. Einmal entdeckte man noch etwas weiter südlich, bei San Stefano, eine Korallenbank mit reichlichem Ertrag an ausgezeichneten Stöcken, die bis dahin nicht bekannt und seit Menschengedenken nicht befischt worden war, und wo sich die Korallen wohl seit Jahrhunderten völlig ungestört hatten entwickeln können. Sie waren aber trotzdem nicht länger, sondern nur etwa um den dritten Teil dicker als die zehnjährigen. Das Wachstum in die Länge bört also offenbar früher auf als das in die Dicke, aber auch dieses ist ein beschränktes.

Daß die Lebensbedingungen auf die Entwicklung der Korallen großen Einfluß ausüben, sieht man unter anderem aus den Beobachtungen, welche die Korallenfischer im Golf von Neapel gemacht haben. Hier sind die an den westlichen Küisten gefundenen Korallen viel schöner und besser gebildet als die von der östlichen Seite, rom Vorgrebirge von Sorrent. Diese Erseheinung wird darauf zuriickgeführt, daß der Untergrund hier an der Sorrentiner Küste aus Kalk, dort, bei den Inseln Nisida, Procida, Ischia usw. aus vulkanischen Tuffen besteht, welche letztere offenbar den Korallen zuträglicher sind als der Kalk.

Un die Wachstums- und Entwicklungsbedingungen der Korallen aufzuklären, hat man schon verschiedentlich besonders darauf gerichtete Versuche ersonnen und unternommen, befriedigende Resultate sind aber noch nicht erzielt worden.

Was die Stellung der Edelkoralle im Tierreich betrifft, so zählt sie zu der in den Kreis der Cölenteraten gehörigen Klasse der Anthozoen oder Korallenpolypen, und zwar zu deren (abgesehen ron den nur fossil bekannten rugosen Korallen) erster Ordnung, derjenigen der Alcyonarien oder Octactinien, deren Körper, wie wir es auch oben bei der edlen Koralle gesehen baben, nach der Achtzahl regelmäßig eingeteilt ist. In dieser Ordnung bildet die Gattung Corallium einen Teil der Familie der Rindenkorallen oder Gorgonirlen. Eine, und zwar die wichtigste Art dieses Geschlechts ist die Edellioralle, das Corallium rubrum Lamarck, das, wie wir oben gesehen haben, nach dem Vorgange ron Linné auch als Corallium nobile, frïher als Isis nobilis, bezeichnet worden ist.

Die Edelkoralle, die immer nur in einzehen kleineren Stïcken vorkommt, unterscheidet sich in ihrer Organisation nicht unwesentlich von den riffbauenden Korallen, deren zu ungeheuerer Größe anwachsende und in beträchtlicher Zahl zusammengewachsene Stöeke, vorzugsweise der Abteilung der Madreporarien angehörig, die Korallenriffe und Inseln (Atolls) der warmen Meere, besonders des Stillen Ozeans, bilden, die hier der Schiffahrt oft so verderblich werden. Die riffbildenden Korallen sind nach der Sechszahl statt nach der Achtzahl gebaut. So haben z. B. ihre Polypen nicht acht; sondern sechs, zwölf oder noch mehr Fangarme um die Mundöffnung herumstehen, deren Zahl immer ein Vielfaches der Sechs betrïgt. sie bilden mit den in den Seewasserarfuarien so vielfach bewunderten, prïchtig gefärbten, der IIartteile entbehrenden See- 
anemonen usw. (Actinien) und mit den manchmal ebenfalls zu Schmucksachen verwendeten ergentlichen schwarzen Korallen der Gattung Antipates, sowie mit noch anderen ähnlich grehauten Tieren in der Klasse der Anthozoen die dritte und letzte Ordnung, die der Irexactinien oder Zoantharien. Die kalkigen Stöcke der riffhauenden Korallen sind fast ausnahmslos rein weib und unterscheiden sich dadurch sofort von den roten Stijcken der Edelkorallen, denen sie aber sonst in der baum- oder strauchartigen Gestalt zuweilen selır ähnlich werden.

Das Vorkommen der Korallen. Korallenbänke. Wir haben nununehr noch die Art und Weise des Vorkommens der Korallen. ihre Fundorte, die Gewinnung und die Verarbeitung, sowie den Handel mit denselben kurz zu betrachten.

Die Edelkoralle findet sich nicht einzeln, sondern stellenweise zu vielen nebeneinander. Eine solche Ansammlunge wird ein Korallenfeld oder eine Korallenbank genannt; deren Ausdehnung kann einige Kilometer betragen. Die Korallenbäumchen bilden hier mit Tangen zusammen unterseeische Wälder, in denen auch zahlreiche andere Tiere leben, denen die fleischige Haut der Korallen zur Nahrung dient. Die Stöcke sitzen meist auf Spalten und Klïften sowie in Höhlen in den Gesteinen, welche die Küsten und den Untergrund des Meeres bilden. Sie bevorzunen dabei Felswïnde, die nach Süden grerichtet sind, fehlen aber auch auf solchen nicht, die nach Osten und Westen sehen; gegen Jorden pflegen sich aber keine Korallen anzusiedeln. Wahrscheinlich ist die echte Edelkoralle, das Corallium rubrum Lam, ganz auf das Nittelmeer mit Einschluf des Adriatischen Meeres beschränkt; die anderwärts vorkommenden roten Korallen grehören wobl, auch wenn sie der echten Edelkoralle sehr ähnlich sind, anderen Arten an, die wir unten noch im Vorbeigehen kennen lernen werden.

Die Tiefe, in der die Kiorallen leben, ist sehr rerschieden. Sie schwankt zwischen $3 \mathrm{~m}$ und $300 \mathrm{~m}$, doch findet man höher als $30 \mathrm{~m}$ nur wenige und ebenso tiefer als $3010 \mathrm{~m}$, wo aber ebenfalls immerhin noch stellenweise einigre angetroffen werden. In so großer Tiefe ist die Entwicklung langsam, und die Stöcke bleiben klein, auch ist die Farbe blaf. Der Strich, in dem sich die meisten und schönsten Stöcke finden, in dem sich also die Fischerei in der Hauptsache bewegt, geht von 30 bis zu $50 \mathrm{~m}$, doch ist das nicht an allen Orten ganz gleich. So werden in der Straße von Messina die ergiebigsten Bänke bei $120-200 \mathrm{~m}$ angetroffen.

Was die Verbreitung der Korallenfelder anbelangt, so ist diese nicht zu jeder Zeit genau dieselbe, und auch die Fischerei wird nicht immer an den nämlichen Orten hetrieben. Bänke, die früher ergiebig waren, wurden ausgefischt oder kamen aus anderen Gründen allmäblich zur Erschöpfung, oder sie mubten aus irgendwelchen Crsachen verlassen werden, meist weil das Meer an der betreffenden. Stelle zu bewegt und daher die Fischerei zu gefährlich ist. Dagegen wurden vielfach nene Felder aufgefunden und durch ihren Ertrag der Ausfall, der durch den Verlust anderer Felder entstand, gedeckt. In kurzer Übersicht sind als Korallen führend die folgenden Teile des Mittelmeeres bekannt, die wir unten etwas eingehender betrachten werden. Es sind die Kïisten des östlichen Algier und die von Tunis; die ganze Umgebung von Sardinien und Korsika auf der Westseite, während die Ostseite beider Inseln nur wenige oder gar keine Korallen liefert; ein Teil der südund Westküste von Sizilien, sowie die Meerenge ron Messina, von wo aus sich die Korallenfelder an der ganzen italienischen Westküste hinziehen, sich dann an den Ufern der Provence fortsetzen und sich auch längs der ganzen spanischen Mittelmeerkïste, einschließlich der Umgebung der Balearen, wiederfinden. Die italienische Ostkïste im Adriatischen Meer ist sehr arm an Korallen, eine gewisse Menge findet sich aber an der gegenüberliegenden dalmatischen Küste zwischen Zara und Ragusa; sie sind jedoch hier im ganzen so sparsam und auch meist so klein, daß sie selten gesucht werden. Unbe- 
deutend ist auch das Vorkommen weiter östlich in den Meeren um Korfu und um Cypern, sowie an einzelnen Punkten vor Kleinasien.

Am wichtigsten und ertragreichsten ist die algerisch-tunesische $\mathrm{K}$ üste. Hier werden jührlich etwa $10000 \mathrm{~kg}$ Korallen gerwonnen. Die Korallen führende Strecke geht nur vom Kap Ferro (Cap de Fer) etwas westlich von Bona in östlicher Richtung bis zum Kap Bon und ron hier südlich in der kleinen Syrte bis in die Gegend von Sfax. Am westlichen Teil der Küste von Algier, also westlich von Kap Ferro, sind trotz vielfacher Nachforschungen noch keine Korallenbänke gefunden worden. Da, wo Korallen vorkommen, geht die Fischerei bis 6 und sogar 8 Meilen in das Meer hinein und bewegt sich in Tiefen, die zwischen 90 und 900 Fuß schwanken. Die aus größeren T'iefen kommenden Korallen sind blasser und nicht so glänzend, als die aus geringerer Tiefe, wie sie vielfach an der italienischen Küste vorkommen. In den genannten Gegenden ist schon vor Jahrhunderten ein reger Fischereibetrieb gewesen, vielfach gestört oder auch zeitweise ganz verhindert durch die jene Küsten beherrschenden Barbaresken. Frïher war der Hauptsammelplatz für die Fischereiflotte die Insel Tabarca, nahe der Küste und ungefähr in der Fortsetzung der algerisch-tunesischen Grenze gelegen. Auch jetzt ist diese sowie die der Küste etwas ferner liegende Insel Galita noch von Bedeutung, am wichtigsten ist aher gegenwärtig für die Gewinnung der Korallen die benachbarte algerische Küstenstadt La Calle, wo die französische Regierung alle möglichen Einrichtungen zur Förderung dieser Industrie bei ihren Landesangehörigen getroffen hat. Andere Punkte, in deren Nähe ertragreiche Korallenbänke liegen, sind Vieille-Calle oder Bastion de France, eine früher zum Schutz der Korallenfischer angelegte Befestigung, ferner das Kap Rosa, wenig westlich von La Calle und noch etwas weiter nach Westen die Bucht von Bona, wo Bona sellsst, sodann CalleTraversa und andere Punkte, weiterhin das Cap de Garde und das Cap de Fer, die, soweit jetzt hekannt, westlichste Grenze des Korallenvorkommens in jenen Meeren, wichtig sind. Gergen Osten ist die Küste von Biserta zu erwähnen, sodann die Gegend etwas südlich vom Kap Bon bei Kelibia und weiter in Süden Mansuria (Sidi Mansur), etwas nördlich von Sfax, gegenïber den Kerkenna-Inseln, im Golfe von Gabes gelegen. Nach der Form sind die afrikanischen Korallen namentlich den sizilianischen gegenüber dadurch ausgezeichnet, daf der sich wie eine Säule erhebende, wenig gebogene Stamm von Strecke zu Strecke sehr geradlinig verlaufende Äste trägt, was für die Verarbeitung besonders griinstig ist, da wenig Abfall entsteht. Manche Stöcke von hier sehen aus wie eine IIand mit ausgestreckten Fingern.

Ertragreich sind besonders in den letzten Jahren auch die sizilianischen $\mathrm{K}$ iisten gewesen. Südlich von Sizilien liegen die kleinen Inseln Linosa und T'antelleria, in deren Nïhe man Korallen gefunden hat. Dasselbe ist der Fall zwischen Malta und dem die Sürlspitze von Sizilien bildenden Kap Passero. Die wichtigsten Fundstätten sind aber bei Sciacea westlich von Girgenti, wo seit der Mitte der siebziger Jahre gefischt wird, sodann auch an der Westküste bei Trapani und den nahegelegenen Ägarlen. Bei Sciacea sind drei Bänke ron verschiedener Größe und in einer mittleren Tiefe von zirka $200 \mathrm{~m}$ ( 148 bis $221 \mathrm{~m}$ ) bekannt. Merkwürdig und abweichend von den anderen Korallenfeldern ist der Umstand, daß hier alle Korallen tot und ihrer Rinde beraubt sind. Die Folge davon ist, daß vicle Stïcke schon ihre schöne rote Farbe verloren haben und schwarz geworden sind, wodurch der Wert auf einen sehr geringen Betrag heruntersank. Dieser Prozels sehreitet immer weiter fort. Seit der Entdeckung der Bänke im Jahre 1575 hat man schon am Anfang und noch mehr in der Mitte der achtziger Jahre eine starke Verschlechterung der Qualitït beobachtet, zudem geht der Vorrat aus Nangel an Erneuerung durch Nachwachsen junger Stöcke rasch seiner vollkommenen Erschöpfung entgegen. Die Ursache des Absterbens liegt wohl darin, daß die Korallen mit einer Schlammschicht bedeckt sind; 
diese ist ihnen. die zu ihrem Lehen stetig sich erneuerndes frisches und reines Wasser brauchen, verderblich geworden. Man bringt diese Schlammbedeckung in Verbindung mit den heftigen, mehr als :3 Monate datlernden untersecischen vulkanischen Eruptionen, die im Jahre 1931 in der Mitte zwischen Pantelleria und reiacea stattfanden. Diese veranlafiten hier die Entstelumg der jetzt wieder versehwundenen kleinen Kraterinsel Furdinandea (Graham oder Julia) und bedeckten höchstwahrscheinlich auf weite Erstreckung den Mexeshoden mit feinen vulkanischen Aschen, die jetzt jenen sichlamm bildern. Die Korallenstïcke von reciacea sind so stark grebogen, dab es dem Gebrauche hinderlich ist, demn leei der Verarbeitung zu den gewöhnlichen Zwecken geht ein erheblicher Teil als Abfall verloren und nur selten ist es, dab zu irgendeinem besonderen Kiunstgegenstande crearade diese starke Krümmung sich eignet.

Auch die kleinen Inseln nördlich ron Sizilien, Ustica und die Liparen (Lipari, Vulcano, Stromboli, Basiluzzo und die anderen) haben Korallenbänke, zum 'Teil ron ziemlichrm Reichtum, in ihrer Nähe, deren Befischung aber durch das vielfach stïrmische Meer sphr behindert und an manchen Stellen ganz unmöglich gemacht ist. Wichtiger als diese sind die Fundorte in der Strabe ron Messina. Sie erstrecken sich, wie schon oben erwähnt wurde, ron der nördlichen Spitze von Sizilien, dem Kap Faro, sechs Mighlien nach viiden, noch drei Miglien ïber Messina hinaus bis gegenüber von Chiesa della Grotta, und sowar noch weiter suidlich, bei San Stefano, sind Korallen vorgekommen.

Dasselbe ist der Fall an der gegenüberliegenden kalabrischen Küste, besonder's hei Scilla und Palmi, wo die Korallen wegen der Schönheit ihrer Farbe besonderen Wert haben, sowie nürdlich davon bis zum Kap Taticano und Tropea und 1 m fiolfe ron San Eufemia, ebenso aber anch südlich bei Altafiumana am Kap dell'Ami und sonst in der Gegend ron Melito, am Kap Spartivento, Kía Bruzzano und bis zum Kap Rizzuto am Golf ron Squillace, sowie weiterhin bis zum Kap Santa Maria di Leuco, das den (rolf von Tarent begrenzt.

Auch im Golf ron Neapel sind fünf bis sechs Mighien rom Lfer mehrere Korallenbänke bekannt, so in der Tähe von Capri, bei der kleinen Insel Nisida zwisehen dem Posilipp und Pozzuoli und beim Kap Miseno, sowie bei Ischia. ferner zwischen Teapel und Vico Equense bei Castellamara auf dem Vorgebirge von Sorrent.

Von erheblicher Bedleutung, am wichtigsten nach den nordafrikanischen Korallenfischereien, sind seit lanser Zeit die in den Gewässern, welche die Insel Sardinien und zum Teil auch Korsika umgehen, aber fast nur auf der West-, nicht auf der Ostseite. Im Süden ron Sardinien sind die Inseln San Pietro mit der Ortschaft Carloforte, sowie San Antioco und del Toro zu erwähnen, weiter nürdlich das Kap San Marco und der Küistenstrich zwischen Bosa und Alghero. Noch reicher ist aber die Straße ron Bonifacio zwischen Sardinien und Korsika. Auf sardinischer Seite werden hier an der Insel Asinara, bei Castelsardo, Longosardo, und um die Inseln Maddalena und Caprera, auf korsikanischer Seite bei Bonifacio Koralien gewonnen, und von hier an längrs des ganzen Westufers der letzteren Insel bis zu ihrer Nordspitze, dem Cap Corse, so im Meerbusen ron Propriano (Golf ron Talinco) und an vielen anderen Orten. Auf der Ostseite ron Sardinien liennt man Korallen nur in spärlicher Zahl beim Kap Corallo, auf der Ostseite ron Korsika sind gar keine bekannt. Dagegen findet man wieder eine crewisse Menge um die Inseln Elba und Giglio, sowie an der gegenüberliegenden toskanischen Küste. Hier liegt auch das schon von Plinius wegen seiner Korallenfischerei genannte Alsidonia (= Ansidonia). Endlich ist an der toskanischen Küste noch der Strich zwischen Cecina im Süden, bei Livorno, und La Spezia im Norden zu nennen. Besonders Montenero bei Livorno war früher nicht unwichtig, die Fischerei scheint hier aber jetzt aufgehört zu haben. 
In Frankreich sind Korallenbänke von geringer Wichtigkeit an der Küste der Provence bekannt, besonders in der Umgebung der Hyerischen Inseln, bei Toulon, sowie auf beiden Seiten des Golfes von St. Tropez. Etwas weiter westlich sind bei der Pointe Riche, üstlich von den Rhônemündungen, Funde gemacht worden. Die französischen Korallen pflegen kurz und dick zu sein, vielfach erhebt sich aber auch auf dem sehr breiten Fulbe eine größere Anzahl dünner Zweige, so dal das Ganze wie ein Haarschopf aussieht.

Nicht ganz ohne Bedeutung sind schließlich noch die Korallenbänke an der spanischen Küste in den Provinzen Katalonien, Valencia, Murcia und Granada, von der französischen Grenze an bis Gibraltar. Die wichtigsten Punkte sind ganz im Norden, beim Kap de Creus, im Golf de Rosas, beim Kap Bagur und beim Kap Sebastiano, sowie bei Palamos, alle nahe dem 42. Breitegrade. Nicht zu vergessen sind die Meere, die die Balearen umgeben. In Spanien sind Stöcke häufig, bei denen aus dem breiten Fuße mehrere verästelte Stämme säulenförmig hervorwachsen. Die spanischen Korallen sind vielfach besonders intensiv rot gefärbt.

Von manchen Schriftstellern, namentlich von solchen des Altertums (Plinius), werden edle Korallen auch aus anderen Gegenden, besonders aus dem Roten Meer und aus den indischen Meeren, erwähnt. Es scheint aber, als ob sie dort, wenigstens heutzutage nicht mehr vorkämen, während riffbildende Korallen in diesen Teilen des Ozeans sich massenhaft entwickeln. Wenn aber auch die echte Edelkoralle (Corallium rubrum) wohl auf das Mittelmehr beschränkt ist, so kommen doch den dortigen sehr ähnliche Korallen, die aber wohl alle anderen Arten angehören, auch sonst vor. Sie werden in manchen Gegenden gleichfalls gefischt und in derselben Weise wie jene verarbeitet. Eine besondere, Art, Corallium Lubrani, sollen die Korallen bilden, die seit einiger Zeit bei den Capverden besonders bei der Insel São Thiago gewonnen werden und die auch in der Nähe der Kanaren vorkommen. Die Fischereien bei Sào Thiago, 90 bis $190 \mathrm{~m}$ tief und 400 bis 1000) $m$ von der Küste entfernt, hat in den siebziger Jahren der Italiener Antonio Lubrano eingerichtet, nach dem die Koralle ihren Namen erhalten hat. Auch bei den Sandwichinseln findet sich eine rote Koralle, deren Stöcke aber weniger intensiv gefärbt sind als die der Edelkoralle. Sie sind meist hell rosarot bis weif und ibre Enden spitzen sich scharf zu, was bei der Mittelmeerkoralle nicht der Fall ist. Zu derselben Art gehört wahrscheinlich auch die Koralle, die gegenwärtig unter dem Namen der japanischen in den IIandel gebracht wird. Es ist das Corallium secundum Danas, von dem auch das Corallium Johnstoni Grays, das in der Nähe von Madeira vorkommt, schwerlich wesentlich verschieden ist. Alle diese außerhalb des Mittelmeeres lebenden Korallen stehen, wenn sie auch immerhin nicht ganz obne Bedeutung sind, doch bezüglich ihres Handelswertes so weit hinter der Edelkoralle zurück, daß sie im folgenden nicht weiter berïcksichtigt zu werden brauchen.

Die Korallenfischerei. Verwendung der Korallen. Handel. Die Korallenfischerei wird in ganz eigenartiger Weise betrieben und ist mit keiner anderen $\Lambda \mathrm{rt}$ von Fischerei zu vergleichen. Sie findet in den sechs Sommermonaten, nur ausnahmsweise das ganze Jahr hindurch, statt. Wenn die Stürme des Herbstes kommen, wird die Sache meistens zu gefährlich; die Schiffe kehren dann mit ihrer Beute nach Hause zurïck, um im Frühjahr ihre Jagdgründe wieder aufzusuchen.

Diese Schiffe werden zur Korallenfischerei eigens hergestellt und gleichen einander äuferlich und in der Einrichtung in allen wesentlichen Punkten. Es sind sehr solid gebaute, seetüchtige, schnellsegelnde, übrigens im Notfalle auch durch Rudern zu bewegende Barken von versehiedener Größe mit einem Gehalt von (; bis 16 Tonnen, deren gröljte eine Läinge von 13 bis 14 , eine Breite von $3^{1 / 2}$ und einen Tiefgang von $1 \frac{1}{2}$ m haben. 
Sie führen eine Bemannungr vom sechs bis zwölf Personen, die bei kärcrlichem Lolıne eine täglich 1 stündige harte Arbeit zu leisten haben. Selten sind ganz kleine Boote unter sechs Tonnen, die mit zwei bis drei Leuten den Fang betreiben.

Die Fischerei findet moist etwa rier bis sechs Sermeilen vom Lande statt. In greringer Tiefe, bis höghstens $10 \mathrm{~m}$ und nahe dem Ufer, geschieht die Arbeit zuweilen durch Taucher, aber die Menge der so gewonnenen Korallen ist erering, da die meisten und schönsten in gröberen Tiefen vorkommen, die auch bei der zweckmäbiersten Einrichtungr für die Taucherei nicht mehr zugänglich sind.

Für solche grobe Tiefen haben die Korallenfischer wahrscheinlich schon seit Jahrhunderten ein eigenartion Instrument, das geerenwirtig fast ausschließlich in allen Teilen des Mittelmeeres benutzt wird und neben dem alle anderen Fangrgeräte von unterweordneter Bedeutung sind. Eswird von den Italienern mit dem Namen Inge gr no, von den Provencalen als Engin bezeichnet. Sein Bau und seine Anwendung sind in allen Teilen des Mittelmeeres ziemlich gleich; Abweichungen sind zwar vorhanden, aber diese sind nur unwesentlich.

Dieses Hauptinstrument besteht aus zwei gleichen, soliden Palken aus Eichenholz, deren Lünge auf großen Barken zwei und zuweilen sogar mehr Meter, auf kleinen oft nicht roll $1 \mathrm{~m}$ betrïgt. Diese sind in der Mitte kreuzweise fest miteinander verbunden, so daß von hier vier gleich lange, nach den Enden zu diunner werdende Arme unter rechten Winkeln ausgehen. In reren Vereinigungspunkt ist ein schwerer Stein, ein Bleiklotz oder ircrendein anderer schwerer Körper befestiunt, der die ganze Maschine im Wasser zum Sinken bringt; in newerer Zeit werden die vier Arme nicht selten in ein schweres Eisenstiick eingelassen, das dann denselben Dienst tut.

An jedem der vier Arme ist auben in einer ringsherum grehenden Kerbe eine starke Leine ron 6 bis 5 m Länge mit ihrem einen Ende festgebunden und im Kreuzpunkt der Balken hängt eine fünfte, noch längere. An dieser Leine sind in gewissen Zwischenräumen die eigentlichen Fangapparate angebracht. Dies sind sehr grobe, viereckige Netze mit einer Maschenweite von mehreren Zentimetern, die aus fingerdicken, nur wenig zusammengedrehten Hanfschnüren gestrickt sind. Jedes derselben wird an einer der vier Seiten zusammengenommen und fest zusammengebunden; sie bilden so an der gegenüberliegenden Seite offene, quastenartige Schnurbïndel, vergleichbar den quastenartigen Geräten, mit denen man die Verdecke der Schiffe aufzuwischen pflegt. Die Lïnge dieser Quasten ist je nach der Grüße des Ingegno, verschieden und geht bis zu, ja zuweilen bis über $2 \mathrm{~m}$. Jede Leine trägt in zweckmäbigen Abstïnden eine gewisse Anzahl derselben, so daß an einer Maschine 30 bis 40 befestigt sind; dazwischen hängen noch ähnliche, aber feinere und engmaschigereAplarate, die meist aus alten Sardinennetzen hercestellt werden.

Beim Fischen wird das Ingegno rom Deck der Barke aus an einem langen festen Seil ins Wasser geworfen, wobei sich die Netzquasten mit ihrem freien Ende horizontal ausbreiten und so eine je nach ihrer Länge mehr oder weniger große Fläche auf dem Wasser, später auf dem Meeresgrunde bedecken, wenn die Maschine infolge ihres Gewichts auf den Boden gesunken ist. Hier rerwickeln sich die herrorragenden Stellen desselben, also vor allem die auf dem Grunde wachsenden Korallenbäumchen, aber mit diesen auch andere Tiere, Gesteinszacken und Pflanzen usw. in die Netze, namentlich in die groben, weitmaschigen, und werden bei der Bewegung der Barke losgerissen. Die größeren Stuicke bleiben in den weiten Maschen hängen, die kleineren fallen durch diese hindurch und werden von den kleineren engmaschigeren Netzen aufgefangen.

Die Handhabung des Ingegno ist außerordentlich mühsam, um so mehr, je größer es ist, namentlich unter der glïhenden Sommersonne der nordafrikanischen Kïiste und des ganzen Mittelmeeres. Je nachdem sie von großen Barken aus mit einer Winde, oder 
von kleinen aus mit der Hand geschieht, unterscheidet man wohl die große und die kleıne Fischerei. Ein Ingegno für eine große Barke wiegt mehr als 2 Zentner; ein solches für eine kleine entsprechend weniger. Die Netze hängen sich oft so fest am Meeresboden an, daß sie sich nicht mehr auf dem gewöhnlichen Wege losreißen lassen. Nan bat dann besondere Instrumente, um sie frei zu machen. Aber auch so gelingt es nicht immer, und die Maschine mit dem daran befestigten Seil ist verloren. was für den Fischer, wenn es sich um ein großes Ingegno handelt, allein für dieses einen Verlust von 200) Franken bedeutet.

Jedesmal, wenn das Ingegno ausgeworfen ist, bleibt es eine Zeitlang im Wasser, und der Fischer macht verschiedene Operationen, um seine Wirkung möglichst zu steigern. Wenn die Barke eine gewisse Strecke zurückgelegt hat, wird es eingenommen; die Beute wird ausgesucht und die sehr starker Abnutzung unterworfenen Netzbiindel erneuert. Dadureh greht jedesmal ziemlich viel Zeit verloren, mehr oder weniger, je nach den gïunstigeren oder minder guinstigen Umständen. In einer Tagestour kann so ein 7 -bis 14 maliges Auswerfen und Einholen des Fangapparates stattfinden, nur in seltenen Fällen ist es öfter nï̈glich. Kleine Barken gehen nach vollbrachtem Tageswerk an Land, größjere bleiben in See, stets nach Bedarf ihren Standort wechselnd, bis sie zur Verproviantierung oder um Schäden auszubessern usw. einen Hafen aufzusuchen genötigt sind.

Die Korallenfischerei ist ein fast ausschließlich italienischer Erwerbszweig. Beinahe alle Barken werden in Italien gebaut, und die allermeisten haben ihre Heimat in italienischen Häfen. In den achtziger Jahren waren es deren etwa 460, darunter 200 kleine und 260 grroße. Der wichtigste Hafen ist Torre del Greco bei Neapel, von wo alljährlich 300) Barken ausgehen, dann folgen mit viel geringeren Zahlen Santa Marghcrita östlich von Genua an der Riviera di Levante (jetzt 49, vor 50 Jahren waren es 200), Alghero und Carloforte in Sardinien (je 19), Trapani (8), Livorno (6) und Messina (3 Barken). Indessen werden auch etwas, aber unwesentlich abweichende Zahlen angegeben.

Da die wichtigsten Bänke im Bereiche des französischen Gebietes an der nordafrikanischen Küste liegren, so hat die französische Regierung von jeher die größten Anstrengungren gemacht, die Korallenfischerei nach Algerien hinüberzuziehen. Dies ist ihr auch in newerer Zeit durch verschiedene zweckmäßige Einrichtungen zur Hebung des Betriebes, und namentlich durch wichtige Vergïnstigungen an italienische Fischer soweit gelungen, dal eine nicht geringe Zahl von diesen mit ihren Barken nach La Calle und in andere afrikanische IIäfen überuesiedelt ist und die französische Flagge angenommen hat. Ton dort fahren jetzt unter dieser Flaggee etwa 100 Barken aus, die aber ebenfalls alle noch durchaus mit Italienern bemannt sind. Nur der verhältnismäßrg geringe Ertrạ der provencalischen Küste wird von Franzosen gewonnen, und ebenso wird die spanische Küste nicht von Italienern, sondern von Landeseingeborenen ausgebeutet, die mit etwa 60 kleinen Barken meist den sogenannten kleinen Fang betreiben.

Die Henge der von einer Barke in einem Jahresbetrieb gewonnenen Korallen ist natïrlich nach den Umständen sehr verschieden. Nicht geringen Einflub hat der Ort, wo gefischt wird, sowohl in bezur auf die Menge als auf die Güte, die sich indessen vielfach gegenseitig bis zu einem gewissen Grade ausgleichen. Nach einem mittleren Durchschnitt erntet eine Barke an der afrikanischen Küste im Jahre $150 \mathrm{~kg}$ im Wert von 75 Franken das Kilogramm, an der sardinischen Küiste $190 \mathrm{~kg} z u \quad 50$ Franken und bei Korsika $210 \mathrm{~kg}$ zu 45 Franken usw.

Die Gesamtmenge der Korallen, die von Barken unter italienischer Flagge im Jahre gewonnen wurden, betrug am Ende des vorigen Jahrbunderts mindestens $56000 \mathrm{~kg}$ im Werte von $12000(0)$ Franken. In Algier wurden jährlich $10000 \mathrm{~kg}$ im Werte von 750)(100) Franken (rbeutet. Die 60 spanischen Barken erlangten $12000 \mathrm{~kg}$, deren Wert 
sich auf soofono kranken bezifferte. Insegesamt kann man den Ertrag der nicht italienischen Barken auf $22000 \mathrm{k}$ im Werte von 15500000 Franken schätmen, so dafs in dem

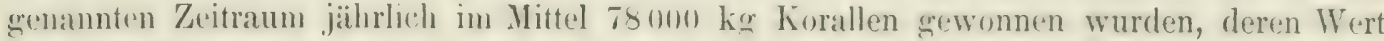
5750000 Franken betrug.

Die von den Fischern in den IIandel getrachten Korallen worden beim Verkauf in verschiedene Sorten geteilt, die einen natiirlich etwas schwankenden mittleren . Marktpreis haben. Sollostverständich ist dieser Preis weit ereringer, als spüter, wenn die Koralle, zu Schmuck verarbeitet, in die Hände des Publikums iibergeht.

Diese Sorten sind die folgenden:

1) Tote oder verfaulte Korallen. Es sind die am Felsen angewachsenen dicken und breiten Fubteile der Stöcke mit deren unmittelbar benachbartem unterem Ende. Diese Stiicke, an denen oft noch das Crestein hängt, auf dem die Koralle festgesessen hatte, sind meist derart ron anderen Heerestieren iiberkrustet, dab man die Qualität schwer beurteilen kann. Der Ankauf dieser Sorte, von $d$ er $1 \mathrm{~kg} 5$ bis 20 Franken kostet, scleicht daher einem Gliicksspiel. Oft kommen sehr wertvolle Stücke aus der unschein\}aren IIiille heraus. Die breiten Fußblätter werden nicht selten zu kleinen Schalen verarbeitet.

2) Schwarze Korallen. Hierber gehören bis innen oder wenigstens bis weit hinein schwarz gewordene Stöcke, die Tranerschmuck geben. Ein Kilo kostet bei guter Beschaffenheit 12 bis 15 Franken. Ton einer anderen schwarzen Koralle wird noch unten die Rede sein.

3) Gewöhnliche rote Qualität. Es ist die Hauptmasse des roten Materials von allen Formen, Größen und Farbennuancen, ganze Stöcke und Bruchsticke. Wegren dieser groben Verschiedenheiten gehen auch die Preise weit auseinander und betragen 45 bis 70 Franken pro Kilo.

4) Ausgewählte Stücke. Besonders schöne und große Stïcke werden getrennt gehalten und entweder einzeln oder ebenfalls in Partien dem Gewichte nach verkauft. Der Preis steigt hier auf 500 Franken und noch höher für das Kilogramm.

Unter den Einenschaften, die den P'reis einzelner Stiicke wesentlich mit bedingen, steht die Farbe obenan, deren Nuancen wir schon frïher kennen gelernt haben. Sie ist natürlich der Mode unterworfen. In frïheren Zeiten waren die lebhaft roten itücke besonder's geschätzt. Heutzutage ist es in Europa vor allem das liebliche frische Rusa, das die Italiener pelle d’angelo (Engelhautfarbe) nennen, und dasselbe ist in den beiden Ländern der Fall, die im Verbrauch der Korallen obenan stehen, Ostindien und China. Gutgeformte Stïcke von dieser Farbe können schon bei zeringer Gröle einen Wert von 100) Franken und mehr haben. Aher allerdings zeigen nicht alle Völker denselben tieschmack; die Araber z. B. bevorzugen noch heutzutage die lebhaft roten Nuancen.

Wie die Gewinnung, so liegt auch die Verarbeitung der Korallen wesentlich in den Händen der Italiener. Nur wenig verbreitet ist dieser Industriezweig in Spanien und auch in Frankreich; hier werden dagegen vicle in Italien verarbeitete Korallen in Schmuchstïcke gefaßt, was zum T'eil mit Diamanten und anderen Edelsteinen zusammen geschieht. In Italien sind etwa 60) Werkstätten, in denen ungefähr 60(0) männliche und namentlich weibliche Arbeiter beschäftigt werden, um alle möglichen Gegenstände, namentlich Schmucksachen, herzustellen, die von hier aus in die ganze Welt grehen. Auch in der Terarbeitung steht, wie bei der Fischerei, Torre del Greco voran. Hier allein sind in 40 Etablissements 3200 Arbeiter, darunter 2S00 weibliche, tätig. Andere Orte, die noch Erwähnung rerdienen, sind Genua, Neapel, Livorno und Trapani und bis zu einem gewissen Grade auch Rom.

Die hauptsächlichste aus Korallen dargestellte Ilandelsware sind größere oder kleinere durchbohrte Stiicke von verschiedener Form, die, auf Schnüre gezogen, als Hals- und Armbänder, Rosenkränze usw. benutzt werden. Speziell sind es Perlen ron kugelrunder und 
sogenannte Oliven von ovaler Form, groß, mittel oder klein, mit oder ohne Facetten. Letztere sind gegenwärtig wentger beliebt als am Anfange dieses Jahrhunderts. Arabische Korallen sind $1 \frac{1}{2}$ bis $2 \mathrm{~cm}$ lange, der Länge nach durchbohrte, sonst nicht weiter bearbeitete Stiicke; diese werden auf langen Schniiren zu sogenannten Bajaderen gefaßt, die im Orient vielfach als Gürtel getragen werden. Auch querdurchbohrte Stücke dieser Art werden vielfach hergestellt und auf Schnüre aufgezogen.

Sehr kunstfertig sind die Italiener in der Uerstellung geschnitzter Sachen in Form von Kameen, von Blumen, Tieren, menschlichen Figuren usw. Sie wissen dabei die kleinen Unregelmäßjigkeiten des Materials äußerst gesehickt zur Hervorbringung verschiedenartiger Effekte zu verwenden. Solche Gegenstände werden entweder einzeln in Broschen, Nadeln usw. gefaßt oder ebenfalls in Arm- und Halsbänder eingereilit. Kleine Enden von Zwveigen sieht man vielfach poliert in ihrer natürlichen Form zu Uhrgehängen, zu Nadeln usw. verarbeitet, und äbnlicher Verwendungen sind es noch viele.

Große Stïcke geben nicht selten Griffe zu Stöcken und Schirmen und ähnliche Sachen ron erheblicherem Umfange. Sie werden zuweilen, namentlich wenn die Qualität hervorragend ist, äußerst kunstvoll geschnitzt und haben dann einen sehr hohen Wert. So wird von einem Griff für den Sonnenschirm der Königinwitwe von Italien berichtet, der einen Wert von 9000 Franken hat.

Der Preis der verarbeiteten Korallen ist natürlich sehr verschieden, weil hier zu der Qualität noch die mehr oder weniger kunstreiche Arbeit kommt. Bei Hals- und Armbändern hängt er von der Zahl und Größe der Perlen, und sehr wesentlich von der Übereinstimmung der Farbe derselben ab. Auf der Berlıner internationalen Fischereiausstellung im Jahre 1880 war ein Halsband im Werte von 120000 Mark zu sehen.

Die Verwenlung der Korallen ist zwar in Europa nicht gering, sehr viel erbeblicher aber im Orient und besonders in Indien und China, wohin der größte Teil der Gesamtproduktion geht.

In Europa wird Korallenschmuck mehr von einzelnen und vorzugsweise von Kindern getragen; nur in gewissen Teilen von Italien, von Österreich und Ungarn, von Polen und besonders in Rußland gehört er zu den Zierraten der großen Masse. In der Türkei dient er nicht allein zum Putz von Männern und Frauen, sondern auch zur Verzierung der IVände in den Wohnungen, sodann zum Schmuck der Pfeifen, Waffen, des Pferdegeschirres und anderer Gegenstände. Groß ist der Verbrauch in ganz Nordafrika, besonders in Marokko, ebenso in Arabien, während die Ägypter die Korallen nicht besonders schätzen.

Die Perser lieben Korallenschmuck sehr, ebenso die Japaner und Chinesen. Bei letzteren werden Korallen ganz allgenein von Männern und Frauen getragen, unter anderem machen sie aus besonders grolien und schönen Stücken Kugeln auf Mandarinenhïte, und bezahlen dafïr zuweilen unglaubliche Summen. Am größten ist jedoch der Bedarf in Ostindien; für mehrere Millionen Franken werden jührlich nach Bombay, Madras und Kalkutta ausgefiihrt. In Indien werden sie zu Hals-, Arm- und Beinbändern und sonst zum Schmuck benutzt, ebenso aber auch zu Rosenkränzen und Amuletten und besonders als Totengabe, die dazu dienen soll, die bösen Geister von den Leichen der Verstorbenen fernzuhalten. Nicht ganz gering ist auch die Ausfuhr nach Amerika, besonders nach Siidamerika, und nach Australien. Vorliebe für Korallen herrscht in allgemeinen bei Völkern, die schon auf einer gewissen Kulturstufe stehen. Man hat schon versucht, Korallenperlen statt Glasperlen bei wilden Völkerschaften einzuführen, aber ganz ohne Erfolg. Diese ziehen durchweg die glänzenderen und viel billigeren Glasperlen vor.

Der nicht geringe Wert der echten Korallen hat die Anfertignug von Verfälschungen zur Folge, die vielfach zu sehr billigrem P'reise in den Ifandel gebracht und den echteh untergeschoben werden. Mäufig sind es Perlen aus rotgef:irbtem Gips, die sich aber 
daran erkennen lassen, dab sie mit sïuren nicht aufbrausen. Auch grebrannte und rotgefärbte Knochen, sowie mit Fischleim und Zinnober oder Nennige zusammengeknetetes Marmorpulver dient zu demselhen Zwecke, sogar runde Kugeln aus rotem Siegrellack kommen vor. Auch Zelluloid wird zu diesem Zweck viefach verwendet.

Wir haben oben schon von den schwarzen korallen gresprochen. Es gibt aber außer den dort erwähnten schwarzen Exemplaren der Edelkoralle noch andere von derselben Farbe, die zuweilen zu Trauerschmuck und zu anderen Zwecken verarbeitet werden. Diese von Natur schwarze Koralle hat von den Zoologen den Namen Anthipates spiralis Pall. erhalten. Um die Mundöffnung der Polypen stehen hier sechs Fangarme, so dab sie der Abteilung der Itexactinien zugerechnet werden müssen. Im Innern scheidet sie einen glänzend pechschwarzen, verïstelten bis zwei Fulb langen und einige Zoll dicken Stock von horniger, nicht von kalkiger Beschaffenheit aus. Wegren dieser letzteren läbt er sich leicht biegen und daher in einem Stïcke zu Armringren usw. verarbeiten. Diese schwarze Koralle lebt im indischen Ozean; sie führt in jenen Gegenden den Namen Akabar. Man benutzt sie dort, wo sie außerordentlich geschätzt ist, vielfach, um Zepter für einheimische Könige und Fürsten herzustellen, daher der Name Königskoralle, den sie ebenfalls führt. Ähnliche Formen kommen auch im Mittelmeere vor, wo sie Giojetto genannt werden.

An der Kamerun- und an der Goldküste wurde früher eine blaue Koralle gefischt und zu Schmucksachen verarbeitet; sie war dort bei den Negern selır geschätzt. Die Eingeborenen nannten sie Akori, von den Zoologen hat sie die Bezeichnung Allopora subviolacea erhalten. Seit langer Zeit scheint diese blaue Koralle aber vom westafrikanischen Narkte verschwunden zu sein, so daß dieser kurze Hinweis genügt. 


\section{Register.}

A.

Abaéte, Rio, Brasilien, Diamanten 185 .

Abgestorbener Edelstein 555.

Acabar $=$ Akabar 751 .

Acetylentetrabromid zur Bestimmung des spezifischen Ge wichts 27.

Achat 618. 620, 627; brasilianischer 632 ; isländischer 550 ; löhlbacher 613 ; mexikanischer 649 ; okzidentalischer und orientalischer 628 .

Achat, Brennen 645 .

Achat, Färbung 642

Achatglas 635 .

Achatjaspis 615 .

Achatmandeln 593. 629. 630.

Achatschichten, harte und weiche (643.

Achatschleife 638. 639.

Achatschleiferei 635.

Achroit 458.

Achsen, optische 59.

Acori $=$ Akori 751 .

Adclaide-Rubin (Granat) 442.

Adern $=$ Risse oder Federn 112

Adular 530.

Adularisieren 78, 530.

Agat siche Achat.

Agstein 683.

Agtstein $=$ Bernstein 657 .

Agua Suja, Brasilien, Diamanten 186.

Ägyptischer Türkis 495 .

à jour, Fassung 108.

Akabar 751.

Akbar Schah (groß. Diamant) 315 .

Akori 751 .

Aktinolith 564.

Alabaster 650 .

Alasmodonta margaritifera 726 .
Albitmondstein 532.

Alessandrinentïrkis 495 .

Alexandrit 382; künstlich 384 .

Alexandritkatzenauge 384 .

Almandin (Franat) 439.

Almandinspinell 374.

Amatrix 503.

Amause 119. 121.

Amazonenstein 526. 575.

Ambre antique 677 .

Ambroid $=$ Preßbernstein 678

Amerikanischer Brillantschliff 92 .

Amethyst 591; edler 591; falscher 651.652 : Farbenänderung durch Radiumstrahlen 72; gebrannter 592. 597; okzidentalischer 591 ; orientalischer 371.591.

Amethystgrotte 594.

Amethystmandeln 593. 630.

Amethystsapphir $=$ Violettrubin 371.

Amorph 9. 11.

Amphibol 553; im Blaugrund, Südafrika 229.

Amphibolgruppe 553.

Amsterdamer (großer Diamant) 313.314

Amsterdamer Rose 97 .

Amulette aus Achat 635; aus Chiastolith 517.

Andalusit 516.

Anfühlen, kaltes und warmes 81 .

Anorthit 526.

Anthrax 334.

Anthrazit 656.

Antwerpener Rose 97.

Apatit 653.

Apyrit $=$ sibirischer Turmalin 459 .

Aquamarin 38T. 402; Farbenïnderung durch Radiumstrahlen 72 ; orientalischer 370 ; sibirischer 402; Vorkommen 403.
Aquamarinchrysolith 387. 40\%.

Arabische Steine 493.

Aragonit, faseriger 649 .

Arbeitsfließen 675 .

Arciscuro(Farbe vonKorallen) 737.

Arizona-Rubine 448 .

Arkansas-Diamanten 585.

Asche des Bernsteins 65T; des Diamants 141.

Aschentrecker (Aschenzieher) 457. Asterien 79. 357.

Asterismus 79 .

Atlasglanz 42.

Atlasspat (Atlasstein) $=$ Faserkalk 649.

Atoll 742 .

Ätzen der Edelsteine 106.

Ätztinte, Verhalten der Edelsteine 8 .

Aufbringen der Edelsteine 109.

Aufgewachsene Kristalle 84.

Augenachat 628.

Augit $=$ Pyroxen, Augitgruppe 553.

Augustine, Sainte, Diamantgrube 214.

Aushöhlen, Auskolben 640.

Ausschlïgeln 98.

Australien, Diamant 283; Edelopal $47 \%$.

Avanturin 615; grïner 616, 626.

Avanturinfeldspat 52\%. 615 .

Avanturinglas 61\% 。

Avanturinquarz 615.

Avicula margaritifera 726, 727 .

Axinit 513.

Azurmalachit 649 .

\section{B.}

Babalpur, Indien, Diamant 178.

Badrachellum, Indien, Diamanten 175. 
Bagagem, Brasilien, Diamanten 156.

Baggerstein 667 .

Baghinfluß, Indien, Diamanten 179.

Bahia, Brasilien, Diamanten 199. Bahias (Diamanten) 202.

Bajaderen (aus Korallen) 750 .

Balasrubin 374.

Banaganpilly, Indien, Diamanten 173.

Banaganpillygruppe 167 .

Bandachat 628 .

Bandelkhand, Indien, Diamant 177.

Bandjaspis 614 .

Barkly West, Diamanten 217.

Barockperlen 723 .

baroques 99 .

Barro 191.

Bart der Perlmuschel 727 .

Bastard 660.676; buntknochiger 660; Grundstein 676; Halb660; Knibbel 676; knochiger 676 ; kumstfurbiger 660 ; perlfarbiger 660 ; Kund- 676 ; wolkiger 660 .

Bastardformen 99.

Bastit 555

Baumsteine 69. 621 .

Bearbeitung der Edelsteine 99 306 ; durch Atzen 106; Bohren 104. 310. 640; Brennen 106 . 645; auf der Drehbank 104; durch Färben 106, 642; Gravieren 104. 310. 641; Schleifen 99. 306.

Beckit $=$ Beekit 609 .

Beilstein 564.

Beintiirkis 501 .

Beiraghar, Indien, Diamanten 177.

Bellary, Indien, Diamanten 172.

Bengalen, Diamanten 177.

Benitoit 522.

Bergmahagony 548. 50 .

Berg des Lichts (großer Diamant) 314.

Bergkristall 582 .

Bernstein 657; -Bastard 660. 676; birmanischer 682 ; Bläschen 661 ; blauer 660. 662: chemische Zisammensetzung 657; Einschlüsse 663 ; eisfarbiger 660 ; Farben 660 ; Farbveränderung 662; flohmiger 660; Fluoreszenz 662. gebräunter 681; geschmolzen 673; Gewinnung 665; Größe der Stïcke 665 ; grüner 6fi2; Handelssorten 660. 675; als Harz 658; im Alluvium und Diluvium 668; in der B a u er, Edelsteinkunde. 2. Aufl. blaten Erde 664; Imitationen und Verfälschungen 676; indischer 652; Inklusen 663; kamadischer 683; I Klar 660; knochiger (Knochen) 660.676; kumstfarbiger 660; im Kunstgewerbe 673; massiver 655; mexikanischer 653; mürber, spröder oder unreifer 650 ; Rauchrequisiten 672; perlfarbiger 660 ; plıysikal. Eigenschaften 658; roter 659.662 ; rumänischer 651 ; runder 676; von San Domingo 683; schaumiger 661; Schmuck 672: schwarzer 659. 663. 691. 693; sizilianischer 681; Trübe 661); -Varictiiten 660. 675; Verarbeitung 671; Verwitterung 663; Vorkommen 664.

Bernsteinbaggern 667 .

Rernsteiubergwerk 669.

Bernsteinbitumen, Bernsteinöl, Bernsteinsäure 657. 655.

Bernsteinfichte 657 .

Bernsteinfirnis, Bernsteinlack65s. Bernsteingräberei 667 .

Bernsteinhandel u. - Handelssorten 674. 675 .

Bernsteininseln 667 .

Bernsteinkolophon 655. 673.

Bernsteinkonsum 674.

Bernsteinkorallen 672 .

Bernsteinkuchen von Spiller 675 .

Bernsteinlack 673.

Bernsteinperlen 672.

Bernsteinplatten 675; Polanger 675 .

Bernsteinregal 670 .

Bernsteinreiter 666 .

Bernsteintaucherei 667.

Berquen, Ludwig van 303.

Beryll 354; edler 356. 387. 401; gemeiner 356 ; Farbe $35 \%$; Farbenänderung durch Radiumstrahlen 72 .

Besondere Farben- und Lichterscheinungen an Edelsteinen $\mathbf{7 7}$.

Besters Kraal - Diamantgrube, Oranjefluß3-Kolonie 254.

Betrug bei Edelsteinen 115.

Bioganga, vulkanisches Gestein, Nuttergestein eines 'Teils der Citrine von Goyaz 587.

Birjpur, Indien, Diamant 17s.

Birmanischer Bernstein (Birmit) 682.

Birnförmiger Schliff 98 .

Bischofsstein = Amethyst, wegen der Verwendung dieses Edelsteins für die Ringe der Bischïfe

Biscauschliff 90, 96.

Black cleavage 270 .

Blischen in Bernstein 661 .

Blaitterbruch, Blätterdurehgang 29.

Blauer Bernstein f60. 662; blaue Erde 664. 669; blauer Jaspis; blane Koralle 761 ; blauer Spinell 376; blauer 'Turmalin.

Blaugrund 212. 224; Mineralien, Südafrika 227; Blaugrund, Deutsch-Siidwestafrika 260, in Gängen 231.

Blauspath $50 \%$.

Blauweiße Diamanten 155.

Blue ground, siehe Blaugrund.

Blue John 652.

Blue stuff 224 .

Blutjaspis 626 .

Blutstein 626. 655; Perlen aus B1. 733 .

Bobrowka-Granat 450).

Bodenstein (Bernstein) 675; natiirlicher 65S; Perlen 673. 67\%.

Böhmischer Diamant ว๊ร; Granat 443; Rubin 599: 'Iopas 597.

Bohren der Edelsteine 104. 641; des Diamants 310.

Bohrkronen mit Diamant 311.

Bonamit, Zinkspath von Nordamerika 525.

Boort $=$ Bort 265 .

Borneo, Diamant 274.

Börnstein 6 5 5 .

Bort, Bortkugeln 268. 269.

Boulders, Suidafrika 226.

Bourguignonperlen 733 .

Bouteillenstein 551 .

Boutonperlen 723.

Brabauter Rose 97.

Brack, Groß- u. Ordinäl, Bernstein) 676 .

Braganza, zweifelhafter großer Diamant 312, 315. 414 .

Brasilianischer Achat 632; Diamant 152; Chrysolith 462 ; Rubin 416 ; Sapphir 415. 463; Smaragd 462; Topas 415.

Brasilian-Topas 599.

Brasilien, Diamanten 182; Bahia 199; Goyaz 199; Mato Grosso 149; Minas Geraës 184 ; Paraná 195; Beschaffenheit 205; Produktion 207.

Brauner Jaspis 613; Topas 5981 Turmalin 463; Vesuvian 512.

Braunschweiger Klar 660 . 
Braunsteinkiesel = Mangankiese; (Rhodonit) כ̌t1.

Breccie, diamantenführende, am Kap 225.

Brechungsindex $=$ Brechungskoeffizient 44.

Brechungskoeffizient 44; $\mathrm{Be}-$ stimmung 62 ; Übersichtstabelle 66.

Brechungsverhältniß $=$ Brechungskoeffizient 44 .

Brennen der Edelsteine 106; des Achats 645 .

Bridschpur, Indien, Diamant 178.

Brillant 90. 91; amerikanischer 92; dreifacher 92; englischer 91; Gang der Lichtstrahlen 52 ; sächsischer weißer 317 ; von Tiffany 319.320 ; zweifacher 91 .

Brillantenleere 305 .

Brillantglas 305 .

Brillantrosette 99.

Brille 403.

Brillengläser 584 .

Brillolettes 98.

Brilloneten 93.

Briolette 98.

Bronzit 555; im Blaugrund, Südafrika 229.

Bruch der Edelsteine (ebener, glatter, muschliger; splittriger, unebener) 32. Blätter- 29.

Brut 87.

Bruttieren (Grauen) des Diamants 307.

Bultfontein, Diamantgrube 213.

Bultfontein mêlé 246.

Bunte Steine, Mursinka 459.

Buntknochiger Bastard 660 : Klar 660 .

Burmit $=$ Birmit.

Beynespoort(Byenest-Poort)-Diamantgrube, 'T'ransvaal 259.

Byon 341.

Byssus der Perlmuschel 727.

Bywater 270.

\section{U.}

Cabochon 98, doppelter 98.

Cacholong 485.

Caesiumberyll 408.

Caire's Stemschnitt 93.

Cairngorms 590.

Calchihuilt 496. 575 .

Calette $=$ Kalette.

Callaina, Callainit $=$ Kallainit 503 .

Callais = Kallais 503,

Cameen $=$ Kameen.
Canavieiras-Diamantgruben, $\mathrm{Ba}$ hia 204.

Cancrinit 539.

Canga 190.

Caĩons, unterirdische, Brasilien. Canteen rush 215.

Cap, Diamanten, siehe Kap.

Cape white 270 .

Carbonado 202.

Carbonat = Karbonat 202.

Carbonetto (Farbe von Korallen) Carborundum 102.

Carbunculus alabandicus 439.

Carmoisieren $=$ Karmoisieren 108.

Carneol = Karneol 623.

Cascalho 190. 191.

Cedarit 683 .

Celluloid $=$ Zelluloid 677 .

Cerachat 620 .

Cerkonier 428.

Ceylanit 377.

Ceylon, Edelsteine 360.

Ceylonesischer Chrysolith 462: Ceylonesisches Katzenauge 379; Ceylonesischer Peridot 462; Ceylanischer Rubin 441; Ceylonischer Zirkon 427.

Ceylonopal 530 .

Chalcedon 617; Färbung 618; gemeiner 620 ; gestreifter und ungestreifter 618; Holz- 609; okzidentalischer u. orientalischer 620.

Chalcedonachat 627.

Chalcedony Park, Arizona 609.

Chalcedonyx 628 .

Chal-che-we-te 496.

Changeant 5̌34.

Chapada, São João da; Diamantgrube, Diamantina, Brasilien 192.

Chaper, Diamant von

Chatoyieren 79. 530.

Chemische Zusammensetzung der Edelsteine 7.

Chennur $=$ Dschenuur, Indien, Diamanten 171.

Chiastolith $\mathbf{5 1 7}$

Chintapilly, Indien, Diamant. 175.

Chips 268.

Chlorastrolith 523 .

Chloromelanit 572 .

Chromdiopsid 556; im Blaugrund; Siidafrika 229

Chromglimmer 562 .

Chromgranat $=$ Uwarowit $\mathbf{4 5 1}$.

Chrysoberyll 377. 379; Farbenänderung durch Radium. strahlen $\lceil 2$.
Chrysoberyllkatzenauge 379.

Chrysocolla = Chrysokoll 521 .

Chrysolith 407. 504. 506. 512.

Chrysolith $=$ Chrysoberyll 381 .

Chrysolith $=$ Demantoid 451 .

Chrysolith $=$ Vesuvian 512;

Chrysolith, brasilianischer 462; Chrysolith, ceylonesischer 462 ; 508; Chrysolith, falscher 508; Chrysolith,okzidentalischer 508; Chrysolith, orientalischer 370 . 505; Chrysolith, sächsicher 415. 508; Chrysolitl vom Kap 523. Chrysopras 608. 609; künstlicher 645

Cincorasteine 202.

Cincora, Diamanten, Brasilien 200.

Citrin 587. 597; Farbenänderung durch Radiumstrahlen 72 .

Claims 237.

Clean stones 272 .

Cleavage 269.

Close goods 268.

Cocaës, Brasilien, Diamanten 185. 193.

Codavetta-Kallu, Indien, Diamanten 175.

Coenenchym der Korallen 734.

Colesberg Kopje = Kimberley grube 214.

Colorado-Rubine 448.

Common and ordinary mêtée 270 .

Compound system 273.

Condapetta, Indien, Diamanten 171.

Condapilly, Indien, Diamanten.

Corallium Johnstoni, Lubrani $u$. secundum 746 .

Corallium rubrum od, nobile 734 .

Cordierit 509.

Couleurte Diamanten $=$ farbige D. 158.

Coulcurte Steine = Halbedelsteine 2 .

Coulour, Indien, Diamanten 174.

Craquelées 107. 5 Ss.

Cristallière 585.

Crystals 270.

Cuddapah-Gruppe der Diamantgruben, Indien 171.

Ciilasse $=$ Külasse.

Cullinan 321.

Cunnapurty, Indien, Diamanten 171.

Cylinder aus Bernstein.

Cylindergemmen 608.

Cyanit 514.

Cymophan 379.

Cyprin 514. 


\section{I).}

Dammstein 670

Damplaats-Diamantgrube, Oranjefluß-Kolonie 254.

Danau radja, groler Diamant 276. Darya-i-nur, großer Diamant 315.

De Beers consolidated mines company 235; mining company 238. de Beer's Diamant 319 ; Diamantgrube 213.

De Beer's rush 213; new rush $=$ Kimberleygrube 214.

Deep brown (Diamanten).

Demant $=$ Diamant.

Demantglanz $=$ Diamantglanz 42 .

Demantoid 450.

Demantspath 372.

Demion = Karneol 623 .

Dendrachat 621 .

Dendriten 69 .

Dentelle der Rosette 97.

Denticĩo 587

Derb 9.

Deutscher Jaspis 613.

Deutscher Laspis (lazuli) oder Lasurstein 645 .

Dentsch-Suidwestafrika, Diamanten 21\%. 270 .

Diallag 5.5.

Diamant 136; Anomale Doppelbrechung 157; Aschenbestandteile 141; blauer, von Hope 317; Bortkugeln 268. 269; chemisches Verhalten 136; Bearbeitung (Schleifen, Gravieren, Durchbohren usw.) 306; Couleurt $=$ farbig 158 ; des Herrn E. Dresden 318; der Kaiserin Eugenie 317; des Sultans von Matan 276; Durchsichtigkeit 154; Einschlüsse 142 : elektrische Eigenschaften 164; Entstehung und Nachbildung 296; Entstehung in Südafrika 230; Farbe 158; des Pulvers 163; Farbenånderung durch Radiumstrahlen 72; Fehler 323; Festigkeit (Zersprengbarkeit) 154; Feuer 41. 52. 156; gepanzerter(nicht rein und klar); Glanz 155; GröBe der Kristalle 149 ; der Brillanten und Rosetten 305 ; große und berühmte 312 ; grüner, in Dresden 317; Härte 153; Kristallformen 143 ; künstl. Nachbildung 300; Lichtbrechung, Brechungskoeffizienten u. Dispersion 156; majästetische
306; Nachahmung und Verfailschung 325; optische Eigenschaften 15.; Phosphoreszenz 90. 163; Preis 271. 322; Schleiferei 306 ; Schleifpulver 102 ; Schlifformen 303 ; sch warze 160 ; Spaltbarkeit 152; spezifisches Gewicht 151; thermische Eigenschaften 164; Verfälschung 328 ; Verbalten in der Hitze, Verbrennen 138; Verwendung zum Drahtzichen 311, Schmuck 302 , technisch 310 ; Wasser 324 ; Werth und Preis 271, 322.

Diamanten, Vorkommen und Verbreitung 164; Afrika 164. 209; Algier 164; Arkansas 291; Australien 283; Böhmen 165 ; Borneo 274; Brasilien 182; Celebes 164; China (Schantung) 164; Deutsch - Südwestafrika 260 ; Guayana 208; Indien 166; Java 164 ; Kalifornien u. Oregon 288; Kapkolonie 209.216. 220; Kolumbien (Antioquia) 164; Lappland 294; Malakka 164; Meteoriten 295 ; Mexiko; Nordamerika 287 ; Oranjeflußkolonie 216.251; Ostindien 166; Rhodesia 260; Pegu 164; Seengebiet Nordamerika299; Sibirien 292; Spanien 165; Südafrika 209; im Blaugrund 227; im Diabas 220 ; in Seifen 217; Suidafrika, Beschaffenheit 263; Siam 164; Sumatra 164; Transvaal 217. 255 ; Ural 292.

Diamanten, berühmte große 312 ; sogenannte Schein- oder Simili 588; Alençon 585; Arkansas 559; böhmische 598; Briançon 585\%; Bristol 589; Fleurus 588; Insel Wight 588; irische 588; Lake George วั88; Marmaroscher 586; okzidentalische 588; Paphos 588; Quebeck 588; San Isidoro $=$ Bergkristalle vom Cerro de San Isidoro in Madrid; Schaumburger 556; Stolberger 586; Vellum 5\$6; Zobeltitz. Diamantenfluß, Indien 176.

Diamantenleere 305 .

Diamantenschwindel, Arizona291.

Diamantensyndikat 269.

Diamantführende Trichter, Südafrika (Kanäle, pipes) 221. 223; deren Entstehung 232.

Diamantführendes Gestein, Sïdafrika 224.
Diamantgewinnung, Kimberley 237.242.

Diamantglanz 42 .

Diamanthandel, Südafrika 268.

Diamantina, Brasilien, Diamant 174.

Diamantinasteine 202.

Diamantino, Diamanten 199.

Diamantkristalle 143. 149.

Diamantpreise 271. 322.

Diamantpulver, Verwendung 311

Diamantschleiferei 302. 306 .

Diamantseele 279.

Diamantseifen $u$. Wäschereien 165.

Diamantspat $=$ Demantspat 372 .

Diatremen, diamantführende, Südafrika 221. 223.

Dichroismus, dichroitisch 73 .

Dichroit 5009.

Dichrolupe, Dichroskop 74.

Dicht 12 .

Dichte $=$ Spezifisches Gewicht. Dichter Quarz 607.

Dickstein 96 .

Dilute Färbung 69.

Diopsid 55 5.

Dioptas 520 .

Dirhem 126.

Dispersion 49; Übersichtstabellen s6.

Distben 514.

Docke, Doppe 100.

Doppelbrechung 53; anomale 61; Erkennung im Polarisationsinstrument 58; Erscheinung in Edelsteinen $5 \%$.

Doppelrose, Doppelrosette 99.

Doppelspath, Doppelbrechung 55 .

Doppelte Cabochons 98.

Doubletten $=$ Dubletten 116. 117 .

Doyls Kopje u. Rush, Diamantgrube 214.

Dragomiten 596.

Drahtziehen, Anwendung von Diamant 311.

Dravit, brauner Turmalin von Kärnten 463.

Drehen der Edelsteine 194.

Dreifacher Brillant 92.

Dreifaches Gut 92.

Driller 204.

Drilling 11.

Drusen 84.

Dry diggings, Südafrika 210. 220.

Dschennurgruben, Indien, Diamant 171 .

Dschinon, Indien, Diamantgrube 171. 
Dubletten, dublierte Edelsteine, echte, halbechte, unechte, hohle 116. 117.

Dudley-Diamant 305.

Dïnnschliff 12.

Dïnnstein 96.

Durchscheinend, Durchscheinenheit 39.

Durchsichtig, Durchsichtigkeit 38 .

Dutch boart im Blaugrund, Südafrika 230 .

Dutoitspan, Diamantgrube 213. Dwts = penny weights 126 .

\section{E.}

Ebefluss, Indien, Diamanten 176.

Ebenezer (Ebenhaezer) -Diamantgrube, Oranjefluß - Kolonie 254.

Ebonit = Hartgummi 686 .

Edel 3.

Edelerden 7 .

Edelkoralle 733 .

Edelkorund 332.

Edelopal 466. (Siehe auch Opal, edler.)

Edelstein, abgestorbener 557 .

Edelsteine 1.-5. Rangs nach Kluge 132; Begriff 2; dublierte 116. 117; unechte 114; Erkennung und Unterscheidung $687 \mathrm{ff}$; Übersicht 132. 134.

Edelsteingewichte 124.

Edelsteinhärte 35 .

Edelsteinkunde 4.

Edelsteinschleiferei 99. 104. 302.

Edelsteinseifen 85.

Edelsteinwäischerei 85.

Edler Beryll 387; Koralle 733; Korund 332. 369; Opal 466; Quarz 580.

Eigenschaften der Edelsteine, chemische 7 ; elektrische 77 ; kristallographische 8 ; magnetische 77 ; optische 39 ; physikalische 12 ; thermische 77 .

Einachsig 59.

Einer 673.

Einfachbrechend 53 .

Einfassung 90.

Eingewachsene Kristalle 83.

Einschlïsse in Bernstein 663; Diamant 142; Edelsteinen 39.

Eisenglanz 655.

Eisenkiesel 611. 613 .

Eisenoxyd 655 .

Eisentongranat 432.

Eisfarbiger Bernstein 660.
Eisige Flecken 112.

Eklogit im Blaugrund, Südafrika 230.

Eläolith 538.

Elektriden 667 .

Elektrische Eigenschaften 82.

Elektron 659.

Elementarstein $=$ Schwefelkies 654.

Elementstein $=$ Edelopal 466 .

Elephantenjaspis, braun mit schwarzen Flecken, von Baumholder.

Elloregruppe der Diamantgruben, Indien 174.

Ely-Rubine 448.

Email 121.

Emden (Enden), flache Diamantsplitter, die zu Rosetten verschliffen werden 270 .

Emeraude reconstituée =é soudée 401.

En cabochon 98.

Engelbautfarbe bei Korallen 737. 749.

Engin 747.

Englischer Brillant 91.

Englisch-Rot 656 .

Enhydros 622 .

Enstatit im Blaugrund, Südafrika 229.

Epidot 518.

Erde, blaue 664. 668 .

Erzdunkel, Farbe bei Korallen 737.

Esmeraldas 419 .

Essence d'Orient 732.

Essigspinell 375.

Euklas 409

Excelsior $\mathbf{3 2 0}$.

Exotische Fragmente im Blaugrund, Südafrika 226.

\section{F.}

Facetten 88.90. 99.

Fahnen 39. 112.

Falkenauge 606 .

Falsche Edelsteine 114; falscher Amethyst 651. 652; Lapis (lazuli) oder Lasurstein 645; Rubin 651. 652 ; Sapphir 651. 652; Smaragd 651.652: Topas 597.651. 652.

Falsonephrite 571.

Fancy stones 67 ; finc- 270 .

Farbe 67.

Farbe, Charakter 65 .

Färben der Edelsteine 73: 106; des Achats 642
Farbenerscheinungen, besond. 7 \%

Farbenreihe 69.

Farbenschiller 7 S. 534.

Farbenspiel 52; des Diamants 156.

Farbenveränderung 70 ; des Bernsteins 659. 662 .

Farbenwandlung 78, 534.

Farbenzerstreuung 49; Übersichtstabelle 66.

Farbig 67.

Farbsteine, farbige Steine 67.

Farbstoff $=$ Pigment 67. 69 .

Fïrbung, dilute 69; künstliche 73. 106; des Achats 642 .

Faschoda-Granaten 449.

Faseraragonit 649 .

Fasergips 649 .

FaserigerAragonit, Gips und Kalk 649

Faserkalk 649 .

Fassung der Edelsteine 108; à jour 108; indische 109; im Kasten 108.

Favas 185. 189.

Federgips oder Federweiß Faselgips 649 .

Federn 112.

Federwage, Jolly'sche 20.

Fehler der Edelsteine 110; des Diamants 323 .

Feijão 18S. 189.

Feinschleiferei 104

Feldspatgruppe 525 .

Feldspat, labradorisierender 533 . Felsenrubin $=$ roter Granat 432: Festungsachat 6.8.

Fettglınz 42

Fettquarz 580 .

Fettstein 538

Feuer 41. 52. 156.

Feueropal 480

Fenerstein 579.

Fine fancy stones (Diamanten) 270.

Fine quality river stones 270 .

Firmamentstein 466 .

Firnis (Bemstein) 676.

Firuzeh 490 .

Nischauge 530.

Flachbeile 574.

Flammenopal 467.

Flash fire beim Edelopal 479 .

Flats 269

Flêches d'amour 601.

Flecken, elsige 112.

Fließen (Bernstein) 658. 675.

Flimmeropal 467.

Floating reefs im Blaugrund, Siidafirika 227. 
Flohmiger Bernstein 660 .

Floors bei Kimberley 244.

Floreutiner, großer Diamant 316.

I'lorstein $=$ Obsidian 5.18 .

Fluoreszenz S0; des Bernsteins 662. 681. 652. 65:3; des Fluß3spats 652 .

Iluorit 650 .

Flußablagerungen, diamantführende, Minas Geraës, Brasilien 19!): Siidafrika $21 \%$.

Fliissigkeiten, schwere, zur Bestimmung des spezifischen Gewichts 22. 27 .

Flußspat 650).

Flußsteine(Diamanten), Siidafrika 220 .

Flußwäschereien, Diamant, Brasilien 156; in Vaal (Kap) 217.

Folien 109.

Folienfarbe 110.

Formation d. brasil. Diamantablagerungen 159.

Fortifikationsachat $62 \mathrm{~S}$.

Fournieren, siehe furnieren 546 . 648.

Fragmente, exotische, im Blaugrund 226.

Frank Smith-Diamantgrube, Kapkolonie 232. 251

Fuchsit 562.

Fïnfzehner 673.

Furchen auf dem Korallenstock 736 .

Furnieren ă46. 648 .

\section{(i.}

Gagat 693.

Galanith 677 .

Galmei 524.

Gänge mit Blaugrund, Siidafirika 231.

Gani, Indien, Diamanten 174.

Gargun = Zirkon 426 .

Garimpeiros, Brasilien 197.

Garnierit 221.

Gebrannter Amethyst 592. 597; Karneol; Rauchtopas 597.

Gebräunter Bernstein 681 .

Gedanit 680 .

Gedrungene Schlifformen SS.

Gefärbt 67.

Gefäße, murrinische 634. 653.

Gehängeablagerungen, diamantfuihrende, Minas Geraës, Brasilien 191.

Gehärteter Kopal 678. 679.

Gekrönte Rose 97.
Gelbblank (Bemstein) 660. 676.

Gelber Kristall 5!95.

Gelbgrund = Yellowground, Siidafrika 224.

Gemeine Steine 3 .

Gemischter Schliff 95.

Gemme, vesuvische 511.

Gemmen 105.

Geode 631).

Geographische Verbreitung der Eilelsteine 84.

Gesaittigte Fürbung 68 .

Gestcinsbohrung mit Diamant 311.

Gestreckte Schlifformen 89.

Gestreifte Sande mit Bernstein bifit. 665

Gestreifter Chalcedon $=$ Achat 618 .

Gesundstrin (i54.

Gewicht, spezifisches 12; $\mathrm{Be}$ stimmung 12; Annäherungsmethode 26; Übersichtstabelle 29 ;

Giojetto (schwarze Koralle) 7 ว 1.

Girasol 357; 467 ; 450 ; 530; 732.

Glanz, gläuzend 41 .

Glanzeisenstein $=$ Hämatit 655 .

Glas, Imitationen von Bernstein 67T; von Edelsteinen 119; Müllersches 482; Straß 119; Vulkanisches 543 .

Glasachat 545 .

Glasätztinte siehe Ïtztinte 8 .

Glaserdiamanten 311.

Glasflïsse zur Imitation von Edelsteinen siche Glas $11 \mathrm{~S}$.

Glasglanz 42.

Glaskopf, roter 65 5.

GLaslava, schwarze 545 .

Glasopal 4S2.

Glaspasten 115 .

Glasquarz 581.

Glasschneiden mit Diamant 311. Glassies 270.

Glassy stones with smoky corners 161.

Glimmer in Blaugrund, Südafrika 229 .

Glockenperlen 723 .

Glyptik 10 5.

Godavery, Indien, Diamanten 175. Godwara, Indien, Diamanten 175. Golapilly, Indien, Diamanten 175. Gold im Blaugrund, Südafrika 230.

Goldberyll 357. 407.

Goldfluß = Avanturinglas 617 .

Goldopal 467. 452.

Goldquarz 601.

Goldtopas 597.
Goleonda, Indien, Diamanten 174.

Goods (close u. pool) 266.

Gorgulho, Minas Gerä̈s, Brasilien 191. 192.

Goutte d'ean 414.

Goutte de sang 374

Goutte de suif 99.

Goyaz, Diamant 119; Bergkristall 557.

Grabstein (Bernstein) 667.

Gradbogen (beim Schleifen) 100.

Grade des Glanzes 41.

Grains, grains troy 121.

Granat 432; Bobrowka- 450 ; böhmischer 44:; ceylonischer 439. 441 ; Deutsch-Ostafrika 449 ; edler (Almandin) 439; Faschoda-; Kolliner 442 ; orientalischer $=$ Almandin 439; rosenroter 451; sirischer (syrischer) 441; im Blangrund,Sïdalrika(Kaprubin) 2.28; Vermeille 440.

Granatscliale 99. 436.

Gran, grän 126 .

Grĩo Mogol (Mogor), Minas Geraës; Brasilien, Diamanten 194.

Graphit im Blaugrund, Südafrika 225 .

Grauen (Graumachen) des Diamants 307 .

Gravieren von Edelsteinen 104. $310.6+1$.

Great White (großer Diamant) 319.

Grecken aus Bernstein 672. 676.

Grenzwinkel der' Totalreflexion 46.

Griquait im Blaugrund, Siidafrika 230 .

Groß Brack (Bernstein) 676.

Größe dex Diamantkristalle 150, der Brillanten und der Rosetten 305.

Große Diamanten 312.

Großer Zweispitz (Rauchtopas) 590.

Großherzog von Toskana (großer Diamant) 316 .

Großnogul (großer Diamant) 313 . Großsteinschleiferei 104.

Grossular 4 j.

Großrater (Rauchtopas) 590

grs $=$ grains 121 .

Grïner Avanturin, Indien und Sibirien 616.626; Bernstein 662 ; Chalcedon 626; Diamant 317; Korund, Jaspis 614; Turmalin 462 . 
Grundfläche der Rosetten 96.

Grundstein 658.

Guayana, Diamanten 208.

Gupiarras, Minas Geraës, Brasilien 191.

Gurgolho $=$ Gorgolho 191. 192.

Giirtel der Sehliffformen 90.

\section{H.}

Haaramethyst $=$ Amethyst mit haarförmigen Eiinschlüssen 600.

Haarsteine 600.

Haiderabad, Indien, Diamanten 175.

Haidingersche Lupe 75 .

Halbbastard 660.676 .

Halbbrillant 93.

Halbdurchsichtig 39.

Halbechte Dublette 117.

Halbedelsteine, Begriff 3 ; Übersicht 133.

Halbflächige Kristalle 10.

Halbgründiger 'Tafelstein 95 .

Halbkarneol 620 .

Halbopal 482.

Halboliven 635 .

Halbperlen 724

Hämatit 655 ; Perlen aus H. 733.

Handelssorten des Bernsteins 675.

Hard bank = Hardibank, Südafrika 225 .

Hard blue, Suidafrika 225.

Harlekinopal 467. 479 .

Härte, Härtegrad, Härteskala 33; Übersichtstabelle38; undSchleifen 36 .

Harte Achatschichten 643.

Hartgummi 686.

IIarze zur Bernsteinimitation 677.

Harzglanz 43.

Haut des Achats 643.

Hauyn 547.

IIauynbestandteil des Lasursteins 541 .

Iledenbergit 556.

Heliotrop 620. 626 .

Hemiedrisch, Hemiedrie 10.

Hemimorph, Hemimorphismus 453.

Hessonit 437.

Hiddenit 557. 558.

Ilira Khund, Indien, Diamant 176.

Hitzlåufer 666 .

Hohldubletten 117.

Hohlmacher 640.

Hohlspat 517 .

Holländische Rose 97.
Holoedriseh, Holoedrie 10.

Holz, verkieseltes oder versteinertes 483. 484. 605 609 .

Holzachat 609. 620 .

Holzlöffelverkäufer(groß.Sapphir) 359.

Holzopal 483. 484.

Holzstein 608.

Hope's Diamant, blauer 317.

Hopetown, Diamanten 210.

Hornblendegruppe $=$ Amphibolgruppe 553.

Hornstein 607; im Blaugrund, Suidafrika 231.

Huf, Schliffform, 96.

Hunderter, Granaten 447.

Hïtchen 635.

Hyacinth 426. 438; = Granat 427. 438 ; = Vesuvian 513; von Kompostella= Quarz,431; ceylonesischer oder falscher = Hessonit 438; gebrannter 428; orientalischer 371 .

Hyacinthgranaten von Dissentis od. vom St Gotthard 439.

Hyacinthtopas 416.

Hyalit 470. 482

IIydrolith 622 .

Hydrophan 484; Ungarn 472.

Hydrostatische Wage 14.

Hypersthen 553.

\section{I.}

Idarer Achatschleiferei 635.

Idokras 511.

Ilmenit im Blaugrund, Südafrika 229.

Imitation von Edelsteinen 118; Spillersche u. Trebitzsche, von Bermstein 678 .

Imperial (großer Diamant) 319.

Indicolith-Indigolith 463 .

Indien, Diamantgruben 166.

Indigolith 463.

Indigosapphir 354.

Indikatoren zur Bestimmung des spezifischen Gewichts 25

Indische Fassung 109.

Indischer Bernstein 682; Schnitt 96 ; Topas 415. 425. 597; Katzenauge 379.

Ingegno 747.

Inkastein 654.

Inklusen im Bernstein 663.

Insulae glessariae 667 .

Intaylien 105 .

Iris 110.329 .602 .603$.

Irische Diamanten 588
Irisieren 77.

Isaaksgrube, Türkis, Persien $49^{2}$.

Iserin 656.

Isis nobilis 734 .

Island in der Debeersgrube 226.

Islindischer Achat 550.

Itakolumit, Brasilien 187. 194. 195.

\section{J.}

Jade 564.572 .

Jadeit 562. 572; roter 576 .

Jagersfontein, Diamantgrube, Oranjefluß-Kolonie 214. 232.

Jagersfontein stones 270 .

Jais 683.

Jargon de Ceylon 428.

Jaspachat (Jaspisachat) 615.

Jaspe fleuri 615.

Jaspis 611. 619; ägyptischer $=$ brauner 613 ; Band- 614 ; blauer, gelber, grüner 614 ; brauner u. roter 613 ; deutscher, gemeiner 613; Kugel- 613; Levante 612 ; Löhlbach 613 ; orientalischer 626; Porzellan- 614; weißer 612 .

Jaspisachat, Jaspachat 627. 628.

Jaspopal 482.

Jequetinhonha, Brasilien, Diamanten 185; farbige Edelsteine 419.

Jet 683 .

Jodmethylen 22. 27 .

Jolith 509.

Jollysche Federwage 20.

Jubiläumsschliff 94 .

Julius Pam, großer Diamant.

Jüngerer Quarzit, Brasilien 157.

Jungferaperlen 720 .

Juwelen 2; Übersicht 132.

\section{Ii.}

Kaalfontein-Diamantgrube,

Transvaal 259.

Kaiserlicher $Y$ ï 616 .

Kalait 486.

Kalette des Brillants 91.

Kalifornit 513.

Kalkehromgranat 432 .

Kalkeisengranat 432 .

Kalktongramat 432 .

Kalkspat im Blaugrund, Sïdafrika 230 .

Kallainit, Kallais 503.

Kallait 486.

Kalmïckenachat od. -Opal 485. Kameen 105. 
Kameriya, Indien, Diamant 178. Kanadischer Bernstein 653.

Kanäle, diamantführende, Südafrika, siche pipes.

Kaneelstein 437.

Kännelkolle 65i.

Kantendurehscheinend 39 .

Kapchrysolith 523.

Kapdiamanten 209.

Kapjes, durch Spalten (306) erhaltene Diamantoktaeder.

Kapkolonie, Diamantgruben 216; 251.

Kappgut 96. 99.

Kaprubin 229. 448.

Kapsmaragd 523.

Kapsteine 209.

Kapweif = cape wihite 270.

Karat 124.

Karatgut $=$ Diamanten unter ein Karat 306.

Karatsteine 306.

Karbonat 202 ; im Blaugrund, Siidafrika 229.

Kirfunkel 334. 435 .

Karfunkelrot der Korallen 737.

Karlsbader Sprudelstein 649 .

Karmoisieren 108.

Karmusiergut (Topas) 419.

Karneol 620. 623; männlich u. weiblich 623.624 ; vom alten Stein 623 ; weiß 620.623

Karneolachat 627 .

Karneolberyll = weißgelber Karneol.

Karneolonyxe 628.

Karnul, Indien, Diamant 173.

Karnulformation 167 .

Kascholong 485.

Käsesteine, rohe Diamanten ohne bestimmte Form.

Kasken 305.

Kasten, Fassung 10 S.

Kastor u. Pollux (Rauchtopas) 590.

Katzenauge 379. 603; ceylonesisches, indisches oder orientalisches 379; Lichtschein 79; okzidentalisches (Quarz-) 603; ungarisches 605 .

Katzensapphir 354.

Kawakawa 571.

Kieselgalmei 524 .

Kieselglas zur Nachahmung von Edelsteinen 122.

Kieselkupfer 521.

Kieselmalachit 521.

Kieselzinkerz 524.

Kimberley, Diamantgewinnung 237; Diamantgruben 213. 214.
Kimberley mining board 241 .

Kimberleygrube 214

Kimberleygruben 215. 214; bergmïnnische Einrichtung 242; Produktionsmenge 247; Qualitiit der Diamanten 267.

Kimberlit, Südafrika 235.

Kimberlitbreceic od. -Tuff 235.

Kirschperlen 724.

Kistapully, Indien, Diamanten. Kittstock 100.

Klar, Bernstein 660 ; braunschweiger u. buntknochiges 660 .

Klarkochen des Bernsteins 661.

Klassifikation der Edelsteine 132.

Klebssche W:äsche 670 .

Klieven des Dianıants 306 .

Klipfontein-Diamantgrube, Oranjefluß-Kolonie 232. 254.

Klipdrift = Barkly-Weet, Diamanten 217.

Klumpige Formen 85.

Knibbel (Bernstein) 65s.

Knochen, knochiger Bernstein 660.

Knochenfirnis (Bernstein) 676.

Knochiger Bernstein (Knochen) 676.

Knopfopal 467.

Koffyfontein, Diamantgrube 214. 254.

Kohärenz 29.

Kohinur (großer Diamant) 313.

Kokrah, Diamanten 17 .

Kolliner Granaten 442.

Kollur, Indien, Diamanten 174.

König (Rauchtopas) 590.

Königskoralle $7 j 1$.

Königstopas, Ceylon 363. 371.

Kopal statt Bernstein 677; gehärteter 679 . 679 .

Korallen aus Bernstein 672.

Korallen 733; blaue 751; edle 733; falsche 750 ; Gewinnung 746 ; lebende 739 ; riffbauende 742 ; rote 733 ; schwarze 737.749 . 751 ; Stellung im Tierreich 739. 751 ; Stock 734; Furchen undVertiefungen darin 736 ; tote 737 . 744. 749; Verarbeitung 749, verfaulte 749 ; Verwendung 750 ; Vorkommen 743.

Korallenachat 609. 628 .

Korallenbänke 743 .

Korallenbruch (Bernstein) 676

Korallenfeld $=$ Korallenbank 745 .

Korallenfischerei 746 .

Korallenhandel $\mathbf{7 4 6 .}$

Koralleninseln 742 .
Korallenriffe 742 .

Korallenstock 734; Furchen und Vertiefungen 736 .

Korubin 102.

Korund 329; edler u. gemeiner 332; Farbe 333; Farbenänderung durch Radiumstrahlen 72 ; männlich u. weiblich 333 ; orientalischer 3ะษ; Schleifmittel 102 ; Südafrika, im Blaugrund 230.

Krappen, Krappeln 105.

Kraut (Bernstein) 666.

Kreisachat 628.

Kreuzrosette 97.

Kreuzstein 517.

Kristall = Bergkristall 593 ; gelber $=$ Citrin 595 .

Kristall, Kristallformen, kristallinisch, kristallisiert, Kristallographie 9.

Kristalle, auf- und eingewachsen $\$ 4$.

Kristalldruse 84.

Kristallhöhle, -Keller, -Gewölbe 585. ว59.

Kristallisiert, kristallinisch 11.

Kristallisierter Quarz 582.

Kristallsysteme 10.

Krokydolith im Quarz 606.

Krokydolithopal 483.

Krone am Brillant 90; an der Rosette 97.

Krone des MIondes (großer Diamant 315 .

Kugeljaspis 613 .

Külasse 90.

Kumstfarbiger Bernstein 660 .

Künstliche Färbung der Edelsteine 73; des Achats 642 .

Künstliche Nachbildung von Edelsteinen 113. 115.

Künstliche Perlen 732.

Kunzit 558. 559 .

Kupferblau 521.

Kupfergrïn 521.

Kupferlasur 649

Kupfersmaragd 520.

Kïraß 640.

Kyauk-tsein 577 .

I.

Labrador, Labradorit, Labradorfeldspat, Labradorstein 533.

Labardorgestein 536 .

Labradorhornblende 553.

Labradorisieren 78. 534.

Labradorisierender Feldspat 533. 
Lace-Diamantgrube, OranjeflußKolonie 25.1.

Lachmanpur, Indien, Diamanten 179

Lagerstätten der Edelsteine 84.

Lake George-Diamanten 588.

Landak (Borneo). Diamant 274.

Land pits, Ceylon 362.

Landschaftsachat 628 .

La Pellegrina (große Perle) 723.

Lapidär 636. 639.

Lapis, deutscher oder falscher 645 .

Lapis lazuli 539.

Large white cleavage 270.

Lasurquarz 600.

Lasurstein, Lasurit 539; deutscher oder falscher 645 .

Lava, Lavaglas 548.

Lavra, Brasilien 196 .

Lazulith 503.

Lechosopal 474. 475.

Lepidolith 562.

Leukogranat 435 .

Leukosapphir 355.

Licht, homogenes, weiles 49 .

Lichtbrechung 43; doppelte und einfache 53.

Lichterscheinungen, besondere 77.

Lichtschein, wogender is.

Liebespfeile 601

Light bywater 270.

Lincotiusche Regel 127.

Linsen aus Diamant 310; aus Sapphir 332.

Lintonit 524.

Lithionamethyst $=$ Kunzit 559 .

Lithionglimmer 562 .

Lithionsmaragd 558 .

Lithoglyptik 105.

Load 23!.

Löhlbacher Achat 613.

Lothperlen 72 .

Luchssapphir oder -stein 354; 509 510 ; tokayer $\mathrm{L}_{\mathrm{.}}=$ Obsidian 548

Lüderitzland, Deutsch-Südwestafrika, Diamanten 260 .

Lumineszenzerscheinungen 80 .

Lupe von Haidinger 74

\section{II.}

Maacles, Mackel, Macle 26S. 270 .

Madeiratopas 597 .

Magnesiatongranat 432.

Magneteisen im Blaugrund, Südafrika 230

Magnetische. Eigenschaften der Edelsteine 84.
Mahanady, Indien, Diamanten 175.

Main reef 226 .

Mainzer Fluß 119.

Majestätische Diamanten 306.

Majgama, Majgoha, Indien, Diamant 178 .

Makassarschalen 729 .

Malachit 646 .

Malavily, Indien, Diamanten 175. Maleti, Indien, Diamanten 175.

Maitheserkreuz 95.

Mamusa, Diamant 215.

Iandelachat 629

Mandeln, Mandelsteine 593.

Mandrill, Refiefs von 536.

Manellen 673 .

Manganepidot 520 .

Mangangranat 439 .

Mangankiesel 561.

Manganspat 562 .

Mangelin 126.

Männliche Steine 333; Karneole 624; Rubine 334; Sapphire 355.

Marathonstein = Obsidian 508 .

Narekanit 5๊ 1.

Margaritana margaritifera 726 .

Markasit 654 .

Narmaroscher Diamanten 586.

Narmor 649 .

Mascha 126.

Massiksteine 643 .

Massiver Bernstein 655; Klar 660.

Matara- orler Matura-Diamant 428. 430.

Mato grosso, Diamanten 199.

Matt 41.

Maxwell-Stuart-Topas 425.

Mazarins 91.

Meer des Lichts, großer Diamant 315.

Mekkastein, blauer Chalcedon aus Arabien.

Melanit 451.

Melíe 265. 270. 272.

Meleagrina margaritifera 726.727 .

Menilit 454 .

Mesotyp = Natrolith 524 .

Metallglanz 42 .

Metallischer Schiller 79 .

Methylenjodid 22. 27.

Mexikanischer Achat oder Onyx 649; Bernstein 683; Opal 469.

Milchopal 470. 483.

Milchweißer Achat, künstlich 645 .

Millionär = Regent, großerDiamant 315.

Minas Geraës, Brasilien, Diamanten 186. 195; Bagagem 186;
Cocäes 193; Diamantina 184; Grao Mogol 194; Rio Abaëte 185; farbige Edelsteine 419.

Minas novas, Edelstene 419.

Mineralien im Blaugrund, Suidafrika 227.

Mineraltïrkis 502.

Mischkâl 126 .

Mixte 116

Mochastein 621

Mohrenköpfe 455 .

Mokkastein 621. 622.

Moldawit 551. 552 .

II onastery-Diamantgrube, Oranjefluß-Kolonie 232. 2 24.

Mond der Berge, groler Diamant 314.

Mondstein 530 .

Montrose-pipe, Transvaal 259.

Moor 109.

Noosachat 622 .

Moosig 112.

Noosopal 483.

Moossteine 600.

Morion 589.

Noroxit 653 .

mountains mahogany 548 .

Mückenachat $=$ Mückenstein 622

Mugelig 90.98.

Mïllersches Glas 482.

Munimadagu, Indien, Diamant 172.

Mïrber Bernstein 650 .

Murrinische Getiiße 634. 653.

Muschelachat 628 .

Inschelkameen 642 .

Muttergestein der Edelsteine 84.

\section{N.}

Naats 265.

Nachahmung (Verfälschung) von Edelsteinen $11 \mathrm{~S}$.

Nachbildung, künstliche, von Edelsteinen 113.

Nadel, elektrische 82.

Nadelsteine 600.

Nandialgruppe, Diamantgruben, Indien 173.

Nassak, großer Diamant 316.

Natrolith 524.

Natiirl. Bodenstein 658 ; rund 658.

Naturspitzen (Bernstein) 676.

Navetteschliff 96 .

Navettebrillantschliff 93 .

Negerkorallen $67 \%$.

Nephelin 538.

Nephrit 562. 564.

Nephritoide 562. 
Neu-Siid-IVales, Diamant 283 ; Edelopal.

New-Gong-Gong, Diamanten 218.

Newkerke, Diamanten 218.

Newlands-Gmben, Diamant, Kapkolonie 232, 251.

Nicol, Nicolsches Prisma 59.

Nierenstein 564. 572.

Nilkiesel 613.

Nizam, großer Diamant 315.

Nonpareils 306.

Noumeait $=$ Numeait 521 .

\section{().}

Obalumpally, Indien, Diamanten 171.

Oberkörper, Oberteil bei Schliffformen 90.

Obersteiner Achatindustrie 635.

Obsidian 508. 548. 5อั1. 55ร3 ; schillernder 549. 550 .

Occidentalische, orientalische Steine 86. 333. 369; Perlen 730.

Occidentalischer Achat 628; Chalcedon 620; Occidentalische Diamanten 558; Occidentalisches Katzenauge 603; Occidentalischer Topas 597 ; Türkis 603.

Ochsenaugen 535 .

Oculus 471; oculus mundi 484.

Odontolith 501

Oeil de boeuf 535.

Offcoloured 271 .

Oitava 126.

Oktave 126.

Old de Beers, Diamantgrube 213. (siehe De Beers).

Oligoklasmondstein 533.

Oligoklassonnenstein 529 .

Oliven aus Achat 635; aus Bernstein 672

Olivin 504. 506; im Blaugrund, Südafrika 229.

Olivin $=$ Demantoid 451 .

Olivinknollen 506.

Onyx 620.625; mexikanischer 649: schwarzer 686.

Onyxalabaster 649 .

Onyxmarmor 649.

Onyxstreifen 645 .

Onyxvase, braunschweiger 642 .

Opak 39.

Opal 464; Australien 477; bunter 484; ceylonesischer э50; edler 466; gemeiner 482 ; mexikanischer 469 ; orientalischer 466. 469; rosenroter
484; Südafrika, im Blaugrund 231; Ungarn 469; Steinheim 483 ; verinperlicher $=$ Hydrophan 484 .

Opal, edler 466; edler, Amerika 474; edler. Australien 477 ; edler, Guatemala 475; edler, Honduras 474; edler, Japan 478; Lechosos 475. '476; edler, Mexiko 474; edler, Neu-Süd Wales 477; edler, Queensland 479; edler, Ungarn 469; edler, Vereinigte Staaten 476; edler, Vorkommen 465; edler, White Cliffs 477.

Opalachat 483 .

Opalin 479.

Opalinglas zur Imitation von Perlen 733.

Opalisieren 79 .

OpalisierenderRubin,Sapphir usw. 357.

Opaljaspis 482.

Opalkatzenauge 483.

Opalmutter 471 .

Opalonyx 467. 474.

Optische Achsen 59.

Optische Eigenschaften 38.

Oranjefluß-Kolonie, Diamanten 216. 251.

Ordinär Brack 676 .

Orient bei Perlen 721.

Orientalische, occidentalische Steine 86. 333. 369; Perlen 730.

Orientalischer Achat 628; Amethyst 371; Aquamarin 370 ; Chalcedon 620; Chrysolith 370 ; Girasol 357; Granat = Almandin 439; Hyacinth 371; Jaspis 626; Katzenauge 379; Perlen 730 ; Rubin 334; Sapphir 354; Smaragd 370; 'Topas 370; Vermeille 371.

Orlow, großer Diamant 313. 314. Orthoklas 526 .

Orthoklassonnenstein 529 .

Österreicher; großer Diamant 316. Otto's Kopie, Diamantgrube 214. Ounce 126.

$\mathrm{oz}=$ ounces 126 .

\section{P.}

Paars (Perlmuschelbänke), Cerlon $\because \cdot 2 \tau$.

Panarfluß, Indien, Diamanten 171. Pannagrappe der Diamantgruben, Bandelkhand, Indien 177.

Paphos-Diamanten 5ss.
Paraná, Diamanten 195.

Parangonperlen 723.

Parangons, große Diamanten 306. 312.

Parcles inferior.

Parisit 394.

Partial, Indien, Diamanten 175

Pascha von ägypten, großer Diamant 317.

Pasten 118.

Pâte de riz 571.

Patparachan 363.

Panlit 553.

Pavillon 90.

Pechopal 482. 484.

Pegmatit, grobkömiger, ganzförmig auftretender Granit.

Pelle d'angelo (Farbe von Korallen) 739.

Pellegrina, la, grole Perle 723.

Pendeloques 96. 9!); en cabochon 9S.

Pennyweight 126.

Peredell = gelbgrüncr Topas.

Peridot 504. 506; ceylonesischer 462. 465.

Peridot $=$ Demantoid 451 .

Peristerit 532.

Perle als Schliffform 95; aus Bernstein 672 ; aus Korallen 750 .

Perlen 715 ; Amerika 729 ; Angreifkarkeit durch Säuren, Schweiß usw. 720; aus Dugongzähnen 733 ; aus Hämatit 733 ; aus Opalinglas 733 ; Ceylon 727; Durchbohrung 724; Eigenschaften und Entstehung 716. 721; falsche 732; große 723. 726; Imitationen 732; Indischer Ozean 729 ; litinstliche 732; Persischer Meer= busen 728: Preis 725; Produktion 730 ; reife 721 ; Rotes Ileer 729 ; Sachalin 729 ; Stiller Ozean 729; Struktur 718; ununreife 722; Verbreitung 727 ; Verwendung 724; Wiederherstellung der schönen Oberflïche 720.

Perlenaugen 723.

Perlenbildung, Ursache 717 ; kiinstliche $\mathbf{7 3 2}$.

Perlenbirnen 723.

Perlenessenz 732.

Perlenfischerei 726

Perlenleere 724 .

Perlenwarzen 718, 725.

Perles an nacre 733.

Perles des Indes 733 . 
Perlfarbiger Bernstein 660 .

Perlmuschelbänke 727; künstliche 730.

Perlmutter 716 .

Perlmutterglanz 42.

Perlmutteropal 485.

Perlmutterschicht $\mathbf{7 1 7}$.

Persischer Türkis 490.

Peruanischer Smaragd 391.

Pfenniggewicht 126.

Pferdekorallen 673.

Pfund Troy 126.

Phantasieperlen 718. 725.

Phantasiesteine $=$ farbige Edelsteine; Diamanten (farbig) $=$ fancystones 270 .

Phenakit 410.

Phosphoreszenz 80; beim Achatschleifen 640 .

Piedra de la hijada 572.

Piemontit 520.

Pigment 67. 69.

Pigott, großer Diamant 317.

Pine fire beim Edelopal 429.

Pingos d'agoa 414.

Pinites succinifer 657.

Pink $=$ mattrote Topas.

Pint, Diamant 147.

Pipes, Suidafrika 212. 221. Ausfïllungsmasse 223; Entsteliung 232.

Piruzeh 490.

Pistazit 518.

Pits, Ceylon 362.

Pitt, großer Diamant 315 .

Plagioklas 526

Planparallele Platte, siehe Platte, planparallele.

Plasma 620626.

Plateauablagerungen, Diamantführende, Minas Geraës, Brasilien 191.

Platte, planparallele Dispersion 50 ; doppeltbrechende 54 ; Lichtbewegung 48.

Platten (Bernstein) 658. 675; Polanger Platten 675.

Pleochroismus 73.

Pleonast 377.

Pniel, Diamanten 217.

Polanger Platten, Berns tein 675.

Polarisationsinstrument 57; Anwendung 61 .

Polarstern, großer Diamant 315.

Polieren 101. 102.

Poliermittel 103.

Polierscheibe 103.

Polierzähne 635. 656.

Pollux, Rauchtopas 590.
Pool goods 268.

Porzellanjaspis 614 .

PorterRhodes,großerDiamant314.

Portraitsteine 305.

Pound troy 126.

Prasem 599.

Praser $=$ Chrysopras 609 .

Prasopal 483. 610.

Prehnit 523.

Preis der Edelsteine, allgemeines 122.

Premier - Diamantgrube, Transvaal 256.

Premier- (Wesselton-) Grube bei Kimberley 214.

Preßbernstern 678.

Prisma, Dispersion 53; doppelbrechendes 56 ; Lichtbewegung 48.

Produktionsmenge d. südafrikan. Diamanten 246. 248.

Pseudochrysolith 551.

Pseudodiamanten (aus Bergkristall) 585-588.

Ptolemäerkamee 642.

Puddingstein 637.

Punamu 571.

Punktachat od. -chaIcedon 621.

Purpurachat 591.

Purpursapphir 371.

Pyknit 413.

Pyknometer 13.

Pyon = Byon 341.

Pyrit 654.

Pyroelektrizität 83.

Pyrop 443.

Pyrophan 485.

Pyrophysalith 413.

Pyroxen; Gruppe 5ว̌3; im Blaugrund, Südafrika 229.

\section{Q.}

Quadrant 100.

Quarz 578.

Quarz, brauner 589; dichter 607; edler 580; Einschlüsse 600 ; Einteilung 581; Farbe 580; Farbenainderung durch Radiumstraklen 72 ; farbloser 582; fasriger 603. 605. 607; gelber 597 ; gemeiner 580 ; irisierender $=$ Regenbogenquarz 602 ; kristallisierter 582; Nachahmung von Diamant585-588; violetter 591.

Quarzglas zur Nachbildung von Edelsteinen 112.

Quarzit, juingerer, Brasilien 187.
Quarkatzenauge 603.

Querfacetten des Brillants 91; der Rose 97.

\section{R.}

Radiumstrahlen, Änderung der Edelsteinfarben 71 .

Ramulkota, Indien, Diamant 174.

Rand der Schliffformen 90.

Raolconda, Indien, Diamanten 174.

Rasura (Bernstein) 676.

Rati 126.

Rauchtopas 589; Farbenänderung durch Radiumstrahlen 72; gebrannter 597 .

Raute (Rose) 96.

Red ground, Südafrika 224.

Reef $=$ Riff der südafr. Diamantgruben 221 ; floatingreef 226 ; mainreef 326 .

Refraktometer zur Bestimmung der Brechungskoeffizienten 62.

Regel von Lincotius, Schrauf u. Tavernier zur Preisbestimmung der Edelsteine 127.

Regenbogenachat od. -Chalcedon 627.

Regenbogenquarz 602.

Regent, großer Diamant 315.

Regina-Diamantgrube, Oranjefluß-Kolonie 254.

Reiben (Grauen) des Diamants 307.

Reibungselektrizität 83 .

Rejection stones 269.

Reproduktion der Edelsteine 113. Rewahgruppe, Indien 167.

Rheinkiesel 585. 588.

Rhodesia, Diamanten 217. 260.

Rhodolith 450 .

Rhodonit 561.

Riff der Diamantgruben, Siidafrika 223 (siehe auch reef).

Riff (Korallen) 742.

Rio Abaëte, Diamanten 185.

River diggings, Vaal. 211. 217.

River stones, fine quality 270.

Roads = Roadways, Kimberley 240.

Roberts Victor-Diamantengrube, Oranjefluß-Kolonie 254.

Röhrenachat 630 .

Rondell 98 .

Röntgenstrahlen, Verhalten der Edelsteine gegen 40.

Rosatopas 416; künstlicher $=$ synthetischer Topas $\mathbf{3 5 2}$. 
Rose $=$ Rosette $90.96 ; \Lambda \mathrm{m}$. sterdamer, Antwerpener, Brabanter, gekrönte, hollindische, recoupée 97.

Rosenquarz 599.

Rosenroter Opal 484.

Rosette $=$ Rose.

Rospoli, großer Sapphir 359.

Rotblank des Bernsteins 660.676.

Roteisenstein 655 .

Roter Bernstein 659. 662; roter Glaskopf 655; roter Jadeit 576; rote Koralle 733; rote Perlen 722 ; roter 'lopas 416 ; Turmalin $45 \mathrm{~s}$.

Rubbish 269.

Rubellit 458.

Rubicell 375 .

Rubin 329. 334; Adelaide 447; Afghauistan (Dschagdalak u. Gandamak) 349; Arizona 448; Badakschan 349; Birma (Mogouk) 338; Birma (Nanya-zeik) 345; Birma (Sadschijinhügel) 345 ; böhmischer 354 . 599; brasilianischer 354. 416; ceylanischer 441; Ceylon 349; Colorado 448 ; d. schwarzen Prinzen 375 ; Ely- 445; falscher 354; Farbe 334; Farbenänderung durch Radiumstrahlen 72 ; Kabul 349 ; Kap- 448; künstlich 351; männlich u. weiblich 334 ; opalisierender 335.357 ; orientalisch334; Schmuckstein337;Siam (Tschantabun) 346 ; sibirischer 354. 459; synthetischer 352; Unterscheidung 353; Vorkommen 338.

Rubinasterie 357.

Rubindubletten 116.

Rubinglas $35 \%$.

Rubinkatzenauge $35 \%$.

Rubinmutter 354 .

Rubinspinell 374.

Rubinsternstein $35 \%$

Rubis balais 374 ; rubis in Uhren 57 ; de Genêve 352 ; reconstitués 352 ; scientifiques 351 ; synthétiques 352.

Ruinenachat 628.629.

Rumänischer Bernstein, Rumänit 681.

Rund, natürliches (Bernstein) 658.

Rundieren der Edelsteine 101.

Rundiste der Schliffformen 90.

Rundsteine 98.

Rush, Suidafrika 212.
Rusty ground, Sürlafrika 224 .

Rutil 656.

Rutte 126.

\section{S.}

Saatperlen 724.

Sächsischer Chrysolith 415; 'To415; weiljer Brillant 317 .

Safiras 419 .

Sägen der Edelsteine 103.

Sahia Lachmanpur, Indien, Diamant 179.

Sakerija, Indien, Diamant 178.

Salobro, Bahia, Diamant 204.

Salzkörner 306.

Sambalpur, Indien, Diamant 176.

Sancy, großer Diamant 316.

Sand 111.

Sandperlen 724 .

São João da Chapada, Diamantgrube, Brasilien 192.

São Paulo, Diamanten, 198.

Saphir = Sapphir,

Sappar (Sapparé) 514.

Sapphir 329. 354. 539; brasilianischer 415. 463; falscher 651 ;

Farbe 355; Farbenänderung durch Radiumstrahlen 72 ; gelber 370; künstliche Darstellung 356. 368; orientalischer 354 ; Verfälschungen 368; Vorkommen 359 ; weiblicher, männlicher 355; weißer 355.

Sapphir = Lasurstein 539 .

Sapphirasterie 35\%.

Sapphirdubletten 116.

Sapphirin 620.621.

Sapphirkatzenauge 357 .

Sapphirquarz 600.

Sapphirspinell 376

Sapphirsternsteine $35 \%$.

Sarder (Sard), Sarduin, sandiger Sarder 625 .

Sardonyx, Sardlagen 528. 629.

Sarkosom der Korallen 734 .

Scepterquarz 593 .

Schah, großer Diamant 315.

Schale (Granatschale) 98.

Schaumburger Diamanten 586.

Schaumiger Bernstein 661 .

Scheindiamant (aus Bergkristall) 55.5-55s.

Schiller, metallischer 79.

Schillernder Obsidian 549. 550.

Schillerquarz 603.

Schillerspath 555.

Schimmernd 41.

Schlange (snake) in der De Beersgrube 235.
Schlauben (Bernstein) 659. 676.

Schleife (Achat-) 638. 639.

Schleifen und Härte 36 .

Schleifen, Vorbereitung 103.

Schleifmühle für Achat 639; für Diamanten 308 (100).

Schleifprozels 88. 99.

Schleifpulver $=$ Schleifmittel 102.

Schleifscheiben 102.

Schlieren 119.

Schliff des 20. Jahrhunderts 94 ; mit doppelten Facetten 95 ; mit verlängerten Brillantfacetten 95.

Schliffformen 88. 90; Diamant 303.

Schmelz 121.

Schmelzbarkeit 81 .

Schmirgel 102.

Schuallensteine (Topas) 418.

Schneckensteintopas $=$ Schnekkentopas 418.

Schneidebiichse 307.

Schneiden $=$ Grauten rles $\mathrm{Di}$ amants $307 ;=$ Gravieren 105 , des Diamants 310 .

Schnitt, gemischter 95; indischer 96 ; mugeliger 95 ; mit doppelten Facetten 95 ; mit verlängerten Brillantfacetten 95 .

Schnittformen $=$ Schlifformen 88. 90; Diamant 303.

Schnurware (Perlen) 725.

Schöpfen des Bernsteins, Schöpfstein 666 .

Schörl = sch warzer Turmalin 463 . Schottischer Topas 590. 593.

Schottländer 537.

Schraufsche Regel zur Preisbestimmung 127 .

Schreibdiamanten 311 .

Schuller - Diamantgrube, Transvaal 232, 259 .

Schwarzer Bernstein 659. 662. 663. 681. 683; schwarze Glaslava 545; Koralien 749. 751; Onyx 686 ; Spinell 377.

Schwarzfirnis (Bernstein) 619.676. Schwarzharz 663 .

Schwefelkies 654 ; im Bernstein 663.

Schwere Flüssigkeiten zur Bestimmung des spezifischen Gewichts 22.27 .

Schwerspat im Blaugrund, Südafrika 251.

Searching system 273.

Sechzehner Granate 447.

Seebernstein (Seestein) 665.

Seeperlmuschel (Seeperlen) 726 .

Seestein (Bernstein) 665. 
Segima, großer Diamant 276.

Seidenglanz 42.

Scidenspat $=$ Faserkalk 649 .

Seifen, Edelstein- 85; Diamant $=$ 165.

Semelpur, Indien, Diamant 177.

Senaille 305.

Serpentin im Blaugrund, Sïdafrika 229.

Serpentinbreccie (-tuff), diamantführende, Südafrika 225.

Serra da Chapada, Brasilien.

Diamanten 200.

Serra da Cincora (Sincora), Brasilien, Diamanten 200.

Serra do Espinhaço, Brasilien, Diamanten, 187.

Serra do Frio, Brasilien, Diamant $18 t$.

Serramassik 643.

Serrasteine 644.

Serviens do eampo 197; do rio 196; da serra 197.

Siam, Edelsteine 359.

Siberit 458 .

Sibirischer Aquamarin 402; Rubin 459 ; Topas 415; Turmalin 459.

Siderit 600.

Siegrelsteine 105.

Silex, Name der Steinschleifer in Idar für Nilkiesel und roten Kugeljaspis (613) und ähnliche Steine.

Simetit 681 .

Similidiamant 558 .

Simla, Indien, Diamant 178.

Sincora-Diamanten od. -Steine 200.

Siuux Falls Jasper 614.

Sirischer (syrischer) Granat 441.

Sizilianischer Bernstein 681.

Sklavendiamanten 414 .

Sklerometer 37.

skulptur 105.

Smaite = Email 121

Smaragd 357 ; brasilianischer 462. falseher- 651; Farbenänderung durch Radiumstrablen 72 ; Fundorte 390; orientalischer 370 .

peruanischer 391; spanischer 391; uralischer 451; Verfälschungen 101.

Siehe auch émerande; vom Kap = Prehnit 523.

Smaragdfluß = grüner Flußspath 651.

Smaragdit 556; im Blaugrund Südafrika 229.

Smaragdmutter 400, 599.

Sinaragdolin 401.
Smirgel $=$ Schmirgel 102 .

Smithsonit 524 .

Smoky stones 161 .

Snake in der De Becrsgrube 235.

Sodalith 547 .

Soft blue, Südafrika 225

Solitäi 360 .

Somabula blue 260, 425 .

Somabula forest, Rhodesia, Diamanten 260.

Sone- und Sonnarfluß, Indien Diamanten 177.

Sonpur, Indien, Diamanten 176.

Sonnenflinten 562 .

Sonnenopal 490.

Sonnenstein 627. 533.

Spaltbarkeit 29.

Spalten (klieven) des Diamants 306.

Spaltungsflïchen 29.

Spaltungsrichtungen 29.

Spaltungsrisse 31 .

Spaltungsstiicke 30 .

Spanien, Diamant 165. 237.

Spanischer Smaragd 391; Topas 597.598.

Spar ornaments 652 .

Spargelstein 653.

Speculative stones 270.

Spektrum 50.

Spessartin 439 .

Spezifisches Gewicht, Bestimmung 12; Annäherungsmethode 26; Übersichtstabelle 29 .

Sphen 521.

Spiegelnd 41.

Spiegelschliff 96 .

Spillersche Bernsteinimitation 678 .

Spinell 372; im Blaugrund, Südafrika 230 ; blauer 376 ; schwarzer 377

Spitzblank (Bermstein) 676.

Spitze der Rose 97

Spitzenametliyst 592 .

Spitzenschlauben (Bernstein) 676 . Spitzstein 95.

Splints 270.

Spodumen 557.

Spodumenamethyst 559 .

Spodumensmaragd 558.

Spotted stones 269.

Spritzlöcher in Achatmandeln 630.

Spröder Bernstein 6So.

Sprödigkeit 37.

Sprudelstein, Karlsbader 649.

Square chips 272.

Staarstein 6u8.

Stachelbeerstein 451.

Stantienit 663.
Star of Serawak, großer Diamant 276.

Staub 111.

Staubperlen 72.

St. Augustine, Diamantgrube bei Kimberley 214.

Staurolith 517.

Stealith 517.

Stechen des Bernsteins 666 .

Stein, armenischer $=$ Lasurstein 539.

Steine, arabische (Türkis) 493; bunte 404 ; couleurte $=$ Halbedelsteine 2 ; farbige 67. 419. 595: occidentalische und orientalische 86.333.

Steinschleiferei 90. 99; Diamant 306.

Steinschneiderei 105.

Stephanstein 621.

Stern der Rosette 97.

Stern von Este, großer Diamant 317.

Stern des Südens, großer Diamant , 318.

Stern von Sïdafrika 318.

Sternachat 628 .

Sternfacetten des Brillants 91 der Rosette 97.

Stermrubin 335.

Sternsapphir 79, 357.

Sternschnitt von Caire 93.

Sternsteine 79. 335. 357.

Stewart, großer Diamant 319.

Stock 101.

Stolberger Diamanten 5 S6.

Stoßperlen 724 .

Strahlenrose 98.

Strahler 584.

Strahlstein 564.

Strandsegen (Bernstein) 666.

Straß3 328

Streifiger Stein 644.

Strich der Edelsteine 83.

Stïcke, unregelmäßige (Bernstein) 659.

Stückperlen 724 .

Stiickrosen 305 .

Succinin 657.

Suecinit 657.

Südafrika, Diamanten 209 ; Menge der gewommenen Diamanten 246. 248; bei Kimberley 237; Kapkolonie 251; Oranjeflußkolonic 251; 'Transvaal 255; Deutsch - Sülwestafrika 260 ; Rhorlesia 260.

Sudanartikel aus Achat 635. Südstern, großer Diamant 315 . 
Sumelpur, Indien, Diamant '17\%. Siißwasserperlen 730 .

Syntlıetische Edelsteine 113; synthet. Alexandrit 113; Rubin 352 ; 'lopas 352.

Symmetrieebenen 10.

syrischer (sirischer) Granat 441 .

\section{T.}

'Tafel des Brillants 91 .

'Tafel von Tavemicr, großer Diamant 315 .

Tafelstein 95 .

Taj-c-mah, großer Diamant 315.

Tanà, diamantfülır. Konglomerat 186 .

Tamah Laut (Borneo), Diamant 276.

Tangiwai 571 .

Tapanhoacanga 190.

Taubenblutfarbe des Rubins 334 .

'Taurischer Topas 41 .

Tavernier's große Tafel, großer Diamant 315 .

Tavernier'sche Regel 127.

Technische Verwendung der Edelsteine ST; des Diamants 310 .

Texasachat 615.

Thalliumglas (od. -paste) zum Nachbilden von Edelsteinen 119.

Thermische Eigenschaften 81.

Thetishaare 600 .

Thomsonit 523.

Thulit 520.

Tiffany-Brillant, großer Diamant 319.

Tiffanyit S0. 155 .

Tigerauge 605; Schiller 79.

Titaneisen 6á6; im Blaugrund, Siidafrika 229.

Titanfavas 188.

Titanit 521.

Topas 411; Topas, falscher 597. 651 ; okzidentalischer ò 95 ; orientalischer 370 ; syuthetischer 352; Farben: blauer 415 ; brauner 595; gelber, roter 416 ; Farbenänderung durch Radiumstrahlen 72 ; Vorkommen 41s; böhmischer 597 ; brasilianischer 415. 598; indischer $415 ; 425$; 597 ; sächsischer 415 ; schottischer 590. 50s; sibirischer 415 ; spanischer 597 ; taurischer 495 ; von Hinojosa ว98; von Salamanca 595; von Uruguay 598

Topasasterie 357 . 371.
Topasbrack 417.

'Topaskatzenauge $35 \%$.

'Topassapphir 370.

'Jornatur 105.

'Totalreflexion 46.

I'ote Korallen 7\%7. 749.

Transvaal, Diamantgruben 217. 255.

'Irauerschmuck 65f(alleSchwarzen Steine, Perlen und Korallen).

Trebitsch, Preßbernstein 679.

Treppenschnitt 94.

Trichter, diamantführende, siehe pipes.

Tropfen (Perlen) 723.

Trimmerachat 629 .

'Tschota Nagpur, Indien, Diamanten 17. .

Tiirkis 486; kïnstlich 5(10); vom alten Stein 456; vom neuen Stein 501; okzidentalischer od. fossiler 501; orientalischer od. vom alten Stein 456; Ringsteine 493; Vorkommen 490; ägyptischer 495; Neu-Mexiko 496; Nordamerika 496; Persien 490 : Sinaihalbinsel 494.

Tïrkischer Stein 489.

Tïrkismutter 496. 499. 500 .

Turquoise de la nouvelle roche 501 ; de la vieille roche 496.

Turmali 468 .

Turmalin 452; edler und gemeiner4 55; Farben: blau 463; braun 463; farblos 45s; grün 462; rot 4อ̆s; schwarz 463; Farbenänderung durch Radiumstrahlen 72 ; sibirischer 459 .

Turmalinkatzeuauge 461 .

\section{U.}

Üherschliffen 100 .

Udesna, Indien, Diamant 178.

Ultramarin 542. 546.

Undurchsichtig 39.

Ungarisches. Katzenauge 605 ; Opal 469.

Unio margaretifera 726 .

Unregelmäßige Stücke (Bernstein) 655.

Unreifer Bernstein 650 .

Unterkörper, Unterteil an Schliffformen 90 .

Unze 126.

Unzenperlen 724 .

Uralischer Smaragd 451.

Uruguay-Topas 595 .

Utahlith 502 .
Uthalithmutter 50\%.

Uwarowit 451 .

\section{V.}

Vaalfluk, Diamantwäschereien, (river diggings) 211.217.

Vaalit im Blaugrund, Südafrika 229.

Variscit 5()2.

Variscitmutter 50)

Vasa murrina 653.

Vellum-Diamanten $5 \$ 6$.

Venushaare 600.

Verbreitung, geographische, der Edelsteine 86 .

Verfälschungen von Edelsteinen 114.

Verbrannte Koralle 737.

Verfaulte Korallen 749 .

Verkienung (Bernstein) 655 .

Verkieseltes, versteinertes IIol7. 608.

Verkieselte Wälder 609.

Vermeille, orientalischer 371.

Vermeillegranat 440. 44 .

Verticfungen und Furchen auf dem Korallenstock 736 .

Verwendung der Edelsteine zum Schmuck und in der Technik 8\%; Diamant 302. 310.

Vesuvian 511.

Vesuvische Gemme 511.

Victoria-Diamant 319.

Viellinge 11.

Vierundzwanziger Granate 447.

Violettrubin 3ั1. 591; Farbenreränderung durch Radium strahlen 72 .

Violettsapphir 3i1. 591.

Virniß (Bernstein) 676.

Vorbereitung der Edelsteine zum Schleifen 103.

Vorkommen der Edelsteine \$4.

Vorspoed, Diamantgrube. Oranjefluß-Kolonie 254.

\section{II.}

Wachsachat 620 .

Wachsglanz 43.

Wachsopal 470. 482. 454.

Wackler 623 .

Wage, hydrostatische 14; Jolly'sche Feder- 20; Westphal'sche 18, 23.

WVajrah Karrur, Indien, Diamanten 172 .

Wajragarh,Indien,Diamanten 177. 
Wälder, verkieselte 609 .

TValzen aus Achat 635.

Wappen, Schlifform 96.

Wardit 503.

Wärmeleitung 81.

Wäscherei, Edelstein- 85; Diamanten- 165 .

Wasser der Edelsteine 39; der Perlen 721.

Wasserchrysolith 551 .

Wasserhell 39.

Wasseropal 530 .

Wasser-pits, Ceylon 362.

Wassersapphir 355. 509.

Wasserstein 622 .

Wassertropfenquarz 601 .

Weibliche Steine 333.

Weiche Achatschichten 643.

Weltauge 484.

Weltefreden, Diamantgrube, Kapkolonie 232. 251.

Wert der Edelsteine, aligemeines 122 ; des Diamants

Wesselton (-Premier-) Grube bei Kimberley 214.
Westphal'sche Wage 18. 23.

Wogender Lichtschein 78.

Wolfsauge 530 .

Wolken 111.

Wolkenachat 628 .

Wolkenchalcedon 620 .

X.

Xanthit 513.

I.

Yellow ground, Südafrika 224.

Xü 564.574. 614; kaiserl. 616.

\section{Z.}

Zähigkeit der Edelsteine 37.

Zahlperlen 724 .

Zahntïrkis 501.

Zebrajaspis, dunkelbraun mit hellbraunen Strichen, Durchschnitte versteinerter Muscheln und Schnecken, Indien.

Zeiger 106.
Zelluloid für Bernstein 677; für Korallen 751.

Zeolithe im Blaugrund, Südafrika 230 .

Zeprerquarz $=$ Scepterquarz 593. Zerschneiden, Zersägen der Edelsteine 103.

Zersprengbarkeit der Edelst. 37. Zinkspath 524.

Zirkon 426; ceylonischer 427. Südafrika, im Blaugrund 230;

Zoisit 520.

Zonochlorit 523.

Zotten aus Bernstein 672.

Ziindhiitchen aus Achat 635.

Zusammensetzung, chemische, der Edelsteine 7.

Zwanziger Granate 447.

Zweier (Bernstein) 673.

Zweifacher Brillant 91.

Zweifaches Gut, Brillant 91.

Zweispitz, großer, (Rauchtopas) 590.

Zwillinge 11.

Zylinder (Bernstein) 673. 





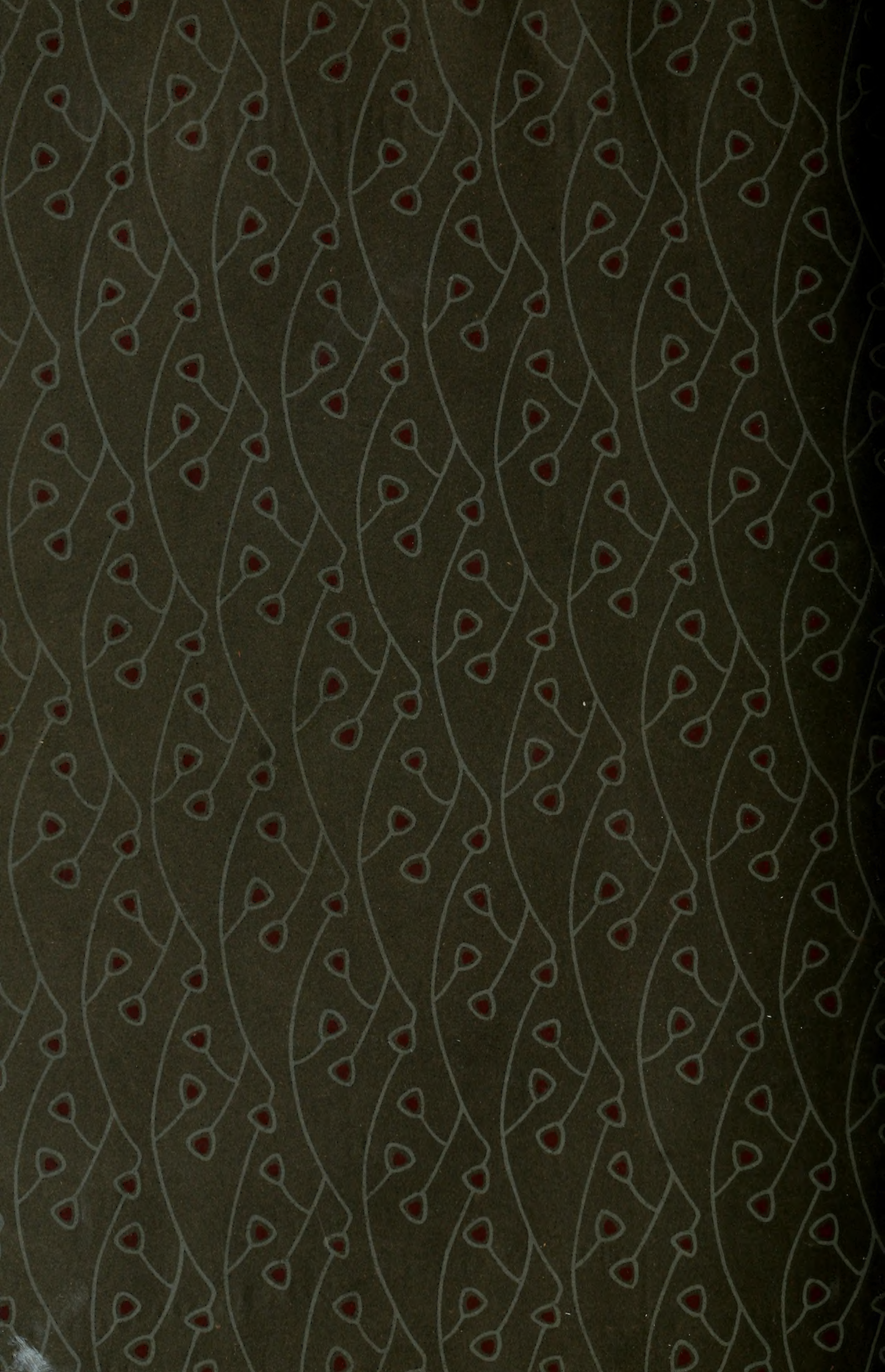




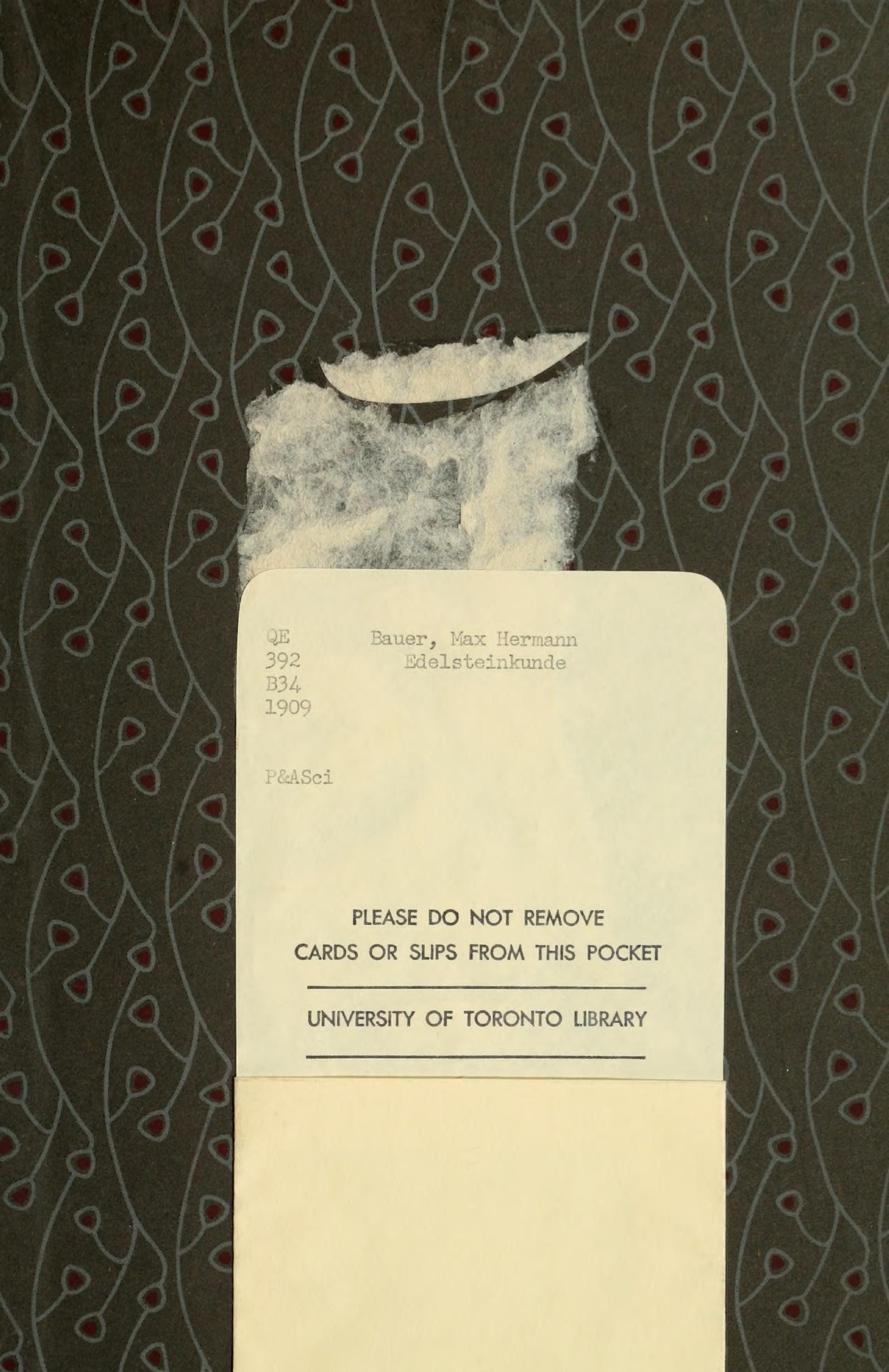


